تارئغ

تازه نواى بعارك

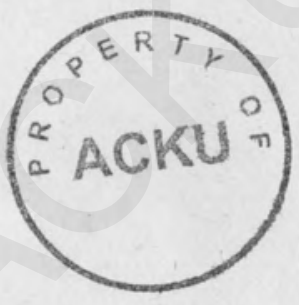

AFGHANISTAN CENTRE AT KABUL UNIVERSITY

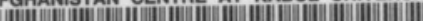

3 ACKU 000054774 
تازه

نواي معارى

تاليف

هنشى عطا متهميّد شكاريوري

$$
\text { A I I }
$$

به تصنيع و تحشيه و تعليق

عبدالحىى حبيبمي افغانى 
ص ص

\section{فم שמت}
( $)$

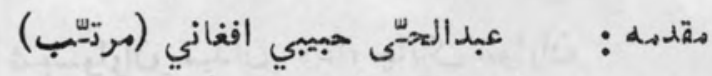
(o)

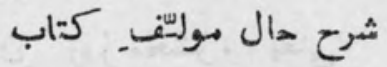
(4)
شغل منشي كري و مالازمت شمكاريور
( $)$

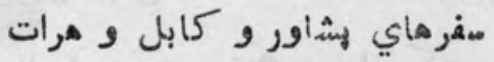
(q)
منتخار كاري" قندهار
(1.)
مشفر هرات
$(1$,
اهتراز از شهول بجنك مسكهر
(ir)
ولادت و وفات بوليست
(ir)
اخلاف موليسف
$(10)$
تاليف كقاب
(19)
ئكى نفر راوي
(1n)
هكونكي" نستخـ خطي" كتاب راوي
خزاين تاريخ

is lüs पy

تازه نواي معارك

1

ديباحه (مولن)

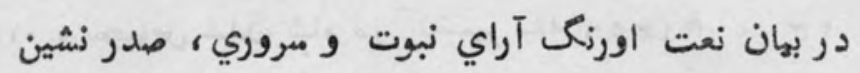

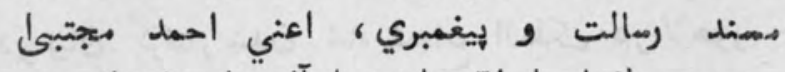

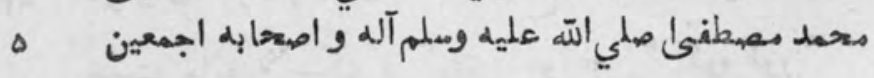


فهرست

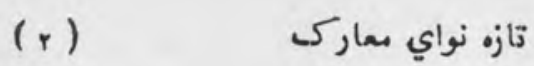

در بيان_ توصيف و ثناي نيران_ اعظم برج اماهت و معروري،

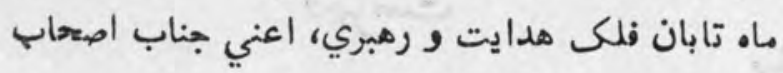

7 كبار، رضوان اله تعالىال عليهم اجمشين

در بيان [منقبت] ثمبسواران_ ميدان_ وغا، هابك مسواران.

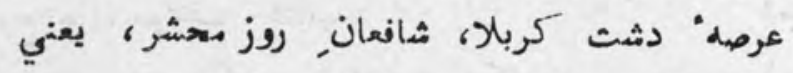

$\wedge$ جناب اماهين الشُهيدين؛ رضي الته عنهها

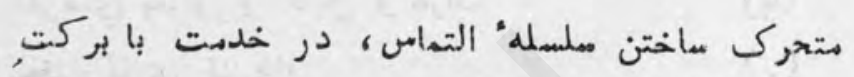
نوازند كان_ قانونبلاغت و مـتخن إروري، و نغهلطرازان

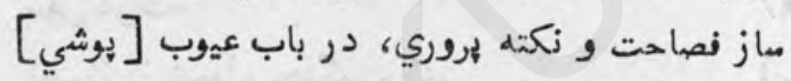

1 .

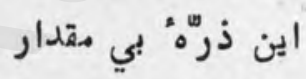

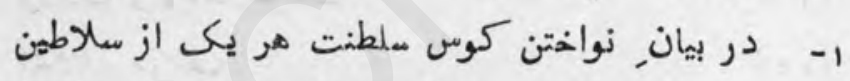
نامدار و خواقين. بلند اقتدار، از ابتداي بادثشاه

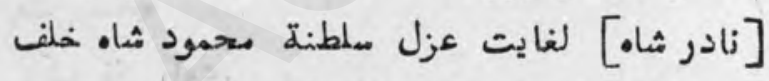

17

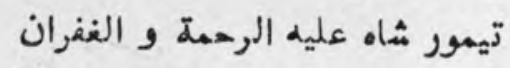

r- در بيان كشته شمدن عاليجاه عطا متحمد خخان باركزني برادر يار متهمد خان از دمت مردار سمندر خان

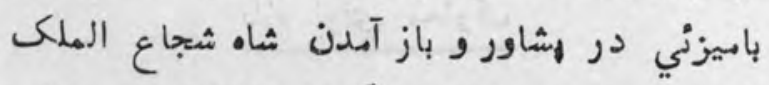

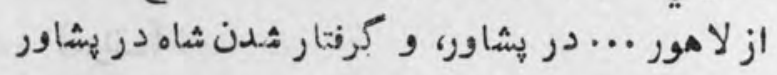

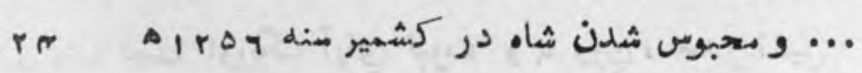
r- مدر بيان كرفتار شدن ثماه شجاع الهلك در لاههور

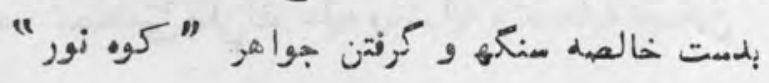


تازه نواي معاركى

خالصه نشنكه از ثاه مهدوح، و فراري ثدن, شاه

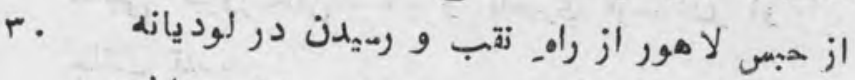

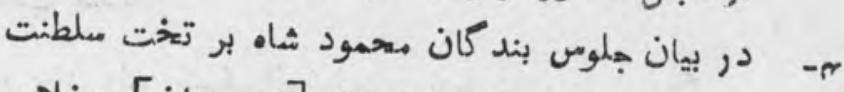

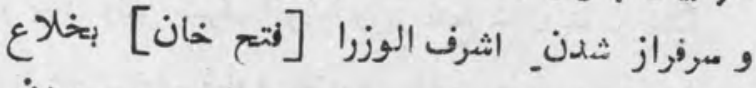

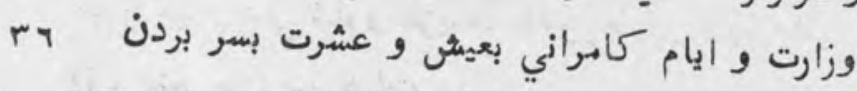

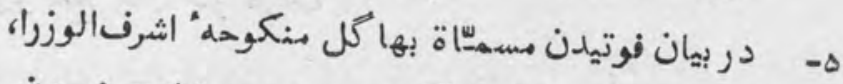

كه از ارباب نشاط, كشمير بود - و شمادي نمودن

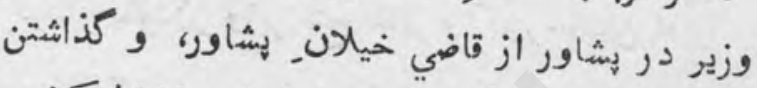

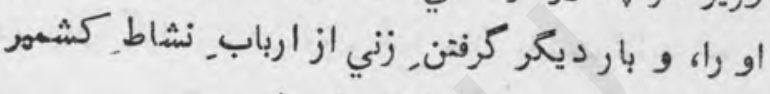

rT

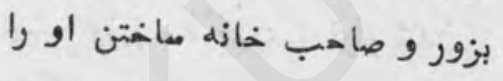

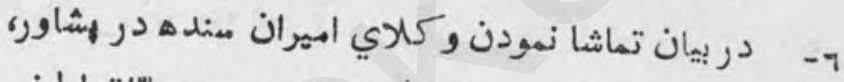

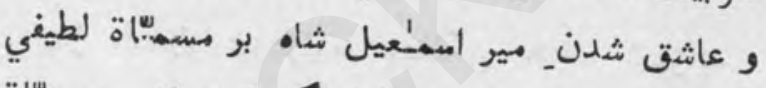

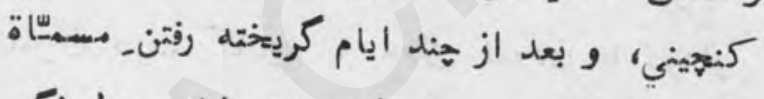

مذكور از خدمت مير اممهـعيل شاه طرف وسول نكر،

و زامه نوشتن طرف او .... و در جوابشى اين خاكسار

ro

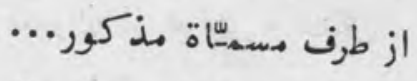

$\rightarrow$

نامه از طرف مير امسمُعيل ثاه

$\pi$

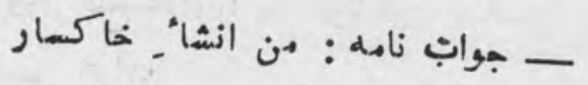

$\Delta 1$

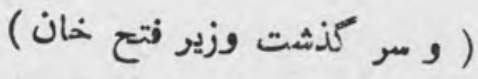

ـ- در بيان رفتن وزير فتح خان در اندرون قلعه هرات بجهت خوردن ضيافت و كرنتار نمودن ( ثرزاده ) 
فهرست

(r) (تازه نواي ماركى

هاجي فيروزالدين شاه، و و باسيري فرستادنـ او را

09

جانب تندهار

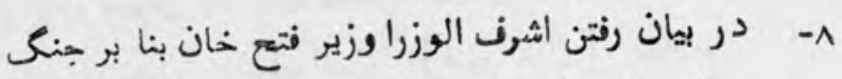

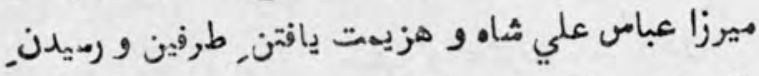

71 وزير فتع خان در هرات فاه ونات

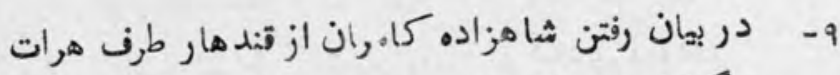

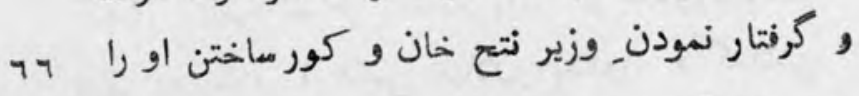

• 1- در بيان كرفتار شدن وزير فتع خان بدست شاهزاده

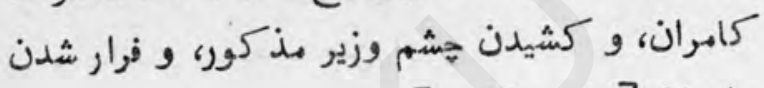

$\angle$.

برادران [وزير •ذ كورة]

1

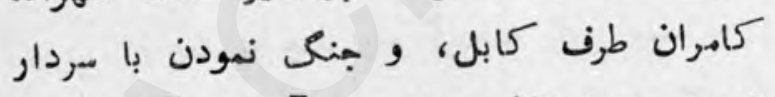

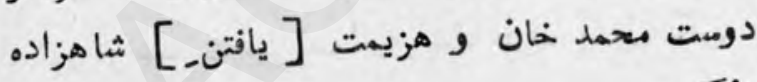

$\angle r$ مذكور

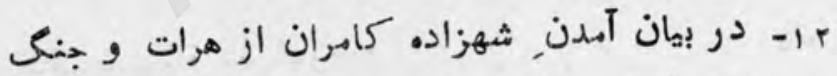

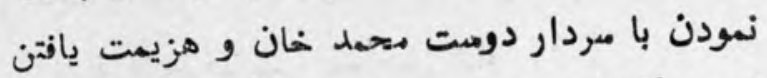

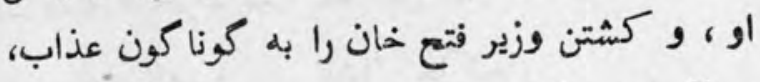

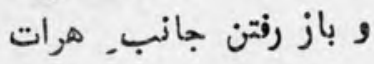

$\wedge r$

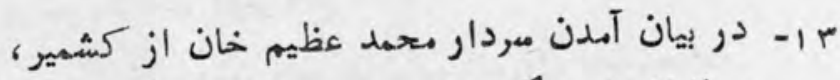

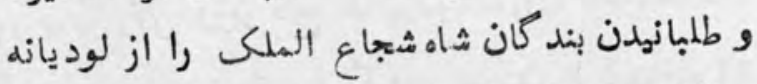

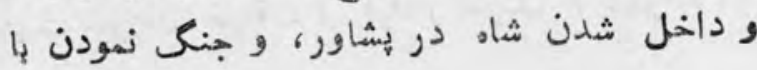


تازه نواي تمار

(s)

فهرست

مردار محمد عظهم خان، و هزيهت يافتن [شاه و $\wedge \wedge$ رميدن.0حمد تيمور شاه ] در مثكاريور

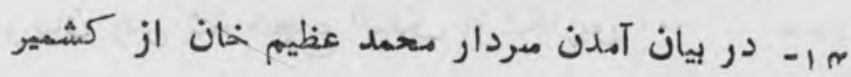

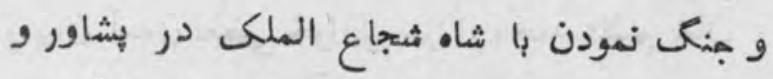

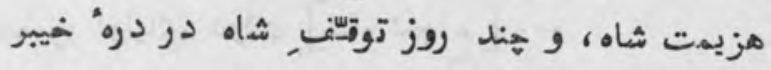

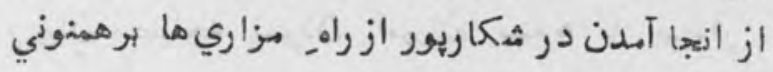

ค० سيد ولي شاء

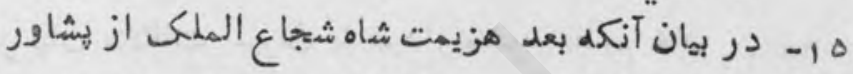
مير صاحبان مهده هدر كشيدن ثان هزاده محمد تيمور

1.1

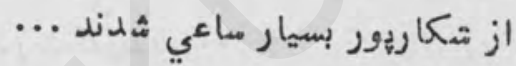

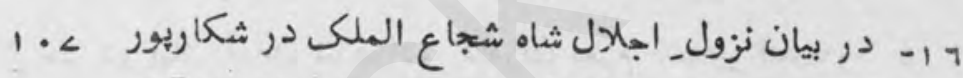
ك ا- در بيان مراجعت فرمائي اولياى دولت ازحيدرآباد

110 و خيرجور

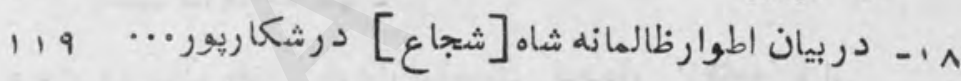

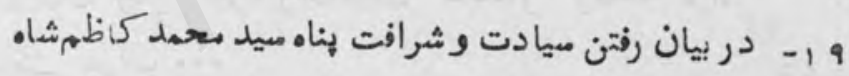

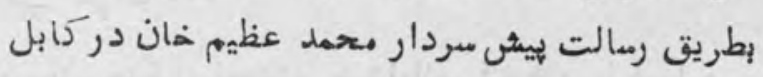

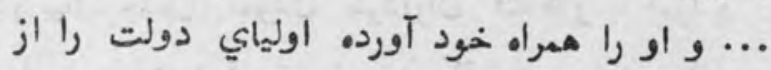

189 شكاروبور كشيدند

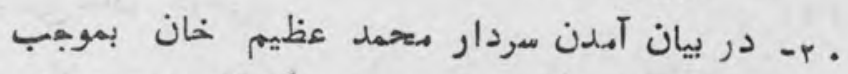
امتدءاي ابيران بنده ه و وقوع كفتكو مابين اولياي

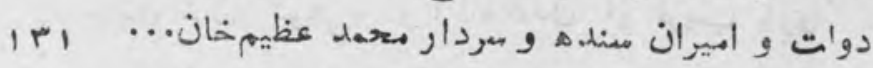

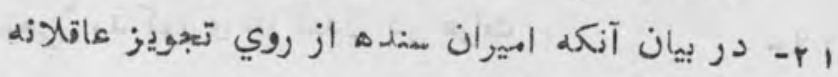


فهرمت

( 1 )

تازه نواي نعارك

امناي دولت [شاه شجاع] را از شكاريور كشيد.

$1 \% 2$

بطرف خود طلبانيدند

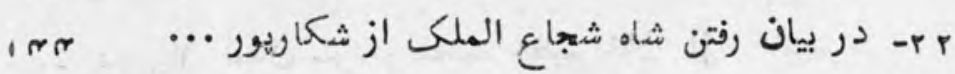

م r- در بيان آمدن بعضى خوازين سردار مدحمد عظيم خان بحضور اولياي دولت [شاه شجاع]

مr- در بيان مصالحه زمودن اميران سنده با سودار

$10 \wedge$

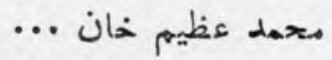

هـ- در بيان مالاقات الميران با سردار محمد عظيم خان

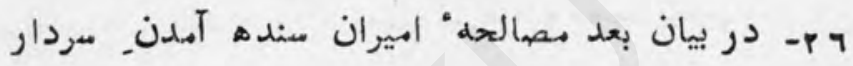

177

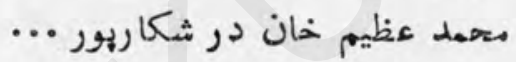

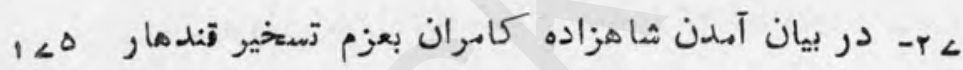

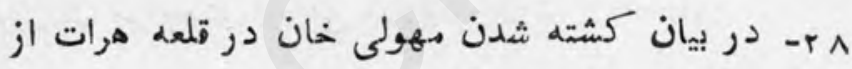

$|\wedge|$

دست شاهزاده. جهانكير.

و ז- در بيان رفتن, سردار صاحبان, قندهار از قلمعه؛ فراه

$1 \wedge 0$

جانب هرات مات

• ب- در بيان جنم نمودن سرداران قندهار با امرا و

خوانين هرات و فريب خوردن از مهدد خان خلن

191 عيسى خان خون كوني

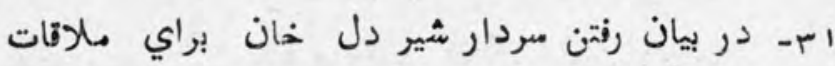

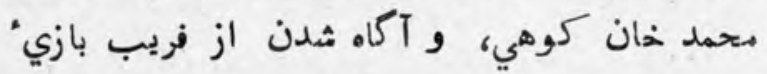

196 كوهي" مذكور و باز آمدن در هرات 
تازه نوي

$(<)$

فهرمت

rr- دور بيان فريب بازي" متحهد خان كوهي و جنك نمودن با مبردار ضاحمان و هزيمت فيافتن كوهيث

r. مذ كور

هr- در بيان مراجعت مردار صاحبان] [تندهار] از هرات

rir

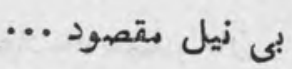

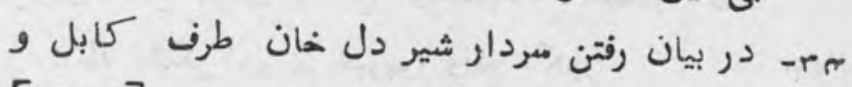

كرفتار نمودن حبيب اله خان خلف مرحوم [سردارد

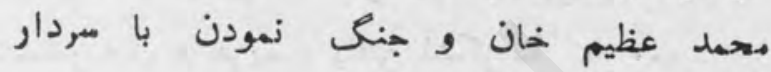

rr

دوست معمد خان.

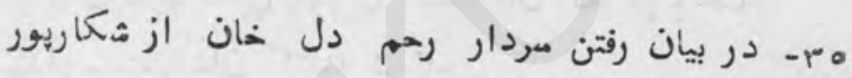
rr.

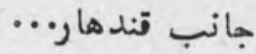

بس- در بيان آمدن [سيد] احمد [بريلوي] ثاه غازي

$r \pi r$

$\cdots$ dinos

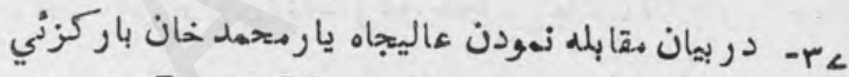

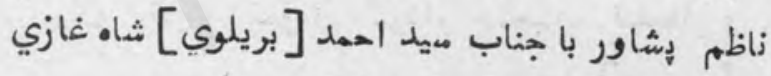

ror

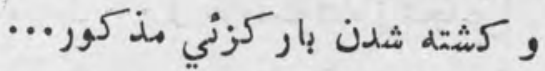

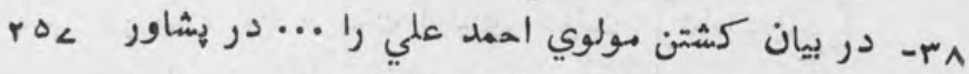

هـ- در بيان ملب, كرم [مرك] عاليجاه مير كرمعليخان

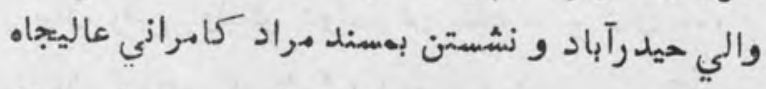

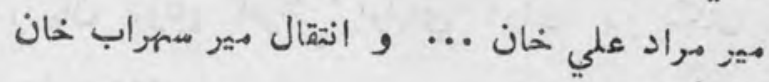

PYT

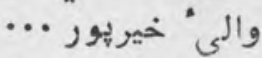

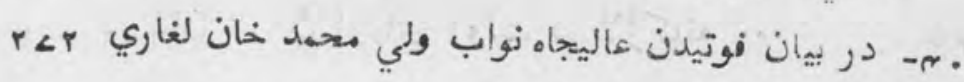


فهر-ت

( $)$

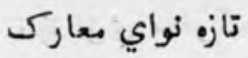

ا r- در بيان رقتن وكلاى اولياى دولت بناء بر عزا برمي rA.

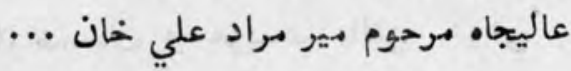

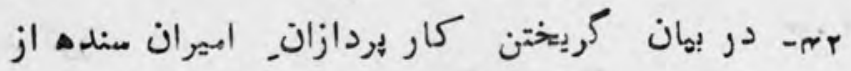

TAA

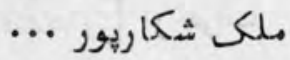

س س- در بيان ماسور نمودن أولياي دولتعاليجاه سمندرخان

$r q r$ در دقابله لشكر أبيران خيريور واقع سمهر

مr- در بيان جنم نمودن لشكر اهيران خيرانور با عاليجاه

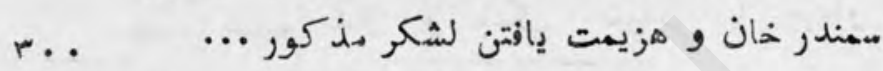

هم- در بيان ماتم داري بلموحان كشته كان كله دروجنم

PI

مردار سمهندر خان كشته شمند لمان

به- در بيان آهدن اميران مثنده با عساكر باراده: هقابله .... و مصالحه نمودن ثشاه.

ع rه- در بيان رفتن اوليايدولت [شاه شجاع]]جانب قندهار

^م- در بيان مقابله نمودن سردار صاحبان قندهار و

امهر دوست محمد خان ... و هزيمت شاه [شجاع

9 م- در بيان بعد هزيمت اولياى دولت [شاه شجاع]

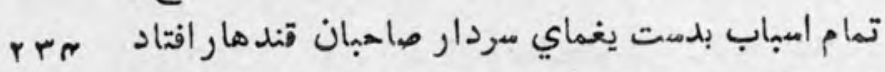

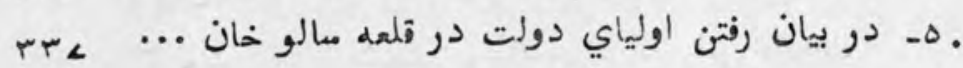

رهـ در بيان رونق افزانيخ اولياي دولت در مكان

re

روجان

$r \Delta$,

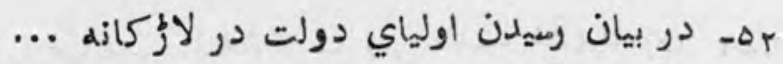


تازه نواى نسارك

(१)

فهرست

مده در بيان فرمسادن. وكلاي امناي دولث لجيمى ror

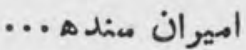

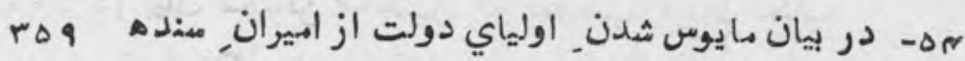
هـ- در بيان رفتن لشكر الواج بحر امواج سركار انكليسه

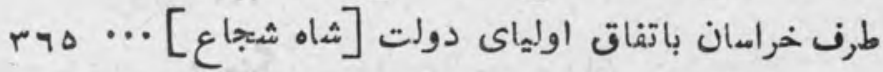

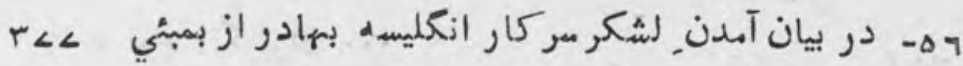

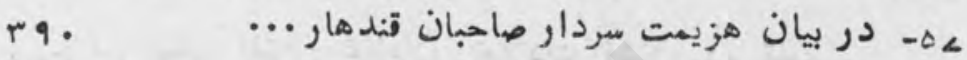

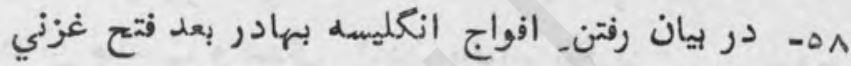
$\mu$

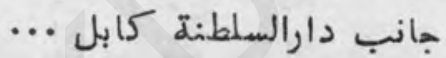

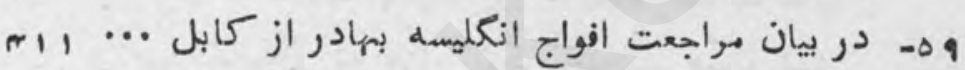

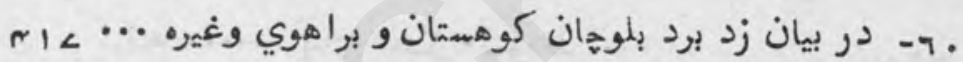
ا NTr و كرفتار نمودن بجار خان دومبكي صيال.... r ج- در بيان رفتن صاحبان_ انكريز بهاد ر طرف قلعه كهان กr و هزيمت صاحبان

سج- در بيان آهدن مهر نصير خان [براهوي] بر قلات חי

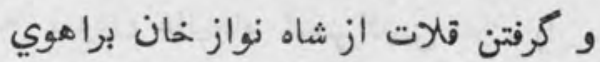

هף- در بيان رفتن جناب راس بيل صاحب بهادر بطرف NeI شال كوت

ه7- در بيان آمدن امير دوست دحمد خان از بخارا ... ج بهم

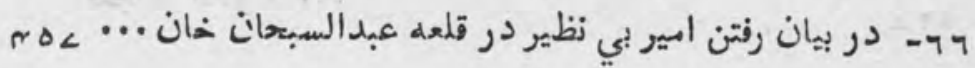


فهومت

تازه نواي مeسرك

عا- در بيان آمدن امير بي نظير [دومست متهد خان]

NTr

خود بتخود در كابل ...

^ 7- در بيان مكناتن صاحب كله بموجب فرهان جناب

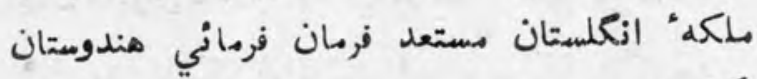
$\pi<7$

كرديده ...

9 - در بيان جنك نمودن عاليجاه عبداله خان إجكزئي rAr

با فوج انكريزان ب...

•

مكناتن صاحب و جنه كردن بافواج انكريز

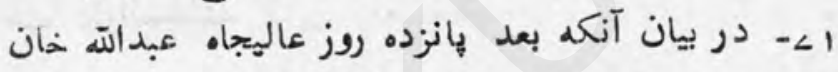

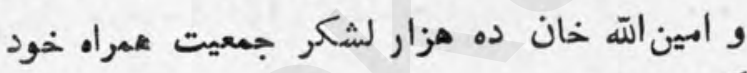

ल9人

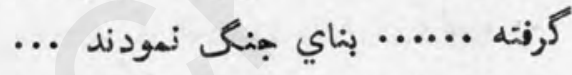

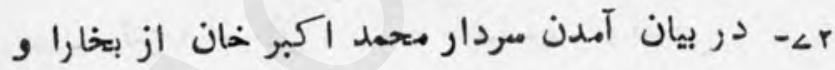

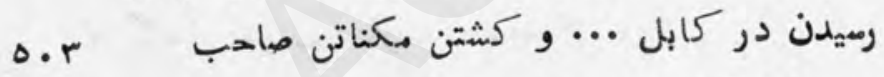

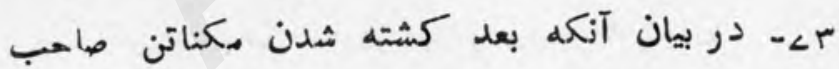

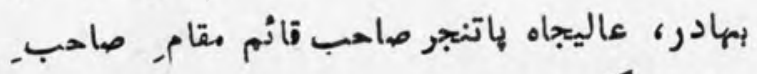

$\Delta 1 N$

مهدوح كرديده....

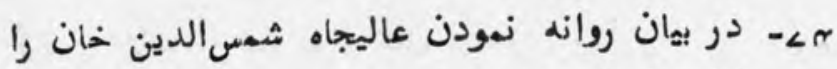
$\Delta_{r}$.

طرف قلمعه" غزنين ...

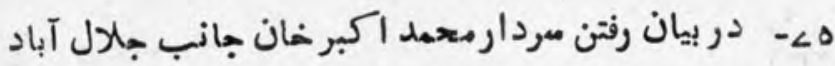

....

DrL

ث:جاع الدوله 
تازه نواي مaسرك

$(1$,

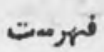

ح>- در بيان بعد قتل شدن اولياي دولت [ثاه شجاع] ore

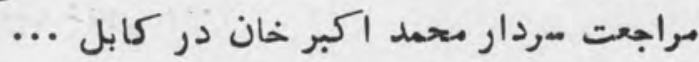

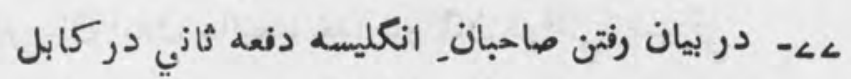
$\Delta \sim r$

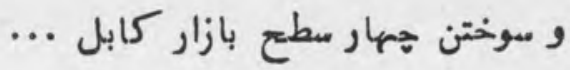
^ـا- در بيان فتع نمودن قلعه غغزنين را بار ديكر عاليجاه $\Delta \Delta r$

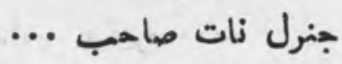

9>- در بيان آنكه راويان مي كويمد كه دفعه ثاني

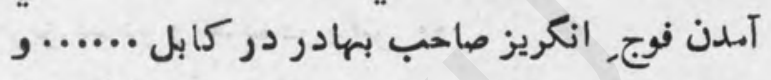
بردن دروازه غزنين از مومنات ... بسازكاريث จั مردار محهد اكبر خان بود برولين

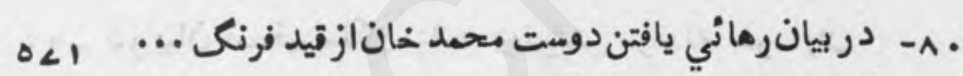
OA [نقل بازان و زاغان

ا م- در بيان رفتن امير بي نظير [دومت محمد خان] هq

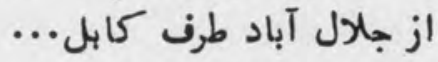

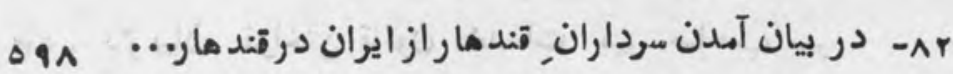
rير- در بهان رفتن ماحبان انكريز بهادر در مرات بهثى 7.8

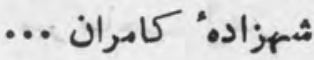

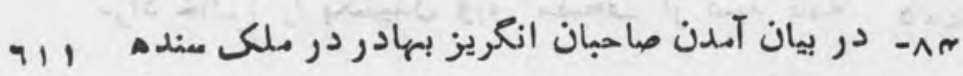
هي- در بيان آمدن صاحبان انكريز از ولايت خرامان ar.

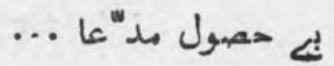


قازه لواي مارك

$(1 r)$

فهرست

ح ^- در بيان رفتن جنرل معر هارلس نيهئر صاحب بهادر 9 9

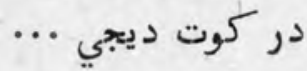

عـ- در بيان آهدن عاليجاه خدا يار خان درَّاني باميزئي न

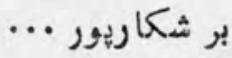

^ی- در بيان رقتن ديوان جيت مل رف از شكاريور و $7 \times 1$ كرفتن مبلغان از هندوان كوداهي وغيره ...

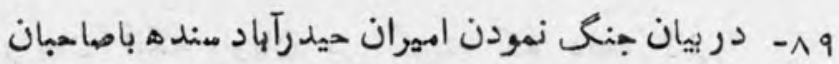

Tor

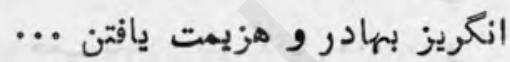

• و- در بيان مقابله عاليجاه مير شير متهد خان با فوج $7<$.

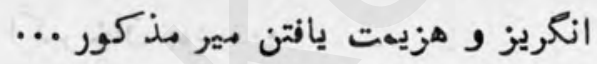

ا و- در بيان تسخير ملكىمنده و نوشتن مرامدله معرداران

Yง قندهار و خر باسن

rو- در بيان رفتن عاليجاه ثير ديهم خان بنا بر آوردن $9 \wedge 7$

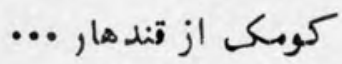

موه- دربيان نواختن قانون خدمات مير صاحب مير

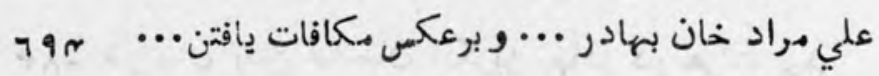

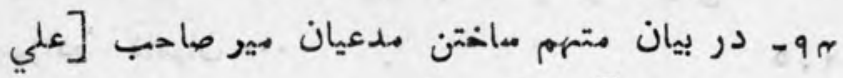

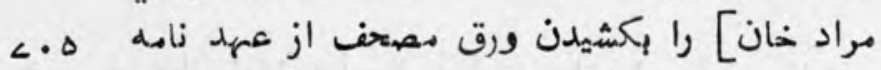
هو- در بيان زهك حرامي شيخ علي حسن و نوازشات <. 9 مير صاحب [علي مراد خان] بهادر, ... 
فهرمت

( 1 r)

تازه نواي مa

حه- در بيان اجلاس صاحبان انكريز در مقدمه دريافت

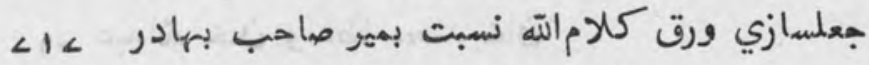

×وه- در بيان رفتن الشكر انكريز بهادر بملك مير علي

$\angle r r$

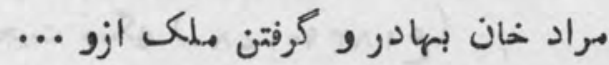

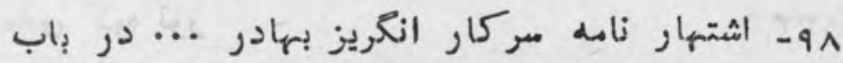

$\angle r q$

عزل ريامت و غصب ملكث...

ه و- در بيان ما يوس ماندن بير صاحب [علي مراد مخان]

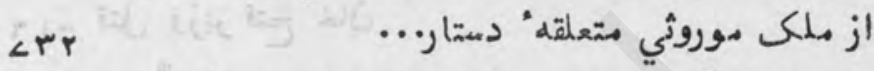

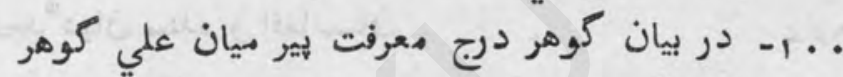

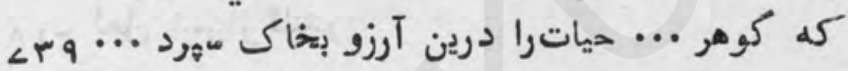

م- تمليقات

Lल

$\angle \Delta$.

$<79$

$\angle 9$.

$\angle 90$

$\angle 91$

$\Lambda \cdot r$

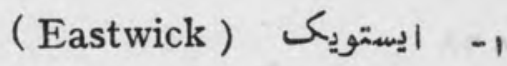

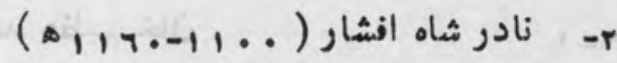
r- احمد شاه ابدالي و دودمانش

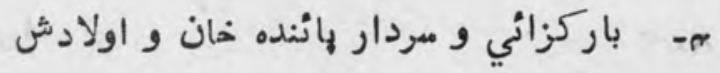
هـ - وزير شير دهمد خان 4- ب- ميران تالهوري مندهـ

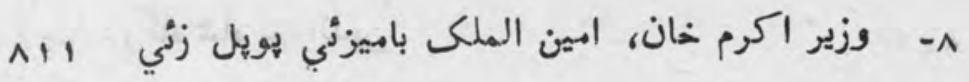


تاز. نواي مارك

$\wedge 10$

ArN

Arq

Ar.

הזr

Aro

ArY

nor

$\wedge \Delta<$

$\wedge \Delta \uparrow$

$\wedge \neg r$

ง

ครา

$\wedge \neg \wedge$

$\wedge<1$

$\wedge<r$

$\wedge<r$

$\wedge<\pi$

$\wedge<\angle$

$\wedge<9$

$\wedge<9$

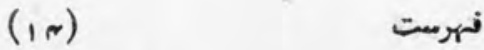

ه- نواب ولي متمد خمان لغاري

• 1- عبداله خان و عطلا محمد خان

ا أ- ا- عبدالغفور خان

(

rا- الماس كوه نور

م ا- . قاضي خيلان بشاور و قاضي دعمد حسن

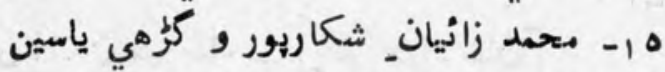

ד ا- قتل وزير فتح خان

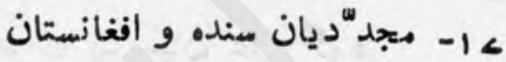

1 ا- ا- لعل ثمهباز تمندر

9 1 - ميان قبول محهد

تلنكه - كنكا جمني - كبول مبار

• r- ميرزا احمد خان

ا ז- عبداله خان المكزني

rr- وفات سردار دحمد عظيه خان

rr- وفات مردار شير دل خان

r r- جنرل وينتورا

هـ- هير صبغةاله و خاندانى

7 r- شهادت ميد احمد بريلوي

ك r- قاضي محمد حسنن

^ז- دركاه شاه خمرالدين 
فهرست

ه r- ثير متحراب خان بلوز و دودمان_ غانان_ تلات

$\wedge \wedge$ I

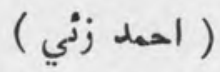

$\wedge \wedge$ ト

. ب- كيول ( مسمر كميهل ( Campbell )

^^^

ا.ب. برنس (Sir Alexander Burnes)

^ง ค

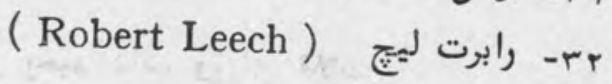

ง १

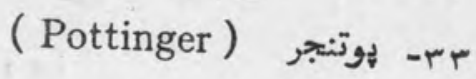

^९ร

$(\varepsilon \mid \wedge r q-1<\wedge r)$

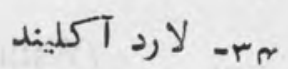

^९ฯ (Sir William Hay Macnaghten) هـ -

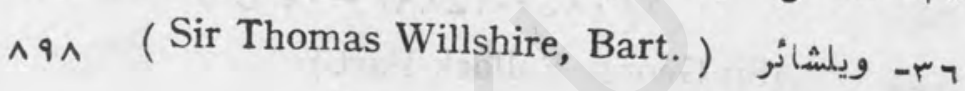

(ع

१.। (Sir Robert Henry Sale)

^r (Williain Frederick Marriot)

و م- ها رلس رابرت كريتن (

१.r (Charles Robert Curreton)

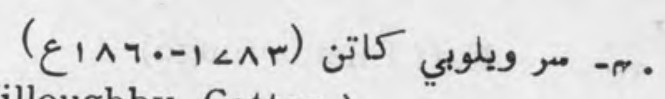

१. ( (Sir Willoughby Cotton)

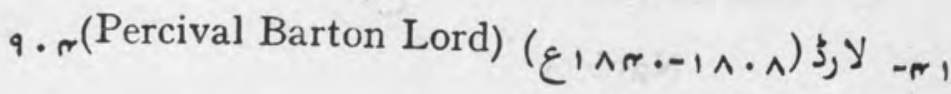

9.0

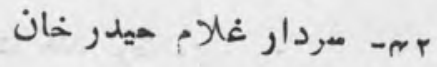

१・^

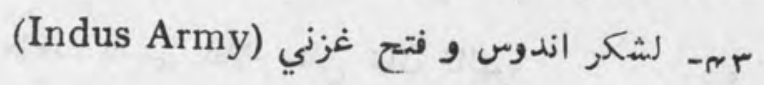


كاز. لمواي معاركى

$(19)$

فهوست

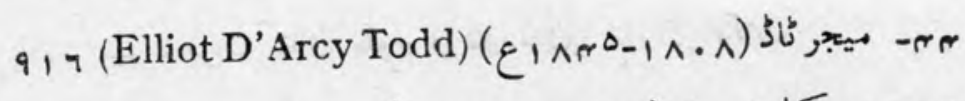
هب

१। (Sir Claude Martin Wade)

$91 \wedge$

لهم- شهادت ثير ميراب خان فلات

9..

L r- مل محهد حسن و رحيم داد، وزراي قلات

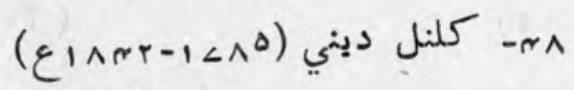

are (William Henry Dennie)

9 r- فيلد مارشل خارك (ع

का (Sir George Pollock Bart.)

Q⿻

• - م- قتل شاه مشجاع

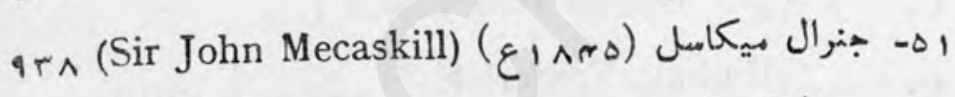

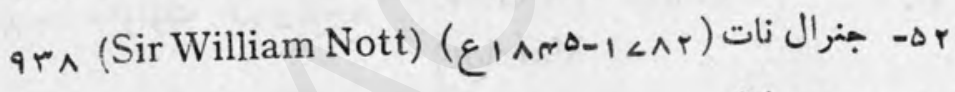
बल.

rه- موهن لال

(Edward Law, First $(\varepsilon \mid \wedge<1-1<9$.$) ( الين$ จก^ Earl Ellenborough)

(Sir Charles James $(\varepsilon \mid \wedge \Delta r-1<\wedge r)$ ن ن

$9 \Delta$.

Napier)

وهـ معاهدات مهران منده با دولت هند برطانوي

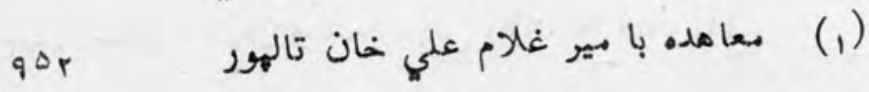


dow

$(1<)$

تازه نواي بـاركى

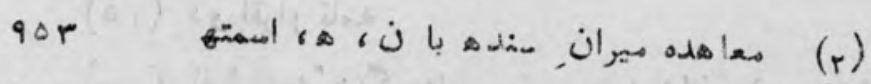

qدم \& اAr

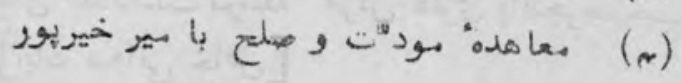

9० ש

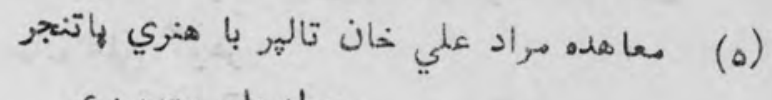

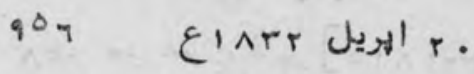

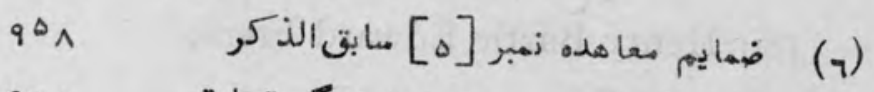

ضهيهم ديكر تجارتي

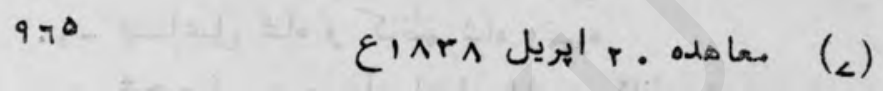

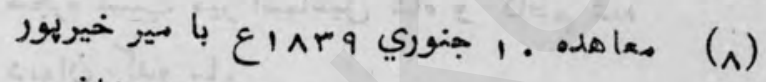

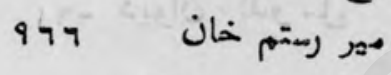

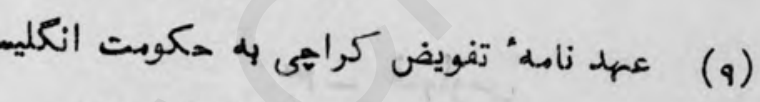
१

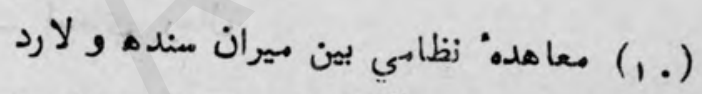

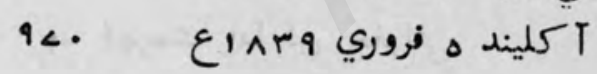

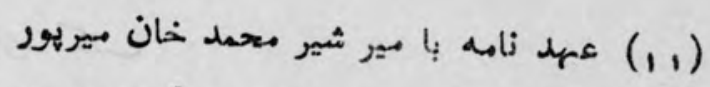

$9<\pi \quad$ ع

$9<7 \quad$ Elarr odses (ir)

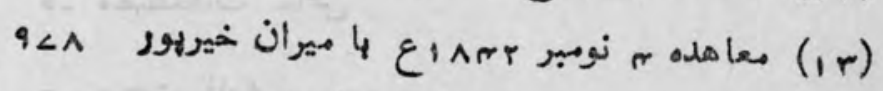

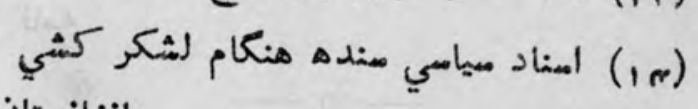

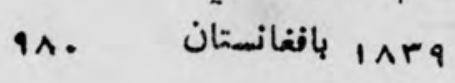


فهرمست

(1^)

تازه نواي مaاركى

9^ ।

(10)

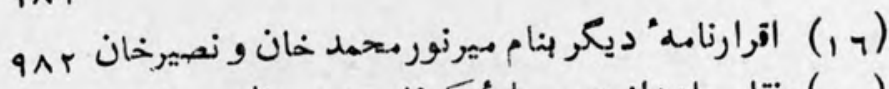

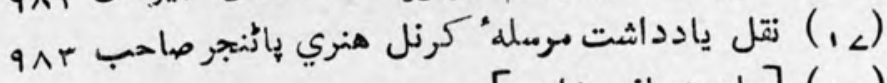

१^า

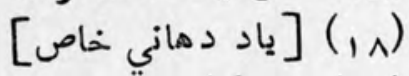

ه^ >

११.

عه- ميان علي كوهر

[ه

११. (Sir Henry Bartle Edward Frere)

9 ז (John Jacob) [ع

११

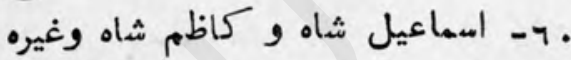

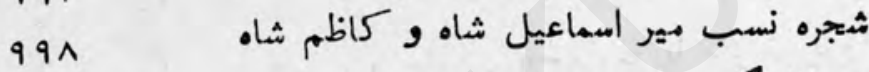

११९

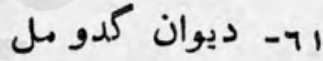

-

$1 \cdots$

$1.0 r$

$1 \cdot \wedge<$

1.99

$11 \cdot 1$

1117
1- فهرست امسماي رجال

r- فهرمت اماكن جغرافي

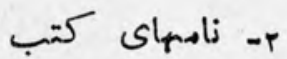

r- (مهاى اقوام و قبانل

ه- مصطلحات خاص

ب- صحت نامه

$\longrightarrow: 0:-$ 
فهرست نسب نامها

$<7<$

$<79$

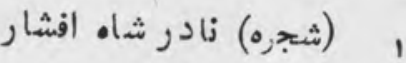

r شجره: ابداليان

r مجره: نسيب شاهان مدوزاني ابدالي ( دراني )

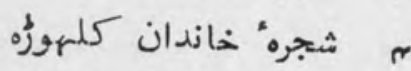

ه شجره: باركزائيان (حصه اول)

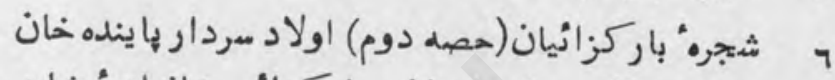

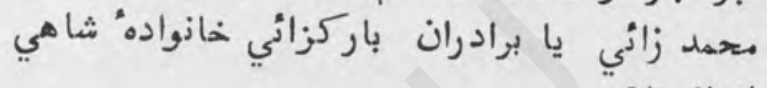

افغانستان

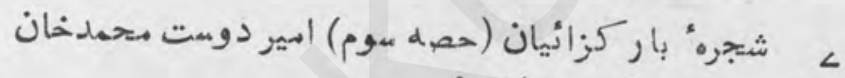

$\angle 9 r$

متحمد زائى، باركزئي

ه

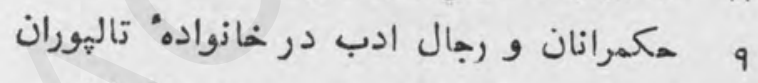

Arr

$\wedge \bullet \wedge$

A

$\wedge<4$

AN

वर

• 1 شجره دودمان نواب ولي دمهد خان لغاري

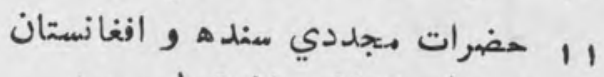

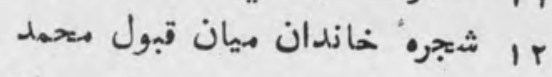

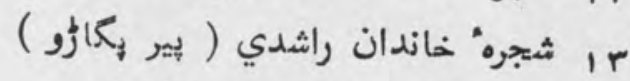

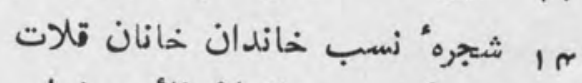

هر شجره" نسب شعاندان نائب خهل

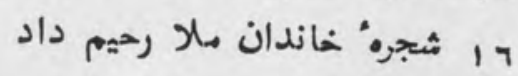

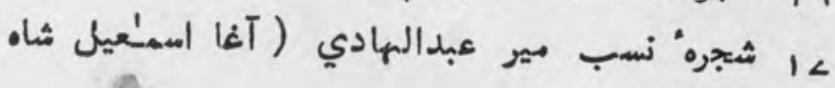

คง ง

و كاظم شاه ) 
فهرس تص تصاوير

ا

$[<9]-$,

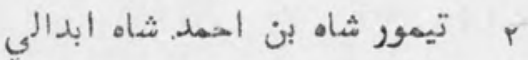

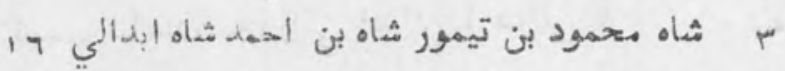

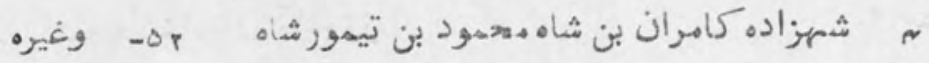

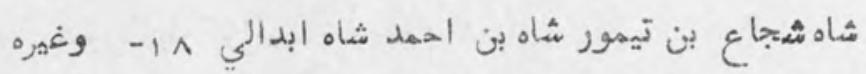

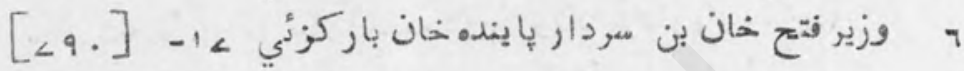

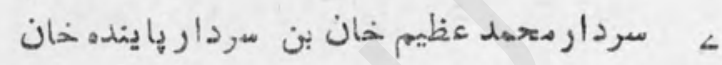
[ب. باركزئي

A مردار بردل خان بن سردار هاينده خان

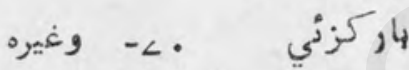

9 سردار شير دل خان بن سردار با ينده خان

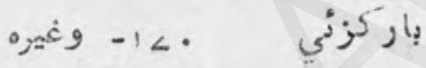

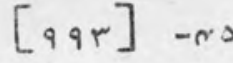

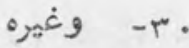

$[<\Delta \cdot]-\Delta a$.

or'

rAT

$[\Lambda+\Delta]-r^{\prime}$

$[\wedge r \Delta]-r a$.

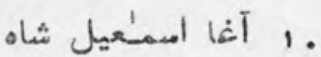
(1.

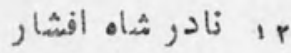

rا بائب امين الله خان لوكري

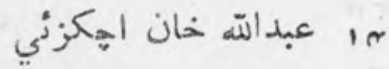
10

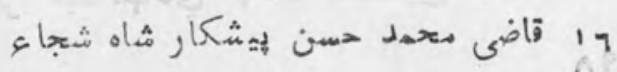


فهرمت تصاوير

(ri)

تازه نواى مalر

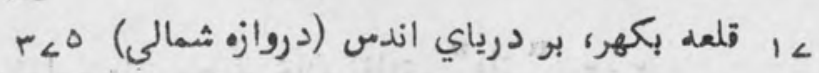

menthan

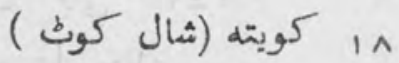

ras

19 19

ए97

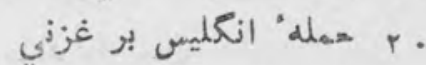

ला

ا r

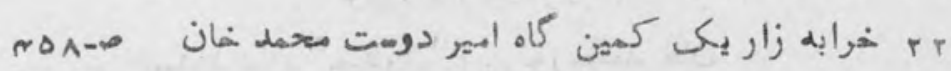

orr

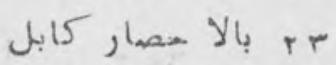

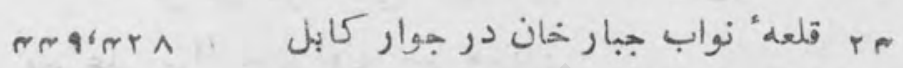

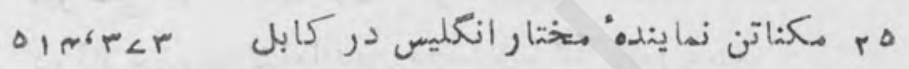

$r \Delta q$

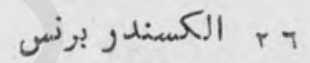

นจ.

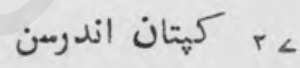

$\Delta$ ir

r

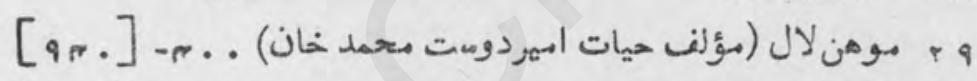

$[9 \cdot r]$

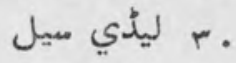

الم المير دوست محمد خان بن سردار راينده خان

r- r r

باركزني

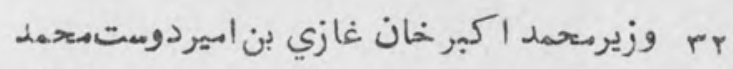

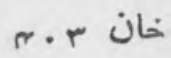

rم سردار غلام حيدر خان وري عهد

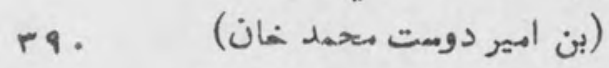

rr مقبره ميركرمعلي خان تالهر (ميرحيدرآباد) ד דجr

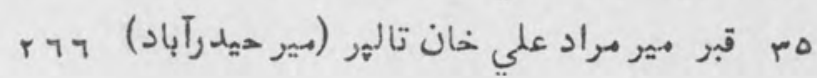


تاز. لواي مaاركى

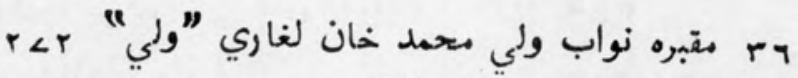

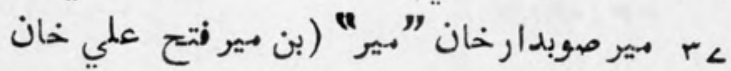

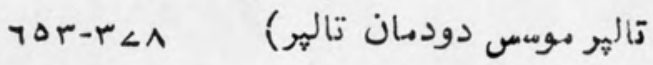

Ar مير نصيرخان"جعفري" (بن مير مراد عليخان

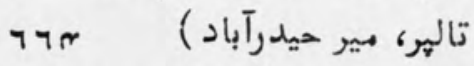

هم ميرشهداد خان "حيدري" (بن نور.تحمد خان

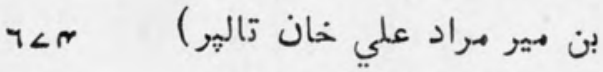

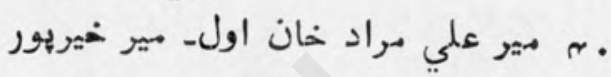

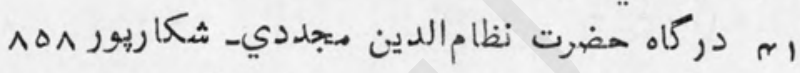
זم دركاه حضرت سجل سرمست (درازا)

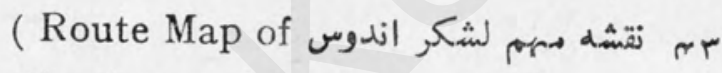
r $>$ the Army of the Indus 1839) 


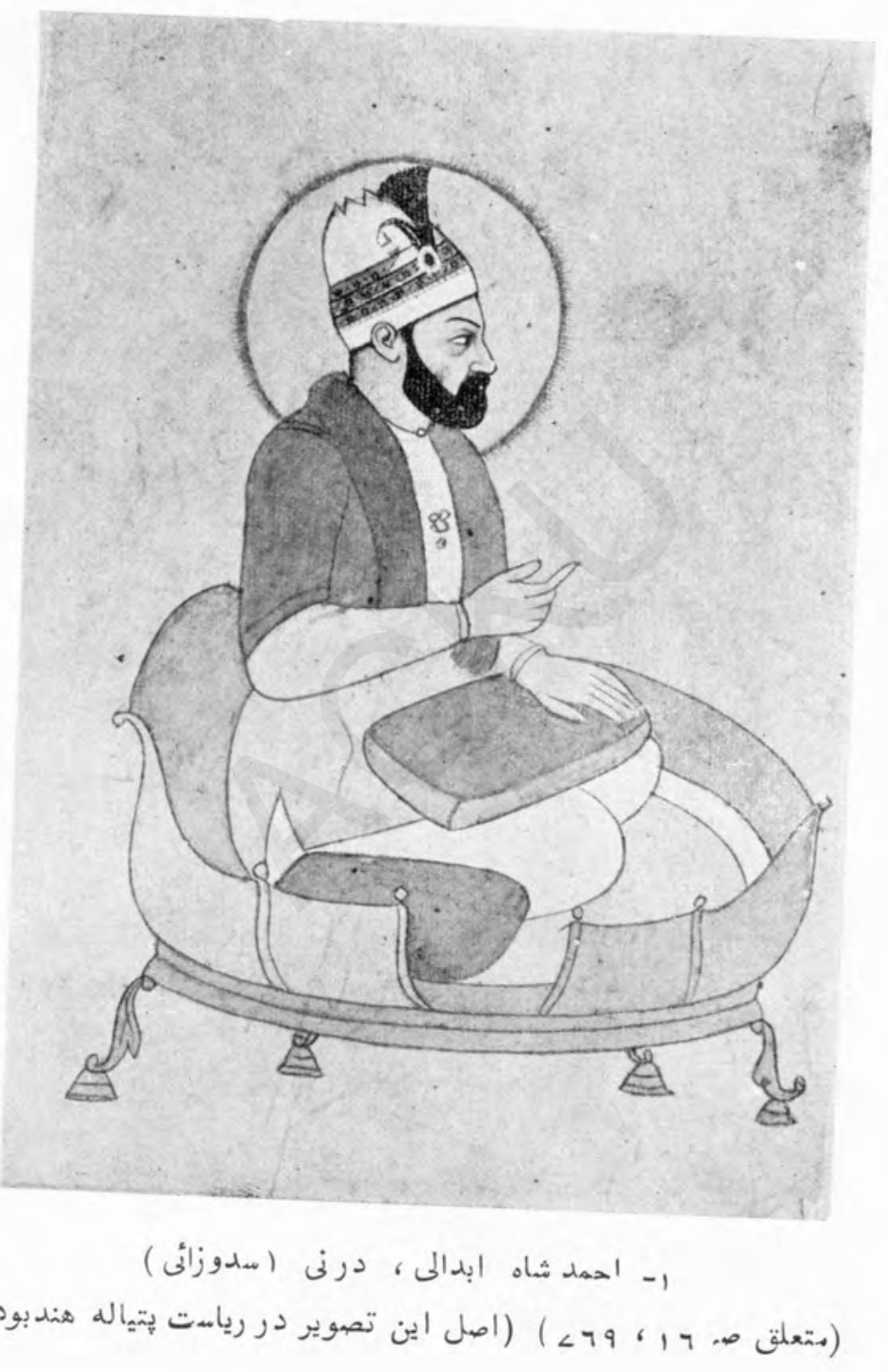




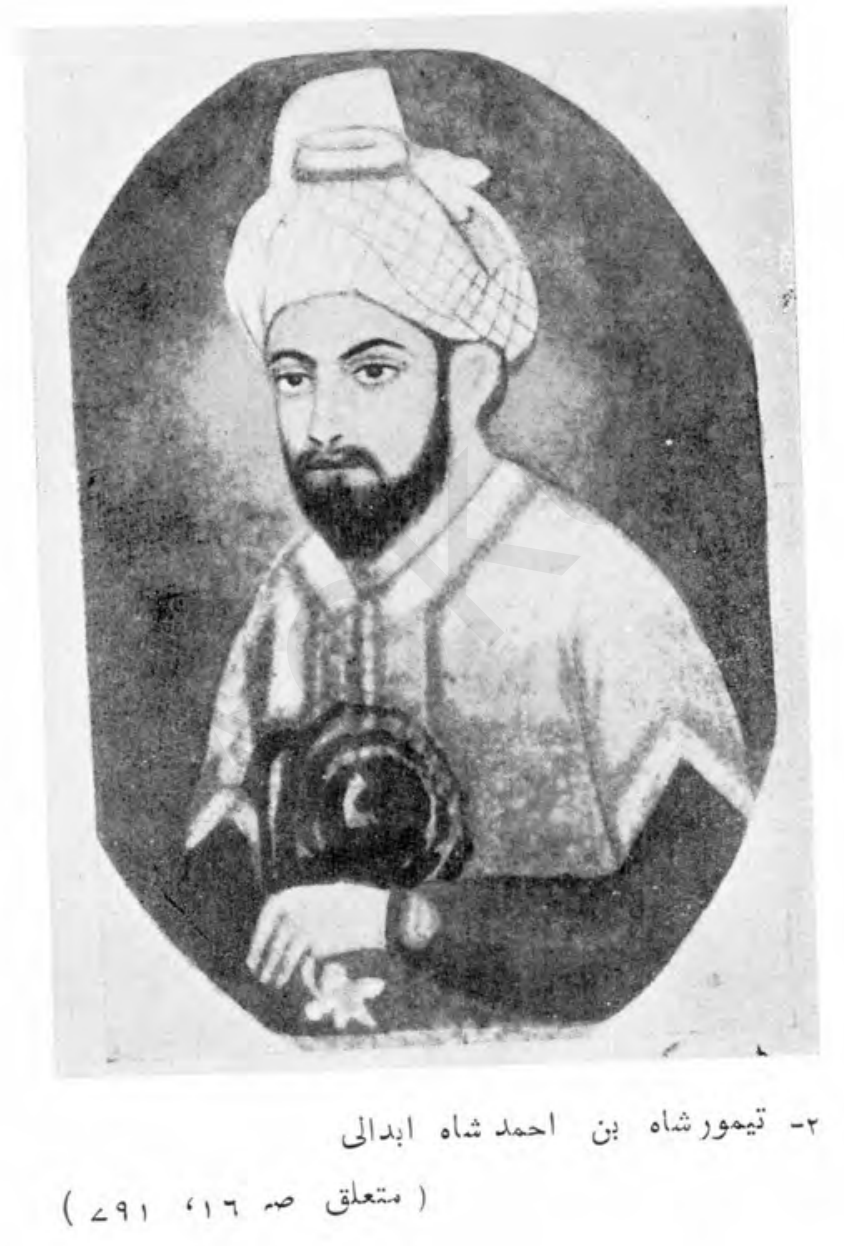




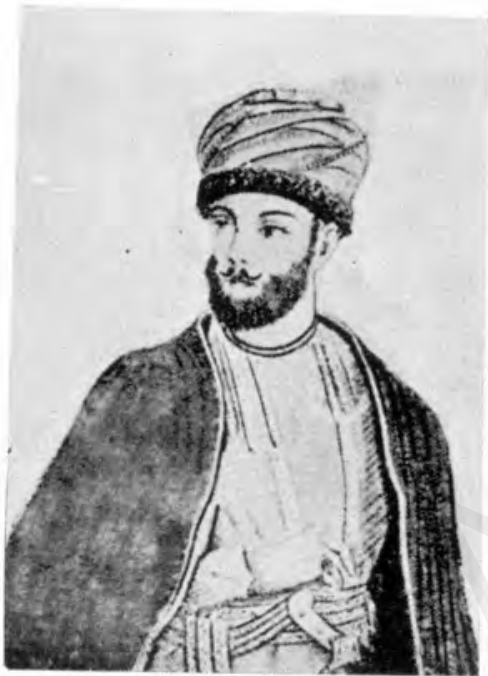

r- شهزاده كامران، بن شاه ممود بن تيمورشاه ( متعلق صـ or و وغيره )

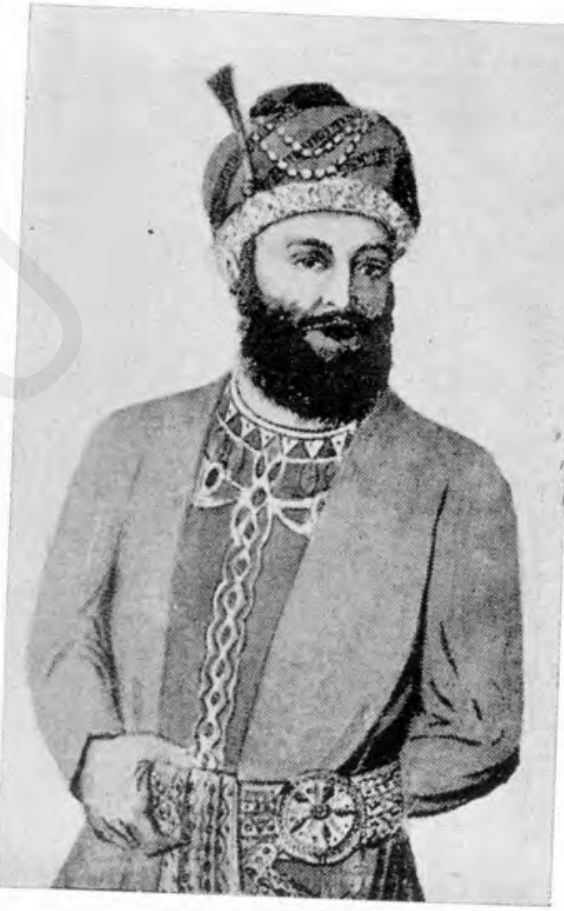

r- شاه عمود بن تيمورشاه بن احهد شاه ابدالى ( $17 \rightarrow$ صlin ) 


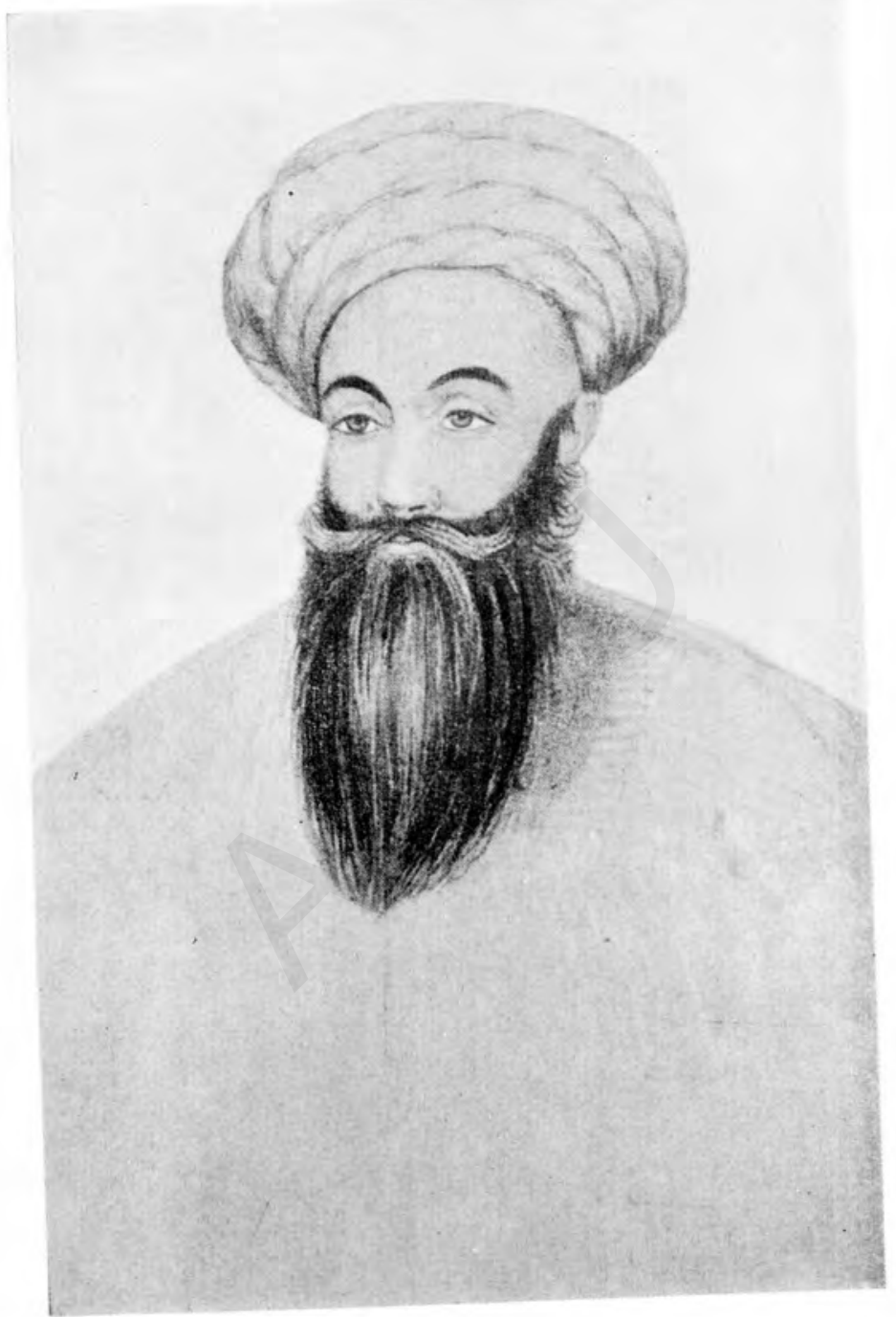

$$
\begin{aligned}
& \text { ه - شاه شجاع بن تيمور شاه بن احهد شاه ابدالى }
\end{aligned}
$$

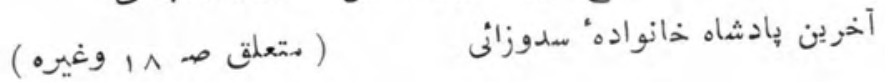




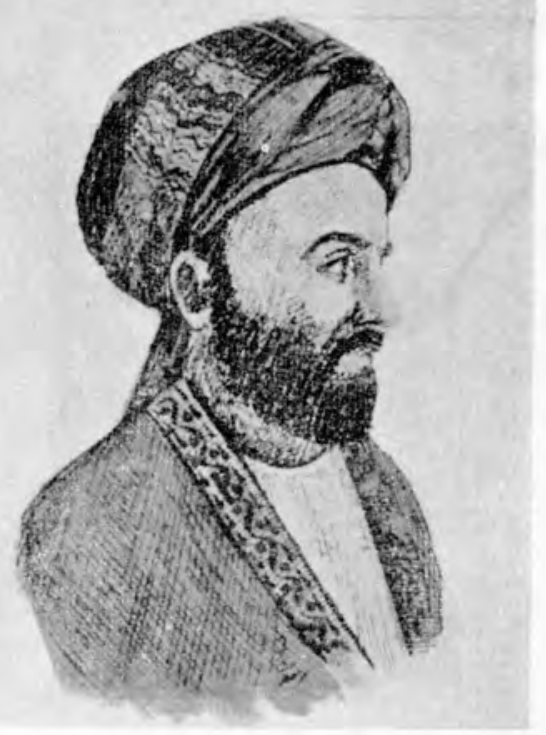

ــ- سردار مكمد عظيم خان بن سردار را ينده خان

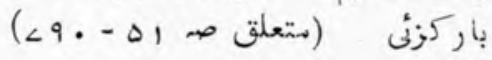

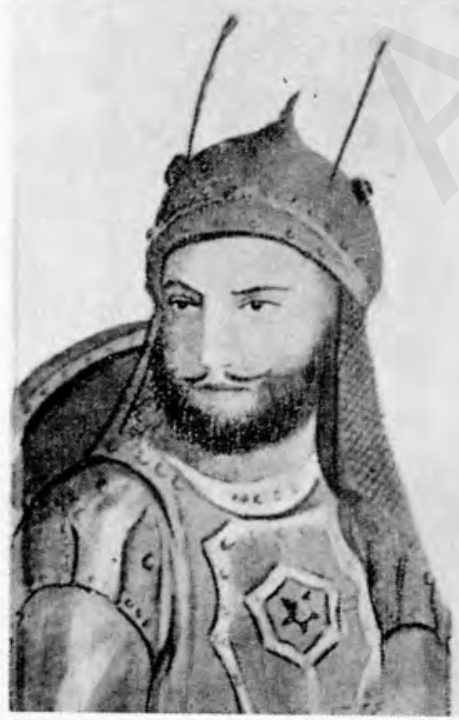

و- سردار شيردل خان بنسردار با ينده خان

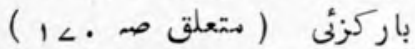

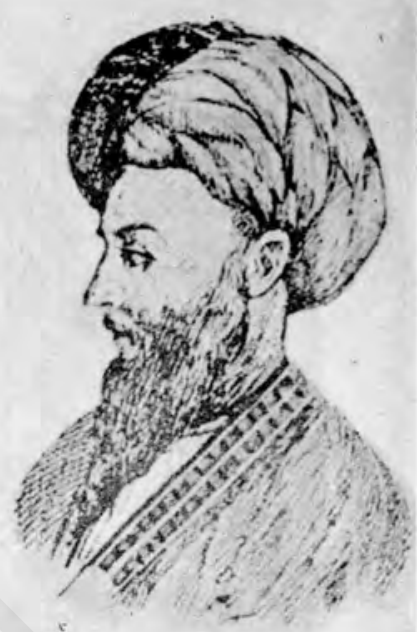

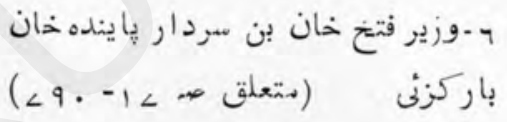

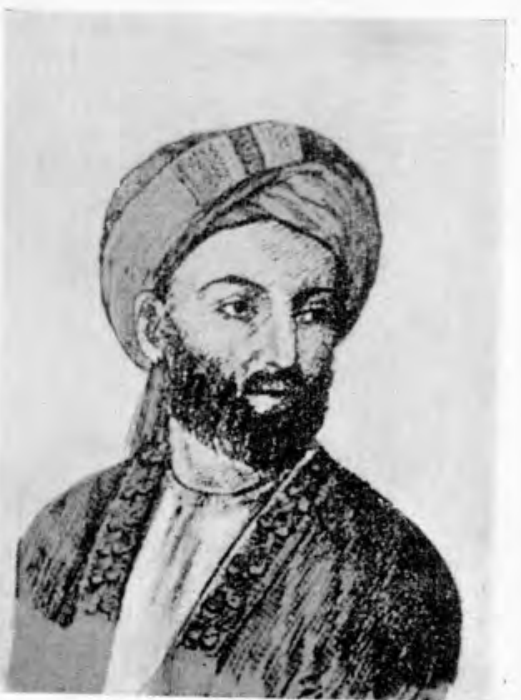

^- سردار يردل خان بن سردار واينده خان باركزئى (هتعلق صـ ..ـان) 

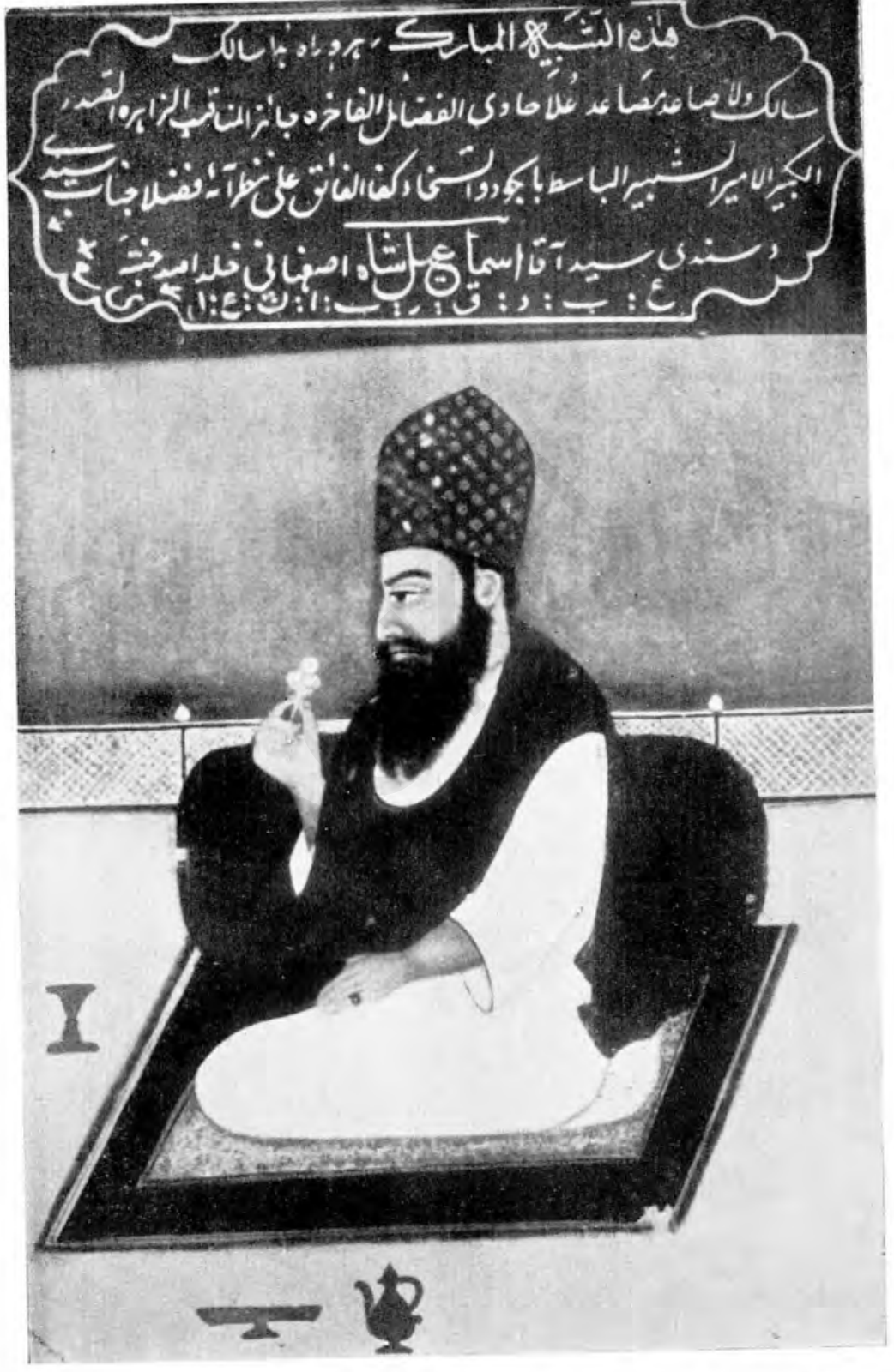

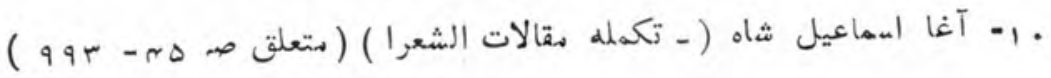




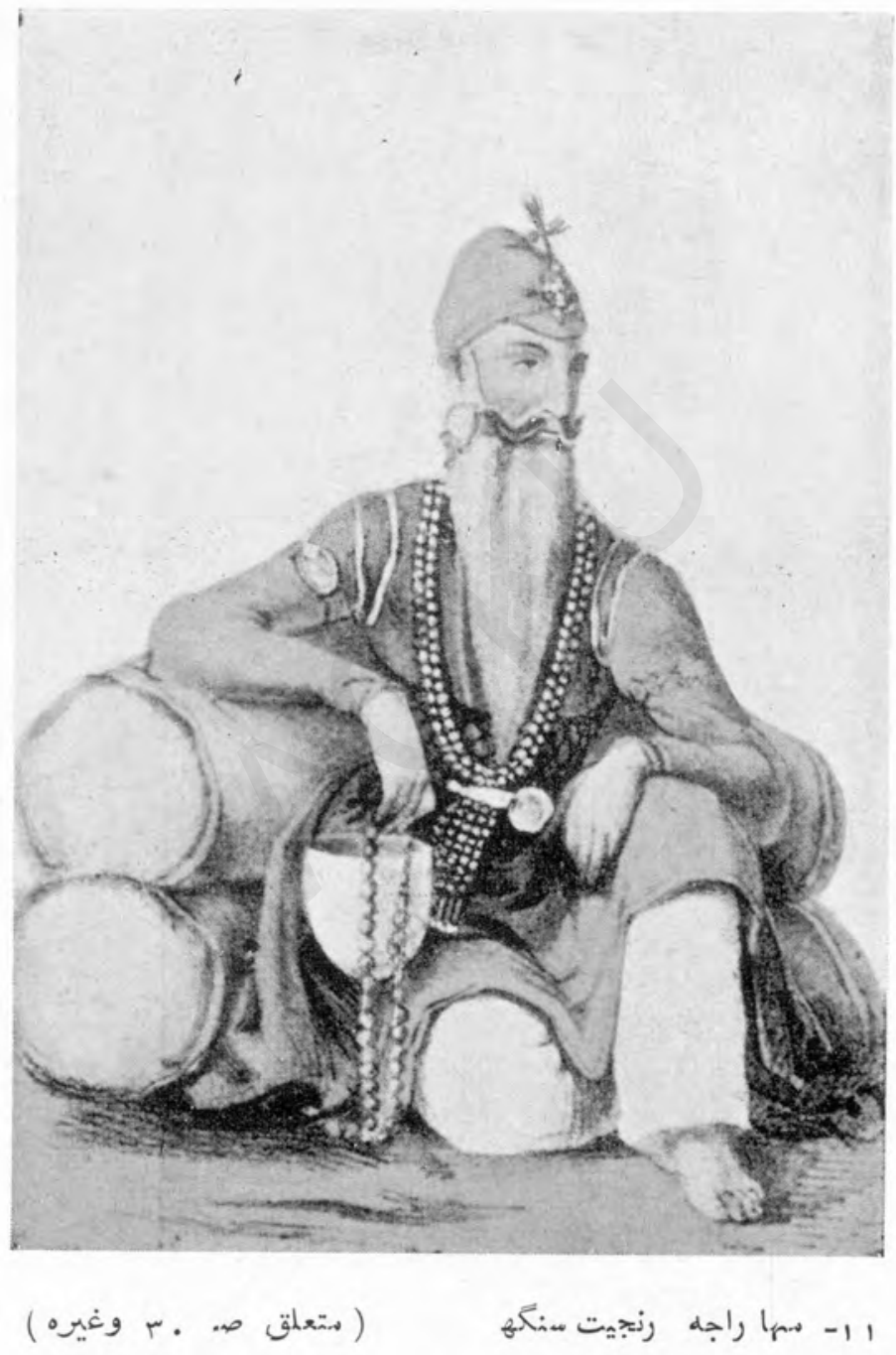




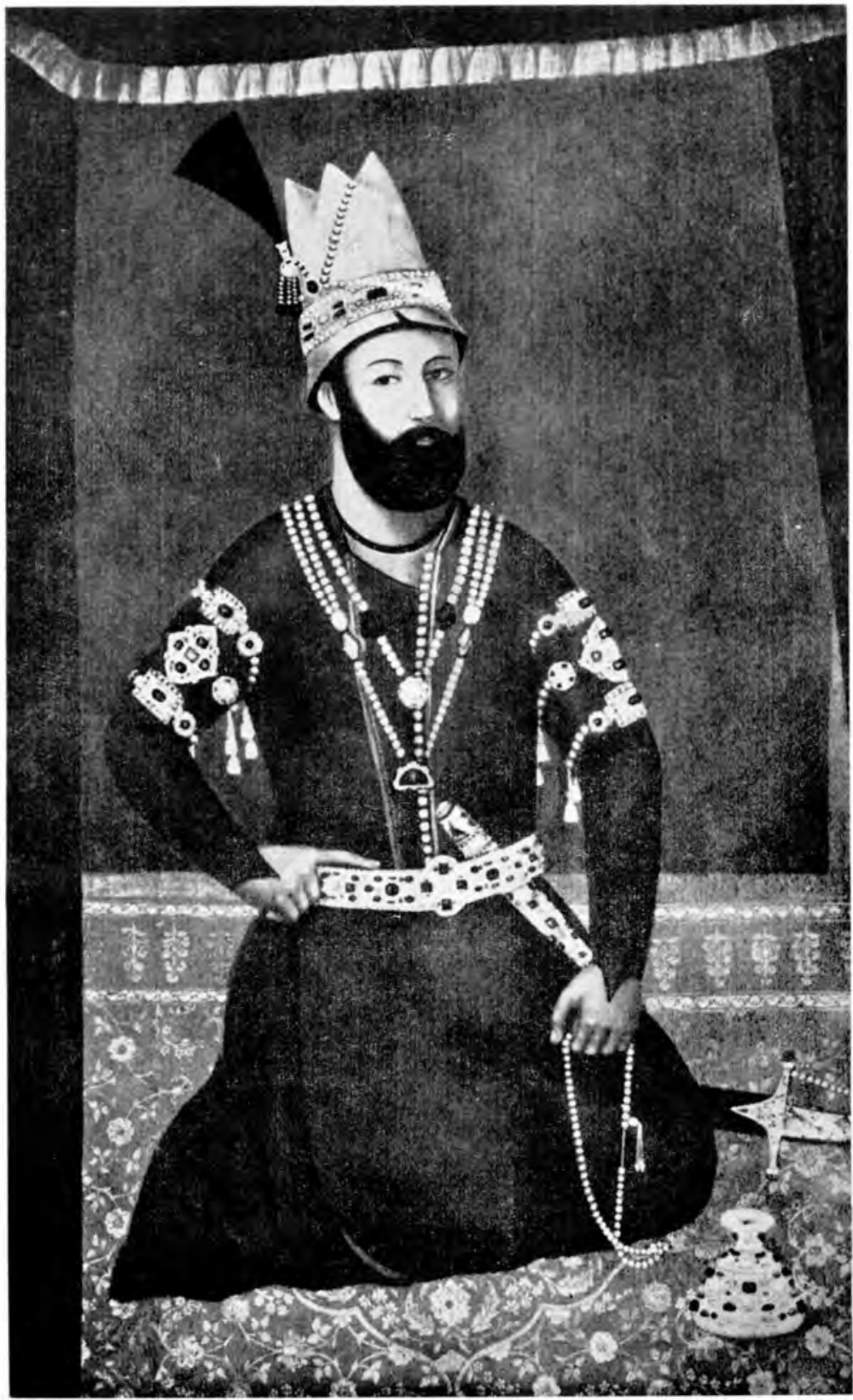

$$
\begin{aligned}
& \text { ( } \\
& \text { rا }
\end{aligned}
$$




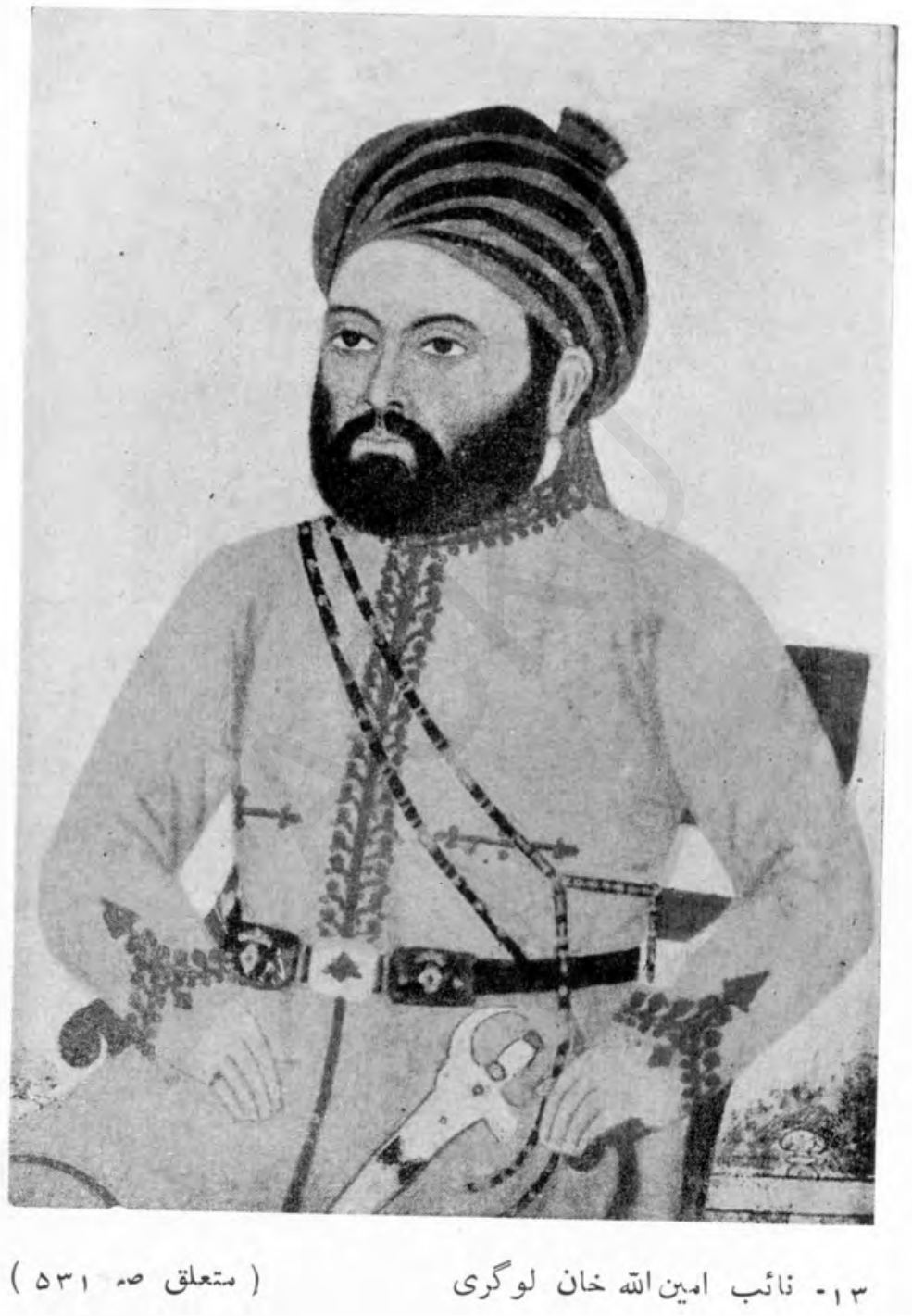



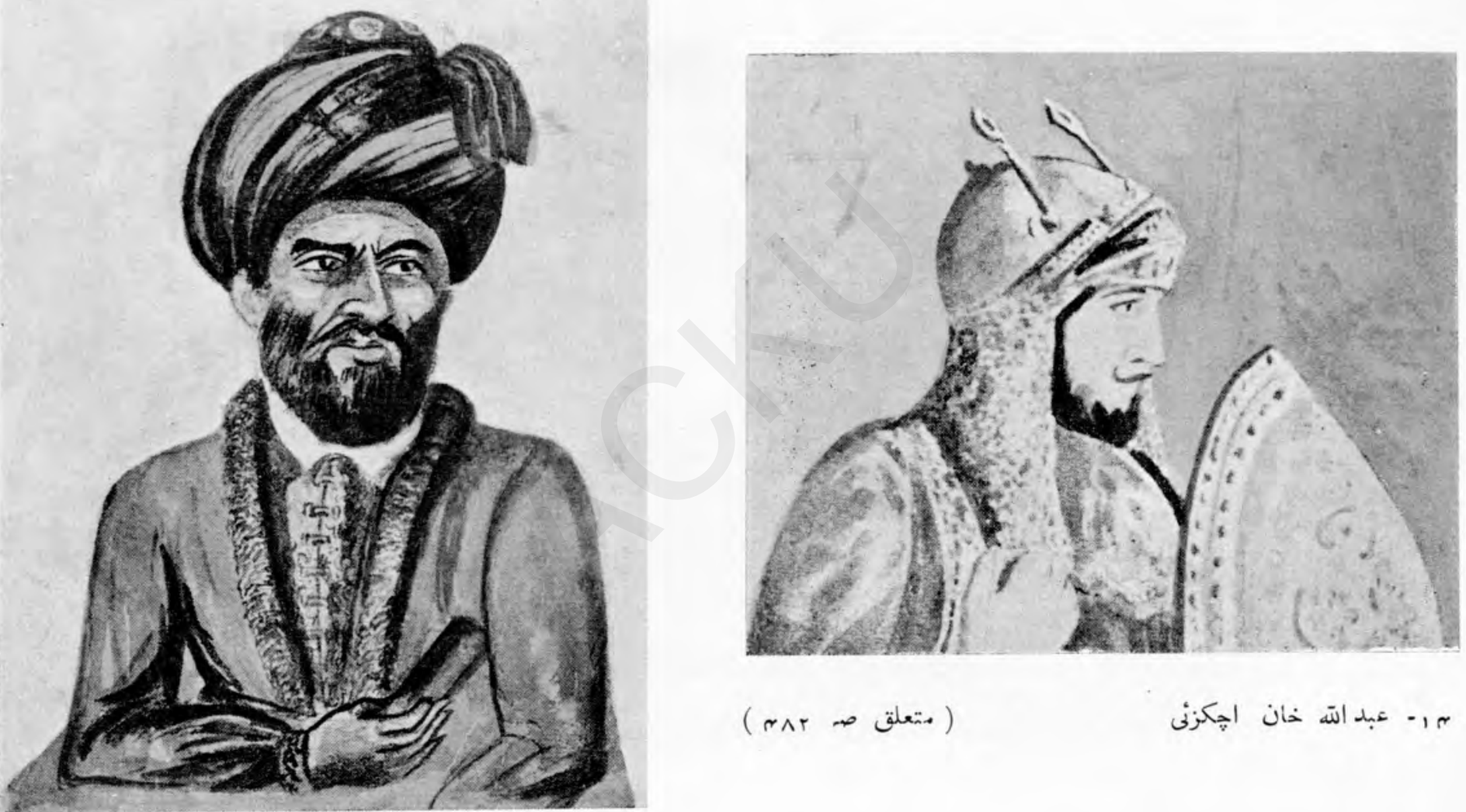

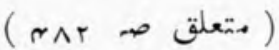

$$
\begin{aligned}
& \text { م ا- عبدالة خان إهكزئى }
\end{aligned}
$$

( ه 1 - عطال محمد خان باديزنى 


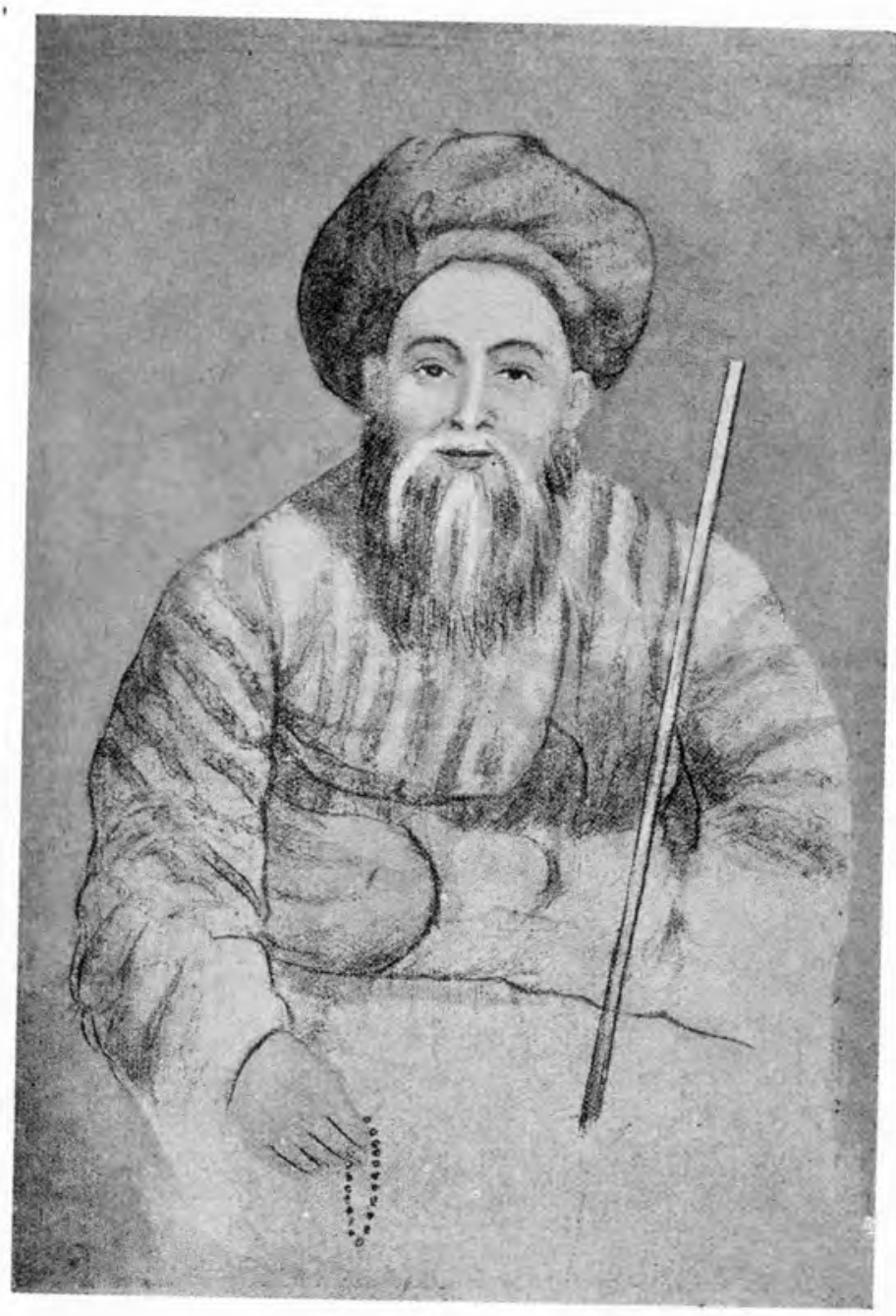

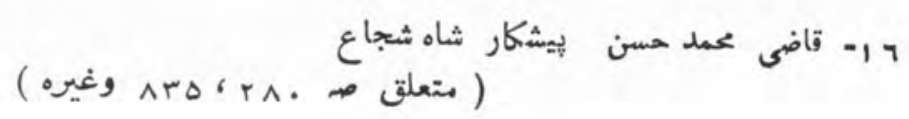




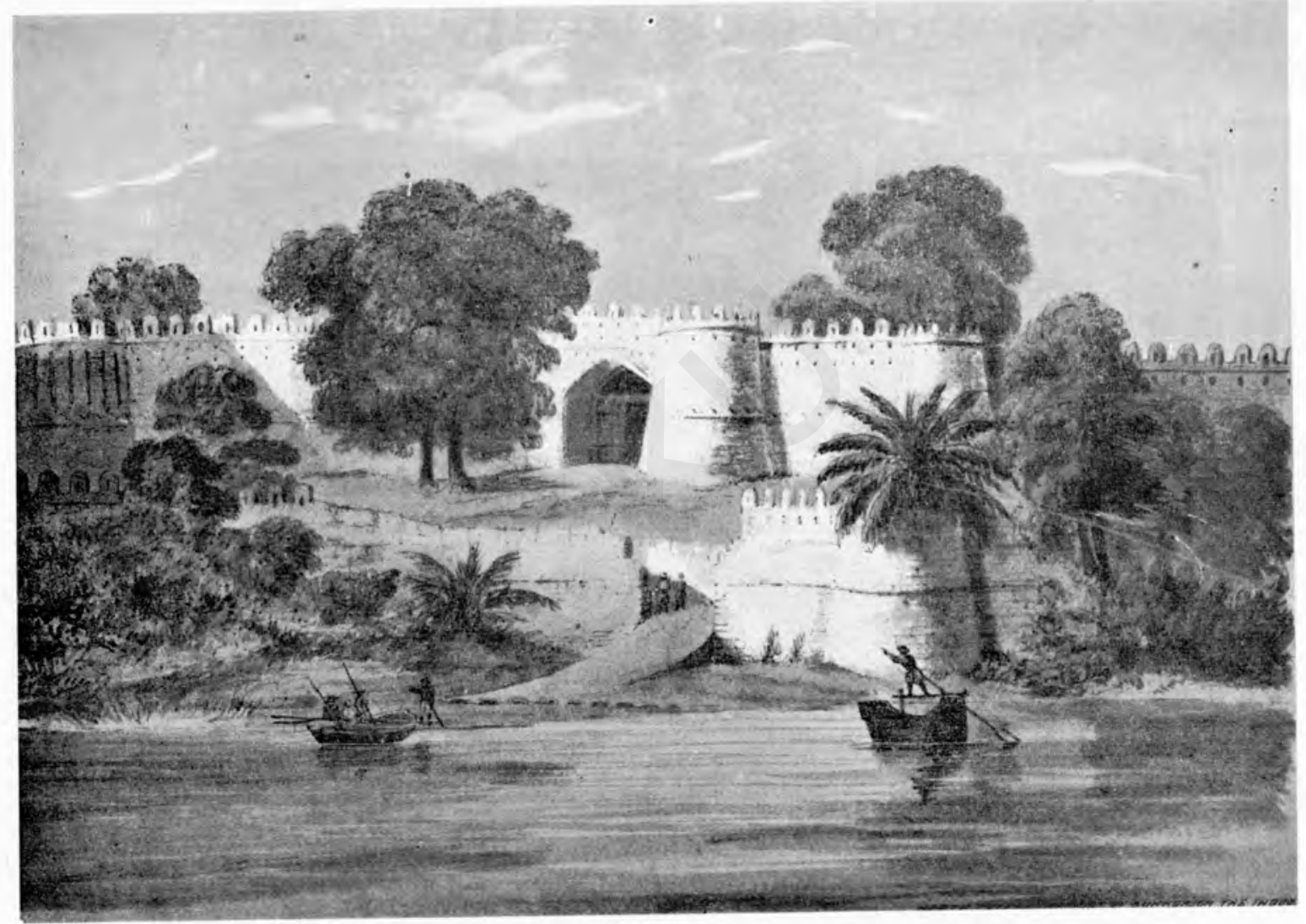

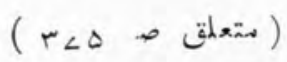

> ا- قلعه بكهز ، بر درياى ازدوس ( دروازه شهالى ) ( از مجموعه تصاوير تاريخى افغانستان ـ طبع سركيته الح، جيكسن، لندن هبماناع ) 


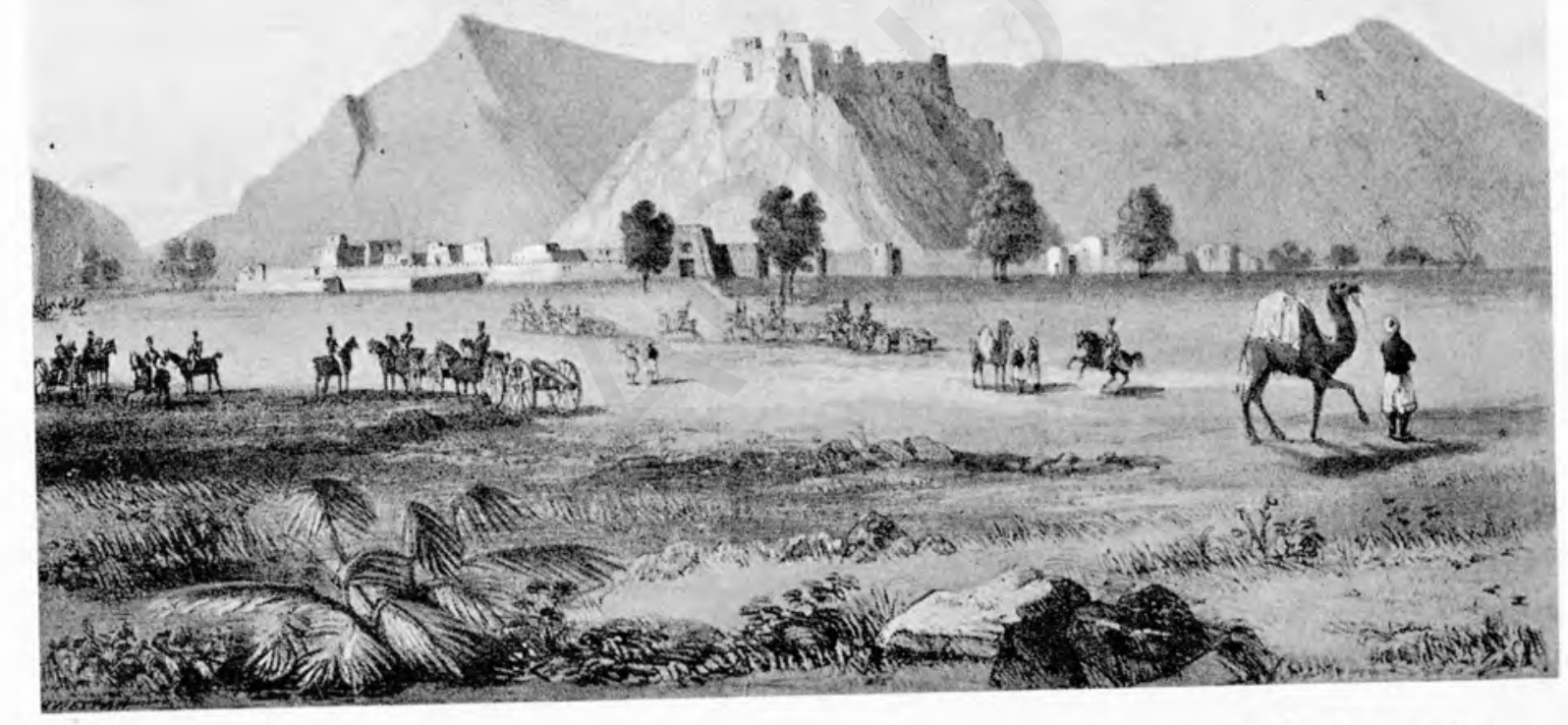

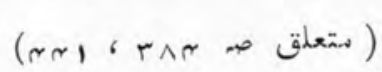

1 ו- كويته ( شال كوت ) هنظر عام

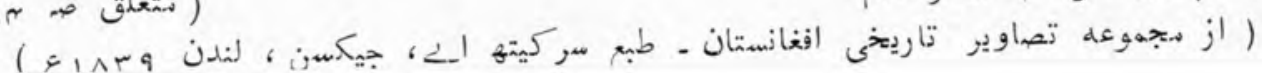




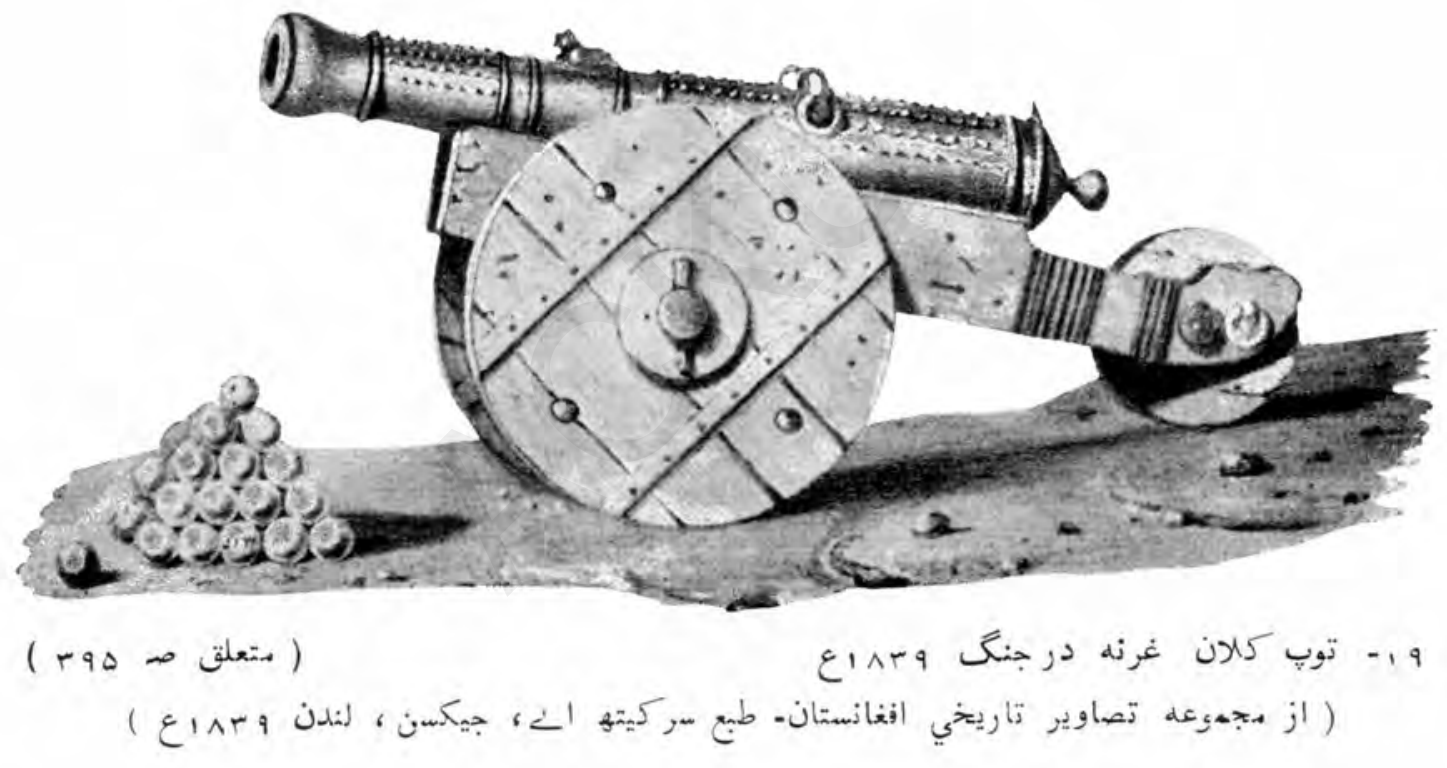




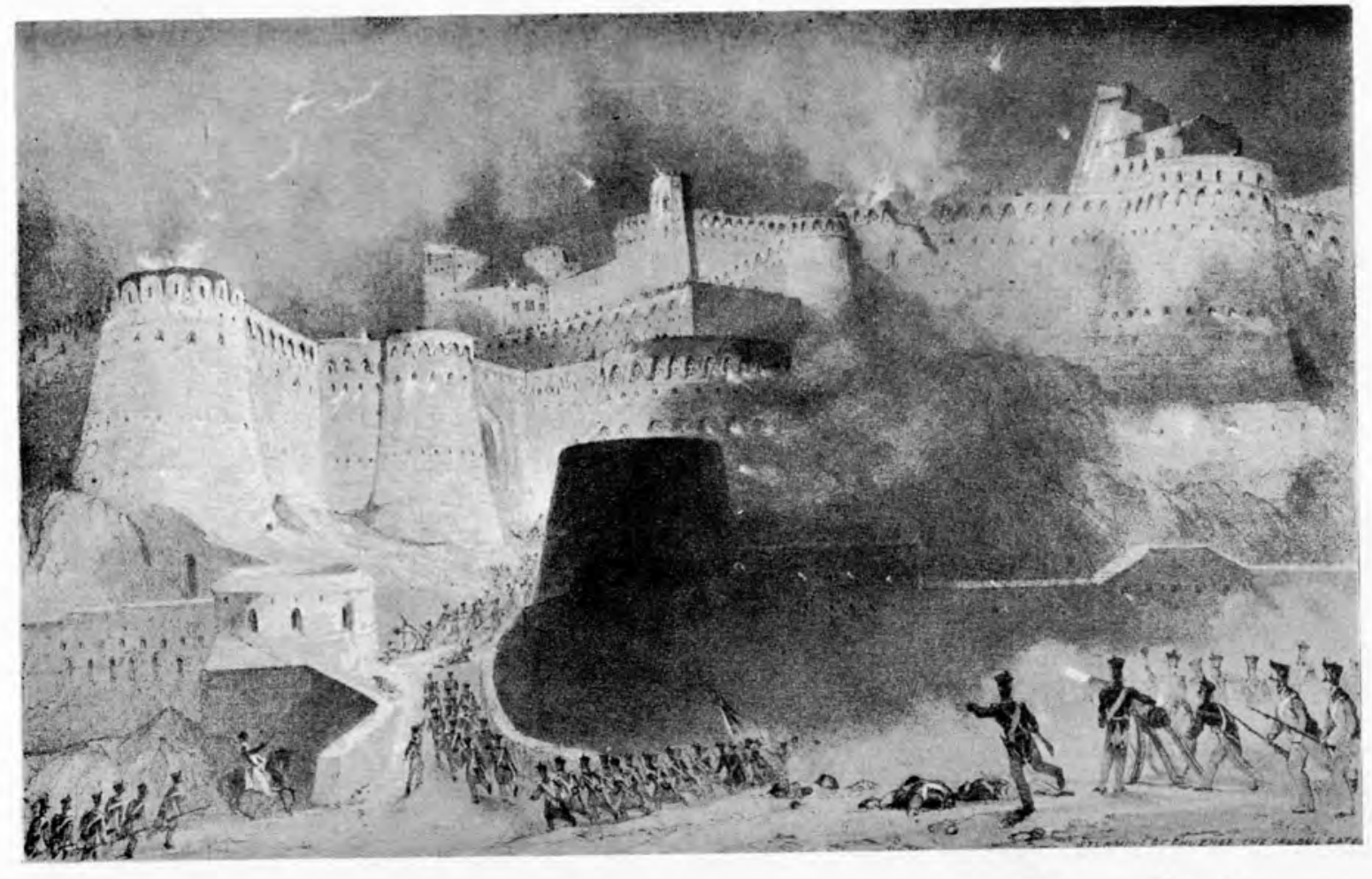

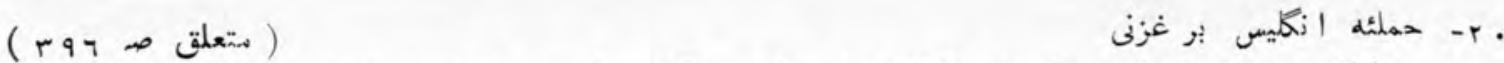

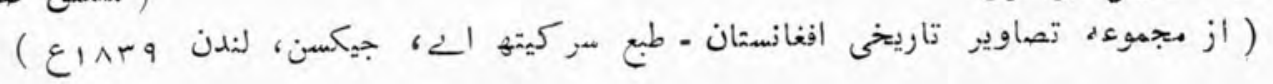




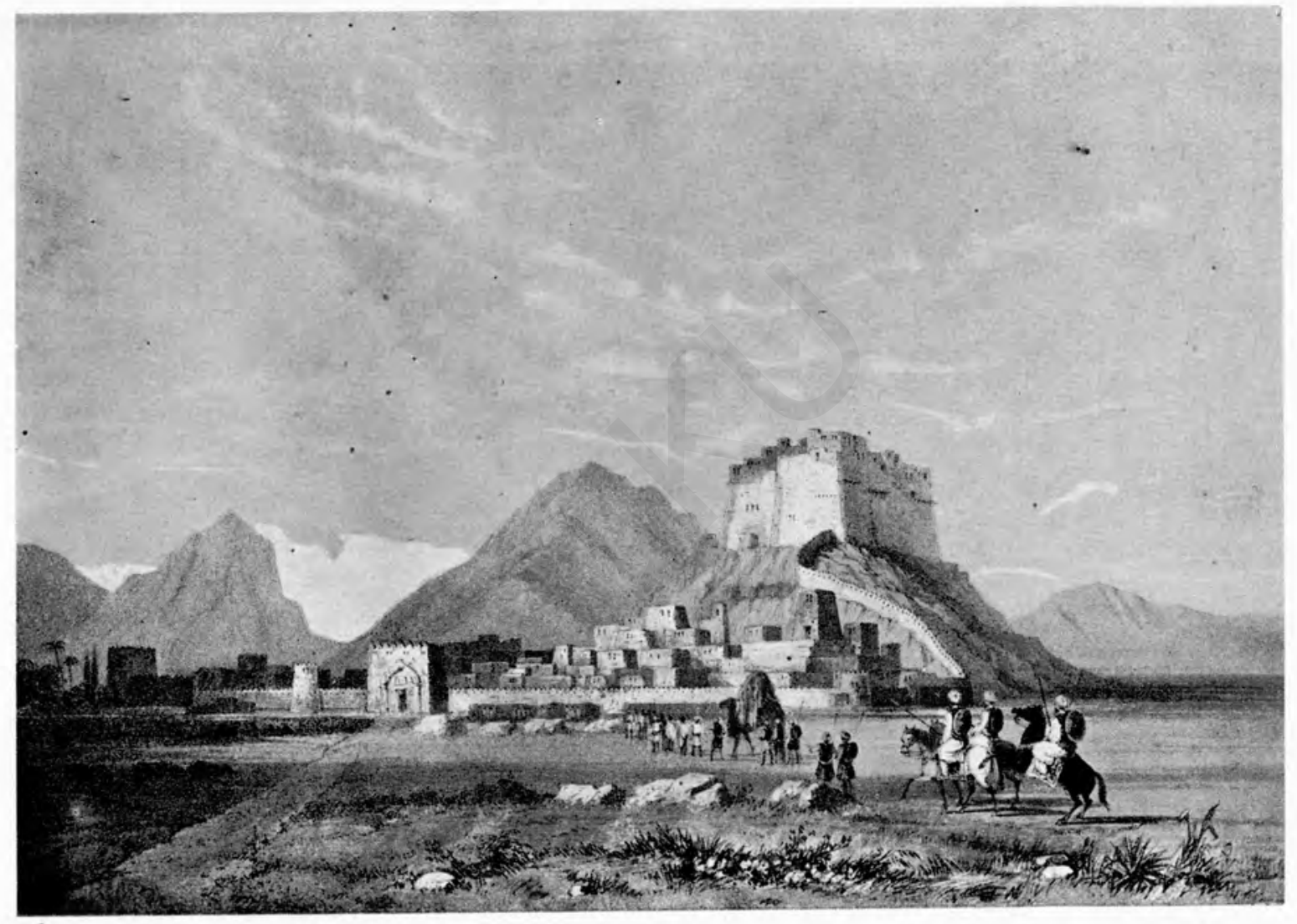

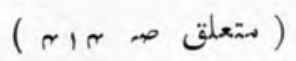

ا ب- قلات ( د,وازد" قندهار )

( از مجهوعه تصاوير تاريخى افغانستان - طبع سركيته احح، جيكسن لندن وبهاع ) 


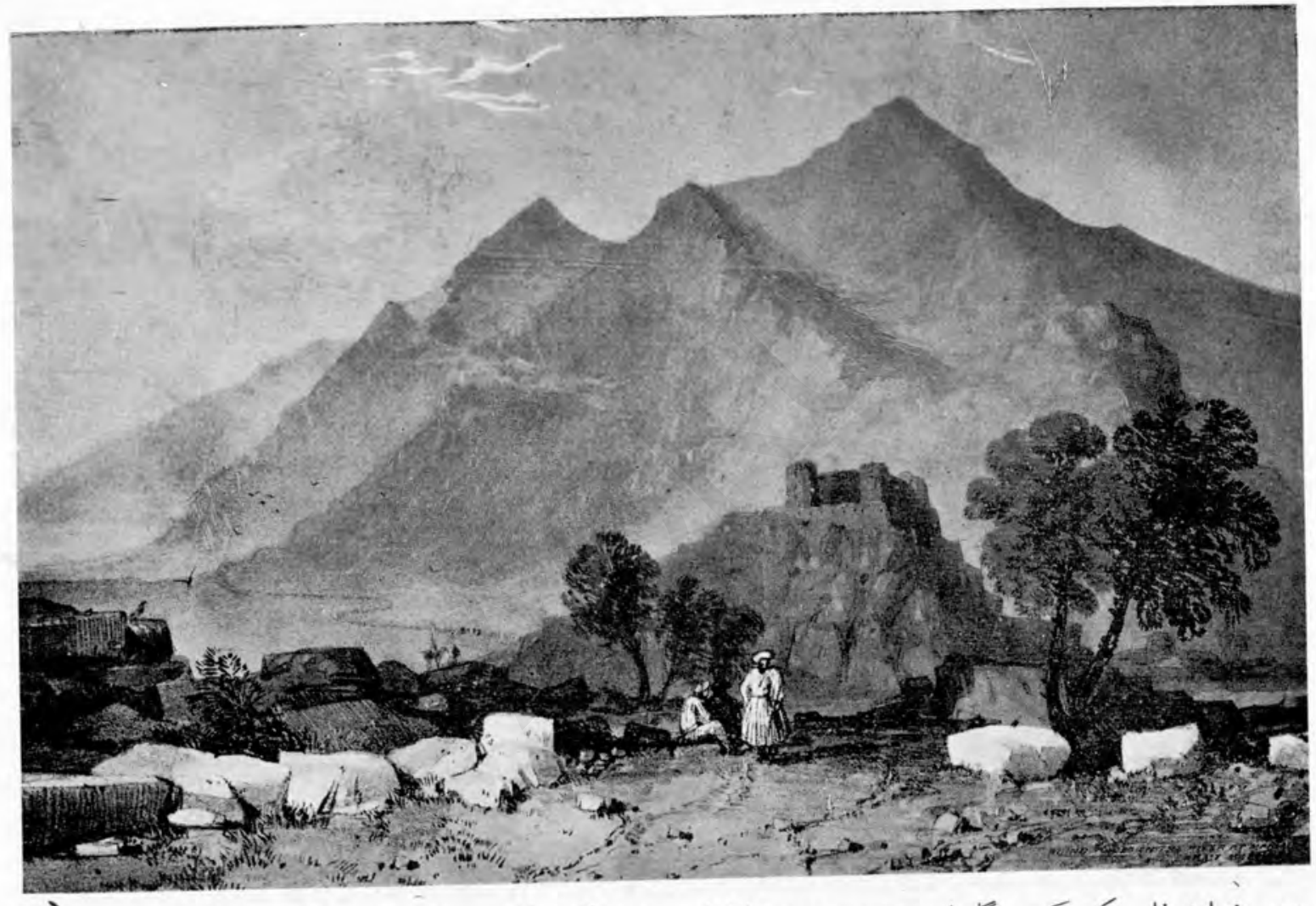

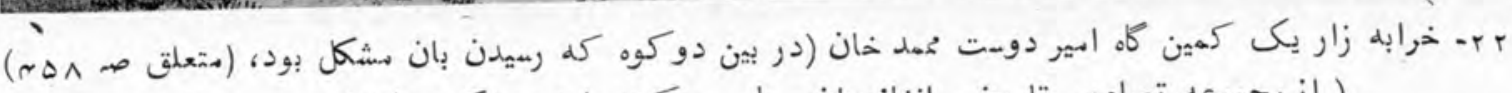

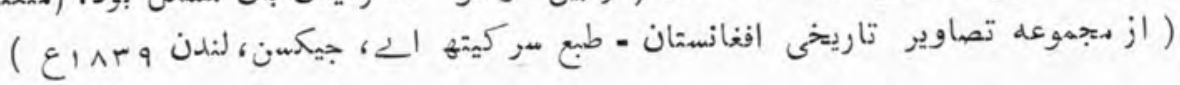




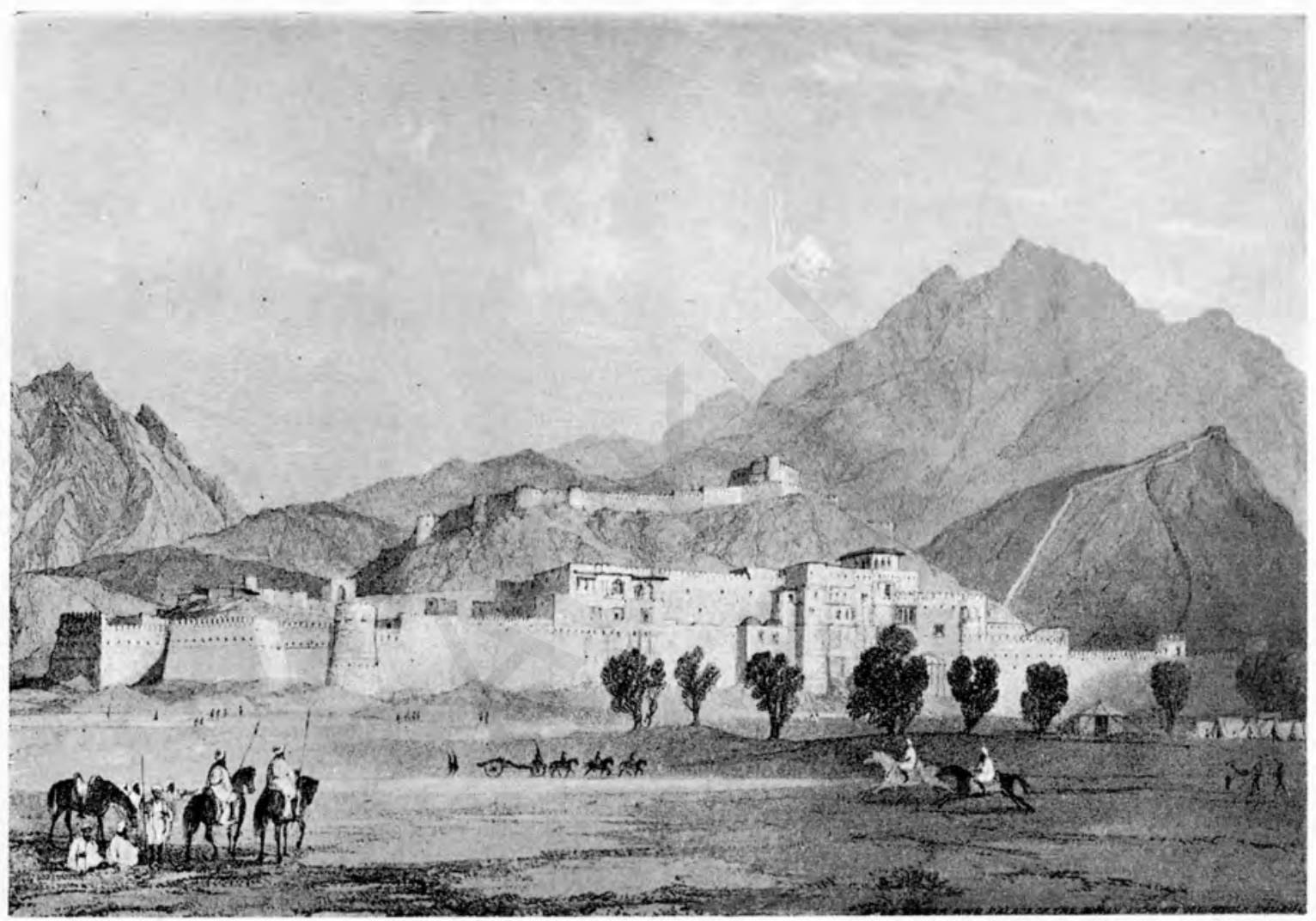

$$
\begin{aligned}
& \text { هتعلق صـ مبر }
\end{aligned}
$$

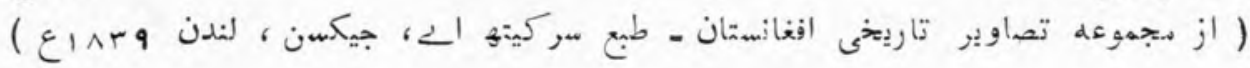




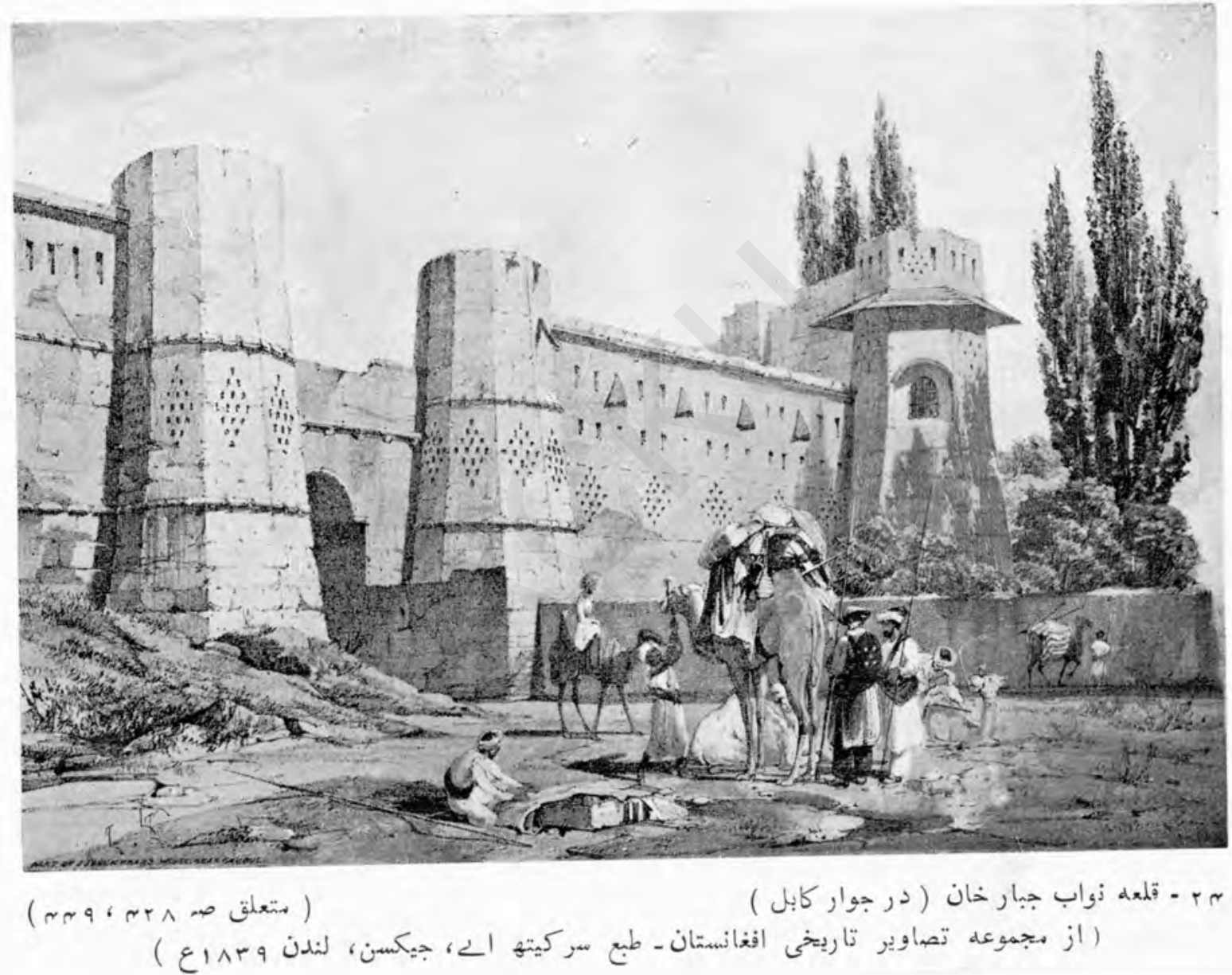




$$
79
$$



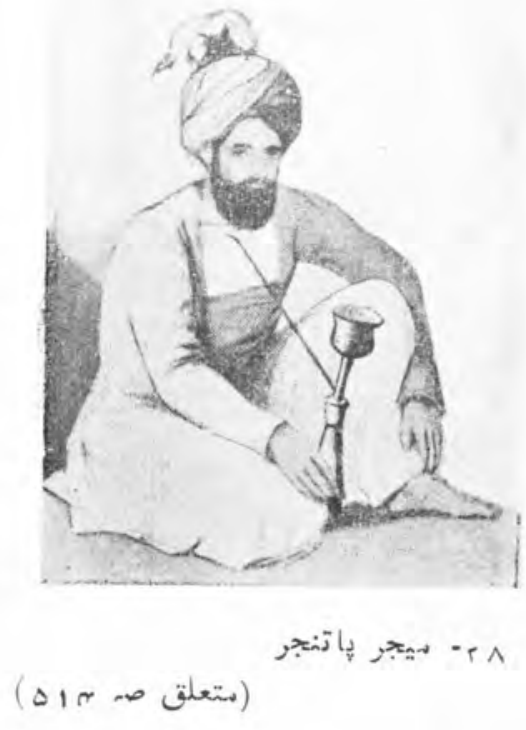
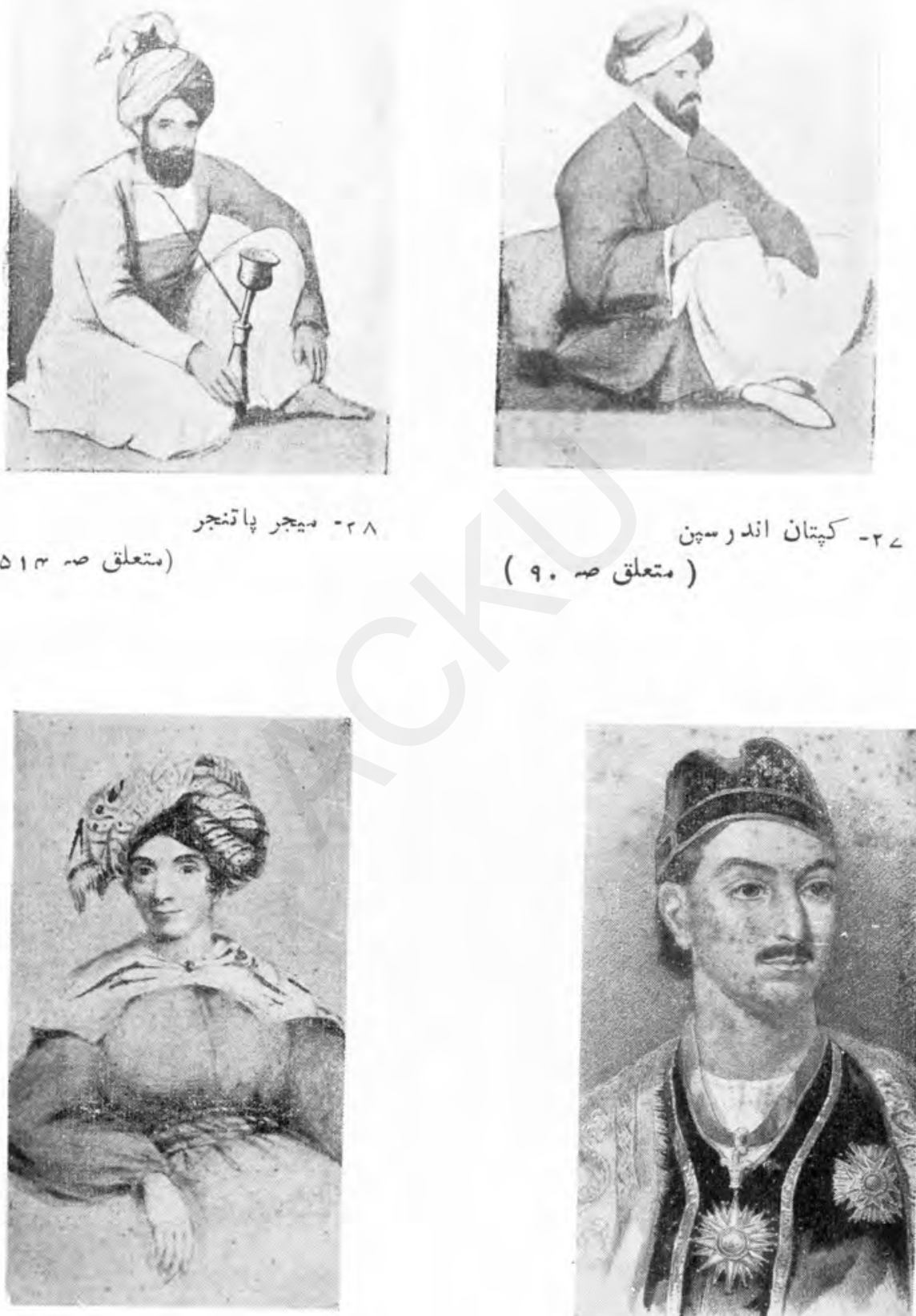

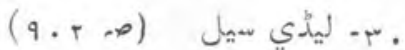

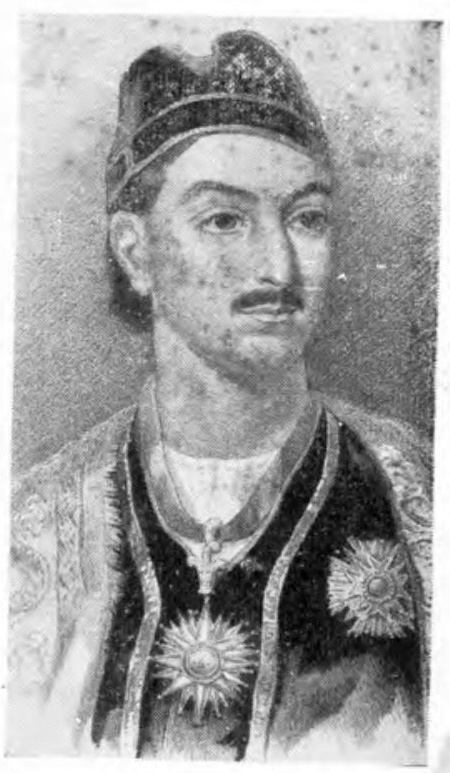

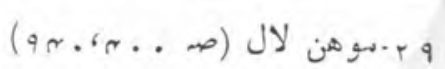




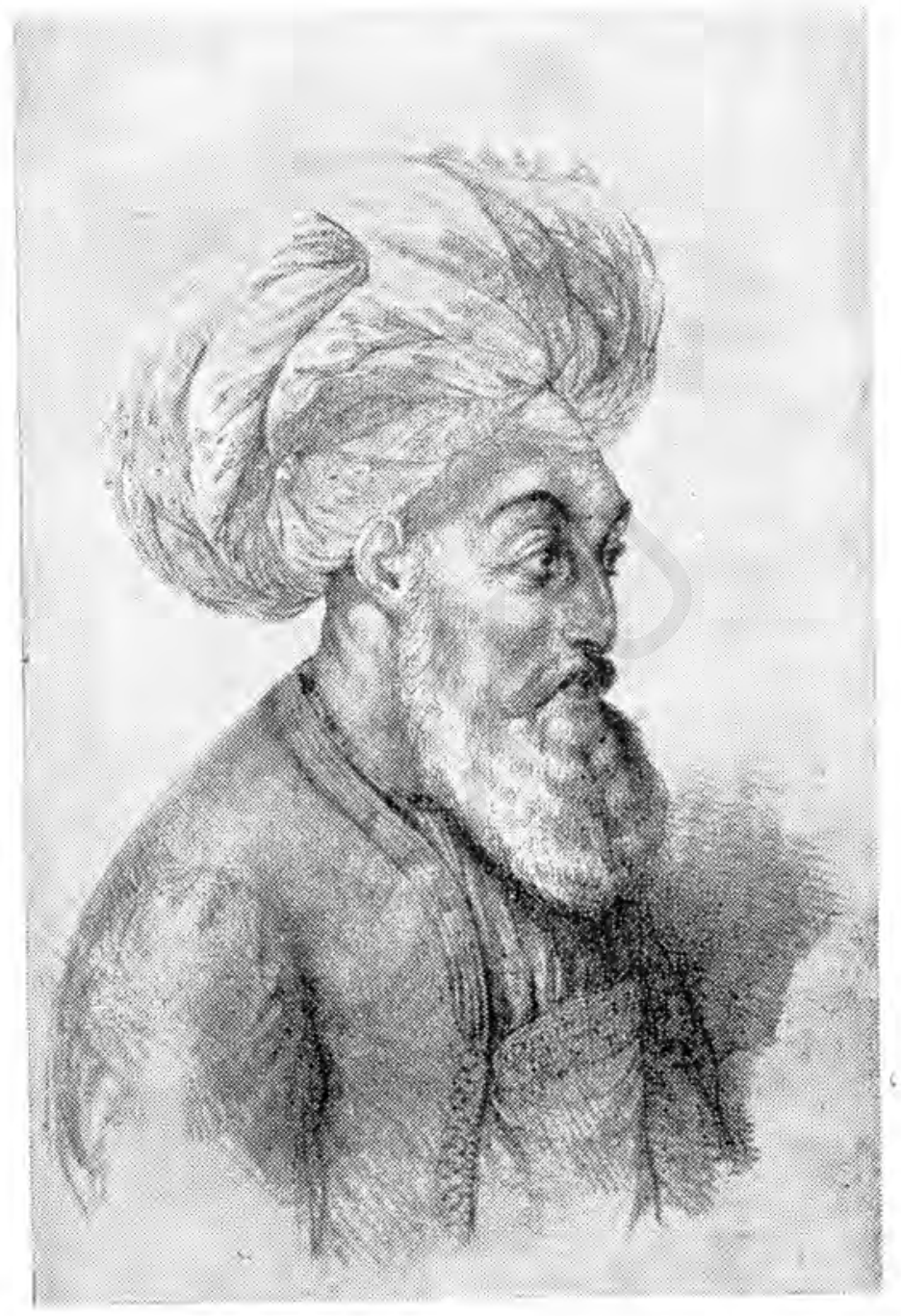

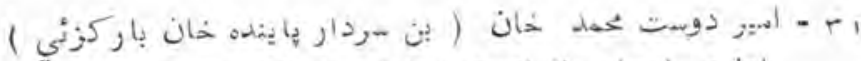

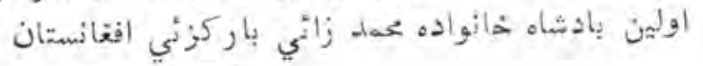
( 


$$
d
$$




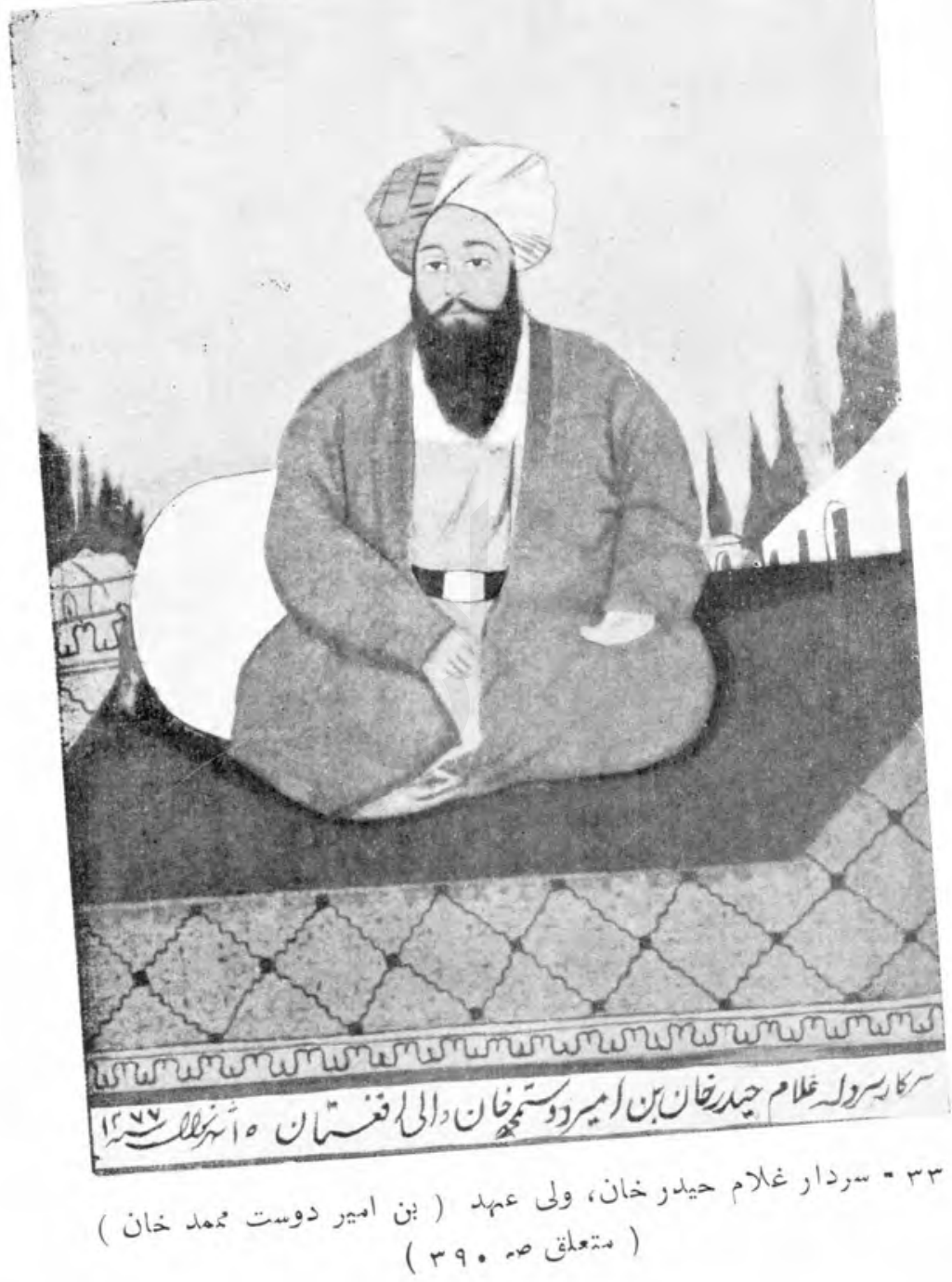




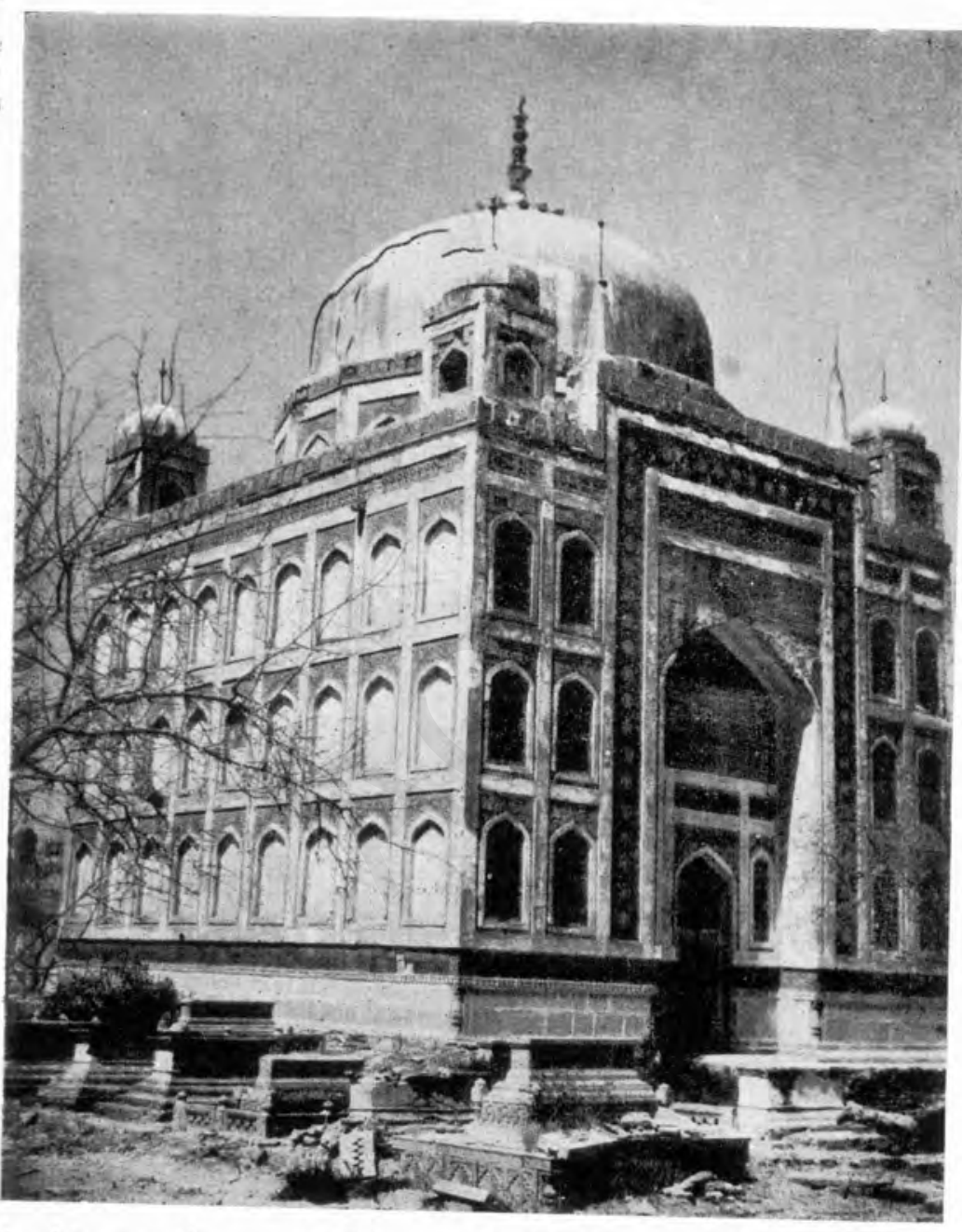
(ص ד r ب وغيره)
مب- هقبره بير كرم على خان تالهي ، (مير حيد رآباد) (_- إنكمله مقالات الشعرا) 


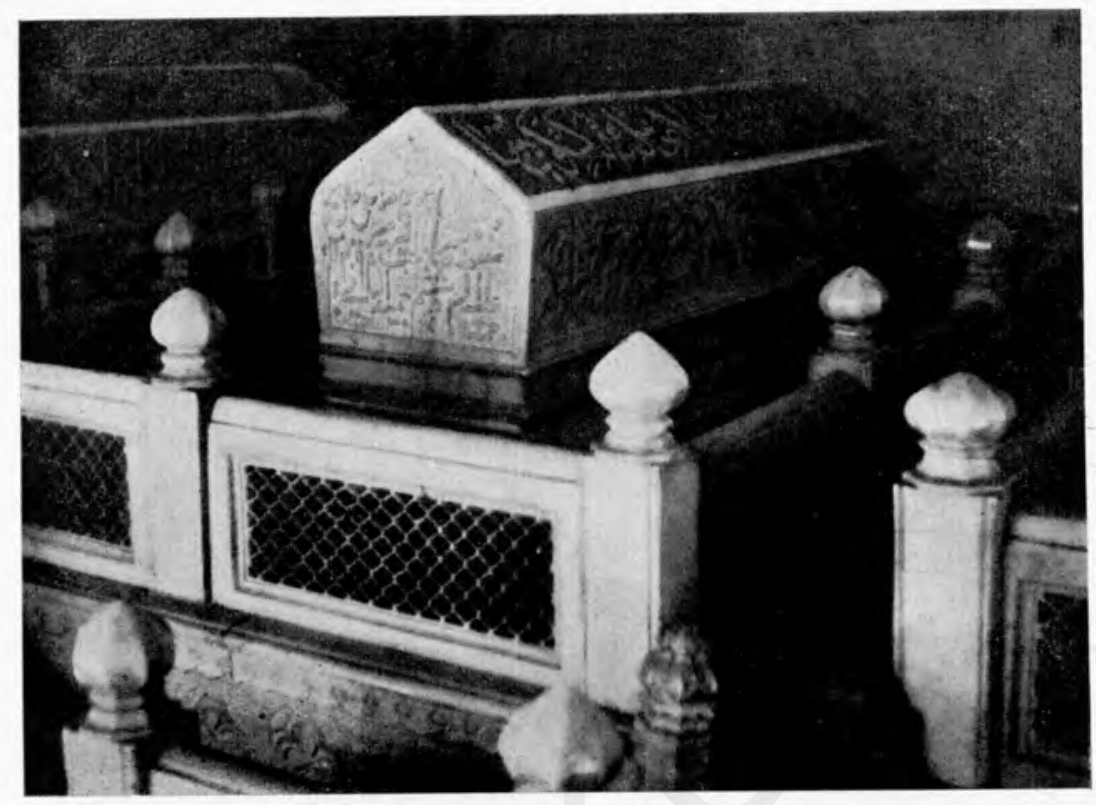

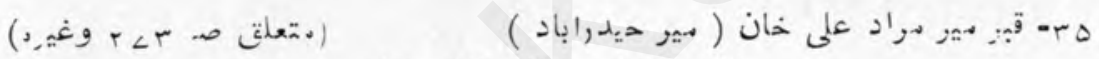

$$
\begin{aligned}
& \text { ( ) }
\end{aligned}
$$

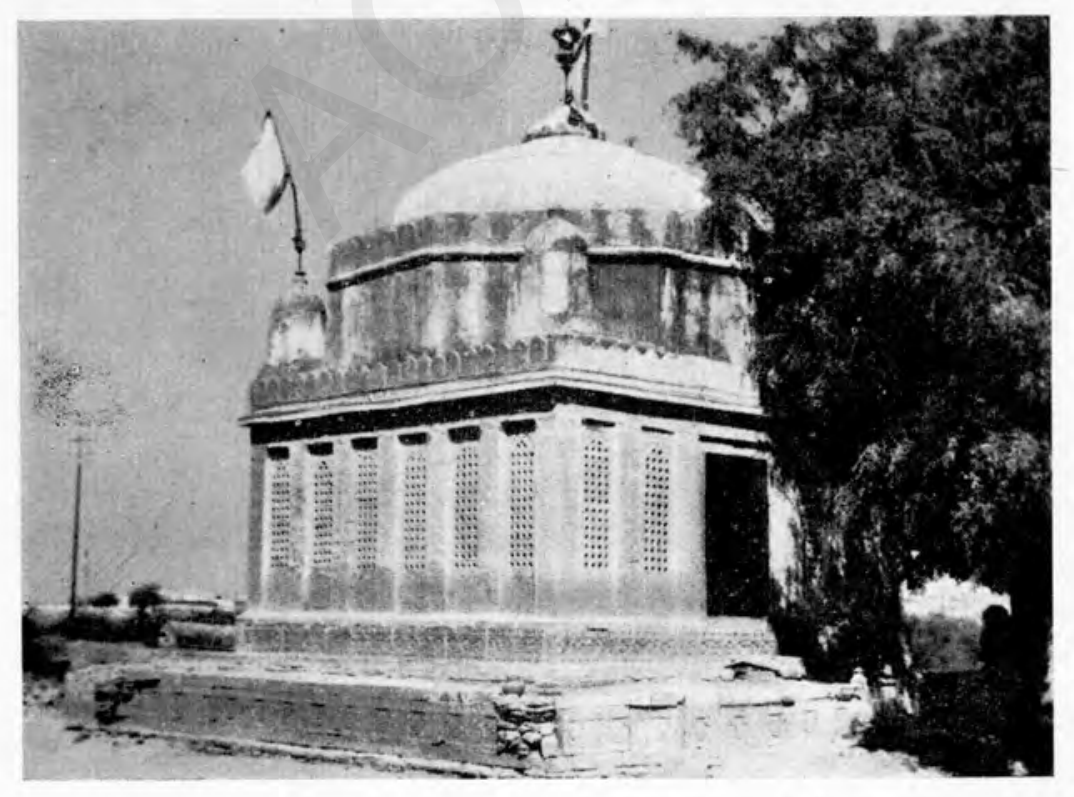

(r<r ص ص (r) )

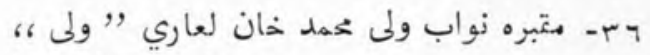
(-تمهله دقالات الشعزا) 


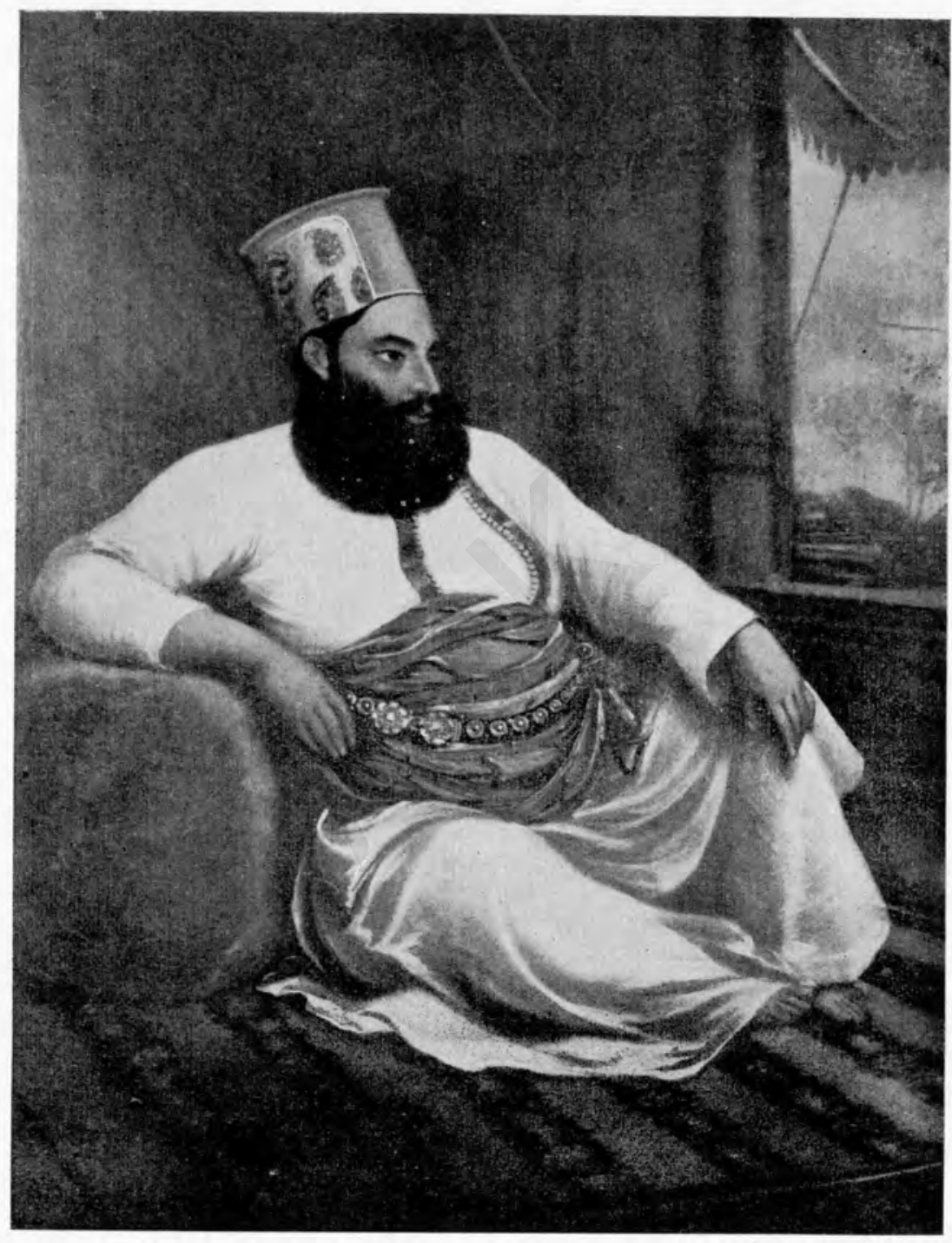

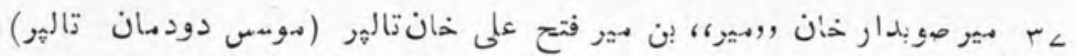

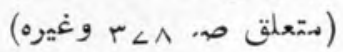

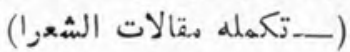




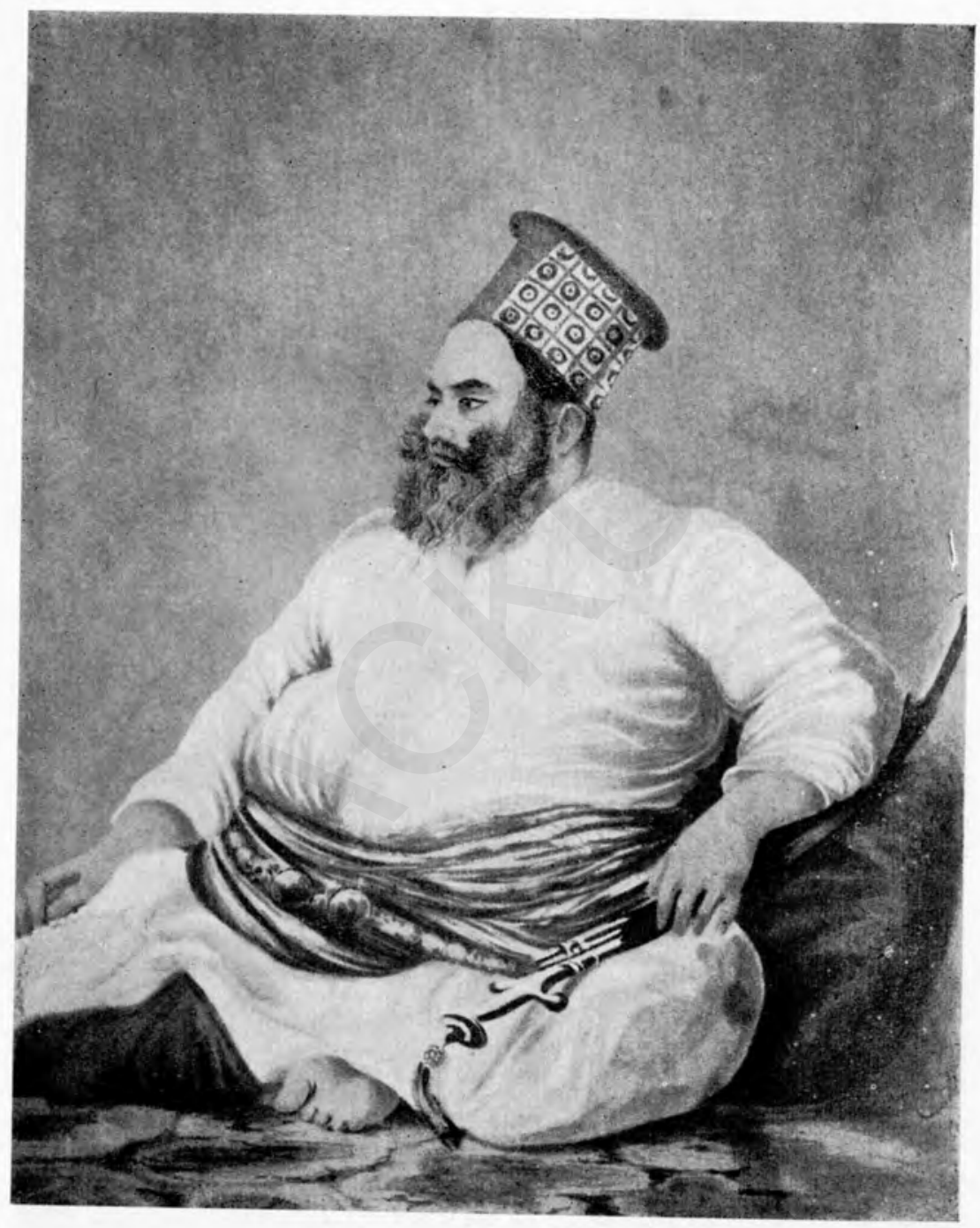

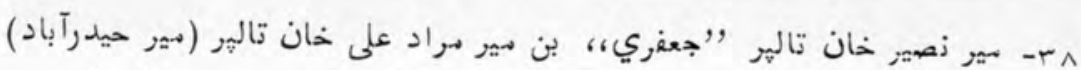

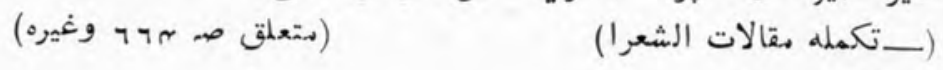




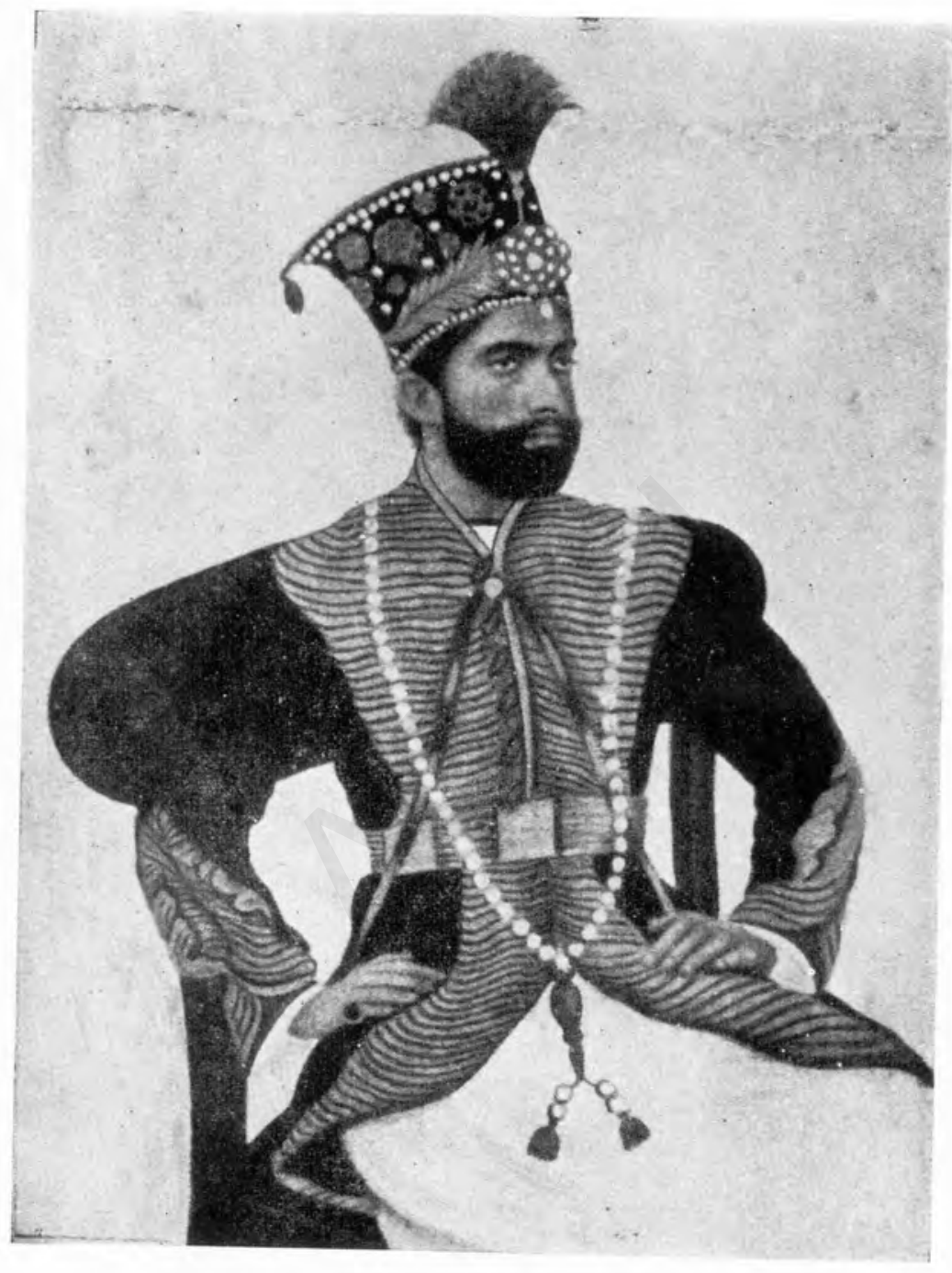

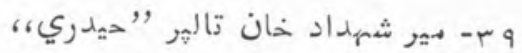

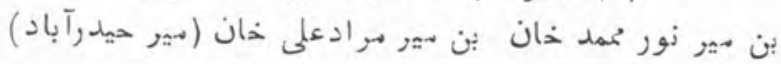

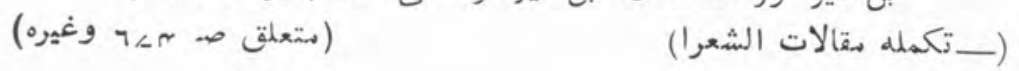




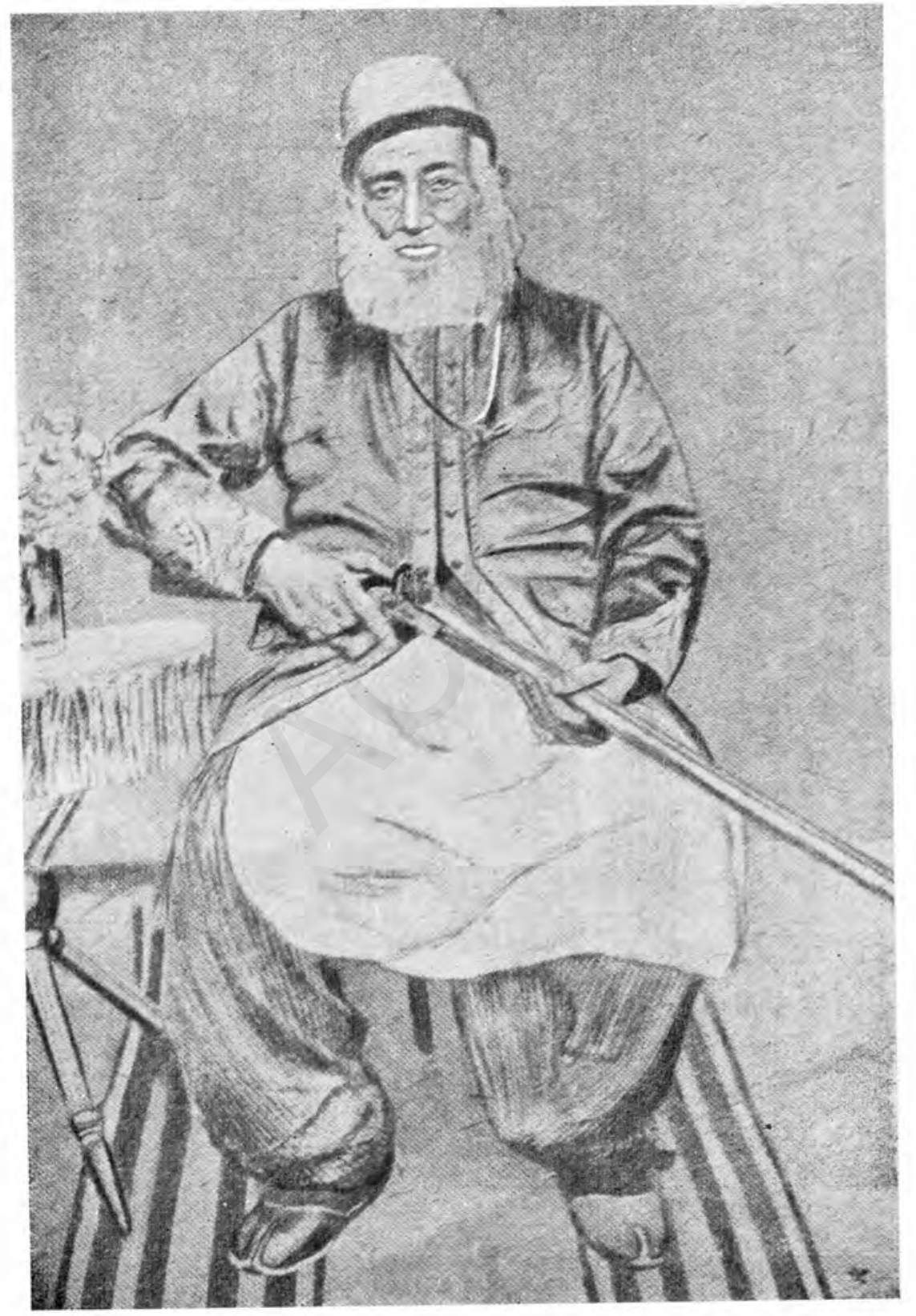

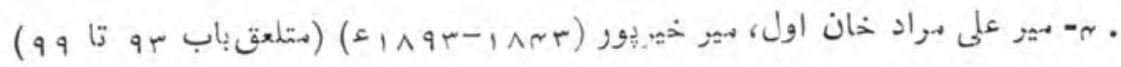




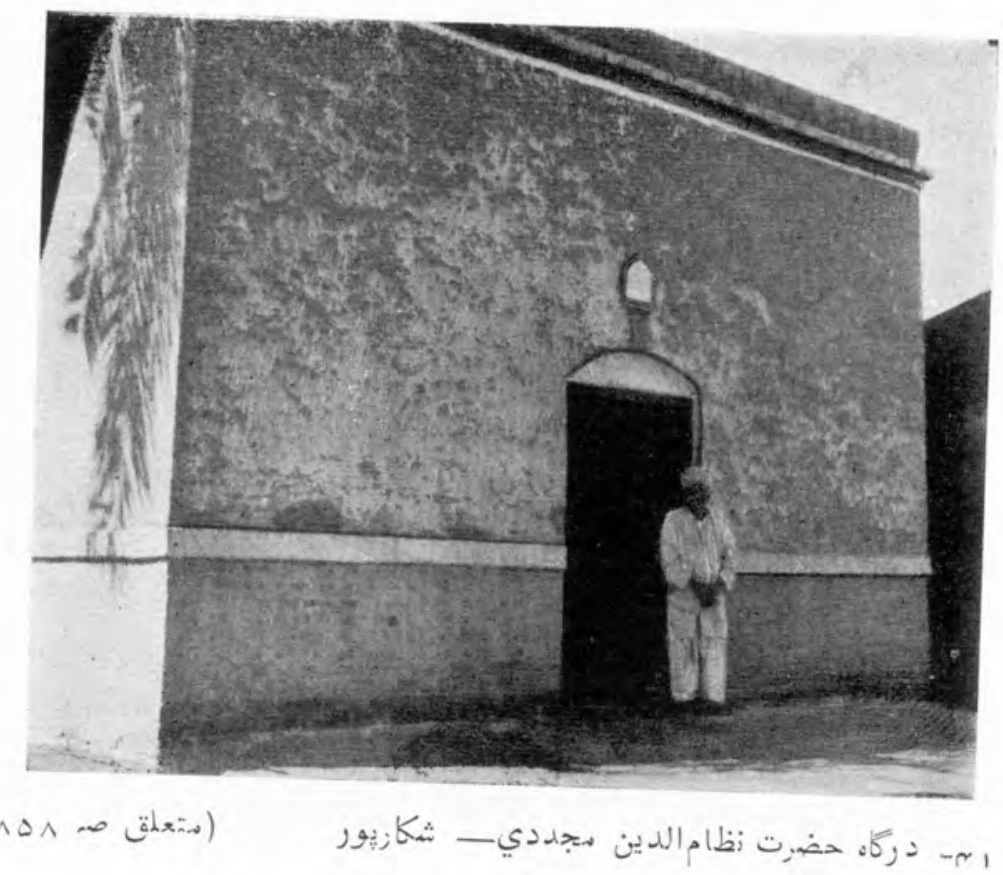




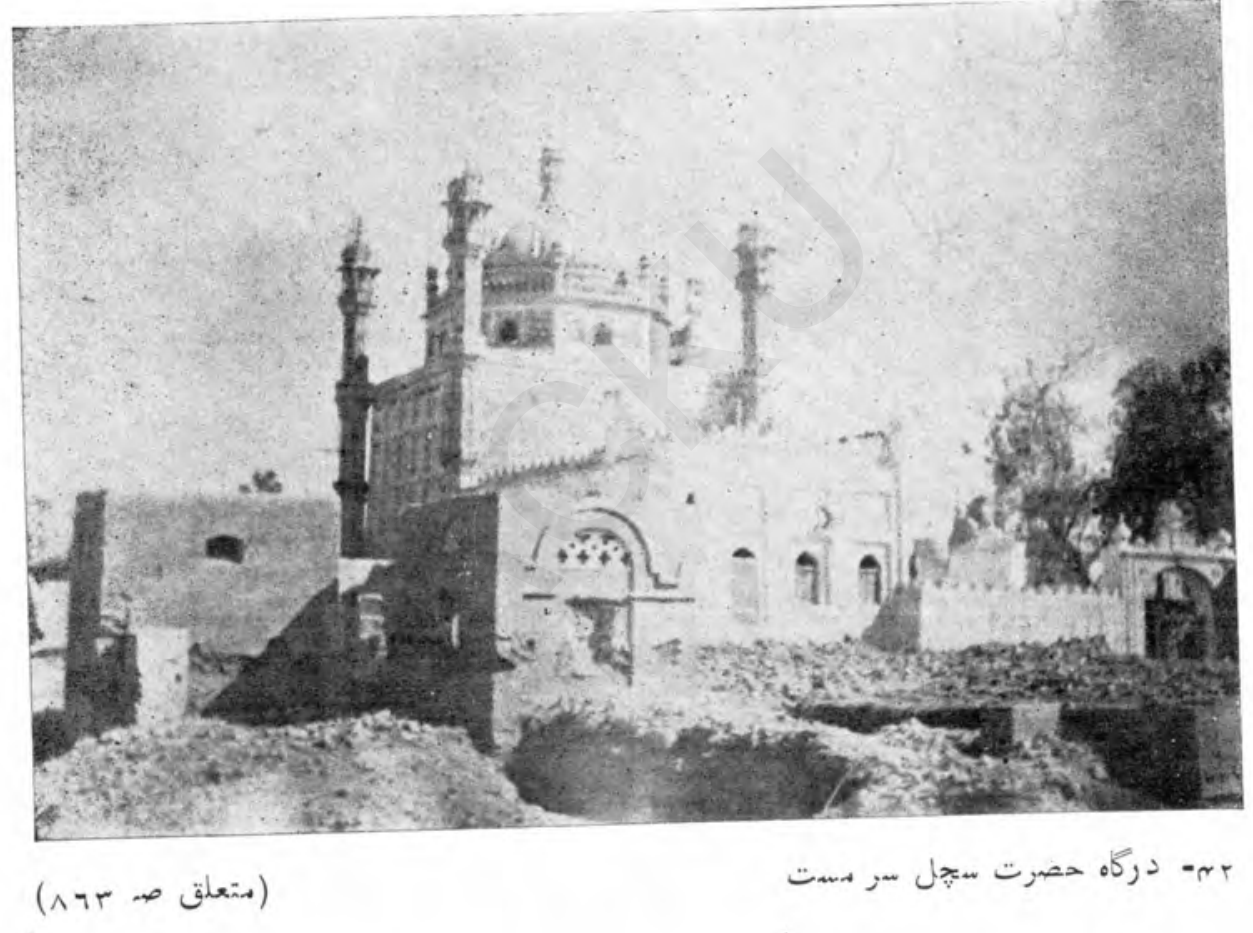




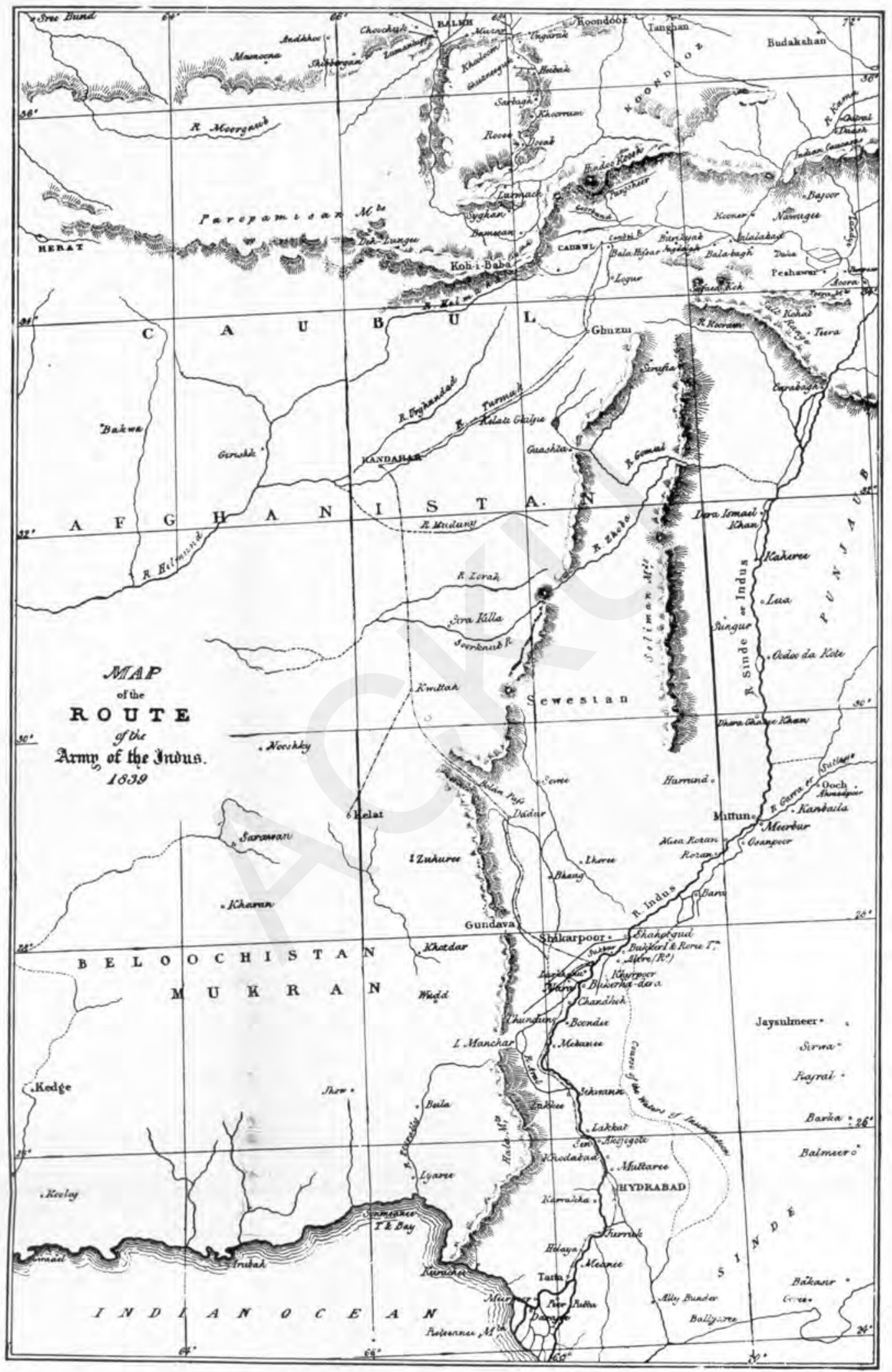

Route map of the Army of the Indus-1839

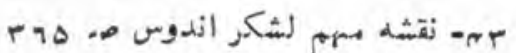




\section{بسمه تعالئل}

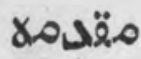

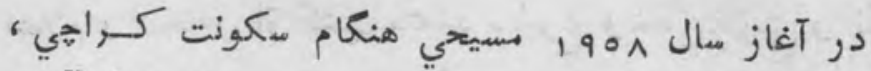
بورد ادبي سنده كار تصهيح و تحشيه و تعليق نسخه هاته "تازه

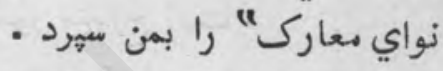

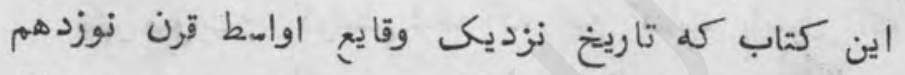

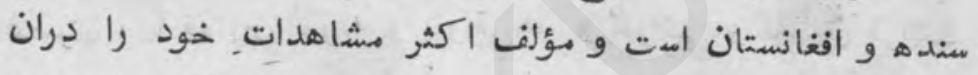

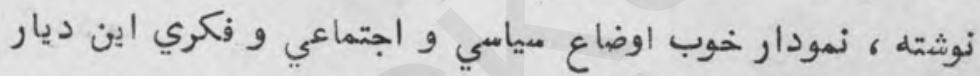

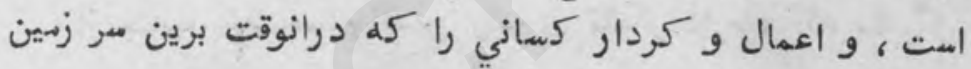

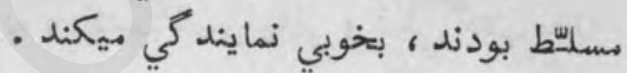

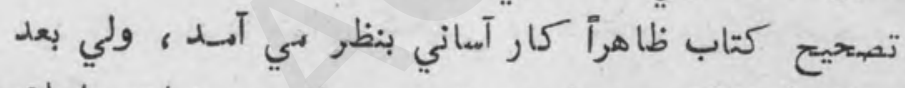

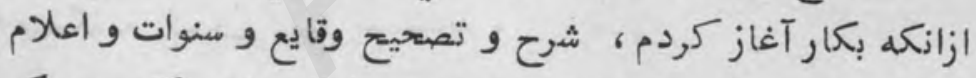

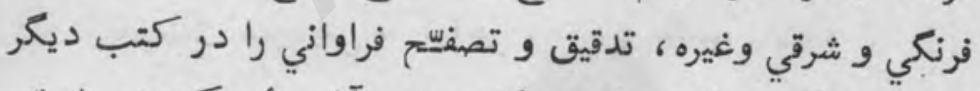

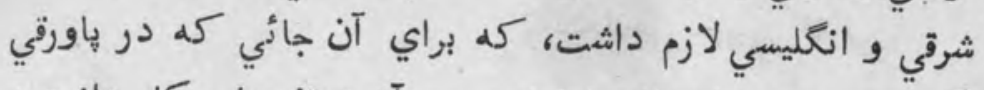

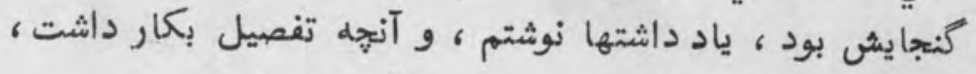

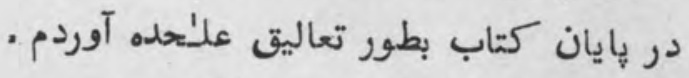
هون انشاي كتاب طوريكه در زمان فتور ادبي اواخر رواج

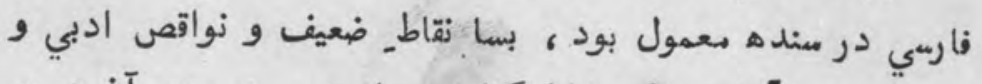

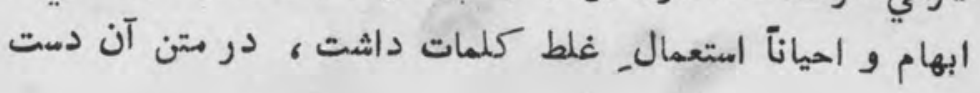


نزدم، و در ياورقي به توضيح آن برداختم. و صورت صحيح اعلام

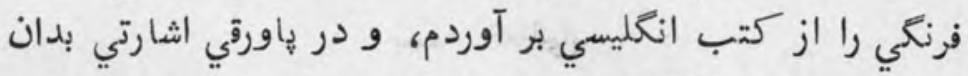

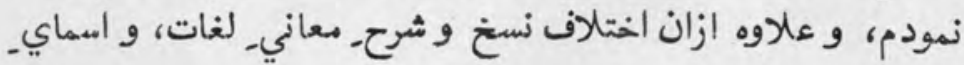

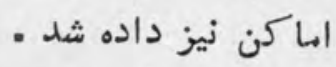
تعاليق آخر كتاب مبني بر تفصيل برخي از وقايع و شرح حال

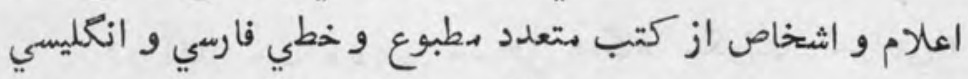

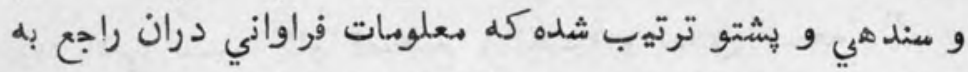

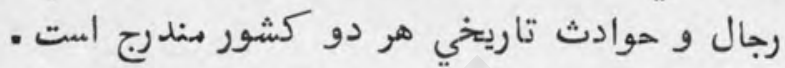

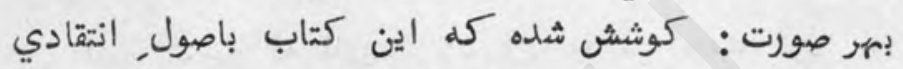

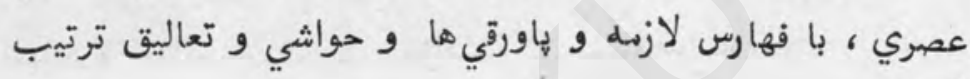

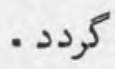

از جناب سيد حسام الدين راشدي تشكر دارم ، كه مشوّّق

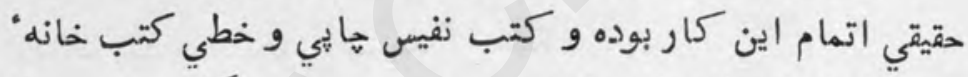

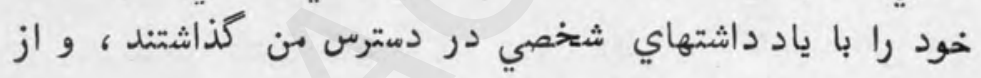

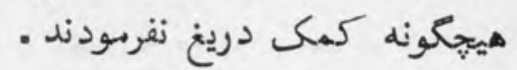

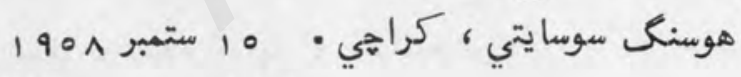
عبدالحي حبيبي افغانى 
شرح حال_ مؤلف كتاب

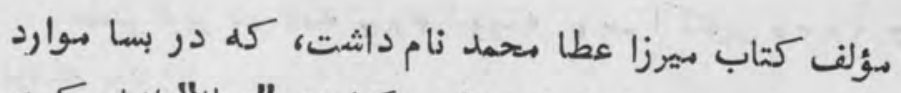

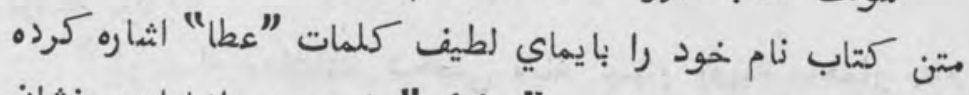

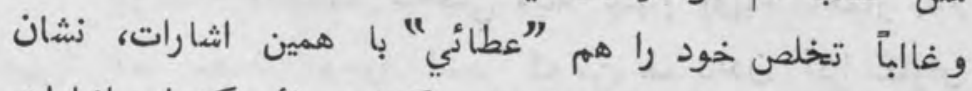

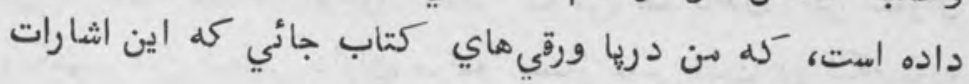

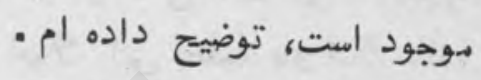

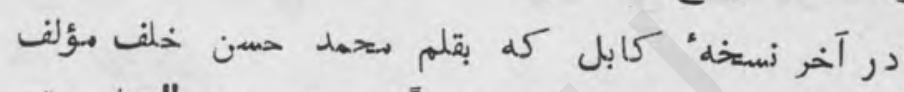

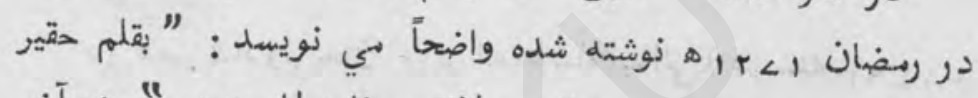

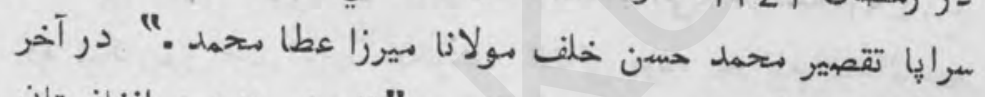

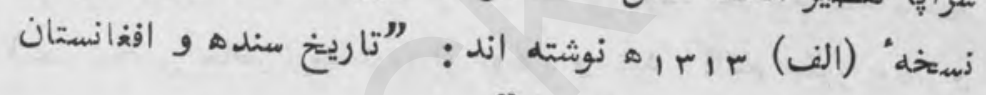

تاليف جناب مرحوم محمد عطا"

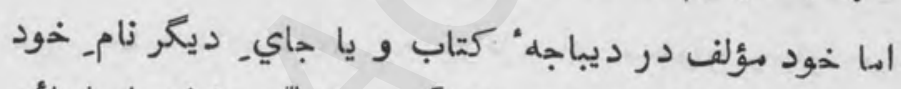

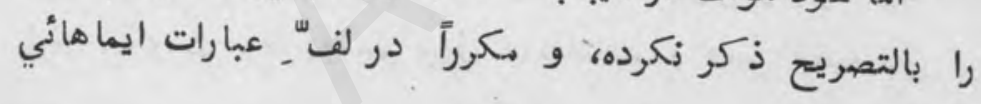

دارد • مانند : بالتهريح

" "....

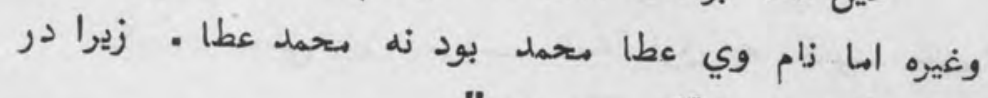

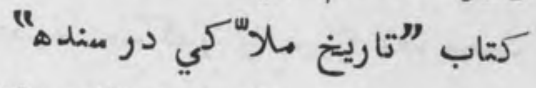

History of Alienations in Sind

جلد دوم كه از اسنادي رمسمي حكومت بمبئي بحكمم ادأره

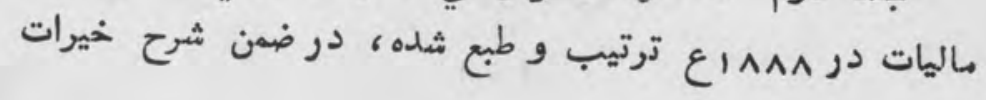


تازه نواي دماركى

مقد هن

داران سنده تحت نهبر بم واضنحاً زام ميرزا عطا محهد بشرح ذيل آمده است : مآ

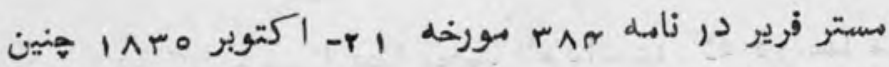

نوشته بود : مستر

” از جمله معاشات شخصي مبلغ حمهار روبيه ماهوار بنام

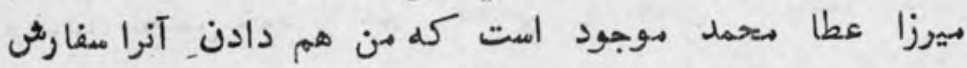

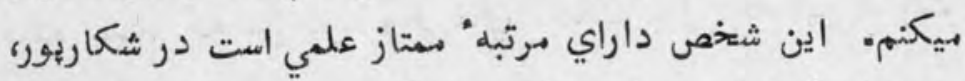

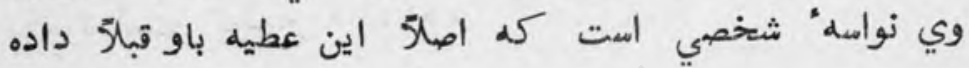

شده بود بود

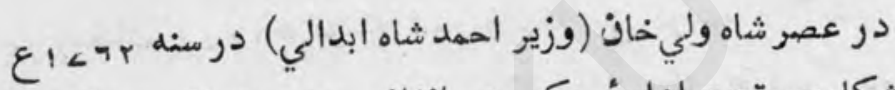

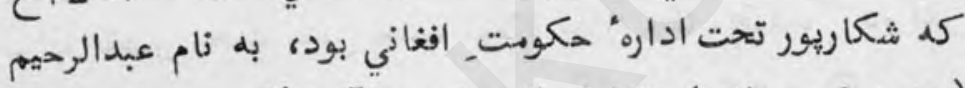

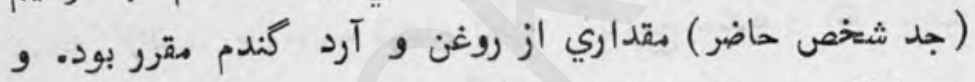

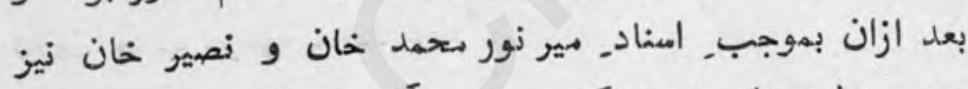

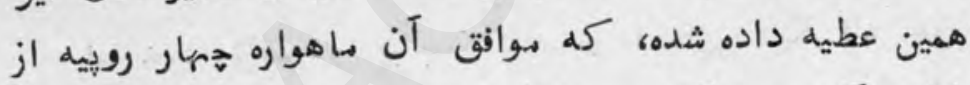
طرف حكوهت برطانيه هم قبول شده است، و همين عطيه قبل از

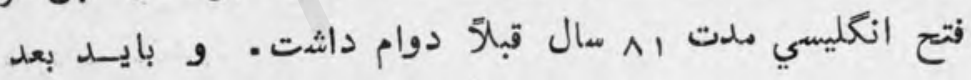

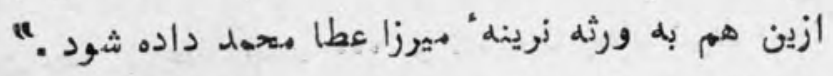

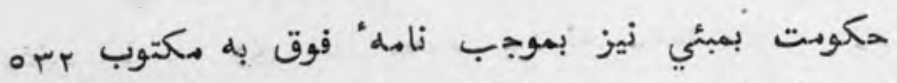

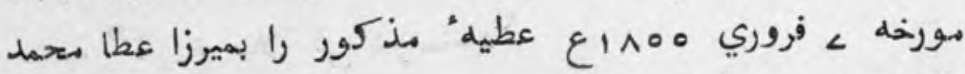

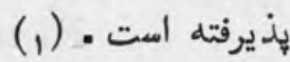

(1) تاريخ مالوهى در سنده (انكليسي) ب-rابr

(r) 
مقدمه

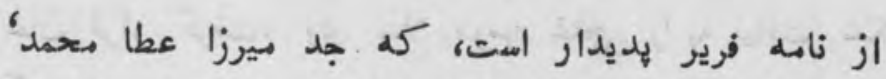

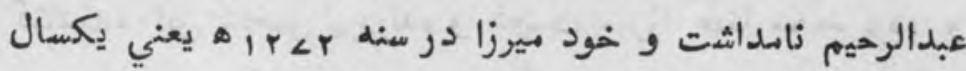
بعد از تاليف اين كتاب هم زنده بودم . ثغل منشي كري و ملازمت شكاريور

ميرزاعطامتحد از ايام جوانيد رشكاريورشغل منشي كريداشت و با حكام متشور بود، در انشاي معمول همان عصور بزبان فارسي دمتي داشت حنانحه خودثى كويد : ״ اين جرعه نوثن باده بي كمالي، اگرحه روزي حند در

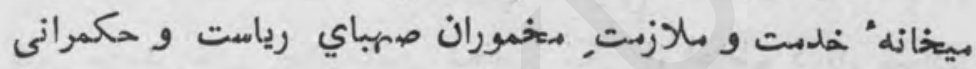

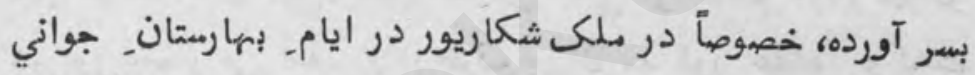

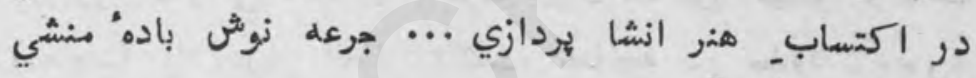
" كري شده (1)

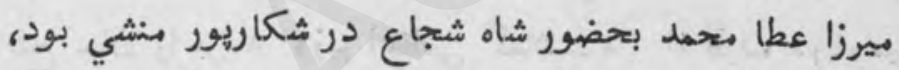

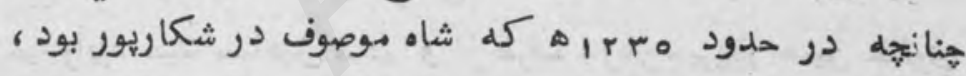

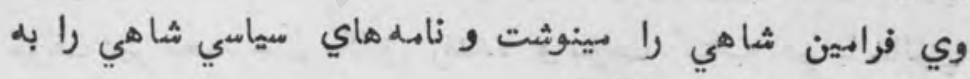

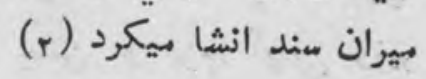

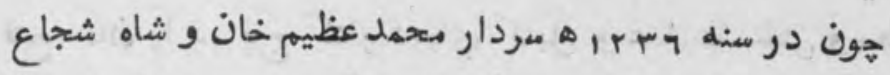

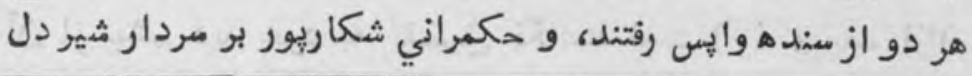

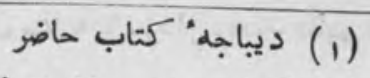
(r) كتاب حاضر بيان نزول اجلال شاه شجاع در شكاريور 
تازه نواى معاركى

مقدمه

خان قرار كرفت، وي ملا مومن غلجي را به نيابت_ شكاريور

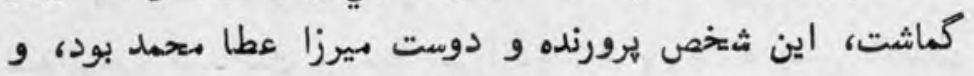

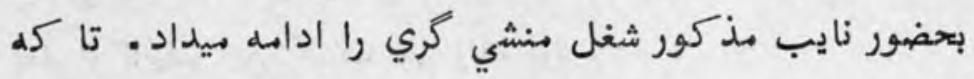

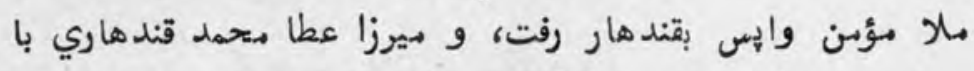

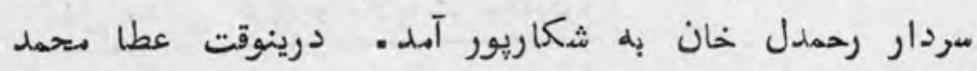

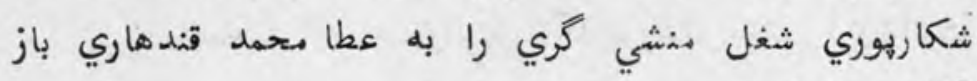

كذاشت (1) (1) كغوري

سفرهاي بشاور و كابل مانو هرات .

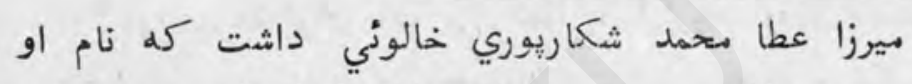

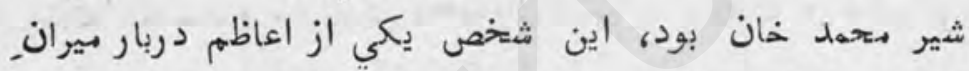

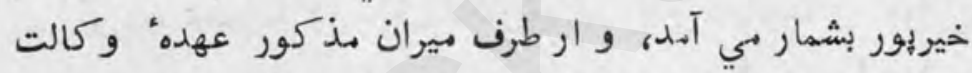

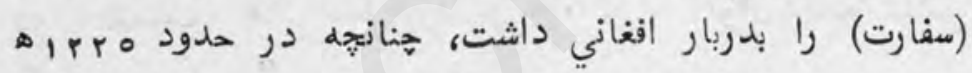

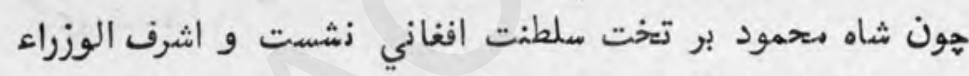

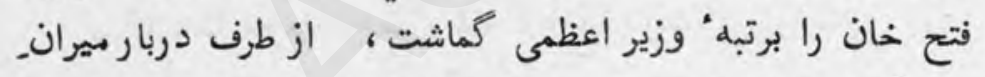

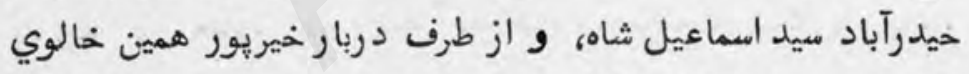

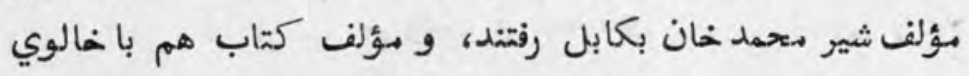

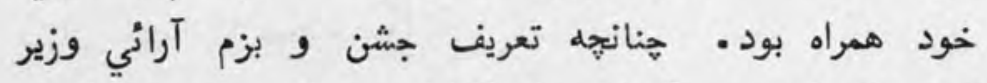

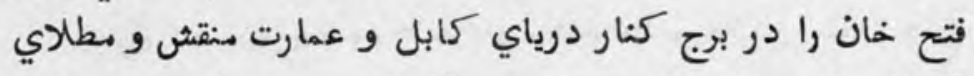

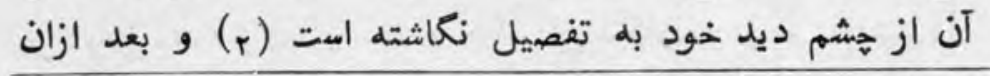

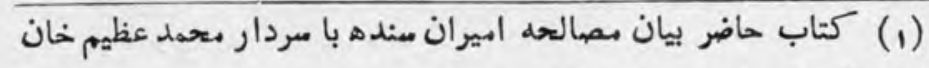

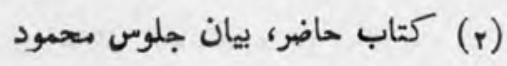

( 1$)$ 
مقدمه

تازه نواي معارى

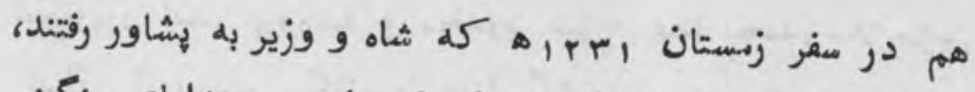

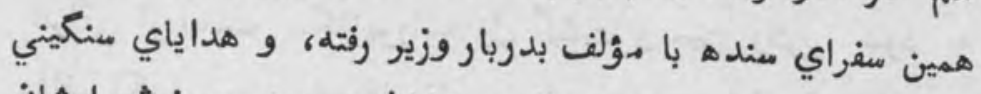

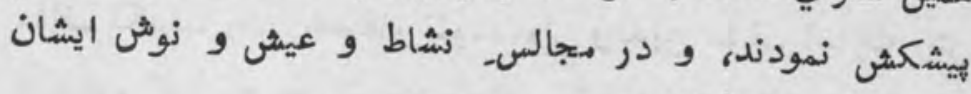

شركت كردند (1)

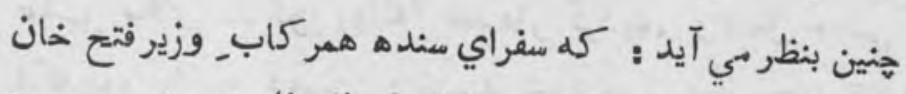

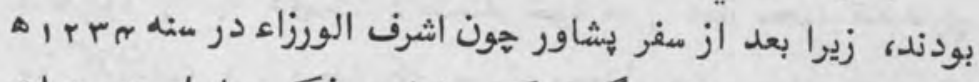

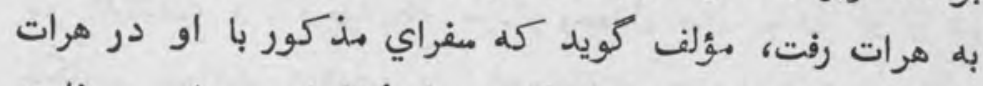

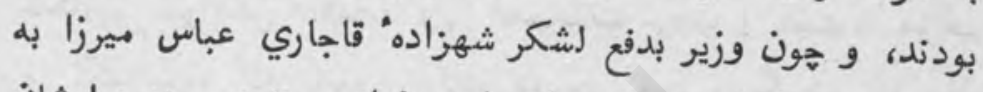

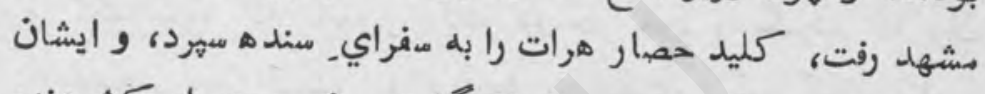

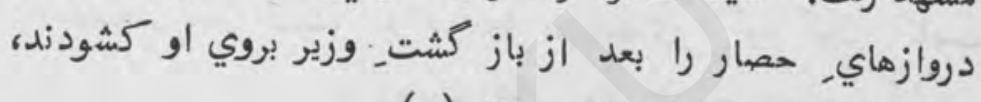

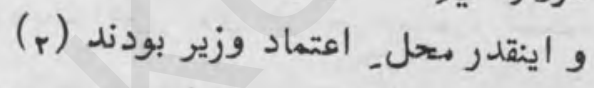

بعد ازين وقايع هون وزير فتع خان در هرات بدست شهرزاده

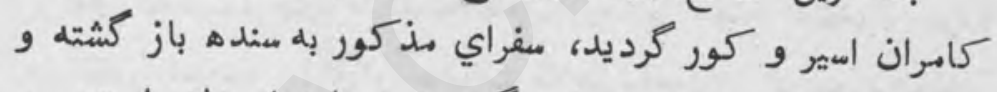

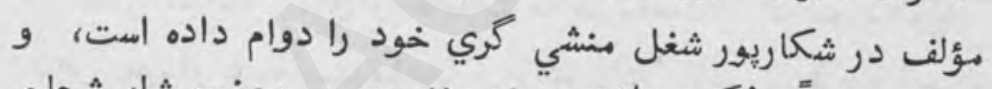

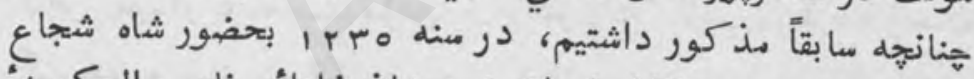

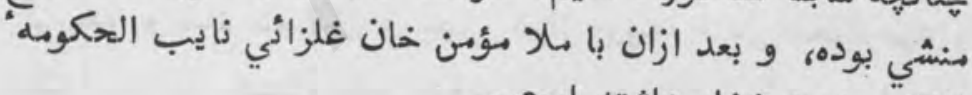

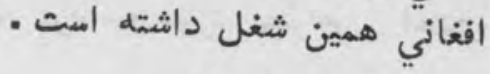

متختار 15اري قند هار

هون در حدود رrr اره سردار رحمدل خان به حكمراني (1) كتاب حاضر، بيان فوتيدن بها كل

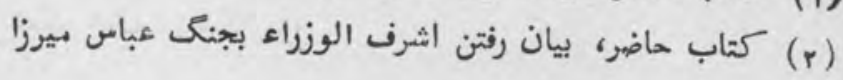

( $<$ ) 
شكاريور آمد، يرورنده و متخدوم ميرزا عطا متحمد، ملا مؤمن

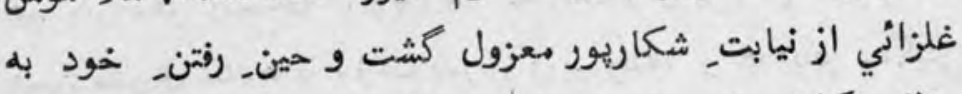

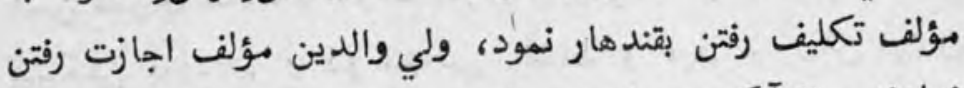

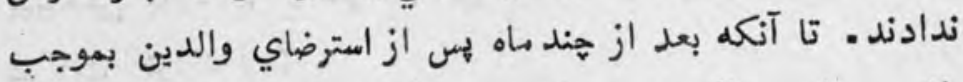

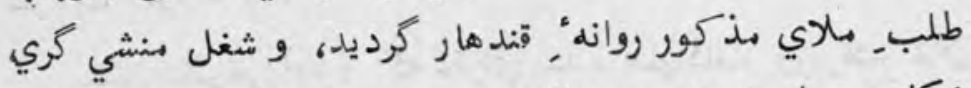

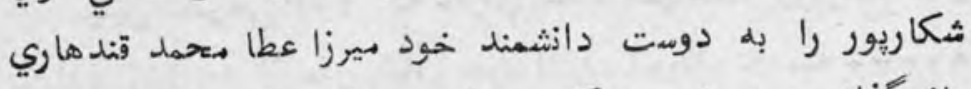

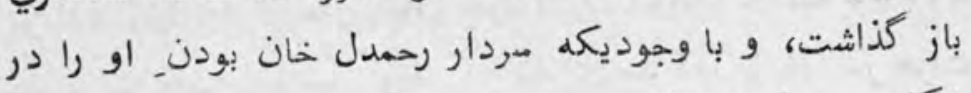

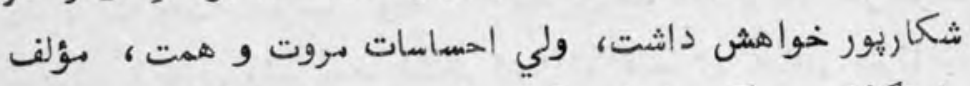

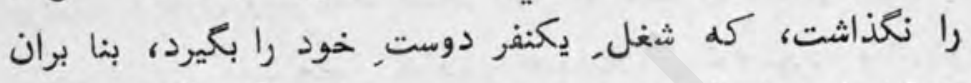

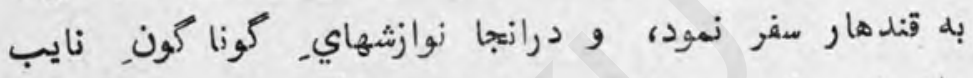

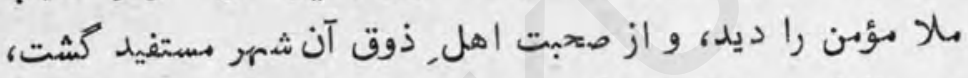

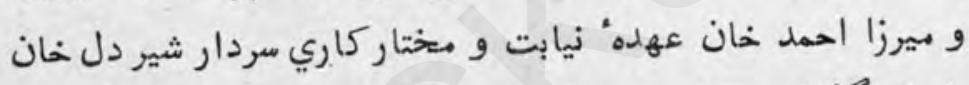

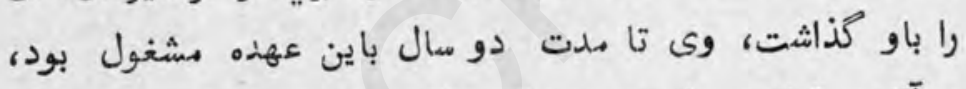

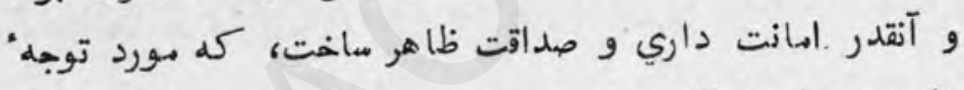

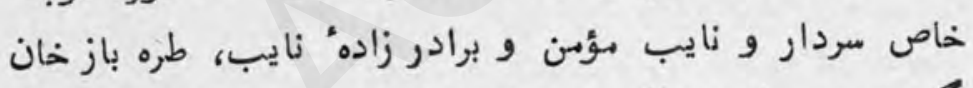

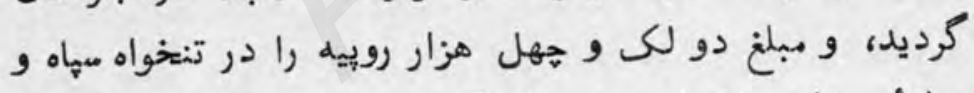

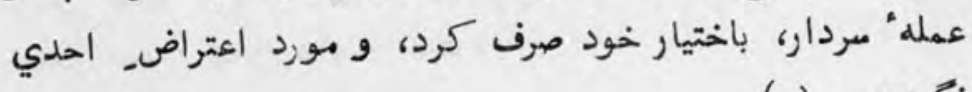

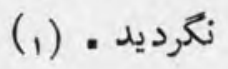

هؤلف ازين اقامت دو ساله" قندهار خاطرات خوبي دارد، و و

(1) كتاب حاضر، آخر بيان مصالحه ابيران سنده و آهدن مردار محمد منيم خان در شكاريور . 
dad

تازه نواي. معارى

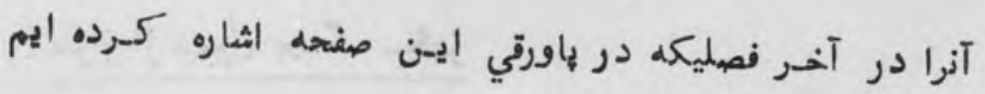

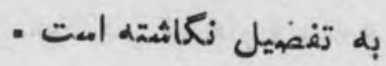

سفر هرات

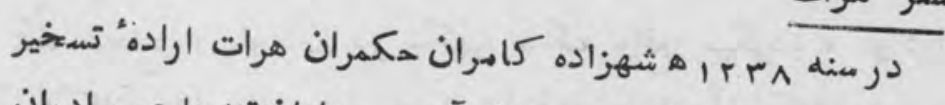

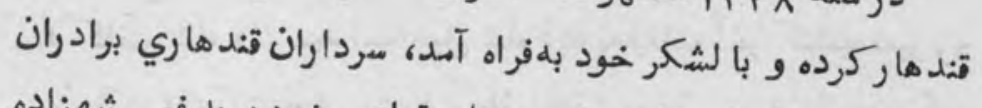

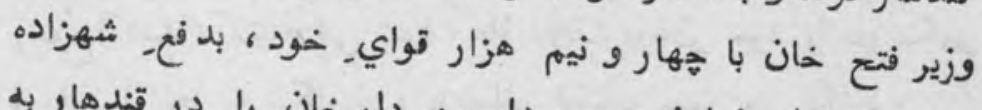

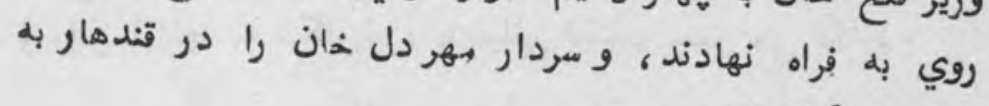

- مكمراني كذايتيند

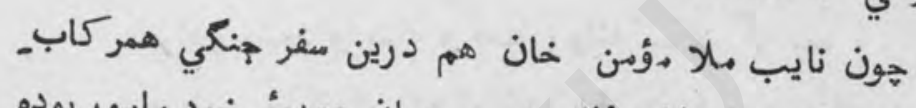

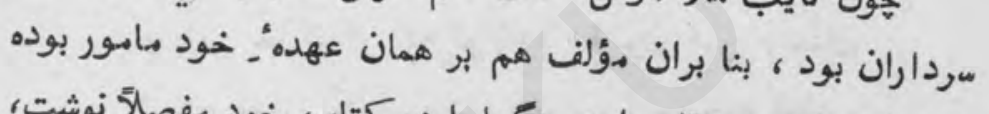

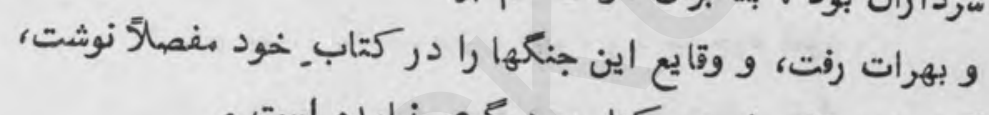

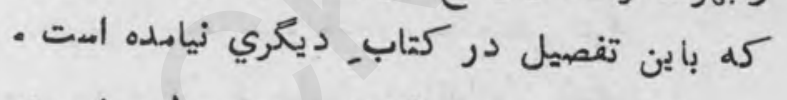
(از روي فهربت كتاب به فصول مختصوص ايـن وقايع

رجوع شود )

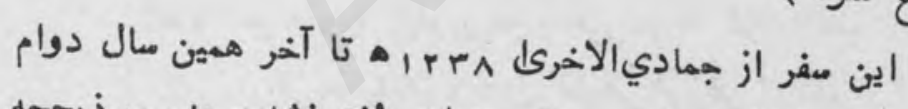

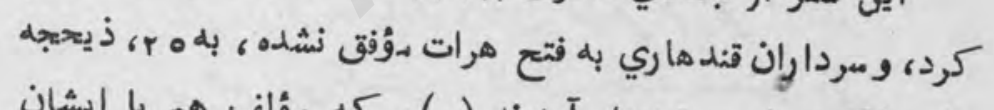

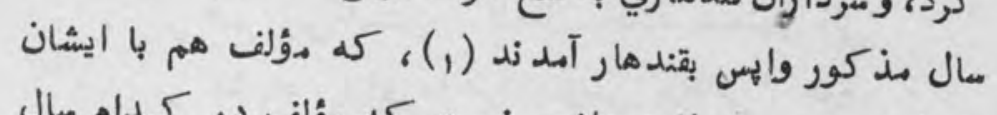

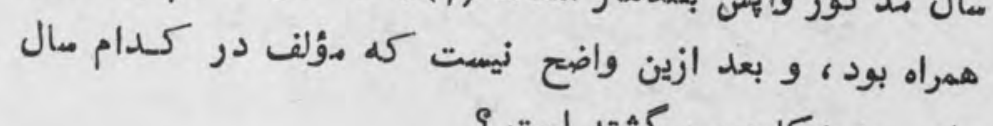

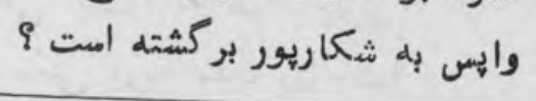

(1) كثاب حاضر ، اواخر بيان مراجعت سردار صاحبان از هرات .

(9) 
تازه نواي. مeرك

مقدمه

احتراز از شمول بجنم سمهر

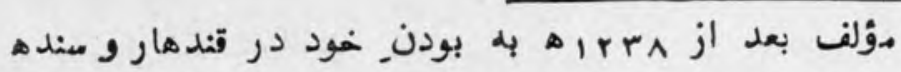

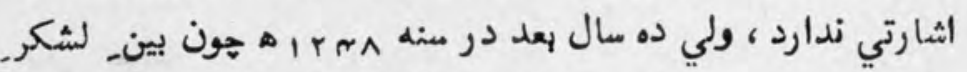
شاه شجاع و بلموجان در سمهر جنك واقع ميكردد ، ود دران ميد كاظم ثشاه ولد سيد اسماعيل شاه (به تعليقات آخر كتاب نمبر • ج

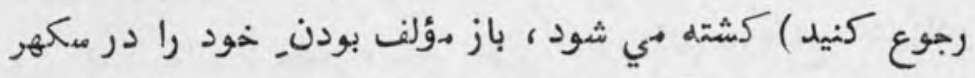

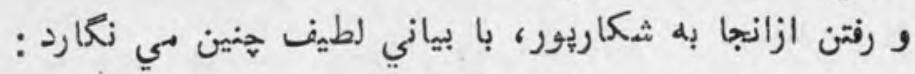
" (سيد كاظم شاه ) باتفاق سيد تقى شاه

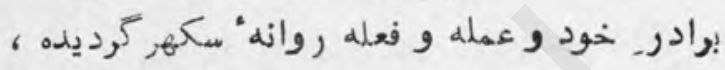

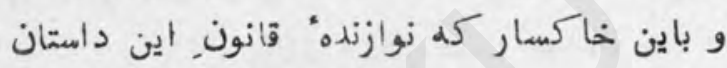
است، بسيا رتكليف بردن همراه ركاب_خود نمود ـ

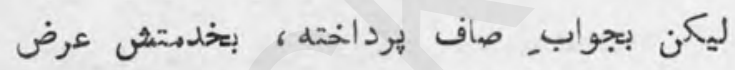

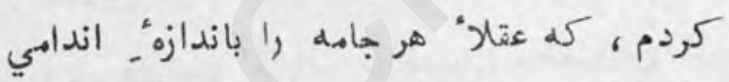

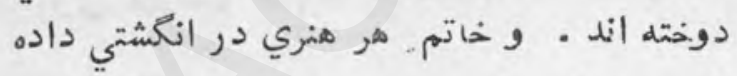

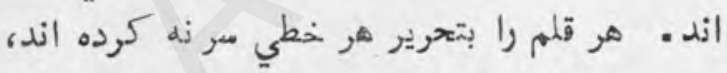

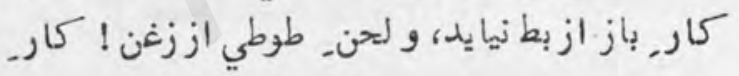

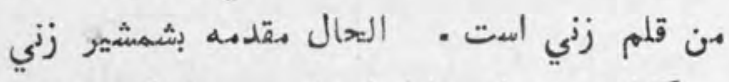

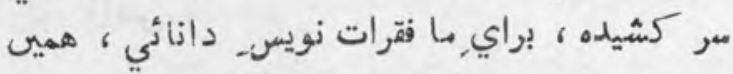

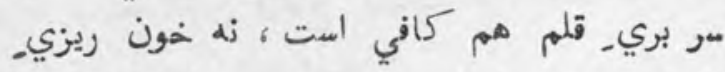

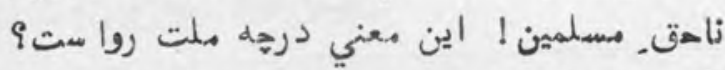

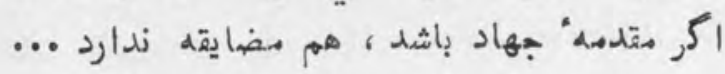
(1.) 
مقدمه

تازه نواي. ماركى

غرض خاكسار باين مسايل و وما يل از خدمبت.

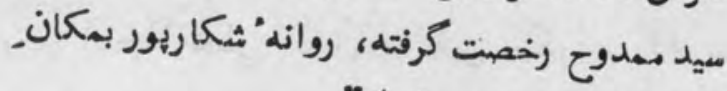

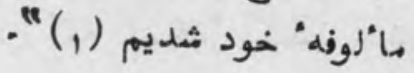

ولادت و وفات مؤلف

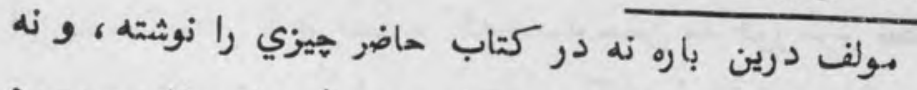

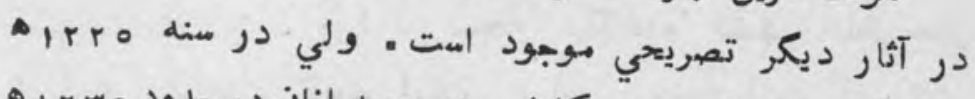

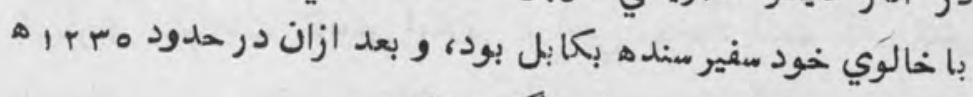

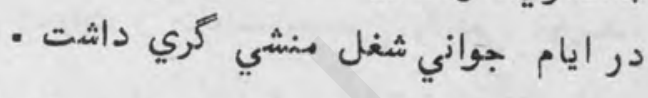

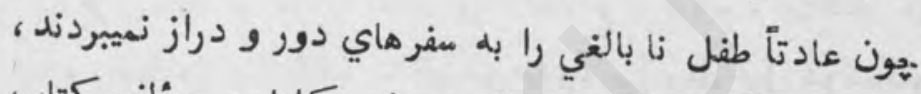

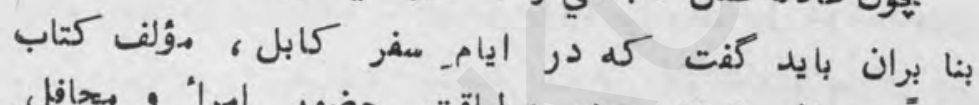

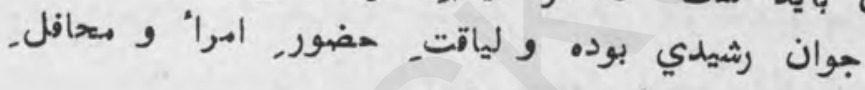

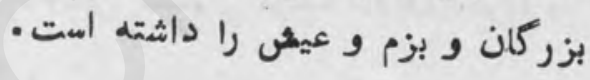

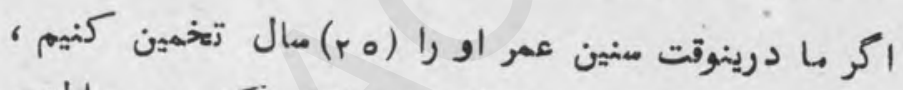

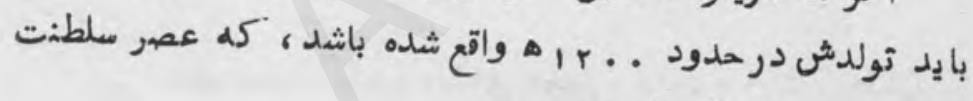

تيهور شاه سدو زائي الهت

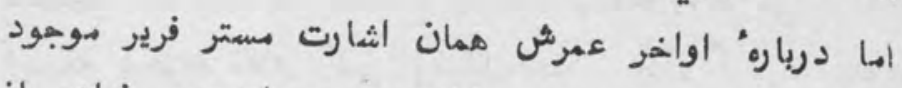

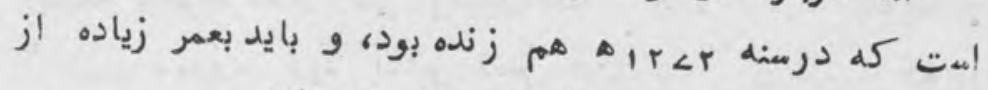

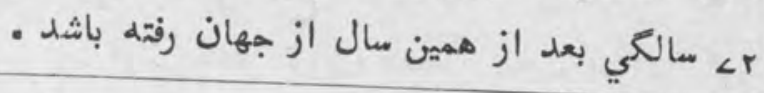

(1) كتاب حاضر ، آخر بيان مامور نمودن اولياى دولت ، عاليجاه

......

$(1$, 
از روي نسخه" خطي كابل به يقين ميكوئيم كم يـك يسر

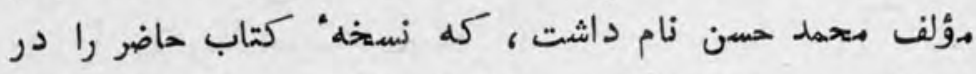

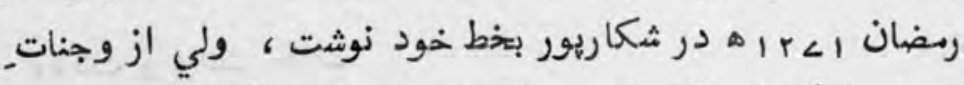

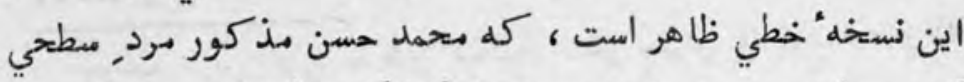

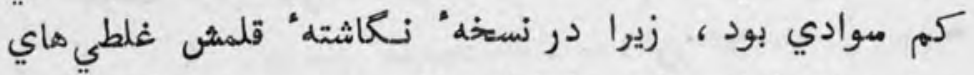

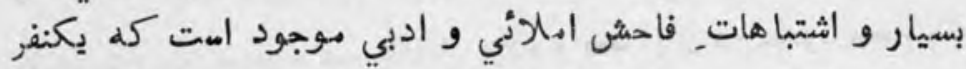

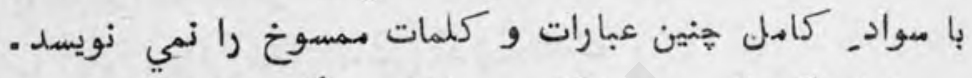

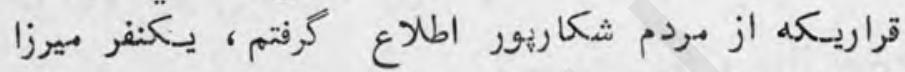

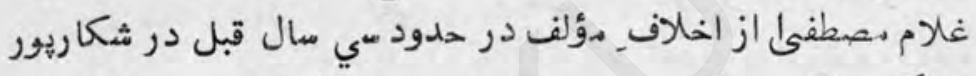

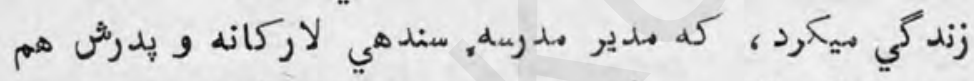

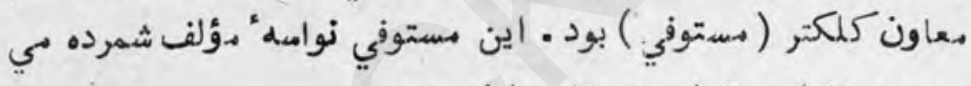

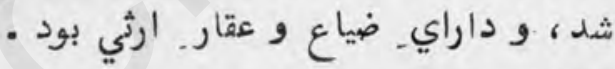
تاليف كتاب

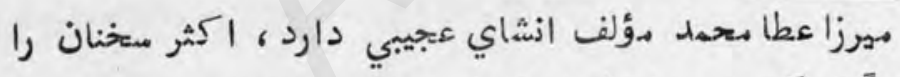

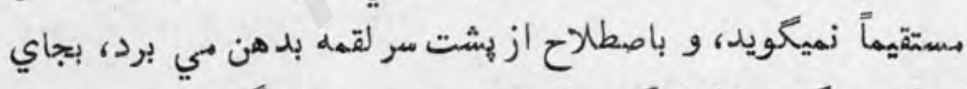

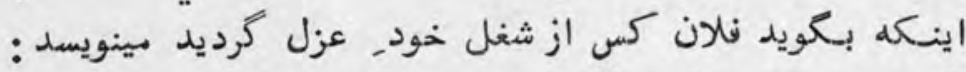

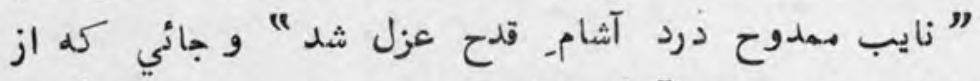

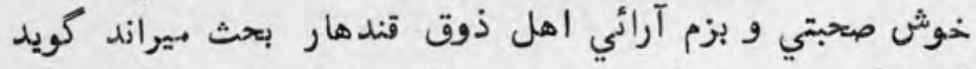

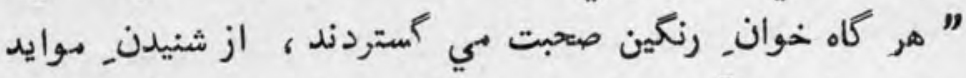

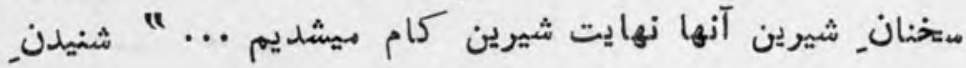


مقلهم

موايد سخنان شيرين و شيرين كابي، تعابير عجيبي امت ، شنيدن

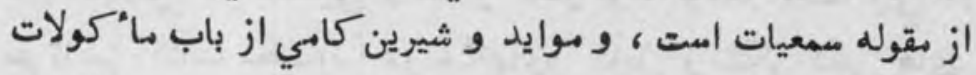

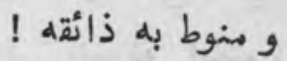

همجنين در سر تا سر كتاب حذف انعال بدون قرينه ، و و تطويل. ناكوار. جمل ، و و ديكر عيوب ادبي و حتي استعمال

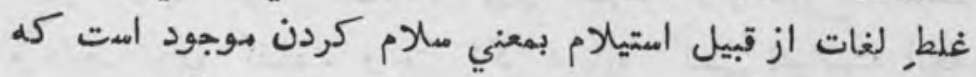

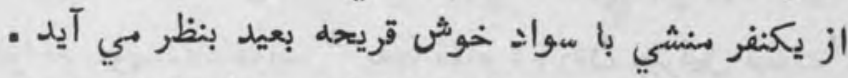

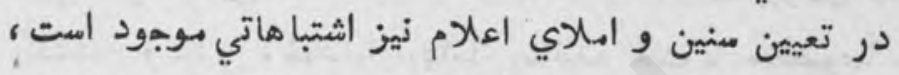
كه دران باره بايد مؤلف رامعذور دانست، زيراشايد حين نوشتن

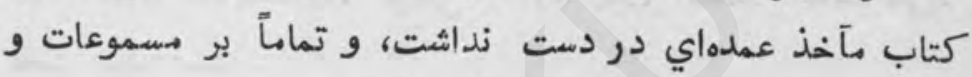

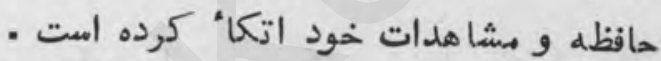

باوجود اين همه عيوب، كتابش خيلي هغتنم و داراي

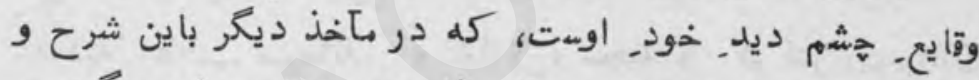

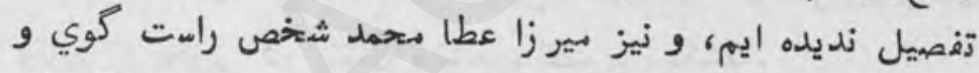
درست كرداري بنظر ميآيد، زيرا در نوشتن. وقير وقايع از كمال.

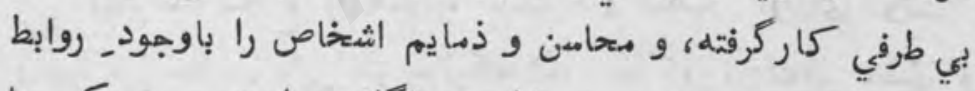

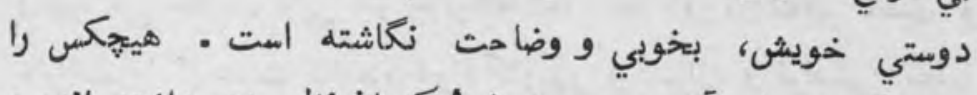

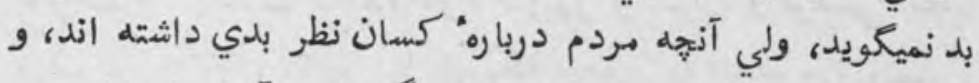

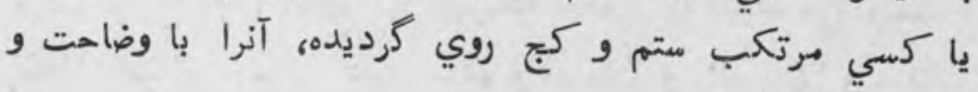
جرائت نوشته است لمرئ

كتاب را طوريكه از مقدمه يديدار امت، بخواهش استويك اهـ 
تازه نواي. معار

مقدهd

نام انكليس كه مستوني و مقتدر عصر بوده نوشته اهت، ولي در

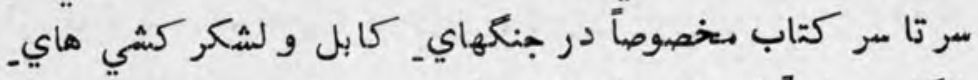

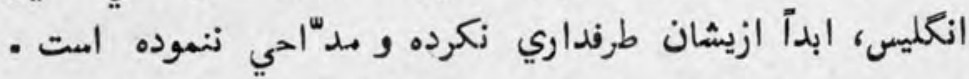

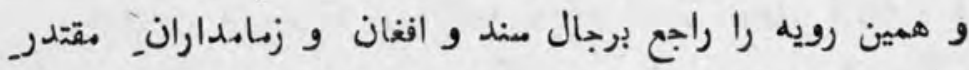

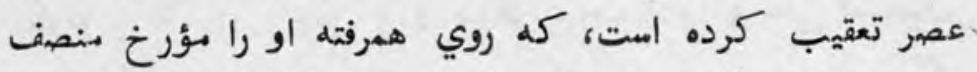

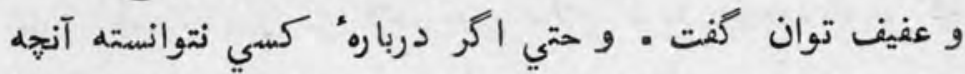
دلش بخوا هلد بنويسد، باشارت " اينجا مقام دم زدن جبرئيل نيست

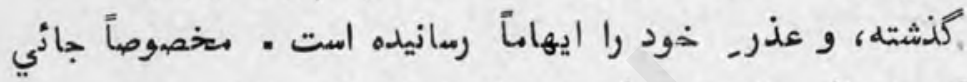

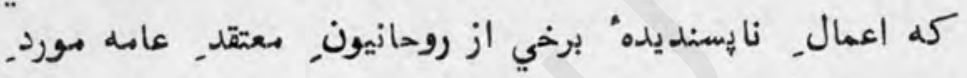
- إنحث بوده المت

كاهي در تصوير وقايع از ريزه كاري خيلي دقيق كار

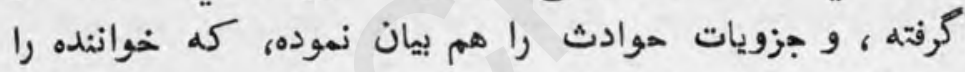

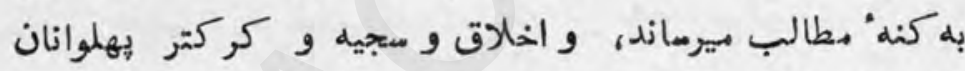

وقايع را بخوبي در كمال وضاحت تصوير بيكشيد .

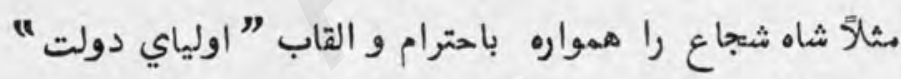

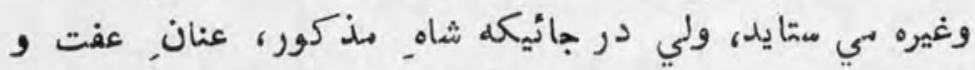

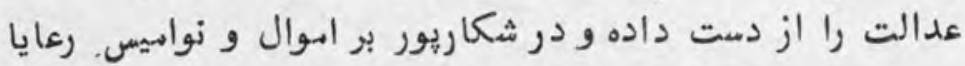

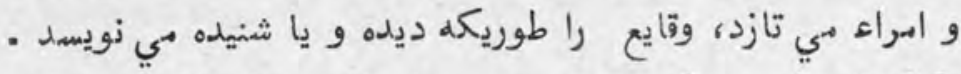

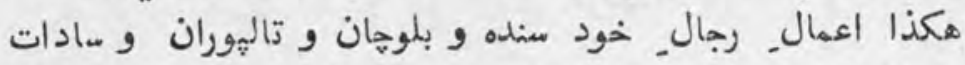

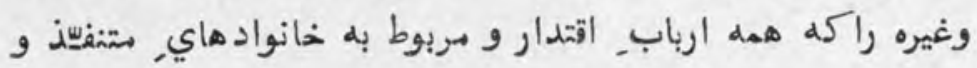
روحاني هم بودماند -

(1n) 
تازه نواي. معارك

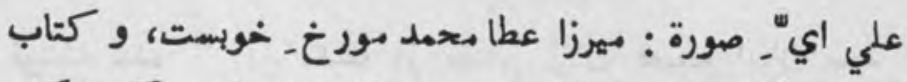

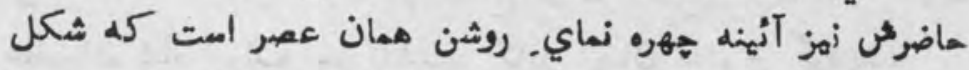

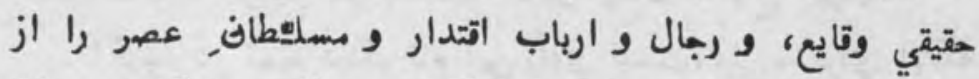

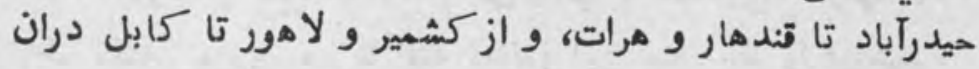

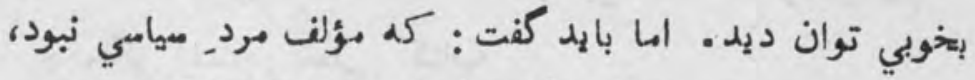
و در اوضاع - عصر و وقايع بكمه_ امرار وعوابل هفيقي و مياسي

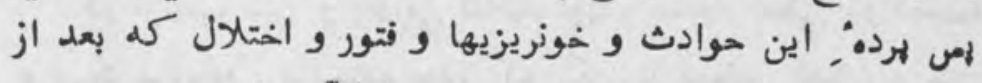

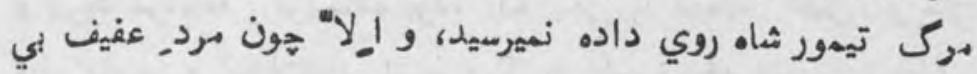

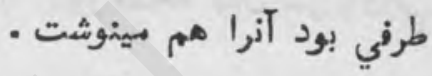
وي ملتفت بود كه حق تلخ است ولي طوريكه در ديباجه

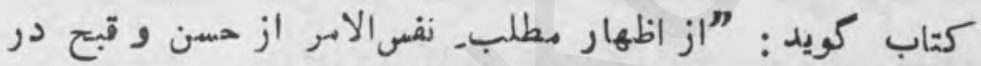

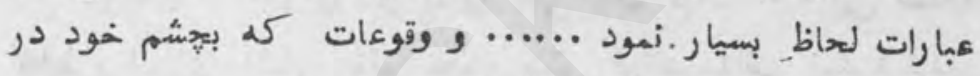

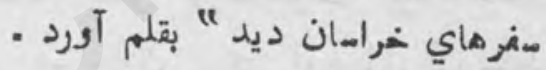

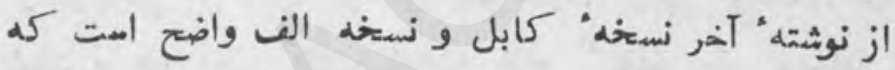

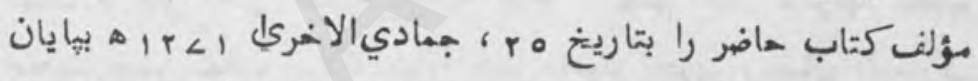

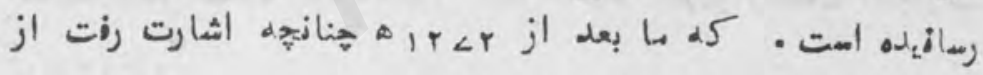

- ميات وي خبري زدارسم يُك نفر راوي

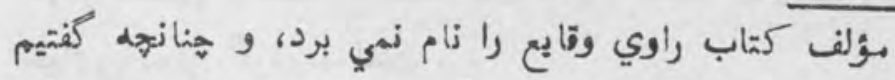

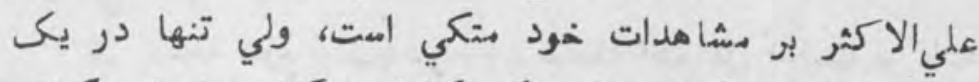

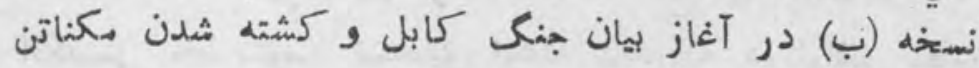

(10) 
نوشته شده " اين مدعا از مفتاح زبان فصيح البيان معيد ميان

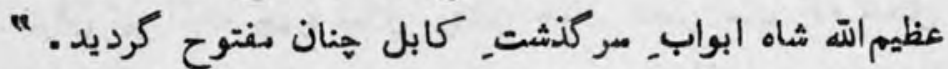
اكرجه در نست ديكر نام اين راوي نيست، ولي ما براي اينكه

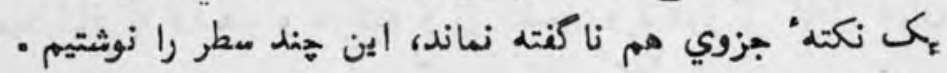

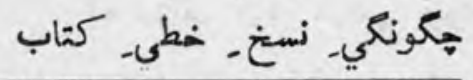

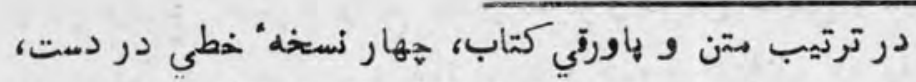

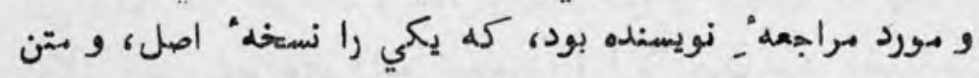

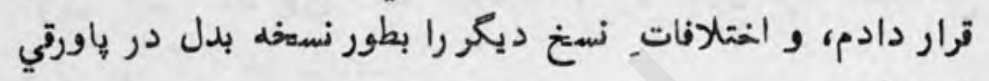

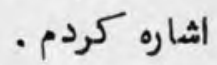

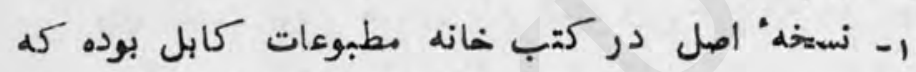

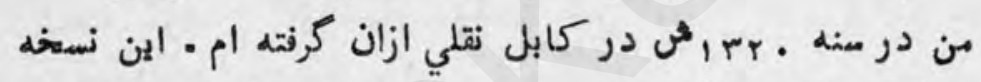

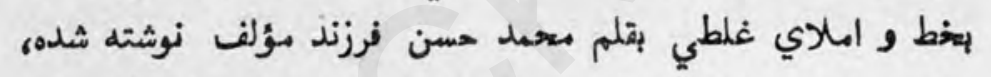

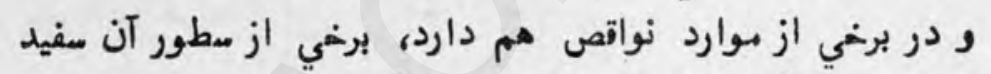

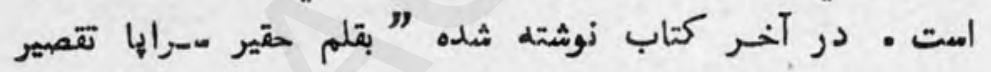

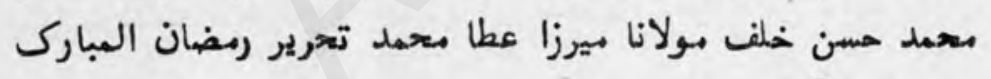
".DIr 1

نواقص اين نستخه و اغلاط. املاوي آن از روي نستخهاي

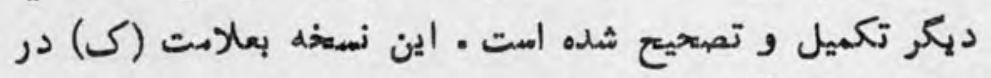
مواثشي هعين كرديده امهت

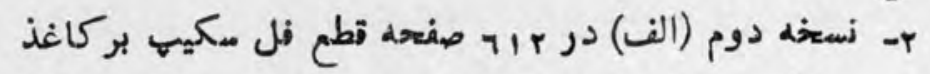

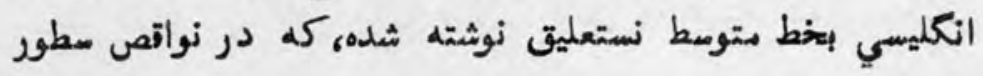


مقدمه

تازه نواي معارك

عيناً با نسخه (ك) شباهت دارد، اهـا ا.لالي آن صجيع تر ازان

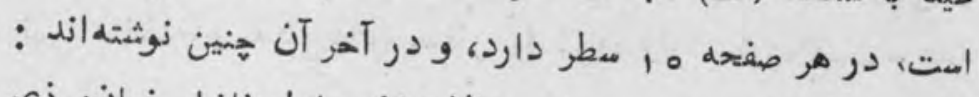

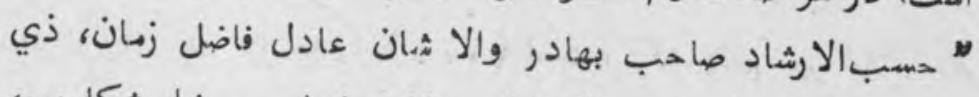

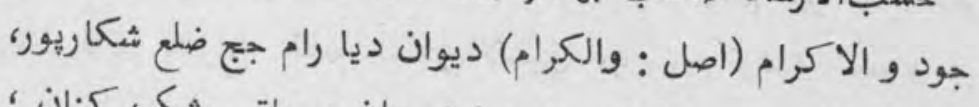

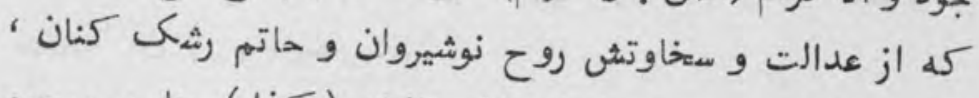

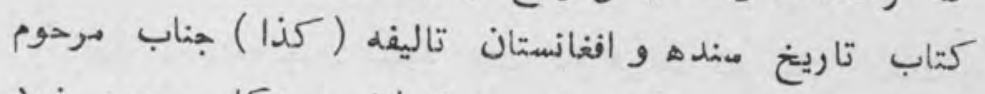

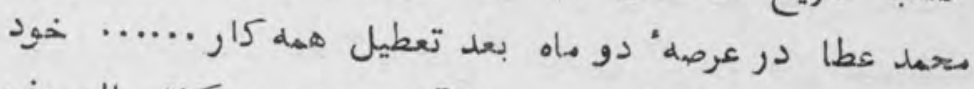

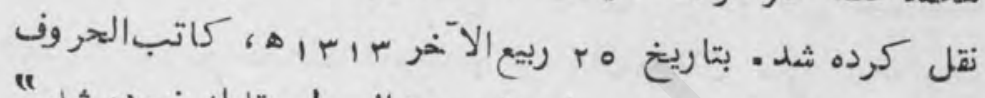

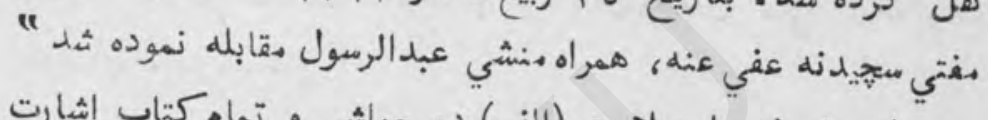

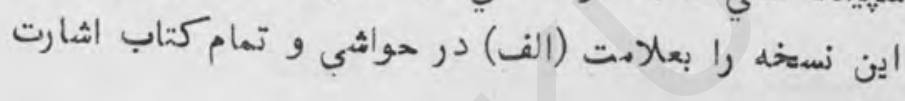

ن موده ام

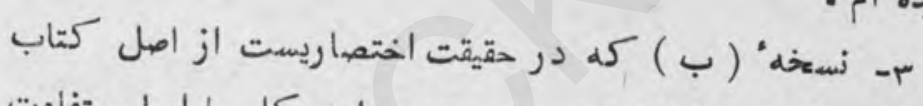

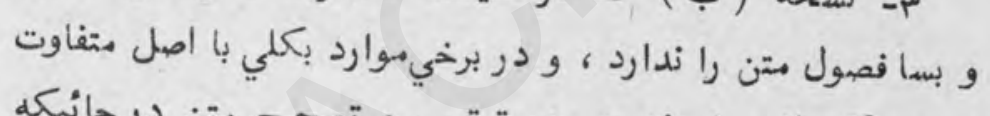

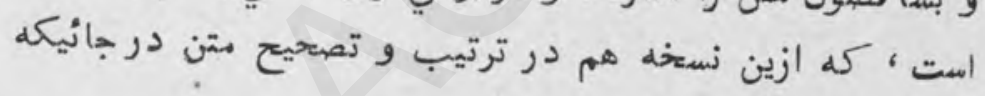

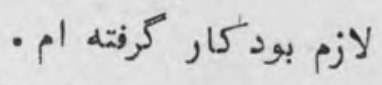

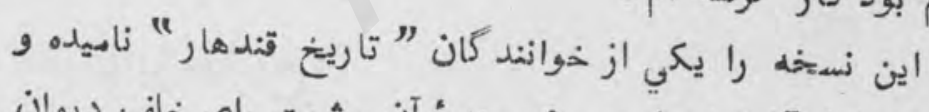

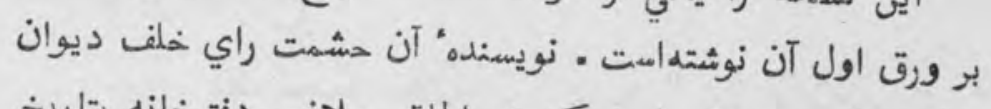

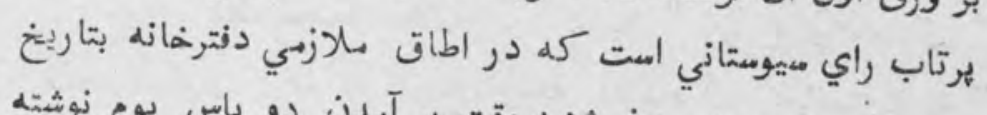

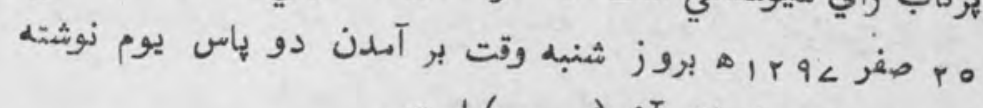

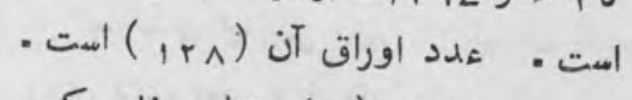

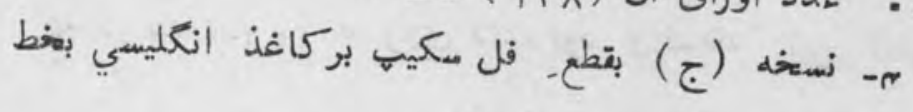
$(1<)$ 
نازه نواى معاركى

مقدمd

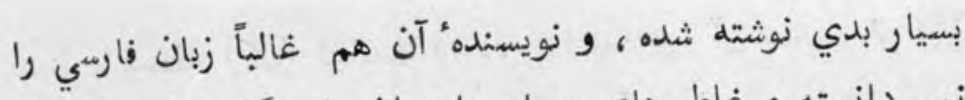

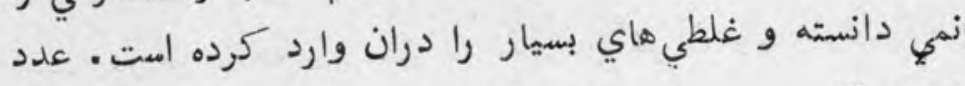

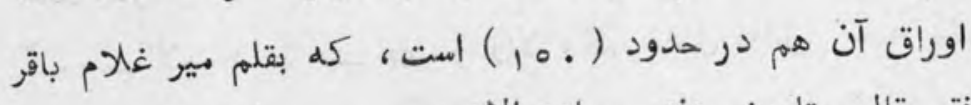

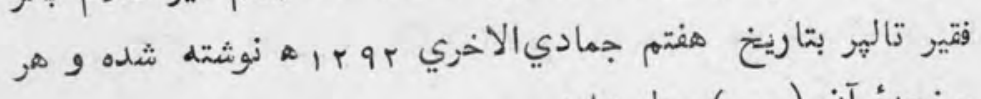

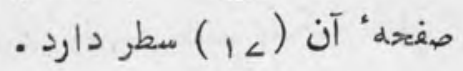

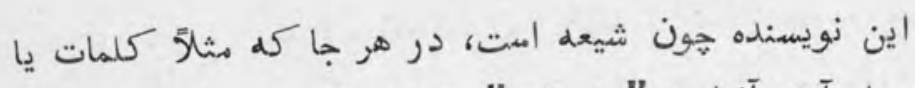

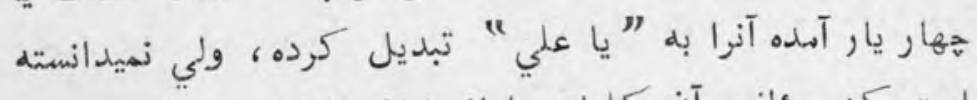

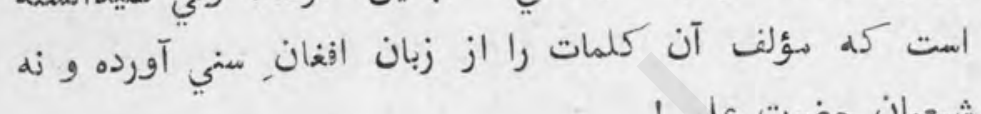

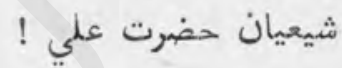

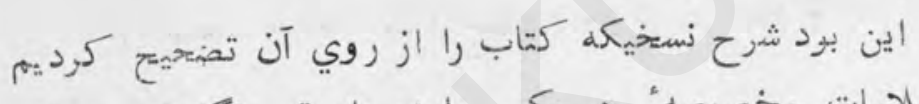

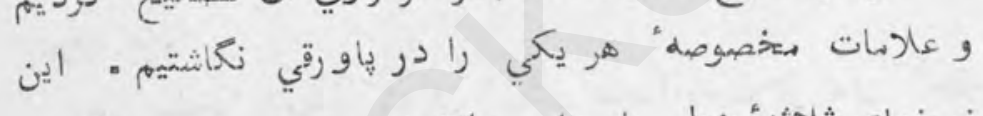

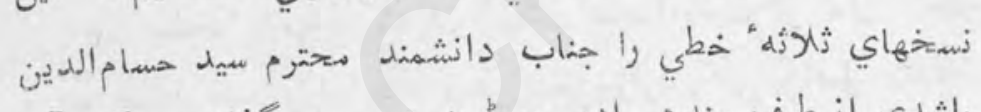

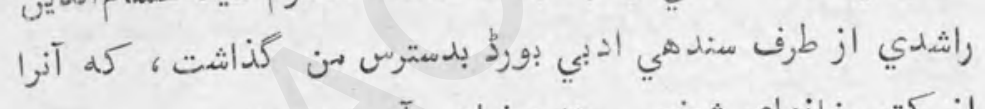

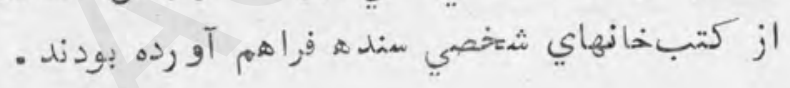

خزين اين تارئن

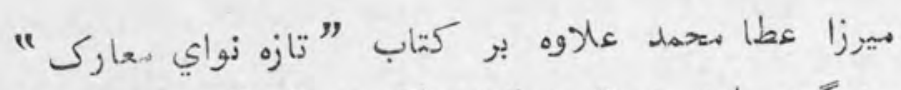

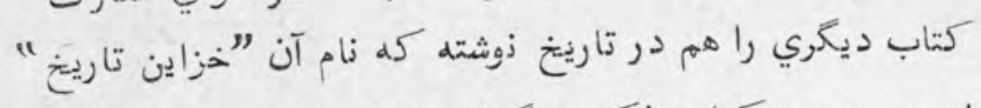

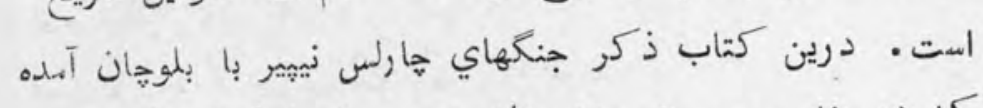

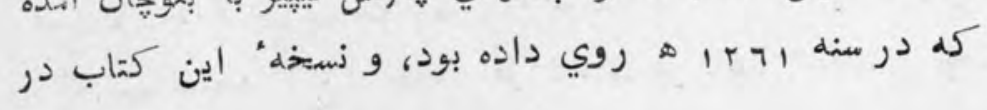

$(1 \wedge)$ 


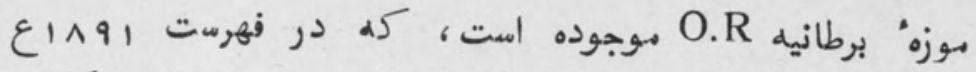

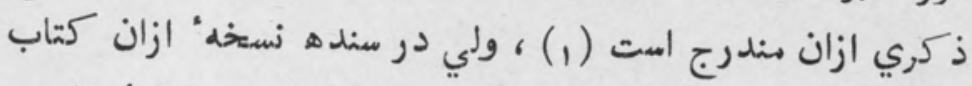

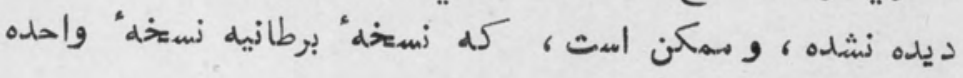

مؤلف بأشد. (x)

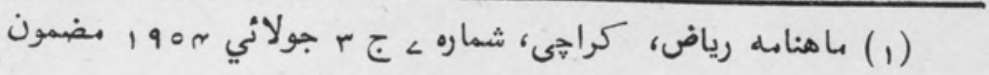

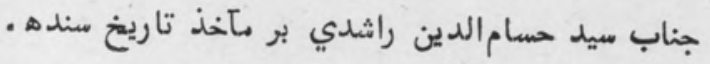




$$
\begin{aligned}
& \text { (1) } \\
& \text { متن } \\
& \text { تازه ذواي مeارك }
\end{aligned}
$$




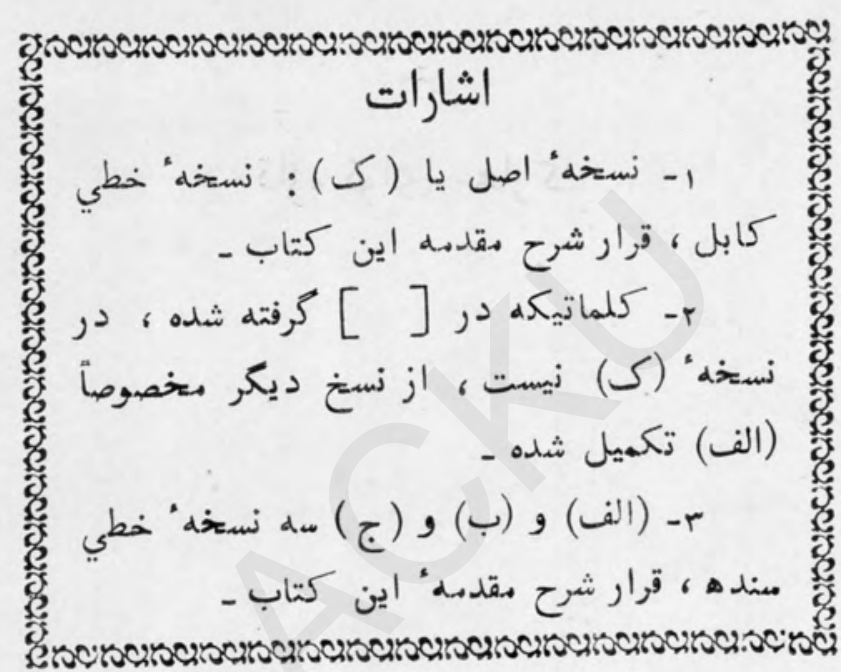




\section{بسم اله الرحمـن الرحيم}

سماس بي قياس كه احشامر (1) افهام [و سهياهـ اوهام] سرير

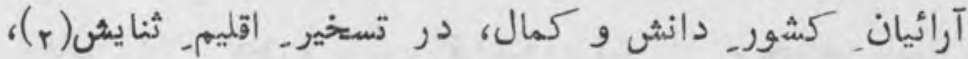

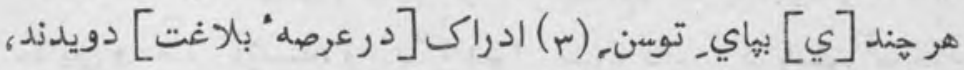

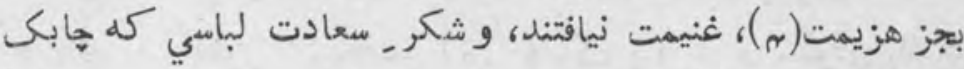

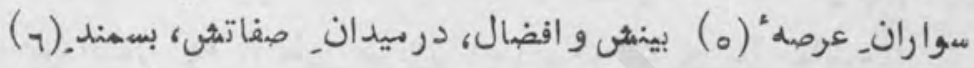

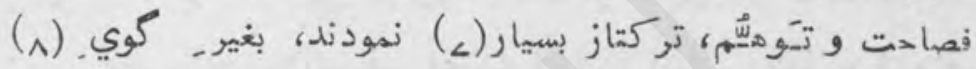

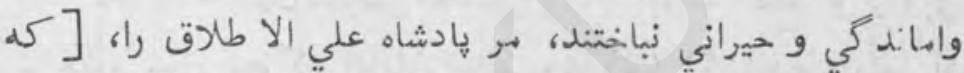

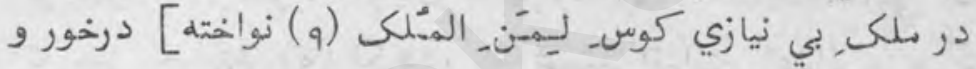

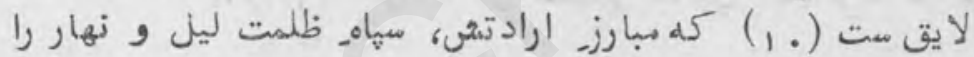

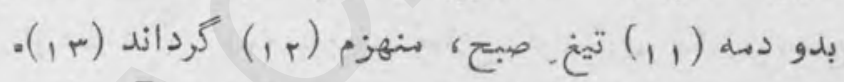

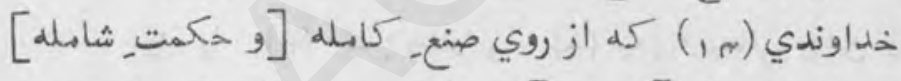

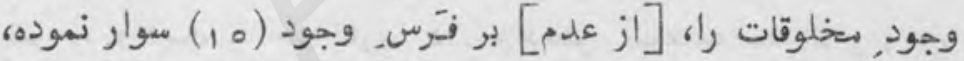

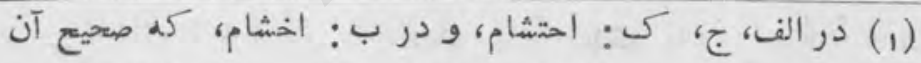

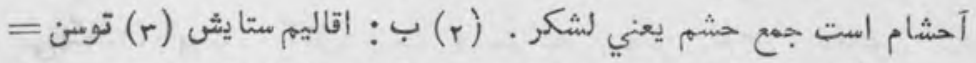

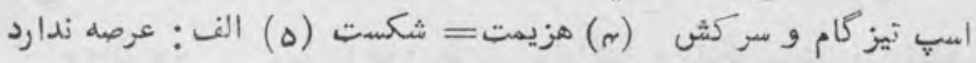

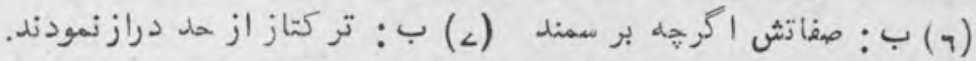

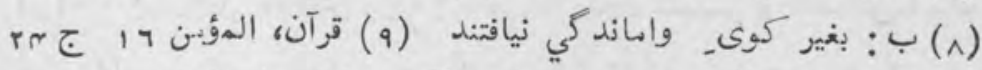

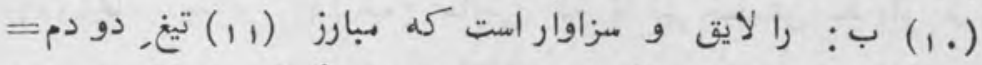

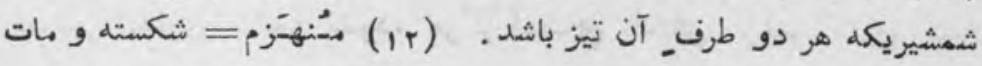

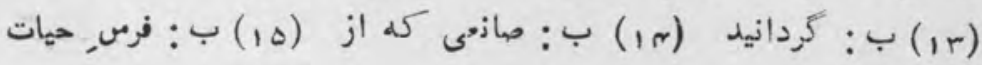


تازه نوأي

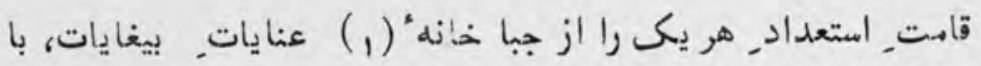

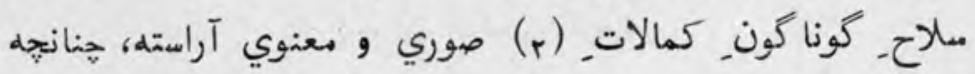

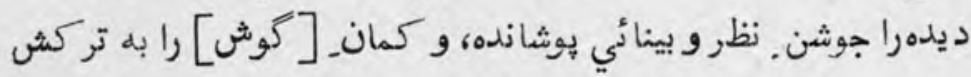

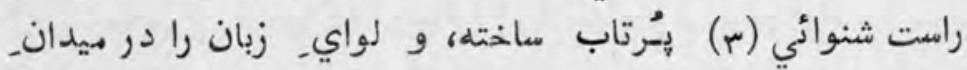

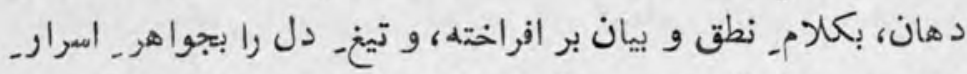

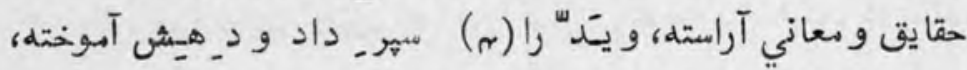

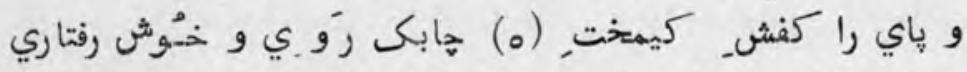

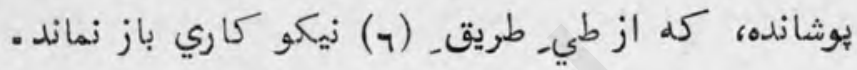

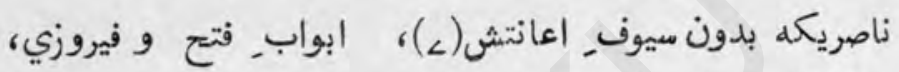

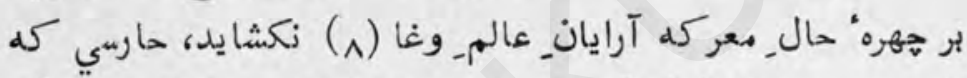

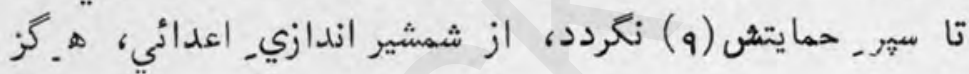

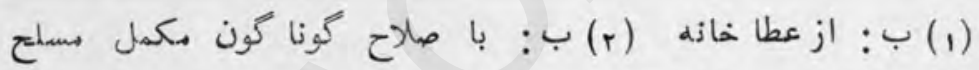

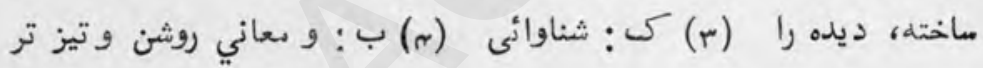
نموده، و دست را سمر داري داد و دهش آموخته، سد راه بر بالاي و

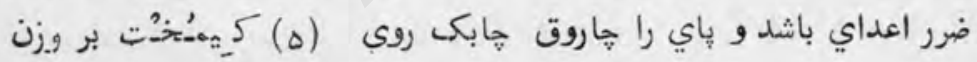

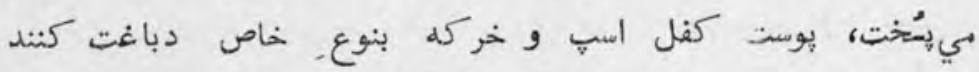
- برهان وهد> ا . (1) ب: طريق سلوكى و نيكو كاري وا نمايند

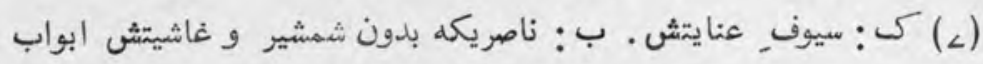

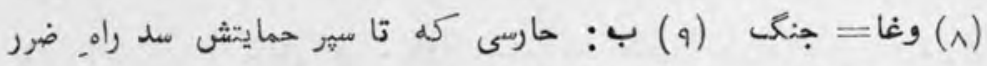
شمشير ازدازي دشمن نشود، هركز اعضاي راحتش بزخم كاري مبتل

. $22, \beta_{i}$ 
اعضاي, راحت احدي، بزخم, كاري ببتلا نكردد .

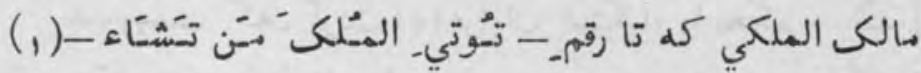

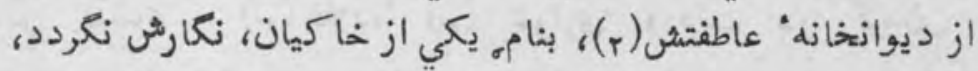

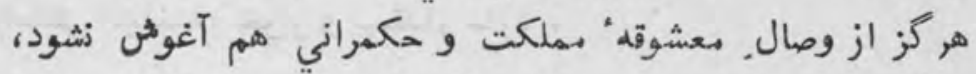

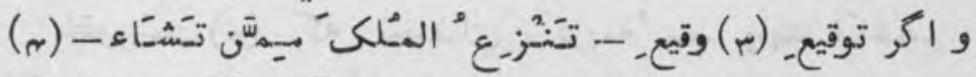

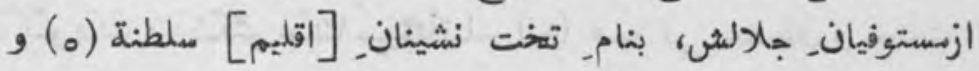

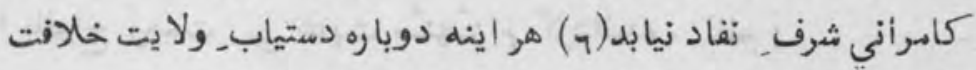

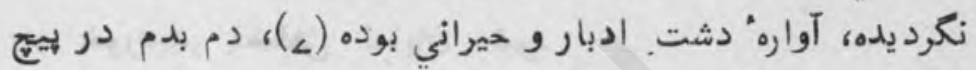

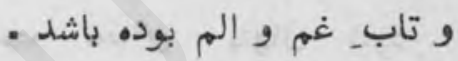

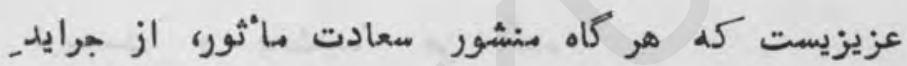

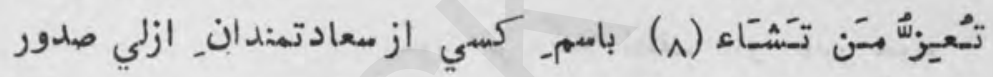

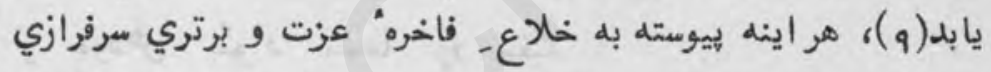

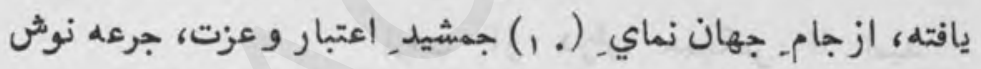

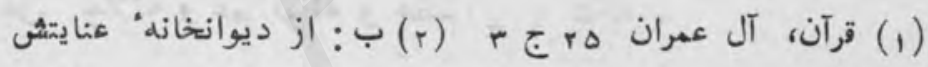

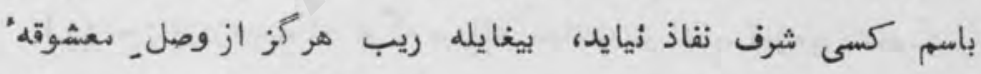

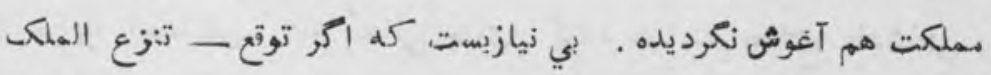

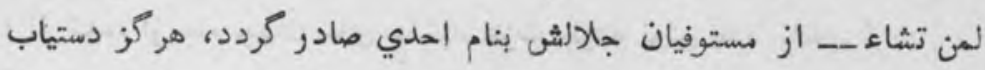

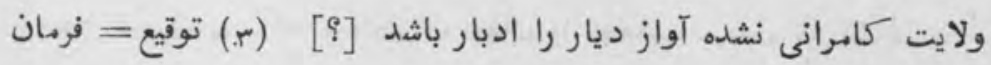

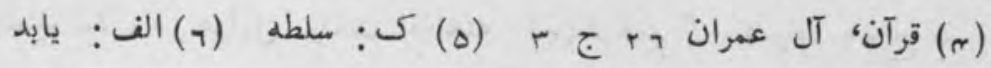

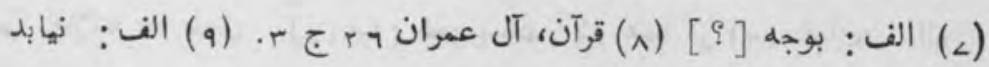
(. (1) الف : جهان فاني . 


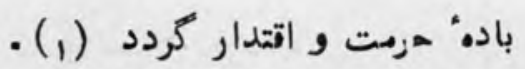

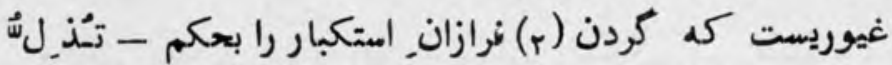

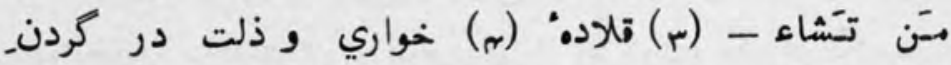

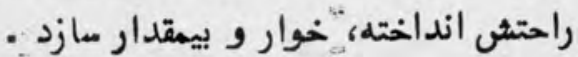

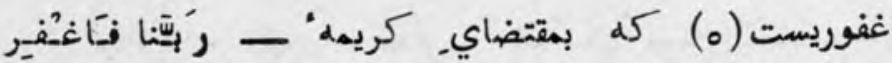

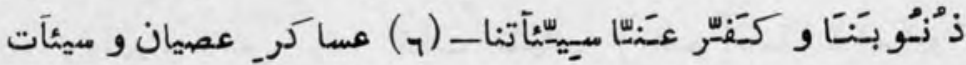

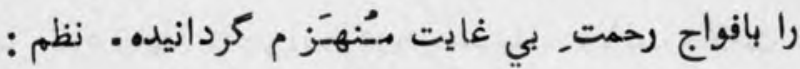

جو خورشيد, فضلدى نمايان شود

كنه همبجو خفاش شود لهنهان شود

كريست و بخشند: هر كناه بـ-ود بر كنه لطف او كذ عذر خواه

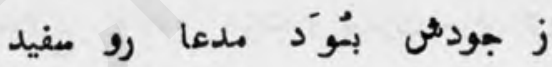

نرفت از درو هيجزكس نا اميد

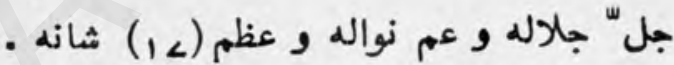

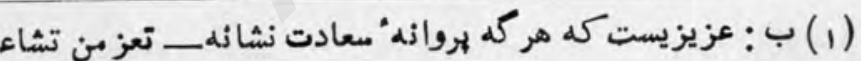

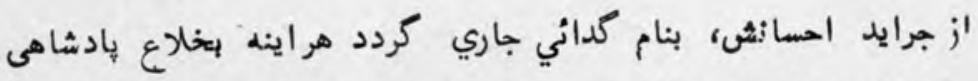

مرفراز شده، از جام جهان نماي جمشيد عزت جرعه نوش باده" راحت كردد .

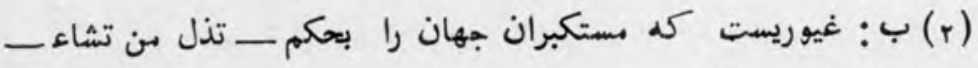

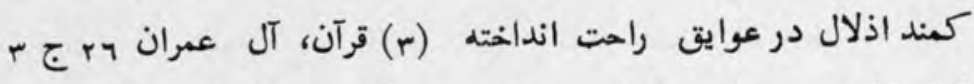

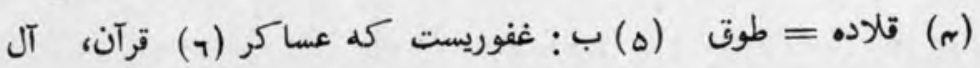

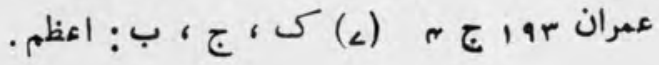


در بيان ذعت اورزك آراي نبوت و سروري

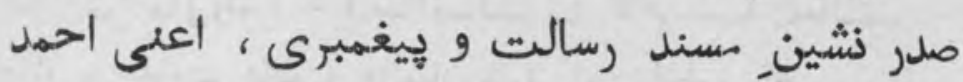
مجتبىلإ محمل مصـطفى ملى الله عليه [ [و سلم ] و آله و اصتحابه اجمعين

نعت و ثناي. بي اذتهاني كه جيوض. (1) عقل و هوش.

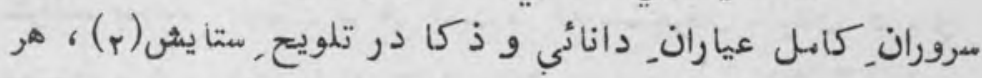

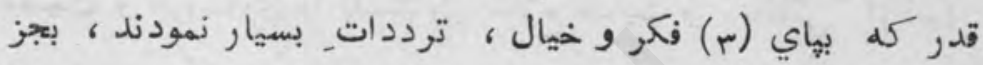

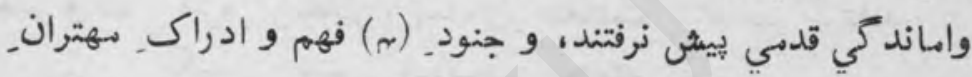

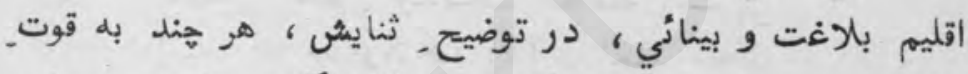

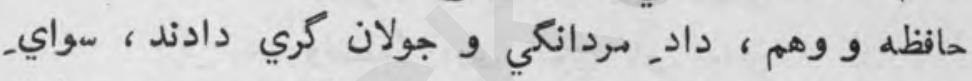

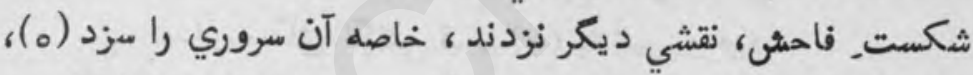

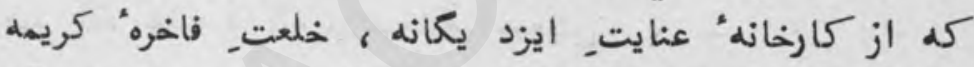

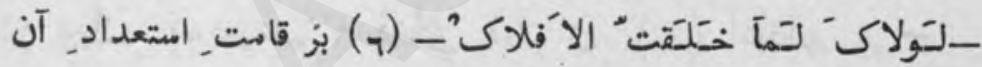
شفيع_ قيامت ، برهاني است مـاطع • بيت لمات كر وجود. او نميشل واسطه تا ابد بودي جهان بيوامطه(_)

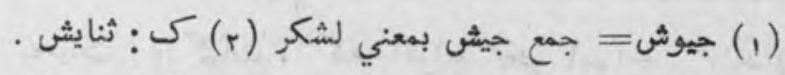

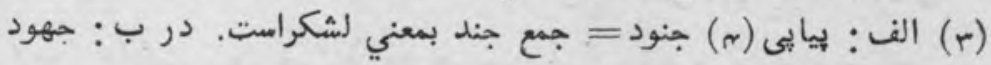

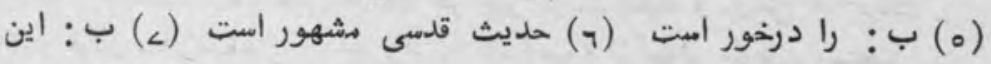
بيت زايد دارد :

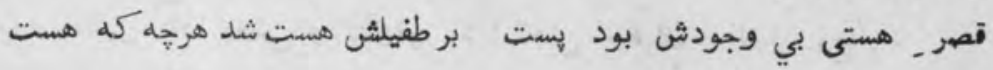


شافعي امت كه از ديوان خانه" عنايت_ (1) نامتنا هي، طغرايـ غُرَّ"

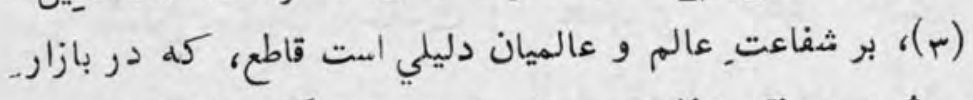

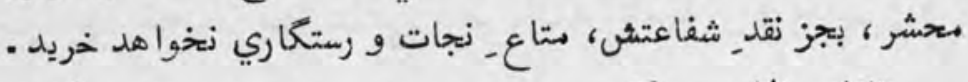

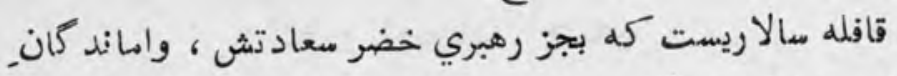

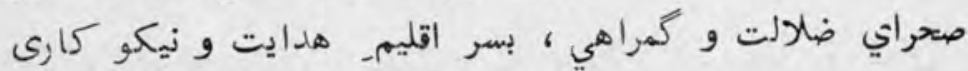

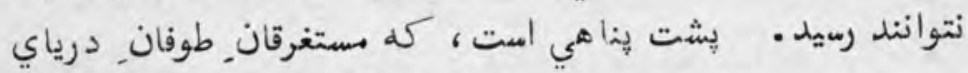

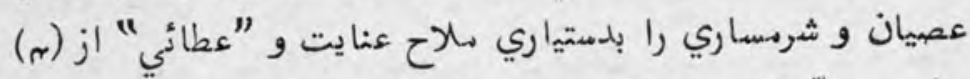

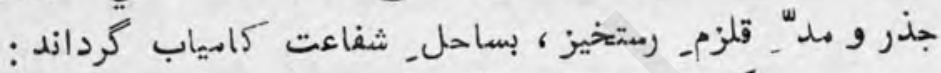

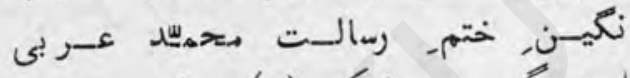

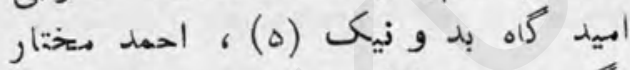

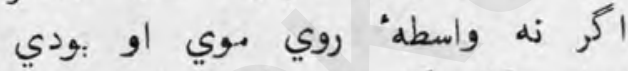

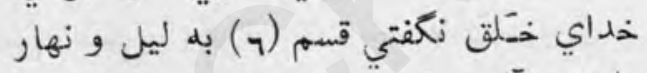

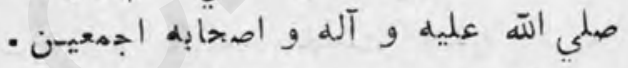

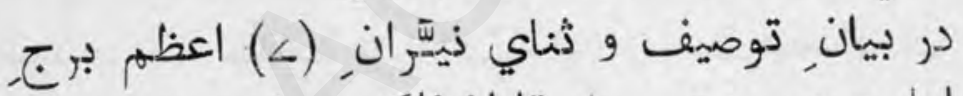

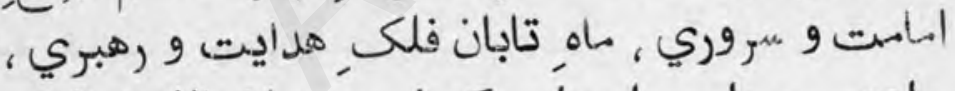
اعنى جـناب, اصغاب كسبار ، رضوان الله تمعالى إنى

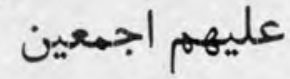

الوفـ تحيات. زاكيات ، كه افواج بحر امواج- فاروسان

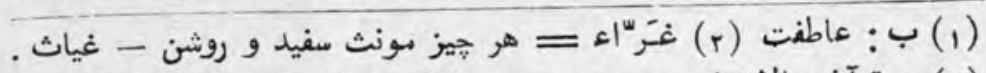

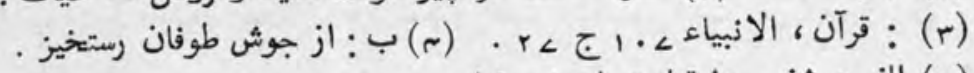

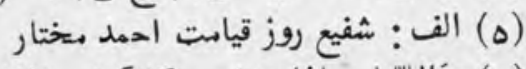

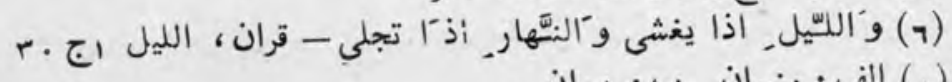

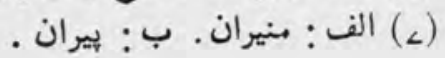




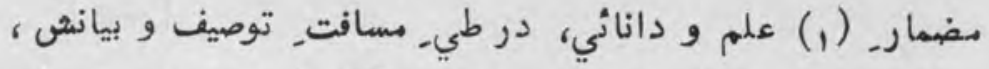

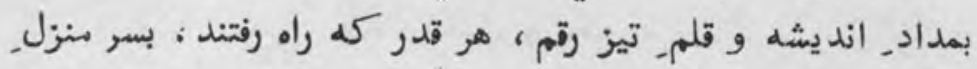

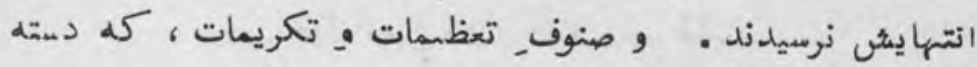

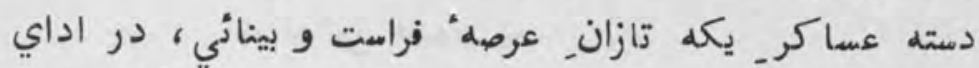

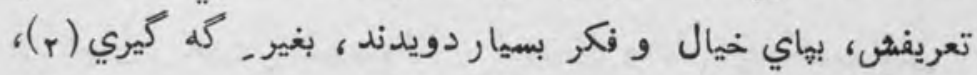

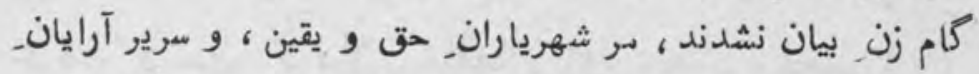

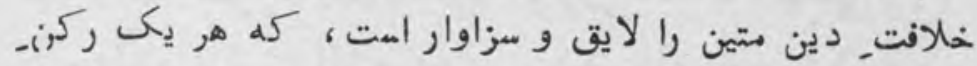

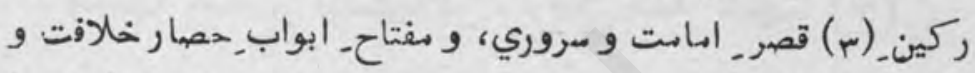

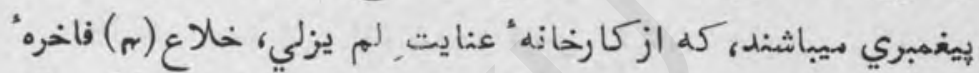

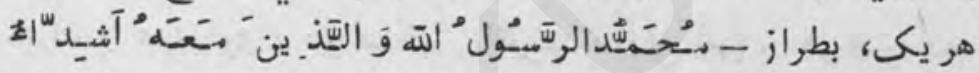

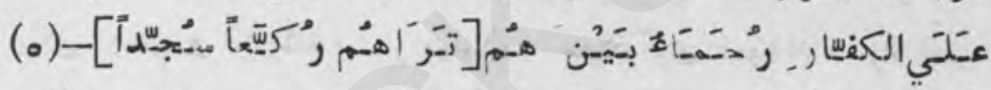

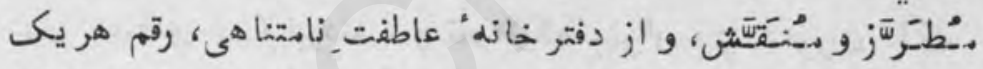

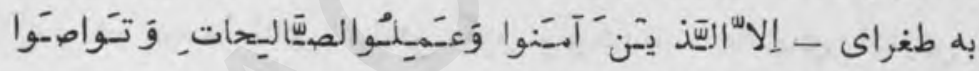

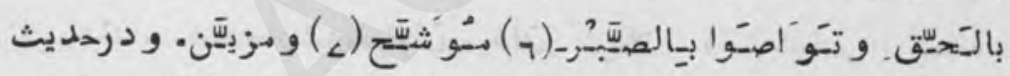

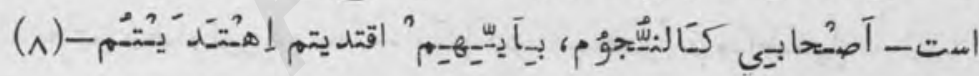

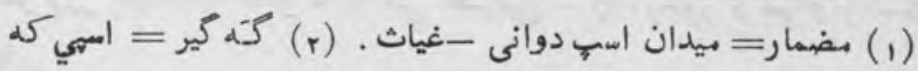

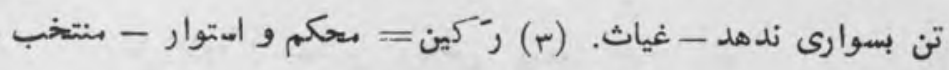

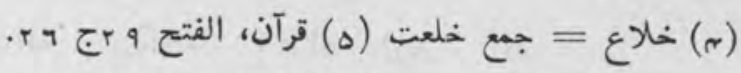

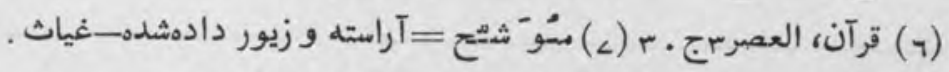
(ه) حديث صحيح است كه سعيد بن مسيب ازعمر رضه روايت و روزين

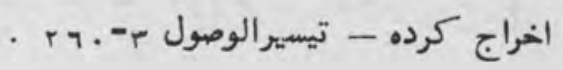




\section{[يت]}

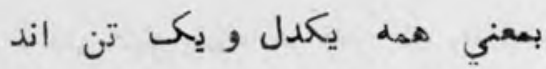

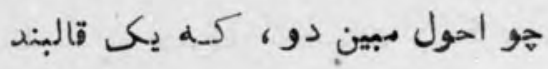

رضوان اله تعالئل عليهم اجمعين.

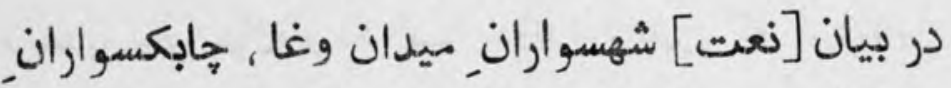

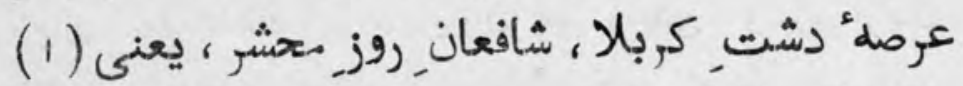

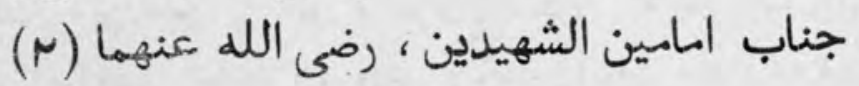

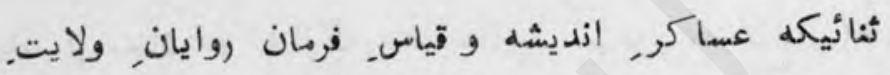

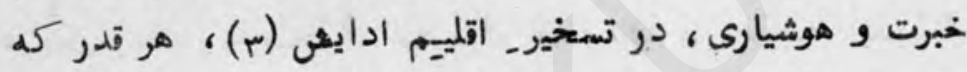

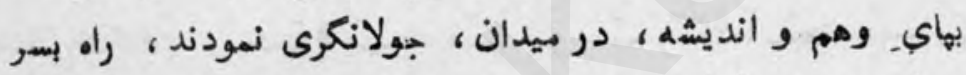

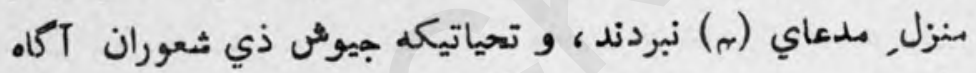

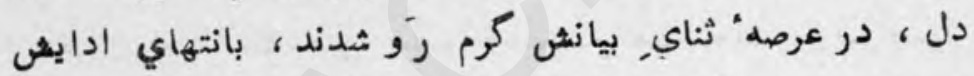

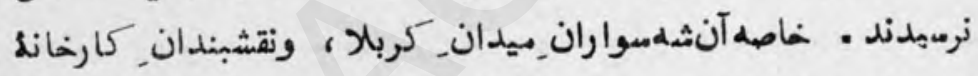

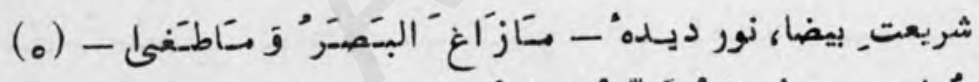

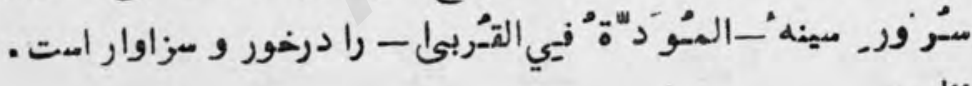

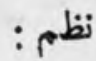

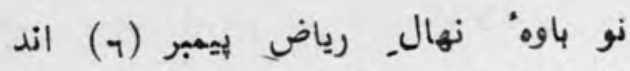

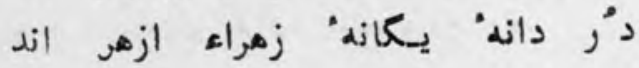

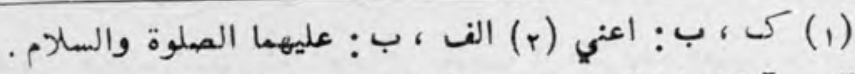

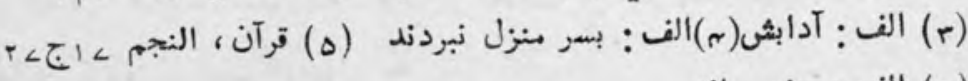

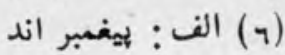




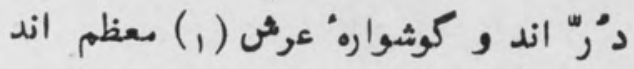

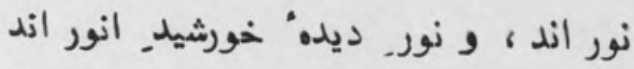

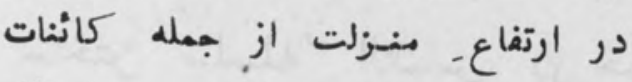

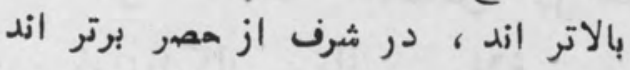

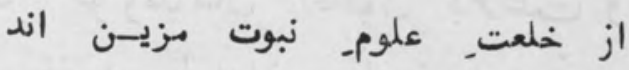

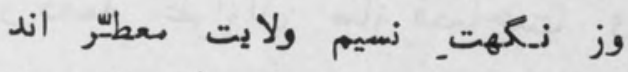

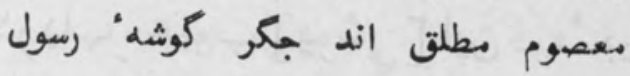

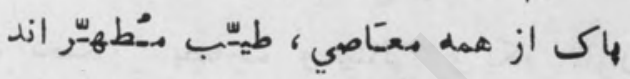

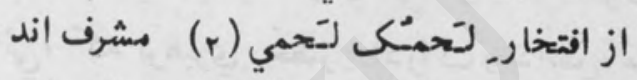

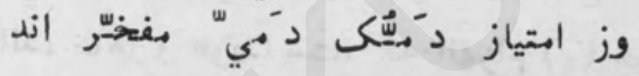

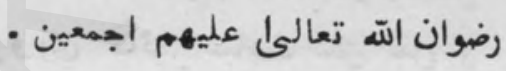

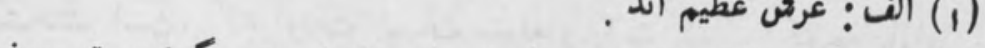

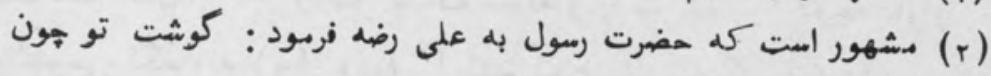

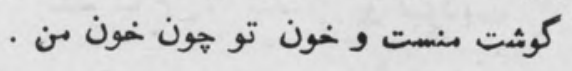


تتحرك ساختن سلسلهء التهاس، در خدمت

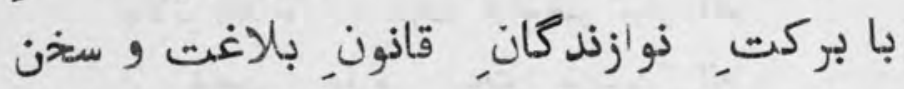
بروري، و نغهه طرازان ساز فصاحت و ونكته

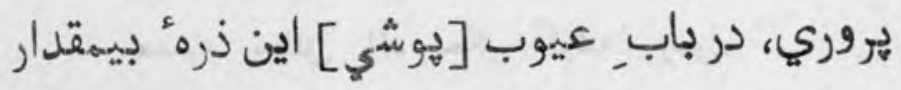

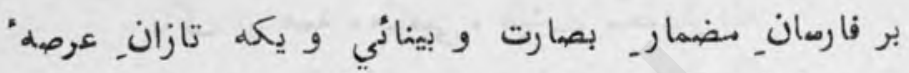

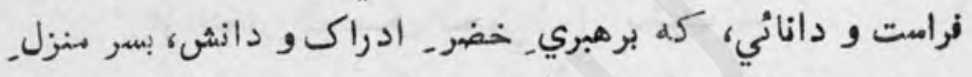

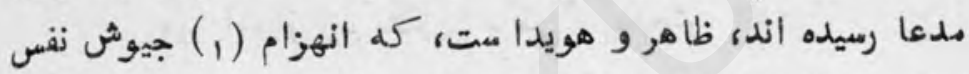

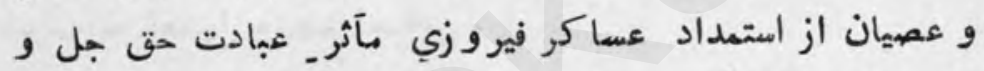

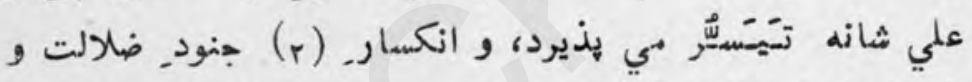

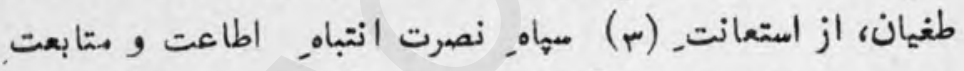

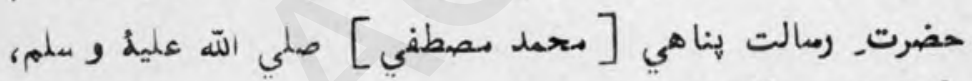

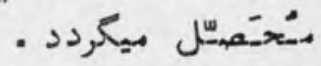

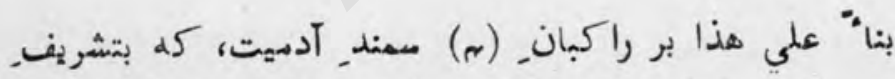

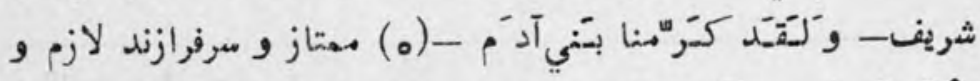

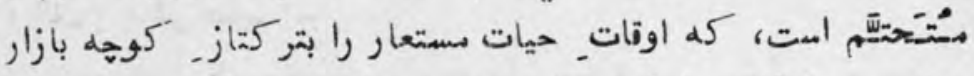

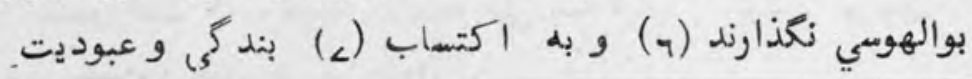

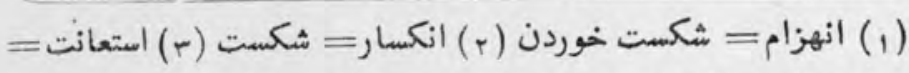

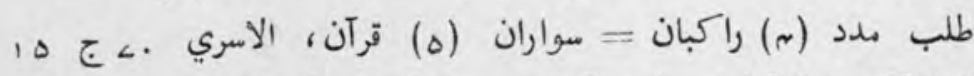

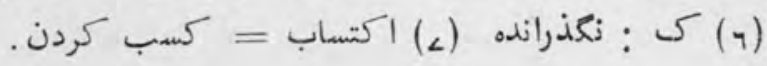


حق سبحانه و تعالى [جل ] شانه و عمََّ نواله، و متابعتـ

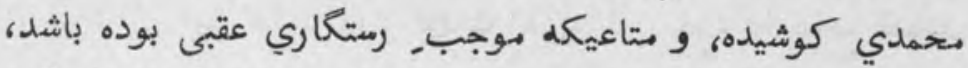

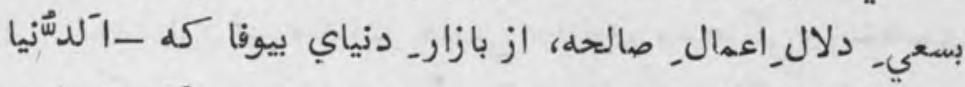

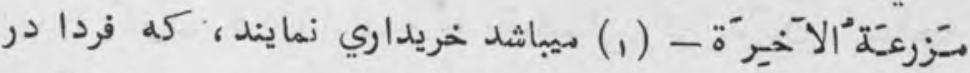

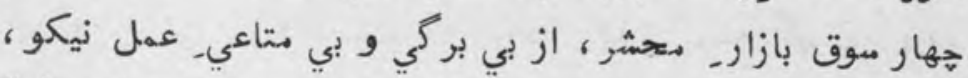

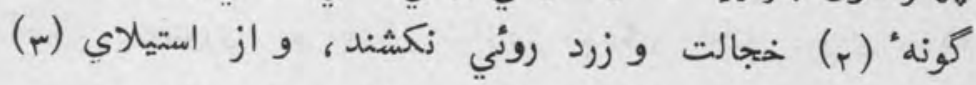

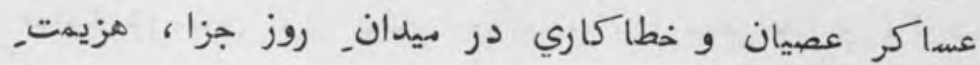

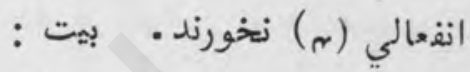

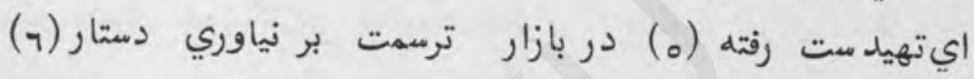

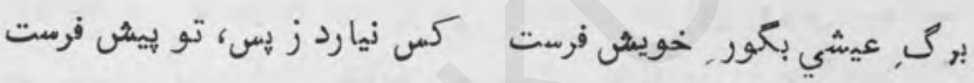

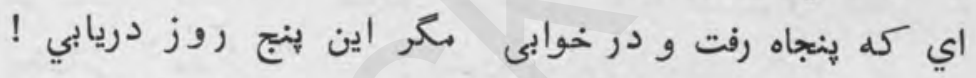

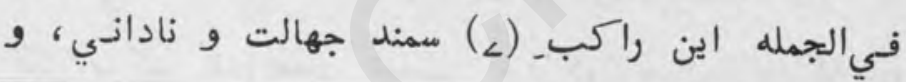

(1) حديثى است كه د ركتب صحاح نيامده، و فقط الديلمى در مسند الفردوس آنرا روايت كرده، و معلوبست وثوقي ندارد. ـ ـ كنوزالحقايق

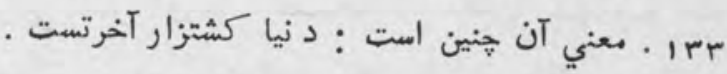
(r) كونه = سفوف مالش روي (r) استيلX

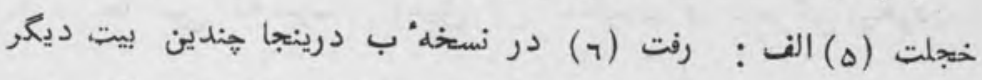

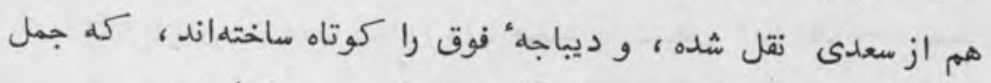

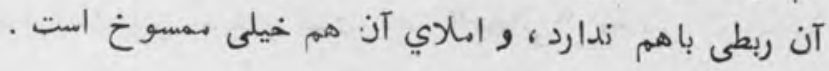

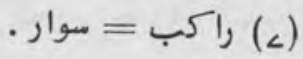




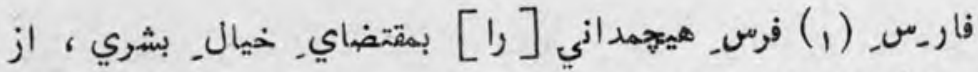
از تركتاز, اين داستانها ، اوقات عزيز تر ـ خود راض ضايع نمودن و از نغمه طرازي اين مقامات_خارجي ، قانون مستخركي و ريشيخندي

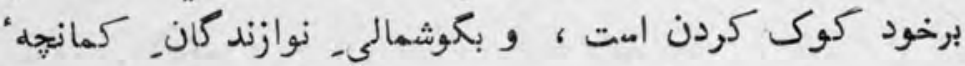

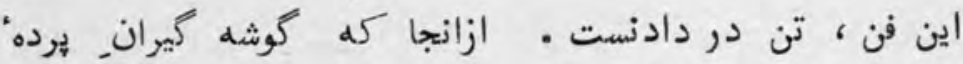

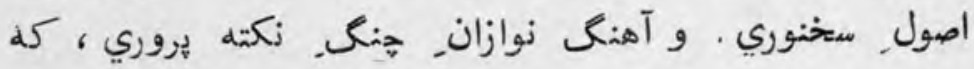
هميشه در مقامر هيرده جيوشى متخالف زوايان سخن طراني ، ثابت

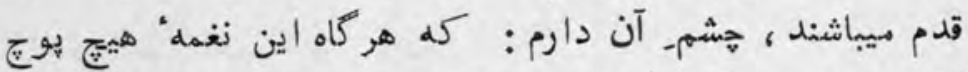

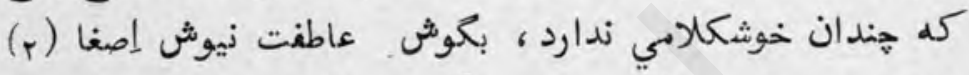

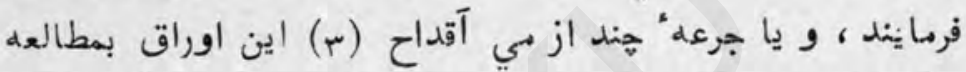

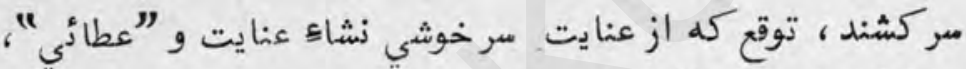

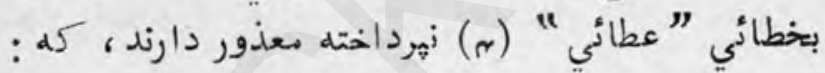
فكر هركس بقدر همت اوست و ازكوزه همان تراود كله د رو ست

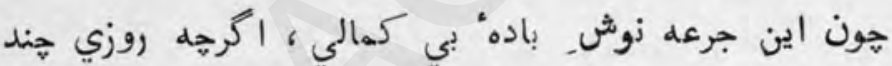

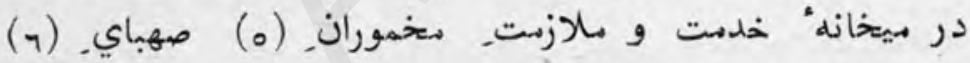
رياست و حكمسراني بسر آورده ، خصوصاً در ملكى شكاريو در درال

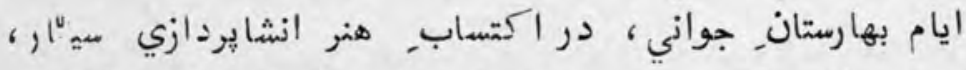
و هر حا كمي كل سرشار, رحيق_ (2) حكوم.ت و كامراني ميكرديد،

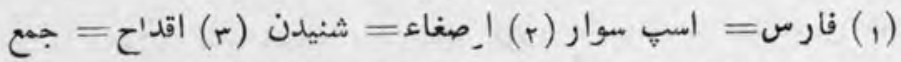

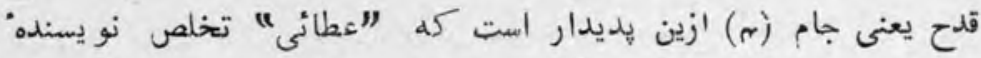

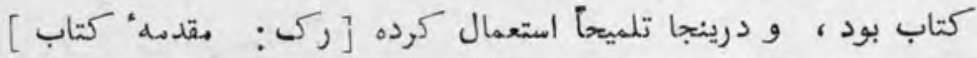

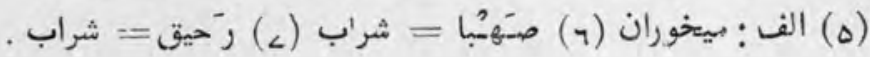




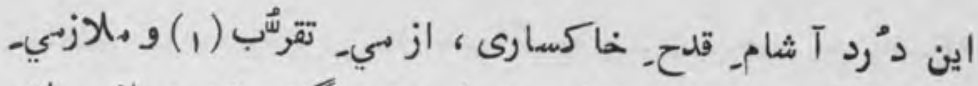

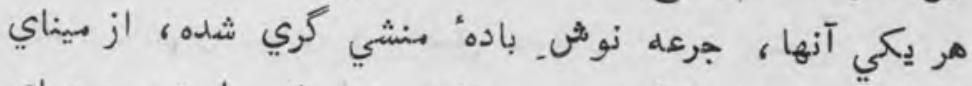

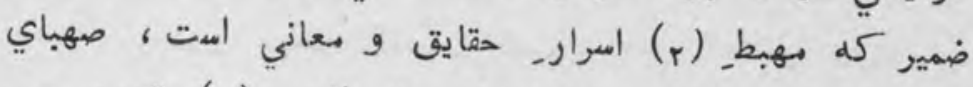

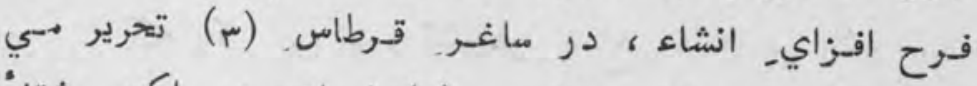

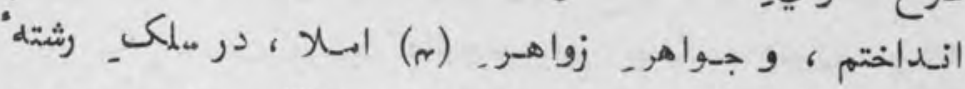

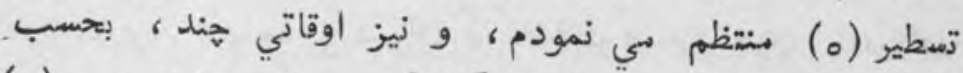

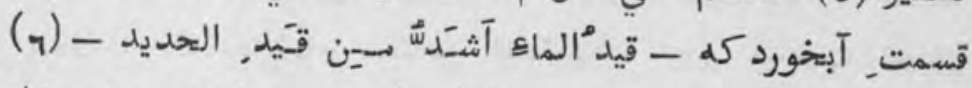

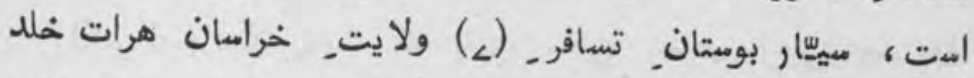
آيات و قندهار و كابل و هشاور كرديده ، بعضي تسويدات

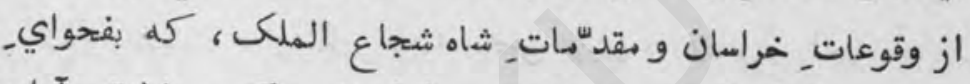

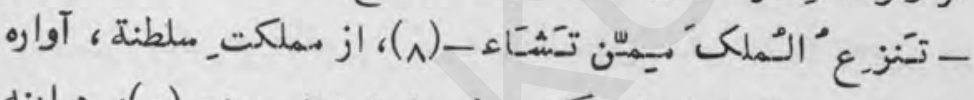

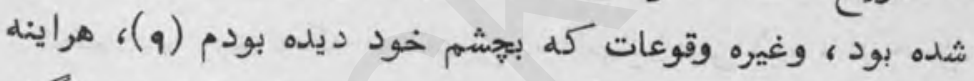

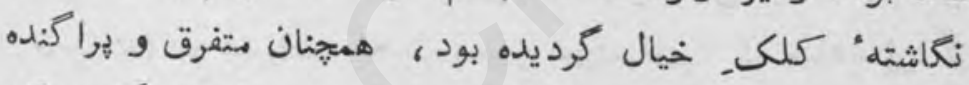

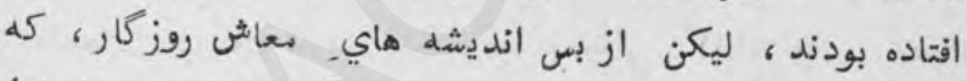

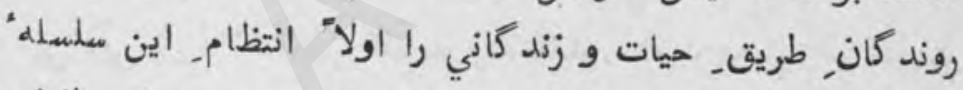

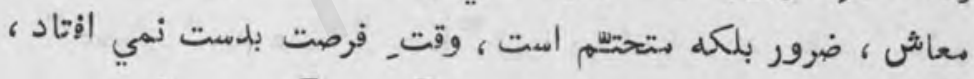

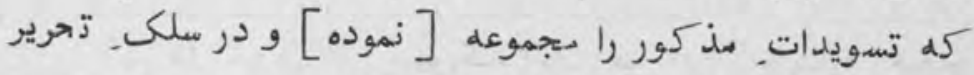

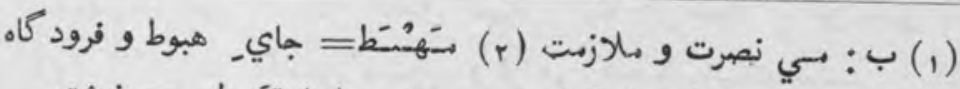

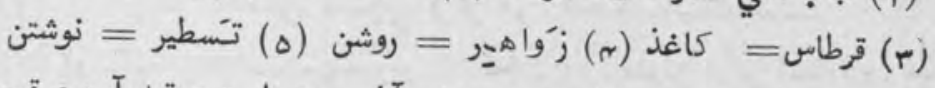

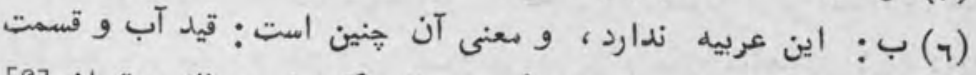

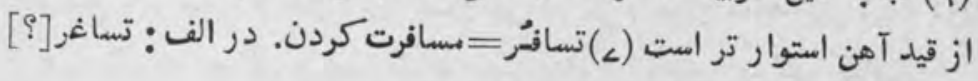

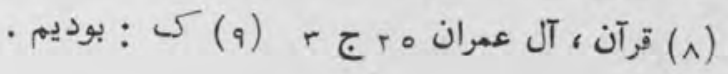


منتظم نموده شود ، دروحال هم اكرحه حمدان دلجمعي و معشوقه" رفاه هم آغوث نبوده، و بر طبق مضمون : [بيت

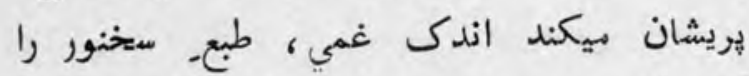

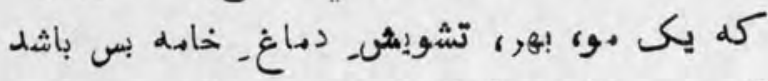

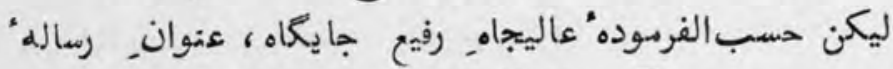
دانشوري ، ديباجه [ديوان] العظام6 نادرةالايام جناب ايسمويكى (1) صاحب بهادر،

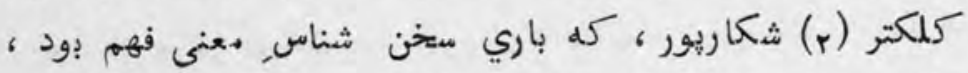

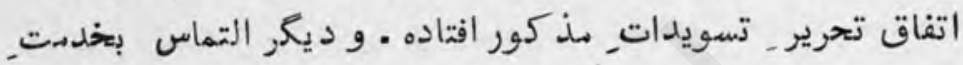

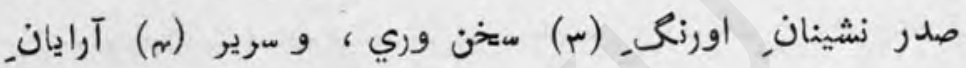

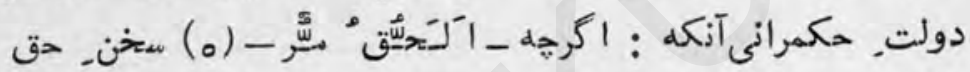
تلخست ، باوجوديكة از اظهار, مطلبـ نقس الامر ، از حسن و

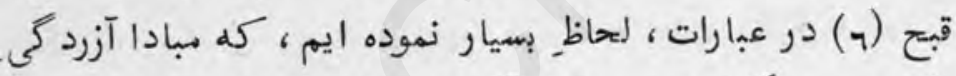
طبيعت_ بزركان شود ، الها اكر در جائي كدام نوايـ مخالف

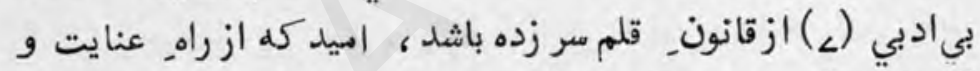

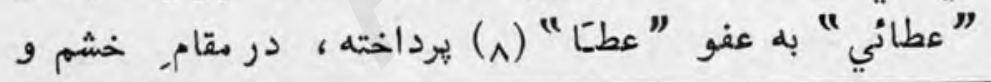

(1) در الف و كى : اسيويك، است. ب اين نام ندارد . صحيح آن اسن

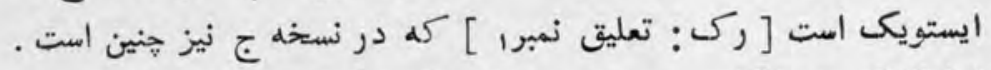

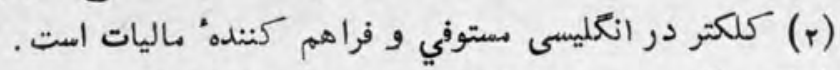

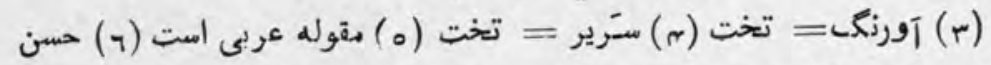

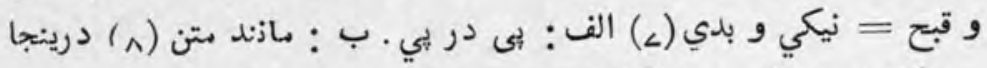

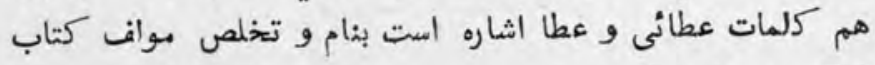
[ [ast : 5, ] 


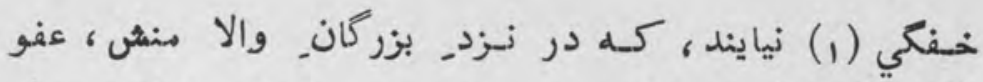

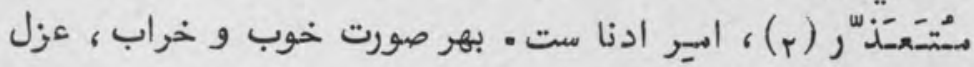

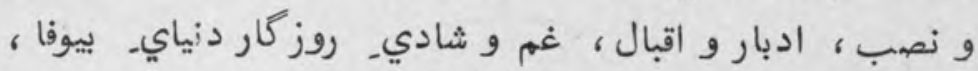

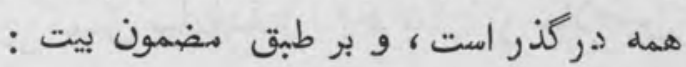
عالم همل مر مببز خيال است خميال

$$
\begin{aligned}
& \text { هر نوع (r) خيال اكر كني ميكذرد } \\
& \text { ] }
\end{aligned}
$$

تا نيست نكردي، وه, هستت ندهند

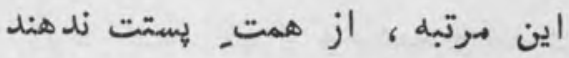

$$
\text { تا شمع (r) صفت بسوختن تن ندهي }
$$

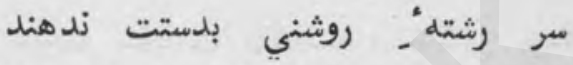

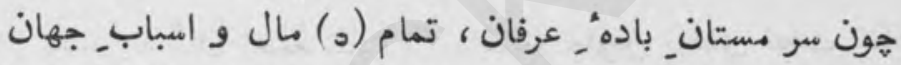

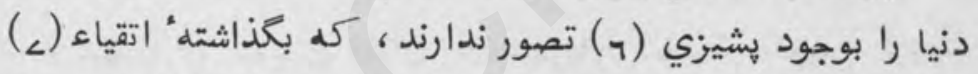

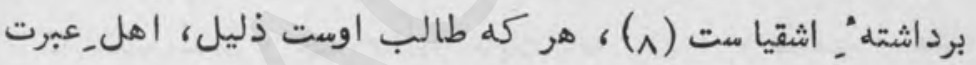

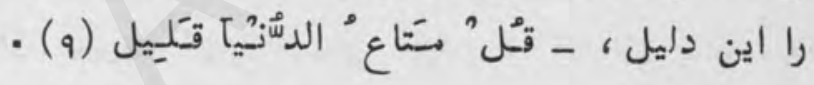

(1) خفكي = در فارسي و رِشتوي افغانستان بمعني آزردكي است .

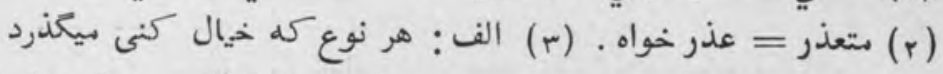

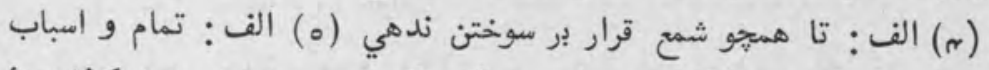

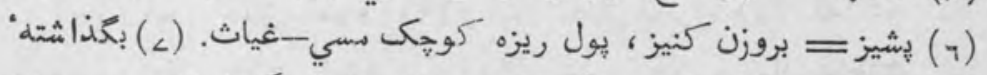

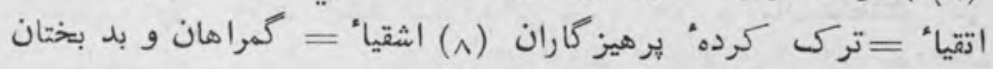

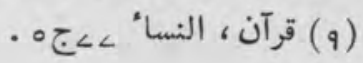




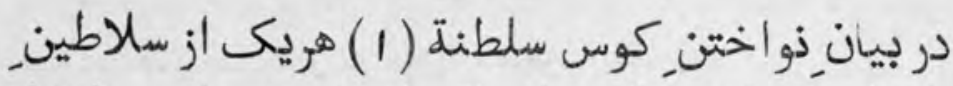

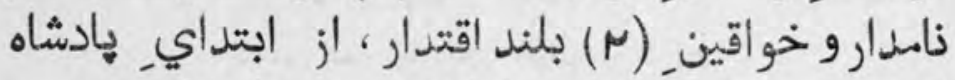

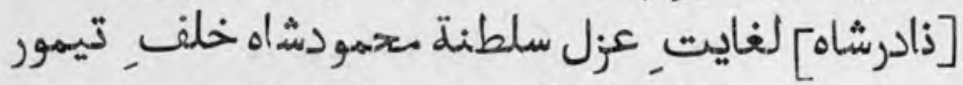
شاه عليدالرحمة و الغفران

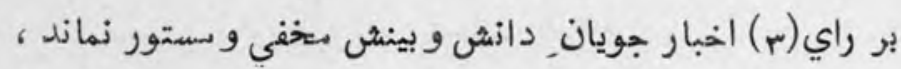

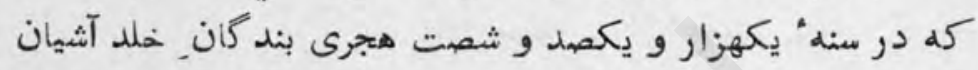

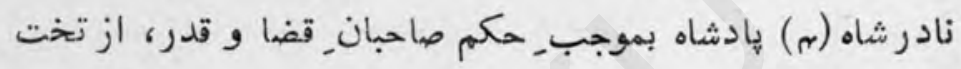

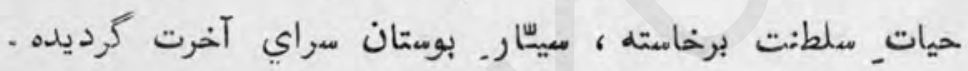

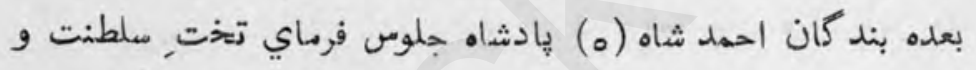

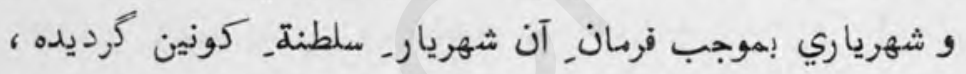

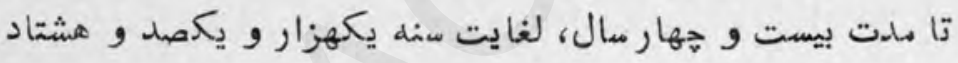

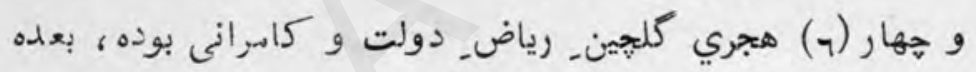

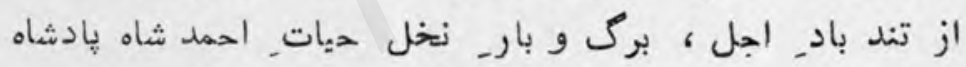

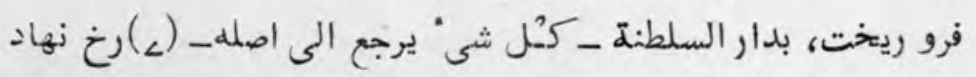

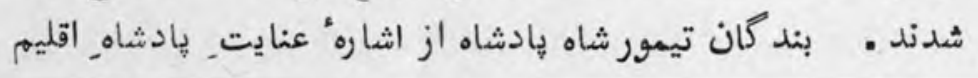

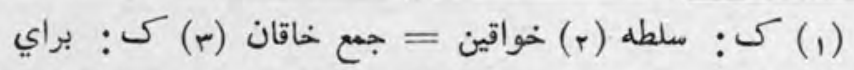

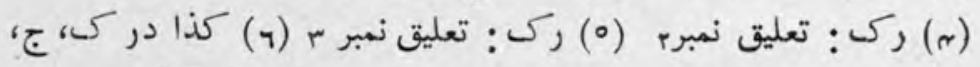

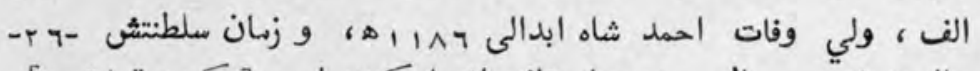

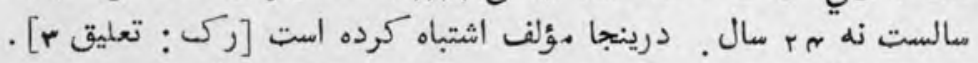

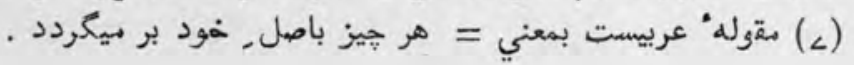




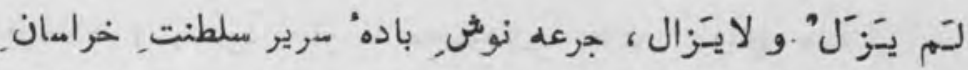

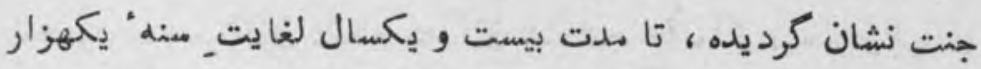

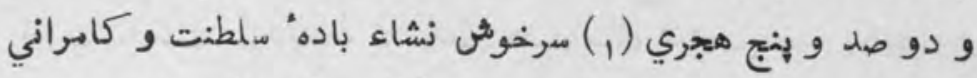

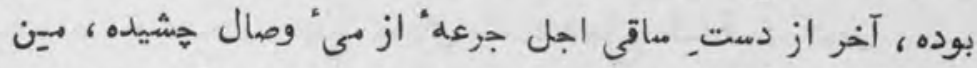

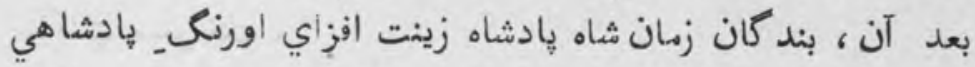

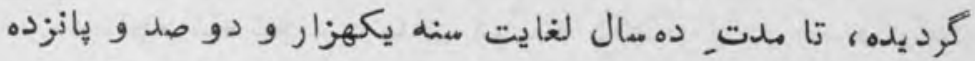

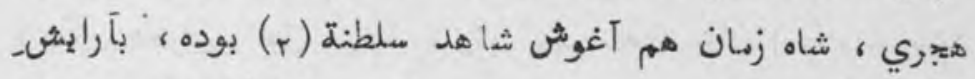

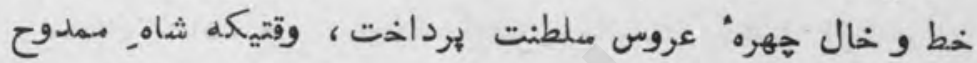

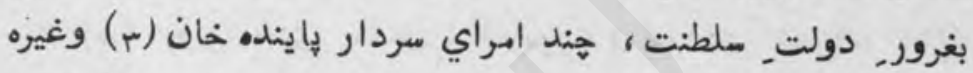

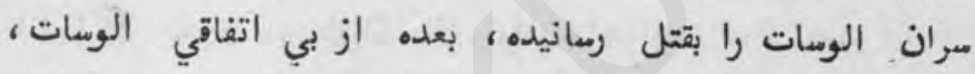

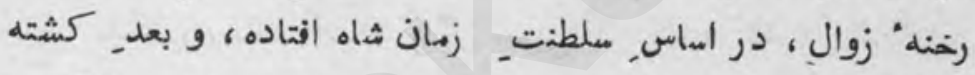

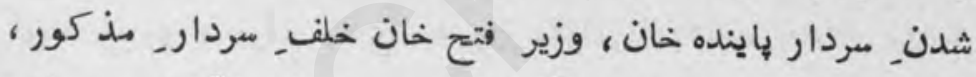

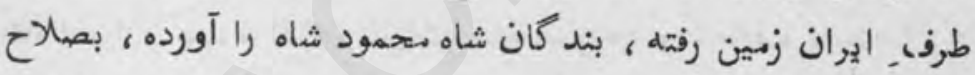

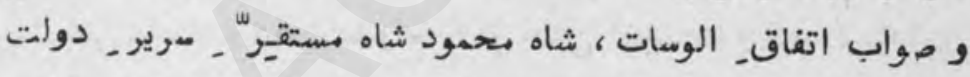

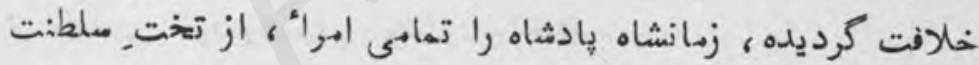

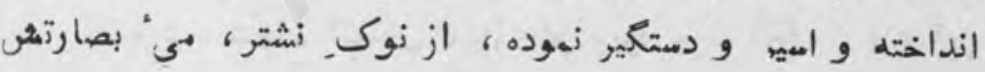

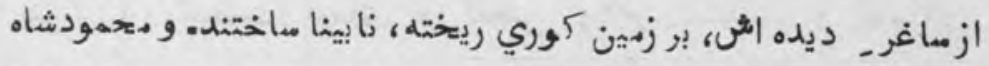

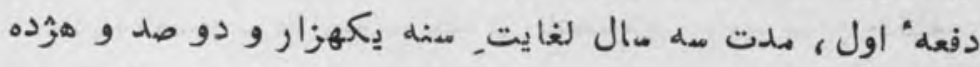

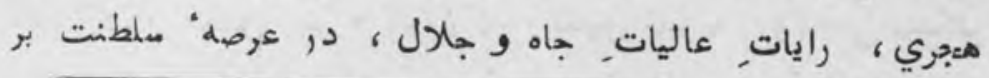
(1) كذا دركى، ج، الف . ولي ابن هم صحيع نيست ، تيمور شاه

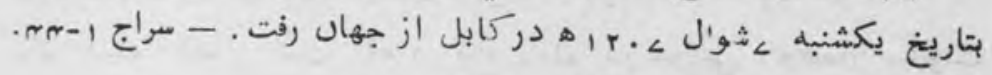

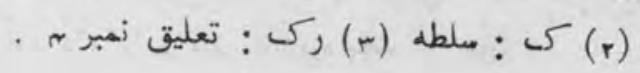




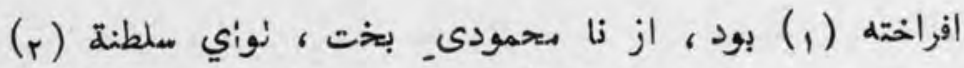

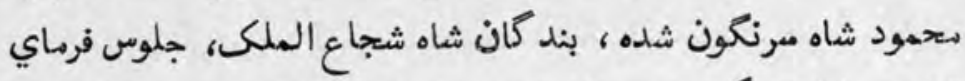

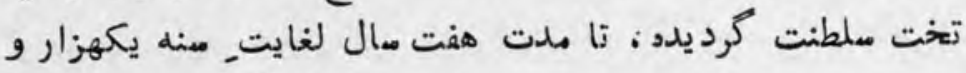

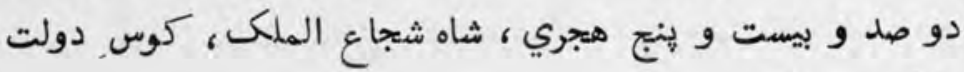

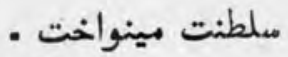
هنانجه شاه شجاع احته الملك در سنه يكهزار و دو صد و ييست

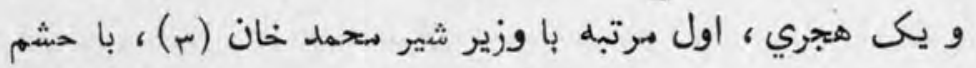

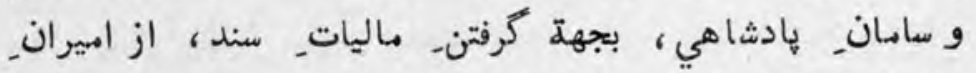

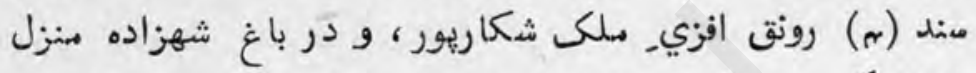

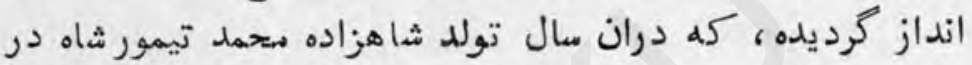

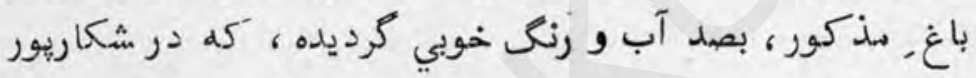

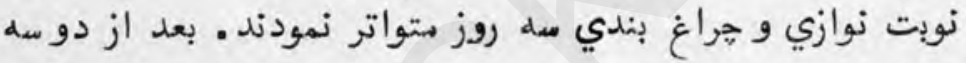

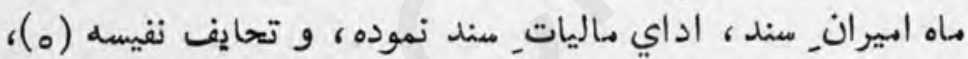

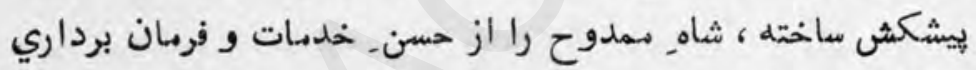
و اطاعت_ خود ، بسيار خوشنون ساختند .

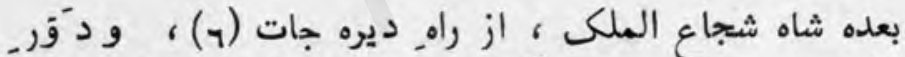

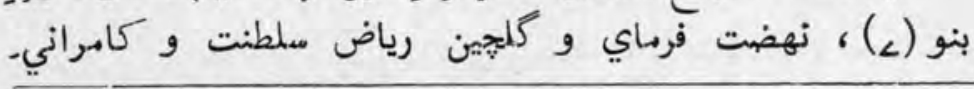

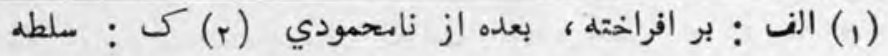

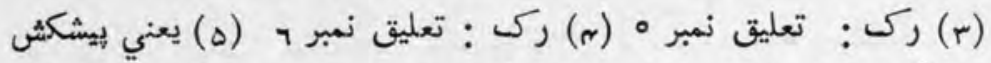

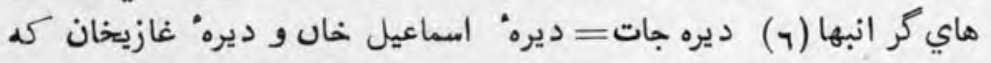

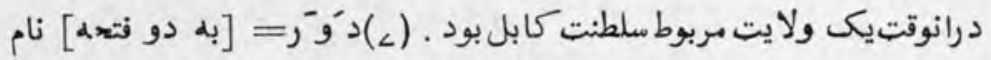

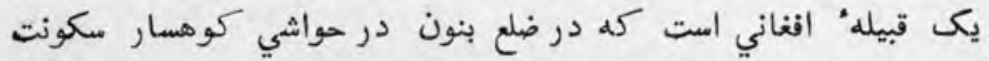

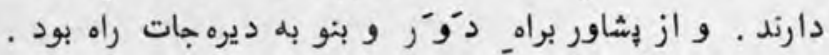


كابل كرديده، تا مدت حهار مسال ، در كابل سرخوثى باده"

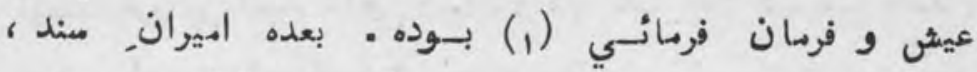

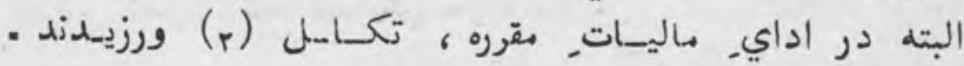

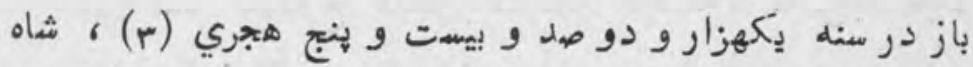

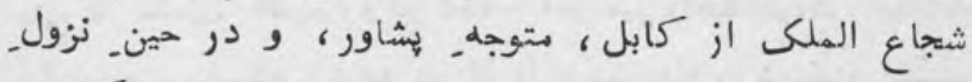

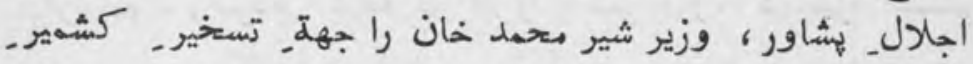

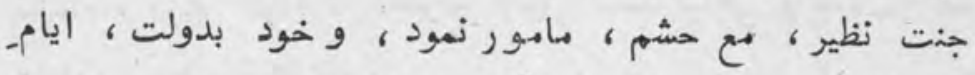

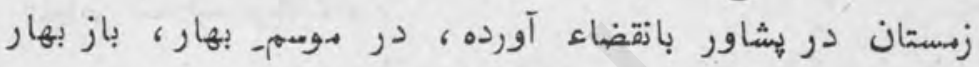

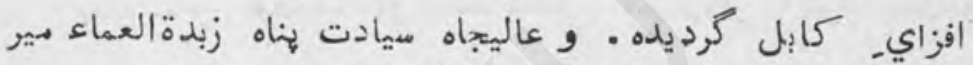

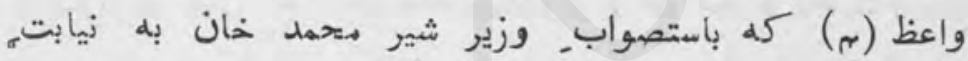

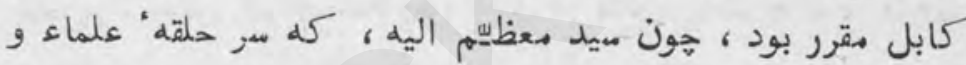

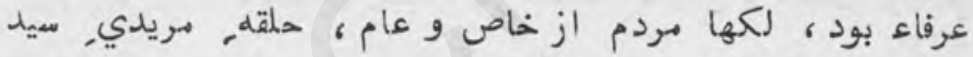

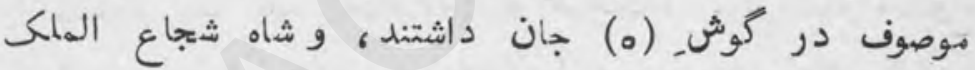

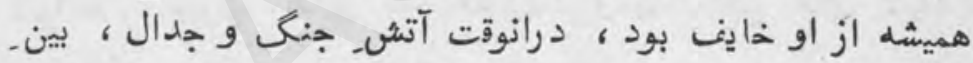

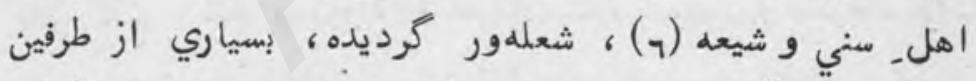

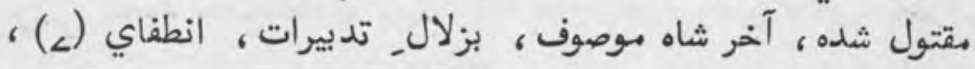
(1) الف: و فردان بوده. . (r) تكاسل = خود را كاهل و سست وا نمودن -غياث. (r) مورخان افغاني اين سفر شاه شجاع و كماشتن

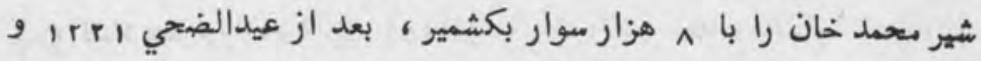

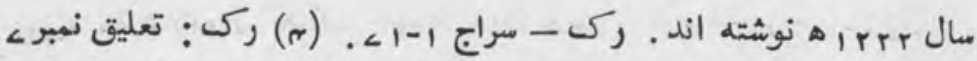

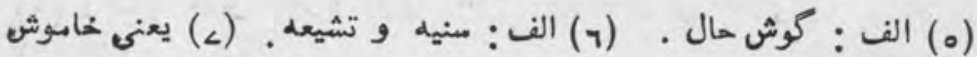
كردن شعله هاي جنك . كوش حال. 


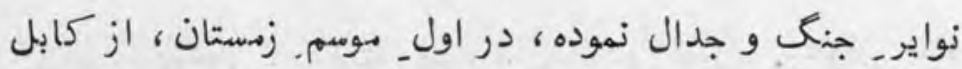

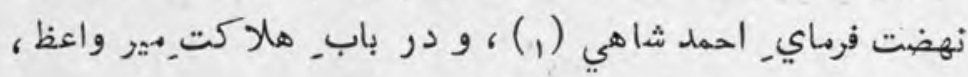

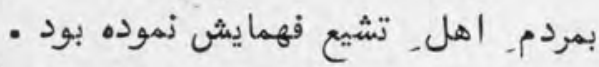

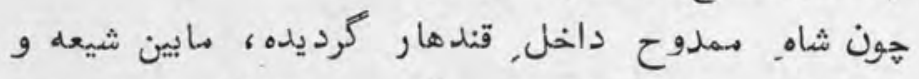

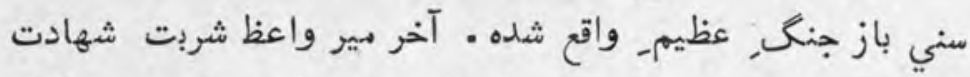

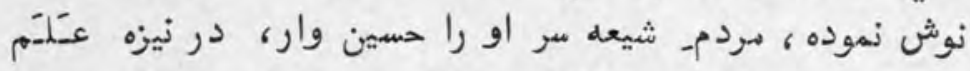

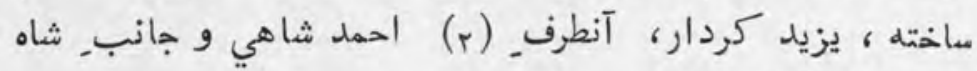

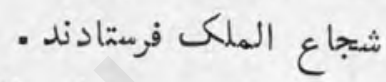

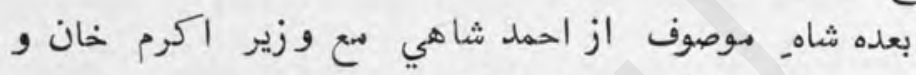

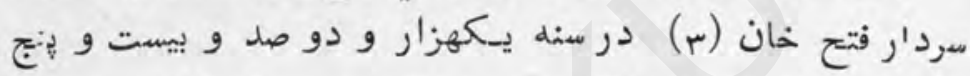

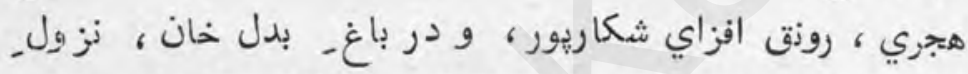

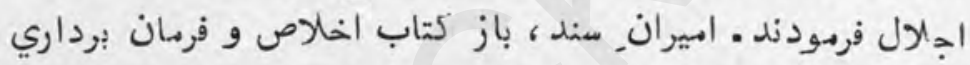

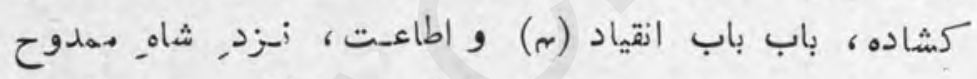

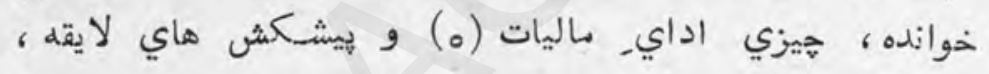

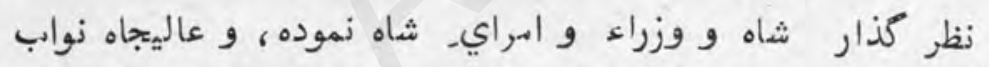

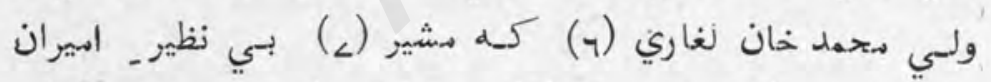

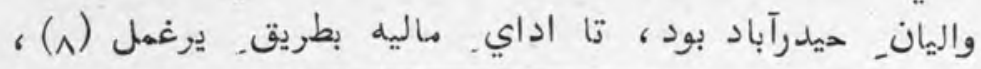

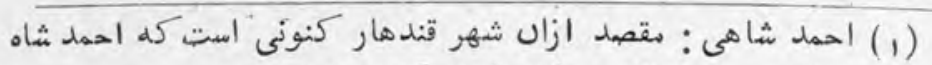

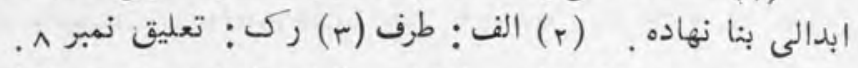

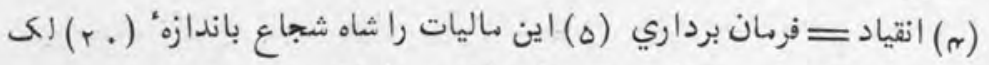

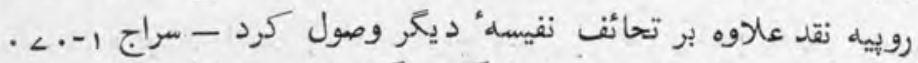

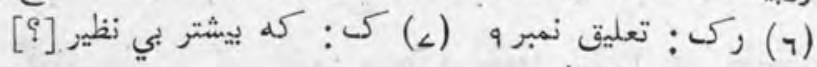

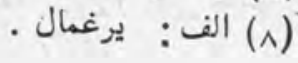


بركاب_ بادشاه تا ديره: غازي خان حاضر بود ، و نوابـ مذكور

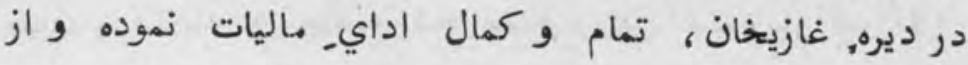

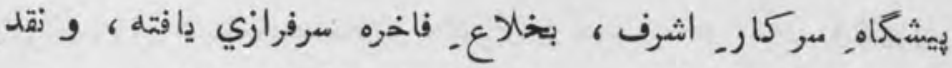

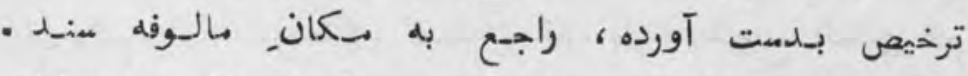

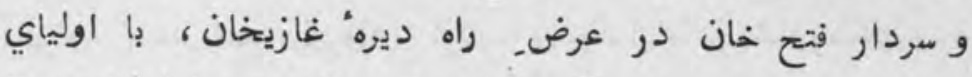

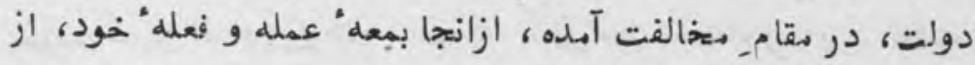

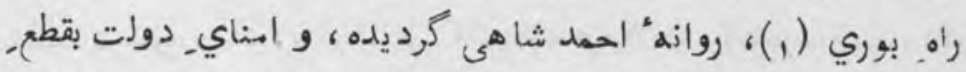

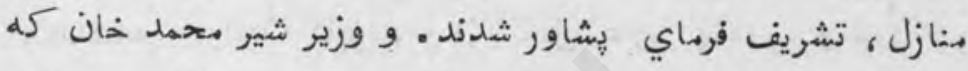

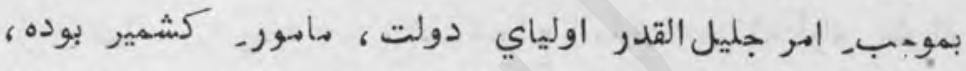

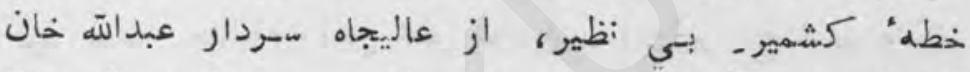

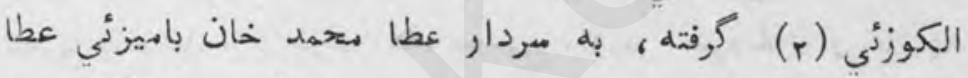

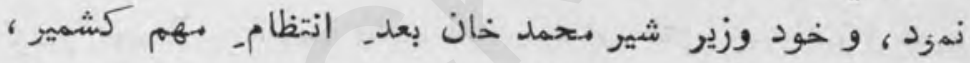

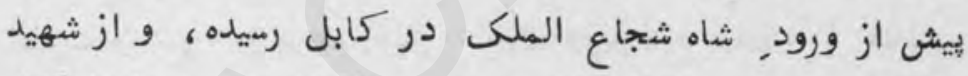

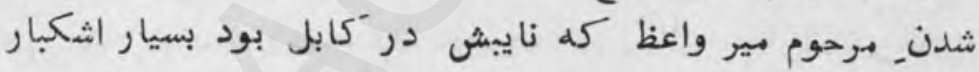

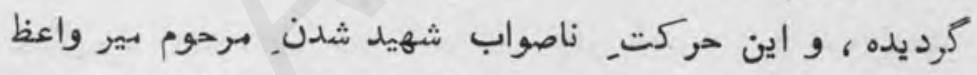

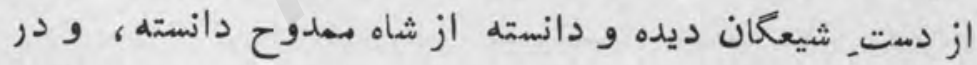

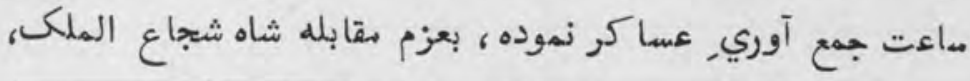

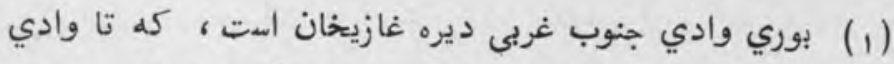

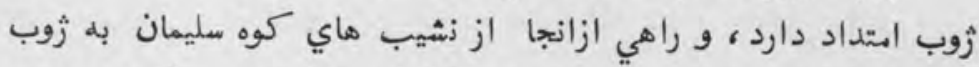

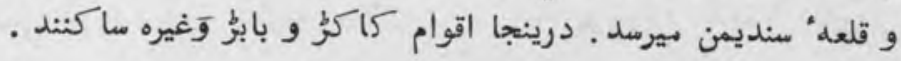

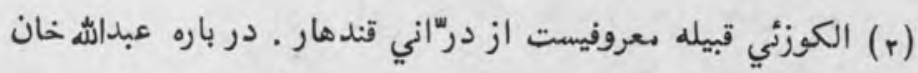
و عطا بحمد خان ركى: تعليق نمبر .1 ال . 
تازه نواي بعارك

rr

از كابل روانه" بشاور، ود در مقام تهكال (1) [تعلقه] بهشاور رسيده، بمقابله و مجادله" شاه مددوح رداخت. از قضاء قادر لايزال ، وزير شير دحمد خان و برادرش وخوجه متحمد خان وشهنواز

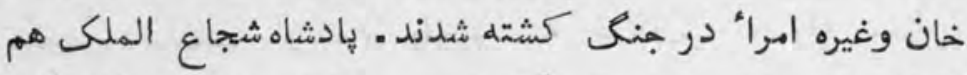

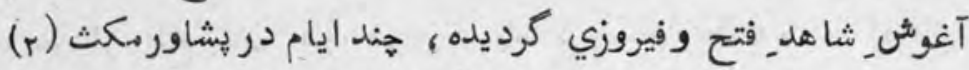

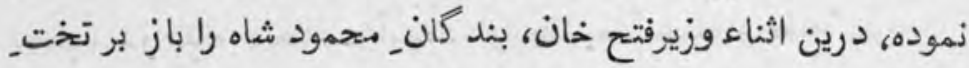

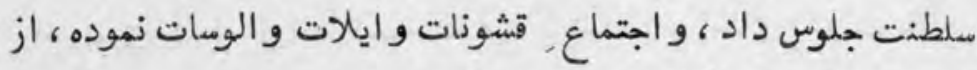

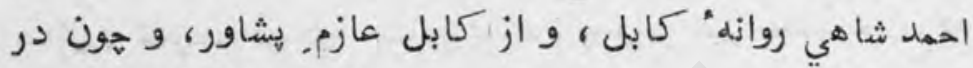

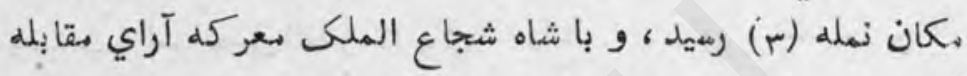

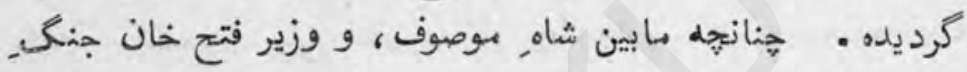
عظيم واقع شه ، از طرف شاه همدوح ، وزير اكرم خان و عاليجاه

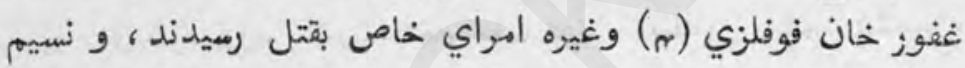

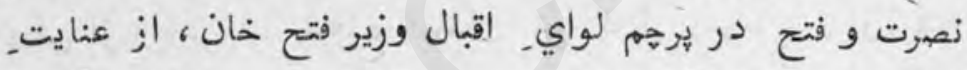

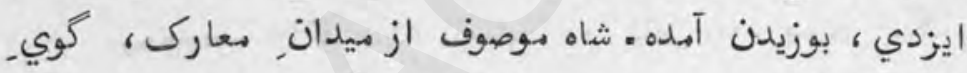

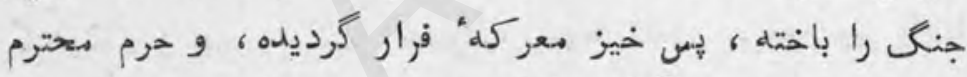

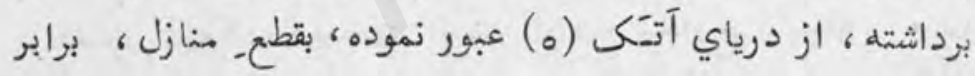

(1) تهركال : در غرب هشاور بفاصله دو ميل واقع و مسيكن اقوام

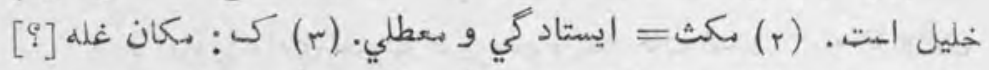

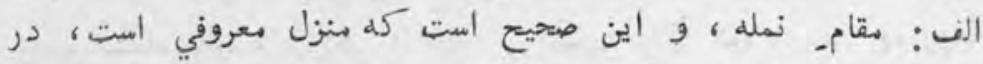

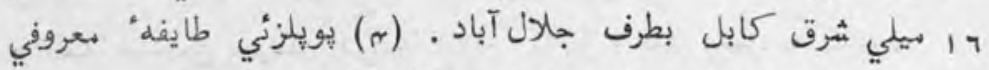

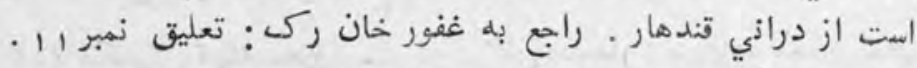

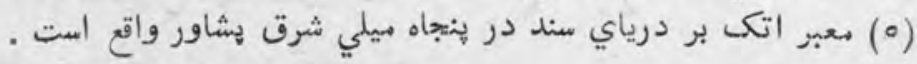


متوجه لاهور كرديده، بيش- خالصه منكه (1) ، ملججاي. خود

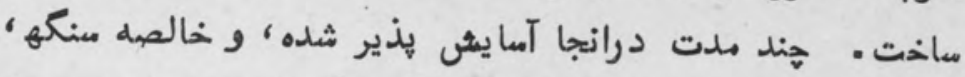
در تعارف و تلافي ، از هر قسم و رمسم ك از شاهـ مهدوح خود را

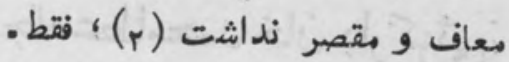

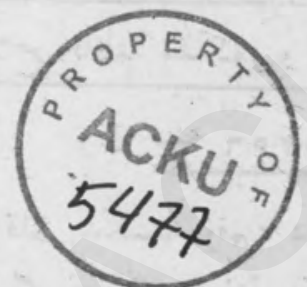

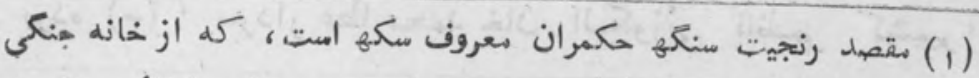
ملطنت افغانى امتفاده نموده و در هنجابحكومت مستقلى را تأسيس نمود.

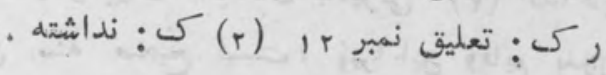




\section{$-r-$}

در جيان كشته شدن عاليجاه عطامتهم خان باركزئي،

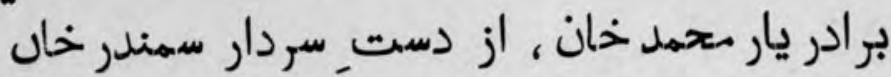

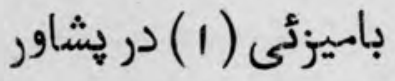

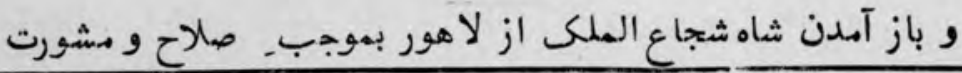

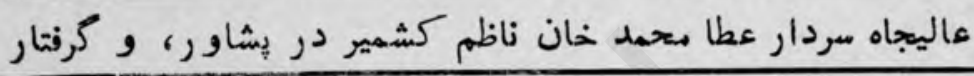
شدن_ شاه در بشاور بدست سردار سمندر خان و جهان داد خان، از قرار صلاح ناظم مذكور و محبوس شدن شاه در كشمير

$$
\text { (r) D D r r o }
$$

شاهينـ قلم, شكسته رقم، در فضاي_ اين مدعا ، هنين بال

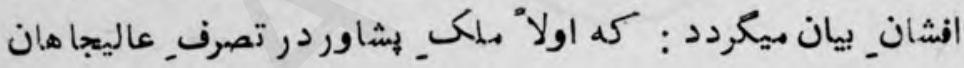

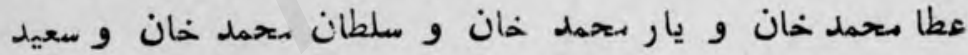

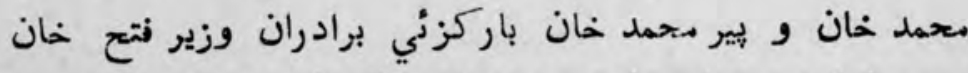

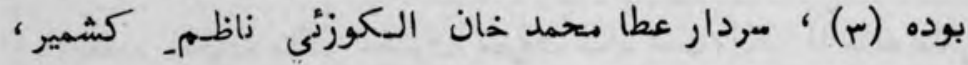

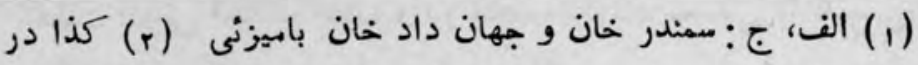

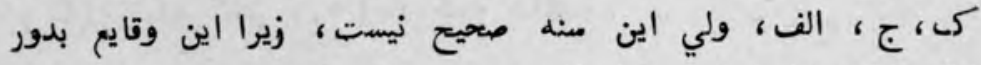

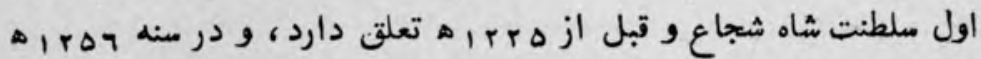

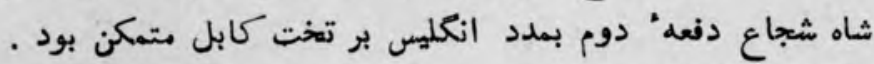

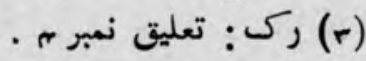


ro

تازه نواي معاركى

عاليجا هان سردار سمندر خان [.و] جانداد خان باميزئي را از

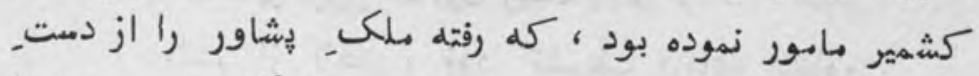

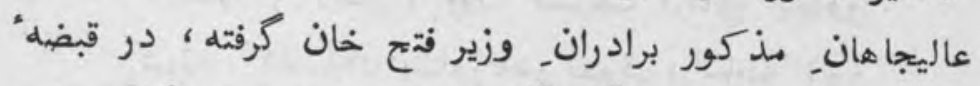

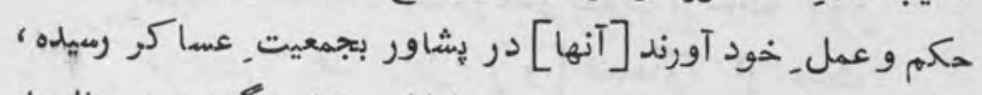

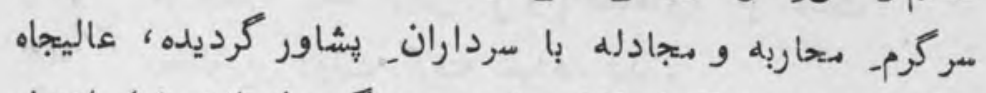

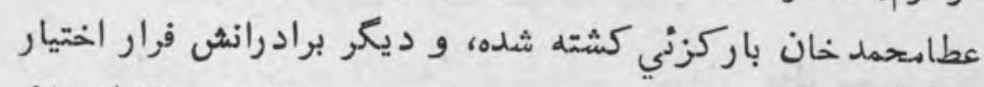

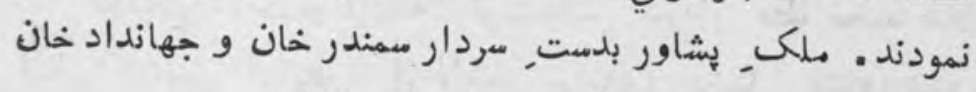

افتاده، جرعه نوش, باده" فتح و فيروزي شدند .

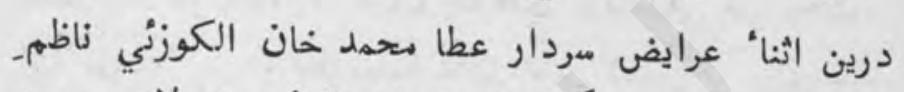

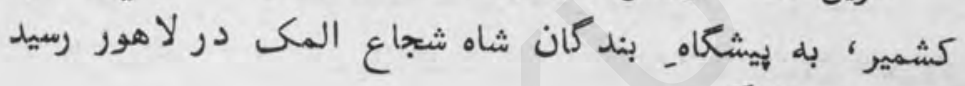

بدين مضمون كمير كله

هميشه رايات (1) عاليات شهرياري_ اوليايـ.

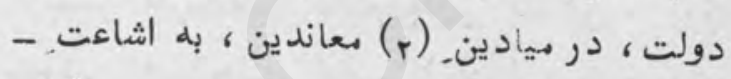

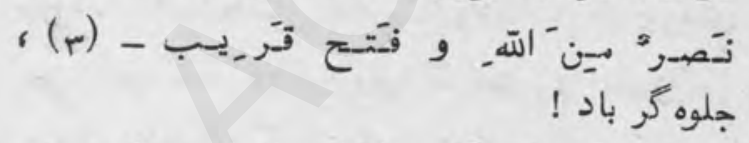

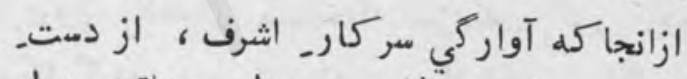

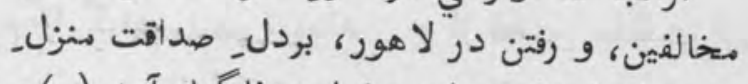

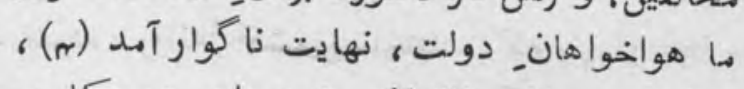

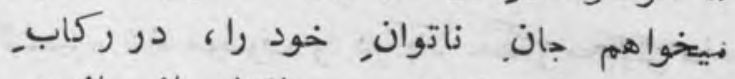

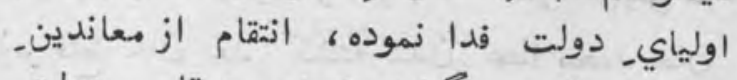

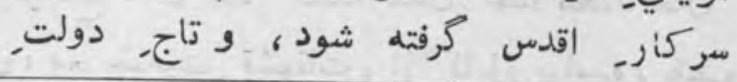

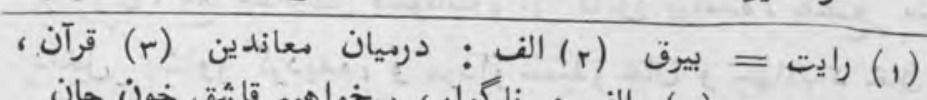

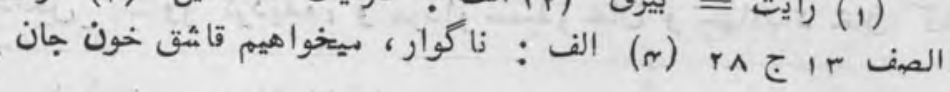


كازه نواي معارك

ry

مـلطنت بر فرق_ همايون زينت هيذير كردد ، امناي دولت از لاهور، زود تشريف فرماي ريشاور

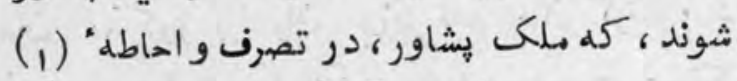

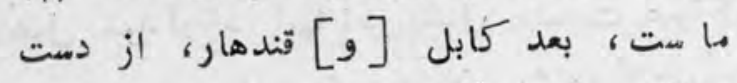

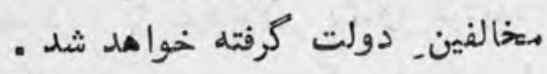

اولياي دولت، فريفته" نوشتجات, مردار عطا بهمد خان

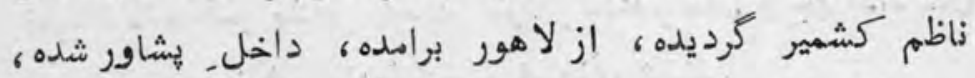

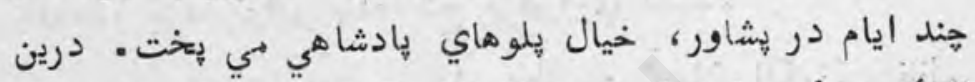

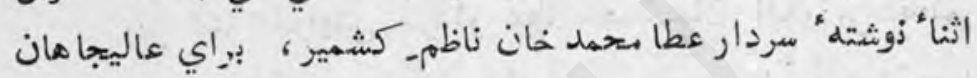

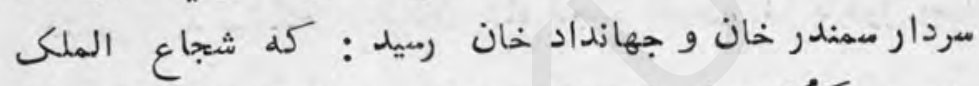

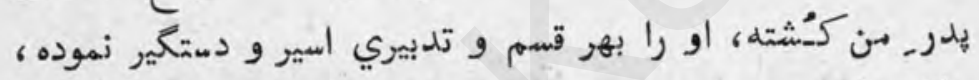

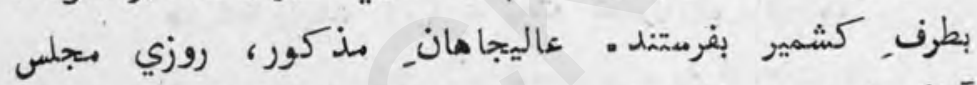

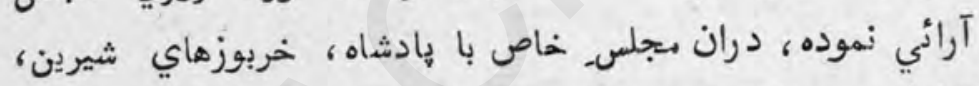

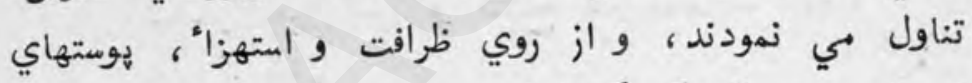

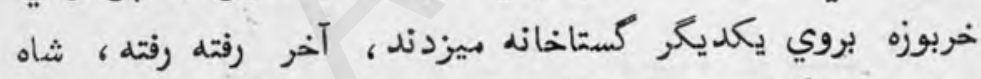
همدوح را كرفته اسير نمودند، ، و از تختـ سلطنت فرو آورده و

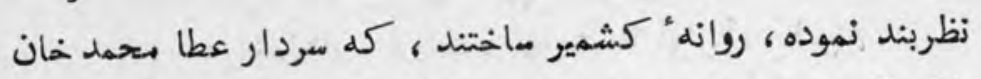

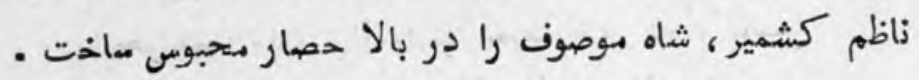

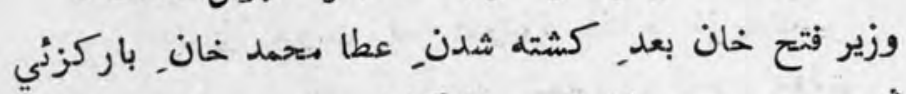

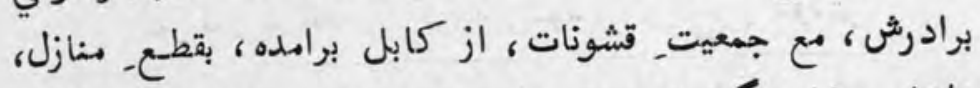

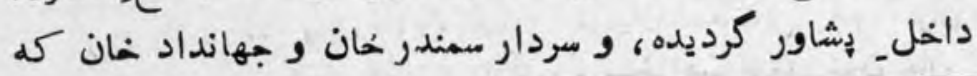

(1) الف : و احتياط ما ست . 
$r<$

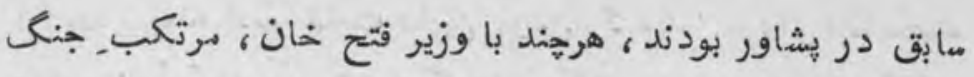

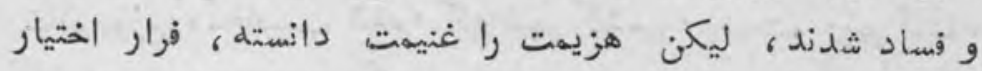

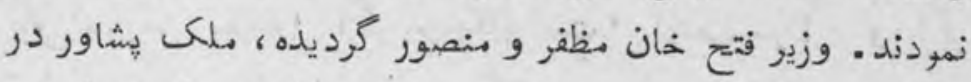

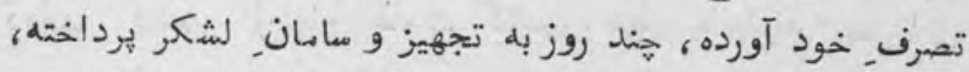

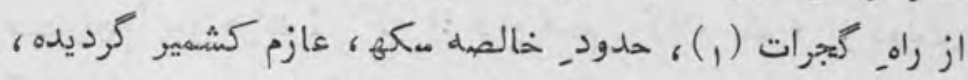

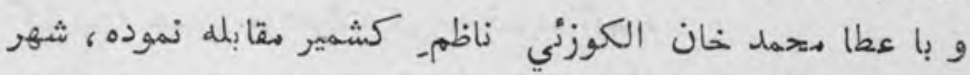

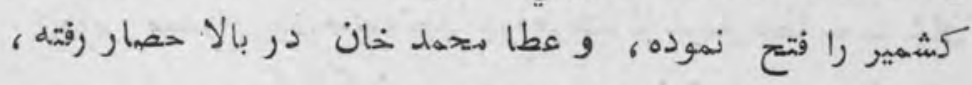

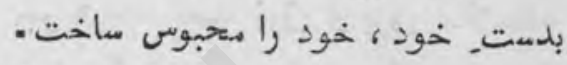

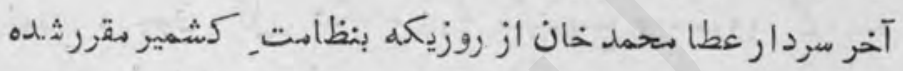

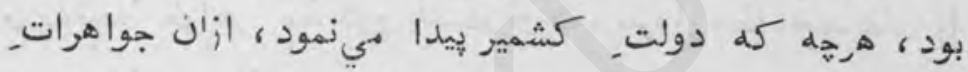

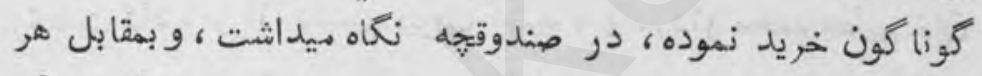

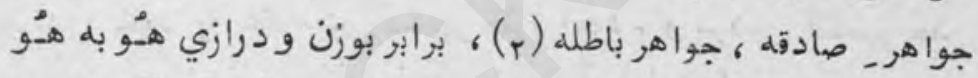

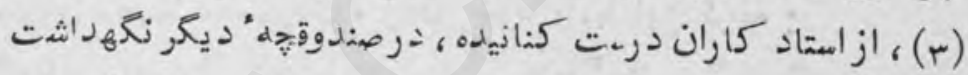

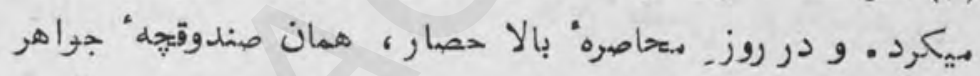

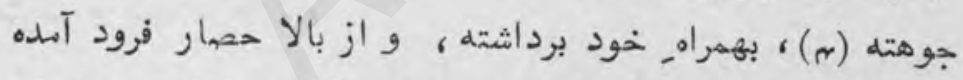

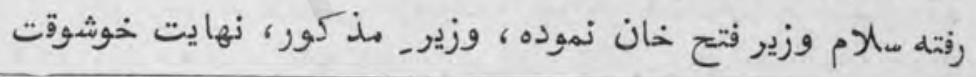

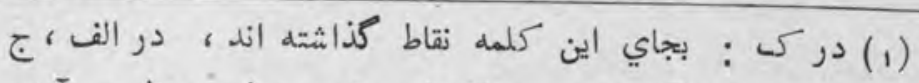

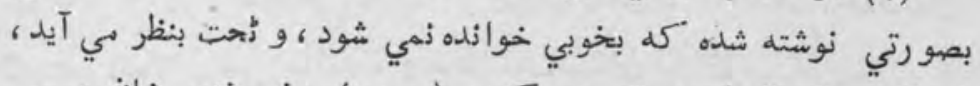

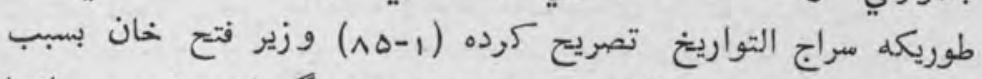

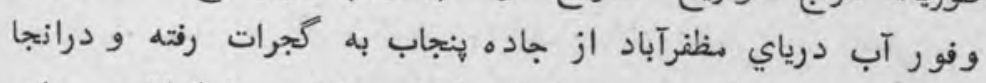

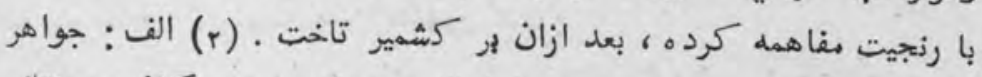

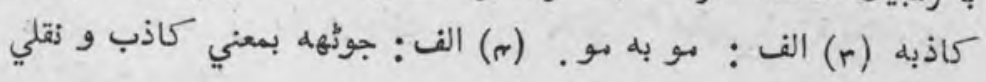
كلماله" هند بست 
كازه نواي دعارك

rA

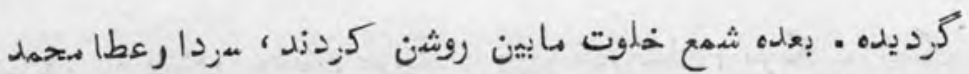

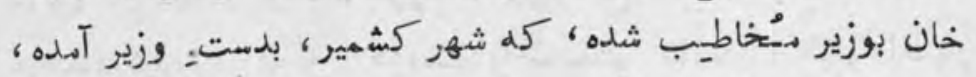

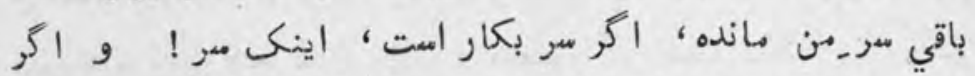

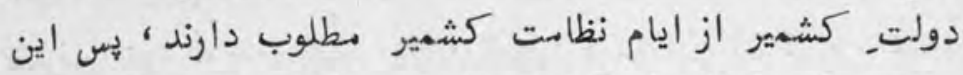

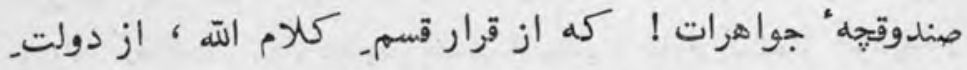

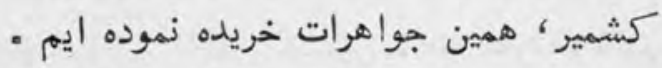

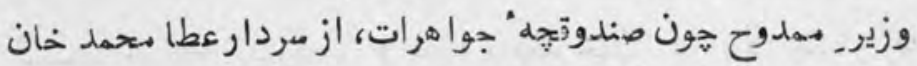
كرفته كشاده ، كوناكون جواهرات بصد زرق و و برق ملاحظه

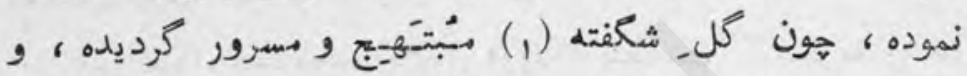

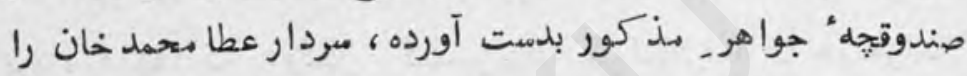
رخصت داد ، و از كشمير بيرون كشيد ، و مردار محمد عظيهم خان

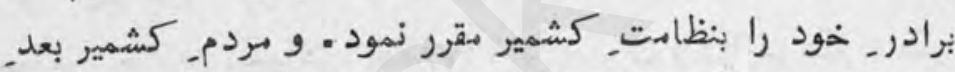

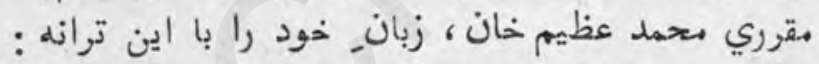

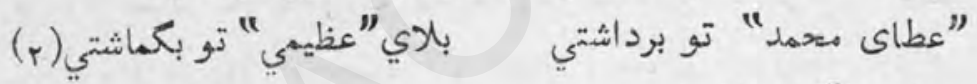

مترنم و آشنا ماختمند

روز_ دوم ، وزير موصوف ، جواهر ثشناسان را طلبانيدهـ،

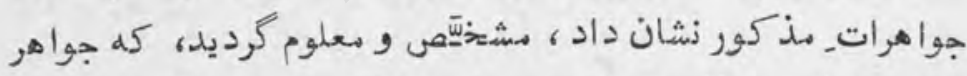

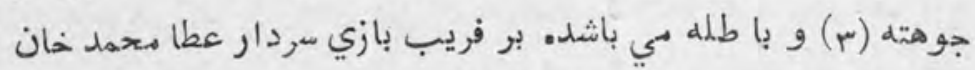

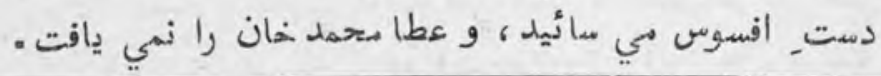

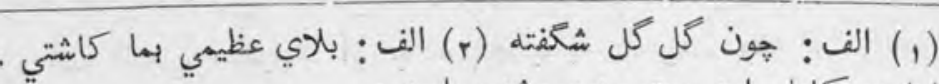

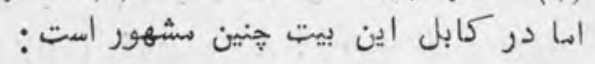

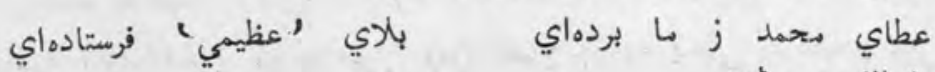

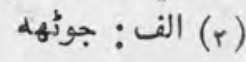


$+9$

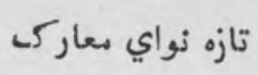

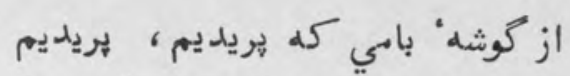

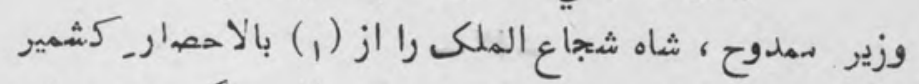

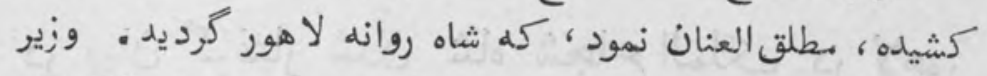

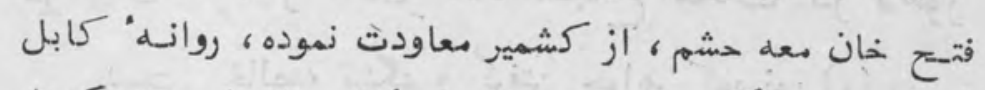

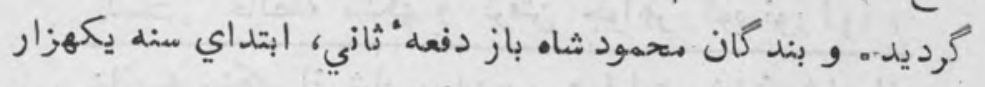

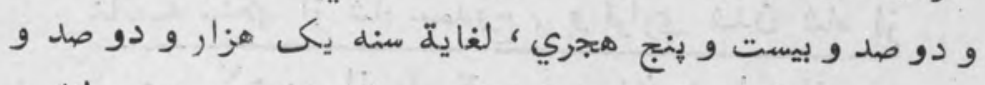

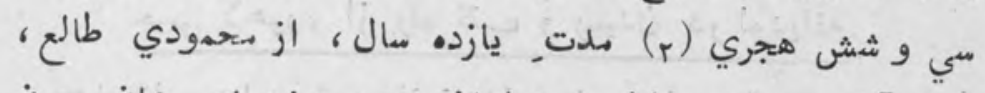

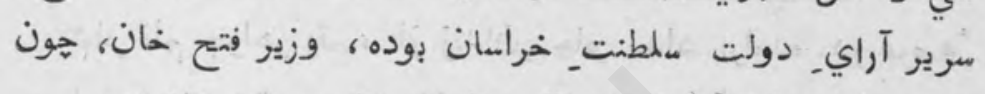

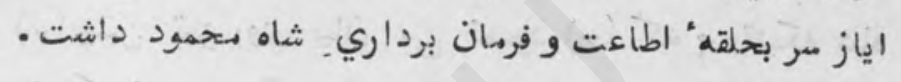

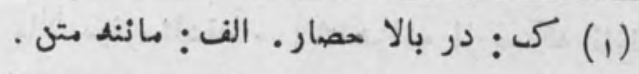

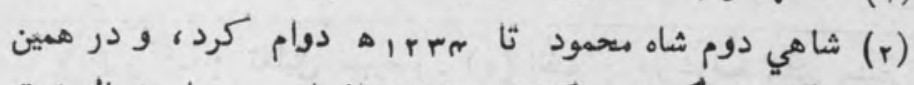

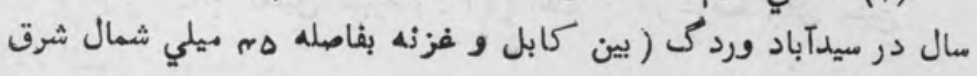

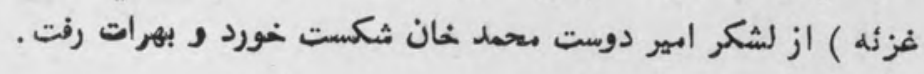


$-\mu$

در بيان كرفتار شدن شاه شجاع الملك در لاهور

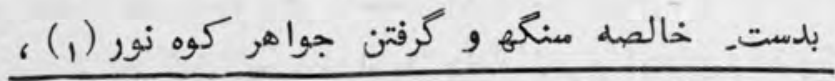

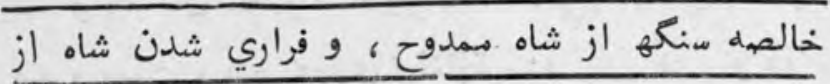

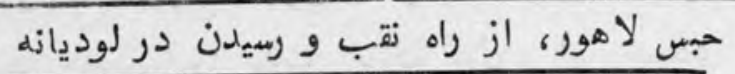

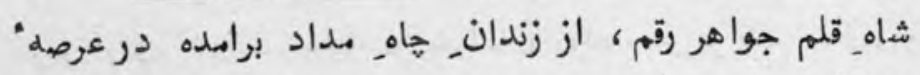

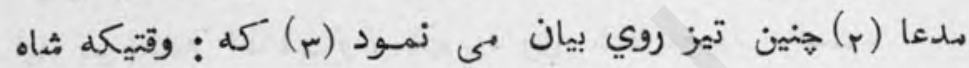

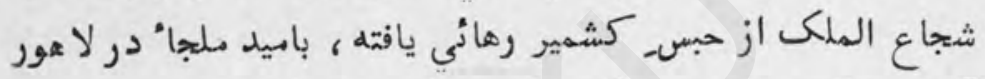

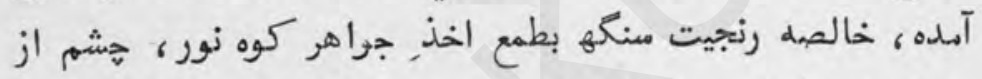

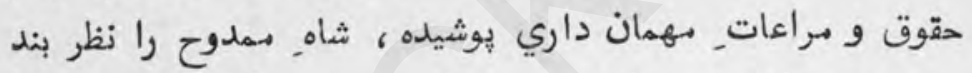

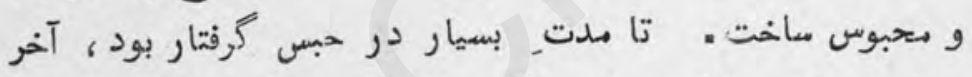

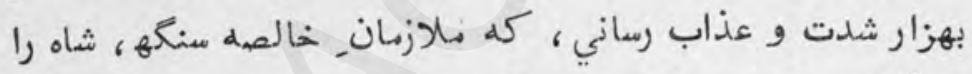

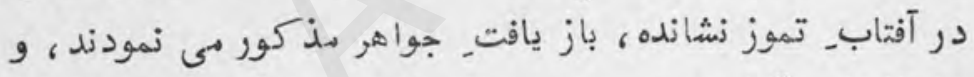

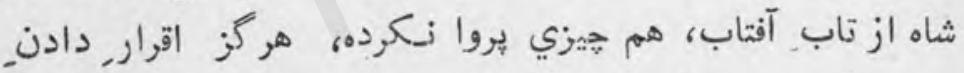

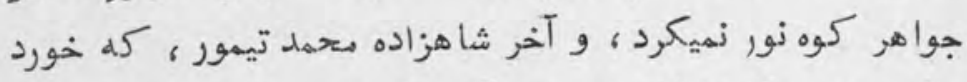

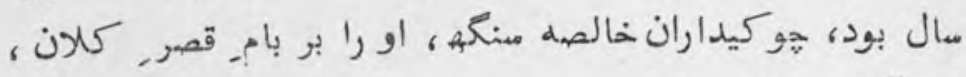

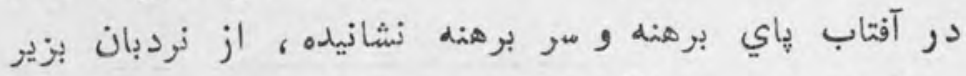

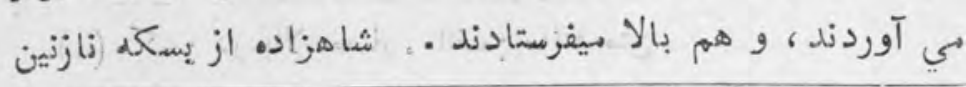

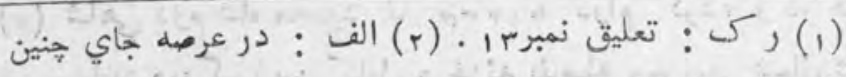
( الص : مي شود : 
اندام بود، از بس مسوختكي آفتاب ، بإي و مرث ميسوخت، و و

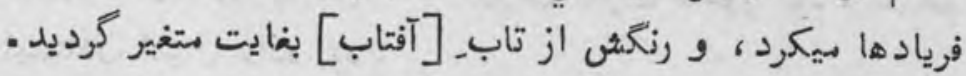

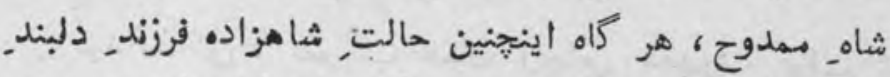

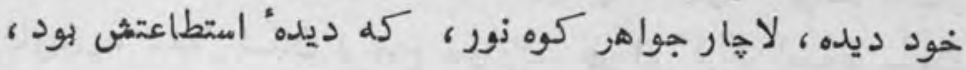

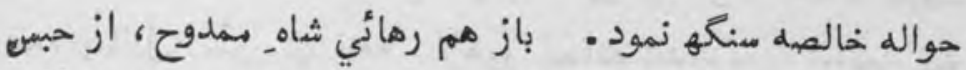
نكرديده، و شب و و روز، دمت,دعا بهزار عجز و زاري بدركاهـ

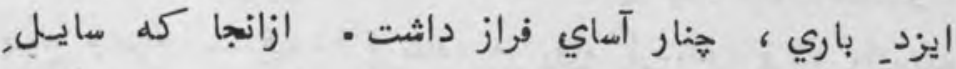

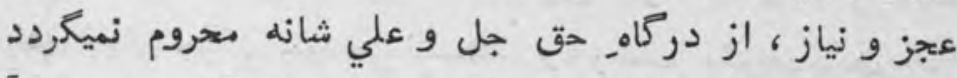

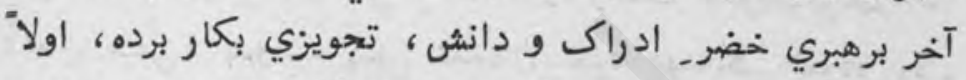

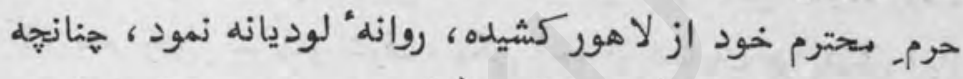

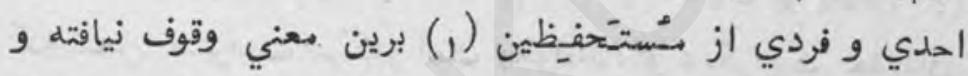

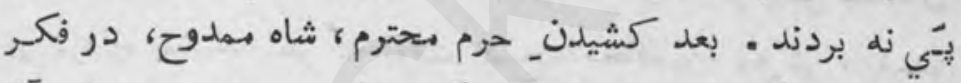

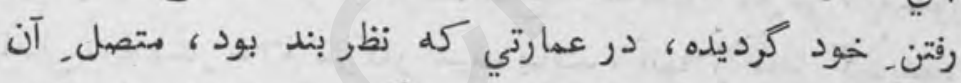

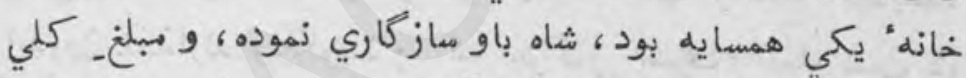

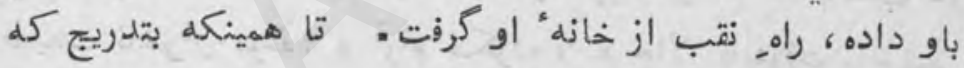

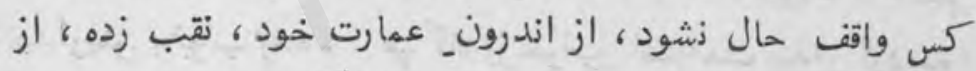

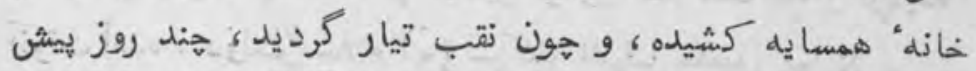

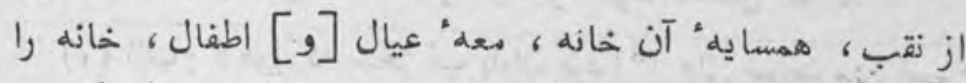

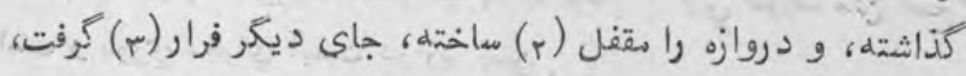

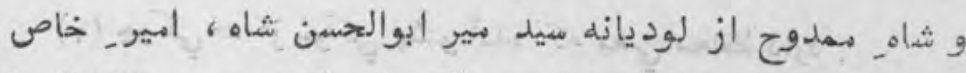

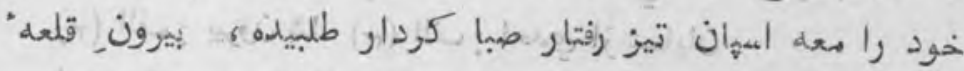

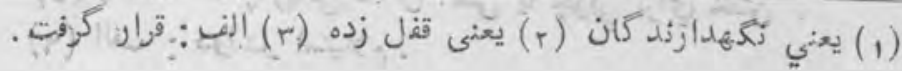




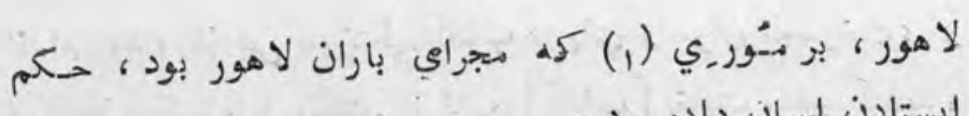

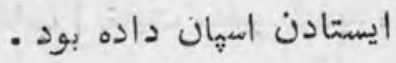

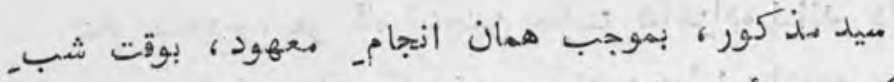

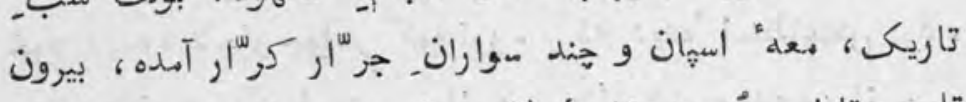

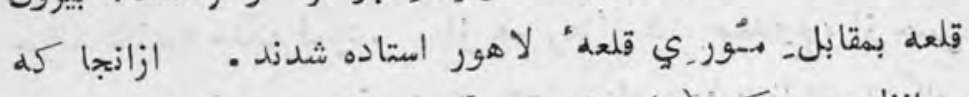

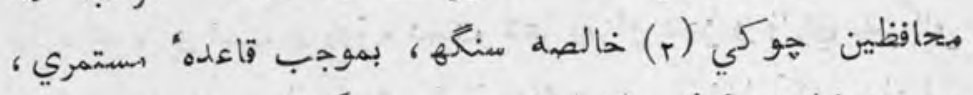

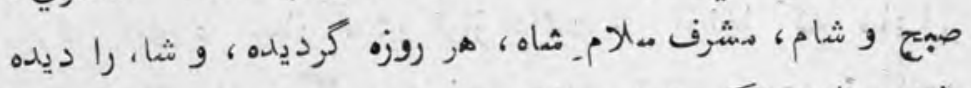

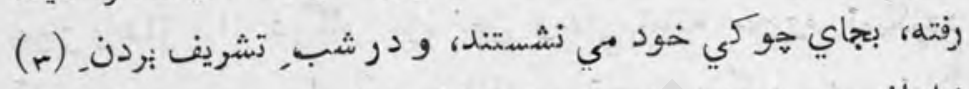

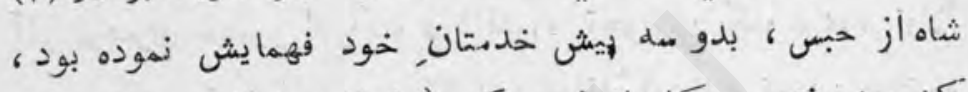

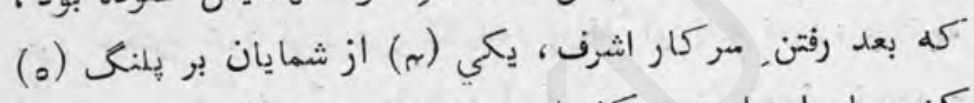

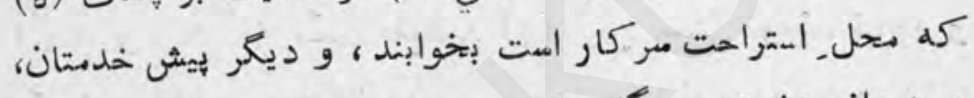

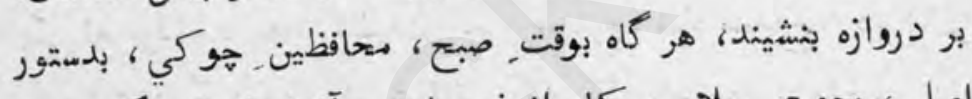

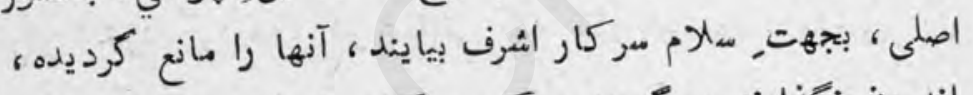

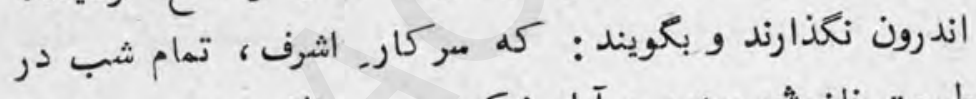

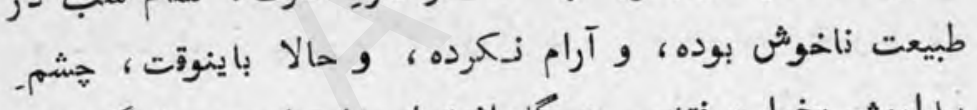

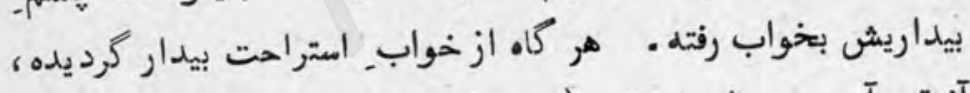

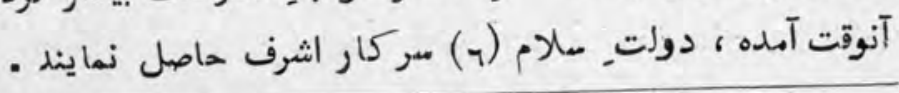

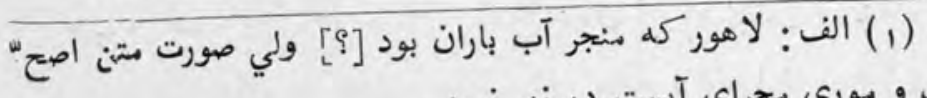

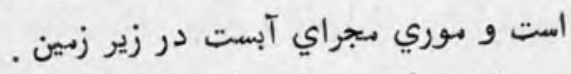

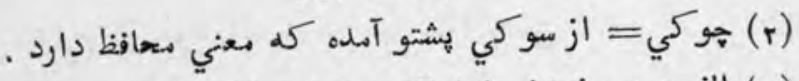

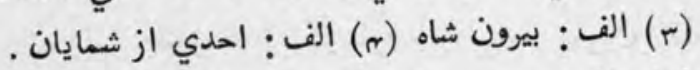

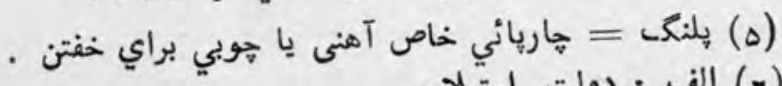
(ب) الف : دولت_ استيلام. 


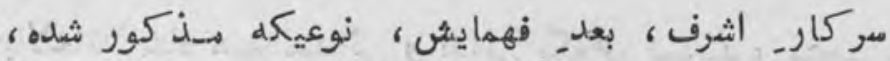

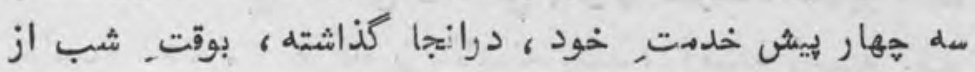

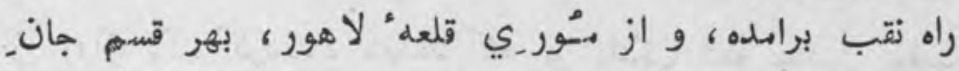
زازنين خود جُبرون كشيده، و بر امهيان_ باد رفتار موار كرديده،

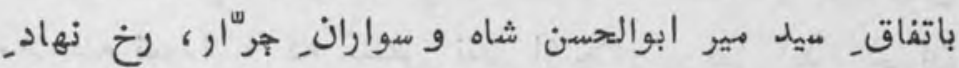

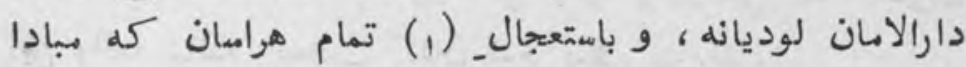

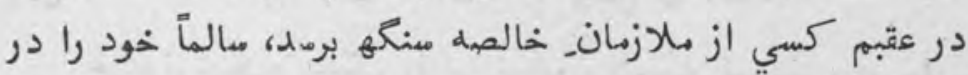
لوديانه رسانيده ، شكر, حيات تازه نمود ، و بيشى خدمتان شاه همدوح كله بجايش مانور بودزند، بموجب_ فهمايش و تعليم شاه عمل نمودند

بوقت صبتع محافظين_ هوكي، براي سلامـ شاه آمدند ،

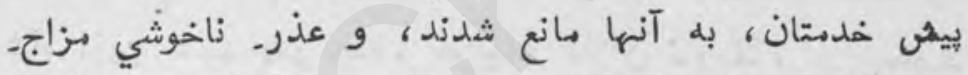

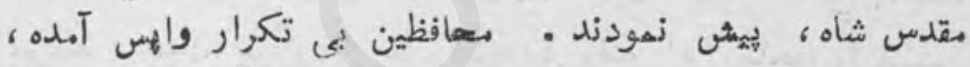

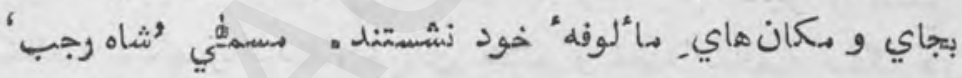

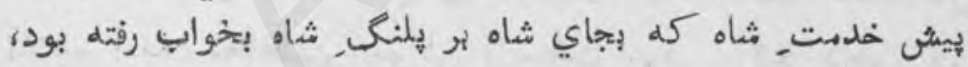

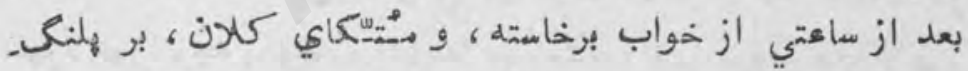

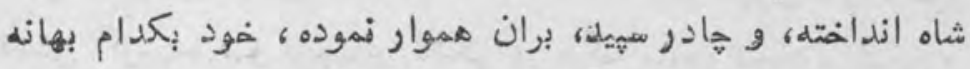

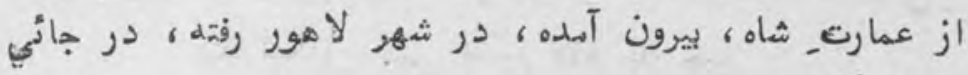
- نهان

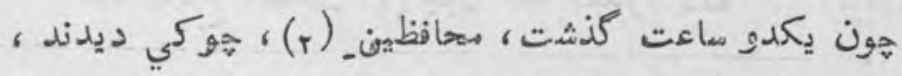

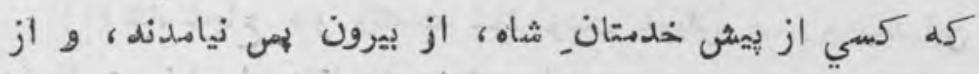
. (1) 
بالاخانه" شاه هيج صدائي و ندائي بكوش نميرسد ، متحير هانده

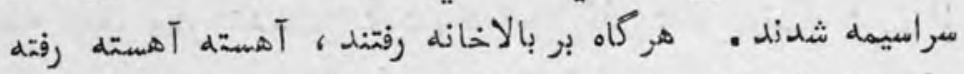

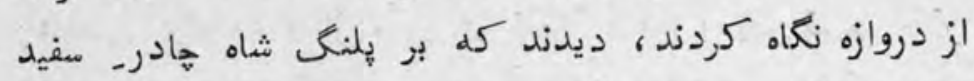

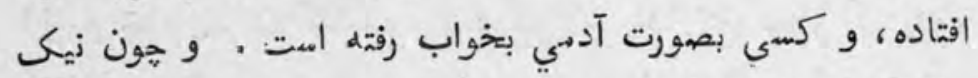

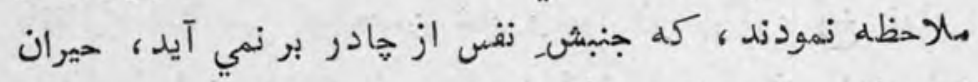

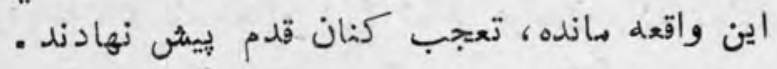

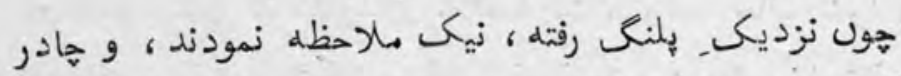

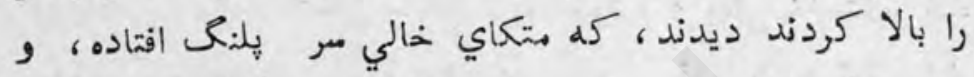

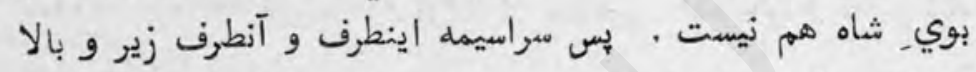

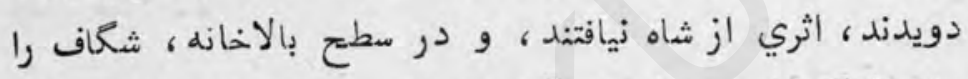

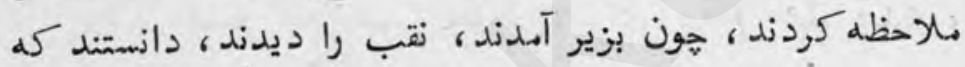

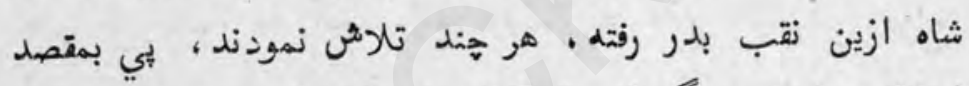

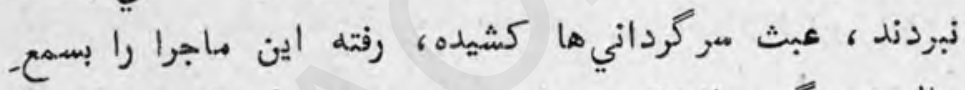

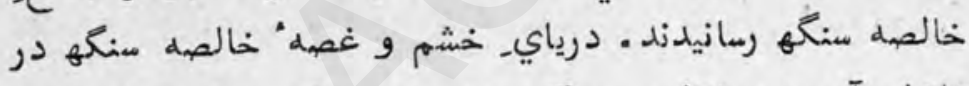

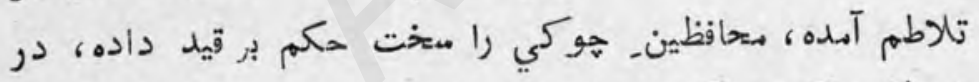

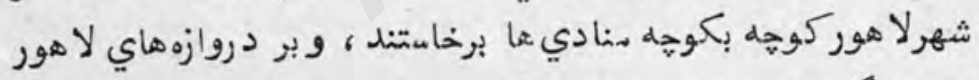

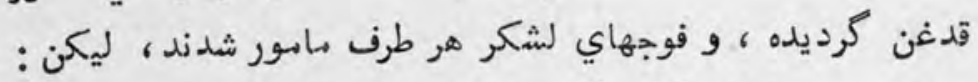

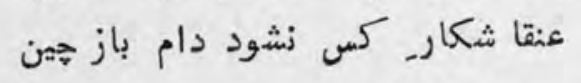

شاه شجاع الملك (1) خون عنقا معدوم ثده ، در دارالانان.

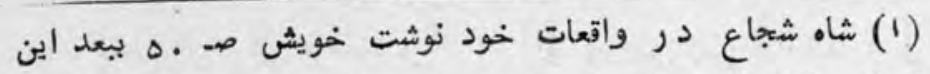

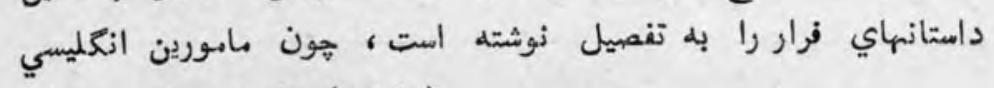

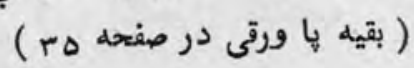




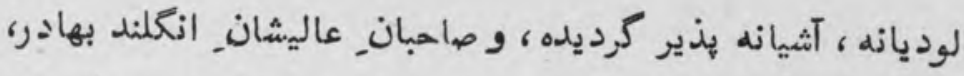

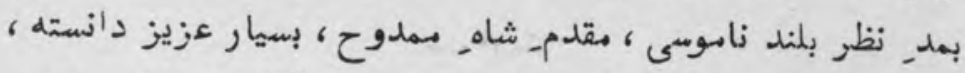

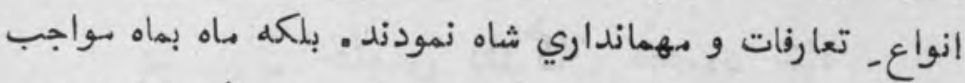

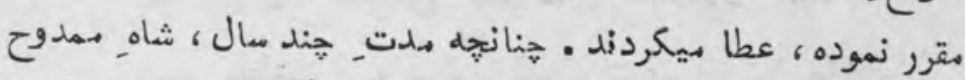

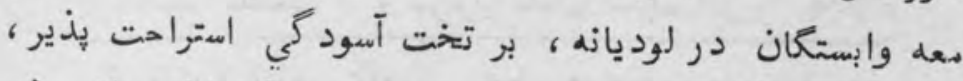

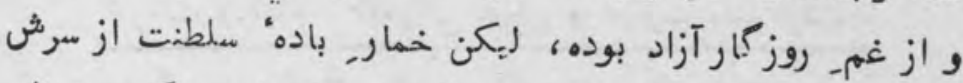

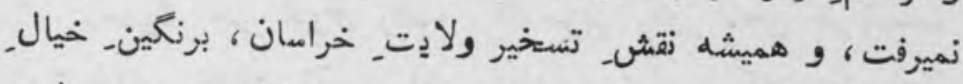

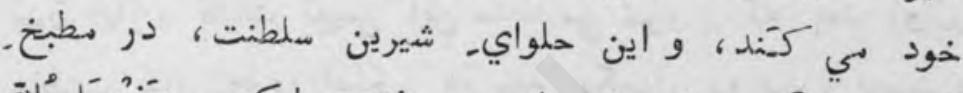

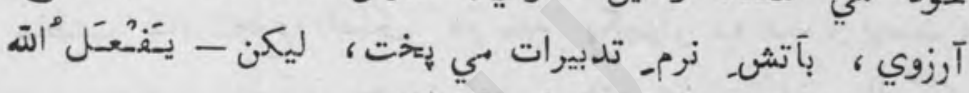

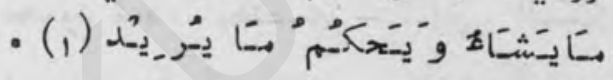

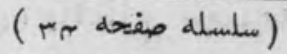

ميخواستند شاه شجاع راع را در وقايع آينده" افغانستان به نفع خود استعمال

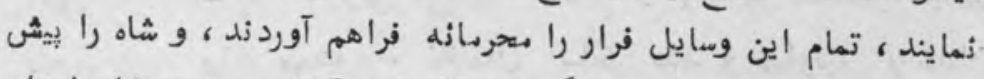

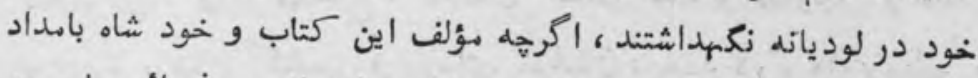

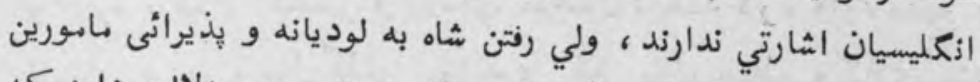

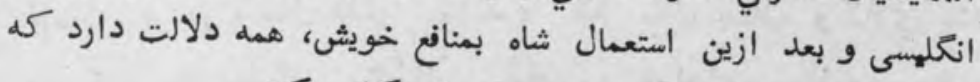

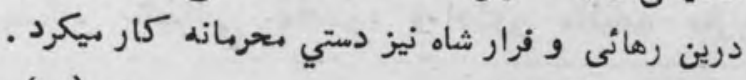

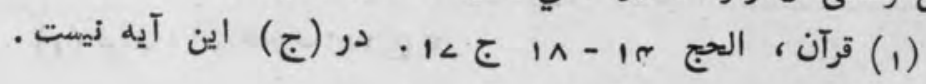


$r c$

مى نهودند، و فقرات دلكشي جود و نوال، و عبارت رزميني(1)،

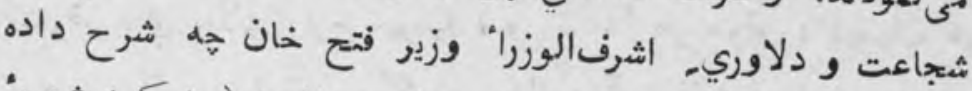

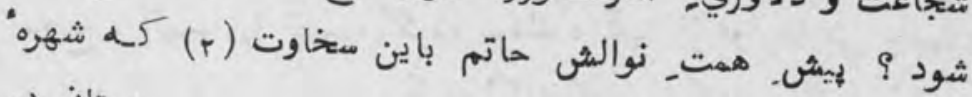

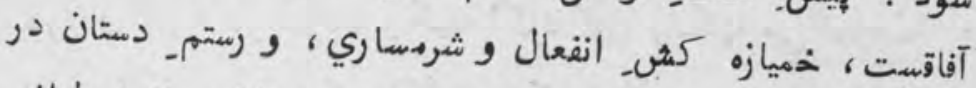
عرصd" شجاعت و بهادري، حون هزار داستان ، نغمه طراز • داستان آفرين خوانه

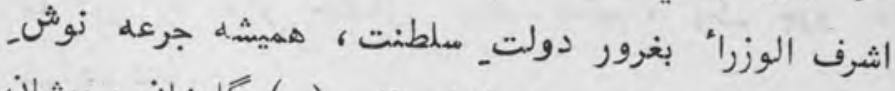

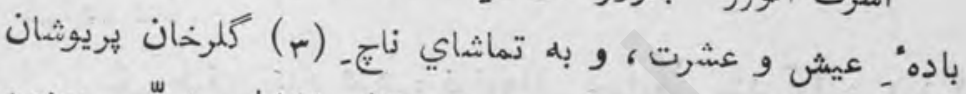

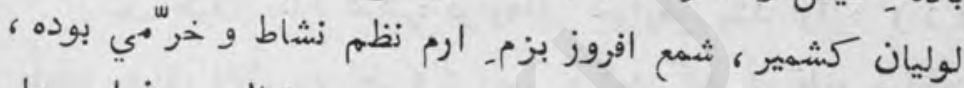

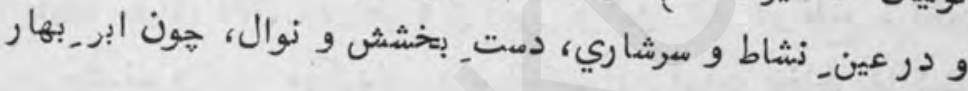

ريزث مي نمود -

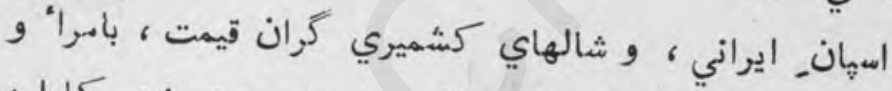

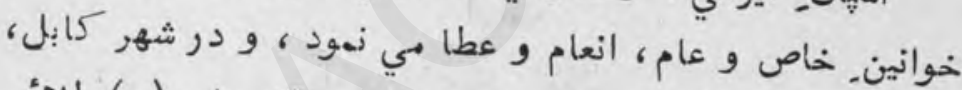

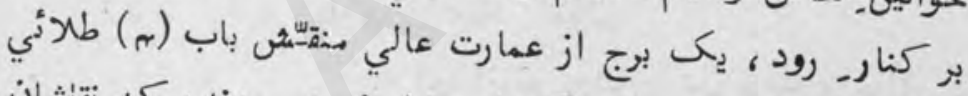

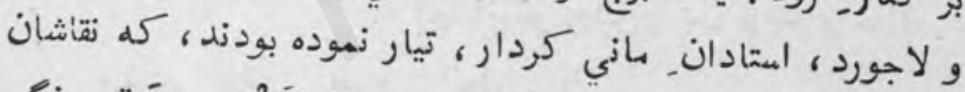

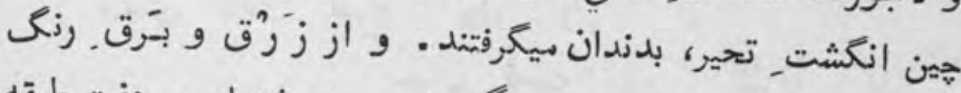

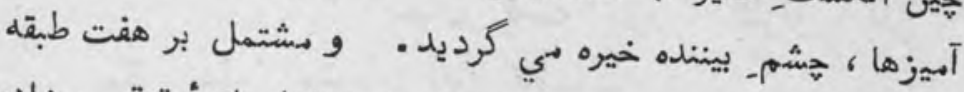

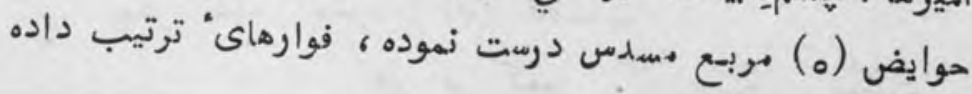

(1) الف ، ج : رنكين (r) الف ، ج : باين همه مخاوت. (r)

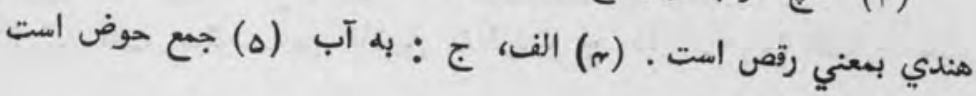


بودند [ و نحوي (1) صنعت كرده بودند] كه آب از دريا در

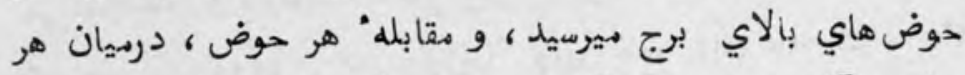

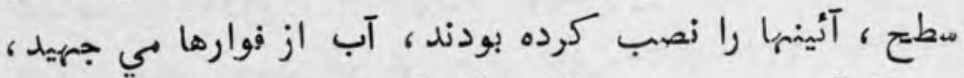

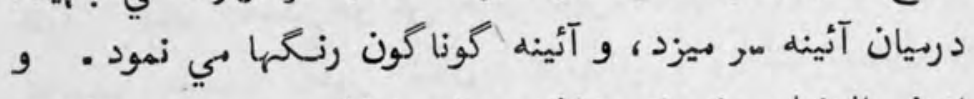

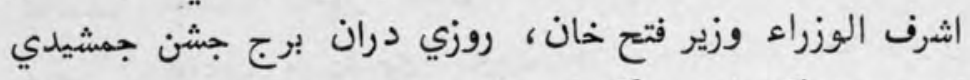

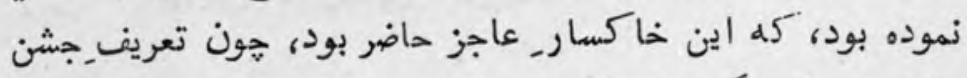

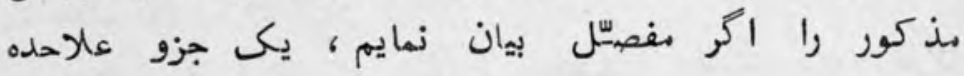

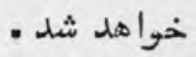

يك طرف نغمه شرشره فوارهاي حوايض بلند آواز، و د دكر

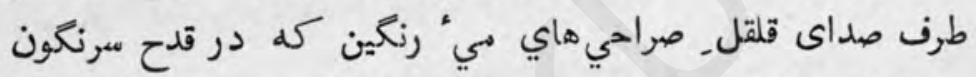
مي شدند و قهقه ميكردند، و درانوقت اين ابيات إيخاطر خاكسار

\section{ابيات}

\section{قدح كرد روزي زمينا موال}

كه اي از تو روشن، دل دوال وجد و حال

صفاي دلت صبع انوار, راز

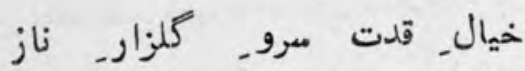

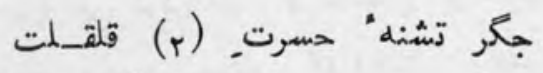

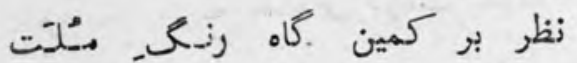

$$
\text { اكر اين نماز است قهقه هرا ست }
$$

وكر لهو باشد سجودت هيت كير است

(1) الف عبارت بين قلابين ثدارد، ج دارد. . (r) الف : حيرتي 
rq

تازه ئواي معارك

صراحي ز غيرت جنون مداز شد

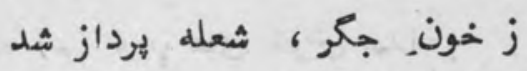

كل اي خشمت از نور عبرت تههي

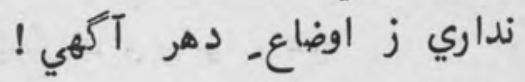

هم هشمهي و نيستي ديده ور همل كوثي و از جهان بيحجبر

بمثل- تو خضر. مقيقت فما

نزيبد براه

كـــه داده است بر قتل _عابد صلاح؟

كـله گفته است، خون مصليّي مباح

ازين غم بدل خون نكريم هرا

بـر اوضاع- دنيا نتخندم هرا ون

يكي غافل از رمزت, ما و منني

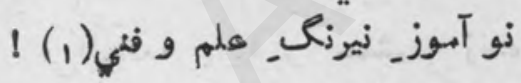

ز طاقـ سرا تافت (r) آثينهاي

صفا در بغل طبع بي كينهاي

دران آينه صورت, خويةن ديد

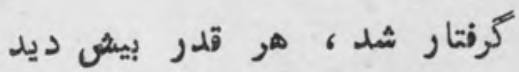

غرض دران مجلم- جدمثيد المام، نغمله مازهاي كوناكون

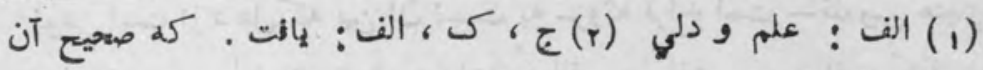

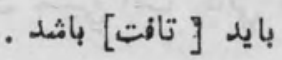


تازه نواي معارك

$\sim$

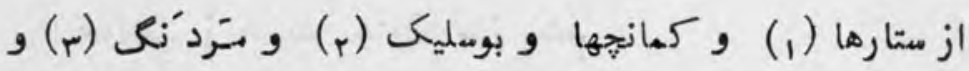

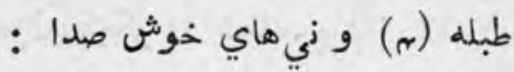

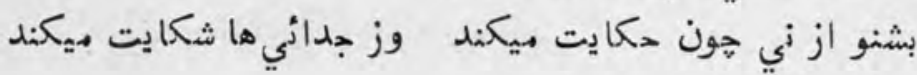

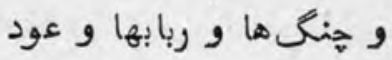

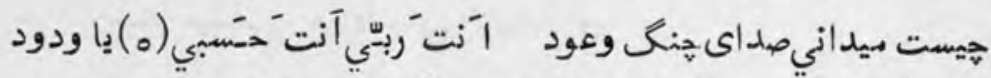

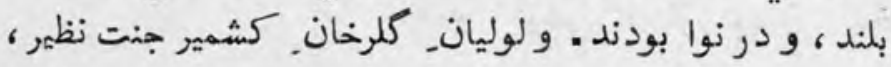

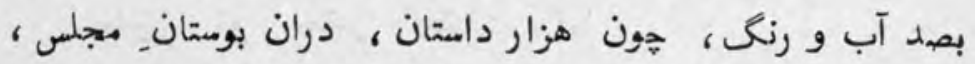

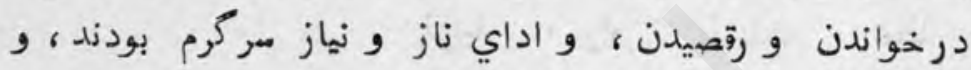

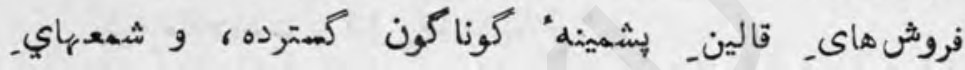

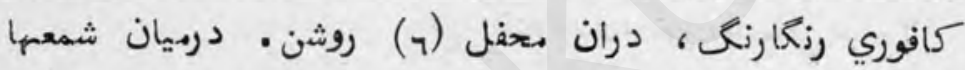
بقدر مفاصله ده انكشت، آتش بازي را ترتيب داده دورن بودند . هركاه

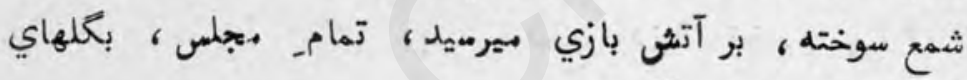

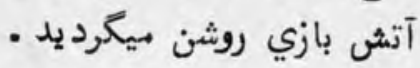

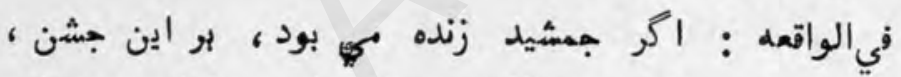
حسرت +ي برد • هراغ بندي كه دوميانـ باغ ، بنا نموده بودند،

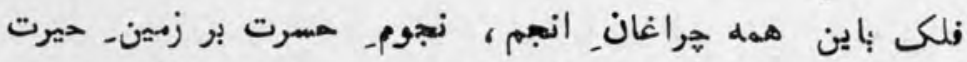

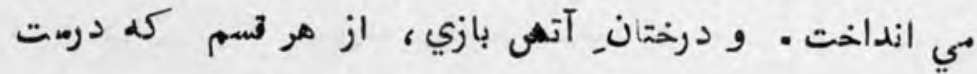

(1) ستار = نام يكى آله ماز منديست (r) بوسليكى = لام مقامي

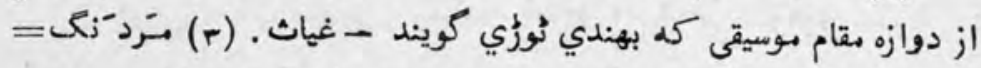

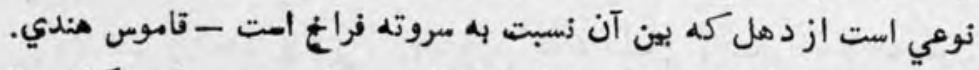

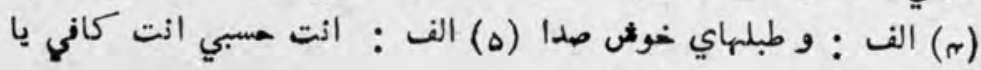

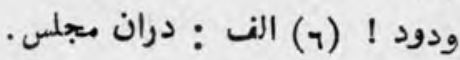


$\sim 1$

تازه نواي معاركى

نموده بودند، بوقت_ آتش دادن، عجب تماشا، ، درجشم-

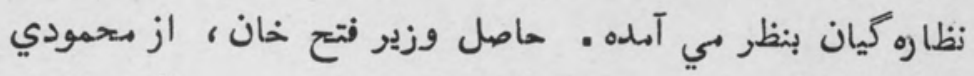

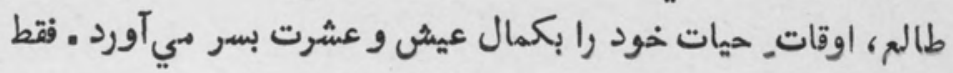




\section{$-\infty-$}

در بيان فوتيدز سسمات بهاكل سنكوحهء اشرف الوزراء

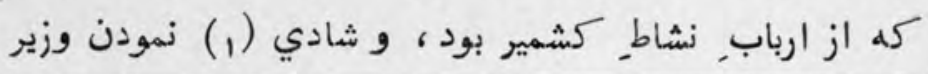

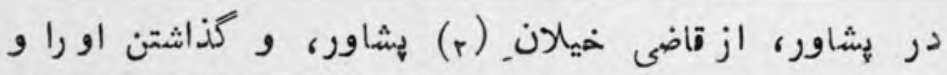

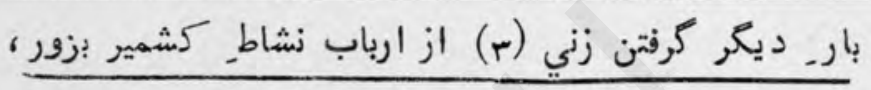

و صاحب خانا، ساختن او را.

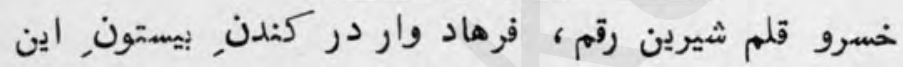

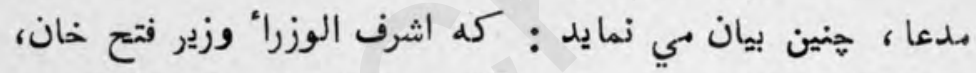

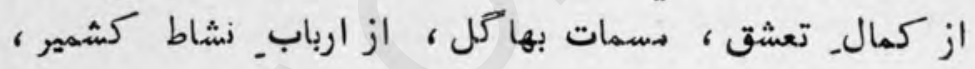

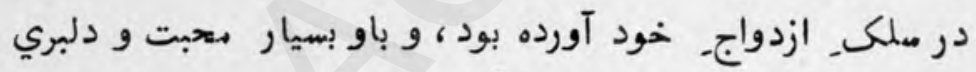

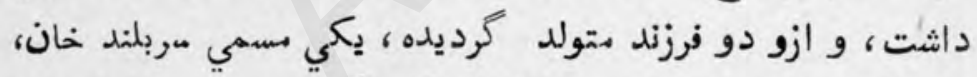

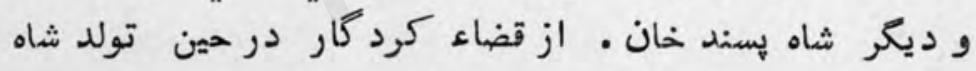

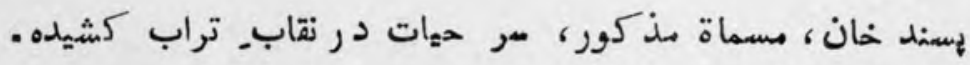

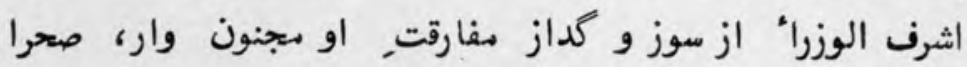

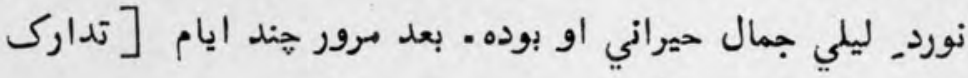

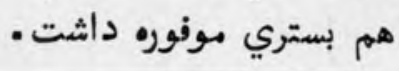

(1) شادي = عروسى . (r) راجع باين دودمان ركى : تعليق

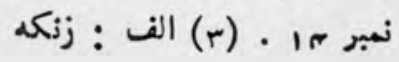




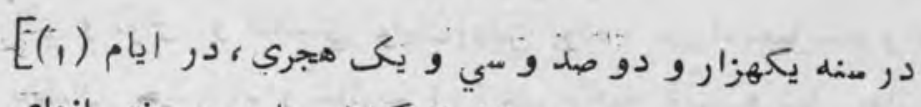

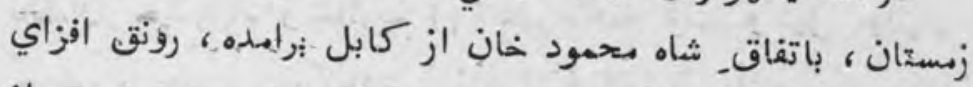

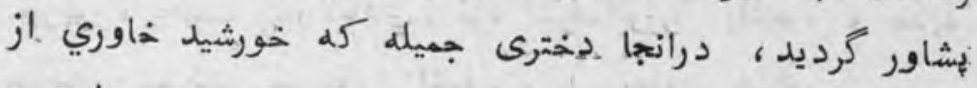

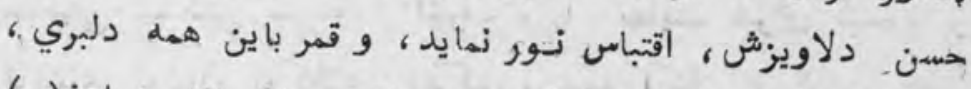

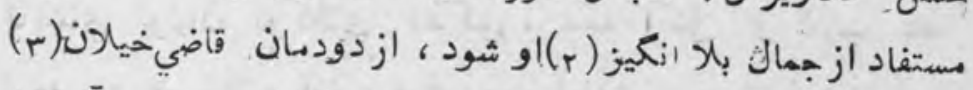

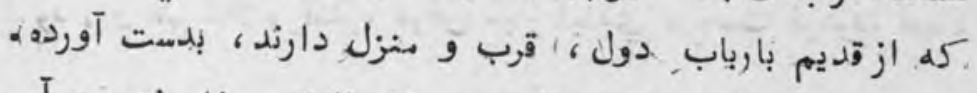

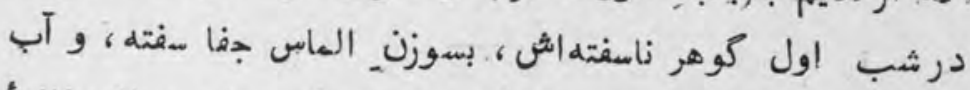

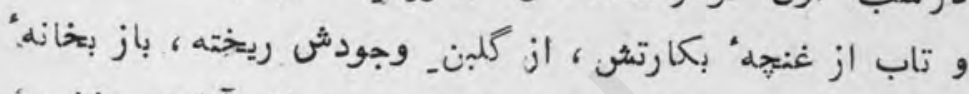

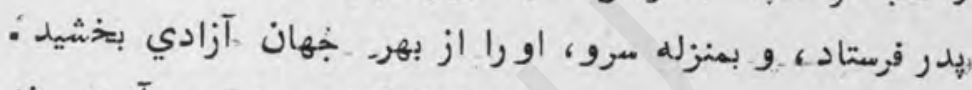

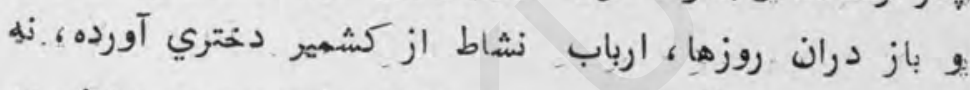

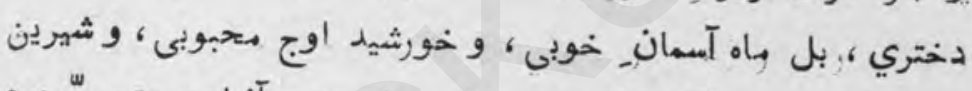

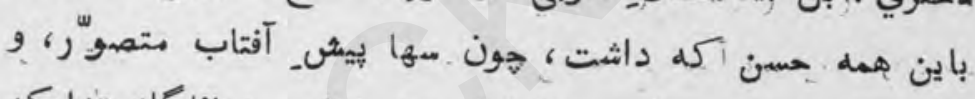

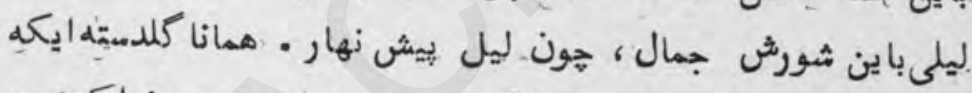

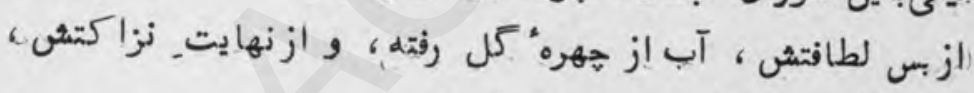

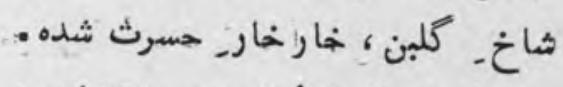

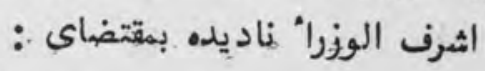

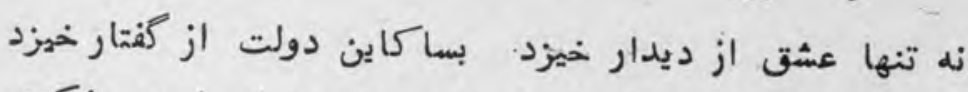

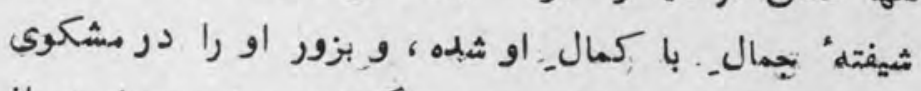

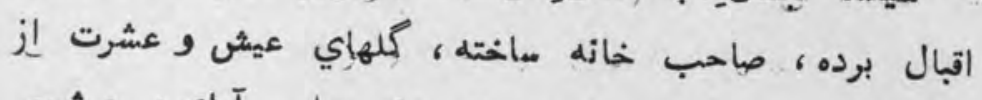

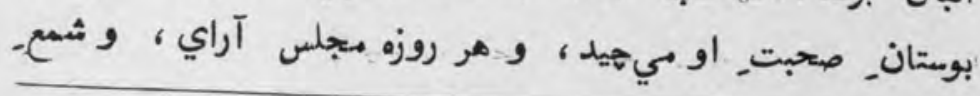

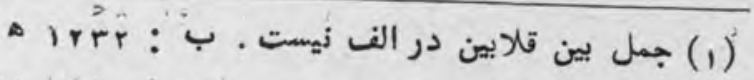

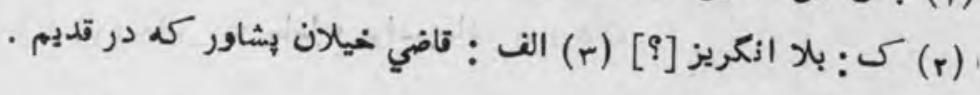


ناي و نوش، و تماشاي لوليان روشن بوده . . دير امدعيل شاه وكيل

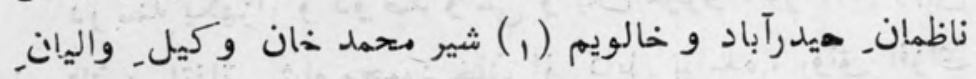

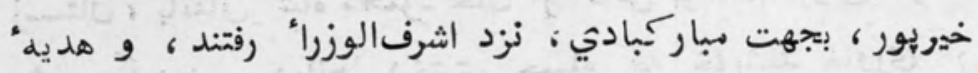

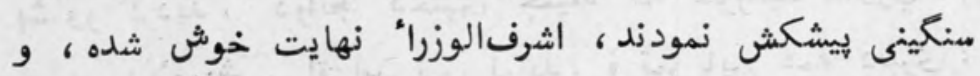

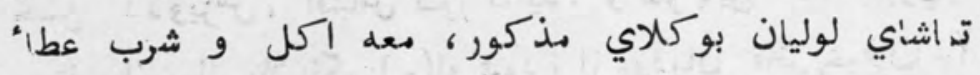
ذ ودد، و هم خلاع_فاخره عوض مباركبادي مرحهت فرمود. فقط.

$$
\text { . }
$$


در بيان تماشا نمودن وكلاي اميران سنده در يشاور

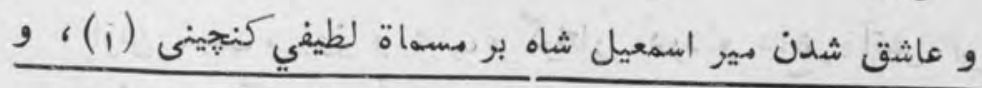

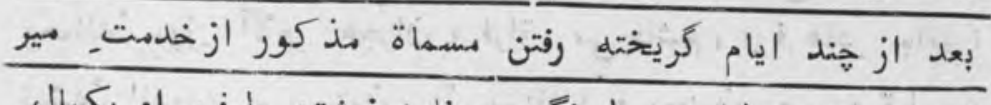

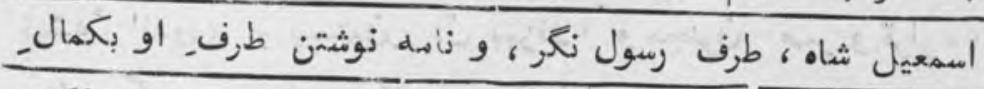

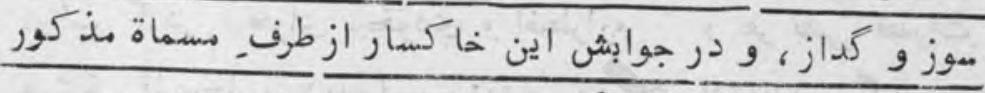

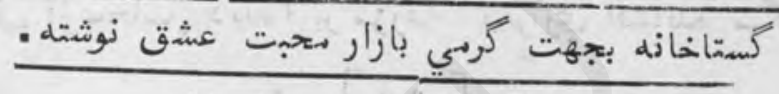

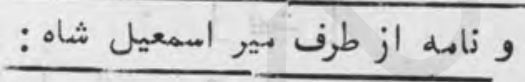

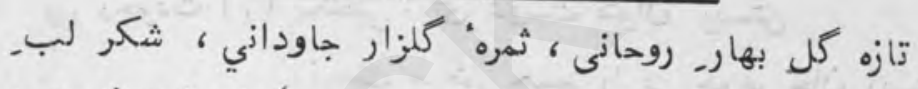

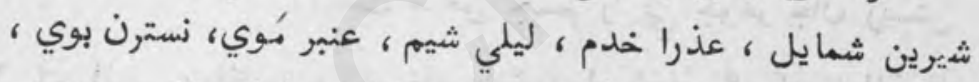

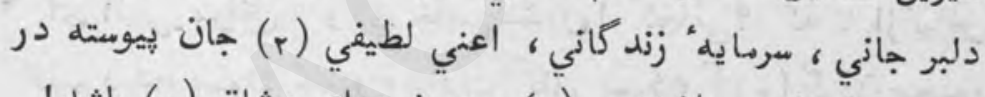

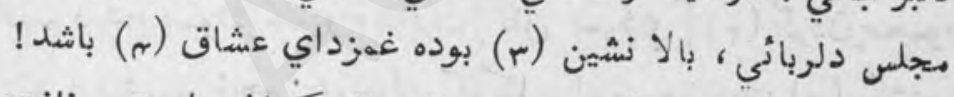

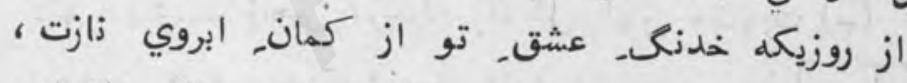

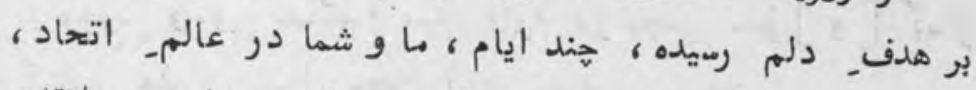

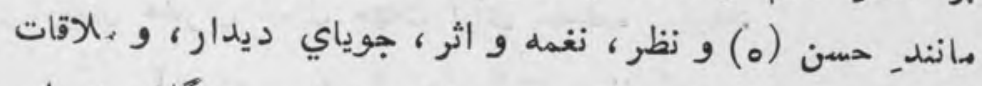

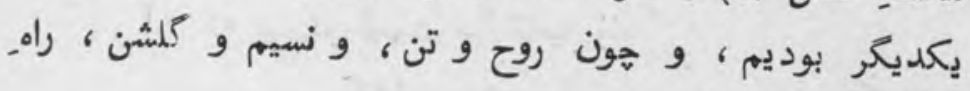

$$
\text { موافقت مي بيموديمر بوديم }
$$

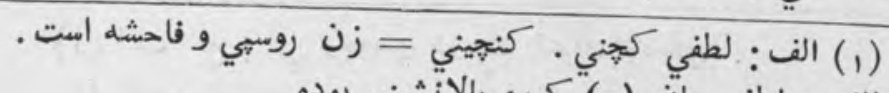

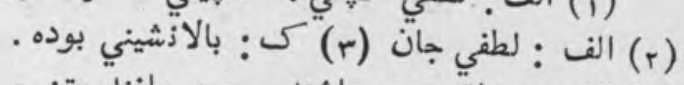

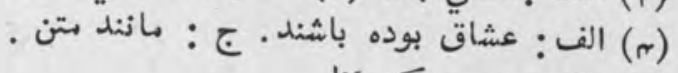

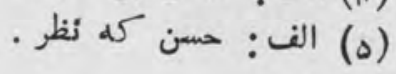


تازه نواي بعاركى

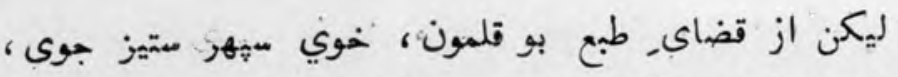

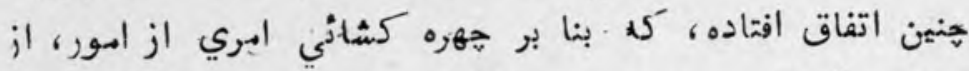

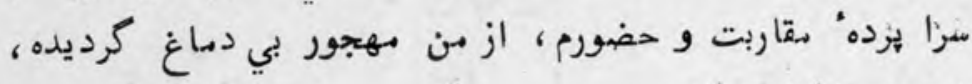
دور و جدا شده اند.

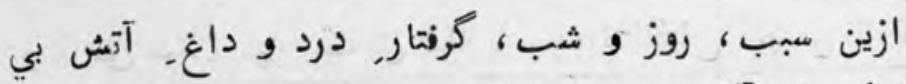

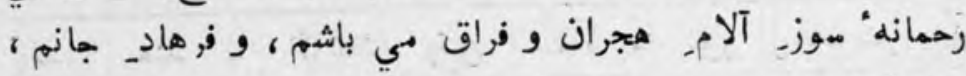

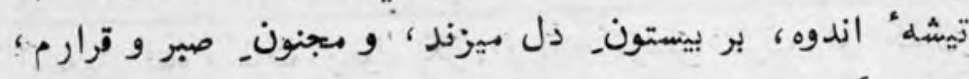

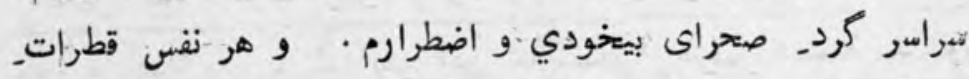

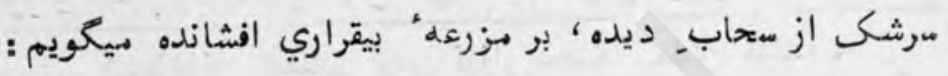

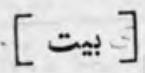

بي وجودت (1) يكنفس' اي دوست نتوان زيستن

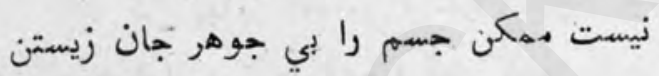

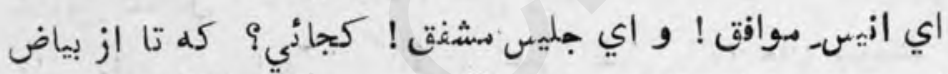

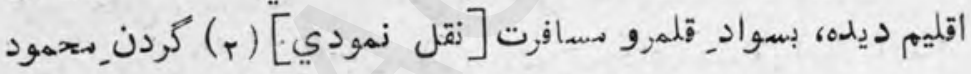

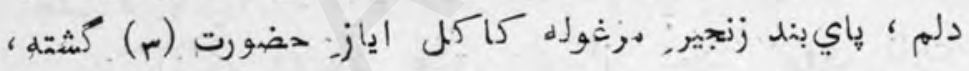

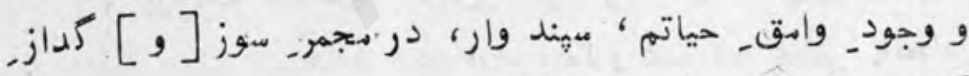

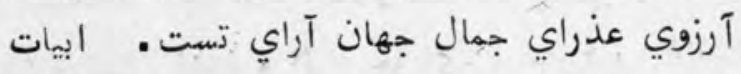

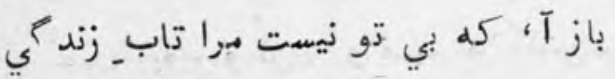

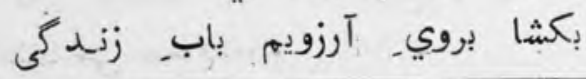

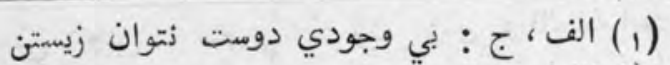

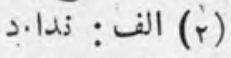
(r) الف: حضوري . نال 


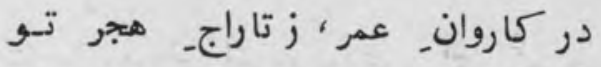

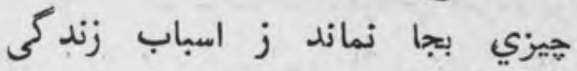

بى جذبه" وصال تو، اي مايه" حيات!

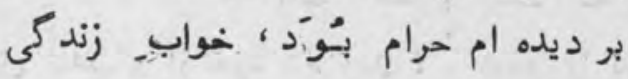

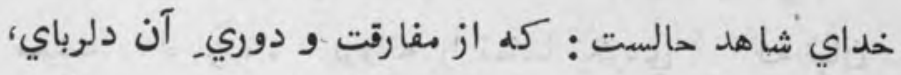

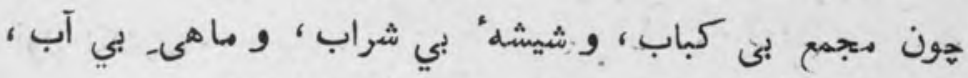

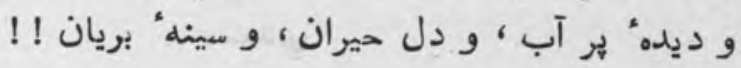

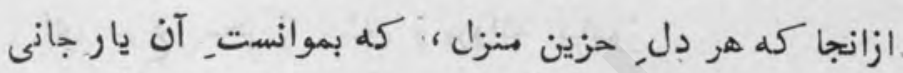

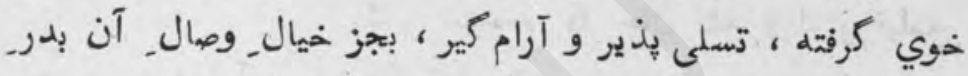

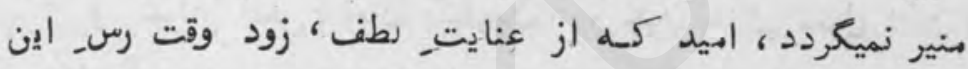

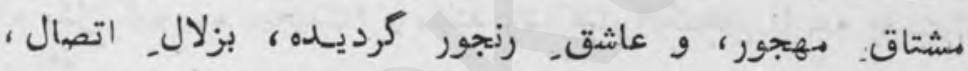

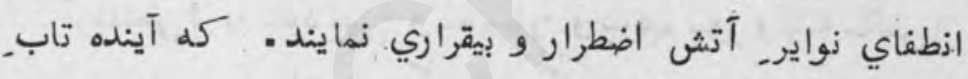

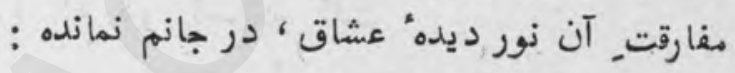
هن از تو دور ندانم (1) كله خوإب راحت حيست

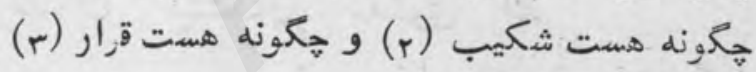

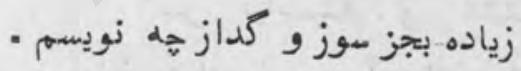

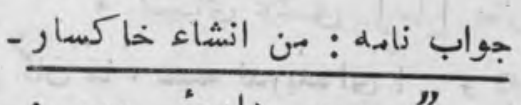

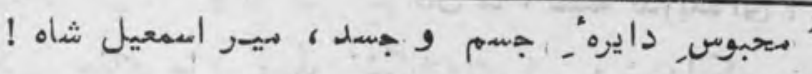

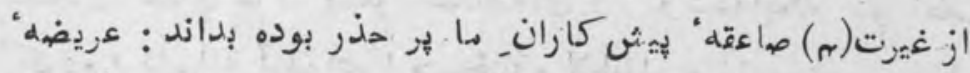

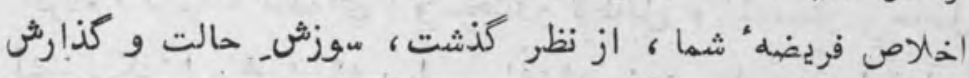

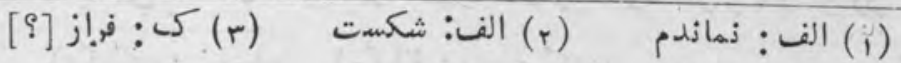

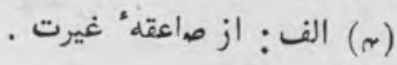




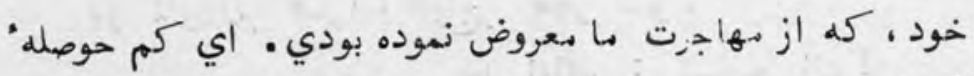

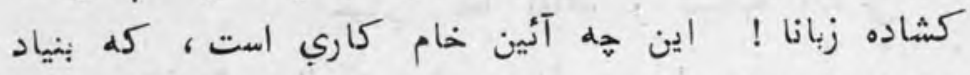

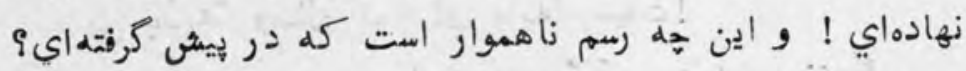

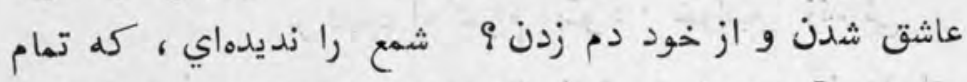

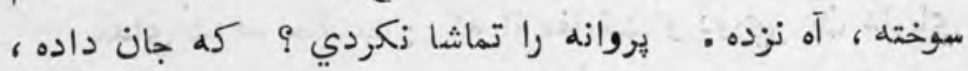

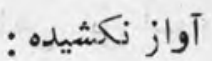

\section{مسعدي}

\section{اي مرغ- ستر ! عشق ز بروانه بياموز}

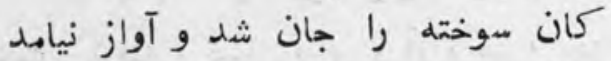

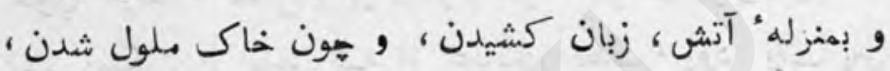

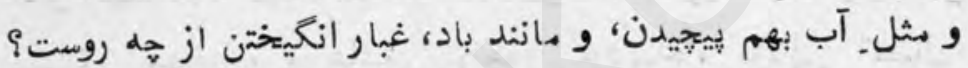

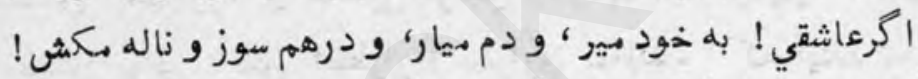

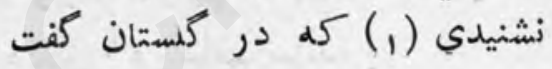

معدي آن إختهه (r) بلبل شعت شيراز

عاشقان كشتكان, معشوق اند

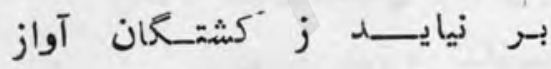

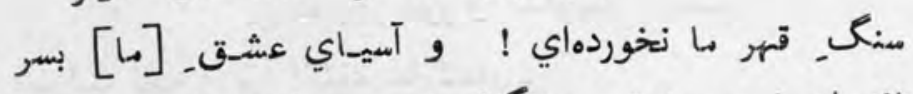

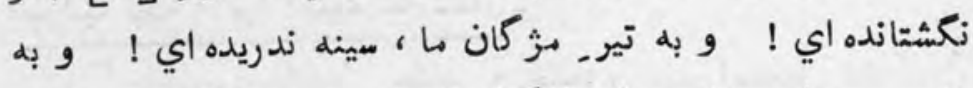

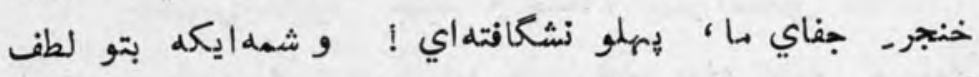

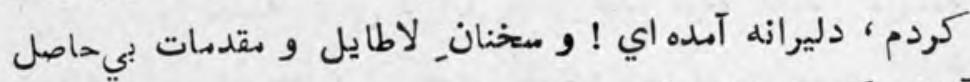

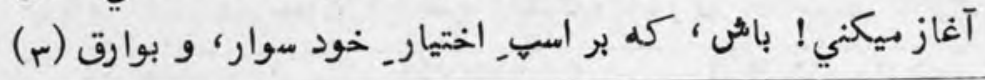

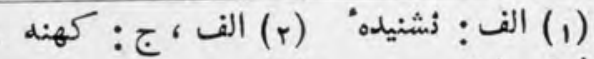

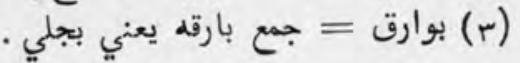


حسن جهان سوز، در خرهن- هستي تو •ي اندازم) و به نوايور(1)

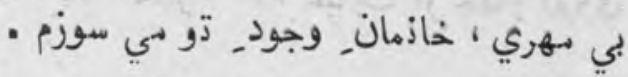
عاشق شوى ' و ميل بآسود گى كنى ؟ انديشه دور دار ! كله اين كار كاركست

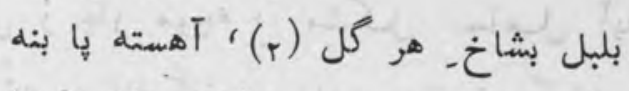

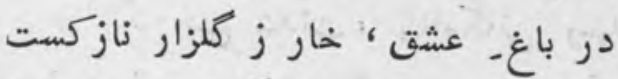

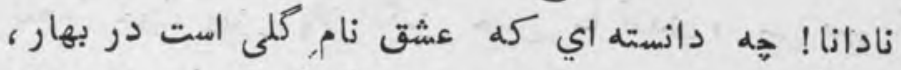

يا دهي (ب) اعت در ديارو نيست! مكر آتشي است جهان سوز،

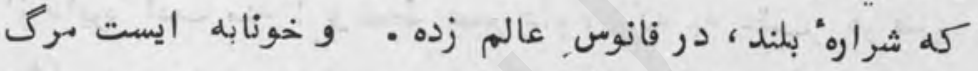

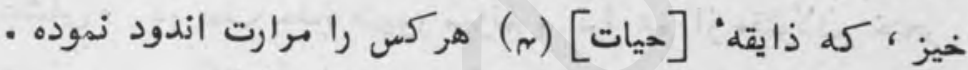

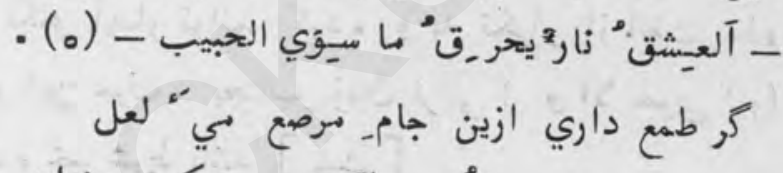

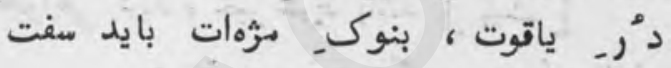

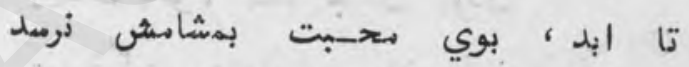

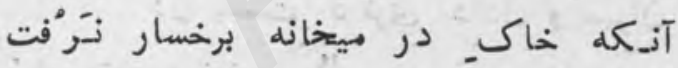

نادازا ! منزل_ عشق دور و ديجور، افتراق (7) هايل ، و عبور از بحر, ناييدا كمار دشوار ، و راه بغايت لبريز اشرار ! بهتر است كله قدم, خود را ازين باديه" هولناك باز كشي! و عبث

$$
\text { . }
$$

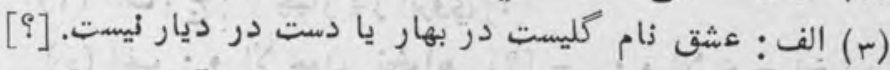

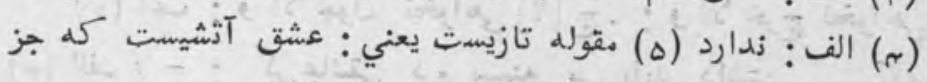

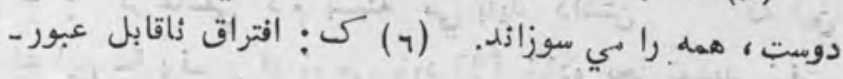




\section{تازه نواى معاركى}

$\circ$.

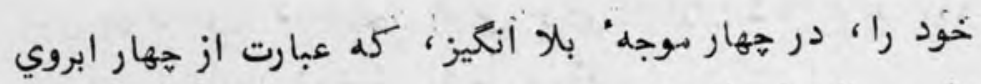

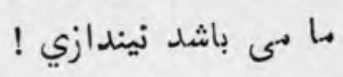
آري ز هار (1) ابروى ، سختست جان كشيدن

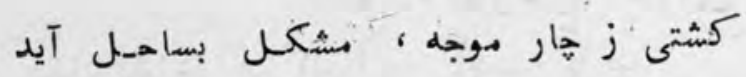

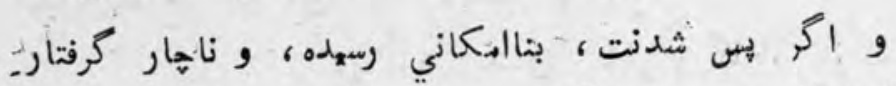

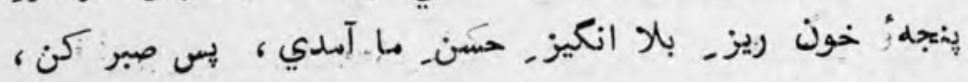

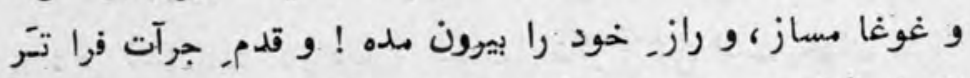

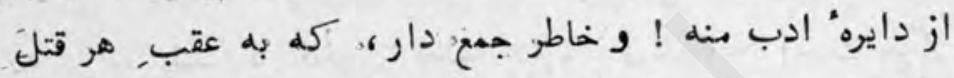

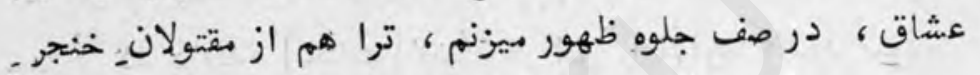

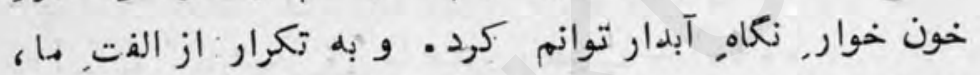

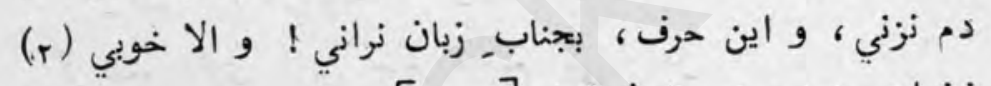

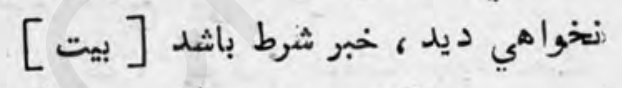

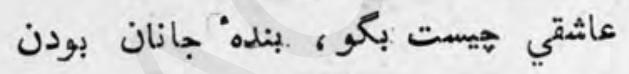

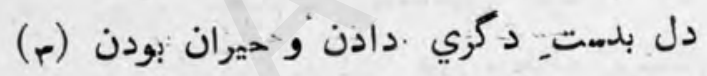

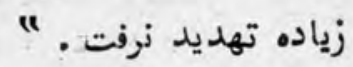

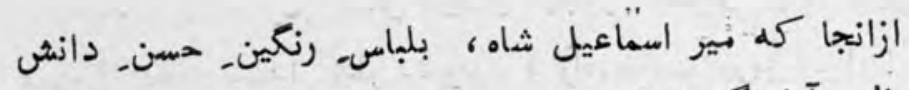

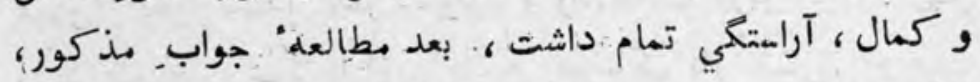

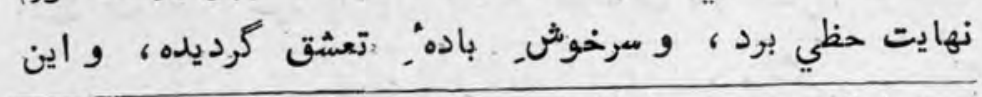

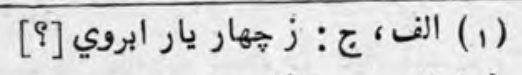

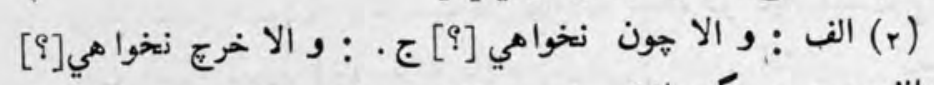

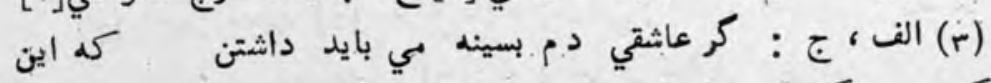

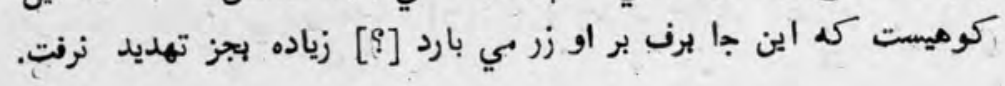


كمترين را بزبان تحسين ، آفرين خواني نمود ، و هم صلهاي ع عال نمود مaت

ازانجا كه ديدهُ حقايق بين ارباب بصيرت، از قطرهاي

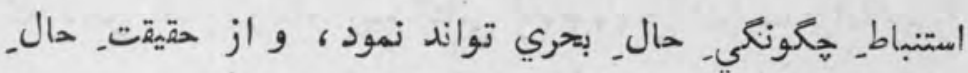

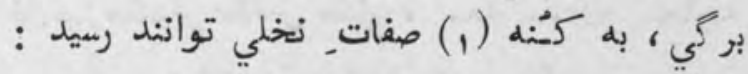

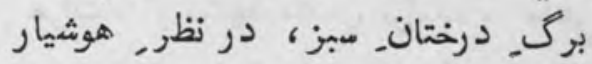

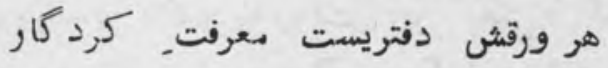
* * * *

غرض كه باز هنـ ــ سر كذشت_ اشرف الوزراء وزير فتح خان

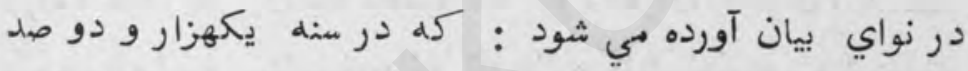

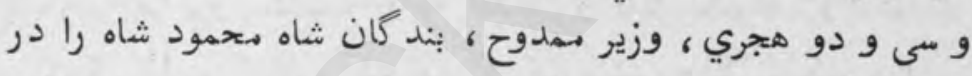

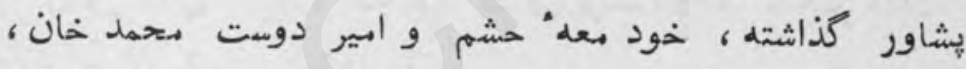

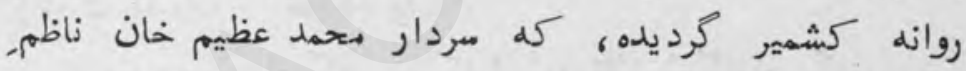

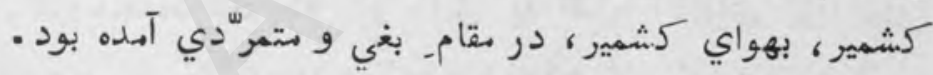

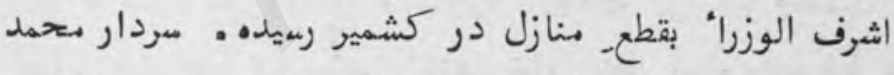

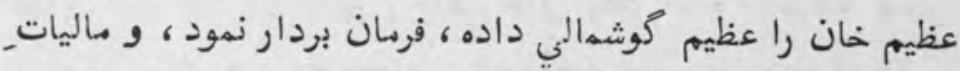

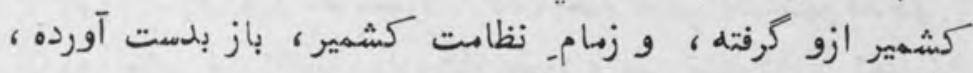

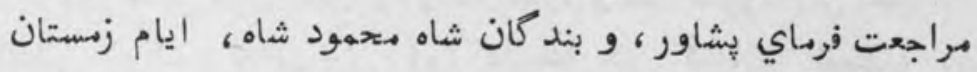

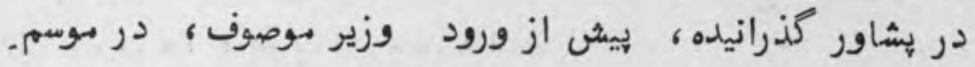

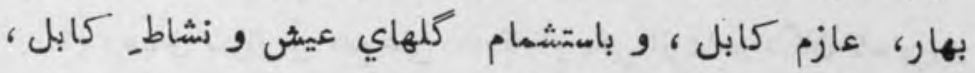

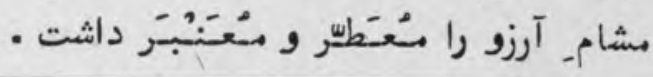
كنه = اصل و 
و شاهزاده كامران (1) ، در احمد شاهي (r) ، جرعه نوش. دوان.

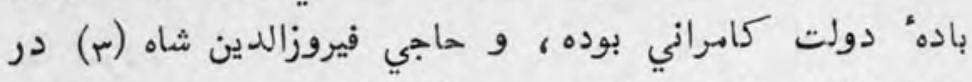

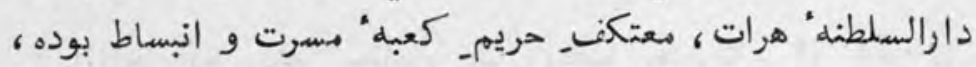

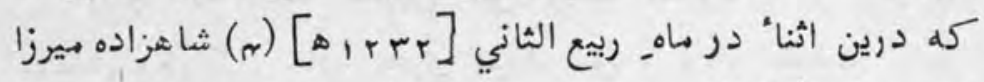

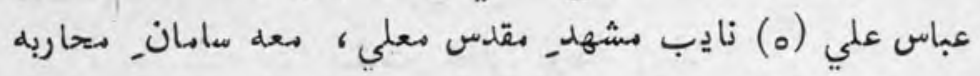

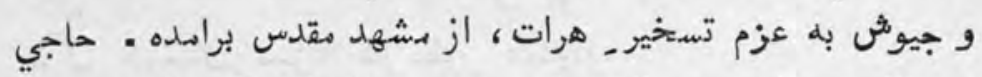

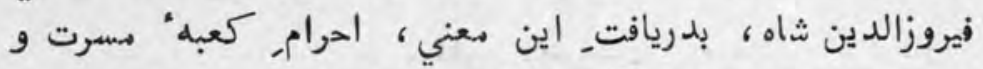

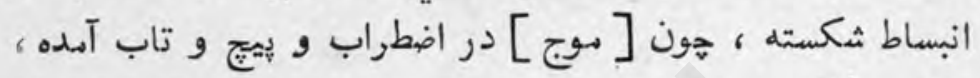

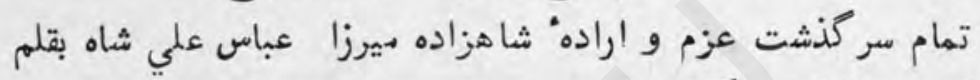

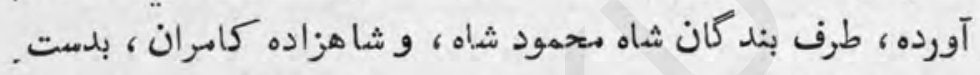

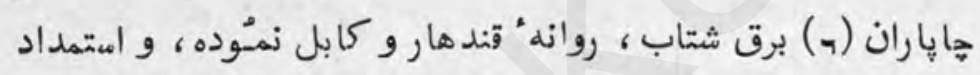

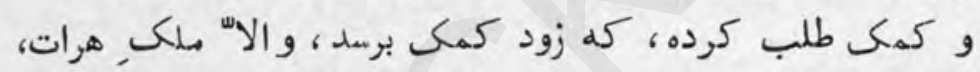

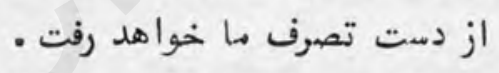

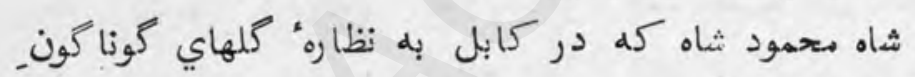

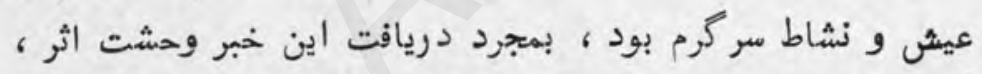

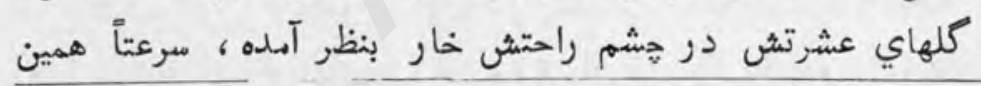

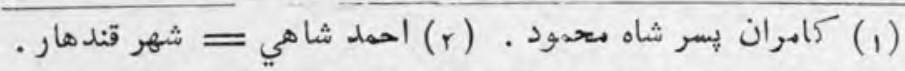

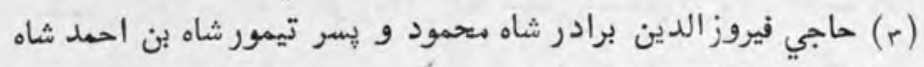
ابدالي [ركى: تعليق r]

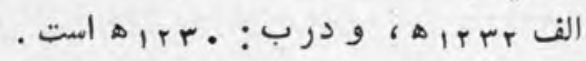

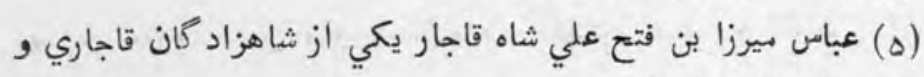

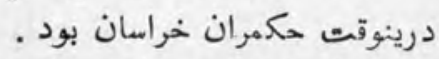

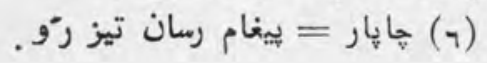




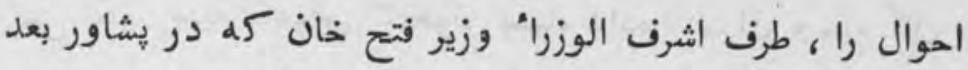

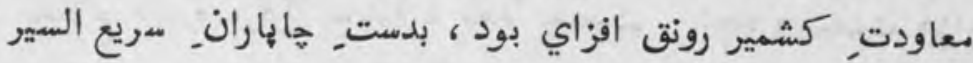

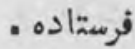

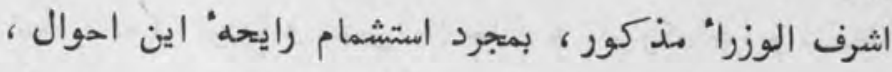

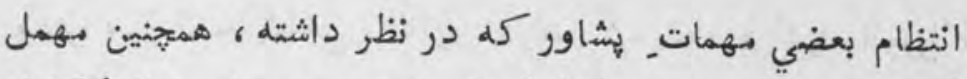

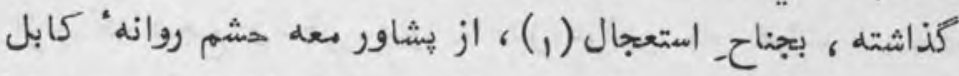

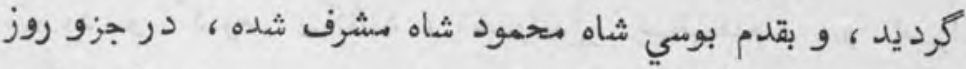

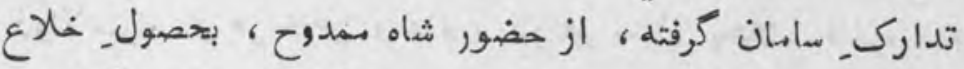

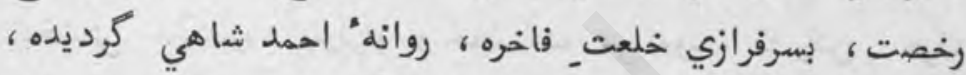

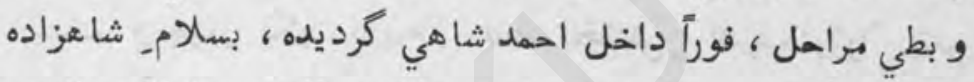

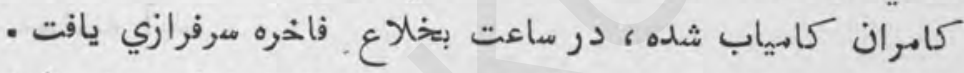

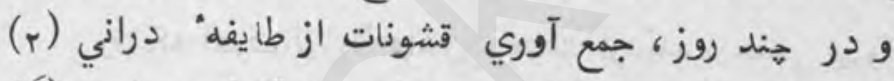

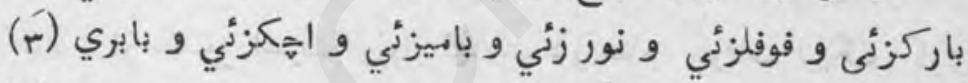

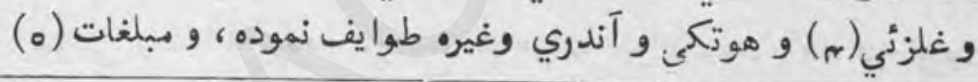

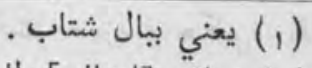

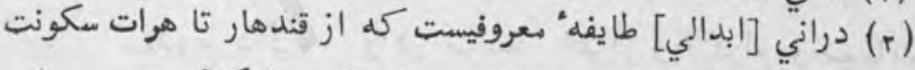

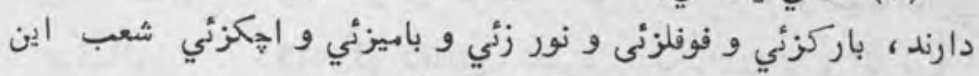

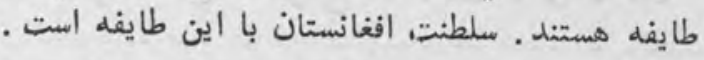

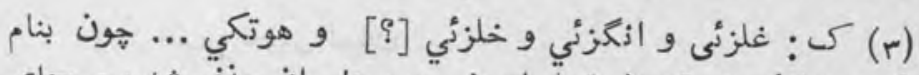

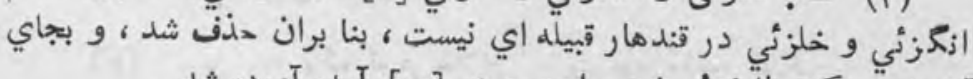

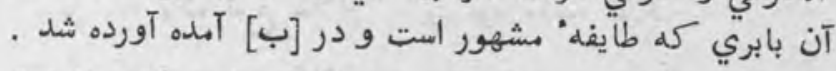

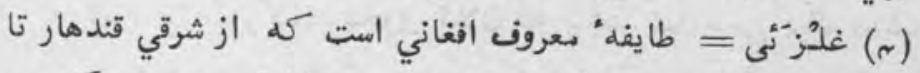

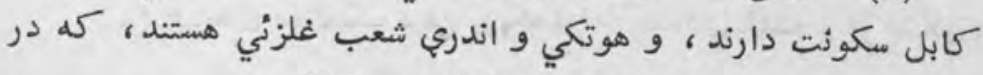
كلات غلزني و غزئي ساكنيد . (ه) الف : مبلغنان. 
سي لكه روبيه ، عوضـ تنخواه بسهاه داده ، سران و مرد گان را

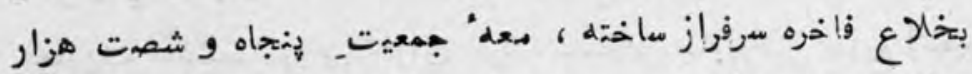

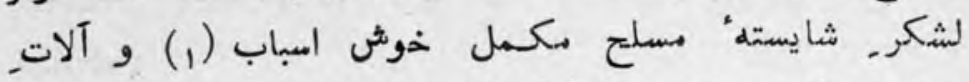

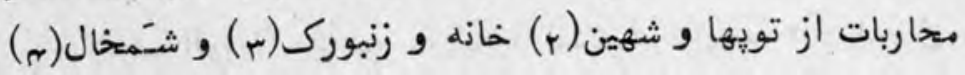

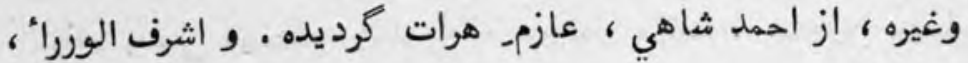

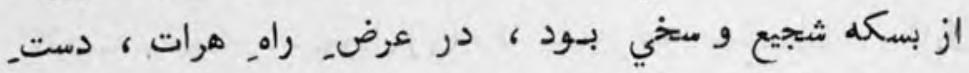

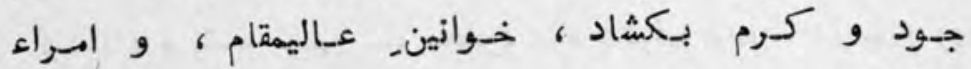

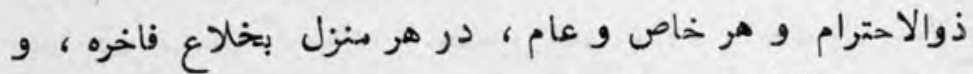

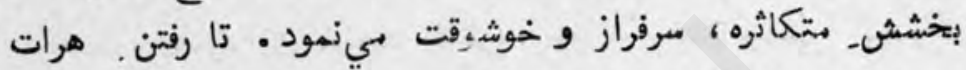

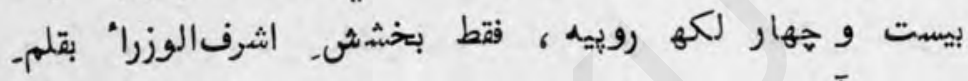

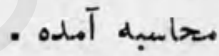

وقتيكه اشرفالوزرا" داخلــ هرات گرديده ، حاجي فيروزالدين

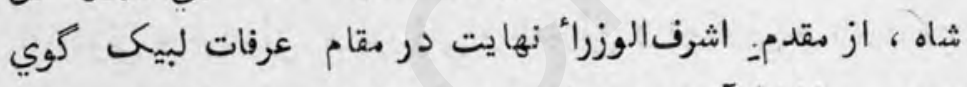

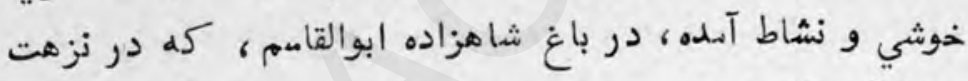

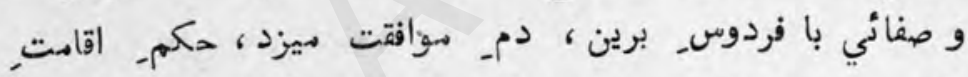

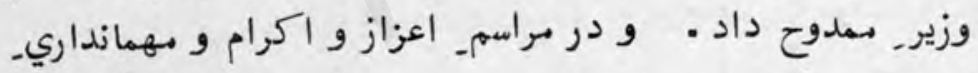

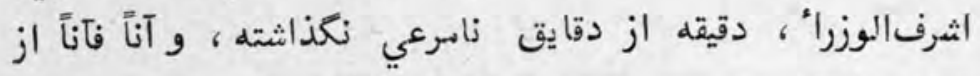

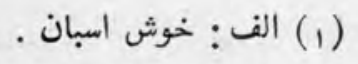

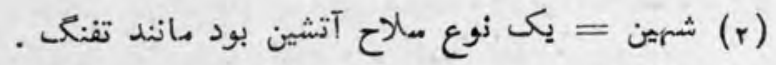

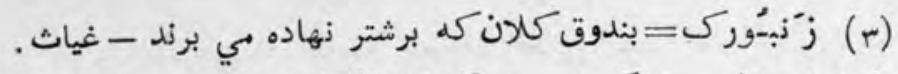

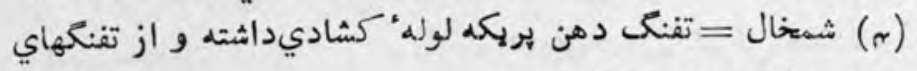
ديكر بسيار منكين بود - نظام. 
$\Delta \Delta$

تازه نواى مalر

اهتزاز نسايم- عنايت شاهانه ، بشكفتكي ازهارات خاطر

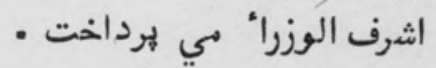

و ساعت بساعت ازمي خوشكوار اشفاقات_ خسروانه، بسرشاريـ

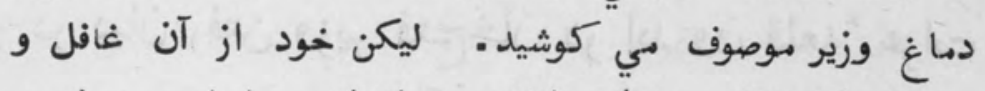

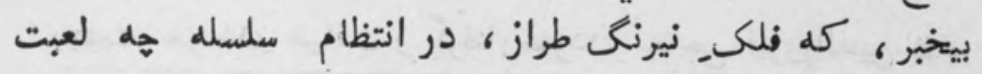

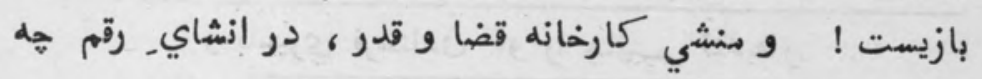

تدبير است ! 
در بيان رفتن وزير فتحخان در ادرون قلعهء هرات

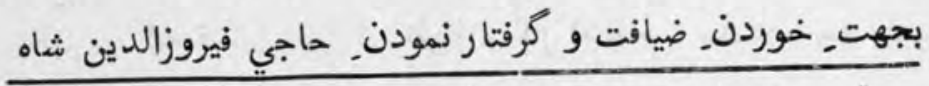
و باسيري فرستادن او را جانبـ قندهار

دير, قلم خوث رقم، انشاي_ اين مدعا را ، بر صحيفه" بيان،

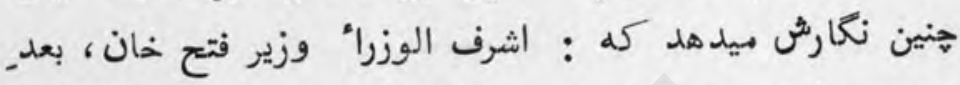

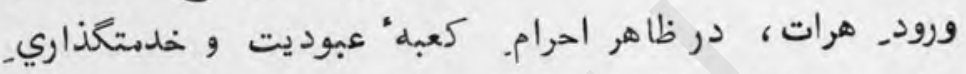

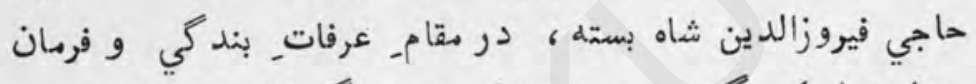

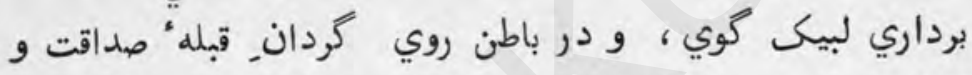

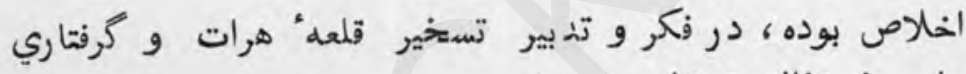

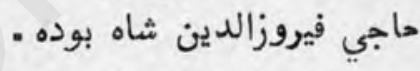

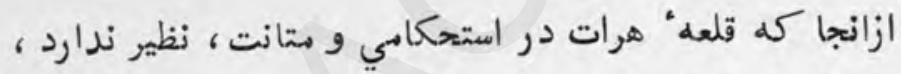

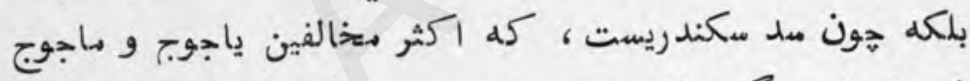

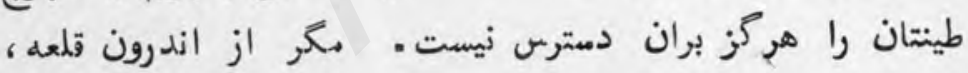

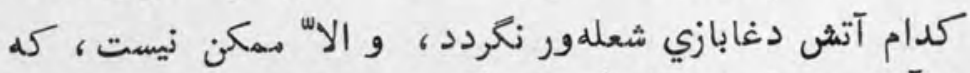

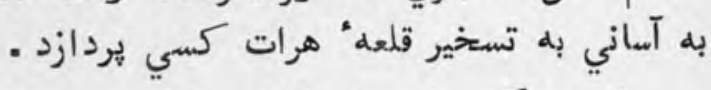

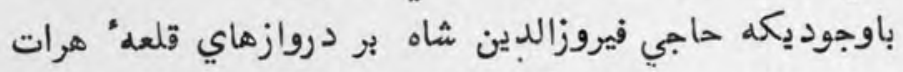

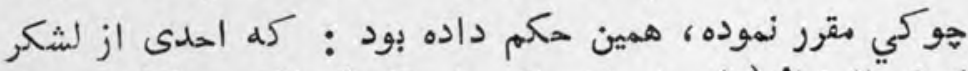

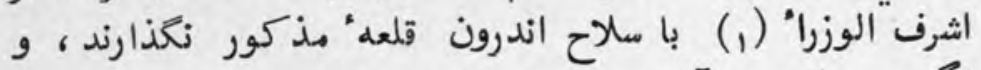

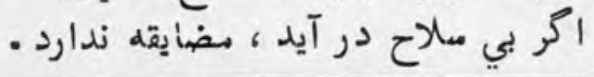

(1) الف: اشرف الوزراء بي سلاح اندرون درايد. 
اشرف الوزرا" !زين ماجرا واقف شده، و صورت اين احتياط

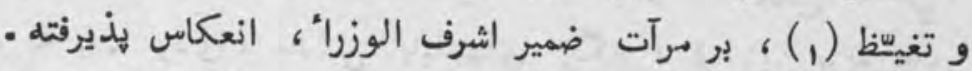

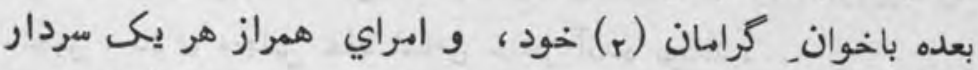

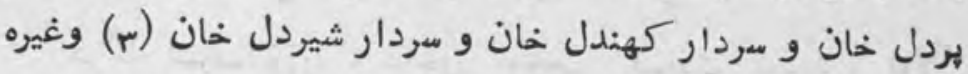

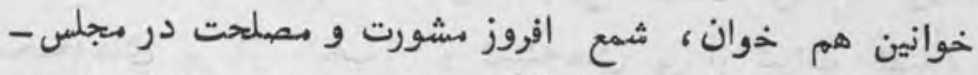

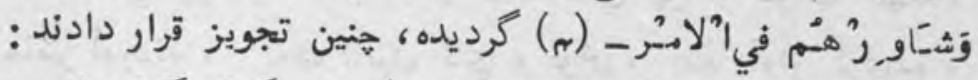

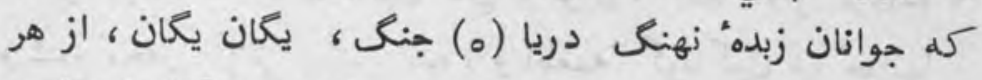

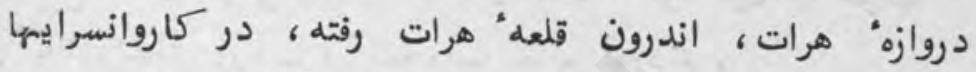

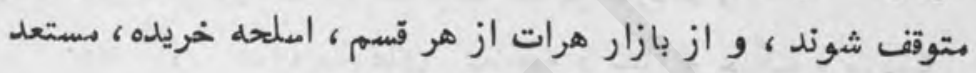

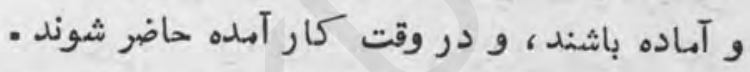

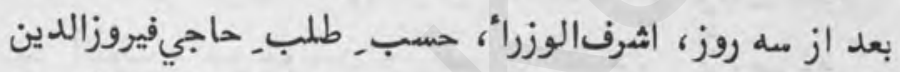

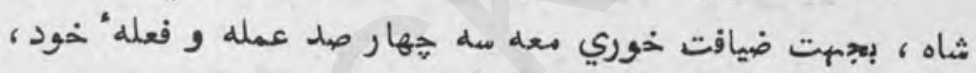

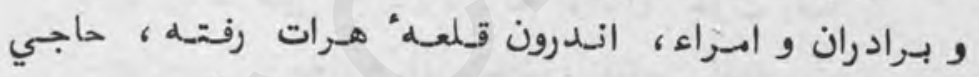

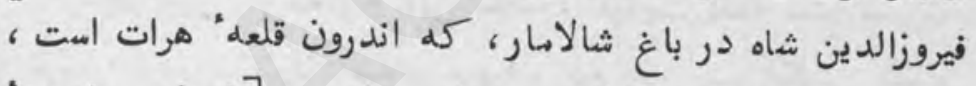

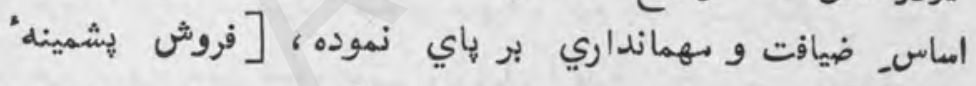

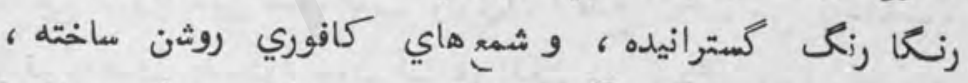

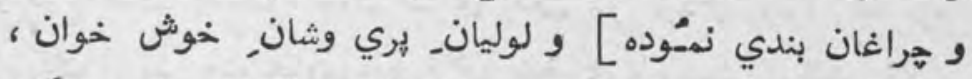

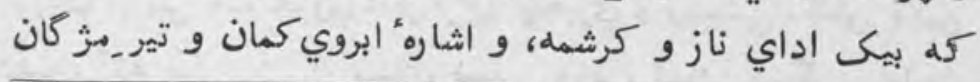

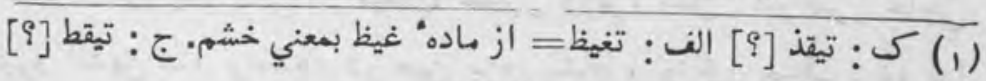

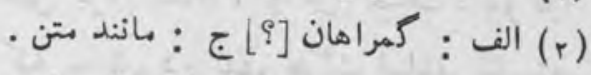

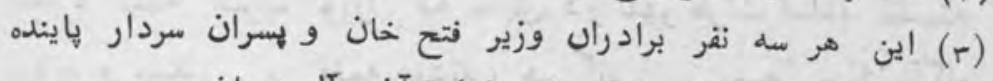

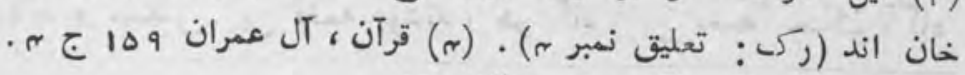
(0) 


\section{تازه نواي مساركى}

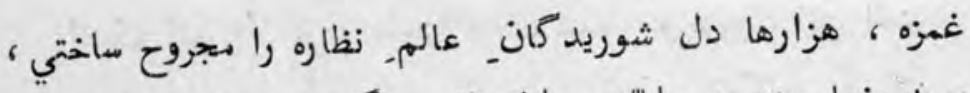

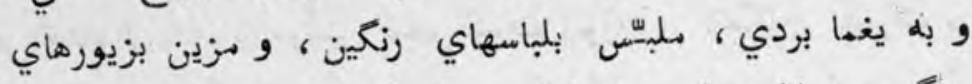

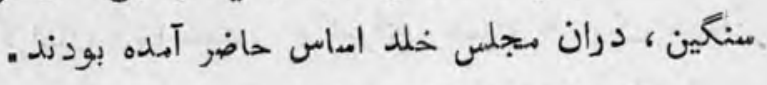

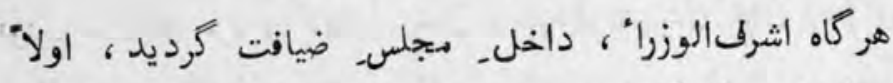

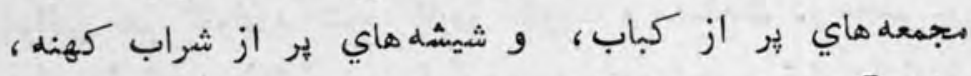

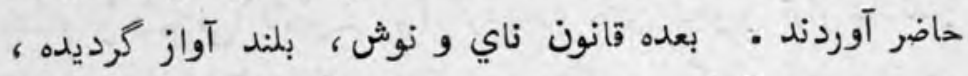

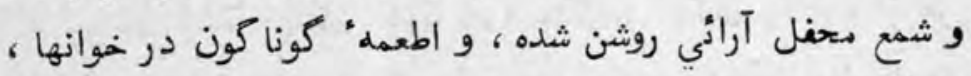

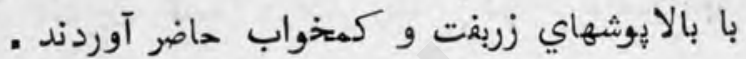

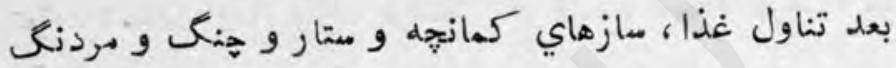

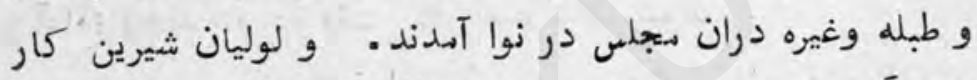

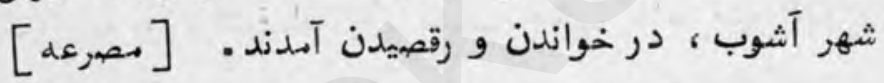

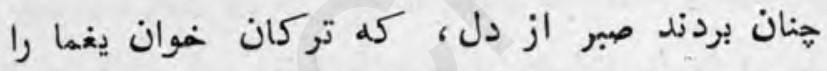

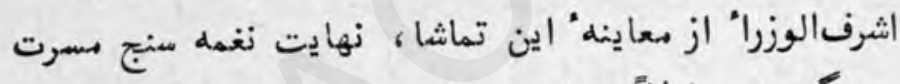

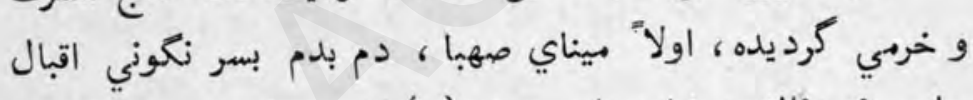

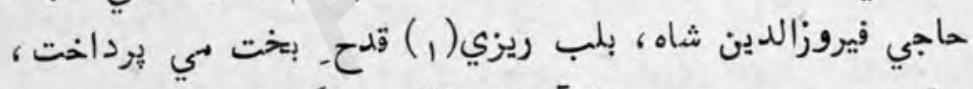

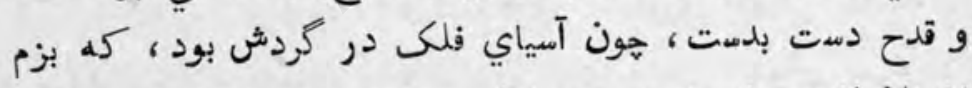

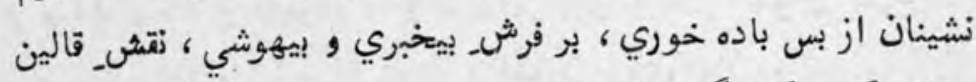

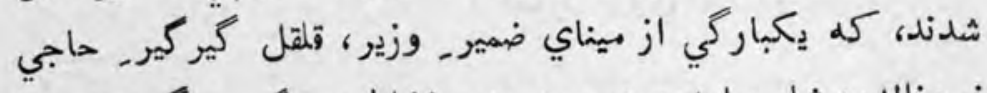

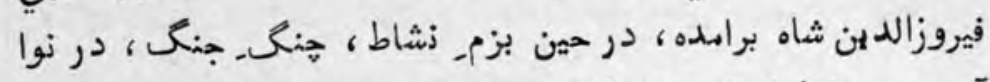

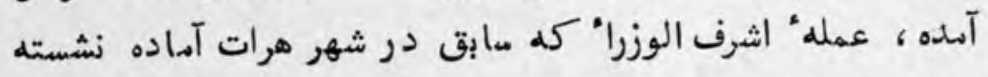

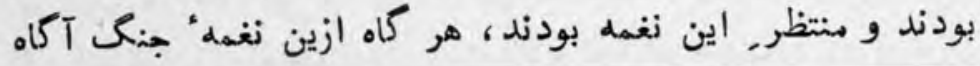

$$
\text { (1) كא: بلب زيرين [؟] . الف: مان:ند متن. }
$$


$\Delta q$

تازه نواي مa

شدند، باتفاق سردار دوست ميحهد خان ، جلموه ريز بر قلعله ارك

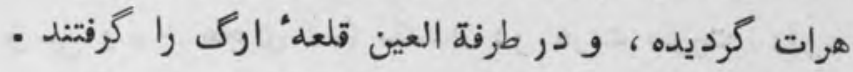

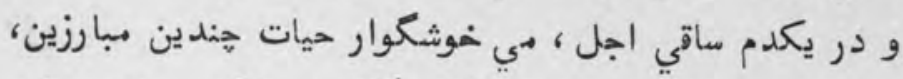

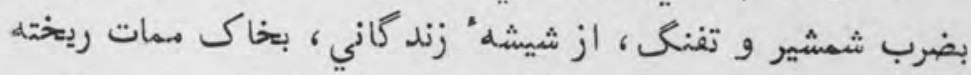

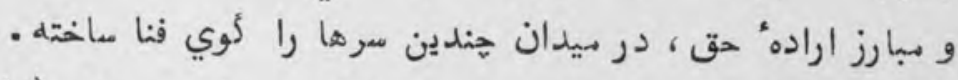

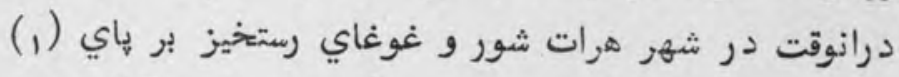

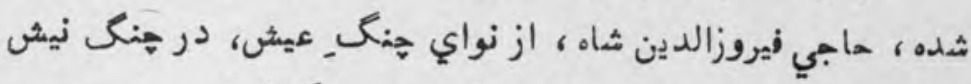

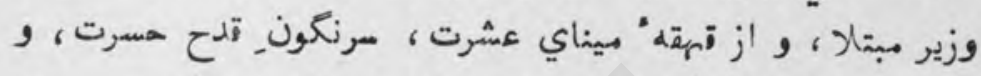

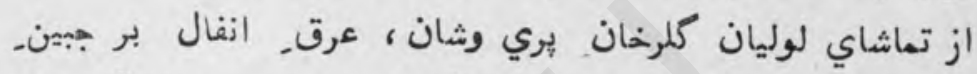

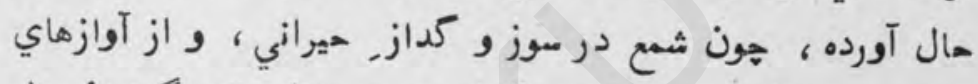

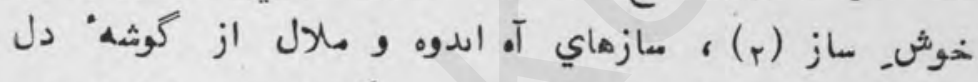

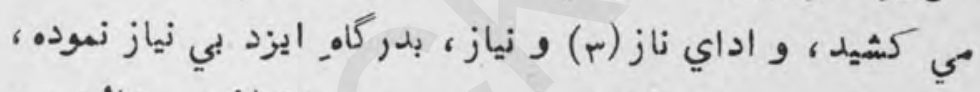

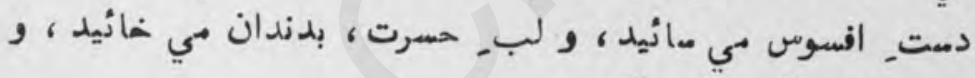

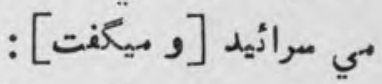

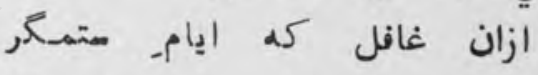

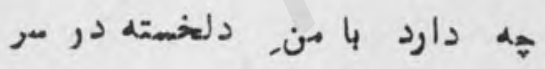
نبودم واقيف از تمهيد ايام

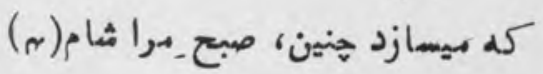
جهان را مقتضاي حال اينست

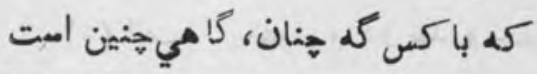

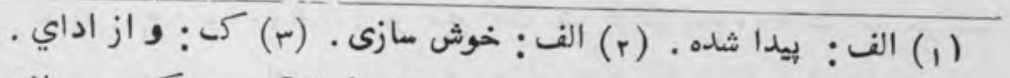

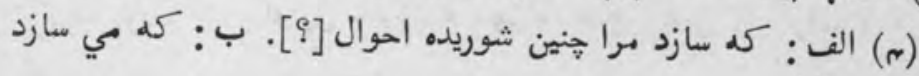

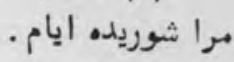




\section{تازه نواي معاركى}

بدرين قرار : (1) اسمهري حاجىفيروزالدين شاه ، در مسنه يكهزار

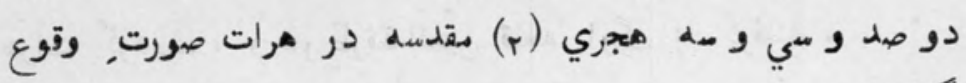

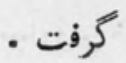

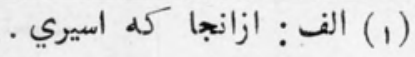

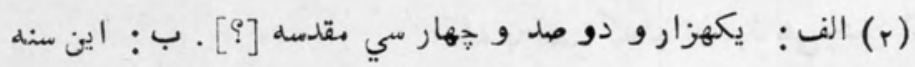

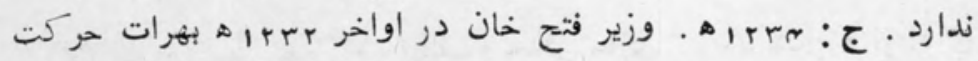

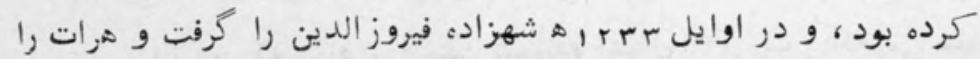

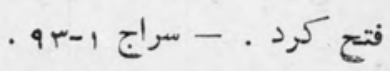


در بيان_رفتن_ اشرف الوزراء وزير فتح خان

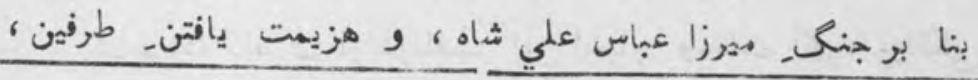

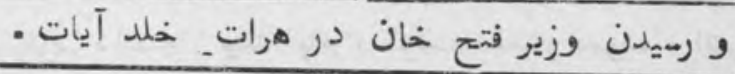

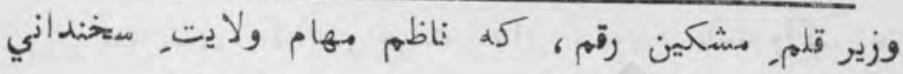

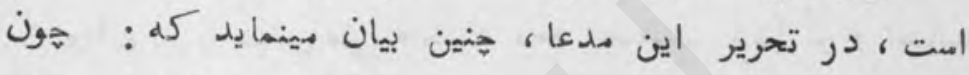

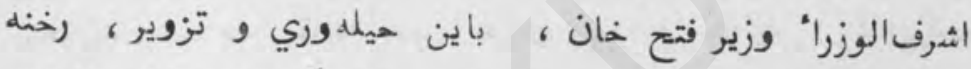

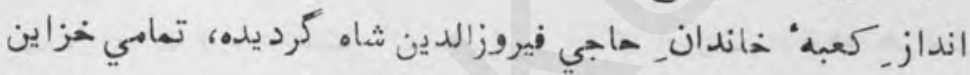

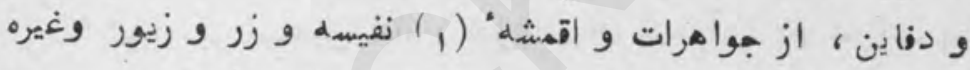

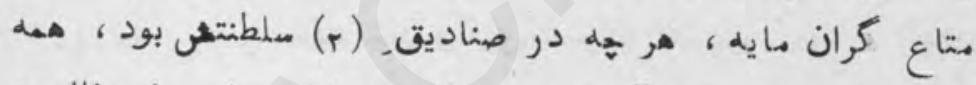

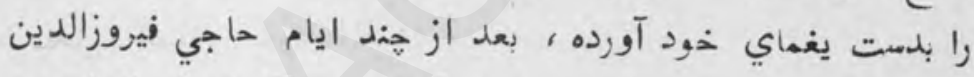

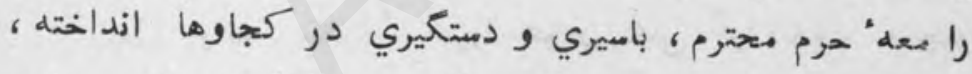

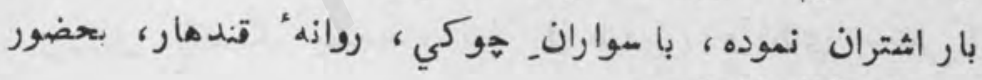

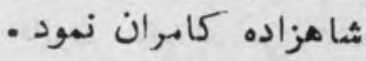

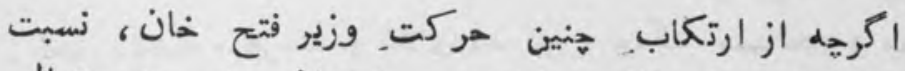

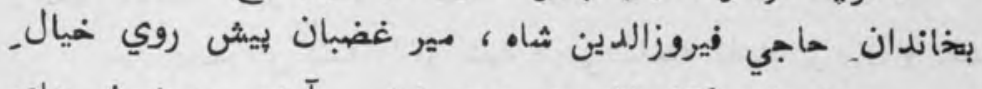

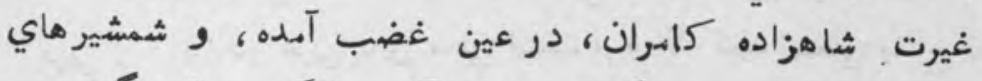

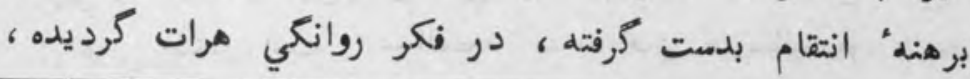

$$
\begin{aligned}
& \text { (1) (1) اقمشه = جمع قماثل بمعنى رخت بوشيدني. }
\end{aligned}
$$

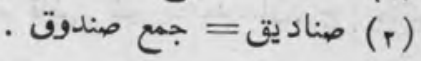


كه انتقام حاجي فيروزالدين شاه را از وزير فتع خان بكيرد ، كم كم

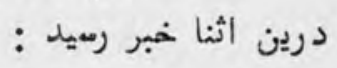

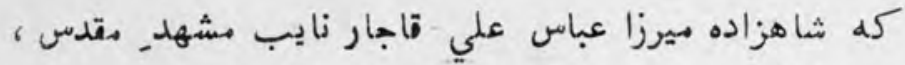

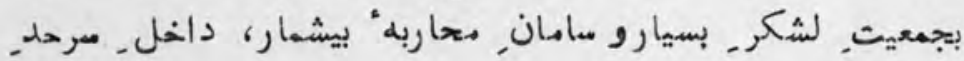

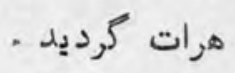

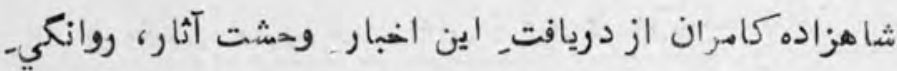

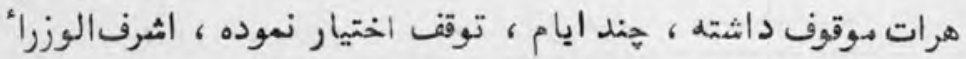

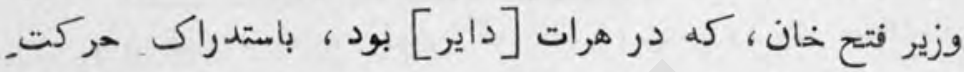

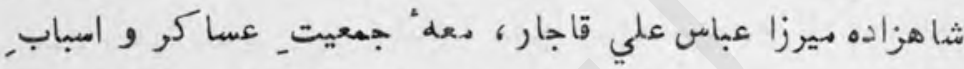

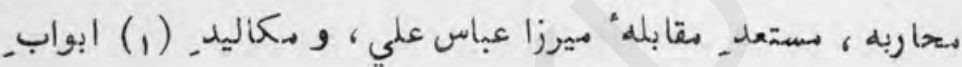

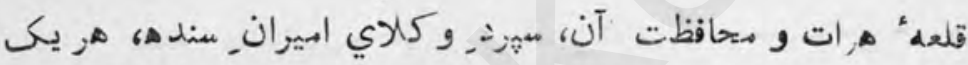

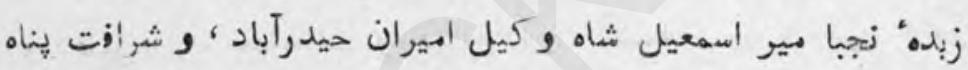

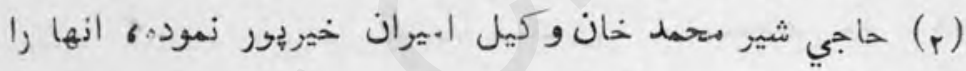

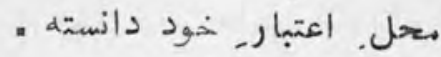

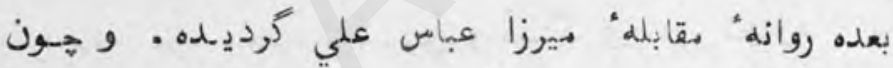

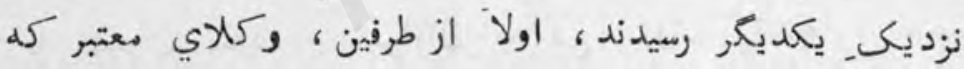

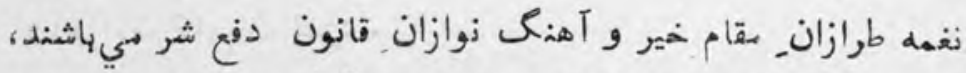

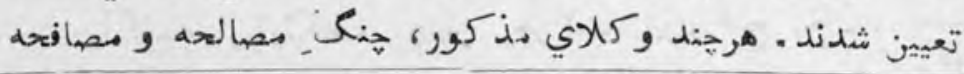

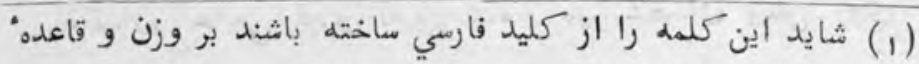

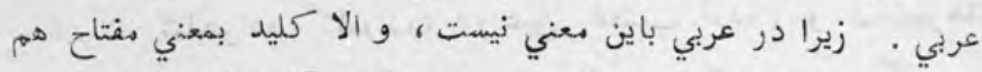

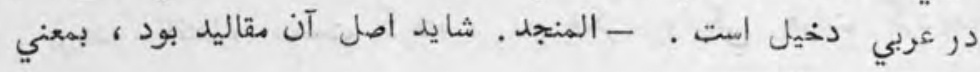

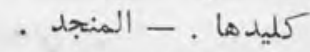
(r) الف : شرافت يناه خالويام قاضي شير متممد خان. ج : مانند متن 
ir

تازه نواي مار

در مهفل. طرفين ، بصد طرز عاقلانه در نوا در (1) آوردند ؛

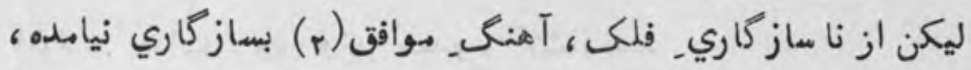

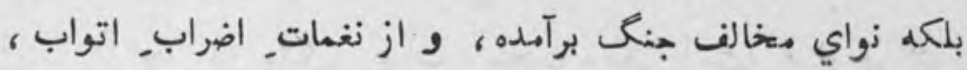

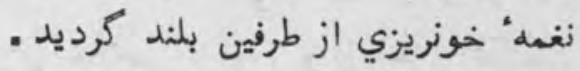

در اين هالت ثير. بيشه" هاددت و بهادري ، و هزبر, كوه.

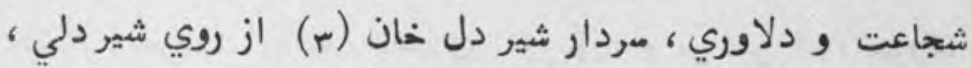

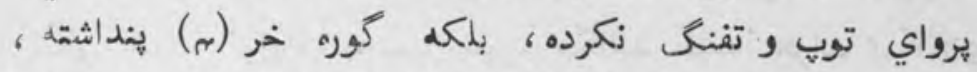

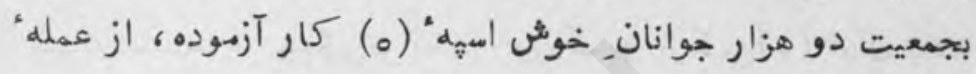

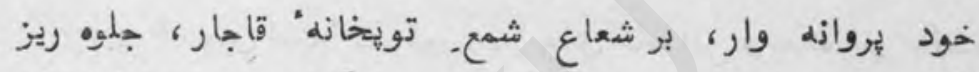

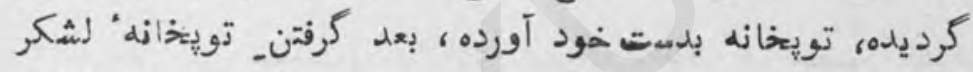

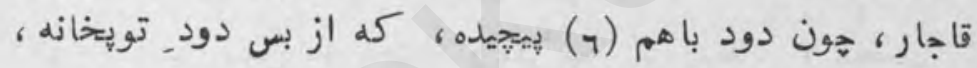

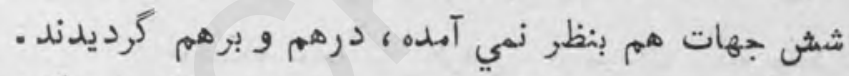

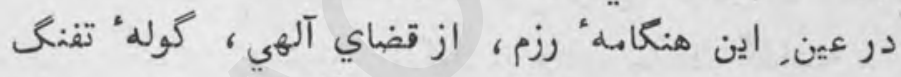

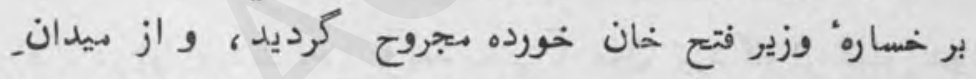

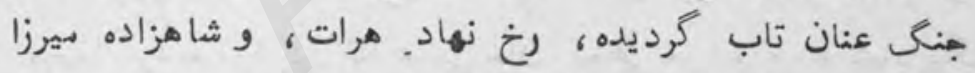

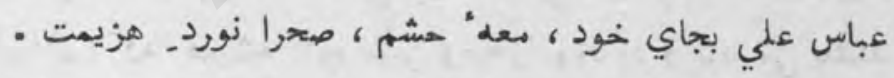

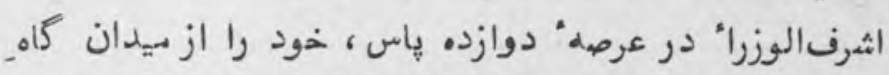

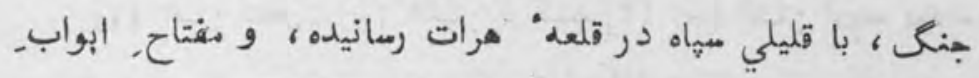

(1) الف: در نواي آوردند: (r) الف: نيرنك موافق.

(r) شير ذل خان برادر وزير فتع خان بود. . (r) الف : كورخر .

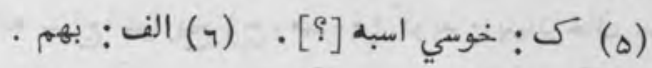




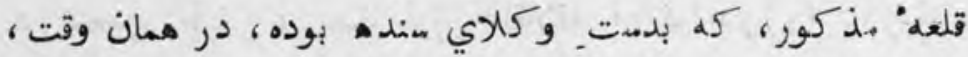
ابواب هرات بروي وزبر همدوح كشادند .

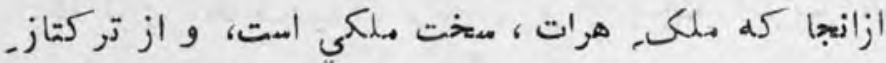

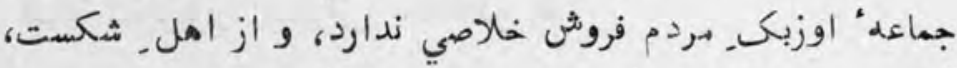

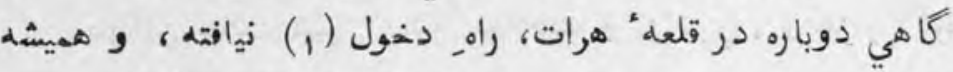

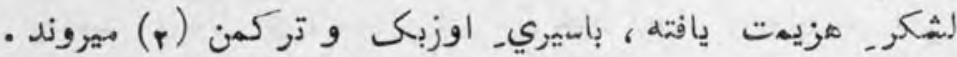

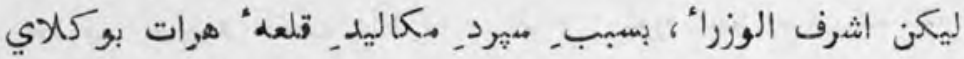

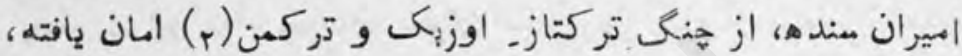

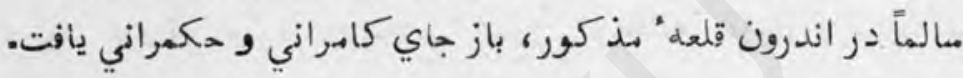
بعن. اين خدهت، وكلاي اميران سمنده در حضور اشرف

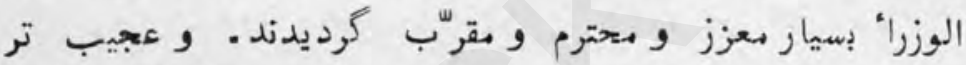

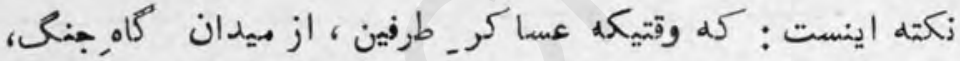

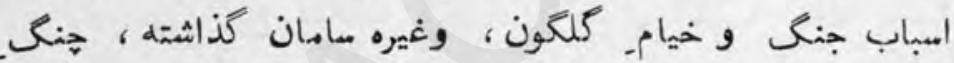

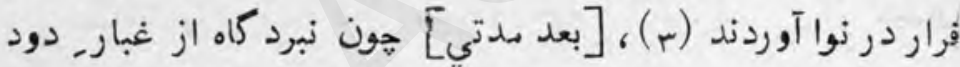

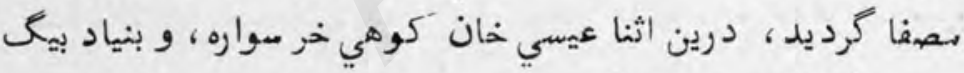

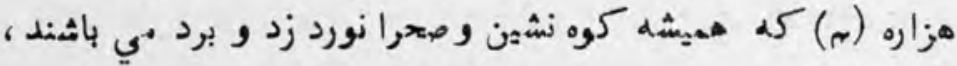

(1) الف: دخل . (r) الف: تركمند [؟] (r) الف: آورده بودند.

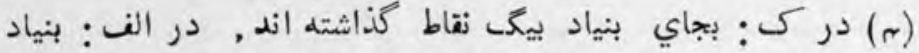

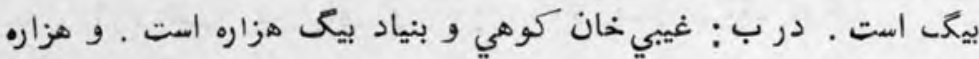

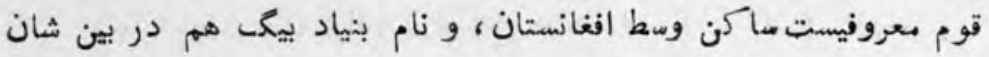

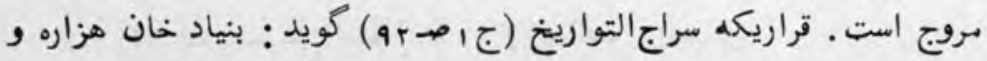

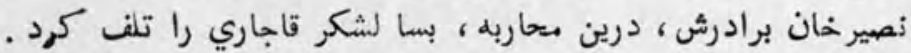


70

تازه نواي معارك

در ديدان كاه. جنك رميده، تمام اهباب از خيام- كملكون وغيره

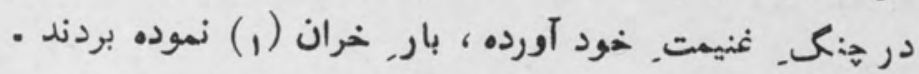

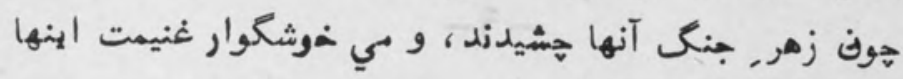

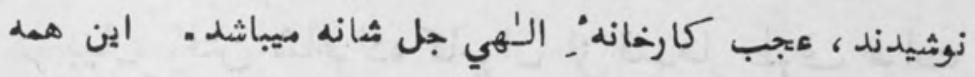

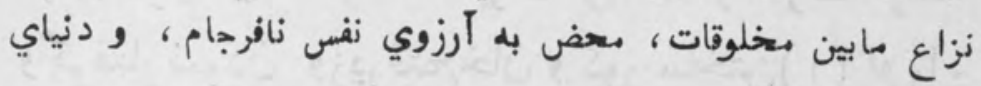

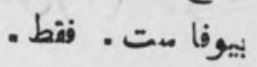
[و اين مقدمه در م-نه يكهزار و دو مد و مي و خهار هجري

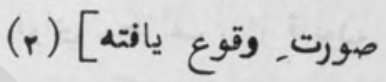

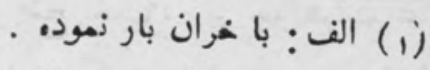

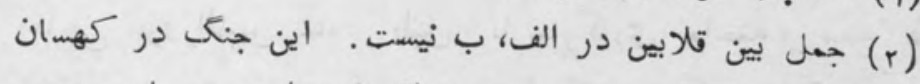

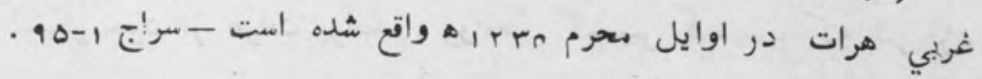

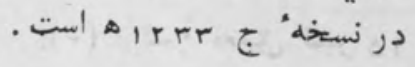


در بيان_ رفتن شاهزاده كامران از قندهار طرف هرات

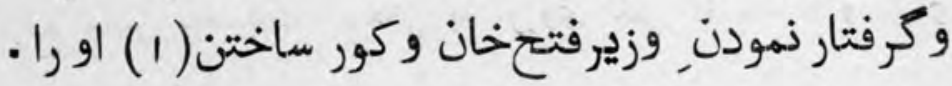

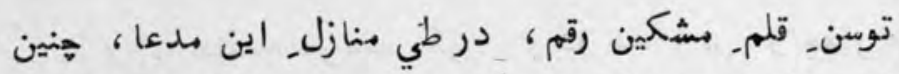

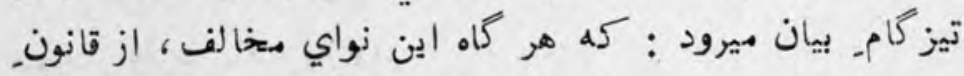

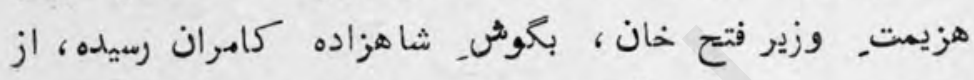

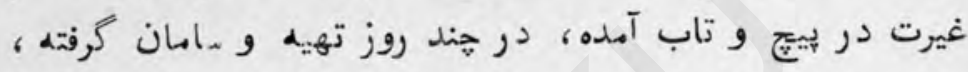

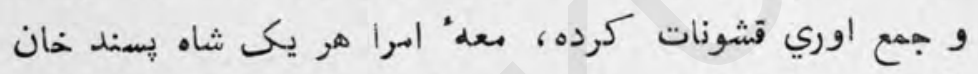

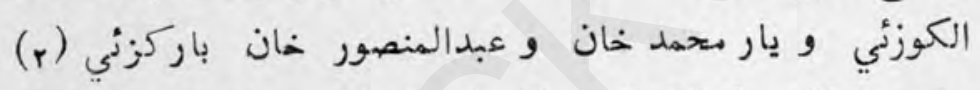

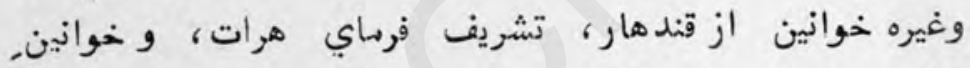

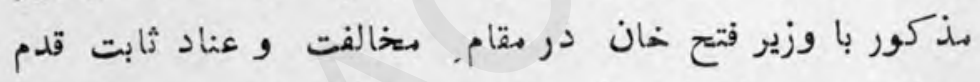

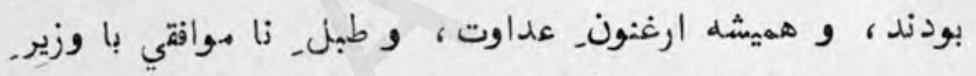

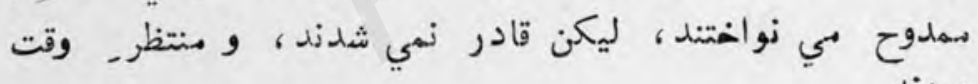
بودند.

هر كاه شاهزاده كامران، بقطع- هنازل، رونق افزاي هرات

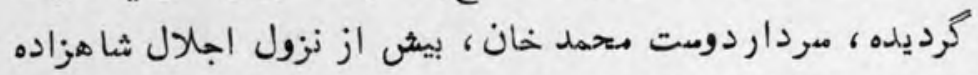

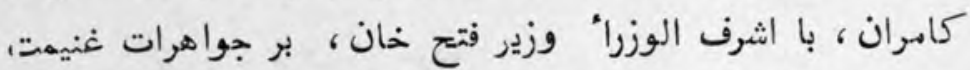

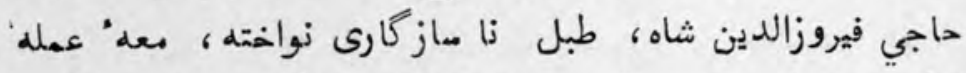

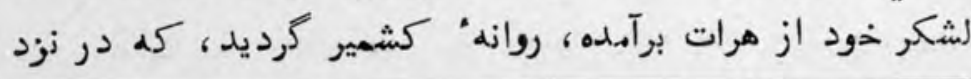

10 10 (r) (1) الف : كور نمودن. 
تازه نواي معاركى

مردار محمد عظيم خان رفته ، خود را بدمت غود ، كرفتار و

• نطربند نمود (1)

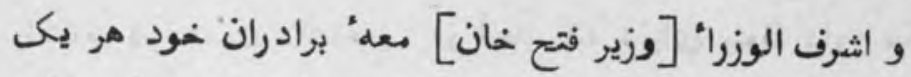

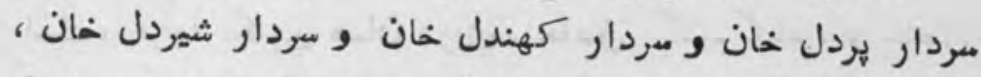

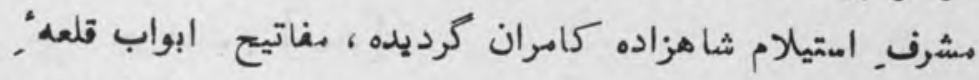

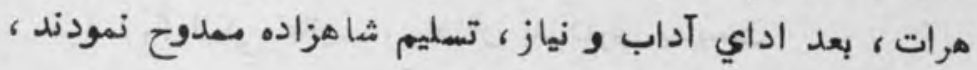

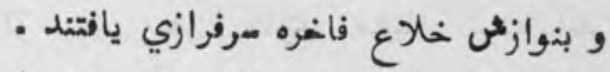

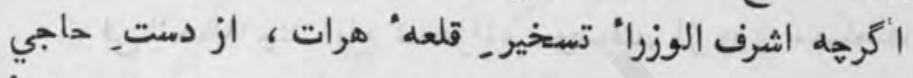

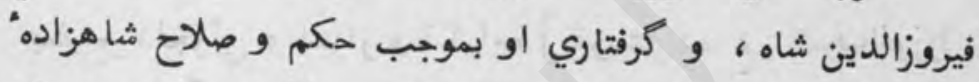

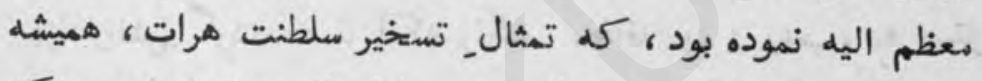

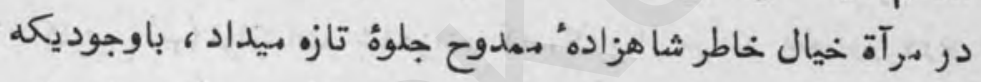

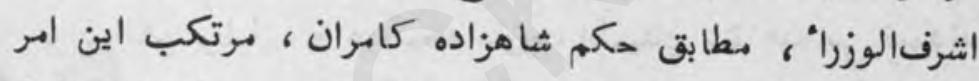

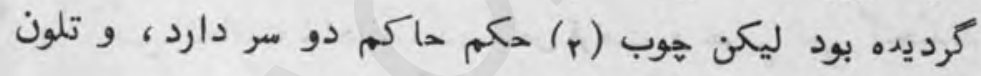

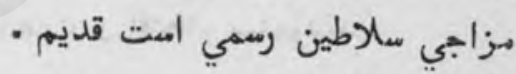

بسب بونا كون بي عزتي و بدرا-وسي [خاندان] حاجي

(1) نيض محمد هزاره مورخ دربار امير حبيب الله بي نويسد :

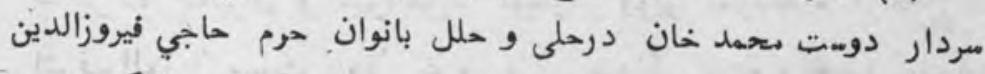

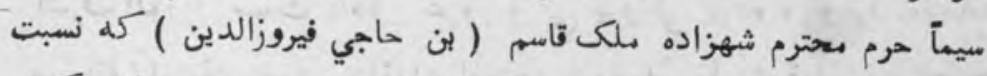

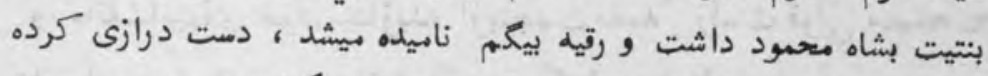

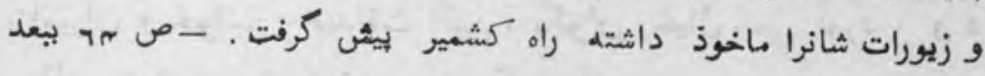

تحفة الحبيب خطي . ركى: تعليق 17

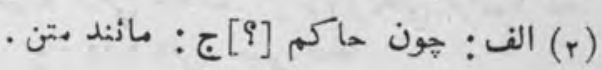


فيروزالدين شاه ، غبار , آزرده كي، بر آثينه ضمير شاهزاده كامران

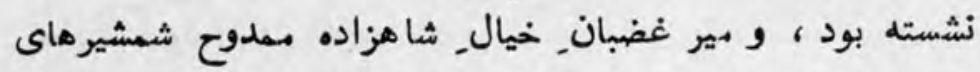

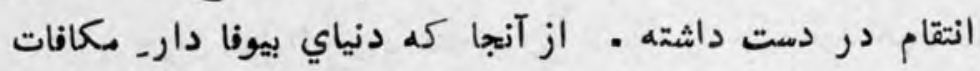

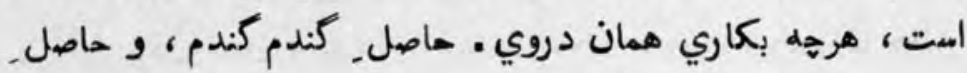

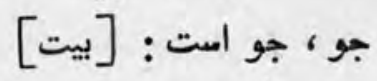

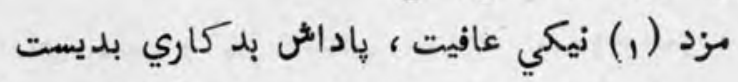

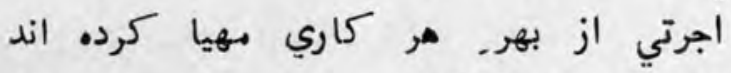

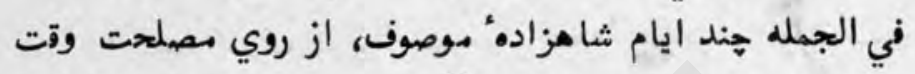

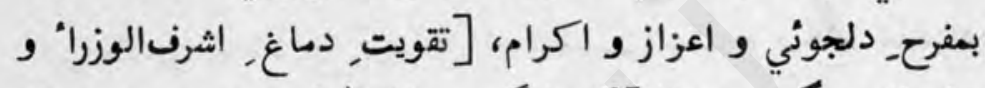

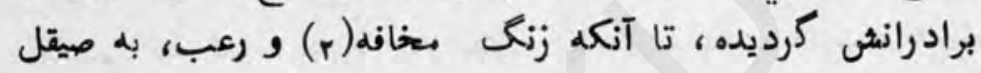

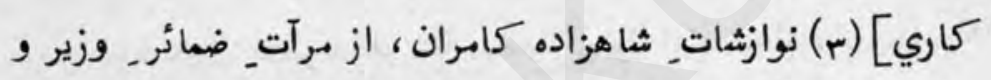

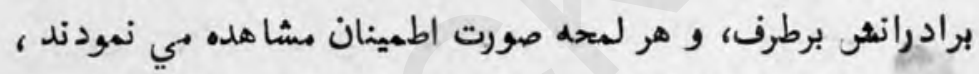

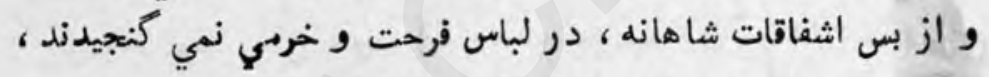

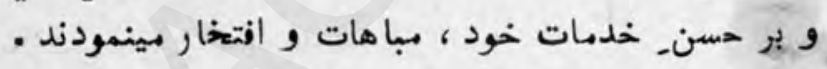

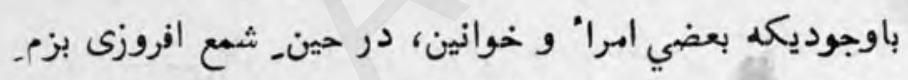

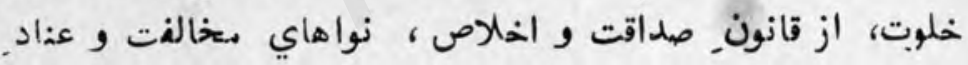

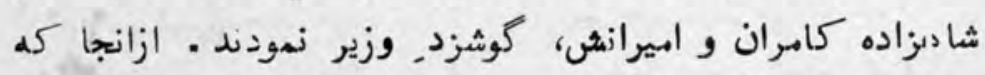

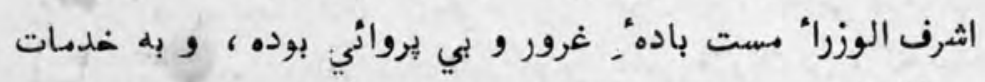

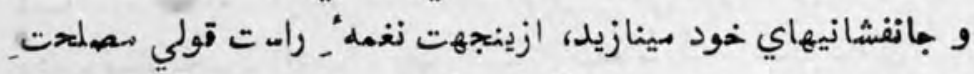

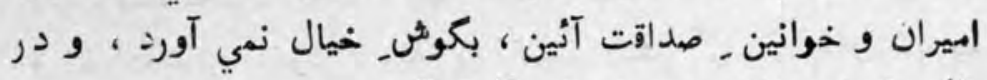

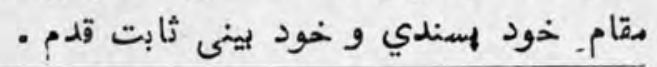

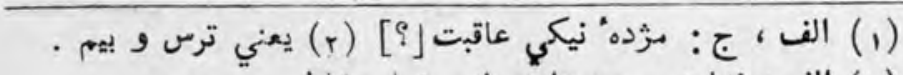

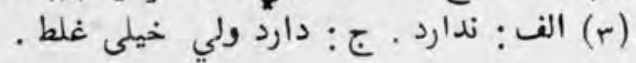


جون خود بهسندي دليل. ناداني است، اشرفالوزراء از جلاد.

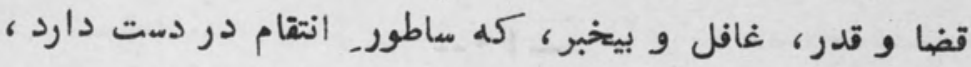

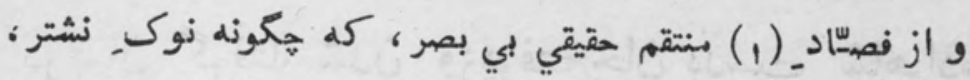

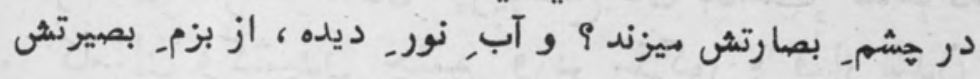
ميريزد

(1) فهيّاد= رك زن. الف: و از قضا و منتخم. 
در بيان, گرفتار شلدن وزيرفتحخان بلسست, شاهزاده

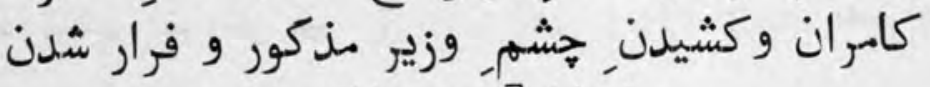

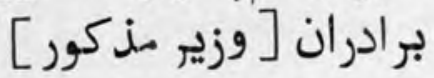

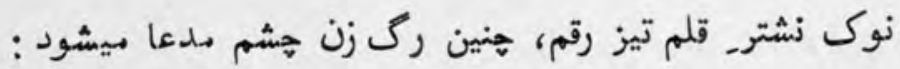

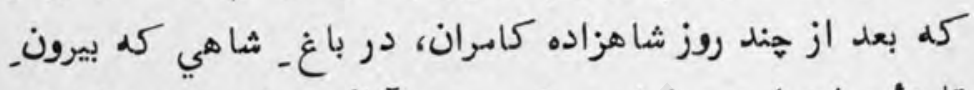

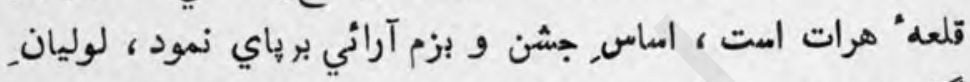

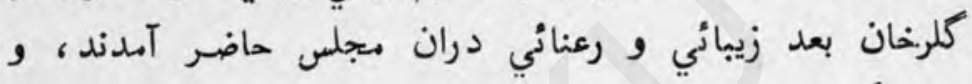

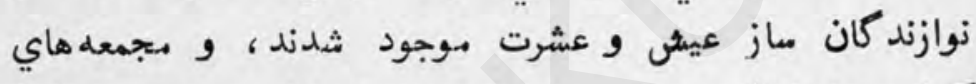

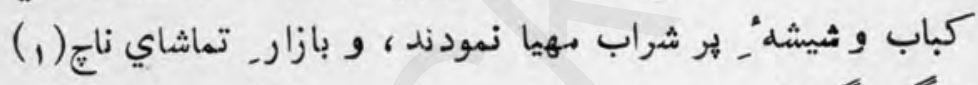

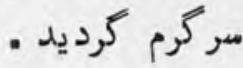

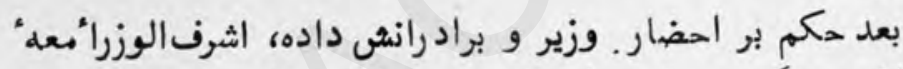

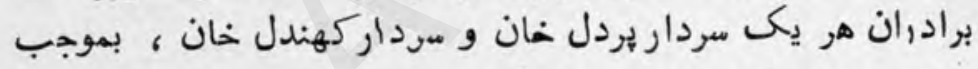

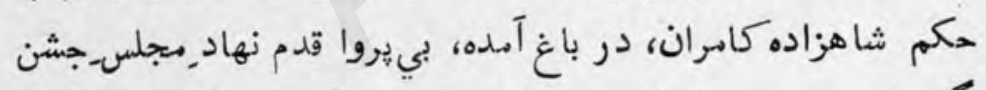

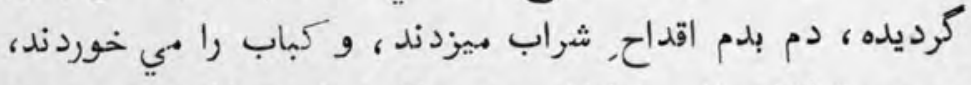

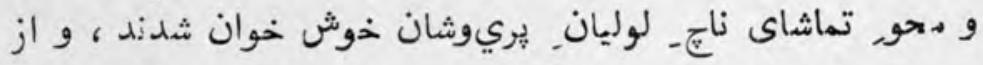

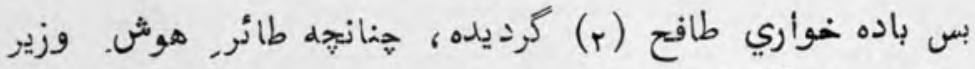

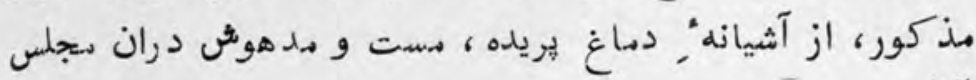
افتاده .

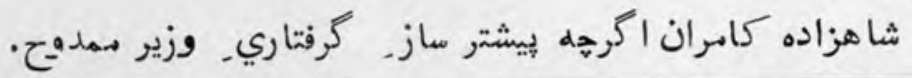
(r)

$$
\text { . نإ }
$$




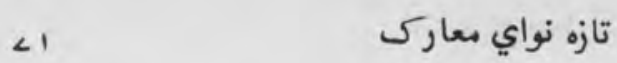

با حريفان هم راز، كوك مـاخته بود ، و در وقت_ بيهوشي وزير

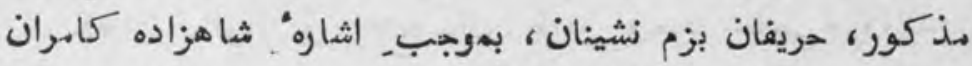

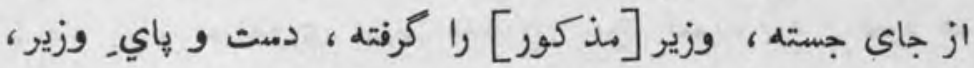

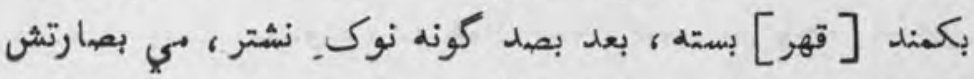

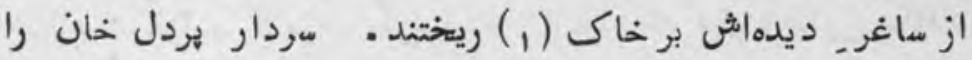
باينهمه هردلي در حبس بردند، و سردار كهندل خان از رودي.

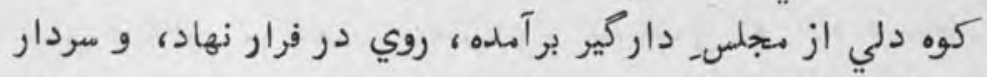

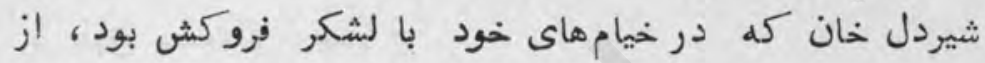

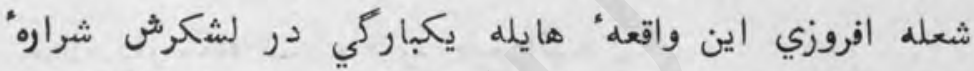

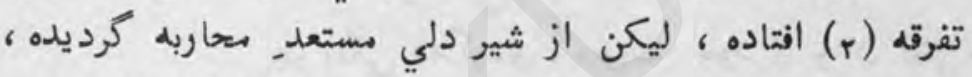
و با عمله" _ جوانان_ بهلوان_ خود، حمالات دليرانه" بسيار نموده،

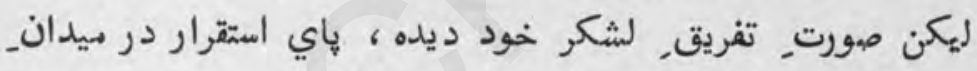

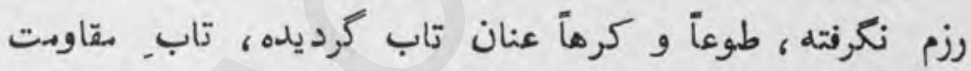

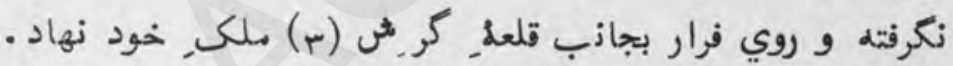
شاهزاده كامران، بعد كوري وزير مذ كور، و كرفتاري بردل خان،

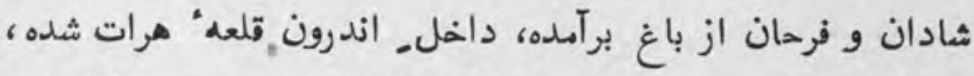
بر تخت_ سلطنت_ هرات جلوس فرماي ، و منادي دور دور حكمراني

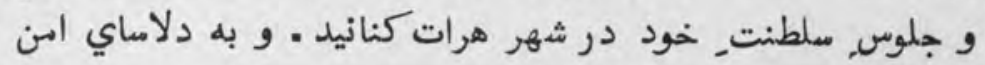
(1) الف : برخاكى بى بصارتش ريختند (r) الف: شراره" افراتفرى

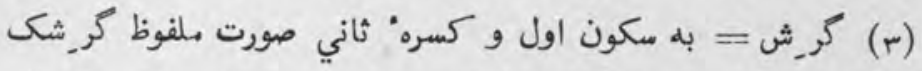

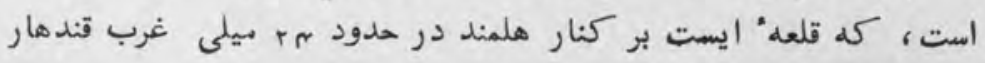
و مسكن اقوام باركزني است. 
تازه نواي معارك

$\angle r$

و امان رعاياي ماكنين. هرات، از خاص و عام برداخت، جهون

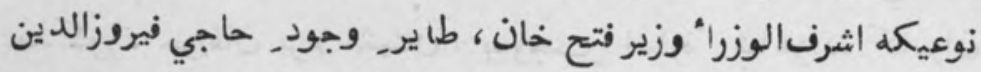

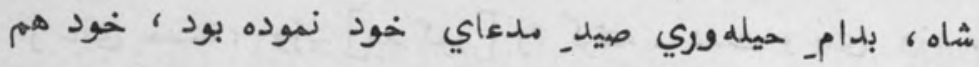

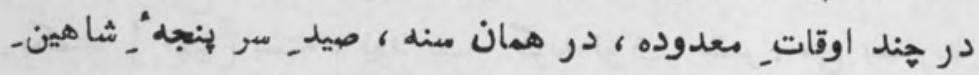

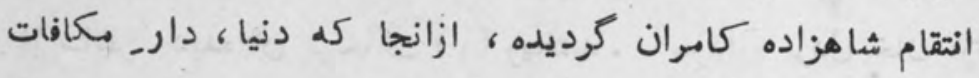

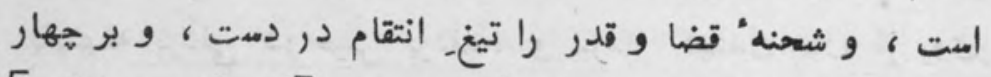

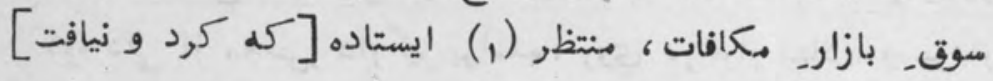

بر طبق مضمون بيت جهان دار ركافاتست ، دارد طبع آثينه بهر رنكي كلكردي ، صورت_ خود را هنان بيني

(1) الف: انتظار ايستاده . 
در بيان آمدن ( 1 ) شاهزاده جهانگير خلف شهزاده كامران طرف كابل

و بهنى نمودن با سردار دوست متحمد خان و هزيمت [يافتن]

$$
\text { شهزاده" هذكور }
$$

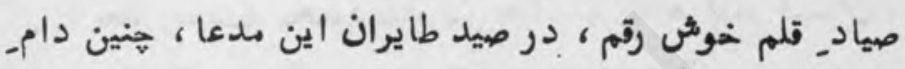

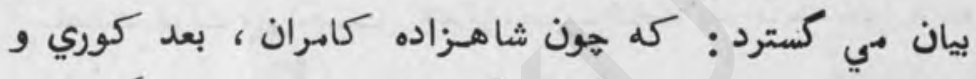

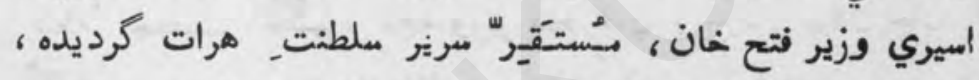

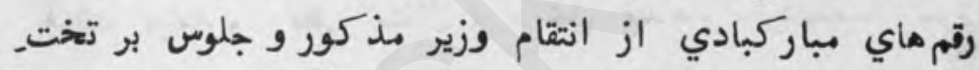

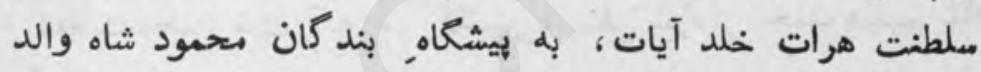

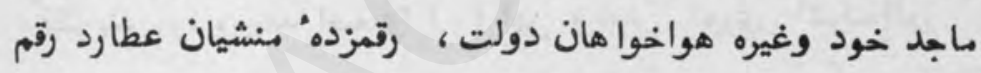

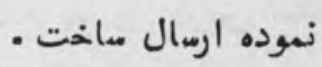

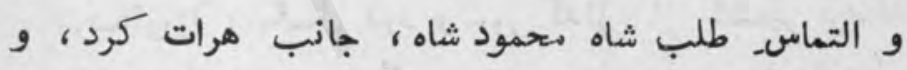

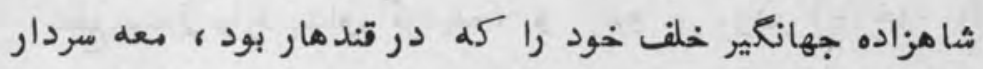

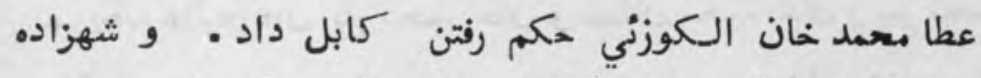
سالطان علي (م) سابق در كابل ، صدر نشين حكمراني بود دان.

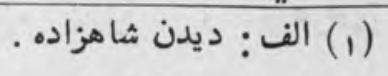

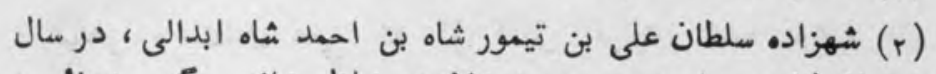

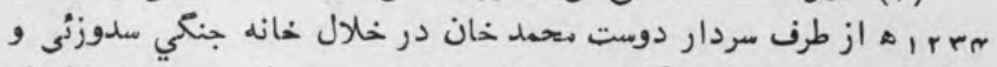

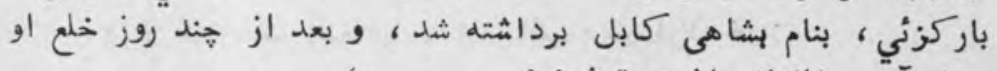

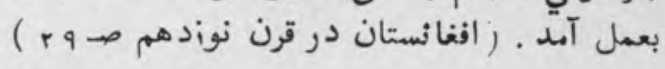


تازه نواي معار

$\angle r$

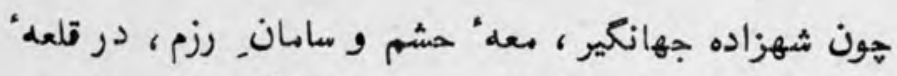

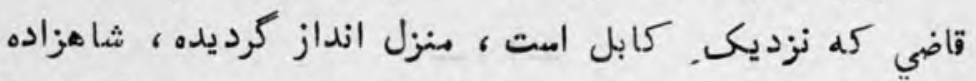

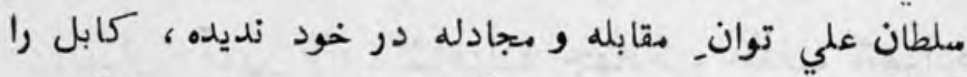

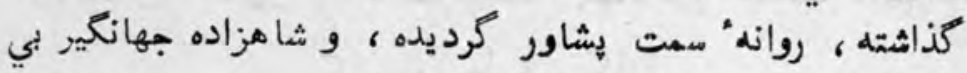

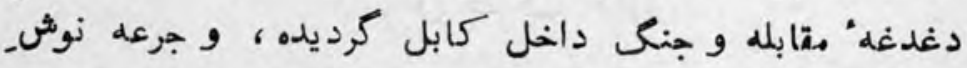
باده حكمراني شده ، و بند كان مجحمود شاه ، حسبب التماس كامران

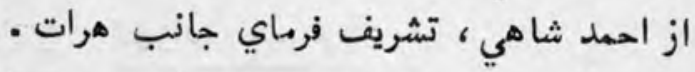

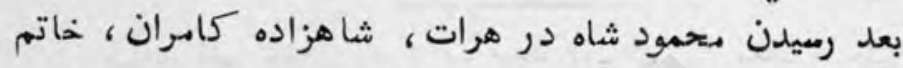

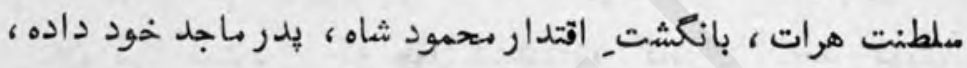

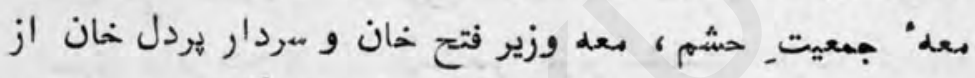

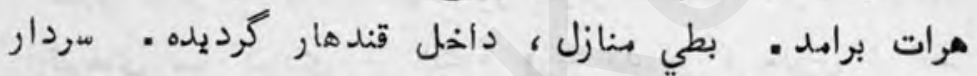

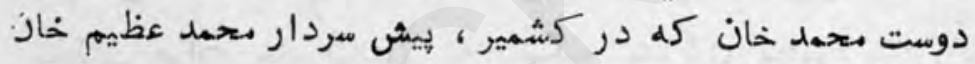

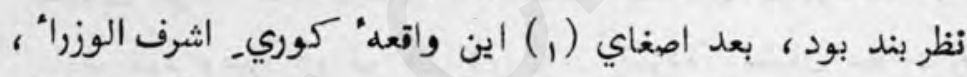
بدوجب, مصلحت سردار ميحمد عظيم خان ، بنا بر كرفتن انتقام

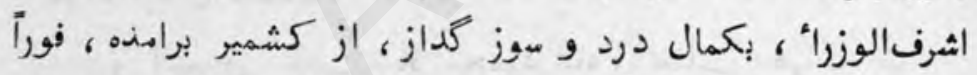

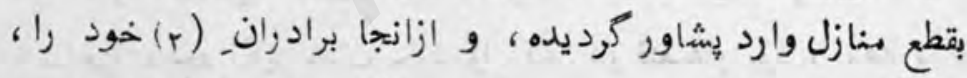

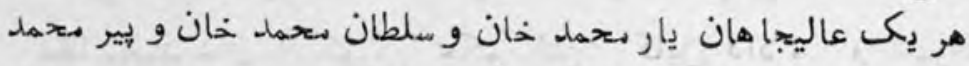

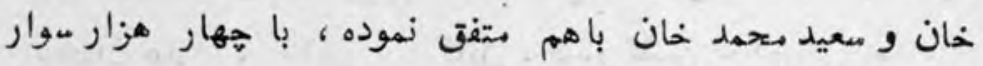

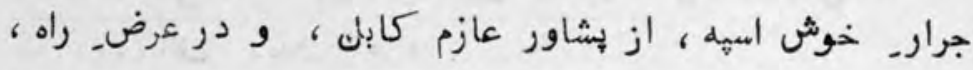
شاهزاده سمطان علي كله از كابل فراري شده بود ، با سردار

(1) אى: خبر اصغاي . (r) الف : سرداران خود . 
دوست بحمد خان ملاقي كرديده . . مردار مهدوح شا هزاده: مذكور

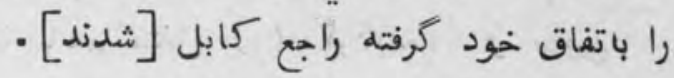

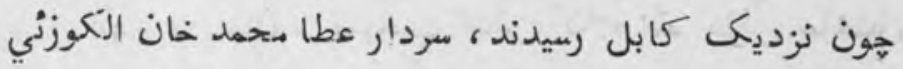

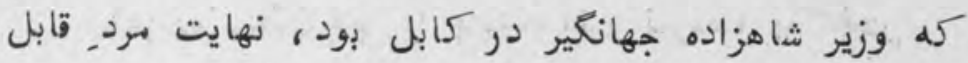

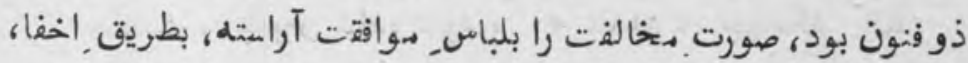

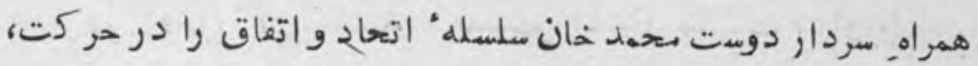

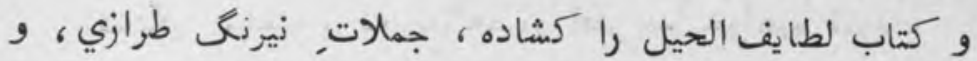

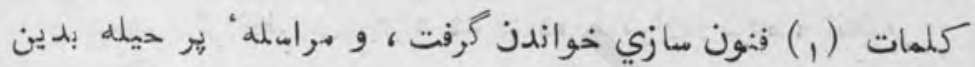

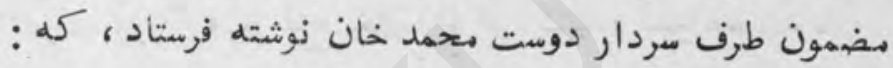

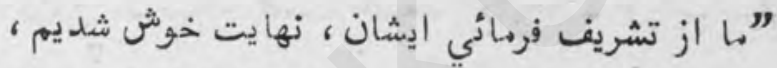

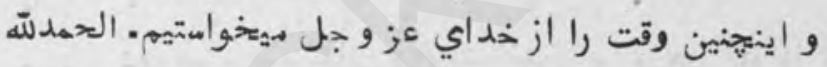
كه بآرزوي دل خود كامياب كرديديم. بر جهان و جهانيان

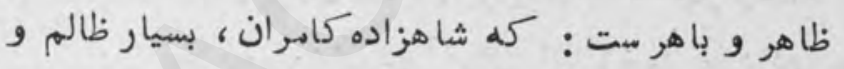

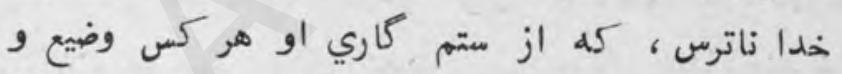

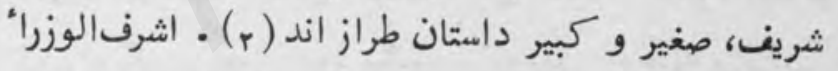

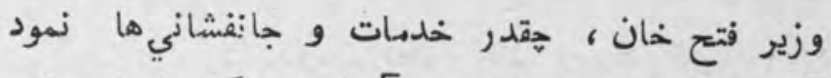

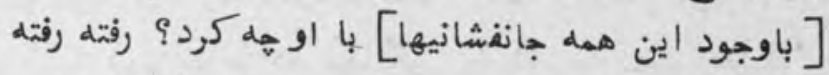

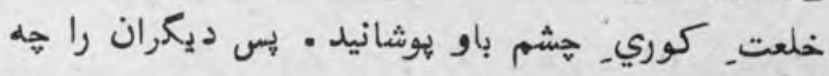

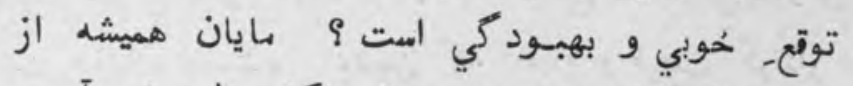

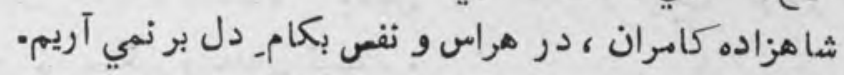

(1) الف: و آيات فنون سازي. ج : و آيات فسون سازي .

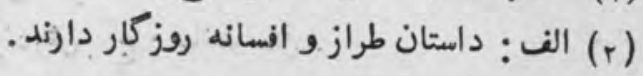


كازه نواي نساركى

$\angle 7$

مدبّّر انديشه و فكرـ ما همين تدبير نموده اهت :

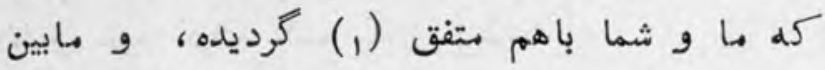

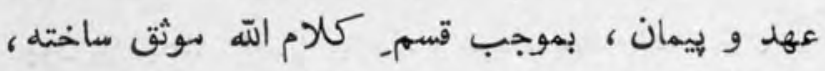
شاهزاده سلمطان علي را يادشاه مقرر نموده ، بر تختــ

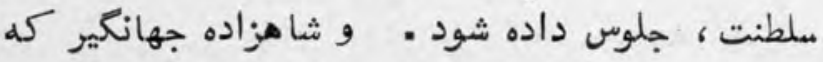

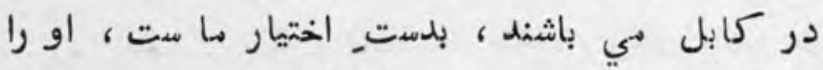
دستكير ماخته ، در بالاحصار نظر بند خواهيم نمود بعنه فكر تخريب بنياد شاهزاده كاسران كرده ، انتقام- دان

اشرفالوزرا" وزير فتح خان از او كشيده خواهد شده .

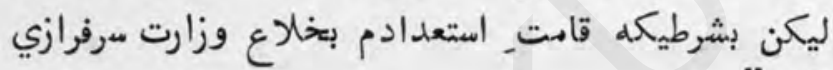
" يابد "

سردار دوست دمهمد خان و برادرانش (r) )، هر كاه از نوشته

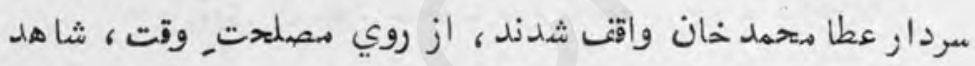

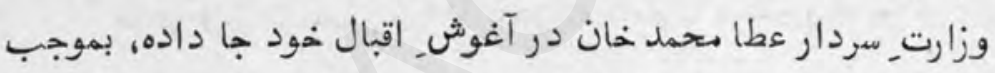

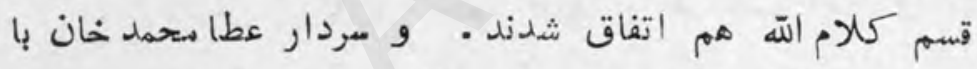
شهزاده جهانگير ، بجاي خود مشوروت نموده، دامحيله و فريب بازي،

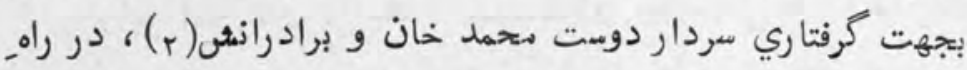

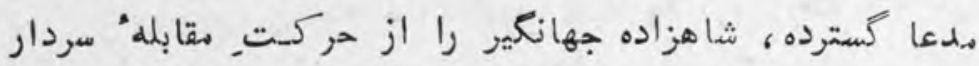

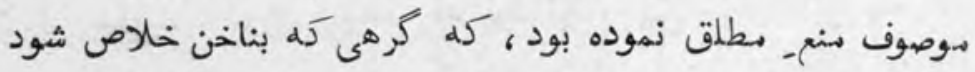

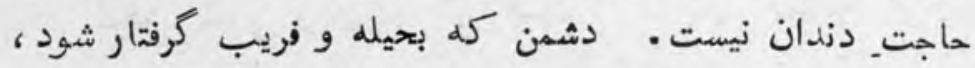

احتياج جناج و جدال نيست (1) الف: الف: اتفاق كرده .

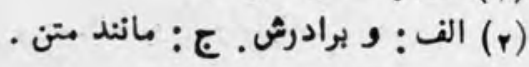




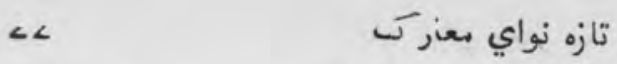

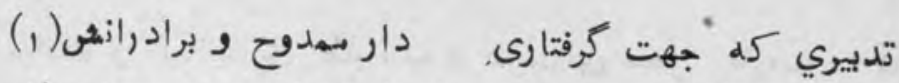

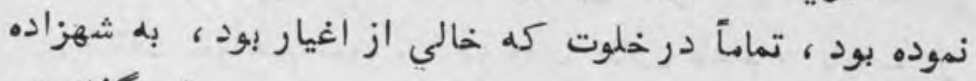
جهانكير حالى نموده ، بالش استراحت بزير, سرش كذاشته ؛

اطمينان_ او نمود جانير

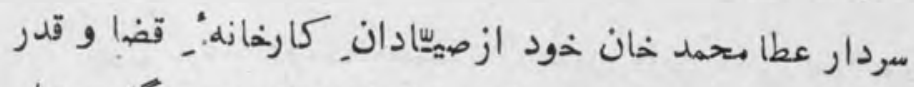

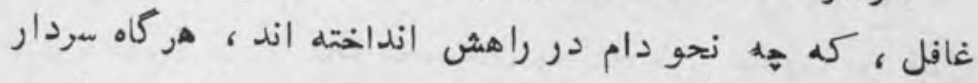

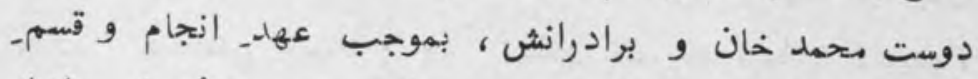

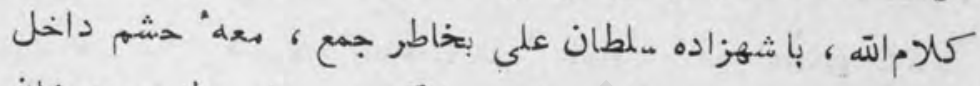

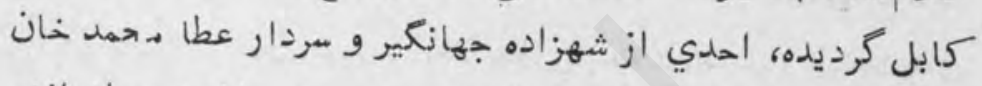

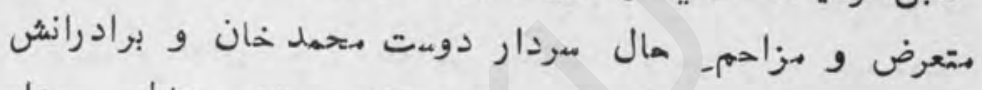

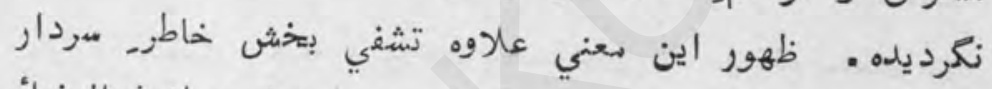

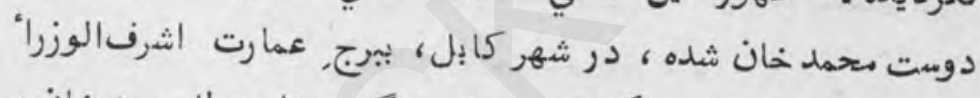

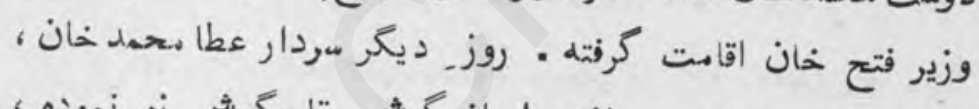

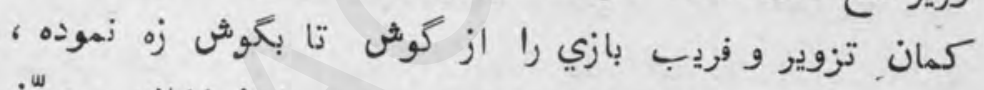

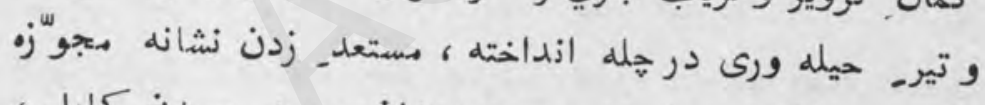

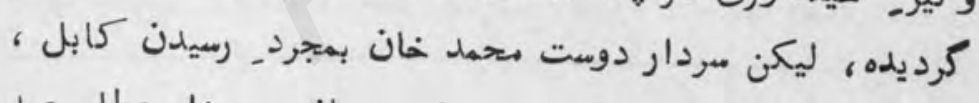

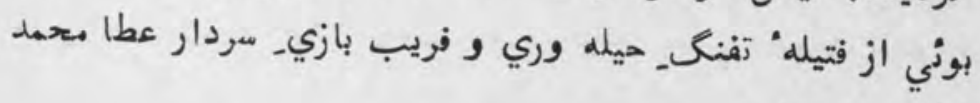

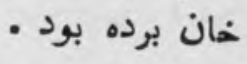

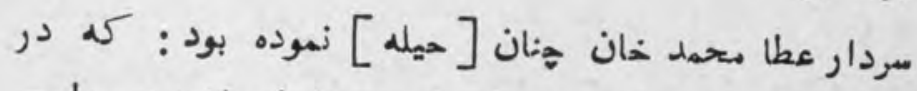

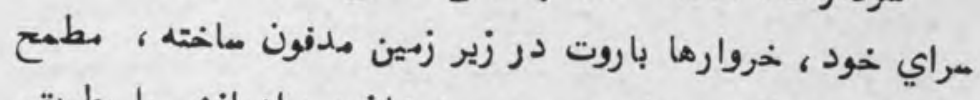
نظر داشت : كله مردار دوست محهد خان و برادرانش رأ بطريق. ردون.

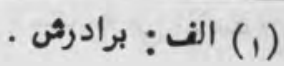


ضيافت و رهمانداري طلبانيده ، درسراي نحل باروت ، مجلس

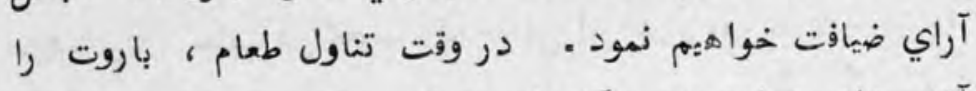

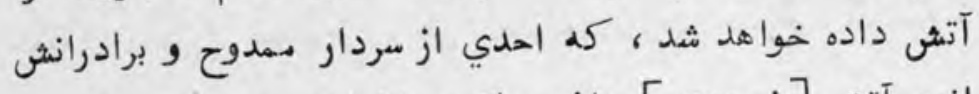

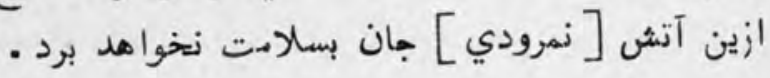
هون سردار دوست دحمد خان هابق ازين دعني اطللمع يافته

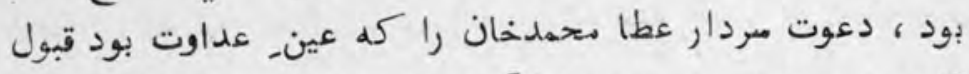

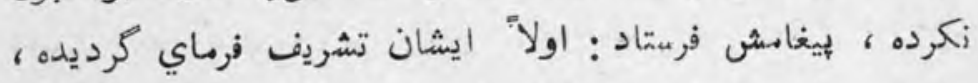

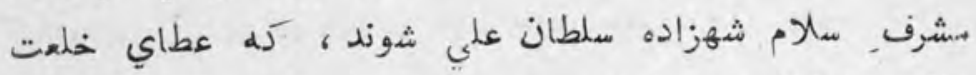

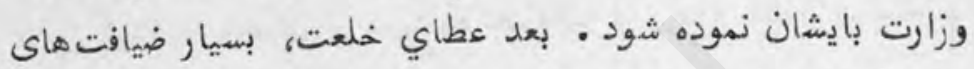

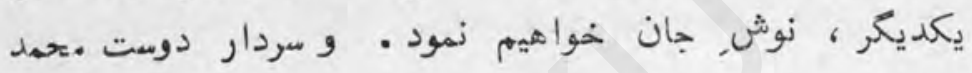

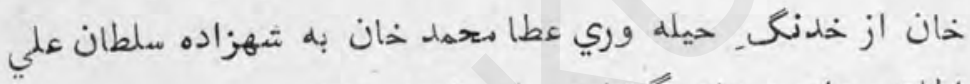

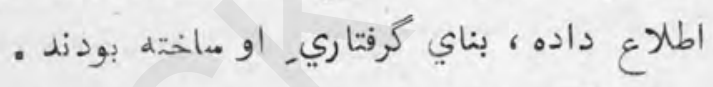

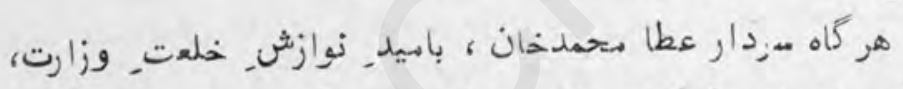

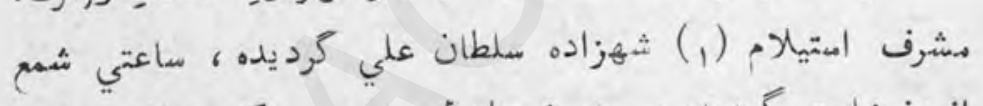

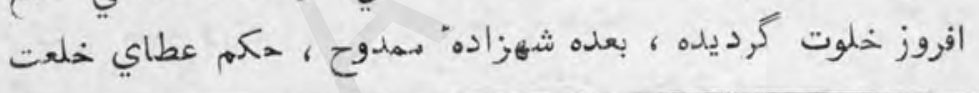

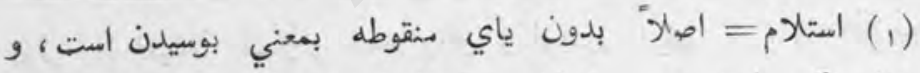

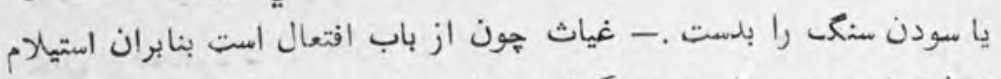

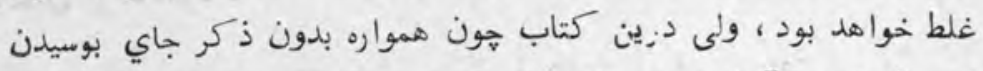

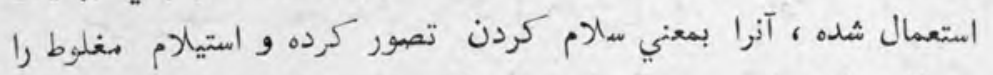

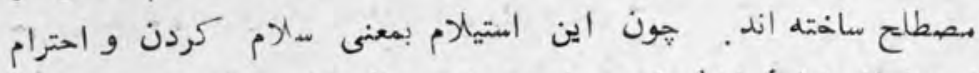

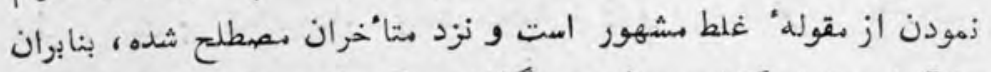

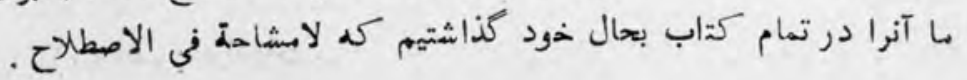


$\angle 9$

تازه نواي معارك-

داد . سردار بير هحمد خان برادر مردار دوست متحمد خان ،

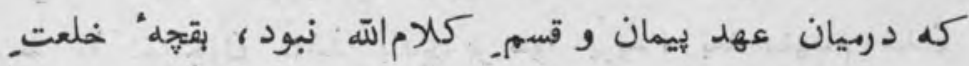

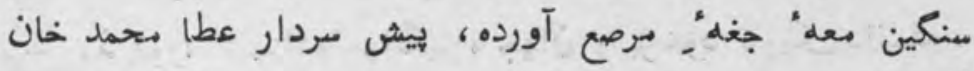
كذاشتهه ، و بدست خود ، خلعت وزارت را بسردار عطا بحمد خان

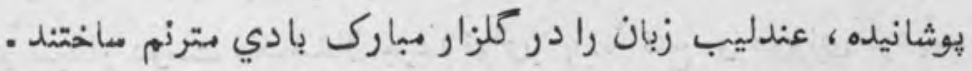
و وقت زدنـ جغd" مرصع، در سر, عطا محمد خان ، مردار

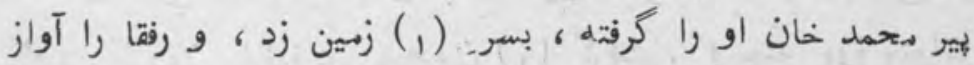

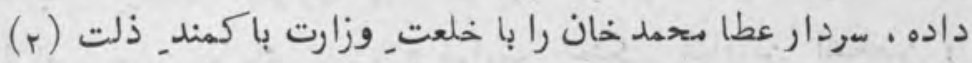

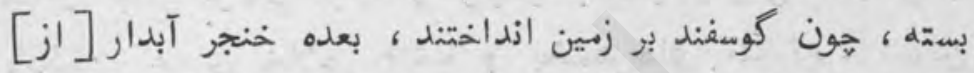

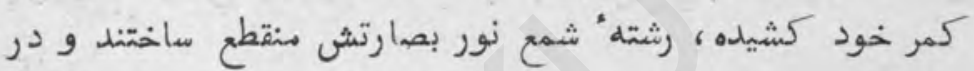

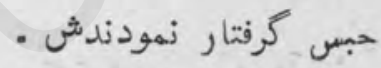
در صورت اين واقعه ، در شهر كابل نواير, آتش. شور و

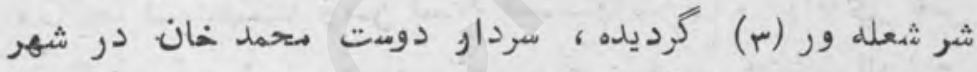

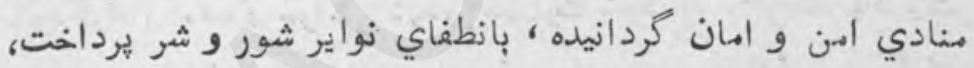

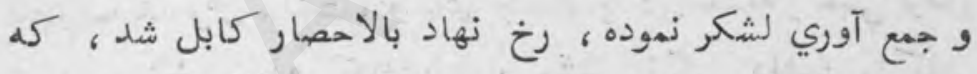

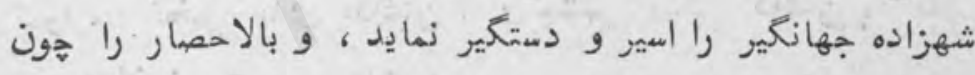

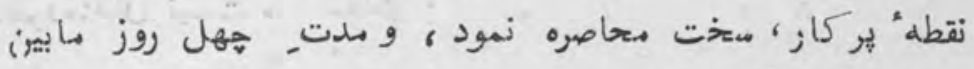

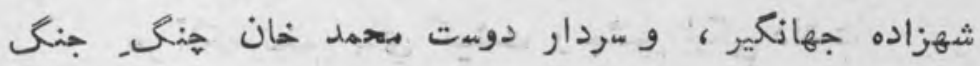

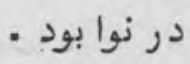

آخر سردارددوست دحمد خان ، بوج قلعه " بالاجصار را نقب زني

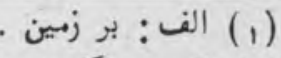

الف : (r)

(r) 


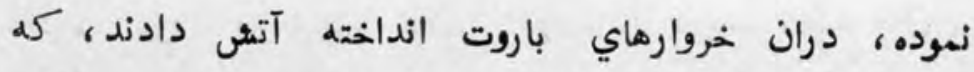

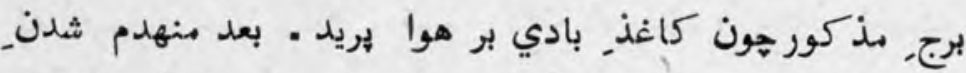

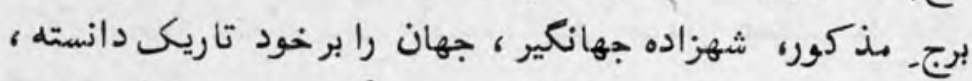

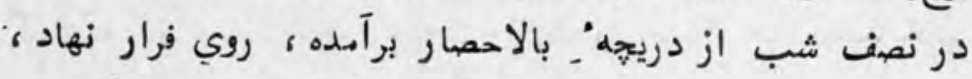
و مردار دوست محمدخان جرعه نوشـ باده" فتح و فيروزي كرديد.

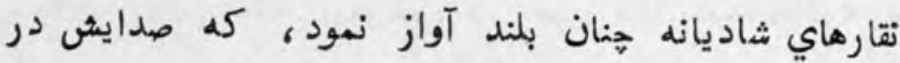

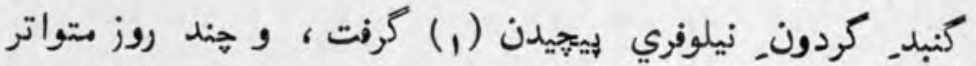

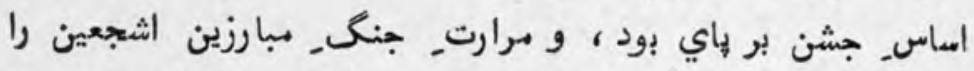

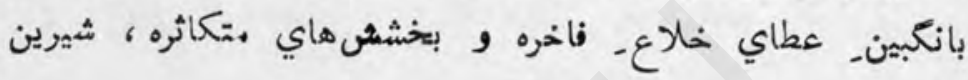
- إم ام نمود

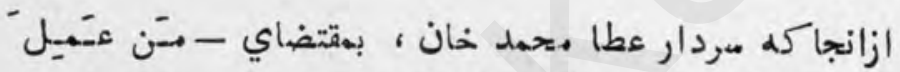

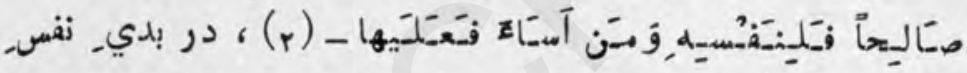

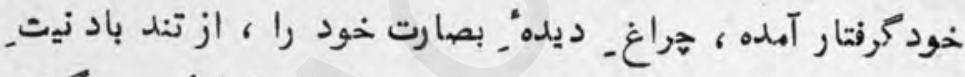

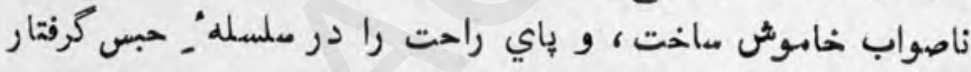

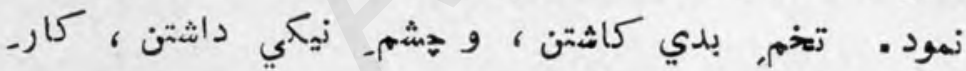

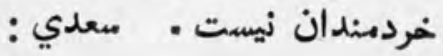

هر آنكه تخم, بدي كِيشت و حشمه, نيكي داشت

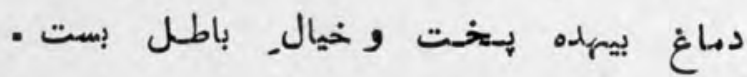
ازانجا كم كوري_ اشرفالوزراء وزير فتع خان، اكرخه از

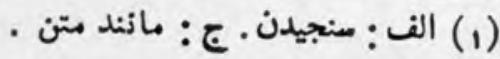

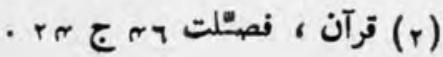


$\wedge$

تازه نواي معارك

تقد يرات_ ازلي و شومي_ اعمالش بود ، ليكن مردار عطامحمد خان

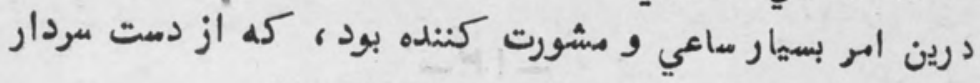

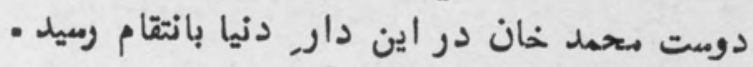


در بيان, آمدن شهزاده كامران از هرات

و جنك نمودن با سردار دوست محمد خان و هزيمت

يافتن_ او، و كشتن. وزير فتح خان را بكونا كون عذاب،

\section{و باز رفتن جانب_ هرات (1)}

شهر يار, قلم، كه سرير آراي اقليم_ سخنوريست، در بـيدان.

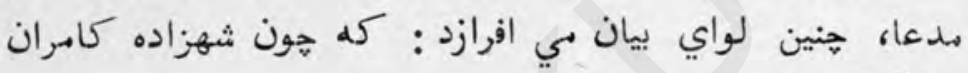

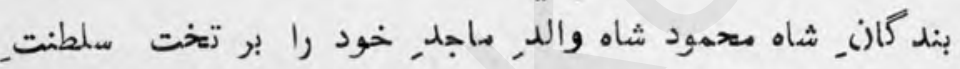

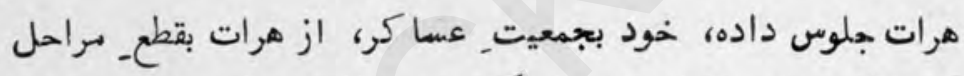

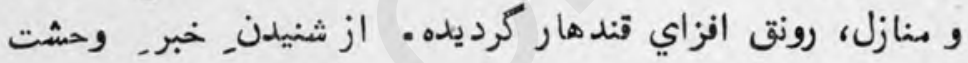

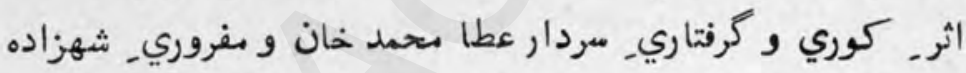
جهانكير خلف, خود، در اضطراب و و بيقراري آمده، بـ بجمعيتـ

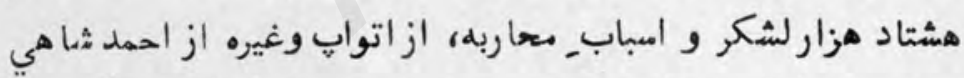

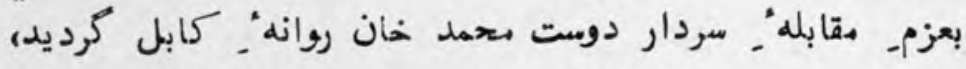

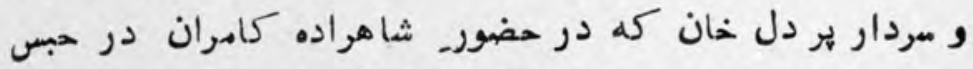

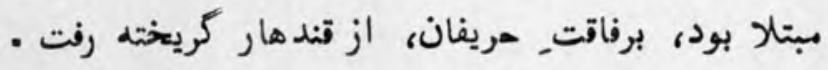

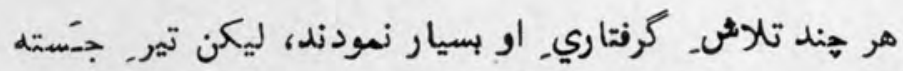

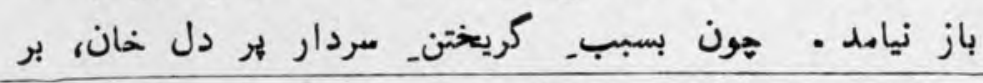

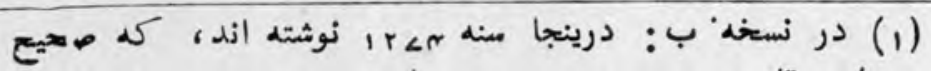

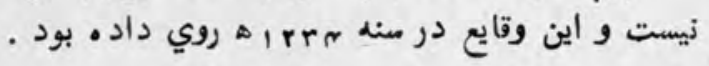




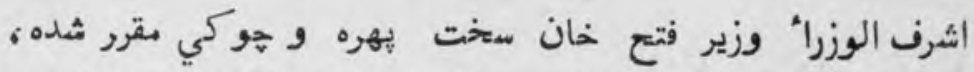

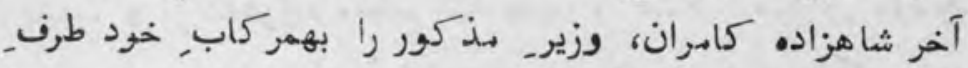

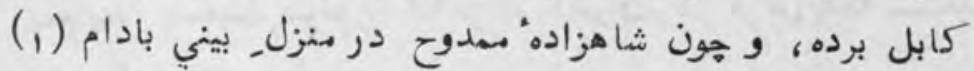

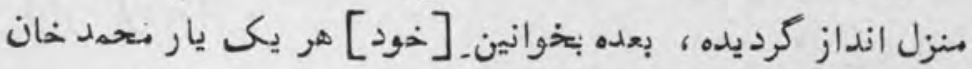
و عطا مهمد خان الكوزتي و عبدالمجيد خان باركزئي وغيره

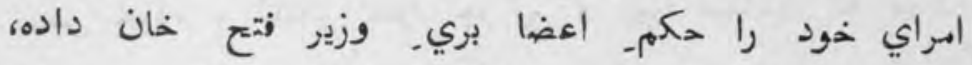

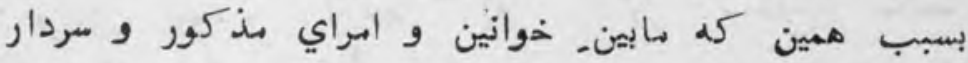

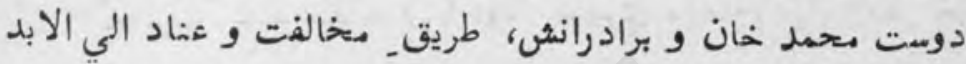

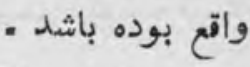

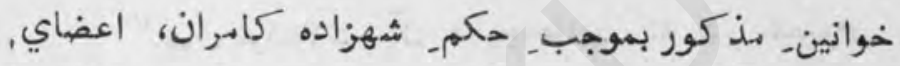

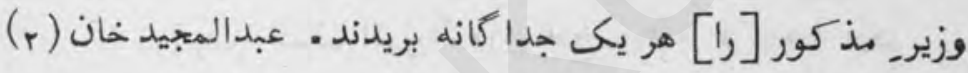

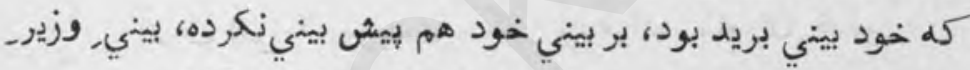

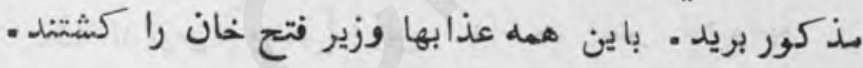

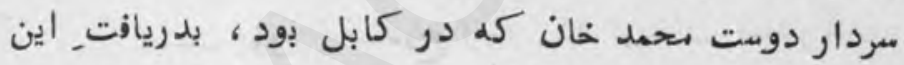

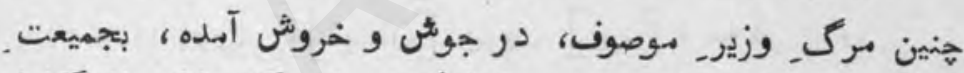

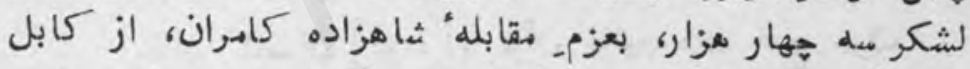

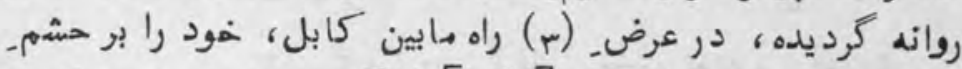

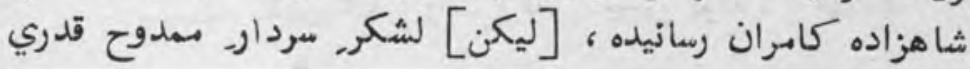

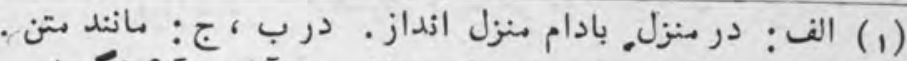

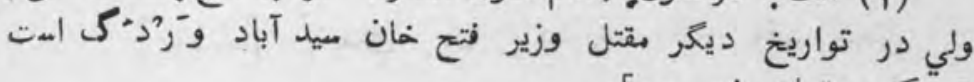

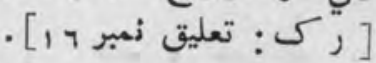

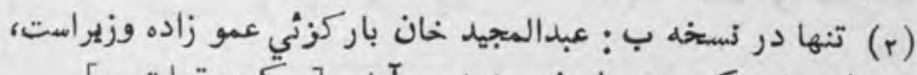

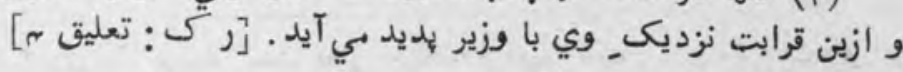

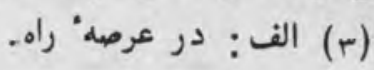


تازه نواني دع

A

قليل، و از شاهزاده معظم اليه بسيار • لشكر, مردار, ـوصوف

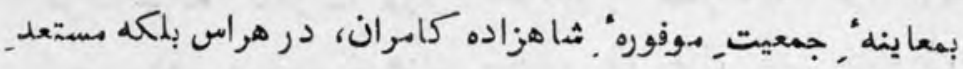

فرار كرديدند -

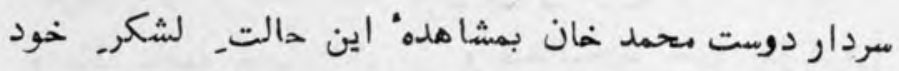

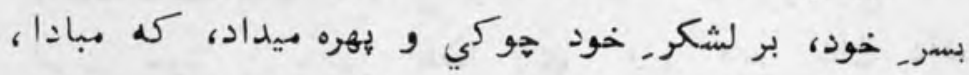

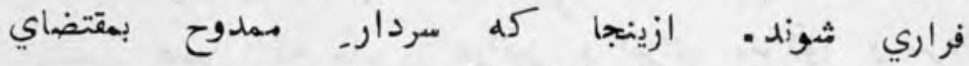

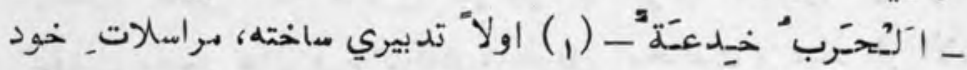

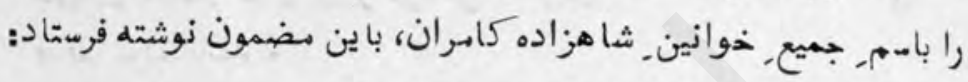

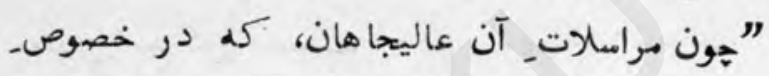

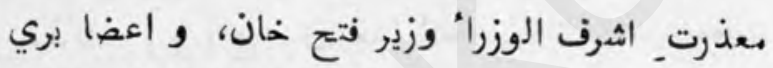

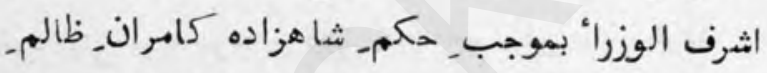

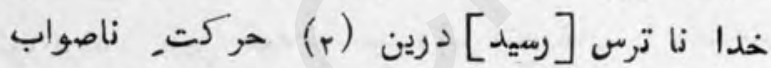

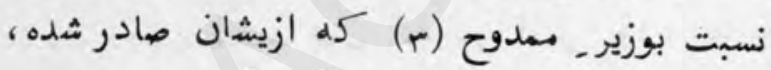
از اختيار, [ايشان]] بيرون [بود] و متحض بزورـ

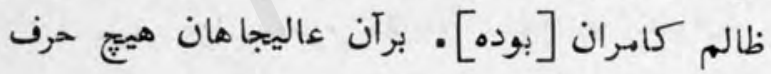
نيست، تقديرات [رب] قدير هنين بوده . نهايت قراردادي ـ كرفتاري. شاهزاده كامران كله نوشته

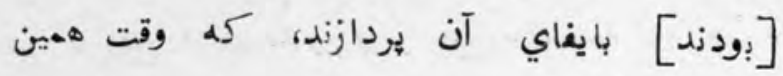

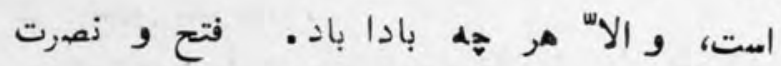
(1) مقوله" عربيه است يعني جنك فريب است . (r) الف : و اين .

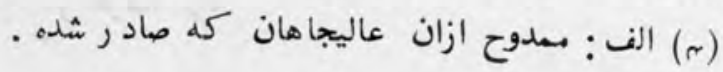




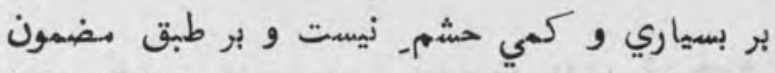

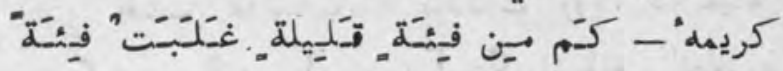

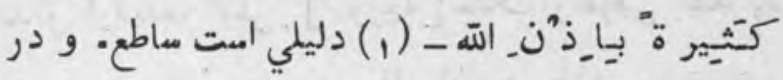

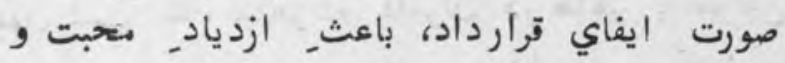

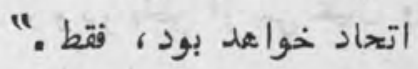

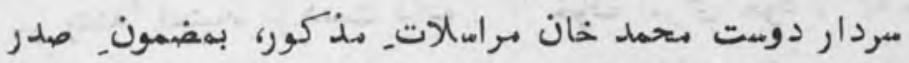

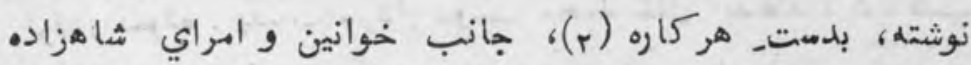

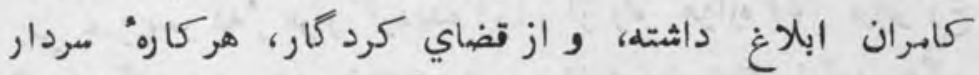

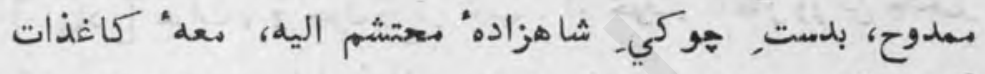

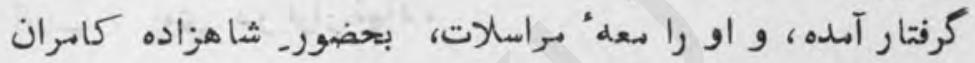

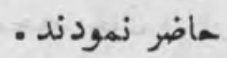

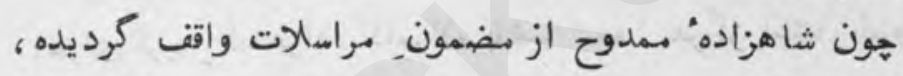

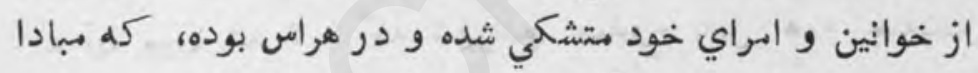

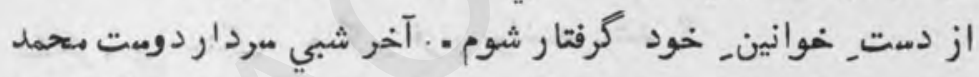

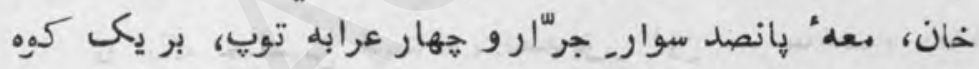

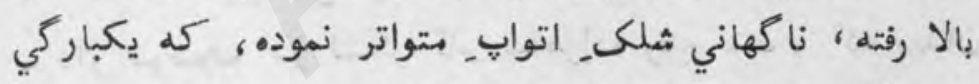

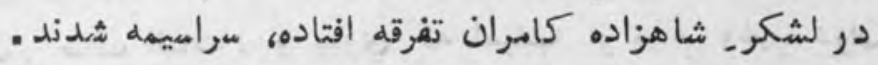

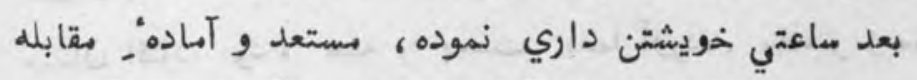

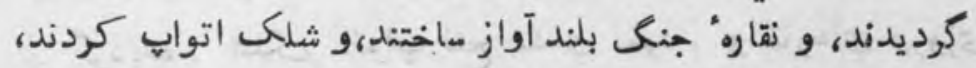

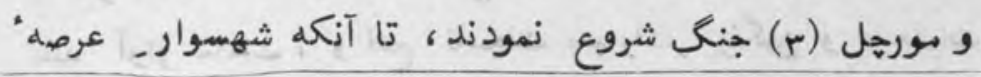

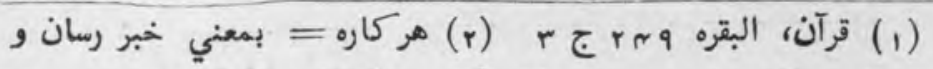
جاسوس است كه در عصر غزنويان مُنهي ميكفتند .

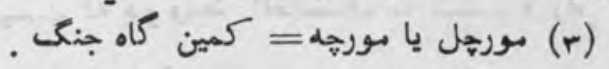


تازه نواي مeار

$\wedge$

فلكى، اعني آفتاب_ عالهتاب، از تردداتــ روز، در خيامـ شام،

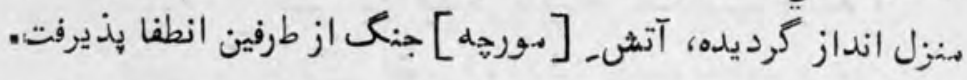
هون شب شده ، شاهزاده كامران در ظاهر بان خوانين- خود

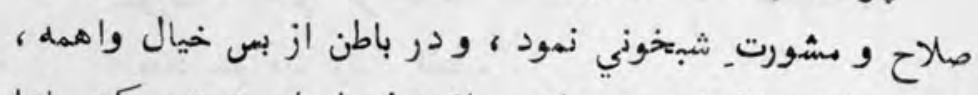

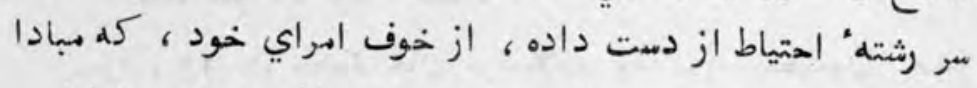

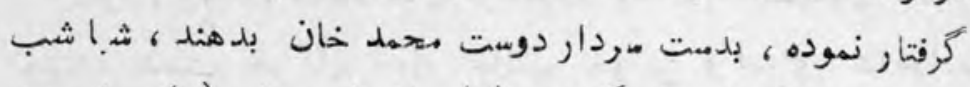

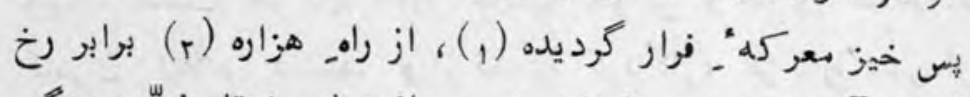

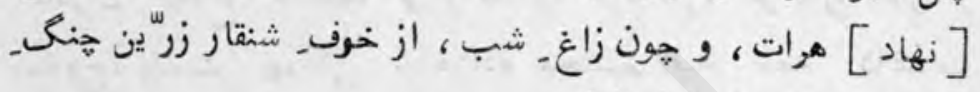

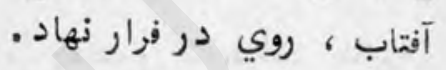

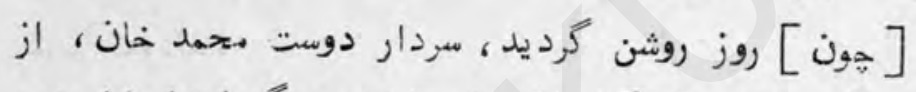

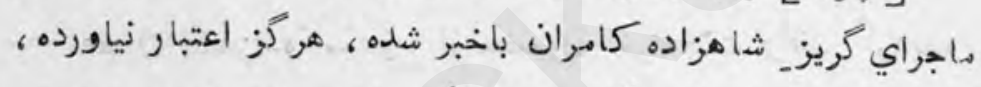

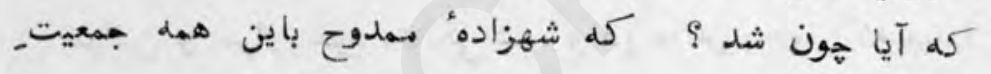

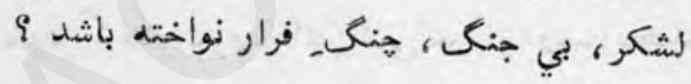

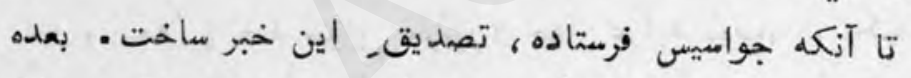

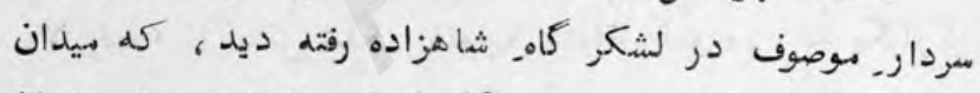

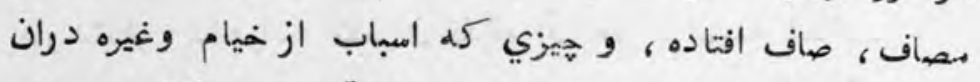

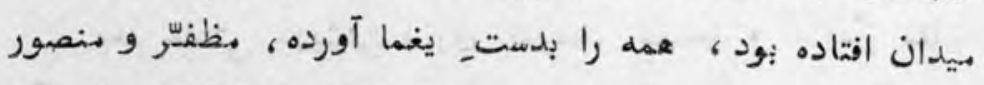

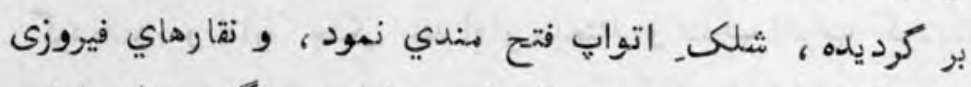

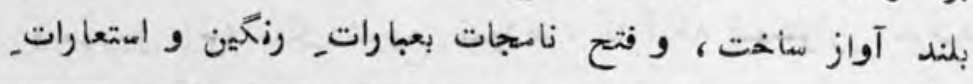

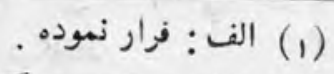

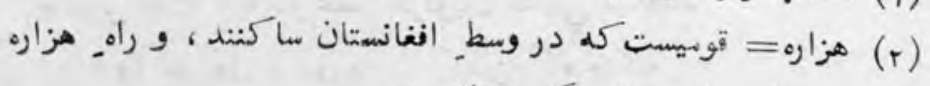

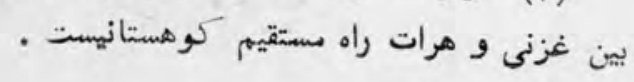


$\wedge<$

تازه نواي معارك

دلكزين ، جانب. كابل و برادران خود هر يك سردار كهندل

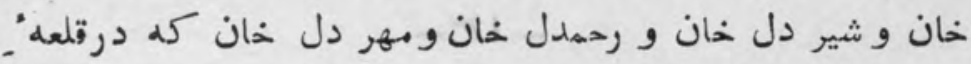
معروف (1) بودند ، نوشته فرستاد ، وخود وخداد مراجعت فرماي

كابل كرديد

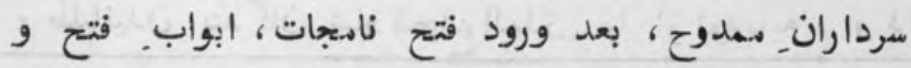

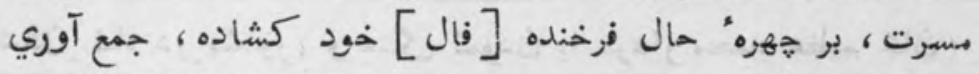

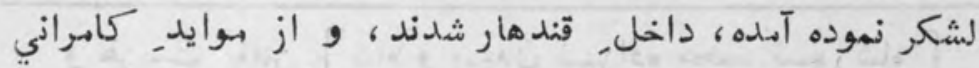

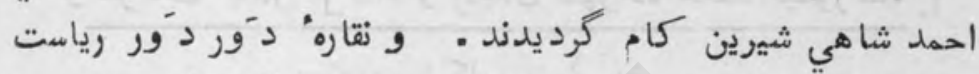

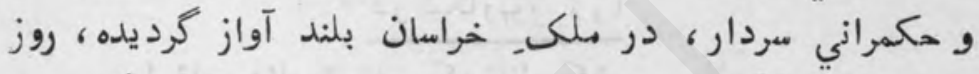

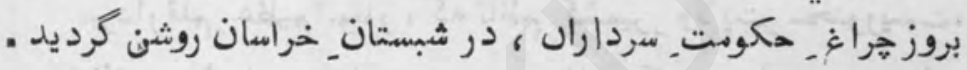

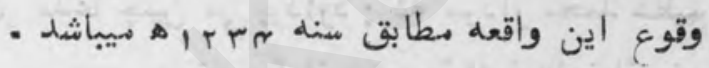

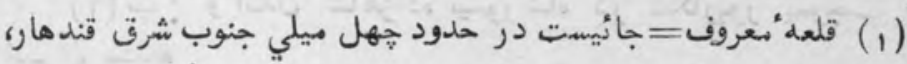

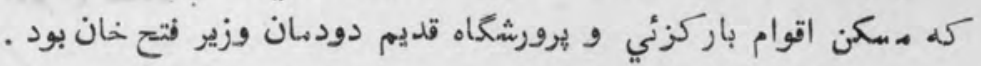


$-I^{m}-$

در بيان, آمدن, سردار مهمد عظيم خان از كشهير و طلبانيدن بند كان شاه شجاع الملك را از لوديانه ، و داخل

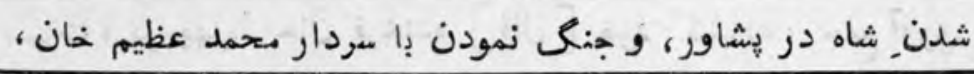
و هزيمت يافتن [ شاه و وسيدن شهزاده محمد تيمور شاه

در شكاريور (1)

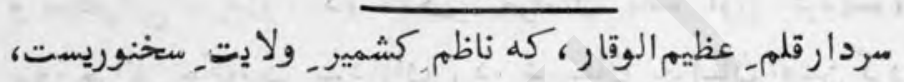

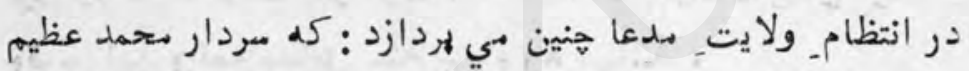

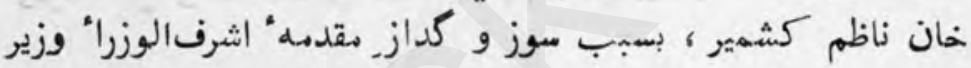

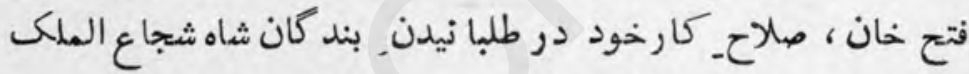

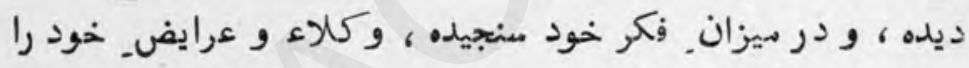

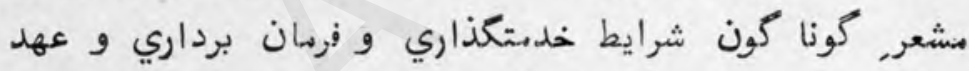

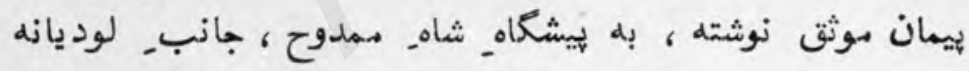

روانه نمود .

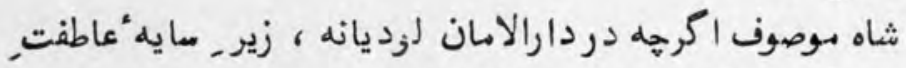

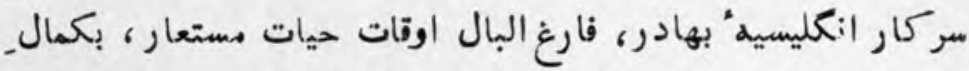

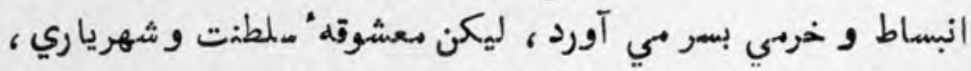

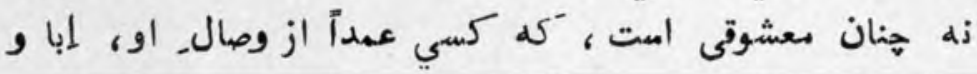

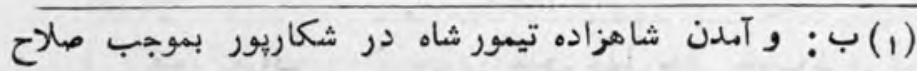

الميران سنده. 


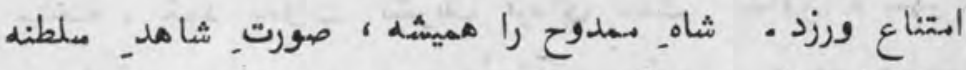

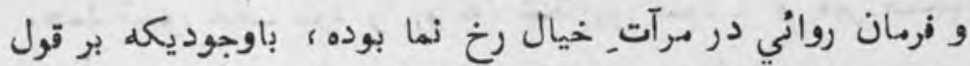

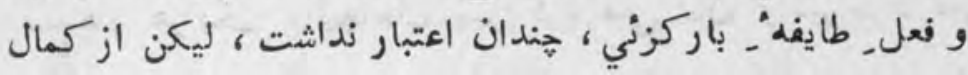

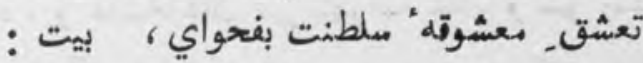

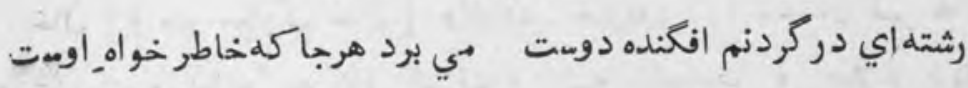

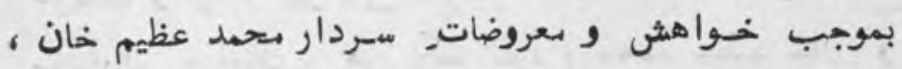

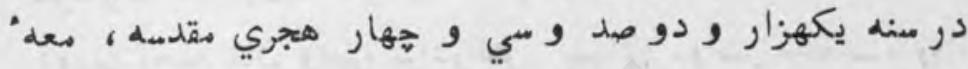

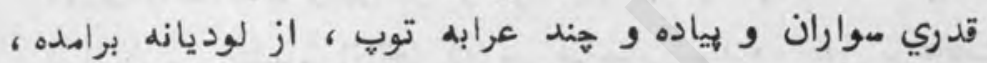

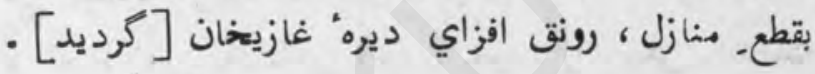

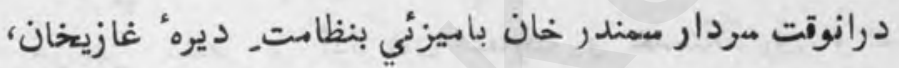

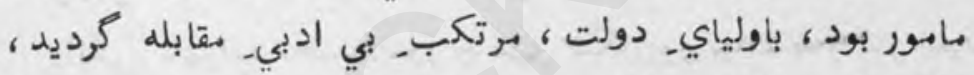

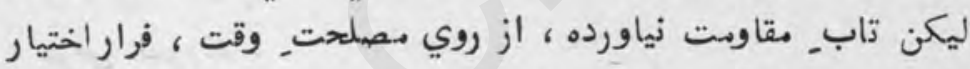

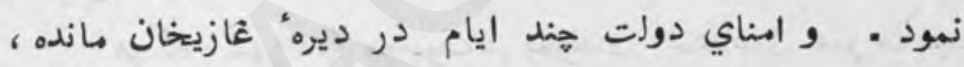

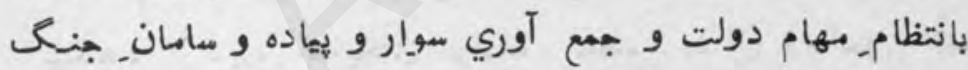

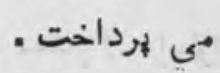

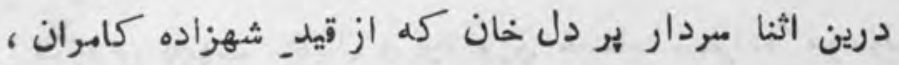

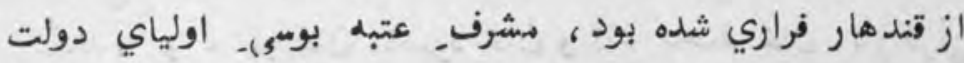

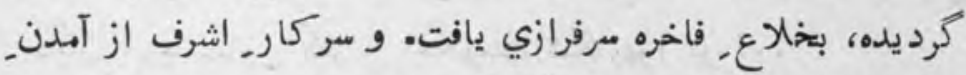

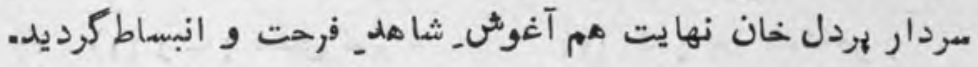

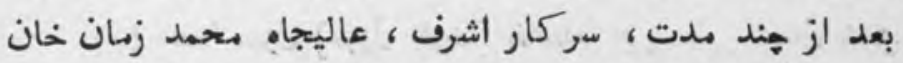

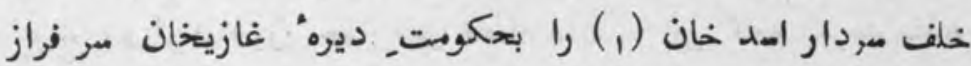
(1) اسم ملمان برادر وزير فتح خان بود [ركى: تعليق نمبر م] 
تازه نواي مe

9.

ساخته ، خود بدولت تشريف فرهاي سهت_ لِشاور، و شهزاده

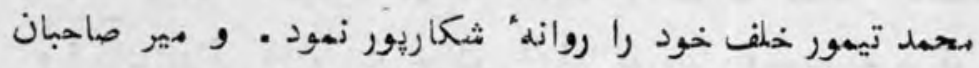

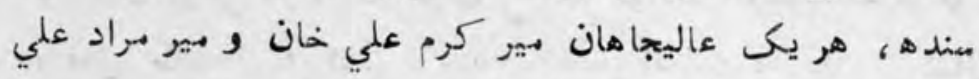

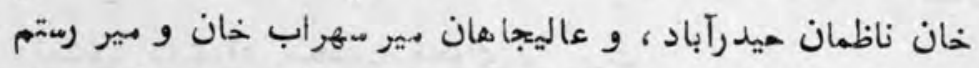

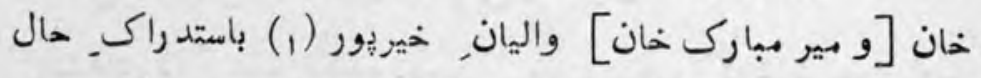

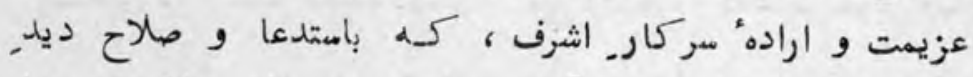

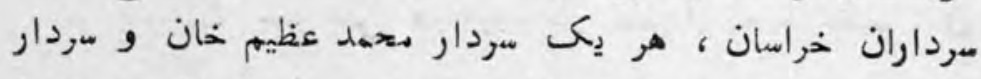

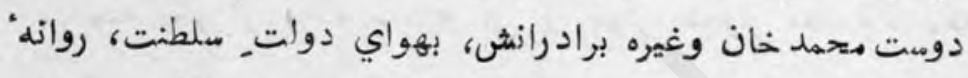

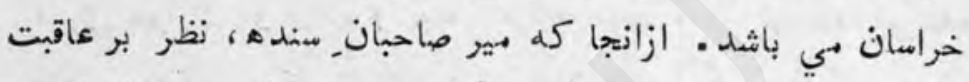

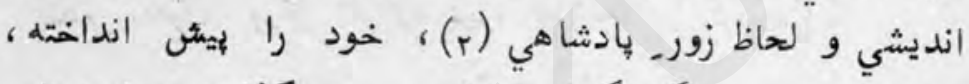

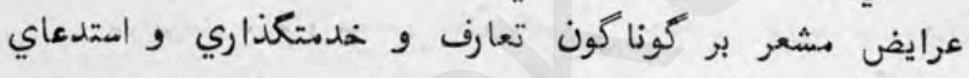

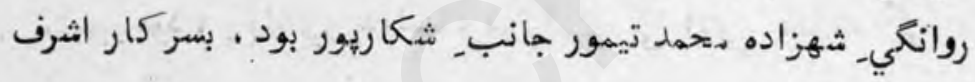

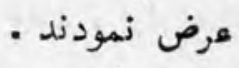

مركاه شهزاده: بوصوف ، بموجب أستدعاي مير صاحبان

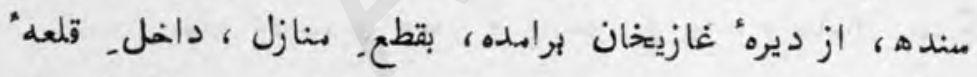

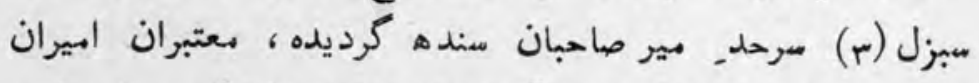

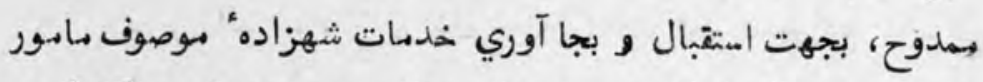

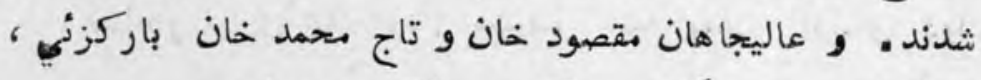

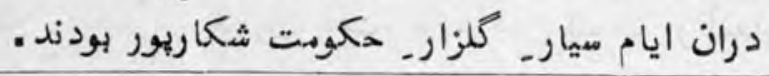

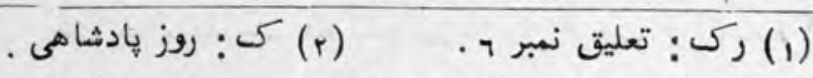

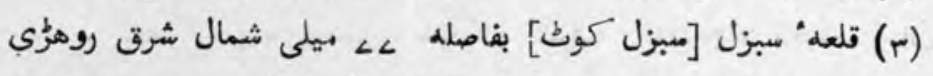

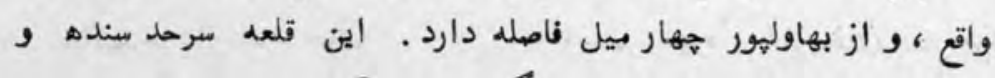

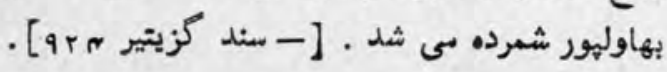


१।

تازه نواي معارك

هركاه عاليجاهان_ مذكور از آسدن_ شهزاده" مذكور، آكاه

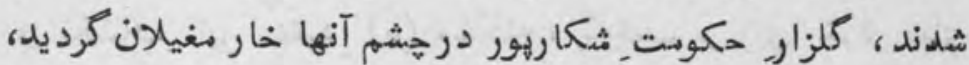

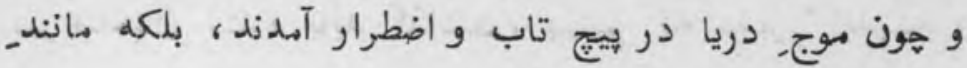

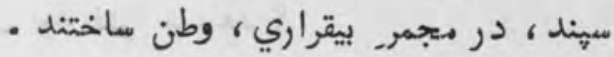

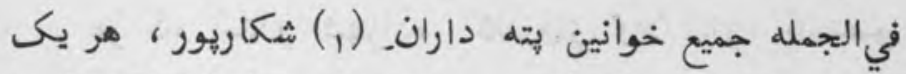
عاليعباه جمعه خان باركزئي و مشعادت شند خدان (r) الركوزئي و خيراله خان و مدد خان فوفلزئي [و مولان داد داد خان فوفلزنئي

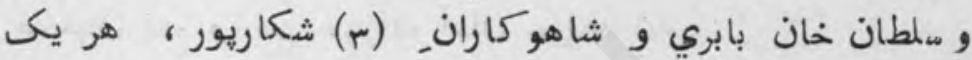

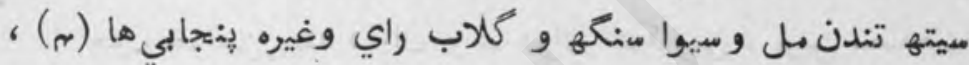

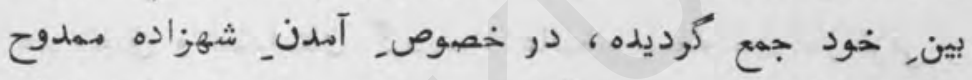

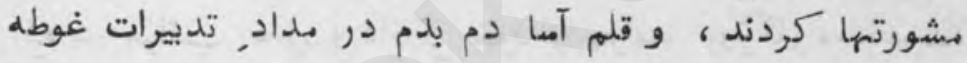

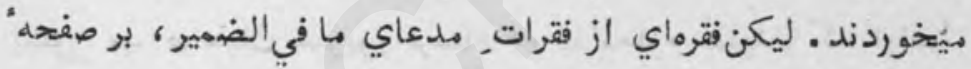

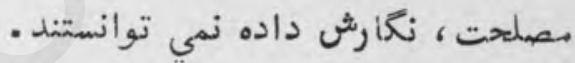

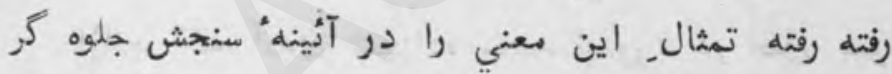

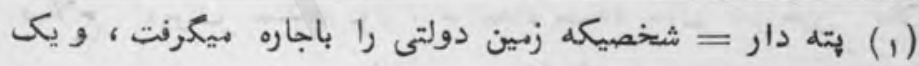
حصهل عوايد آنرا بحكومت دمار ميداد .

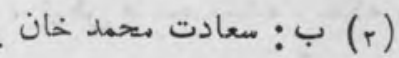

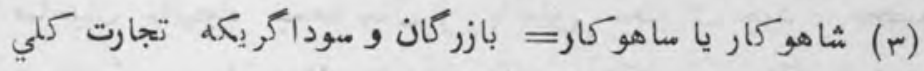

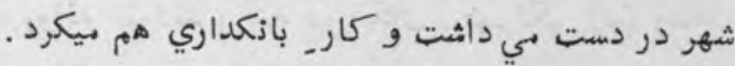

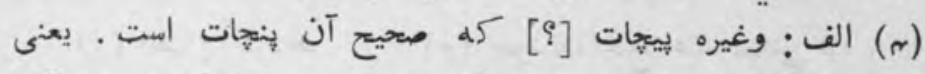

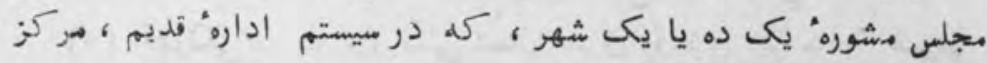
فيصله تمام امور مردم بود . 
نمودند(1) :5 كه درين بابت با مير صاحبان_ينده مشيورت با يد نمود، و انكشاف_ اين عقود_ (r) مشكله ، دوقوف بر راي خرد زماي

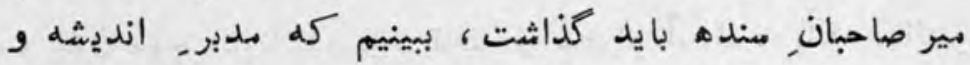

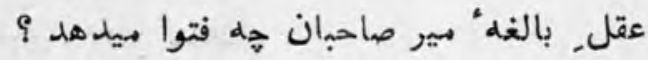
هر كاه آمدن شهزادهُ كامرواي والا تبار، باستصواب و

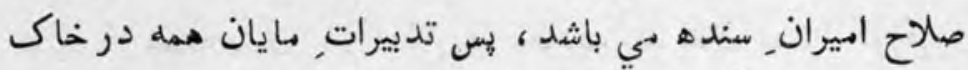

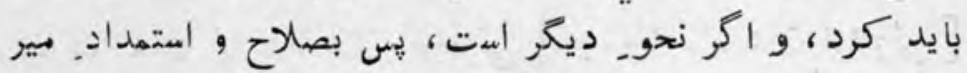

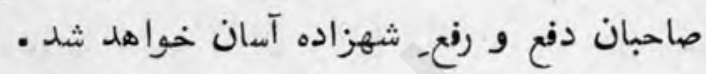

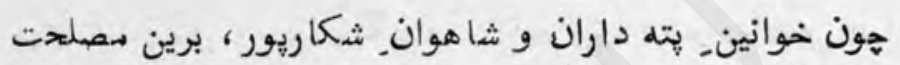
هم اتفاق و همداستان كرديده، ، عاليجاه جمعه خان باركزئي را هو كه در مراتب, عقل و دانائي خود را سرامدـ روز كار ميدانست، بيشى بير صاحمان خيريور فرستادند، تا دعلوم زهايد، كه اراده:

بير صاحبان جيnست

ازانجا كل آمدن, شهزاده محمد تيهور، در اصل بموجب.

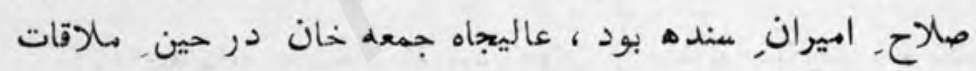

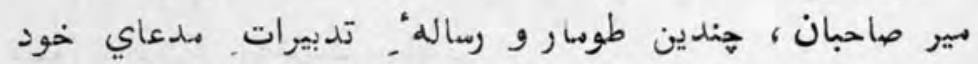

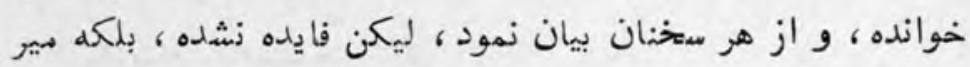

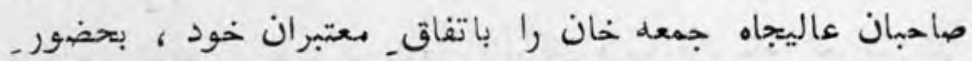
شهزاده" موصوف روانه ندودند، كه در مكان كهوتكي (r) رفته،

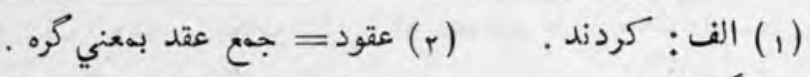

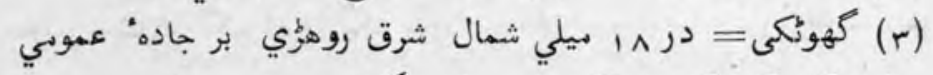

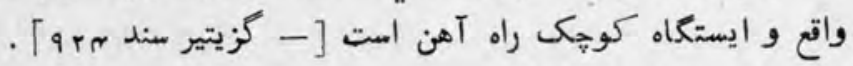




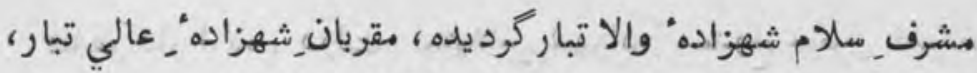

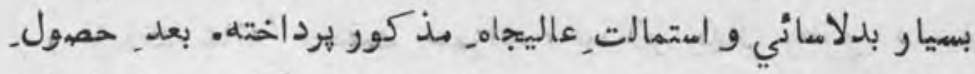

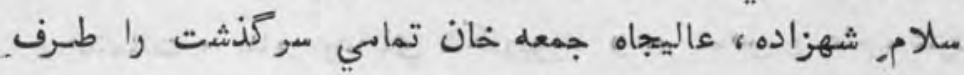

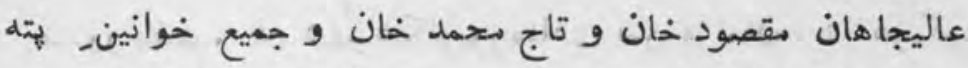

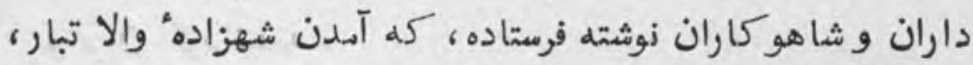

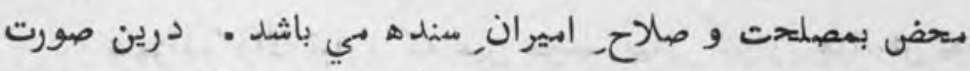

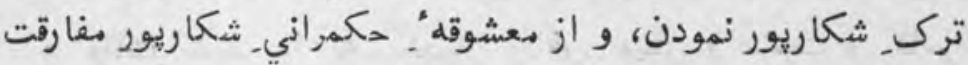

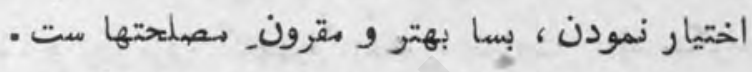

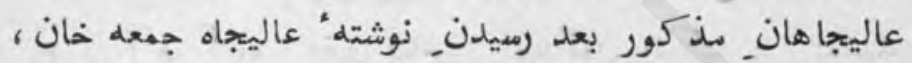

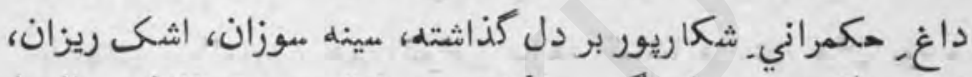

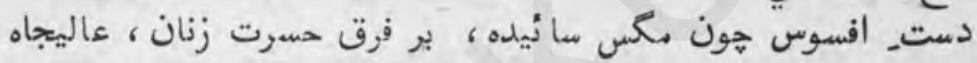

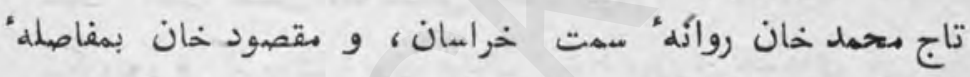

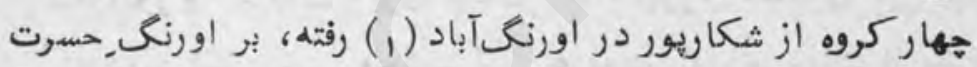

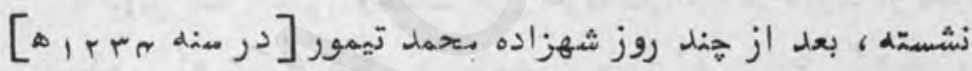

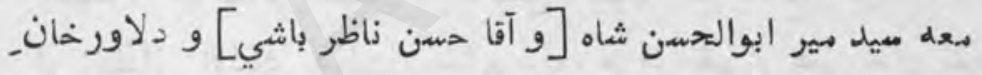

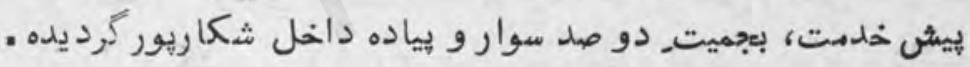

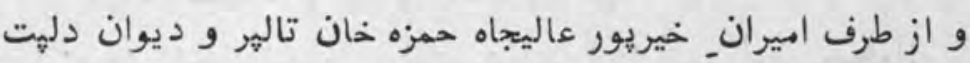

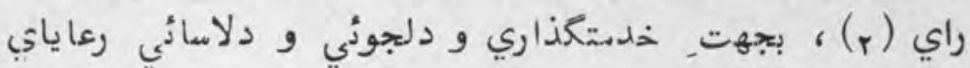

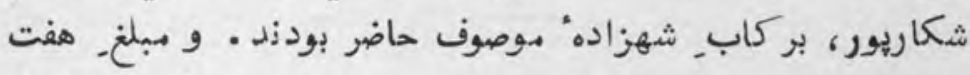

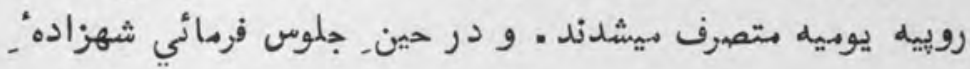

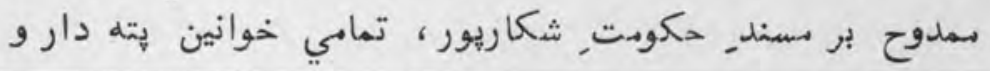
(1) اوزرنك آباد = تاكنون بهمين ذام موجود و مشهور است.

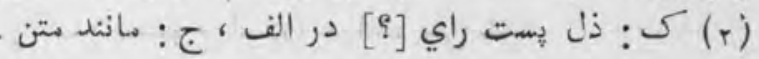


شاهو كار آهده، دولت استيلام_ شهزاده؛ ممدوح حاصل نمودند .

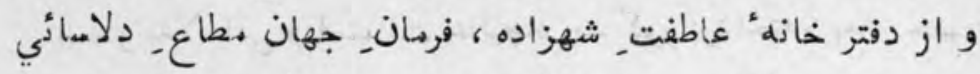

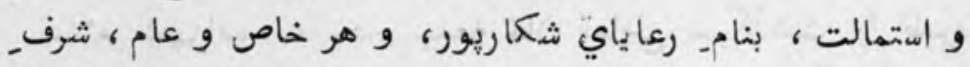

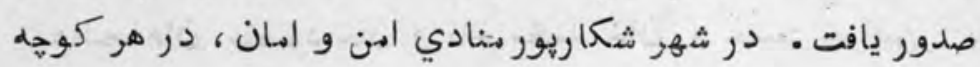
و برزن كردانيدند .

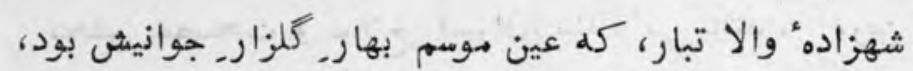

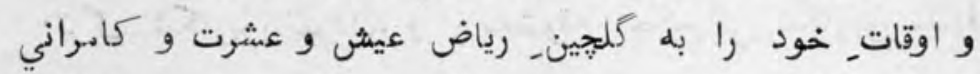

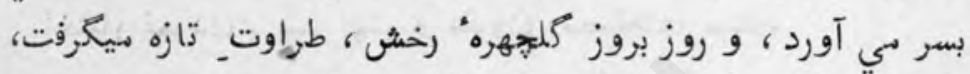

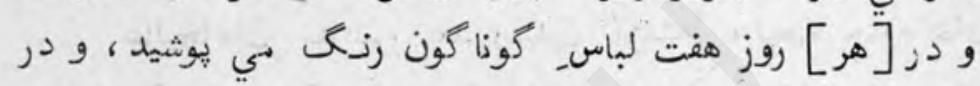

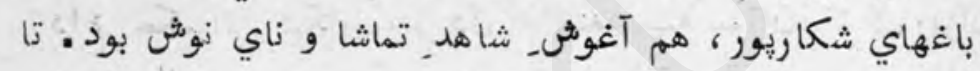

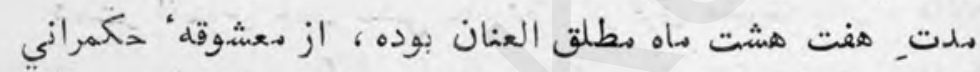

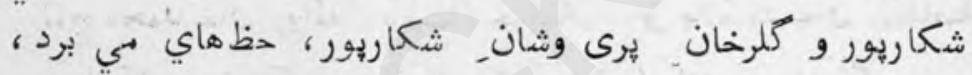

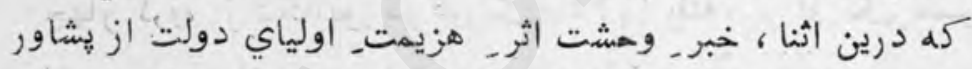

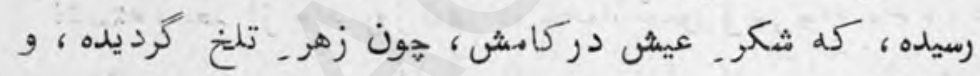

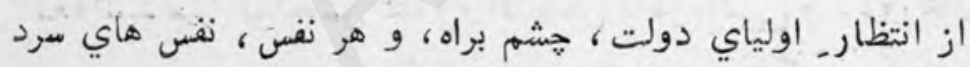

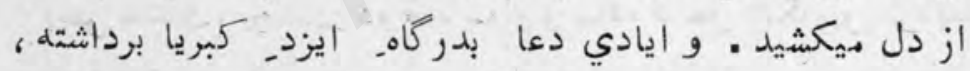

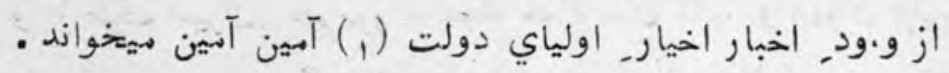

درك: : مسسوخ است، خوانده نمي شود . 
در بيان, آملدن سردار متهمل عظيم خان از كشمير و جنح نمودن با شاه شجاع الملك در زيشاور، ، و هزيمت شاه ، و حند روز توقف, شاه در درو خيبر • ازازجا آهدن در شكاريور از راه_ هزاري ها (1) برهمنوني سيد ولى شاه

هزار داستان_ قلم__ خوش رقم ، در نغمه طرازي اين داستان ،

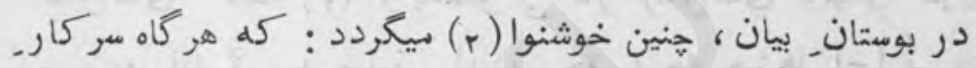

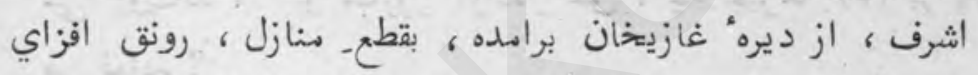

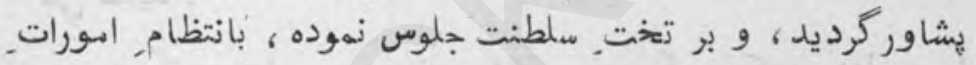

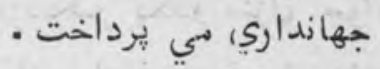

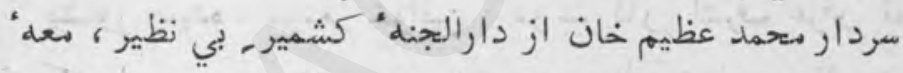

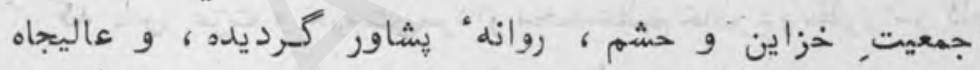

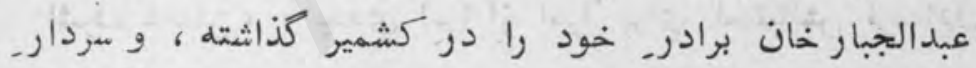

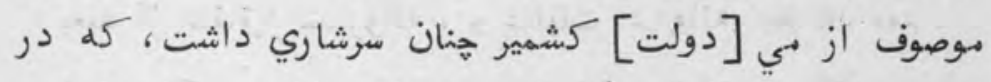

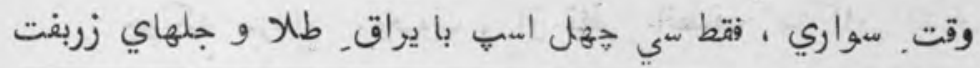

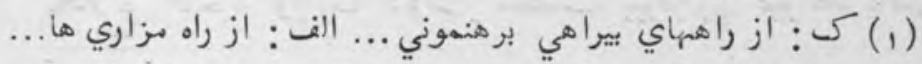

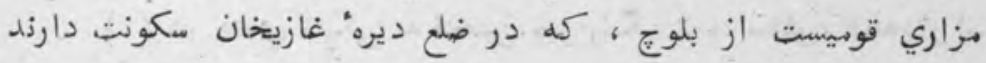

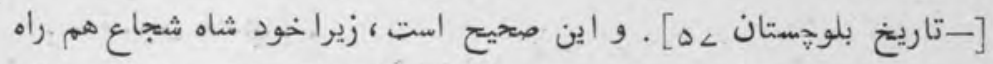

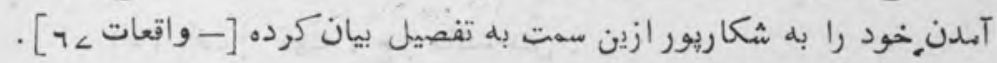

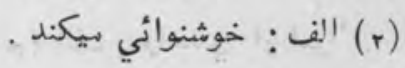




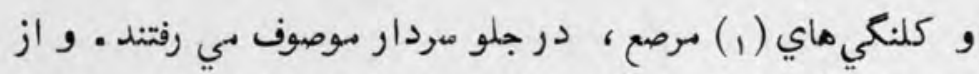

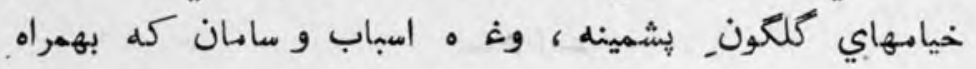

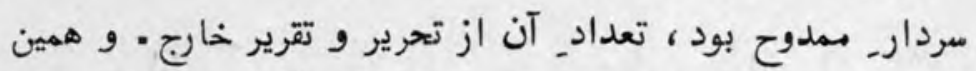

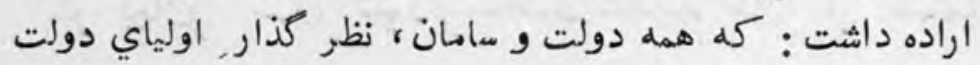

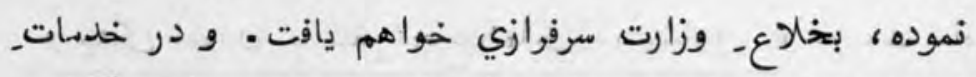

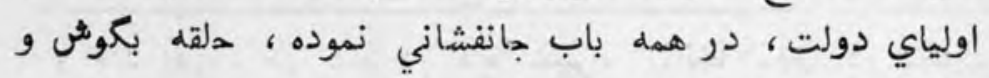

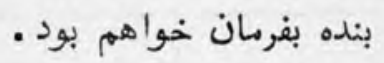

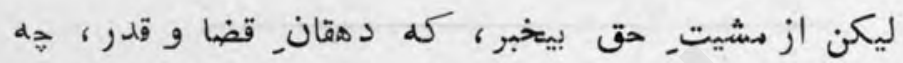

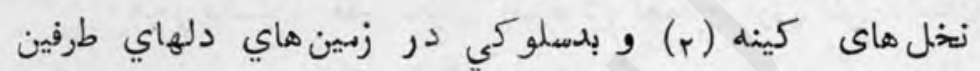

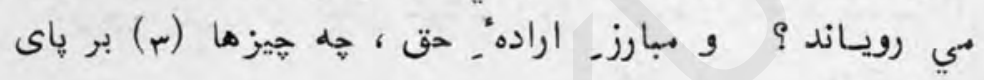
مي نمايد ؟ بون

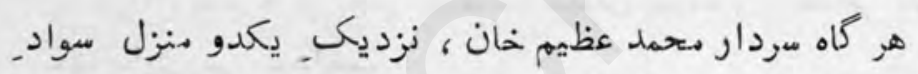

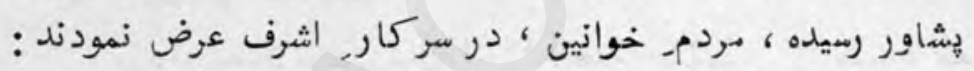

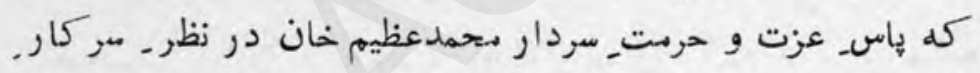

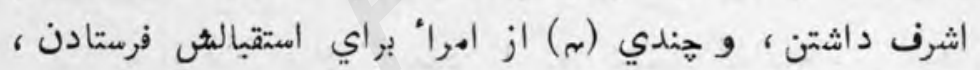

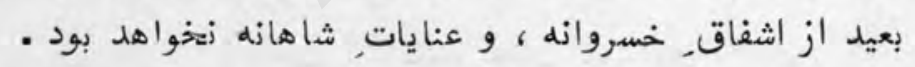

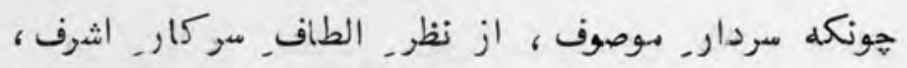

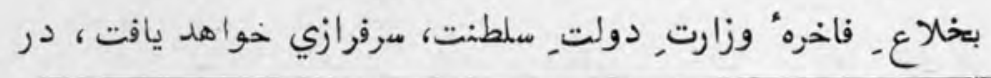

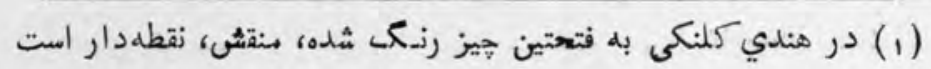
[ [ [ابوس هندي]

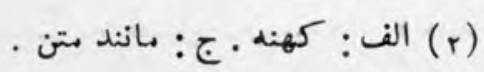

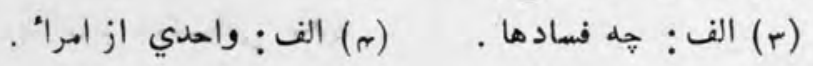


صورت_ اقبال اين التماس مـا هواخواهان_ دولت ، يكي نيكنامي

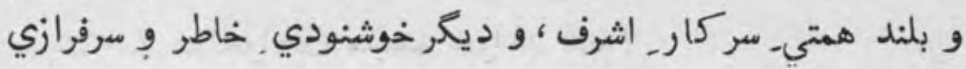

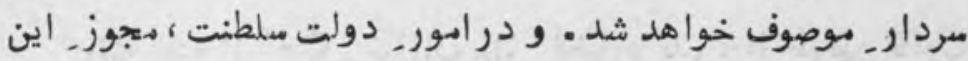

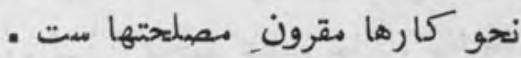

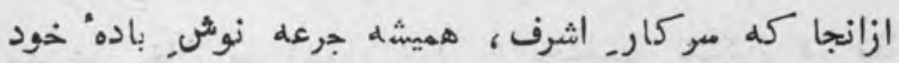

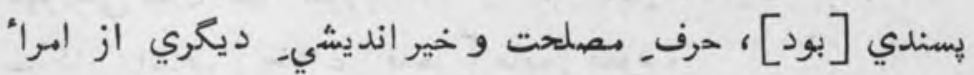

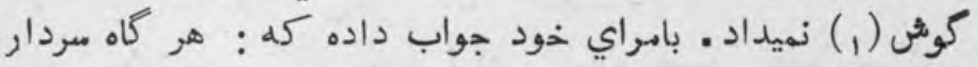

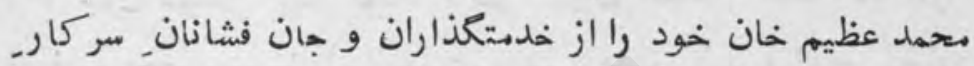

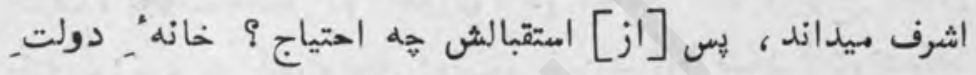

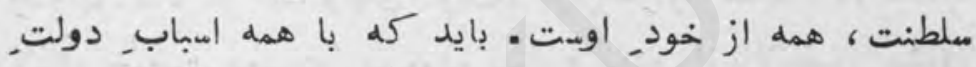

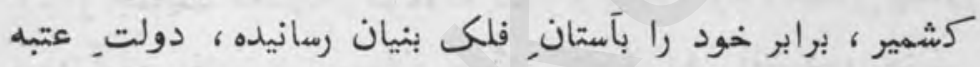

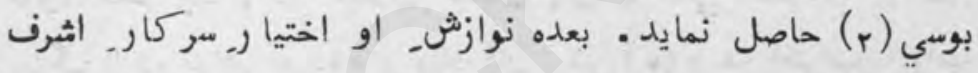

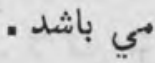

هر هند خوانين درين باب بارها عرض كردند، ليكن بدرجه"

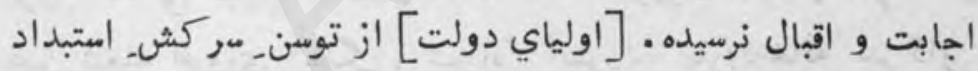

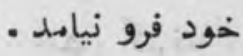

درين صورت : دانستله , سردار ميحمد عظيم خان شده ، كم اول

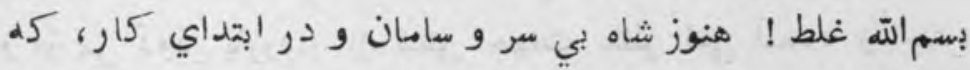

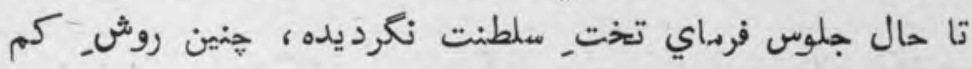

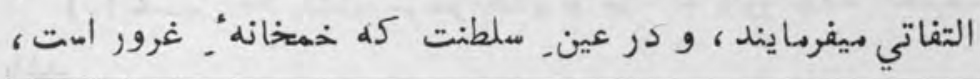

$$
\begin{aligned}
& \text { (1) الف: ديكري از امراء كوز خر بيدازست . } \\
& \text { [ } 5 \text { (r) }
\end{aligned}
$$




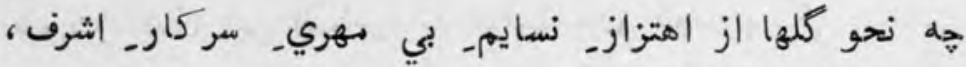

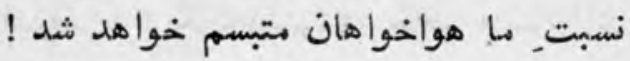
رفته رفته از آهنغ نوازان سـاز قضا و قدر ، از طرفين قانون.

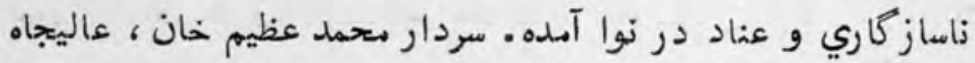

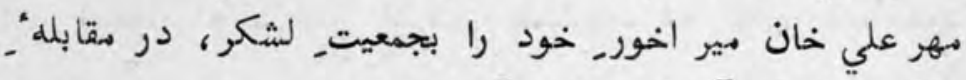
سركار اشرف [بخال ع_ فاخر

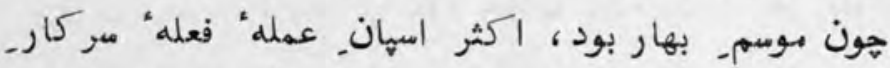

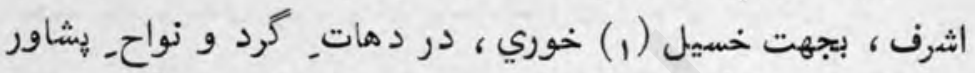

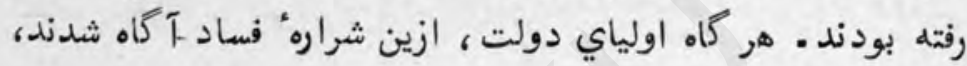

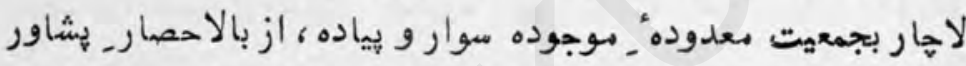

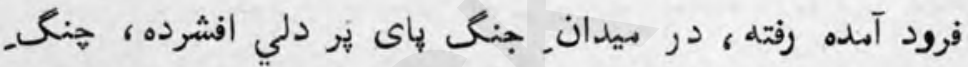

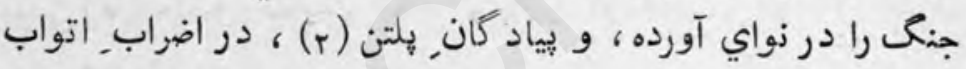

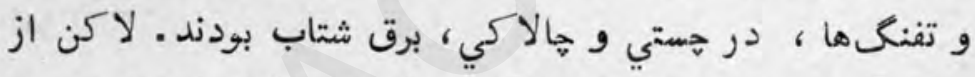

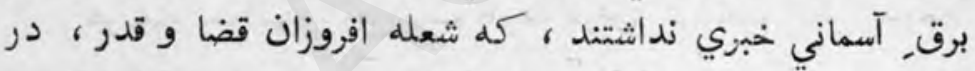

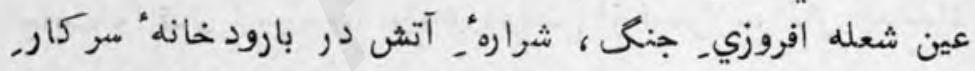

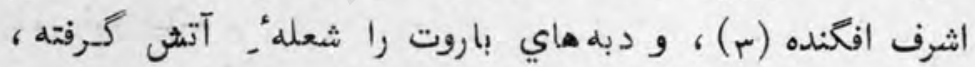

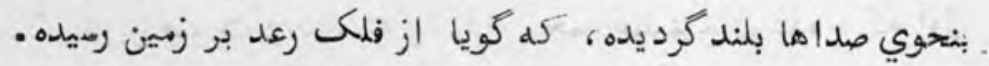

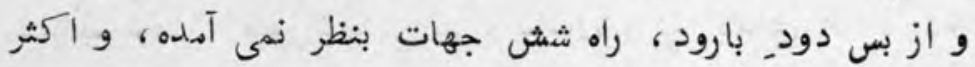

(1) خَسيل = كشتِ سرسبز كندم و جو كه هنوز دانه نكشيده باشد .

(r) الف: بيلتن . اما بهلتن بمعني عسكر مسملح تربيه شده است.

$$
\text { ك (r) }
$$


9

يباد كان شاه، هِون كاغذ بادي برباد رفتند .

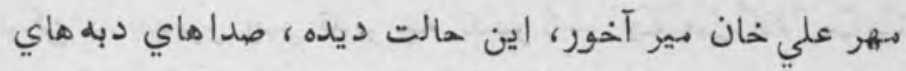

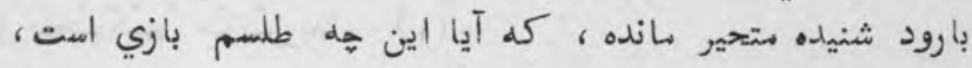

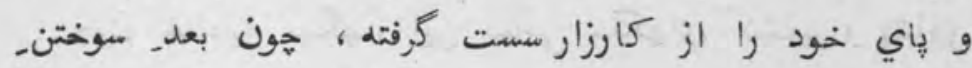

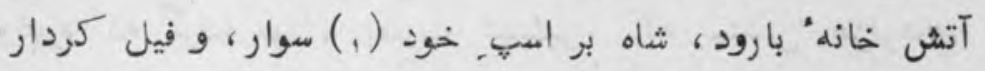

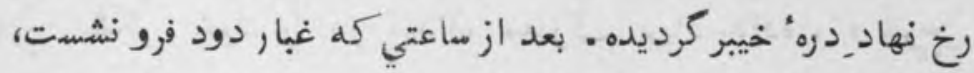

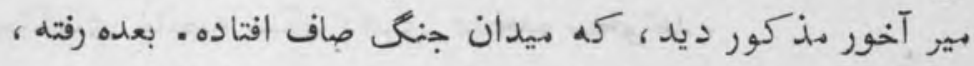

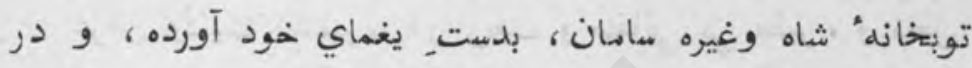

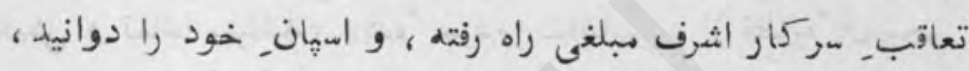

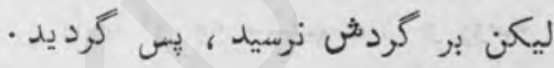

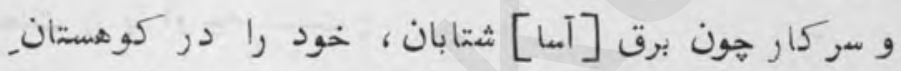

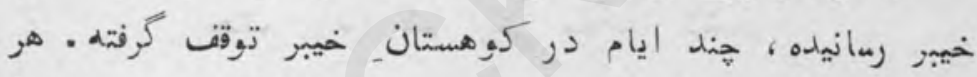

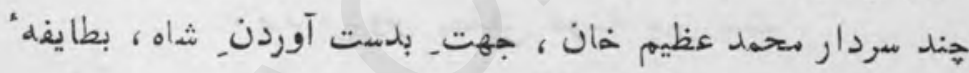

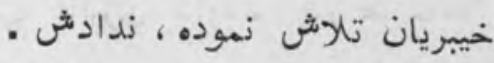

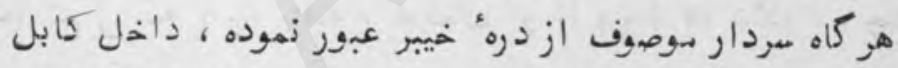

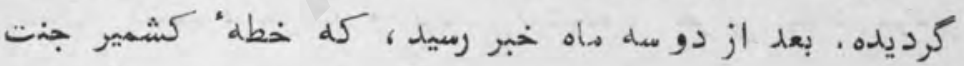
نظير را خالصه رنجيت سنكه فتع نمود ، و عبدالجبار خان فراري

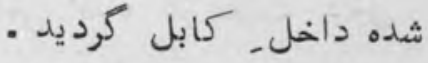

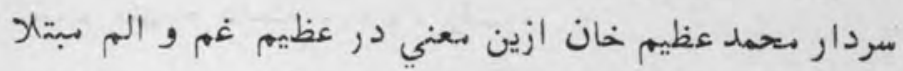

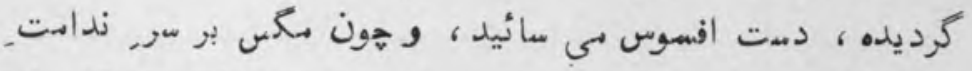

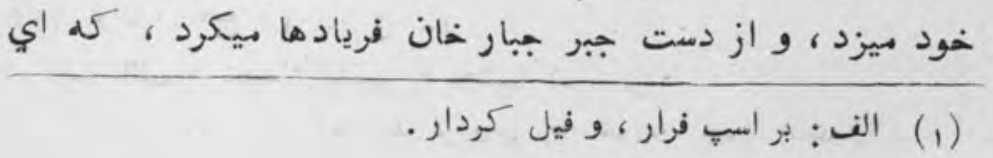




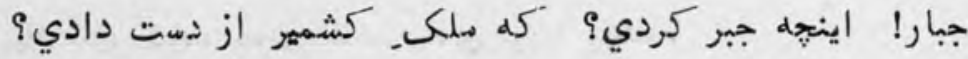

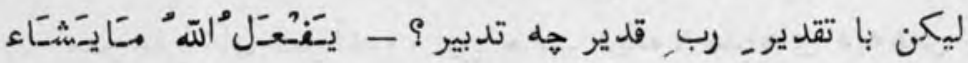

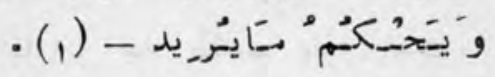

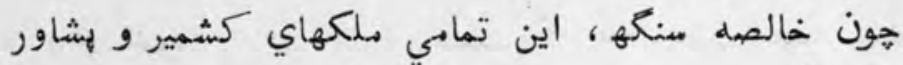

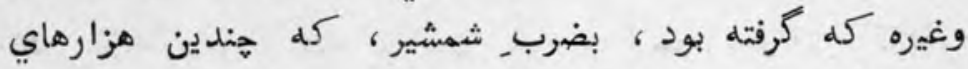

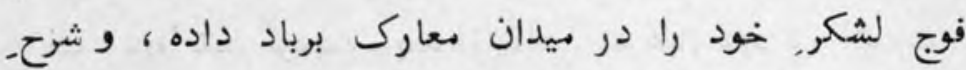

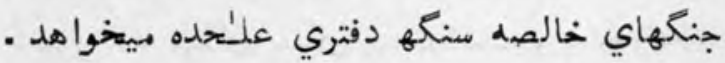

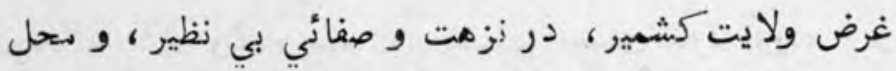

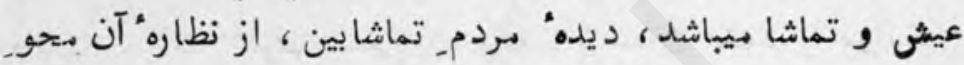

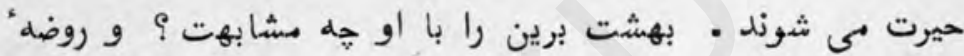
جنت را با او حه نسبت :

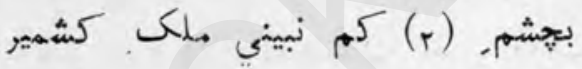
كله صد فردوس קِيشش خوشه

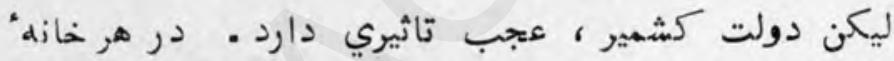

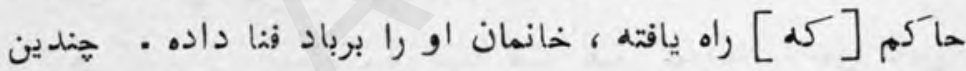

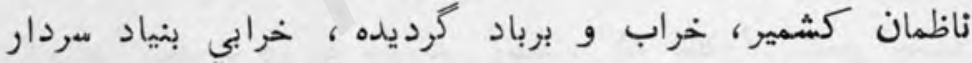

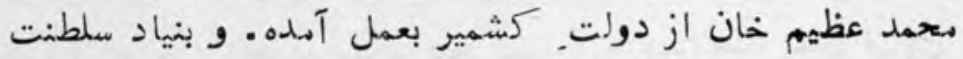

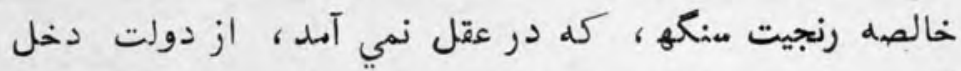

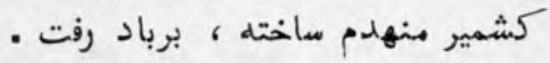

$$
\text { قرآن ، الجج }
$$

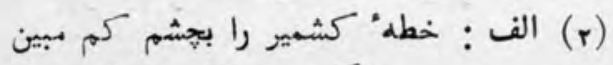

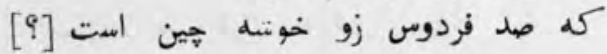


$-10-$

در بيان آنكه بعد_هزيهــــش شاه شجاع الملك از خشاور مير ماحبان سنده در كشيلن شاهزئ اده بحمد تيمور از شكارهور بسيار ساعىى شدند

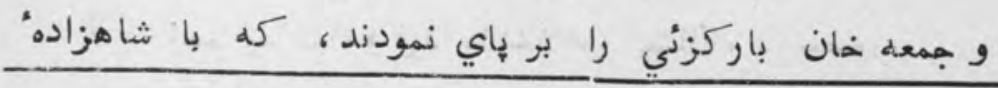
سمدوح جنم نموده ، فراري شده و آهدن در شكاريور

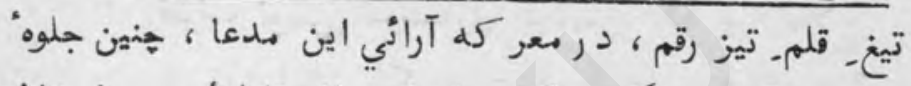

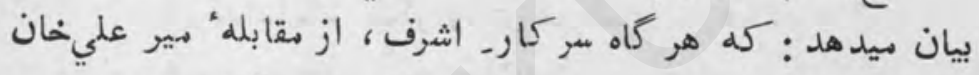

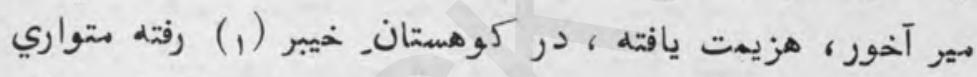

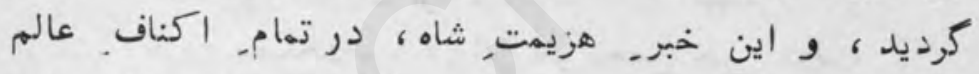

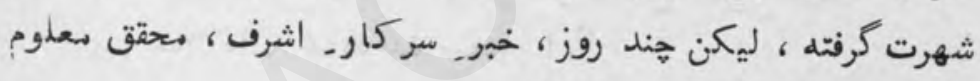

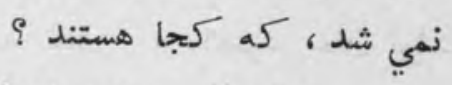

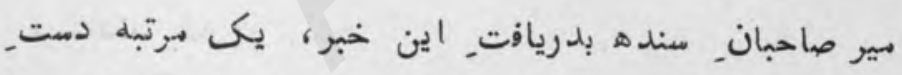

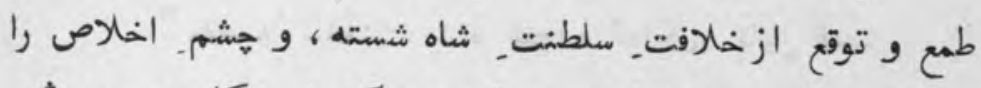

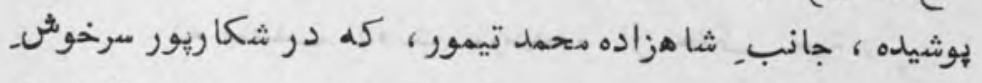

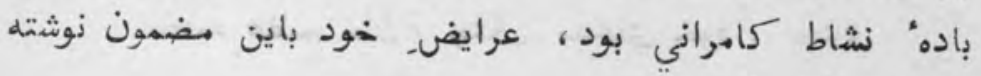

فرستادند

"از تقديرات_ الـهي، مقدمده خلافت سركار.

همايون، باين قسم درمهم برهم كرديده،

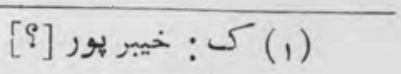


احوال كما [هو] حقه اولياي دولت معلوم نيست كله كجا نزول, اجلال دارند ، و طا يفه - بار كزئي درقرب و جوار شكاريور، بلكه د ر عين_ شكاريور توقف دارند، و او شان منتظر ر هنين وقت بودند ، مبادا از روي متيزه و كينه وري، با دلازمان شاهزاده ، در دقام- سر كشي در آيند ، و هشمّم زخم رمانزد ، و فردا ما اخلاص كيشان ، در حضور

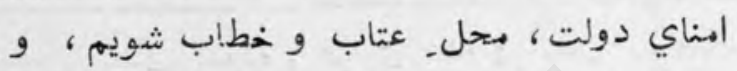

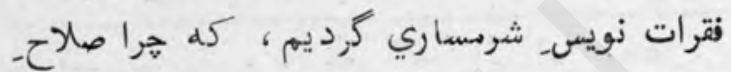
خير ندادند - بفكر و راي خير نماي ما هواخوا مانمان

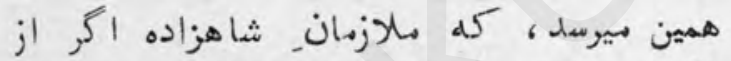

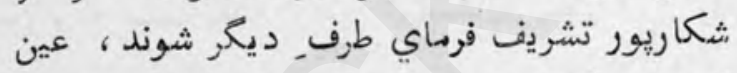

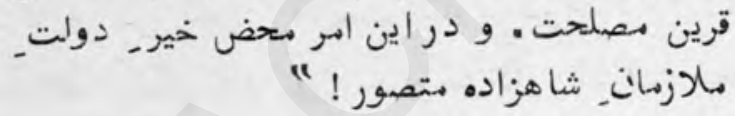

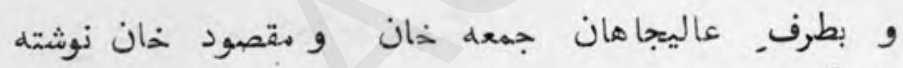

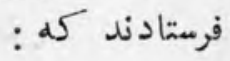

" مقدمd" سلطنت شاه شجاع الهلكى، باين قسبم

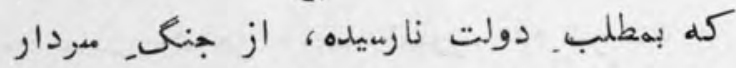

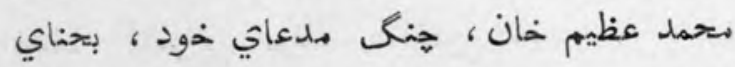

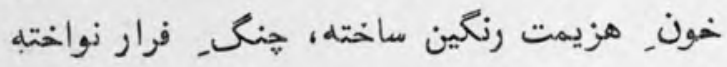

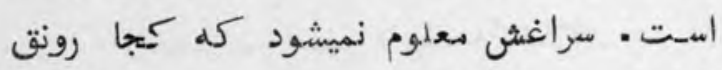
افزاي هيباشند (1) . دروسل مال توقف, شاهزاده 
$1 \cdot r$

تازه نواي معارك

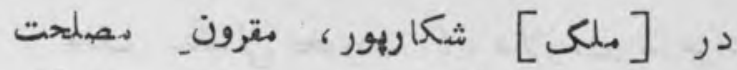

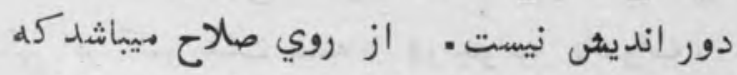

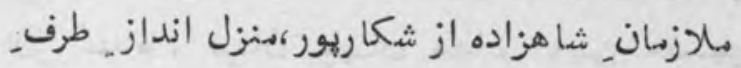
ديكري شوند، كله بهتر است ايشان همم هتحركـ إن

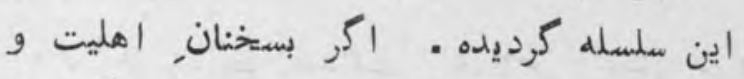

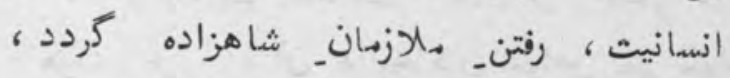
زهى احسن : و الاس بمقتضاي مضمون :

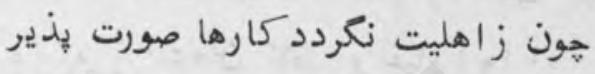

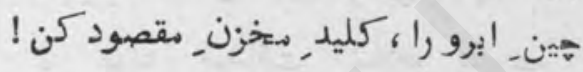

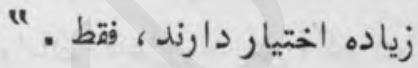

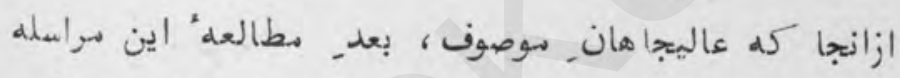

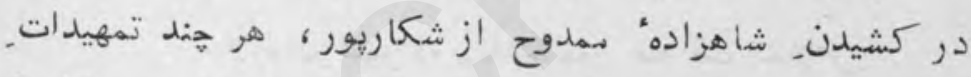

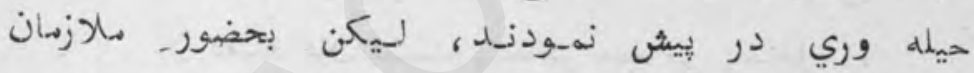

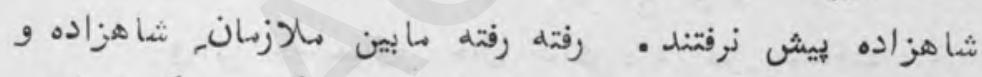

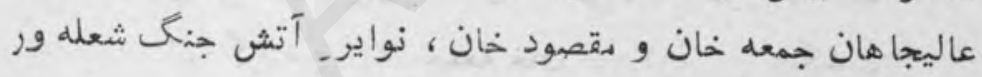

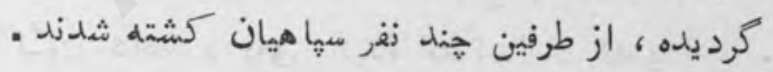
آخر عاليجاه جمعه خان باركزني ، از روي مصلحت ، فروار

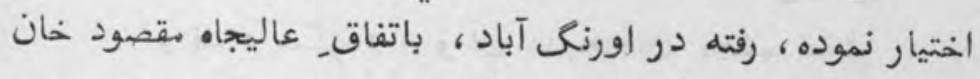

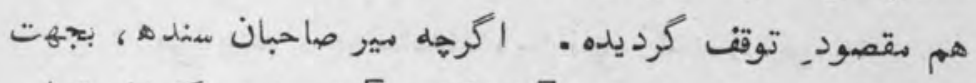

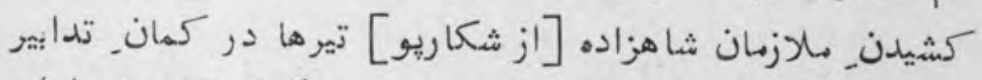

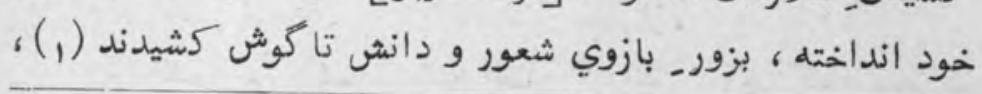

(1) الف: كشيدن كرفتند . 
تازه نواي معار

1.4

ليكن بر هدف_ مدعائي نخورده (1) ، مالزمان_ شا هزاده، شهشير

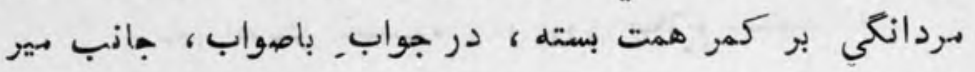

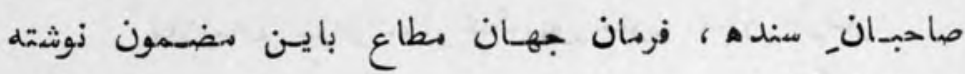

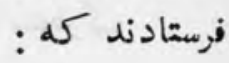

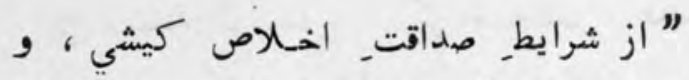

هواخواهي كله آن عاليجاهان خواص خير خواهـ

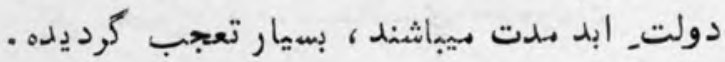

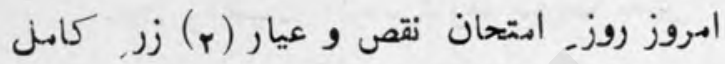

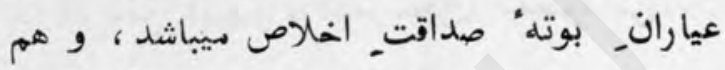

از قانون مخالف نوايان_ دغل انديش آكاه شدن

الهت

ملازمان_شهزاده، باستظهار ـ صداقت اخلاصـ

آن عاليجاهان نشسته ، خاطر جمع بي باشند(ب) .

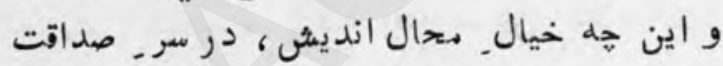

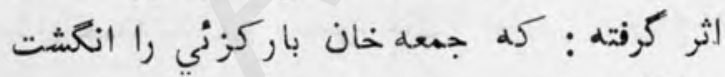

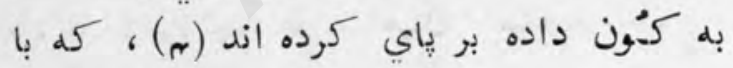

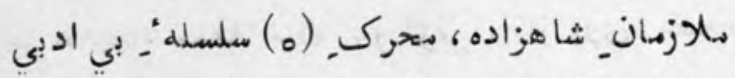

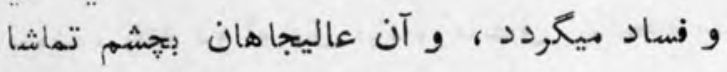

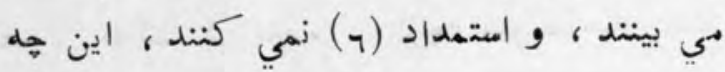

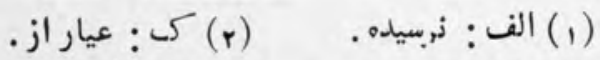

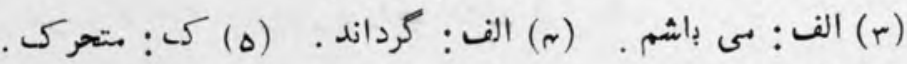

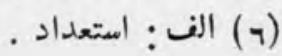




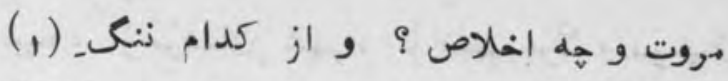
مسلماني و قرب و جوار تصور نموده سي شود ؟ [de. [

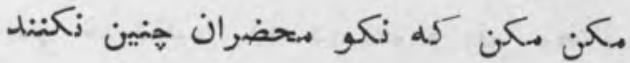

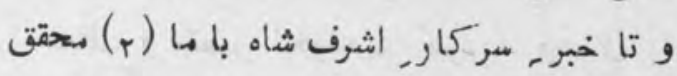

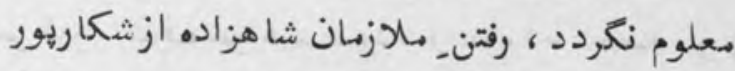

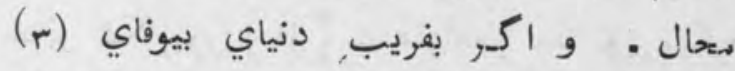

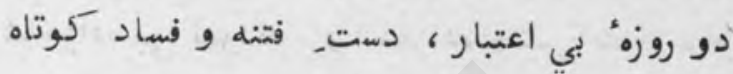
ندارند ، اختيار دارند ، بيت : بل

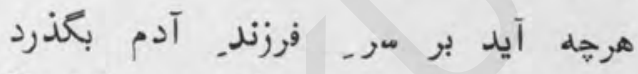

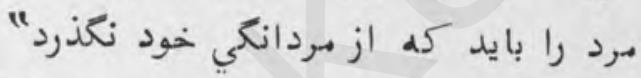

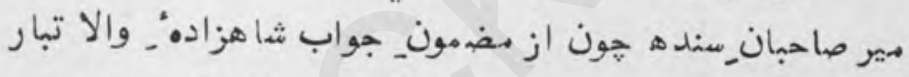

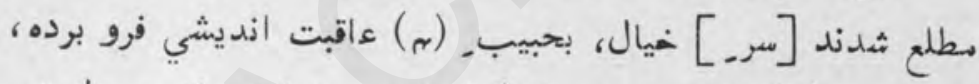

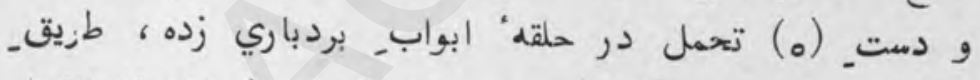

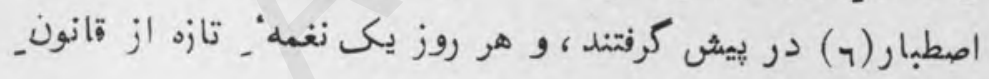

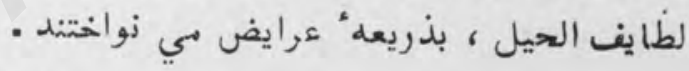

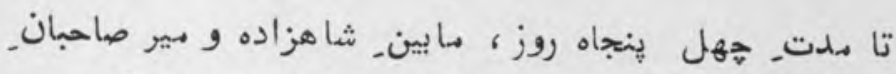

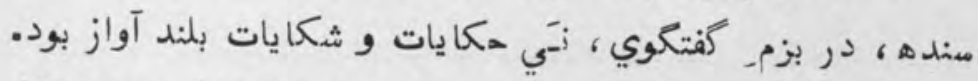

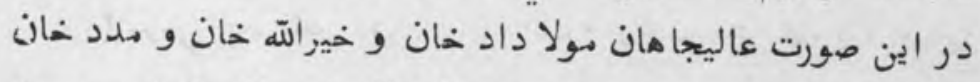

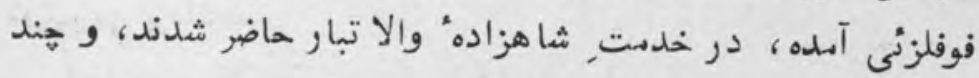

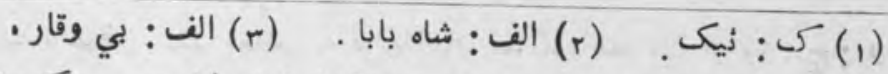
( ) الف: بجهت (ه) الف: دوست [؟؟] (ج) اصطبار = صبر كردن.
} 


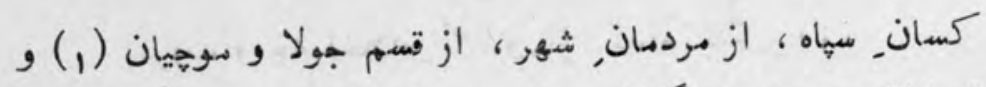

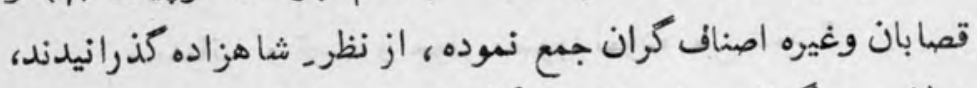

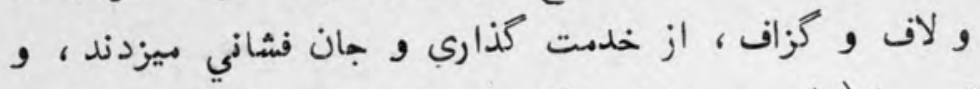

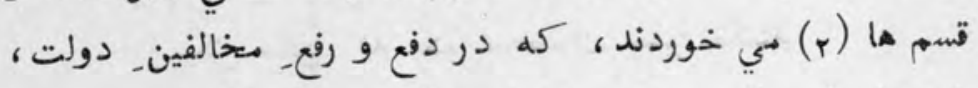

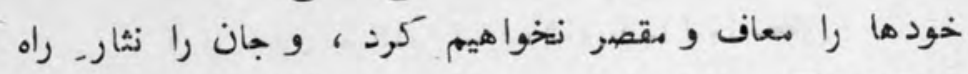

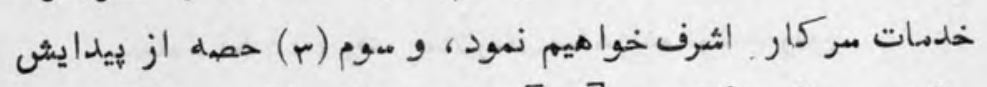

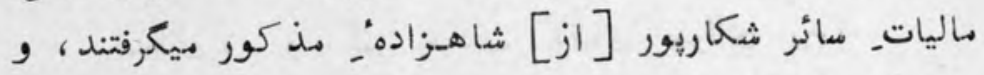

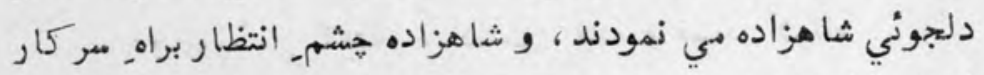

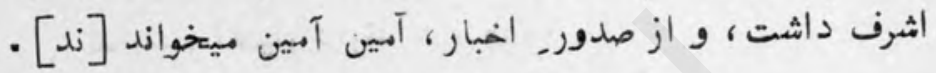

(1) موجي = كفش دوز . (r) الف : و قسم هاني شاه بابا اولياي

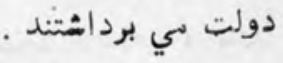

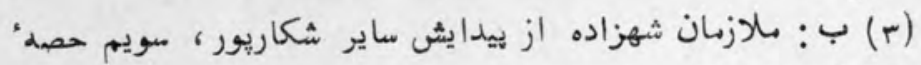

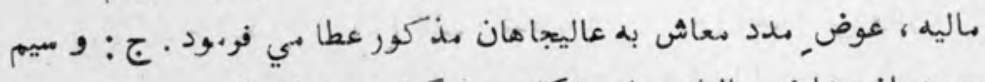

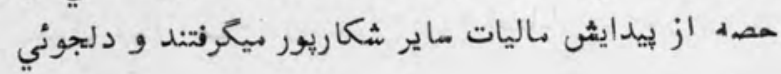


$-14-$

در بيان, ذزول, اجلال, شاه شجاع الملك د, شكار \$جور

و بجلدي تشريف بردن شاه بيمن. هير صاحبان سندهـ،

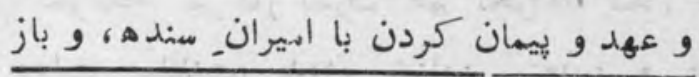
تشريف آوردن در شكار بور

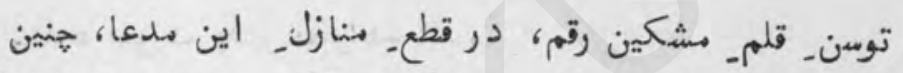

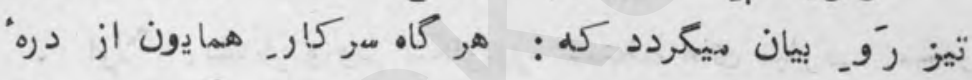

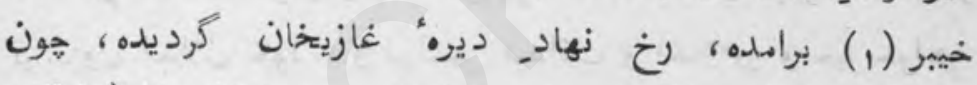

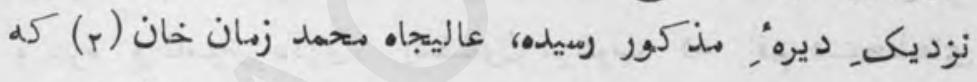

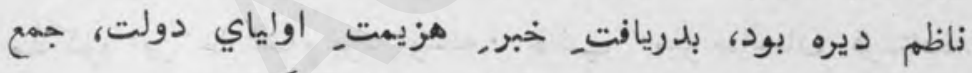

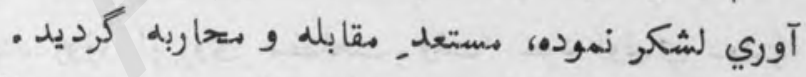

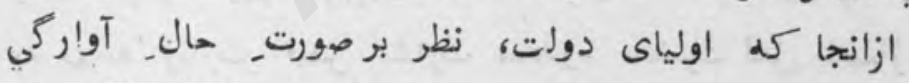

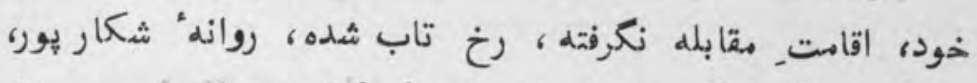

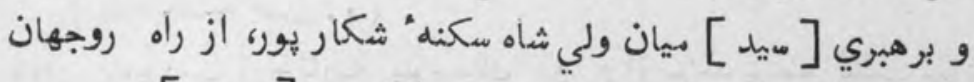

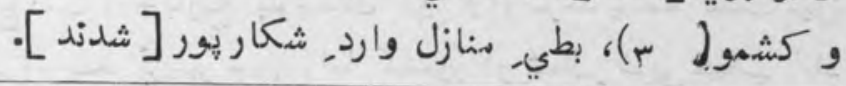

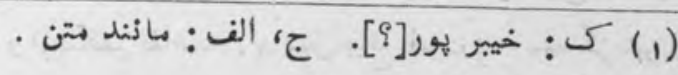

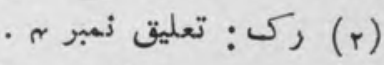

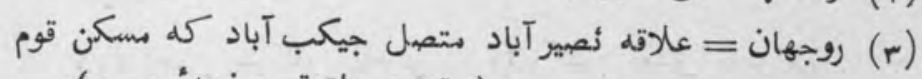

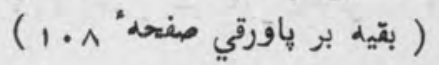




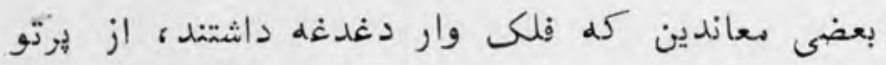

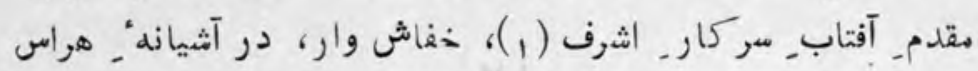

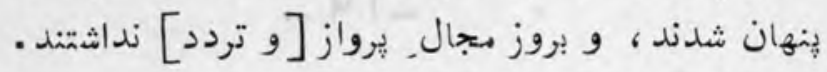

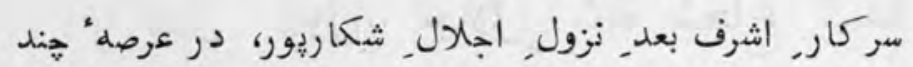

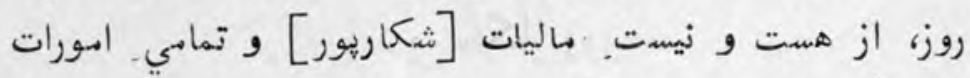
واقف كرديده' دانست كل كه ازين ماليات_ ساير شكار خيور ، حفظـ

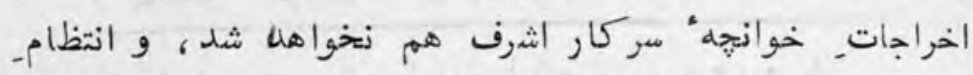

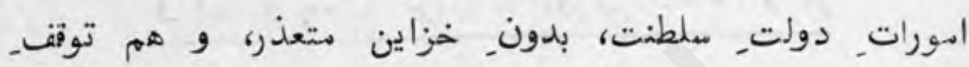

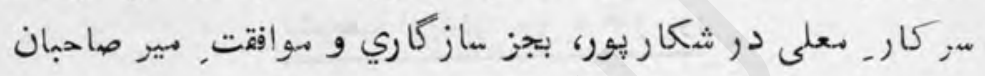

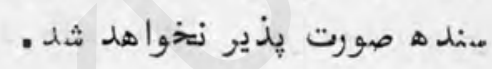

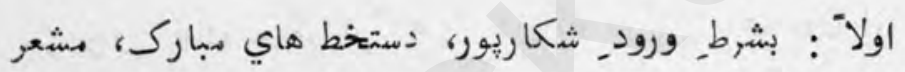
بر نزول اجلال خود، و مراسم- صداقت و اخلاص و خير خواهي و شرم و ناموس داري، بهضمون مرغوب كله راقم دمتيخطهايى مذ كور اين خا كسار بود نوشته، جانبـ بير صاحبان فرستاده،

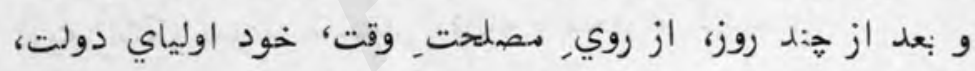
به بهانه' زيارت, فيضى بشارت ميخدوم حضرت لعل شهباز (r)

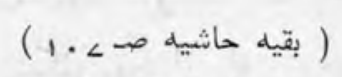

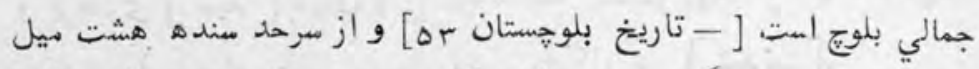

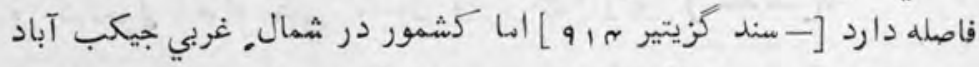

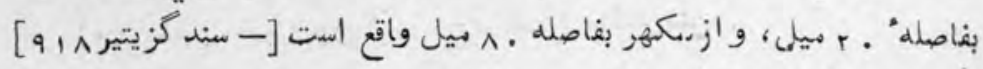
.

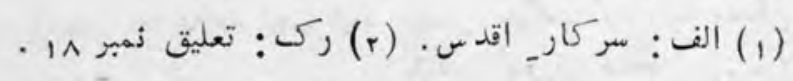




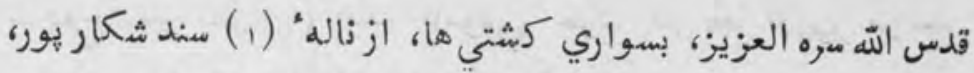

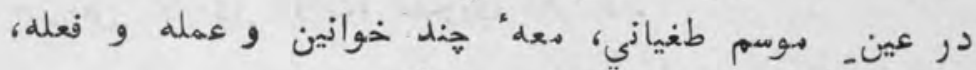

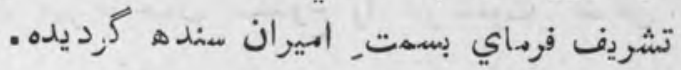

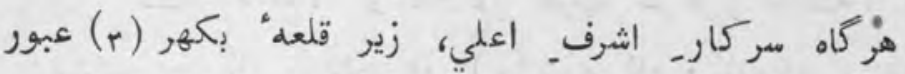

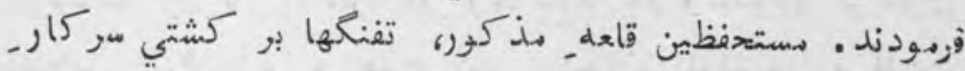

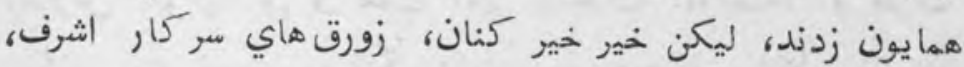

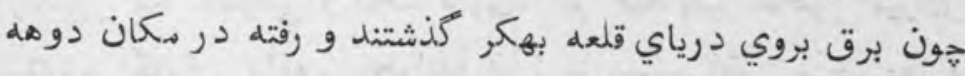

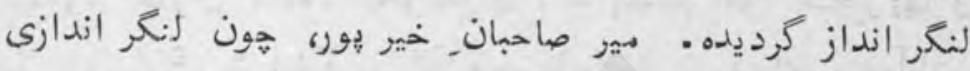

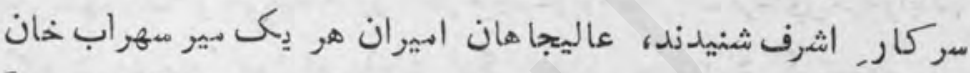

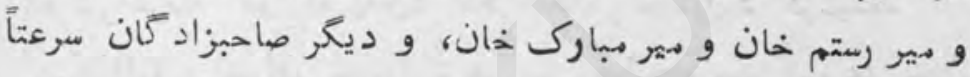

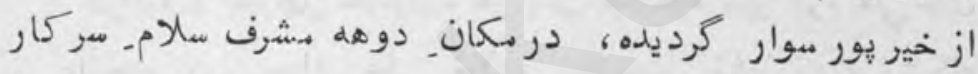
اشرف- اعلي كرديدزند، و آداب- عبوديت و اخلاص را بتجا

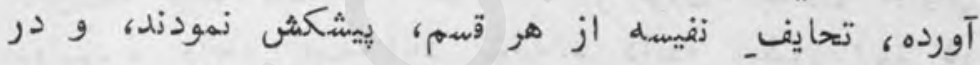
تعارف_ مهمانداريــ اوليايـ دولت، دقيقه از دقايق نا مرعي

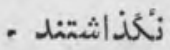

به مدر, نظر اينكه صدر نشينان , دولت و اقبال، كه جرعه

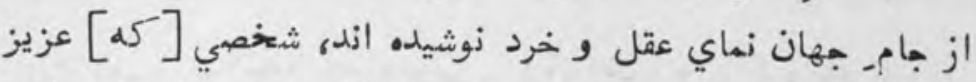

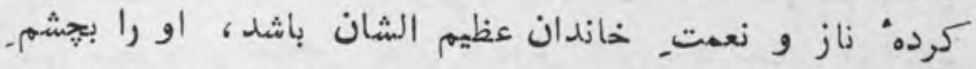
حقارت ملاحظه نهيكند ، جه جائي كله يادشاه باشده، اهيران

$$
\text { . }
$$

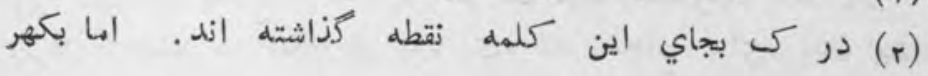

مقابل سكهر بين درياي سنده است . 


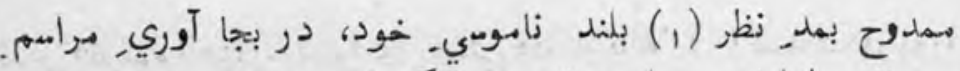

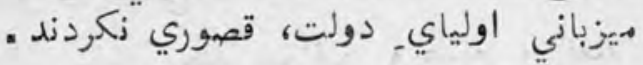

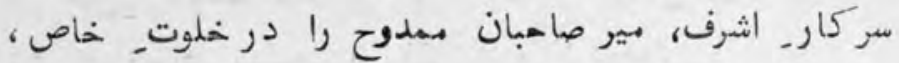

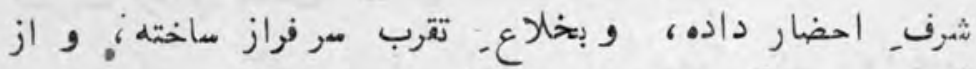

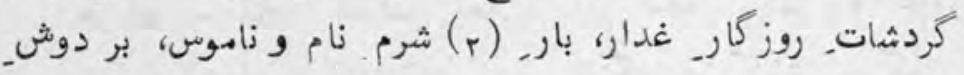

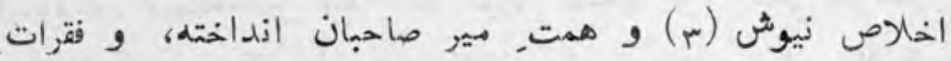

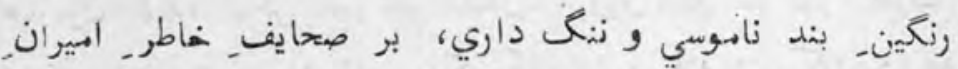

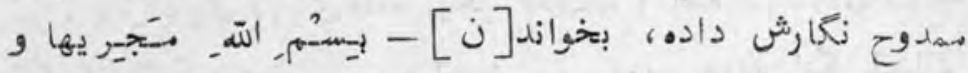

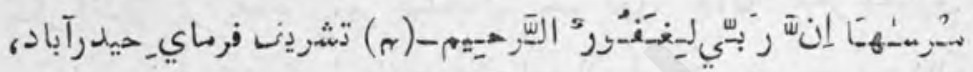

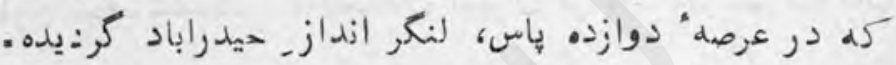

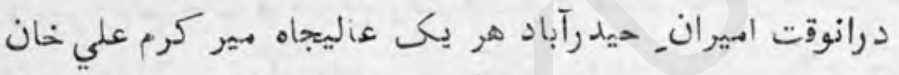

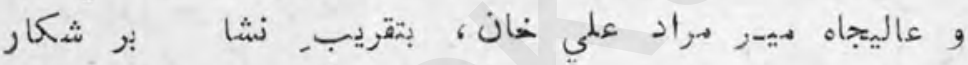

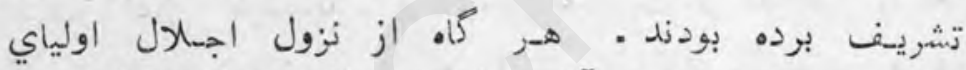

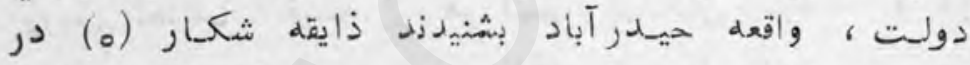

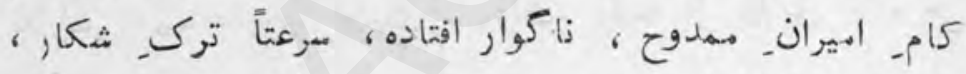

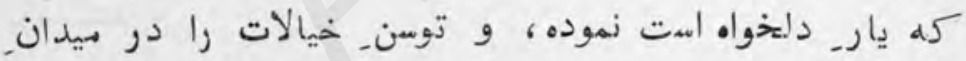

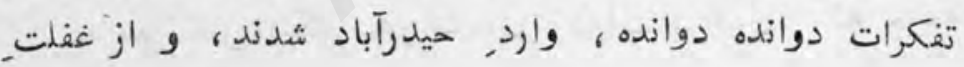

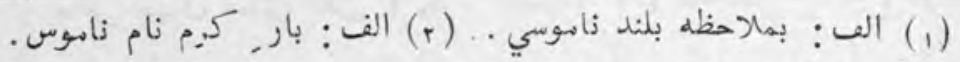

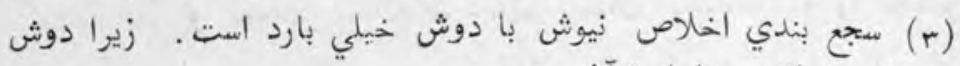

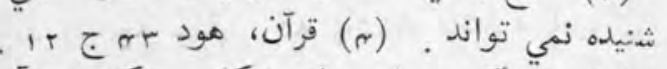

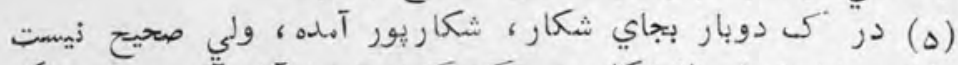

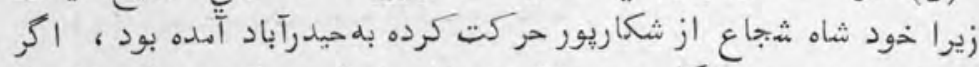

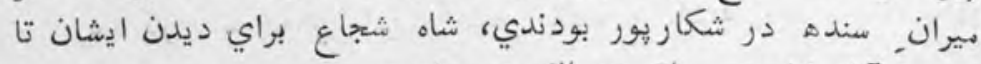

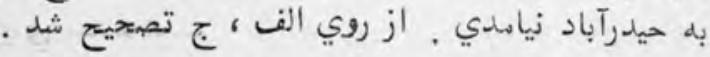


كار بردازانـ خود، نهايت در جوض. خشمم شدند، كه از آبدن.

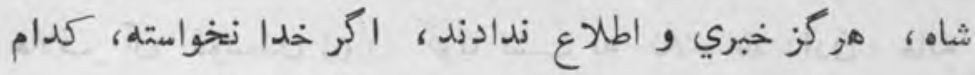

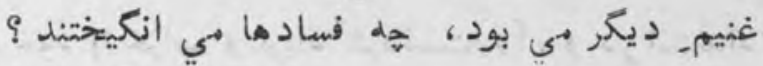

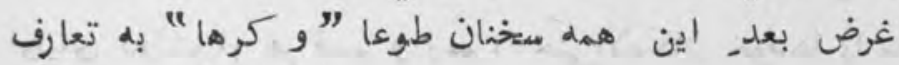

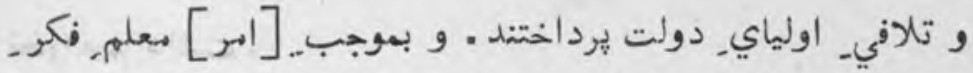

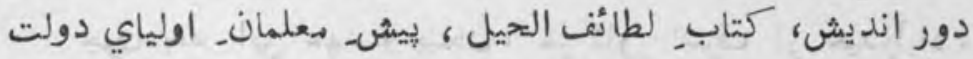

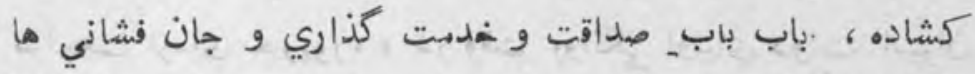

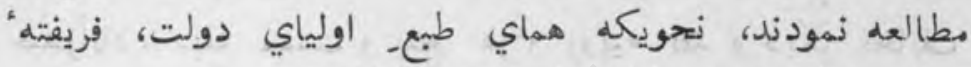

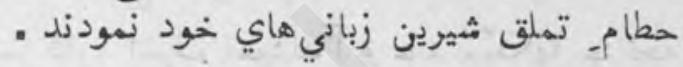

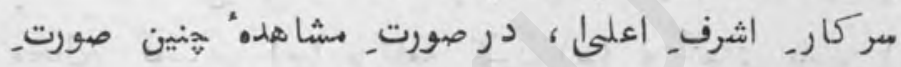

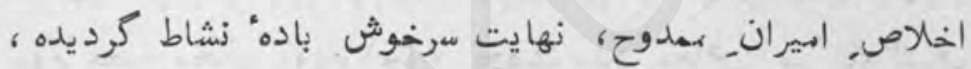

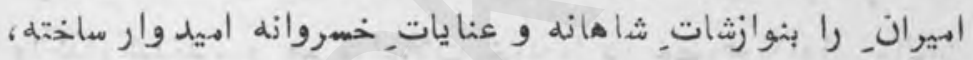

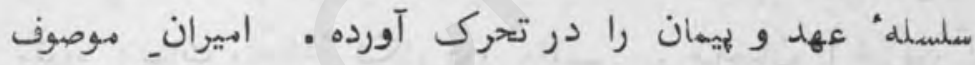

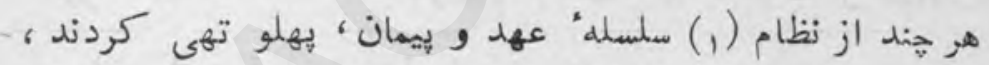

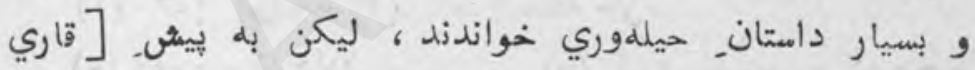

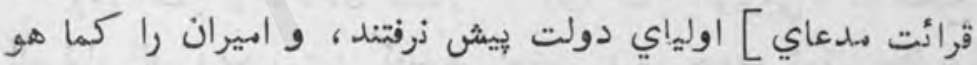

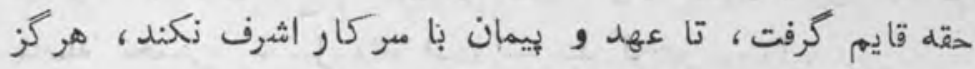

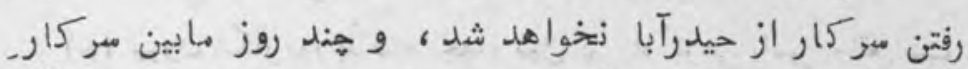

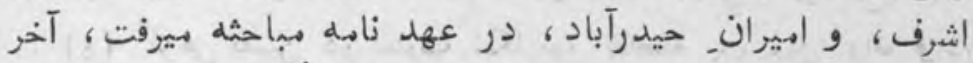

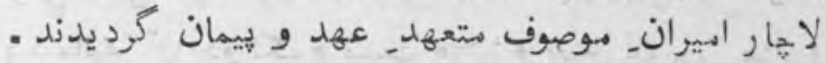

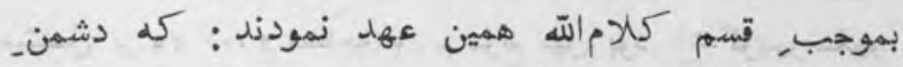

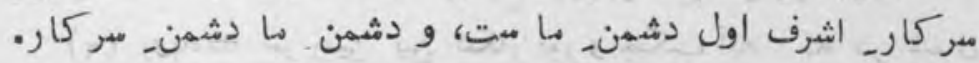




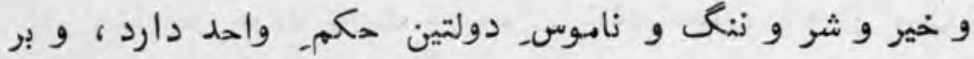

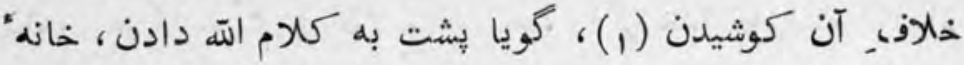

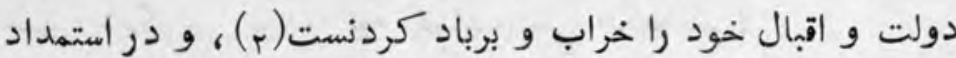
اولياي دولت از هر قسم و رسمى، حتي الامكان خودها ها را مقصيّر نخواهيم داشت -

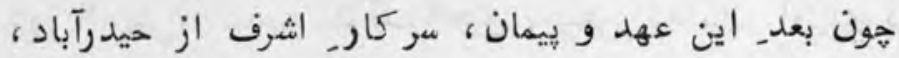

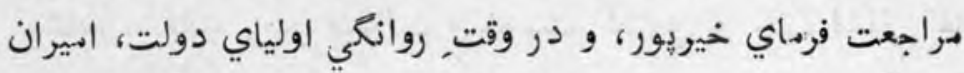

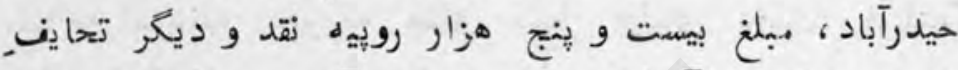

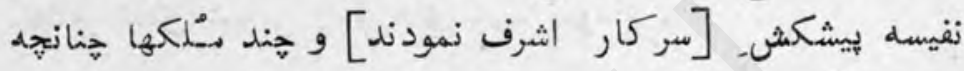

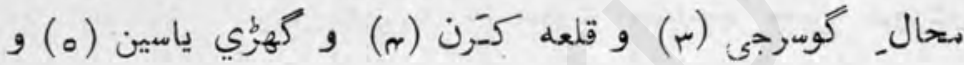

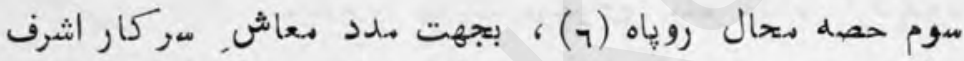

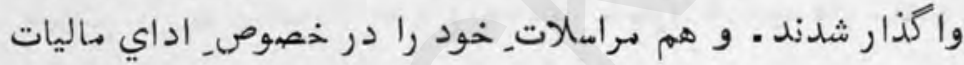

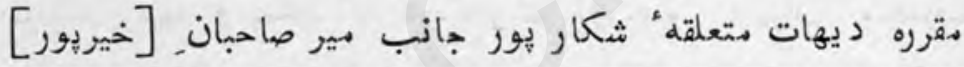

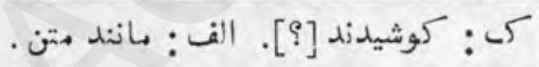

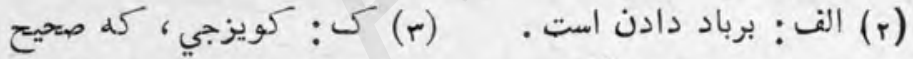

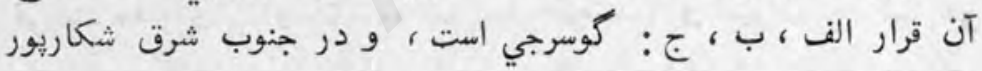

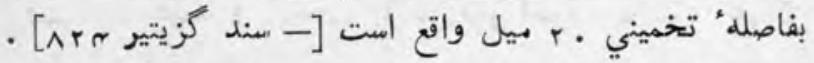

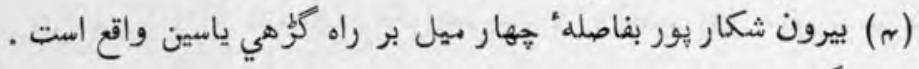

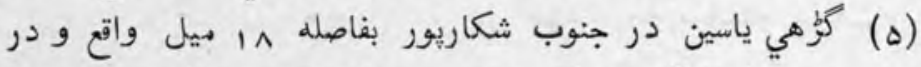

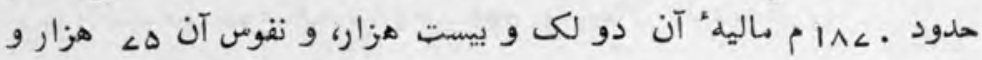

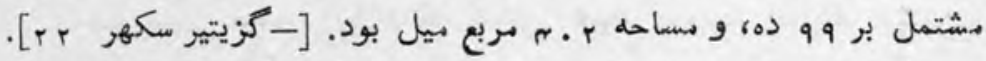

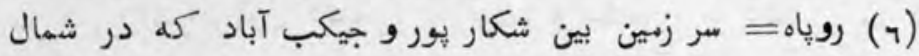
شكار بور واتعست. 
نوشتشد، كله مأه بهاه بهوجب. اقساط رسانيده باشند ، و بهر حال

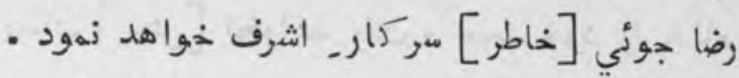

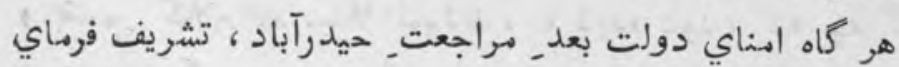

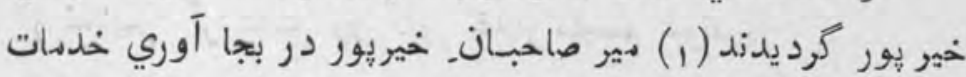

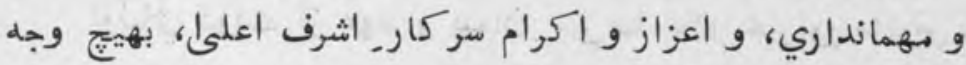

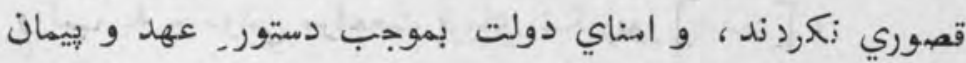

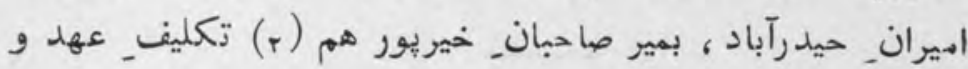
ريمان نمود .

ازانجا كله بير سهراب خان كله داناي زمان و ديرينه سال

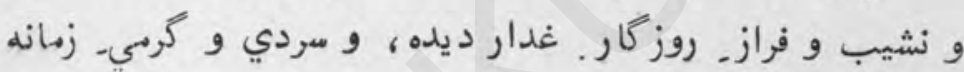

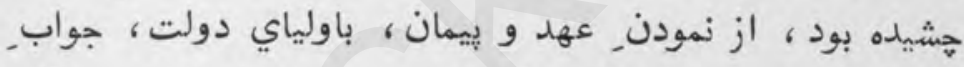

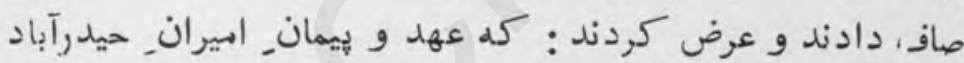

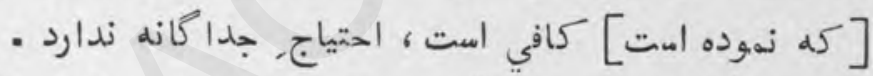

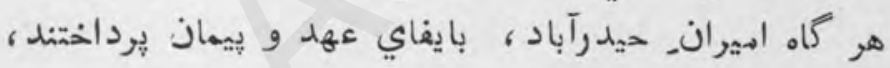

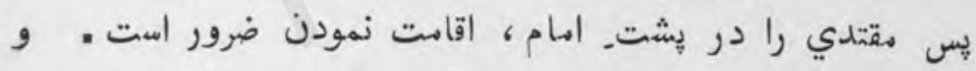

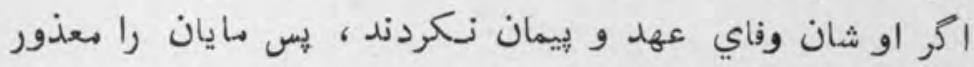

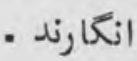

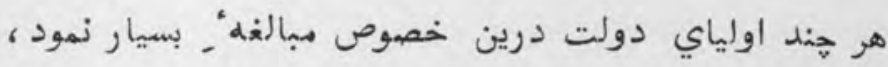

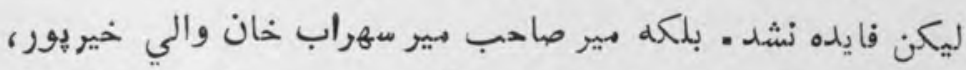

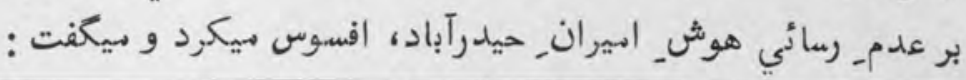

(1) در كى ، ج اين جمله دغشوش است از الف تصحيح شد. ك (r) 
تازه نواي معاركى

$11 \%$

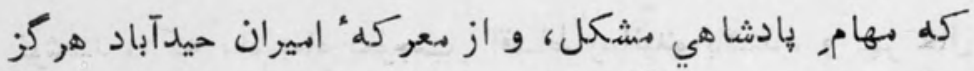

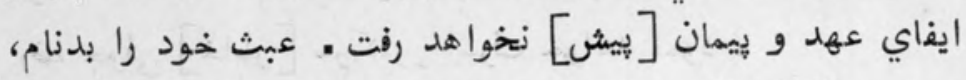

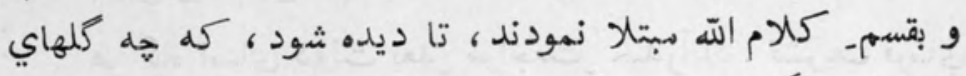

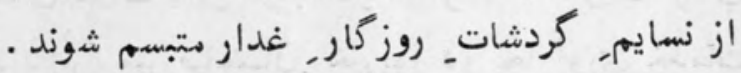

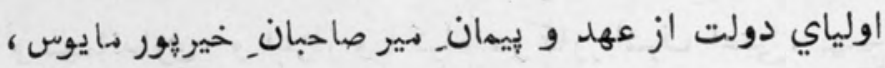
و لب به خاموشي مراجعت فرماي شكاريور [شدند] ، 
در بيانِ مراجعت فرمائى اولياى دولت از حيدرآباد

$$
\text { و خيريور }
$$

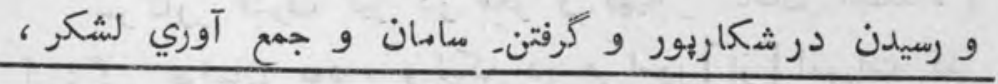

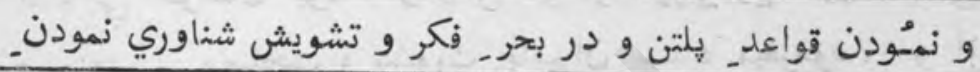

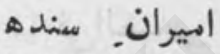

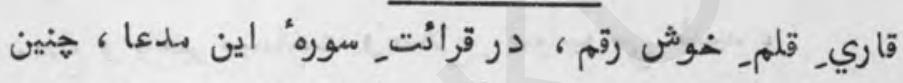

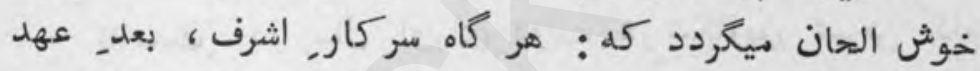

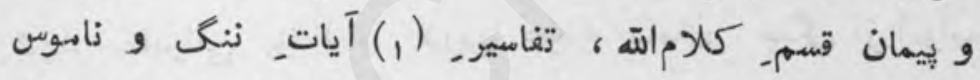

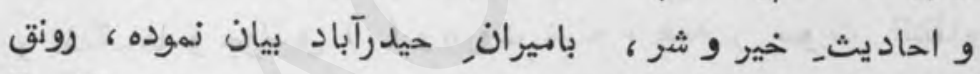

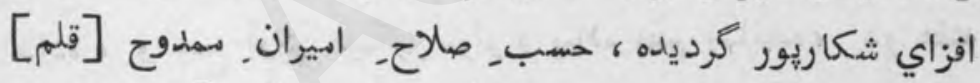

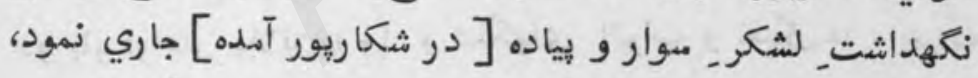

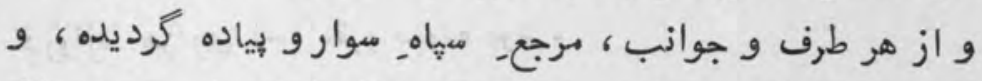

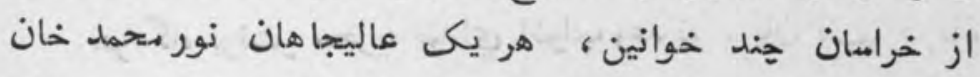

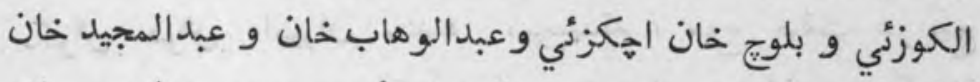

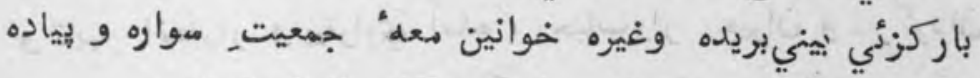

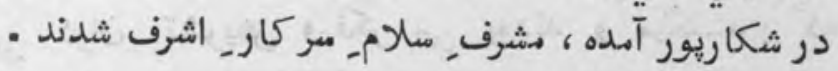

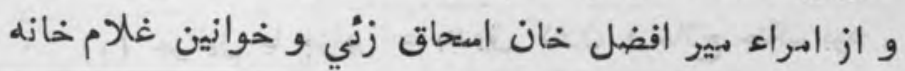

$$
\text { (1) الف : و تفسير · ج ، كى : مانند متن : }
$$


تازه نواي معار

119

هر يرى عاليجاه خان شيرين خان جوان شير و بيات و قزلباش و

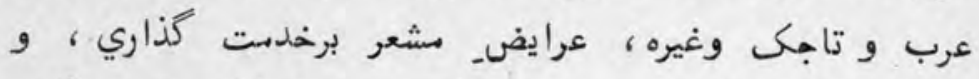

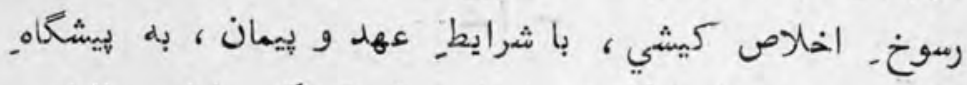

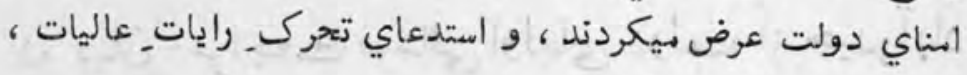

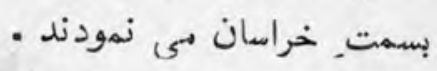

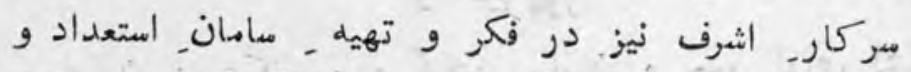

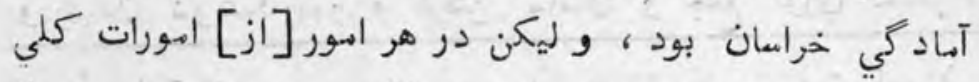

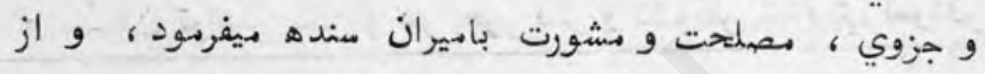

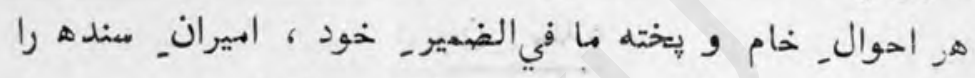

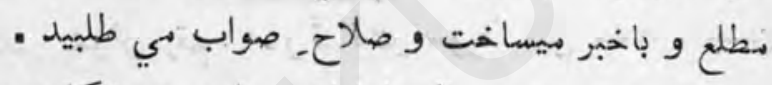

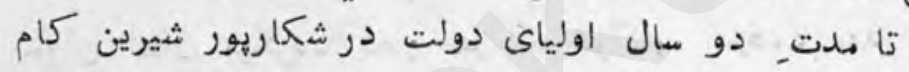

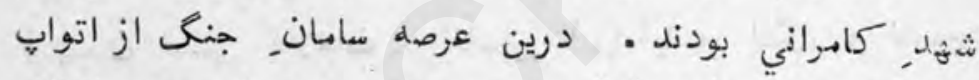

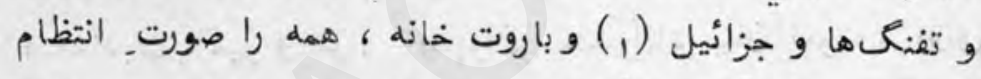

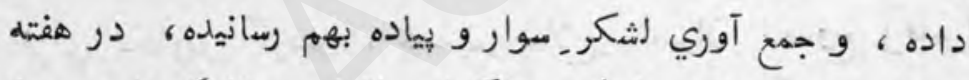
دو بار قواعدـ ضاكلن (r) و شلكهاي اتواي و تفنط ها ، بيرون

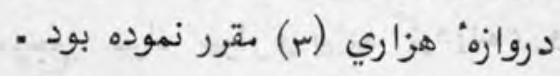

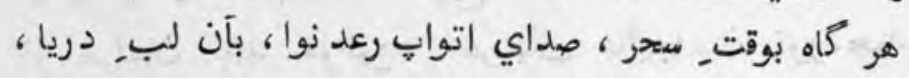

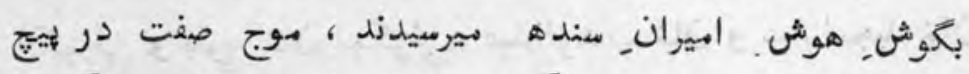

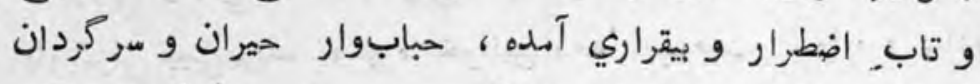

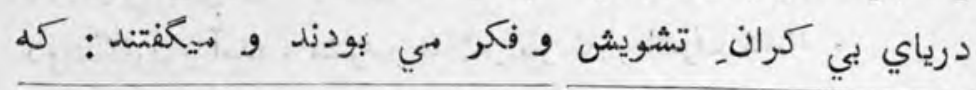

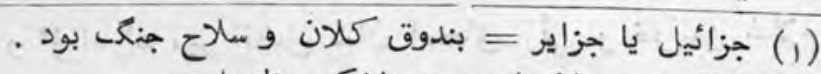
.

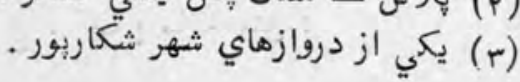




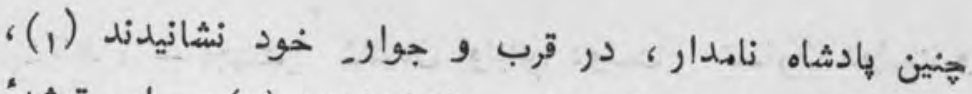

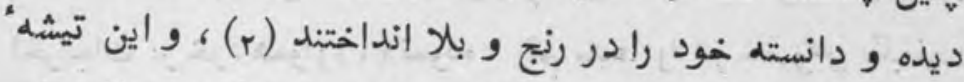

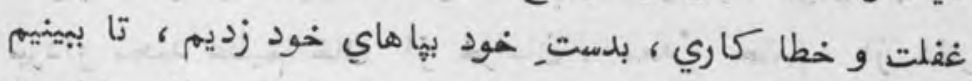

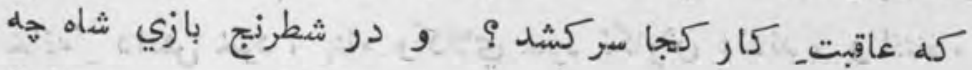

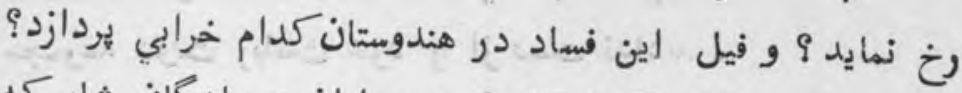

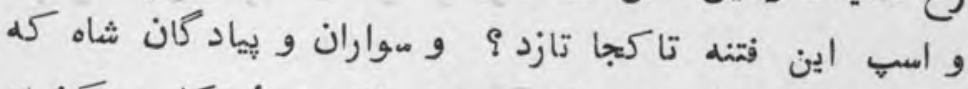

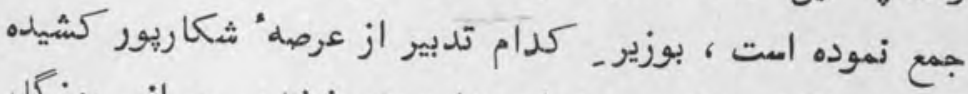

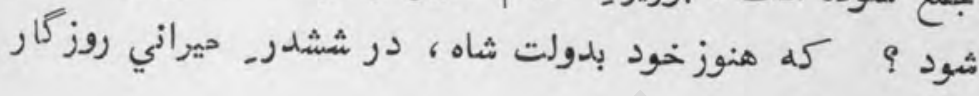
خود مات الست

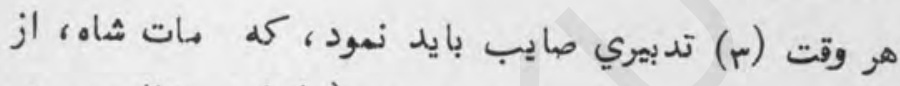

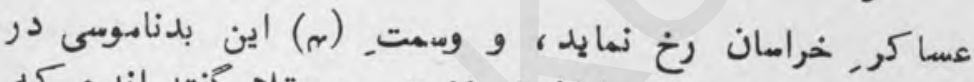

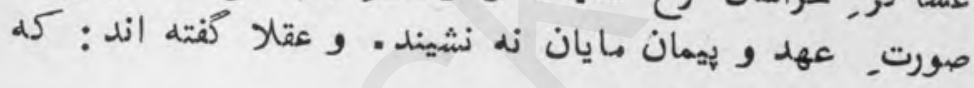

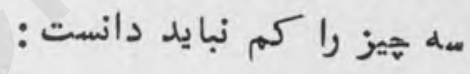

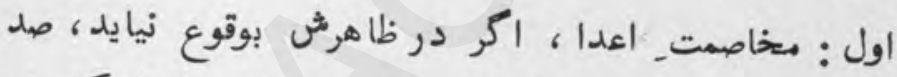

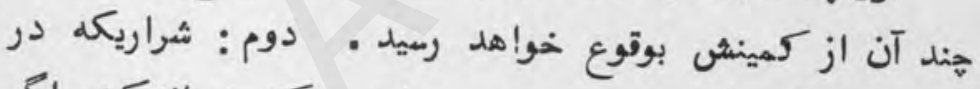

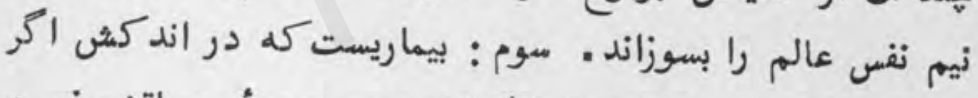

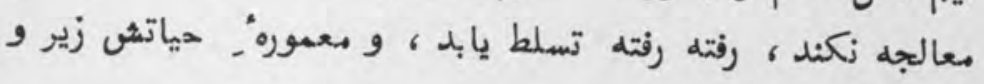
زبر مازد - معاز في الجمله اميران سندهـ، بمقتضاي : نه يار رنجد و نه لعل بل

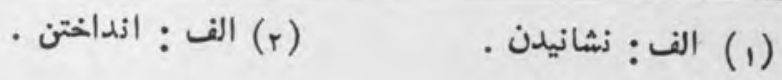$$
\text { (r) }
$$

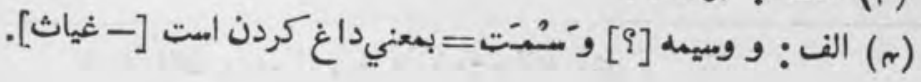


بشكند ، - بجرت ـ كشيدن اولياي دولت ، خساره؛ دولـت و اخراجات بر خود هموار (1) نموده، رقم مدعا را در خصوص طلبانيدنـ

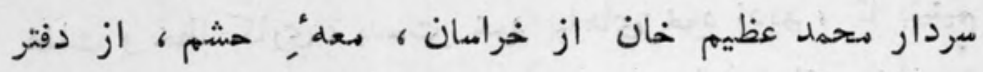
خازd" دانش خود ، بنام وكلاي خود نكارش دادند ، و انتظام

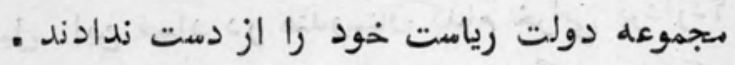

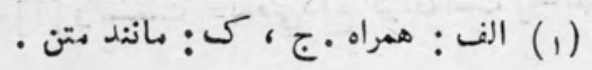


در بيانِ اطوار , ظالهانهُ شاه در شكاريور

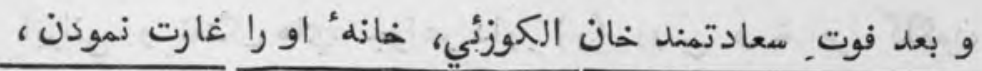

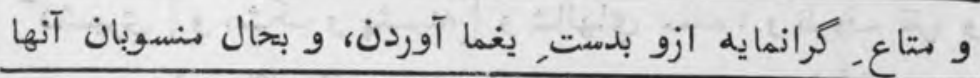

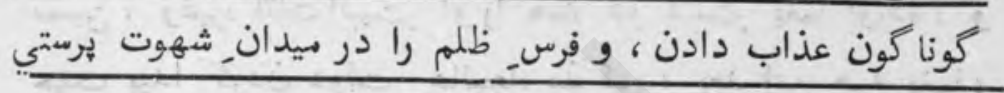

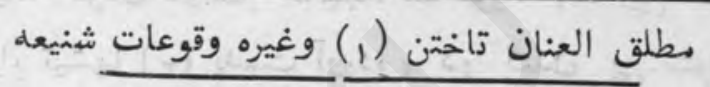

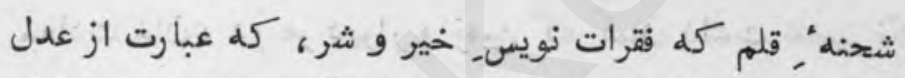

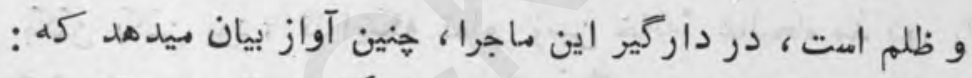

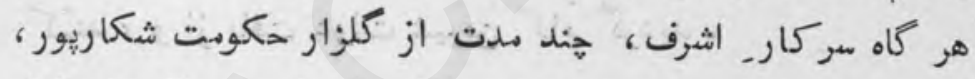

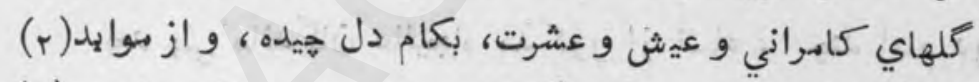

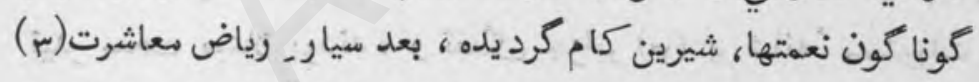

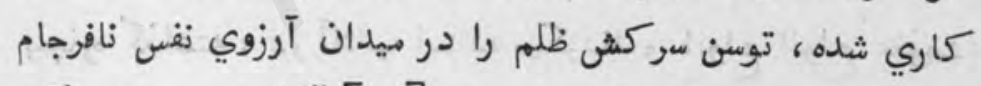

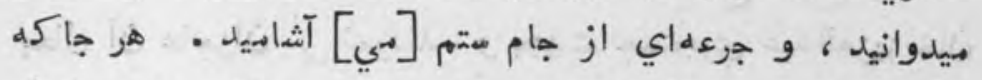

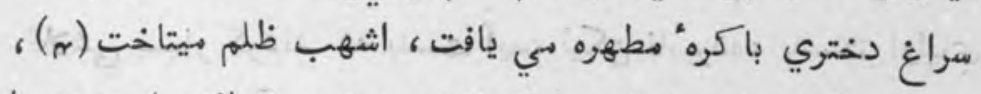

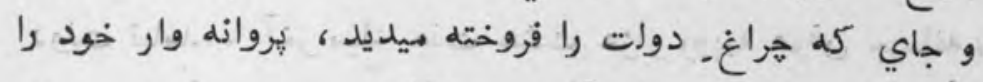

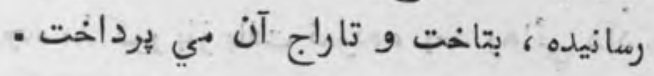

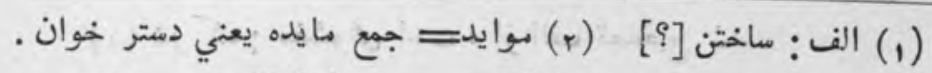

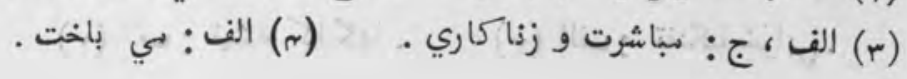


تازه نواي معارك

$1 \%$.

اولا" : خانه" عاليجاه سعادت [مهد] غان الكوزّي و نايبش

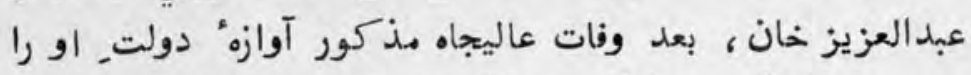
شنيده ، حكماً و جبراً [ بحيّز نقد و جنس ، از قسم طلا و ويورات مرصيّع و مينا كاري و و

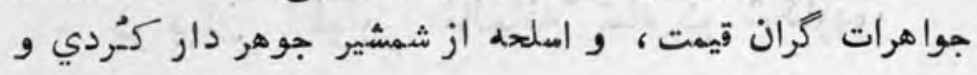

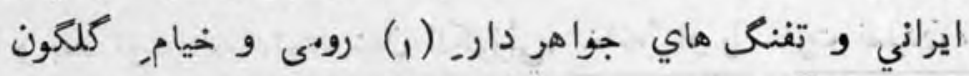
كشميري [و مشكى و بشمينه]] و شالهاي عهده، و ظروف نقري

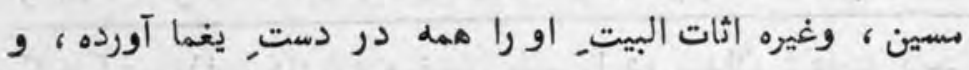

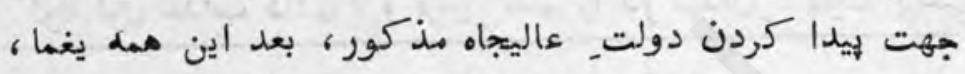

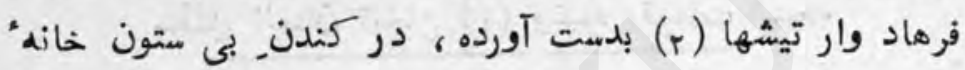

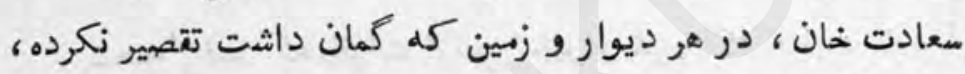

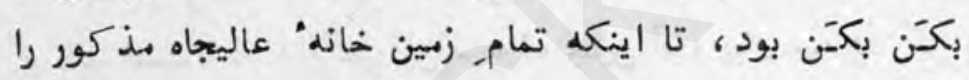

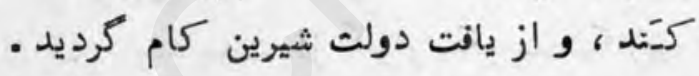

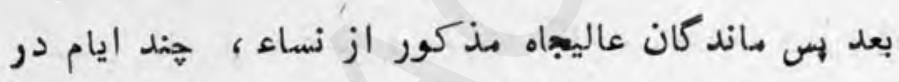

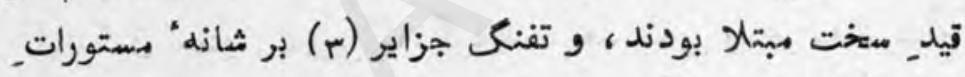

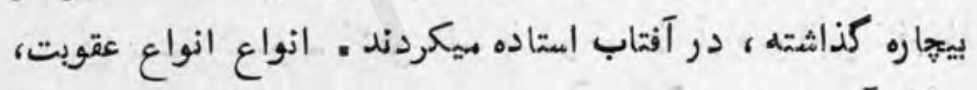

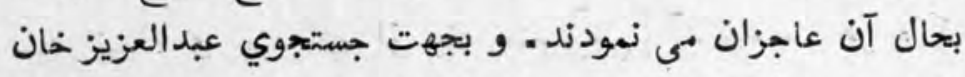

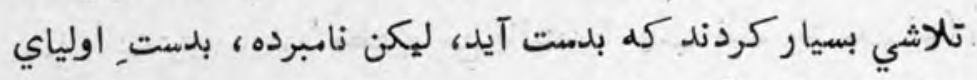

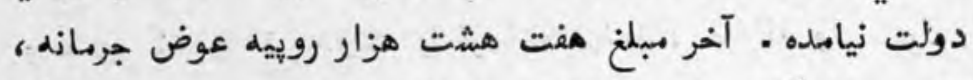

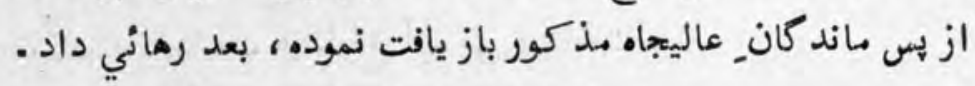

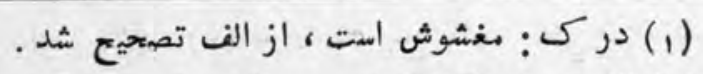

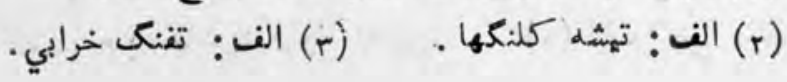




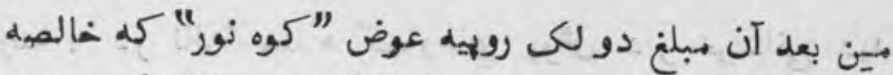

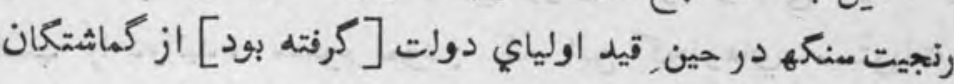

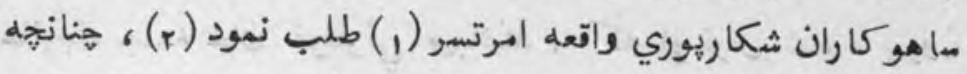

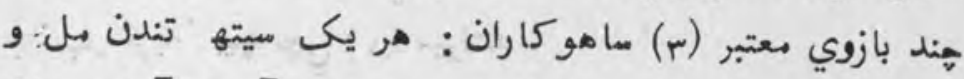
بيته كاب راي وغيره در صندوق خانه زيشى [متحمد] قد ير خان

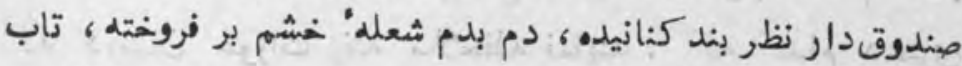
و دهشت بر سا هوكاران مي انداخت، كلم زود مبلغان مذكور،

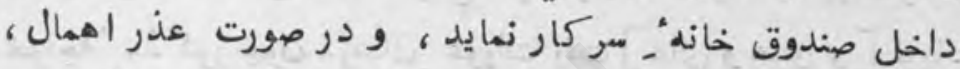
در حق ايشان خوبي و بهبود كي زخواهد شله ، و آب و آبروي و عزت خود نريزند

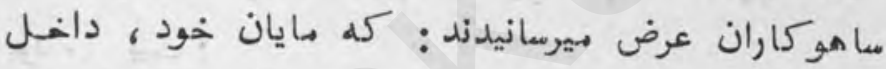
صندوق خانه" معركار مي باثشيهم، احتياج ادخال مبلغان نيست .

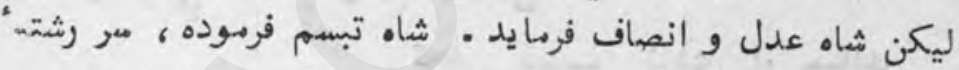

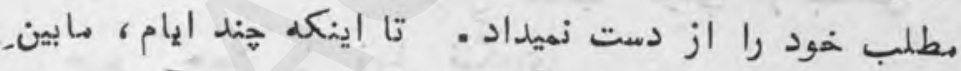

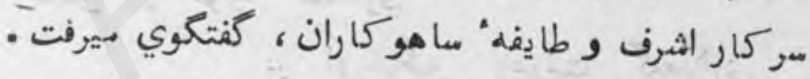

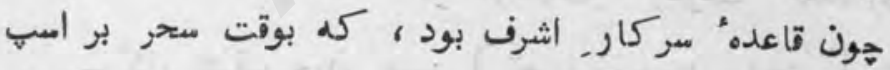
] دلخواه] خاصه ميوار كرديده ، بجهت_ هوا خورى رفته تشريف بيرون شهر تا نالهُ منده هيروند • . روزي كله براي هوا خوري

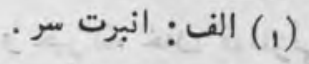

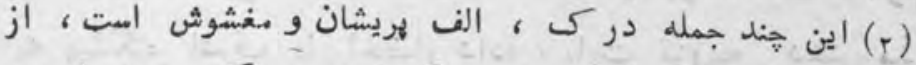

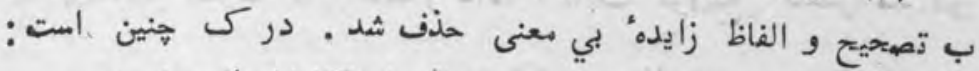

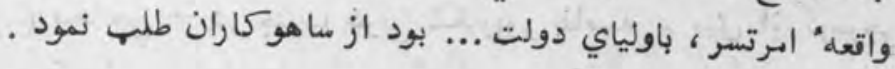

$$
\text { [?] [ }
$$




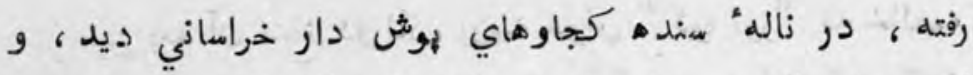

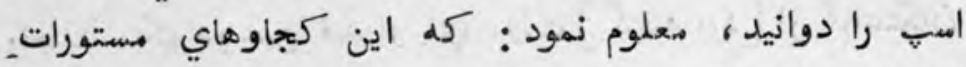

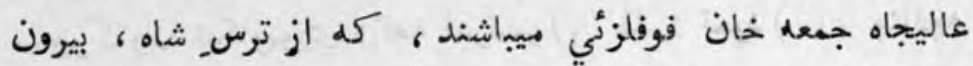

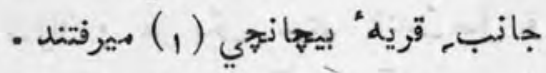

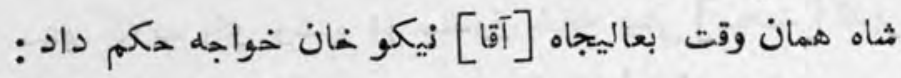

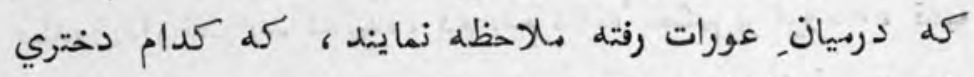

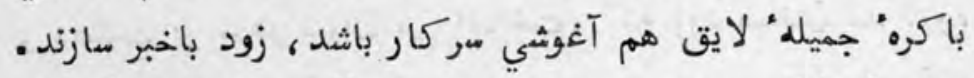

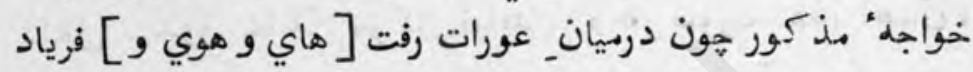

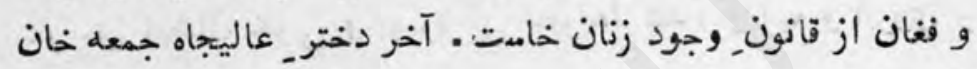

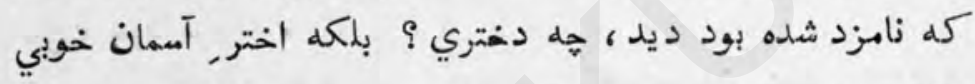

$$
\begin{aligned}
& \text { بود - بيت : } \\
& \text { دل آرابي كه هـه وقت_ كمالش }
\end{aligned}
$$

تجلي كسب كردي از جمالشى

سرير حسن را زيبا نـاري

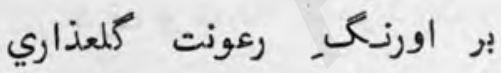

سركار اشرف هون حنين [ تعريف حسن- دختر]

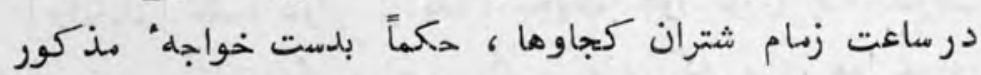

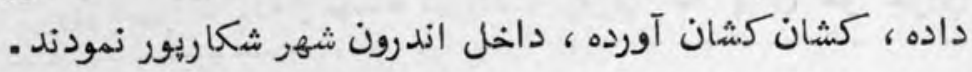

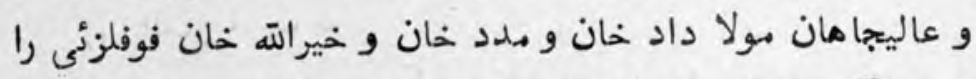

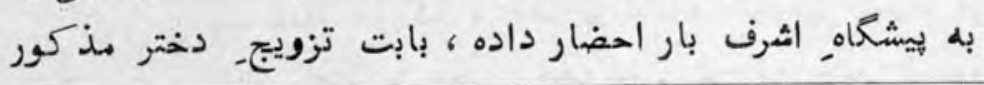

(1) بيجهانجي = در جنوب غربي شكاريور بفاصله م ميل از كوسرجي

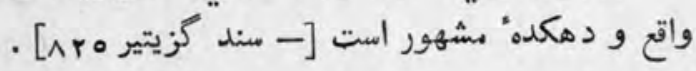




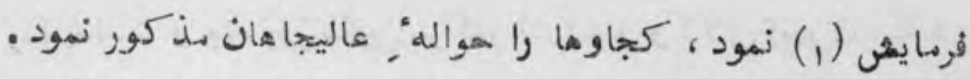

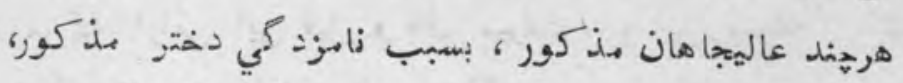

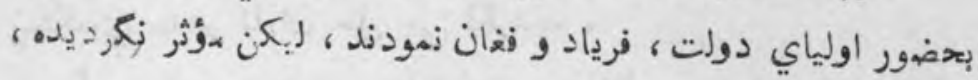

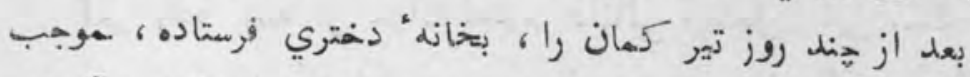

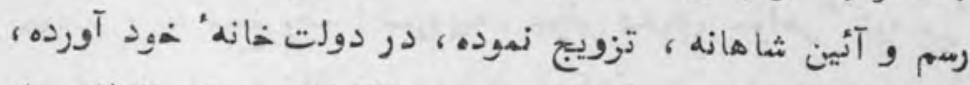

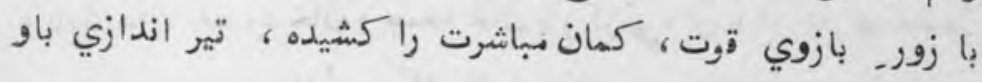

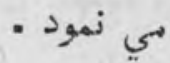

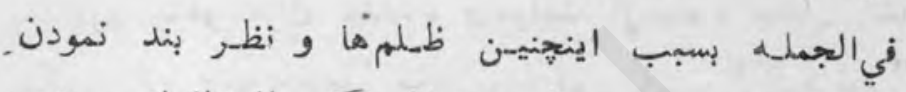

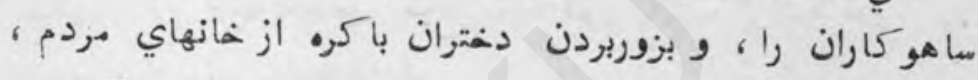

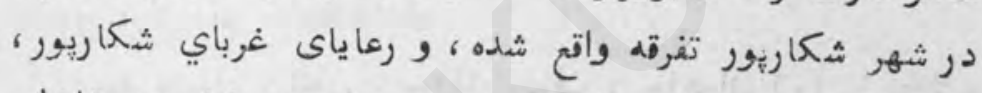

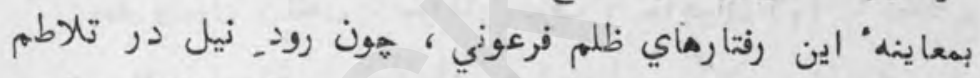

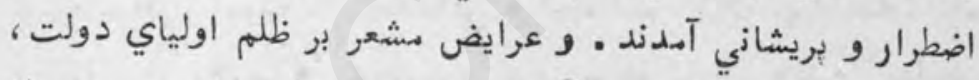

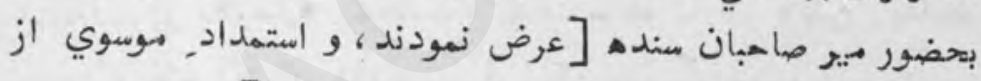

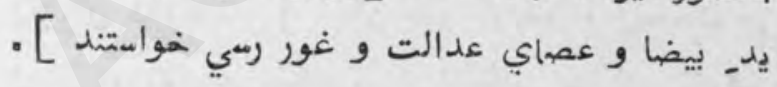

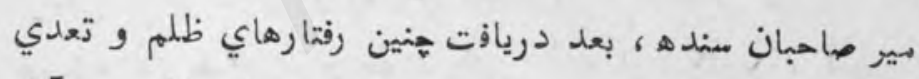

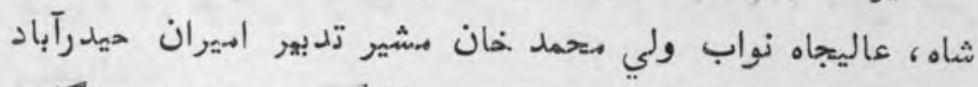

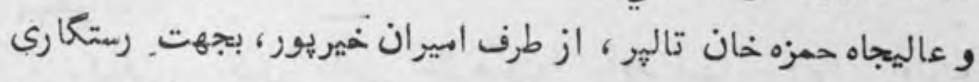

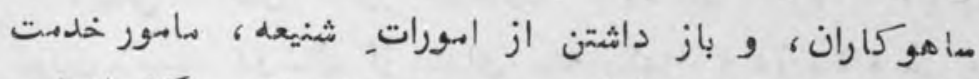

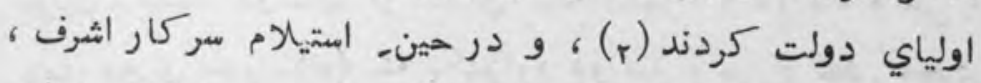
درخلوت سخنان نوث آميز نيش انكيز را بسمع دورئ اولياي دولت

$$
\begin{aligned}
& \text { (1) الف : فهمايش . }
\end{aligned}
$$

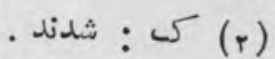


رسانيدند، و هيند زوز مابين سركار اشرف و وكلالي اميران سندهـ،

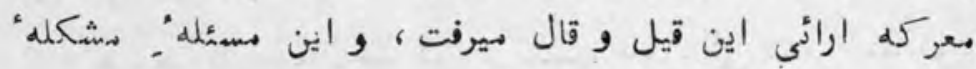

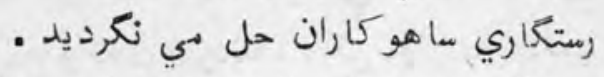

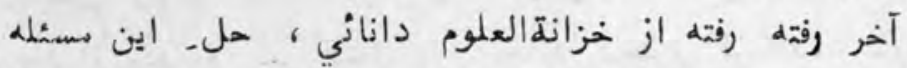

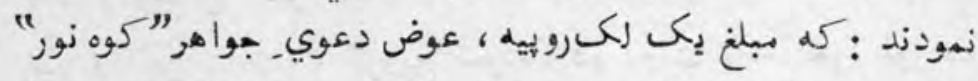

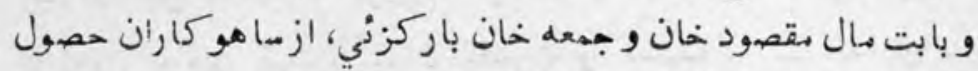

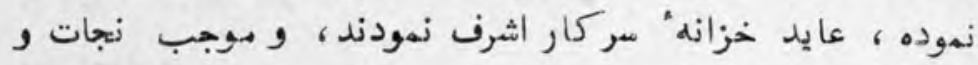

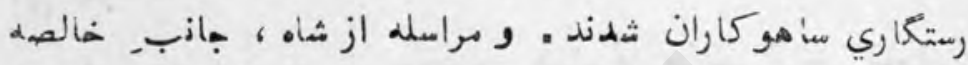

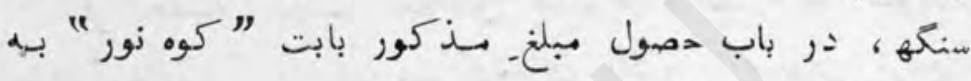
سا هو كاران نويسانده دادزئد

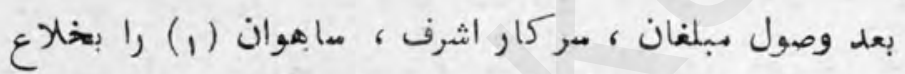

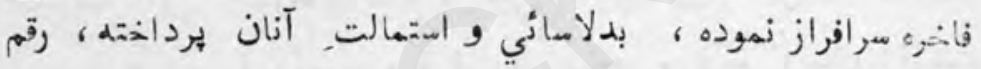

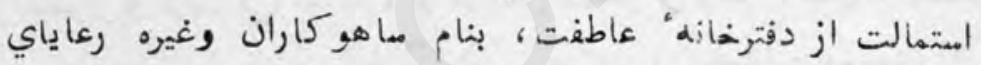

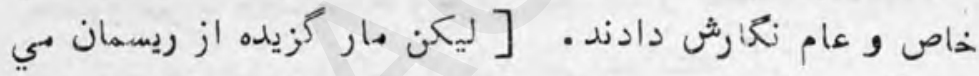

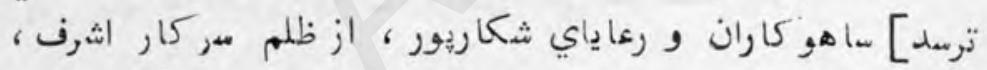

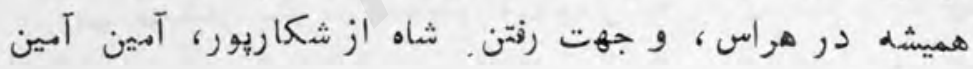
ميخواندند

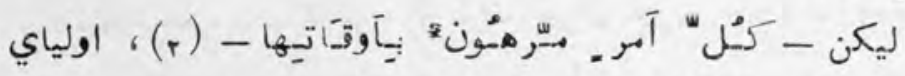

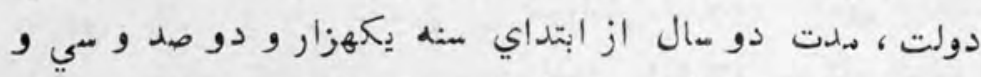

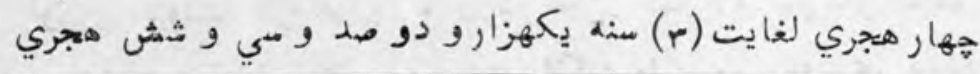

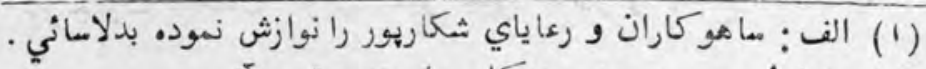

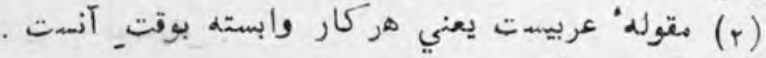
. $5(r)$ 
درشكاريور داير بوده. . تا اينكه اميران مندهـ ، وكلاني خود را جانب_ خراسان، بيش سردار محمد عظيم خان فرستاده ، تجويز.

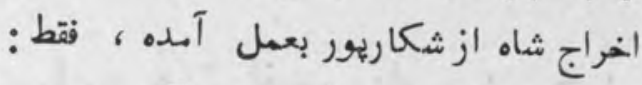

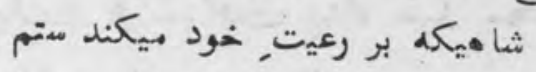

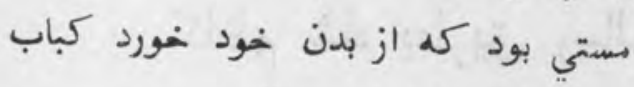

*

* *

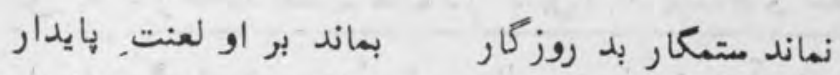

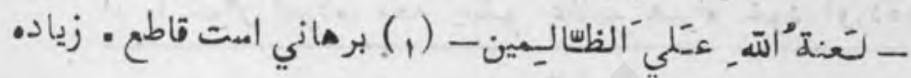

زياده است (r)

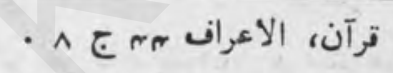

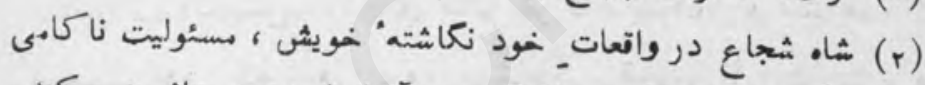

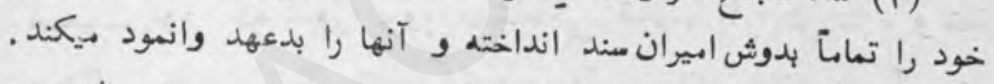

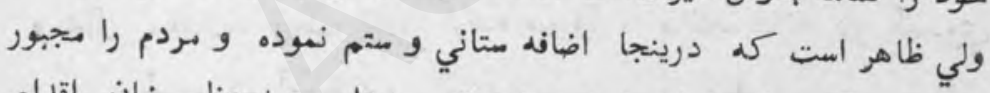

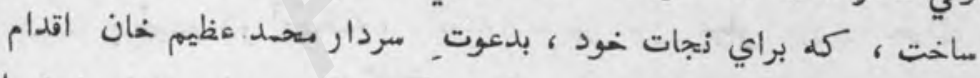

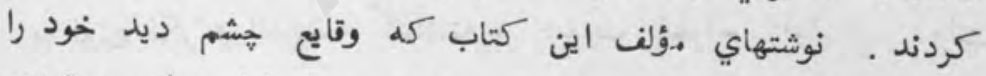

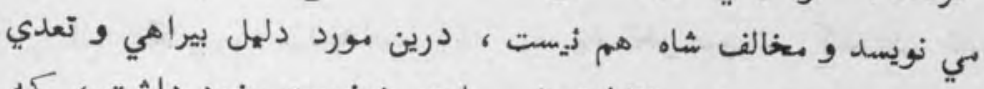

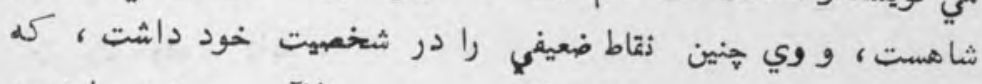

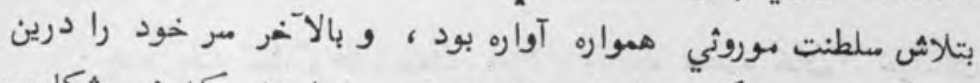

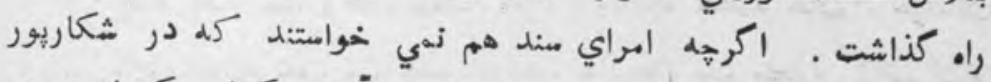

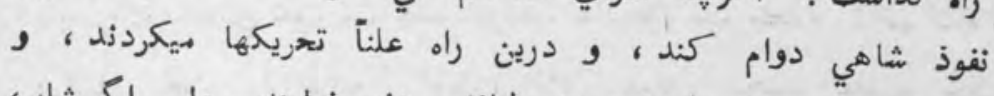

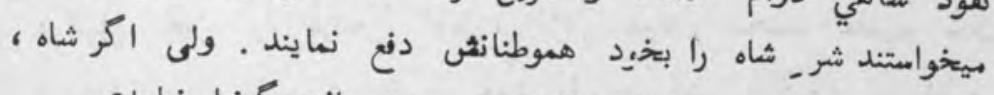

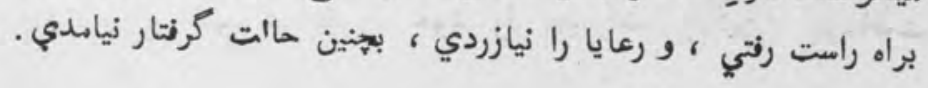


$-19-$

در بيانـ رفتن_ سيادت و شرافت يناه سيل منهل كاظم شاه بطريق رسالت

ويش- سردار متهد عظيم خان در كابل، و بوعدهاي عظيم

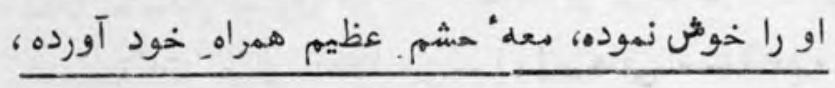
اولياي دولت را از شكاريور كشيدند

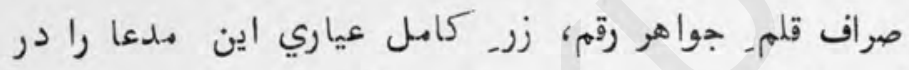

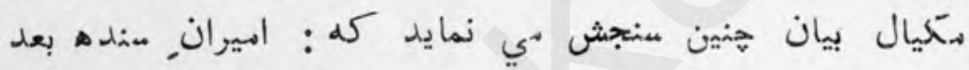

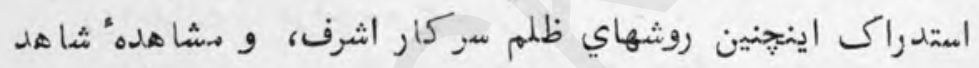

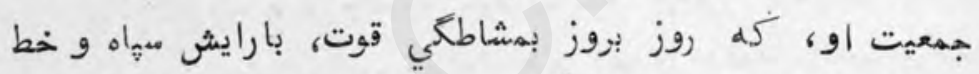

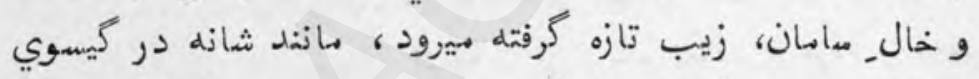

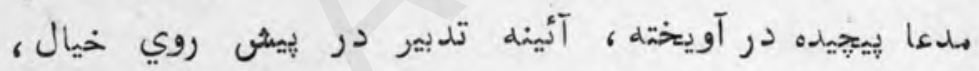

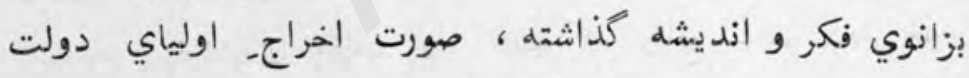

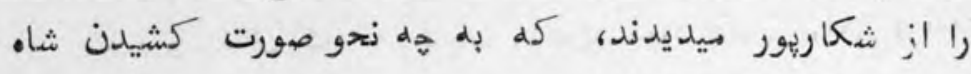

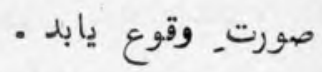

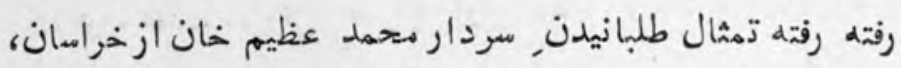

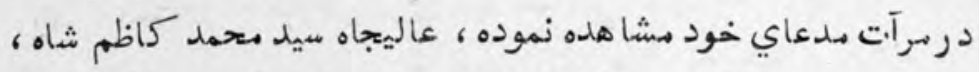

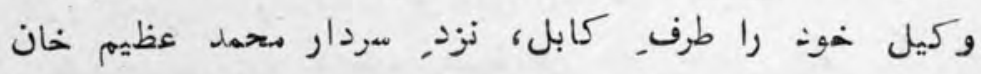

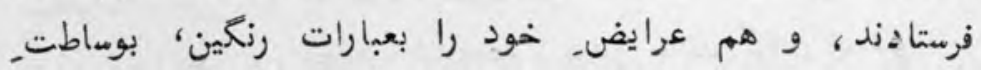




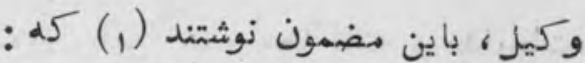

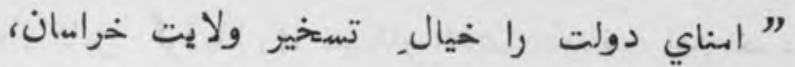

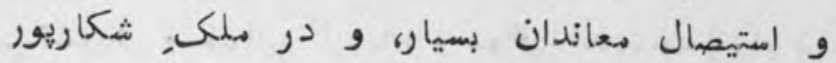

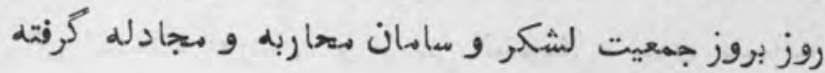

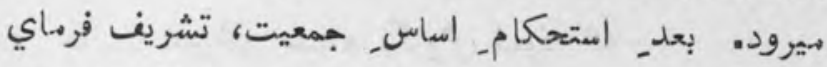

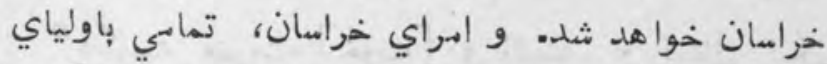
دولت، همدمر مصلحت و همان هم اتفاق بنظر مي آيند.

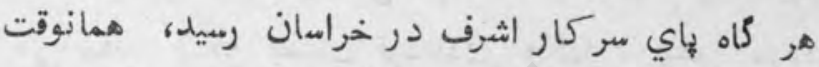

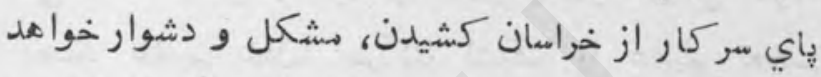

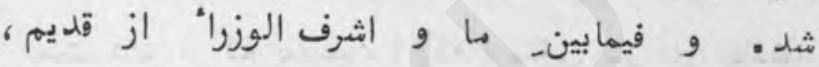

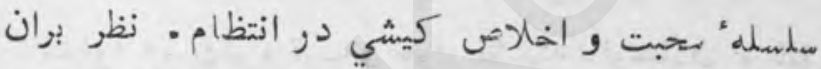

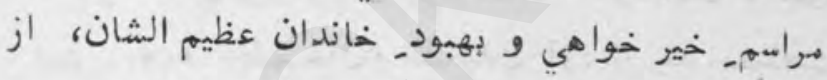

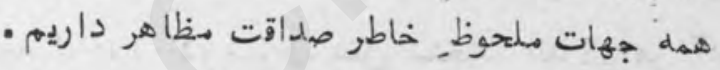

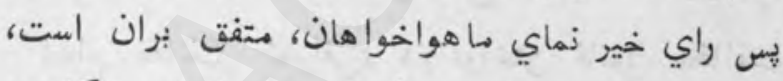

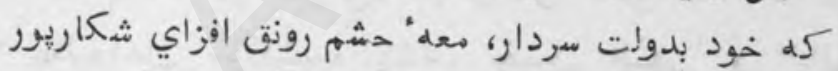

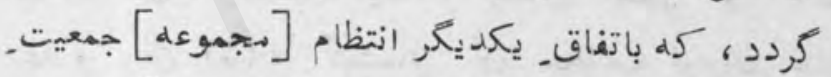

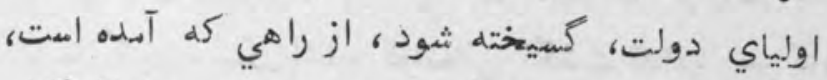

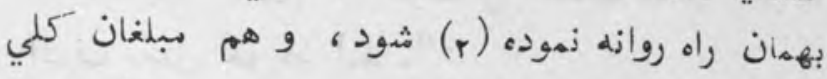

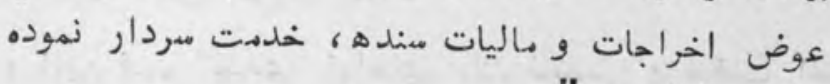

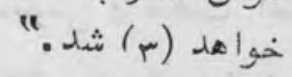

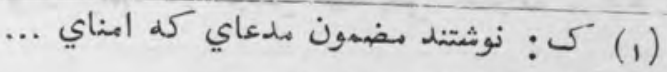

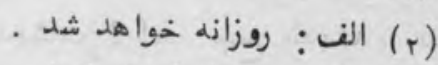

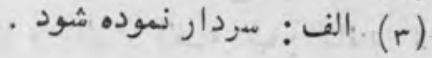




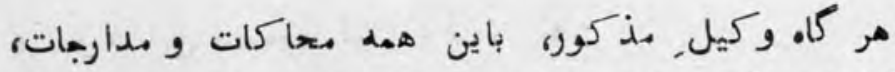

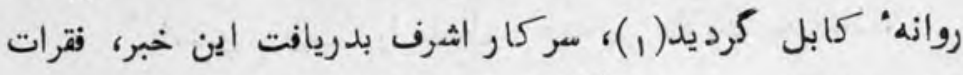

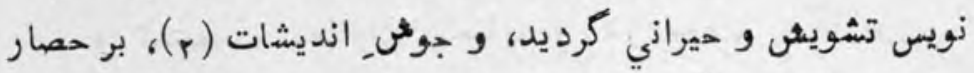

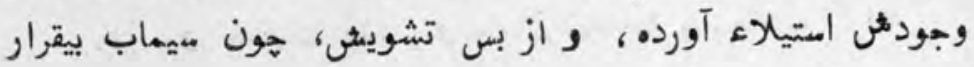

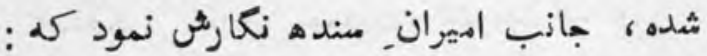

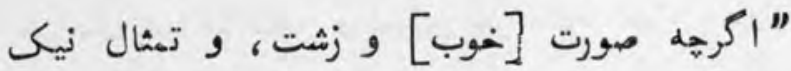

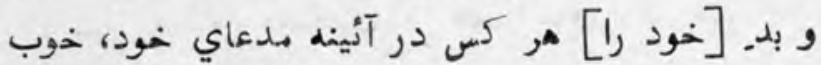

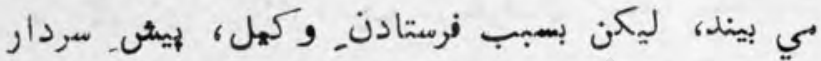

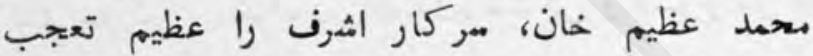

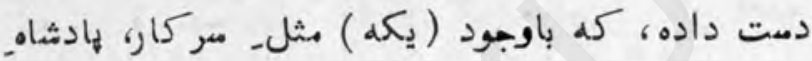
زامدار، در بهلو و قربو جوار نشسته ، فرمتادن وركيل

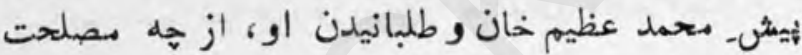

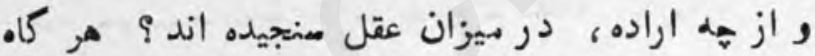

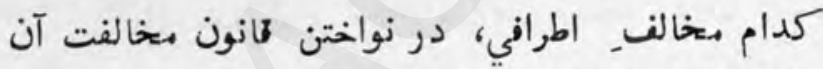

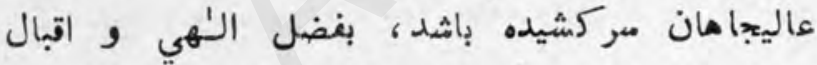

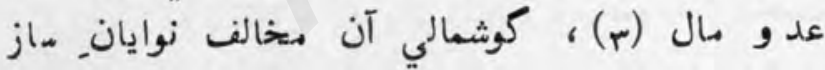

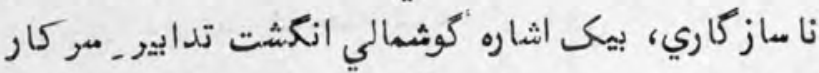

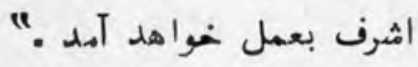

و ازين قسم هندي نوامهاي بلند نامومي و عاقبت انديشى،

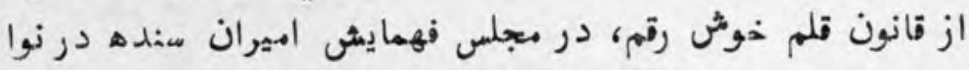

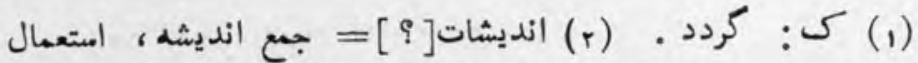

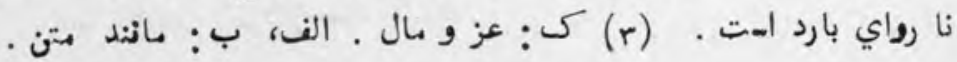


آورده، ليكن در كوث, سماعت نياوردند، سوالي و جوابي ديكر

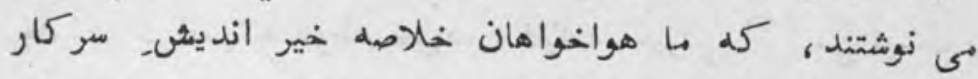

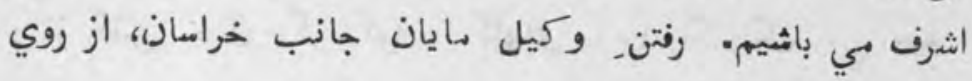

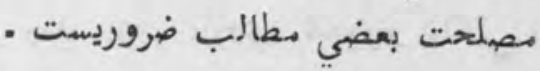
اولا : وكلاي (1) صاحبان انكليسي بهادر، در حيدرآباد

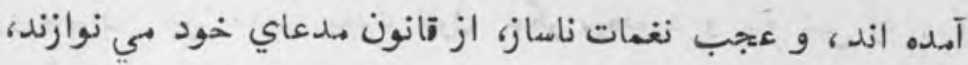

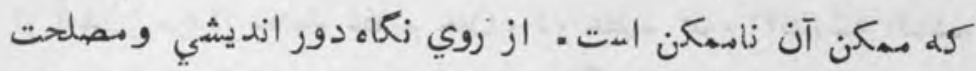

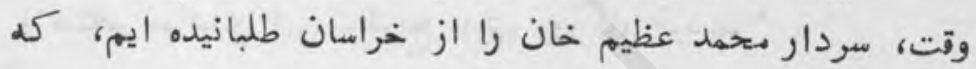

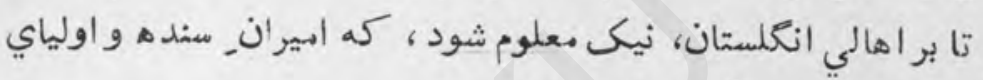

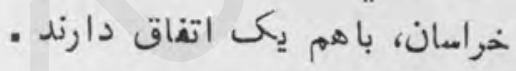

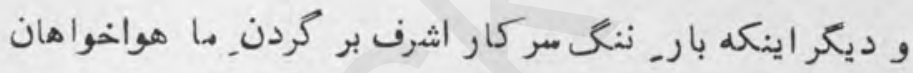

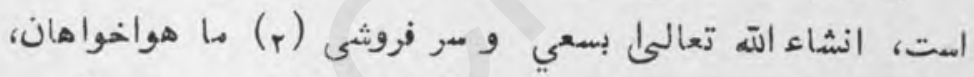

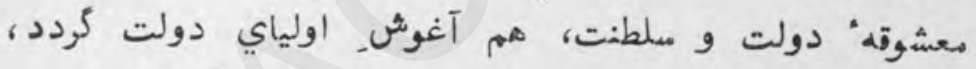

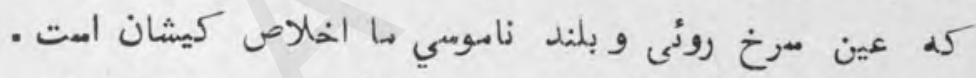

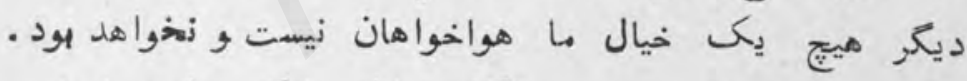

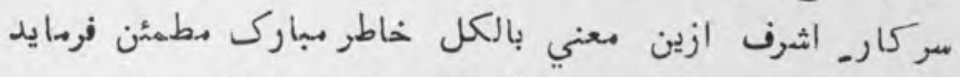

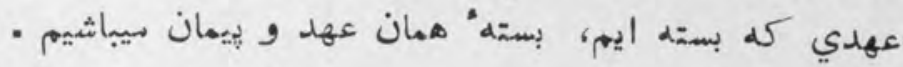

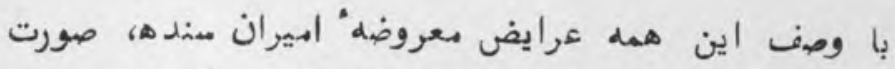

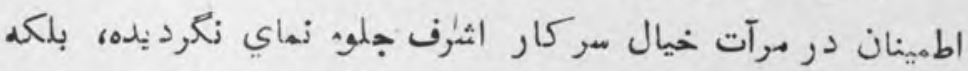

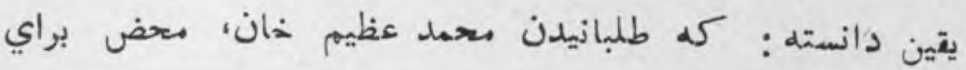

(1) الف: وكلاي سركار انكريز بهادر. (r) الف: مرجوشي • 
تازه نواى ثماركى

ir.

كشيدن سركا: اشرف خواهد بود . دم بدم مثل قلم ، در سيه

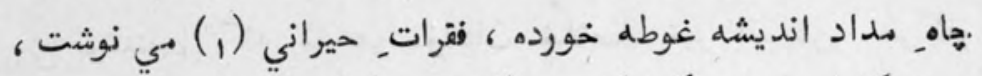

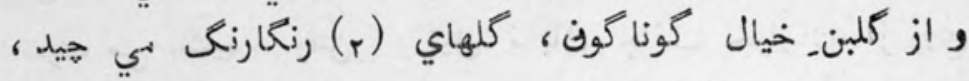

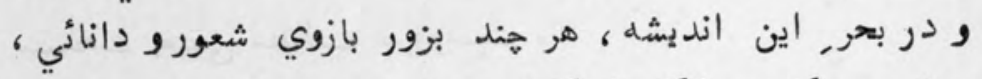

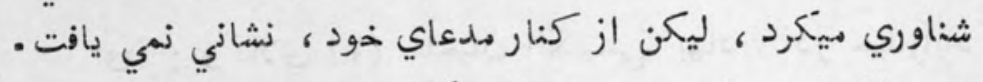

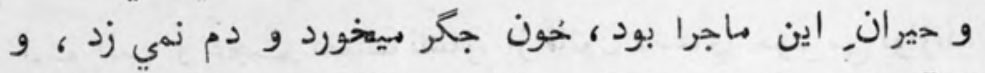

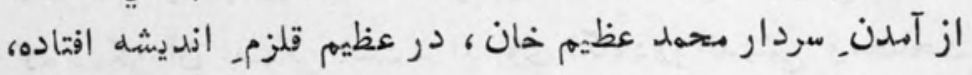

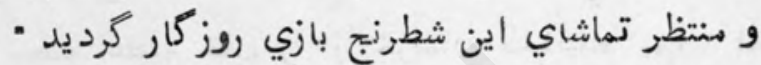

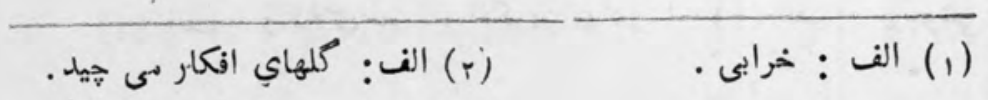




\section{$-\mu \cdot-$}

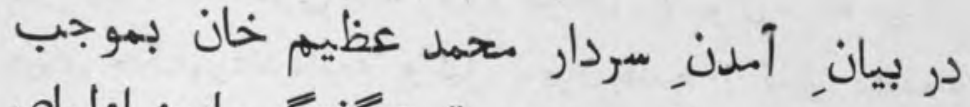
استدعاي اميران سنده و و وقوع گفتخو مابين اولياي

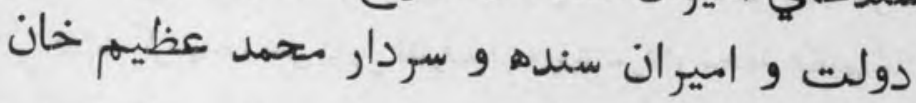

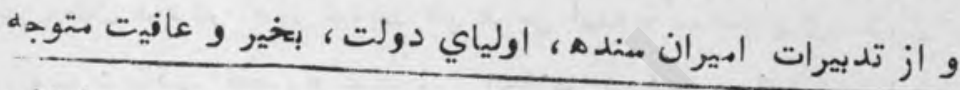

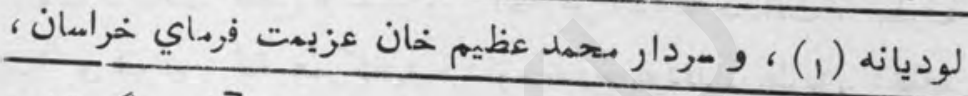

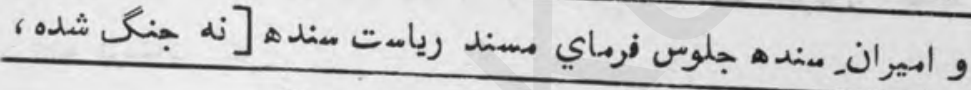

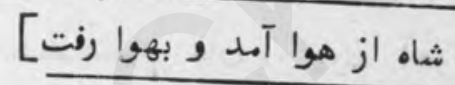

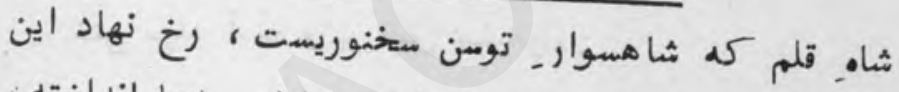

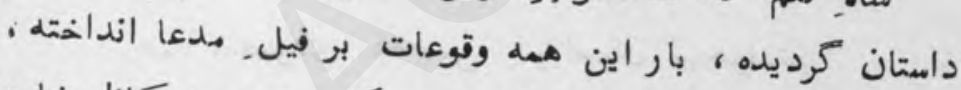

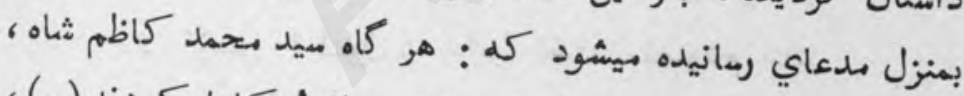

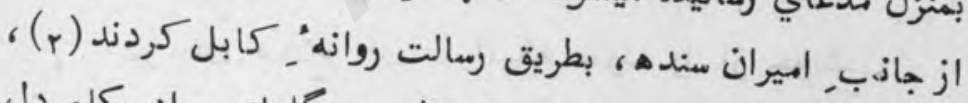

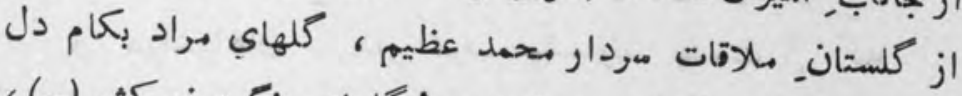

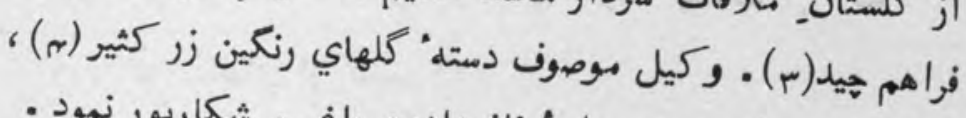

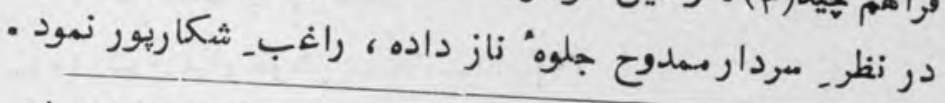

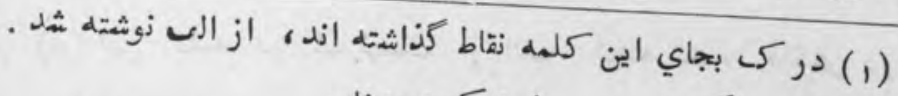

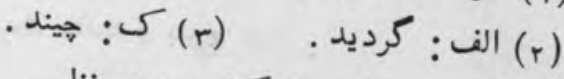

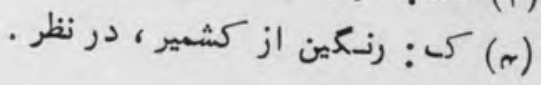


تازه نواي معاركى

IrT

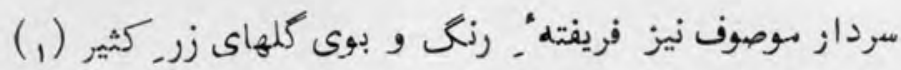
كرد يده، معنه" برادران و سرداران هر يك سردار دوست مهمد خان

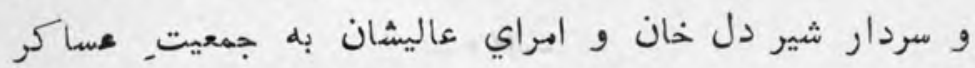

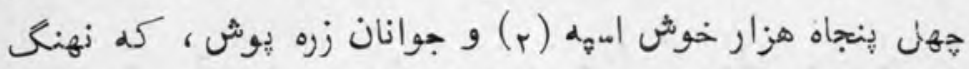

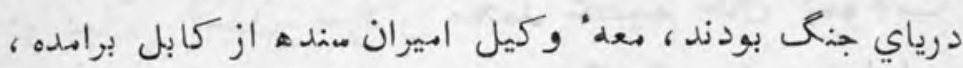

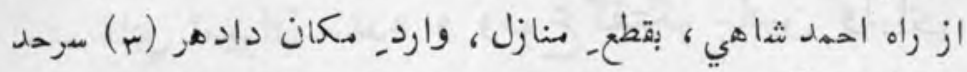

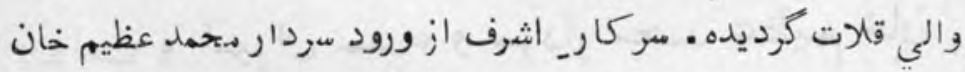

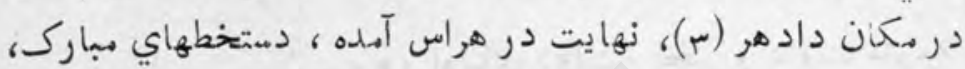

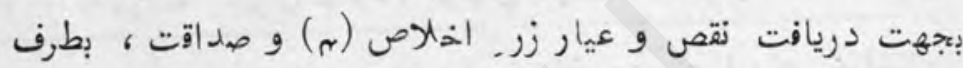

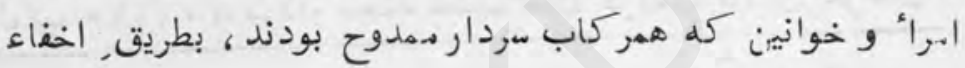

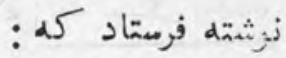

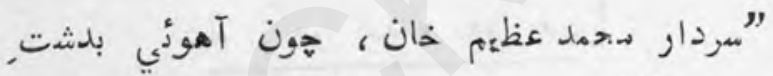

ختن مراد آمده و بر طبق مضمون : مدرد

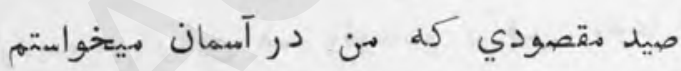

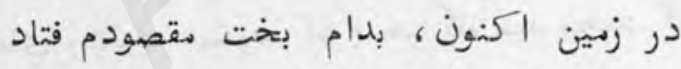

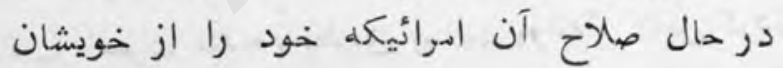

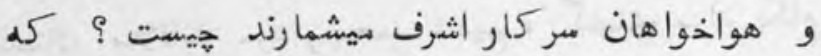

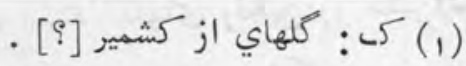

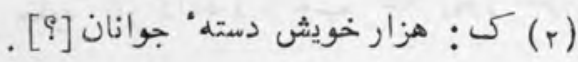

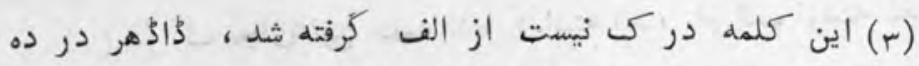

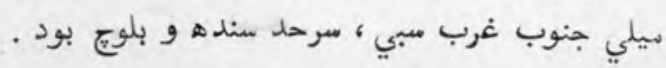

. 
r

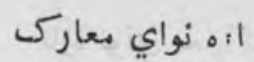

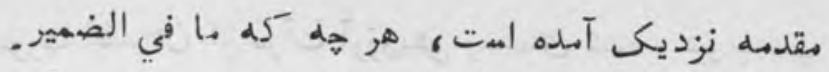

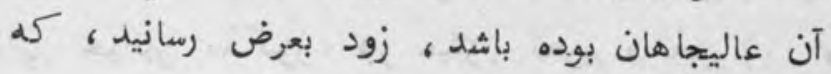

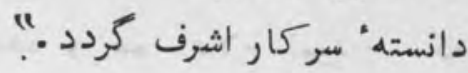

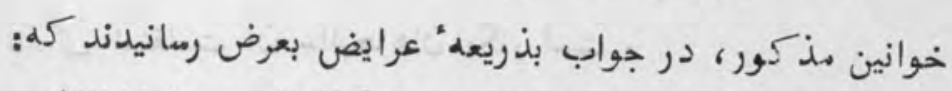

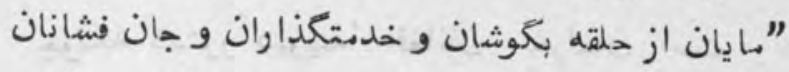

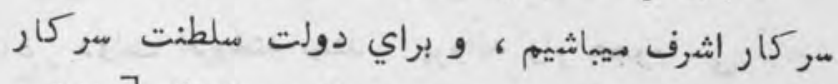

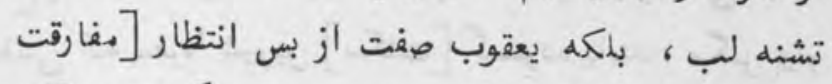

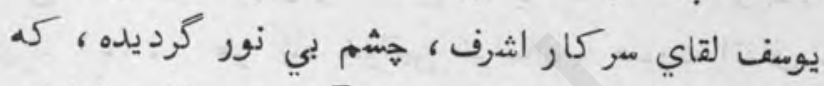

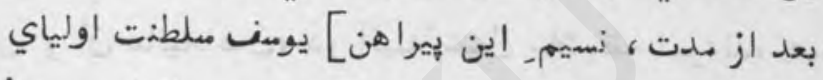

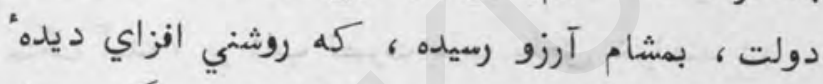

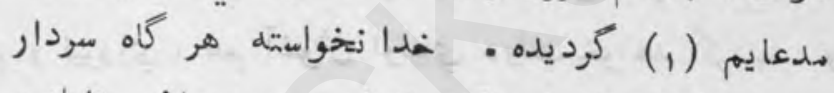

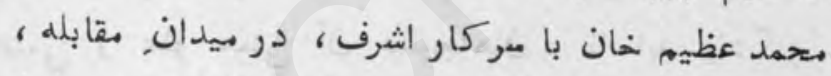

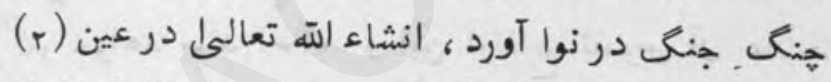

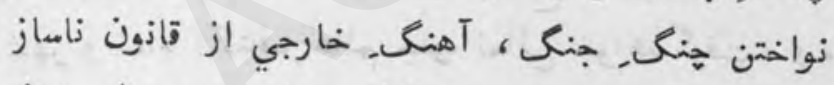

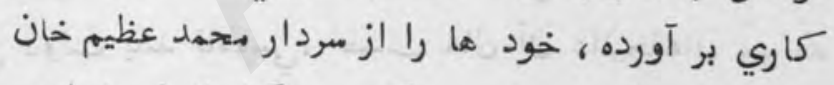

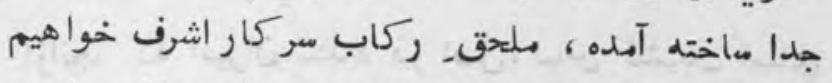

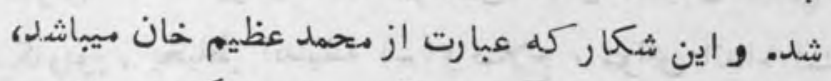

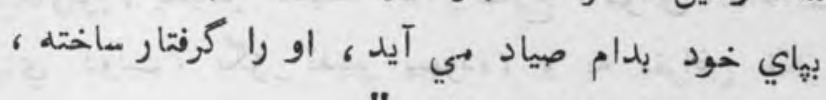

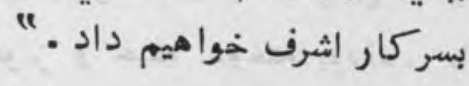

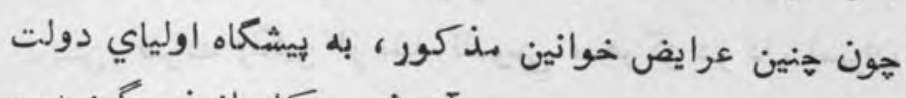

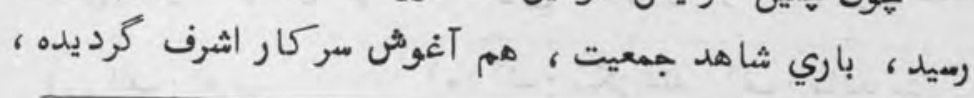

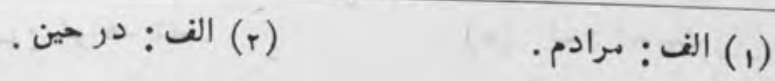


و صورت اطمي:ان از مرآت آرزويش رخنماي شده ـ. در ساءت همين

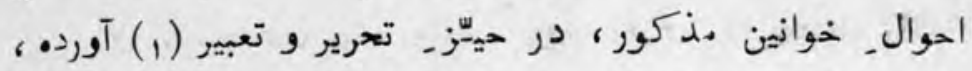

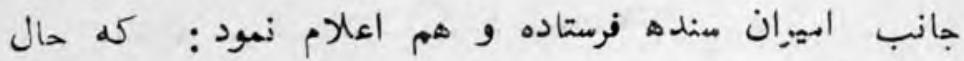

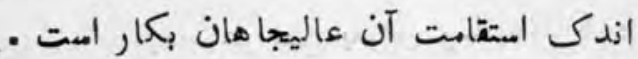

حونكه دستور ديرينه' افغانان. خراسان اهت ، هرجاذيكه

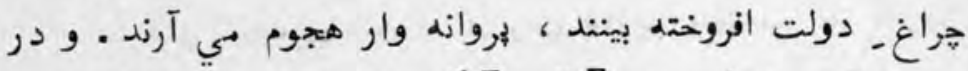

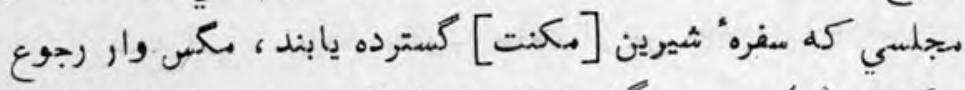

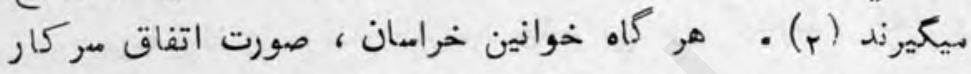

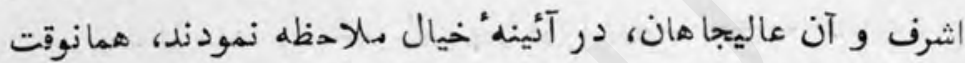

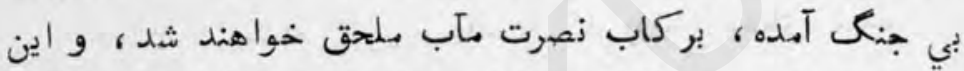

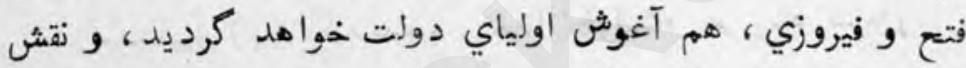

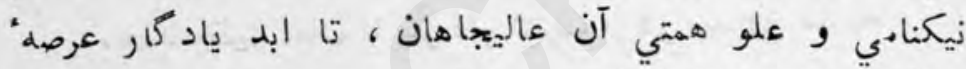

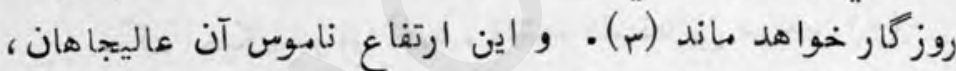

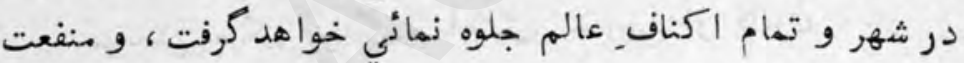

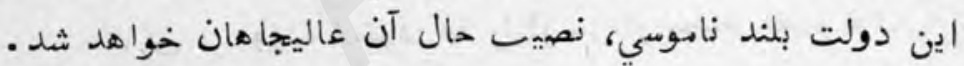
ازانجا كله اميران سنده در اصل، لباس كشيدن المناي دولت

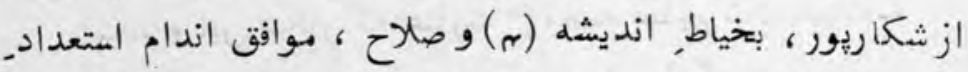

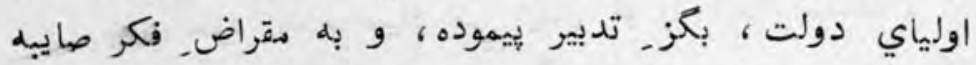

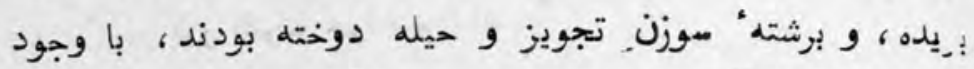

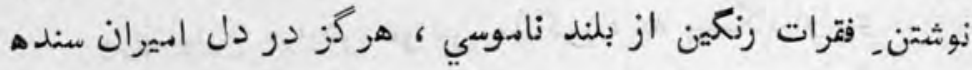

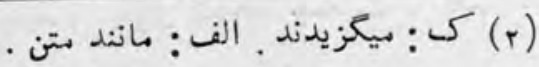
(1) الف : تقرير .

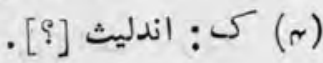

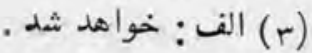


مرايت نميكرد، ، و اصلًا [ملتفت] نوشتمجات اولياي دولت

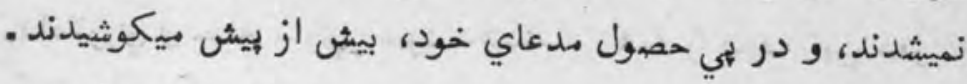

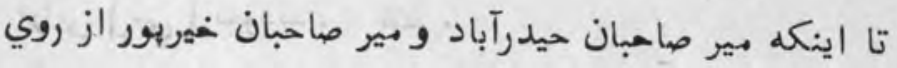

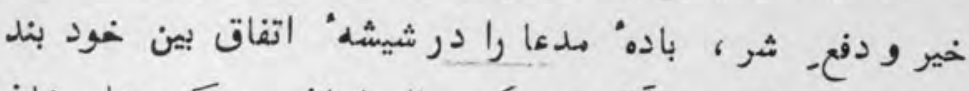

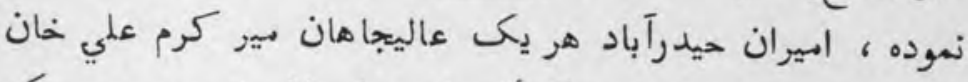

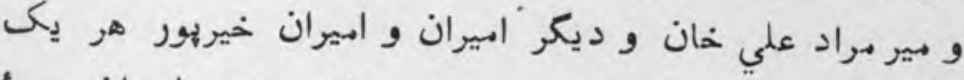

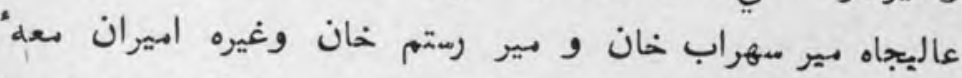

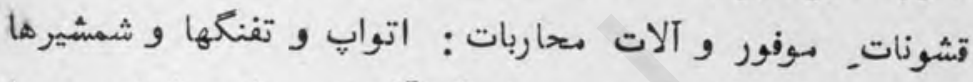

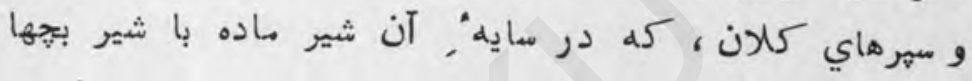

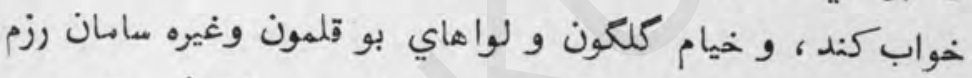

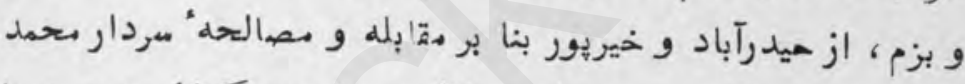

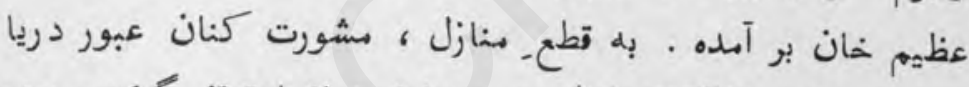

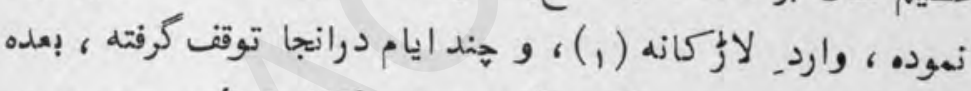

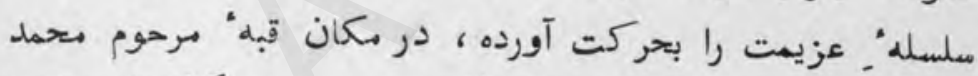

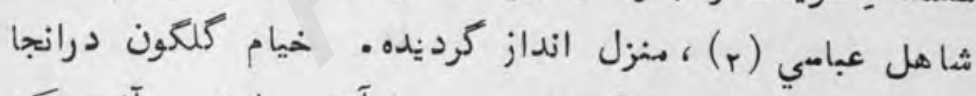

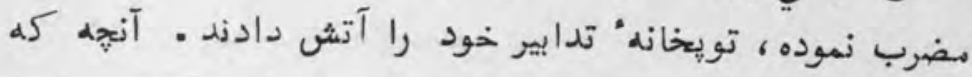

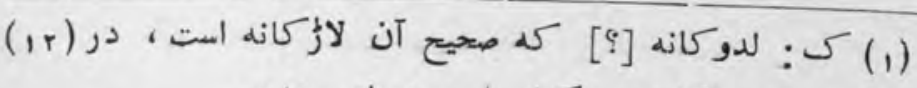

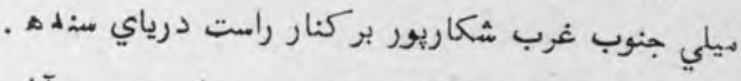

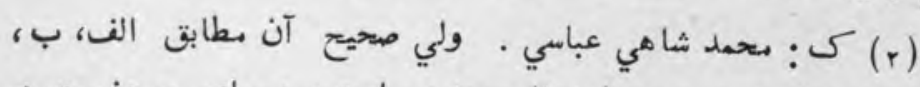

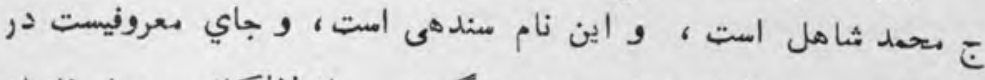

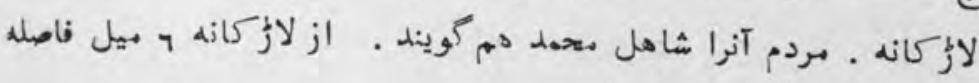

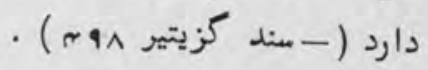




\section{تازه نواي معاركى}

باروت خانه از فن و دازشى خودها ، ، در صندوقخانه" استعداد.

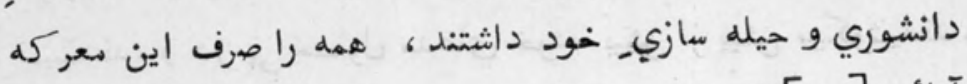

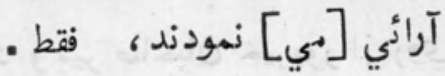




\section{${ }^{-\mu 1}$}

در بيان آذكه اميران سنده از روي تجويز عاقلانه

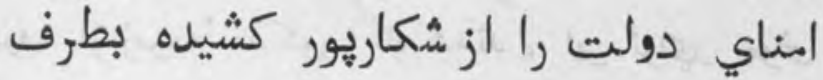
خود طلبيازيدنل

قانون قلم مشكين رقم، در نواختن نغمات اينمدعا، درمبحفل

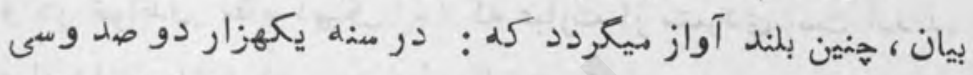

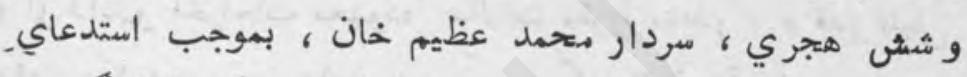

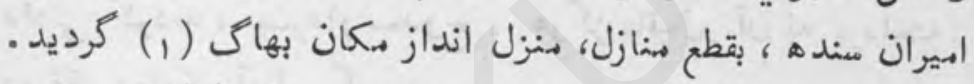

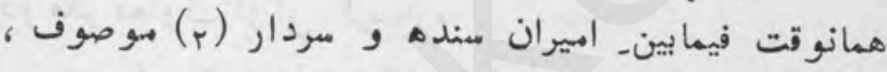

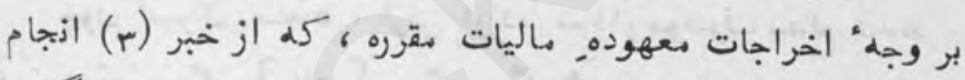

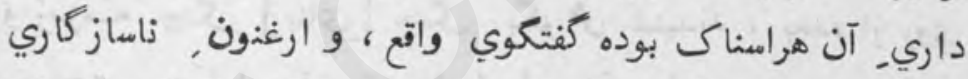

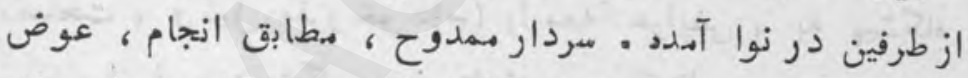

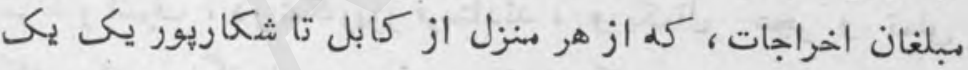

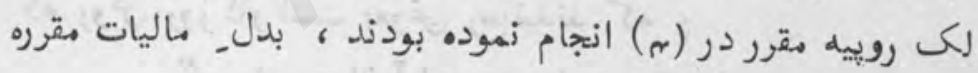

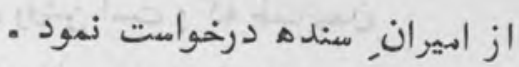

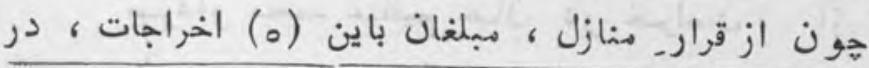

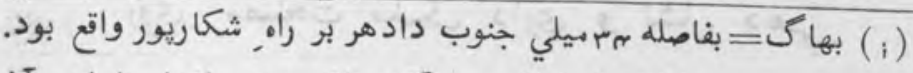

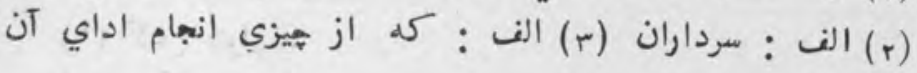

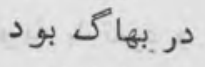

(ه) الف : مقر رو انجام نموده بودند ، بدون باد ماليات (ه) الف : بابت اخراجات 
نظر اميران منده إسيار آمده ، و هم مورت اين ماجرائيكه

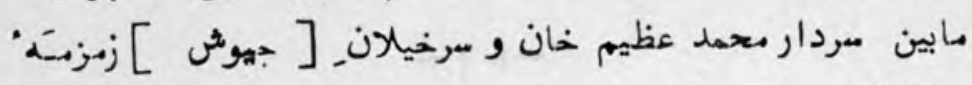

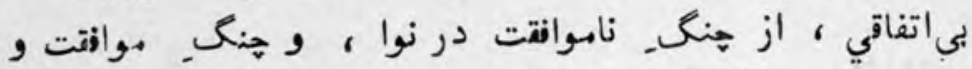
اتفاق، در بزم آرزوي اولياي دولت مي نوازند (1) ، هون اميران

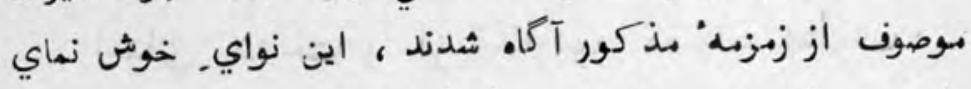

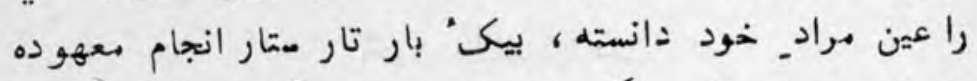

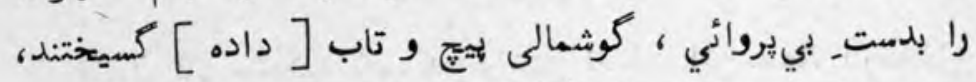

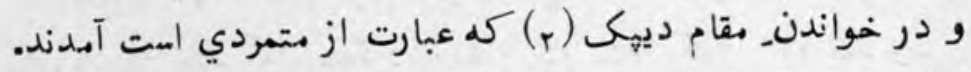

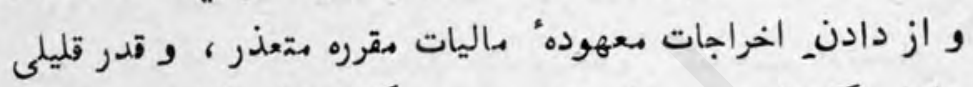
دادني كردند • مدردار مسدوح ، هر كز باقبال. آن نه بوداخته،

$$
\text { در فكر معارك آرائي كرديد . }
$$

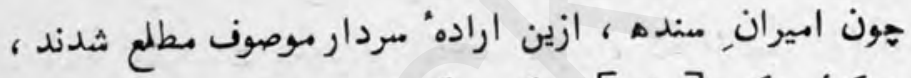

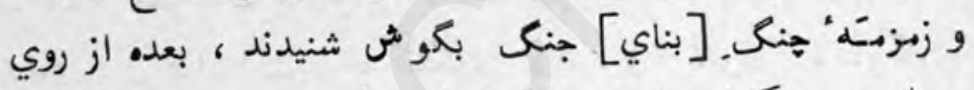

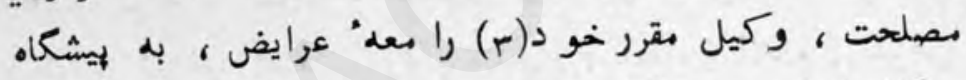
مركار اشرف ، در شكاريور فرستادند ، و بكمال. عجز و و تملق

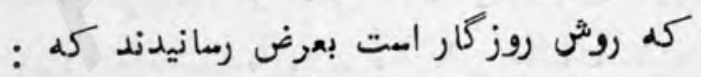
"بر راي جهان آراي روشن است : كه طلبانيدن.

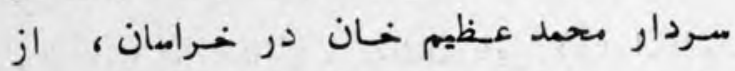
روي. مصلحت ملك داري و نشان دمي-

$$
\text { كى : بنوازند }
$$

(r) ديبك = يكي از متامات مو ميقي هنديست كه كو يا با تمرد و

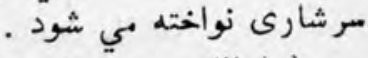

$$
\begin{aligned}
& \text { (r) الف : معتبر خود نودي لغود }
\end{aligned}
$$




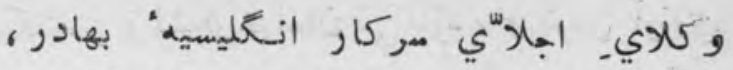

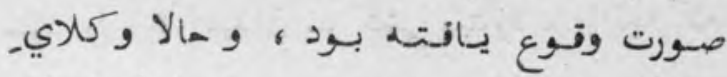

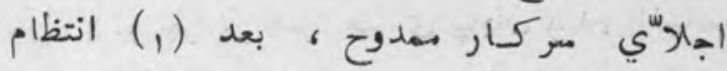

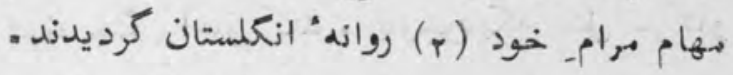

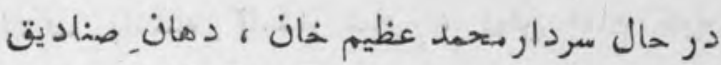

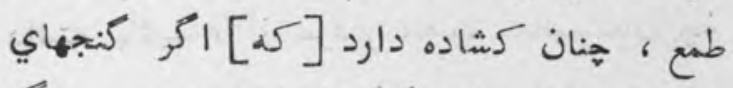

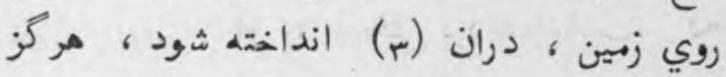

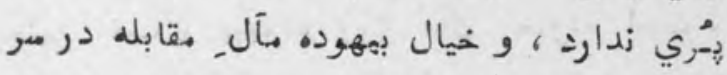

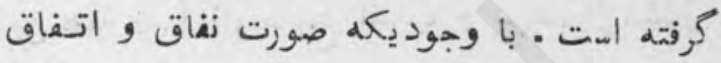

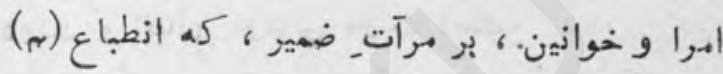

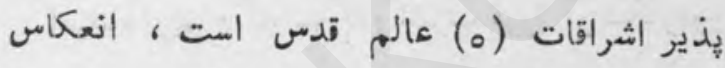

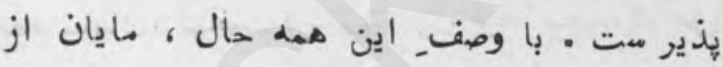

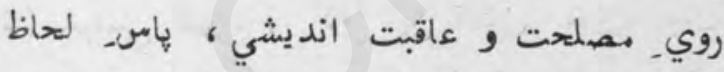

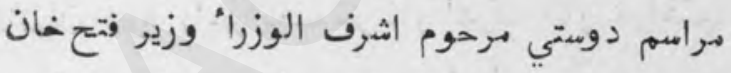

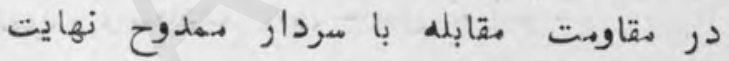

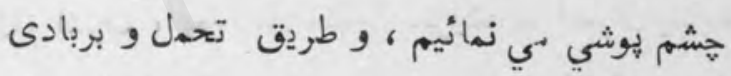

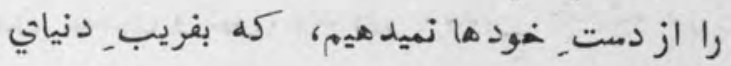

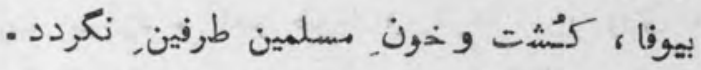
ليكن مبردار محمد عظيم خان باغوإي_ دولت

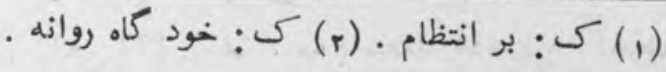

$$
\begin{aligned}
& \text { • }
\end{aligned}
$$

(ه) الف : اثر جات. كى :اشرقات ــولي اشراقات بمعني روشني هاست. 
تازه نواي مارك

10

كشمير و لشكرخراسان مي نازد ، و تومن آرزوي

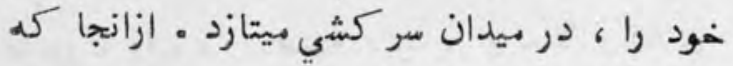

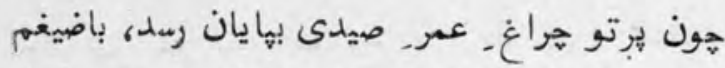

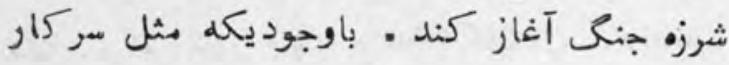

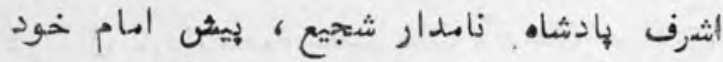

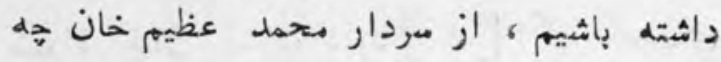

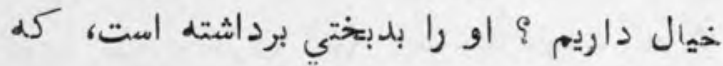

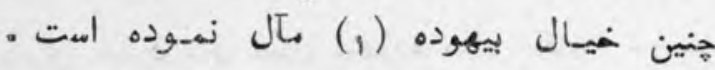

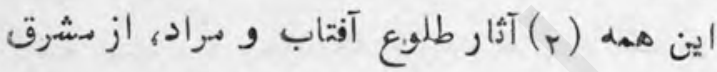
دولت و اقبال اولياي دولت است.

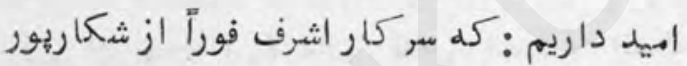

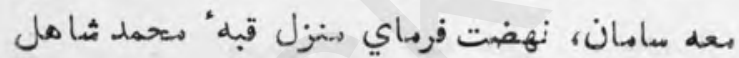

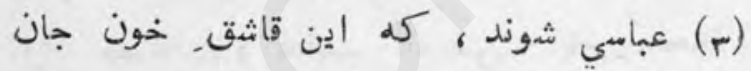

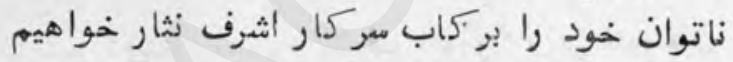

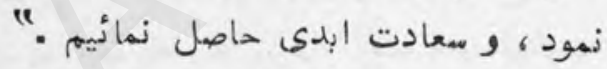

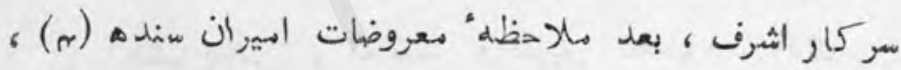

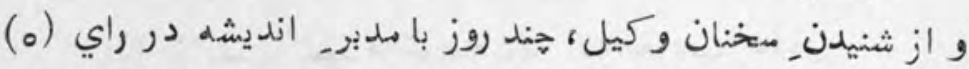

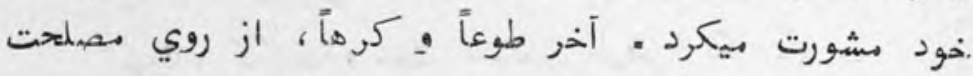

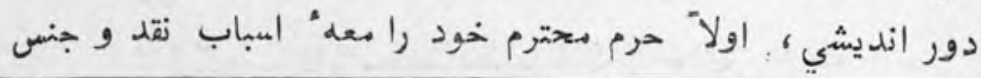

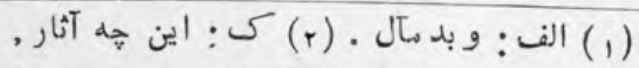

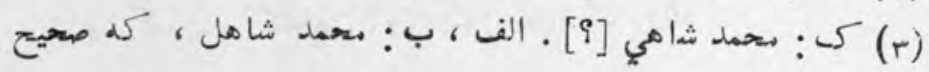
(م) كى: سند بوده و از شنيدن. (0) الف: و امراي خود . 


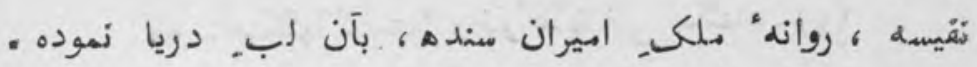

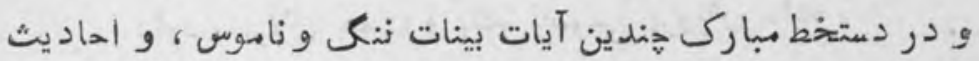

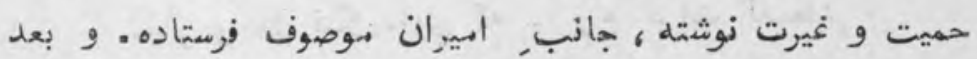

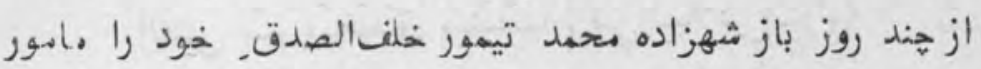

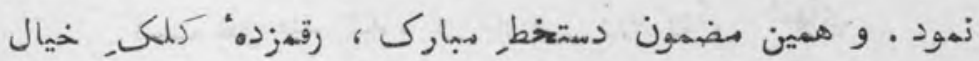

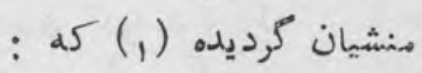

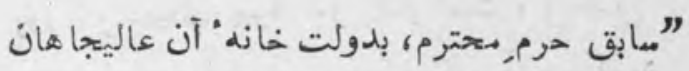

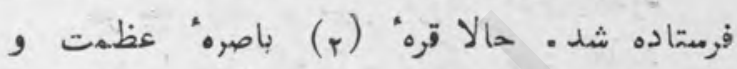

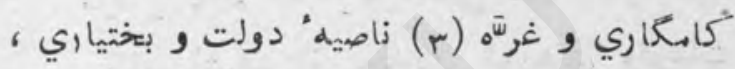

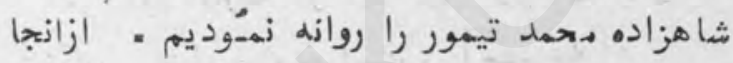

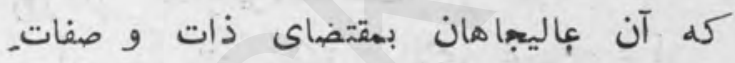

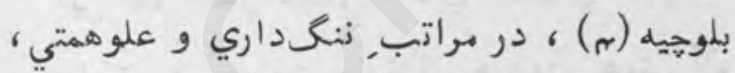

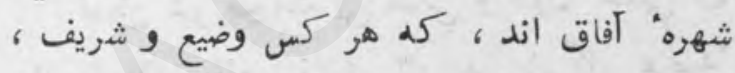

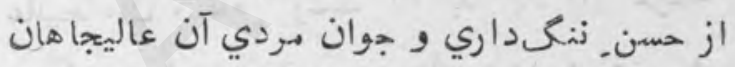

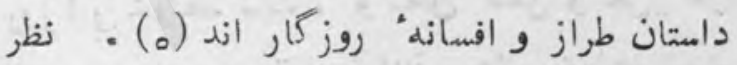

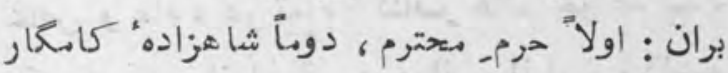

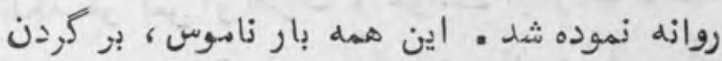

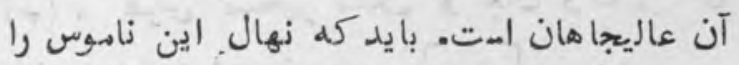

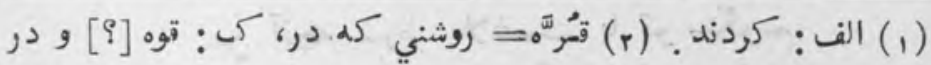

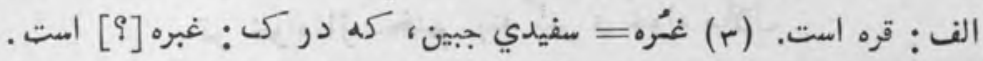

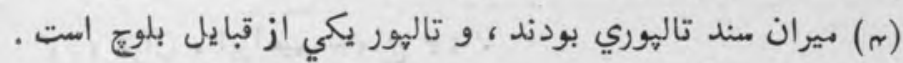

$$
\text { (ه) }
$$




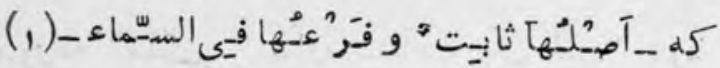

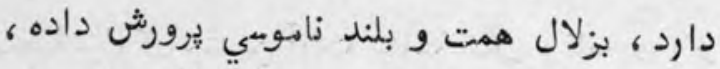

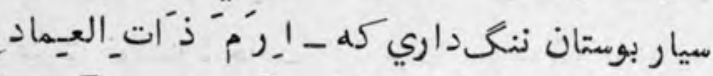

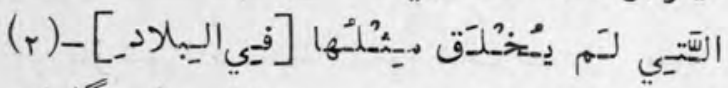

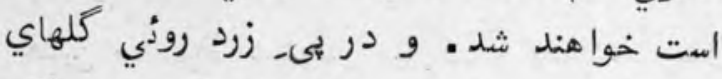

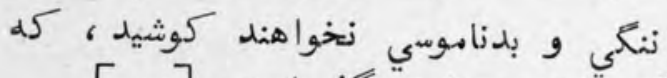

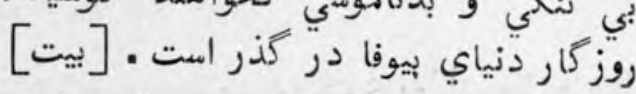

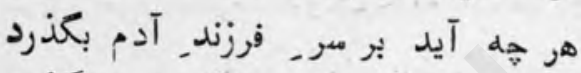

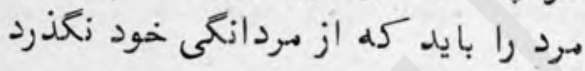
مركار_ اشرف از حندين كورهاي وقوعات

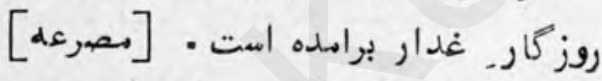

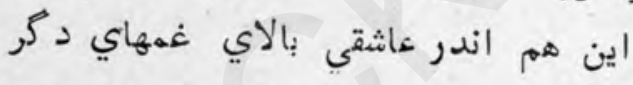
ليكن در صورت بي ننكي و دون همتي آن آنا

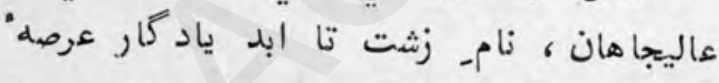

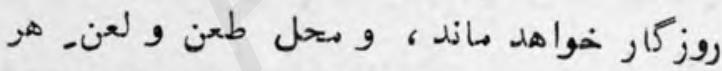

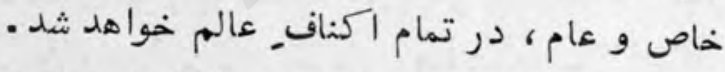
بلكه هر كس از اطراف و جوانب از ارباب داع داعيه

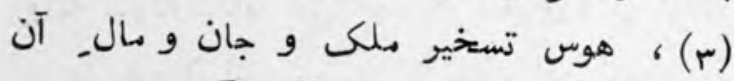

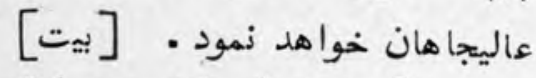

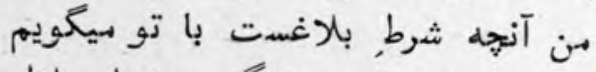

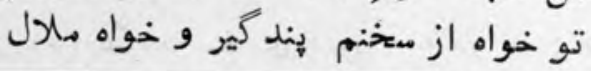

كى: (r)

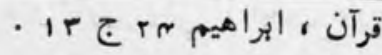

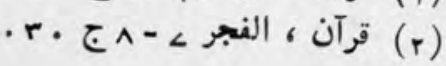


int

تازه نواي معاركى

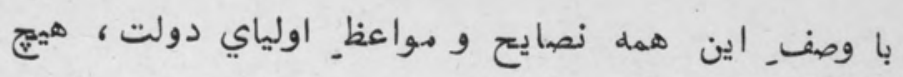

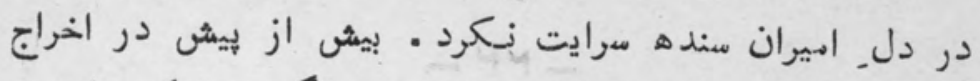

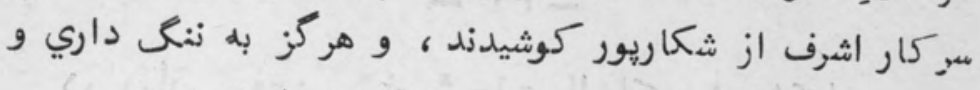

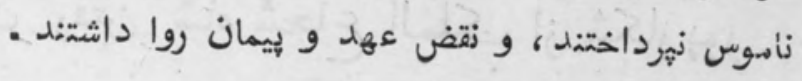


$-\mu r-$

در بيان رفتن, شاه شجاع الهلك از شكار ثيور

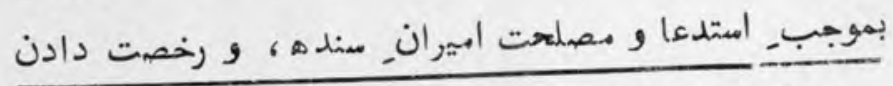

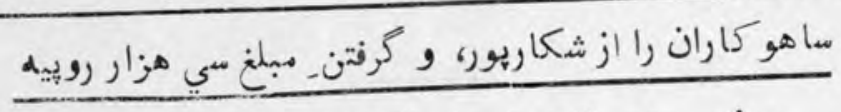

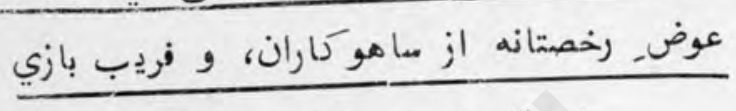

ابيران نسبت اولياي دولت

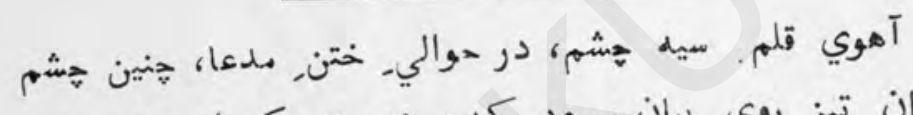

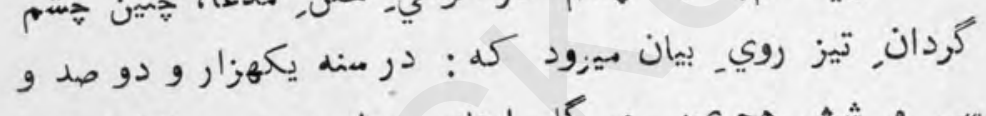

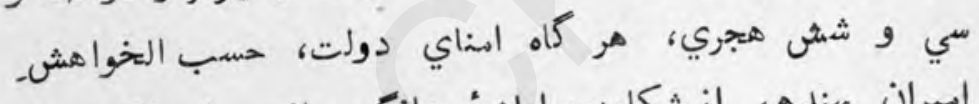

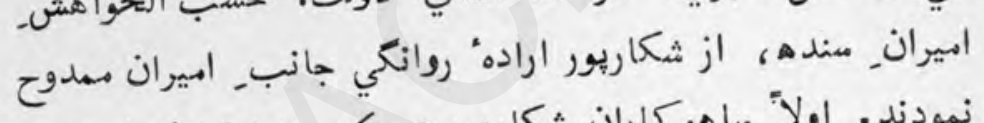

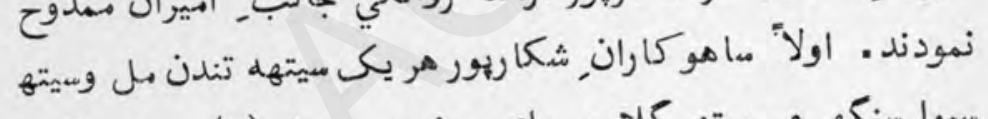

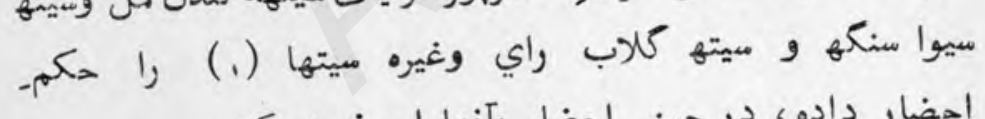

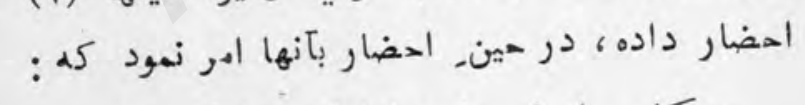

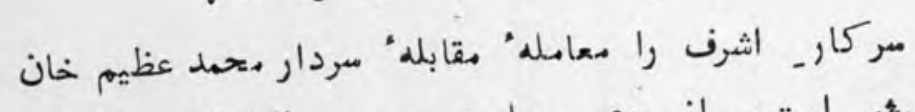

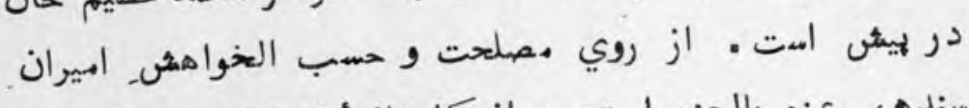

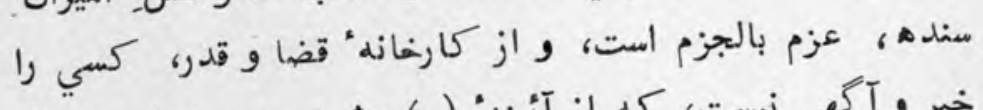

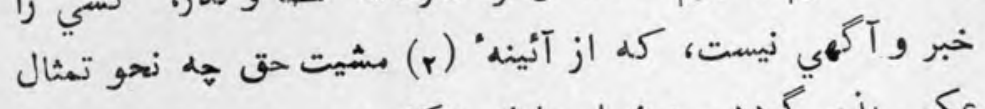

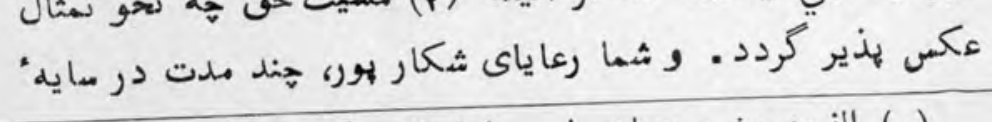

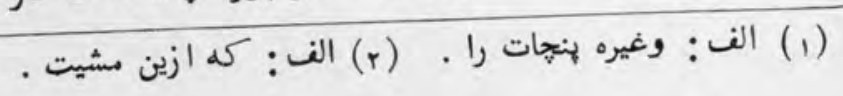


عاطفت_ سركار بسر آورده. اند' و با مركار. ـ اشرف بدنام شده

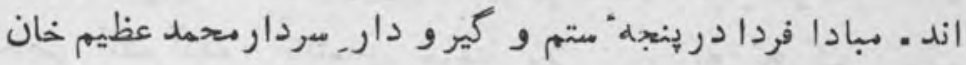

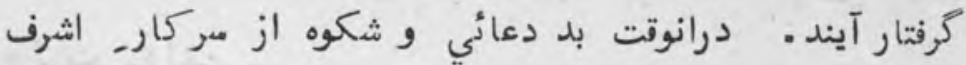

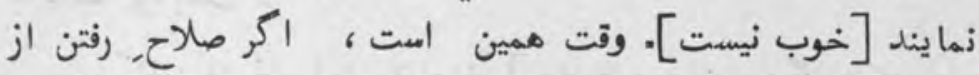

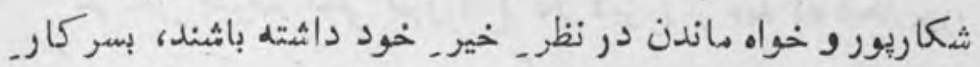

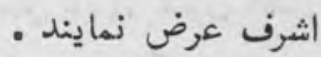

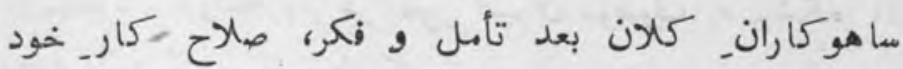

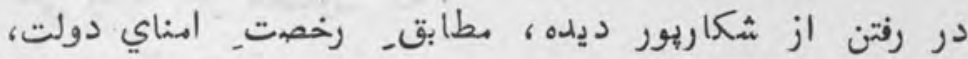

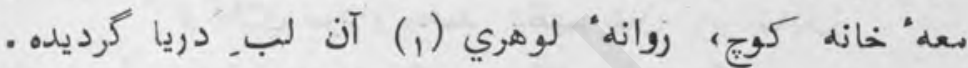

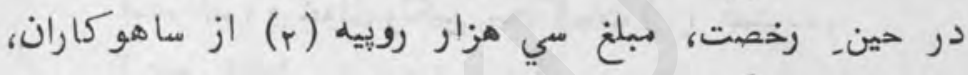

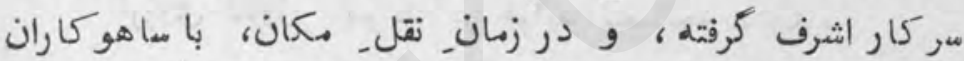

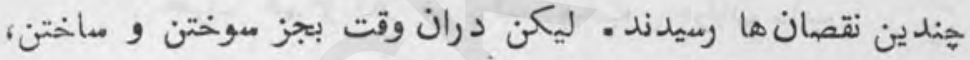

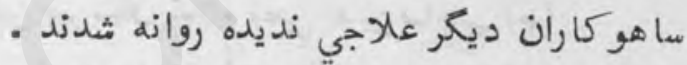

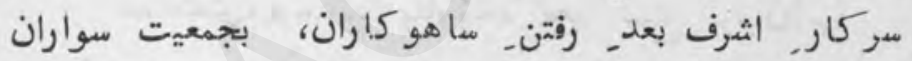

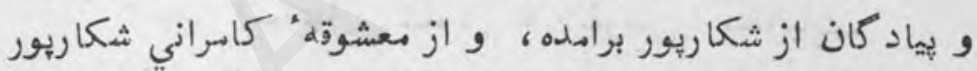

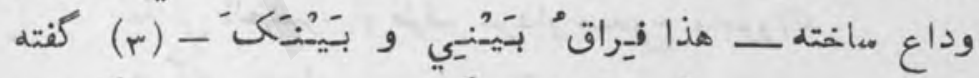

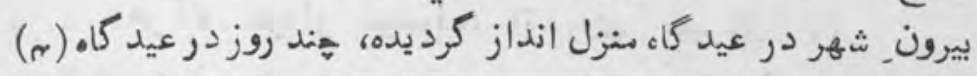

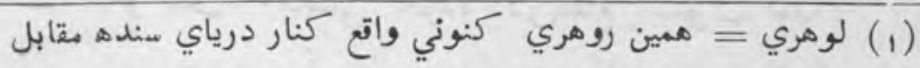

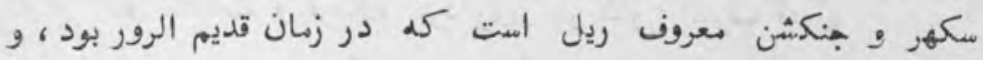
مورّخان عرب بدين نام آورده اند . معرف

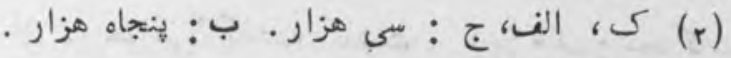

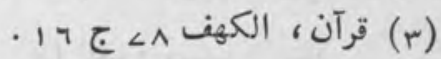

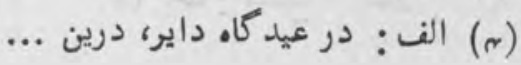


تازه نواي معارك

107

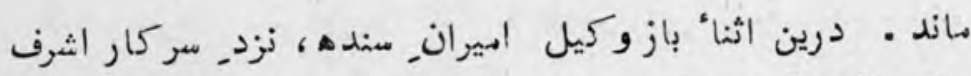

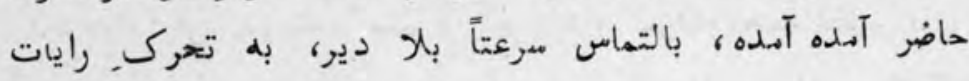

عاليات لريداخت

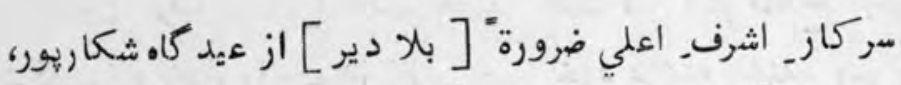

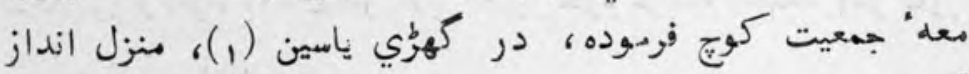

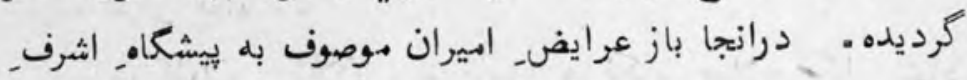
اعلي رميد باين مضمون كمه :

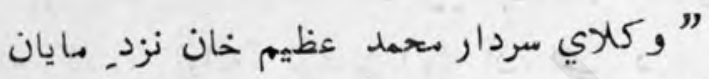

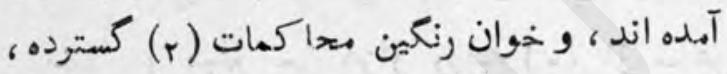

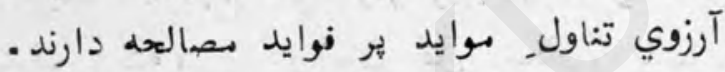

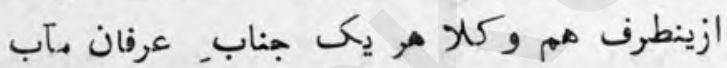

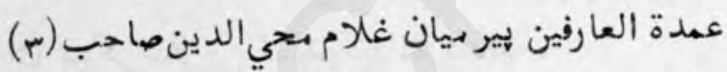

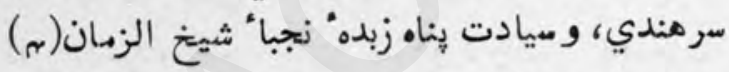

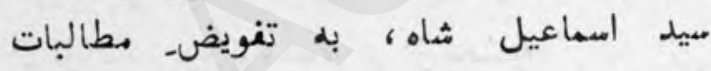

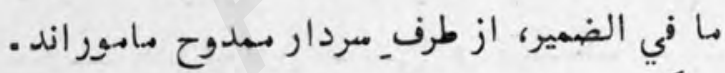

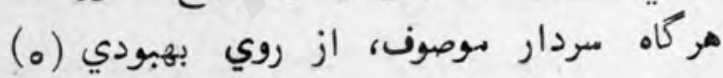

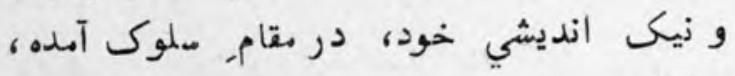

و اطاعت و فرهان برداري سركار_ اشرف قبول

نموده، عين مدسّعا . . و الاله بر خالف آن رفتاري

(1) شرح آن در حواشيث كذثته كذشت . (r) الف : محاكات.

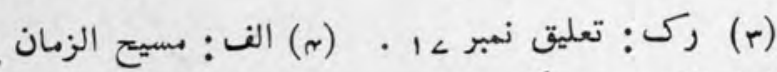

(ه) 


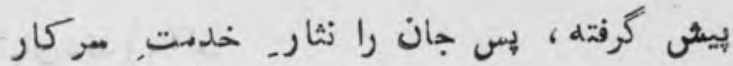

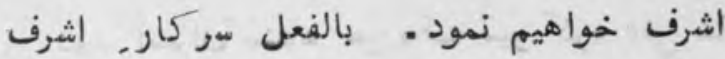

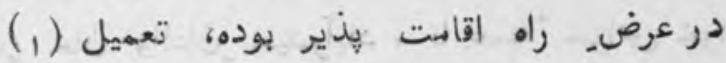

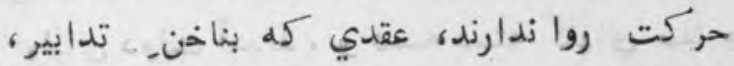

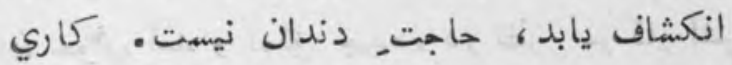

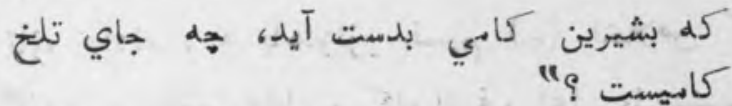
مركار اشرف باستدراك ــضمون عرايض اميران متشتشم اليه،

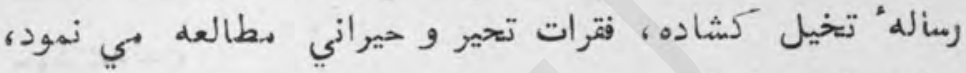

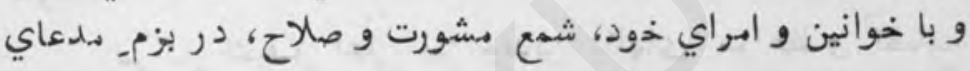

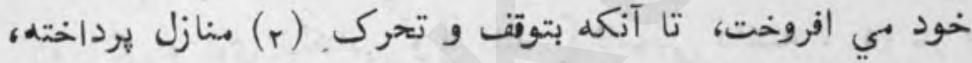

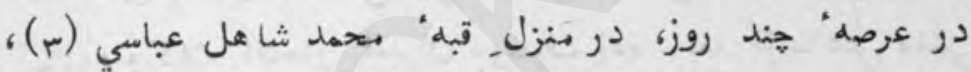

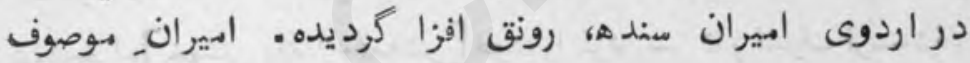

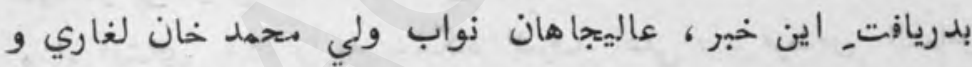

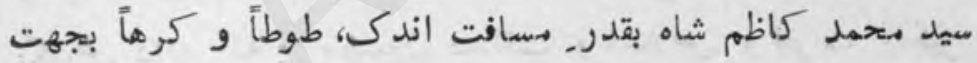

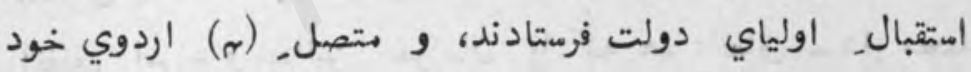

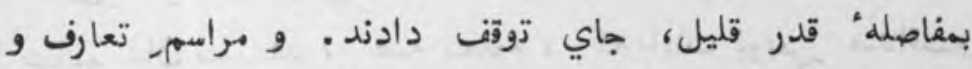

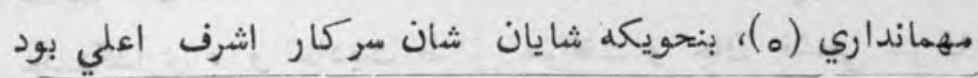

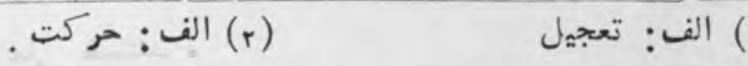

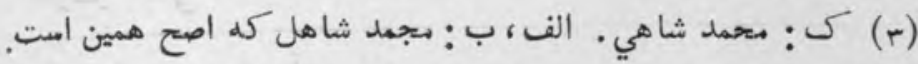

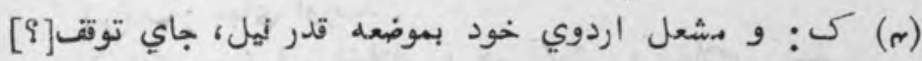

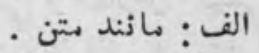
الف: جهانداري. 
بجاي نياوردند (1) - بون

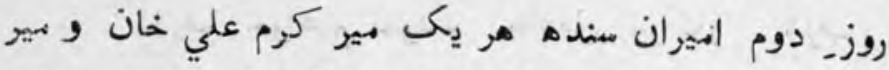

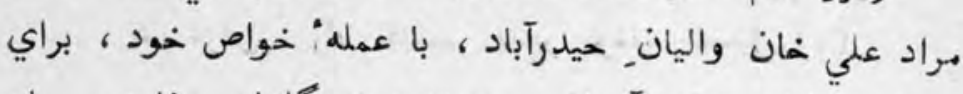

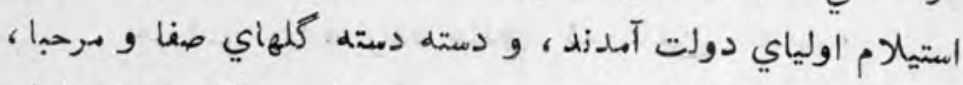

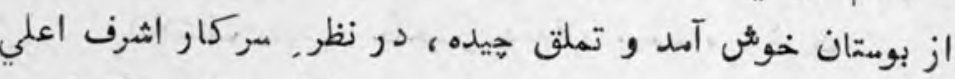

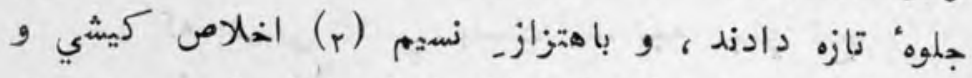

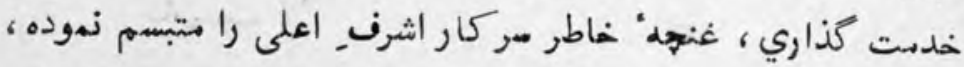

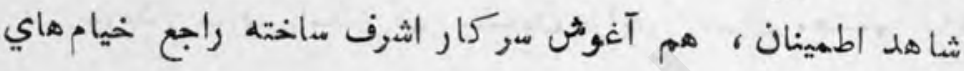
خود شدند - خ ماند سركار اشرفــاعلي نيز هندين كلهاي مواعظ و نصايح

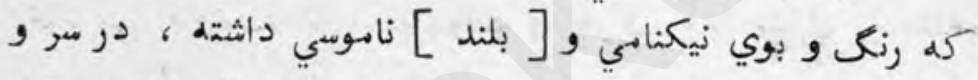

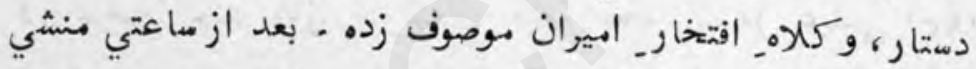

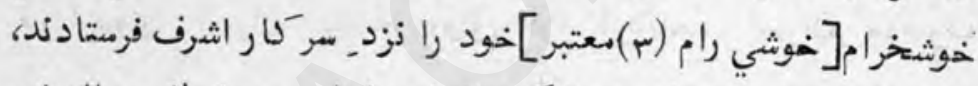

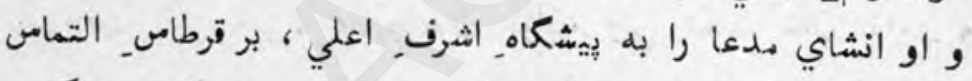
نكارش داده كه : مضمون صهاقت و اخللاص و فقرات رات رنكين.

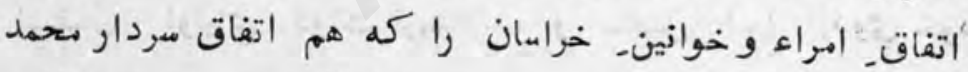

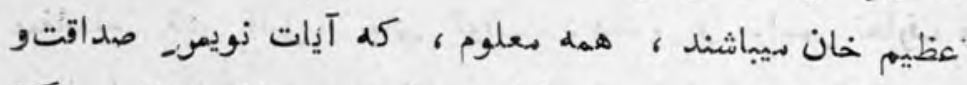

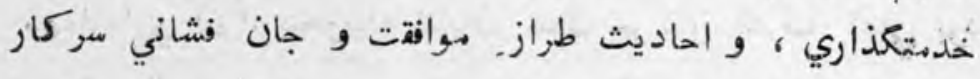

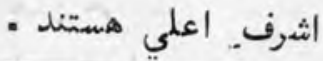

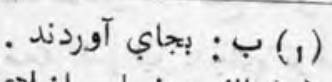

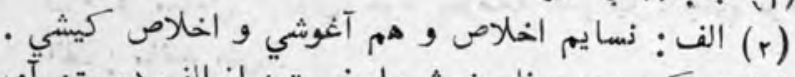

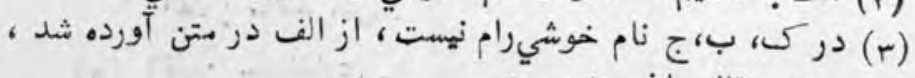

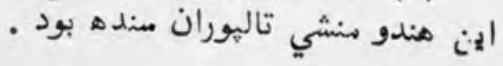


البته درين نزديكي ، عرايض مشعر بر صداقت و اخلاص.

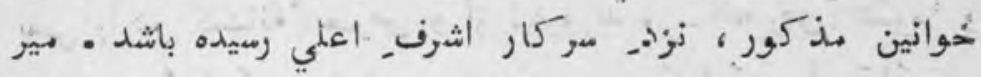

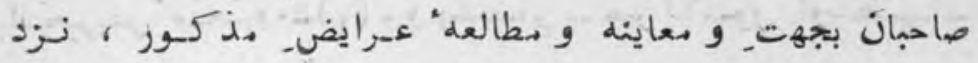

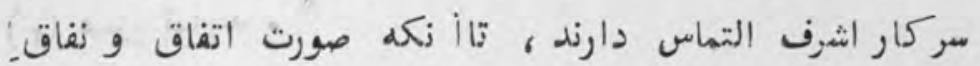

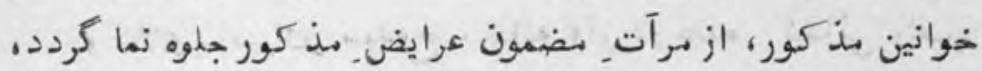

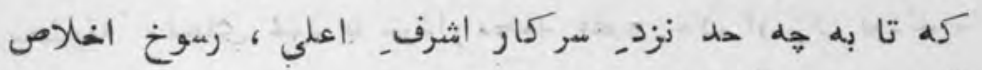

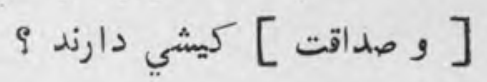

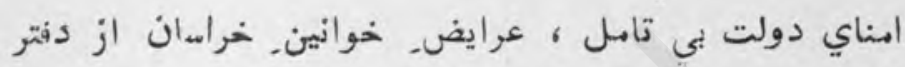

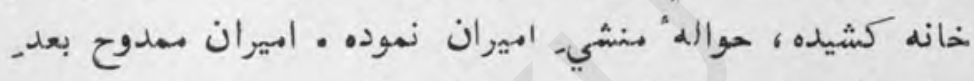

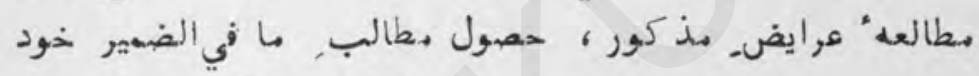

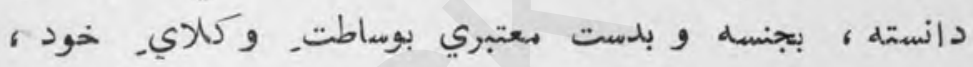

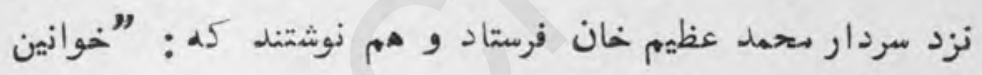

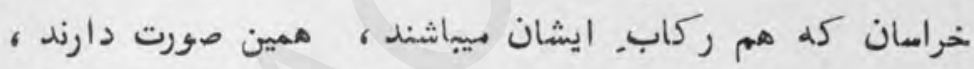

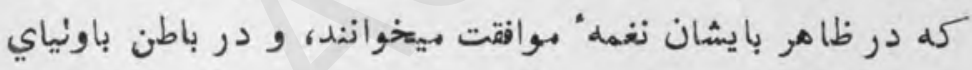

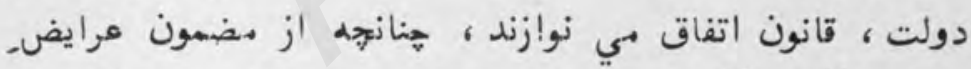

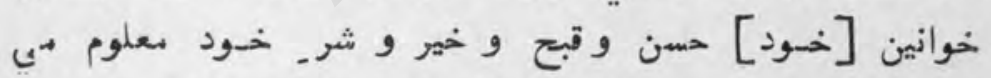

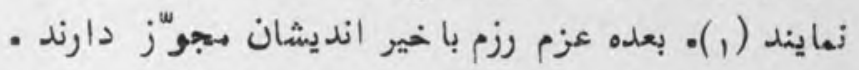

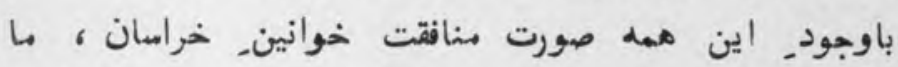

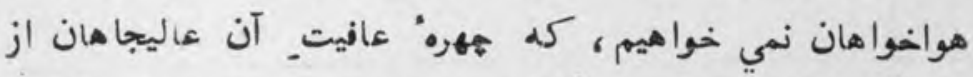

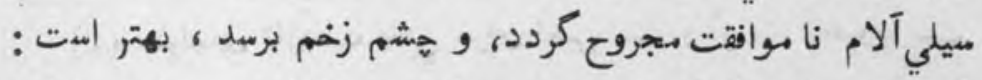

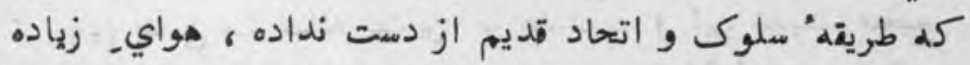


تازه نواي مeارك

10.

طلبي اخذ, ماليات و اخراجات مجوّز; ندارند ، و شسع طمع آرزوي.

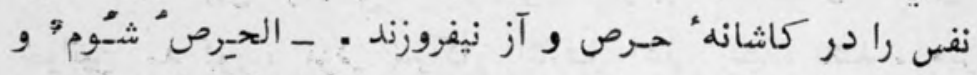

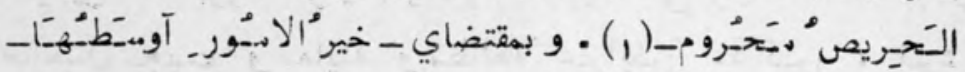
". عمل نمايند (r)

وكلاي_ اديران_ همدوح ، شانه وأر درعقده كشائي زلف.

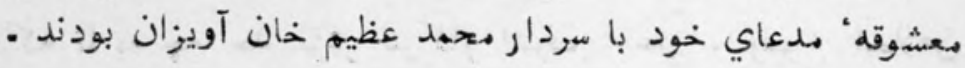

(1) مقولهاى تازيست يعني حرص ذيحس است و آز مند مهروم است.

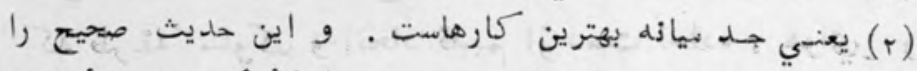

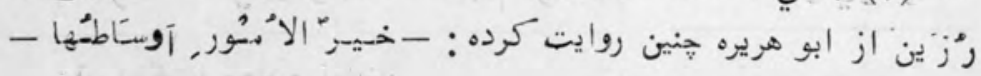

] - تيسمير الوصول الو هرئره 


\section{$-\mu \mu$}

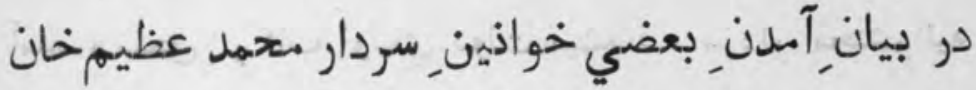

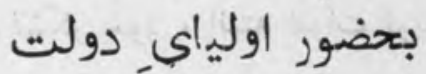

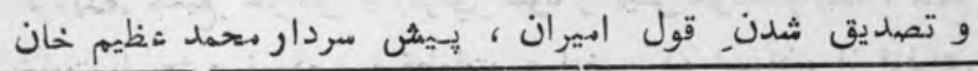

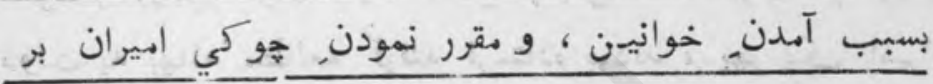

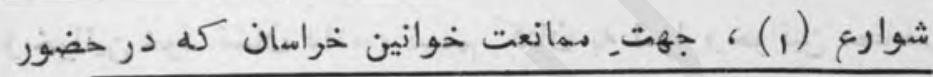

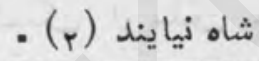

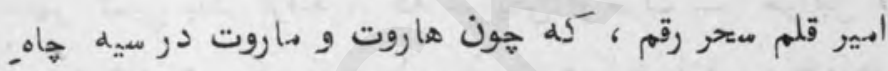

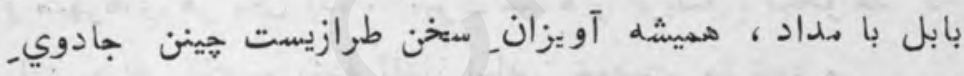

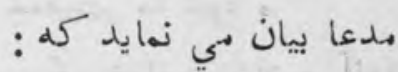

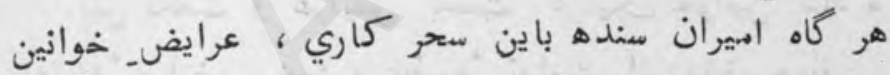

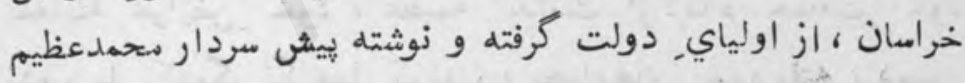

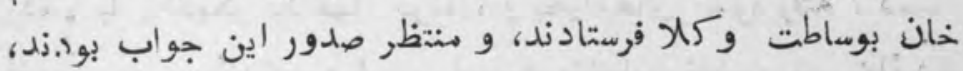

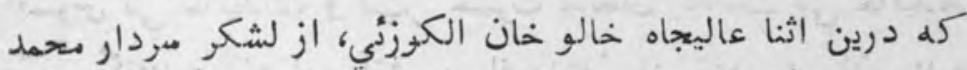

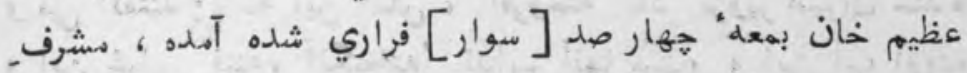

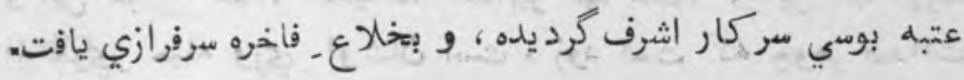

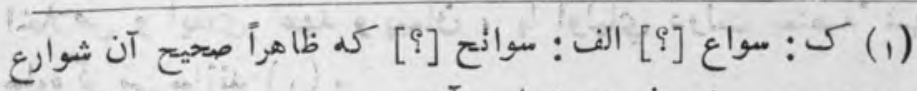
اسث ، ودر متن شضمون هم شوارع آمانده [?] 
تازه نواي معار

lor

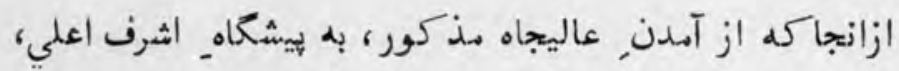

موجب تصديق قول ابيران، در هيش سردار مهمدوح شده ـ. هم

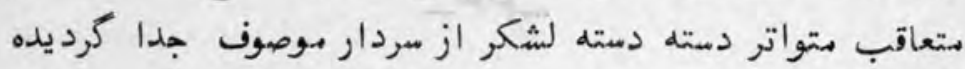

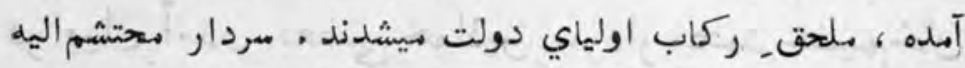
إمعا ينه اين حالت لشيكر خود ، البته فقرات نويس تردد و حيراني

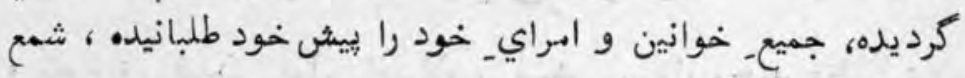
خلوت را روشن نموده ، و وقطعات_عرايض كمده كه اميران، از اولياي

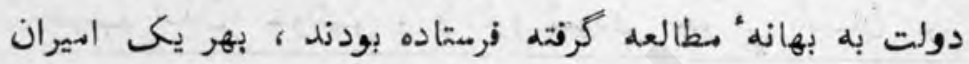

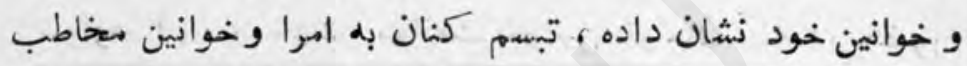

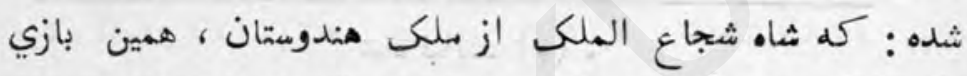

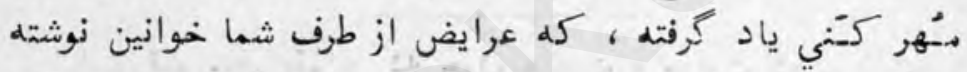

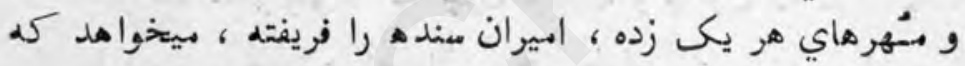

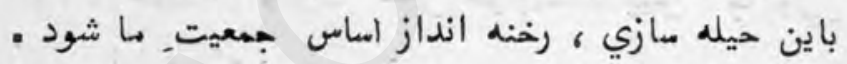

اين بكفت و عرايض بلدست هر يك خوانين داد م ـ آنها

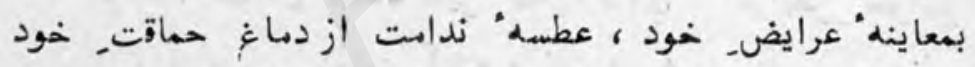

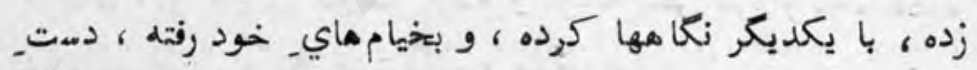

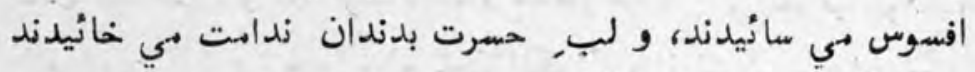

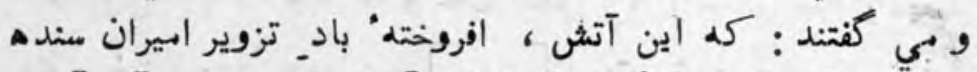

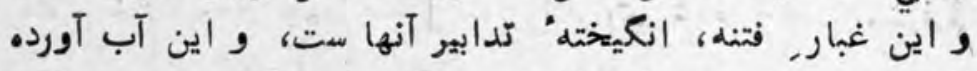

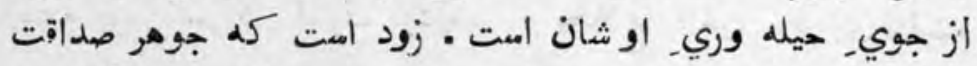

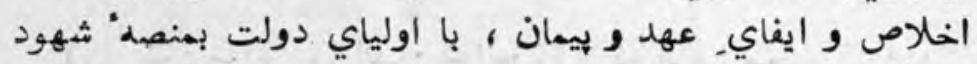

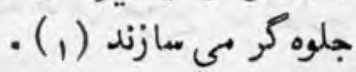

(1) الف: جلوه كر مي شود . 


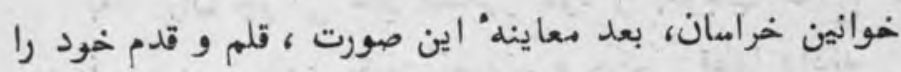

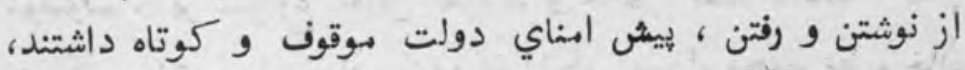

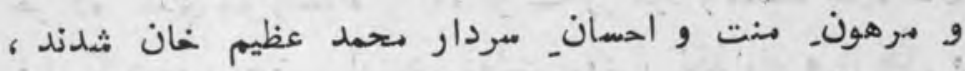

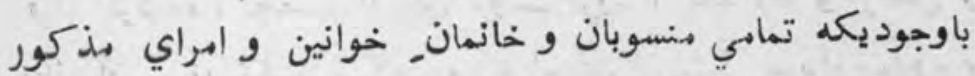

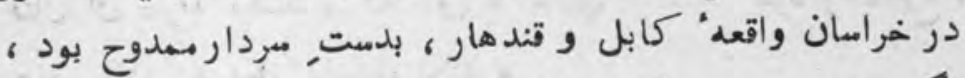

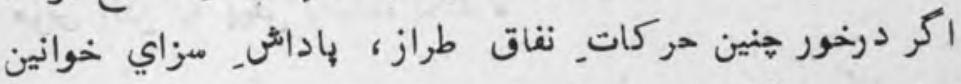

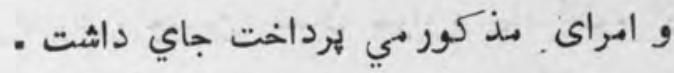

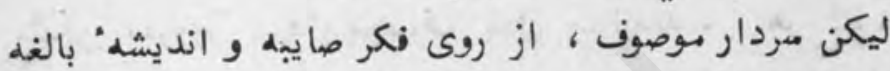

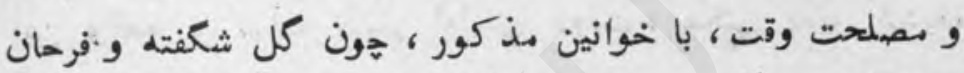

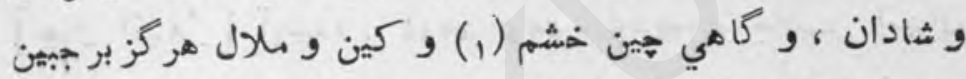

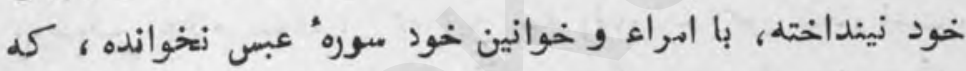

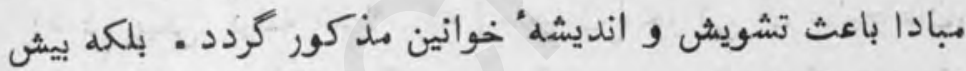

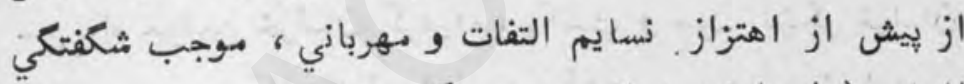

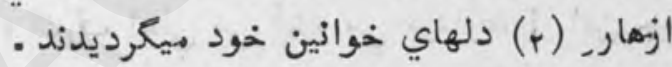

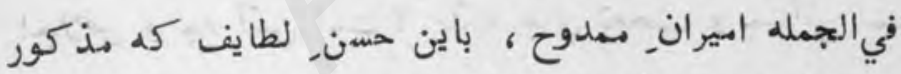

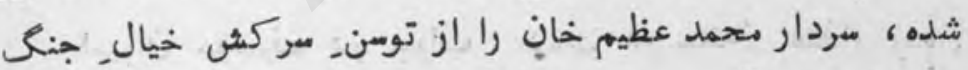

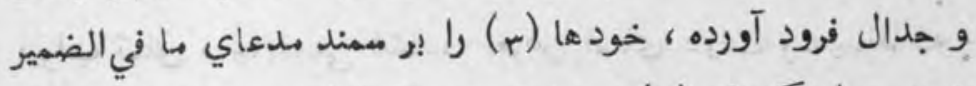

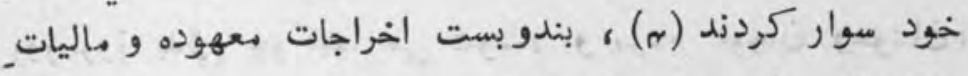

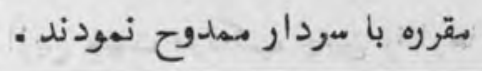

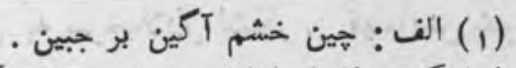

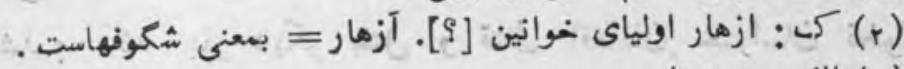

$$
\begin{aligned}
& \text { (r) الف : خود ها بر الف الفيات }
\end{aligned}
$$

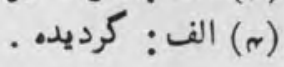


تازه نواي معار

100

بعد ازان هوكي هاي لشكر ـ خود را بموجب صلاح سردار

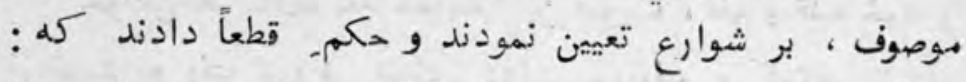

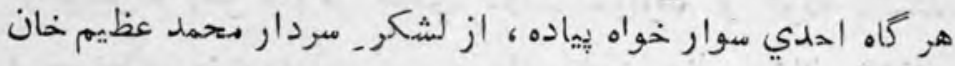

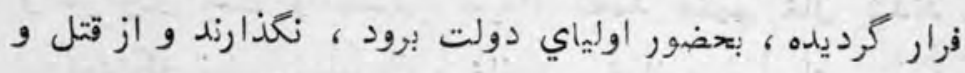

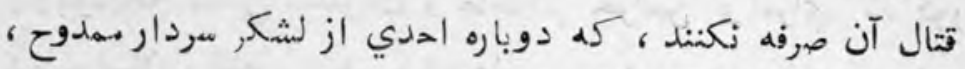

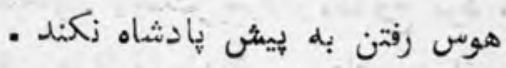

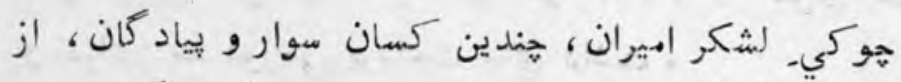
لشكر, مفروره" سردار موصوف بقتل رسانيدند - " هر كاه صورت

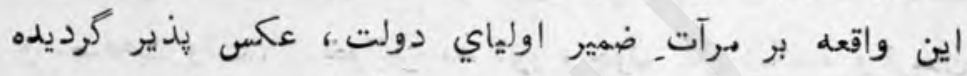

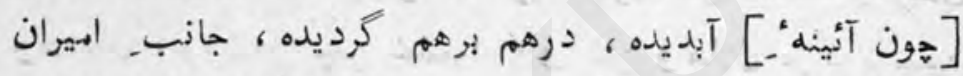

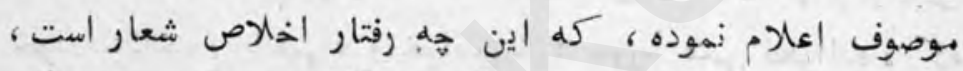

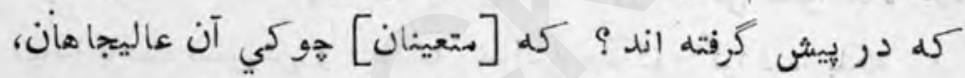

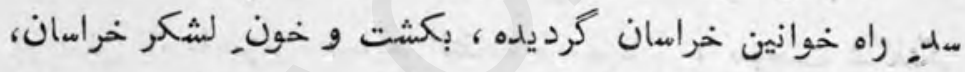

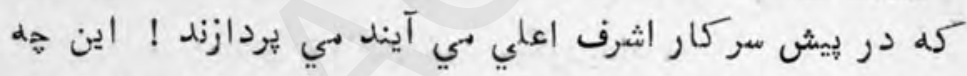
اخلاص و حه آئين است ؟ ـبلكه جاي تعجب و حيراني است ؛ اريران موصوف در جواب ، دست در حلقه" اعتذار زده ،

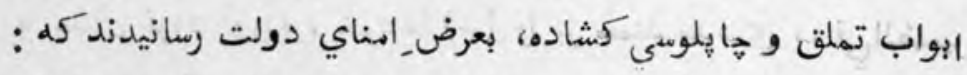

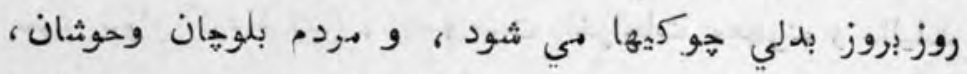

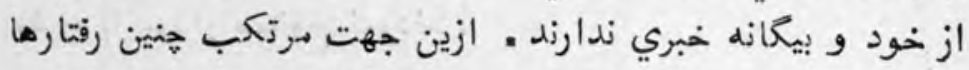

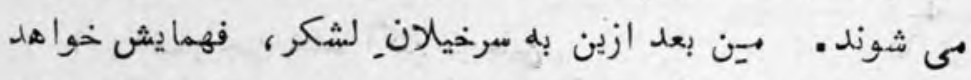

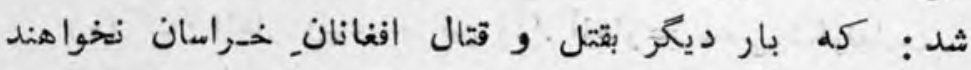

مرداخت 
100

تازه نواي ملفرك

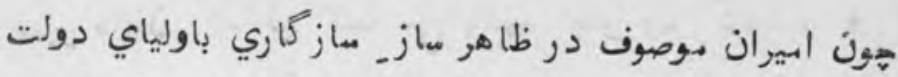

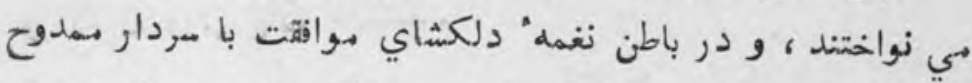

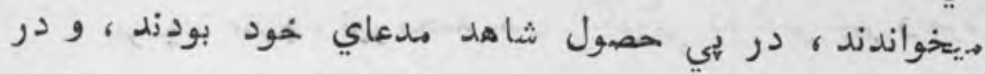

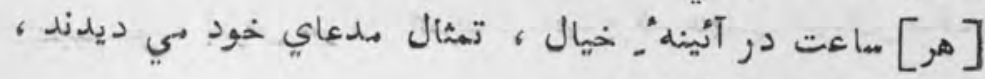

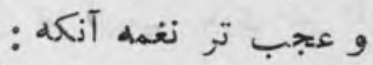

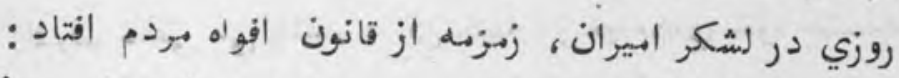

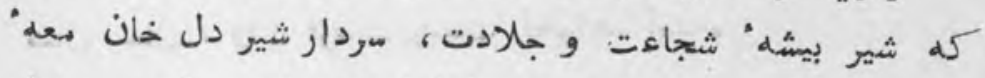

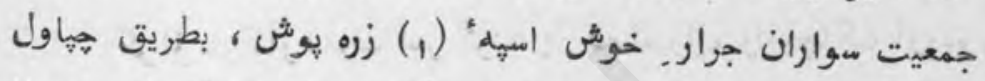

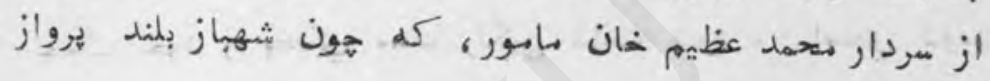

خوأاند افتياد

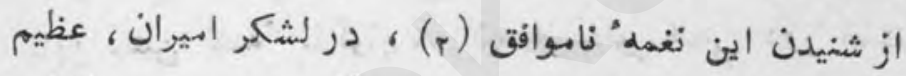

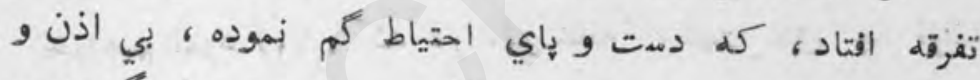

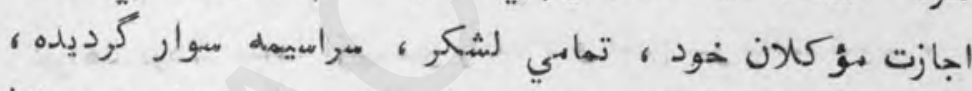

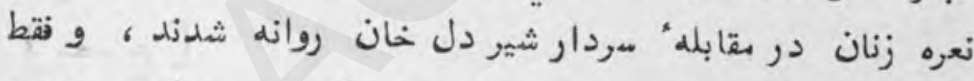

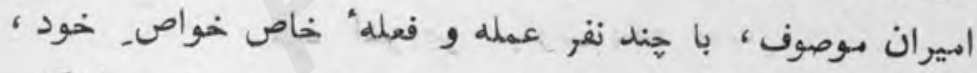

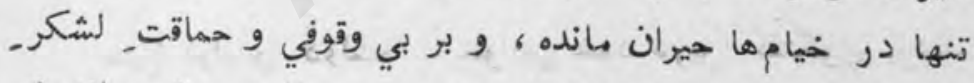

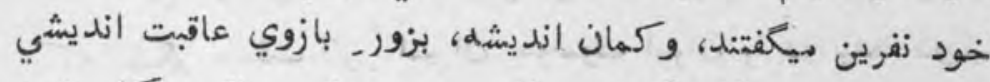

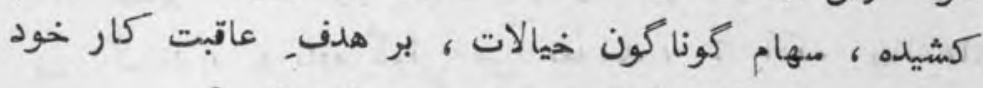

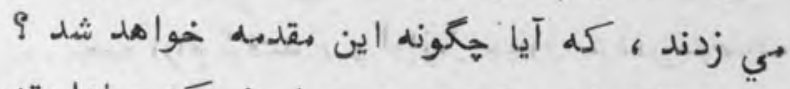

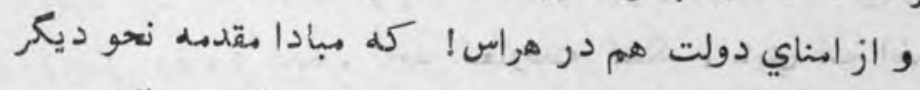

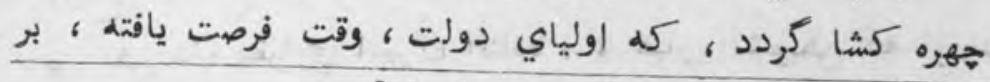

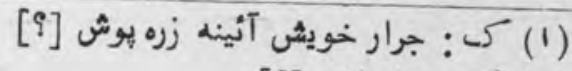

[؟] كى: (r) 


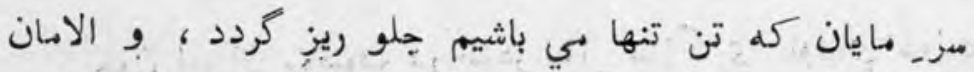

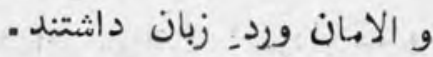

هر خيند عاليجاه نور محمد خان الكوزئي كه إميركبير و مردح. شجيع بود، بعرض سركار اشرف رسانيد :كه عجيب ديدان_صاف!

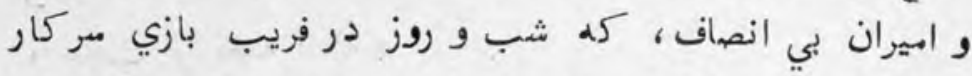

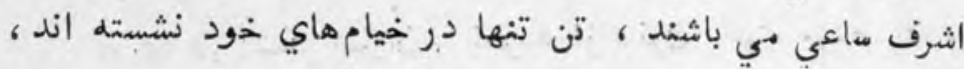

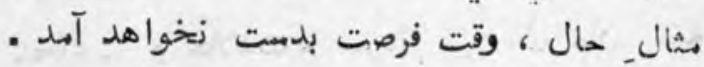

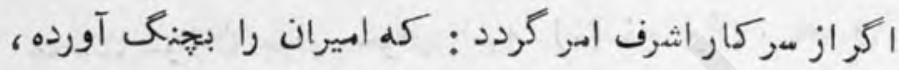

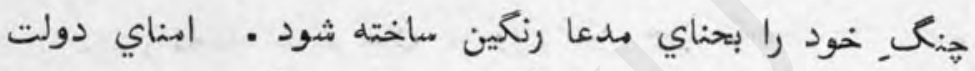

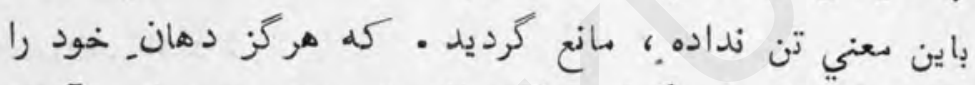

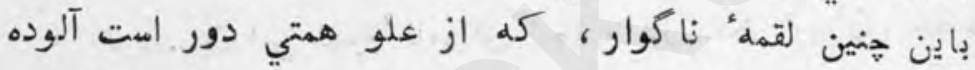

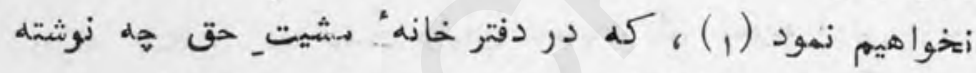

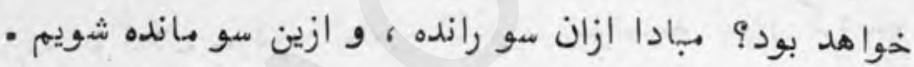

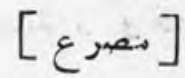

مرد آخر بين مبارك بنده است

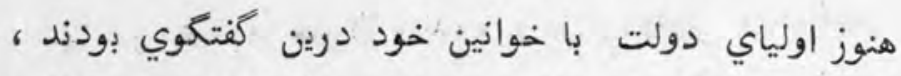

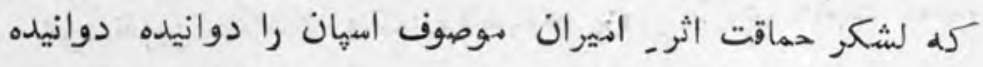

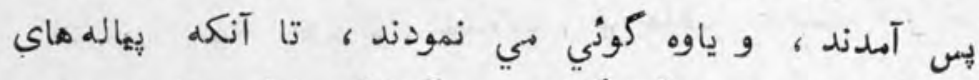

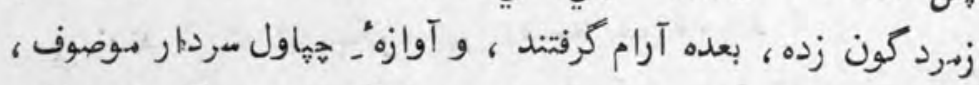

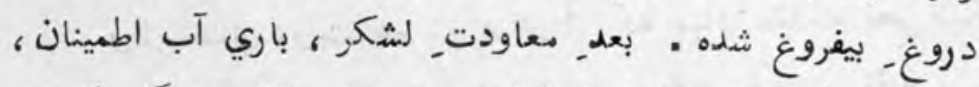

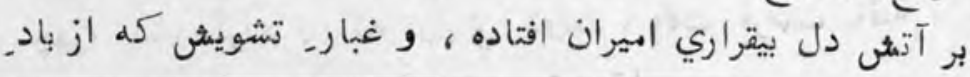

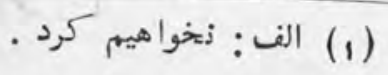


$10<$

انديشها ، در ضماير, امي-ران انكيخته بود فرو نشستت ؛ و

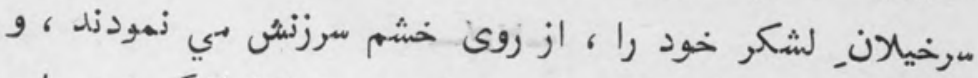

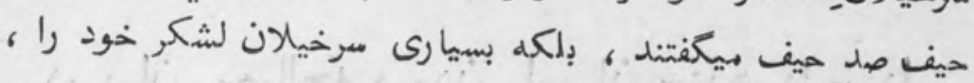

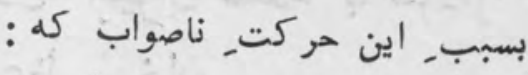

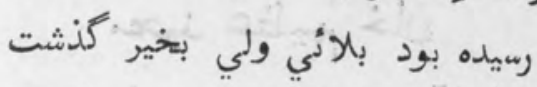

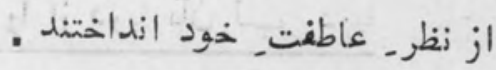

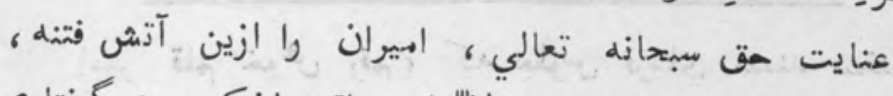

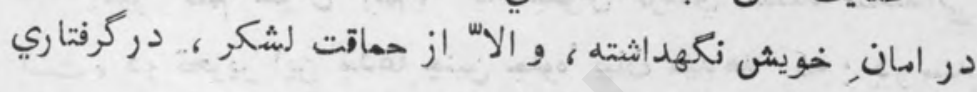
اميران موصوف جيزي باقي نمانده بود ، بـ بيت :

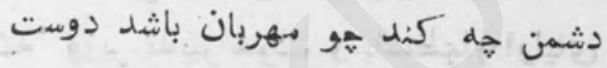
در ظل خودش نكاه دارنده هم اوميت 
در بيان_ مصالحه نمودن اميران سنده با سردار

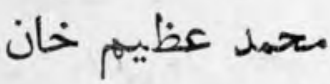

و عبور كنانيدن ، شاه را از دريا بآن لبـ دريا

ابير, قلم خوثل رقم، كله جلموس فرماي مسند سخنداني

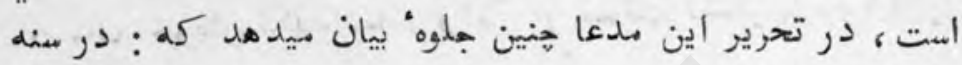

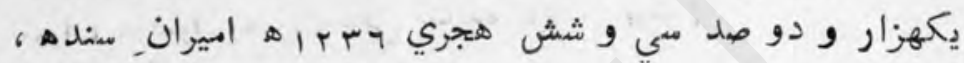

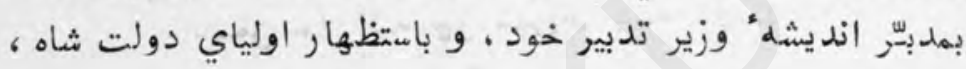

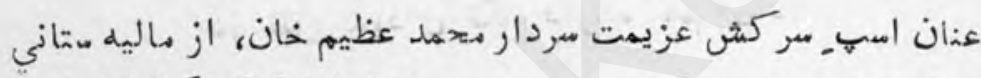

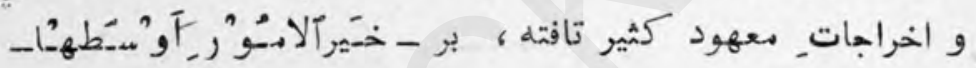

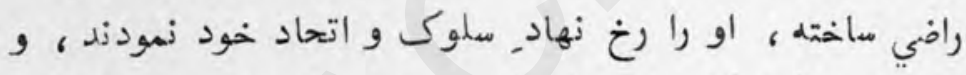

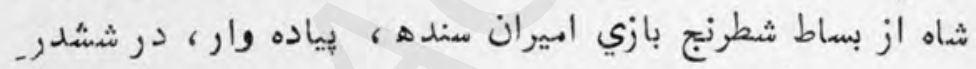

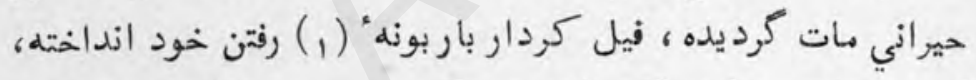

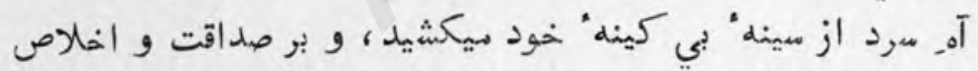

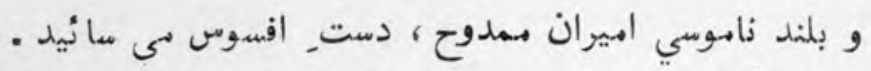

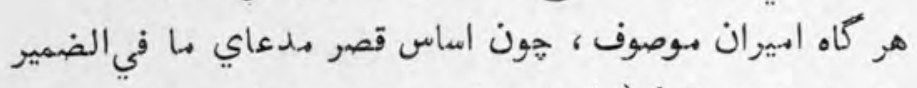

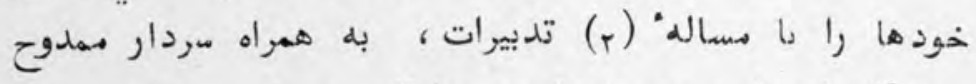

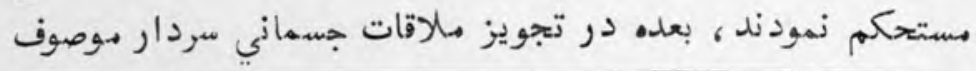

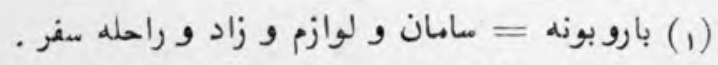

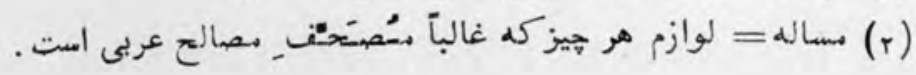


109

تازه نواى مeر

شدند ، و ابواب رسل و رمايل ، بر حهره حال يكديكر مفتوح

ماختمند

ليكن مبردار معظم اليه ، بسبب بي اعتباري امسرا" و خوانين

خود ، دل نهاد مالاقات نكرد يده ، باميران موصوف نوشته فرمتاد :

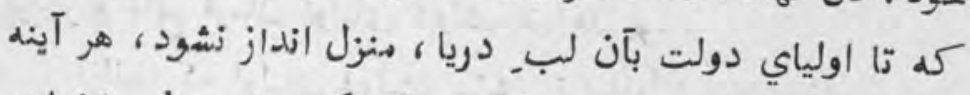

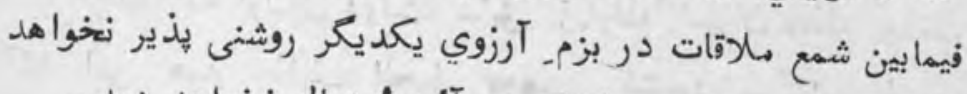

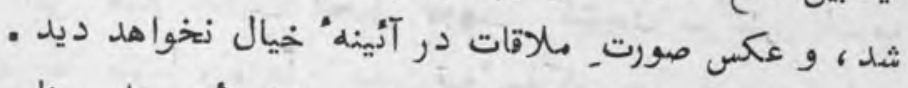

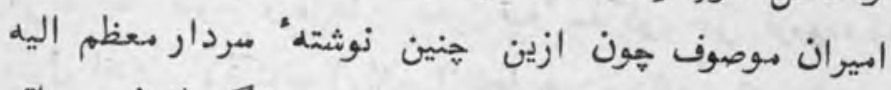

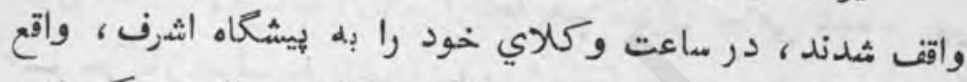

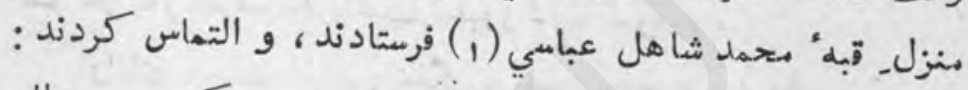

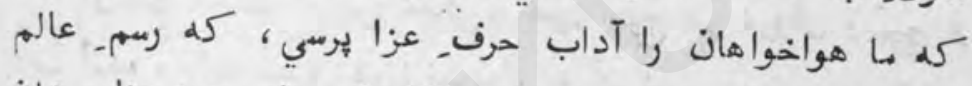

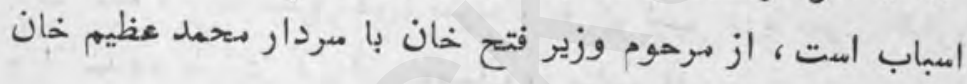

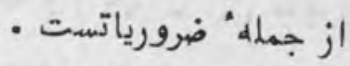

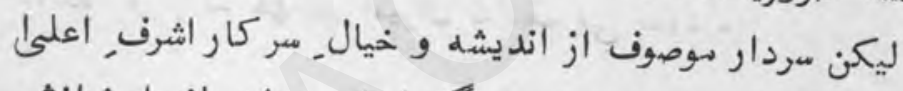

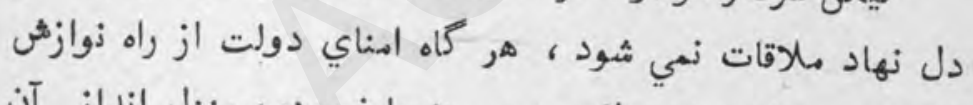

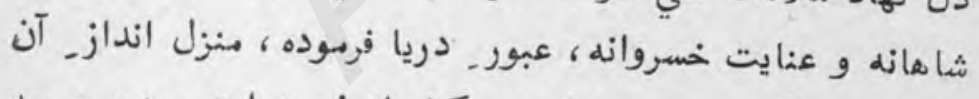

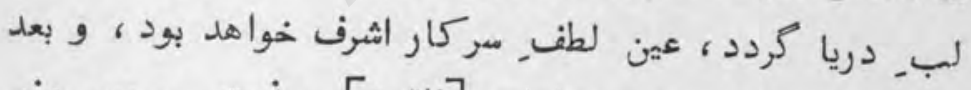

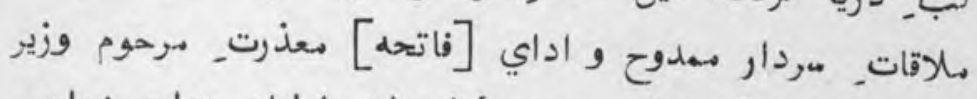

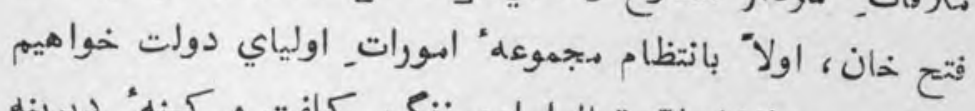

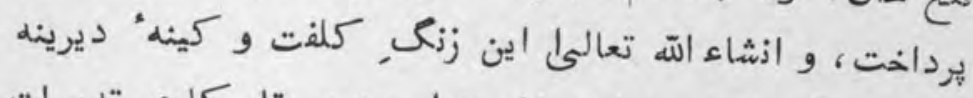

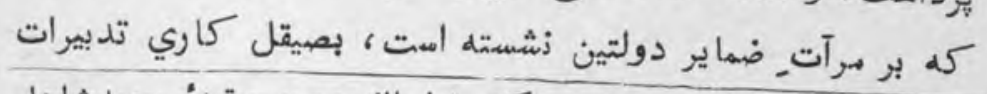

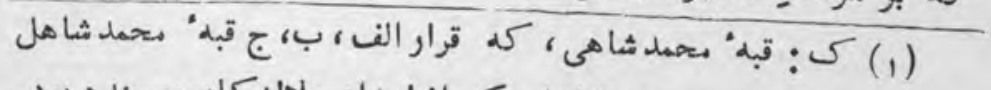

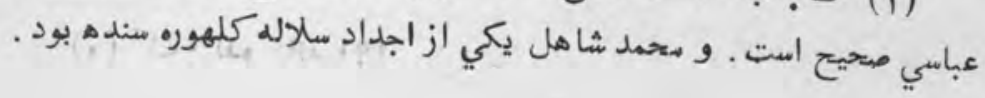


صايبه مصفا نموده، خهره" شا هد دولت ملططنت ، بكام دل ادناي

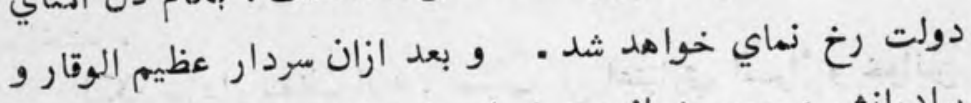

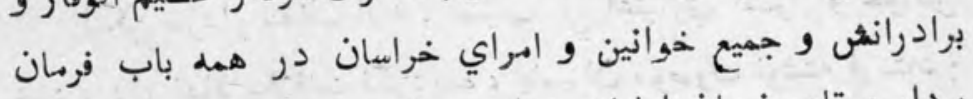

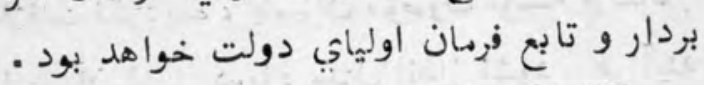

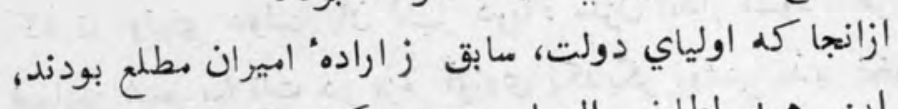

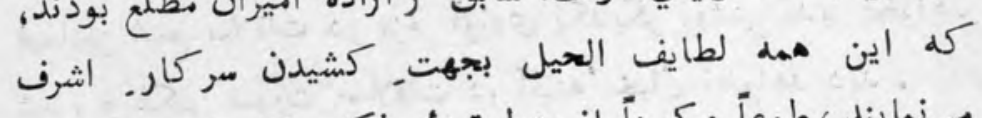

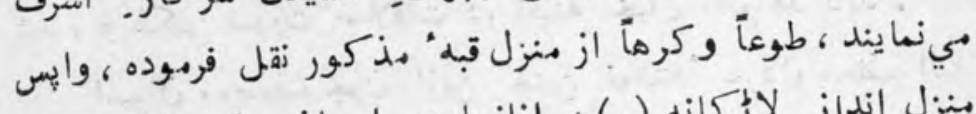

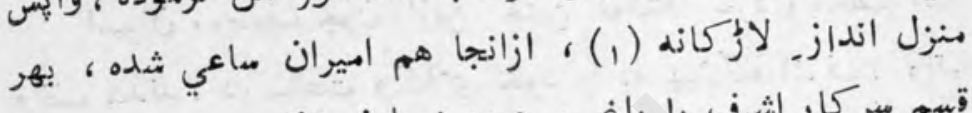

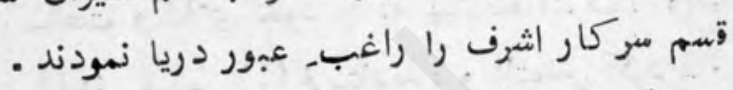

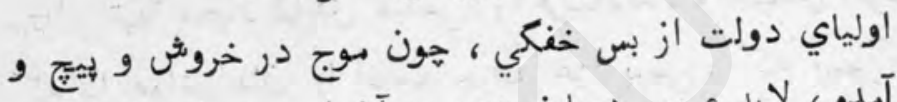

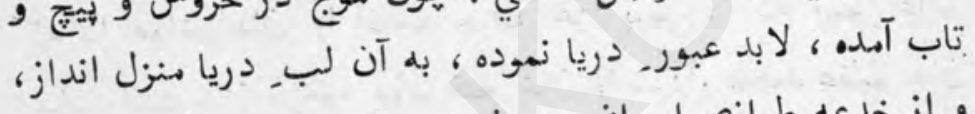

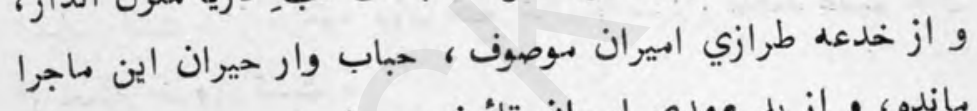

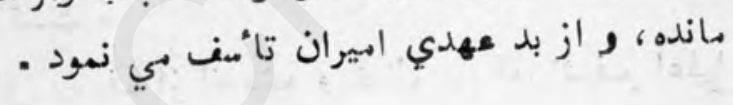


- NA -

در بئان بـاقات الهيران باسردار محمد عظيم خان. و ضيافت نمودن با يكديكر

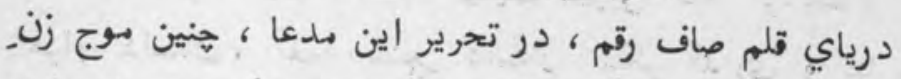

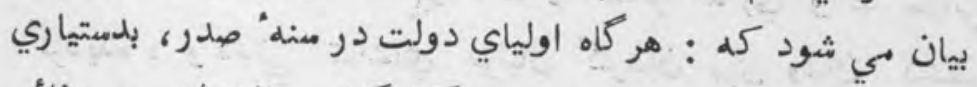

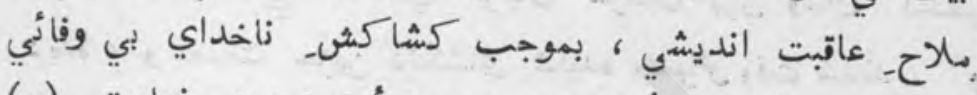

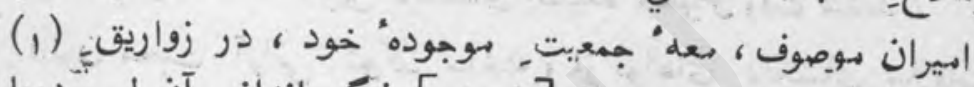

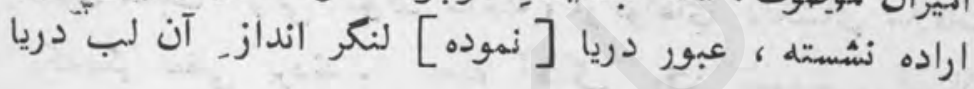

كرديده - ماده

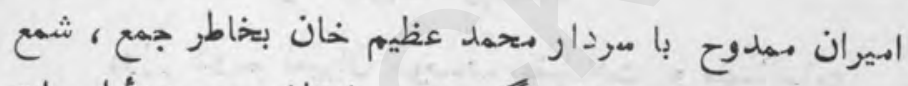

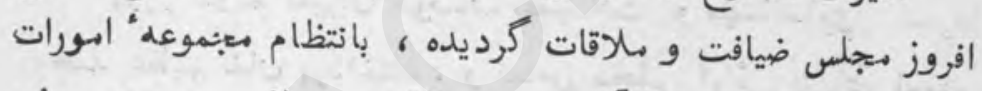

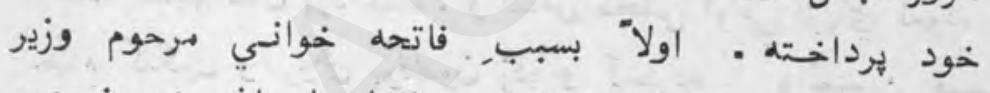

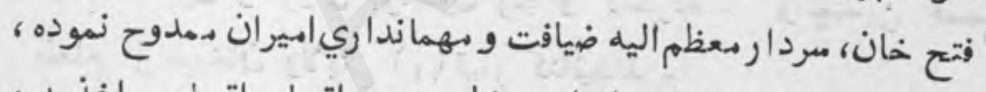

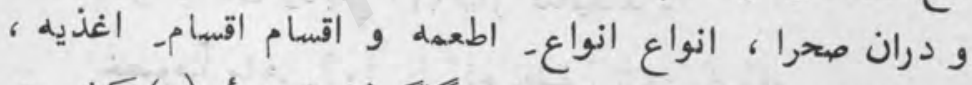

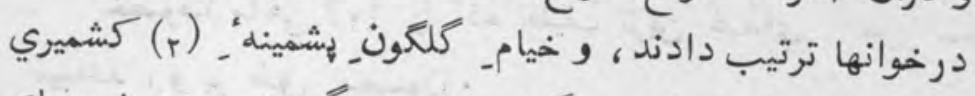

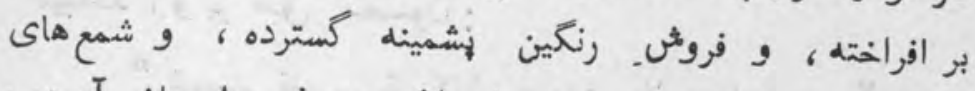

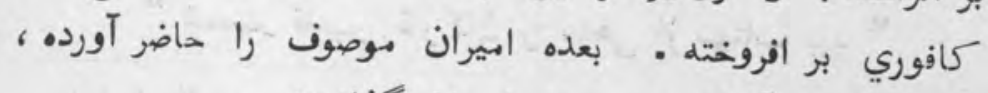

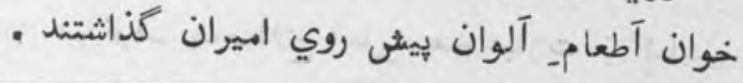

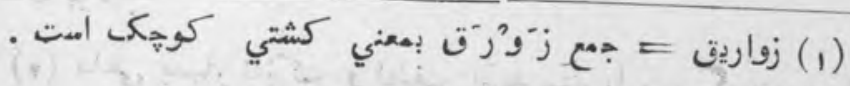

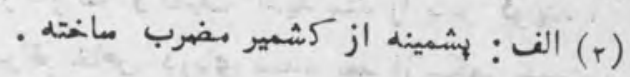




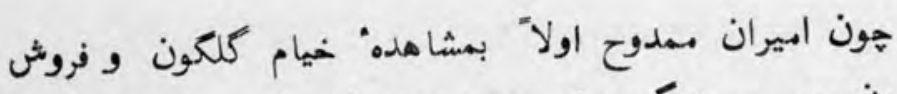

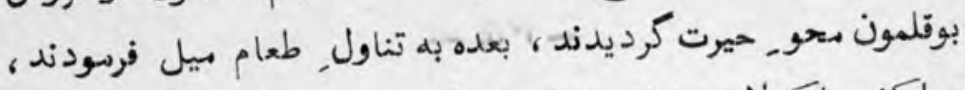

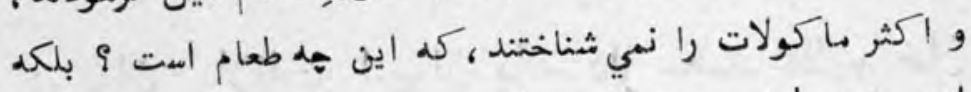

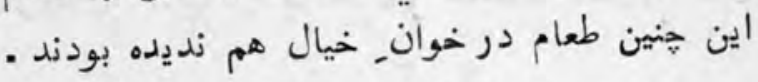

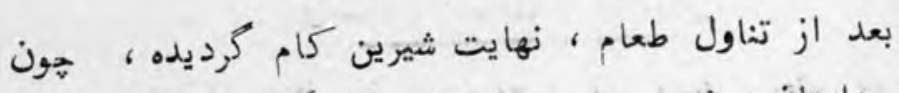

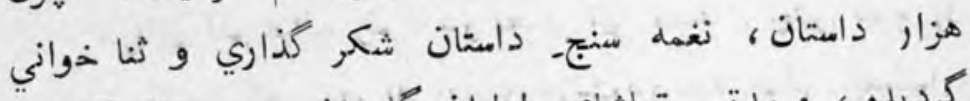

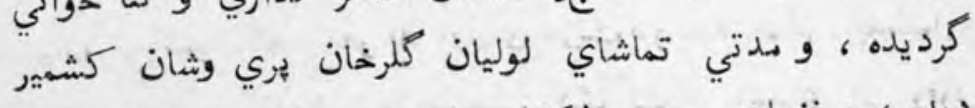

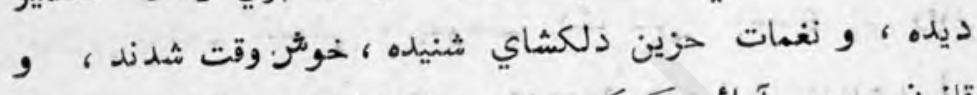

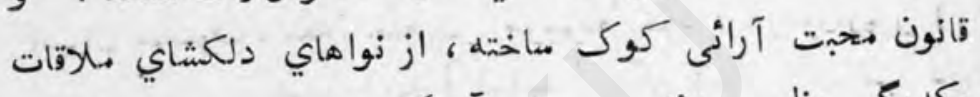

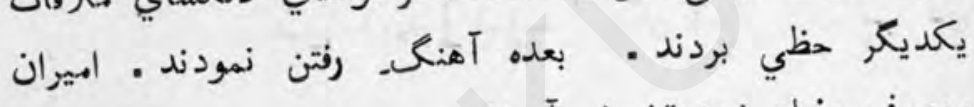
موصوف بخيام خود تشريف آوردند . بردند

روز دويم اميران بوصوف بضيهافت و بهمانداري, سـردار

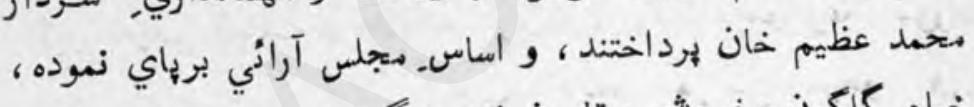

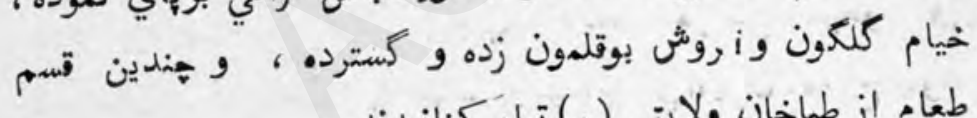

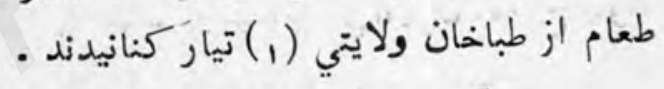

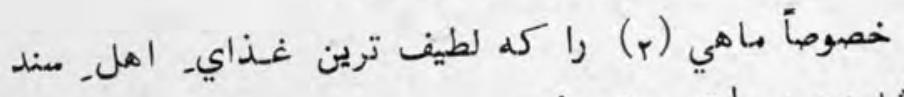

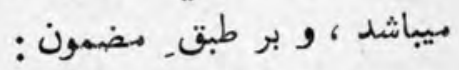

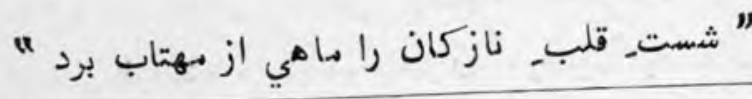

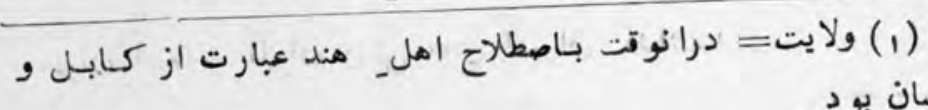
خراسان بود .

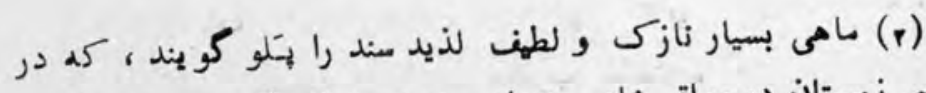

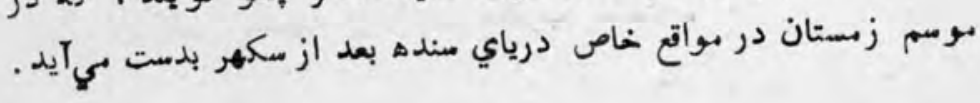


بصد آب و رنهل بتخته ، در خوانهاي الطعام رنكين ؛ در مجلس سردار بوصوف حاضر آوردند ابل

مردار و برادرانش ، و جميع- امراء از اكلب. ماهي ، هردم در درياي_ التذاذ غوطه ميخوردند ، و از شناوري تعريفثى بكنار_ انتهايش نرميده مير نمي شدند . بعد تناول. ماكولات،

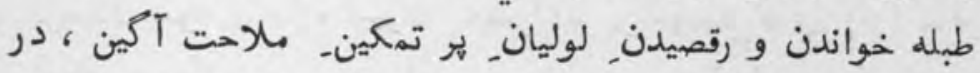
هجفل بمند آوازكرديده ، تا مدتى بازار, ماز و ناز و نياز, لوليان

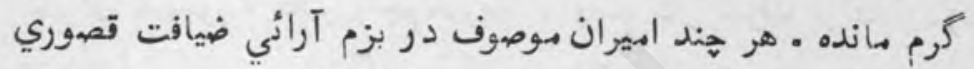

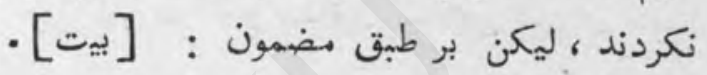
آن ـه " تابان كجا ، و و آن عارضـ جانان كجا

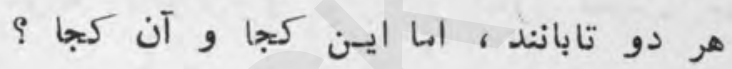
ازانجا كله ضيافت و بزم آرائي ابيران را با ضيافت و مجلس

$$
\text { آرائي سردار موصوف حه زسبت }
$$

بين تفاوت_ راه از كجا ميت تا بكجا هو

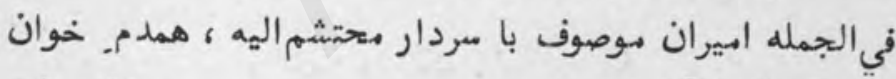

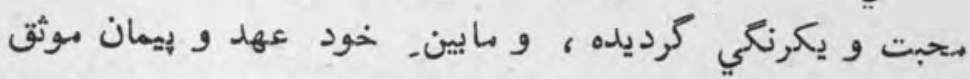

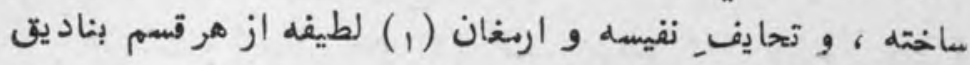

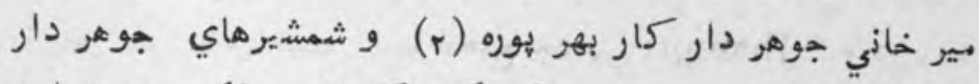

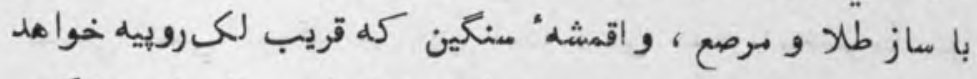

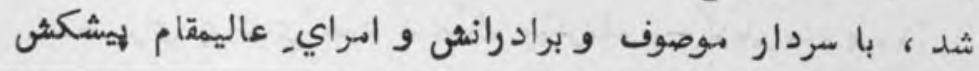

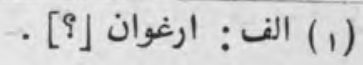

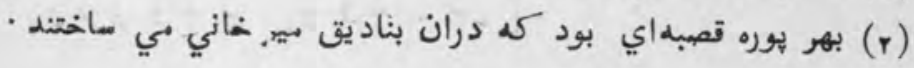


تازه نواي معار

$17 \%$

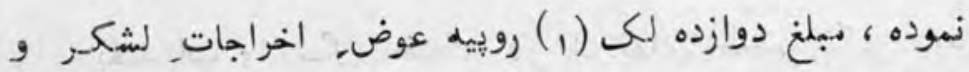

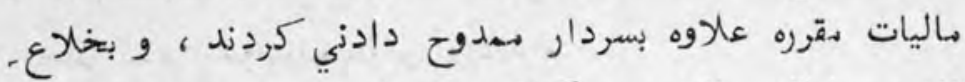

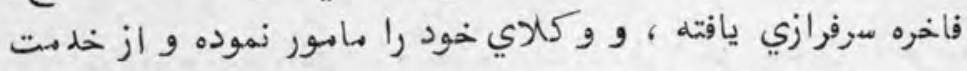
سردار معظم اليه شرف ترخيص حاصل نموده ، از بـ بس شوق

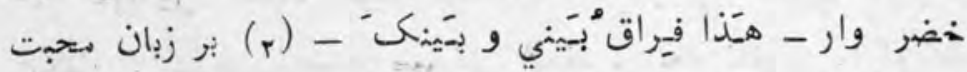

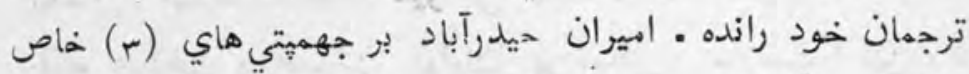

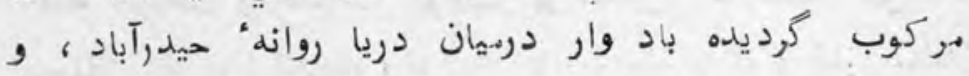

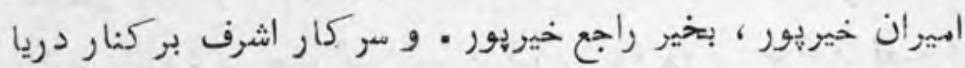

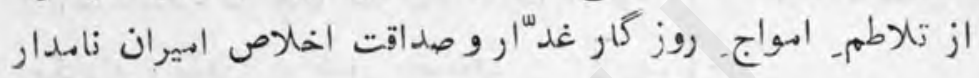

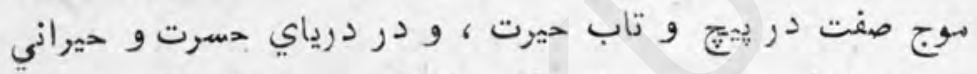

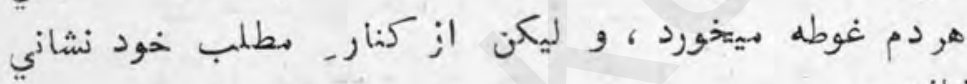

-

آخر هون خضر، كشتي مدعاي خود شكسته ، بكمال لمايوسي

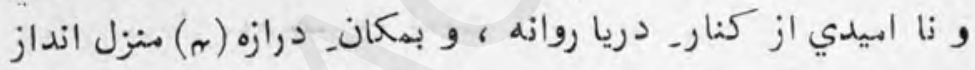

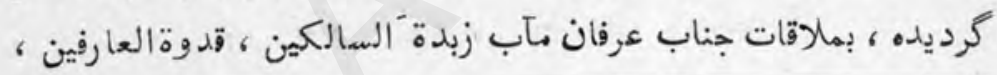

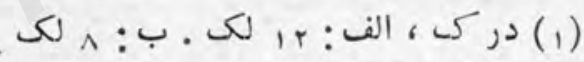

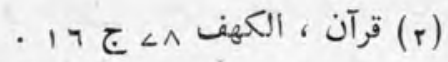

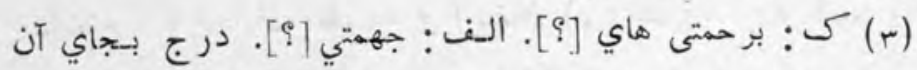

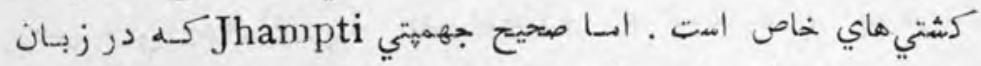

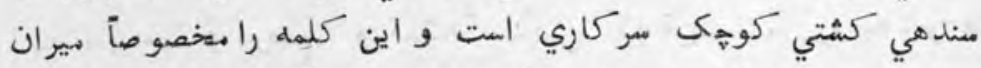

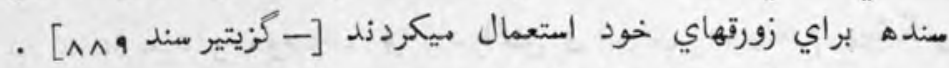

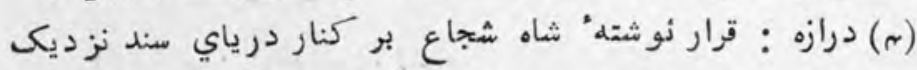

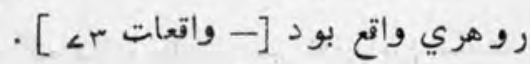


فقير هيان قبول متحهد صاحب (1) فايز كرديده هند روز آنجا

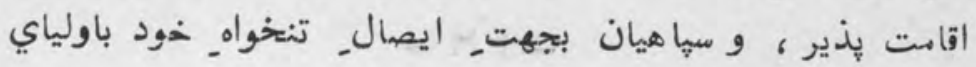

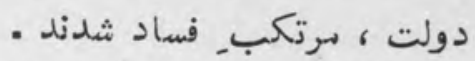

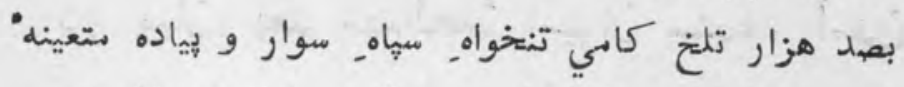

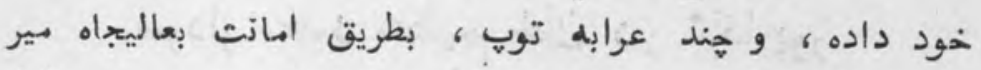

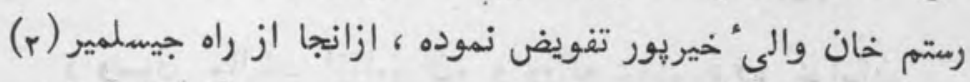

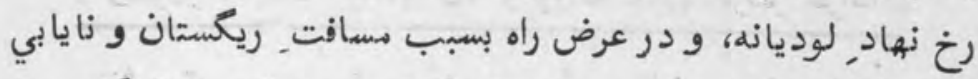

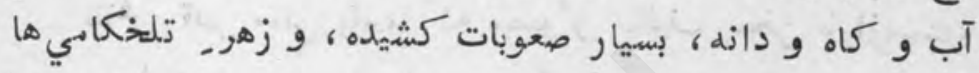

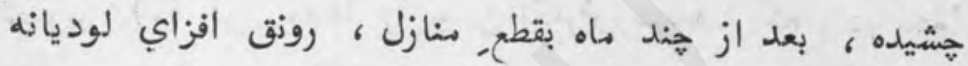

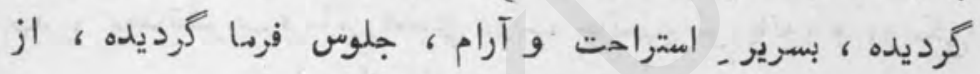

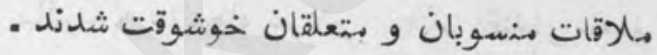

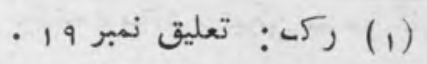

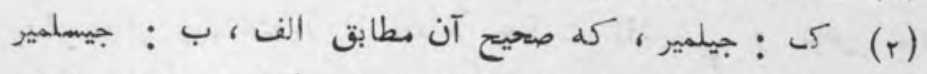

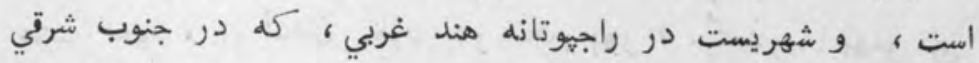

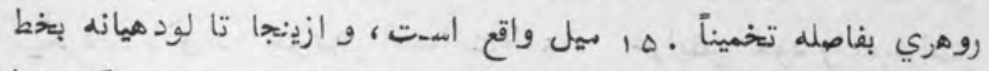

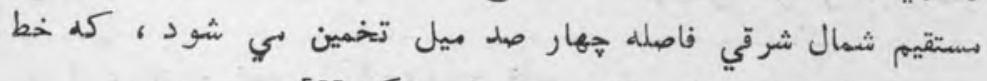

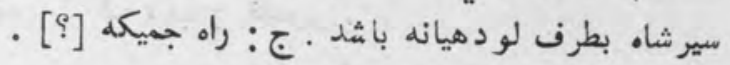


در بيان بعل مصالحهء اميران سنده ، أمدن سردار مهملم عظيم خان در شكاريور

و وصول_ ماليات از ابيران، و روانه شدن طرف, خرامدان

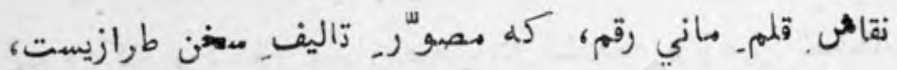

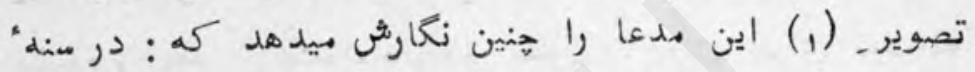

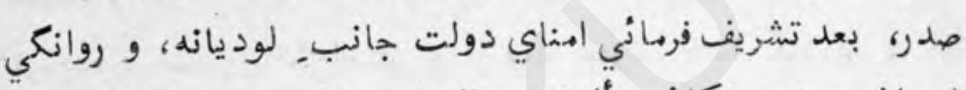

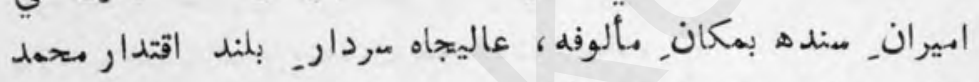

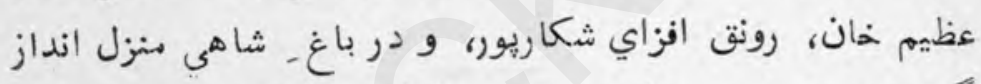
كرديده، ثيب و روز در ناي و نوث و تمهاشاي لوليان. شهر

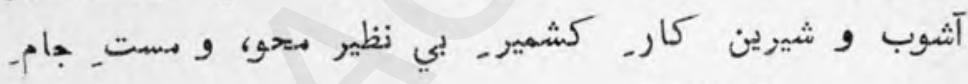
مي عيش و عشرت بود - معرين

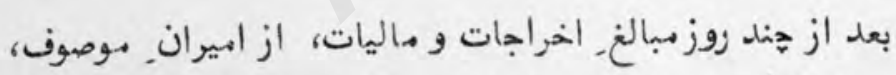

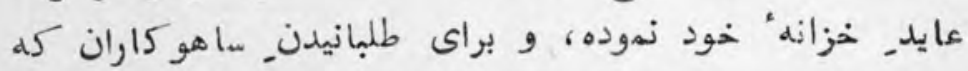

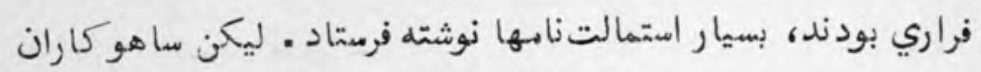

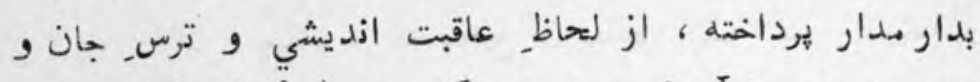

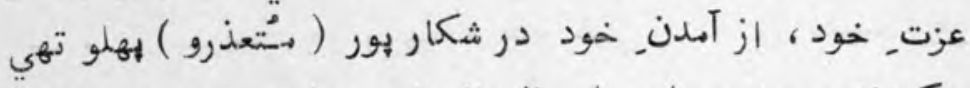

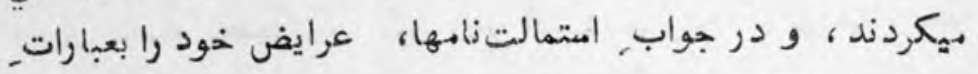

$$
\text { (1) الف: تصور. كى، ب: تصوير . }
$$


174 تازه نواي معارك

مرغوب بعرض رسانيده، بخوش دلي سردار منمدوح مي برداختيند،

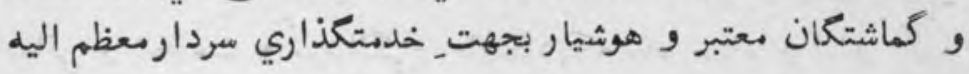

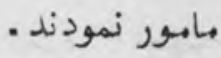

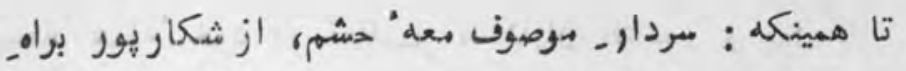

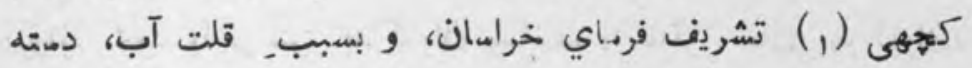

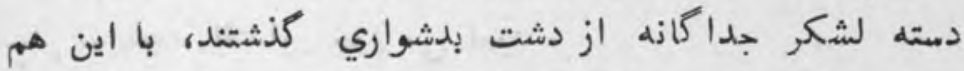

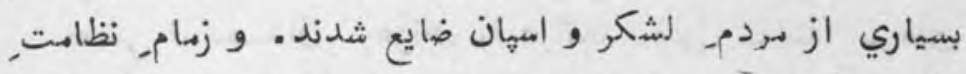

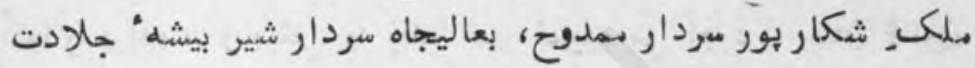

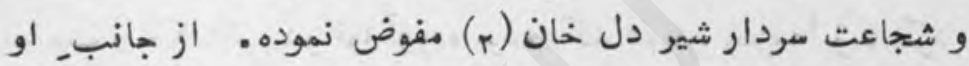

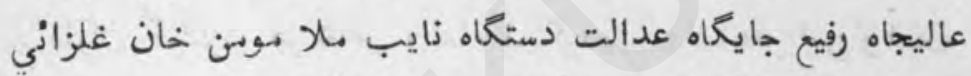
به نيابت_عهده" نظامت_ شكار يور ماسور كرديد .

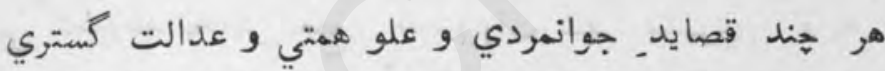

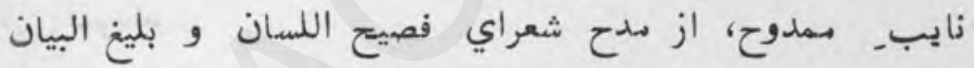

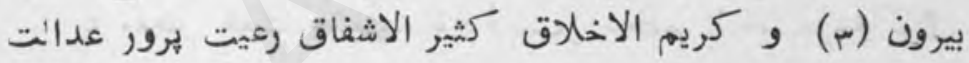

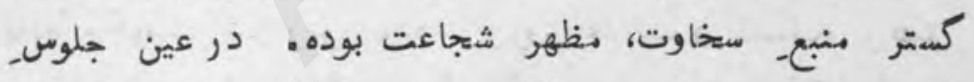

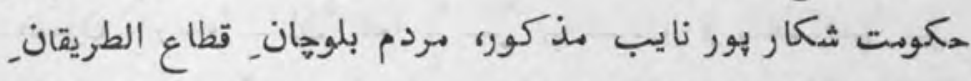

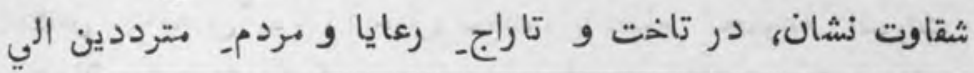

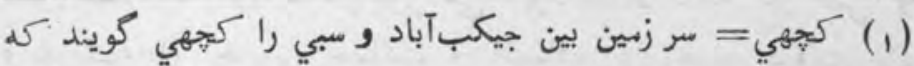

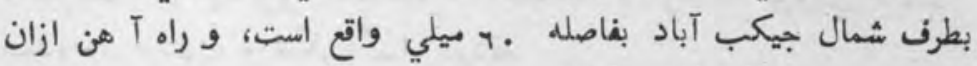

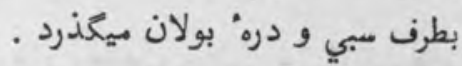

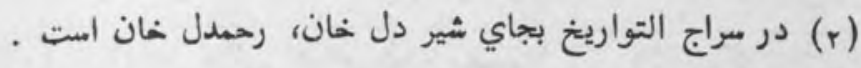

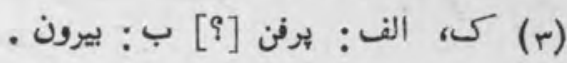


تازه نوأي بـازي

171

دروازه" شكار لهور صرفه نميكردند . نايب_ بمدوح از روي غيرتـ

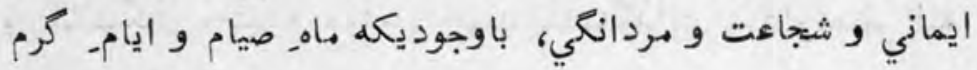

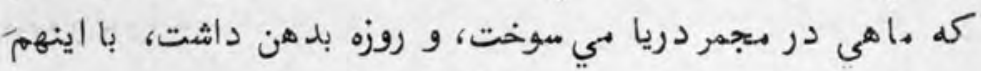

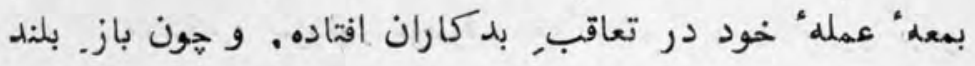

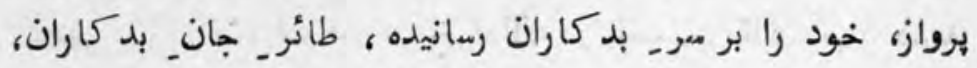

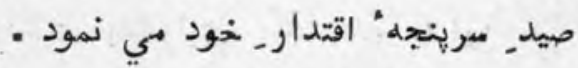

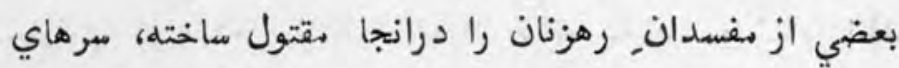
آنها را بريده، و برخي را زنده اسير نموده مي آورد . هينان قانون

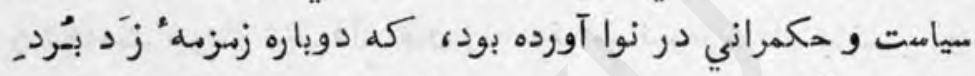

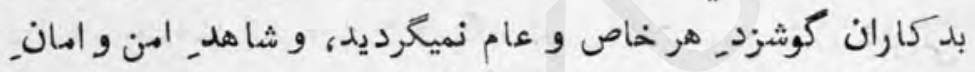

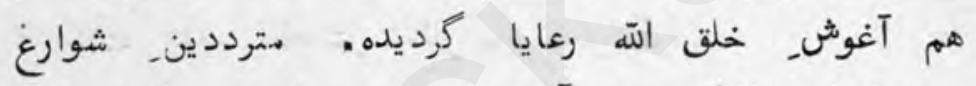
بي دغدغه بخاطر :جمع، آمد وروت شهر بشهري، قريه قريه

- تي نيودن

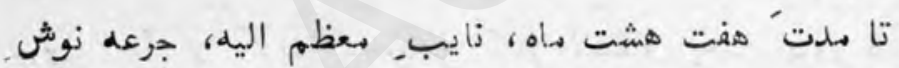

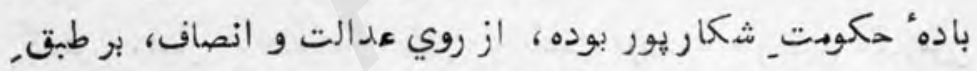

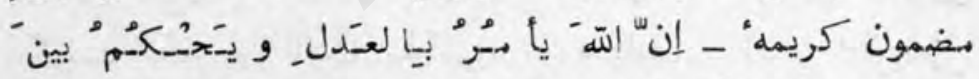

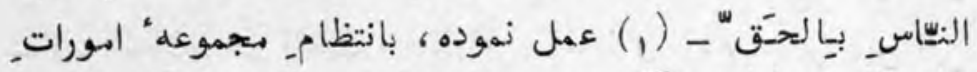

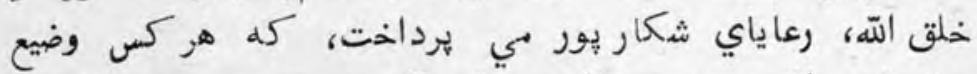

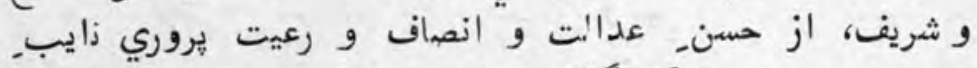

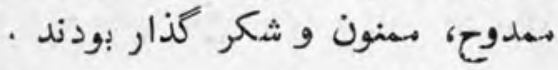

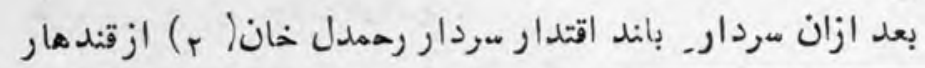

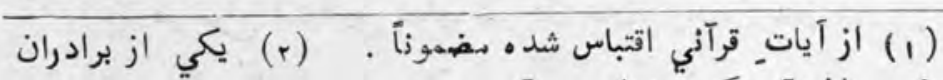

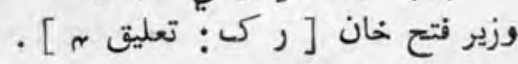


بذا بر حكوهت شكاريور تشزيف فرباي گرديدند. . و نايب, ممدوح،

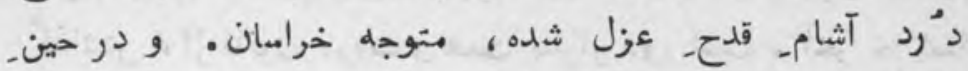

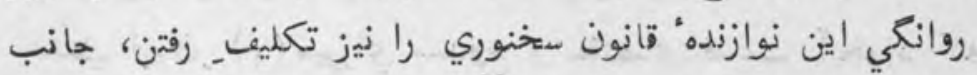

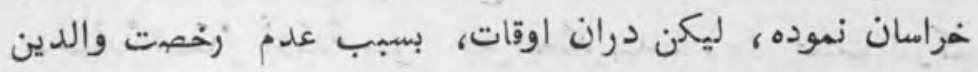

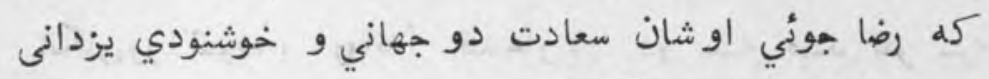

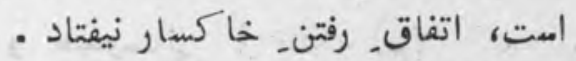

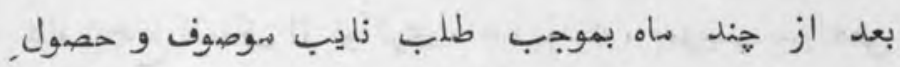

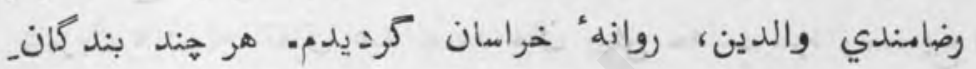

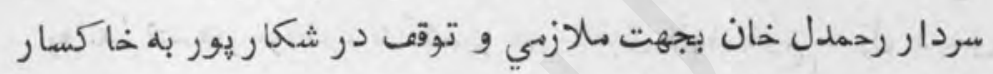

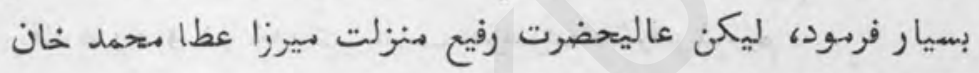

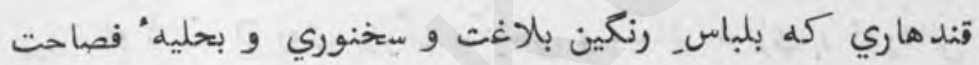

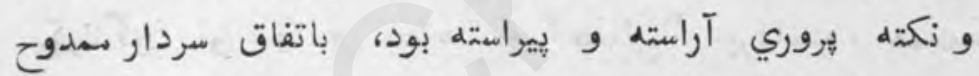

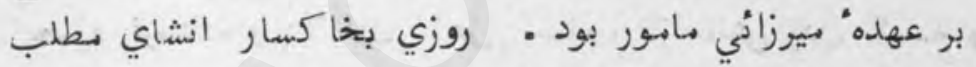

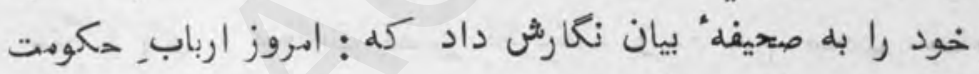

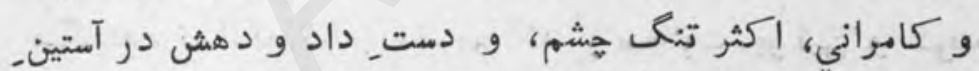

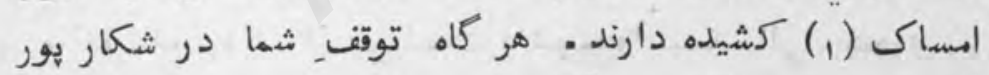

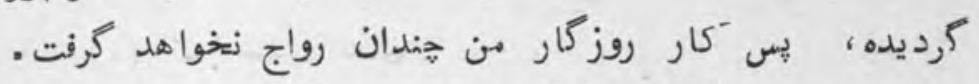

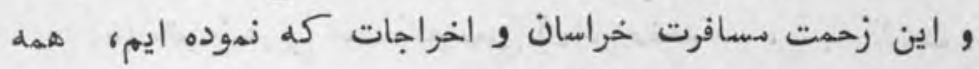

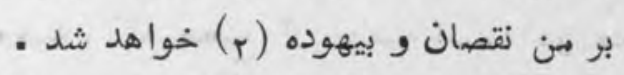

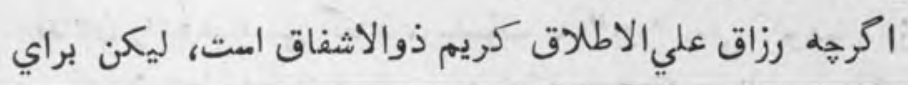

$$
\begin{aligned}
& \text {. (1) } \\
& \text { [9] كא : (r) }
\end{aligned}
$$


تازه نواى ملى

16

نغس نافرجام ، خار, راهـ ديكري ثمن ور باي بر روزي. ديكري

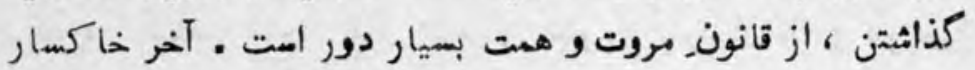

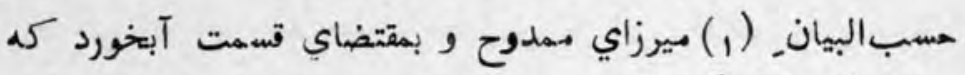

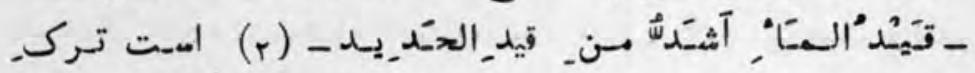

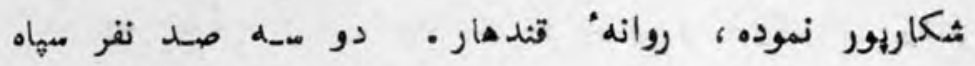

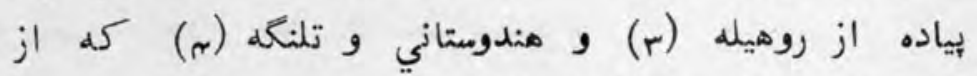

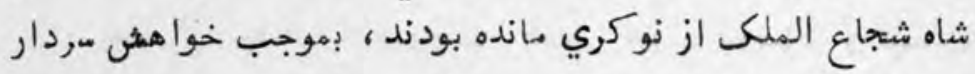

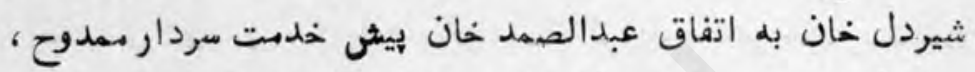

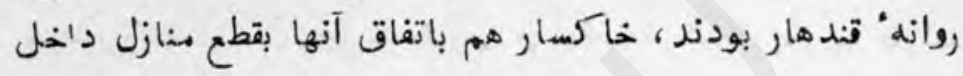

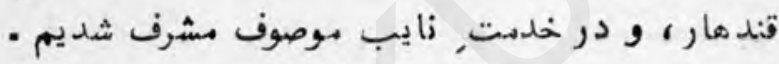

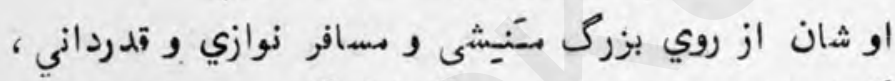

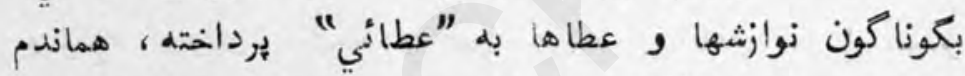

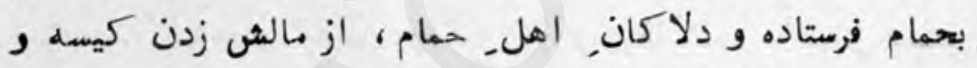

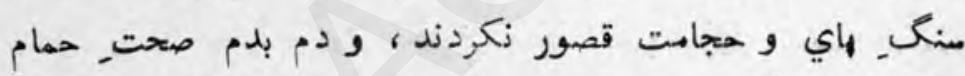

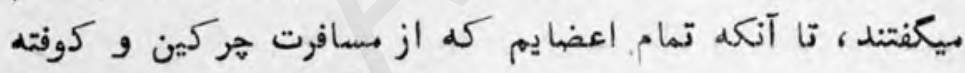

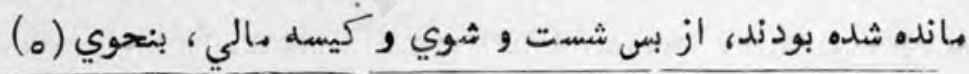
. (1)

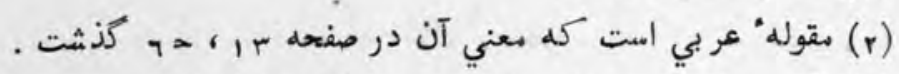

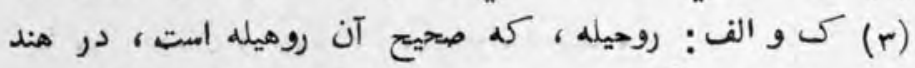

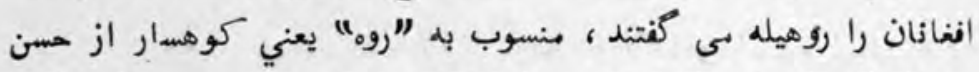

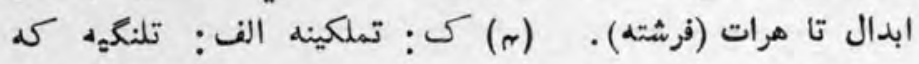

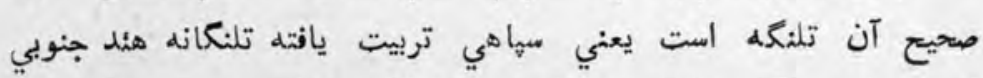

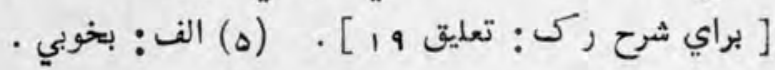


ياك و صاف نمودند ، كه كويا نو تولد شديم، و اثري ازماندكى

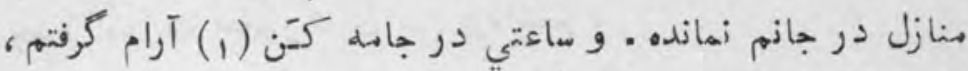

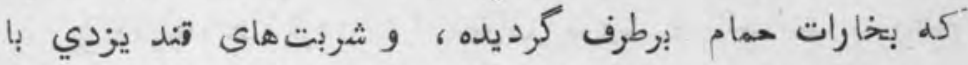

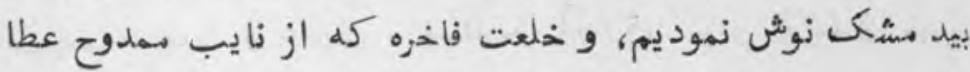

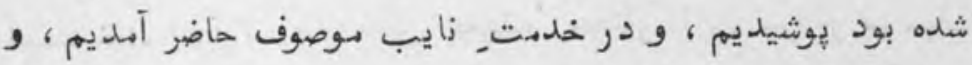

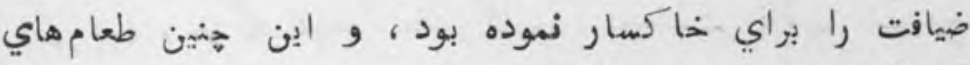

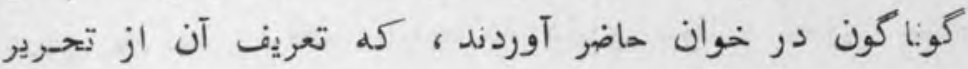

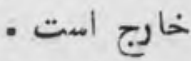

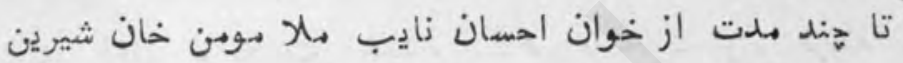

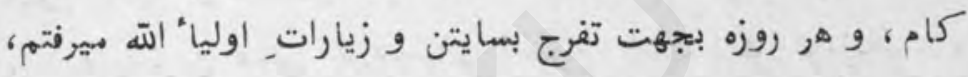

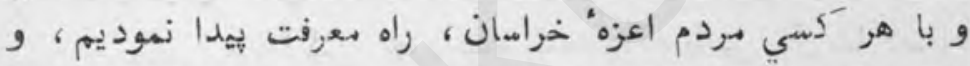

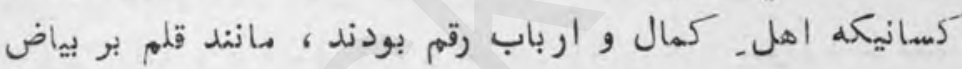

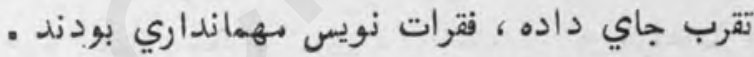

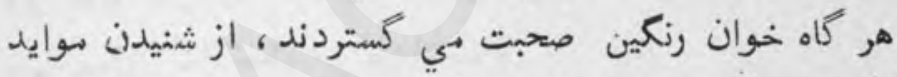

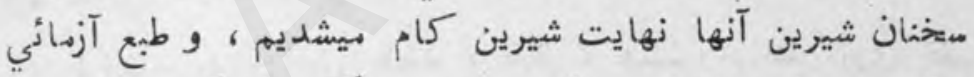

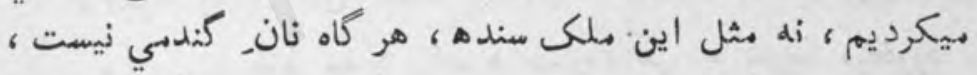

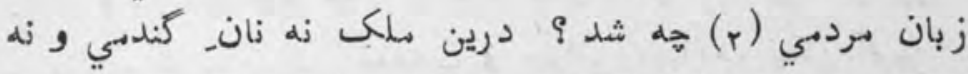

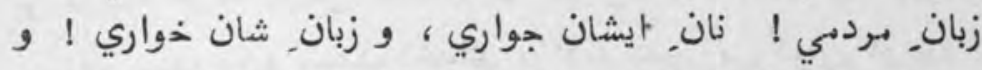

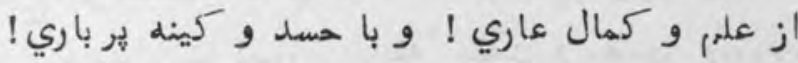

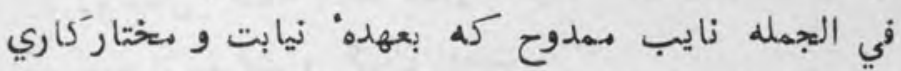

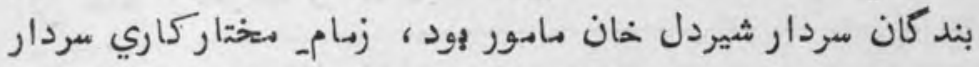

$$
\begin{aligned}
& \text { (1) جامه كَن = الطاق جامه كتني در حمام. }
\end{aligned}
$$

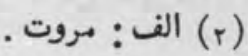


موصوف، تفويض_ خاكسار نمود ، كله بافضال رب رب متعال، بانتظام

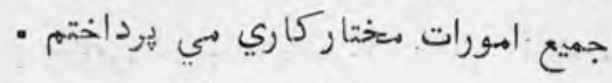

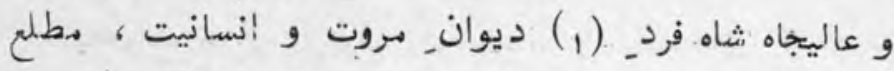

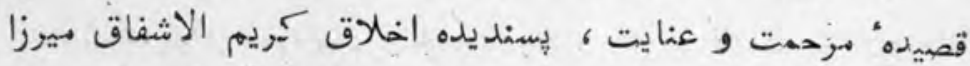

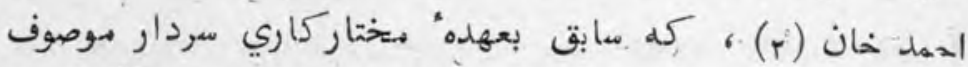

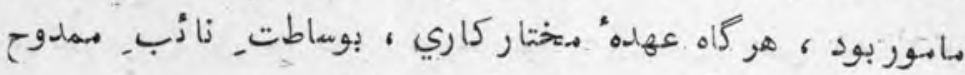

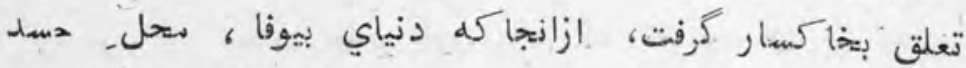

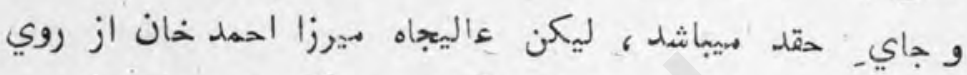

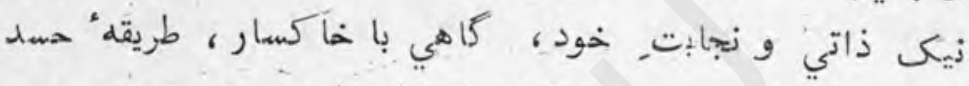

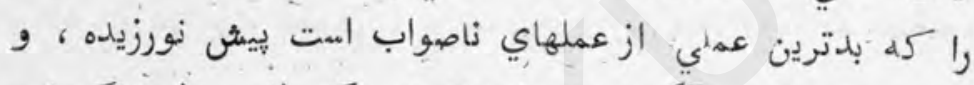

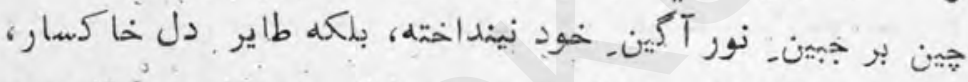

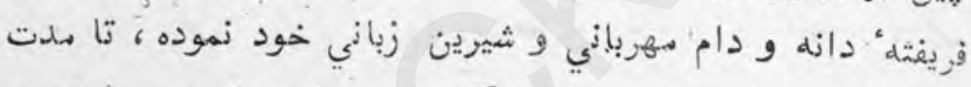

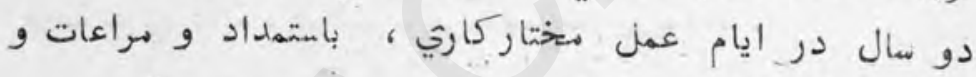

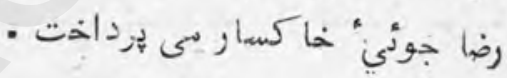

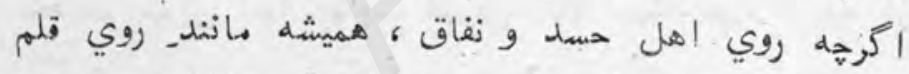

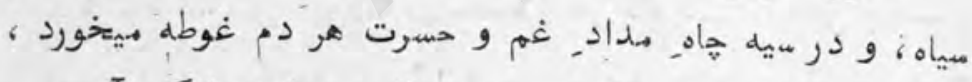

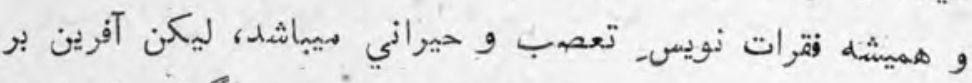

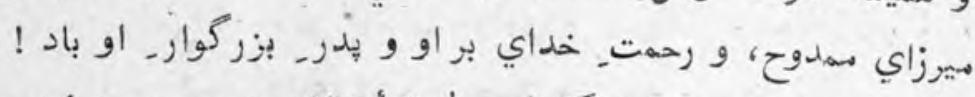

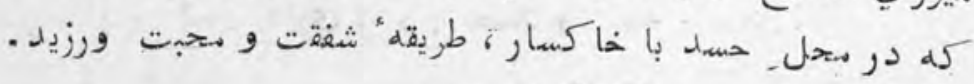
اين همل إزمعرفت و مل كمال اوست

$$
\text { · (1) }
$$

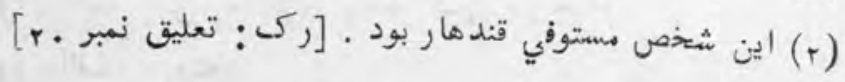


تازئ نواي

هر هيند روزكار بيوفا همجيجون برت در كذر است، ليكن از

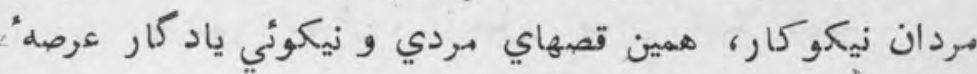

روز كار ميماند، و بر طبق مضهون : مبرن

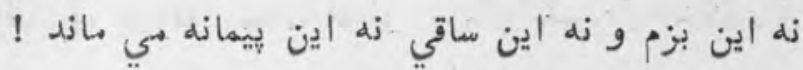

همين حرف مروت در جهان افسانه هي ماند إ بان

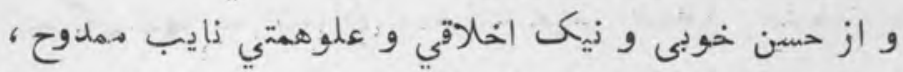

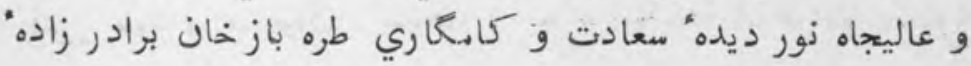

نايب موصوف حه انشا نها يهم :

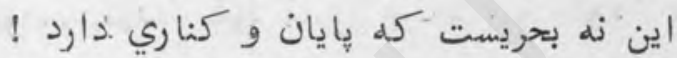

خداي شا هد حالستت : كل ددر ايام متختاركاري ، مبلغ دو

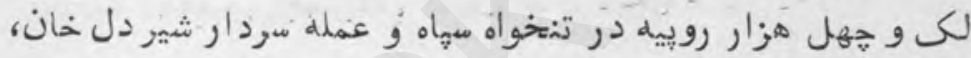

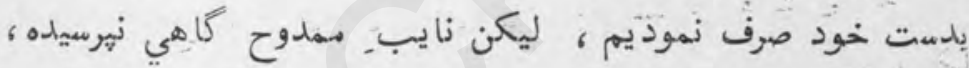

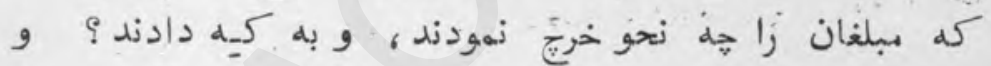

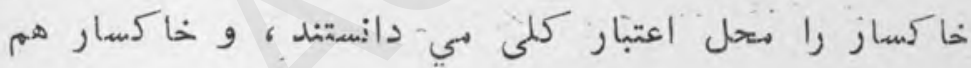

بمقتضli

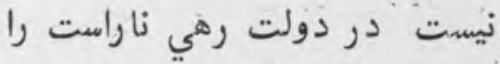

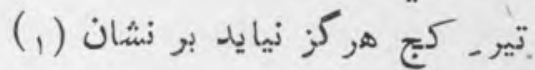

از روي امانت و ديانت ، كله شيوه. مجاهدين طريق

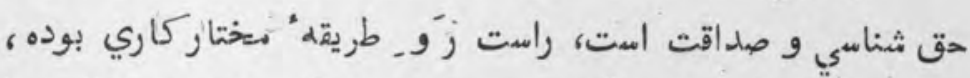

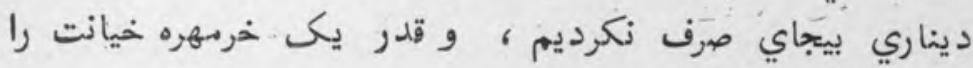

روا نداشتم و بفحواي مضمون : بهري

(1) الف: بر نشائه درست. 
تازه نواي مع

$1<r$

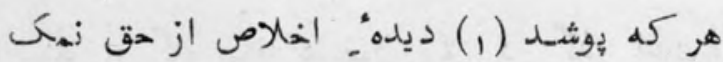

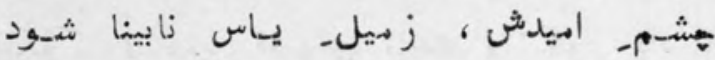

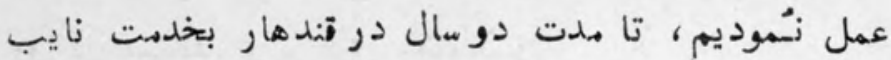

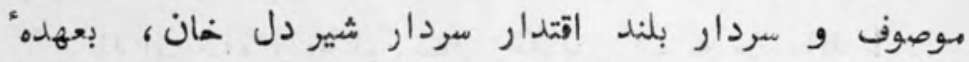

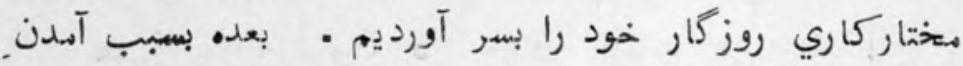

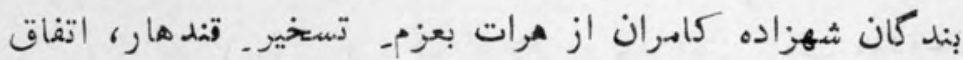

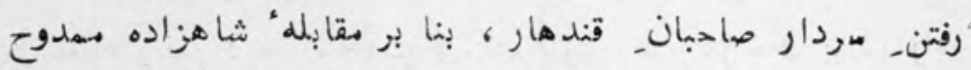

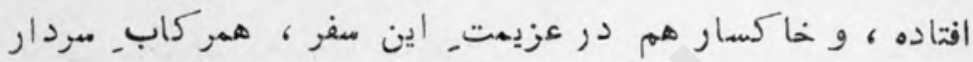

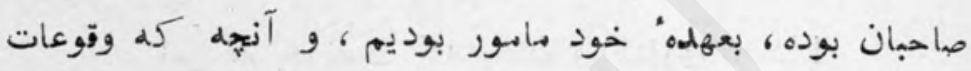

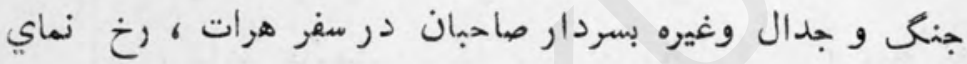

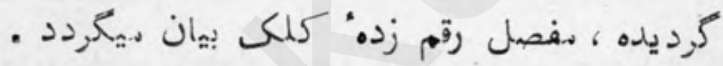

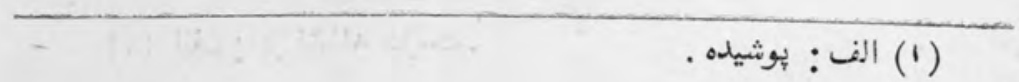


در بيان_ آمـنـ_ شاهزاده كامران بعزم تسخير قندهار و داخلل شـدن در قلعه فراه (1) ، و رفتن سر:اران

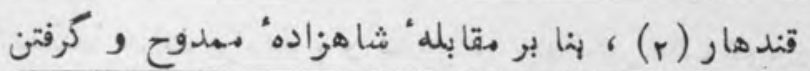

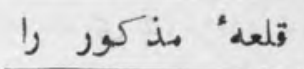

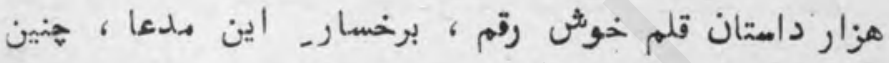

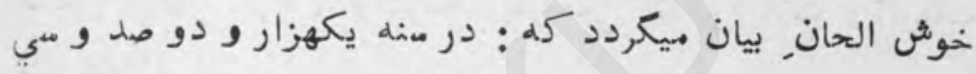

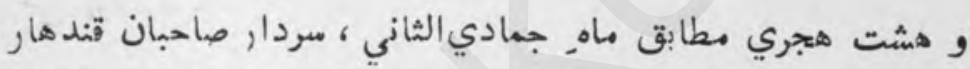

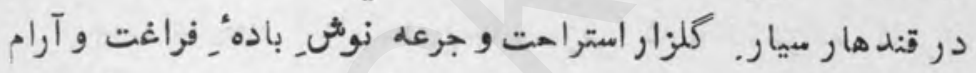

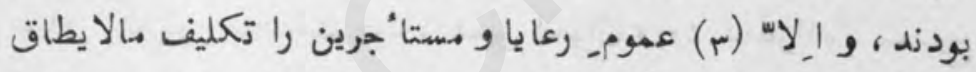

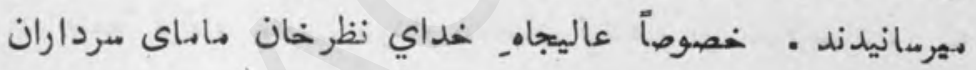

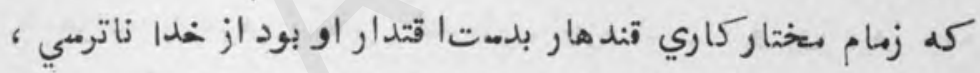

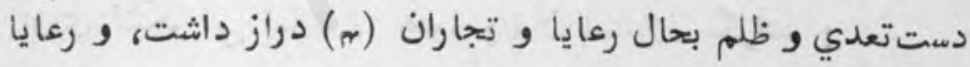

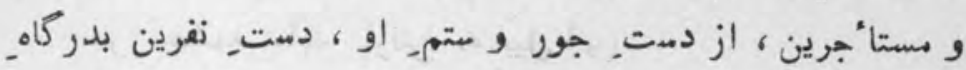

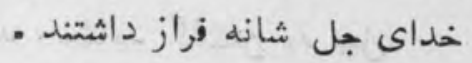

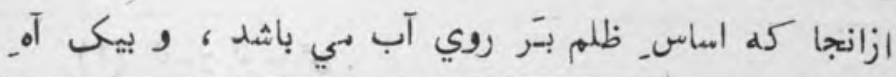

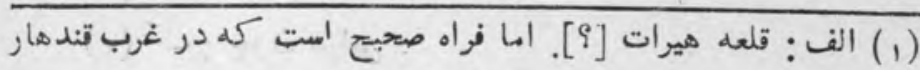

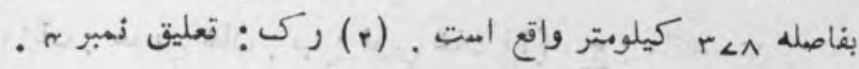
.

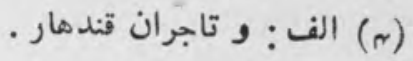


هظلومي از ياي درايد، و بر طبقـ مضمون :

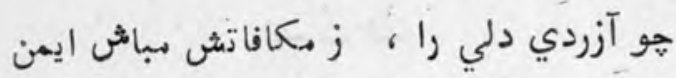

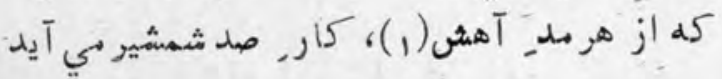

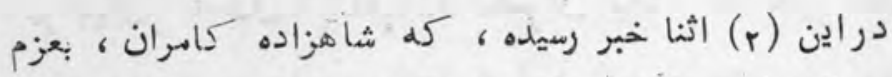

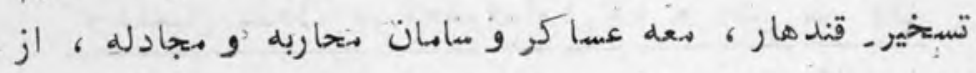

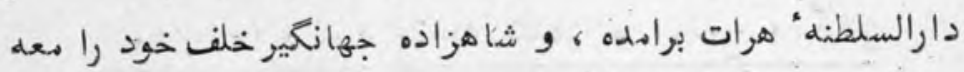

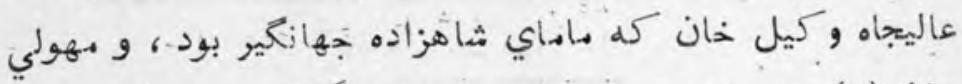

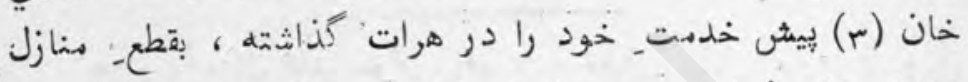

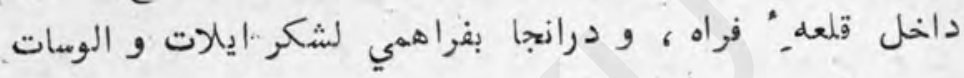

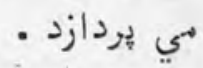

هون عاليجاه كلزارخان (r) باميزتُى كله با شاهزاده كامران

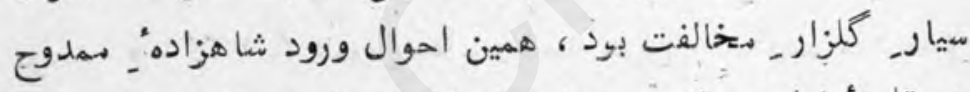

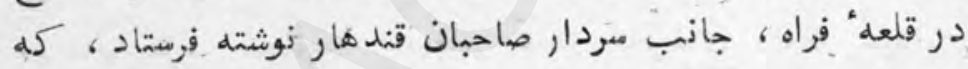

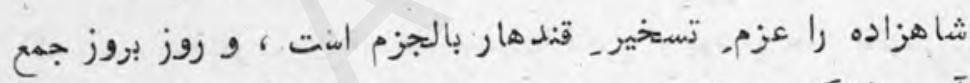

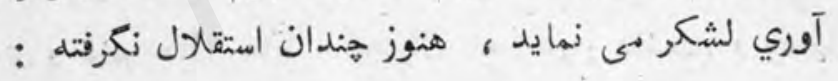

$$
\text { مسر حشمه شايد كرفتن به بيل (o) }
$$

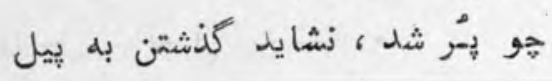

$$
\begin{aligned}
& \text { (1) الف : آه مدش . (1) }
\end{aligned}
$$

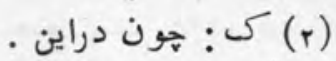

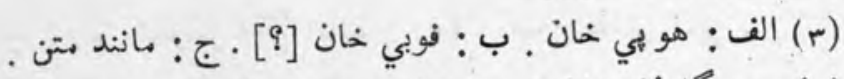
(ه) ب : كلعذار خان عموي شاه بِيسند باميزئي

$$
\text { ك (ه) }
$$


تازه نواي معارك

هر كاه بدفع شاهزاده موصوف برداززند ، وقت بـتر از حاللا

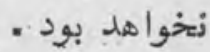

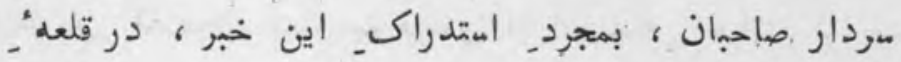

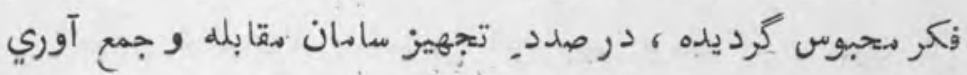
لشكر شده، در عرصه اندكن جمع آوري قشونات و سامان نموده،

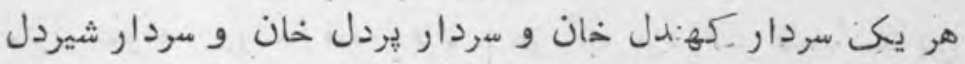

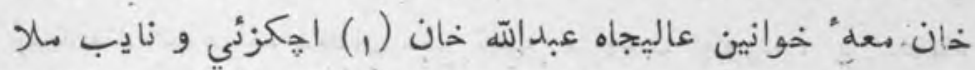

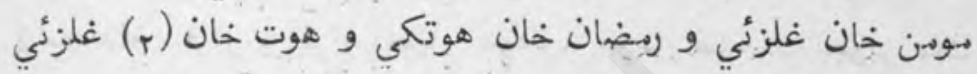

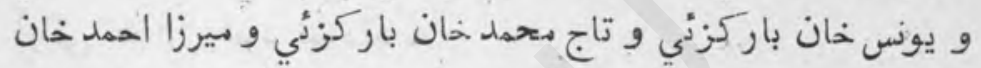

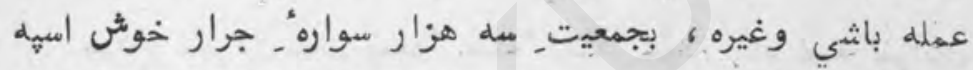

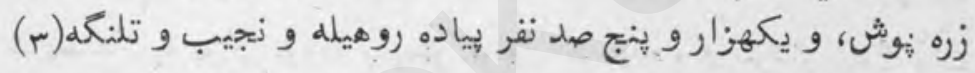

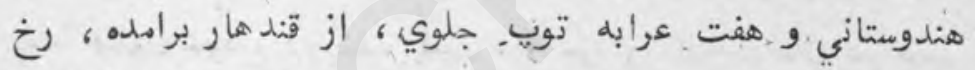

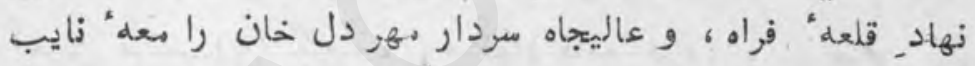

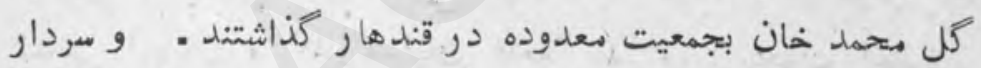

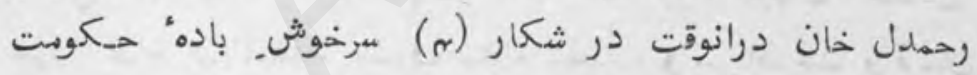

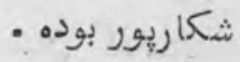

هر كاه سردار صاحبان سمدوح، بطي هنازل در منزل خرساركى(ه)

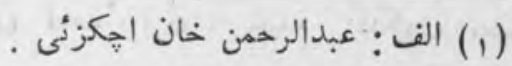

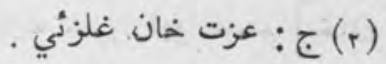

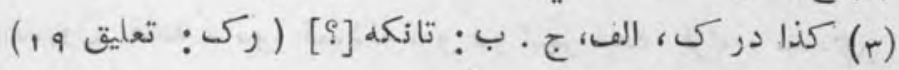

(r)

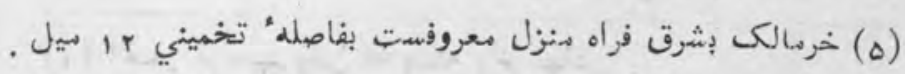


تازه نواي معارك

$1<\wedge$

هنزل انداز كرديدنده، درانجا خبر رميد ، كه شاعزاده كامران،

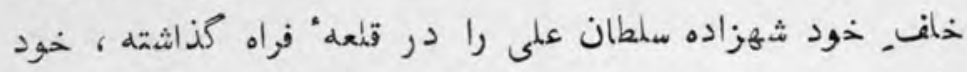

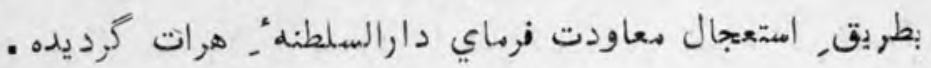

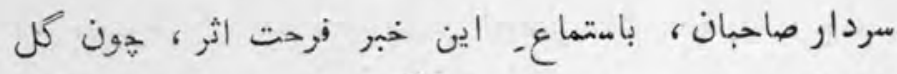

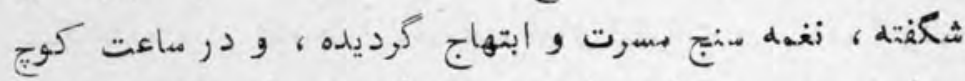

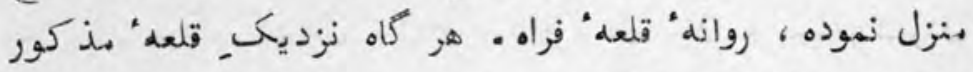

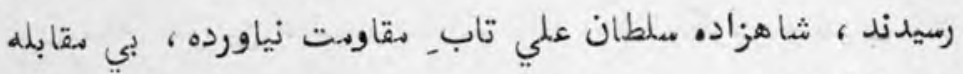

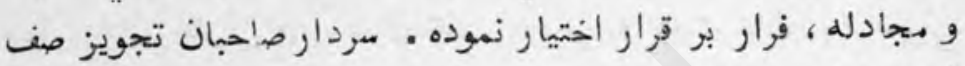

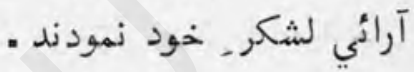

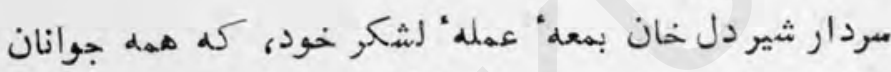

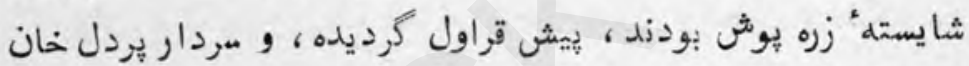
معله قشون خود ، در صف قلب ، و مردار كهندل خان در صف.

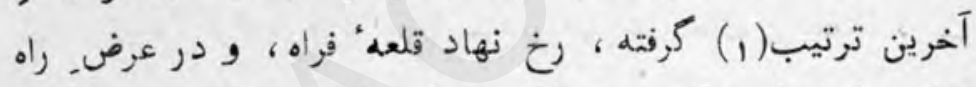

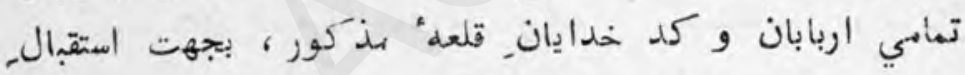

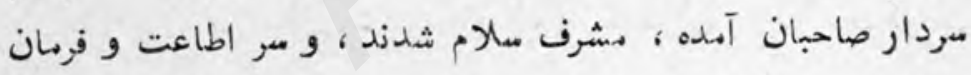

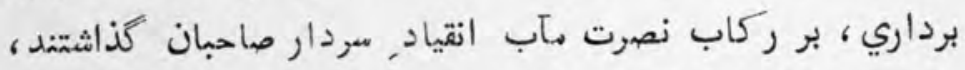

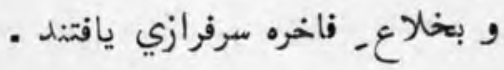

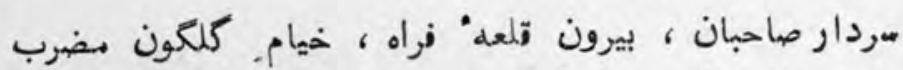

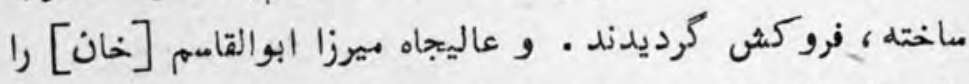

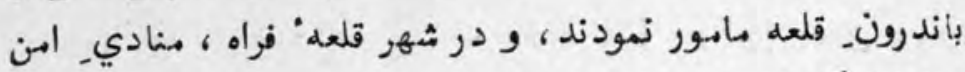

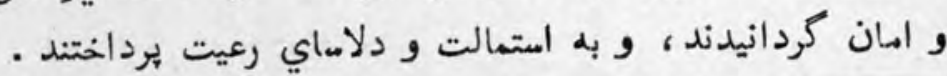
(1) الف: ترنيب يلتن ها بسته رخ نهاد . 
بعد از همند روز ، قلم تحصهيل ماليات جاري نمودند، و فتتح

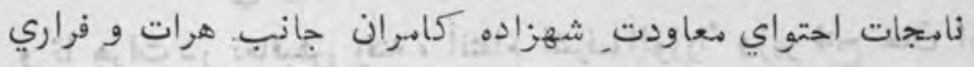

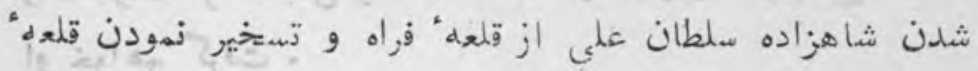

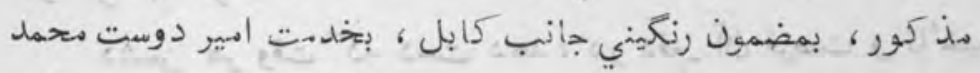

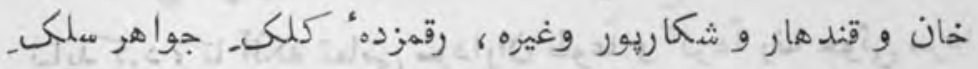

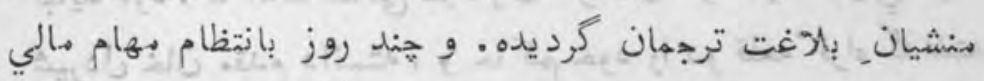

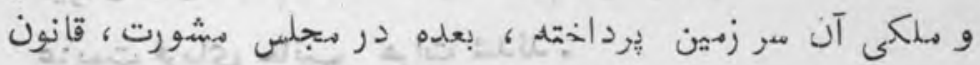

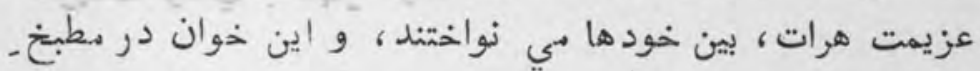

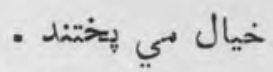

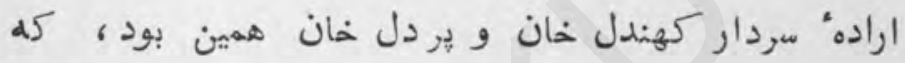

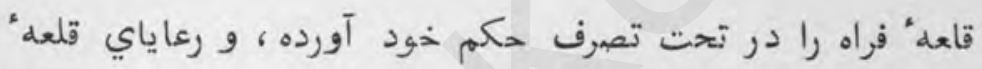

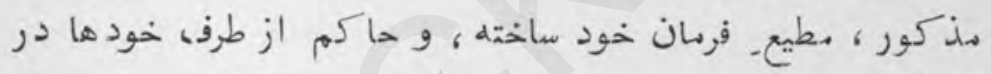

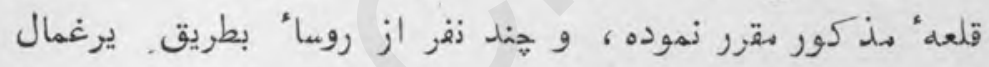

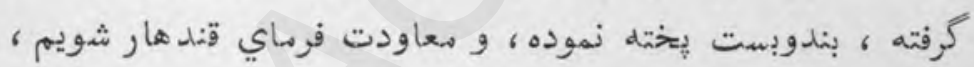

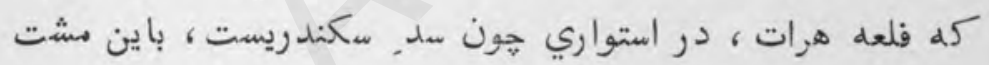

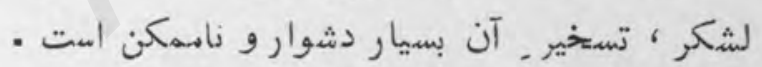

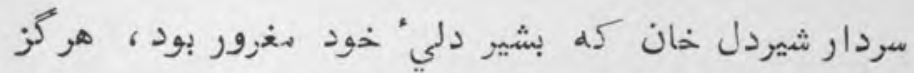

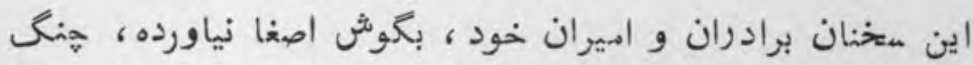

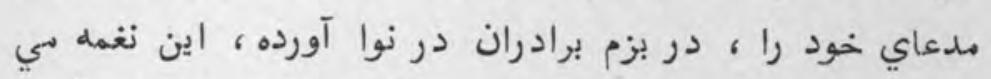

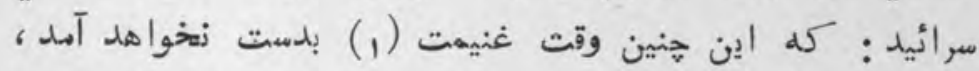

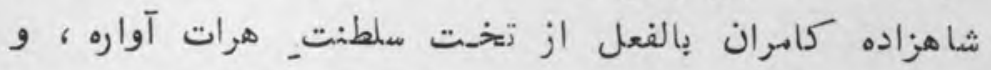

$$
\text { · (1) }
$$




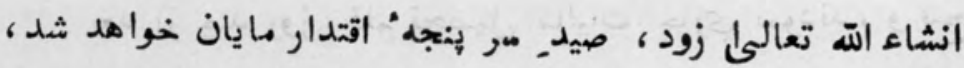

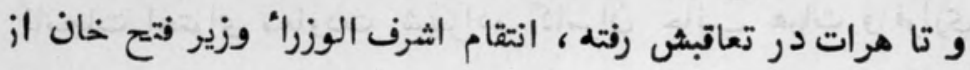

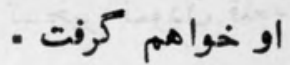

دشمن هر وقت كه دمت دهده ، در دفع- آن فرصت و تأخير

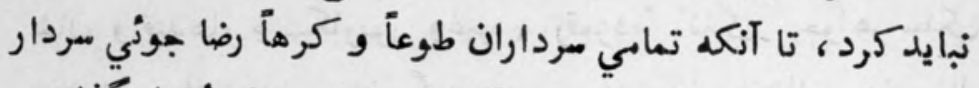

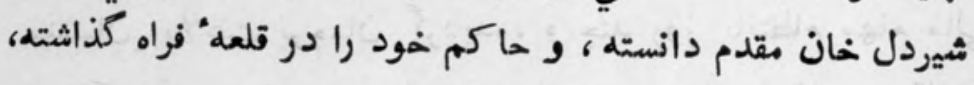

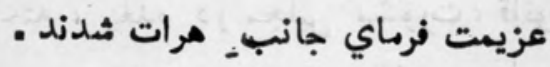


در بيان كشته شدنِـ. هـولىخان در قلعه هرات از دست, شاهزاده جهانكير

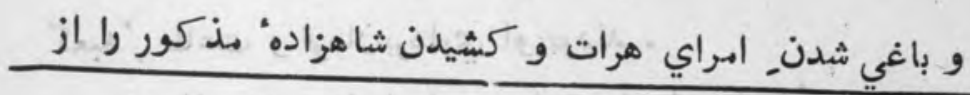

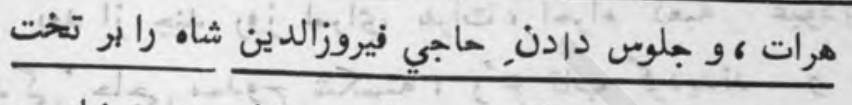

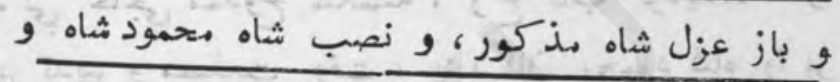

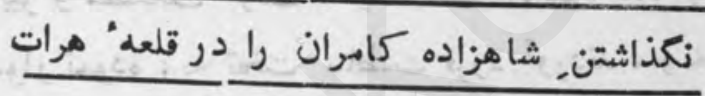

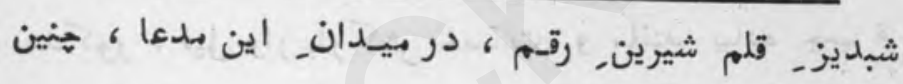

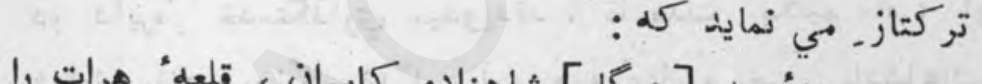

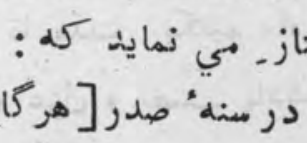

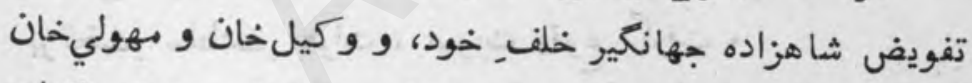

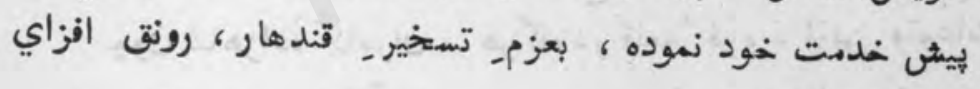

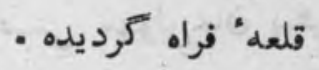

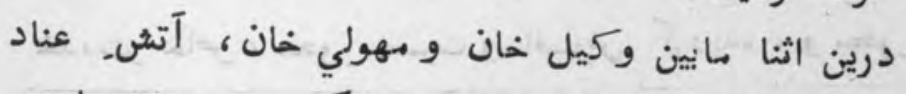

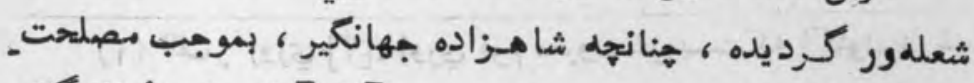
وكيل خان خالوي خود، صورت حيات_ [ اوـ ] از صنهل زند كاني

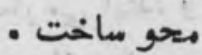

ازانجاكم دنيا ، دار ـ كافاتست ، بعد از هند روز عاليجاهان 
مصطفي خان زوري( )، و دوست محهد خان ابدال زئي وديكر امراء

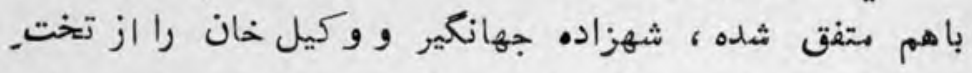

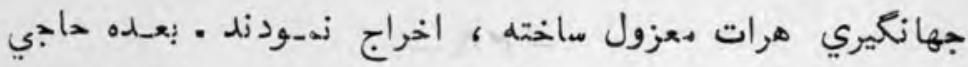

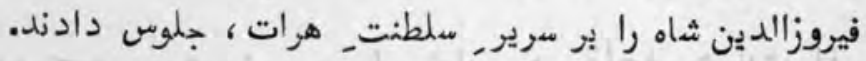

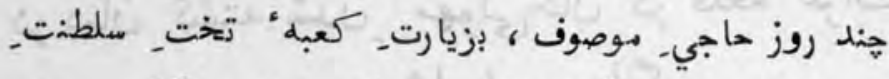

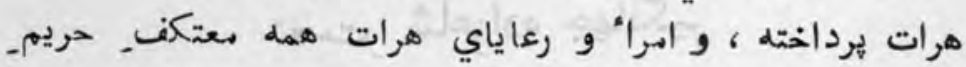

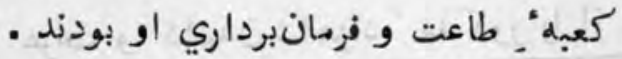

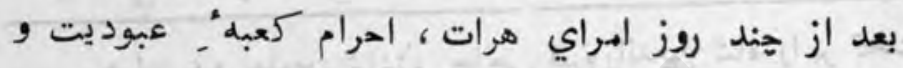

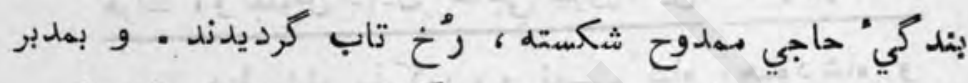

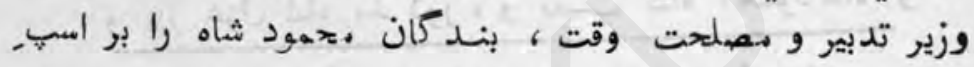

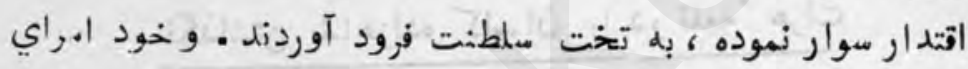

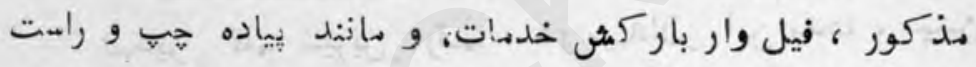

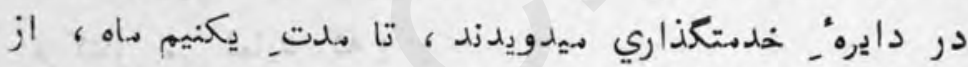

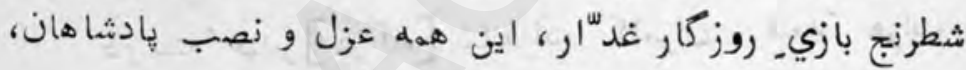

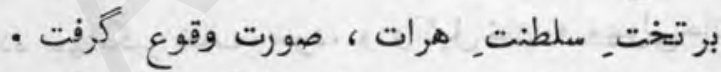

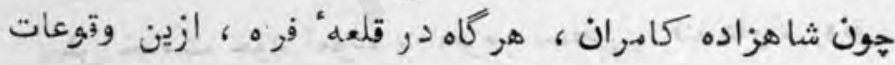

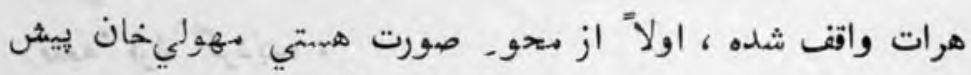

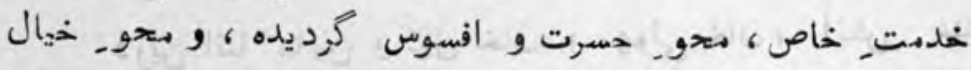

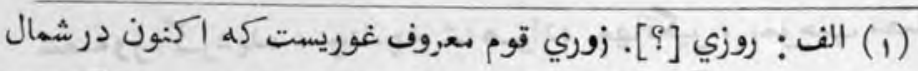

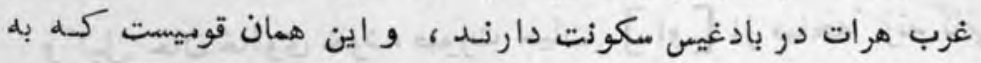

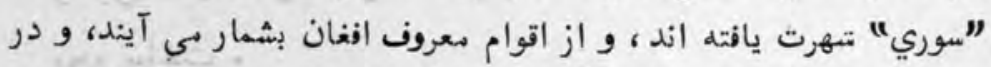

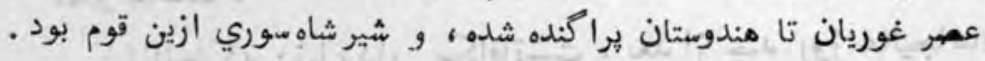

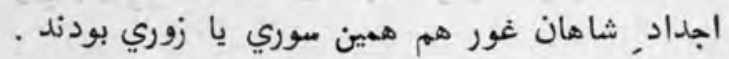


تازه نواي معار ك

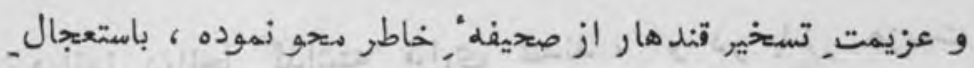

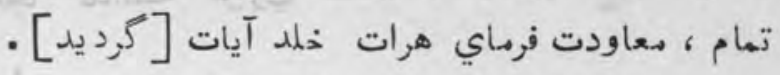

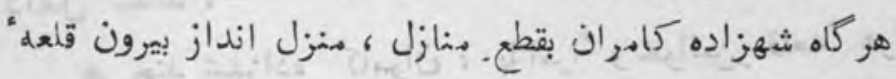

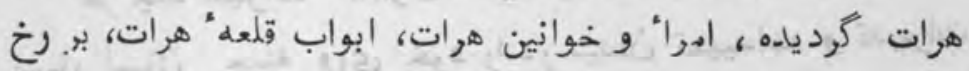

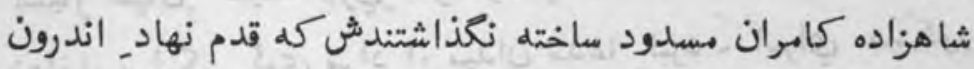

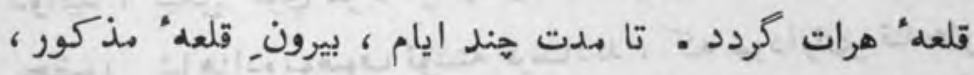

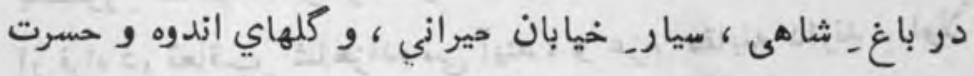

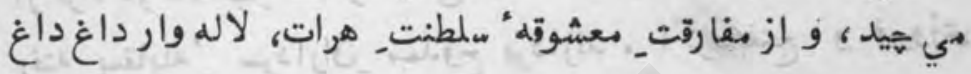

حزن و بيقراري .

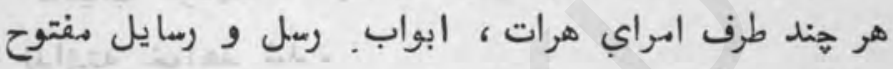

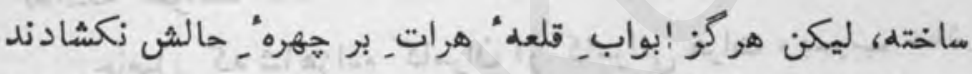

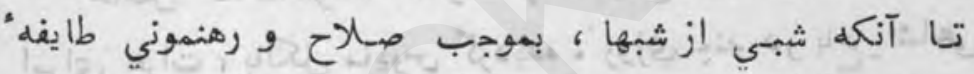

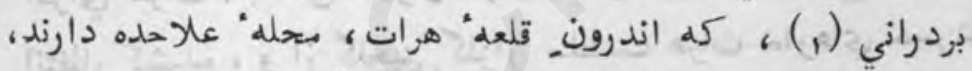

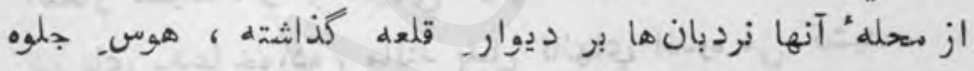

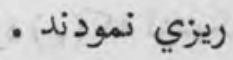

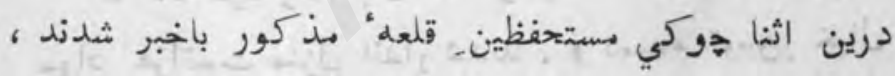

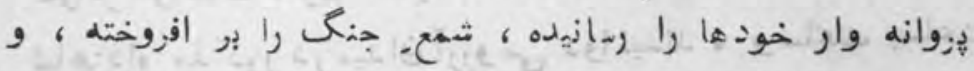

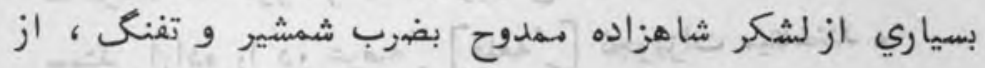

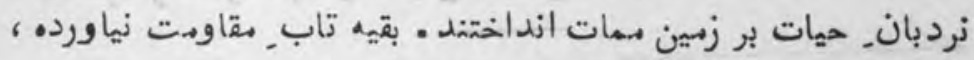

(1) بَردرانى طايفه ايست از افغانان ، كه بـ بادراني از يكى نثرادند.

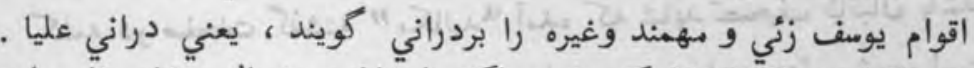

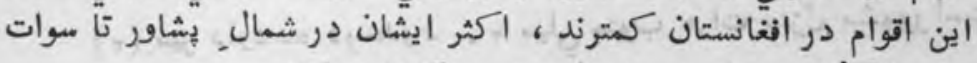

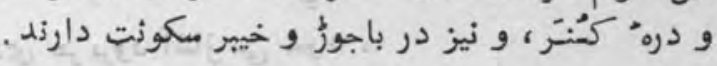


تازه نواي معارك

IAN

نردبانها درانجا كذاشته فراري شدند ، - و در باغ- هزيمت

- داخل شدند

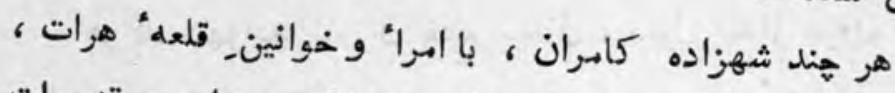

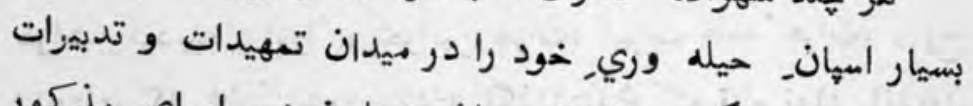

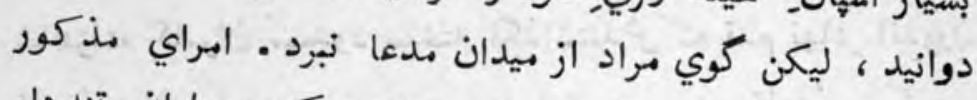

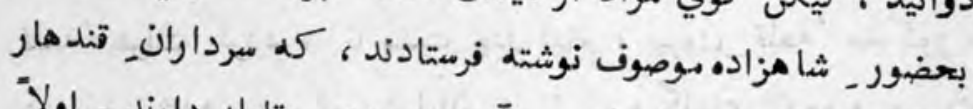

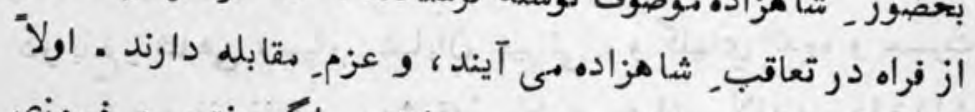

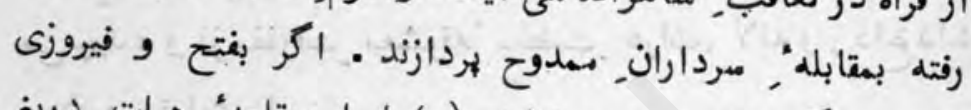

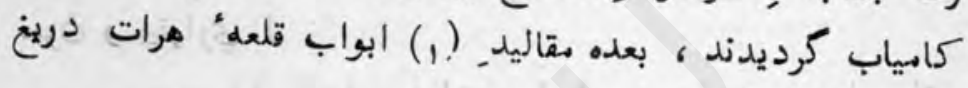

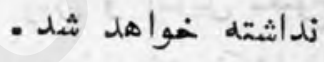

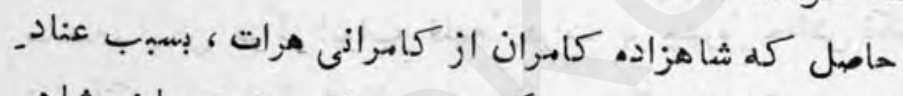

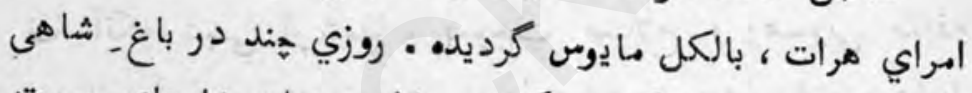

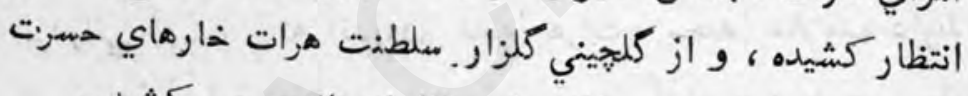

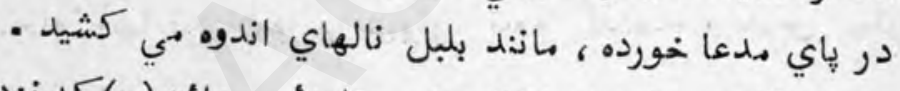

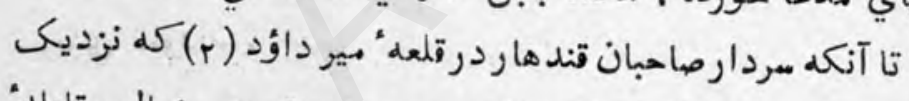

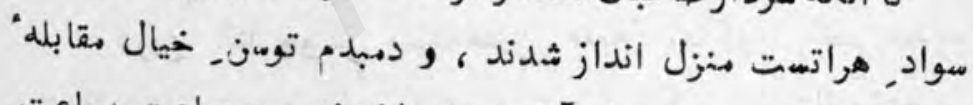

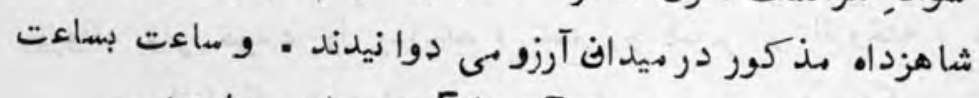

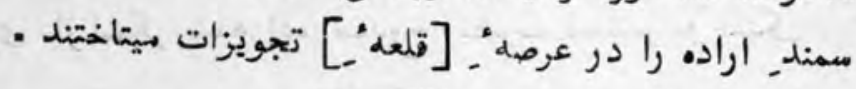

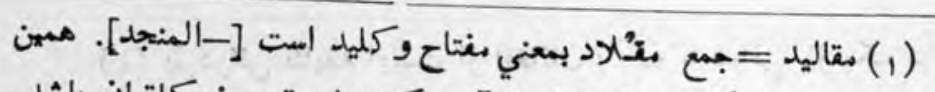

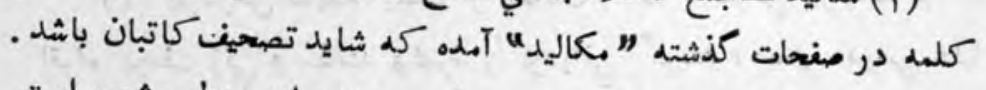

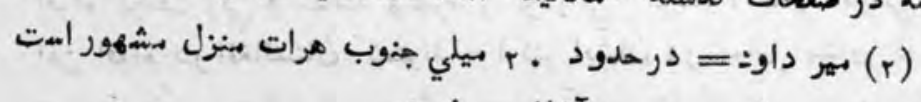

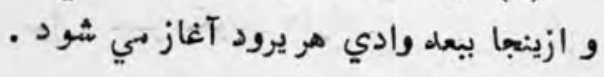


- rq-

در بيان. رفتن سردار صاحبان قندهار از قلعهء فراه

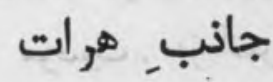

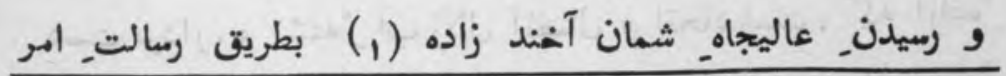

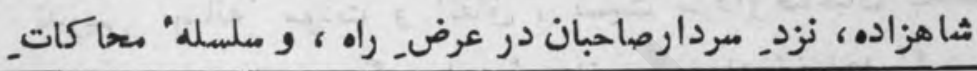

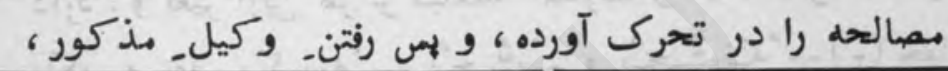

بيحصول_ بدعا

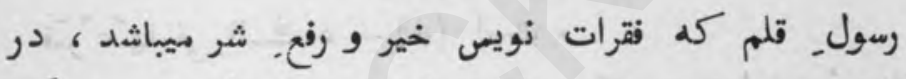

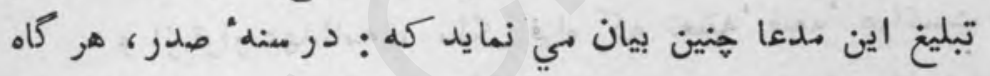

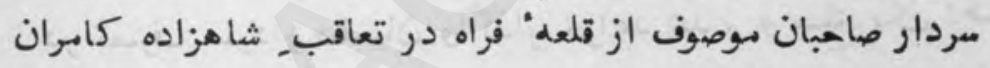

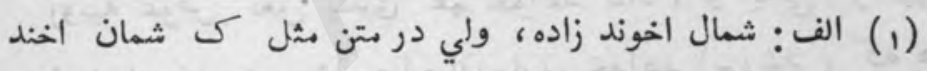

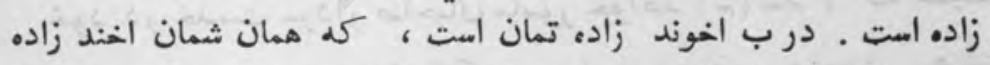

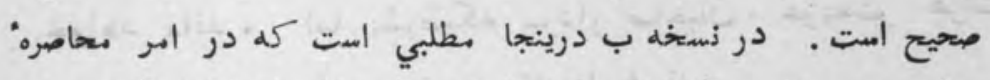

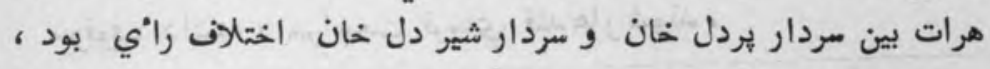

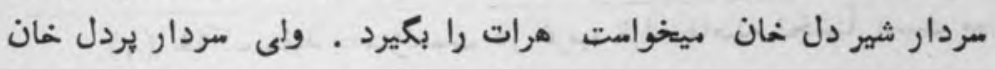

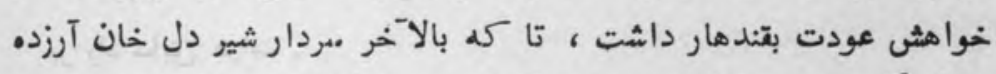

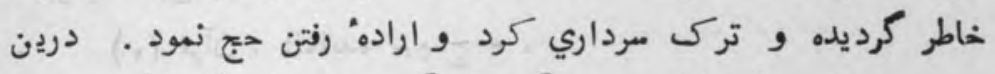

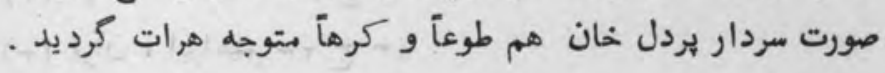




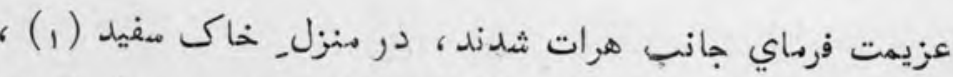

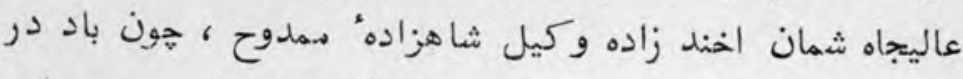

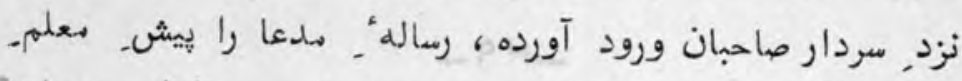

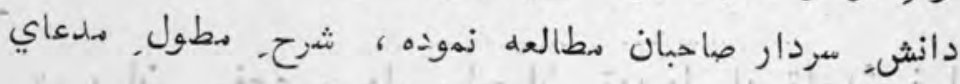

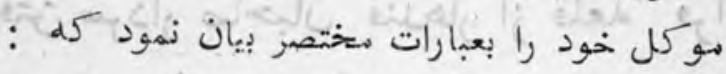

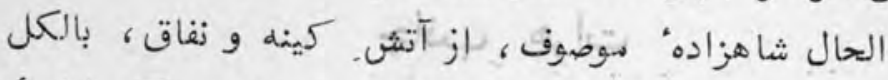

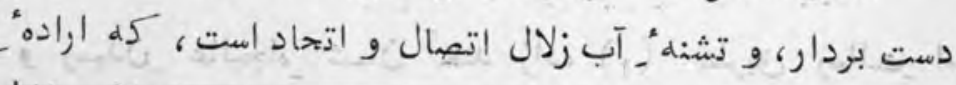

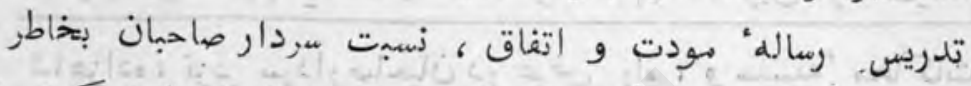

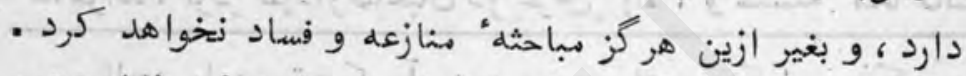

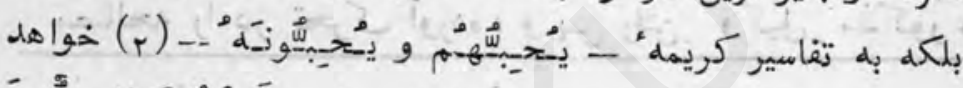

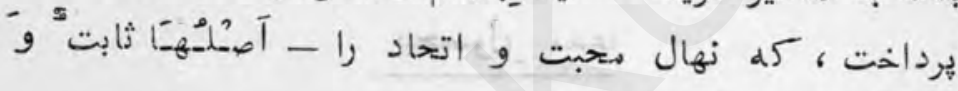

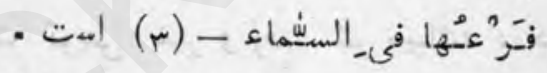

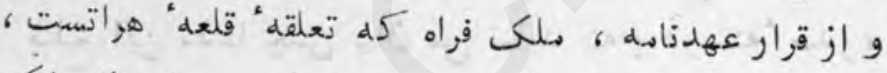

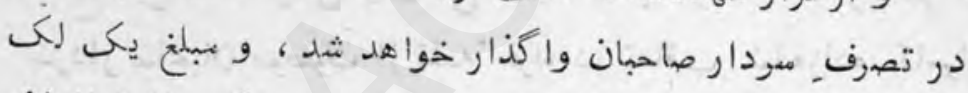

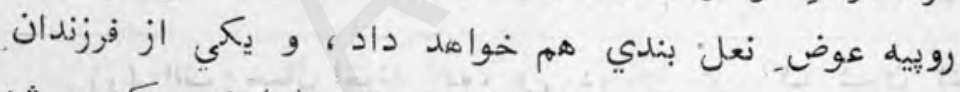

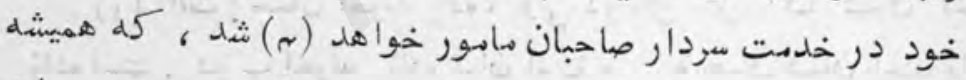

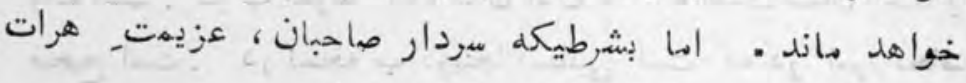
موقوف داشته ، مـراجعت فرهاي قنده هار شوند.

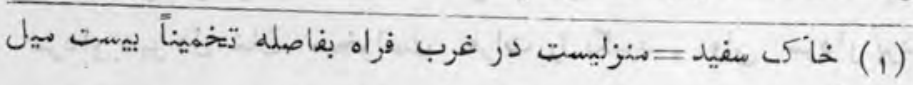
بر راه سابق هرات .

· قرآن ، المايده (r)

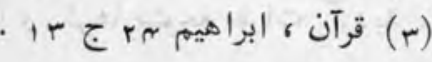

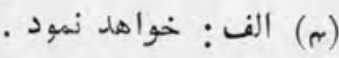


هر كاه سردار صاحبان از [بيان] شمان اخند زاده وكيل

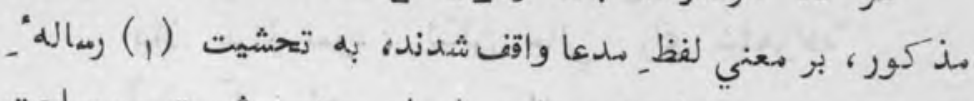

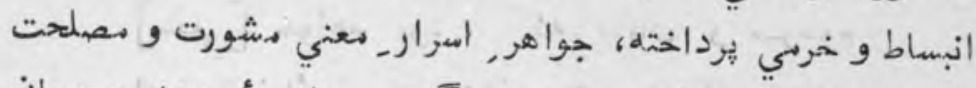

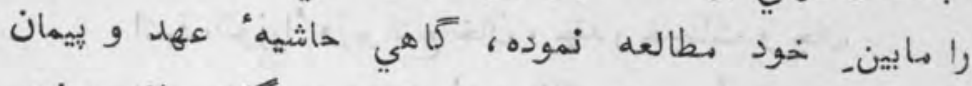

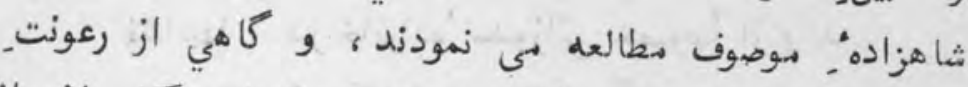

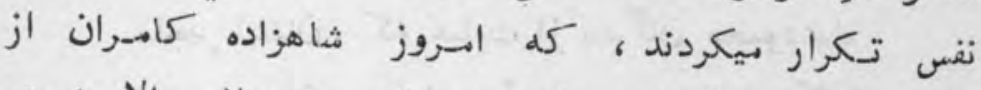

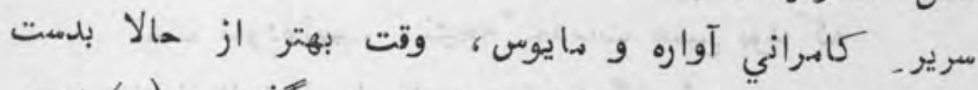

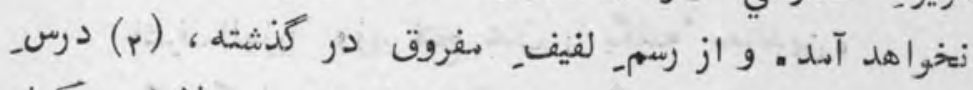

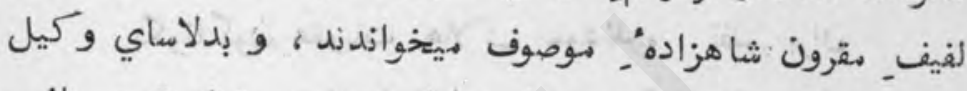

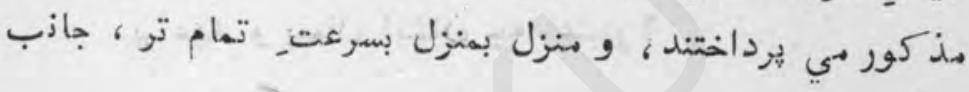

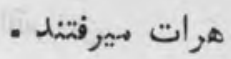

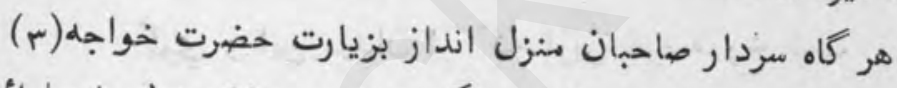

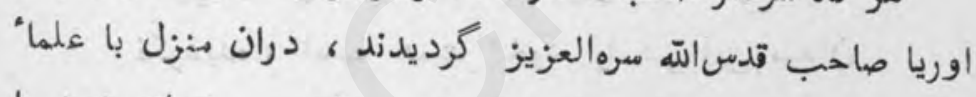

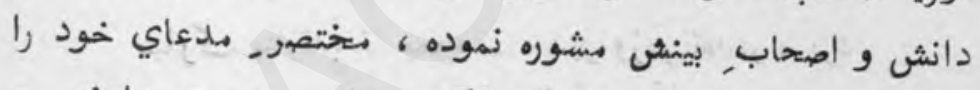

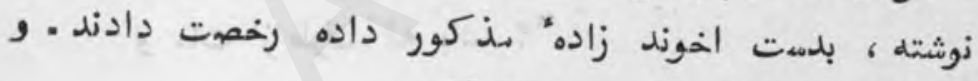

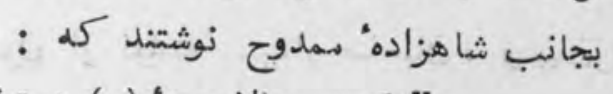

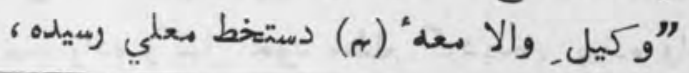

$$
\begin{aligned}
& \text { (1) الف : الخست رساله . }
\end{aligned}
$$

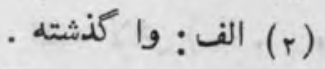

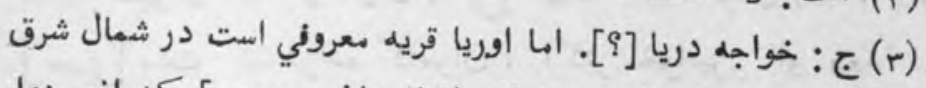

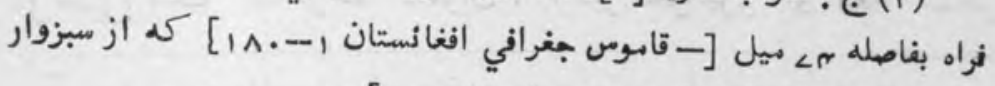

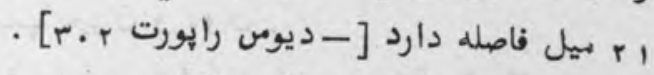

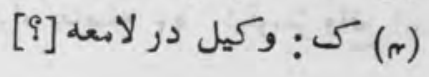


تازه نواي معارك

$1 \wedge \lambda$

سخناني كله مقرون مصالحه و رفع. منازعه بود بيان طراز نمود ، ليكن حاليـ راي شاهزاده:

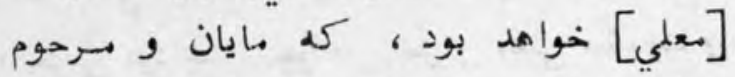

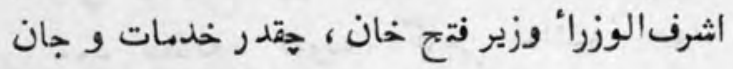

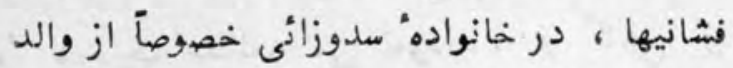
ماجد_ايشان، كله عبارت از بند كان محمود شاه

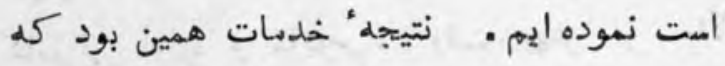

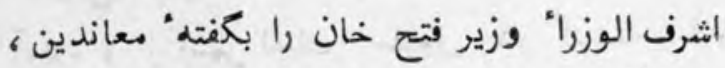
بكونا كون عتوبات هلاكى نهودند . نظر بران بر عهل و بيهمان ايشان حه اعتبار

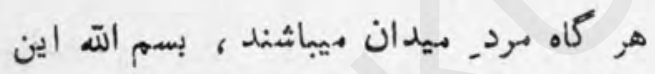

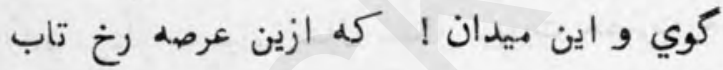

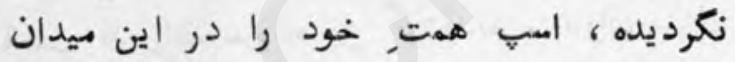
مبارك بتازند، تا بموجب مدبر وزير تقدير ، برد

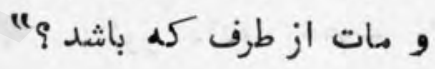

شاهزاده كامرن هون از نوشته" سردار صاحبان ، و بيان_

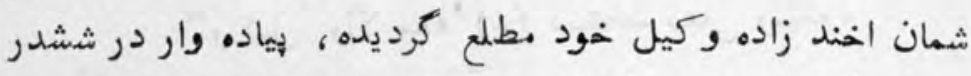

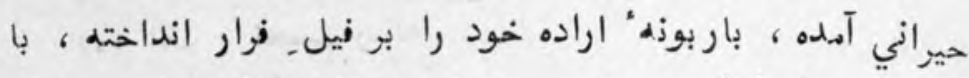

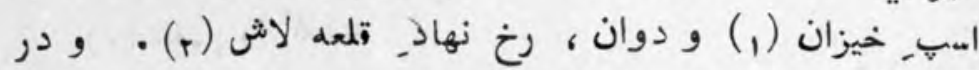

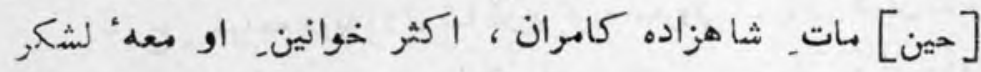

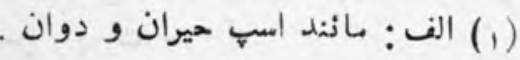

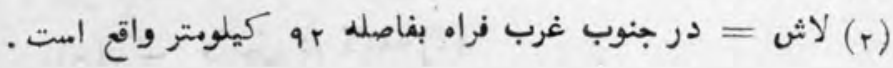




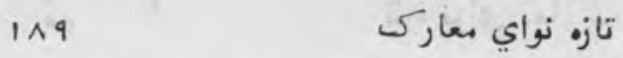

آمده ، مشرفـ امتيلام مردار صاحبان شدند، و بخغلاع فاخره

مرفرازي يافتند مئد

و باز درين اثنا" وكلاي بند كان محهود شاه و امراي مرات ،

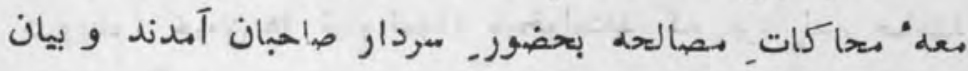

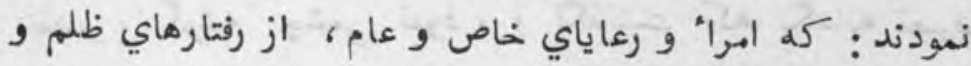
تعدي شاهزادهُ موصوف ، در كوره" عذاب و ناخوشي (1) بودند.

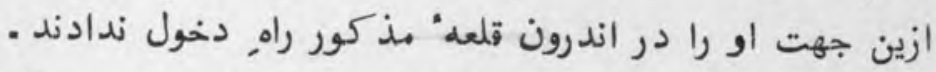

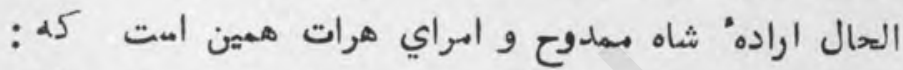

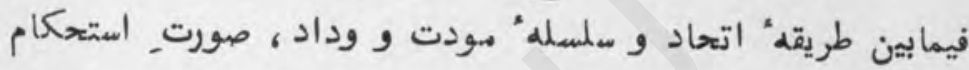

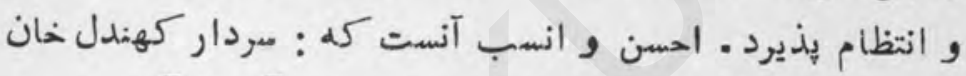

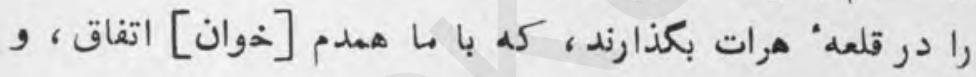

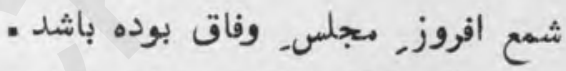

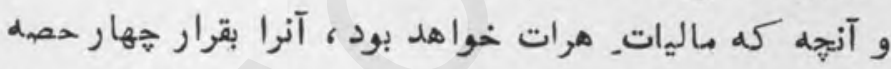

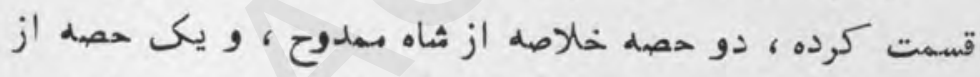

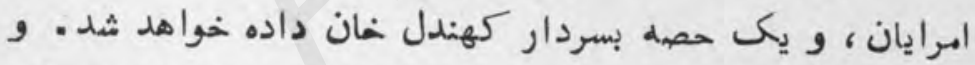

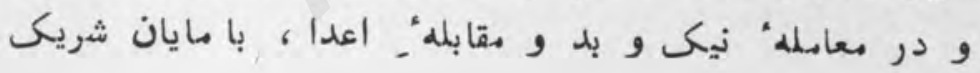

خواهد نود بود

مردار صاحبان باين قسهت راضي نشدند . بلكه فريسب بازي

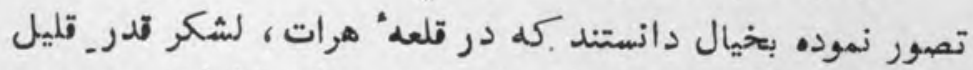

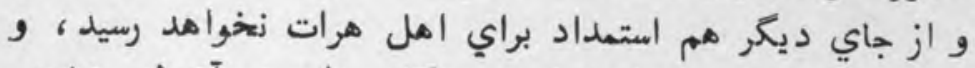

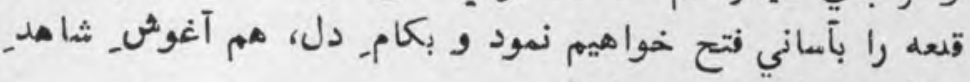

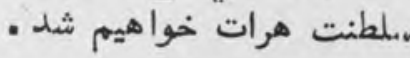

• (1) (1) 
تازه نواي معاركى

وكلاي امراي هرات را بجواب صاف برداخته رخصت داد دادند.

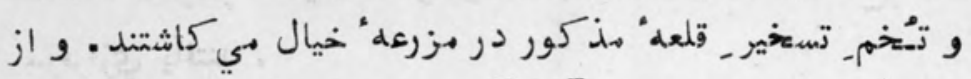

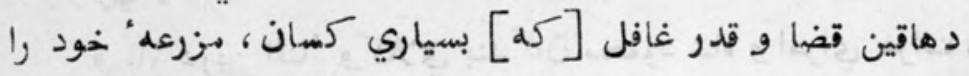

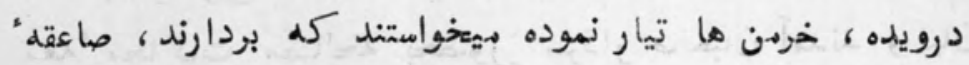

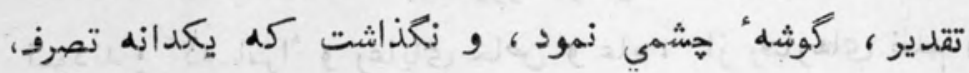

نمايند . 


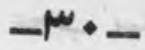

در بيان_ جنك نمودن_ سردارانـ قندهار با امراء و خواذين_ هرات و فريب خوردن ان از محمد خان

\section{خلف عيسي خان كوهي}

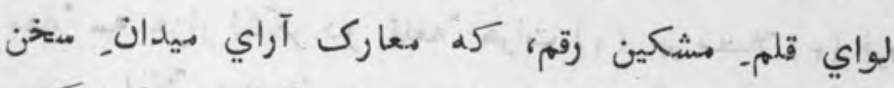

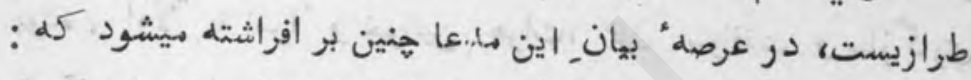

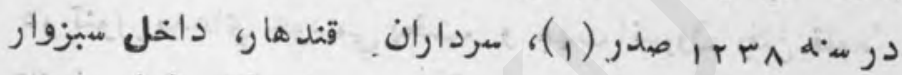

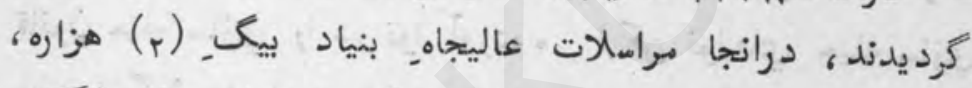

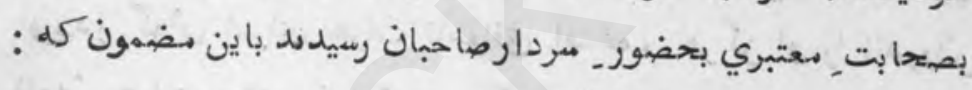

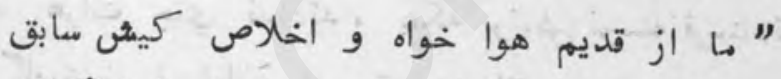

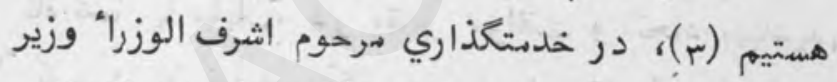

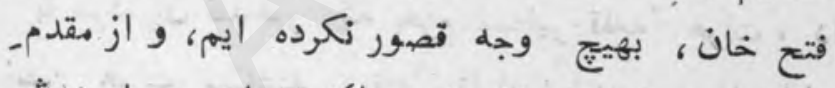

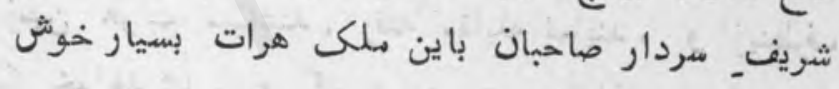

$$
\text { • منديم }
$$

در حال قلعه هرات، خالي أقتاده، بدون سصطفي خان

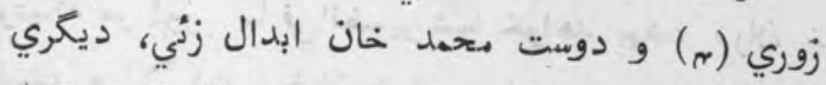

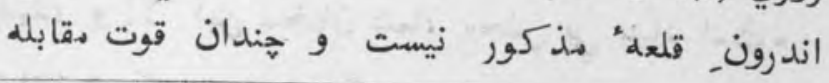

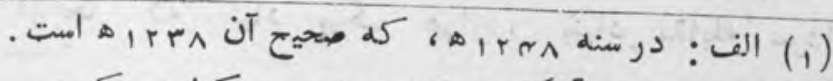
(r)

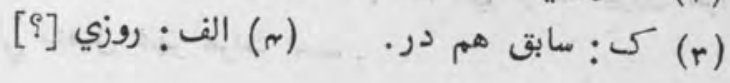


تازه نواي مبارك

195

ندارند. هر كاه سردار صاحبان بزودي تشريف فرماي

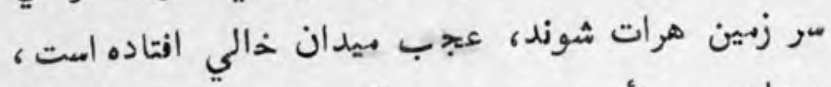

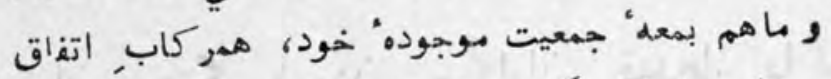

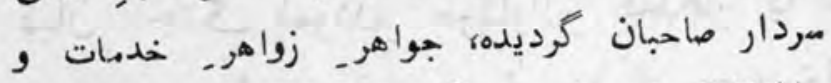

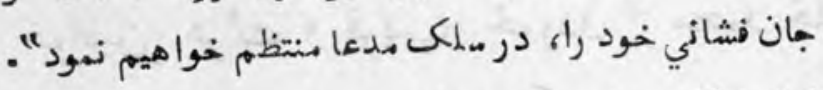

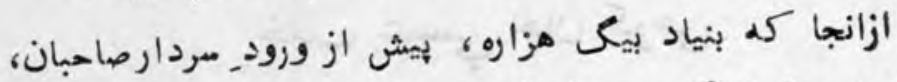

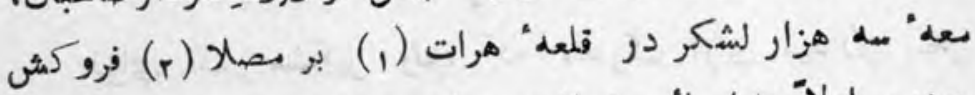

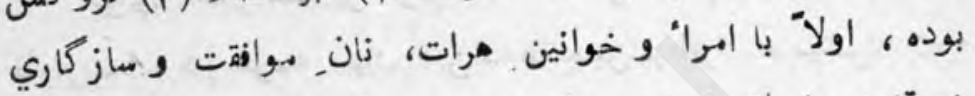

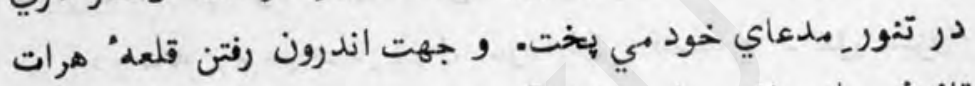

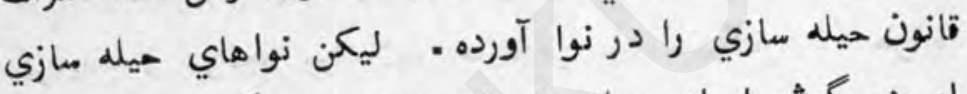

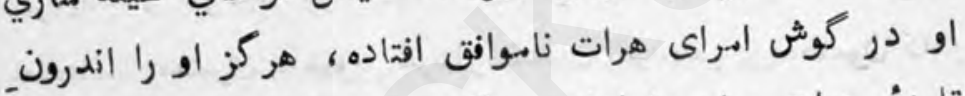

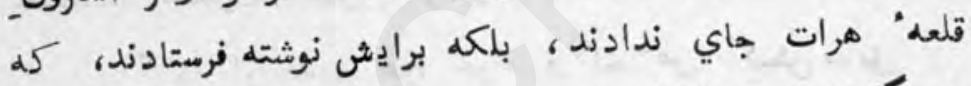

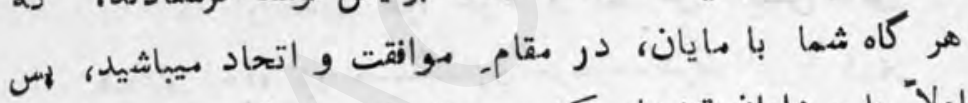

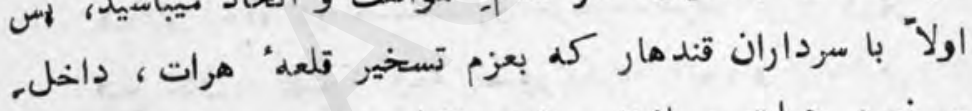

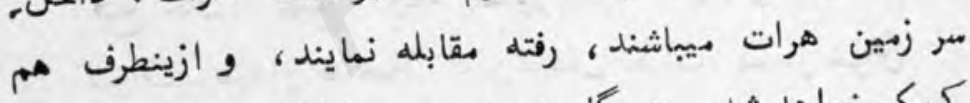

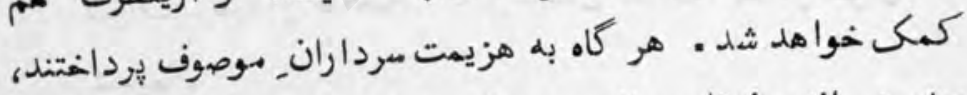

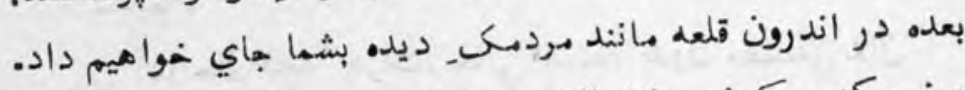

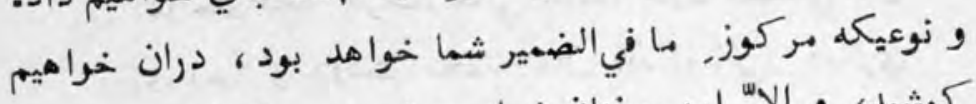

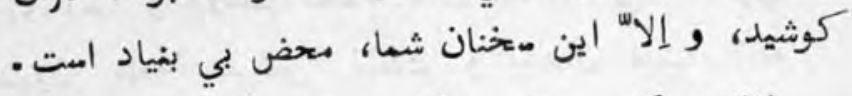

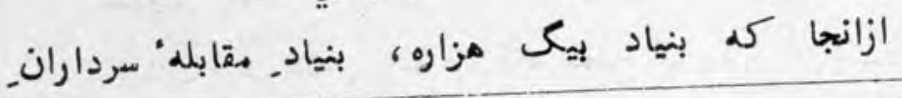
(1) الف: لشكر واقعه هرات. ب : مصلاي واقعه بيرون هرات.

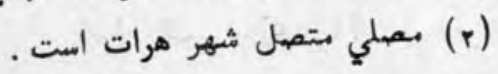


19

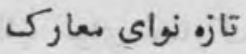

مذكور نداشت، و از امراي هرات هم بنياد كار ـ خود مبحكم

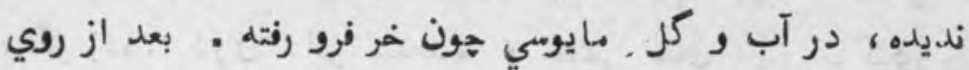
مصلحت، بوضع ارتفاع بنياد. كأخ محبت و اتحاد مردار صاحبان

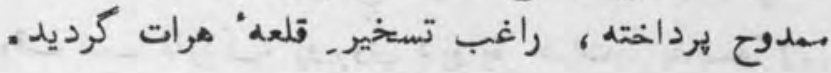

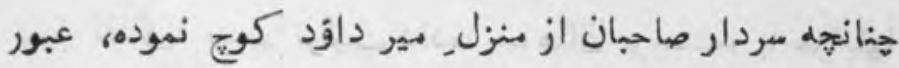

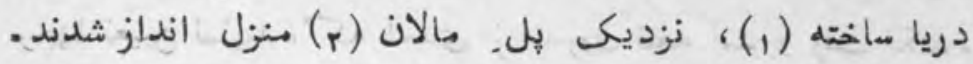

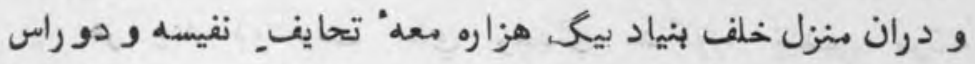

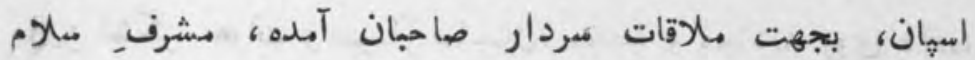

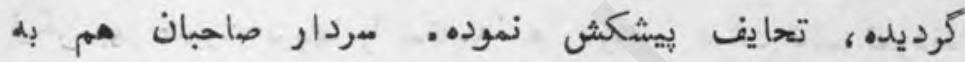

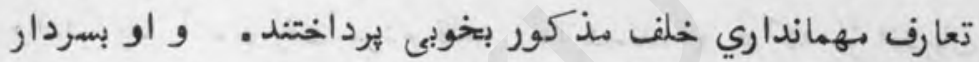

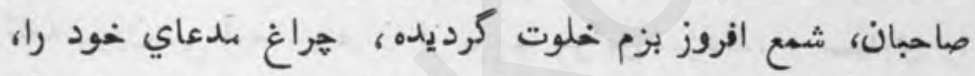

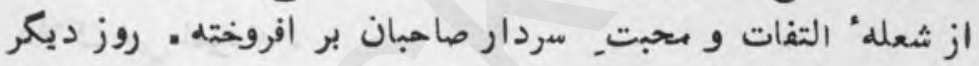
رقم رخصتي از دفتر خانه 'مهرباني و عنايت سردار صاحبان ممدوح

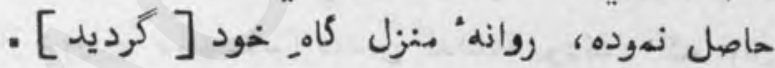
روز- سوم عاليجاه سردار كهندل خان، بجهت مالوقات

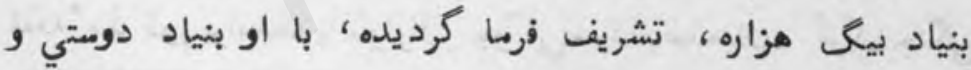

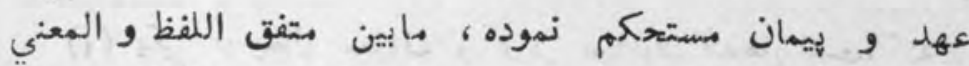
شدند • بعده در تجويز و تدبير وضع بنياد محاصره "تلعه "هرات

- ماعي كرديدند

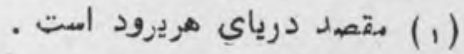

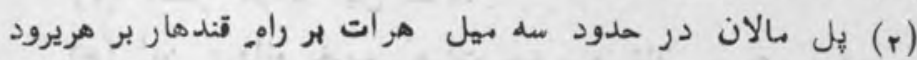

واقع امت . 
سردار صاحبان طرف نشرق، بفاصله" نيهم كروه قلعه" هرات

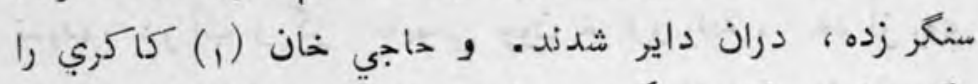

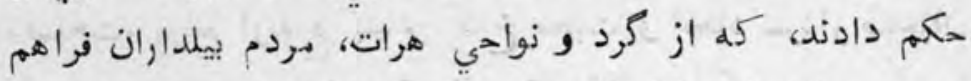

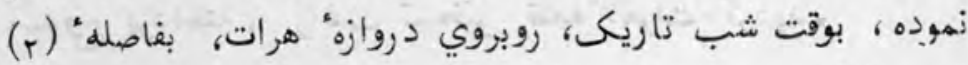

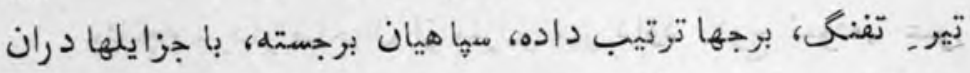

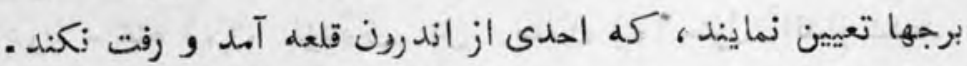

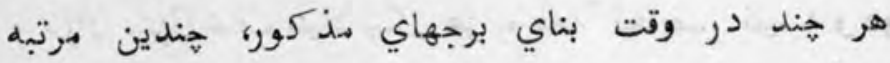

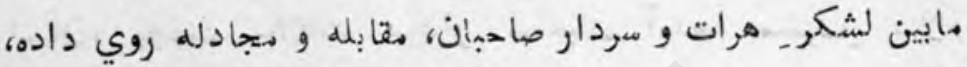

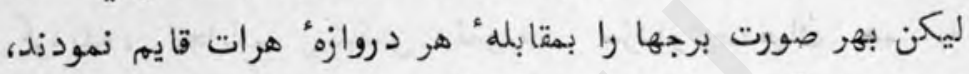

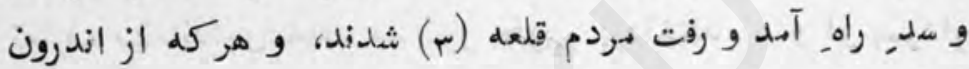

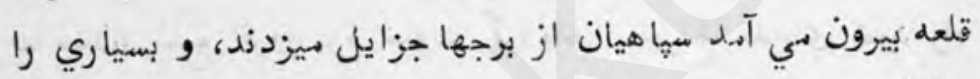

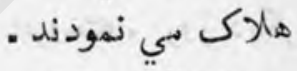

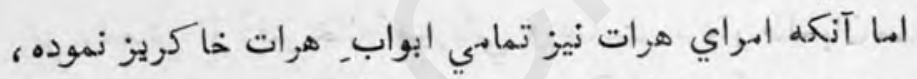

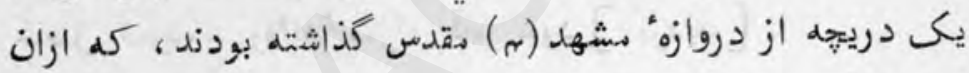

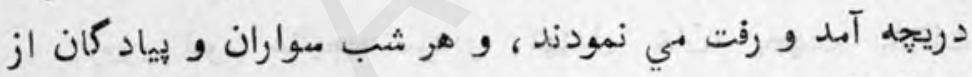

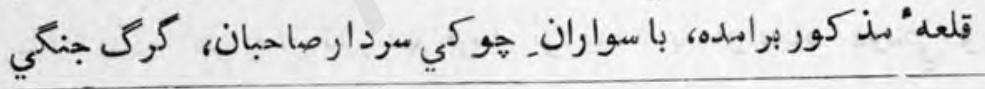

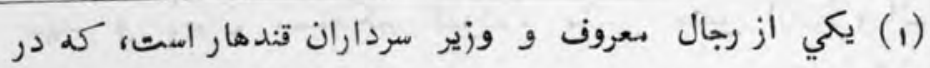

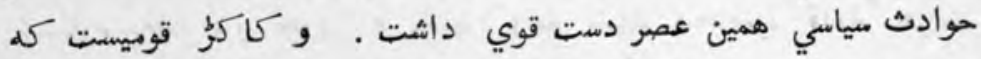

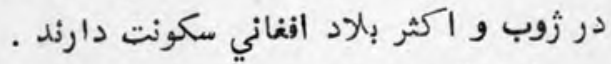

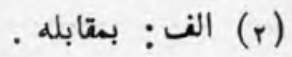

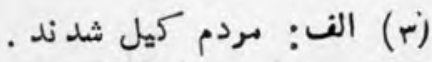

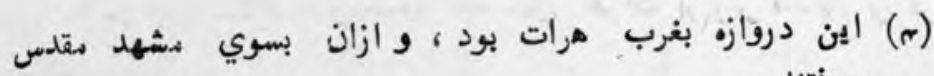


تموده ، كشته و كشتانده باز باندرون قلعه" مذ كور ميرفتند،

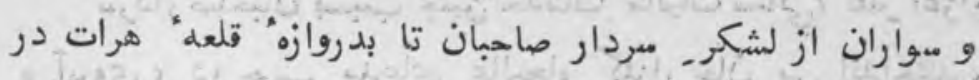

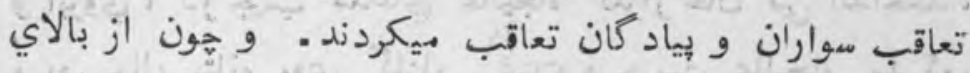
قلعه، ، شلكـ اتواي و جزاير (1) مي نمودند، سواران سردار

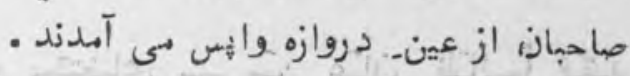

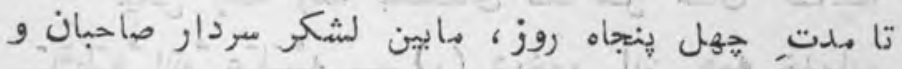

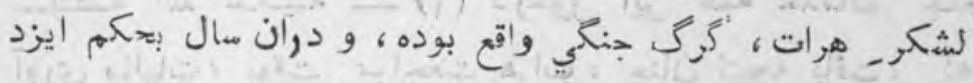

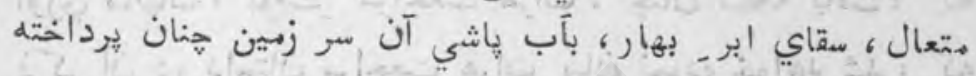

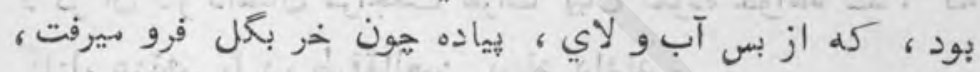

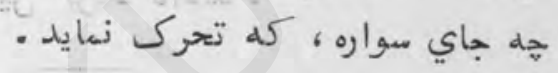

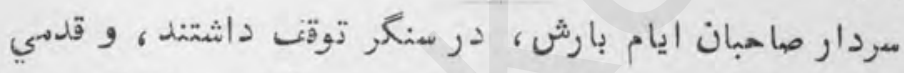

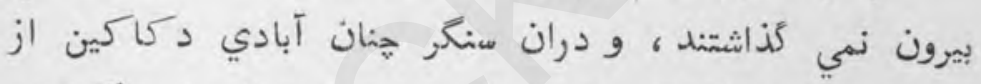

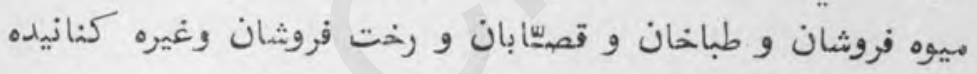

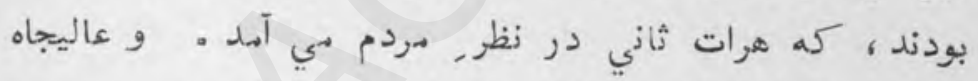

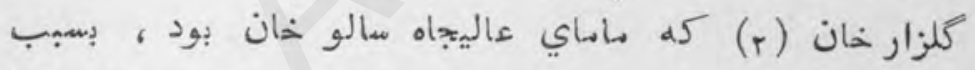

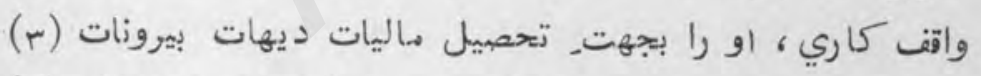

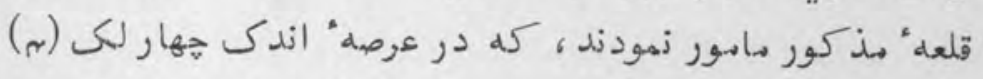

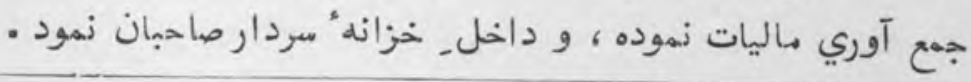

$$
\begin{aligned}
& \text { (1) الف: و ج جزائيل ها بي نمودند . }
\end{aligned}
$$

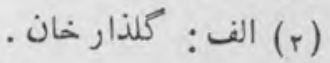

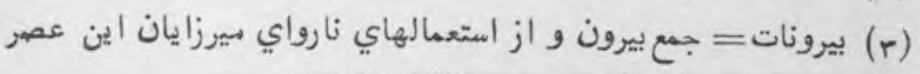

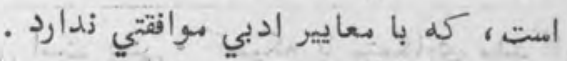

$$
\begin{aligned}
& \text {. }
\end{aligned}
$$




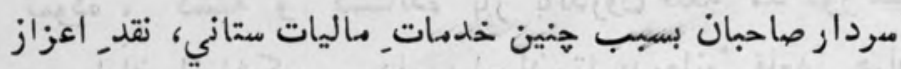

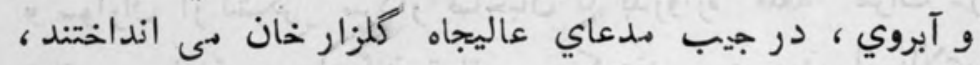

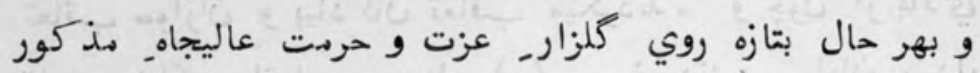

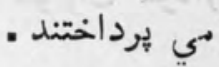

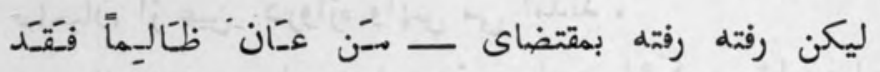

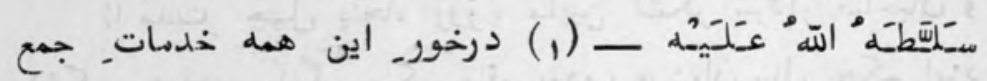

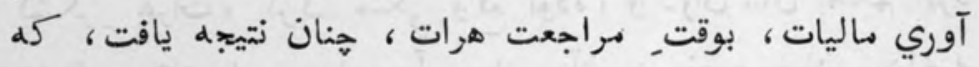

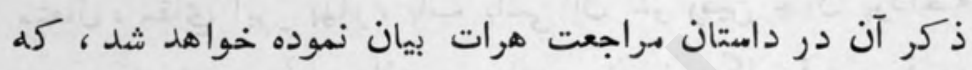

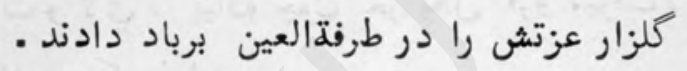

(1) مقوله" عر بى است يعني : كسيكه با ستمكاري مدد كاري كرد ،

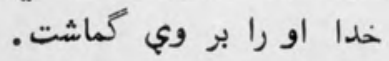


در بيان رفتنــ سردار شير دل خان براي ماكاقات محمد خان كوهي و آكاه شدن از فريب بان بازى كوهيى مذكور و باز آمدن در هرات آكات

ابر_ قلم سيه رقم، كمه اقطار (1) بار لآلي. سيخنان آبدار

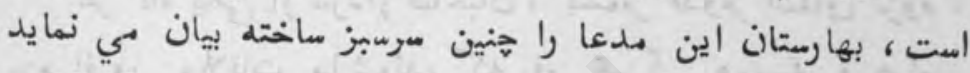

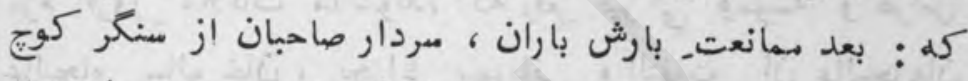

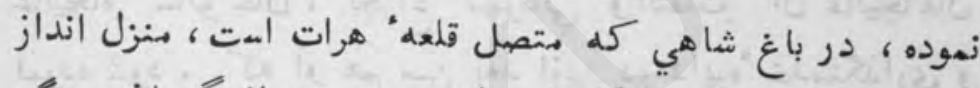

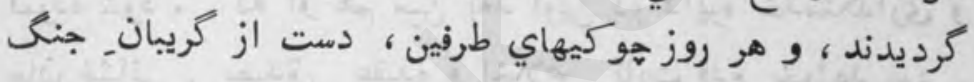

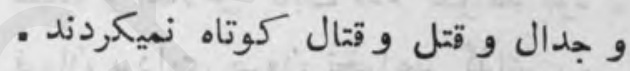

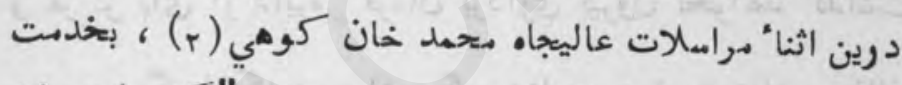

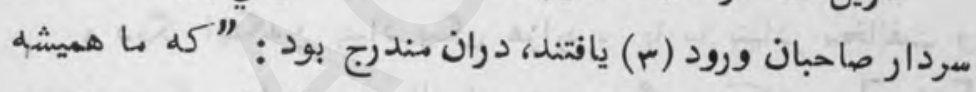

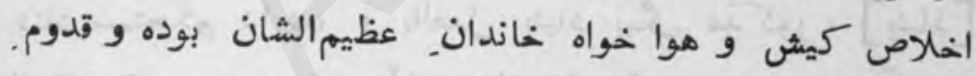

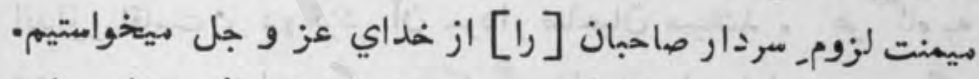

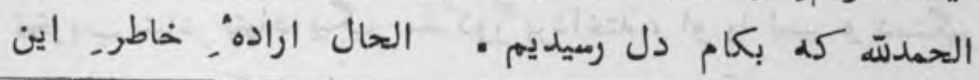

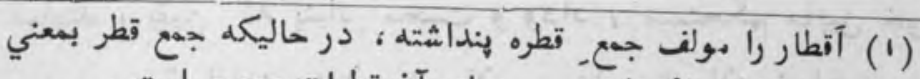

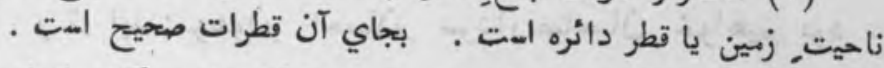

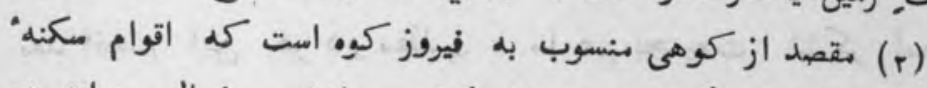

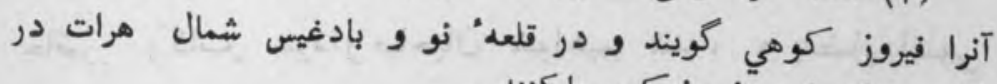

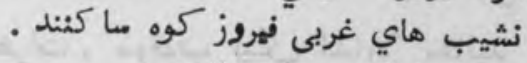
ك (r) 
تازه نواي مeارك

$19 x$

اخلاص كيش همين است كله باهم متفق كرديده ، مهرم تسخير

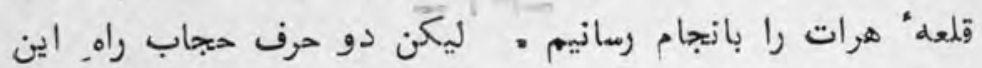

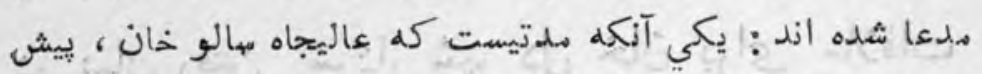

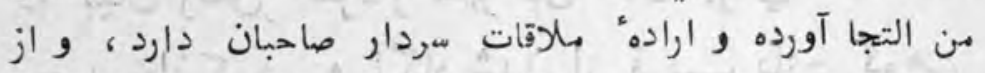

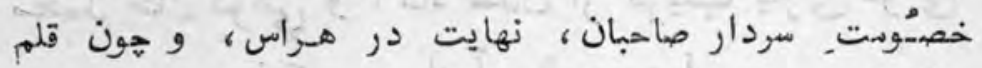
سركردان فقرات نويس. وسواس !

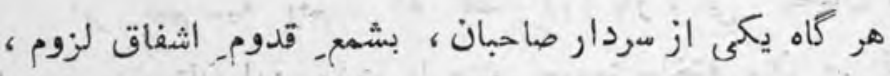

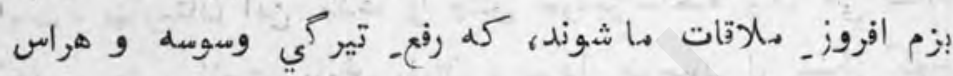

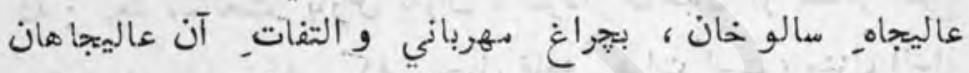

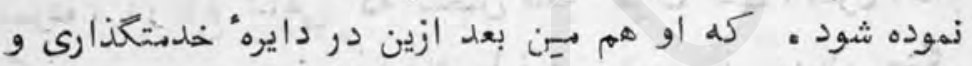

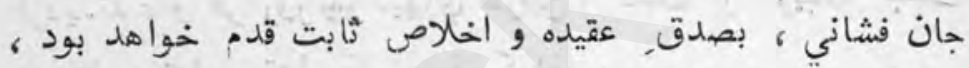

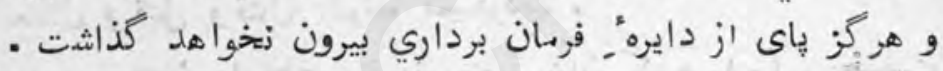

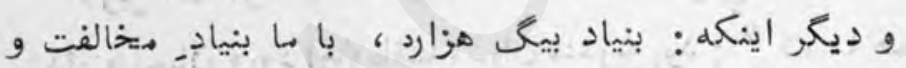

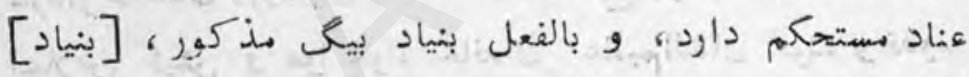

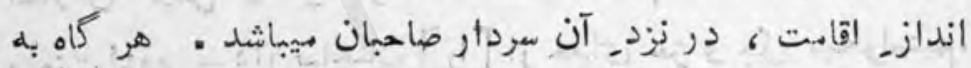

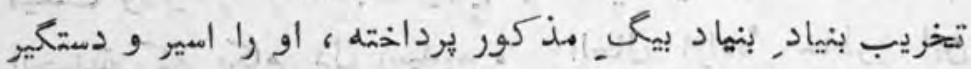

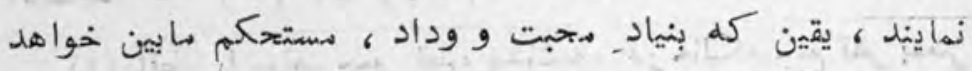

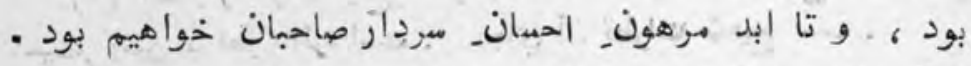

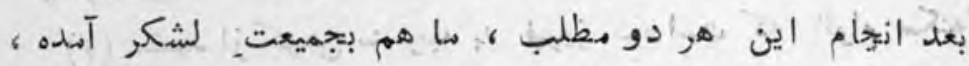

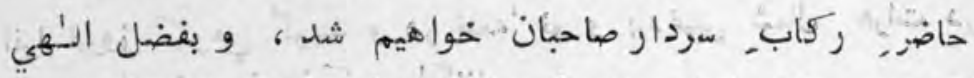

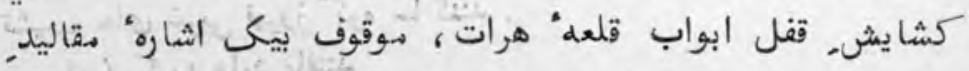

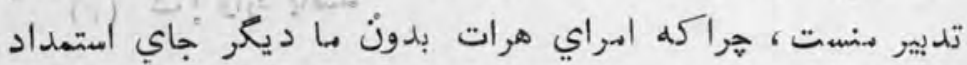




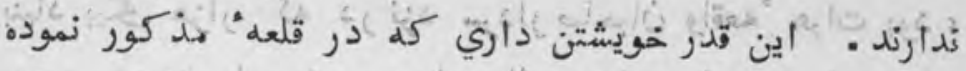

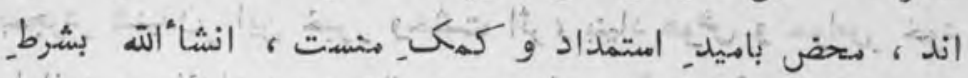

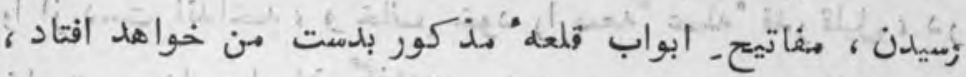

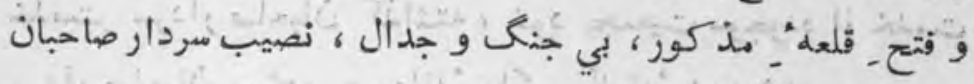

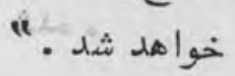

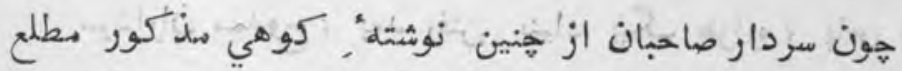

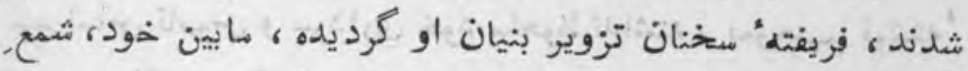

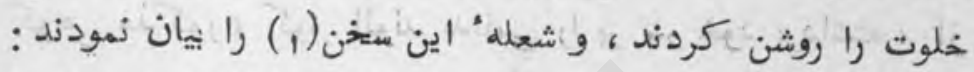

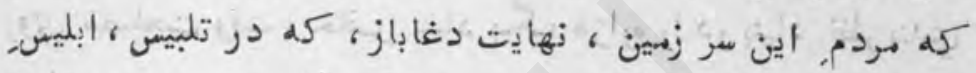

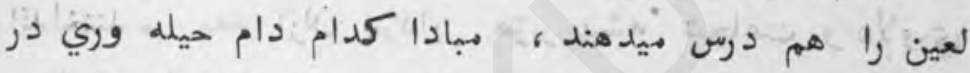

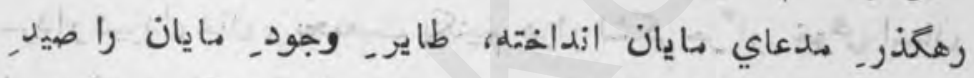

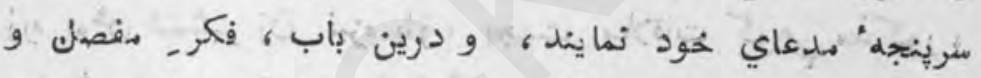

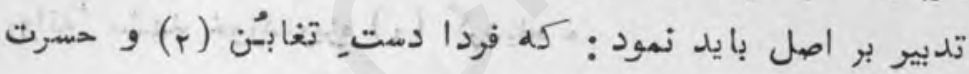

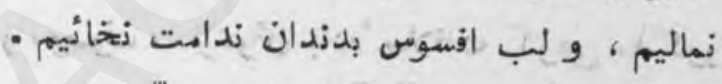

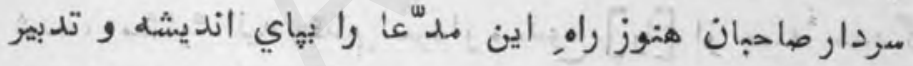

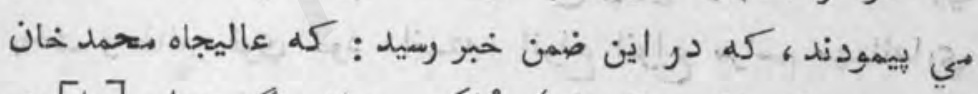

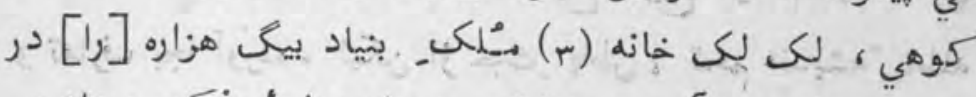

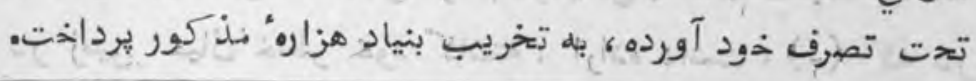

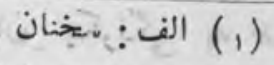

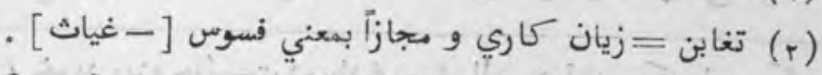

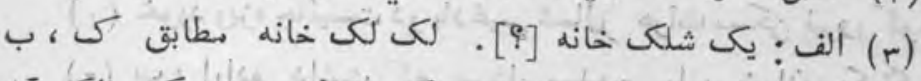

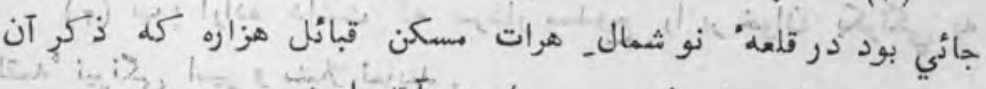

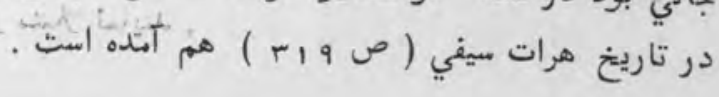


تازه نواي بعارك

r.

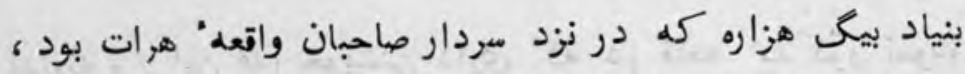

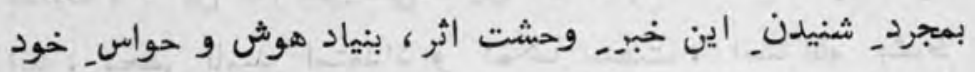

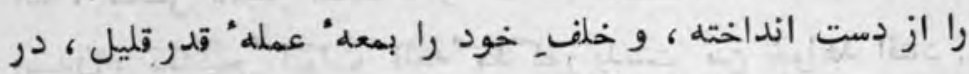

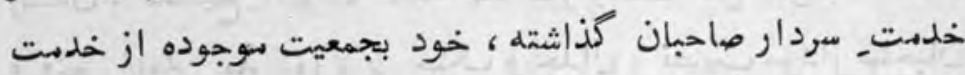

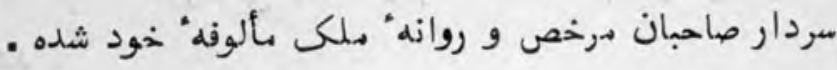

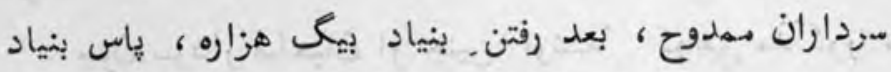

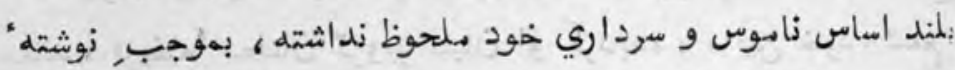

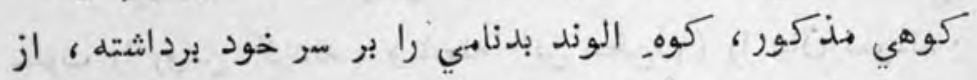

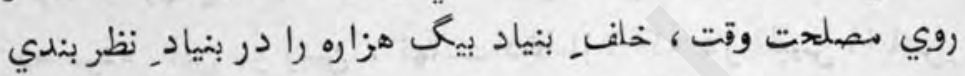

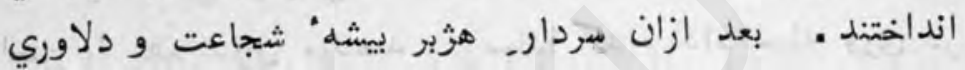

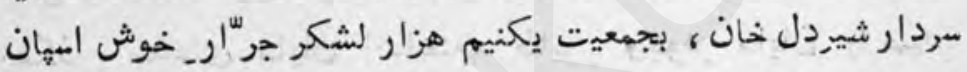

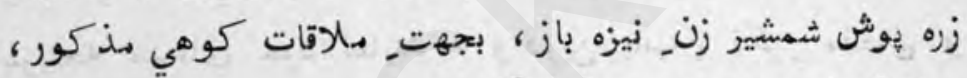

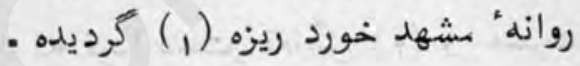

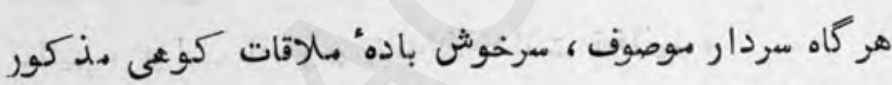

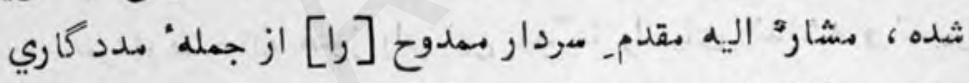
بخت و طالعـ قوي خود دانسته، انواع انواع براسم مهمانداري

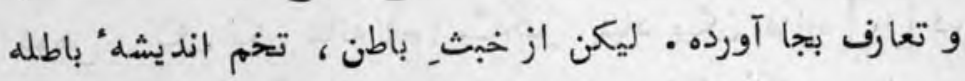

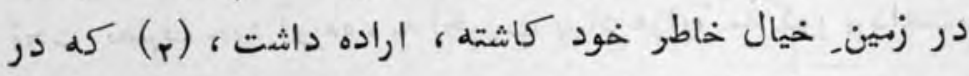
حين_ شمع افروزي دجلم- ضيافت، بر خوان_ يكرنكى به لقمله (1) خورد ريزه جائيست در بادغيس شمال ـ هرات مسكن فيرور كوهي .

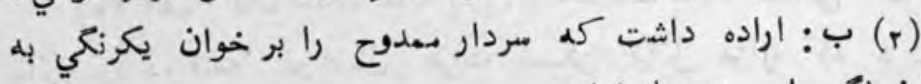
اقمه" نيرزنحي اسير و متبلا نمايند . 


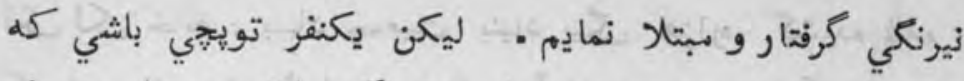

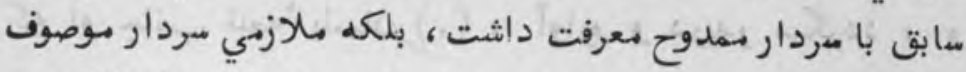

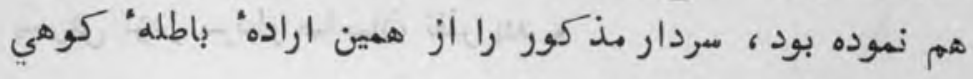

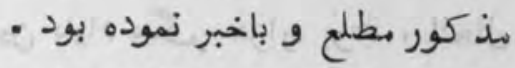

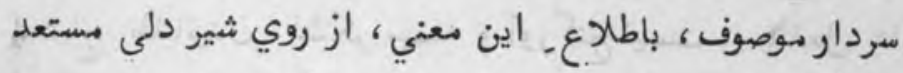

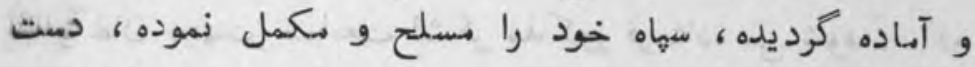

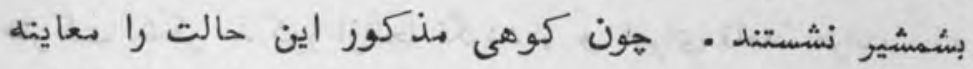

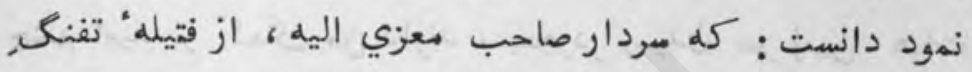

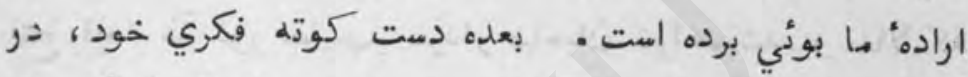

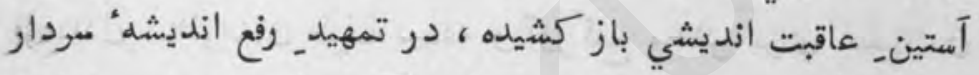

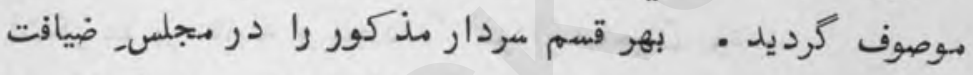

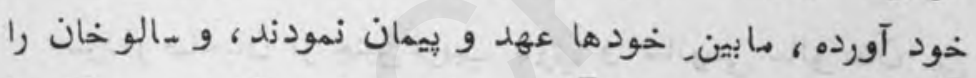

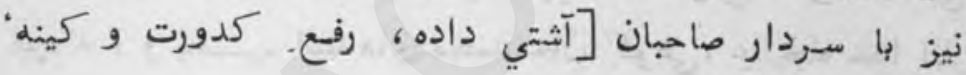
ديرينه نمودند - ميز

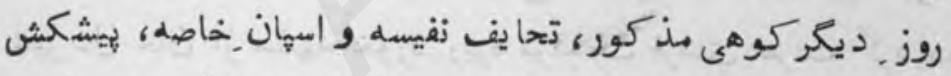

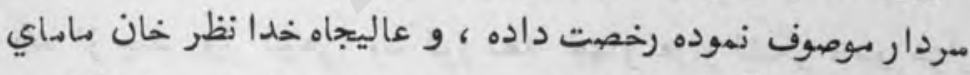

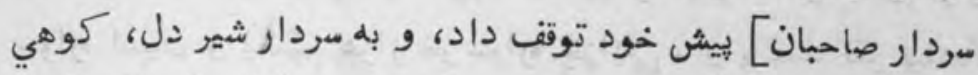

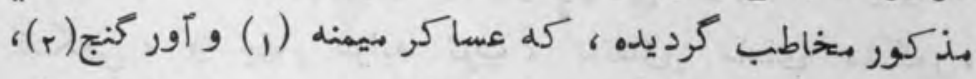

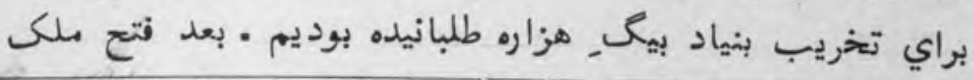

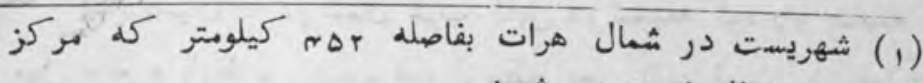

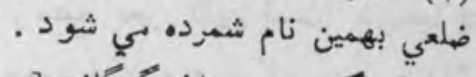

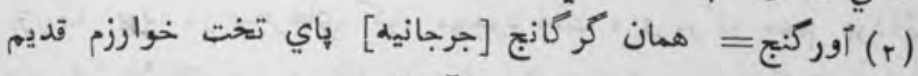

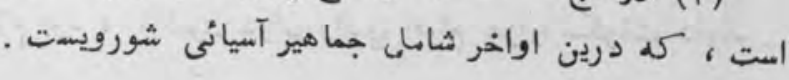




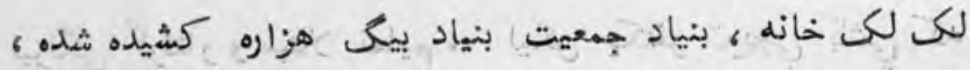

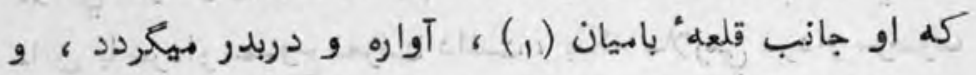

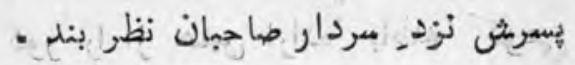
دشمن قوي بنياد هن، همين بنياء بيك, هزاره بوده ، الحال

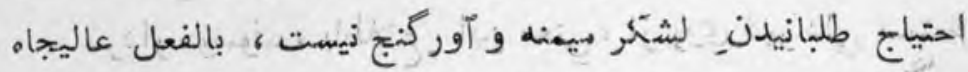

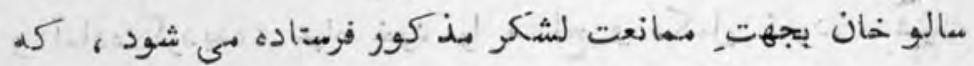

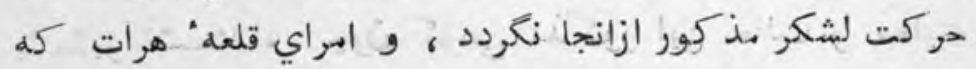

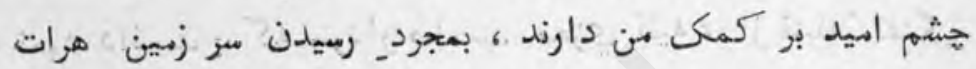

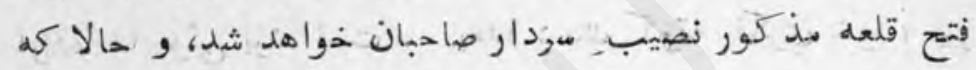

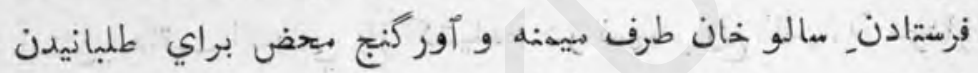

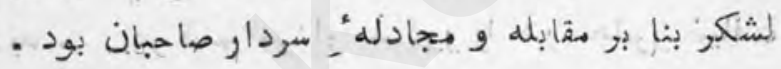

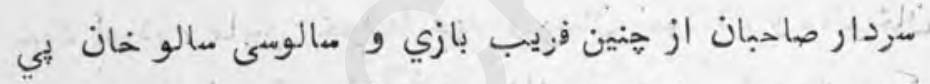

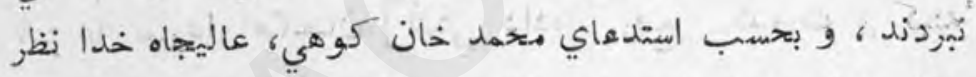

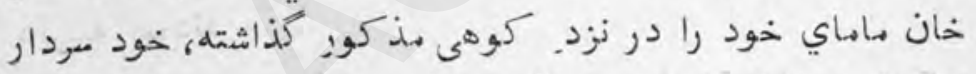

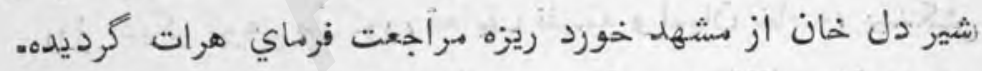

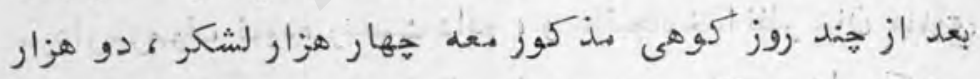

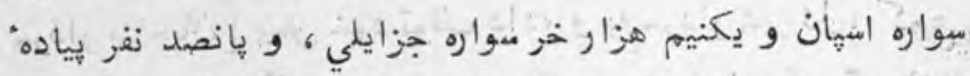

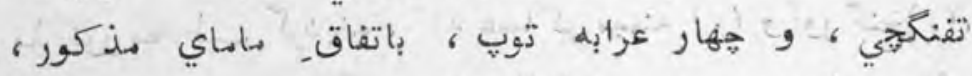

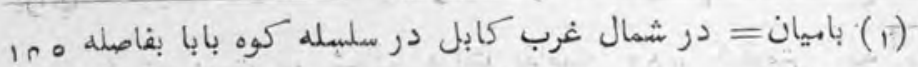

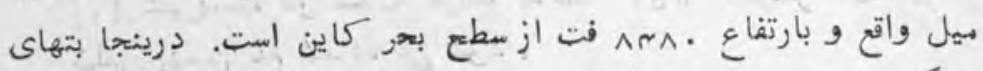

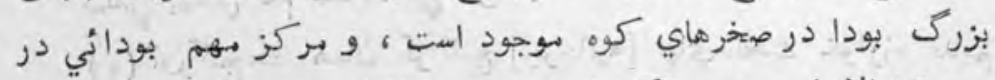

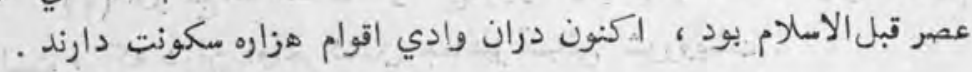


تr

بقطع منازل داخل هرات كرديده ، برل لب درياي (1) هتصل

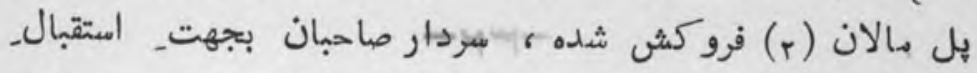

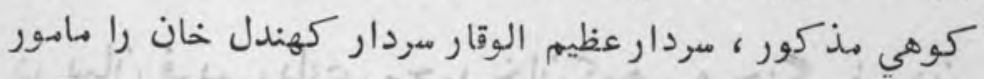

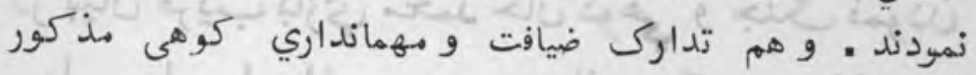

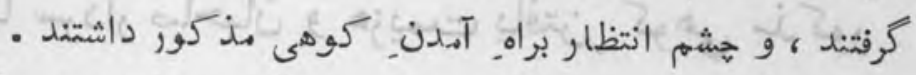

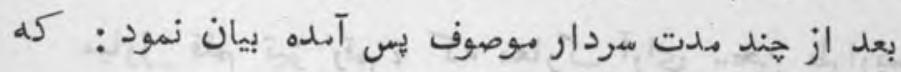

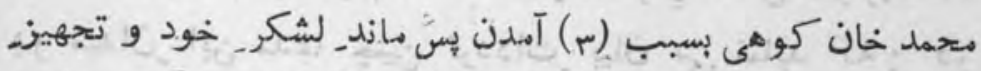

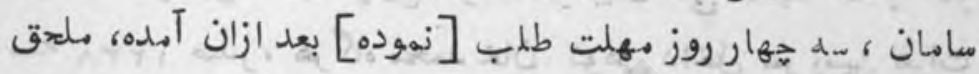

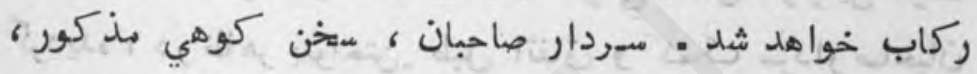

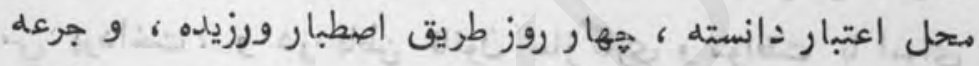

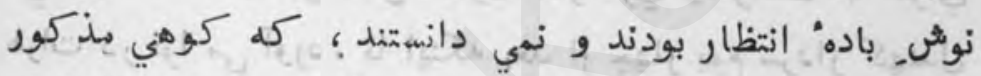

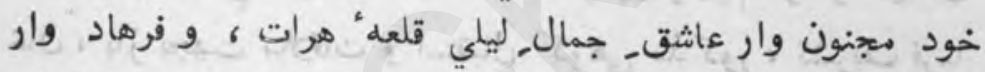

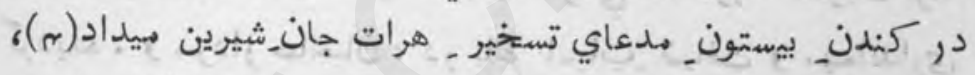

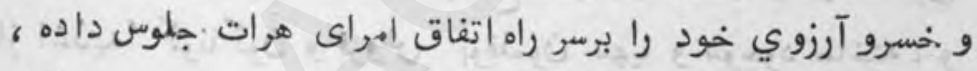

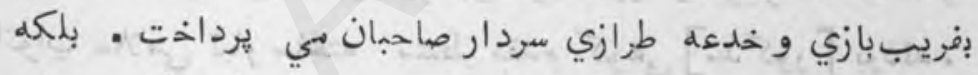

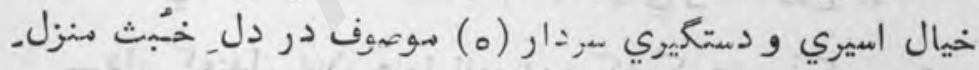

خود داثت ، ليكن قادر ندي وندي

.

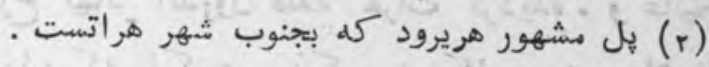

- ك (r)

(م) الف (r) ميدار)

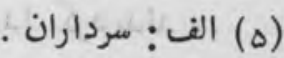




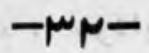

در بيان فريب بازي محهد خانكوهي و جنـ نهودن

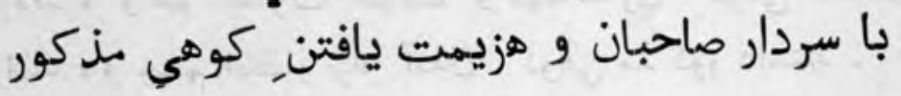

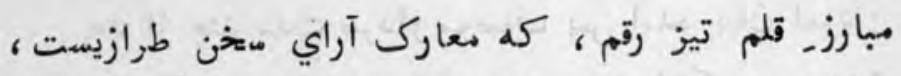

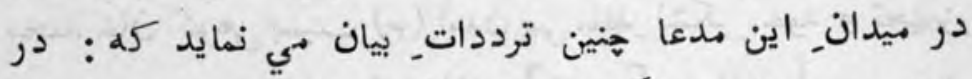

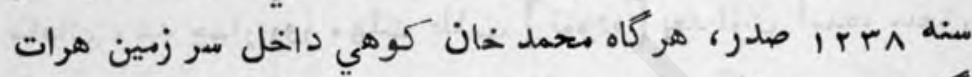

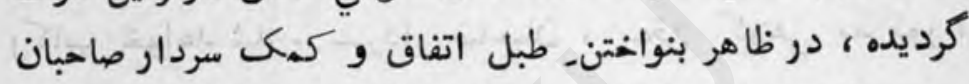

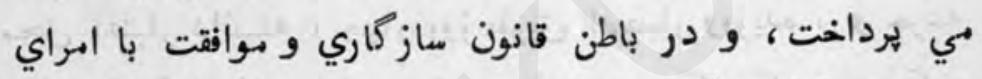

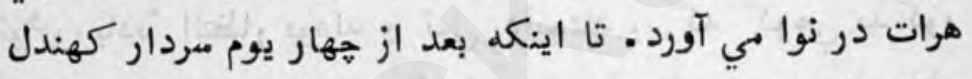

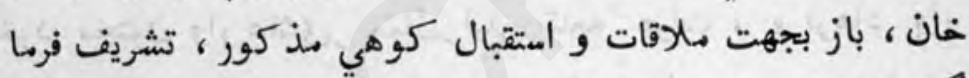

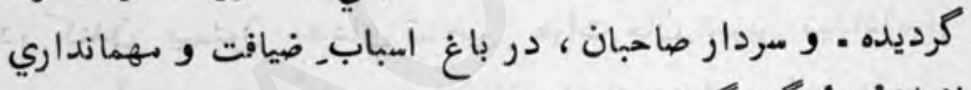

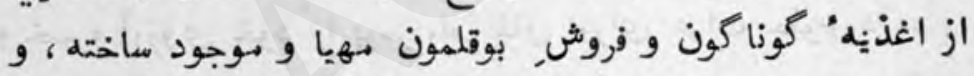

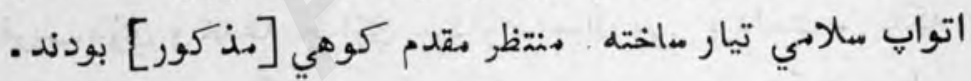

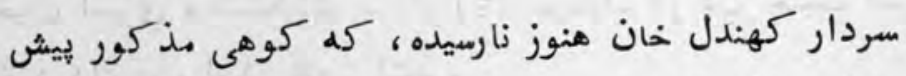

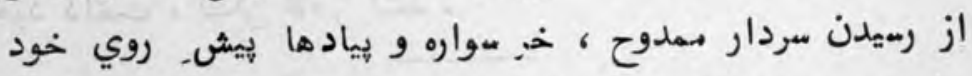

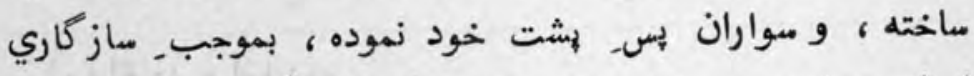

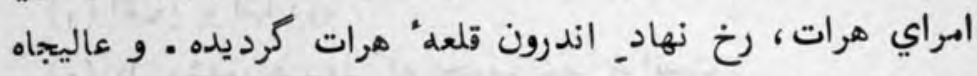

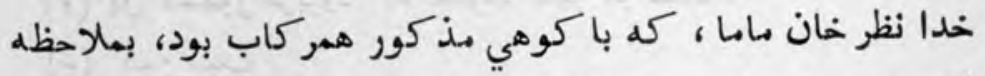

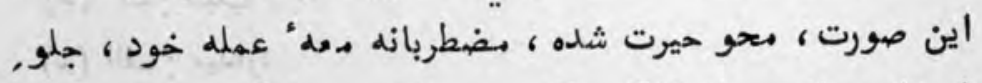

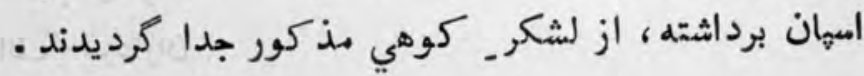



P.

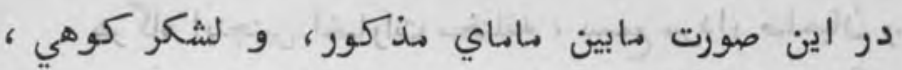

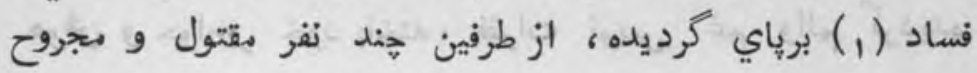

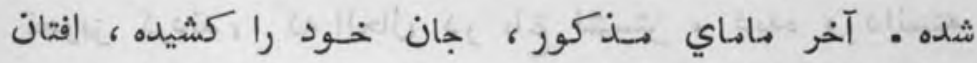

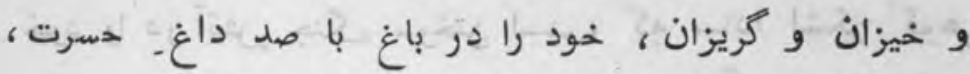

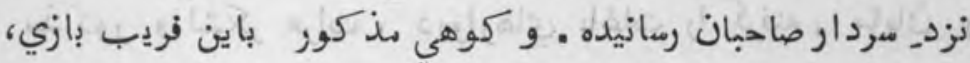

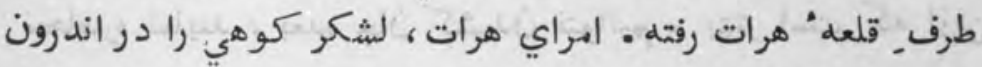

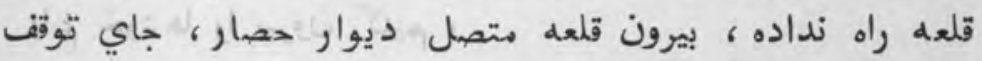

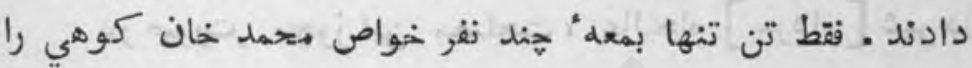
در اندرون قلعه بردند -

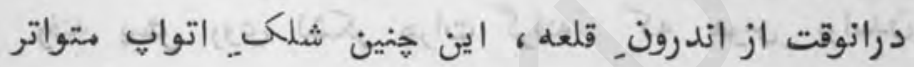

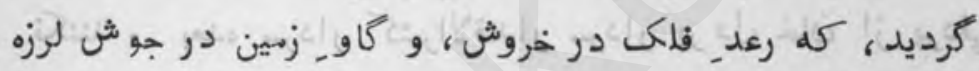

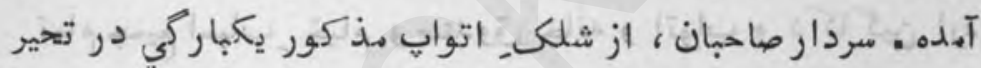

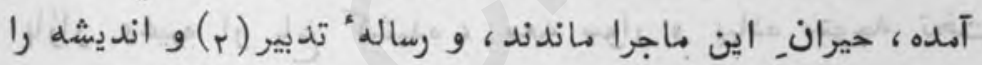

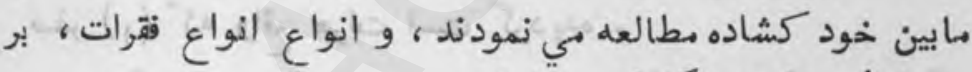

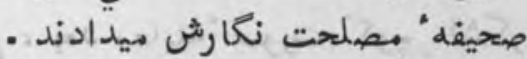

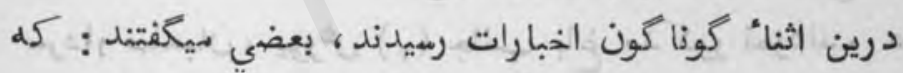

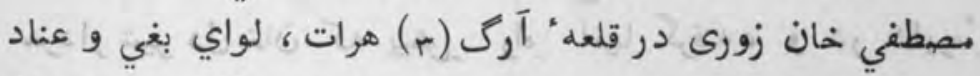

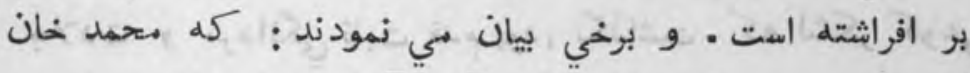

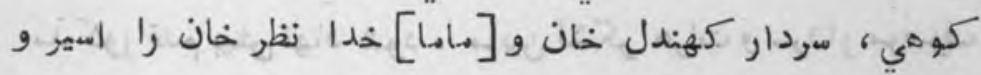

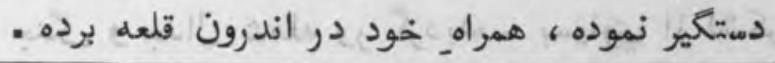

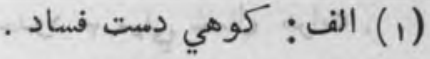

$$
\begin{aligned}
& \text { (r) الف: تديير و دلاسه را . } \\
& \text {. }
\end{aligned}
$$


تازه نواي معارك

r. $T$

هر كاه اينتخنين اخبارات متختلفه ، بسمع سردار صاحبان رسميده ،

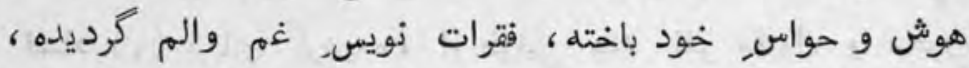

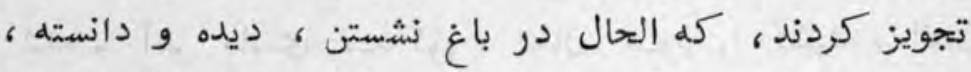

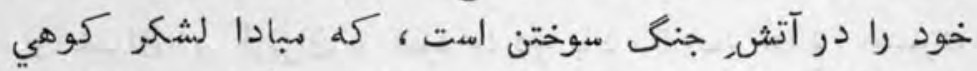

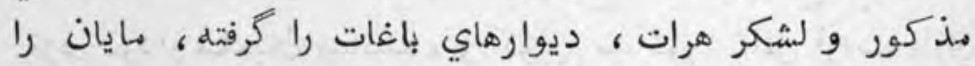

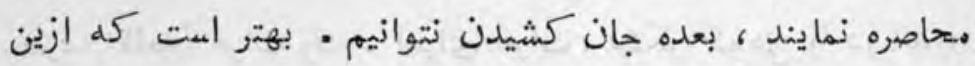

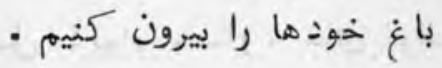

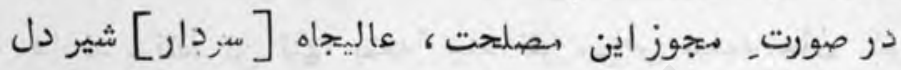

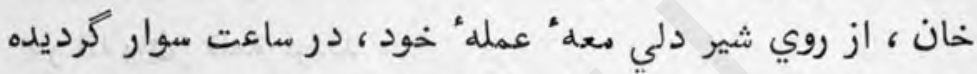

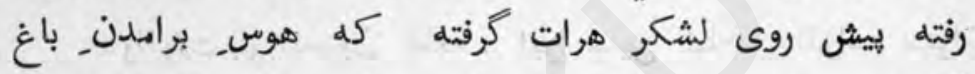

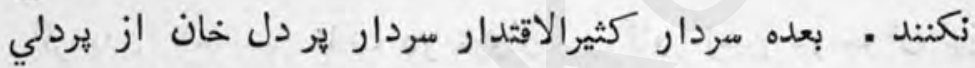

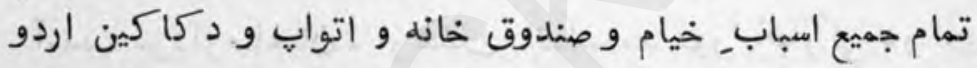

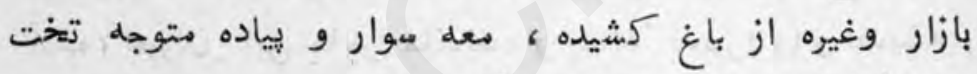

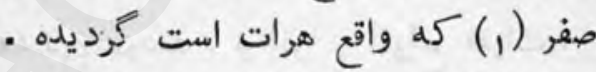

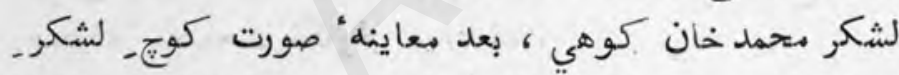
سردار, صاحبان ، يورث (r) جانب باغ من كور نمودند . عاليجاه

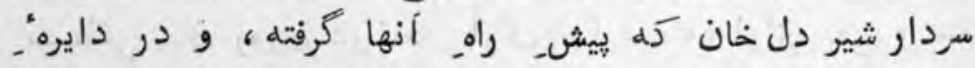
جاددت و مردانكي ثابت قدم بود، نكذاشت كله لشكر كوهي

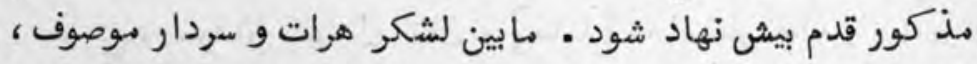

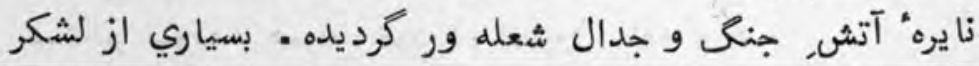

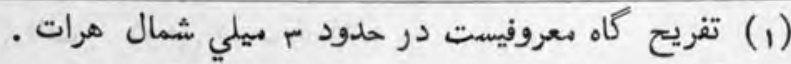

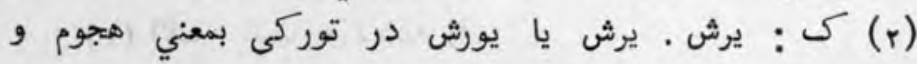
حمله امت . 
كوهى مذ كور، هون بزهاي كوني ؛ بساطور, جلادت و دلاوري

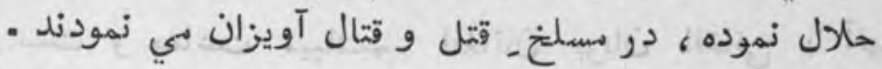

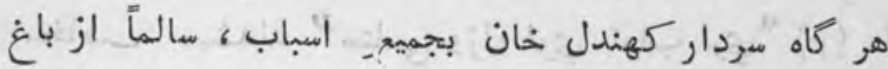

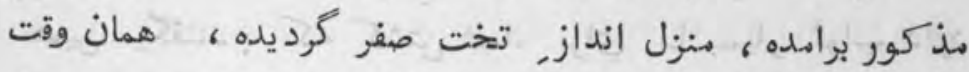

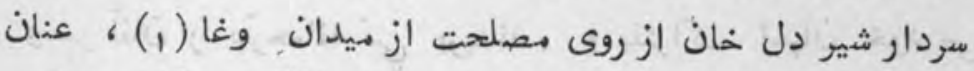

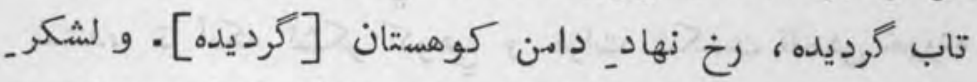

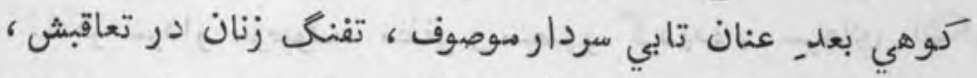

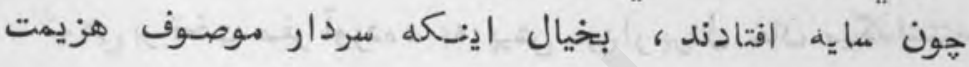
خورده بيرود .

هون لشكر, كوهي و هرات، از ديوارهاي باغات بيرون آمدند،

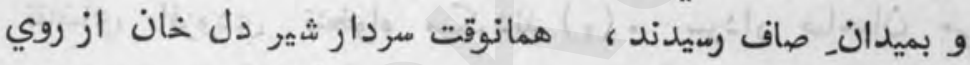

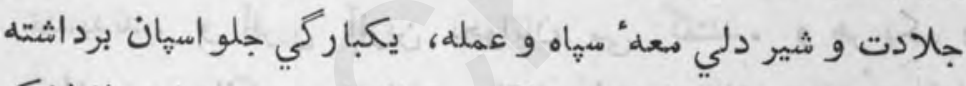

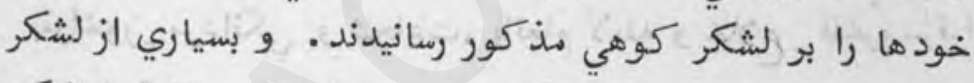

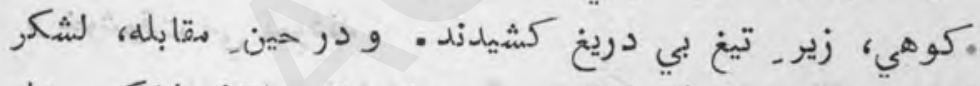

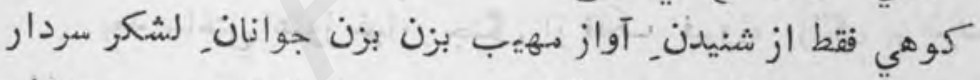

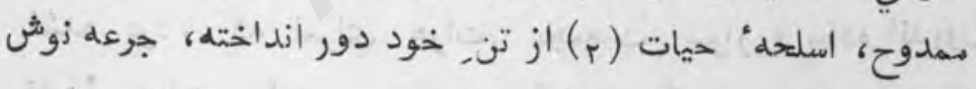

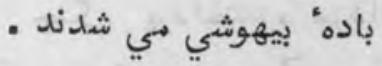

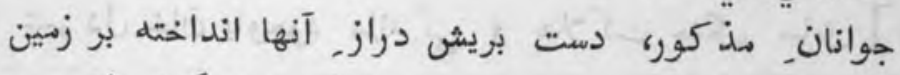

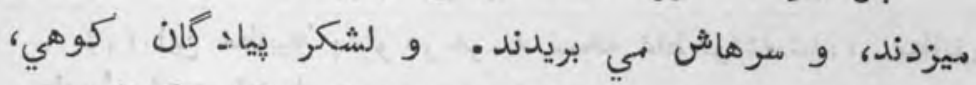

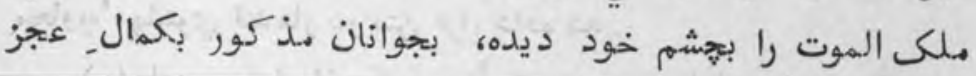

$$
\begin{aligned}
& \text { (1) ونا } \\
& \text { (r) الف : سلاح حيات . }
\end{aligned}
$$


تازه نواي ماي

$r \cdot \wedge$

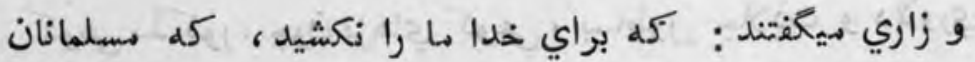
اهل مثنت و جماعت ميباشيم. افغانان بزبان افغاني با آنها مخاطب ميشدند ”متامي وزل لوي ثواب لري" (1) افغانان

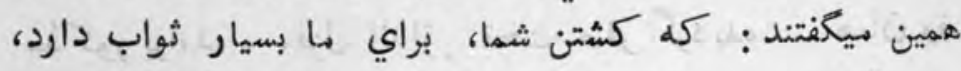

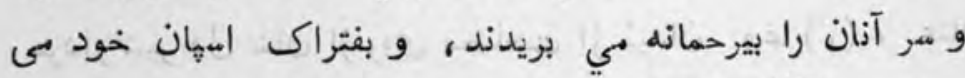
بستيند، تا آنكه لشكر كوهي و هرات شكست فاحشى خورده.

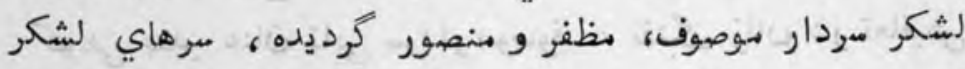

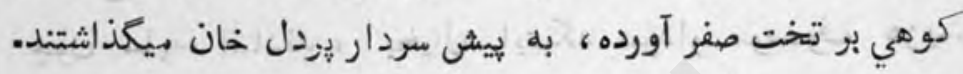

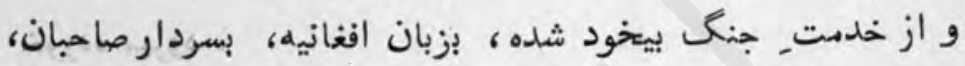

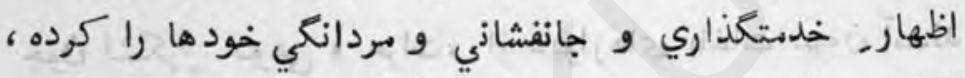
تقاضاي افزودي تنخواه ميكردند (r) •. سردار صاحبان مي وني

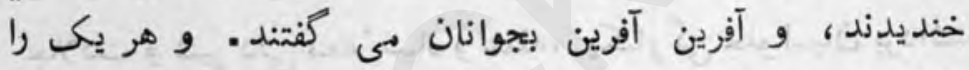
بفراخور مردانكي و شجاءت، بانعام لايقه و خلاع ـ فاخره سرفراز

و خوشوقت بي نمودند.

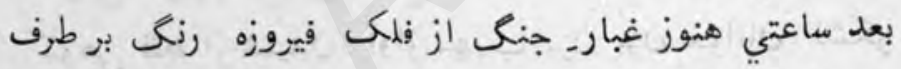

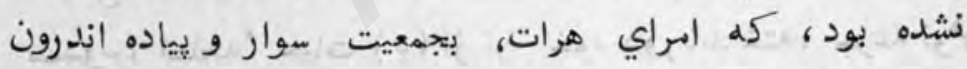

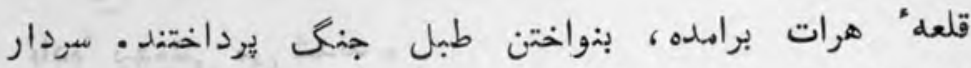

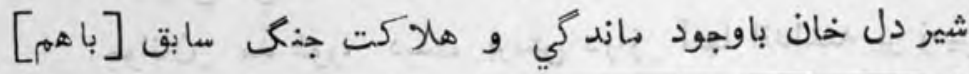

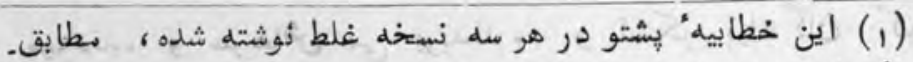

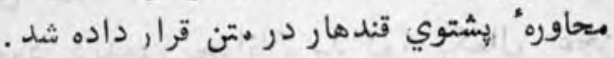

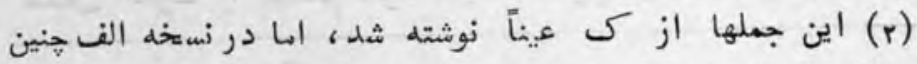
است: " بزبان افغانيه بسردار صاحبان ميكفتند : داسرونه دد شمثنانوستا $(r i q-\rho, د)$ 


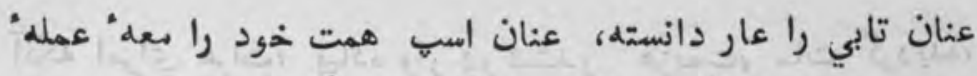

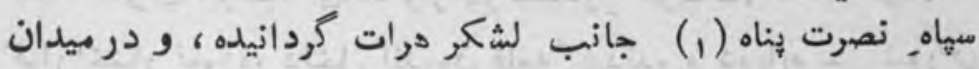

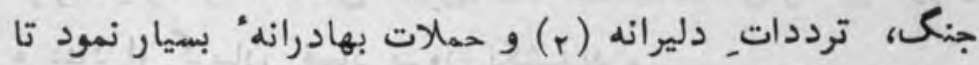

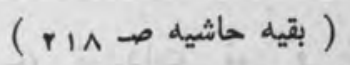

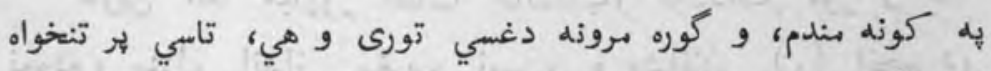

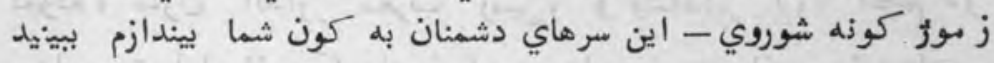

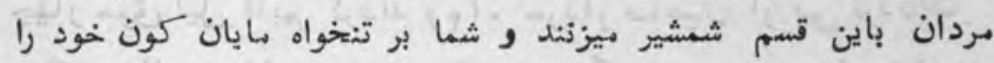
شورش ميدهيد !"

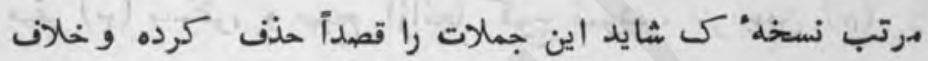

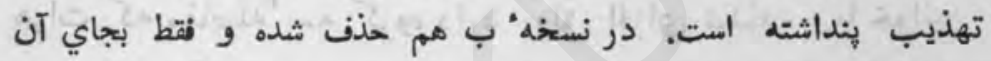

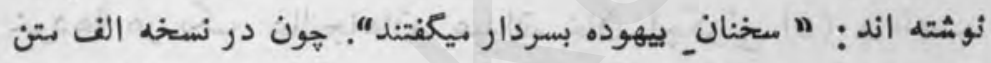

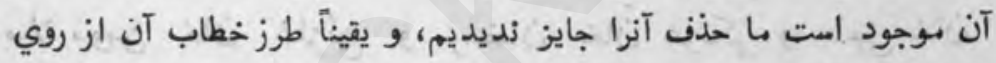

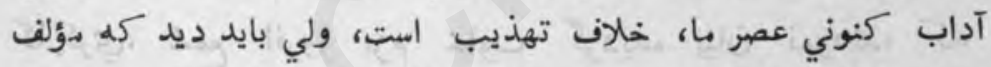

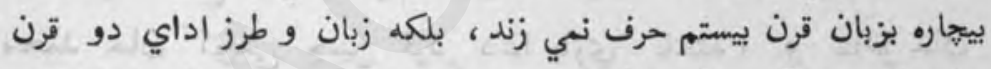

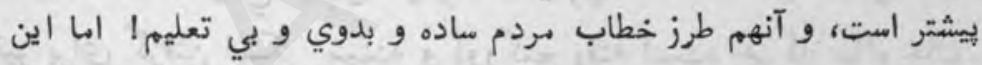

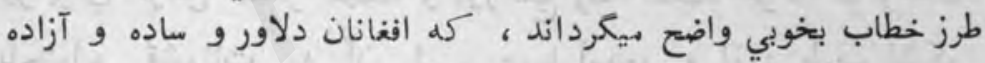

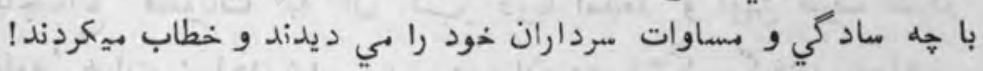

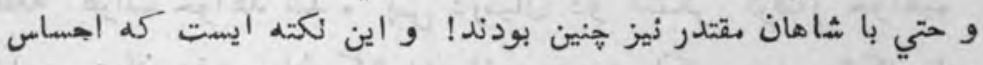

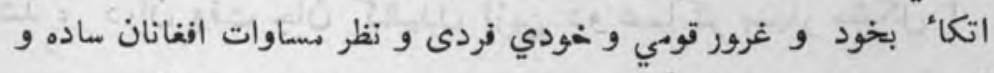

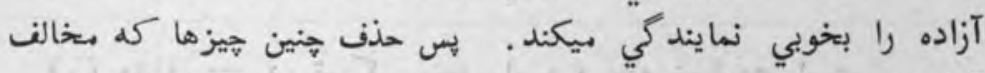

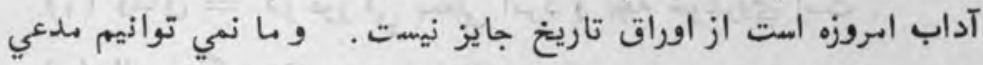

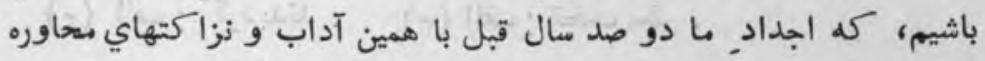

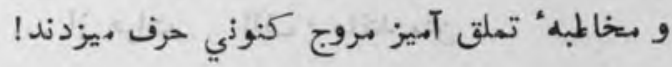

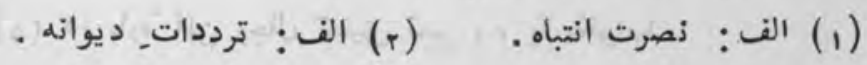


آنكه امراي هرات، هياده وار در ششدر ـ هزيمت، مات كرديده،

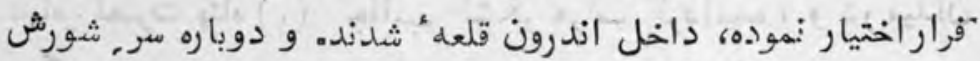

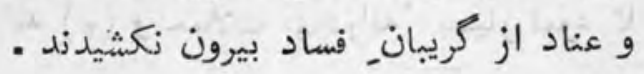

دوين اثنا مبارزه آفتاب عالمتاب، تردداتــ نور و ضها

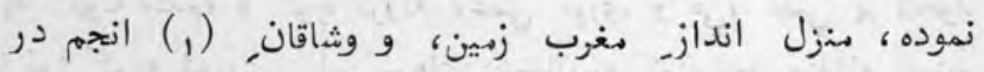

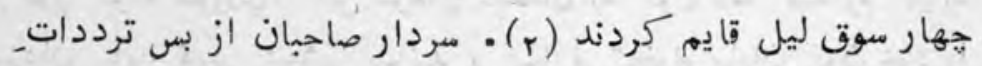

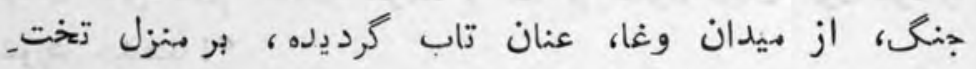

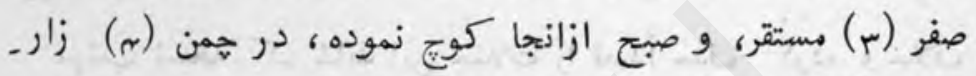

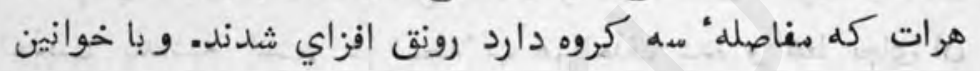

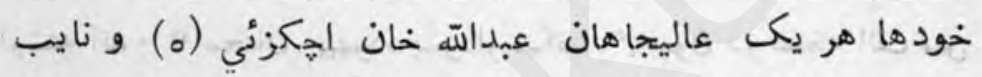

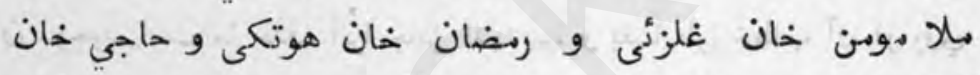
كاكري، شمع افروز بزم خلوت كردئ كان

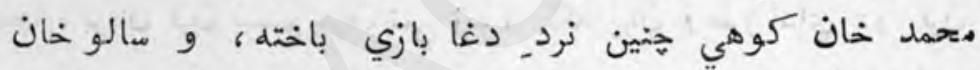

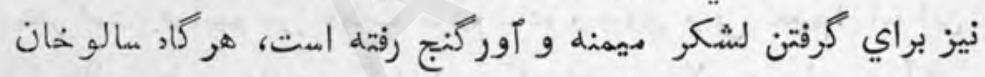

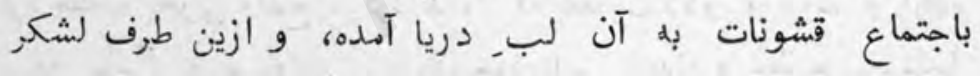

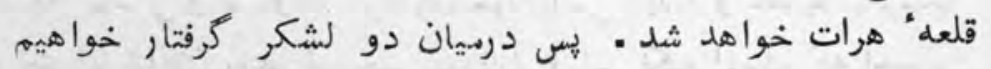

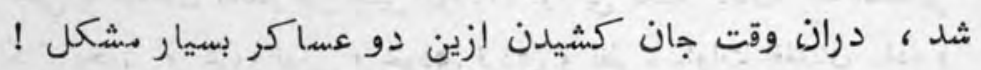

(1) وشاق = در توركي بمعني امرد و بجه خوشروي است .

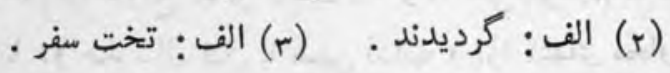

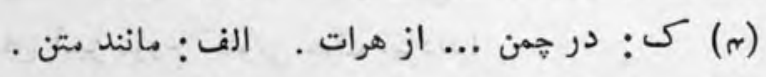

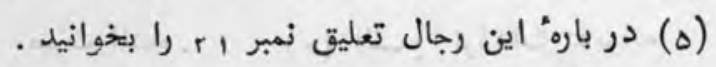




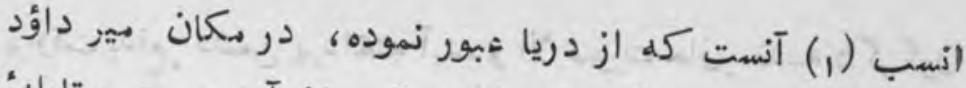

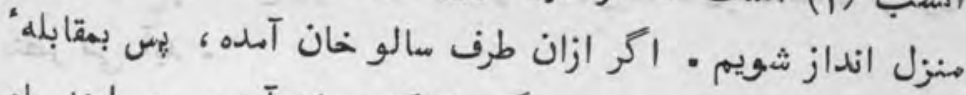

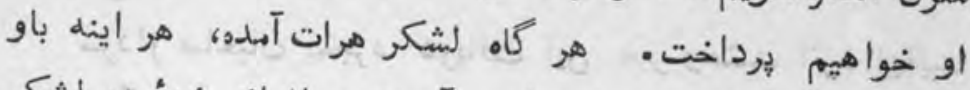

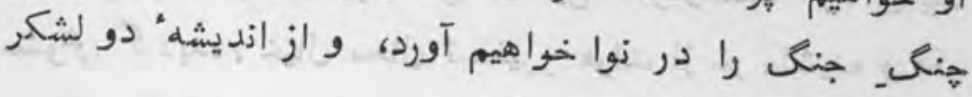

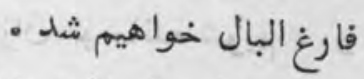

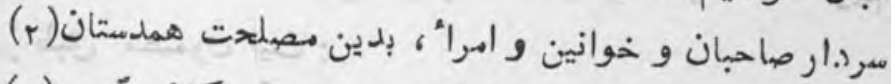

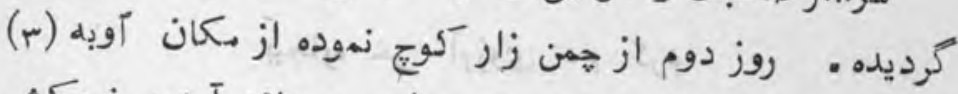

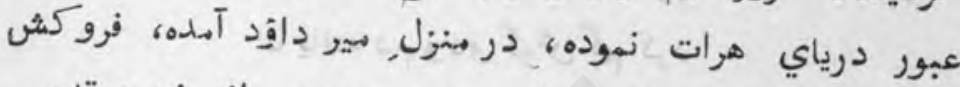

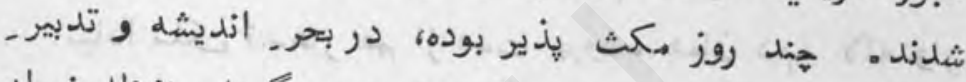

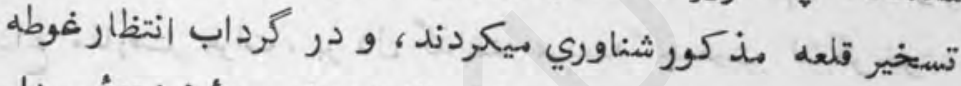

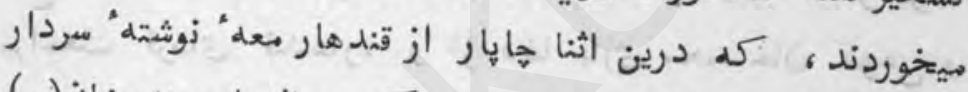

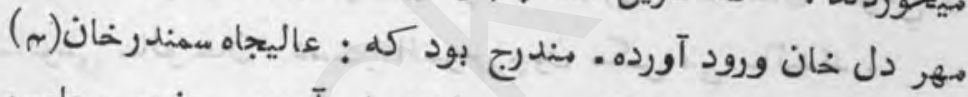

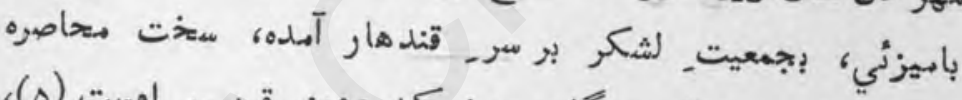

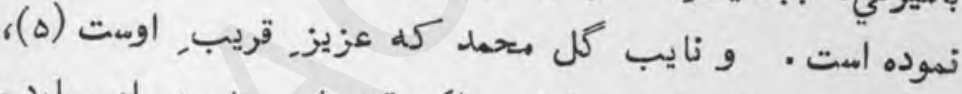

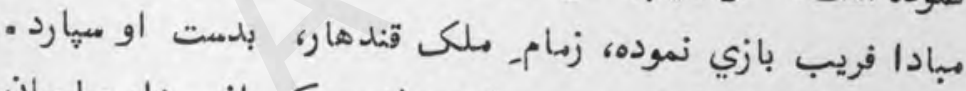

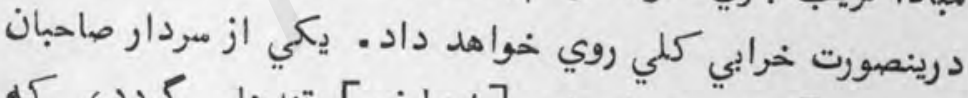

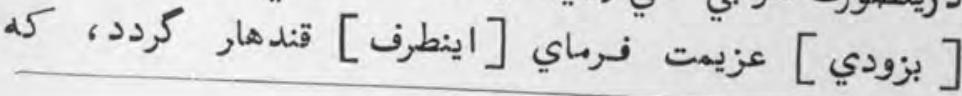

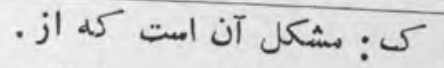

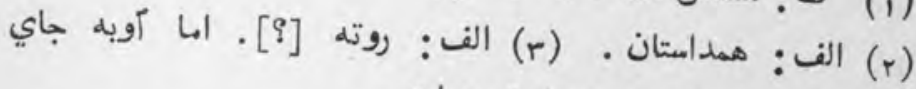

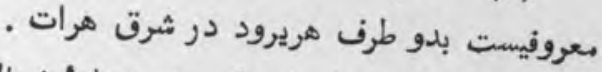

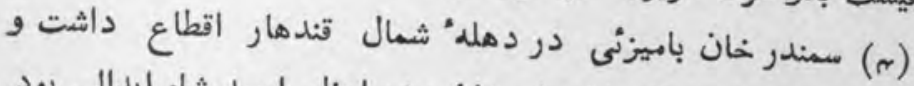
نايب كل محمد خان فرزند شاه ولي خان صدر اعظم احمد شان شاه ابدالي بود. شمان.

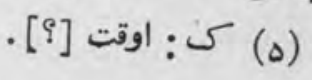




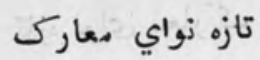

rir

بر وقت بدفع_ دشمن برداخته آيد، و الا صورت حال مقدمه د كركون

- نظظر مي آيد

مردار صاحبان بمجرد دريافت اين خبر وحشت اثر، نهائ نهايت

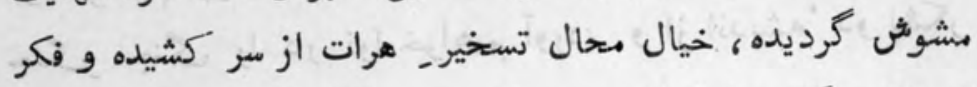

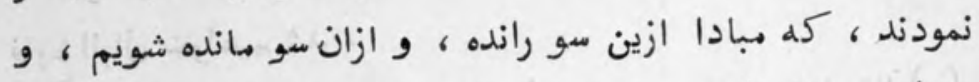

بر طبق مضمون بيت

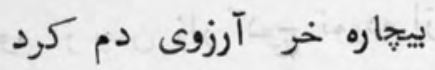

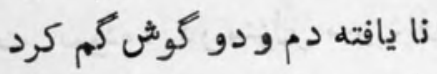

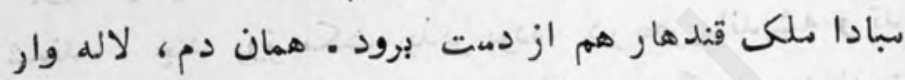

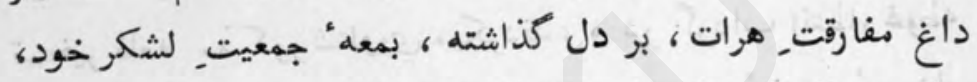

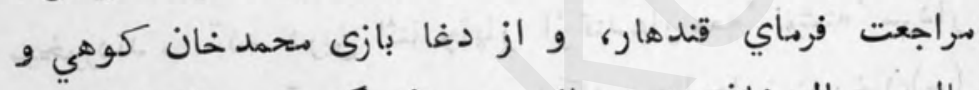

مالوسي سالو خان ، دست ـ افسوس هون مكس مي سائيدند . 


\section{_}

در بيان مراجعت_ سردار ماحبان [قندهار] از هرات ني نيل مقصود

و در عرض راه غارت نمودن شهزاده سلطانعلي خلف شهزاده

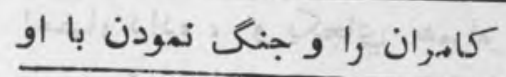

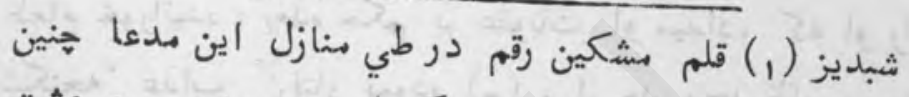

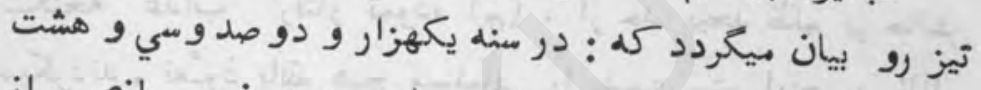

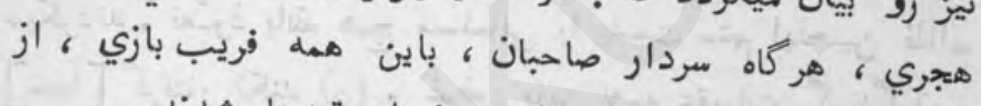

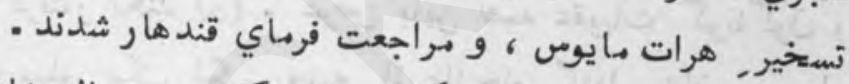

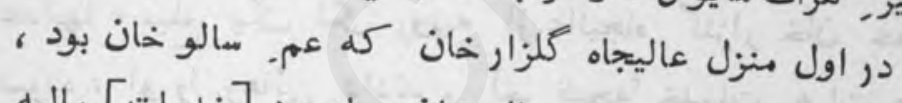

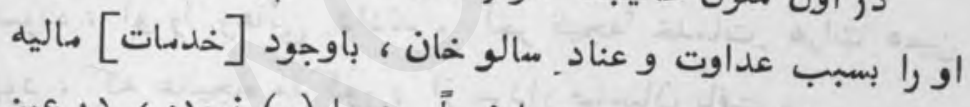

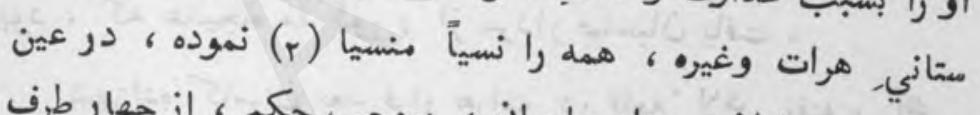

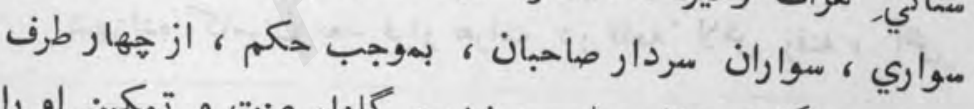

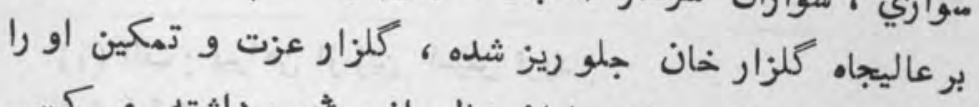

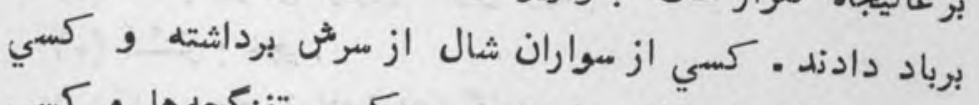

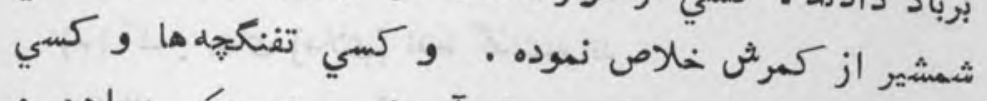

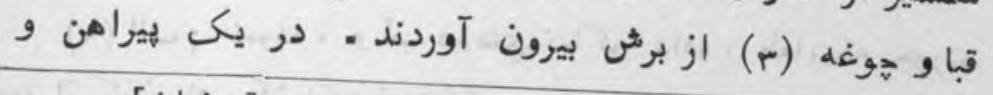

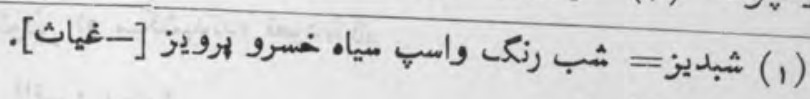

$$
\begin{aligned}
& \text { • يعني فراموش (r) (r) } \\
& \text { (r) }
\end{aligned}
$$


تازه ئواي مارك

PIN

زير جاهه (1) ، از امهيث فرود آورده و بازويثى بريسهان بسته ؛

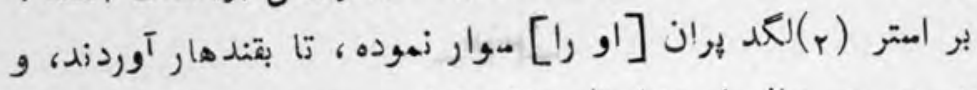

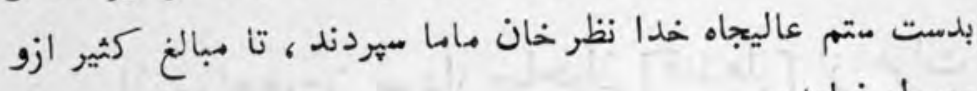
- حصول نمايد ماساي مذكور در صورت(ب) مهلاي خدا ترس، ود در متتم كاري

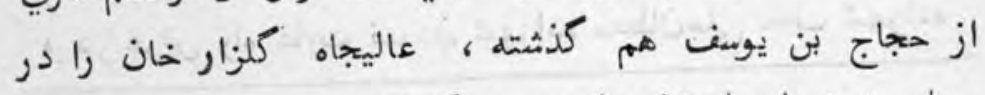

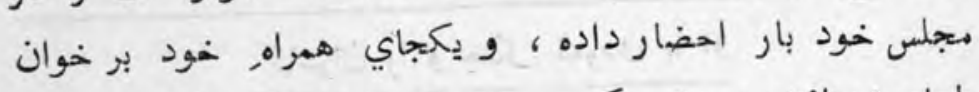

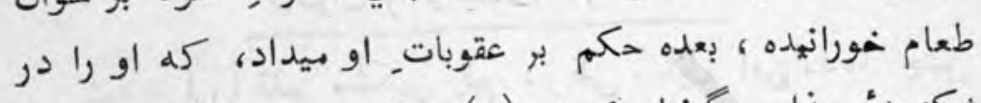

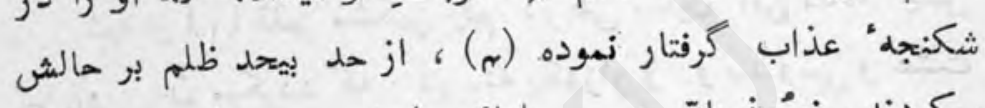

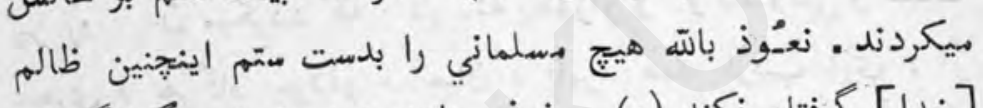

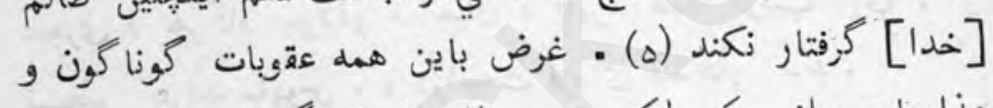

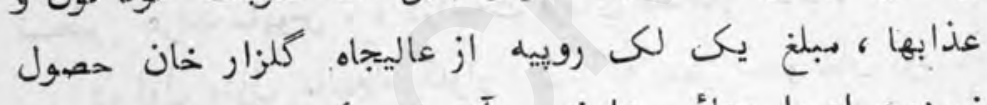

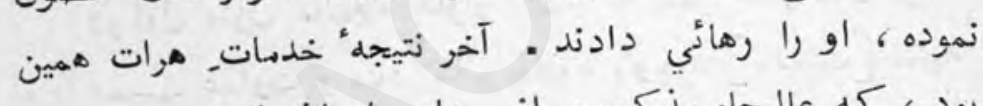

بود ، كله عاليجاه سذكور ، از سردار صاحبان يافت .

شهزاده كامران بعد فرار هرات در قلعهُ لاثن رفته ، آثي.

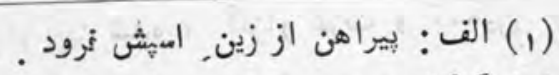

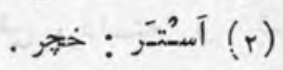

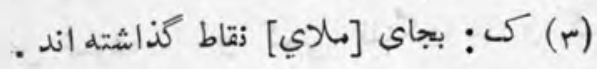

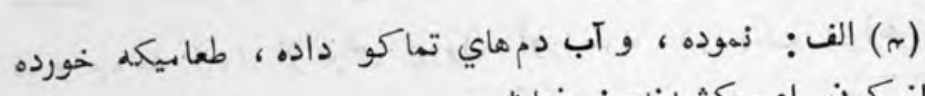

بود از كون او او ميكشيدند، نعوذباله .

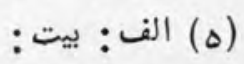

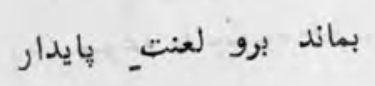

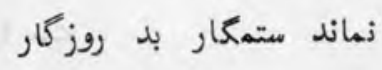




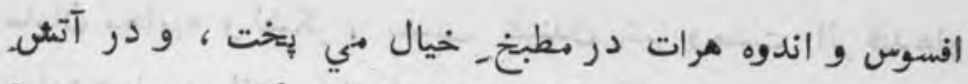

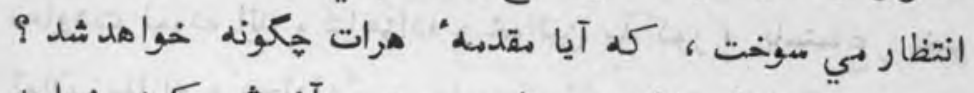

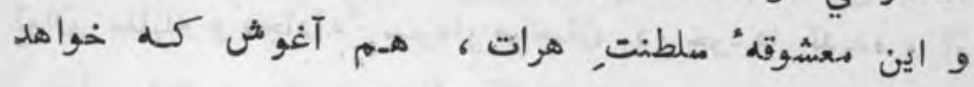
كرديد

مغني(1) قلم- مشكين رقم ، هنين نغمه طراز بيان ميشود كله :

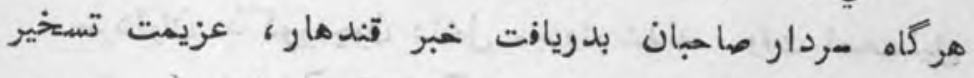

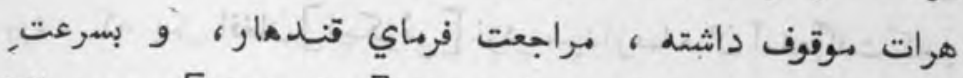

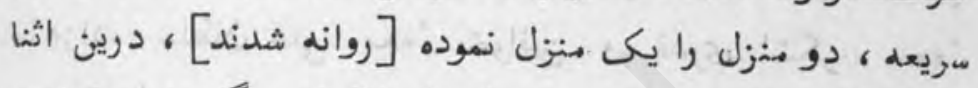

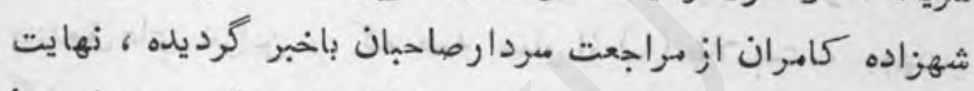

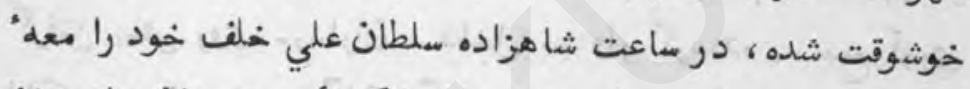

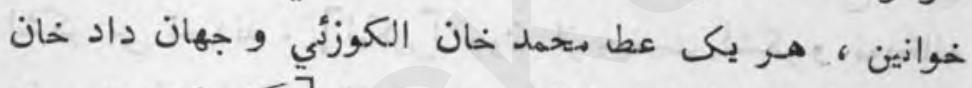

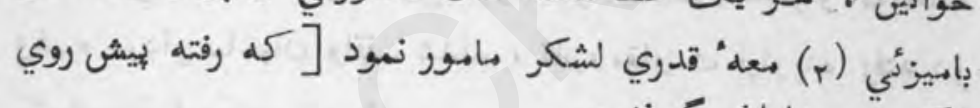

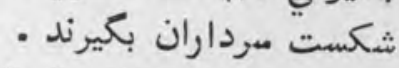

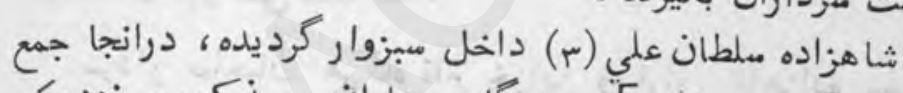

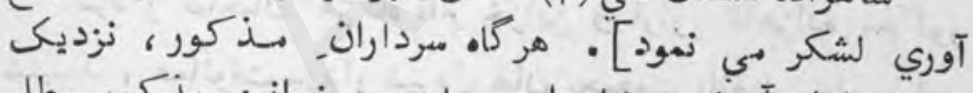

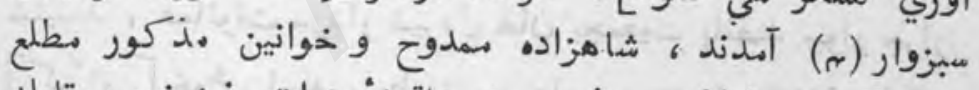

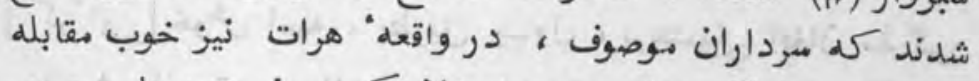

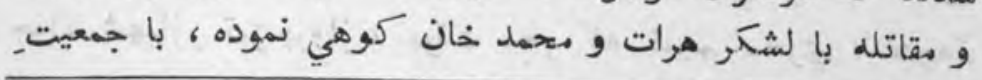

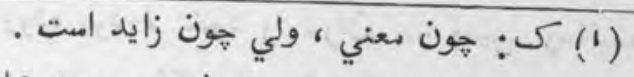

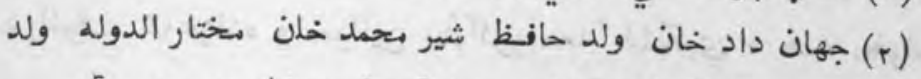

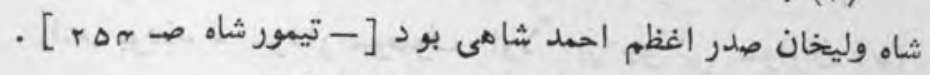

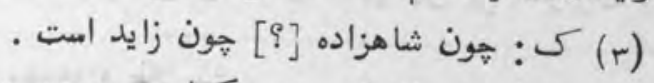

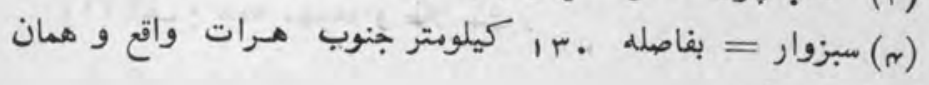
اسفزار تاريخى است مسزوار 
تازه نواي معارك

ris

ماهان متحاربه و لشكر ؛ بسبب شيندن خبر وحشث اثر قندهار

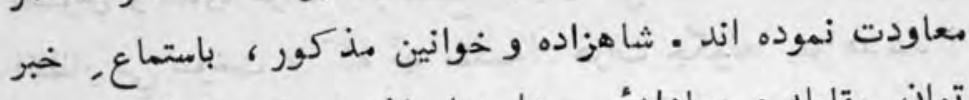

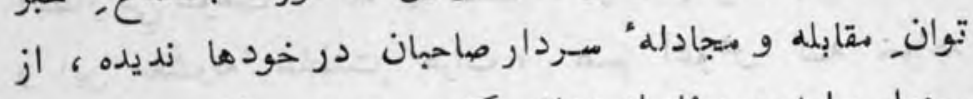

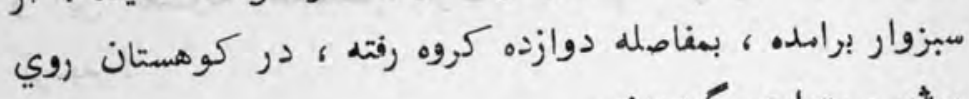

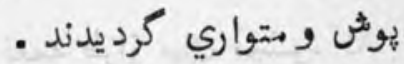

سرداران مذ كور جون داخل سبزوار شدند ، وقت نصف ليل

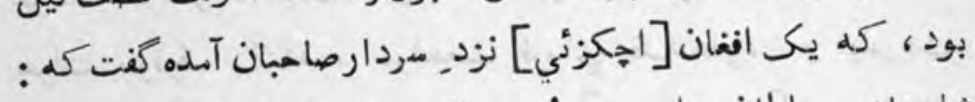

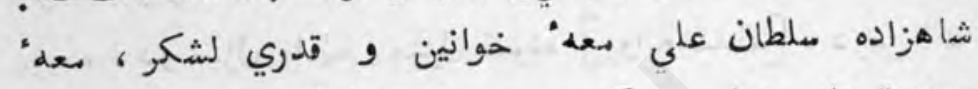

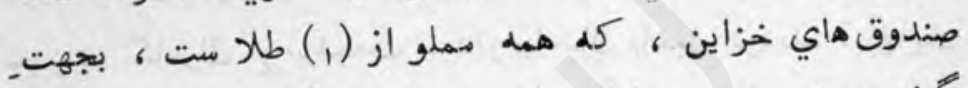

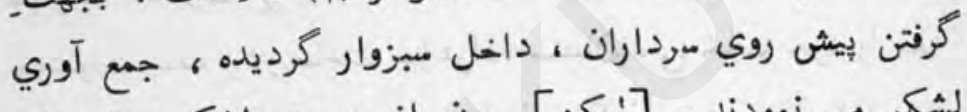

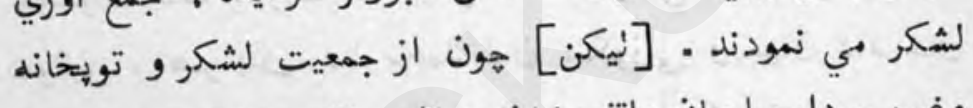

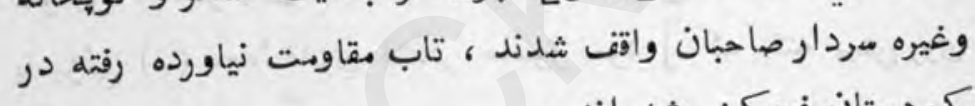

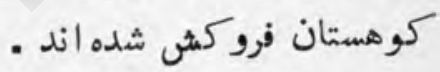

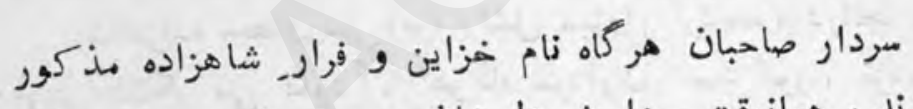

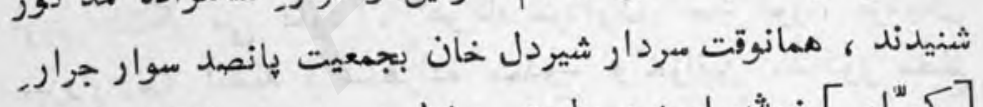

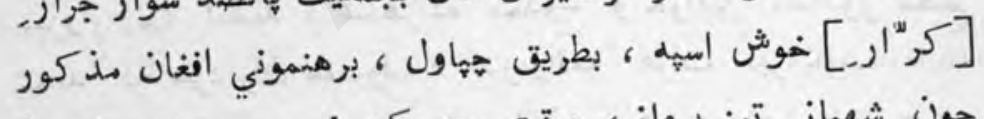

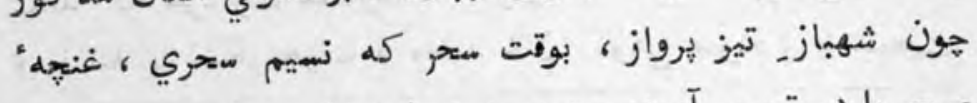

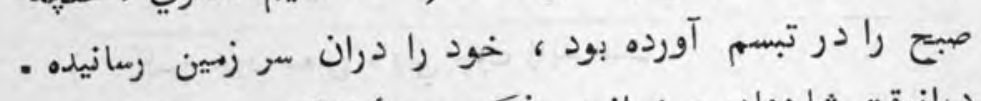

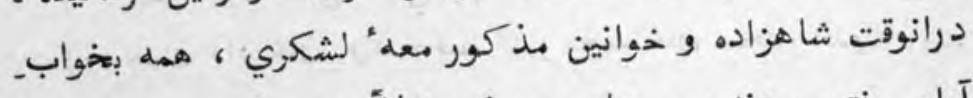

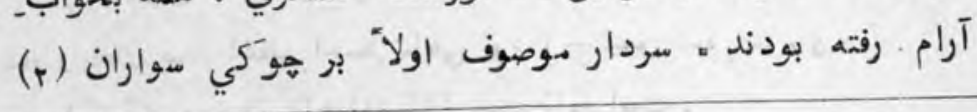

(1) الف: همه مهرها و طلا ست . (1)

(r) الف : سرداران : 
آنها كه بر شوارع مـامور بودند رسيده ، واز قضاي كرد كار

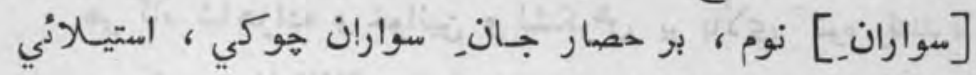

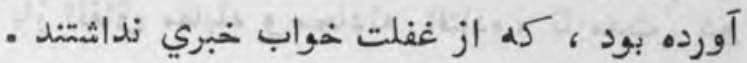

مردار ممدوح، مسواران خوكي مذكور ، اسير و دستخير

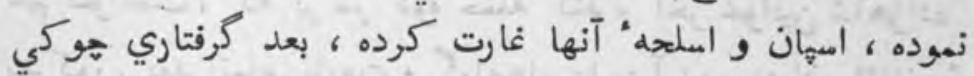

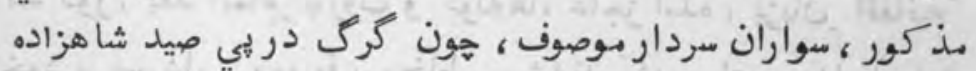

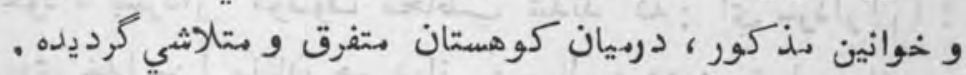

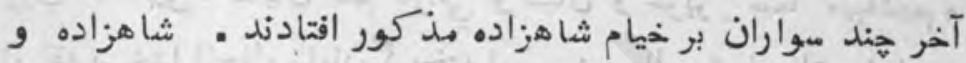

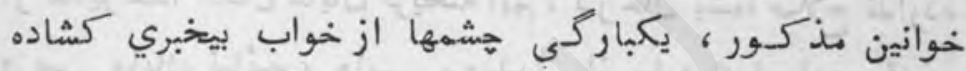

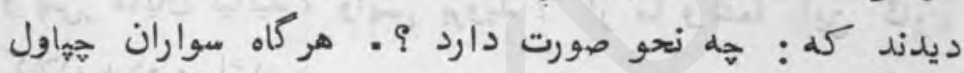

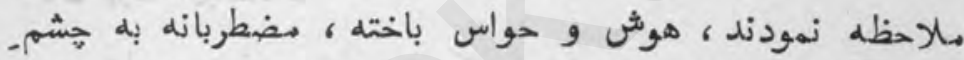

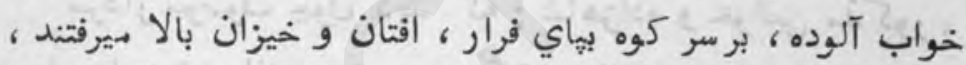

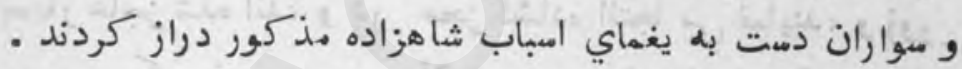
هر كاه شا هزاده: مذكور به مر. كوه رقته ديد، كه سواران

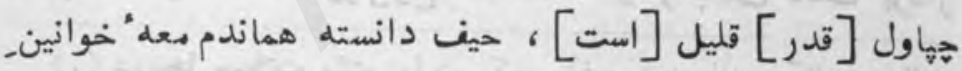

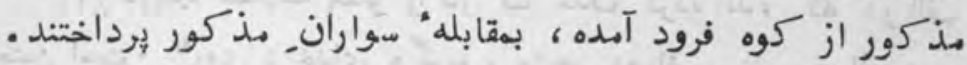

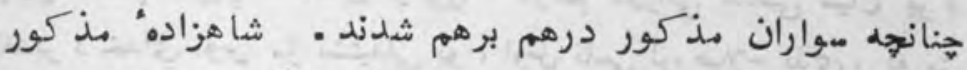

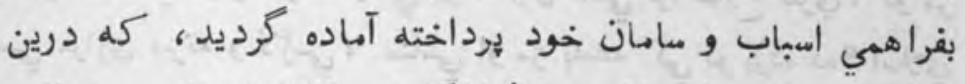

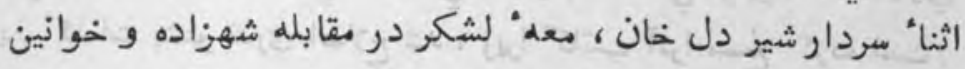

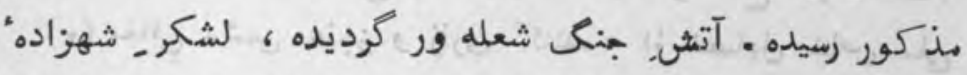

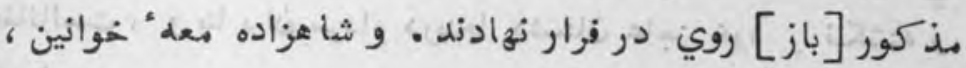


باي بياده بر مر كوه افتان و خيزان ميرفت .

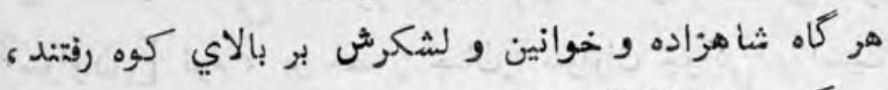

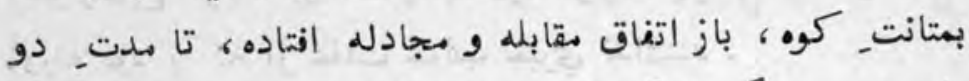

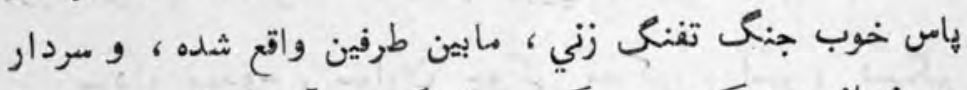

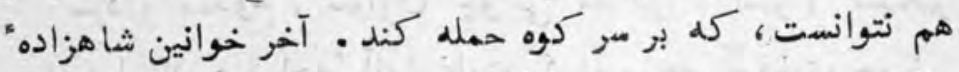

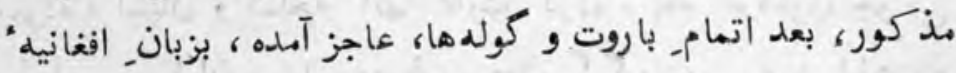

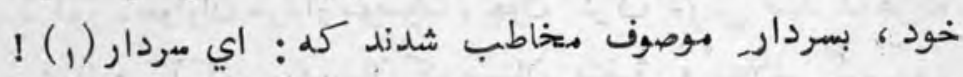

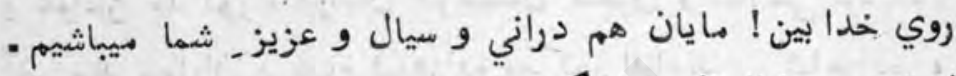

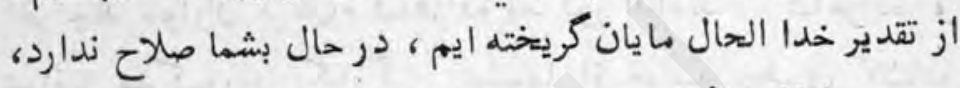

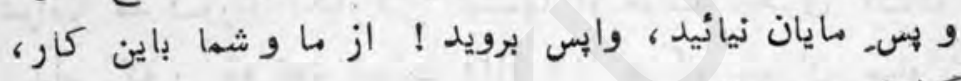
كلان برده ميباشد ماند نياند

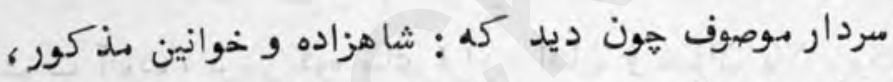

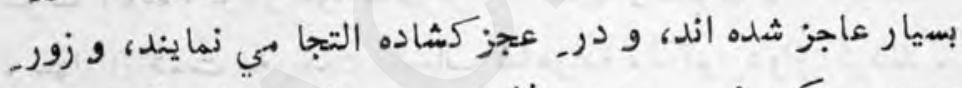

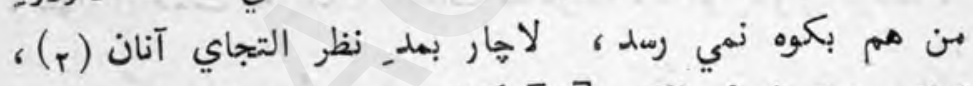

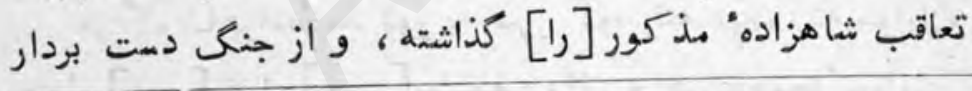

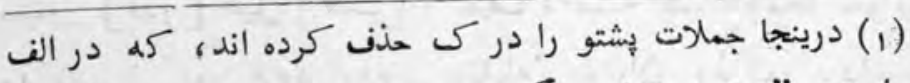

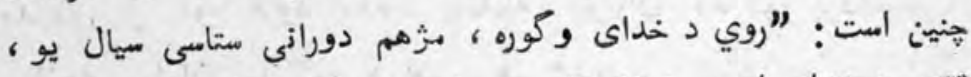

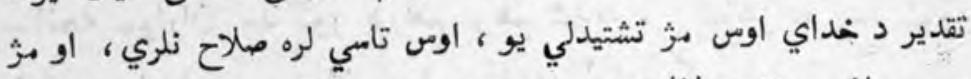

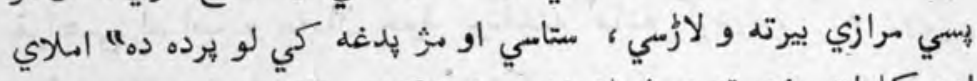

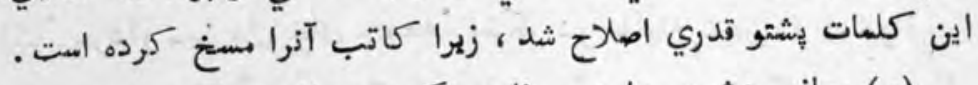

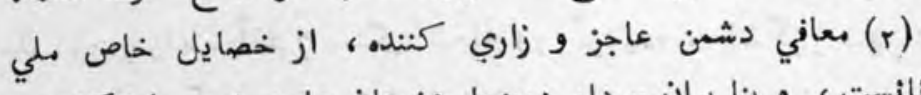

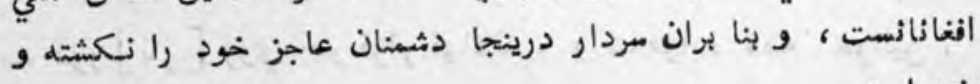
رفته امت . 
تازه نواي معاركى

كرديده ، آنحه كم خيام و فروش و اسمان وعيره اسباب شاهزاده

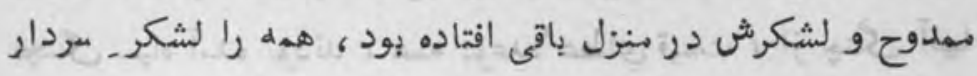

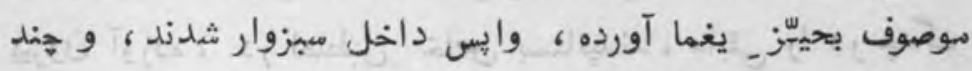

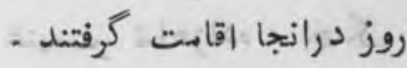

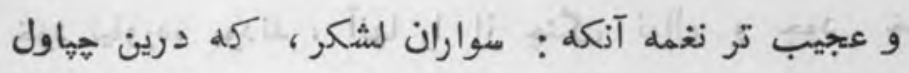

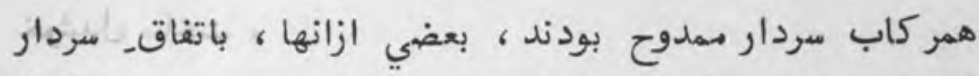

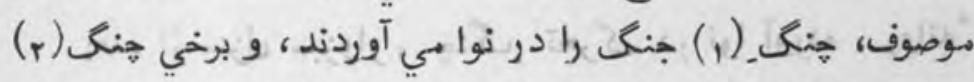

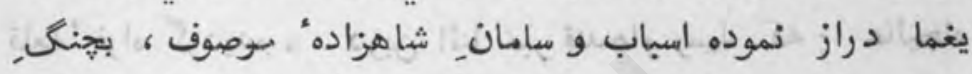

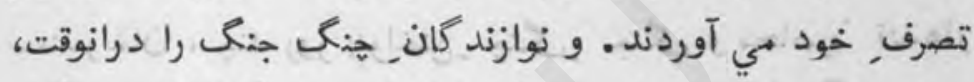

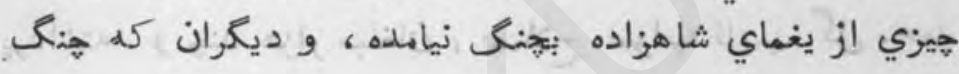

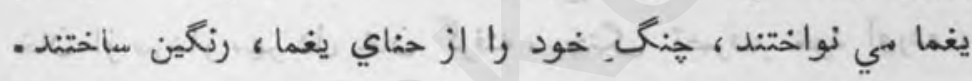

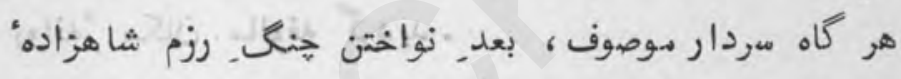

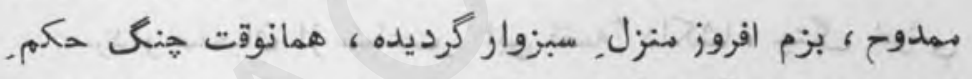

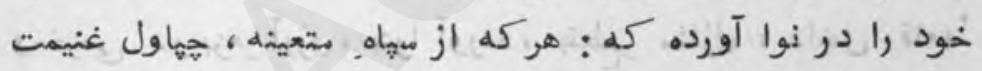

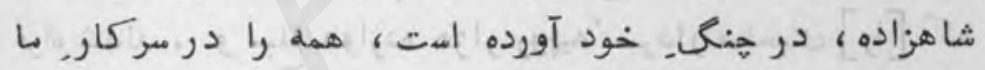

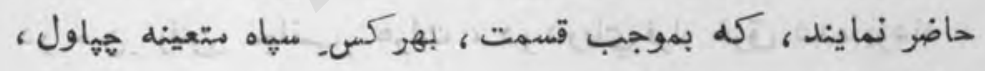

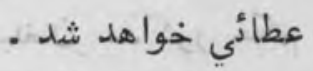

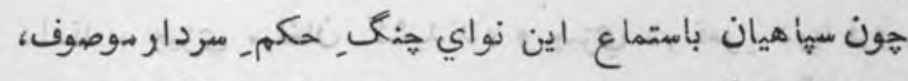

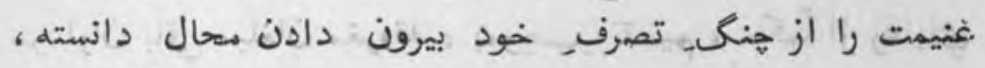

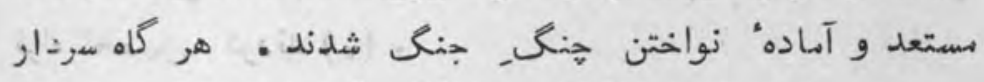

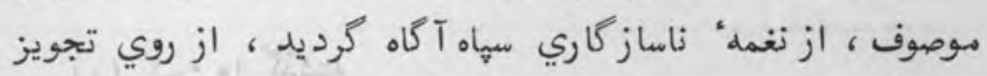

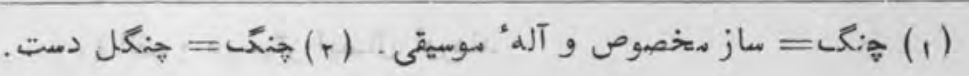


عاقلانه ، آنجه كله اسهان خوب و خاصه از يغماي شاهزاده: مذ كورز

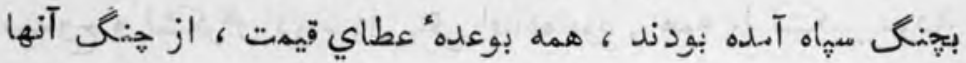

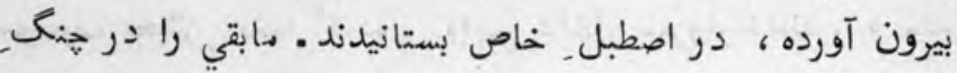

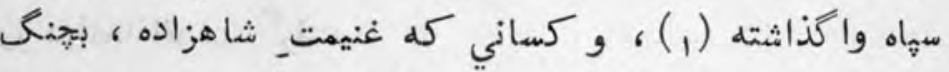

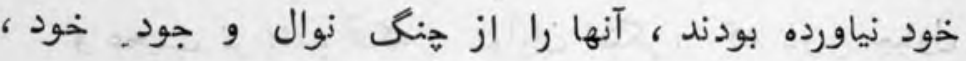
. خوشدل ساخت .

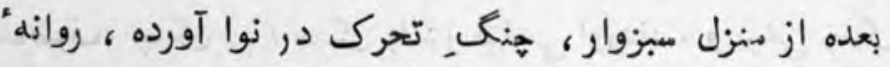

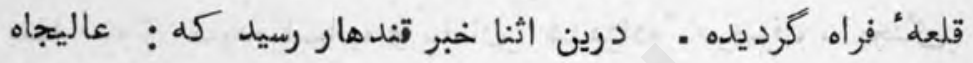

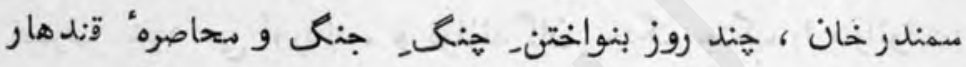

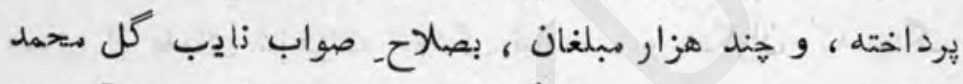

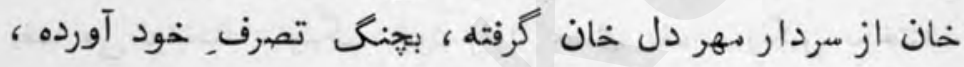

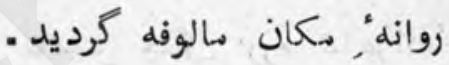

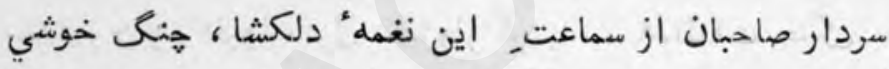

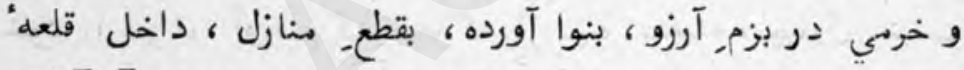

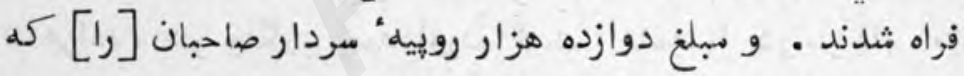

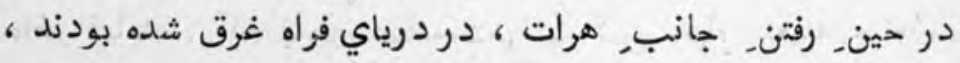

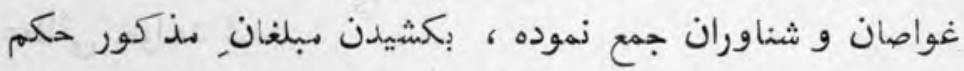

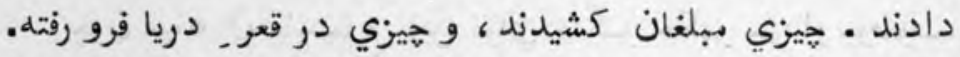

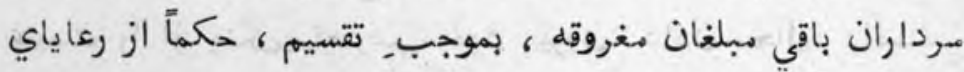
فراه تحصيل كردند (r)

$$
\text { . }
$$

(r) الف: درحيّز ايصال آوردند. 


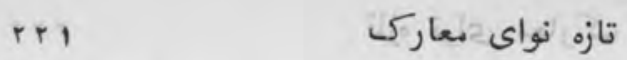

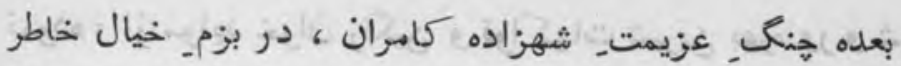

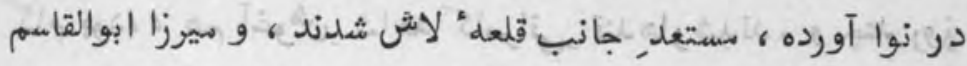

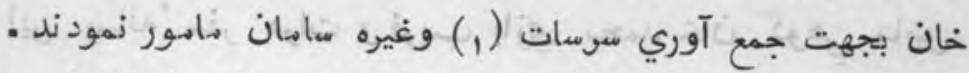

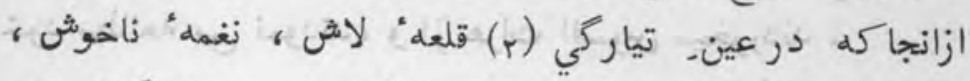

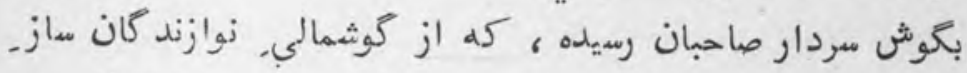

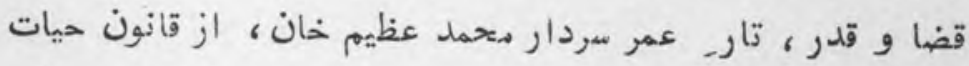

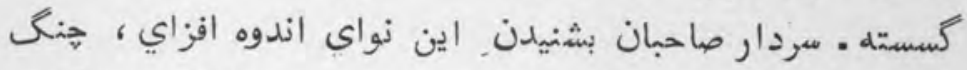

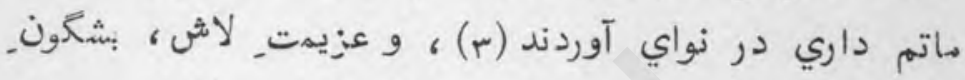

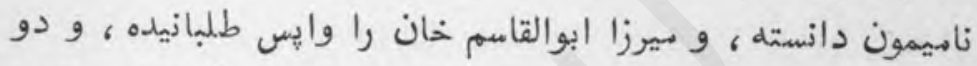

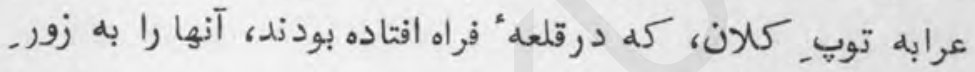
باروت شكستانده ، تكه تكه نموده ، بر شتران بار نمونده ، بطريق

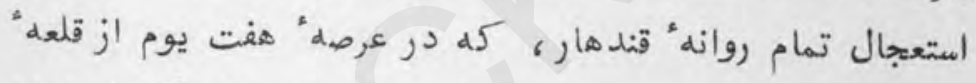

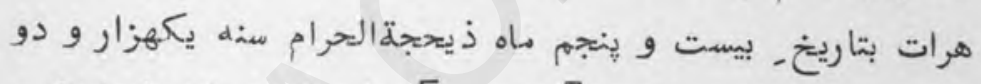

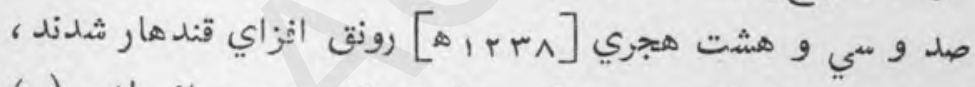

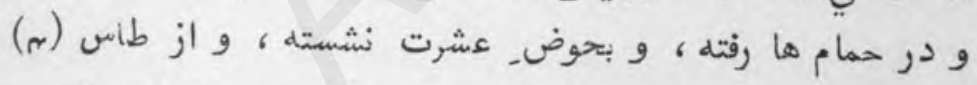

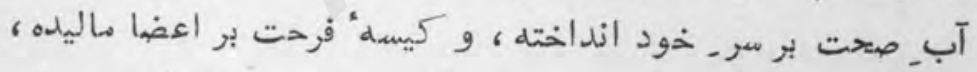

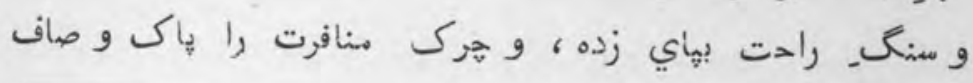

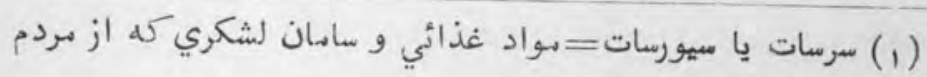

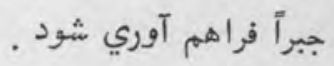

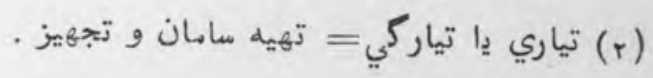

•r r r (r)

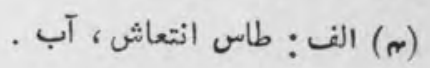


تازه نواى معاركى

نموده ، از موايد خوان رنكين و فواكهات شيرين بهره ور و شيرين

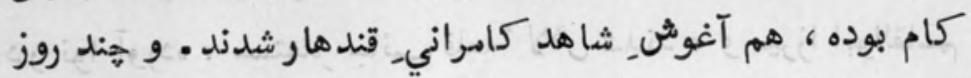

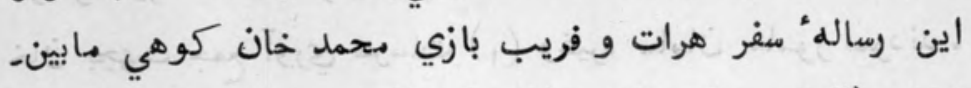

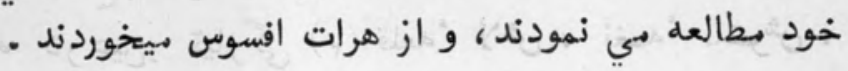


$-m{ }^{n}-$

در بيان_ رفتن. سردار شير دلخـان طرف كابل و كرفتار نمودن حبيب اله خان خلف مرحوم [مردار] محمدعظيم(1)

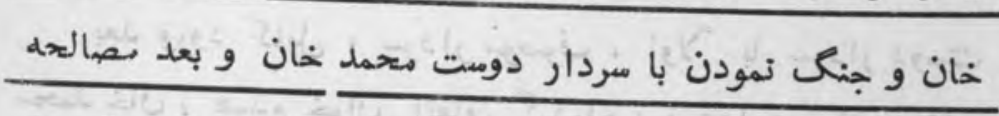
نمودن، و تمام دولت مرحوم محمد عظيم خان را بدست آوردن و باز داخل قندهار شدن

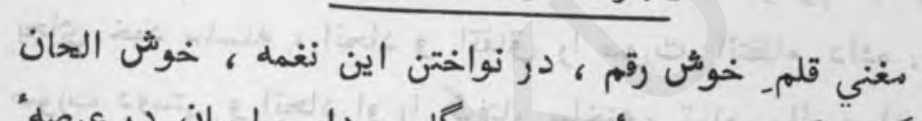

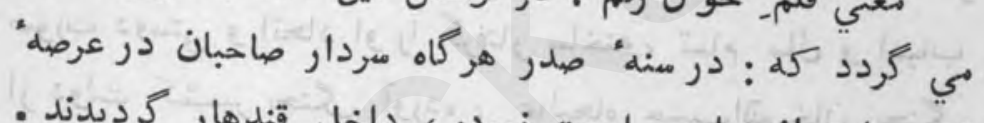

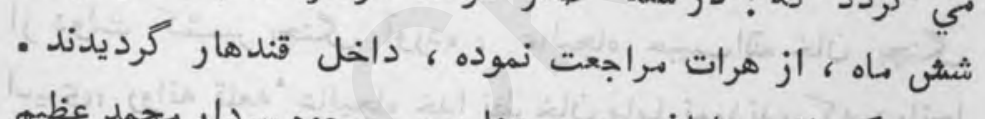

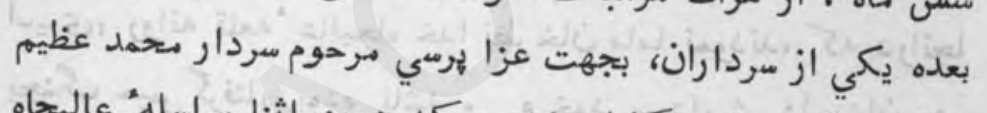

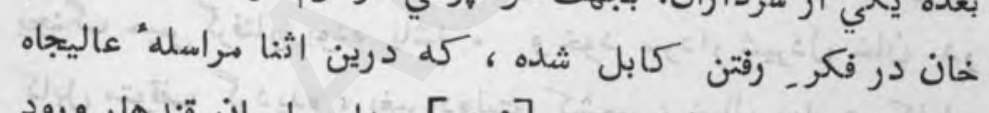

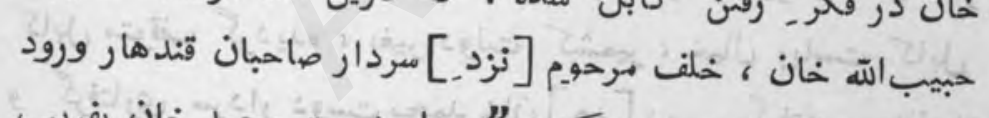

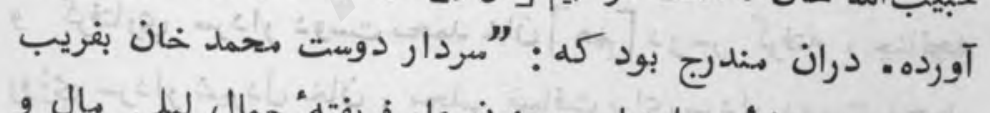

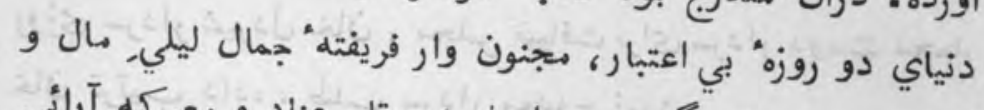

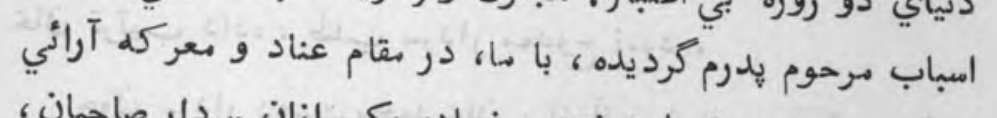

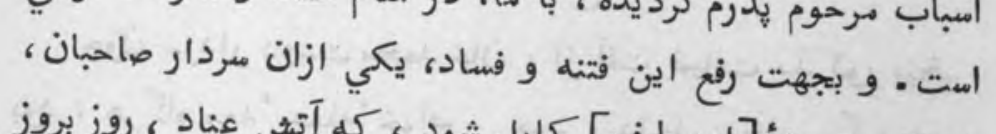

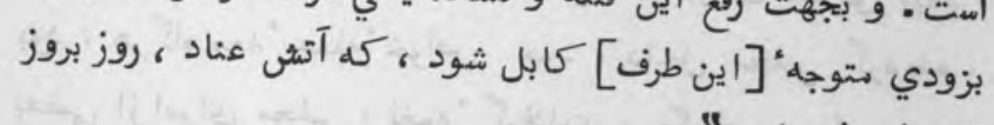

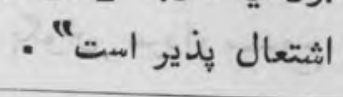

[ [? (1) 
تازه نواي معاركى

rer

مبردار صاحبان ، بعد دريافت اين مضمون ، مايبن, خود

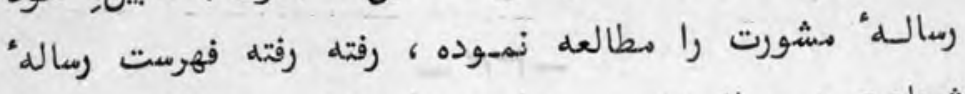

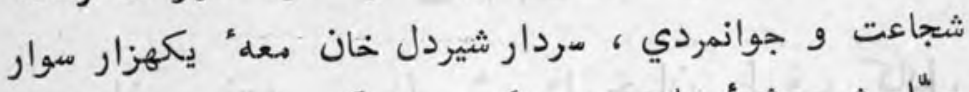

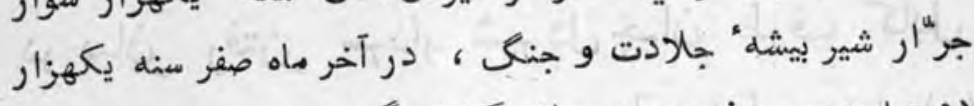

دو صد و مي ونه هجري روانه كابل كرديد .

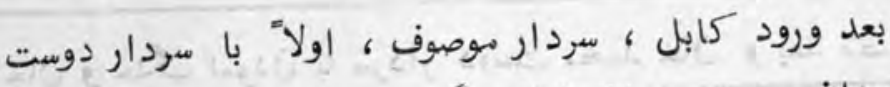

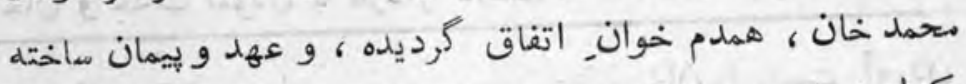

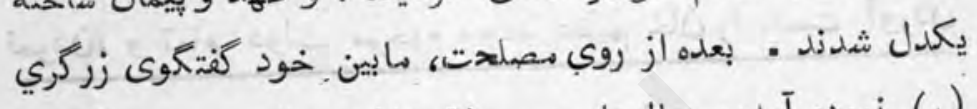

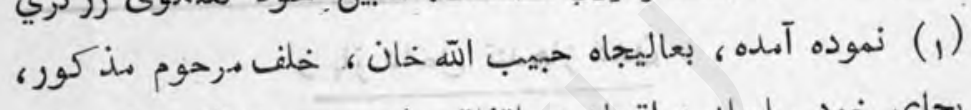

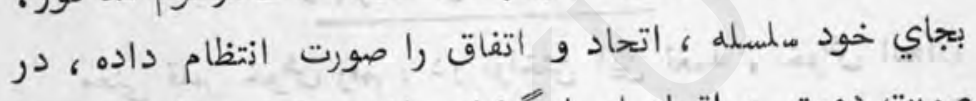

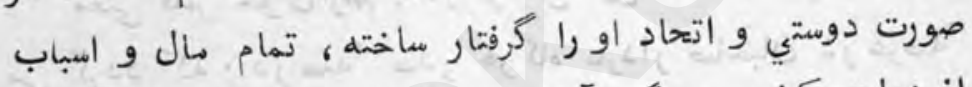

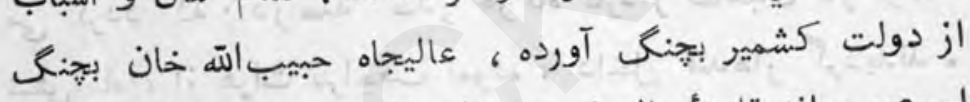

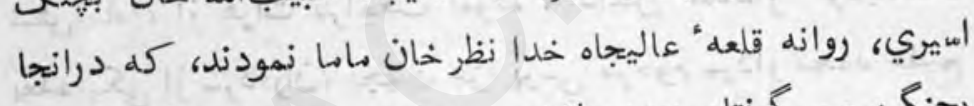

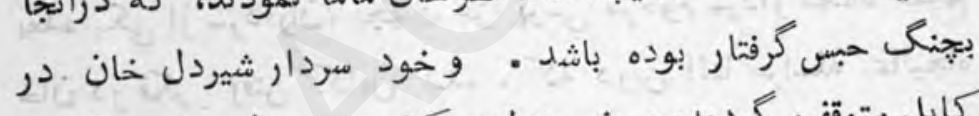

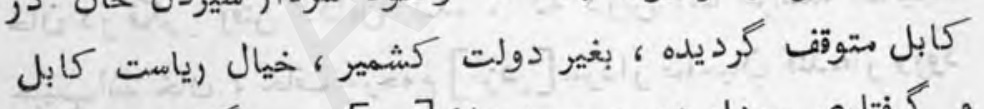

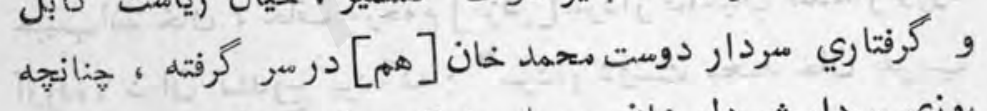

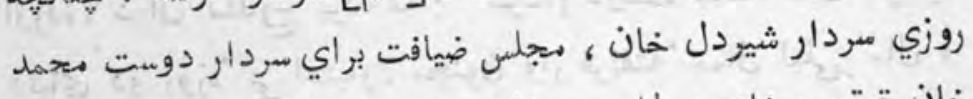

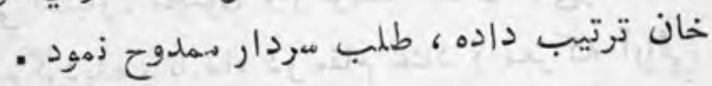

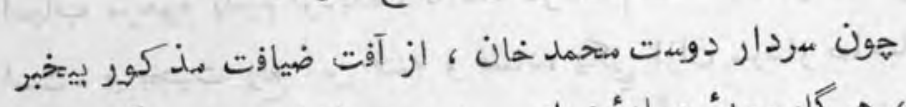

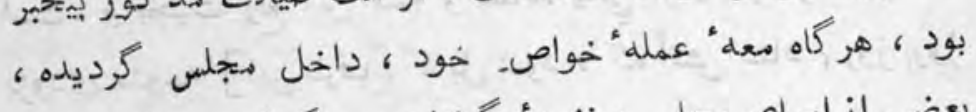

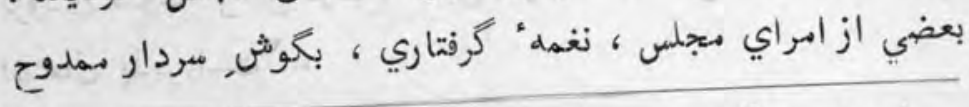

(1) الف: كفتيكو از سر كرمى ذمودهه. 
ت

وسانيدند • هماندم ترك مجلس نموده برخامته ، روازه بجايخود

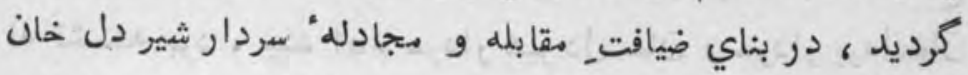

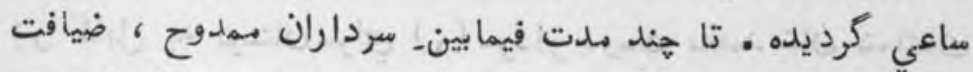

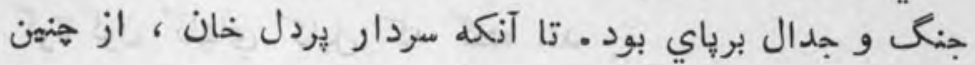

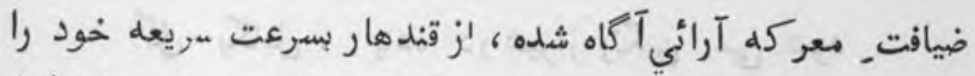

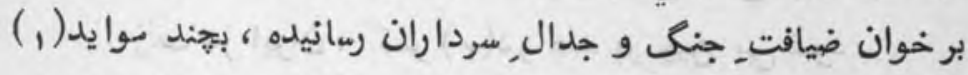
مواغظه و نصايح ، رفهع تلخ كامي نفاقـ سرداران مهدوح

- دودمد

ليكن سردارشير دل خان، مـوايد_ ــواعظه را نا كوار دانسته،

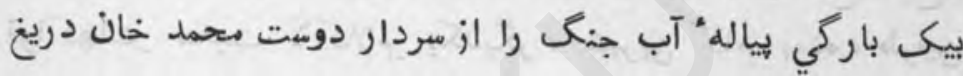

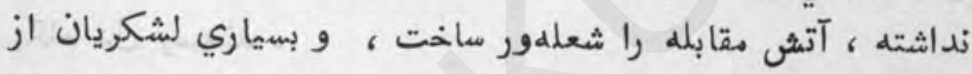

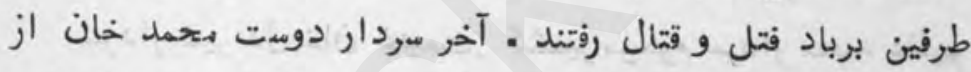

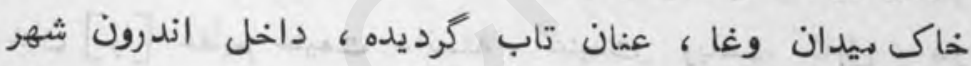

مابل كرديد

سردار شيردل خان ، بعد عنان تابي سردار دوست محمد خان،

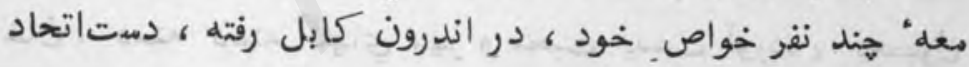

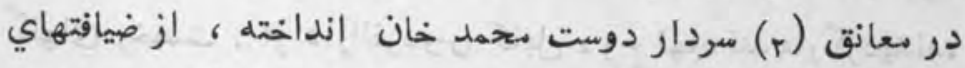

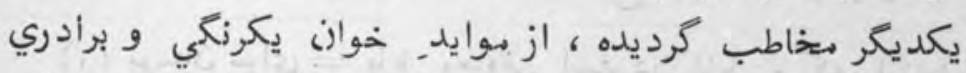

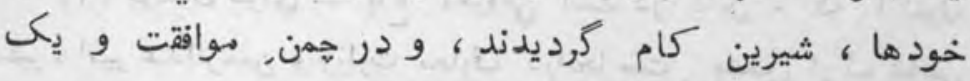

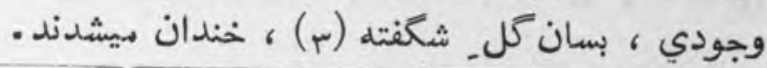

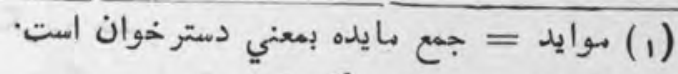

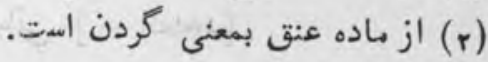
(r) الف: كل كل شكفته 
كويا غبار, كينه و فنساد بر دامن حال سردار صاحبان ممدوح

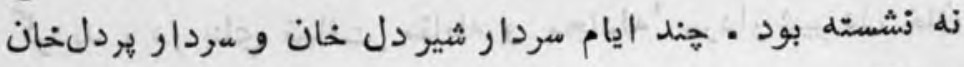

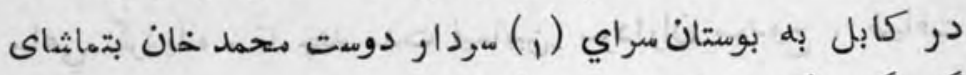

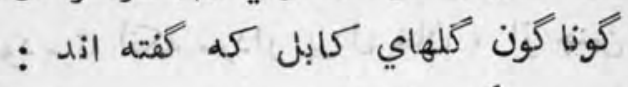

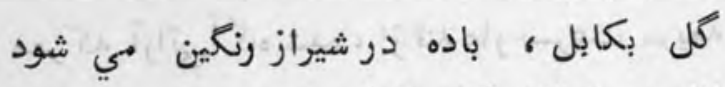

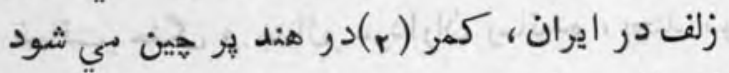

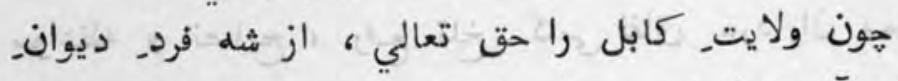

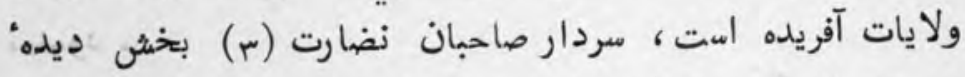

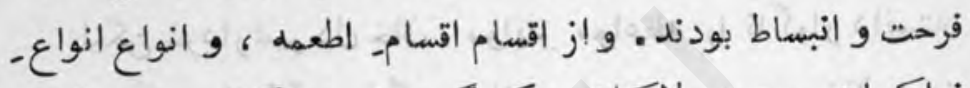

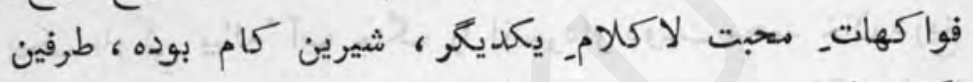

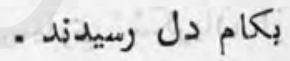

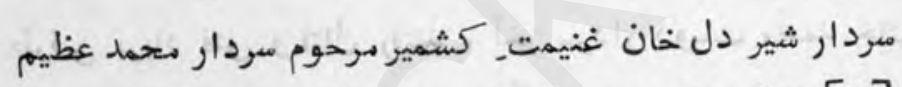

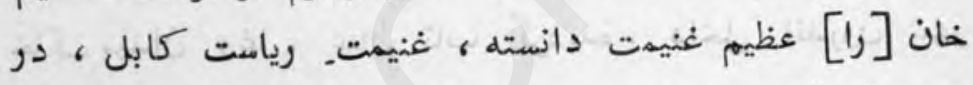

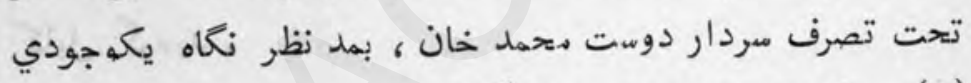

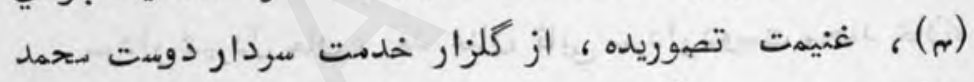

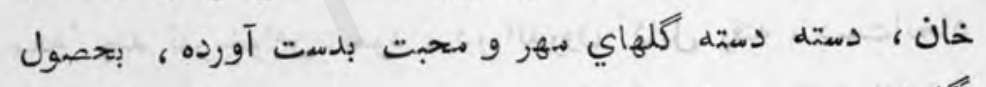

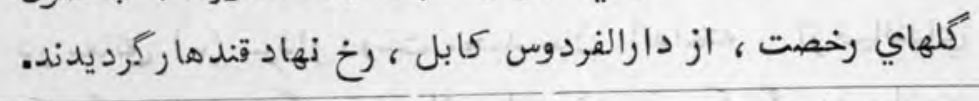
(1) بوستان سراي = باغ معروفي است در كابل ، كم اكنو اكنون

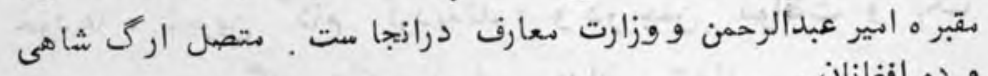
و ده افغانان.

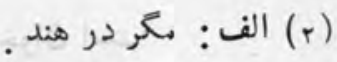

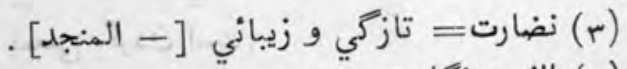

$$
\begin{aligned}
& \text { (r) الف: زمَاه وجودي. }
\end{aligned}
$$




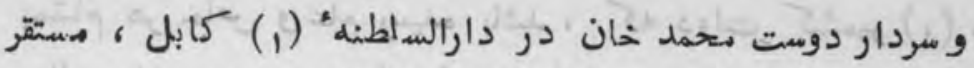

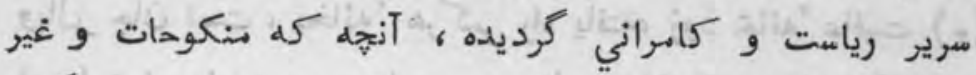

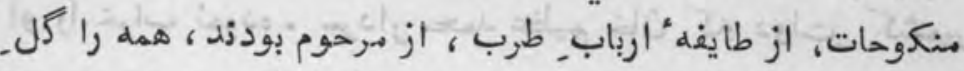

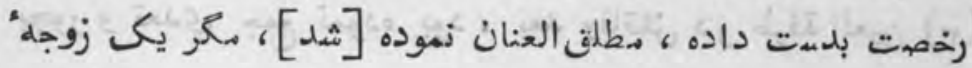

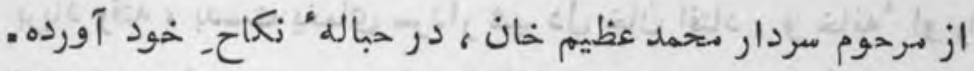

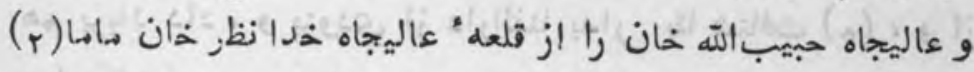

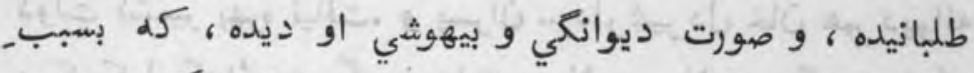

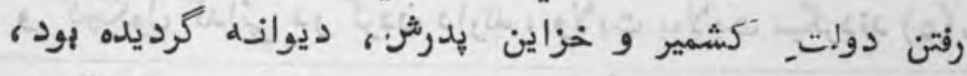

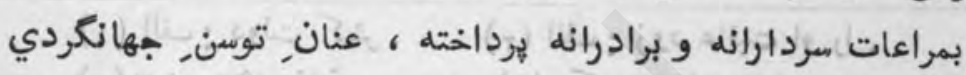

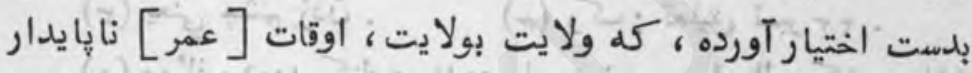

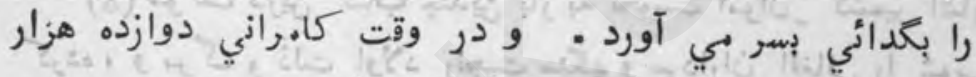

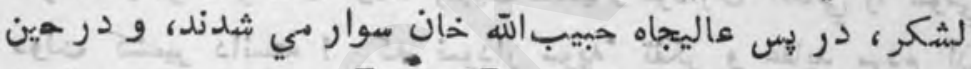

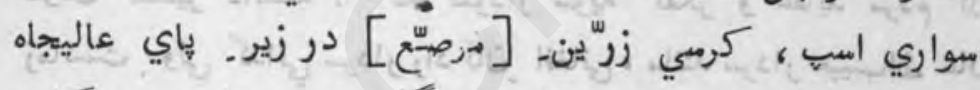

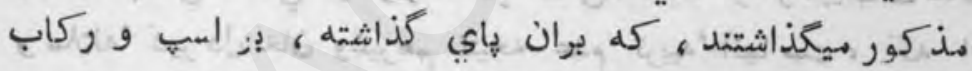

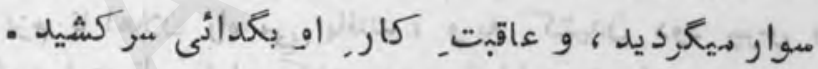

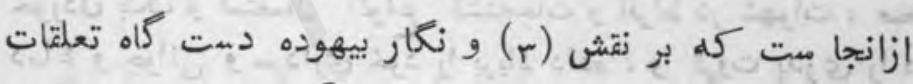

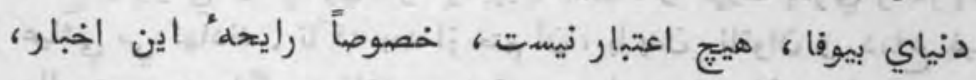

$$
\text { (r) }
$$

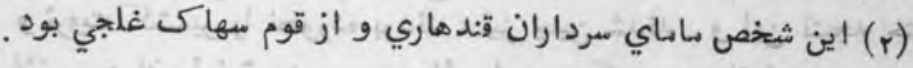

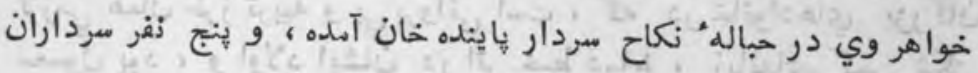

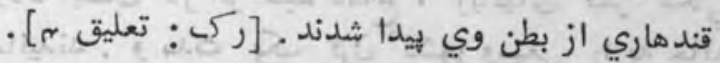
. ك : (r) 


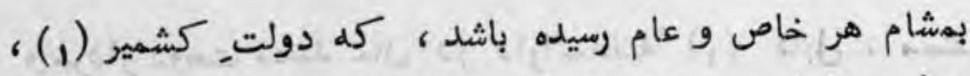

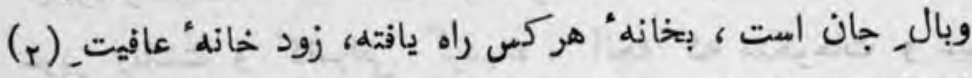

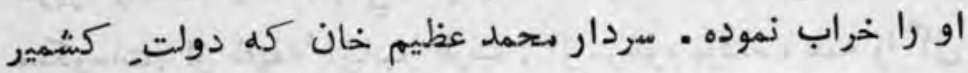

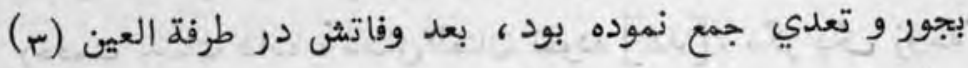

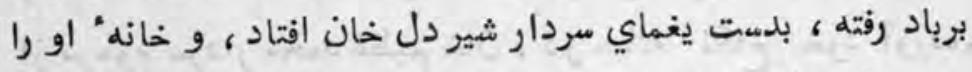

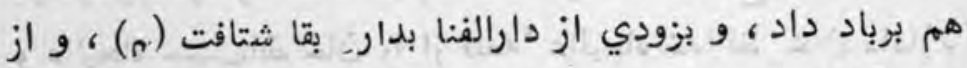

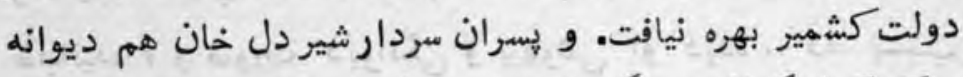

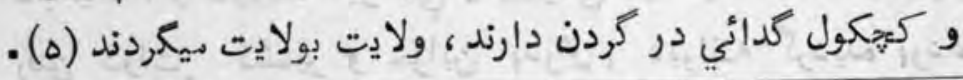

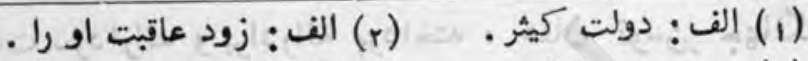

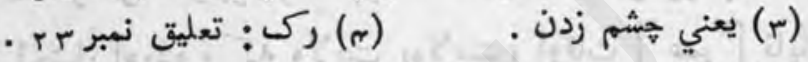

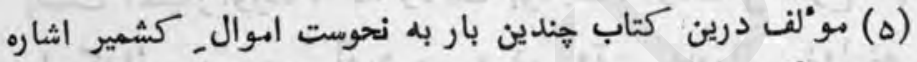

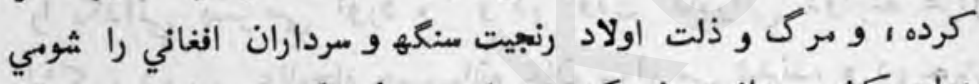

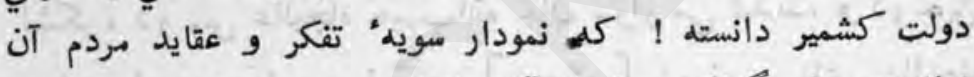

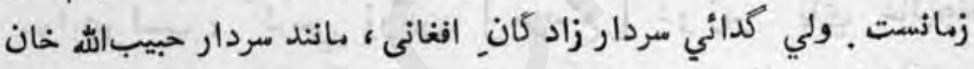

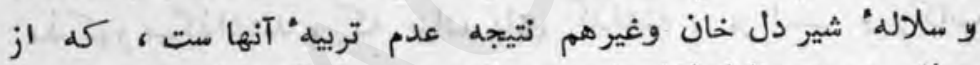

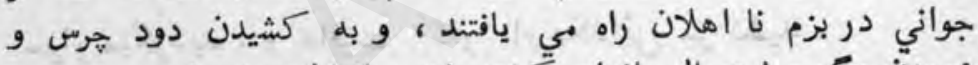

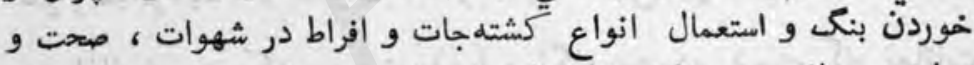

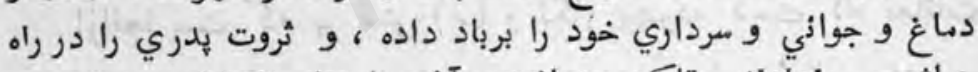

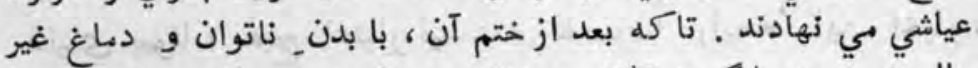

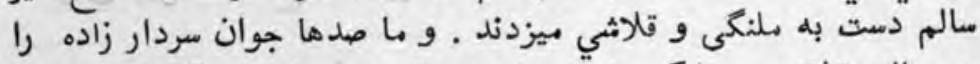

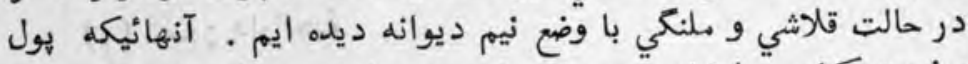

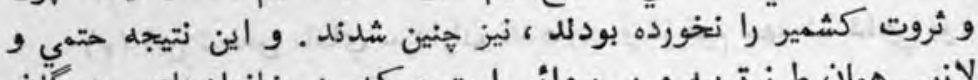

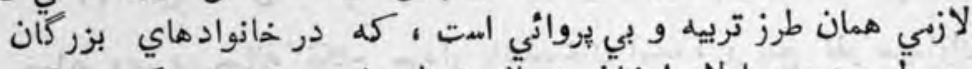

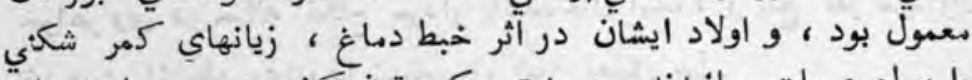

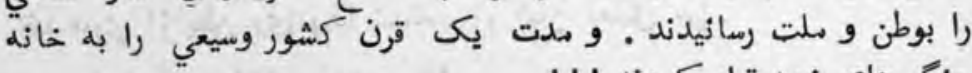

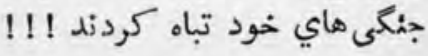


ديد دنيا هو دون دختر

حالـ دنياي دني اينست : زاهدي خواب رفت دن دري فكري

\section{كرد از وي سوال : كاي دختر !}

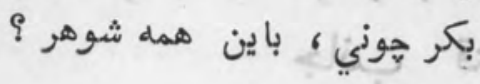

$$
\text { كفت دنيا: كله من بكويم راست }
$$

كم مرا هر كله مرد بود نخواست

$$
\text { هو كل نامرد بود خواست مرا }
$$

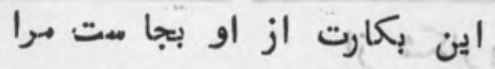

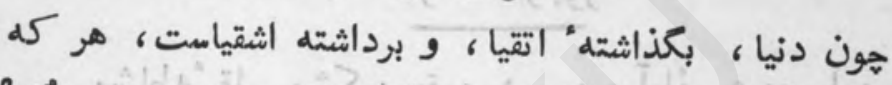

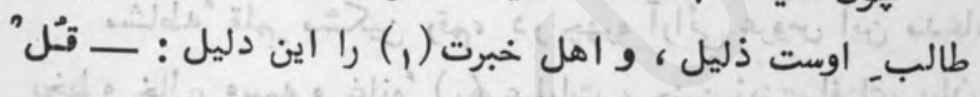

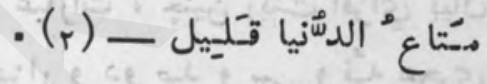

\section{एक्य}

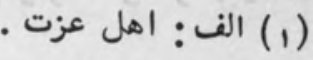

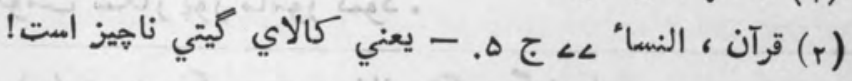


در بيان, رفتن سردار رحمدل خان از شكار يور

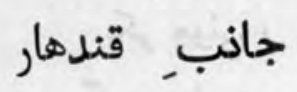

و مقرر نمودن_عاليجاه عبدالمنصور خان بعهده" حكودت شكاريور،

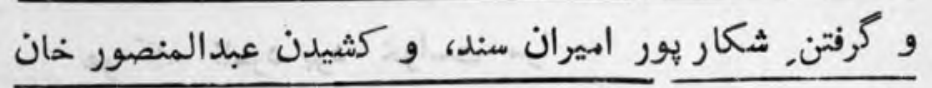
از شعار بور

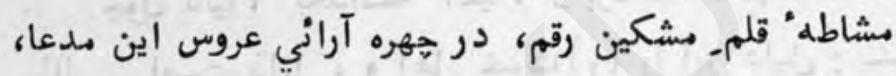

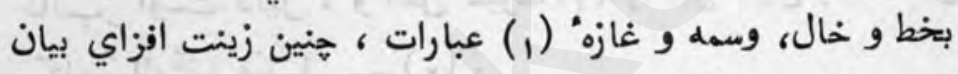

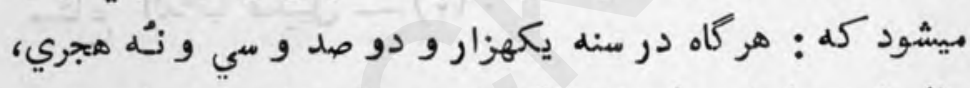

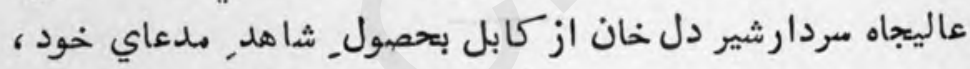

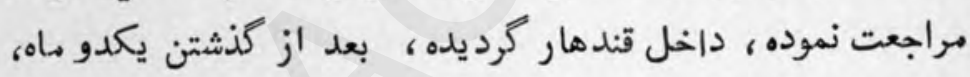

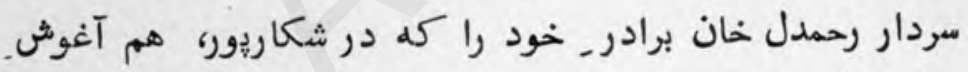

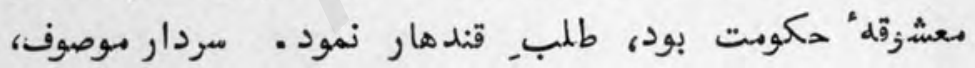

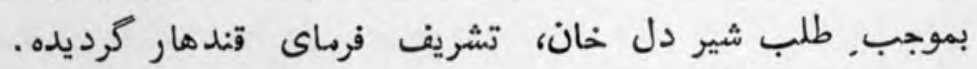

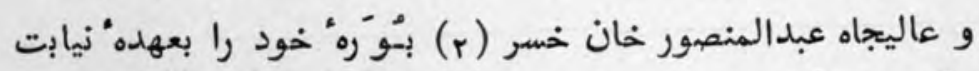
حكومت شكار يور مامور نموده

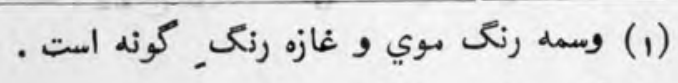

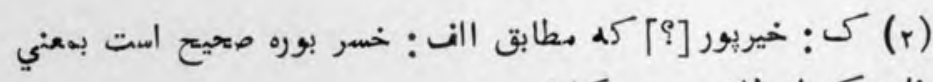

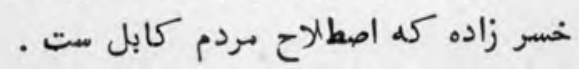


تازه نواي معاركم

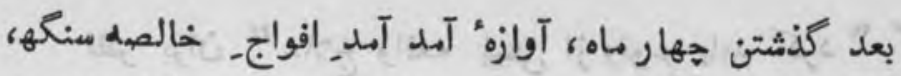

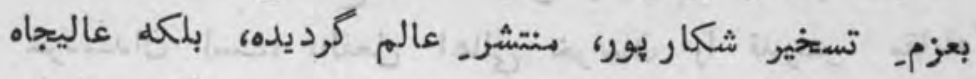

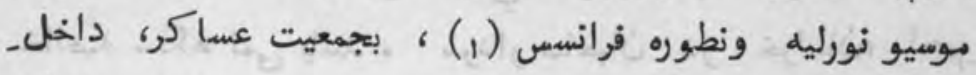

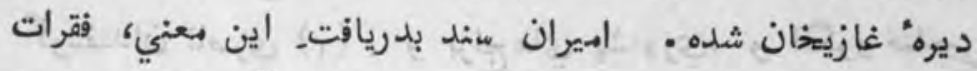

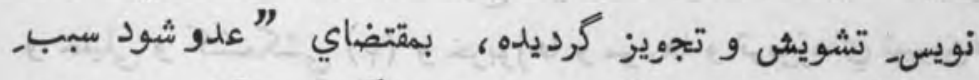

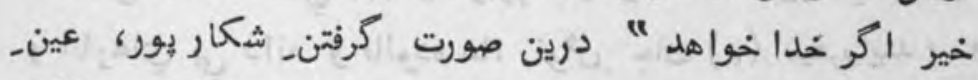

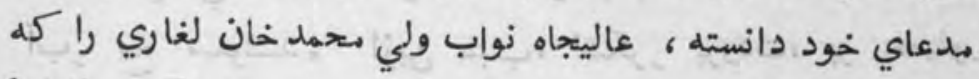

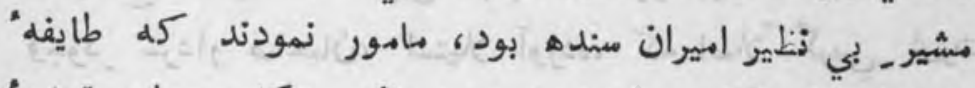

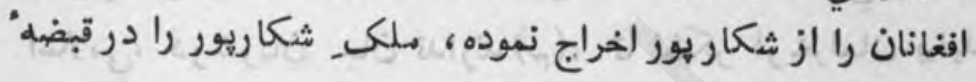

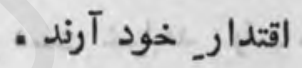

نواب_ مذكور اولاً از لازكانه (r)، نوثتجات_ خود را

متواتر، بطرف عاليجاه عبدا'منصهورخان بهمين مضمون فرستاده كله :

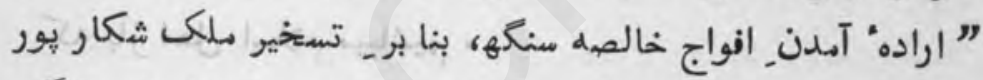

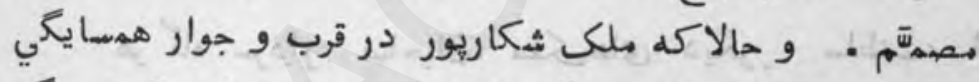

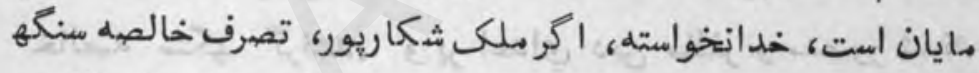

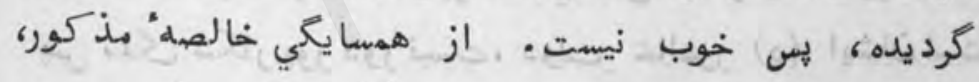

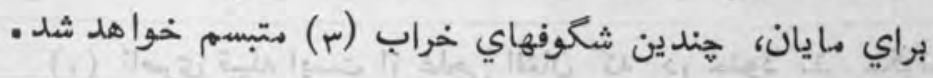

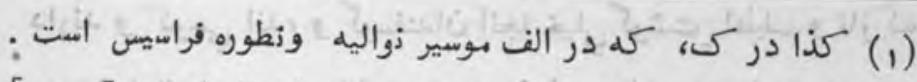

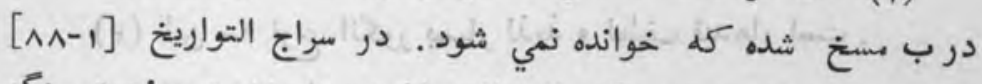

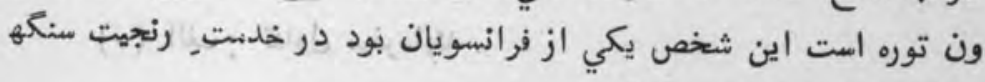

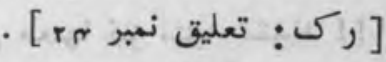

(r) الف، ب : خرابي ·

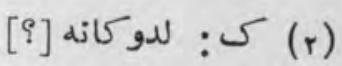


نظر بران "علاج واقعه بييق از وقوع بايد كرد " كفته"

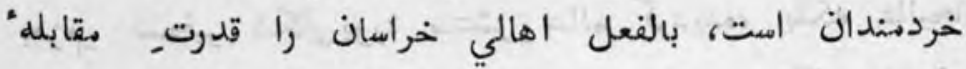

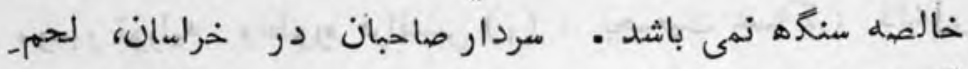

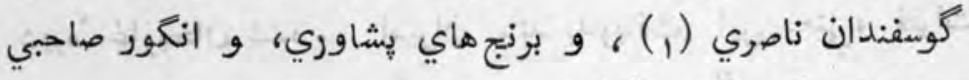

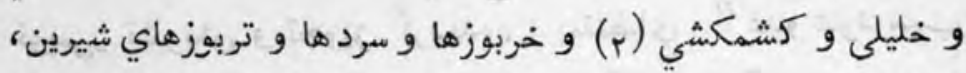

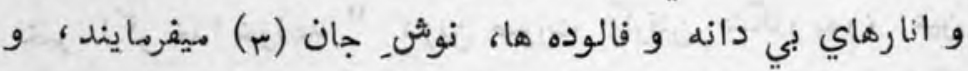

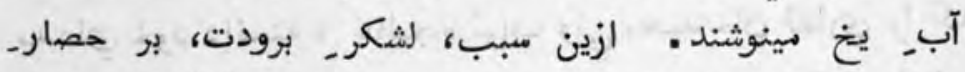

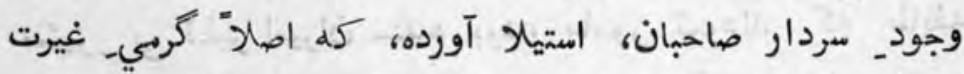

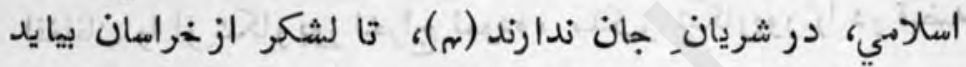

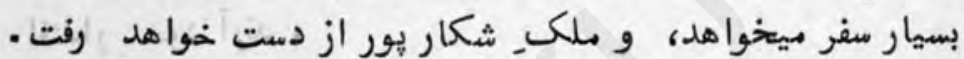

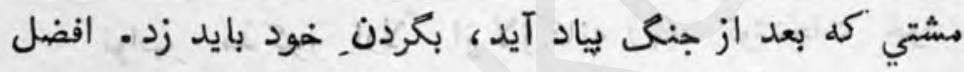

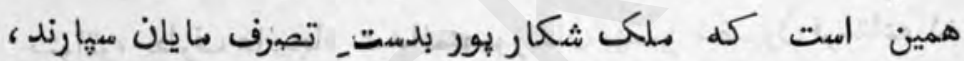

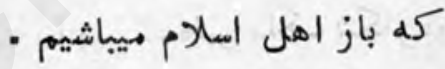

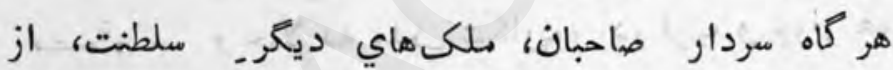

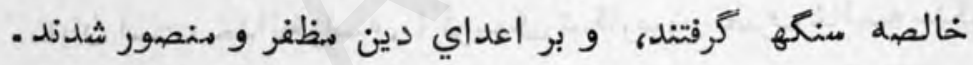
يس هلك شكار يور دور نيست، دولت_ خالصـ (ه) ايشان است.

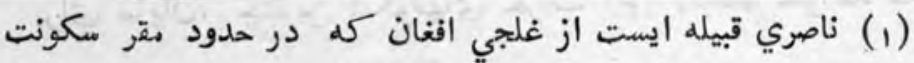

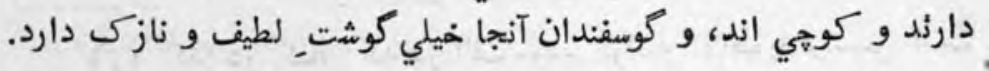

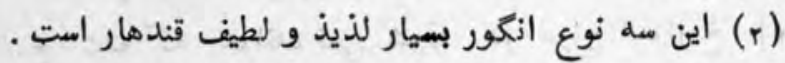

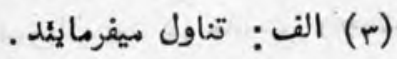

(م) فسوسا! كه سردار صاحبان ازين طعنها نيز متنبه زشدند !!!! (ه) الف: دولت خاص. 
تازه نواي مع رك

الجال مهرباني نموده، بزودي بلا توقف، ئكدم تشريف فرماي

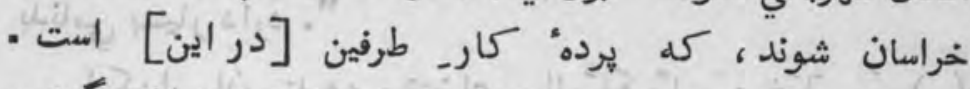

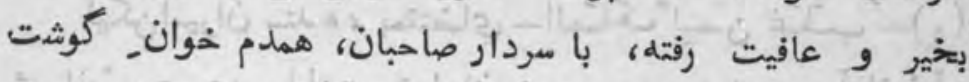

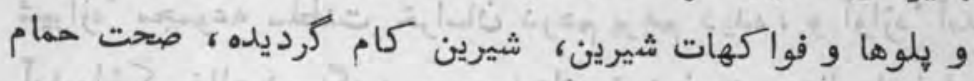

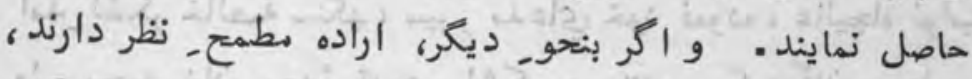

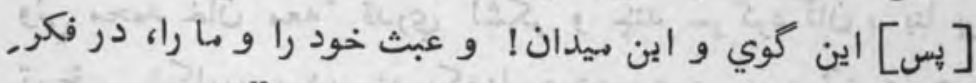

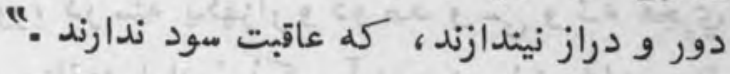
عاليجاه عبدالمنصور خان هر كاه، از هنين زوشتجات نواب

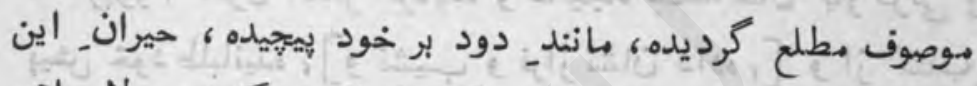

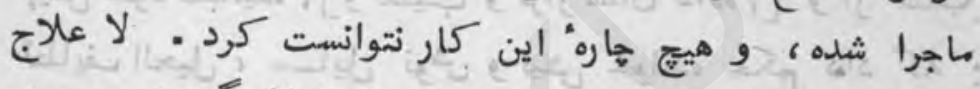
در فكر_ تدارك روانكي خود، جانب خرامسان كرديده .

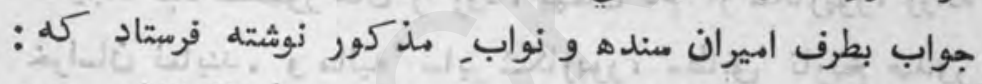

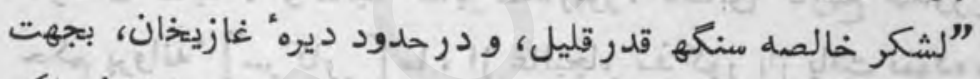

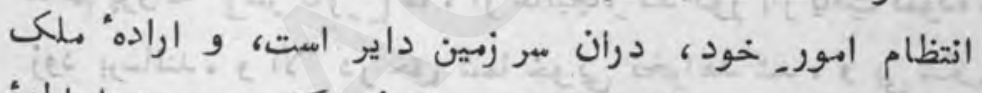

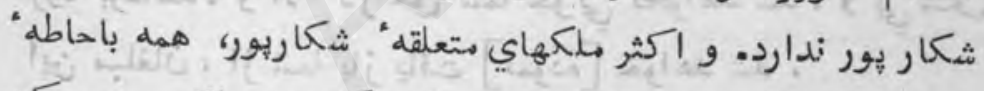

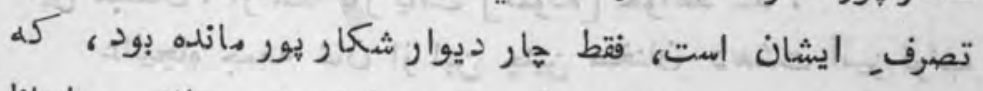

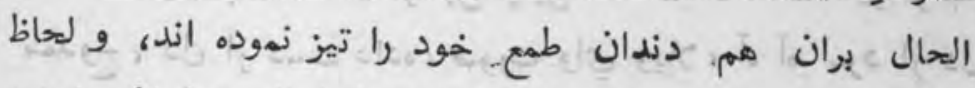

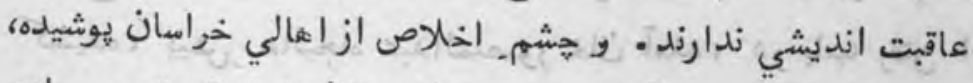

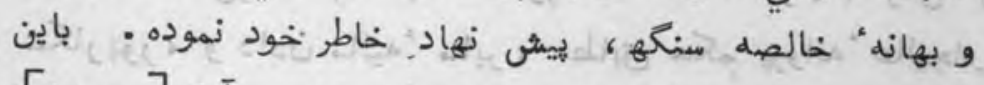

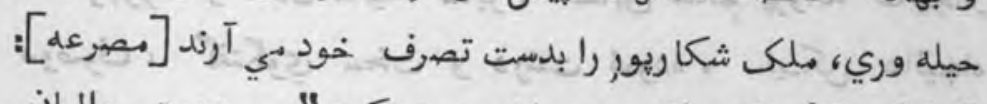

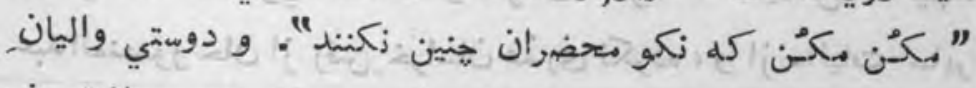

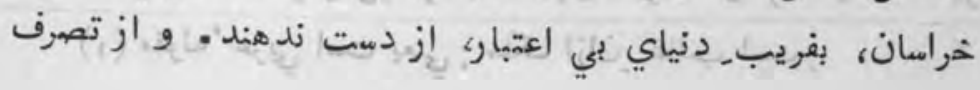


شكار يور هيتج نتيجله خوبي و بهبود كي نخوالهد ديد، بلكه

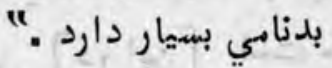

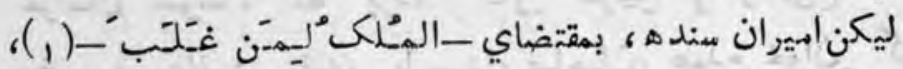

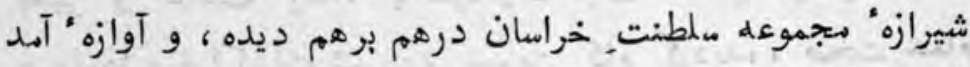

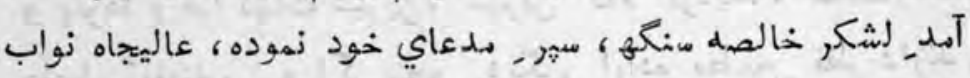

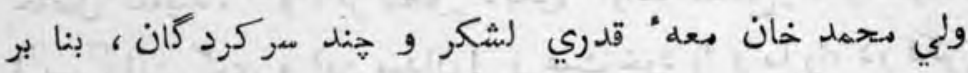

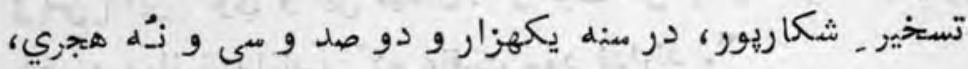

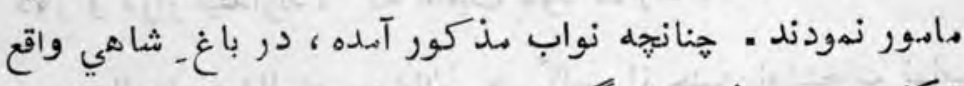

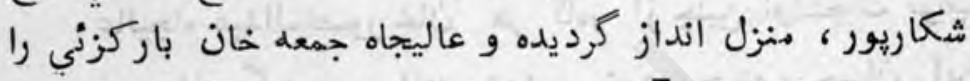

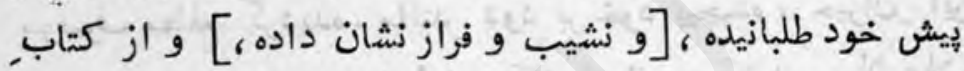

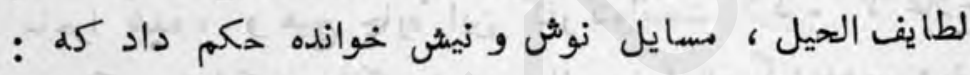

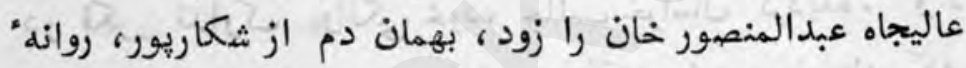

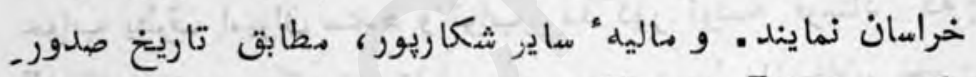

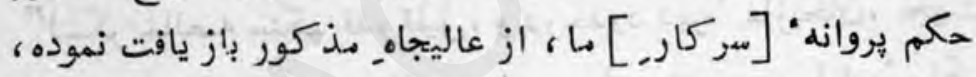

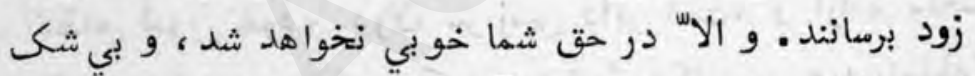

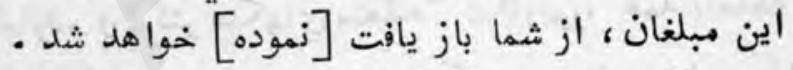

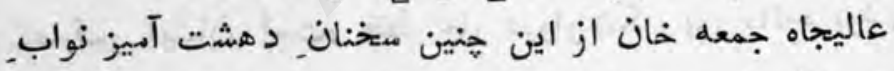

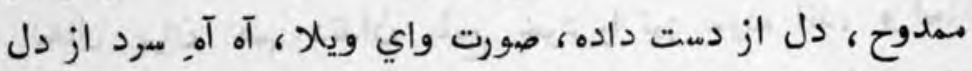

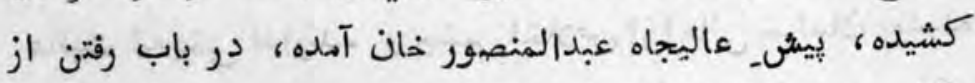

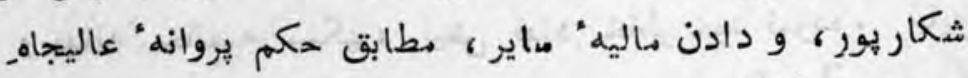

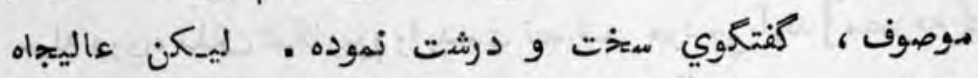

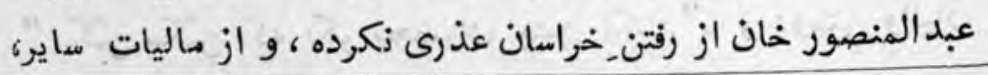

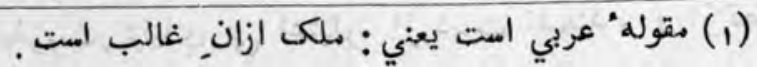




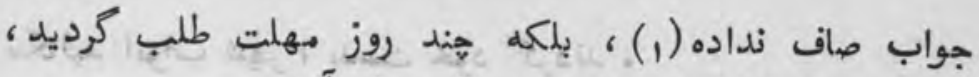

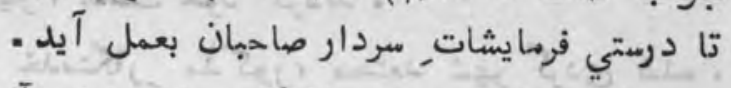

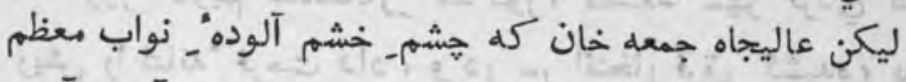

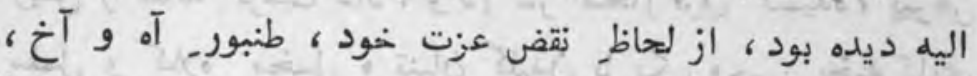

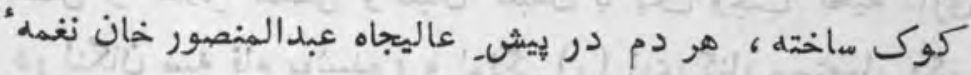

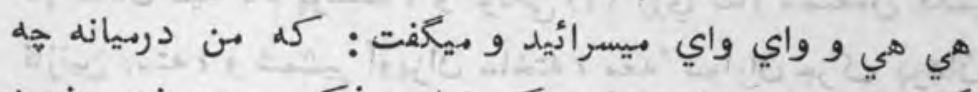

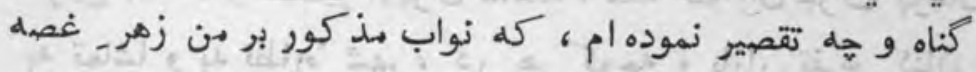

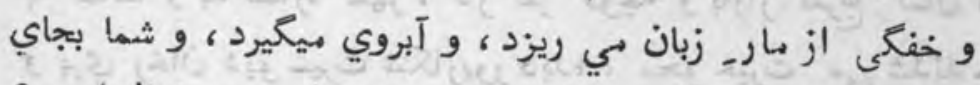

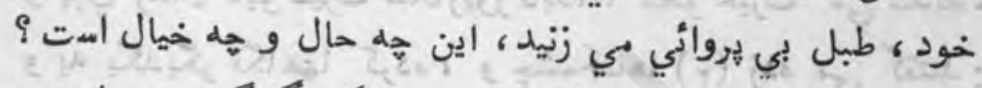

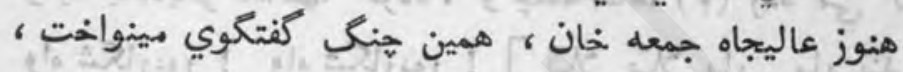

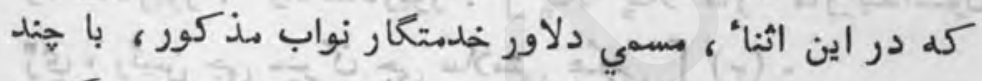

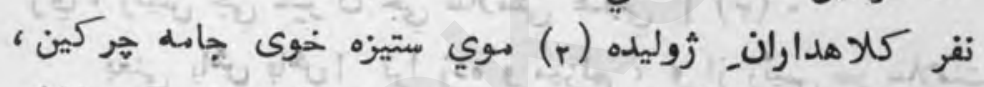

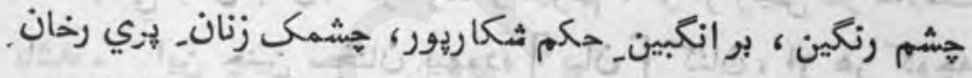

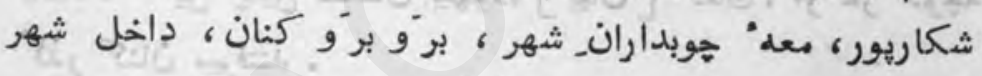

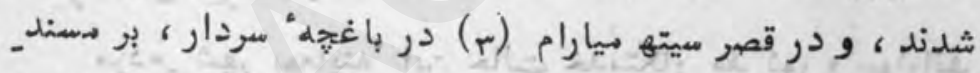

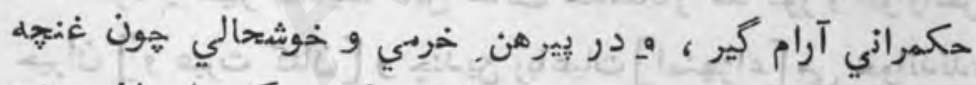

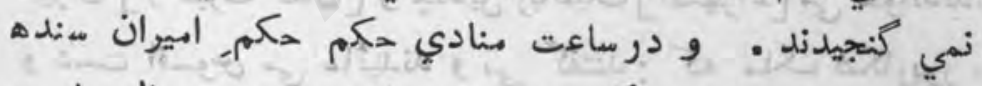

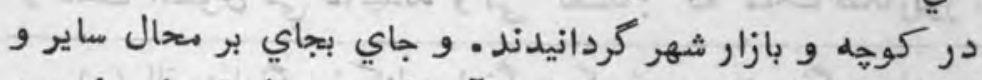

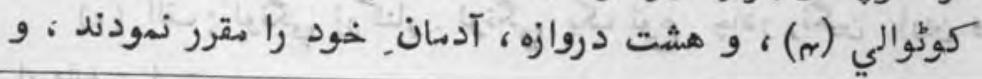

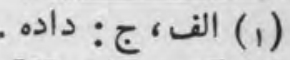

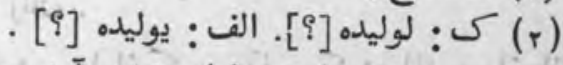

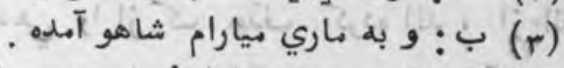

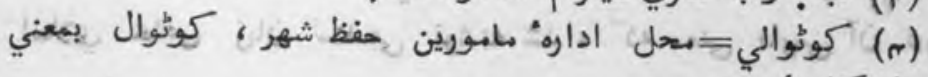

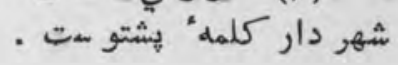


تازه نواي معارك

ret

.كاليد ابواب شهر ، بدست خود كردند .

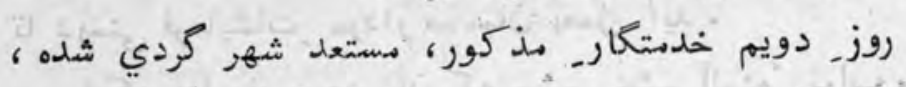

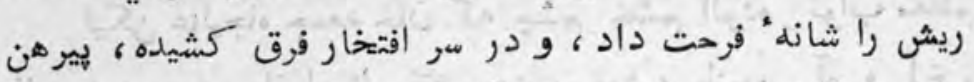

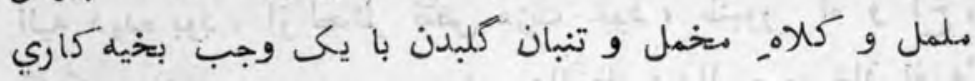

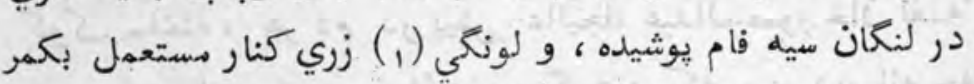

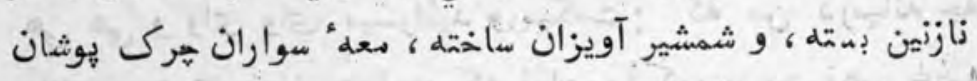

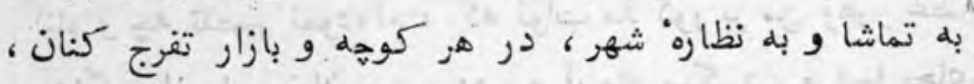

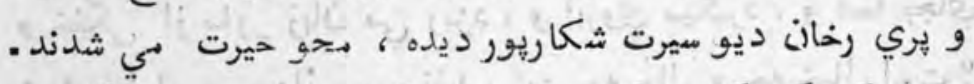

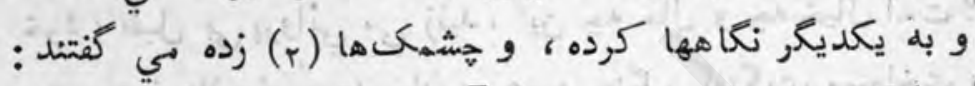

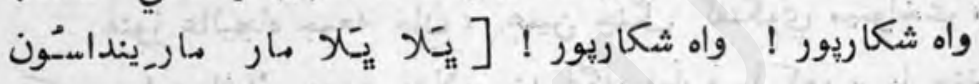

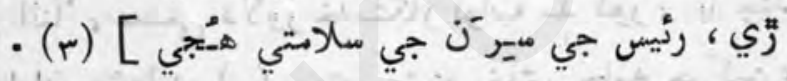

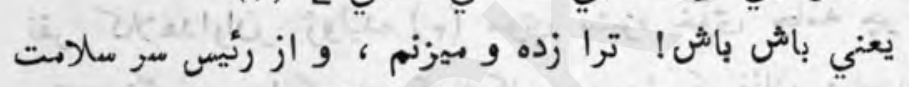

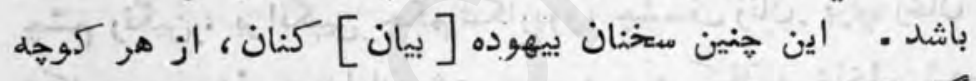

كذر كنان ميرفتند .

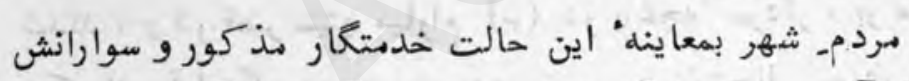

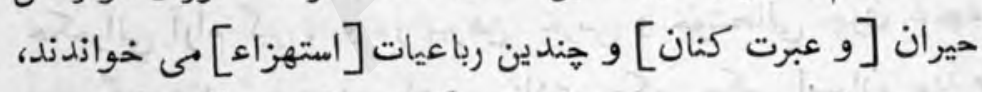

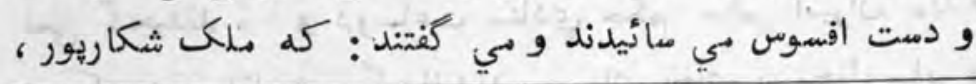

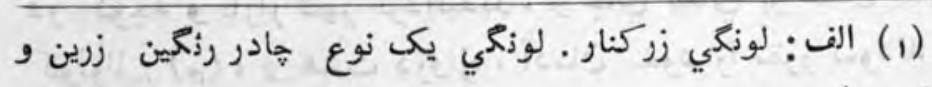

ابريشمين است .

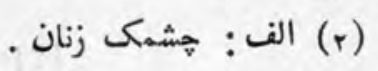

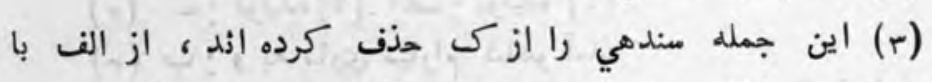

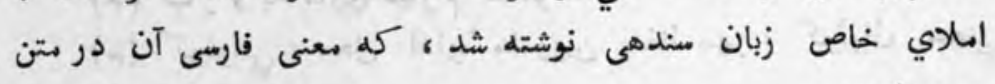

موجوداست . 


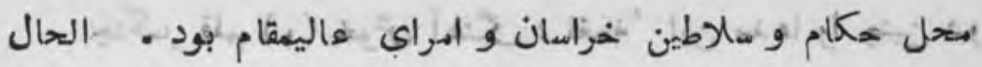

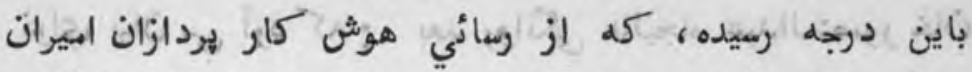

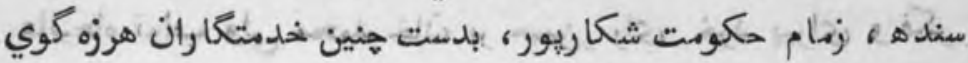
الفتاده المنت

في الجمله : روز بوم عاليجاه عبدالمنصور خان ، بموجب

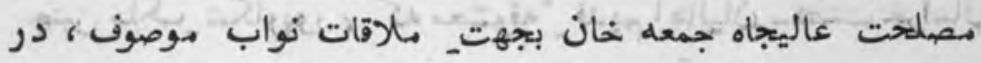

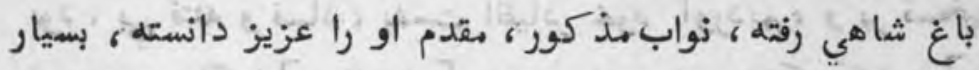

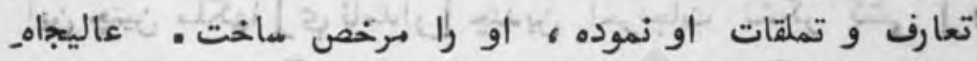

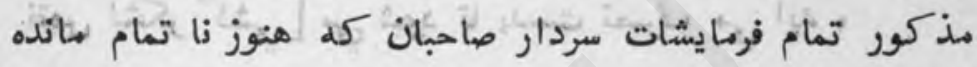

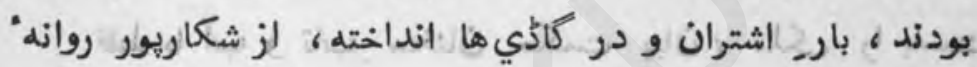

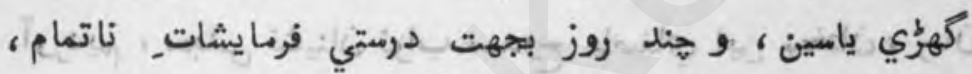

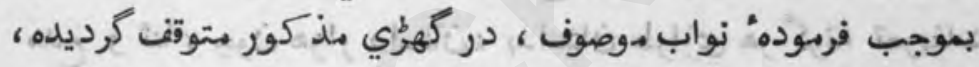

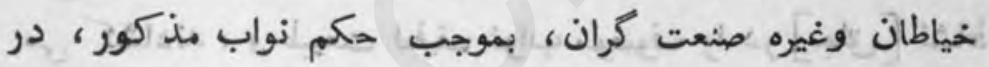

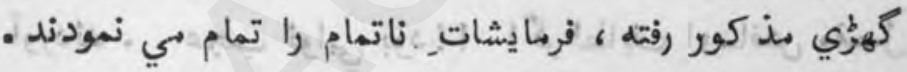

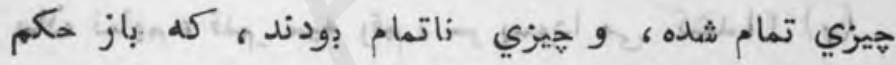

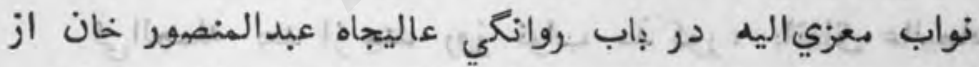

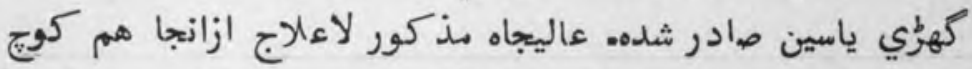

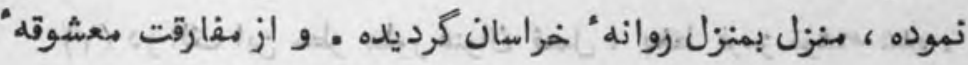

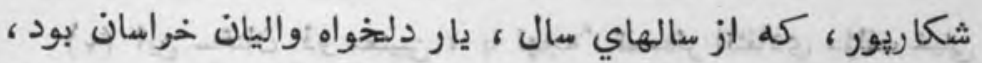

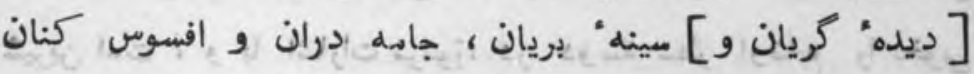
ميرفت - 


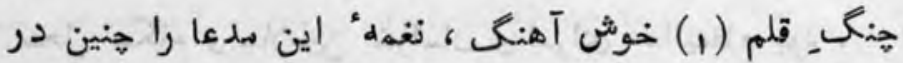

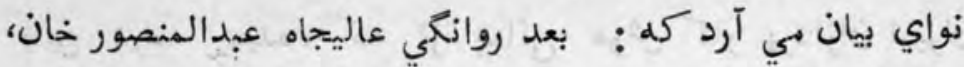

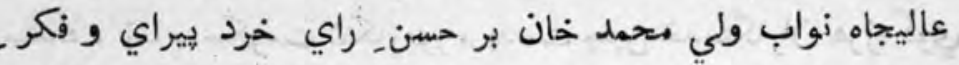

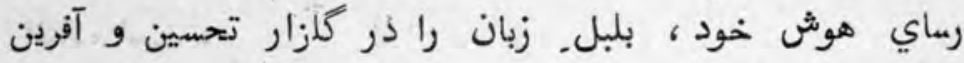

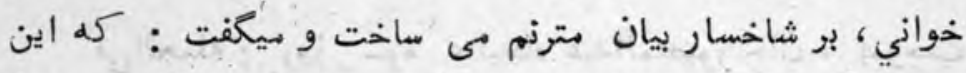

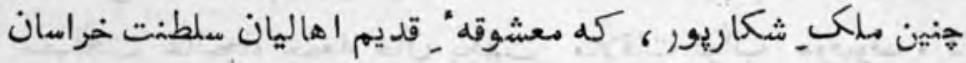

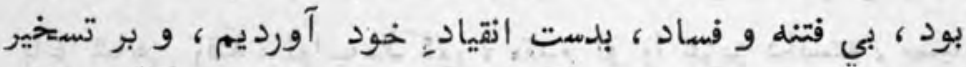

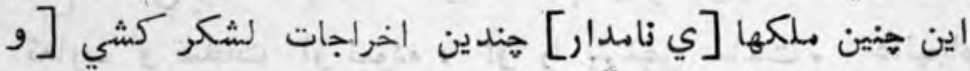
نتص اشكر كشي] [ي شود تا بدست تصرف مي مي آيد . فقط با آب و تاب سبخنان حكمت بيان ، ملك را بدست

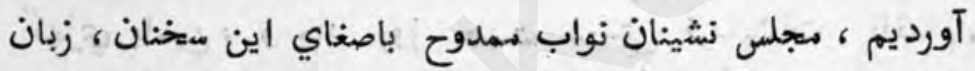

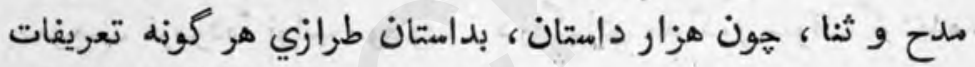

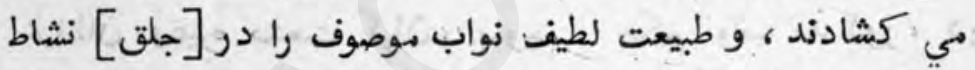

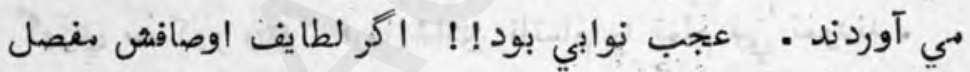

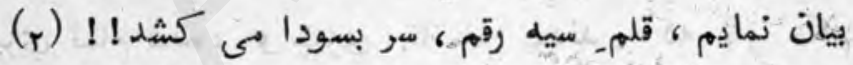
في الجمله بعد از همند روز نواب مذكور، باتفاق عاليجاه

(1) در الف اين سطر بطور عنوان فصل ، بخط قرمز نوشته شده .

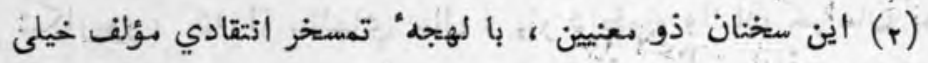

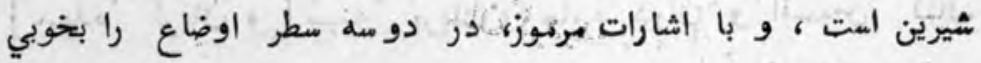

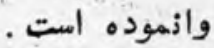




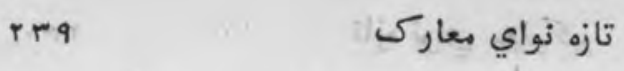

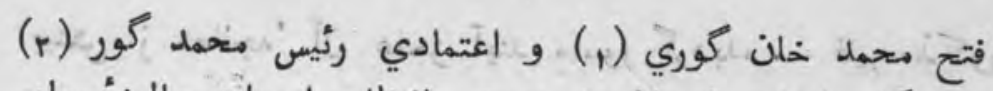

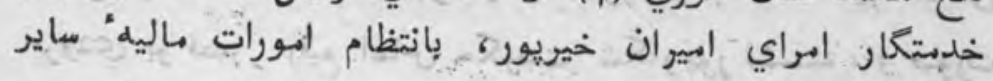

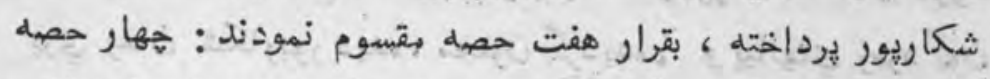

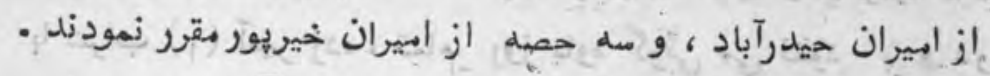

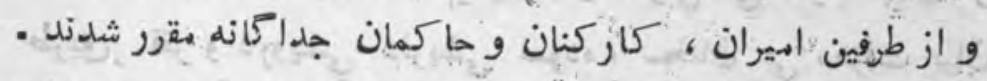

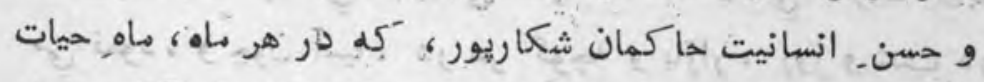

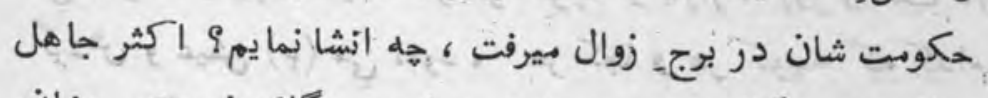

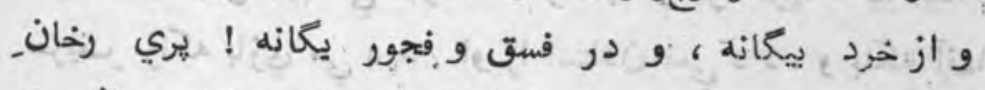

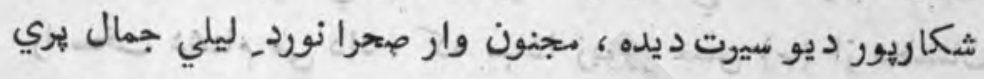

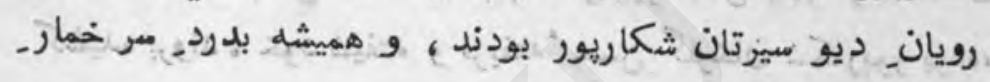

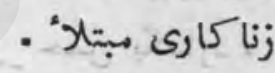

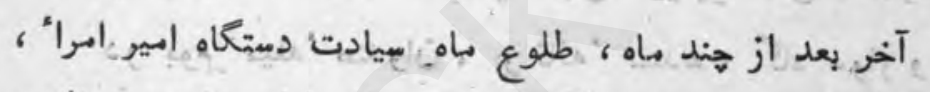

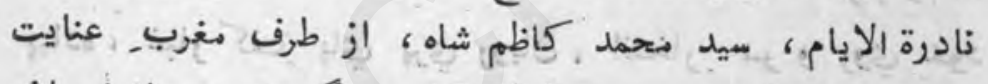

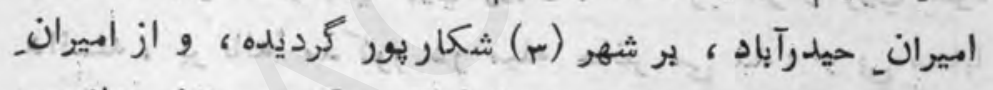

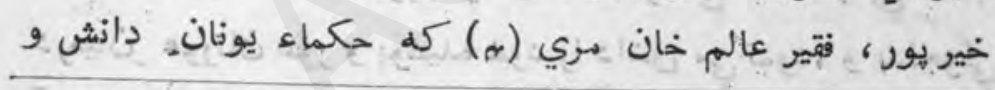

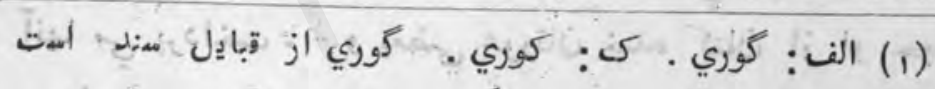

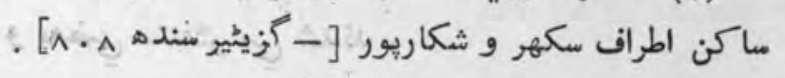

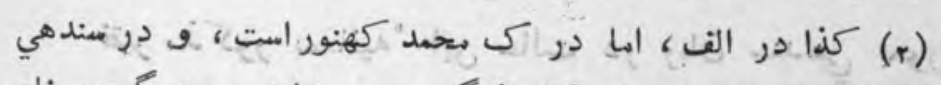

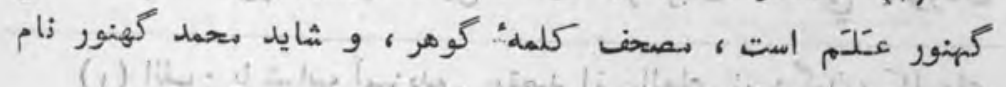

اين شخص بود .

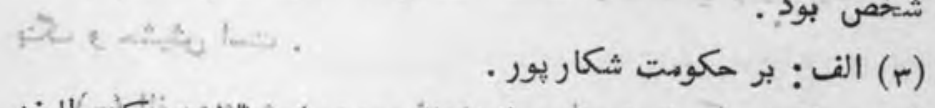

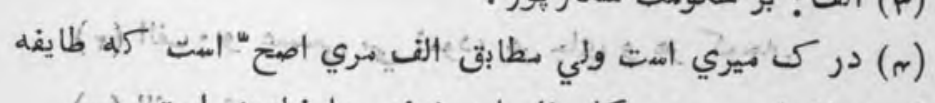

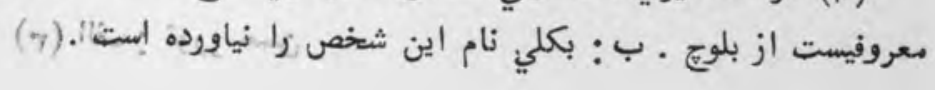




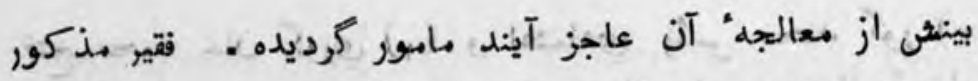

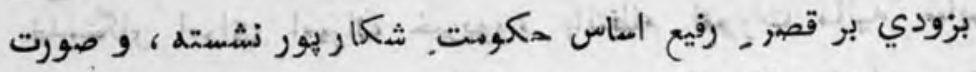

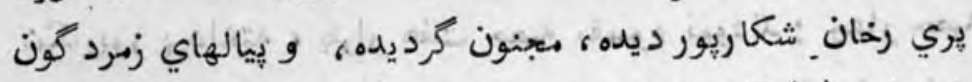

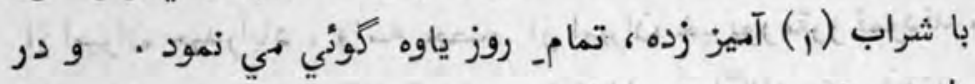

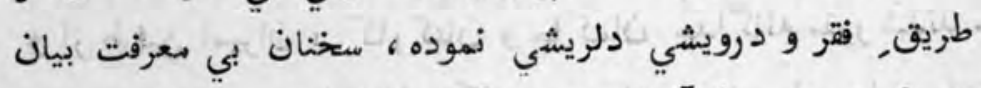

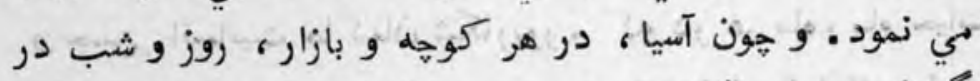

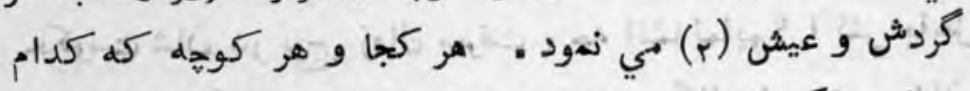

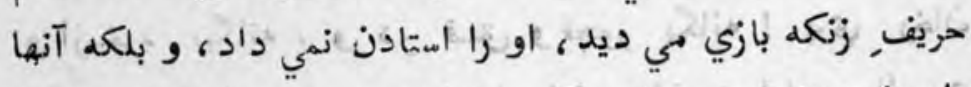

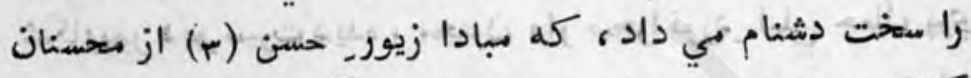

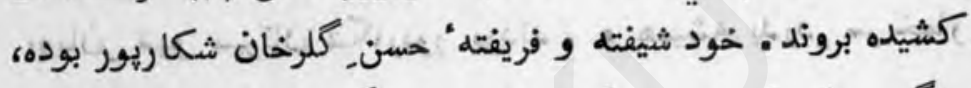

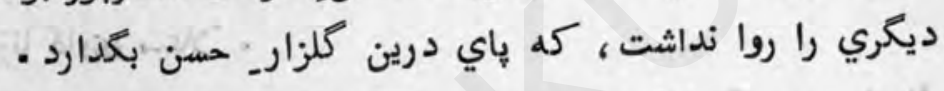

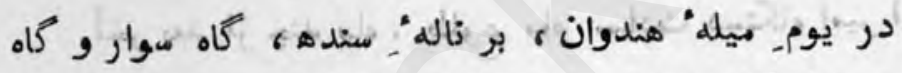

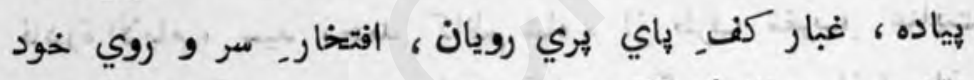

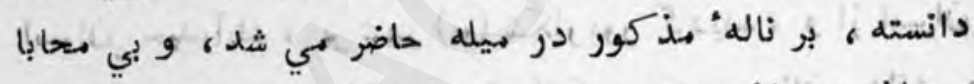

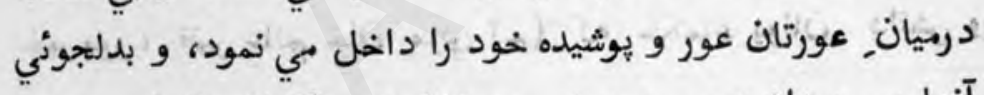

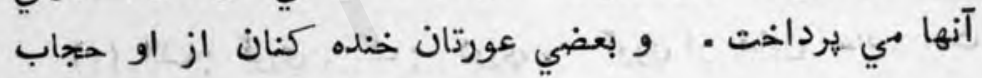

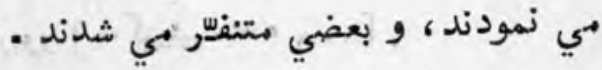

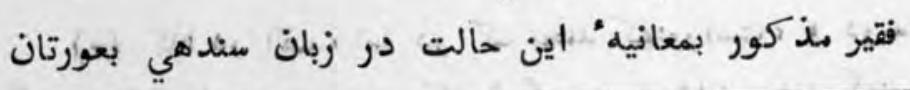
(1) الف: با شراب آميزيده. . مقصه از بيالهاي زمردكون، كاسهاي نيك و حشيش است.

(r) الف: و و عسسى بي نمود، هر جاي و هر كوحهـ.

$$
\text { (r) }
$$


: (1)

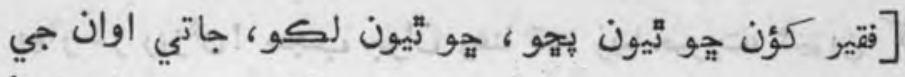

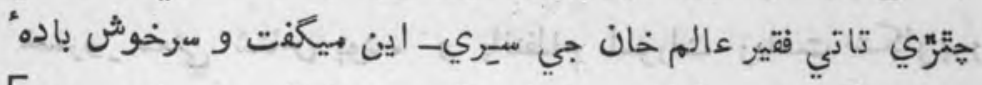

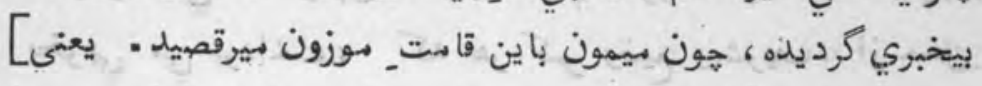

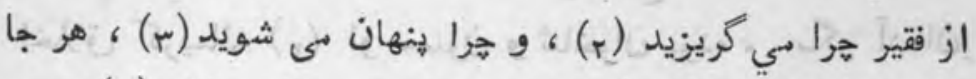

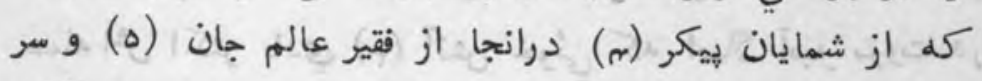

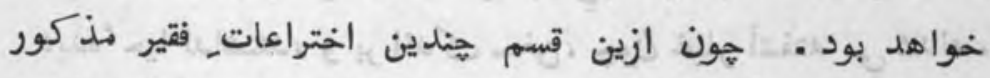

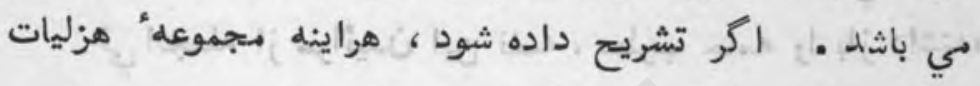
خواهد شد باند

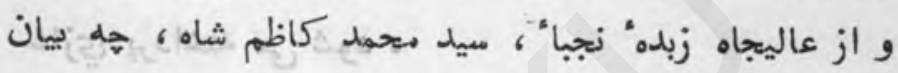
نمايم ؟

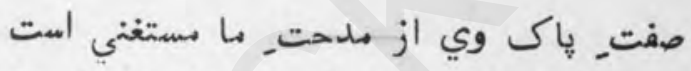

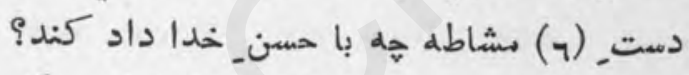

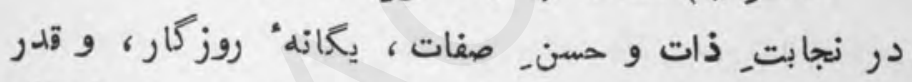

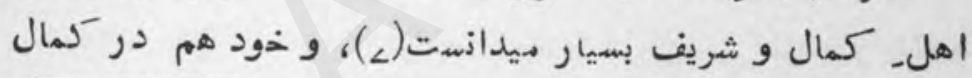

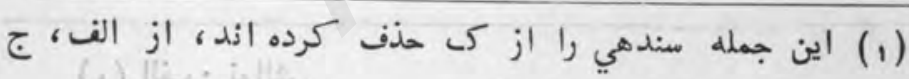

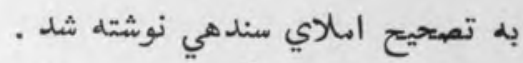

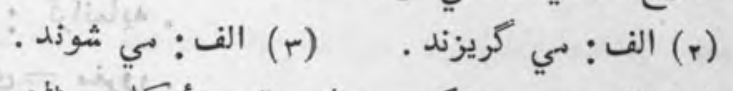

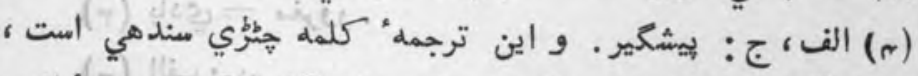

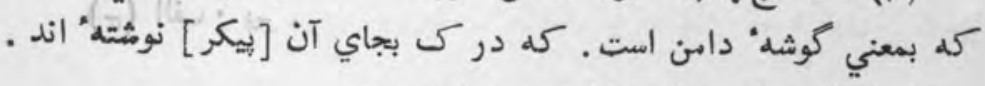

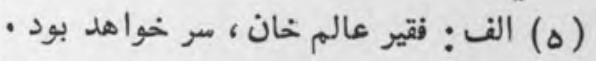

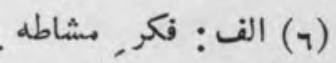

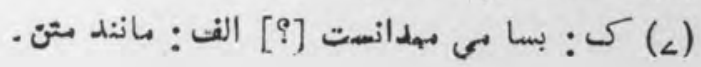


حسن و صورت معني نظير نداشت • و دستــ نوازث (1) حون ابر.

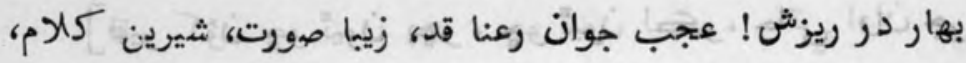

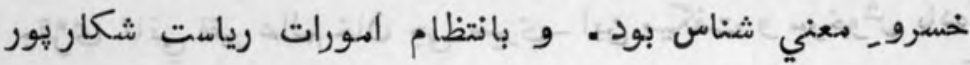

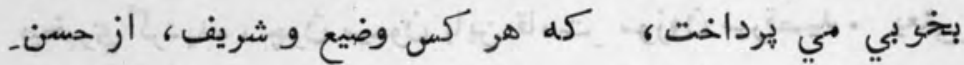

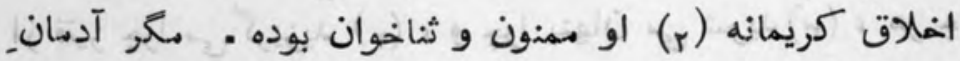

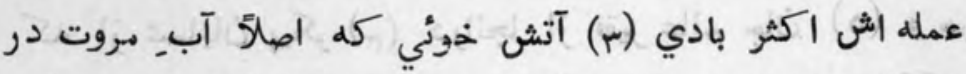

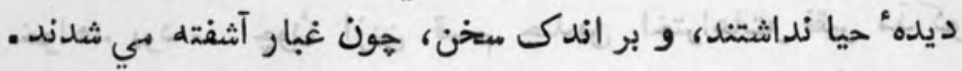

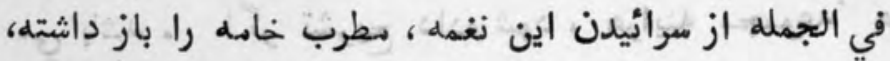

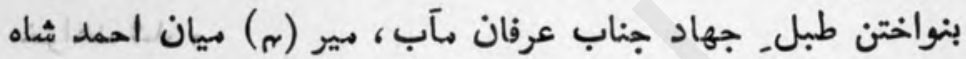

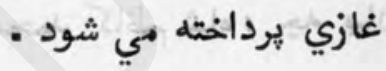

$$
\begin{aligned}
& \text { (1) الف: نوالش (r) }
\end{aligned}
$$

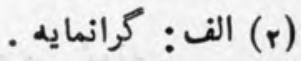

$$
\begin{aligned}
& \text { (r) (r) بادي = مغرور (r) } \\
& \text { (ه) الف: بير . بادي }
\end{aligned}
$$


در بيان, آمدن احمل شاه غازي در سند

و دعوت نمودن, طايفه" مسلمين خاص و عام بجهاد، و بعده

روزانه شدن_ــاو طرف_ خراسان

واعظٍ قلم خوثى رقم، در تفسير, آيات, جهاد، بر منبر, بيان

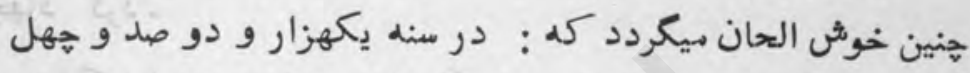

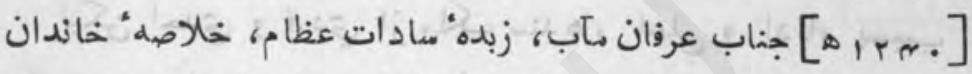

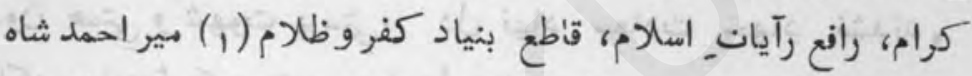

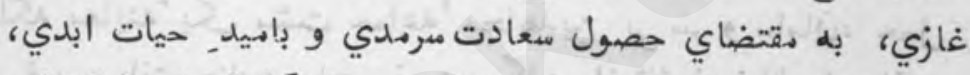

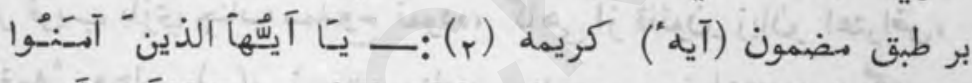

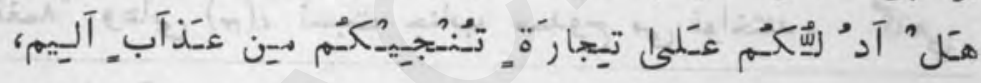

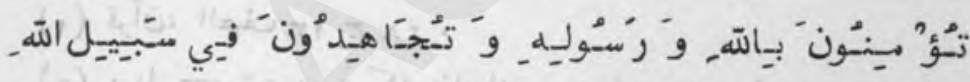

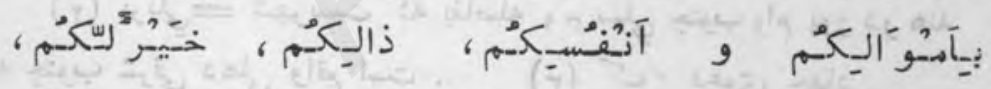

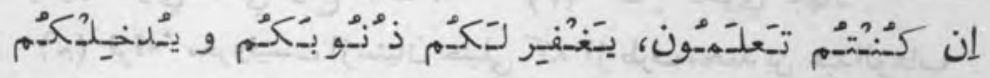

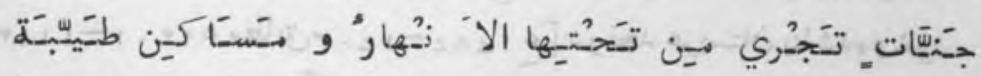

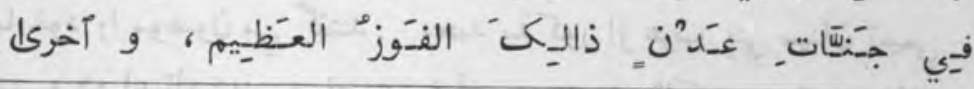

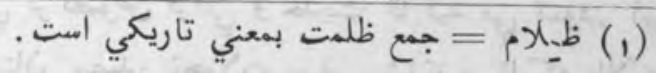

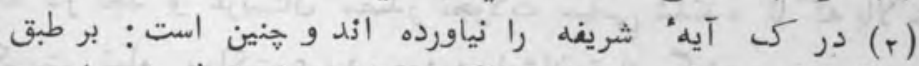

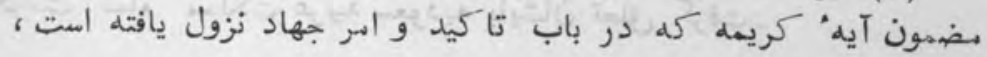
عهل نموده 


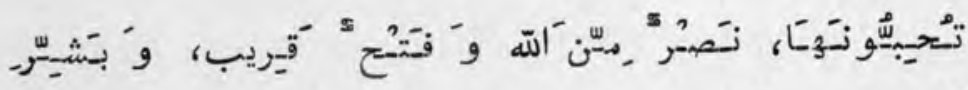

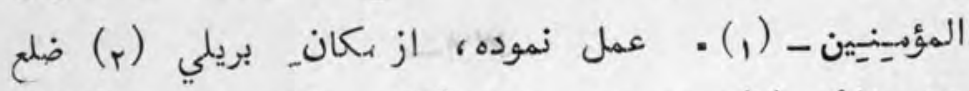

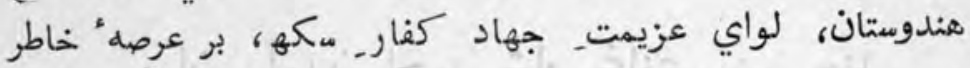
همت مظاهر بر افراشته ، با هشت جماءله" مسلمين منجاهلهدين.

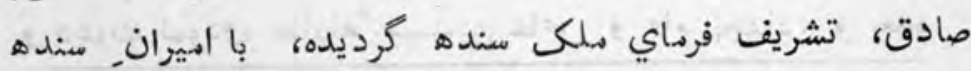
و سادات عظام و علماي كرام وام امراي عاليمقام و مشايخ.

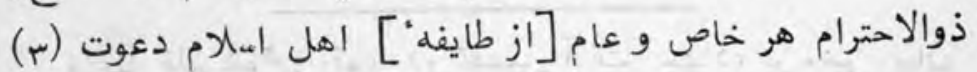
.

ريكن احدي و فردي از بلكى سندها، اعلي و ادنا، بسجب

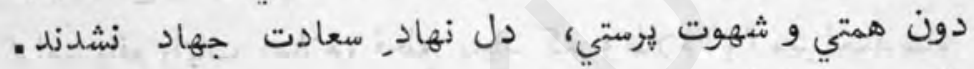

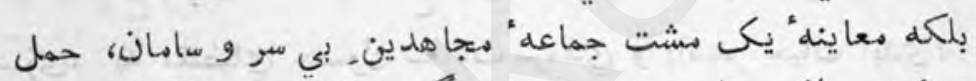

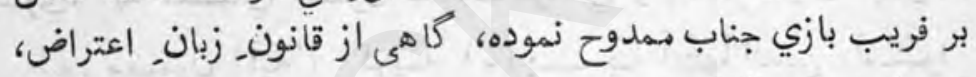

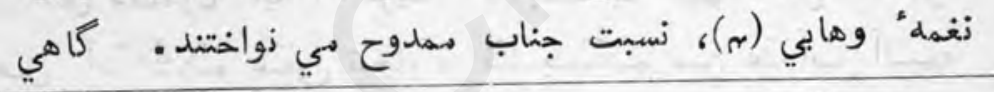

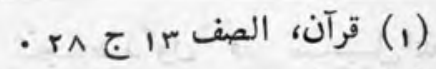

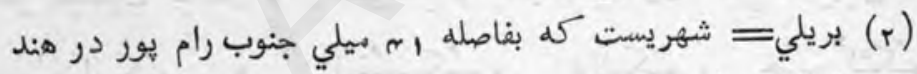

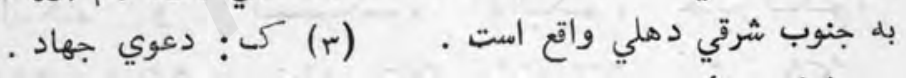

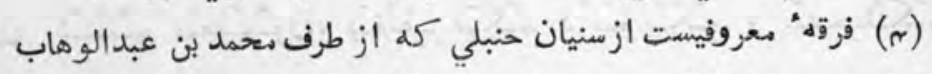

أنها

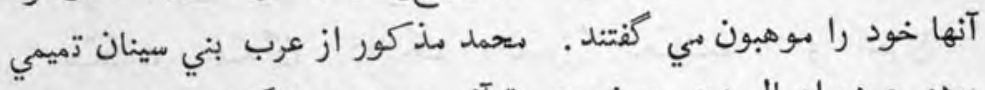
بود، و در اعمال ديني بر نصوص قرآني و حديث تاكيد مي نهود. اين اين

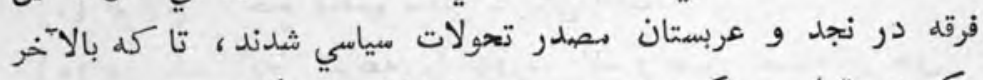
حكوهت تمام مملكت عربيه سعوديه بايشان تعلق كرفت فرون. [- دائرة المعارف اسلكني] 


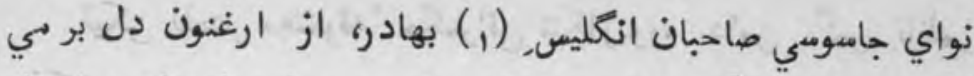

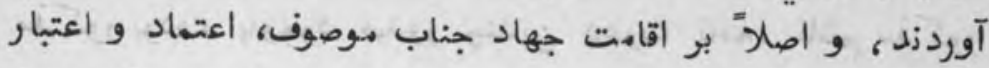

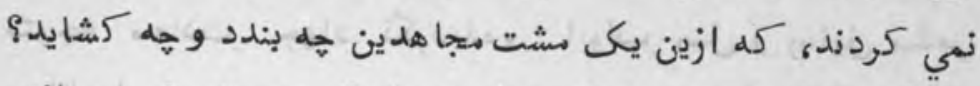

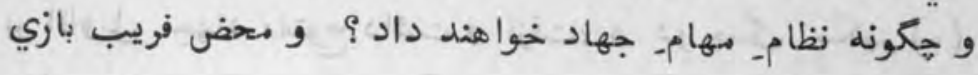

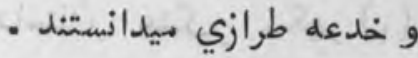

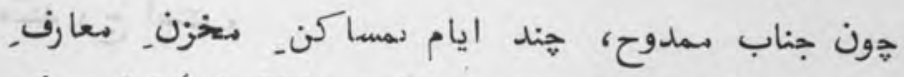

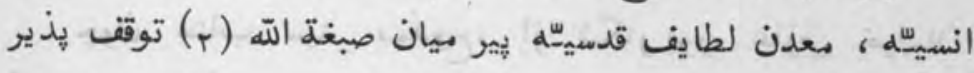

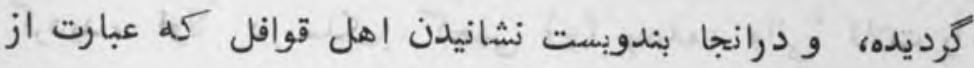

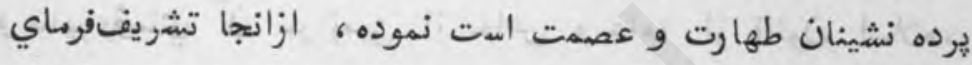

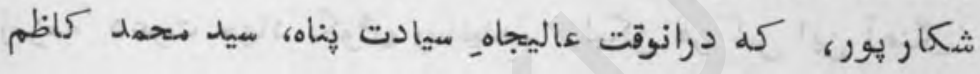

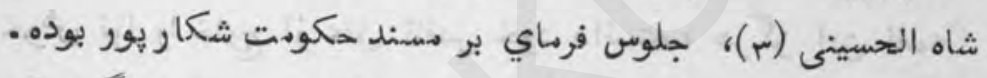

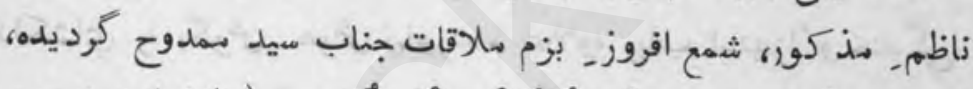

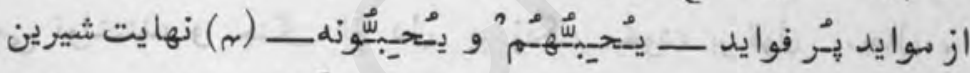

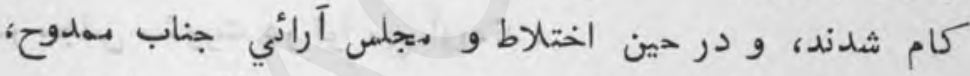

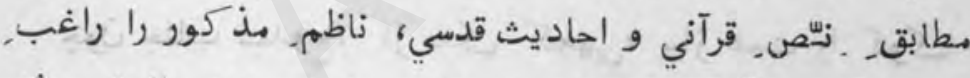

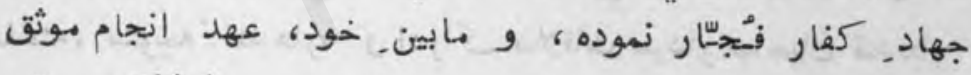

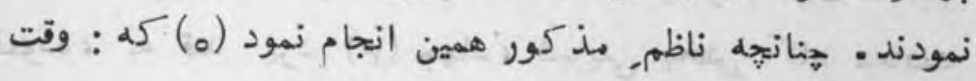

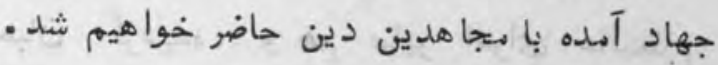

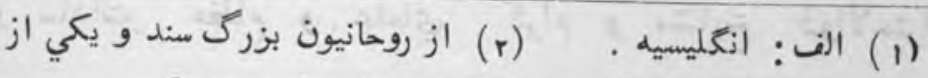

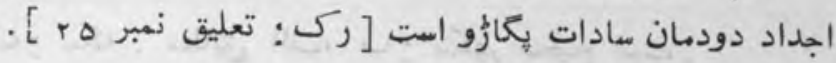

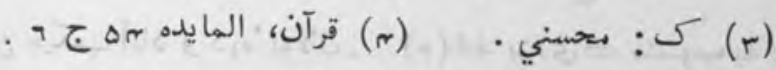

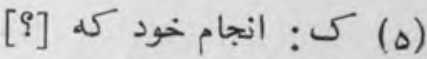


تازه نواي معارك

reT

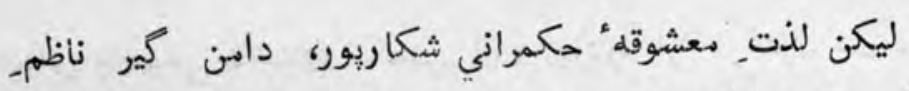

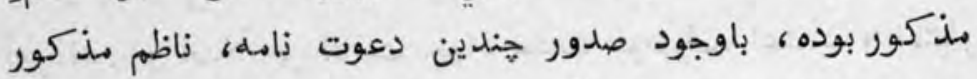

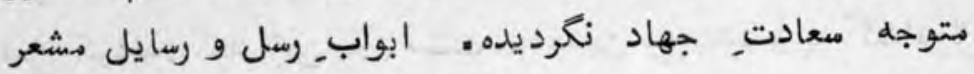

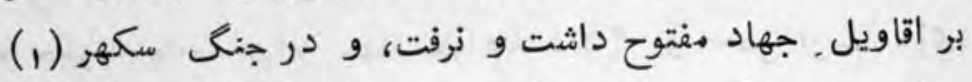

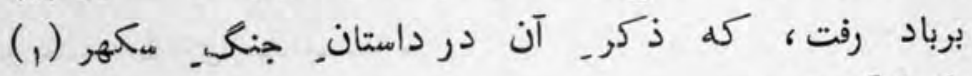

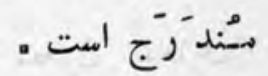

جون جناب سيد, مهدوح، از شكار بور، عازمر خراسان

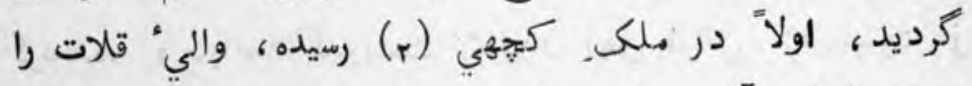

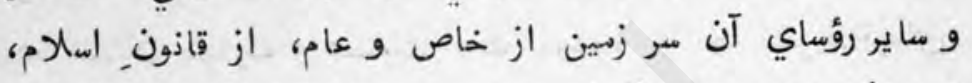

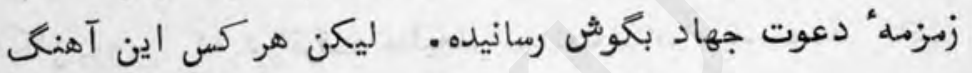

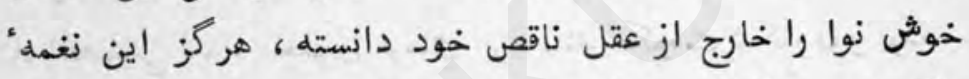

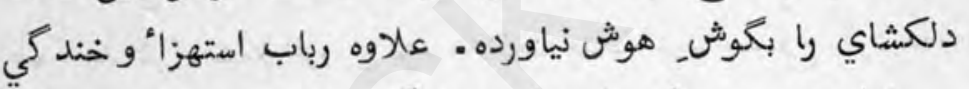

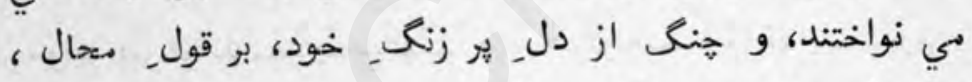

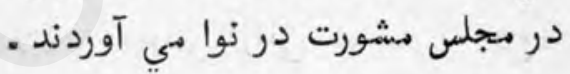

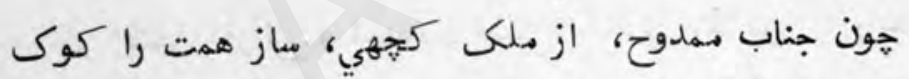

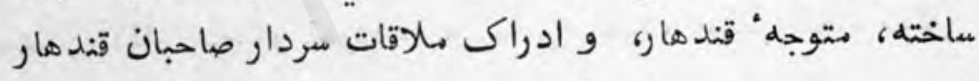

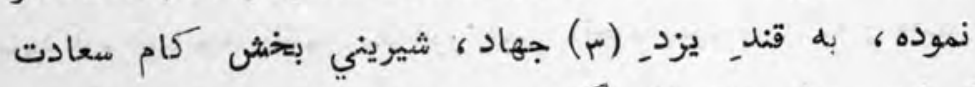

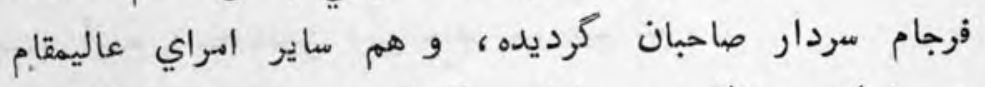

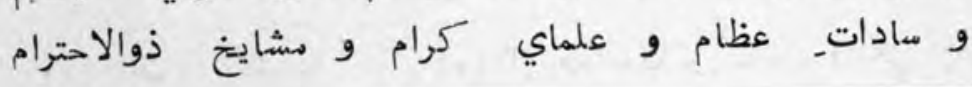

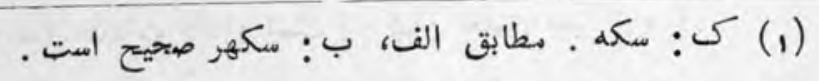

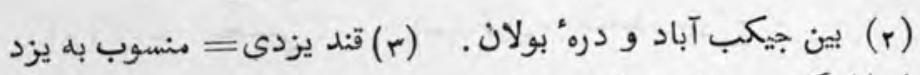

$$
\begin{aligned}
& \text { شه: ايران كه در قندهار شهرت داشت داثل }
\end{aligned}
$$


و هر خاص و عام [را]] دعوت جهاد نموده علماي قند هارد در صورت دعوت جهاد، عداوت دانسته، با سيد صاحب مدموح ، معر كله آراي

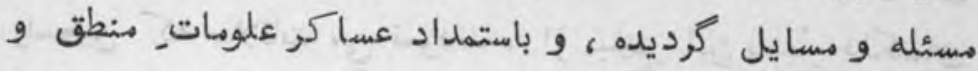
معاني ، و اصول و فروع و صرف و نحو و فقه و تفانمير و احاديث

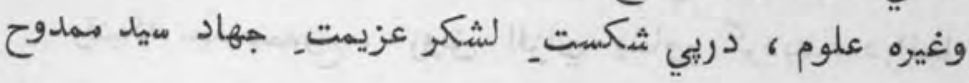
- شli

تا خند ايام ، مابين علماي قندهارو سيد_موصوف ، مباحثه ميرفت • ليكن بناب سيد مهدوح (1) نيز علماي متبحسِر همراه

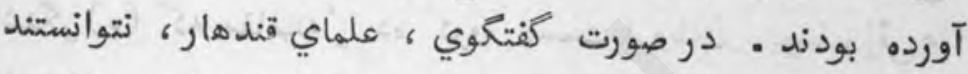
كل شكست افواج. بحرامواج عزيمت_ جهاد سيد صاحب زمايثند.

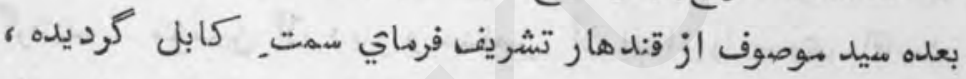
در اثناي راه ، با مؤهنين. رامغخين و مسلمين. صادقين ؛ از صغار

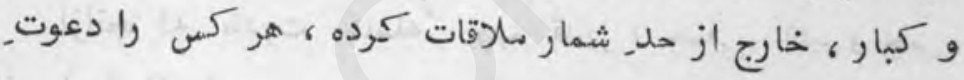

$$
\text { - جهاد مي نمود }
$$

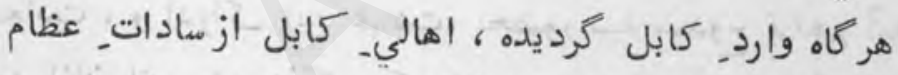

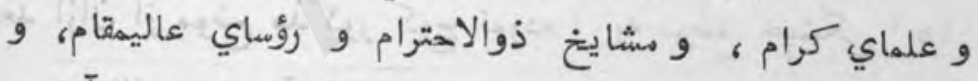

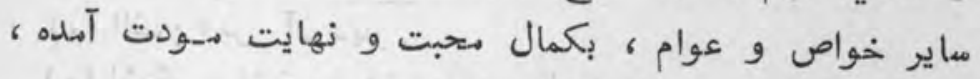

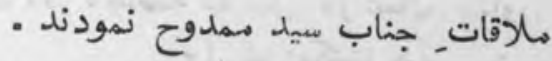
دران ايام فيمابين مرداران كابل ، مقدمه" قتل و قتال و جنع و جدال واقع بود • سيد ممدوح ، جهت اندفاع ، اين شرارت و انطفاي اين نايره آتش_ فساد ، مابين_ سرداران_ ماذ كور ، بسيار

(1) الف: ممدوح را نيز علماي متبحر همراه بودند. . 
معي و تلاش نموده ، ليكن موثر نشد . بعد از جهل و و ينج روز

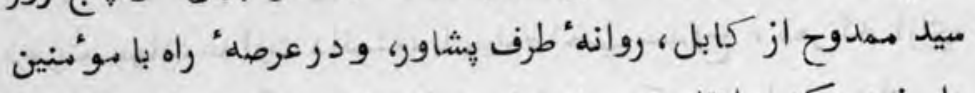

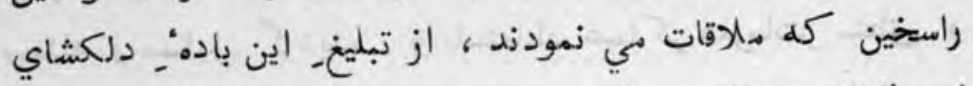
فرح افزاي دعوت_ جهاد ، سرثار و خبردار مي نمودند . وقتيكه سيد ممدوح ، مونق افزاي نهشاور كرديد ، دورانجا

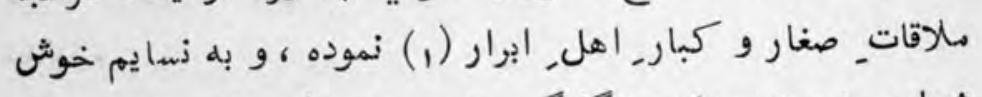

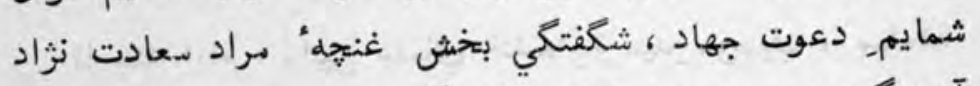

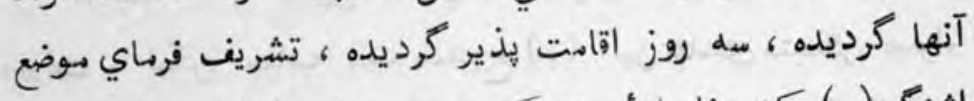

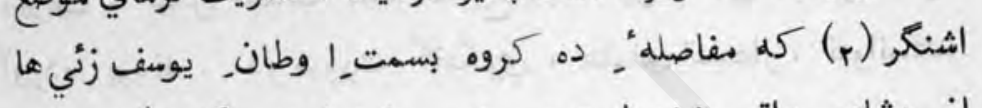

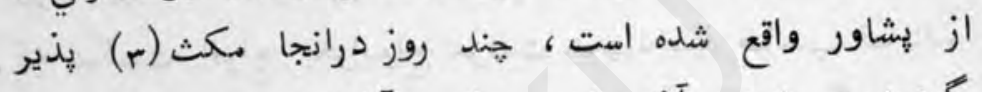

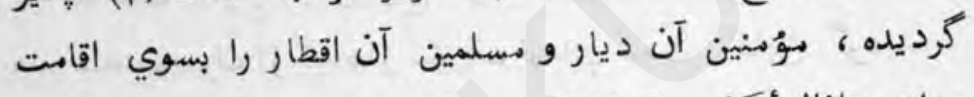

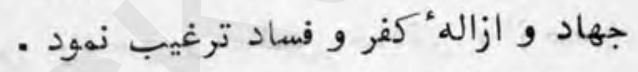

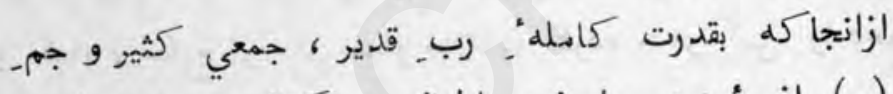

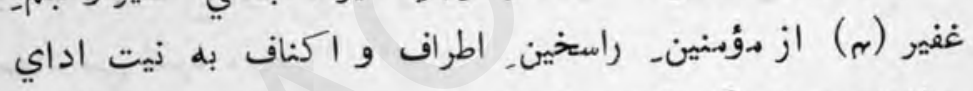

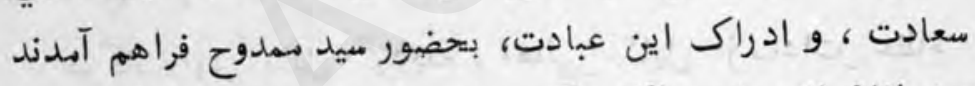

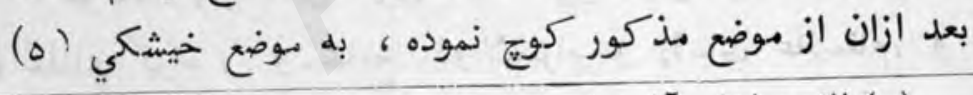

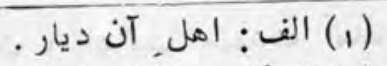

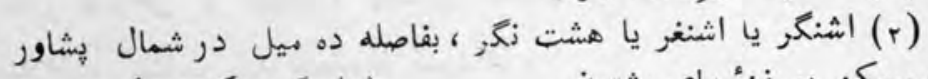

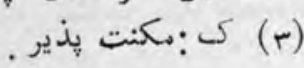

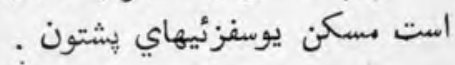

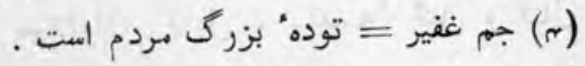

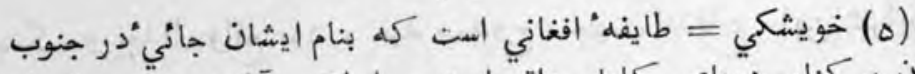

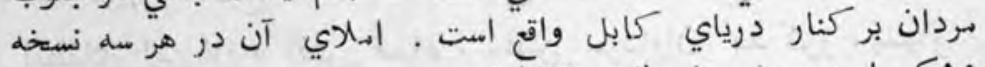

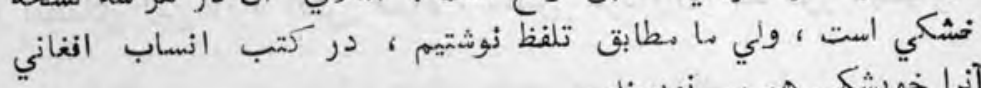

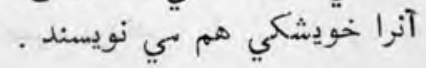




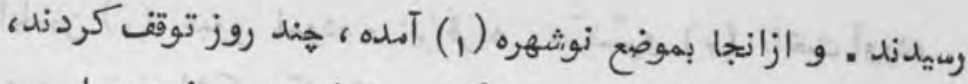

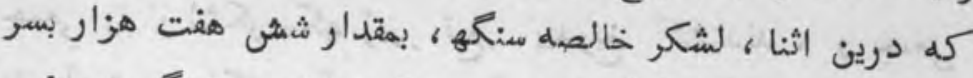

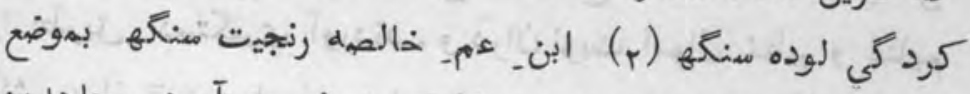

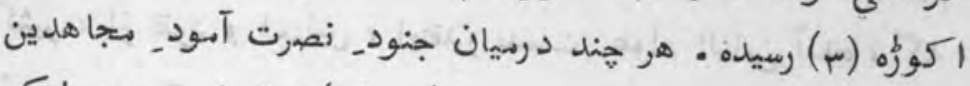

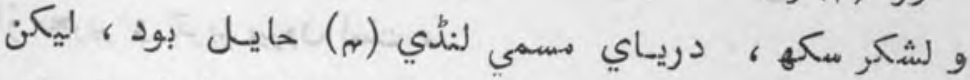

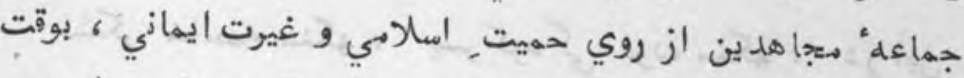

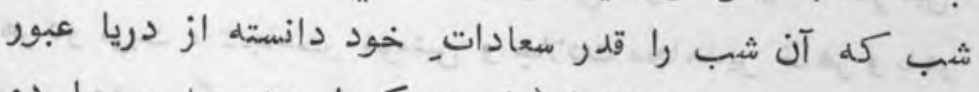

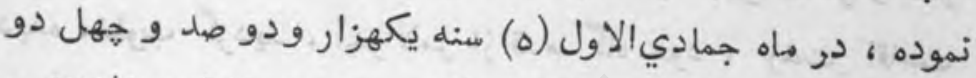

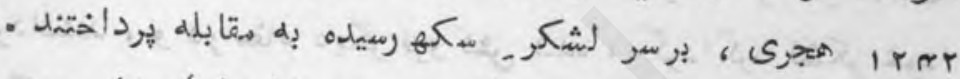

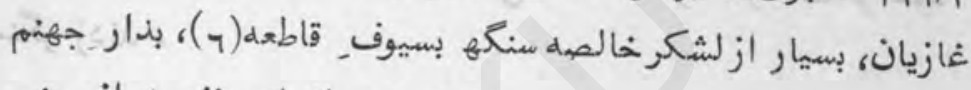

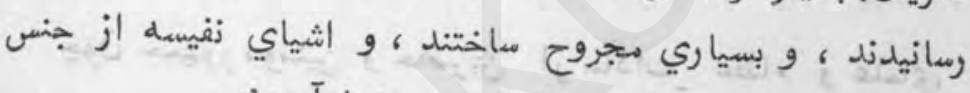
اسهان و اشتران و آسلحه و اقهشيه به به يغما آوردند.

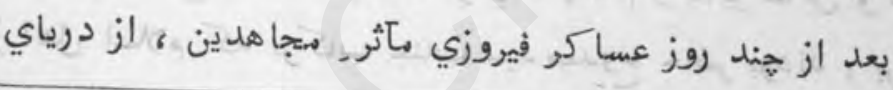

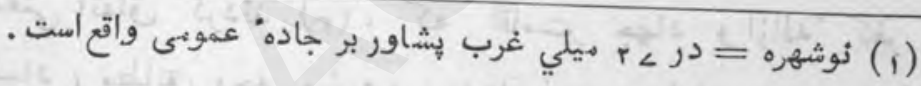
- (r)

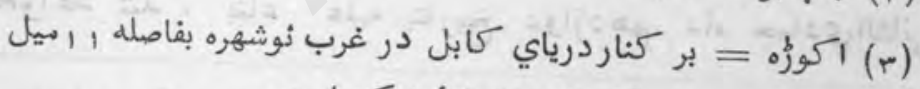

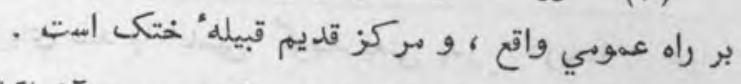

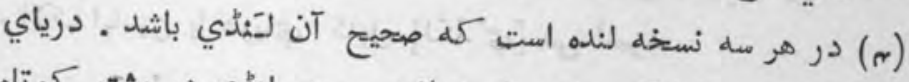

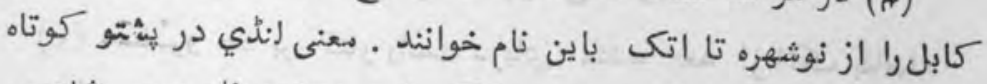

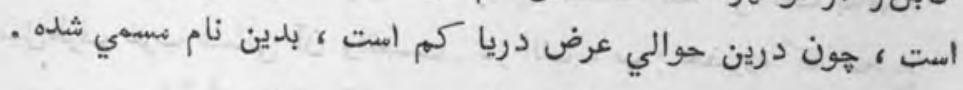

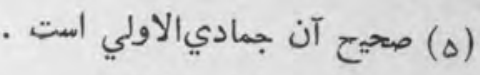

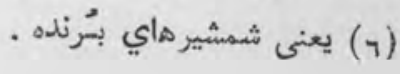




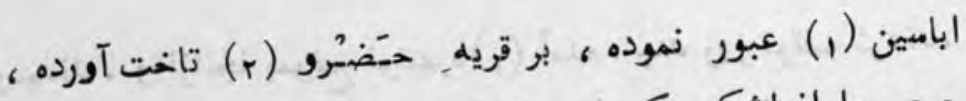

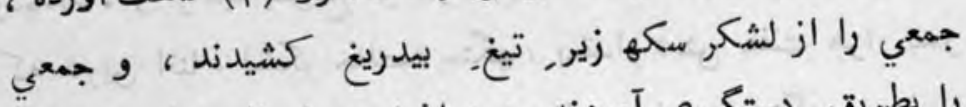

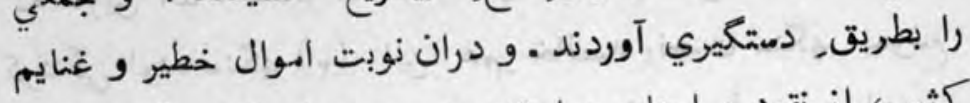

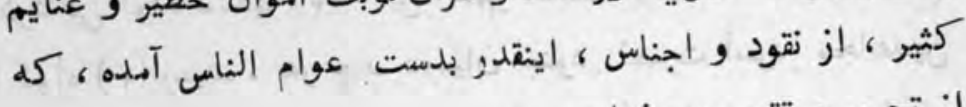
از تحرير و تقرير بيرون است .

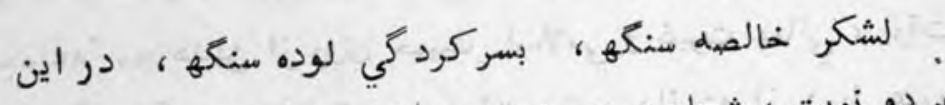

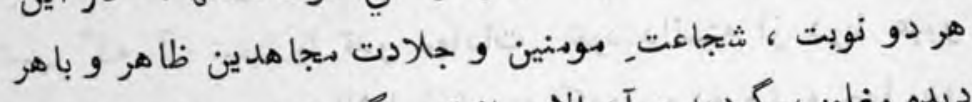

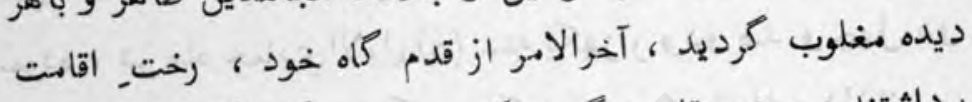

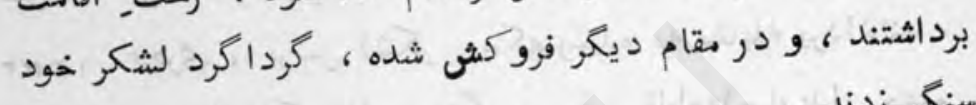

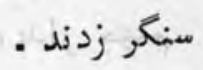

جون جهورو مومنين و حاضرين از سادات_ عظام و علماي

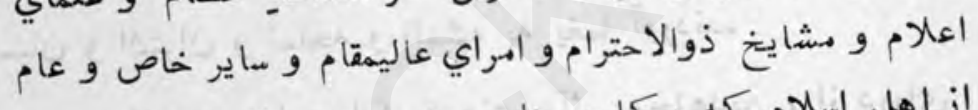

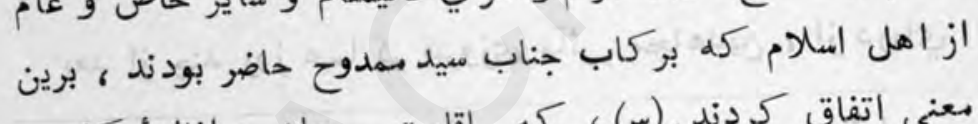

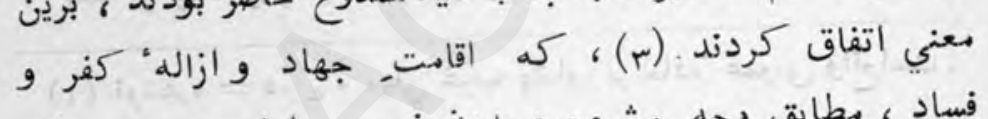

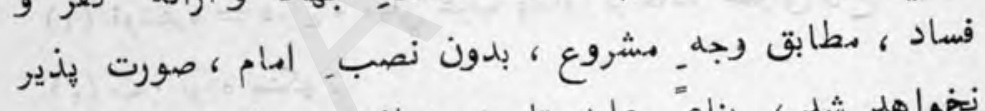

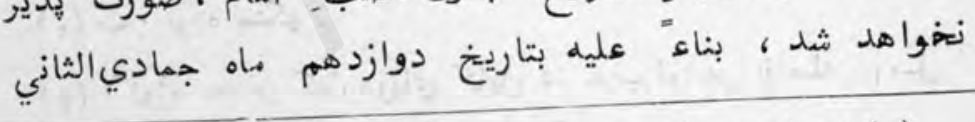

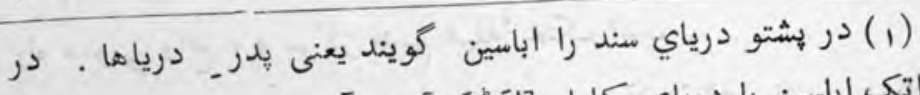

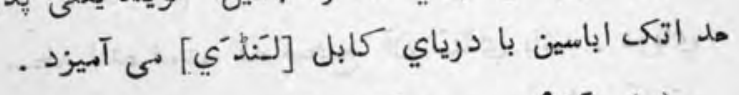

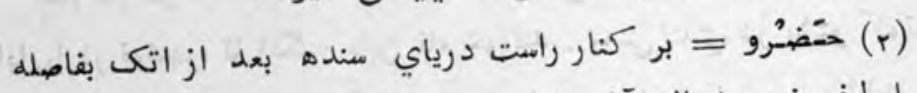

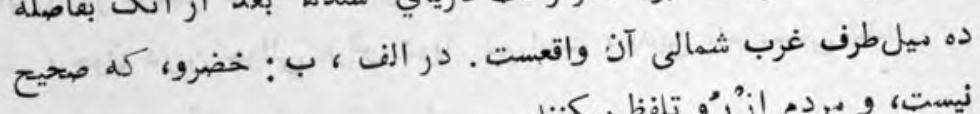

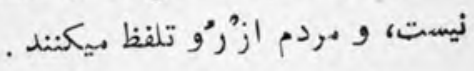

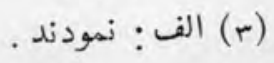




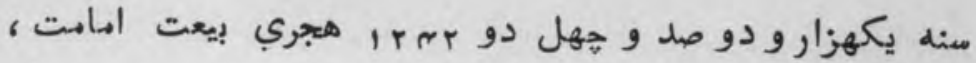

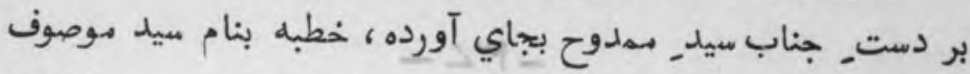

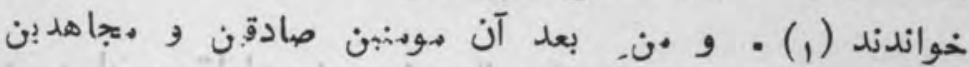

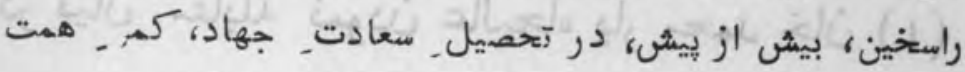

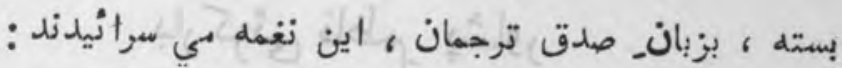

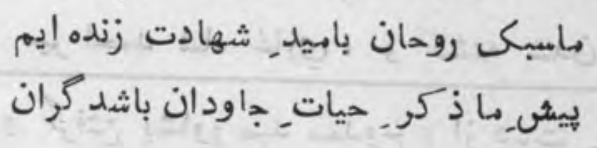

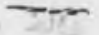

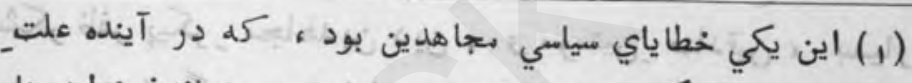

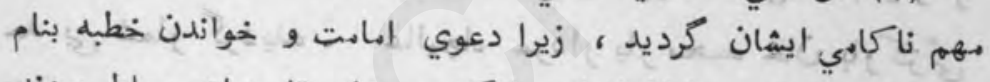

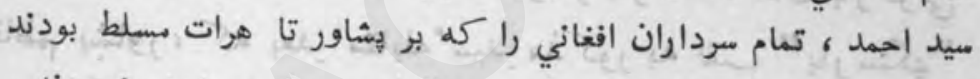

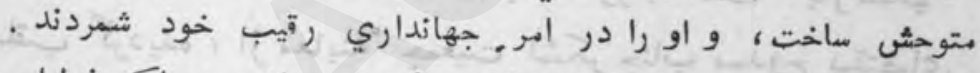

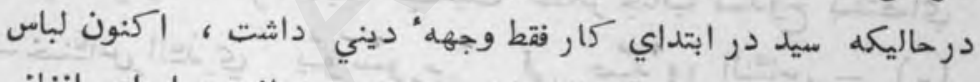

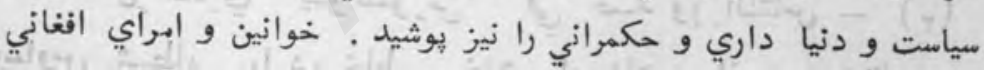

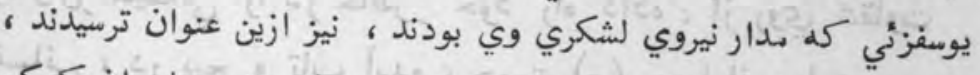

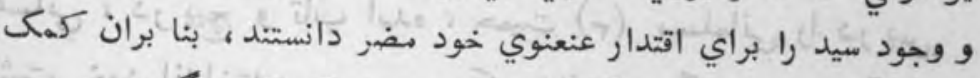

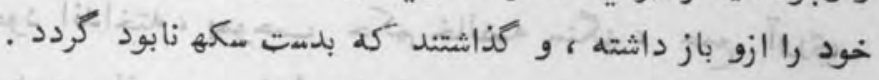

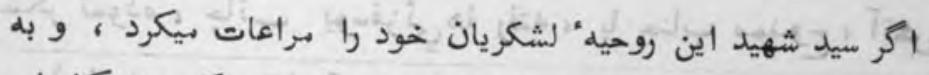

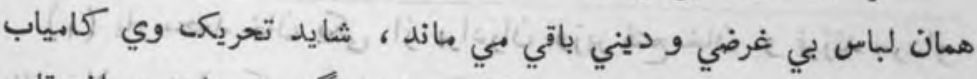

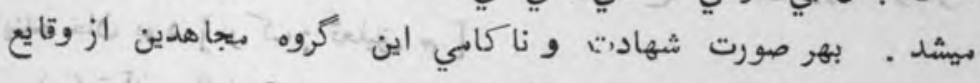

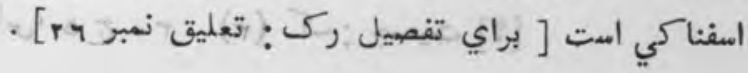


$-\mu \angle-$

در بيان مقابله ذهودن عاليجاه يار بحمل خان (1) باركزئى ناظم, يشاور

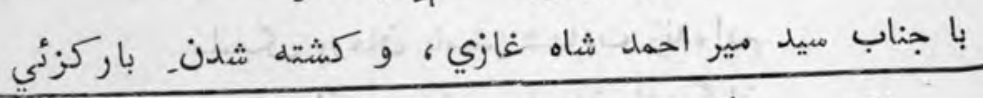

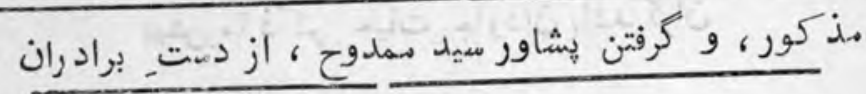
يار محمد خان مذكور

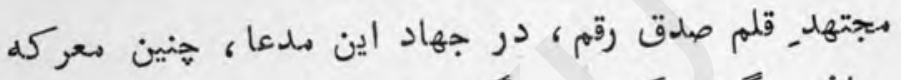

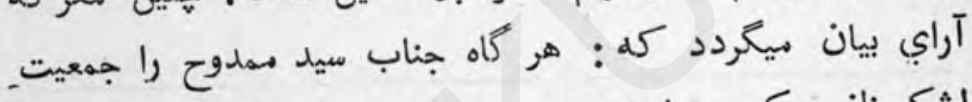

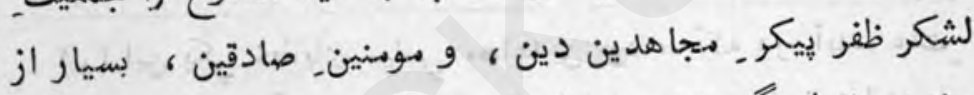

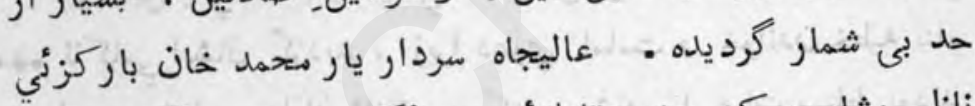

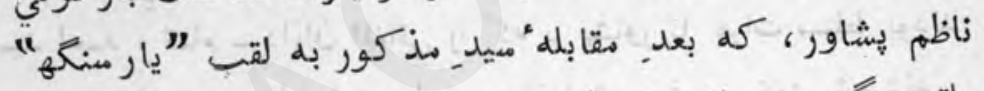

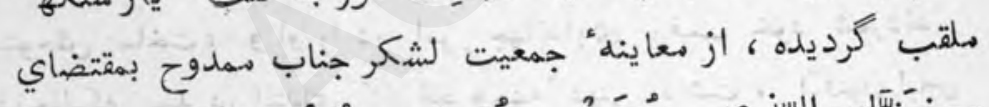

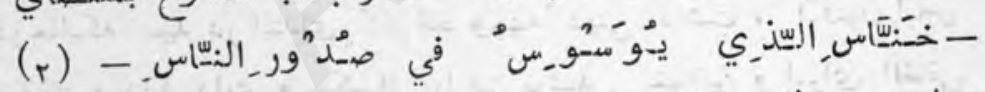

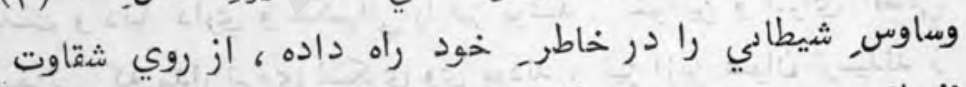

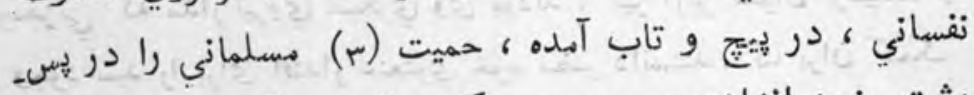

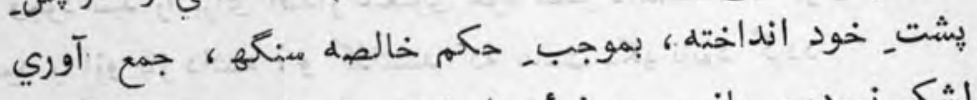

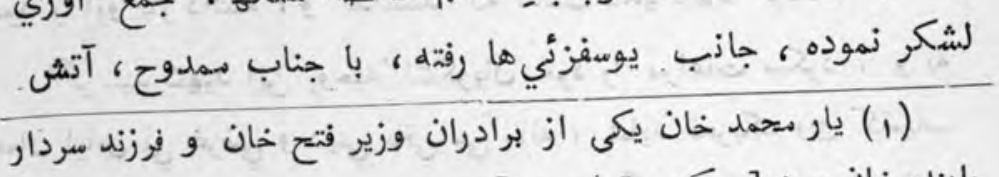

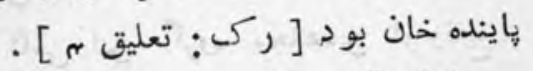

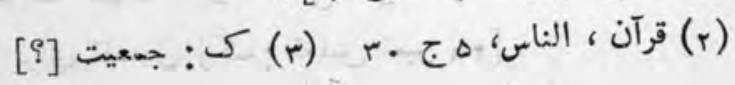




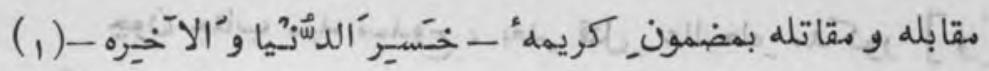

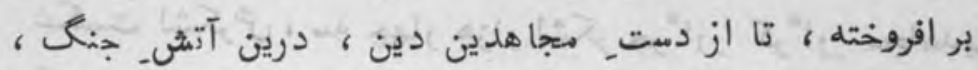

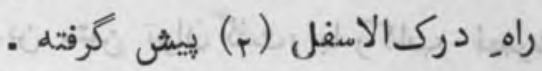

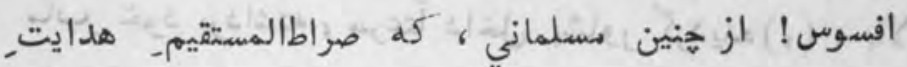

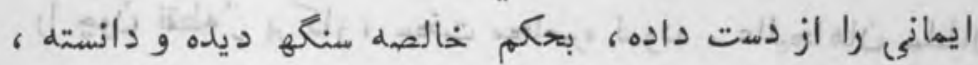

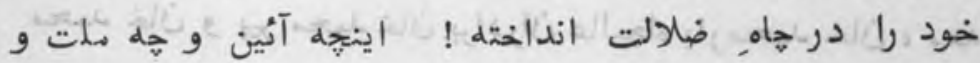

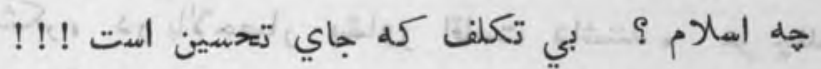

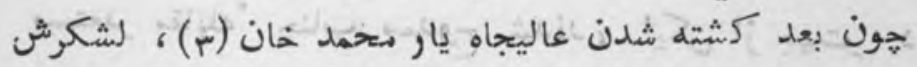

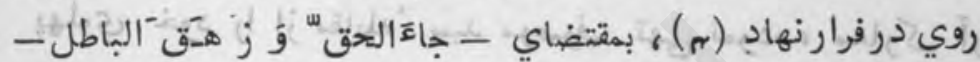

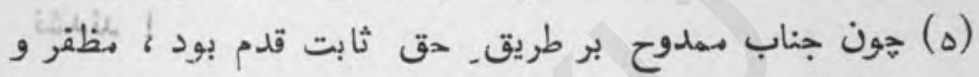

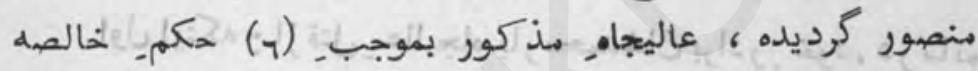

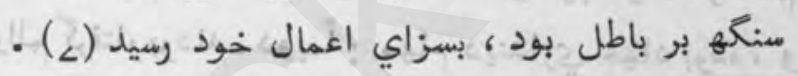

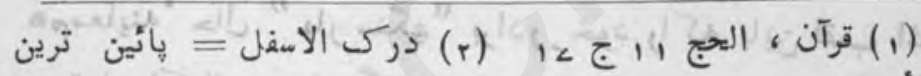

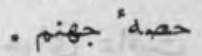

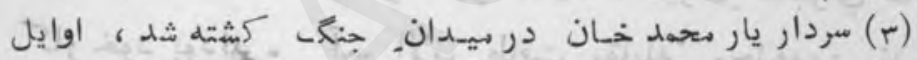

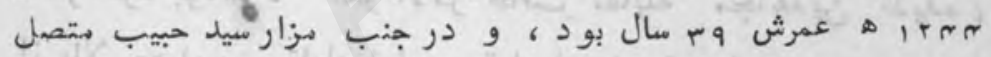

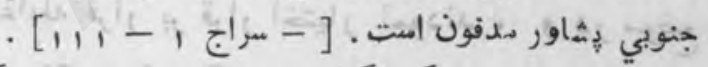

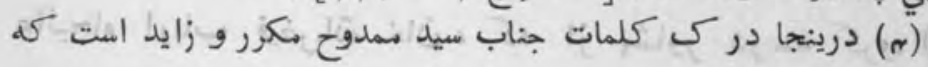
حذف شد . حآ درن . 10 (هر)

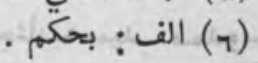

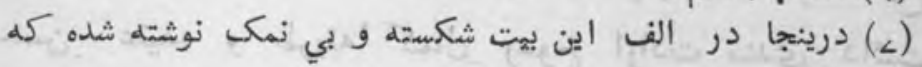
دركى، زيست . دريتها در الت از ادب دين رسيدن بر سرير اعتبار

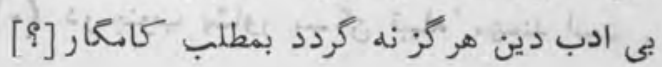


تازه نواى مـارى

ror

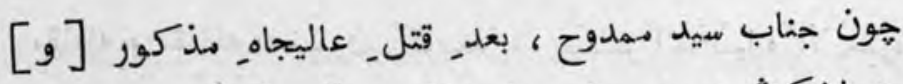

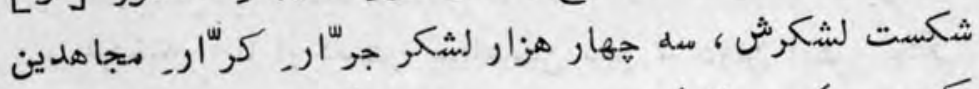

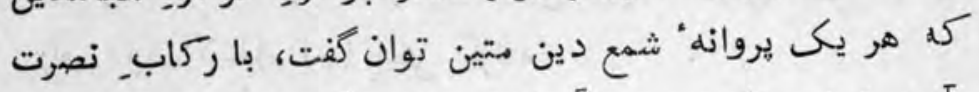

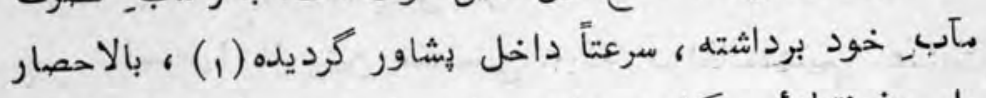

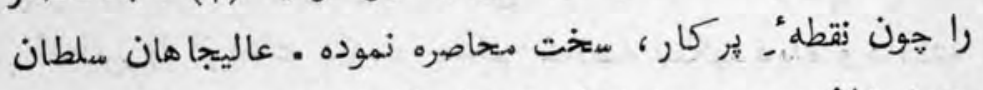

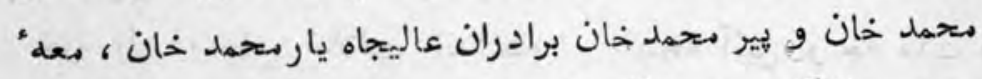

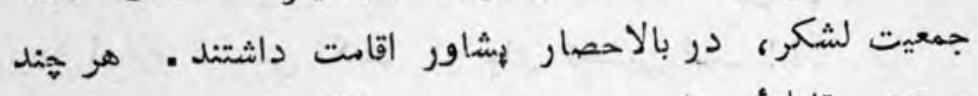

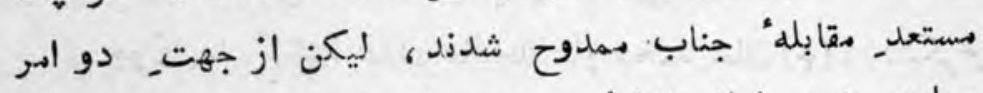

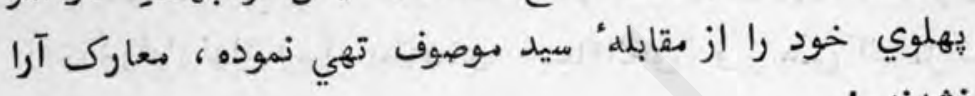

نشدند !

اول اينكه : ازقتل_عاليجاه يار متحمخان برادر ر خود، در ماتم

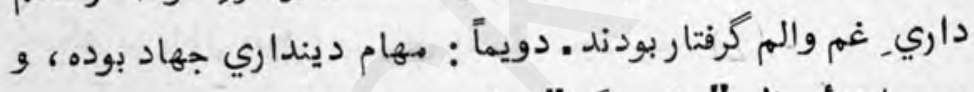

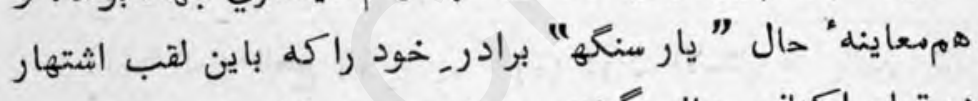

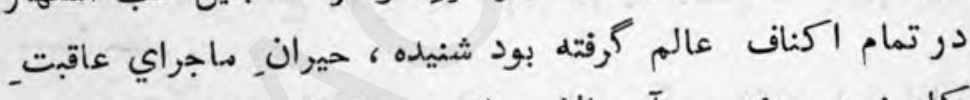

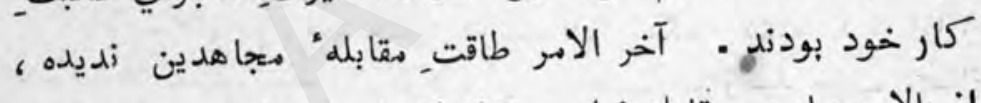

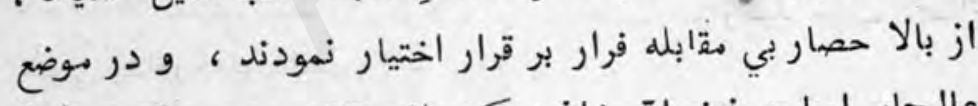

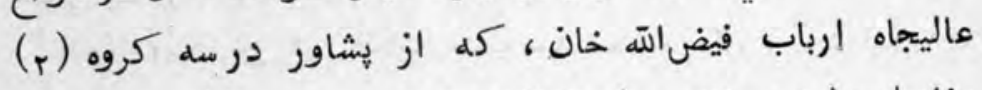

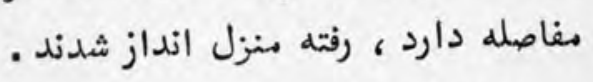

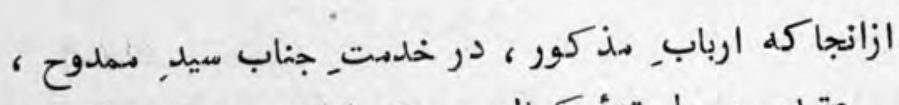

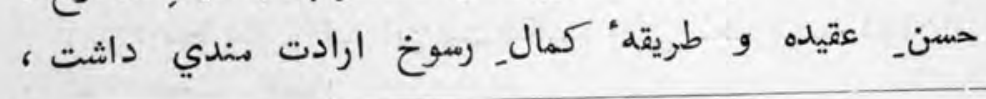

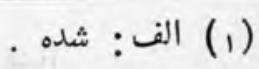

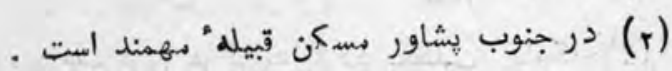


عاليجاهان مذكور ، بوساطت ارباب مشارث اليه ، با جنابـ سيد.

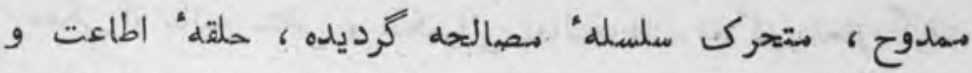

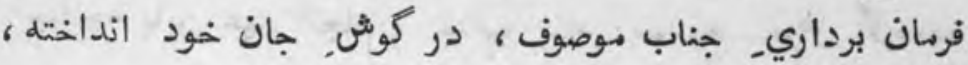

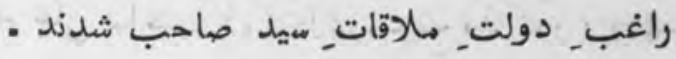

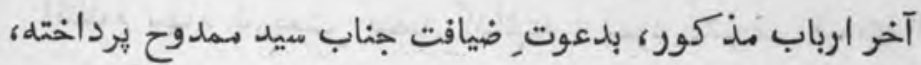

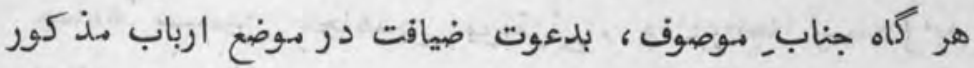

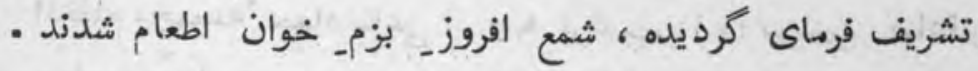
درانوقت عاليجا هان سلطان متحمد خان و يير بحمد خان، برهبري.

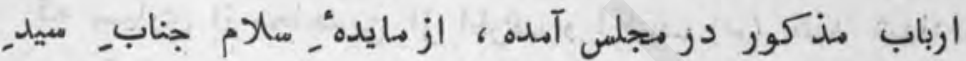

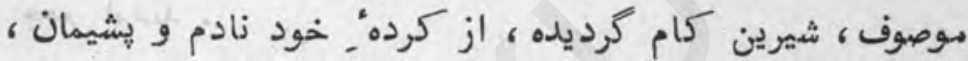

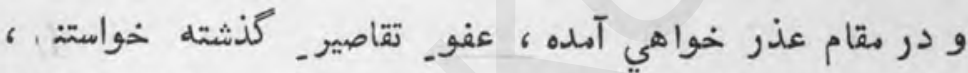

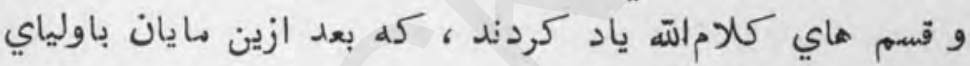

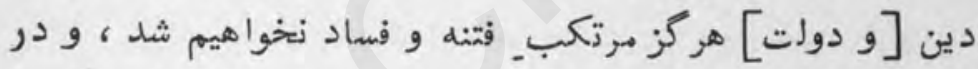

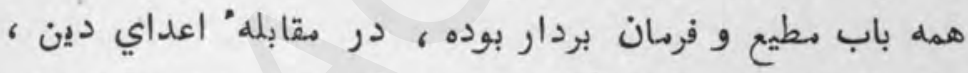

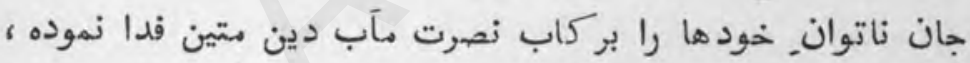

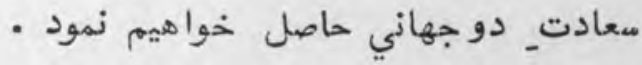

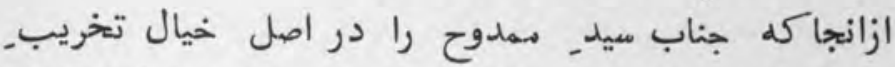

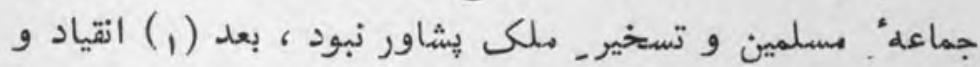

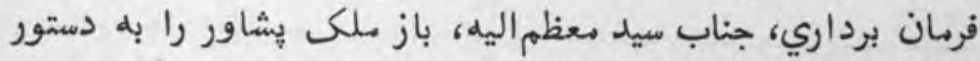

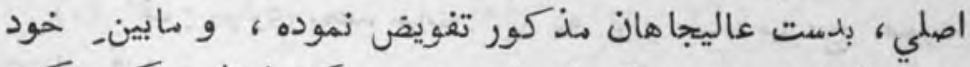

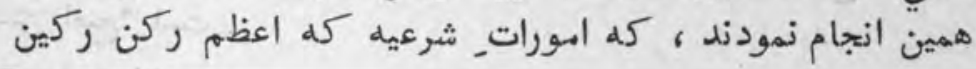

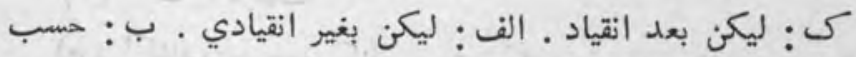




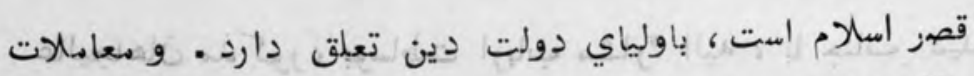

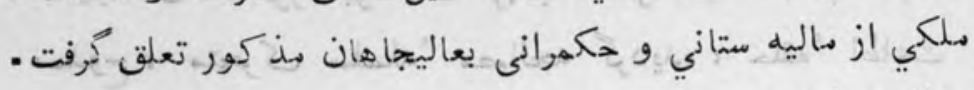

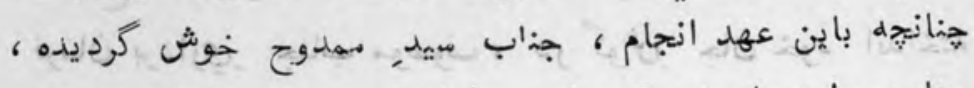

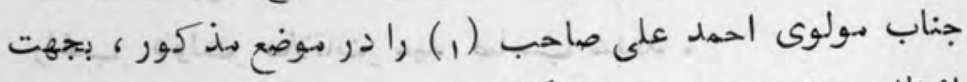

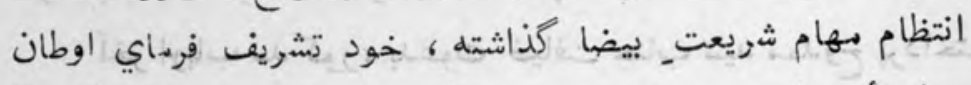

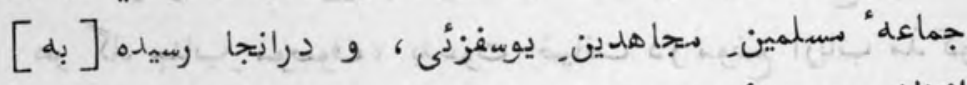

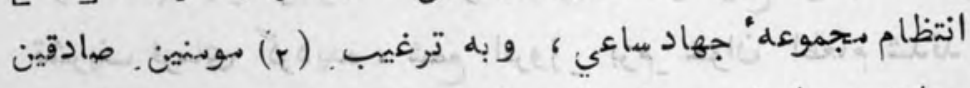

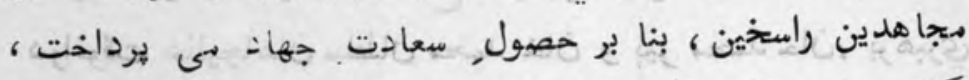

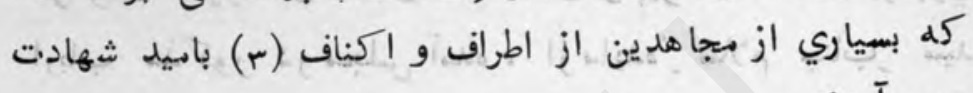
-

(1) الف: مولوي محمد حيات [؟] كه قرار كى ، ب ، ج صورت متن اصح" است .

$$
\text { (r) }
$$

(r) اكناف= جمع كنف بمعني كناره و طرف [- منتخب]. 


\section{در بيان كشتن هولوي احمل علي را}

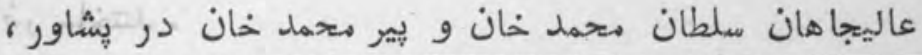

\section{بفريب, ضيافت}

شمع-قلم روشن زقم ، در مجلس افروزي اين مدعا هنهين

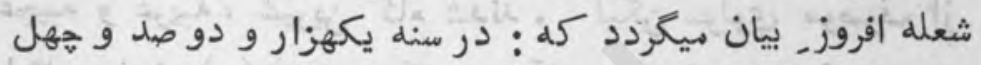

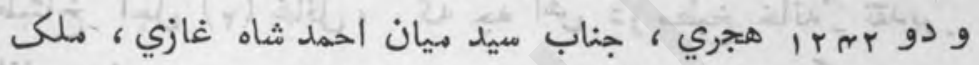

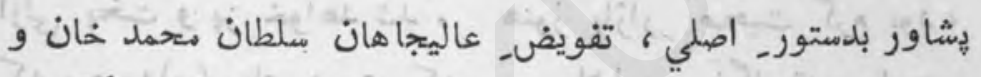

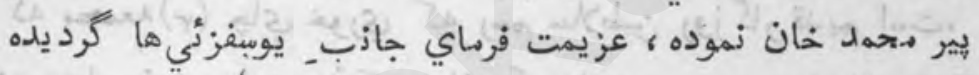

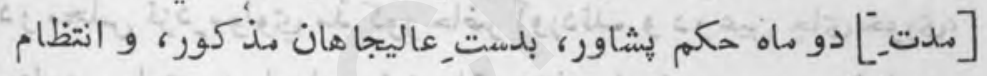

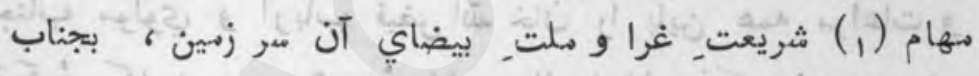

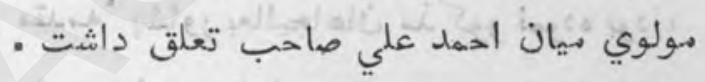

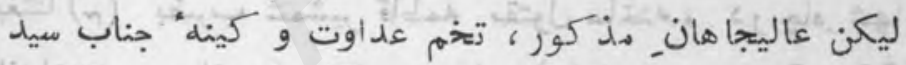

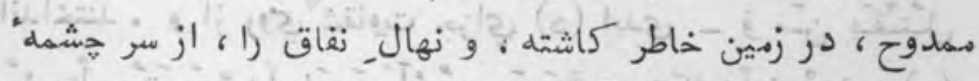

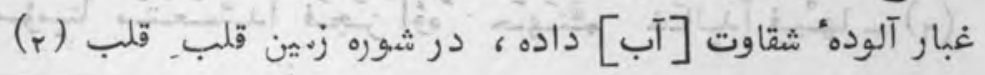

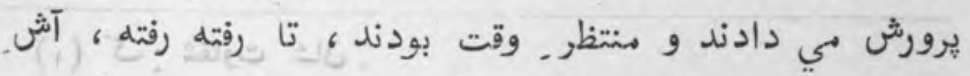

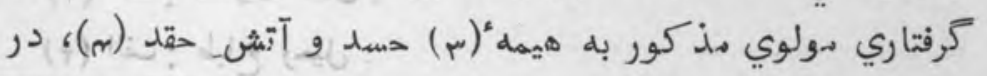

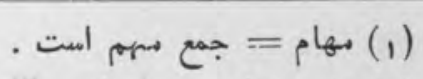

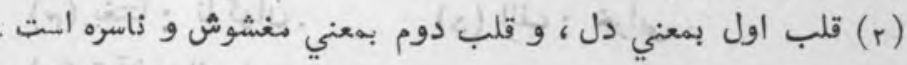

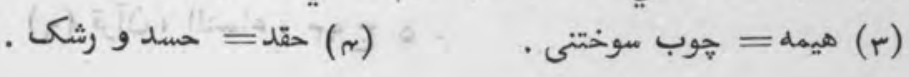


تازه نواي معارك

$r \Delta A$

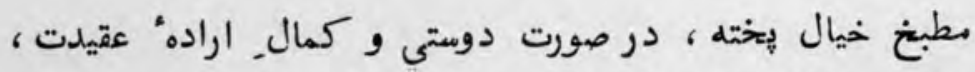

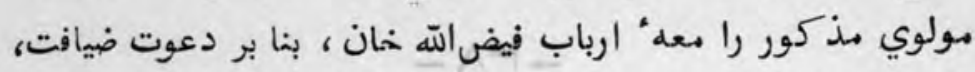

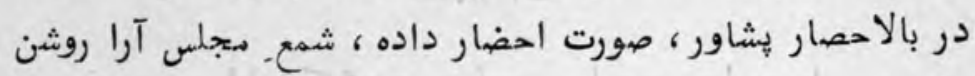

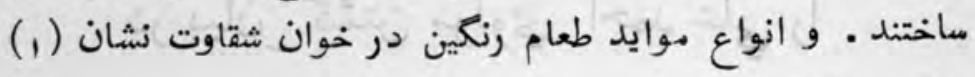

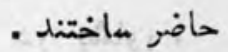

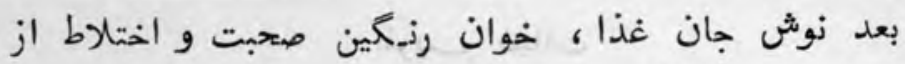

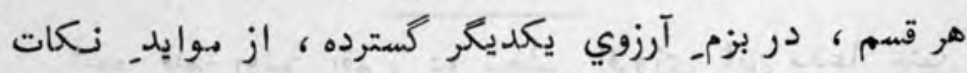

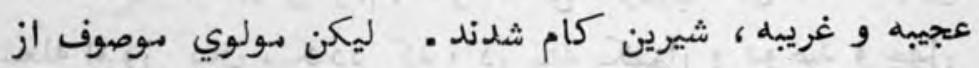

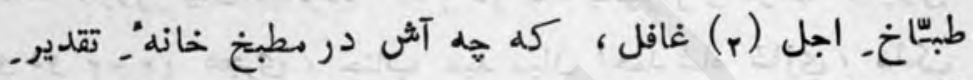

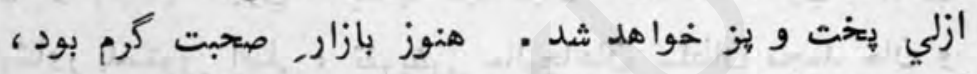

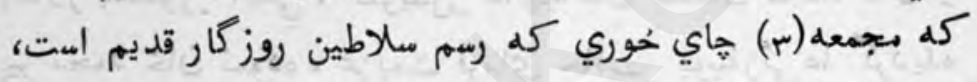

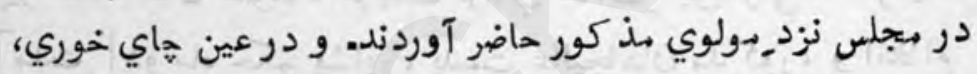

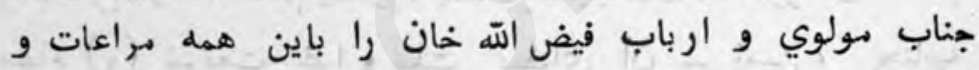

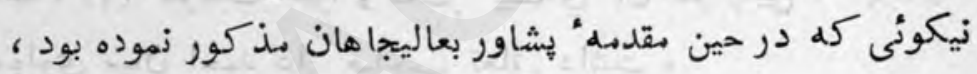

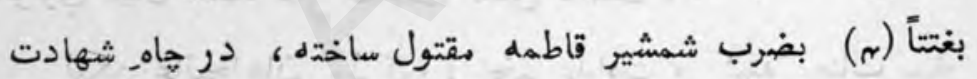

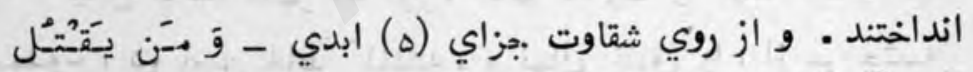

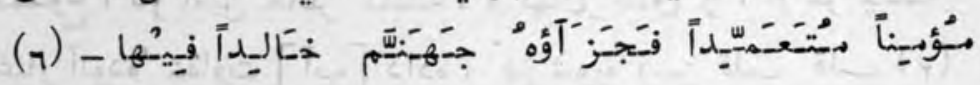

ك (1)

(r)

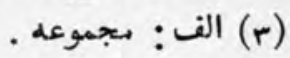

(ه) الف : خرابى .

(r)

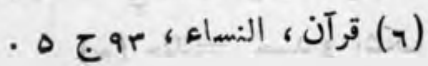


حاصل نموده، و بر التقام كشى عاليجاه ياز سنكه به مبب ميد

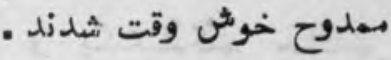

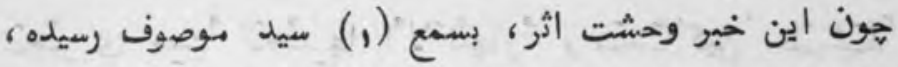

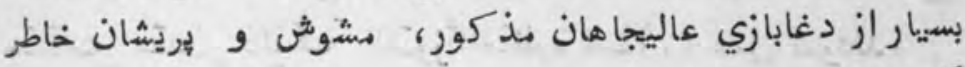

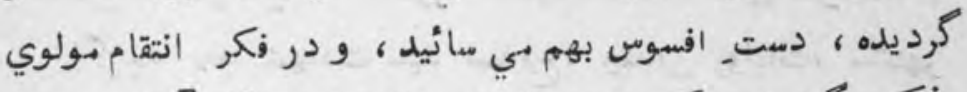

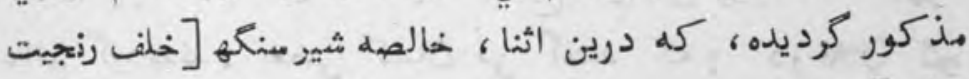

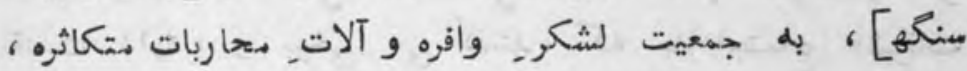

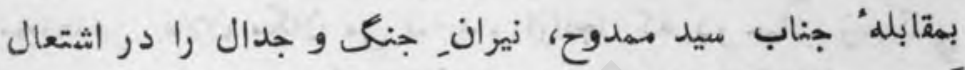

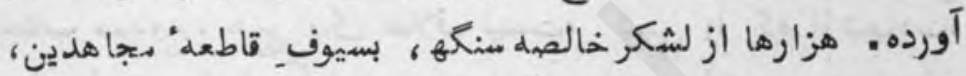

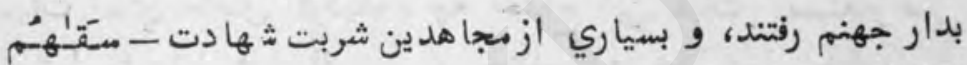

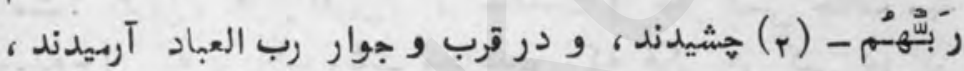

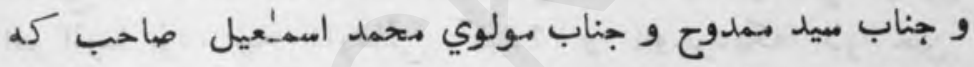

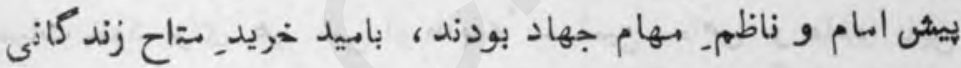

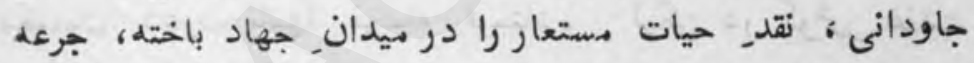

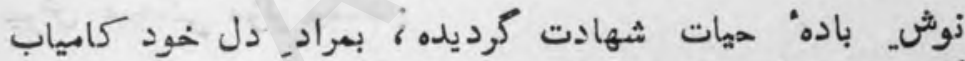

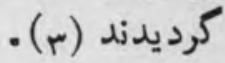
خوشا (م) بحال كسانيكه نقد حيات مستعار، بر خريد متاع

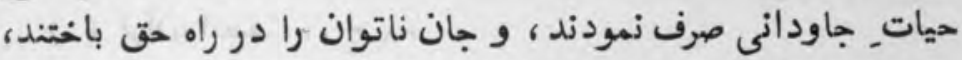

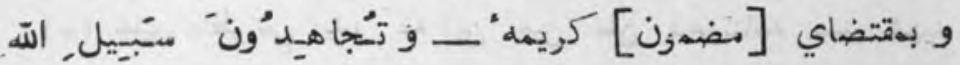

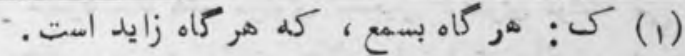

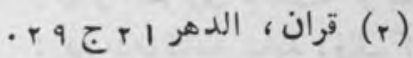

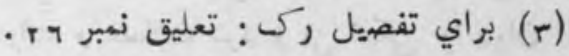

$$
\begin{aligned}
& \text { (r) الف: خوشحال كسانيكه. }
\end{aligned}
$$




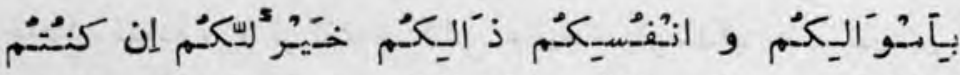

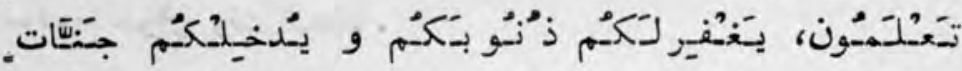

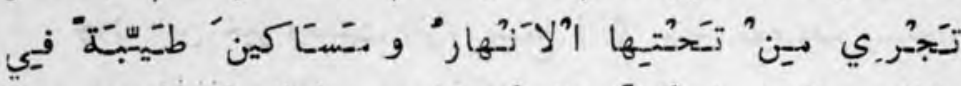

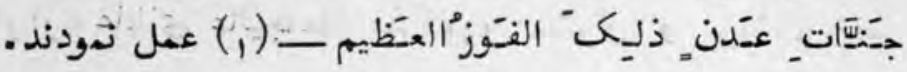

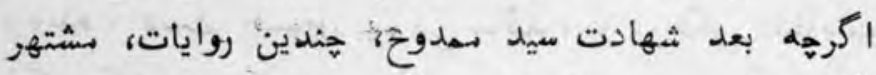

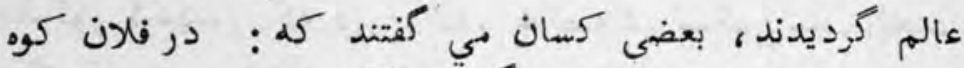

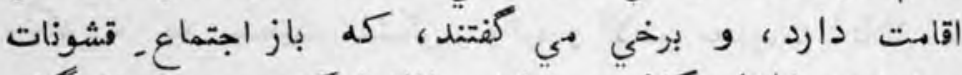

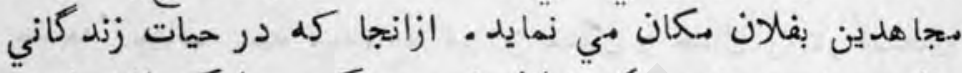

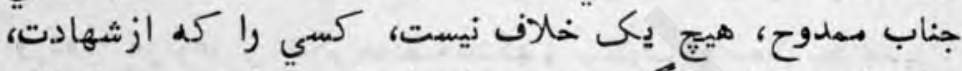

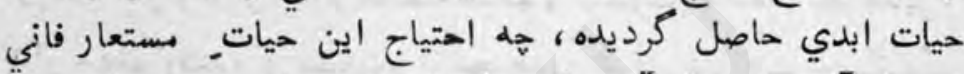

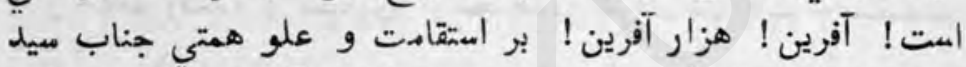

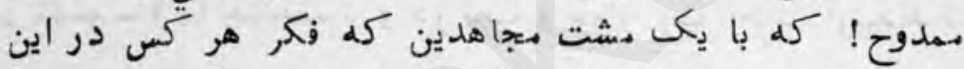

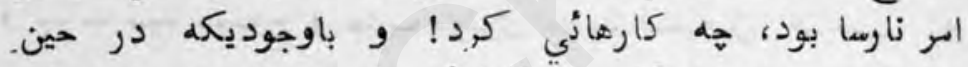

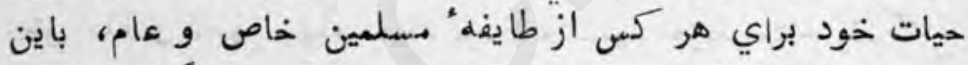

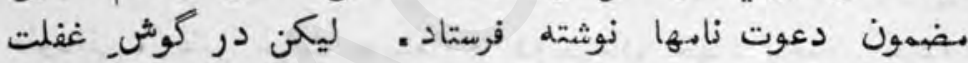
نيوش هيجكس مؤثر نيفتاد :

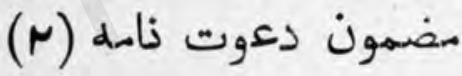

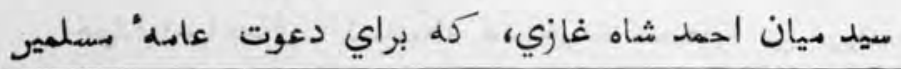

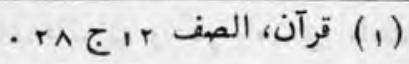

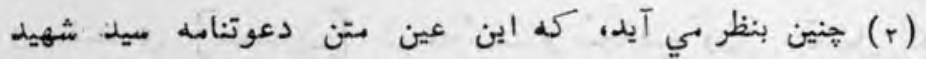

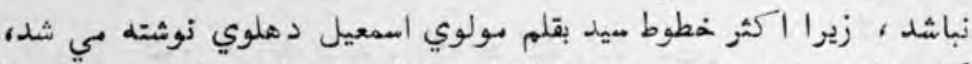

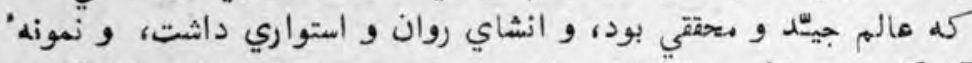

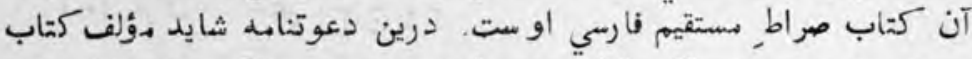

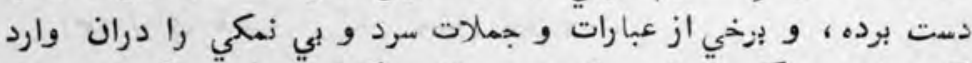

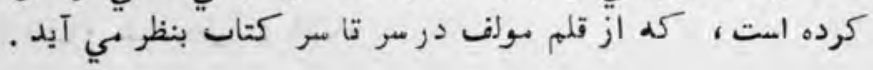


مؤنسين نوشته بود :

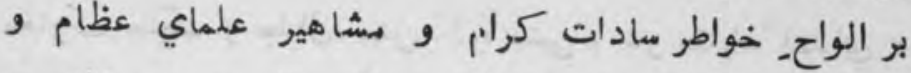

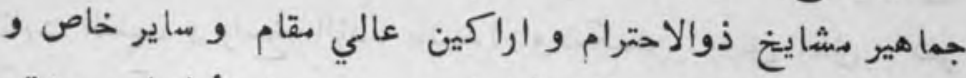

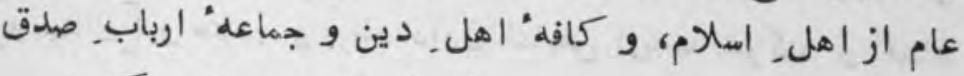

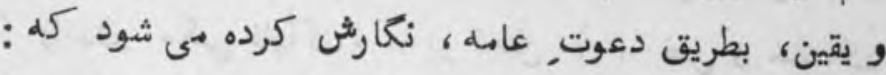

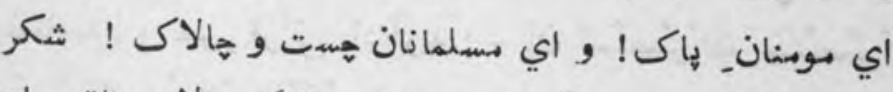

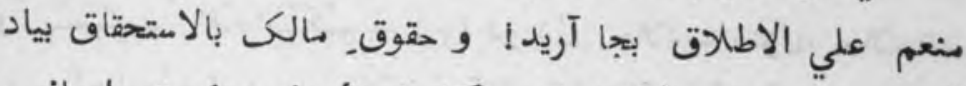

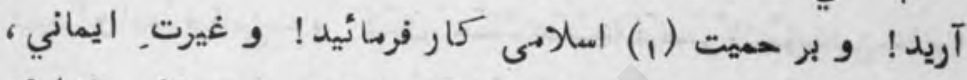

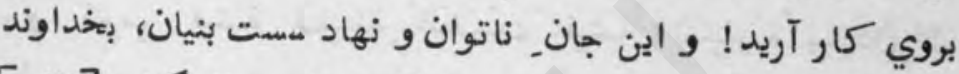

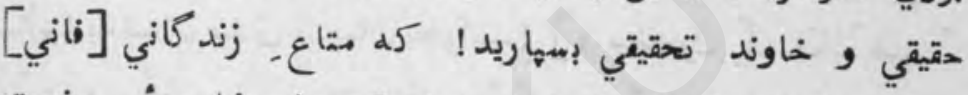

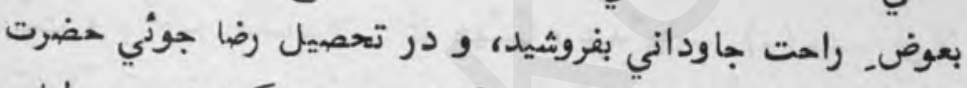

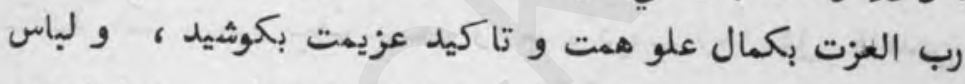

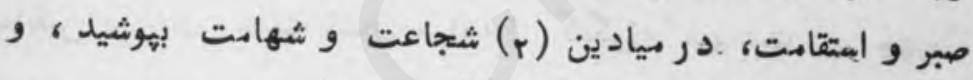

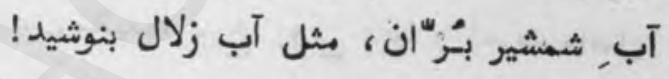

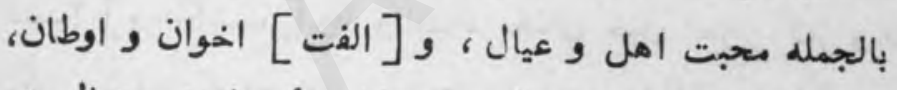

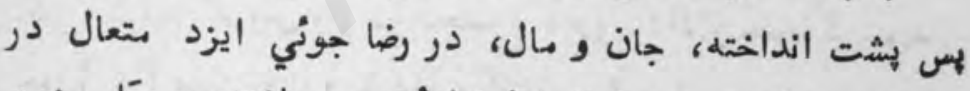

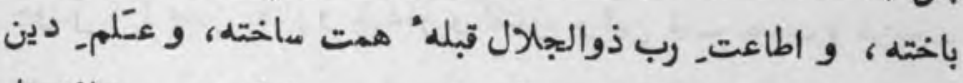

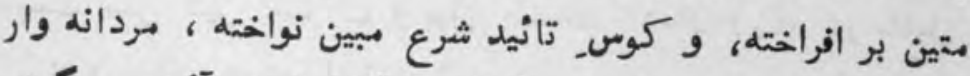

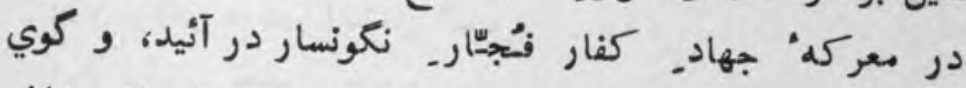

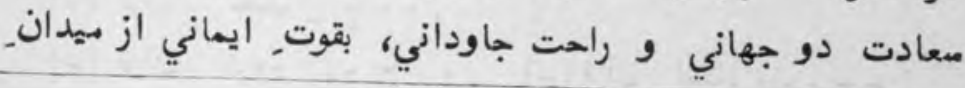

$$
\begin{aligned}
& \text { [? (1) (1) (1) }
\end{aligned}
$$

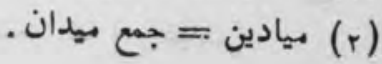




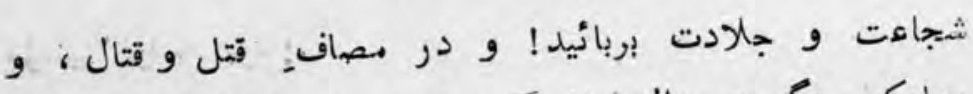

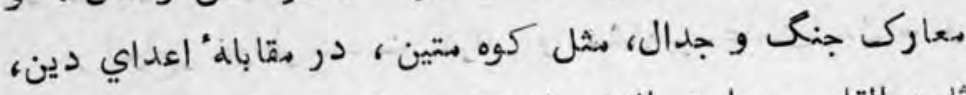

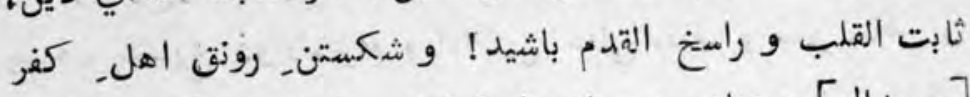

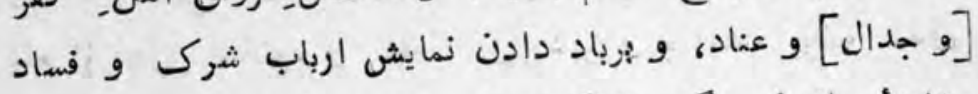

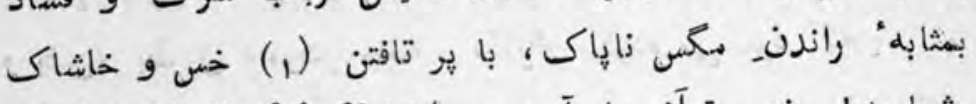

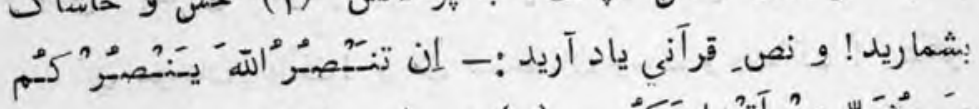

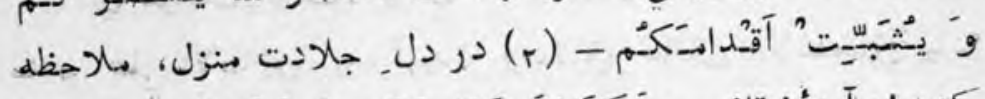

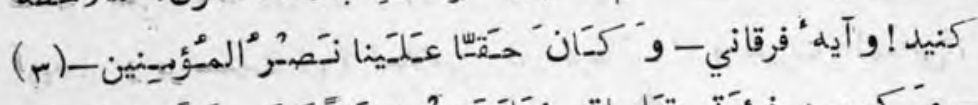

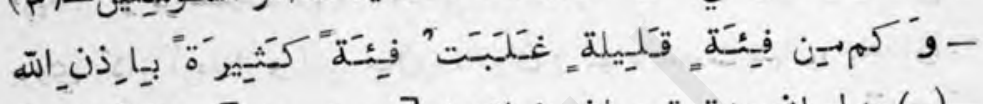

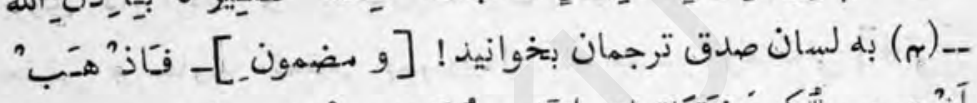

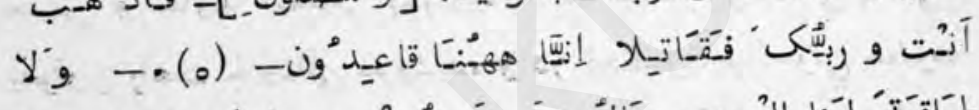

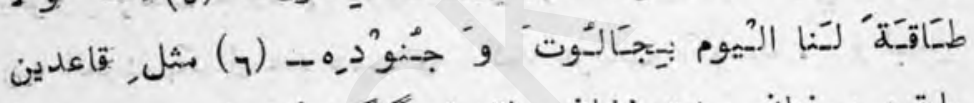

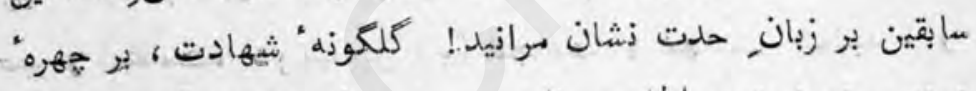

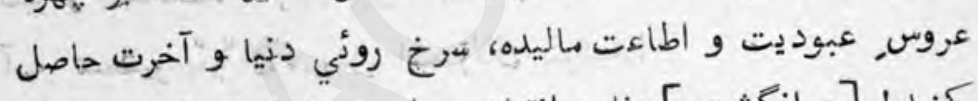

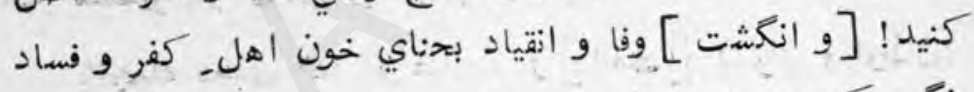

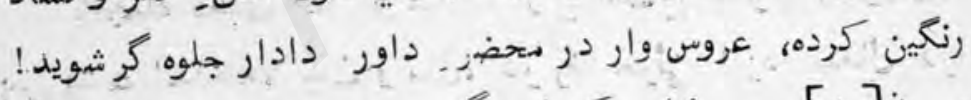

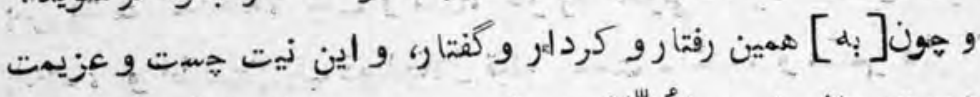

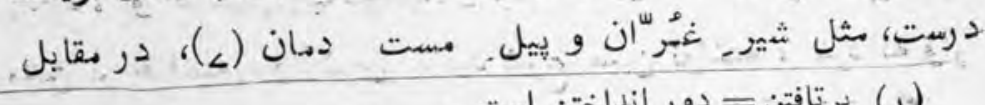

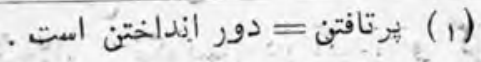

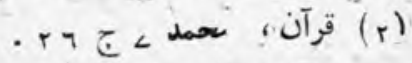

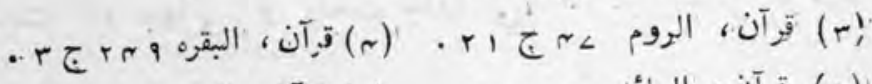

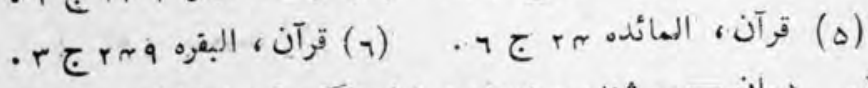

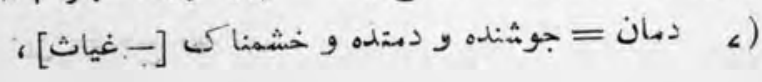


الهل, كفر و طغيان خواهند رمديد، ضرور بالضرور بر طبق مخمون

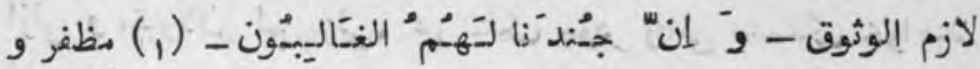

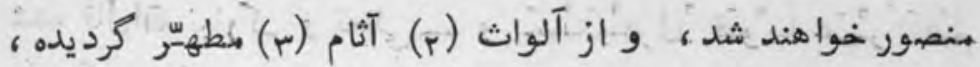

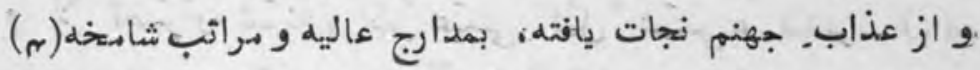
در رياض جنان و روحـ ريحان (م) در جوار_,ملك المنان خواهند

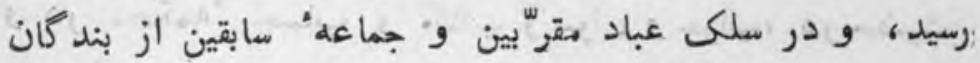
خاص و مقبولان ذوالاختصاص هنسلك خواهند كرديل .

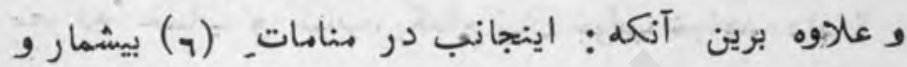
معانلات خارج از حل و حصار، در باب سرانجام دادن اين الهر.

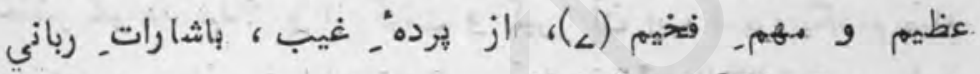

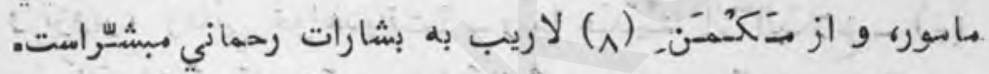

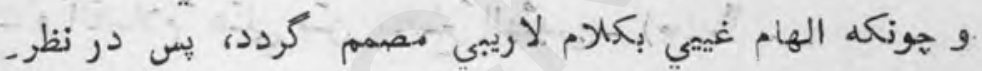

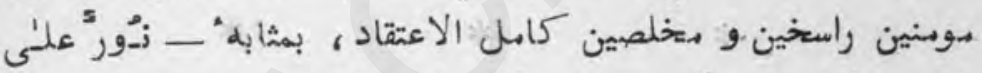

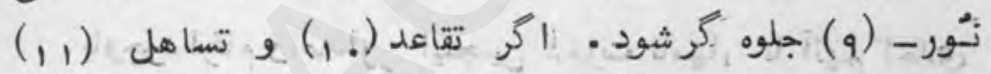

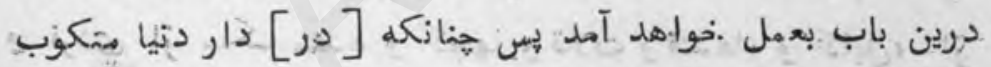

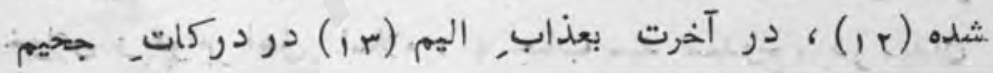
.

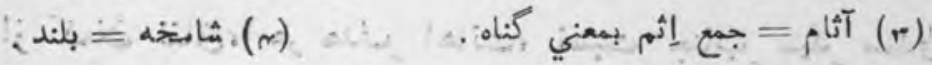

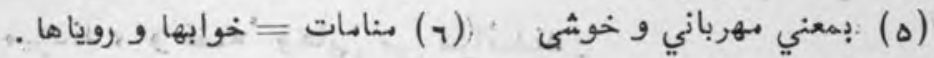

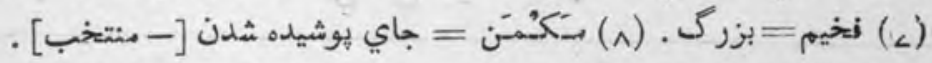

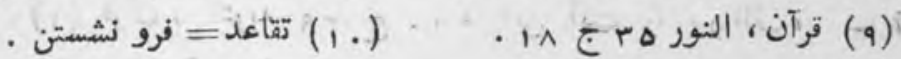

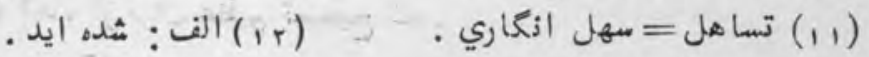
. 
كرفتار خواهد كرديد، و در عوض, ايشان، ديكر سعادتهندان

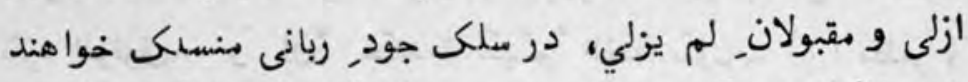

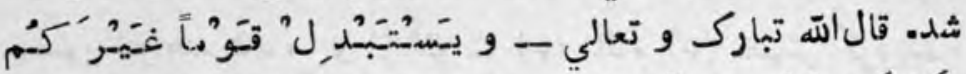

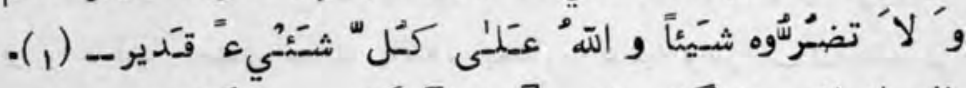

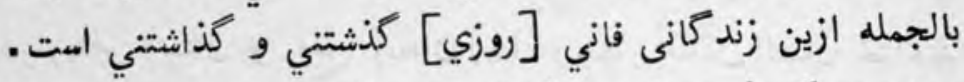

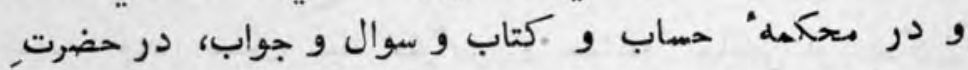

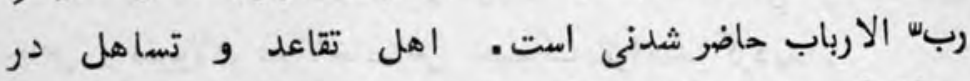

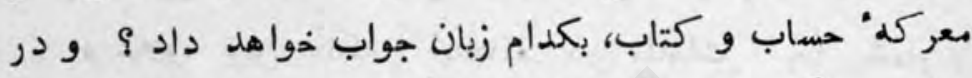

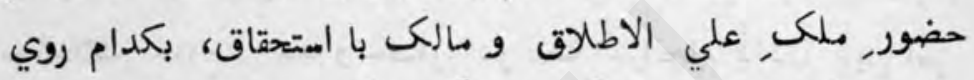
حاضر خواهد شد؟ و از كرفت و كير, آن رب قدير، بكدام هميله

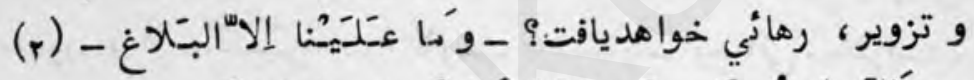

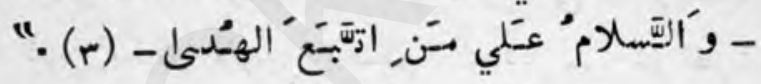
*

* *

باوجود ارقام واصدار, اينجنين دعوت نامها، با آنهم احدي

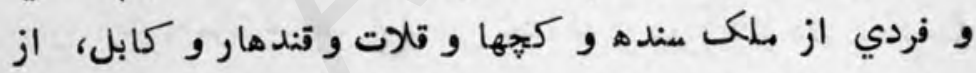
خواص و عوام, اهل, املام ، با جناب سيد مهدوح، در ميدان

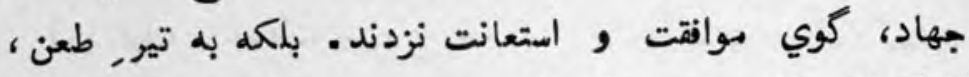
از كمان نقاق، هر هدف, اهانت، نسبت, جناب, سيد, مهدوح

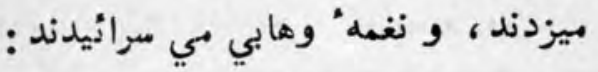

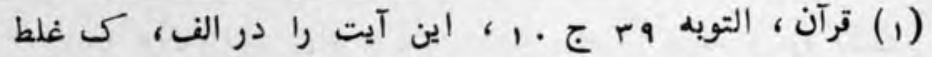

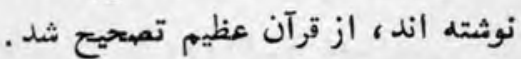

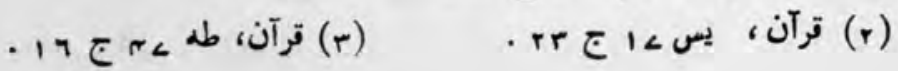




\section{حه حكمتست كمه در فرقه" مسلمانان}

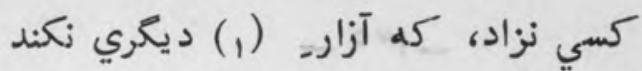

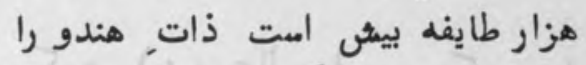

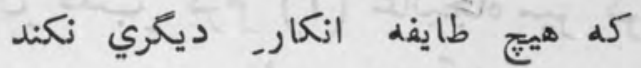

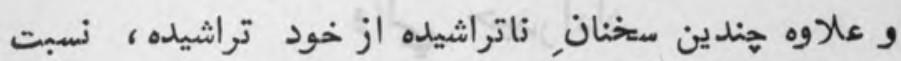

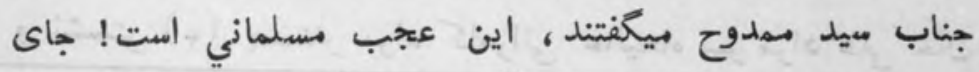

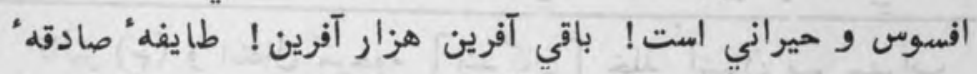

يوسفزئي را، كله حون [يوسف]

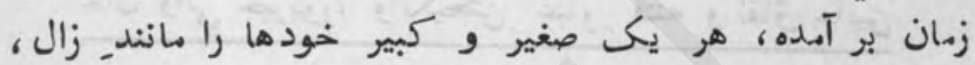

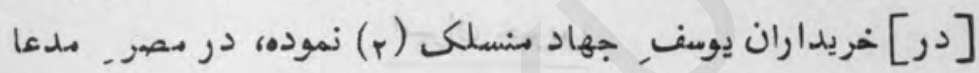

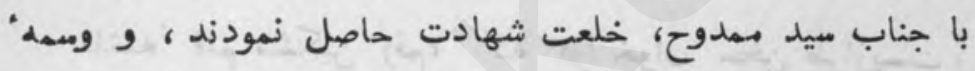

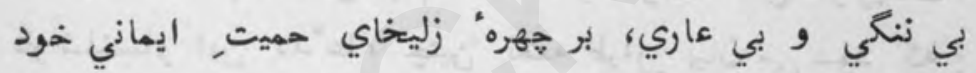

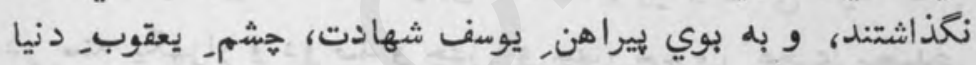

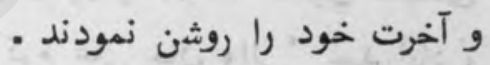

(1) الف: كه استهزا ديكري.

$$
\text { . }
$$


- ma -

در بيانِ قلبـــرمـ ( ) عاليجاه مير كرم علي خان والي حيلرآباد

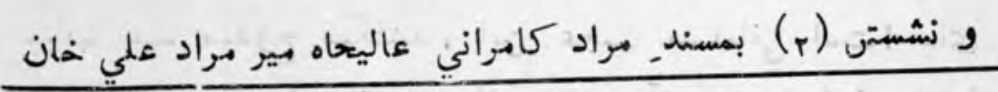

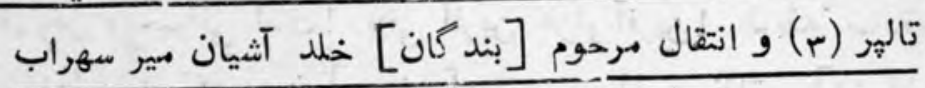
خان والي خيربور، وانكيختن, غبار فتنه و و نفاق مابين

$$
\text { ا-ميران خيريور }
$$

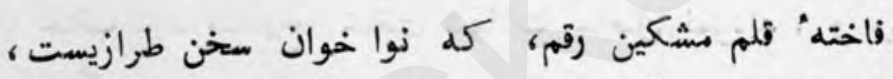

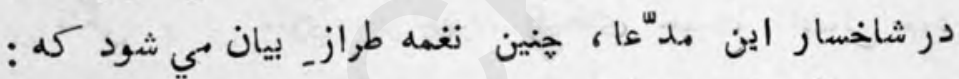

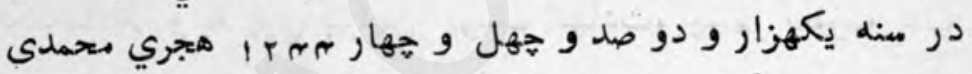

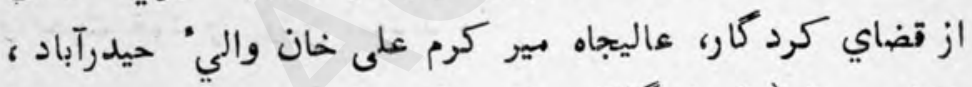

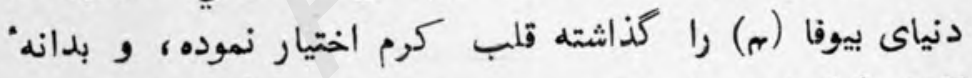

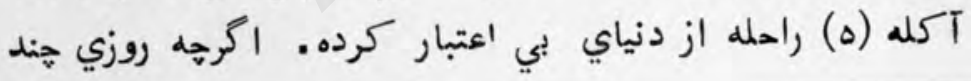

(1) مقصد مرك است.

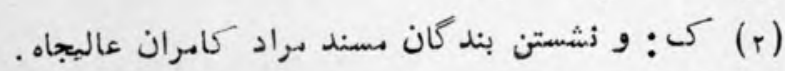

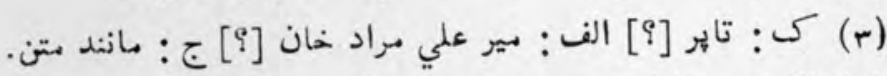

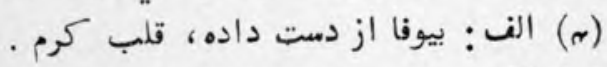

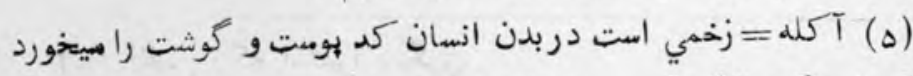

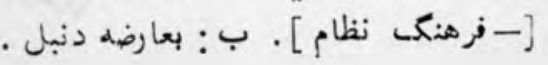




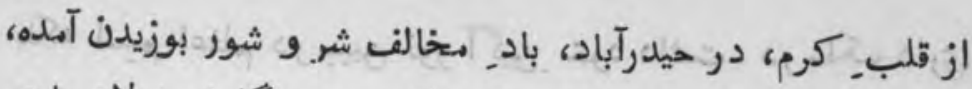

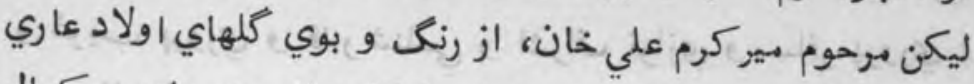

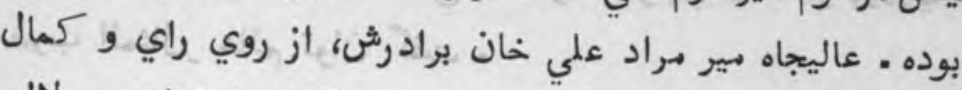

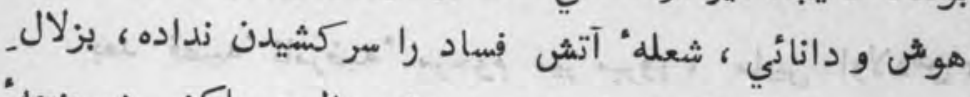

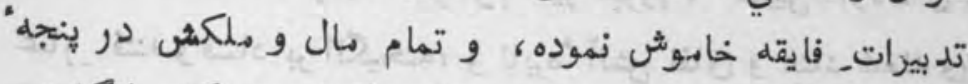

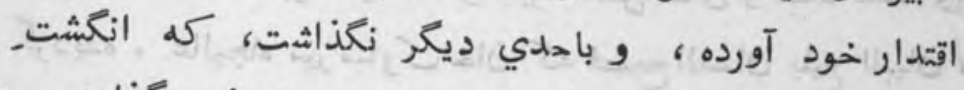

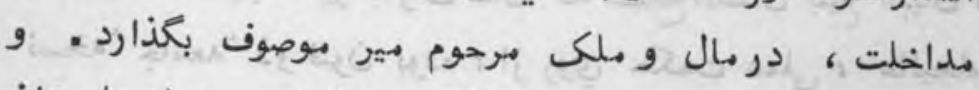

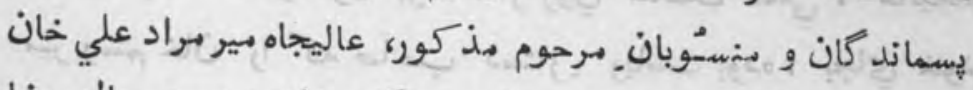

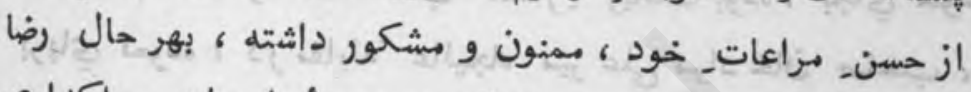

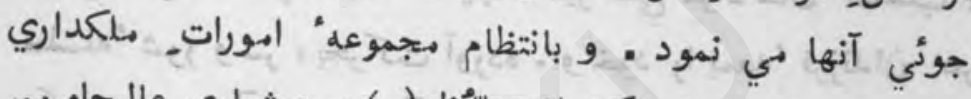

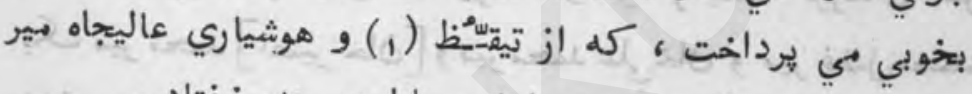

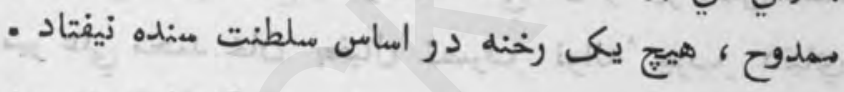

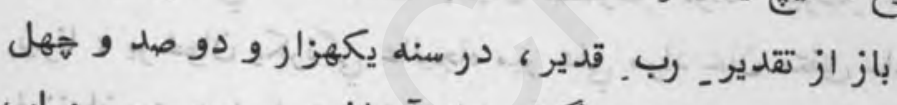

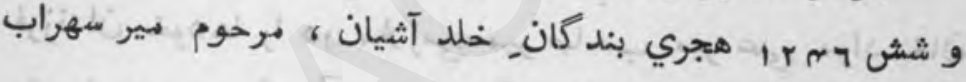

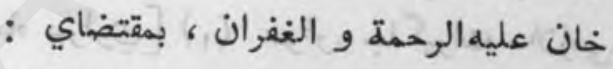

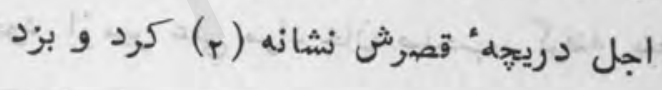

هطابق بيست و هفتم ماه صفر، سفر آخرت اختيار نموده، از بام-

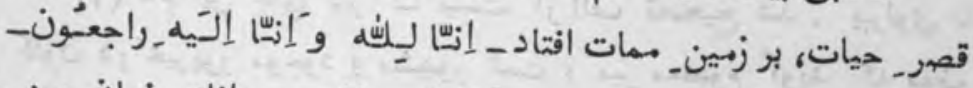

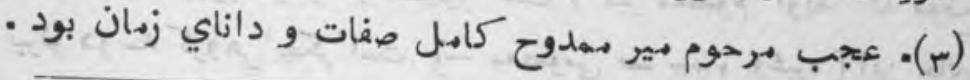

$$
\begin{aligned}
& \text {. (1) تيقظ = بيداري }
\end{aligned}
$$

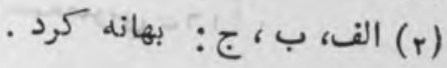

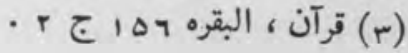




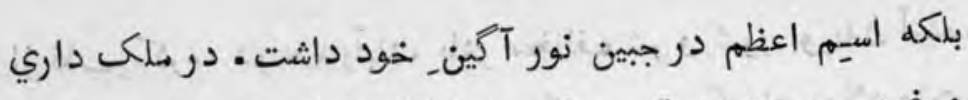

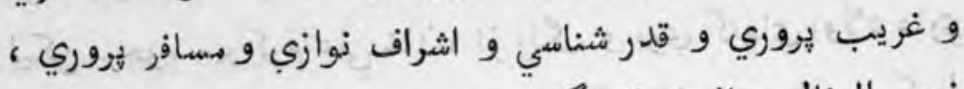

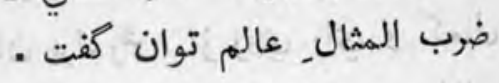

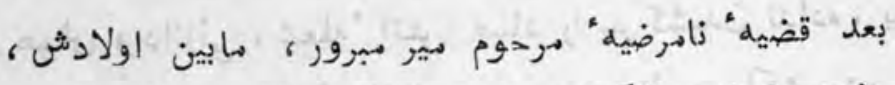

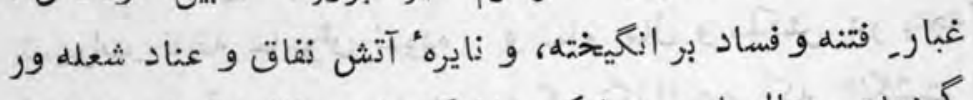

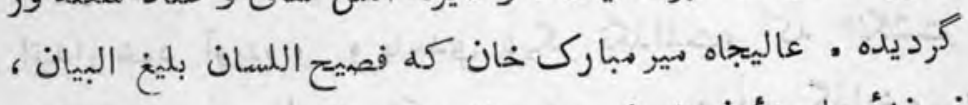

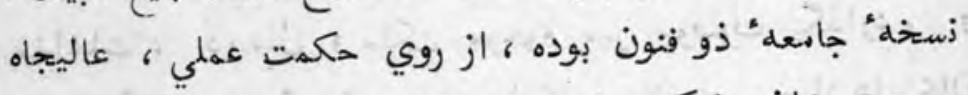

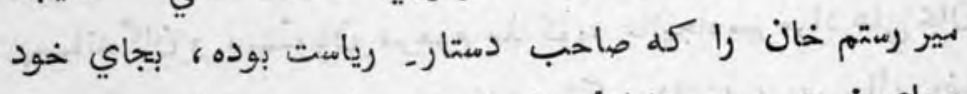

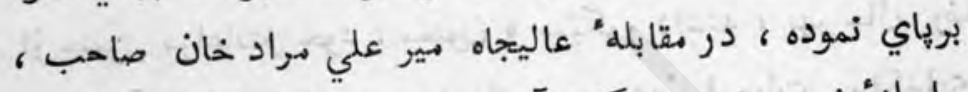

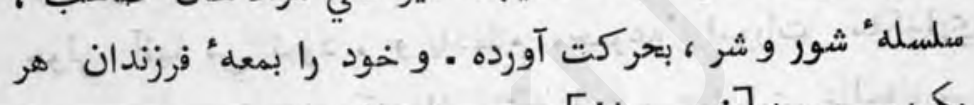

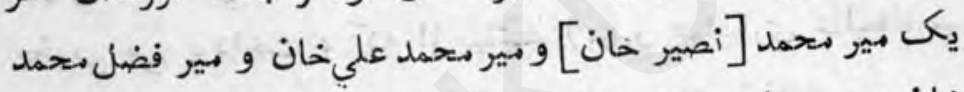

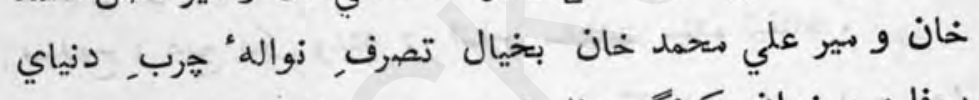

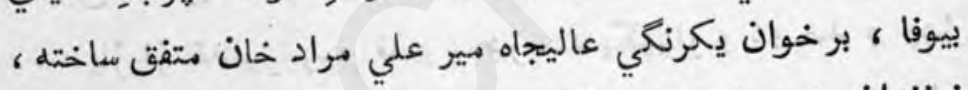

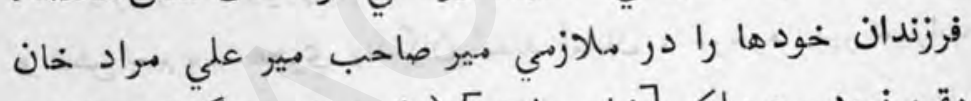

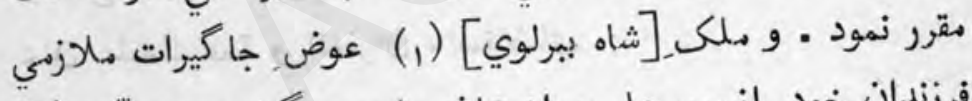

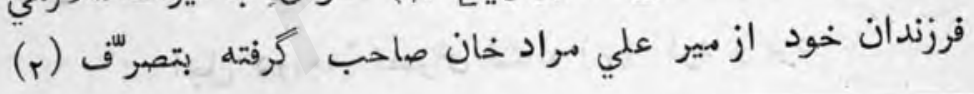

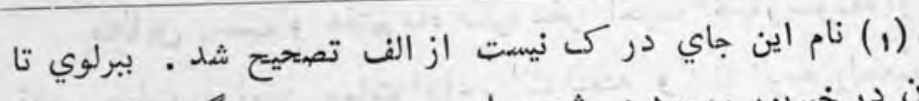

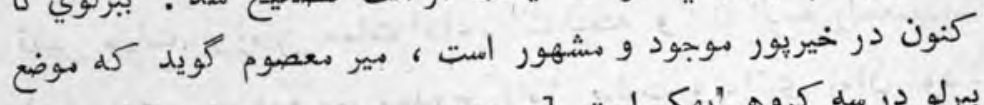

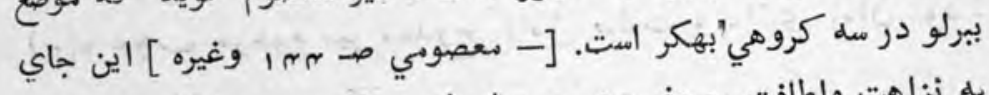

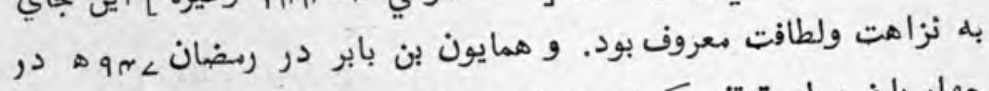

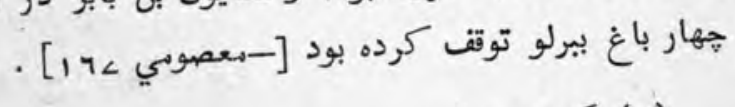

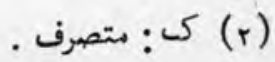




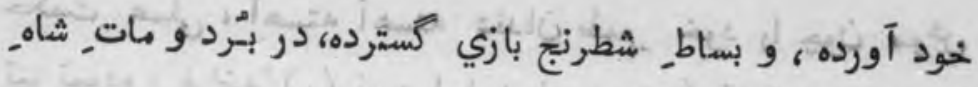

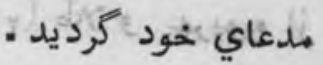

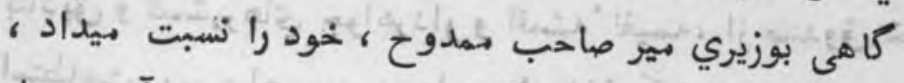

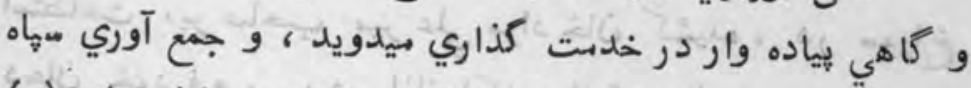

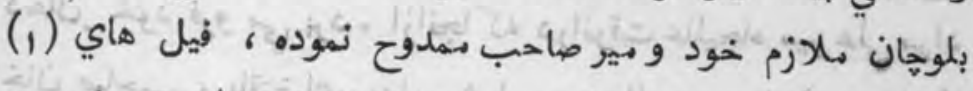

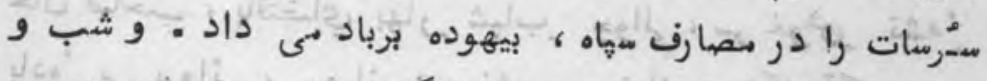

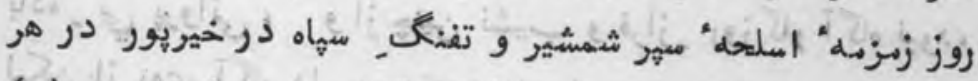

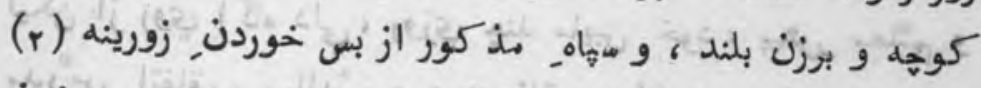

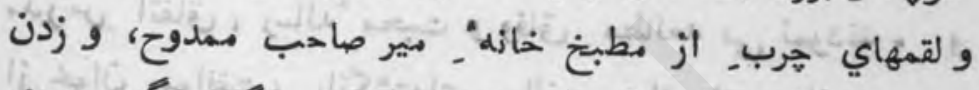

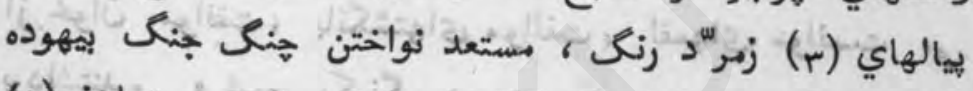

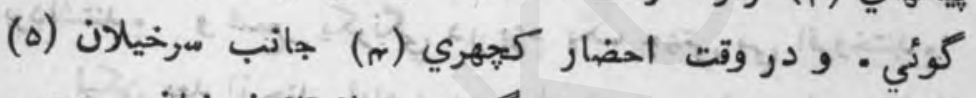

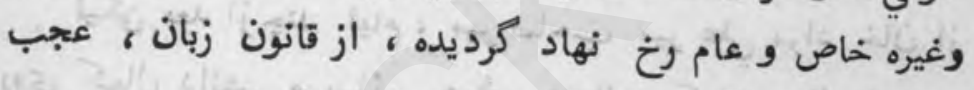

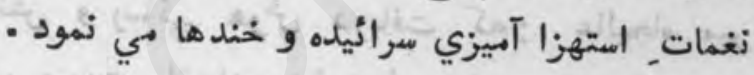

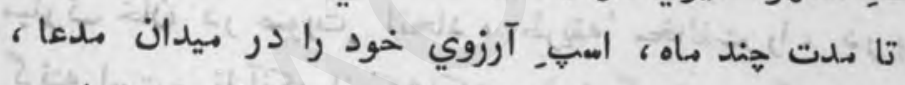

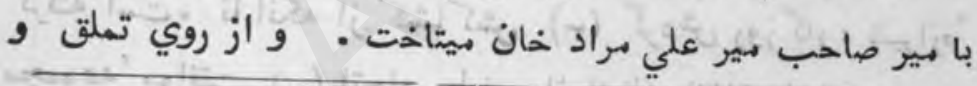
(1) كذا در الف، كى . شايد صحيع آن يولها باشد يعني مبالغ

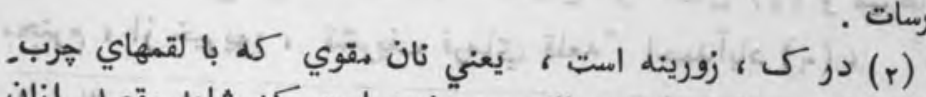

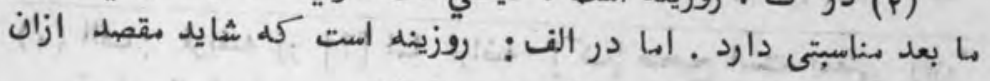

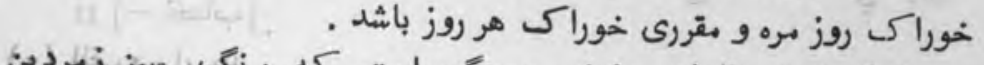

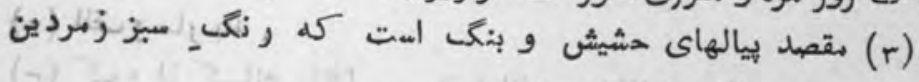

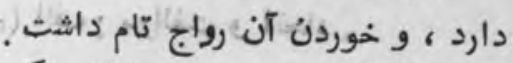

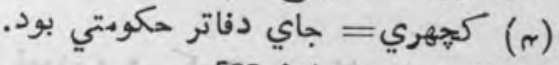

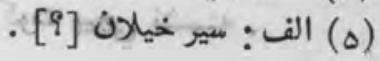




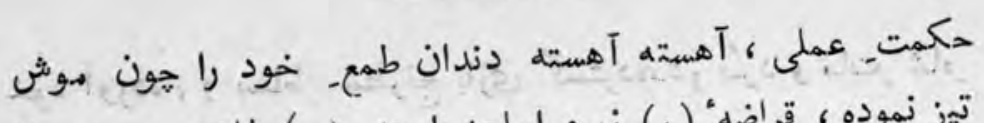

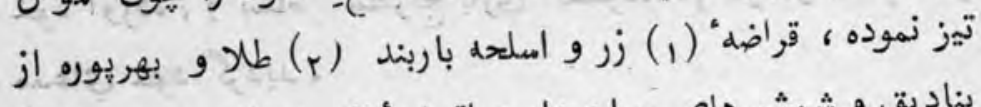

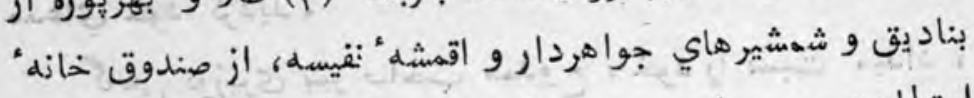

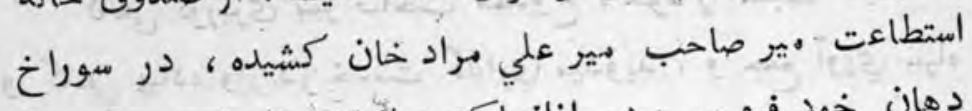

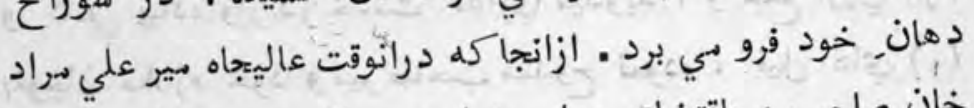

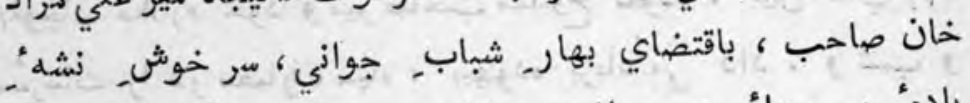

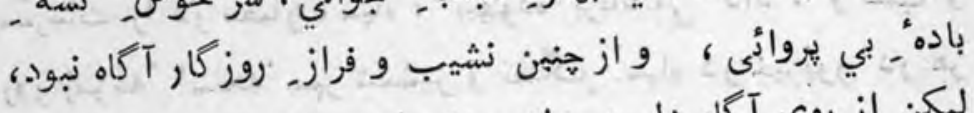

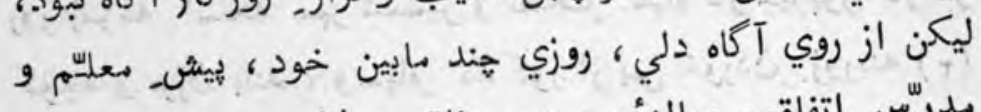

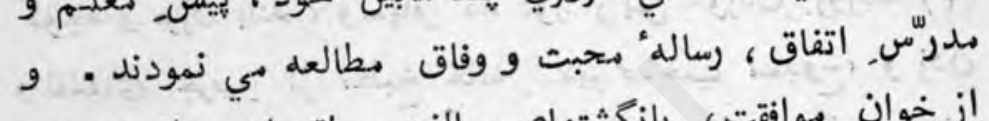

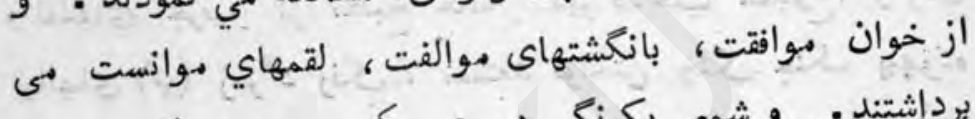

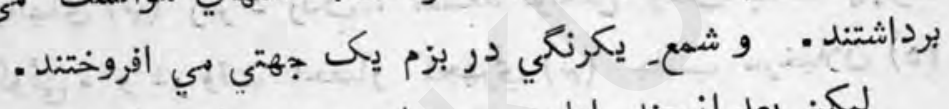

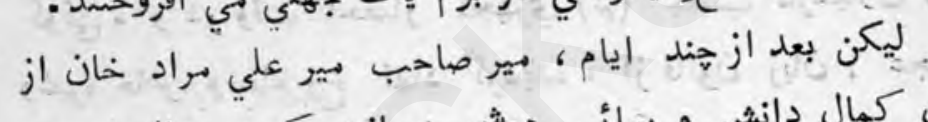

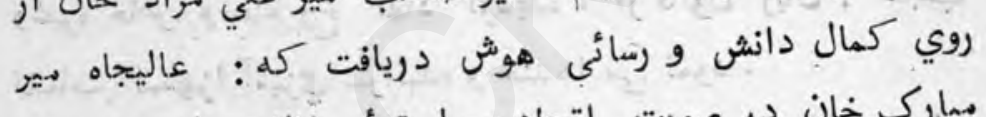

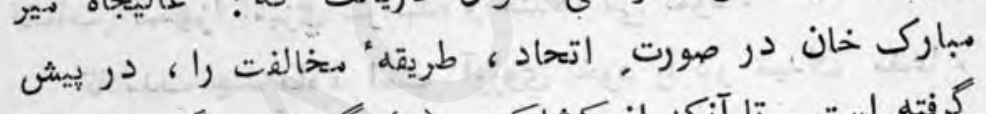

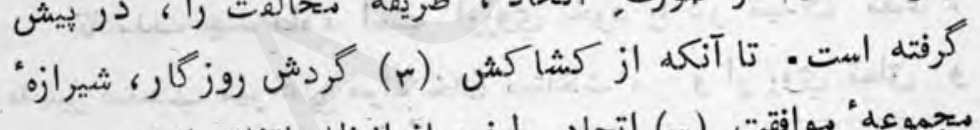

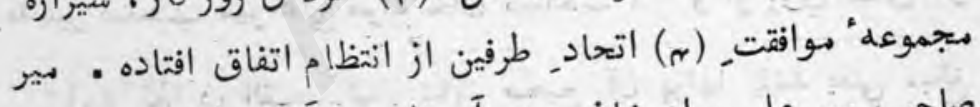

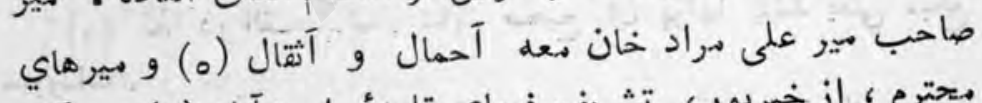

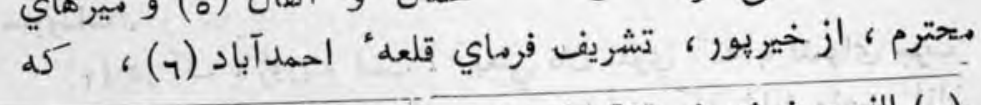

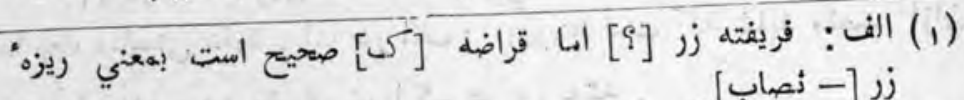

$$
\begin{aligned}
& \text { زر [- ـــاب]. } \\
& \text { (r) }
\end{aligned}
$$

(ه)

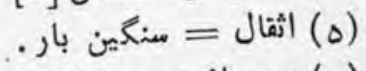

(1) ب: از خير يور انتقال نموده و در كوت يبيجي نشسته . 
درانجا رفته اقامت كرفت، و دادي مردانكي و همتــ خود را از

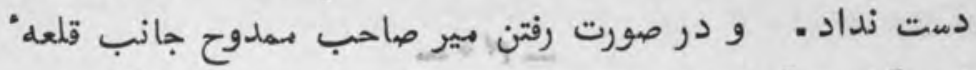

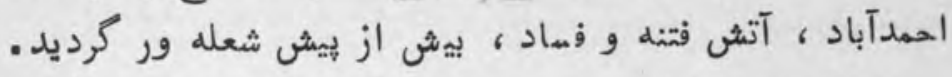

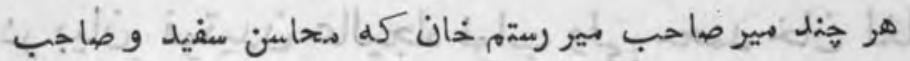

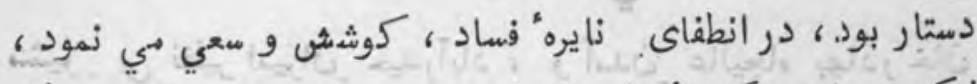

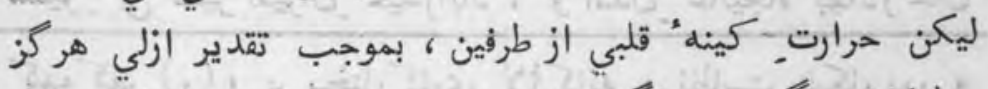

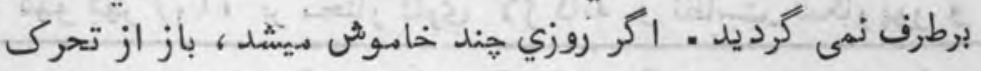

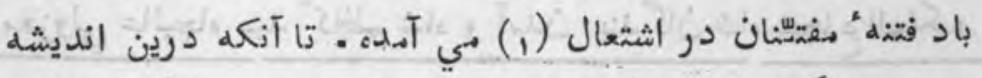

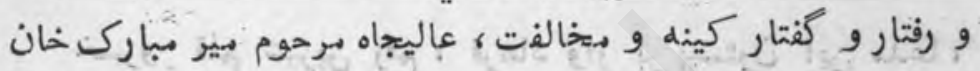

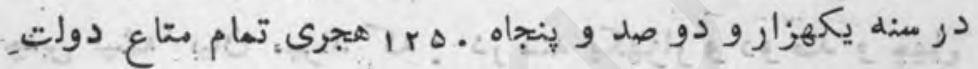

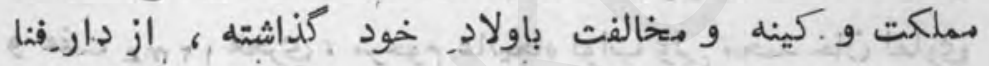

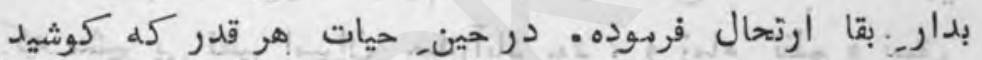

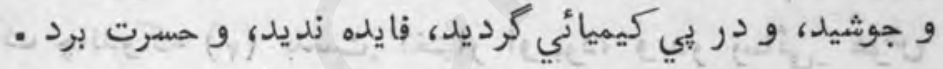

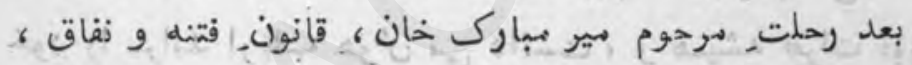

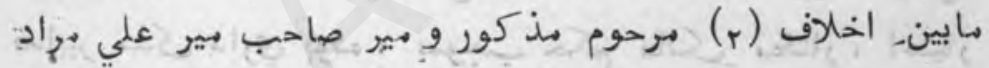

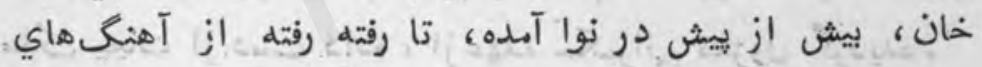

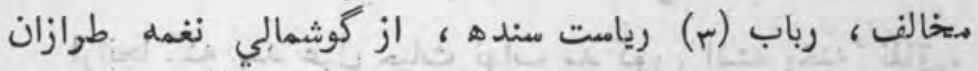

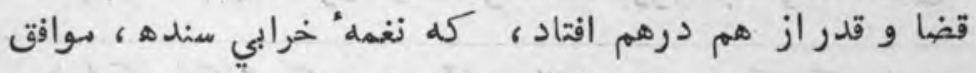

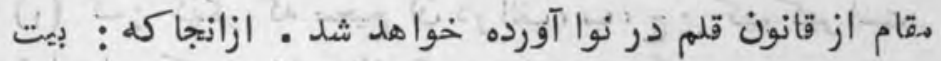

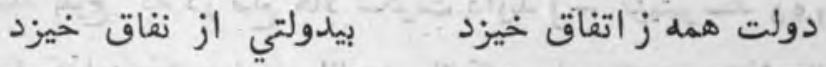

$$
\begin{aligned}
& \text { - الشعله }
\end{aligned}
$$

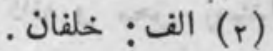

$$
\begin{aligned}
& \text { (r) الف: زبان [؟] }
\end{aligned}
$$


در بيان_ فوتيدن عاليجاه ذواب ولي محمد خان لغارى سشير بي نظير اميرانـ حيدرآباد ، و آمدني عاليجاه بهادر خان

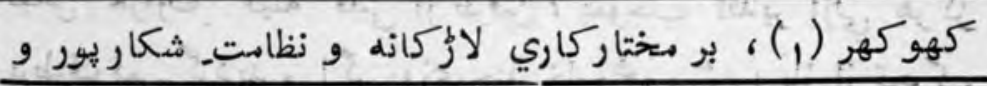

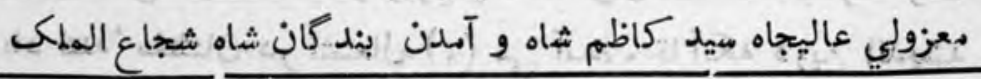

خسزو قلم شيرين رقم ، فرهاد وار بر بيستون اين مدعا ،

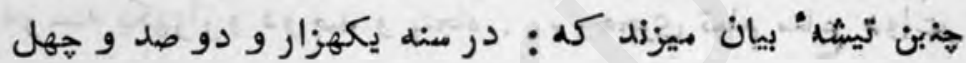

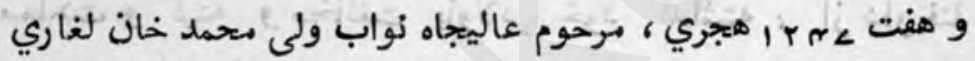

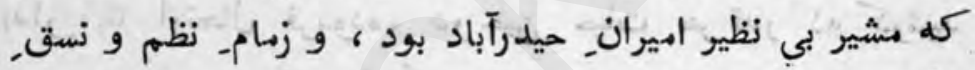

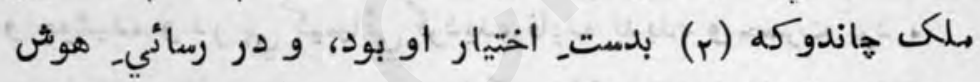

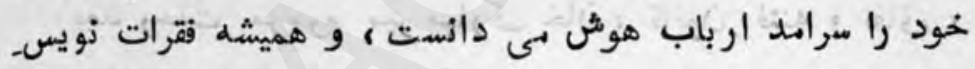

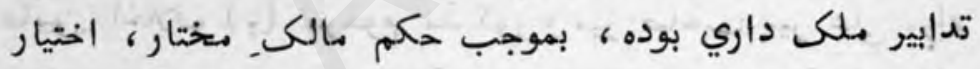

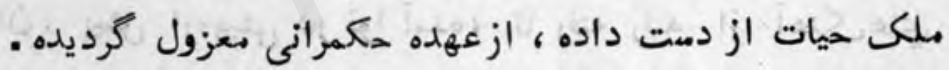
ازانجا كه بعد عزل حيات نواب مذكور، البته رخنه" نفاق،

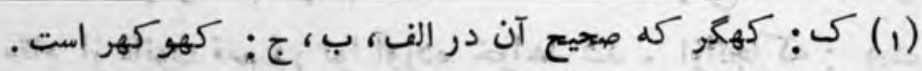

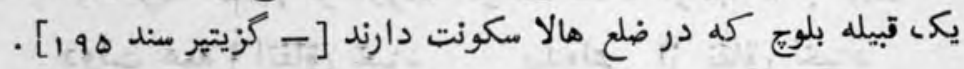

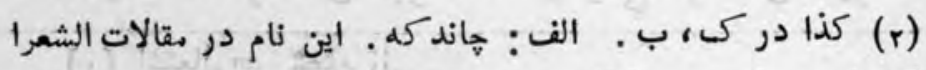

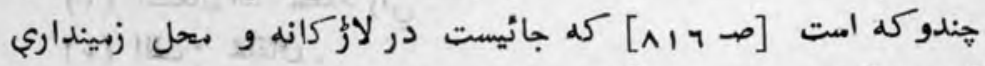

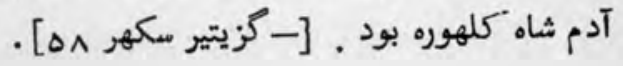


در اسهاس اتفاق هير صاحبان سند بوقوع آهده . عاليجاه هير مراد

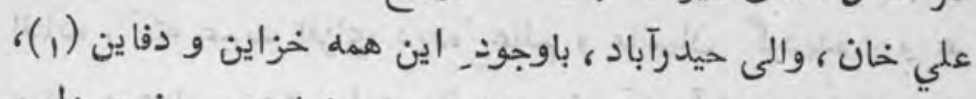

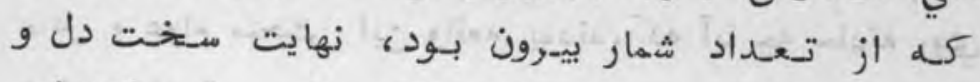
دست تخغ (r) بود ـ مرحوم نواب مذ كور ، كله بر است كاغ كاغذي

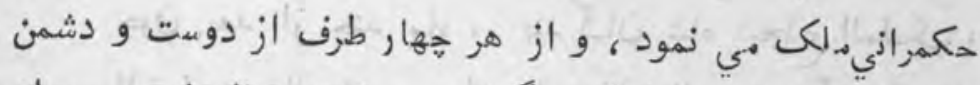

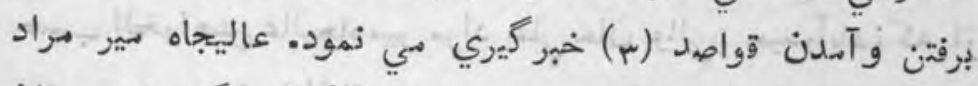
علي خان ، بسبب اخراجات قاصدان هم تخكدل نيخرديد، و بيان

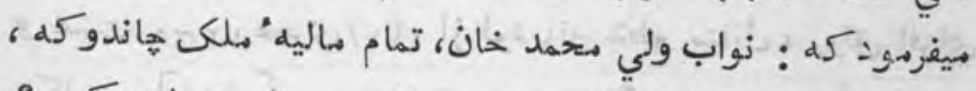

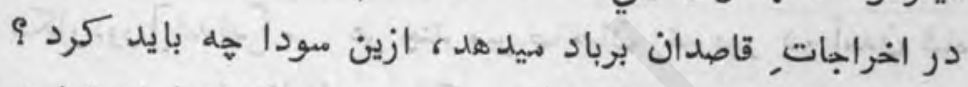

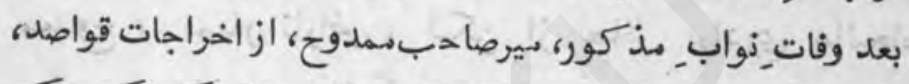

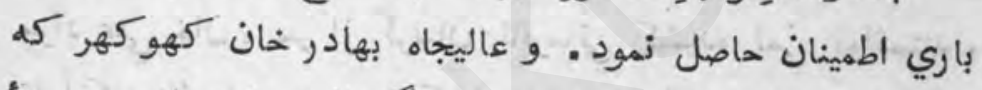

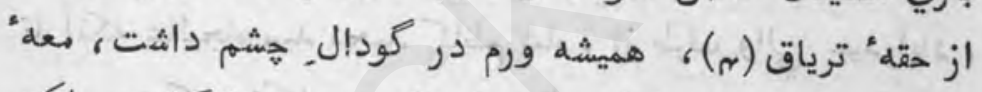

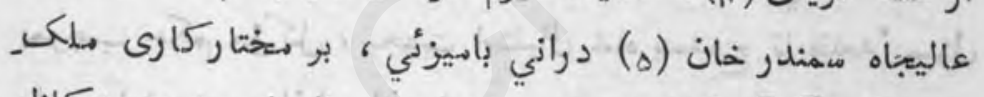

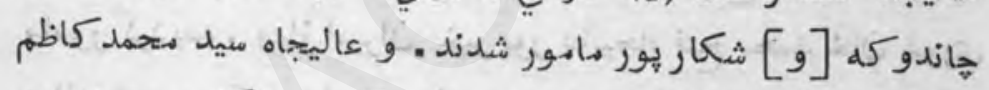

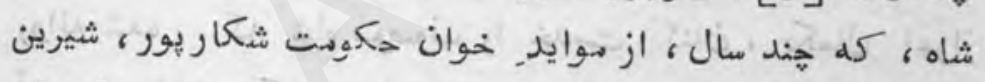

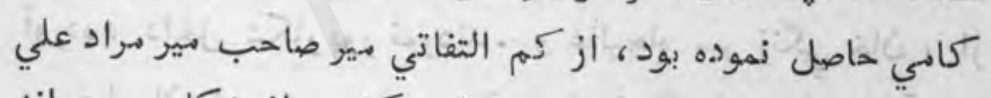

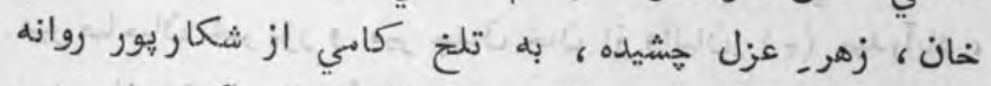

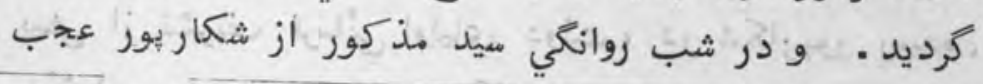

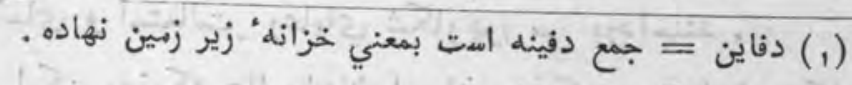

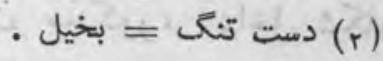

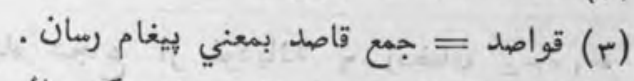

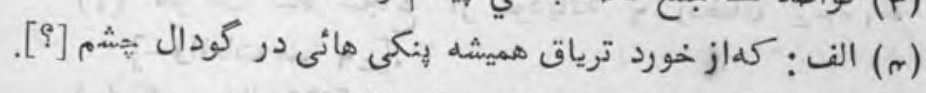

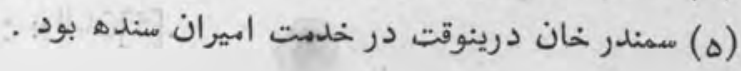


تازه نواي معار كى

$r<C$

واقعه صادر شده، كله ازفنلك فيروزه رنگ، اين قدر متاره بر زمين

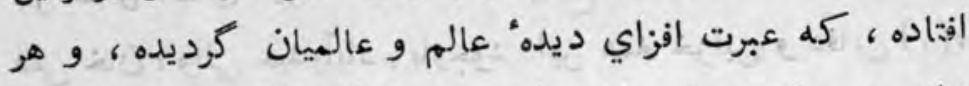

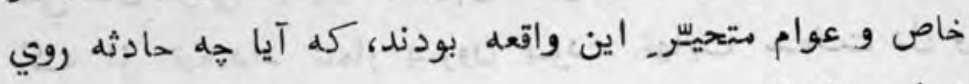
خوا هد داد

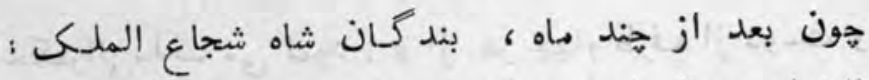

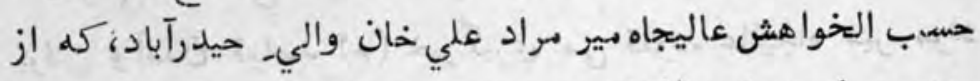

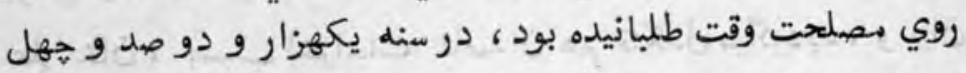
و هشت ^م م ارهجري (1) ، از لوديانه بقطع منازل ، رونق افزاي

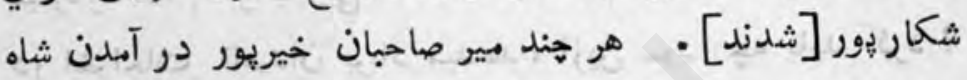

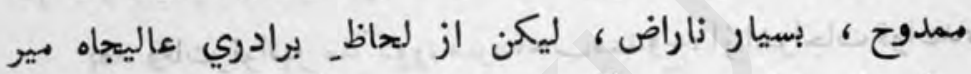

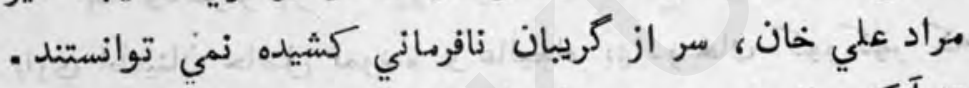

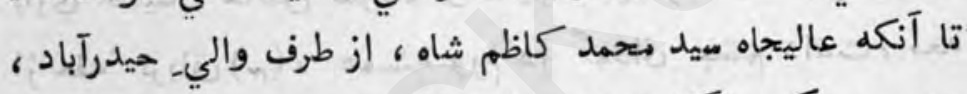
بموجب حكم مزوكل ، بجهت استقبال شاه ممدوح تا بقلعه ' سبزل

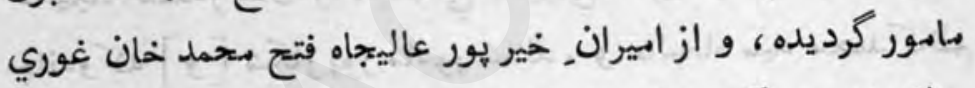

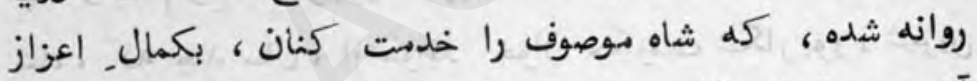

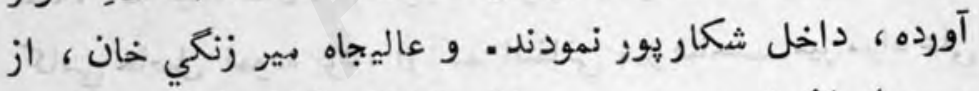

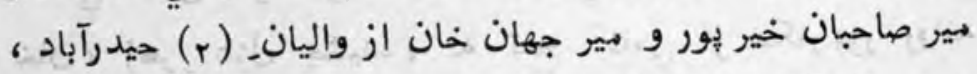

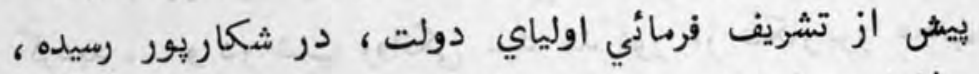

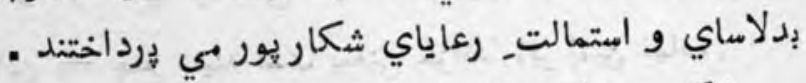

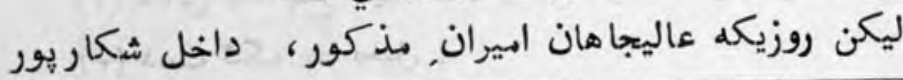

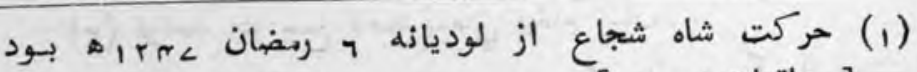

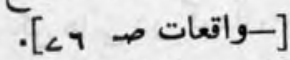
[r) 
تازه نواي

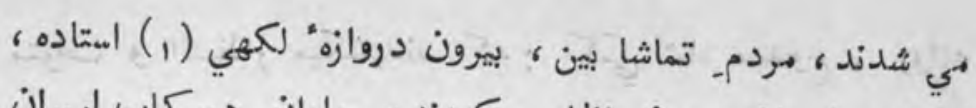

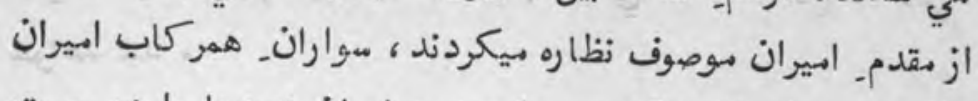

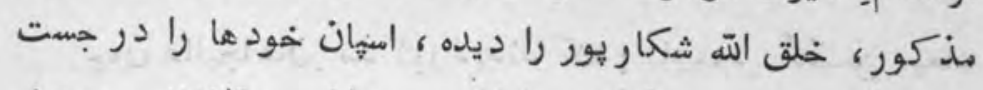

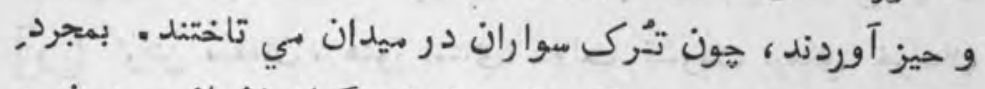

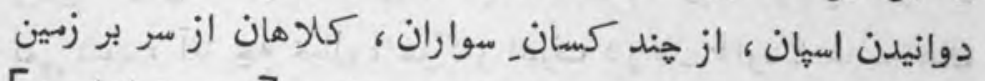

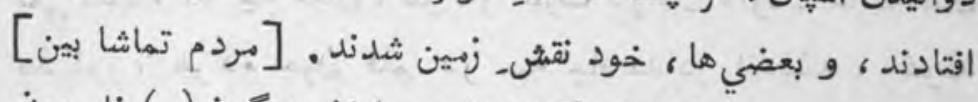

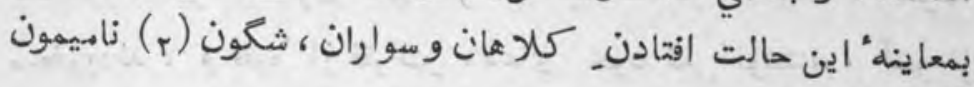

- كرفئن

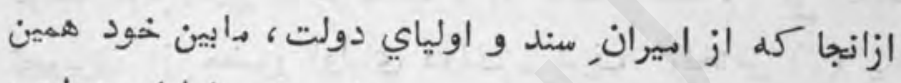

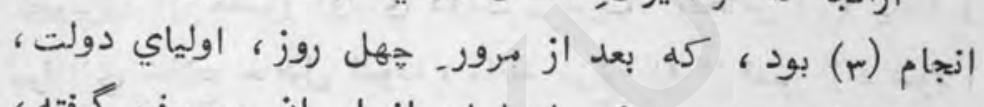

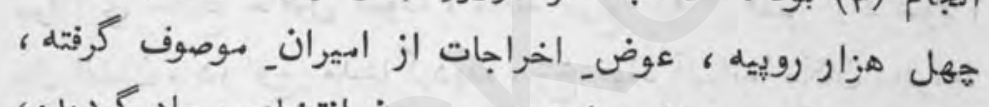

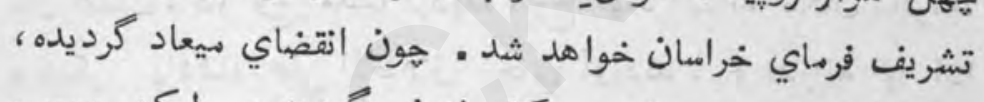

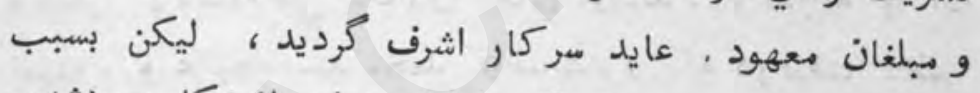

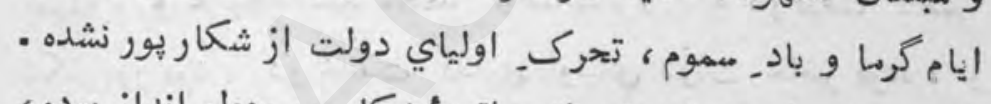

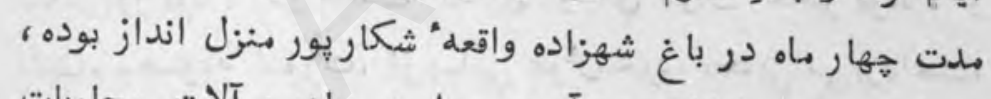

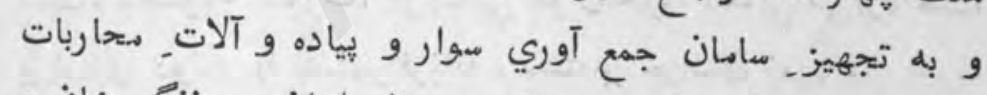

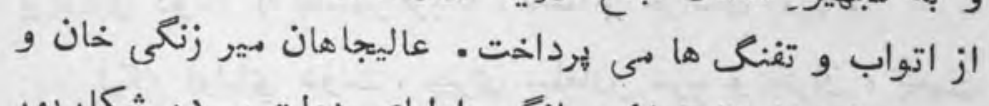

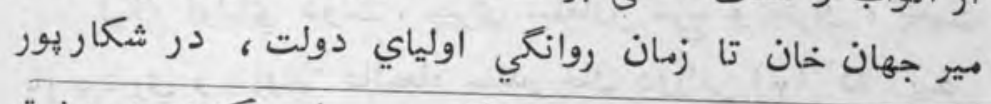

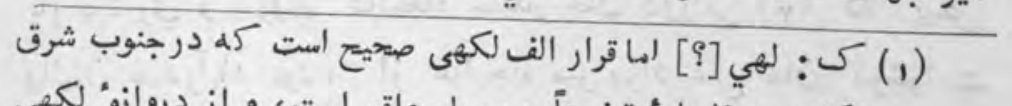

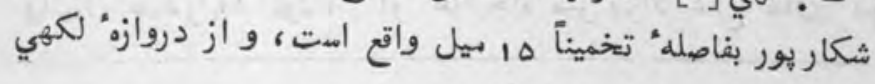

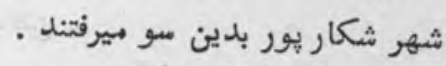

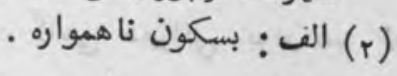

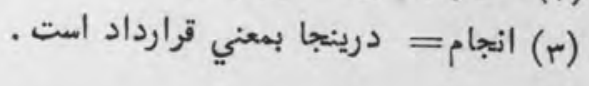




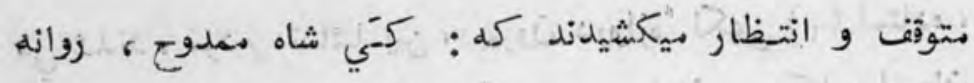
خوا هلد شد

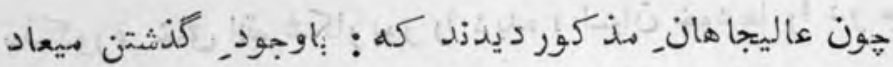

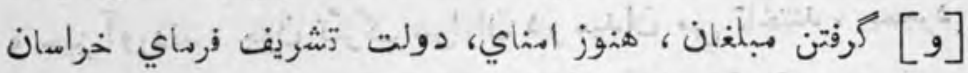

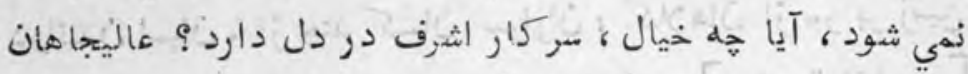

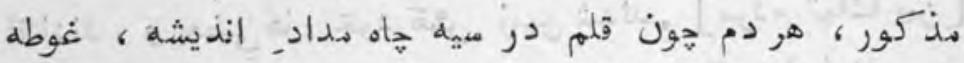

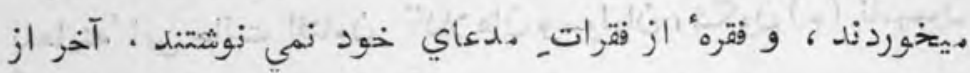

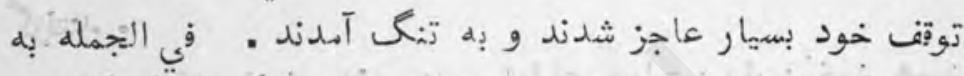

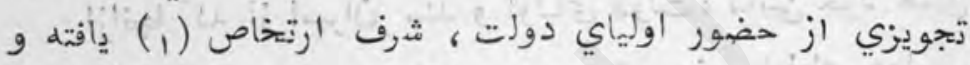

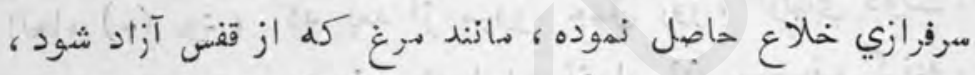

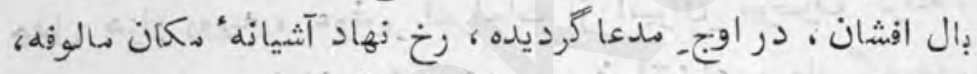

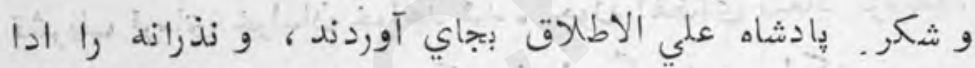

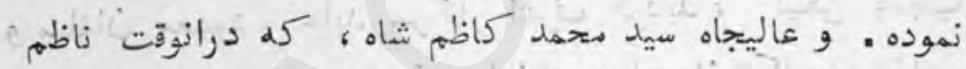

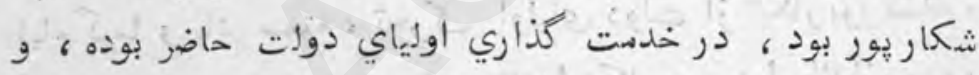

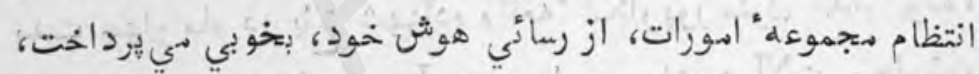

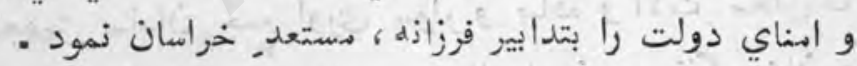

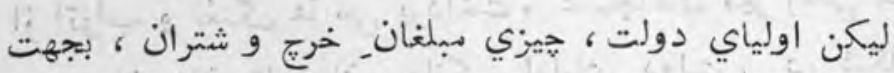

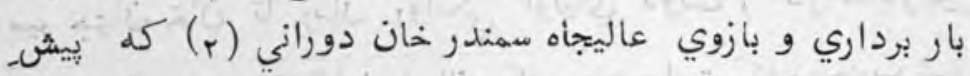

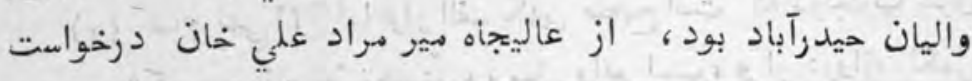

·

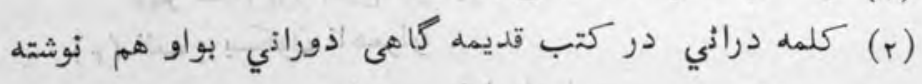




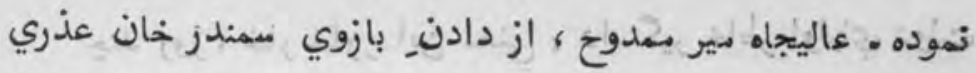

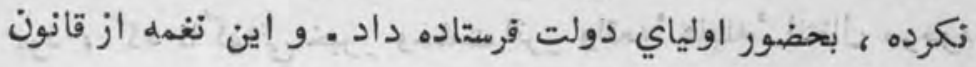

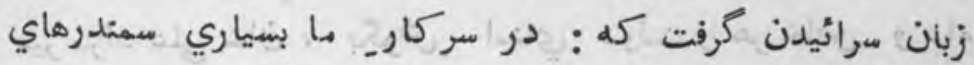

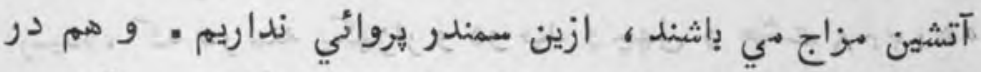

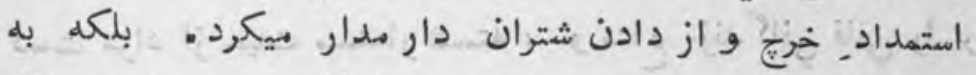

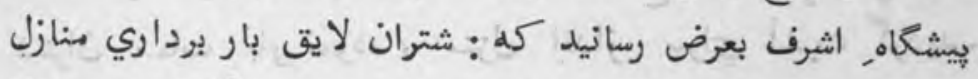

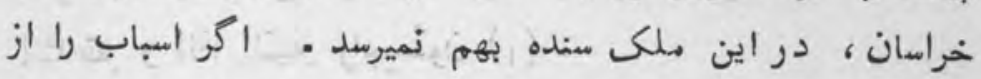

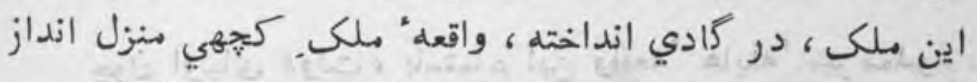

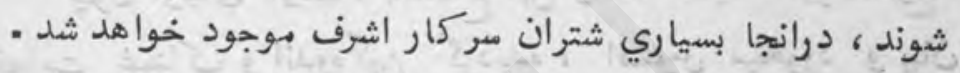
اولياي دولت از هنين التماس مير دمصوف ، نهايت در توجهب

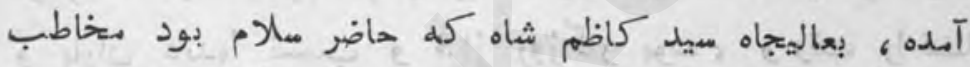

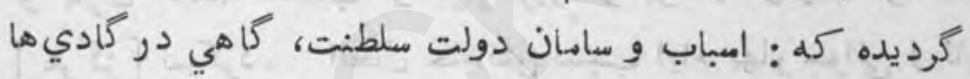

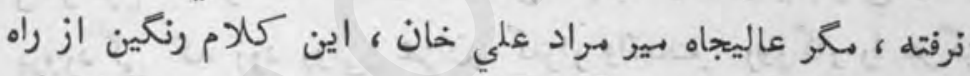

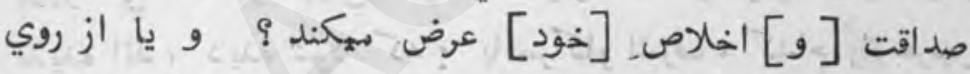

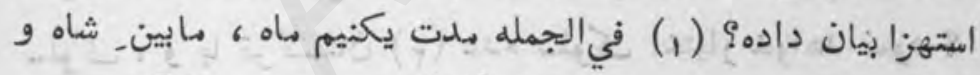

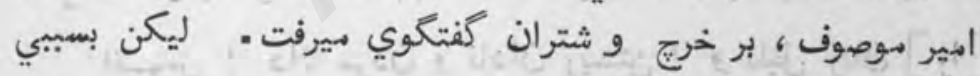

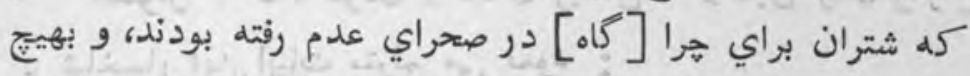

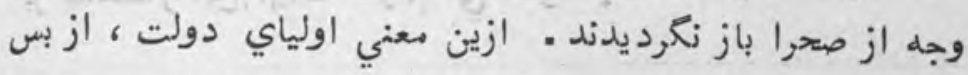

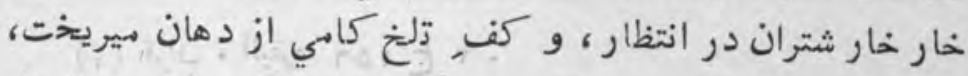

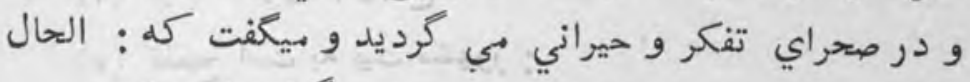

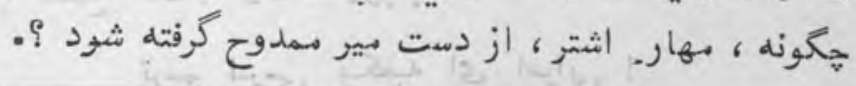


جند روز، خار خار اين منعني ، دامنكير خاطر اولياي دولت

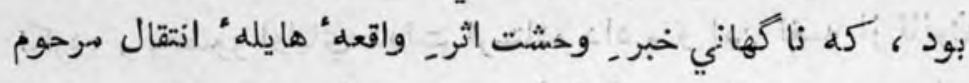

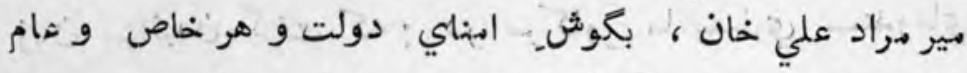

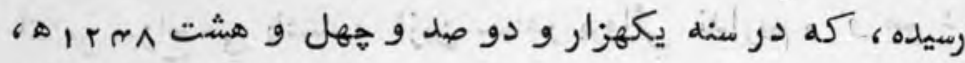

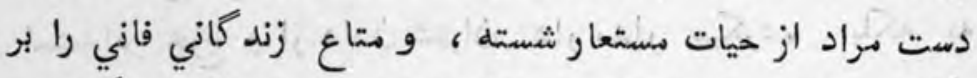

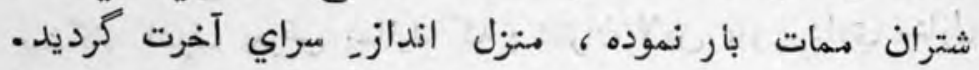

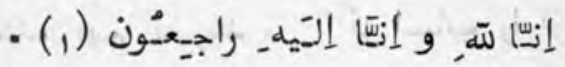

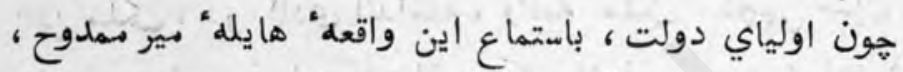

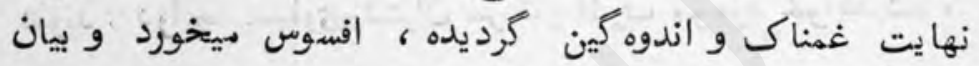

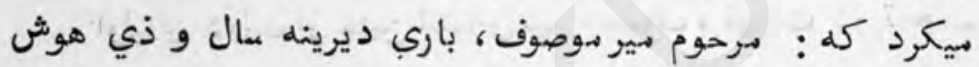

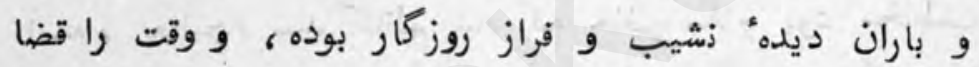

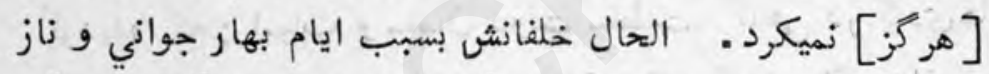

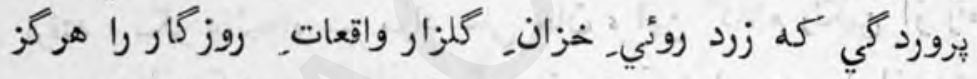

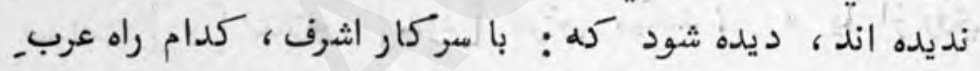

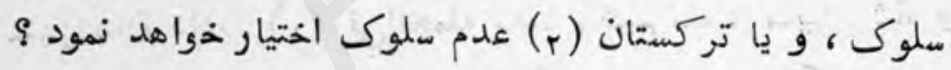

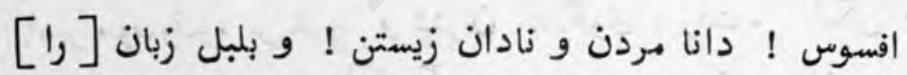
بر شاخسار اين ابيات مترنم هي نمود :

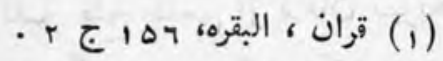

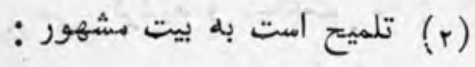
ترسم نترسي بـكعبه اي اعرابي ! كاين رهكه تو بيزوى به تركستان است 


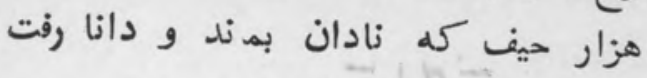

$$
\text { بوقت. (1) نزع شنيدم كه كفت افلاطون }
$$

$$
\text { حه جاي مجلس عيش است اين مراي دو درو }
$$

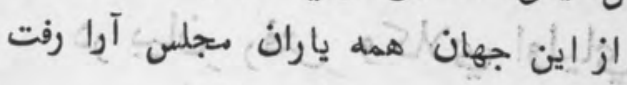

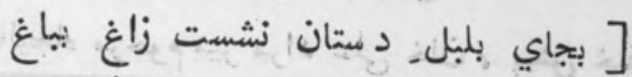

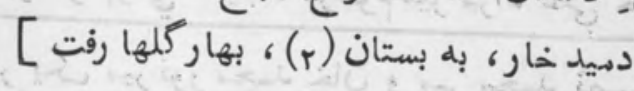

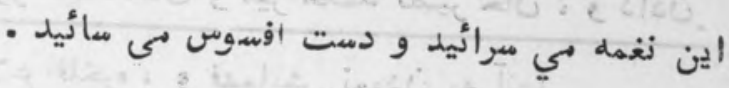

(1) الف: شبي بوقت نزع كفت اقلاطون [؟] .

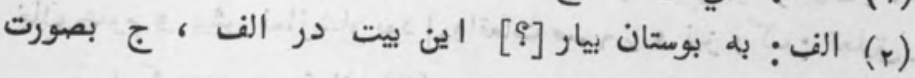

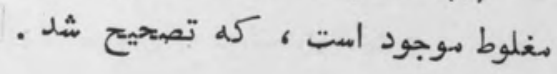


در بيان رفتن, وكلاي اولياي دولت

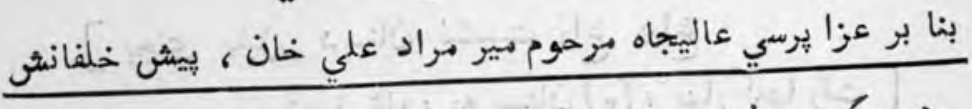

هر يك مير نوز مجمد خان و مير محمد نصير خان ، و د دادني.

خلاع فاخره، و فهمايش نمودن به آنها

هنشى [باشي] قلم خوث رقم ، در تحرير بر دستخط اين مدعا،

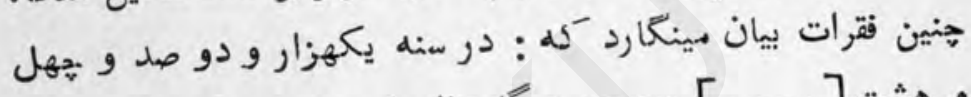

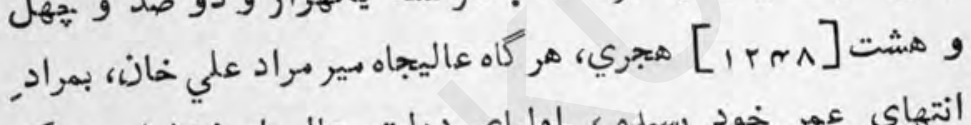

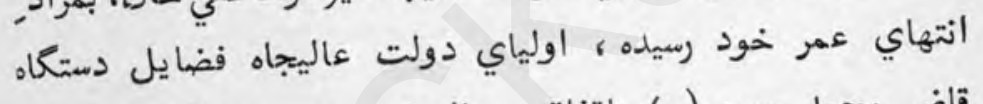

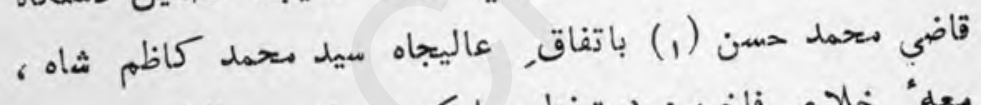

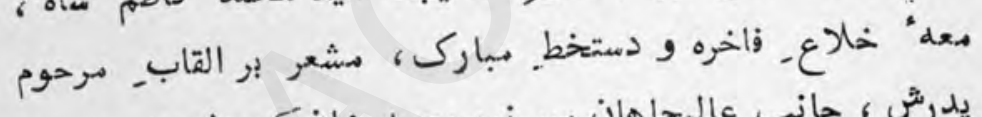

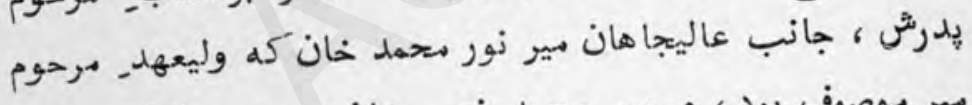

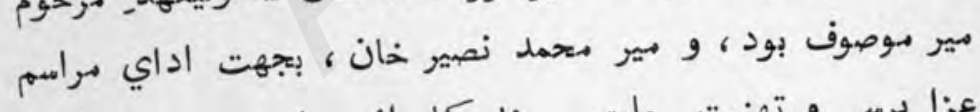

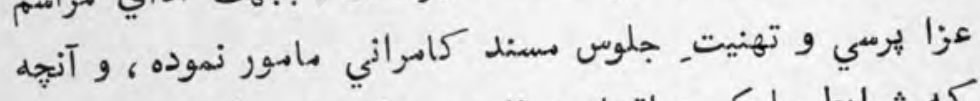

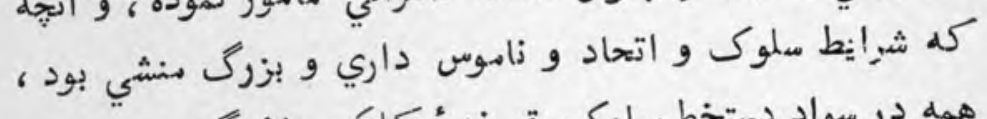

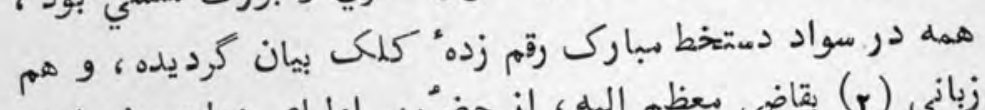

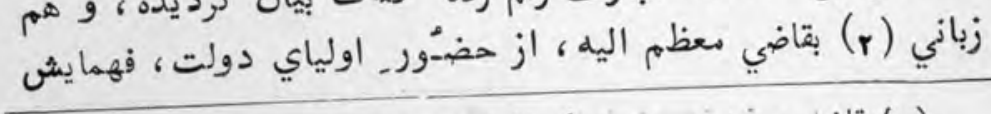

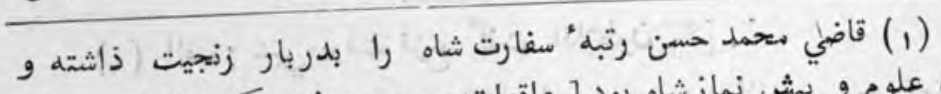

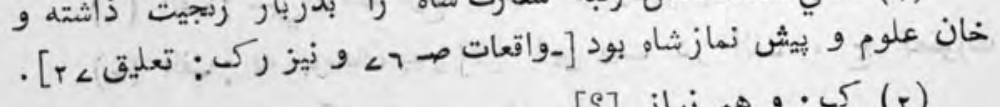
. 
رفته و منتظر استمداد خرج و اثشتران بوده.

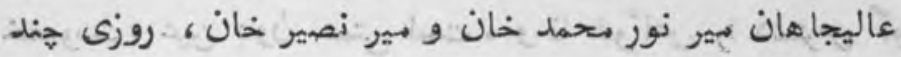

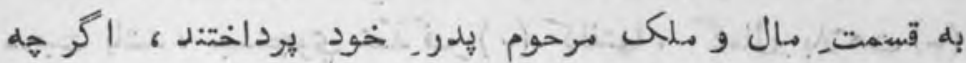

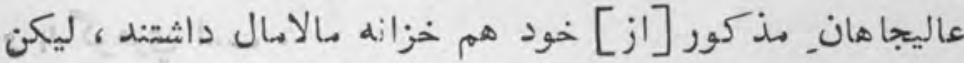

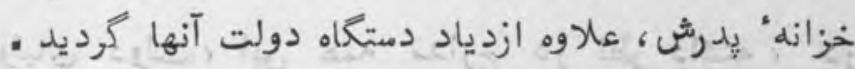
ازانجا كله خمار دولت دول را غرور بسيار ميباشدل، عاليجاهان

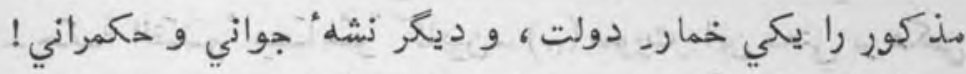

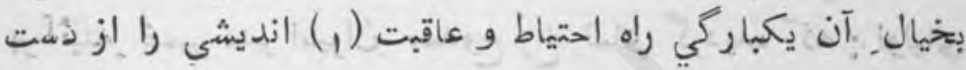

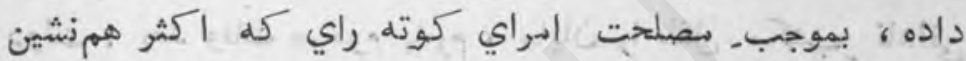

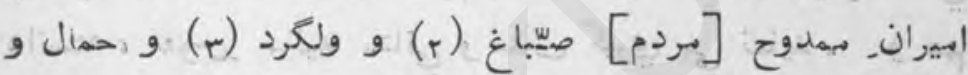

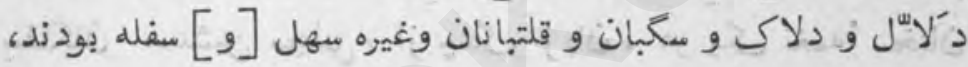

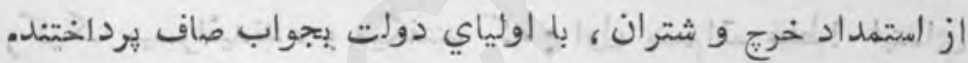

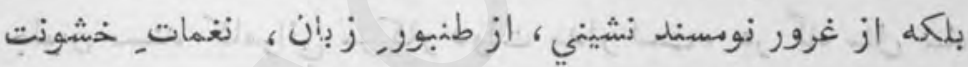

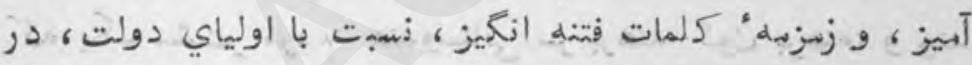
نوا آوردند

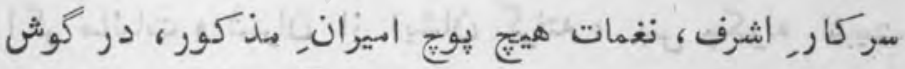

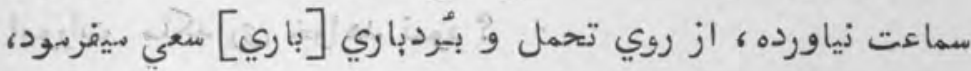

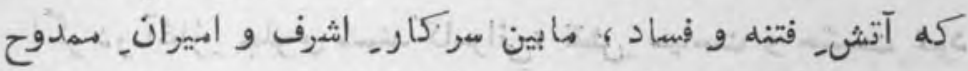

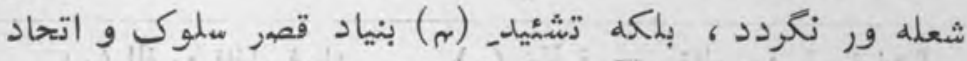
بعمل آيد . و به مقتضاي آنكه انسان را تا مقدور كاشتن

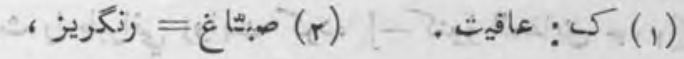

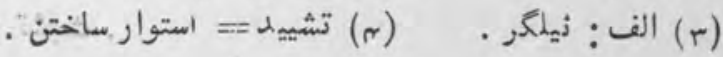




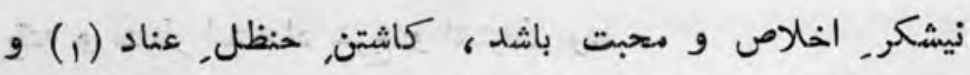

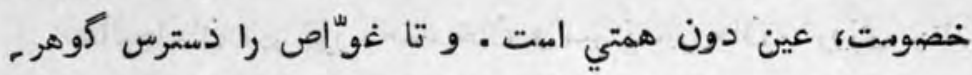

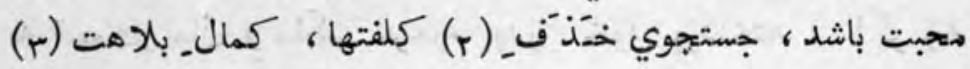

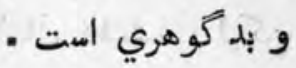

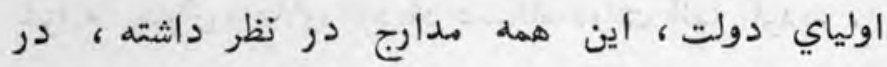

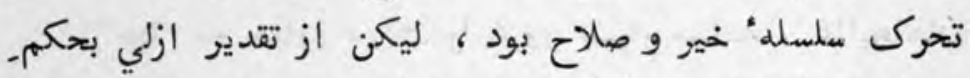

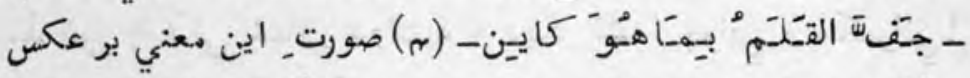

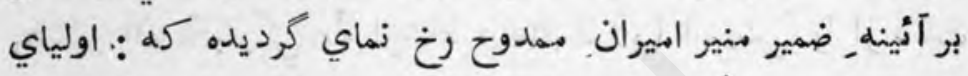

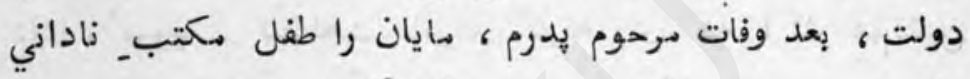

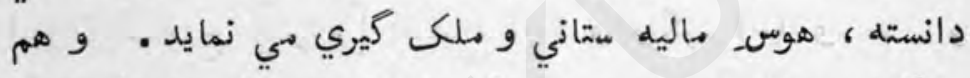

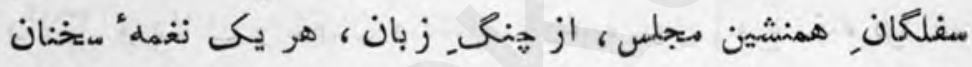

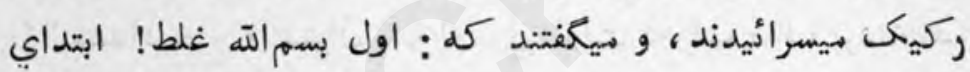

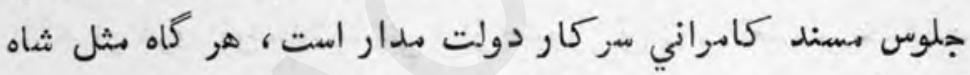

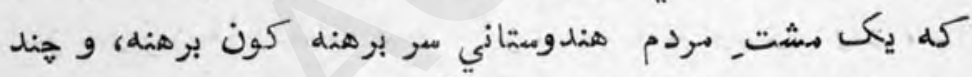

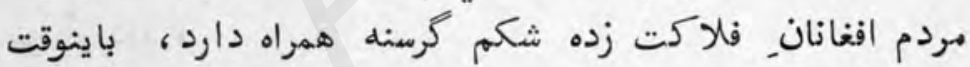

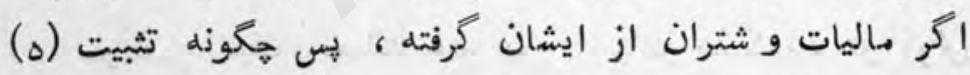

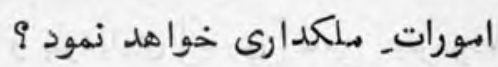

اكر در آغاز. جلموس مسند كامراني، نقش. سياست و حشمت_خود

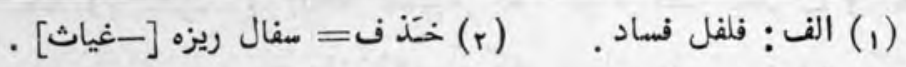

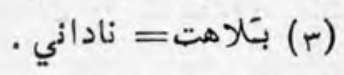

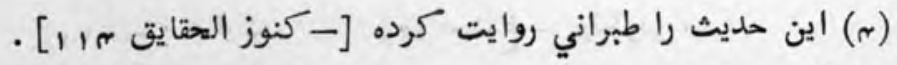
(ه) الف: تشبث آن حلثيث 


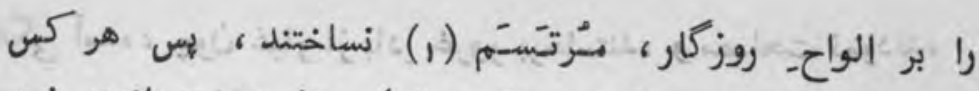

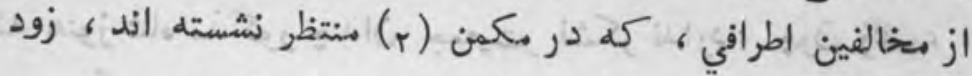

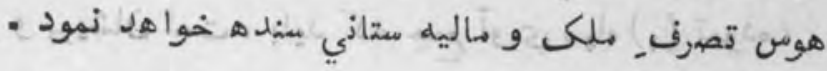

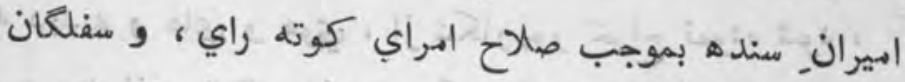

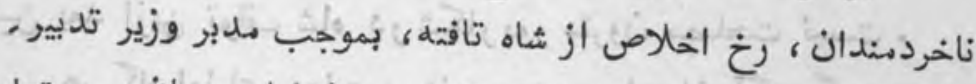

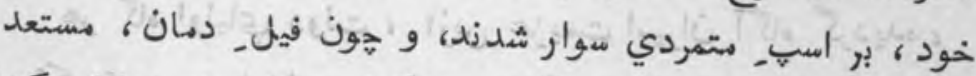
ميدان جنى كرديده [ليكن

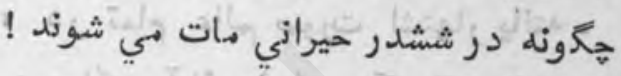

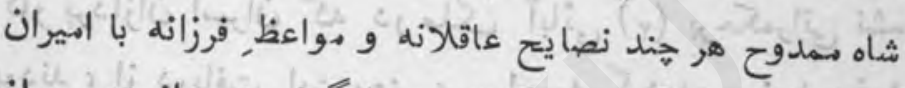

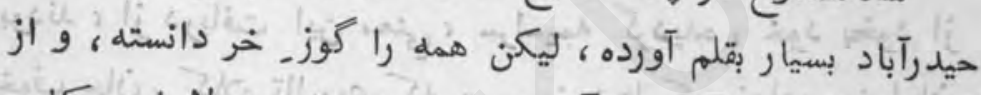

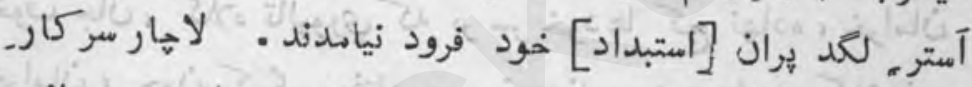

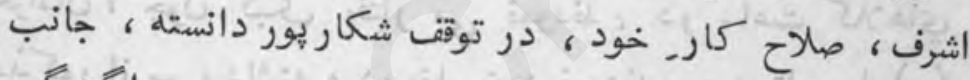

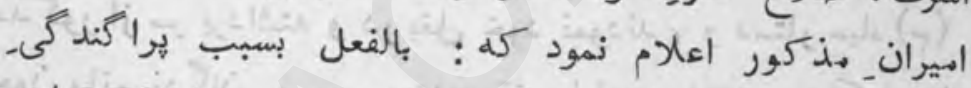

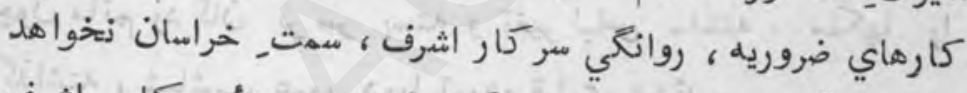

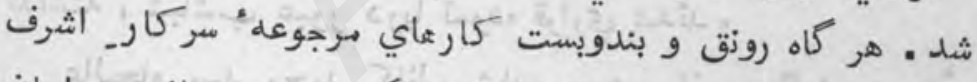

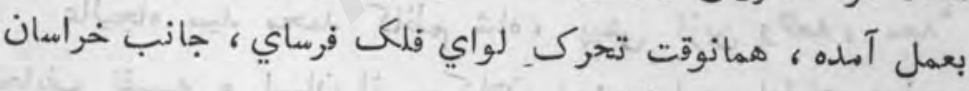

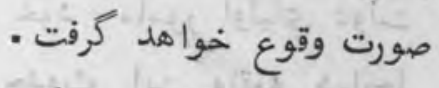

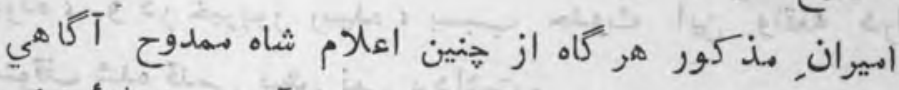

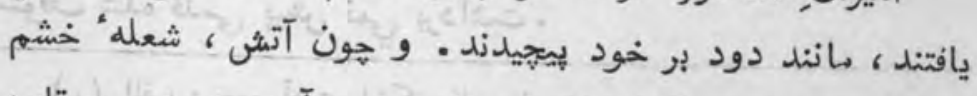

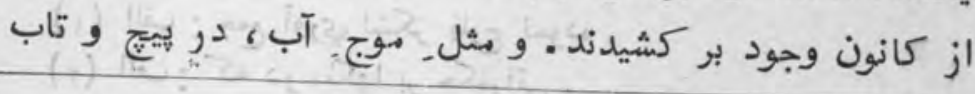

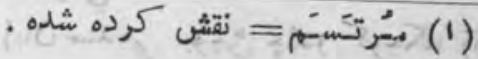

$$
\begin{aligned}
& \text { • الف : (r) }
\end{aligned}
$$


خفكي آمده ، هون غبار از بادي غرور برخاستشن، و مصلحت نمودند،

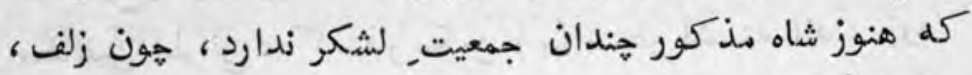

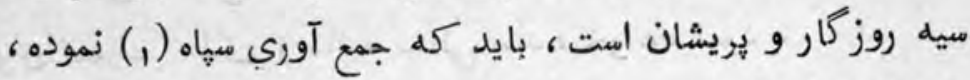

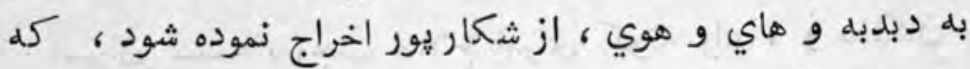

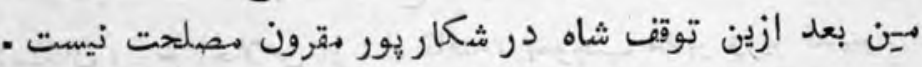

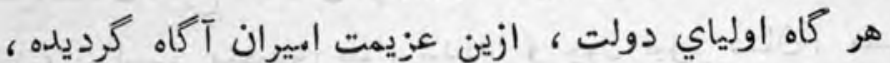

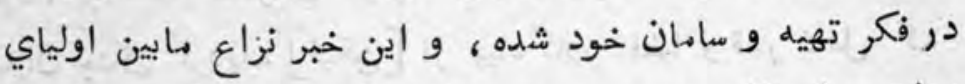

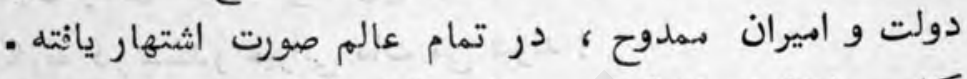

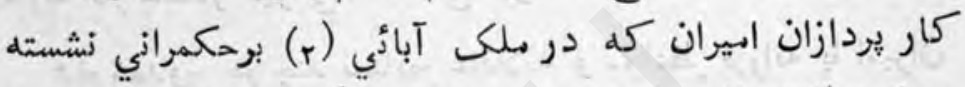

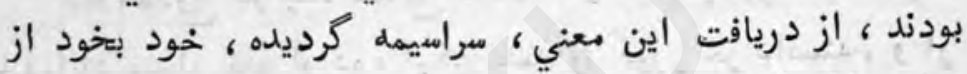

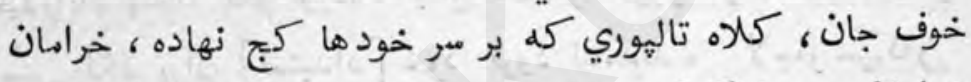

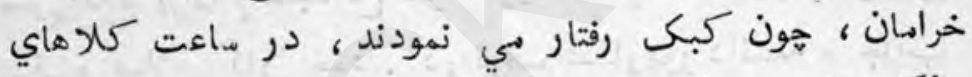

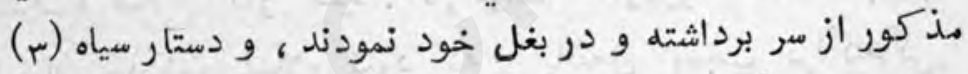

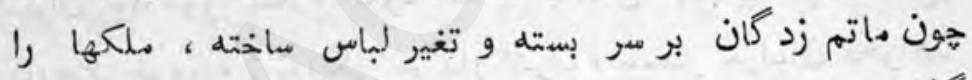

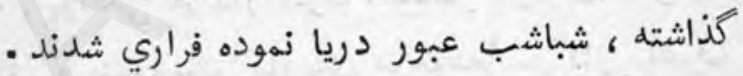

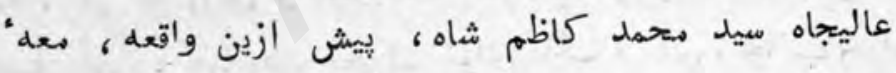

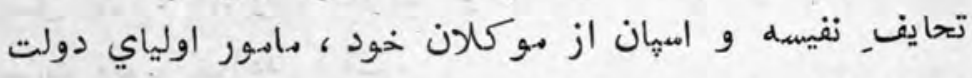
بوده، و درخيريور رسيده ، بسبب حدوث ائ اين واقعه درانجا

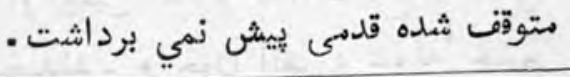

$$
\begin{aligned}
& \text { (1) الف : جمع آوري الشكر بلوج زموده. }
\end{aligned}
$$

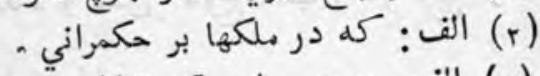

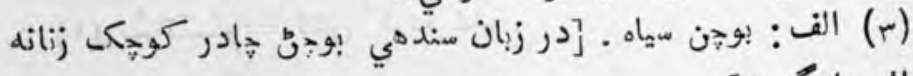




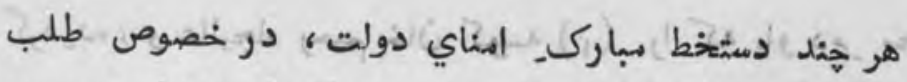

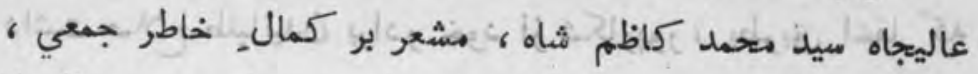

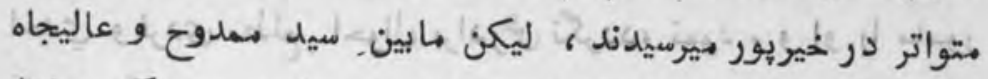

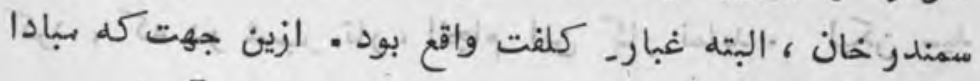

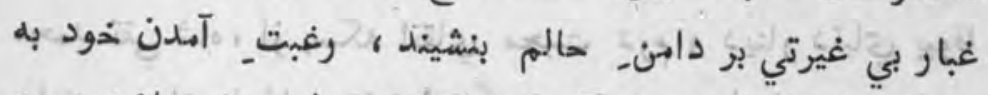

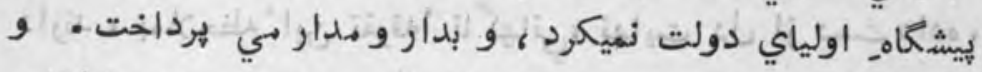
با وجوديكه سر كار اشرف ، براي عاليجاه سيد موصوف ، دمتخطماي

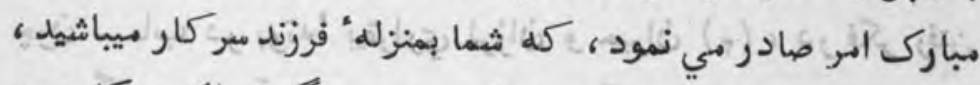

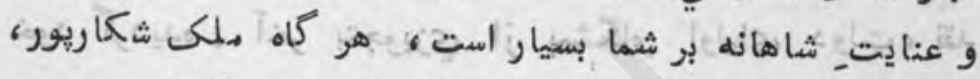

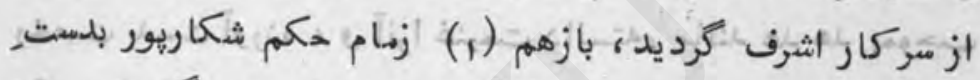

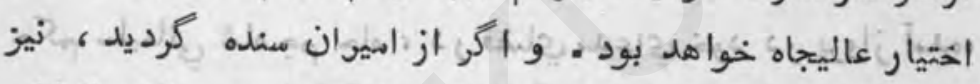

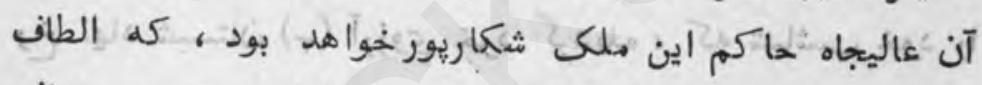

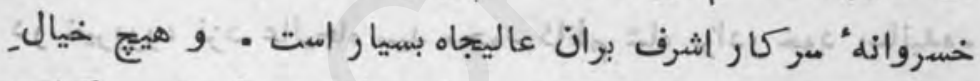
ديكر بخغاطر خود زيارزند، در هيتج ملت و دين و آنين (r) روا نيست

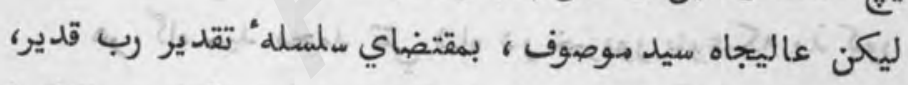

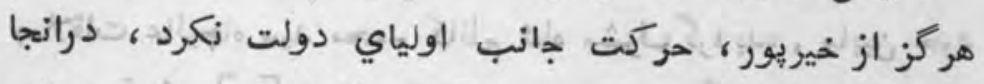

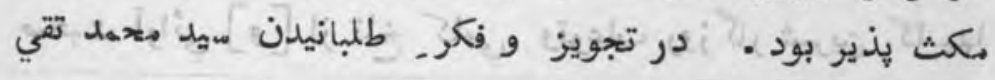

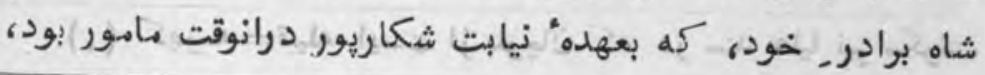

$$
\text { • (1) }
$$

(r)

(r) 
كرديده، و عاليجاه رجيم خان كوسه (1) .را كم باو دمر متحبت

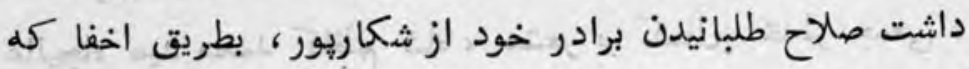

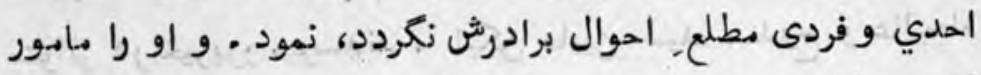

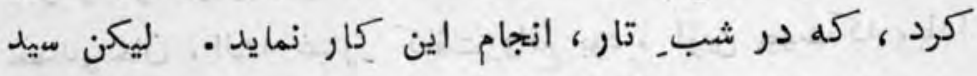

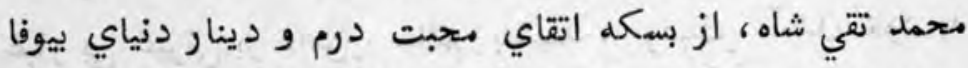

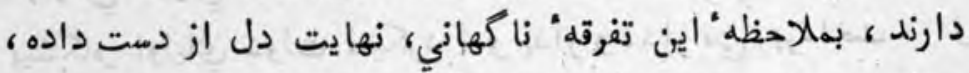

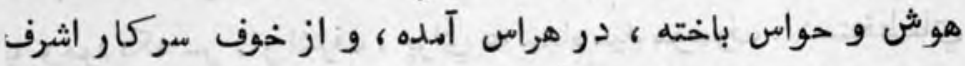

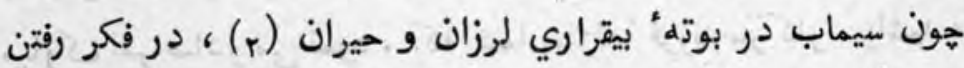

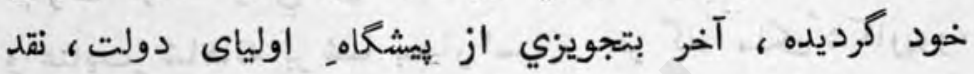

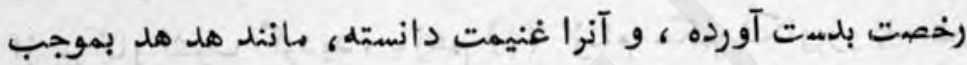

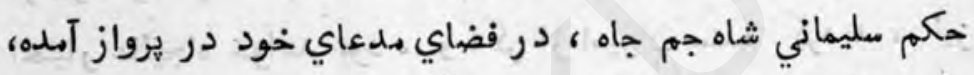

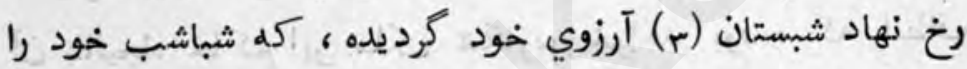

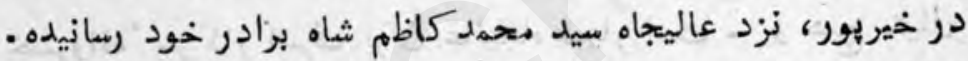

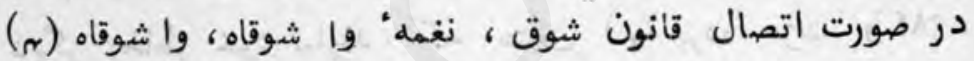

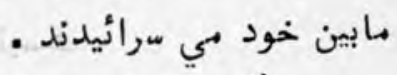

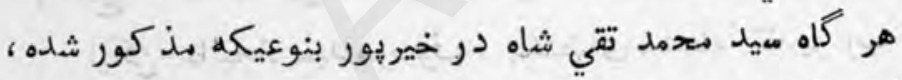

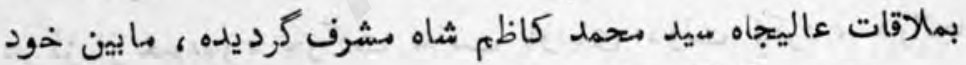
صحبت آرائي [و] از تلخ كابي وقوعات روزكار شيرين كابيها

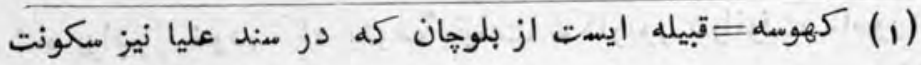

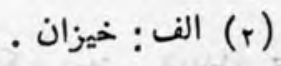

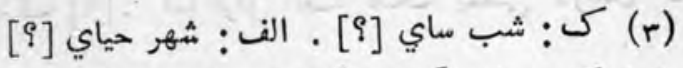

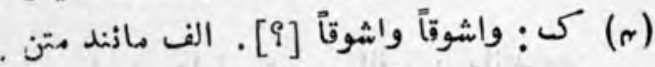


تازه نواى معاركى

نمودند. آخر بعد اين ممه زغهد [خواني] ها ، رفته رفته از

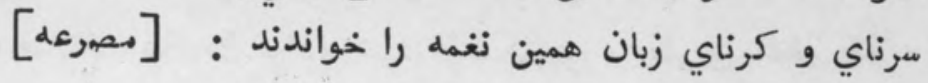
رسيده بود بالئي ولي بتخير كذشت

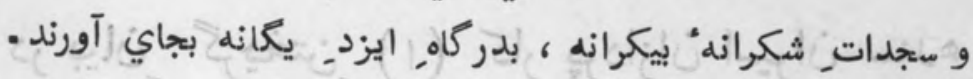
[i W

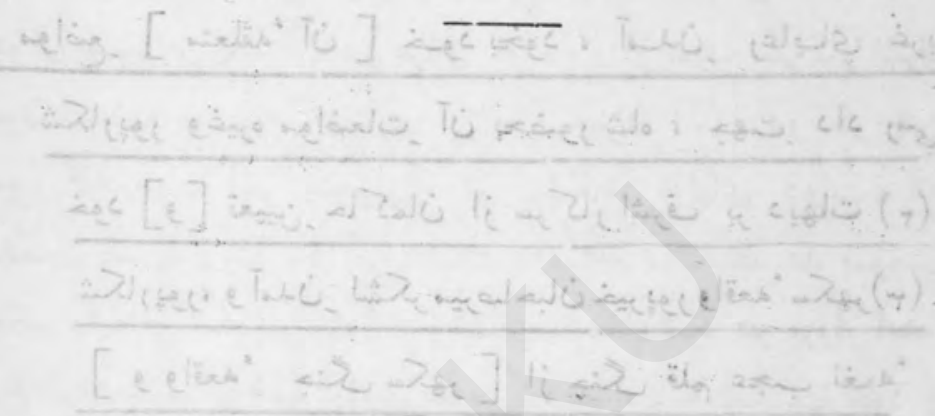

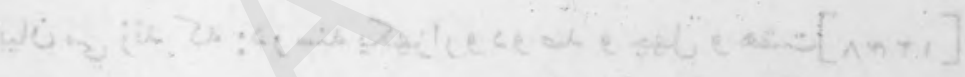

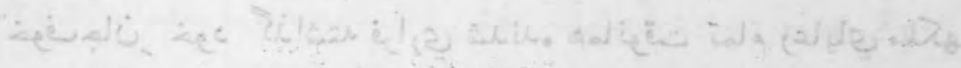

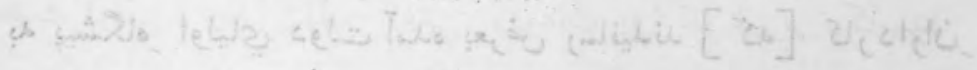

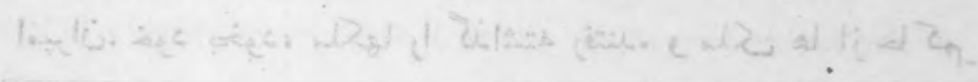

(1) 2 : 2 is

(4) 2 ; tallio arbec [?]

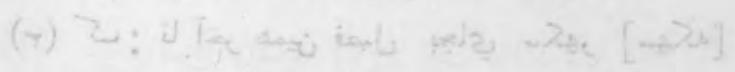

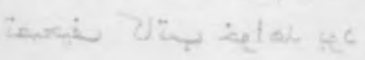


$-4 r-$

در بيانِ گريختن, (1) كار بردازان اميران سنده

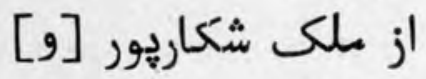

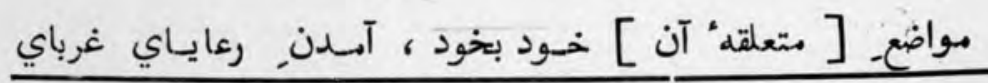

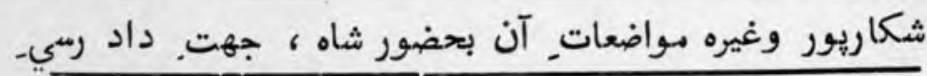

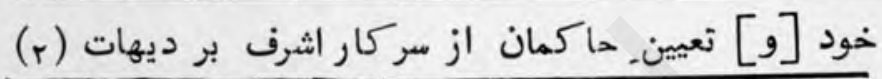

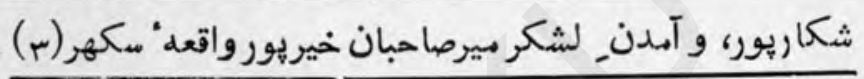

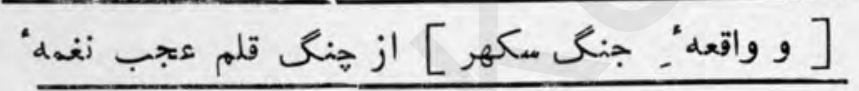

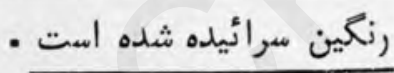

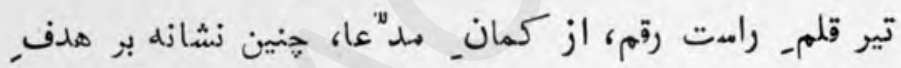

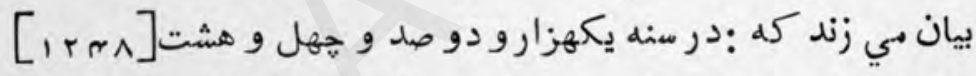

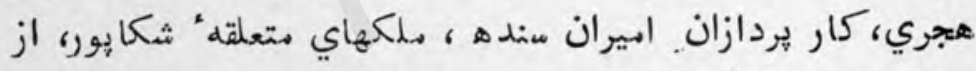

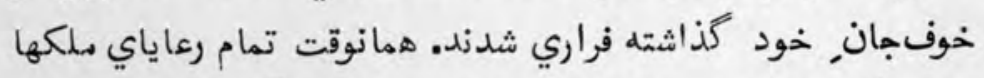

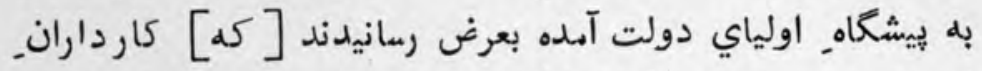

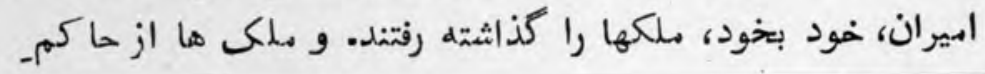
.

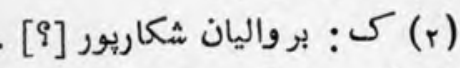

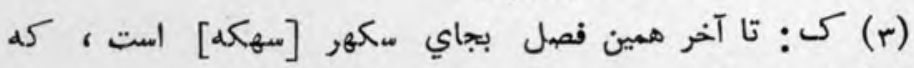
تصحيف كاتب خواهد بود آنر هن في 


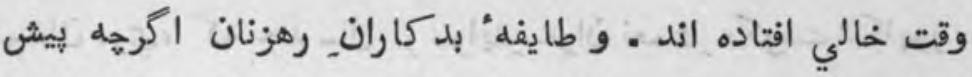

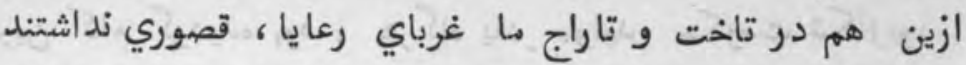

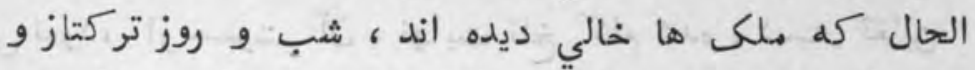

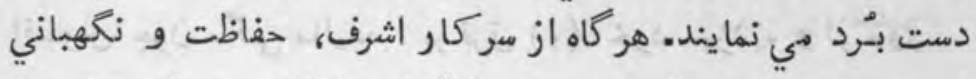

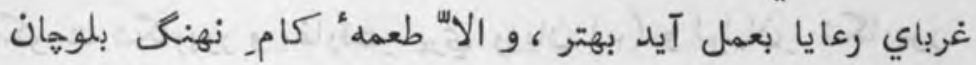

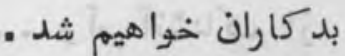

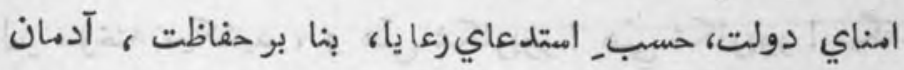

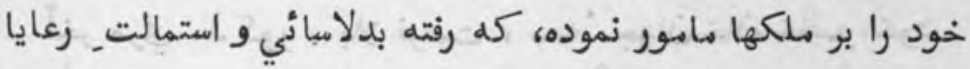

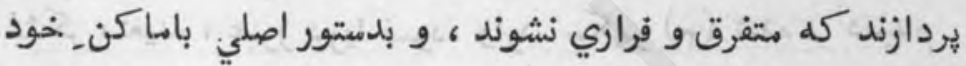
آبادان باشند -

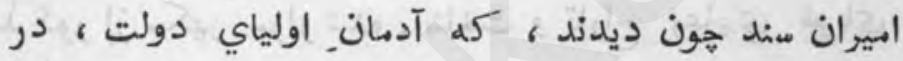

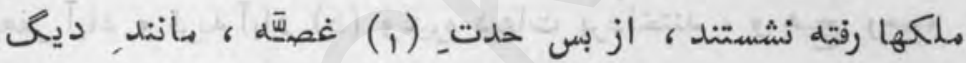

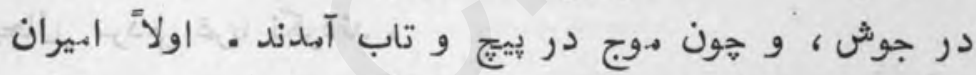

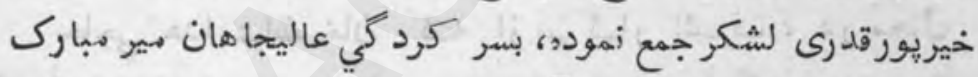

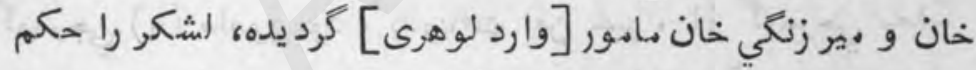

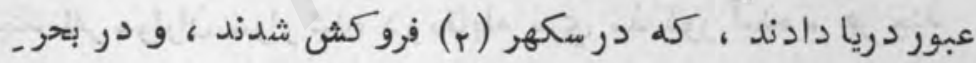

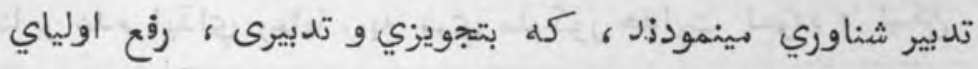
دولت از شكاريور نموده شود .

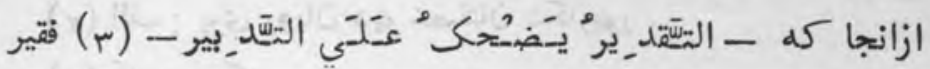

$$
\begin{aligned}
& \text {. }
\end{aligned}
$$

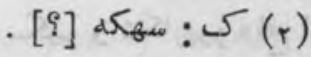

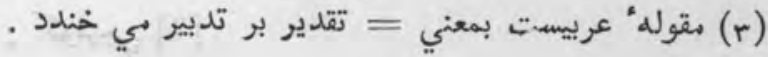




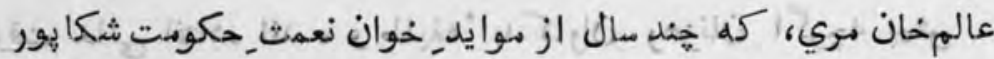

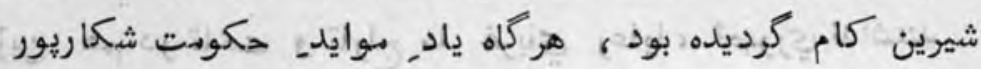

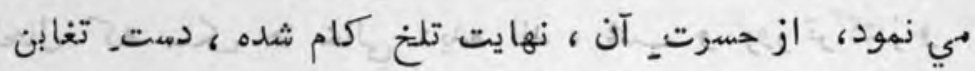

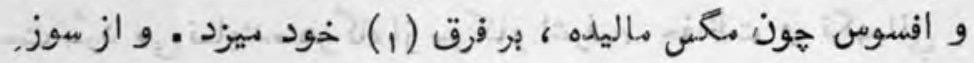

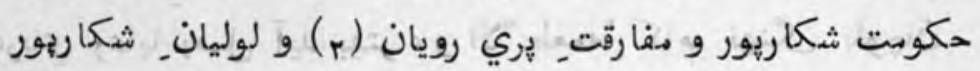

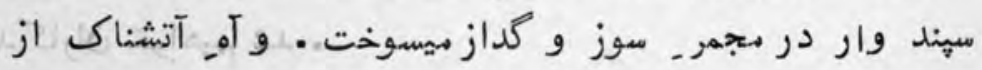

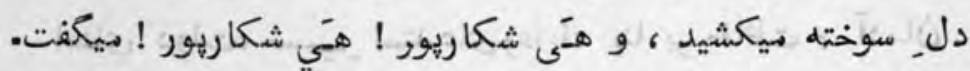

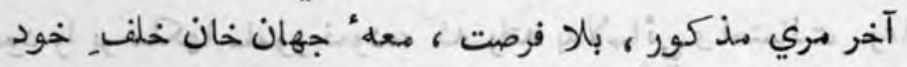

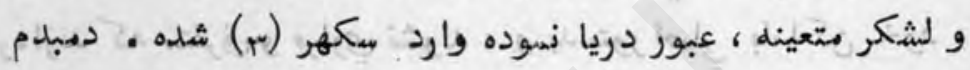

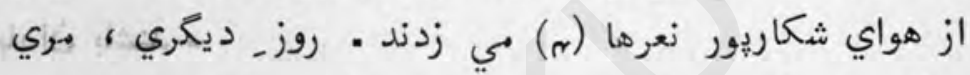

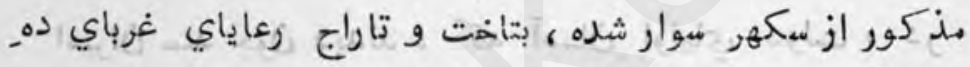

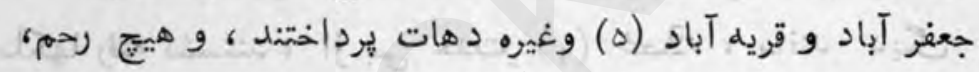

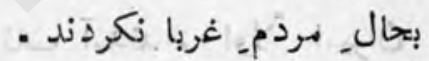

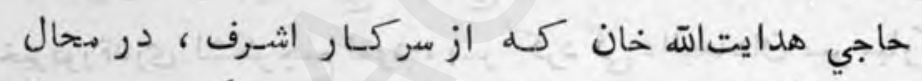

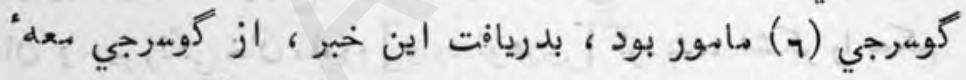

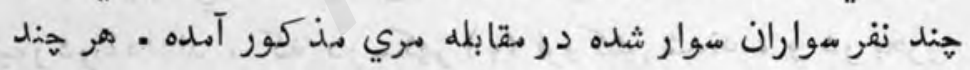

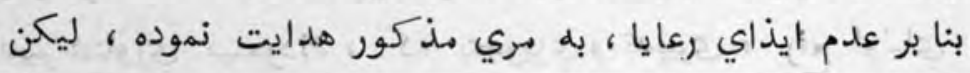

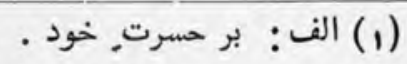

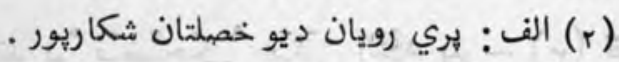

$$
\text { ك(r) }
$$

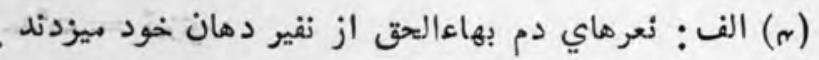

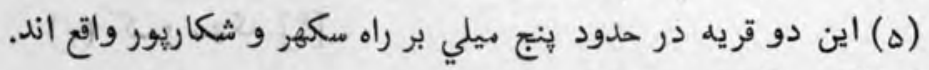

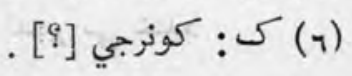




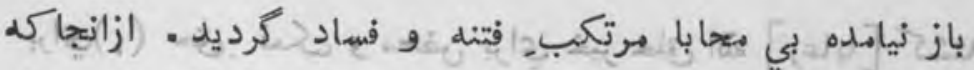

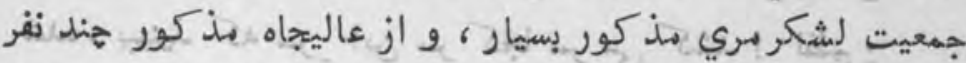

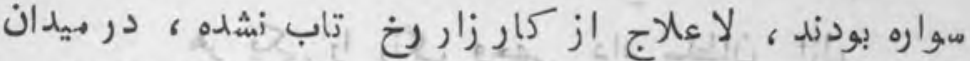

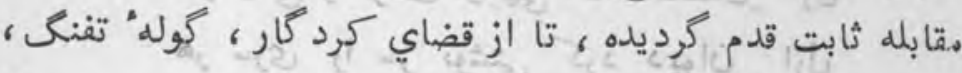

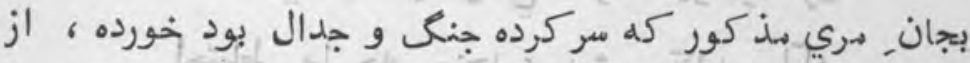

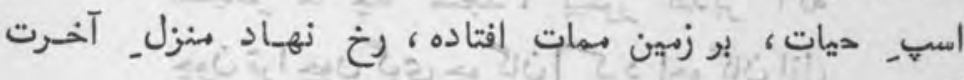
. كرديد

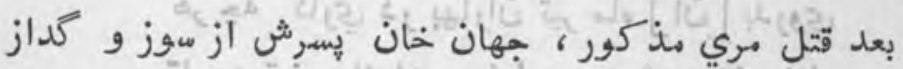

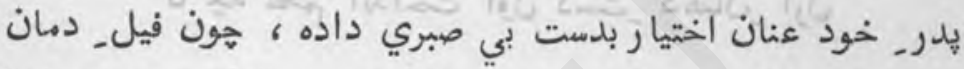

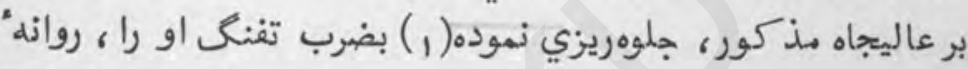

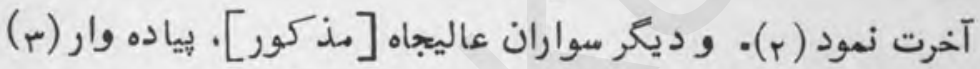

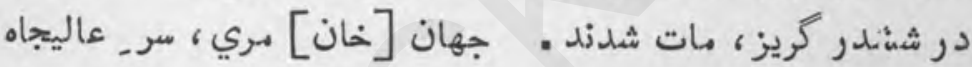

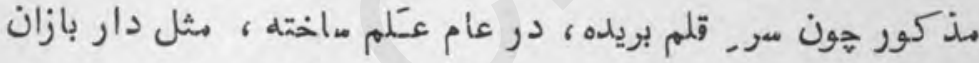

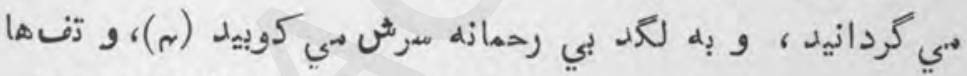

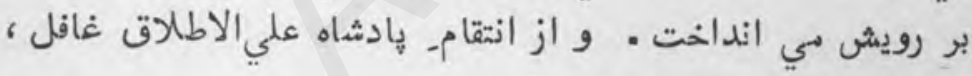

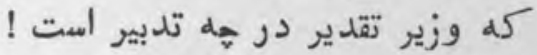

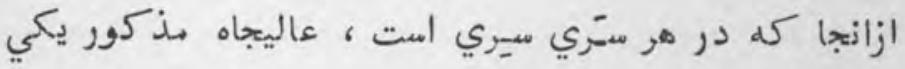

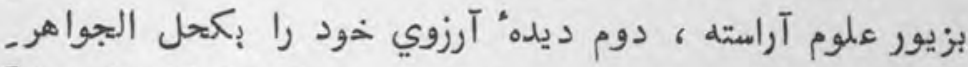

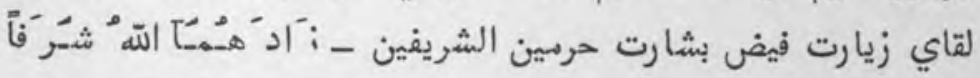

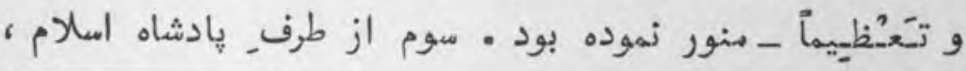

$$
\begin{aligned}
& \text { (1) الف: جلوه ريزى كرده . }
\end{aligned}
$$

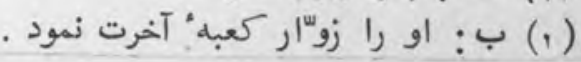

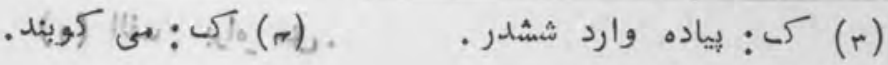


براي(1) حق. نمك و متحض براي خير خلق الته [(عايا] كثته

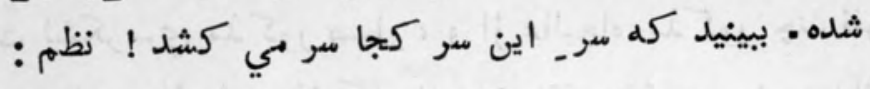
هر يكي را رنگ وجهي داد سلطانـ ازل هر سري را سر نوشتي كرد ديوانـ ازل

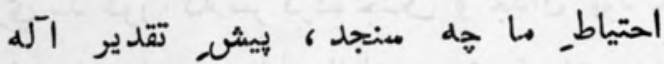
هون ترا هون كوي هو گان [كرد هر حه كاري كاري در بهاران تير ماه [آن] بدروي

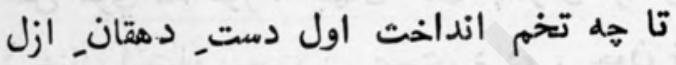




\section{$-\mathrm{Nin}^{2}-$}

در بيان ماكور نمودن, اولياي دولت، عاليجاه سمندر خان

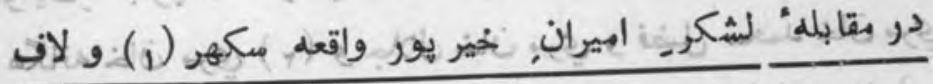

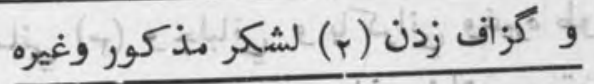

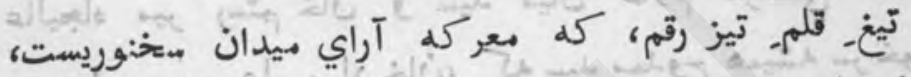

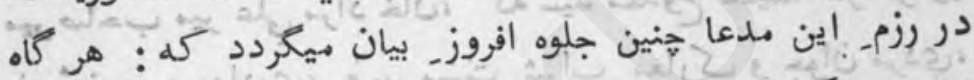

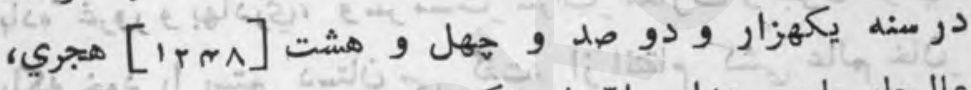

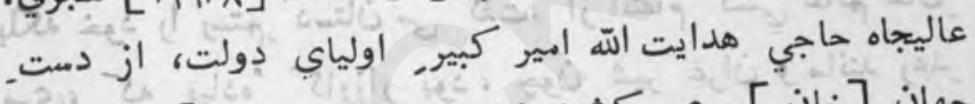

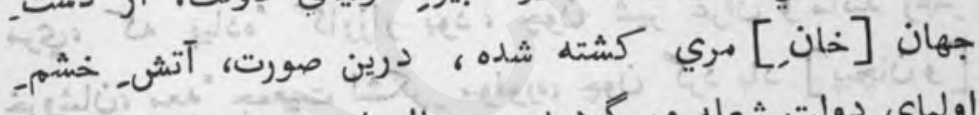

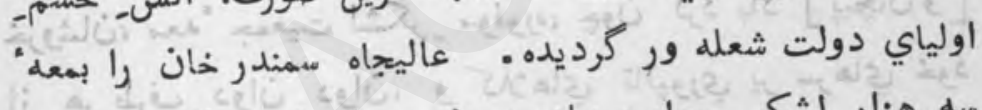

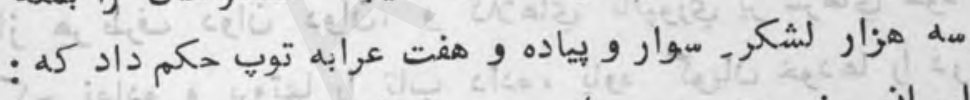

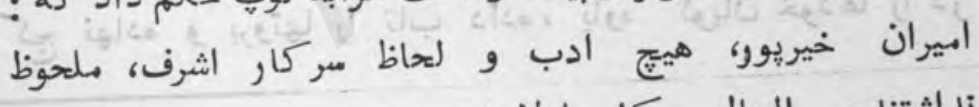

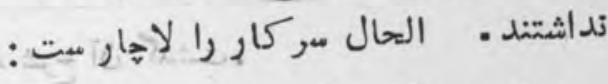

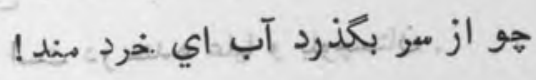

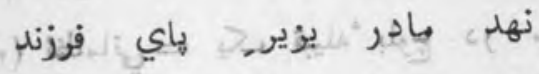

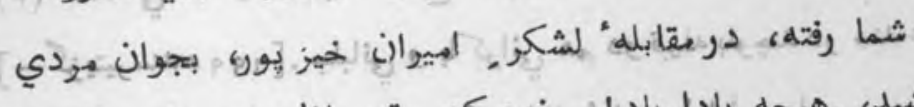

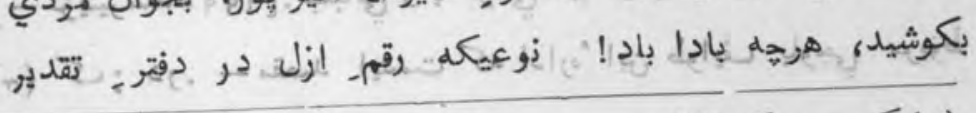

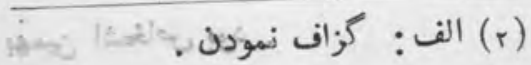
[?] 


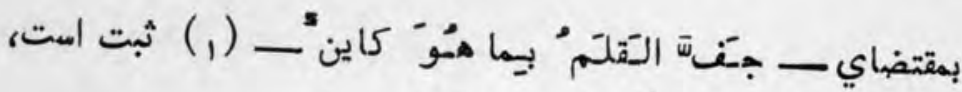

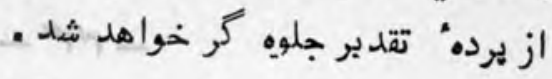

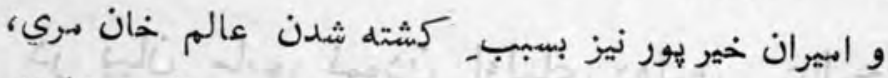

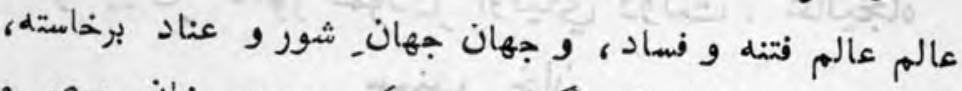

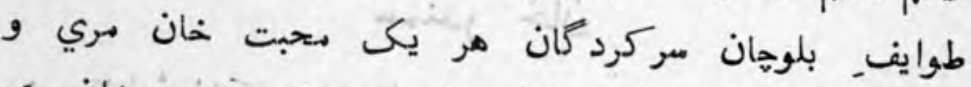

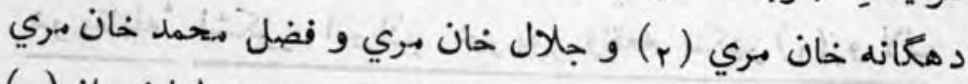

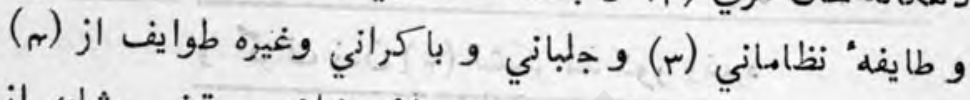

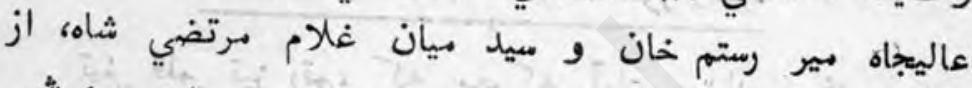

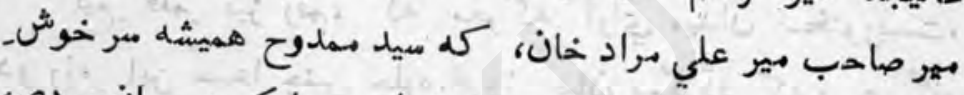

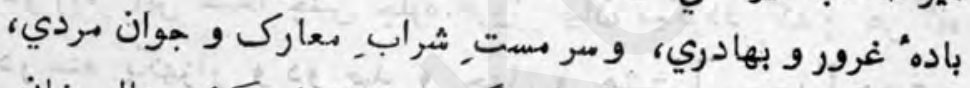
بلكه خود را رستم, دمتان مي كفت، از انتقام كشي عالم خان

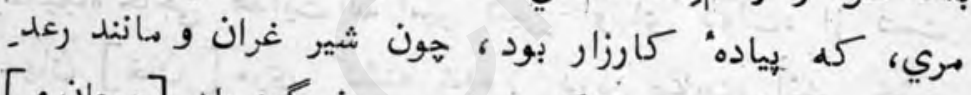

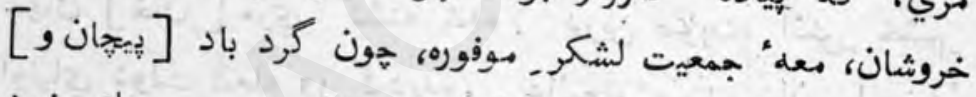

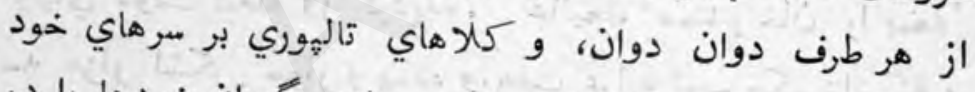

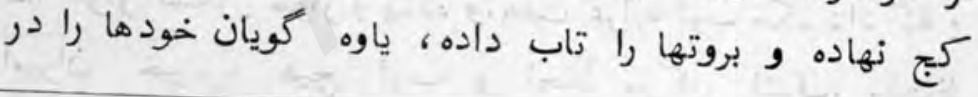

$$
\text { (1) حديث شريف است كه شرح آن كذشت. }
$$

(r) مري = قبيله معروف باوت است در سنده عليا و بلوحيتان.

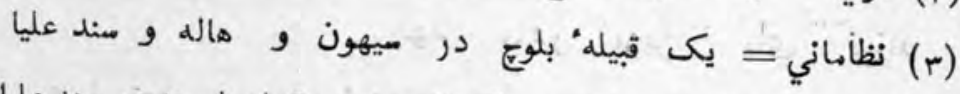
[-كزيتيرسنده 999] ] جلباني و باكراني هم دو قبيله بلوحند در سند عليا.

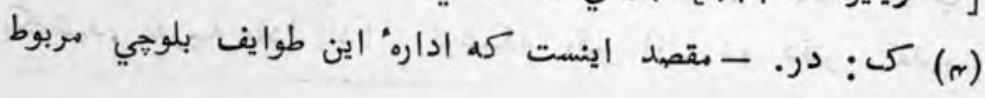

بهمين اشخاص بود . 
لوهري رسمانيدند. و عبور :دريا نهوده در مقام بكهو (1) رسيده6

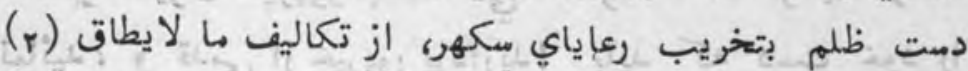
دراز نمودند ـ . و ادب دركاه فيض يناهــ حضرت شاه خير الدين(ب)

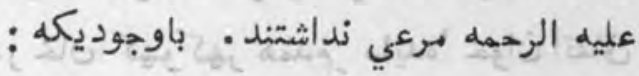

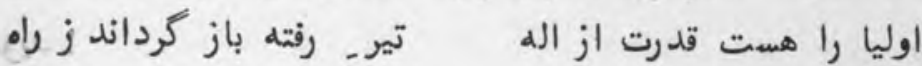
هر تله در مهام، توسل و استمداد از اولياء الته نجويد،

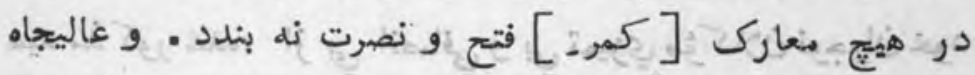

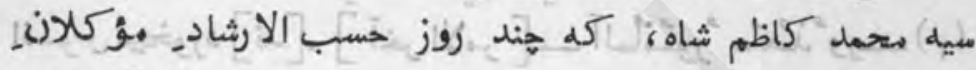

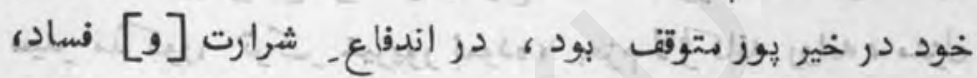

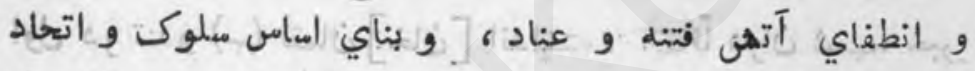

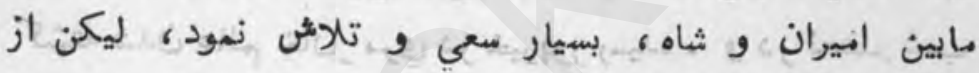

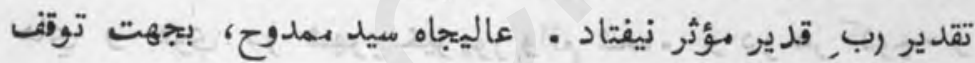

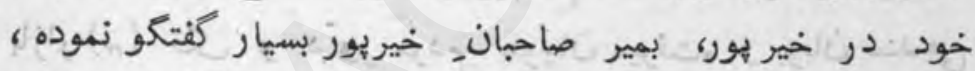

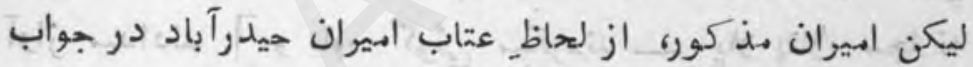

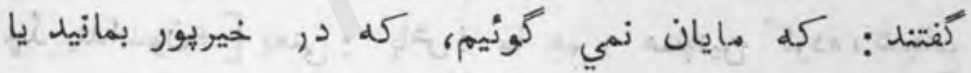

$$
\text { برويد، اختيهار خود داريد! }
$$

آخر بعد از هند ايام، لهروانه" اهيران_ حيدرآباد، موسومهل مديد دوصوف صدور يافته . مضضونش ايذكه : لذت خوان رنكين

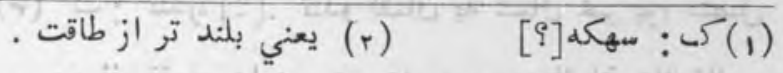

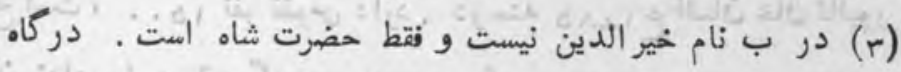

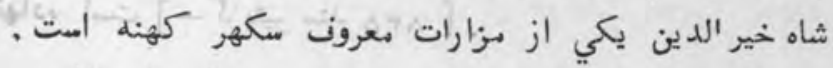

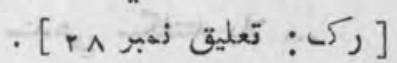




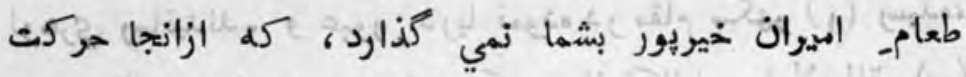

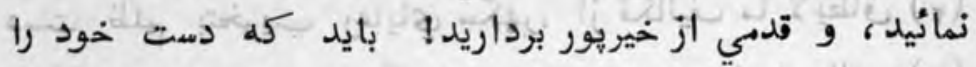

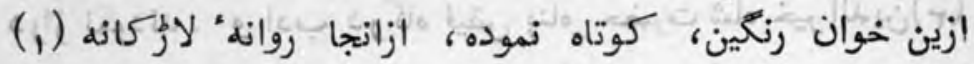

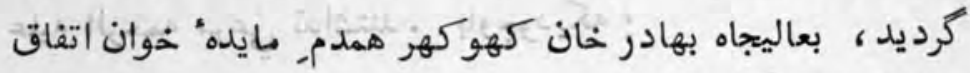

شويد !

هون از صدور أينجنين بروانه، بسيار بكروه. طبيعت عاليجاه

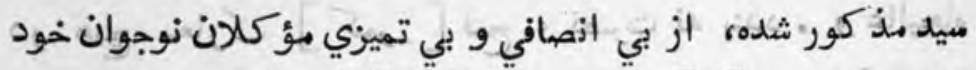

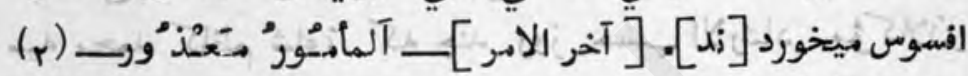

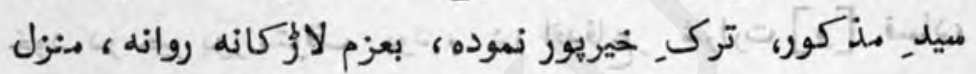

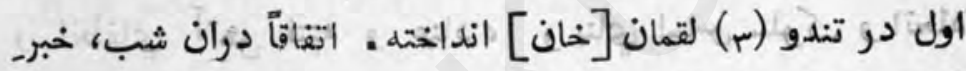

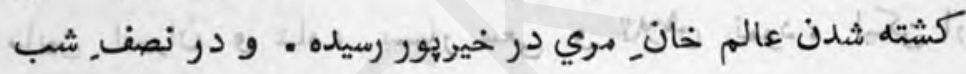

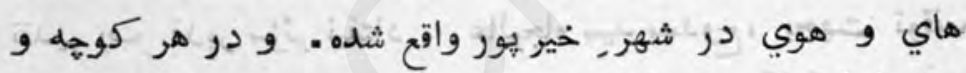

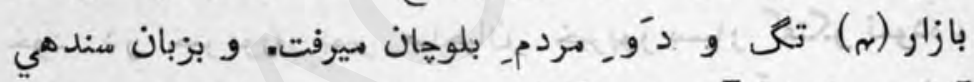

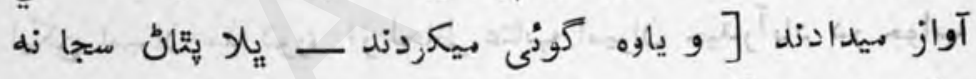

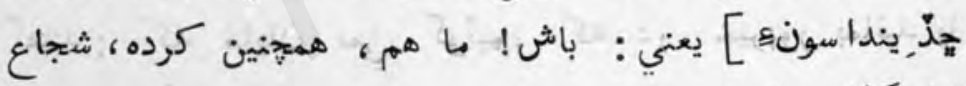

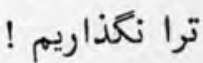

كى: لدوكانه [؟] معذور است . (r) كى: تندوه [؟]. تندو لقمان به شمال خير يور, متصل

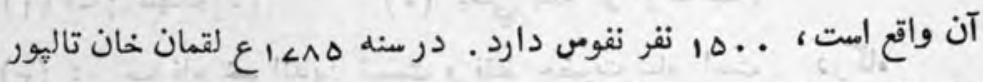

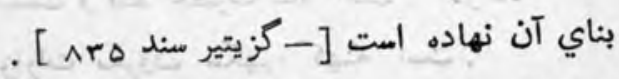
(م) الف: و بازار بلوحان ميرفتند و بزبان سندهي ميكفتند يلا ل... 
هون صبع شد، عاليجاه سيد محمد كاظم شاه بدريافت اين خبر

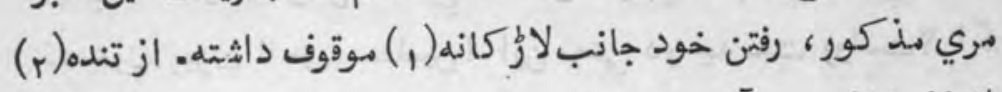

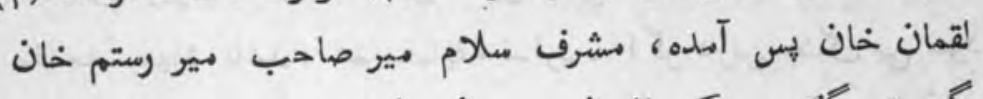

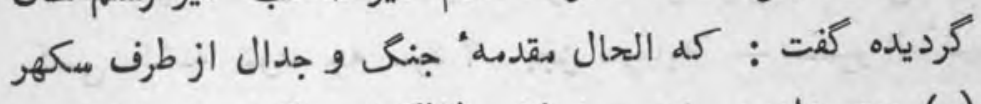

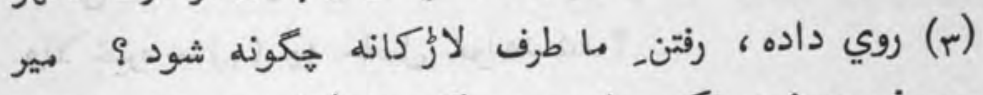

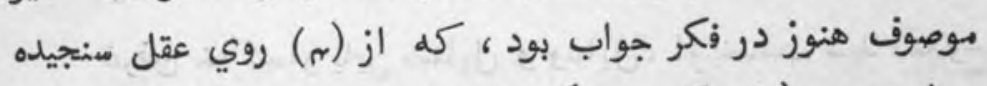

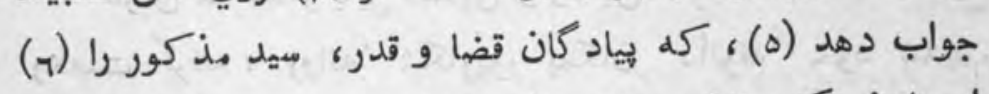

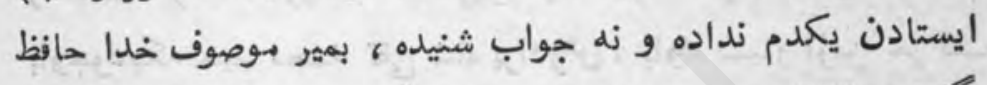

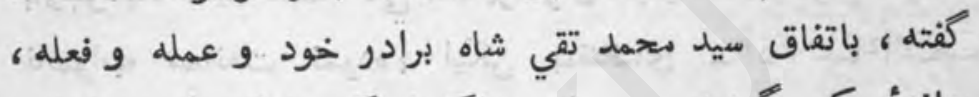

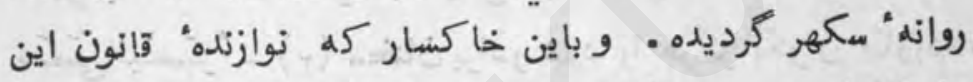

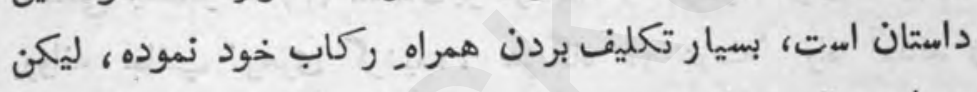

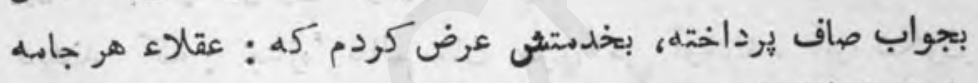

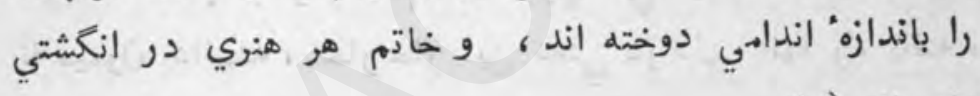

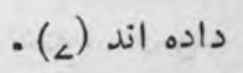

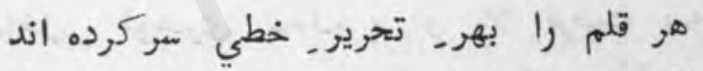

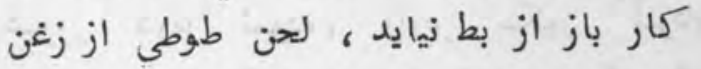

كارِمن قلم زني است . الحال مقدمه بشهشير زني سر كشيده.

$$
\begin{aligned}
& \text { - } \\
& \text { (1) } \\
& \text { (r) الف: كمه ببالغه عقل . } \\
& \text {. [؟ [ }
\end{aligned}
$$

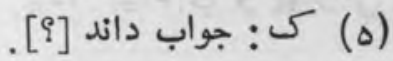

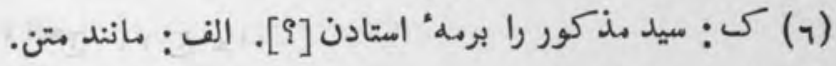

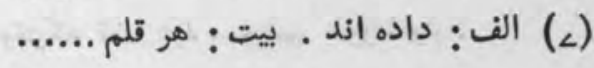


تازه نواي مارك

r.9A

براي ما فقرات زويس دانائي، همين مسربري قلم هم كافي است ،

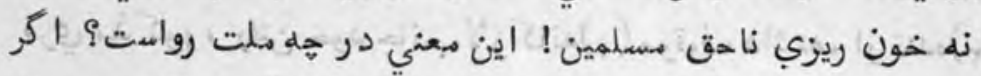

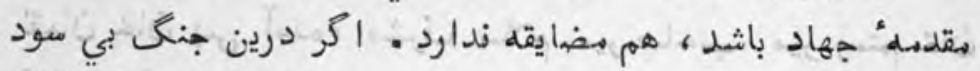

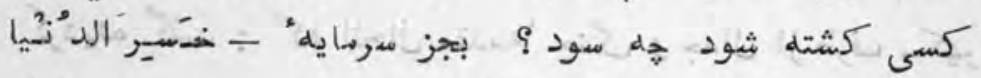
والآخيتره - - (1)

غرض خاكسار باين مسايل و ومايلك، از خدمت سيد مهدوح

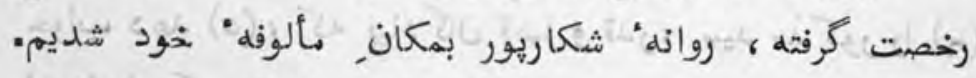

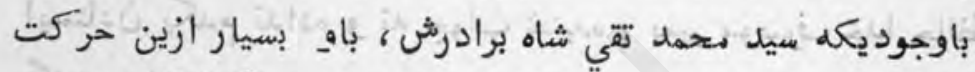

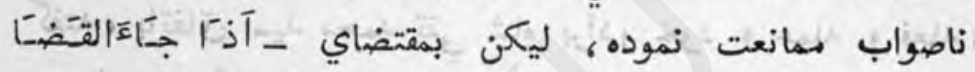

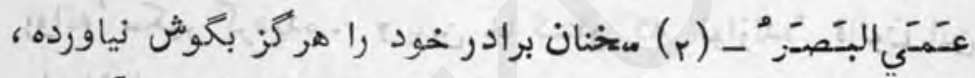

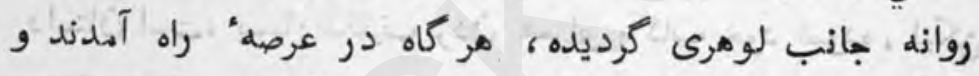

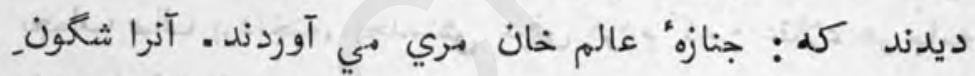

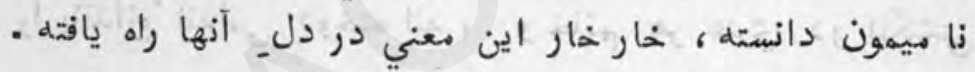
و يك طاقه شال بر نعش مري مذكور انداخته، ، وسوومه

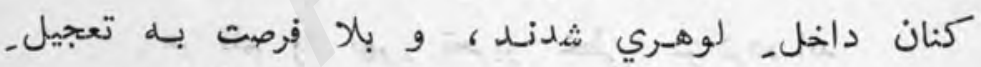

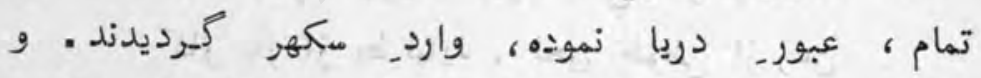

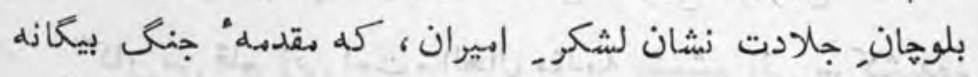

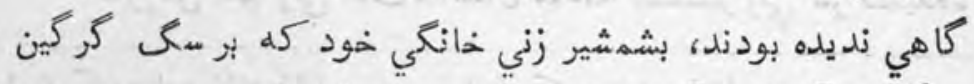

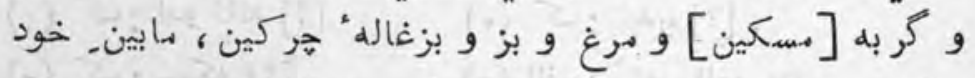

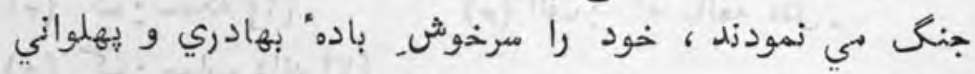

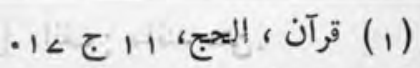

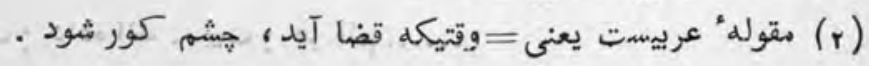




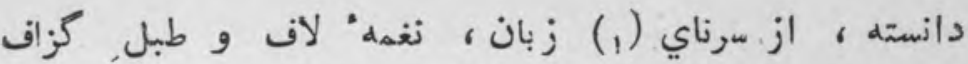

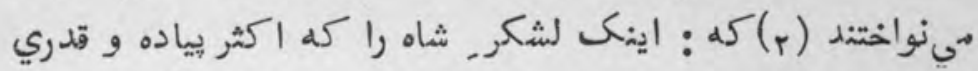

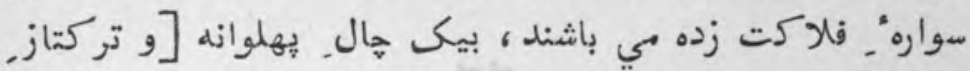

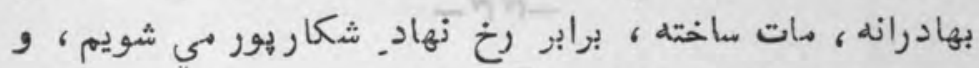

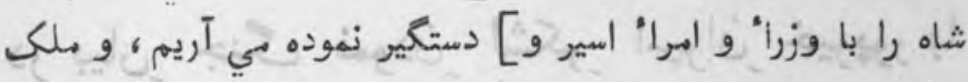

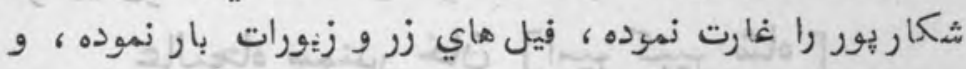

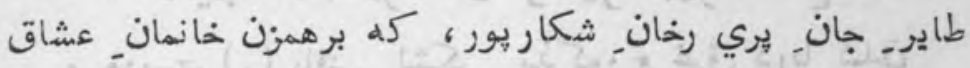

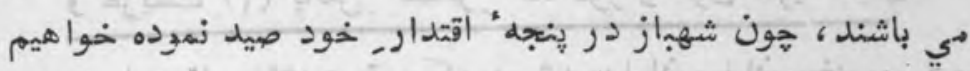

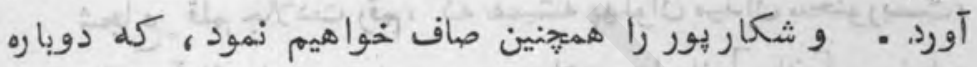

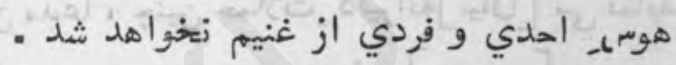

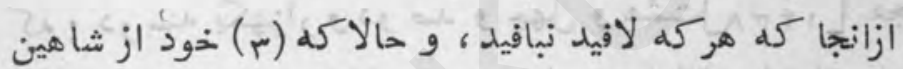

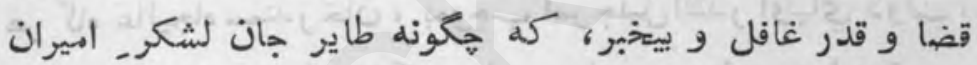

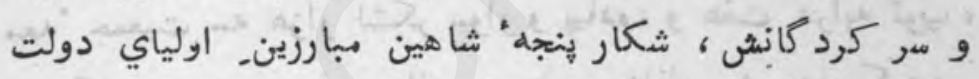

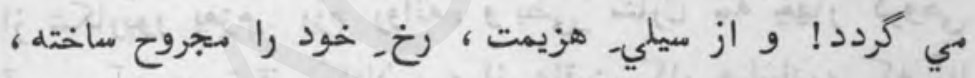
غرقـ دريا بي شوند إ بردي

(1) الف: از (1) مرناي زبان.

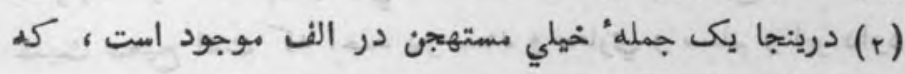

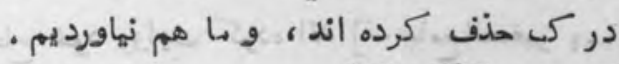

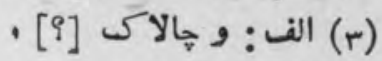


در بيان, جنك نمودن, لشكر, اميرانِ خيريور با عاليجاه سمندر خان [اسير كبير شاه ]

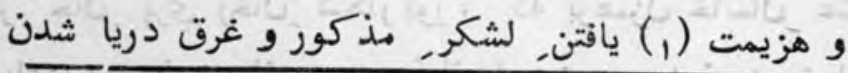

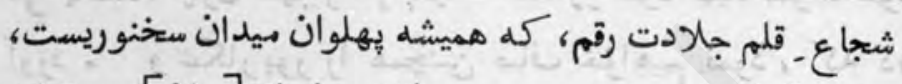

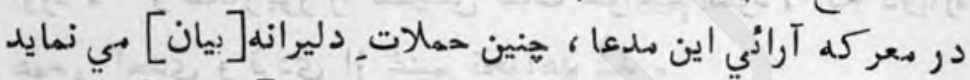

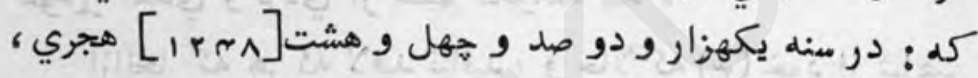

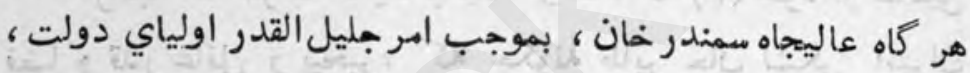

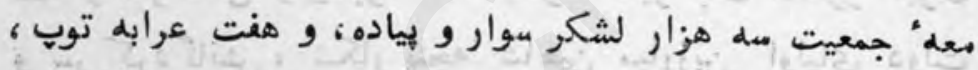

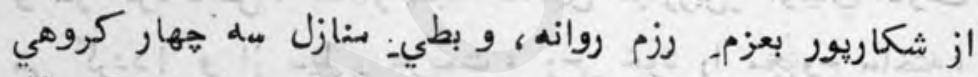

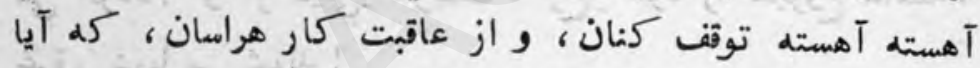

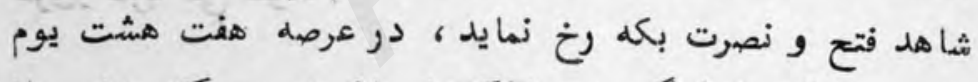

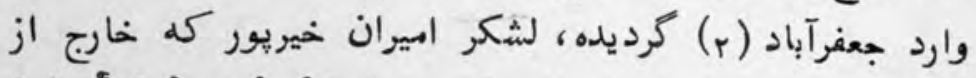

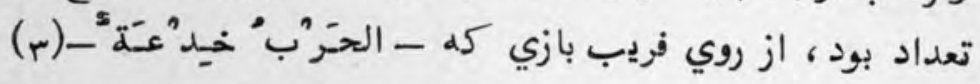

$$
\text { · [؟ (1) }
$$

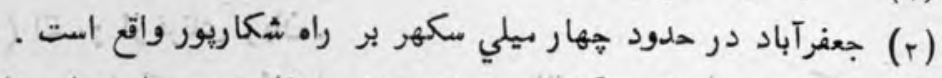

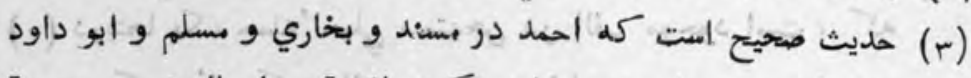

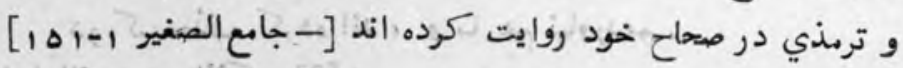

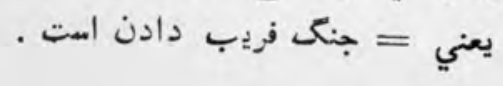




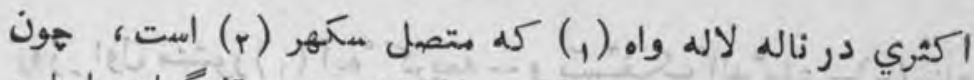

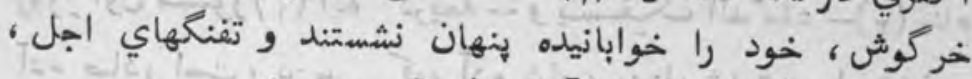

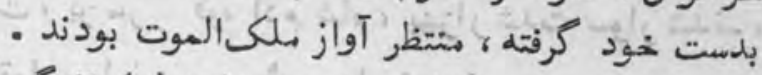

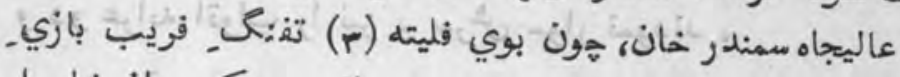

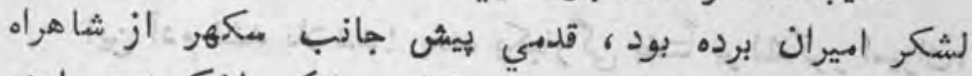

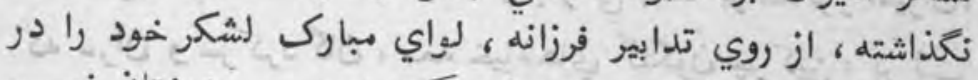

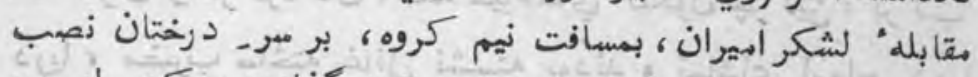

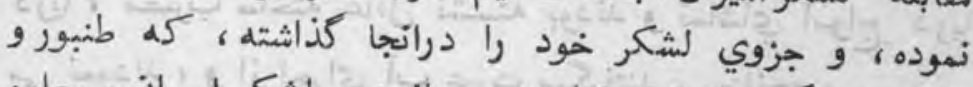

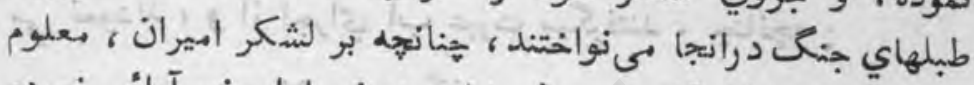

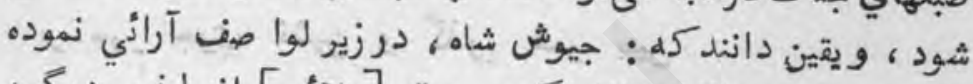

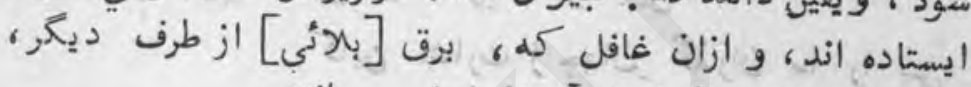

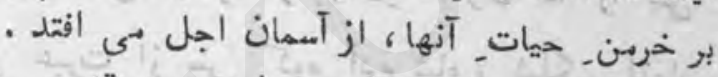

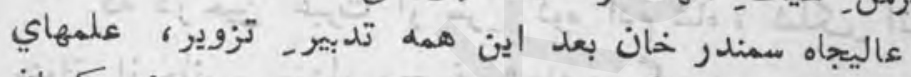

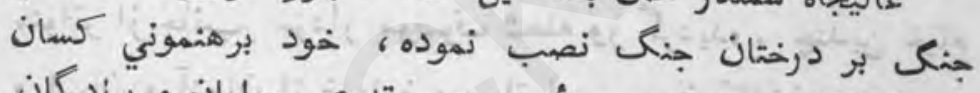

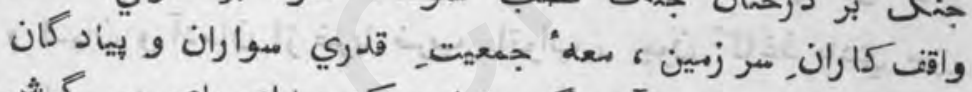

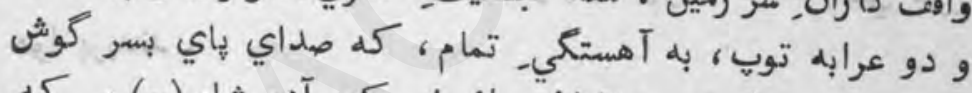

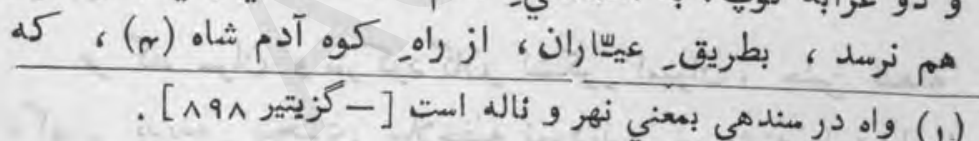

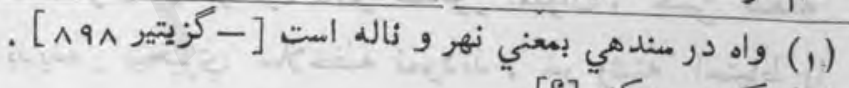

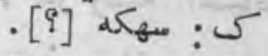

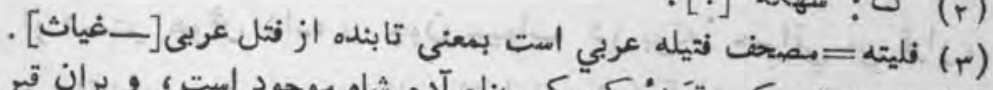

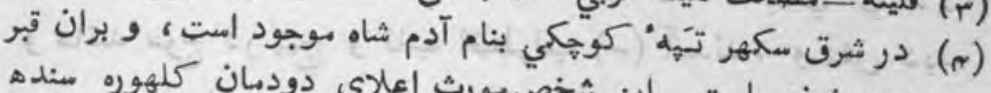

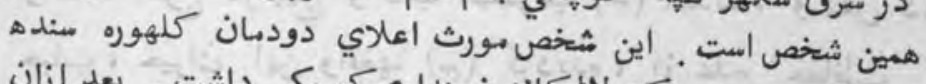

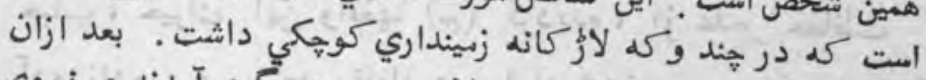

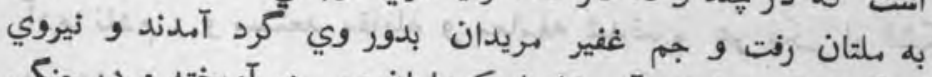

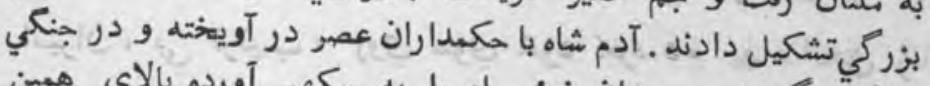

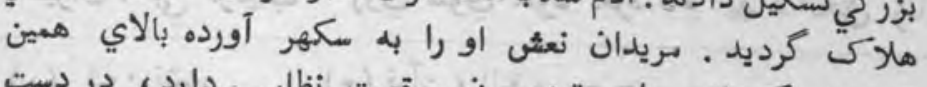

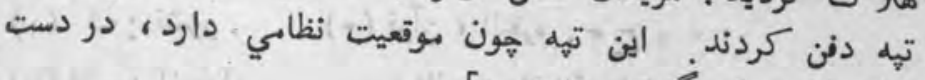

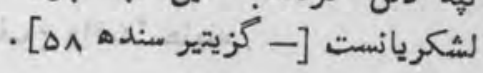


تازه نواي مas

$r \cdot r$

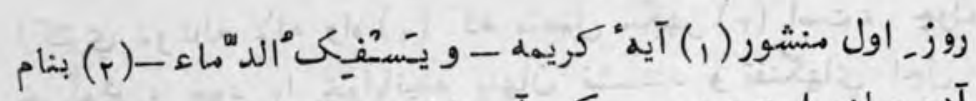

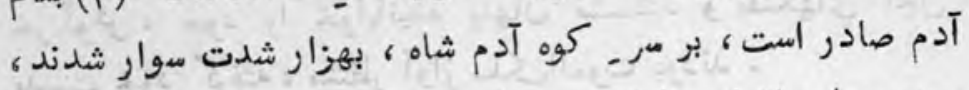

و دو عرابه اتواي را نيز بر سرش سوار نمودند .

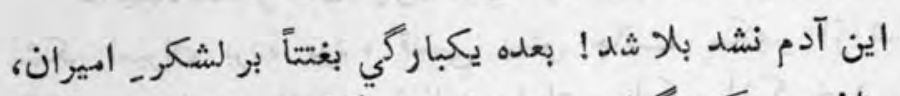

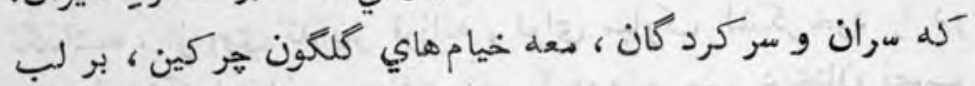

دريا ، مضرب ساخته غافل زشسته بودند و تماشاي امواجـ دريا

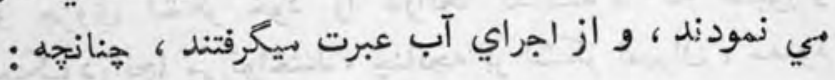

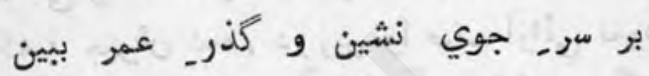

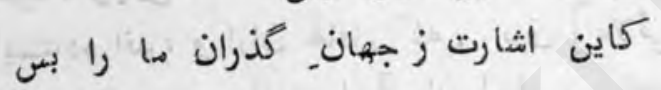

كه درحين عبرت از سر, كوه آدم شاه ، شلكى اتو'ي متواتر از جانب, سردار موصوف شعله ور كرديده . مهندين خيام

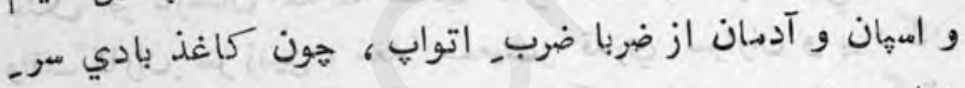

هوا هويدند

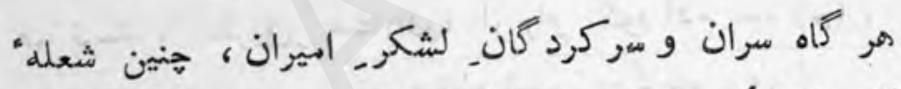

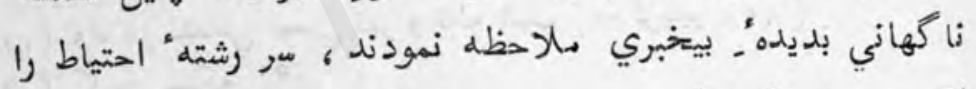

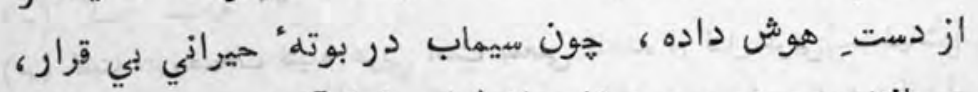

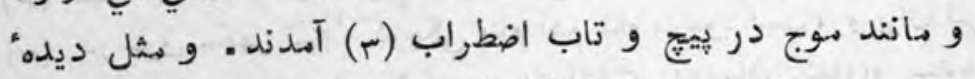

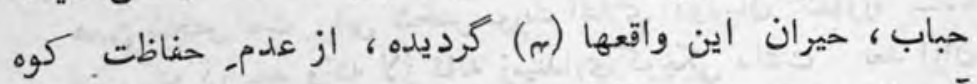

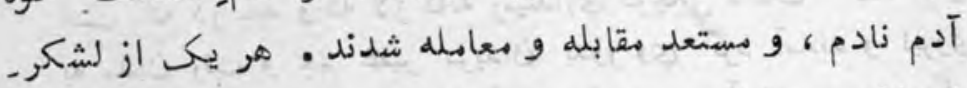

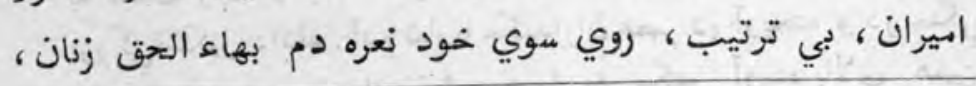

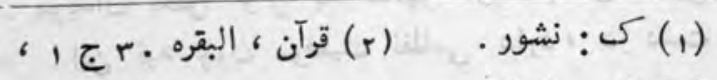

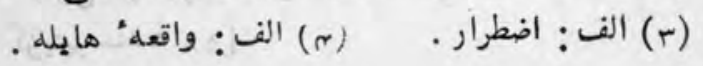




\section{بنا بر مقابله رخ نهادي كوه شدند - ماند}

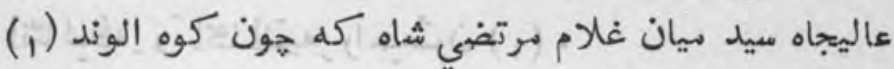

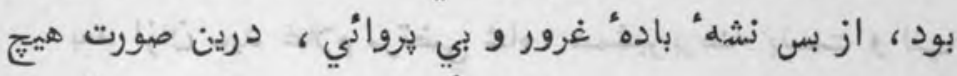

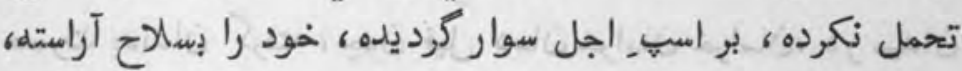

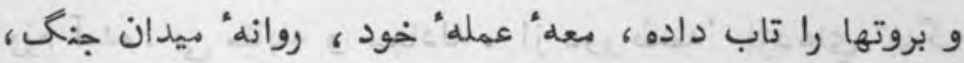

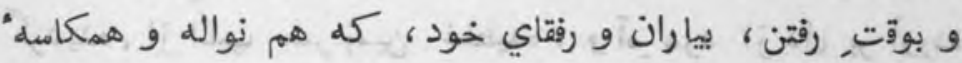

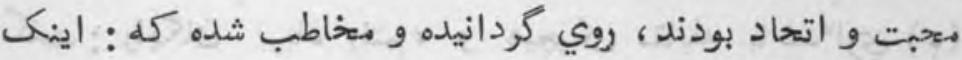

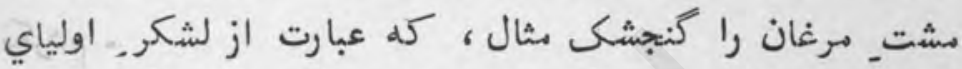

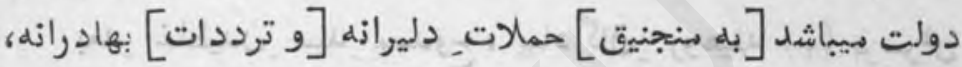

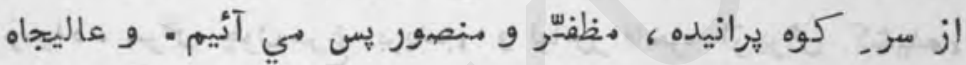

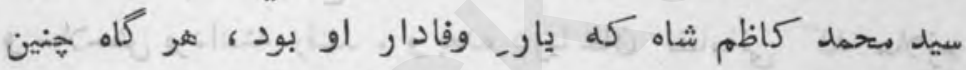

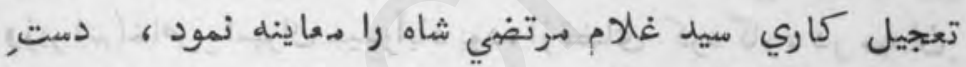

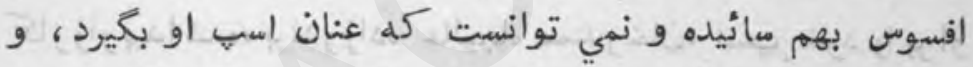

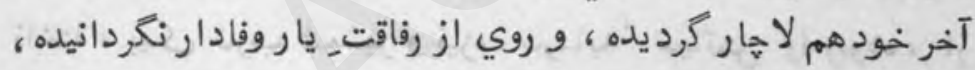

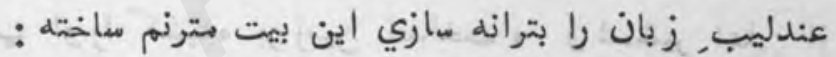

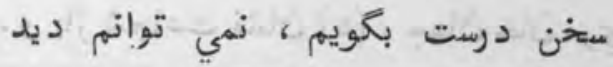
كه متي خورند حريفان و من نظاره كنم كنم

اين بكفت و در ساعت بر اسبــ اجل راكب شده، رخ نهاد

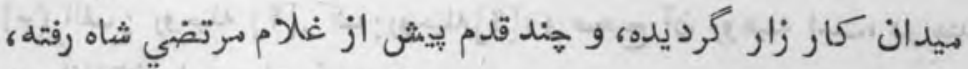

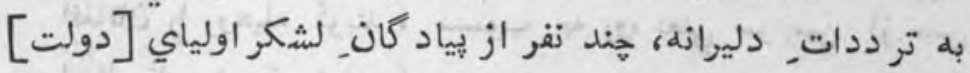

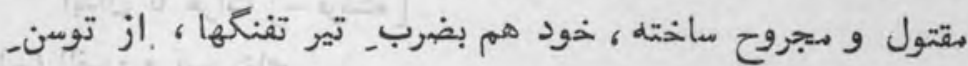




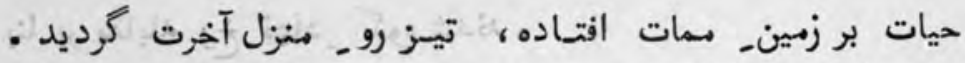

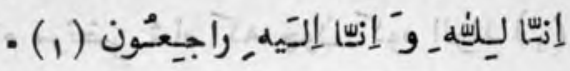

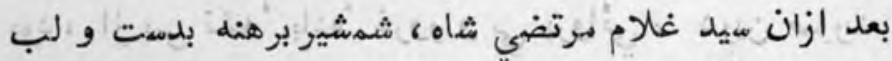

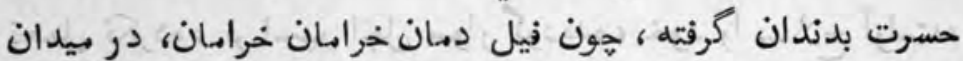

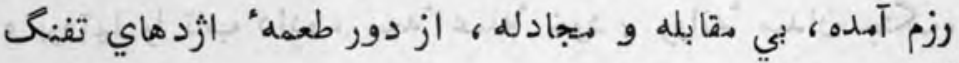

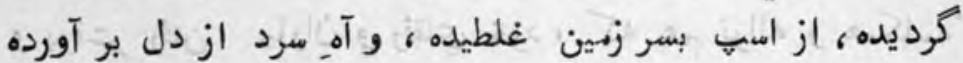

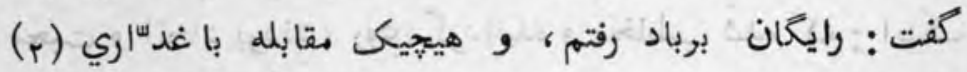

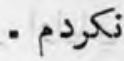

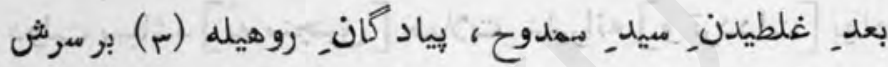

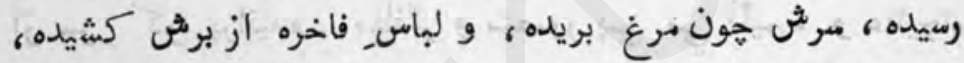

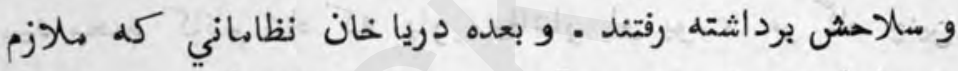

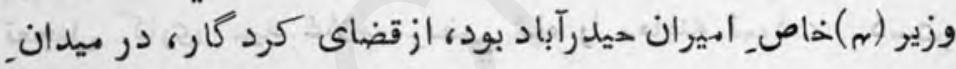

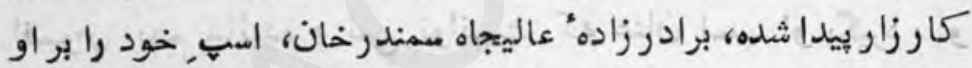

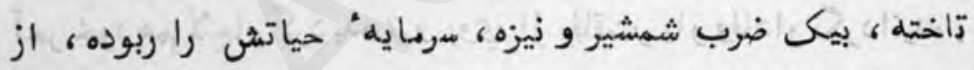

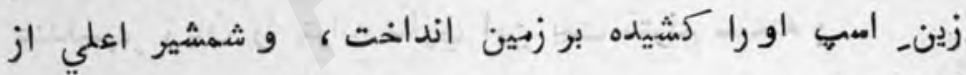

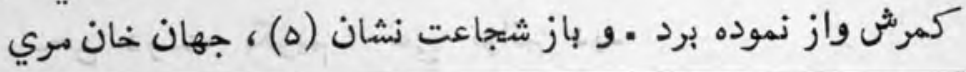

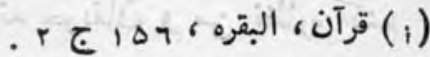

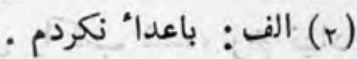

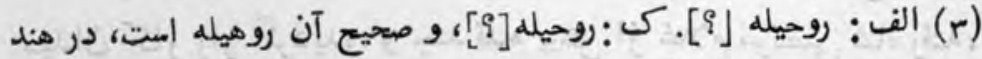

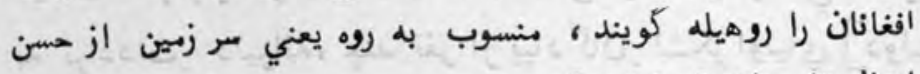

$$
\begin{aligned}
& \text { ابدال تا هرات [-فرشته] . } \\
& \text { (م) الف: و ابير خاص. }
\end{aligned}
$$

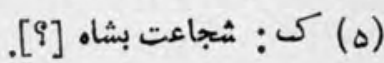


مبه" هنجاه شصت نفر مبارزين اشجعيني، دامنهاي بيراهن-

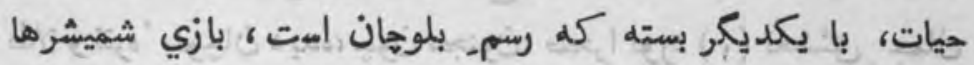

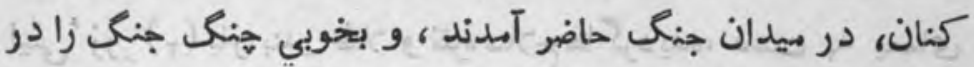

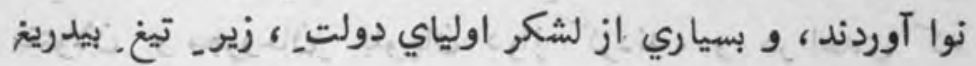

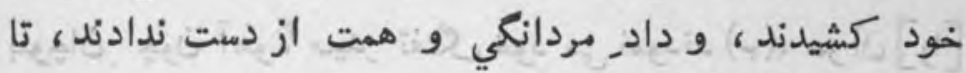

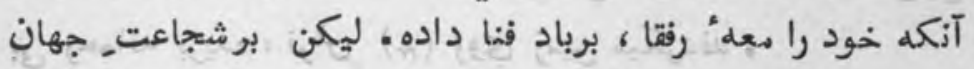

خان مري جهان جهان آفرين بايد نمود إنهاد إنهان

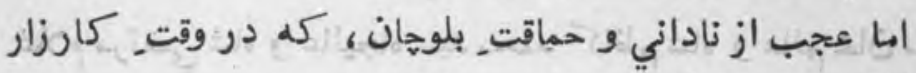

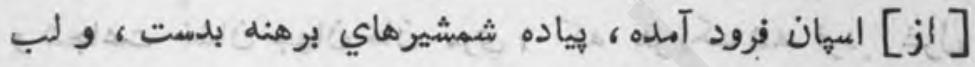

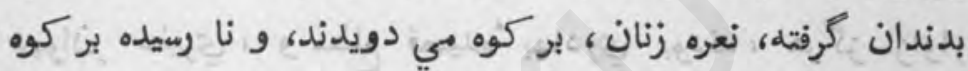

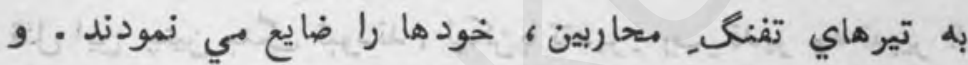

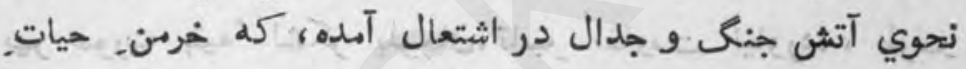

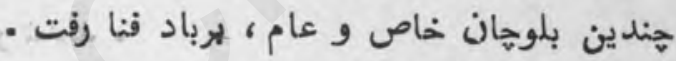

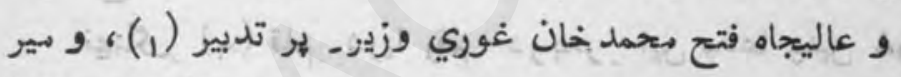

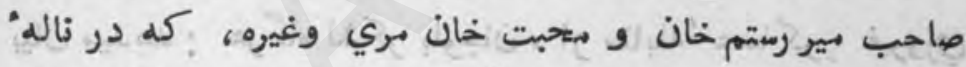

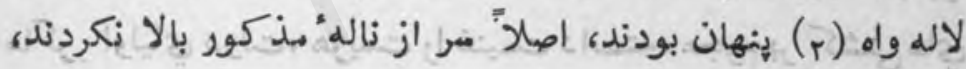

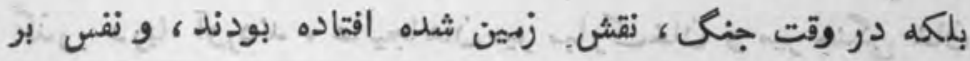

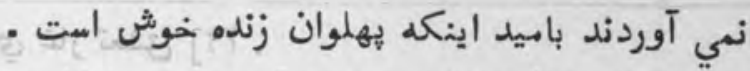

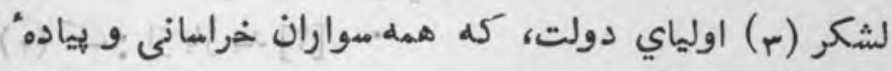

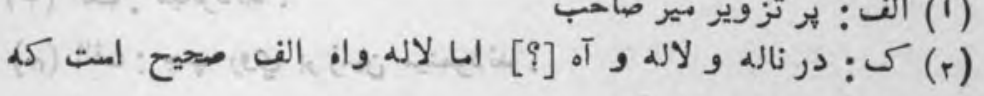
ناله ايست متصل مكهر . . [?] (r) 
روهيله و هندونتاني بودند ، سلاح- شمشيرها و و تفنكهاي باربنا

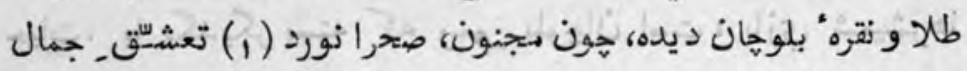

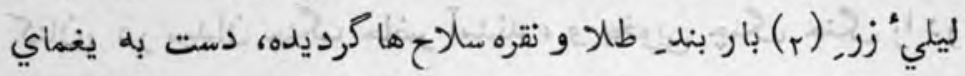

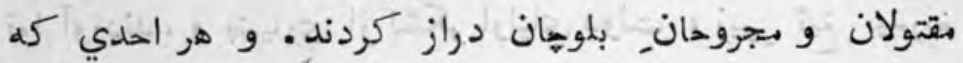

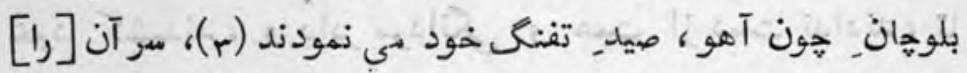

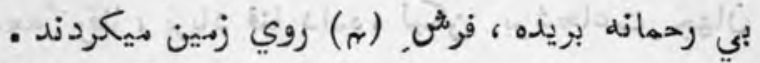

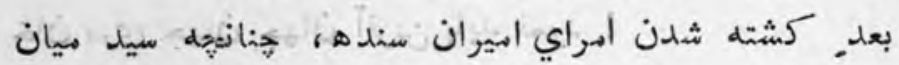

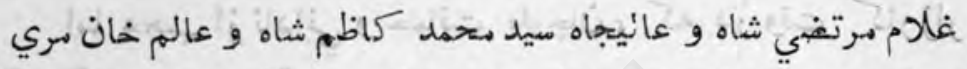

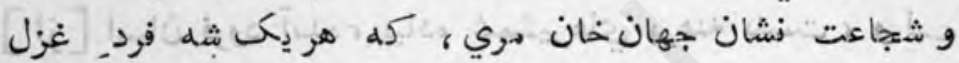

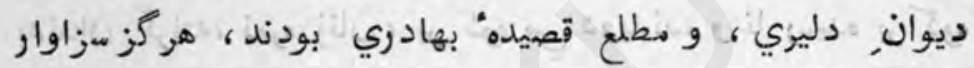

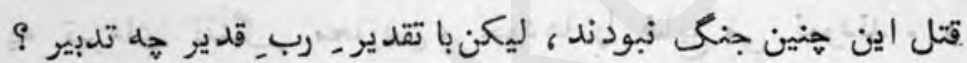

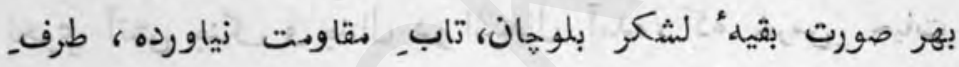

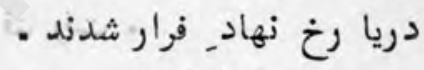

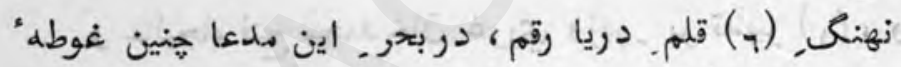

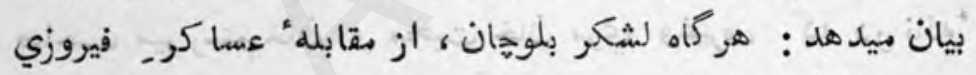

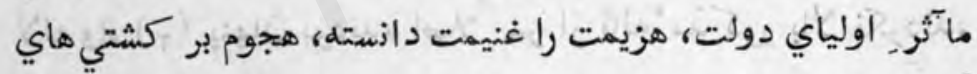

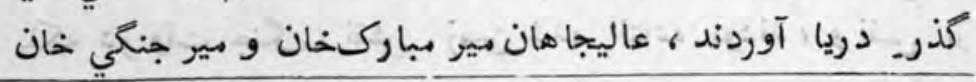

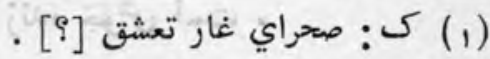

$$
\begin{aligned}
& \text { ك(r) } \\
& \text { (r) الف: ميكردند : (r) }
\end{aligned}
$$

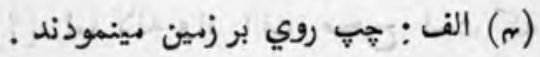

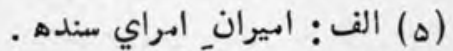

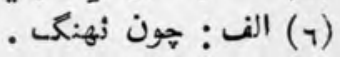




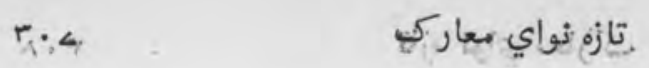

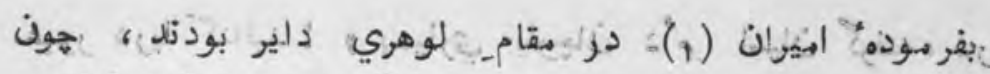

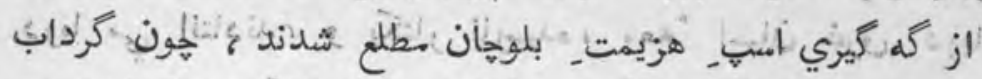

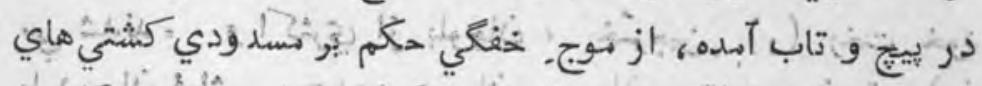

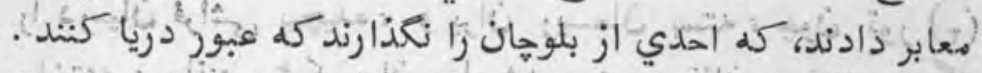

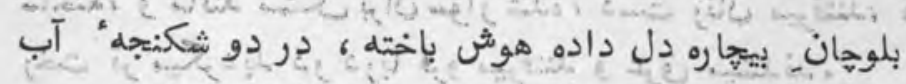

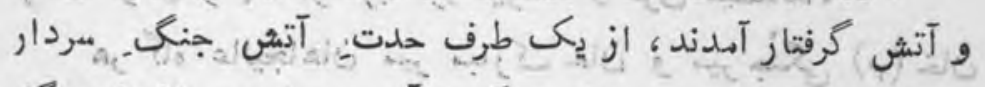

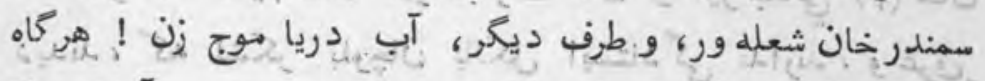

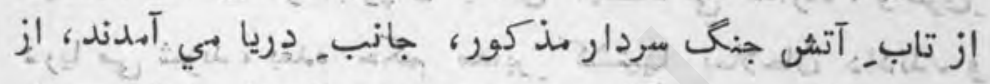

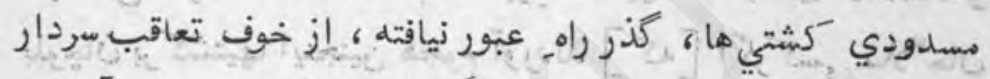

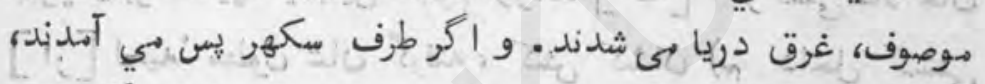

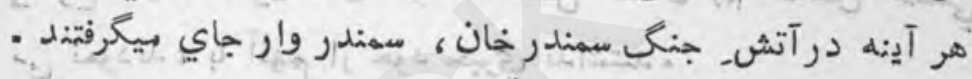

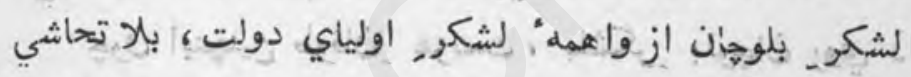

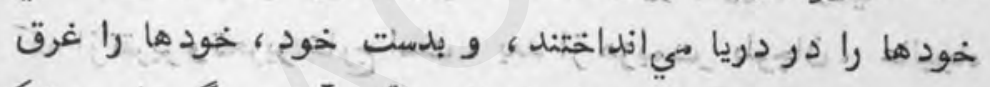

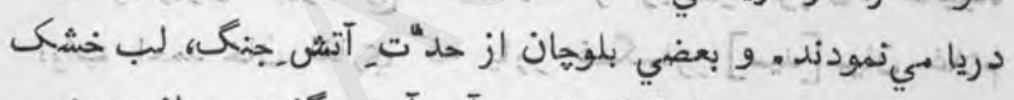

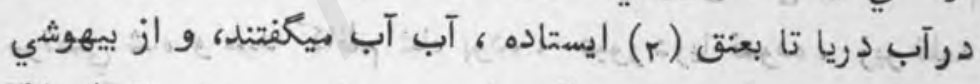

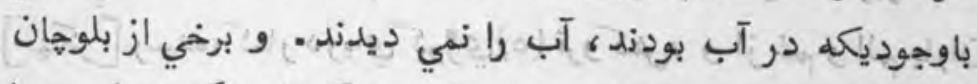

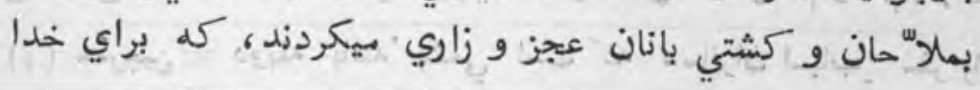

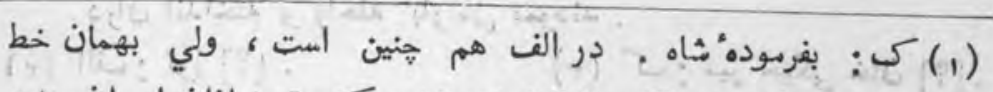

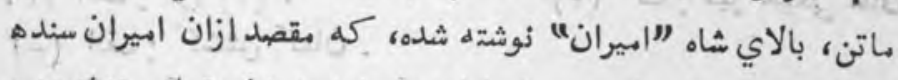

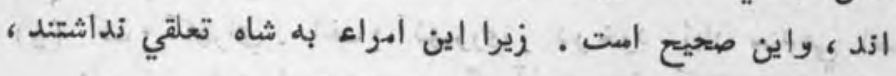
بكلى نقابل وى بودند .

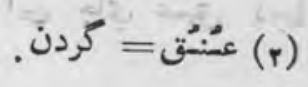


عبور دريا كنازيد ! و بسياري بلوحان دُمه اسهان كرفته، درر

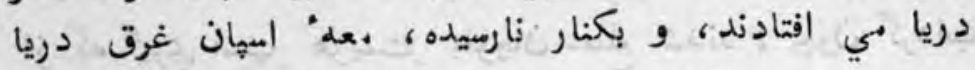

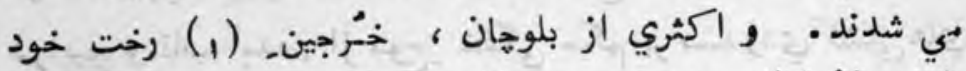

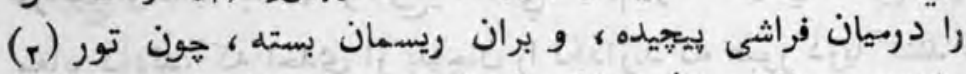

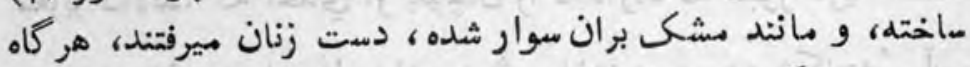

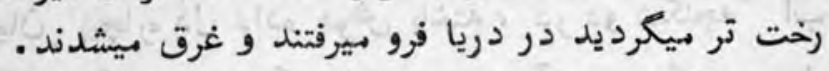

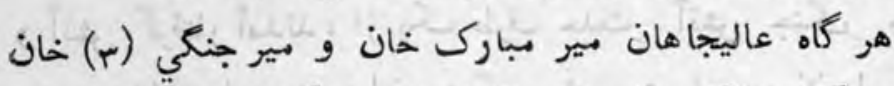

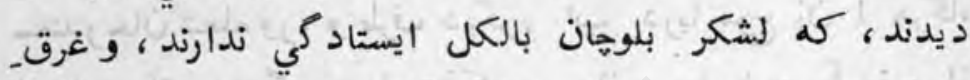

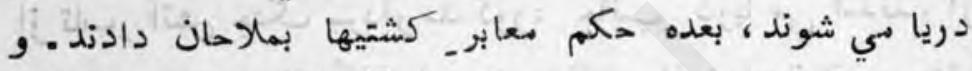

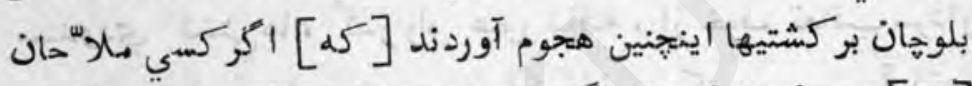

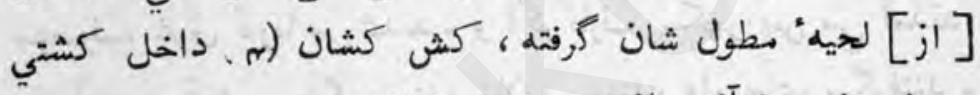

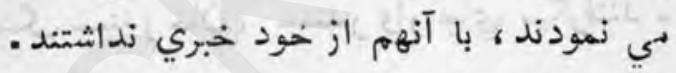

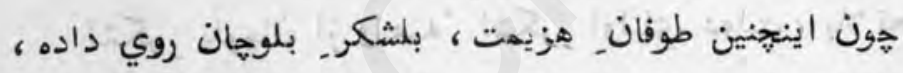

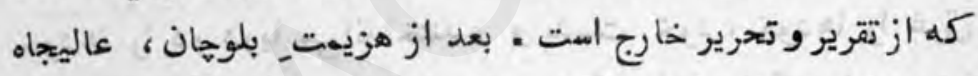

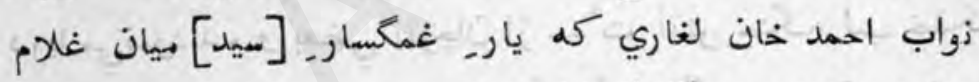

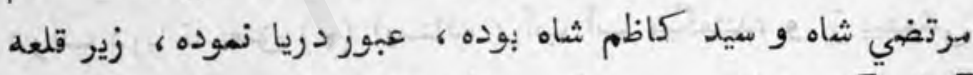

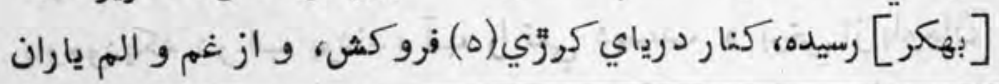

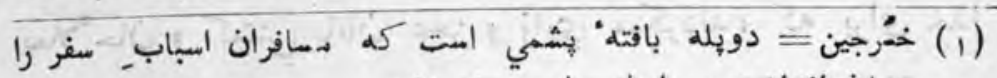

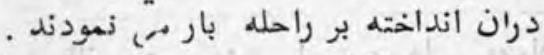

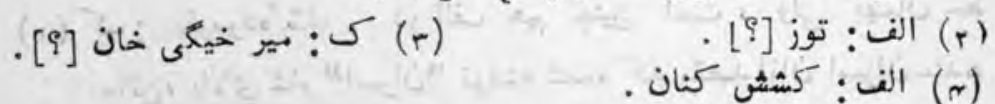

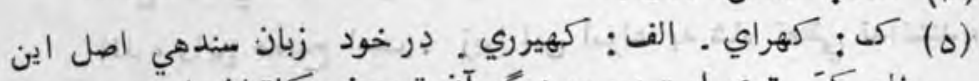

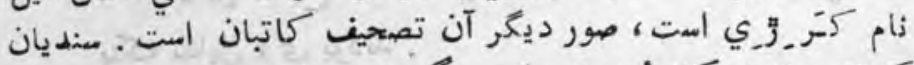

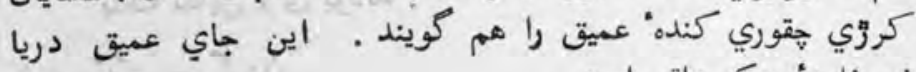

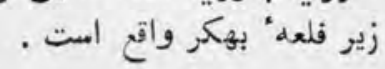




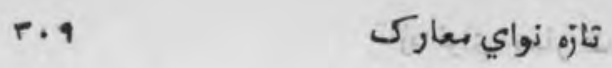

غمكساران خود ، اشكـــ حسرت از ديده" تاسف بير يخت و دست.

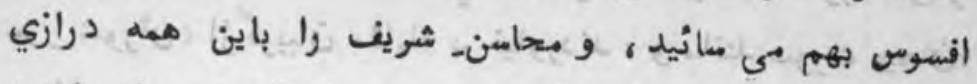

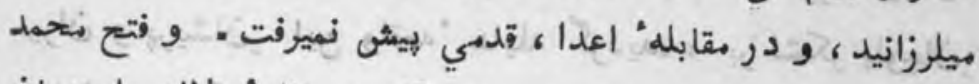

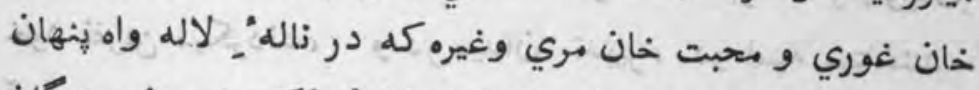

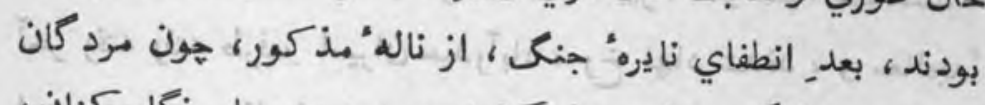

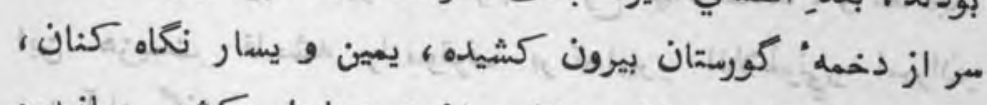

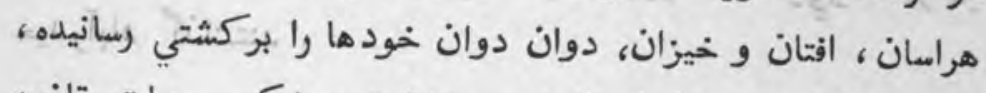

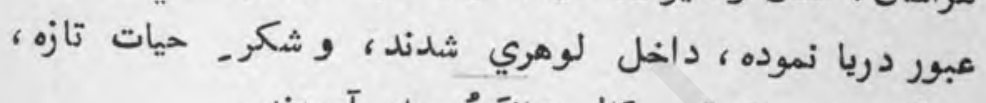

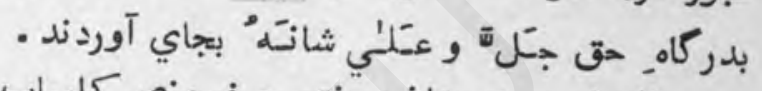

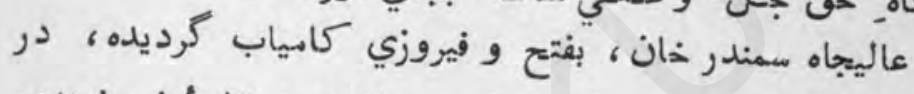

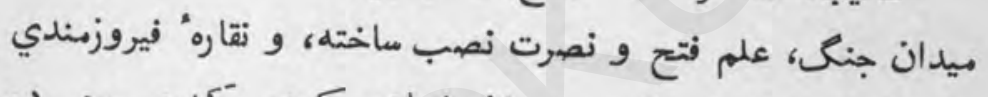

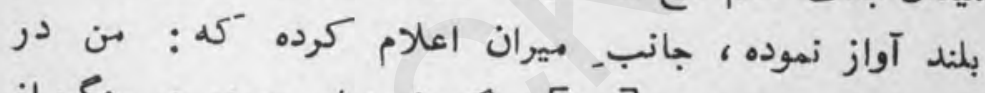

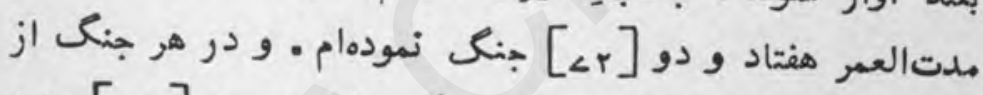

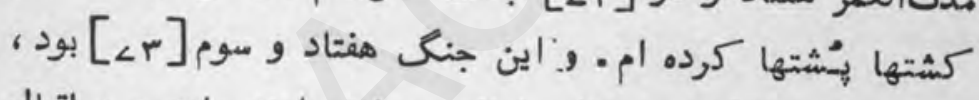

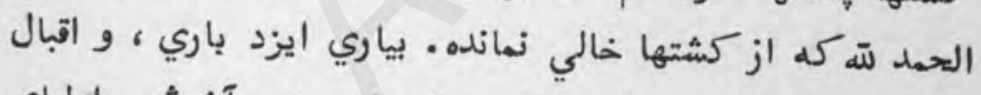

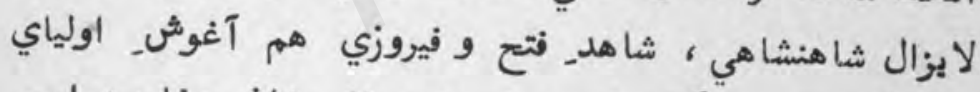

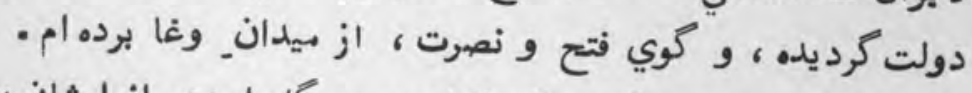

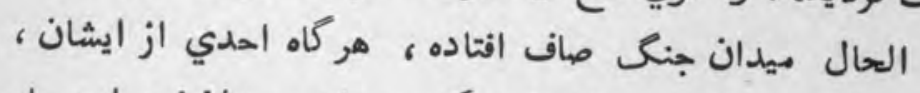

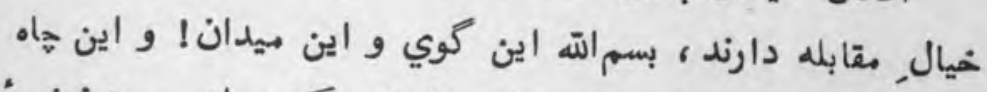

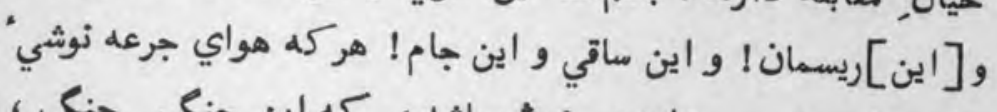

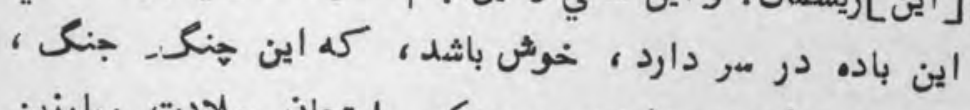

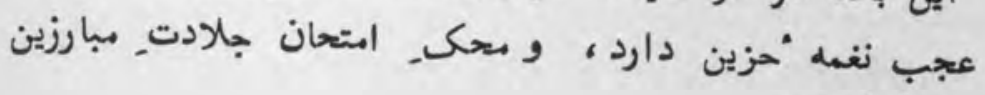

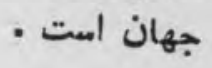




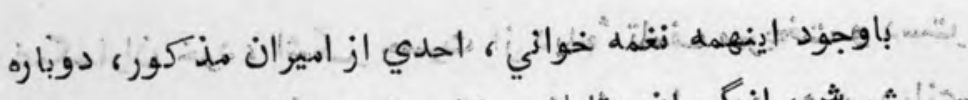

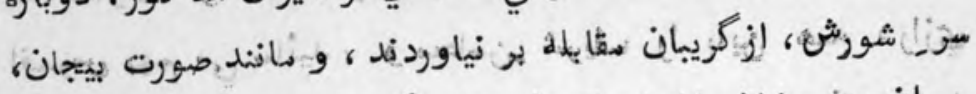

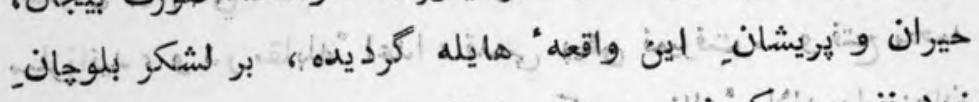

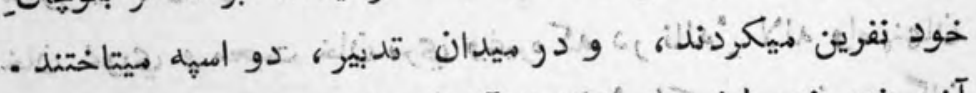

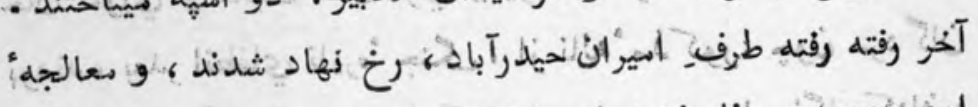

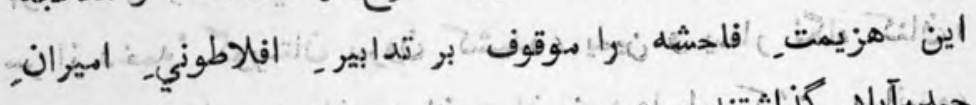

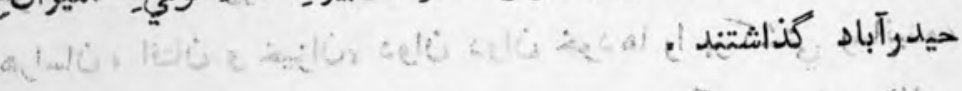

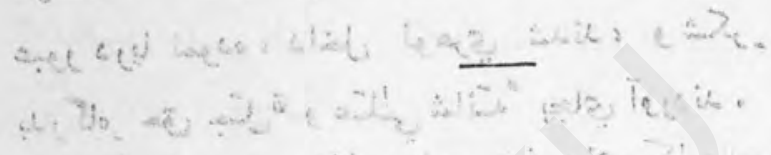

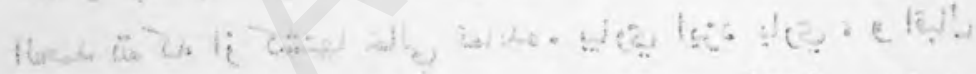

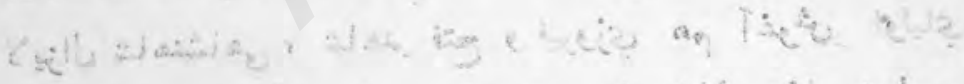

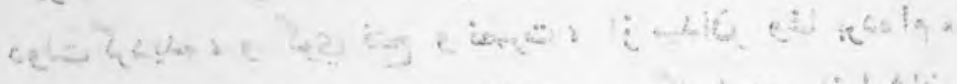

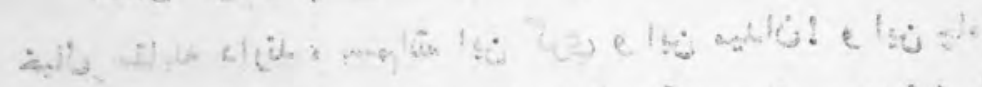
[1 aris 


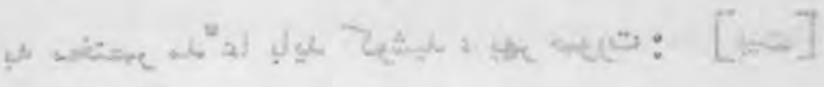

$$
-N A-
$$

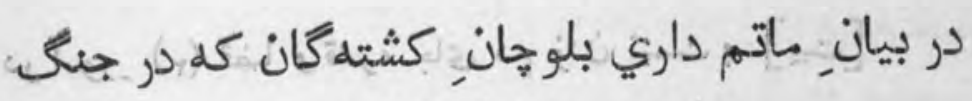

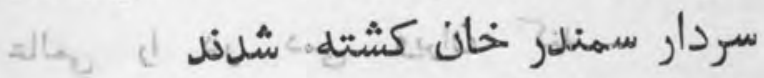

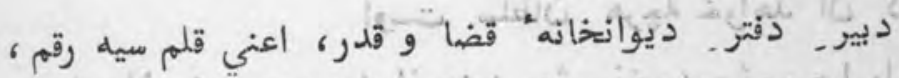

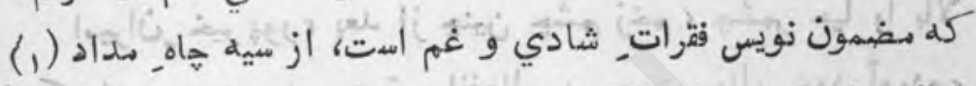

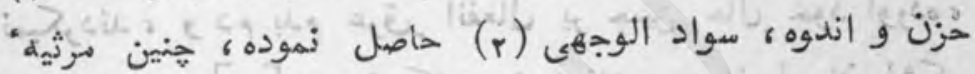

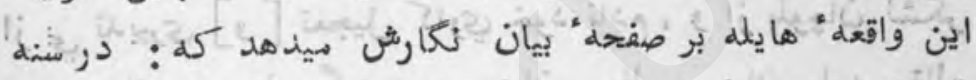

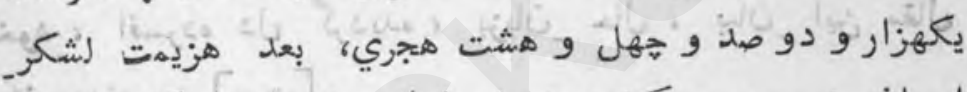

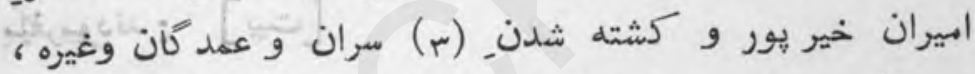

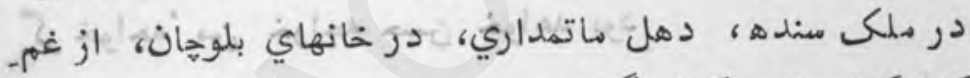

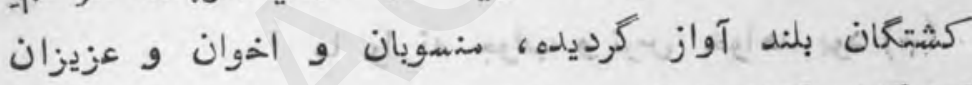

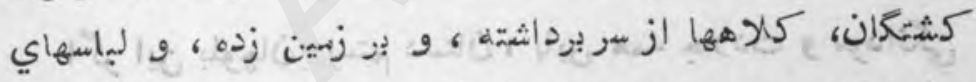

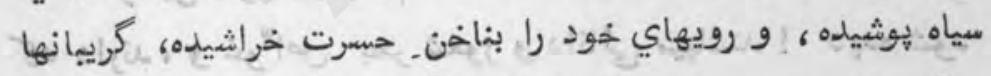

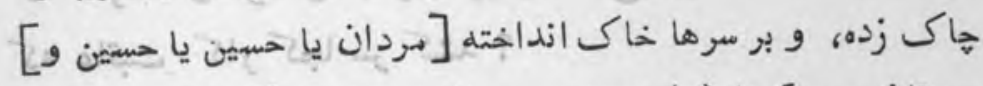

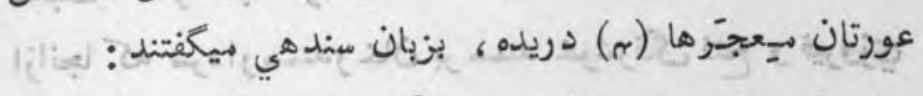

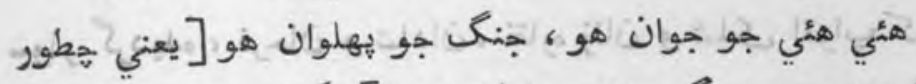

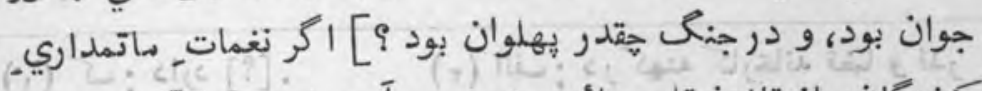

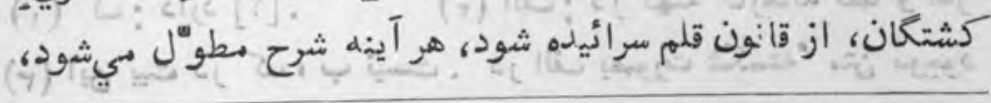

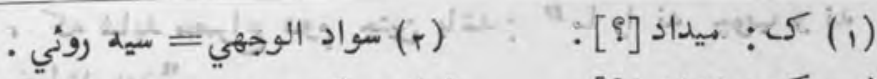

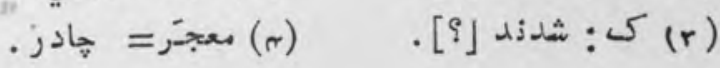


به مختصر مد"ّعا بايد كوشيد ، بهر صورت : عبت

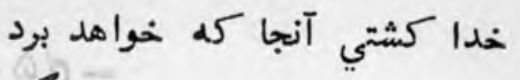

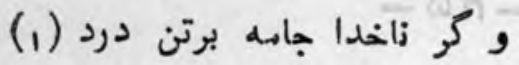

در امور (r) قضا و قدر، جاى دم زدن نيست : [بيت]

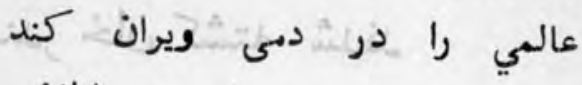

اوست سلطان هريه خواهد آند آن كند

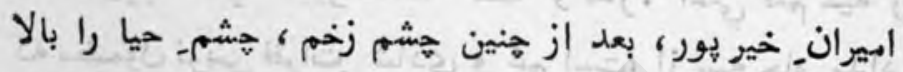

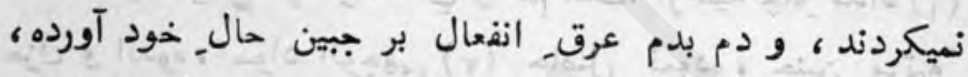

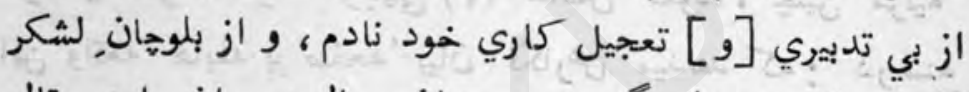

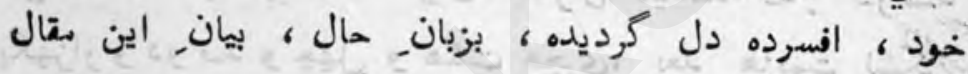

$$
\text { ميفرمودند: }
$$

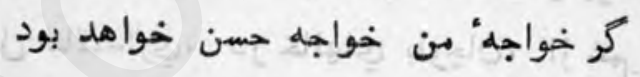

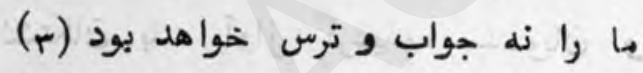

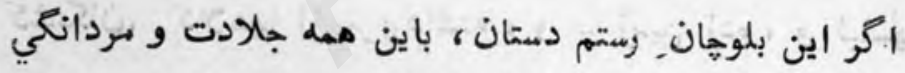

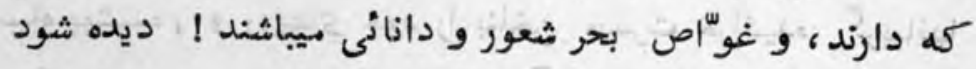

$$
\text { كله عاقبت } 15
$$

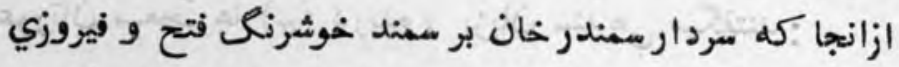

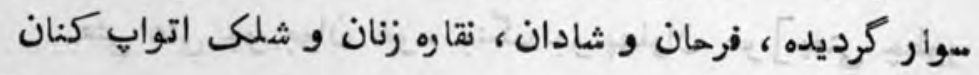

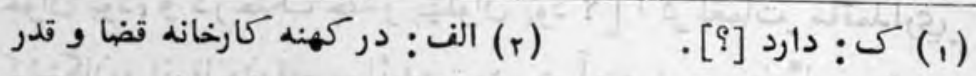

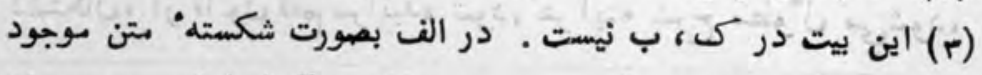

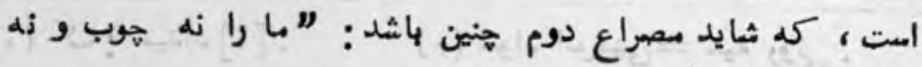

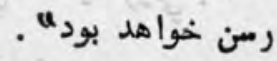


از مكان سكهر (1) رخ نهادي شكار يور، و بقططع مسافت ، مشرف

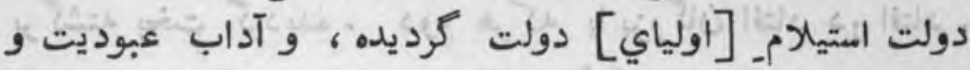

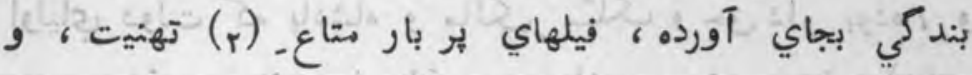

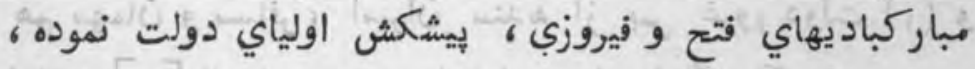

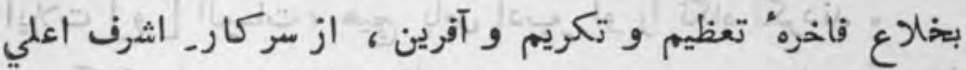
سرقرازي ياقت

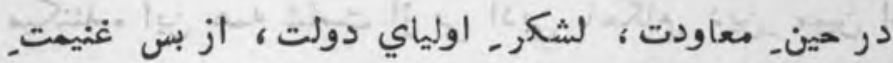

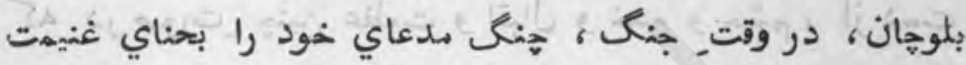

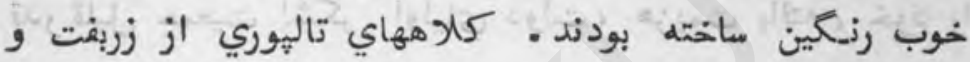

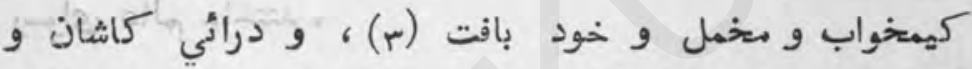

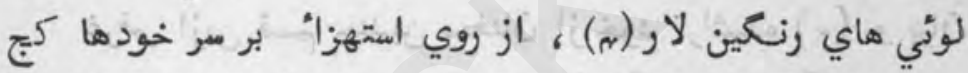

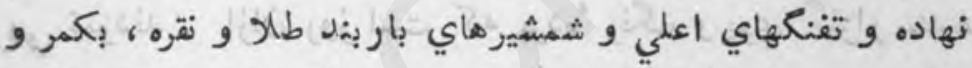

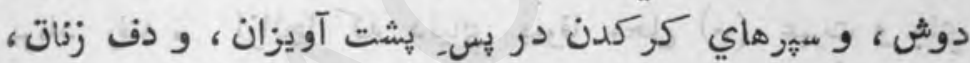

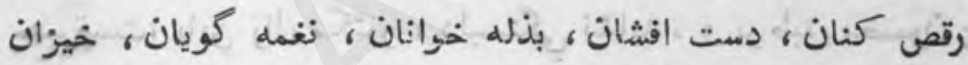

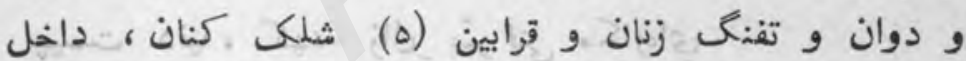
شعار بور شدند - موان

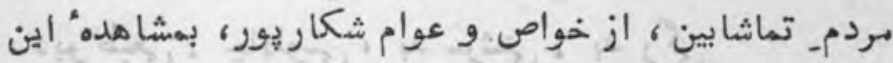

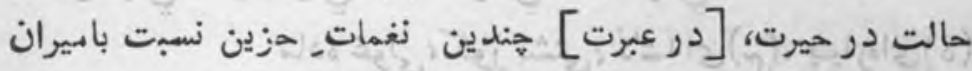

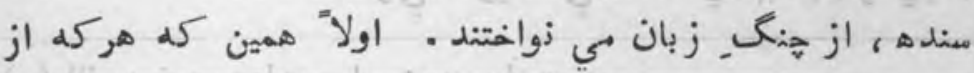

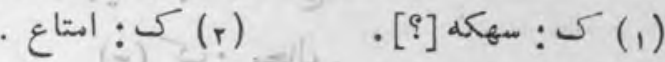

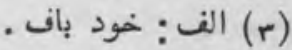

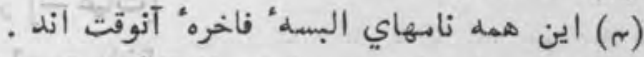

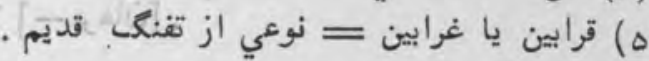


روي متابعت نفس زافرجام، إز راه شريعت بيضا بركثمته، هرآينه

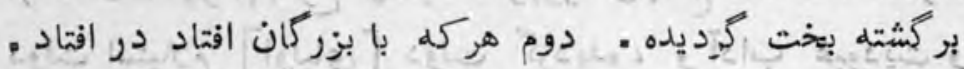

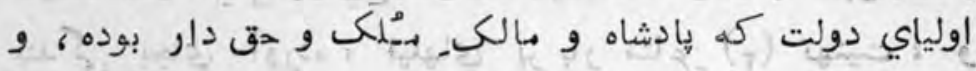

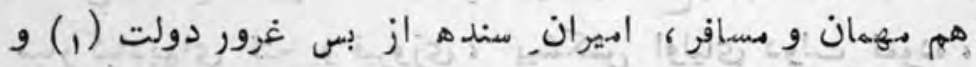

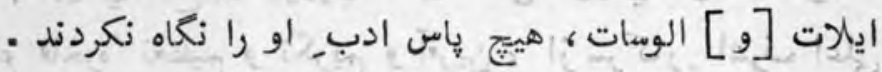

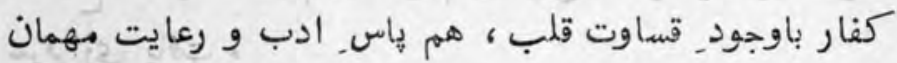

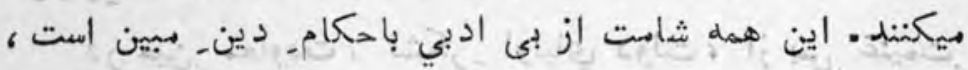

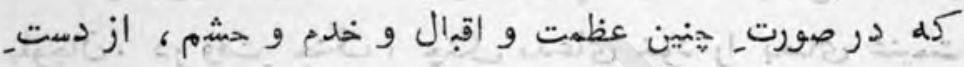

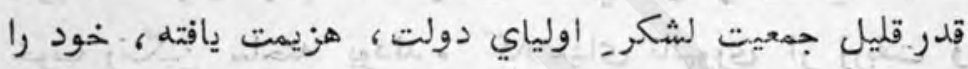

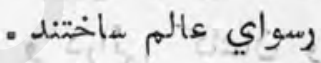

نرض ازين قسم همندين ميخنان إز خود تراشيده (r) و و بيان

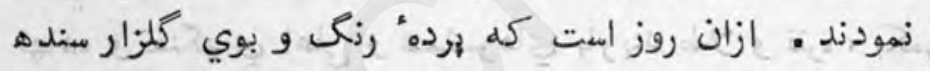

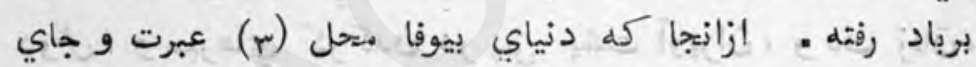

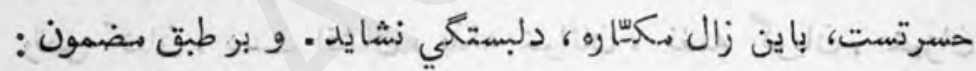

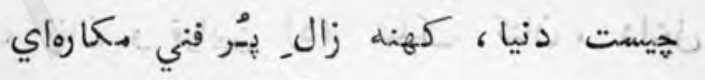

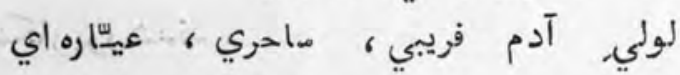

ديو طبعي، جإيلومي، بد سرشتي ؛ بد ركي

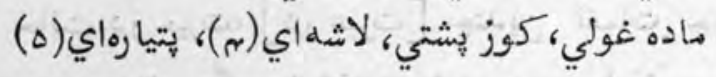

(1) الف: غرور دولت و ابيري و رياست هيج.

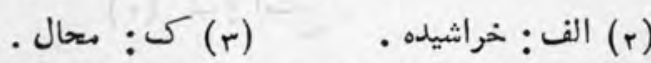

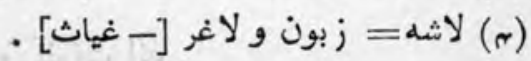

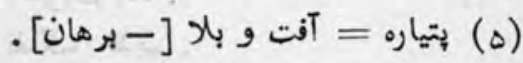


سـات عهدي، بيوفائي، زود رنجي ، ظالمي

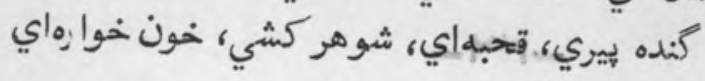

هركه دل بندد بدين زال فسونكر، همست او:

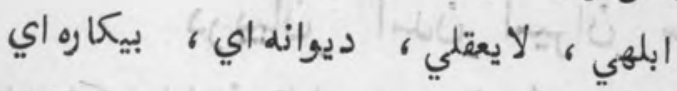

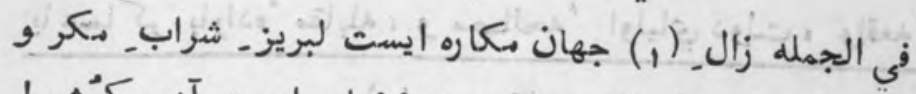

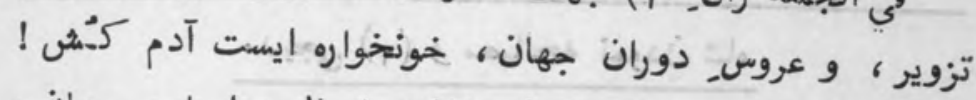

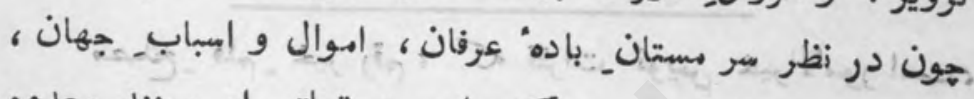

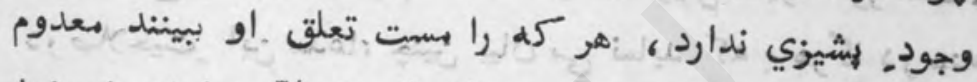

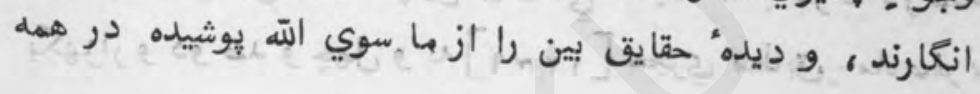

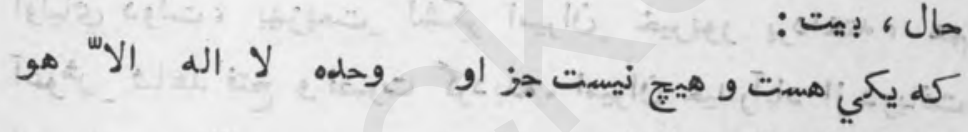

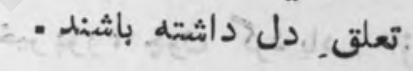

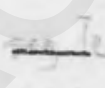

(1) زال =يير مسفيد بوي [- غياث] . 
-NY

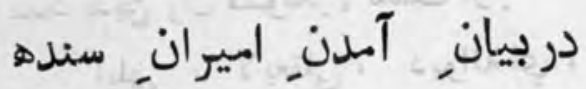

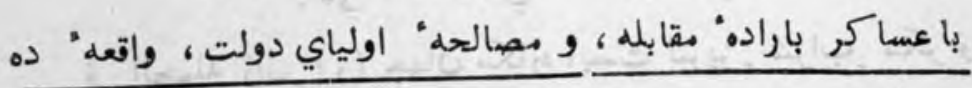
مديجي (1) و مصرالحه نمودن شاه

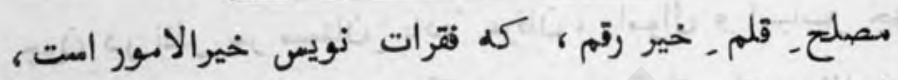

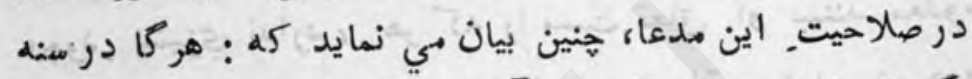

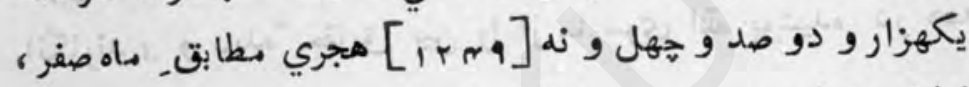

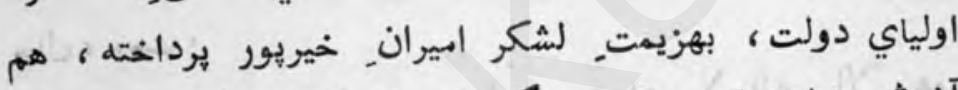

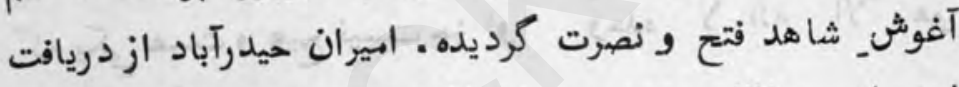

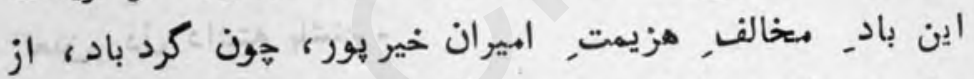

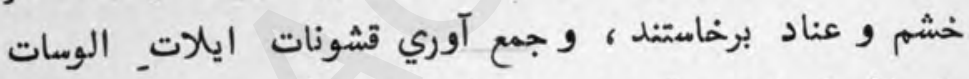

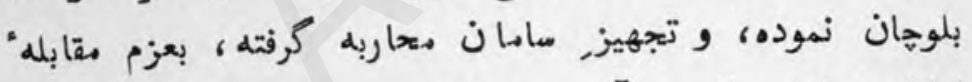

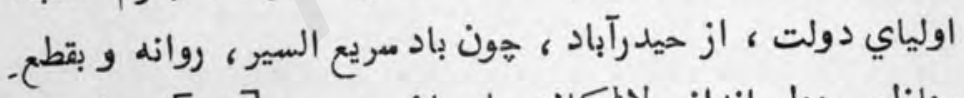

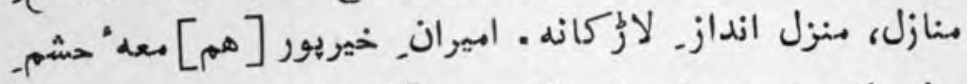

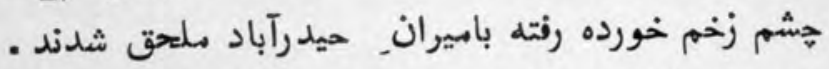

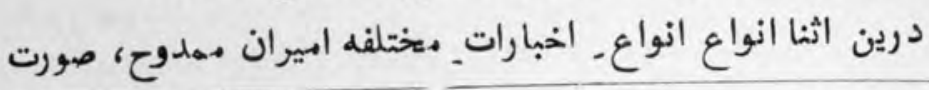

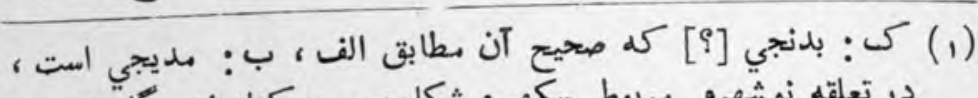

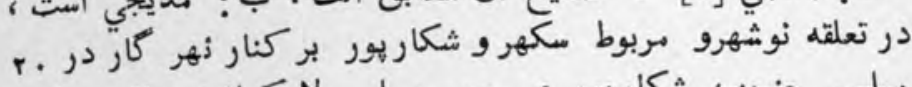

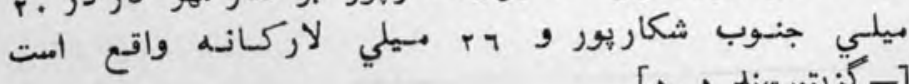

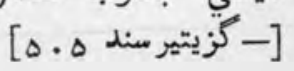


تازه نواي

اثثوار كرفته ــ اولياي دولت ، هـركز اخبارات مختلفه ، در كوش

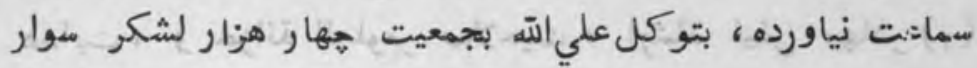

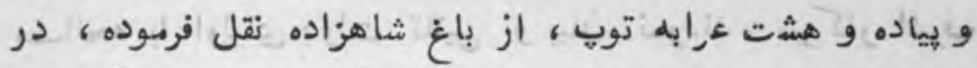

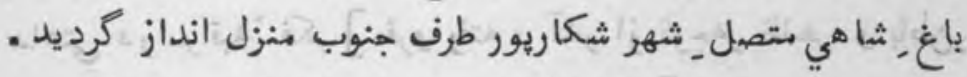

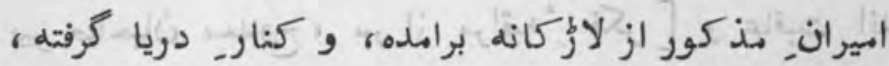

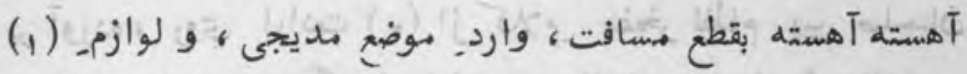

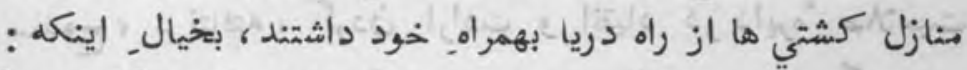

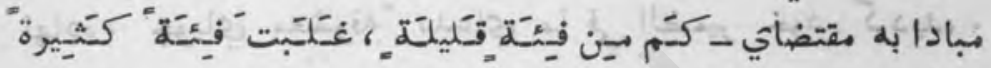

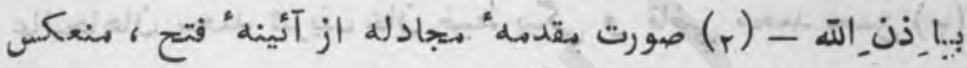

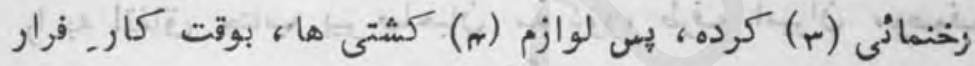

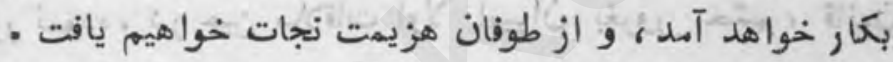
باين همه لحاظظها، اميران بوصوف، باز ابواب رمل و رسايل به بيشاءه أولياي دولت مفتوح ماختند، و خدَام كرام ذوالاحترام

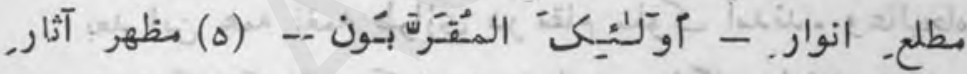
-

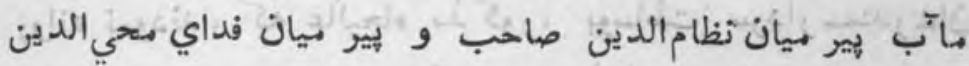

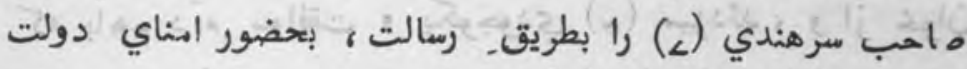

- أموز نمودند

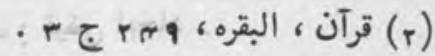

(1) (1) الف: (1) (1)

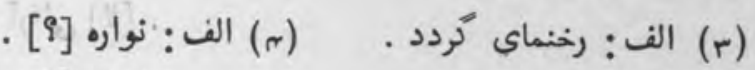

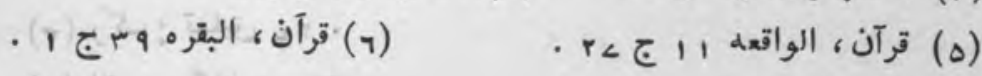

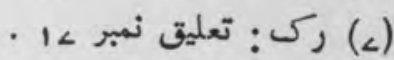


تازه نواي معارك

ris

بهيز صاحبان_ ممدوح ؛ بعد از استيلام، از كنز العرفان.

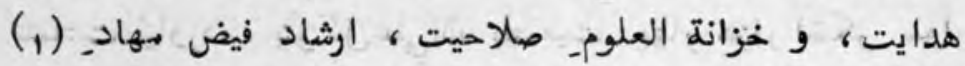

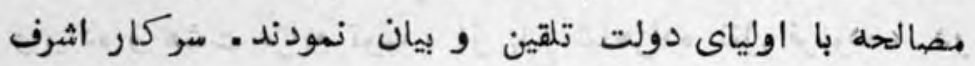

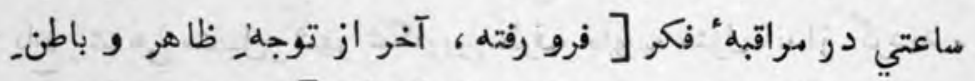

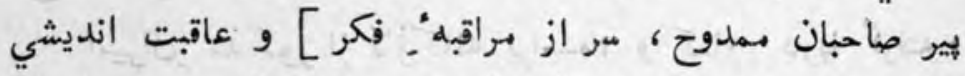

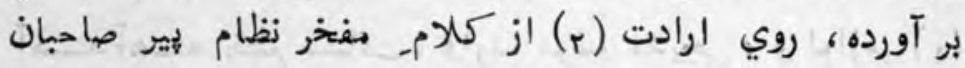

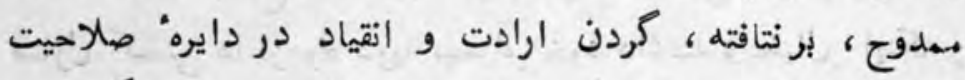

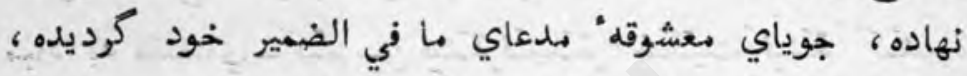

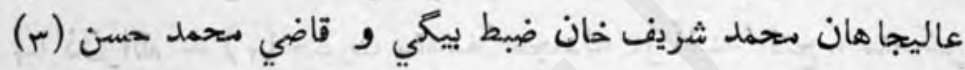

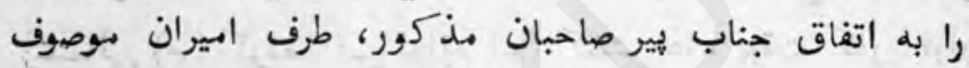

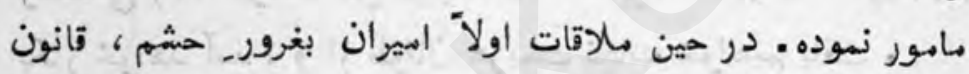

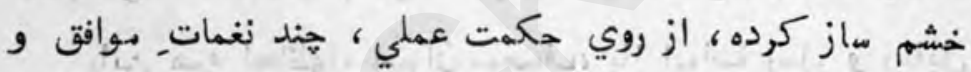

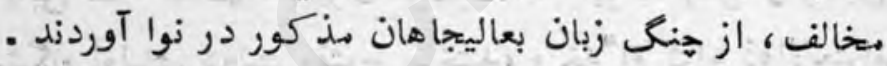
بعد اين همه نغمه طرازي در مقام سلوكى آمدند . وعاليجاه

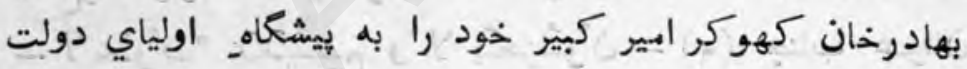
روانه نمودند، كله عاليجاه مذكور، بوساطت_ مردار سمندرخان

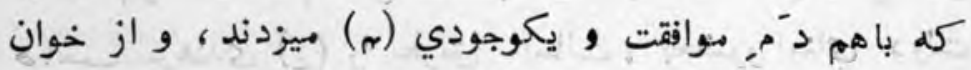

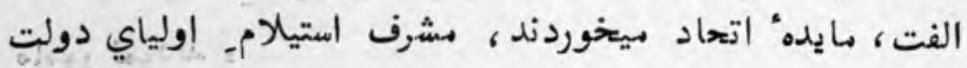

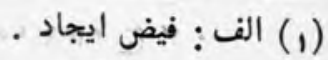

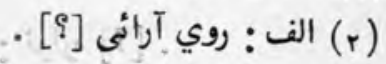

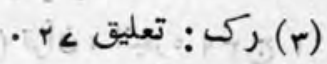

(r) الف : يكان وجودي : تعلين 
كرديده، و بتدابير عاقالانه و تجويزات_ فرزانه، برضا جوئي سبركار

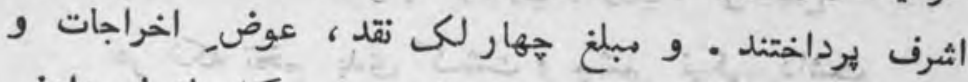

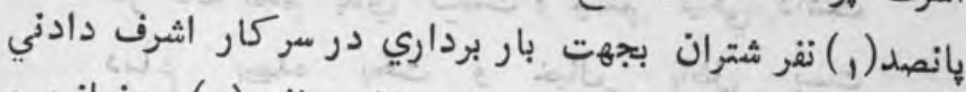

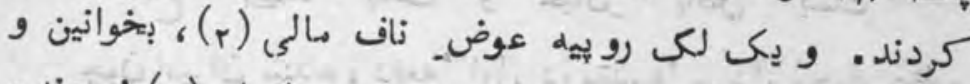

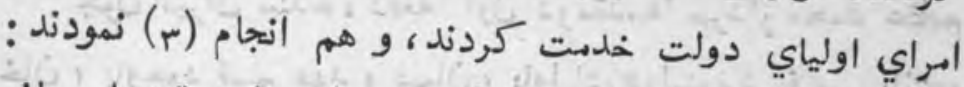

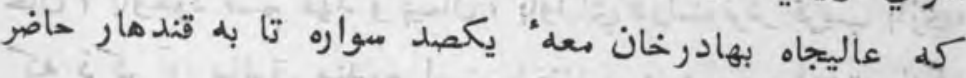

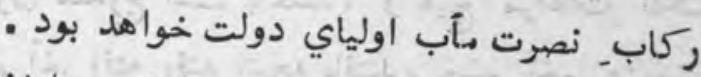

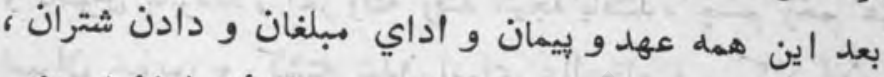

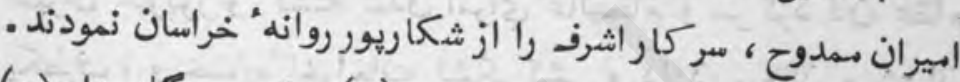

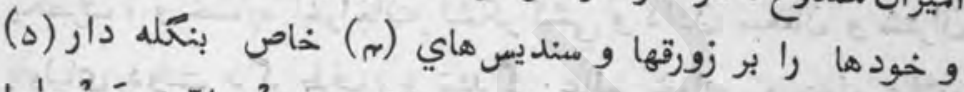

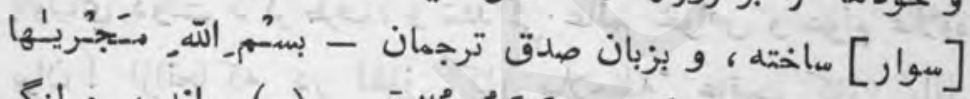

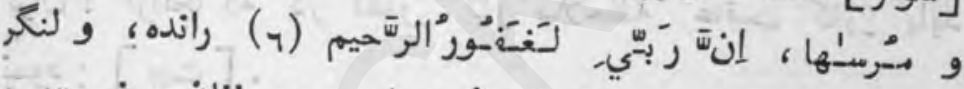

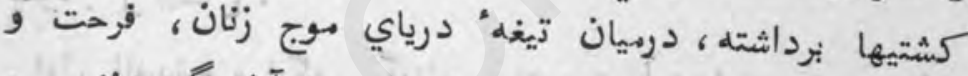
خرّّي كنان ، هون باد ، تشريف فرهاي حيدرآباد كرديدند.

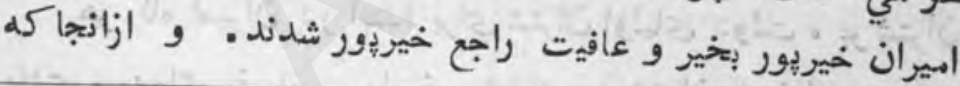

$$
\text { . (1) }
$$

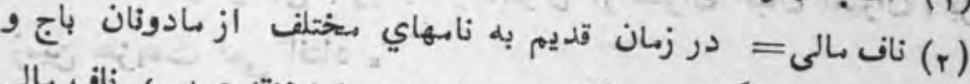

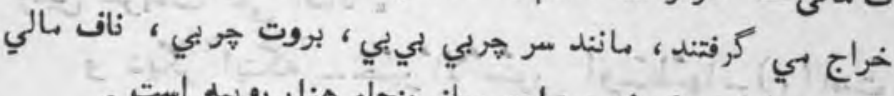

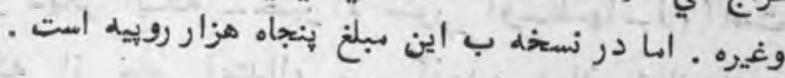

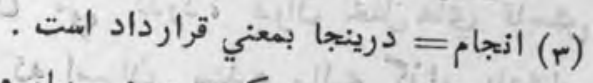

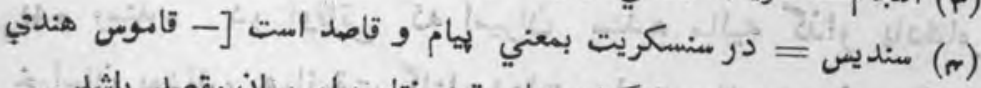

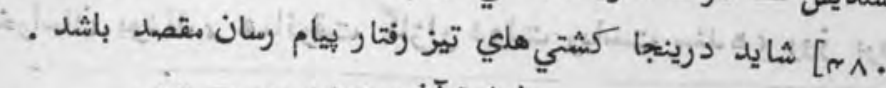

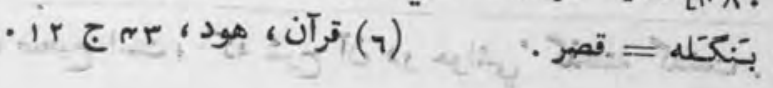


تازه أراي بعاركى

r.

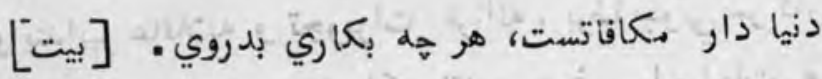

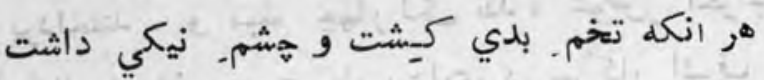

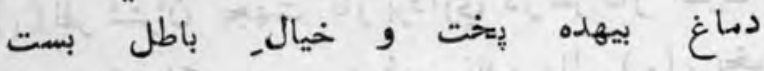

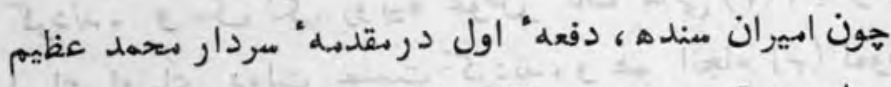

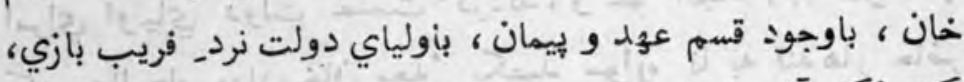

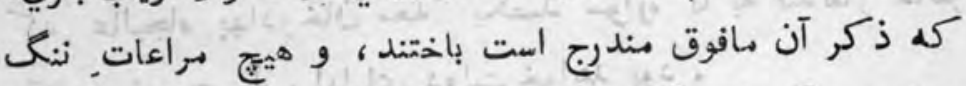

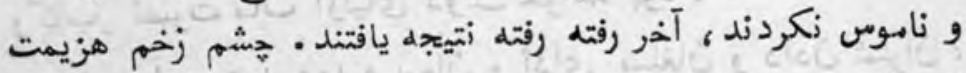

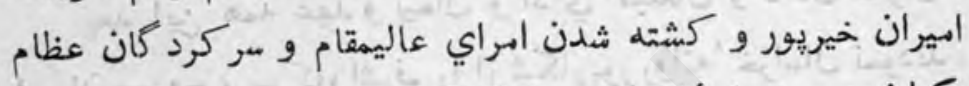

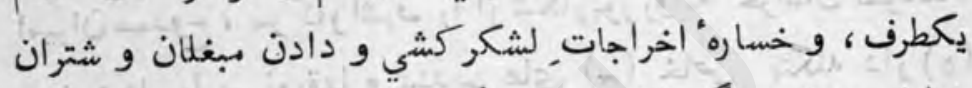

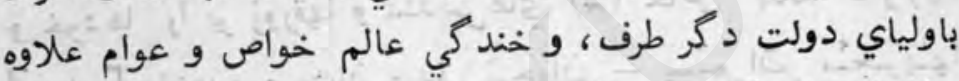

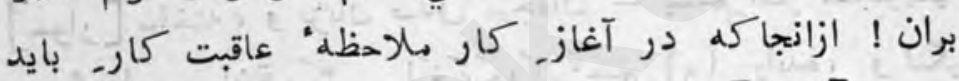

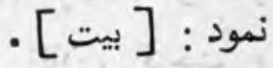

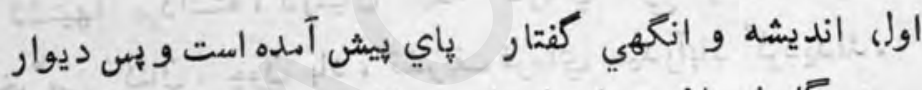

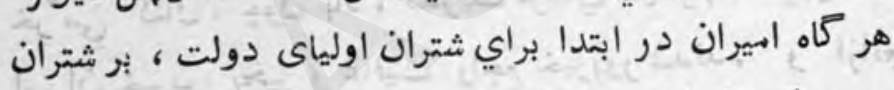

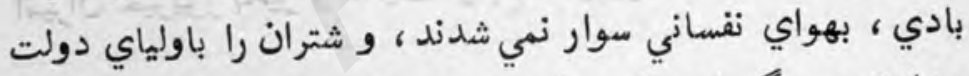

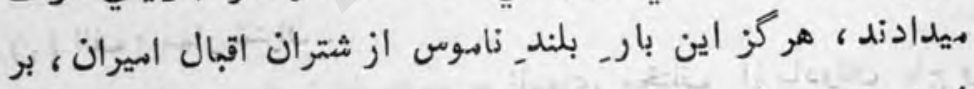

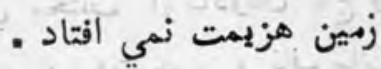

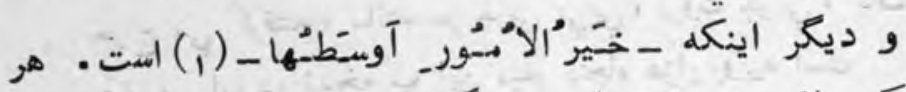

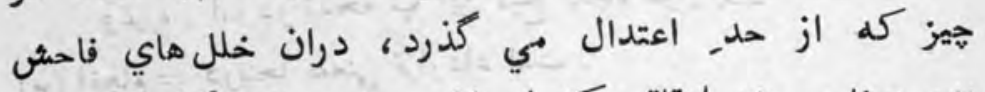

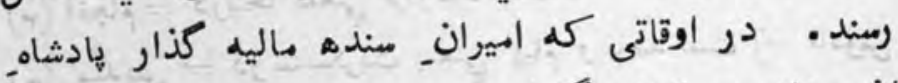

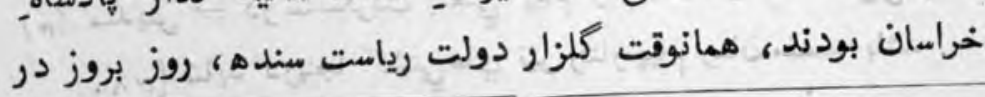

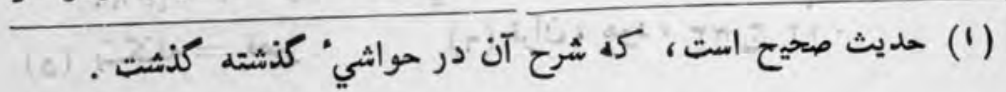


نشو و زماي ترقي دوات كه هر خاص و عام ازملزار دولت اميران

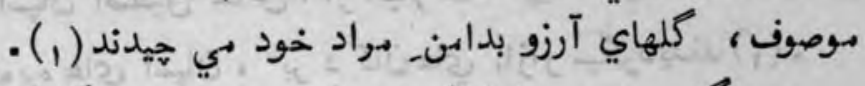

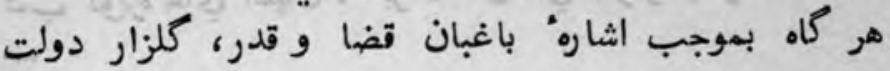

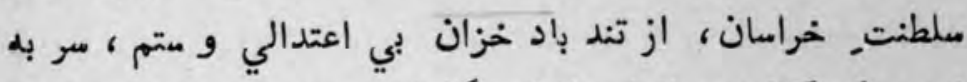

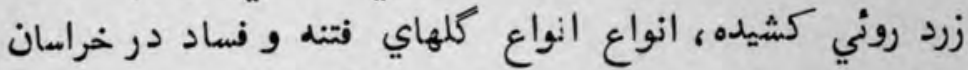

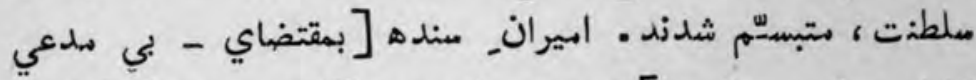
فضل خداي - دانسته] دست تصرف در ملكهاي متعلقه" شكاريور

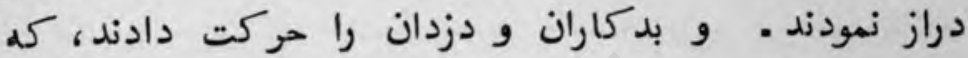
تا دهن_ دروازهُ شكاريور بتاخت و تاراج غرباي رعاياي شكاريور

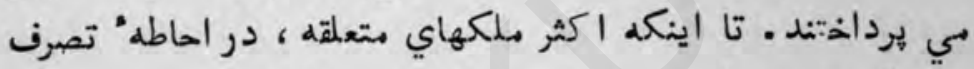

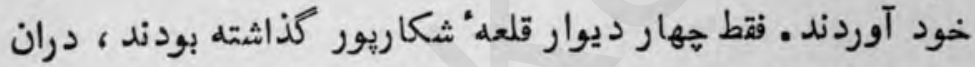

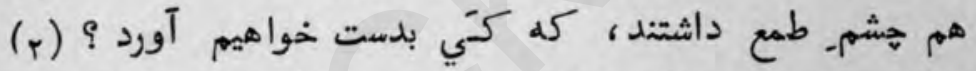

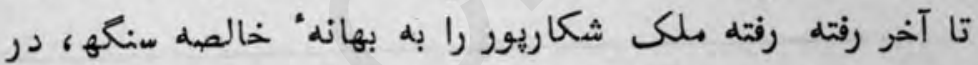
تحت_ تصرف_ خود آوردند.

بعد تصرف شكاريور، هيج تمثال خوبي و بهبود كي درون

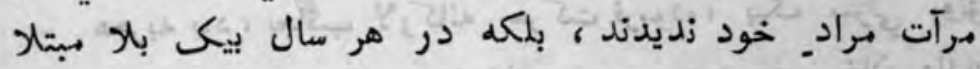

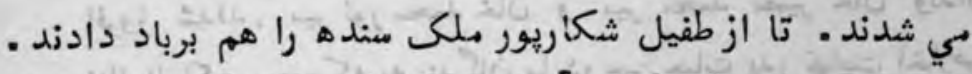

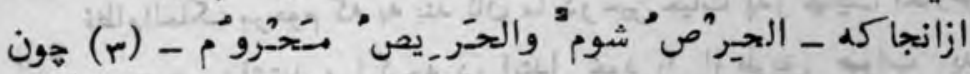

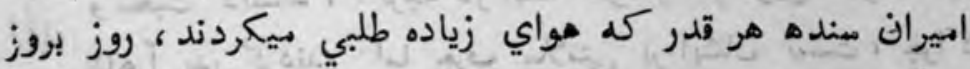

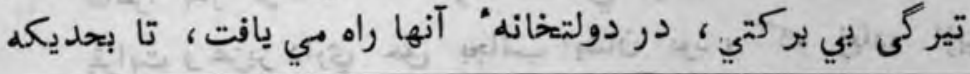


تازه نواي معازي

$r+r y$

دانه" اسيان اصطبل خاص، از انبار خأنه بيدا نميشد، تا نصفت

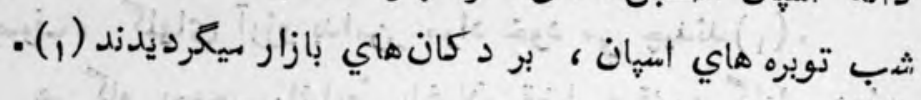

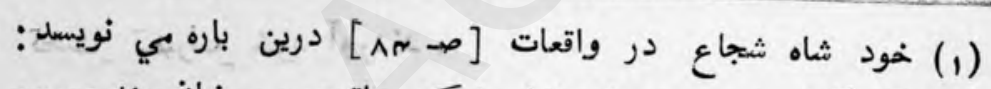

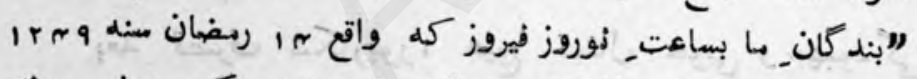

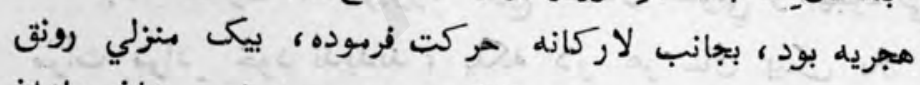

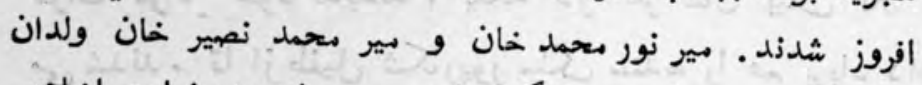

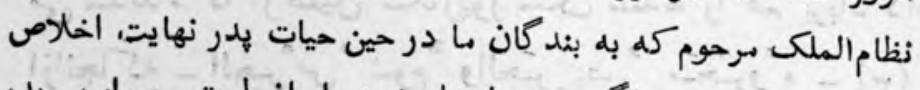

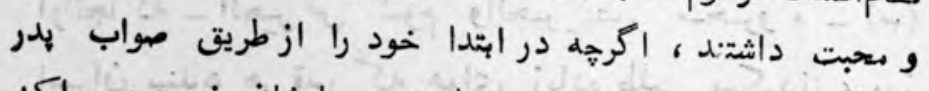

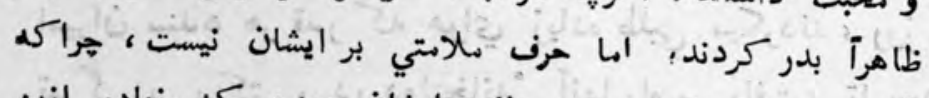

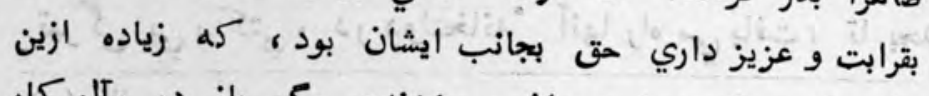

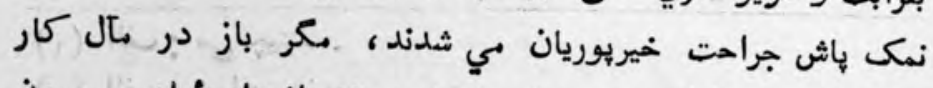

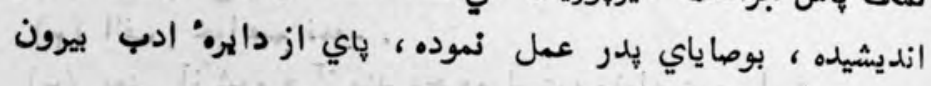

“ نهادنذ 
در بيانـ رفتن اولياي دولت جانب قتدهار

و جنع نمودن با سرداراني قندهار و هزيمت يافتن او

هـلطان قلم زرّين رقم ، كله سرير آراي ولايت سخنداثي

است ، در اقليم مدعا ، هنين بيان مينمايد كله : در معنه يكهزار

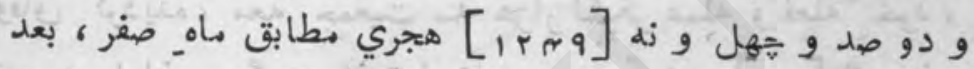

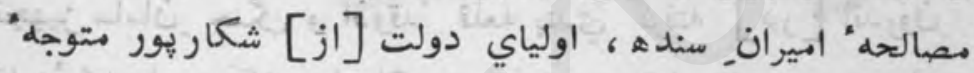

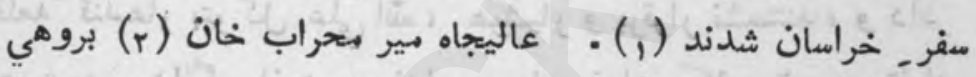

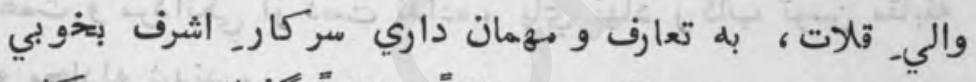

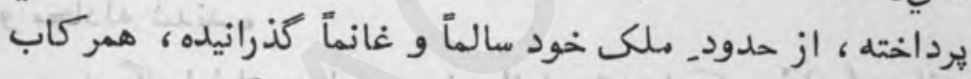

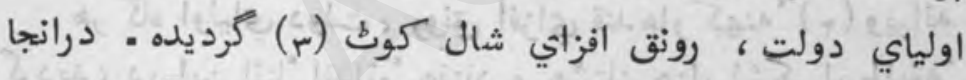

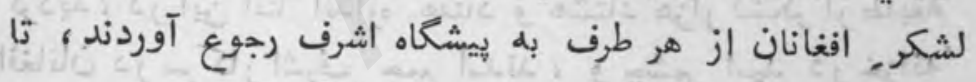

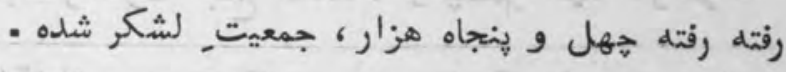

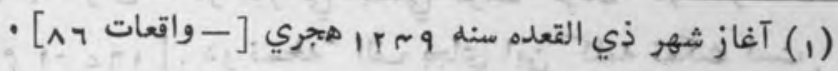
. r (r)

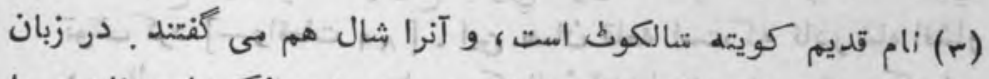

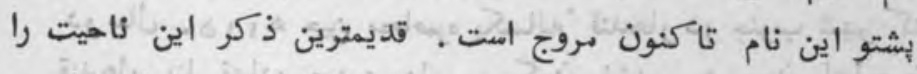

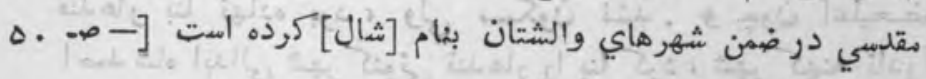

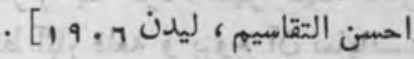


بعد از اوتراكى (1) هند ايام، از شال كوكُ، اولياي

جولت ، لواي فلك فرساي عزيمت سمت_ قند هار بر افراشته .

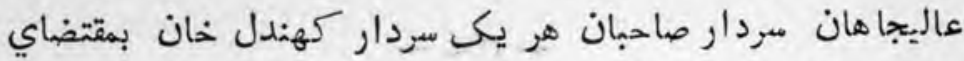

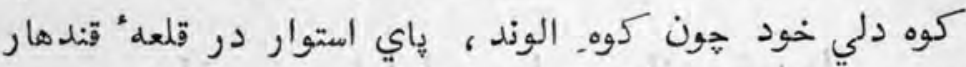

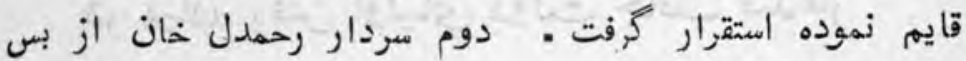

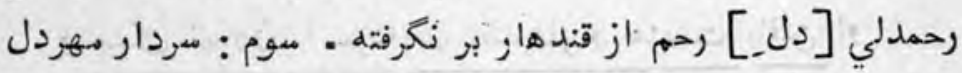

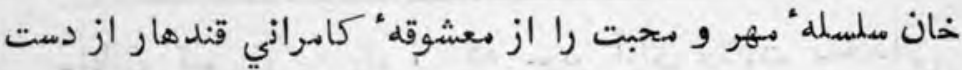

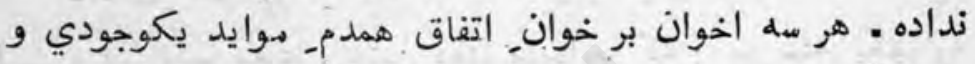

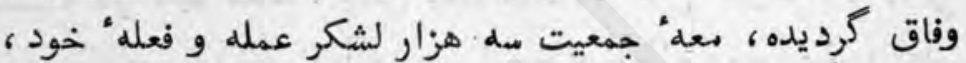

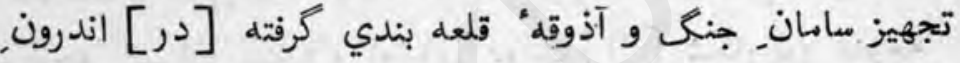

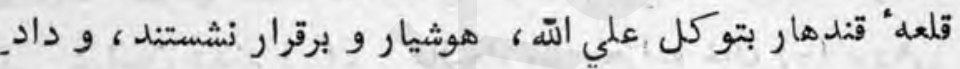

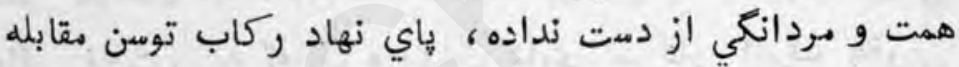
و منجادله شدند -

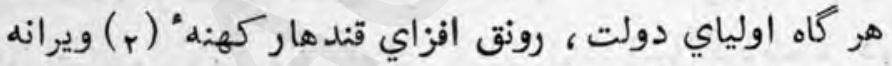

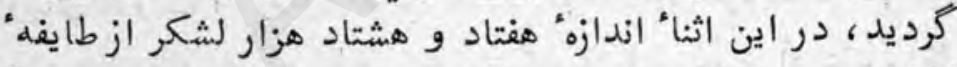

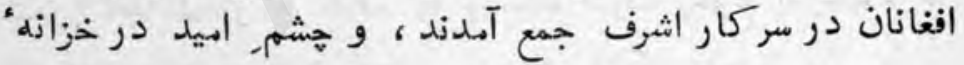

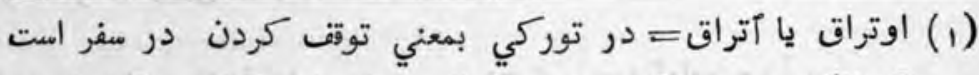

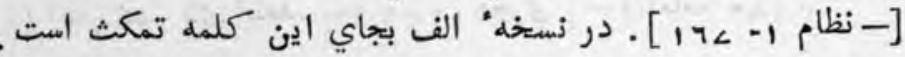

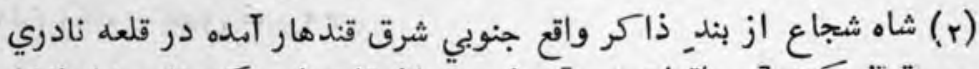

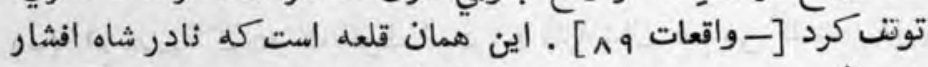

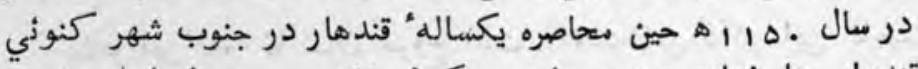

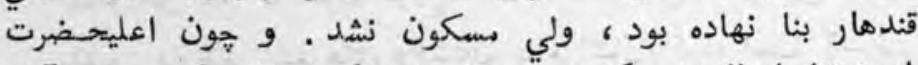

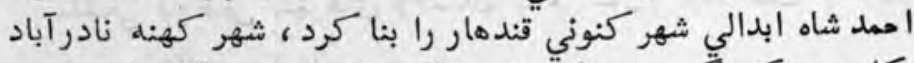

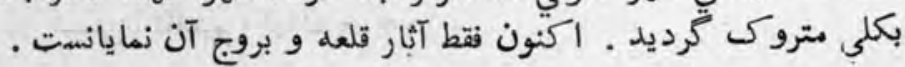


rro $\quad$ تازه نواي

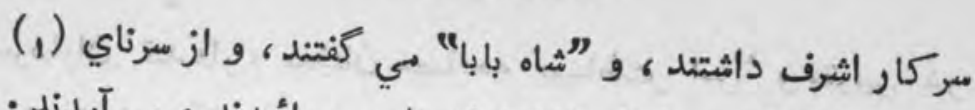

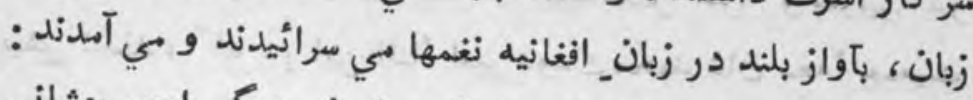

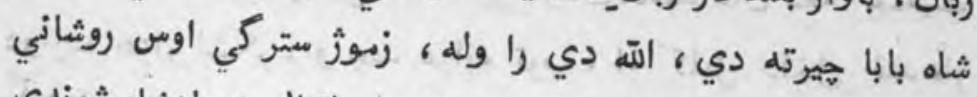

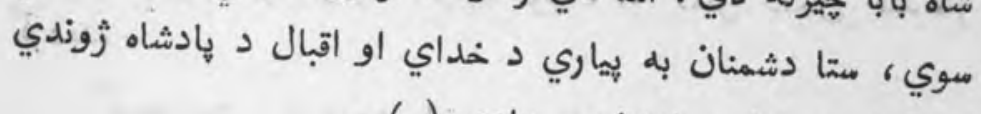

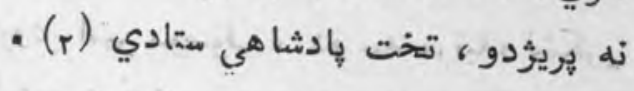
يعني هادشاه بابا كجاست (r) ! خداي ترا بياورد (م) التحال

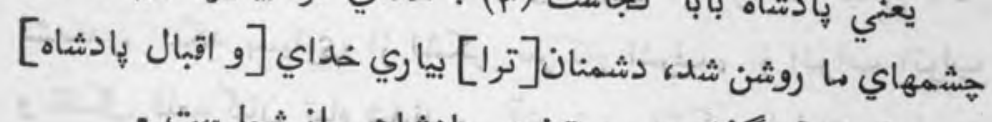

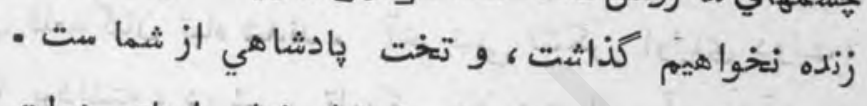

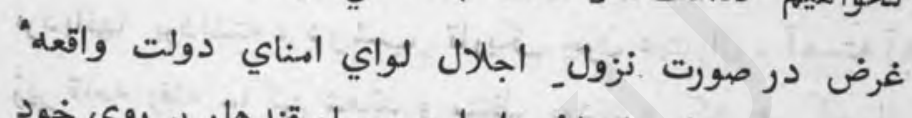

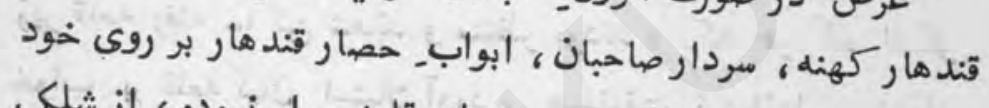

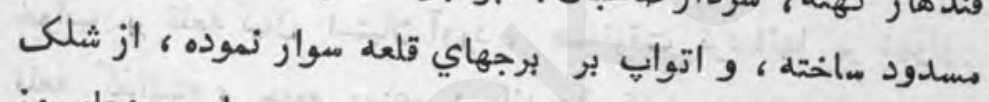

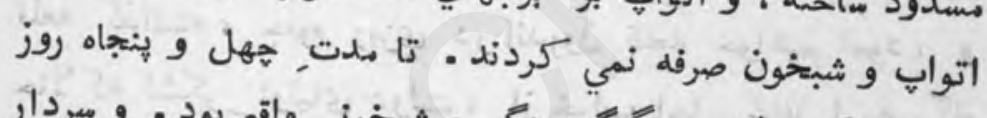

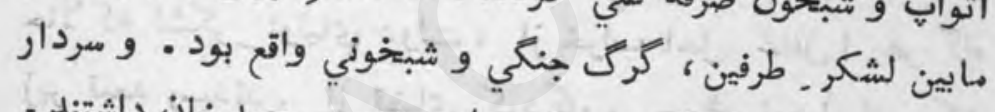

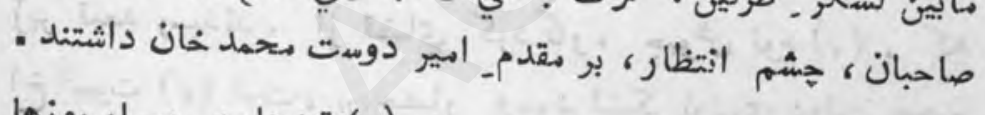

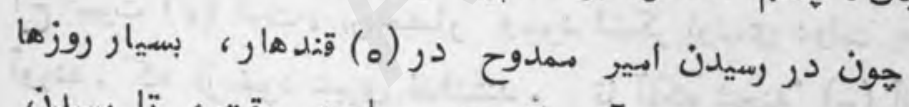

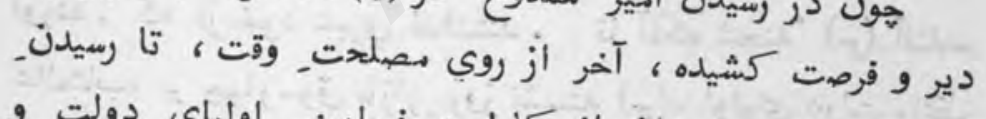

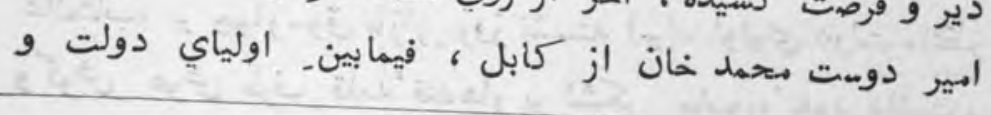

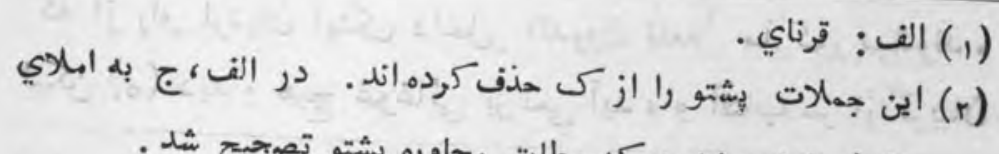

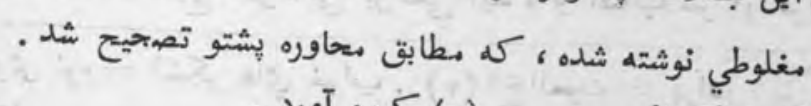

. آور • 5 (r) • (ه) 


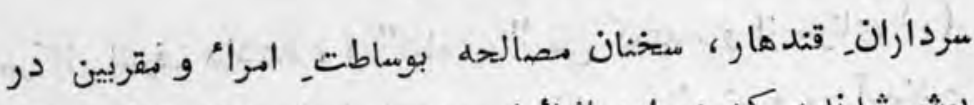

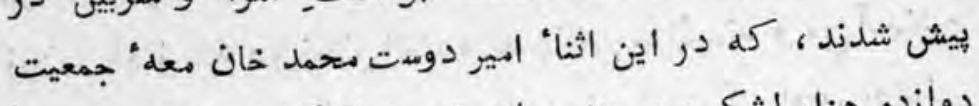

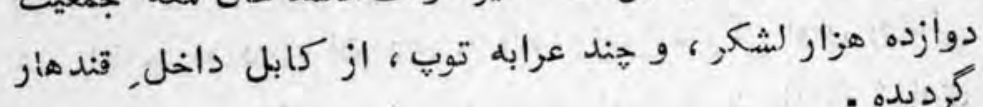

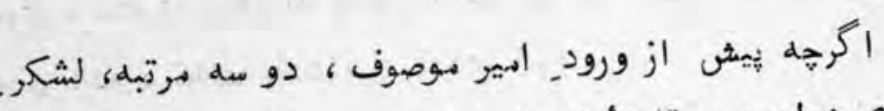

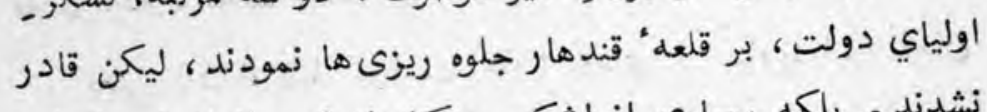

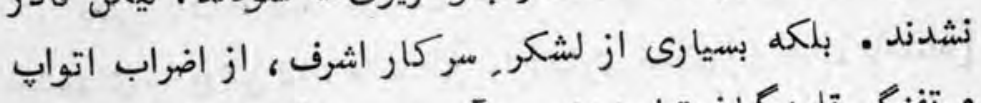

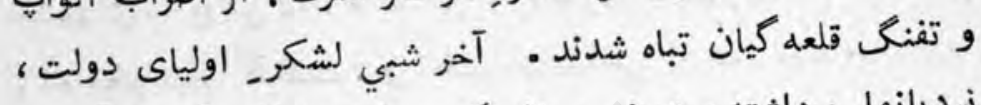

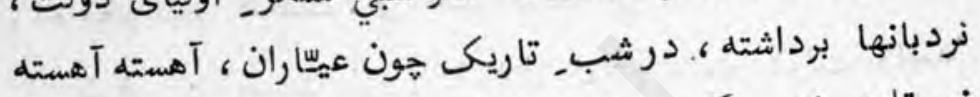

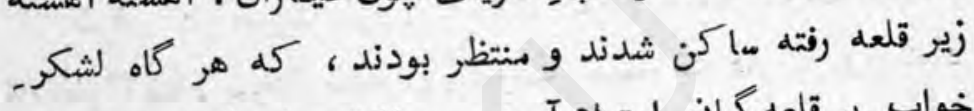

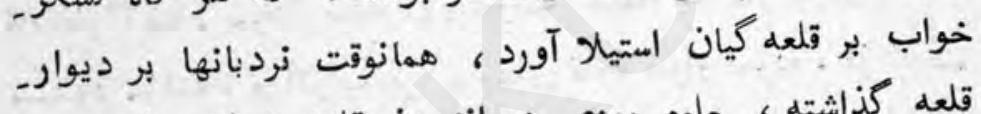

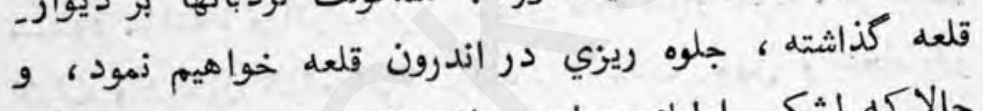

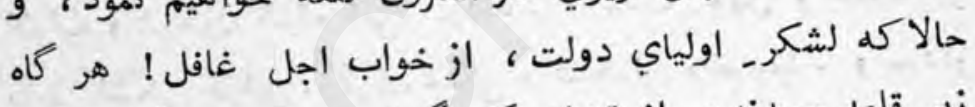

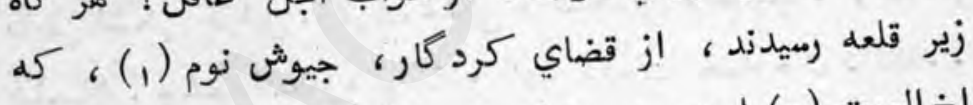

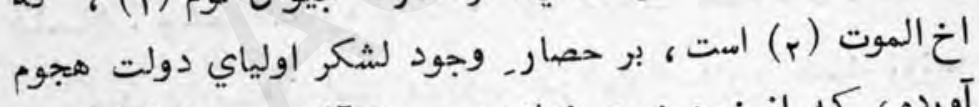

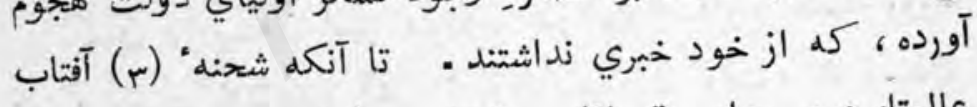

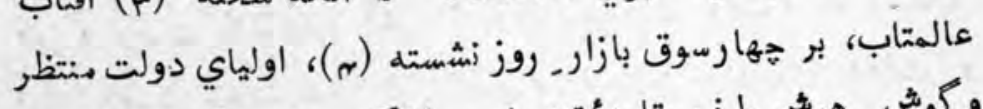

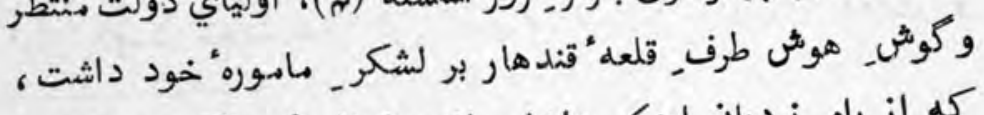

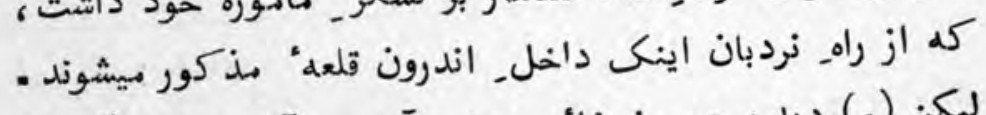

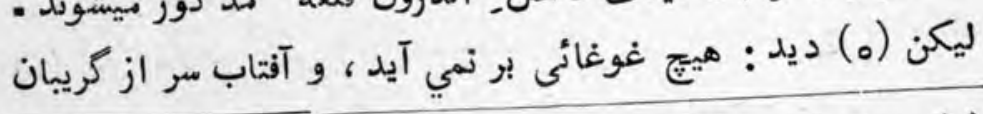

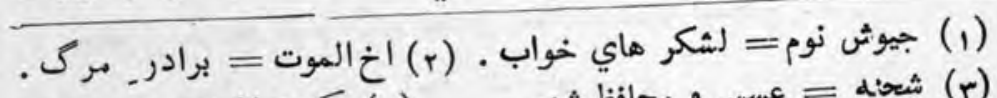

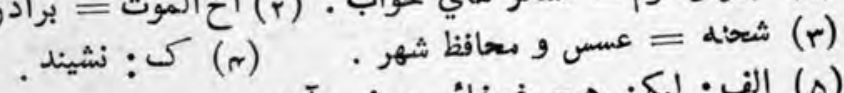

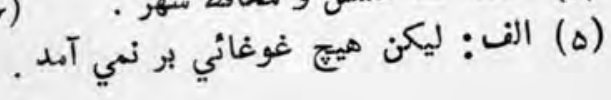


rrs

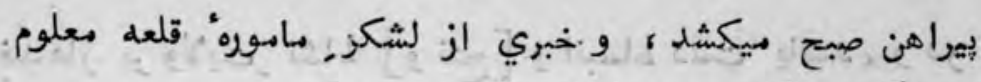

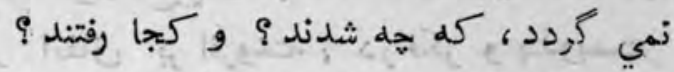

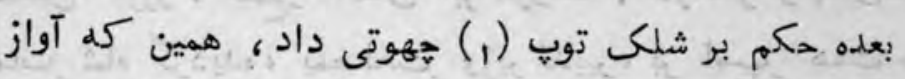

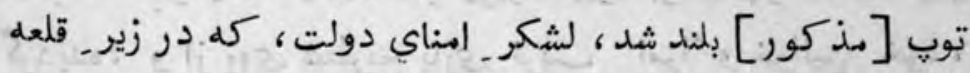

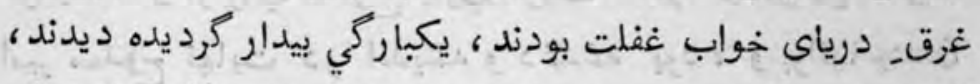

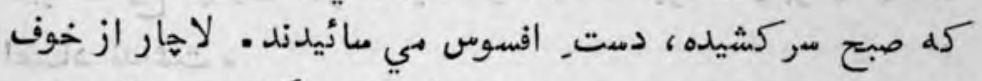

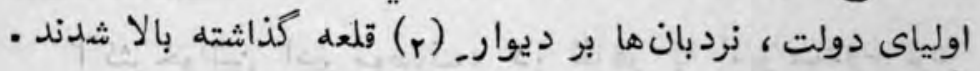

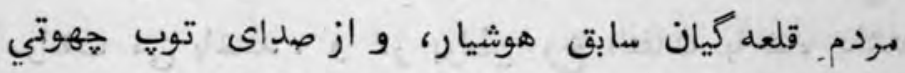

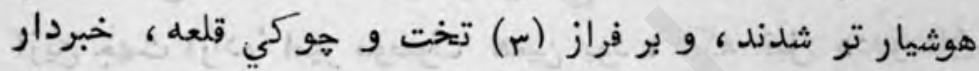

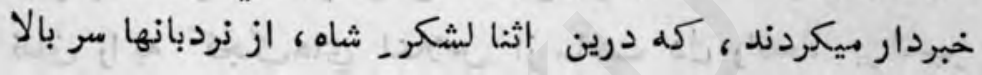

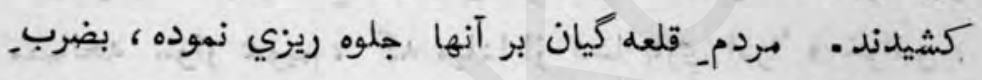

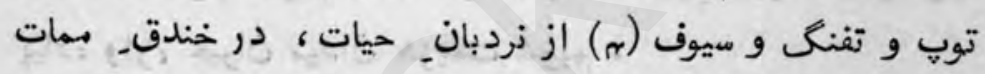

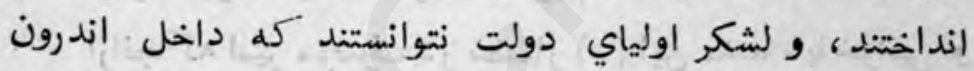

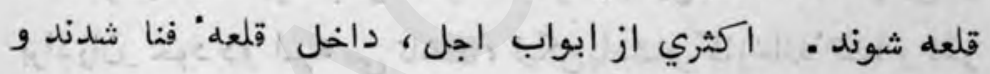

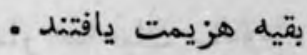

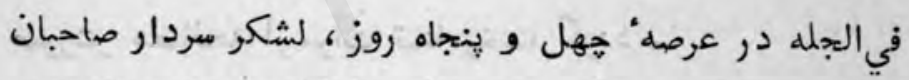

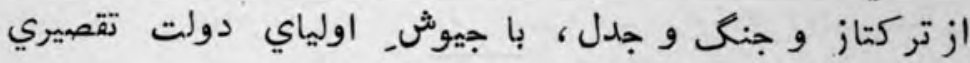

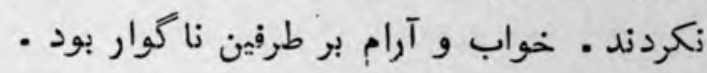

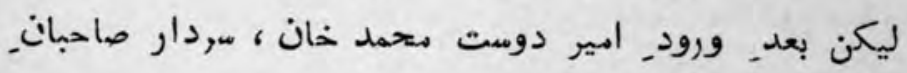

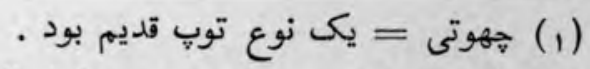

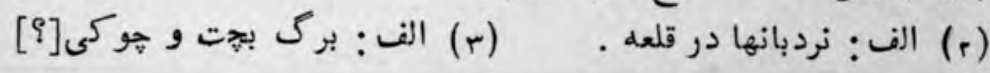

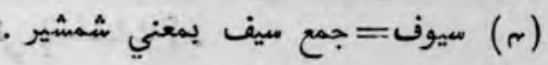




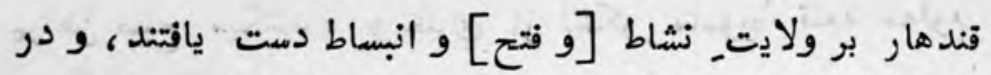

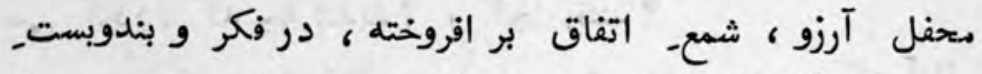

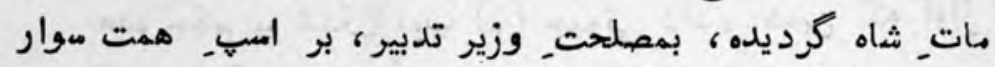

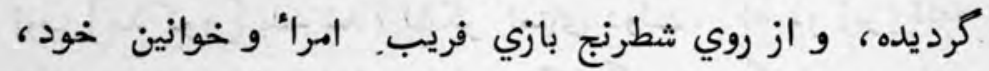

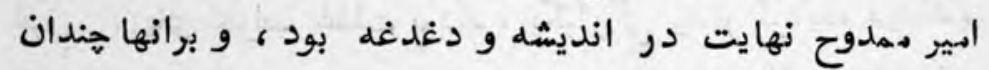
اعتماد نداشت .

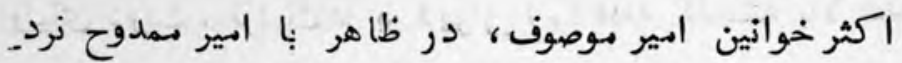

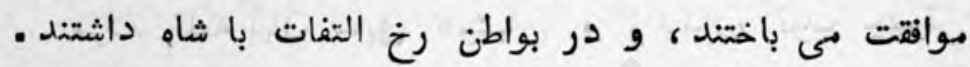

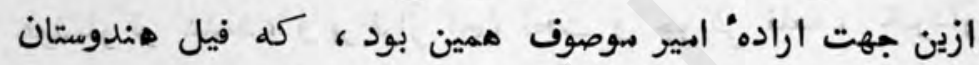
نفاق را به كجك هاي اخلاص از ساحت دل رانده، بر السي.

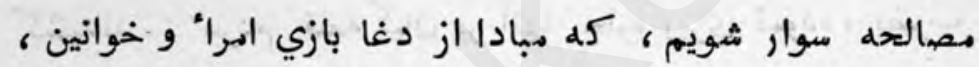

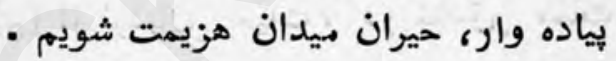

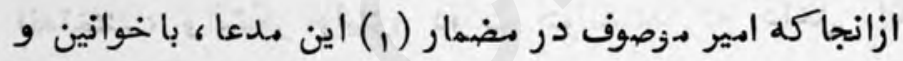

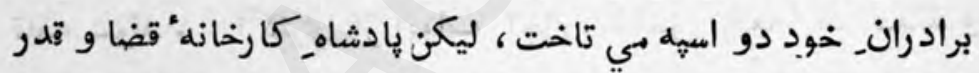

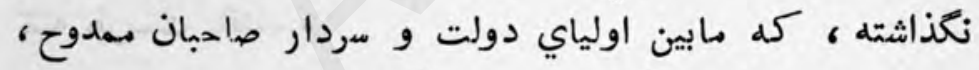

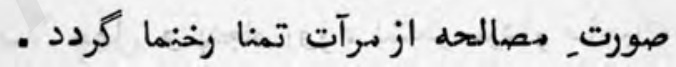

(1) مضهار = ميدان اسب دواني [- غياث] ] 
در بيان مقابله نمودن سردار صاحبان قندهار و امير دوست منحمد خان

باولياي دولت، و هزيمت شاه، و رفتن جانب قلعهُ سالو خان

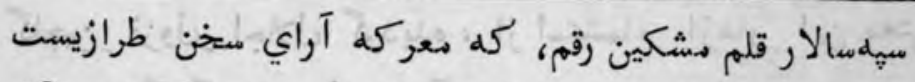

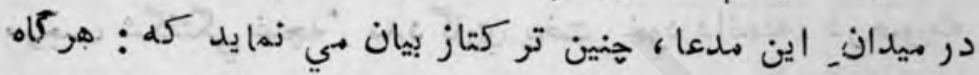

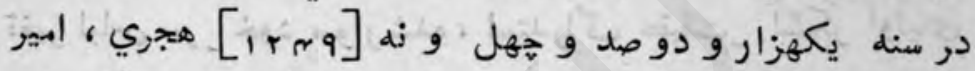

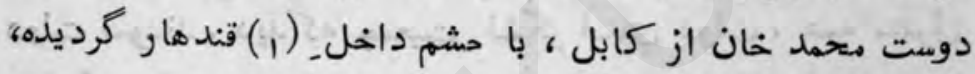

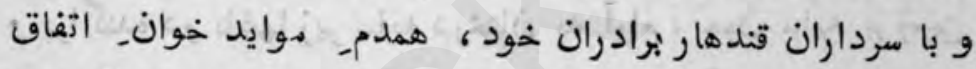

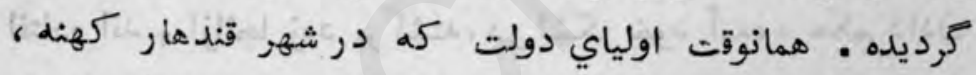

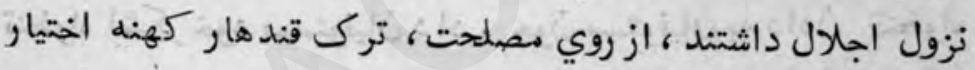

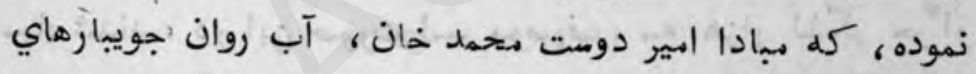

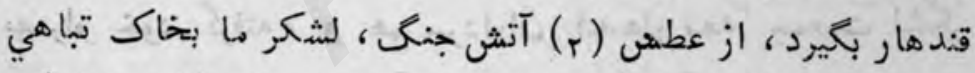

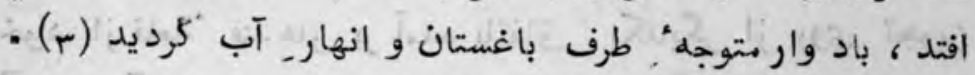

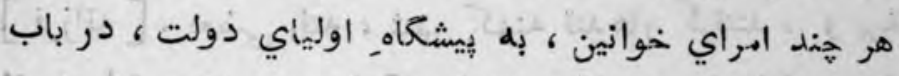

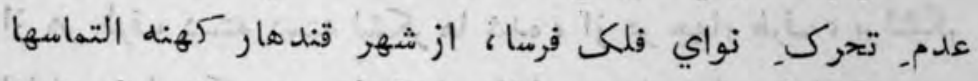

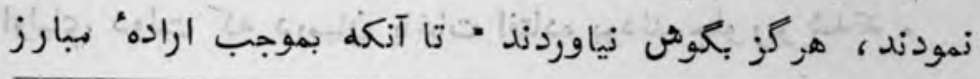

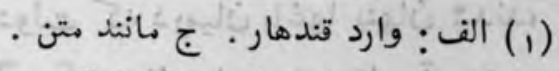

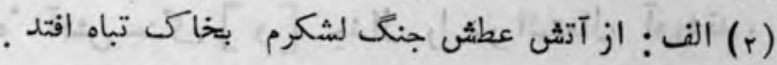

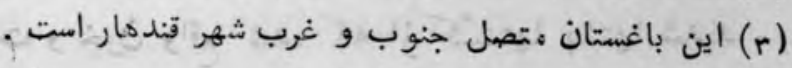


قضا و قدر، اولياي دولت ازشهر قندهار، معه خدم و حشثم

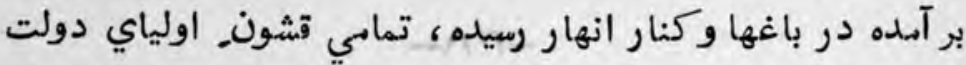

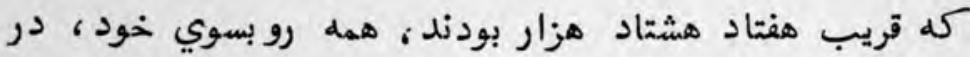

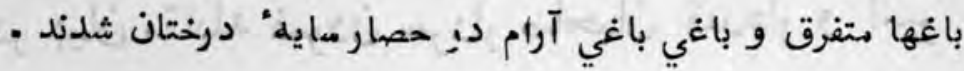
امير دوست متحمد خان خون د يد كله : اولياي دولت ، شهر

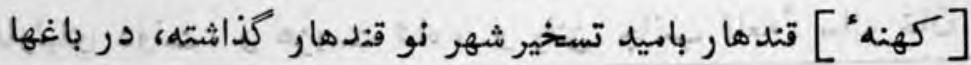

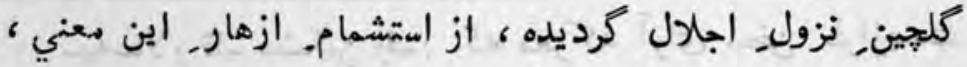

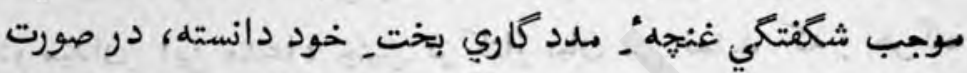

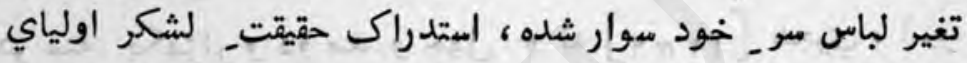

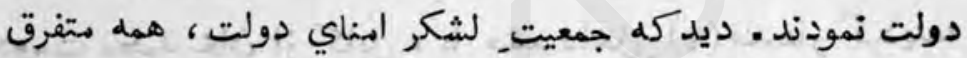

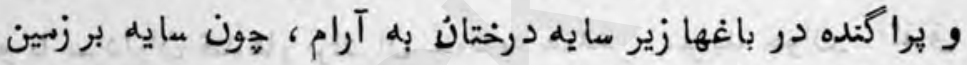

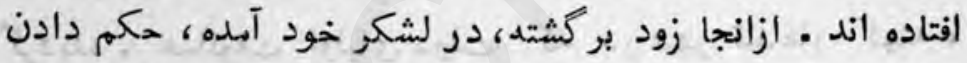
تنخواه اشكرخود بمستوفيان د اد ـ هون مستوفيان به د ادني تنتخواه

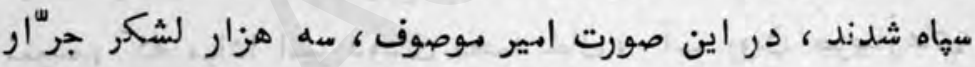

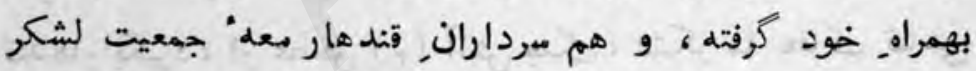

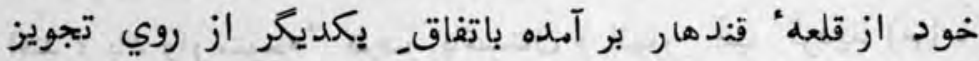

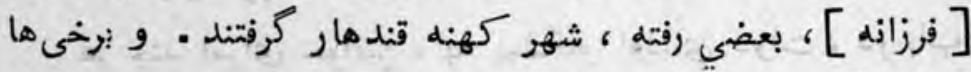

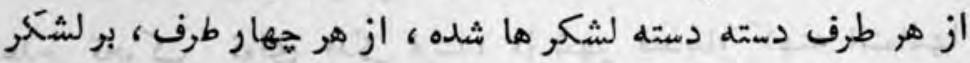

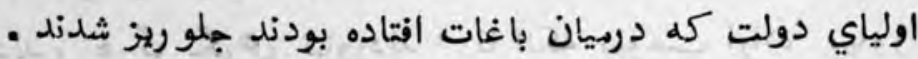
اكثري از لشكر اولياي دولت كل دربيان باغها ينهان شدند،

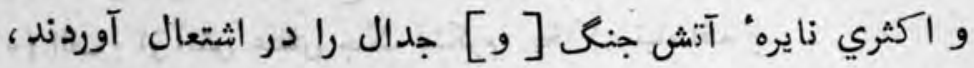

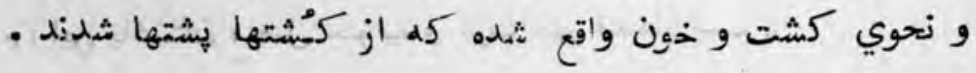


نزديك بود : كله جمعيت لشكر مردارصانجان دروهم و بر هم كردده.

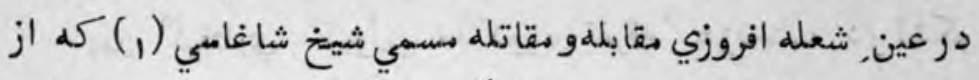

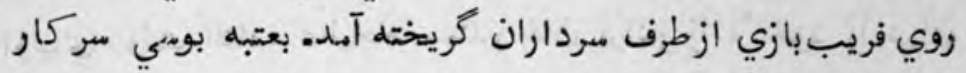

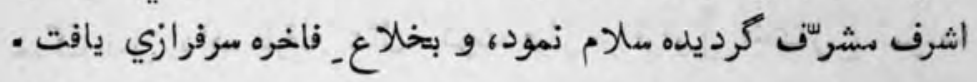

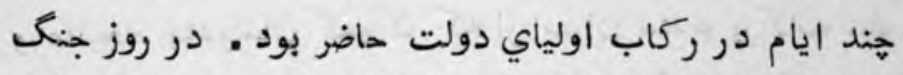
شاغاسي مذكورحيله بر انكيخته،درولشكر اوليايدولت، همين آواز

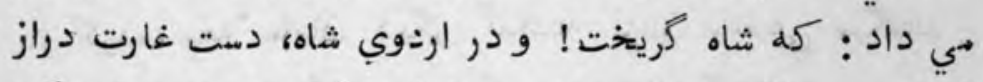

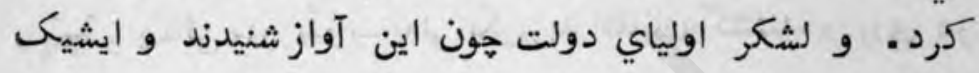

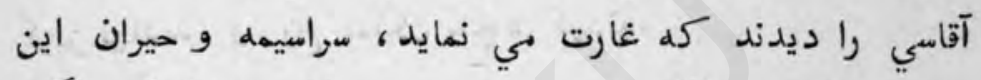

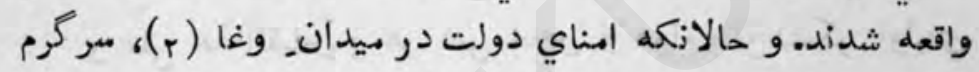

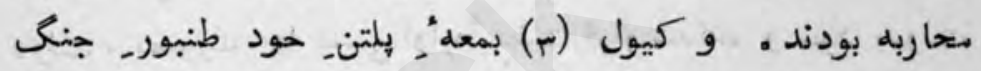

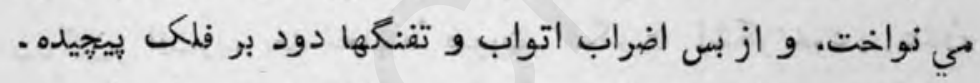

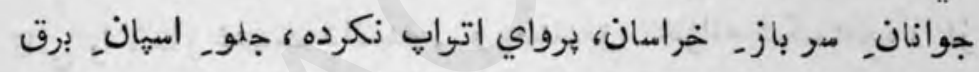

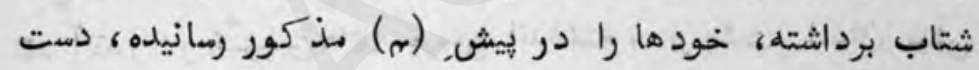

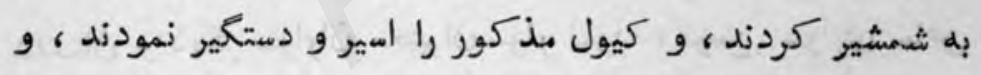

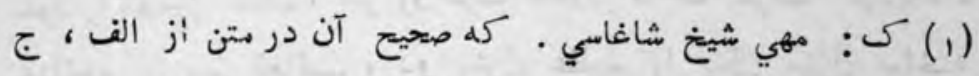

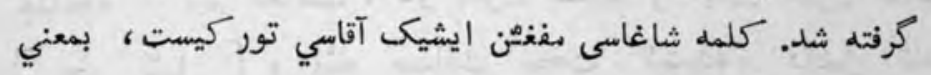

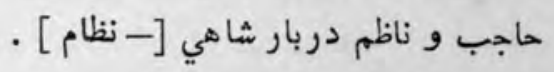

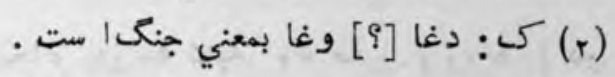

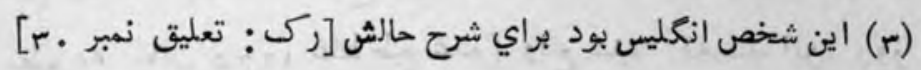

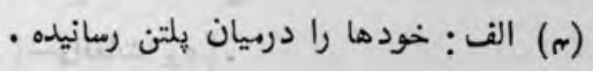




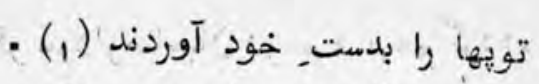

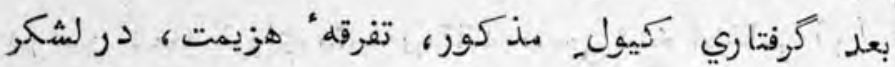

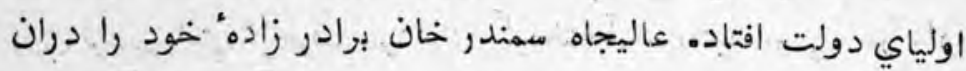

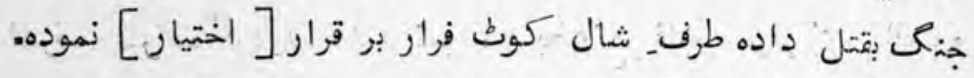

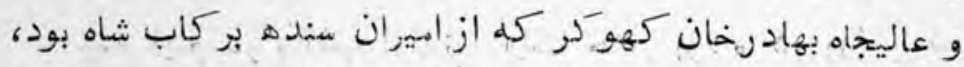

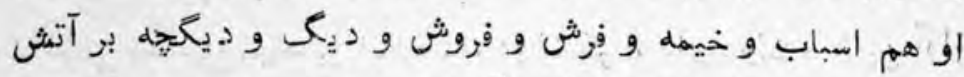

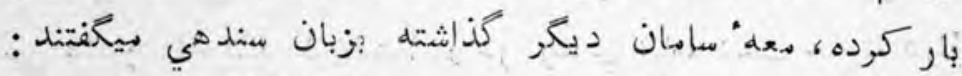

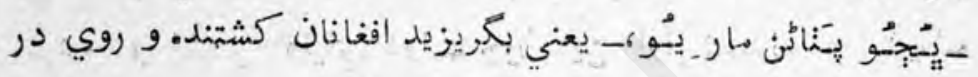

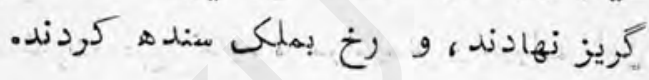

و علي هذالقياس : هر كس خاص و عوام، از لشكر اولياي

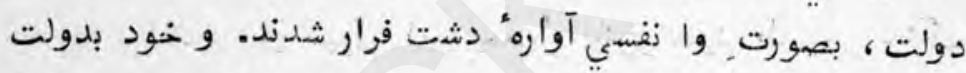

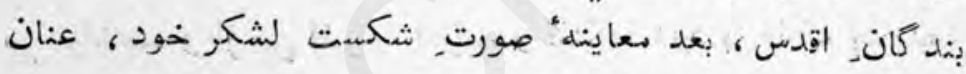

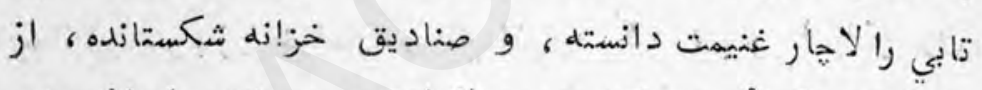

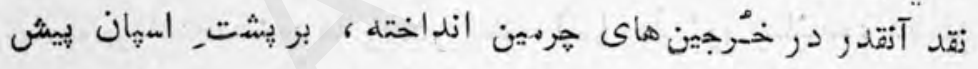

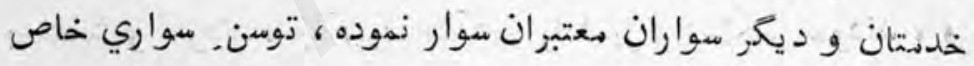

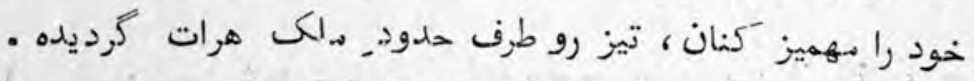

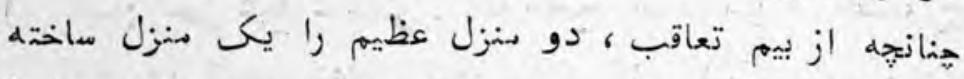

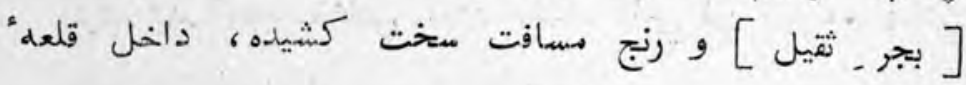

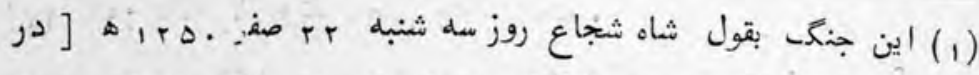

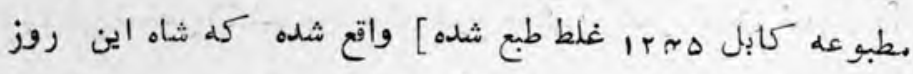

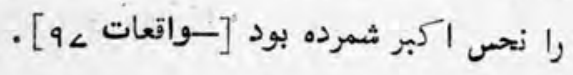




\section{• (1اليجاه سالوخ خان كرديد (1)}

باري اطمينان نفسر سوختهاش شده . ليكن عاليجاه سالوخان

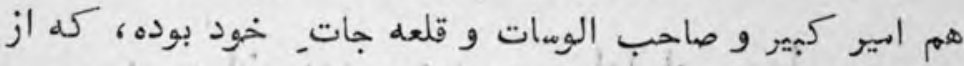

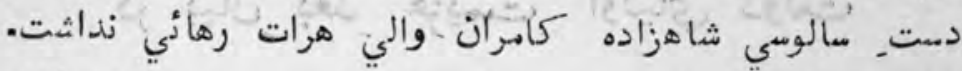

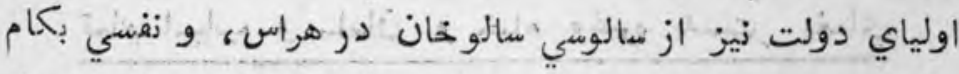
دل نميزد . هر حند ناهبرده بدل جوئي اواياي دولت بسيار ليرداخته، ليكن اطمهينان_ خاطر اولياي دولت نهي شد . طوعاً و

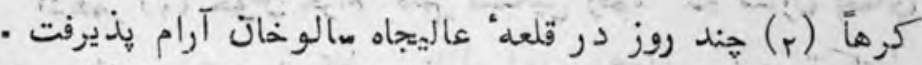

(1) شاه شجاع از قندهار بسوي غرب حركت كرده، بغد ازعبور درياي

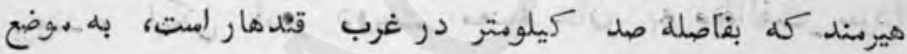

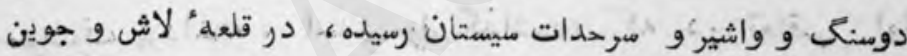

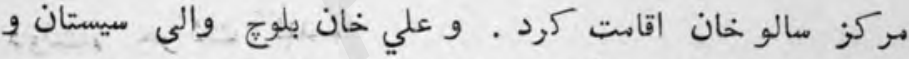
غلام رسول خان ولد بزرك سنالو خان ازو هنيرائي كردند و تان دو دو ماه

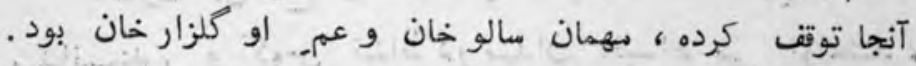
درين اثنا ناههاى شهزاده كاهران برادر زاده" وي كله حكمران هرات بود رسيده، و شاه را دعوت آددن هرات نمود , و نيز قايم" مقام حكمران مشهد، خسرو ميرزا بن نائبالسلطنه عباس سيرزان نانها

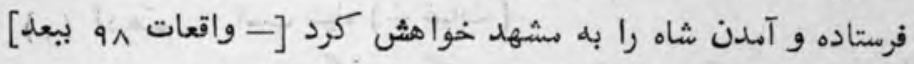

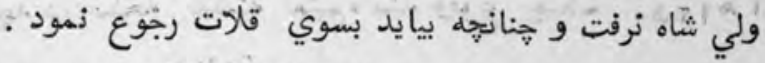

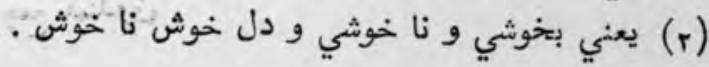


در بيان بعد هزيمت اولياى دولت

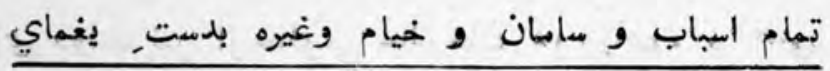

سردار صاحبان قندهار افتكاد

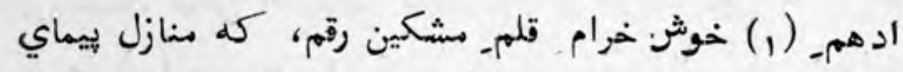

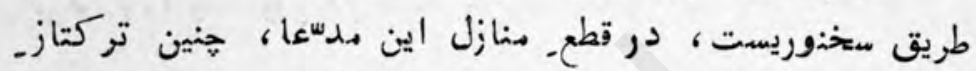

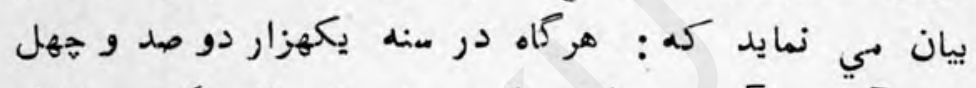

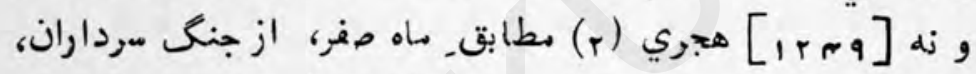

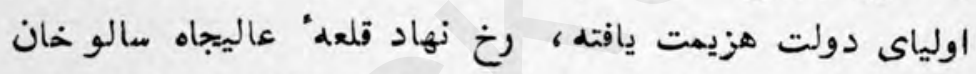

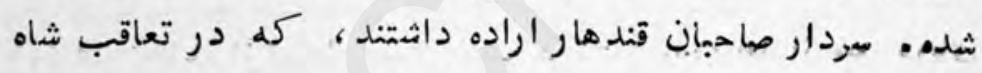

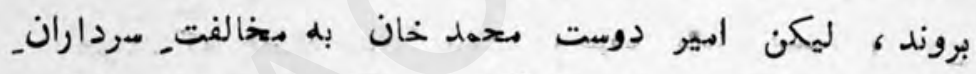

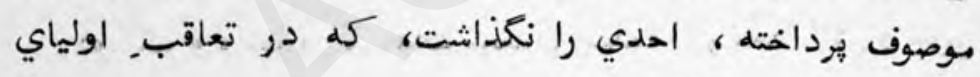

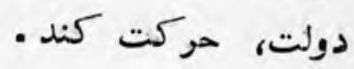

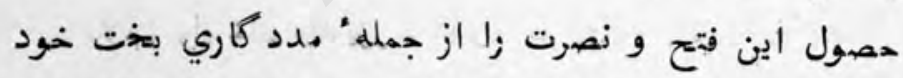

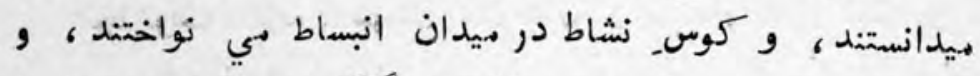

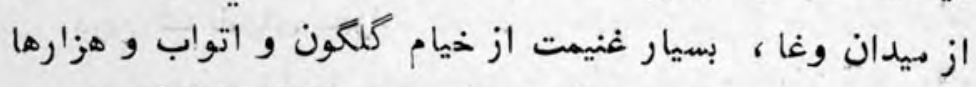

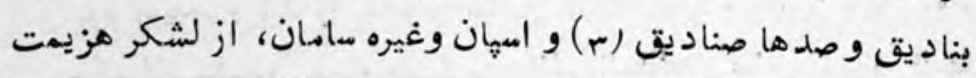

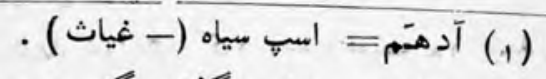

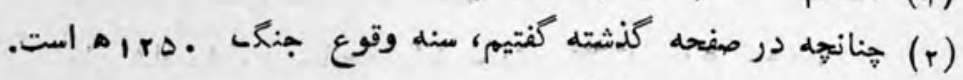

• صناد (r) 
اثر, اولياي دولت، بدست_ عساكر فيروزي مآثر سردارصاحبان

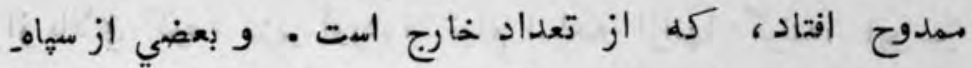
شاه جم جاه، كله طرف ريكستان فراري شده بودند، ، سواران

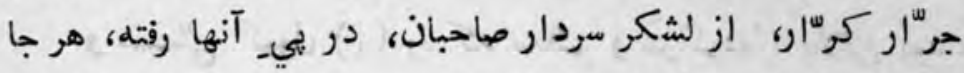

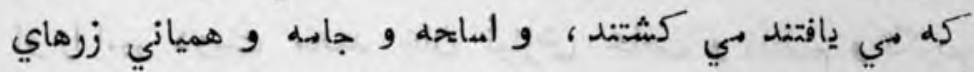

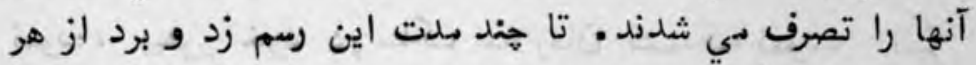

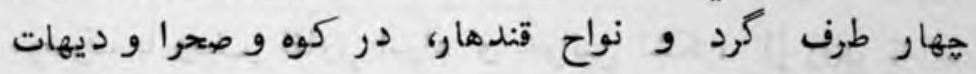
جاري بوذ -

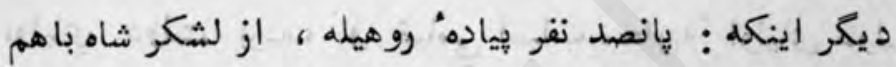

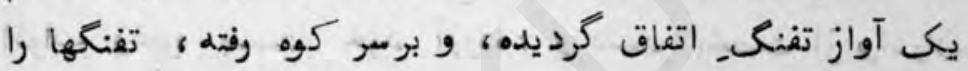

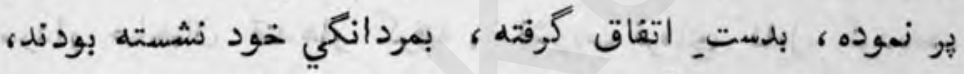

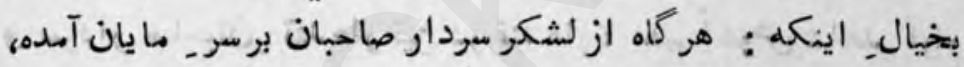

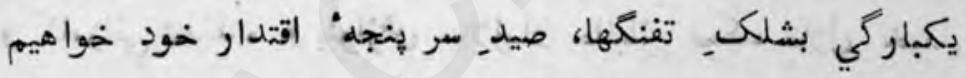

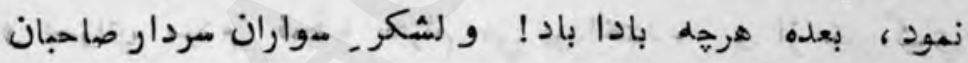

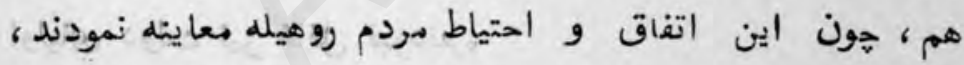

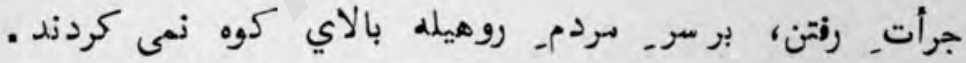

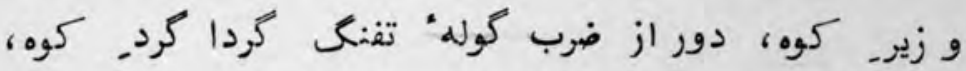

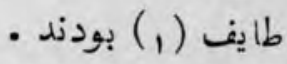

تا مدت_ دو سه روز مهين حالت مابين روهيله (r) و لشكر

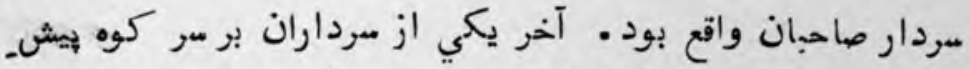

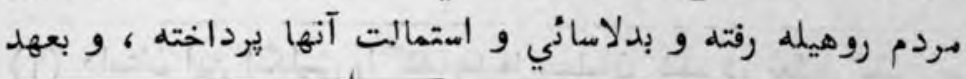

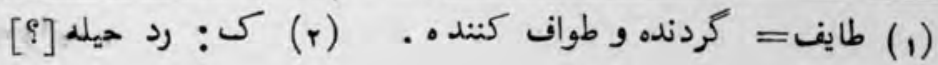


. تازه نواي معاركى.

rrs

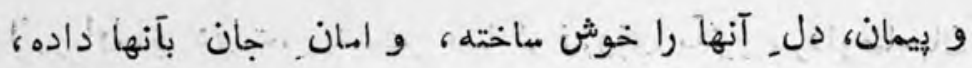

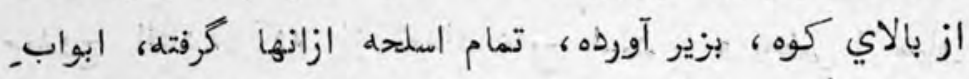

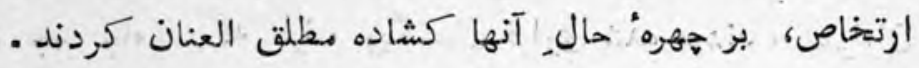

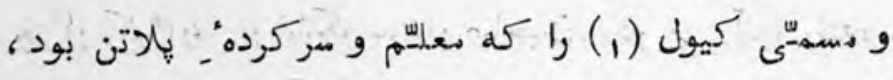

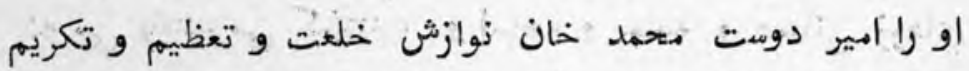

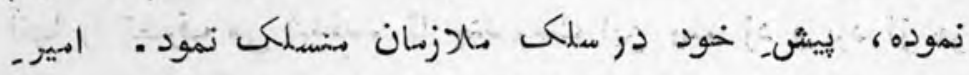

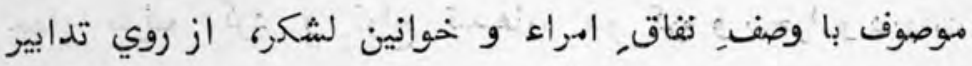

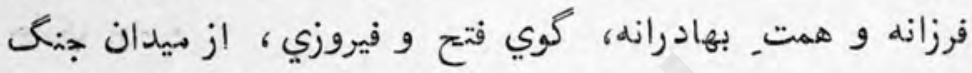

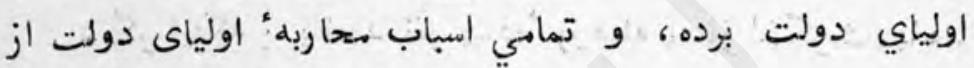

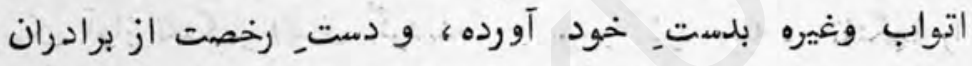

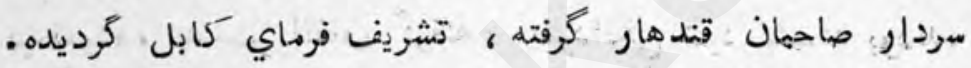

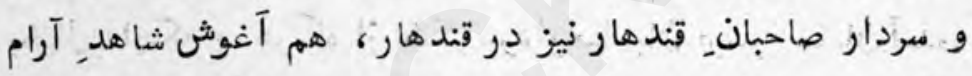

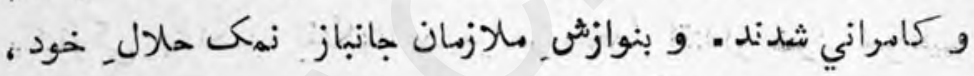

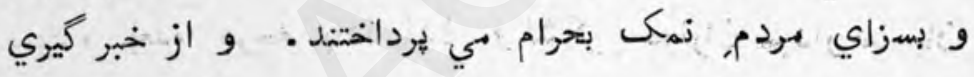

اولياي دولت نيز غافل نبودند.

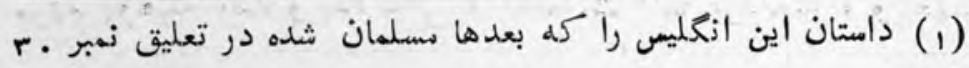
بخوانيد . 
$-\omega \cdot-$

در بيان, رفتن اولياي دولت در ( ) قلعهُ سالو خان و آمدن خلف شاهزاده كاسران بنا بر كمكى أولياي دولت، و و فرارى شدن از قلعه" مذ كور، و رخ نهادن جانبـ قلات، و آمدن مردار رحمدل خان در تعاقبش

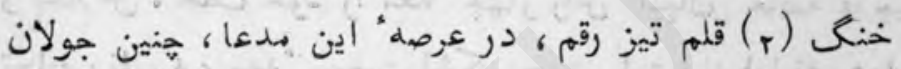

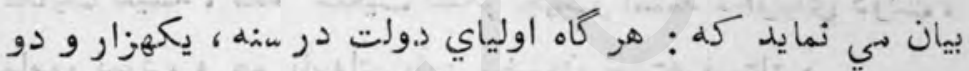

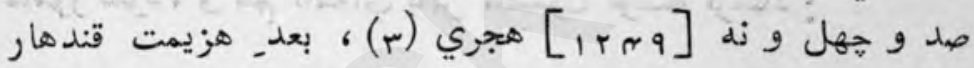

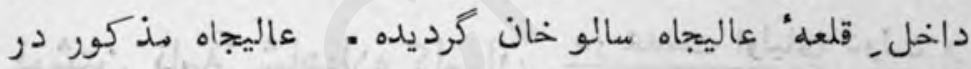

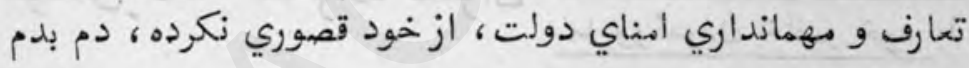

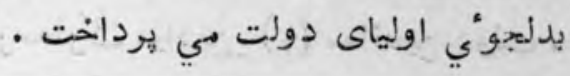

(1) الف : واقعه قلعه سالو خان .

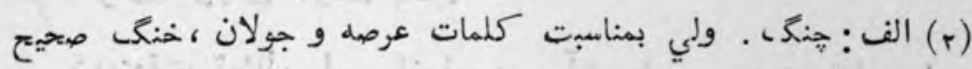

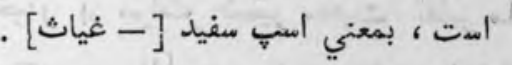

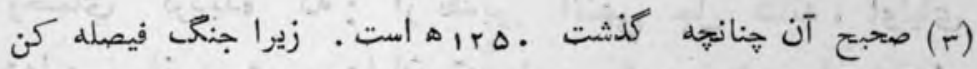

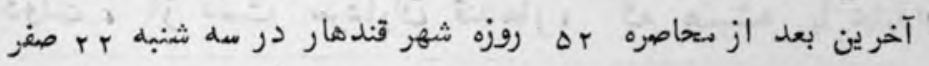

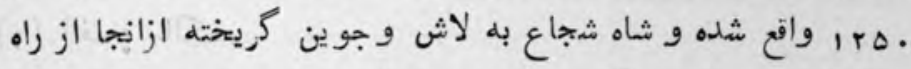

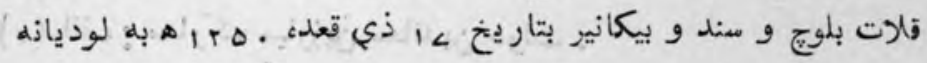

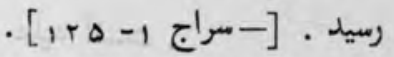


تازه نواي معارك

rrs

حونكه عاليجاه مذكور صاحبـ (1) ايلات والوسات بوده

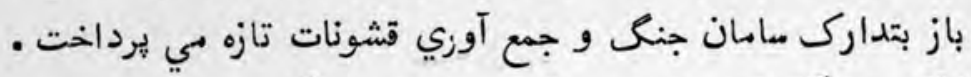

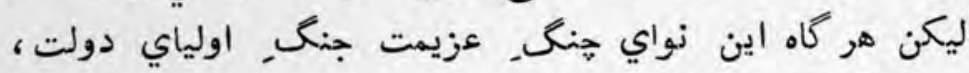

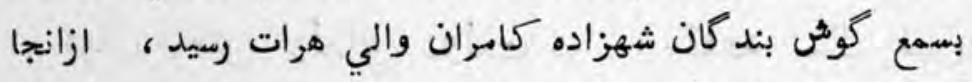

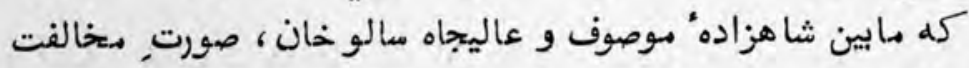

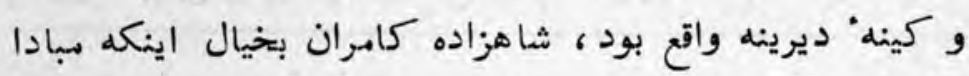

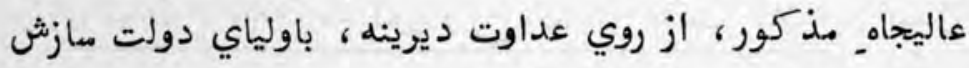

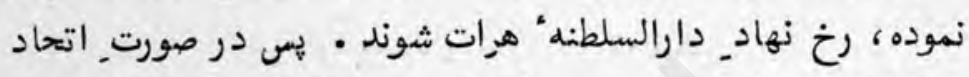

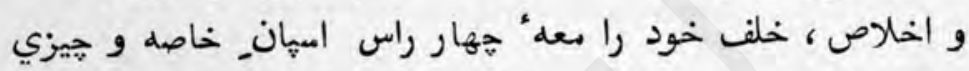

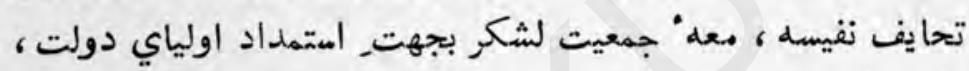

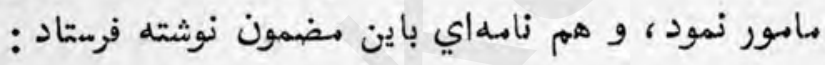

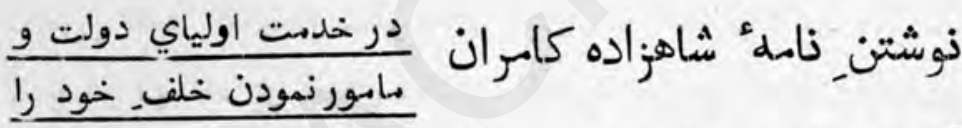

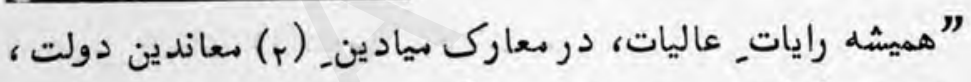

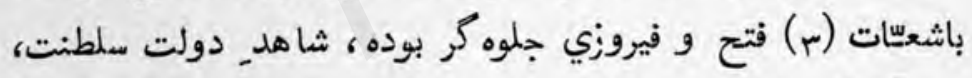

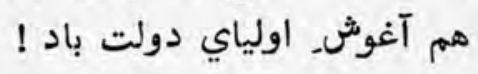

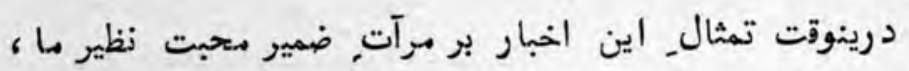

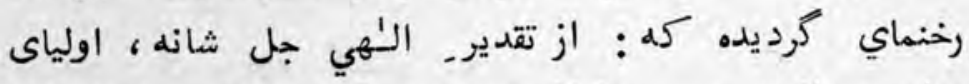

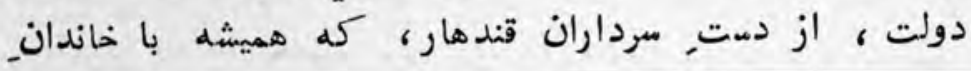

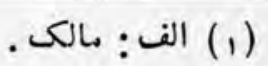

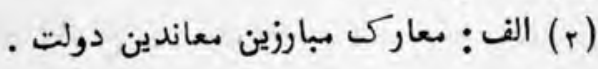

(r) الشعه = جمع شعاع و اشعات مزيد عليه آنست. 
rrq

تازه نواى معارك

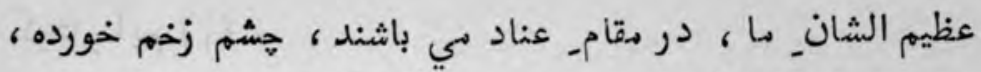

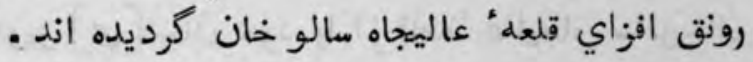
ازين معني افواج_ اندوه و تشويش ، بر حصار ـ وجودم بسيار

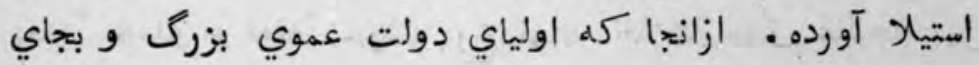
هيدر بزركوار، من مي باشند ، اكر باين طرف هرات تشريف فرماي شوند، عين- سعادت و سرفرازي ما ست، ، و بر طبق. مضمون : [بيت]

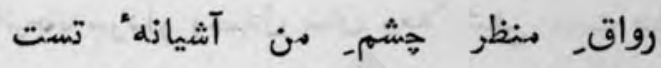

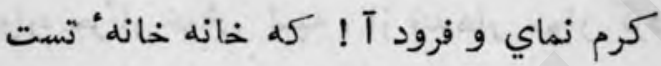

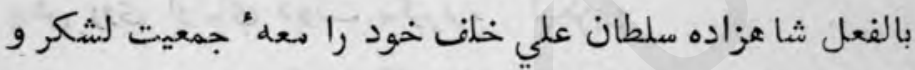

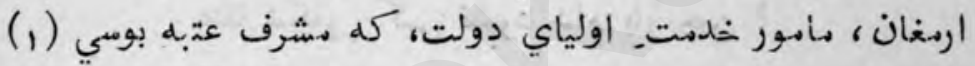

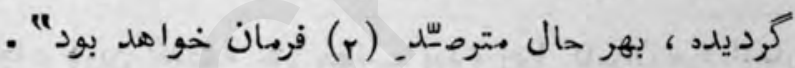

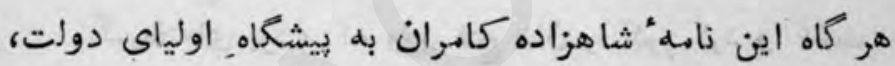

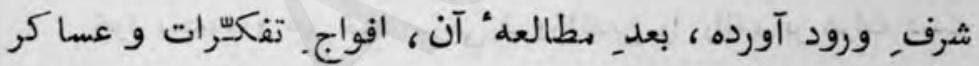

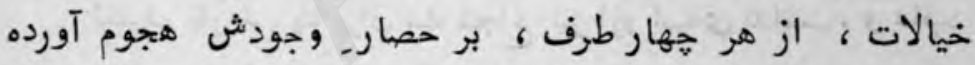

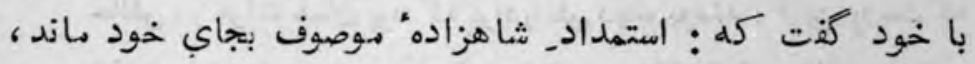

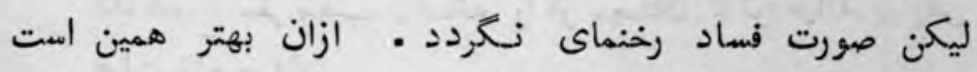
كه بيش از رسيدن, شاهزاده سلطان علي خلف - شاهزاده كاهران ، خود را ازين ملك بيرون كشمى، كله خار خار سالوسى سالو خان

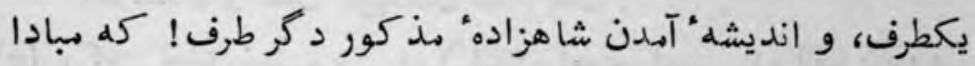

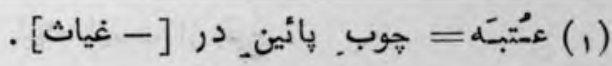

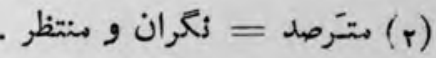


تازه نواي بعارك

re.

- كرفتار آيم (1)

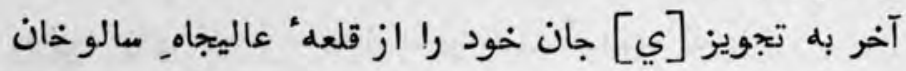

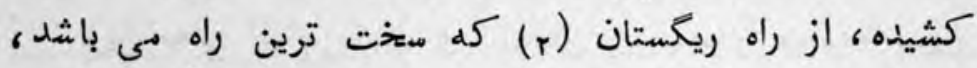

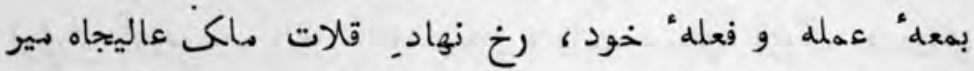

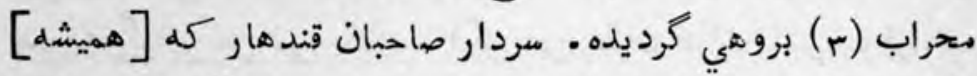

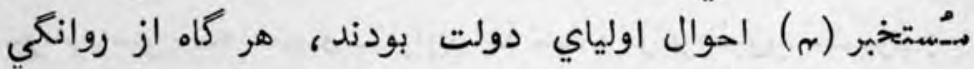

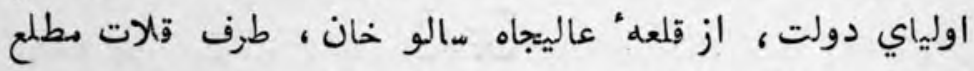

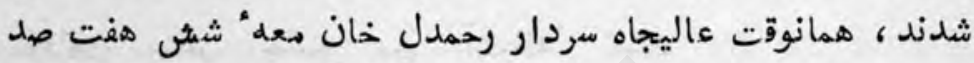

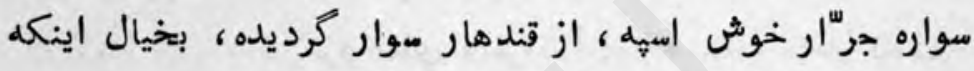

بيش روي اولياي دولت بكيرد. . ليكن :

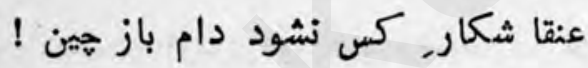

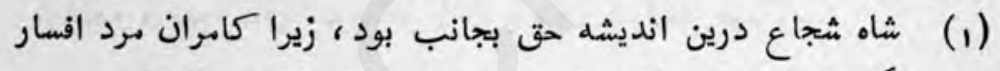

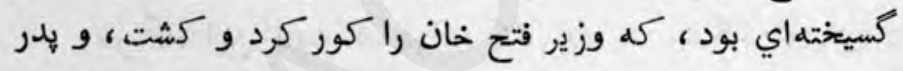

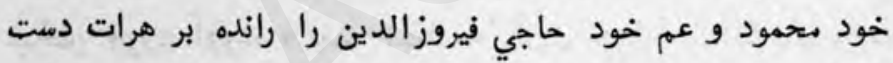

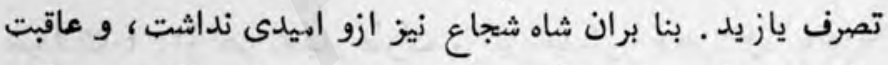

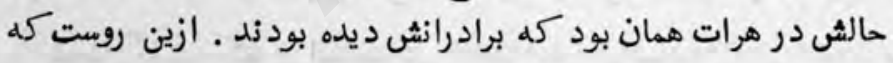

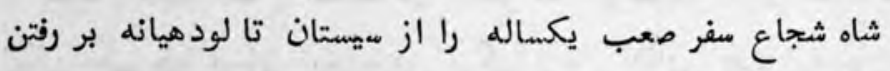

هرات ترجيح داد . مان.

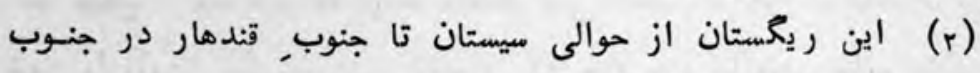

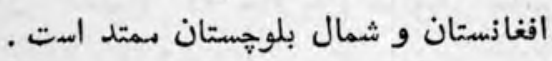

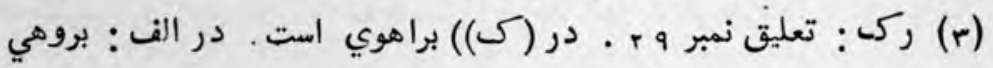

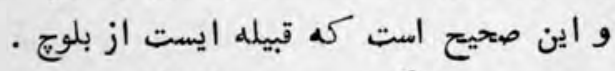

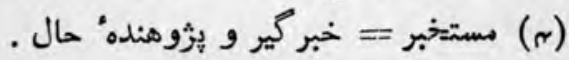


تازه نواي معارك

مردار ممدوح در عرض راه، باولياي دولت مالاقي نكرديده - مأها

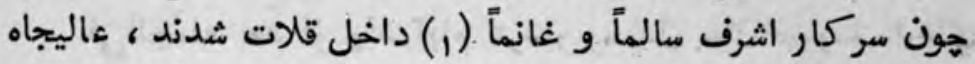

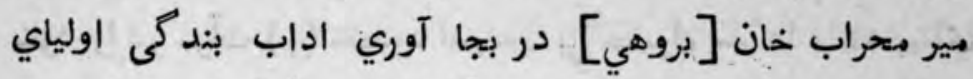

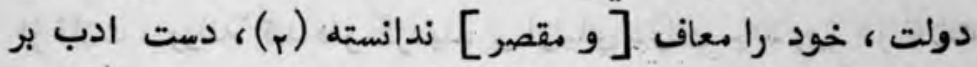

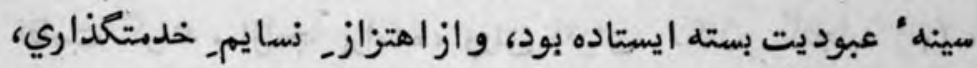
هر دم شكفتكي بتخث غ:خهل خاطر اولياي [دولت] بوده، تا اينكه روز سوم سردار رحمدل خان واردـ قلات شده، ، و بهمراهـ عاليجاه مير ممدوح ، در خصوصـ طلب بازوي شاه، معركم مد آراي

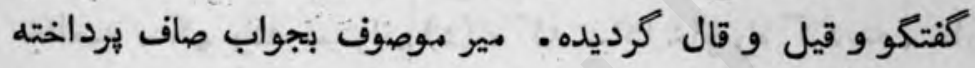

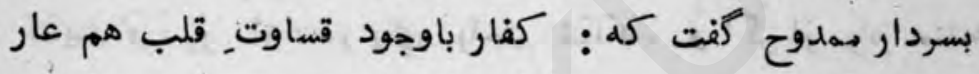

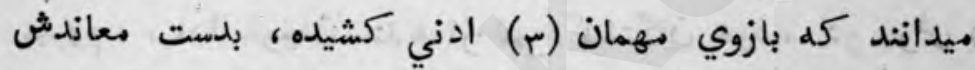

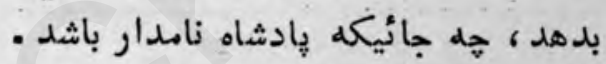

با وصف اين همل خاندان [Lا] كله هادشاه. كوهستان

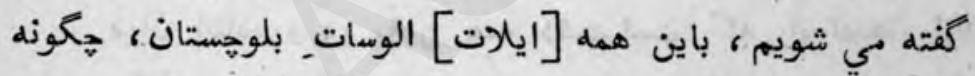

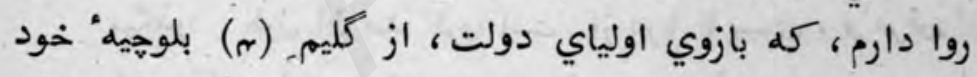

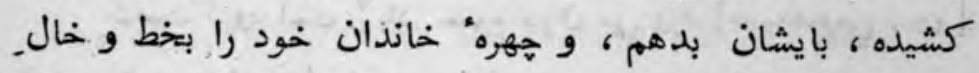

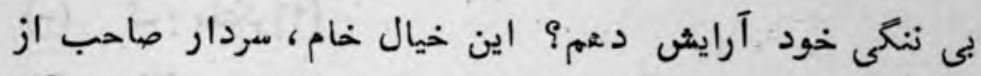

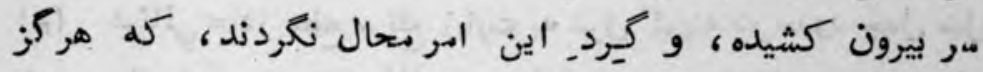

· (1) يعني بسلامتى و غنيهت يابي (r)

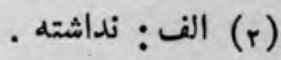

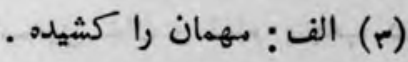
(r) الف: از حكم بلوحهه. 
تازه نواي معارك

rer

تمثال اين آرزو در آئينه مراد خود نتخواهد ديد في الجمله بعد از هند ايام سردار رحمدل خان صورت بروت مدورداي

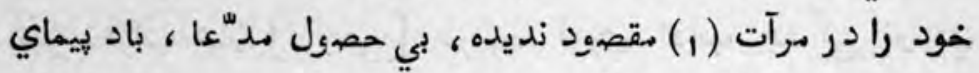

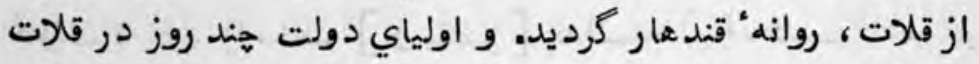

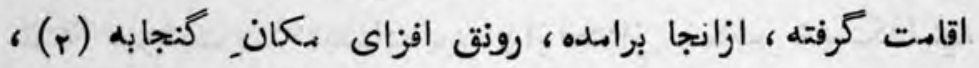

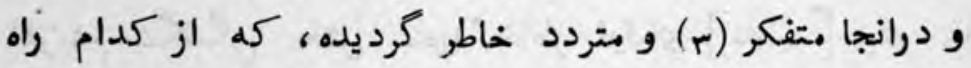

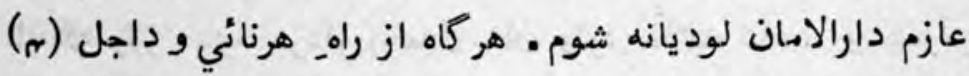
اتفاق رفتن اولياي دولت واقع شود ، يس از خار خار سون مزاج

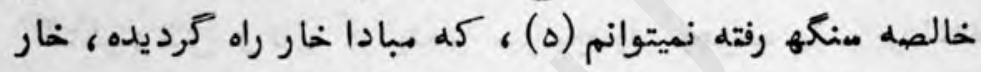

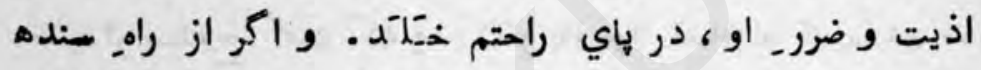

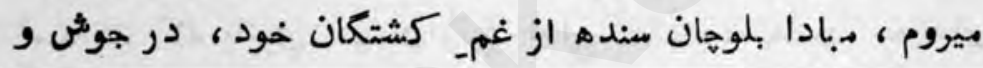
. كئين (1)

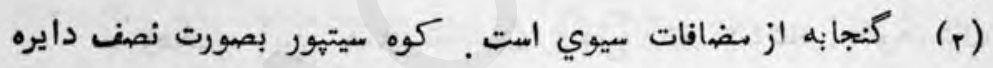

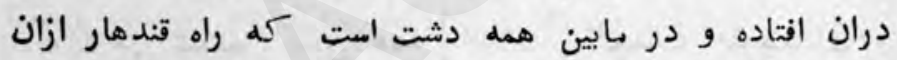

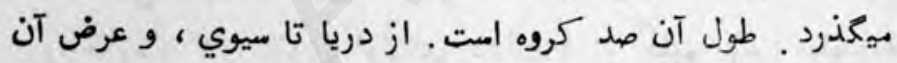

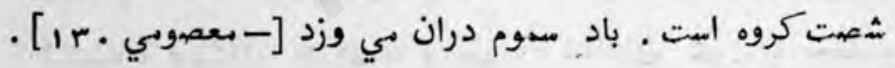

كى : مفتكر

هرنائي =در سطع مرتفع زيارت به شرق كويته در حدود ههل ميل

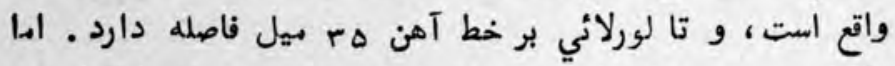

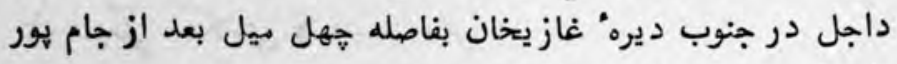

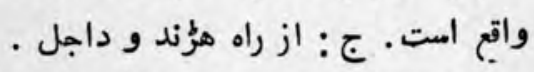

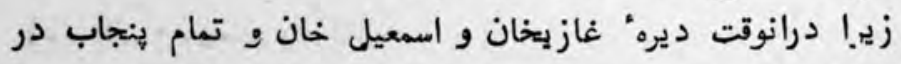
$(\Delta)$

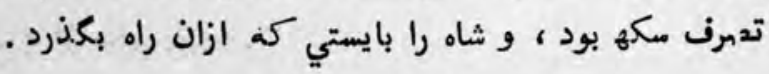




\section{خروش آمده ، ماتمداري تازه نمايند .}

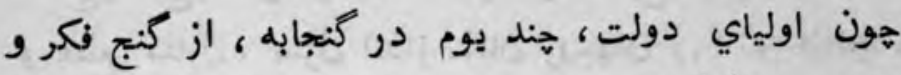

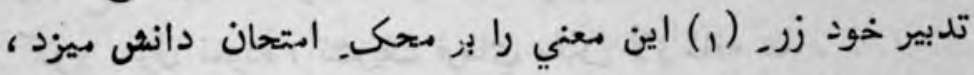

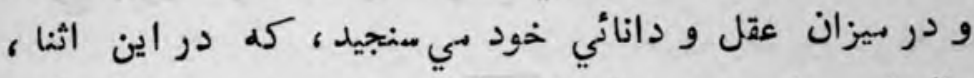

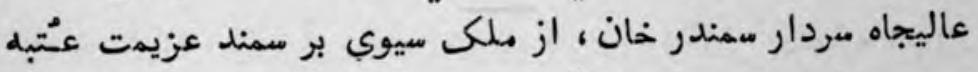
بومي سركار اشرف سوار كرديده أمده، دشرف استيالام اولياي

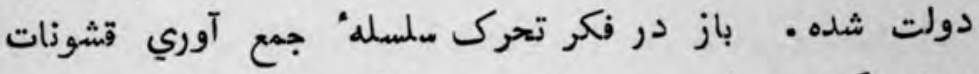

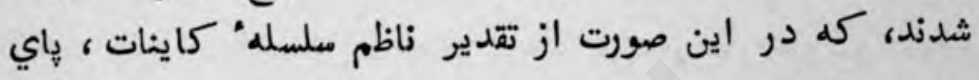

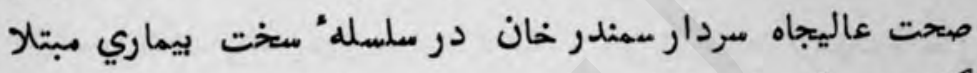

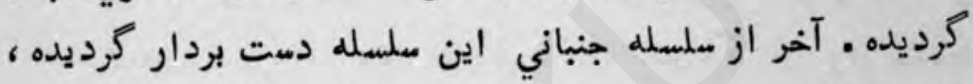

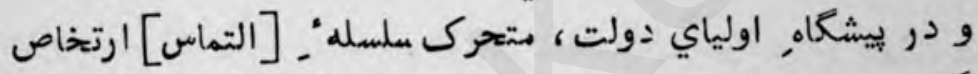

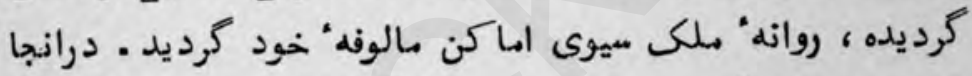

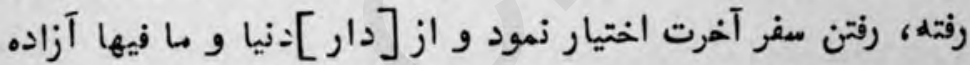

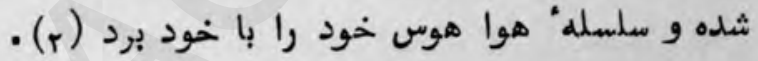

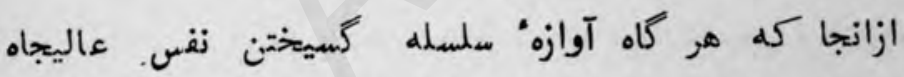

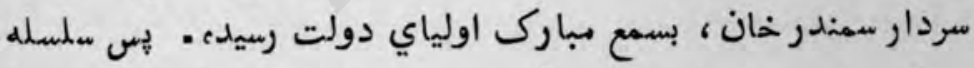

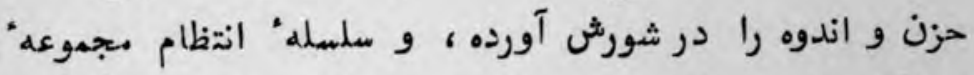

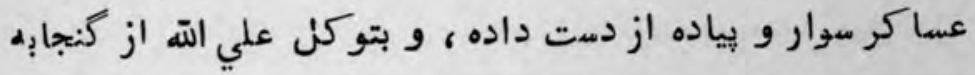

$$
\text { كى، الف: ازين مدعا [ب] }
$$

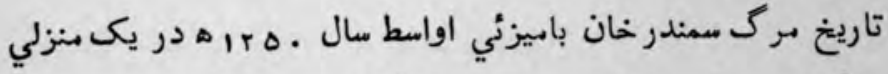

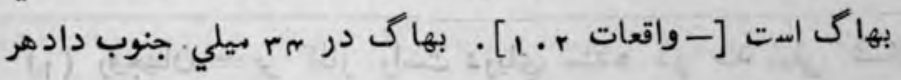

$$
\text { واقع و از سبى ه7 سيل فاصله دارد . }
$$




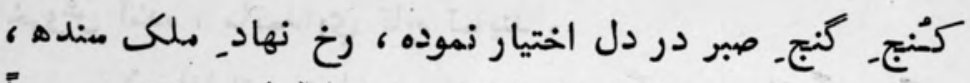

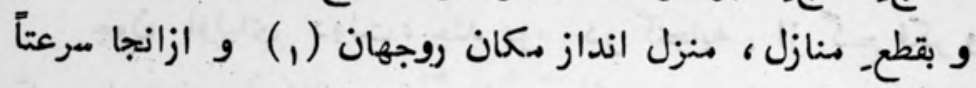

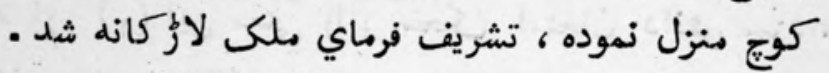

(1) روجهان = بر كنار راست درياي سنده در صد ميلي شمال شرق

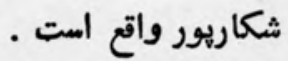




\section{$-\Delta I-$}

در بيان_ رونق افزائى اولياي دولت در مـكان روجهان و رفتن سيد دحمد تقي شاه برادر سيد محمد كاظم شاه از شكاريور

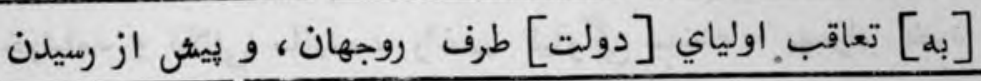

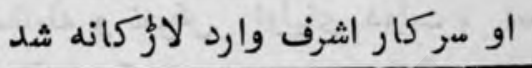

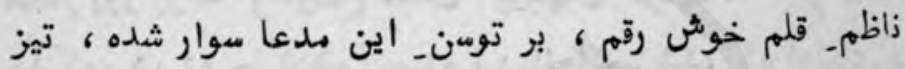

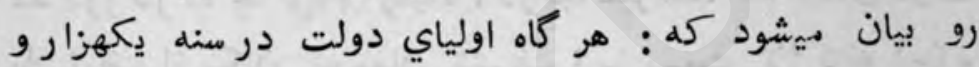

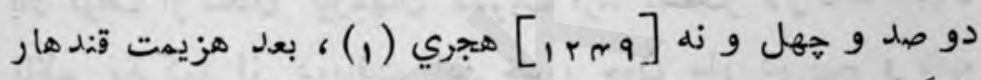

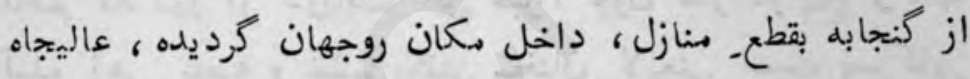

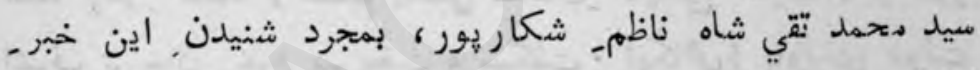

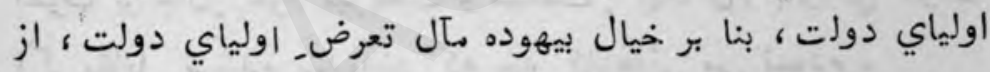

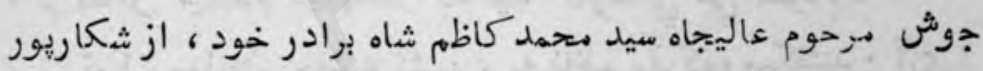

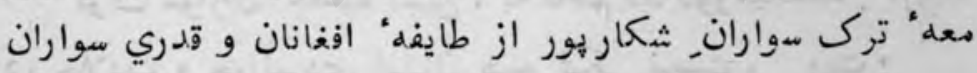

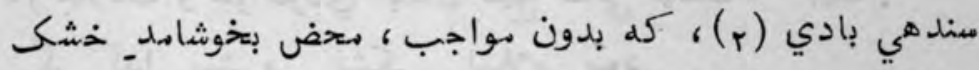

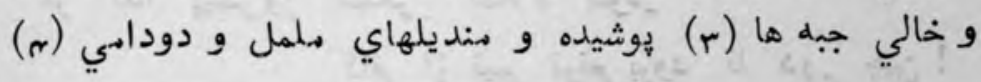

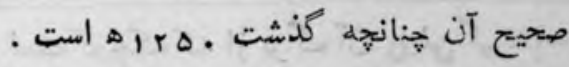

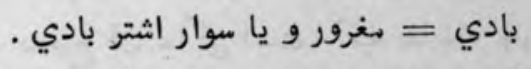

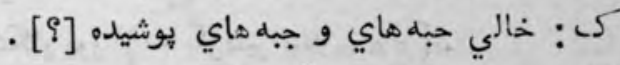

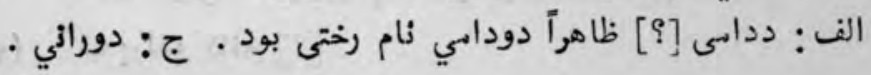




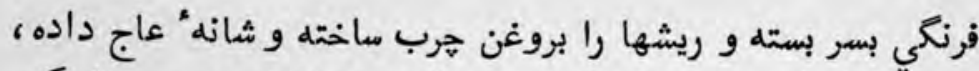

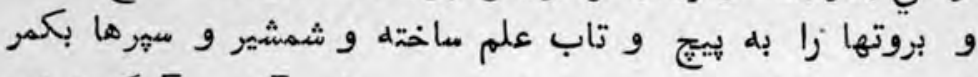

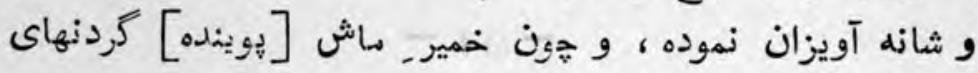

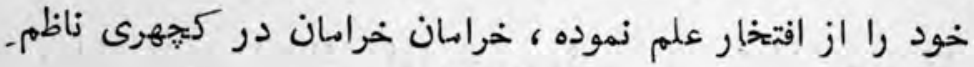

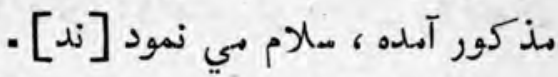

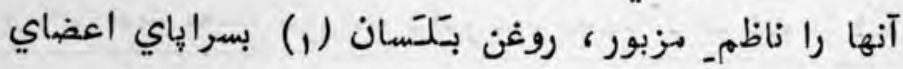

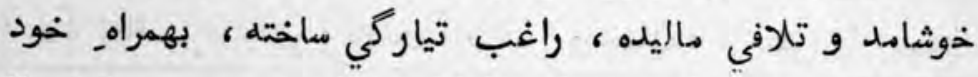

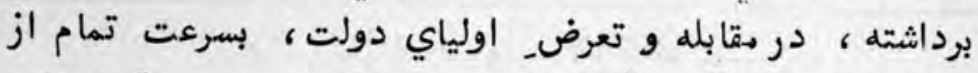

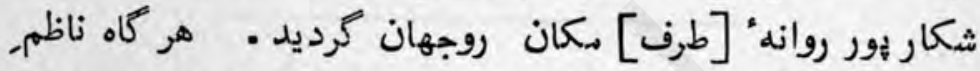

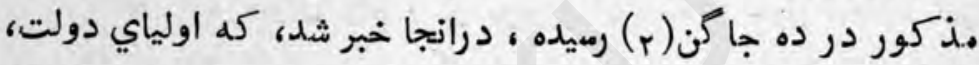

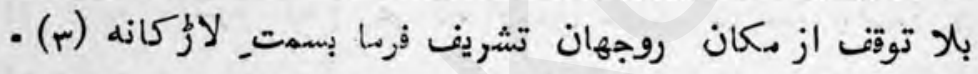

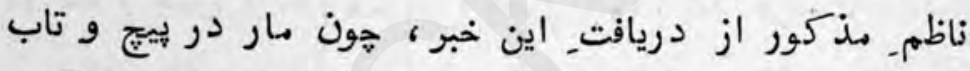

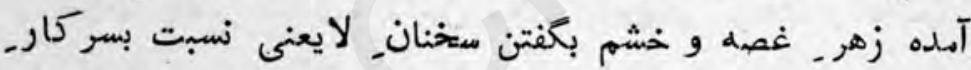

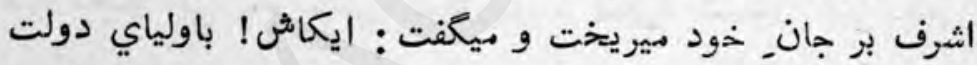

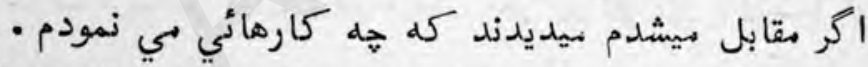

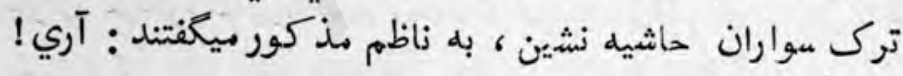

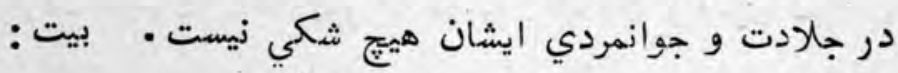

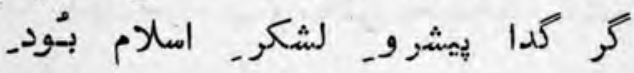

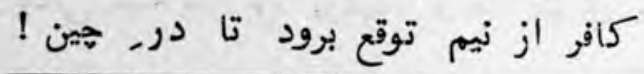

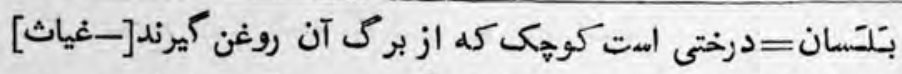

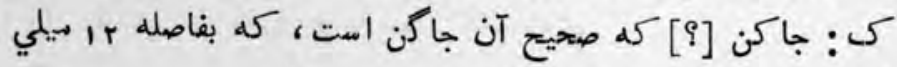

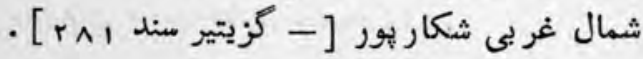

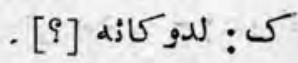


آخر ناظم مذكور از ده جاكن. باز اراده" رفتن. لازٔكانه

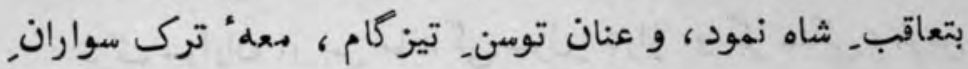

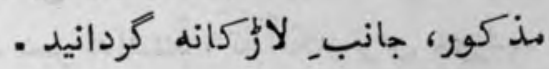

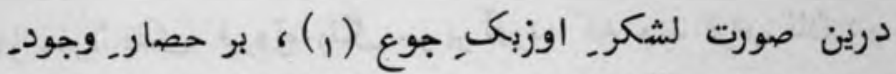

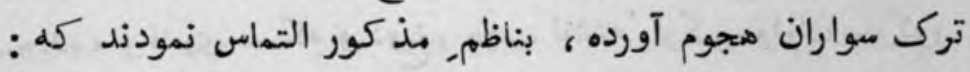

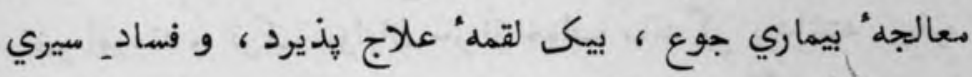

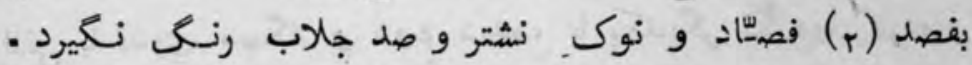

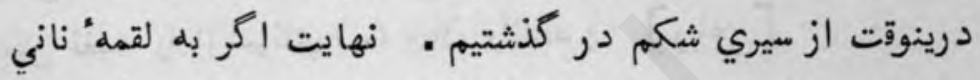

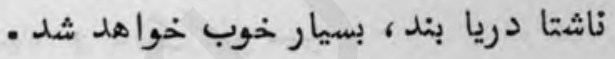

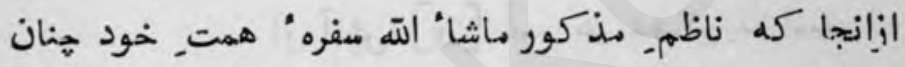

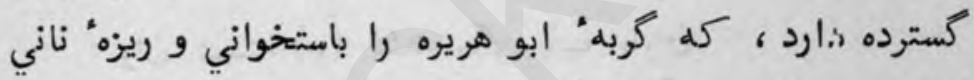

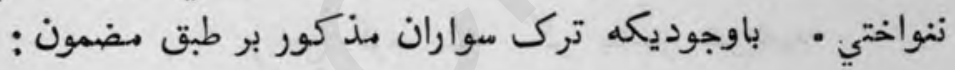

\section{بيت}

\section{عقده: امساكى, مaسك وا نشد مانند. قفل}

\section{تا كليد آسا ، كسي انكشت در كونش نكرد}

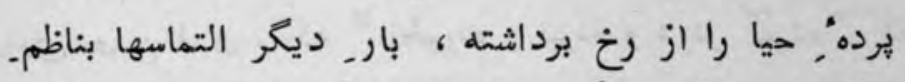

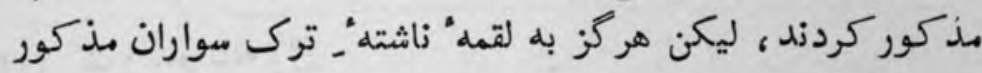

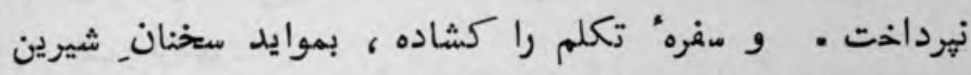
خوشاهد آميز هر يك ترك مواران مذكور برداخته، ازانجا شكم رانم

$$
\begin{aligned}
& \text {. كرسنمى } \\
& \text { (r) (r) يعني رك. ركزن. }
\end{aligned}
$$


تازه نواي معارك

ren

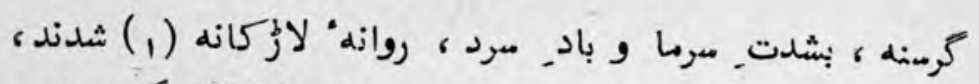

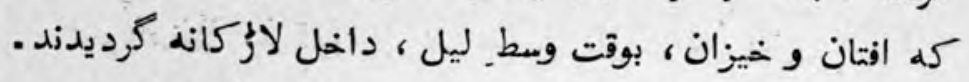

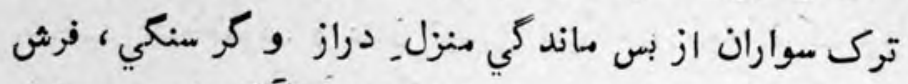

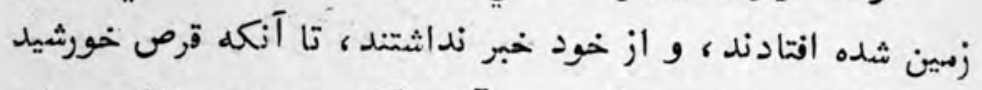

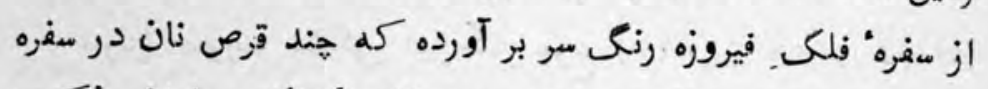

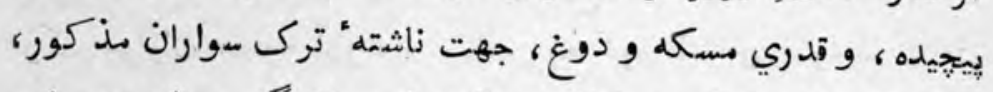

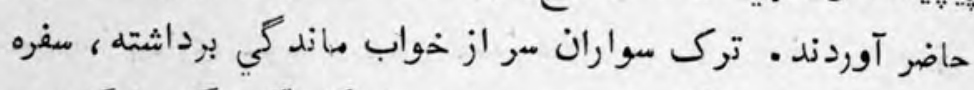

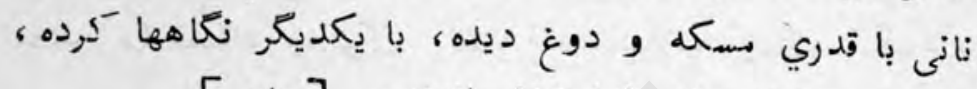

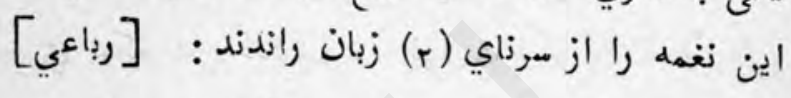

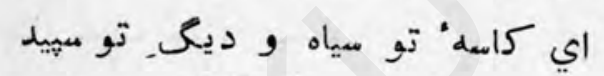

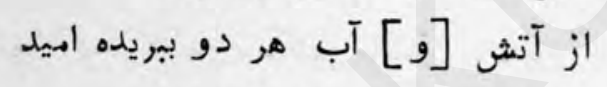

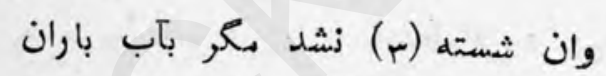
و اين كرم نشد بكر بكر بتاب, خورشيد

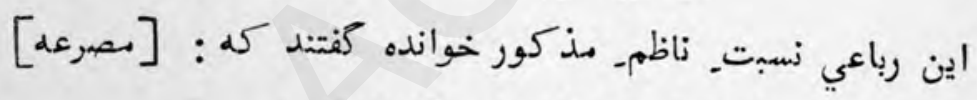
كوفته را نان تهي كوفته است

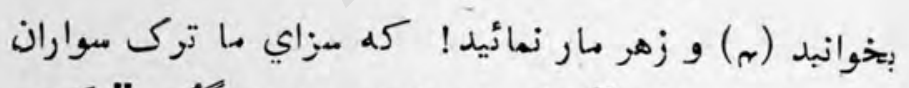

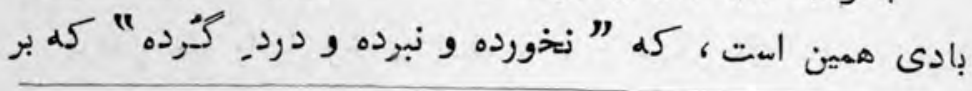

[? (1)

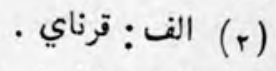

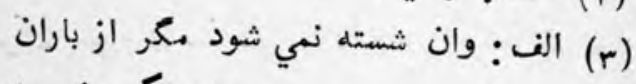

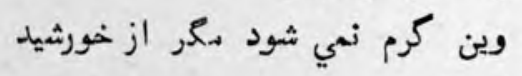

(م) الف: بخغرند وزهر مار نمايند . 
زاحق در مقابله اولياي دولت، با هنين ناظم صاحب كرم [!] تركتاز نمود در نقابله

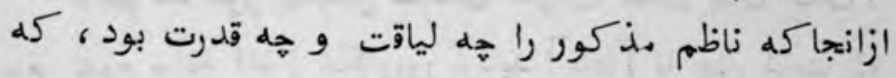

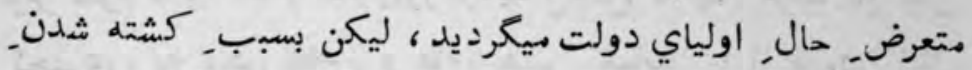

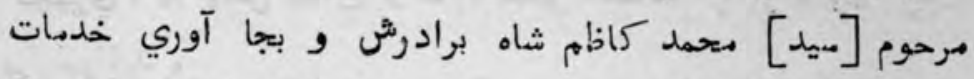

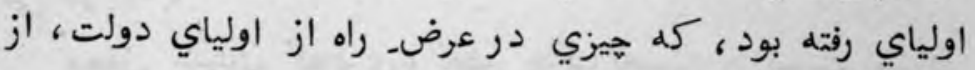

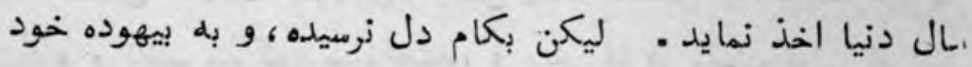

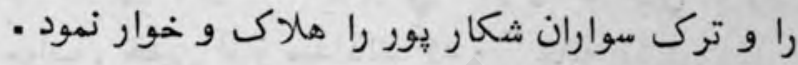

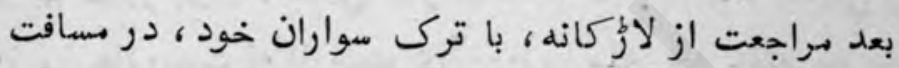

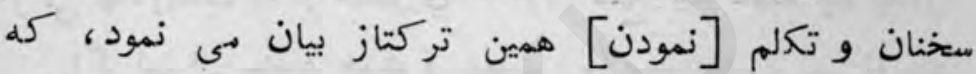

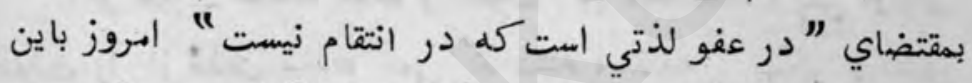

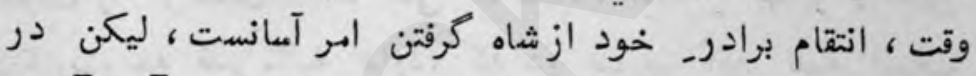

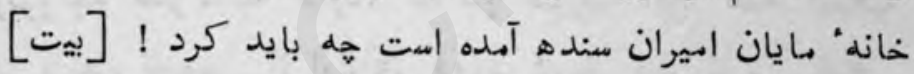

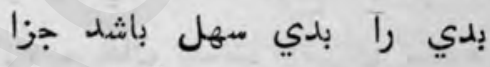

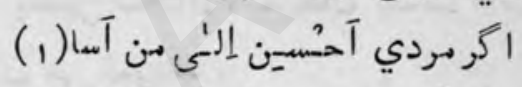

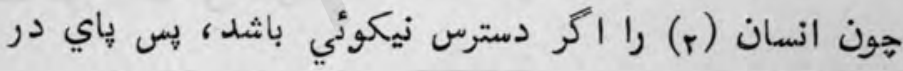

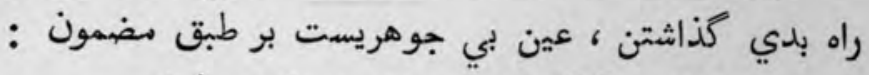

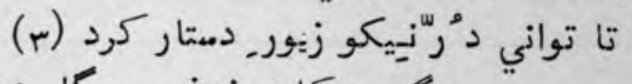

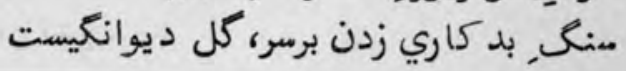

$$
\begin{aligned}
& \text { (1) يعني نيكوئي كن با كسيكه بدي كرد . }
\end{aligned}
$$

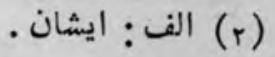

زب) الف: تا توائي در نكوني زيور دستاركن. ج: ناتواني در نيكوي

$$
\text { زيور دستار كرد . }
$$


تازه نواي معاركى

ro.

دومشى با دوستان جندان ندارد هنتي (1)

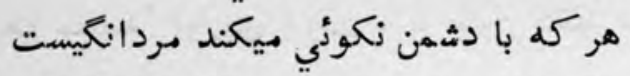

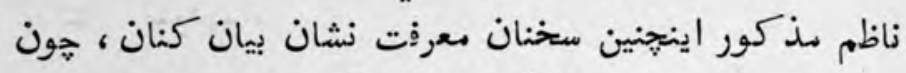

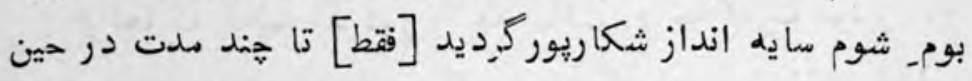

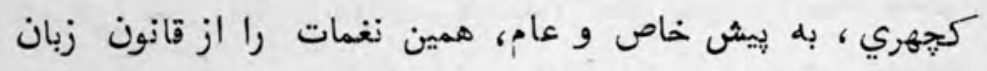

مي سرائيد .

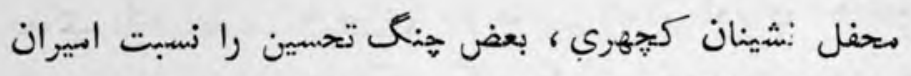

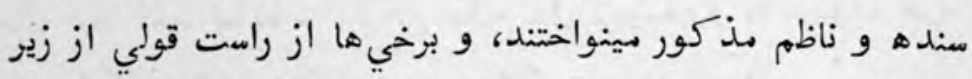

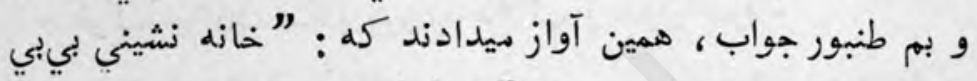

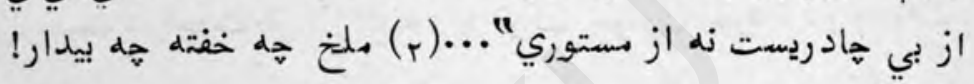

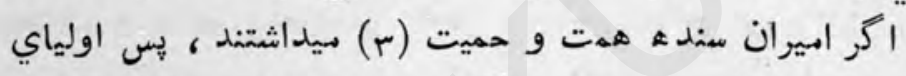

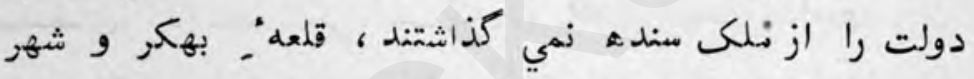

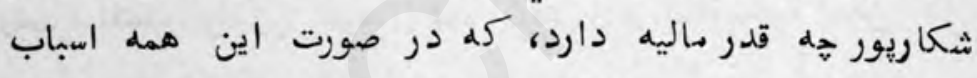

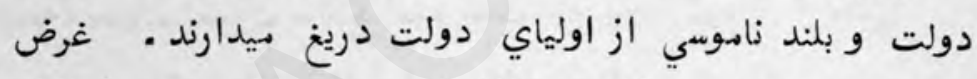

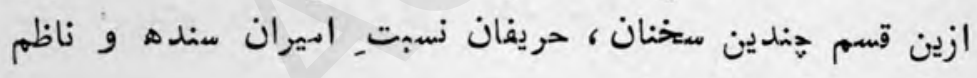

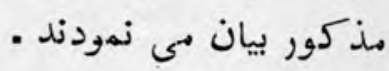

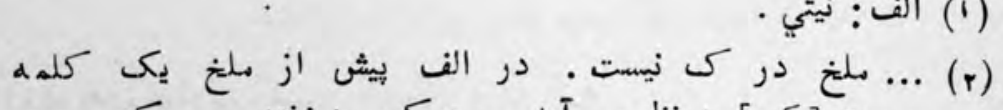

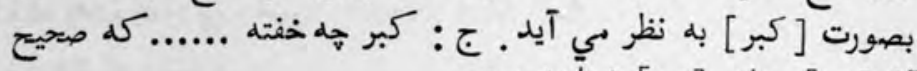

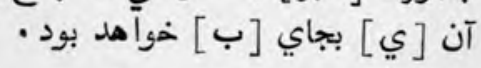

ك (r) 
دربياني رسيدذي اولياي دولت در لإمكانه (1) و عدم التفات مير امسعيل شاه مختاركار لاز كانه ، و كفتكوي

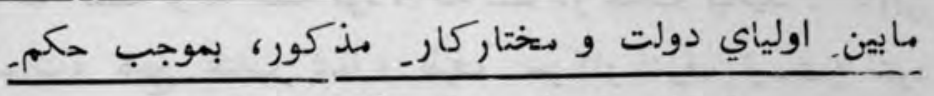

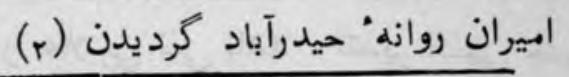

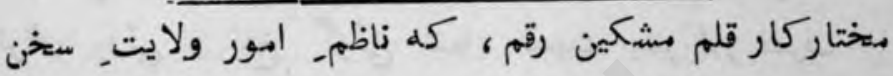

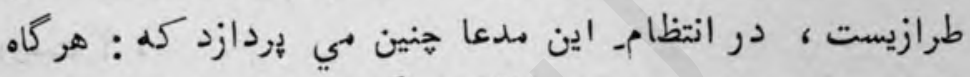

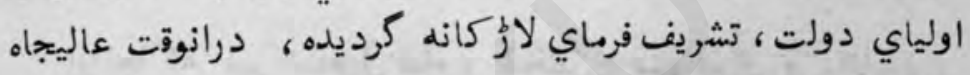

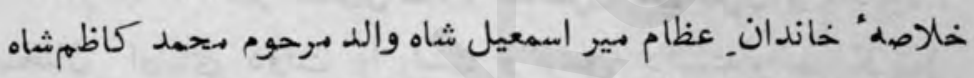

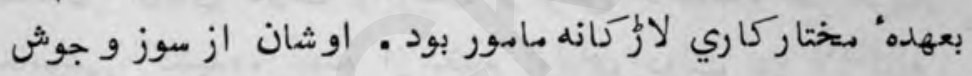

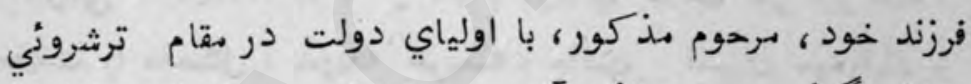

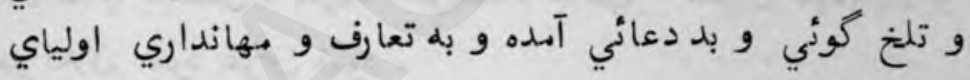

$$
\text { دولت نهرداخته . }
$$

هر هند اولياي دولت ، طرف ميرد اسمعيل شاه شاه كفته فرستاده،

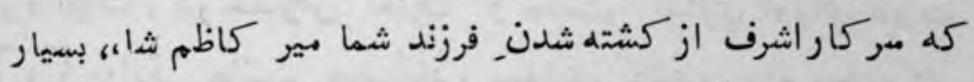

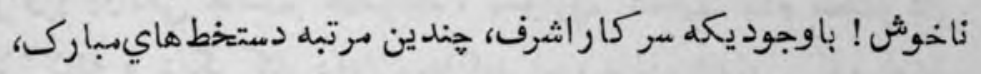

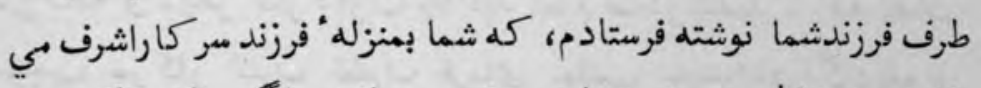

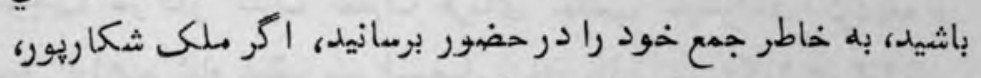

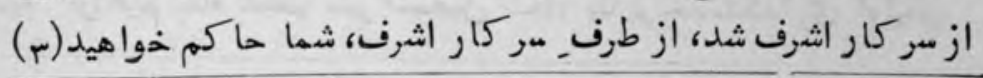

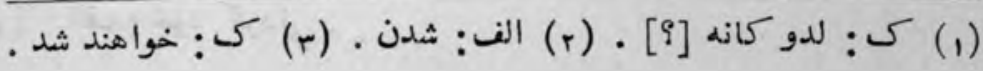


شد . و اكر از اميران كرديده هم مالك ميباشيد ! با وصفـ اين همه صدور دستخطها هركز فرزند شما ، به اله

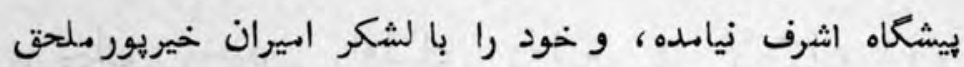

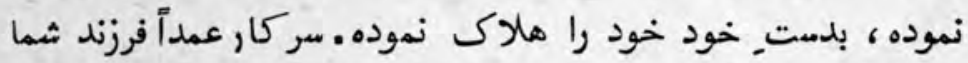

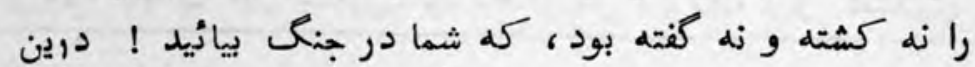

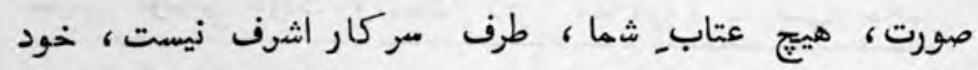

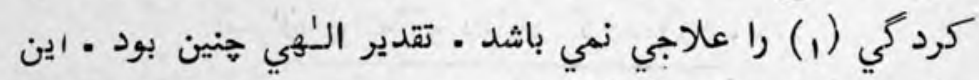

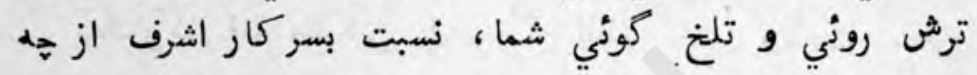

- روست ؟

ازانجاكله مير اسمعيل شاه ، شخصـ ذي هوش و دانابود ، سخنانِ اولياي دولت را راست و برحق دانسته ، سر بكريبان

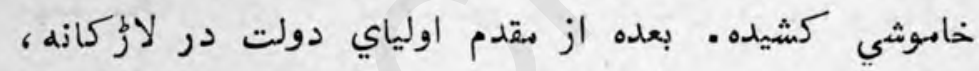

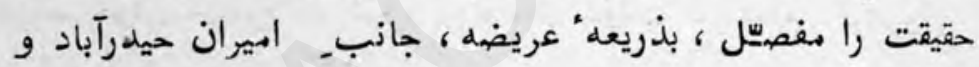

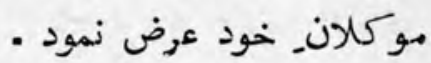

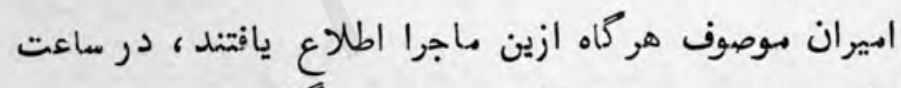

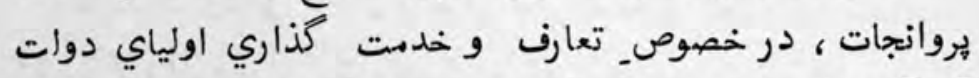

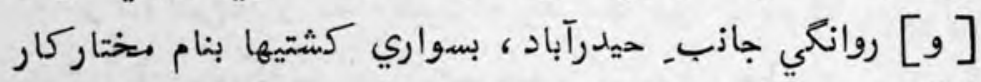

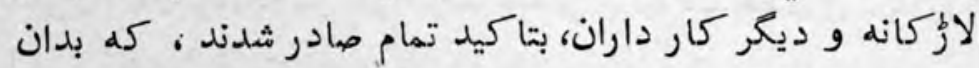
موجب مركار اشرف تشرف فرماي جانب حيدرآباد كرديده و

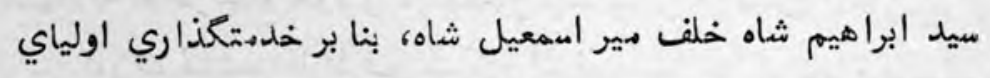

$$
\text { الف:خود كردني . }
$$




\section{دولت ، تا به حيدرآباد مامور كرديد (1) .}

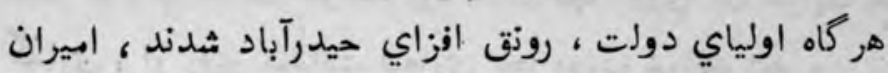

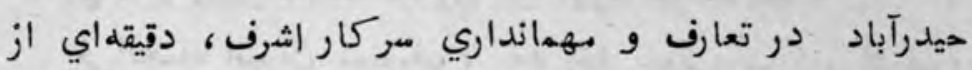

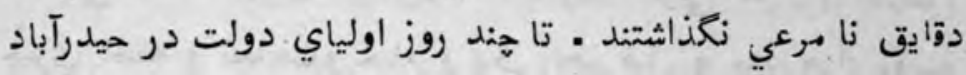

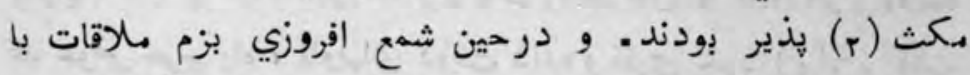

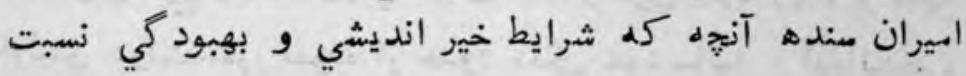

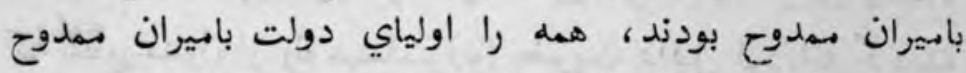

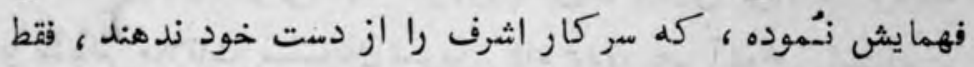

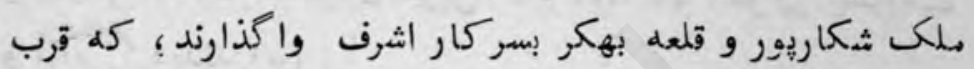

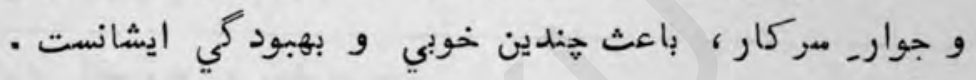

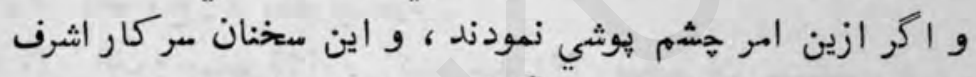

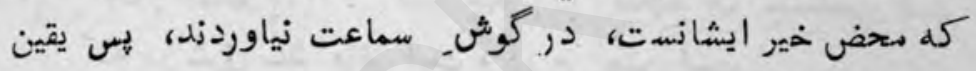

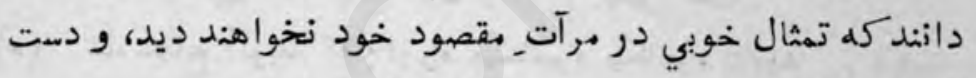

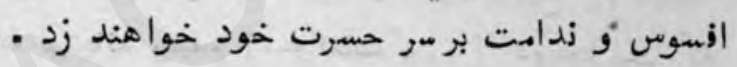

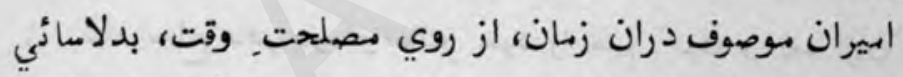

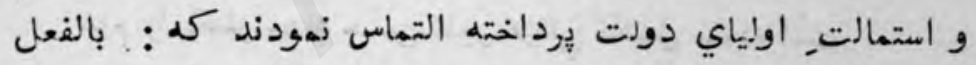

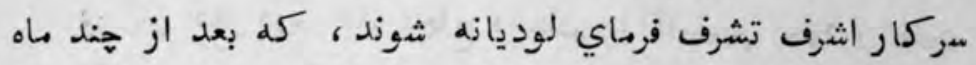

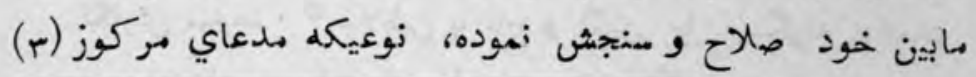

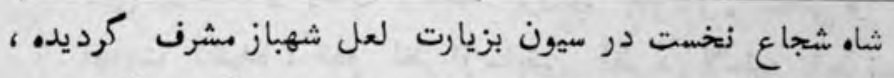

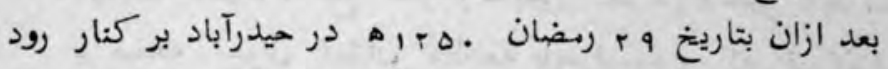

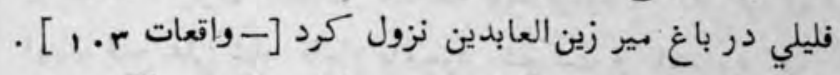

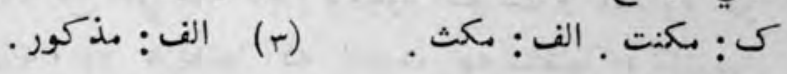


خاطر اولياي دولت خواهد بود، در بجا آوري آن شرايط خددت

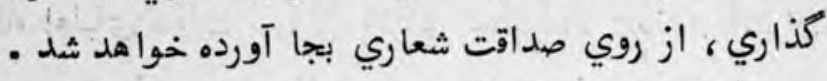

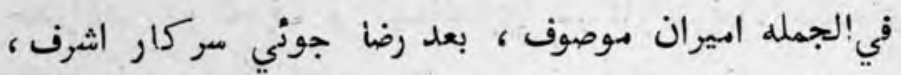

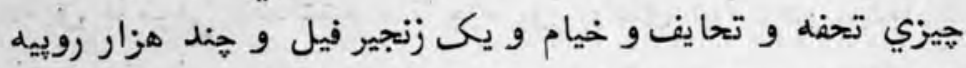

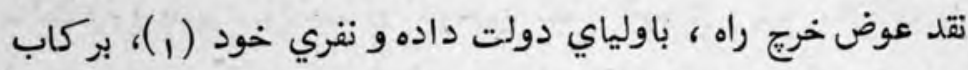

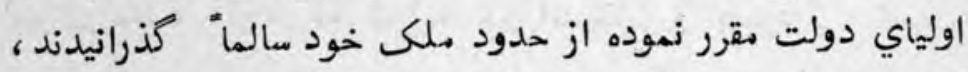

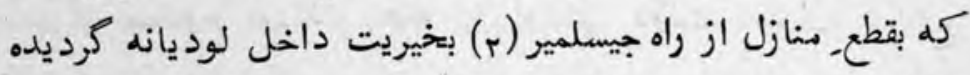

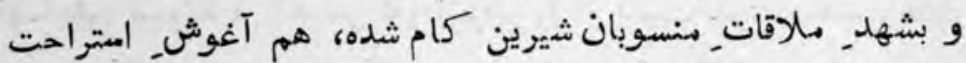

$$
\text { • (r) وآرام كرديدند ماندات }
$$

$$
\text { الف، ج: و معتبري خود . }
$$

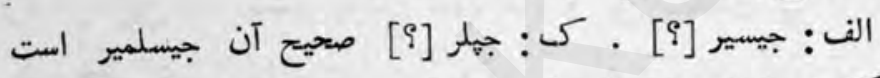

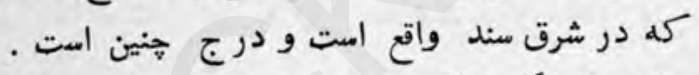

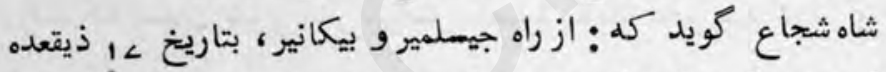

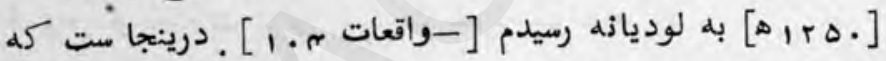

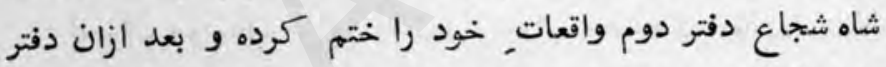

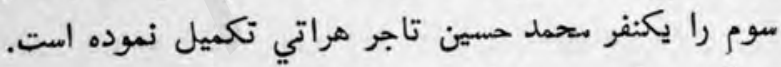

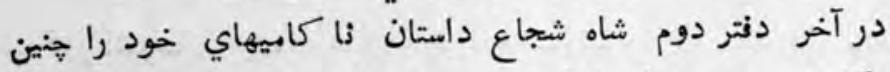

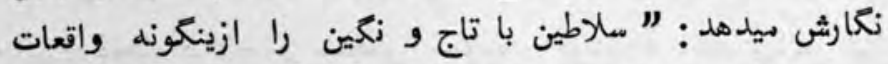

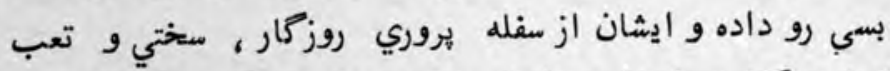

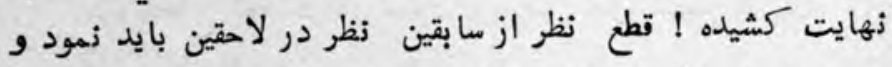

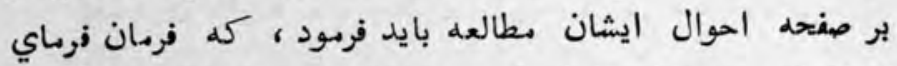

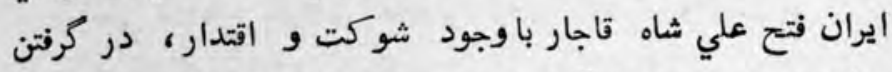

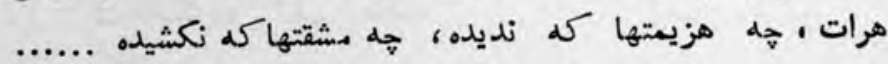

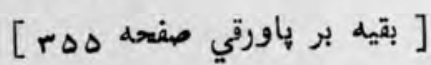


(بقيه حاشيه صفحd ) (ror )

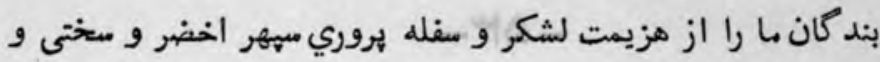
تعب_سفر، هندان باكى وخطر نبودهو نيست، امبا ازينجهت غمناكى

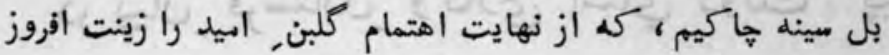

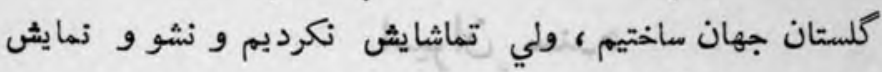

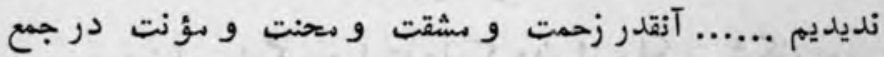

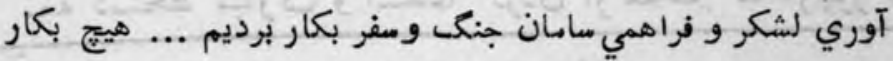

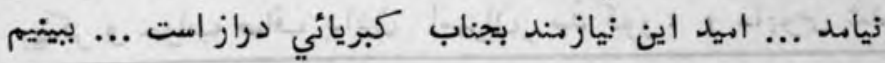
$:$ :

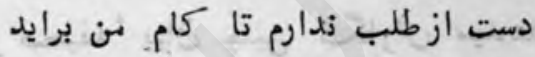

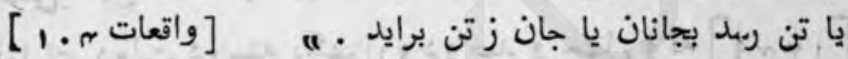

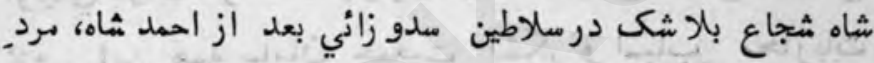

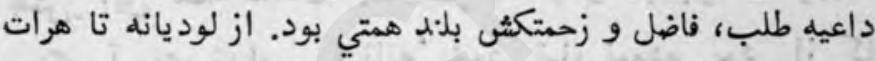

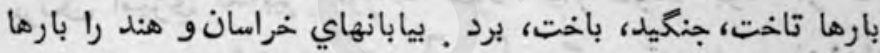

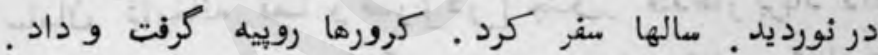

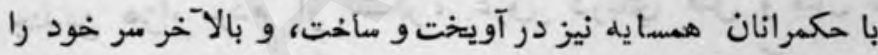

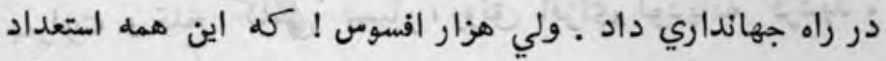

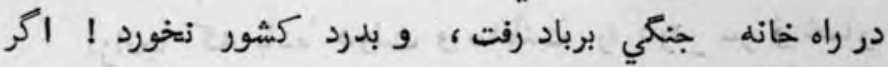

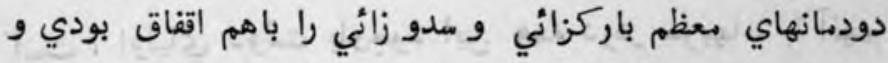

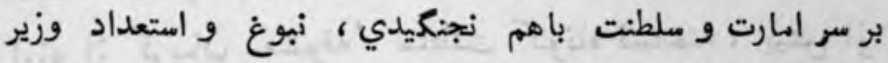

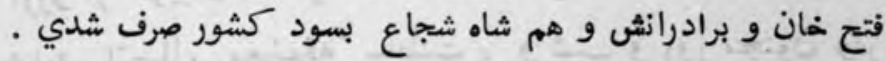

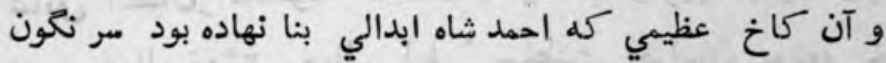

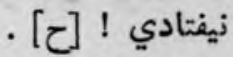


$-\Delta \mu$

در بيان, فرستادن وكلاى امناي دولت، بيش

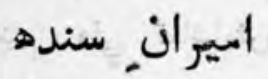

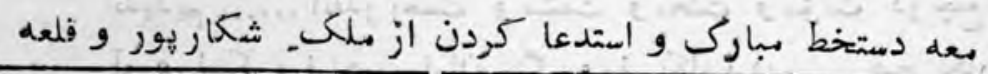

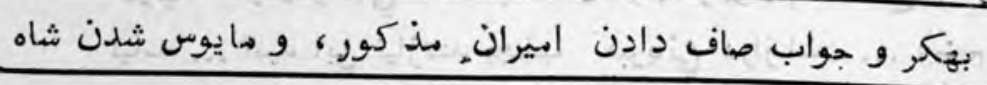

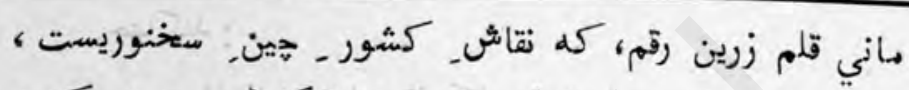

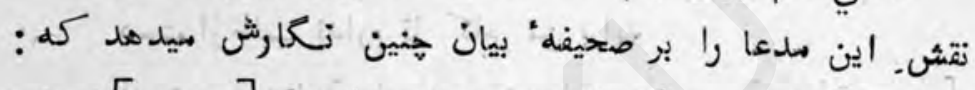

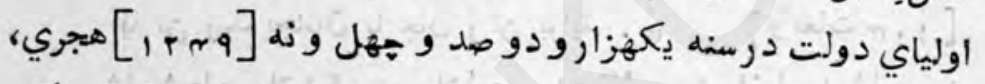

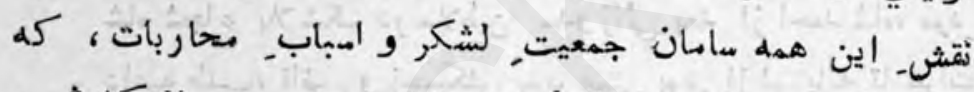

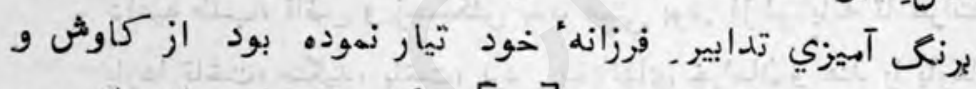

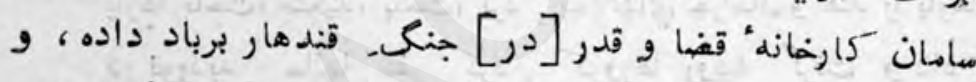

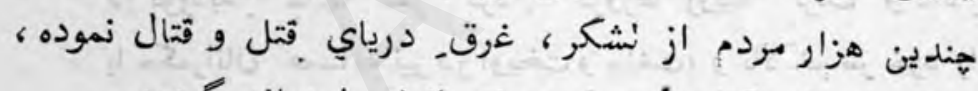

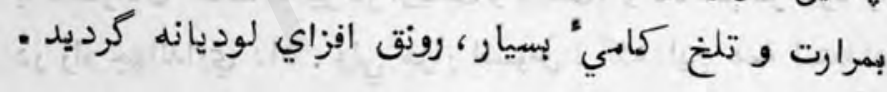

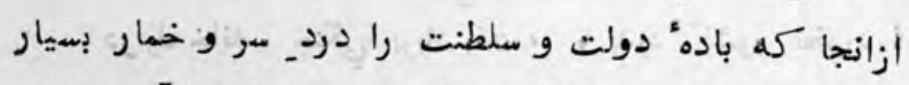

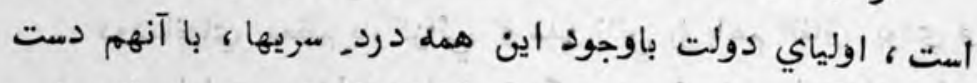

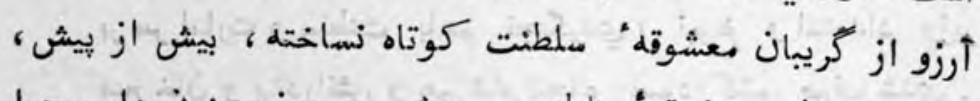

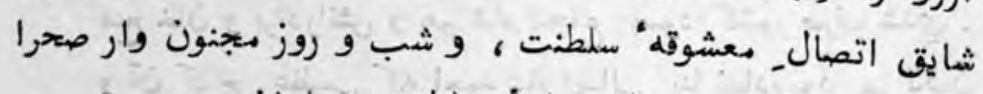

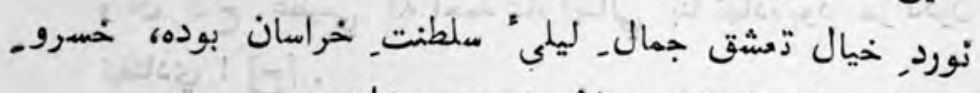

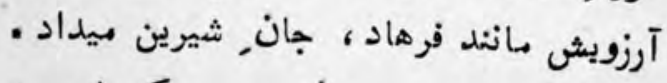

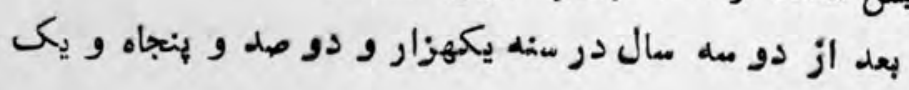




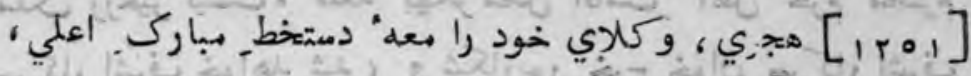

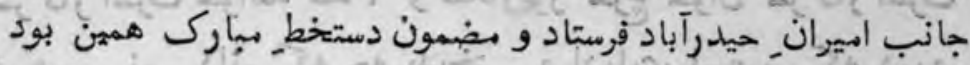

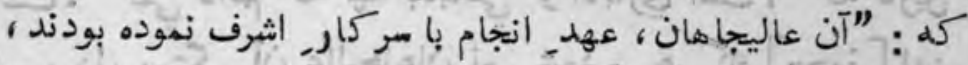

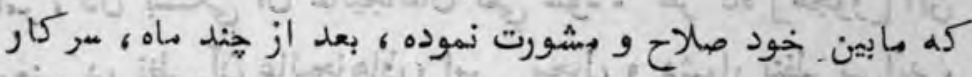

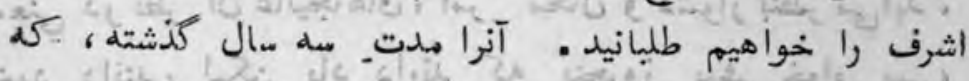

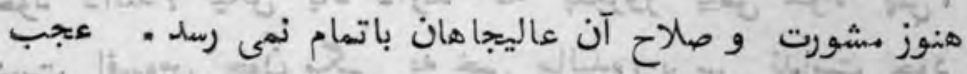

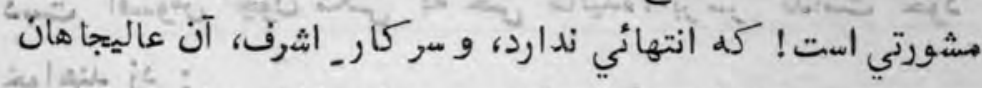

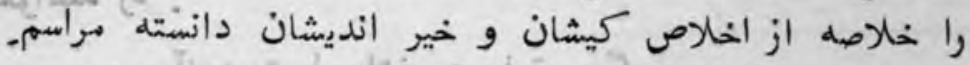

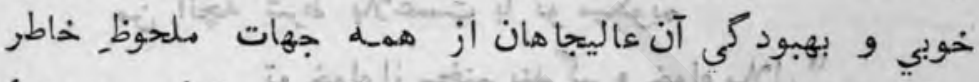

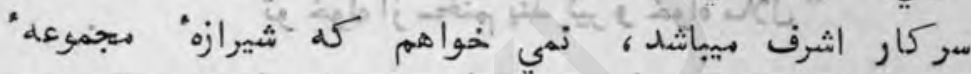

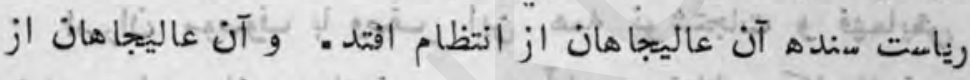

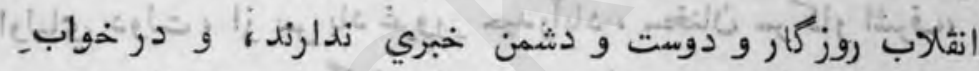

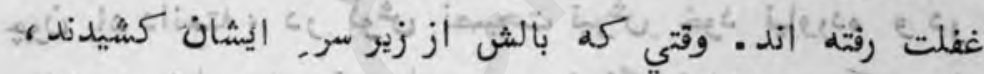

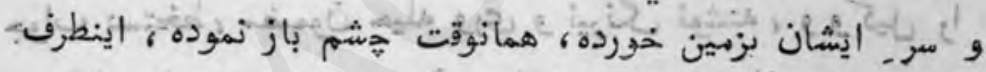

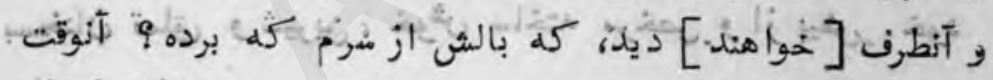

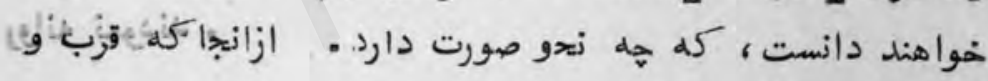

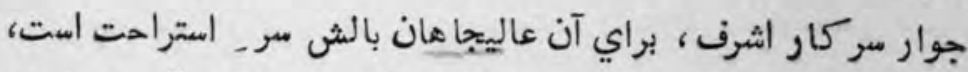

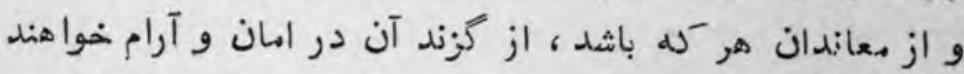

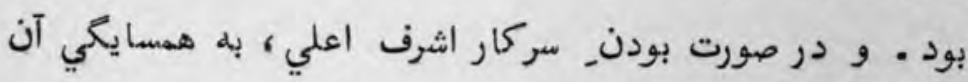

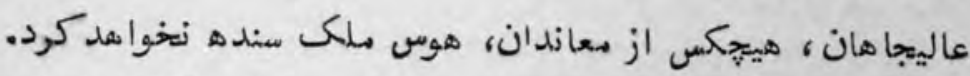

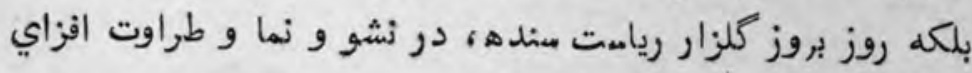
ابدي خواهد بود. قلعه بهكر و جهار ديوار شكاريور، هندان 
تازه نواي معاركى

ron

ملك زرخيز نيست • قلعه" بهكر محل اقامت_ اهل حرم محترم سركار اشرف خوالهد شد ، و شكاريور خرج خوان سركار اشرف

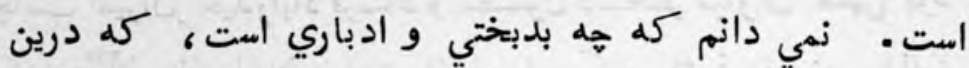

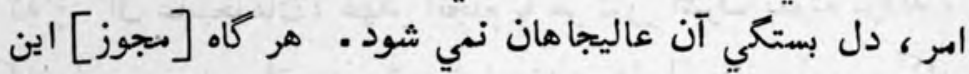

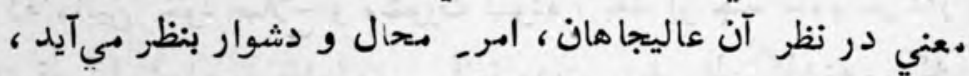

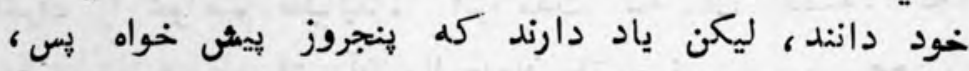
دست افسوس هون مكس به خس ماليده، برسر. ندامت خود

خواهند زد :

من آنهه شرط باغضست با تو ميكويم

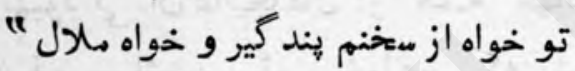

اميران موصوف با وصف, اين همل نوشتجات و فهمايش

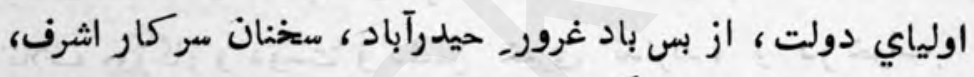

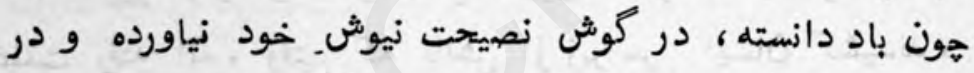
جواب دستخط ، مضمون حيله وري و نيرنگ نوشته ، و و وكيل را بسخنان تملق و شيرين ، خوث ساخته مرخص و از زيشل خود

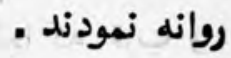


در بيان مايوس شدن اولياي دولت از اميران سنده

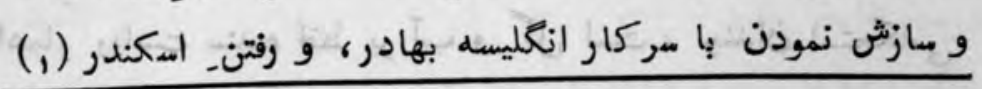

$$
\text { برنس صاحب بجانب_ خراسان }
$$

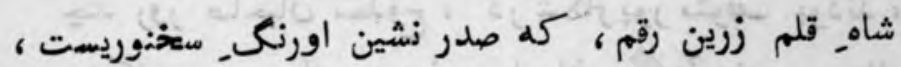

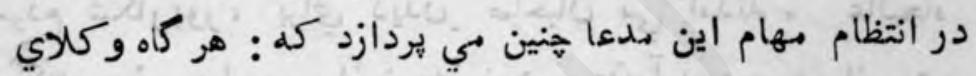

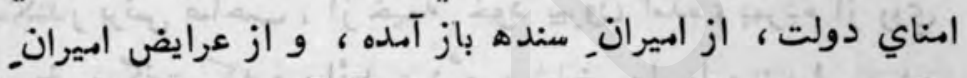

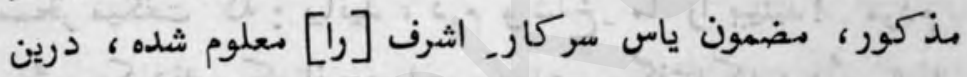

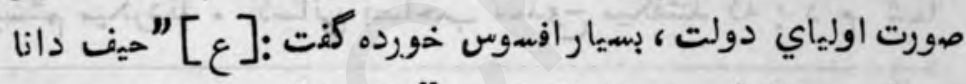

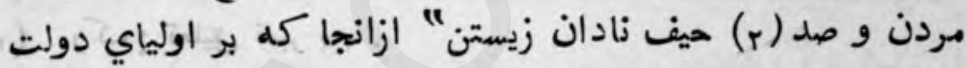

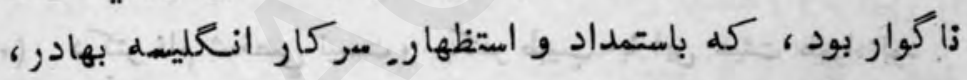

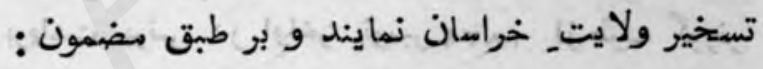

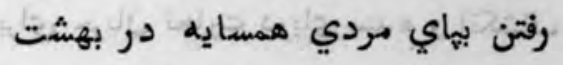

حقا كه با عقو بت دوز دوزخ برابر است

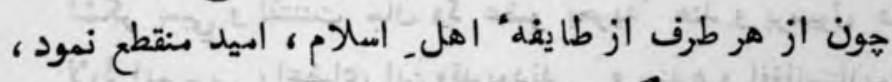

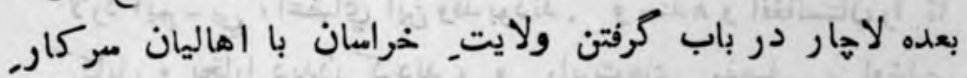
انكليسه" بهادر بندو بست نموده : اولاً عاليجاهان امكندر برن برنس

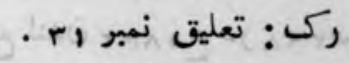

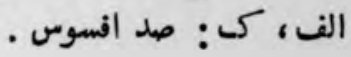


صاحب بوادر و ليج (1)صاحب بهادر و داكتر(r)صاحب بهادر،

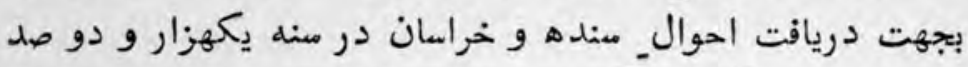

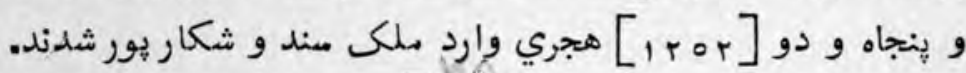

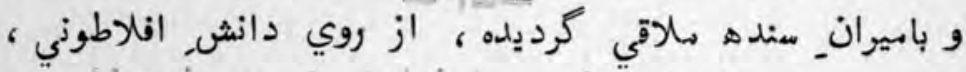

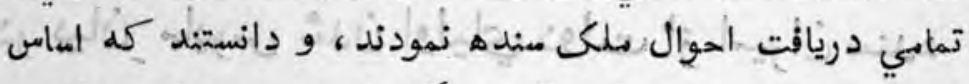

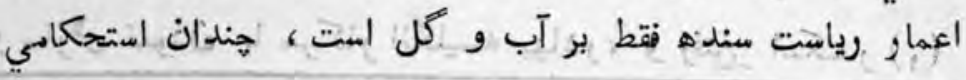

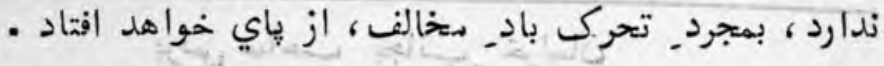

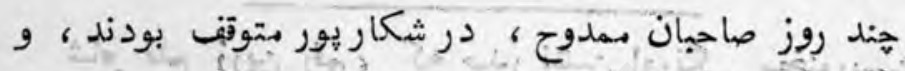

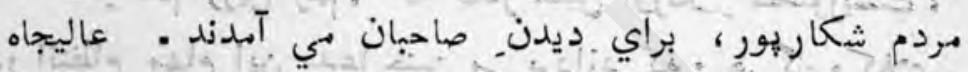

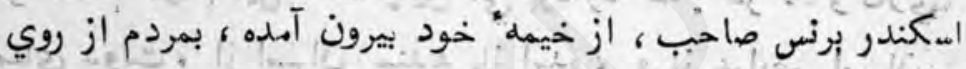

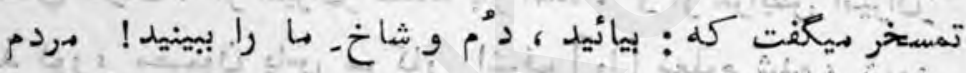

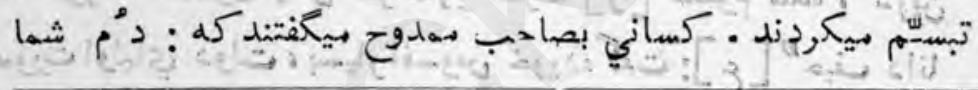

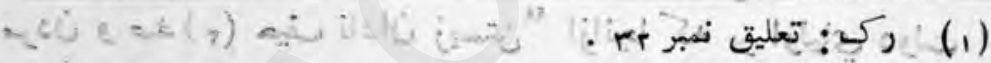

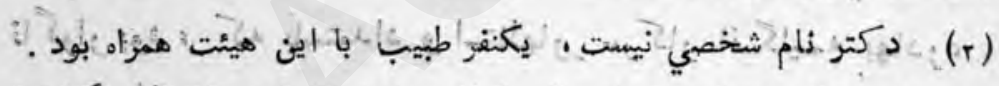

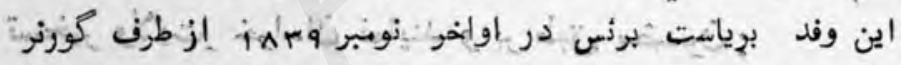

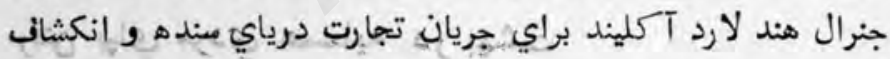

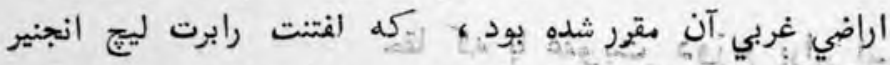

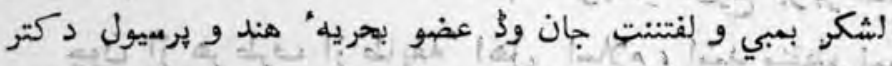

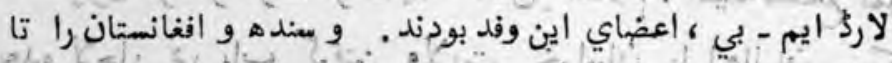

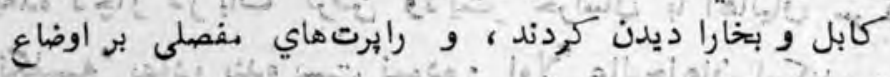

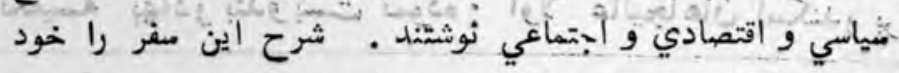

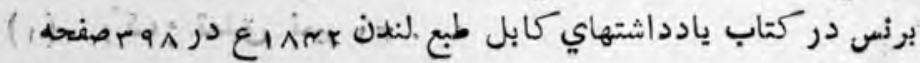
نوشته است . برنس در 
دراز تا بولايت انكلستان، و شاخ شما در خراثان سر خواهد

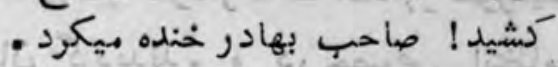

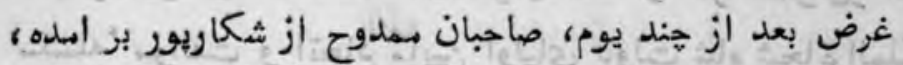

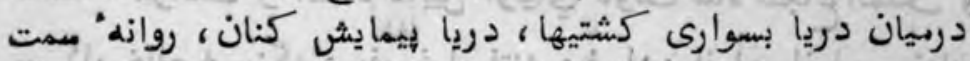

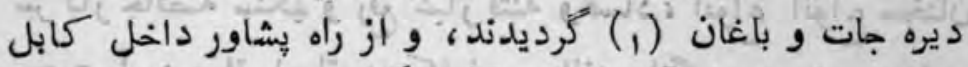

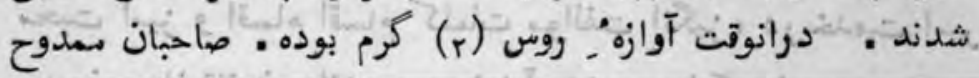

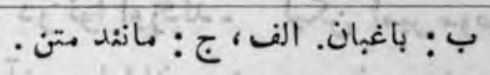

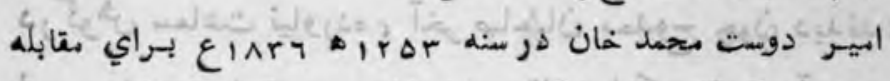

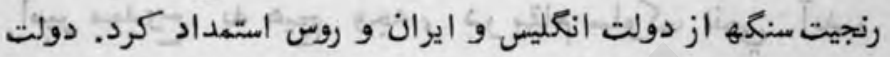

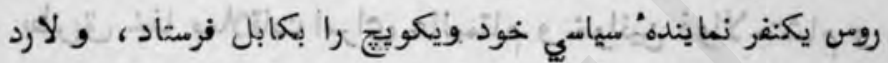

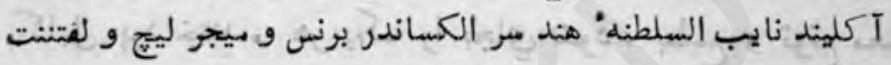

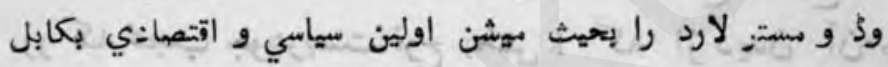

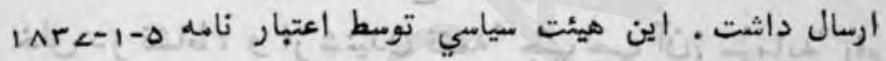

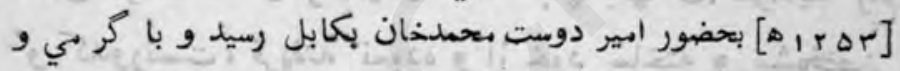

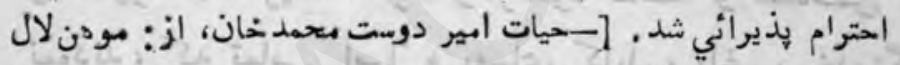
روس، در بr-1

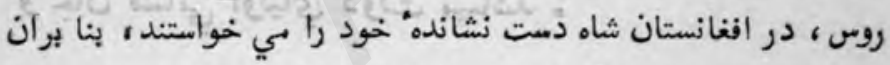

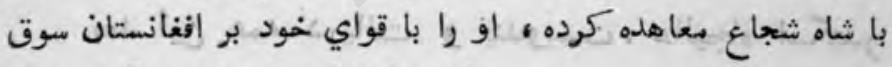

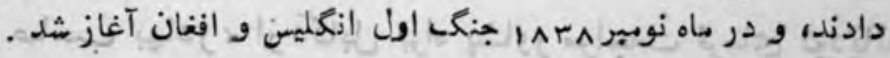

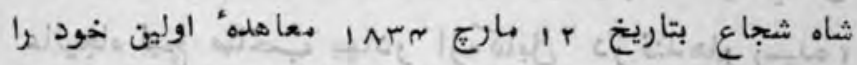

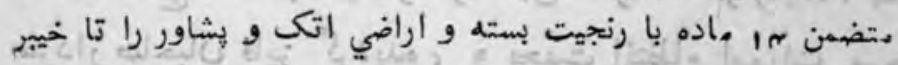

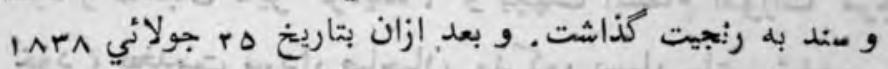

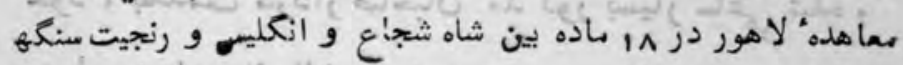

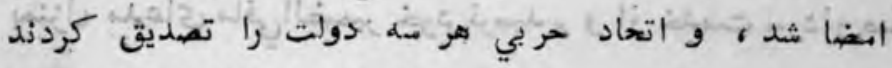

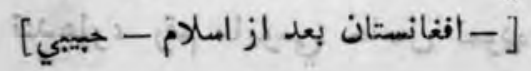


در كابل سر خوثــ باده" ملاقات_ سردار فلكى اقتدار _ خورشيد

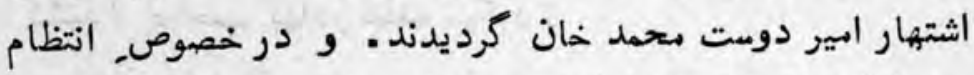

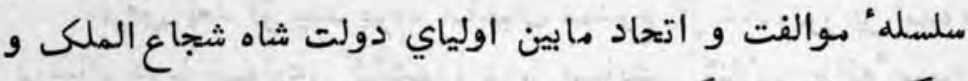

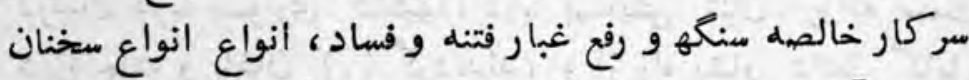

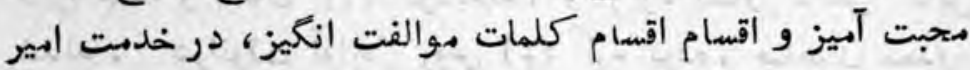

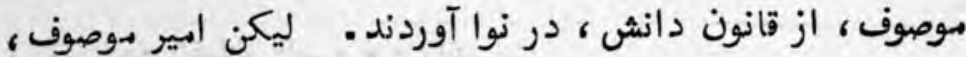

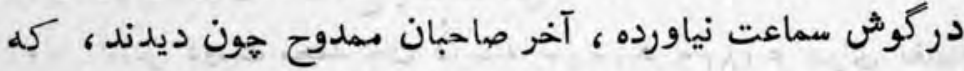

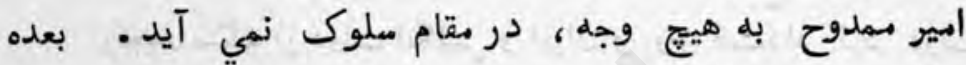

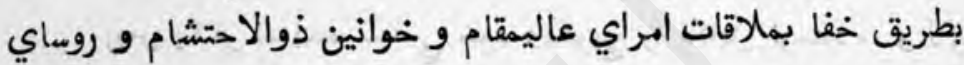

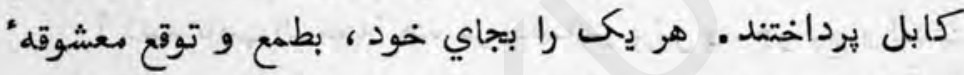

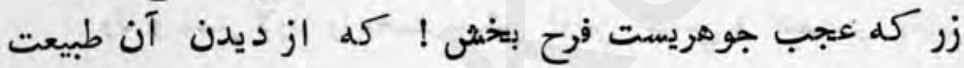

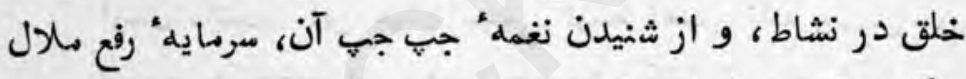

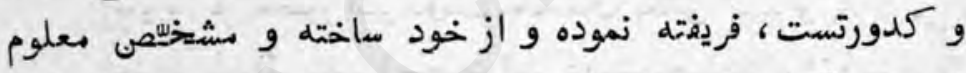

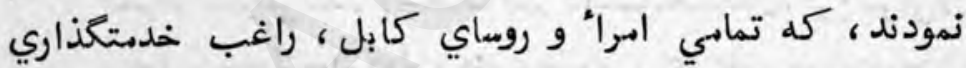
و جان فشاني اولياي دولت ميباشد .

بعد اين همه دريافت و نبندوبست، عاليجاه اسكندر برنس

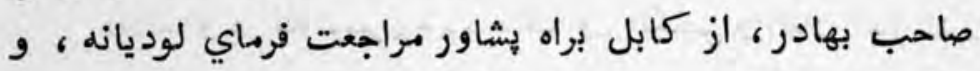

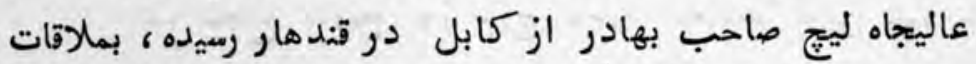

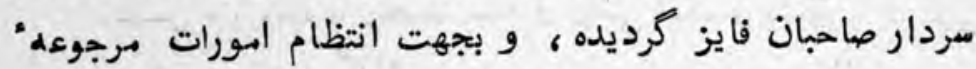

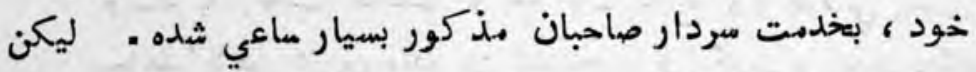
بمنزل مدعاي مافي الضمير خود نرميد. . و از خدمت سردار صاحبان قندهار، رقم هايوسي حاصل نموده، باز بجاي خود ، با امراي 
خوانين قندهار ديده، و ديده" هر يك خوانين را جنانجه حاجىخان

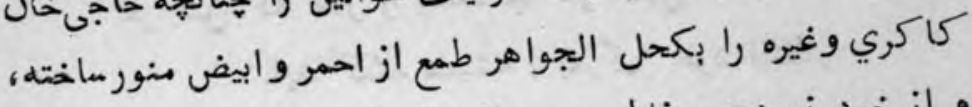

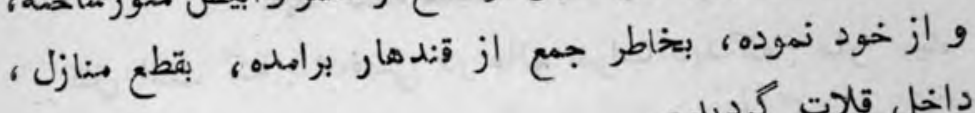
داخل قلات كرديد.

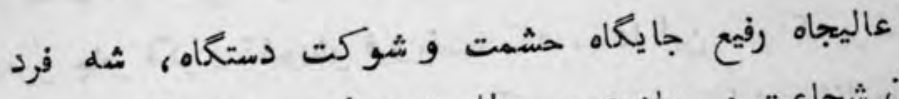

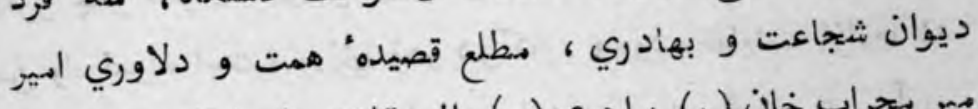

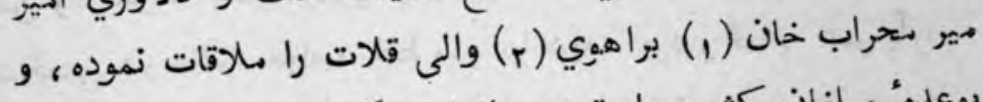

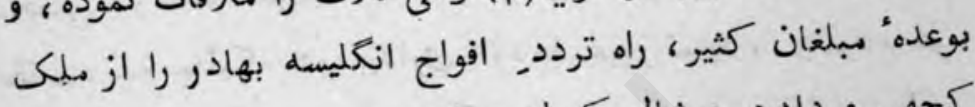

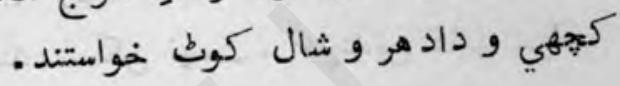

عاليجاه بير مهدوح نيز بطمع جيفه 'دنياي بيوفا ، انجامر دادن.

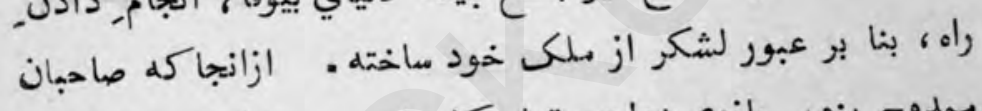

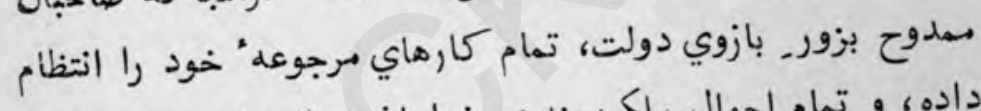

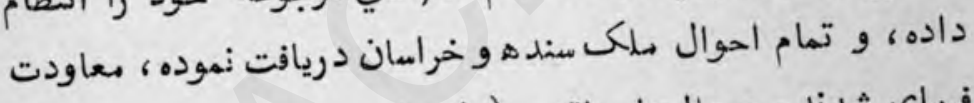

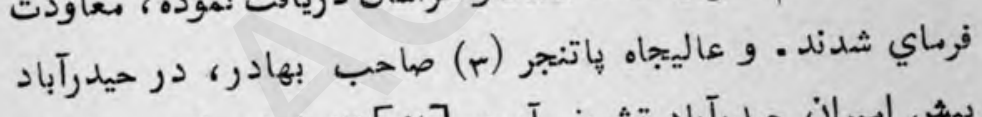

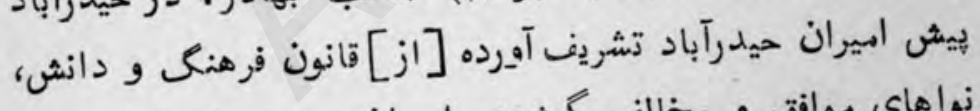

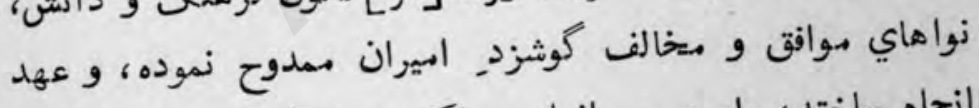

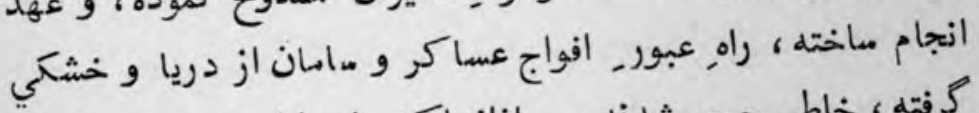

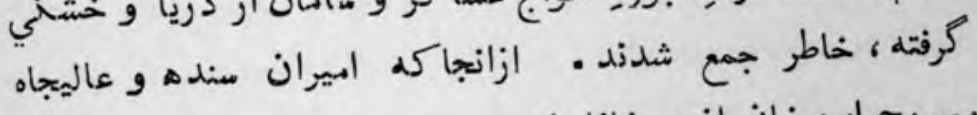

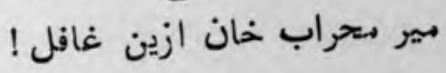

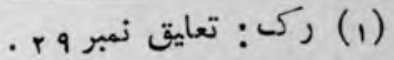

$$
\begin{aligned}
& \text { (r) الف: بروهوي. } \\
& \text { (r) (r) (r) الف: تعليق نمبر سب. }
\end{aligned}
$$




\section{بيت}

$$
\text { هر كس كله نار را بدهد جا در آستين }
$$

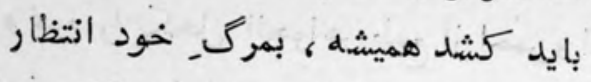

نقل است كله : شخصي در عالم خواب ديد كل : مار مسياه

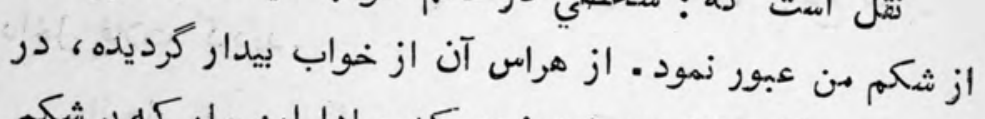

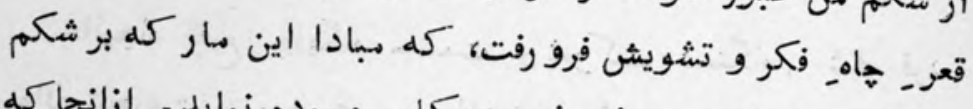

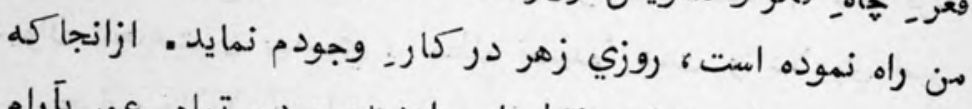

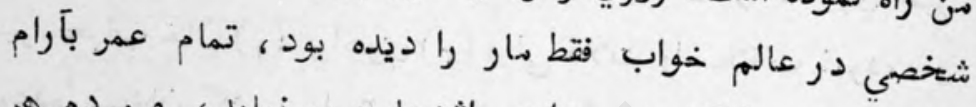

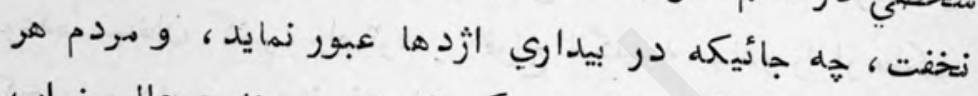

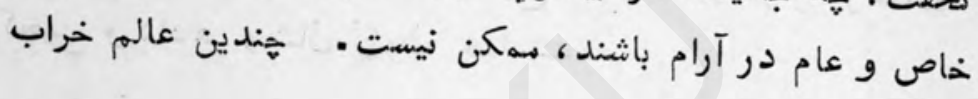
و آباد خواهد وعام نمود . 
در بيانـ رفتن_ لشكر افواجـ بحر ابواجـ سركار اذخحليسه بهادر طرف خر خراسان

\section{باتفاق اولياي دولت و شاهزاده بحمد تيمور}

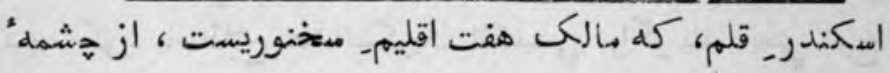

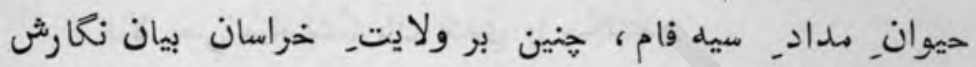

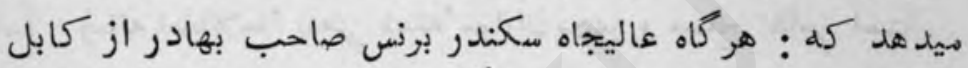

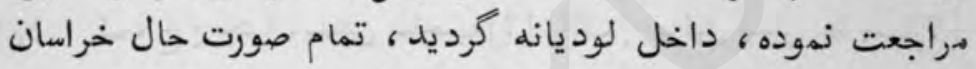

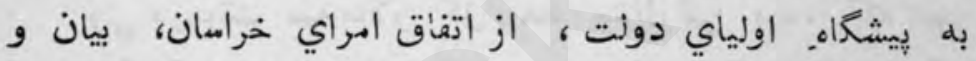

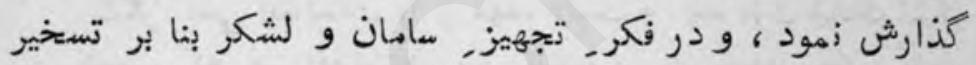

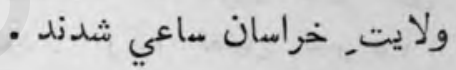

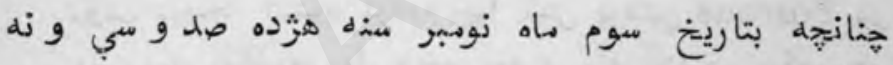

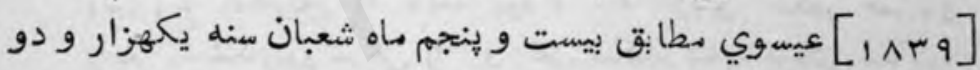

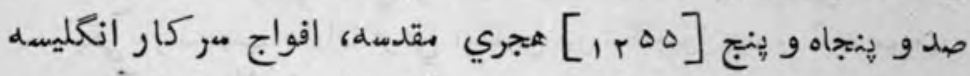

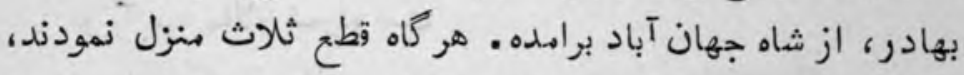

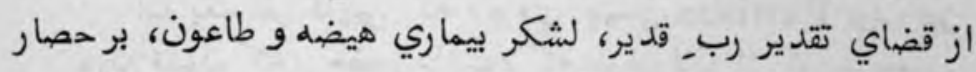

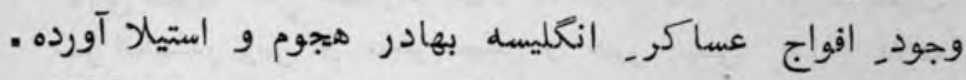

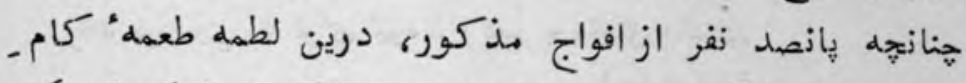

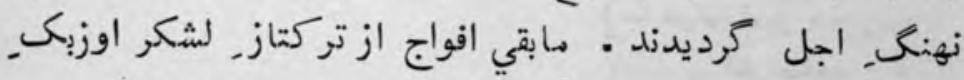

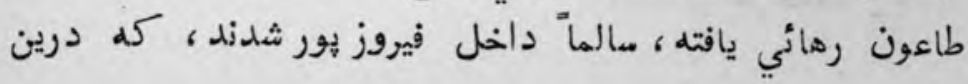


اثنا لارد اكلمند (1) بهادر شانزده رجمنـ (r)، و ديكر هفتم

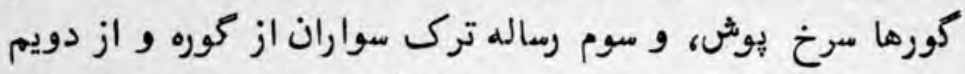

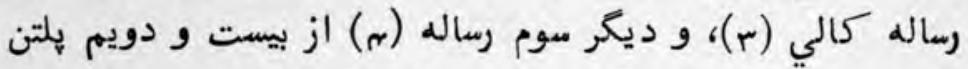

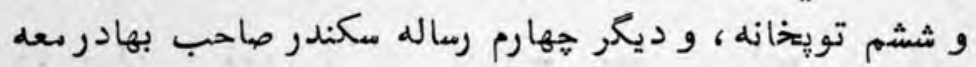

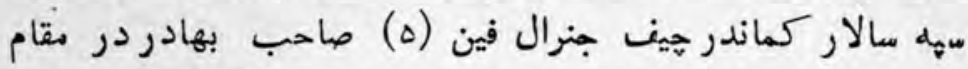

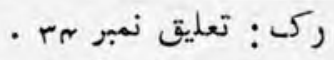

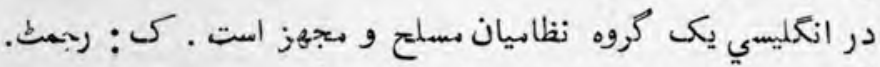

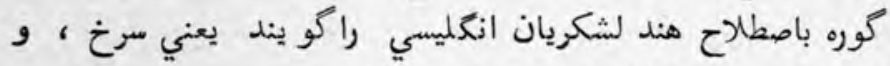

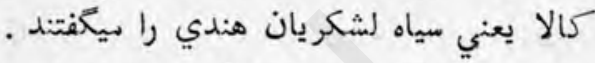

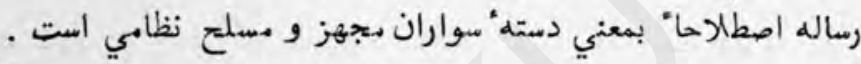

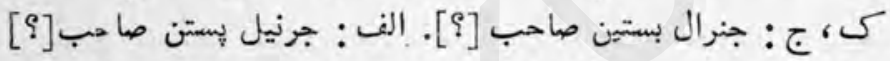

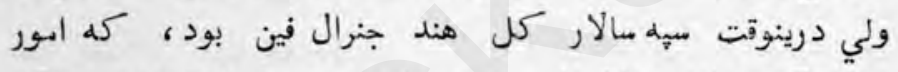

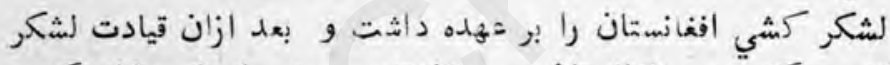

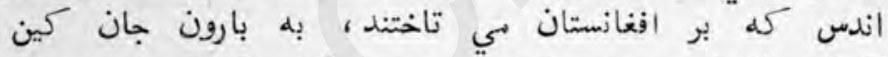

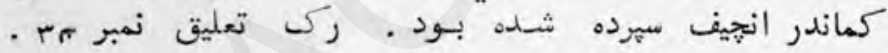

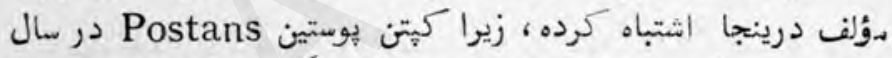

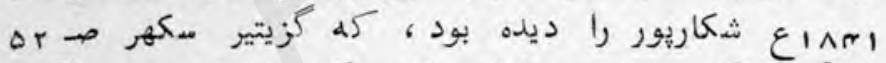

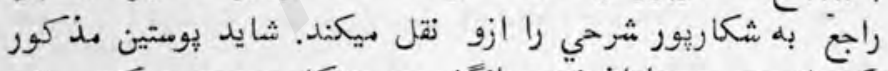

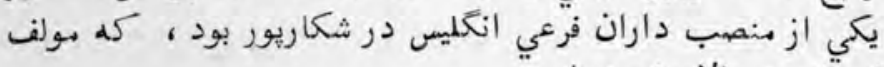

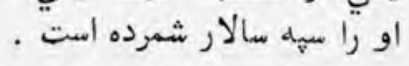

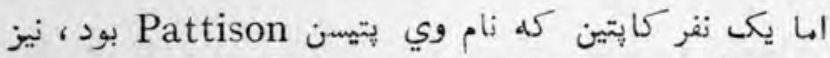

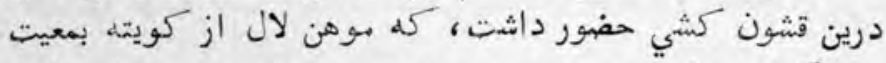

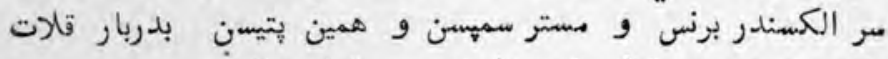
رفته بود.وي به قواي نيزه دار نمبر 7 ارتعلق داشت.

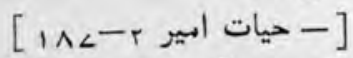

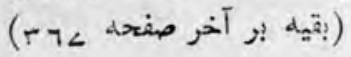


فيروزيور رونق افزاي شدند. در اين ضمن مهاراجه رنجيت سنكه

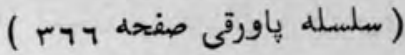

شايد مولف را با نام اين شخص خلط و اشتباه روي داده باشد . هنين بنظر بي آيد كه مآخذ اين فصول كتابسيت بنام تاريخ افغانستان، كه بزبان اردو از طرف مير اشرف علي باني مجمع الاخبار

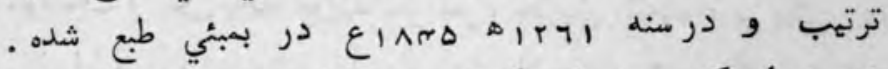

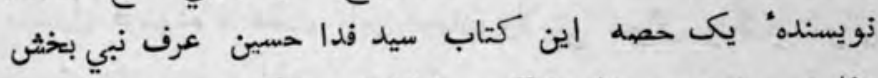

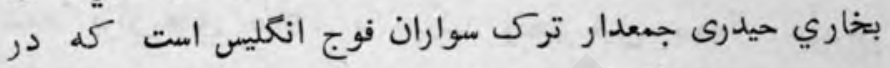

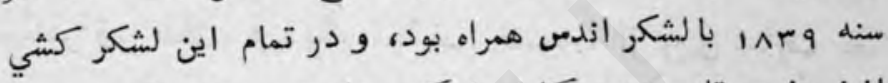

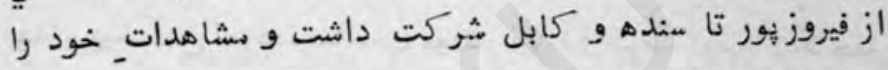

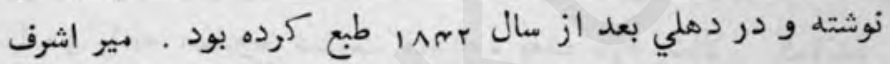

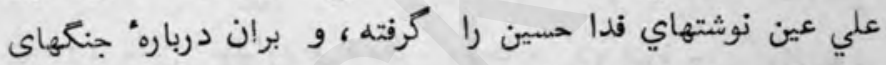

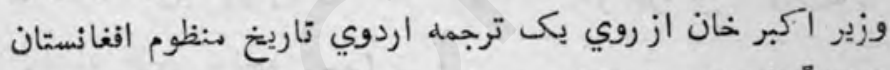

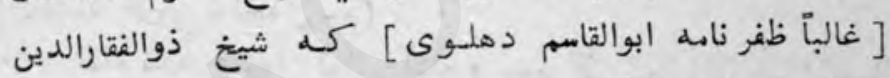
سجونهيوري باردو كرده بود، و هم از روي اطلاعات جرايد

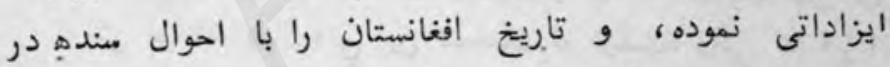
.

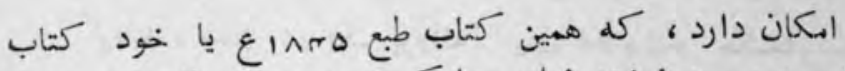

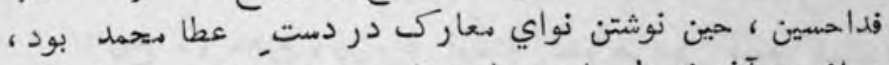

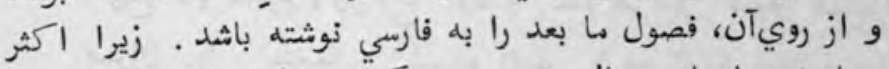

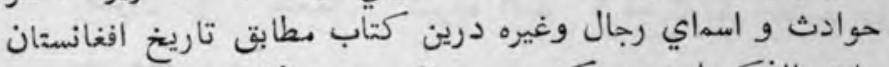

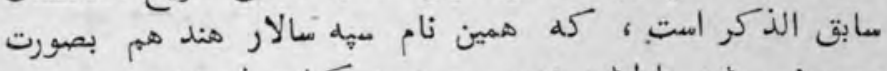

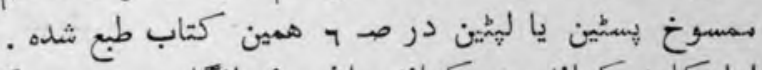

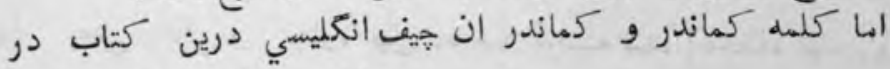
(بقيه بر آخر صفحه 
تازه نواى بعارى

ras

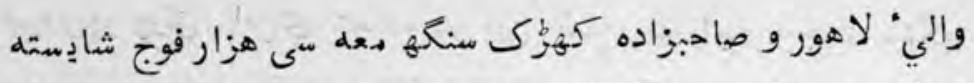

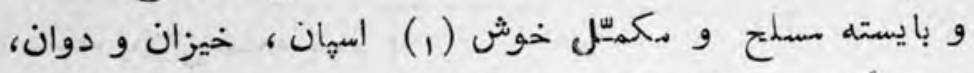

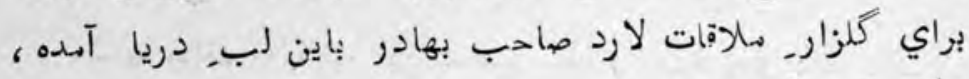

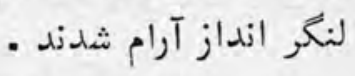

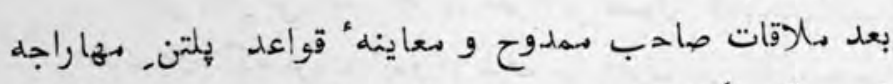

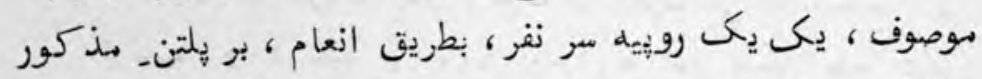

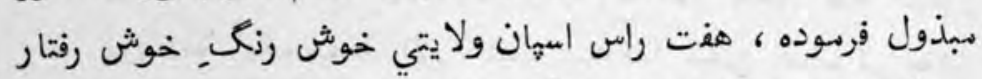

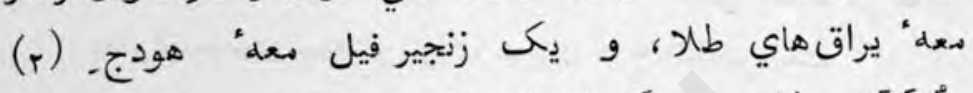

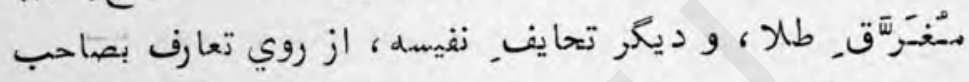

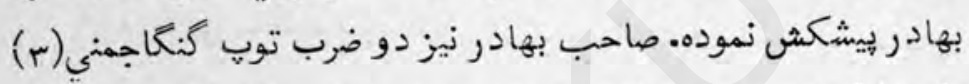

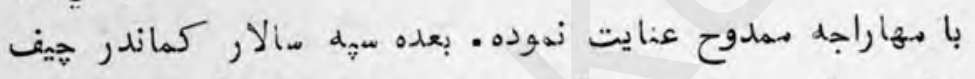

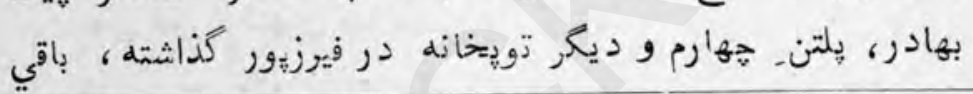

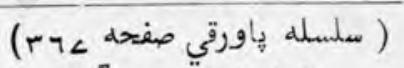

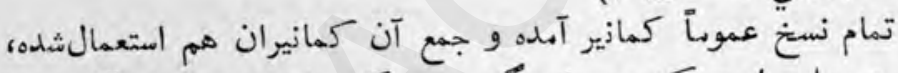

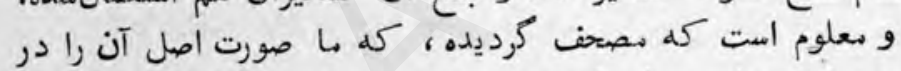

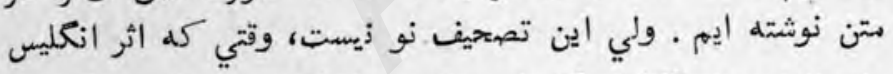

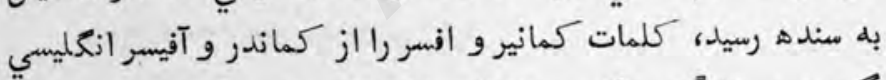

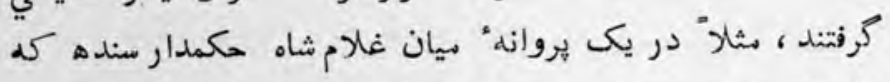

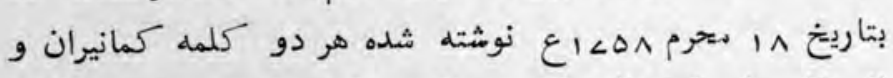

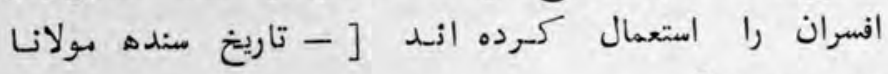

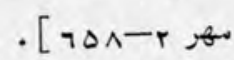

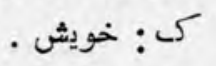

(1)

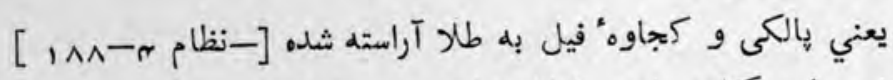

(r)

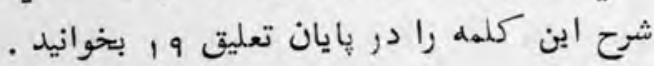

(r) 


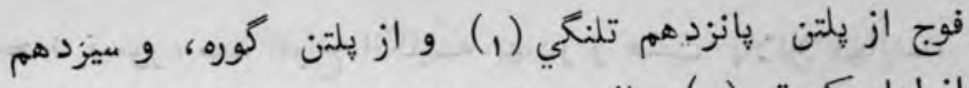

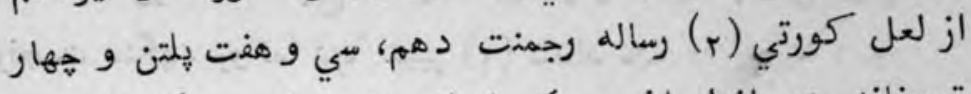

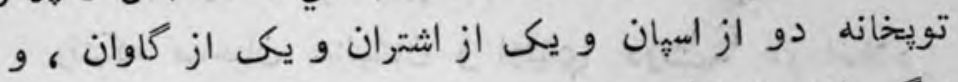

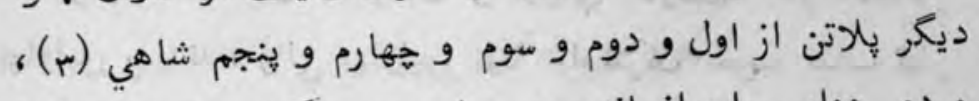

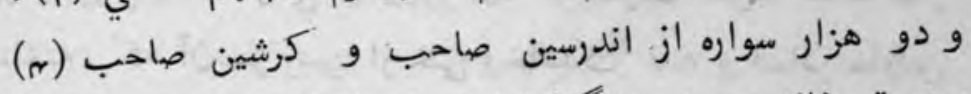

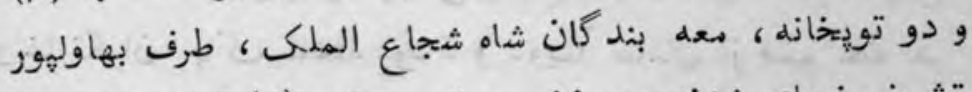

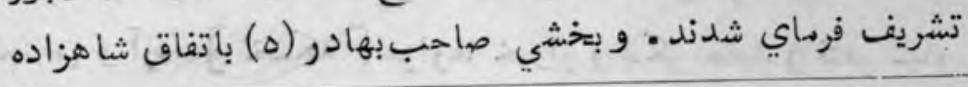
كى: ملنكي [؟] الف : تلنكي. تلنكه و تلنكي نام لشكر هندي

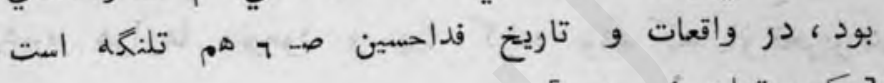

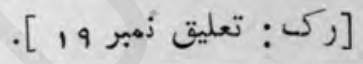

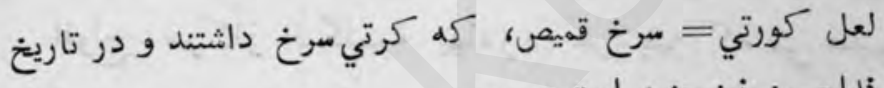

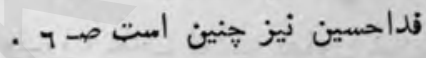

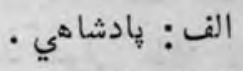

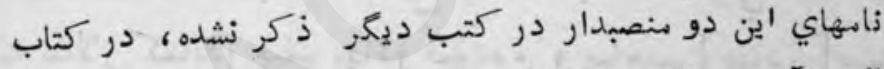

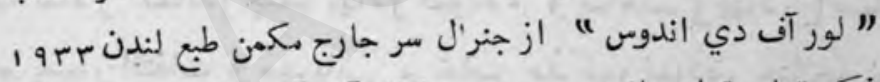

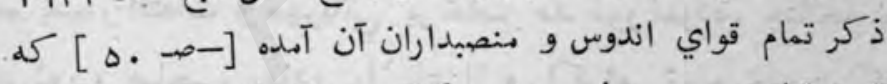

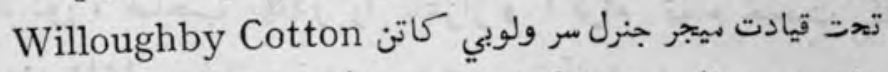

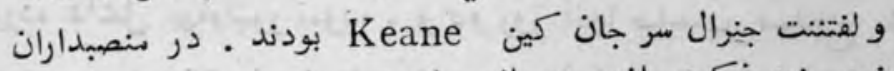

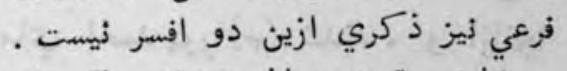

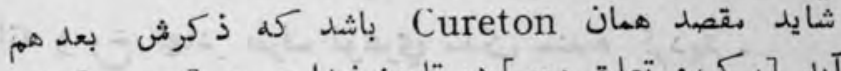

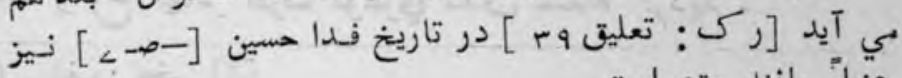

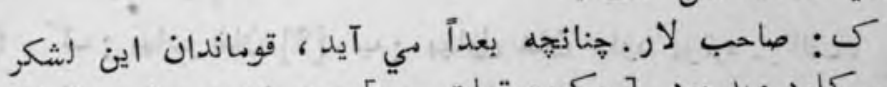

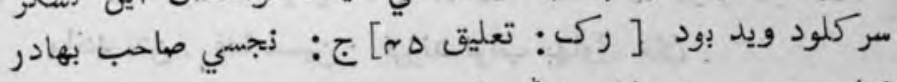

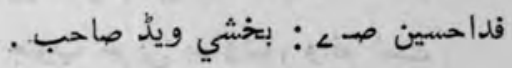


متحمد تيمور ، معل افواج انكليسه بهادر و هشت رإلاتن مهاراجه

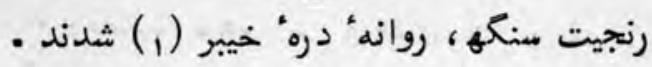

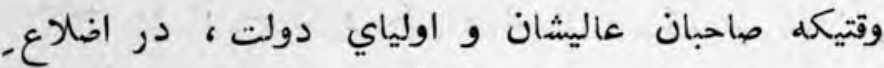

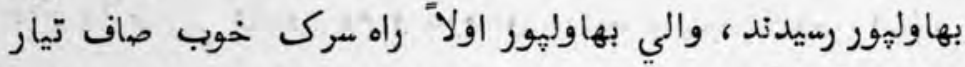

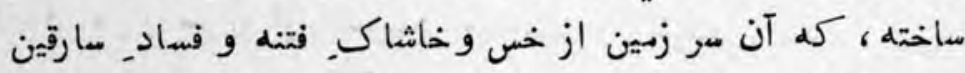

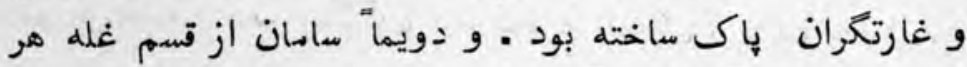
اجناس و آرد [ خشكه ] هزارها خروار و شكر سفيد و قثند, سياه

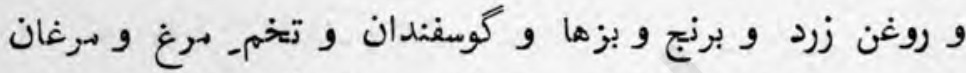

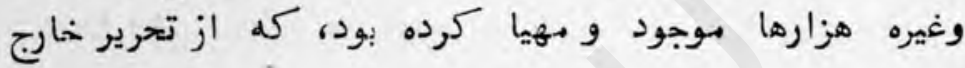

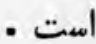

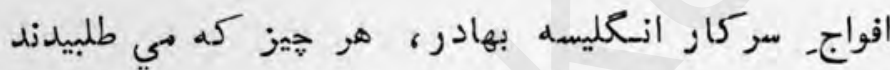

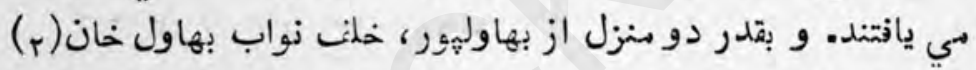

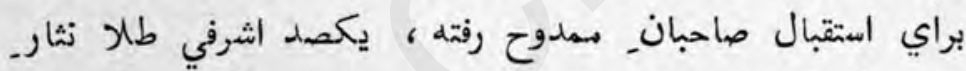

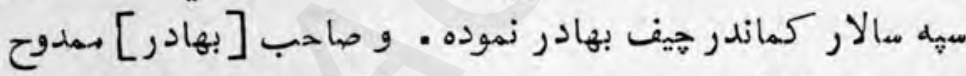

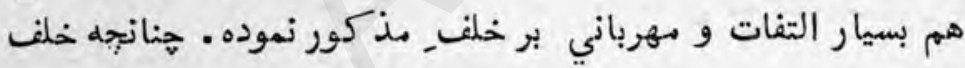

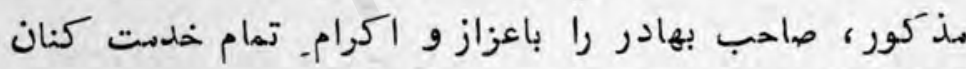

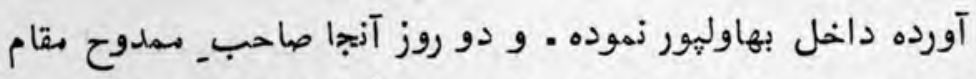

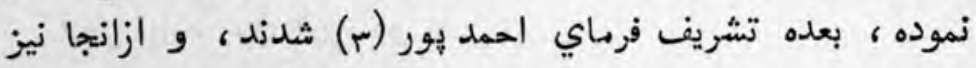

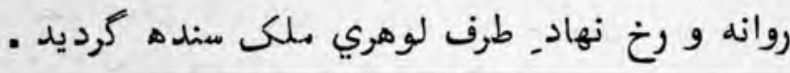

$$
\text { الف: بخير [؟]. }
$$

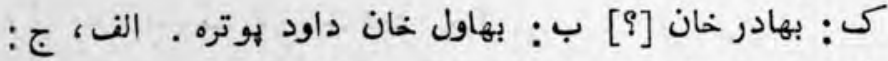

مانند متن. . فدا حسين : فرزند نواب بهاول خان .

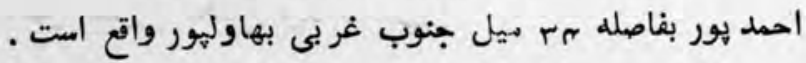


هر كاه افواج بقطع منازل ، در جنغل لوهري وسيدند ، بسبب

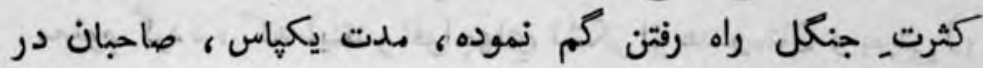

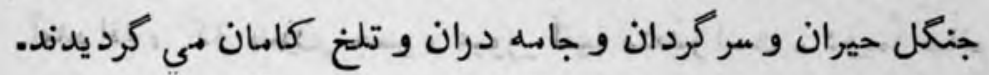

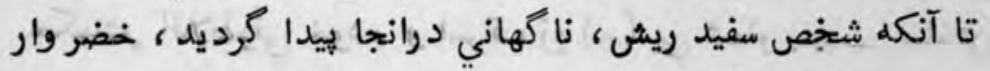

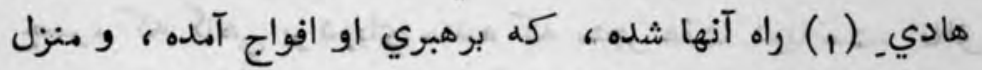

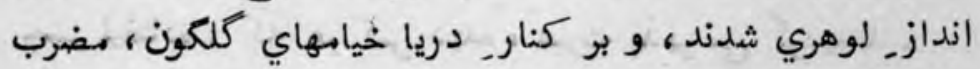

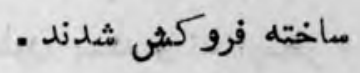

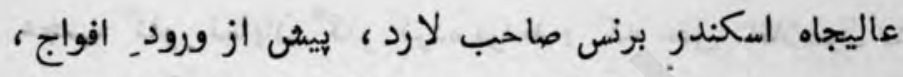

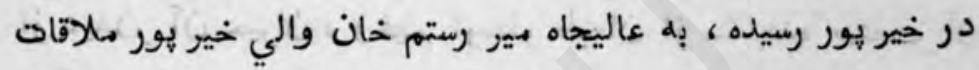

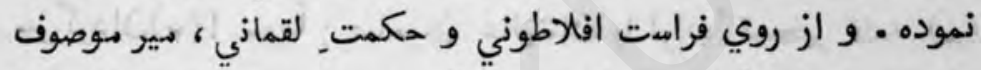

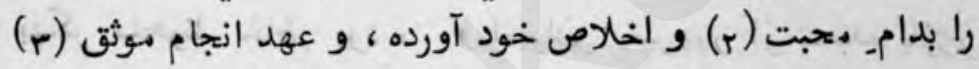

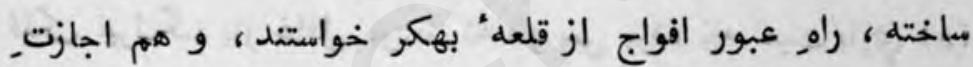

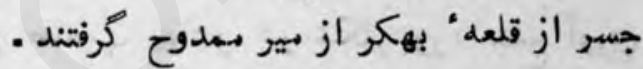

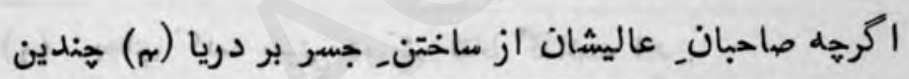

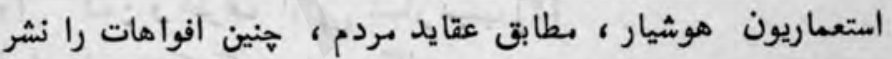

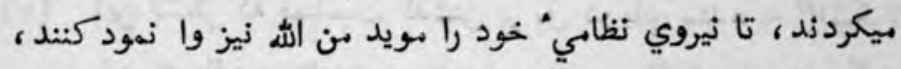

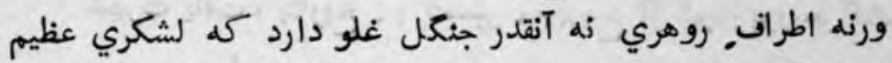

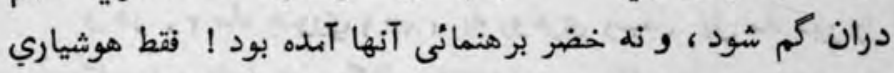

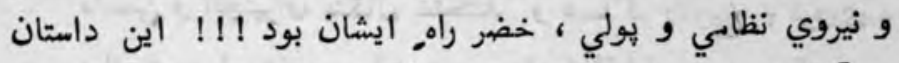

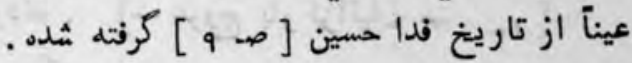

$$
\begin{aligned}
& \text { كى: صحبت [؟] }
\end{aligned}
$$

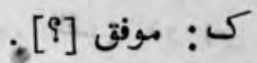

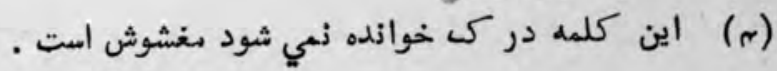


تازه نواي مaماركى

$r<r$

مدعا ها در نظر داشتند : يكي آنكه بر هر خاص و عام تا به خراسان

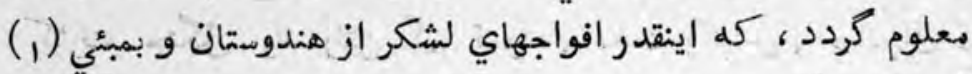

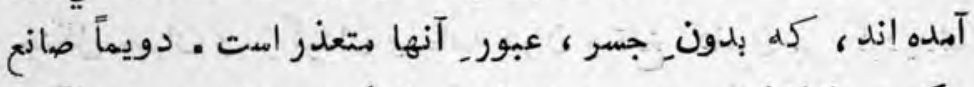
حكمت_ افلاطوني خود ، و اسراف زر (r) بي شمار بسببــ ساختن

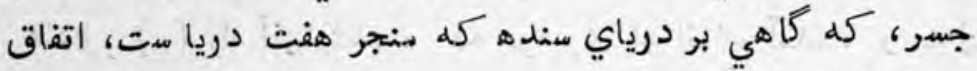

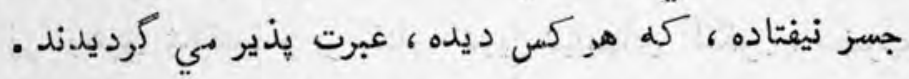
في الحقيقه اين جنين جسر نه افلاطون بسته و نه أرسطو !

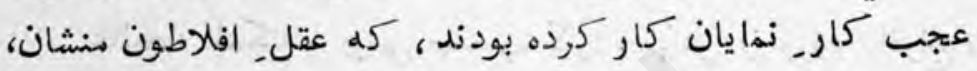

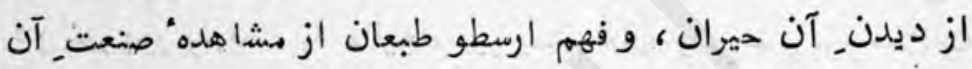

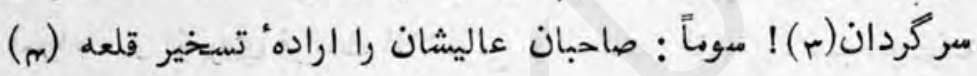

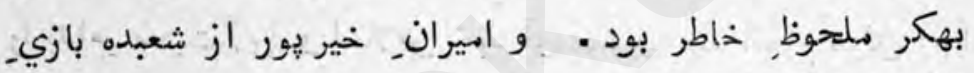

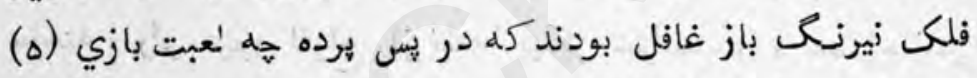

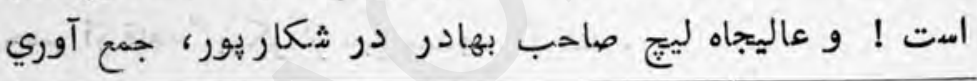
(1) : بجاي كلمه بمبئي دركى لقاط كذاشته اند .

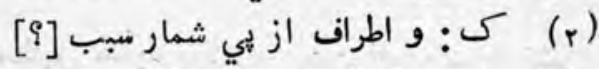

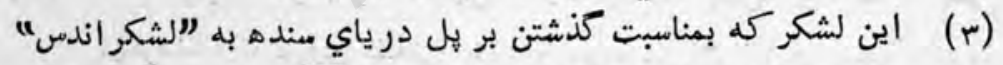

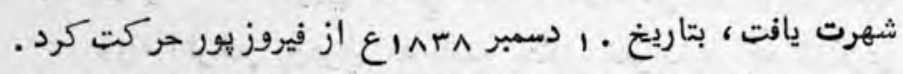

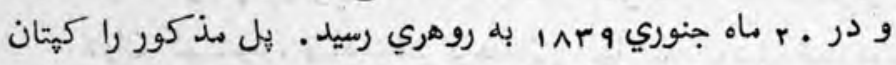

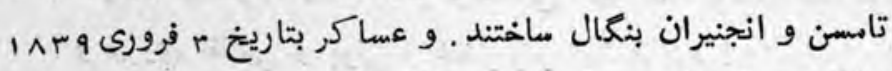

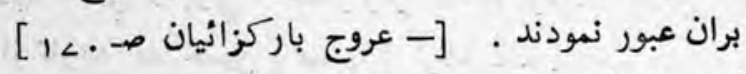

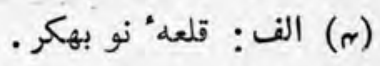

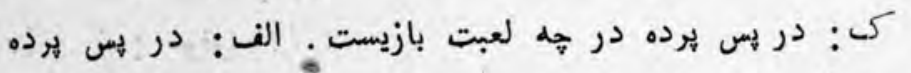

$(\Delta)$

حه بازيست 
تازه زواي معارك

مرسات و مدامان ساختن كجاوها و صندوقها وغيره مي ليرداخت .

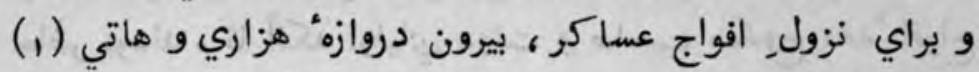

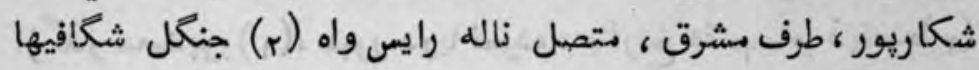

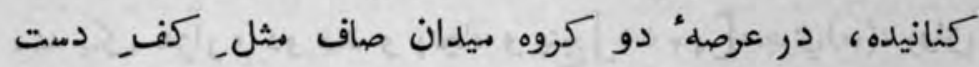

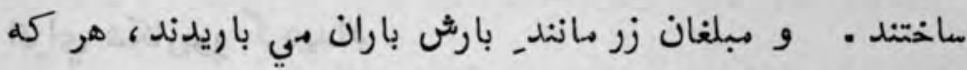

اينتجنين زر افشاني ميديد محو حيرت ميشدند ماندان

بعد از مدت معدوده، (r) اولياي دولت و عاليجاه وليم

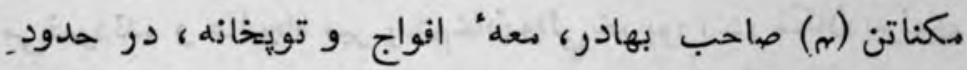

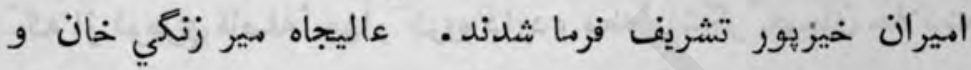
فتح محمد خان غوري از اميران خيريور، براي الستقبال اولياي

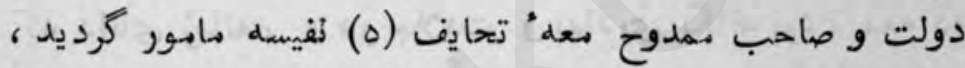

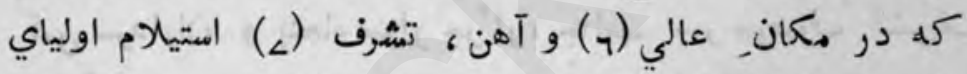

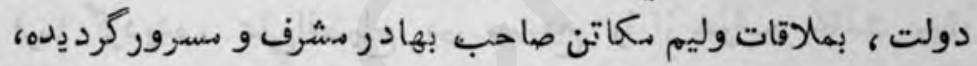

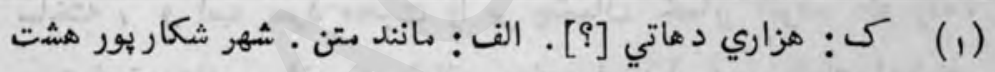

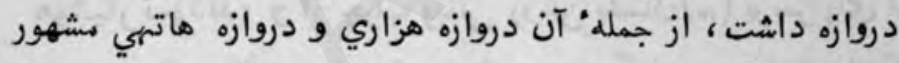

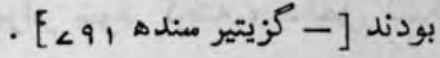

كى، ج: ناله بس واه [؟] الف: زاله ريس واه. شهر شكاريور از

(r)

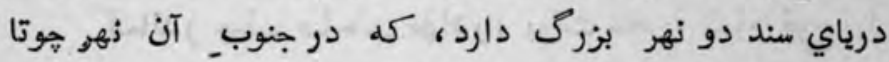

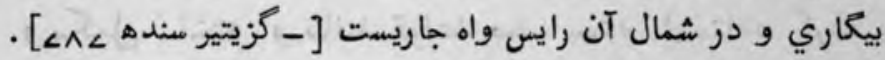

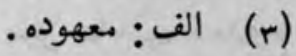

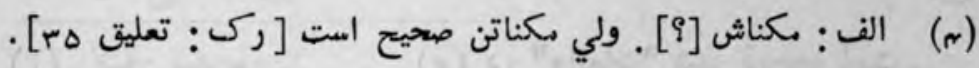

كى: : تحالف [؟]:

$(\Delta)$

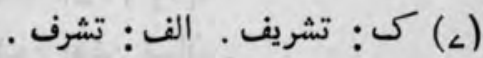

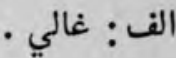

$(y)$ 


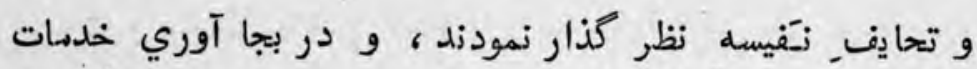

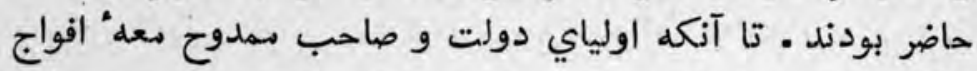

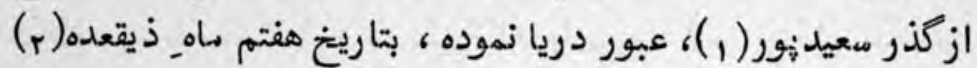

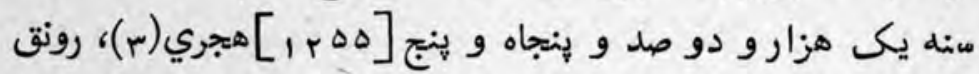

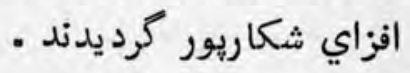

و سهي سالار كماندر هيف بهادر وغيره صاحبان واقعه لوهري

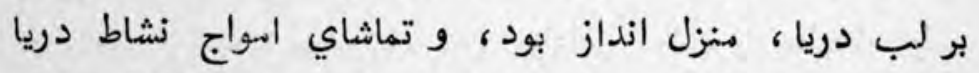

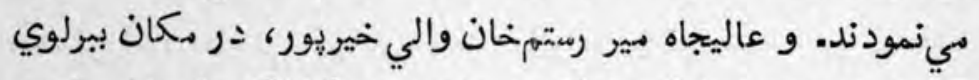

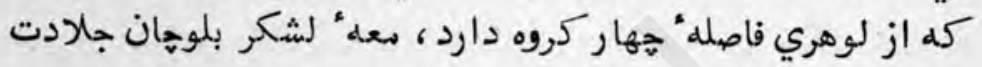

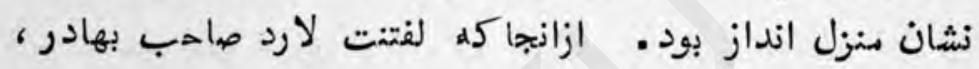

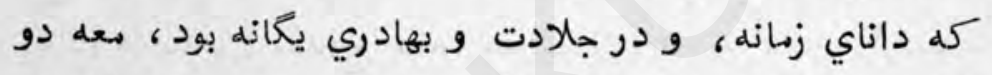

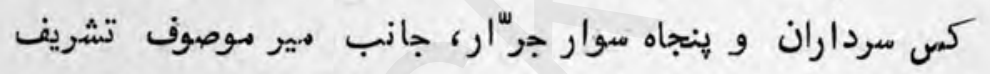

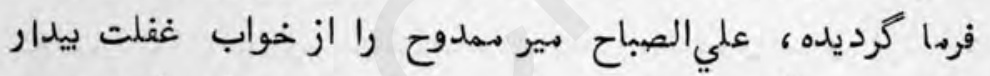

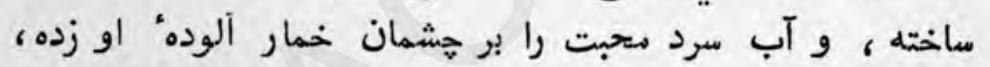

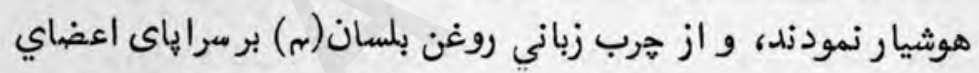

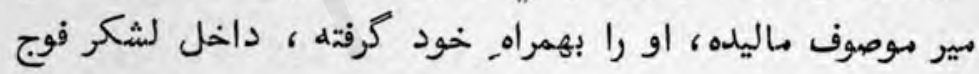

$$
\text { خود كرديد . خوصوف مالمبل }
$$

كماندر هيف صاحب بهادر، بوقت سحر، تمام فوج را مسلح

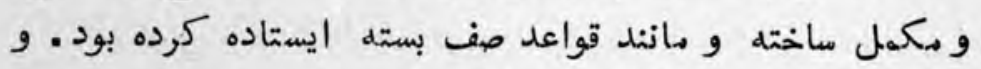

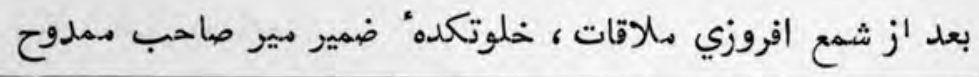

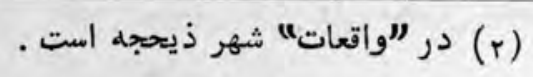

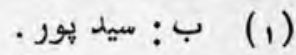

$$
\begin{aligned}
& \text { [? [ ror: } \\
& \text { (r) كس: روغن لسان. }
\end{aligned}
$$


را بانوار سخنان شيرين و رنگين هنور و هسرور ساخته ، بمير موصوف

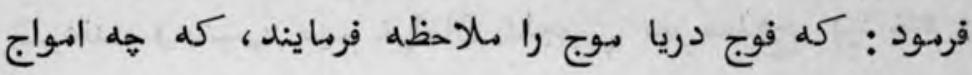
إيزند

تا مدت يكهاس بازار صحبت هابين خود كرم نموده ، بعده مير

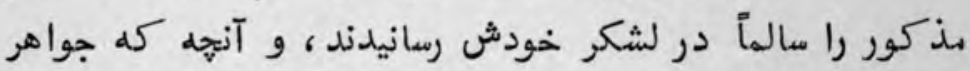
استعدادش بود ، صاحبان ممدوح همه را دريافت نمودند، و در

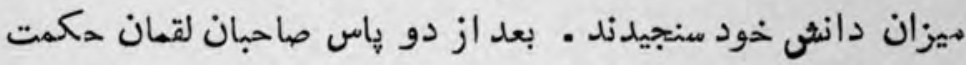
و افلاطون صفت ، قلعه" بهكر را خالى از لشكر الميران ديده ؛ ديده" تستخير بران كشاده و دو ضرب توب و هـار كشتيبان (1)

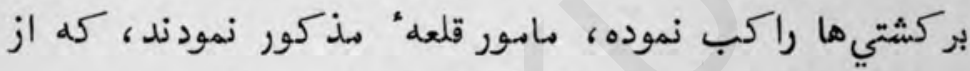
دريا عبور كرده 6، داخل قلعه" بركر شدند. و علم و نشانها بر برجهاي قلعه منصوب نموده، طنبور سرور و فتح و فيروزي در نوا آوردند ، و قلعه را محل (r) خواند و سامان مقرر نمودند . اميران خيريور در صورت كرفتن قلعه" بهكر، صورت مايوسي

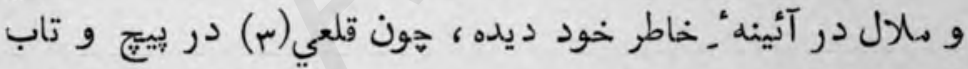

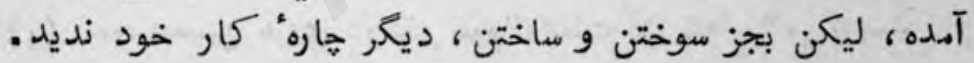
و صاحبان فرنغ (r) از روي كمال دانش افلاطوني، زود غبار مايوسى مير صاحب ممدوح بعطاي يك لك روييه به عاليجاه

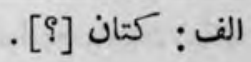

در كى بجأي اين كلمه نقاط كذاشته اند.

$$
\text { الف : قلعه . }
$$

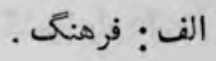


فتح محمد خان غوري وزير مير رستم خان از مرآت خاطر برطرف

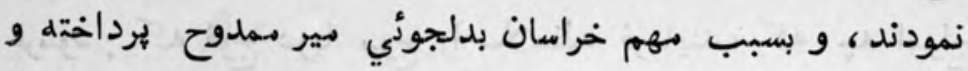

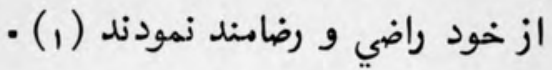

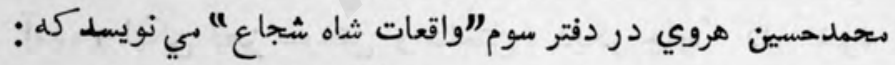

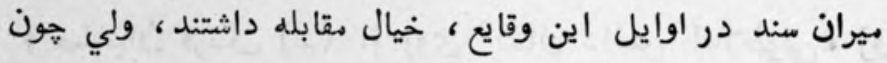

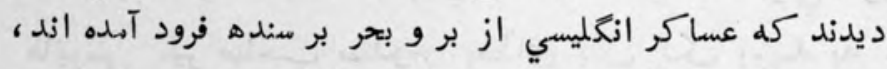

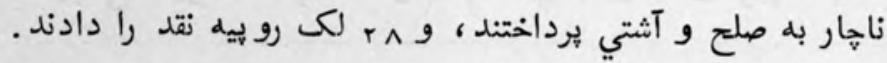

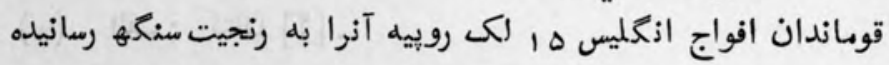

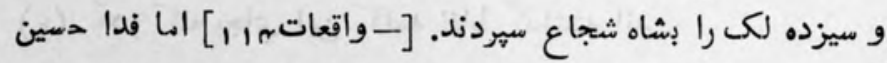

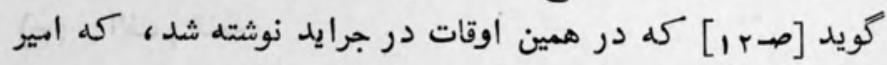

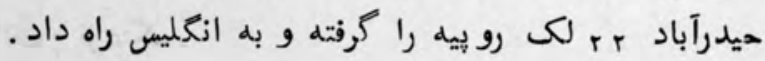




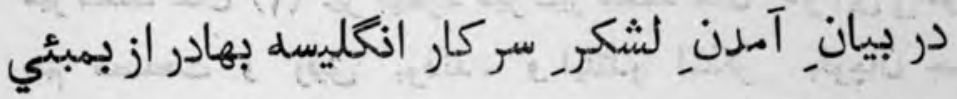

و شورش فساد نمودن بلوجان، و غارت نمودن يجهاونى (1)

$$
\text { و رفتن. فوج طرف ق قند هار و تستخير قند مار }
$$

ضيغمر قلم شجاعت رقم، در بيشه' اين مدعا هنين صيد

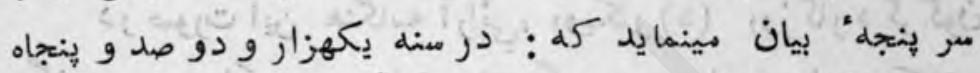

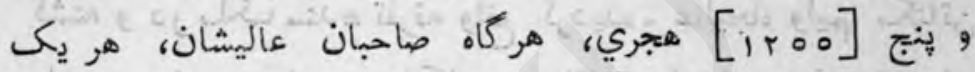

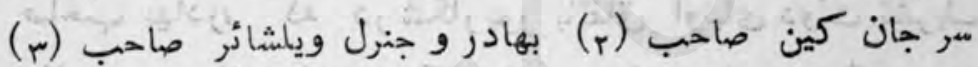

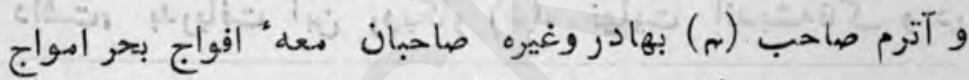

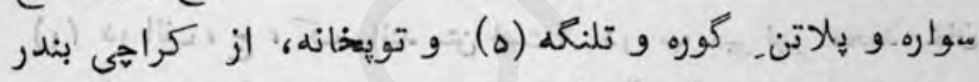

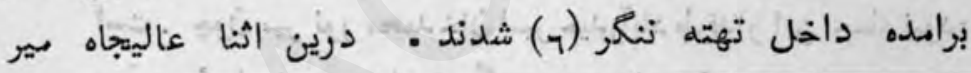

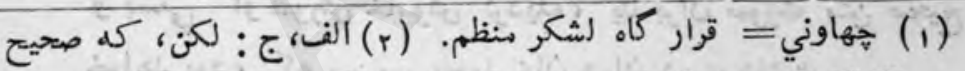

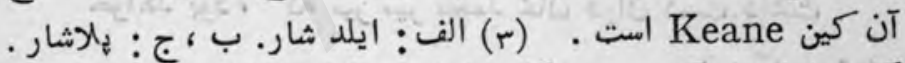

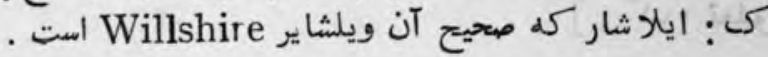

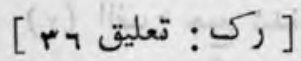

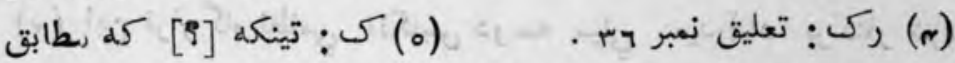

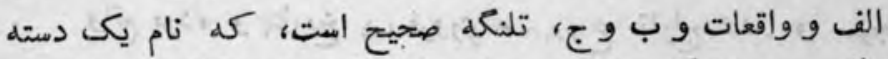

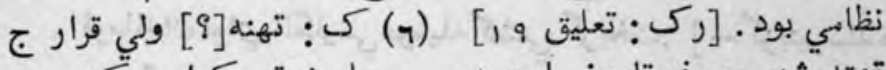

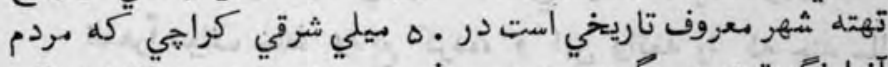

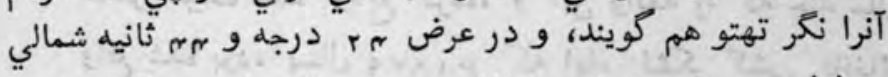

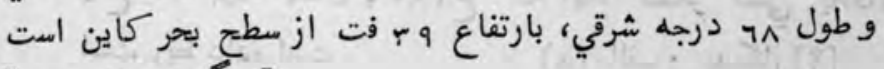

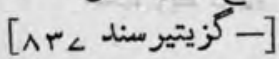


شير محمد خان جمع آوري لشكر بلوحان نموده، مستعد بهقابله

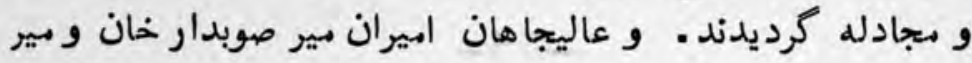

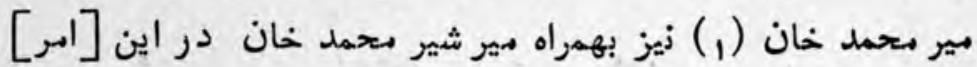

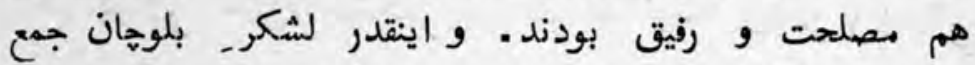

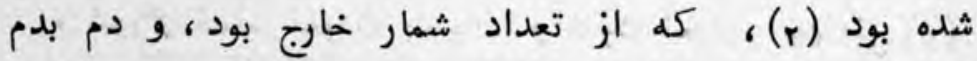

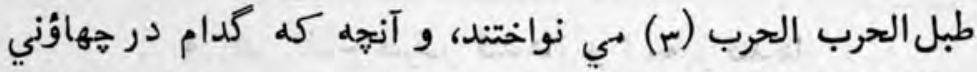

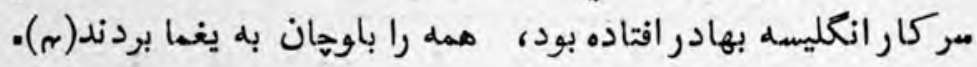
در صورت اين هنكايه آرائي، رويكار (0) روزكار دوكركون

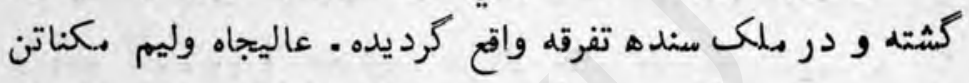

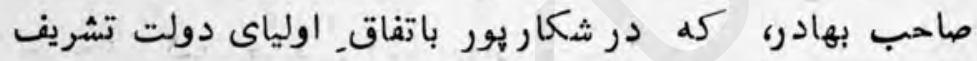

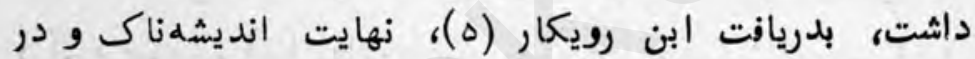

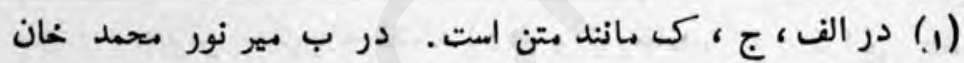

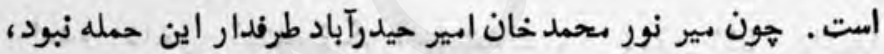

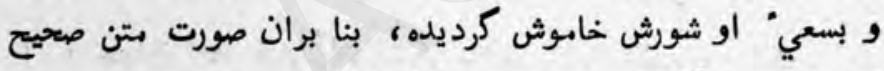

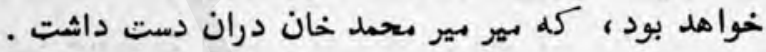

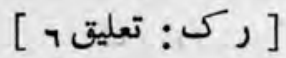

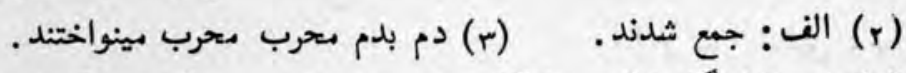

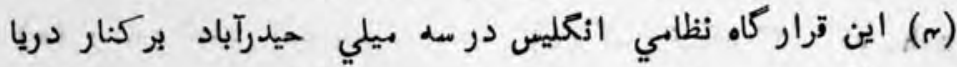

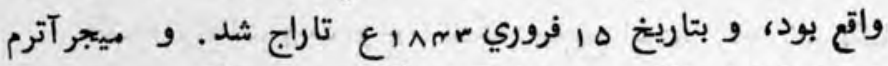

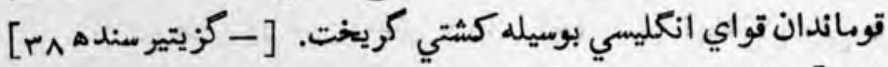

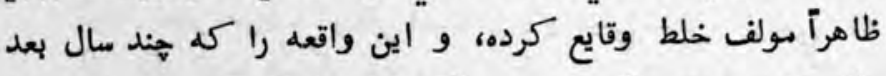

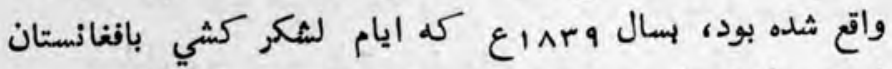

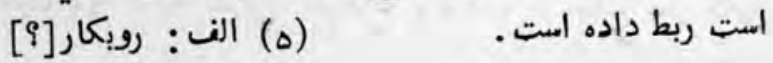




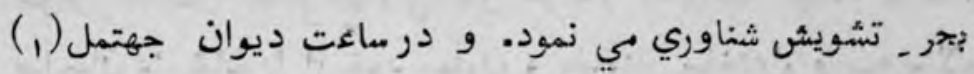

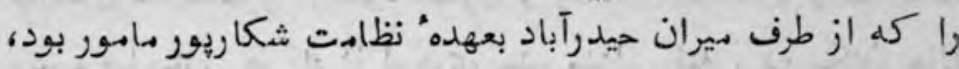

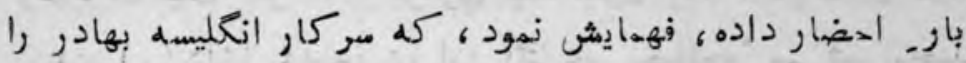

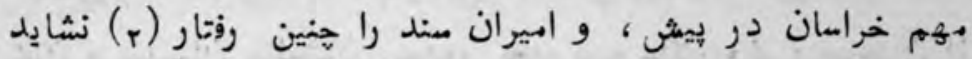

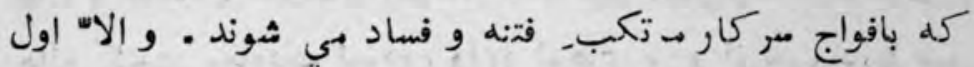

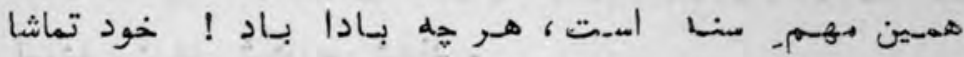

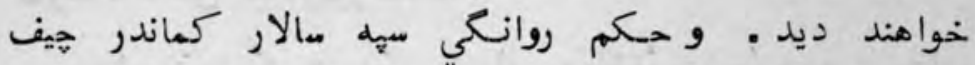

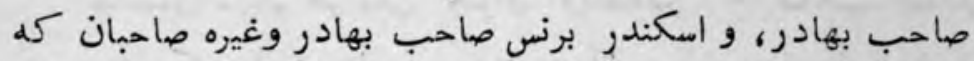

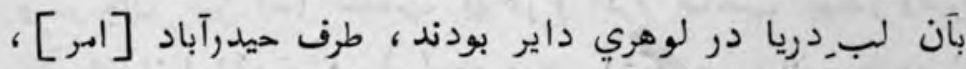

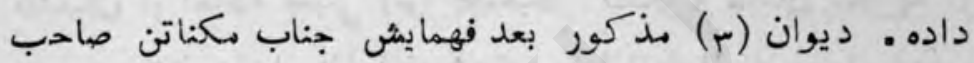

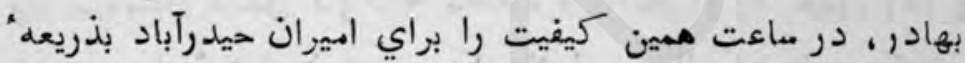

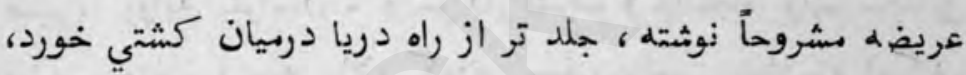

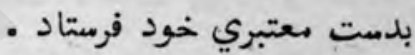

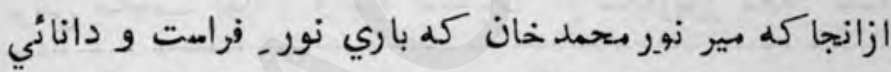

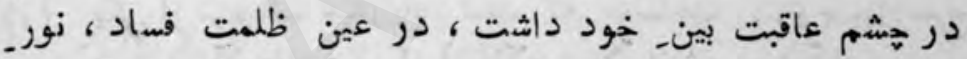

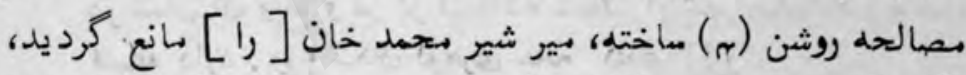

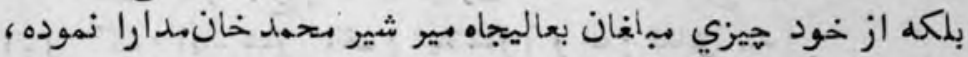

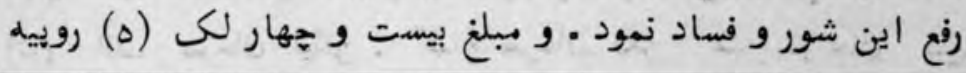

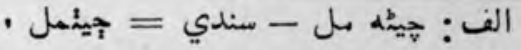

$$
\begin{aligned}
& \text { الف: الف: روش . }
\end{aligned}
$$

ديواناصطلاجاً بطور لقب اعزازي هندوان استعمال شده، شثل لالا.

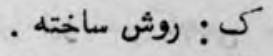

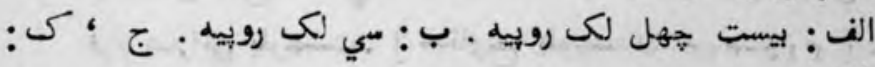

$$
\text { ماند متن }
$$


تازه نواي معارك

rA.

عوض غارت كُدام ههاوني در سركار انغليسه بهادر داده

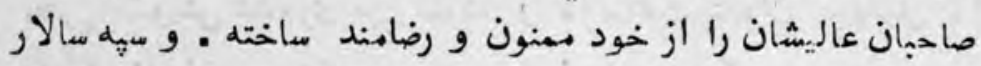

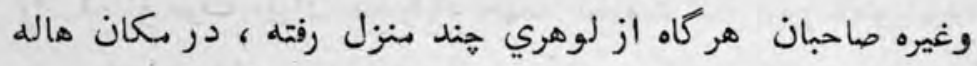

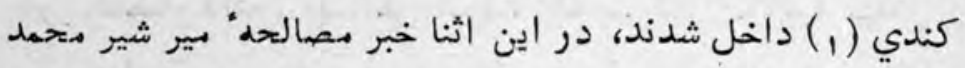

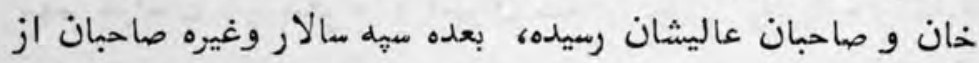

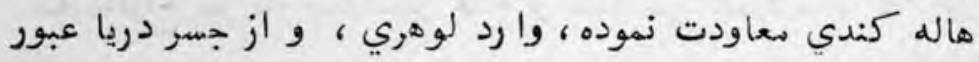

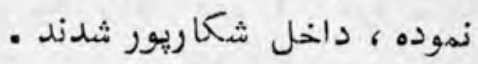

صاحبان ديكر هر يك جنرال ويلشائير (r) صاحب بهادر و مر جان كين (r) صاحب بهادر و آترم صاحب بهادر وغيره

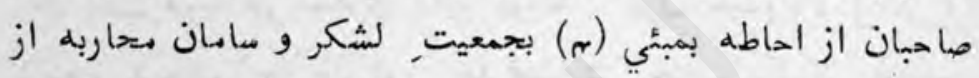

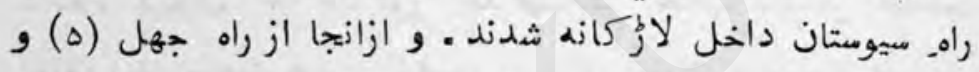
طنبو، روانه' خراسالن . و سركار اشرف و عاليجاه وليم مكناتن

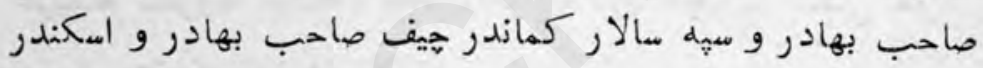
برنس صاحب بهادر وغيره صاحبان از شكاريور معله وعساكر و

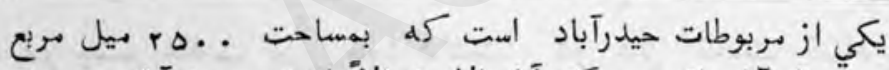

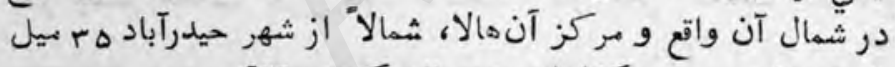
(1)

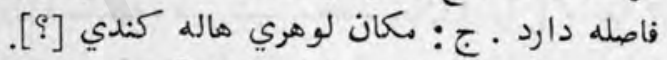

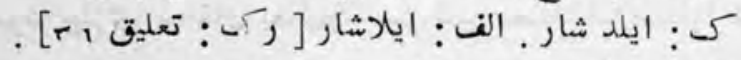
$(r)$

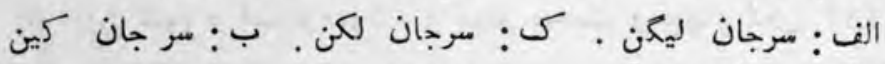
$(r)$

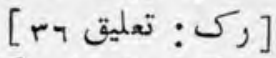

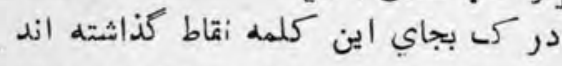
( $)$ الف ، كى: جهل و طنبور [؟] أما جهل در مر زبين كمجهي واقع (ه)

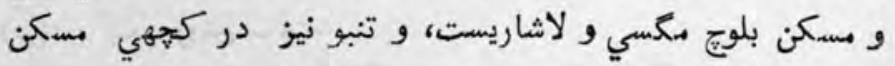

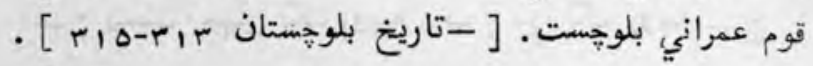


آلات. محاربات، تشريف فرهاي خراسان كرديدند .

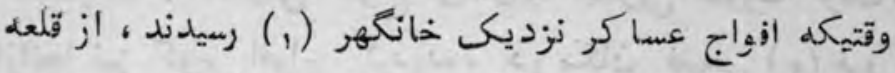

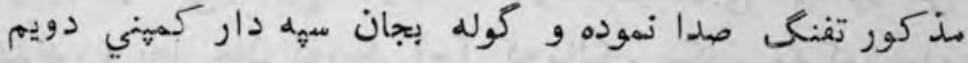

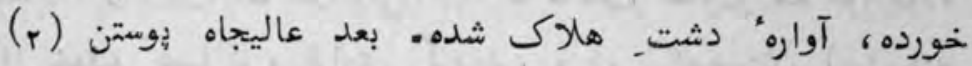

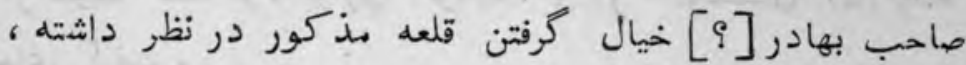

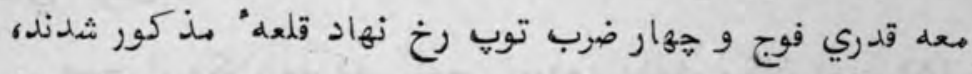

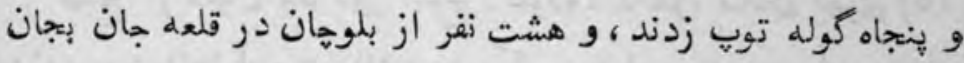

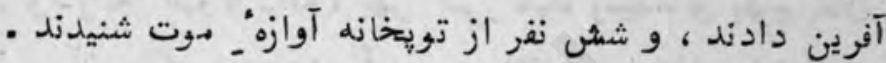

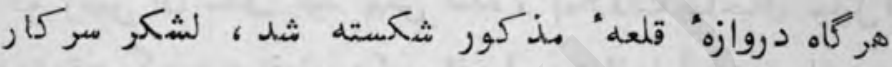

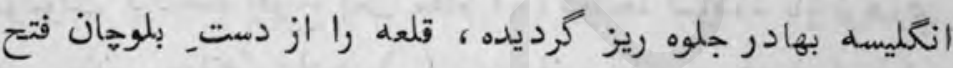

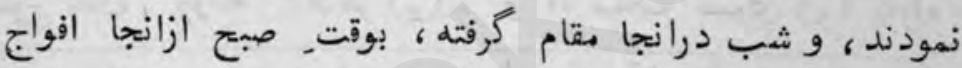

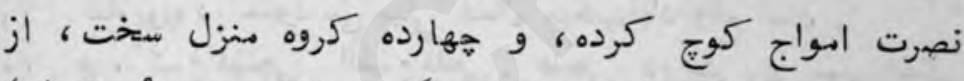

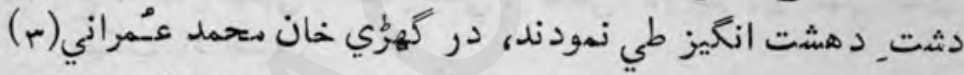

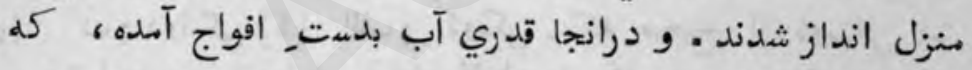

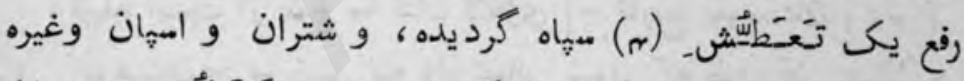

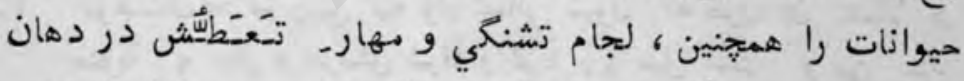

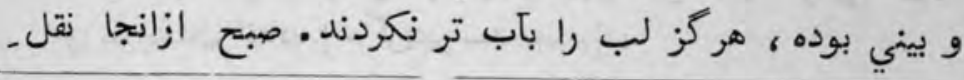

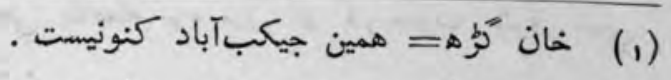

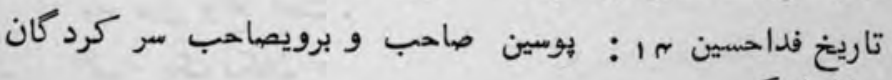
همان لشكر.

عُمراني = يكي از قبايل بلوج است كه در منجوتي سر زمين كجهي

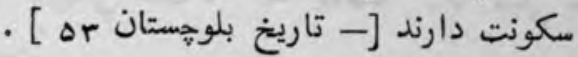

$$
\text { تعطش = تش:كي. }
$$


منزل نموده، داخل مقام شاه بوره (1) شدند، و درانجا بسبب

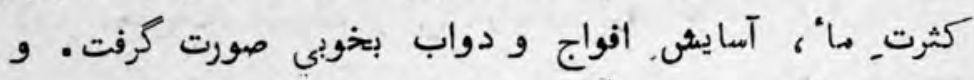

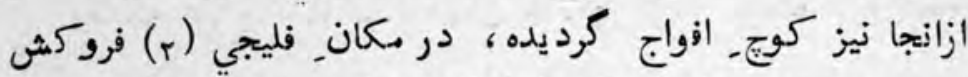

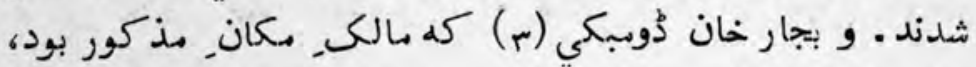

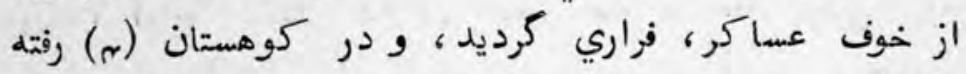
- جاي كرفت

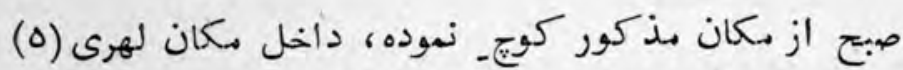

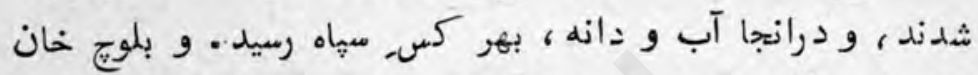
كه رئيس آن ملك بود بيش آهده ، بملاقات صاحبان جليل القدر

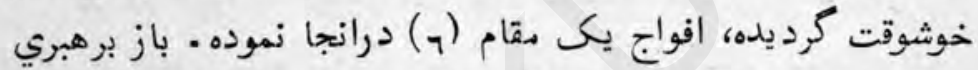

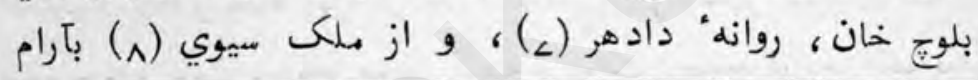

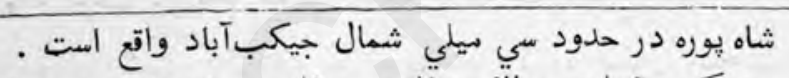

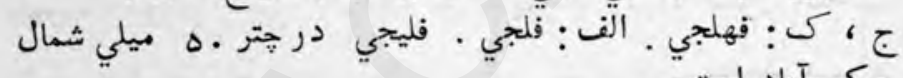

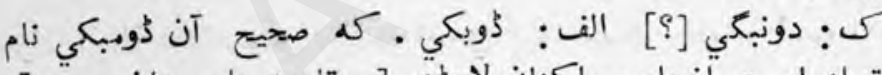

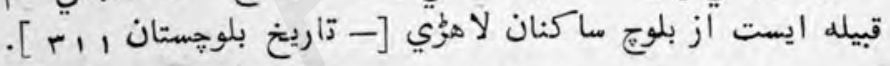

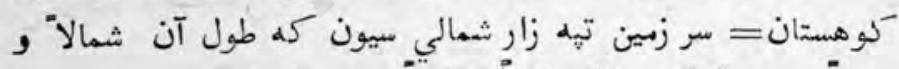

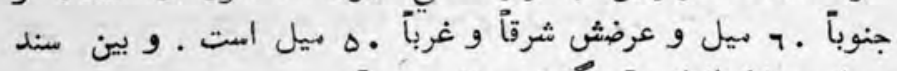

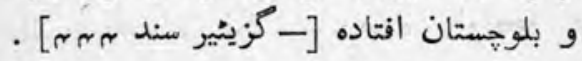

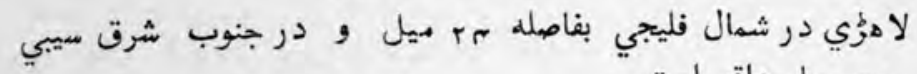

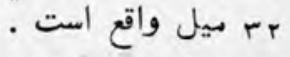

$$
\begin{aligned}
& \text { الف : يكى دكان . }
\end{aligned}
$$

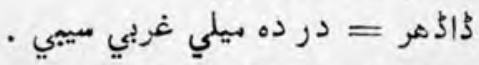

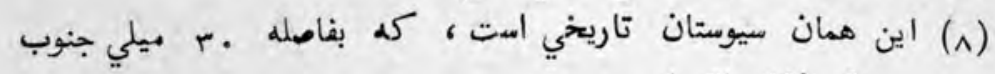

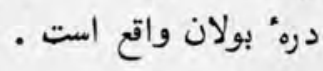


تمام كذر كرده ، داخل دادهر شدند . ليمكن هابين. راه از زد و

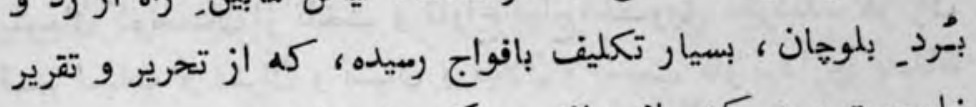

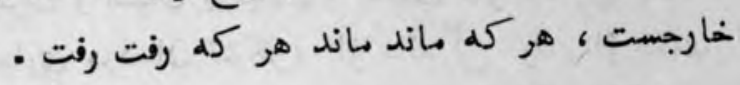
ليكن صا=بان عاليشان ، از دشت_ جهنم آسا ، به تهويزي

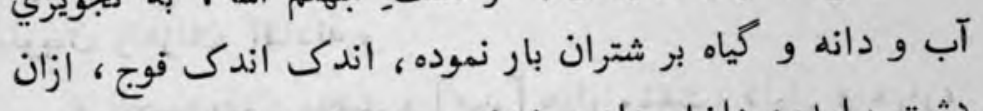

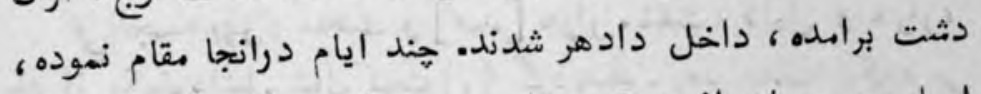

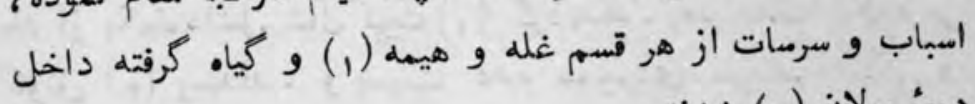

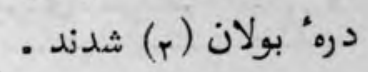

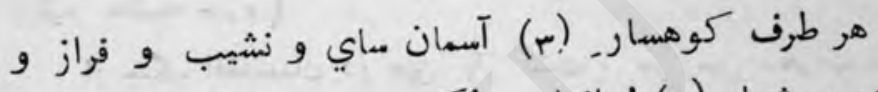

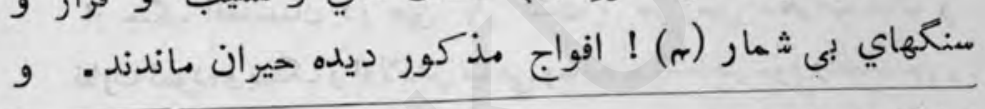

(1) كل: غله و يا مهمه . الف : مانند هتن . هيمه بمعني هوب سوختني است .

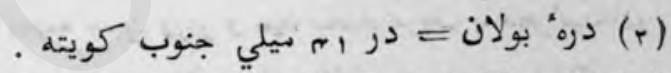

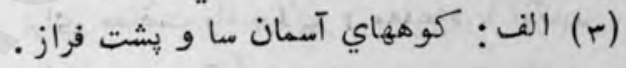

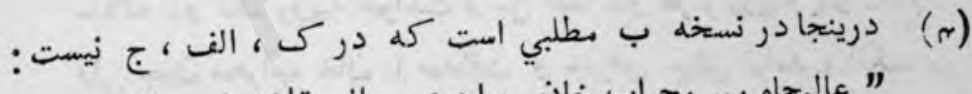

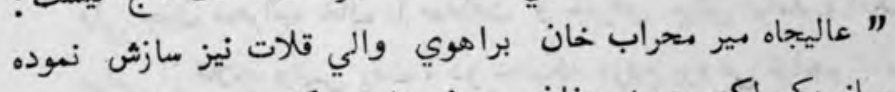

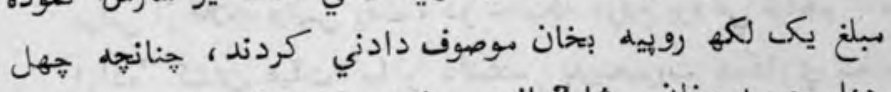

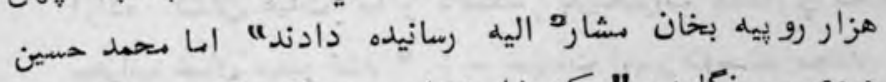

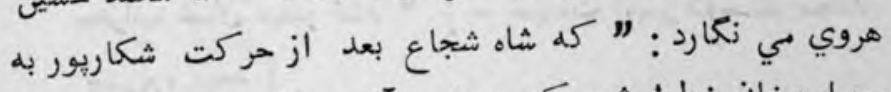

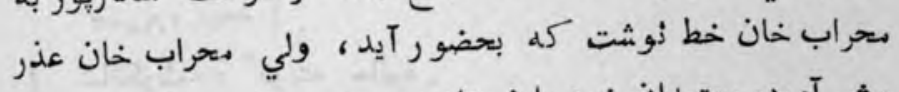

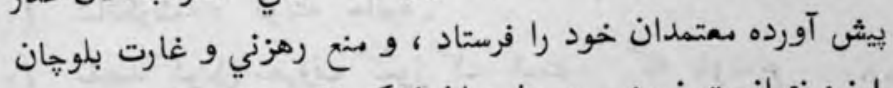

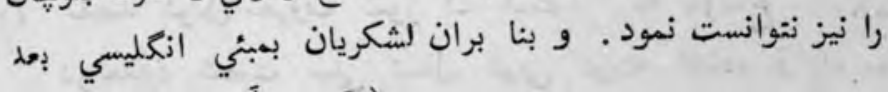

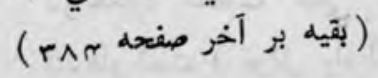


تازه نواي مار

rAr

بلوهان كوهستان از تاخت و تاراجافواج، قصوري نكردند. هزاران

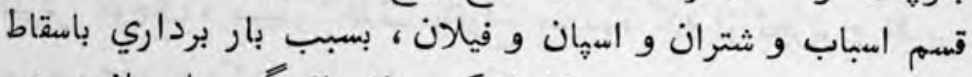

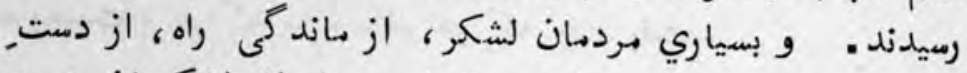

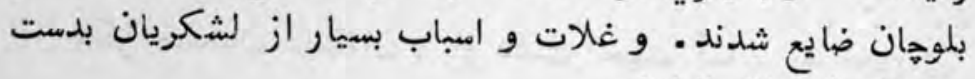

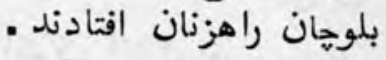

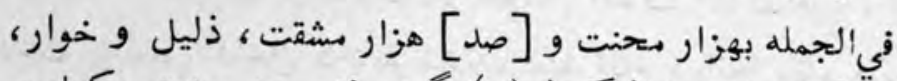

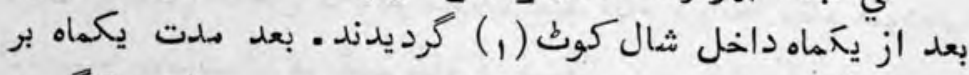

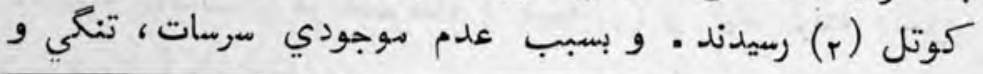

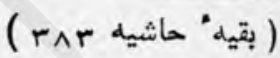

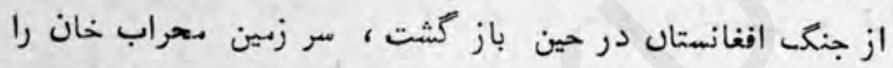

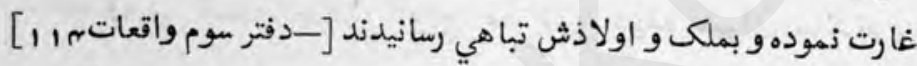

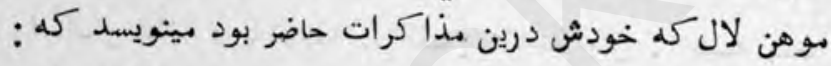

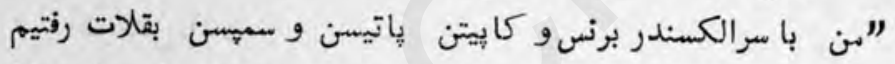

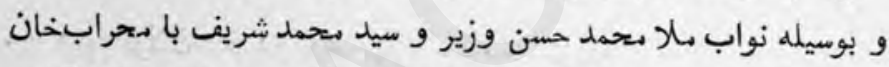

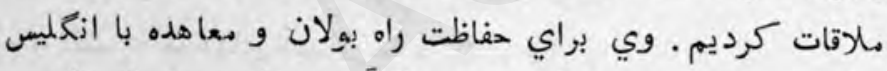

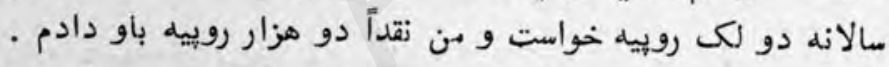

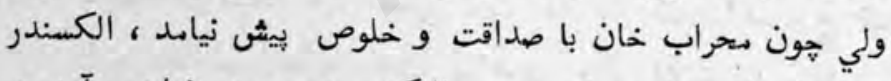

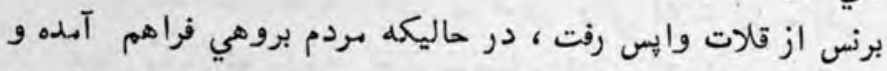

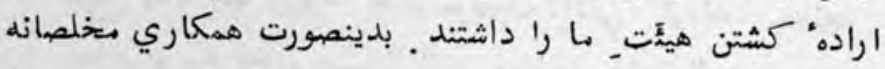

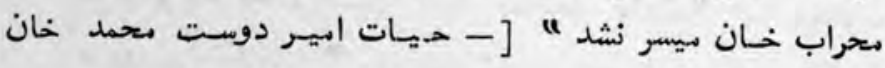

$$
\text { [ [ ] } 1 \wedge<-r
$$

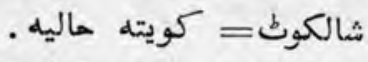

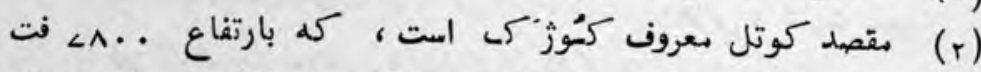

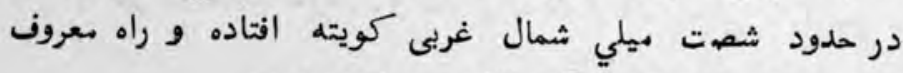

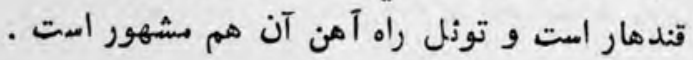


تازه نواي معاركى $\quad$ rی

عسرت كذران بحدي شده، كه يك آثار (1) آرد- خشكه مري

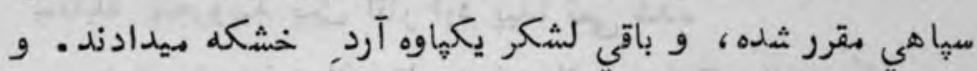

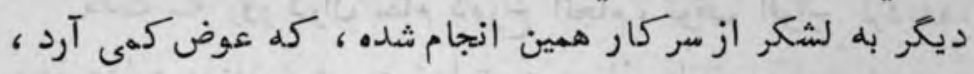
درم نقد بموجب نرخ زوز مره ، ماه بماه از سركار عنايت - خواهد شد

و از هاري (r) كوتل ، كذشتن عساكر و سامان نهايت

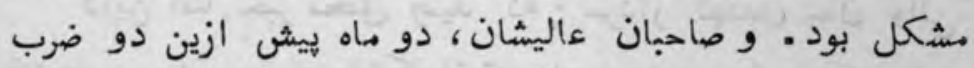
توب و هزارها خروار باروت، بر كوتل جهت صون صفاب راه فرستاده

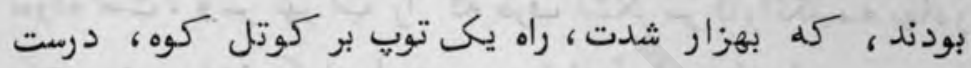

نموده بودند آن آن

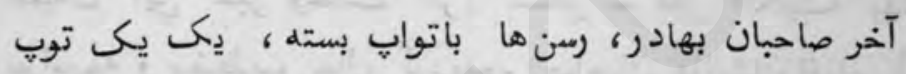

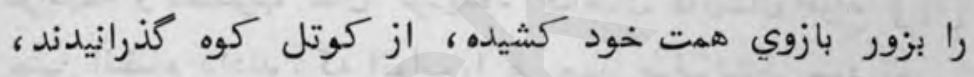
و ديكر, اسباب و سامان نيز علي هذالقياس از كوه مذ مذ كور

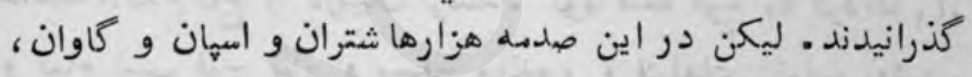

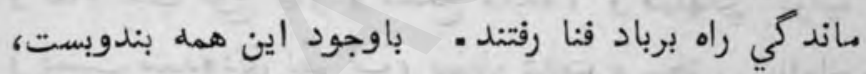

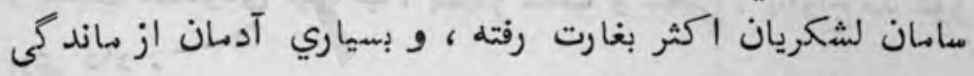

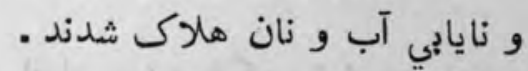

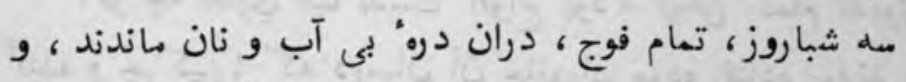

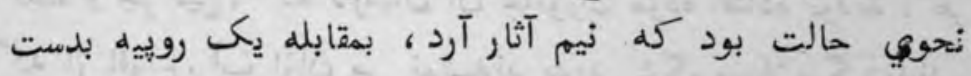
نمي آ.ده - بعد از اندك فرصت، همان نيم آثار آرد هم نا يبدا كرديد،

$$
\begin{aligned}
& \text { (r) }
\end{aligned}
$$

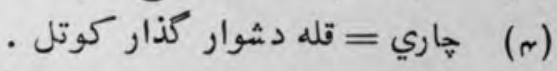


بهقابله هينجروبيه يك آثار آرد بيدا نمى شد. مدت سه روز دران مقام دوزخ انجام، توقف افواج كرديده.

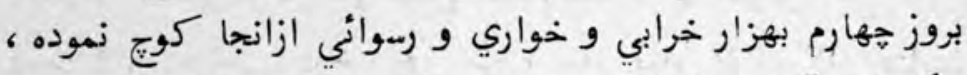

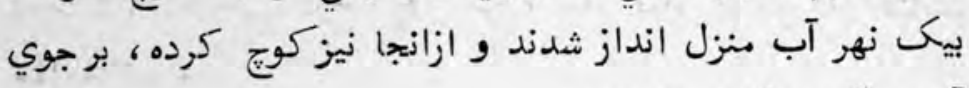

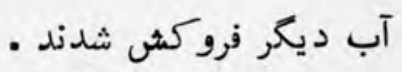

درين اثنا خبر مجقق وسيد كه : سردار كهندل خان والين

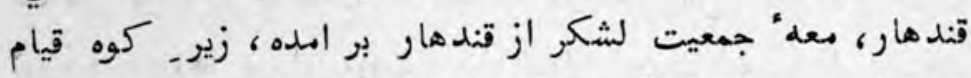

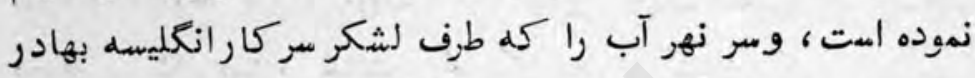

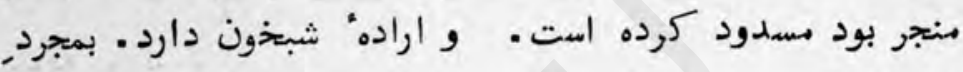

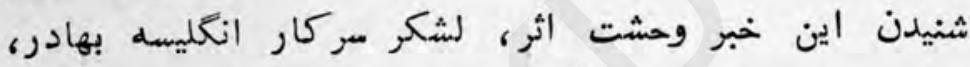

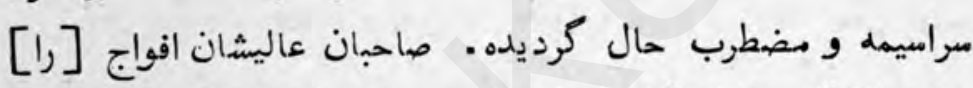

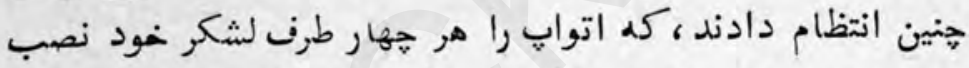

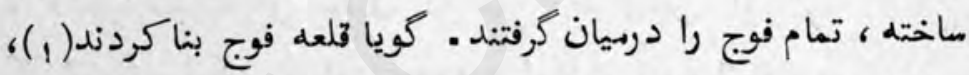

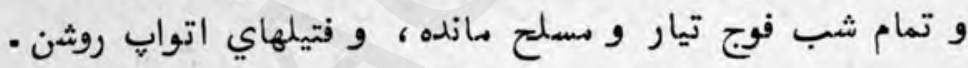

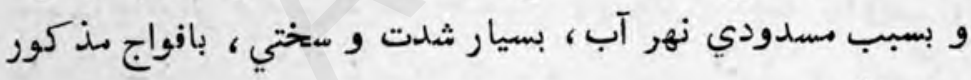
روي داد .

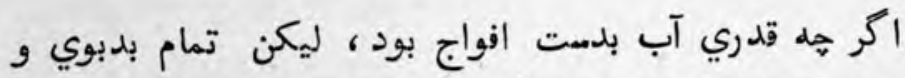

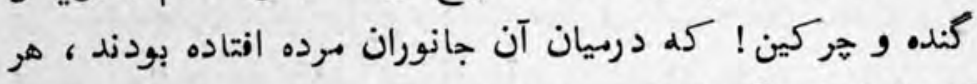
كه از افواج، آب ازان مي نوشيدند بدرد_ شكمي مبتلا ميكرديدند،

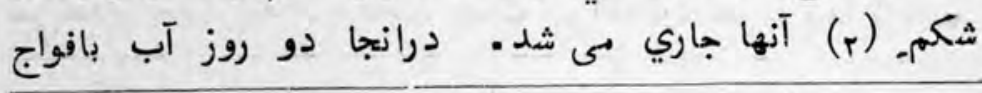

$$
\text { الف: كرديده. }
$$

الف: و اطلاق از شكم . كرديد 
بدست نيامده، ازين جهت، آدمان الشِكر و اسيان و شتران و

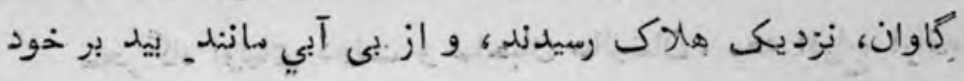

ميلززئ منيد

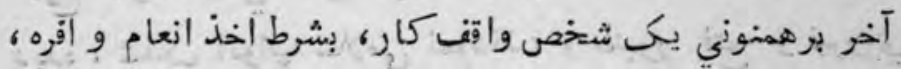

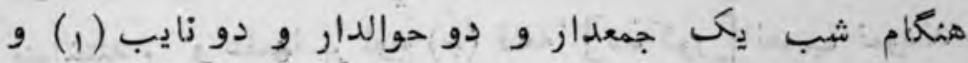
بيست نفز سوار و سي نفر عهله دار ب، براي بريدن. بند. نهر مامور

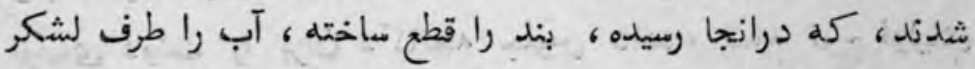

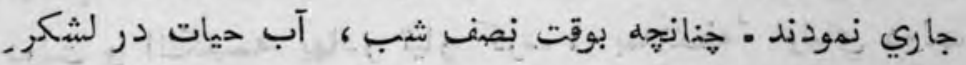

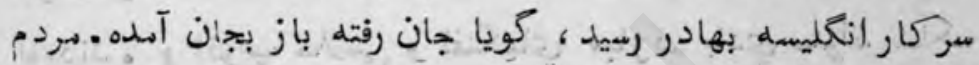

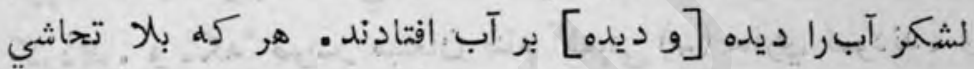

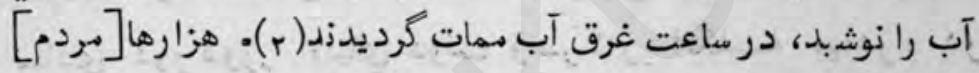

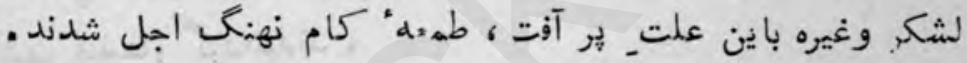

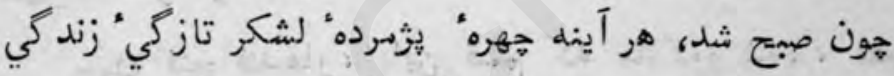

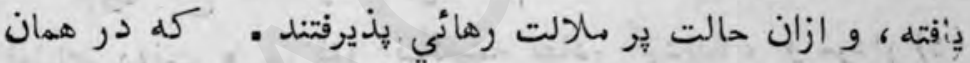

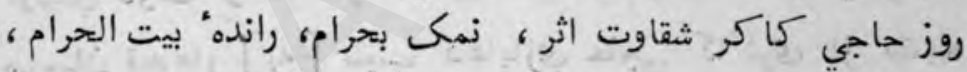

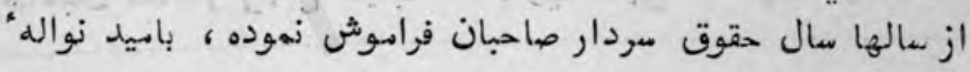

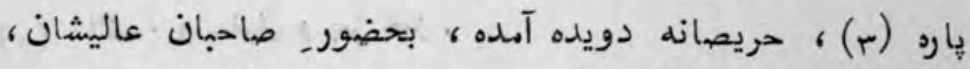

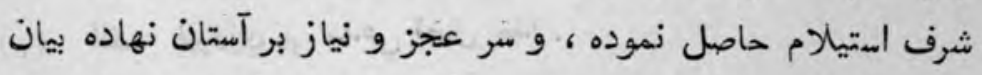

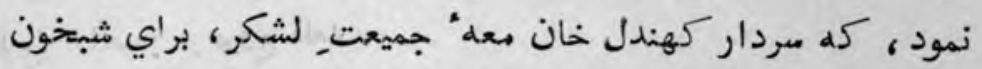

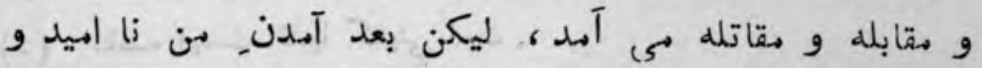

$$
\begin{aligned}
& \text { النح: نايكى . }
\end{aligned}
$$

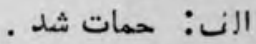

الف : نواله" تازه خون سمات دويده آمده . 


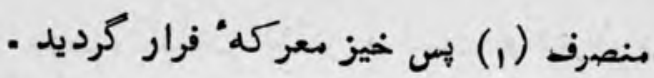

سحر گاه اولياي دولت و صاحبان عاليشان ، معه افواج ازانجا

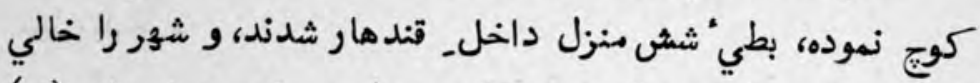

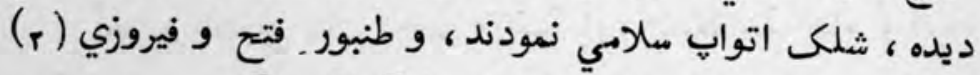

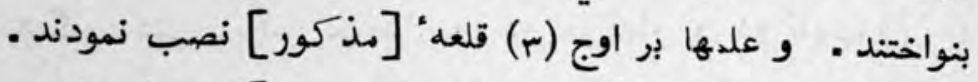

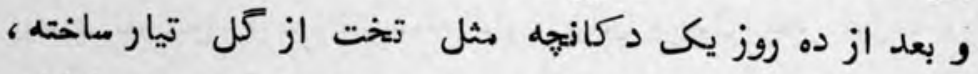

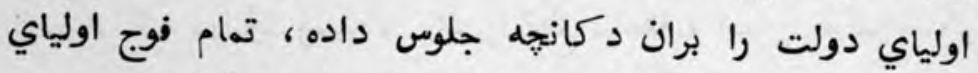

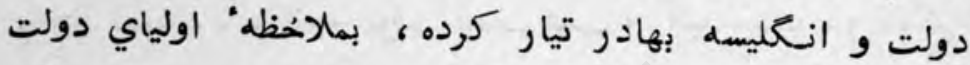

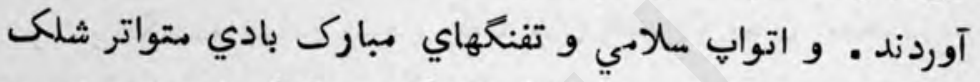

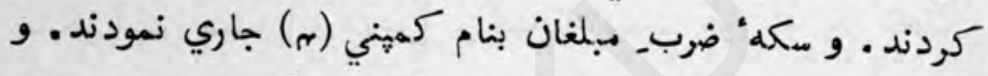

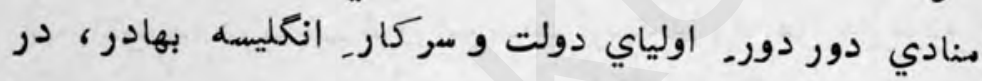

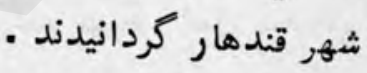

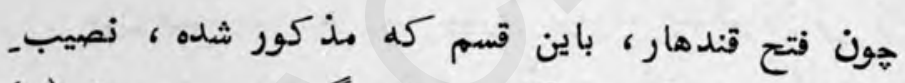

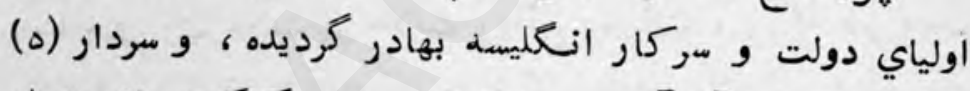

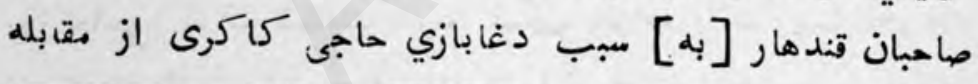

$$
\text { الف: و متفرق و يس خيز · }
$$

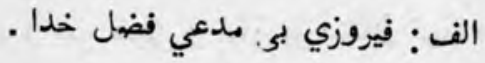

$$
\text { الف : بر بروج قلعه . }
$$

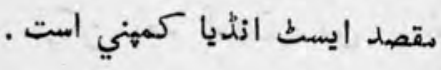

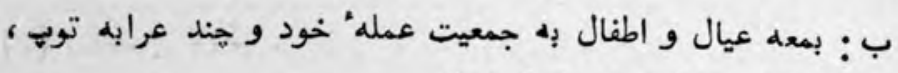

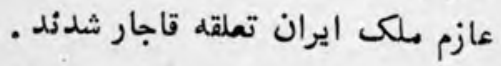




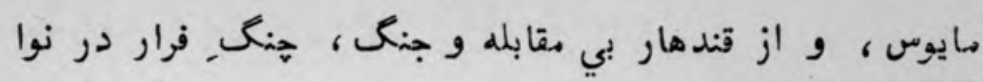

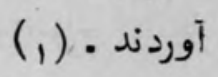

نام حاجي خان كاكري اصلاً "تاج دممد خان بود كه درينجا از

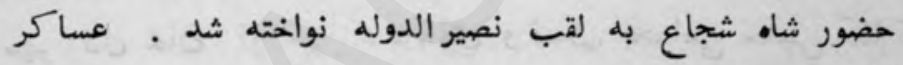

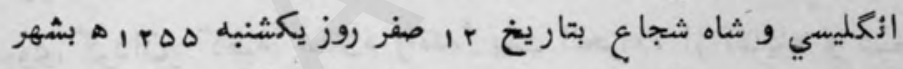

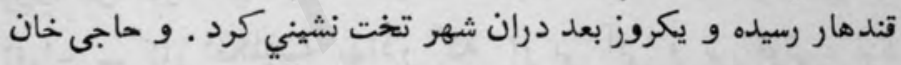

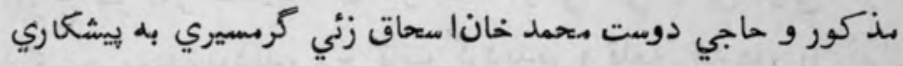

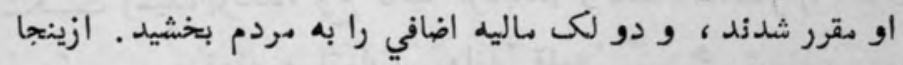

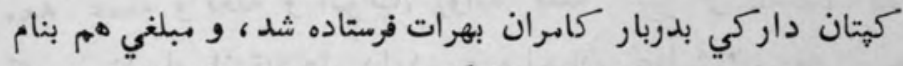

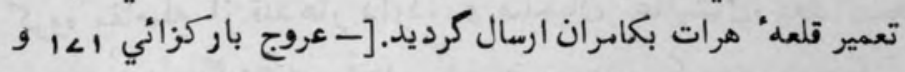

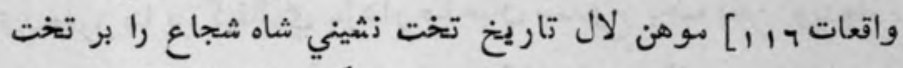

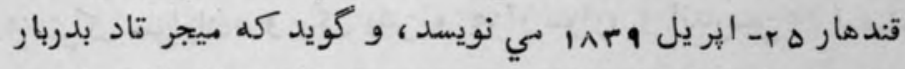

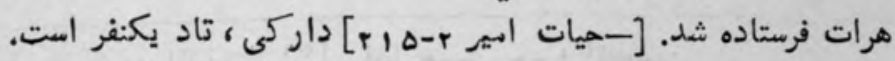

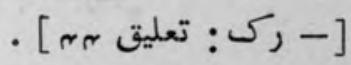




\section{$-\omega<-$}

در بيان هزيمتــ سردار ماحبان قندهار و توقف فوج در قندهار [و كشيدن بيما:ي] و بعد دو ماه

روانه شدل جانب قلعd" غزني و فتع قلعه" مذكور،

و دستكير نمودن عاليجاه شجاعت دستكاه غلام حيدرخان

خلف الصدق ابير دوست محمد خان

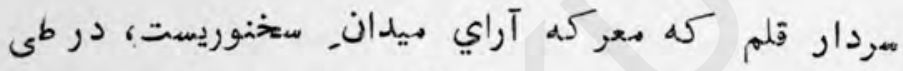

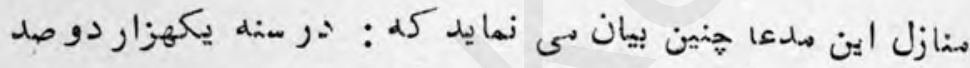

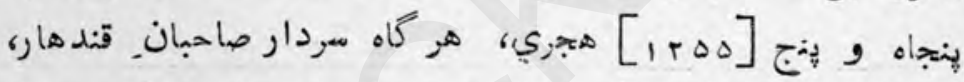

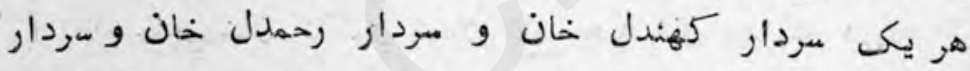

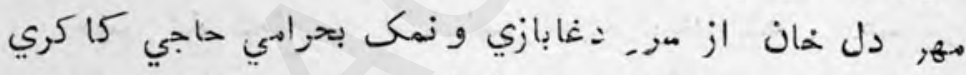

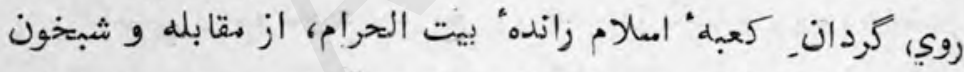

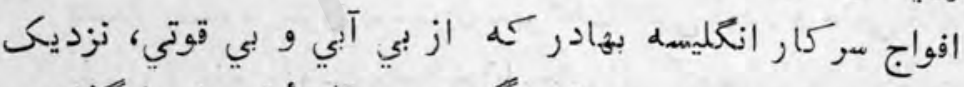

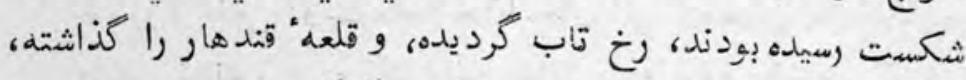

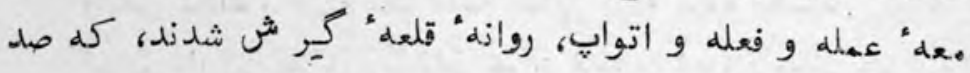

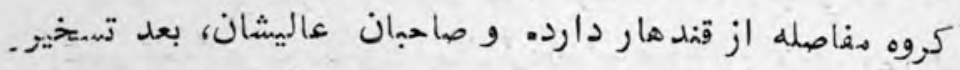

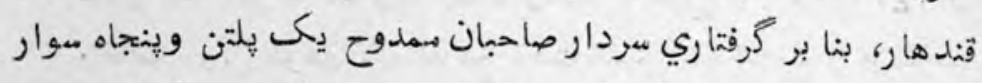

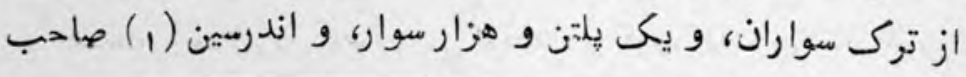

• (1) 
:هادر، و از فوج- اولياي دولت، دوضرب توب و ديكر اسباب

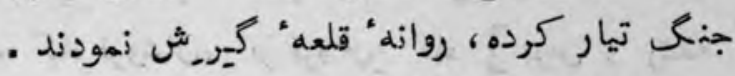

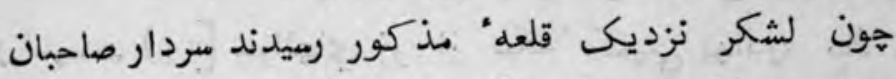

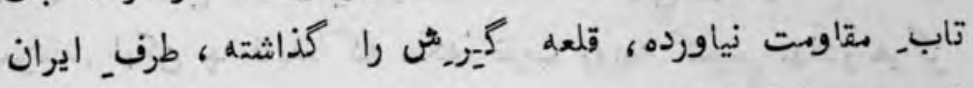

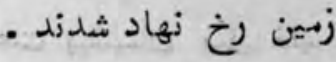

بعد رفتن مردار صاحبان، فوج يكى هلتن از اولياي دولت

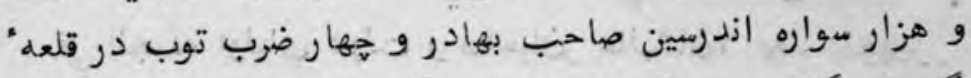

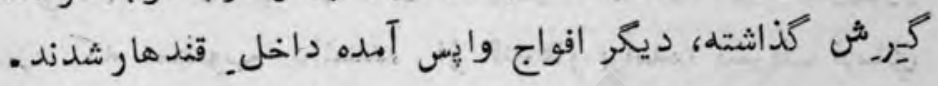

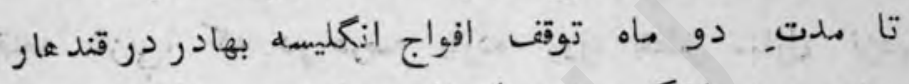

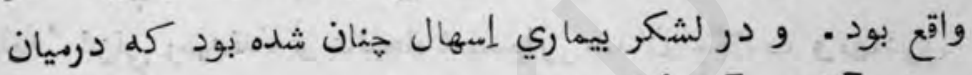

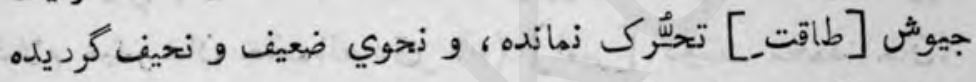

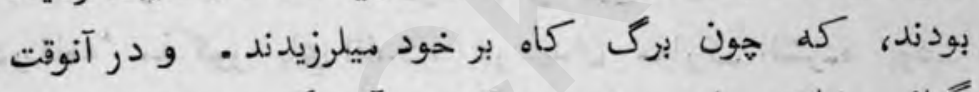

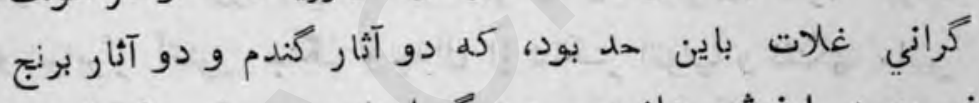

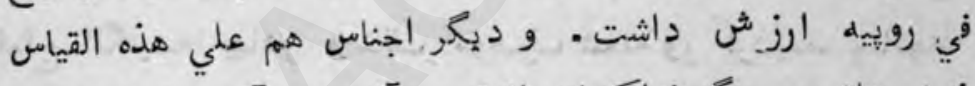

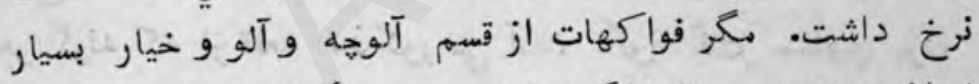

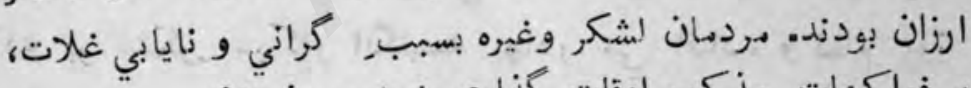

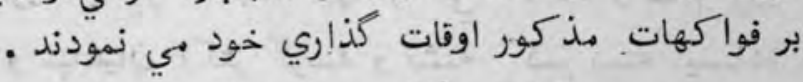

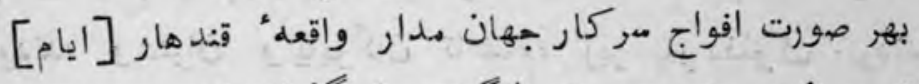
سخت و نحس و مصيبت انكيزي را كذرانيدند. . و و بسياري

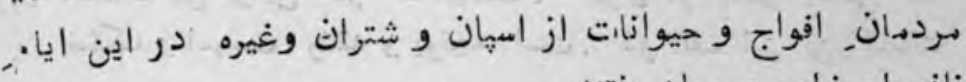

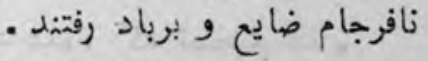

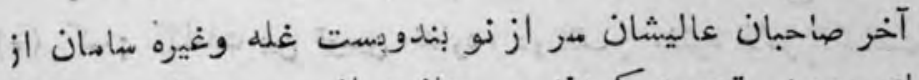

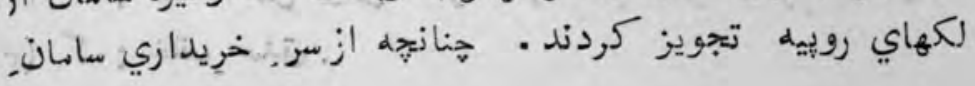




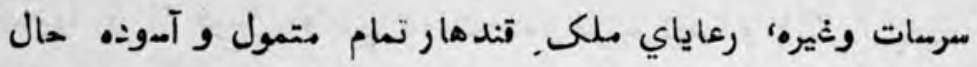

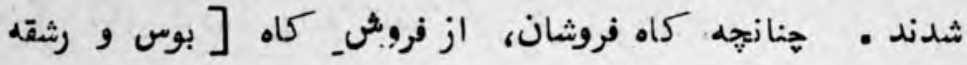

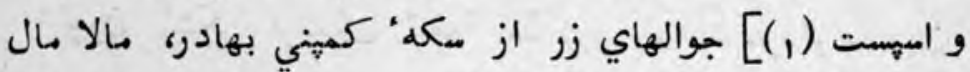

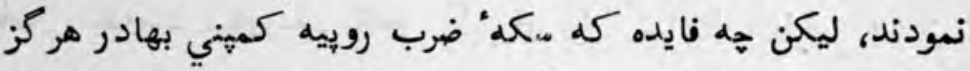

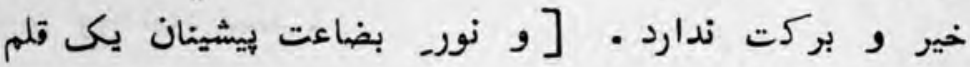

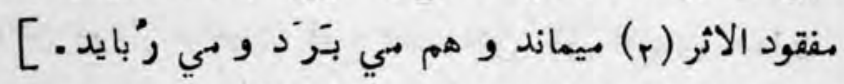

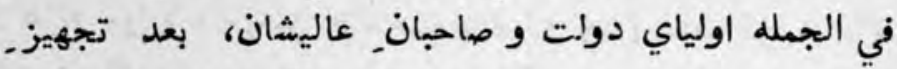

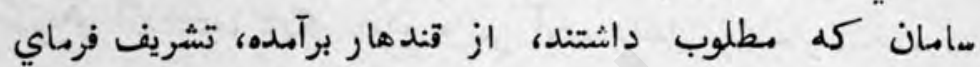

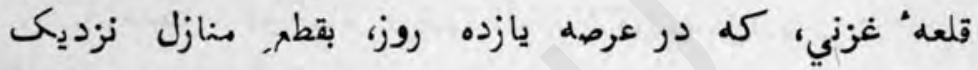

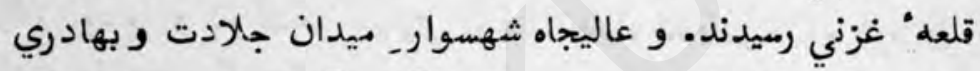

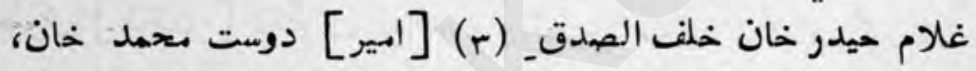

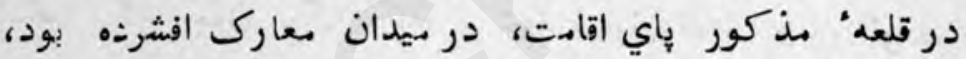

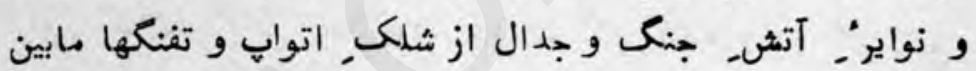

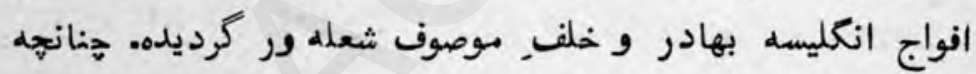

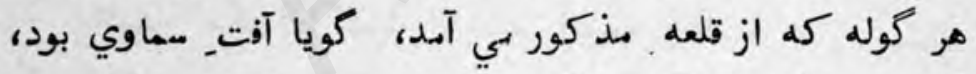

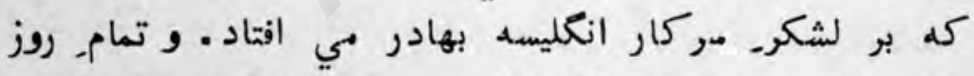

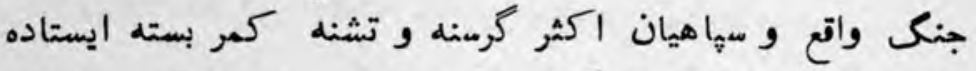

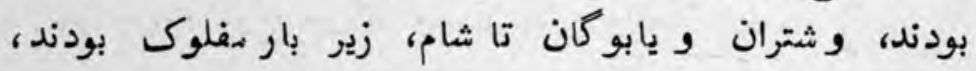

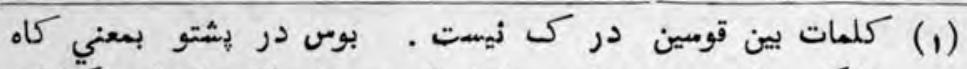

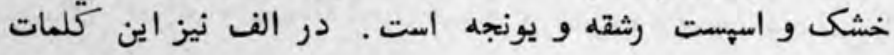

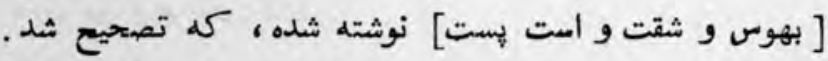

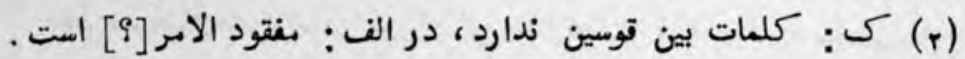
(r) 
بعد ازشام، جاب مورجه بندي منزل انداز شده، از جنمق آرام گرفتند.

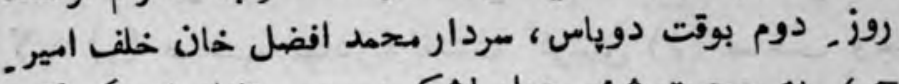

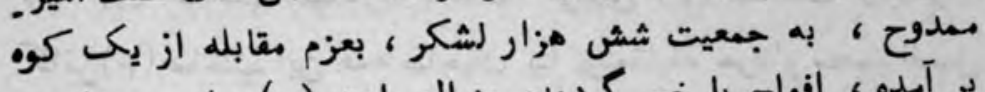

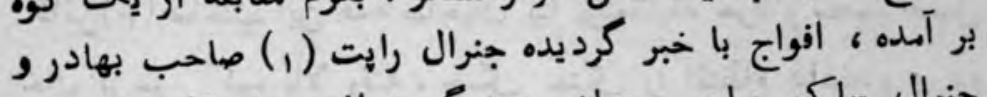

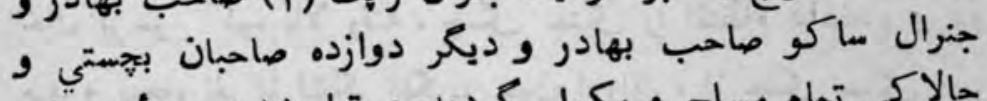

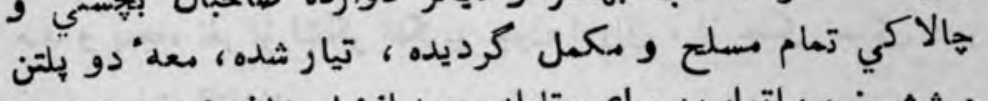

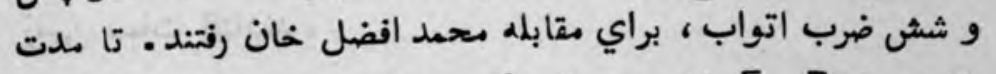

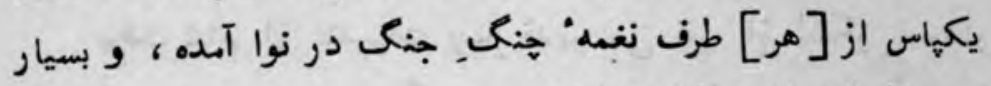

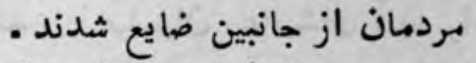

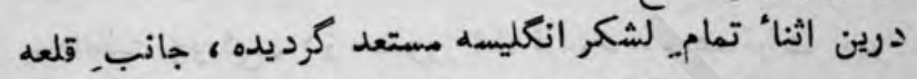

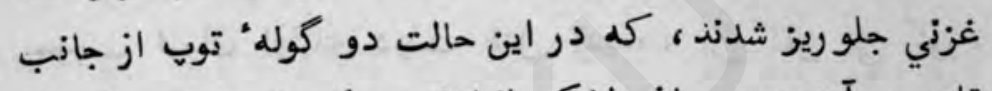

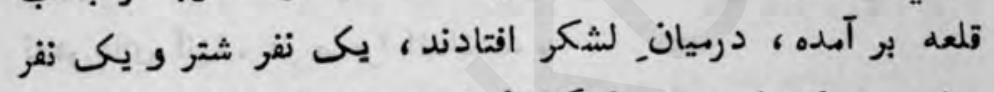

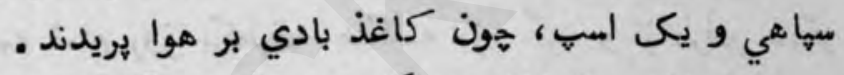

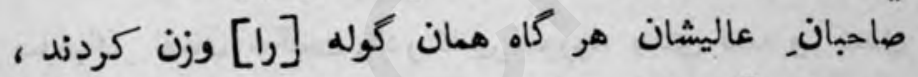

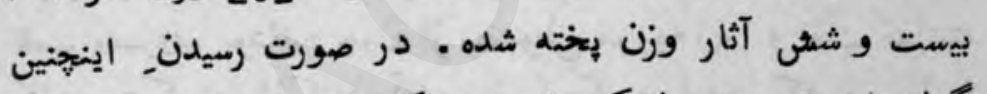

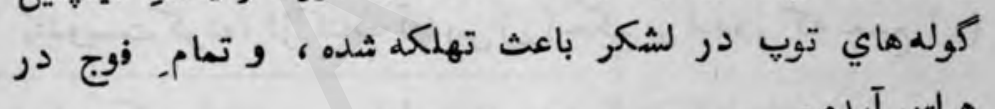
هراس آمده - ماسه آخر صاحباني عاليشان هر يك كرنيل ميرت (r) صاحب بهادر كى: رايت. ج : رايت كه در محاوره" عوام رابرت را رابت كفته اند،

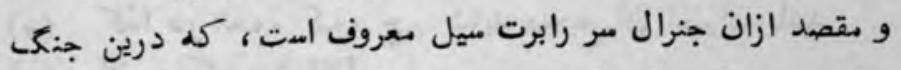

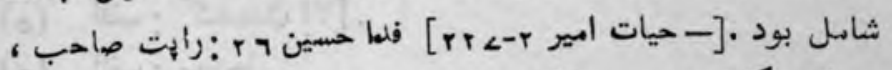

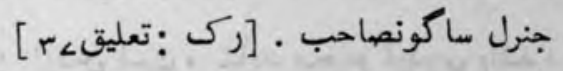

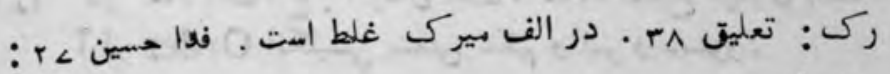


و ميجر كالس صاحب سعل كمينى كوره و فوج بادشاهي و كهيتان

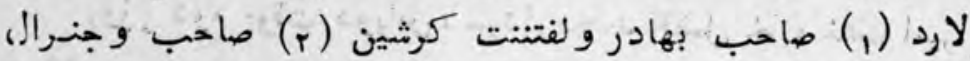

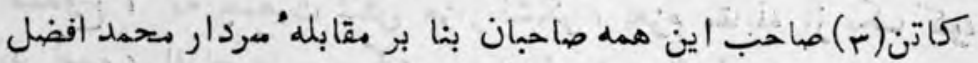

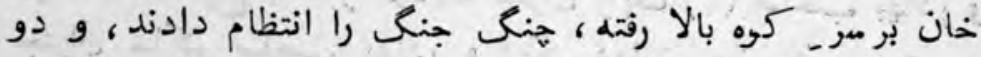

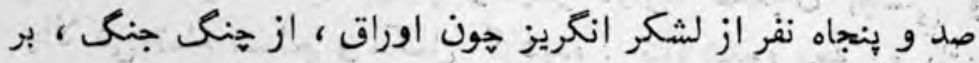

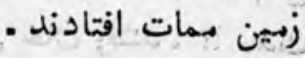

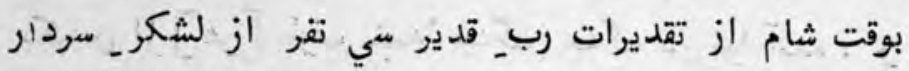

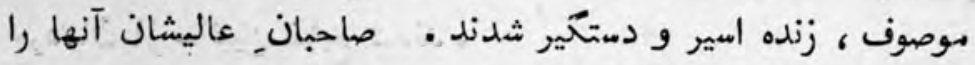

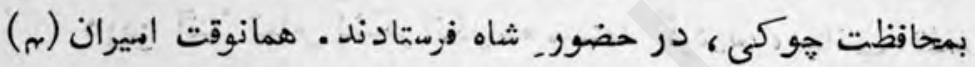

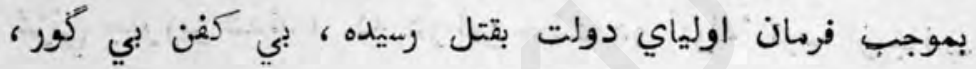

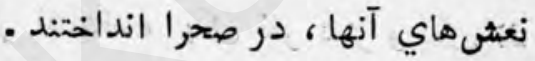

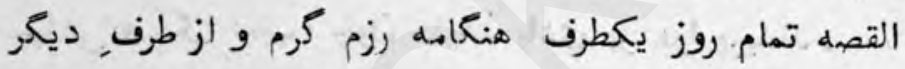

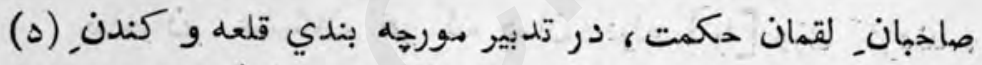

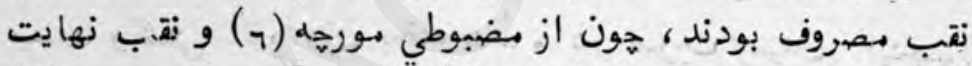

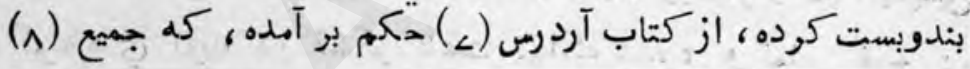

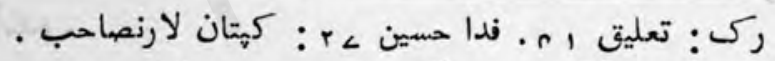

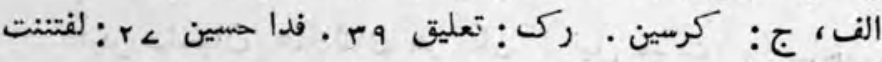
كرسين صاحب جـ ركى: تعليق . مـ .

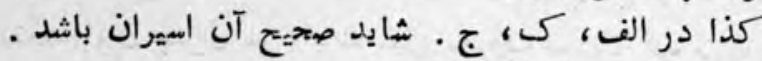
الف: كنديدن [؟].

الف: موزهل .

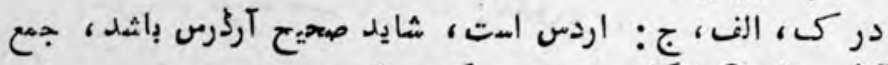

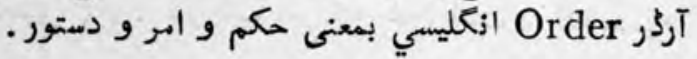

$$
\text { - } 1 \text { ( } 1 \text { ( }
$$




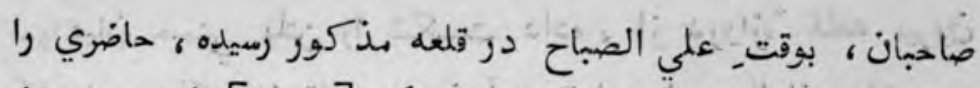

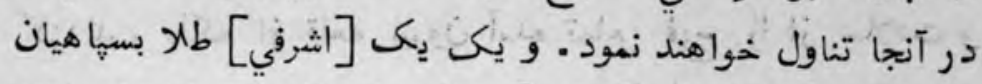

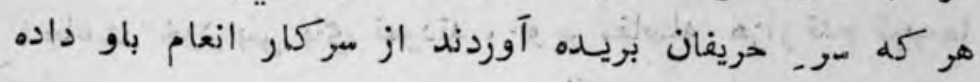
خواهد شد هر كاه

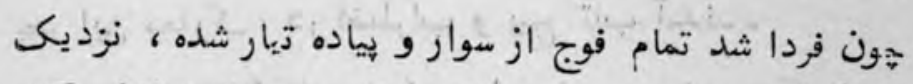

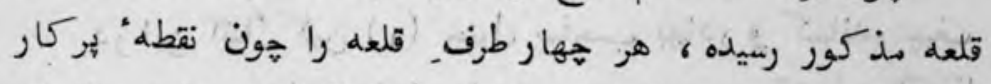

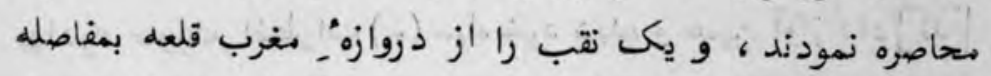

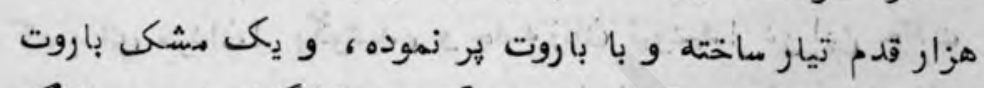

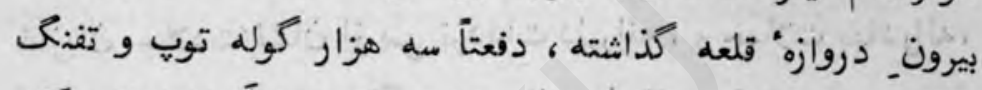

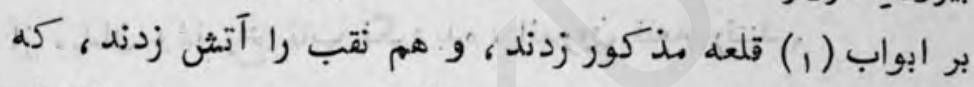

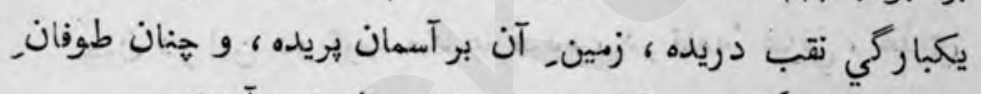

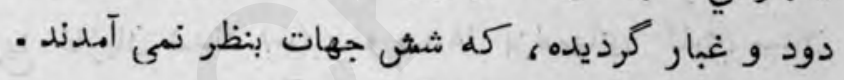

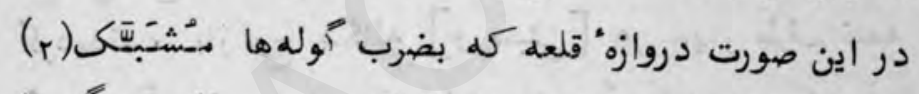

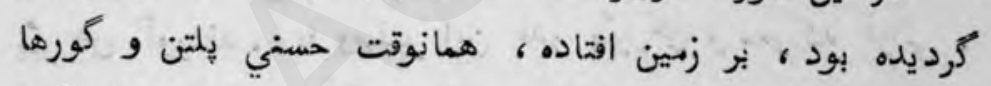

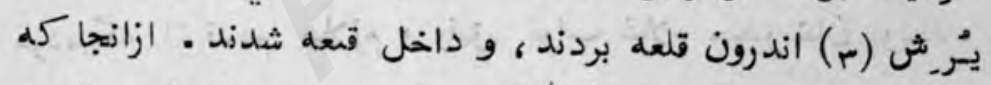

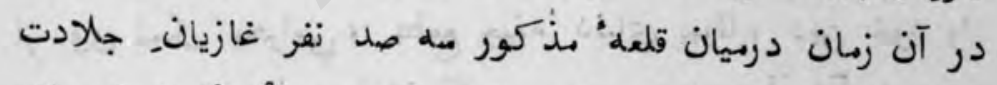

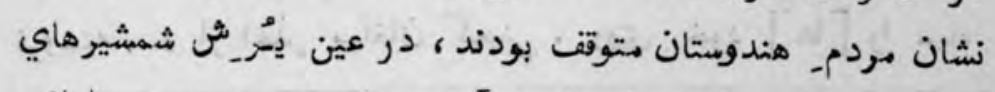

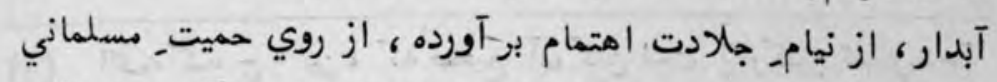

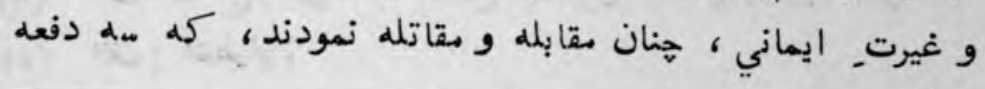

$$
\begin{aligned}
& \text { كى : بر اتواب . }
\end{aligned}
$$

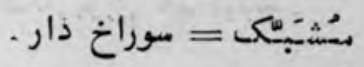

$$
\begin{aligned}
& \text { يُرِرش يا يورش = هجوم و حسله . }
\end{aligned}
$$


تازه نواي معارك

ra9

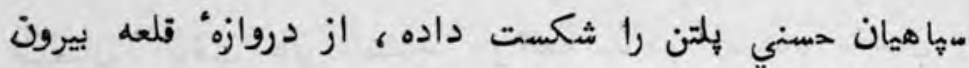

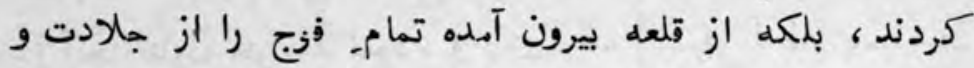

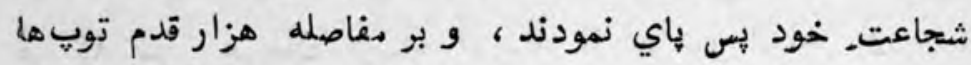

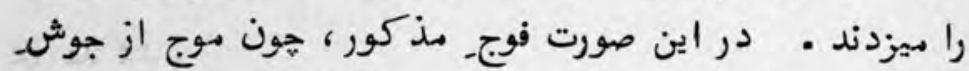

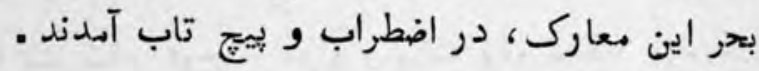

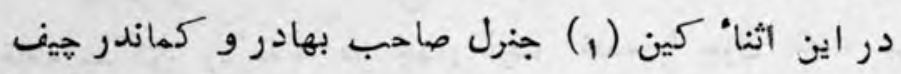

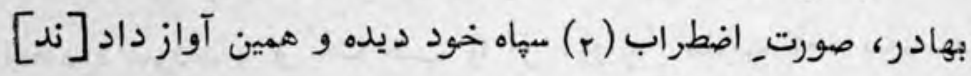

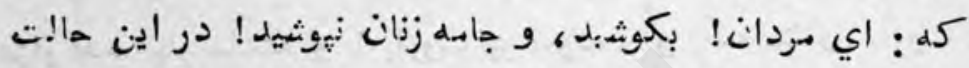

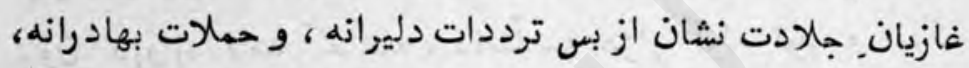

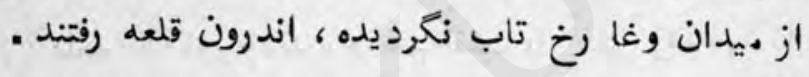

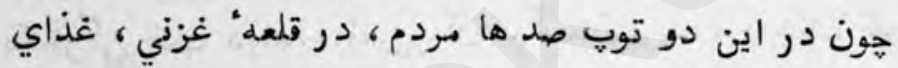

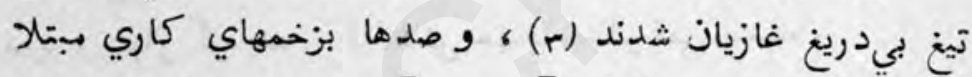

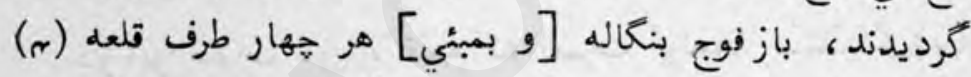

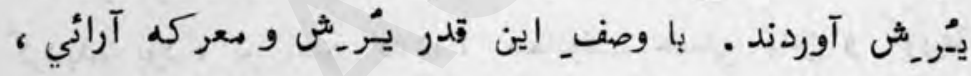

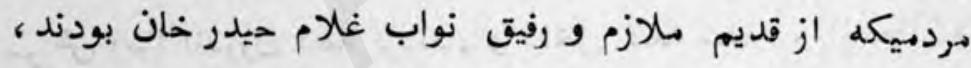

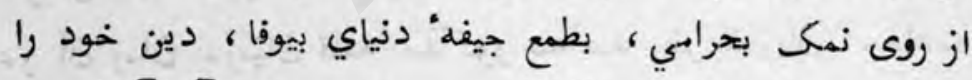

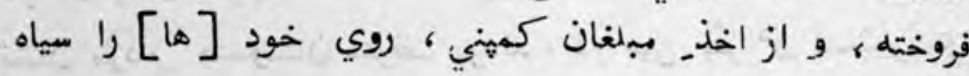

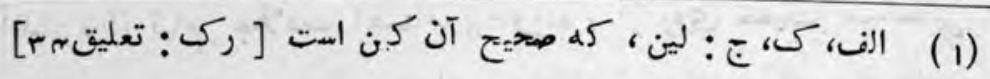

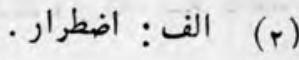

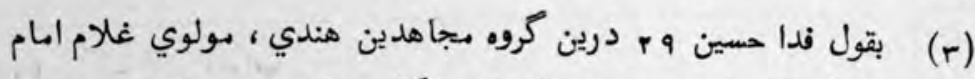

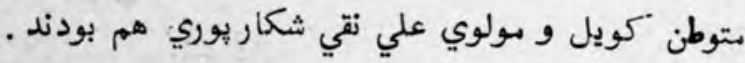

كى: نعله.

$(\sim)$ 


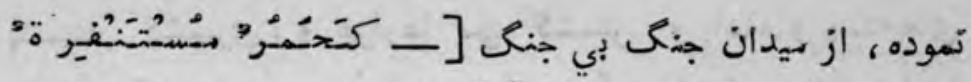

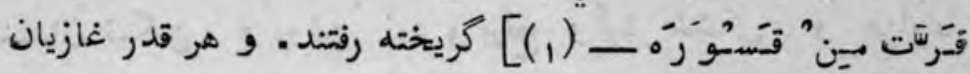

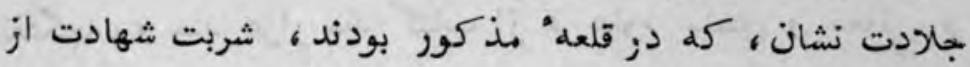

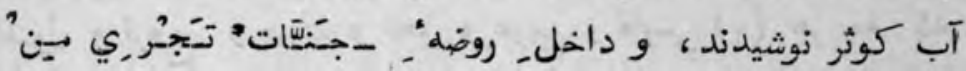

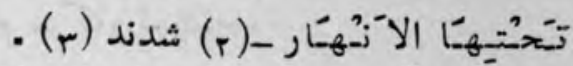

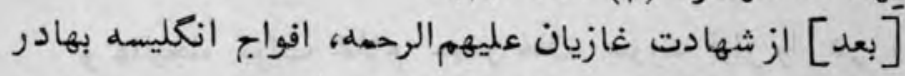

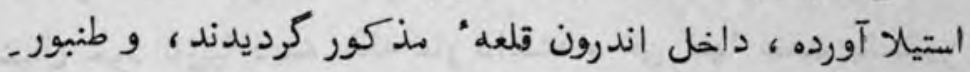

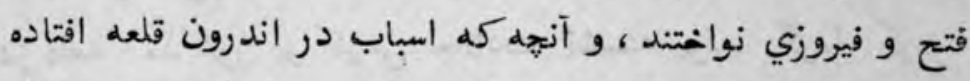

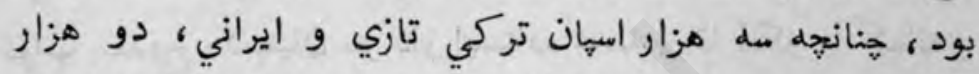

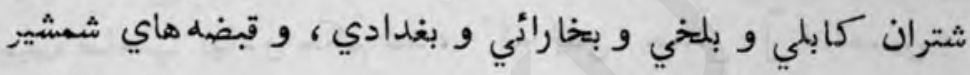

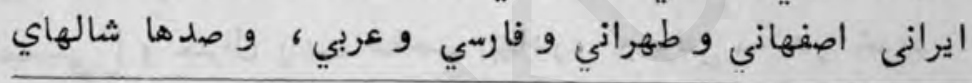

$$
\begin{aligned}
& \text { قرآن، الهدثر ، اهه ج وه. }
\end{aligned}
$$

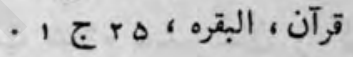

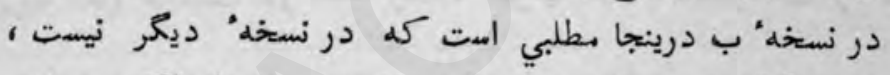

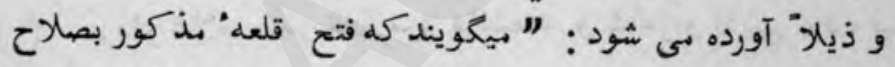

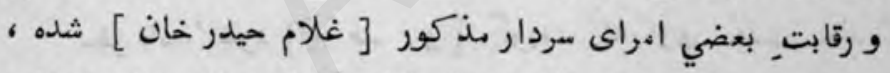

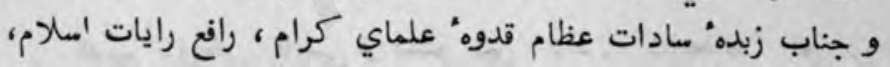

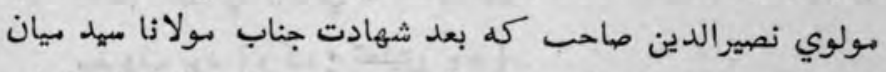

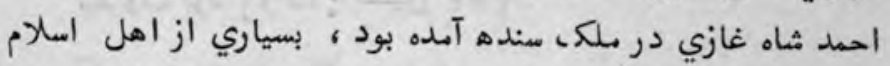

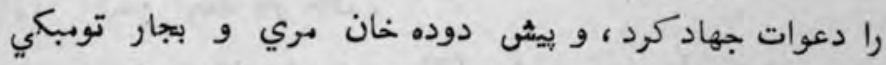

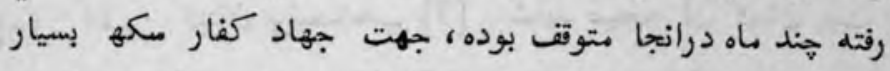

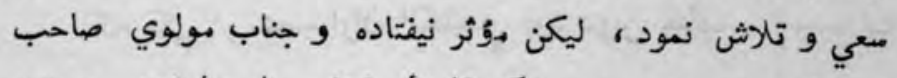

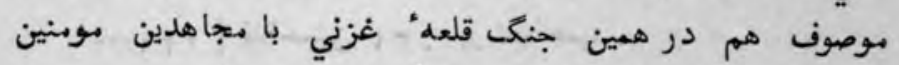

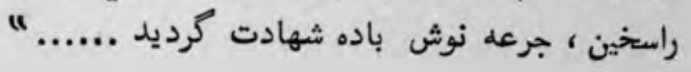


تازه نواي معاركى

raA

هُشمينه كشمهيري، و هزارها من كشمش و بادام و بسته هاي

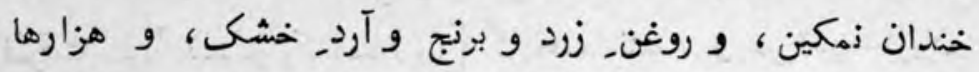

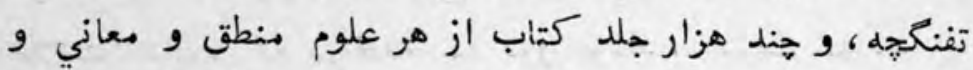

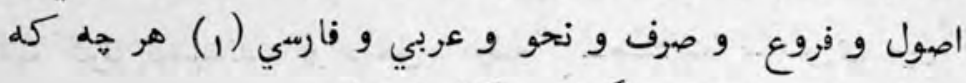

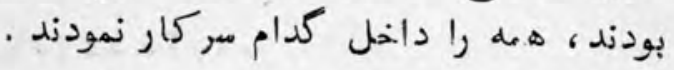

و عاليجاه نواب غلام حيدر خان صورت فرار را در مرآت

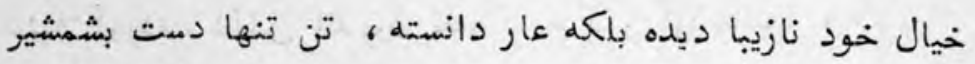

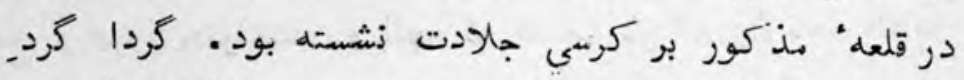

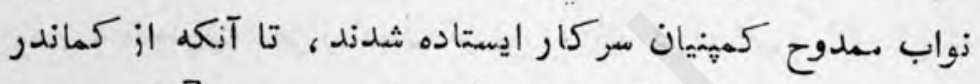

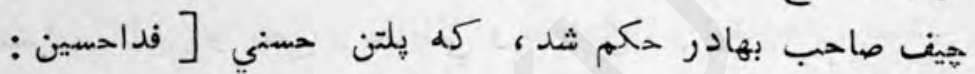

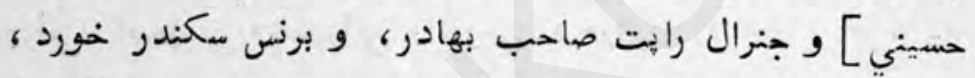

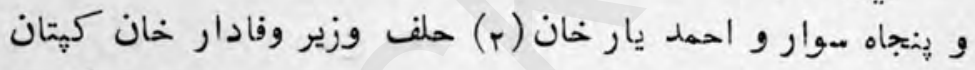
يرت (r) صاحب در قلعه رفته، نواب غلام حيدر خان را كرفته وانه

(1) سردار غلام حيدر خان مرد دانشهند و شاعر و اديبي بود ، بيلو در

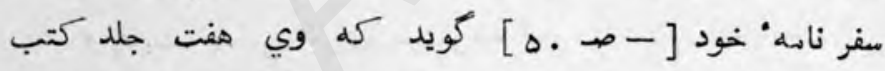

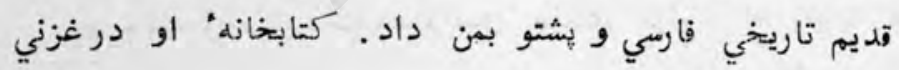

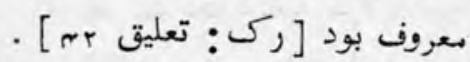

. (r)

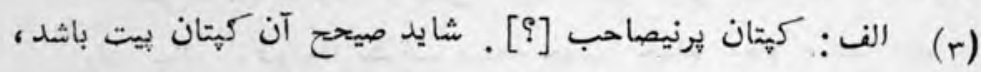

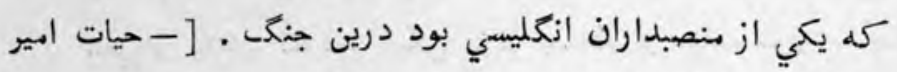

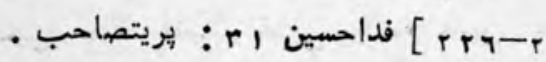




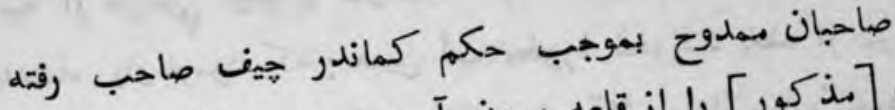

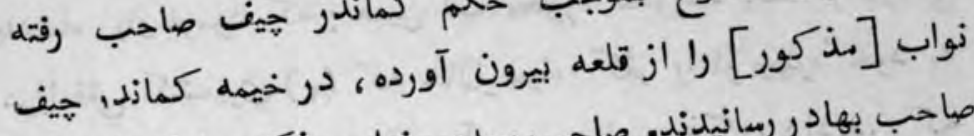

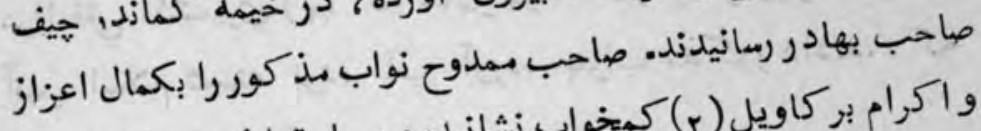

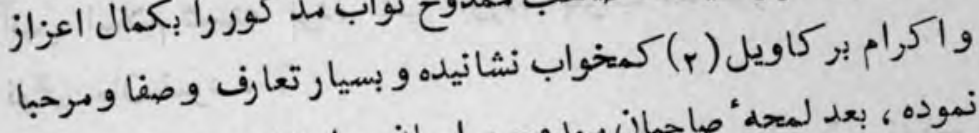

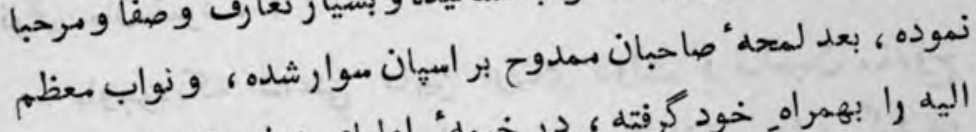

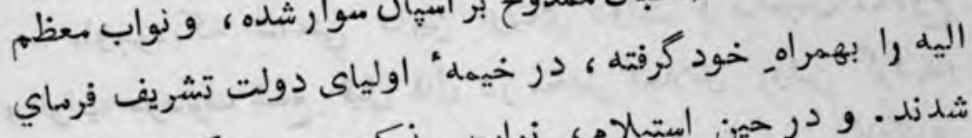

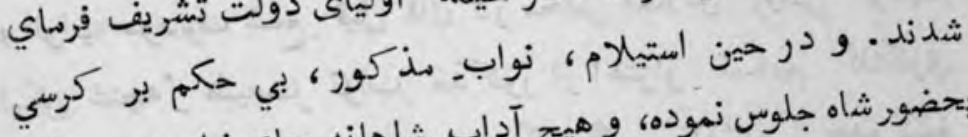

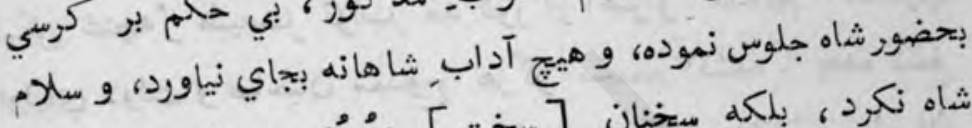

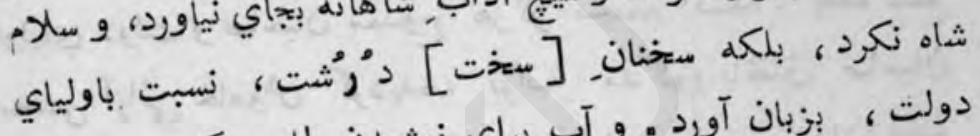

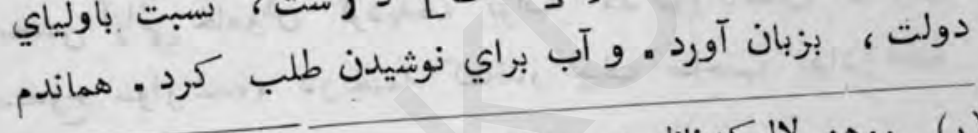

بوهن لال كه ناظر همين وقايع بود بي نويسد: بتاريخ مبرجولاني

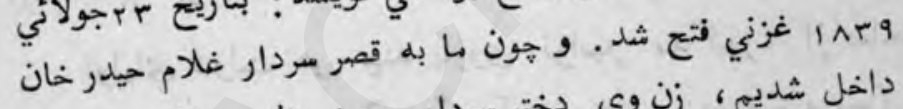

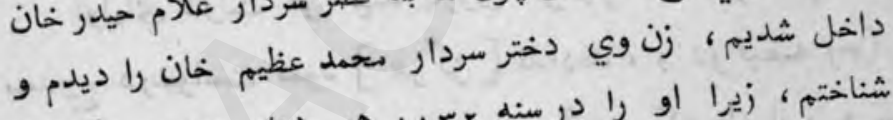

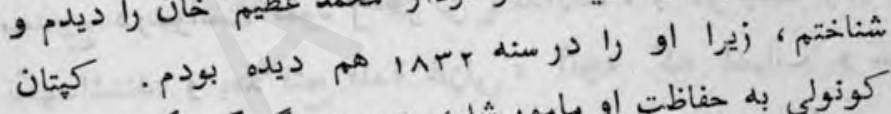

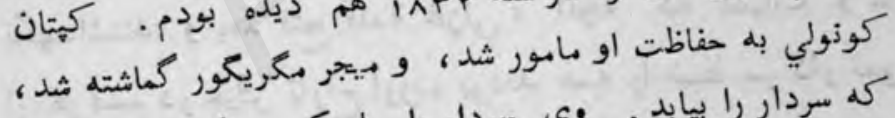

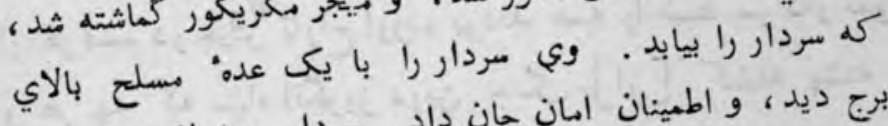

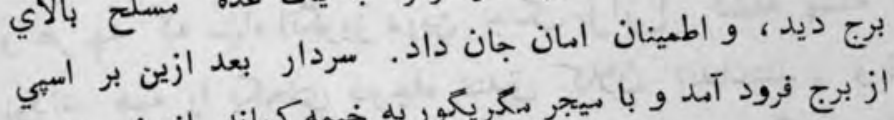

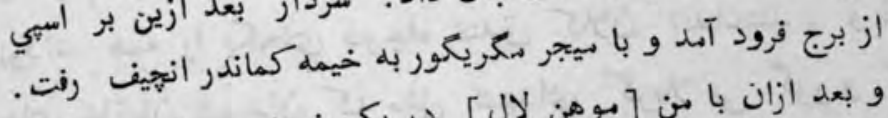

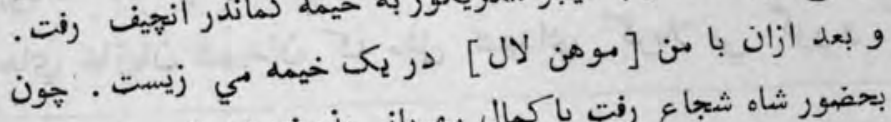

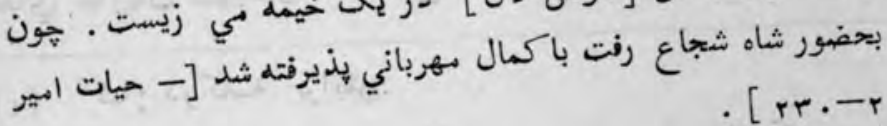
. [rr.tr

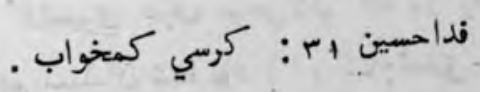


آب از صراحي اولياي دولت ، در گلاس (1) برايش آوردند.

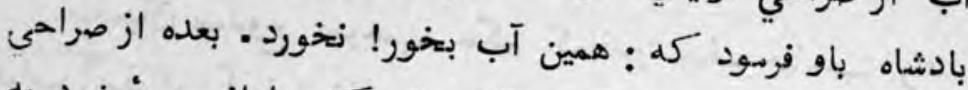

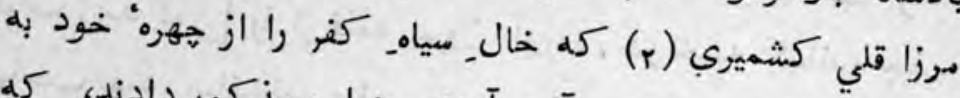

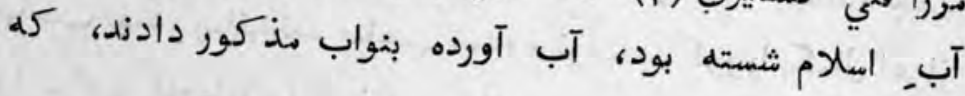

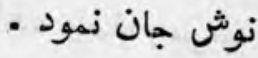

باوجوديكه ساعتي مابين اولياي دولت و صاحبان مهدوح

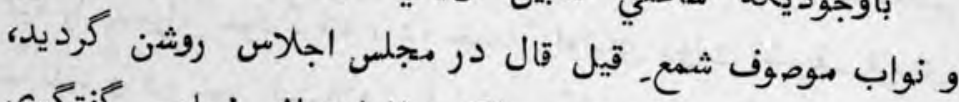

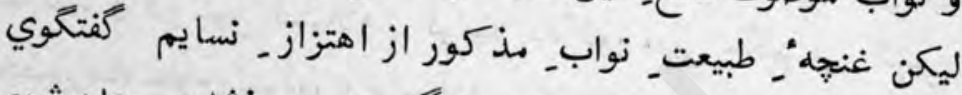

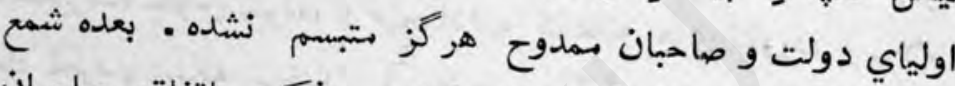

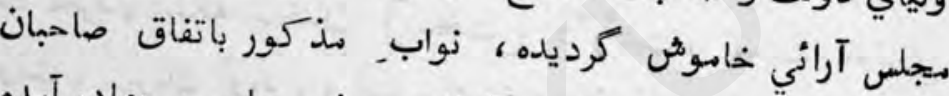

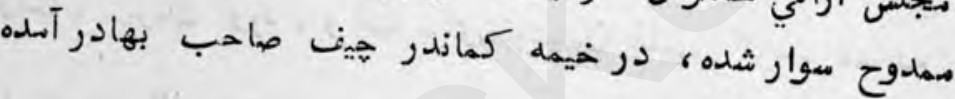

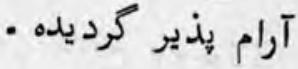

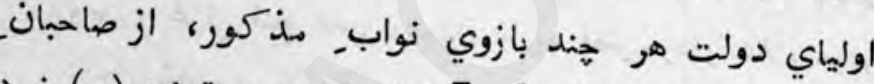

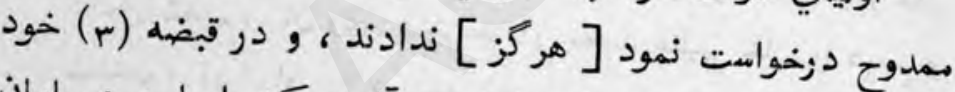

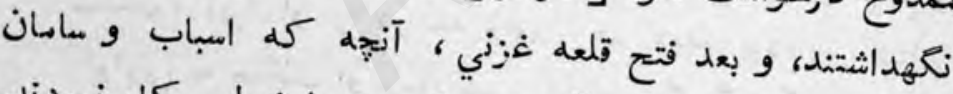

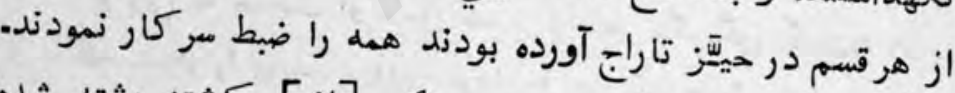

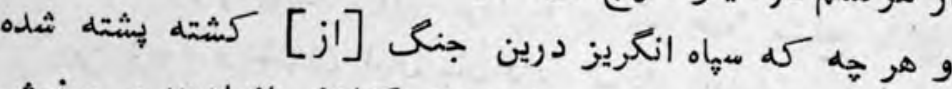

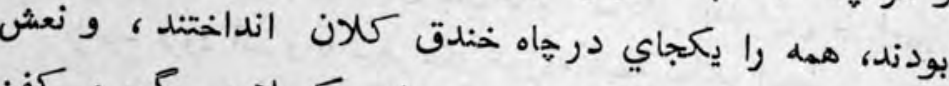

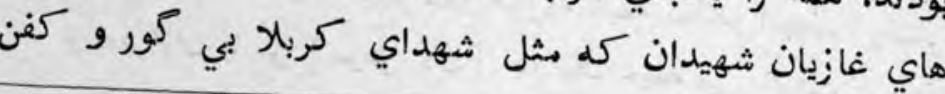

$$
\text { ك: دركاسه برايش. }
$$

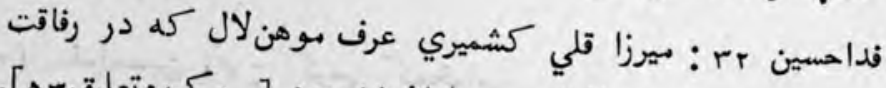

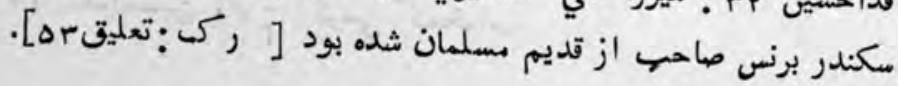


$\pi$

تازه نواي ملعاركى

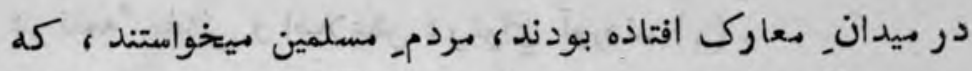

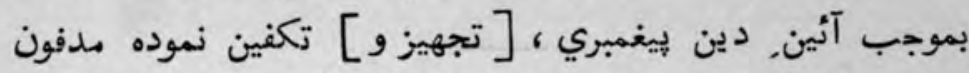

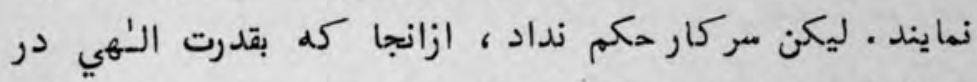

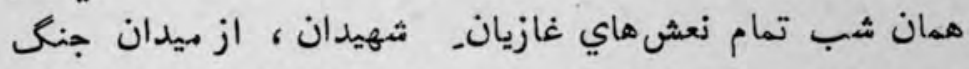
غايب شدند، و الهه اعلم، بقدرت كامله ذوالجالكل و عنايت_ شامله

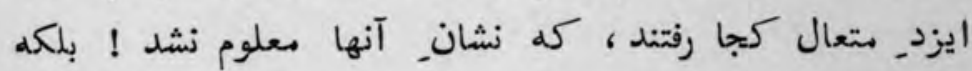
خون شهيدان كه بر زمين زيخته بود، از آن نيز اثري ييدا نكرديد. و عجب ترآنكل : يكفر غازي اندرون_ بر ــجملعه نشسته بود، و كوله هاي تفنح ميزد ، هنانهي هنتاد نفر از لشكريان برباد داده. هر كه از لثكر بر او ميرفت باز زنده نمي آمد. آخر بعد از سه روز، همان غازي سعلوم نشد كه كجا رفت ؟ و دريان قلعه" غزني، اين هنين زير زمين هاي عظيم بودند، كه تا مدتي ازين معني، بافواج. سركار, انكليسه" بهادر خبر نبود ـ آخر بعد مدت_ حهند ماه ، هشت صد عورات محترم خورد ساله معه' اطفال و پانصد مردان خراساني، و سه صه راس اسبان از زير زهينها برآمده بطرفي رفتند، و احدي و فردي از لشكريان مزّاحِم و

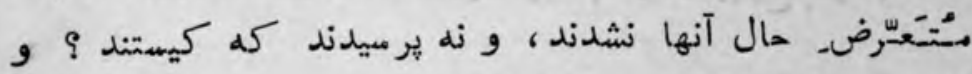
كجا بودند ؟ و كجا ميروند ؟ حون بعد از هنج روز تمام امباب از قلعهُ غزني، صاحبان عاليشان، بيرون كشيدند ، طبل حكمراني مركار انكليسه بهادر 
در قلعه" غزني و اضلاعش در نواي آوردند (1) ؛

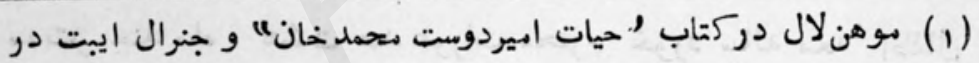

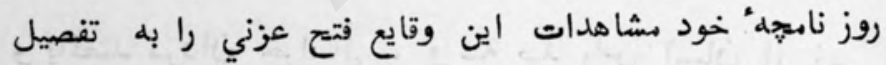

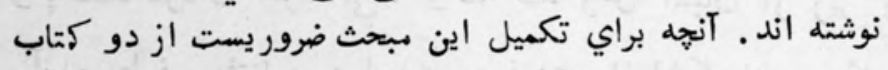

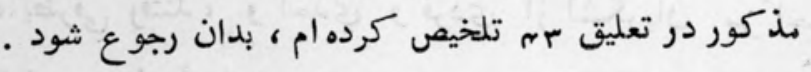


در بيان رفتن افواجـ انكليسه بهادر، بعد فتح غزنى جانب دارالسلطنه ' كابل

و برامدن امير دوست محمد خان بعزم يقابله تا به قلعه"

قاضي (1)، و از دغابازي خوانين نمك بحرام بي مقابله

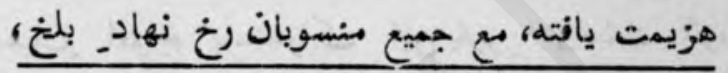

وكرفتارشدن امير مذكورو مهدم اكبرخان

در نزده بإدشاه بخارا

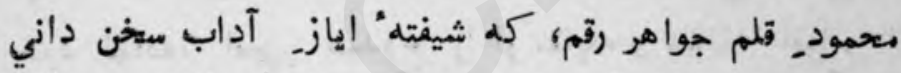

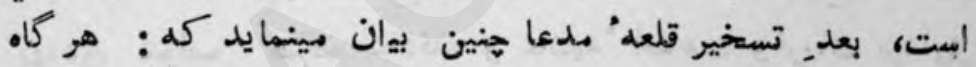

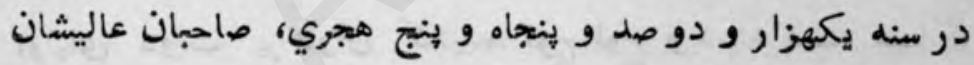

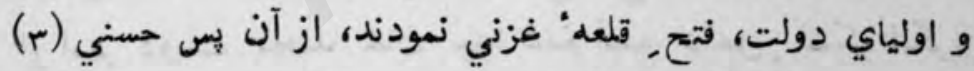

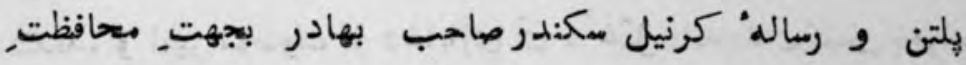

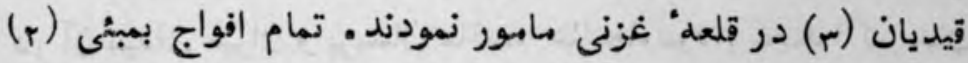

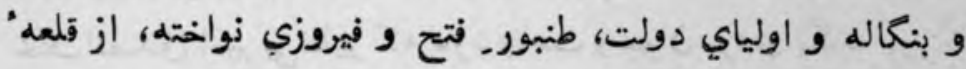

(1) قلعه" قاضي بفاصله هر ميكيلي غربـ كابل بر راه قندهار واقع است.

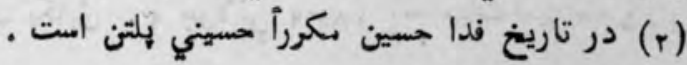

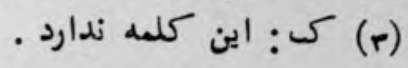




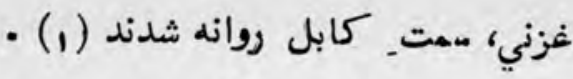

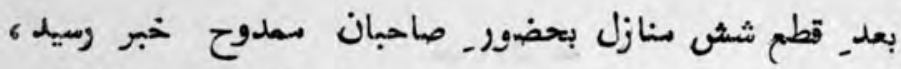

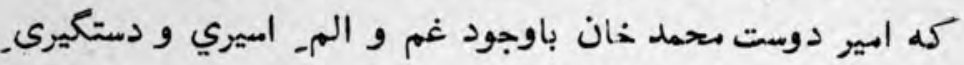

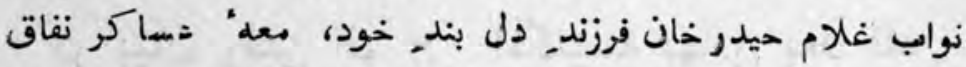

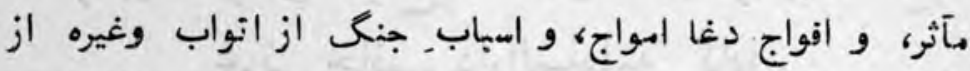

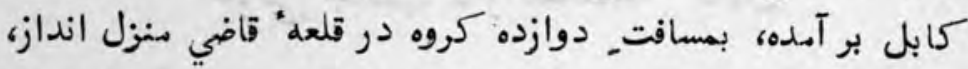

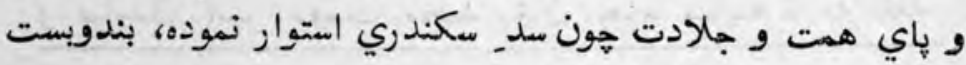

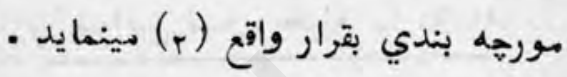

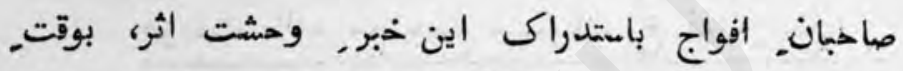

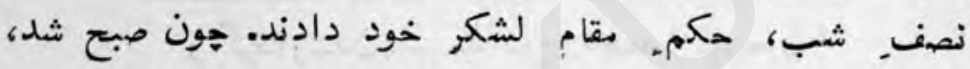

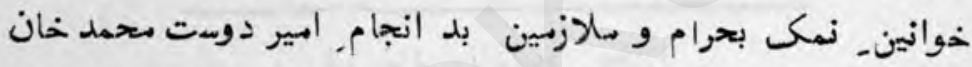

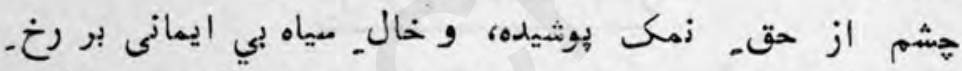

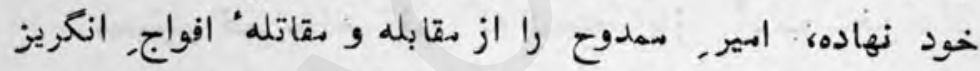

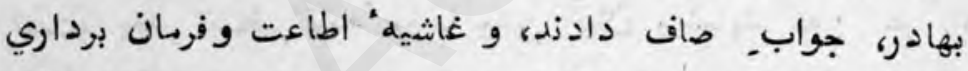

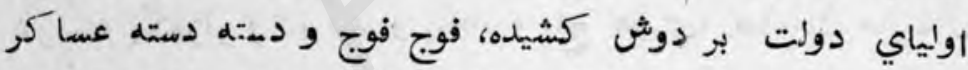

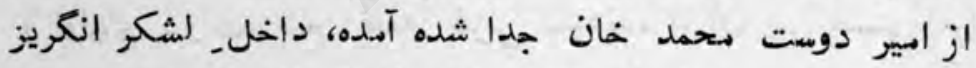

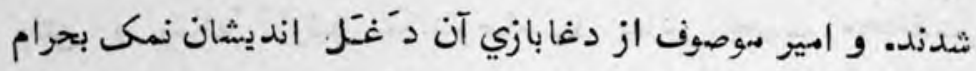

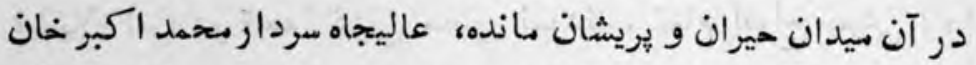

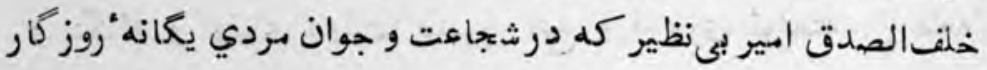

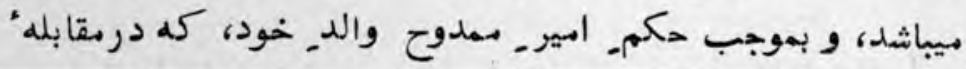

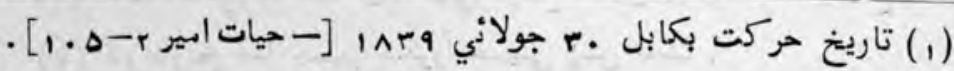

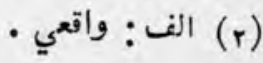




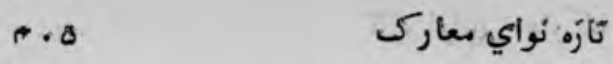

شأهزاده متحمد تيهور و بخشي ويد (1) صاحب بهادرو فوج

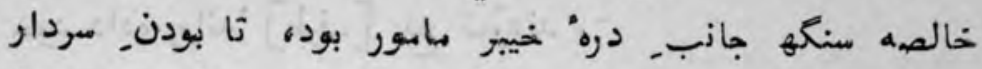

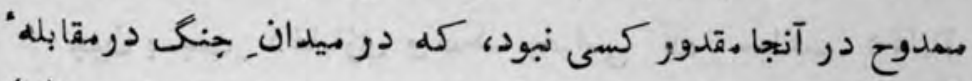

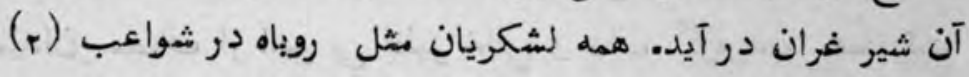

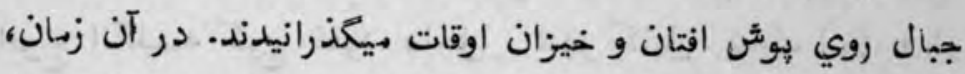

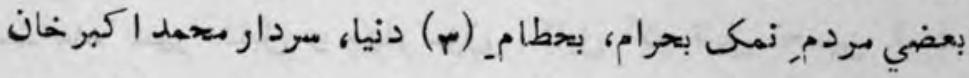

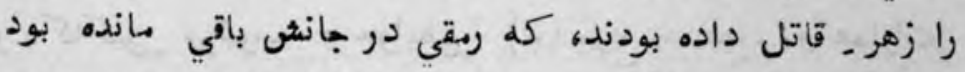

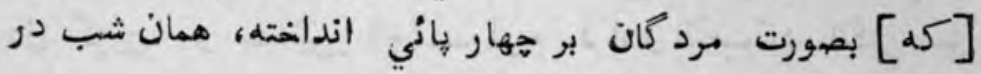

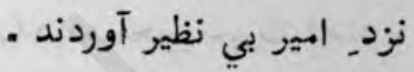

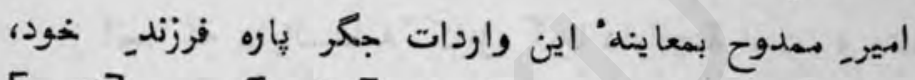

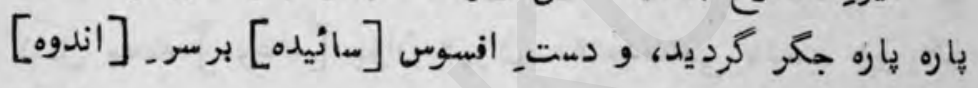

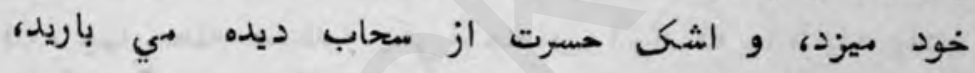
و آه و زاري مي كرد. ليكن بجز صبر و شكيباني و سوختن و ماختن

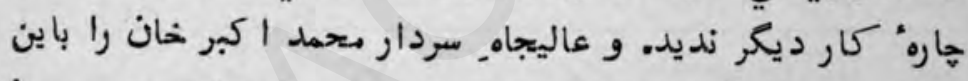

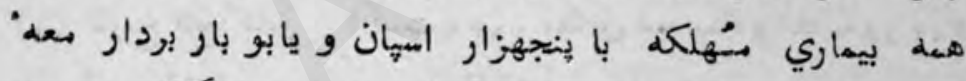

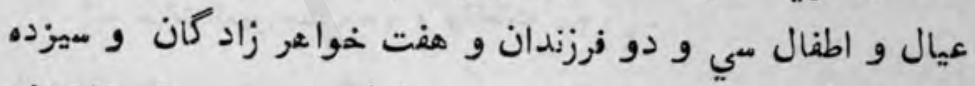

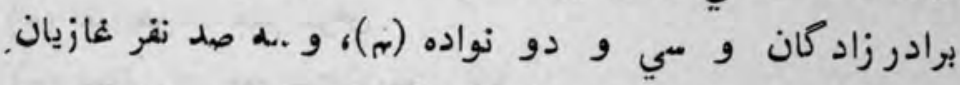

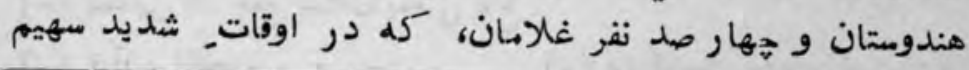

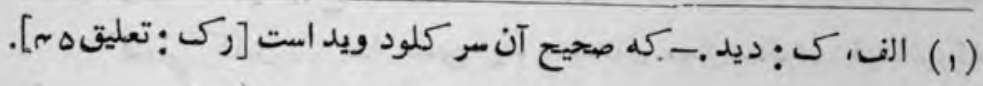

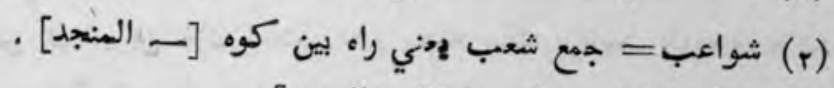

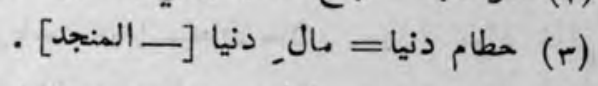
(r) الف : قورصه . فدا حسين هم : بيست و سمه فرزند و بيست و مسه نواسه 
و غمخوار او بودند، همراهـ سردار محمد اكبر خان فرزندـ دل بند.

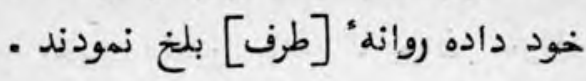

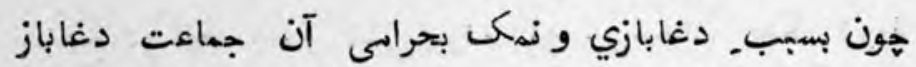

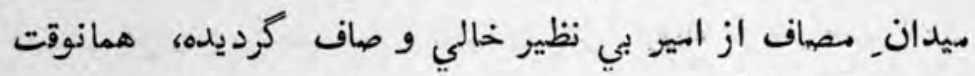

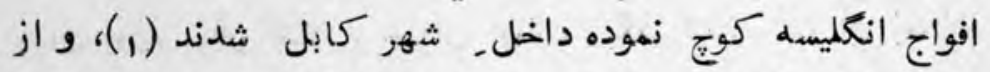

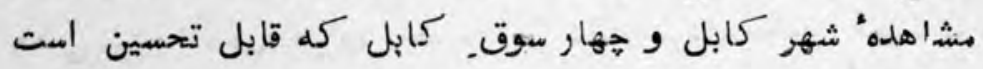

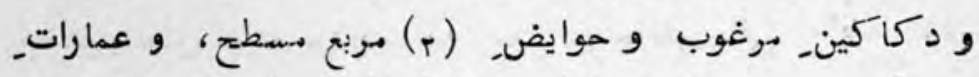

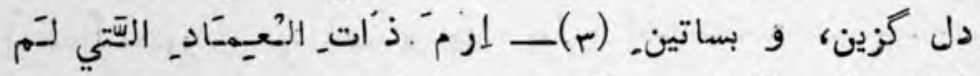

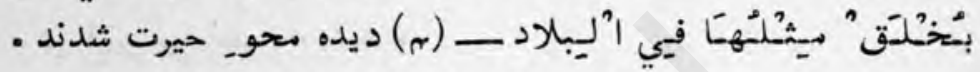

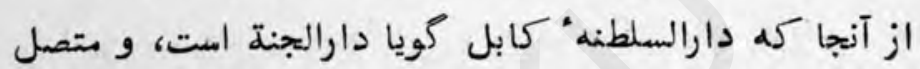

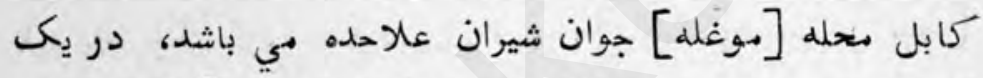

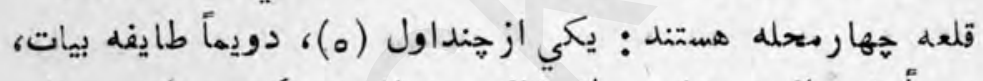

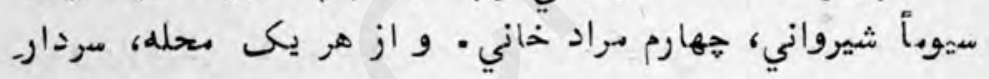

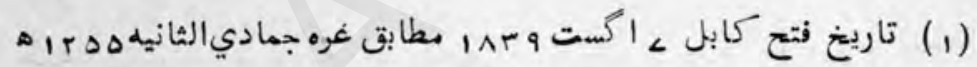

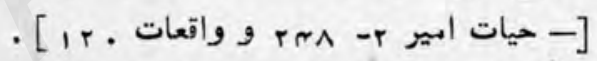

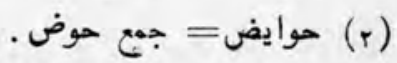

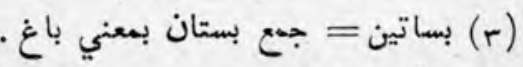

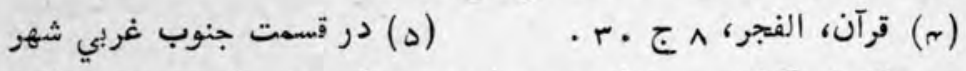

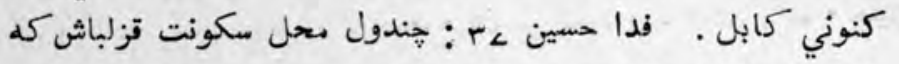

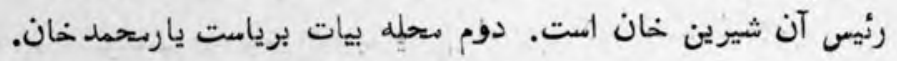

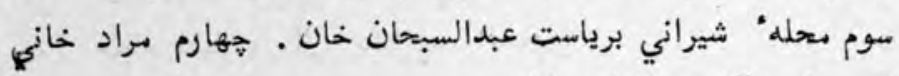

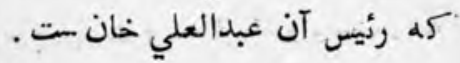


تازه نواى معاركى $\quad$ ك.

علاحده جداكانه مقرر است، و كسي راطاقت نيست، كه بي اذن

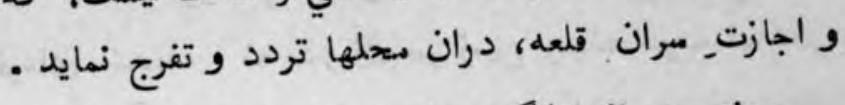

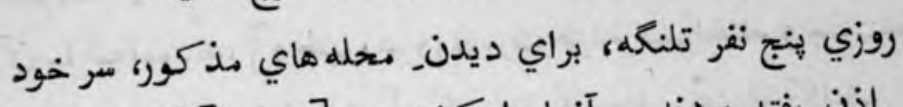

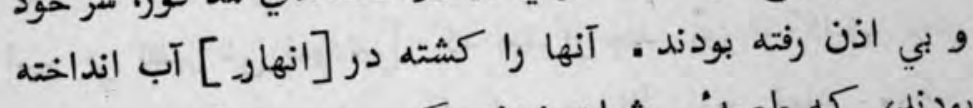

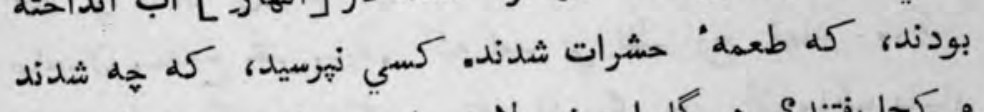

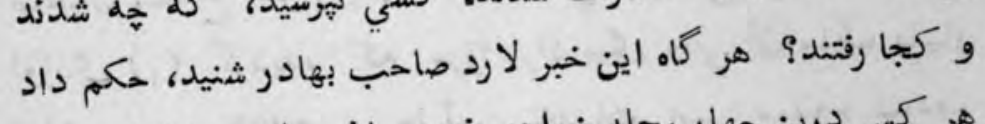

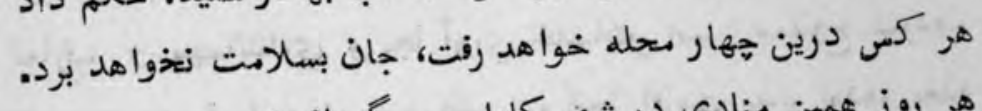

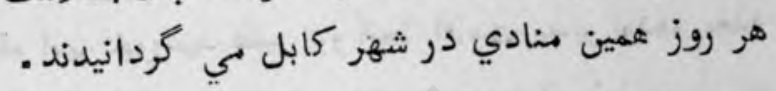

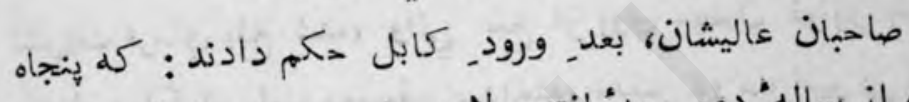

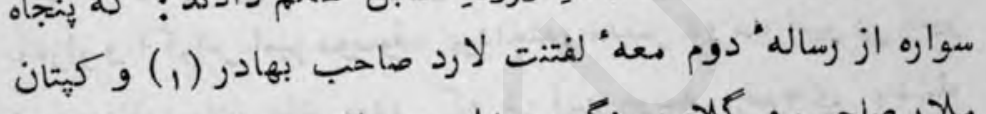

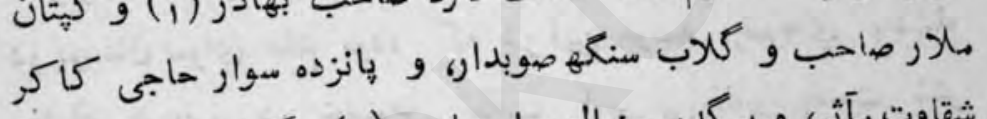

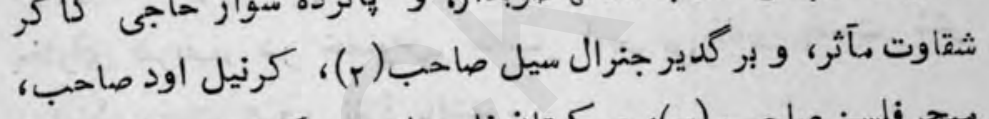

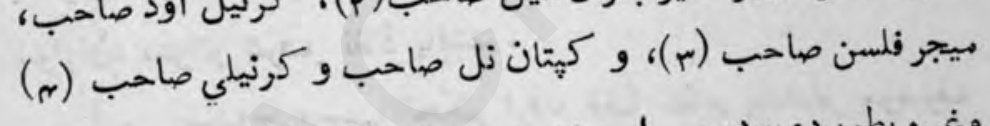

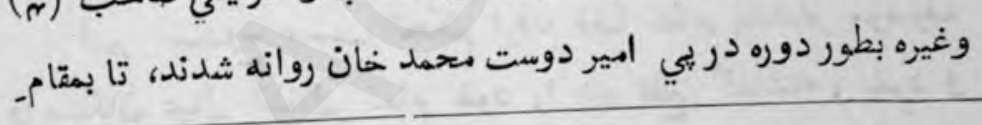

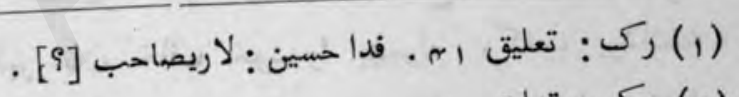

$$
\begin{aligned}
& \text {. r r ر : (r) }
\end{aligned}
$$

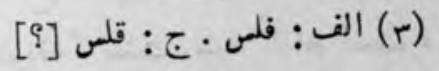

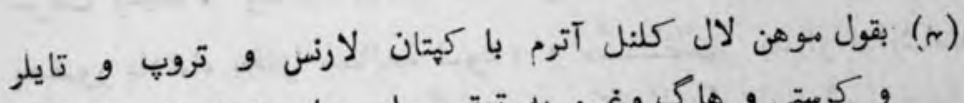

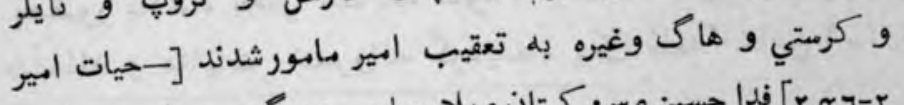

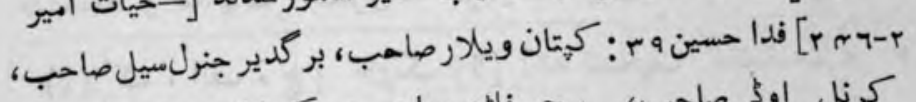

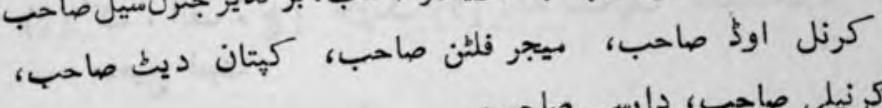

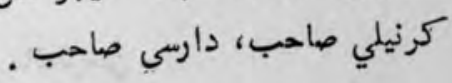




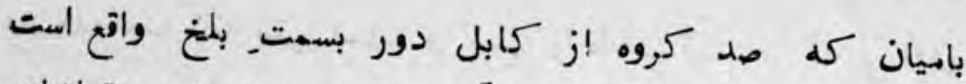

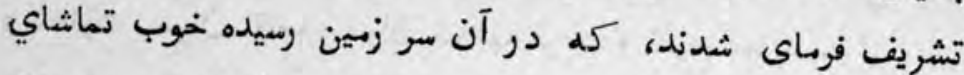

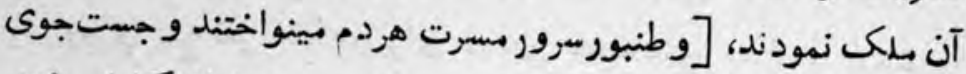

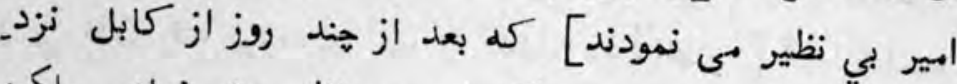

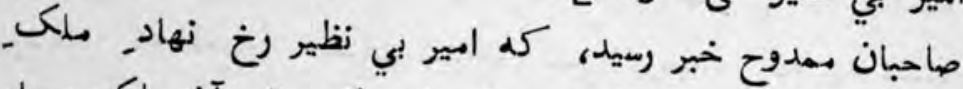

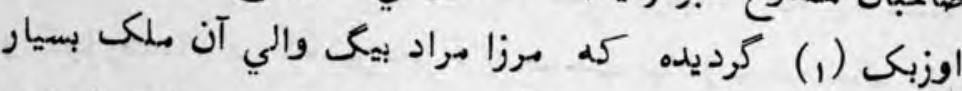

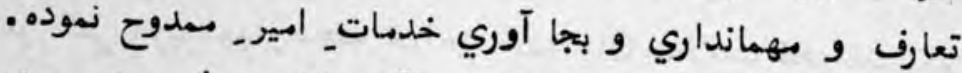

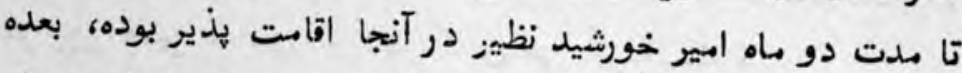

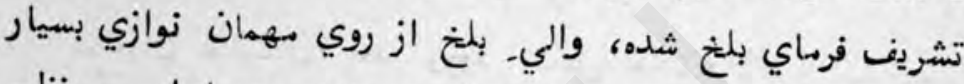

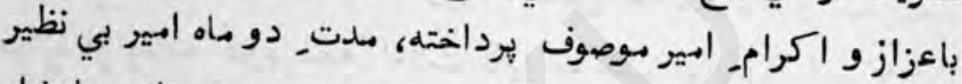

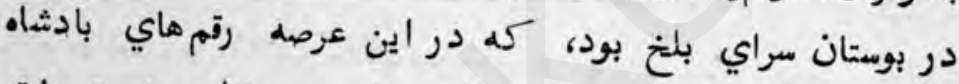

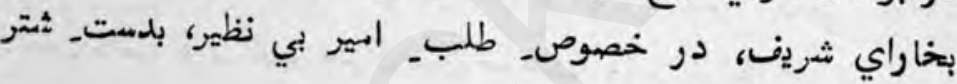

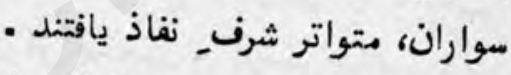

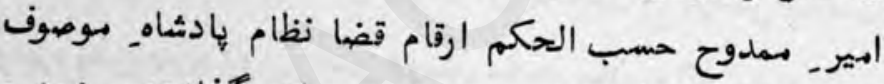

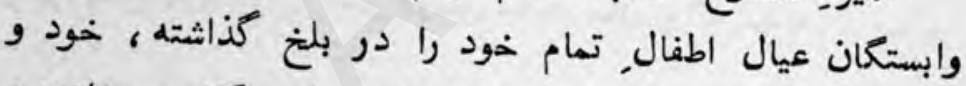

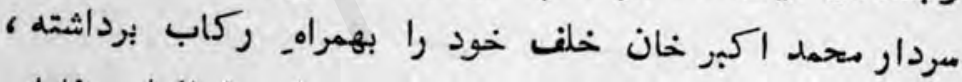

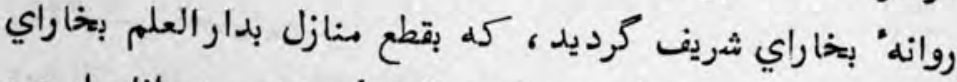

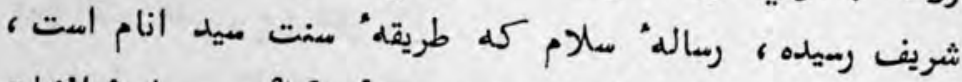

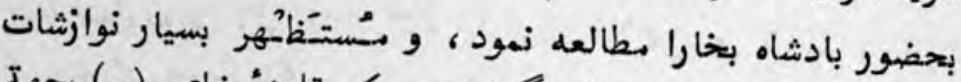

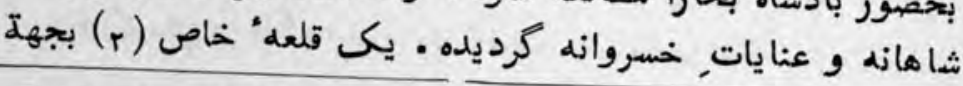

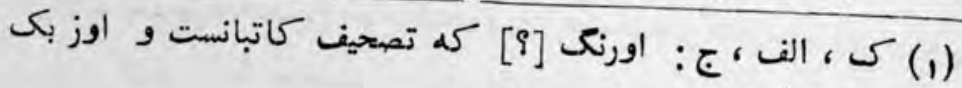

$$
\begin{aligned}
& \text { صحيع امت . }
\end{aligned}
$$

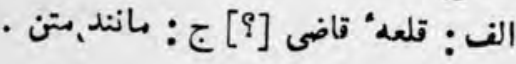


توقف امير بى نظير، از سركارشاه مسدوح عطا شده ، و از اخراجات

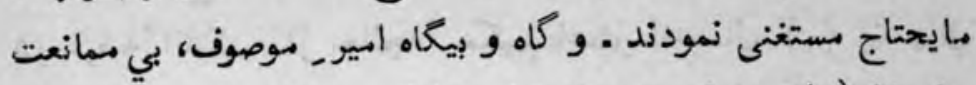

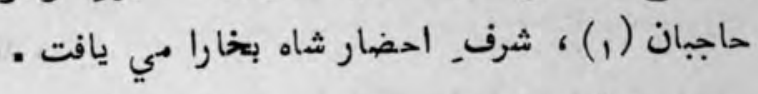
بعد از حند مدت روزي در مجلس_ خاص، ب بادشاه ممدوح

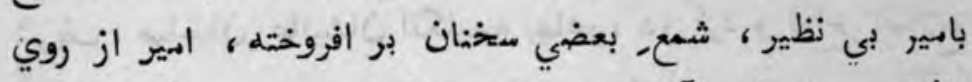

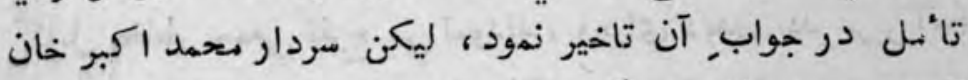

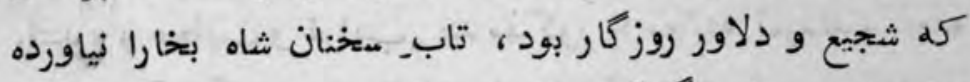

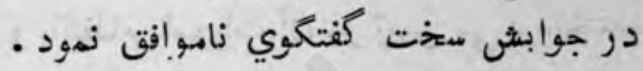

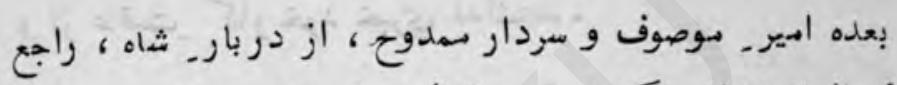

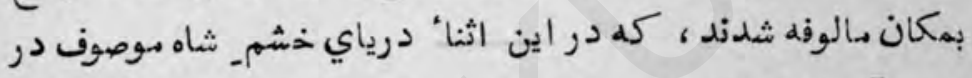

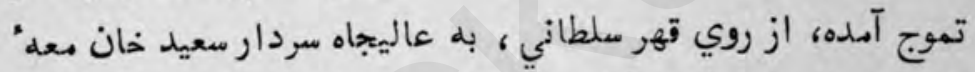

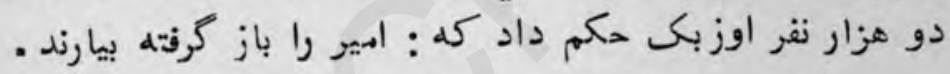

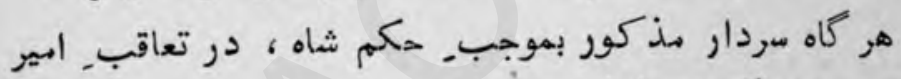

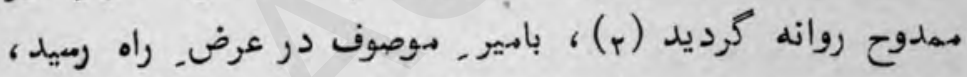

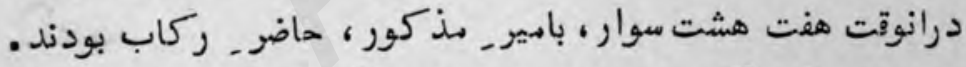

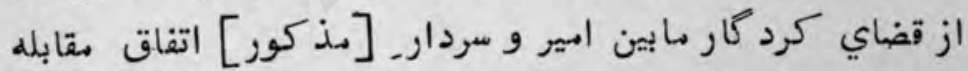

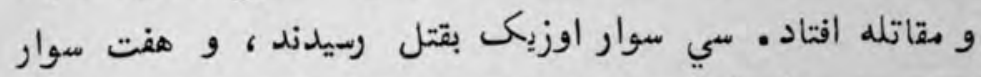

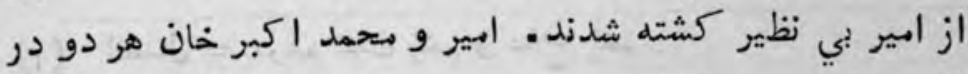

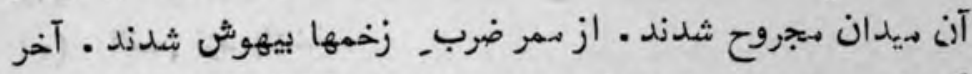

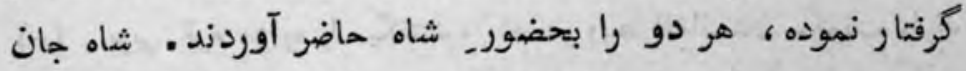

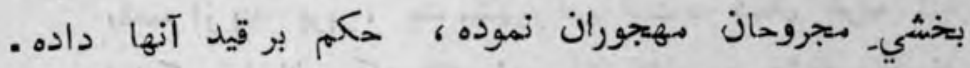

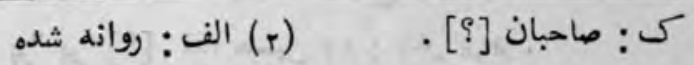




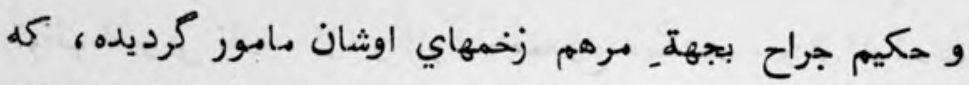

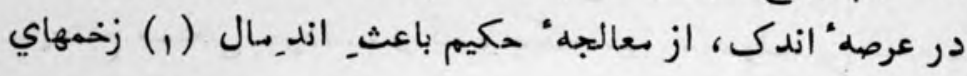
مجروحان شدند مرعه در حين حبس امير. ممدوح نزديكى (r) بادشاه. بتخاراى

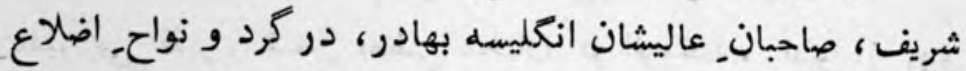

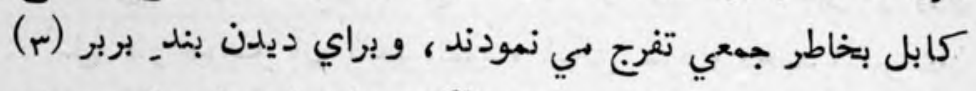

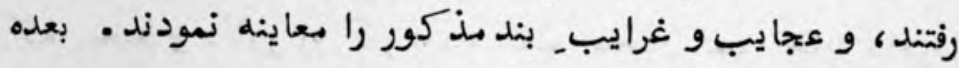

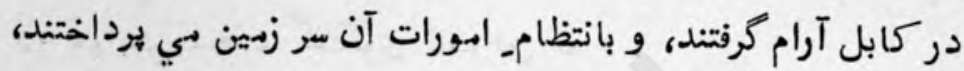
و از عاقبت_ كار خود خبري نداشتند .

$$
\begin{aligned}
& \text { اندمال = مرهم شدن زخم و علاج زخمم • } \\
& \text { الف: نزد קيادشاه. }
\end{aligned}
$$

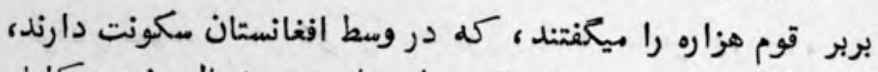

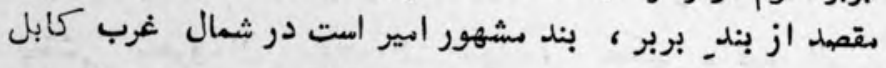

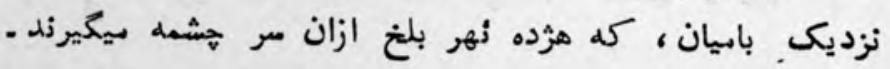

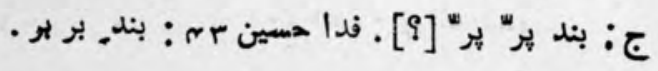


ور بيان مراجعت افواج انغليسه بها:ر از كابل و مقابل شدن با كاليجاه مير محراب خان براهوي والي قلات و

\section{شهيد نمودن او را}

هزار داستانِ قلم خوش رقم ، بر شاخسار بر اين مدعا هينين

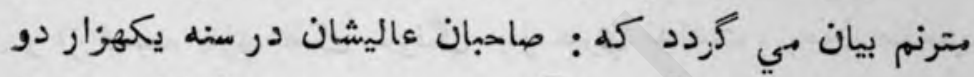

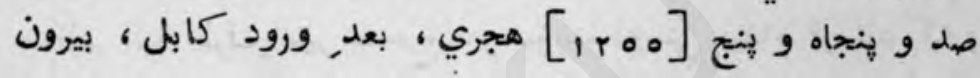

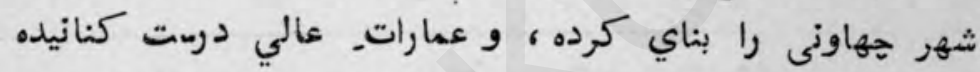

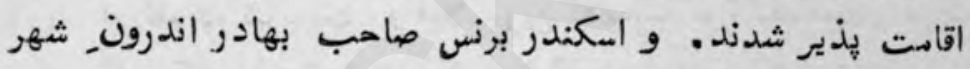

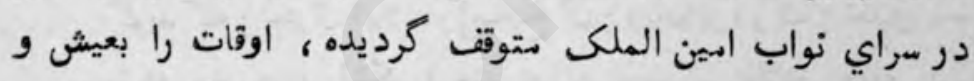

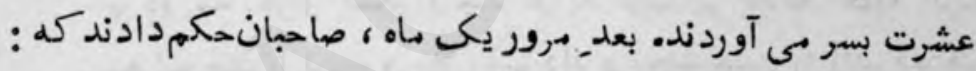

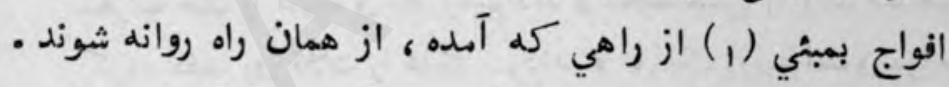

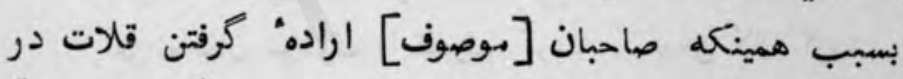

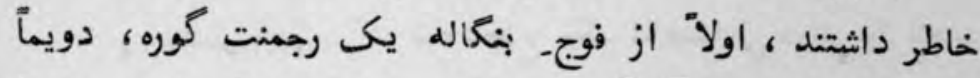

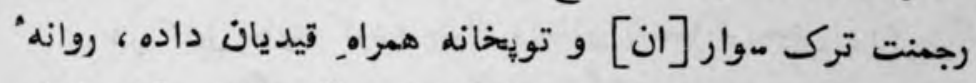

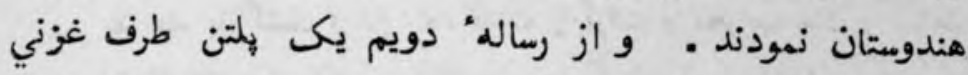

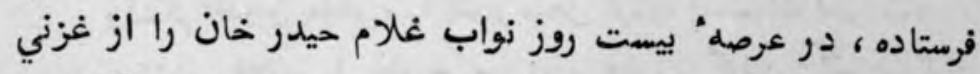

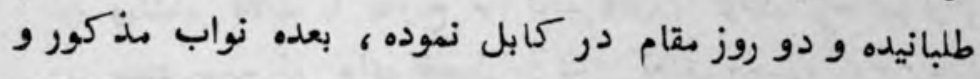

$$
\text { كى: اين كلمه ندارد . }
$$


تازه نواي معاركى

mit

حاجى كاكر را بهمراه جنرال [ماكول] (1) صاحب بهادر از راه

يشاور روانه نمودند .

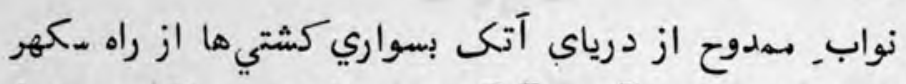

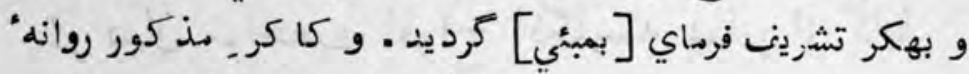

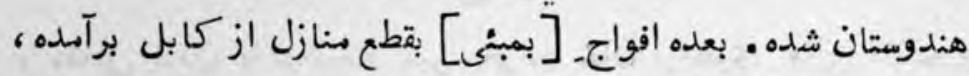

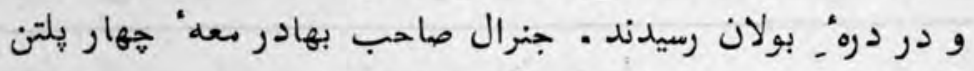

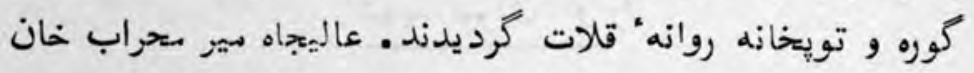

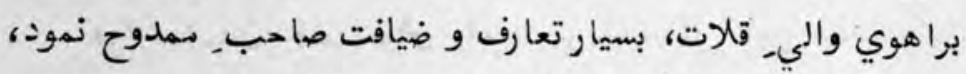

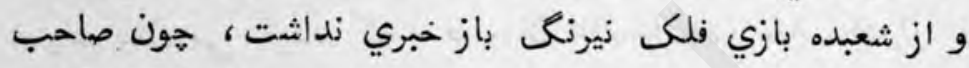

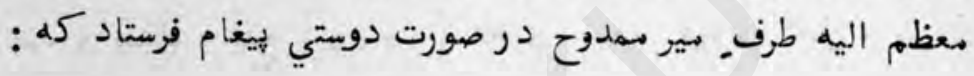

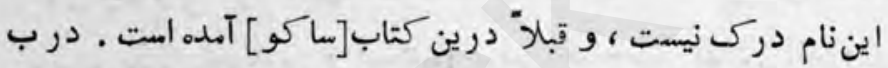

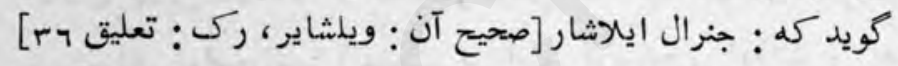

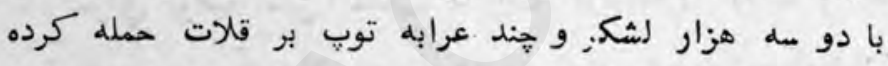

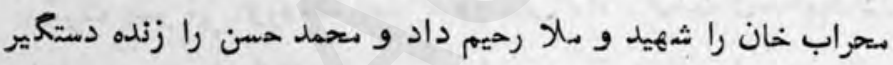

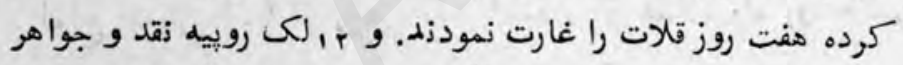

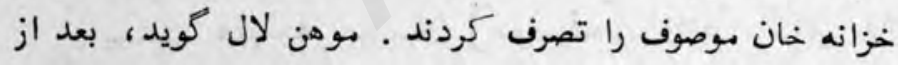

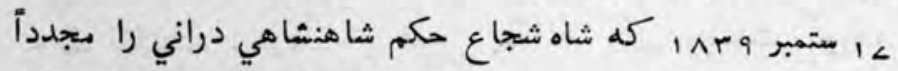

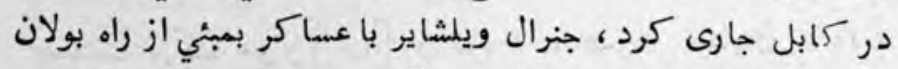

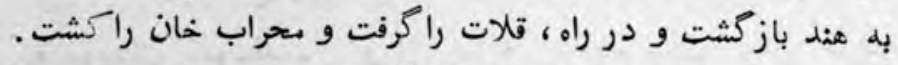

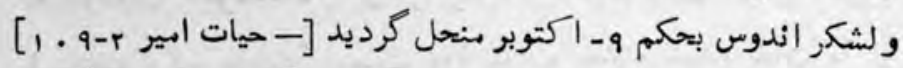

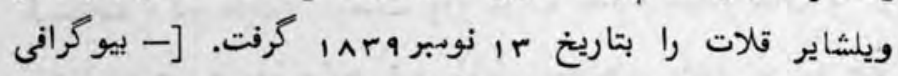

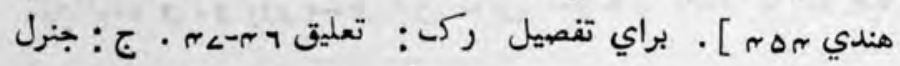

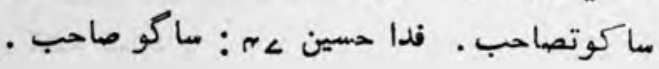




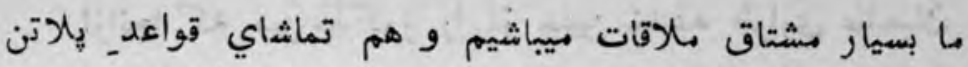

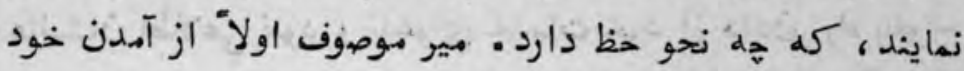

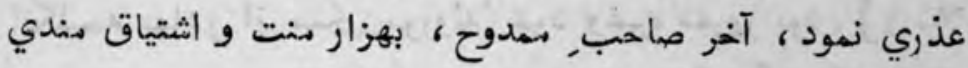

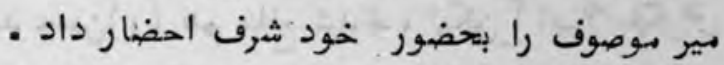

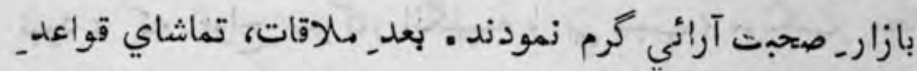

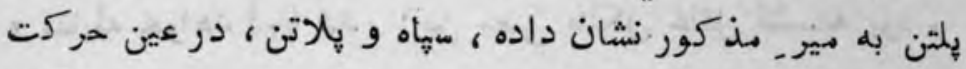

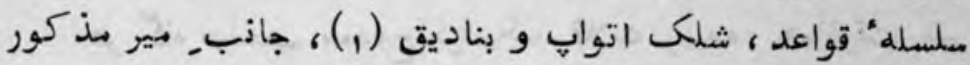

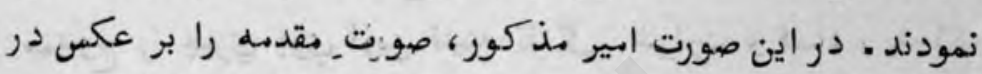

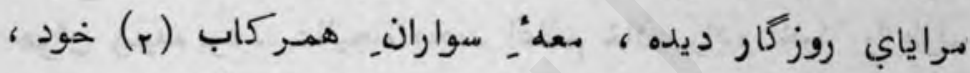

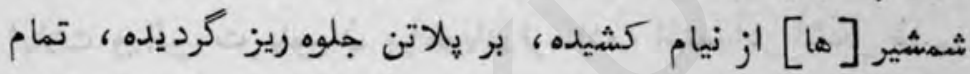

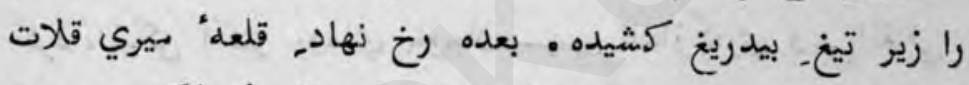

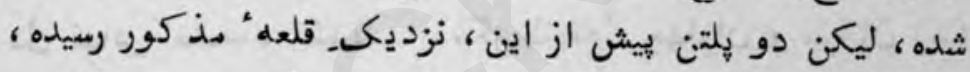

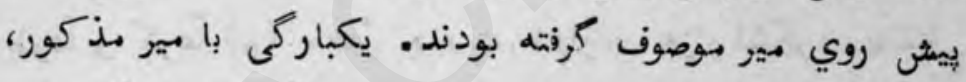

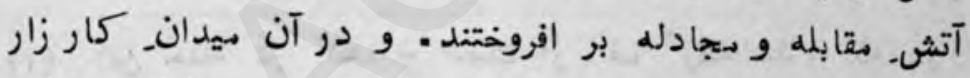

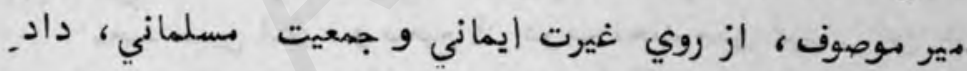

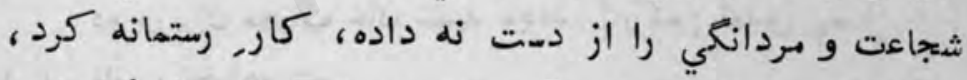

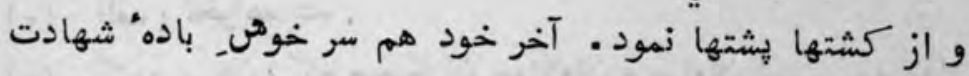

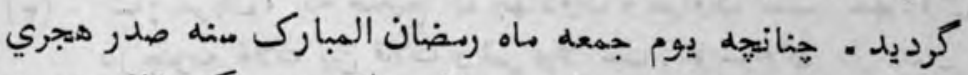

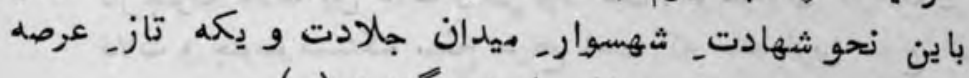

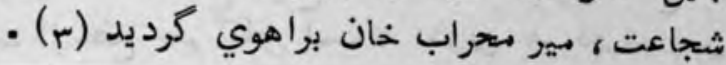

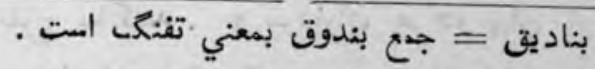

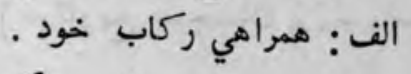

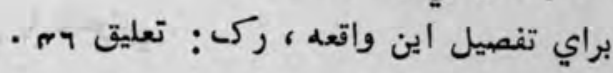


تازه نواي معارك

$N 1 \pi$

ازانجا كه مير مذكور را از هنين خدعه طرازي صاحبان.

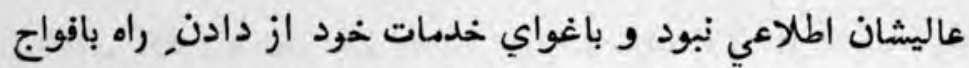

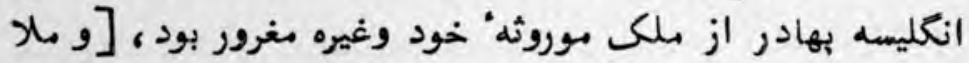

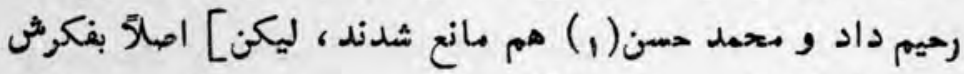

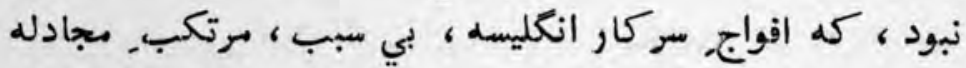

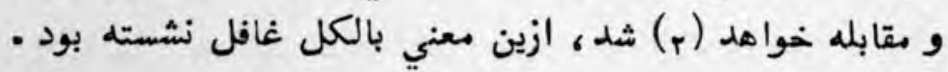

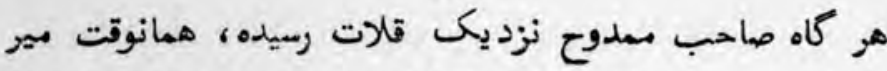

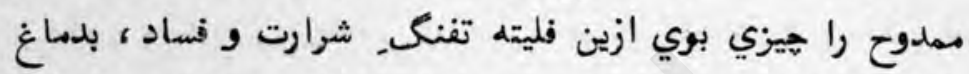

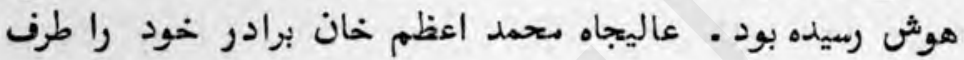

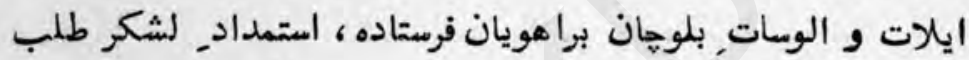

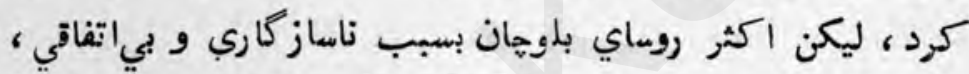

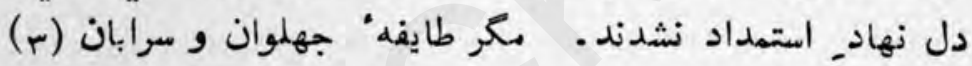

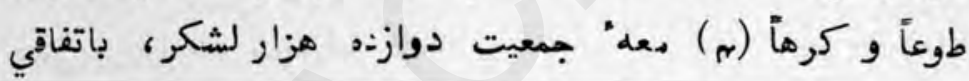

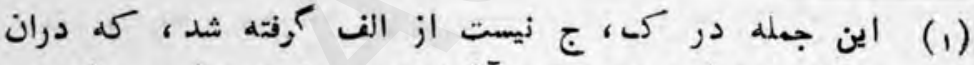

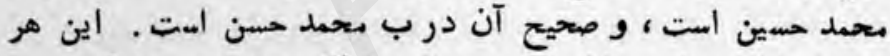

دو وزيران شحراب خان شهيد بودند. [ ركى: تعليق >r ]

(r)

ك: سر بان، كة صحيح آن جهالاوان و سراوان است ـ جهالاوان

(r)

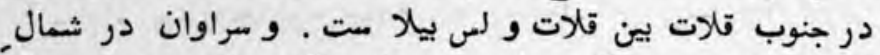

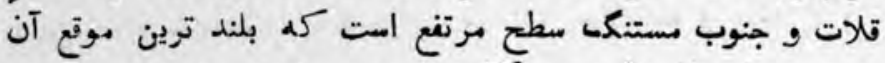

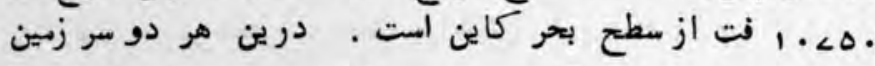

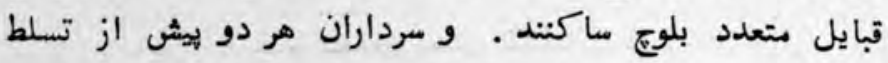

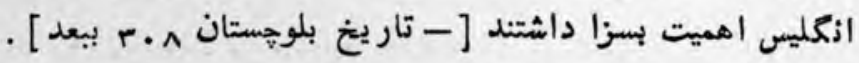

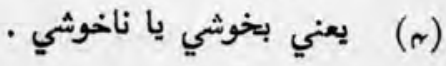


CI

تازه نواي معارك

عاليجاه متهد اعظم خان بنا بر استمداد ، رخ نهاد, قالات شدند .

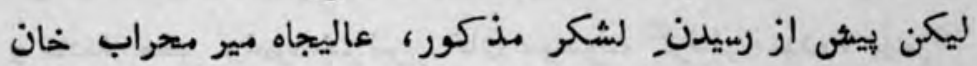

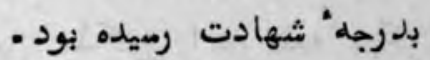

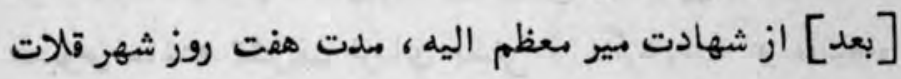

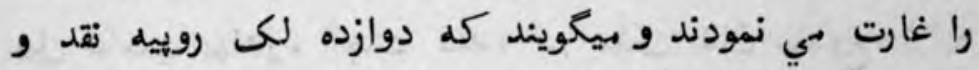

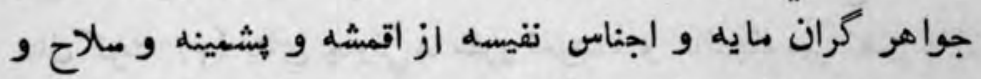

شهشيرهاي جواهر دار و تفنك هاي رومي و اسهان_ خاصهـ ولايتي

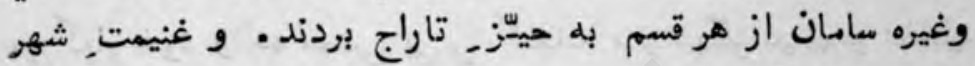

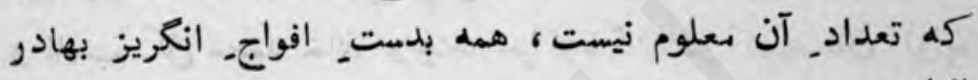

افتاد .

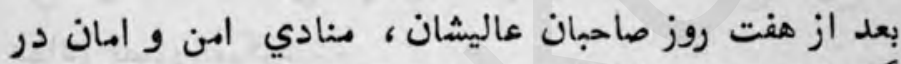

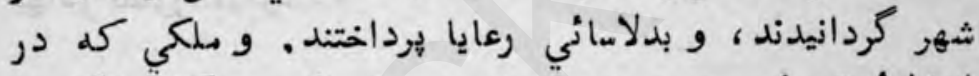

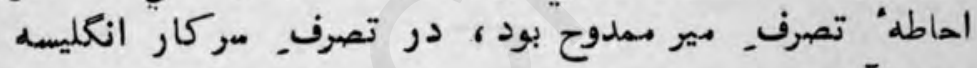
بهادر آمد - ماطد

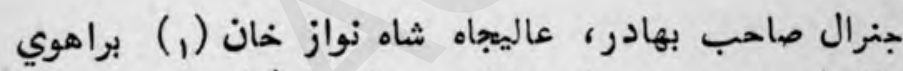

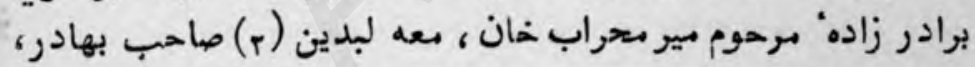

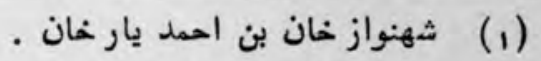

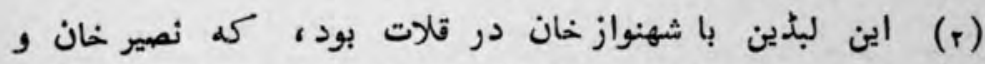

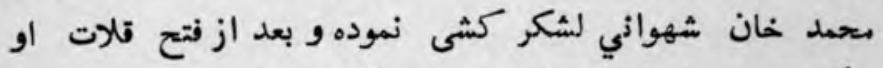

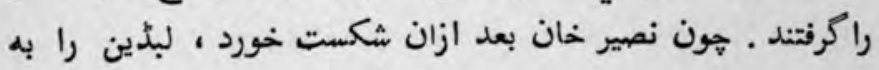

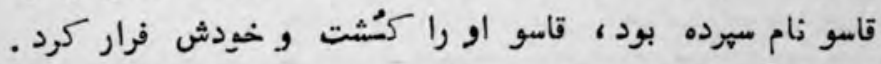

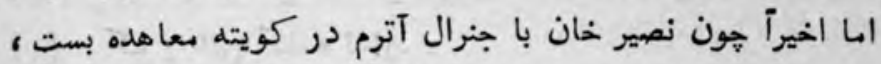

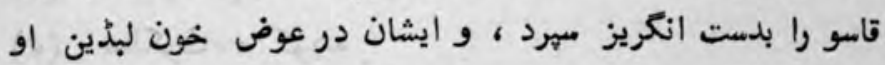

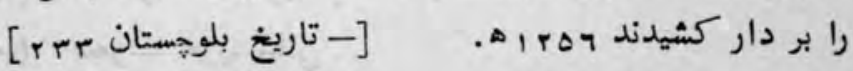




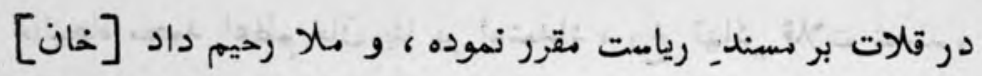
و محمد حسن وغيره خوانين, خان موصوف كرفتار نموده، بهمراه

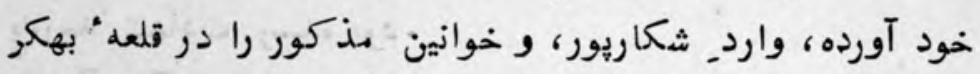

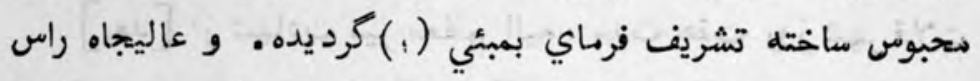

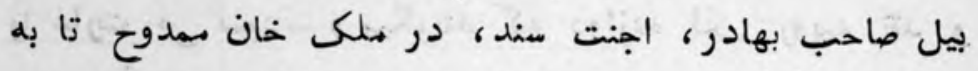
شال كورك (r) بناي هاوني ها مقرر نموده. بـ و عاليجاه مير نصيرخان

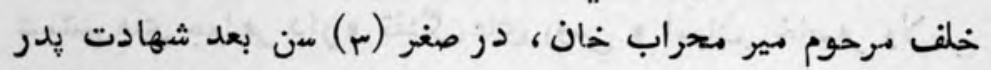

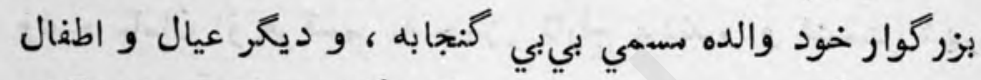

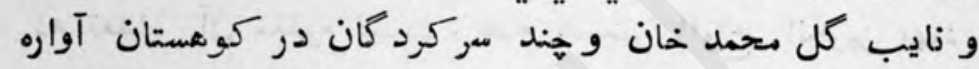
مي كرديدند، ليكن در ترك تاز و تاخت و تاراج افواج انكريز بهادر قصور نميكردند.

$$
\begin{aligned}
& \text { كى : اين كلمه ندارد. . } \\
& \text { شالكوث = كويته . } \\
& \text { صغر= خورد سالي . نوانه }
\end{aligned}
$$


در بيان زد برد بلوحان كوهستان [و] براهوي وغيره

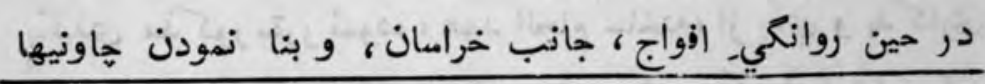

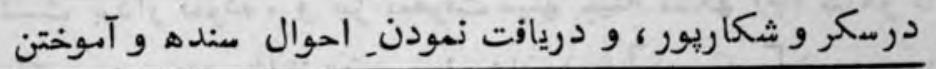

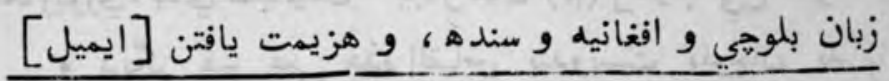

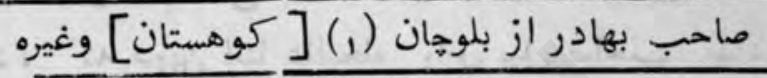

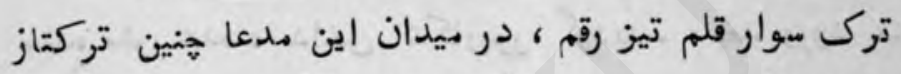

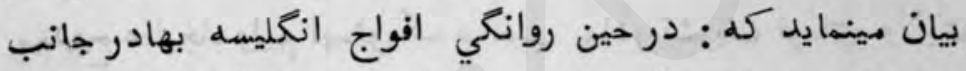

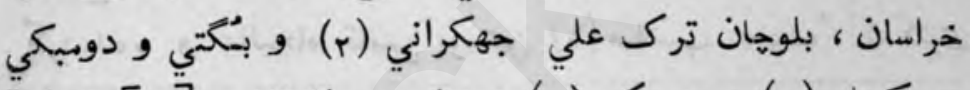

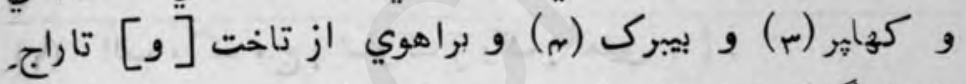

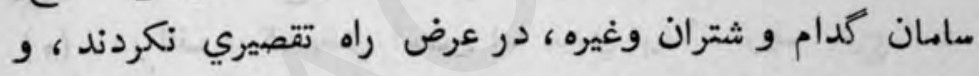

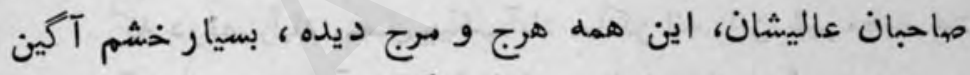

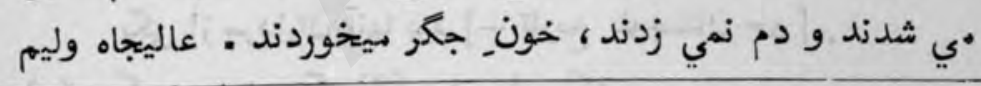

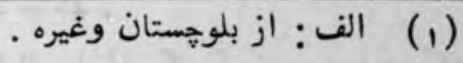

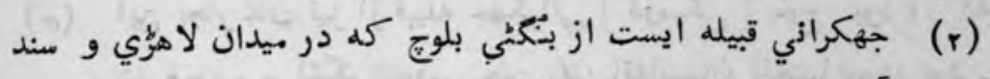

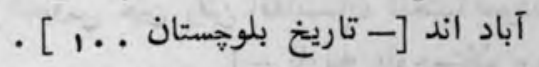

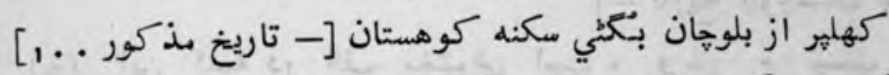

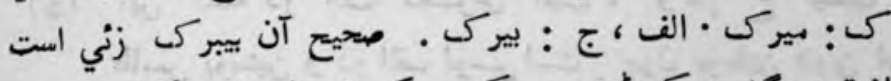

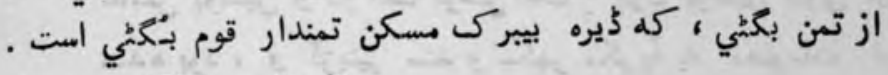

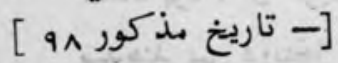


ايستويكى (1) صاحب بهادر در شيكاريور رسيده، در تجزويز و

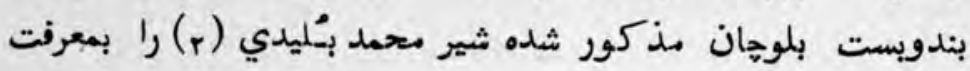

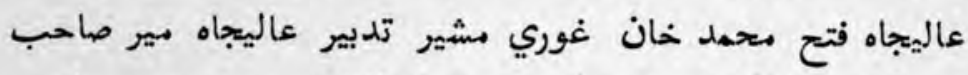

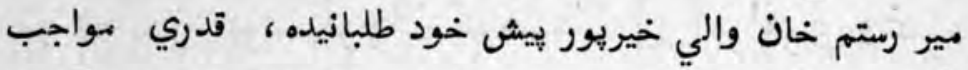

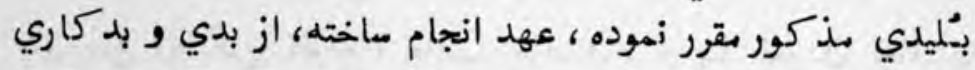

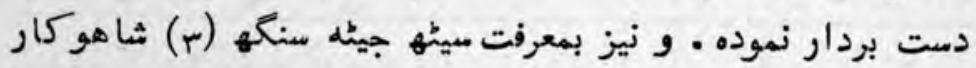

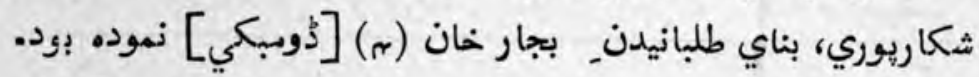

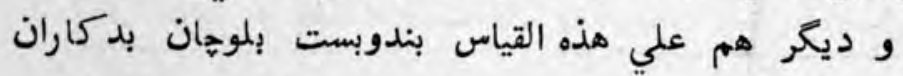

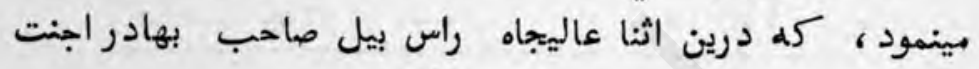

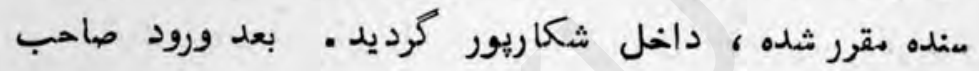
ممدوح عاليجاه وليم ايسمويك صاحب بهادر تشريف فرماي ولايت

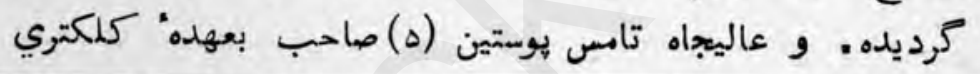

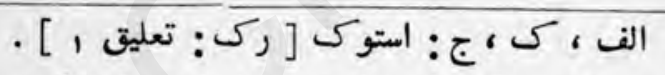

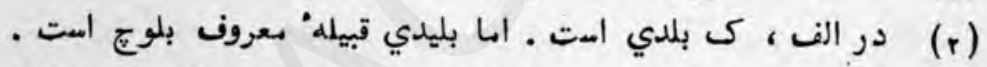

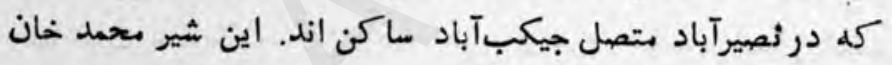

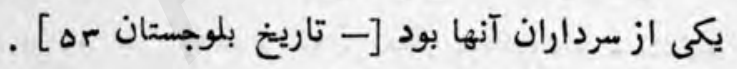

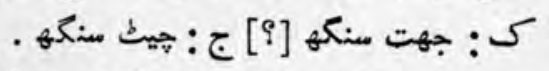

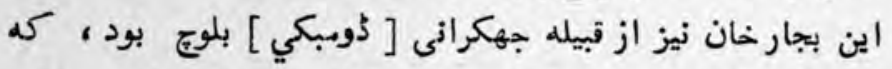

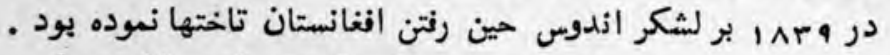

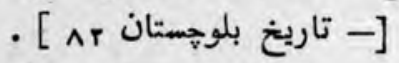

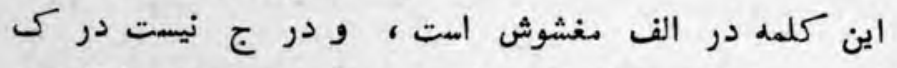

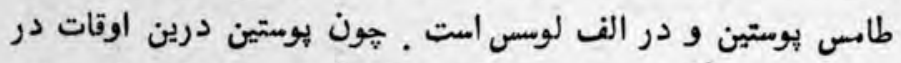

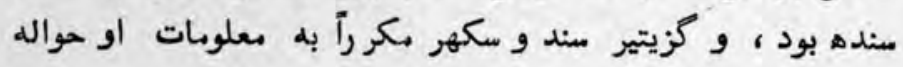
ميدهند بس درينجا هم نام وي صحيح خواهد هو بود . 
شكاريور مامور شده، و ايستويك صاحب خورده، نيز بقهراه كلكتر

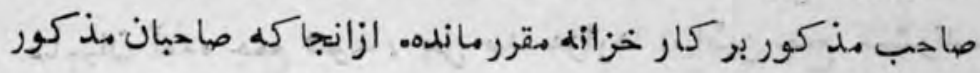

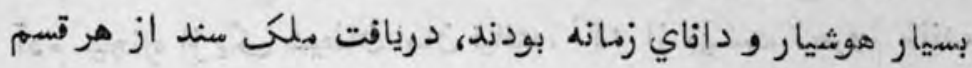

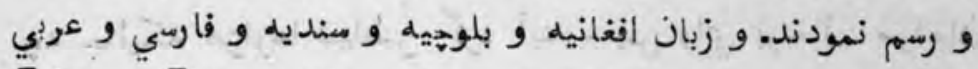

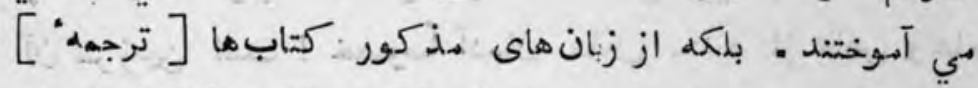

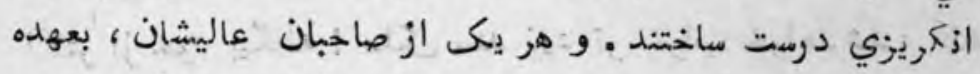

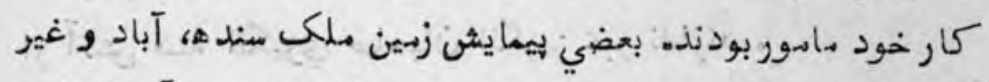

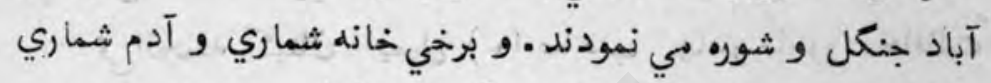

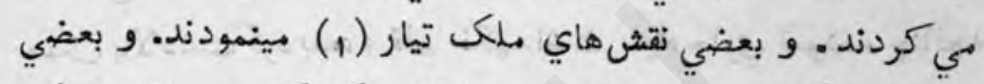

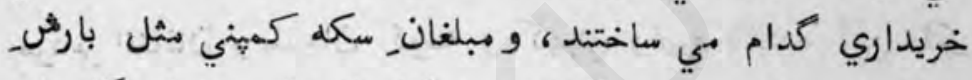

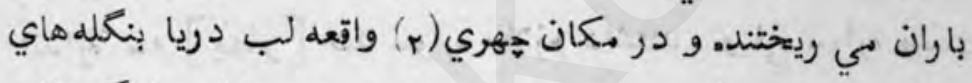

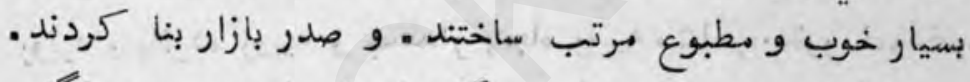

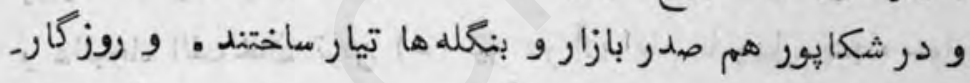

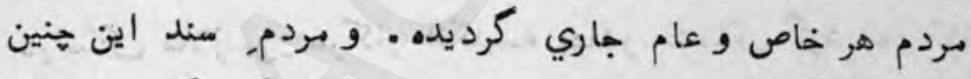

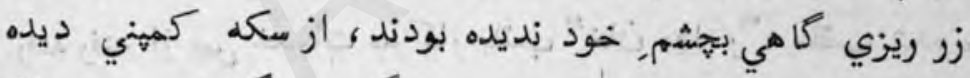

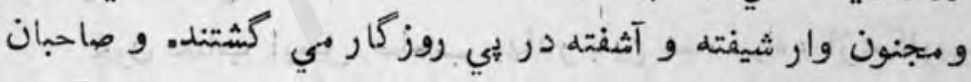

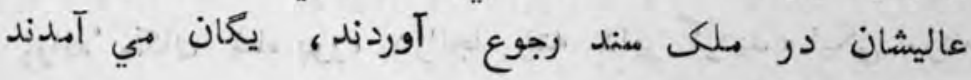

از زبان بعضي رفتند صاحبان شنيده شد كل به به كفتند : كله هركاه

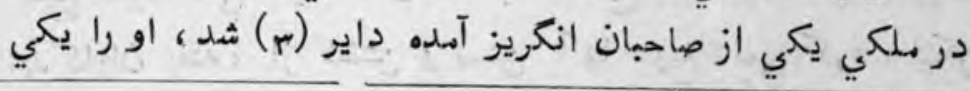

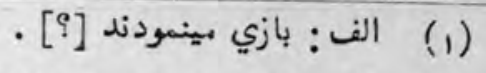

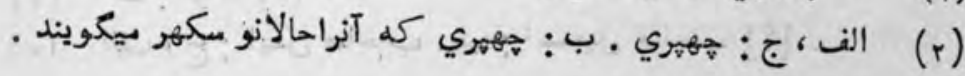

$$
\text { الف: وارد شد: }
$$


تازم. نواي مقاركى

r.

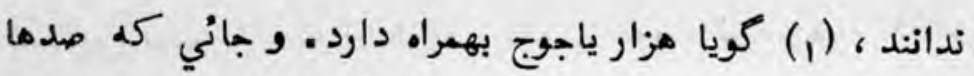

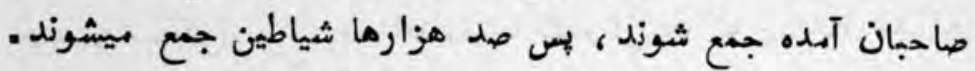

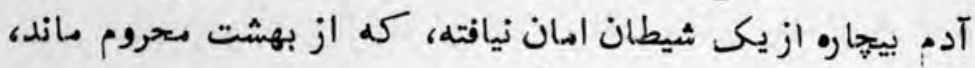

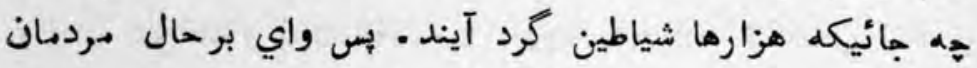

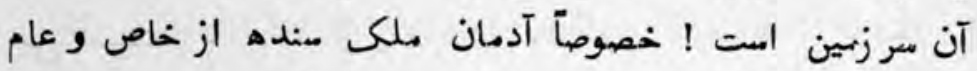

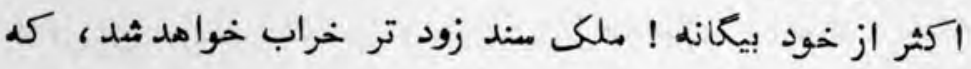

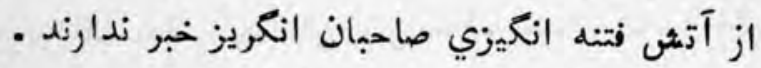

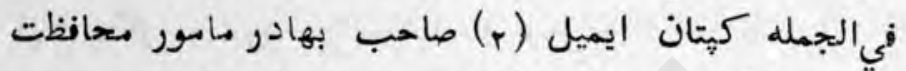

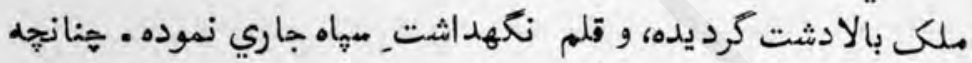

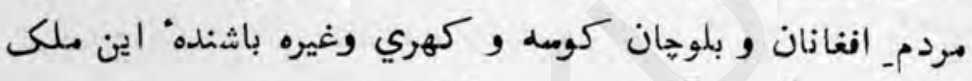

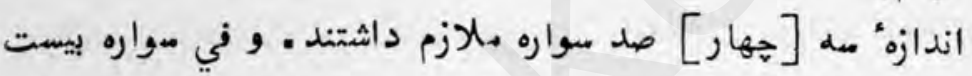

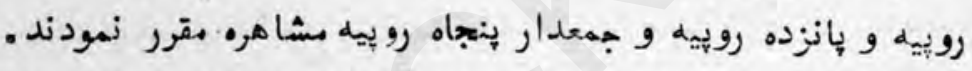

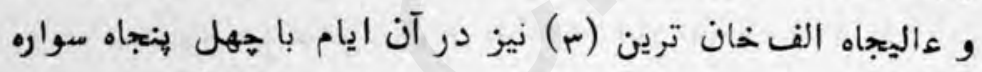

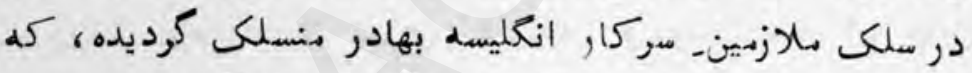

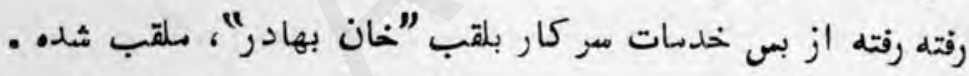

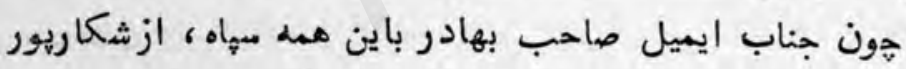

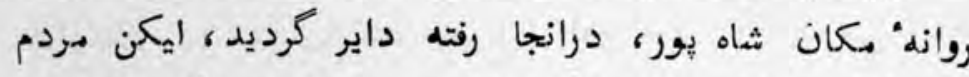

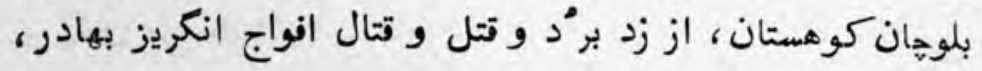

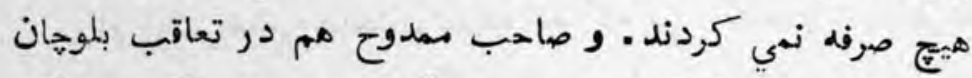

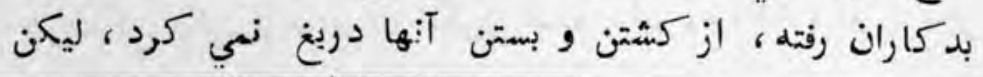

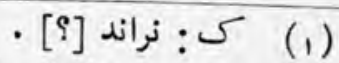

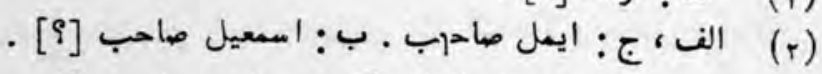

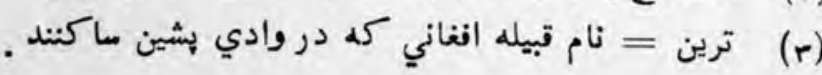


تازه نواي نماركى

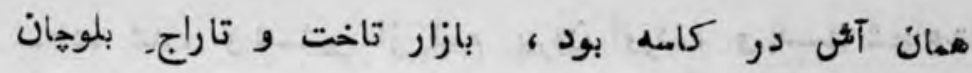
روز بروز كرم • - مان

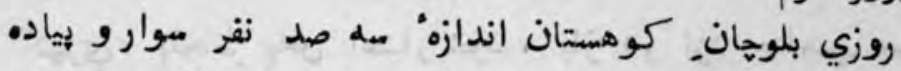

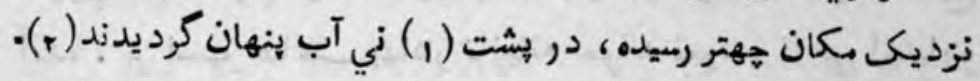

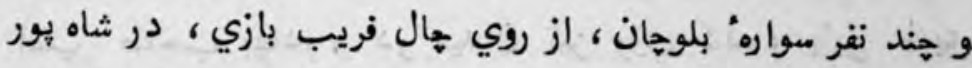

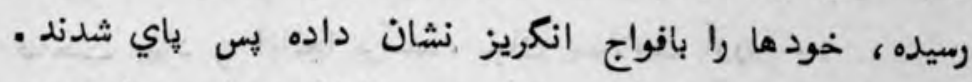

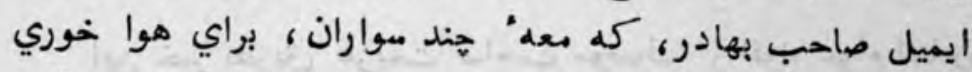

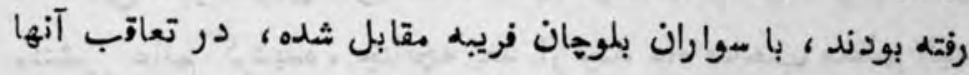

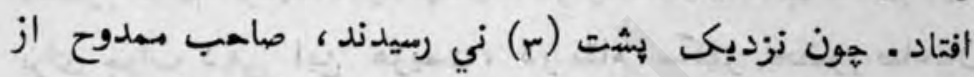

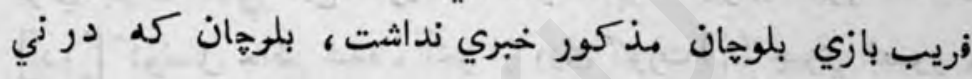

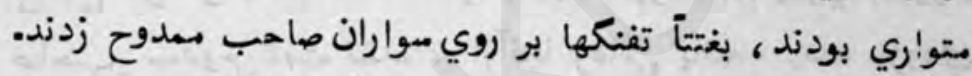

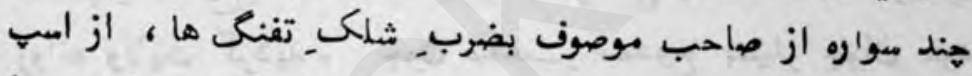

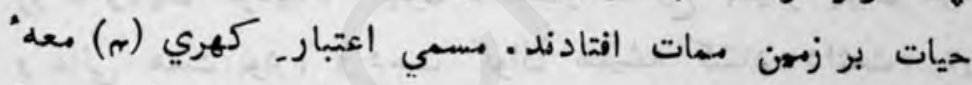

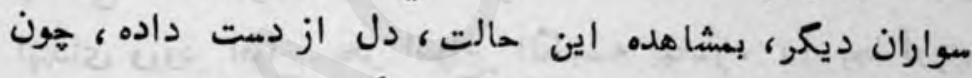

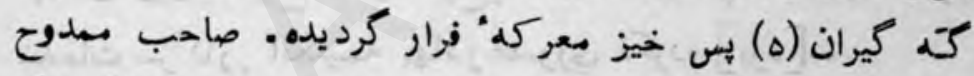

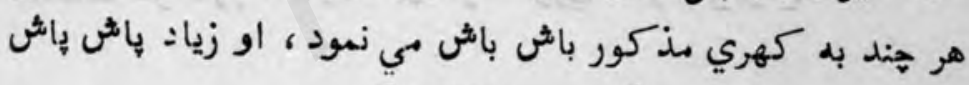

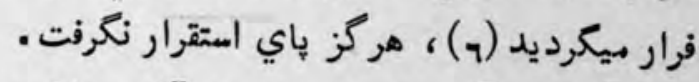

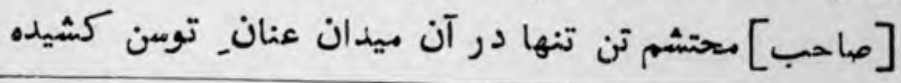

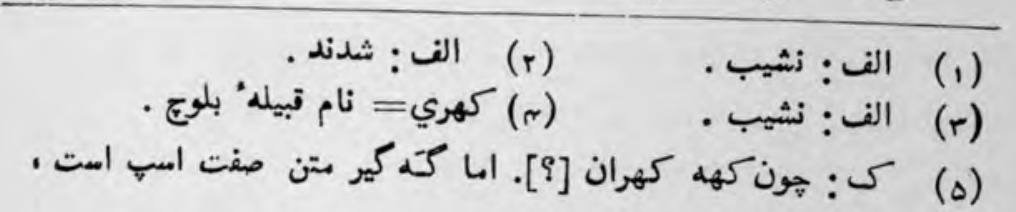

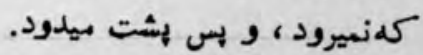

(7) الف: ميكرد. 
الستاده شد، و شمشير از نيام بيرون آورده، و بلده شجاعت

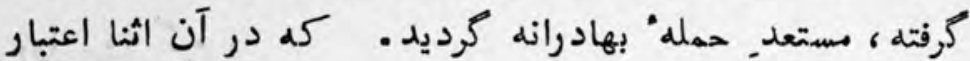

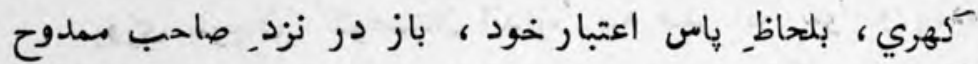

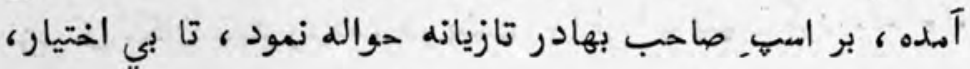

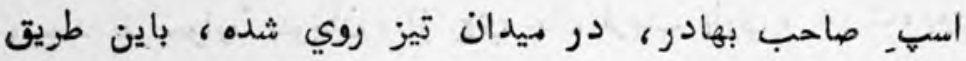

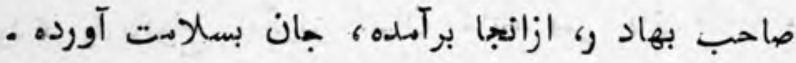
اين خبر بطريق هزيمت صاحب موصوف از افواه عوام الناس

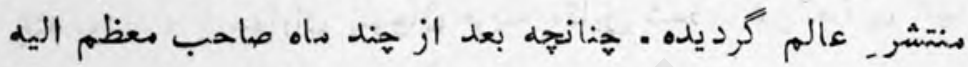
براي جواب دهي اين هزيمت، در مقام. سكهر بحضهور صاحبان

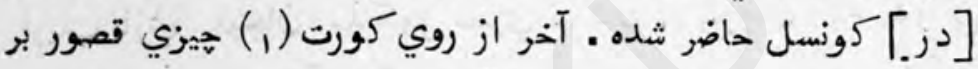

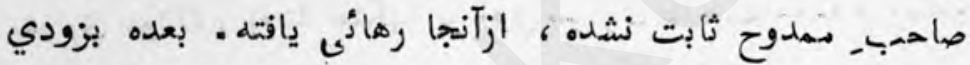

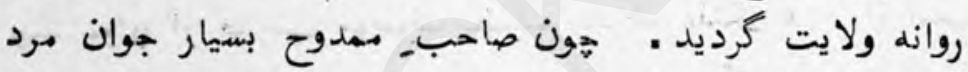

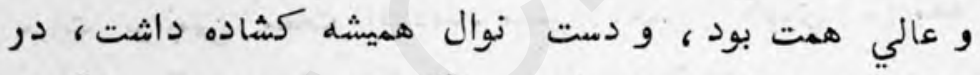

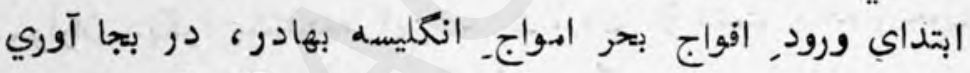
خدمات سركار, انكليسه بهادر قصوري نكرده [بود] -

كورت در ازخحليسي بمنى محكمه است . 
در بيان رفتن, ماحبان , عاليشان طرف جهتر و (1) فليجنى

و كرفتار نمودن بجار خان (r) دومبكي و تركى علي جكهراني وغيره جكهرانيان

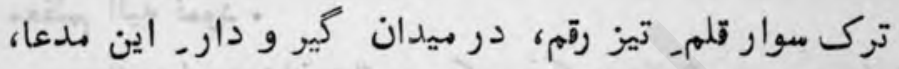

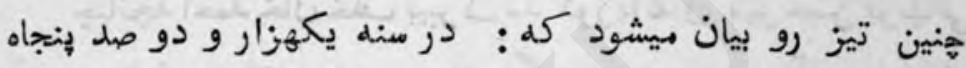

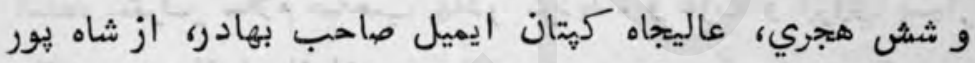

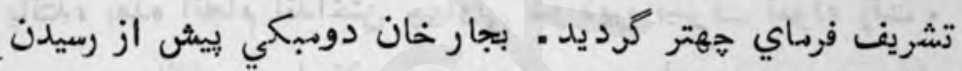

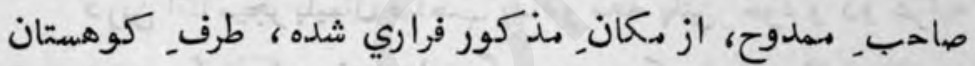

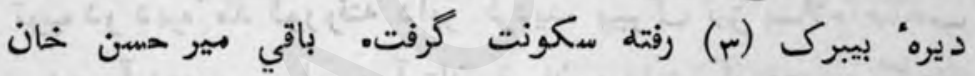

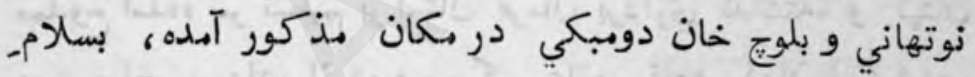

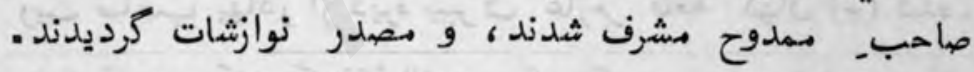

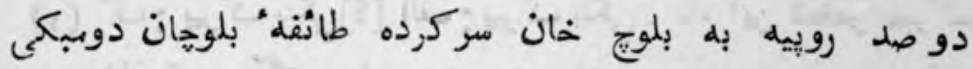

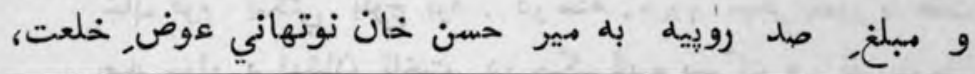

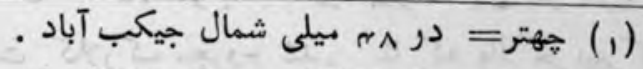

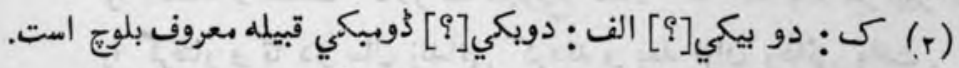

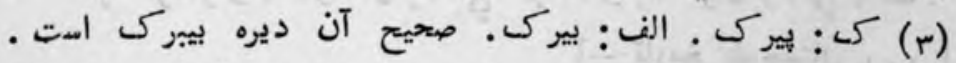

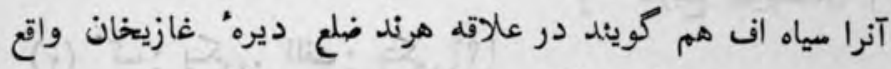

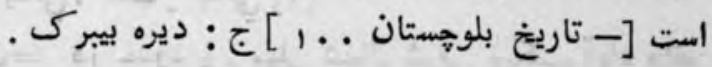


صاحب_ ممدوح عطا نمود. و آنها را از خود بسيارخشنود نمود.

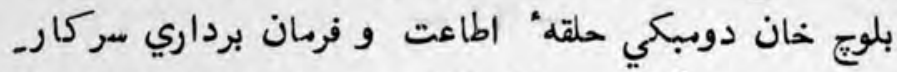

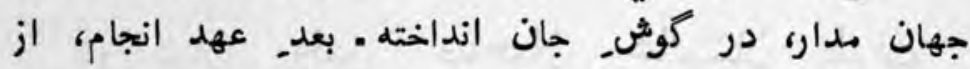

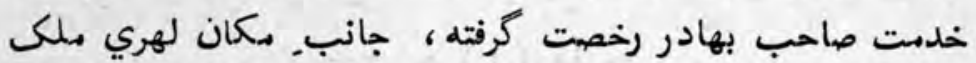

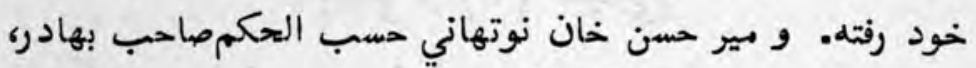

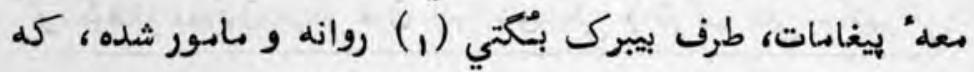

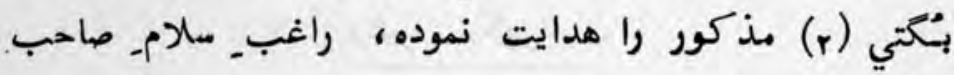

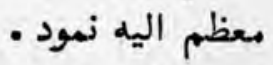

خمانجه احمد خان خلف بيبرك مذ كور باتفاق مير حسن نوتهاني

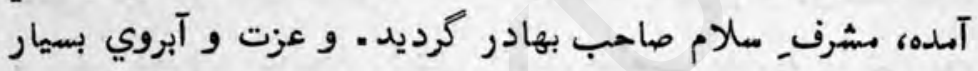

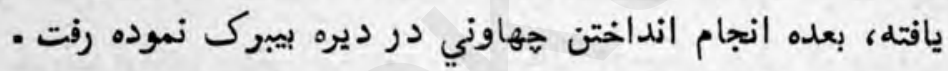

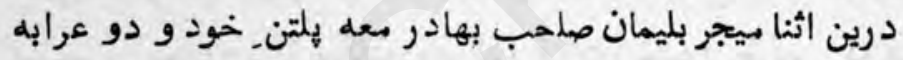

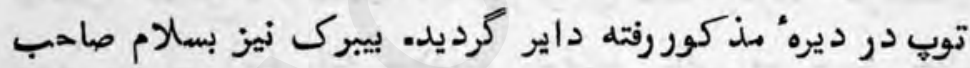

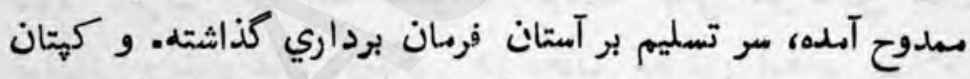

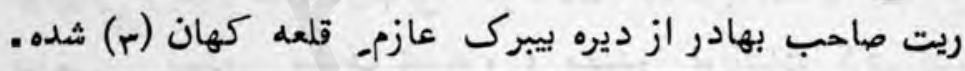

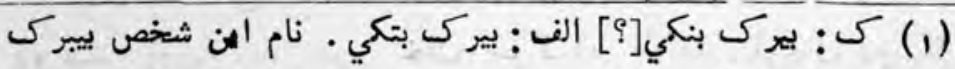

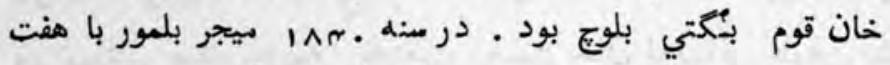

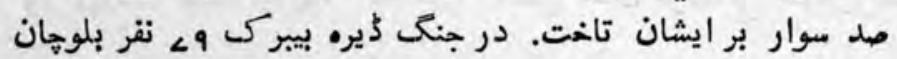

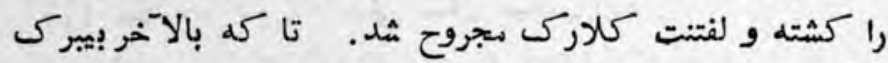

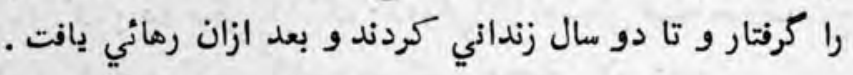

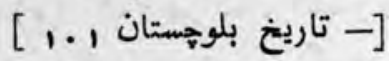

$$
\text { [ [r) }
$$

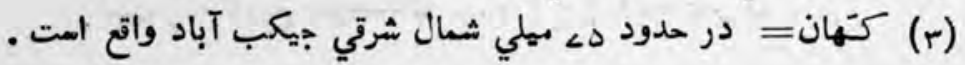


و شجاءت نشان دوده خان مري معه' بانصهد مواره از ملعه كهان

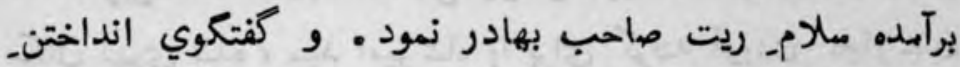

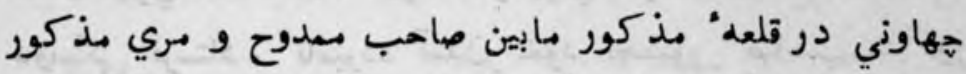

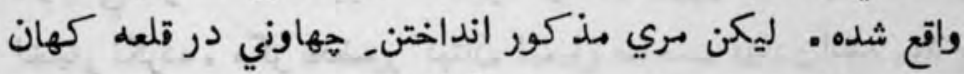

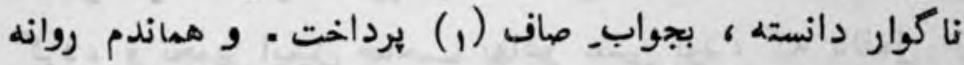

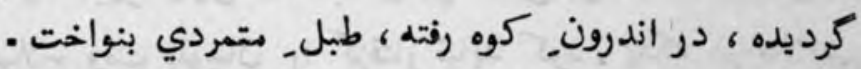

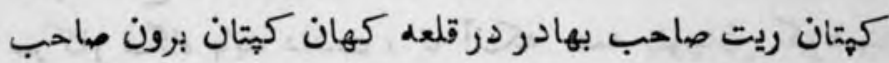

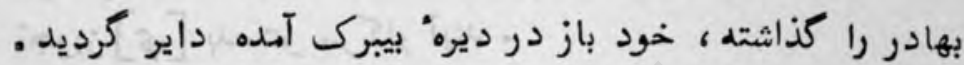

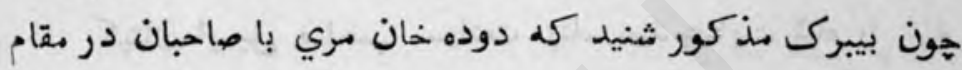

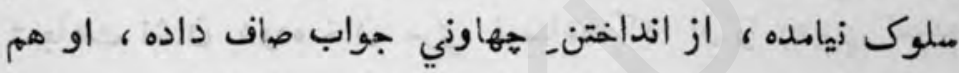

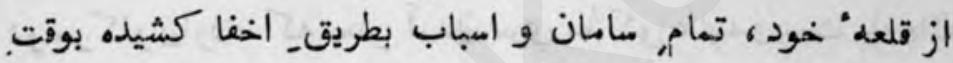

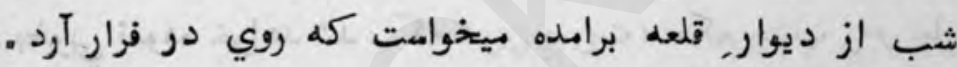

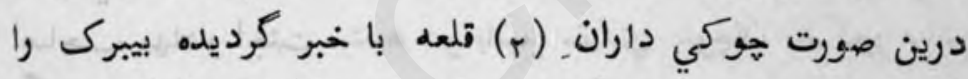

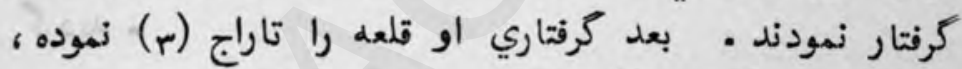

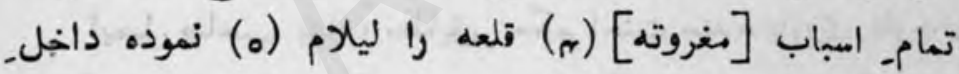

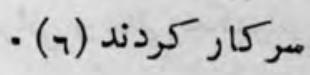

$$
\text { كى: صاحب . }
$$

الف: درينصورت متعينان. هوكي قلعه .

$$
\text { الف: قلعه را وا نموده . }
$$

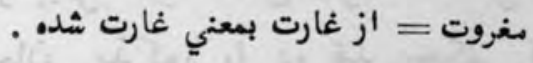

$$
\text { الف الف: كيلام كرديدند. }
$$


تازه نواي معاركى

ir?

درين اثنا" عاليجاه طاهس بوستن (1) صاحب بهادر داخل

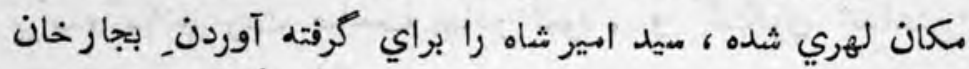

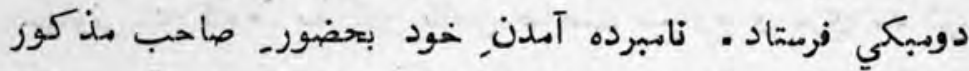

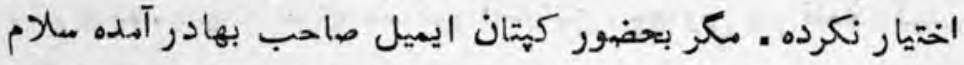

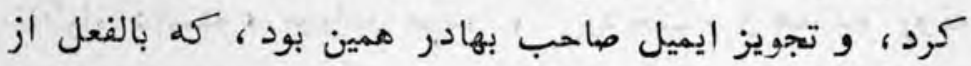

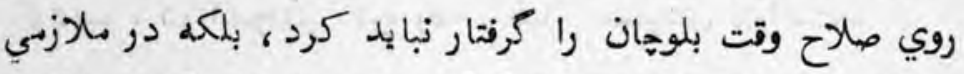

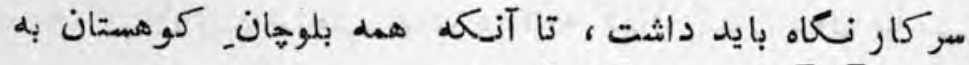
تجويز [ي] بدست_ سركار آيند ماند آنس

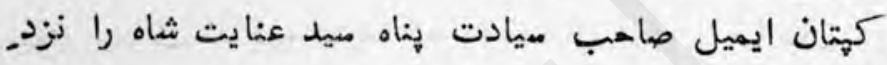
شجاعت نشان دوده خان مري فرستاده كه او او را رهبري نموده

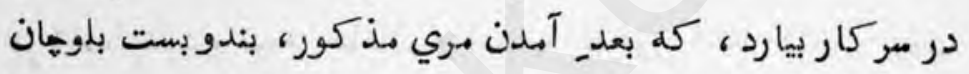

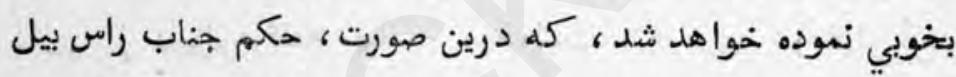

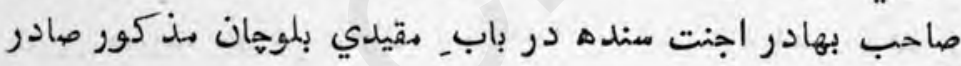

كرديد.

أيميل صاحب بهادر بطابق. حكم اجنت سنده بازوي بلوجان

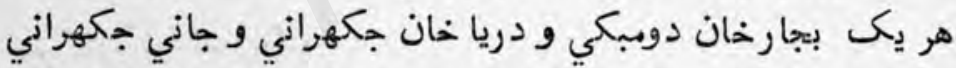

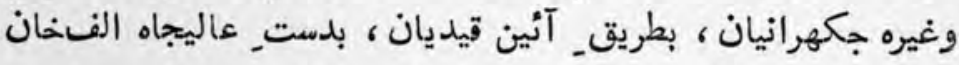

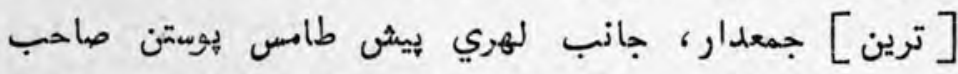

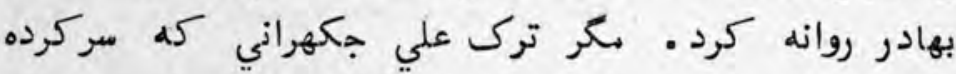

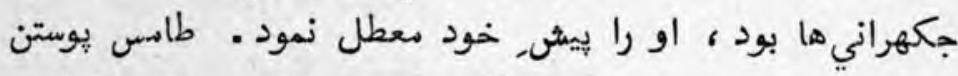

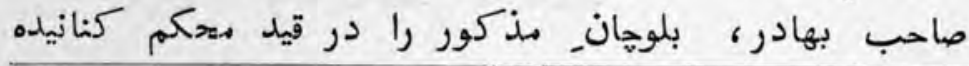

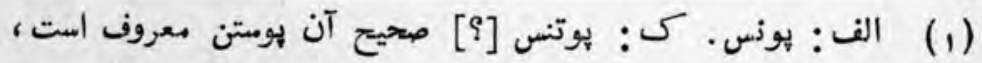

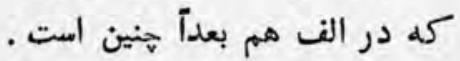




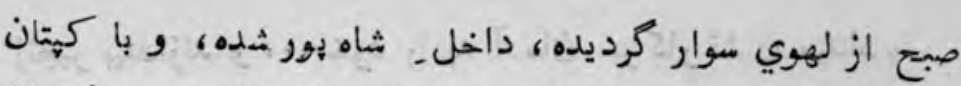
ايميل صاحب بهادر مشورت نموده، همل بلوهان ران مهرد كيتان

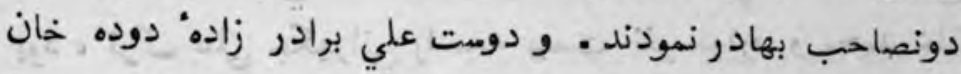
مري، "كل بموجب هدايت ميد عنايت شاه ، بجهت ملام صاحبان

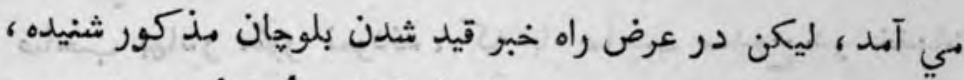

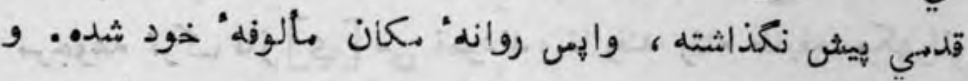
ميد مذ كور باز آمده، صورت حال ليس رفتن دومت علي مبري

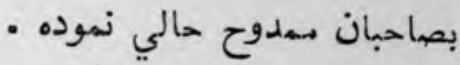
بعده كهيان دونصاحب بهادر معل بازوي بلوحان قيدي

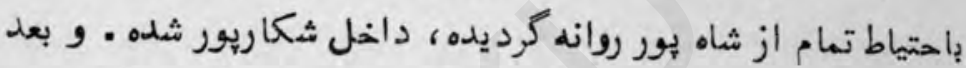
از حهند روز طاهس بهوستن صاحبب تشريف فرهاي شكاريور كرديده.

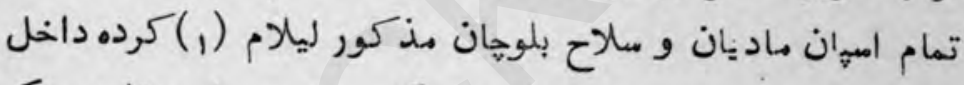
سركار نهودند .. و بجار خان دومبكي وغيره را در تلعه بهكر

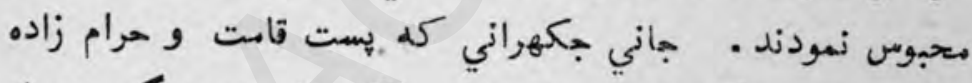

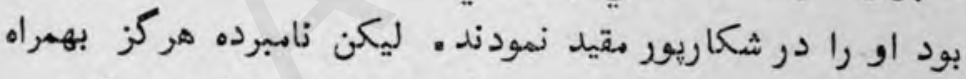

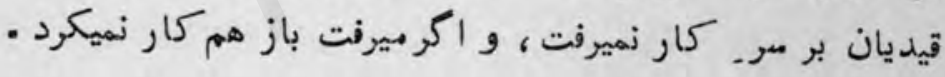
باوجوديكه مجافظين هوكي او را ميزدند، هزارها مـخنان.

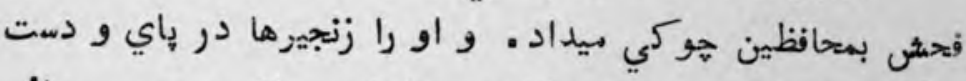

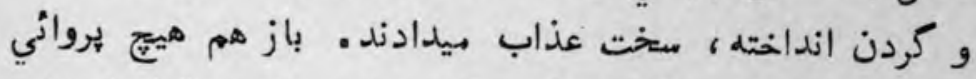

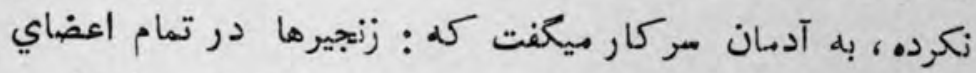

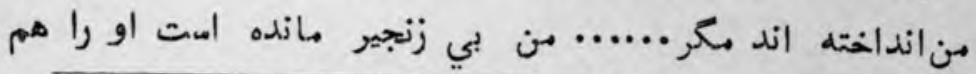


تازه نواي مقارب

MYA

زنجير بيندازند و ... خود را به آدمان سركار نشان ميداد. حون جهكرافي مذكور هنين معركش و بي باكى و شوخ بود ، ترك علي جكهراني را معه بيست نفر موارو و متمد خدان

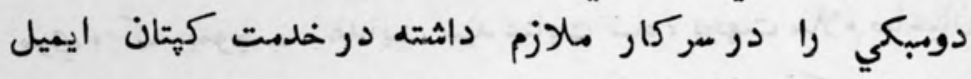
صاحب بهادر مقرر نمودند، كله با صاحب مهدوح در مر خدمات مرجوعه ترك تاز [ي] مي نمودند ، تا رفته رفته طايفه جكهراني از مهرباني سركار جهاندار كامياب مطالب مدا في الضمير خود

شدند 
$-4 \pi-$

در بيان رفتن ماحبان اذگريز بهادر طرف قلعه كهان

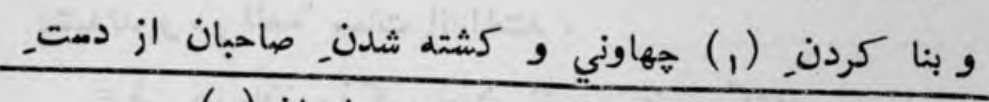

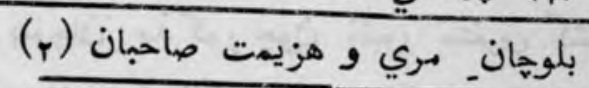

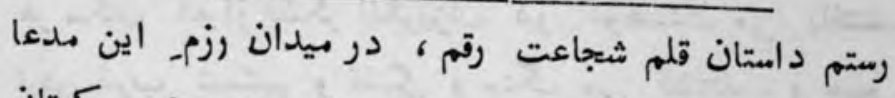

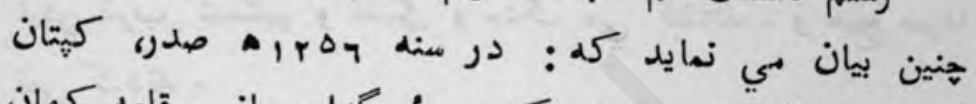

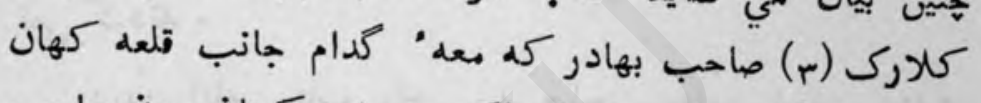

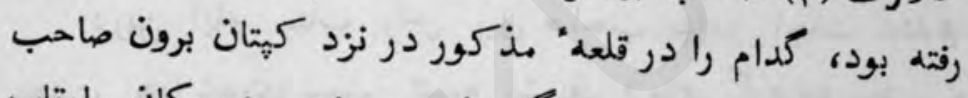

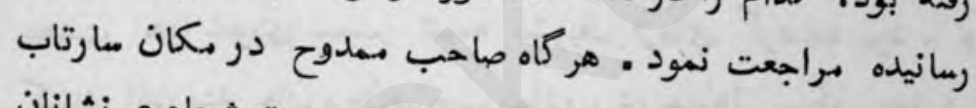

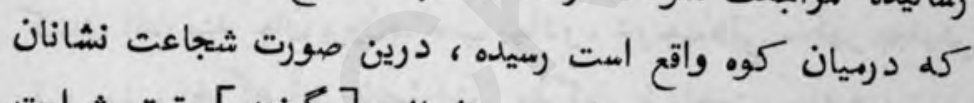

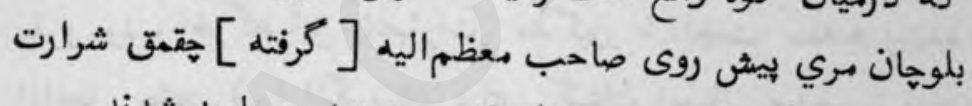

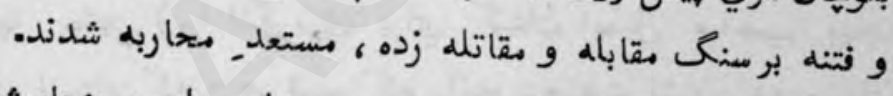

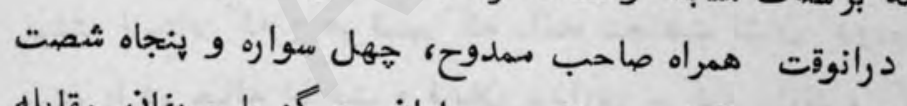

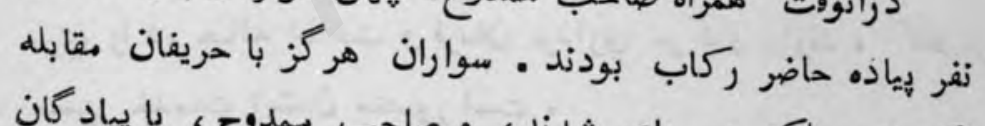

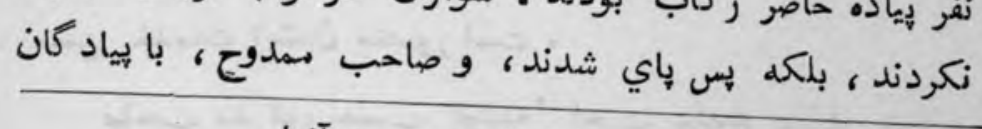

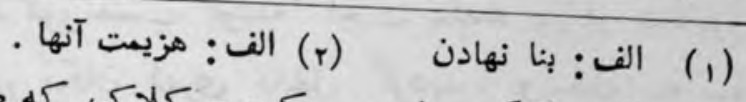

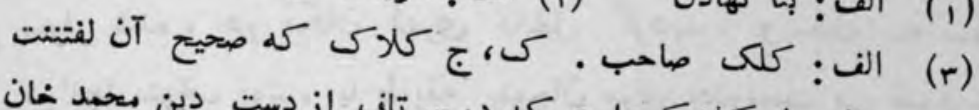

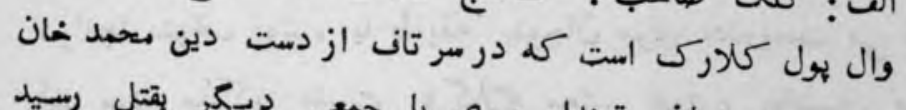

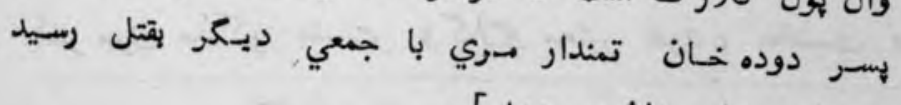

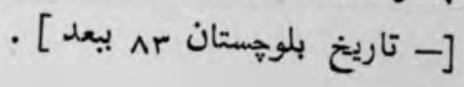




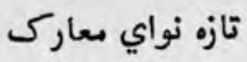

rr.

جنح كنان از دست بلوحان كشته شده م. و هفت هشت صد نفر

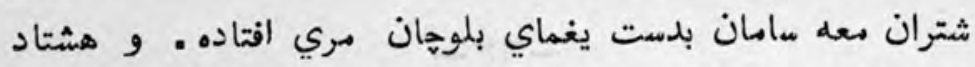

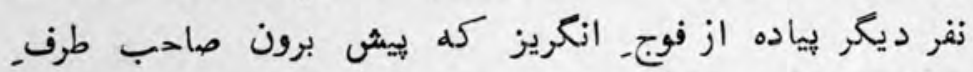

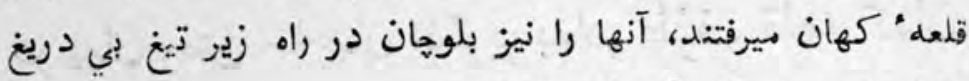

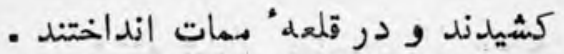

غرض بلوجان_ مذ كور هون زنبور متفرق كشته ، هر هان جا و

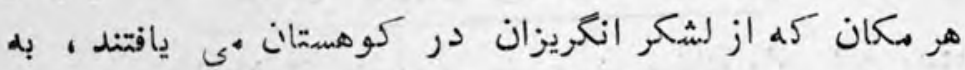

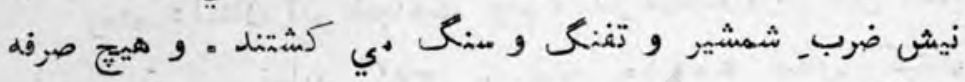

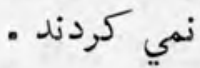

درين ايام جناب راس بيل صاحب بهادر اجنت سندها،

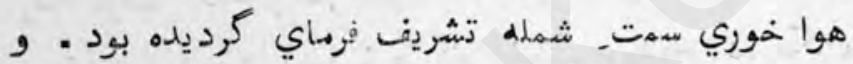

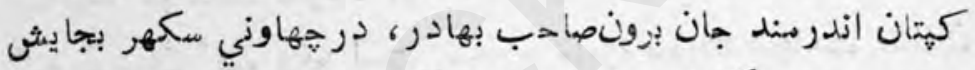

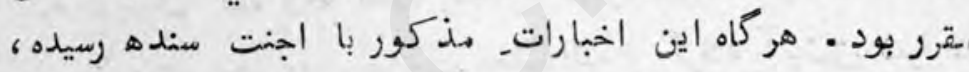

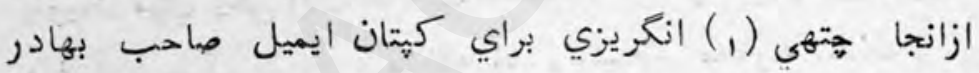

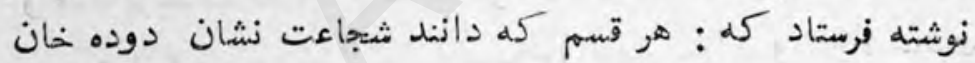

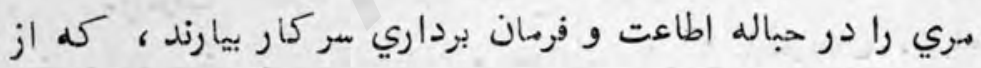

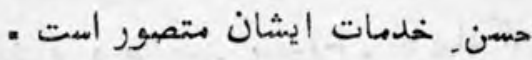

صاحب مذ كور حسبب نوشته" اجنت سنده باز از شاه بإور

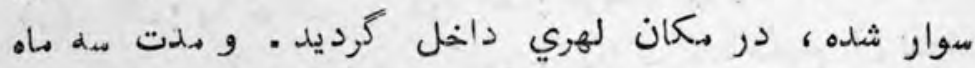

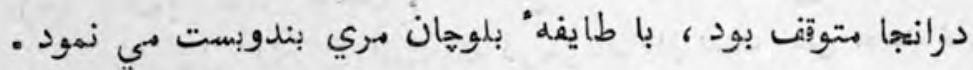

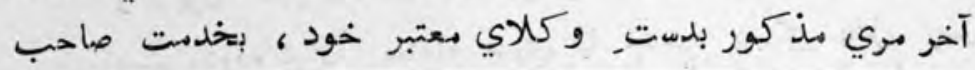

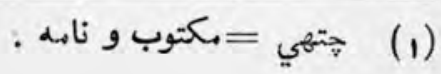


همدوح جيغام فرستاد، كله ما مردمي بلوحان، كوه نشين و صحرا

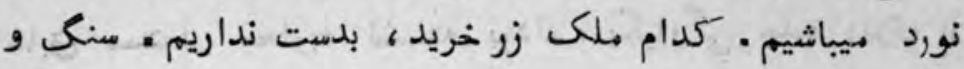

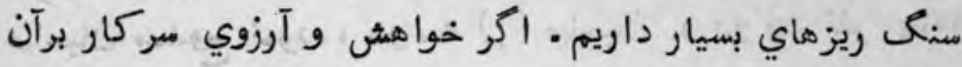

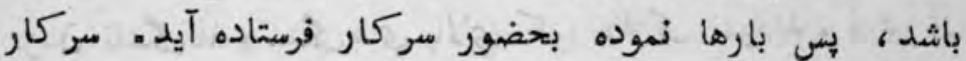

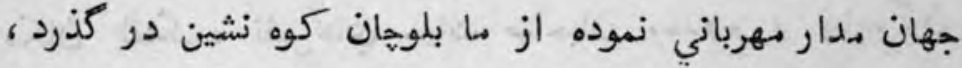

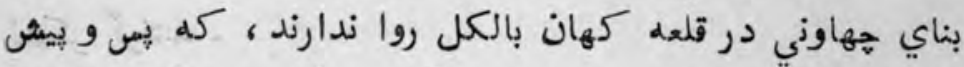

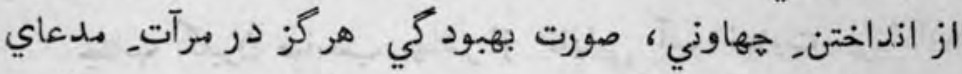

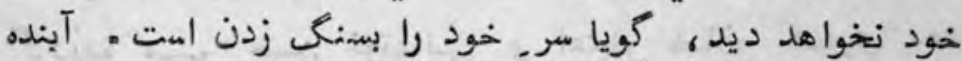

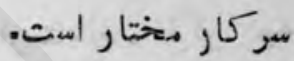

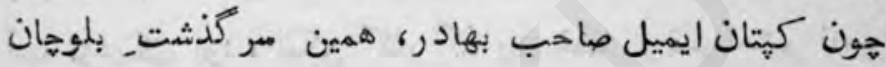

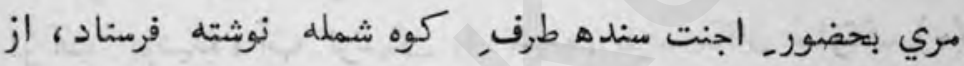

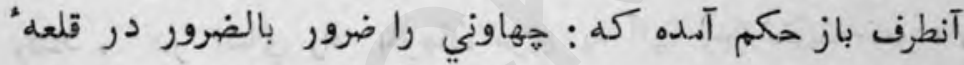

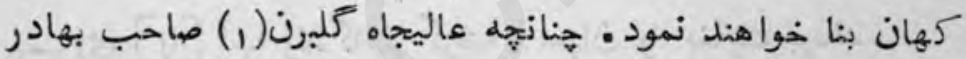

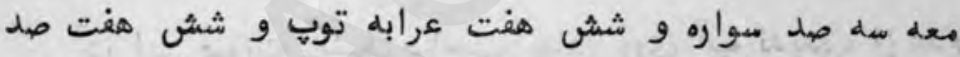

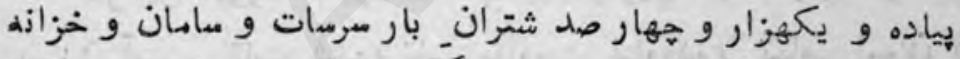

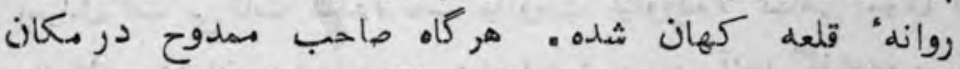

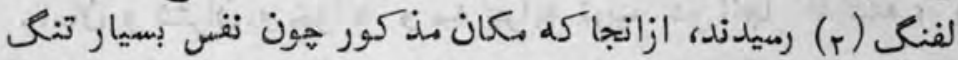

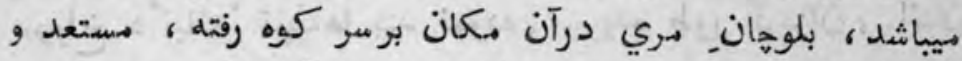

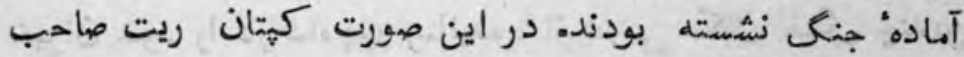

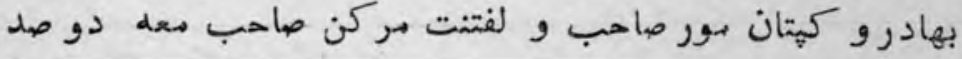

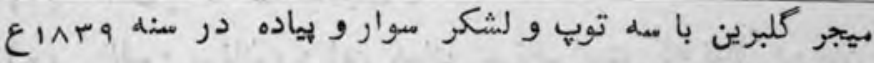

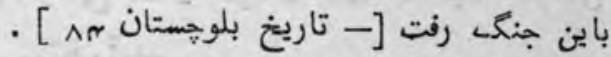

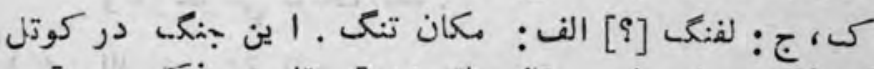

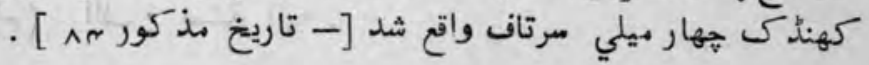




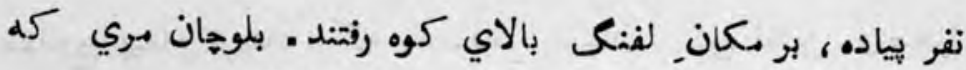

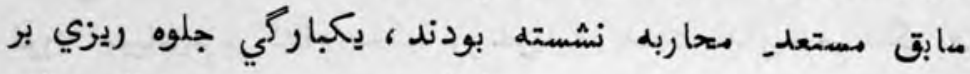

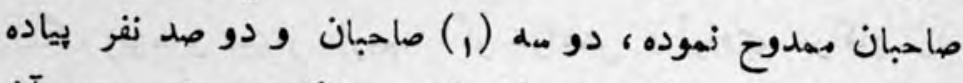

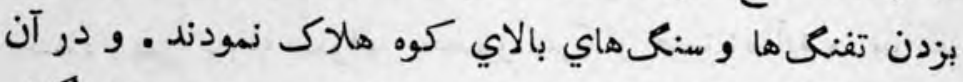

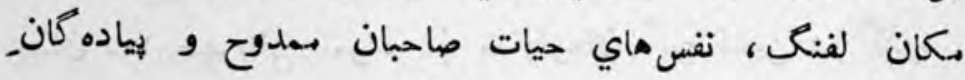
لشكر كرفت: لهند

جناب كلبرن صاحب بهادر از نايابي آب نهايت بي تلاب

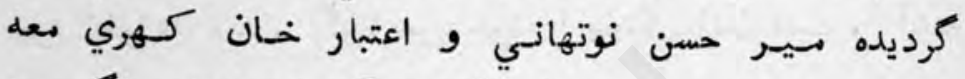

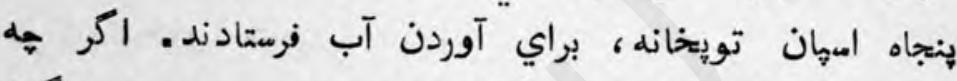
آب نزديك بود، ليكن كار كذاران قضا و قدر حشم نامبرد كان

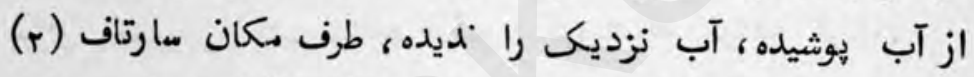

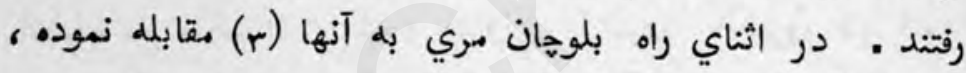

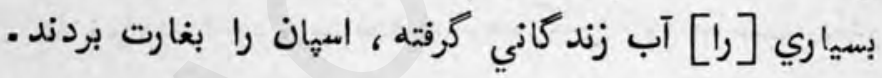
در اين صورت كلبرن صاحب بهادر روي آب نديده، ازعدم

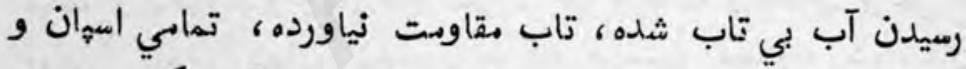

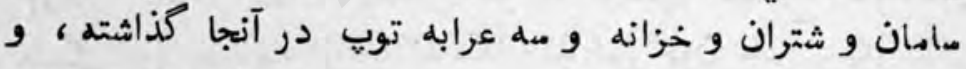

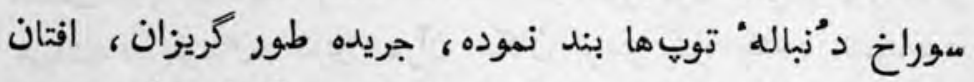

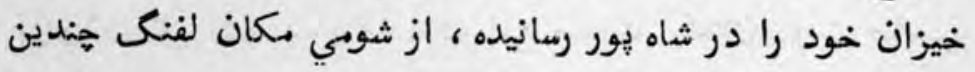

$$
\text { الف: كله سه صاحبان . }
$$

الف: سرنان، و اين ممان سرتان است كمه قبلاً در متن سرتاب

و در حواشي سرتاف آهده.

$$
\text { الف: بمشار الهيه }
$$




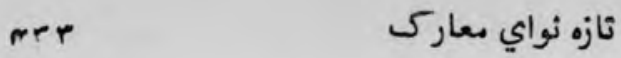

نفس هاي لشكريان برباد داد. نفس خاص خهود رادر شاه هور

آرام داده ، نفسى بكام دل بر آورده .

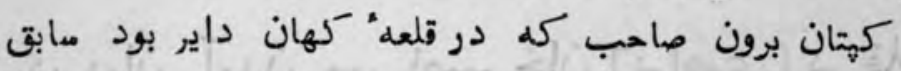

از عدم رميدن و موجودي مسرسات بسيار تنكدل بوده . خصوصاً

از شنيدن خبر هزيمت و كشته شدن صاحبان ممدوح بسيار بي قرار

و مشيوث احوال كرديده ـ آخر از روي صالح وقت، بهمراه بلوحان

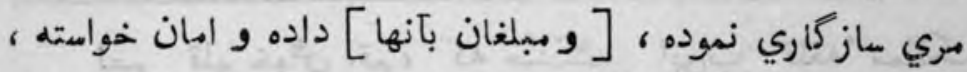

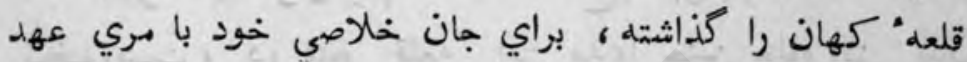

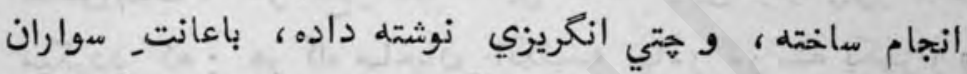

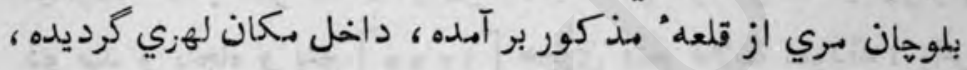

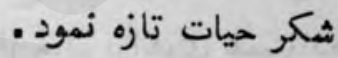

صاحبان انكريز بهادر، از روي انصاف، از جوان مردي و

شجاعت بلوهان مري خود ماحترف و آفرين آقرين ميكويند.

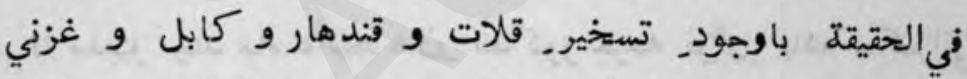

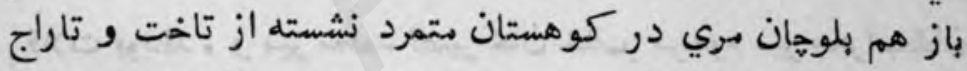

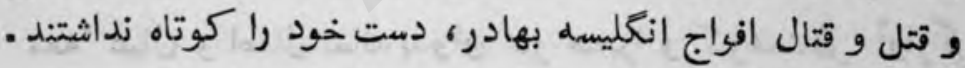

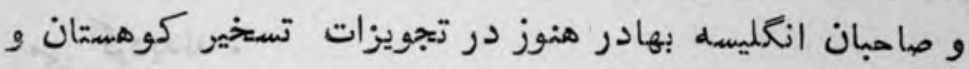

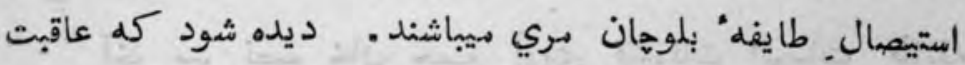

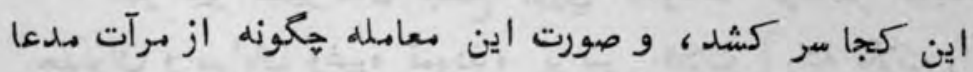

رخنما كردد . 
$-4 \mu-$

در بيانِ آمدن مير ذصير خان [براهوي] بر قلات و كرفتن قلات

از شاه نواز خان براهوي و كشته شدن لبدين صاحب [بهادرب]

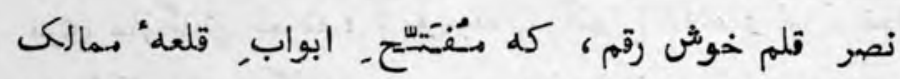

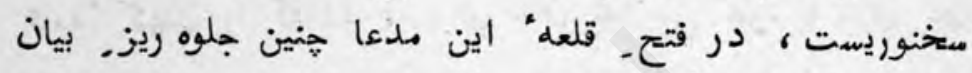

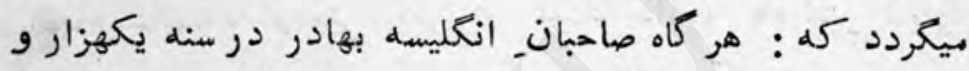

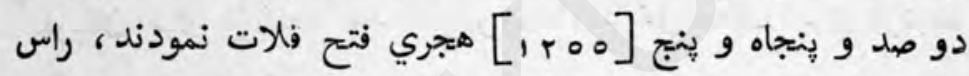

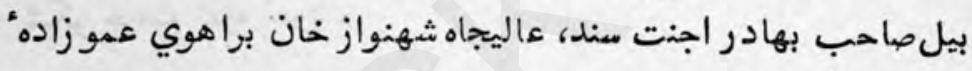

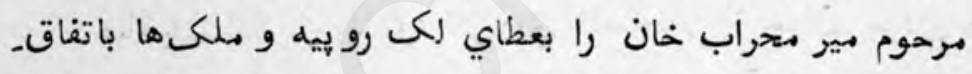

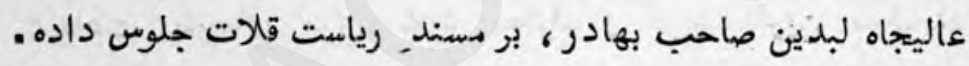

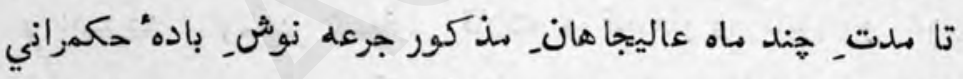

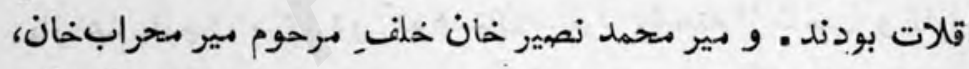

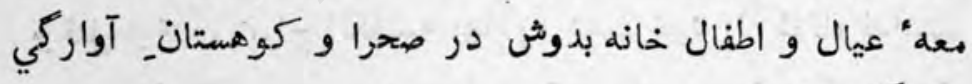

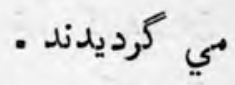

آخر بير نصير خان جمع آوري قشونات الوساتِ طايفهُ

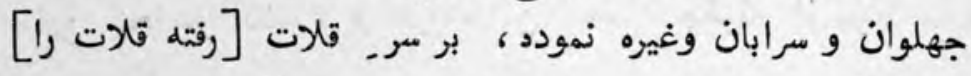

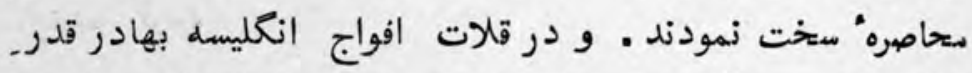

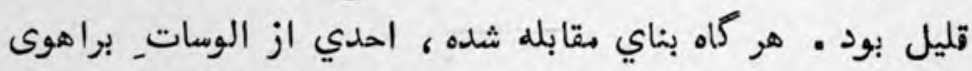

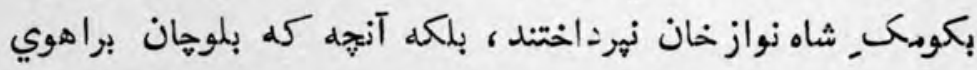


rro

اندرون_ قلعه" قلات بودند ، همه از اندرون برآهده با عاليجاه

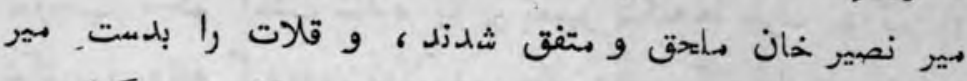

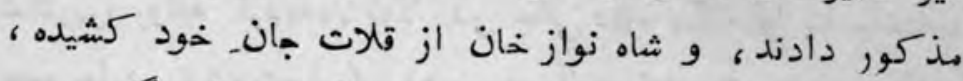

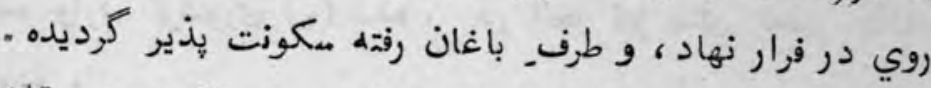

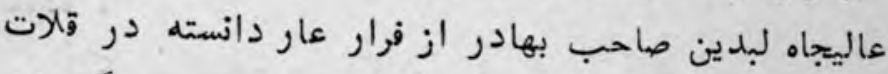

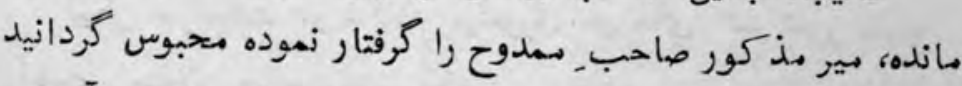

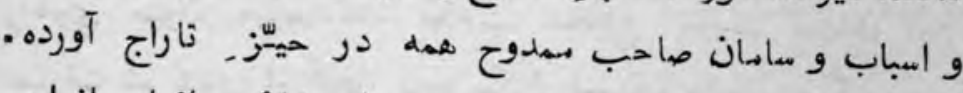

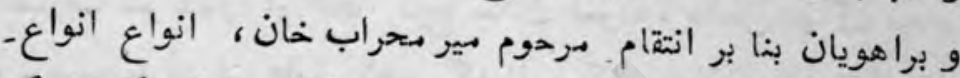

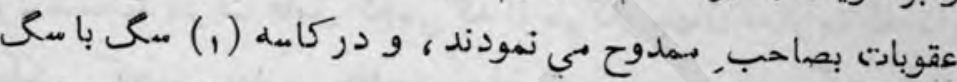

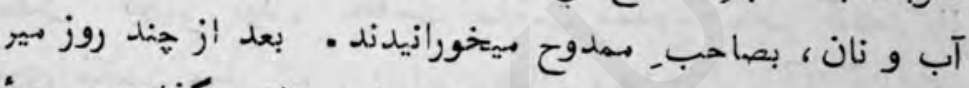

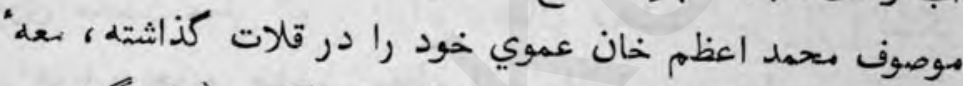

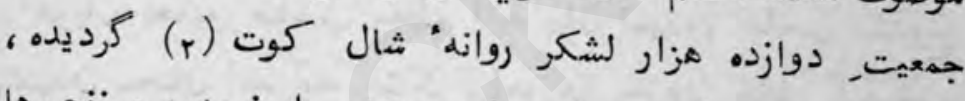

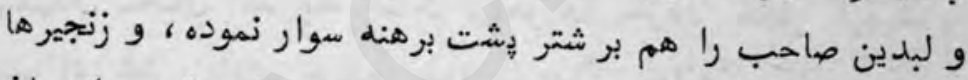

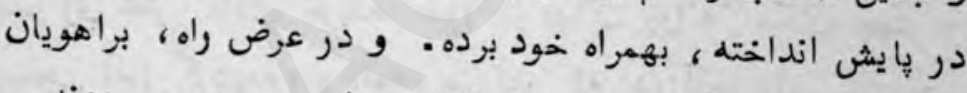

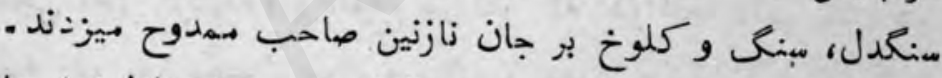

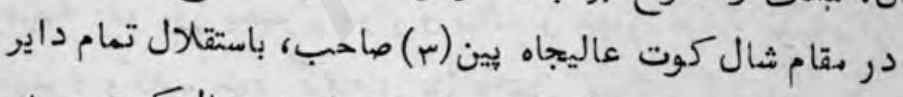

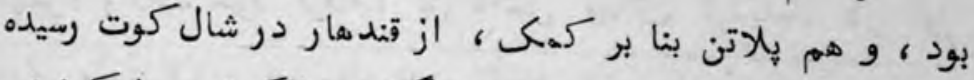

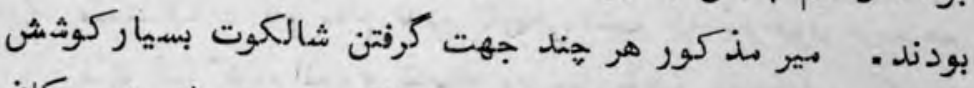

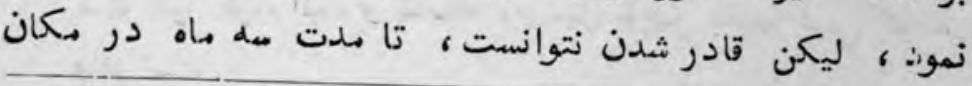

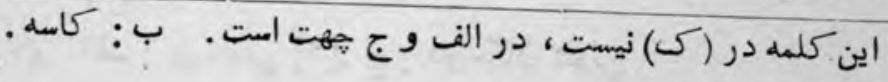

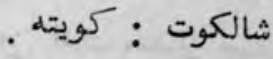

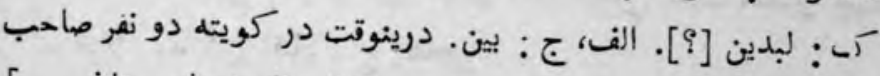

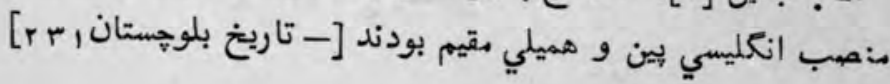




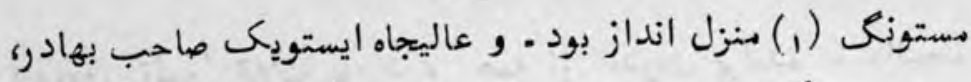

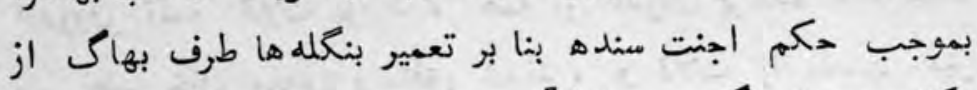

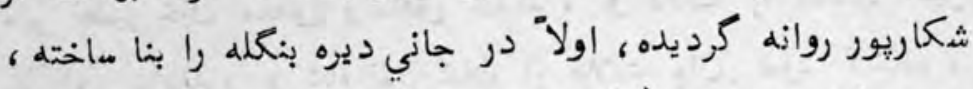

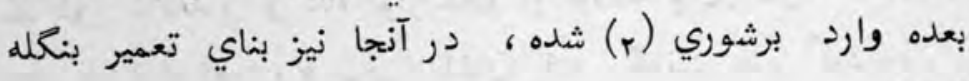

نموده .

ليكن درانوقت در مكان برشورى خبرهاي شر شور بلوحان

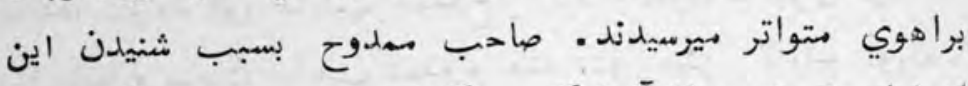

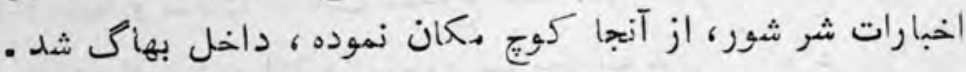

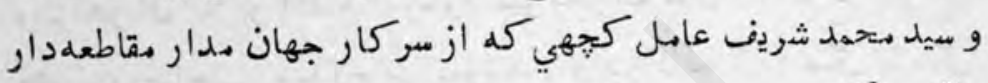

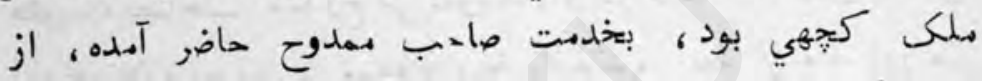

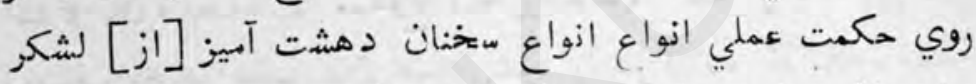

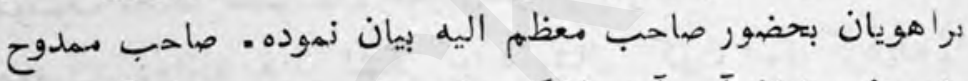

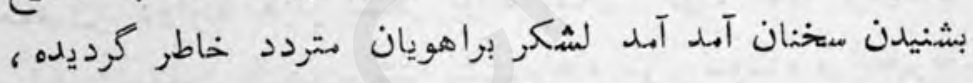

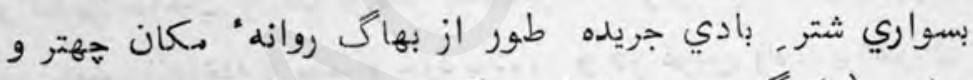

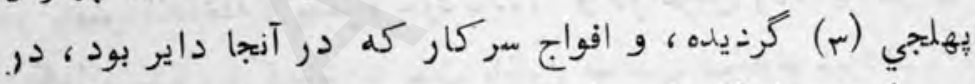

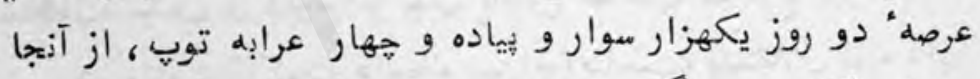

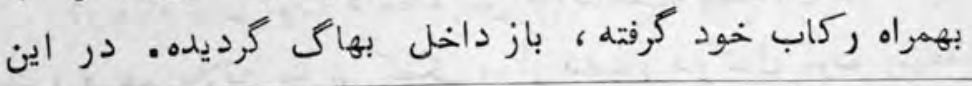

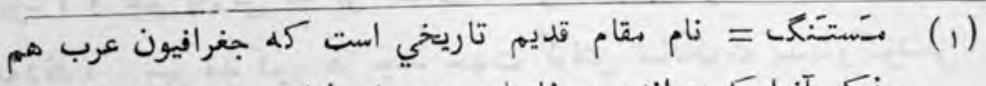

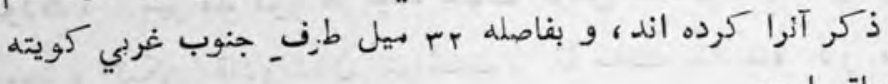
واتع است.

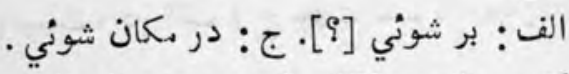

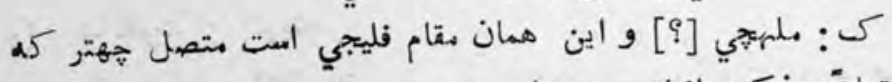

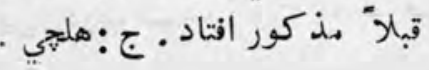


صُوت باري الطمينان رعاياي بهاك شده .

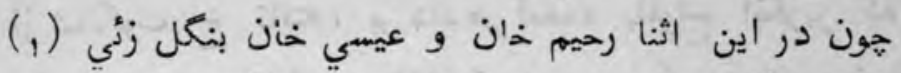

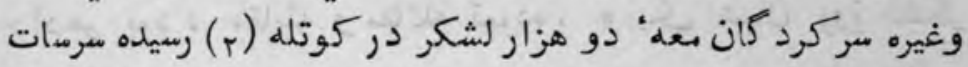

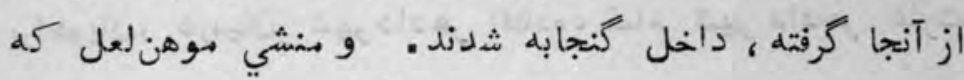

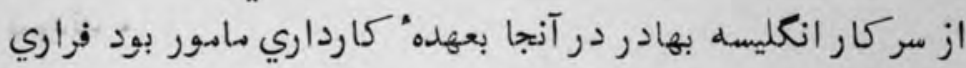

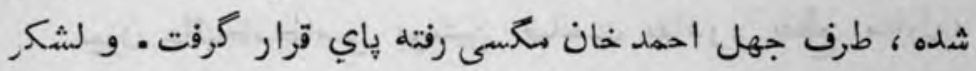

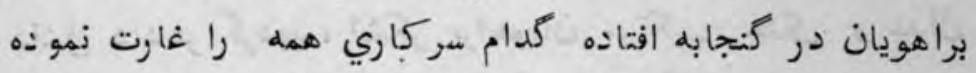

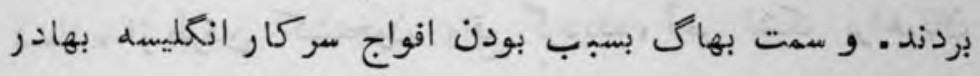

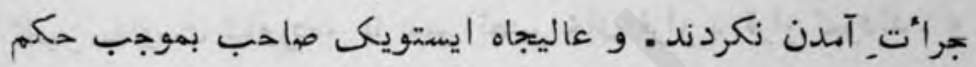

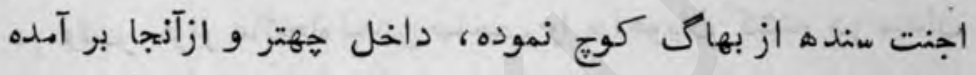

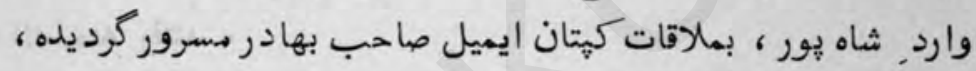

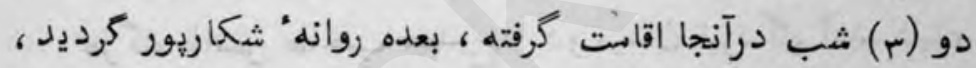

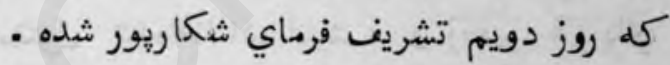

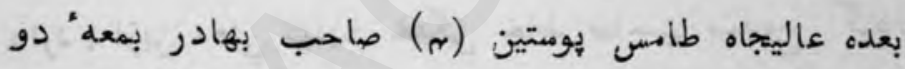

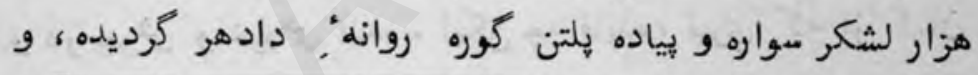

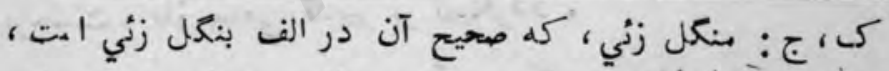

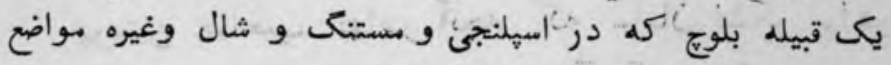

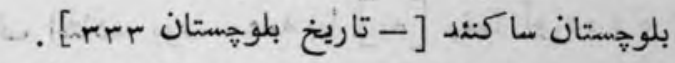

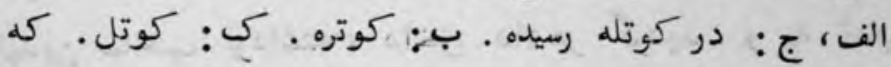

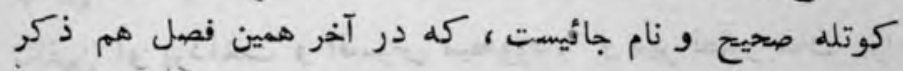
آن آمده. الف: در شب .

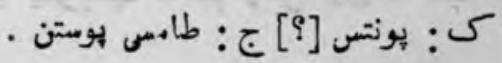


تاز. نواي ماركى

$\sim r \wedge$

كاليجاه مير نصير خان زيشى از رسيدن_ عاليجاه صاحب ممدوح

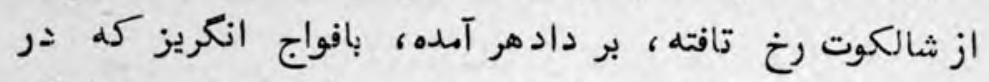

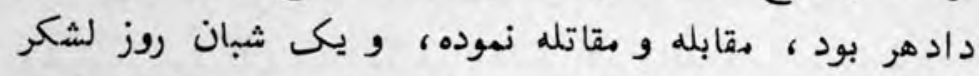

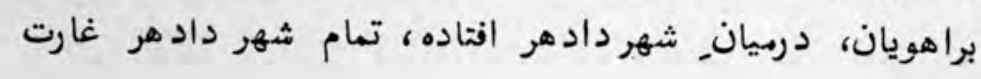

نمودند ن برويال

هون عاليجاه طاهس يومتين صاحب بهادر، بقطع مشازل،

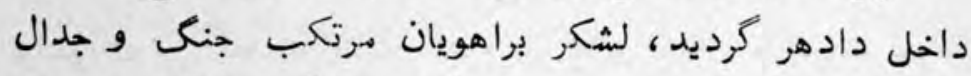

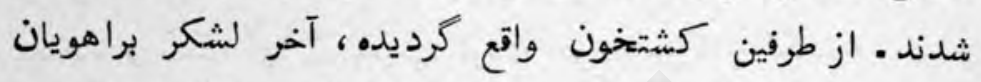

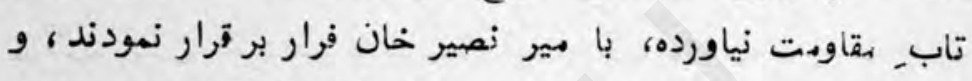
در وقت, فرار عاليجاه لبدين صاحب را براهويان كشته در بيدان

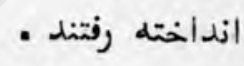

هر كاه طاهس صاحب مدموح، در ميدان نبرد كاه آتده ديد،

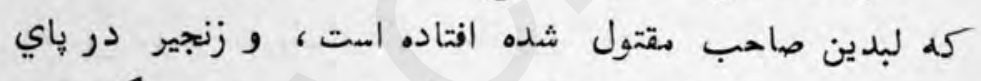

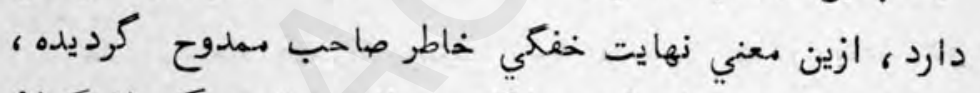

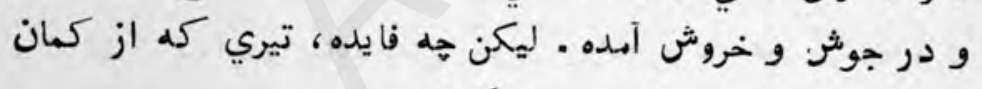

برجسهت ، باز بسعي تدبير بر نميكردد .

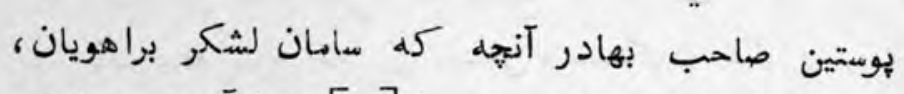

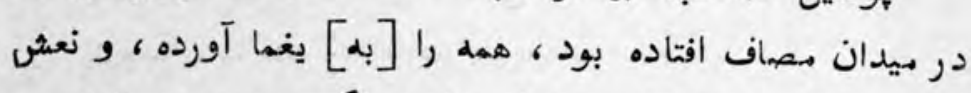

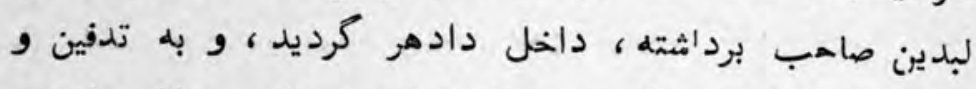
تكفين او لرداخت و افسوس ميخورد. . و مير نصير خان براهوي

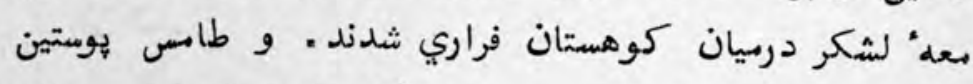
صاحب بهادر، بعد اين فتح بموجب حكم راس بيلصاحب بهان بهاد: 
rq

اجنت منده مراجعت فرماى شكايور كرديد.

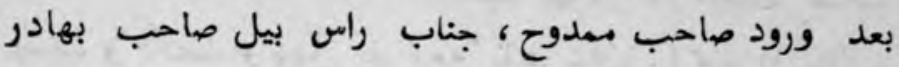

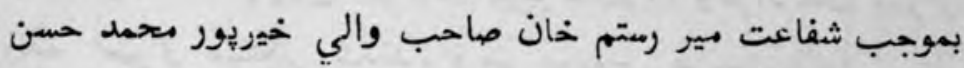

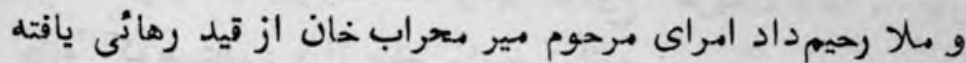

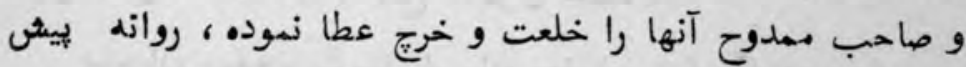

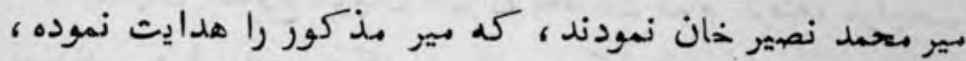

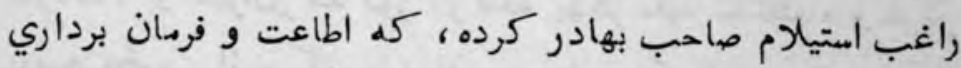

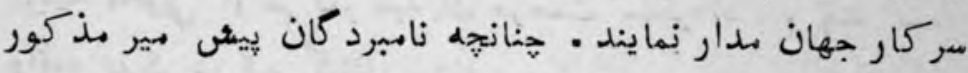

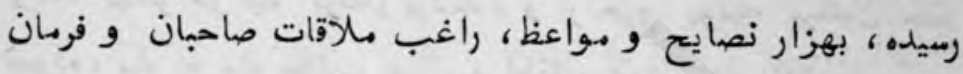

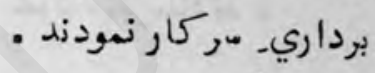

هركاه مير نصير خان نزديك كار كوتله رسيد صاحبان عاليشان

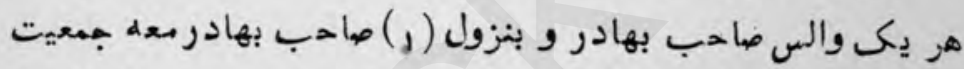

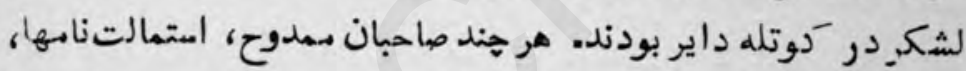

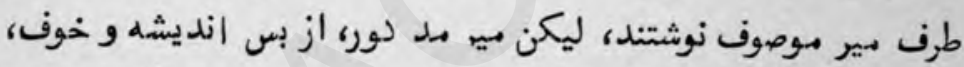

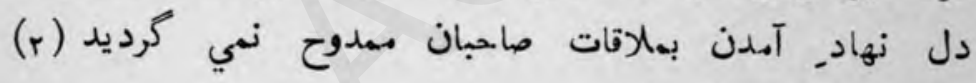

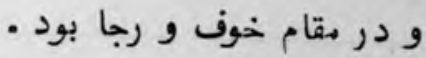

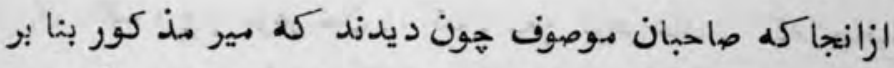

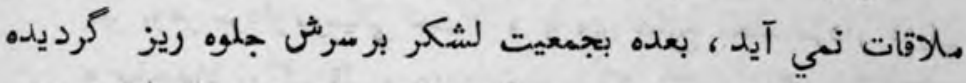

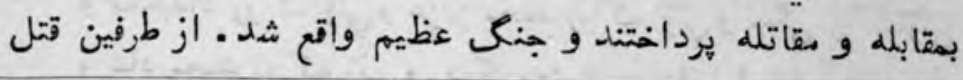

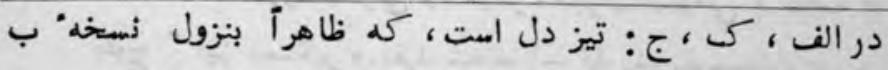

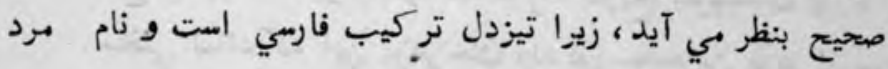

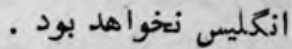

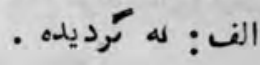




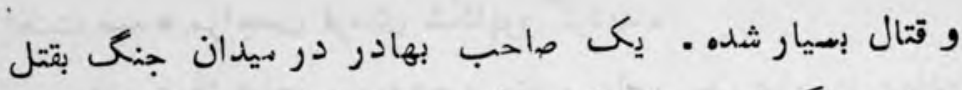

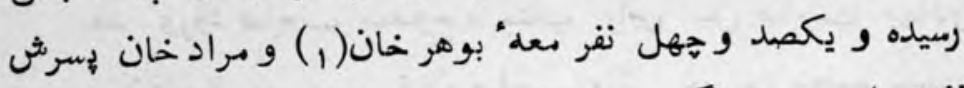

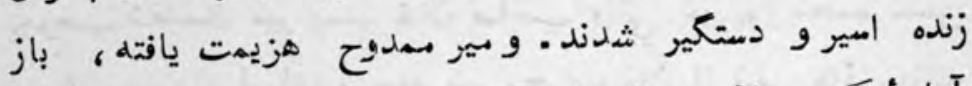

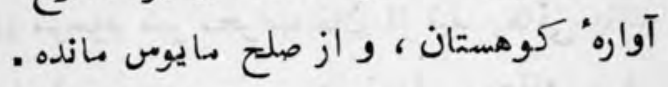

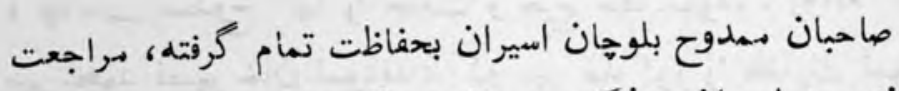

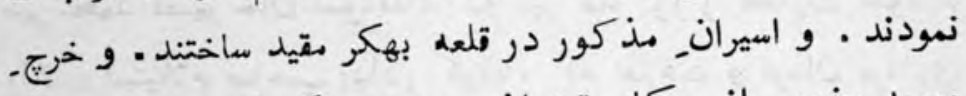

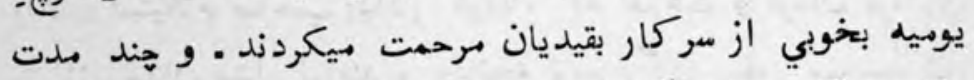

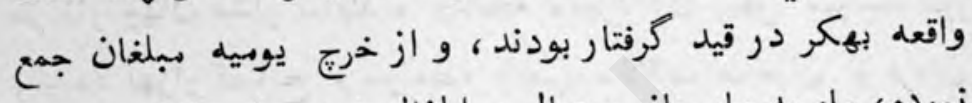

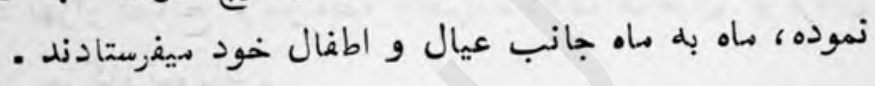

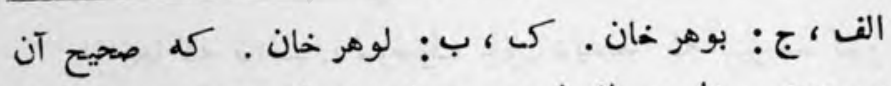

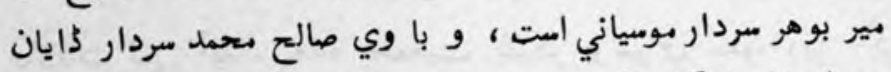

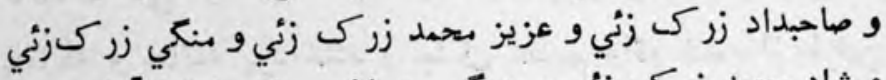

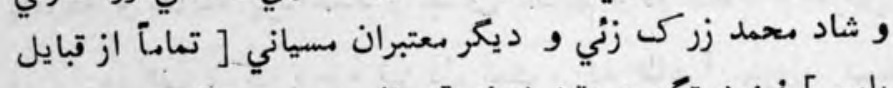

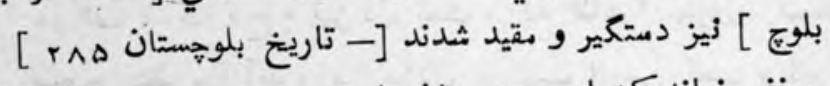

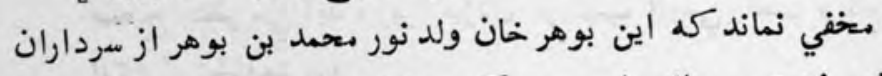

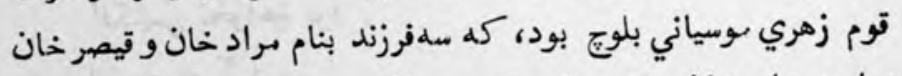

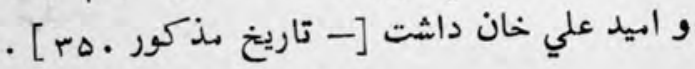


$-4 N-$

در بيان. رفتنـ جناب راس بيل صاحب بهادر بطرف شالكوت

و بندو بست نمودن امورات_ آن سر زمين و فوتيدن درانجا (1) سوت

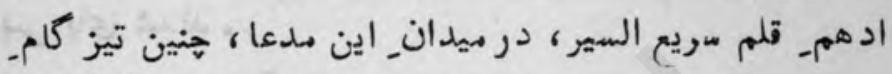

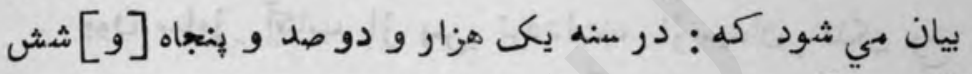

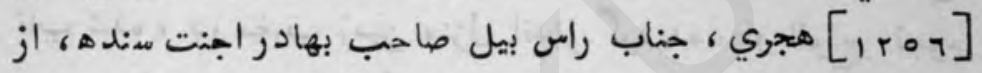

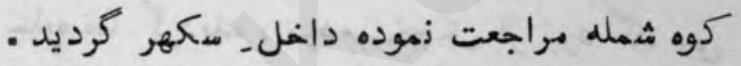

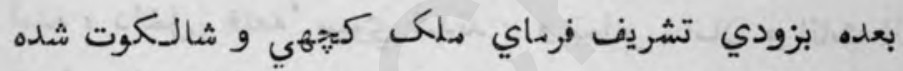

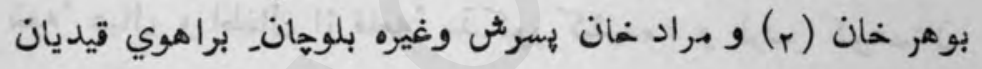

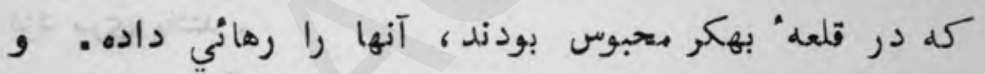

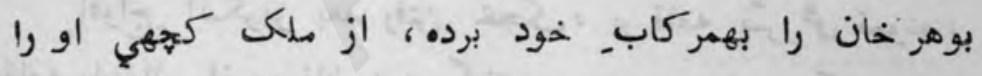

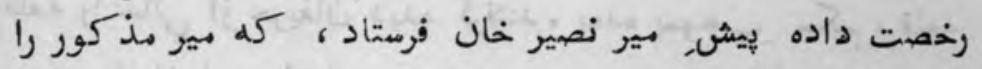

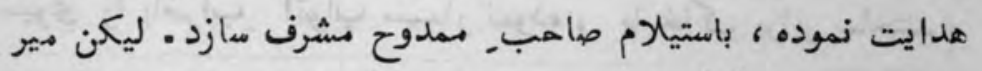

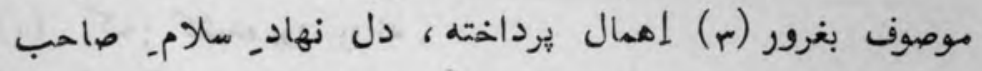

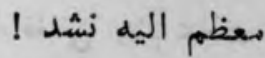

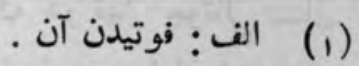

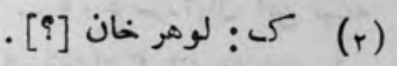

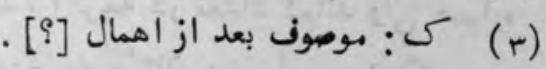




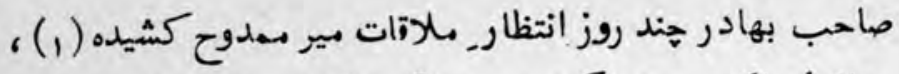

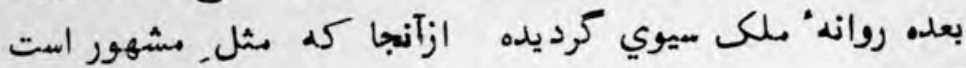

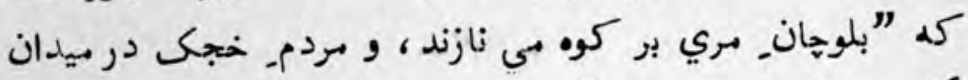

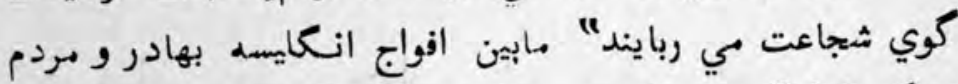

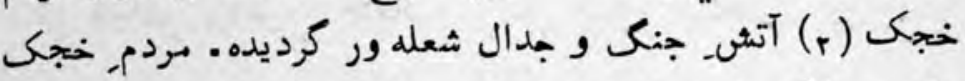

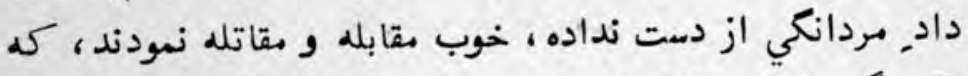

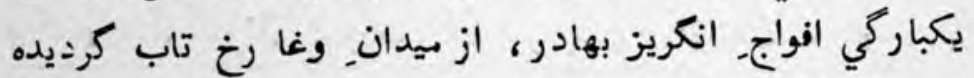

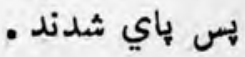

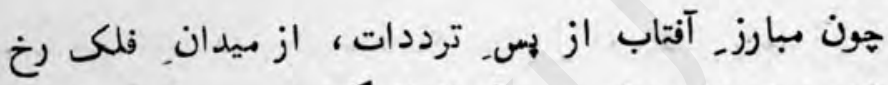

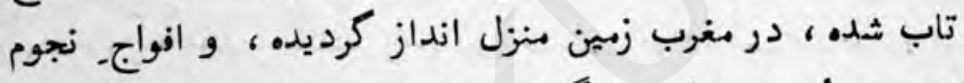

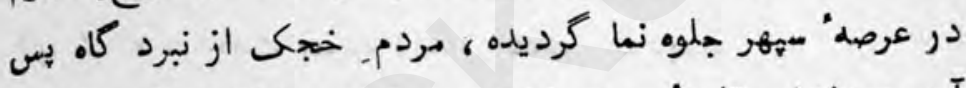

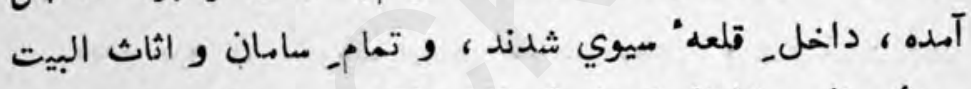

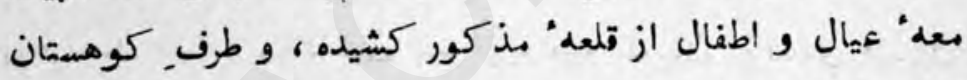

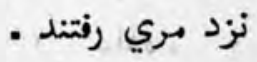

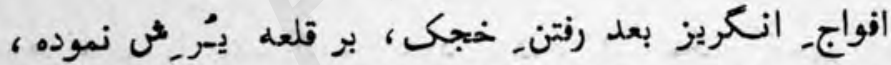

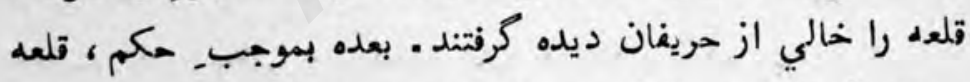

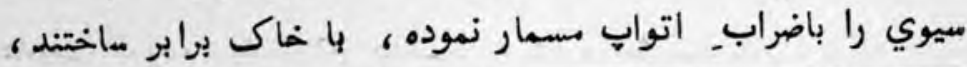

$$
\text { كى: كشيده بوده روانه . }
$$

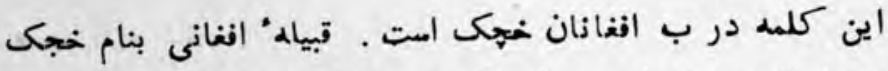

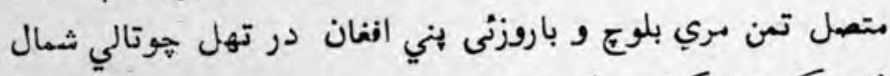

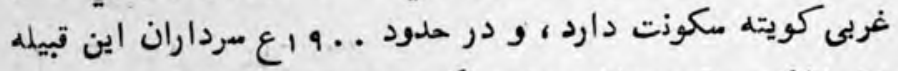

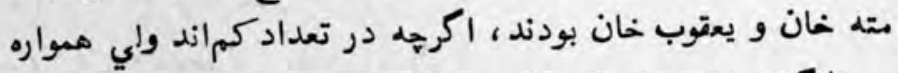

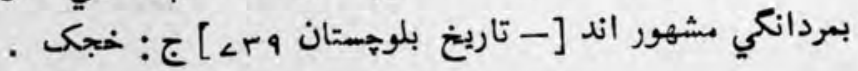


و غنيهت را بلدمت تصرف خود آوردند -

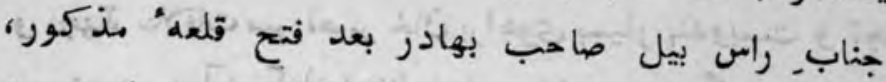

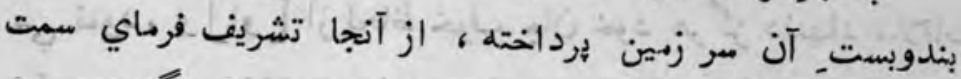

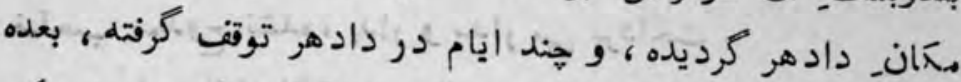

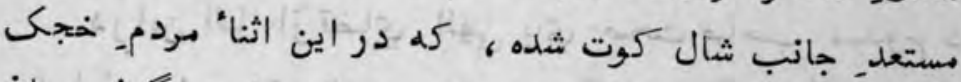

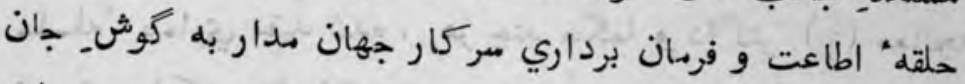

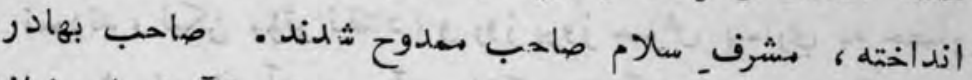

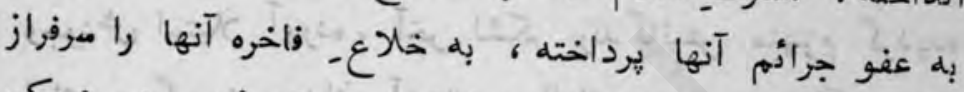

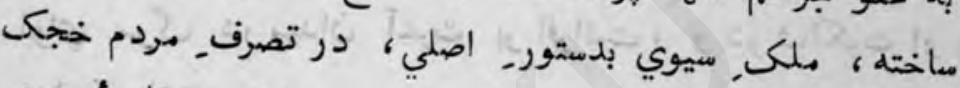

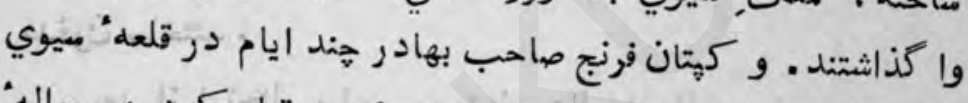

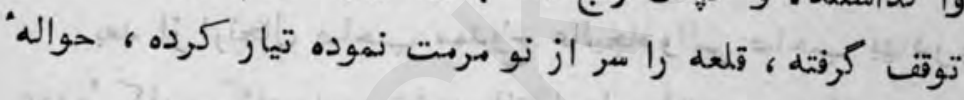

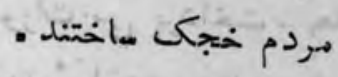
درحين توقف جناب راس بيل صاحب بهادر دم رو ملكى سيوي

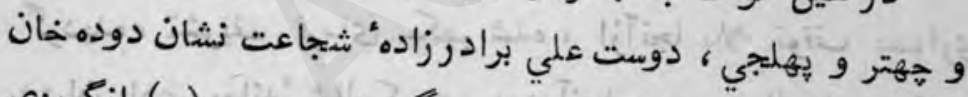

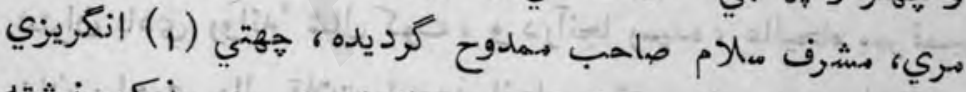

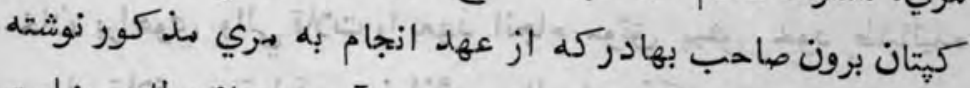

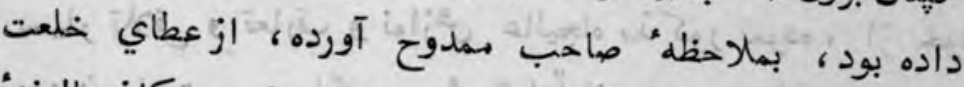

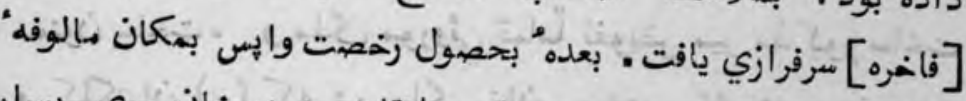

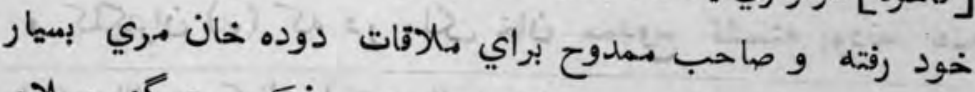

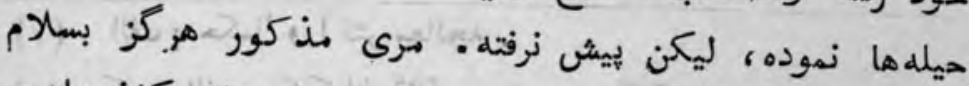

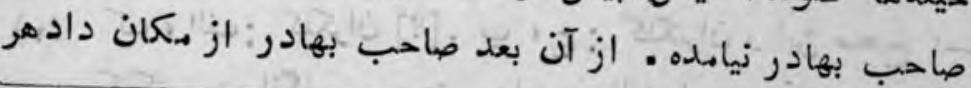

ك : جهتر [?] · مهتي بمعني مكتوب و نامه امت : 
تشريف فرماي شال كوت، و ثهند ماه درآنجا رونق افزاي بوده ،

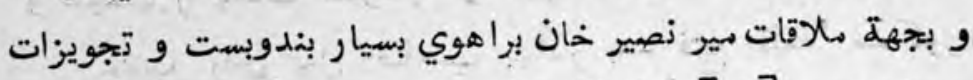

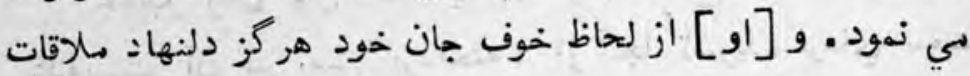

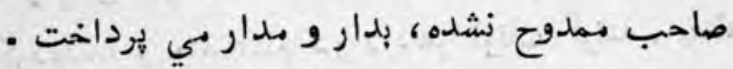

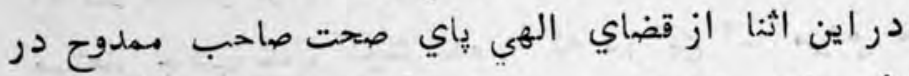

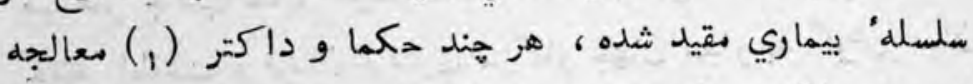

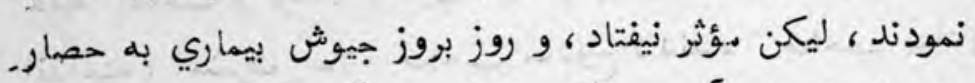

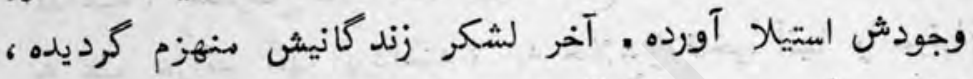

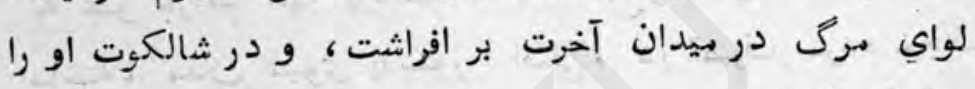
مدفون ساختيند . بعد از ارتحال صاحب ممدوح عاليجاهوالس صاحب بهادر بر

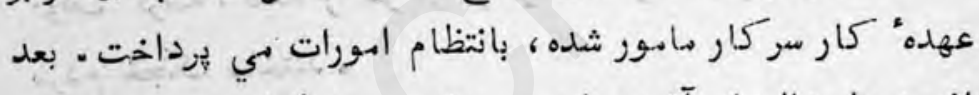

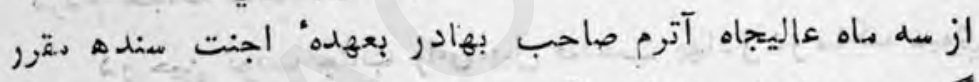

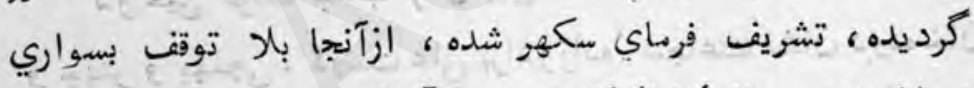

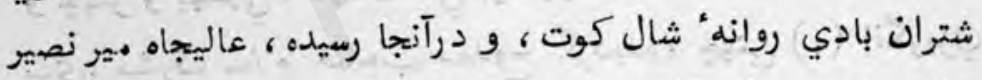

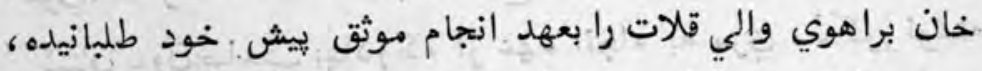

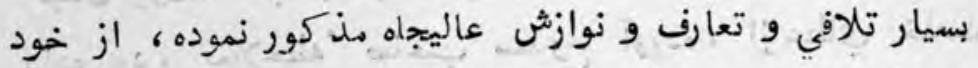

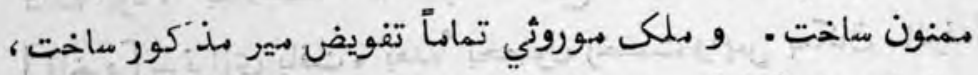

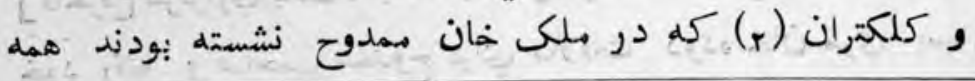

$$
\text { الف: جكماء واكثر مeالجه . }
$$

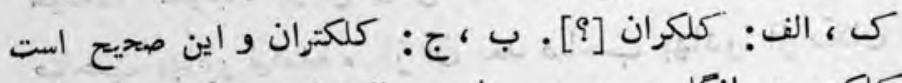

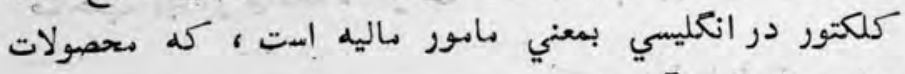

$$
\text { دولتي را فراهم آورد . }
$$


red

تازه نواي معاركى

موقوف شدند . و تعميرات كه در مـلك خان مذك كور درمت ساخته

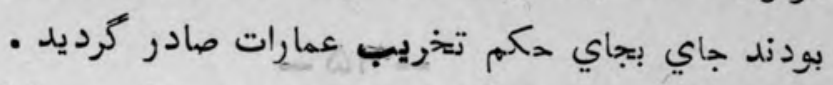

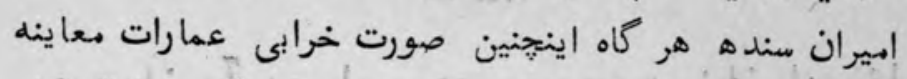

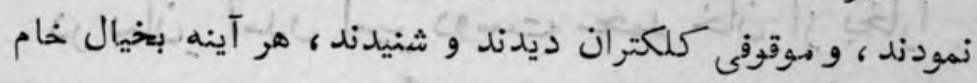

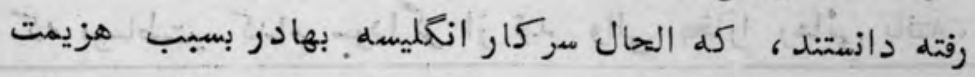

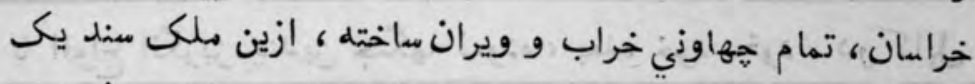

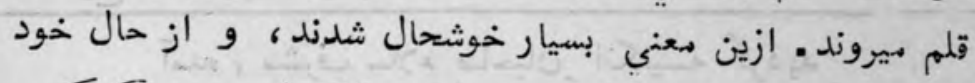

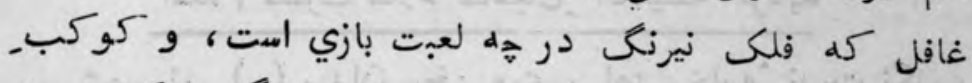

نيت (1) صاحبان انكريز بهادر، در اورج فريبند

است، از آنجا كله شرح- تستخير سند موقوف بر وقوع واقعه داشته،

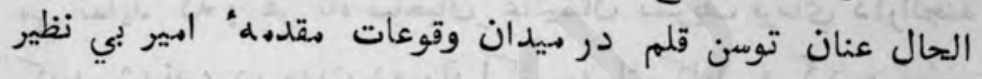

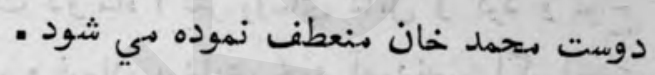

الف: كوكب نسب [؟] . ج: مانند متن . 
$-4 \Delta-$

در بيان آتـدن امير دوست ــمهد خان از بخارا

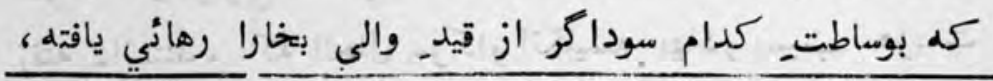

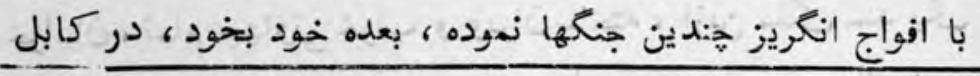

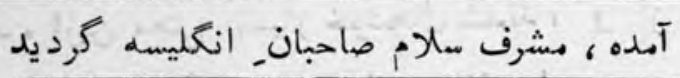

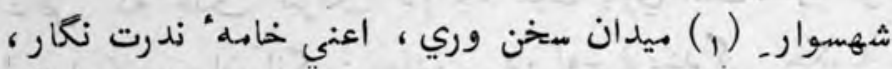

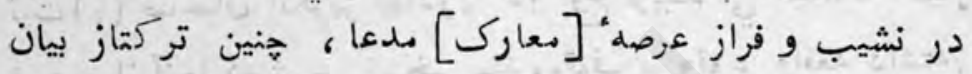

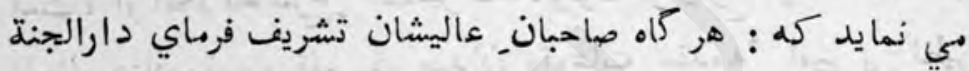

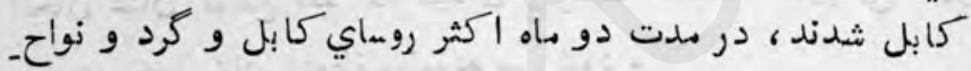

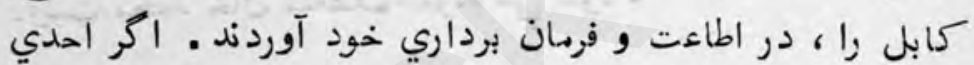

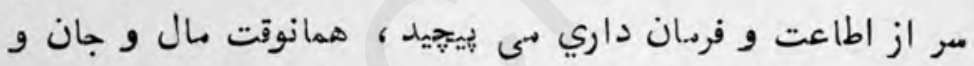

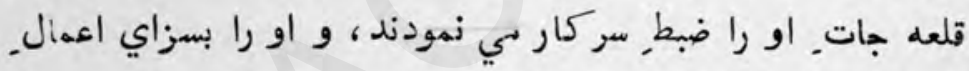

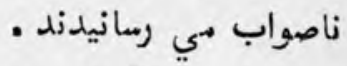

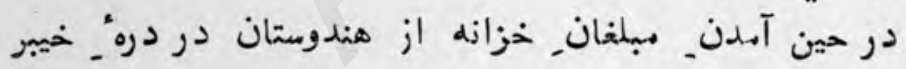

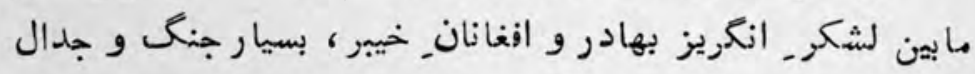

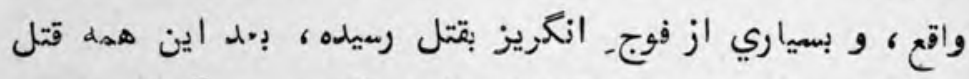

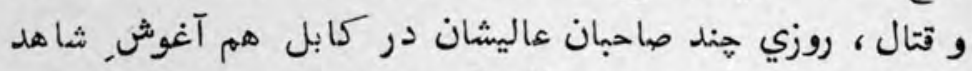

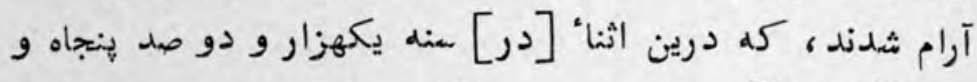

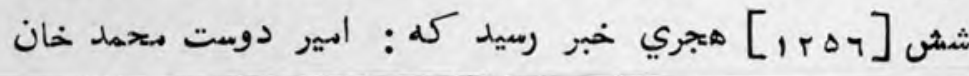

. (1) 


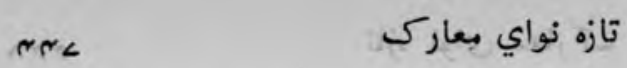

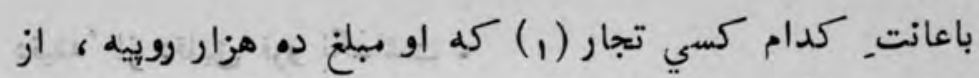

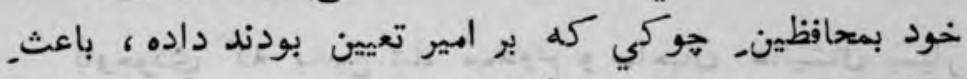

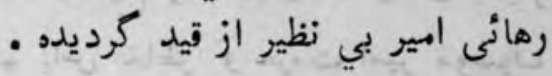

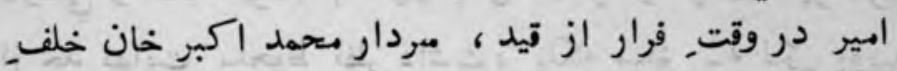

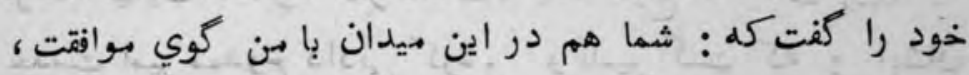

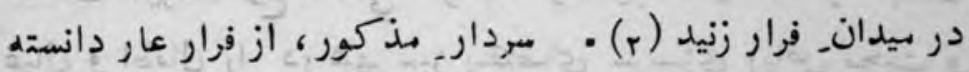

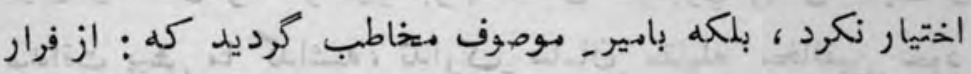
مردن بصد درجه در صورت_ مردانكي بهتر و خوث تر است .

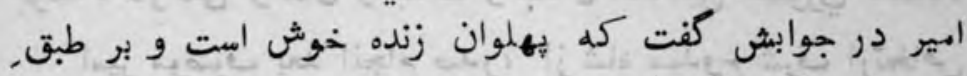

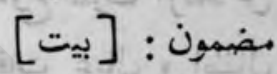

حو از سر بكذرد آب خردد مند

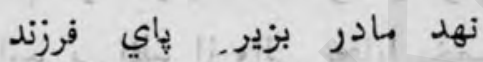

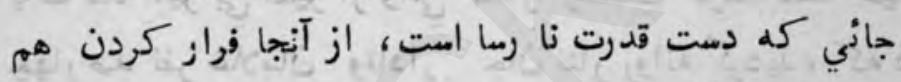

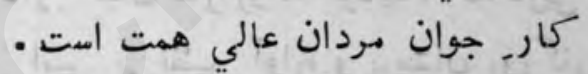

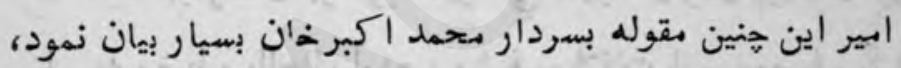
ليكن [سردار] در كوث سماءت نياورده قبول نكرد . آخر ادير

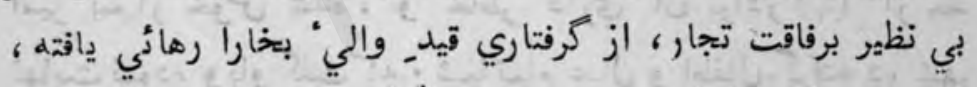
بقطع_ منازل_ مطول ، در شهر سبز (r) بحضور شاه مردان والي شهر سجز داخل كرديده. شاه موصوف از مقدم ادير بي نظير بسيار خوشوات شده در مراسم تعارف و مهمان داري امير بي نظير

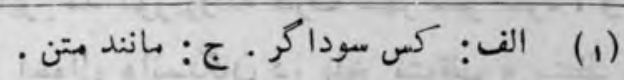

.

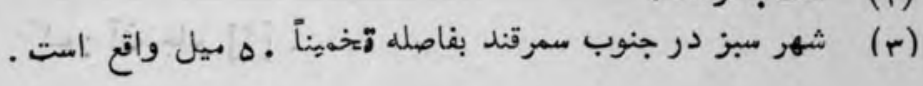


دقيقل ' از دقايق"فزو نكذاشت .

باوجودي كا هابين شاه مهدوح و صاحبان عاليشان بسيار

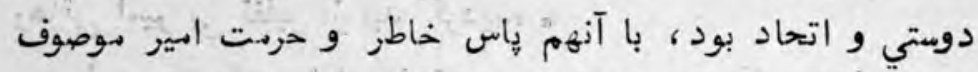

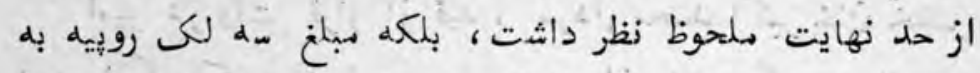

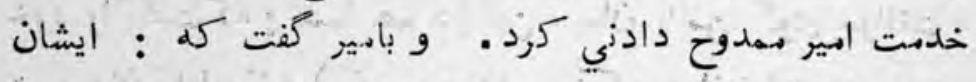

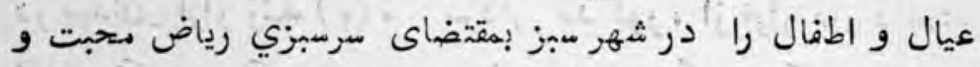

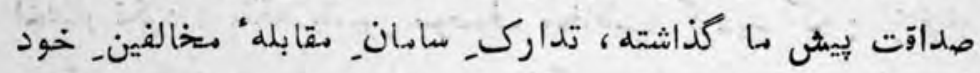

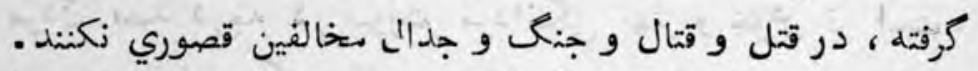

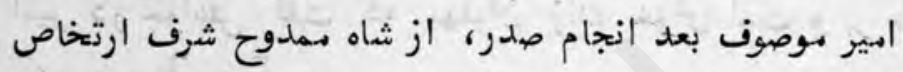
حأصل نموده، روانه طرف بلخ كرديده، بمالاقات عيال و اطفال

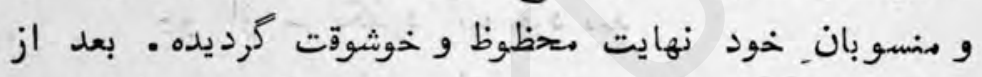

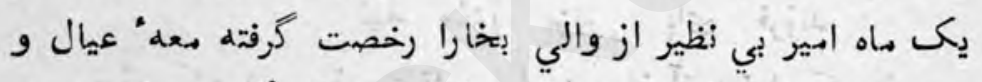

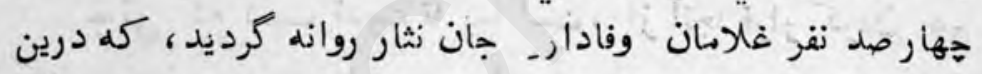

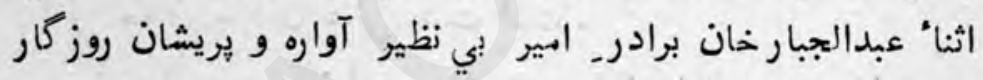

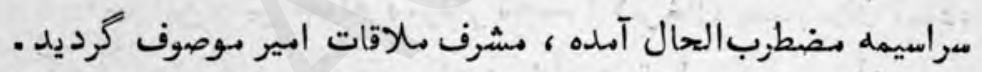

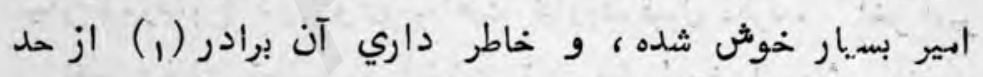

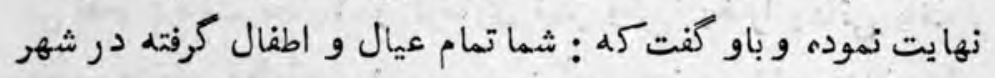

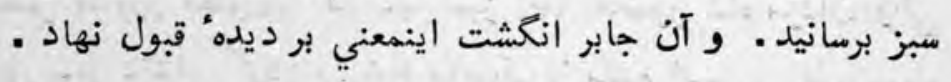

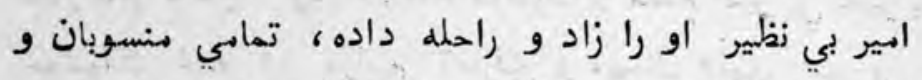

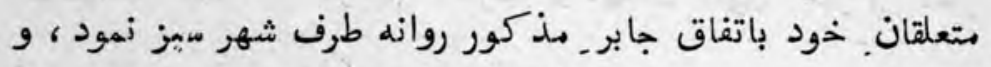

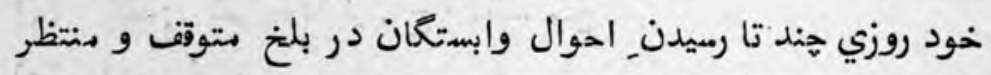

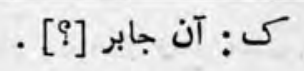


$\operatorname{rad}$

تازه نواي مارك

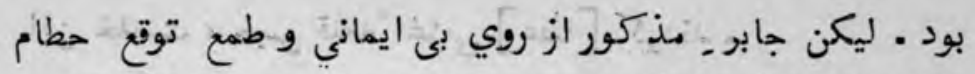

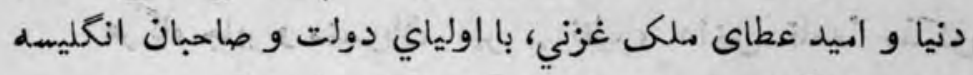

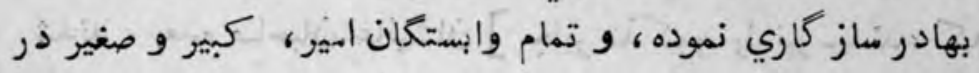

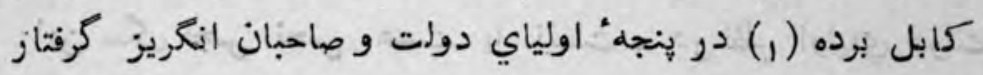

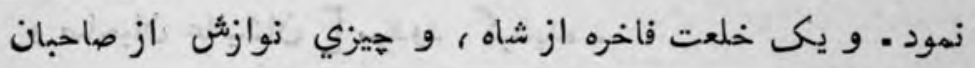

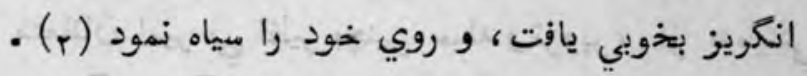

بعد از آن يكهزار موار و ده عرابه توي و از وساله دوم ده

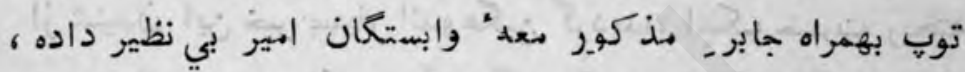

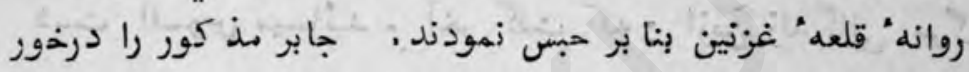

[? [؟ (1)

(r)

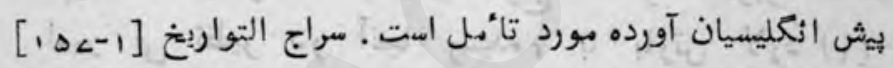

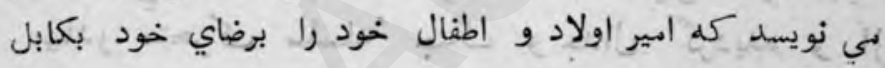

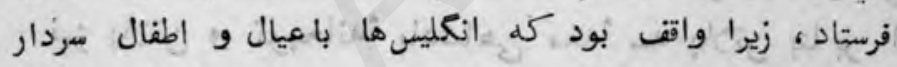

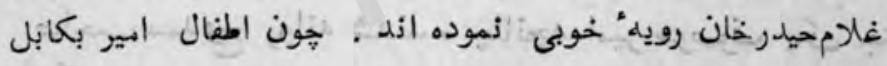

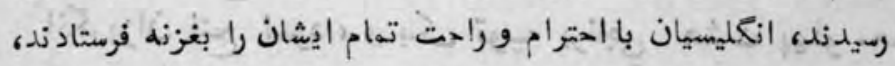

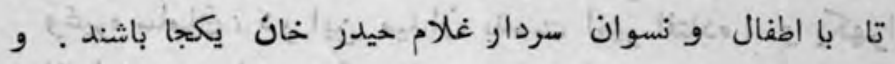

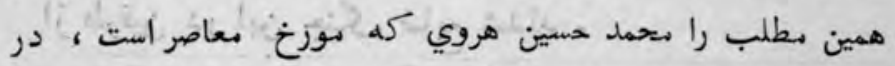

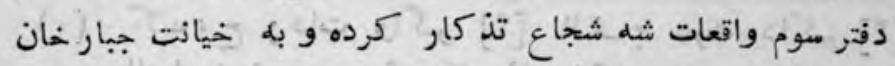

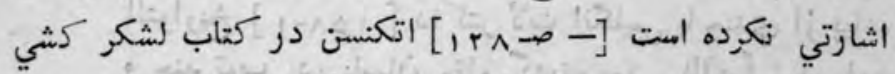

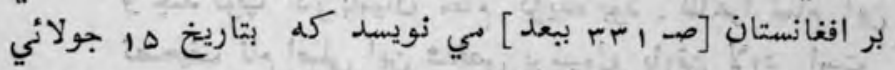

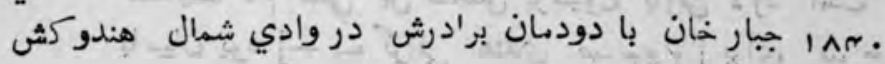

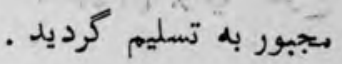


تازه نواي ملرك

$\sim \Delta$.

اين خدمت ، حبس قلعه" غزني [عطا] كردند .

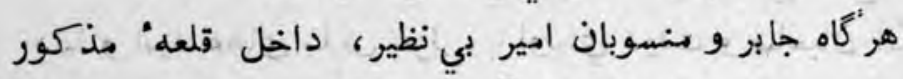

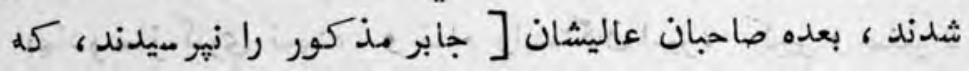
اين سح نجس نحس هست يا نيست . در نظر اولياي دولت

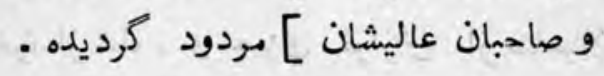

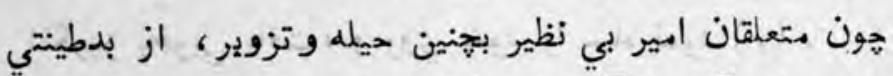

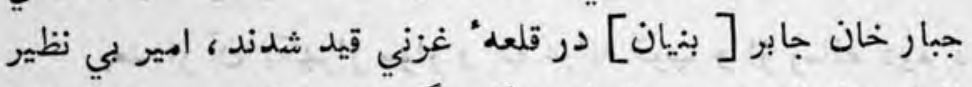

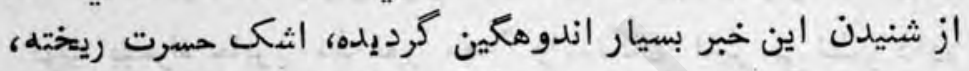
دست افسوس ميسائيد • آخر كفت كله : ازين زند كاني مرك بصد هزار درجه بهتر است. هماندم فاتحه خوانده بر خواسته ،

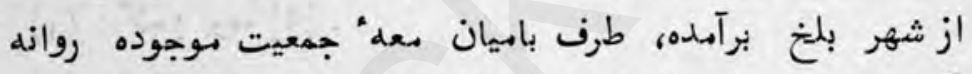

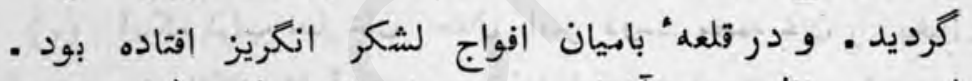

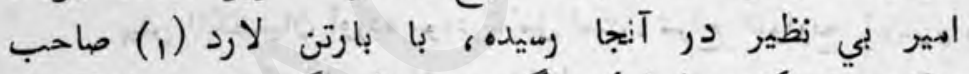

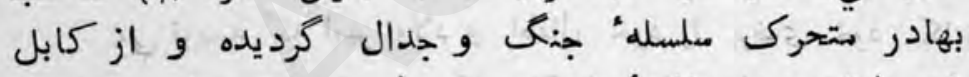

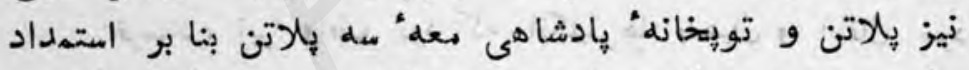

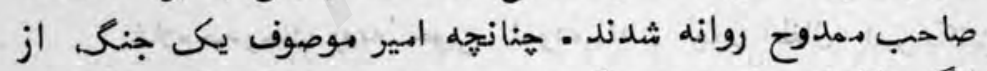

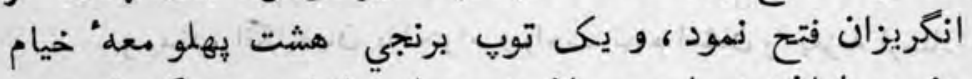

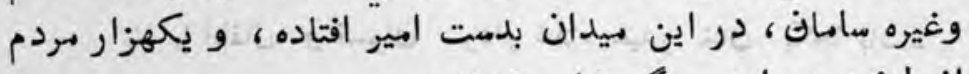

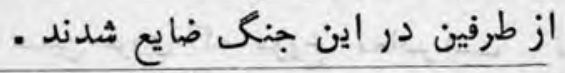

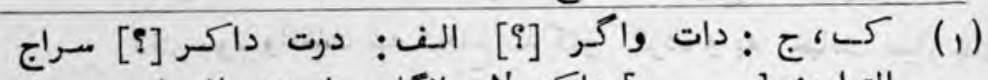

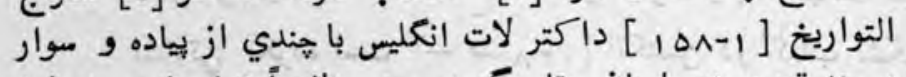

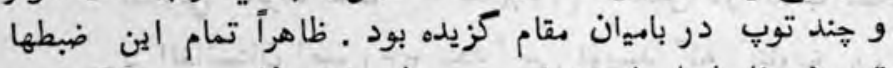

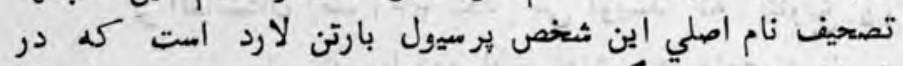

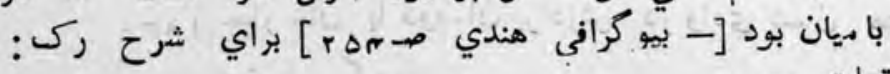

تعليق 1ـ 


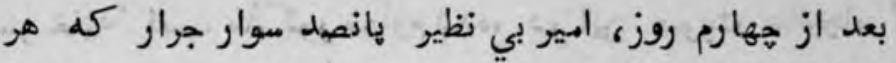

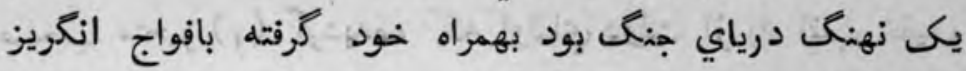

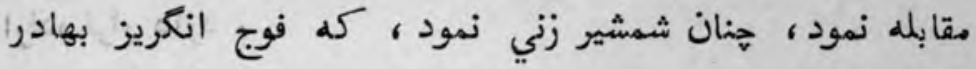

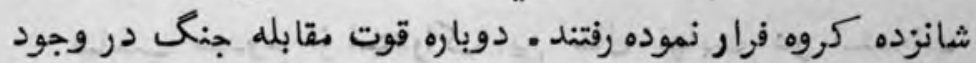

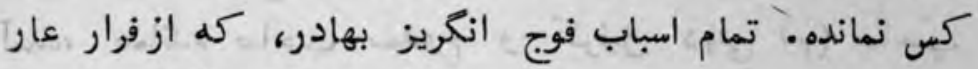

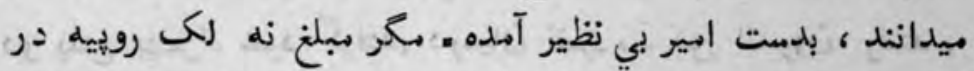

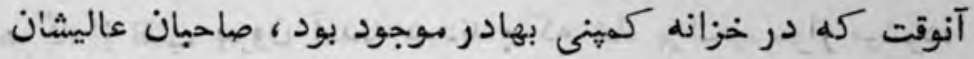

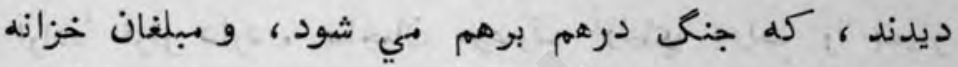

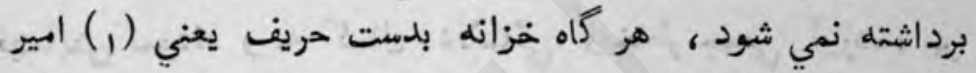

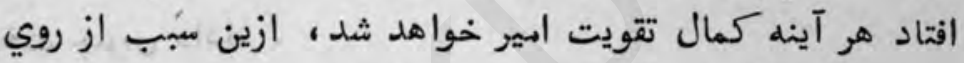

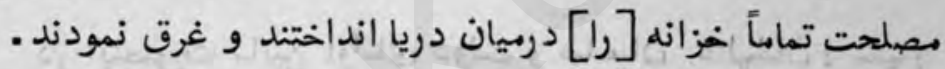

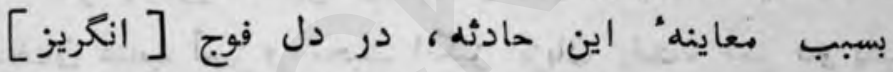

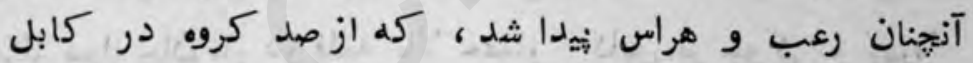

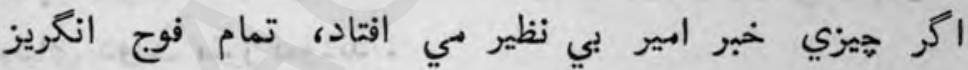

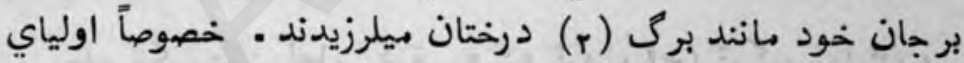

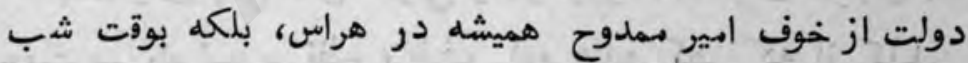

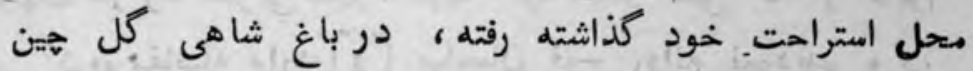

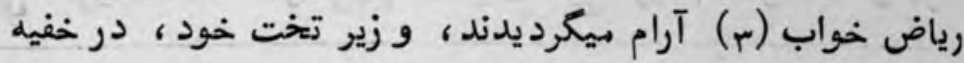

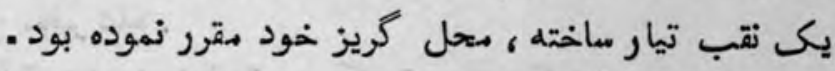

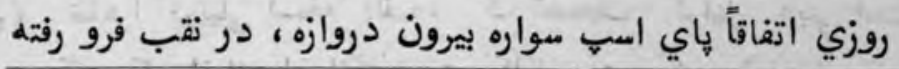
الف: اعني الف الف الني

الف: مانند ورق بيد ميلوزيدند .

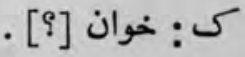


تازه نواى بـارى

$r \Delta r$

سر خفيل" نقب مذكور معلوم شده. در اين صورت عاليجاه لارد صاحب متحير (1) كرديده، كله اولياي دولت از راه نقب خفيه،

اراده فرار دارد ماحب ماد

صاحب ممدوح از استدراك اين حال نهايت در استعنجاب

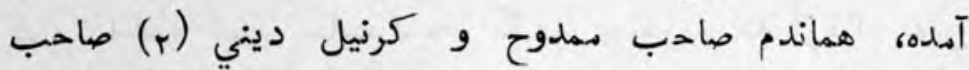

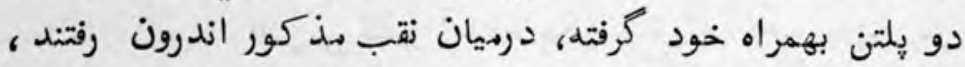

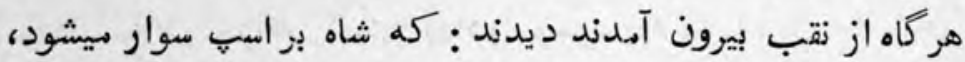
و اراده" فرار دارد . صاحبان موصوف اولياي دولت را بـ بسيار

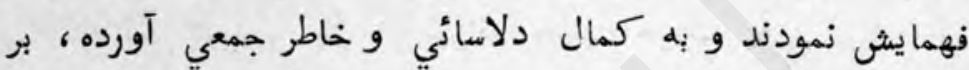

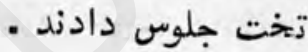

در اينصورت مابين اولياي دولت و صاحبان عاليشان ، بسيار

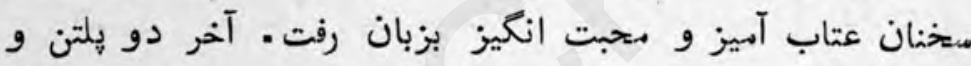

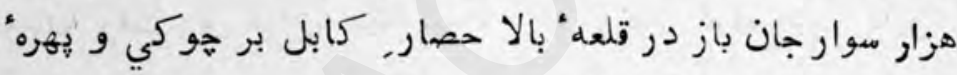

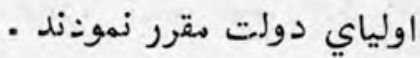

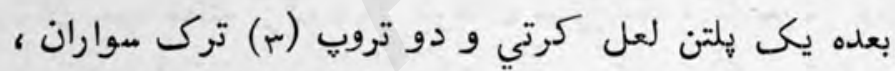
بجهت سر راه امير بي نظير، طرف كوه هندو كش كه از كاز كابل سي كروه مفاصله دارد [و] صاحبان فوج روانه نمودند. و ودر

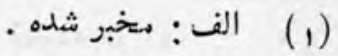

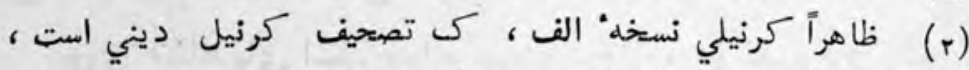

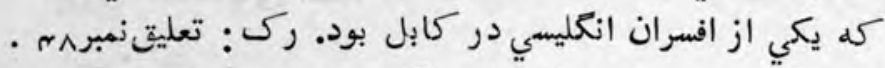

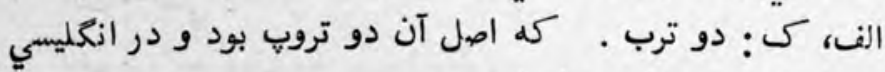
(r)

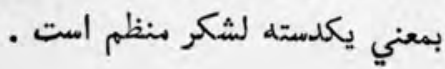




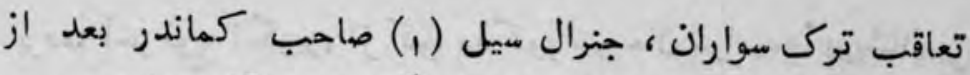

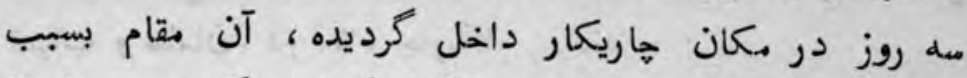

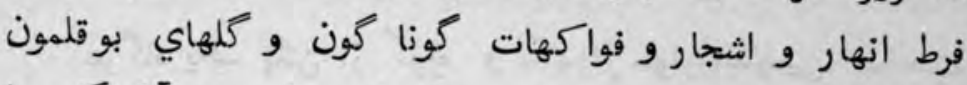

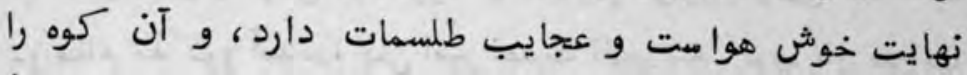

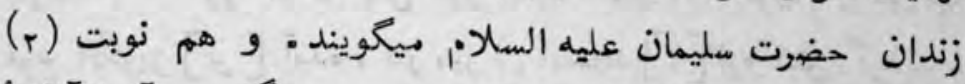

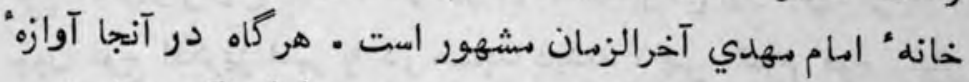

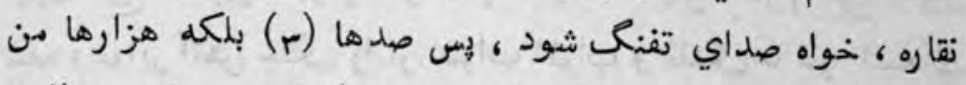

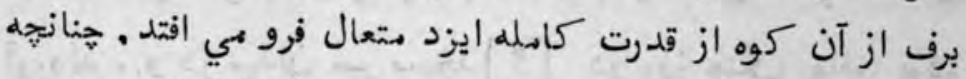

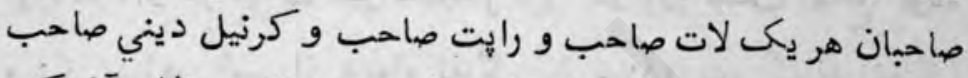

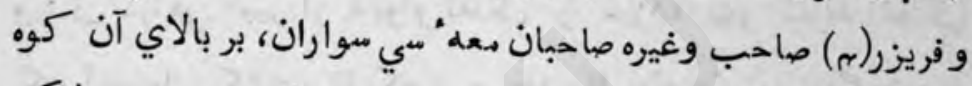

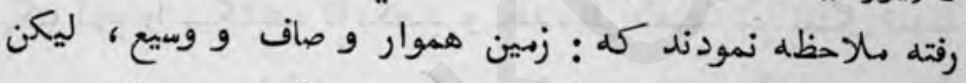

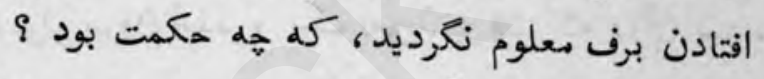

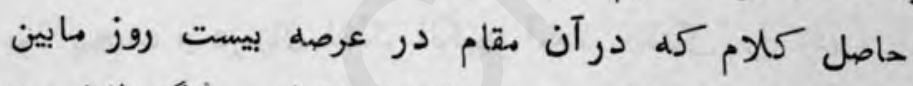

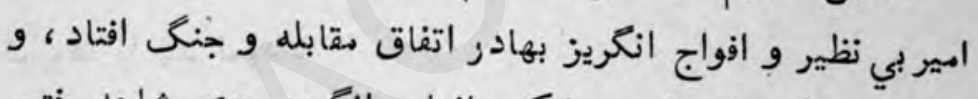

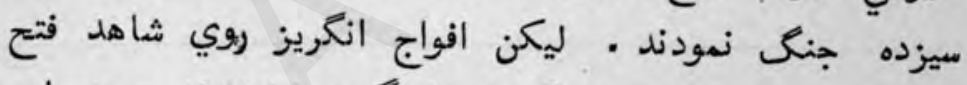

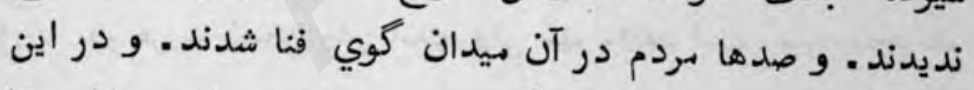

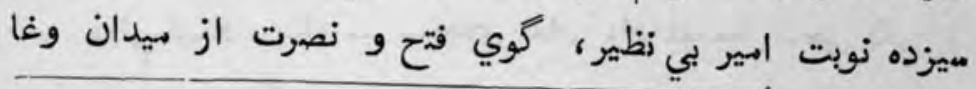

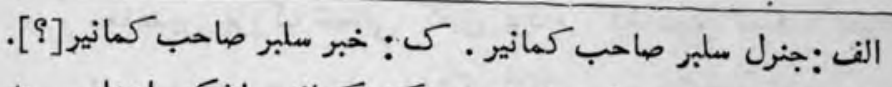

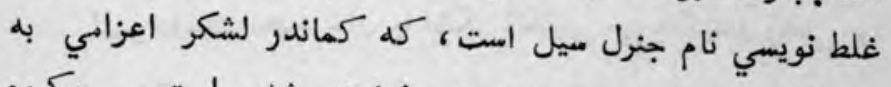

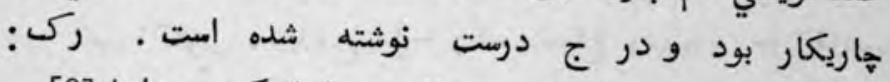

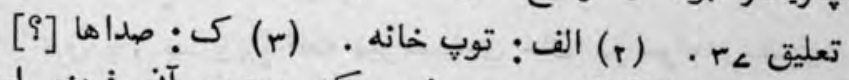

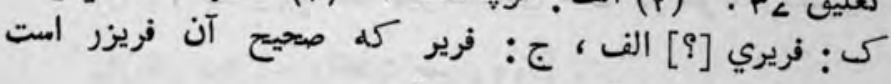

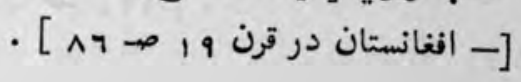


برده. آخر فوج انكريز، از كوه مذكور نيم جان سراسيمه هيريشان بي

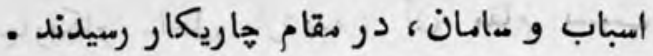

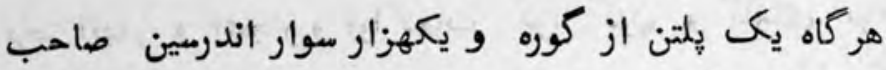

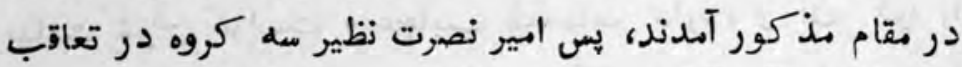

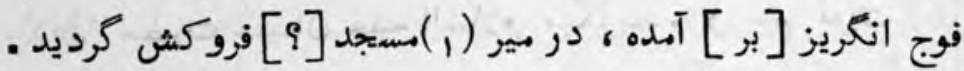

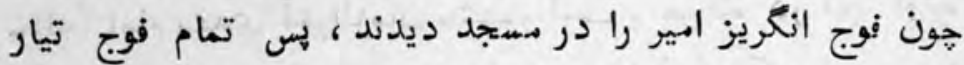

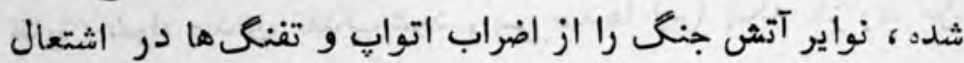

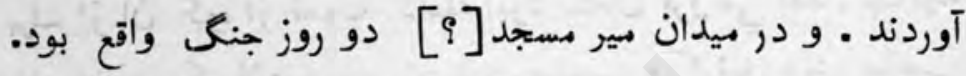
و يك سهاهي امير از ديوار تفنك را بيزد، بهر كلوله تقنى يدك آدم را ميكشثت، تا يكصد و هفده نفر طعمه" تير تفنك نموده بعد از ديوار بيرون آهده و يكى تعويذ ير قبر كه درآن بير مسجد

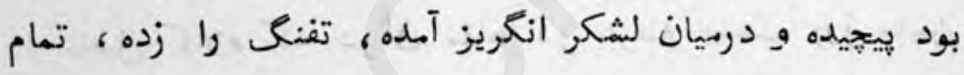
توبها را بند نمود .

در هر سه نسيخه هنين است، ولي سهو مؤلف است. مير سسجد نام

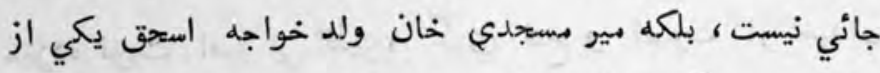

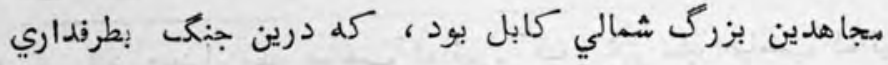

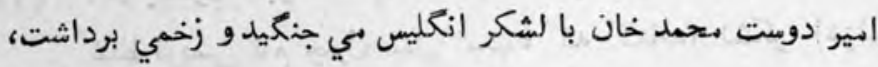

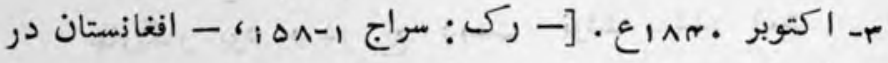

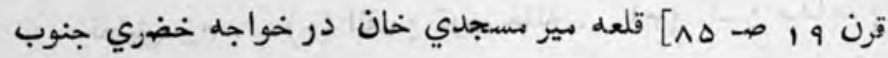

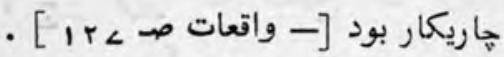




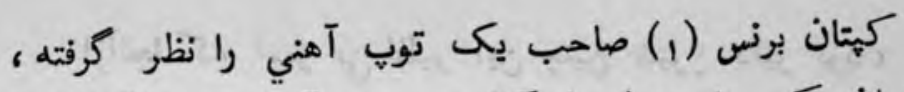

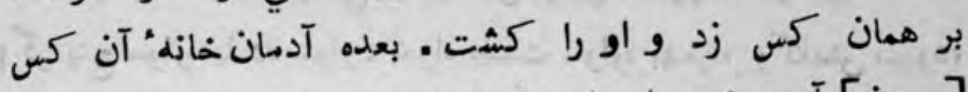

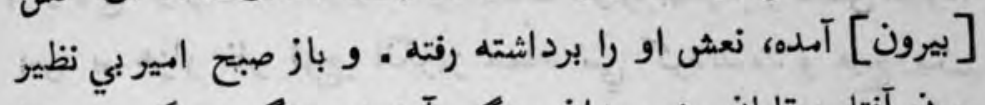

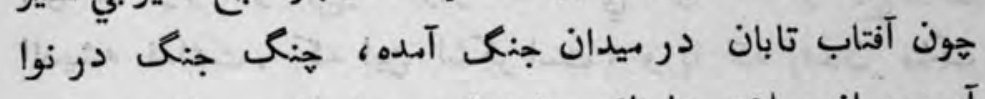

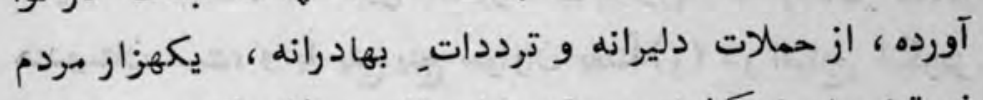

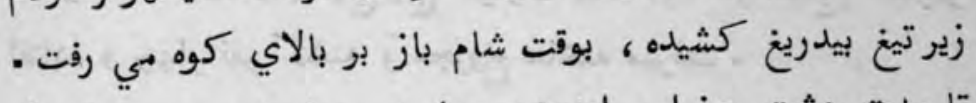

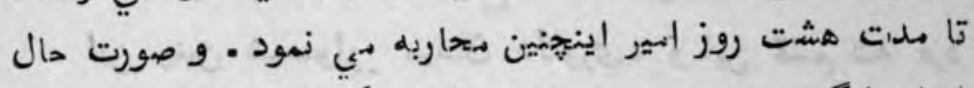

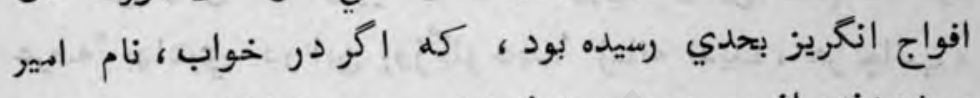

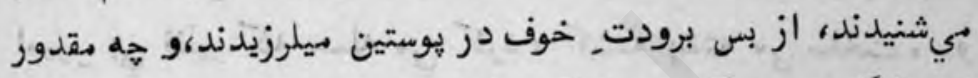

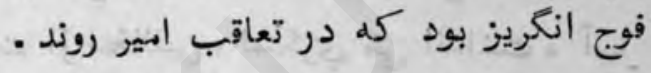

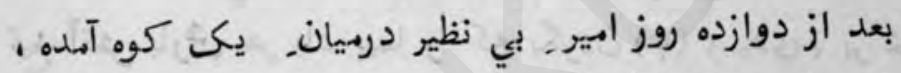

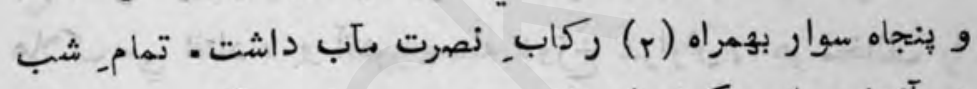

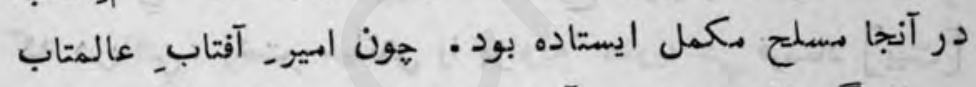

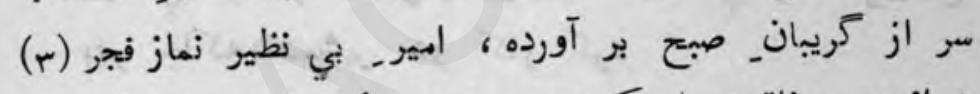

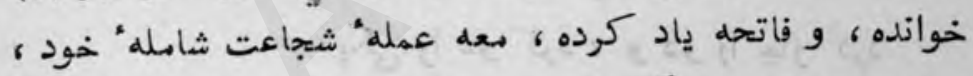

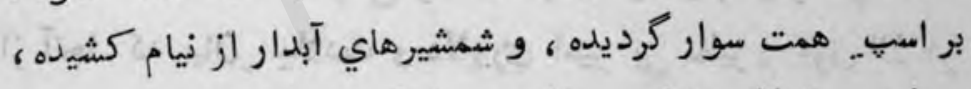

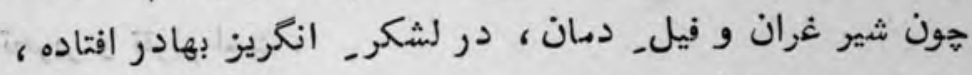

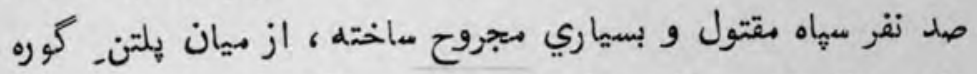

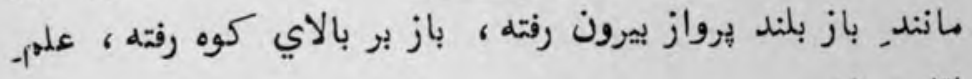


تازه نواي معارك

ror

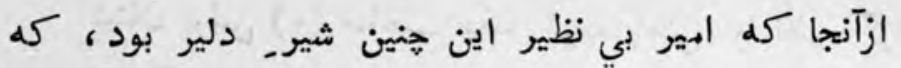

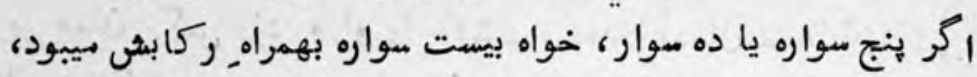

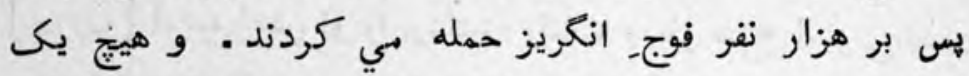

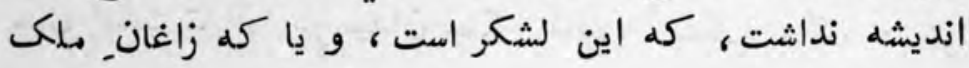

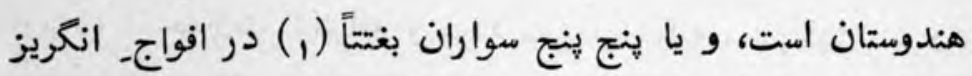

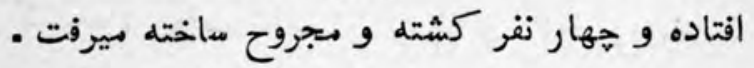

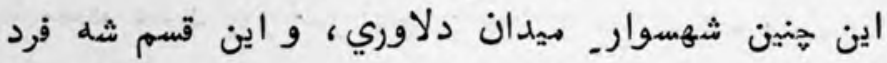

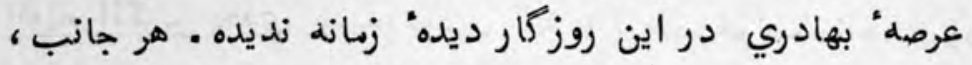

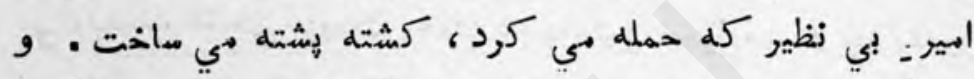

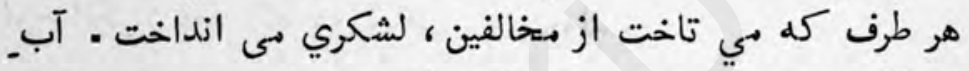

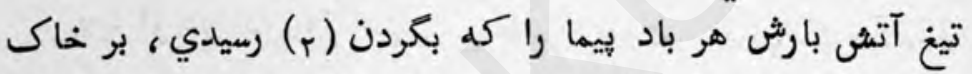

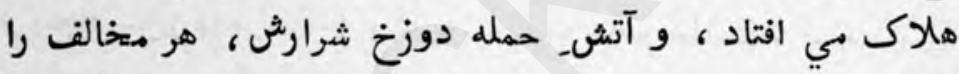

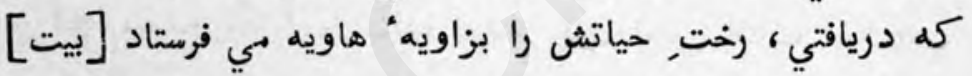

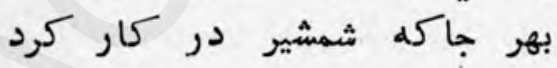
يكى را دو كرد ، و ودو روا خار كرد

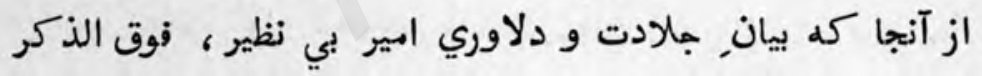

تحرير و تقرير است .

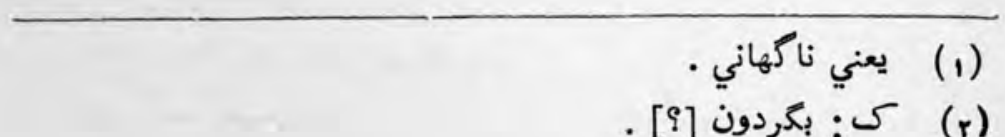

. 
$-44-$

در بيان_رفتن امير بى نظير در قلعهُ عبد السبحان خان

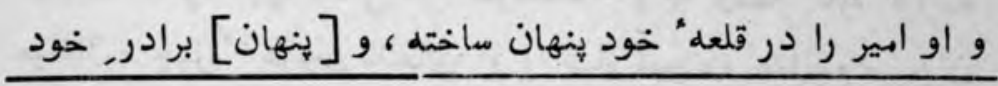

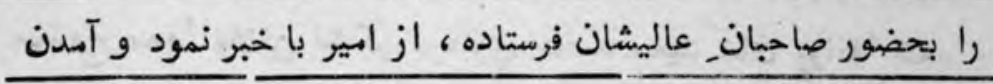

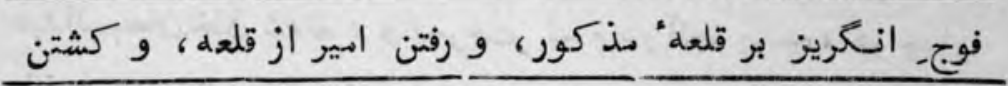

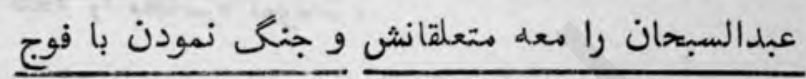

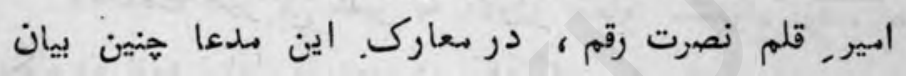

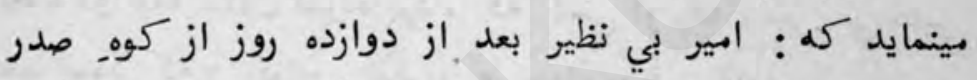

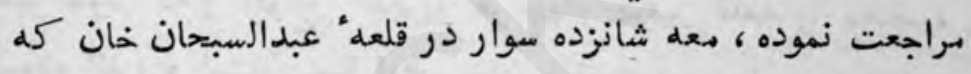

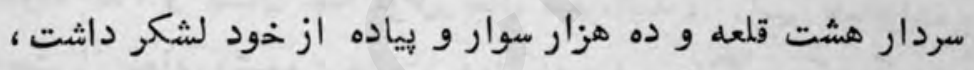

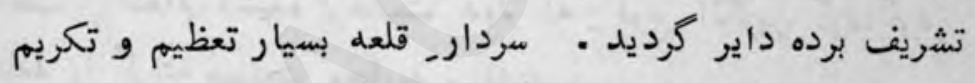

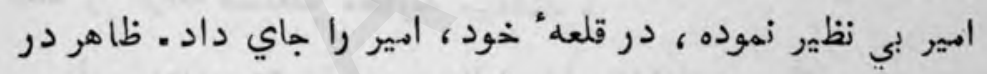

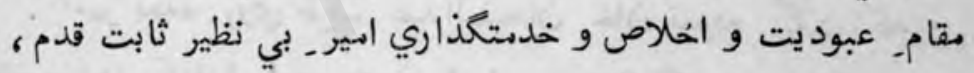

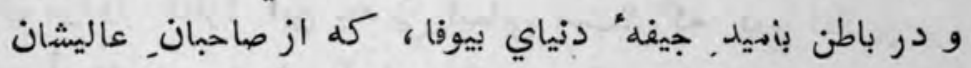

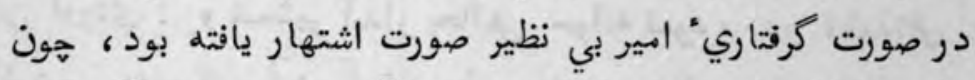

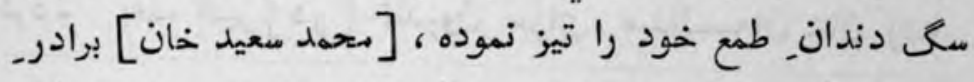

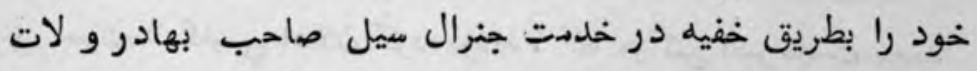

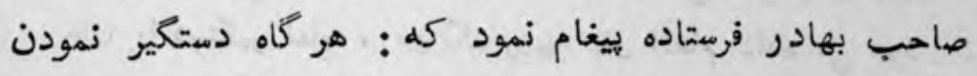

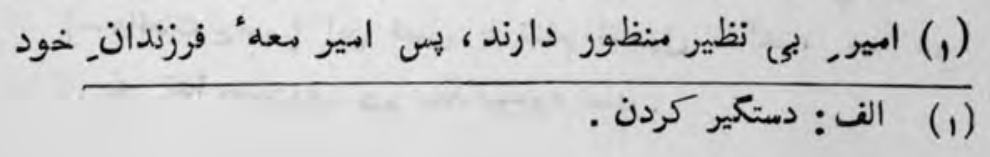




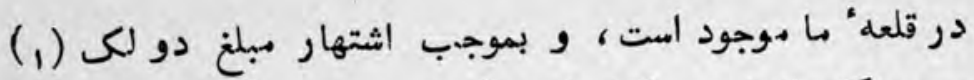
رو ويه كله انجام- سركار امت آن نيز مرحمت كردد . صاحبان مهدوح بسبب_ آوردن خبر امير ، از محمد معيد خلان

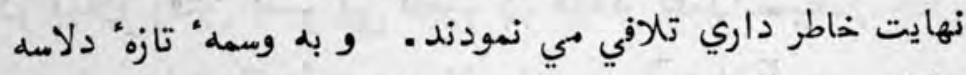
مبلغان ، ههره" عروس مدعاي او را معياه نموده ، هماندم صاحبان

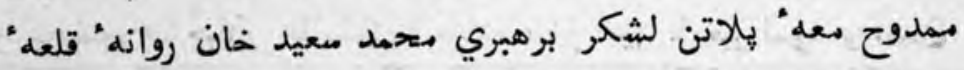

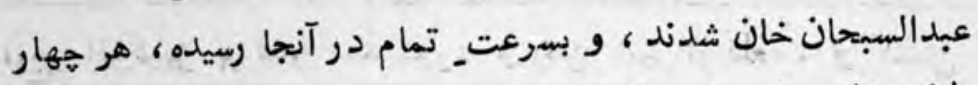
طرف قلمعه را مشاصره نمودند . درانوقت امير بي نظير به تناول. طعام مشغول بود . هنوز يـك دو لقمه تناول نموده بود ، كل كسي از رفقا بامير- بي نظير

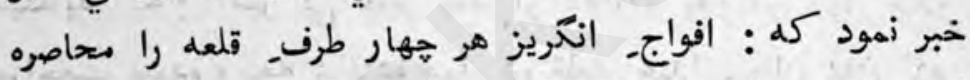

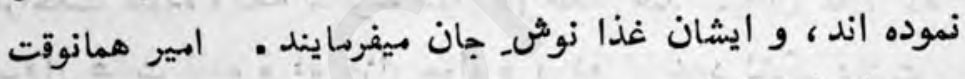
دست از طعام كشيده برخاست ديد كه : فوج- انكريز كردا كرد,

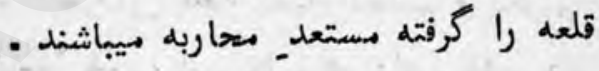

امير بعده روي طرف عبدالسبحان خان نموده كفت كله :

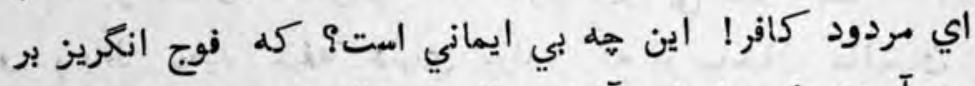
من آوردي ! و شمشير آبدار بجانشى حواله نمود؛، دو قطعهاث اثلى

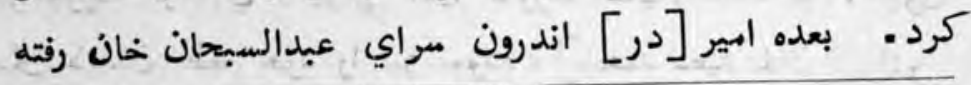

سران انـخليسي اعلان كرده بودند ، كه هركس ابير دومت بعمد

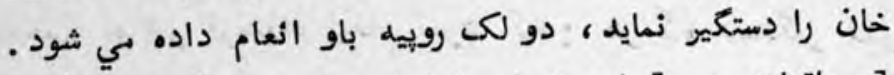

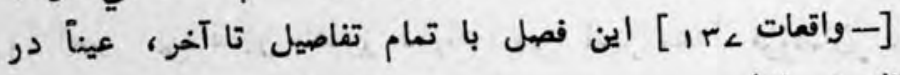

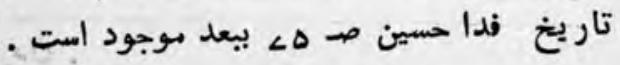


جهل و هِنج نقر آدمان خانه" او را از عورات وغيره بقتل رسانيده .

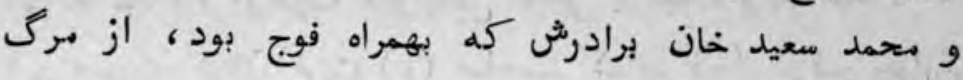
امان يافت

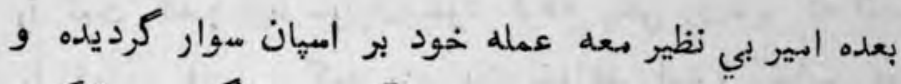

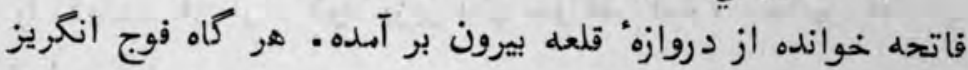

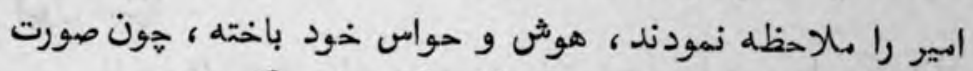

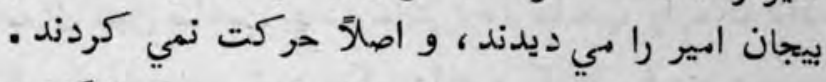

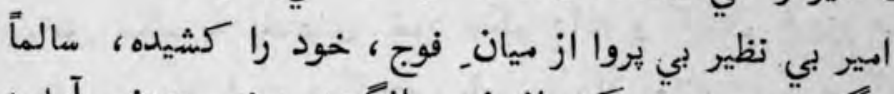

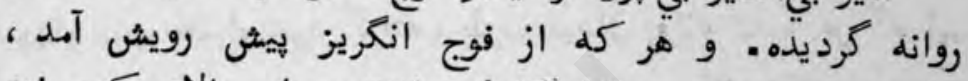

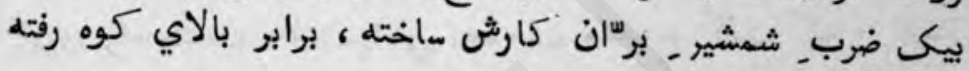

$$
\text { آرام كرفت فرب. }
$$

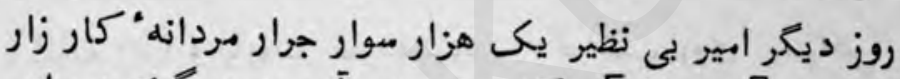

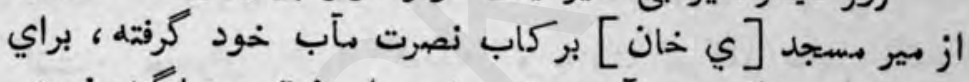

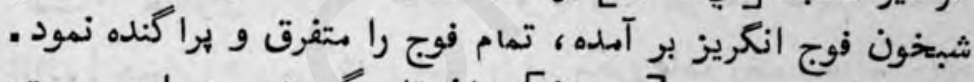

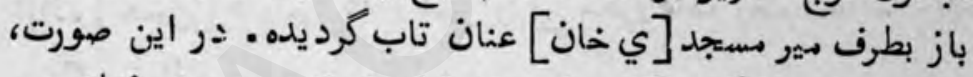

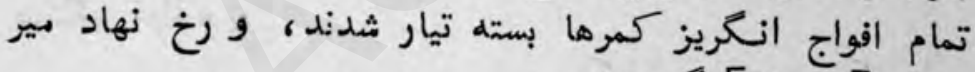
مسجد [ي خان] كرديدند

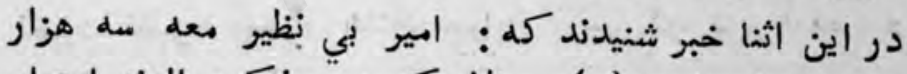

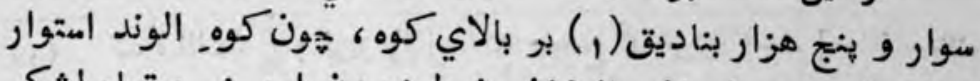

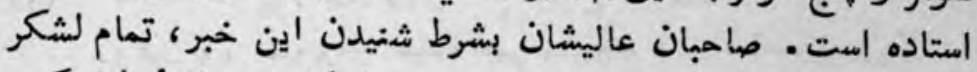

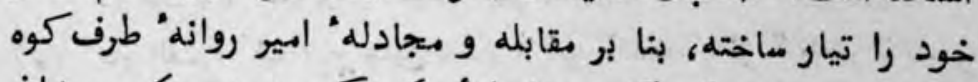

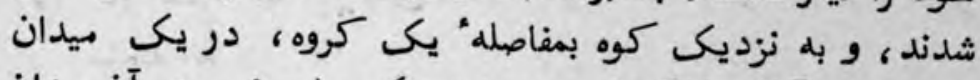

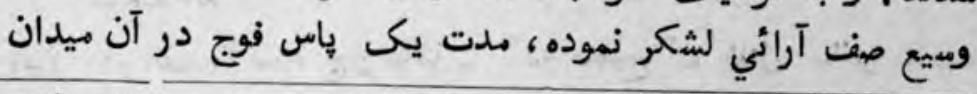

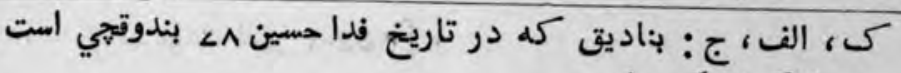

$$
\text { يعني اشكر تفنك دار مار مات }
$$


تازه نواي معارك

$\pi 9$.

استاده بود ، و ازطرف امير يِيش دستي و سبقت واقع نشده. در مار

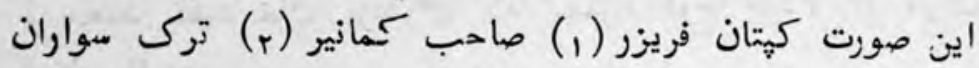

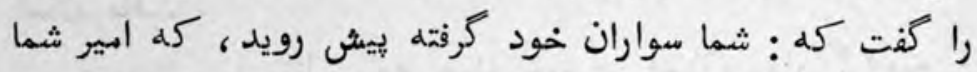

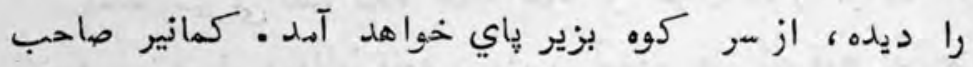
قبول نكرد .

باز جنرال سيل صاحب بهادر سالتر (r) صاحب را حكمم داد.

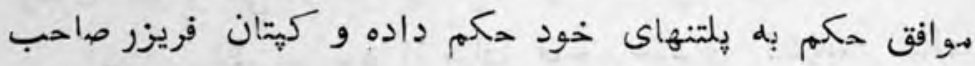

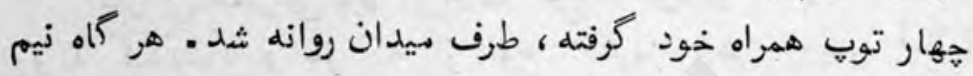

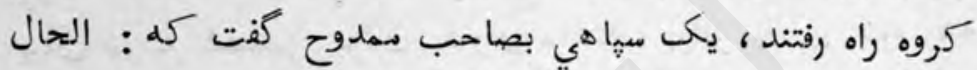

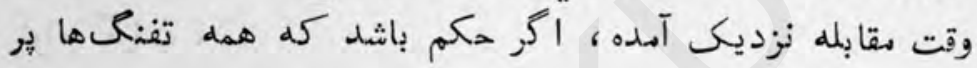

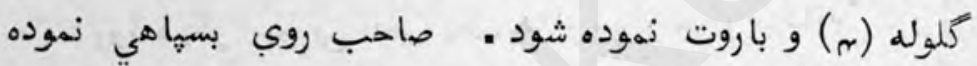

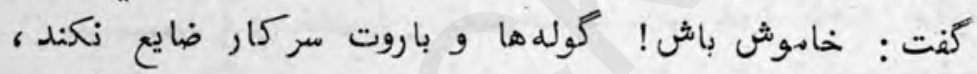

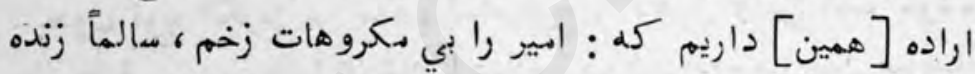

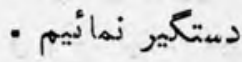

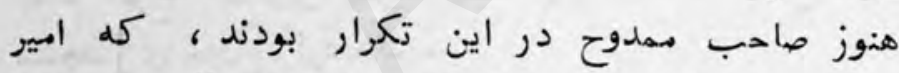

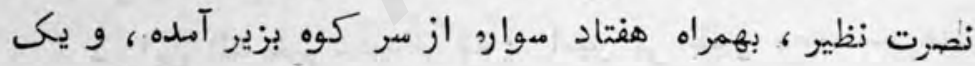

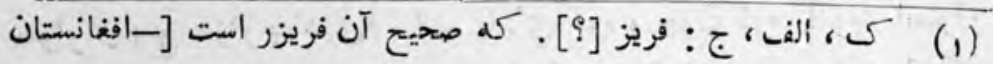

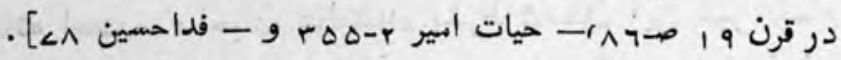

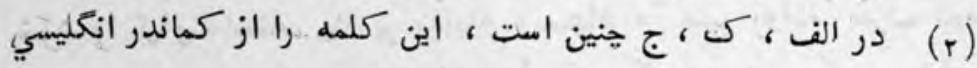

ساخته اند.

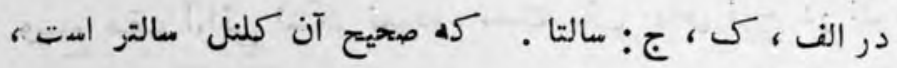

(r)

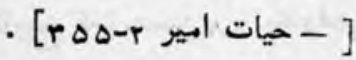

الف: بر بكوله و باروت .

(r) 
علم- سرخ همراه داشت، برابر سر فريزر صاحب جلوه انداز

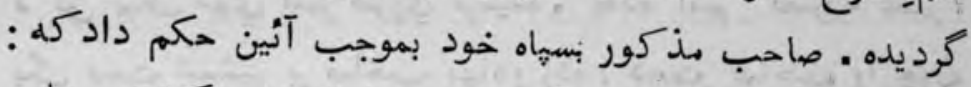

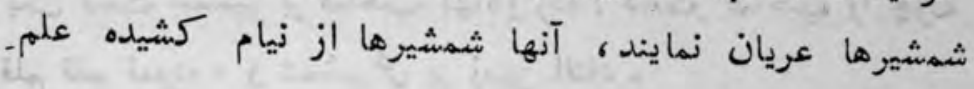
ساختيند

در اين اثنا امير بي نظير، فاتحه خوانده، شهشميرها از نيام

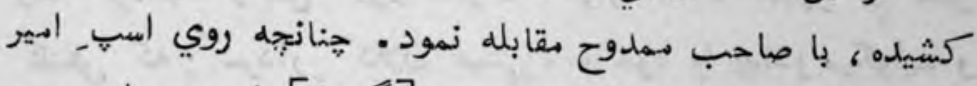

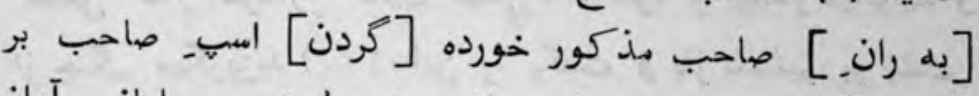

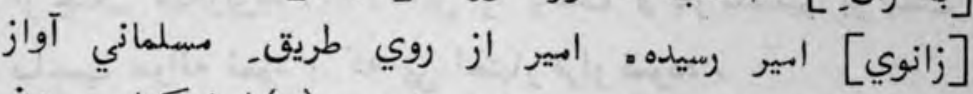

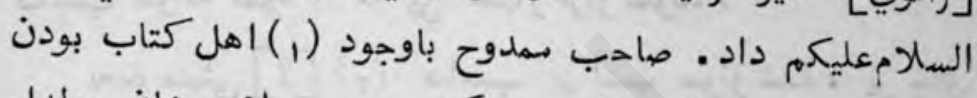

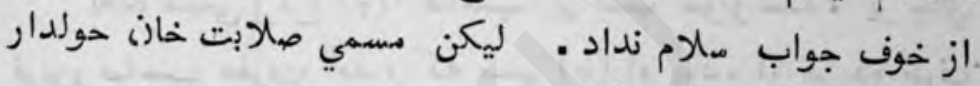
جواب وعليكم السالام كفت نوف نداب صاحب مذكور روي بطرف حولدار مذكور كردانيده كفت :

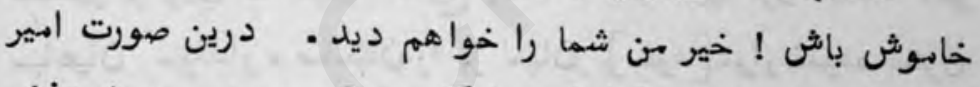

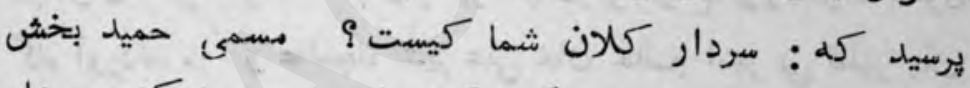

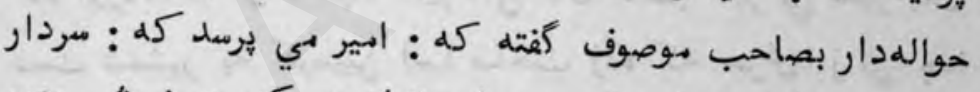

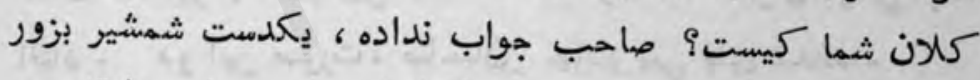

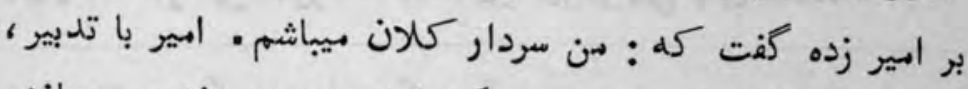

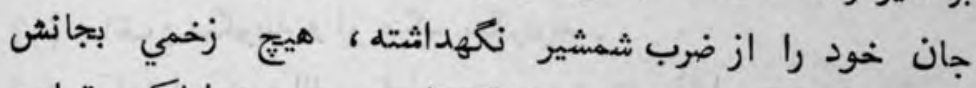

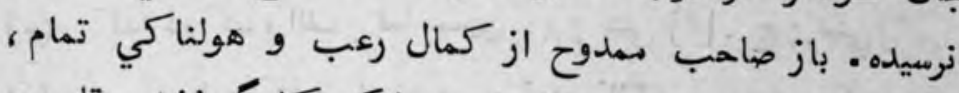

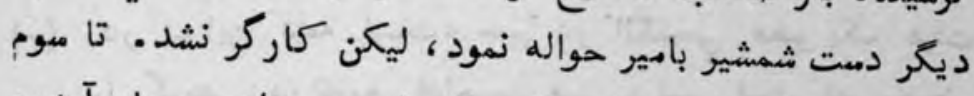

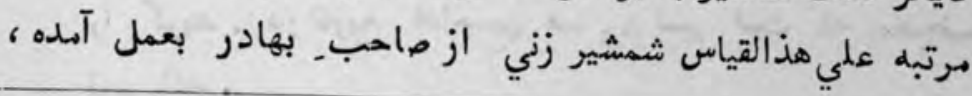


لاكن بيك موي ابير ضروي نرسيده . بعده امير ـ نصرت نظير

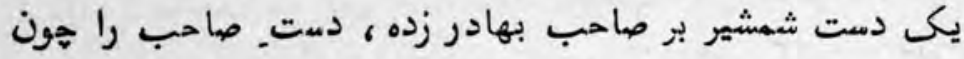

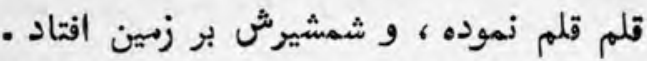

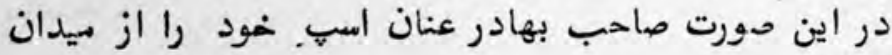

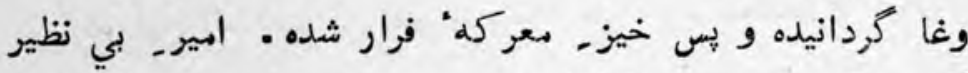

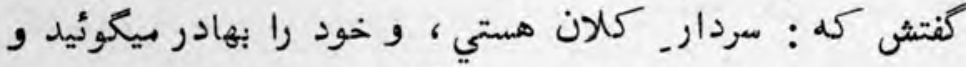

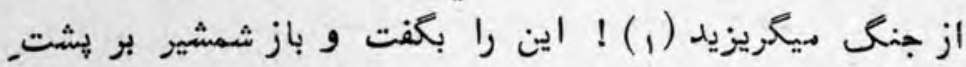

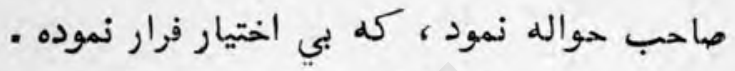

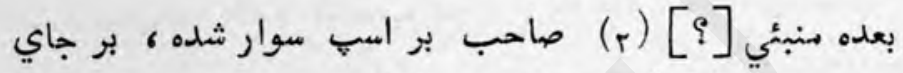

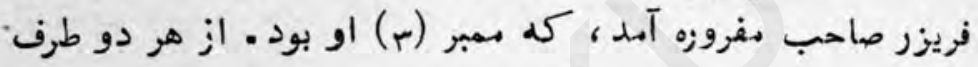

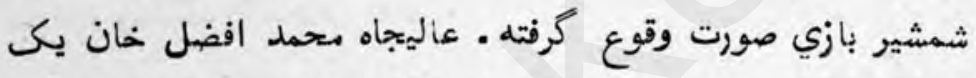

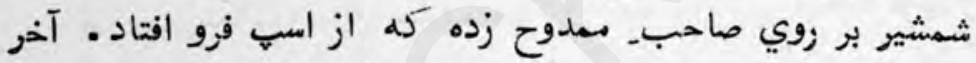

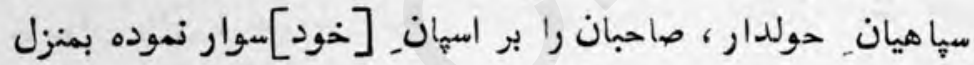

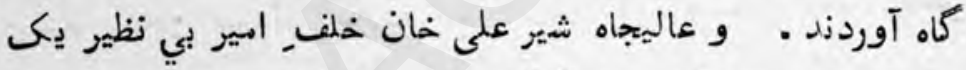

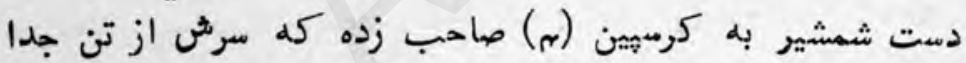

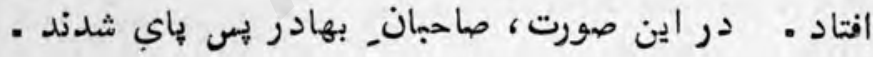

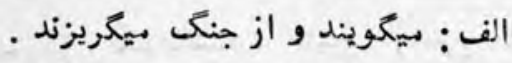

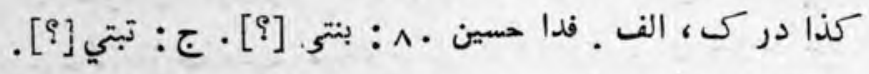

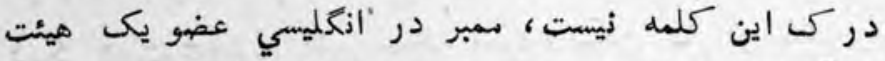

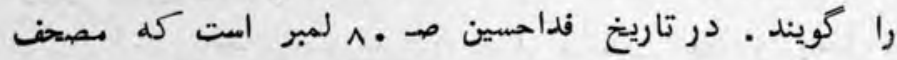

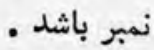

الف ، كس، :كرستين [؟] . بقول موهن لال كرسيين صحيح است. 
آخر ميجر اير صاحب بهادر دو ضرب توي بهمراه خود برده.

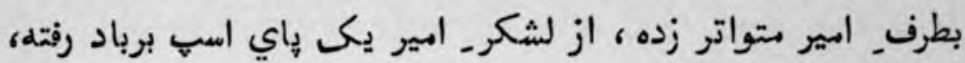

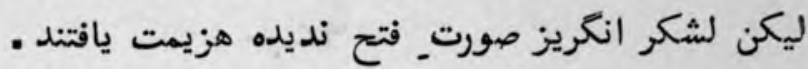

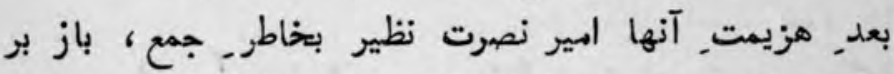

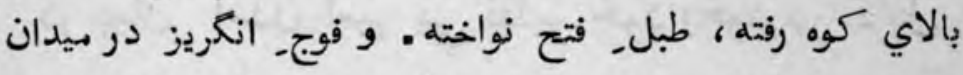

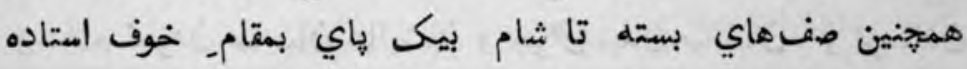

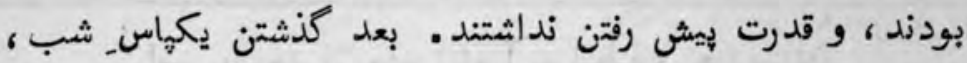

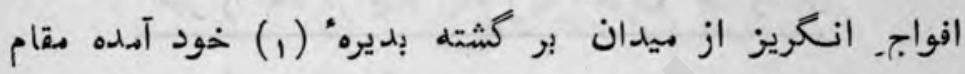

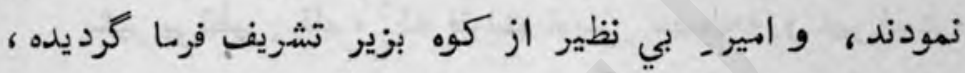

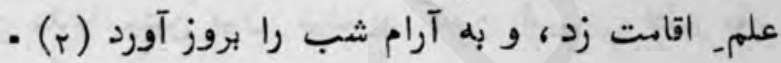

ديره در بشتو بمعني قيانحاه و قراركاه است ، و در فارسى افغانستان

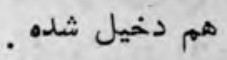

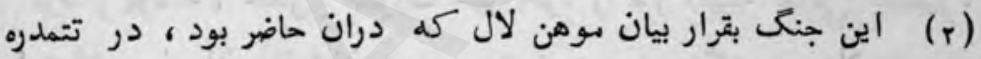

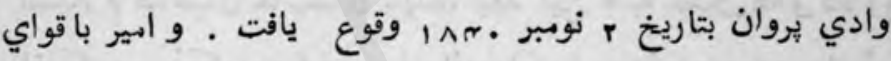

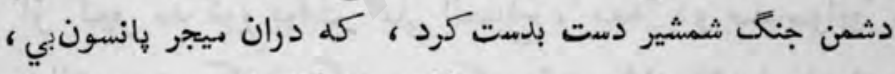

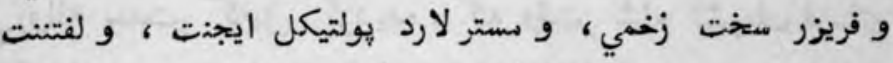

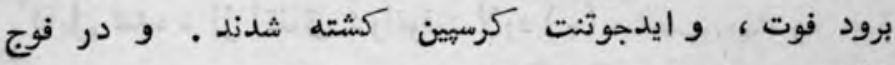

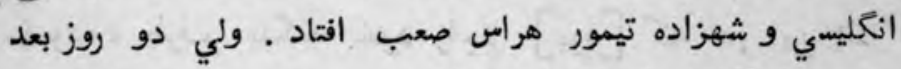

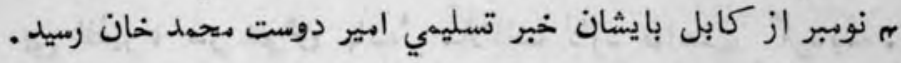

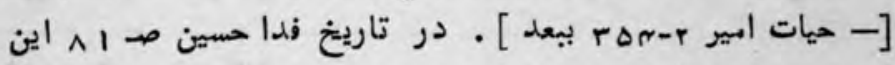

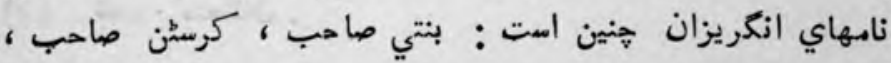
كهيتان انير صاحب انكائ 
در بيانِ آمدن امير بي نظير خود بخود در كابل و ـالام نمودن صاحبان عاليشان و خوو شدن صاحبان ، و فرستادن امير را بعد از هند ايام [بهـ] طرف, هندوستان

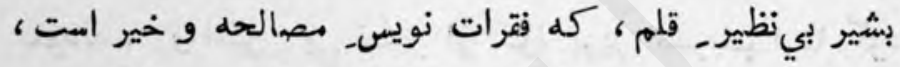

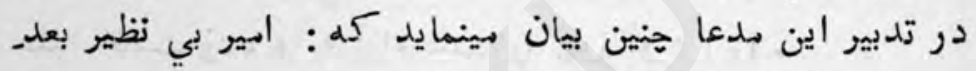

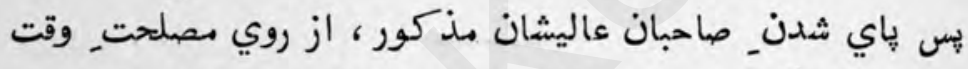

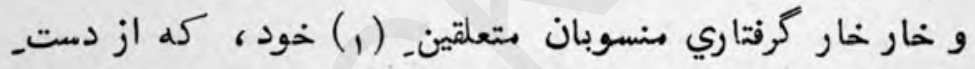

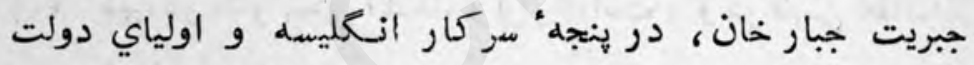

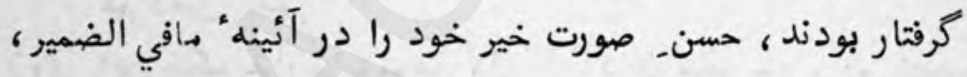

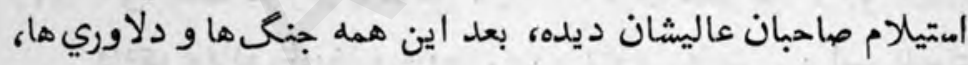

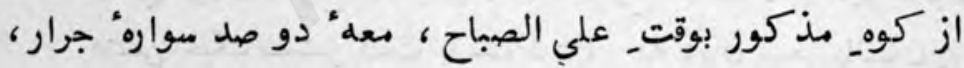

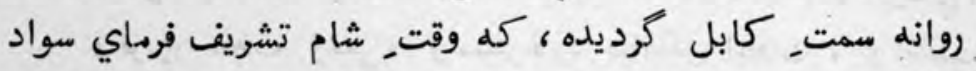

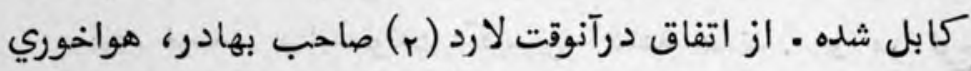

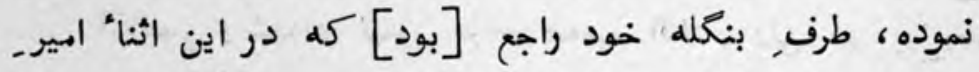

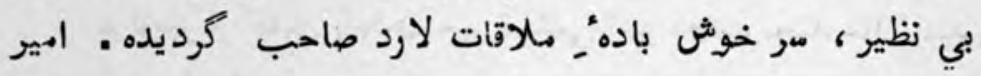

$$
\text { الف الف متعلقان . }
$$

مقصد مكناتن حكمران انكليسي كابل است . 
بي نظير يك قطعه كاغذـ مرقومه بدستــ صاحبـ ممدوح - (1)

ازآنجا كله صاحب معظم اليه امير بى نظير را كاهي نديده

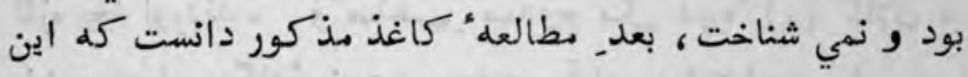

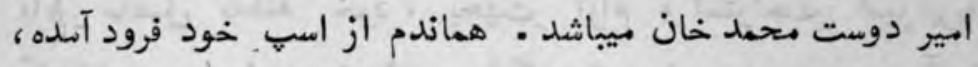
از بس ذوق و شوق ، هلال آسا آغوش كشاده ، هم آنم آغوش.

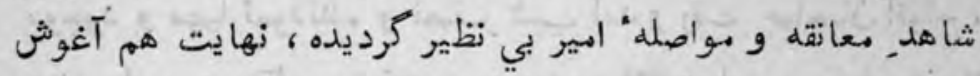

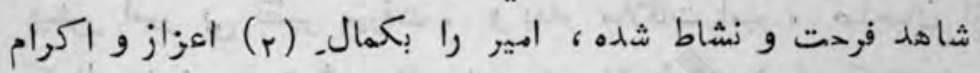

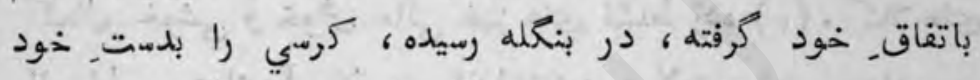

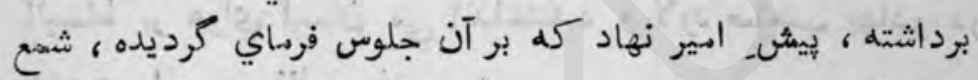

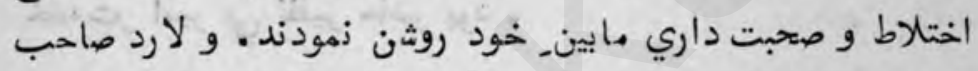

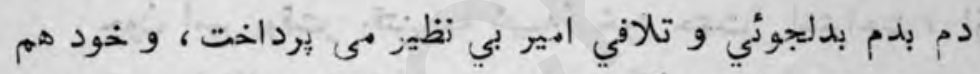

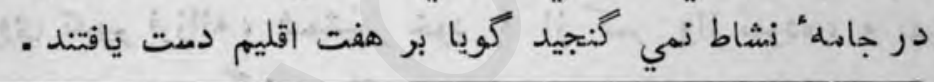

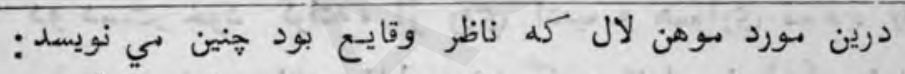

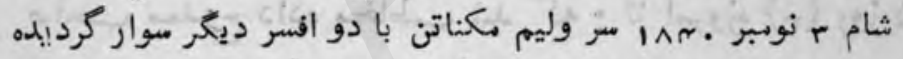

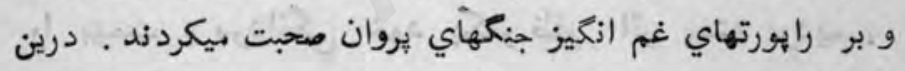

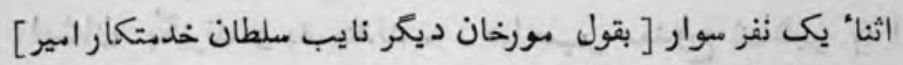

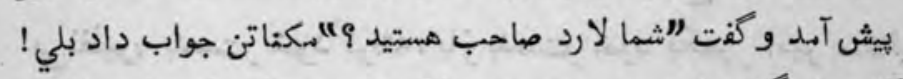

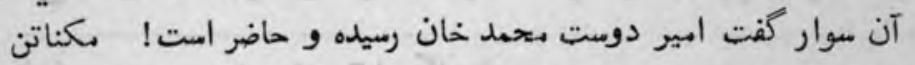

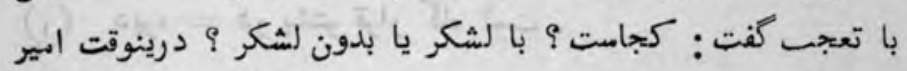

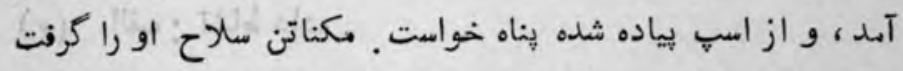

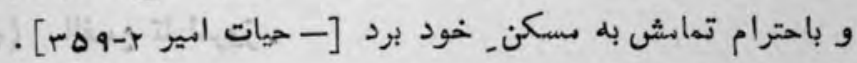

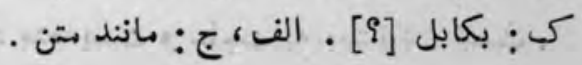


ازآنجا كه اين خبر, فرحت اثر تشريف آوري امير بي نظير

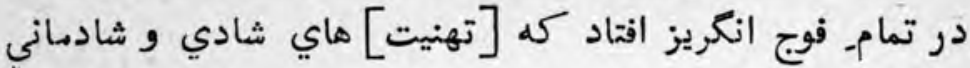

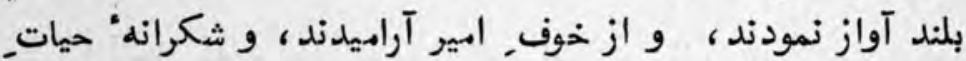

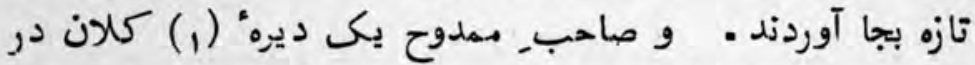

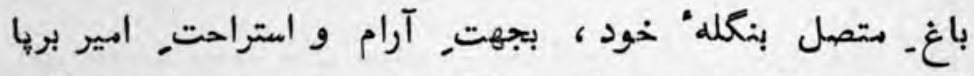

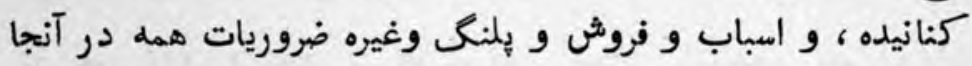

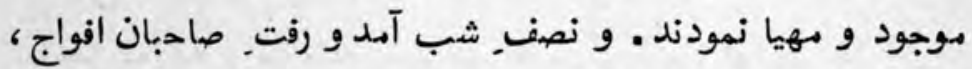

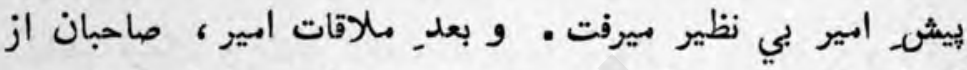

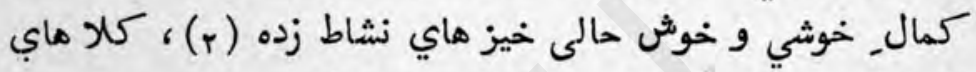

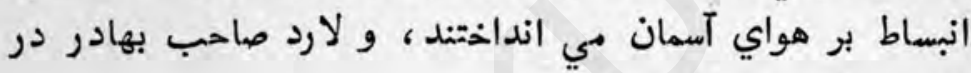

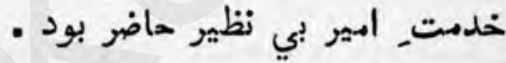

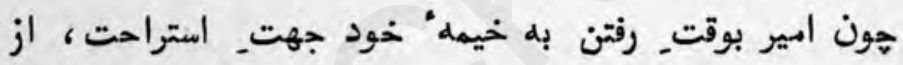

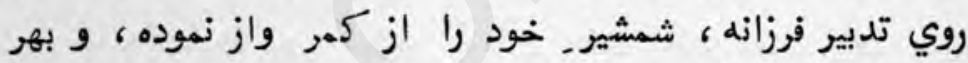

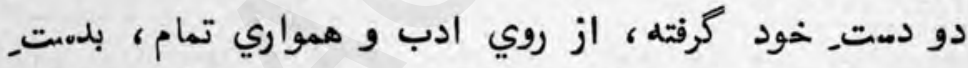

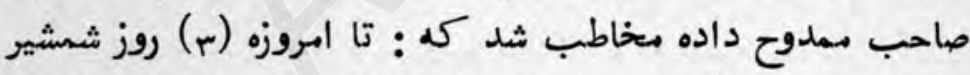

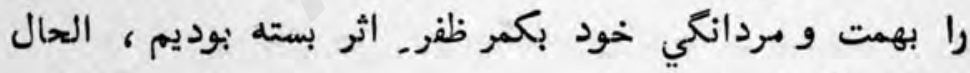

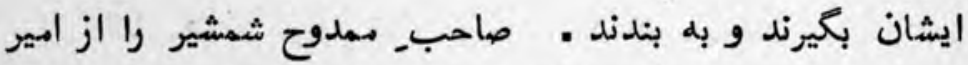

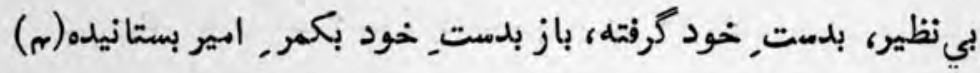

$$
\begin{aligned}
& \text { ديره = در بشتو قرار كاه امت . } \\
& \text { الف: نشاط داده . } \\
& \text { الف: تا امروز . }
\end{aligned}
$$

مصدر بستن خود متعديست و حاجت به بستانيدن نيست . 
$\cap 9<$

كفت كل : سابق شهشيرك، بخخوشي خود، بر كمر همتـ خود ،

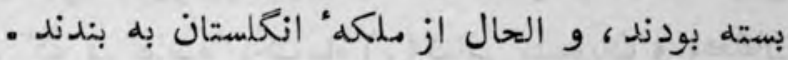

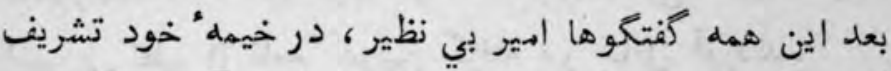

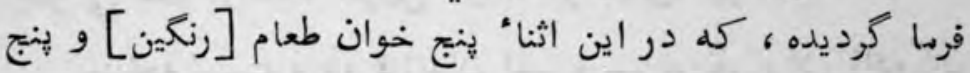
خوان_ فواكهاتـ بو قلمون، از طرفــ اولياي دولت، بدستـ بيش خدمت 6 بيش. اهير بي نظير آمده • لارنس صاحب بهادر بادير

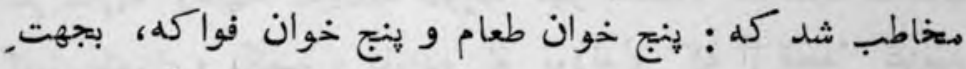
تناول اهير ، اولياي دولت فرمتاده اهت م اهير كفت وإيس بد هند

هر هند صاحب مهدوح درين باب بسيار تكرار (1) كرد ، ليكن، اهير اختيار زكرد • بعد از اندك فرصت سه خوان طعام و دو (r) خوانهُه ديوه ، عاليجاه شيرين خان براي اهير بي نظير اروسال نموده ـ صاحب_ ممدوح باز ازين معني بامير اطلاع داد داد. امير حكم دادكله : خوان_ طعام و فوا كله" شيرين خان بيارند - و بساط (r) راكستردند ، و امير به تناول_ طعام شيرين خان شيرين كام كرديد

هون صبع شد جنرال صاحب بهادر حكم براي طلب ميل صاحب بهادر داد 6، كه سيل صاحب معله" فوج از كوه مراجعت نموده، داخل كابل كرديده. . بعده يكهزار سوار (r) از رساله"

الف: تكرار نمود .

الف: و ده خوانهه .

الف: الف و سماط ران

الف : سواران رساله . 
تازه نواي معار

גר

جانباز بجهت كرفته آوردن بـ عيال و اطفال اهير از قلعه" غزنين

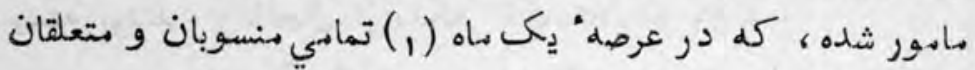

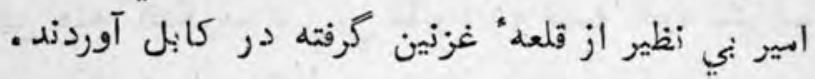

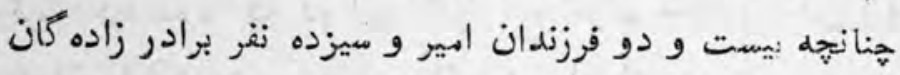

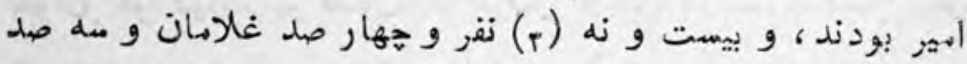

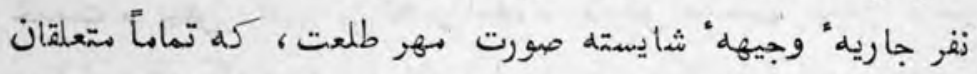

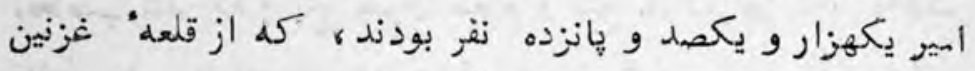

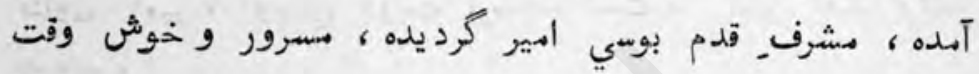

- شدند

بعد رسيدن منسوبان امير مذكور، حكمم صاحبان عاليشان در باب روانكي اسير بي نظير، جانب لوديانه صادر كرديده.

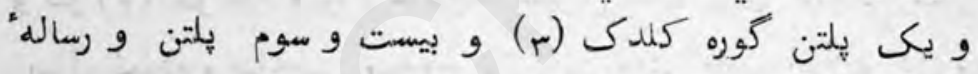
تركى معواران و يدى تويخانه ، بهمراه اسير بي نظير بعين نمودند .

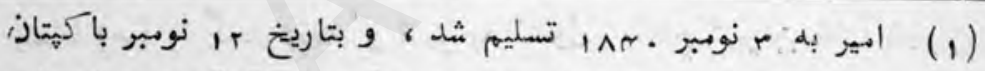

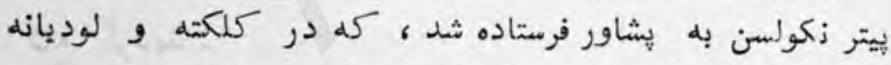

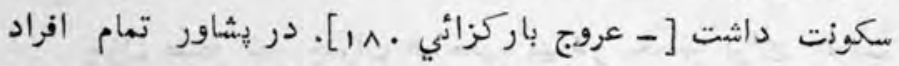

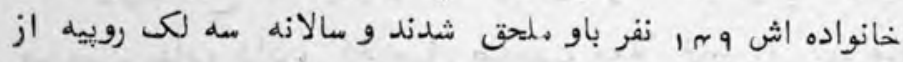

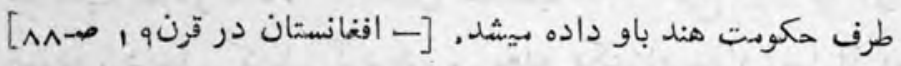

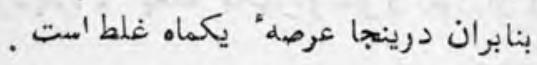

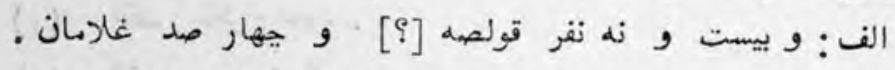

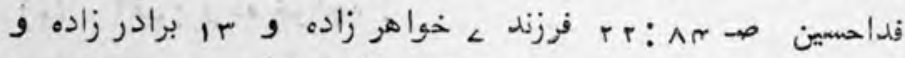

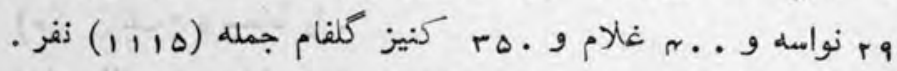

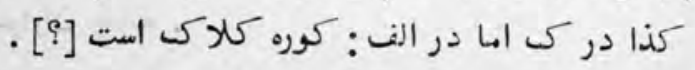

(r) 
तथ

تازه نواي معاركى

و در حين روانكي لارنس صاحب بهادر بامير كفت كه : باين وقت

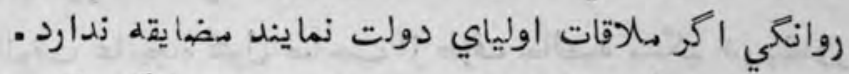

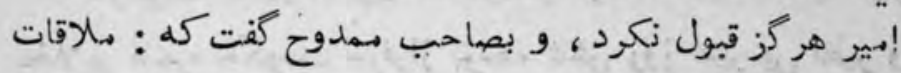

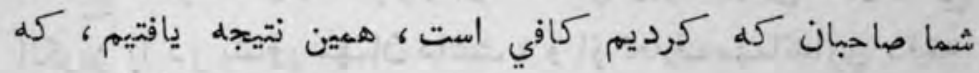

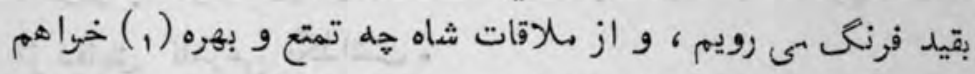

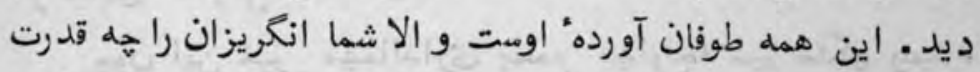

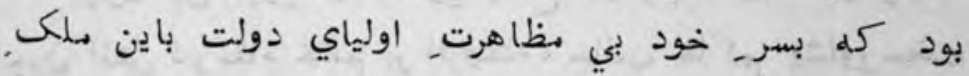

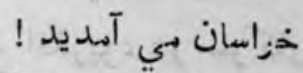

بعد اين همل كفتُكوي آخر امير بي نظير معله جميع منسوبان

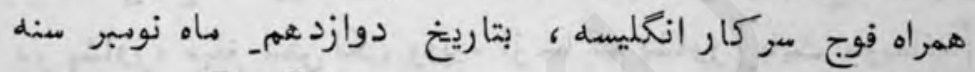

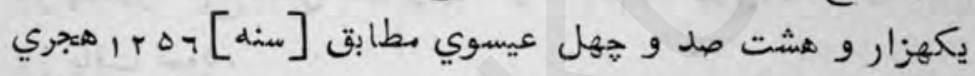

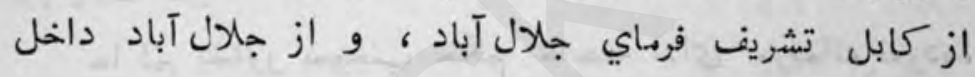

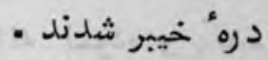

في نفر يكروييه بعاليجاه طره باز خان مبردار طايفله" خيبريان

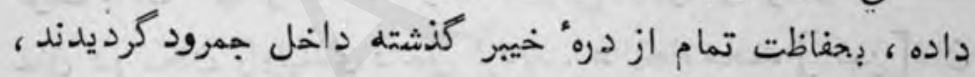

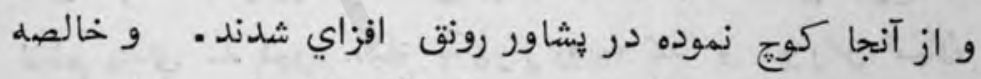

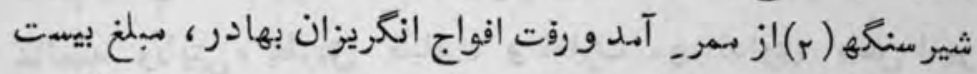

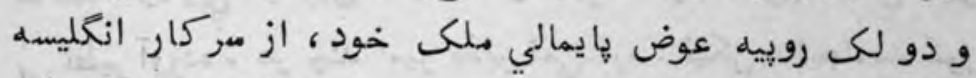

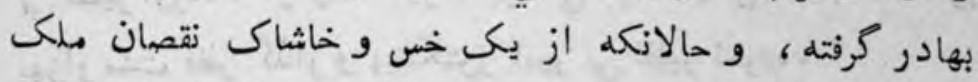

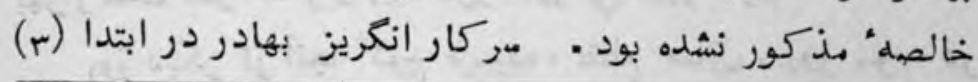

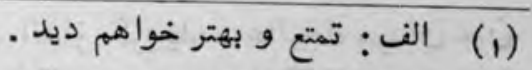

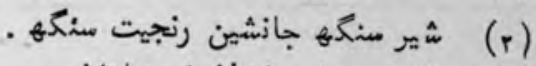

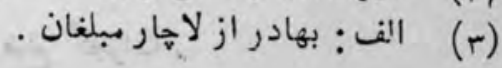


مبلغان مذكور ادا كرده (1) و دادند .

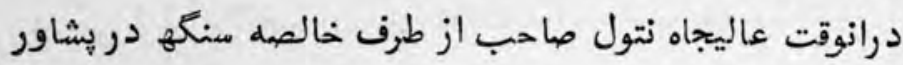

بخلاع فاخره حكومت سرفراز بوده ـ شش روز ادير بي نظير و فوج

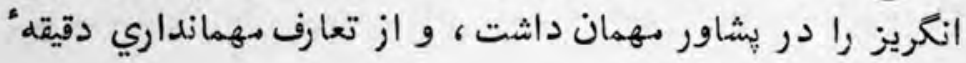
از دقايق نامرعي نكذاشت •

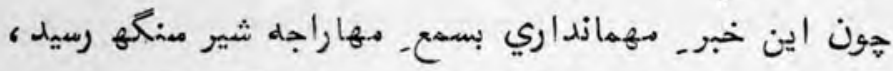

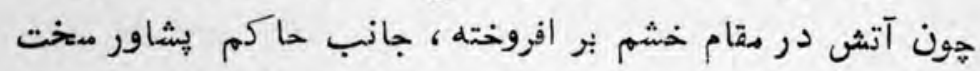

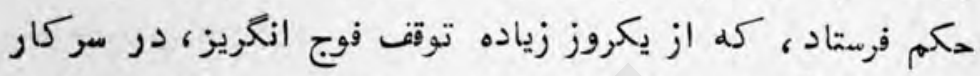

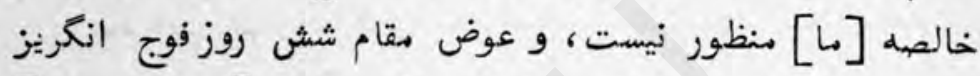

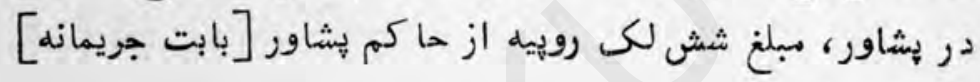
باز يافت نمود.

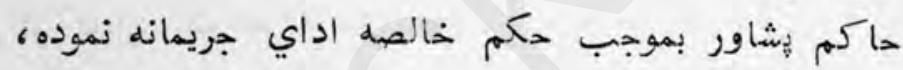

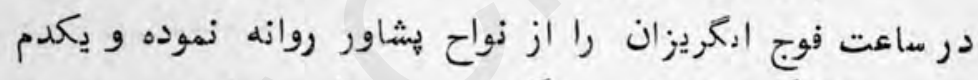

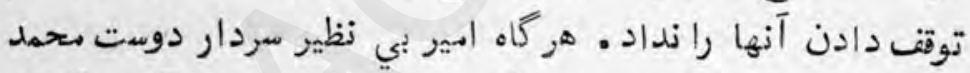

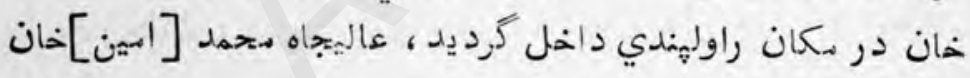

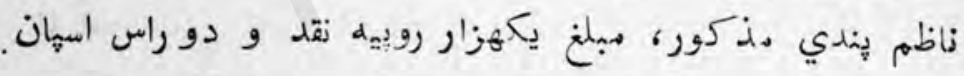

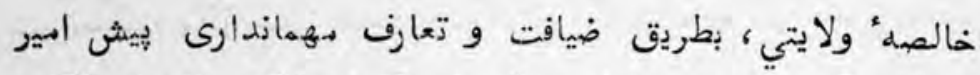

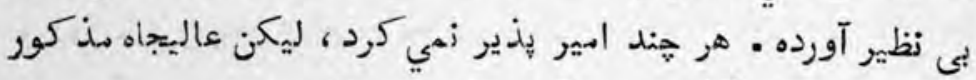

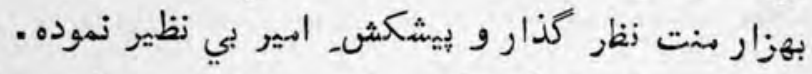

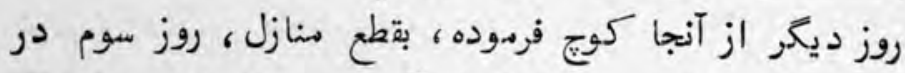

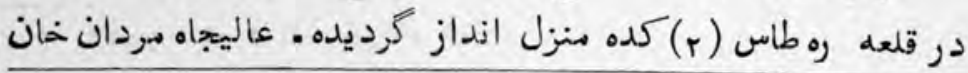

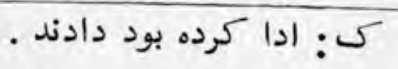

رهتاس = حصار سشهور واقع ضلع كجرات . 
حاكم آنجا مبلغ دو هزار روييه نقد و دو راس اسيان و دو قطعه

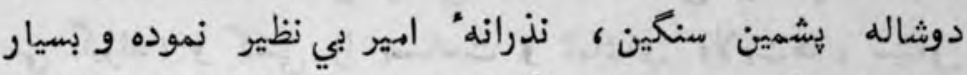

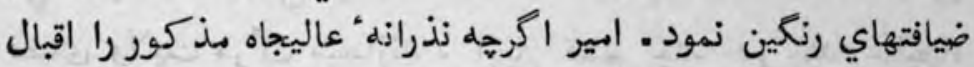

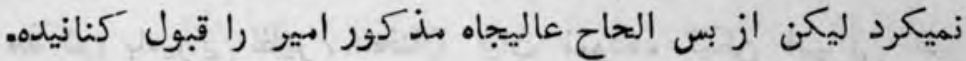

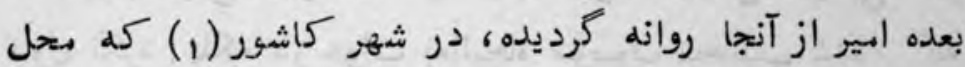

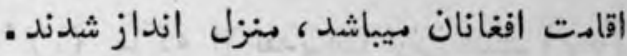

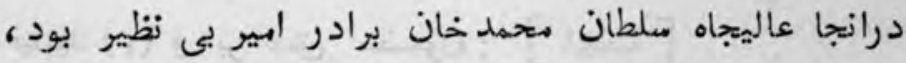

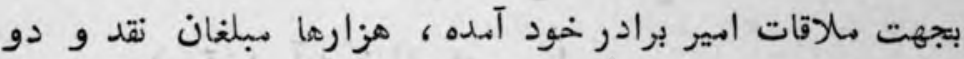
طاقه دوشاله يشمينه و حهند توي، كمخخواب وغيره نفايس. تفيسه

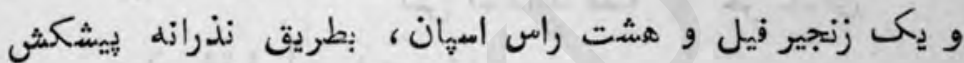

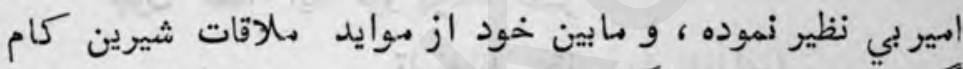

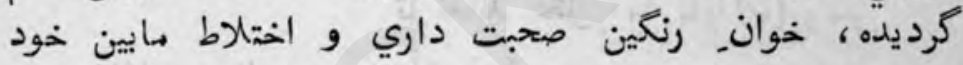

$$
\text { كستردند (r). }
$$

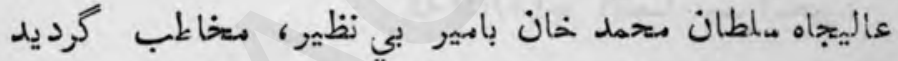

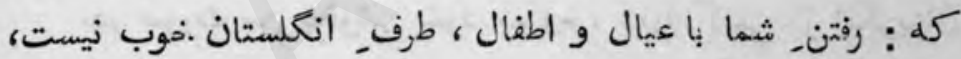

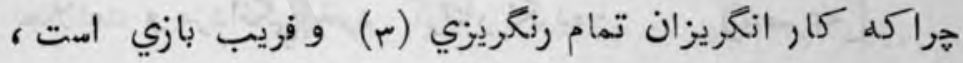

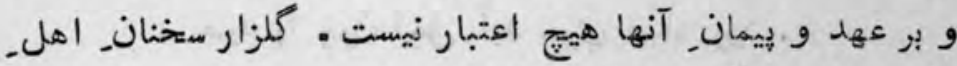

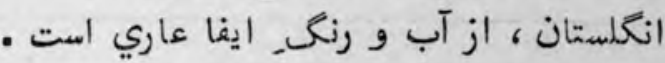

الف، كى، ج: كاشور، كه مـلب ازان كاسور [قصور] شهريست

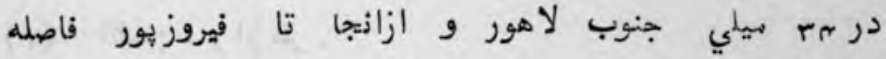

$$
\begin{aligned}
& \text { حا ميل است . فداحسين صـ ه م : كاسور . } \\
& \text { الف: كسترانيدند . }
\end{aligned}
$$

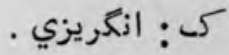


ازقيد فرنگ كسي رهائي نيافته . كسي را درو قيد جان

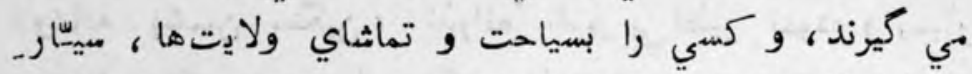

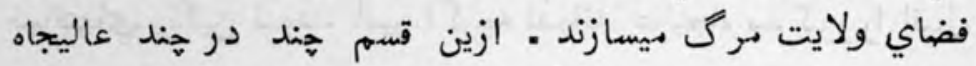

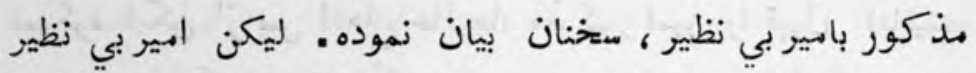

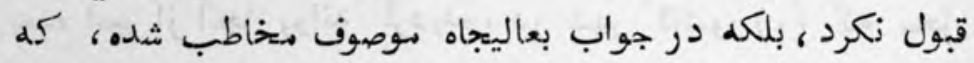

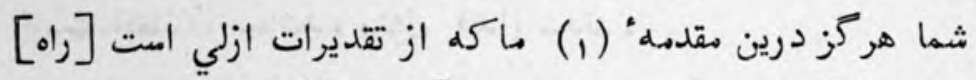

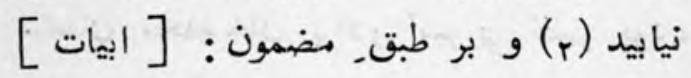
جون قضا آيد نماند فهم روان كس نميداند قضا را جز خداي

خون قضا آيد فرو بوشد بصر

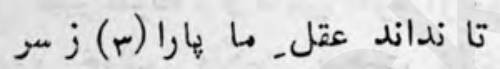

$$
\text { زان امام المتقين داد آن (ب) خبر }
$$

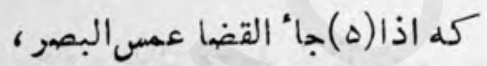

بور صورت من بخوشي خود ميروم، ، مارا كسي از انكريزان

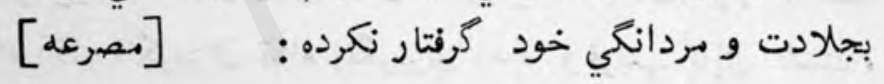

$$
\text { صيد را هون اجل آيد سوي صياد رود . }
$$

$$
\begin{aligned}
& \text { (1) الف: درين امور ما . (1) } \\
& \text { (r) الف : نيايند : (r) }
\end{aligned}
$$

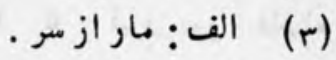

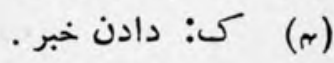

$$
\begin{aligned}
& \text { يعني وقتيكه قضا آدد، حشم كور شد . }
\end{aligned}
$$


$r<r$

ثازه نواي مارك

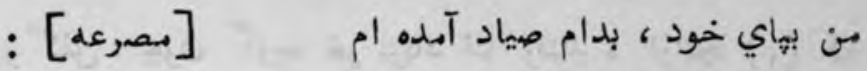

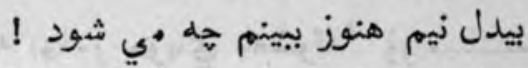

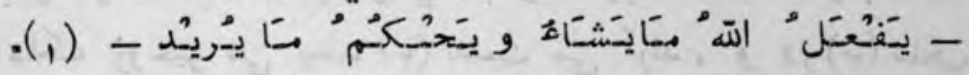

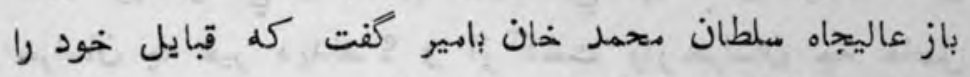

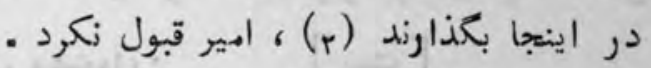

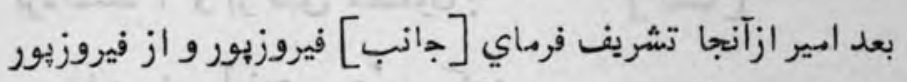

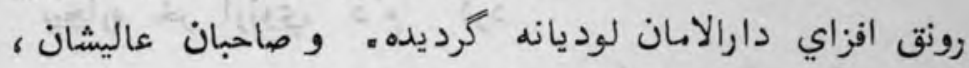

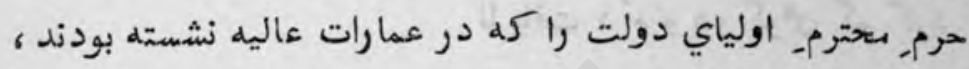

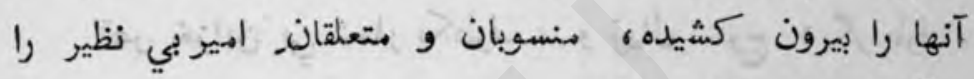

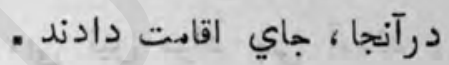
بعد از حهند يوم حرم متحترم اولياي دولت و و بند كان زمان شان

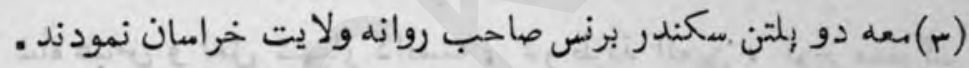

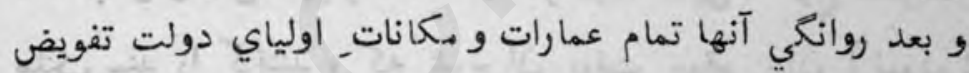
أمير بي نظير نمودند ، كل معه جميع متعلقان و منسوبان درآنجا

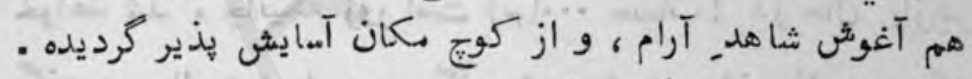

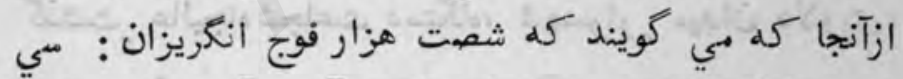

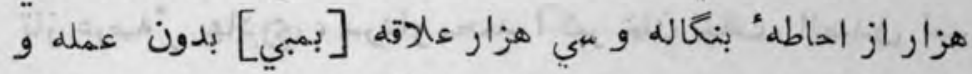

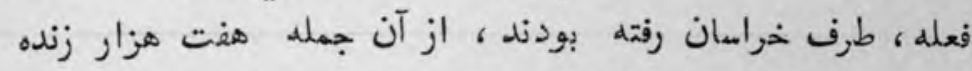

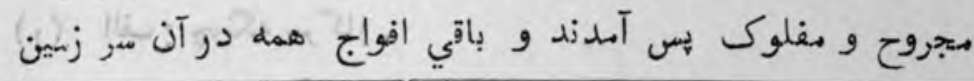

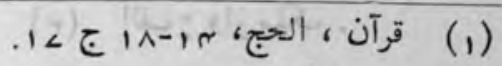
. (r)

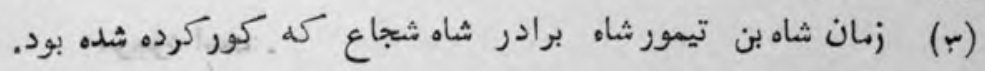

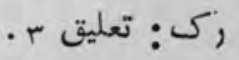


تاز هنواي معارى

r $4 \pi$

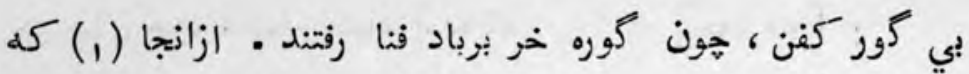

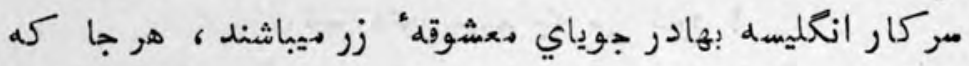

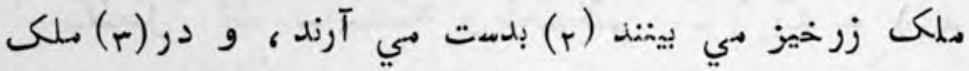

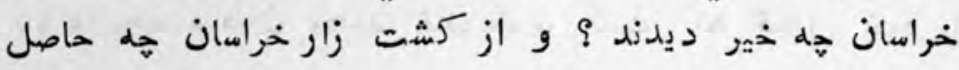

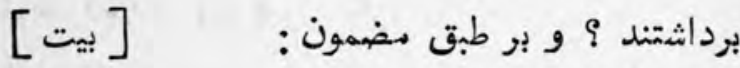

بيجاره خر آرزوي دُم كرد

نا يافت دُمُ ود دو كوش كم كرد

تقص خزاين بي شمار يكطرف ، و زوالـ فوج ديكر طرف.

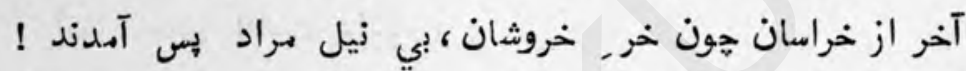

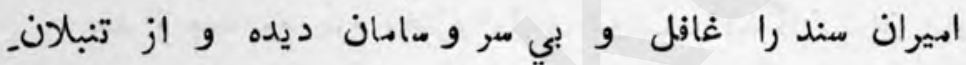

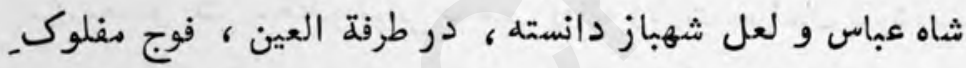

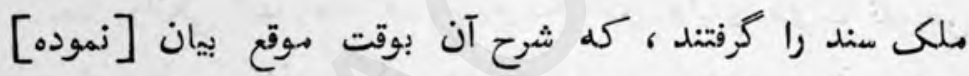

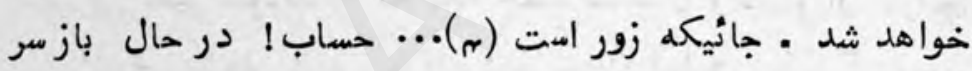

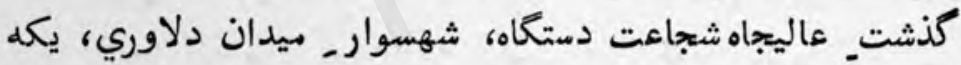
تاز عرصه", بهادري ، سردار محهد اكبر خان خلف الصدق امير

(1) الف: هونكه سركار.

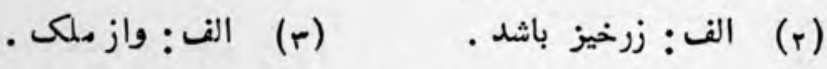

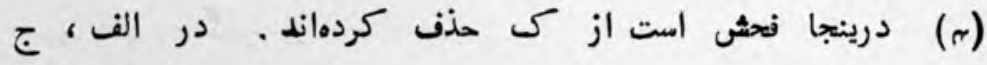

موجود است. 
$r<\Delta$

تازه نواي معاركى

دوست مجمد خان ، و امراي جلادت بيراي عاليجاه عبداله خان

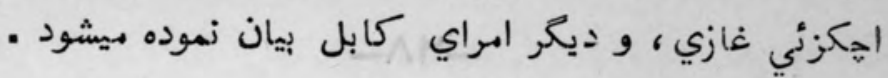

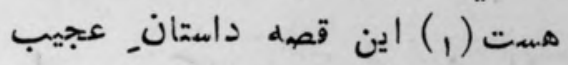

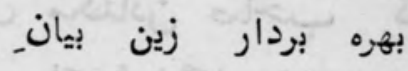

عقل بايد كله زكته كوش كند

مرد بايد كله جرعه نوش كند كند (r)

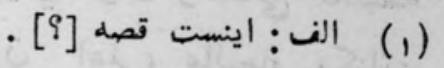

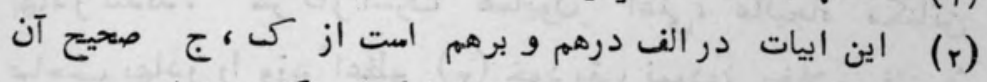

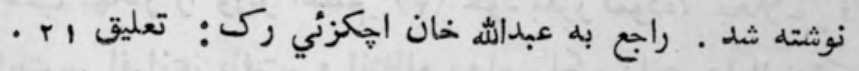




\section{$-4 \Lambda-$}

در بيان مكناتن ماحب كله بموجب فرمان جناب ملكه' اذخلستان مستعل فرمان فرمائى

$$
\text { هندوستان گرديده }
$$

[و] خوشي ها نموده، و ددر بابـ كرفتاري بعضي امراي كابل

تدابير در خاك بي نمود [و] اولياي دولت، دولت

$$
\text { مصلحت نموده و در رجاهـ نيت, خود افتاده }
$$

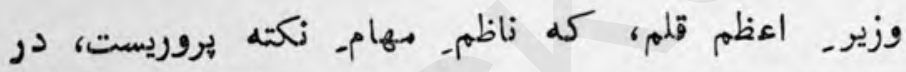

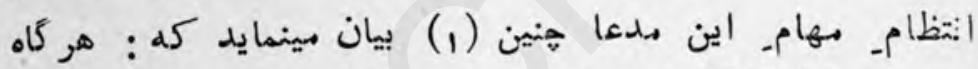

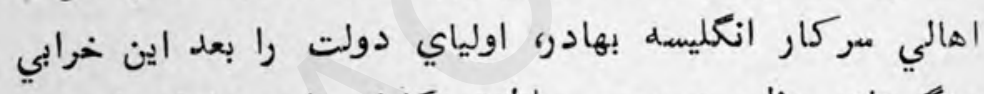

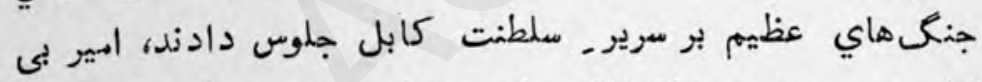

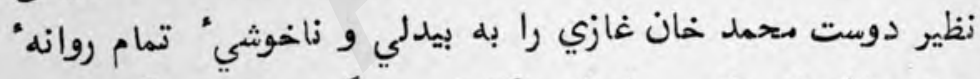

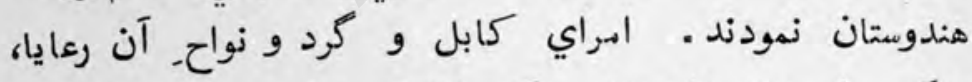

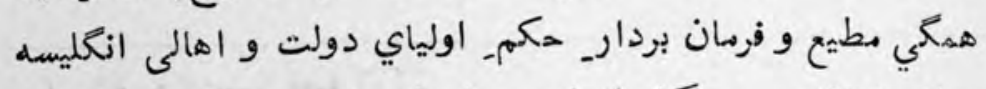

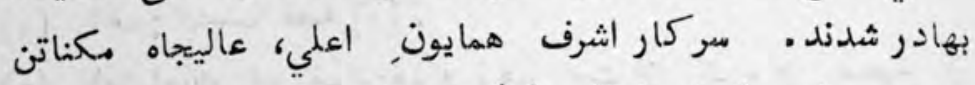

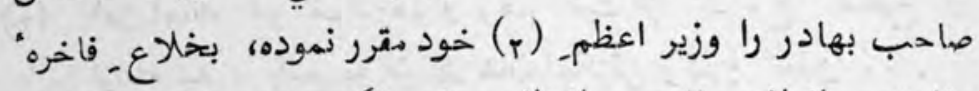

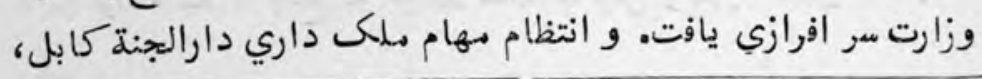

(1) الف: مدعاي خوش بيان .

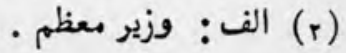


$r<L$

همd تفوبض صاحب مهدوح نموده و انكشاف عقود تمام مهام ، موقوف براي افلاطوني صاحب مهدوح خذاتتته ، و خود بدولت بر سريو سلطنت ، هم آغوث شاهد هد استراحت بود . قانون مدءعاي

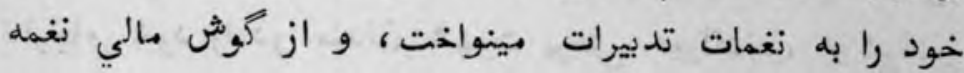

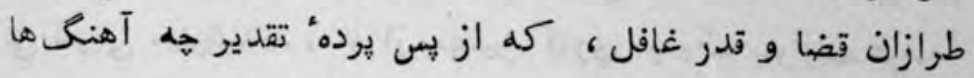

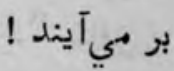

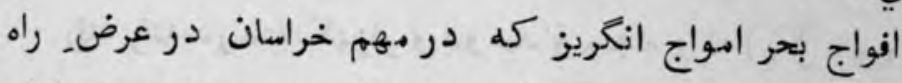

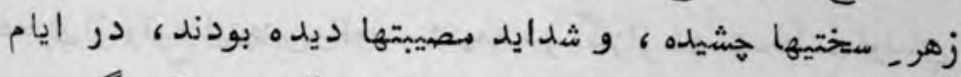

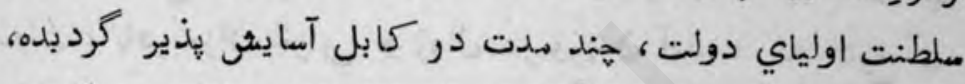
از تناول اقسام طعام از كوشت هلمو و لوزيفه و فالوده و وكباب وغيره كونا كون فواكهات از قسم انخور صاحبي و خلميلمي و خايه

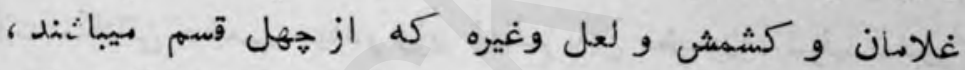

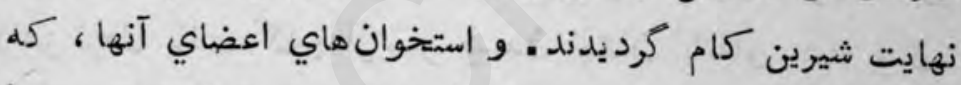

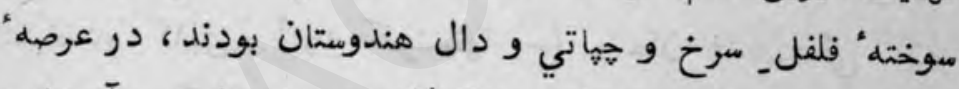

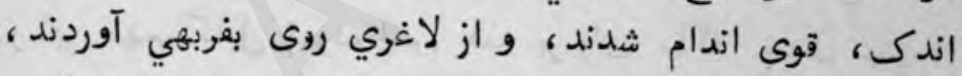
و از دال و حهاتي هندومعتان نادم و بزبان حال ميكفتشد (1) :

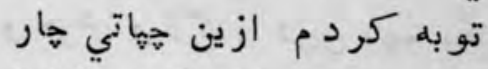

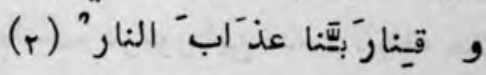

غرض در آن ايام، دور حكم اولياي دولت و صاحبان

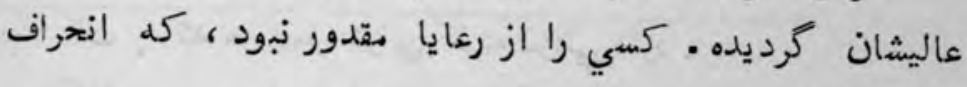

$$
\text { حكم+ ورزند - }
$$

يعني= خدايا ما را از عذاب آتش زمهدار ! قرآن، البقره، ا ـ بجن 
از آنجا كله افواج انكريز و صاحبان. افواج ، بمقتضاي اينكه

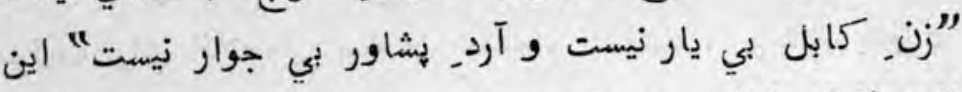
نغمه از ني زبان مردم شنيده، شب و روز تومن. آرزويـ نقس.

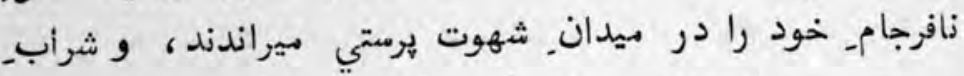

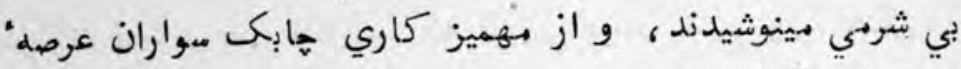

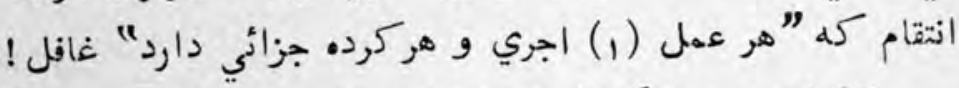

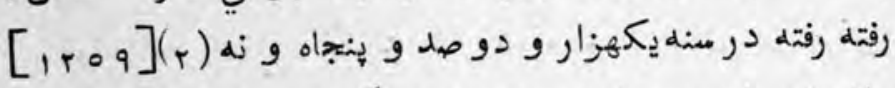
هجرياز وقوع اينجنينواقعات شنيعه در كلزار دولتملططنت اولياي

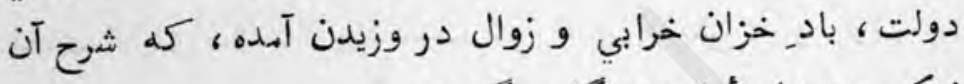

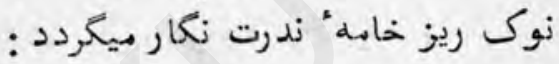

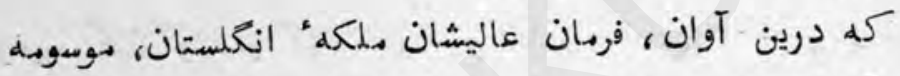
لات مكناتن صاحب بهادر وزير اعظم باين مضمون ، شرف صدور و عز نزول يافت كه : از مهر رسيدن ايشان باتفاق شاه فلكى اثتبهاه در كابل ، آنجه كوششها (r) و و جان فشانه

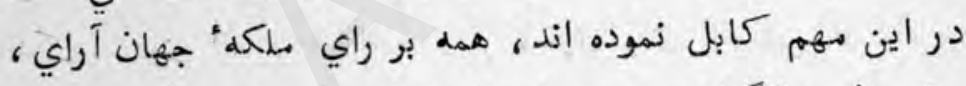
يرتو، ظهور افكند . و حسن اوصاف تدابير و مراسم نيك تجويز،

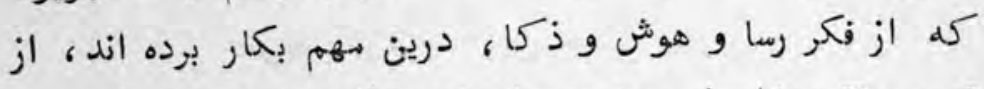

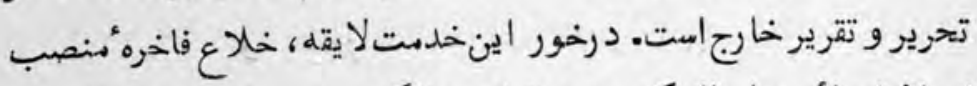
فرهان فرمائي دار الجكومتت و تمام مهالرك هندوستان ، ماد ام ألحيات

$$
\text { الف : كله هر عمل خرابى كرده سزاني دارد . }
$$

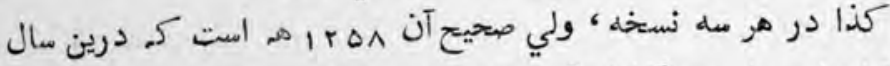

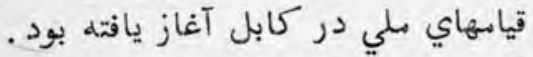
الف : كوشش ها و سرجوشي و جان فشاني ها. 
$\pi<9$

تازه نواي مارك

در بارو" ايشان عنايت و مرحهت كرديده است. لازم كان

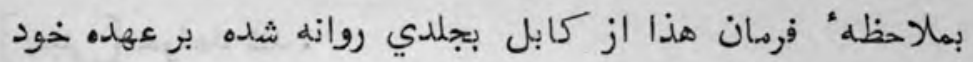

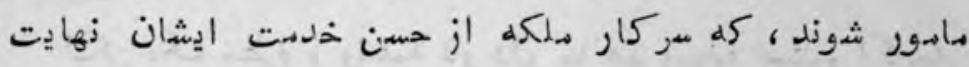

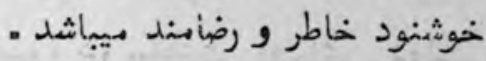

مكاتن صاحب بهادر بصدور فرهان مذكور از به سرور

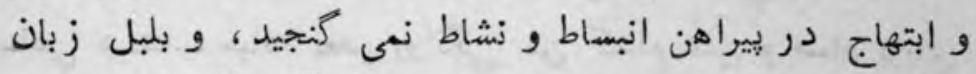

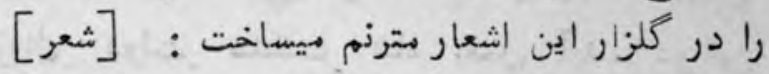

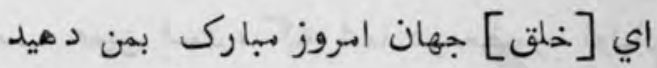

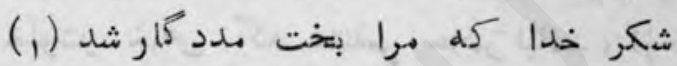

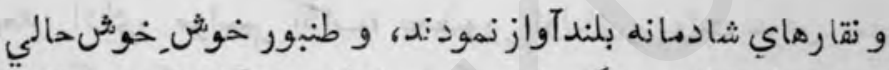

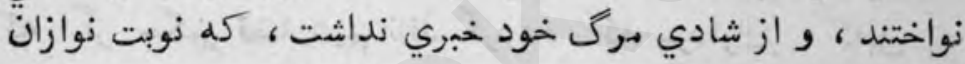

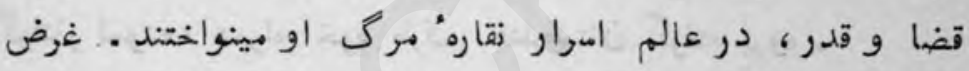

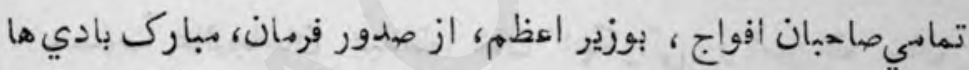

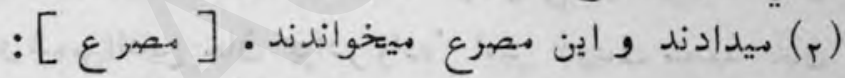

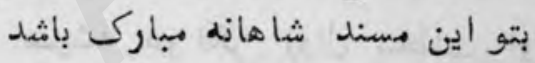

مكر اولياي دولت به سبب روانكي وزير اعظمم در بحر تفكر و انديشه فرو رفته . وزير اعظمب، عاليجاه مستر برنسصاحب بهادر

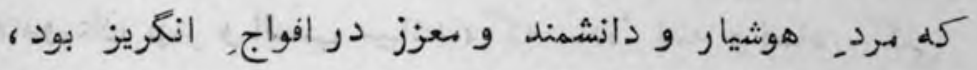

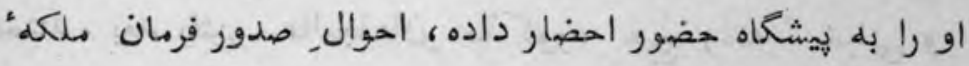
انكلمتان، و روانگي, خود بيان نمود ، و هم او را بر عهدهُ وزارتـ

كذا ... ولي نظم ذيستت، وزن عروضي صجيع ندارد .

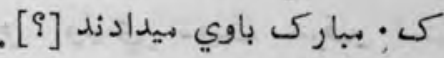

(r) 
تازه نواي بعارك

$\sim \wedge$.

خود دقرر نمودد كفت : كه بعد. دو روز روانكي [ما] جانب

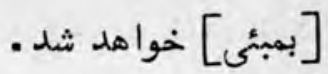

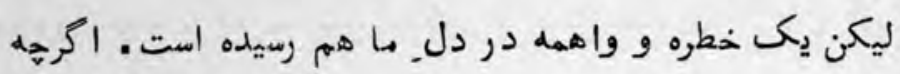

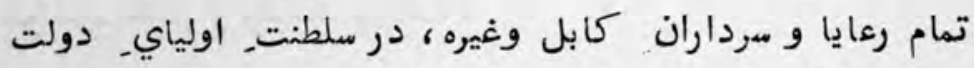

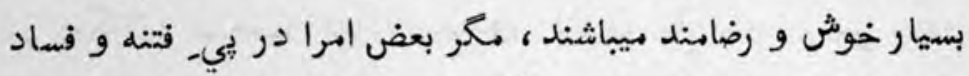

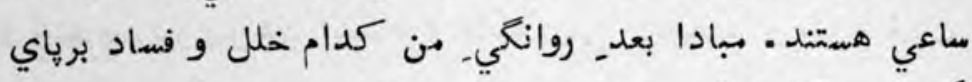

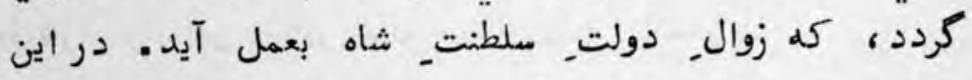

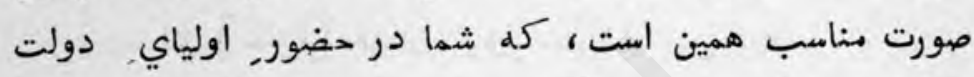

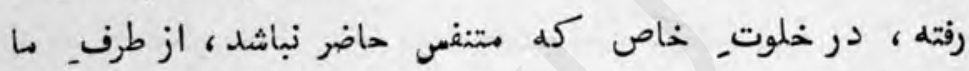

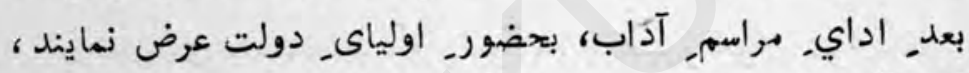

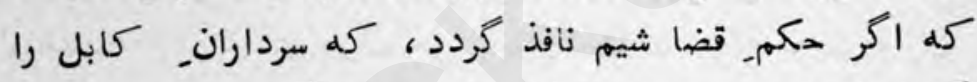

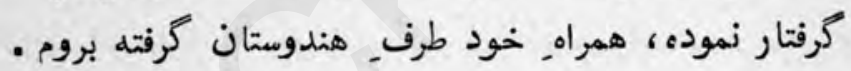

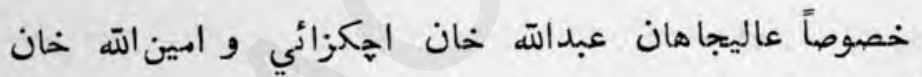

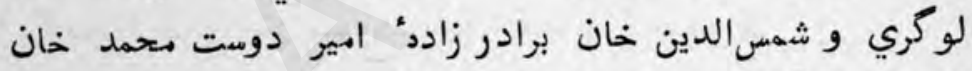

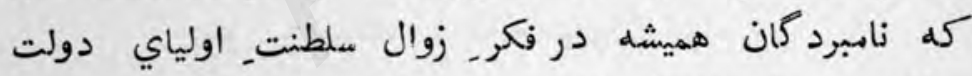

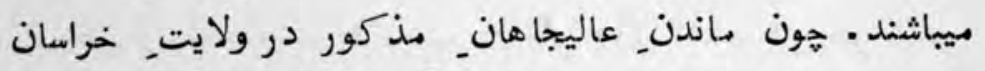

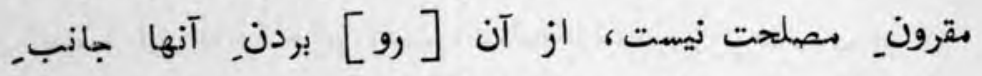

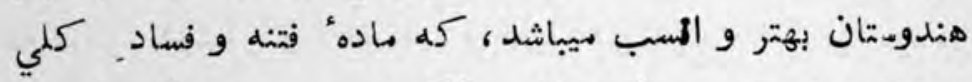

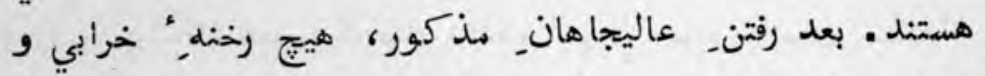

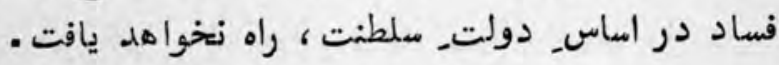

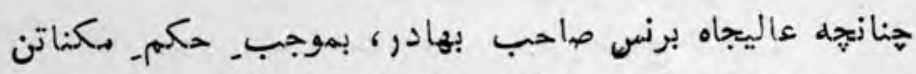

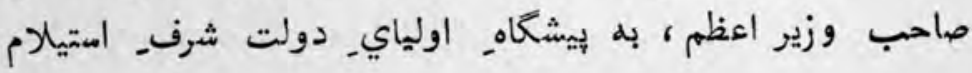


ก I تازه نواي معارك

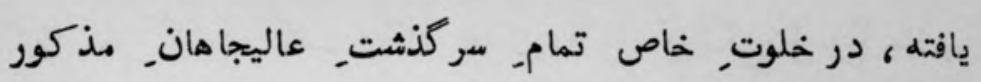
بسمع. اشرف اعلي رسانيدند .

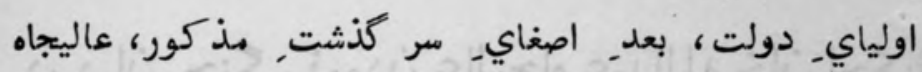

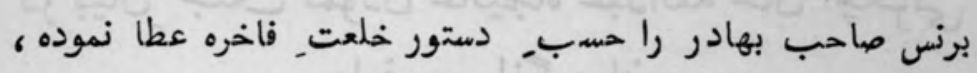

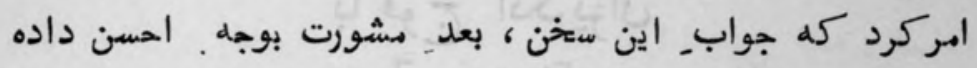

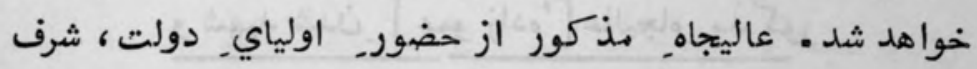

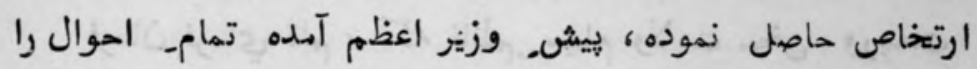

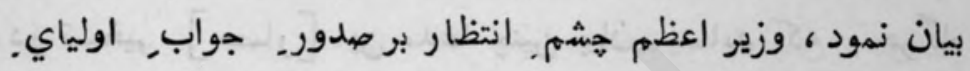

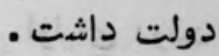




\section{$-49-$}

در بيان جنى ذهودن عاليجاه عبدالله خان اجِكزئى

$$
\text { با فونج, انكريزان }
$$

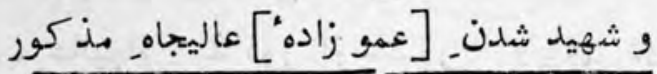

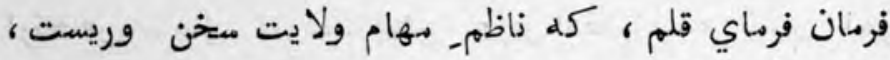

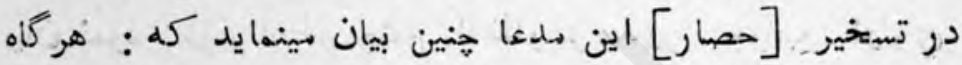

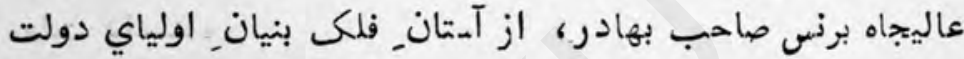

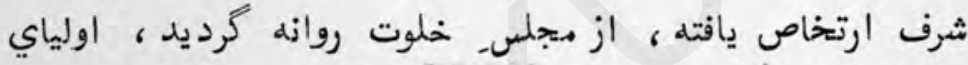

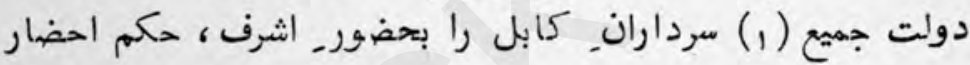

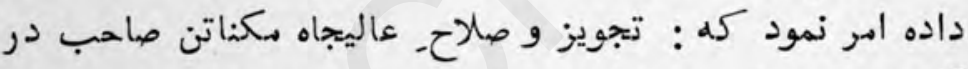

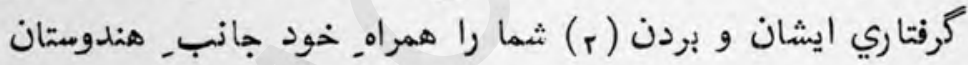

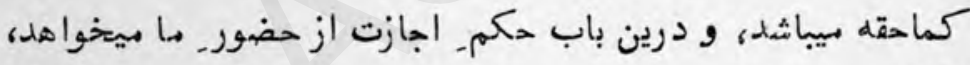

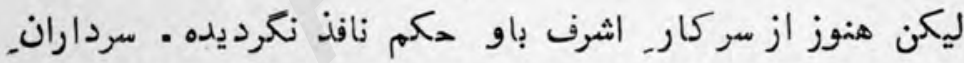

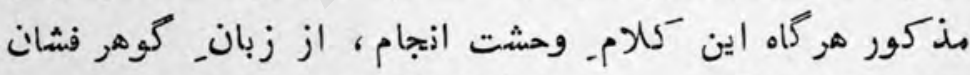

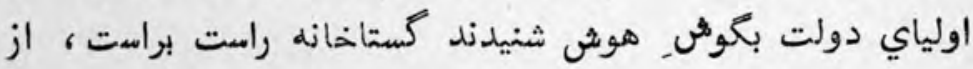

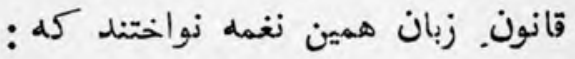

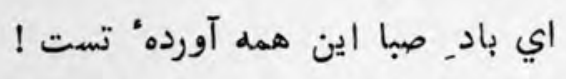

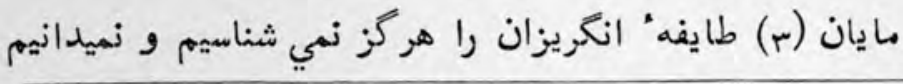

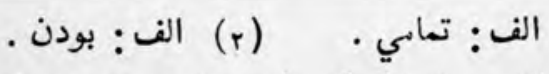

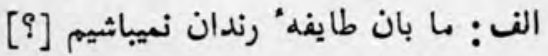


كله از كجا هستشند و كيستيند 9 سركار. اشرف سالهاي مال

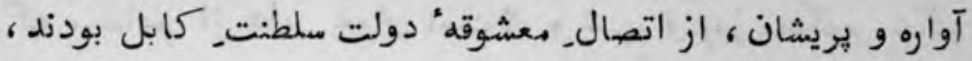

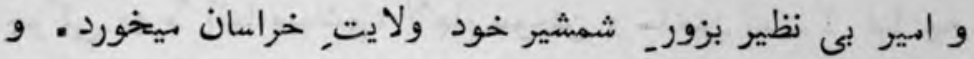

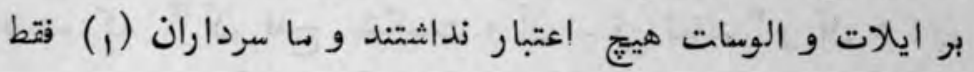

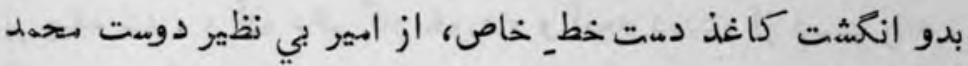

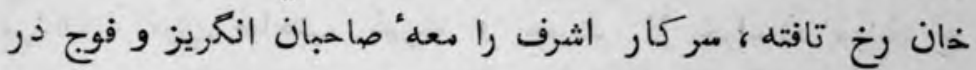

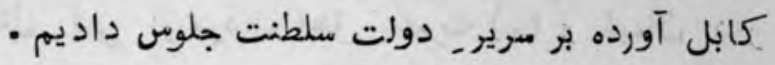

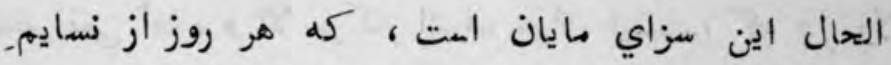

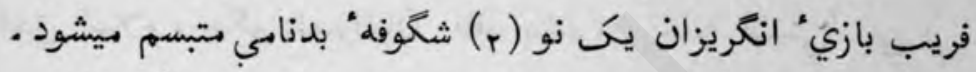

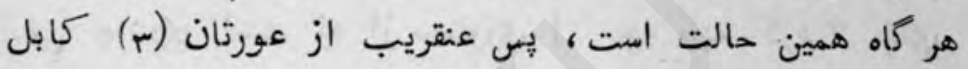

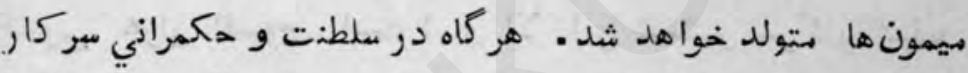

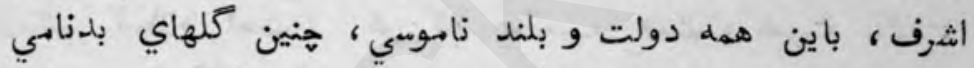

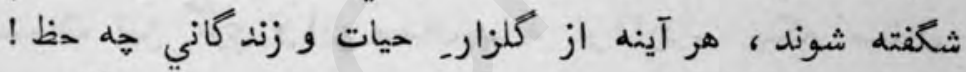

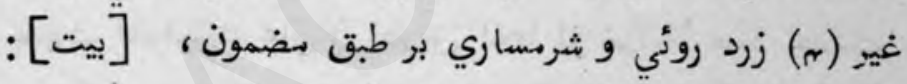

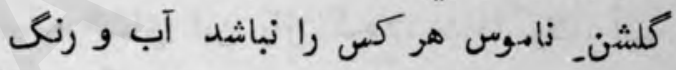

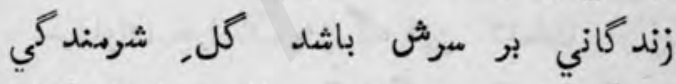

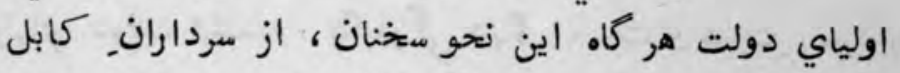

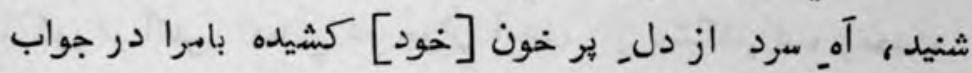

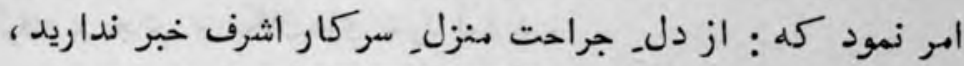

$$
\begin{aligned}
& \text { كى: و ما برادران [؟] } \\
& \text { ك. } \\
& \text { عورت = زن . نوع. } \\
& \text { الف : عين زرد روني • }
\end{aligned}
$$


تازه نواي معاركى

"AN

كله سركار اشرف ، اين قدر تابعدارى و فرمان برداري انكريزان

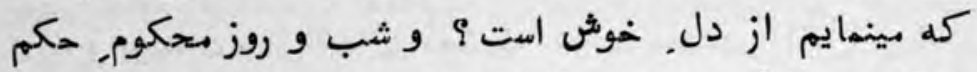

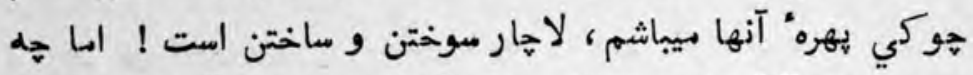

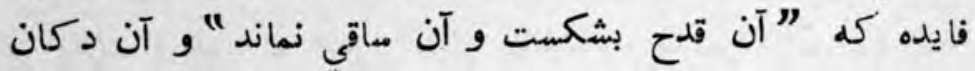

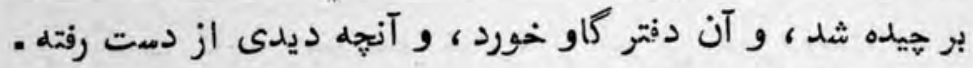
مردان كاري صاحب غيرت و حميت از خراسان مردند و وران رفتند ! در حال كس از مردان اهل غيرت غيرت (1) و ايمان دار فران

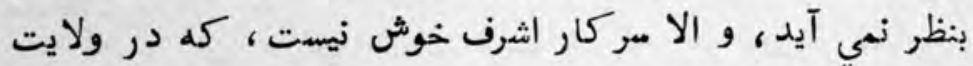

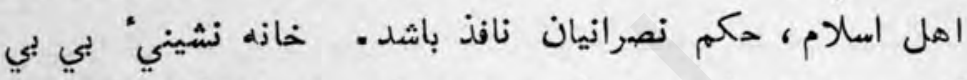

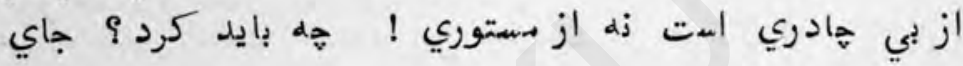
افسوس هزار افسوس است ! و الا اين شهشير مركار اشرف

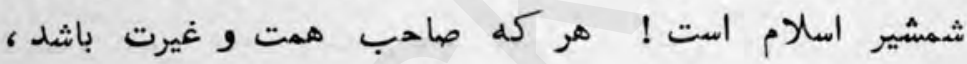

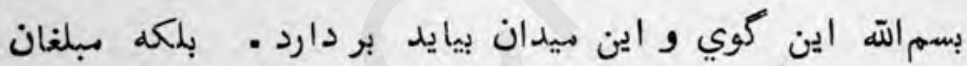

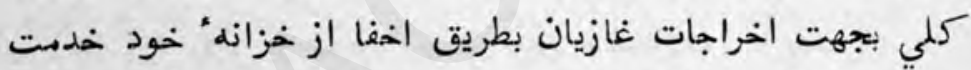

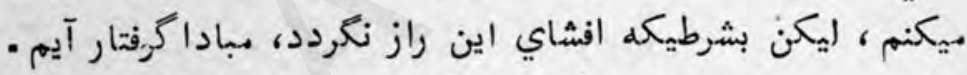

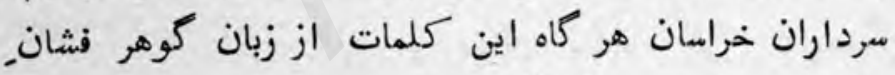
اولياي دولت شنيدند ، يكباركي ديم حميت و غيرتـ مرداران

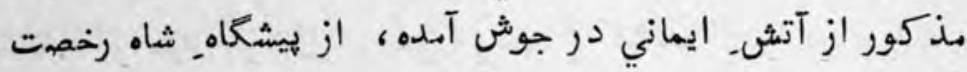
كرفته ، بجاي و دكان هاي خود آندي آمدند .

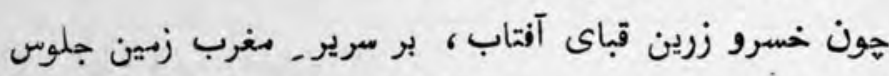

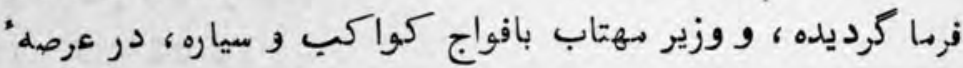

(1) 


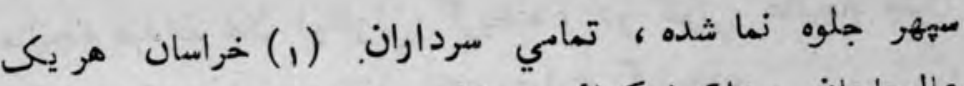

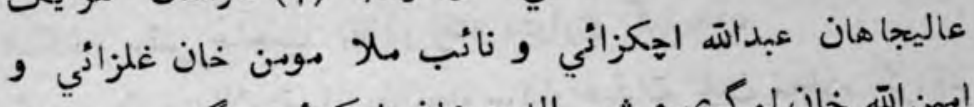

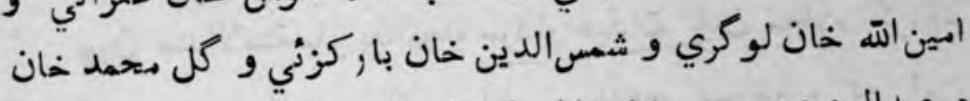

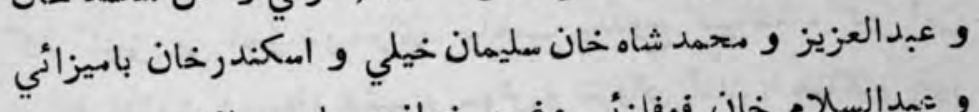

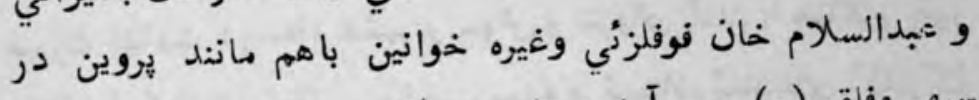

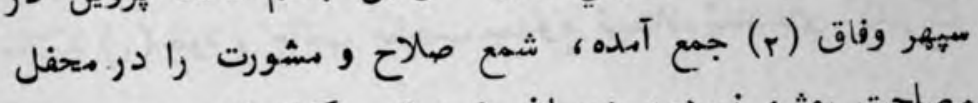

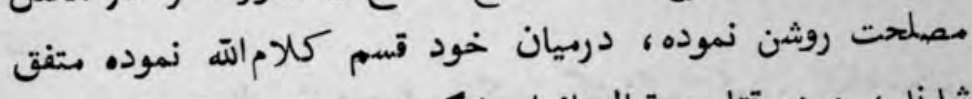

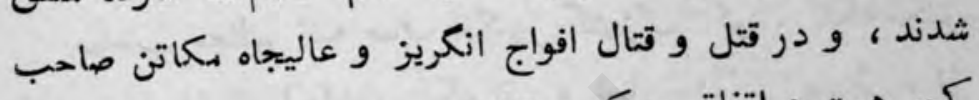

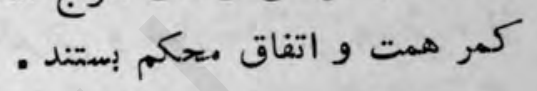

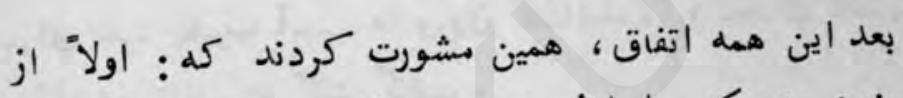

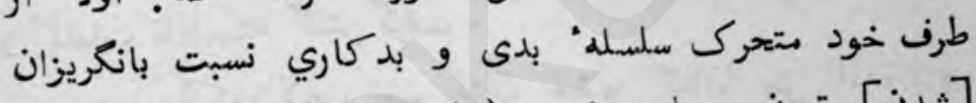

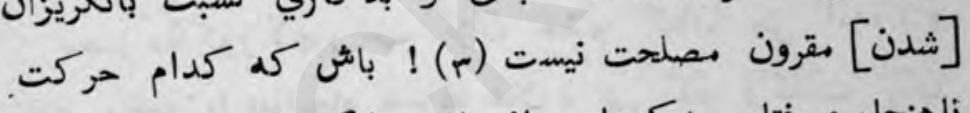

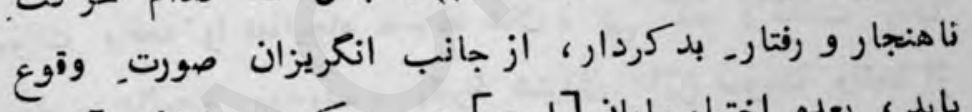

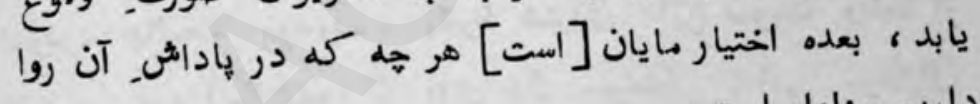

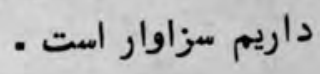

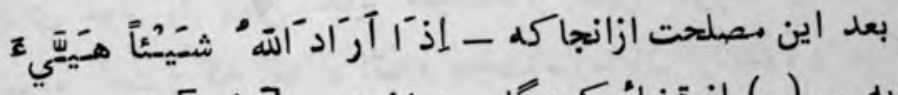

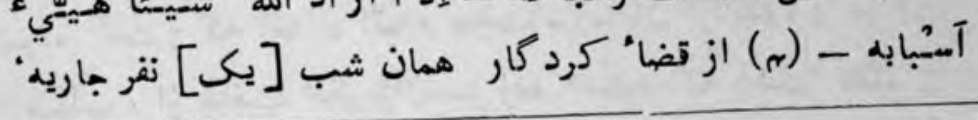

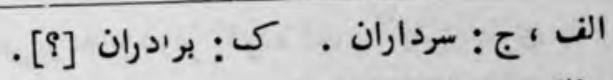

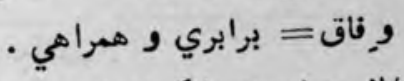

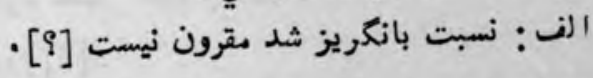

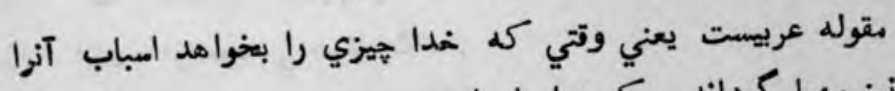

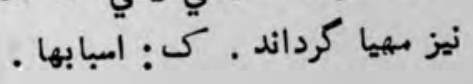




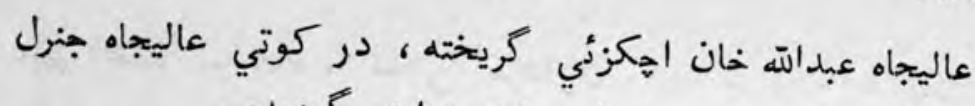

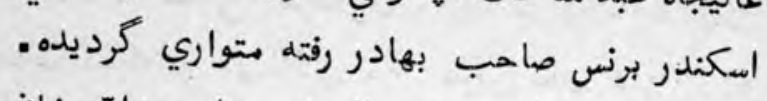

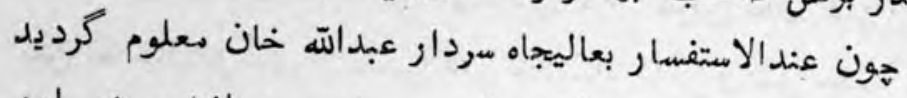

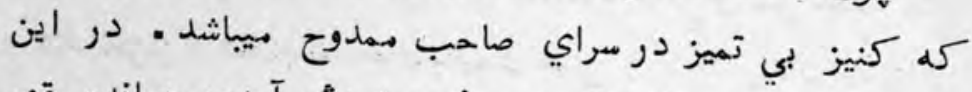

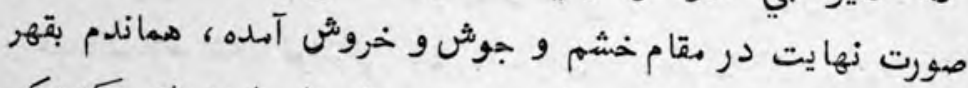

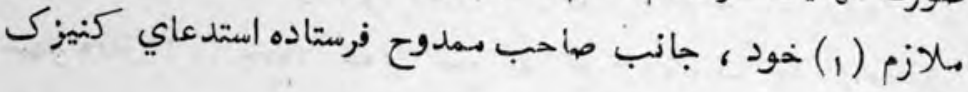

\section{نمود}

صاحب معظم اليه صاف انكار ركنيزك كرده، بلكه دعتبر

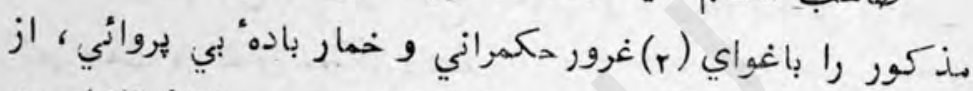

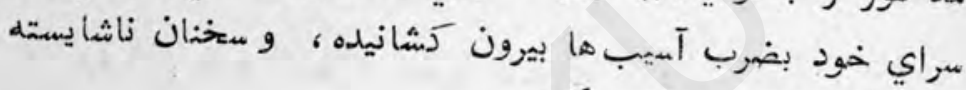

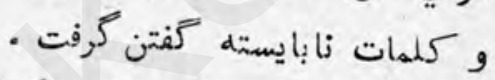

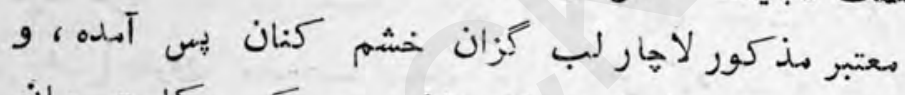

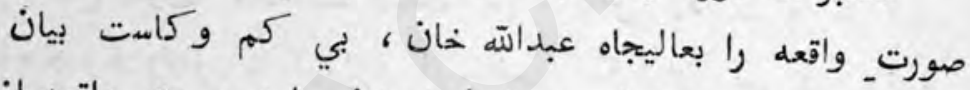

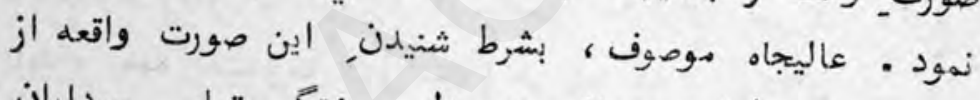

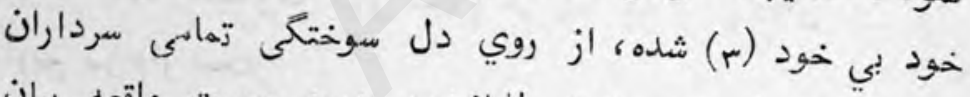

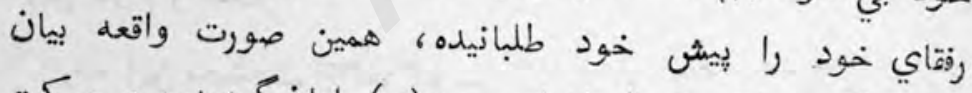

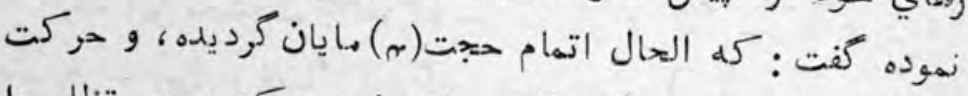

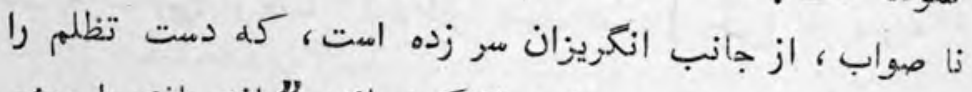

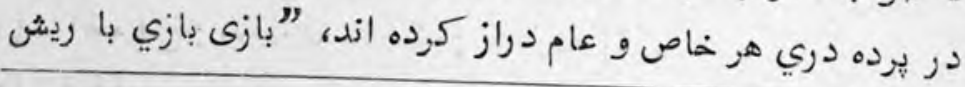

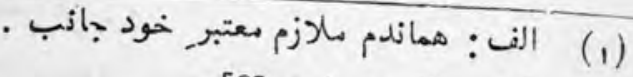

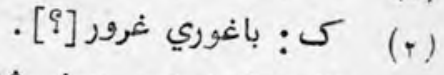

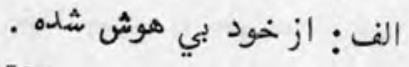

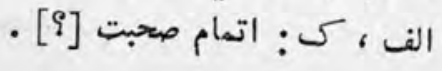


بابا هم بازي" ! اكر تدارك اين كار كنيزك كله كائيدن كنيزك انه

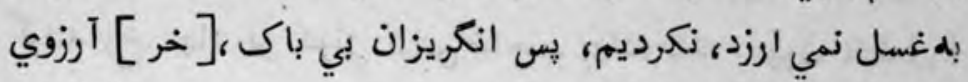

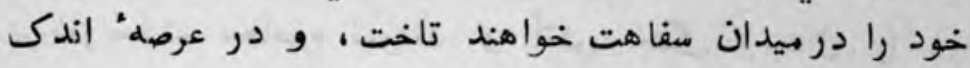

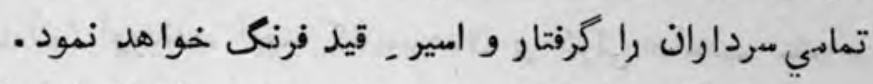

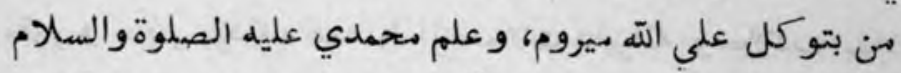

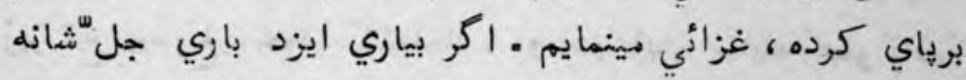

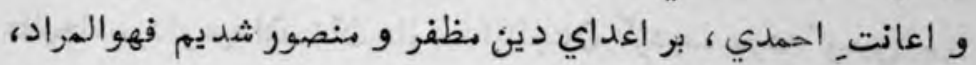

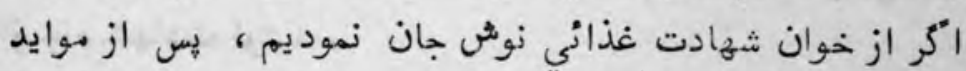

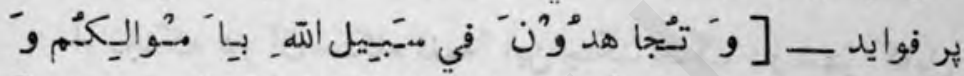

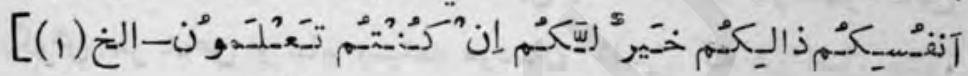

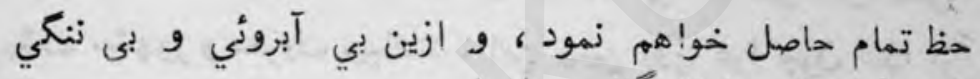

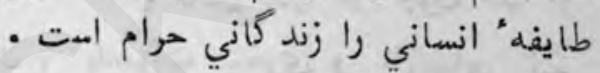

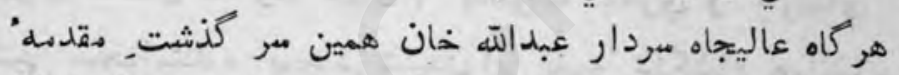

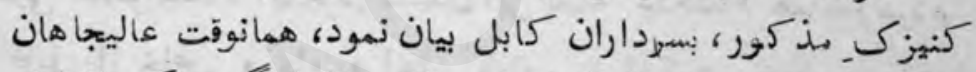

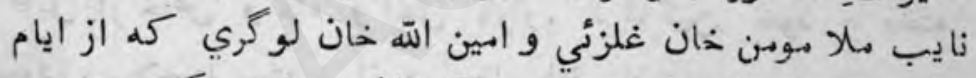

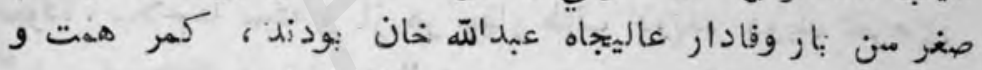

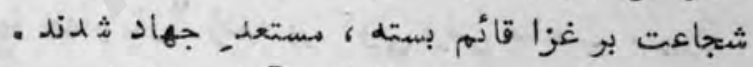

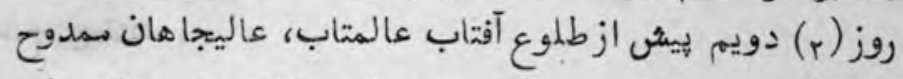

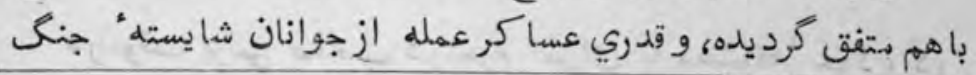

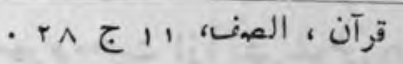

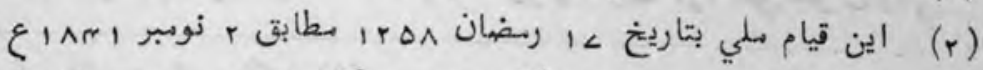

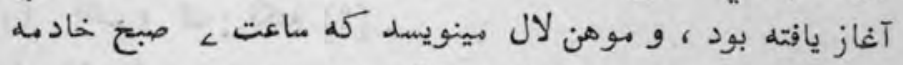

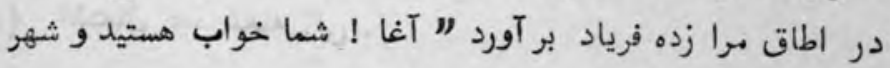

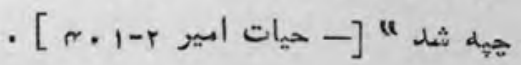


آزموده جانباز شمشير زن نيزهانداز، بهمراه ركاب_ نصرت مآب خودها ها

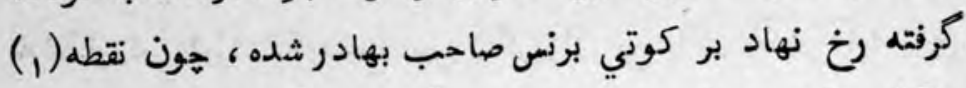

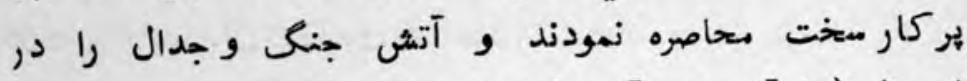

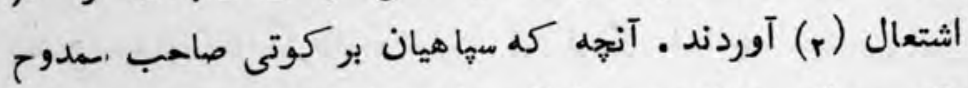

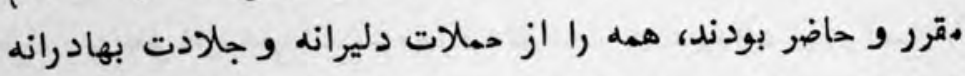

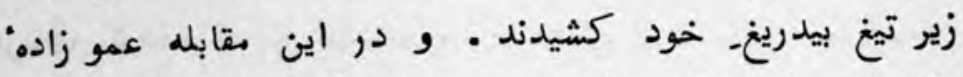

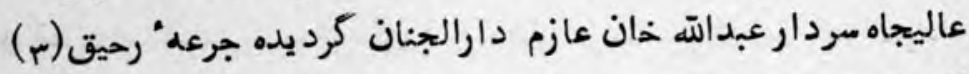

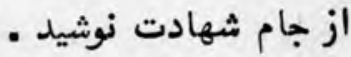

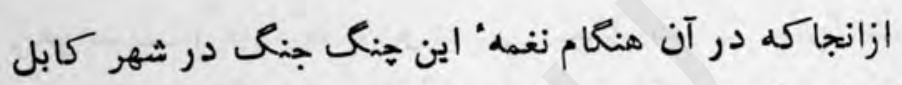

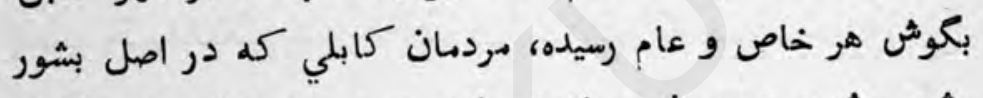

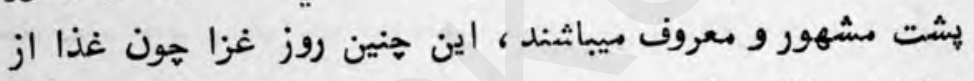

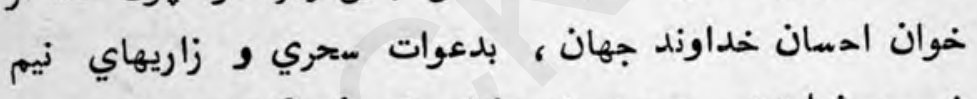

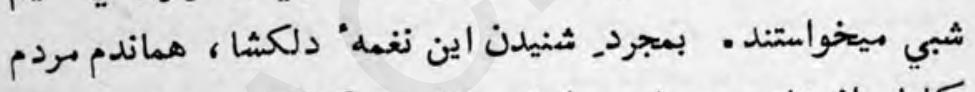

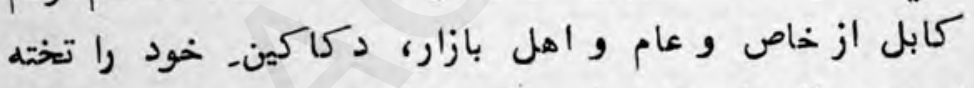

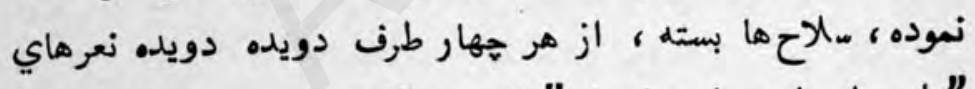

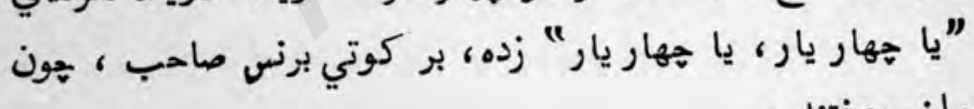

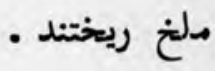
درانوقت برنس صاحب در حرم سراي با معشوقه خود ، درر

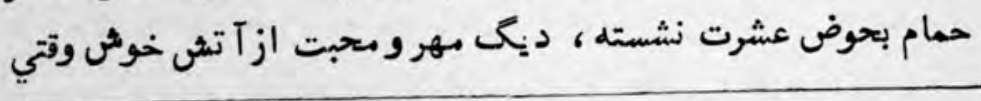

$$
\begin{aligned}
& \text { الف ، ك: نكته [؟] - } \\
& \text { اشتعال = شعله زنى . رحتى } \\
& \text { رحيق = مي }
\end{aligned}
$$


تازه نواي معاركى

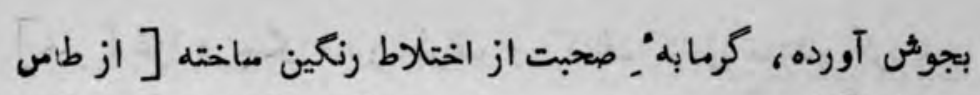

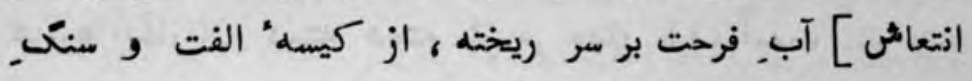

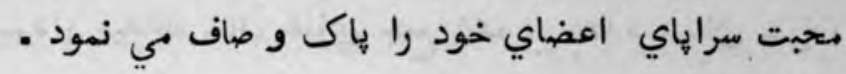

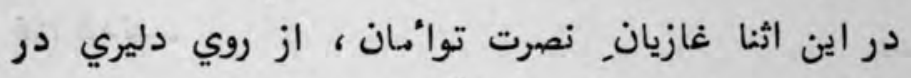

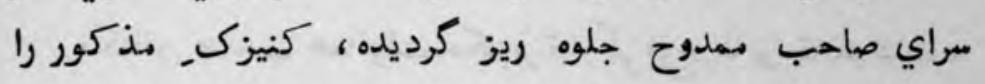

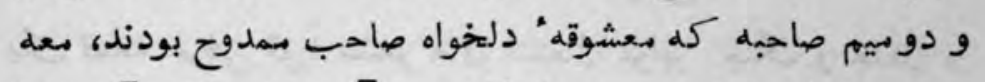

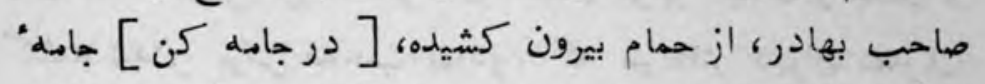

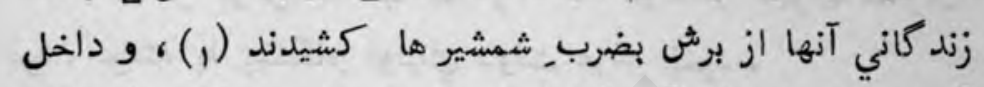

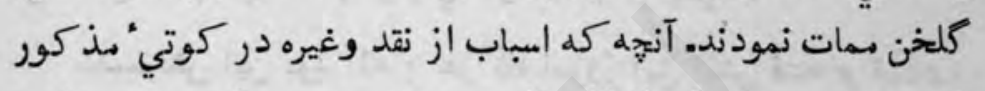

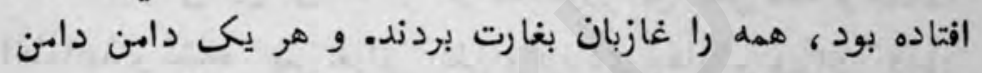

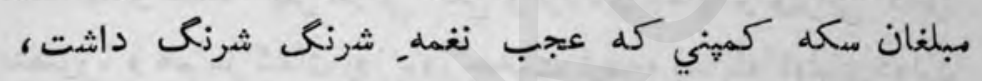

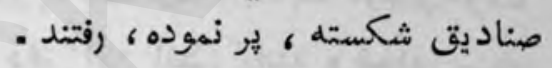

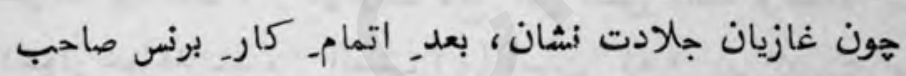

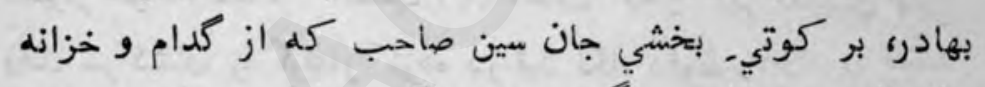

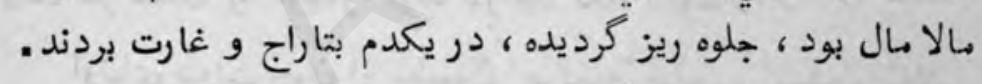

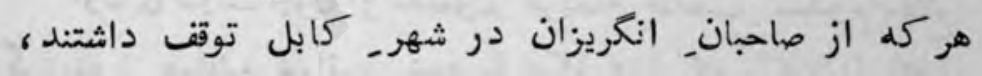

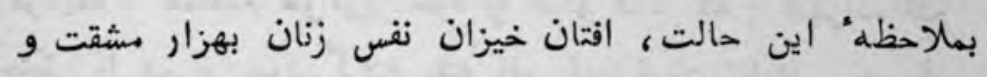

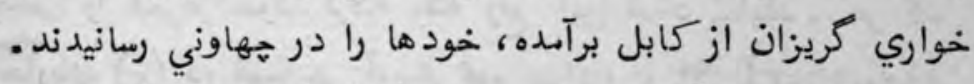

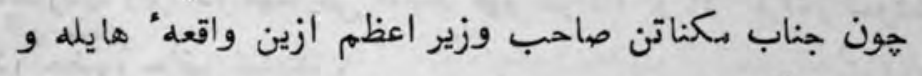

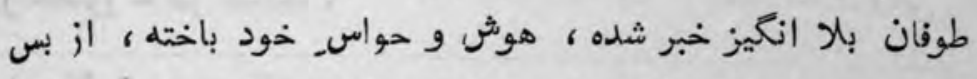

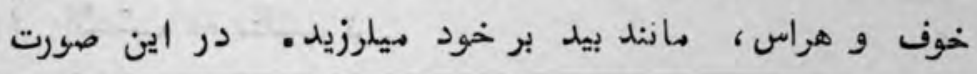

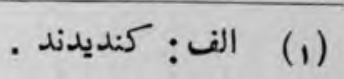


تازه نزاي معاركى

$\sim 9$.

[خبر ] غزا و جنمك ، در اطراف و اكناف كابل منتشر كرديده.

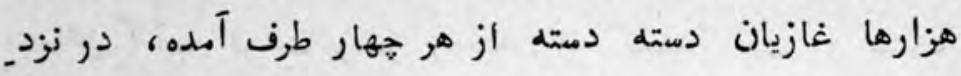

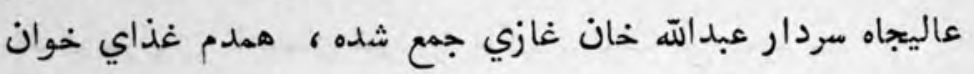

• غزا شدند .

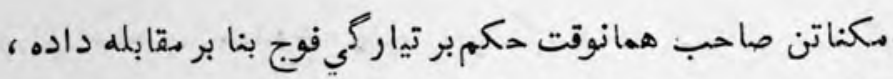

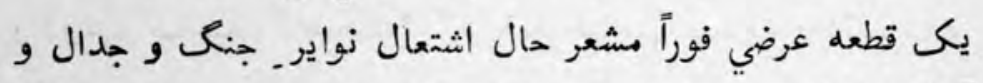

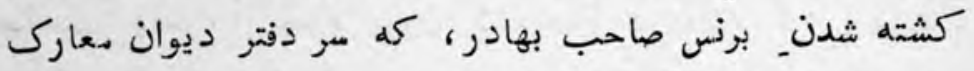

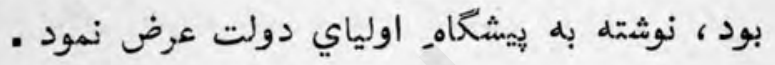

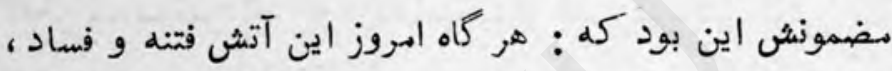

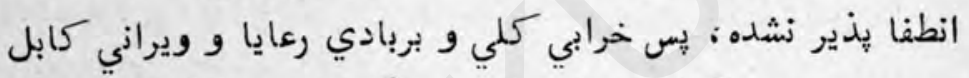

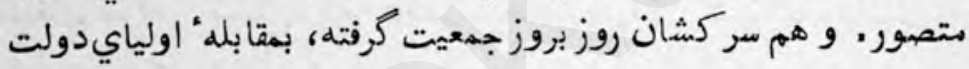

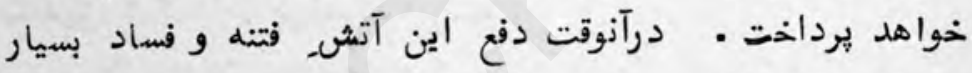

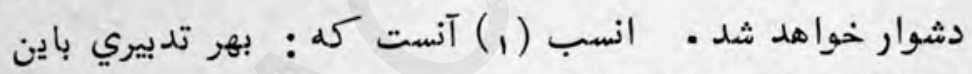

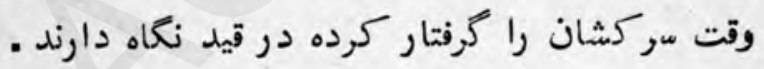

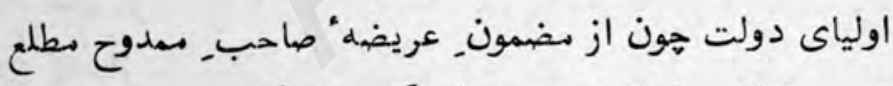

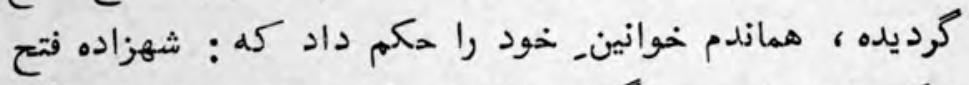

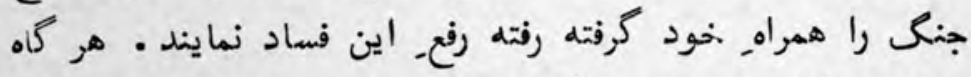

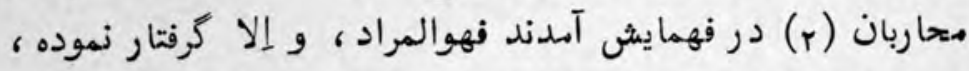

در حضور حاضر نمايند - مان

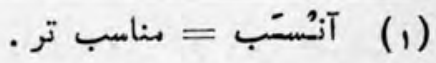

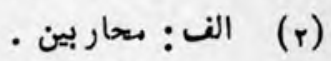




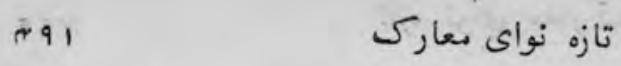

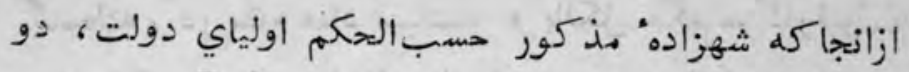

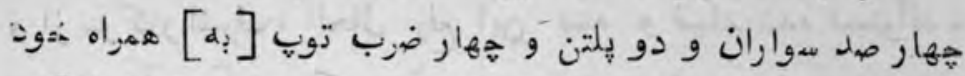

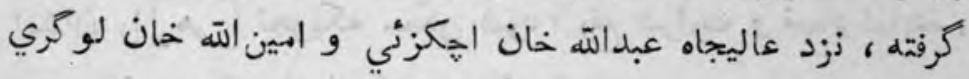

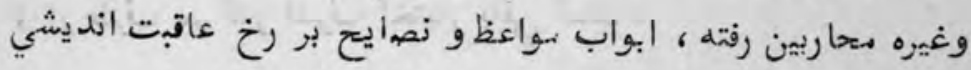

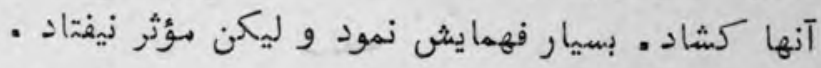

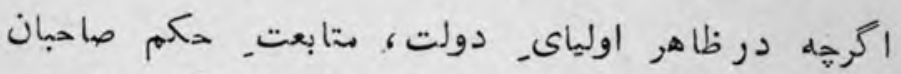

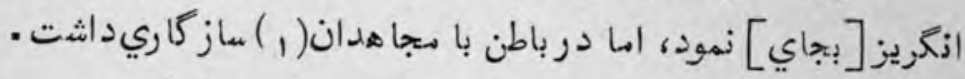

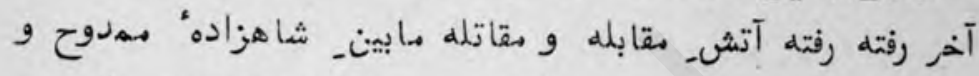

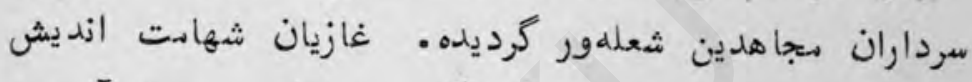
و بهادران شجاءت كيش ، يكباركي برشهزاده، همله آورده ،

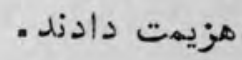

و عاليجاه متهد شريف خان ضبط بيكي دران ميدان ، زشئريف

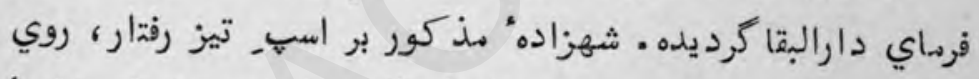

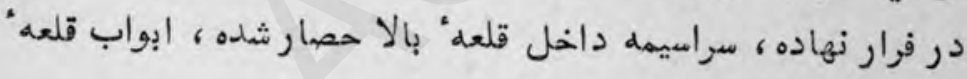

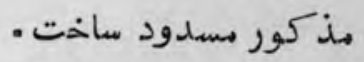

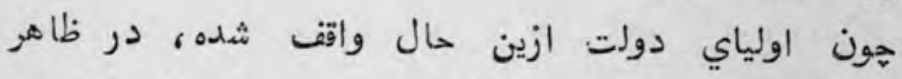

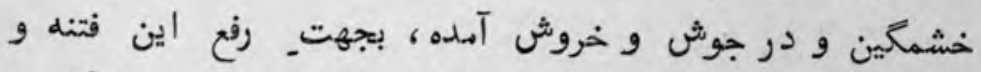

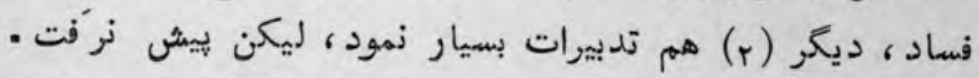

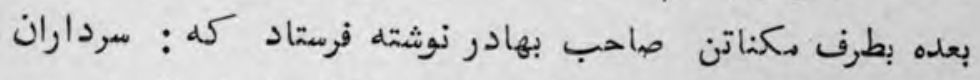

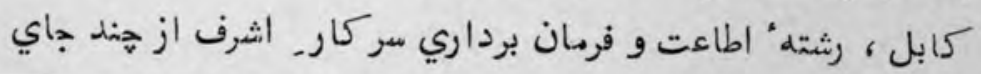

ك : با مجاهدين · ج : ندارد

(1)

• (r) 
تازه نواي معارت

$\sim 9 P$

كسيخته ، در مقام عناد ميباشند و بالكل حكم سركارقبول ندارند

و از سركار اشرف، الحال رفع اين فتنه و فساد شده نميتواند .

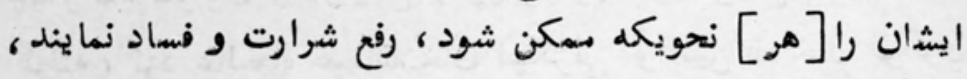

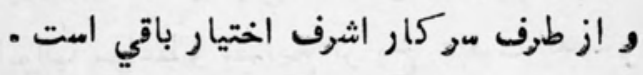

$\sim$ 
در بيانــ رفتن غازيان جلادت ذشان ( ) در قلعهء مكناتن ماحب بهادر و جنگ كردن بافوأجـ انكريز

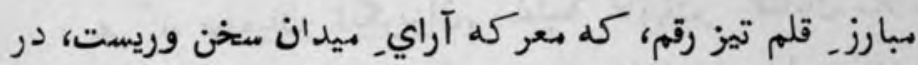

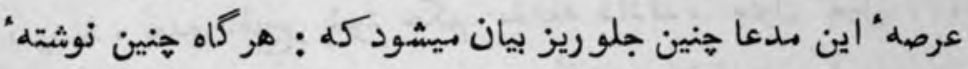

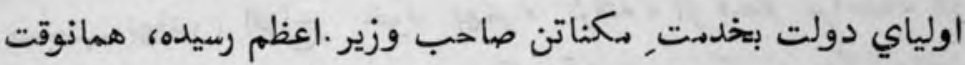

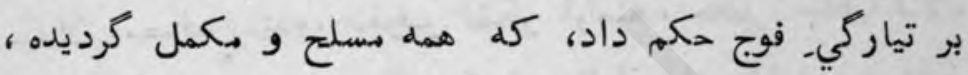

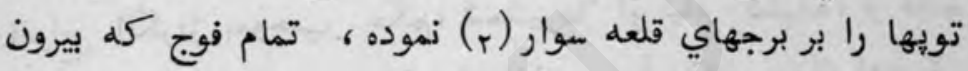

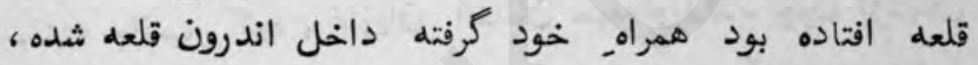

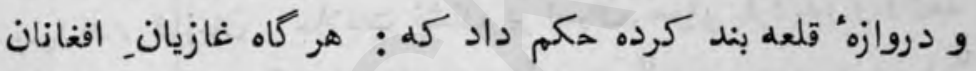

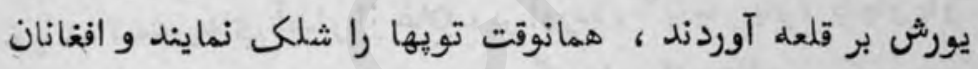

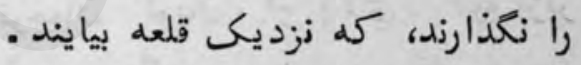

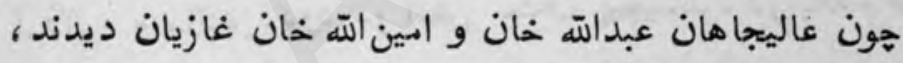

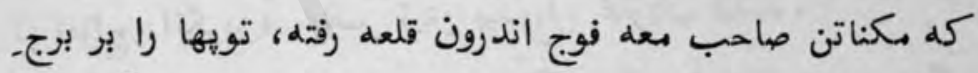

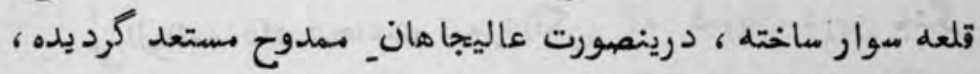
ارادة" ريتن، جانب. قلعه نمودند.

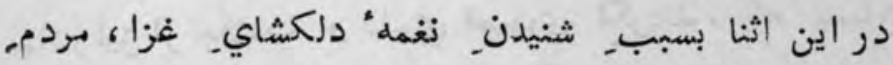

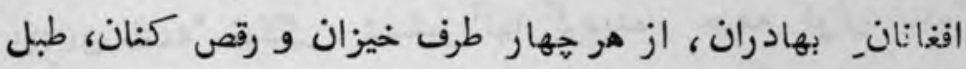

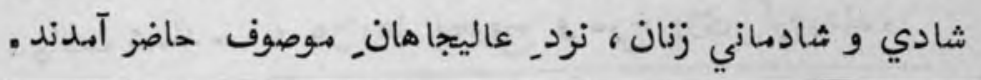

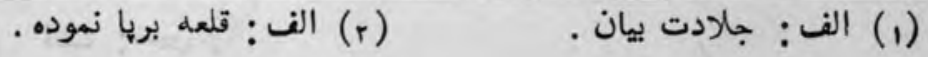


تازه نواي معاركى

तथल

هون جمعيت_ غازيان ، موفوره كرديده، همانوقت عاليجاهان

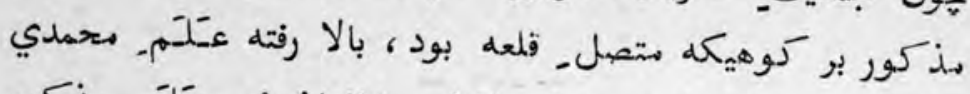

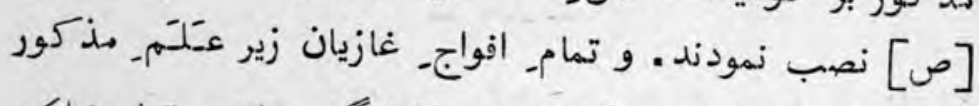

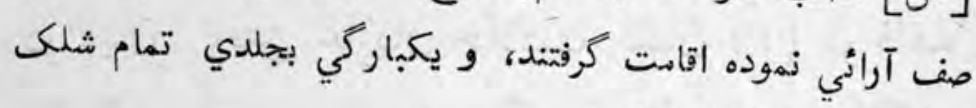

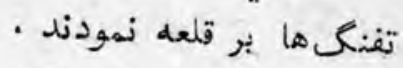

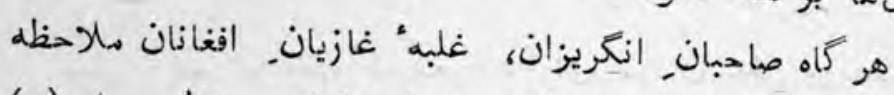

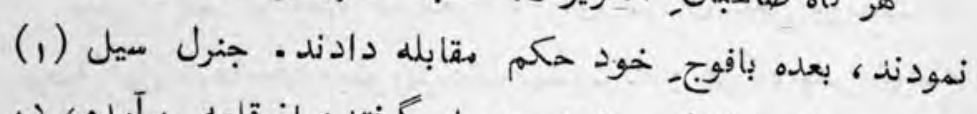

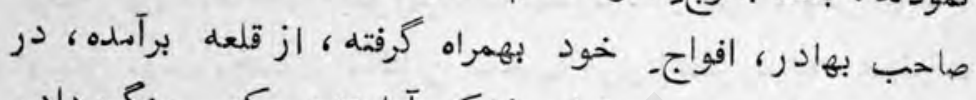

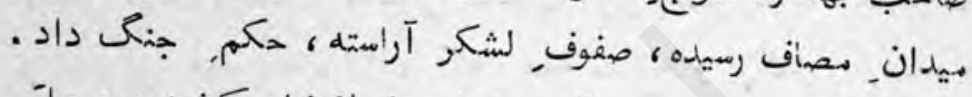

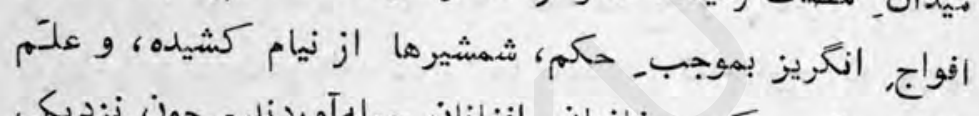

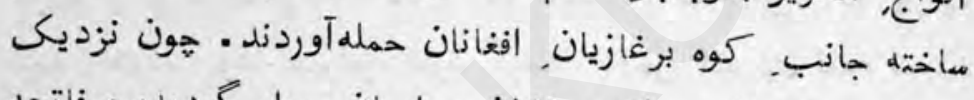

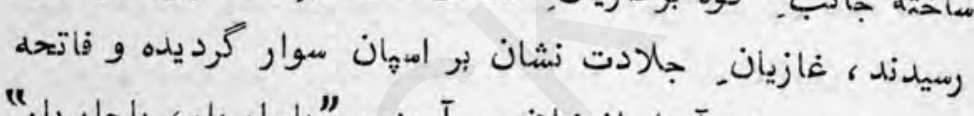

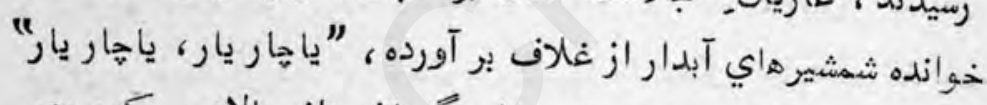

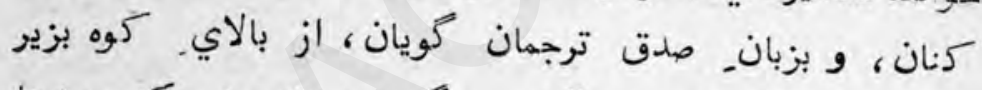

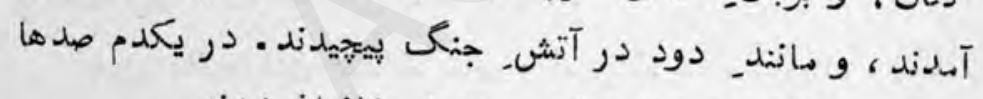

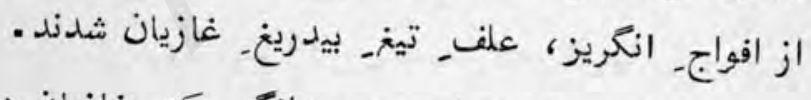

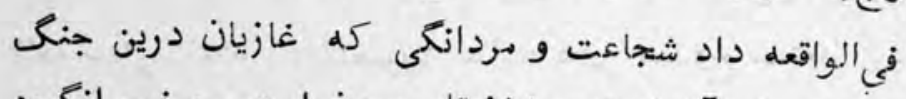

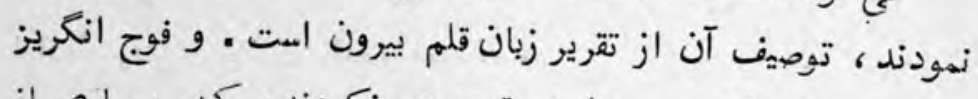

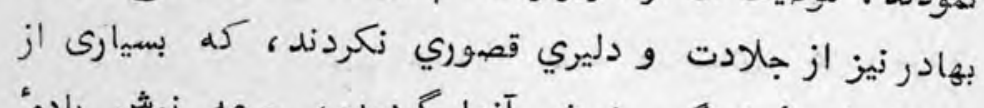

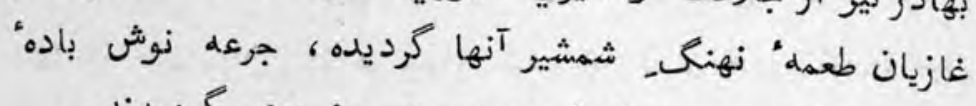
شهادت شدند. . هزارها مجروع و سرخ روي كرديدند.

[؟] 
$\pi 98$

تازه نواي معاركى

آخر غازيان از ميدان رزم هِ هاي شدند، و و جانب كوهستان

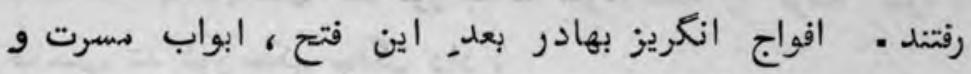

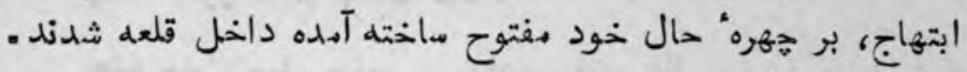

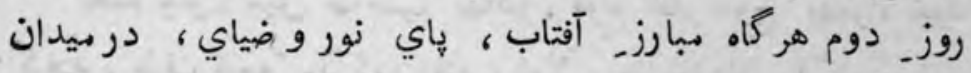

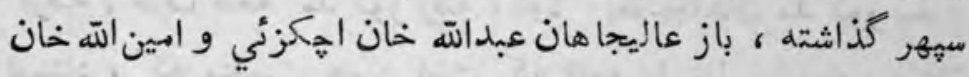
لوكري در باب غارت نمودن كدام مركارى بأهم مشورت نموده ،

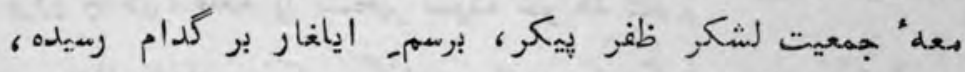

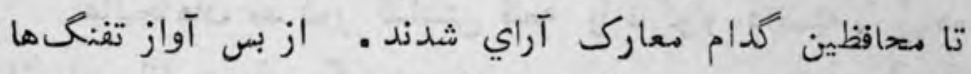

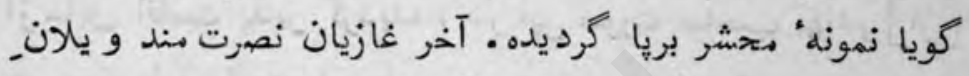

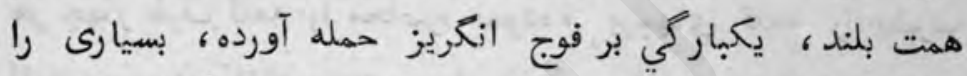
رهاراي مطموره " (1) نيستي نموده ، تمام اسباب كدام از جنس

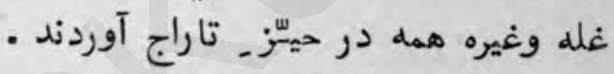
عاليجاهان ملنكور بعد حصول اين فتح و فيروزي ، تشريف فرماي يك قلعه كله متصل قلعه شاهي بود كرديده ، سامان كمام مغروته (r) در آن قلعه نكاه داشته بلا فرصت طرف قلع فه صاحبان

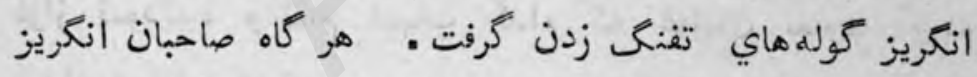
دليري و شجاعت از غازيان ملاحظه نمودزيد نهايت (r) درشئدر

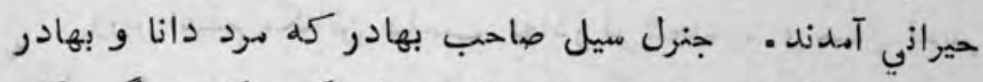

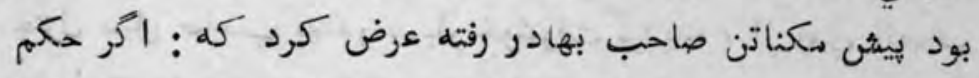

مَطمُوره = بدفن و جاي زير خاكى نهادن و ته خانه [-غياث] .

(1)

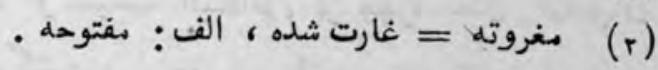

. 
تازه نواي معاركى

49

باشد كل بعاليجاهان مذكور جنح أموده قلعه را كرفته شود .

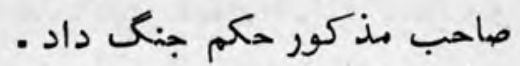

بعده جنرل سيل صاحب بهادر، فوج ظفر بوج بهمراه خود

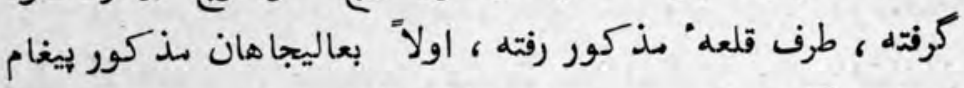

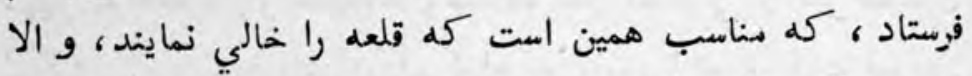

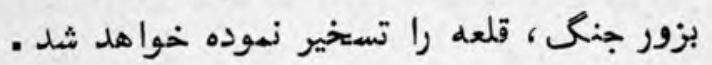

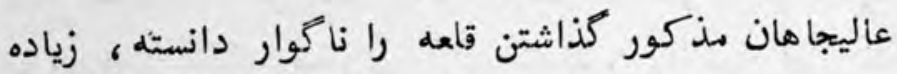

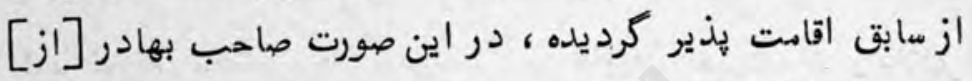

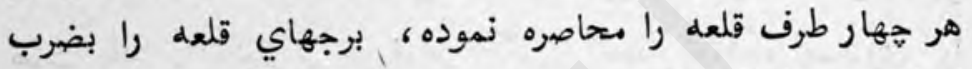

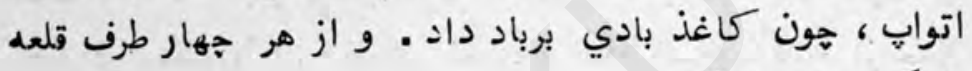

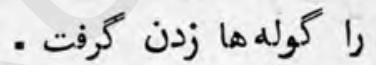

عاليجاهان مذكور از روي مصلحت ، به جوان مردي و همت

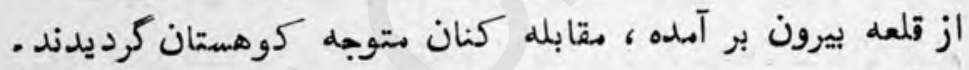

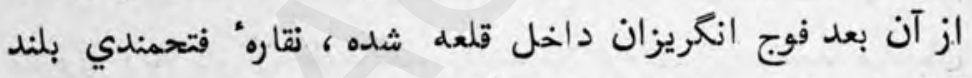
آواز نمودند، و تمام اسباب كدام كه غازيان بغاوت آورده

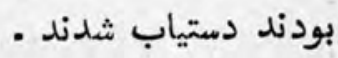

وزير اعظم مكناتن ضاحب بهادر از شجاعت و حسن تدبير

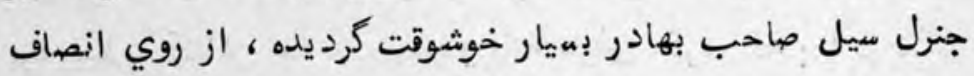

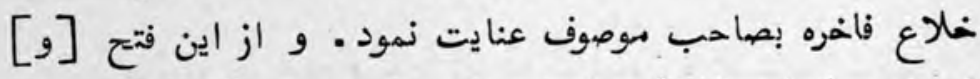
فيروزي، ابواب نشاط و اسباب انبساط، بر حهره مال صال صاحبان

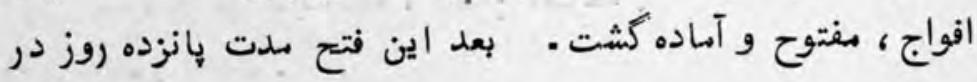


$\mathrm{NQ}_{2}$

تازه نواي معارك

كلمتان شهر كابل ، كُلهاي امن و امان از نسيمم آرام ستبسم شدند، و خار شر و فساد در ياي الستراحت احدي و فردي نخليد،

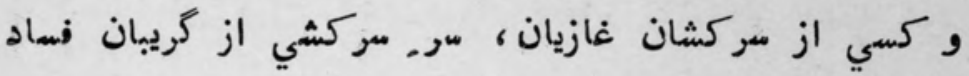

- بالا نكردند 
در بيان_ آذكه بعد يانزده روز عاليجاه عبدالله خان

$$
\text { و امين الله خان }
$$

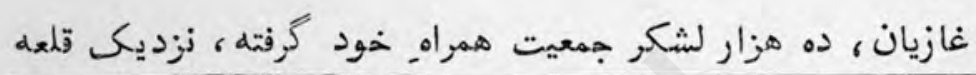

بناي جنى نمودند [و شهادت عبداله خان الجكزئي]

غازي قلمه نصرت رقم ، در غزاي اين بهم هنين نعارثر.

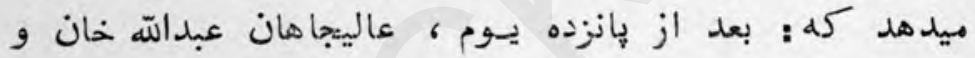

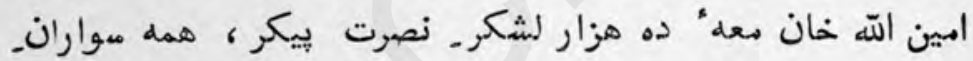

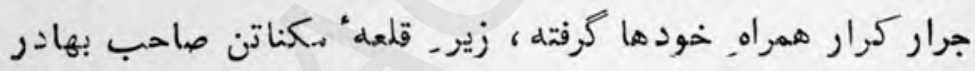

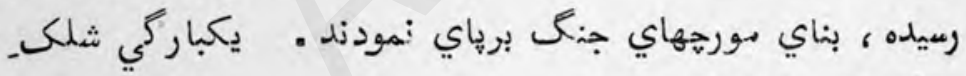
تفنگ ها بر قلعه نمودند .

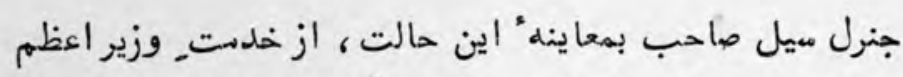

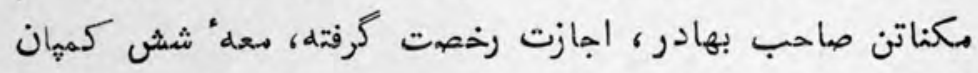

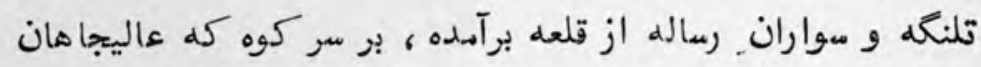

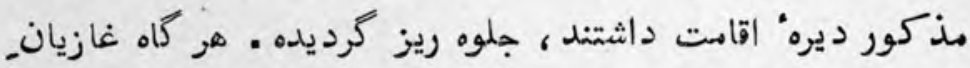

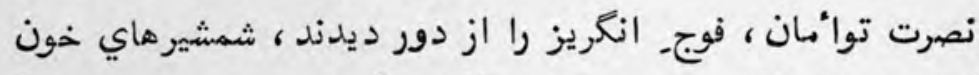

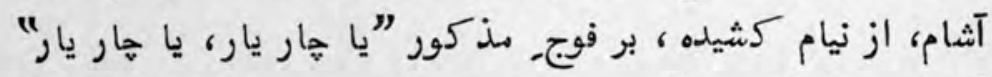

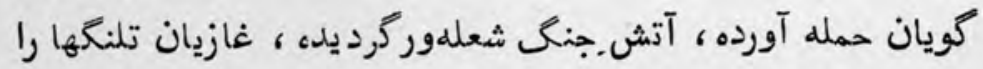


ก ११

تازه نواي مeارك-

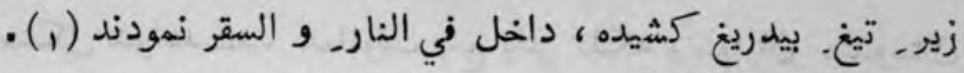

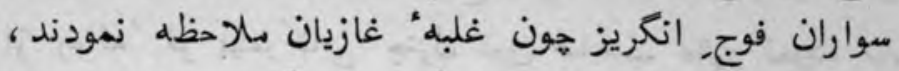

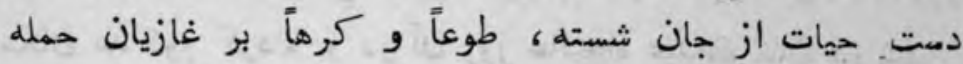

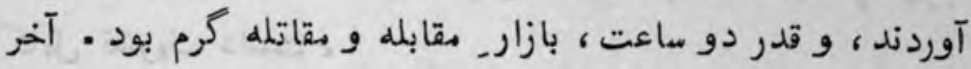

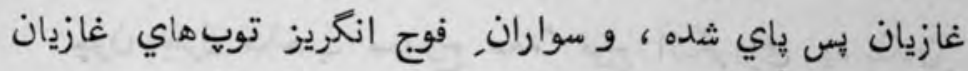

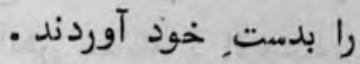

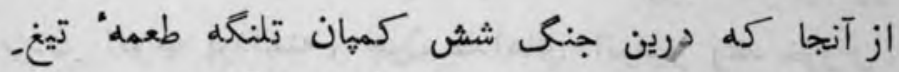

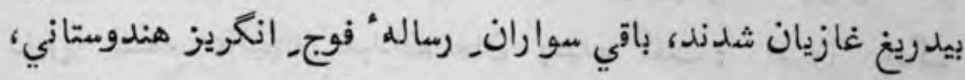
همت و جوان مردي نمودهه ، فتح_ اين جنم نمودند . جنرل سيل صاحب بهادر از شجاءت و جوان مردي سواران, هذكور نور نهايت

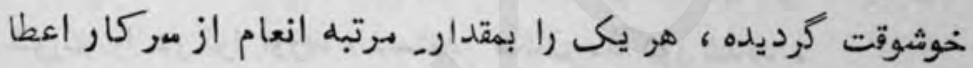

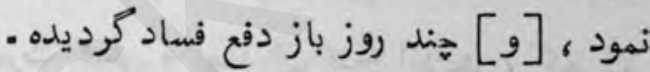

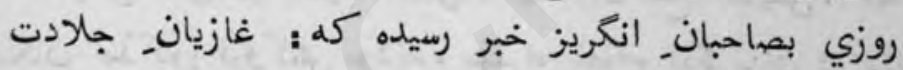

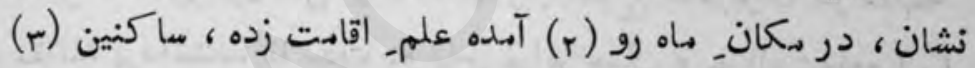

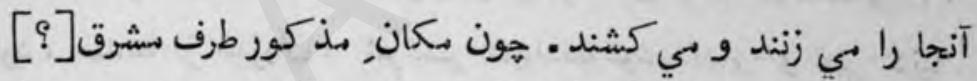

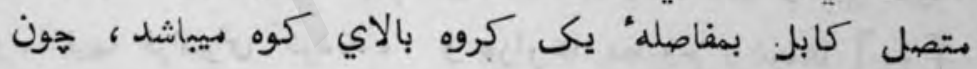

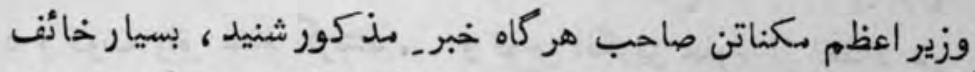
كرديده ، به جنرل سيل صاحب به بهادر كفت كاته كه : هر كاه غازيان

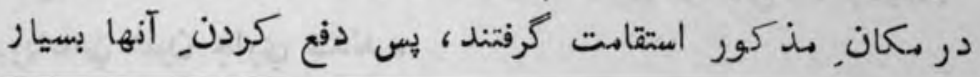
. الف (1)

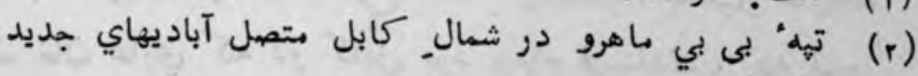
واقع است. (r) 


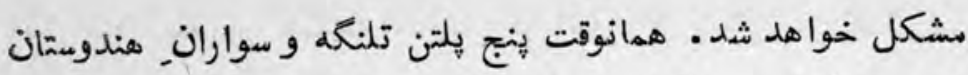

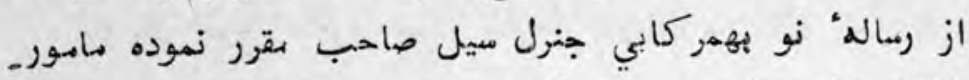

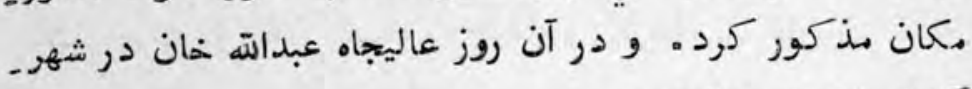

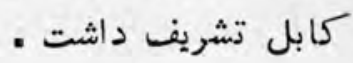

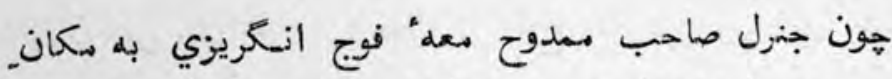

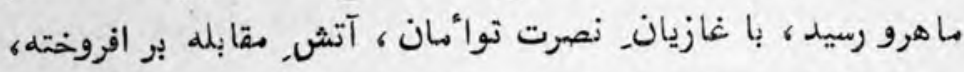

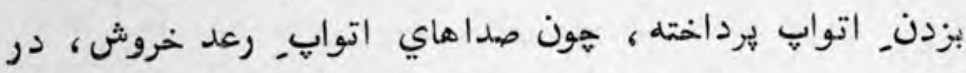

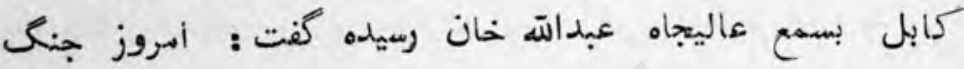

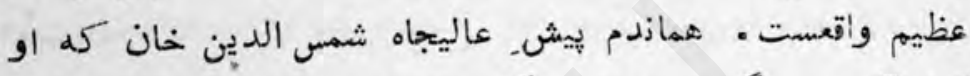

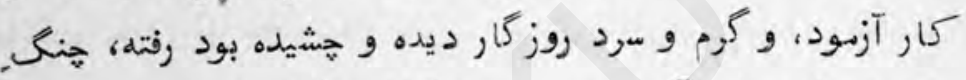

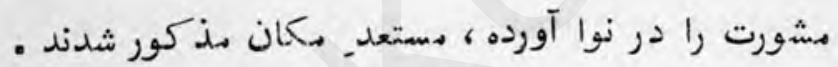

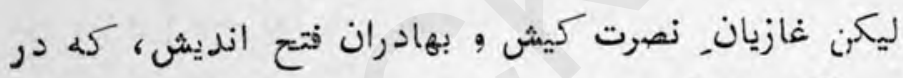

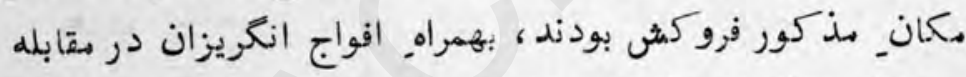

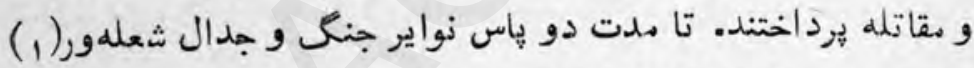

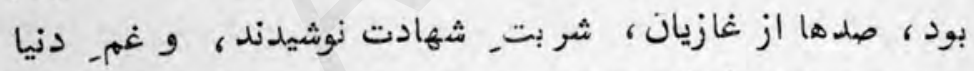

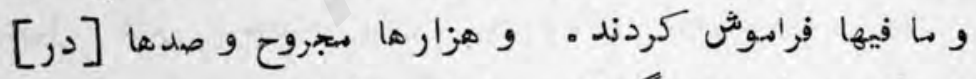

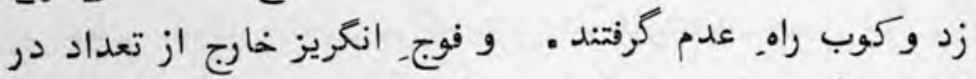

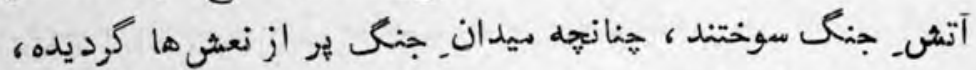

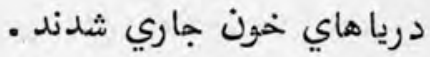

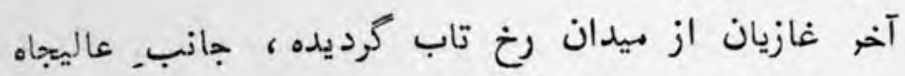

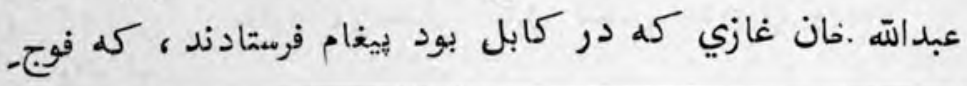

$$
\text { كى: شعبه ور [?] }
$$


تازه نوايى معاركى

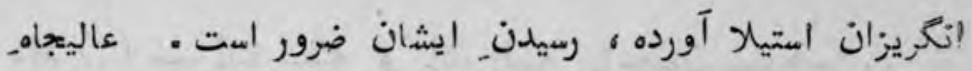

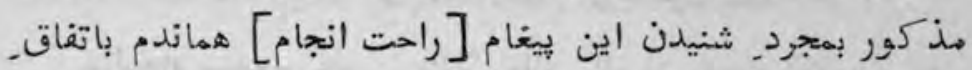

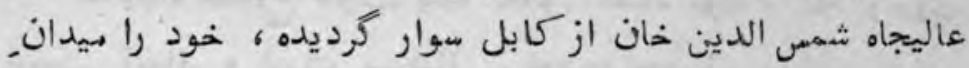

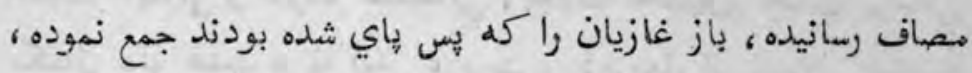

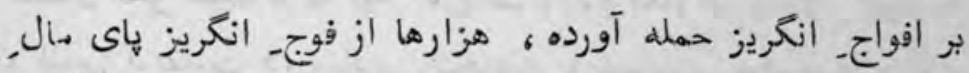

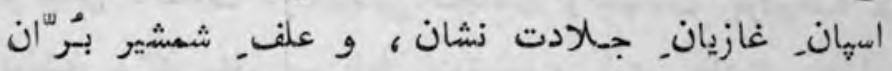

كرديدند

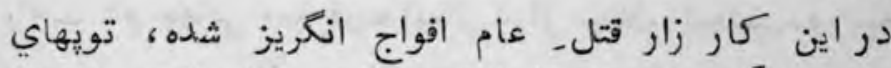

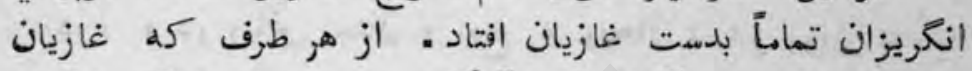

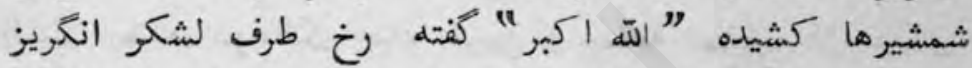

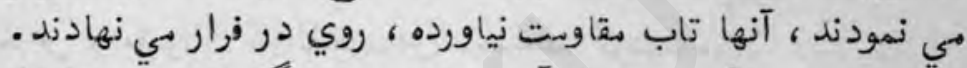

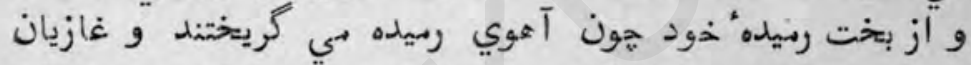

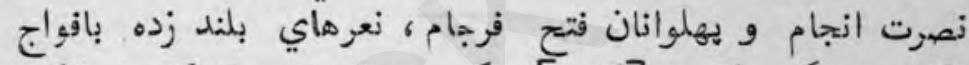

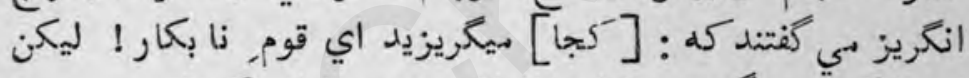

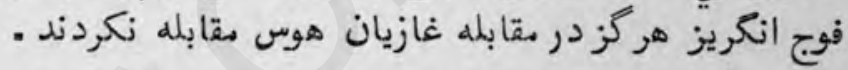

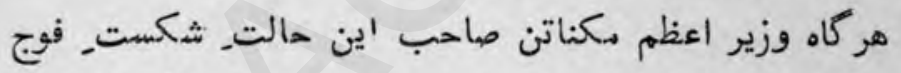

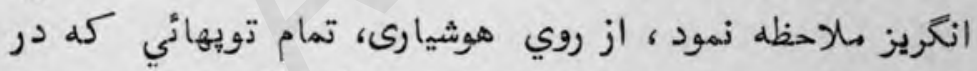

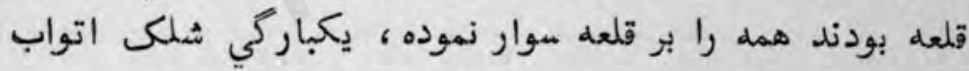

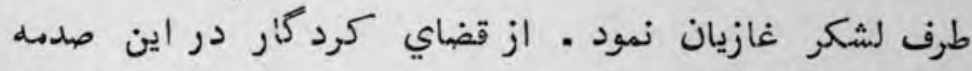

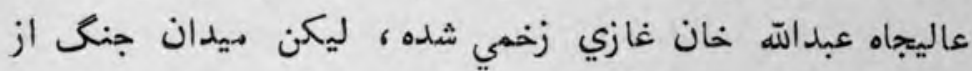

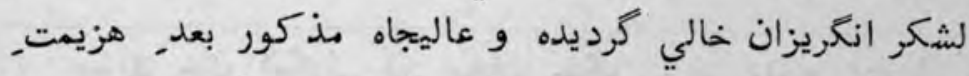

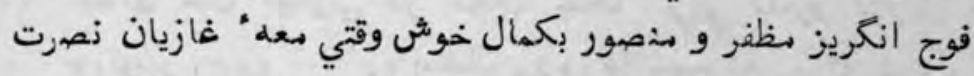

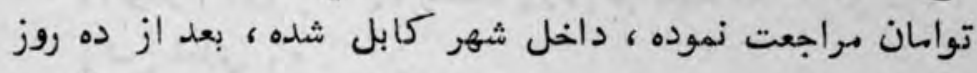

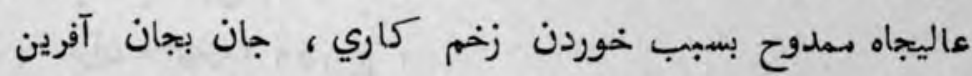


تازه نواي معاركى

D.P

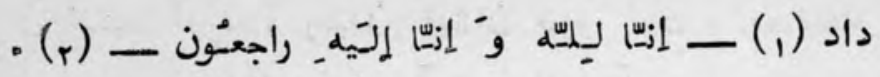

عاليجاه مهدوح عجب بنده" خالق العباد بوده، كله از روي حميت_ ايماني و غيرت_ مسلماني ، بجهت تحصيل ــ رضاي يزداني

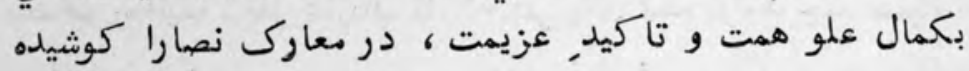

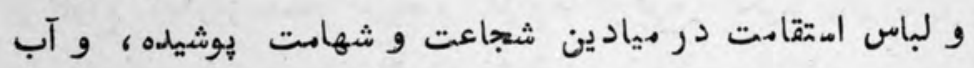

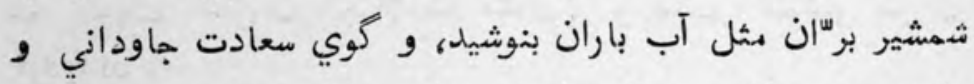

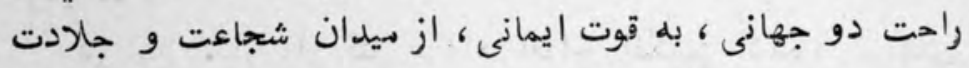

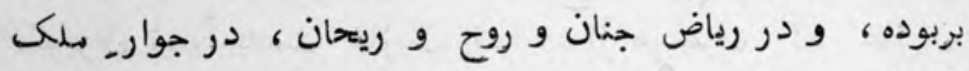

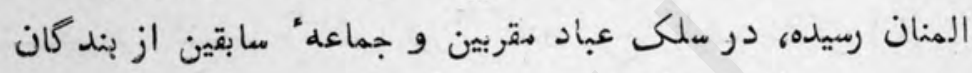

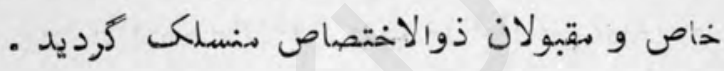

(1) عبداله خان إهزني در ميدان جنك بي بي ماهرو بتاريغ

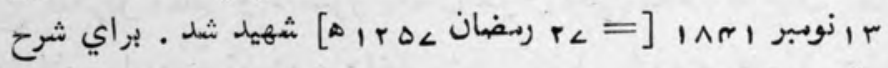

رآ

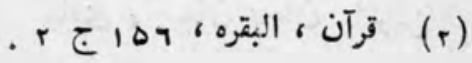


$-\angle \mu-$

در بيان آمدن, سردار معمد اكبر خان از بخارا

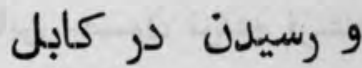

و ملاقات نمودن بعاليجاه دكناتن صاحب بهادر و كشتن, او دابل اكبر ناسهار. قلم. شجاءت رقم ، به جيوش اناسل ــ (1) تجزير

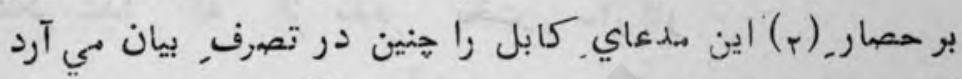

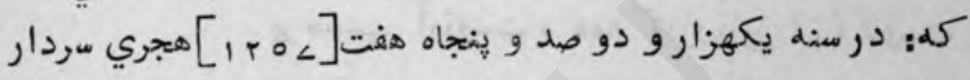

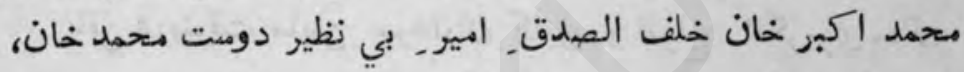

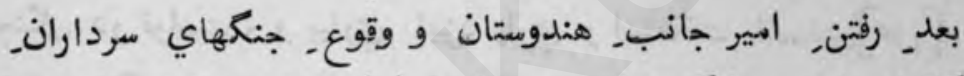

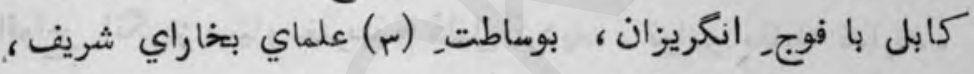

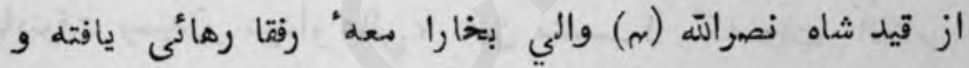

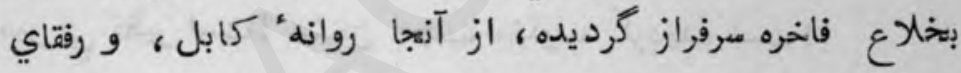

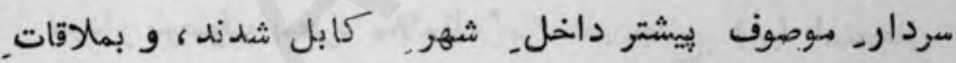

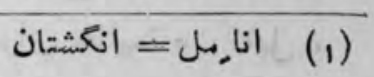

كى، الف: بر حضار [؟] ولي بر حصار همان بالا حصار است.

$(r)$

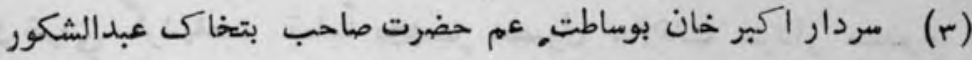

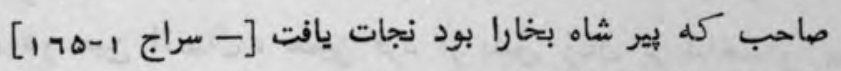

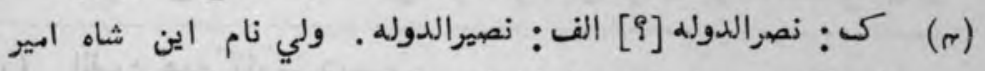

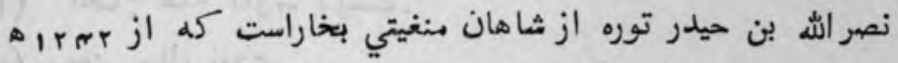

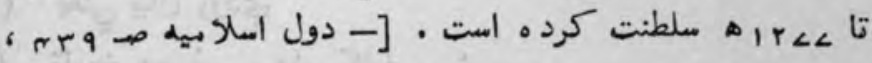

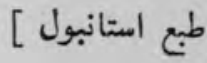




\section{عزيزان و دومتان خوشوقت كرديدند.}

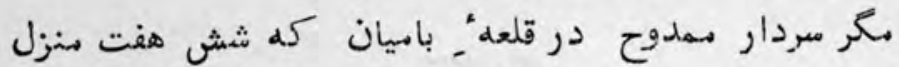

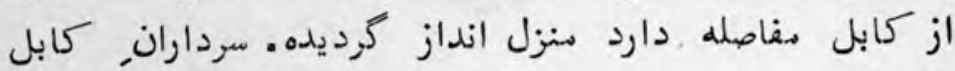

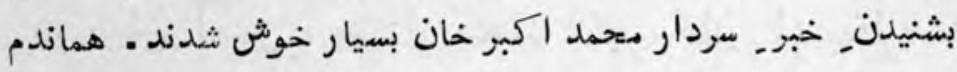

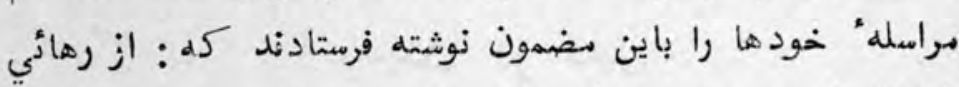

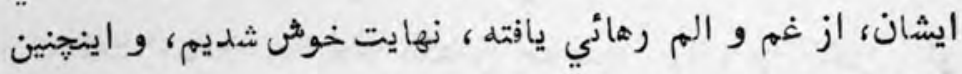

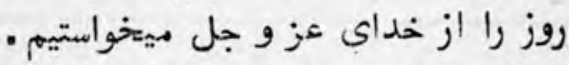

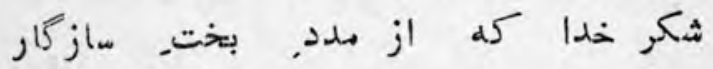

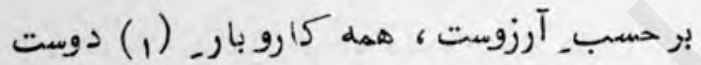

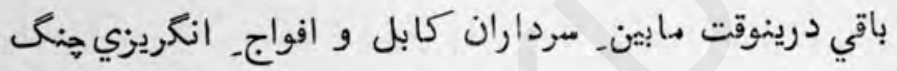

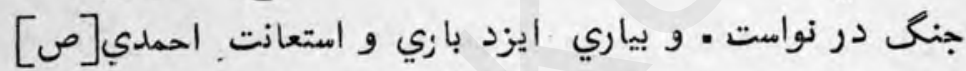

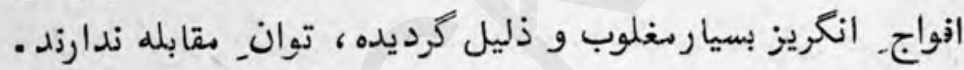

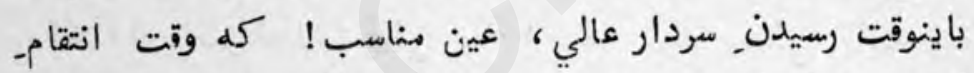

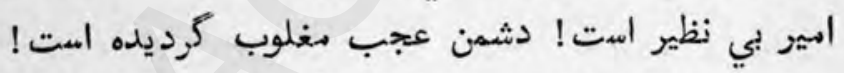

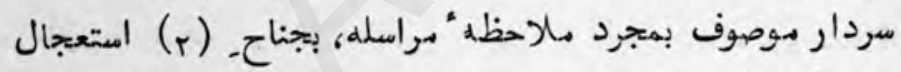

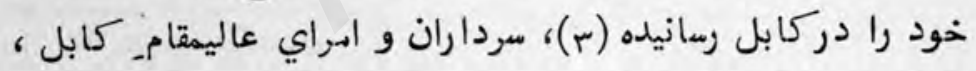

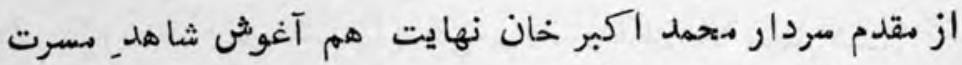

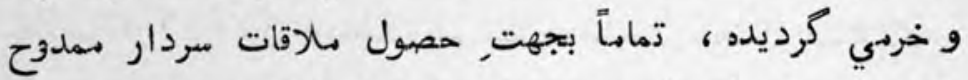

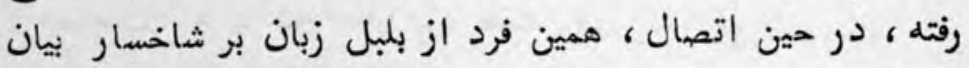

$$
\text { الف : همني ببال زوداريا درست. }
$$

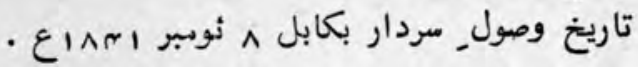


$\Delta . \Delta$

تازه نواي معاركى

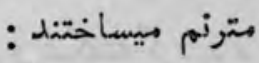

خوث آبدي كله خوث آهد مرا ز مآمدنت

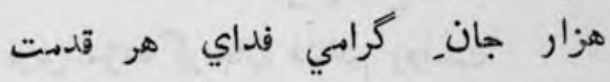

ليكن اولياي دولت را از آمدن سردار محمد اكبر خان اين

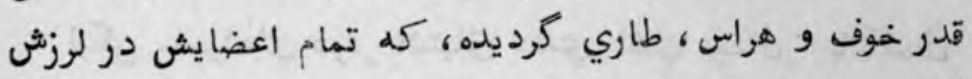

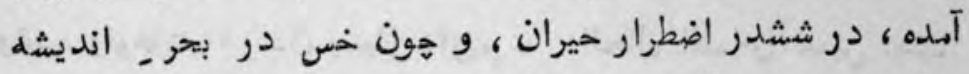

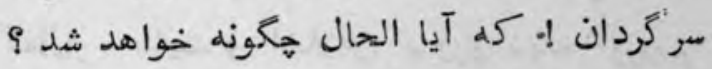

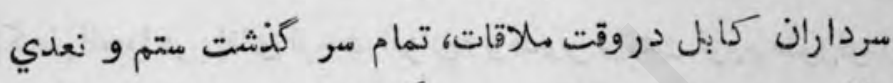

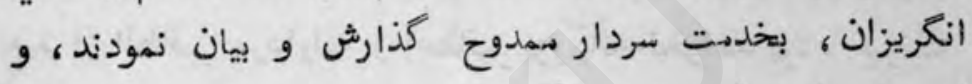

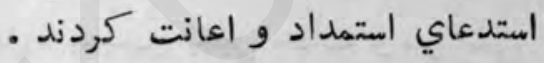

سردار سمدوح از هر قسم و رسم ، بخاطر جمعي و تسلاي

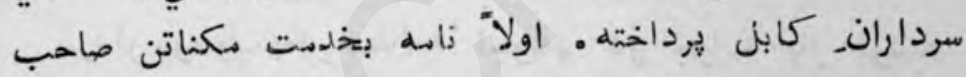

وزير اعظم ، در خصوص كمال الشتياق و آرزوي مالاقات و تشئيد

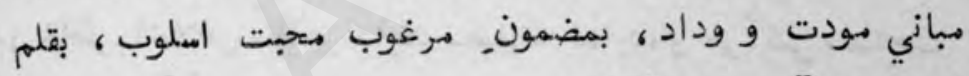

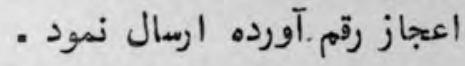

وزير اعظم بعد مطالعه" نامه" دلكزين جان روباي سردار

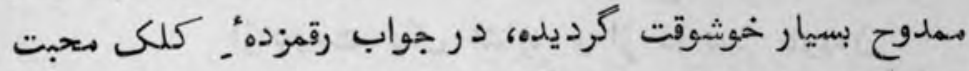

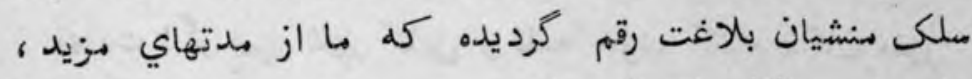

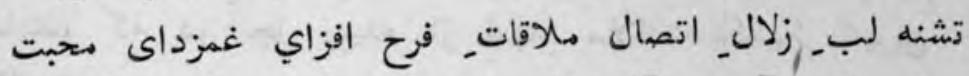

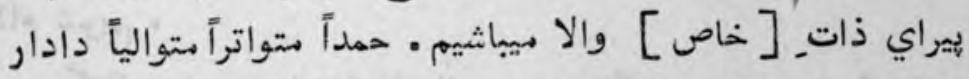

جهان را است كله : ازذلت و خوارى قيد والي بخارا كمه نصيب اعدا باد، رهائى يافته، سالماً و غانماً تشريف فرماي كابل فرايل ولايت 
تازه زواي معارك

0.7

مالوفه گرديده اند. ازينهعني انواع انواع كلواي زشأط ، و اقسام

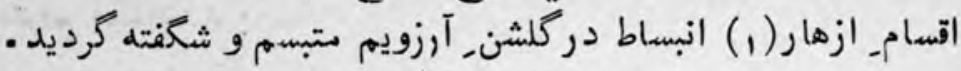
[بيت

برين مثده كر جان فشانم رواست

كه اين مثره آسا يش جـ جان ماست ماست

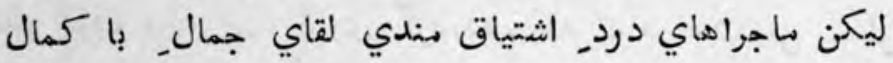

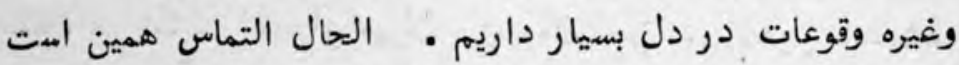

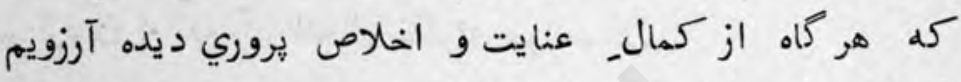

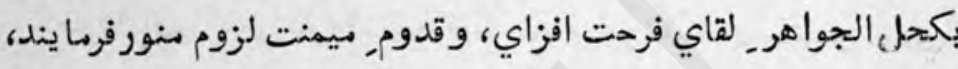

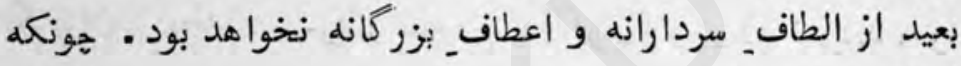

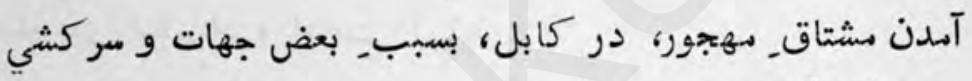

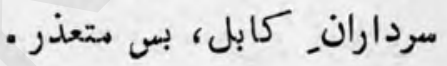

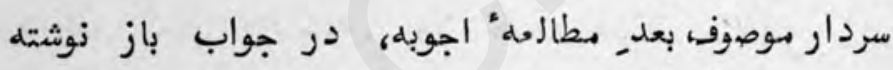

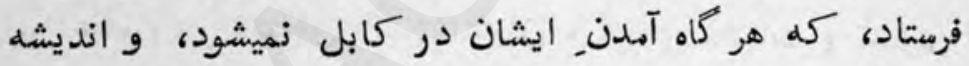

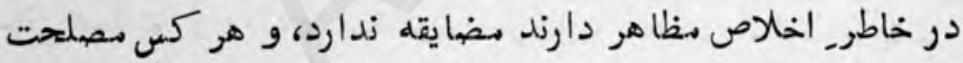

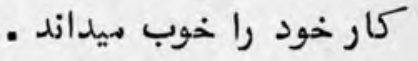

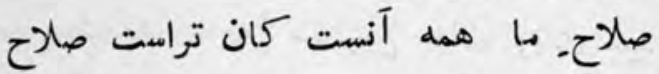

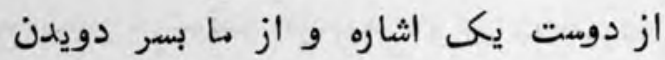

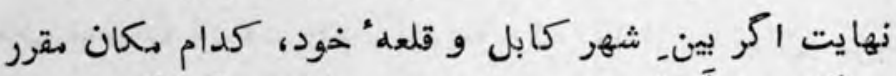

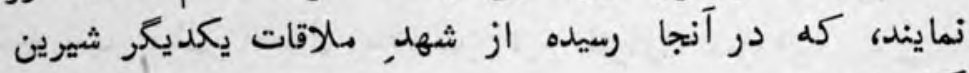

- كام شويم

مكناتن صاحب وزير اعظم ازين معني انكشتــــــا رضا بديدهُقبول

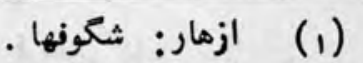


قبول نهاكه، مكاتى را بجهت_ ملاققات، تعين نمودند . روز_ دويم

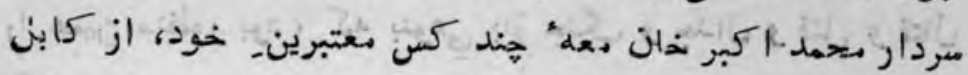

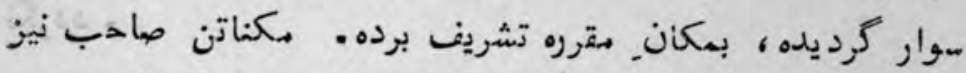

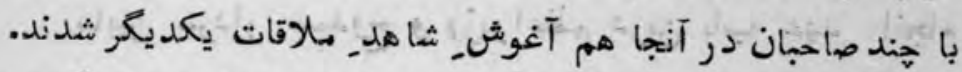

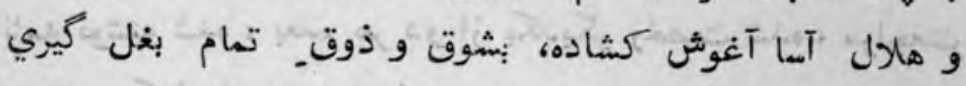
ما بين_ خود ها نمودند بعد صفا و مرحما خلوت كزين كرديدند ، و درو خلموت_ خاص

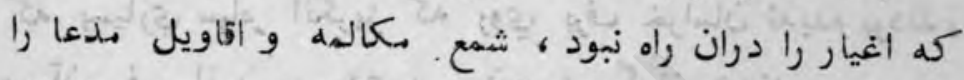

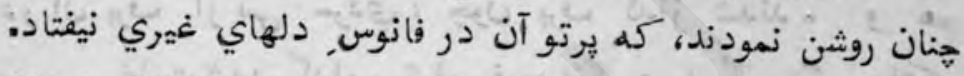

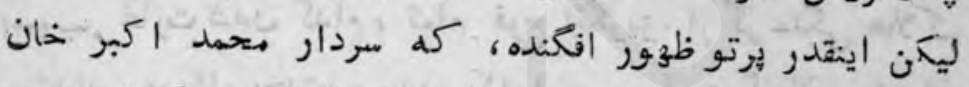

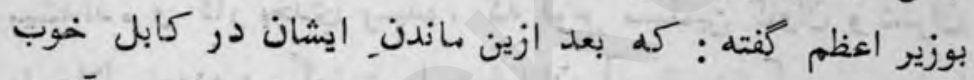

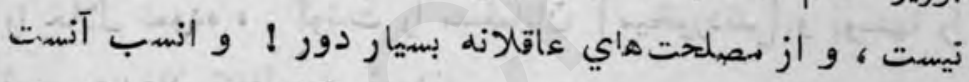
كله يكي از صاحبان عاليشان رانزد_. من كذاشيته، خود تشريف

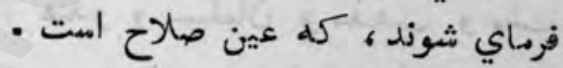

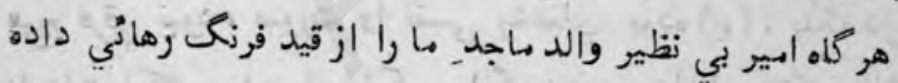
روانه اين طرف خراسان نمودند . بعده صاحب عاليثان ران

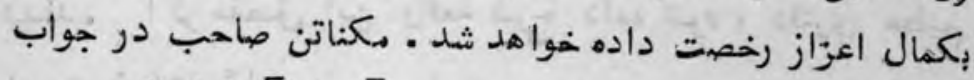

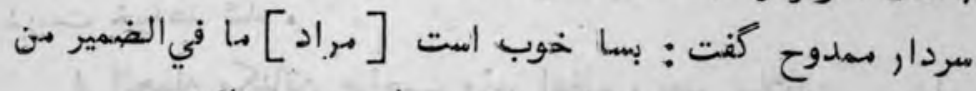

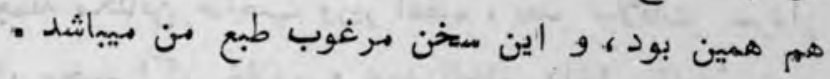
از هر هي بك بذرد سخخن دوست خوشتر است

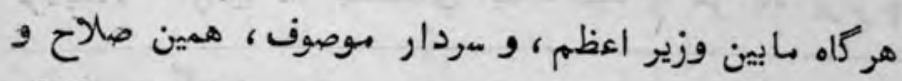
مصلحت قرار كرفت، هر كس كل اين سخن ثي شنيد، زبان. 
خود را به تحسين خواني آشما ميكردند ، و تماي اهماليان انكريز

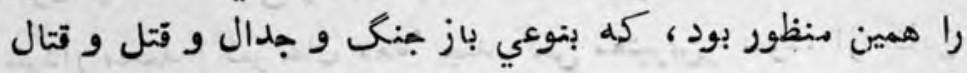
نكردد ن

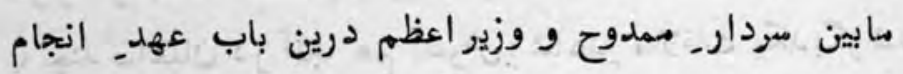

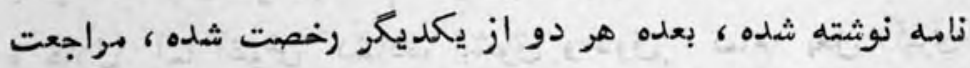

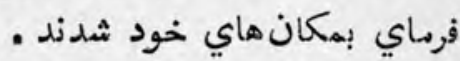

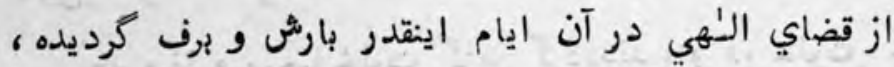

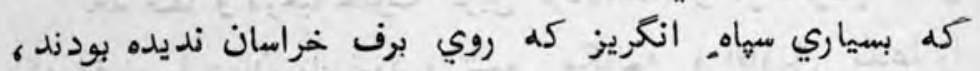

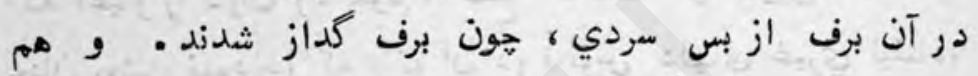

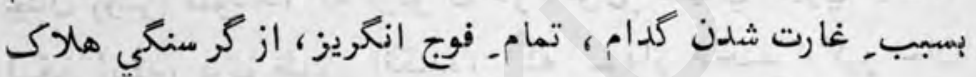

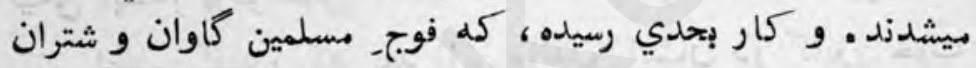

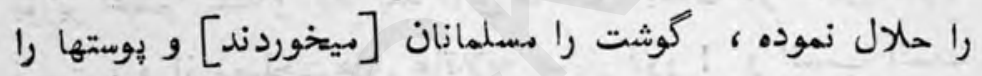

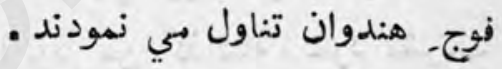

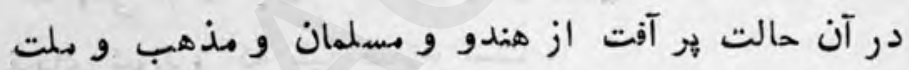

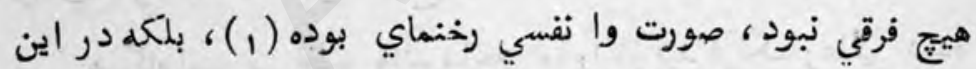

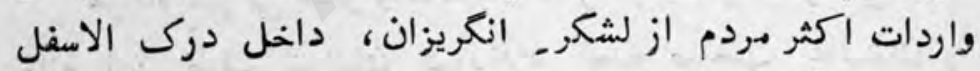

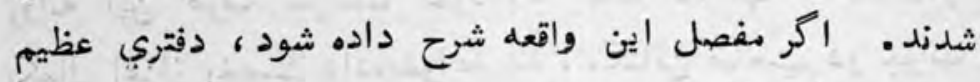

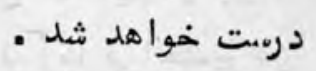

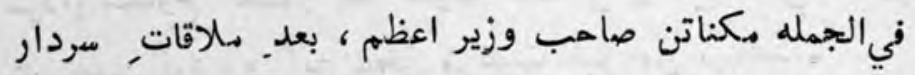

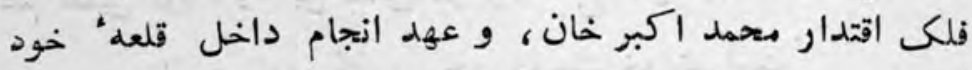

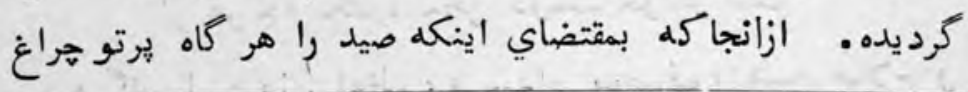

$$
\text { الف: كرديده . }
$$




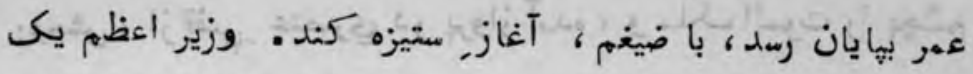
خطـ خفيه طرف امراي اولياي دولت باين مضمون نوشته فرمتاد :

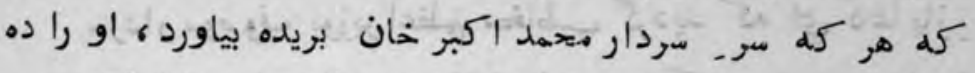
هزار روييه از سر كار انعام اعطا خواهد شد و هم نائب كار هن

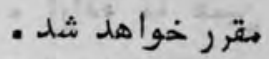

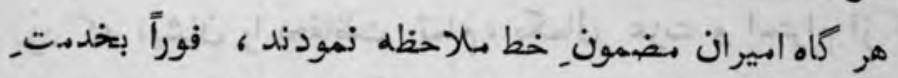

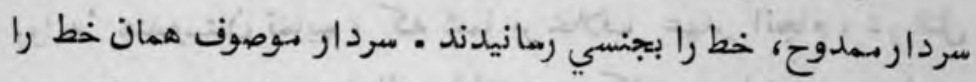

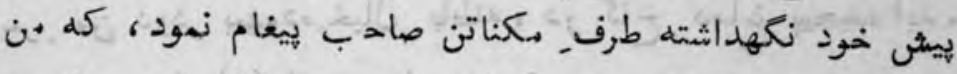

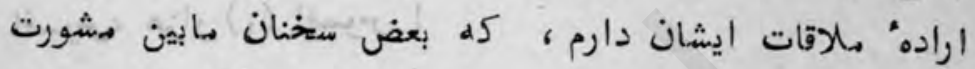

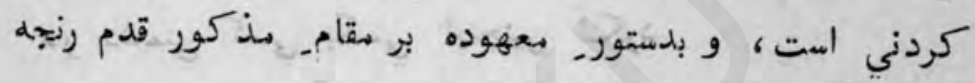
فرما يند

از آنجا كله وزير اعظم از ماجراى خطي خود غافل بود ، اكر

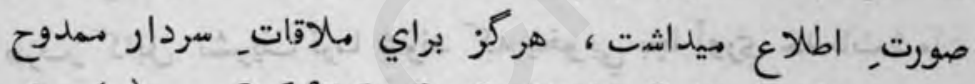

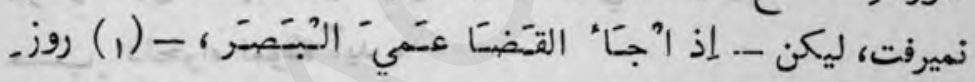

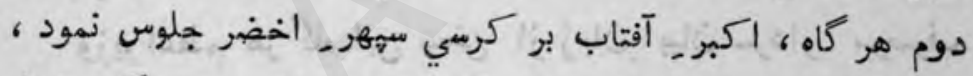

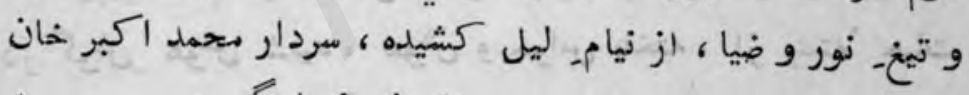
و وزير اعظم در مقامـ معهوده . تشريف فرما كرديده في و

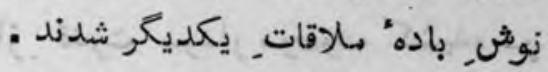
مردار ـهدوح همان خط را بجنسه بوزير اعظم نشان داده ،

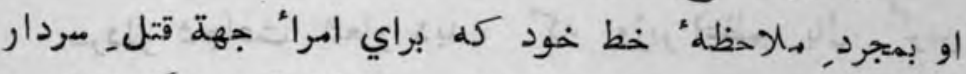

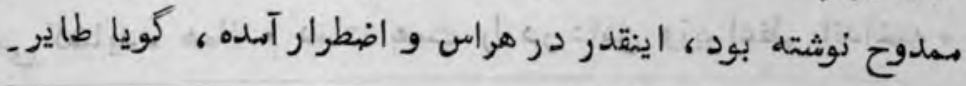
مقوله" عربي است ، يعني : هون قضا آمد خششم كور شد ـ. 
تازه نواي معارك

$\Delta 1$.

روحشى ، از قفس. عنصري در يرواز آمده ، و ملكى الموت را. بهشم

ماينه نمود نمون

سردار موصوف بوزير اعظم متخاطب كرديد كه اي دغا باز

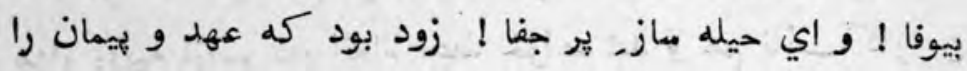

بجاي آوردند و شرط, مروت را بظهور وسانيدند . اراده؛ ما همين

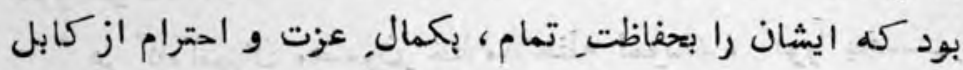

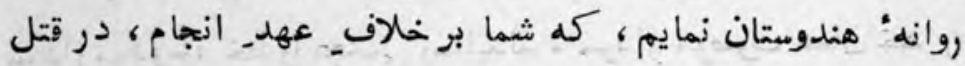

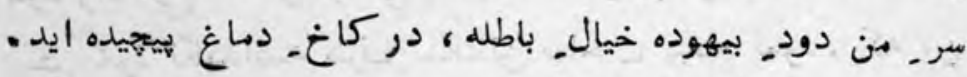

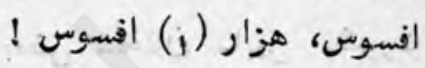

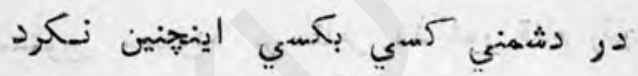

آخر هرا تو اين همل در دوستي كني ! آنين

در حال انسب آنست كه همين وقت ايشان ، باتفاق. من

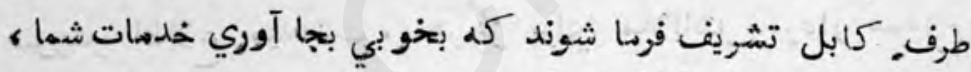

•

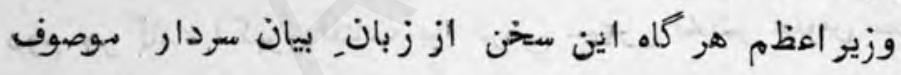

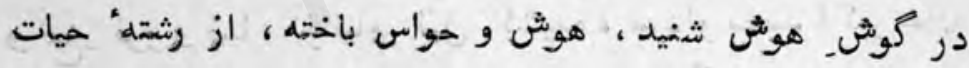

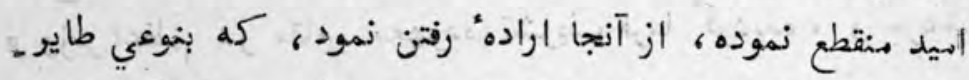

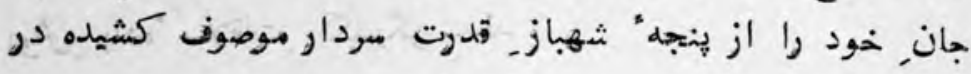

مرواز آيد مال

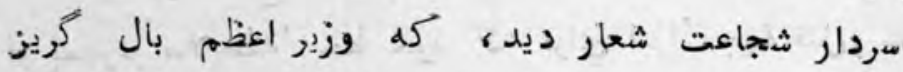
مي كشايد . هماندم دست ههت را در داهن وزيد اءظم ازداخته كه

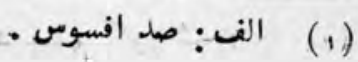


تأزه نوائي ماركت

بعركه آرابي قيل و قال و هشثت و مشتت مابين خود شدند. مآخر

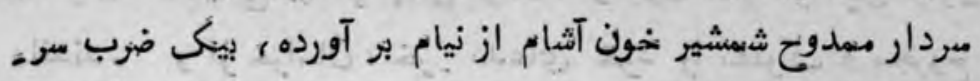

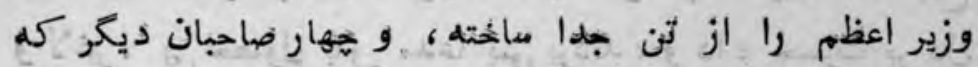

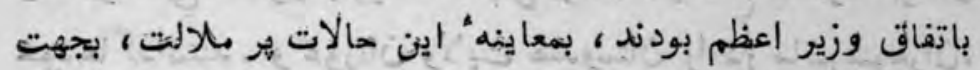

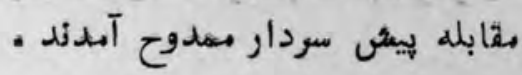

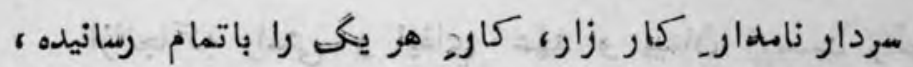

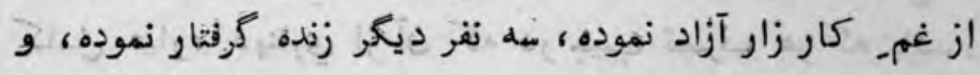

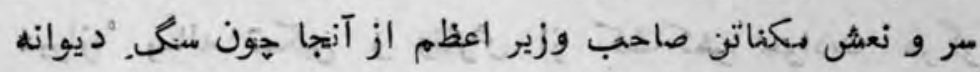

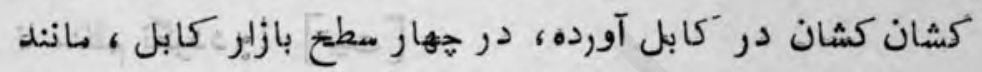

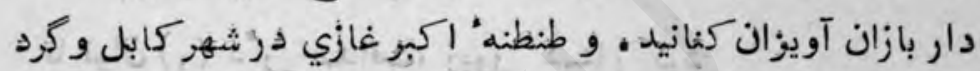

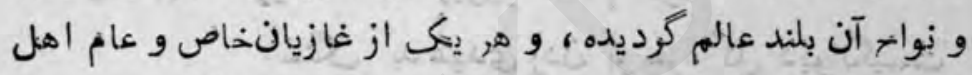

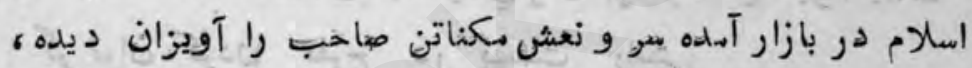

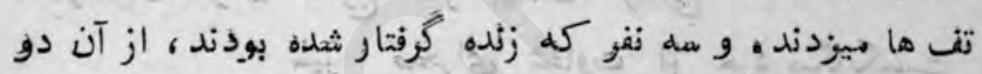

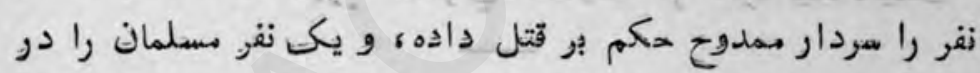

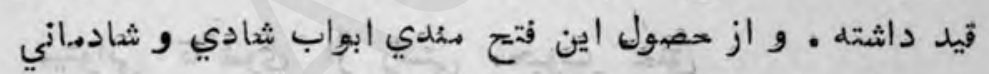

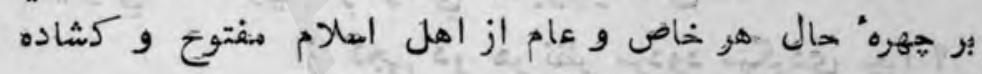

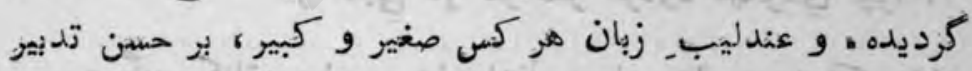

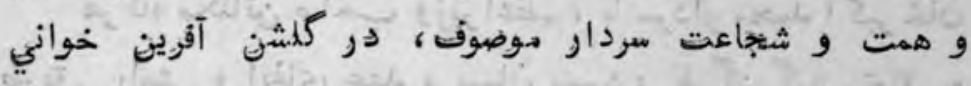

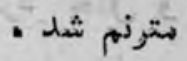

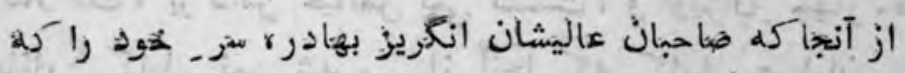

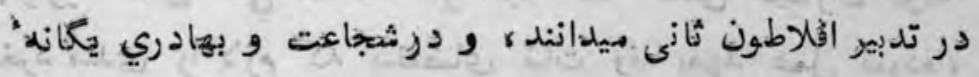

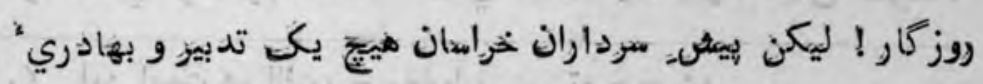


تازه نواي معاركى"

Dir

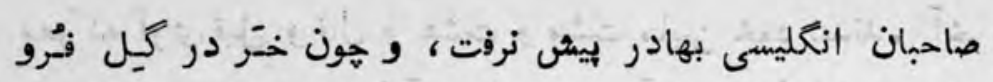

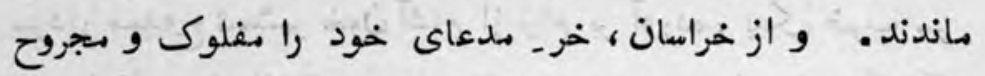

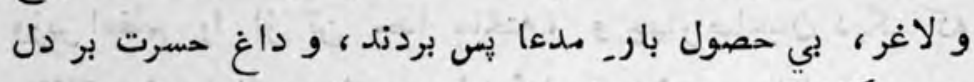

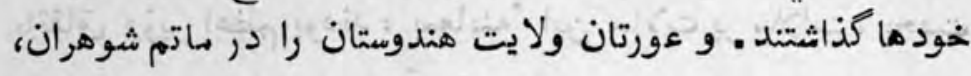

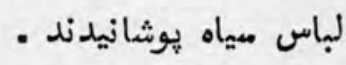

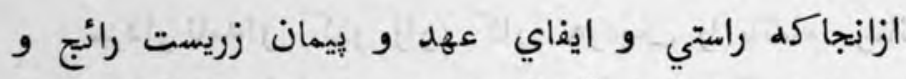

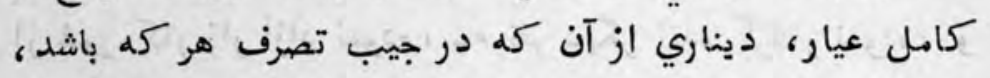

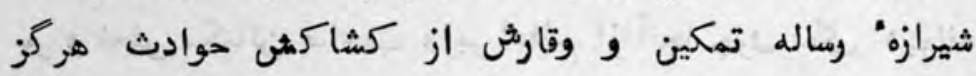

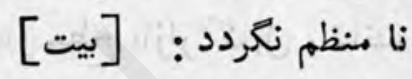

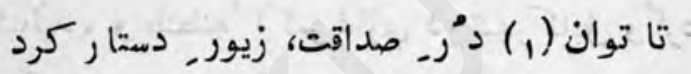

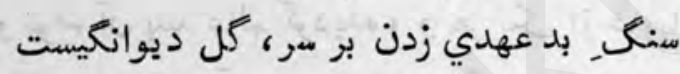

كر توان كردن تفرج در بهشت رئت راستي بردي شير. ضحراي شقاوت از خرد بيكانكيست

ميتواني تا شوي از راستي متحبوبـ خلق

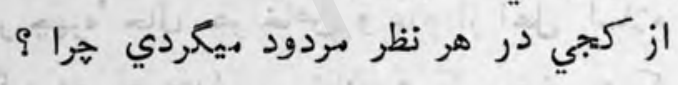

هركاه مكناتن صاحب وزير اعظم، با سردار بحمد اكبر خان

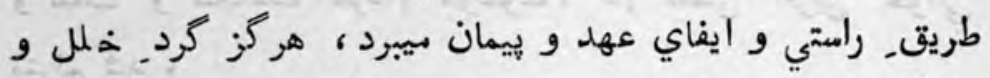

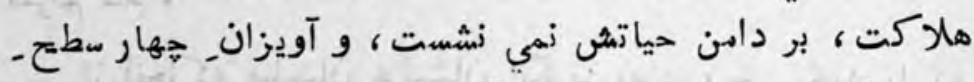

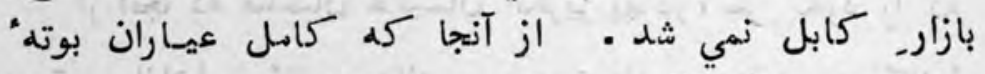

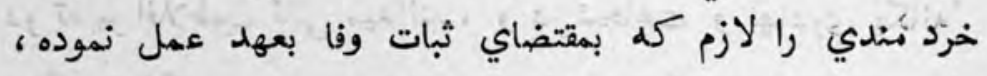

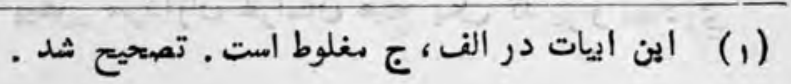




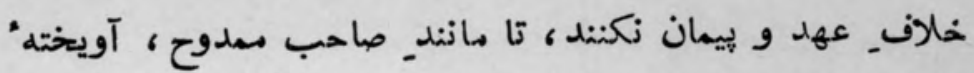

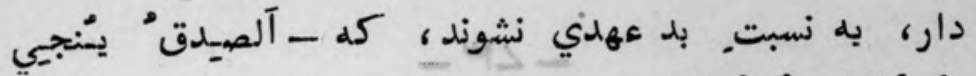

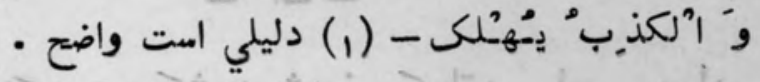

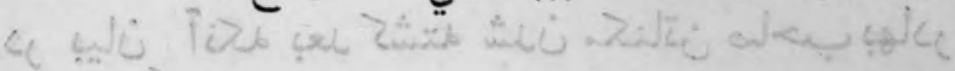

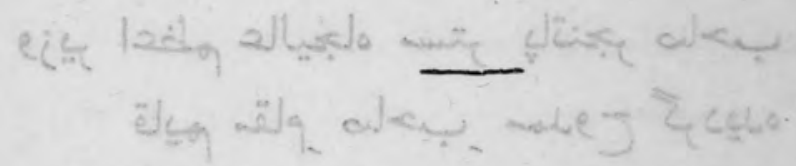

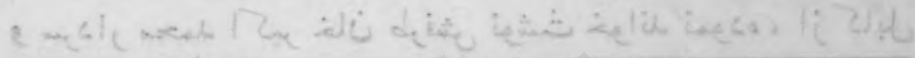

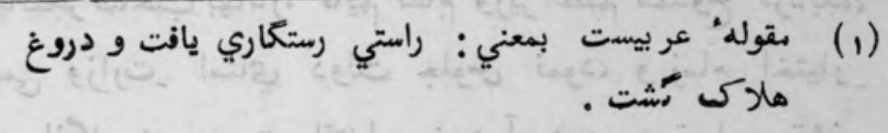

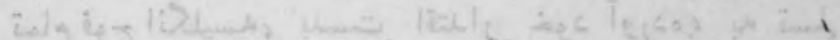




\section{$-\angle \boldsymbol{H}$}

در بيان, آنكه بعد كشته شدن مكناتن ماحب بهادر وزير اعظم عاليجاه سستر هاتنجر ماحب بهاب بهادر قايم مقام هاحبـ سمدوح گرديده

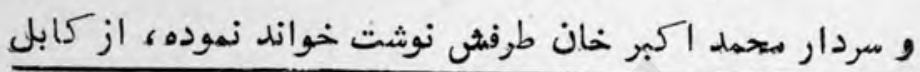

\section{كشيده نمارتش نمود :}

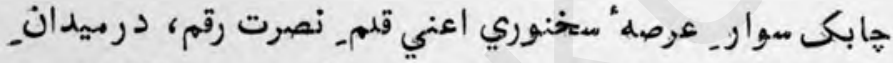

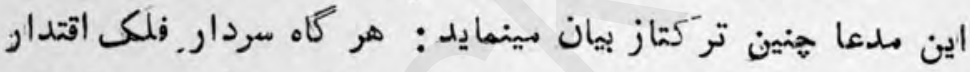

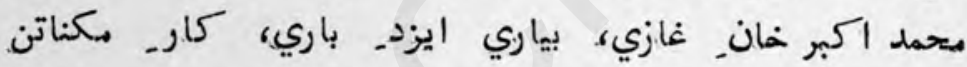

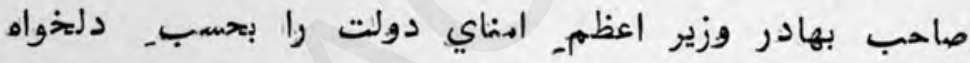

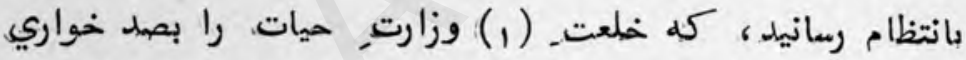

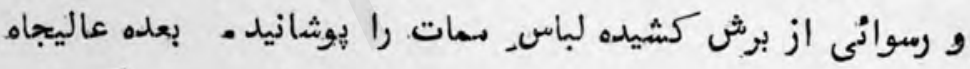

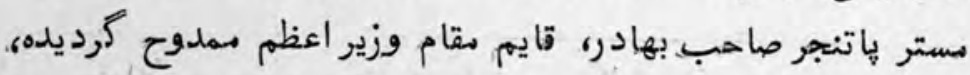

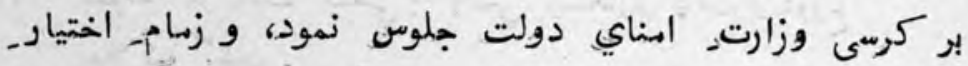

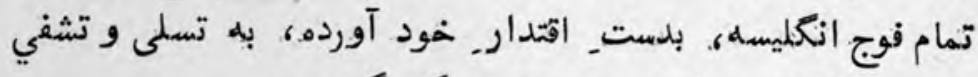

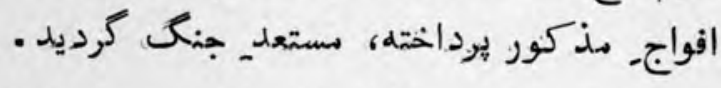

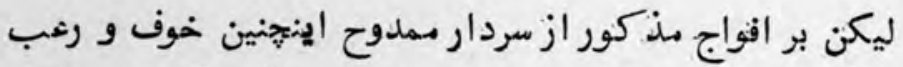

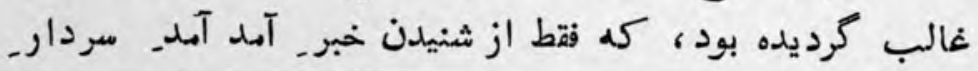


موصوف، ـالحـ حيات از تن مي انداختتد، ليكن امر. نوكري

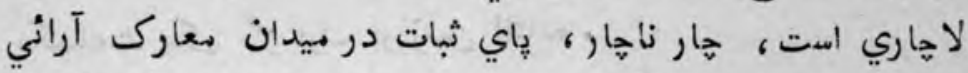

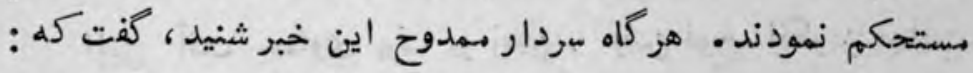

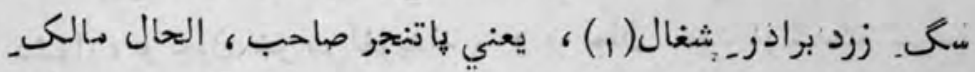

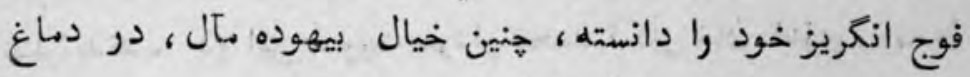

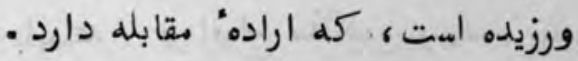

همانوقت تعلقجهل (r) رفيعه باين مضمون نوشته طرفش فرستاد

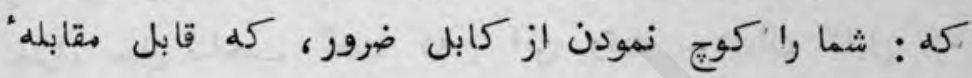
غازيان جالادت نشان نيستيد! عبث خود را برباد ندهيد، كله مسودي ندارد ـ مقرون مصلجت_ عاقلان) همين است كله : هر قدر اسباب

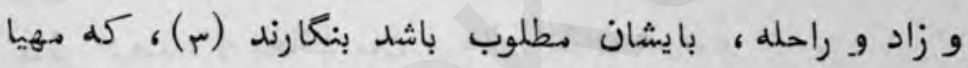
و موجو: نموده، براي ايشان فرمتاده آيد .

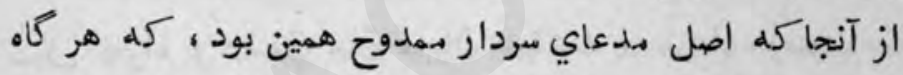

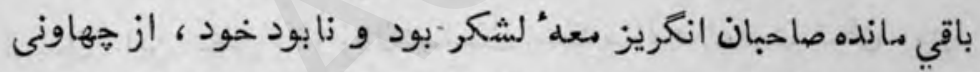

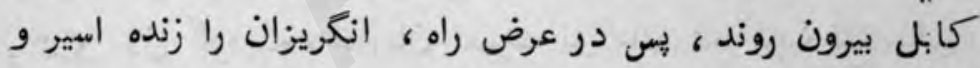
- كرفتار نمائيم

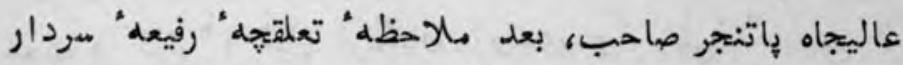

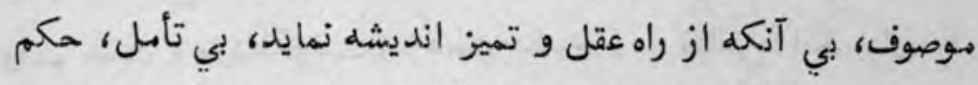

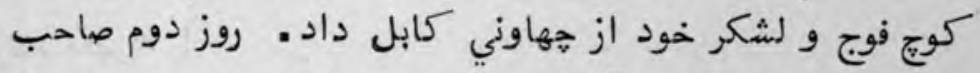

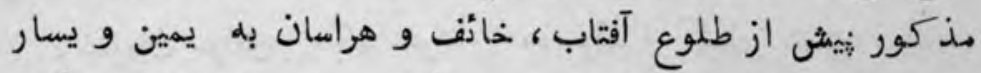

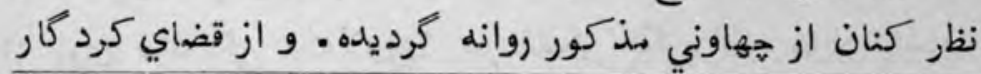

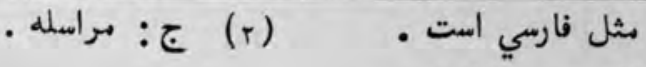

$$
\begin{aligned}
& \text { الف: بر زمارند . }
\end{aligned}
$$


تازه نواي بعارى

019

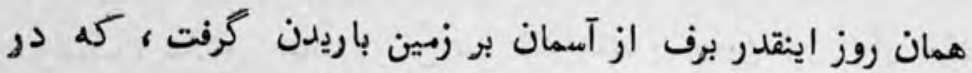

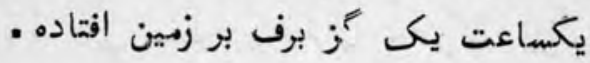

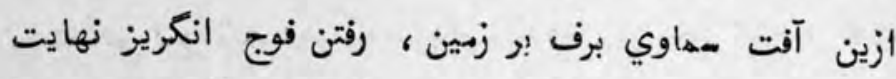

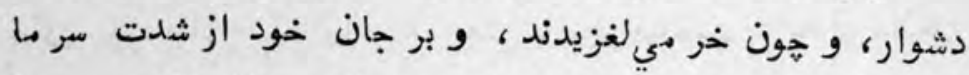

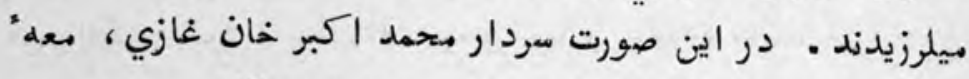

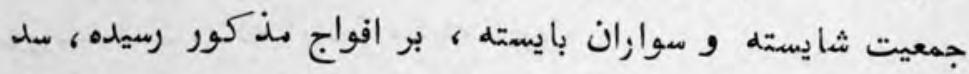

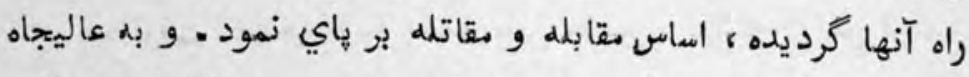

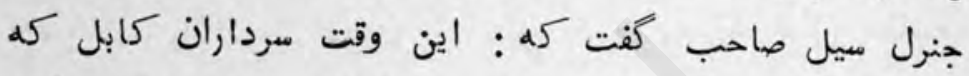

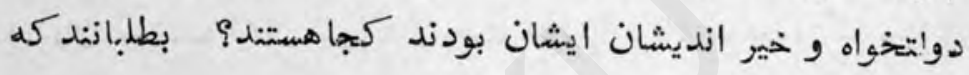

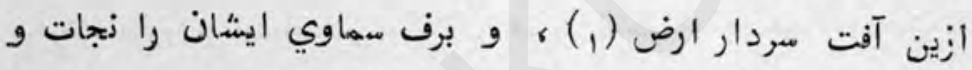

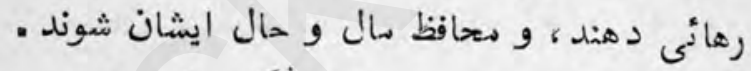

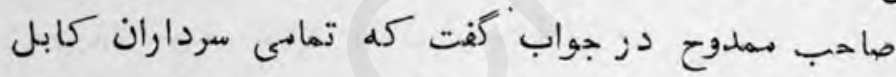

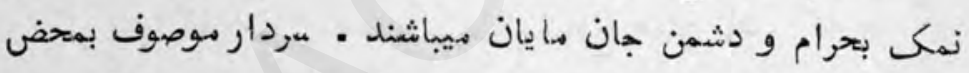

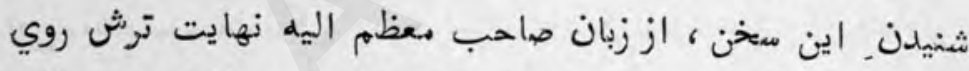

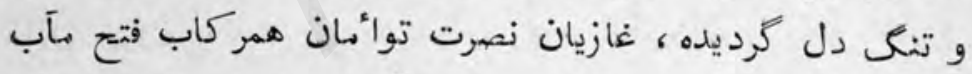

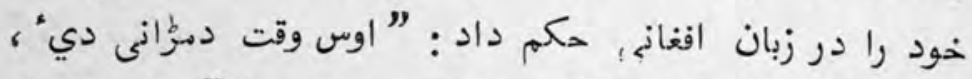

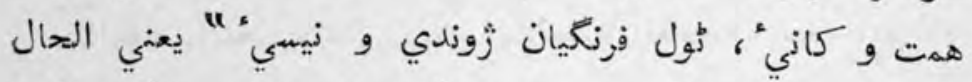

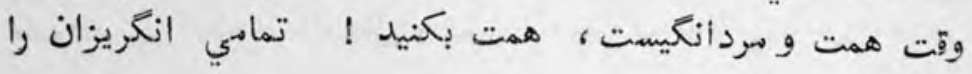

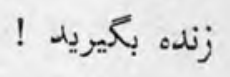

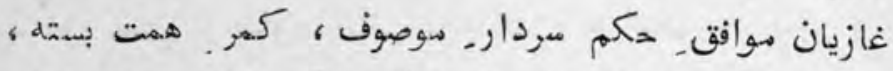

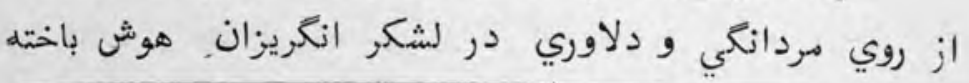

. (1) 
دل سوخته كالاويز (1) كرديده. مِاتنجر صاحب و ديكر صاحبان

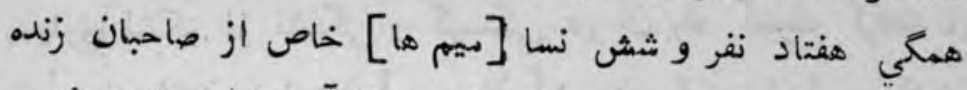

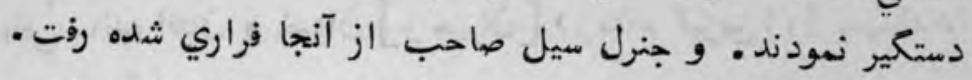

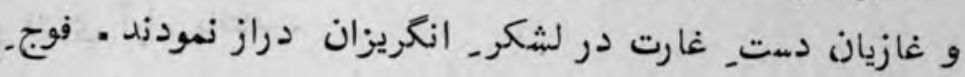

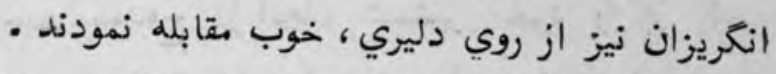

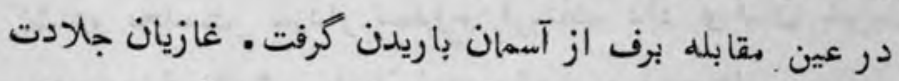

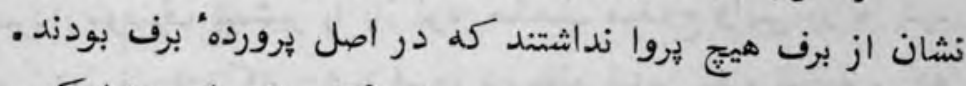

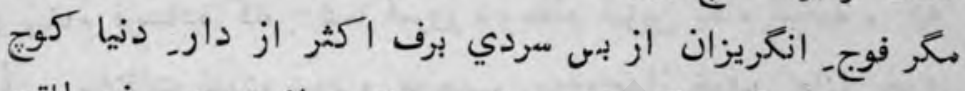

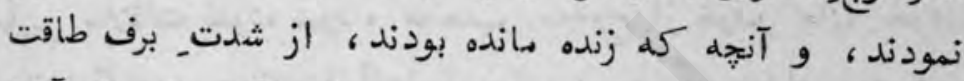

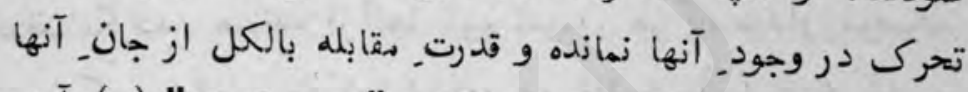

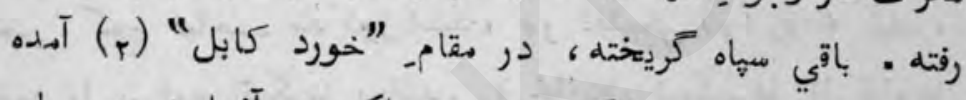

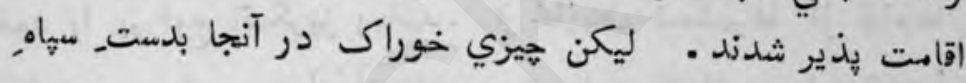

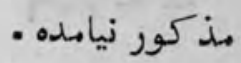

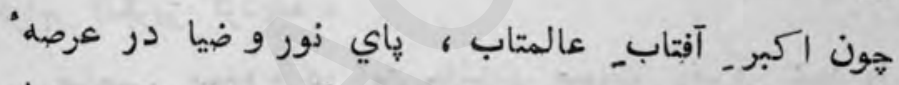

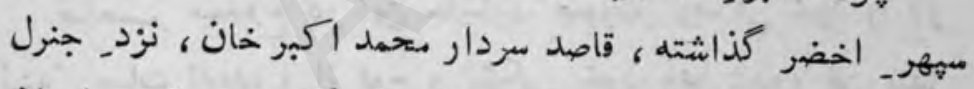

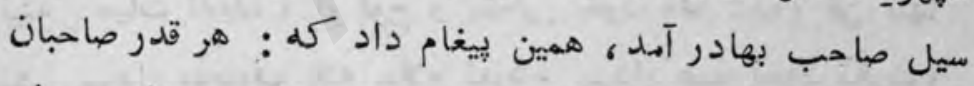

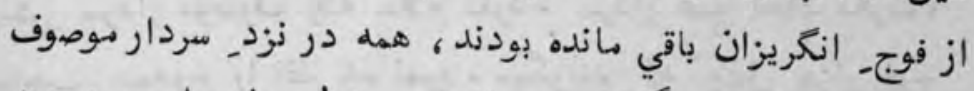

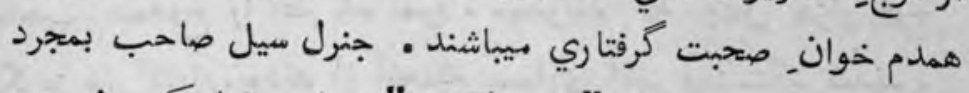

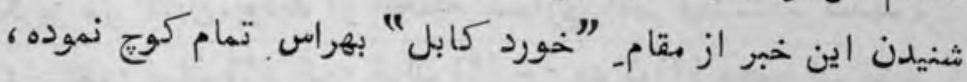

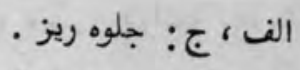

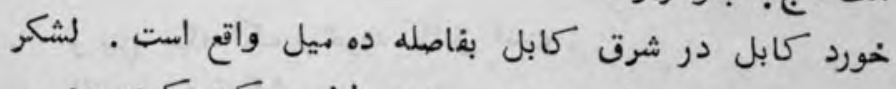

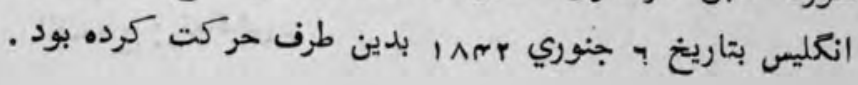


روانه" بيشتر كرديد . ليكن از بس هراس، راه. گم نمودند و

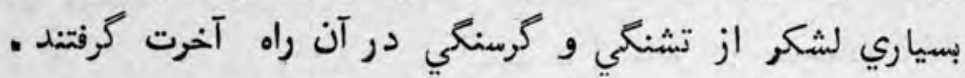

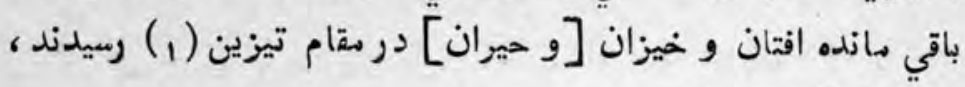

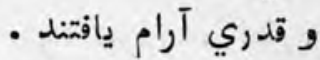

جنرل صاحب مهدوح از آنجا ، شمشير. خود رام را از كمر

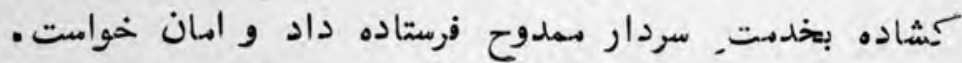

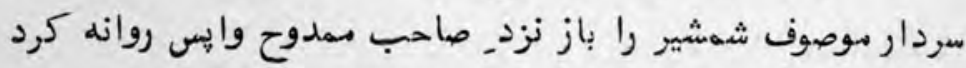

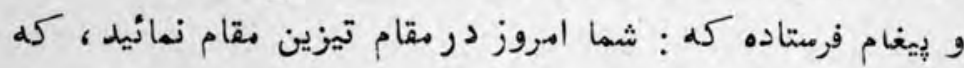

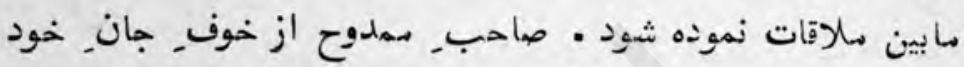

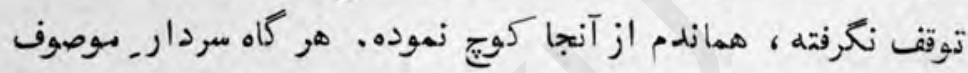

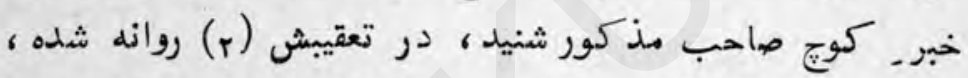

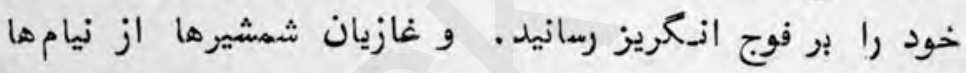

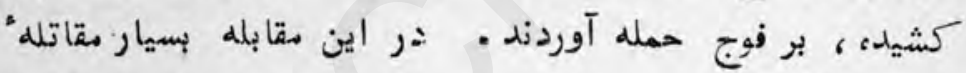

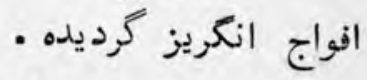

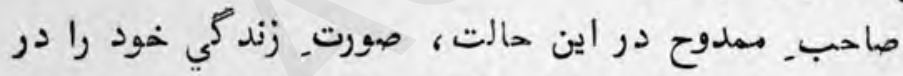

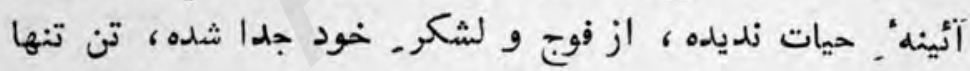

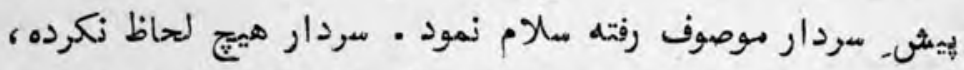

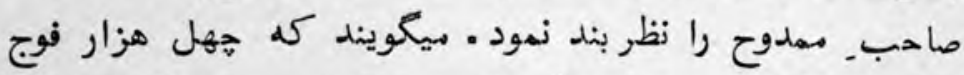

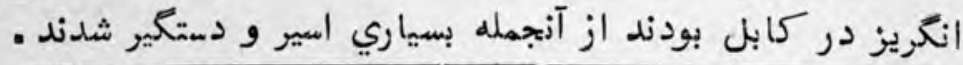

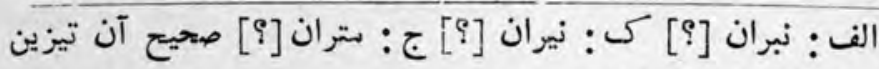

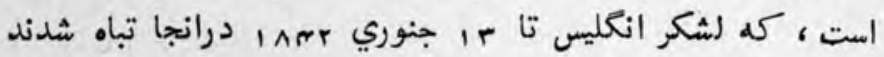

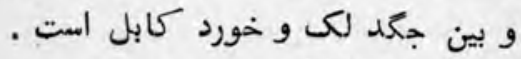
الف، ج ج تعاقبش . 
$\Delta 19$

تازه نواي معاركى

و بسياري دمت و واي بريده در كابل ماندند. باقي همه فوج

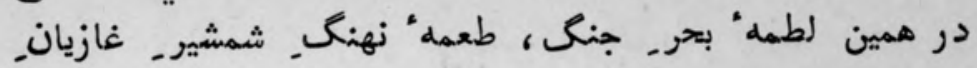

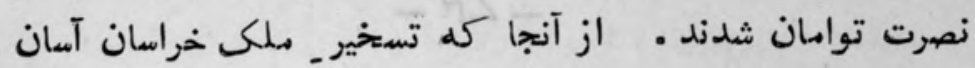

نيست : ديت

درين و.رطه كشتي فرو شد هزار

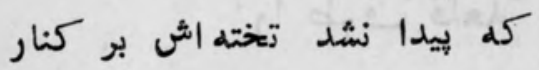

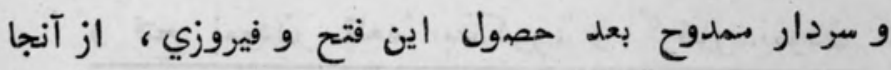

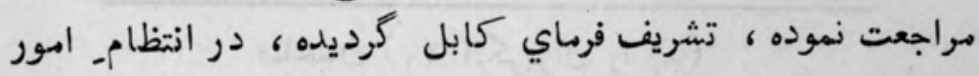

باقي مانده متوجه كرديد - معرده 
در بيان. روانه نمودن عاليجاه شهس الدين خان را طرف قلعهء غزنين

و فتع نمودن_ قلعه" مذكور، و كرفتار نمودن

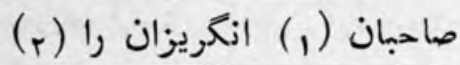

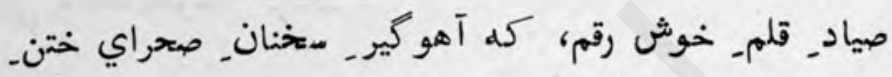

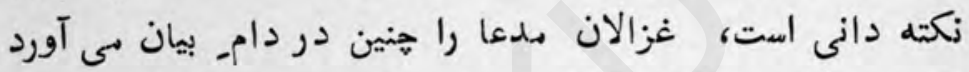

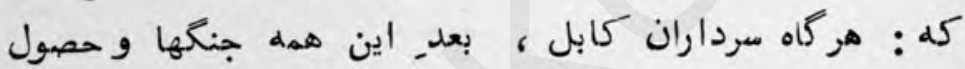

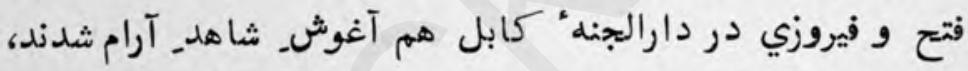

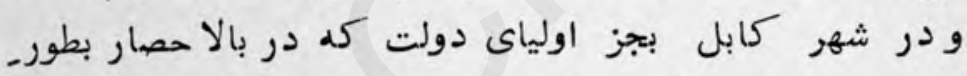

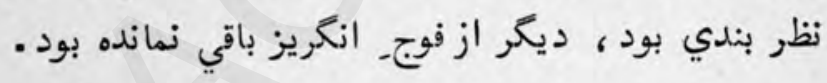

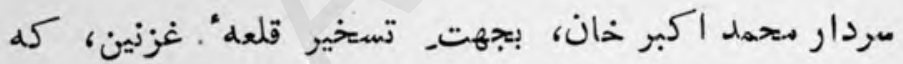

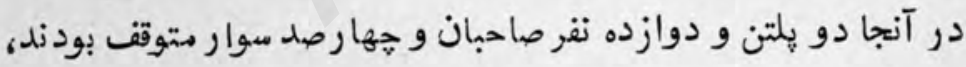

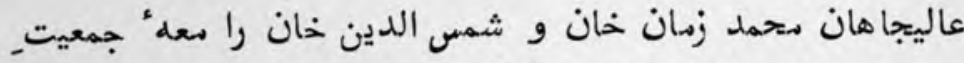

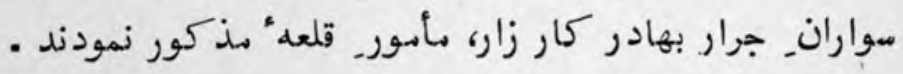
ليكن در اياميكه در كابل ما بين, سرداران و وصاحبان انكريز،

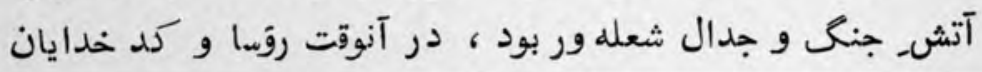

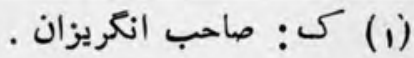

$$
\begin{aligned}
& \text { (r) اين فصل در (ج) نيست. }
\end{aligned}
$$




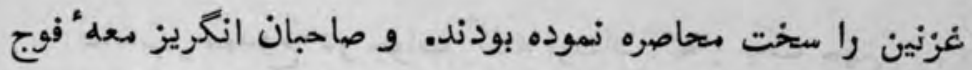

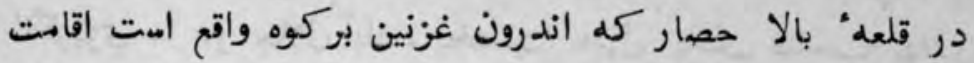

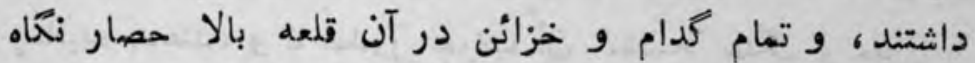

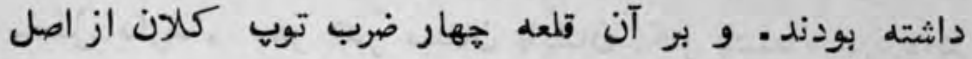

سوار بودند .

هون روسا و زمينداران و رعيت. غزنين هر كاه خمبر ـ آمدن

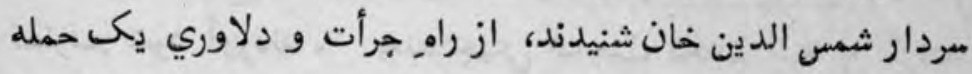

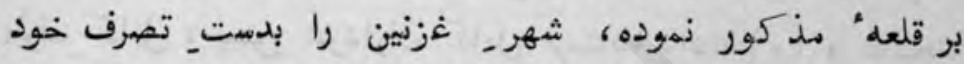

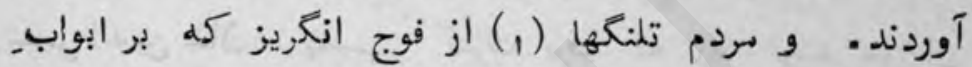

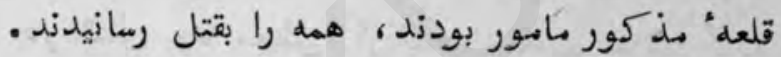

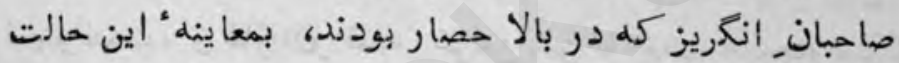

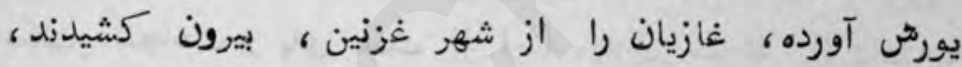

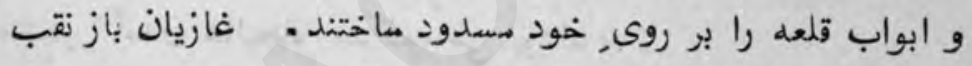

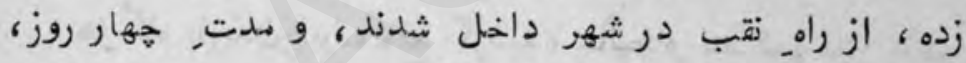

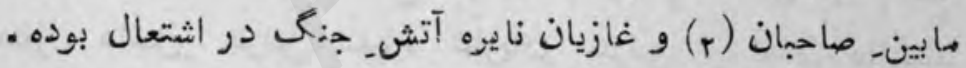

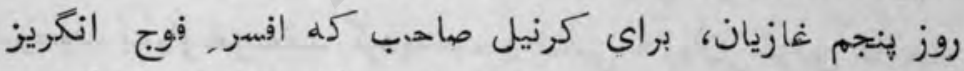

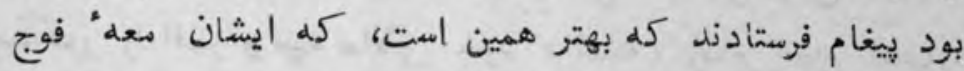

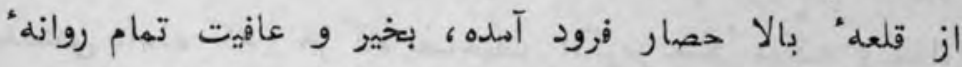

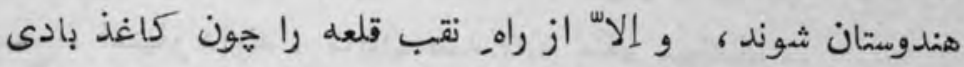

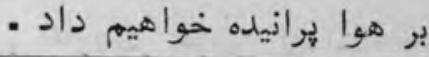

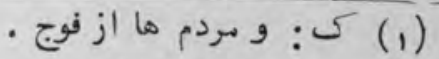

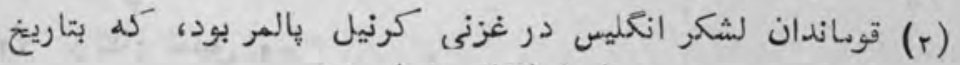

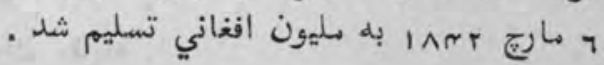


صاحب, مهدوح در جواب كفته فرستاد كه : يك جهتي (1)

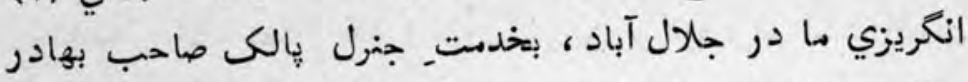

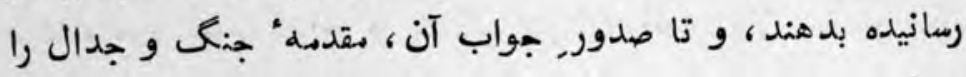

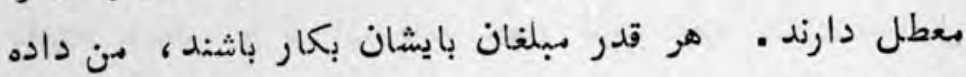
- ميتوانم

غازيان مبلغ ده هزار روييه از كرنيل صاحب كرفته ، در

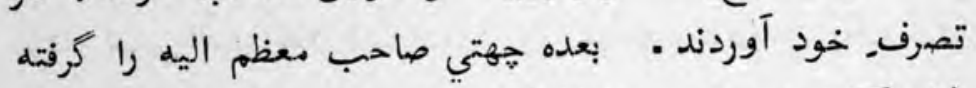

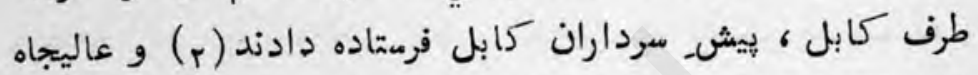

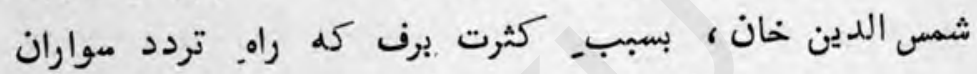

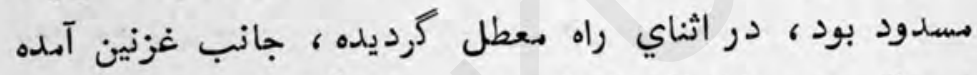

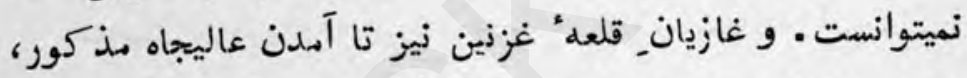

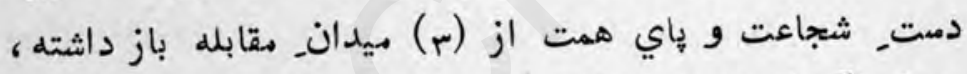

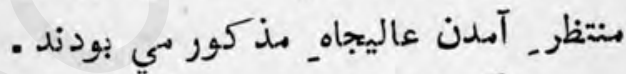

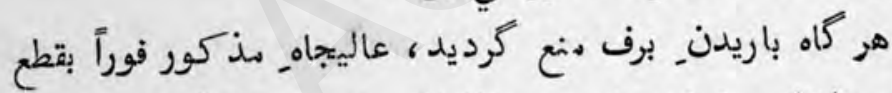

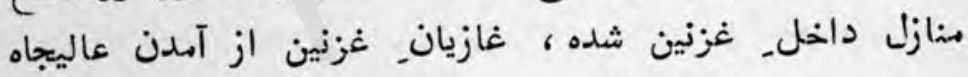

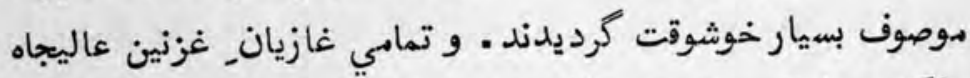

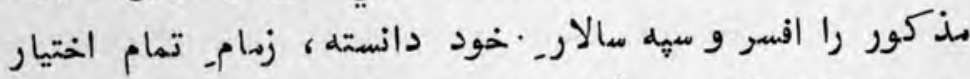

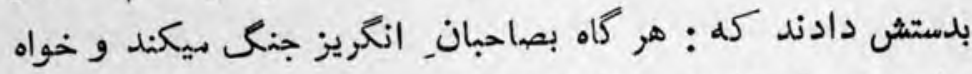

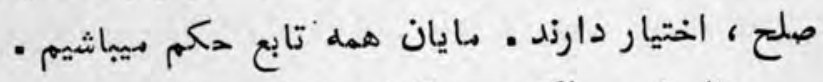

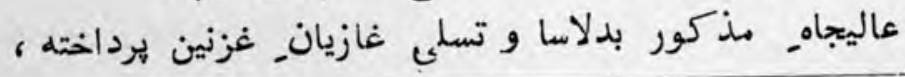

$$
\begin{aligned}
& \text { ههتي = ركتوب و نامه . }
\end{aligned}
$$

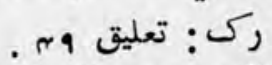


هند روز آرام كرفت ، در اين صورت كرنيل صاحب بهادر بسبب

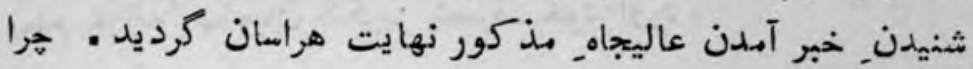

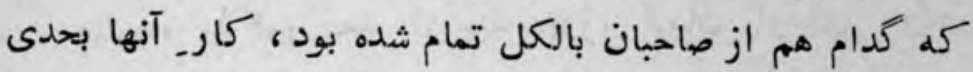

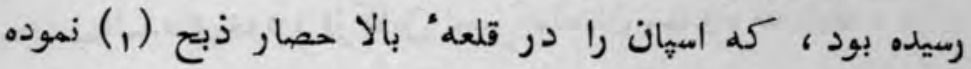
ميخوردند ، و برف را كرم نموده آب مينوشيدند . عاليجاه شمس الدين خان طرف صاحب مهدوح بيغام نموده

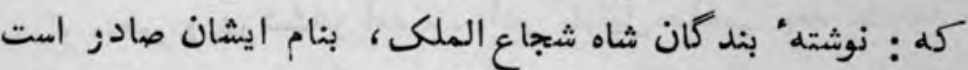

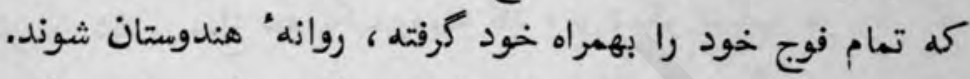

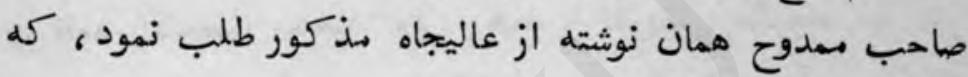
- معاينه نماني ازآنجا كه نوشته " اولياي دولت ، جيش عاليجاه مذك كور موجود

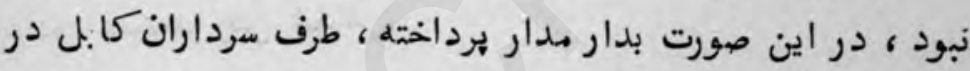

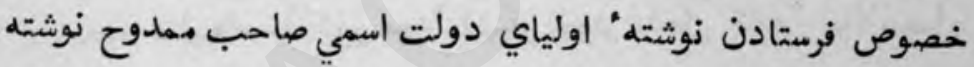

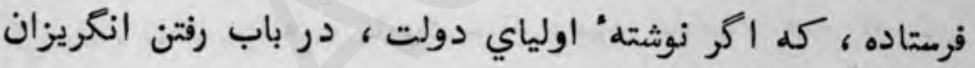

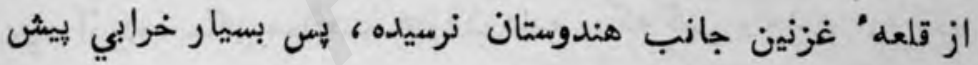

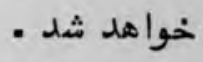

سرداران كابل حسب نوشته" عاليجاه مذ مورو در خصوص فرمان مذكور بحضور اولياي دولت عرض كردند - امنايدولت

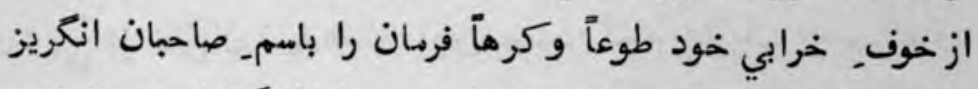

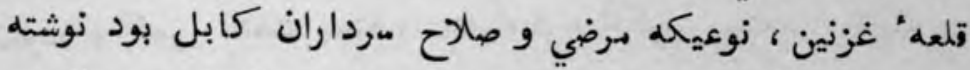

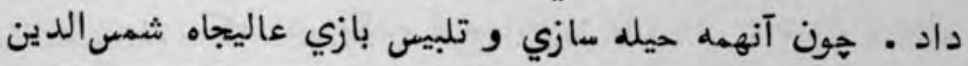


خان بود، براي همينكه صاحبان انكريز را زنده كرفتار نمايد، و و و

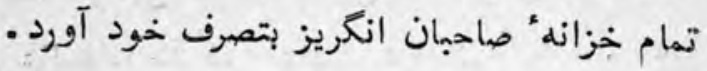
عاليجاه مذكور بعد ازهيند روز، فرمانٍ اولياي دولت

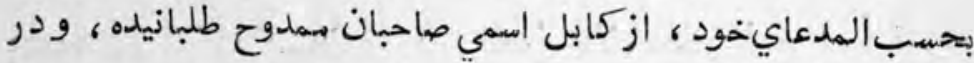

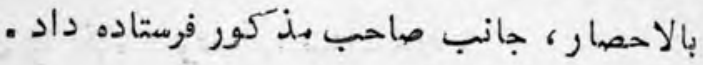

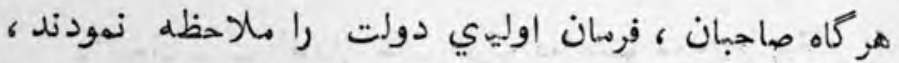

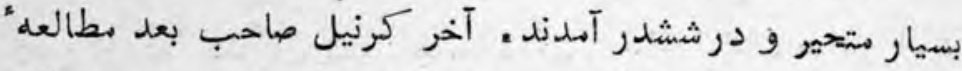

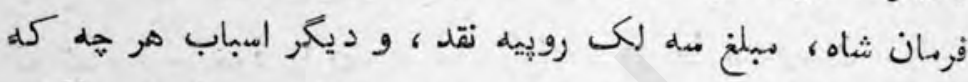

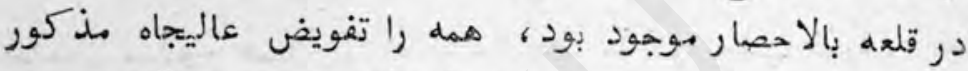

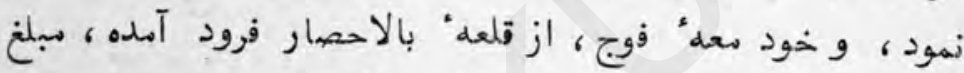

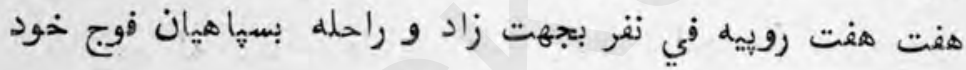

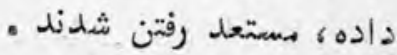

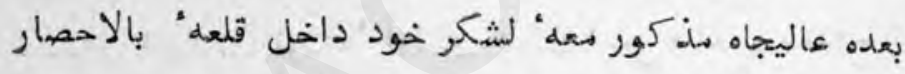

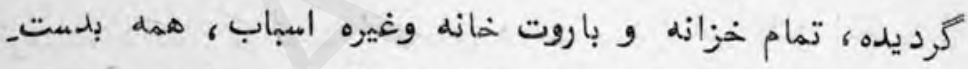

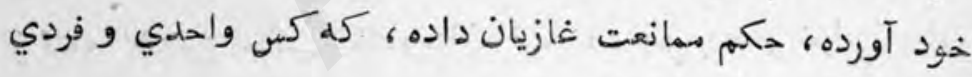

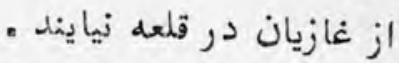

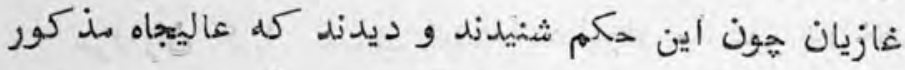

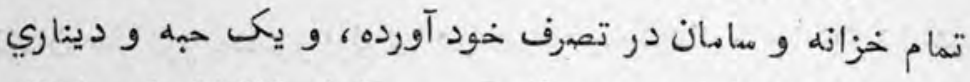

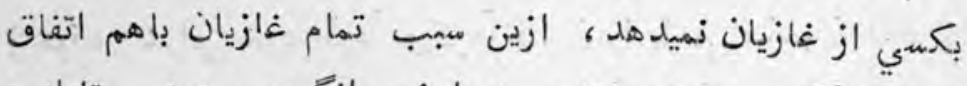

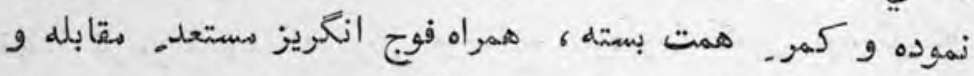

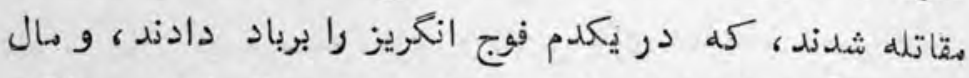

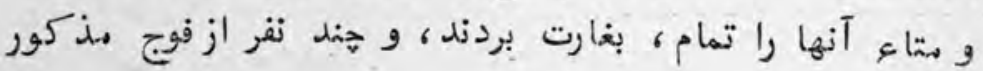


زتده اسير و دستكير نموده آوردند، كله از آن كار مزدوري ميكرفتند.

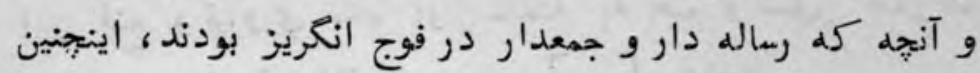

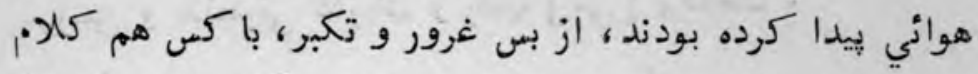

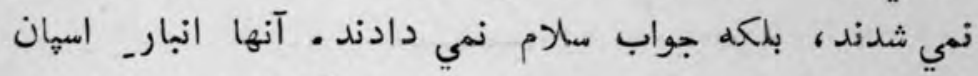

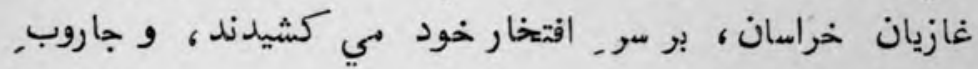

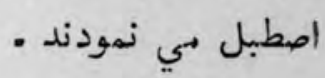
في الجمله بوقت مقابله غ غازيان، صاحبان انكريز فراري شده،

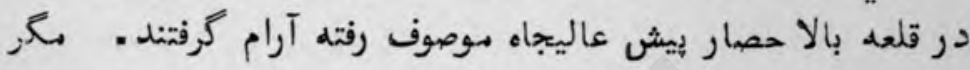

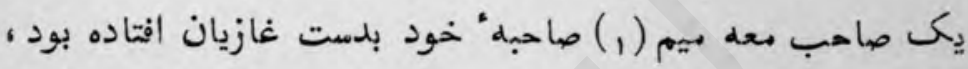

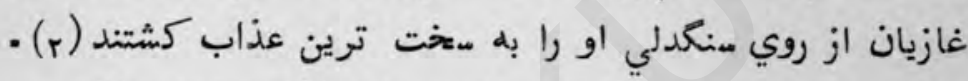

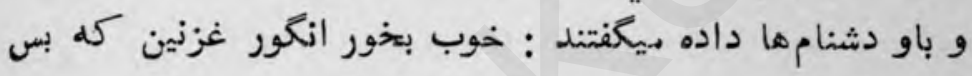

شيريز، است

حاصل كلام آنكه تهامي صاحبان انكريز كله بيش عاليجاه

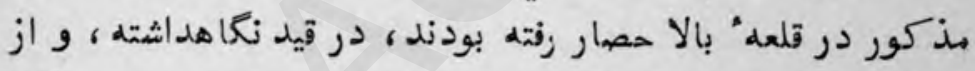

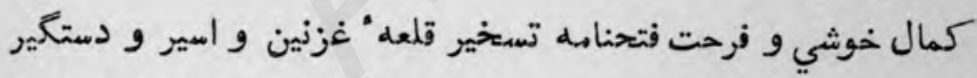

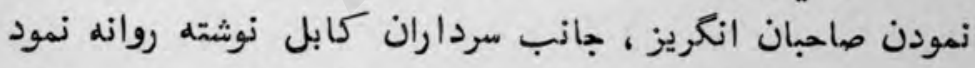

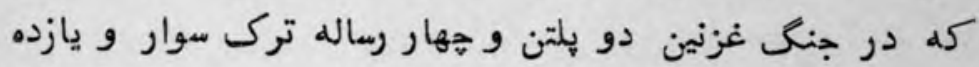

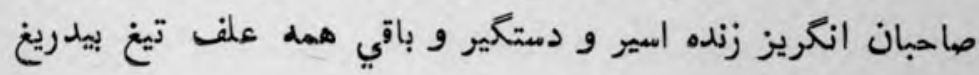

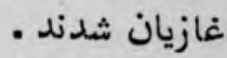

$$
\text { ميم = بانوي فرنكي . }
$$

الف: عذاب كشيده باو ميكفتند كه اثي ...... خوببخور 
ثازه نواى بهارك

org

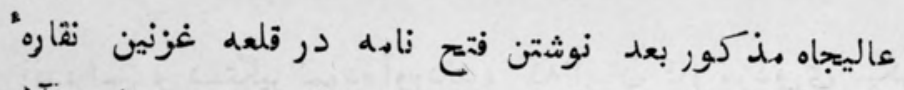

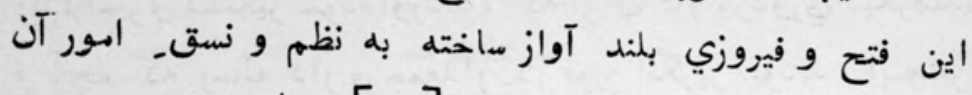

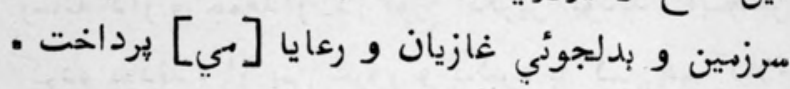


$-\angle \Delta-$

در بيانـ رفتن سردار محمد اكبر خان جانبـ. جلال آباد

و محاصره نمودن صاحبان انكريز را ، ، كشيته شدن شجاع الملى از دست شجاع الدوله بموجب تأثير اسم در كابل

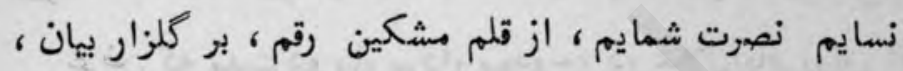

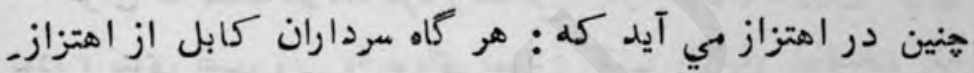

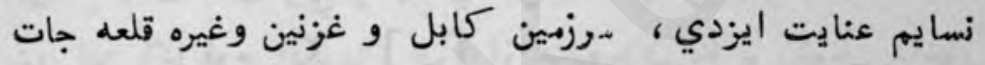

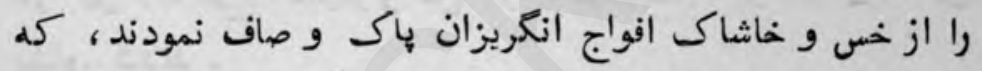

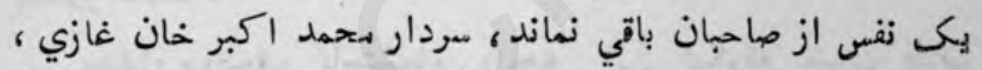

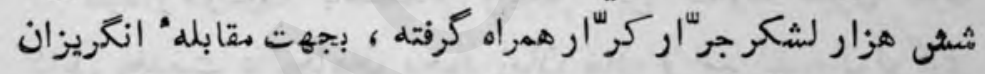

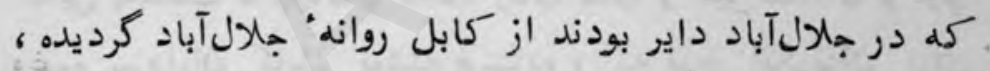

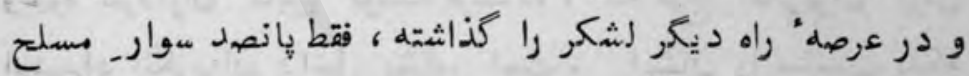

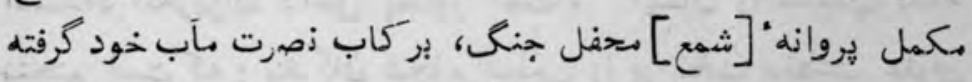

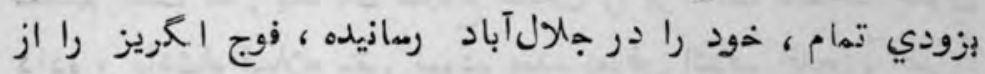

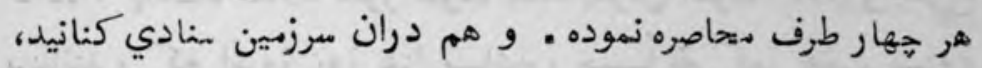

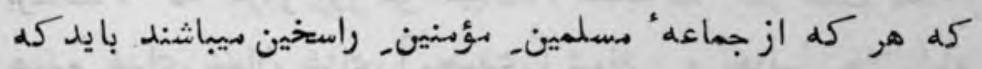

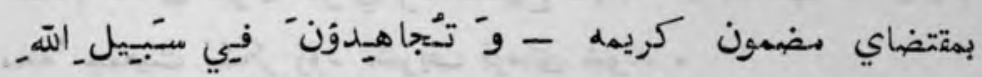

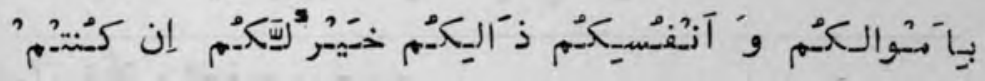


تازه نواى مeر

orA

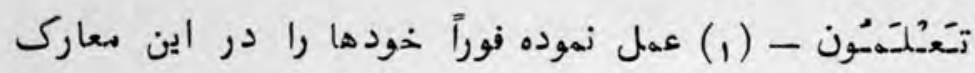

- نصارا حاضر نمايند

باثر_ منادي دو هزار جوانان جان نثار ايمان دار نزديـ سردار مجهد اكبر خان غازي حاضر آديدند. . و مافي الضمير سردار هوصوف ههمين بود. زوعيكه در كابل صاحبان انكريز را زنده

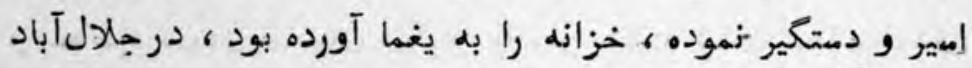

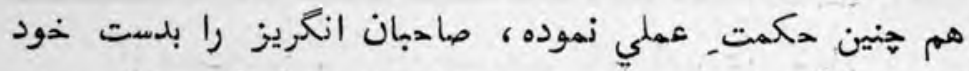

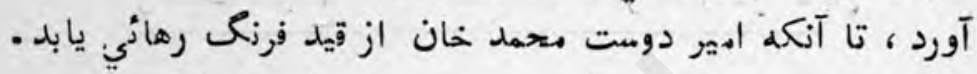
غرض كه مدت دو ماه مردار مـمدوح، در جلال آباد رونق افزاي

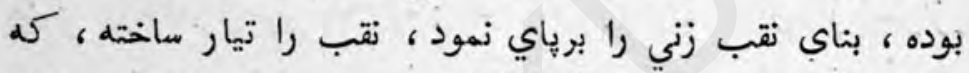

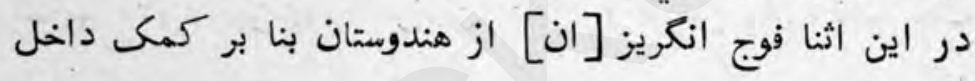

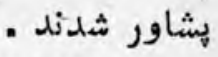

سردار موصوف باستشهام رايحهـ اين شخوفه خبري طرف

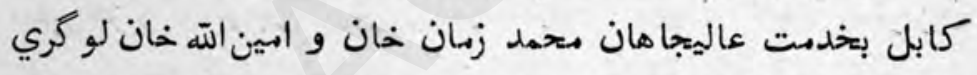
وغيره سرداران كابل نوشته فرستاده، كله فوج انكريزان بران براي

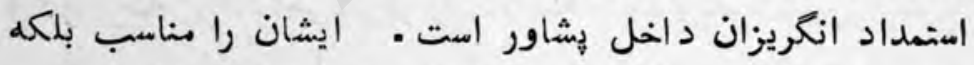

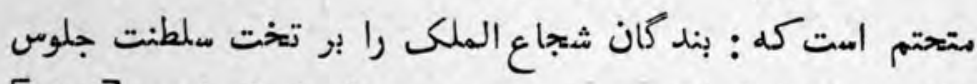
داده ، رادشاه اسلام مقرر زموده بعده بعرض اشرف اقدس [اعلي]

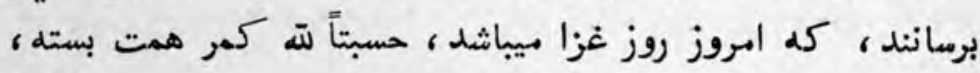

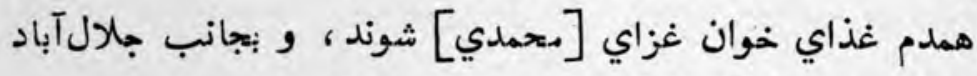

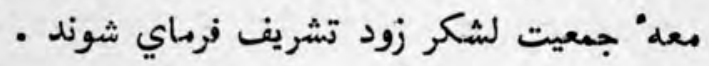

• قرآن ، الصف، 1 إج (1) 
تازه نواي معارك

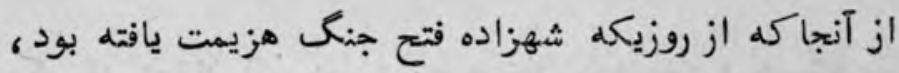

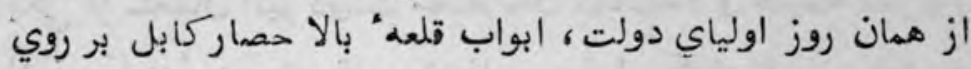

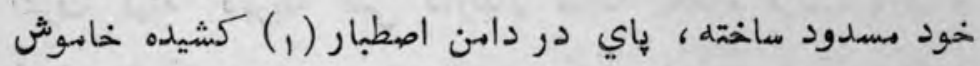

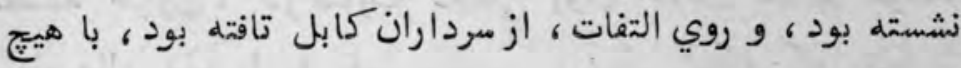

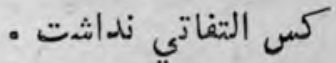

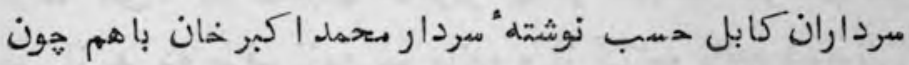

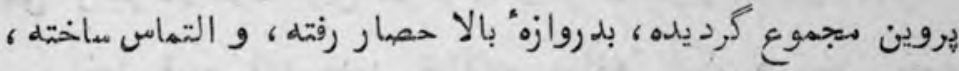

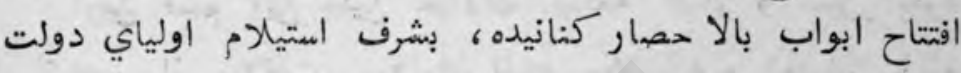

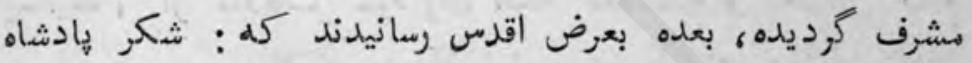

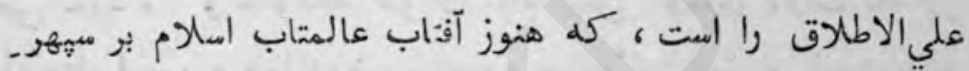

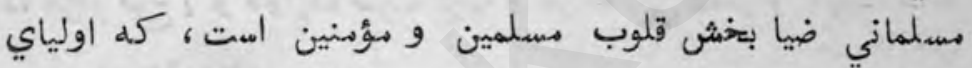
دولت جون مهر انور ، نور افزاي سرير سلطنت ميباشند ، و الحال

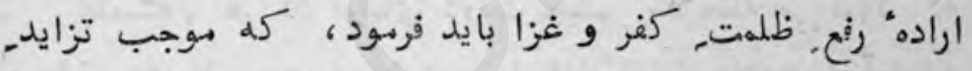

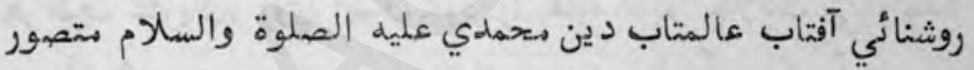

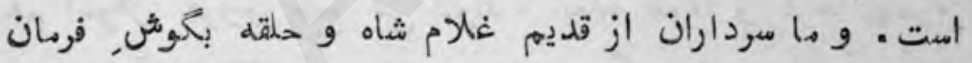

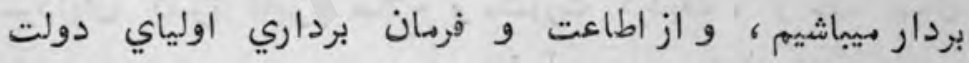

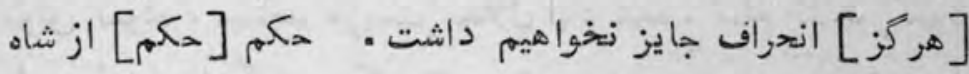

و از بند كان بسر دويدن است .

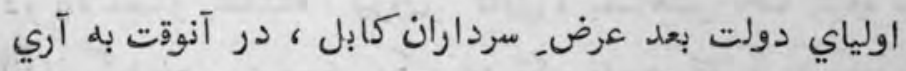

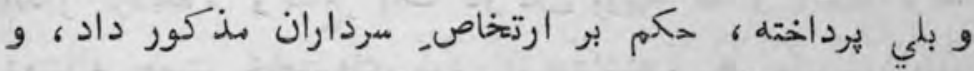

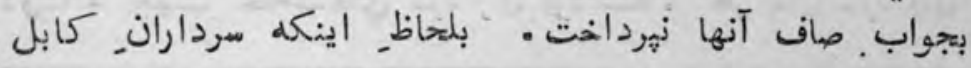

. (1) 
يكي از متعلقان امير دوست محمد خان ميباشيد، و و هميشه بسركار

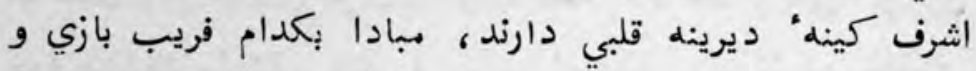

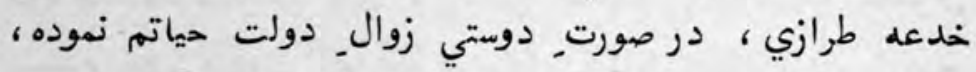

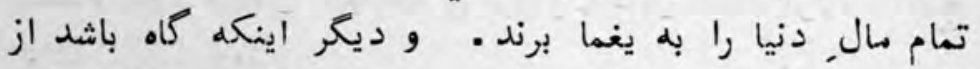

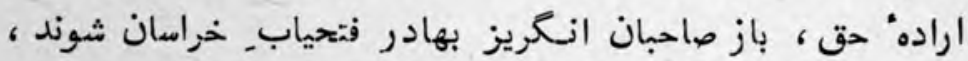
هي از هر دو طرف ازين سو مانده و از آن سو رانده شوند( ) . ازين قسم اين هنين خيالات ببالغه" فـكر و تميز, خود

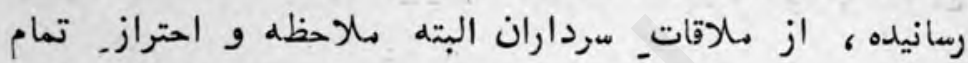

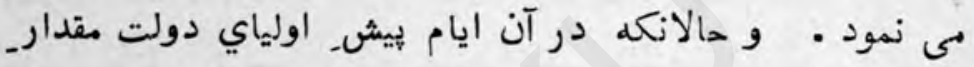

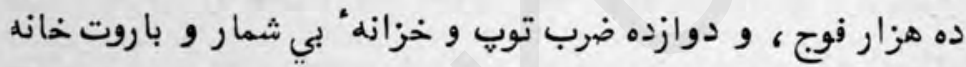

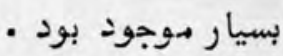

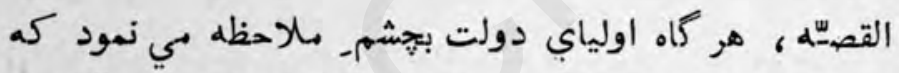

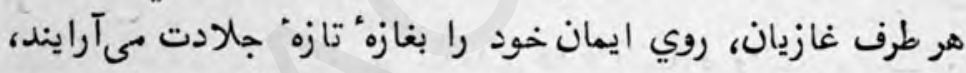

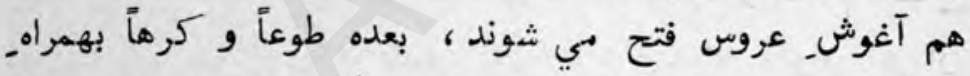

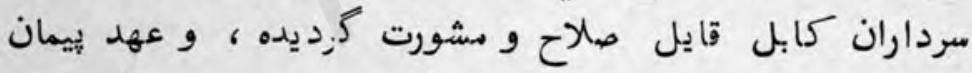

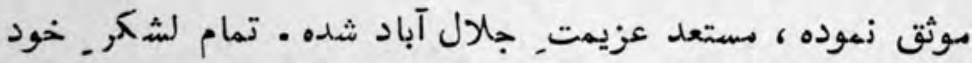

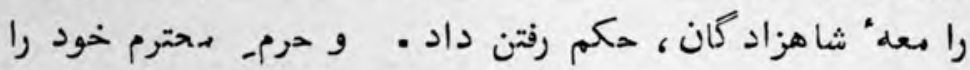

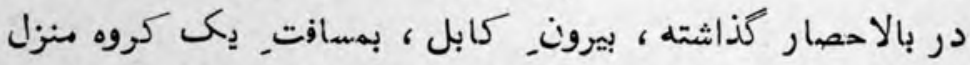

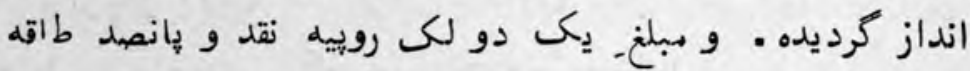

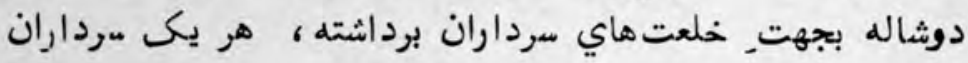


تازه نواي مارك

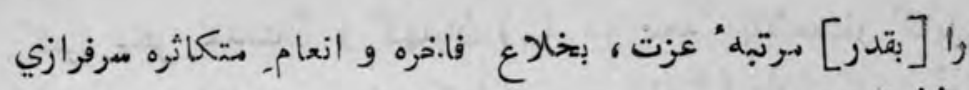

نخشيد

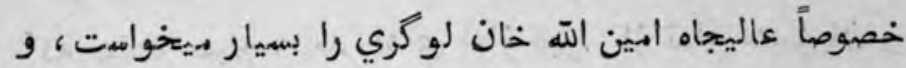

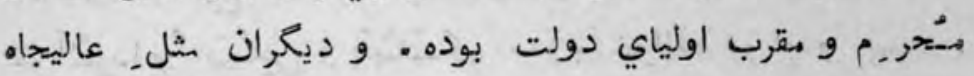

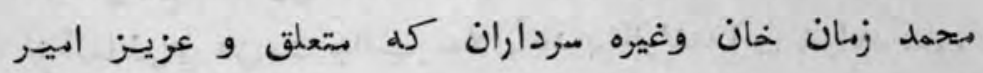

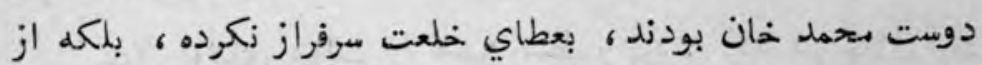

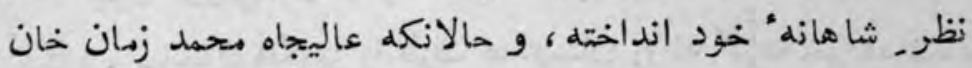

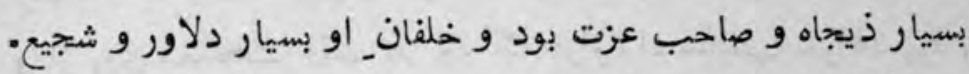

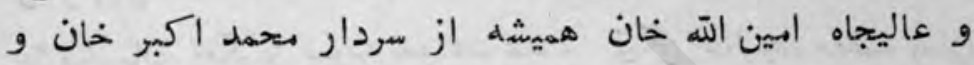

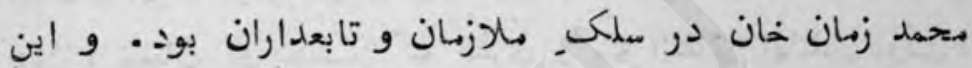

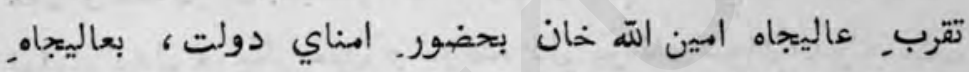

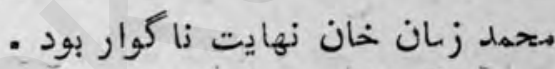

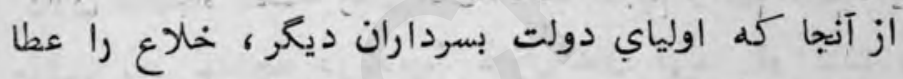

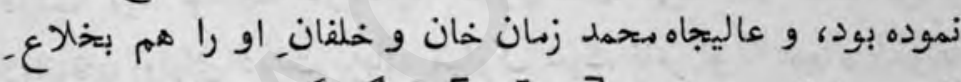

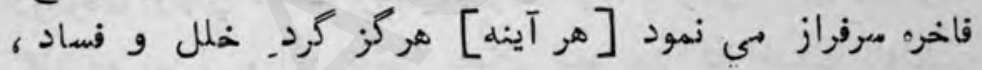

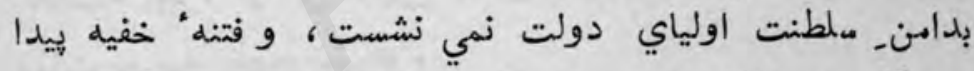

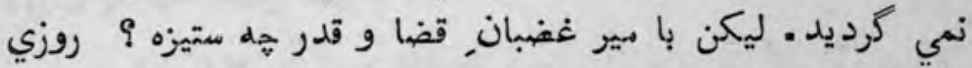

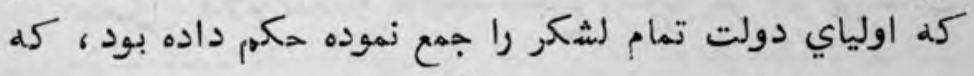

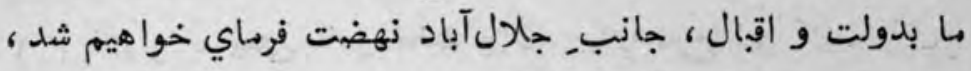

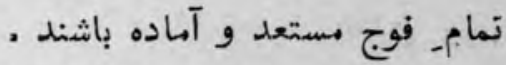

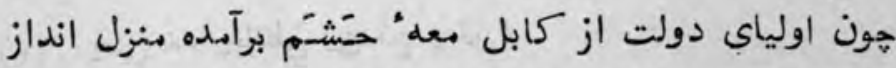

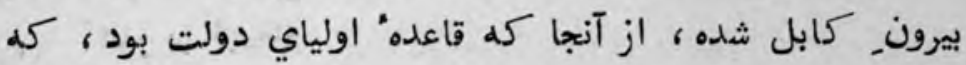

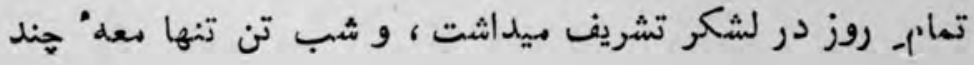




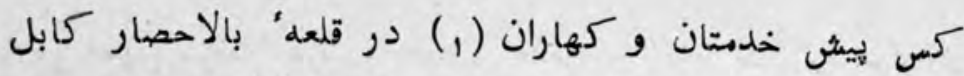

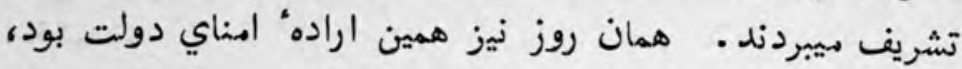

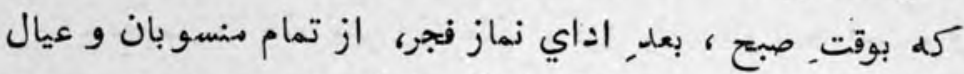

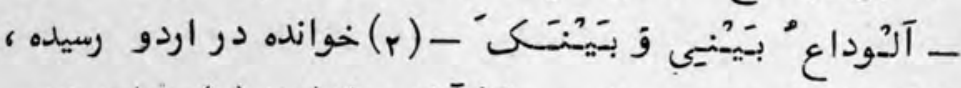

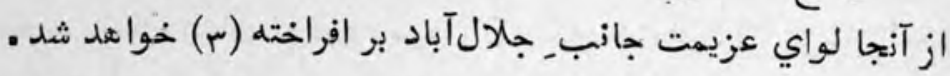

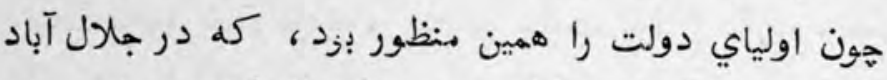

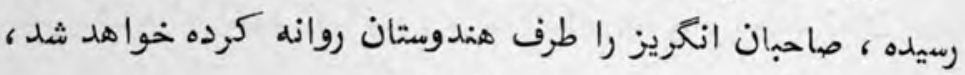

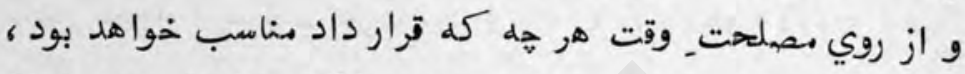

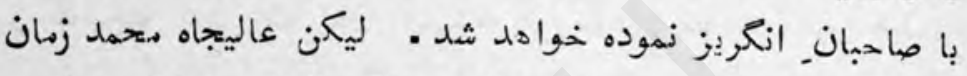

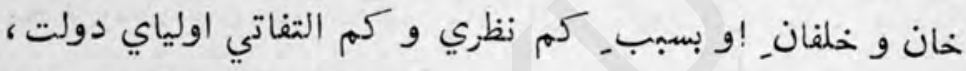

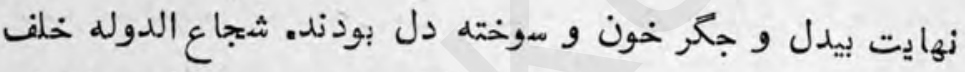

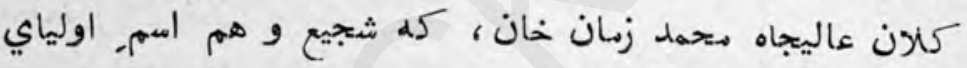

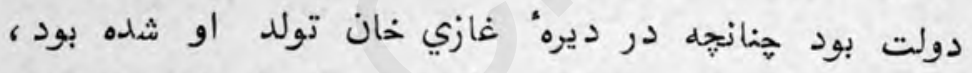

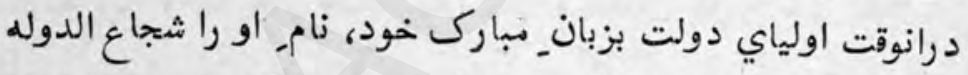

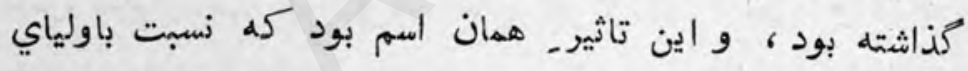

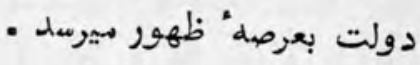
حاصل كلام آنكه : عاليجاه شجاع الدوله هر كاه اين حالت

(1) كهار= =يعني حاسل تخت روان، براي شرح اين كلمه ركه: تعليق 9 ـ.

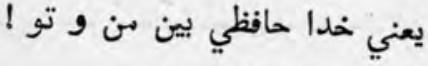

$$
\begin{aligned}
& \text { كى: بر افروخته هـ }
\end{aligned}
$$


$\Delta r r$

كم التفاتي و كم نظري اوبياي دولت ملاحظه نموده، بسياز

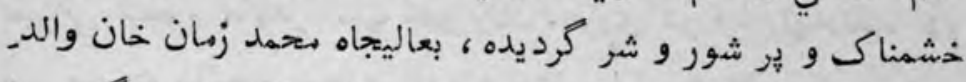

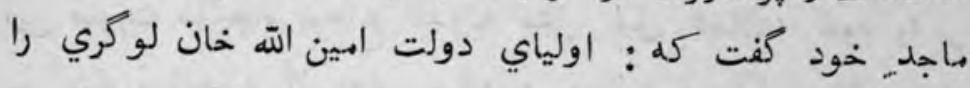

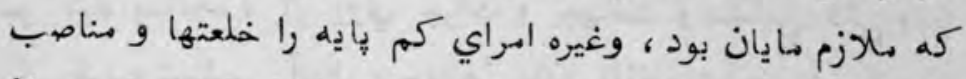

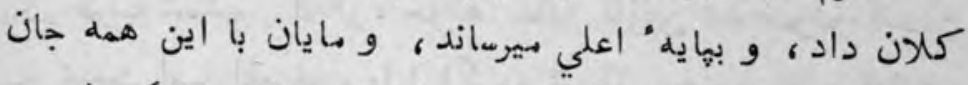

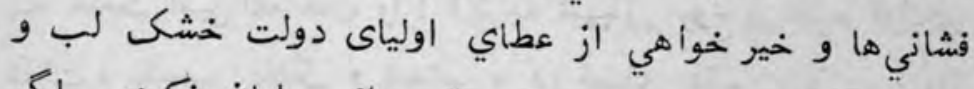

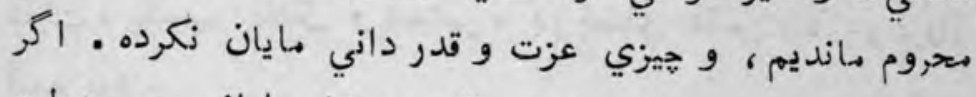

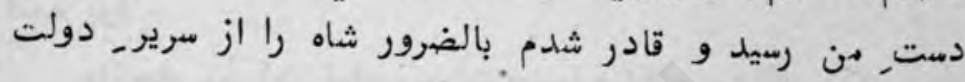

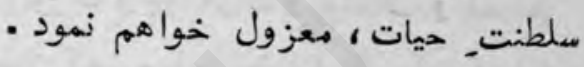

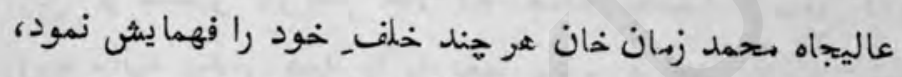

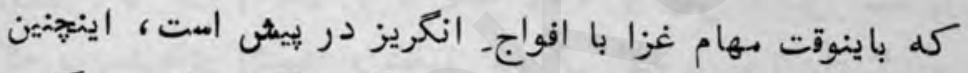

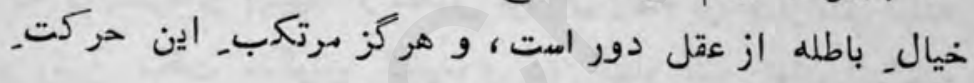

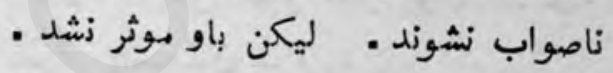

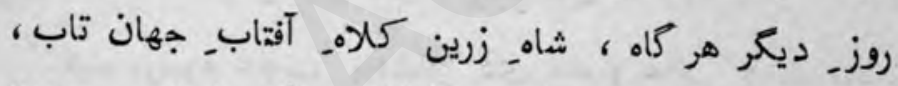

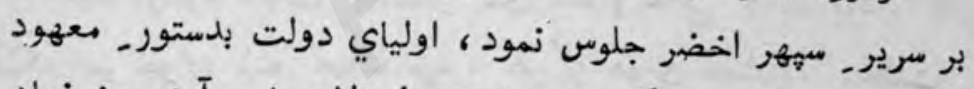

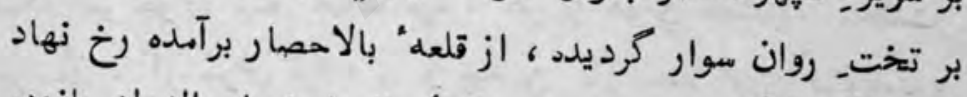

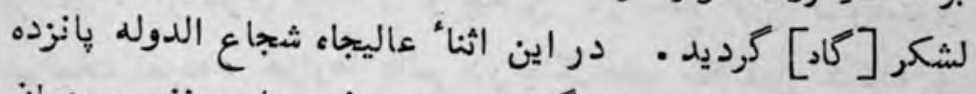

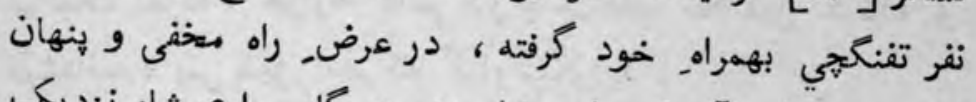

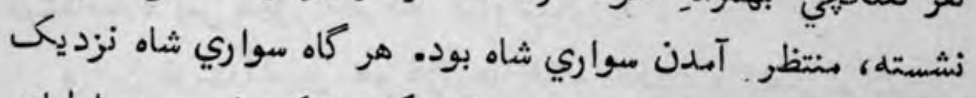

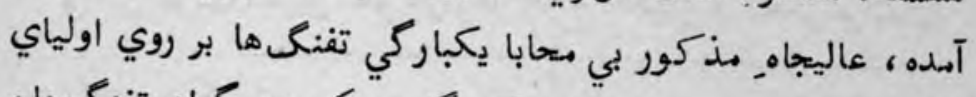

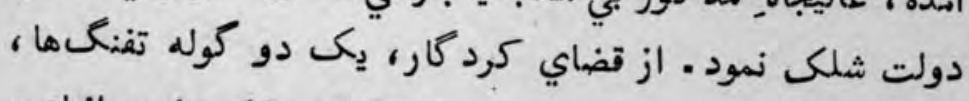

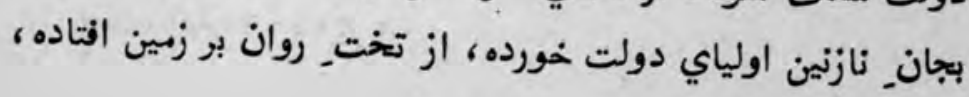


سواران و حمالان بمعاينه' اين حالت جون بياد كان در ششدز

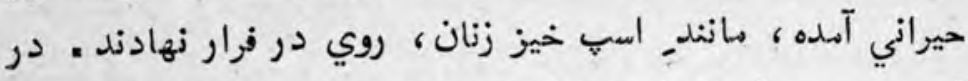

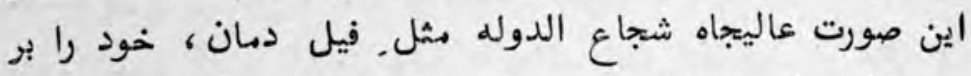

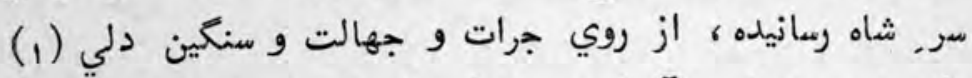

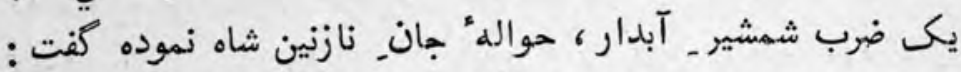

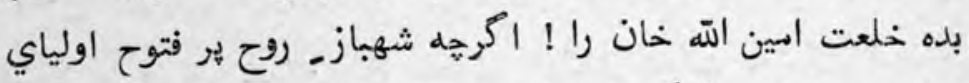

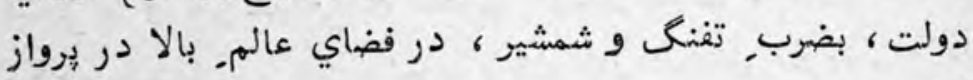
آنده بود مولت

عالبعجاه مذكور تمام زيورات و جواه هرات و بوشاكى وكمربند.

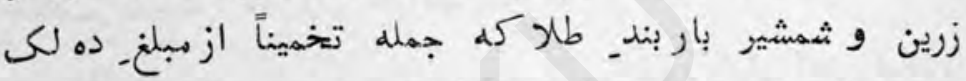

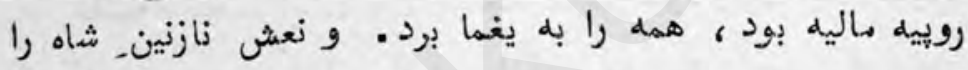

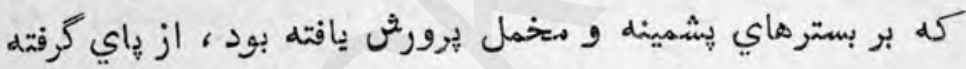

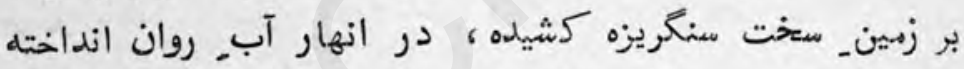

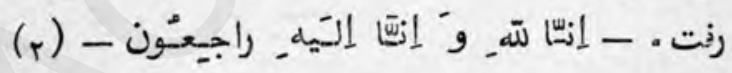

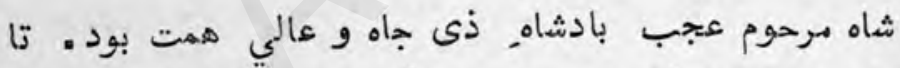

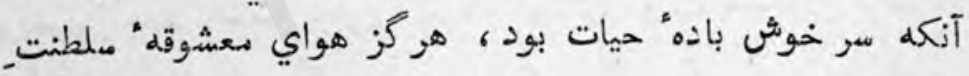

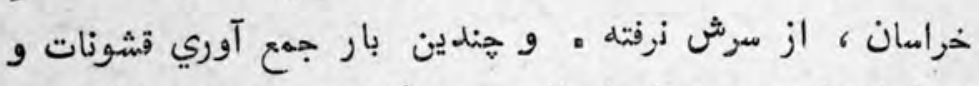

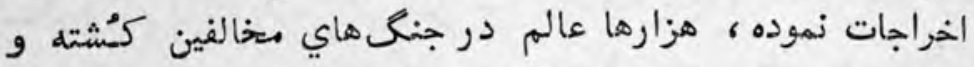

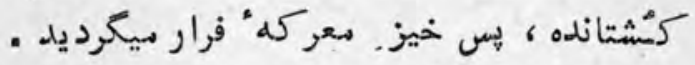

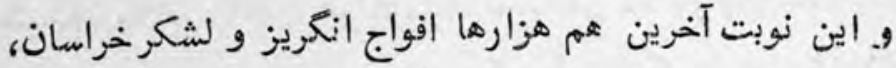

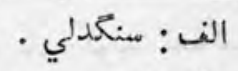

قرآن، البقره، بهاج r ب ل 
بوكاب خود از عالم فنا بعالم بقا برده تن تغها نرفته . هزارها افواج بركاب خود كرفته رفته است . معلوم أيست كله در آنجاي درو

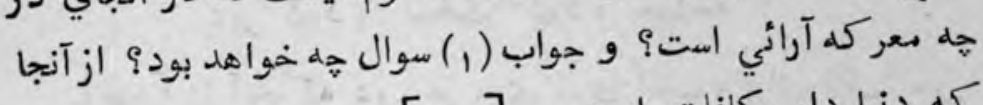

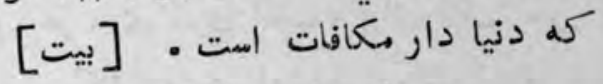

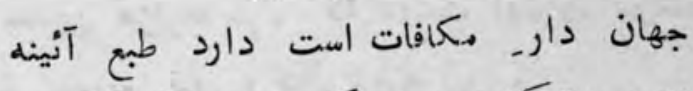

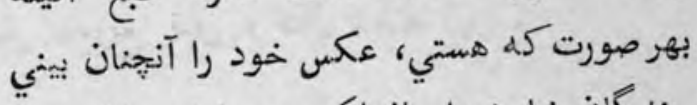

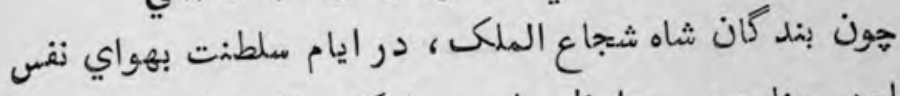

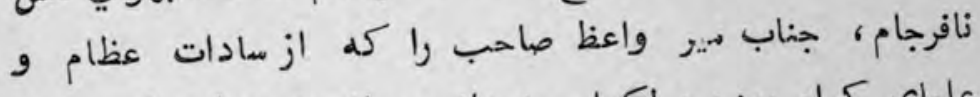

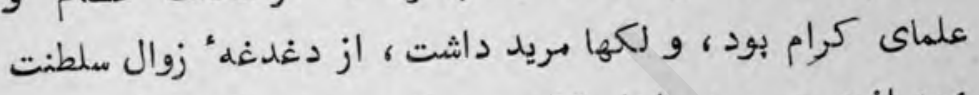

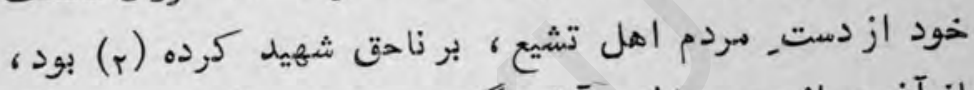

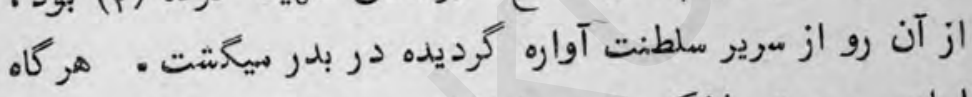
اساس_ جمعيت_ لشكر وغيره ماهان درست ساخته روانهُ خراسان

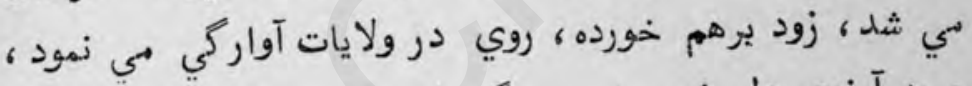
و بله آرزوي دل ذهيرسيد · مكر اين ذوبت باستظظهار صاحبان

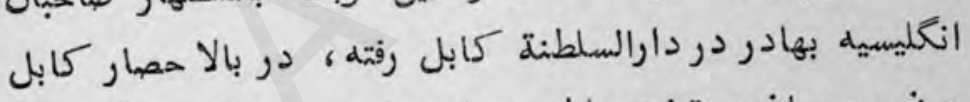

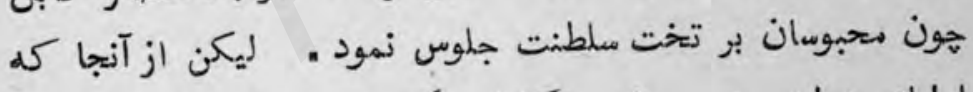

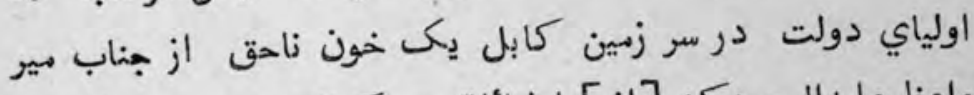

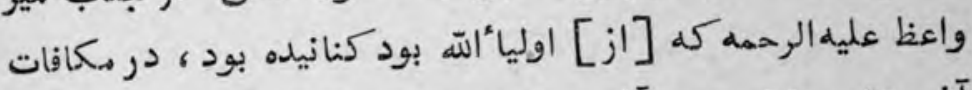

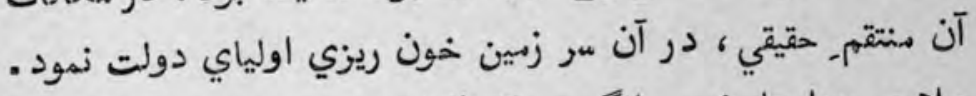

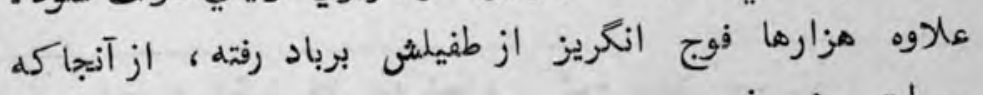
بر طبق مضمون

$$
\begin{aligned}
& \text { كى: و جواهد [؟]] } \\
& \text { الف: كشتاندانده }
\end{aligned}
$$


تازه نواي معارك

orr

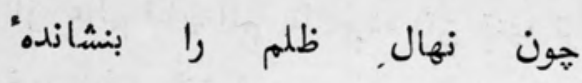

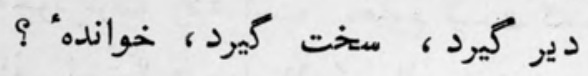

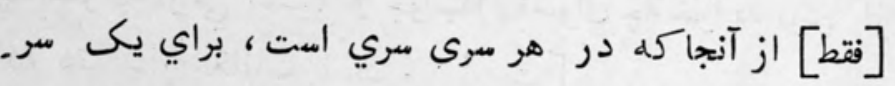

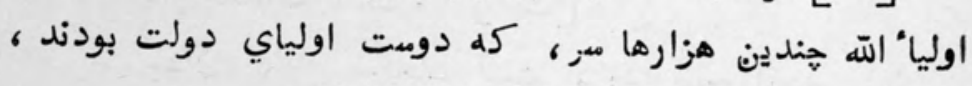

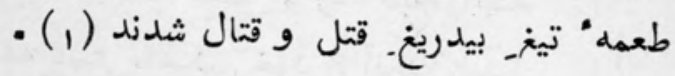

(1) راجع به تفصيل قتل شه شجاع ركى: تعليق نمبر .ه . 
$-<4-$

در بيانِ (1) بعد, قتل شدنِ اولياى دولت سردار محمد اكبر خان توقف خود در جلال آباد مقرون

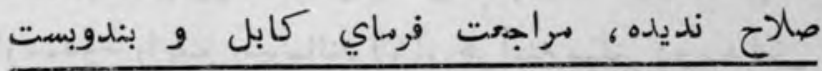
نمودن كارهاي آنجا

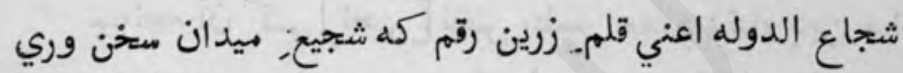

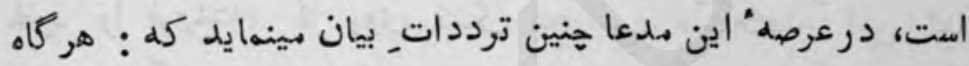

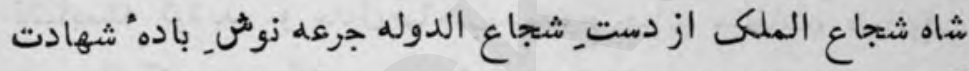

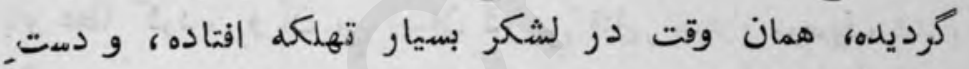

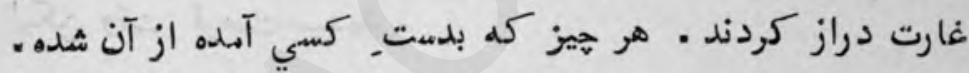

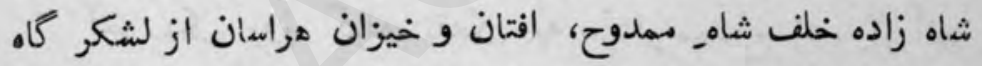

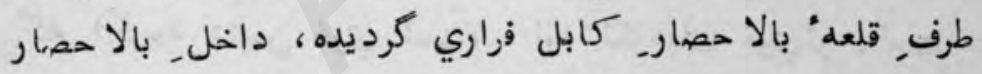

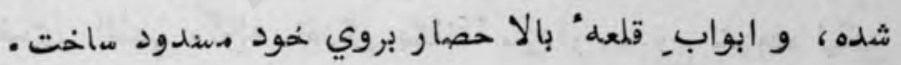

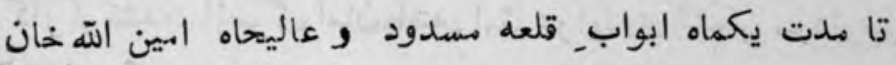

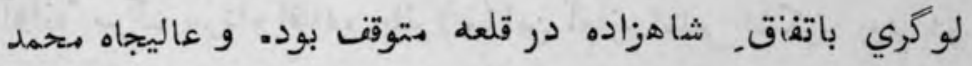

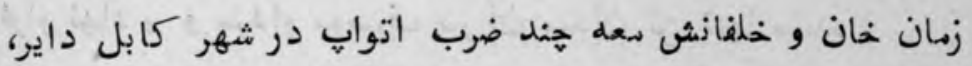

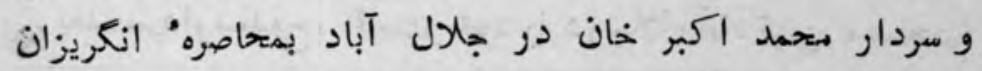

(1) اين فعل در الف ، كى وارد است، در ب ؛ ج نيست. 


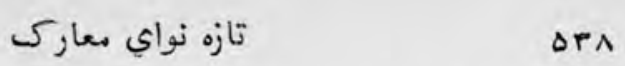
مختت يرداخته بود، و عاليجاه شهس الدين خان در قلعه غرنين - قامت نذير

در اين صورت جرنيل صاللى صاحب بهادر بجهت كشيدن سردار, همدوح از جلال آباد، بسيار تجويزات هيكرد، ليكن

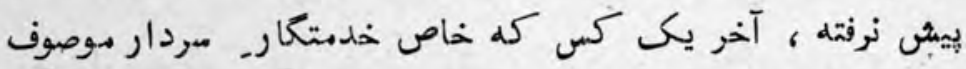
بود ، او را بطريق, اخفا نزد، خود طلبانيده كفت كله : هر كراه سردار مهدوح را بقتل ميرسانمد (1)، هر آينه مبلغ دو ميه لكى روبيه

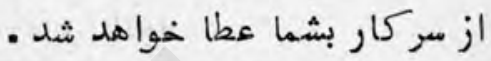

هنانهِه آن كس [نحس] نجس بطمع حطظام دنيا، دين و ايمان

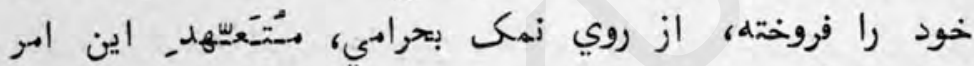

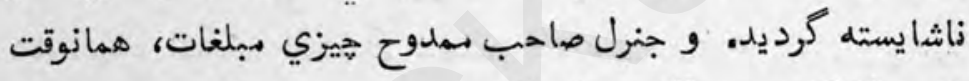

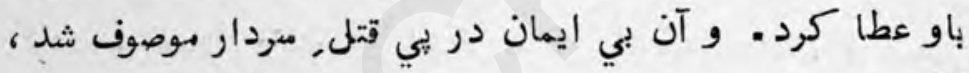

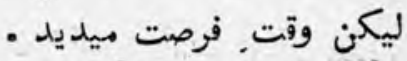

آخر يك روز كوله تفنح به سردار مهدوح زده. از آزجا

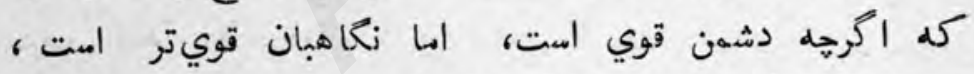

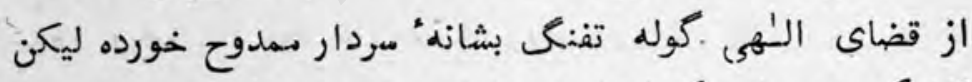

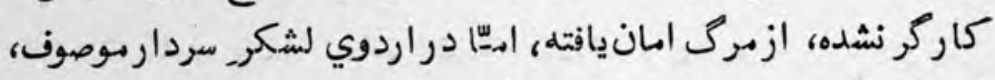

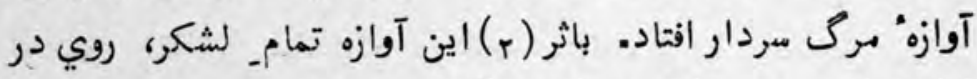

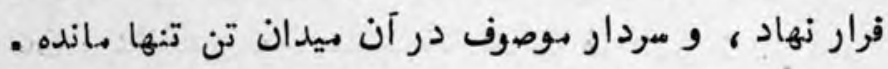

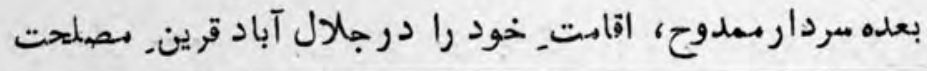

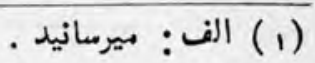

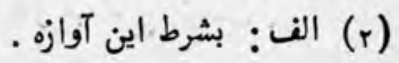


orq

تازه نواي معار

نديده، و هم خبر رسيدن فوج انكريز نزديك جلال آباد

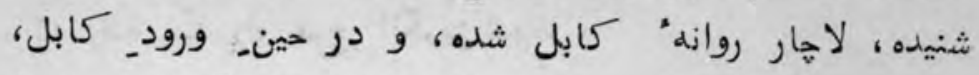

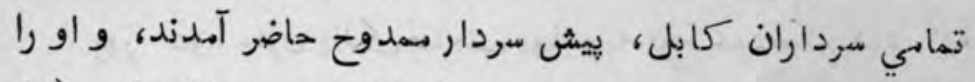

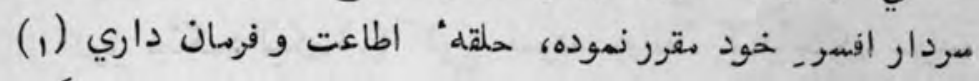

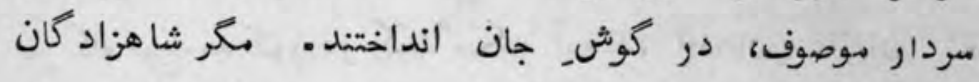
و ديكر متعليّقان اولياي دولت، درو رياست سردار ممدوح بسيار

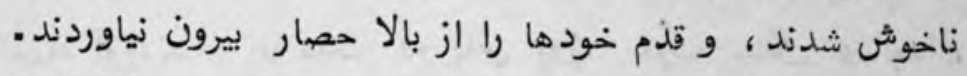

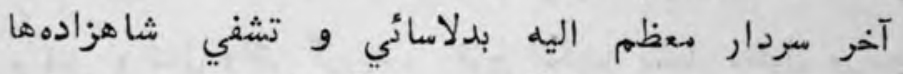

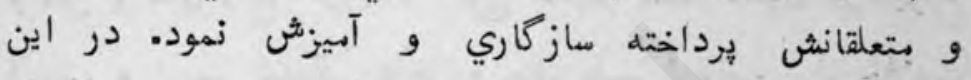
اثنا جنرل هالك صاحب بهادر و جنرل سيل صاحب أز راهـ

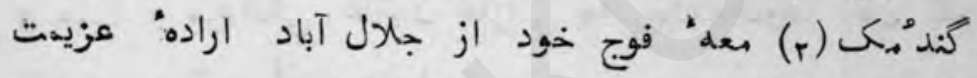

- كابل نمود

اولا" جنرل سيل صاحب بهادر جاسوس. خود را طور مخغفي

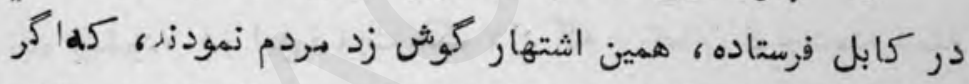

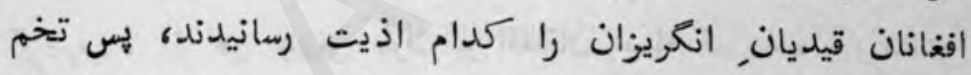

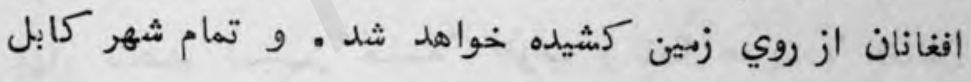

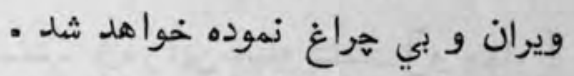

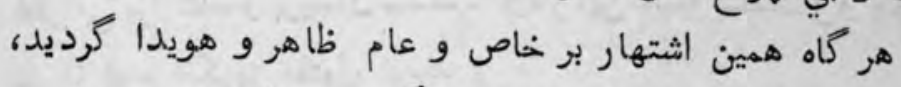

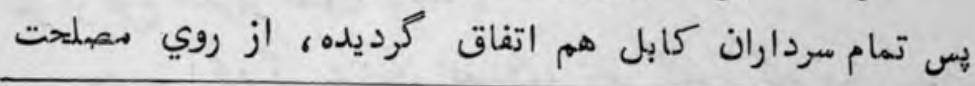

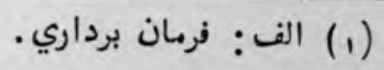

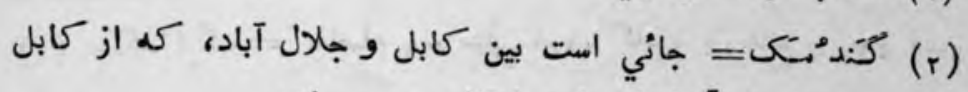

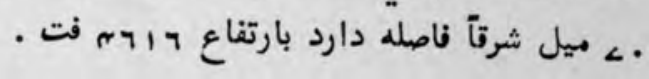




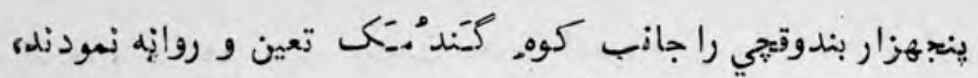

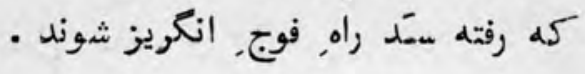

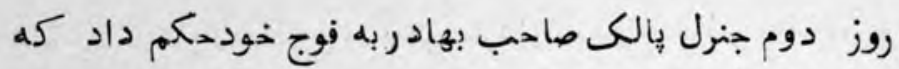

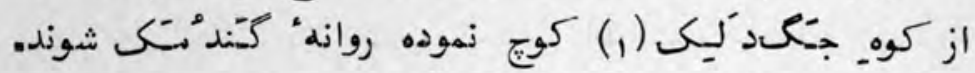

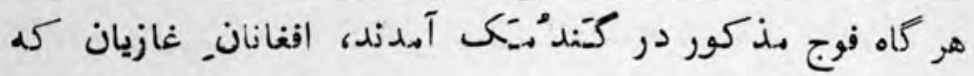

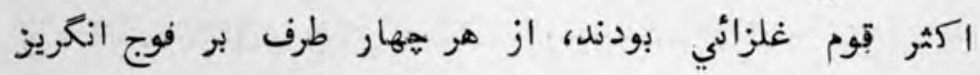

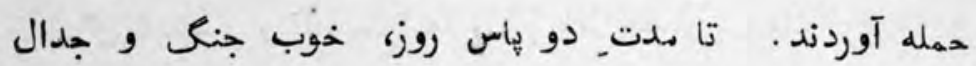
و قتل وقتال واقع كرديد. فوج انكريز بسيار مقتول و مجروح

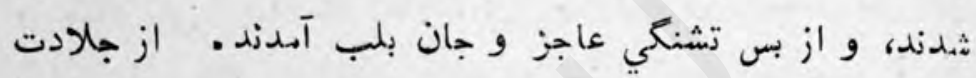
و همت و مردانكي غازيان غلزائي هله نوشته شود، زبان قلم از تحرير و تقرير آن بيرون است فردان

هر كاه جنرل صاحب مالاحظه نمود كه فوج انكريزي مفت تباه ميشود، در اين صورت حكم داد كه : تمام فوج دسته دسته

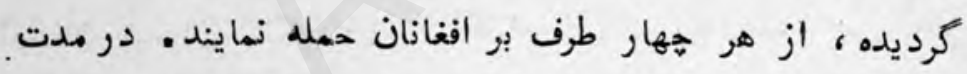

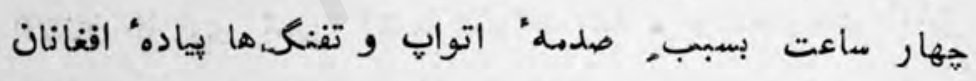

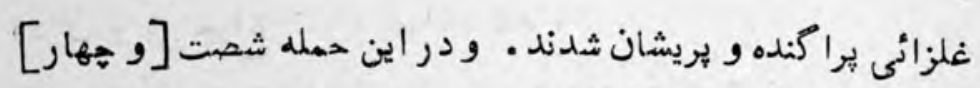

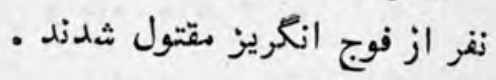

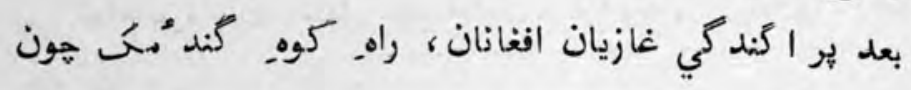

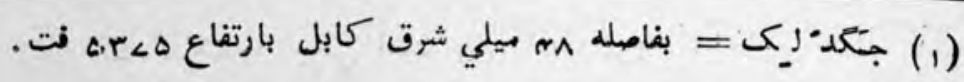


درز. كندم كشاده شد . بوقت شام، تمام فوج انكريز، از بالاي كوه بزير آمدند، و در آنجا مقام نمودند .

جون اين خبر هزيمت_ غازيان غلزئي در كابل بسمع سردار

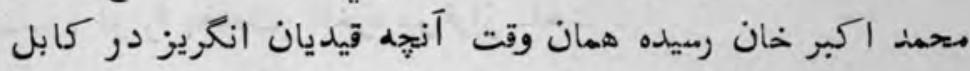

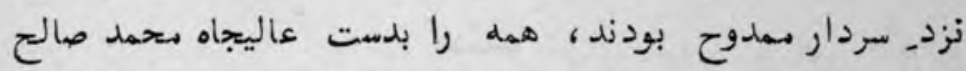

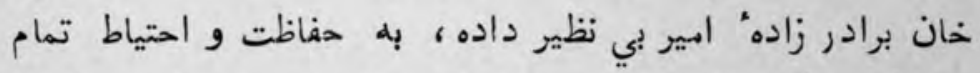

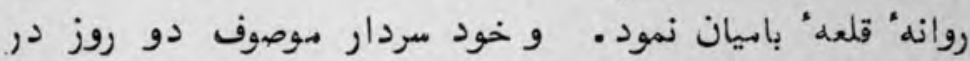

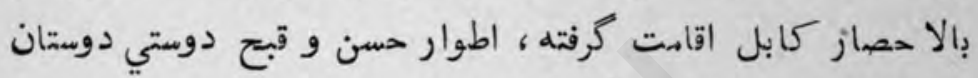

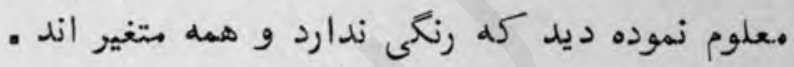

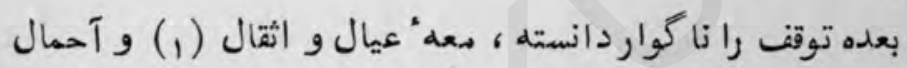

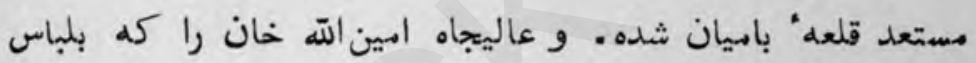

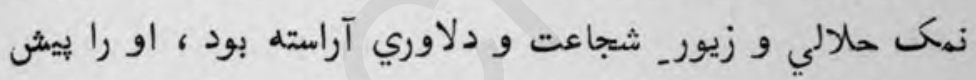

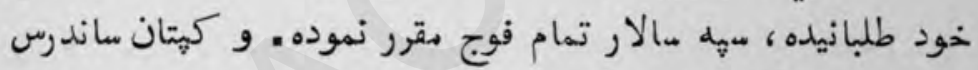

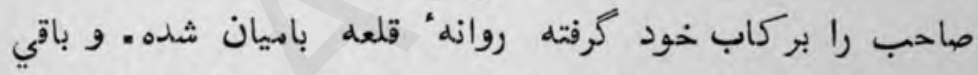

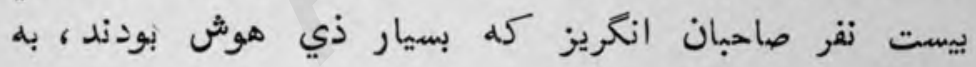

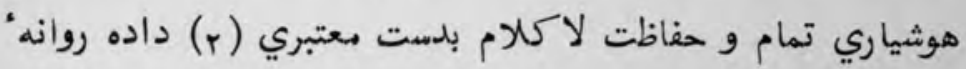

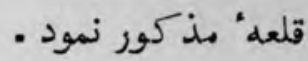
در حين رفتن مردار موصوف عاليجاه محمد شاه خان غلزئي

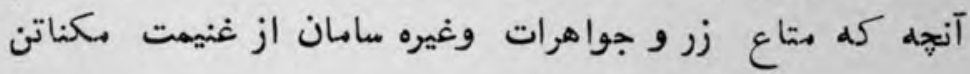

$$
\text { يعني ييزهاي كرانبار . }
$$

اين كله در كى نيست ، بجاي آن نقاط كذاشته اند . 
تازه نواي معارك

$\Delta N Y$

صاخب وزير اعظم بدمت يغماي خود آورده بود ، همه را آورده

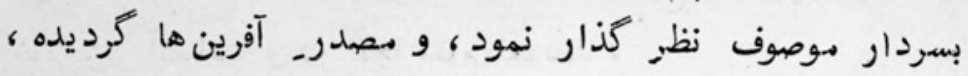

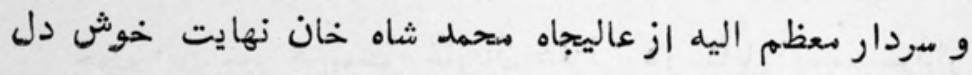

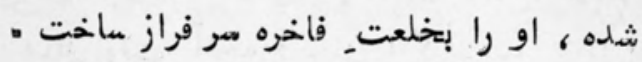


$-\angle \angle-$

در بيانِ رفتن صاحبان اذخكليسه دفعله ثانى در كابل و سوختن. جهار سطح (1) بازار كابل و رهانيدن قيديان خود (r)

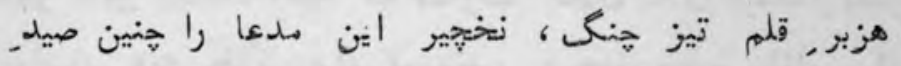

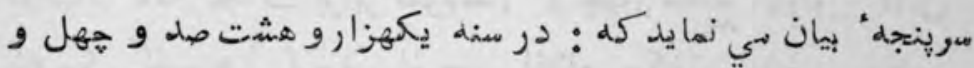

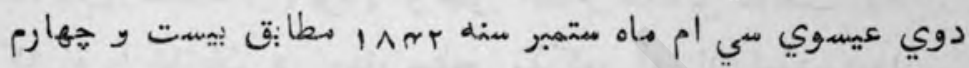

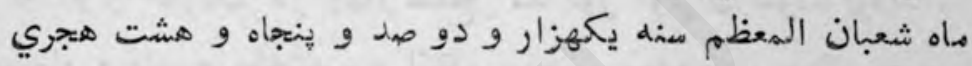

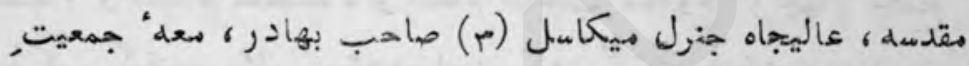

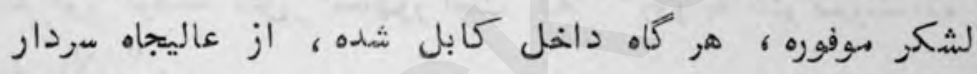

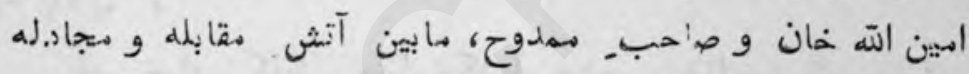

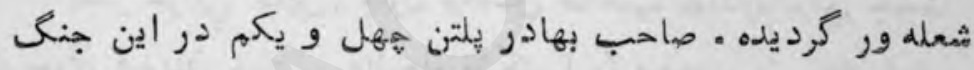

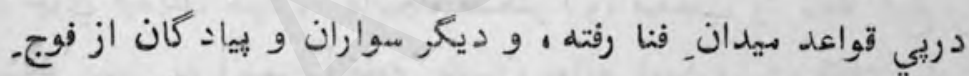

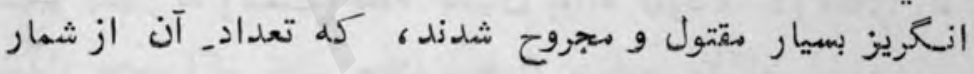

بيرون است .

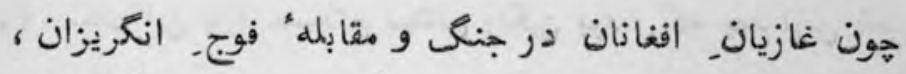

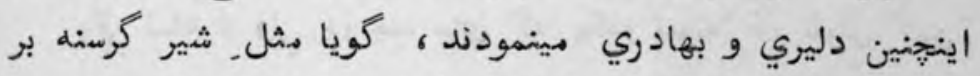

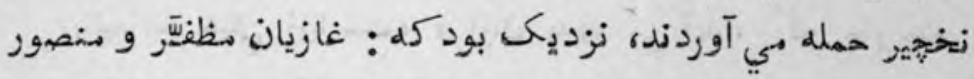

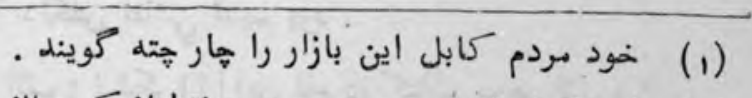

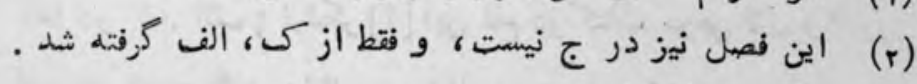

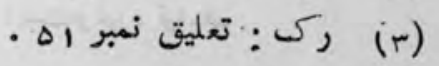


تازه نواي ــأركى

$\Delta N$

شوند، كله درين اثنا توي خازهُ انگريزان رسيده ، و از هر جهار

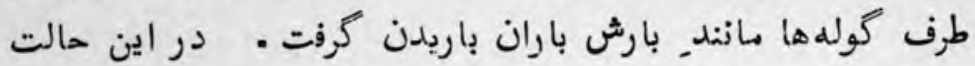

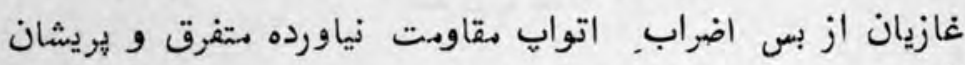

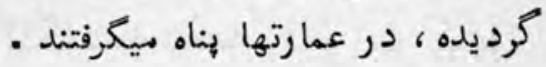

فوج. انكويزان در اين صورت بيشى رفت نموده آهده ، داخل كانل

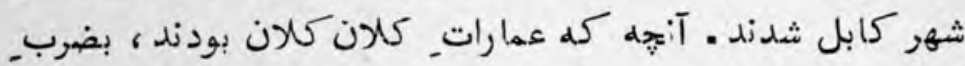

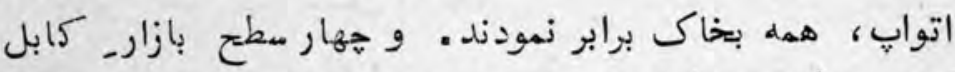

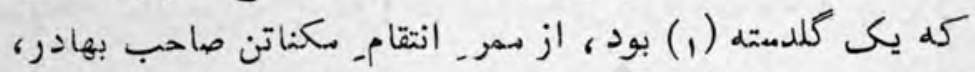

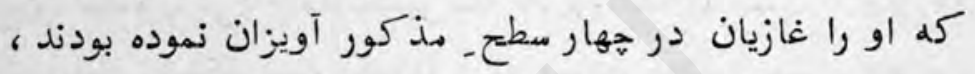

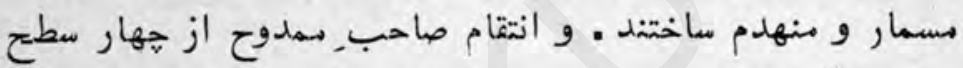

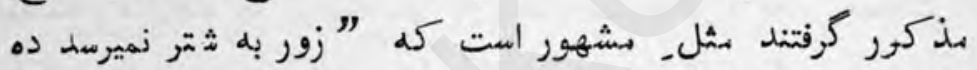

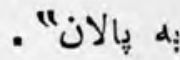

بعد خرابي كابل، جنرل مكاسل صاحب بهادر، براي جست

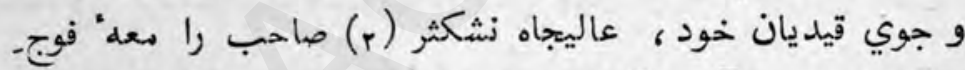

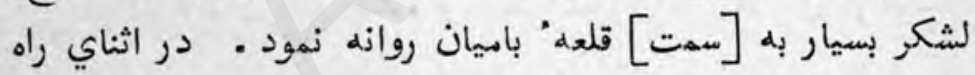

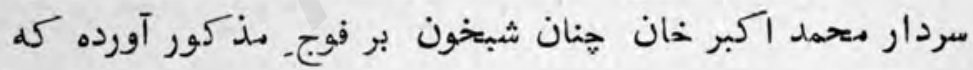

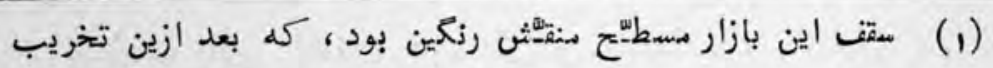
باقي نماند ، ولي در هند جاي كه يكدو نمونه' آن نقوش كهن باقيمانده خيلي زيبا ست، و ازان هيديد سي آيد، كه كه هار هته

مذكور نمونه" دلكث نقاشي قديم بود . كذا در ك. الف : نيشكر [؟] اين نام در كتاب موهن لال و "لور (r) آفى دي اندوم" و روزناميجه جنرال ايبت وغيره نياهده. 
تمام (1) اجناس_ مودي خانه (r) و باروت خانه همه در قبضه

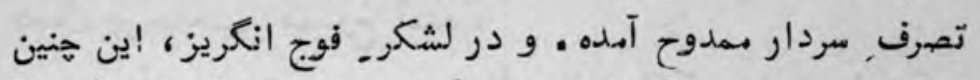

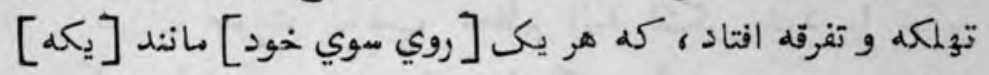

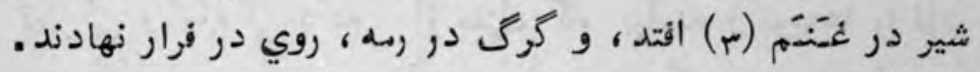

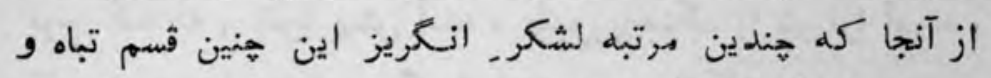

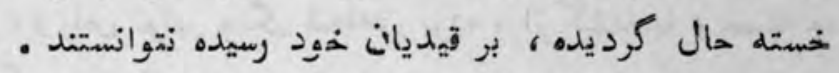

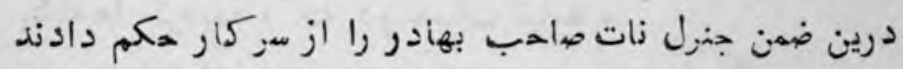

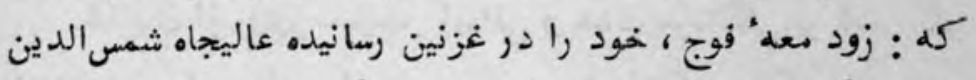

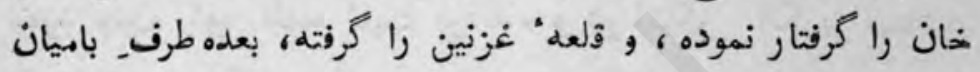

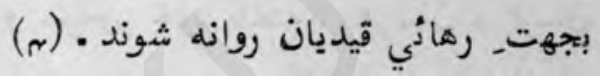

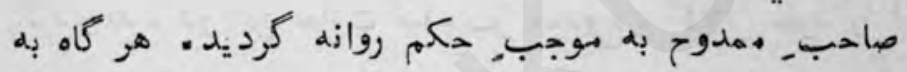

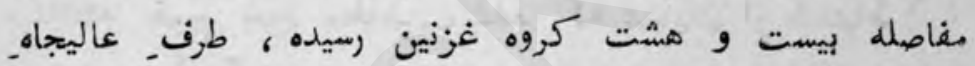

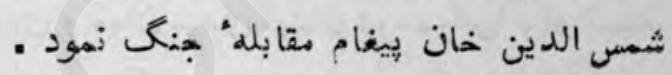

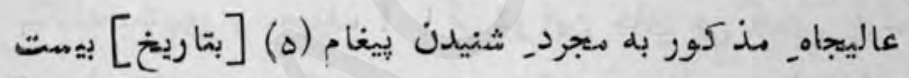

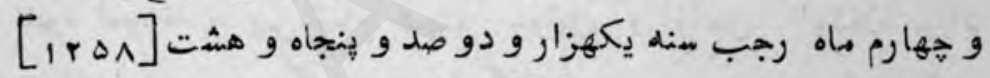

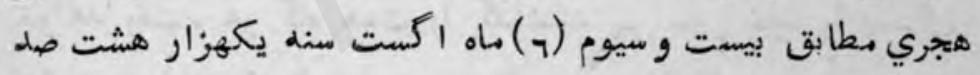

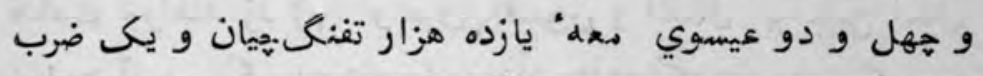

$$
\text { كى: كه تمام فوج اجناس . }
$$

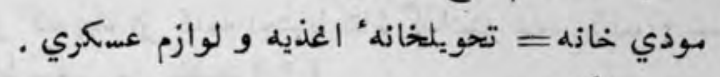

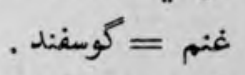

ركى: تعليق نمبر rه ه . درين اوقات جنرل نات در قاتلهنار بود .

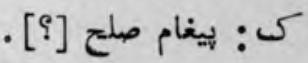

$$
\begin{aligned}
& \text { الف: بيستم ماه بـ }
\end{aligned}
$$


توي در داسن. كوهستان يخهان ساخته، و دو هزاز لشكر طرف.

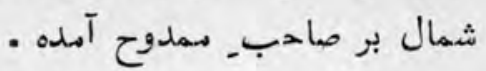

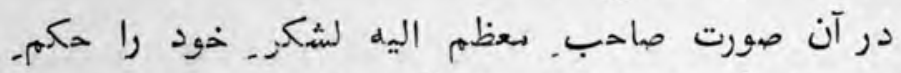

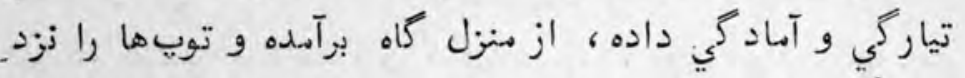

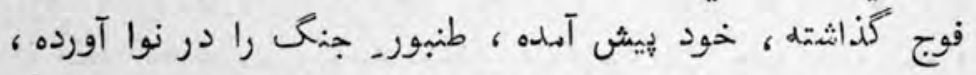

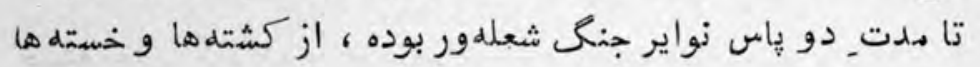

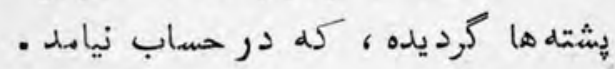

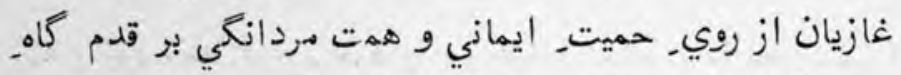

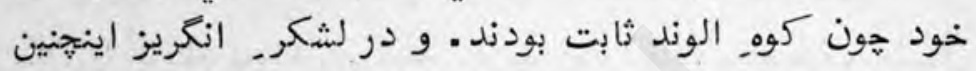

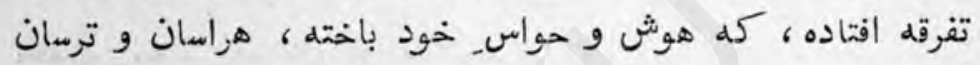

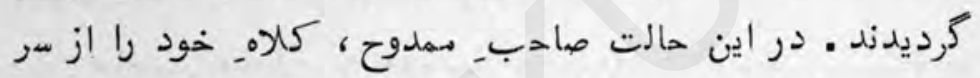

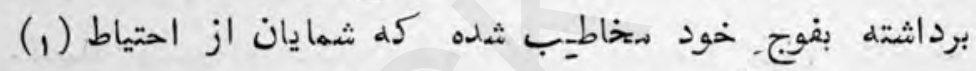

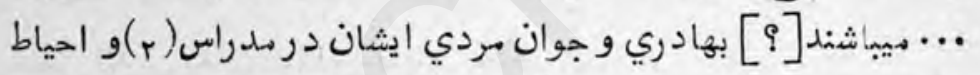
بنغاله هشهور و معروف ! اكر در اين جاي بي همتي ران شعار بردي

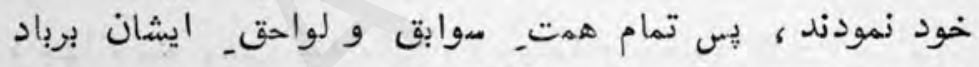

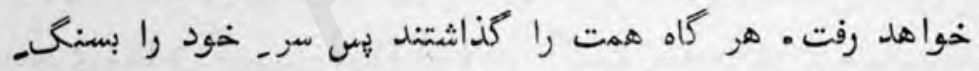

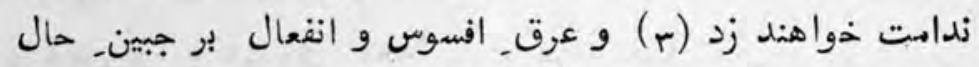

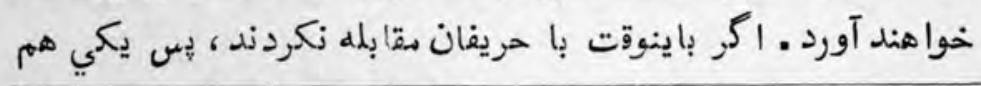

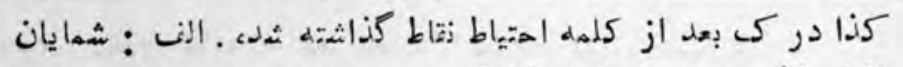

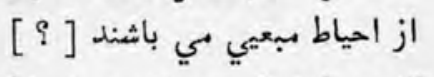

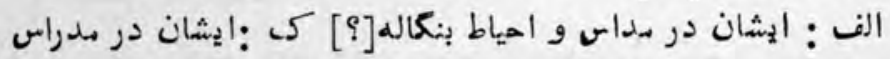

$$
\text { و احتياط هينكاله [ }
$$

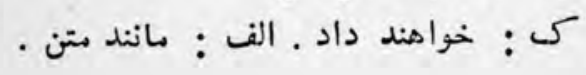


زنده نتخواهد ماند، بهتر همين است كم يكبارگي تمام- فوج

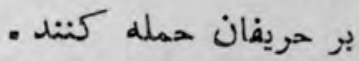

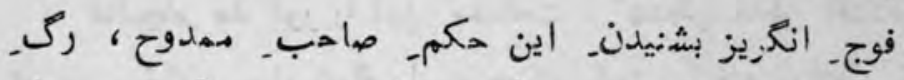

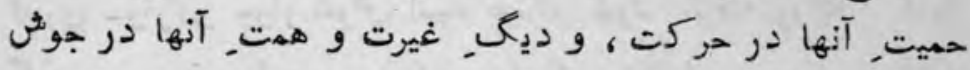

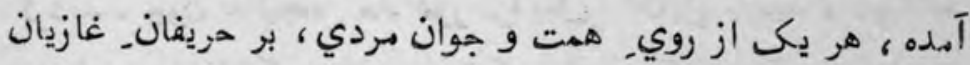

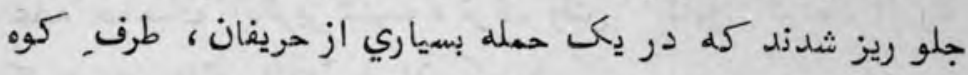
و جنكل فراري شدند ثلد

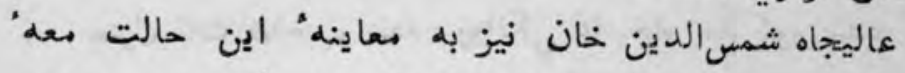

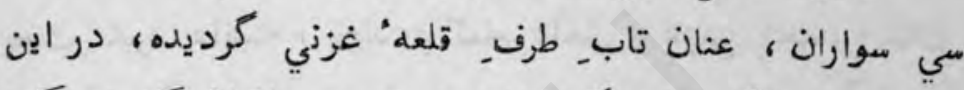

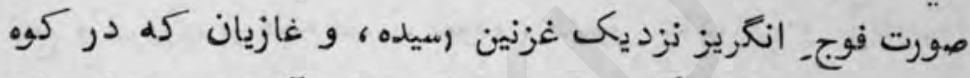

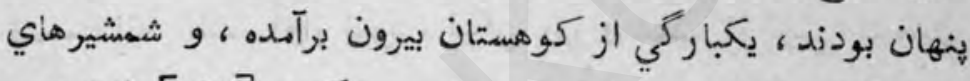

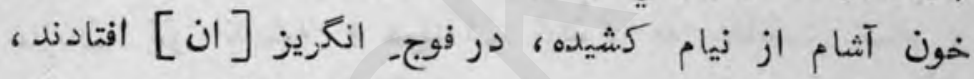

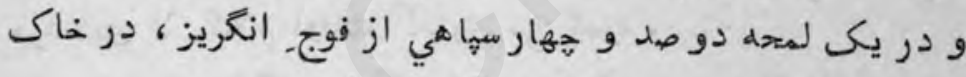

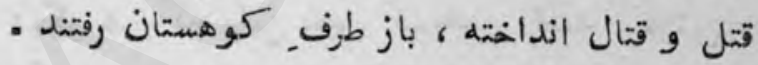

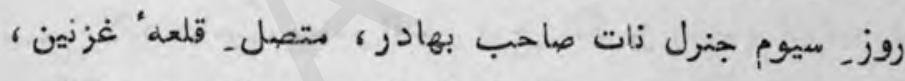

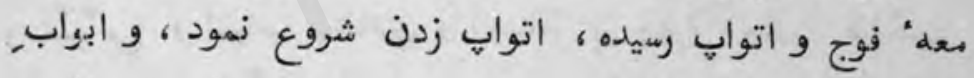

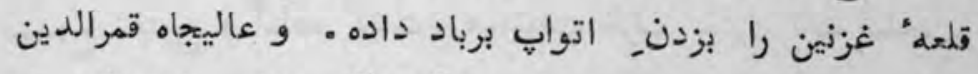

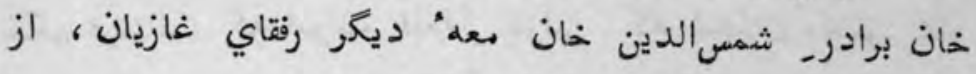

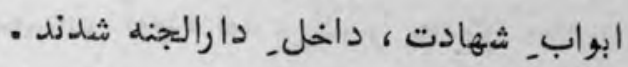

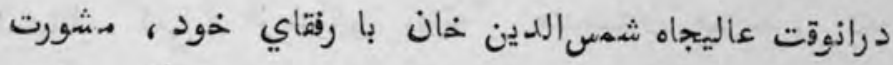

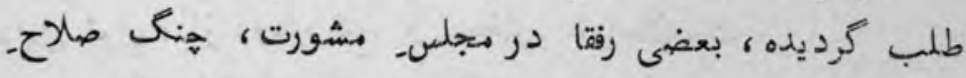

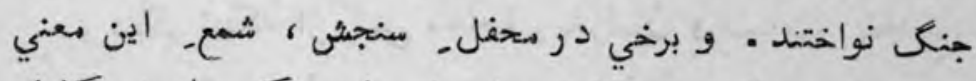

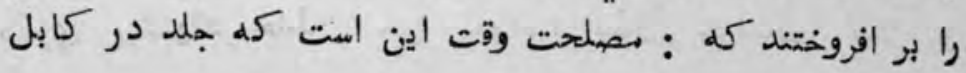


تازه نواي معار

0 A

رسيده ، و از آنجا جمعيتـ لشكر موفوره كرفته آمده ، بعده بناي

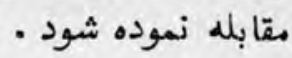

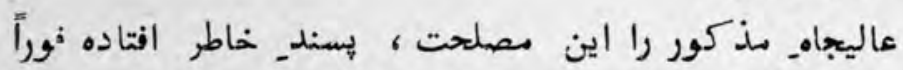

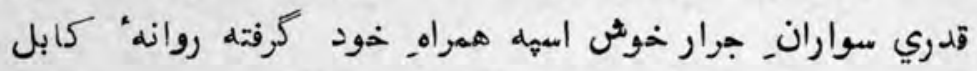

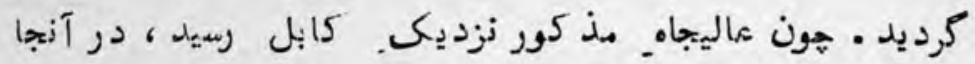

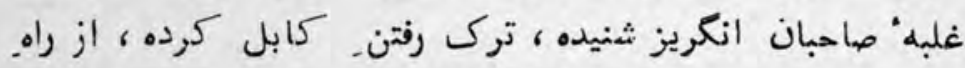

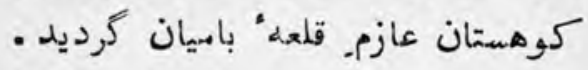

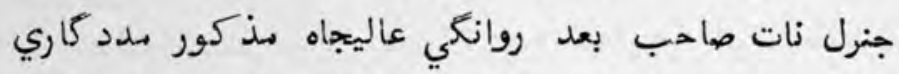

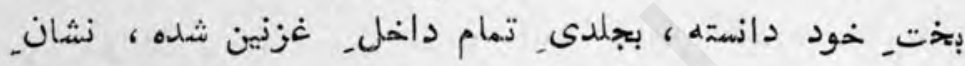

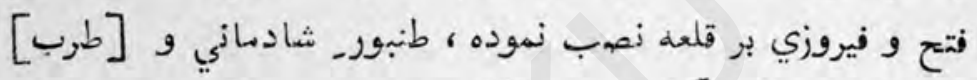

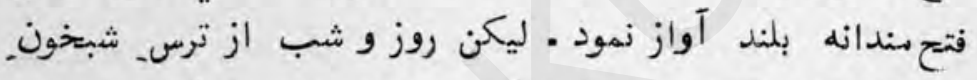

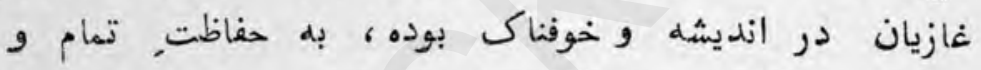

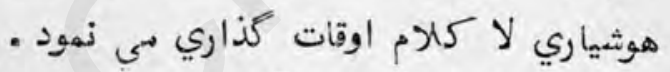

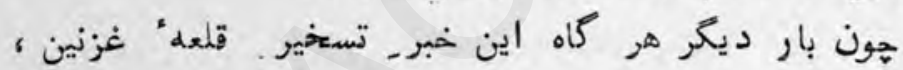

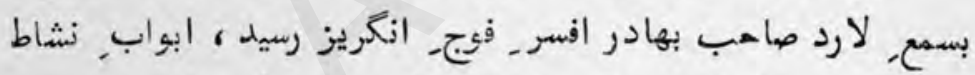

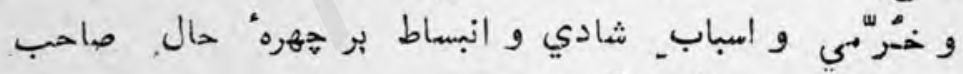

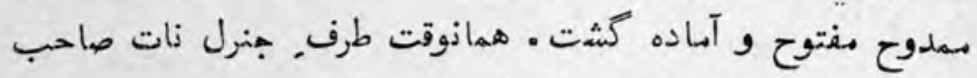

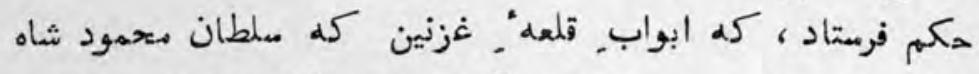

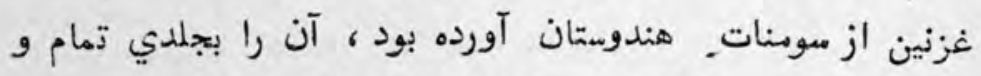

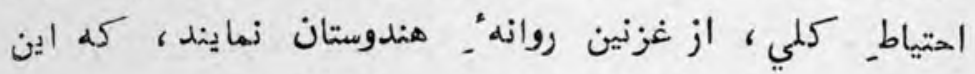

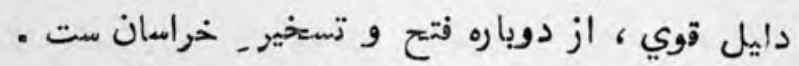

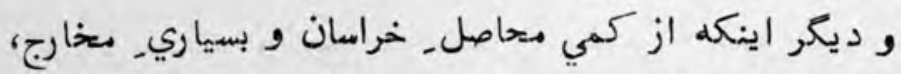

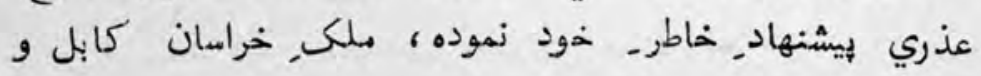




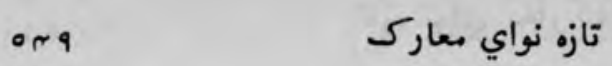

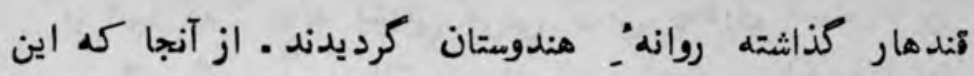

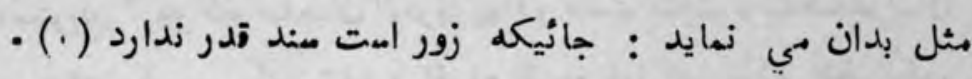

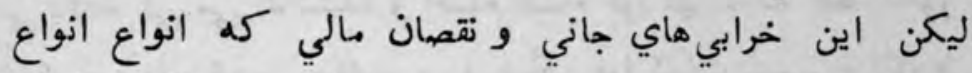

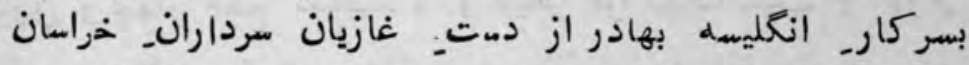

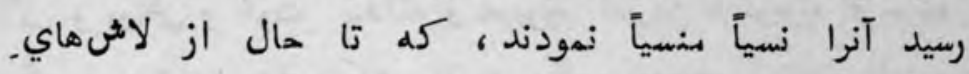

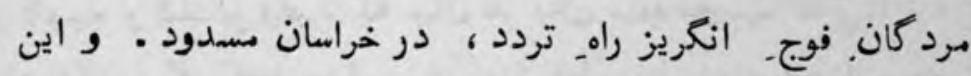

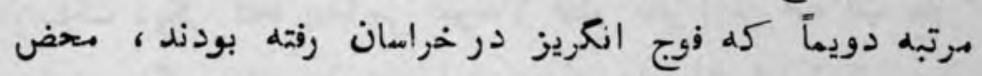

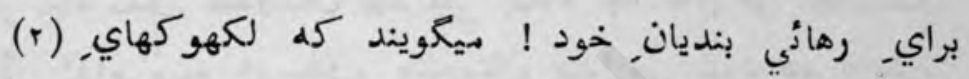

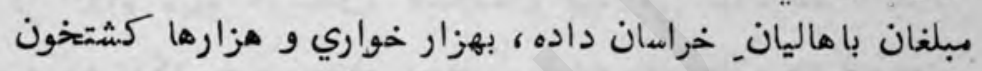

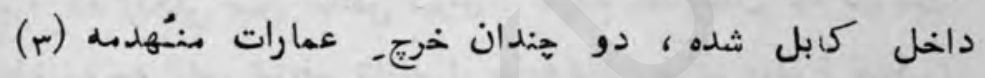

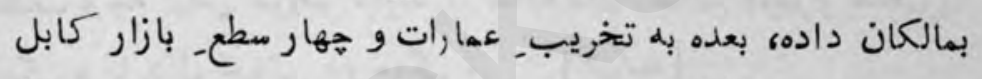

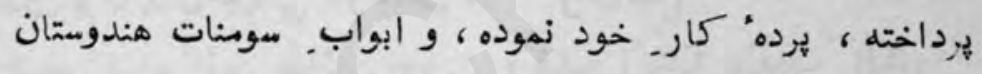

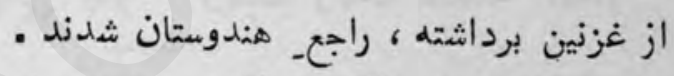

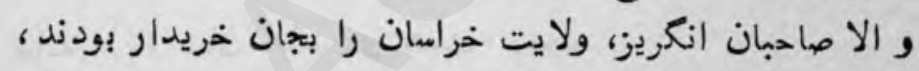

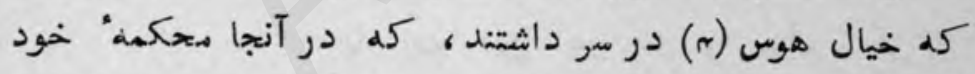

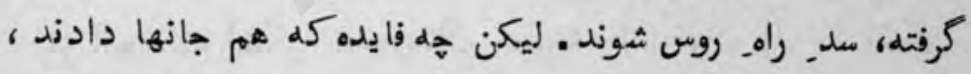

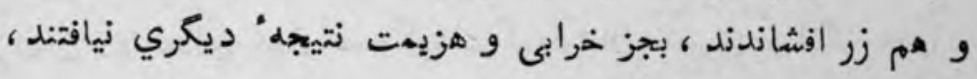

و داغ حسرت بر دل كذاشتيند .

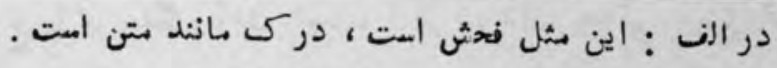

(1)

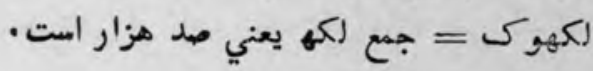

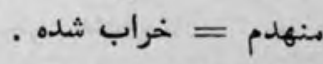

(r)

الف: خيال اروس در سر .

(r) 
5ازه نواي مارك

$\Delta \Delta$.

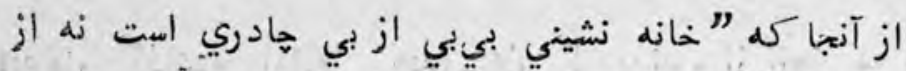

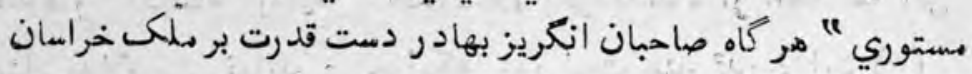

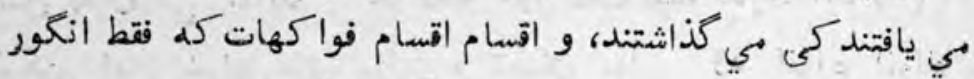

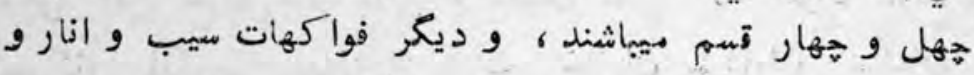

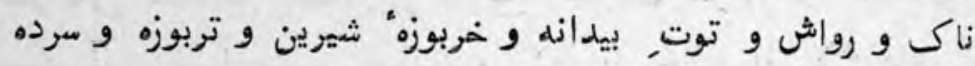

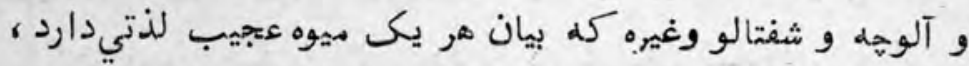

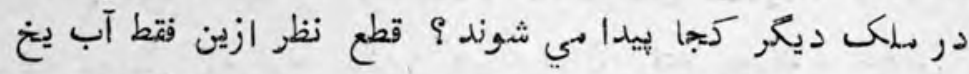

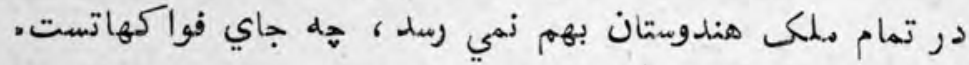

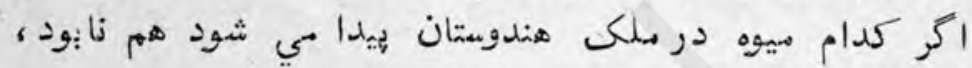

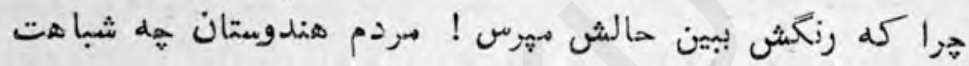

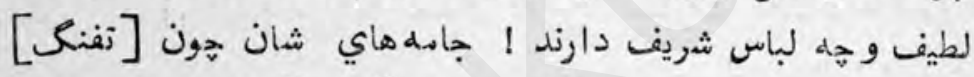

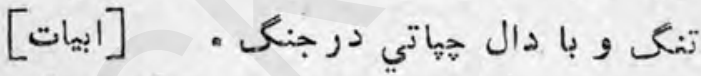

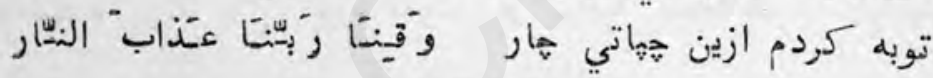

خانه' (1) شان بلند و هـت بيت

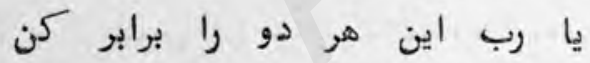

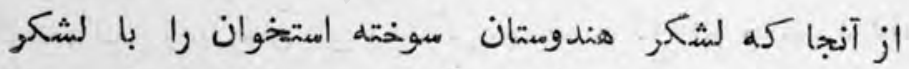

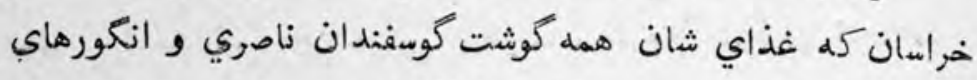

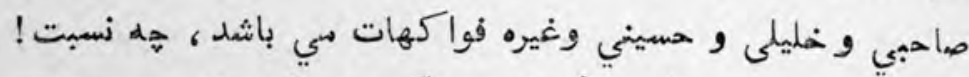

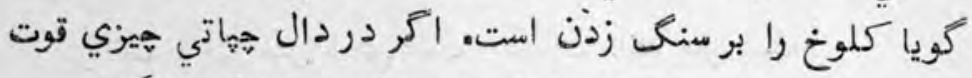

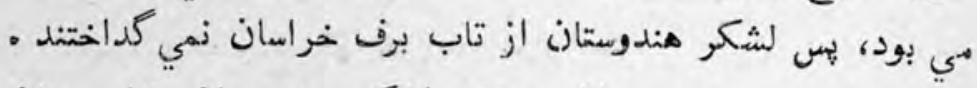

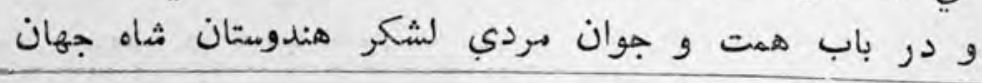

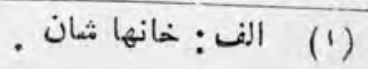




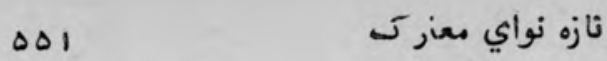

دادشاه هندوستان عجب نغمه از قانون طبع نواخته است، "باباي

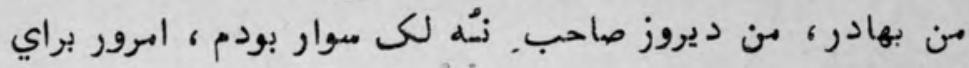

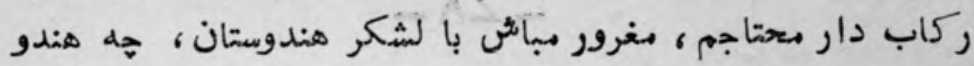

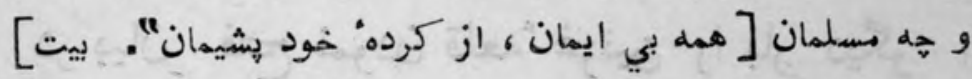

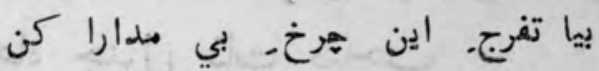

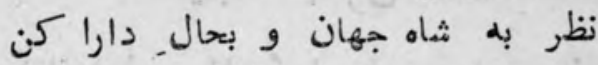

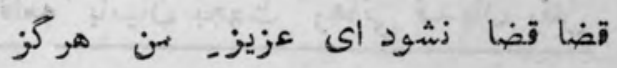
تو خواه فال بزن خواه استخارا كن

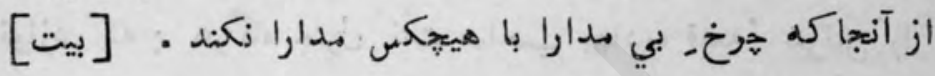

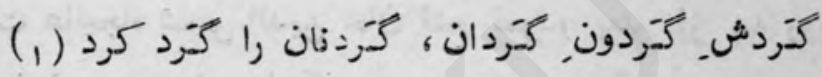

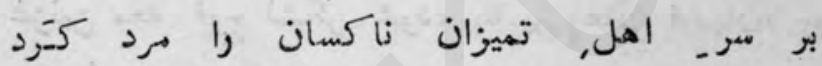

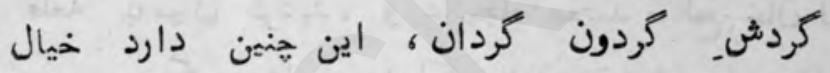

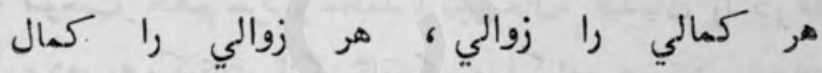

(1) اين بيت دركى مسغ شده، از الف تصنيح شد . . 
در بيانِ فتح ذمودن قلعهء غزذين را بار ديخر عاليجاه جنرل ذات صاحب

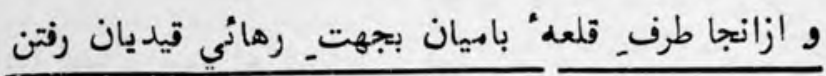

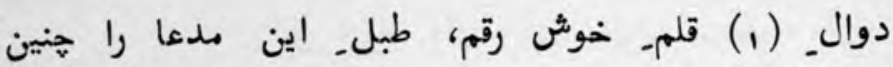

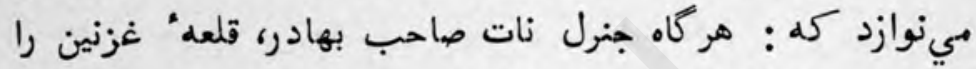

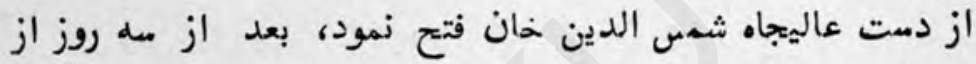

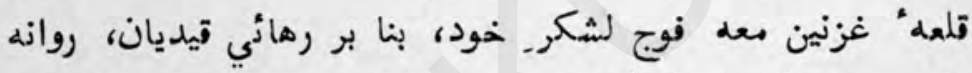

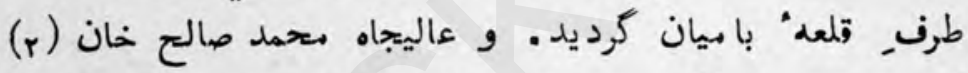

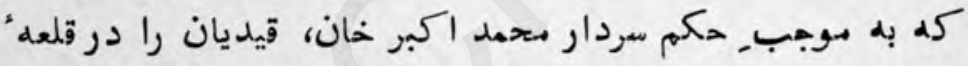

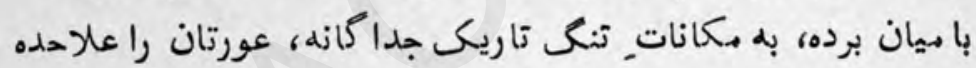

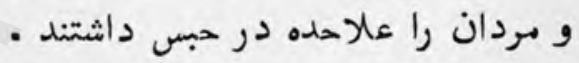

(1) دوال = تسمه" تابيده" هرم كه بدان طبل بي نواختند

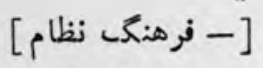

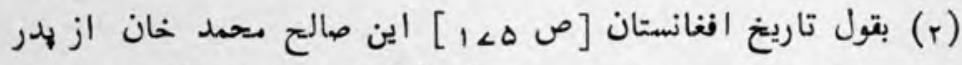

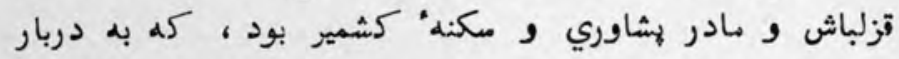

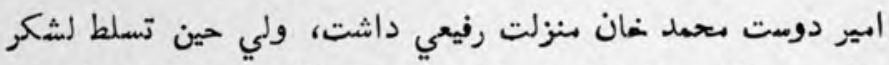

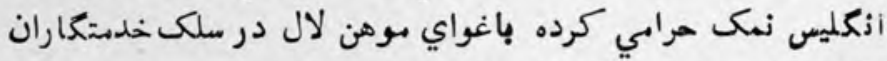

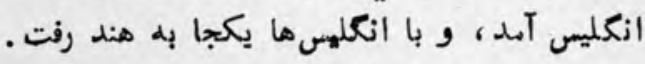

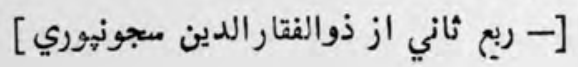


$\Delta \Delta r$

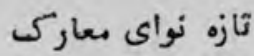

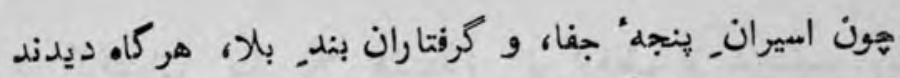

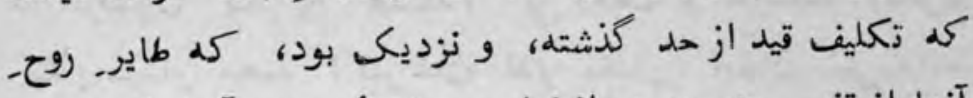

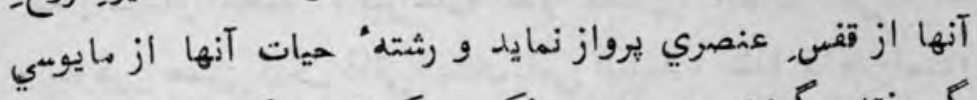

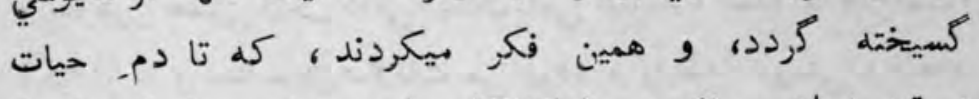

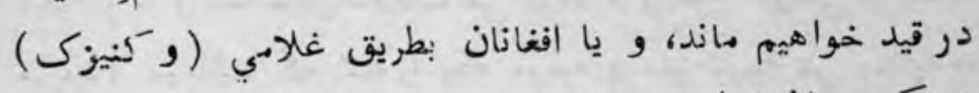

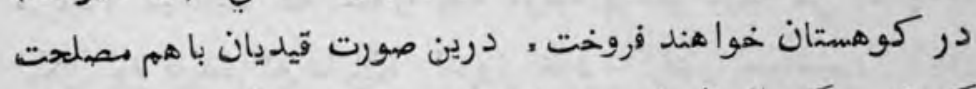

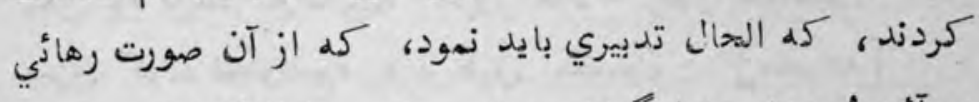
در آنينه هدعا رختما كرددة، و تير. تدبير را از كمان_ انديشه،

حنان بايد زد ، كلم بر نشانه مراد خورد .

از آنجا كه قيديان عاليجاه لارنس صاحبب بهادر را در اين

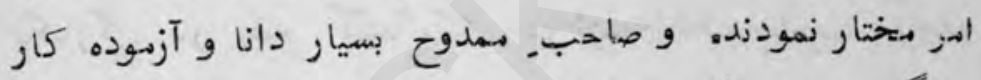

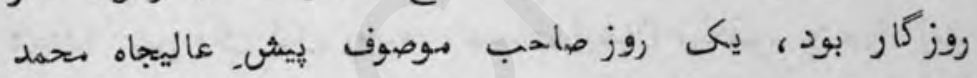

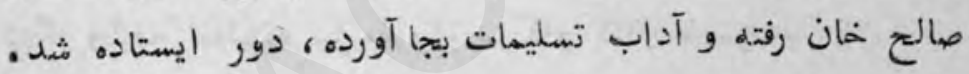

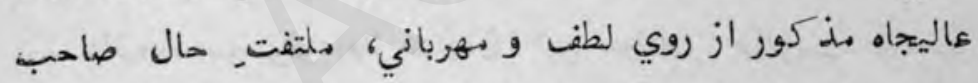

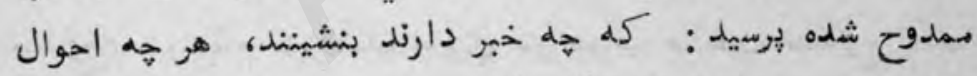

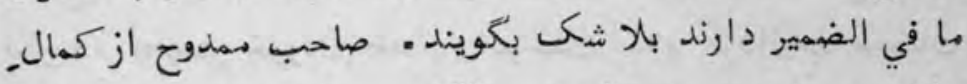

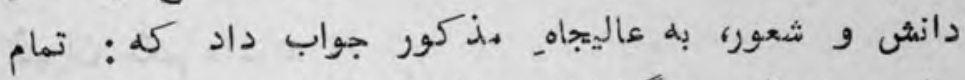

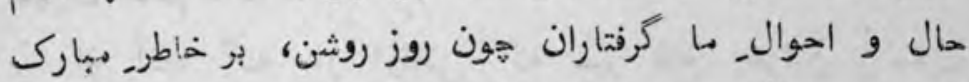

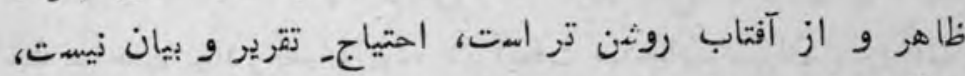

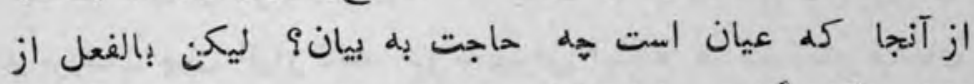

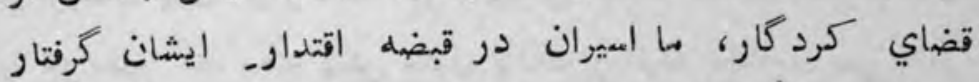

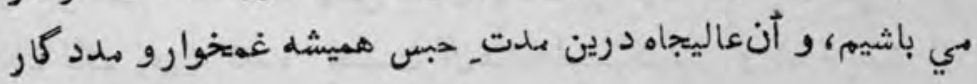


تازه نزاي معاركى

Dor

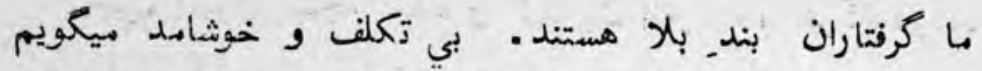

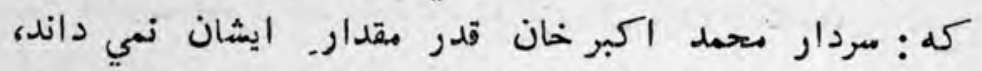

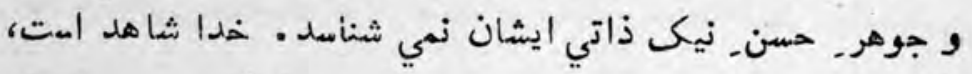

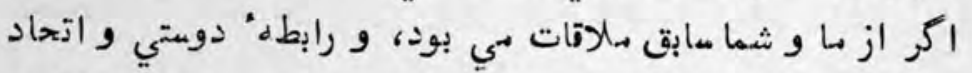

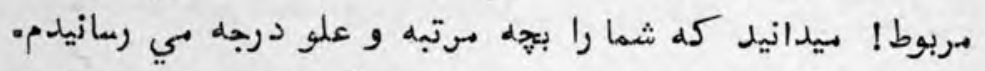

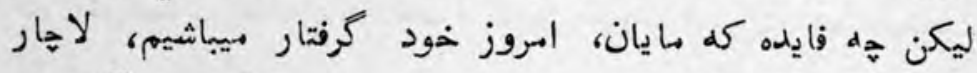

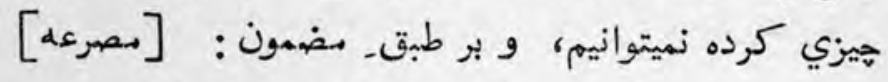
او خويشتن كم است كرا رهبري كند

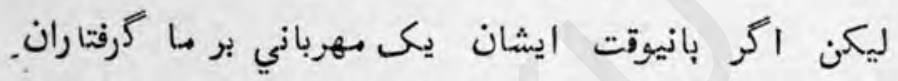

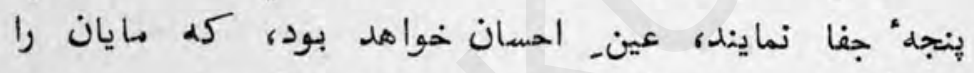

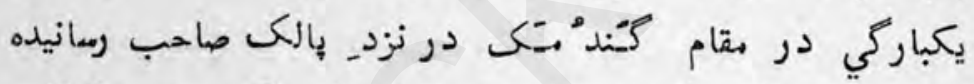

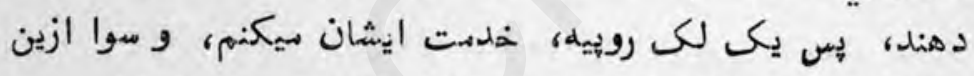

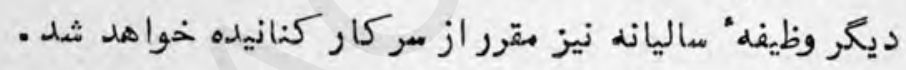

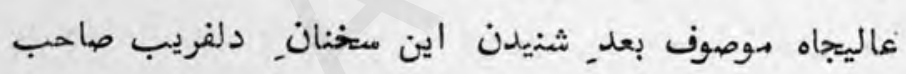

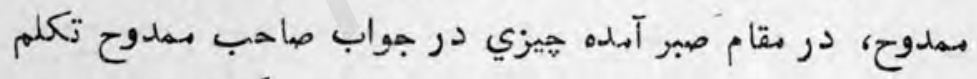

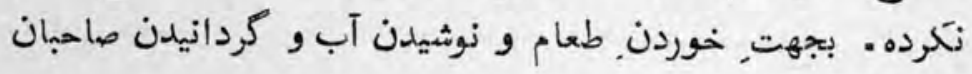

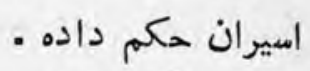

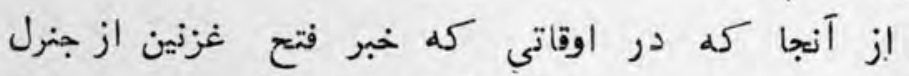

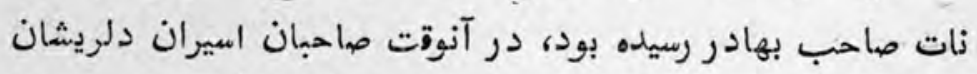

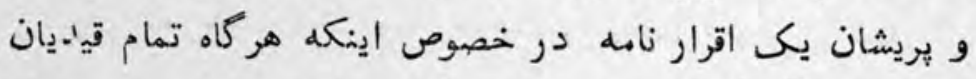

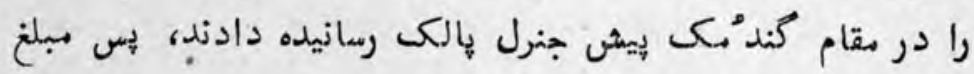

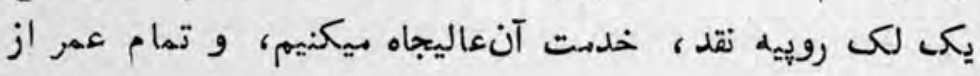




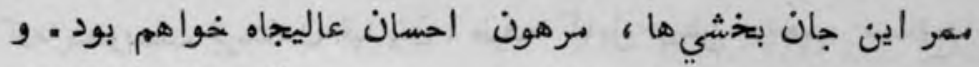

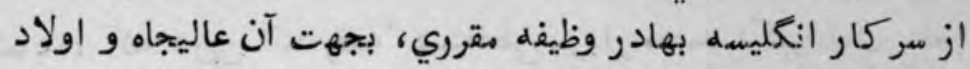

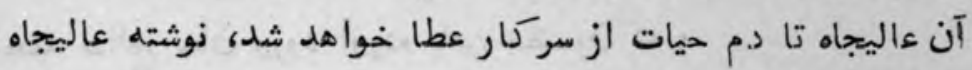

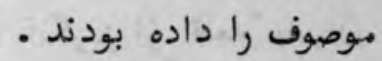

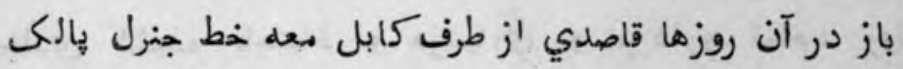

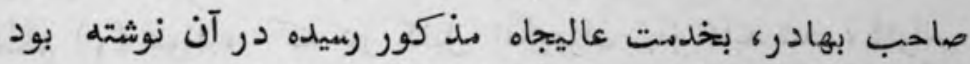

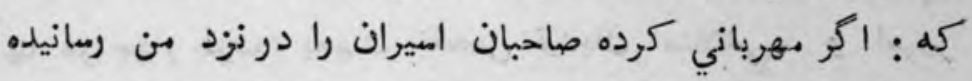

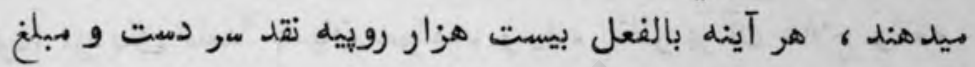

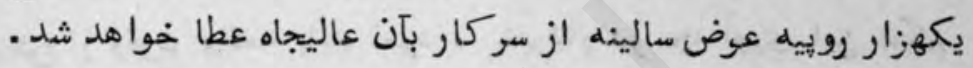

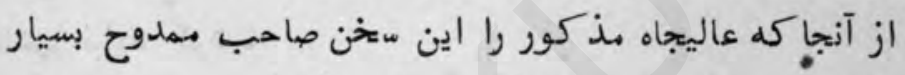

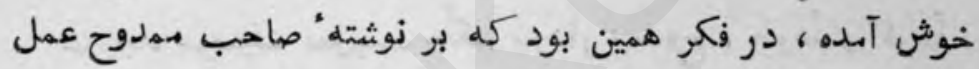

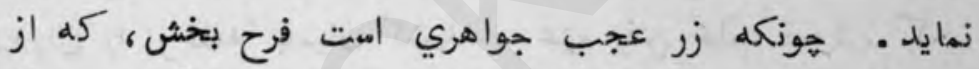

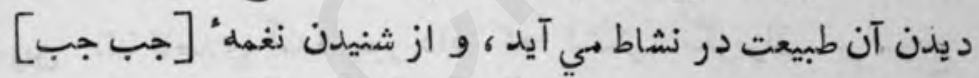
آن، مايهُ رفع ملال بي شود [از آنجا] [بيت]

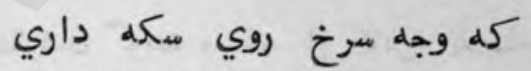

عزيزي ! قابل صاحب عياري !

كهي بكرفته خوبان را سر دمت كرئ

كهي سيمين بران را كرد دان بان بست

فرح بخش درونهاي بريشان

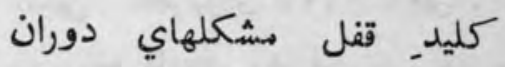

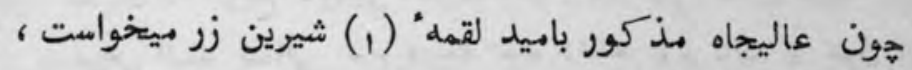

S : نغمه 
كه بندوبست فرستادن قيديان، طرف كابل ريش صاحب ممدوح

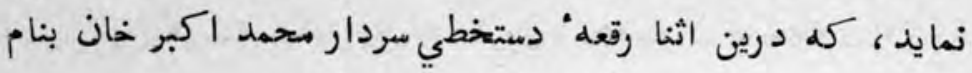

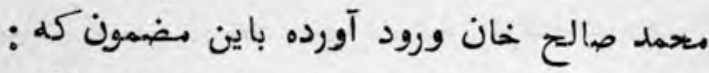

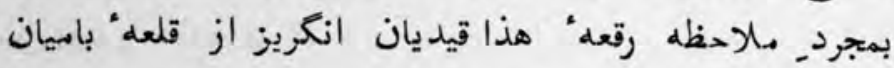

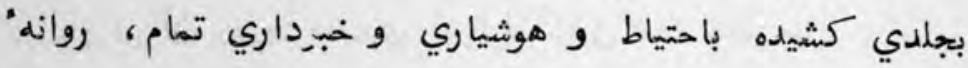

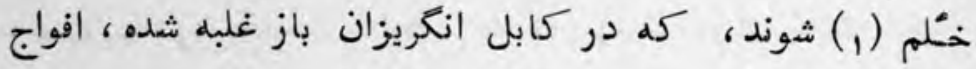

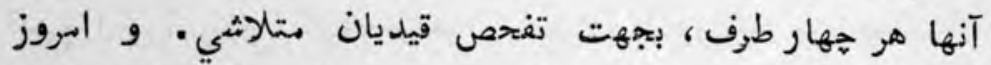

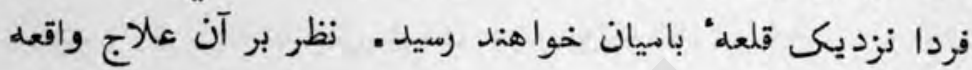

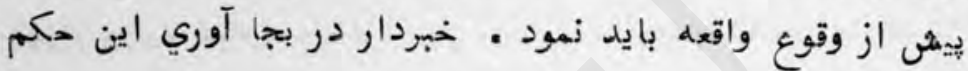
تاخير نبايد كرد .

عاليجاه موصوف بموجب حكم سردار بهدوح ، طوعاً و كرهآ

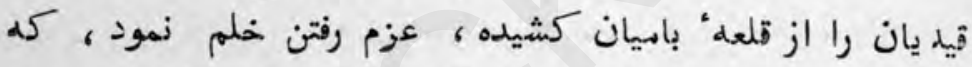

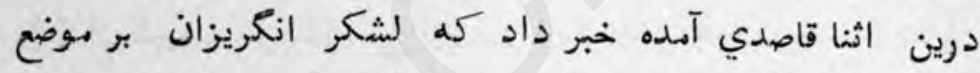
تاجبين (r) كله متصهل باميان ست (r) وسيده ، با افغانان مقانيله

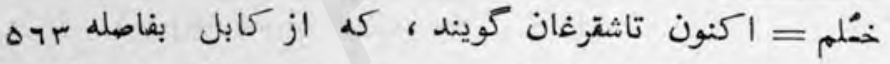

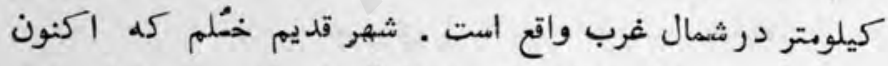

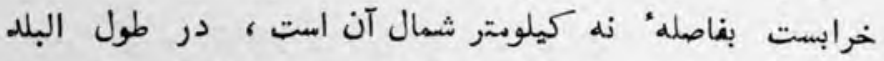

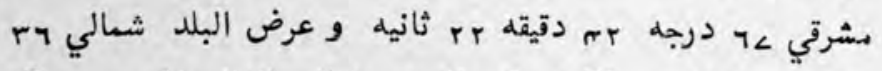

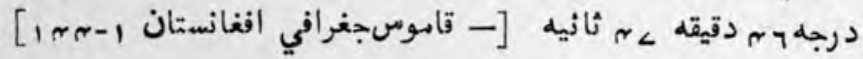

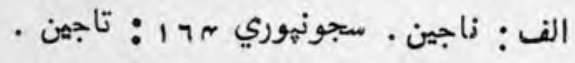

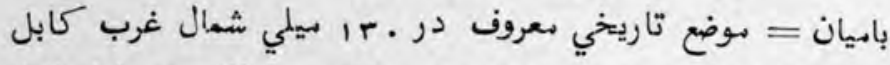

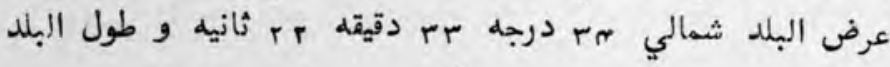

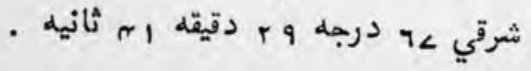


نمودند و شكست فاحش بافغانان داده اند ماند

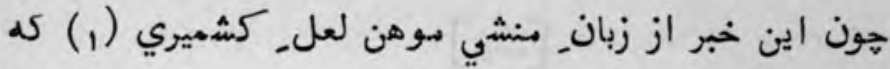
رفيق برنس صاحب بود ، بعاليجاه لارنس صاحب رسيده ، بسيار

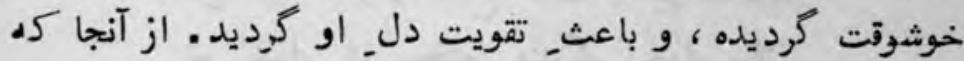
قيديان بسبب شنيدن خبر آمدن فوجــ انكريز و خوردن شكست

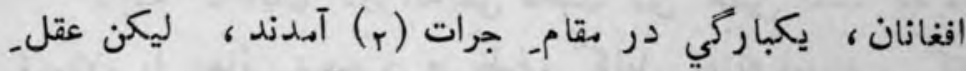

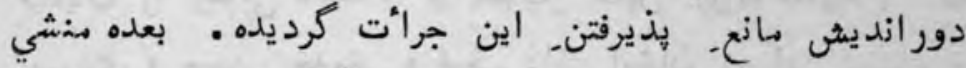
مذكور لارنس صاحب بهادر همراه خود كرفته، ليشثى عاليجاه محمد صالح خان آمدند و كفتند كله : مايان شنيده ايم ؛ كل فوجسركار, انظايسه بهادر، فتح- موضع تاجيمن (r) نمودند ، و و

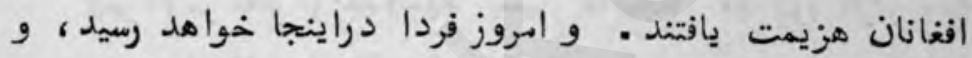
خوب ميدانيم كله شها يان را طاتت و توانائي مقابله" فوج- انكريز بالفعل نيست، طرفة العين درهم و برهم خواهيد شد . . و اين

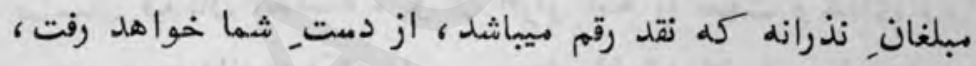

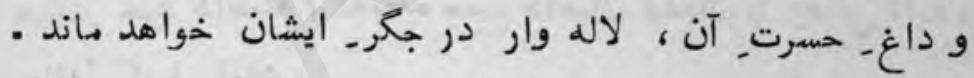
بلكه بيم آنست كل هبادا طاير, وجود شريف6، در دامفوج انظليسه بهادر كرفتار آيده بعد خرابي بصيرت حه مود ؤ و تمام عمر بعسرت و افسعوس بسر خواهند آورد و في الواقعه كله مايان

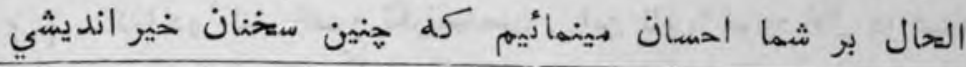

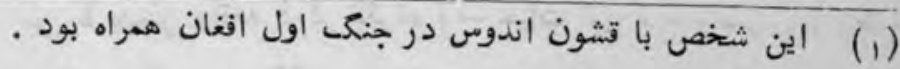

$$
\begin{aligned}
& \text { رك : تعليق مات } \\
& \text { الف : حيرت }
\end{aligned}
$$

الف : مجونيوري تاريخ افغاستان مه 1 : تاجين · 


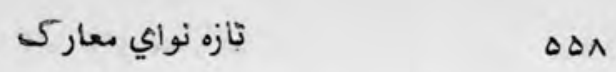

[و به طلبي] از روي اخلاص بشما كفتيم ، آينده اختيار باقي [بيت]

هن آنجه شرطـ بلاغ است با تو ميكويهم

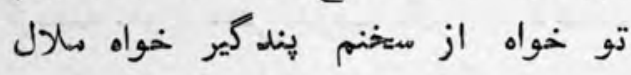

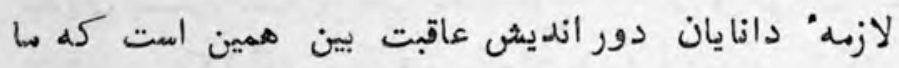

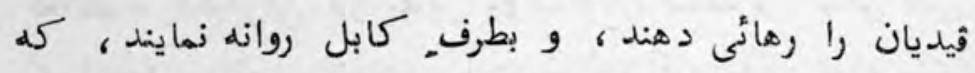

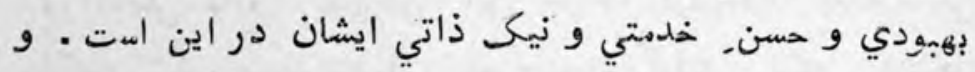
آنجه، كه رفقاي عاليجاه متحمد صالح خان بودند، آنها نيز همين صالح و تلبير بهتر دانسمته يسنديدند آخر الامبر بعد از جدوجهد بسهيار عاليجاه. مذكور اقرار زاهه

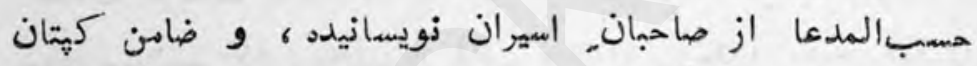

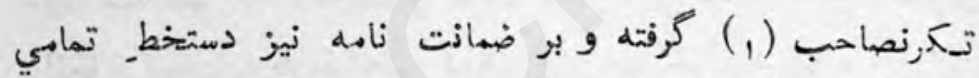

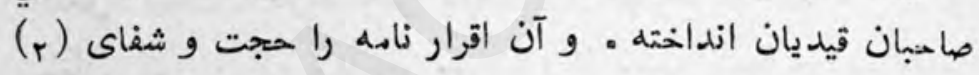

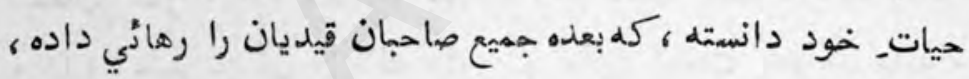

روانه"

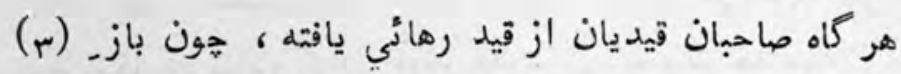

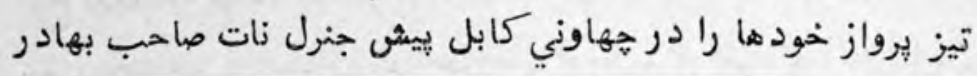
كذا در ك. الف: تكرلصاحب . اين نام را موهن لال در اسناد (1)

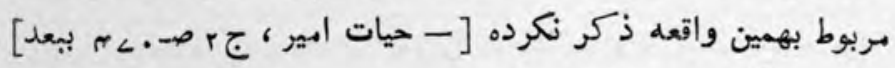

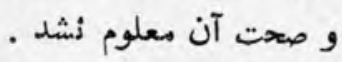

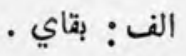
$(r)$

الف: باز شهير تيز برواز .

(r) 


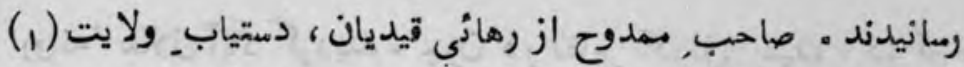

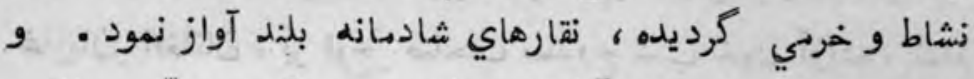

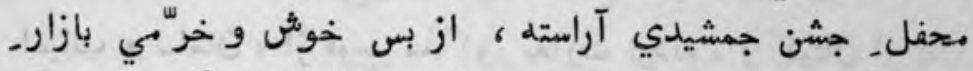

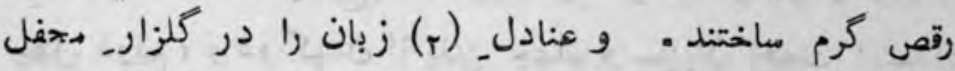

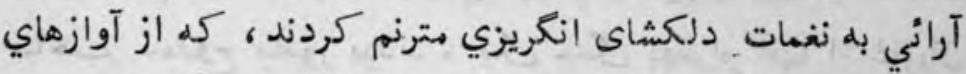

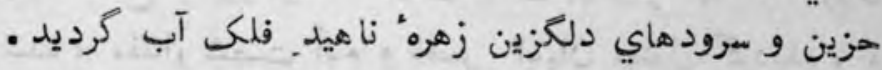

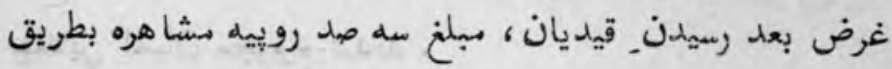

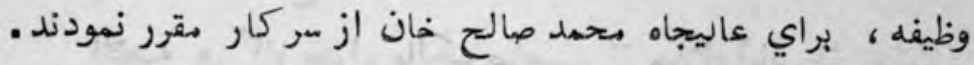

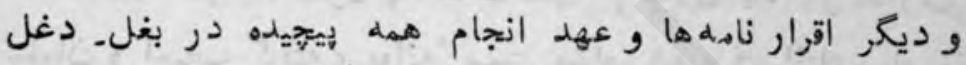

خود د اشتتند -

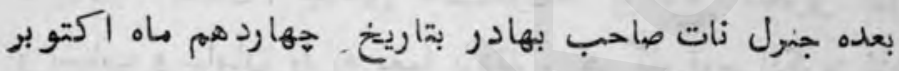

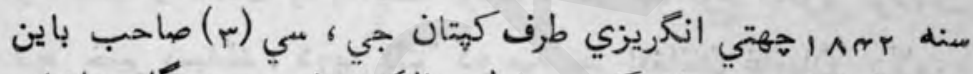

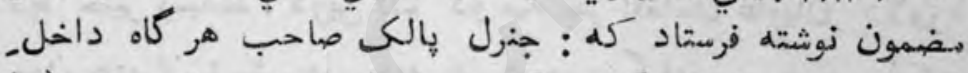

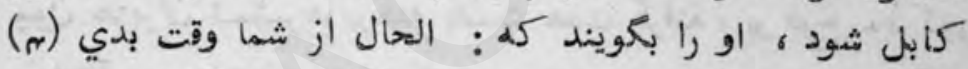

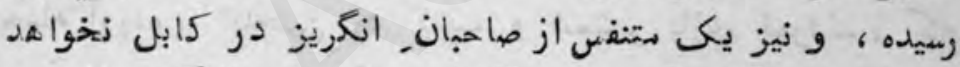

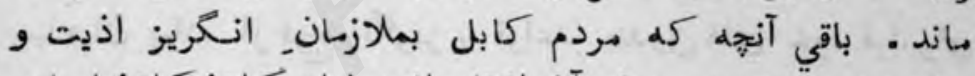

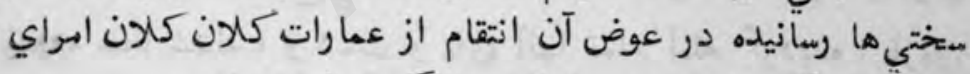

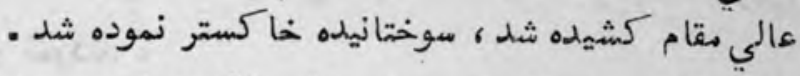

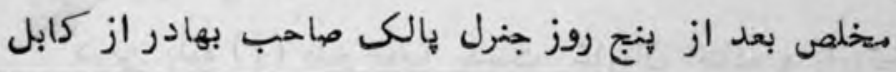

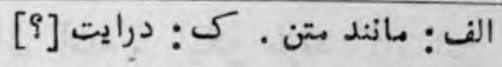

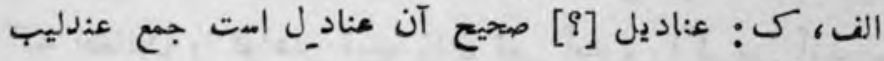

بعني بلبل المبل

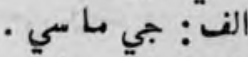

الف: الف: وقت بدلي ميان 
روانه" جلال آباد كرديده - جون در دقام, كوتل رسيده ، در آنجا

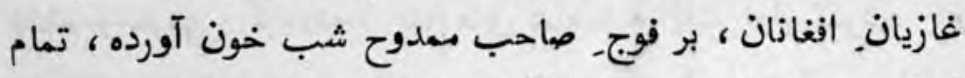

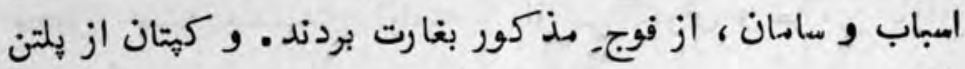

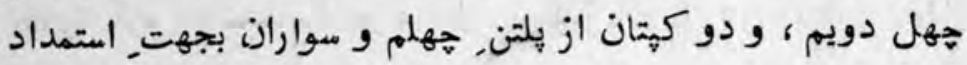

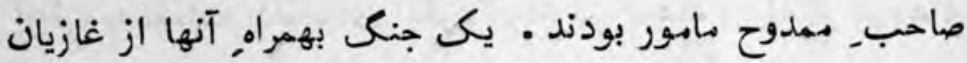

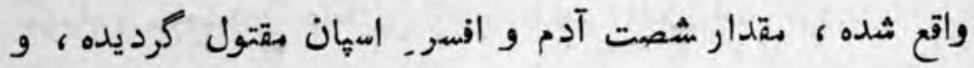

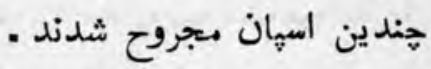
القصه هر كاه جنرل بإلى صاحب از جلال آباد باز تدارك

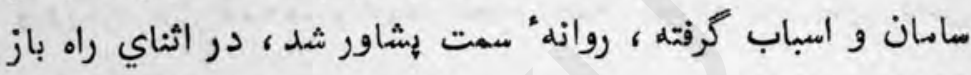

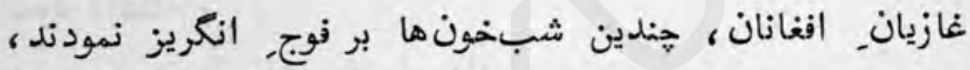

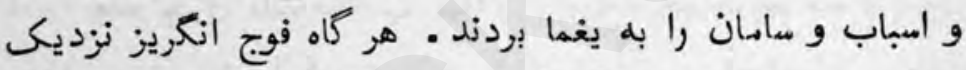

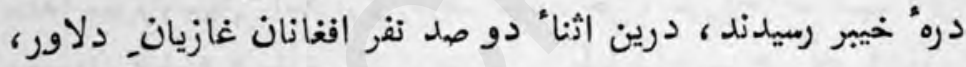

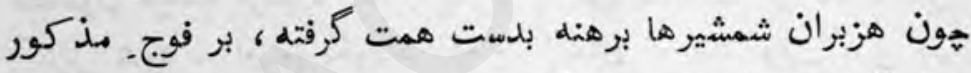

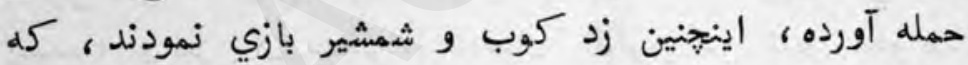

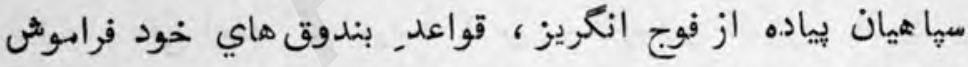

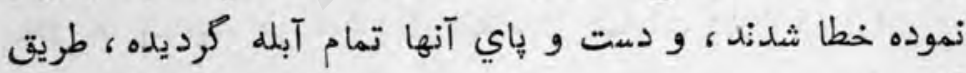

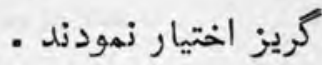

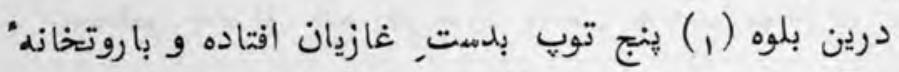

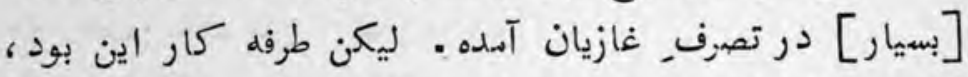

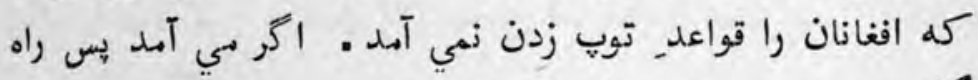

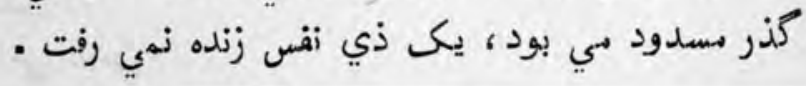


وي الجهمله هر قدر كه افواج انكريز بهادر، وقت آهد و رفت

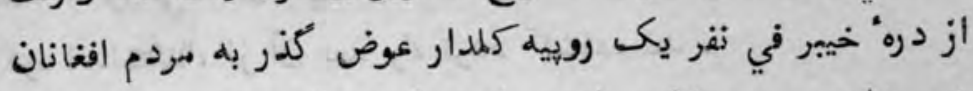

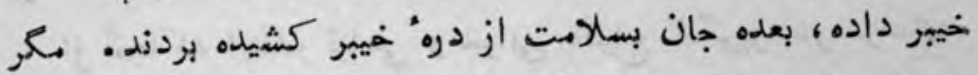

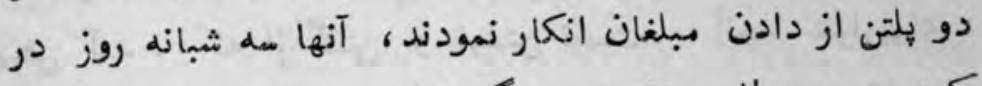

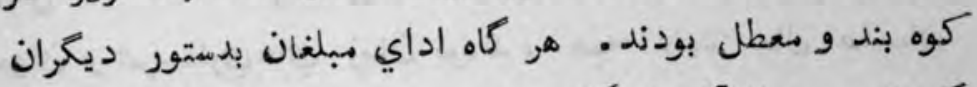

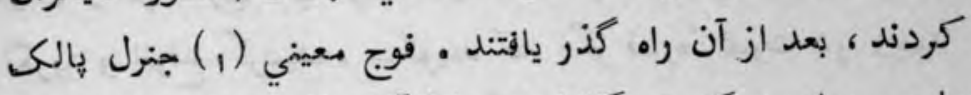

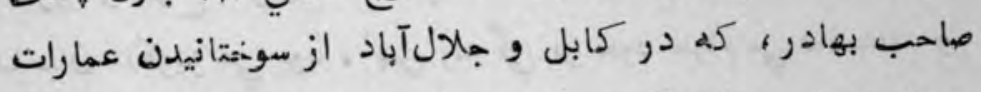
هيزي دمت و باي زدهه، اسباب را جمع نموده بودند، و و بكمال

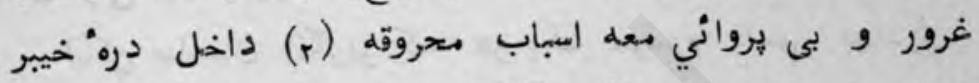

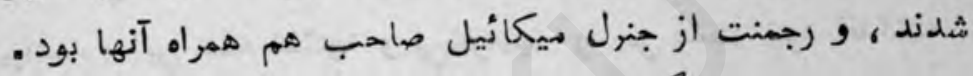

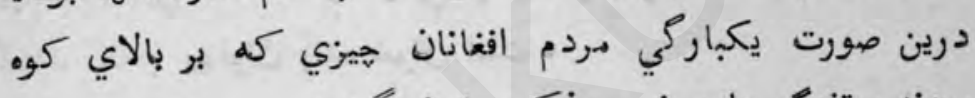

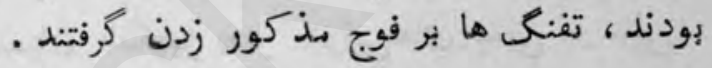

در اين ضهن يكى جهأهل بياده مر و باي برهنه از افغانان

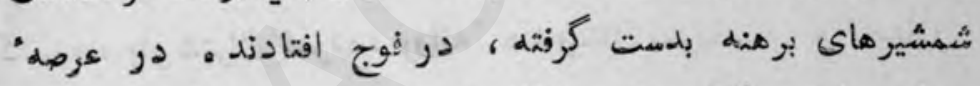

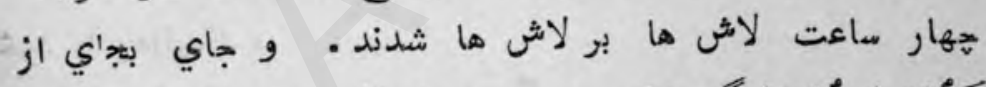

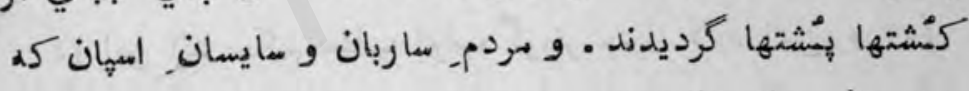

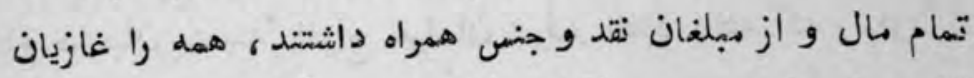

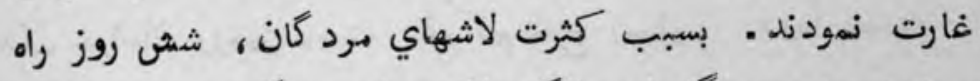

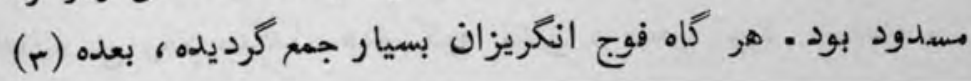

$$
\text { الف: الف: تتعينه . . }
$$




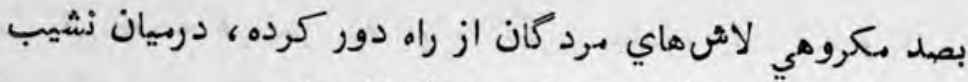

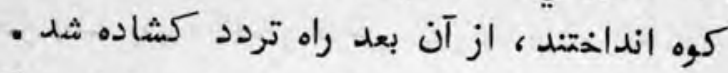

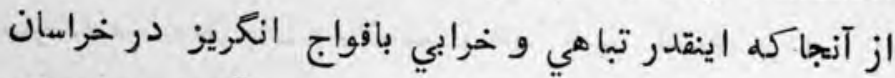

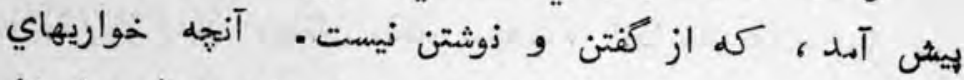

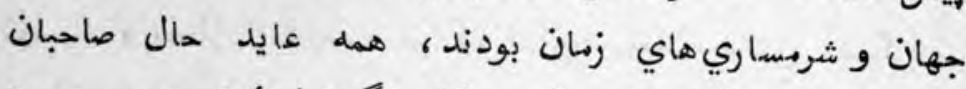

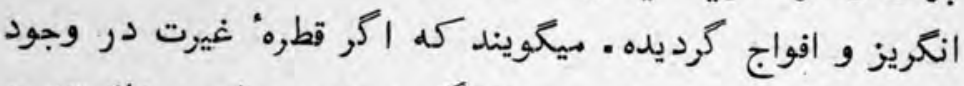

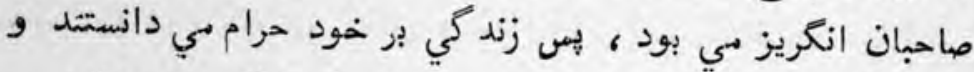

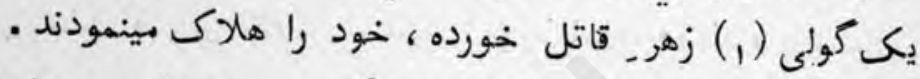

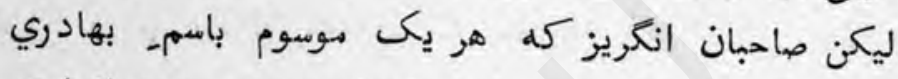

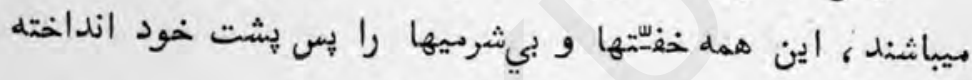

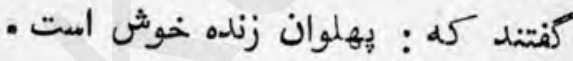

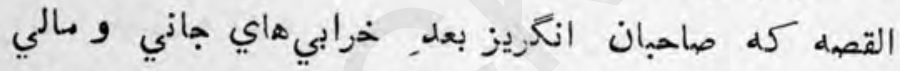

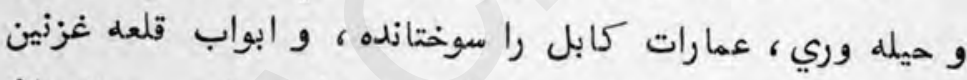

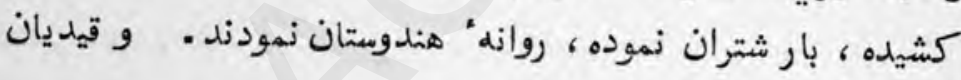

$$
\text { خود را رهانيدند }
$$

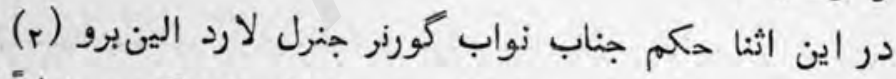

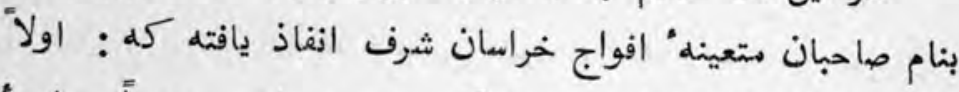

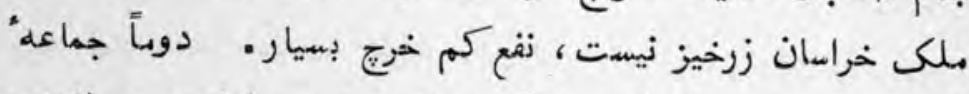

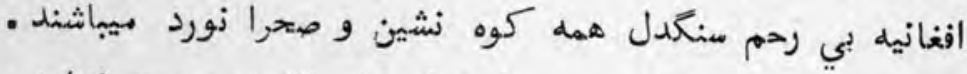

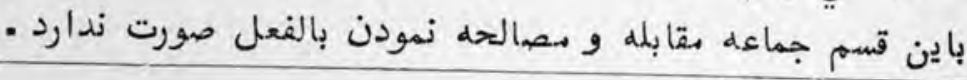

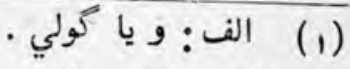

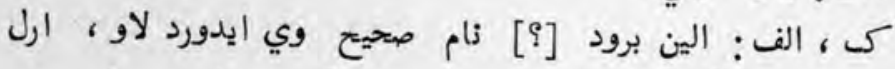

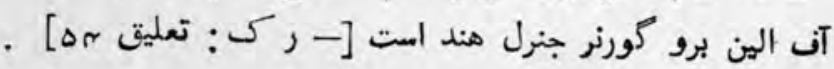


تازه نواي معارك $\quad$

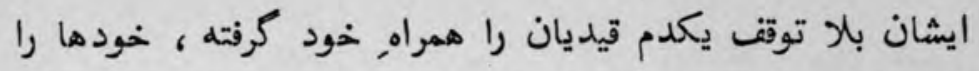

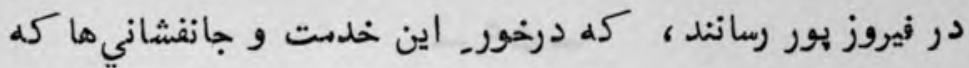

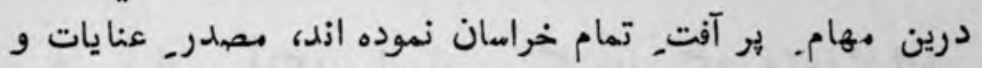

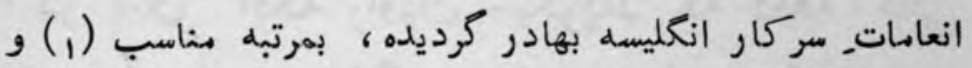

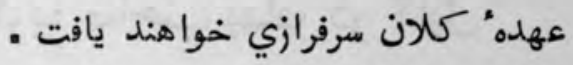

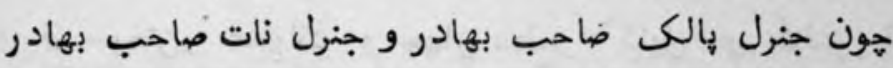

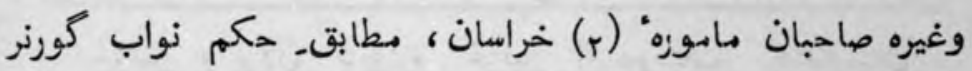

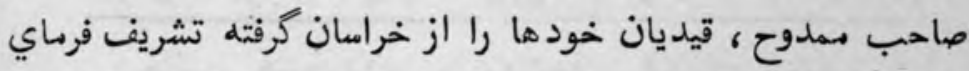

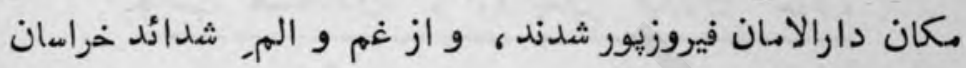

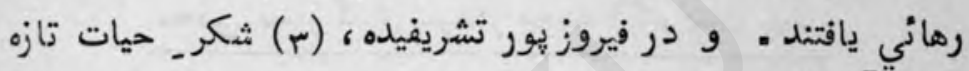

بجاي "آوردند -

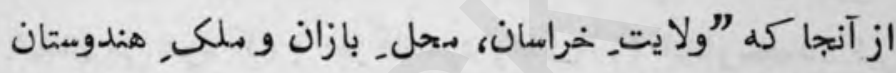

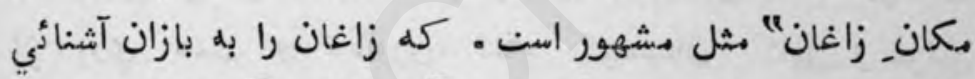

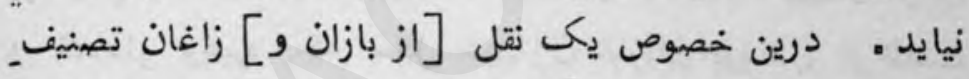

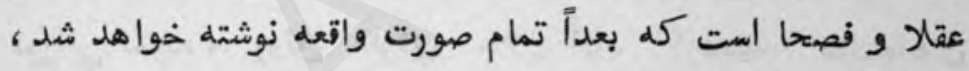

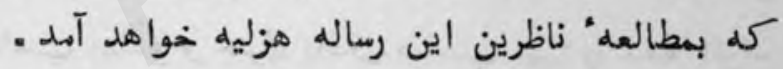

(1) الف: مرتبه مناصب اعلا و عهده: كالان .

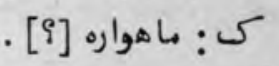

(r)

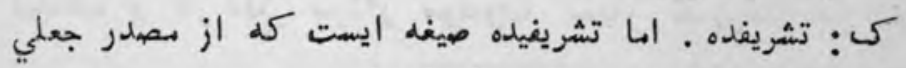

(r)

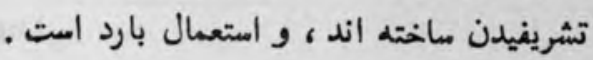




\section{$-\angle 9-$}

در بيانِ آنكه راويان بيكويند كه دفعله ثانى آــدن فون انخريز ماحب بهادر در كابل ريل

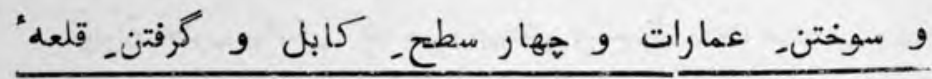

غزنين و بردن_ دروازه" غزنين از سومنات_ هندوستان

جانب هندوستان، و رهانيدن قيديان خوده،

متحض بساز 13 ري سردار مهمد اكبر خان بود .

بلبل قلم, خوش رقم، در بوستان اين داستان حنين خوش

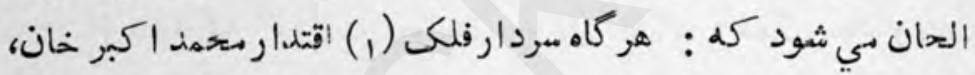

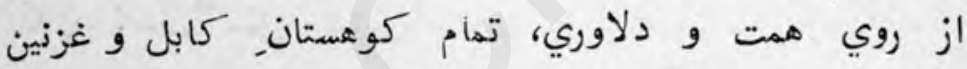

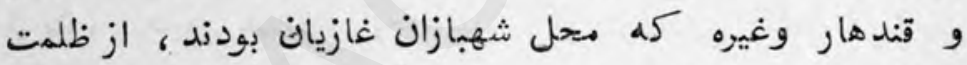

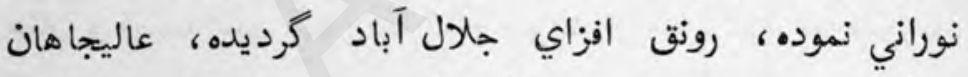

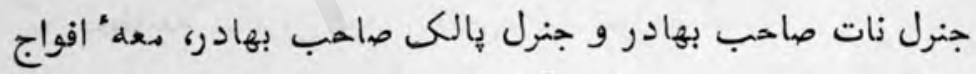

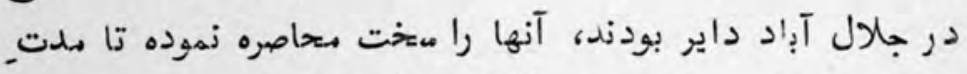

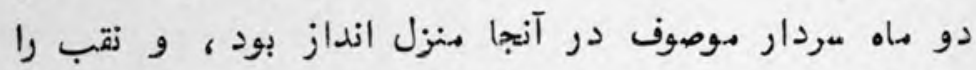
تيار كنانيد.

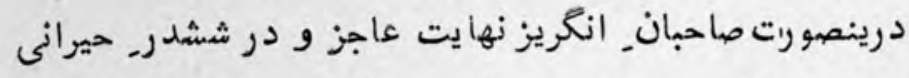

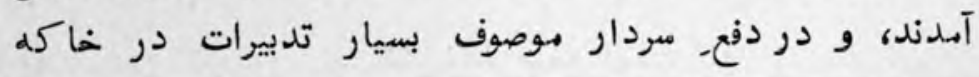

(1) الف: ملك اقتدار . 
$\Delta T \Delta$

تازه نواي مارك

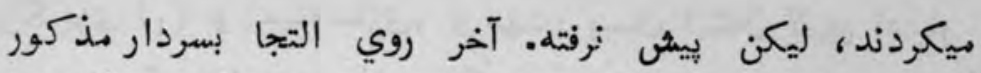

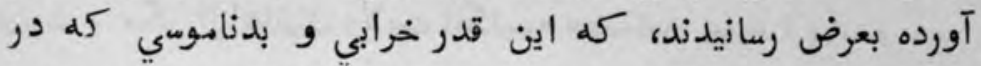

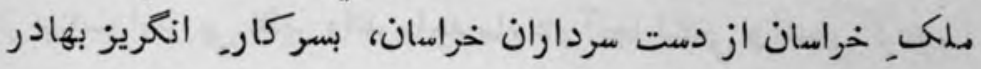

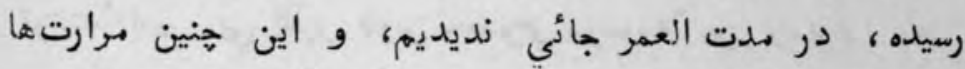

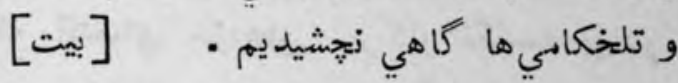

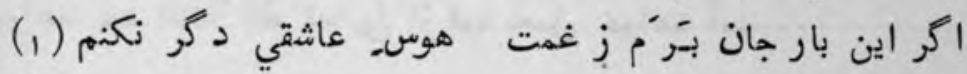
اين سزاهاني كله يافتهايم كافي، و اين (r) كه كشيدهائم

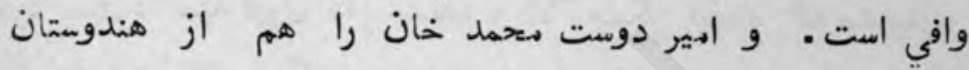

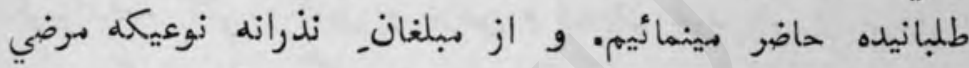

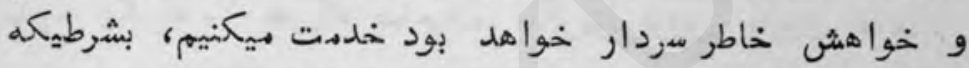

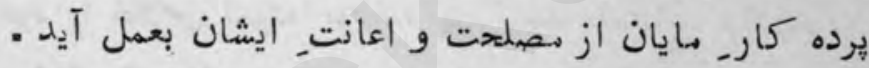
اولاً اينكه قيديان مايان را رهائي بخشند . و ديكر اينكه مايان معله فوج يكباركي در كابل و غزنين رسيده، انتقام

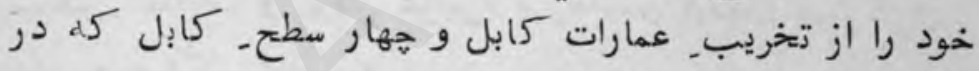

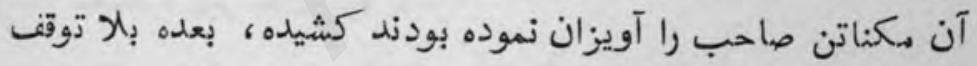

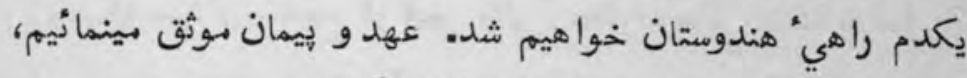

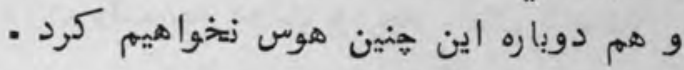

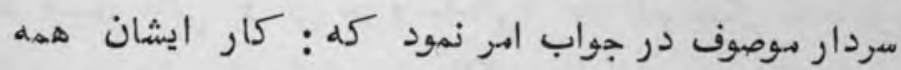

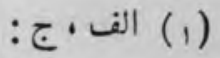

اين بار اكر جان برم ز غمت ديكرم عاشقي هوس نشود

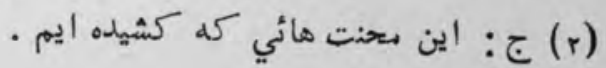


تازه نواي مارك

טצT

رنكريزي (1) و >يله سازي، و عهد و ويمان ايشان لايق اعتبار

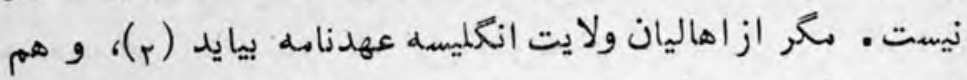
از جناب امير بي نظير والد داجد ما، حر آنجا تشفي و تسلي كردده،

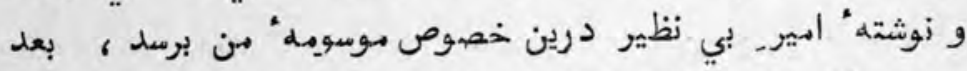

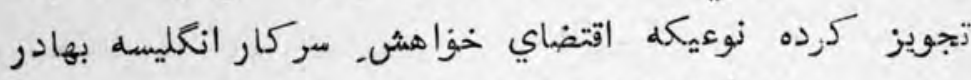

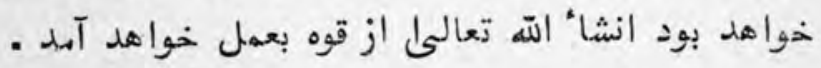
هون صاحبان انكريز مصلحت_ امر, سردار موصوف بجانـ

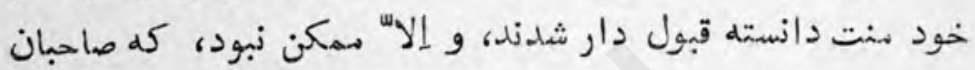

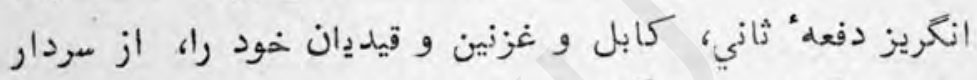

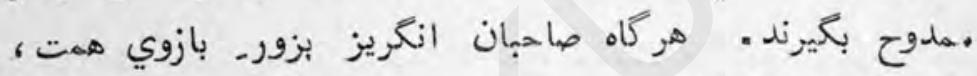

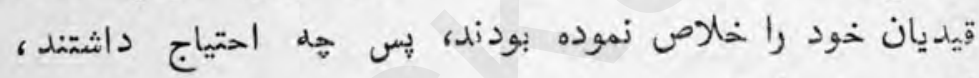

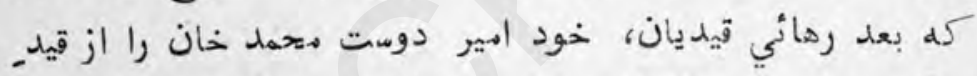

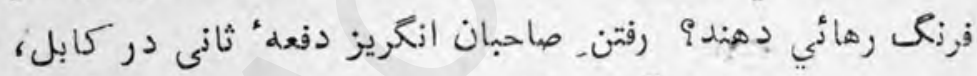
و سوختن_ عمازات و كرفتن غزنين، و رهانيدن قيديان بساز

سردار متمد الكبر خان بودمان

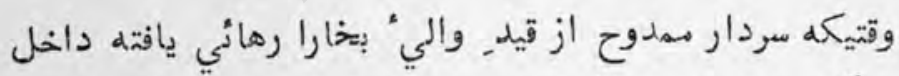

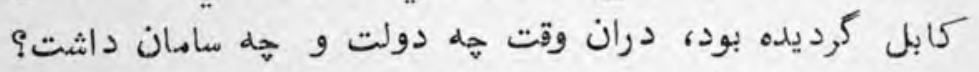

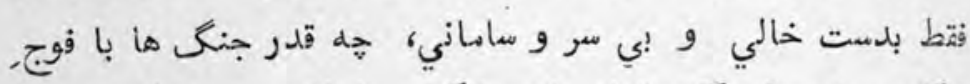

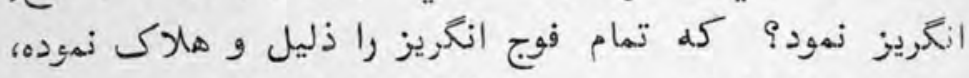

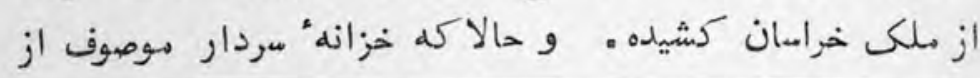

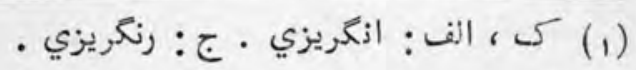

. $5(T)$ 


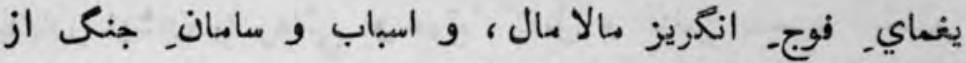

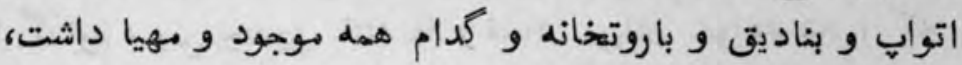

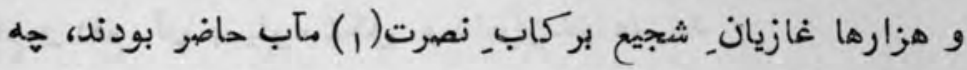

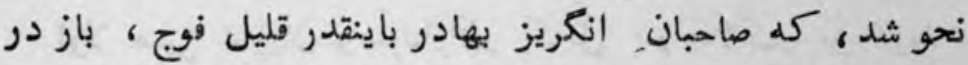

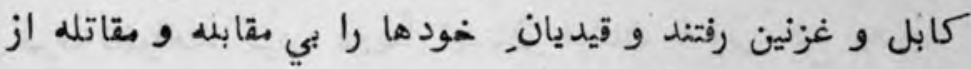

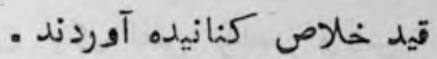
از آنجا كم فرمان روايان. خطةه" عقل و دانش و سرير

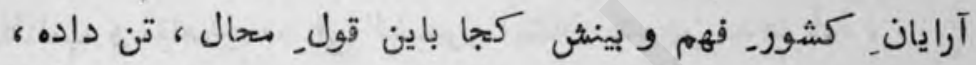

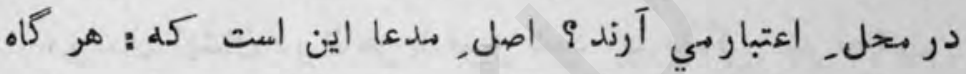

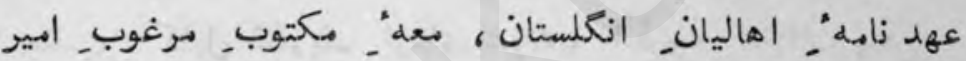

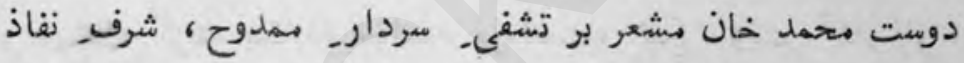

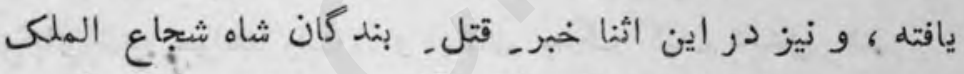

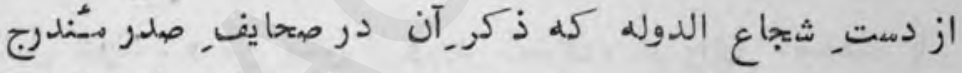

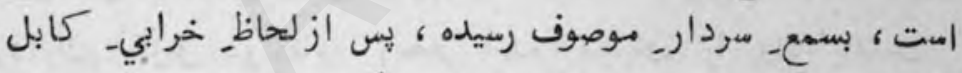

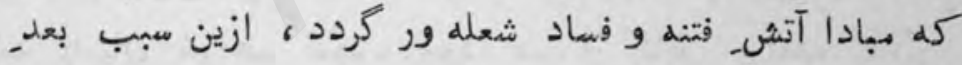

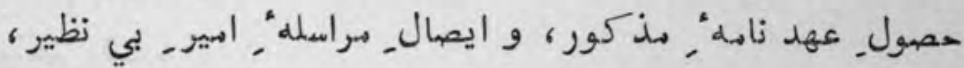

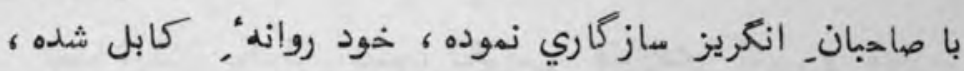

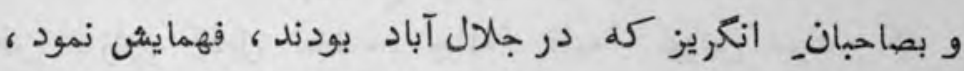

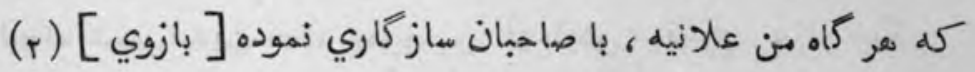

ك : نصرت بالش . الف : بركاب نصرتش · ج : مانند متن . بازو = درين كتاب مكرراً بمعني يرغمل آمده است . 
تازه نواي معارى

$\Delta 7 \wedge$

قيديان ايشان را رهائي و حوزه" كابل و غزنين بدست ايشان

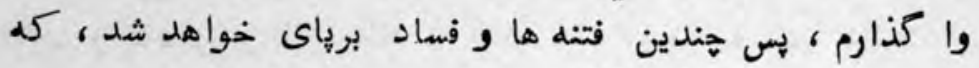

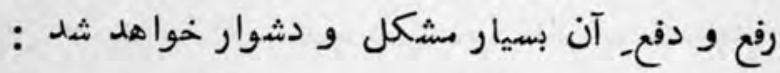

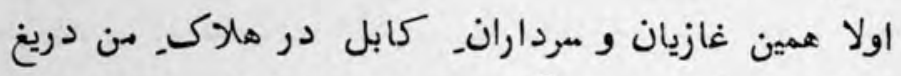

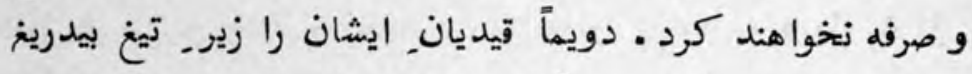

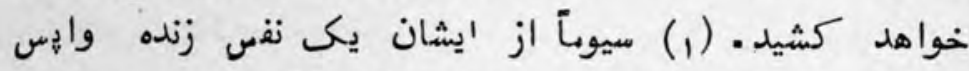

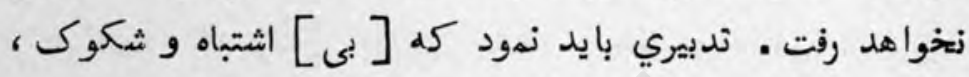

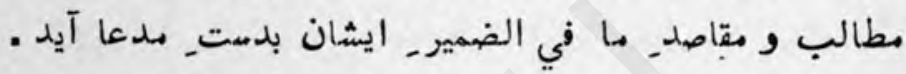

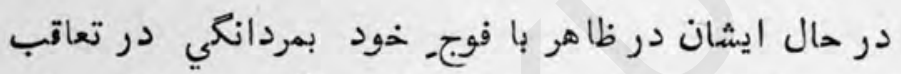

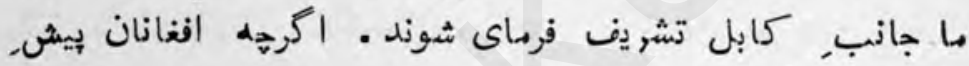

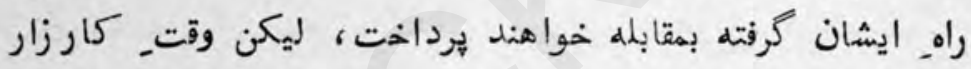

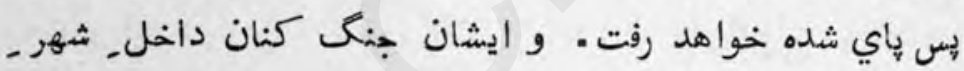

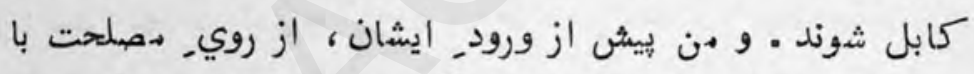

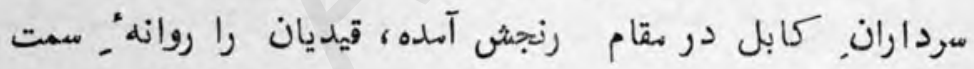

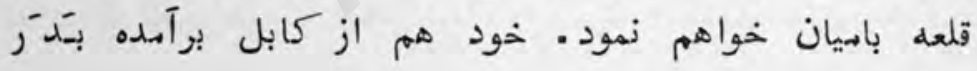

خواهم رفت .

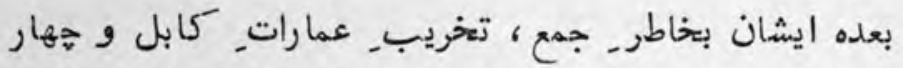

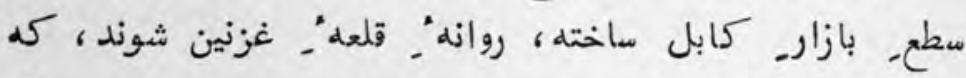

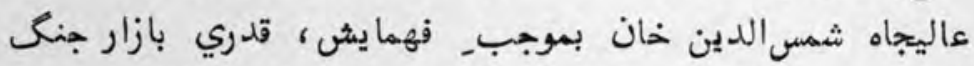

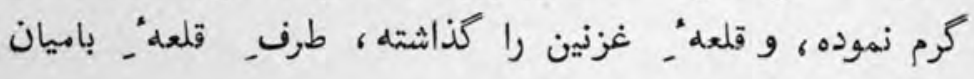
(1) الف : بايدكشيد. ج) كل : مانند متن 
تأزه نواي ماري

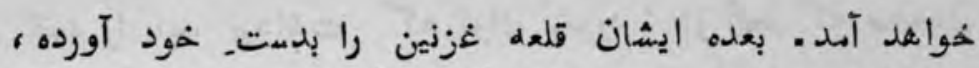

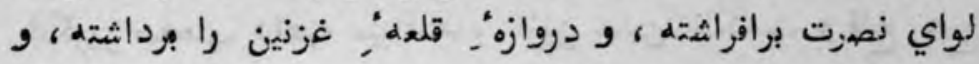

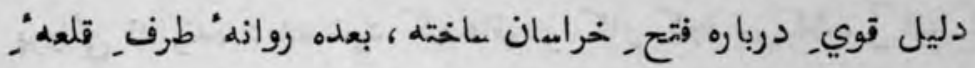

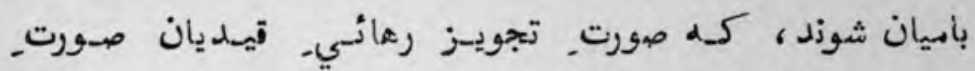

وقوع يابد - وقنا

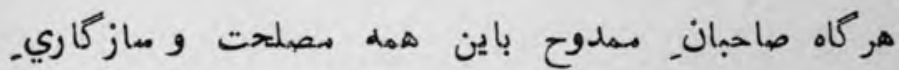

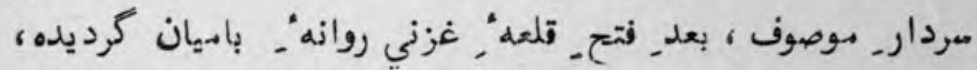

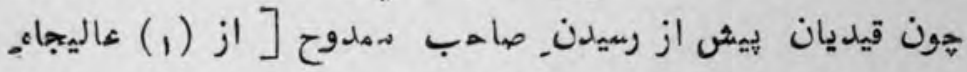

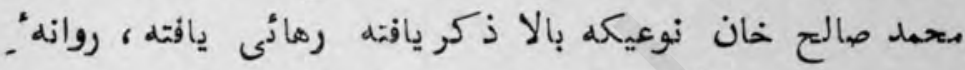

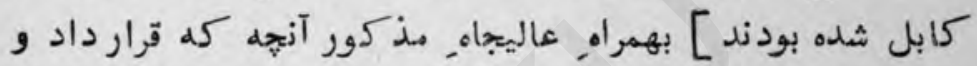

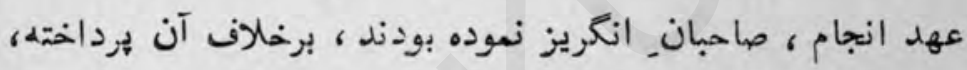

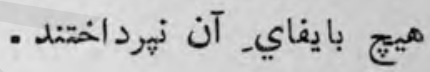

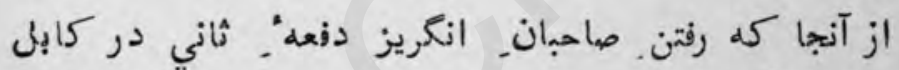

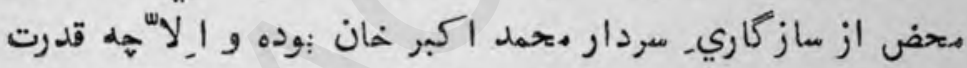

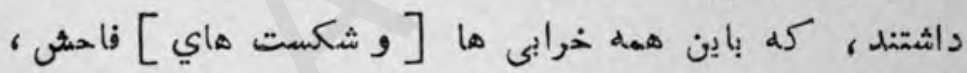

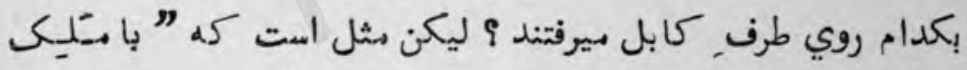

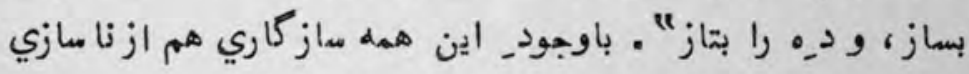

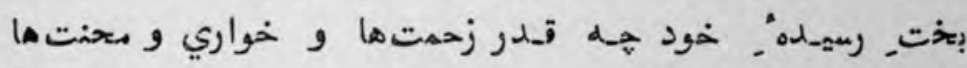

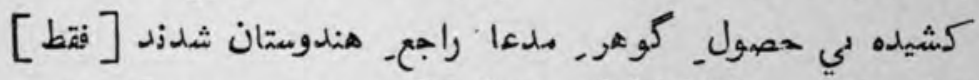

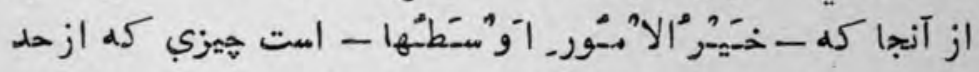
اندازه بيرون مي شود ، در آن خلل هاي. فاحش. بسميار بيشيوند،

كلمات بين قوسين در الف نيست ـ در كى ، ج موجود است .

(1) 
تازه نواي معارك

$\Delta<$.

لقهه را بايد برداشت كله توان خورد • از آنجا كله صاحبان.

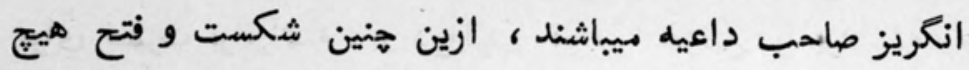

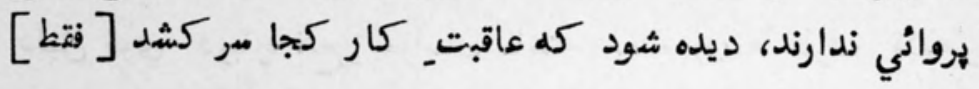


در بيان_ رهائى يافتن امير بى نظير دوست محمد خان

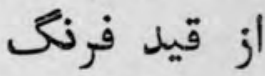

بزور. بازوي همت_ سردار هحمد اكبر خان غازي، و وملاقات

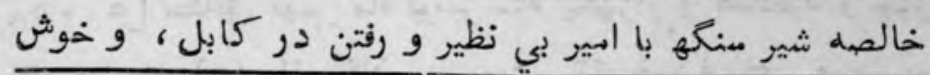

وقت شدن از ملاقات سردار محمد اكبر خان فرزند.

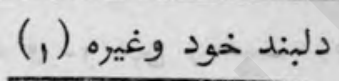

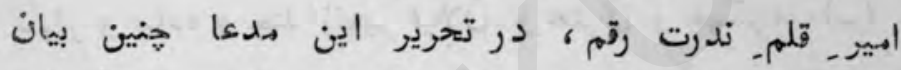

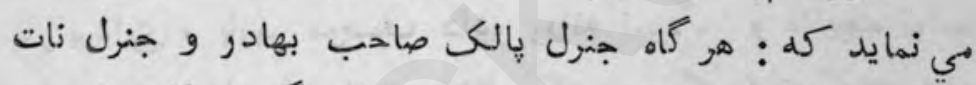

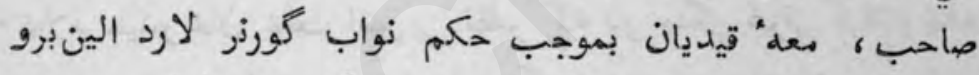

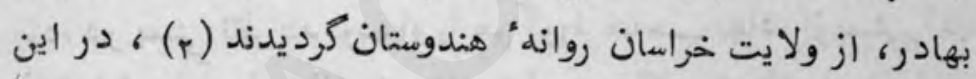

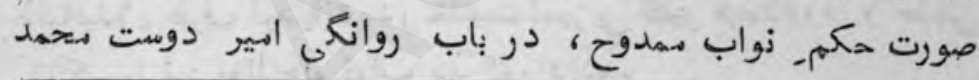

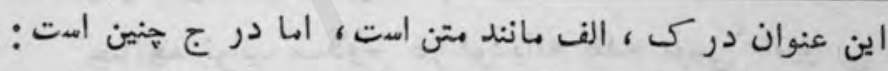

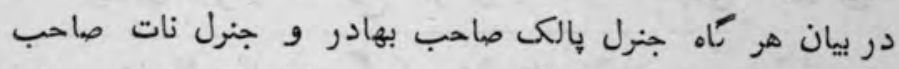

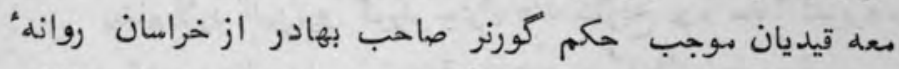

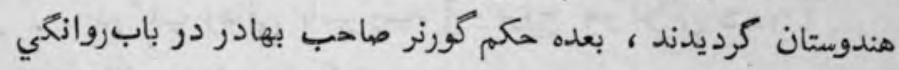

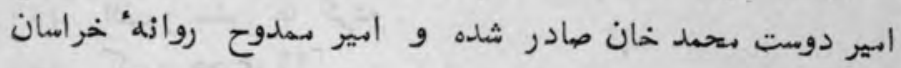
كرديده.

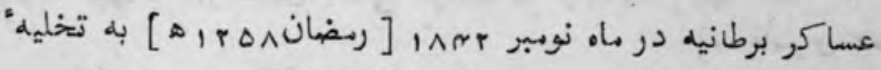
(r)

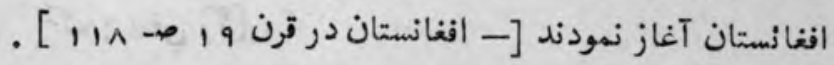


خان، دعله جميع هنسوبان و متعلقان ، جانب خراسان شرف نفاد

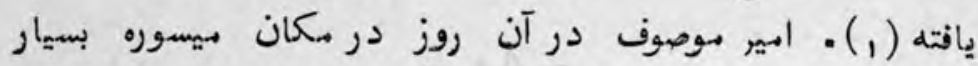

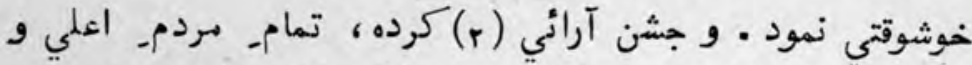

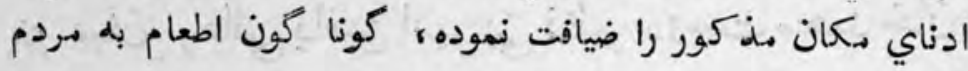
خورازيد - خوايل

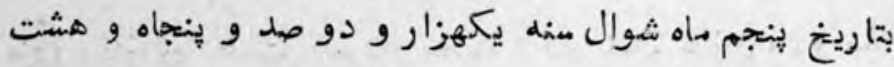

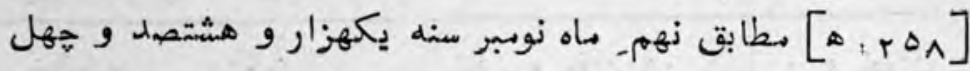

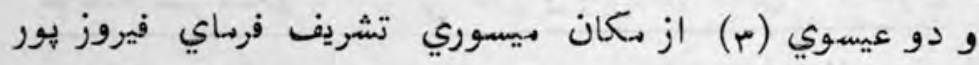

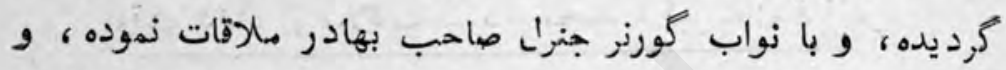

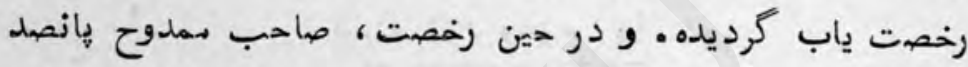

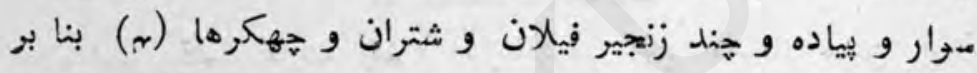

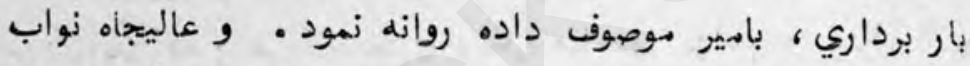

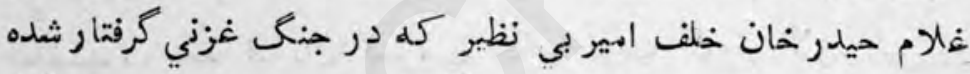

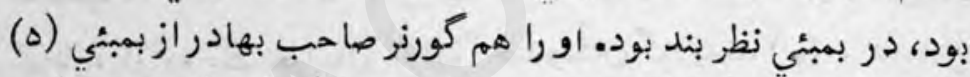

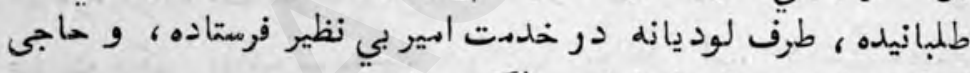

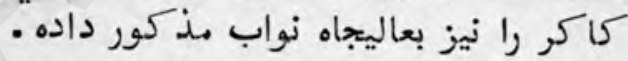

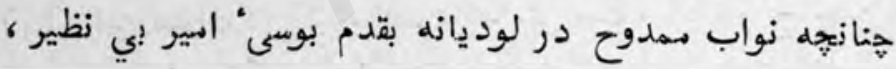

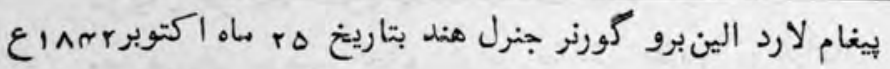

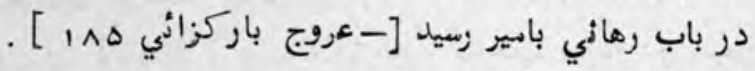
الف: جشن ها كرده .

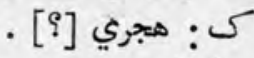

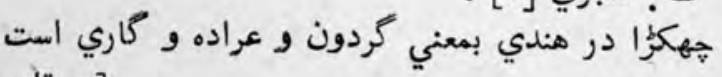

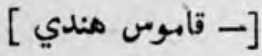

$$
\text { ك : بيغي [?] }
$$


والد ماجد خود مشرف كرديده، مسرت اندوز شده، شب ديجور.

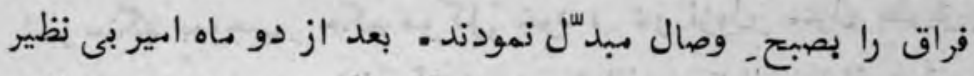

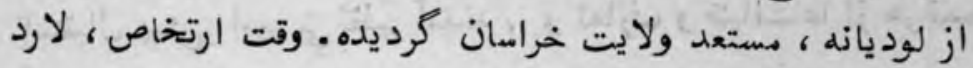

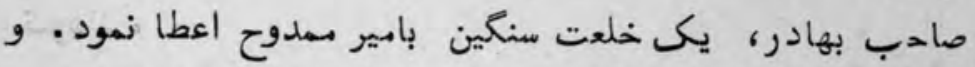

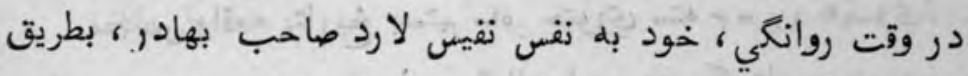

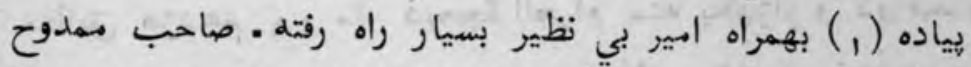

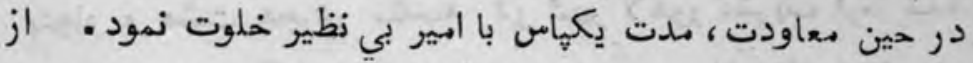

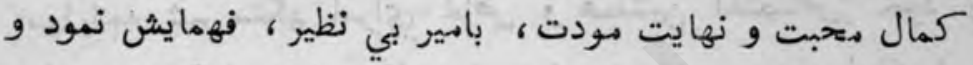

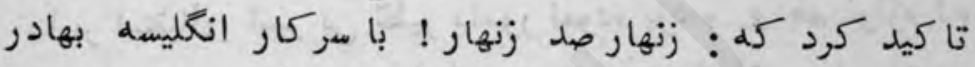

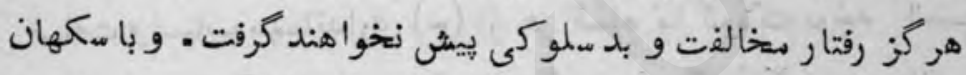

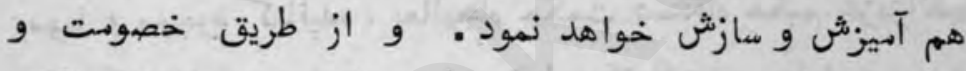

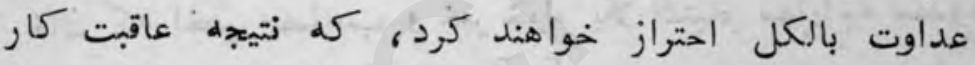

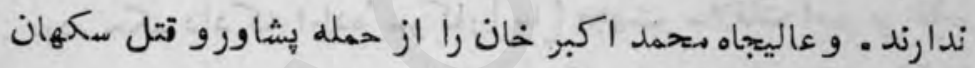

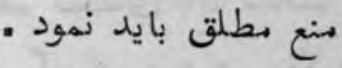

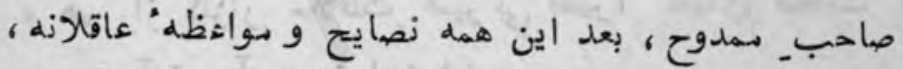

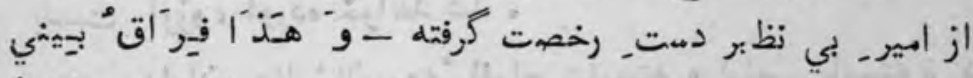

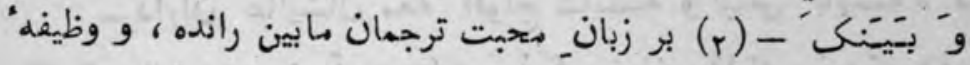

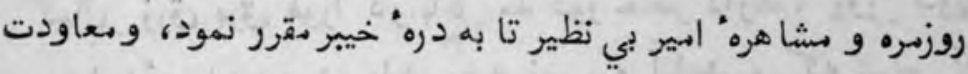

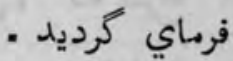

هون امير بي نظير، بقطع_ منازل رونق افزاي سرهد مهمارك

$$
\text { كئ: بطريق اعاده. }
$$




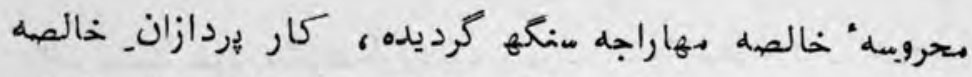

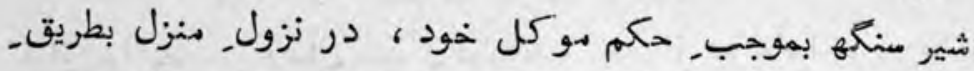

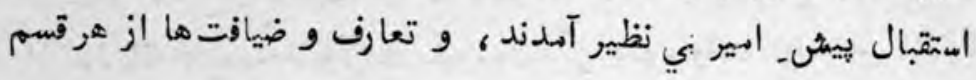

نمودند -

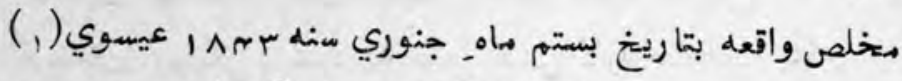

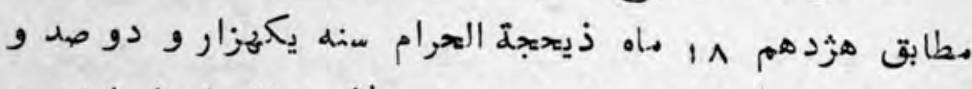

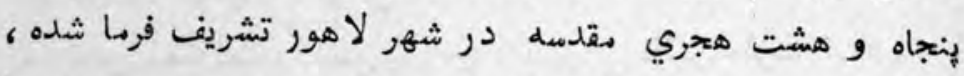

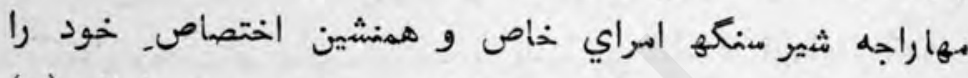

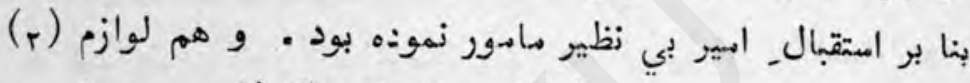

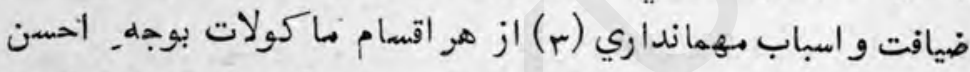

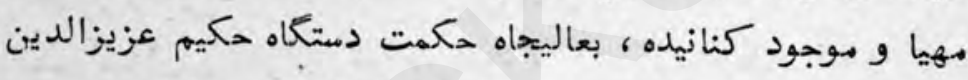

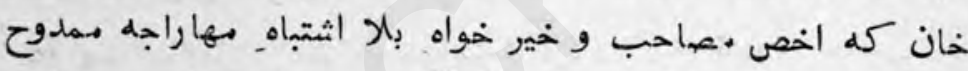

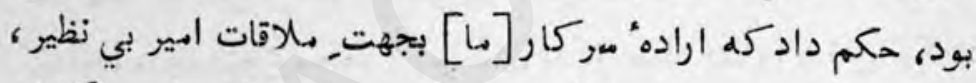

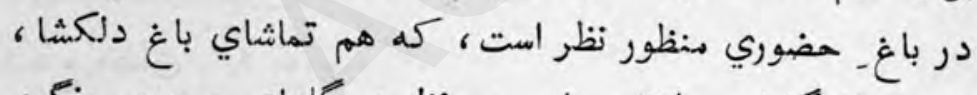

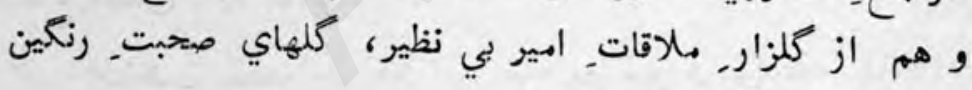

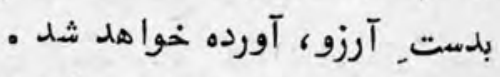

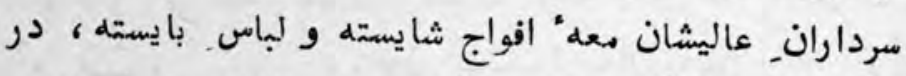

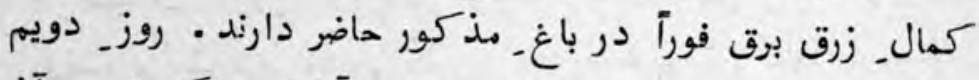

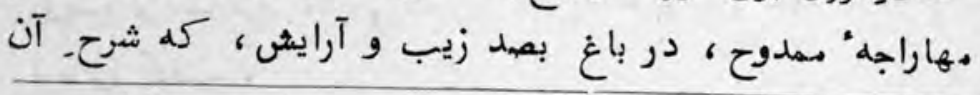

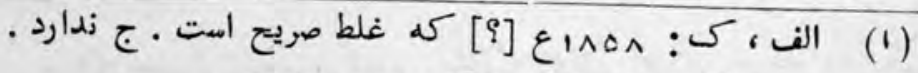

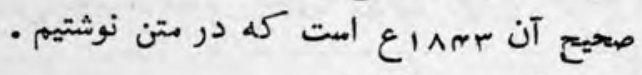

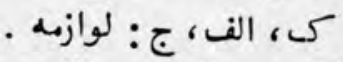
ك : جهانداري . الف، لوانه : مانند متن. 


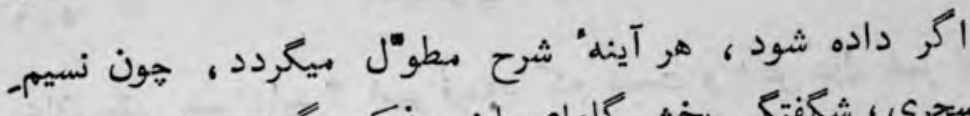

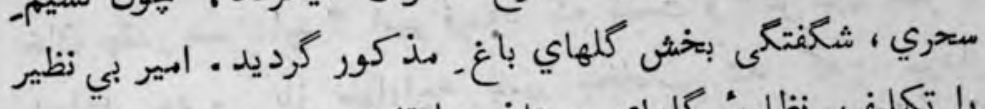

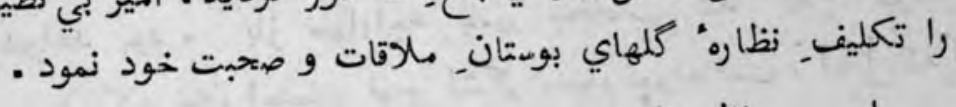

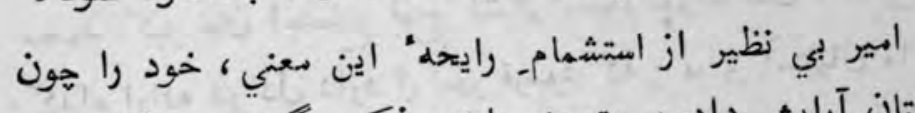

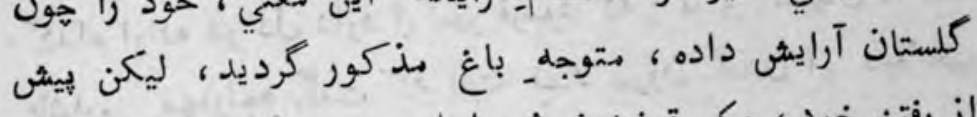

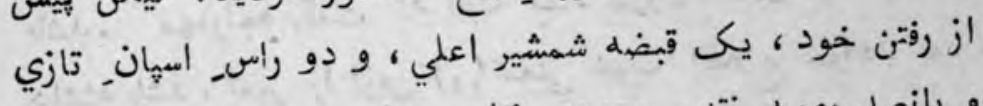

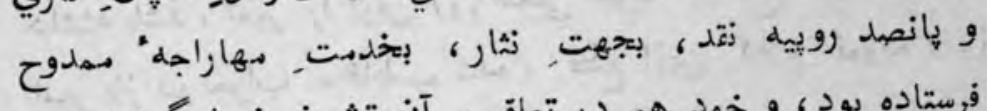

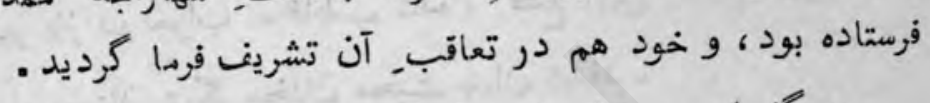

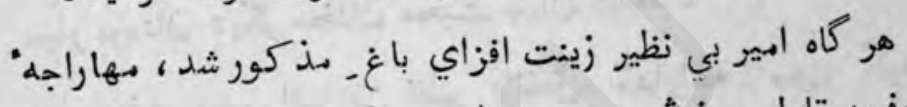

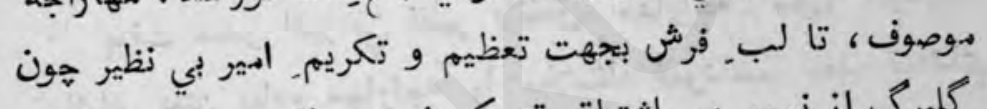

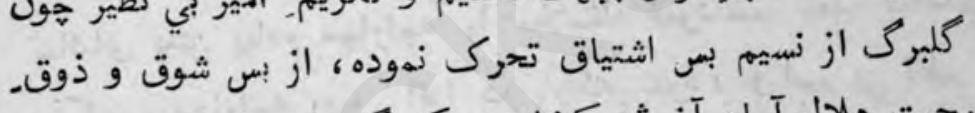

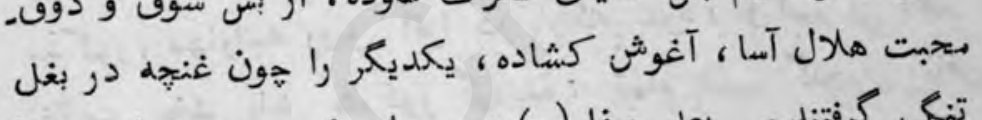

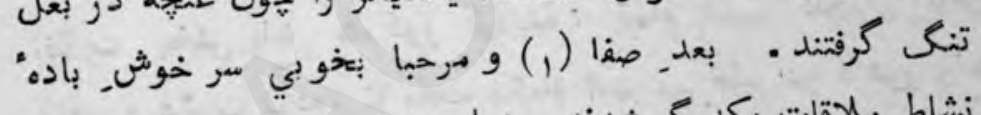

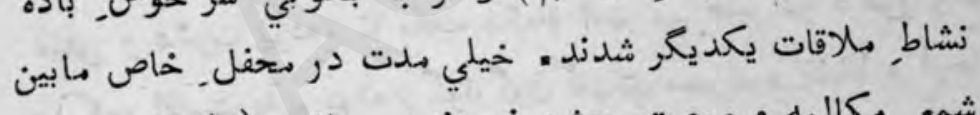

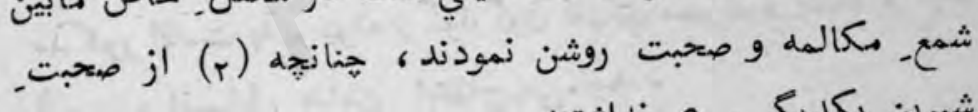
شيرين يكديكر سيري نداشتند ف وشيت

در اين اثنا بحضور _ـهاراجه خبر وسيد كه : سردار متحمد اكبر

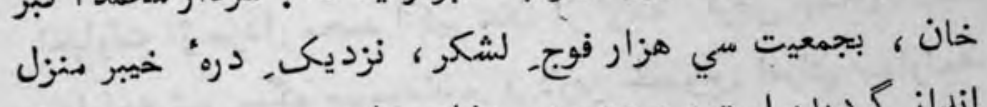

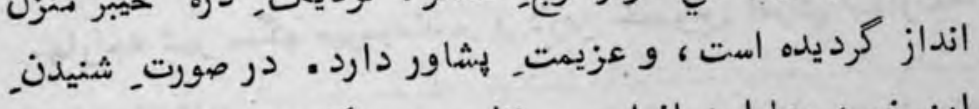

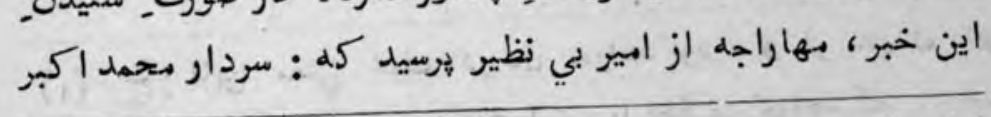

$$
\begin{aligned}
& \text { الف: صفائي و مرحبائي . } \\
& \text { الف: حنانكه . }
\end{aligned}
$$




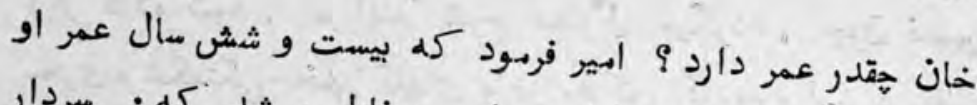

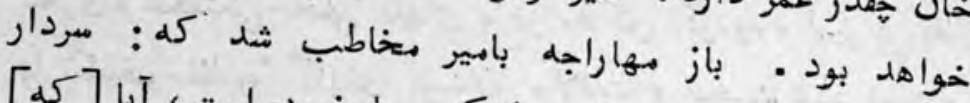

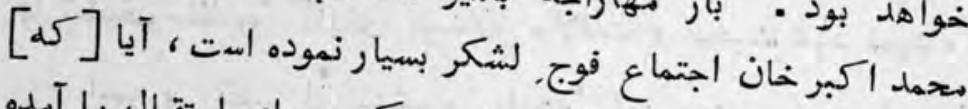

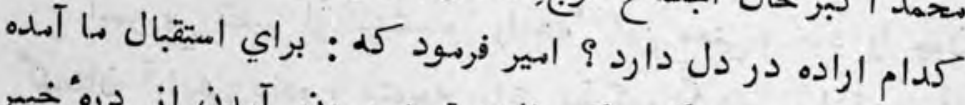

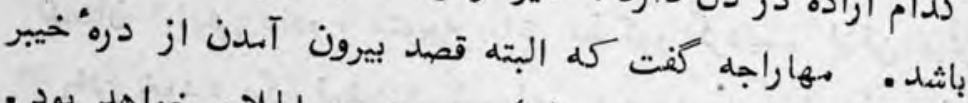

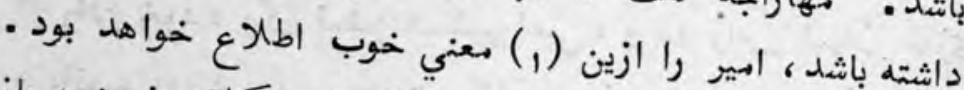

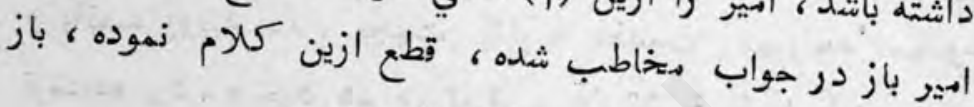

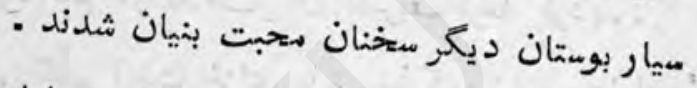

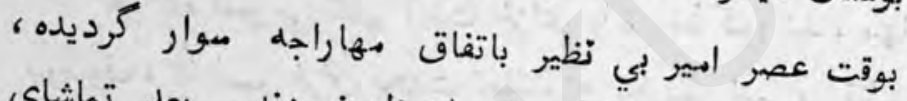

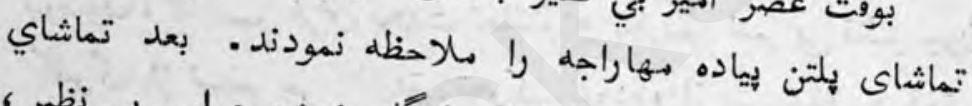

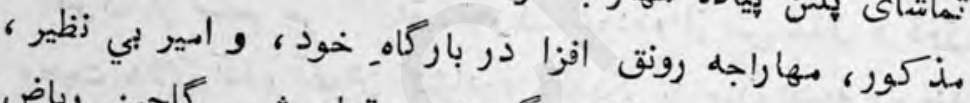

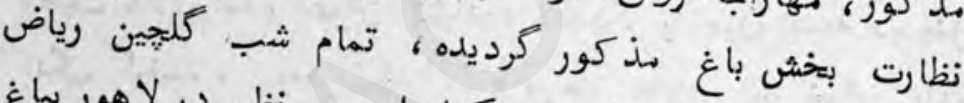

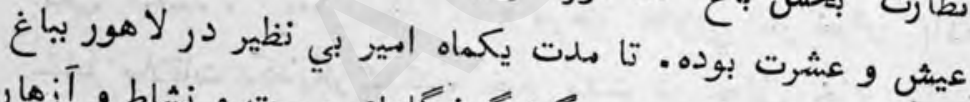

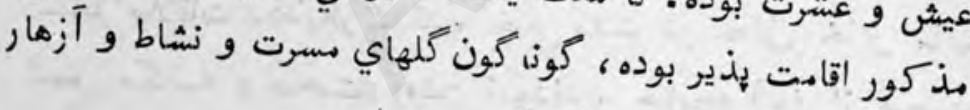

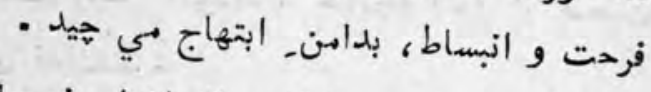

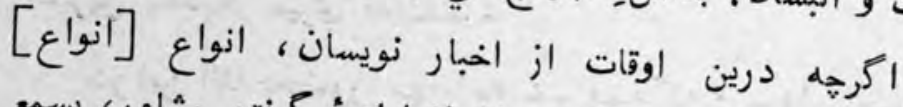

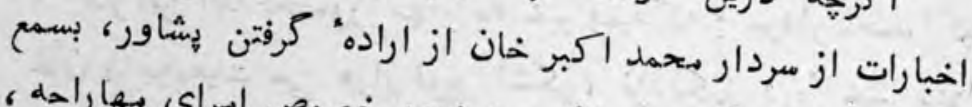

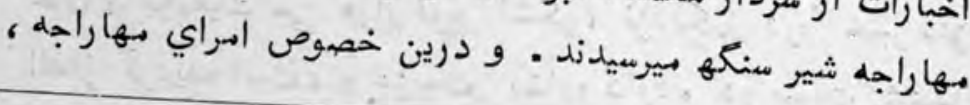

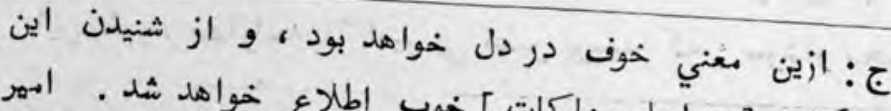

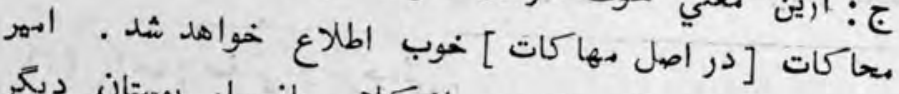

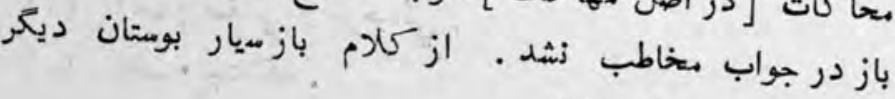

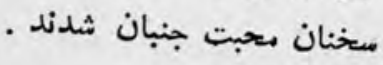


قيندين خيالات [1, - مي كردند آخرالامر راجا دهيان سنگه و ديكر سرداران و اسيران مهاراجه ثير سنكه در خدمت امير بي نظير شرف احضار يافته ، از توقفـ حند روز ديكر، ، بسيار عرض و التماس (r) نمودند . و هم استدعاي

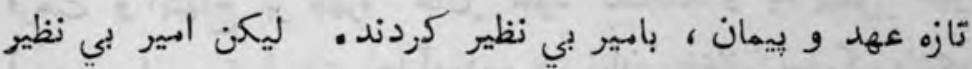

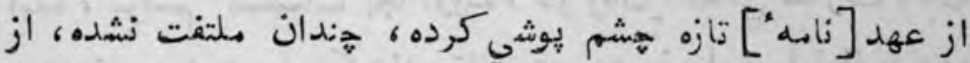
لا هور روانه كرديد

هر كاه امير بي نظيو, دو منزل از [درب] لاهور دور شده

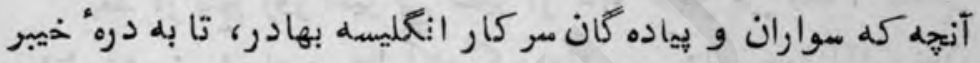
بركاب ابير بي نظير هامور بودزله، همله را طرف فيروز بور رخصت داد

در اين اثنا هجار هزار فوج خراساني بركاب المير بي نظيز

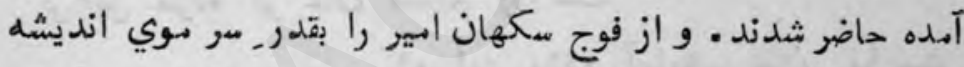
و خيال نبود · و در دل سكهان ، خوفه و هراس ، از فوج خراساني

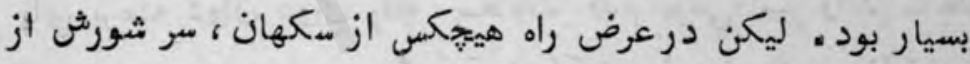
كريجان خود بالا زكرد زلد . و يك مدردار از سكهان همراه ركاب اهير. بي نظير، در خدمت كذاري حاضر مانده ، كله در هر هنزل

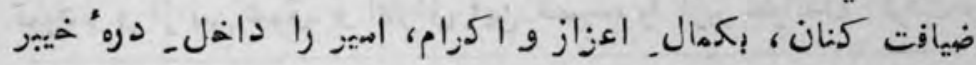
زمودند . بعده اهير ـ مكهان رخصت يابكرديده ، و بعطاي خلعت

$$
\begin{aligned}
& \text { (1) الف: كى: راه كرده . . ج ، الف: مانند متن . } \\
& \text { الف: التماس هـ نمودند . }
\end{aligned}
$$


تازه نواي معارك

$\Delta \triangle \wedge$

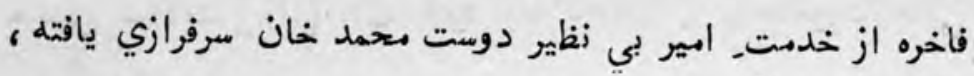

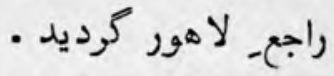

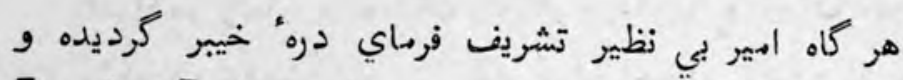

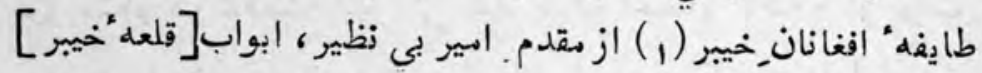

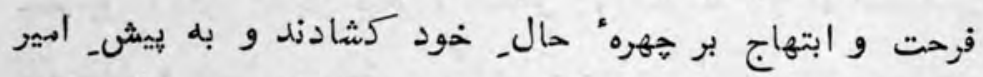

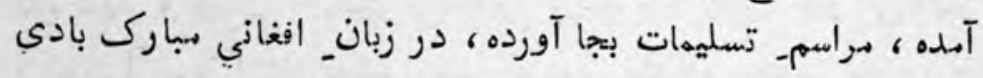

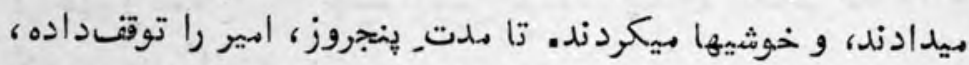

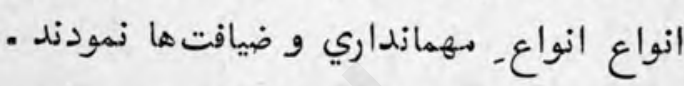

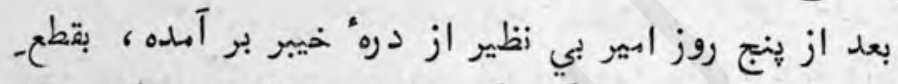

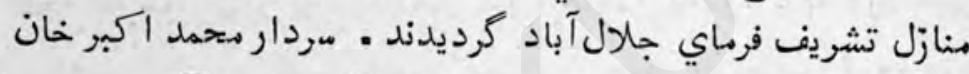

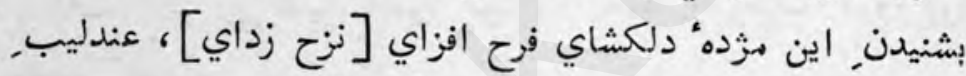

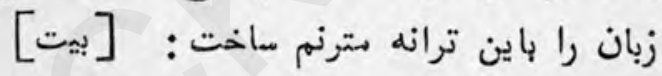

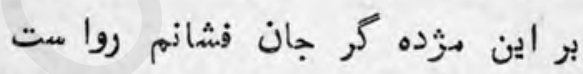

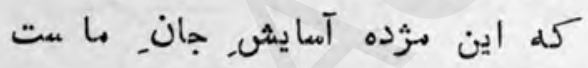

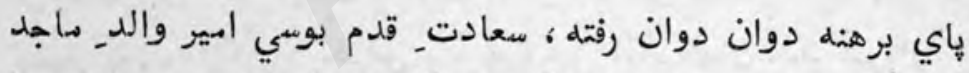

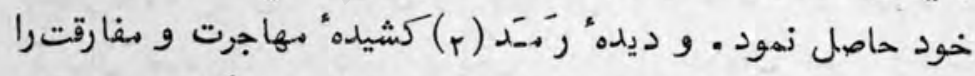

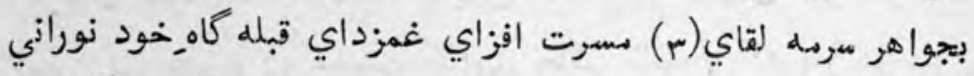

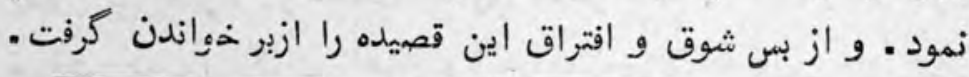

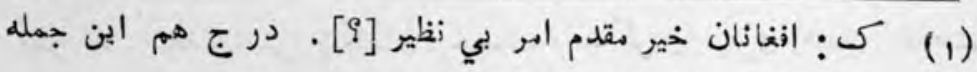

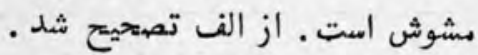

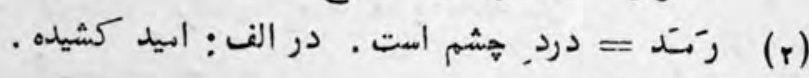

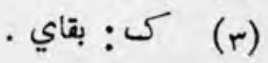


$0<9$

تازه نواي معاركى

قصيده (1)

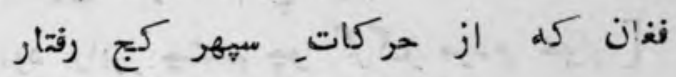

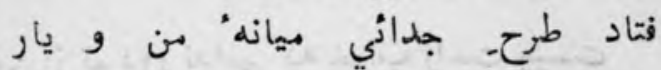

زمانه هيش. بن آورد آن هينان روزي كله روشنم شد از آن [ روز]

هو ان كلي كله ز كلمزار, وصل او هيدم ز هجر بر دلم آهد هزار نشتر. خدار

بدامن- مثر رُفتن [ز] طرف خارا خمب

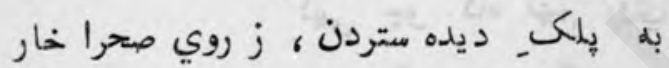

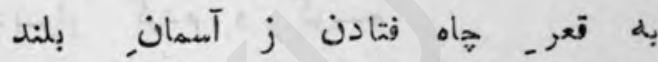
بفرقـ مر (r) شدن ازدشت ك جانب_ كهمار

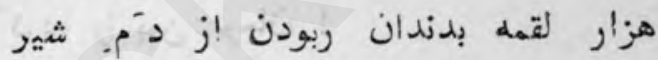

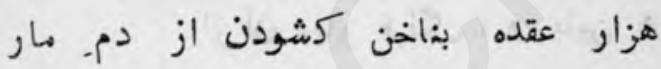

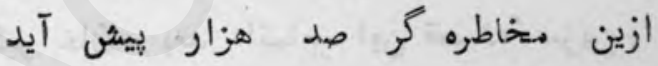

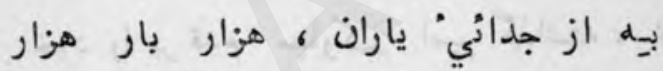

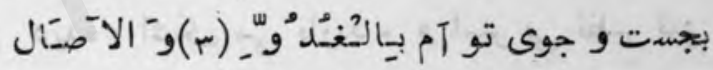

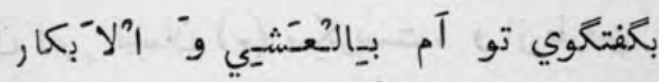

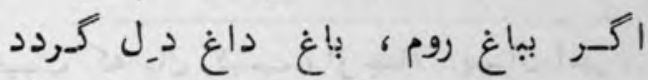

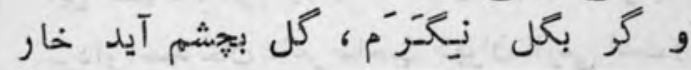

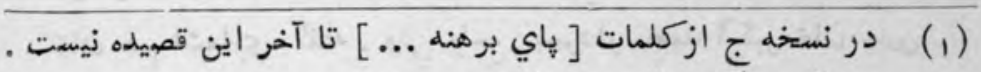

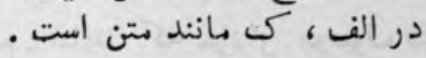

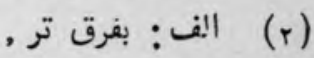

(r) 
[ اكر به يوسف مصري نظر كنم بي تو :

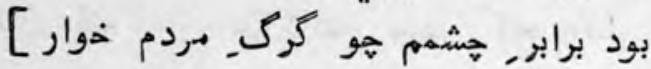

من از تودور ندانم كله خواب راحت هيست

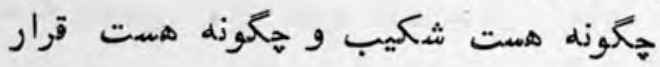

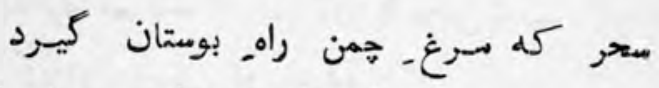

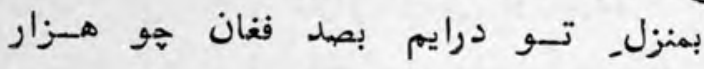

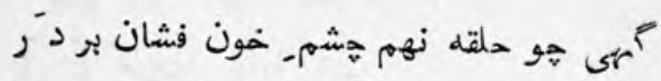

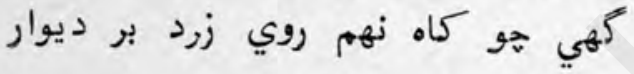

$$
\text { بكرد- آن در و ديسوار كردم و كويسم }
$$

بآه و ناله ، كله اي كرد كار. ليل و نهار !

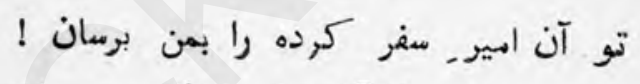

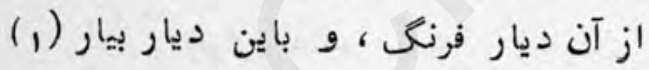

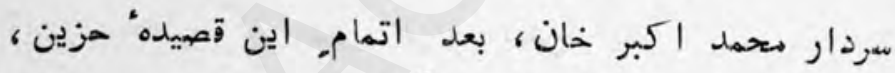

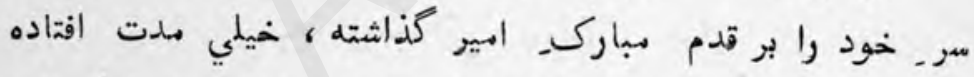

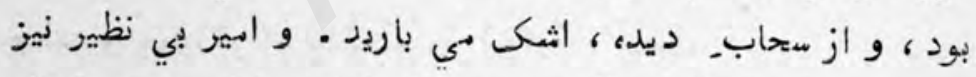

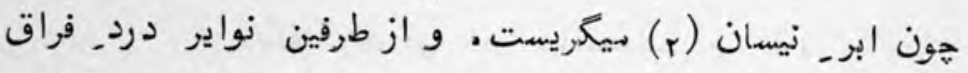

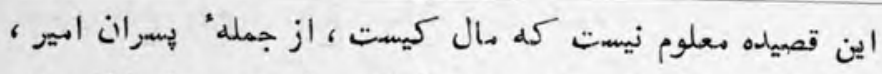

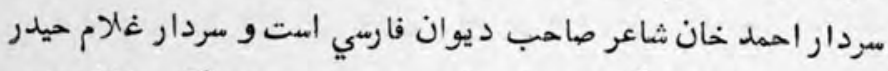

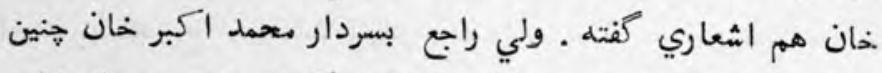

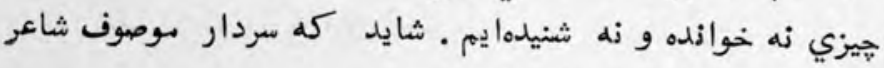

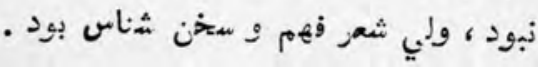

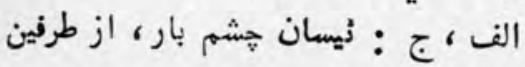




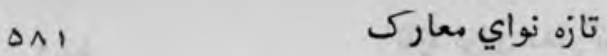

مدر بفلك كشيد -

آخر الامر ابيرـ بي نظير از روي مهر يدري، سردار مذ كور را در

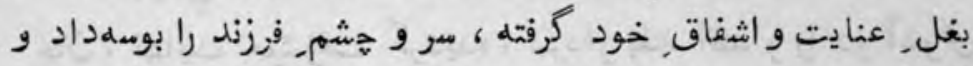

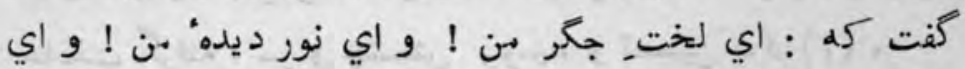

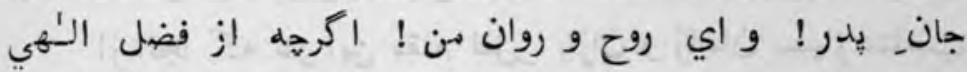

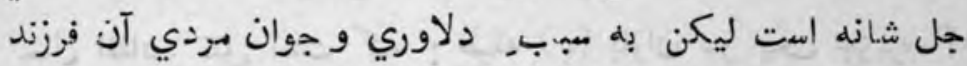

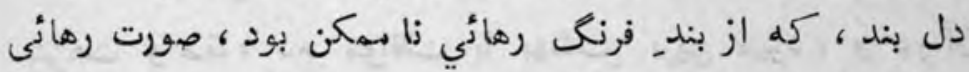

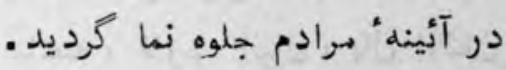

سردار. مهنوح در جواب التماس كرد كله : اين همه از كاز

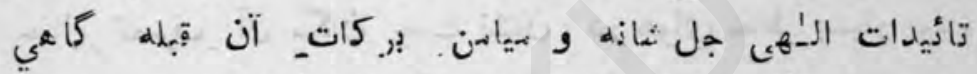

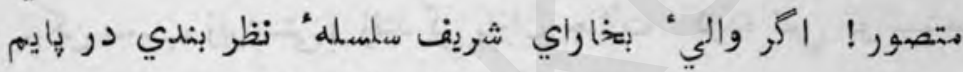

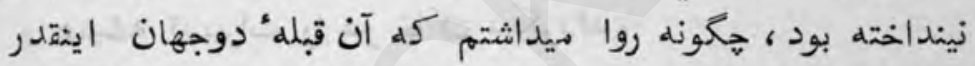

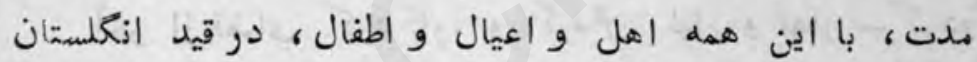

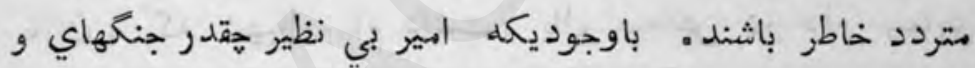

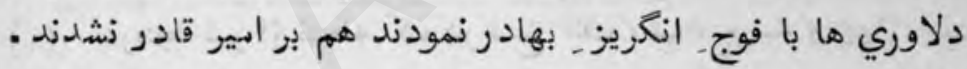

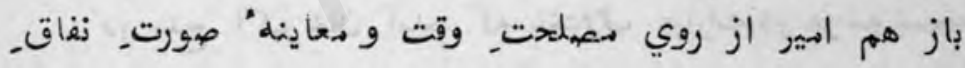

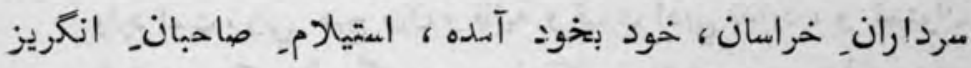

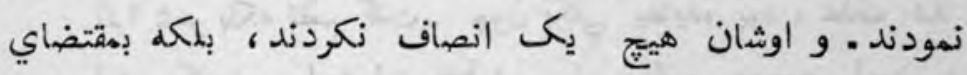
بي انصافي و حق ناشناسي ، اسير را هون اسيران ، روانه "ه:دوستان

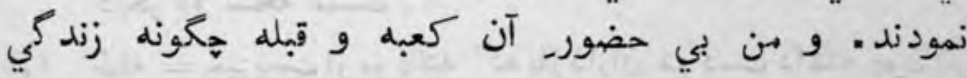

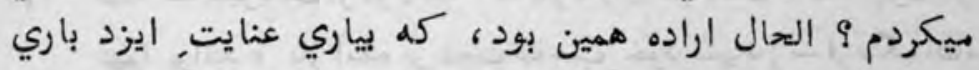
جلشانه ، و اعانت_ هضرت رسالت هنا هي، لواي نصرت انتماى 
اسلكم در ولايت نصب مينمودمم

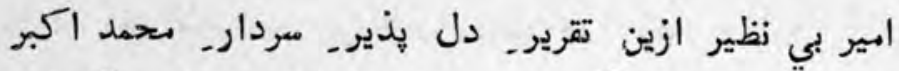

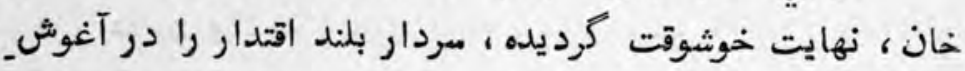

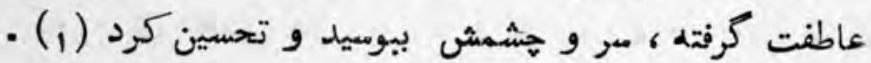

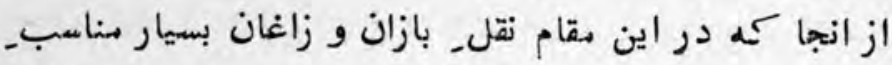

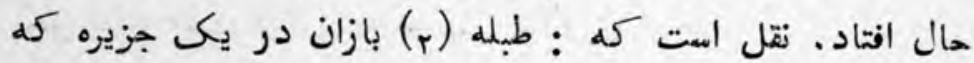

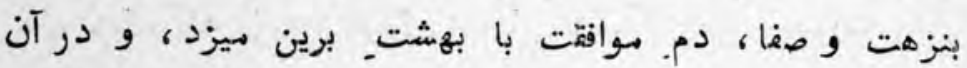

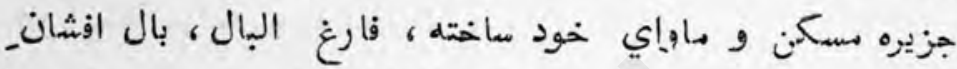

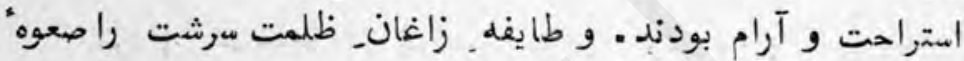

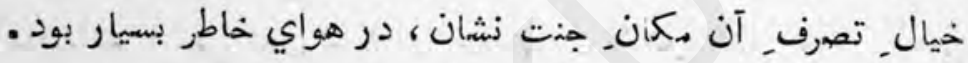

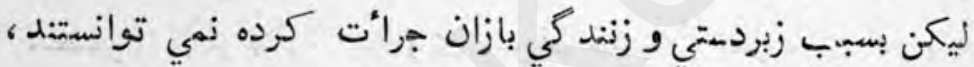

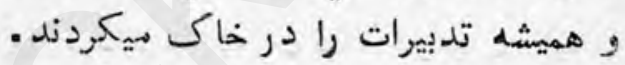
آخر از قضاي كردثار، و كردث. ليل و نهار سركرده"

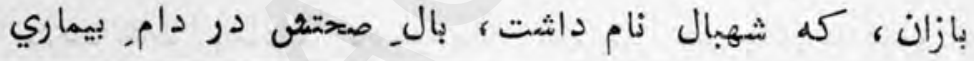

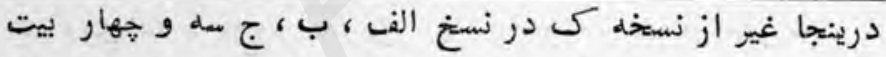

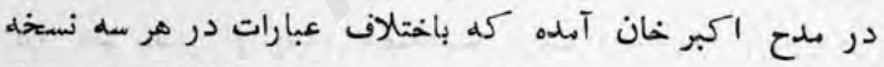

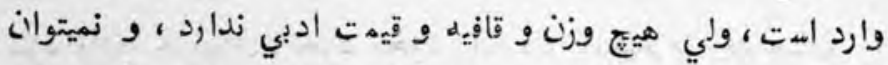

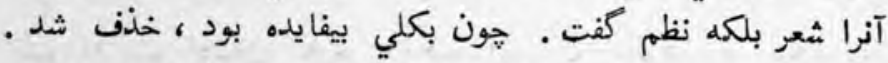

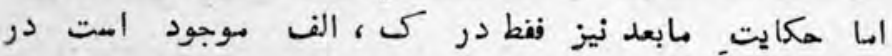
ديكر دو نسخه نيست .

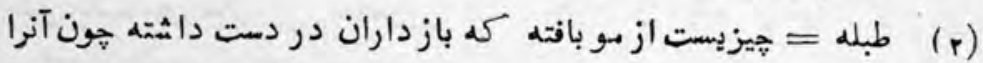

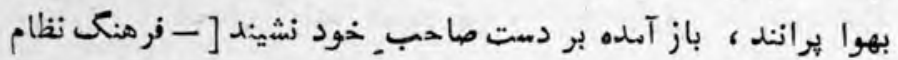

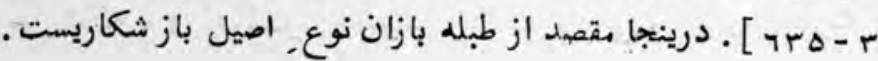


تازه نواي معارك

ي يججيده ، جند مدت در جزيره رنجور بود . از آنجا كمه بموجب.

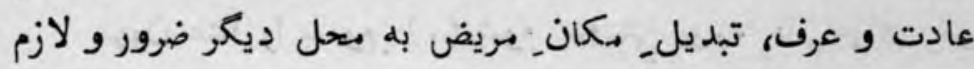

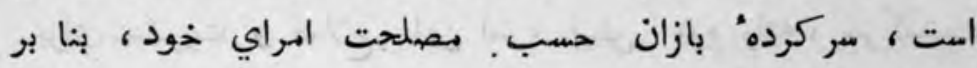

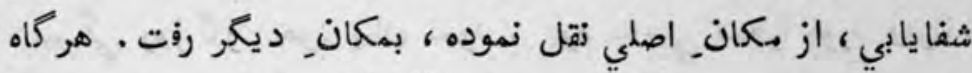

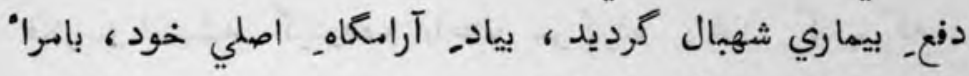

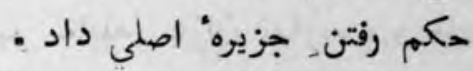

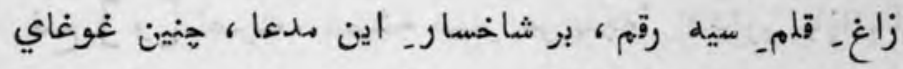

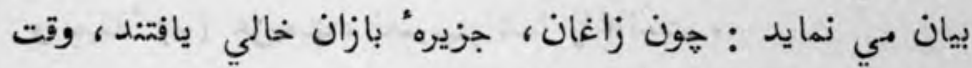

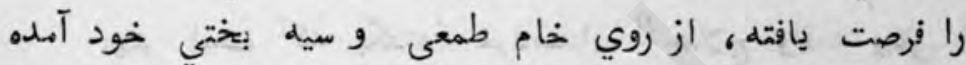

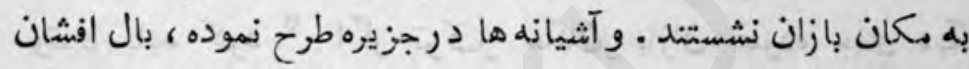

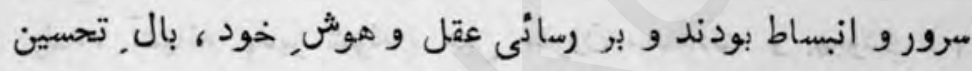

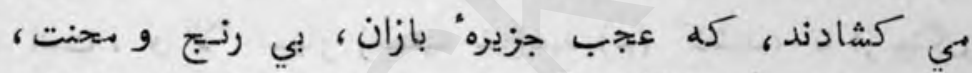

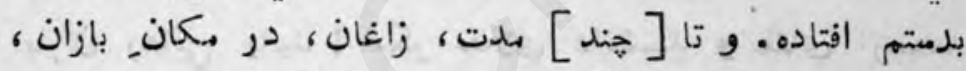

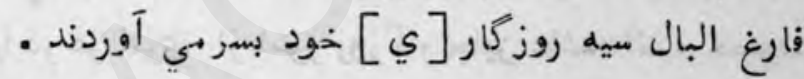

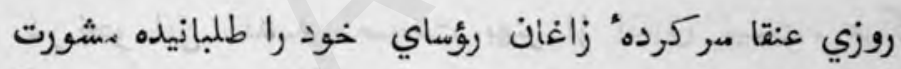

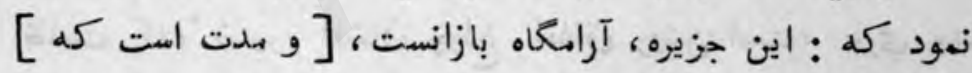

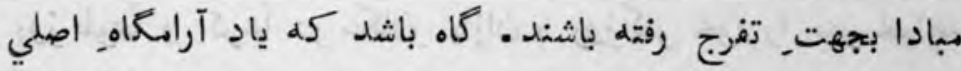

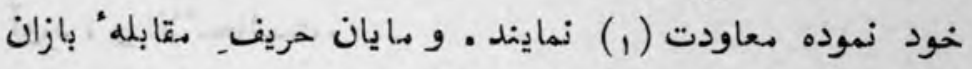

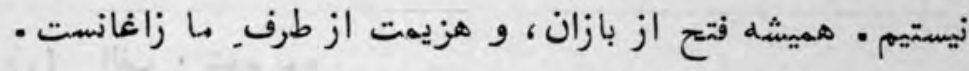

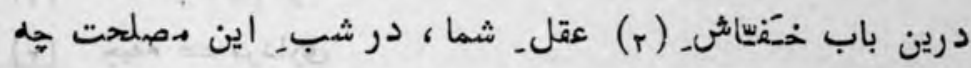

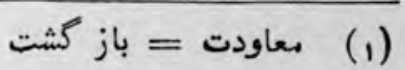

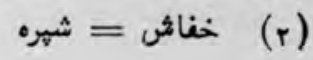


تازه نواي بعاركى

$\Delta \wedge N$

يرواز مينهايد ؟

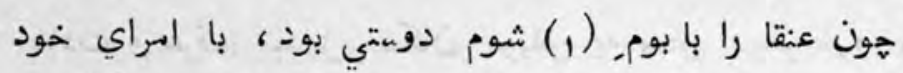

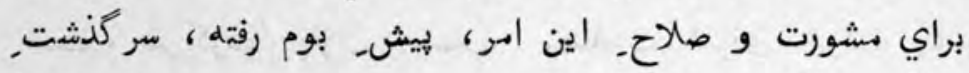

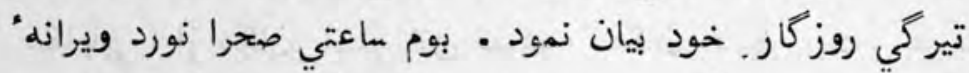

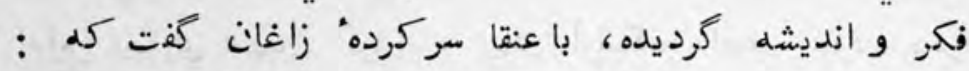

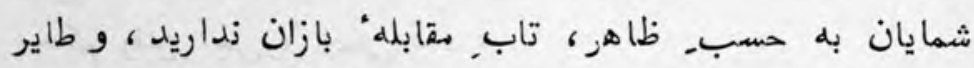

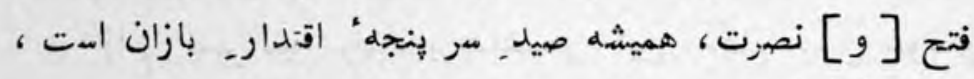

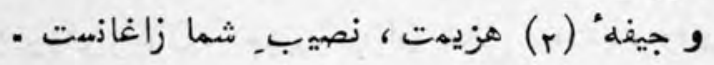

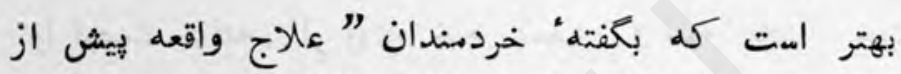

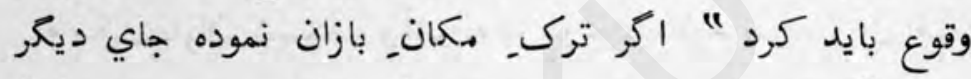

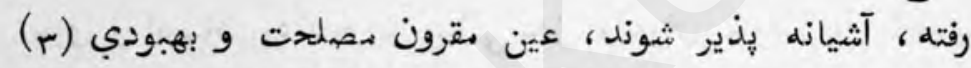

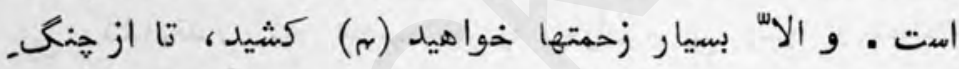

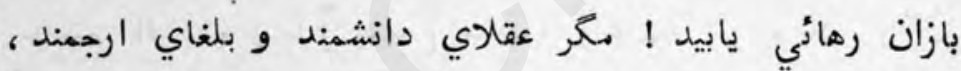

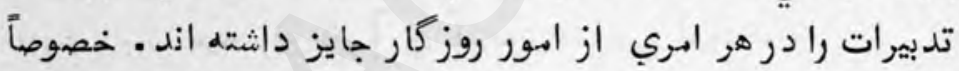

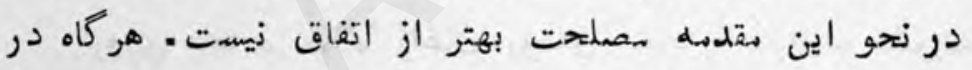

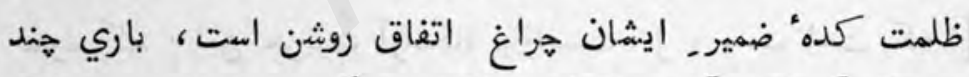

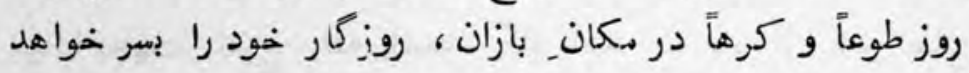

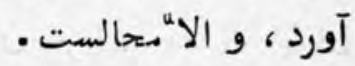

(1) الف : شوم بوم

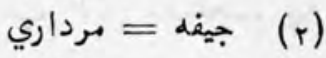

(r)

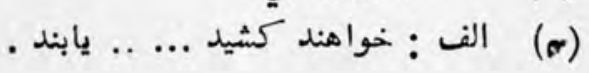


درينصورت عنقا مركردهُ زاغان، روي طرفـ امرا" خود

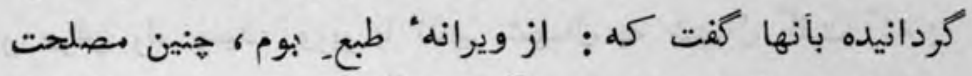

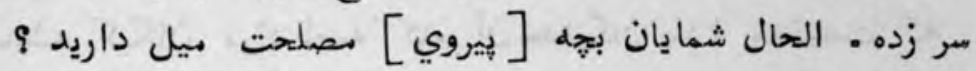

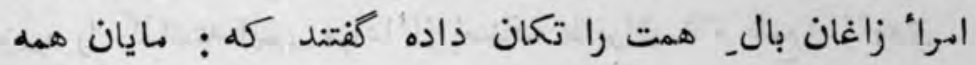
در جيفه خوري اتفاق ثابت قدم مي باشيم، و كركس وار بران بهنال

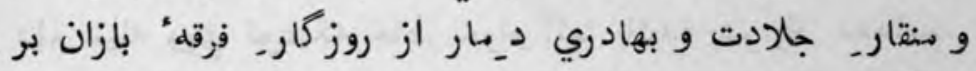
ي آريم، و روي همت را از كارزار. بازان نيخواهيم تافت.

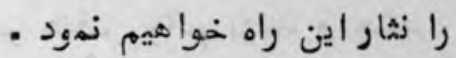

عنقا سركرده" زاغان هون اين ستخنان تهوراذه، از امراء

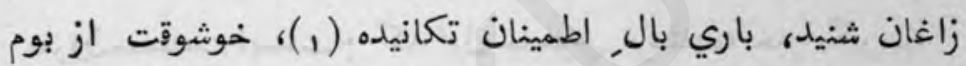

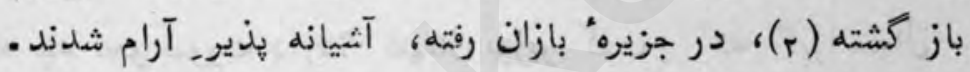

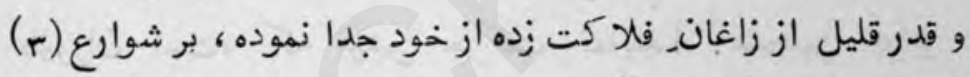

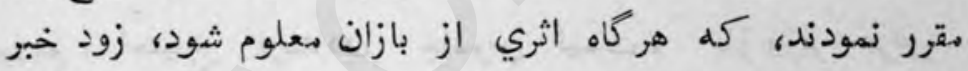

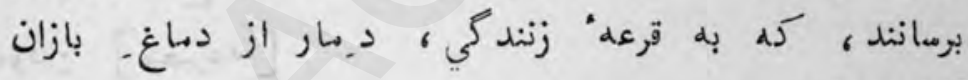

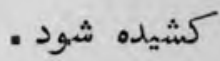

ازانجا كله هر كاه زاغان به تمهيدى كه كه مذكور شده، دامه

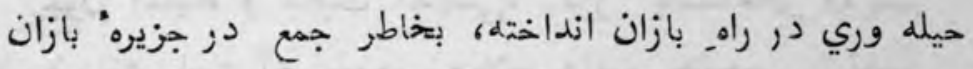

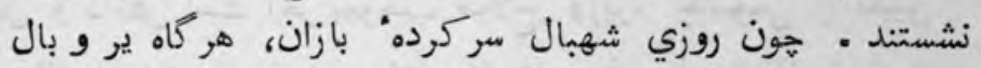

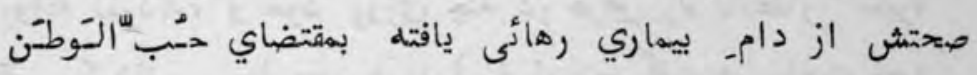

$$
\begin{aligned}
& \text { (1) الف: تكيده. } \\
& \text { (r) (r) الف: باز كشيده . (r) }
\end{aligned}
$$

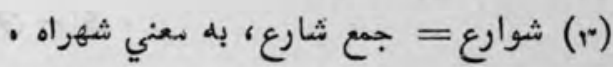


تازه نواي مerارك

$\Delta \wedge T$

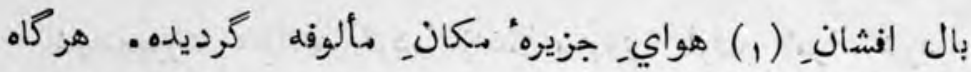

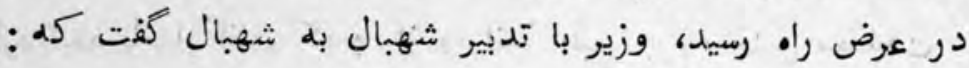

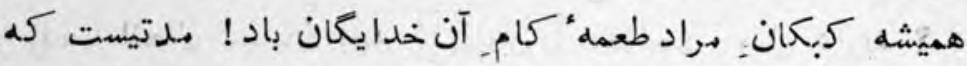
جزيره را كذاشته ايم، هبادا از اصفاف طايران خام طهع، از روي

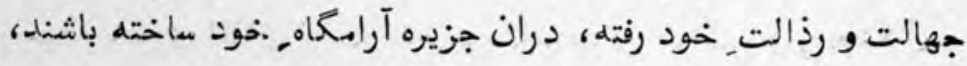

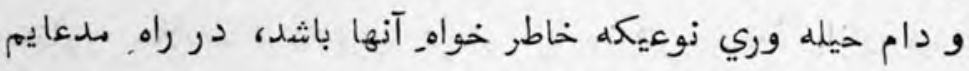

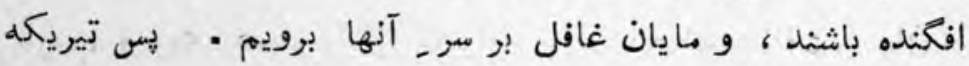

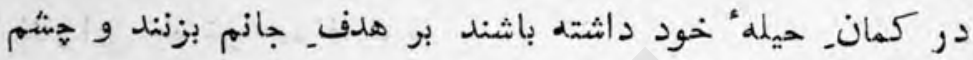

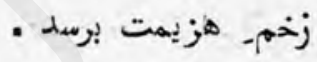

مقرونمصلمحت اينست : كله اول جاسوس فرستاده، خبر بكيريمب،

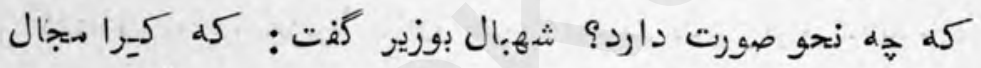

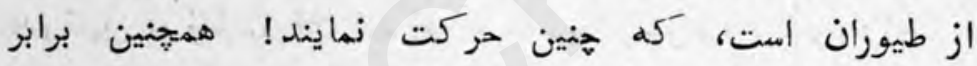

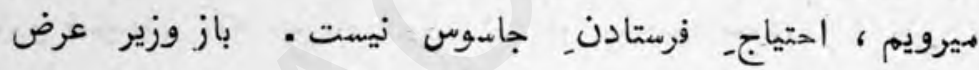

$$
\text { [ds,ص. }
$$

مردي آخر بين مبارك لبنه است

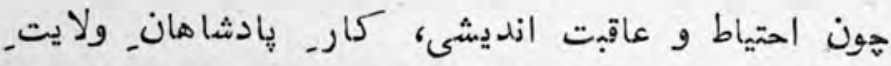
عقل و دانش است آخر بهوجب صلاحــ وزير، جاسوسي را تعيين

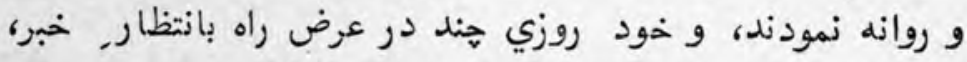

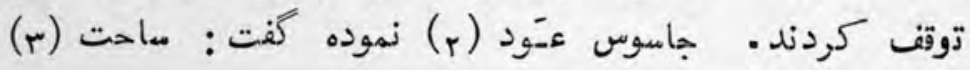

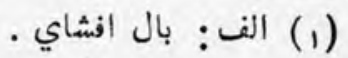

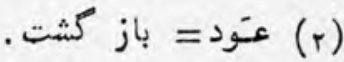

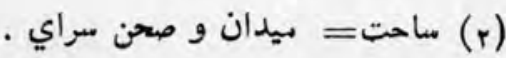


$\Delta \wedge \angle$

تازه نواى مار

دارالهلك, امير، نزهتخاه و نزول. زاغان ظلمت سرشت شده ؛ ] سرادق استقامت كنده، ثابت قدم

- اندازي

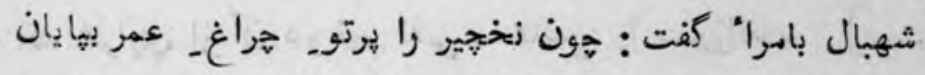

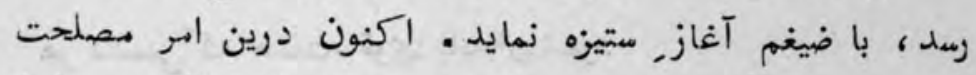

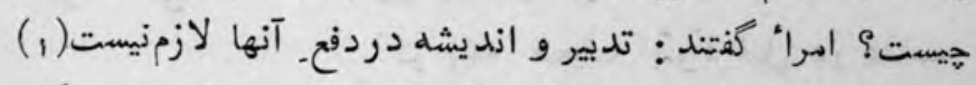
همين كله همه را بيمن_ اقبال ملك كشاي اميرك اسير و دمتاكير

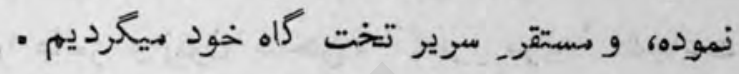

شهبال كفت: فرقه" (r) زاغان بحيله ورى و و بازند

سشهور اند، تا بوجهي از وجوه دلجع تِناه بحصار اطمينان نبوده

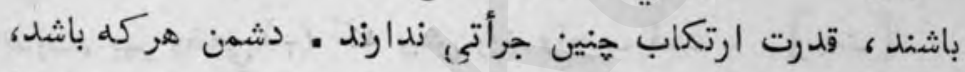

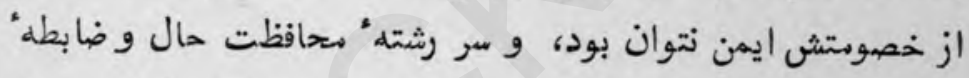

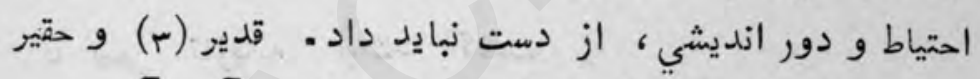

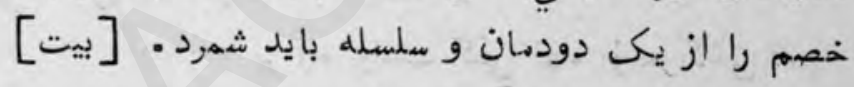

خصم را عاجز شهردن نيست آنين. خرد

يكى شور بنياد صد خرمن كند زيند زير و زبر

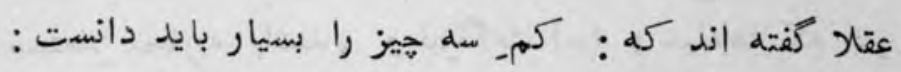

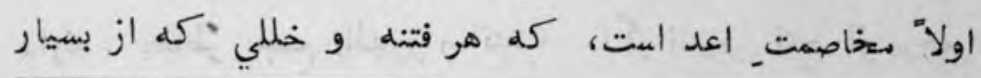
(1) الف: لازم است، شان بيوجودان را هندان اعتنا و وقعي نمي باشد.

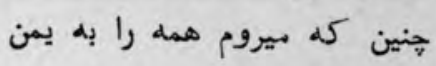

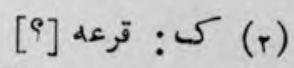

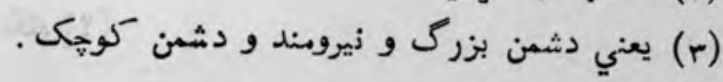


تازه نواى +ـعاركى

$\Delta \wedge \wedge$

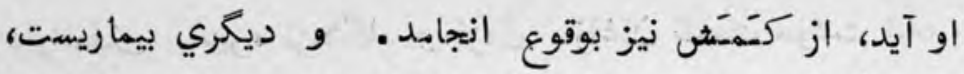

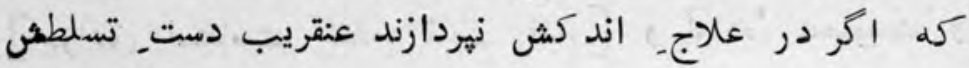

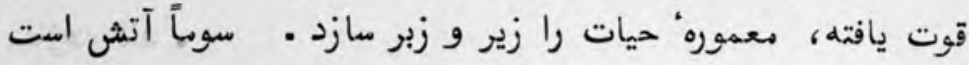

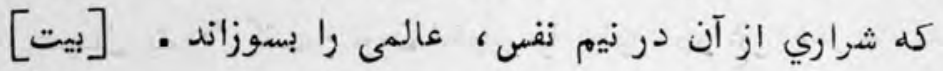
هر دشمنى كه هست، قوي بايدش شمرد

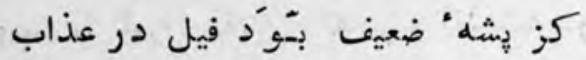

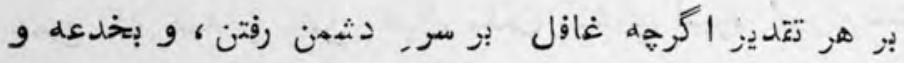

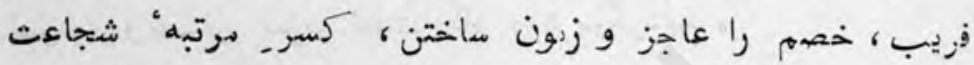

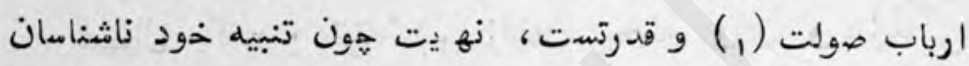

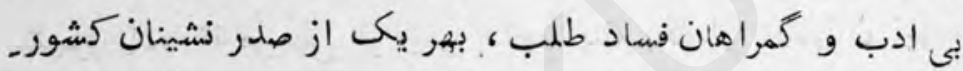

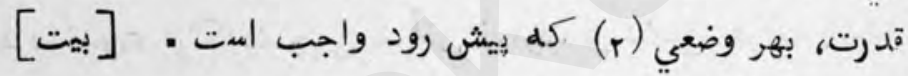

تأ بيم. تازيازه نبشا كميد

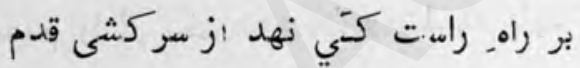

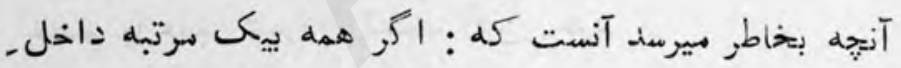

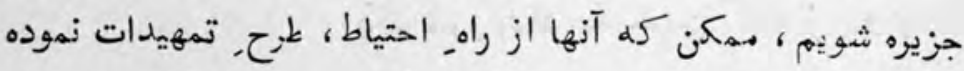

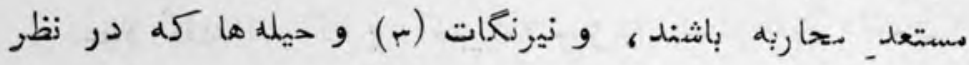

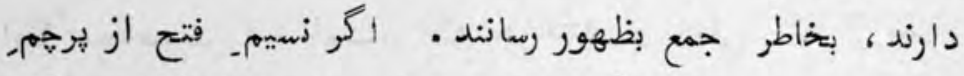

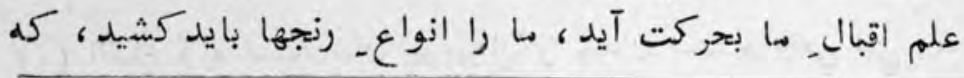

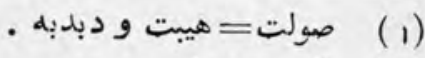

(r)

[؟] (r) 


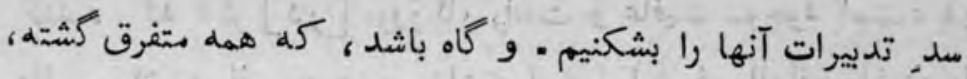

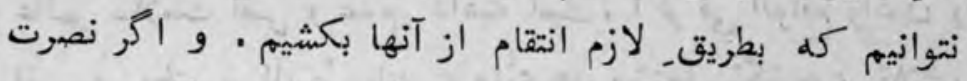

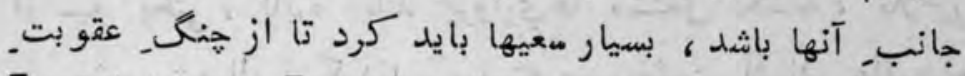

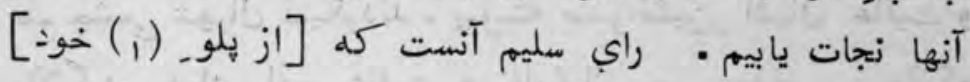

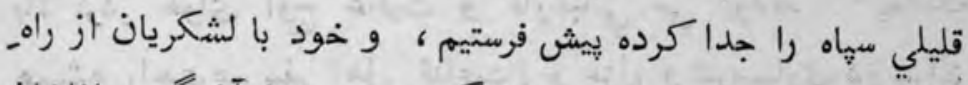

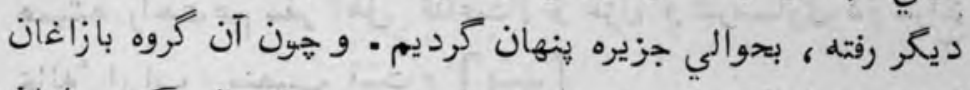

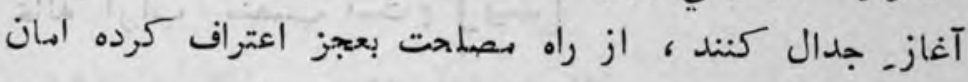

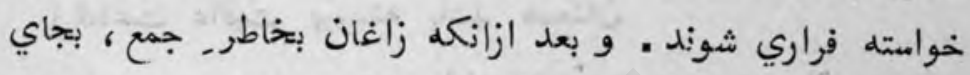

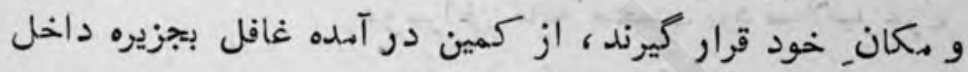

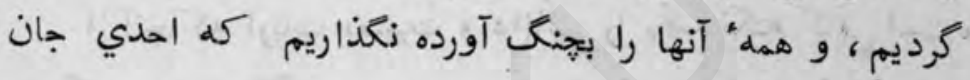

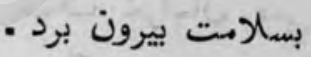

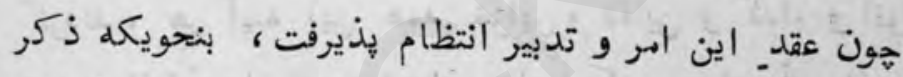

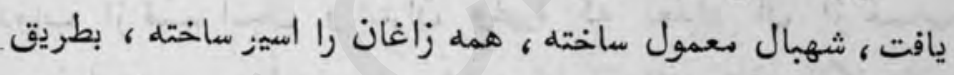

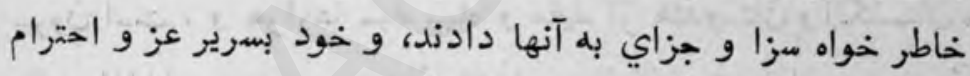

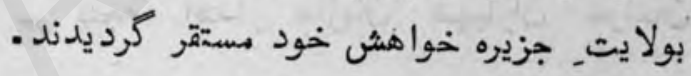

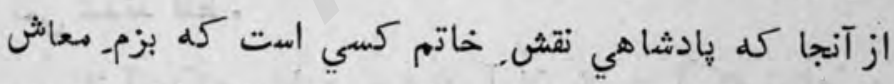

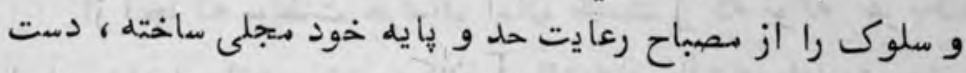

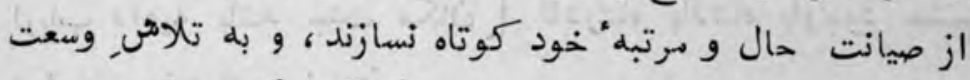

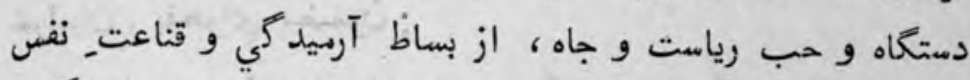

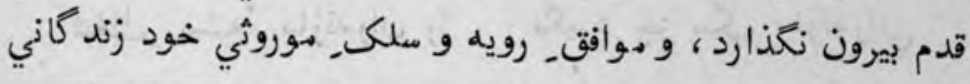

$$
\text { يَّتو = كلمه ضشتو ست ، يعني از جانبــ خود . }
$$


تاز منواي معارك

$\Delta q$.

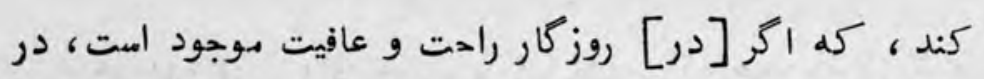

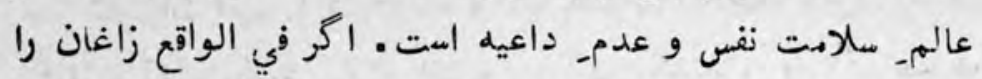

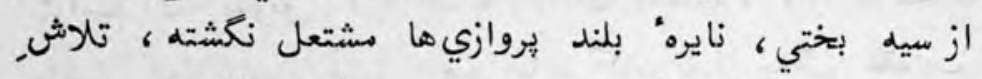

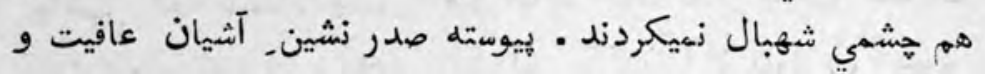

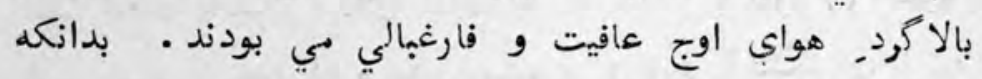

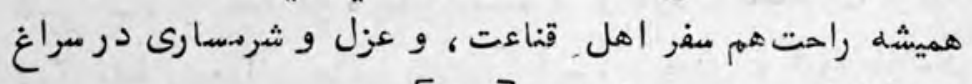

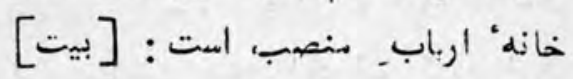

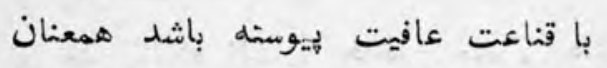

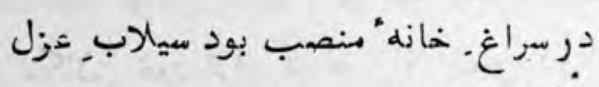

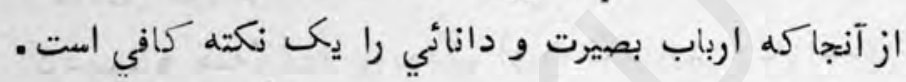

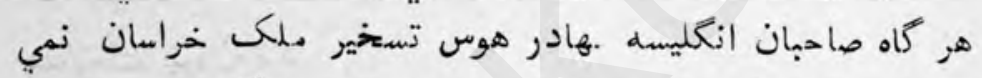

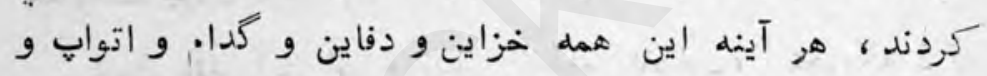

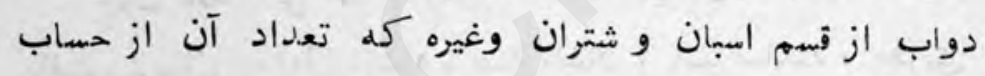

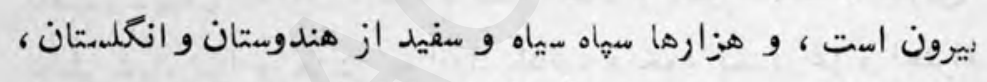

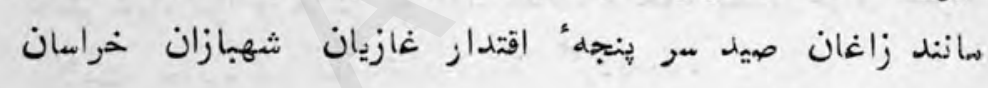

نمي شدند فتط ماندان صان

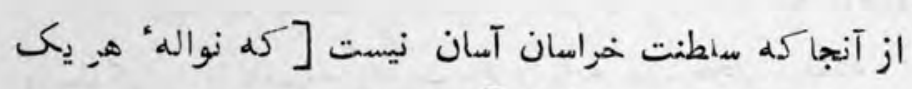

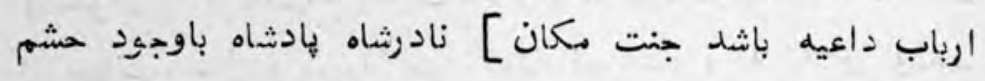

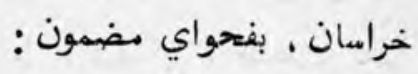

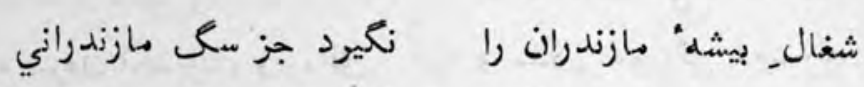

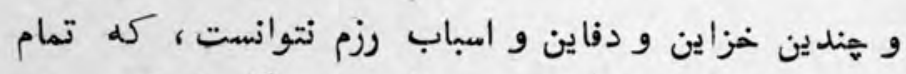

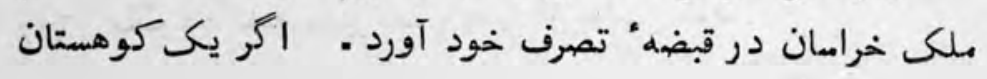


$\Delta q 1$

تازه نواي مـار

ميكرفت ، ديكر كوهستان ياغي و باغي مي بود • و حهندين سالها

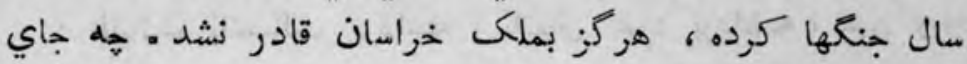

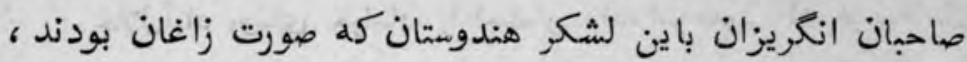
كله در عرصه "ده يازده ماه تصرف ملك خراسان نمائد . [مصرعه

صيد را هون اجل آيد، سوي صياد رود

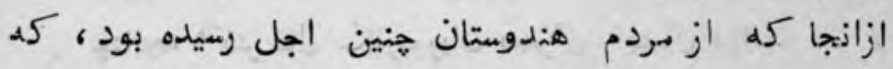

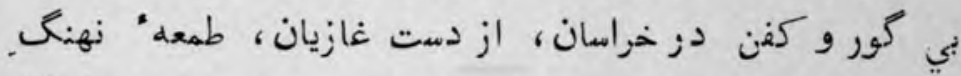
درياي هلاك شدند . و غازيان اسلام كه هميشه (1) تشتهـ" زلال

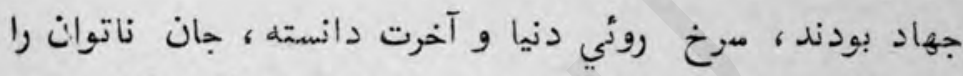

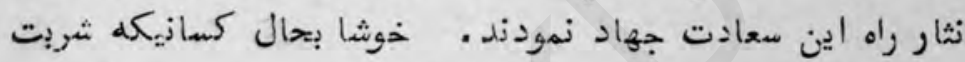

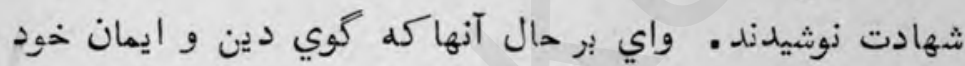

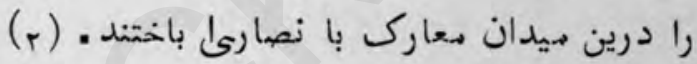

- dos : S (1)

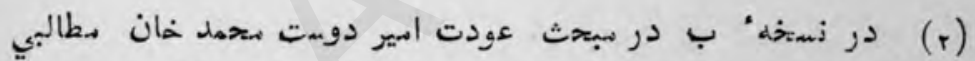

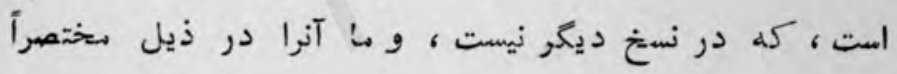

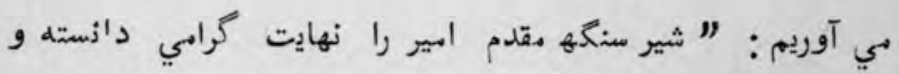

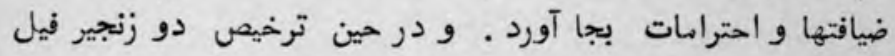

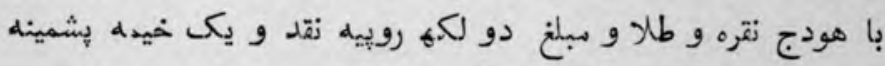

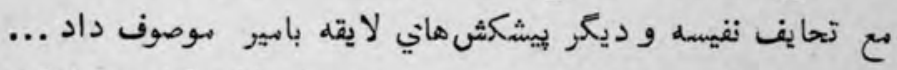

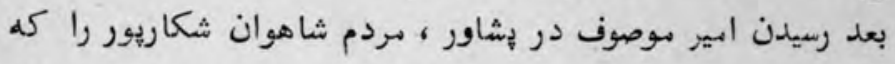

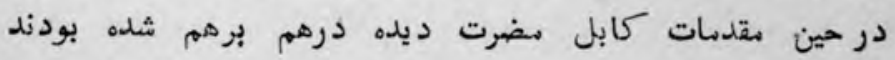

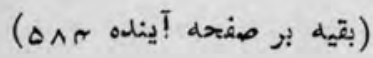


تازه نواي معارك

$\Delta 9$

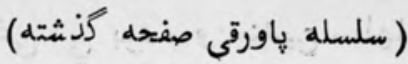

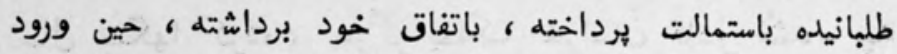

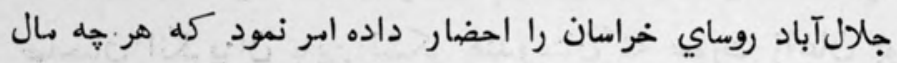

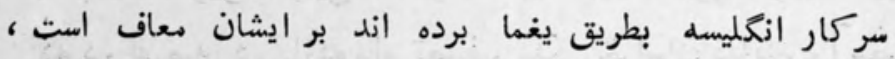

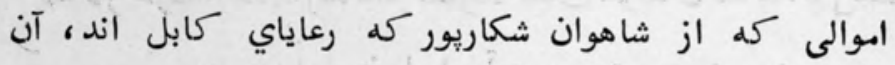

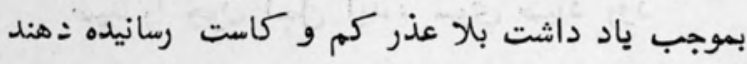

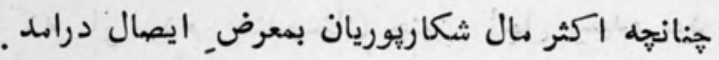


$-\wedge 1-$

در بيانِ (1) رفتن امير بي نظير از جلال آباد

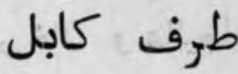

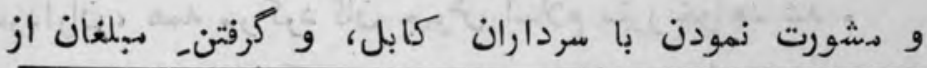

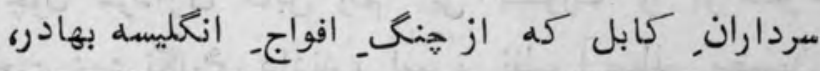

بدست, يغما آورده بودند [وغيره]

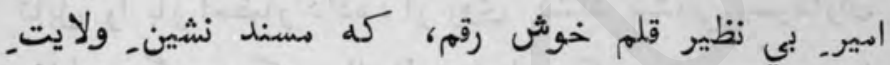

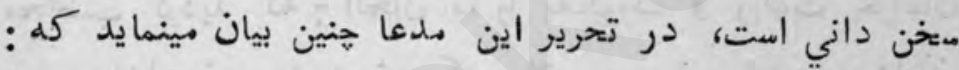

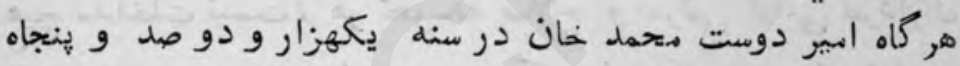

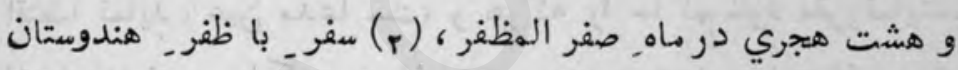

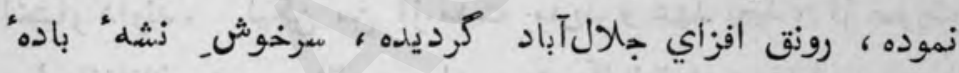

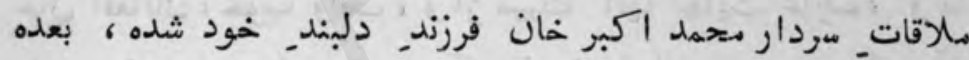

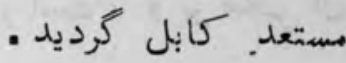

جون اين خبر آمدن. امير بي نظير ، بسمع سردارانــ كابل

(1) اين فصل در نسخه" ب ، ج نيست.

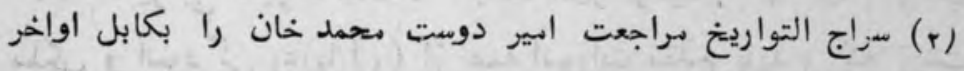

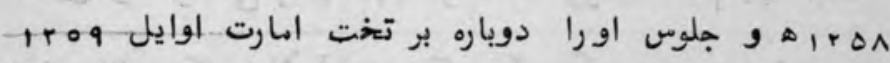

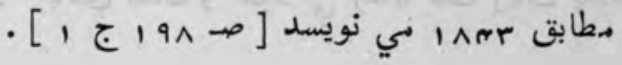




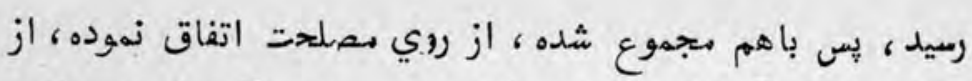

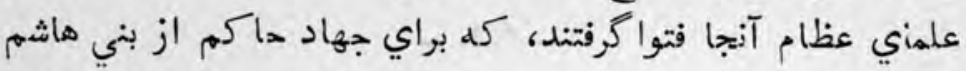

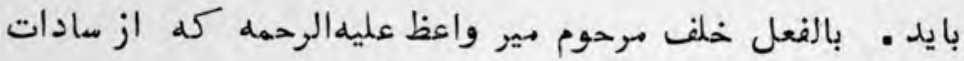

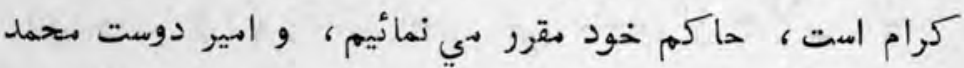

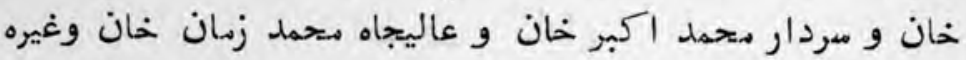

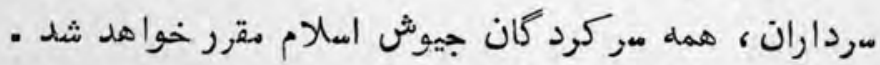

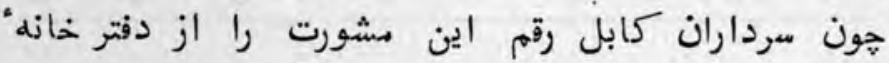

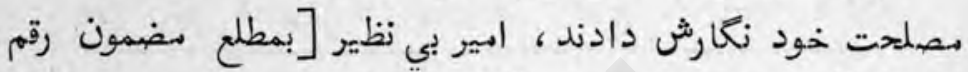

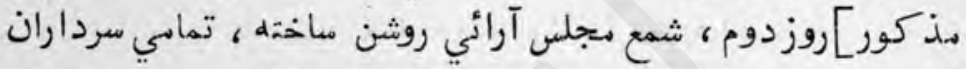

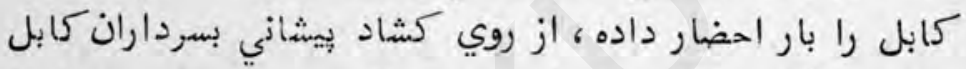

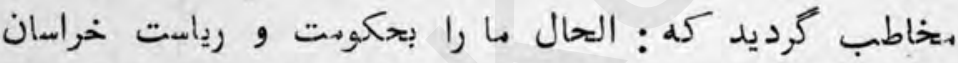
هيمج مداخلت نيست، هر نحويكه صلاح و مرضي تماسي سرداران

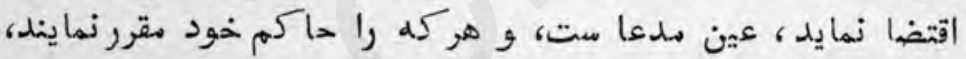

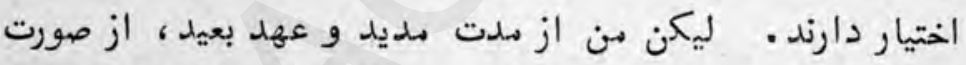

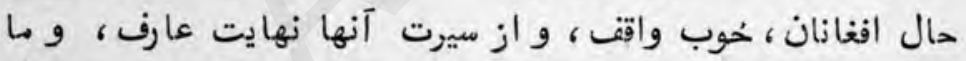

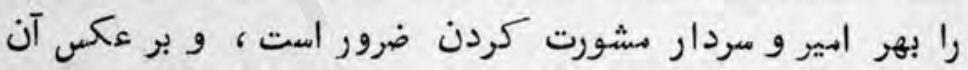

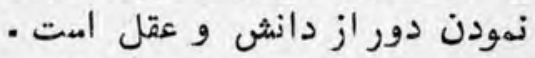

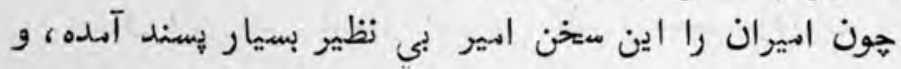

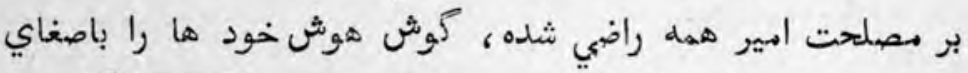

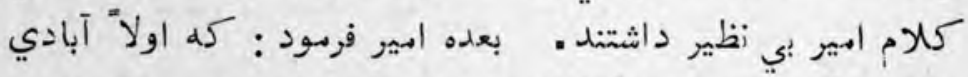

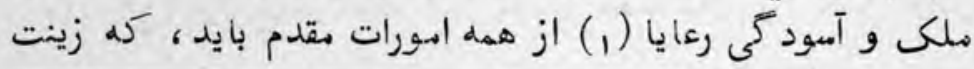
الف : كه اولاً آبادي ملكى و آسودكي رعايا ست زينت بادشاهي. دويماً 
$\Delta 9 \Delta$

تازه نواى معارك

دلبران خط و خالل، و وسهل و غازه و زينت بادشاهي آبادي

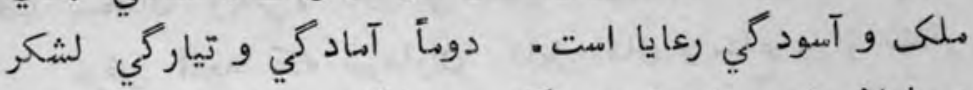

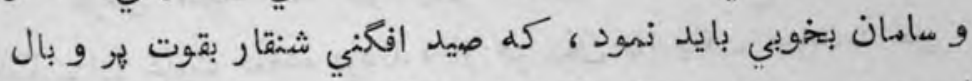

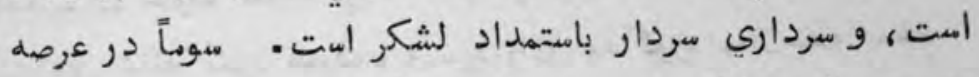

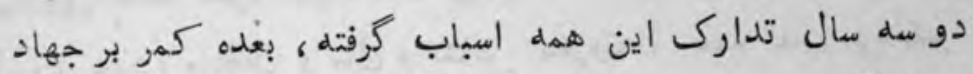

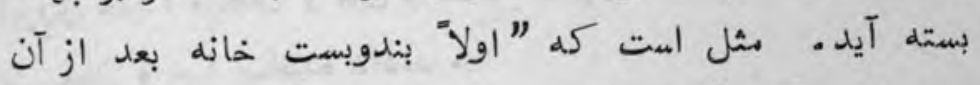

عزم سفر بيمانه " بايد كرد . سله سرداران كابل هون اين كلام از زبان امير بي نظير شنيدند ،

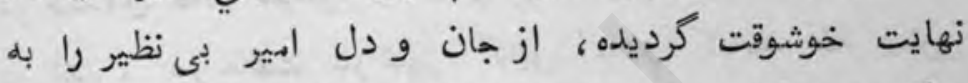

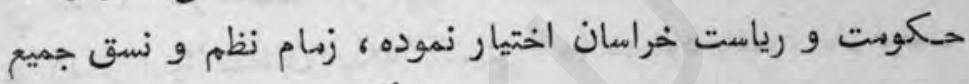

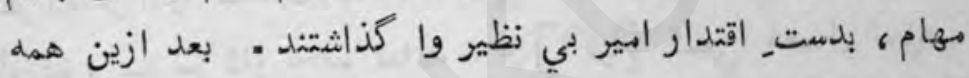

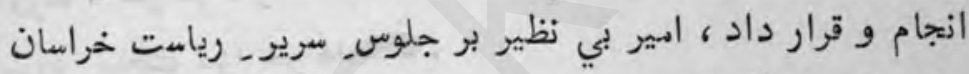

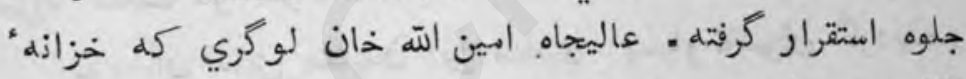

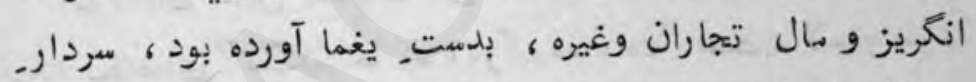

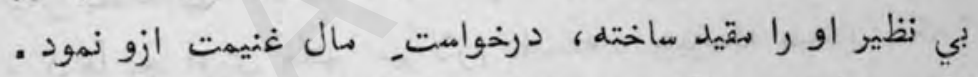

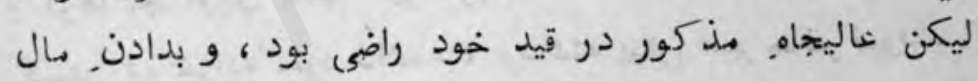

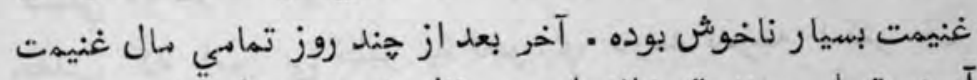

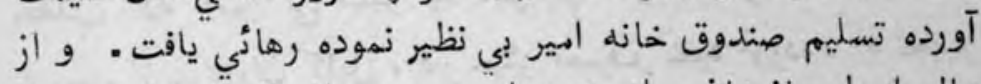

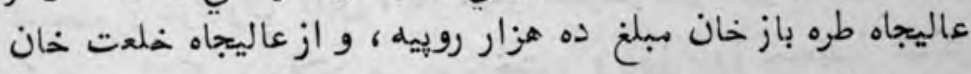

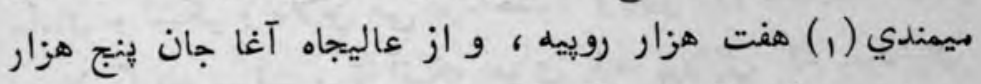

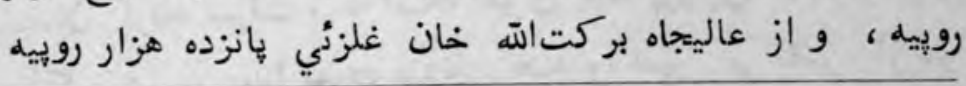

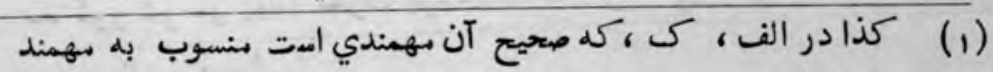

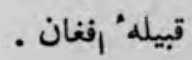




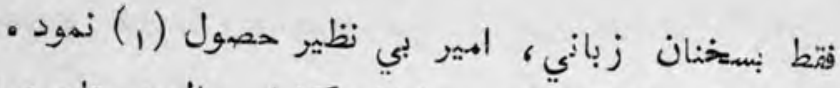

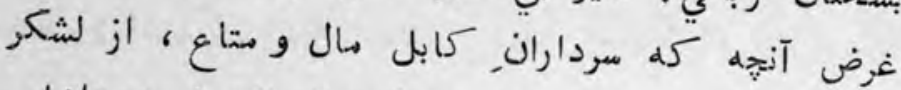

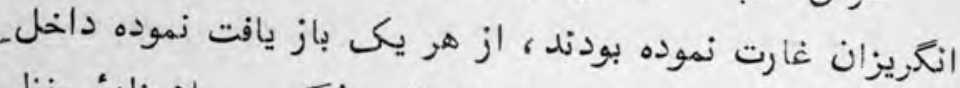

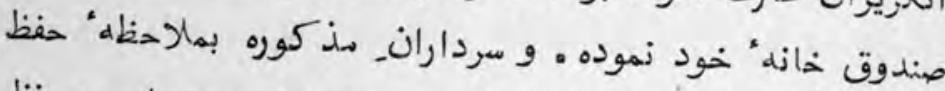

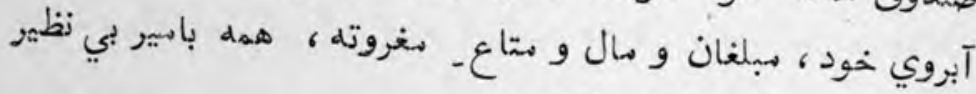

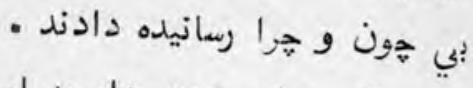

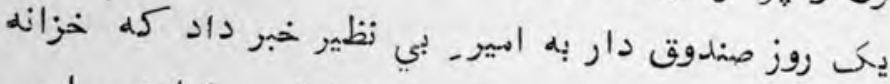

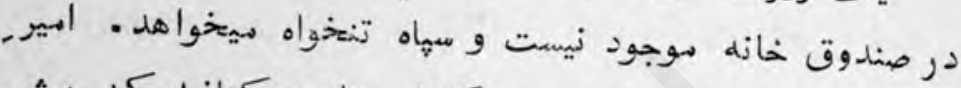

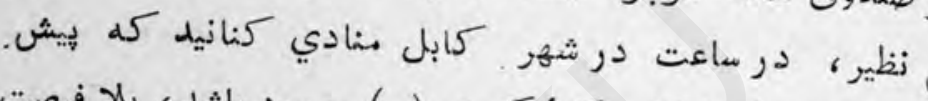

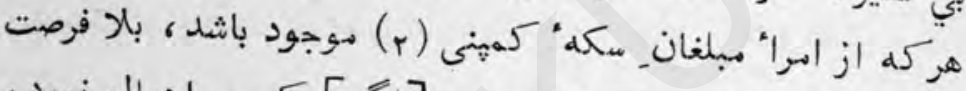

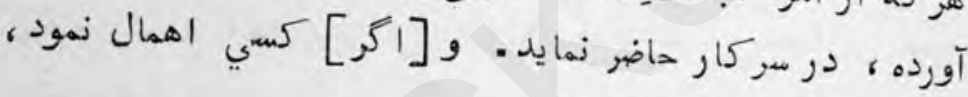

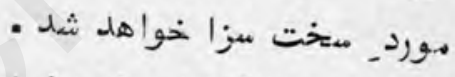

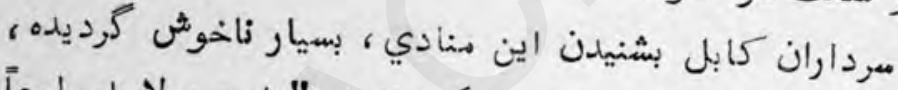

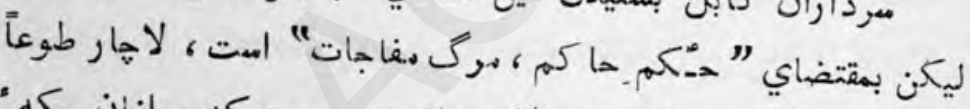

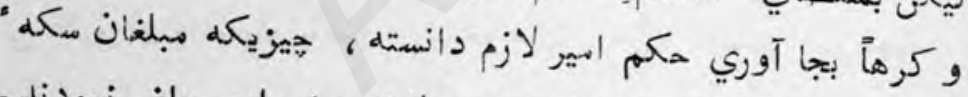

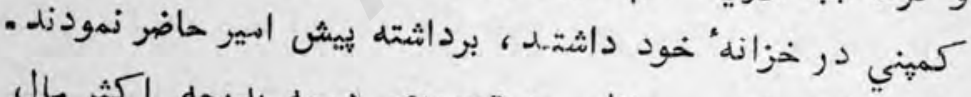

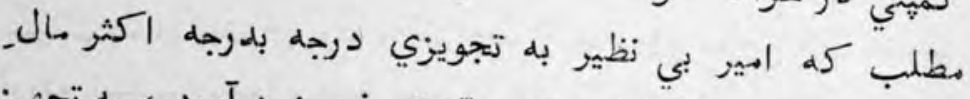

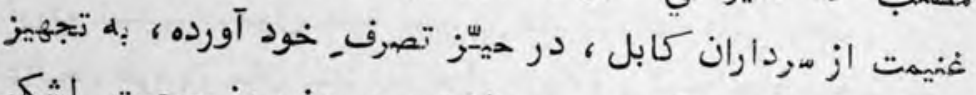

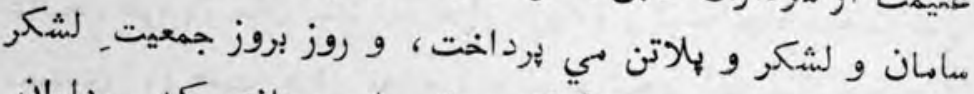

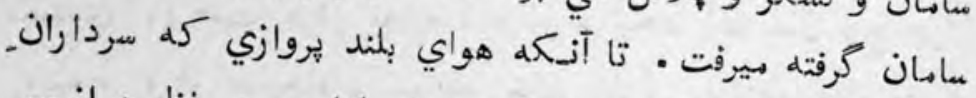

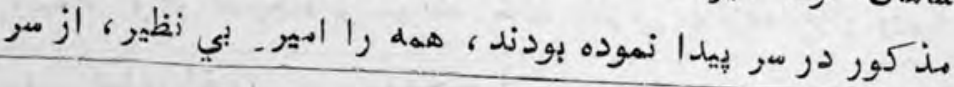

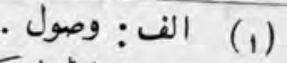

$$
\begin{aligned}
& \text { - (r) }
\end{aligned}
$$


آنها كشيده ، در هر باب مطيع و فرمان بردار شدند. و بعضي

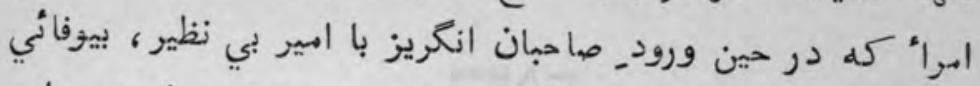

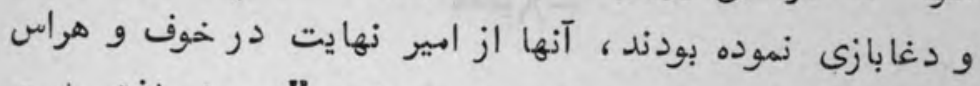

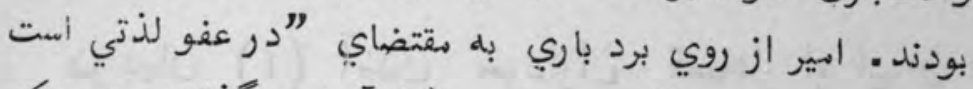

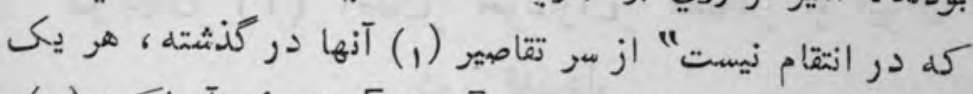

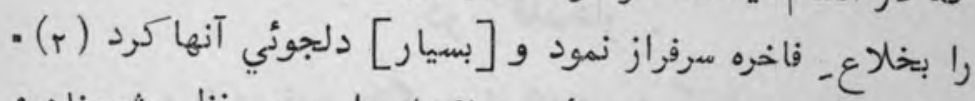

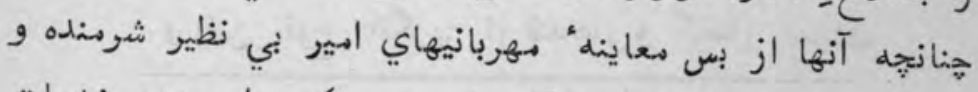

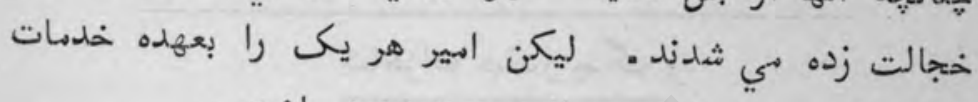

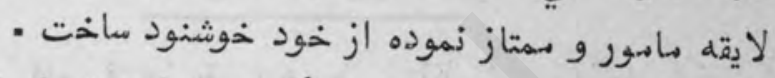

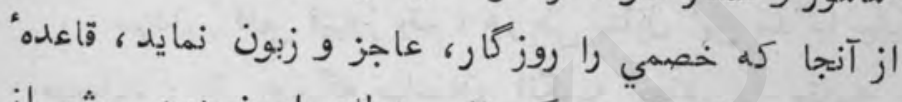

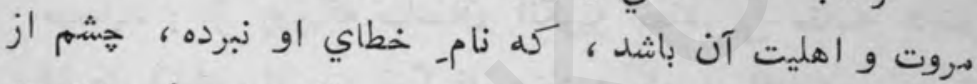

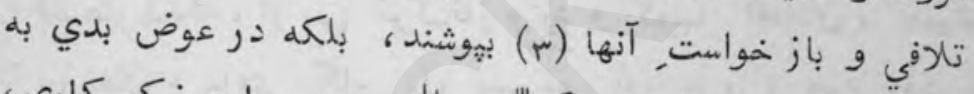

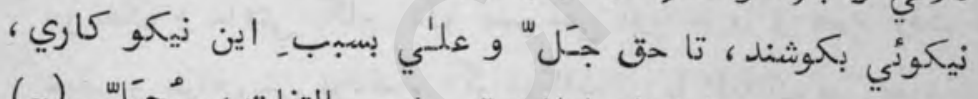

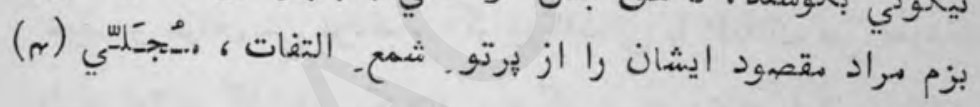
كرداند فقط - نوراد

$$
\begin{aligned}
& \text { تقاصير = جمع رتصير بمعني كناه . } \\
& \text { كى: نموده. } \\
& \text { الف : آن . نوده }
\end{aligned}
$$

سجلي= = روشن و فروزان . 


\section{در بيانـ ( ) آسدن سردارانِ قندهار از ايران در 'قندهار}

و رقتنـ فوجـــانكريز از قندهار و كرفتار نمودن

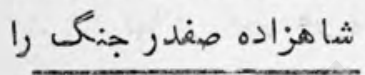

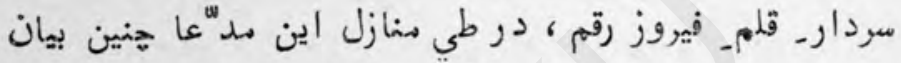

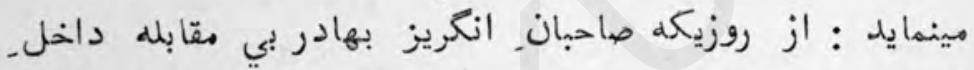

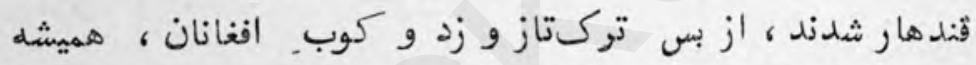

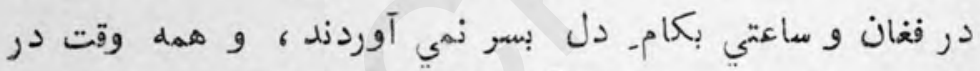

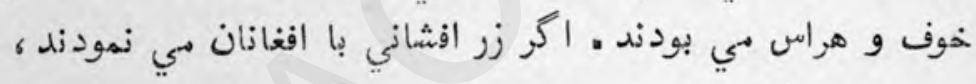

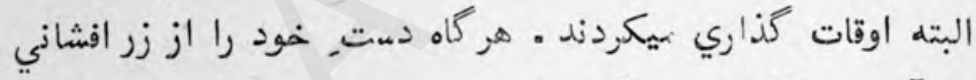

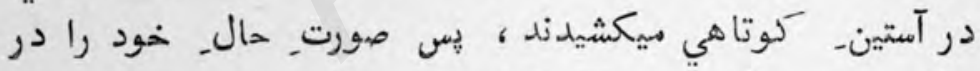

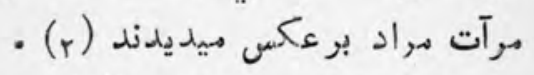

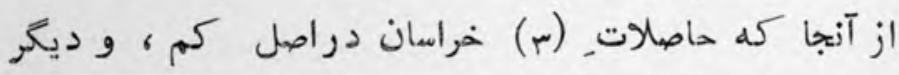

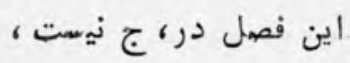

الف ، ب : ميديدند . هون افغانان خراسان هر يكى هانيد كوه

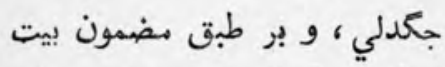

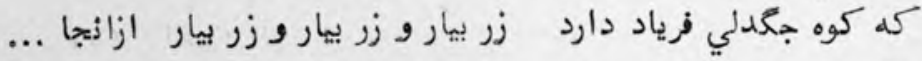
الف : محاصل 
จ१

تازه نواي معاركى

تجصيل_ ماليات ، از افغانان_ رعايا كه در كوهستان سا كن ازيد

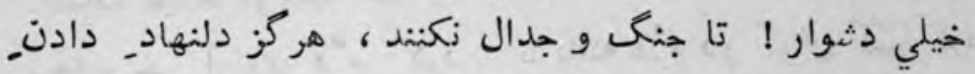

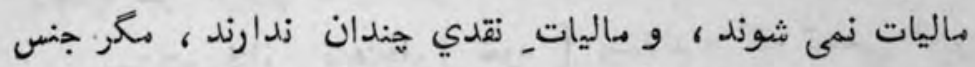

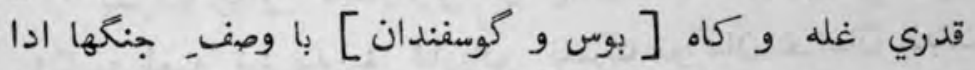

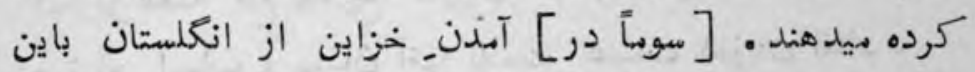

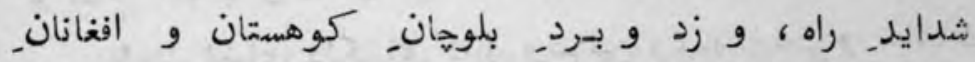

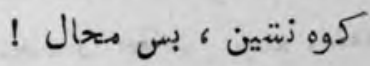

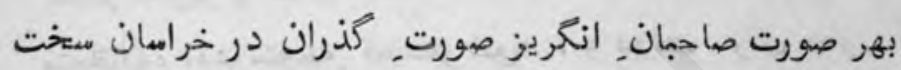

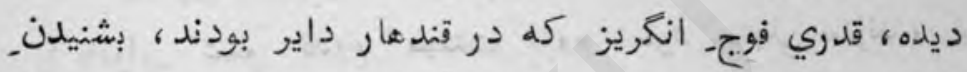

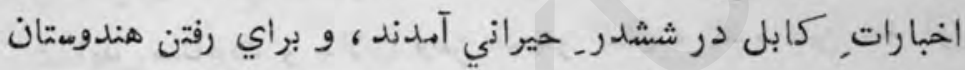

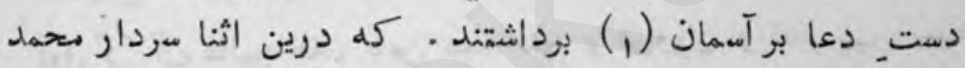

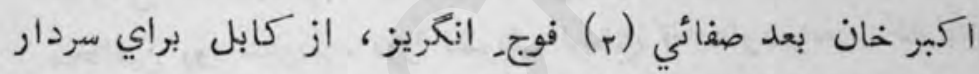

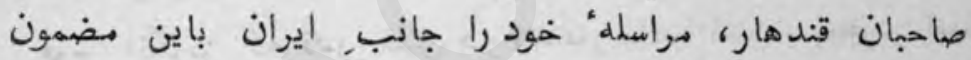

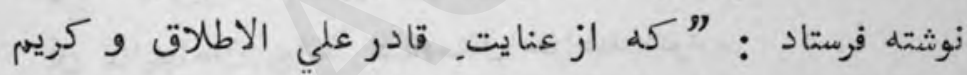

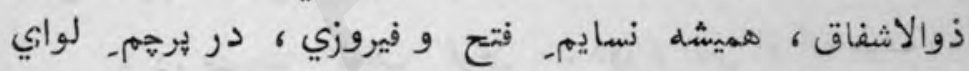

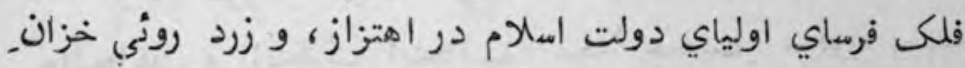

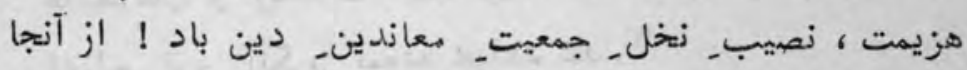

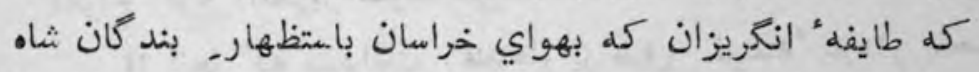

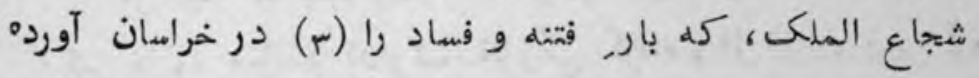

(1) الف : درآسمان داشتند

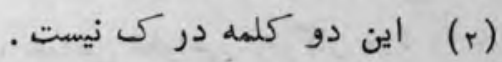

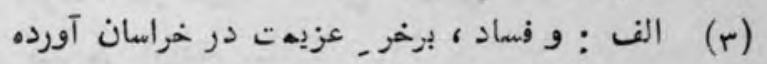


:

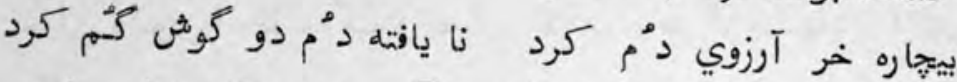

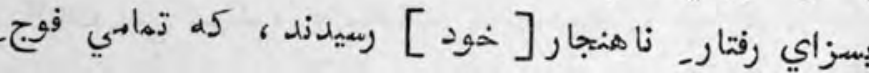

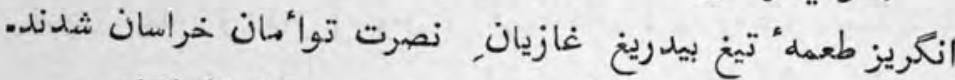

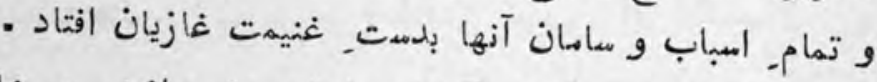
الحال فضاي دلكشاي كابل و غزنين وغيره ازخس و خاشهاك

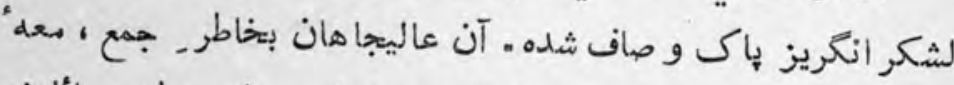

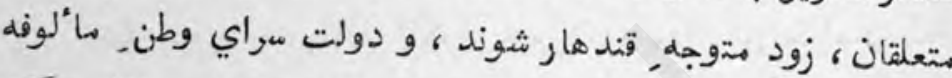

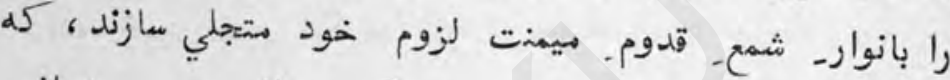

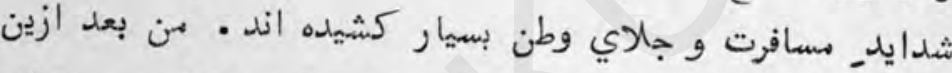
آواركي آن عاليجا هان باين همه فتح و فيروزي و تخريبـ بنياد.

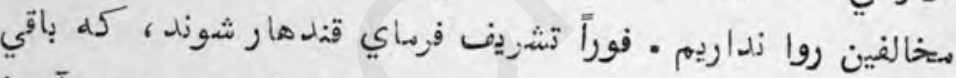

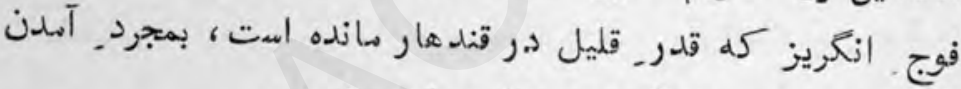

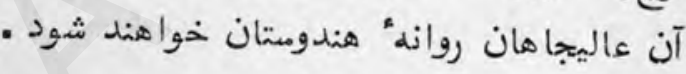

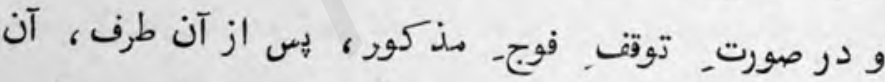

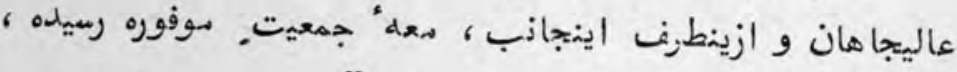

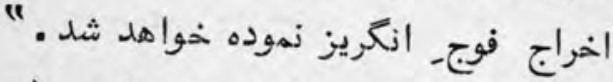

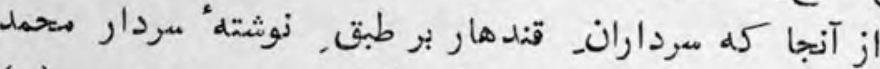

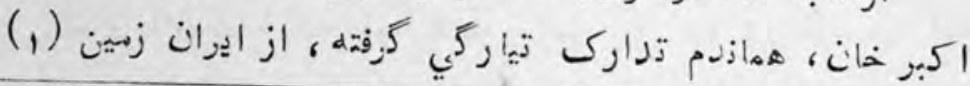

ب : ميكويند كه والي ايران بهمزاه سرداران سمدوح هندان

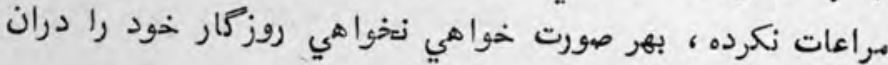

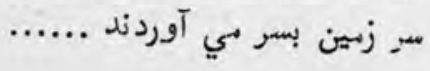




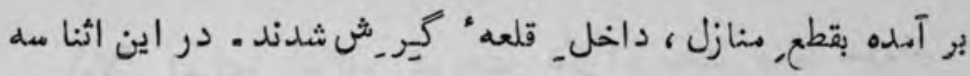

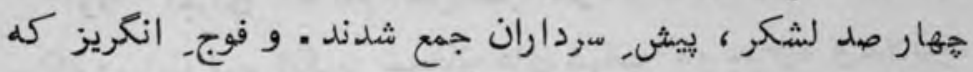

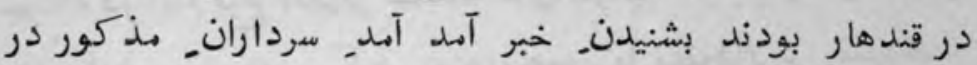

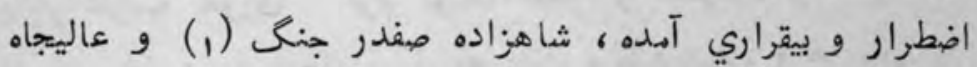

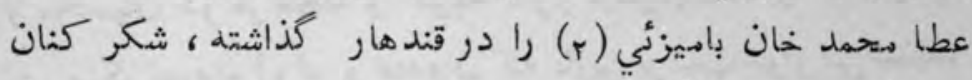
روانه" هندوستان كرديدند و بزبان مال بيان هي نمودند

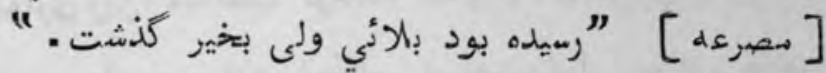

هون مردار صاحمان نزديدك قندهار آيدند، شاهزادهـ سمدوح

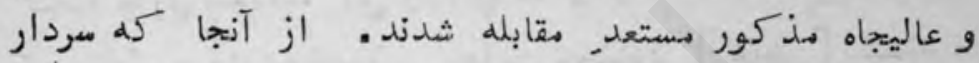
صاحمان را بر لشكر خود اعتماد نبود، و تماهى افغانان قتهدهار با سردار صاحمان در دمقام صخالفت بودند، از روي تدبير فرزانه

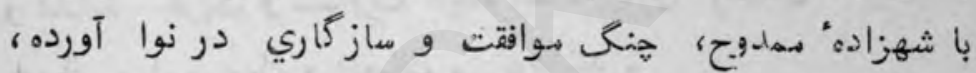

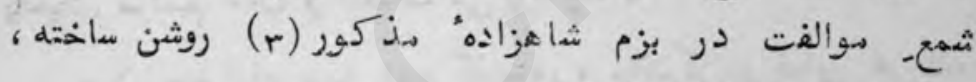

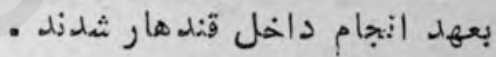

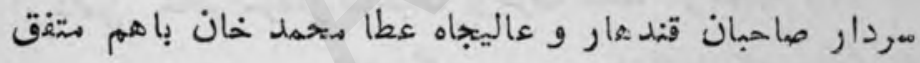

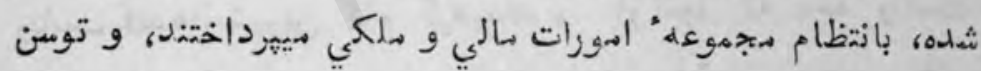

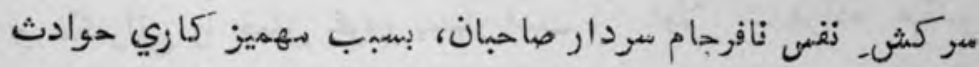
روز5ار، و جالوي وطن، و هنازل زشيب و فراز، باري سربآخور

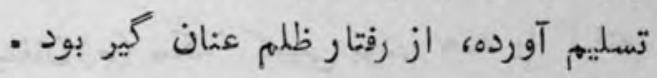

$$
\text { بن شاه شجاع }
$$

(r) (r) بلف نرحوم سردار ميمندر خان

الف: موصوف . 
تازه نواي معارك

T.P

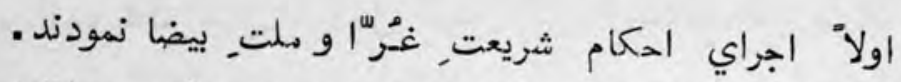

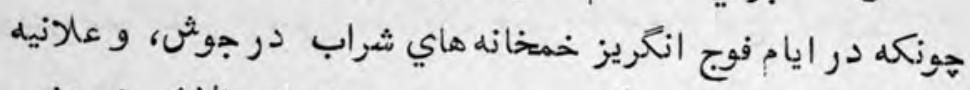

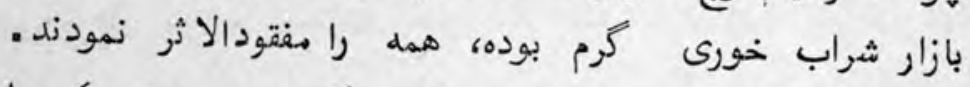

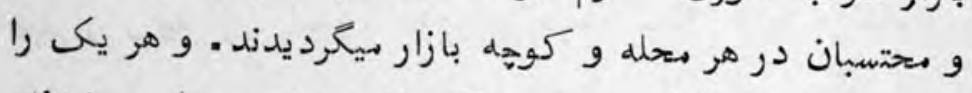

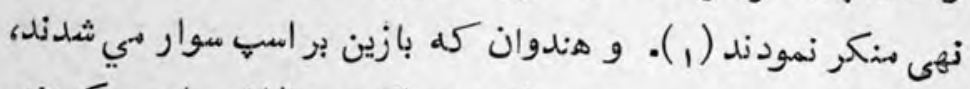
آنها را ازمبواري زين، مهانعت كردند، كله بر ڤإلان سوارئميكردند. هر كاه سردار صاحبان، احكام شريعت غرا، موافق حكمم رونم

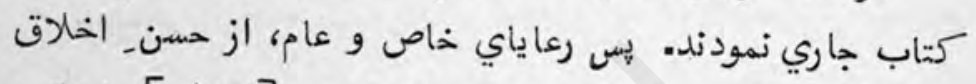

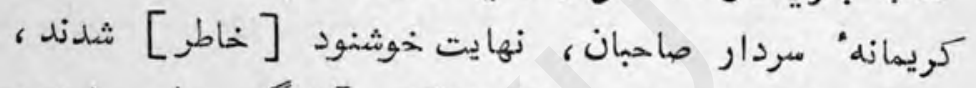

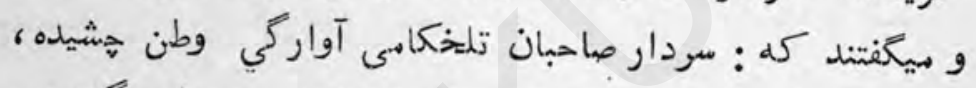

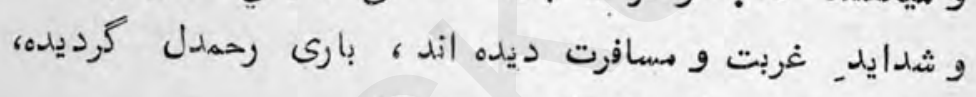

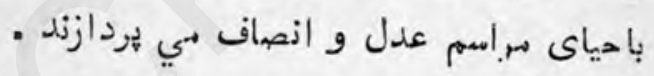

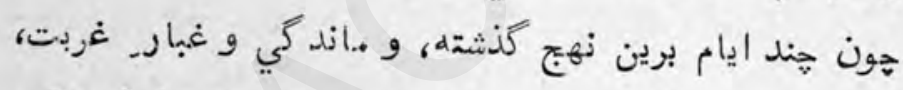

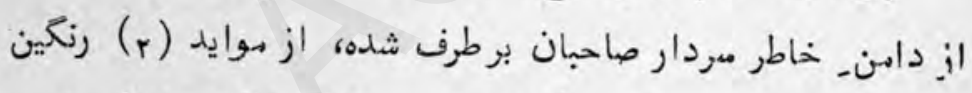

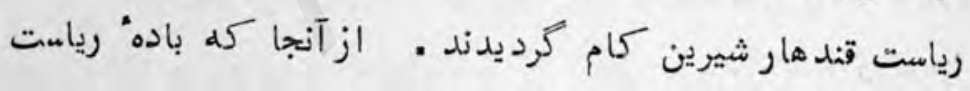
و حكمرانى را .خمار, غرور بسيار است • اولاً شاهزاده صفدر

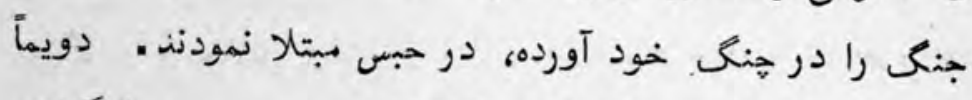

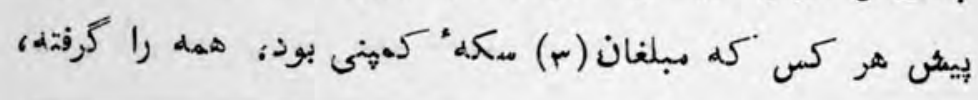

(1) الف: را از نهي و منكر منع_ مطلق ماختند. (r) موايد = جمع مايده يعني دستر خوان.

(r) 
در كورة" آتش كداز نمودهم، مـكه" خود را جاري نمودند . و از

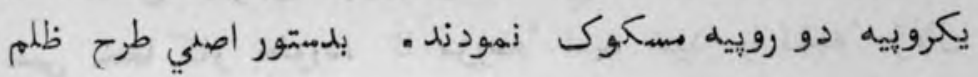

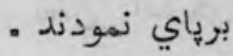

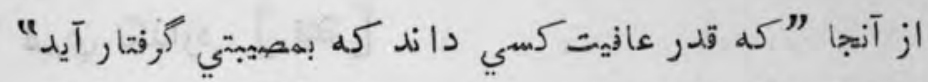

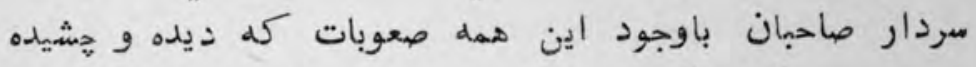

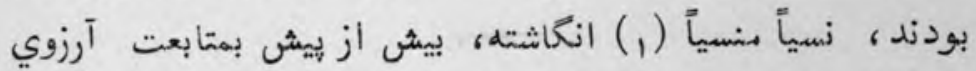

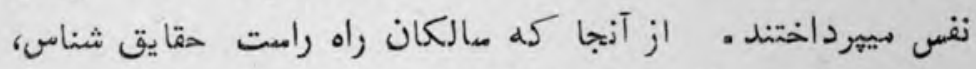
هرگز باطاعت نفس نافرجام نهرداخته، و و قدمي بآرزوي نفس آنس

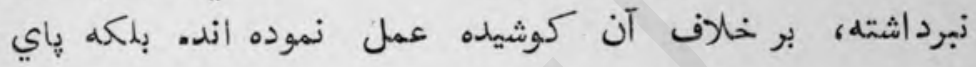

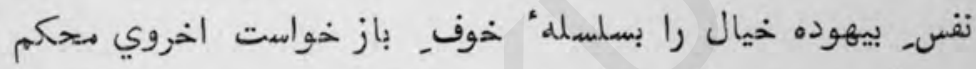

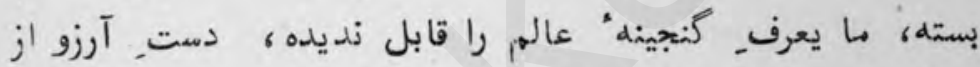

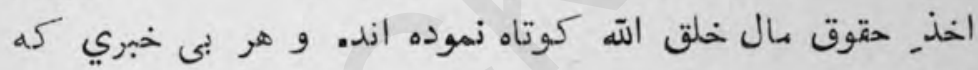

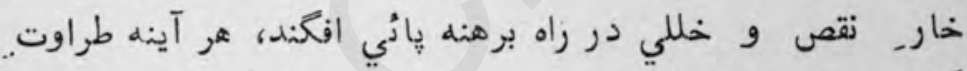

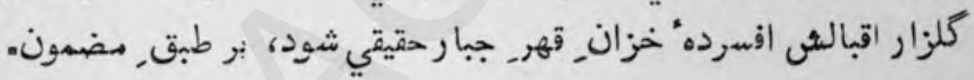

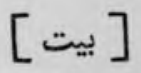

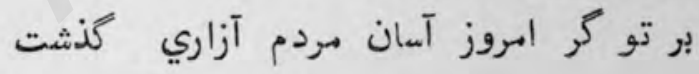

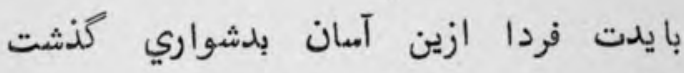

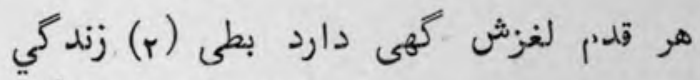

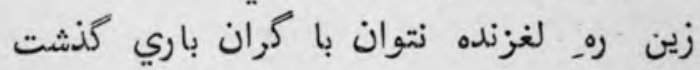

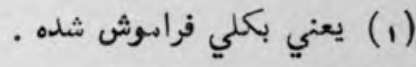

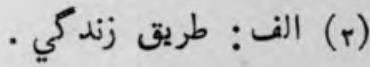


تازه نواي معاركى

T.

كامل عيار بوته جوان مردي كسي است، كه فريب شيطان

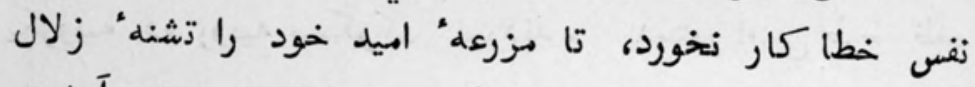

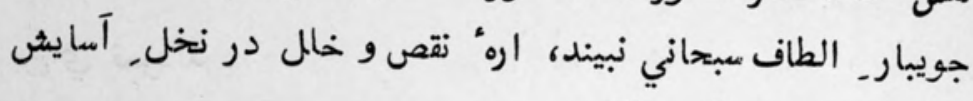
غيري نكذارد [فيطان 
در بيانِ رفتن ماحبان انكريز بهادر در هرات ييش شاهزا:ه كامران

بطريق. وسالت ، و از دستـ يار دحمد خان وزير مايوس شدن

\section{از مدعاي خود}

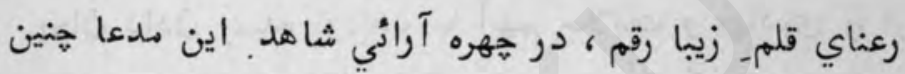

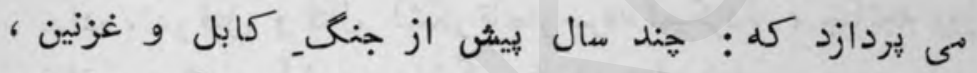

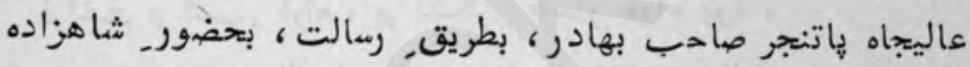

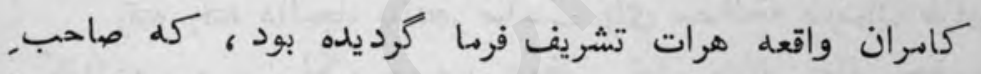

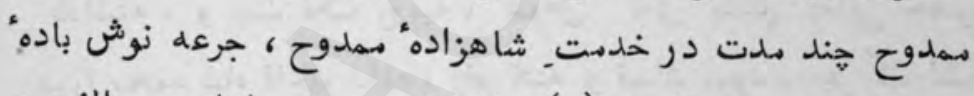

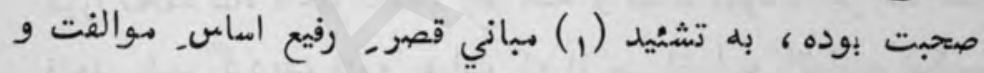

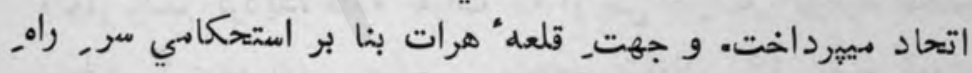

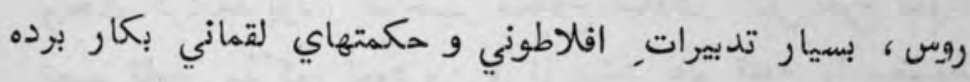

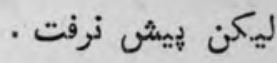

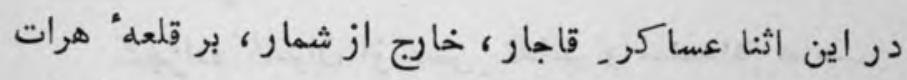

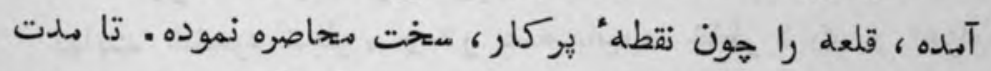

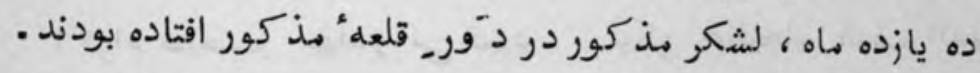

$$
\text { تشئيد = استوار ساختن . }
$$


تازه نواي مa

7..

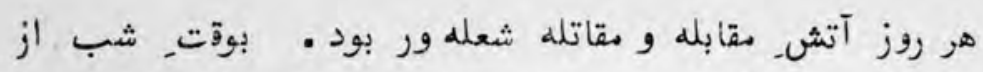

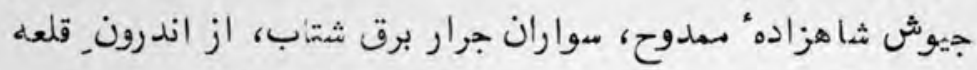

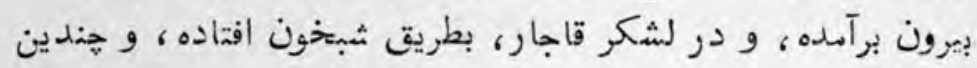

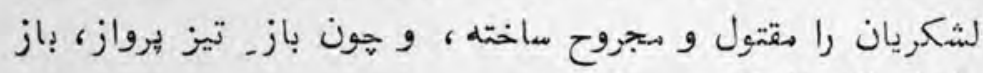

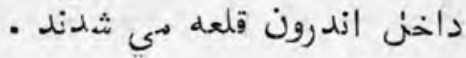

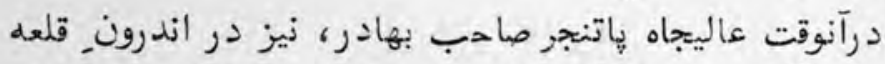

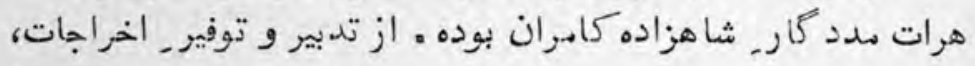

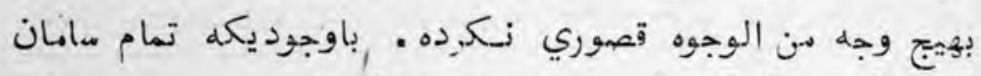

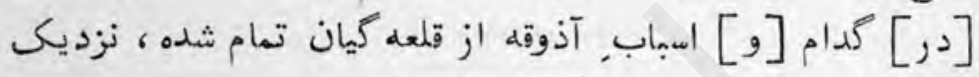

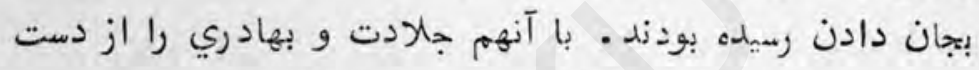

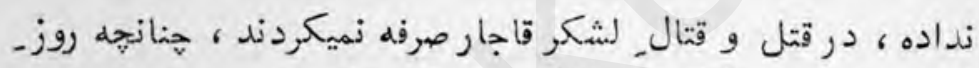

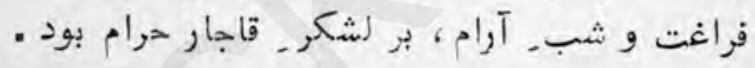

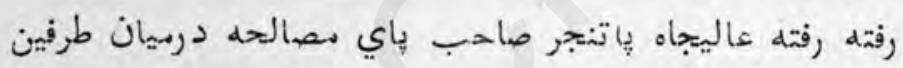

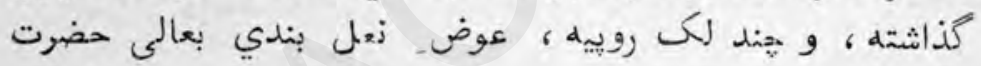

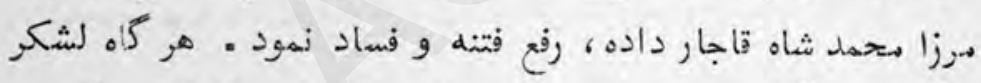

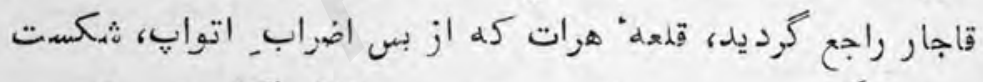

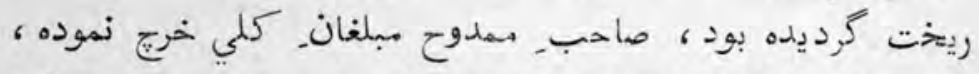

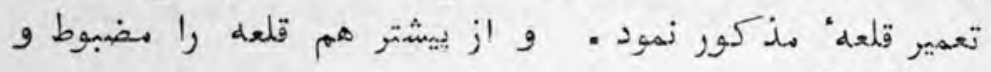

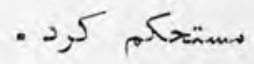

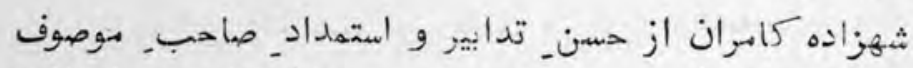

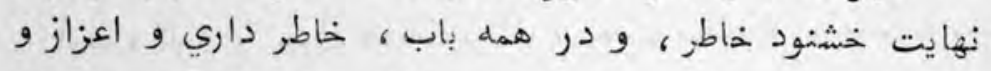

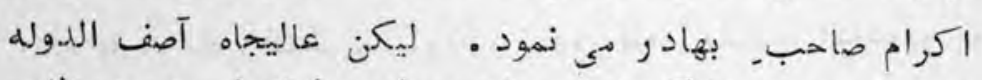

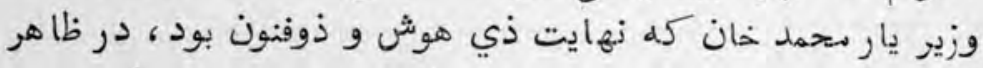

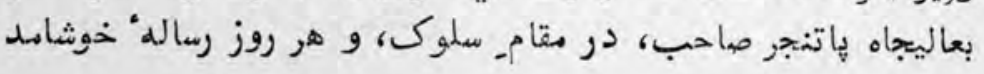


7.2

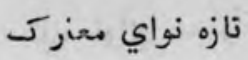

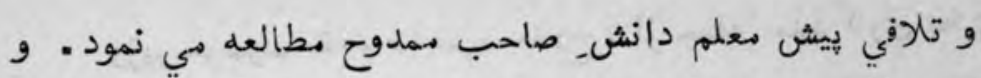

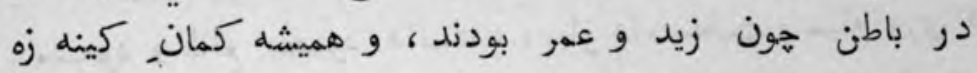

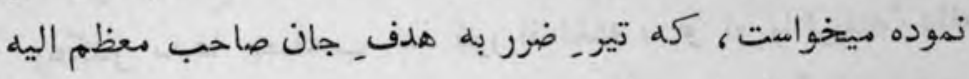
بزند • و بخوش اختلاطي و شيرين زباني، دمر هر ماه ( ) مبلغان

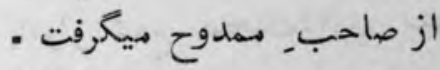

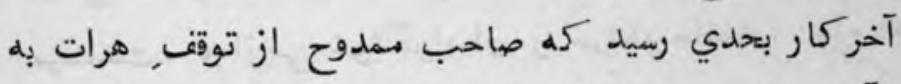

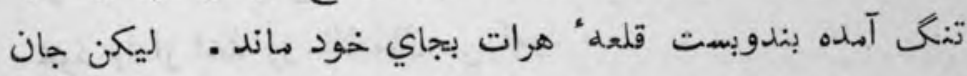

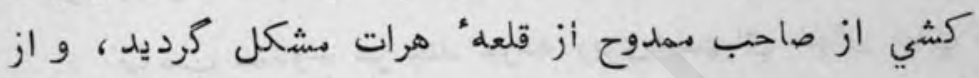

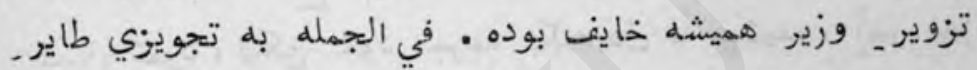

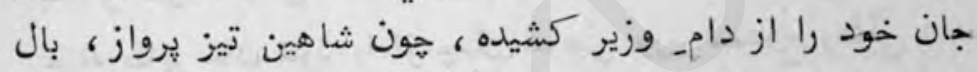

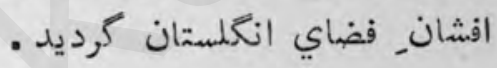

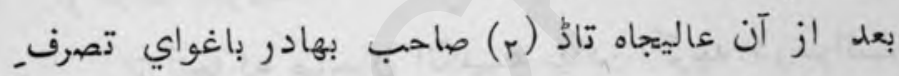

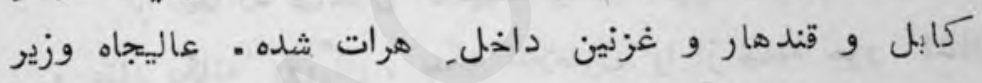

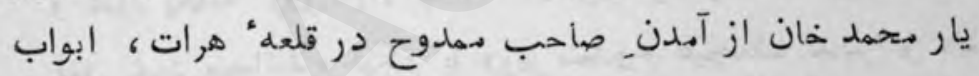
شادي و شادماني بر هرهة" حال خود منفتوح ماخته ، و و كلاه.

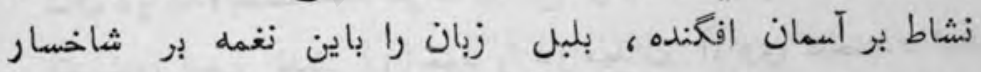

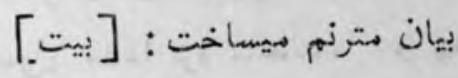

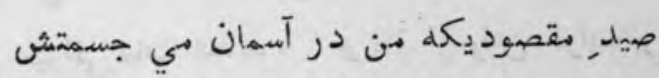

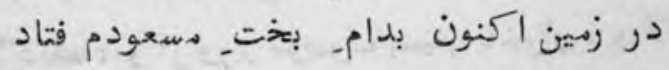

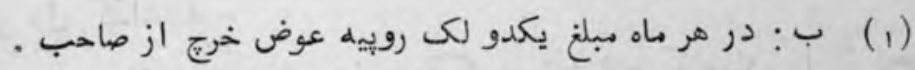

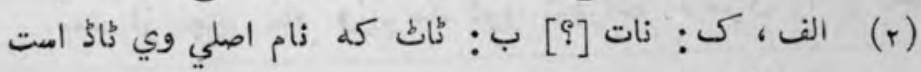

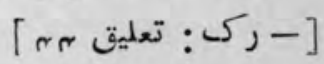




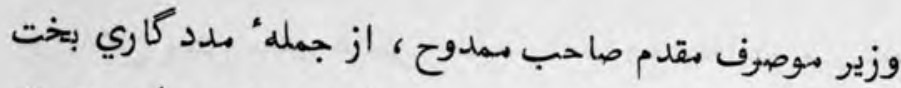

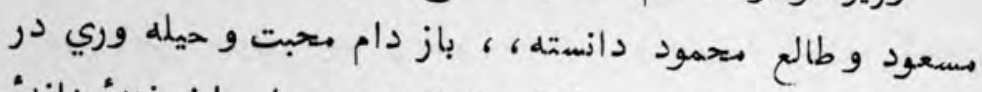

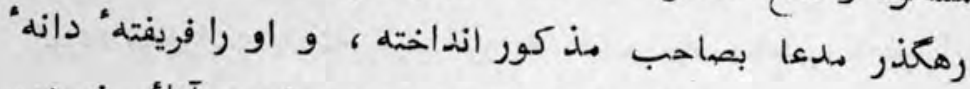

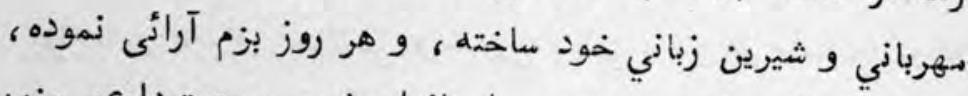

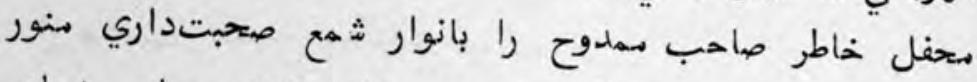

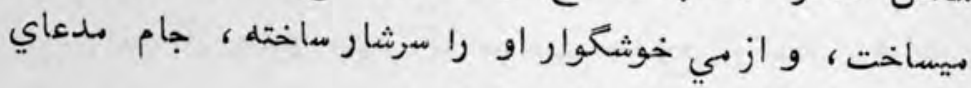

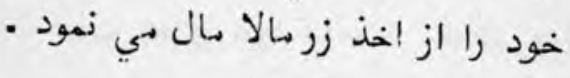

صاحب مهدوح هر هند جرعه ريزي صهباي خوش نماي زر

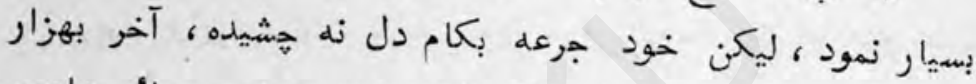

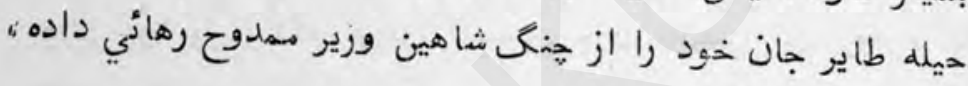

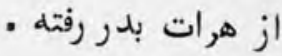

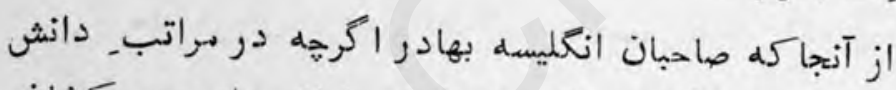

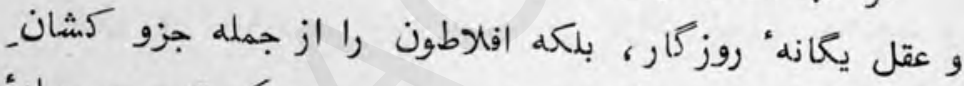

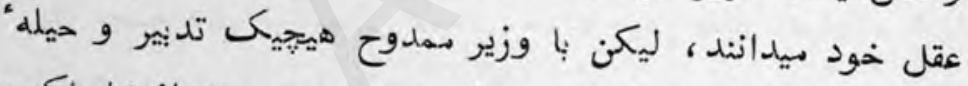

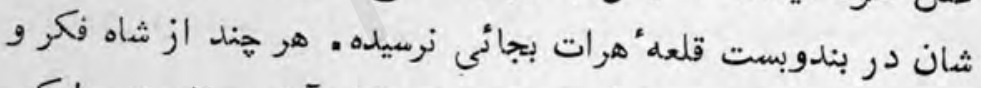

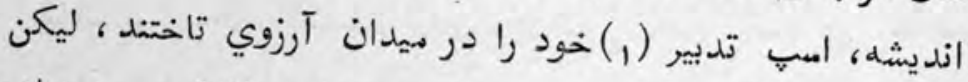

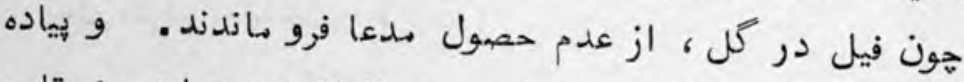

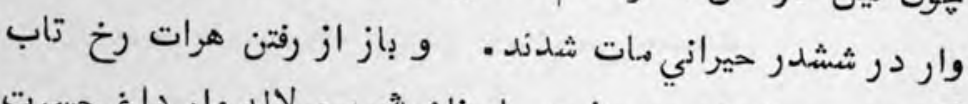

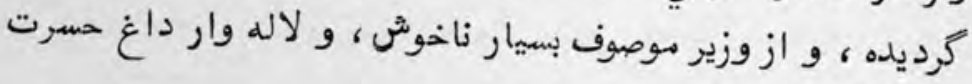

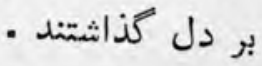

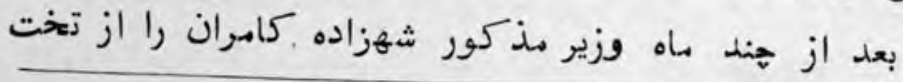

$$
\text { ك : خواست تدبير [؟]. }
$$


تازه نواي معاركى

كامراني هرات انداخته، بر تخت حبس جلوس داد ــ ـ و به سخت

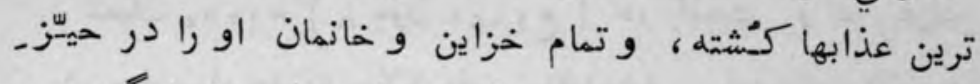

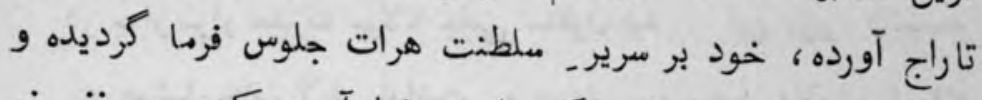

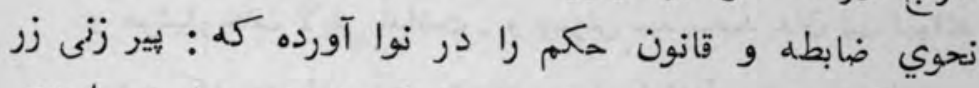

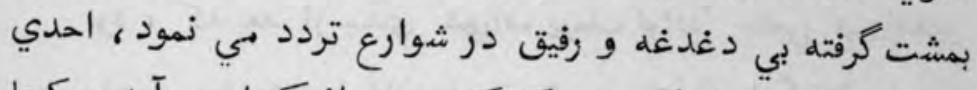

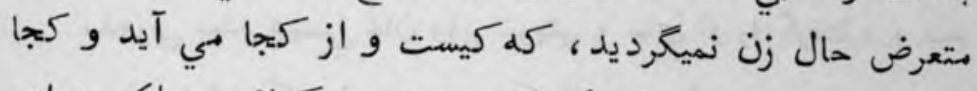

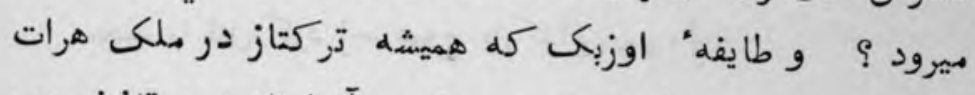

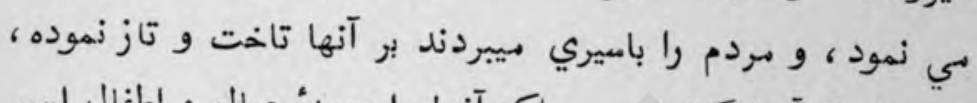

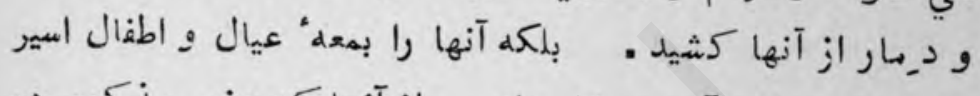

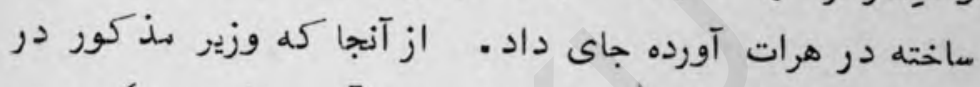

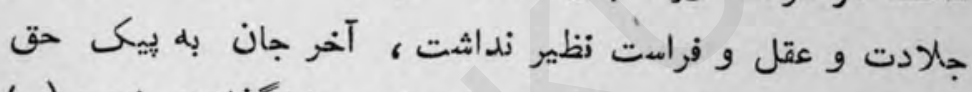

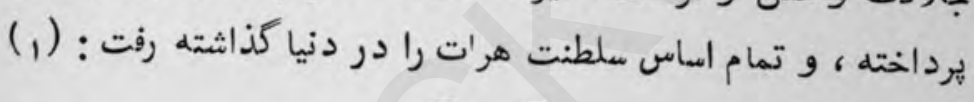

$$
\text { [بيت }
$$

هر كه را خوابكه آخر به بيان خاكى است

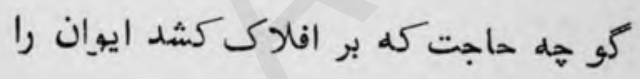

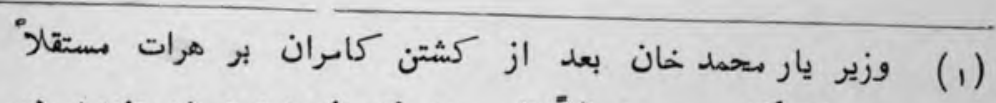

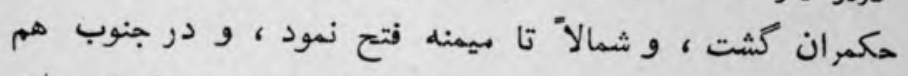

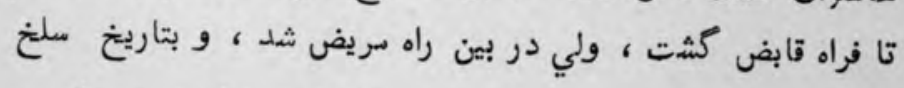

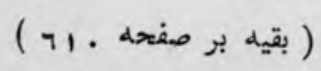


تازه :زياي معار ك

71 .

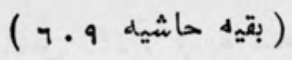

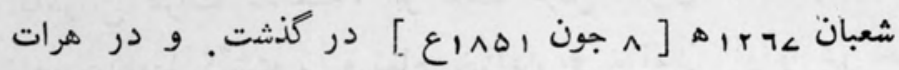

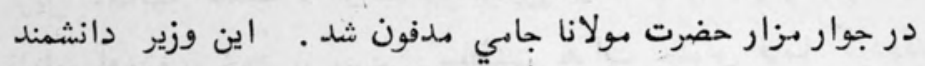
و هوشيار خاف لايقي نداثت ـ و بسرش سيد مخمد خان نيم ديوانه بود ، كمه بعد از هندي ثهزاده يومف نواده" حاجي فيروزالدين

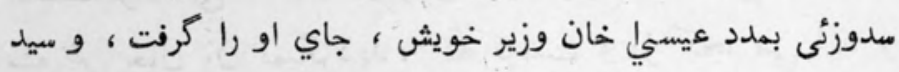

مدمد را قتل كرد [- عروج باركزائى 1<1 1] . 
در بيان آمدن, ماحبان انكريز بهادر در ملك سنده دان و راه كرفتن از دريا و بيمايش نمودن آبـ دريا، ، و انداختن

\section{طريق سلركى وغيره وقوعات}

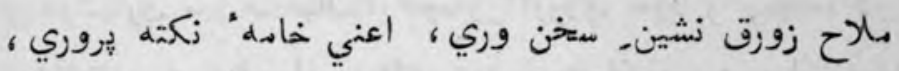

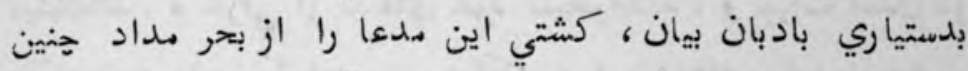

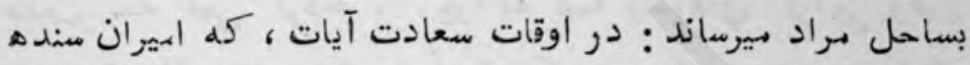

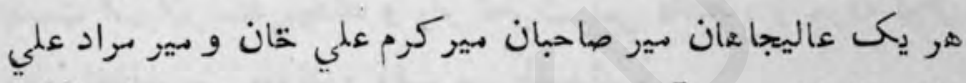

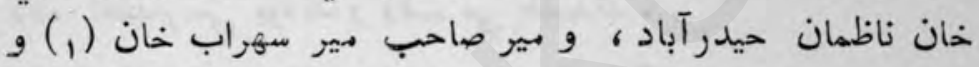
هشيران هر يك نواب ولي متحمد خان لغاري و سيد [ميان] كوله

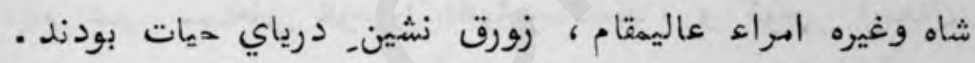

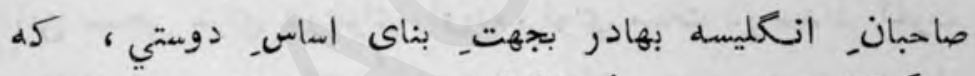

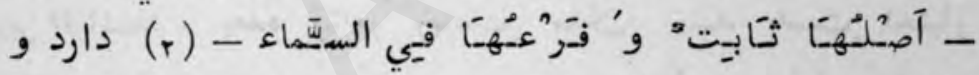
انداختن جهاوني در ملكى سنده بسيار سعي و تدبيرات افلاطوني

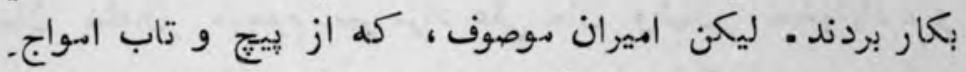

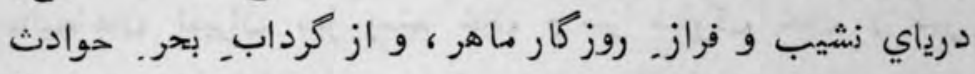

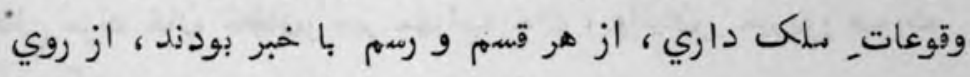

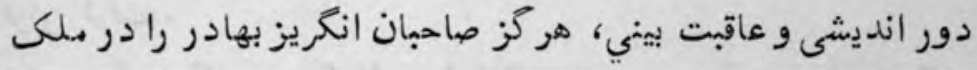

$$
\text { قرآن ، ابراهيم؛ سهراب خان والي خير بور . }
$$




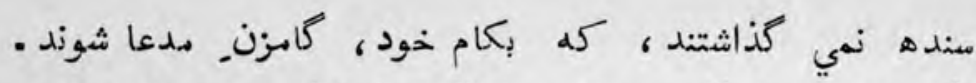

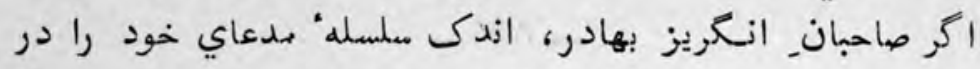

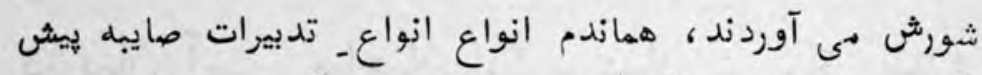

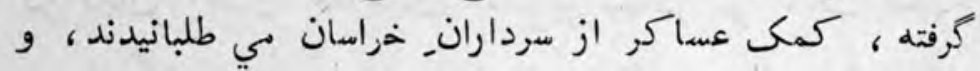

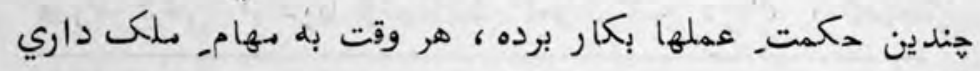

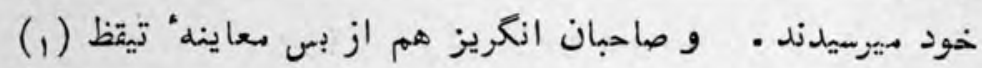

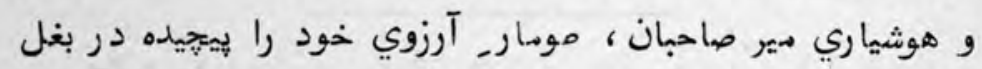

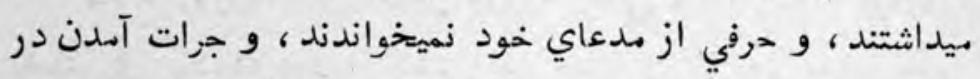

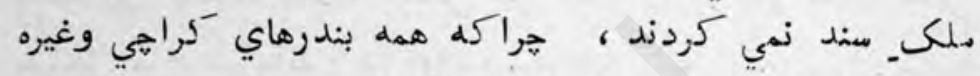

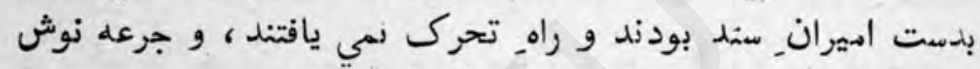

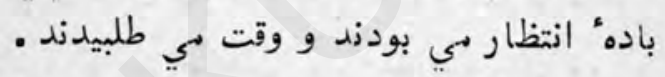
تا آنكه بعد از مدتي ازقضاي كرد گار، ابيران. مهدوح

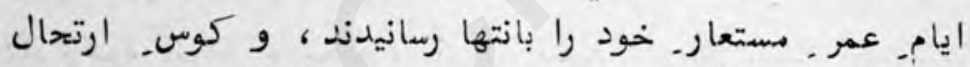

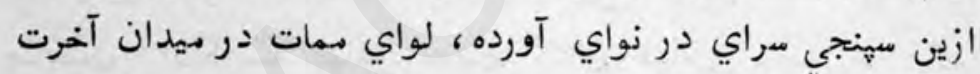

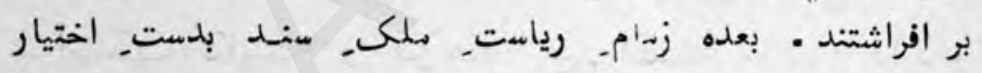

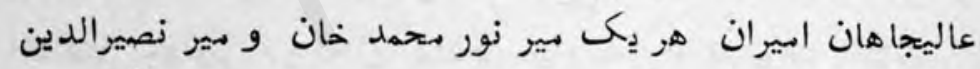

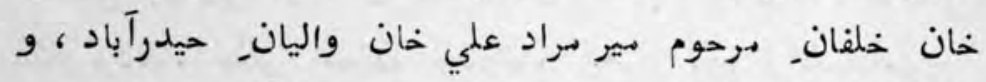

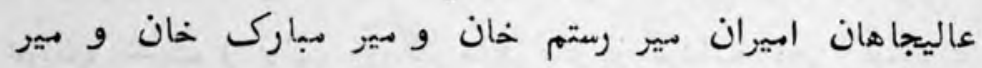

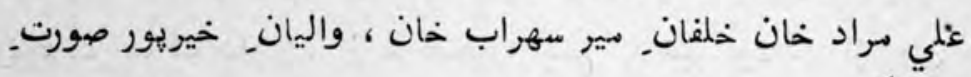
قرار كرفت . - مراد

از آنجا كله هر كمالي را زوالي، ، هر بهاري را خزاني

$$
\text { تقيظ = بيداري . }
$$


در بي امت ، بموجبـ شعبده بازي فلكلـ بر نيرنك ، مابين

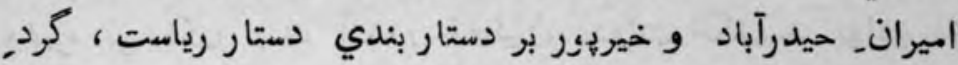
نفاق بر دامنــ اتفاق نشسته ، روز بروز از وزيدن_ بادـ دخالف،

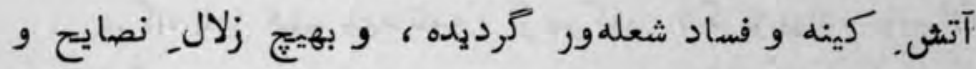
بواعظ خاموث نشده، رفته رفته دستار نفاق را بر مر اتفاق - مجكم بستيند

در اين اثنا صاحبان انكريز وقت را فرصت يافته ، در صورت

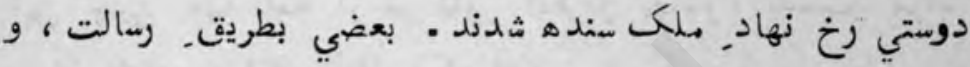

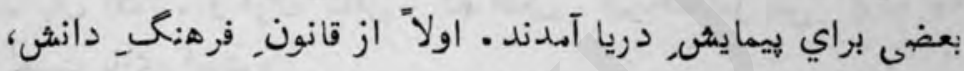
نسخه" اخلاص و اختصهاص منتخب نمو:هه ، بعاليجاه مير نور محمد لئد خان ، كه صاحب دستار و ولي عهد مرحوم بير مراد علي خان

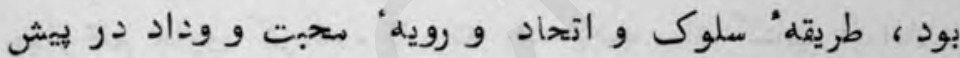

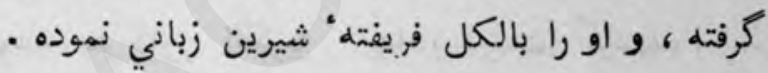

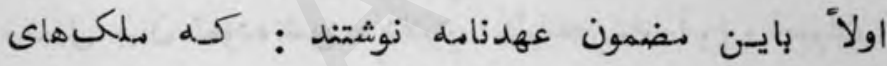

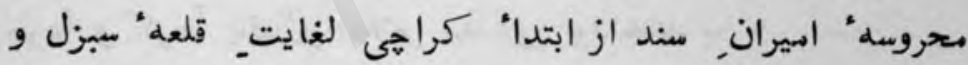
ديكر قلعه جاتـ ريكستان بدستور همده در تصرف ابيران.

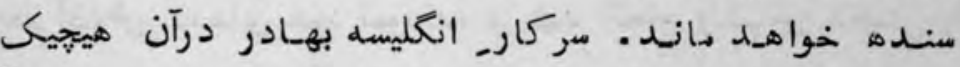
مداخلت (1) نخواهد كرد ، مكر جهاوني سركار واقع كوتله

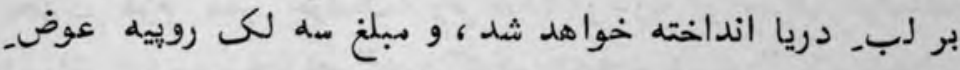

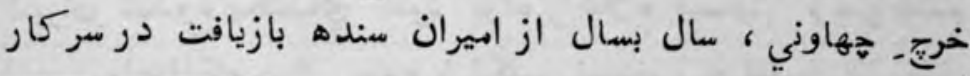

$$
\text { : دخل (1) }
$$


انحليسه بهادر خواهد شد. و اكر كدام غنيمر, اطرافي ازخراسان

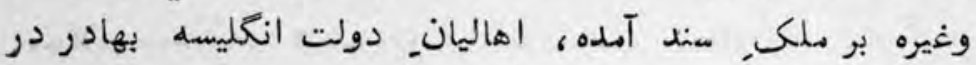

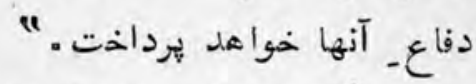

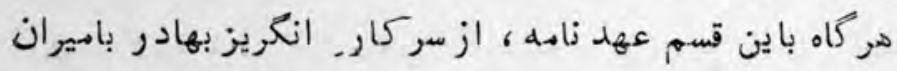

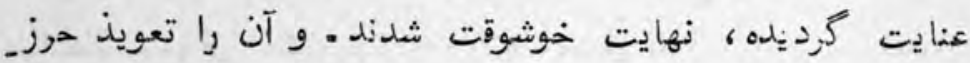

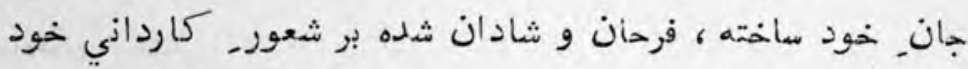

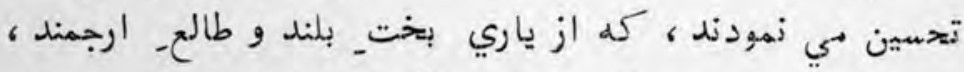

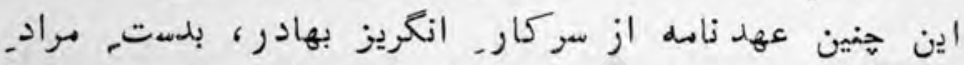

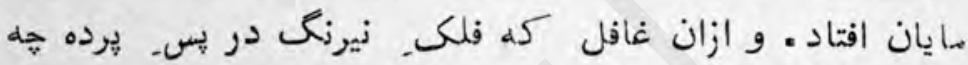

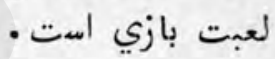
بعد از هند روز، باز صاحباذهـ انكريز دوازده قلم ديكر بيشى

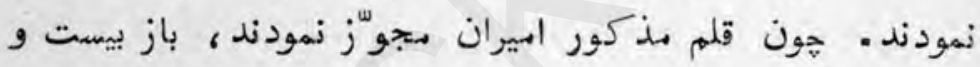

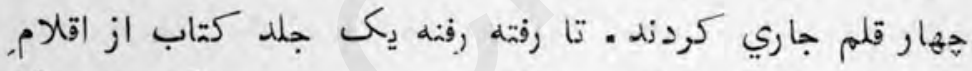

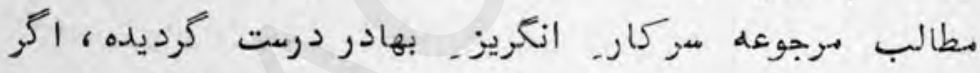

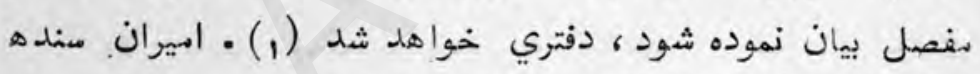

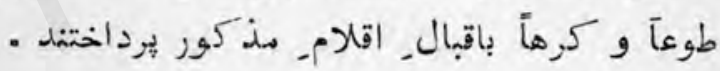

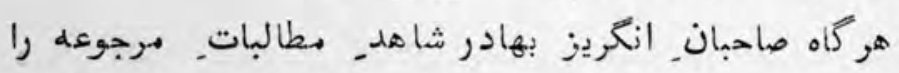

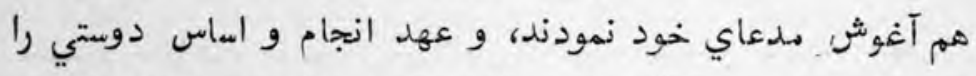

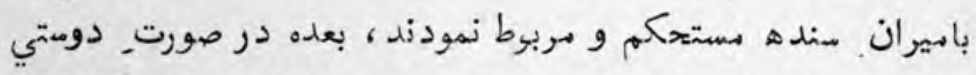

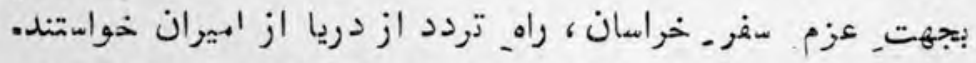

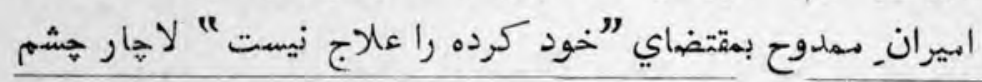

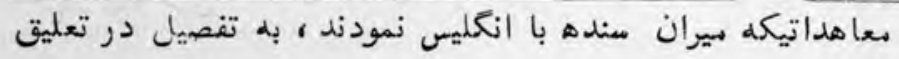

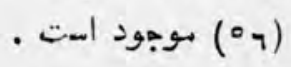


از اخلاص_ ديرينه واليان_خراسان بوشيده ، بلكه بار ـ عداوت_ آنها

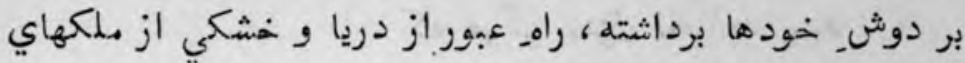

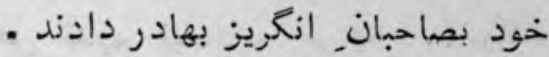

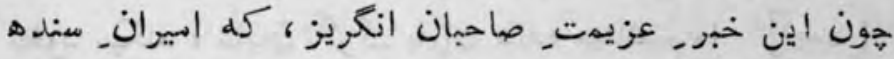

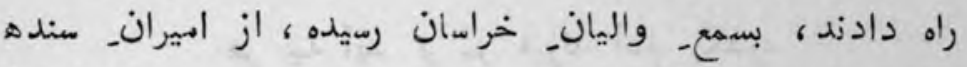

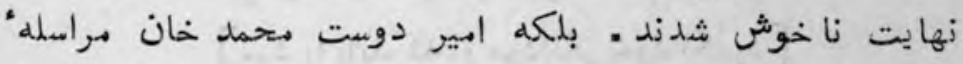

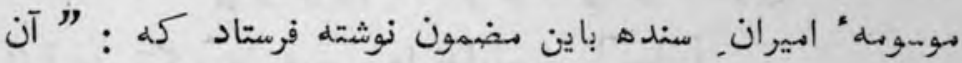
عاليجاهان هميشه از اخلاص. كيشان وخير انديشان دولت

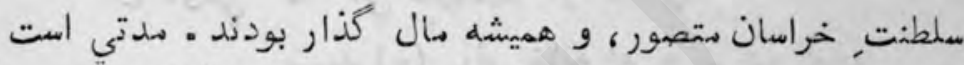

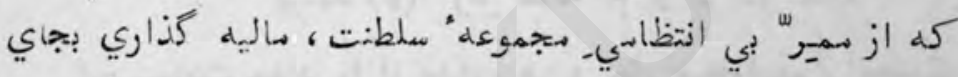

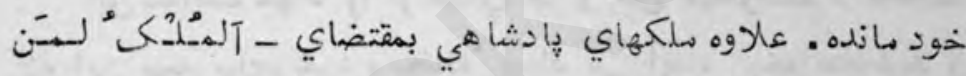

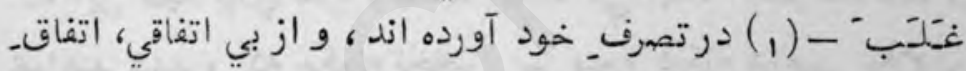

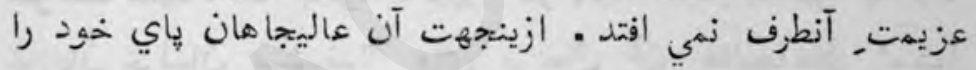

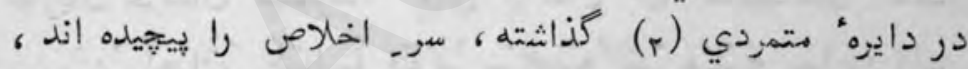

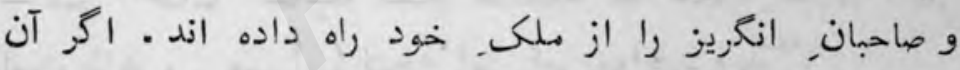

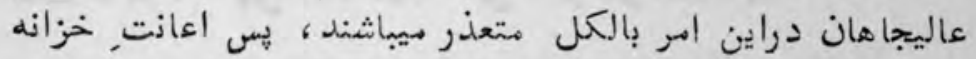

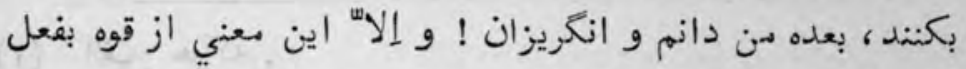

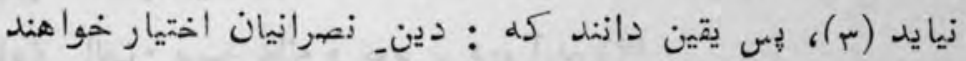

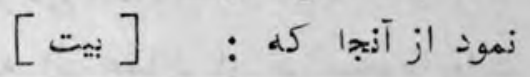

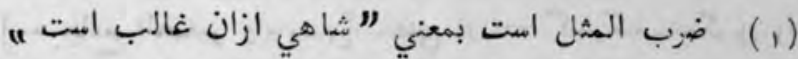

$$
\text { الف : براه تمتمدي }
$$


خافف هيمبر كسي رو كزيد

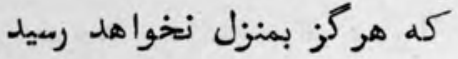

اين شرط مسلماني و اخلاص قديم نيست . هو حه (1) ميكند

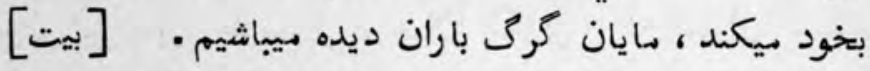
هر حه آيد بر سر فرزند آدم بـنذرد

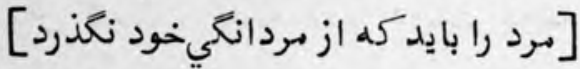

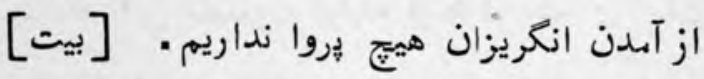
آن دولتي .كه مي طلبيديم از خداي

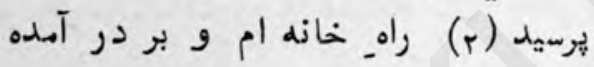

اين سعادت جهاد را ازخداي عز و جل ميخواستمه ، الحمدله كله اين صيد بهاي خود ، بخانه" صياد بي آيد. خواهند دديد و

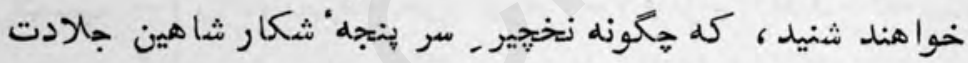
غازيان خراسان ميشوند؟ واي بر حال آن عاليجاهان استا

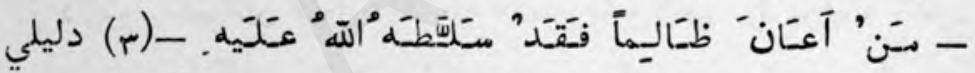

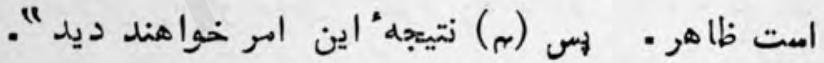

$$
\text { الف: هركم ه . }
$$

الف: برسيد خانه و خود بر درم آهده [؟]

اين حديث ضعيف است كله ابن عساكر از ابن مسعود روايت

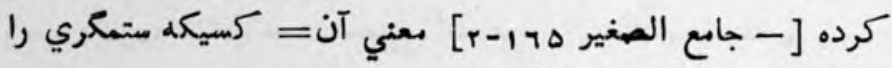
كمك نمايد ، خدا بر وي كماردش . 
تازه نواي معارك

از آنجا كه باوجود اين همه نوشتله" امير بى نظير سردار

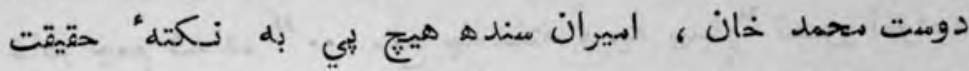

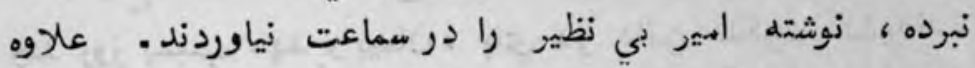

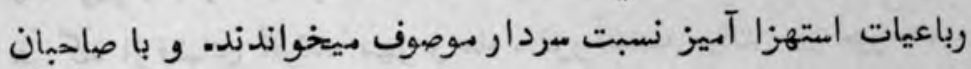

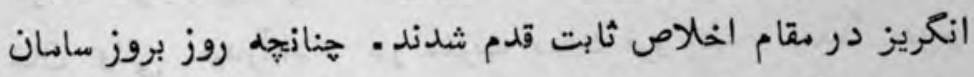

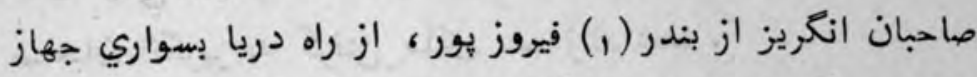

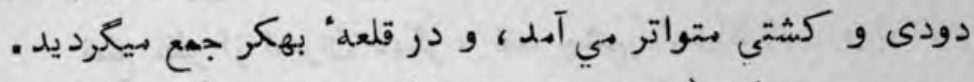

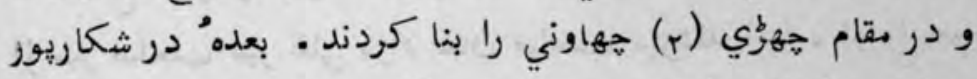
هاوني را قرار دادند، و دريافت ملك سنده بخوبي مى نمودند و از زبان سندهي و بلوهي و افغاني كتاب هانَى درست ساختند .

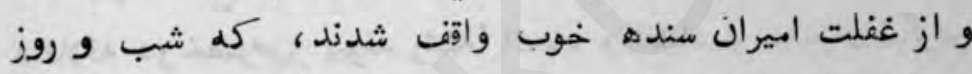

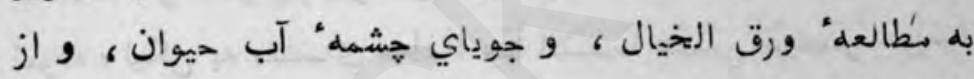

$$
\text { [بيت }
$$

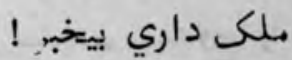

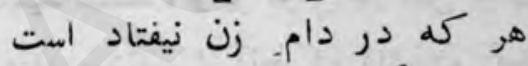

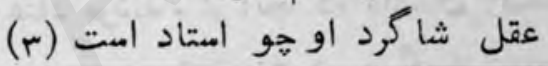

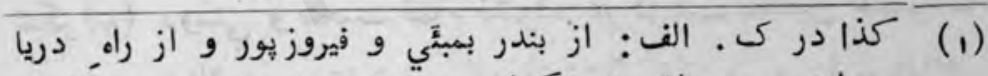

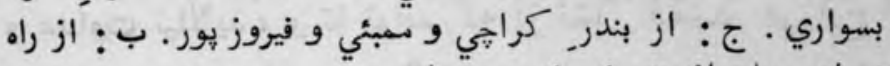

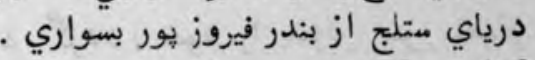

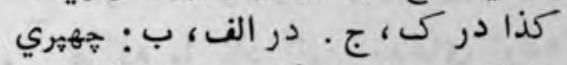

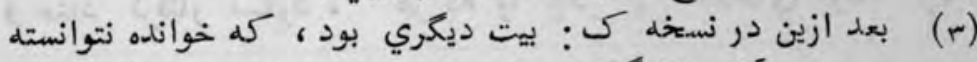

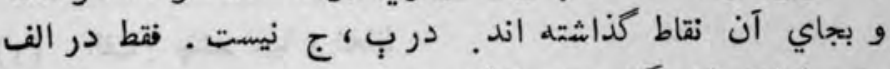

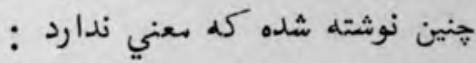

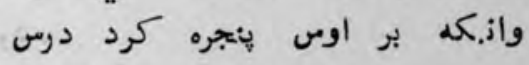

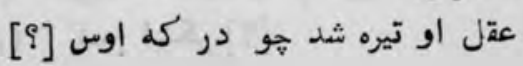


صاحبان انكريز، هركاه بيخبرى و بيهوشي ابيران سندهديدند

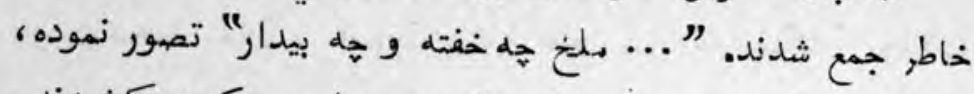

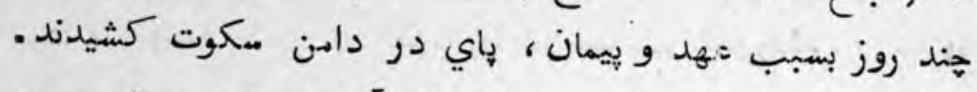

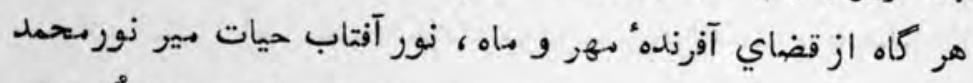

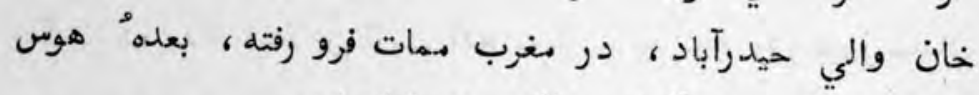

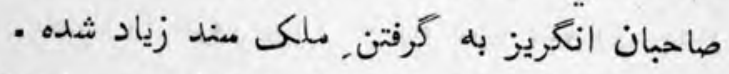

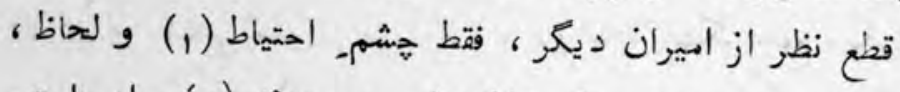

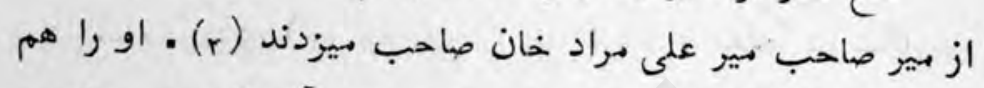

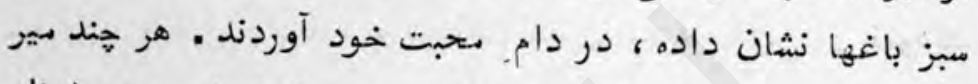

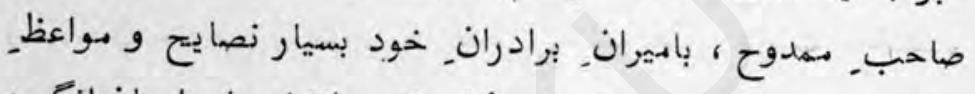

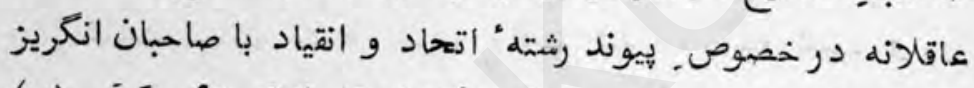

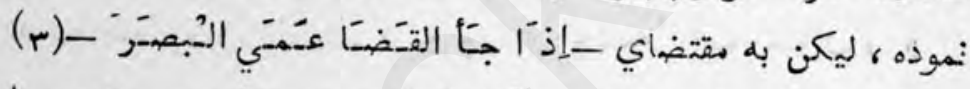

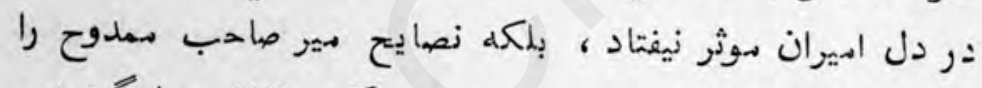

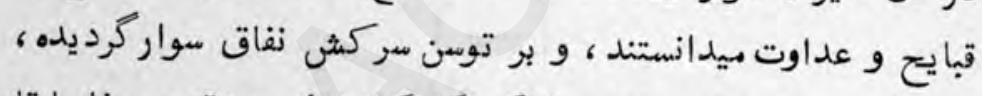

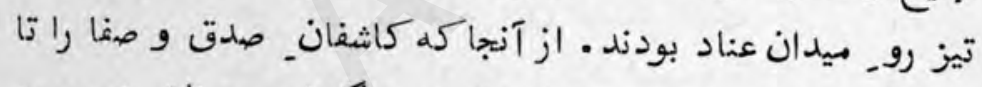

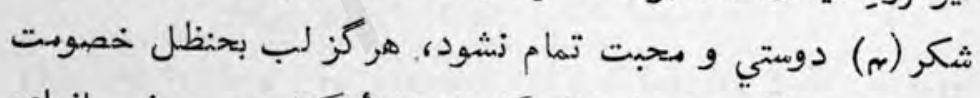

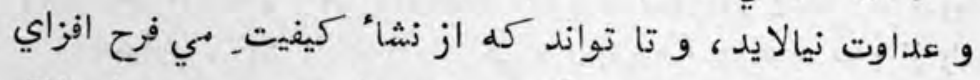

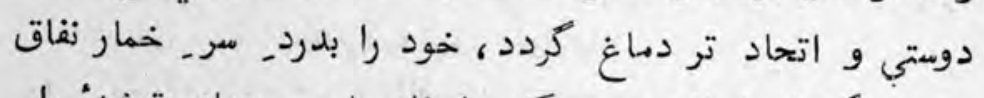

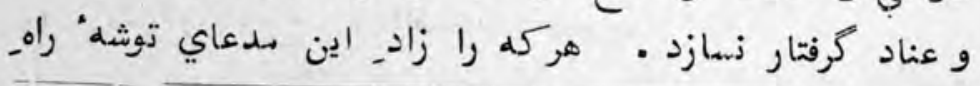

$$
\begin{aligned}
& \text { الف : حشمم حيا و لحاظ. } \\
& \text { الف : بـيكردند. } \\
& \text { حون قضا آيد جششم كور شود . } \\
& \text { ك }
\end{aligned}
$$


هفر منجبت طلبي باشد ، البته حسب المرام طي. مراحل. اقليم

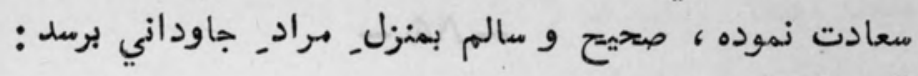
[بي]

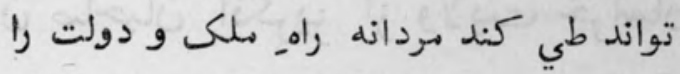

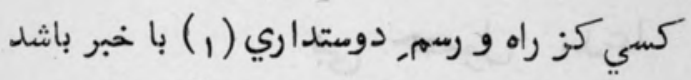

و ذلتهاي عالم، در سرـ راه نفاق و عناد مهيا و آماده است . 
در بيانِـ آسلن ماحبان انكريز از ولايت خراسان

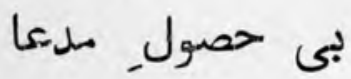

و كرقتن ملك منده و كفاق ازداختن مابين اميران سندها

و فرار شدن دير وستم خان از خيريور، و دستار دادن

به مير علي مراد خان وغيره وفوعات

دبير. ثير تدبير قلم باغاغت رقم، در انشاي اين مدعا هِنين

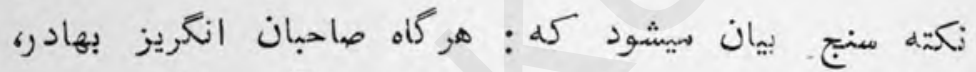

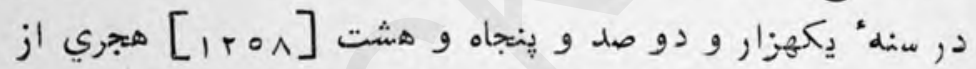

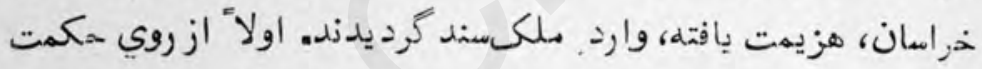

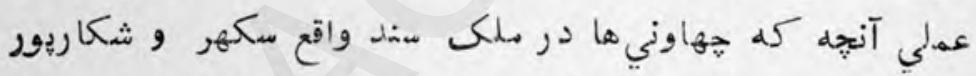

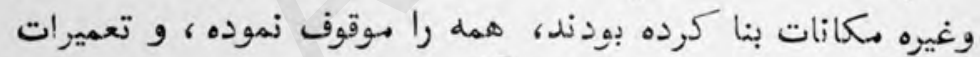

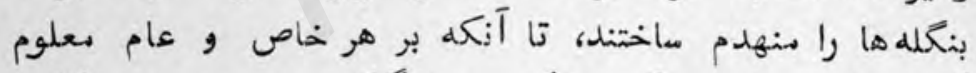

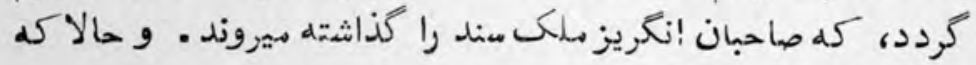

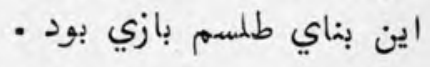

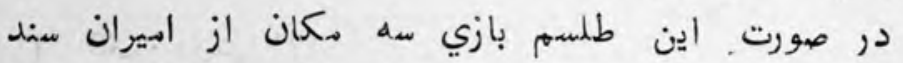
درخواست نمودند : يكى كراجيى بنزو، دويماً قلعه بهكر، سيوماً

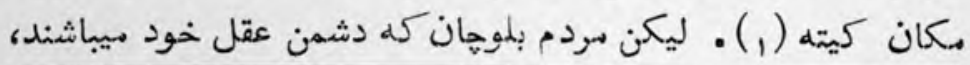

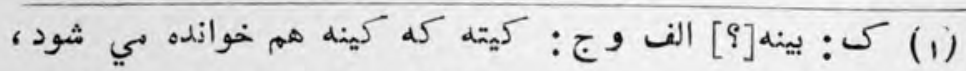

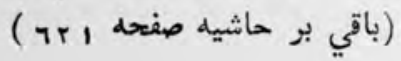


تازه نواي مrer

شجأعت و بهلد ري افغانان خراسان شنيده مغرور شدند. . و اراكين

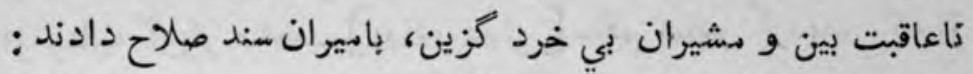

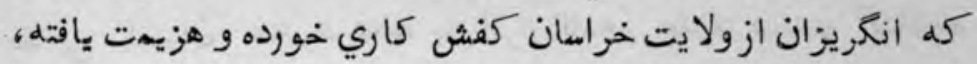

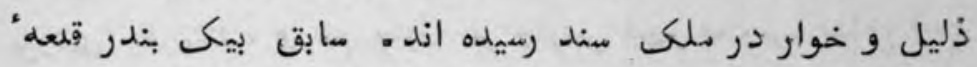

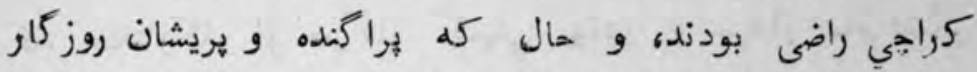

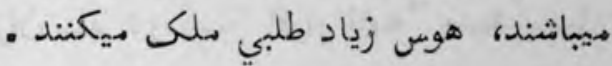

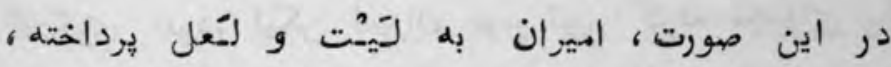

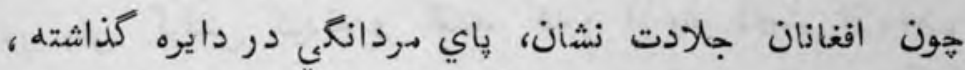

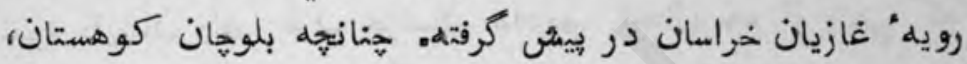

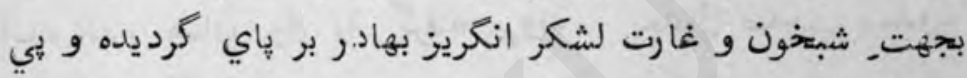

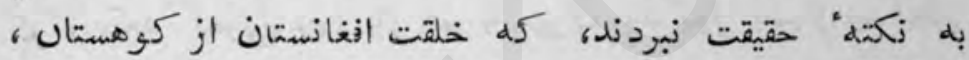

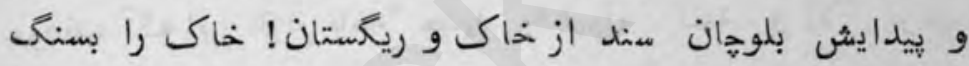

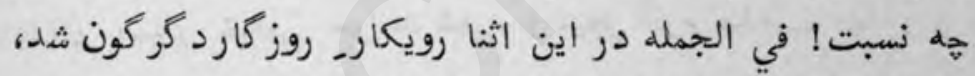

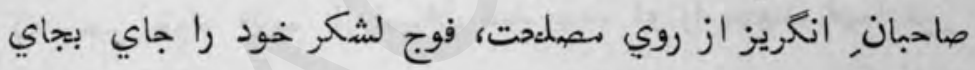

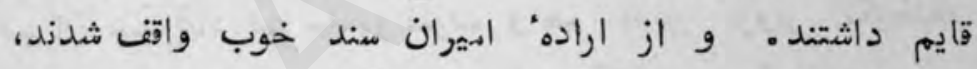
بلكه در فكر تجويز همين كرديدند كل " "كلوخ انداز را مإداش

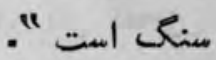

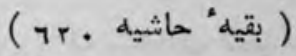

مدكن است مقصد كيتي باشد كله بر كنار درياي سند در آخر حصهن

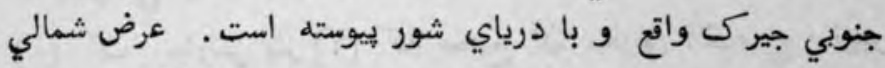

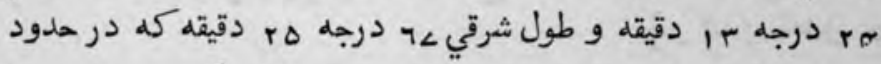

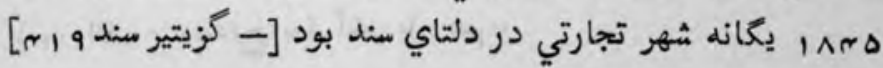


تازه نوأي معاركى

TrT

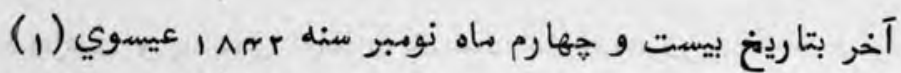

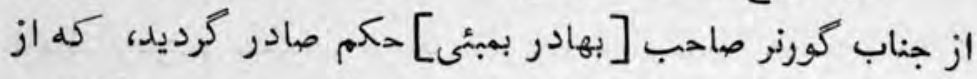

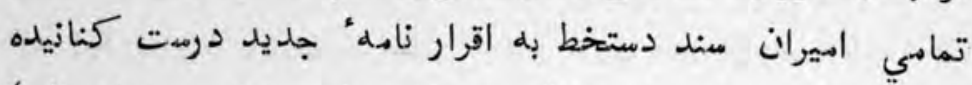

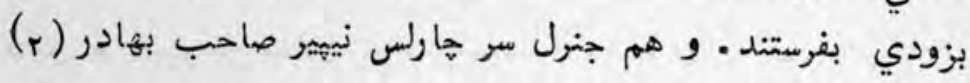

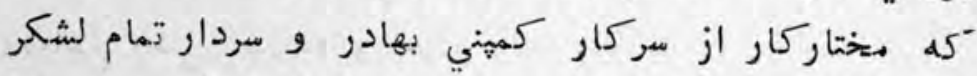

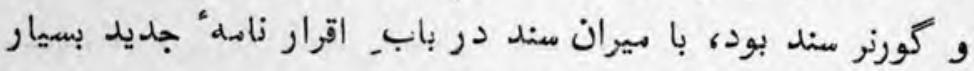

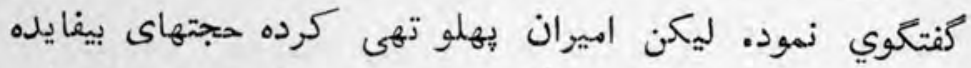

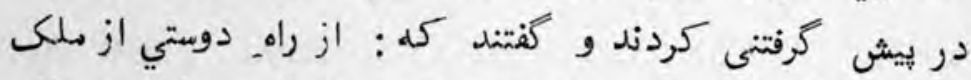

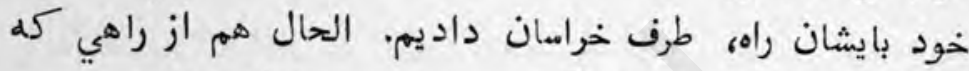

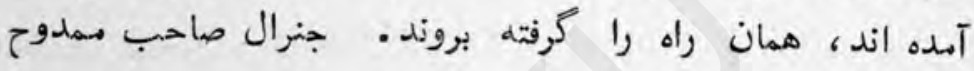

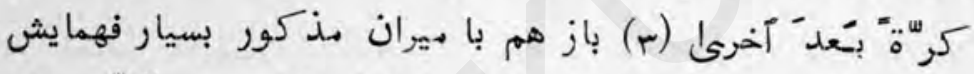

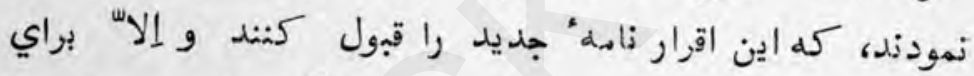

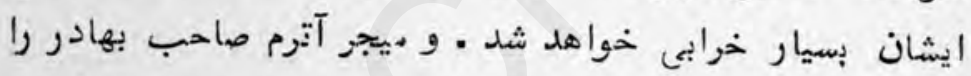

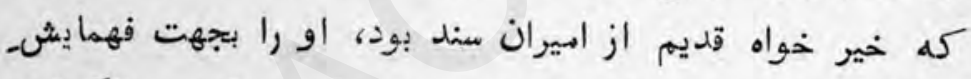

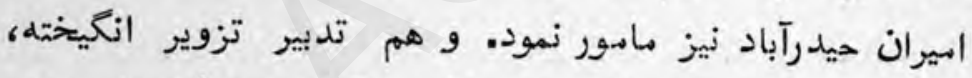

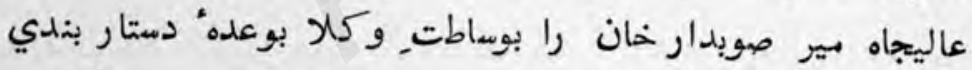

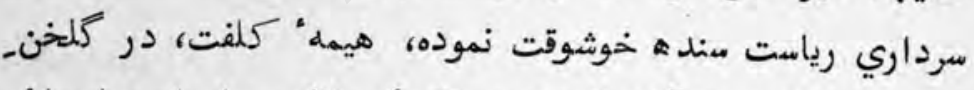

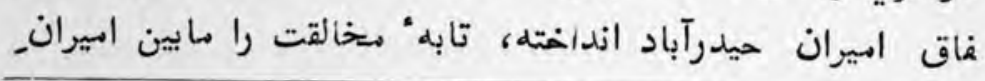

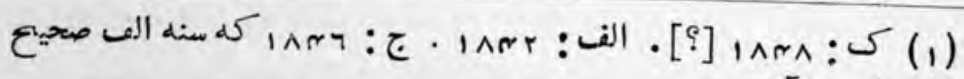
بنظر بي آيد.

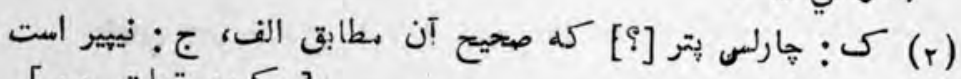

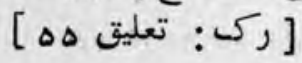

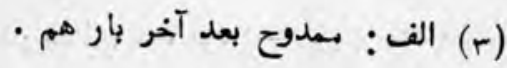


تازه نواي

حيدرآباد كرم ساخته، خود صاحب سمدوح رونق افزاي مقام مكهر كرديده، و با مير صاحب مير علي مراد خان مالاقات نموده،

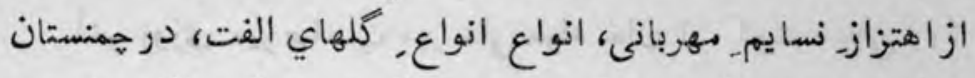

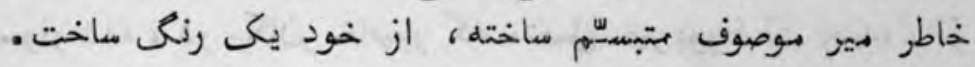

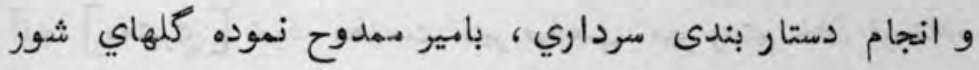

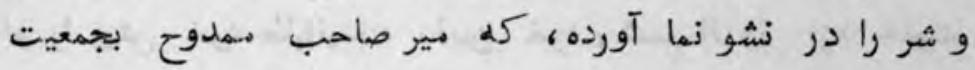

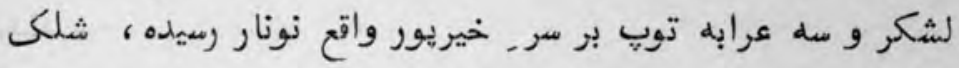

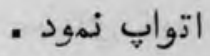

اميران_ خير يور هر يك دير رستم خان و ميرنصير خان و مير

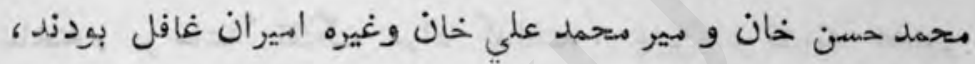

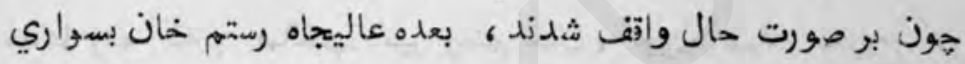
خاصه واقع نونار رفته ، مالاقات بير صاحب مير علي مراد خان

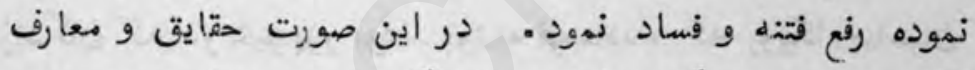

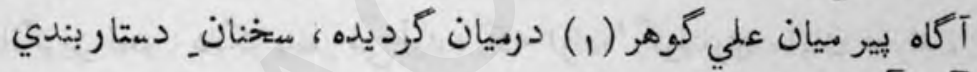
- يميث نمودني

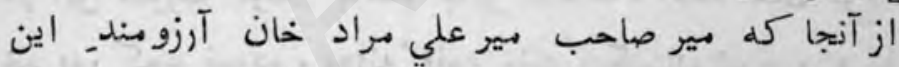

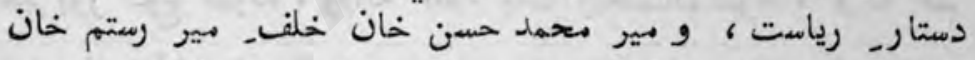

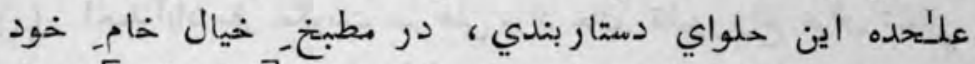

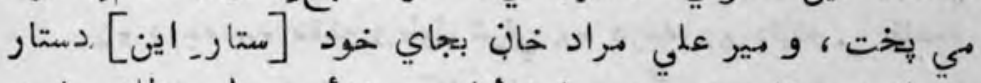

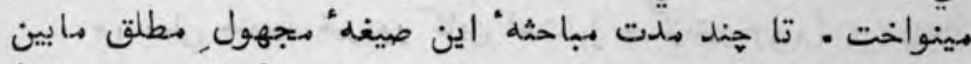

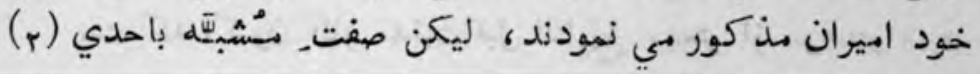

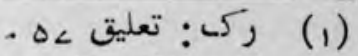

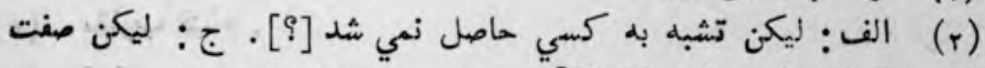

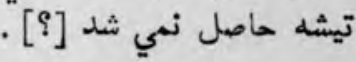


حاصل نمي شه، ، و هر يك درين آرزو جون حرفـ علت واي واي سي نمودند - ماصن

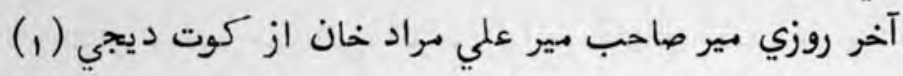

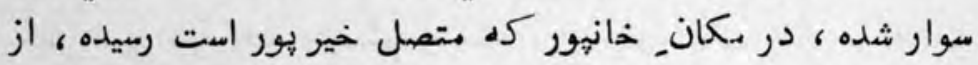

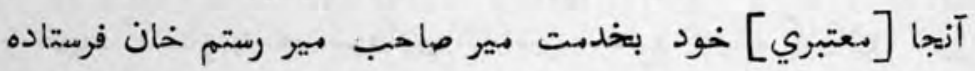

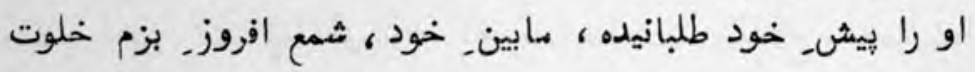
شدند . شورا

مير صاحب مير علي مراد خان [نظر] بر صيد. مدعاي خود

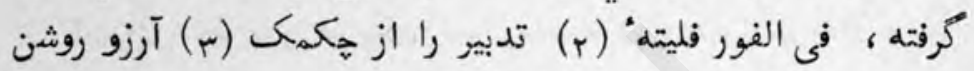

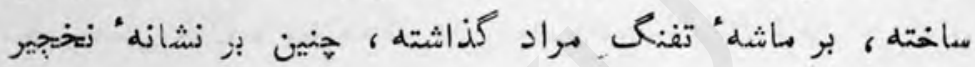

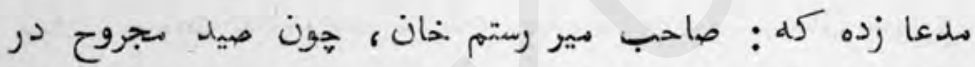

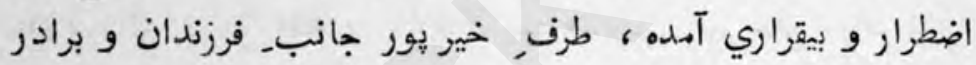

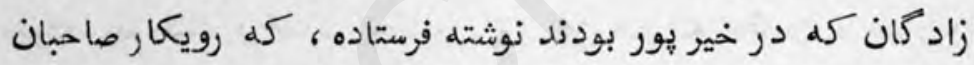

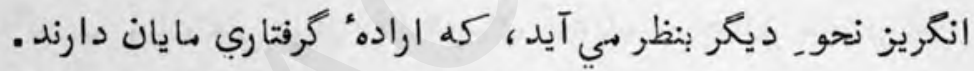

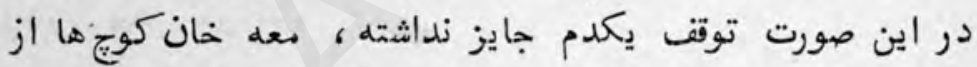

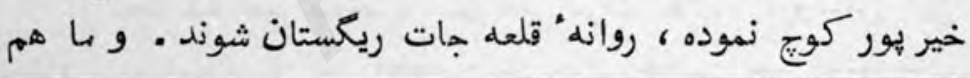

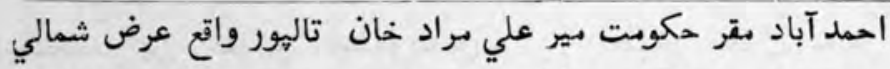

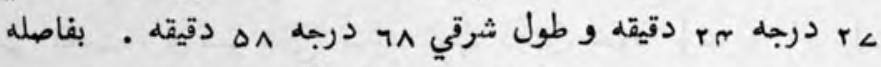

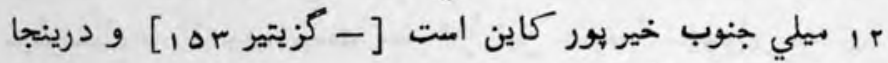

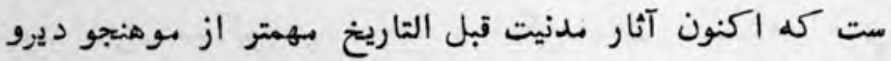
يجدا شده است مله مقلوب فتيله .

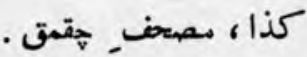


Tro

تازه نواي معارك

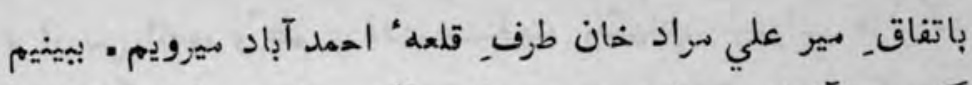

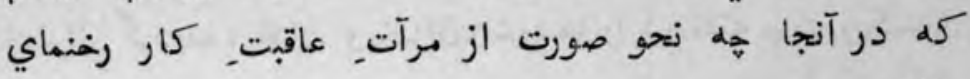

-

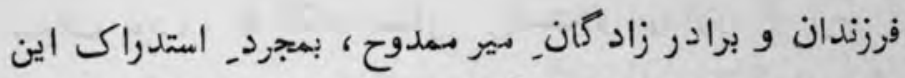

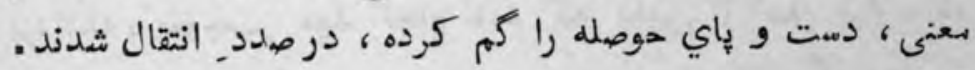

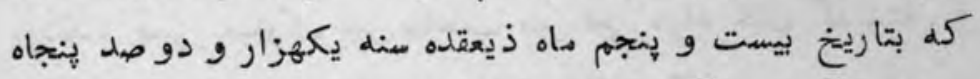

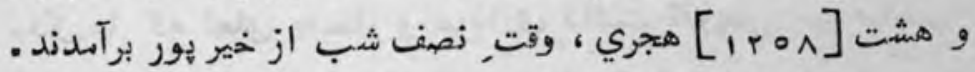

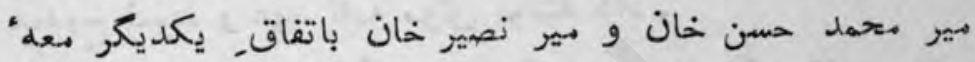

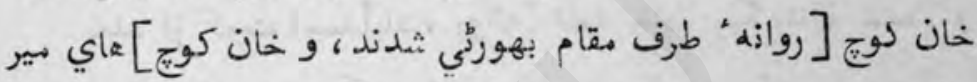
صاحب دير رستم خان جانب_ قلعه جات ريكستان ستوجه كرد يدنه .

و ديكر صاحبزادها روي موي [خود] بطرفى رخ نهاد شهدند .

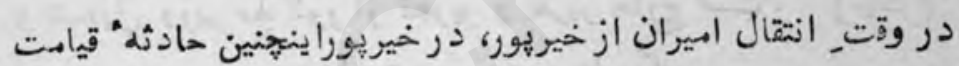

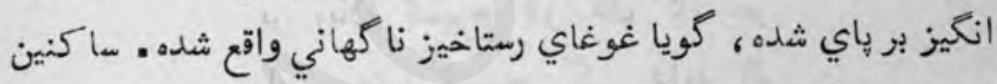

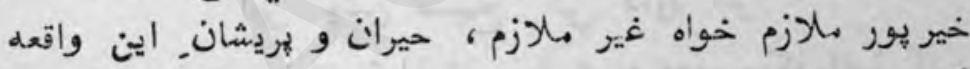

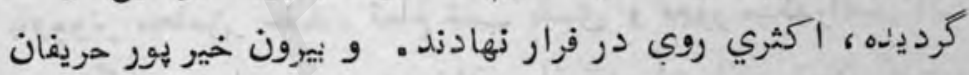

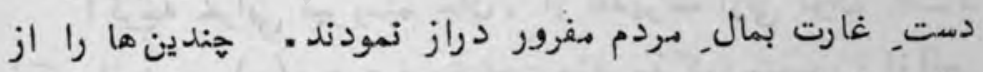

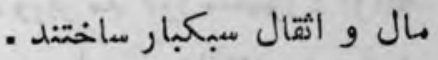

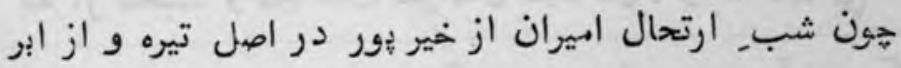

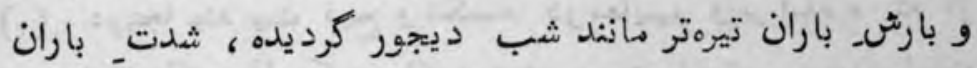
و سرها يكطرف، و تيركي شبهاي آواركى درك طرف. برده نشينان

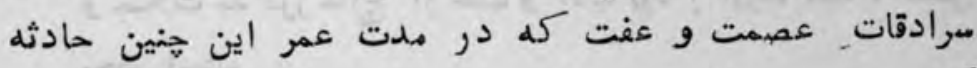

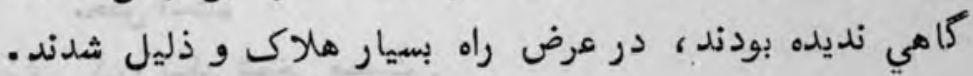


تازه نواي معاركى

TrT

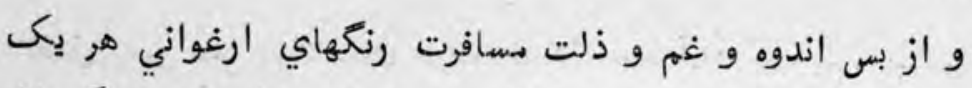

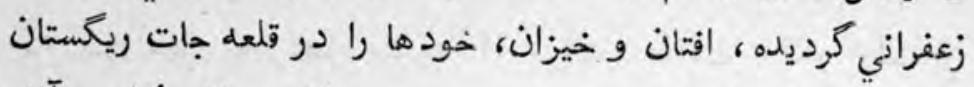

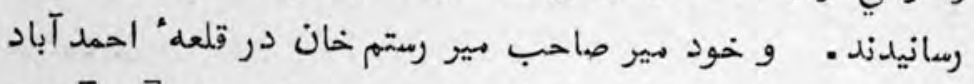

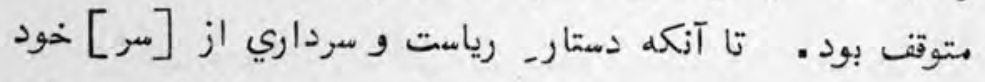

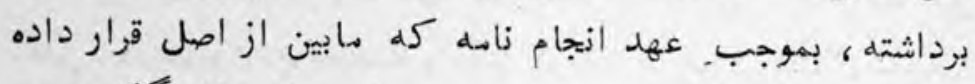

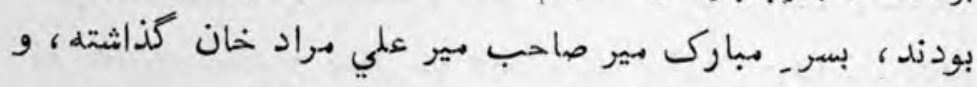

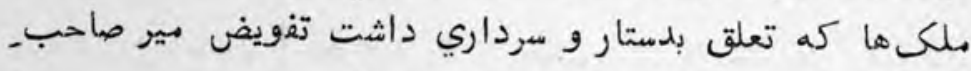

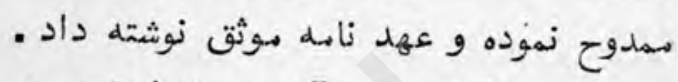

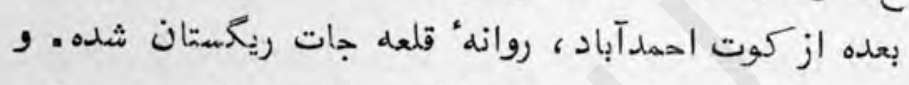

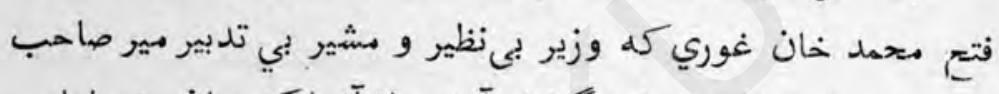

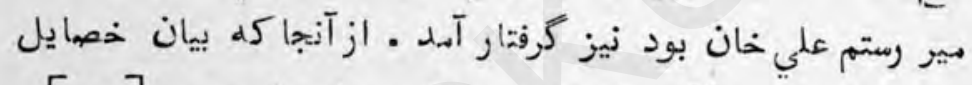

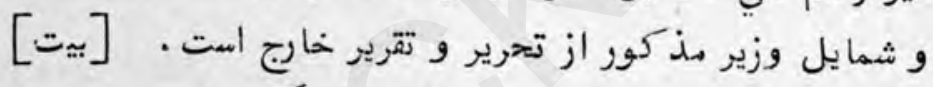

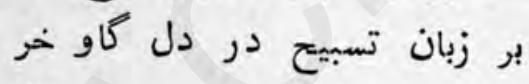

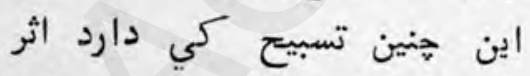

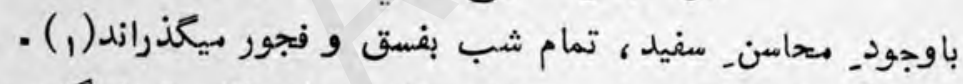

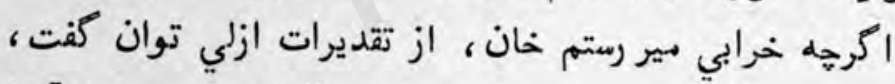

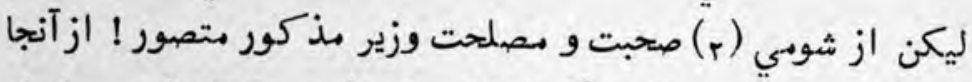

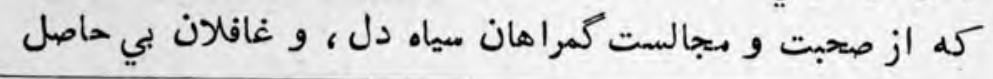

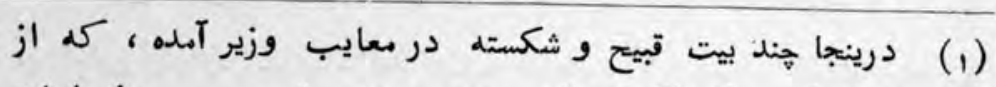

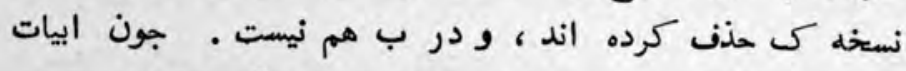

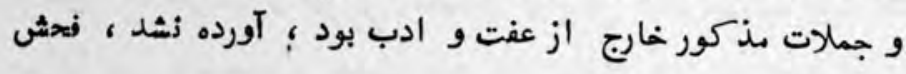

محض است.

(r) 


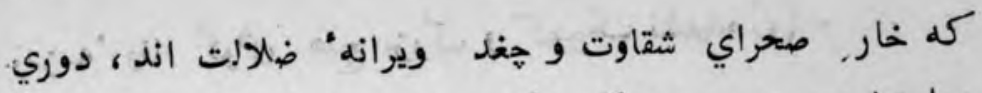

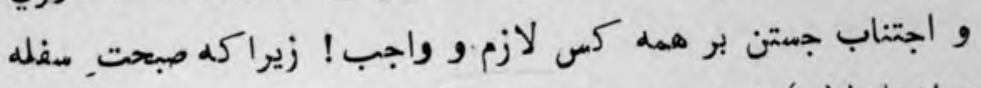
و اختلاط (1) ناجنس ؛ سيلابي است كله قصر زيمنامي ارباب ننح و نام را از هِاني در آورده، و صاعقه ايست (r) كله در يك نفس زورقهاي عافيت و حيات خاص و عام را بدست طوفان هـار

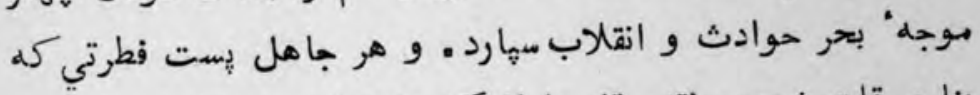
بنا بر قلت شعور، نقد وقار را از كف اختيار، بسوداي بي منفعغت

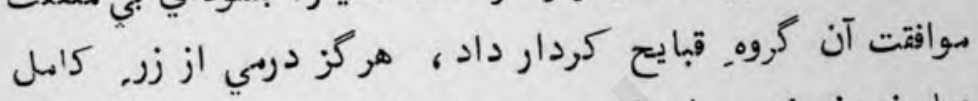
عيار فيروز بتختي و اعتبار در جيب تصرف خود نديد . ز

ضرور است بر خاص و عام احتياط

ندانند حق. نمك خواركي ز انصاف دوراند يك باركي ز تلجيس كرم اهت بازار, شان بود يار بازي ده:

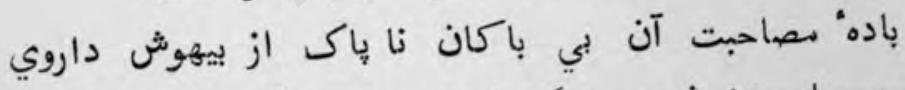
خدعه و حيله مغشوش، و ديخ ياري و مبعاونت آن دغل بيشخان.

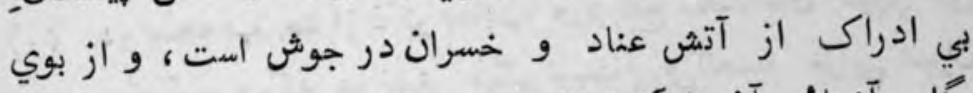

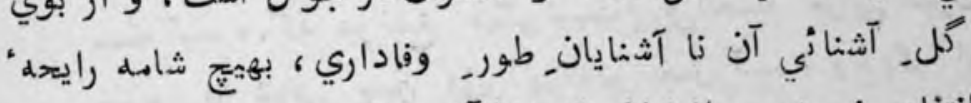

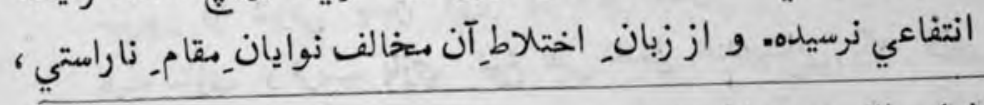

$$
\text { كى: الف: و خلط, زاجنس . }
$$


تازه نواي معارك

TrA

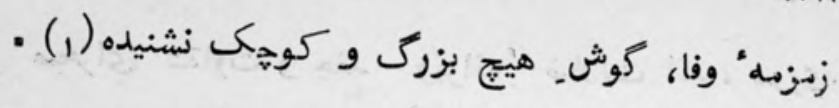

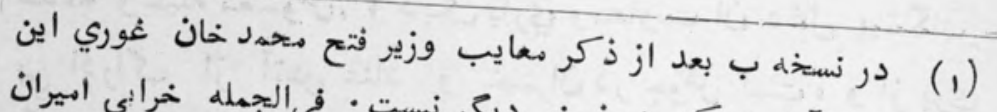

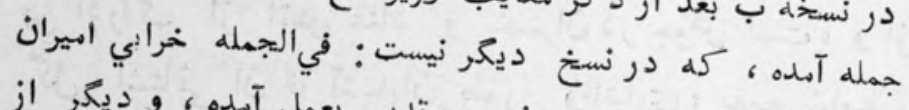

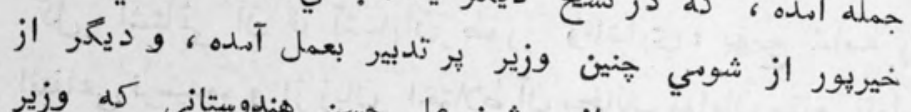

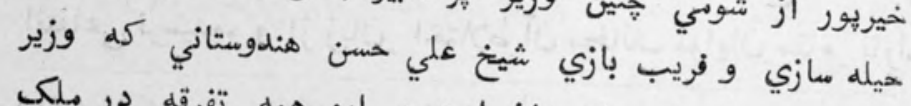

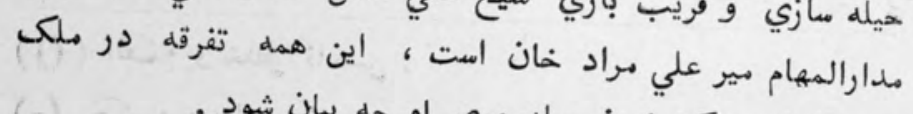

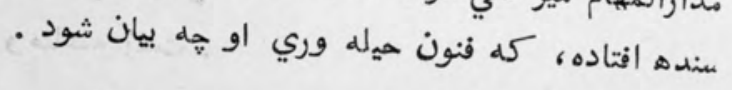


$-14-$

در بيانٍ رفتن جنرل سر خارلس نيبير صاحب بهادر در كوب ديجى

و فرستادن نيجر آترم صاحب بهادر مير صاحب مير علي مراد خان

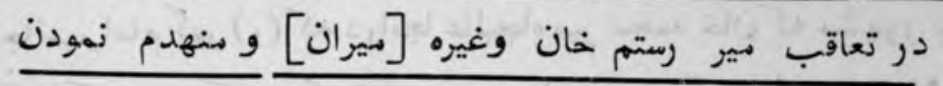

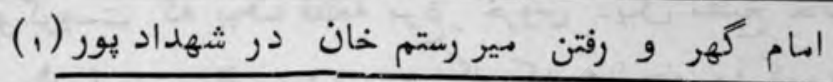

وغيره وقوءات

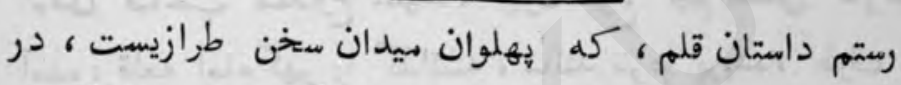

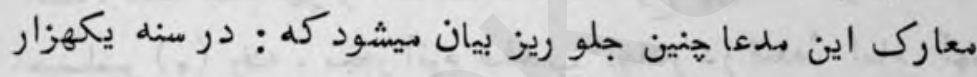

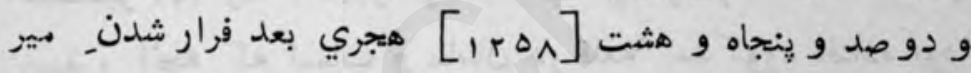

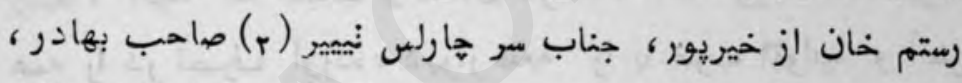

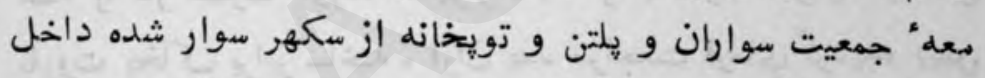

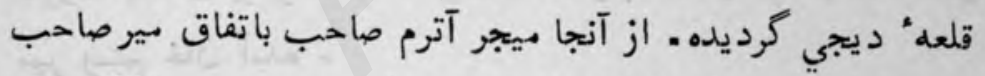

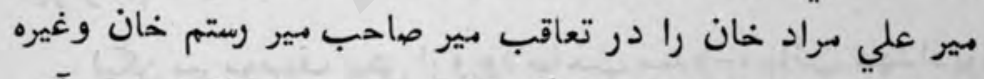

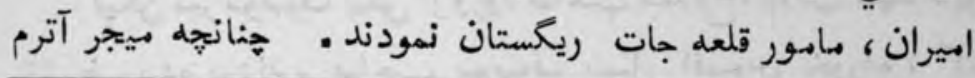

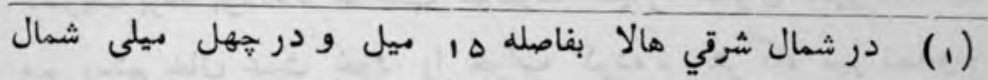

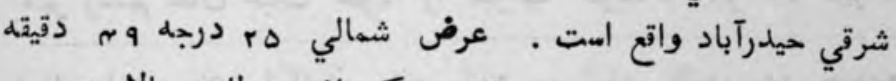

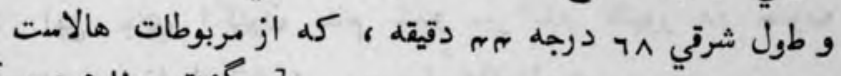

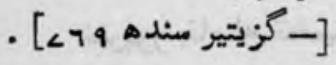

[? (r) 
تازه نواي معاركى

Tr.

صاحب ، در قلعه ريكستان با مير رستم خان مالاقي شده بدلجونى دير موصوف برداخته، خاطر جمعي تمام داده انجام نمود كله :

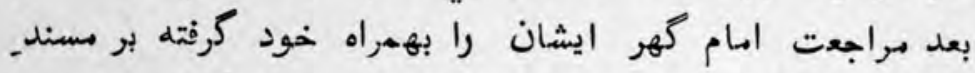

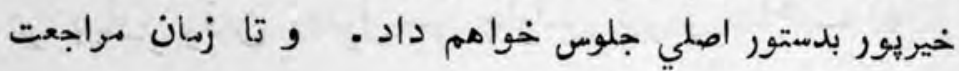

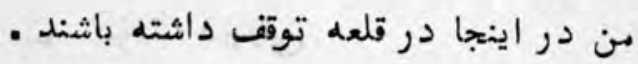
صاحب مهدوح بعد مالاقات مير موصوف و انجام مذكور، عازم

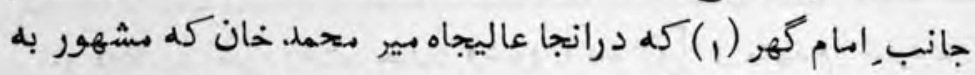
كهوكريست كه بيك قطعه مرغ ـ خروس ديمى مطبخ خانهاش

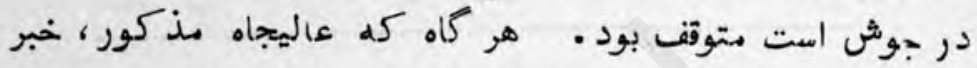

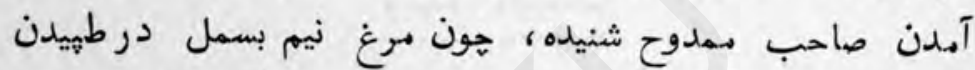

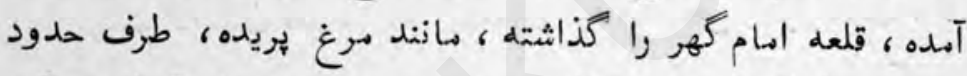

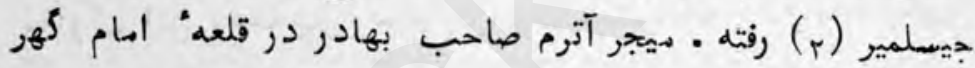

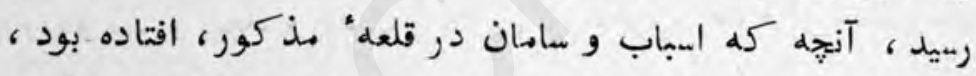

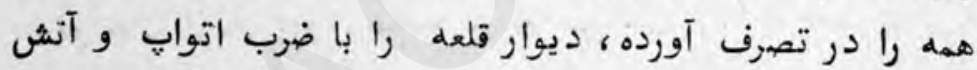

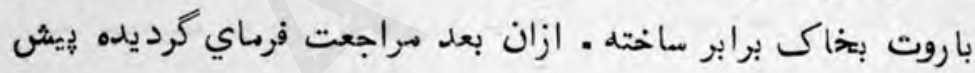

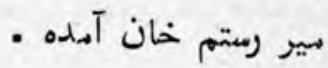
ليكن مير مـوصوف بيش ازورود صاحب ممدوح، جانب شهداديور

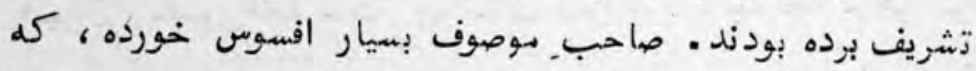

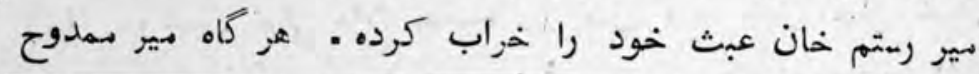
(1) اين جاي اكنون بنام تندو سير ايسام تالهور در جنوب شرقي

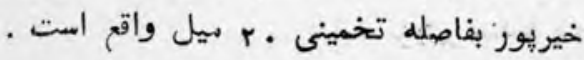

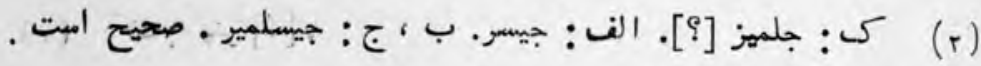


تازه نواي معارك $\quad$ Ir

هاخل_شهداديوِر كرديده در آنجا ده دوازده هزار لشكري بلوحان

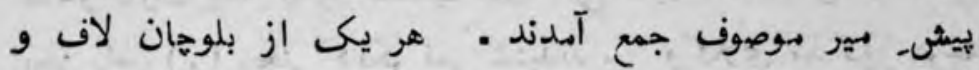

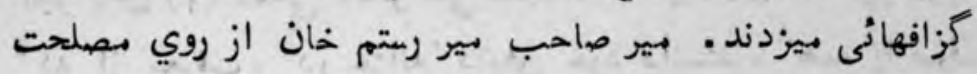

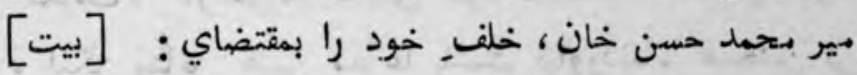

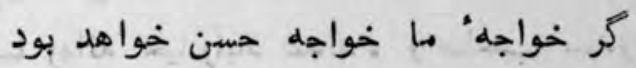

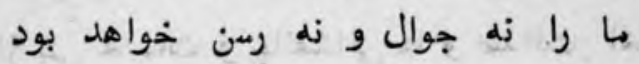
بسر كرد كي لشكر, بلوحان در شهداديور كذاشته ، خود دير صاحب مير رستم خان و مير محمد نصير خان روانهُ حيدر آباد • بيثـ اميران حيدرآباد شدند

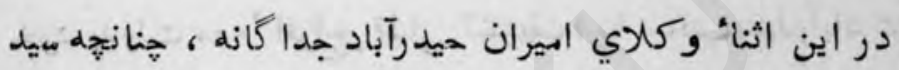

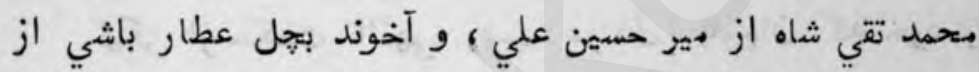

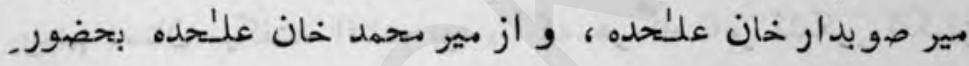

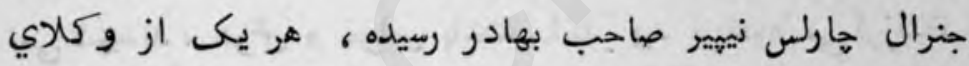

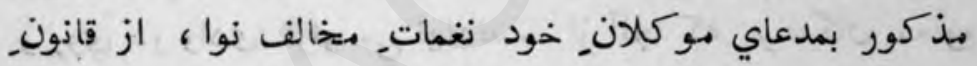

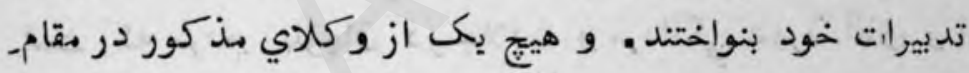

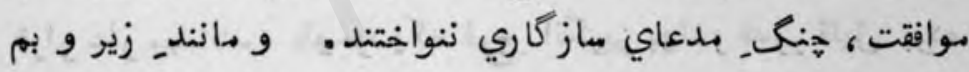

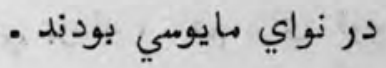

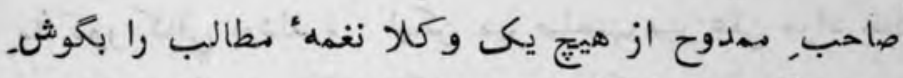

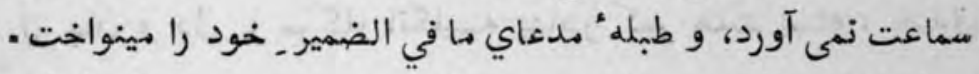

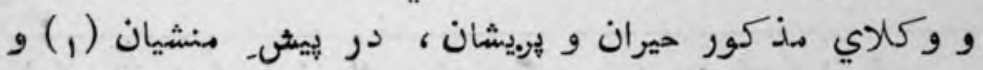

ج : در بيش نشينان شاهو كاران .

(1) 
تازه نواي معارك

TrP

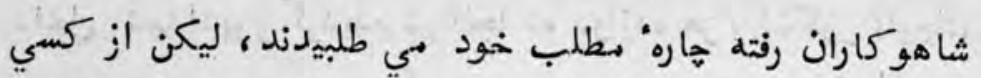

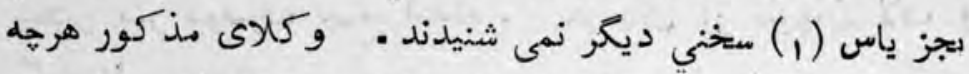

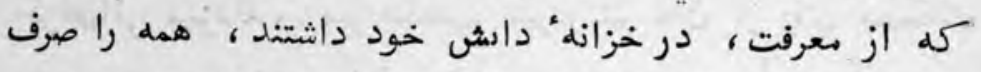

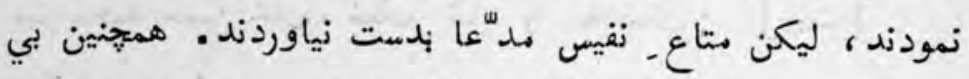

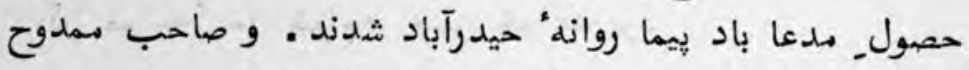

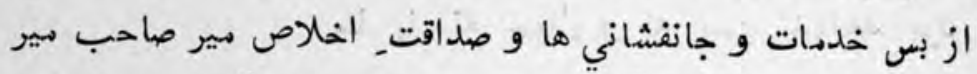

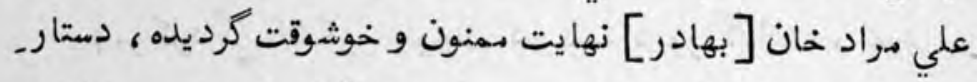

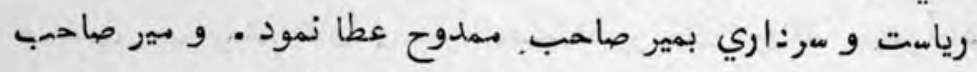

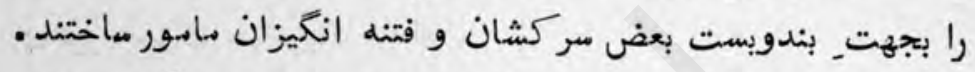
خود بدولت معه افواج_ قلياىى تشريف فرها جاذب حيدرآباد شدند .

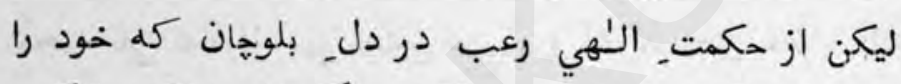

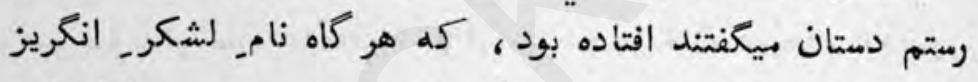

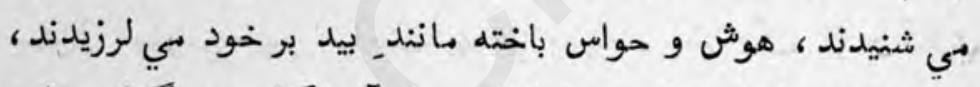

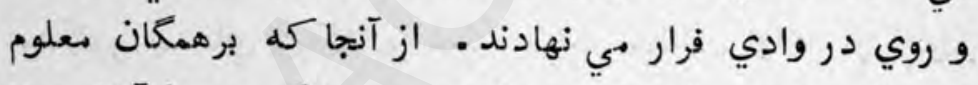

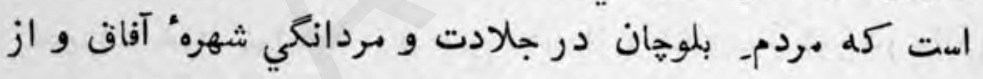

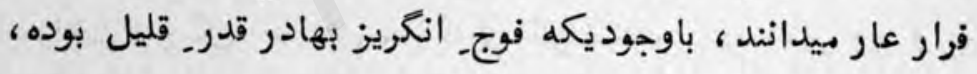

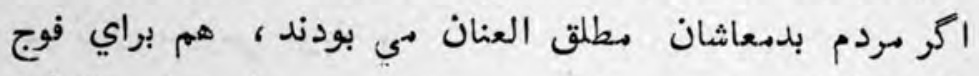

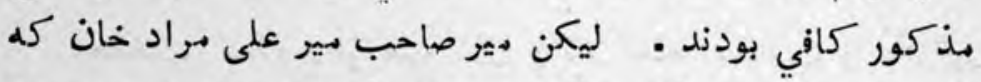

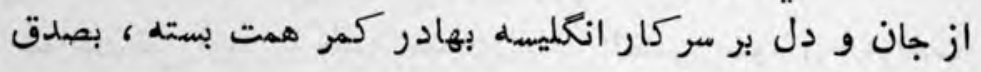

الف: ياس و زر یاش مخنن ديخر . . ج: بجز ياس و از ياس

(

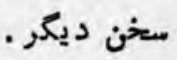


rיד

تازه نواي معارك

اخلاص در بجا آوري خدهات از هر قسم و ومهم هدد كار بوده،

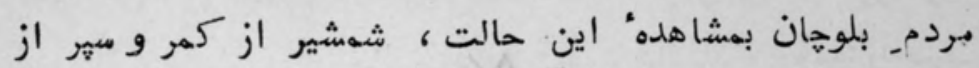
دوش و تفنح از دست كذاشته ، بهثل بـ " آب ناديده موزه كشيده" 460.7

- ميرفتند 
$-\wedge<-$

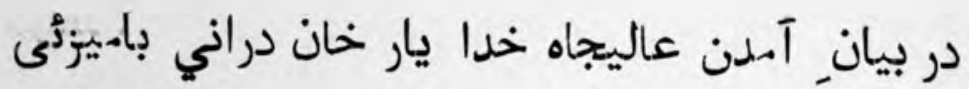
بر بكاريور

و مقابله نمودن با شيخ غلام حيدر خان (1)

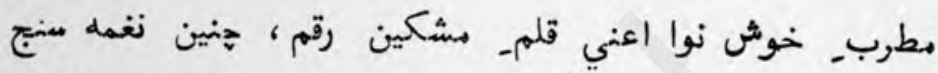

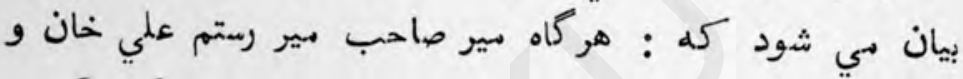

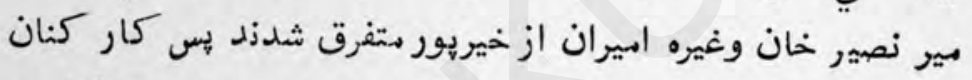

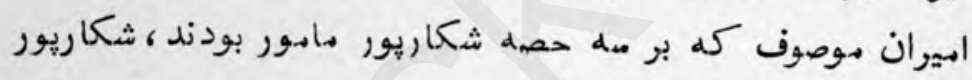

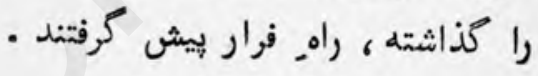

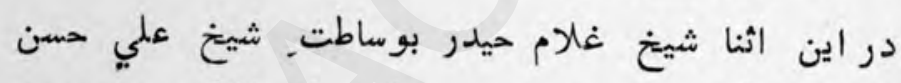

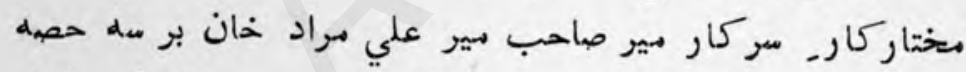

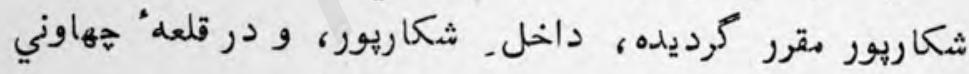

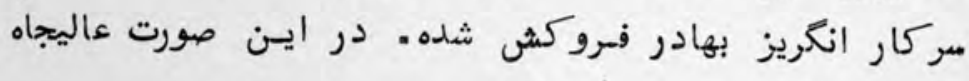

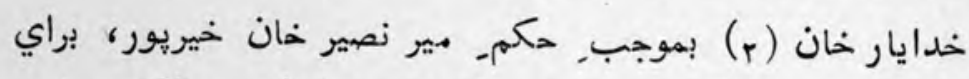

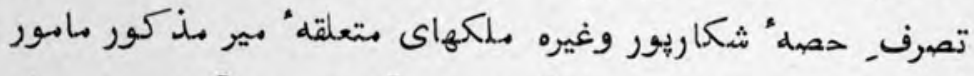

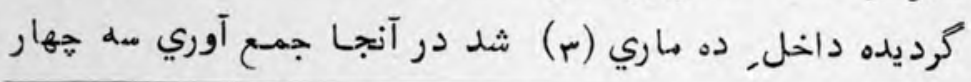

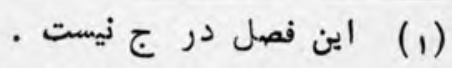
(r)

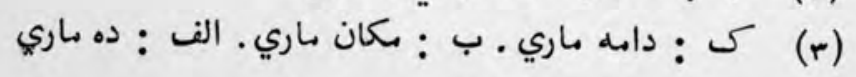


irs

تازه نواي معارك-

صد سوار و هيياده نموده ، لشكر, بازاري كه فقط بر يكنيم هاو آرد

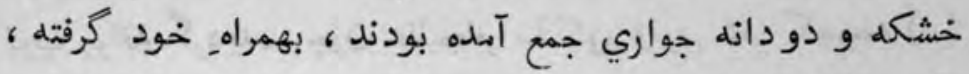

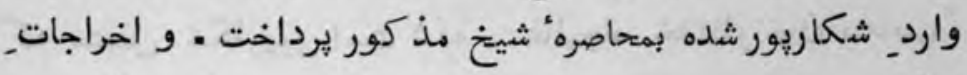

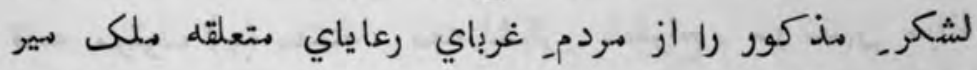

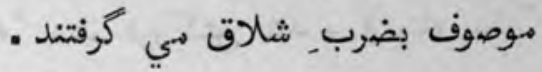
خصوصاً شرارت شعار, ابليس كردار مسوس مار كرهه جونجه (1)

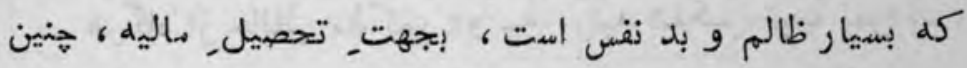

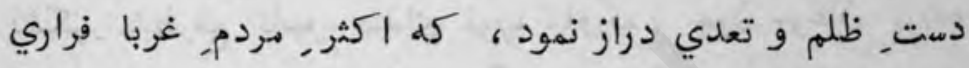

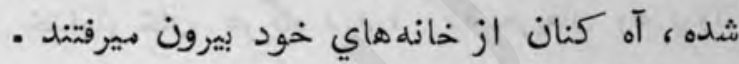

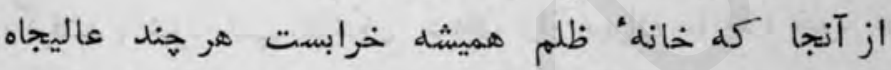

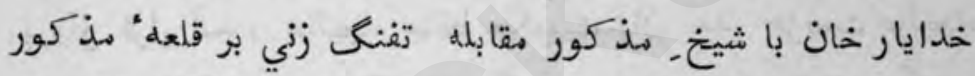

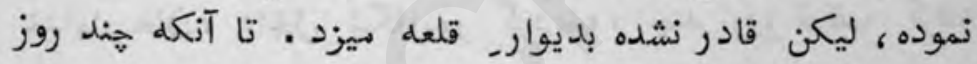
بيرون_ قلعه اقتاده بود . . و در شهر_ شكاريور سيد ابراهيم شاه

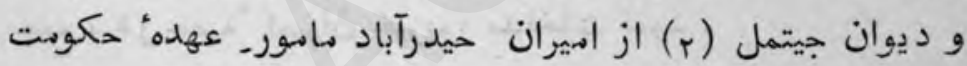

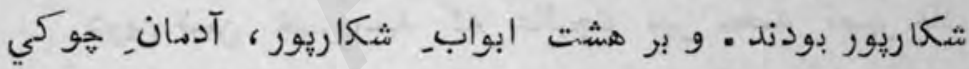

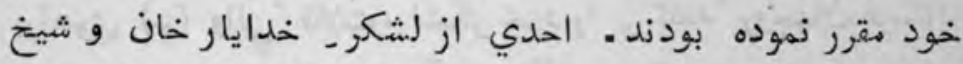

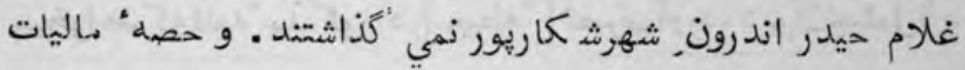

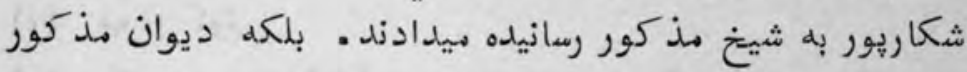

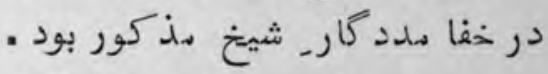

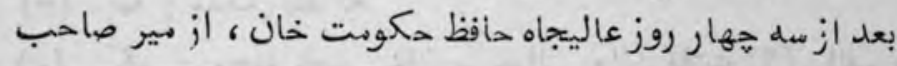

الف : كهله جونيجه [؟؟] . ب : اهركهل نام جونجه [ [؟] .

(1)

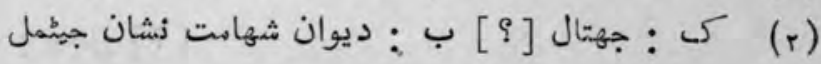




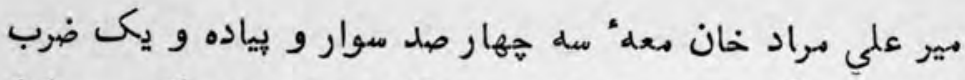

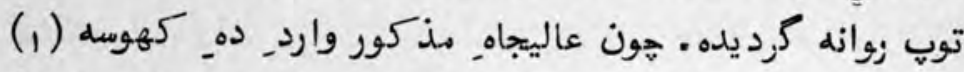

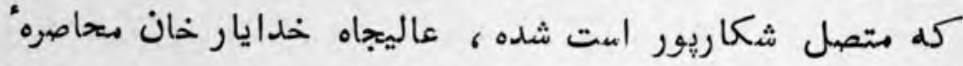

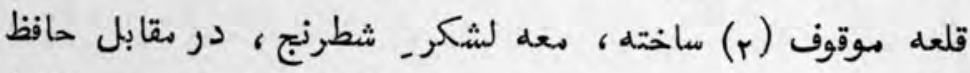

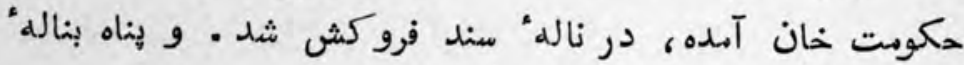

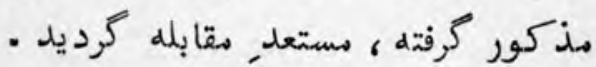

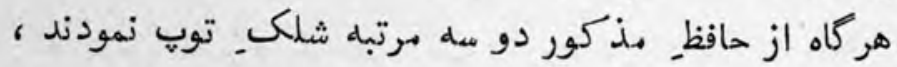

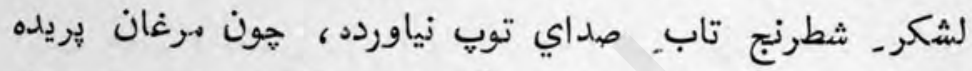

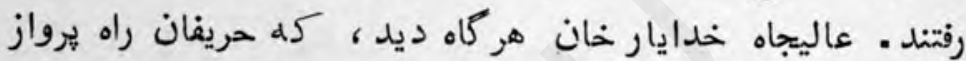

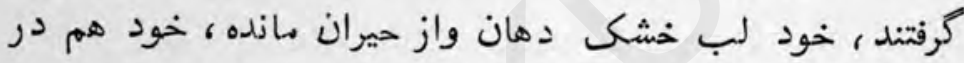

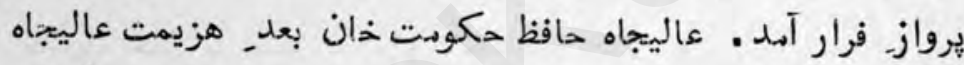

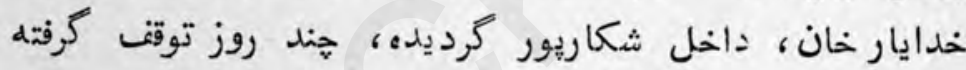

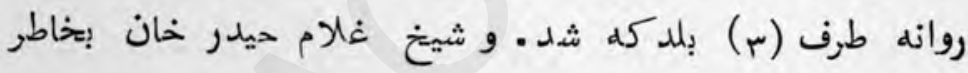

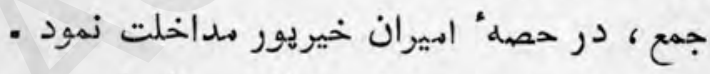

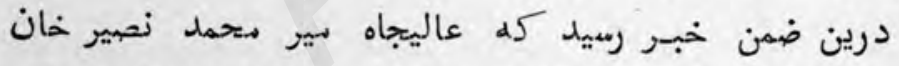

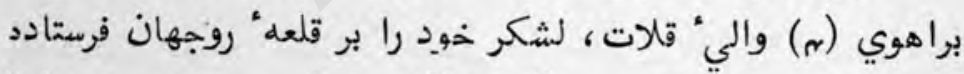

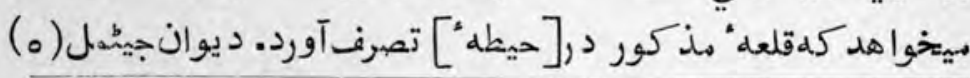

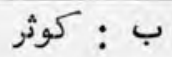

كى : موصوف [ : كوئ

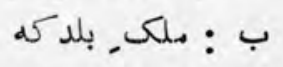

كى : محمد نصير خان بر حوالى والي قلات [ـ] . الف ، ب ب :

$$
\text { مانند متن . }
$$

$$
\text { [؟] ك }
$$


تازه نواي معارك

مطابق. حكم- مدوكلان. خود، جمع آوري لشكر, بلوحان و

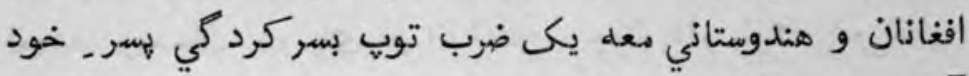

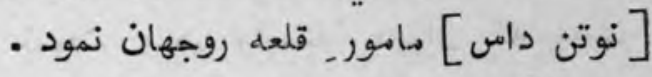

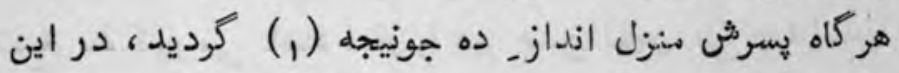

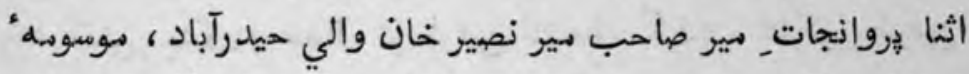
ديوان_ مذ كور باين. مضمون ورود آورده كله : اكريوه مابين.

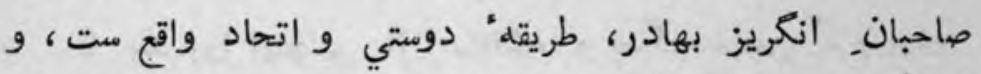

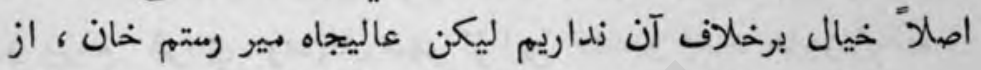

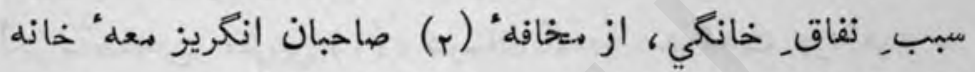

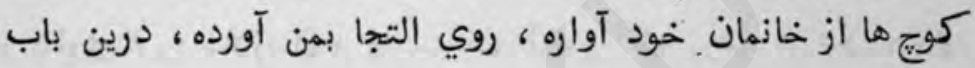

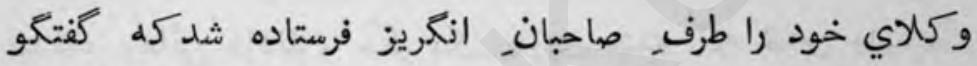

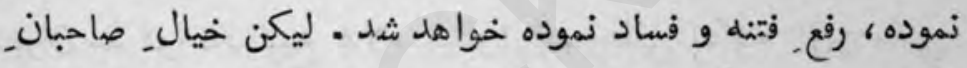

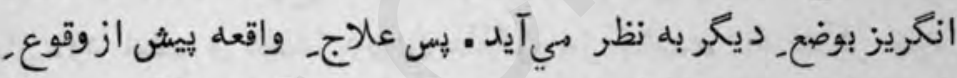

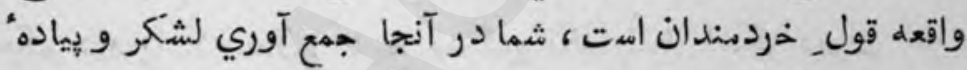

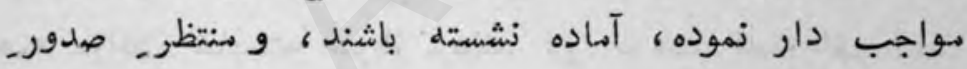

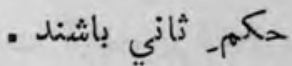

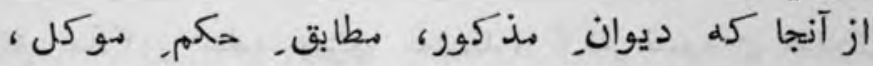

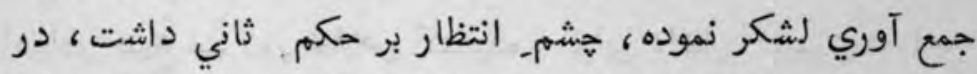
اين صورت از اتفاقات ، ما بين_ ديوان_ مذ كور و شيتخ غالامحيدر

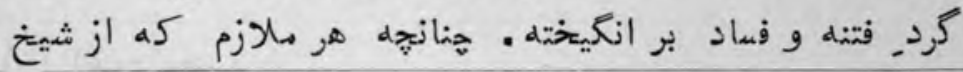

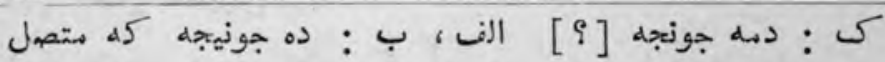

(1)

شكاريور است.

ترن 
مذ كور، بدست_ ديوانب موصوف ميآدد، او راخوب كفشى كاري

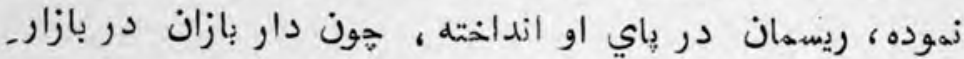

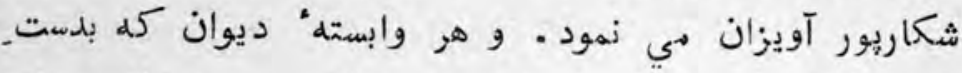

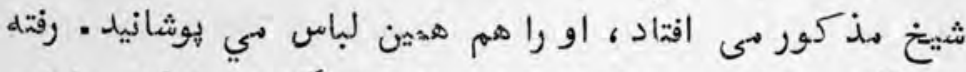

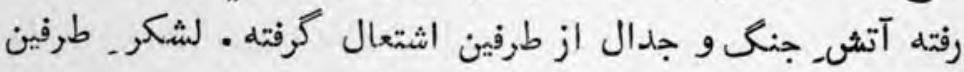

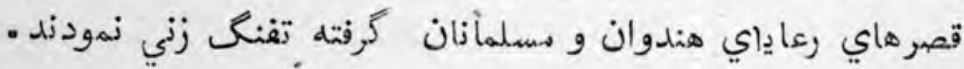

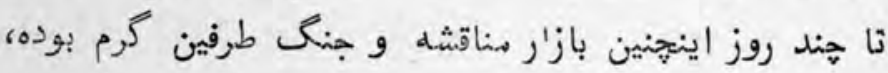

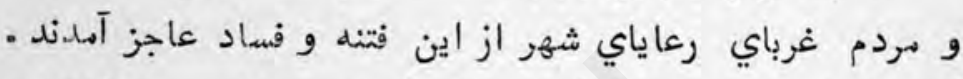

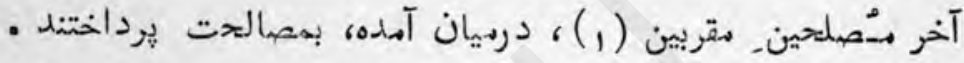

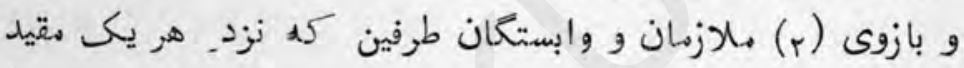

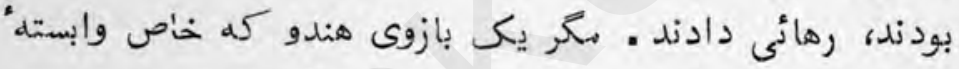

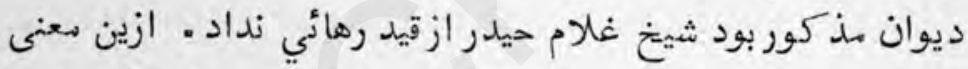

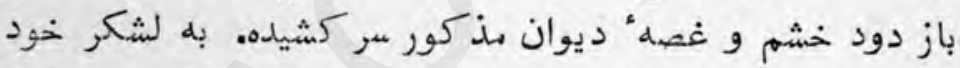

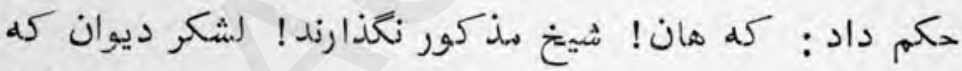

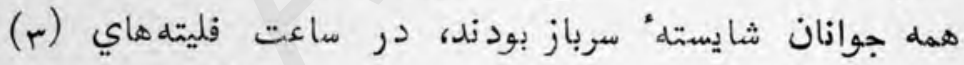

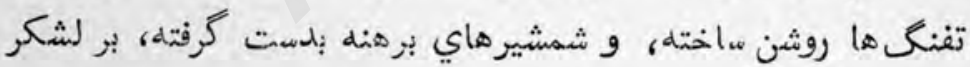

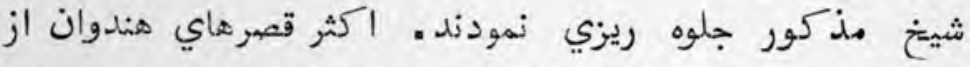

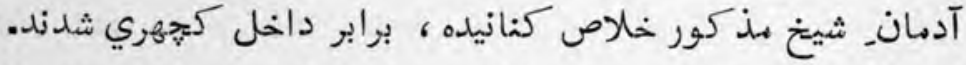

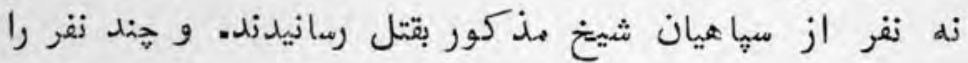

$$
\text { ( ) (1) الف: معتبرين }
$$

(r) بازو= درين كتاب مكرراً بهعني يرغمل استعمال شده.

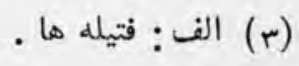




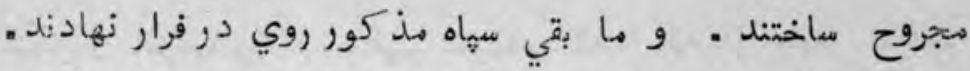

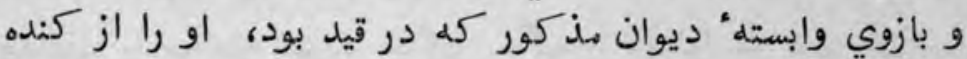

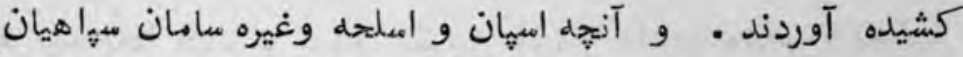

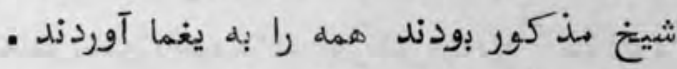

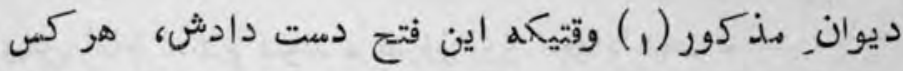

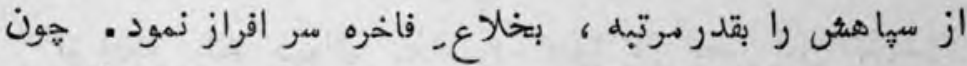

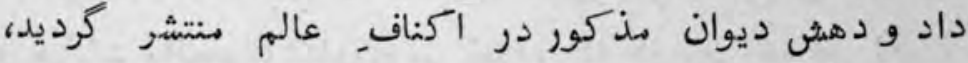

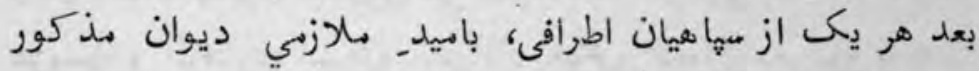

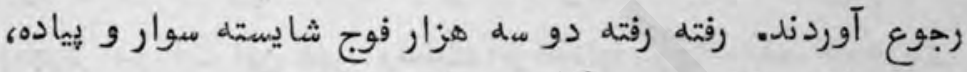

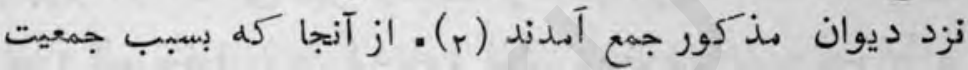

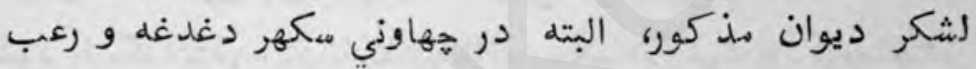

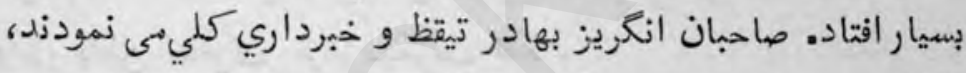
بلكه در عوض. راهـ سكهر و شكاريور، سما هيان هو كي تعين

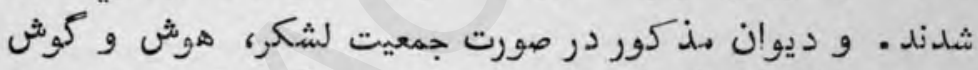

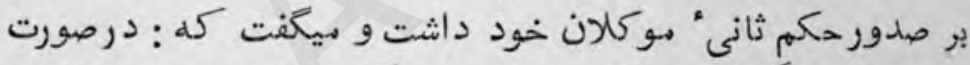

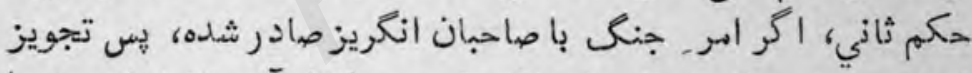

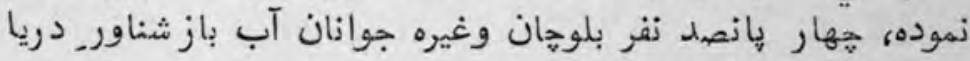

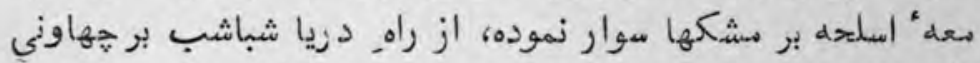

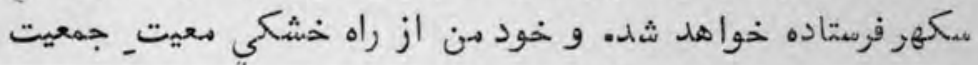
(1) الف: ديوان مذكور، بعد اين فتع ديت. داد و دهث بر سياه

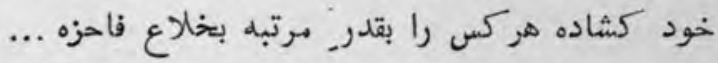

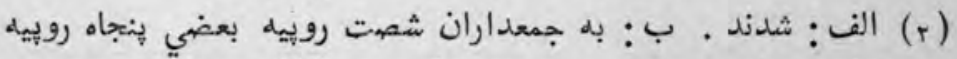

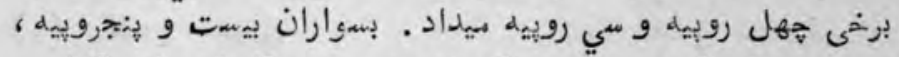

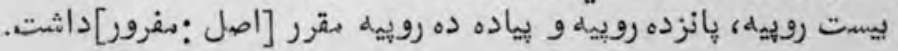


لشكر و اتواب روانه سكهر خواهم شد، كه از جهار طرف،

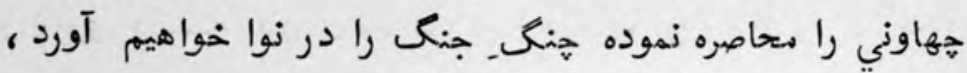

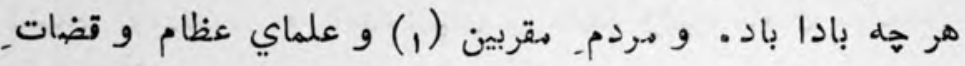

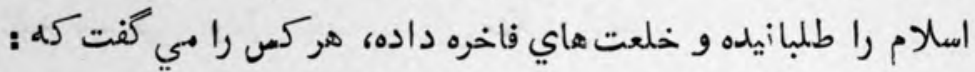

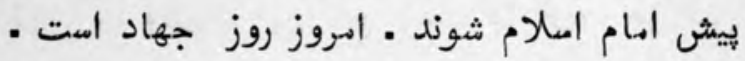
از آنجا كله ديوان مذكور، هنوز در بحر_ اين انديشها

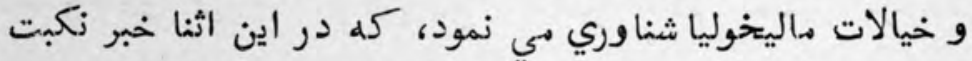

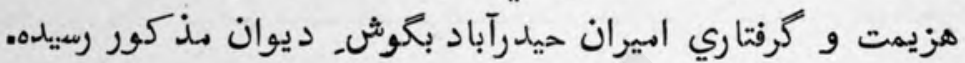

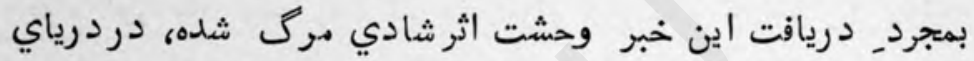

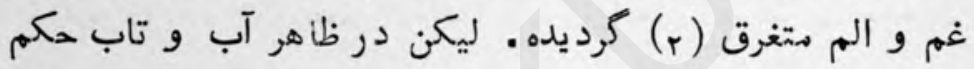

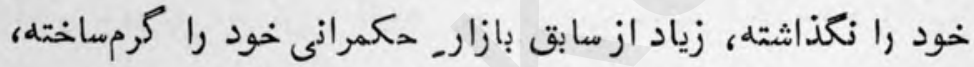
و در باطن تداركـ فرار ميكرفت فتط . 


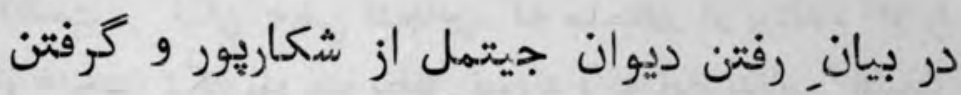
مبلغان از هندوان كودايى وغيره

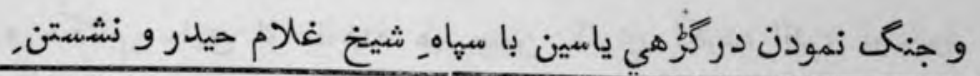

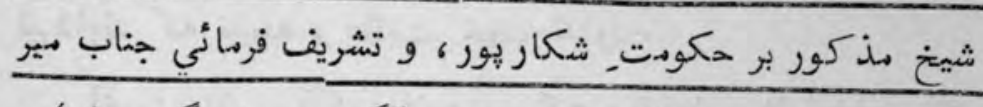

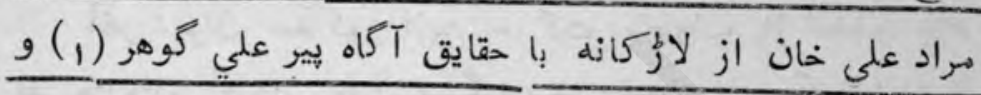
مناقب آن [حضرت

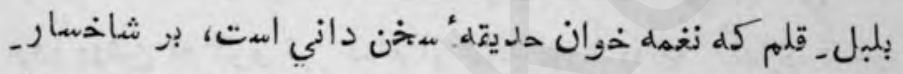

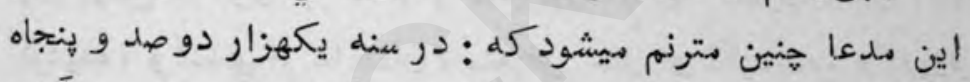

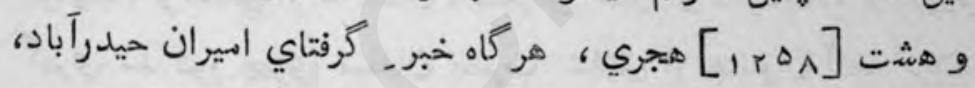

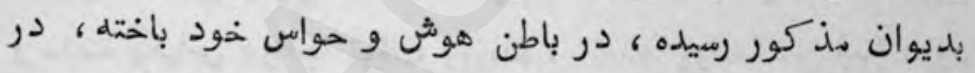

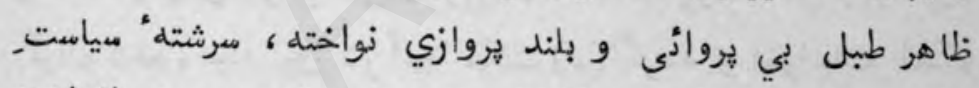

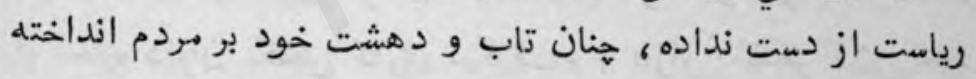

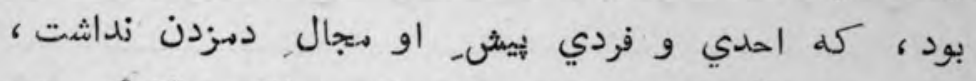

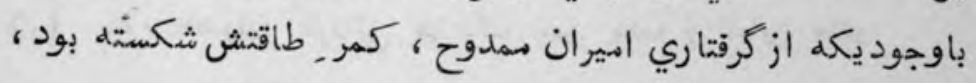

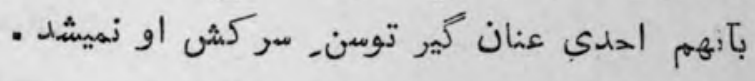

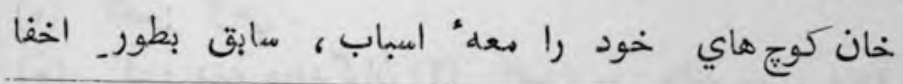

$$
\text { (r) }
$$


كشيده بود - خود هم اراده داشت ، كله شهر شكار يور را دست

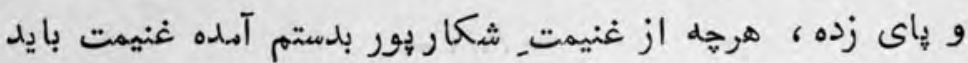

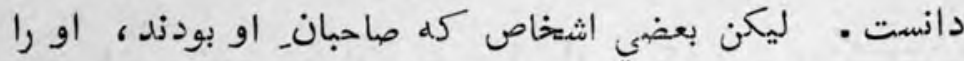
از غنيمت_ شكار ريور منع مطلق نمودند ، كه اين بدنامي" غنيمت

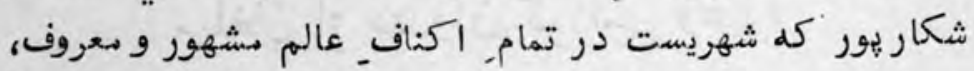

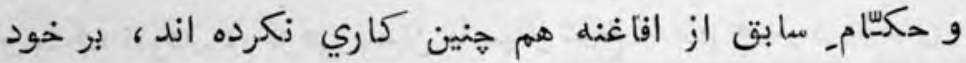

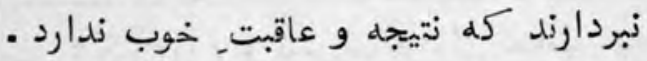
آخر ديوان. مذكور ازين حركتي ناصواب باز آمده ، هند

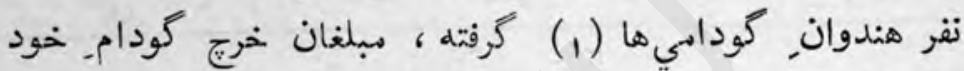
ازانها كشيده و از خانه" قيهت راي هندو، بي ثرد كي ساخته ،

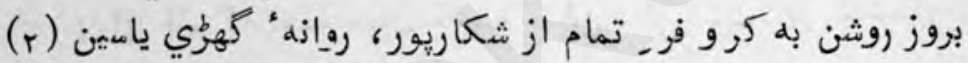
كرديده، و و احدي از حاكمان ، متعرض, حال او نكرديده . و و بورود كهري مذكور جيزي مبلغان بضربـ شالاق از هندوان آنجا كرفته و مدت يكياس درانجا توقف ورزيده ، بعده" روانه" ده. (r) دورد

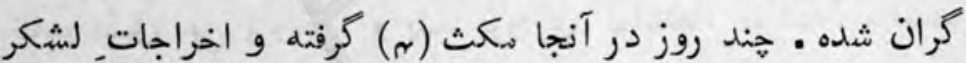
از اجاره داران بكفش كاري ميركرفت • و بازار ـ لشكر كشي خود

ب: هندوان كوداني هر يك جمن هندو و ناراين هندو

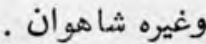

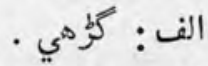

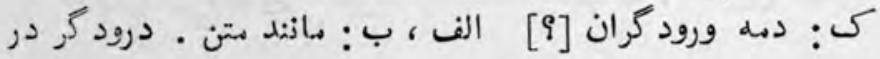

فارسي بمعني نجار است [--فرهنع نظام] . ك : مكنت . الف : .كث . ب: توقف . 
كرم داشت ، و هنتظر خبر ثاني حيدرآباد بود .

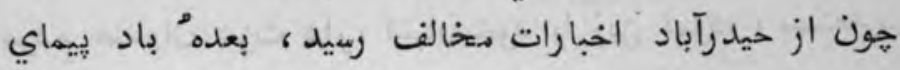

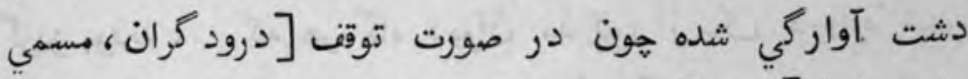

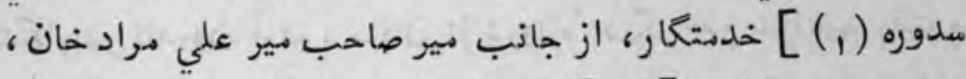

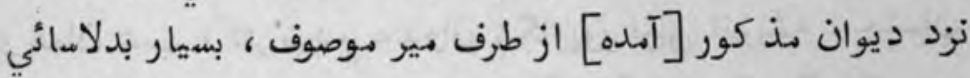

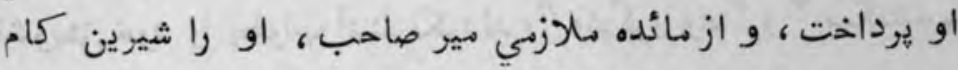

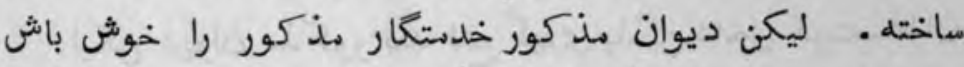

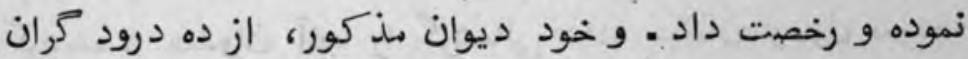

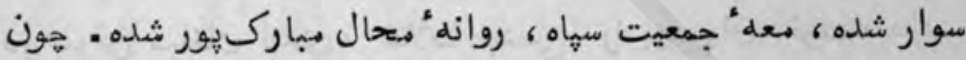

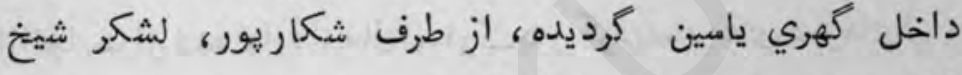

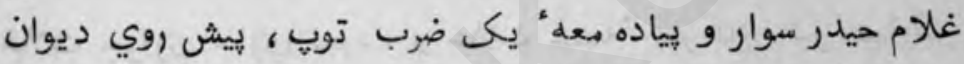

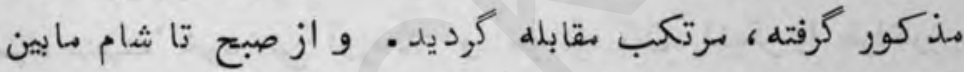

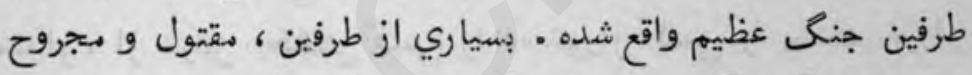

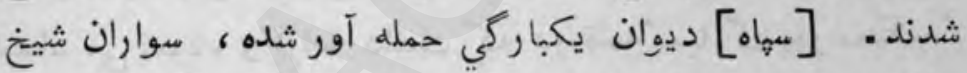

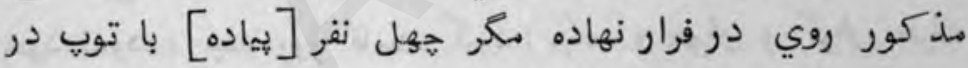

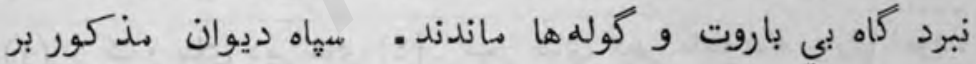

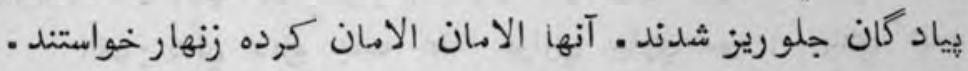

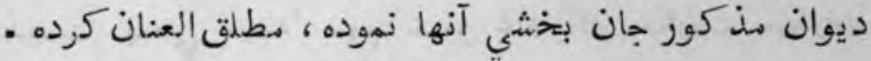

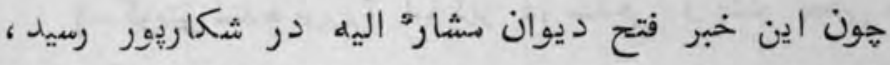

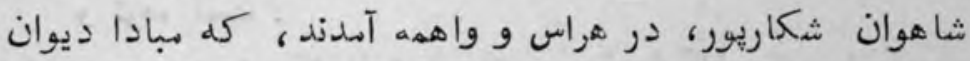

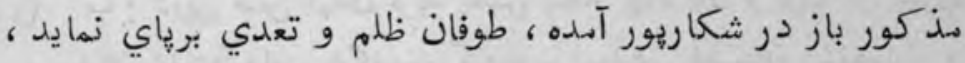


تازه نواي مeسرك

Tre

و هرده" عزت و ابروي مردم عزت دار بر دارد ازين سببب

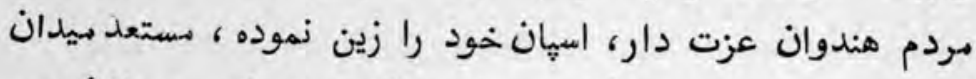

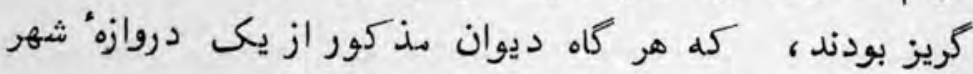

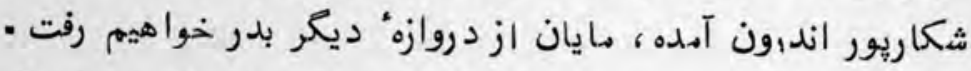

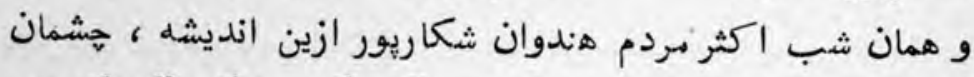
تشويش خود را بخواب آشنا نكردند ، " واه كرو واه گرو " ميخفتند . ليكن ديوان مذكور بعد فتح كهري ياسين داخل كوت سلطلان

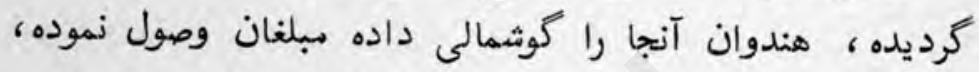

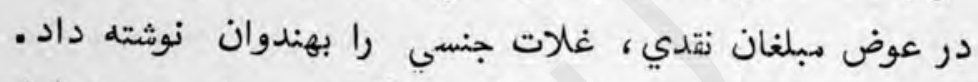

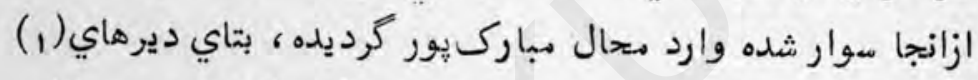

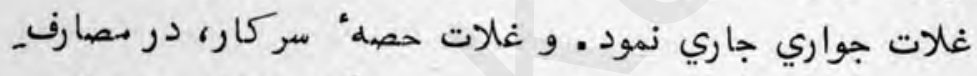

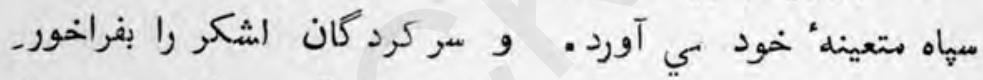
مقدار، از خردن بخشش كسي را ده خروار كسي را بيست خرورار

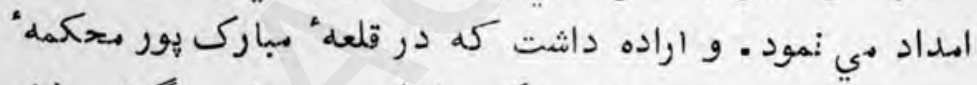

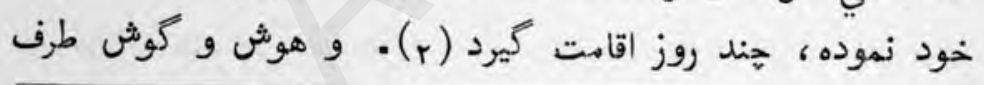

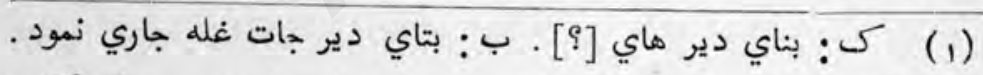

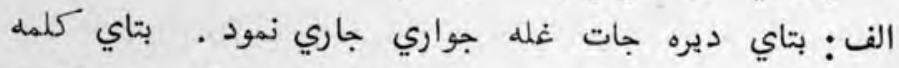

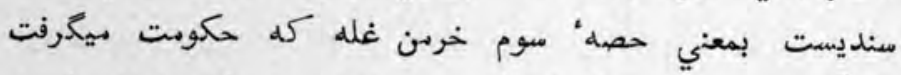

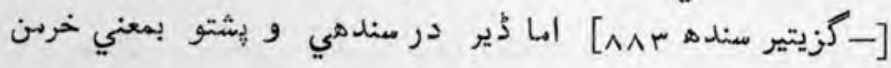

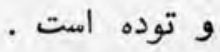

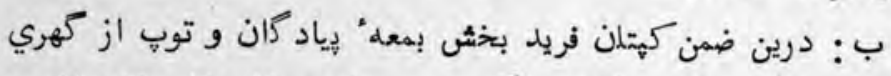
(r)

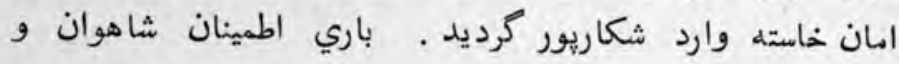
شيخ سن كور كرديد . 
اخبار عاليجاه مير صاحب مير شير متحمد خان داشت .

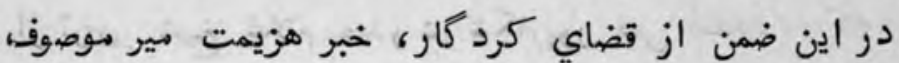

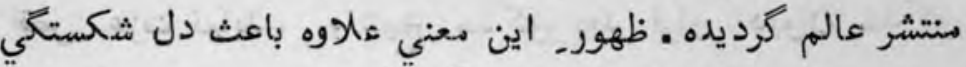

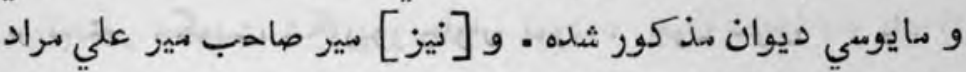

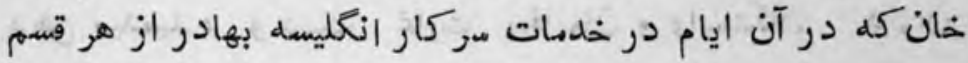

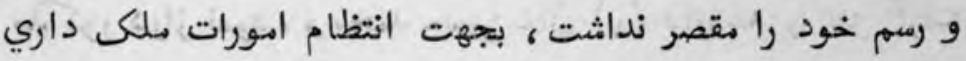

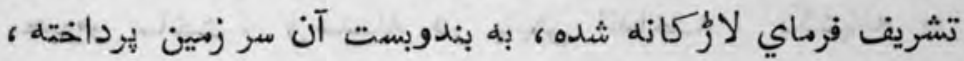

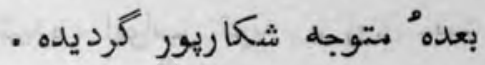

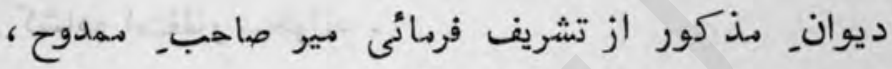

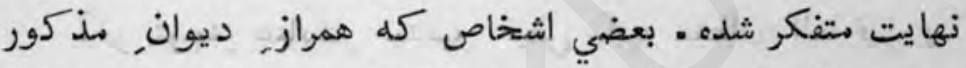

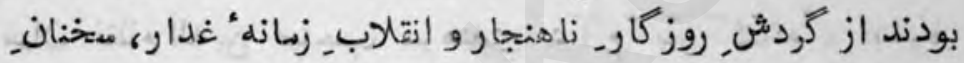

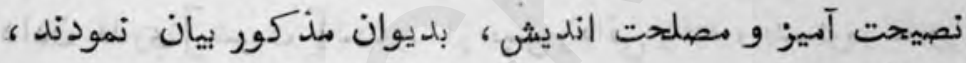

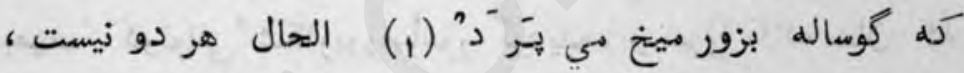

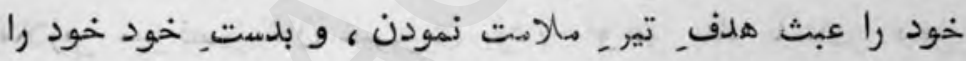

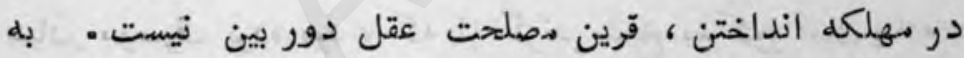

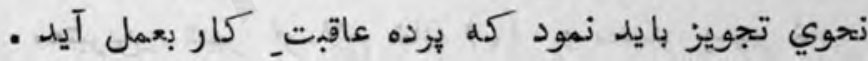

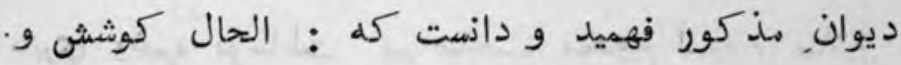

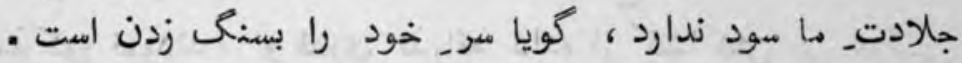

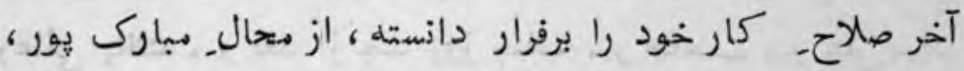

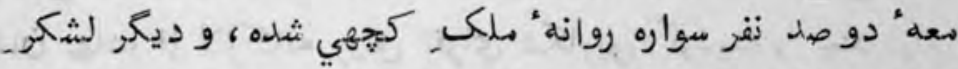
ديواني مذكور، روي بسوي خود رفتند ـ. و مردمر معتبر ساكنين. (1) الف : بي جهد ، و كنيزك بكير آغا بي زازد ، الجال ل... 
تازه نواي معارك

7ח4

شهر شكاريور، كله از روى مصلحتـ وقت باتفاقـ مذكور بودند،

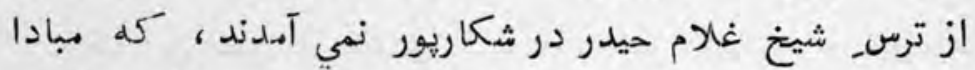

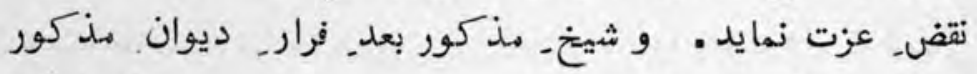

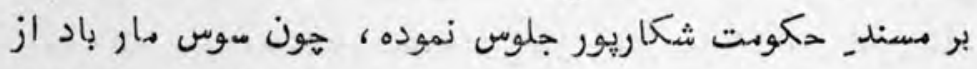

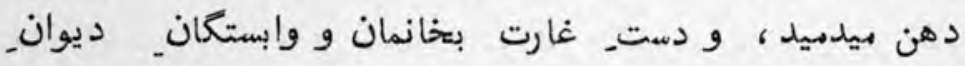

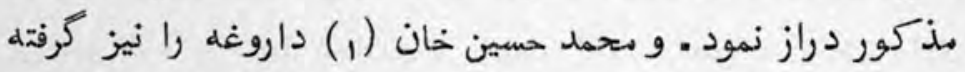

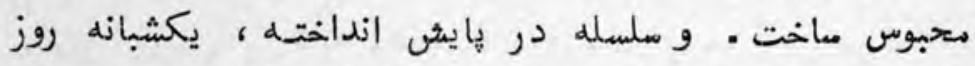

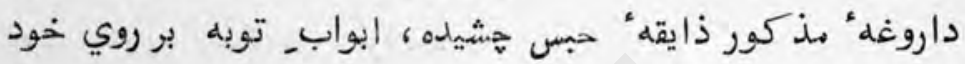

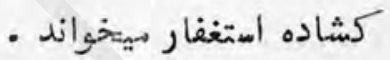

آنر بتوجه عنايت, جنابـ فيض مأب سلطان العارفين بير

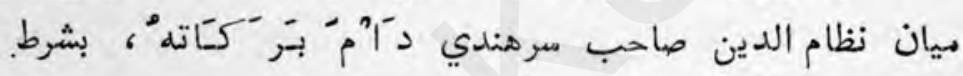

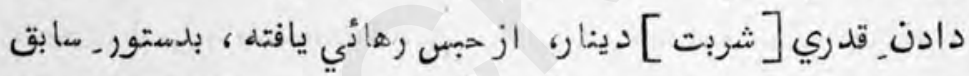

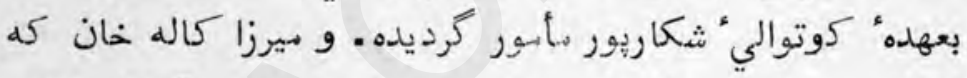

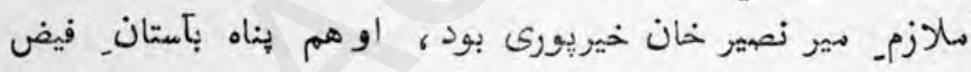

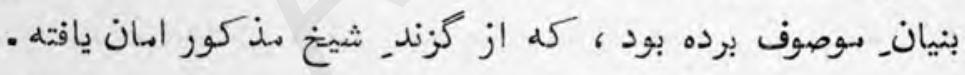

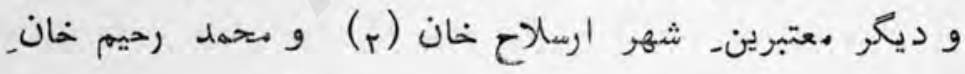
بابري وغيره بوساطت_ بير صاحب ممدوح آدده ، سلامر شيتخ هذكور زهودند، ، و قدري نذرانه داده از كشا كش بـ بي عزتسي رهائي يافتند . و بعد از هند روز جناب مير صاحب هير هير على مرأد خان بهادر از لازكانه رونت افزاي شكاريور كرديده، هيند ايأم

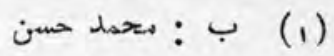
(r) 
TrS

تازه نواي معاركى

توقف كرفته ، بعده تشريف فرماي خيريور • و كوهر درياي معرفيت

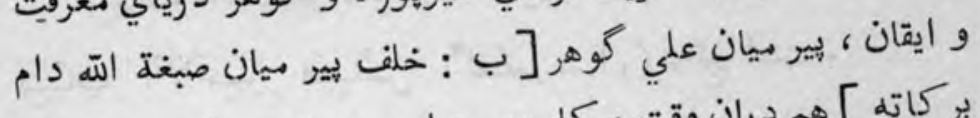

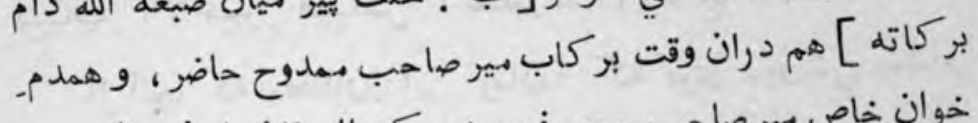

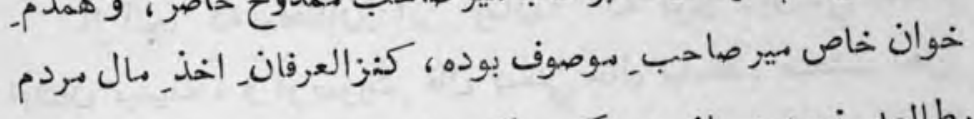

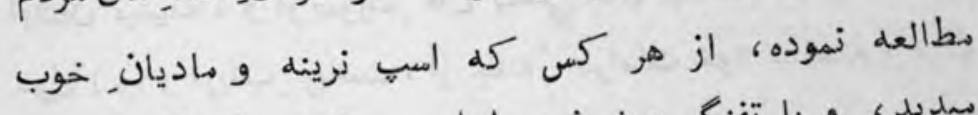

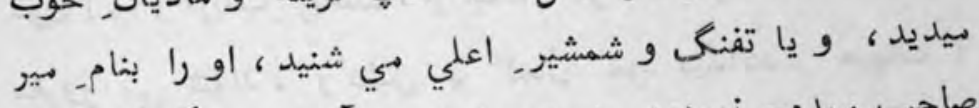

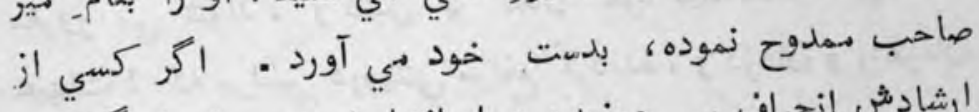

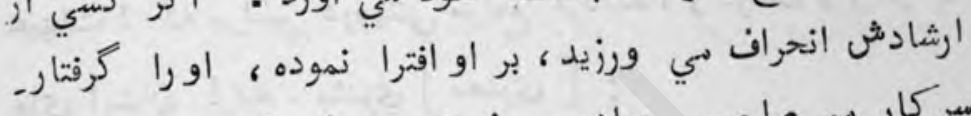

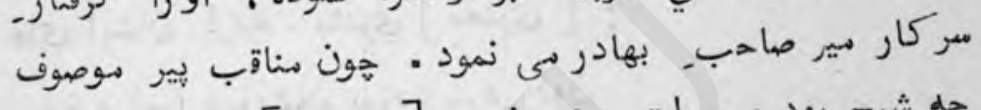
] جو كفر از كعبه بر خيزد كجا ماند مسلهانى

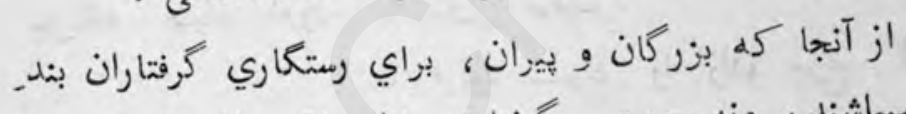

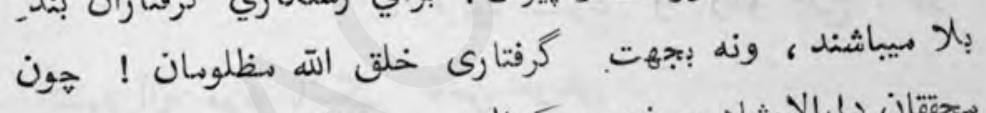

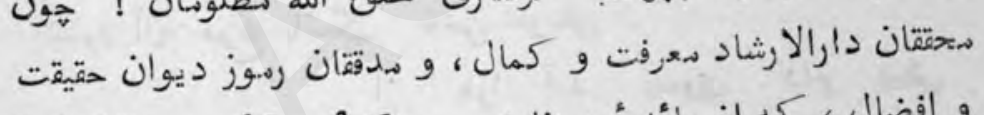

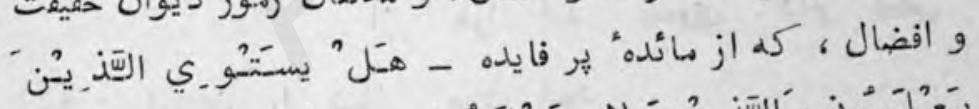

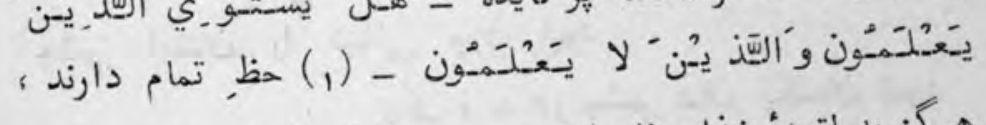

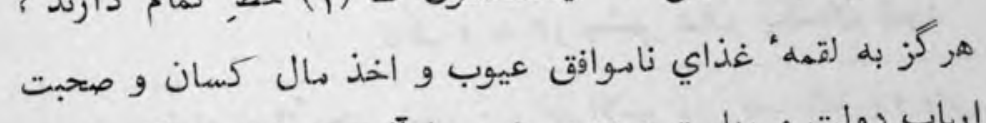

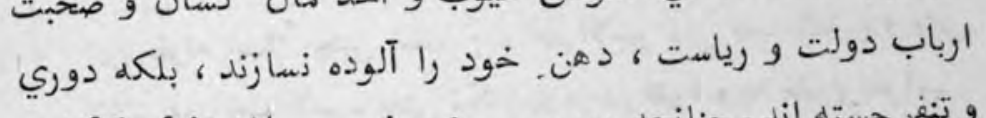

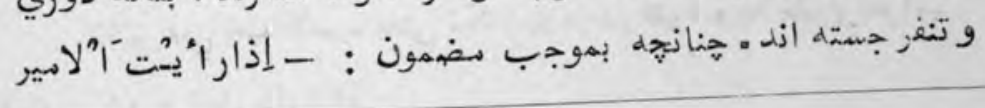
يعئي = آيا دانشمندان با نادانان برابر اند ؟

(1)

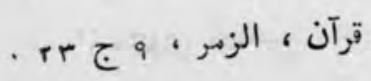


تاز هنواي معارك

INA

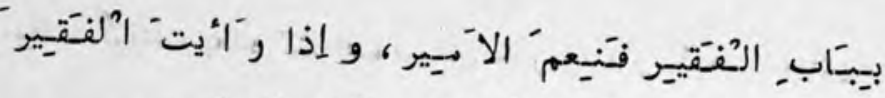

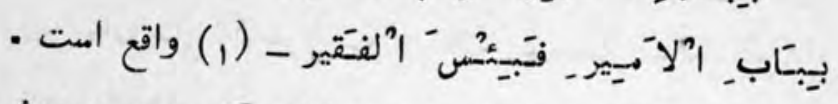

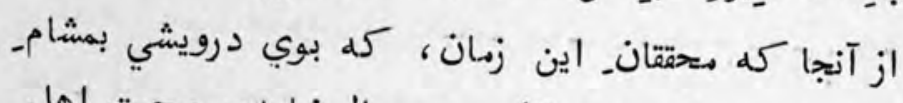

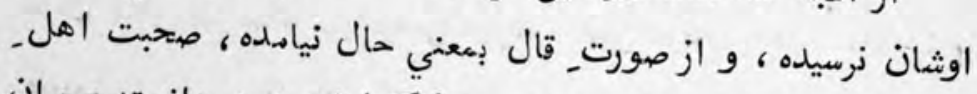

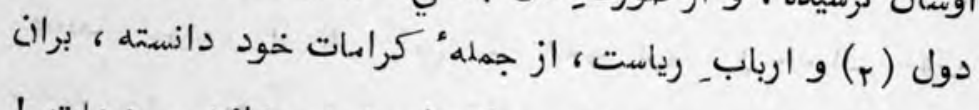

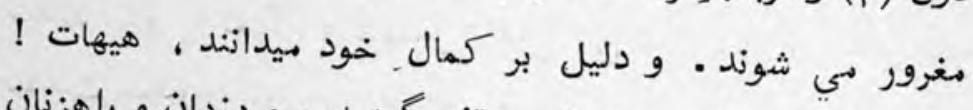

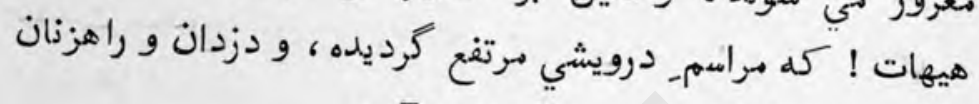

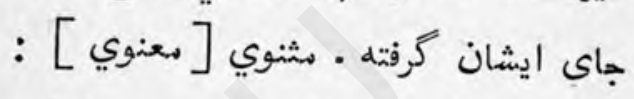

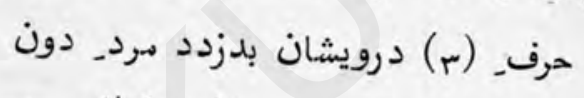

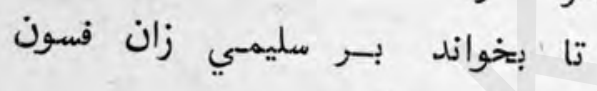

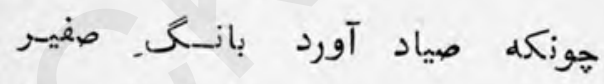

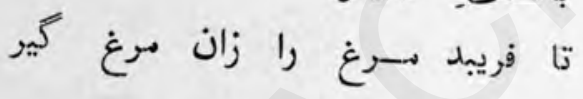

بشنود آن مرغ بانـع. جنس خويش

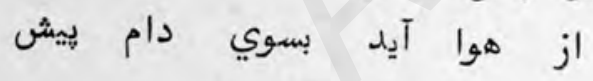

جشمبر ايشان را ضيائي هون نبود

نيك و بد دروخشمه شان نيود يكسان نمود

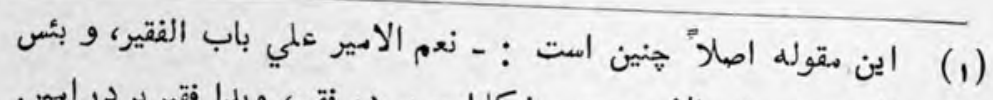

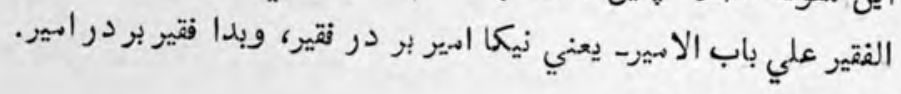

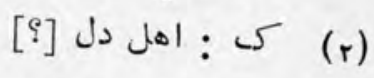

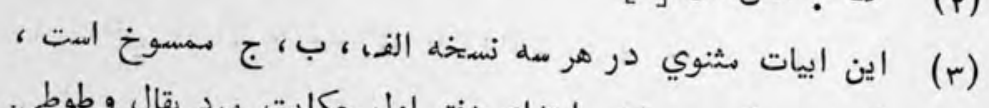

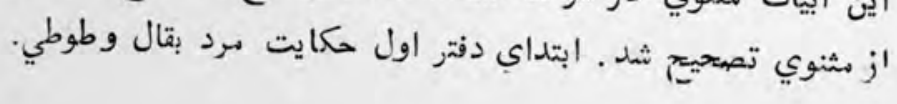


$7 \times 9$

تازه نواي معارك

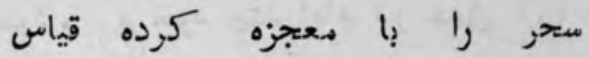
هر دو را يكرنگ يندارد امداس

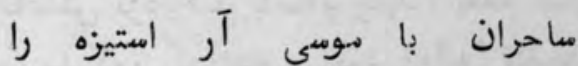
بر كرفته هون عصاي اون ونه

آنקֶ d بردم ميكند بوزينه هم

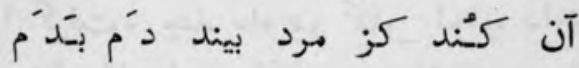

او كمان برده ك له دن كردم هو او فرق را كَي داند آن استيز رُو رُو

اين كند از آهر و آن بهر, متيز

بر سر- استيزه رويان لخاك ريز ريز

[ب]

هر كسى را نتوان كفت كله صاحب نظر است

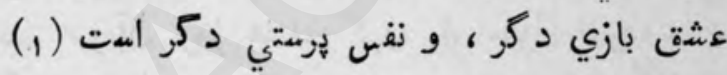

في الجمله ديوان جيُمل در ملك. كَهاي واقع مكان. جهل

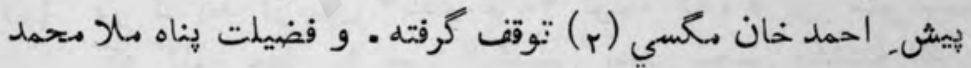

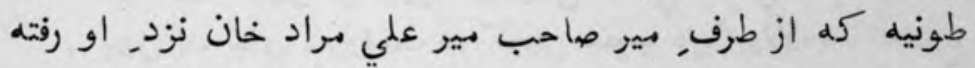

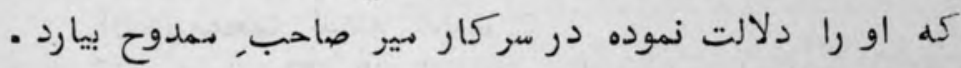

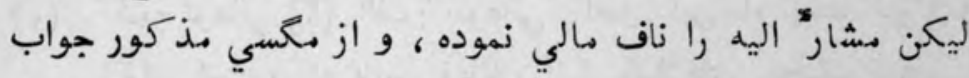

(1) الف : حق هيرستي [؟] )

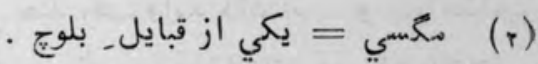




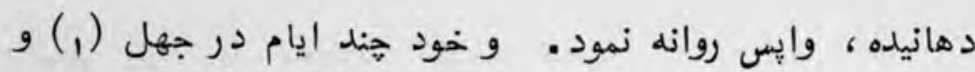

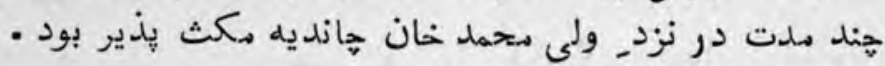

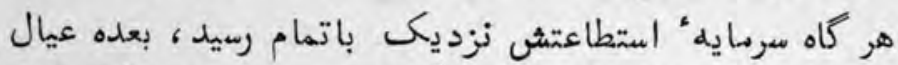

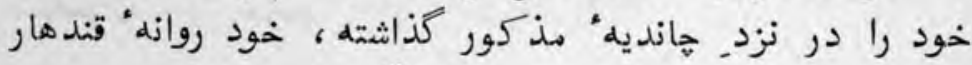

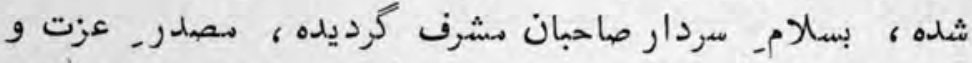

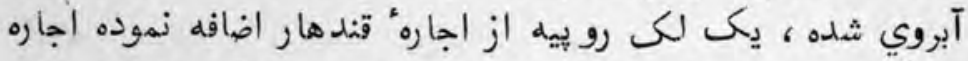

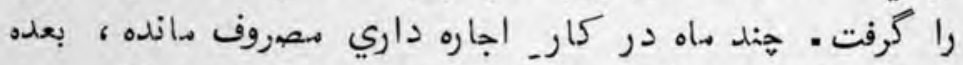

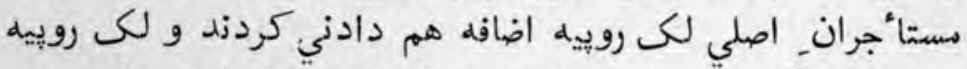

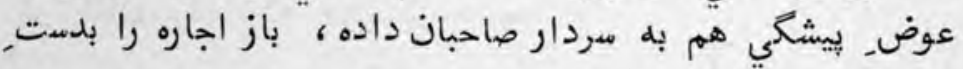
خود آورديند .

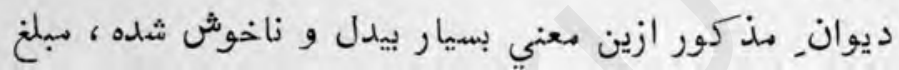

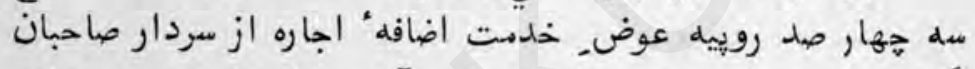

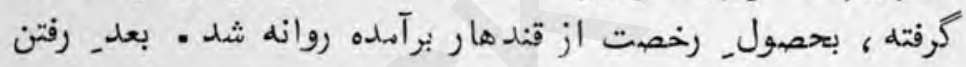

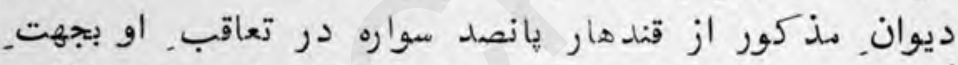

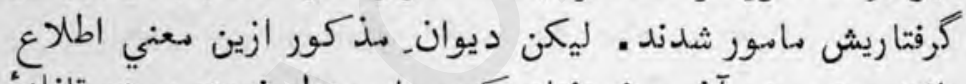

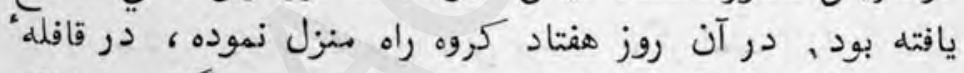

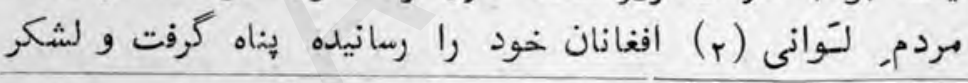

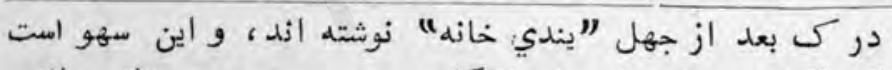
(1)

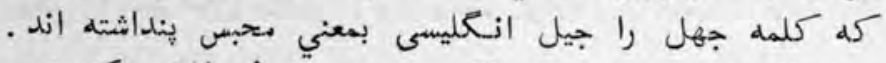

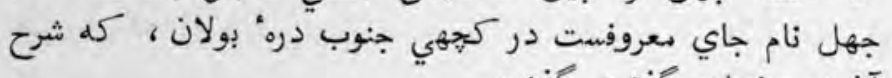

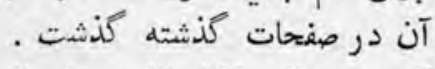

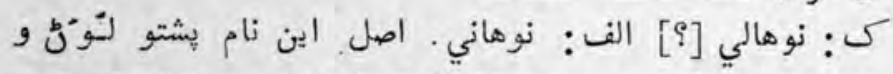

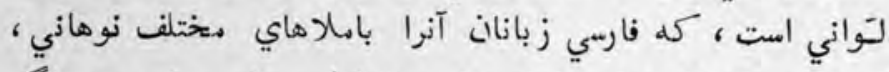

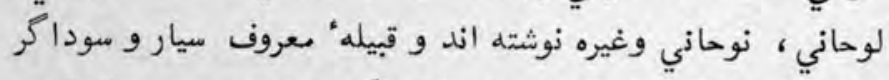

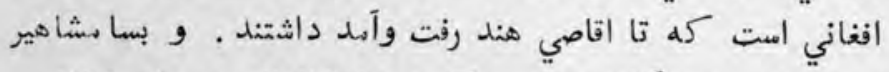

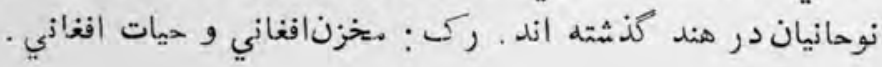




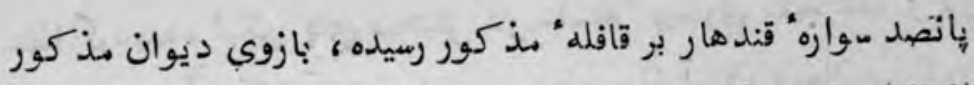

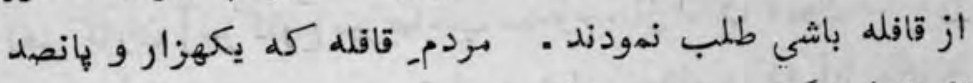

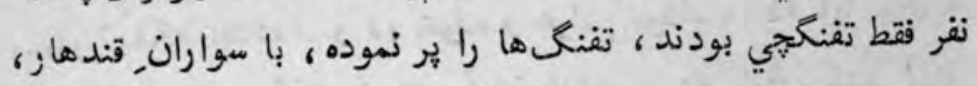

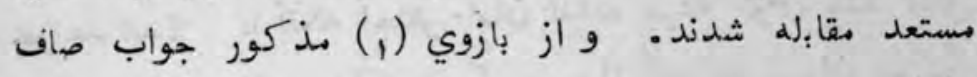
مادند

مواران قند هار طاقت مقا بمه زد يده وإيس روانه" قتندهار شدند.

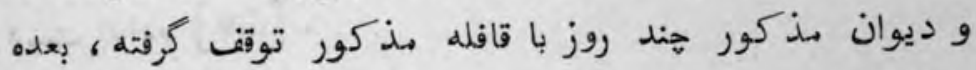

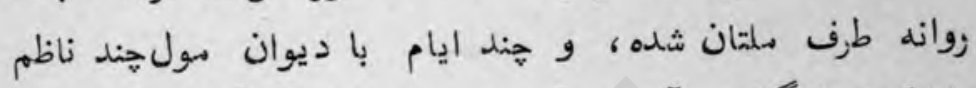

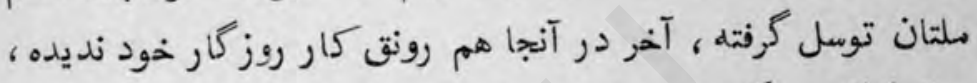

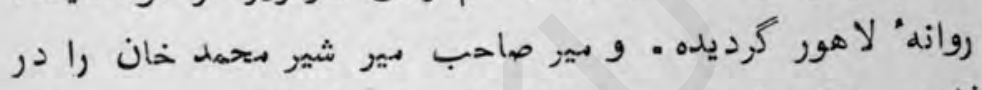

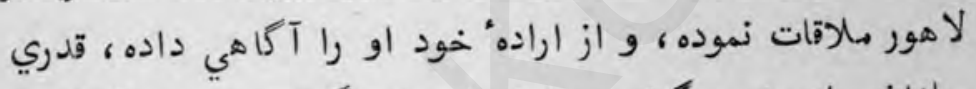

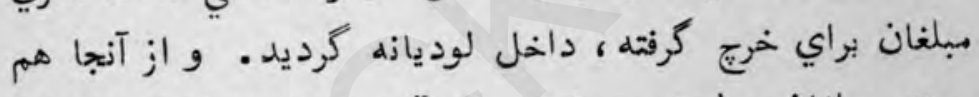

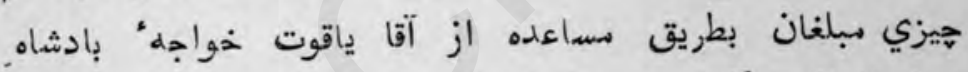

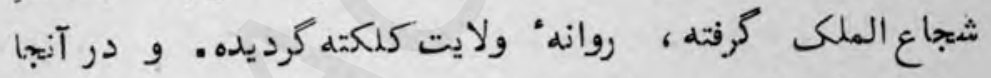

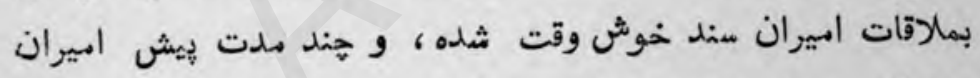

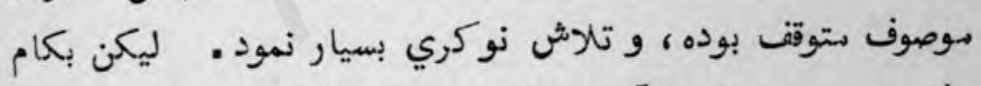

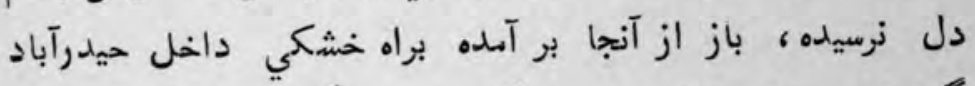

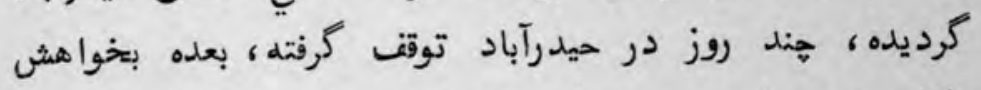

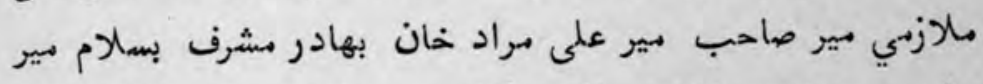

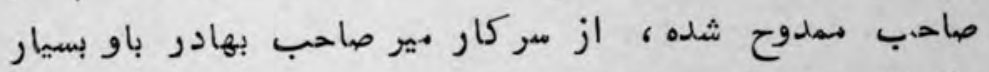

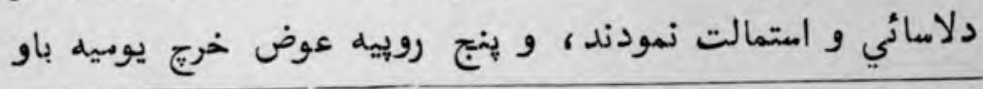

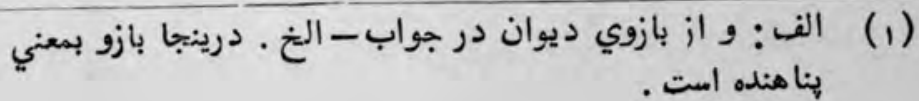




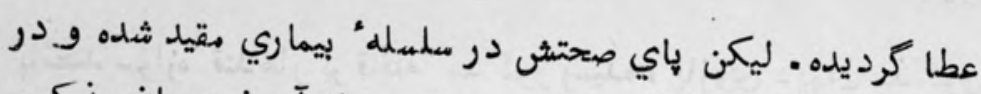

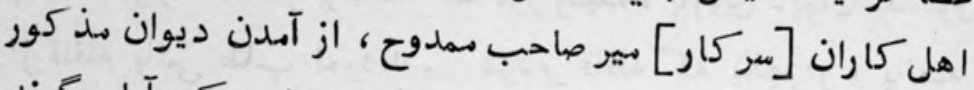

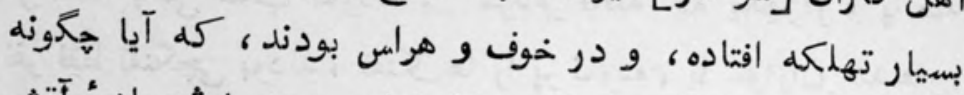

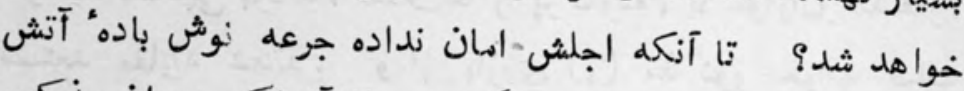

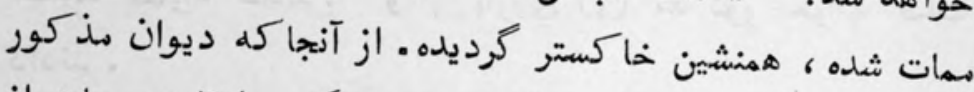

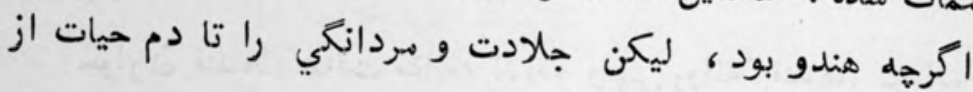

مست نداده [نقط] 
$-\wedge 9-$

در بيانِ جنش نمودن_ اميران حيدرآباد سنده با هاحبان انكريز [بهادر]

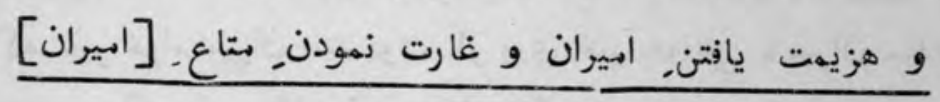
از قلعه" حيدرآباد وغيره وقوعات

غواصـ بحرـــخن وري، اعني قلمه جواهر رقم، لولوي مدعا

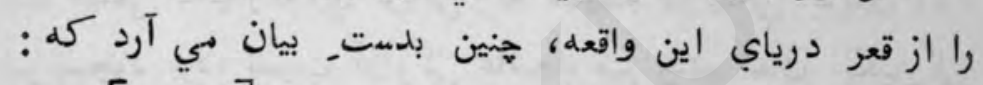

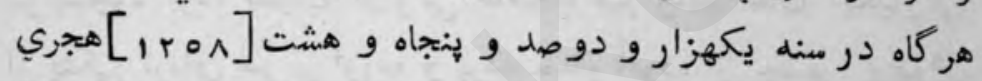

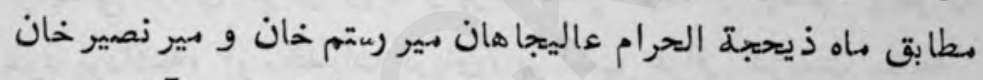

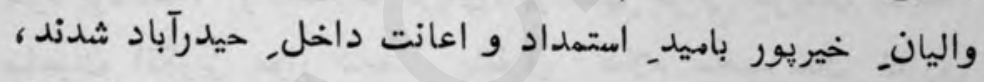

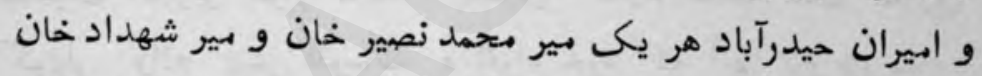

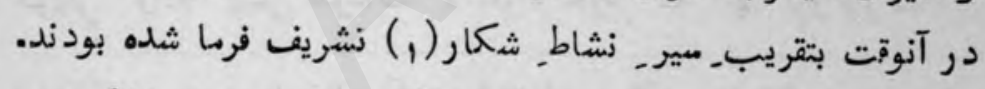

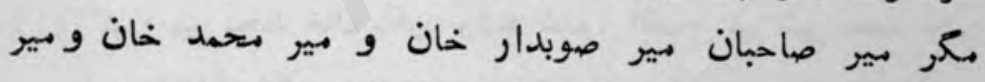

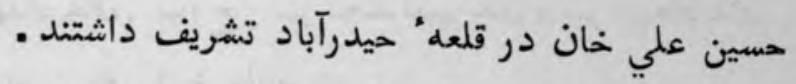

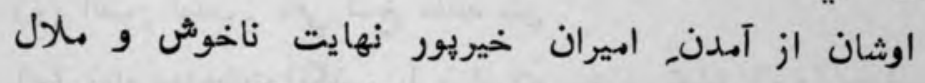
آكين (r) شدند، و هندان ملتفتـ احوال اميران خيريور نشدند.

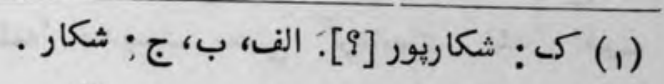

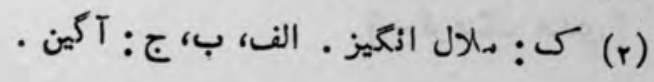


بعد از دو سهه روز، مير صاحبان مير متحمد خان و مير شهداد خان( (1)

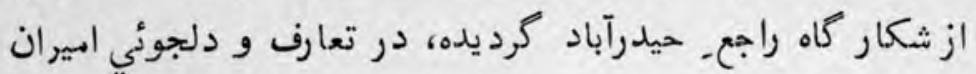

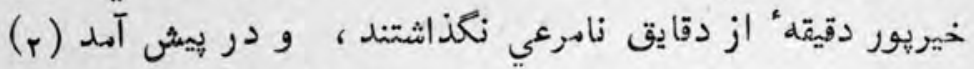

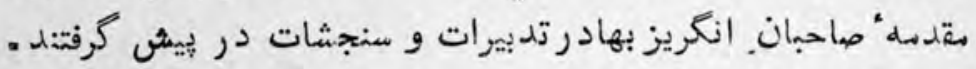
هر هند الديران حيدرآباد را خيال. مقابله و مجادله" صاحبان

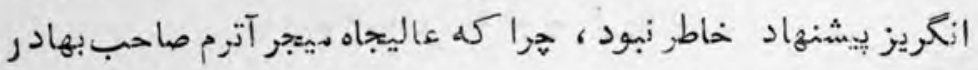

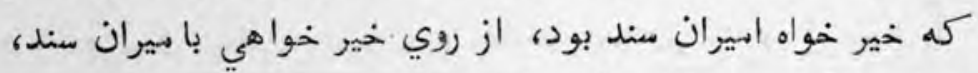

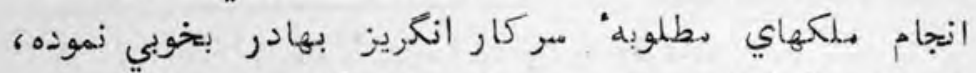

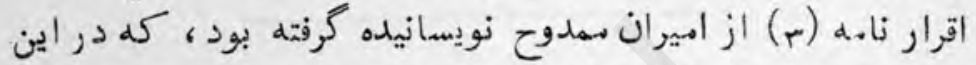

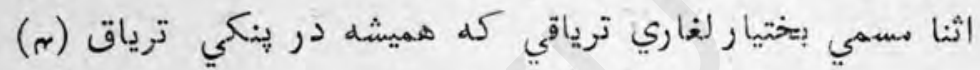

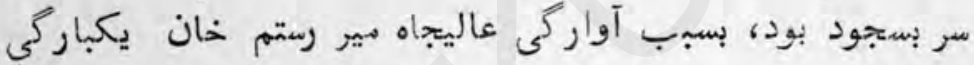

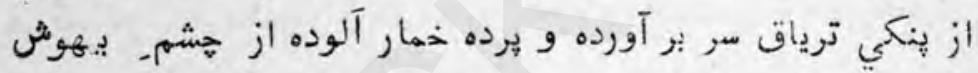

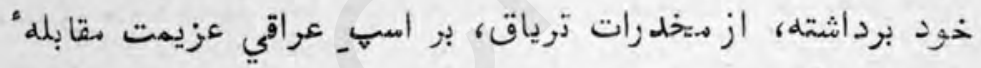

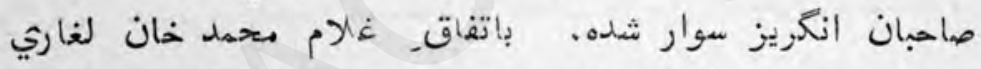
كويلي واله هِيش الوسات و اقوام خود كله آنها ازو در مقامـ

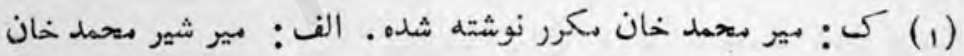

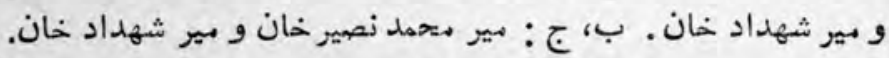

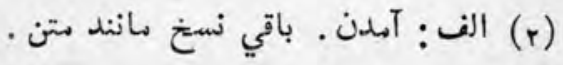
(r) تمام دعاهدات ازخليس را با امراي سند در تعليق [حهـ] بخوانيد.

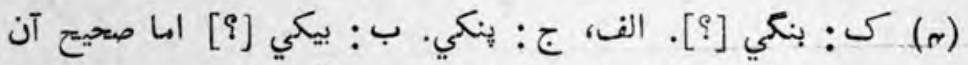

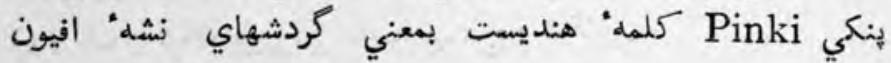

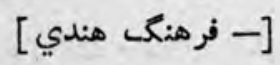


$T \Delta \Delta$

تازه نواي معار ك

بي دماغي بودند رفته، آنها را آشتي داده ، از خود ماختند . بعده بيش مير جان ديحمد خان ولد برحوم بير بوده جان رفتشن،

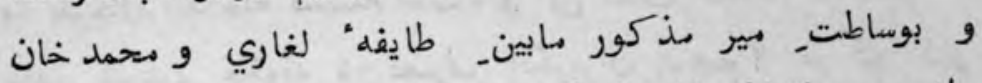

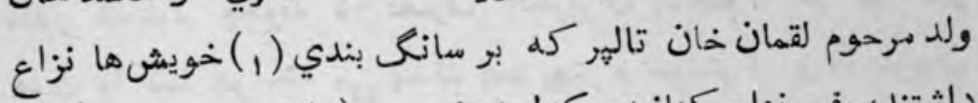

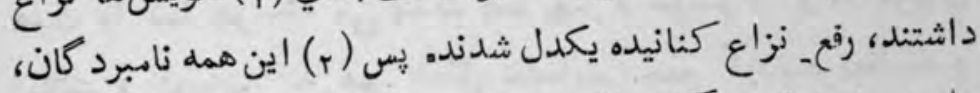

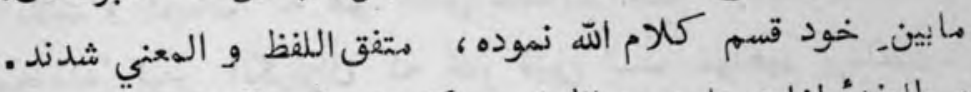

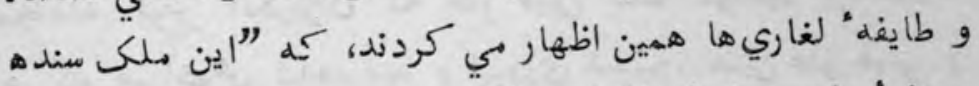

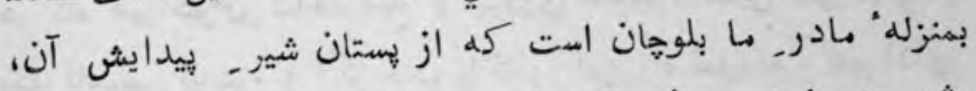

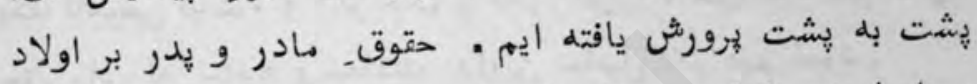

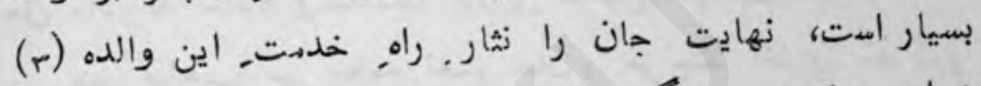

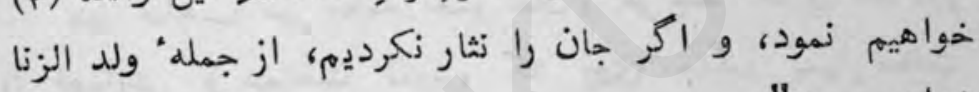

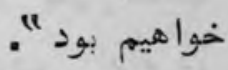

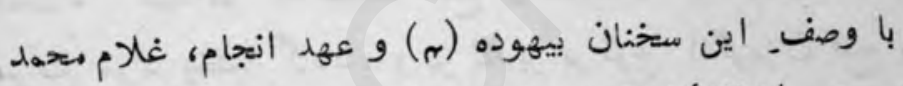

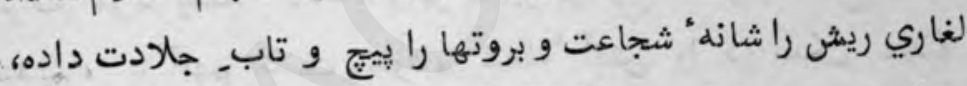

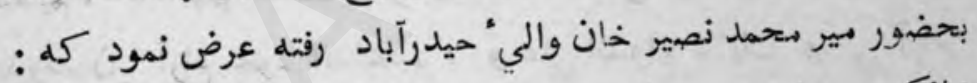

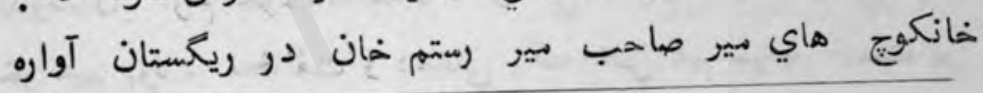

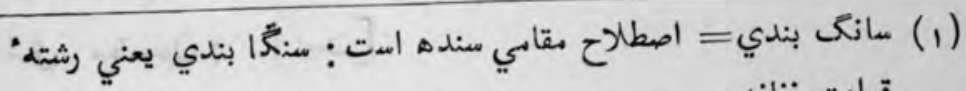

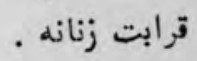

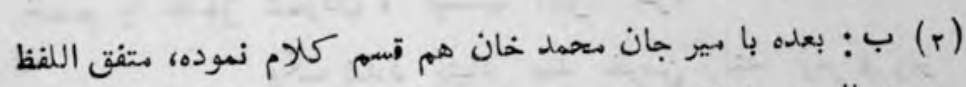

و المعني شدند . بعاده باله

· (r) كى ج : والدين

. 
تازه نواى مار

707

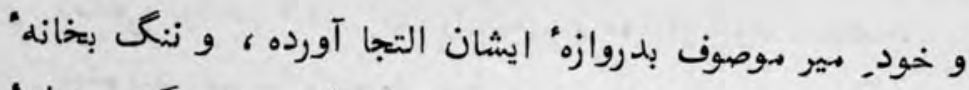

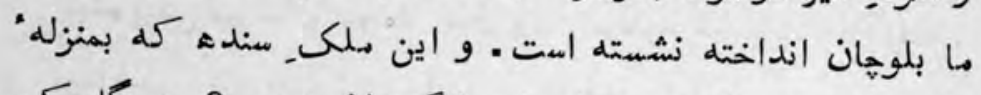

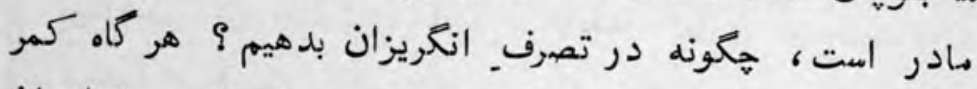

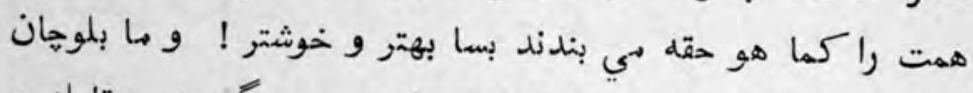

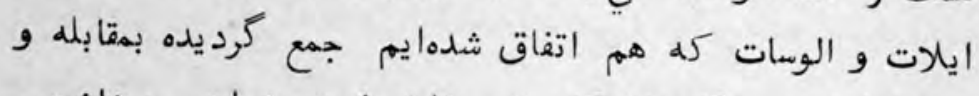

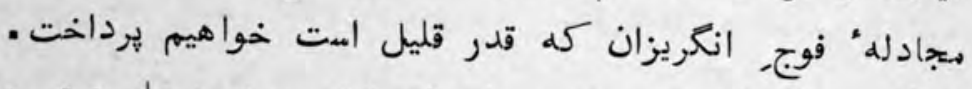

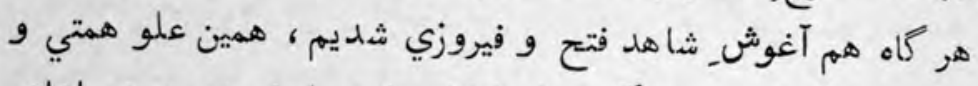

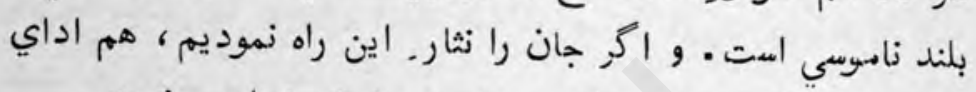

حق مادرانd" سنده و مهعادت_ دارين حاصل خواهيم نمود .

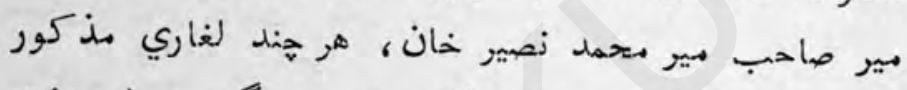

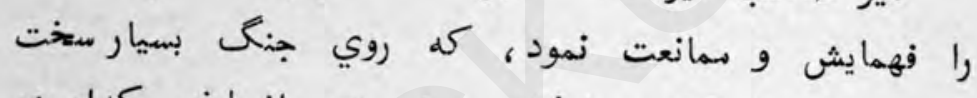

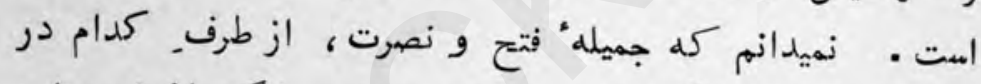

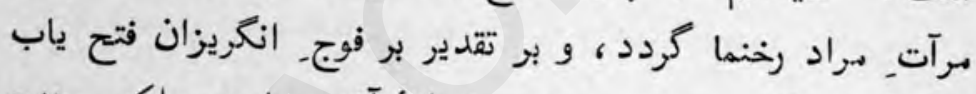

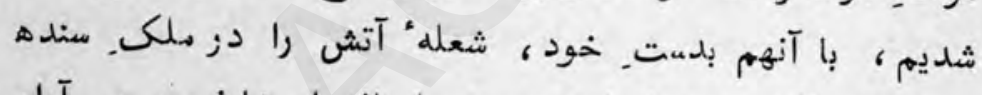

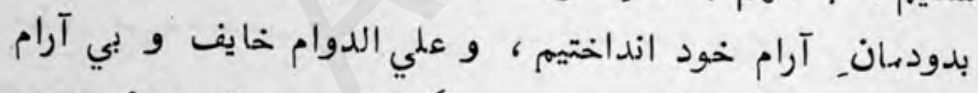

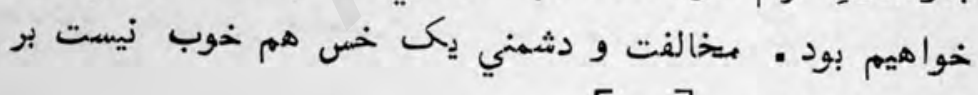

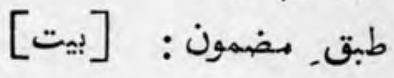
خصم را عاجز شهردن ، نيست آئين. خرد

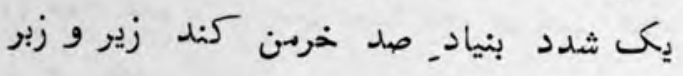

هر دشهني كاه هست قوي بايدش شمرد

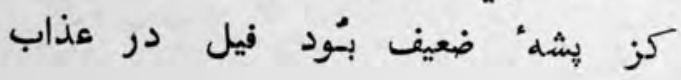




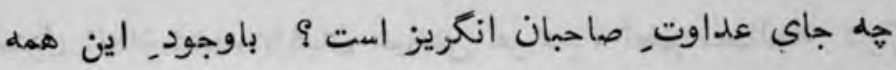

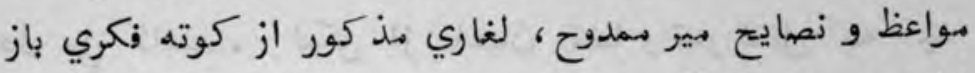

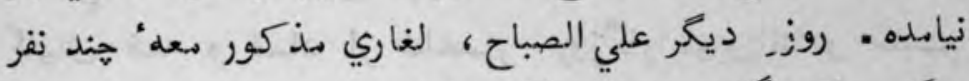

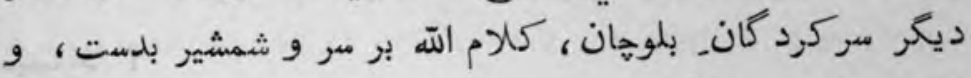

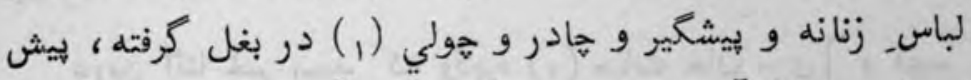

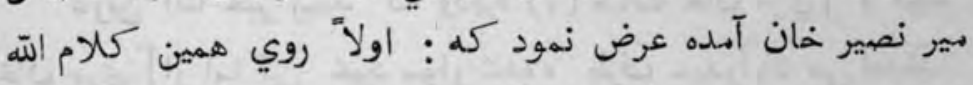

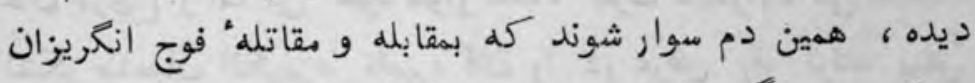

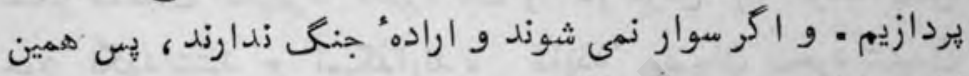

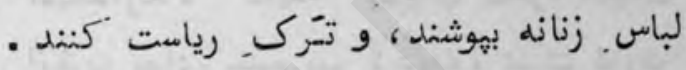

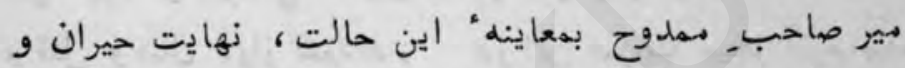

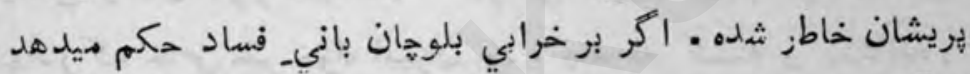

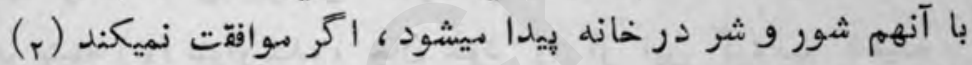

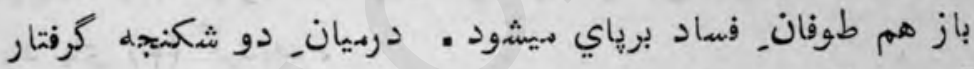

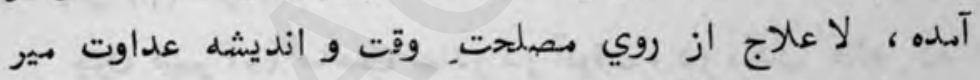

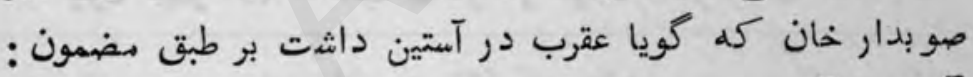
[dعرen

\section{اقرب هيو عقربست زند نيش خويش را}

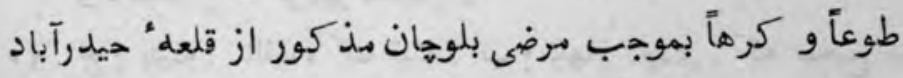

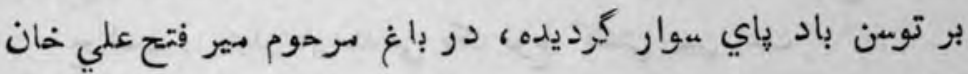

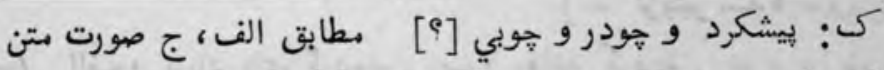

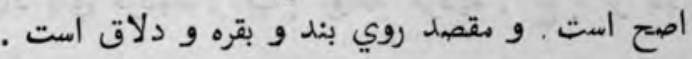

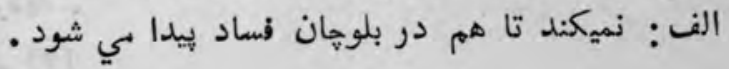




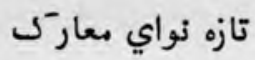

$7 \Delta \Lambda$

منزل انداز شده . باغبان خيالش هر دم ، تخم مصالحه درزمين

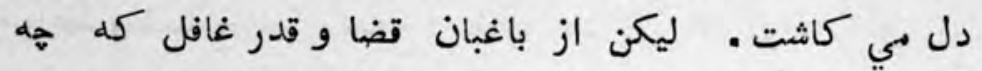
كلهاى فتنه و فساد از شاخسار روز روار ميرويناند و متبسم ؟ ميساز

درين اثنا خبر رسيد كله وذُيره (1) حيات خان مرثي [ و فهيم

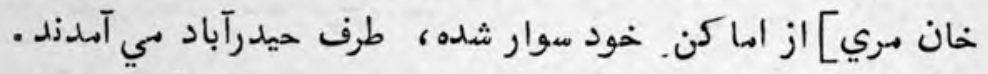

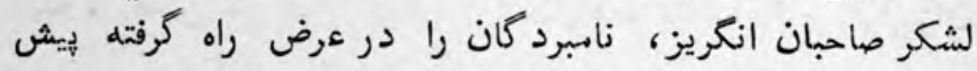
خود نكهداشتند و نميمذارند . طأيفه" بلوحان بمجرد شنيدن

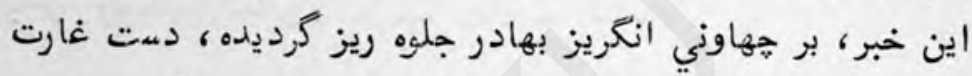

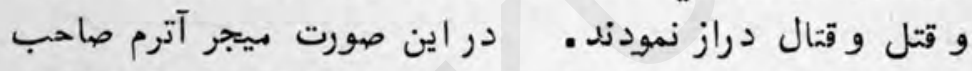

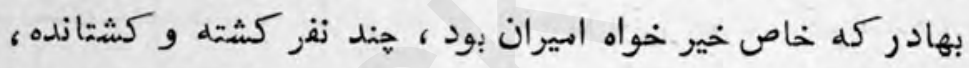

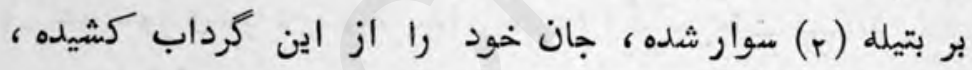

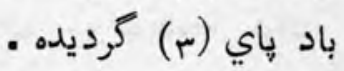

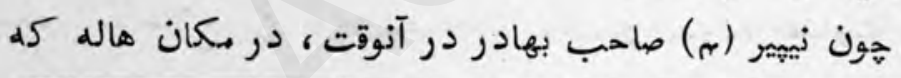
(1) الف: ديره جات خان مري [؟] كه مطابق ب، ج، كى: مانثد

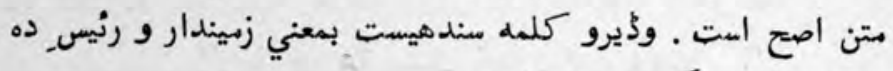
و دهخدا [- كزيتير سندها]

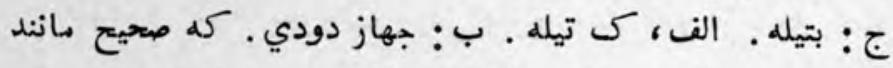
(r)

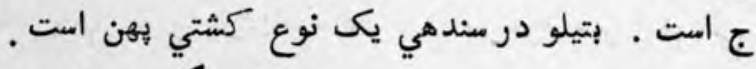

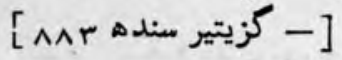

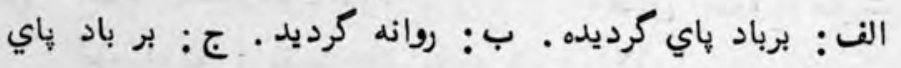

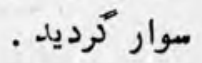
ك : بنر

(r) 
7०

تازه نواي مار

بيست كروه از حيدرآباد فاصله دارد . منزل ازداز بود، هر كاه

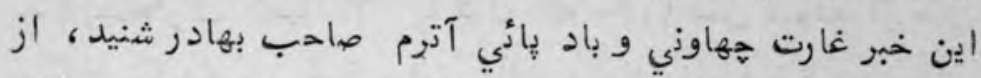

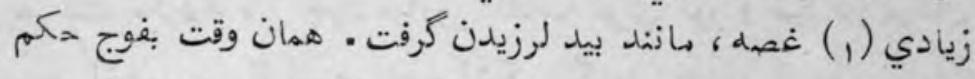

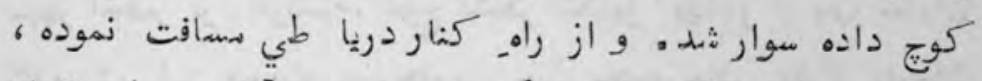

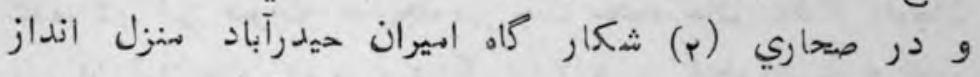

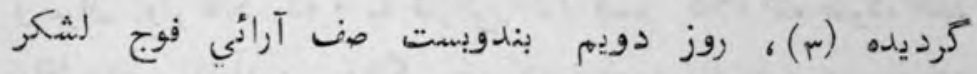

- خود أمود

در اين صورت مير صاحبان حيدرآباد هر يـى بير دحمد نصير

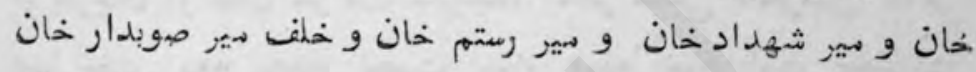

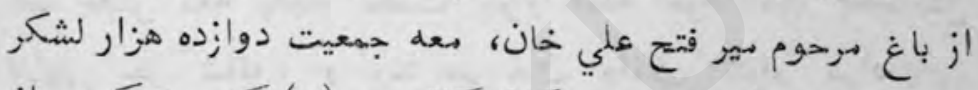

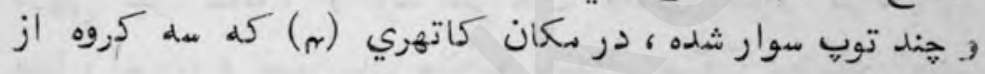

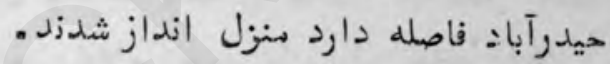
درين اثنا دوست متحمد خدمتشار براي اميران موصوف خبر

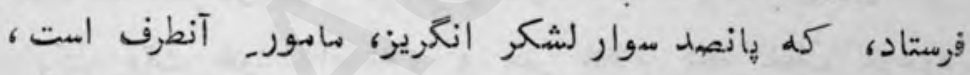

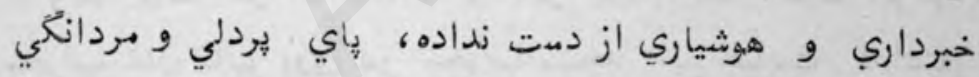

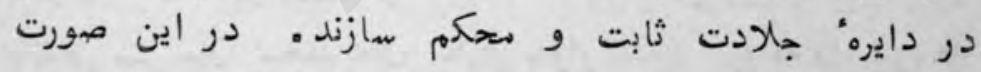
امير صاحبان بمدوح به لشكر خود حكم دادند كله : سوار شده

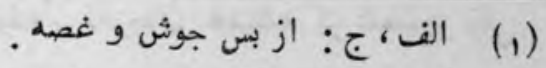

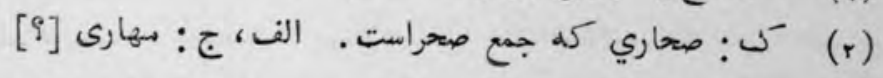

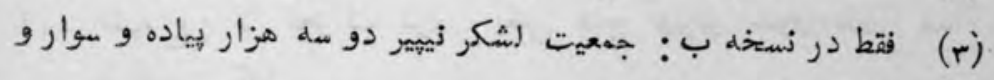

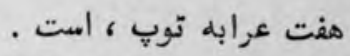

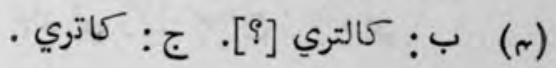




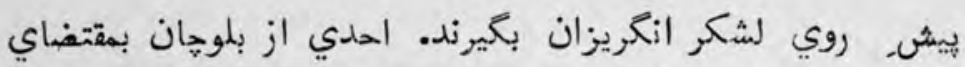

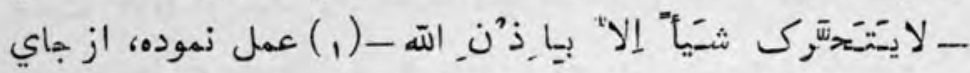

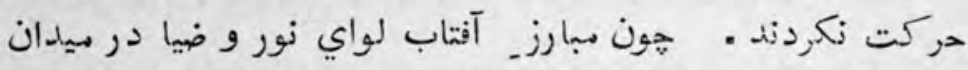

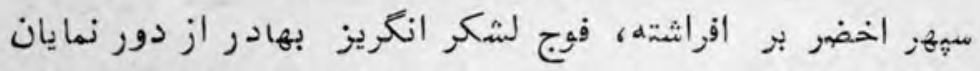

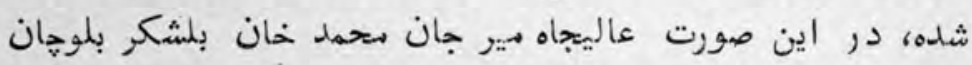

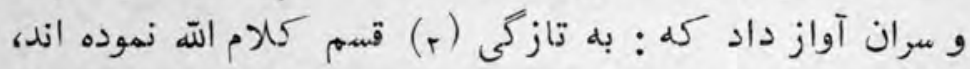

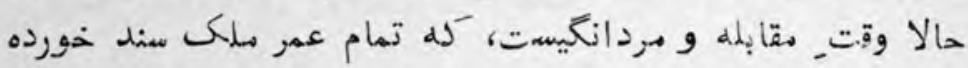

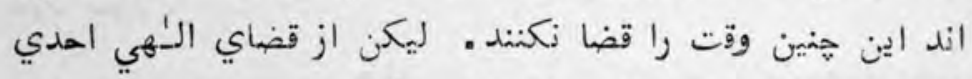

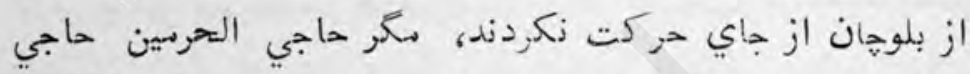

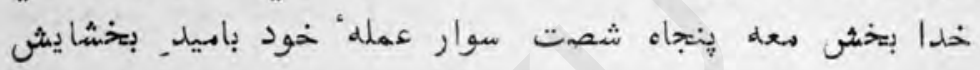

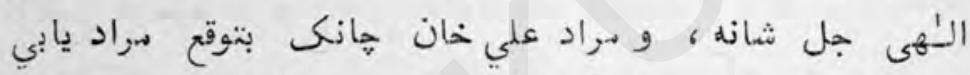

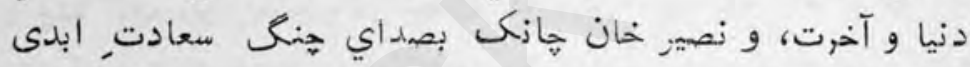

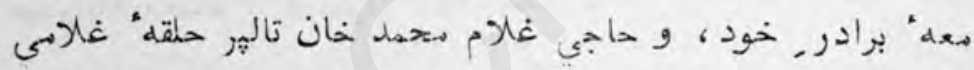

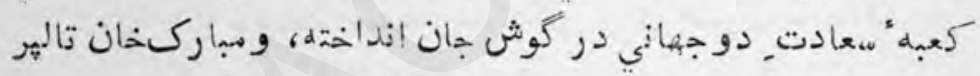

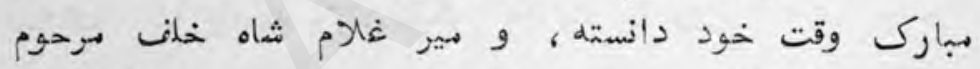

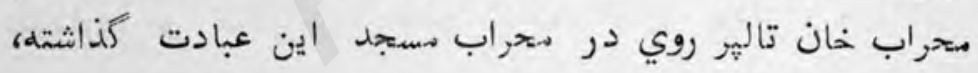

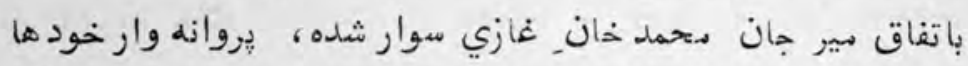

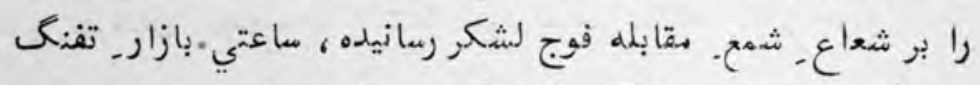

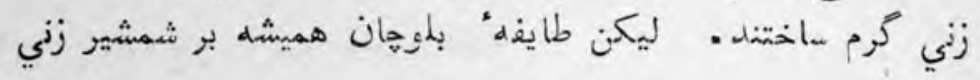

(1) الف، ج: لا تحرك ذرة . يعني هيج هيزي بدون انذن خدا

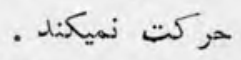

$$
\text { كى: بتاريكي [؟؟]. الف: تباركي [؟؟]. ب، ج : بتازكي . }
$$




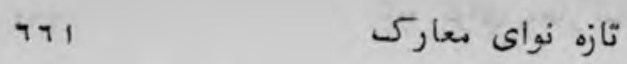

•ي نازنذ، از روي مهيت ايماني و غيرت هسلماني از يناه كاه

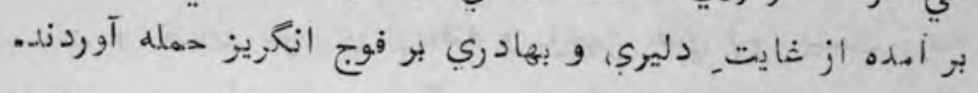

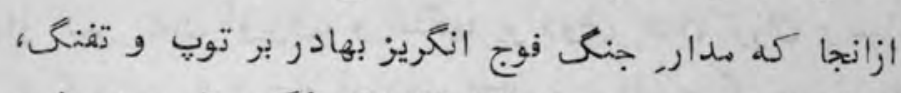

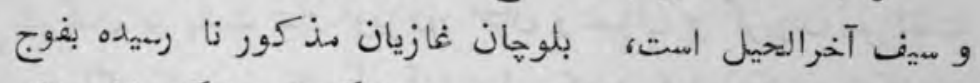

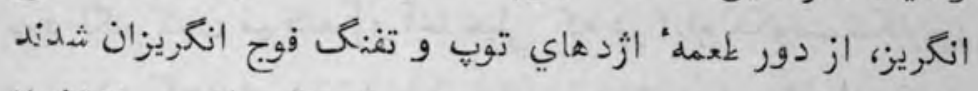

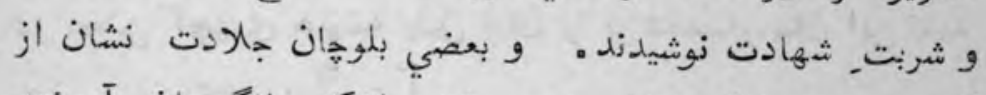

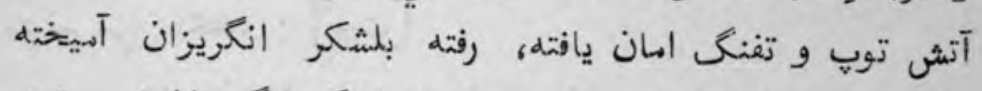

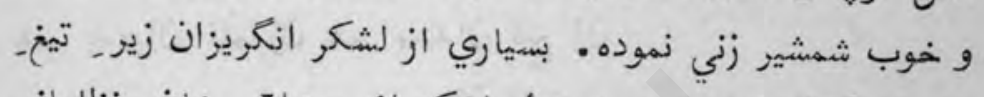

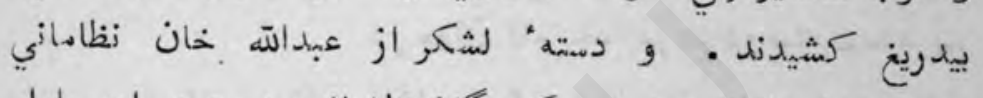

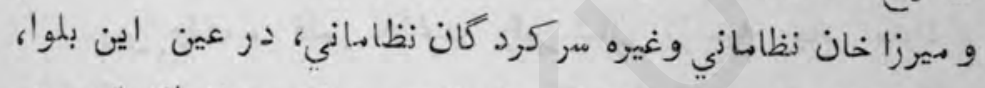

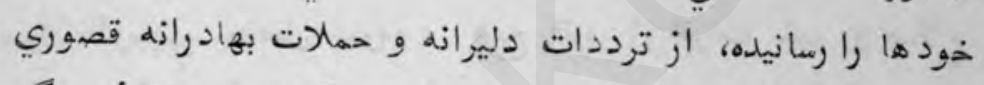

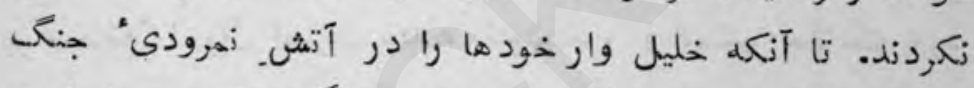

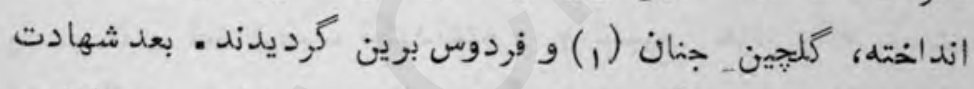

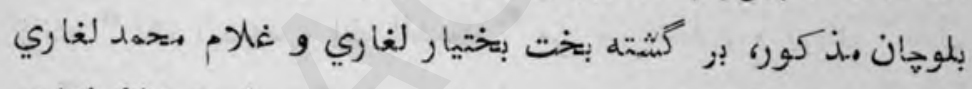

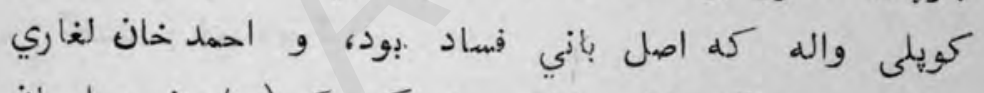

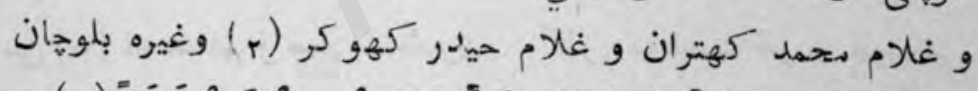

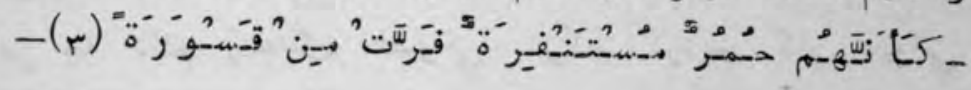

(1)

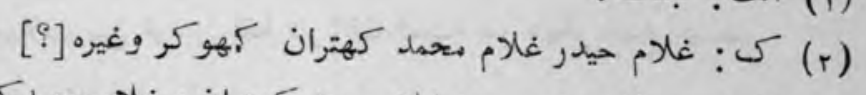

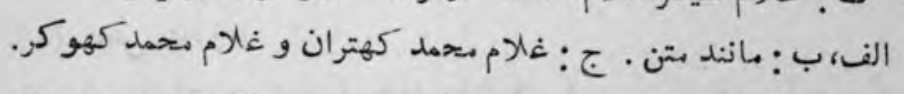

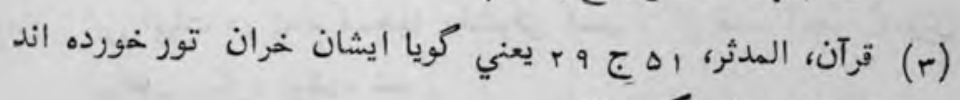

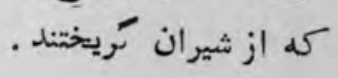


تازه نواي مسماركى

Tar

فرار برقرار اختيار نهودند ـ [ و در حين (1) كريختن ازار بنديَ شان

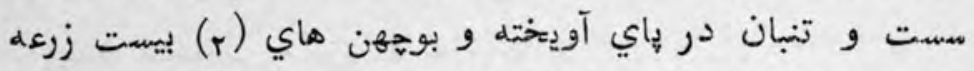

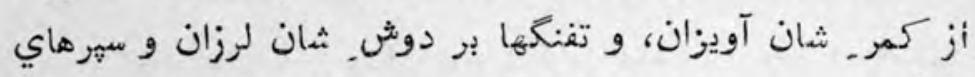

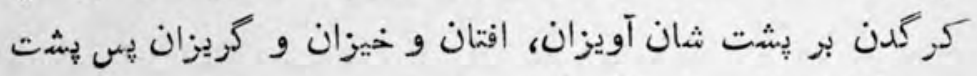

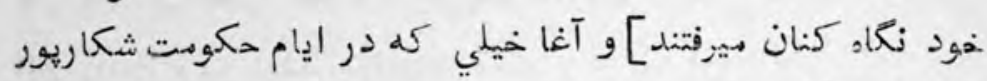

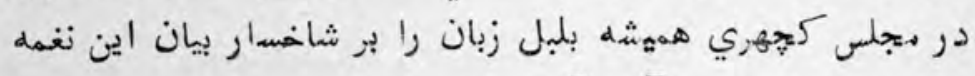

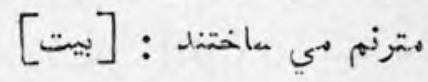

هم+ بديوان قلم زن هم بميدان تيغ زن

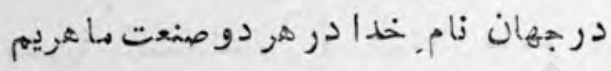

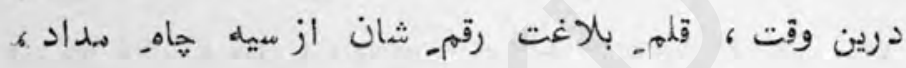

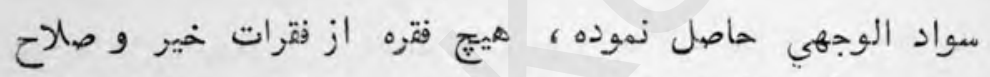

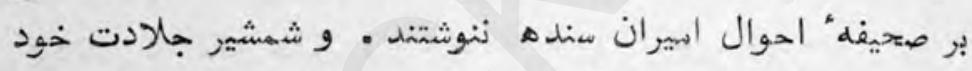

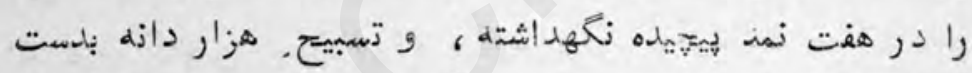

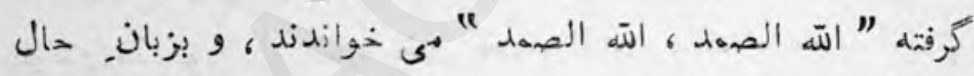

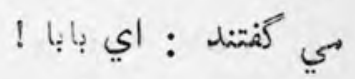

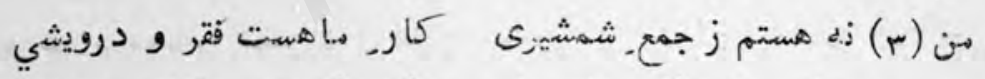

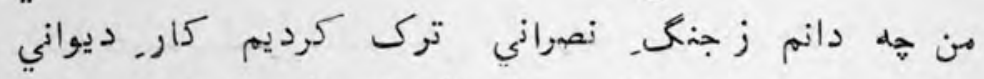

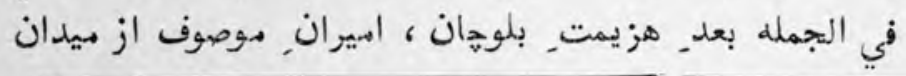

(1) جمالات بين قوسين فقط در الف است، در ديكر زستخ نيست.

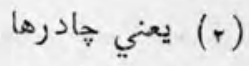

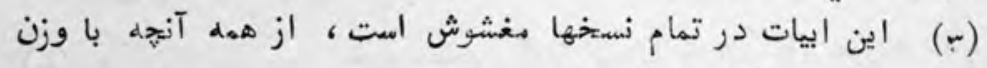

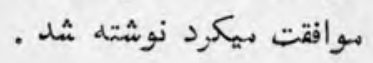




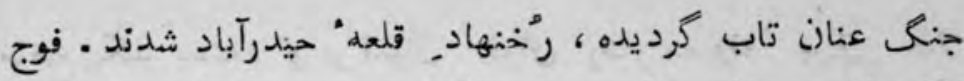

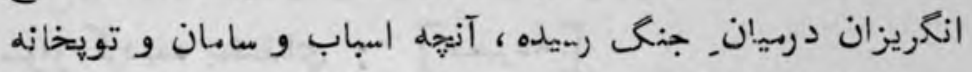

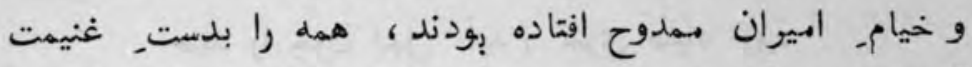

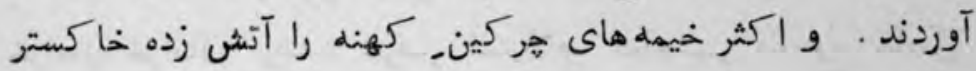
نمودند الورد

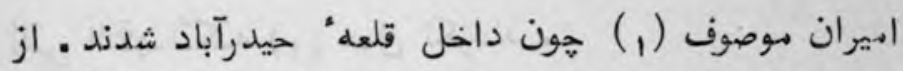

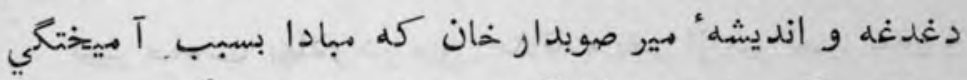

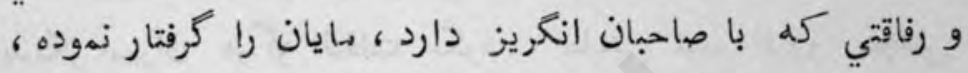

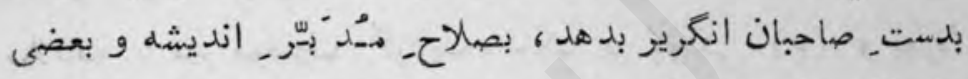

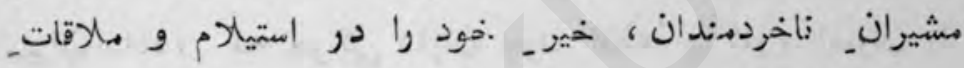

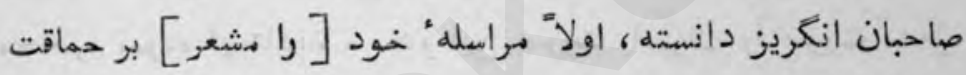

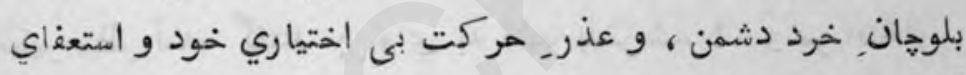

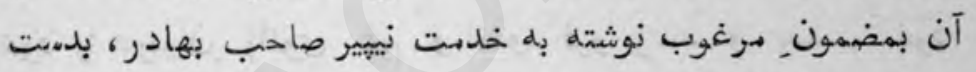

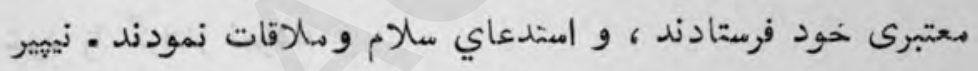

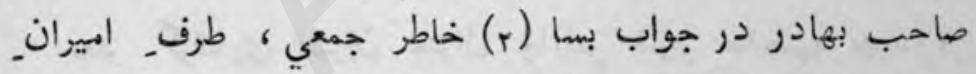

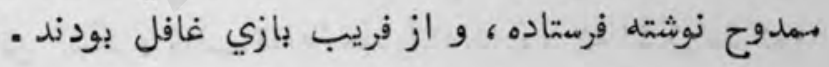

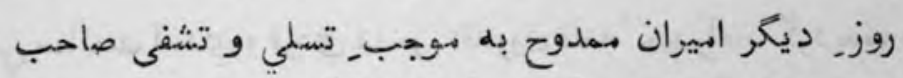

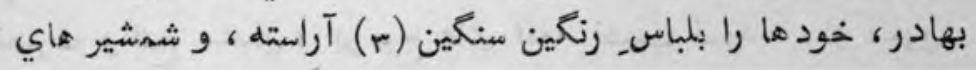

ب : موصوف هر يكى بير محمد نصير خان و بير شهداد خان و مير حسين علي خان.

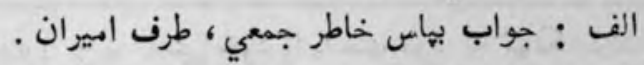

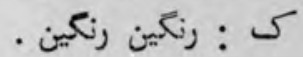


تازه :ثاي معار

Trल

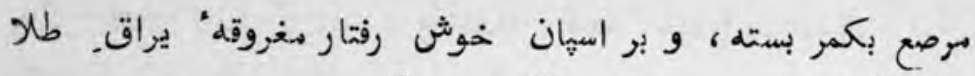

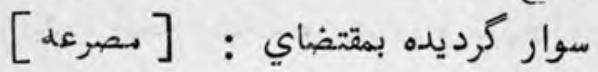

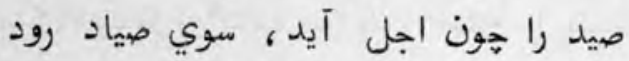

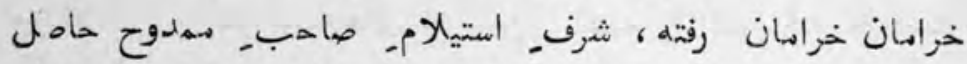

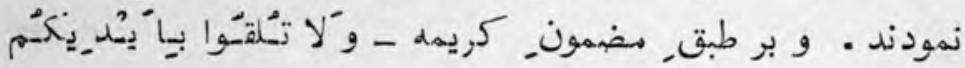

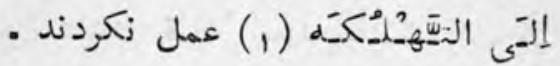

نيهير صاحب بهادر در حين. ماقات بغير از مير نصير خان ،

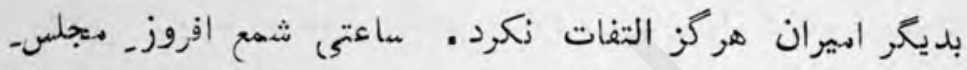

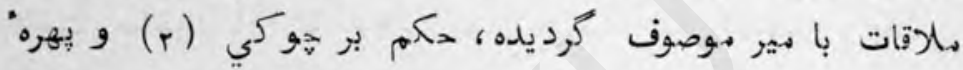

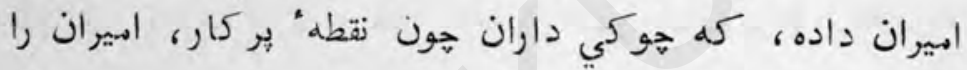

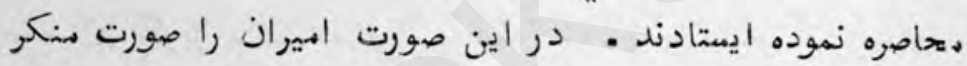

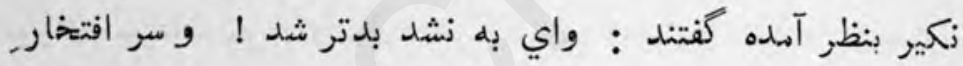

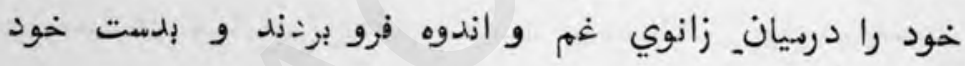

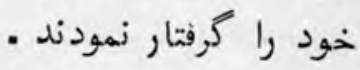

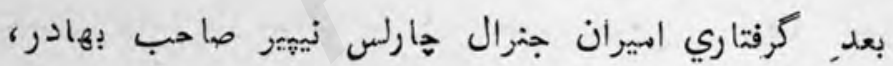

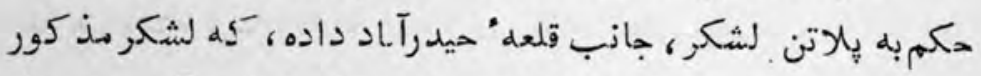

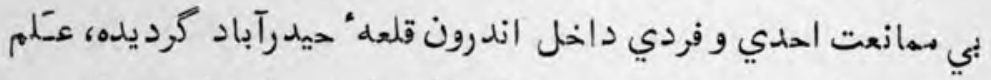

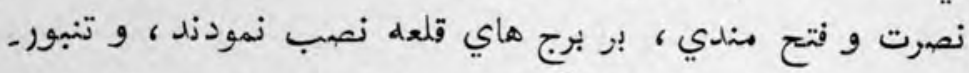

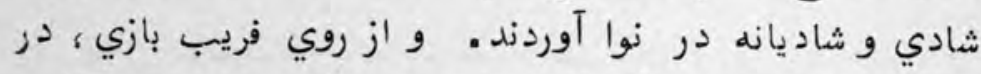

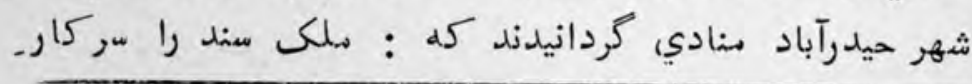

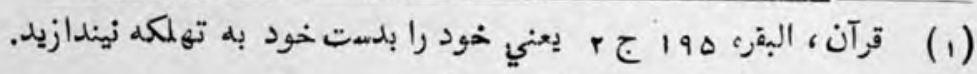

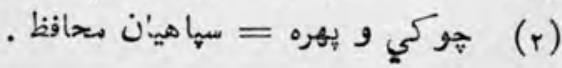


97

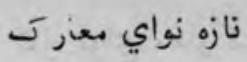

انحليسه بهادر فتح نموده، و زماام رياست و سرداري از مركار، تفويضـ بعاليجاه ميير صوبدار خان شده و دستار, سرداري تمام بلوهان سند تعلق بعاليجاه مير موصوف دارد • بر خزاين و دوفاين

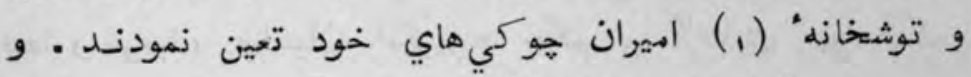

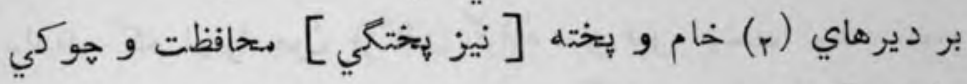

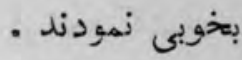

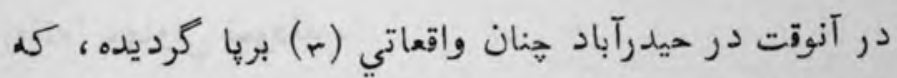

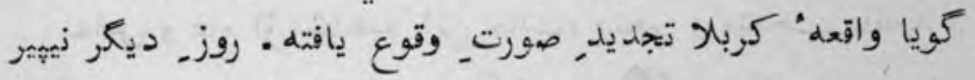

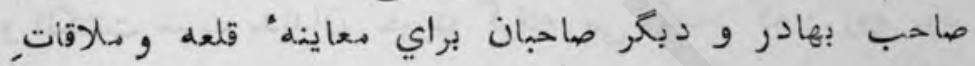

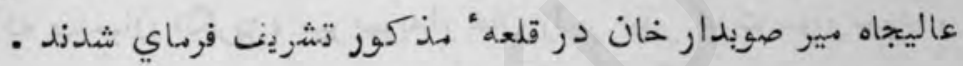
ثاليجاه مير مهدوح كالم بعهد انجام صاحبان بأبت رياست و دستار سرداري سرخوش باده" نشاط بود ، دربار كجهري خود

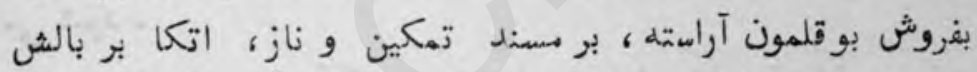

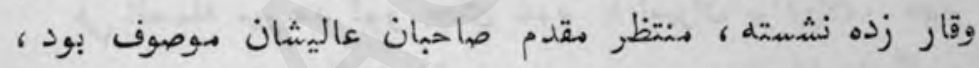

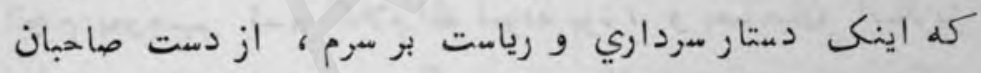

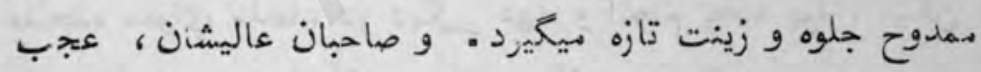

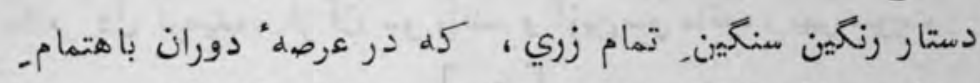

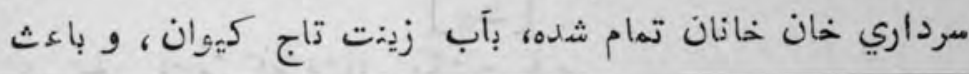

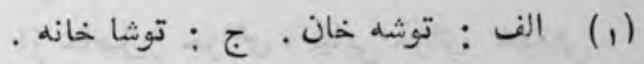

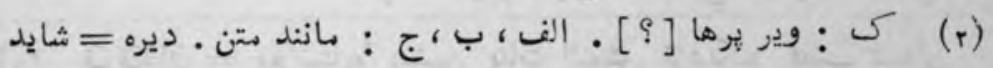
مقصد ازان زنان حرم بيران باشد. . الف (r) 
سرفرازي فرقـ فرقدان (1) بود ، بمير موصوف بستانيدند • هنانجه

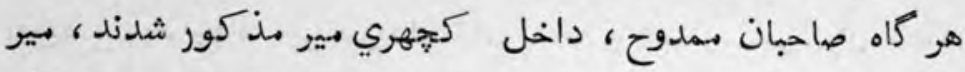

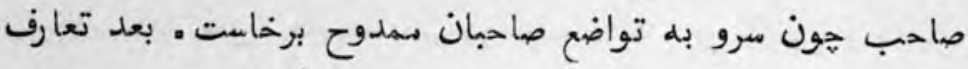

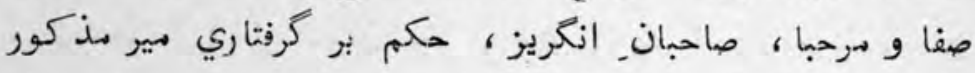

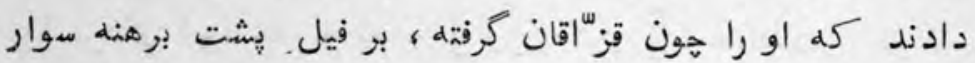

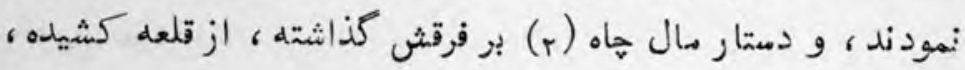

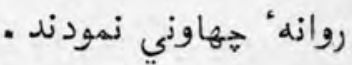

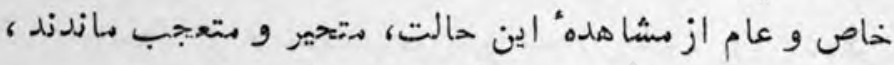

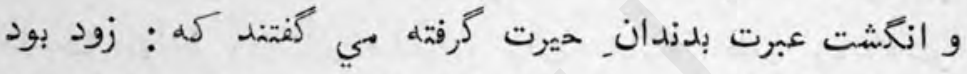

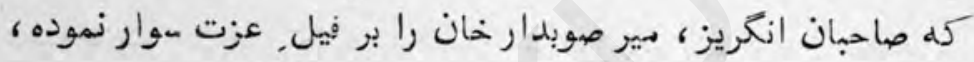

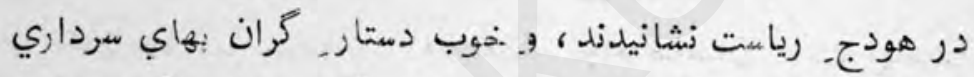

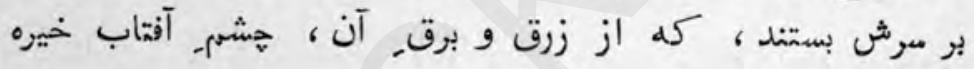

- مي شود مترك

في الجمله دير مذكور بجاي خود با اديران برادران، عهد بهد

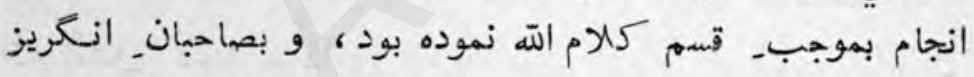

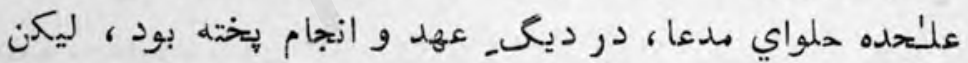

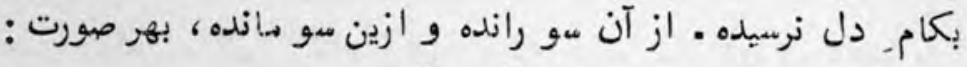

$$
\text { [بيت] }
$$

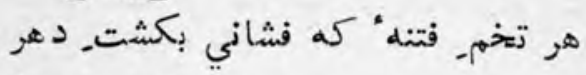

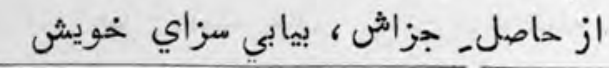

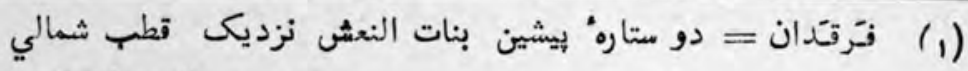

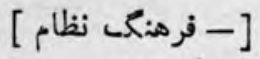

كذا در الف، ج، كى كله معني آن فهميده نشد. 


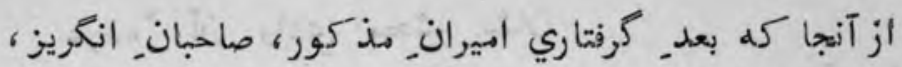

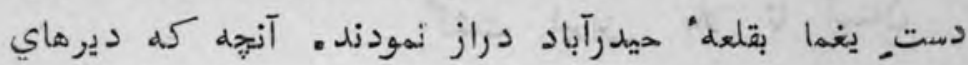

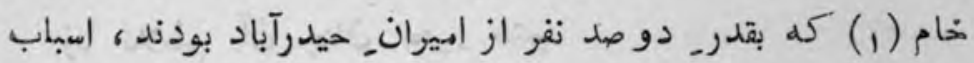

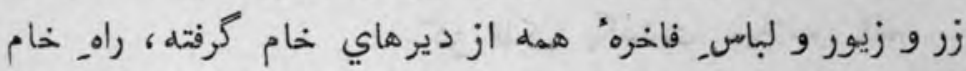

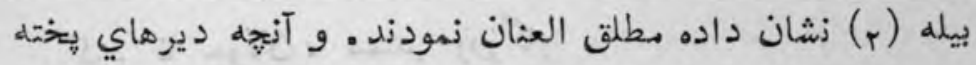

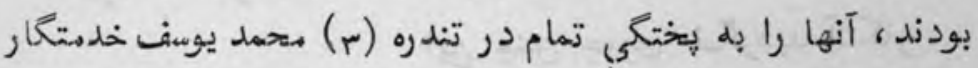

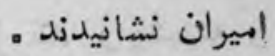

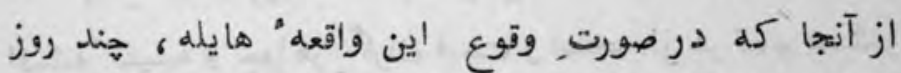

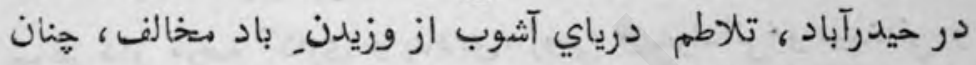

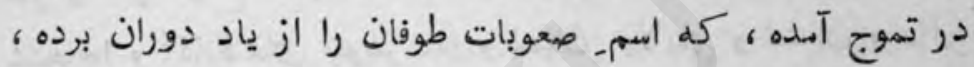

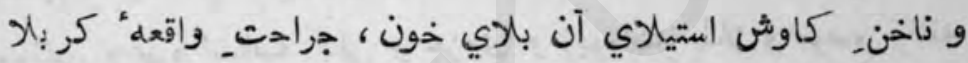

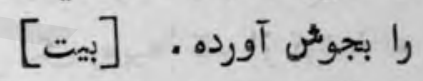

آن خنان شوري بلند آوازه شدره

كز ظهورش خون_ طوفان تازه شد

شايد مقصد ازان سراري و زنان حرم ميران باشد. .

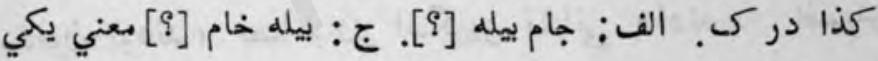

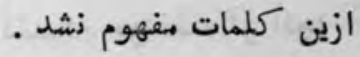

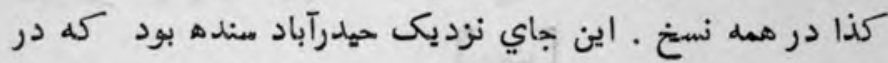

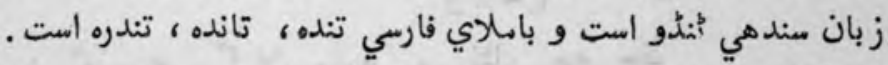

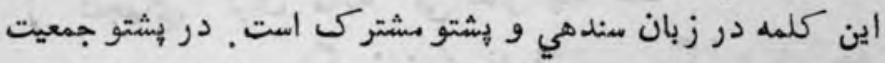

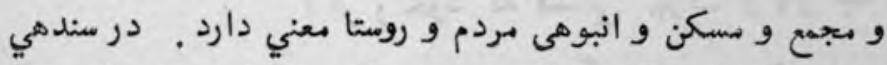

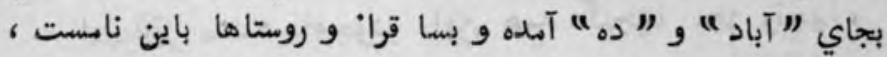

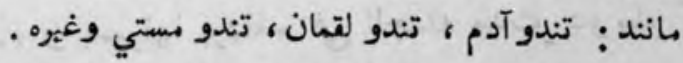




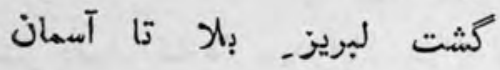

$$
\text { عرصهُ آن وادي منشر نشان }
$$

زد تلاطم آن حنان بحر- ستم

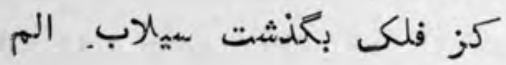

$$
\text { كرد تا جولان، سمندـ روز }
$$

اين هنين جوري نمخرديد آشكار

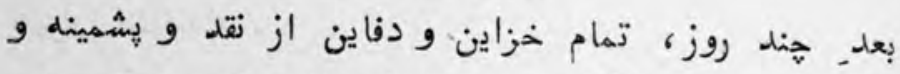

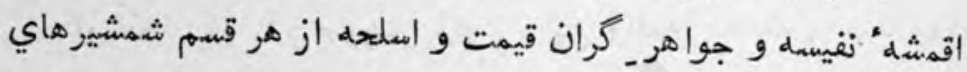

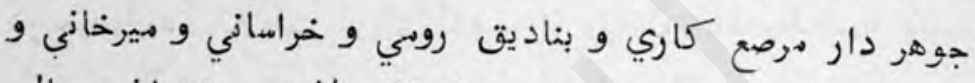

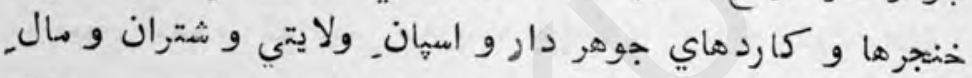

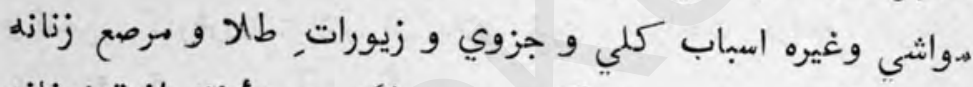

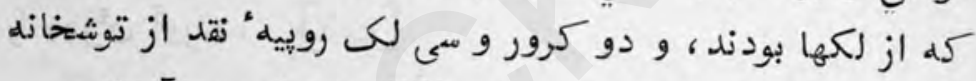

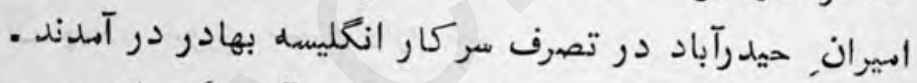

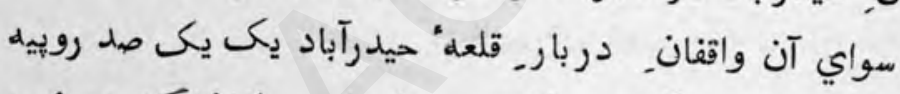

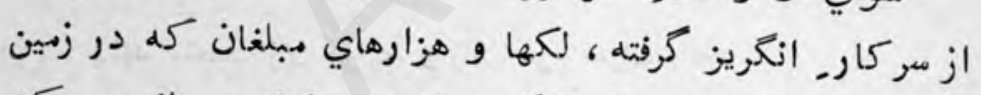

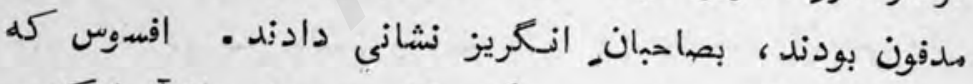

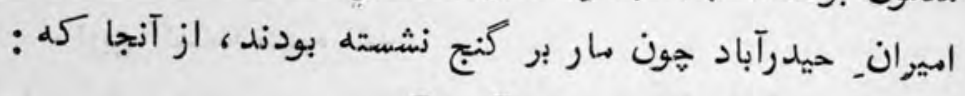

$$
\text { [بيت] }
$$

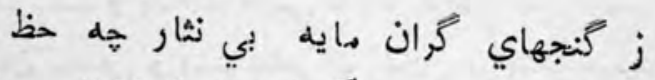

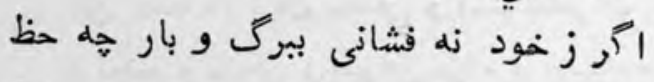

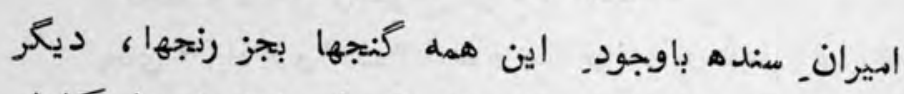

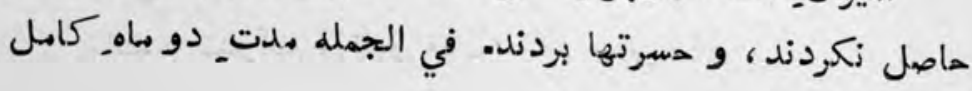


979

ثازه نواي معارك

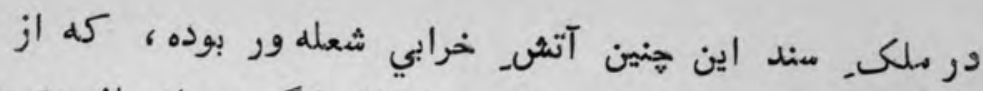

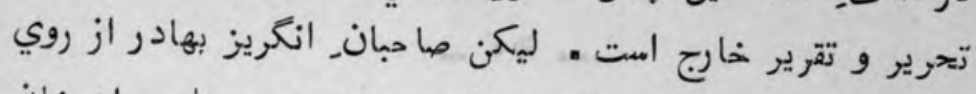

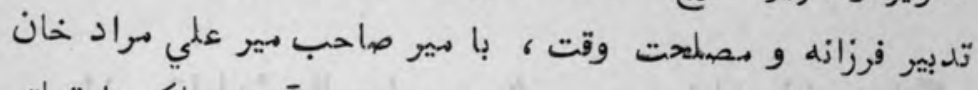

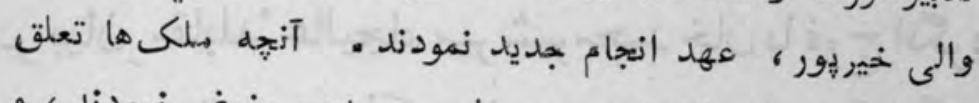

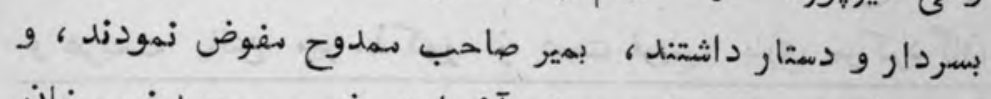
آنهجه ملمكهاي والي قلات بودند، آن را بتصرف ـ مير بحمد نصيرخان

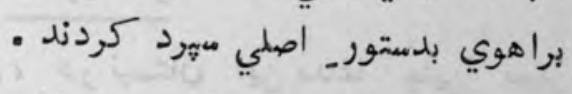

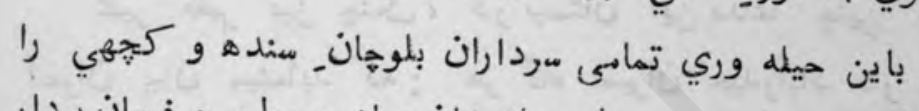

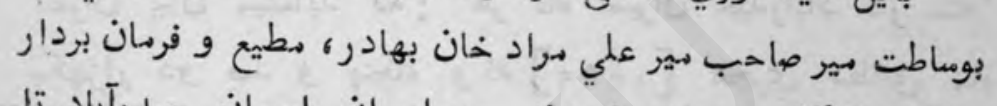

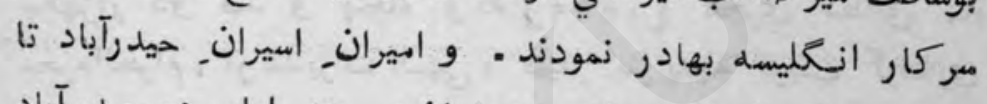

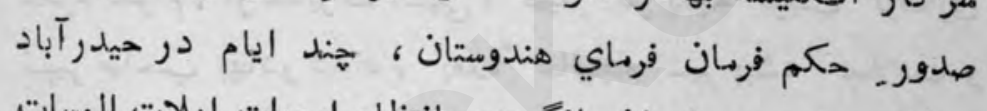

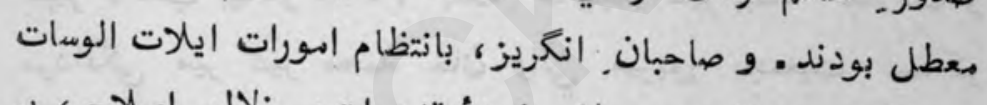

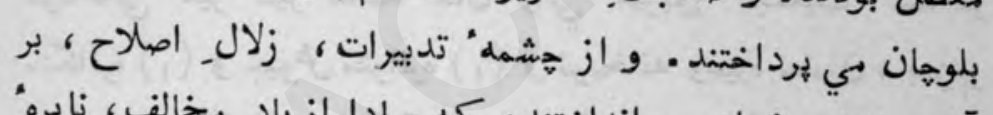

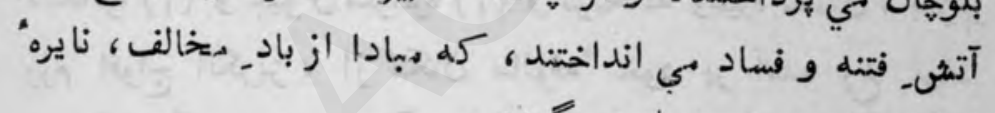

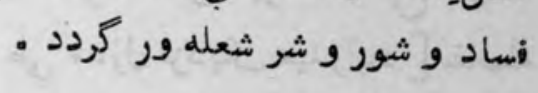


$-9 \cdot-$

در بيانِ مقابله عاليجاه مير شيرمتحمد خان با فوج انكريز

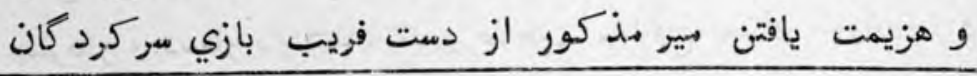

لشكر, خود

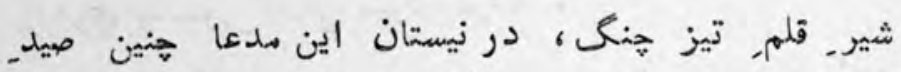

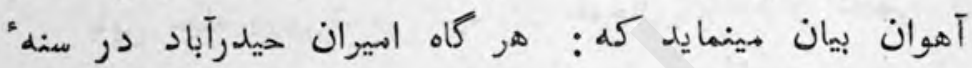

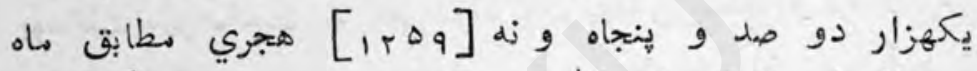

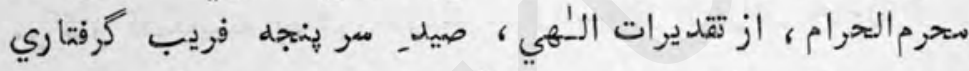

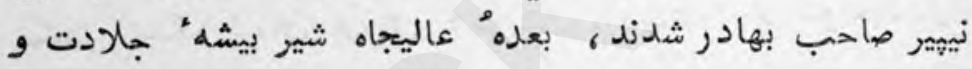

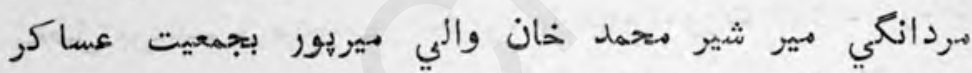

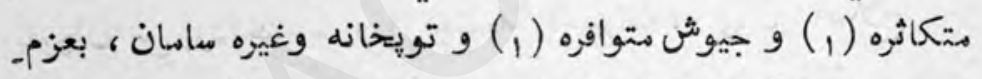

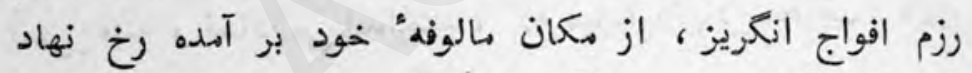

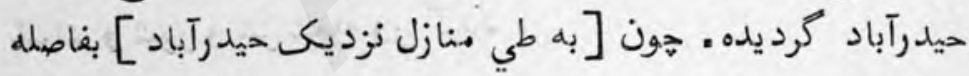

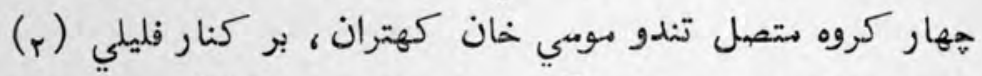

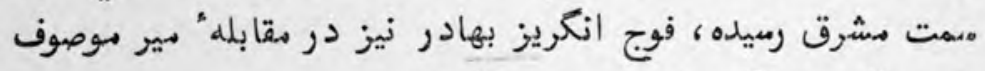

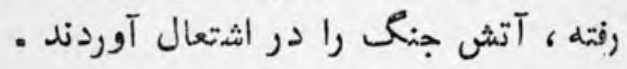

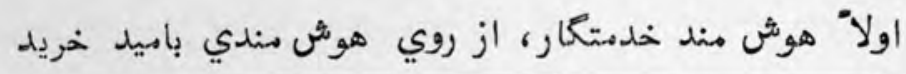

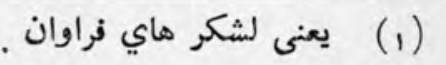

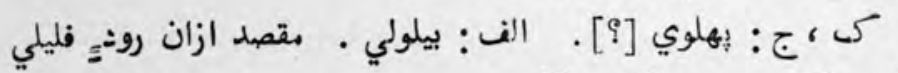
(r) است كه در حيدرآباد ميكذرد . 
$9<1$

تازه نواي معاركى

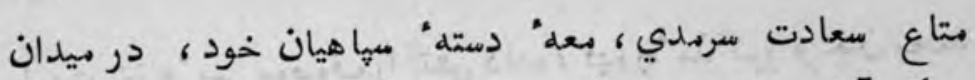

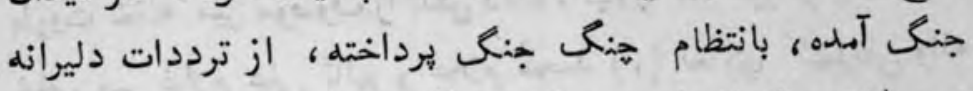

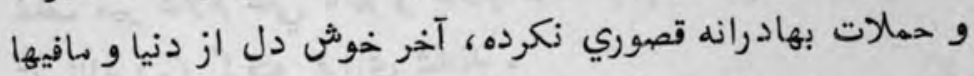

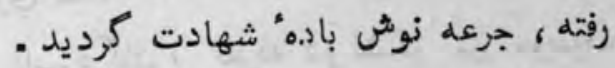

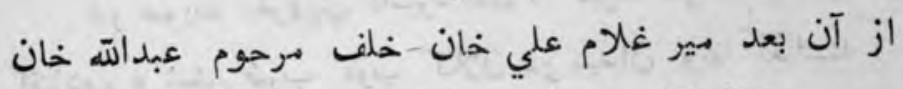

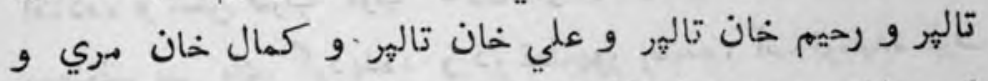

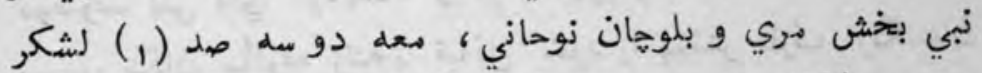

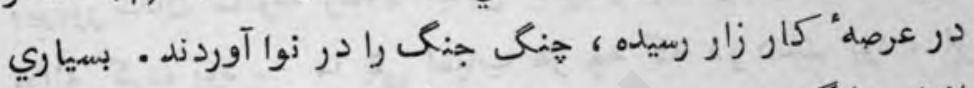

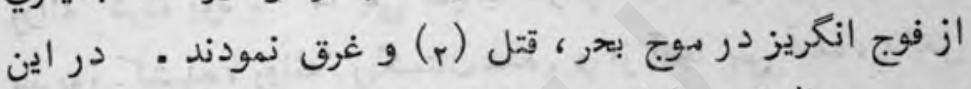

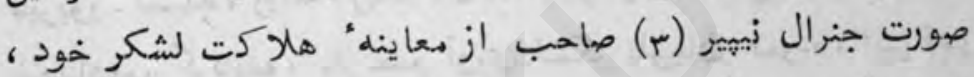

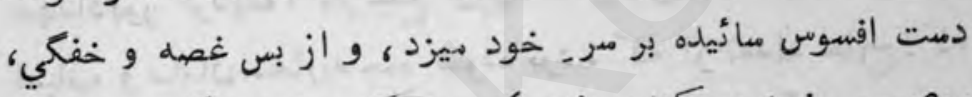
هوي سر, خود مي كند، نزديك بود كه ـ. فوج انكريز درهم و

برام شود

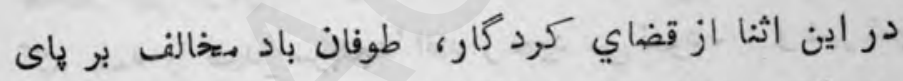

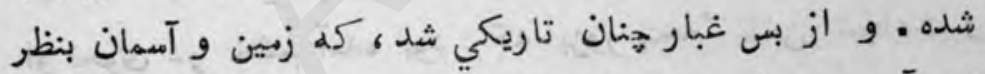

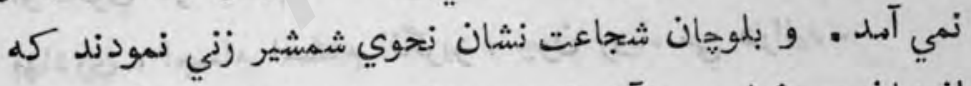

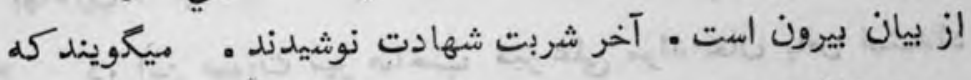

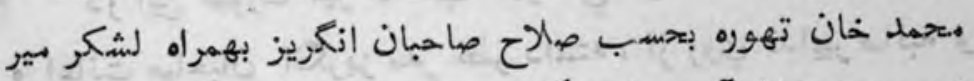

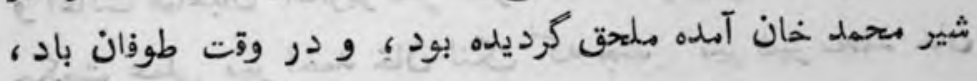

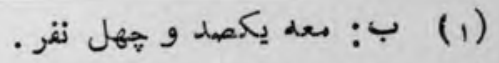

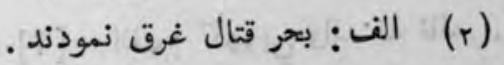

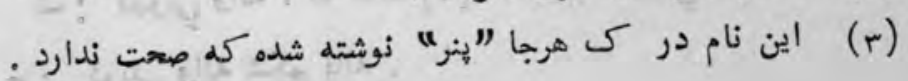


باروت خانه' هير سوصوف را آتش داده، تهوره مذ كور وخان ميحمد

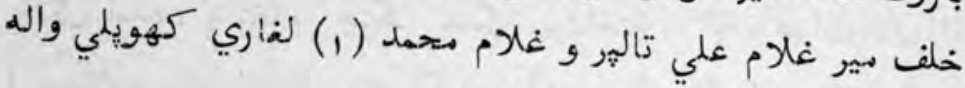

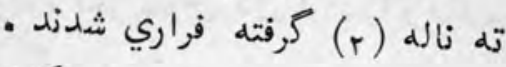

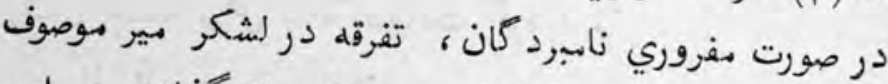

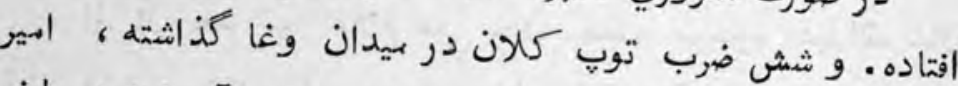

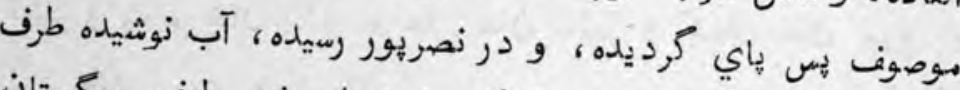

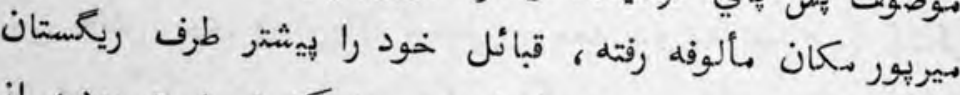

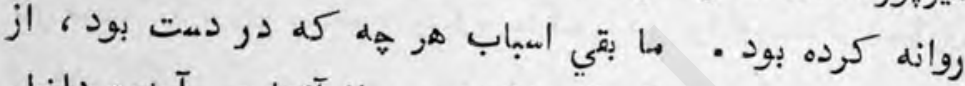

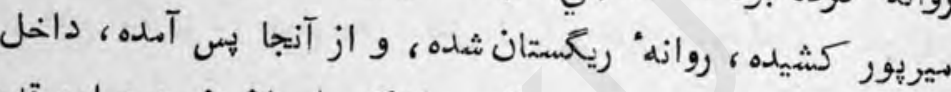

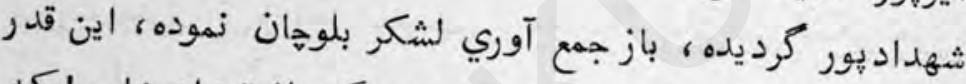

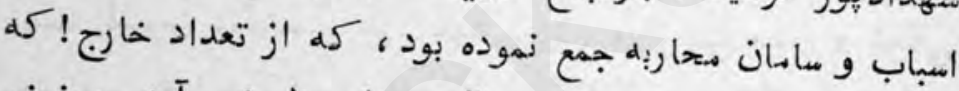

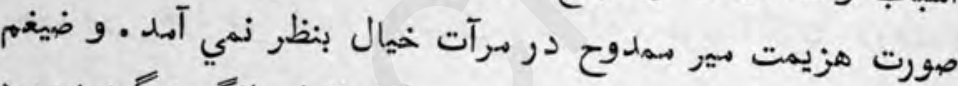

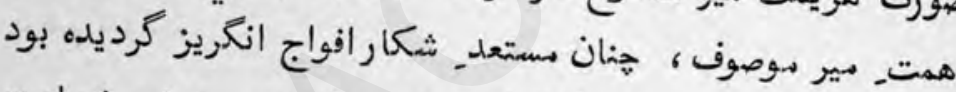

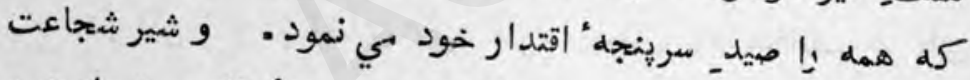

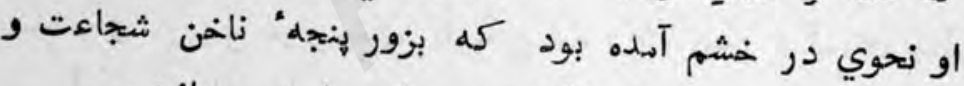

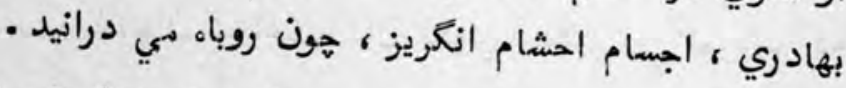

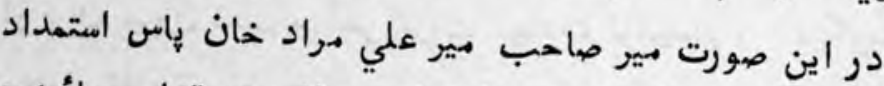

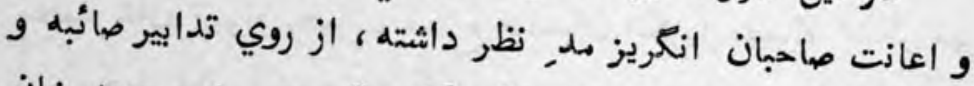

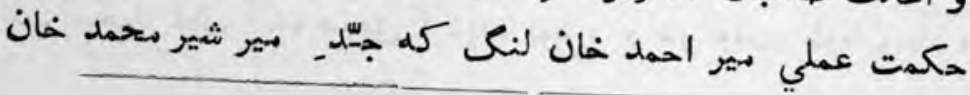

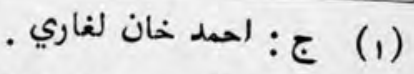

كى: كهويي واله ، نه هاله [؟؟] . الف : كهوبي واله ته ناله .

ج: كويلي واله شكم ناله . 
بود و ديكر سرخيل هاي لشكر كه باني بنياد جنم و فنساد

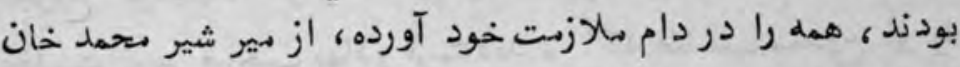

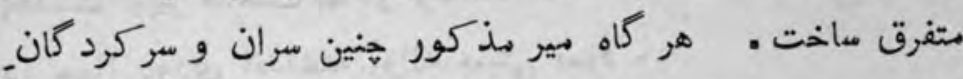

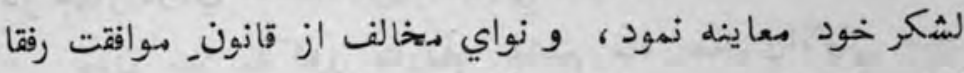

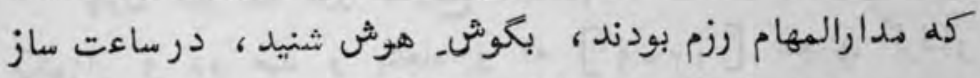

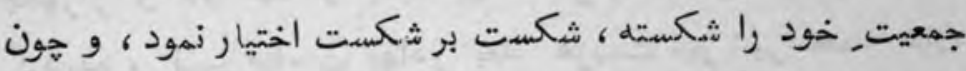

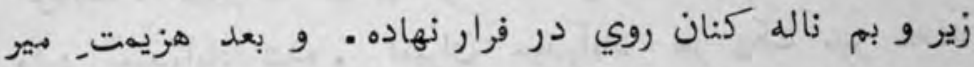

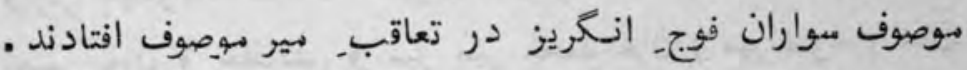

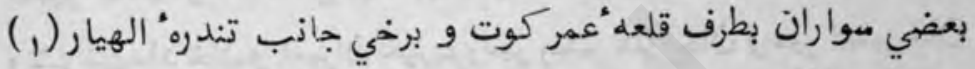

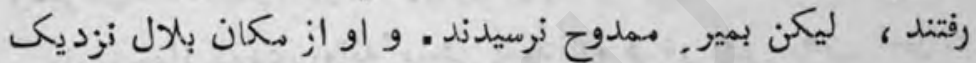

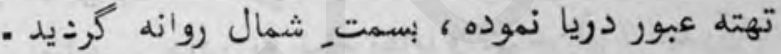

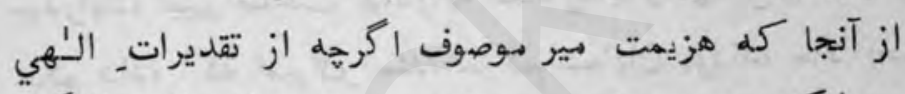

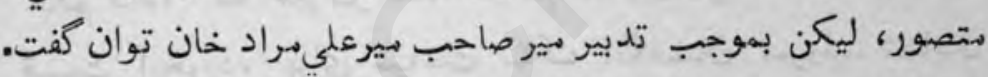

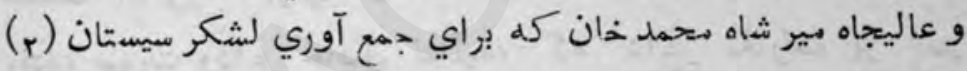

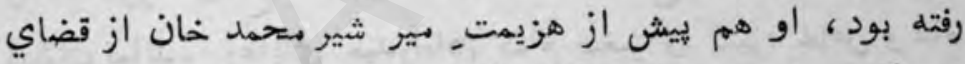

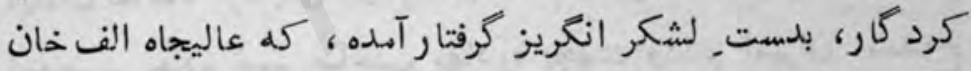

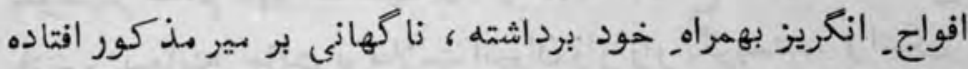

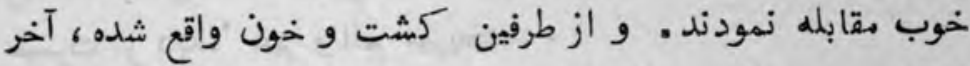

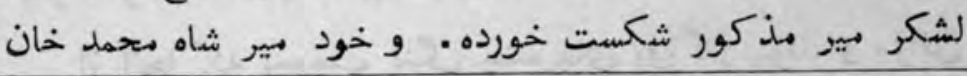

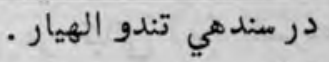

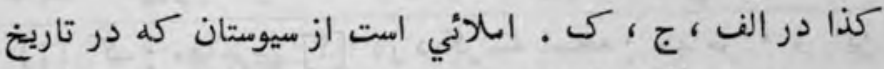

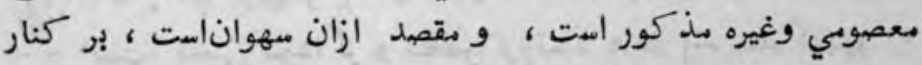
هِ درياي سنده در شمال غرب حيدرآباد سنده ـ. 
تازه نواي معارك

$7<\pi$

هجروح كرديده. آخر ززنده اسير و دستخير نموده، جانب حيدرآباد

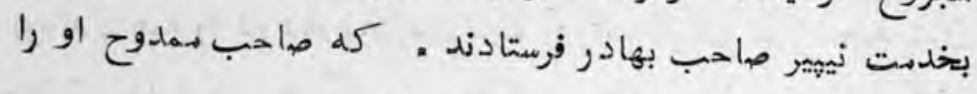

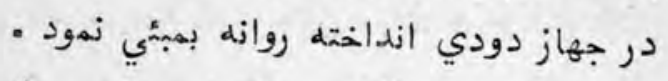

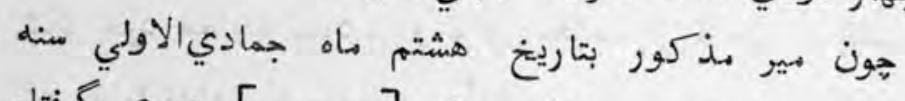

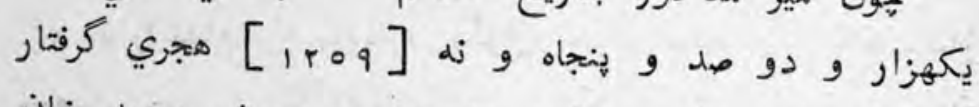

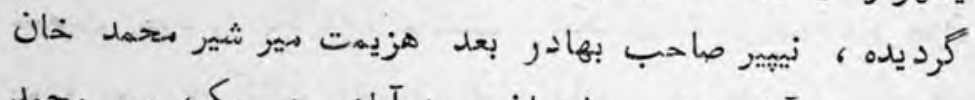

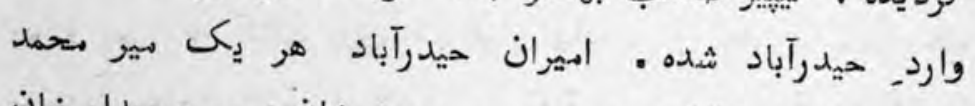
نصير خان و خلفانش و مير مير هتحمد خان و مير صوبدار خان

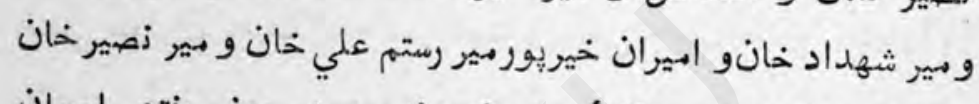

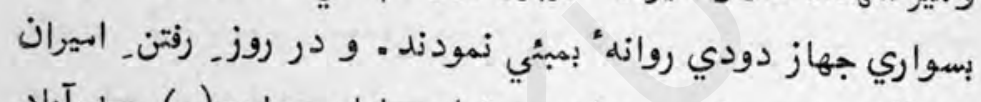

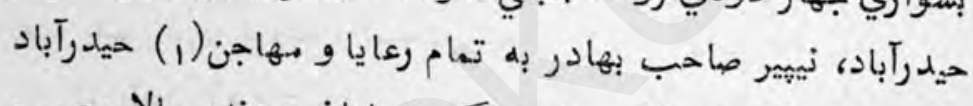

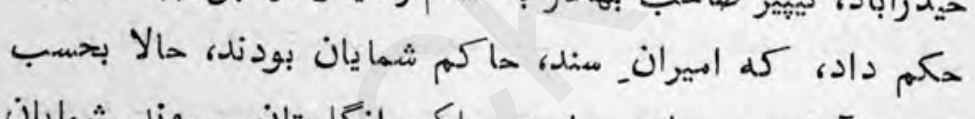

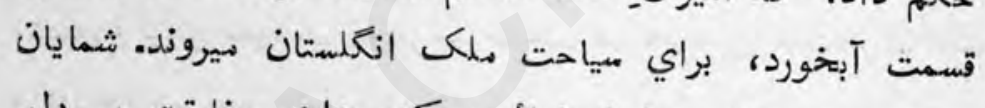

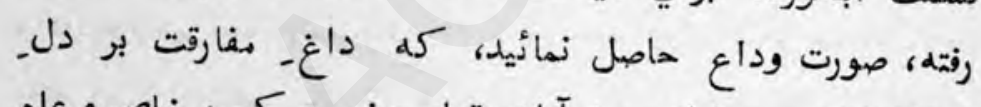
ايشان نماند، رعاياى حهدرآباد، تمام صغير و و كبير، خاص و وعام

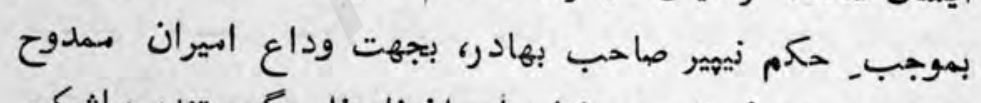

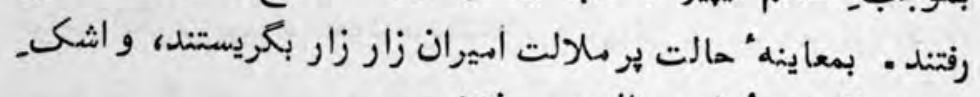

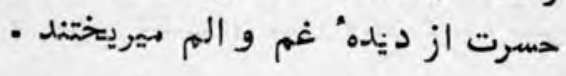

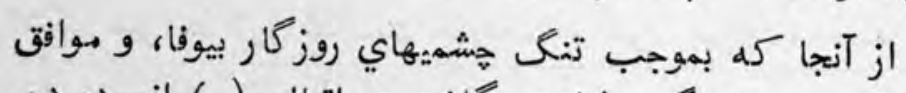

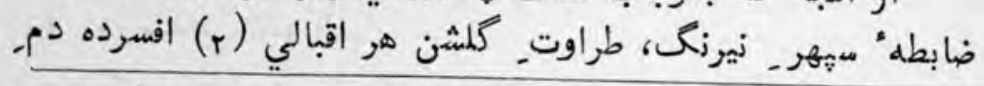

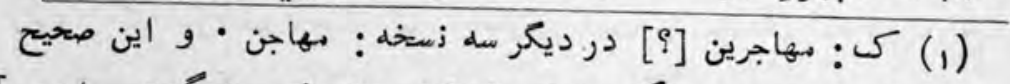

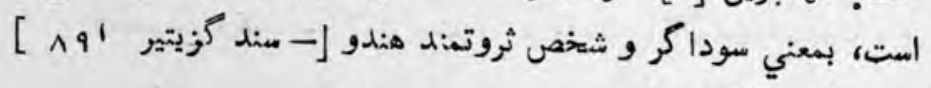
[؟] [ (r) 


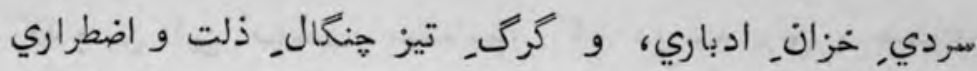

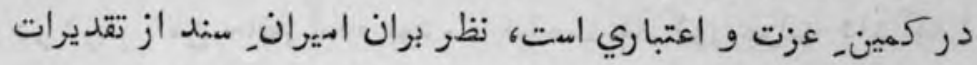

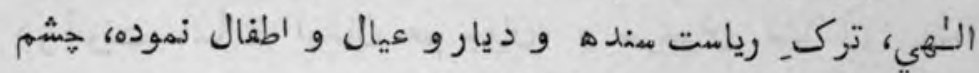

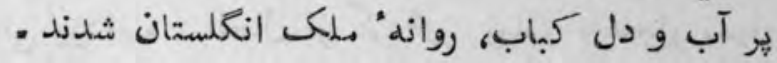

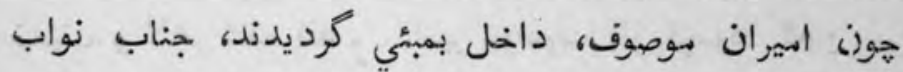

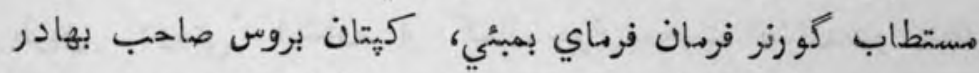

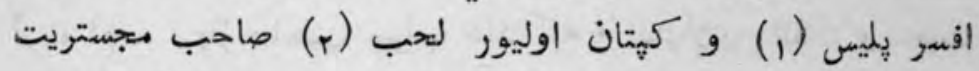
و الي صاحب (r) سمكرتري تعلقه عامه، بنا بر استقبال اميرانـ

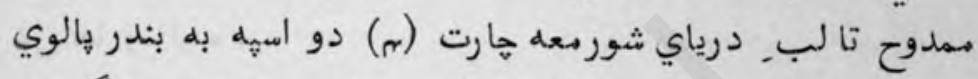

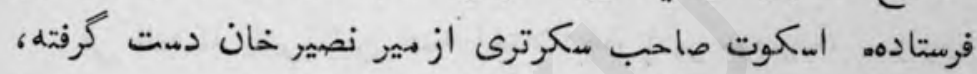

$$
\text { از كشتي بركنار فرود آورد . }
$$

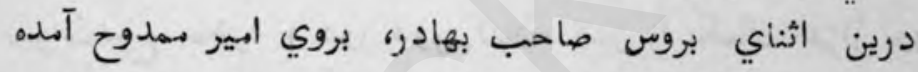

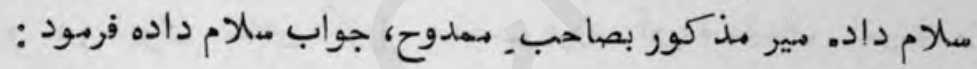

$$
\text { [؟ ك : }
$$

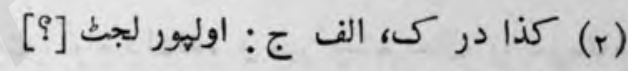

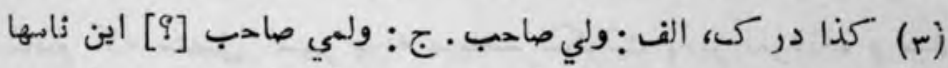

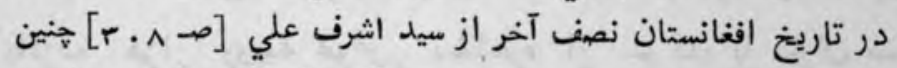

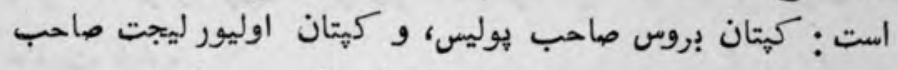

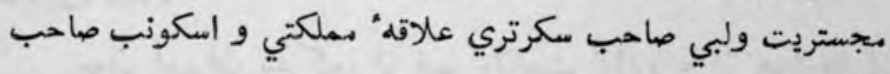

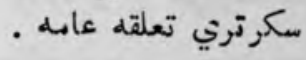

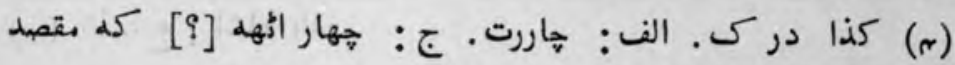
ازان كاري اسي است. 


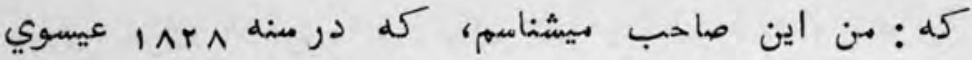

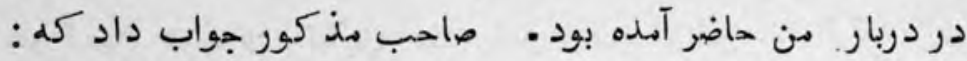

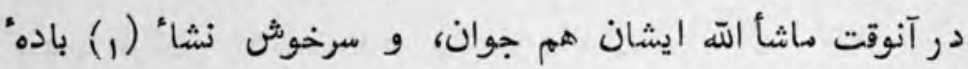

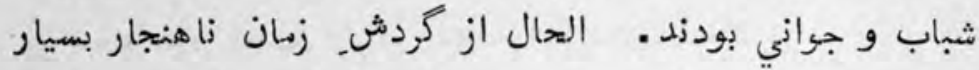

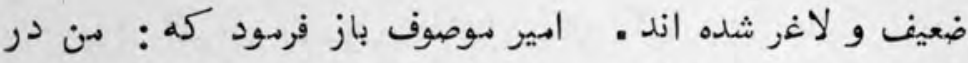

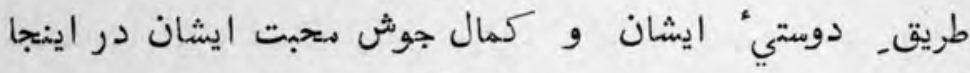

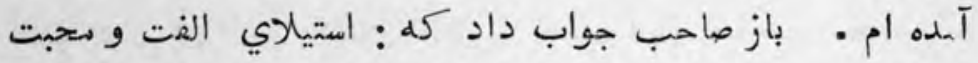

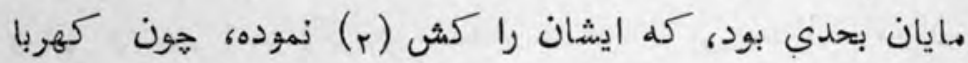
درينجا رسانيده مان لئن

في الجمله بغيو, اين همل اختلاط ها، امير مـوصوف، بسواري

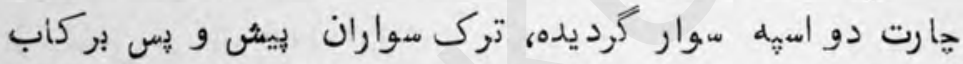

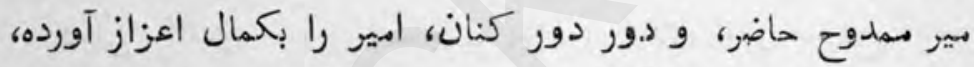

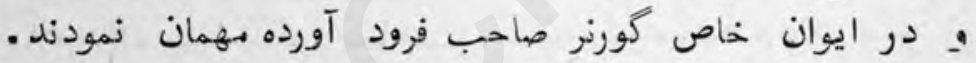

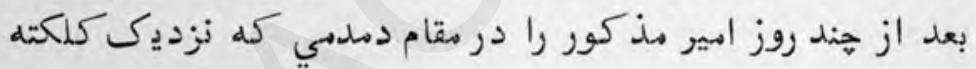

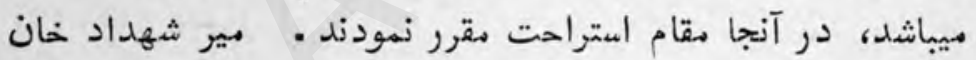

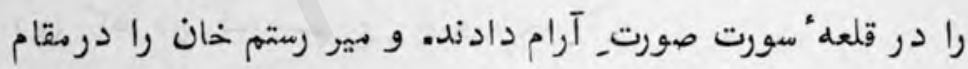

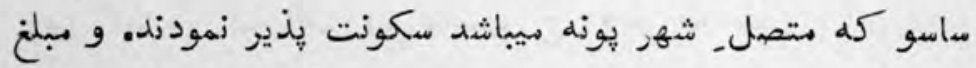

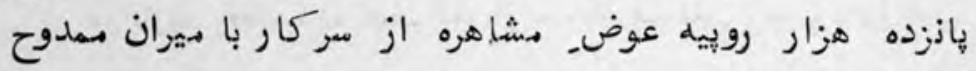
عنايت شده هون اديران مذكور از غمـ رياست آزاد، و از هزارها افكاري

(1) الف، ج: زشاط باده . (r) الف، ج: كشش : (r) 
$T<\angle$

تازه نواي مeسر

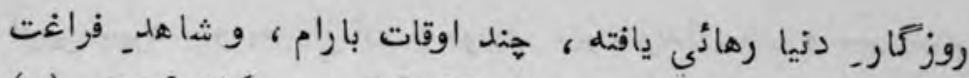

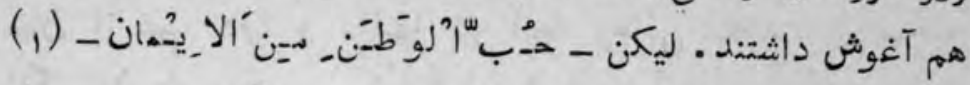

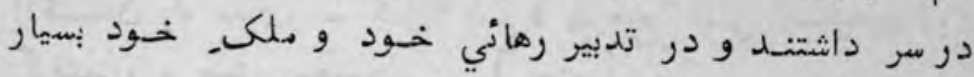

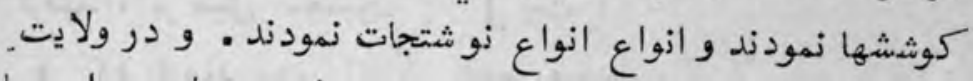

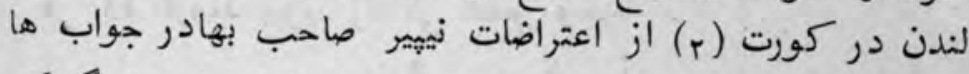

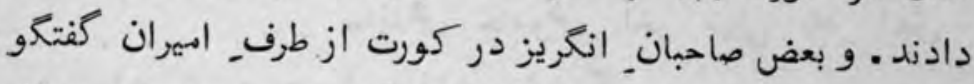

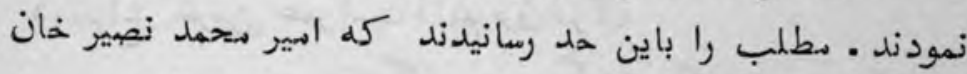

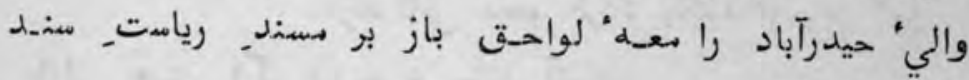

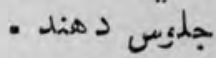

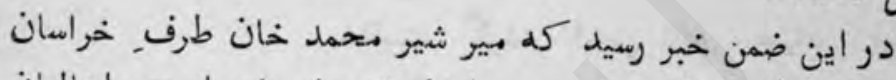

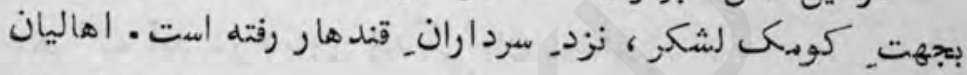

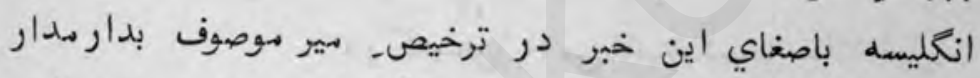

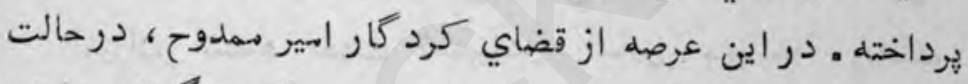

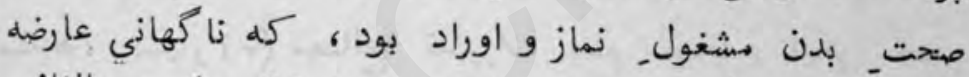

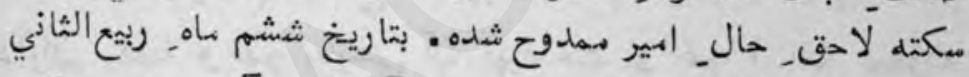

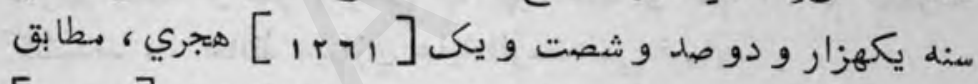

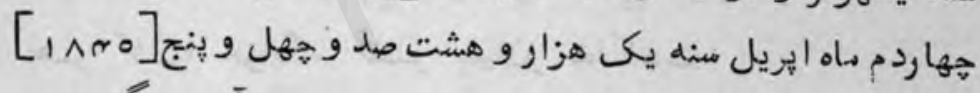

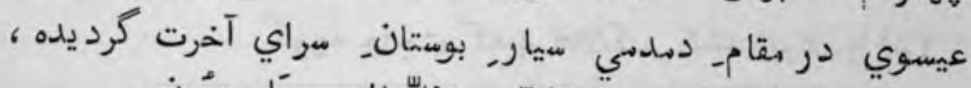

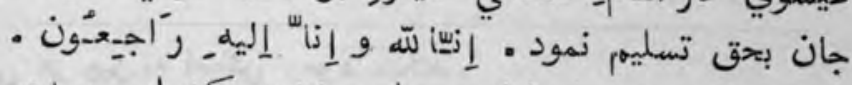

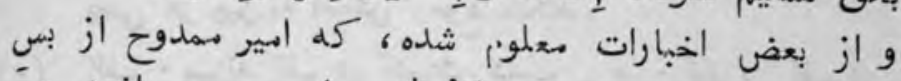

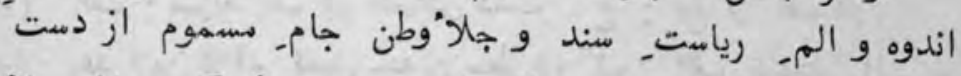

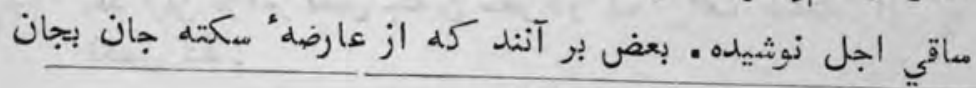

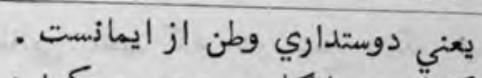

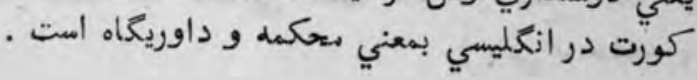

(r) 
تازه نواي مeاركى

$9<1$

آفرين سهيرد • و بعد از آن مرحومان مير صوبدار خان و مير وستمه

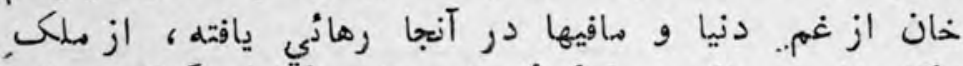

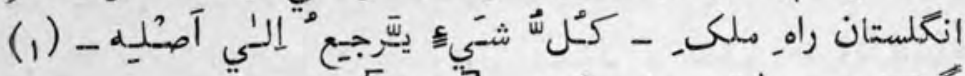

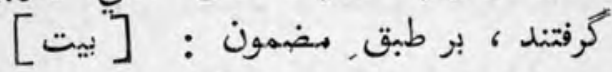

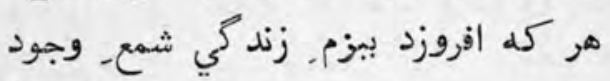

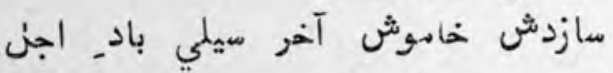

درسراغ _خرمن_ عمر است دايم برق مرك

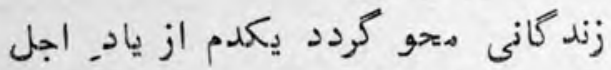

طائر هuتي اكر در هرخ سازغ آشيان

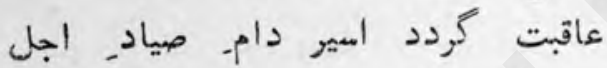

هر كله آيد در ديار. زندكي زان زيشثتر

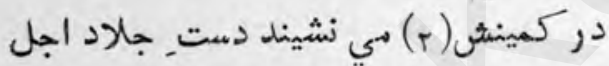

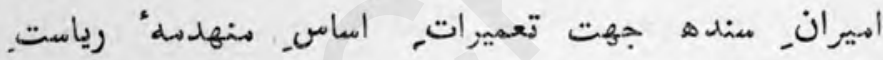

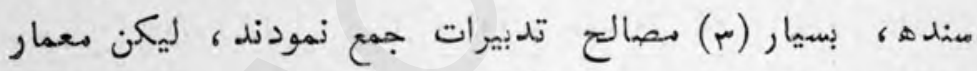

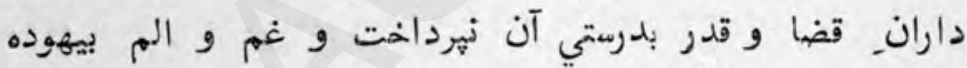

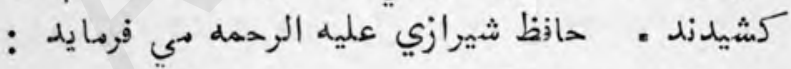
هـ-ر كسرا خوابكه آخسر بهيان. خاكست

كو

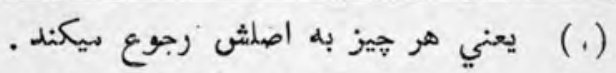

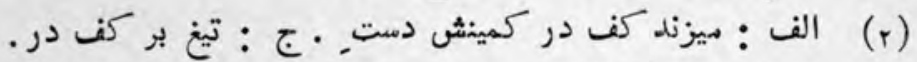

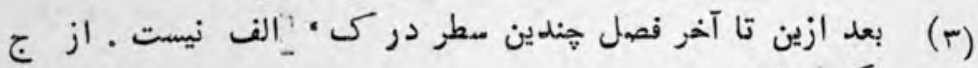

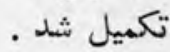

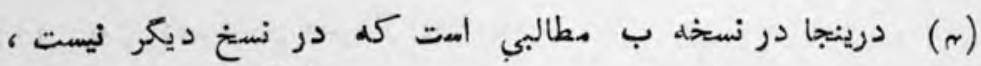

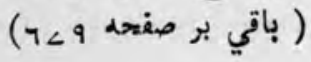




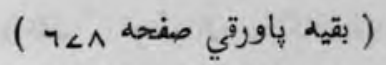

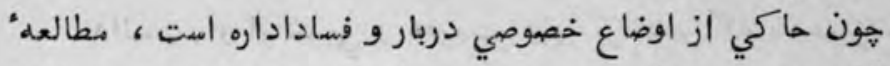

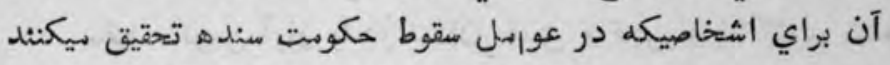

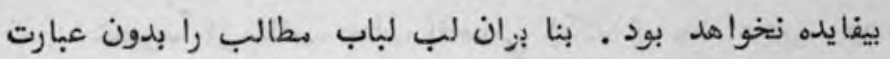

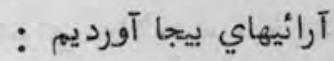

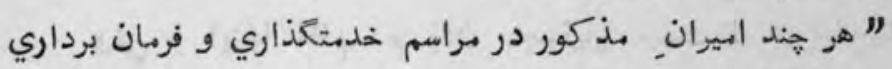

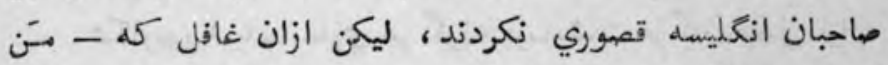

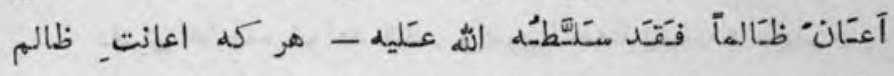

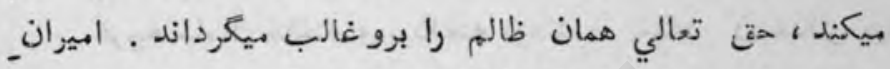

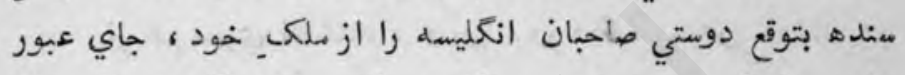

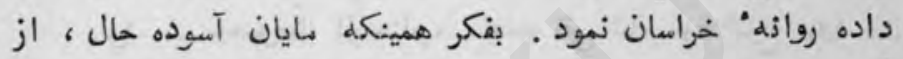

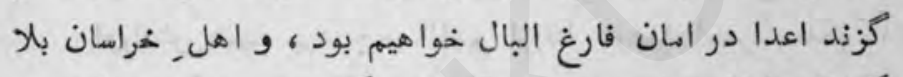

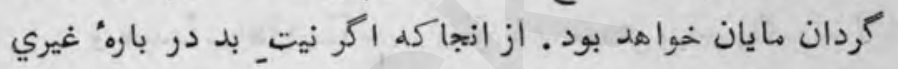

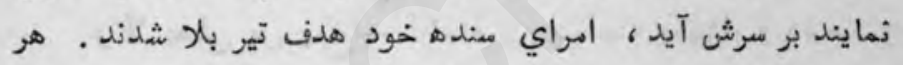

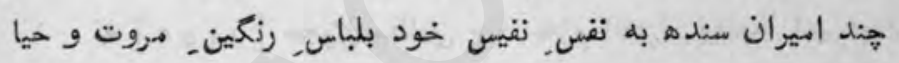

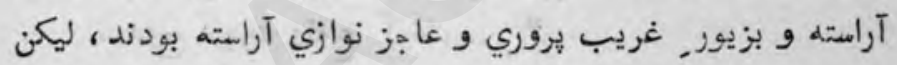

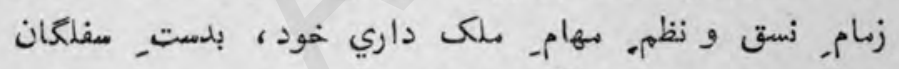

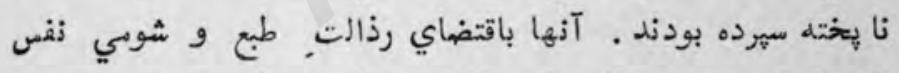

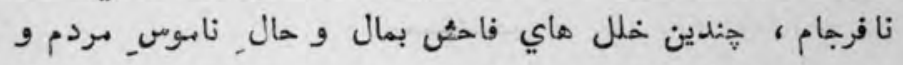

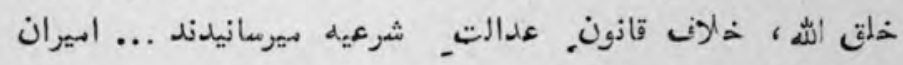

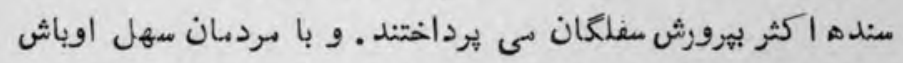

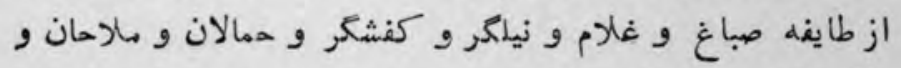

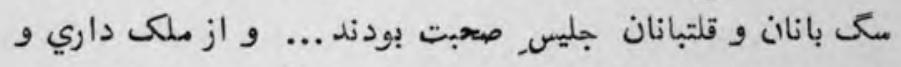

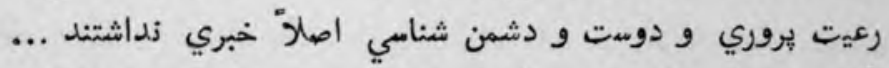

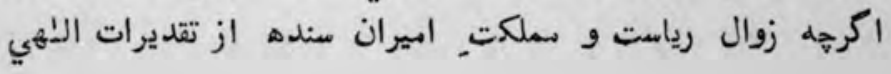


تازه نواي معارك

7^.

امت ، ليكن همه از شوبي بد نفسي و ظلم كار كنان سفلعان بايد

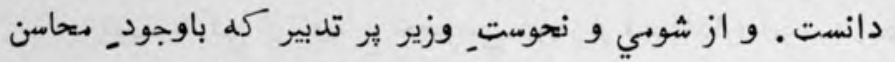

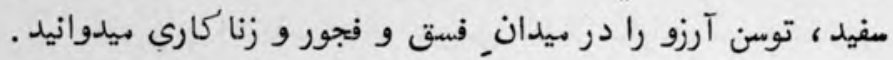

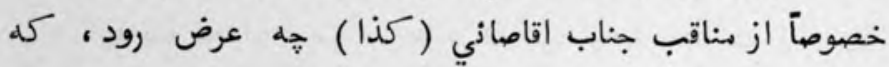

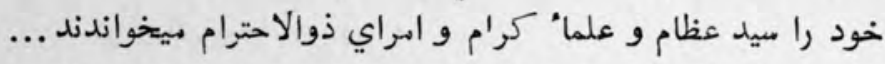

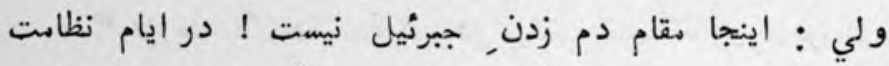

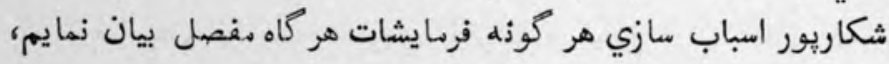

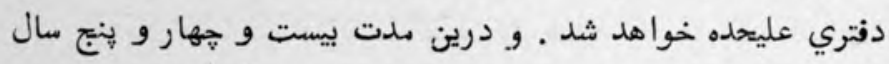

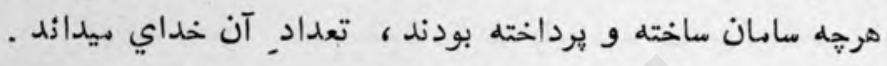

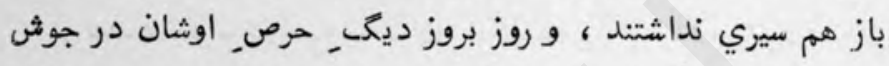

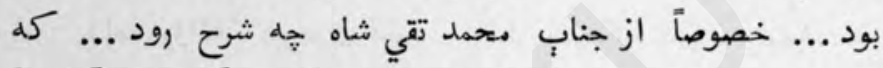

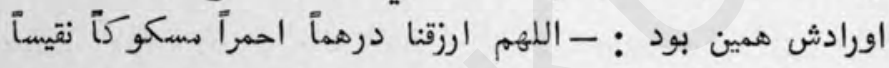

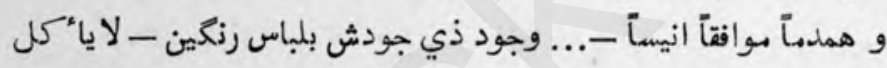

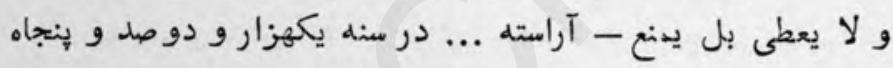

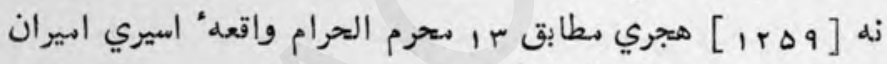

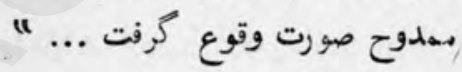


در بيان ( ) تسخير, ملك سندها، و ذوشتن مراسلهء

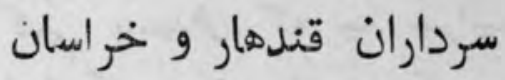

با ثيرانـ سنده، كه انكريزان را از ملكـــ خود هركز

\section{باينطرف راه ندهند}

قلم صداقت رقم ، در تشريح, اين خدعه طرازي بر صحيفه.

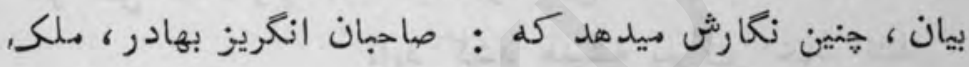

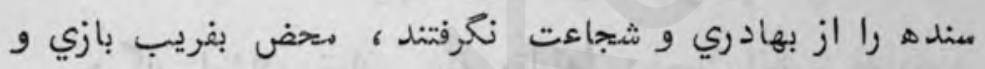

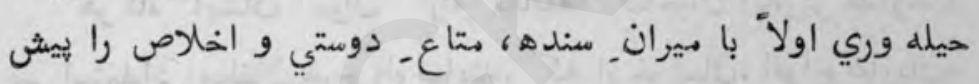

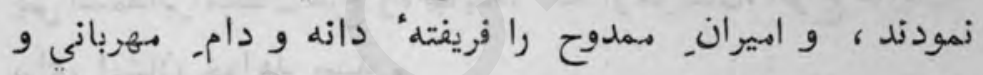

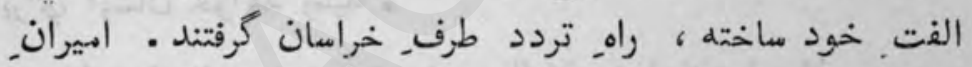

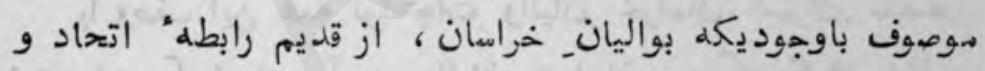

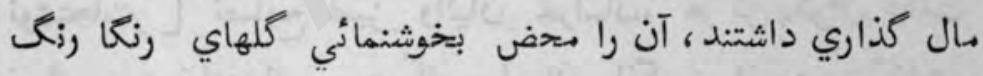

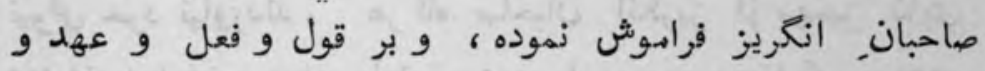

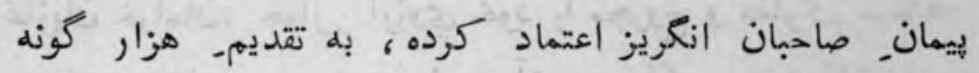

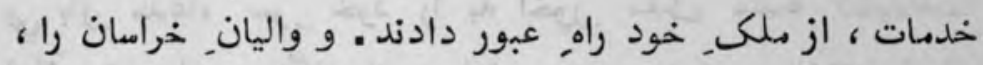

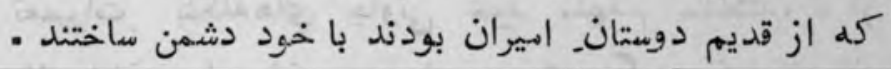

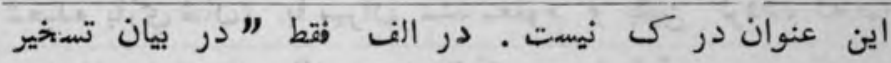

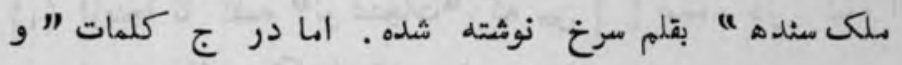

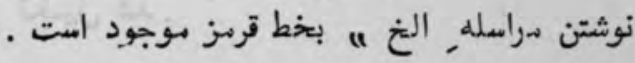


تازه نواي

rAr

باوجوديكه و واليان خراسان، كرّات و مرّات بطرف اميران

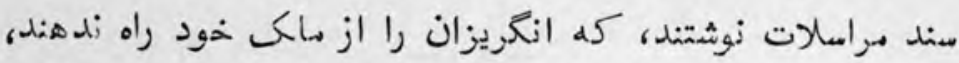

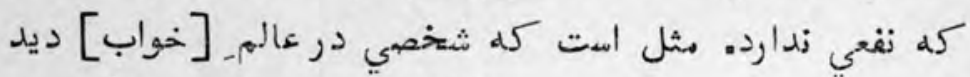

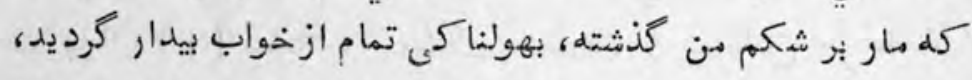

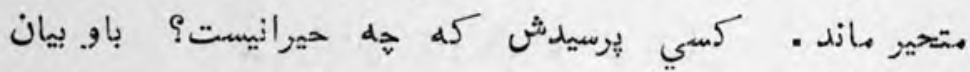

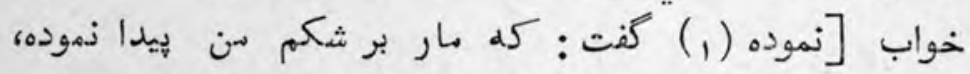

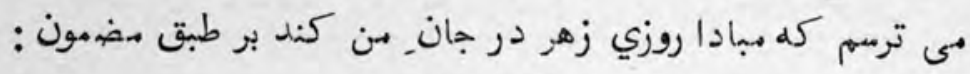

[بيت]

هر كس كd مار را بدهيد جا در آستين

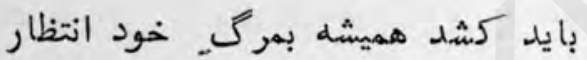

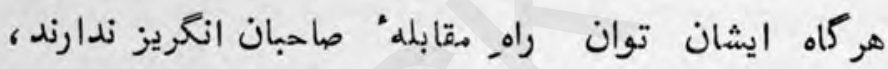

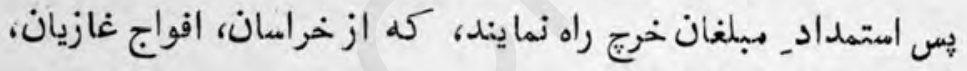

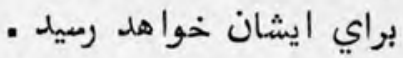

با وصف اين همه نوشتجات_ واليان_ خراسان، اميرانـ سندهـ،

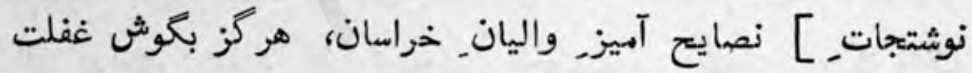

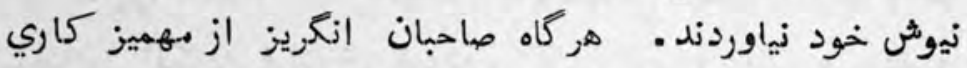

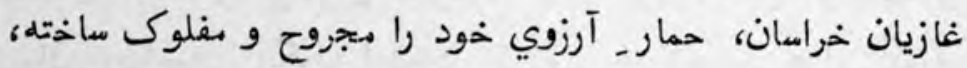

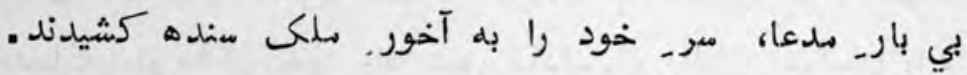

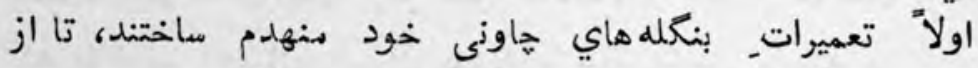
شعبده بازي شان، با ميران_ سند معلوم و يقين كردد، كه صاحبان

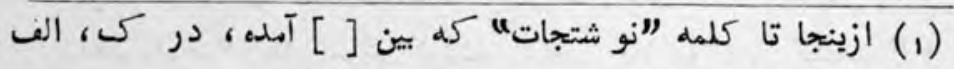

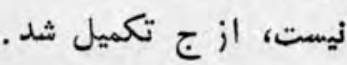




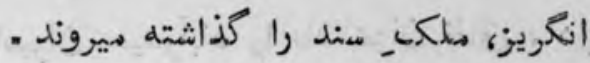

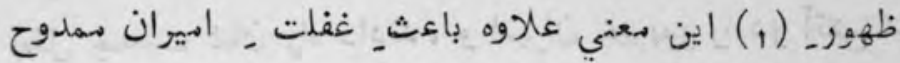

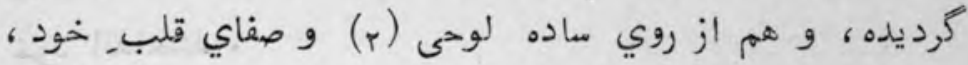

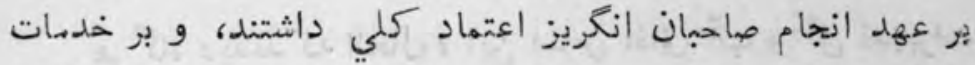

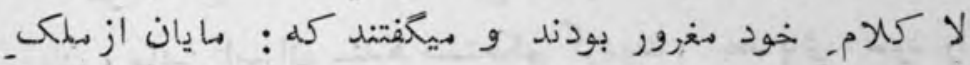

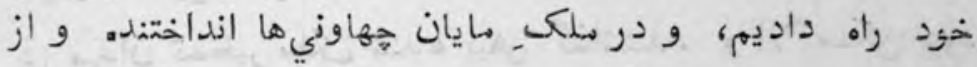

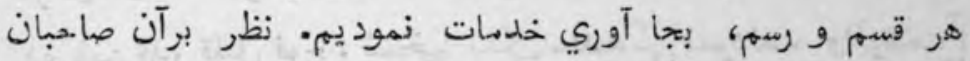

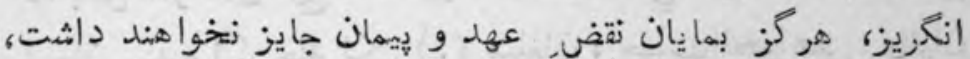

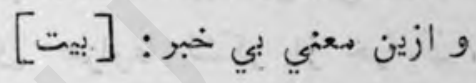

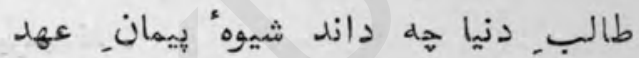

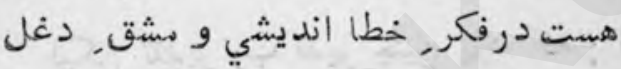

$$
\text { ازبراي اخذ مال و حبــ جاه و (ب) روز مار }
$$

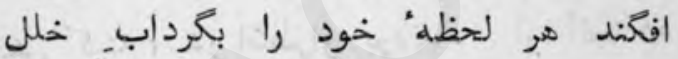

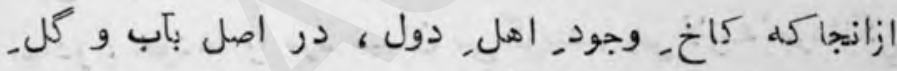

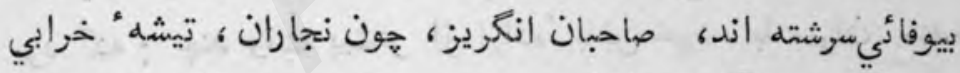

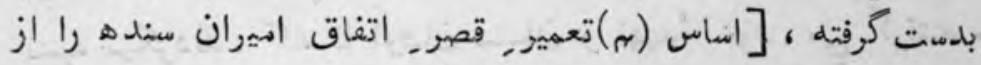

$$
\begin{aligned}
& \text { [?] (1) }
\end{aligned}
$$

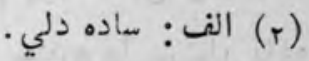

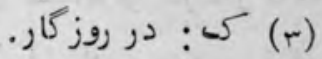

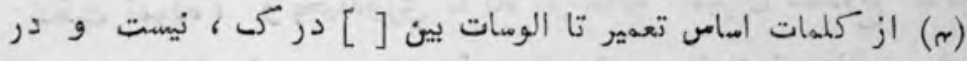

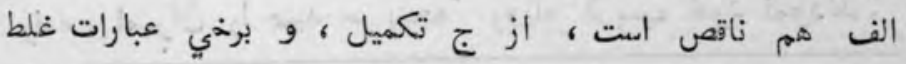




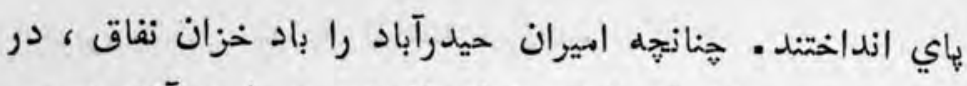

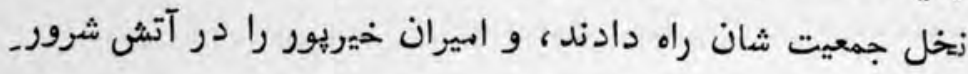
- خود انداختيند جميت

هر گاه ديدندكم الحال ، اين اساس نفاق آب و كل تدبيرات

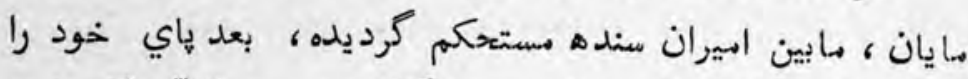

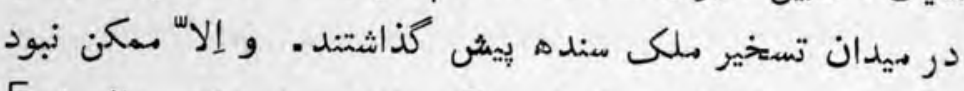

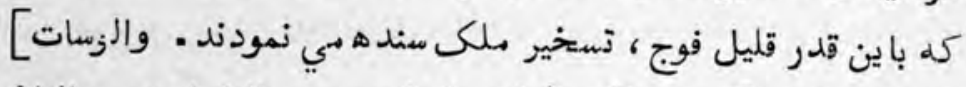

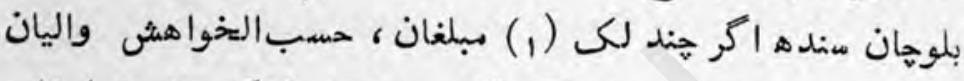

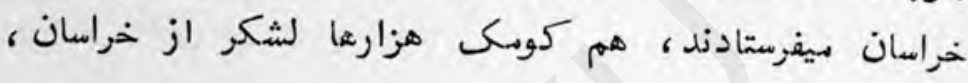

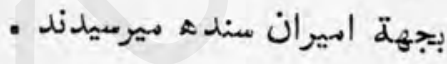

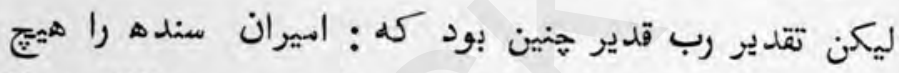

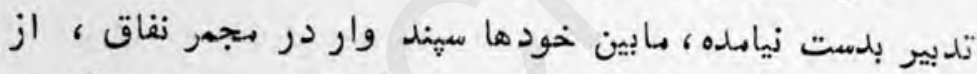

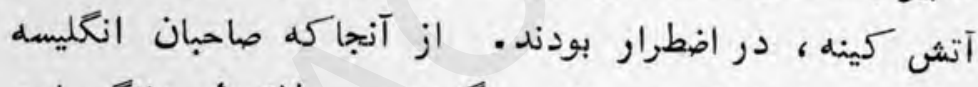

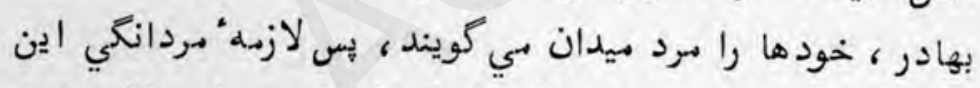

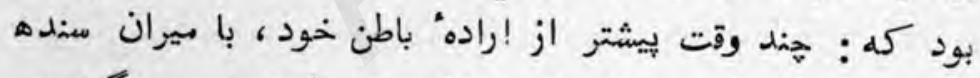

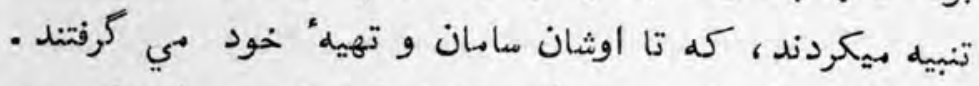

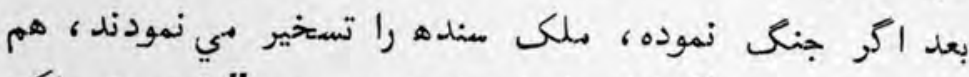

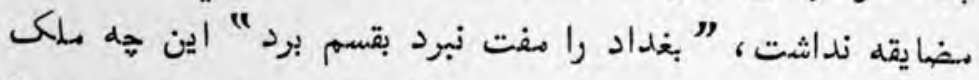

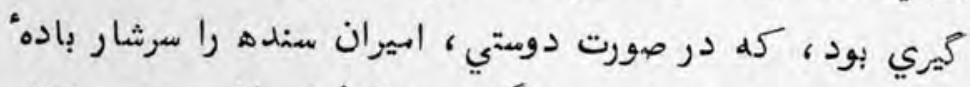

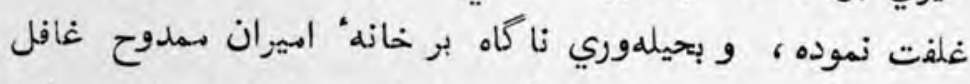

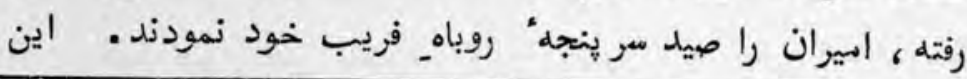

$$
\text { الف: هند لكى روييه را حسب الخواهش . }
$$


$7 \wedge 0$

تازه نواي معارك

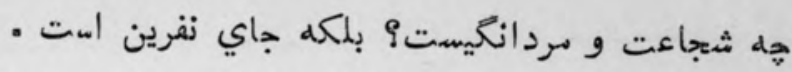

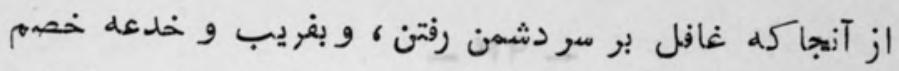

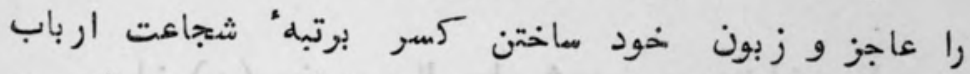

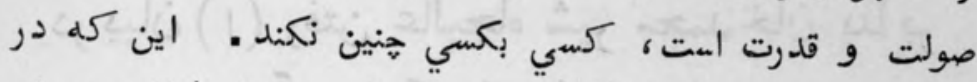

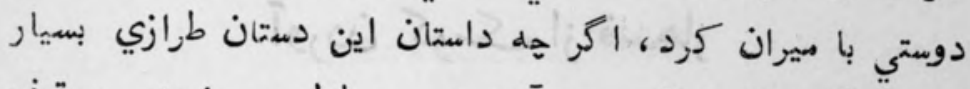

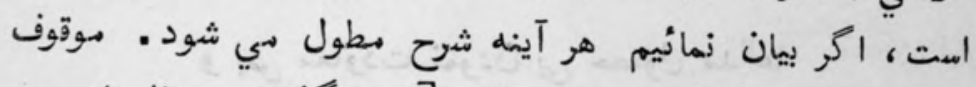

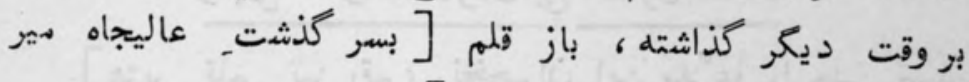

شير محمد خان آثنا نموده مي شود 
$-94-$

در بيان ( 1 ) رفتن عاليجاه شير محمد خان بنا بر آوردن كوميك از قندهار

و وِّ معاودت زمو:ن بي حصمول مدهّعا

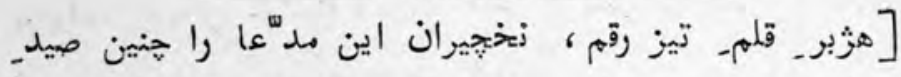

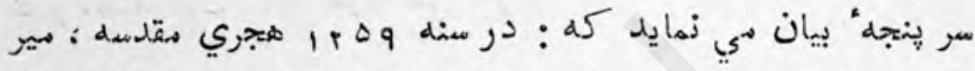

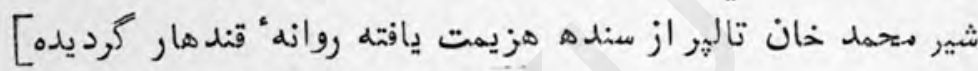

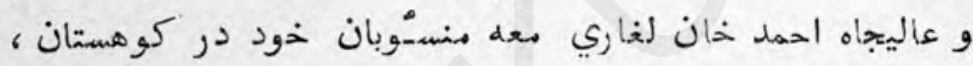

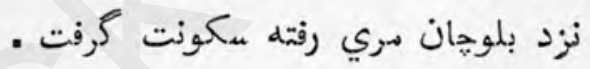

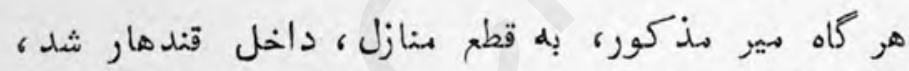

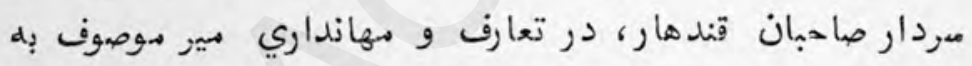

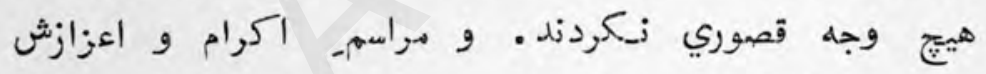

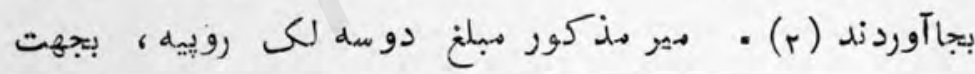

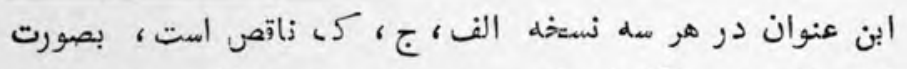

(i)

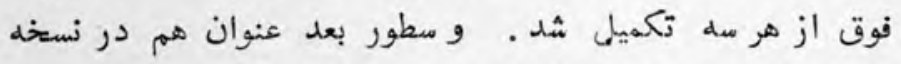

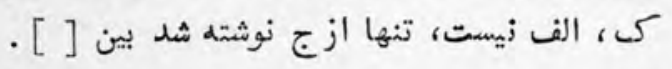

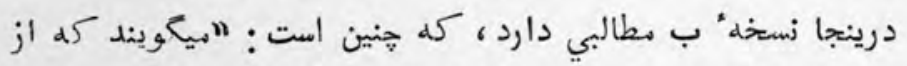
$(r)$

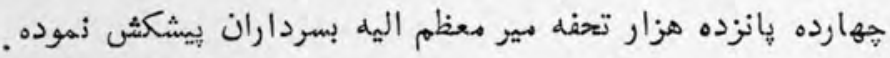

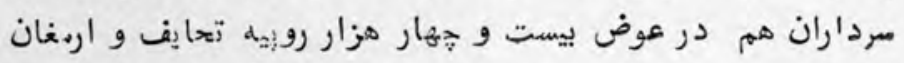

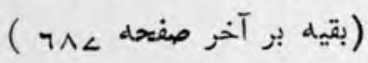


$7 \wedge<$

تازه نواي معارك-

كومهـ لشكر، بسردار صاحمان قندهار، بالفعل بشرط رسيدن شال كوت دادني كرده ، بندوبست كار مرجوعاده" خود نمودهـ.

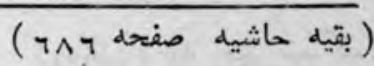

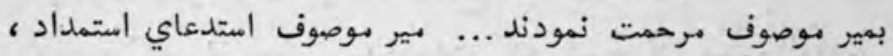

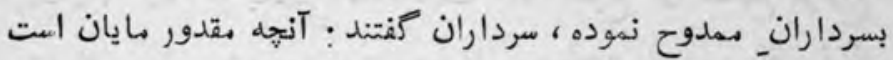

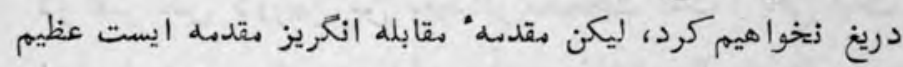

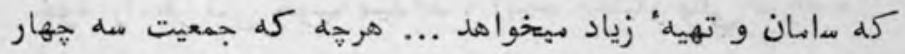

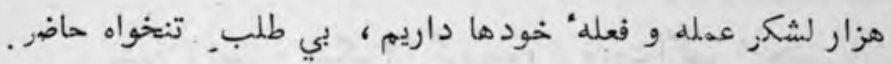

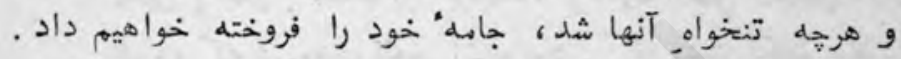

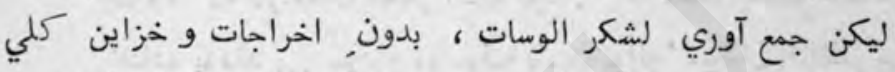

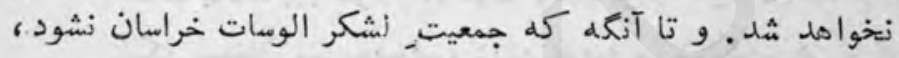

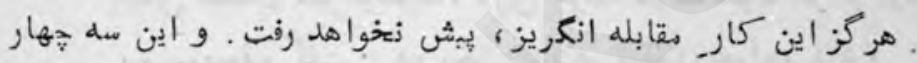

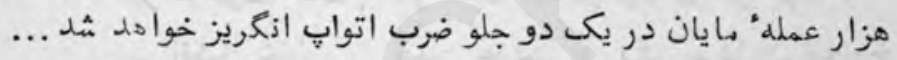

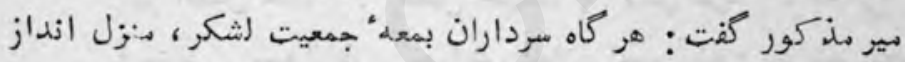

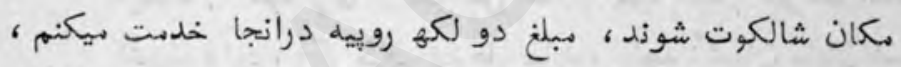

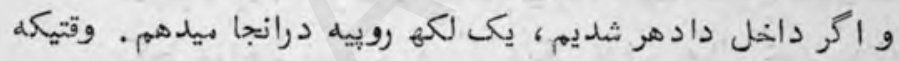

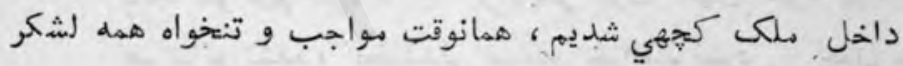

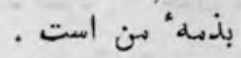

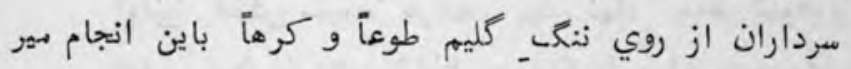

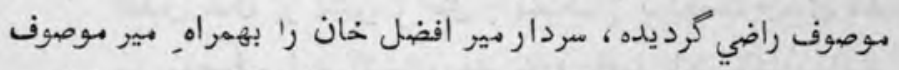

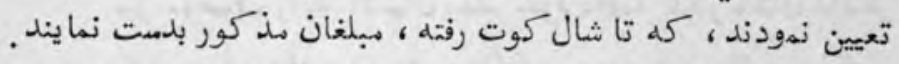

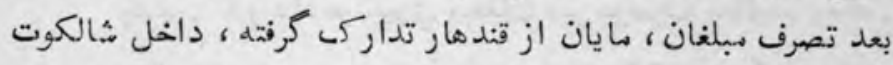

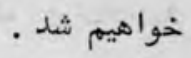
وقتيكه سردار بير افضل خان ، باتفاقـ بير بوصوف رونق افزاي

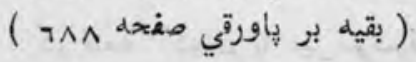


سردار صاحبان اين حقيقت مير موصوف مشروحاً جانب امير

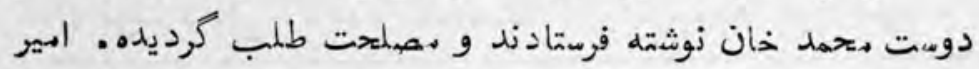

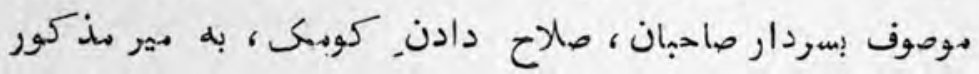

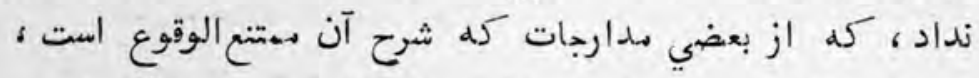

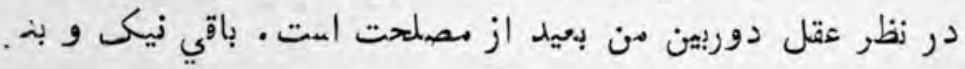

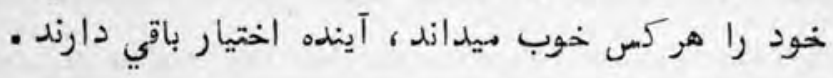

يشين [ اعل : بتنع ؟؟] كرديده، ازقدرت الكهي اينهنين بارش باران

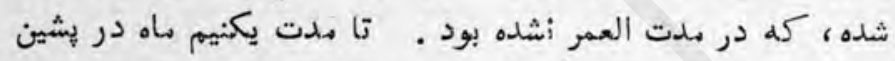

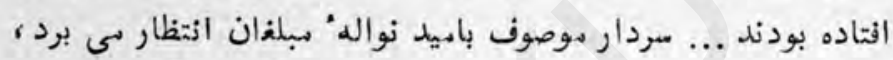

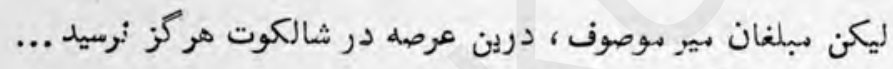

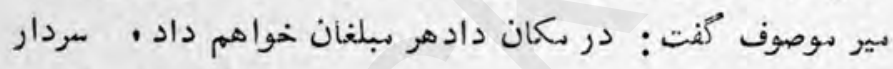

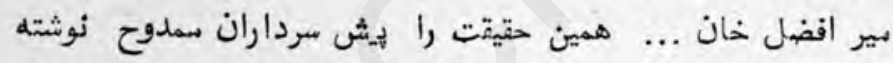

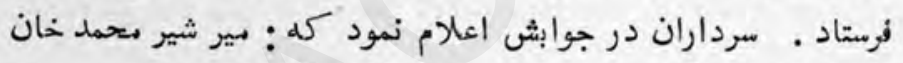

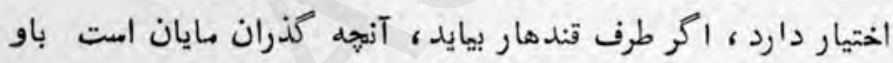

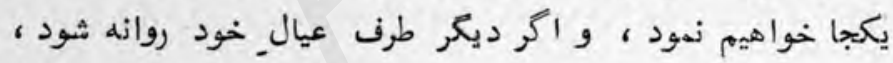

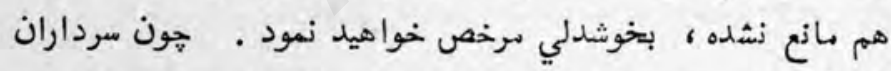

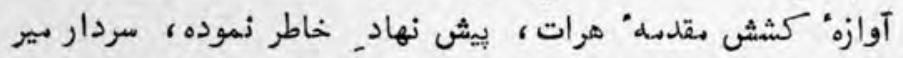

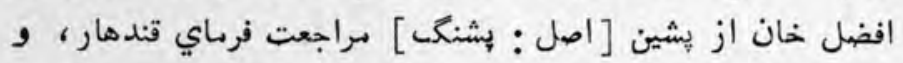

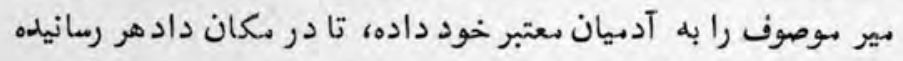

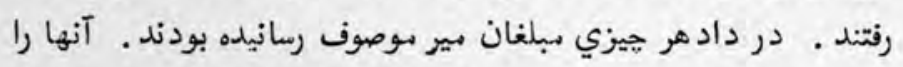

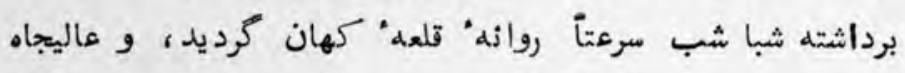

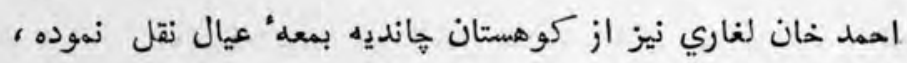

در قلعه" كهان با مير موصوف ملحق كرديد...." . 


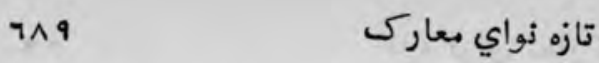

مردار صاحبان قندهار بعد نوشتهُ امير متوصوف، عنان توسن

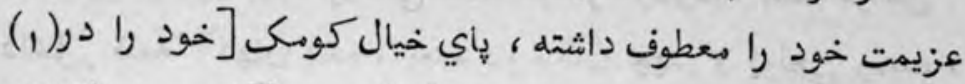

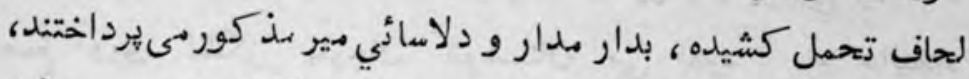

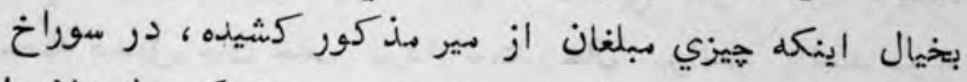

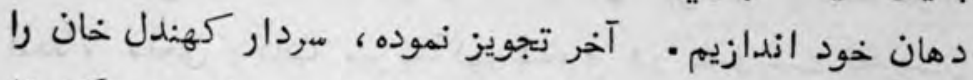

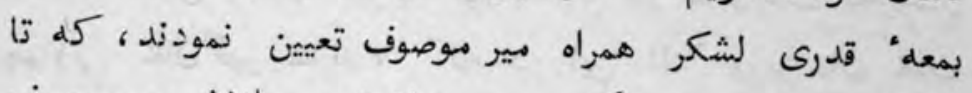

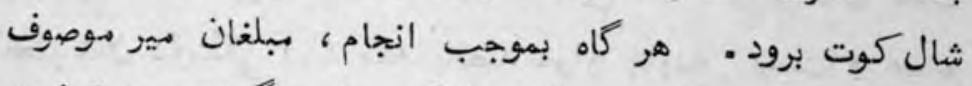

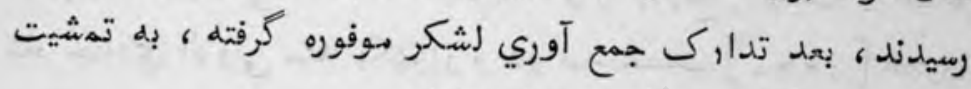

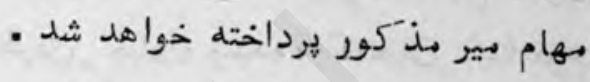

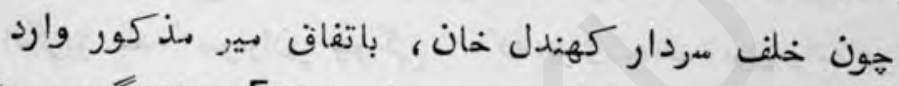

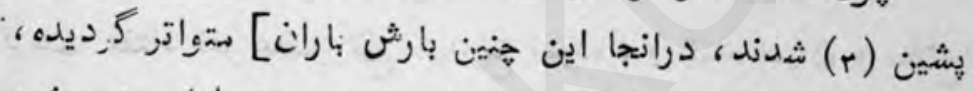

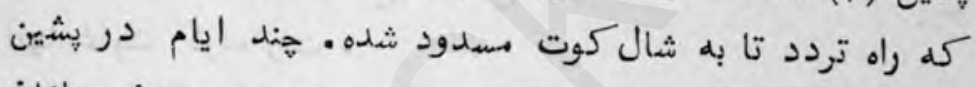

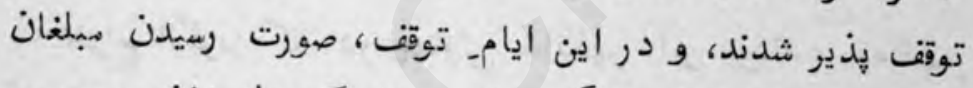

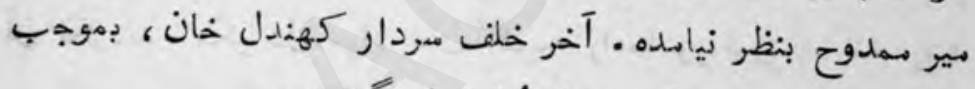

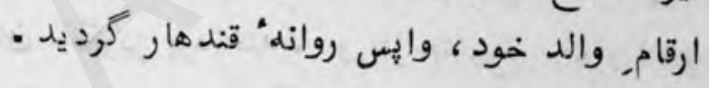

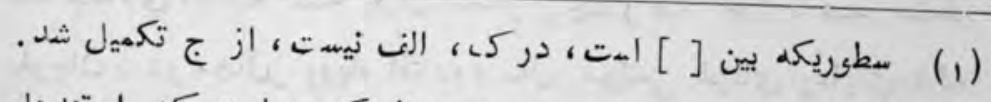
(r)

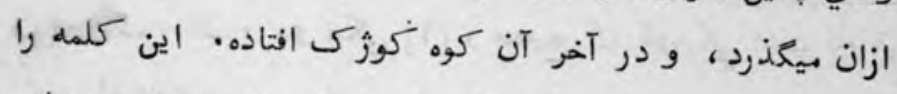

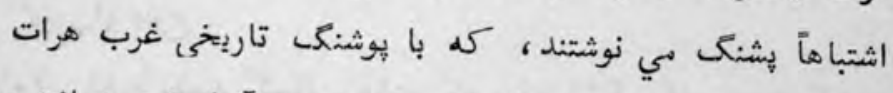

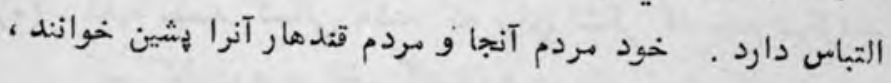

و اين صحيت است . 
تازه نواي معارى

79.

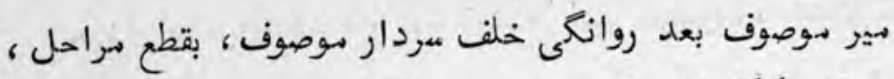

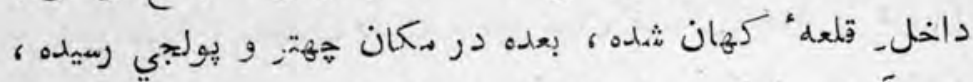

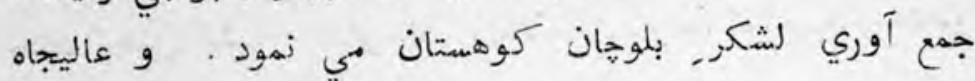

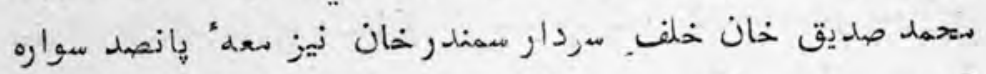

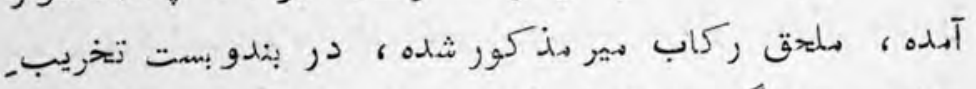

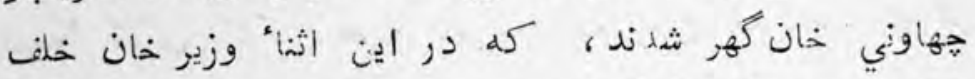

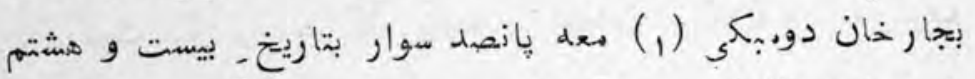

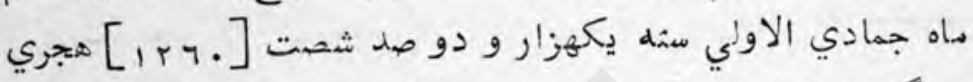

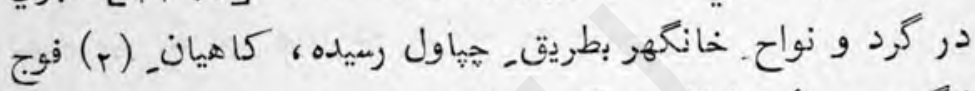

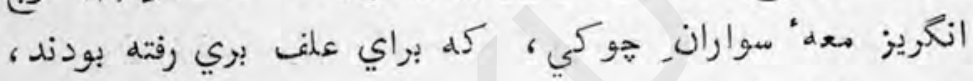

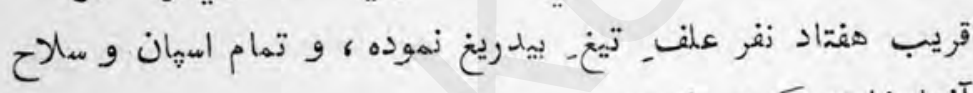

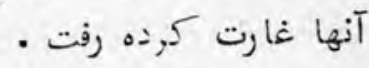

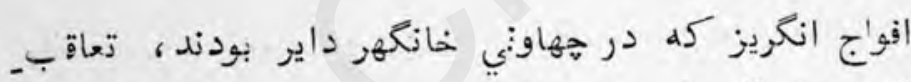

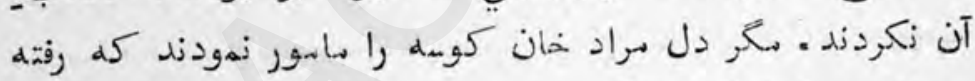

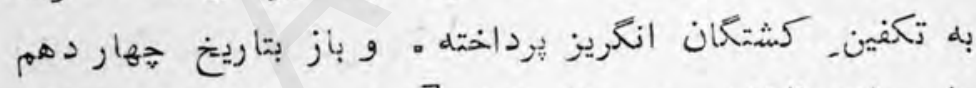

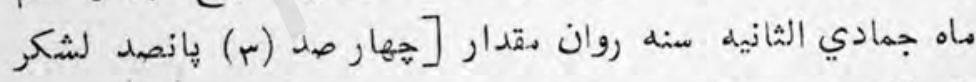

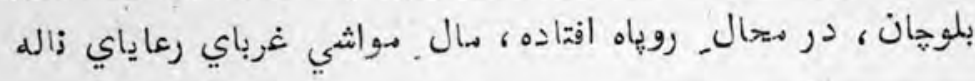
كس، الف : دو نبكي [أ] و صحيح آن ذوم.كي است نام قبيله اي

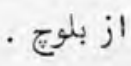

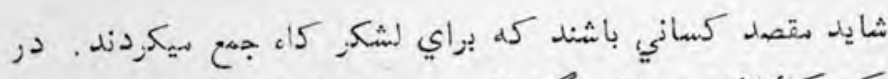

(r)

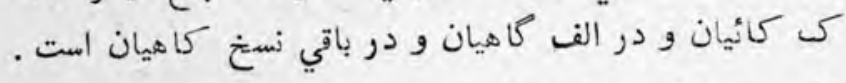

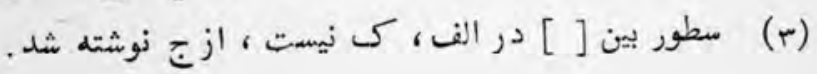




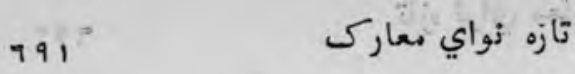

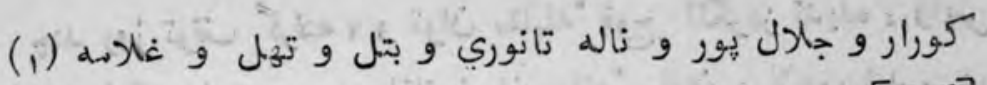

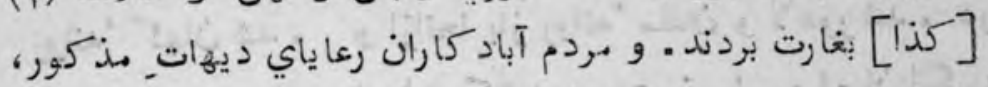

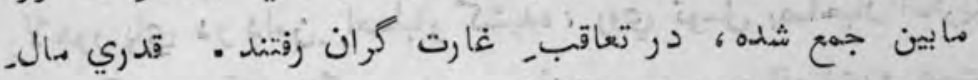

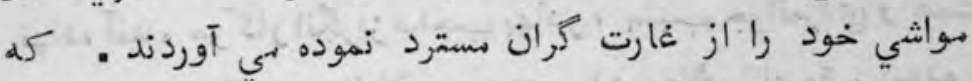

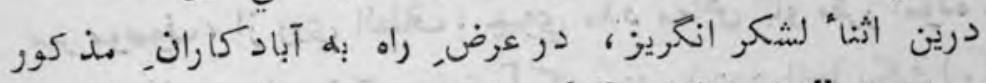

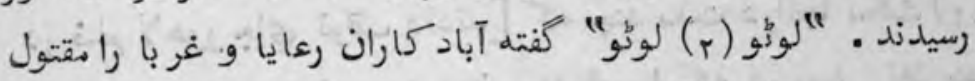

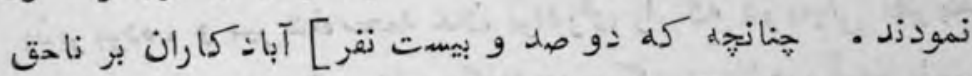

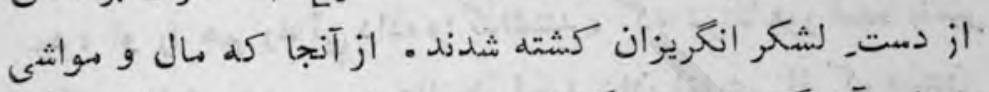

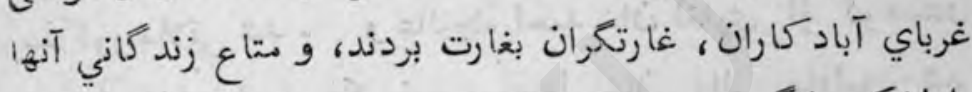

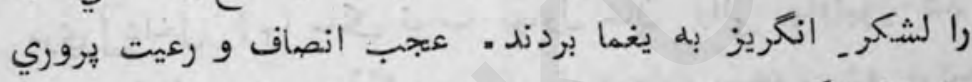

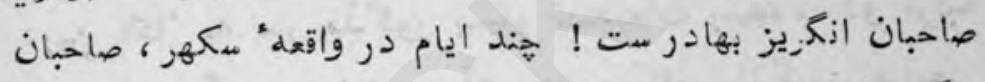

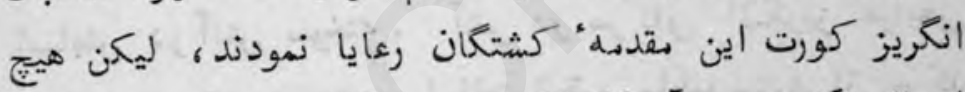

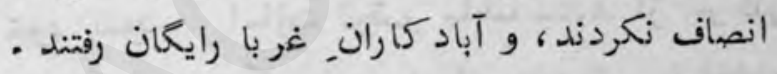

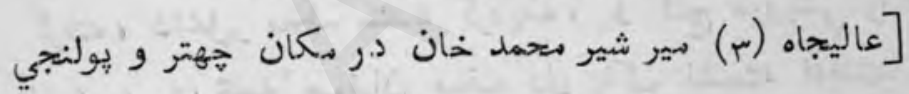

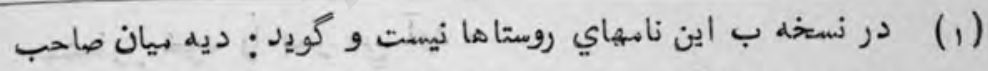

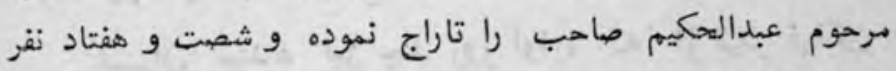

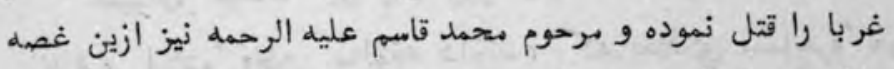

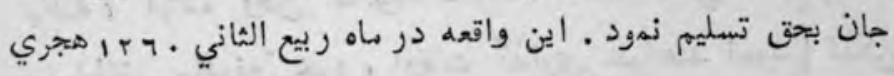

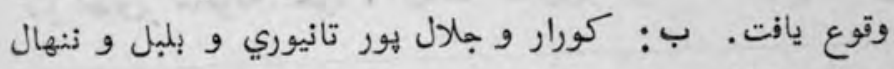

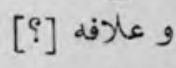

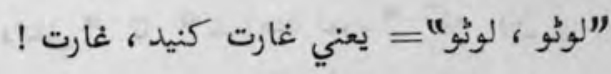

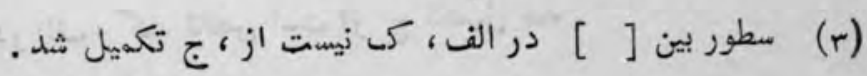


تازه نواي بعاركى

795

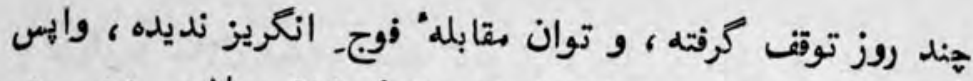

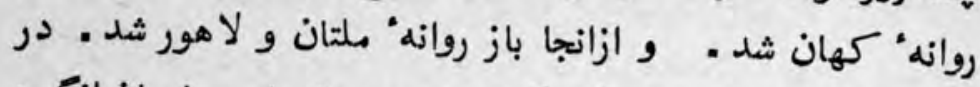

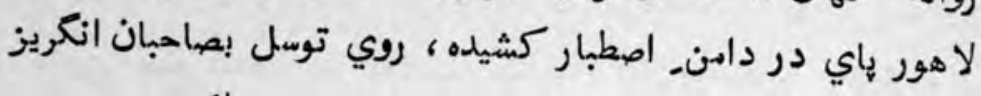

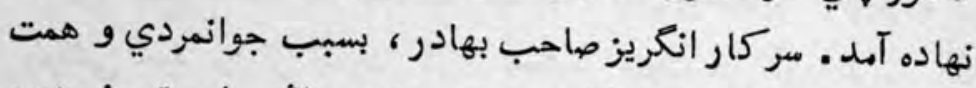

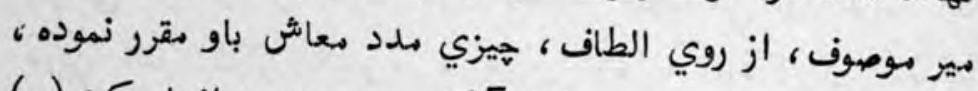

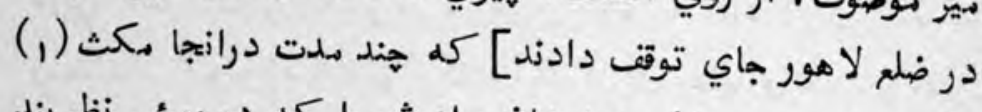

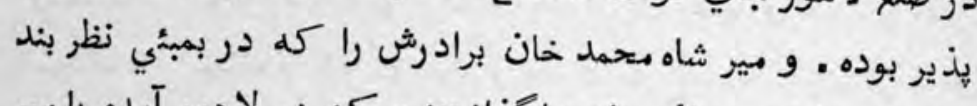

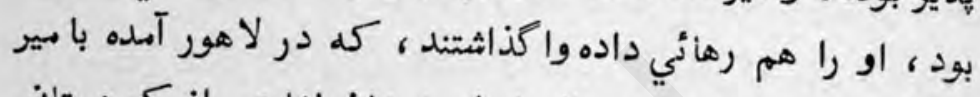

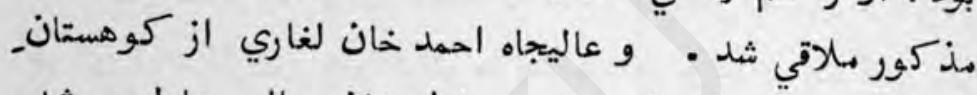

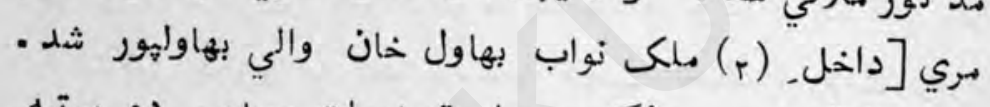

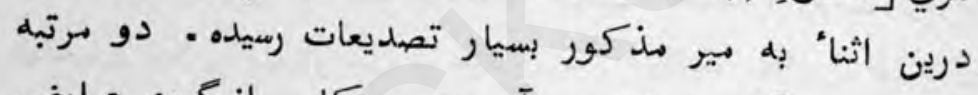

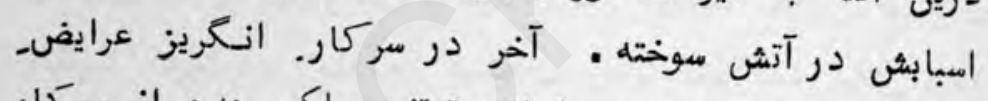

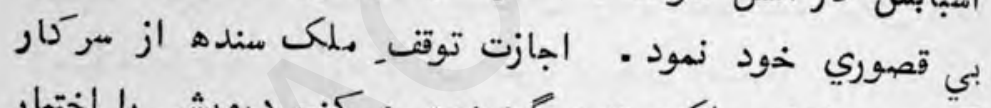

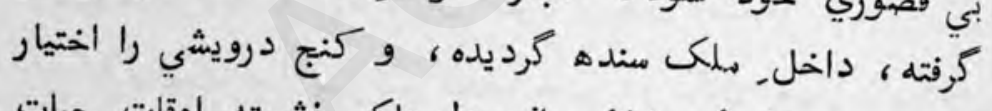

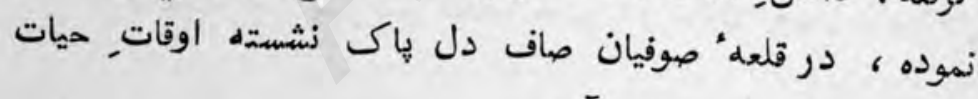

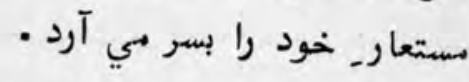

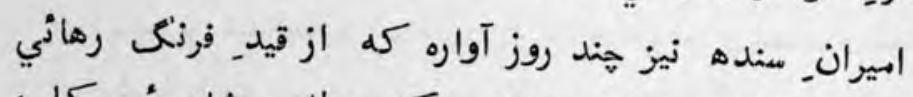

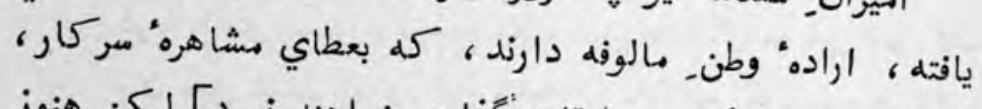

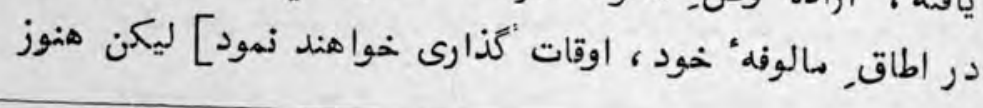

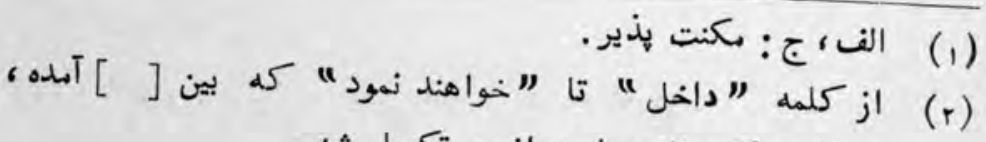

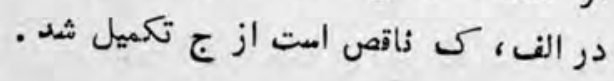




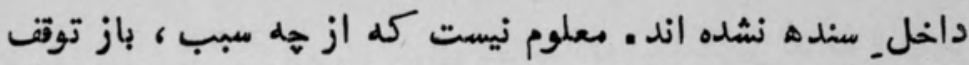

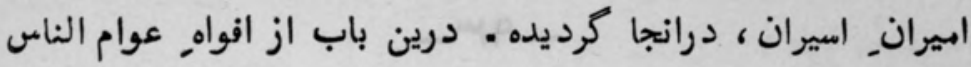

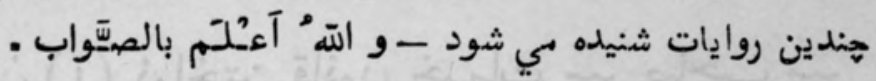




\section{$-9 \mu$}

نر بيان_( ) ذواختن قاذون خدمات مير ماحب مير

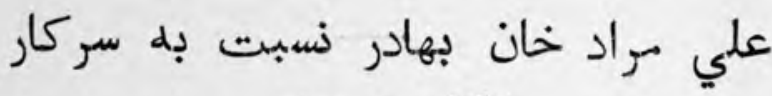
ازخليسه بهادر

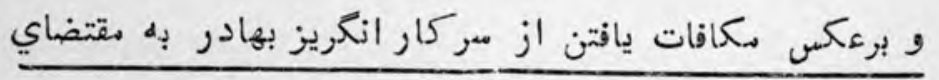

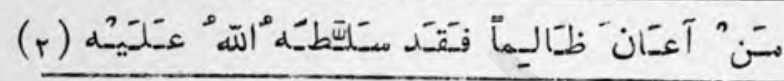

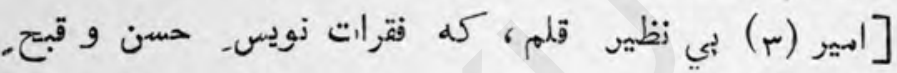

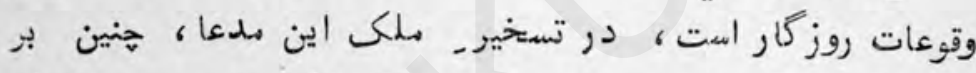

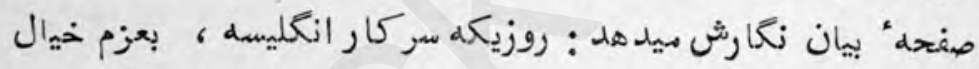

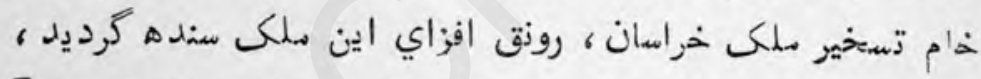

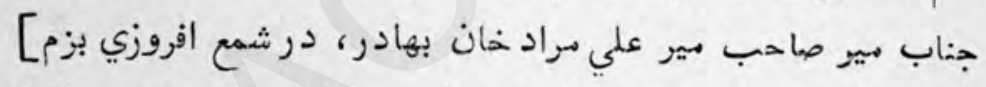

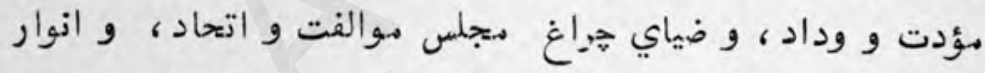

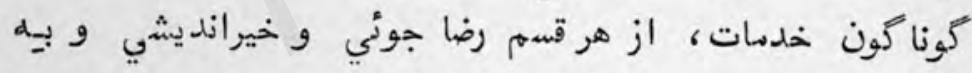

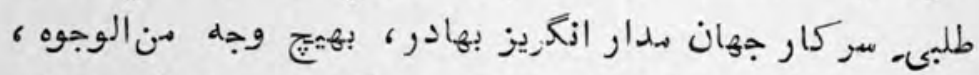

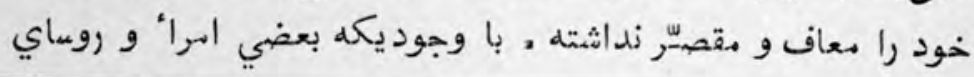

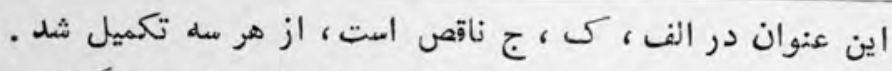

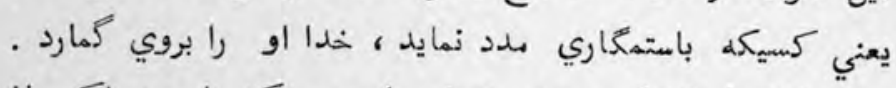

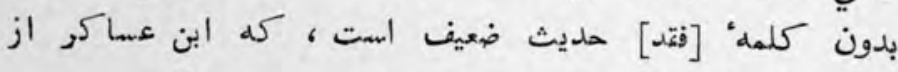

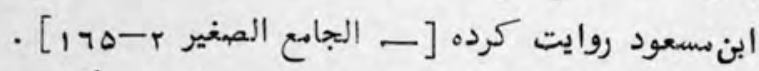

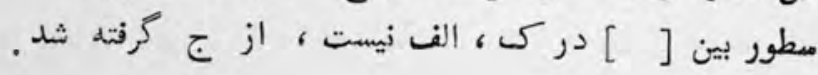




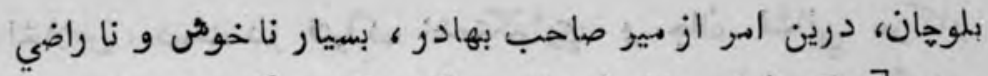

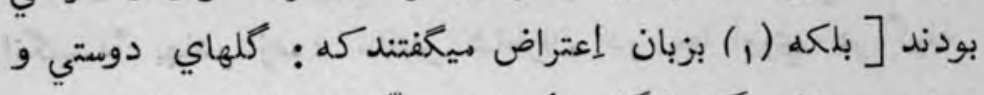

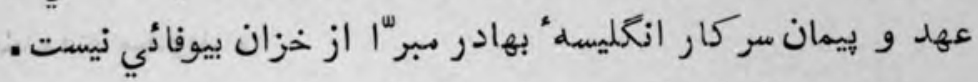

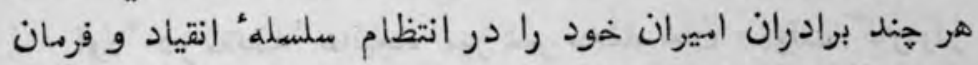

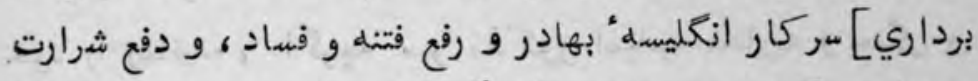

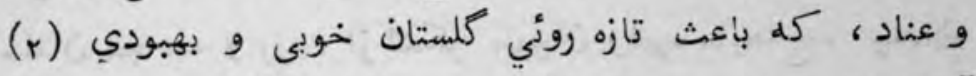

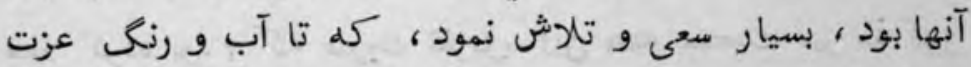

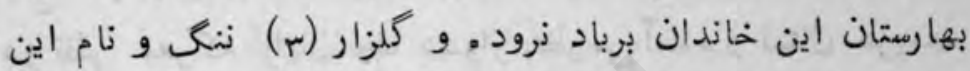

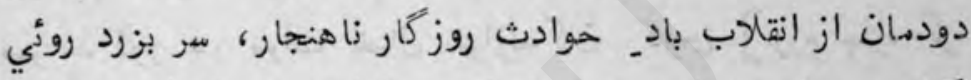

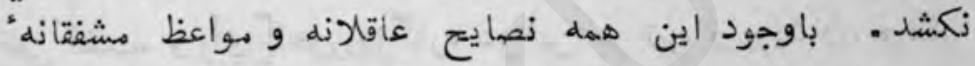

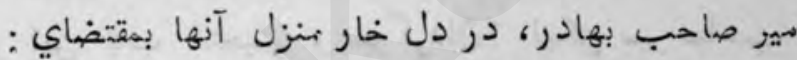

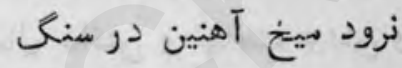

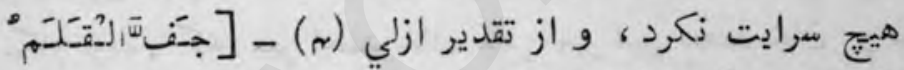

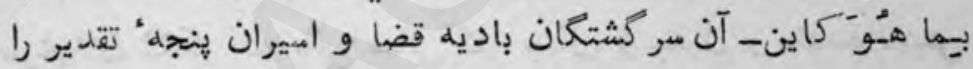

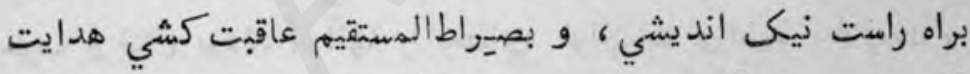

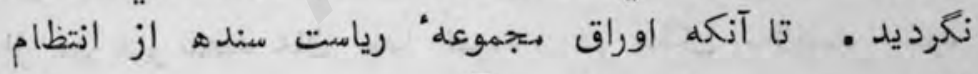

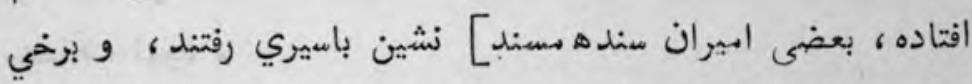

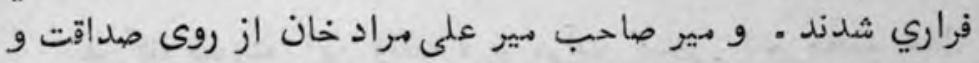

سطور بين [ [ ] در كى نيست ، در الف هم ناقص است .

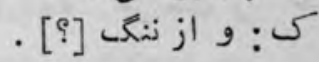

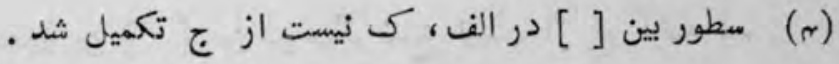


تازه نواي معارك

799

اخلاص، دمت در فتراك خدمتكذاري و جان فشاني مروار

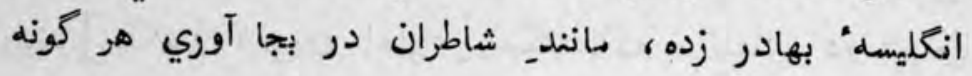

- خدمات ميدويد

اولا" در مقدمه" عاليجاه مير شير معهد خان ، بوقت كار زار

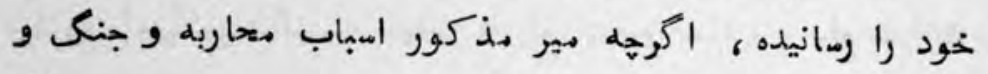

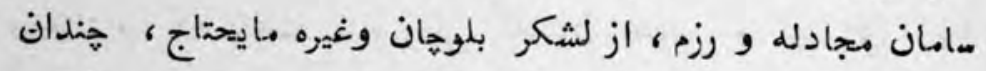

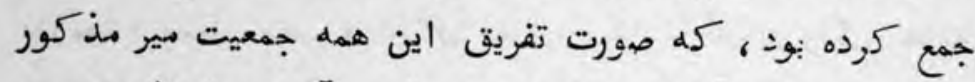

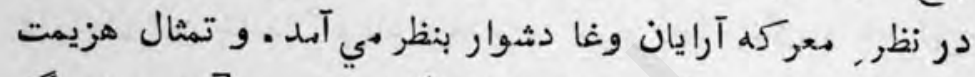

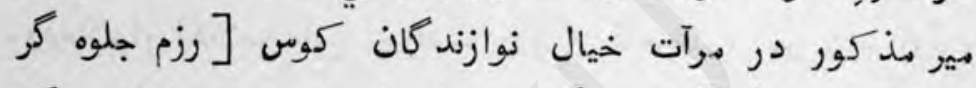

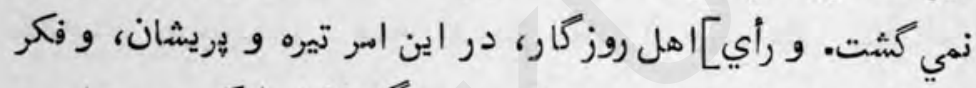

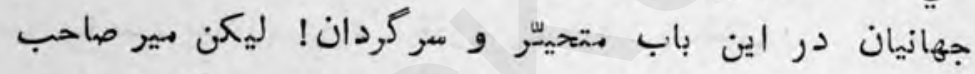
[بهادر] از راه كمال دانش و نهايت بينش و فرزانكي، تدبيري

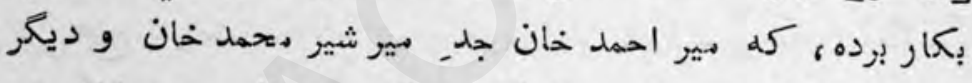

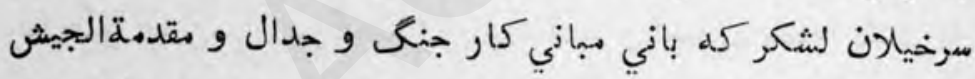

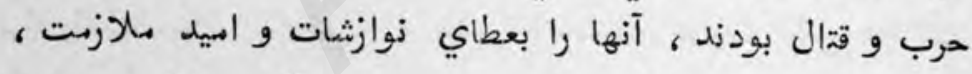

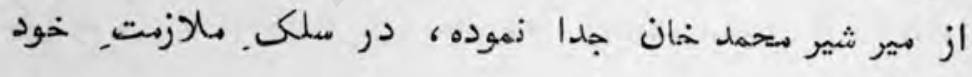

- نمون Sam

هر كاه صورت_ اين واقعه ، بر مرآت_ ضمير ـ شير مفحم خان

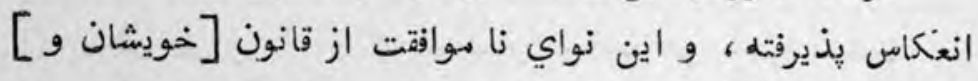

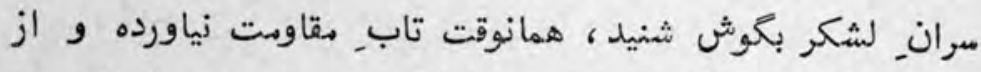

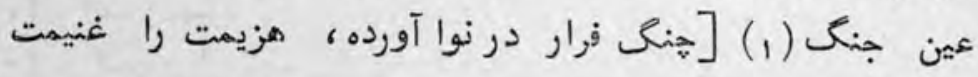
(1) اين سطور بين [ ] ] نيز در ديكر نسغخ نيست از جرفته شد. 
دانست • هر گاه از حسن تدبيركامله و فرغ بالغه مير صاحب

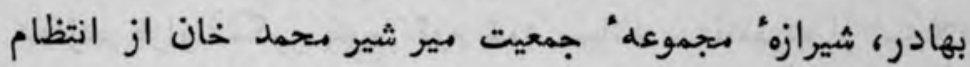

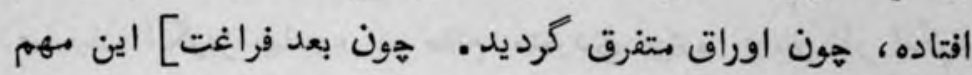

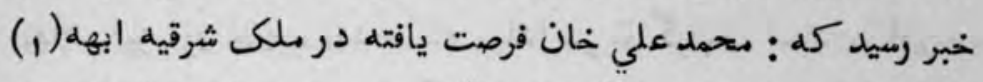

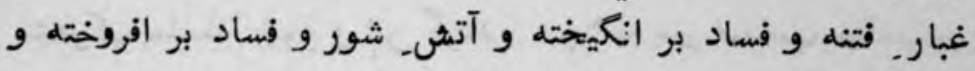

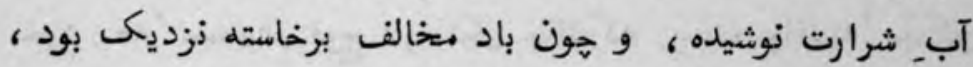

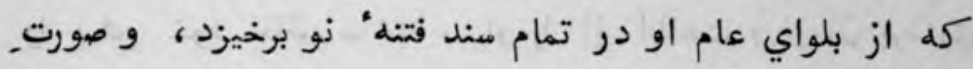

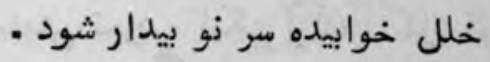

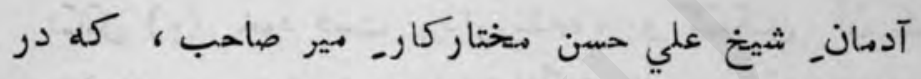

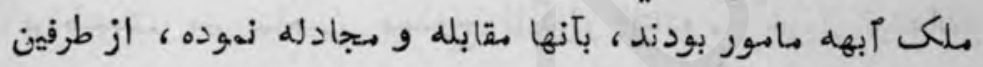

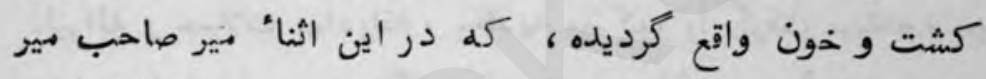

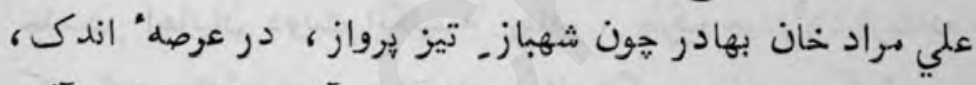

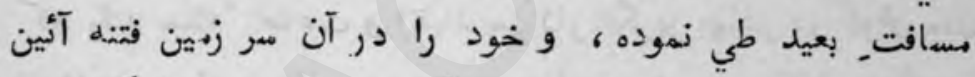

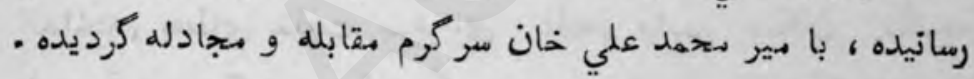

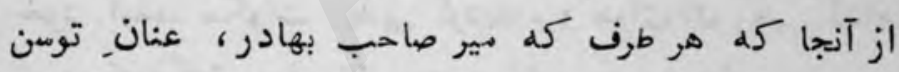

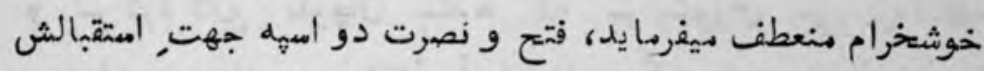

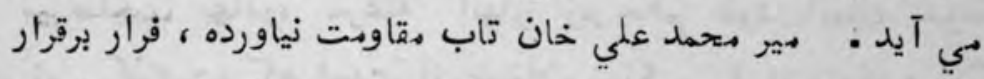

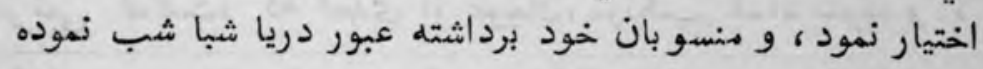

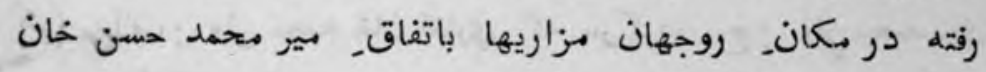
خلف مير رستم خان توقف كرفت .

$$
\text { اين دو كلمه درك نيست. الف: مانند تمن · ج : اوبهه . }
$$


و ديكر وديره ولي ثحمد خان هانديه (1) كله مبركرده:

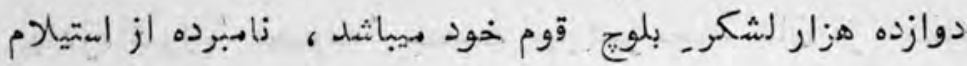

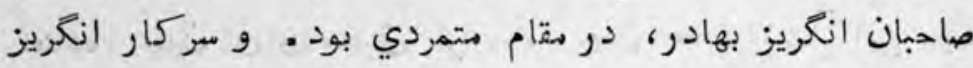

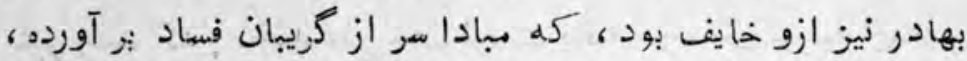

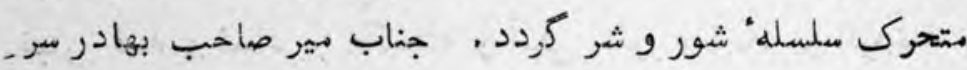

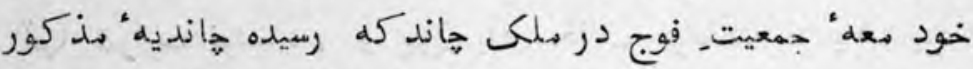

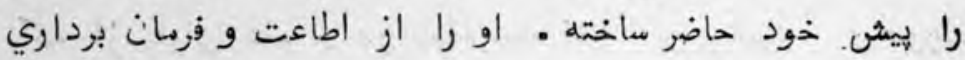

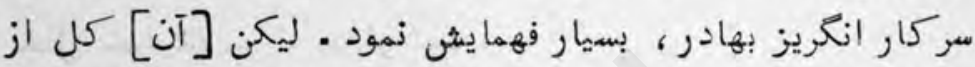

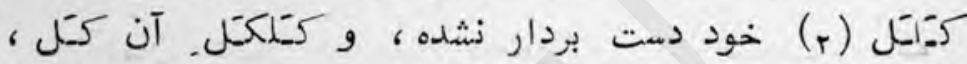
بر طبيعت, دير صاحب_ مهدوح ناكوار افتاده. . آخر از ترددات

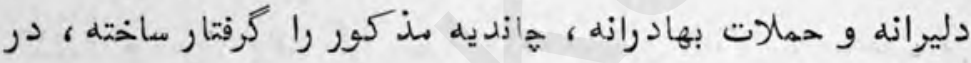

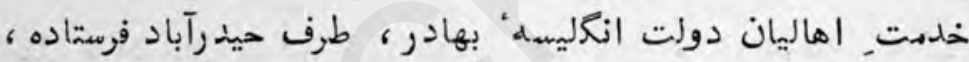

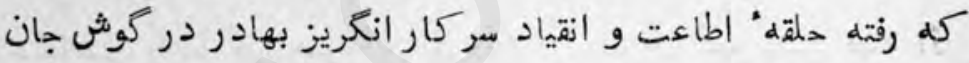

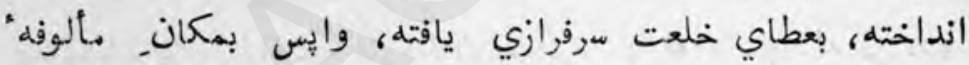

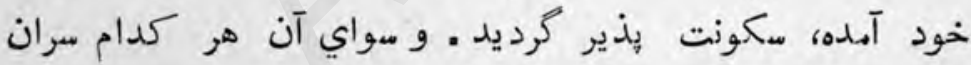

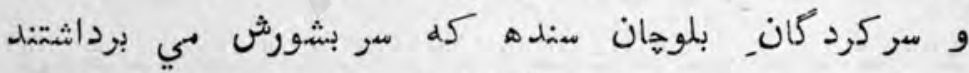

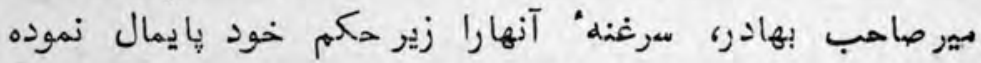

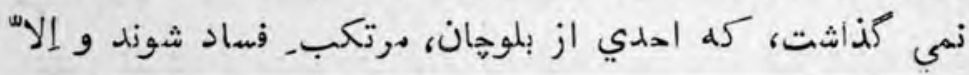

الف: ولى مشهد خان لغاري كه مركرده. . ج : ولي دمهد خان

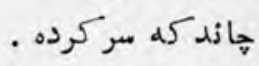

الف، ج: ليكن آن از قلقل كرده خود دست بردار نشهده و قلفل آن

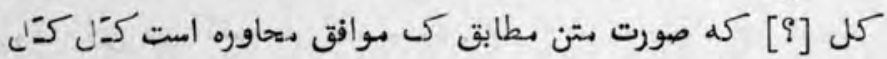

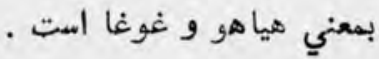


799

تازه نواي معارك

يدمعاشان بلموخان ياجوج ماجوج طينتان اكر مطلق العنان

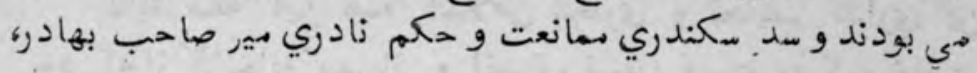

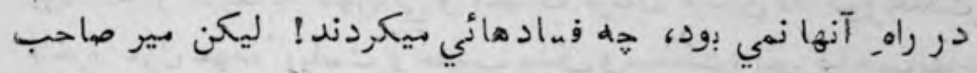
بهادر براي زوسأي بلوهان سخت احكاهـات جاري داشته، كله زنهار

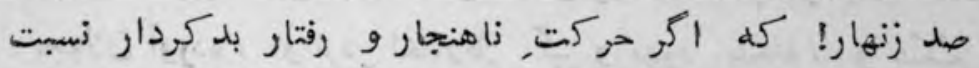

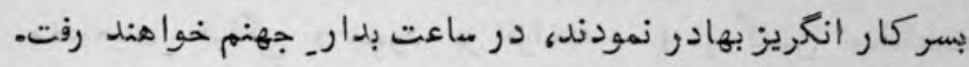

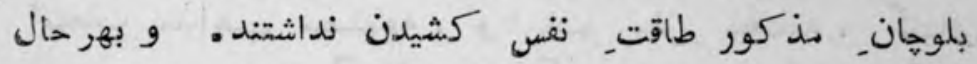

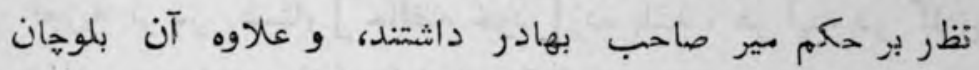

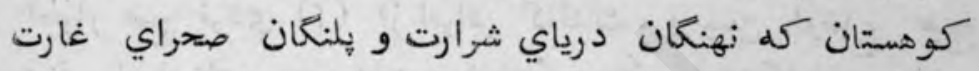
بودند، هنانجه [ابيات]

خون خوار، ظالمان. سيه كار هي جفا (1) بي باك و شوخ تر ز يهودان خيبري

غارت كران و راه زنان جمله عاصيان

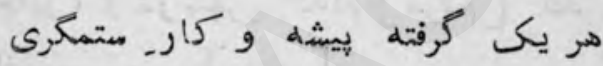
هر يُك (r) سمند ديو جفا كار كينه ور

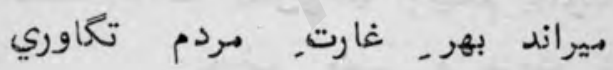
ازصولت ومهابت_شان روز و شب بجان ترسنده دل رعيت و لرزنده لشكري مسدو: كشت راه همله رهروان وز فتنه و ومه فهاد ازين قوم مضطزي

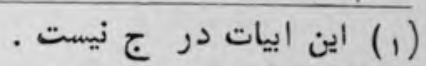

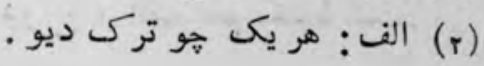


ني ديده هيجكم عَّلَمَ, كاويان مكر نشنيده اين كروه گهي طبل- سنجري

نكرفت دست_اين همه د يوان_ جنك جوي.

در دور, حكم خويش، سليمان ز داوري

هركز نه (1) بست درورـ ياجوجيان مكر دوري

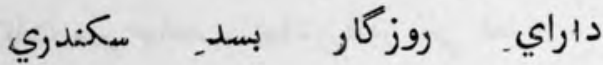

[تسخير,كس نكشت بر اين كوه اين كروه

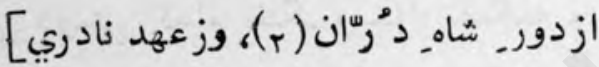

كشور كشاي سنده عدو بند. صف شكن

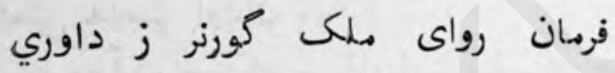

$$
\text { آورد جيث از بي. تنبيه_ (r) اين كروه }
$$

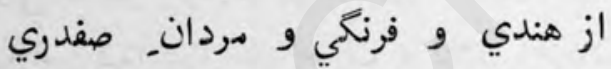

$$
\text { كردند تاخت بر سر ادن كوه و اين كروه }
$$

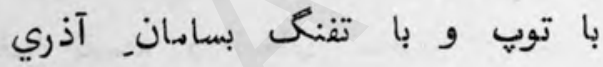

شد بيشواي. الشكر انكليسيه همه

مير علي مراد، بصد شان, سروري

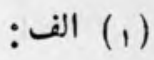

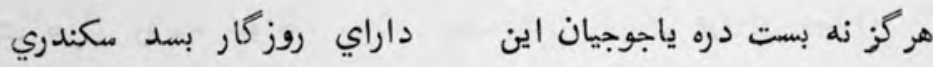
(r) مقصد اهمد شاه ابدالي افغان و نادر شاه افشار است. [r) 
L. I

تازه نوائ معارك

مير علي مراد بر افراخت هون عَّلَمبم

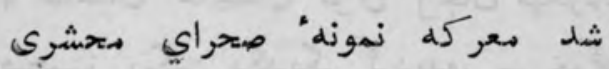

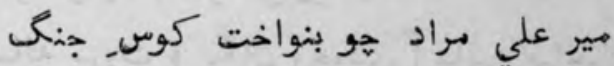
شد در غريو كنبد كرودئ كرون اخضرى

هير علي مراد به تدبير, كار, جنم

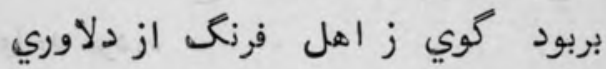

ازحسن راي و دانش و فرهنكه و فكر و هوث بري

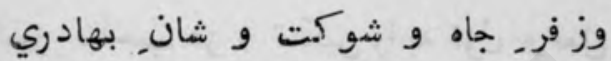

مير بلند شان ، سران كروهي كوه

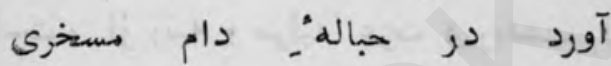

فيروز كشت خسرو, اسلام داد كر

مير انير [اين] بصد فرّه

شد فتح مند بير المم در زمان خويش

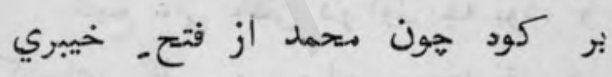

كفتيند صاحبان, فرنكى، آفرين تمام

بر مردي و شجاعت آن مير كوهري (1)

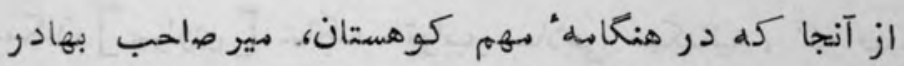

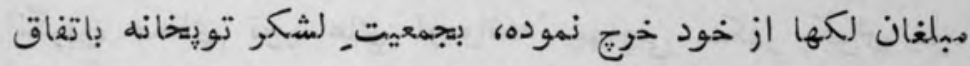

[؟] (1) 
نيهير (1) صاحب كورنر سند بر كوهستان رقته، بجار خان

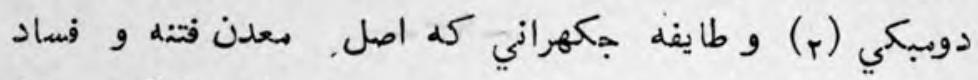

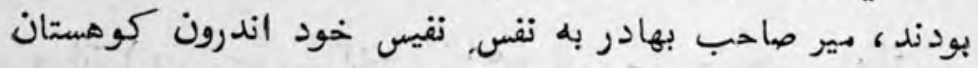

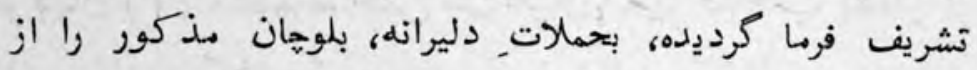

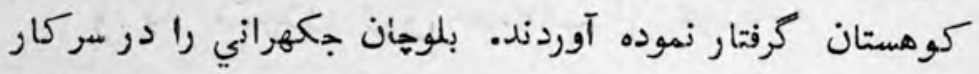

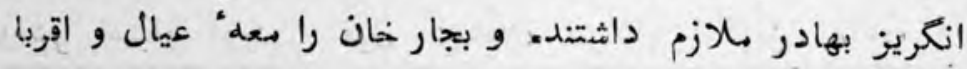

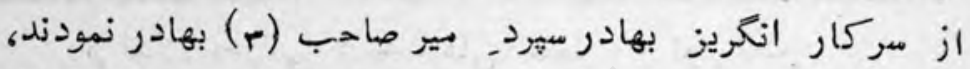

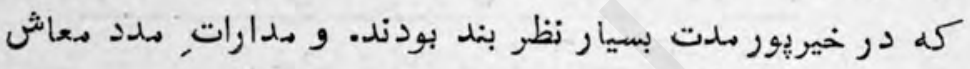

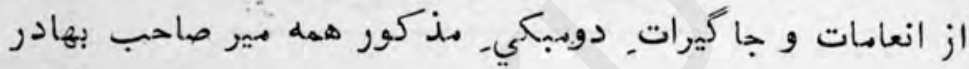

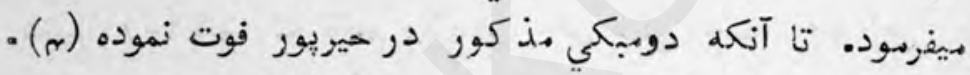

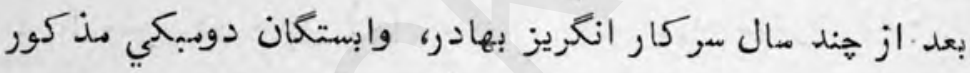

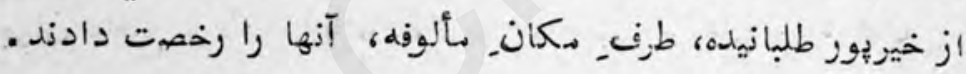

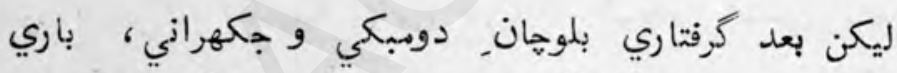

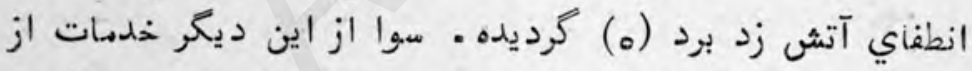

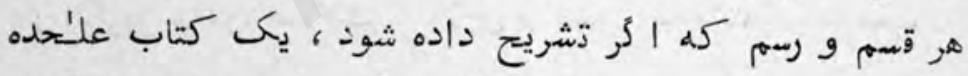

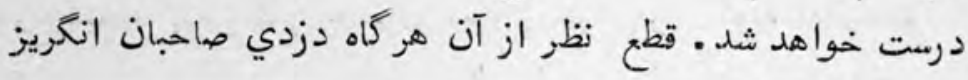

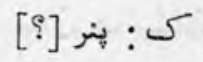

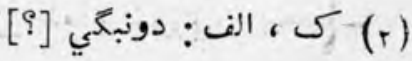

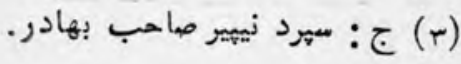

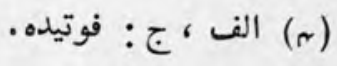

$$
\text { ك : روبرو }
$$


و خواه مردم مترددين، در حدود ملمك مير صاحب بهادر

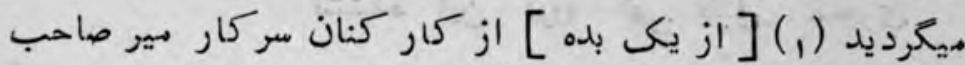

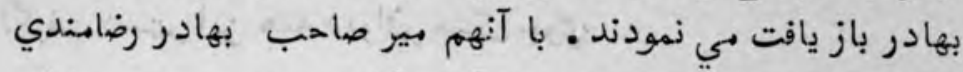

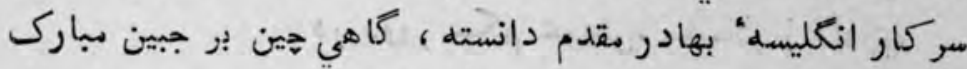

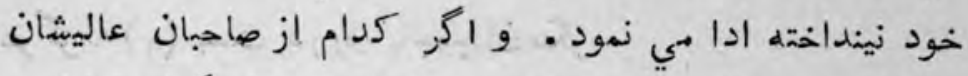

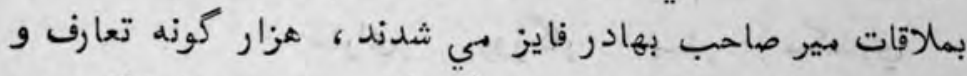

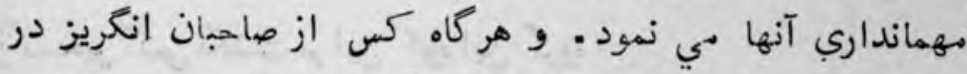

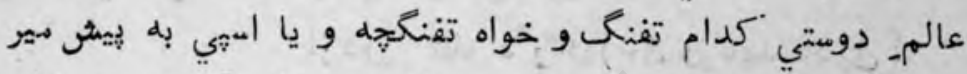

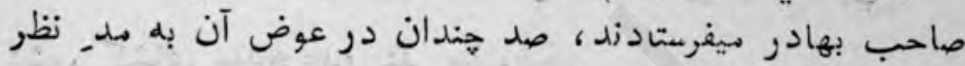

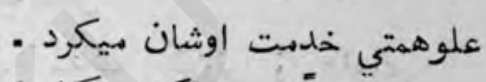

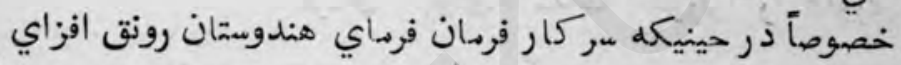

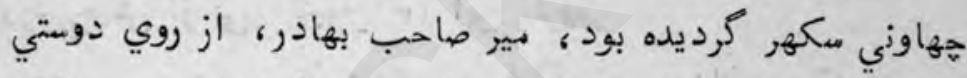

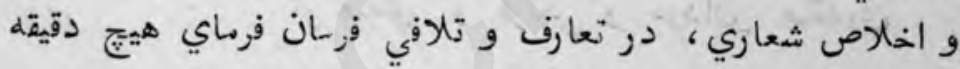

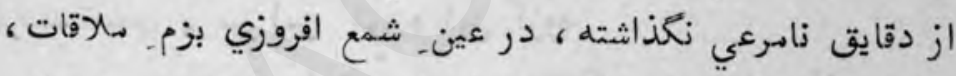

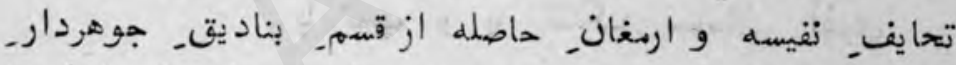

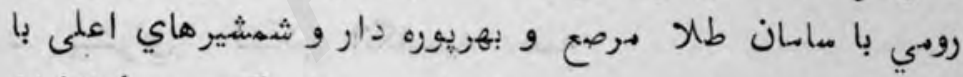

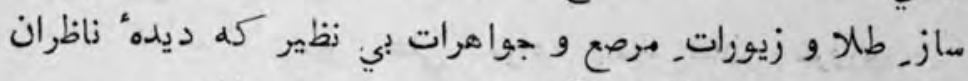

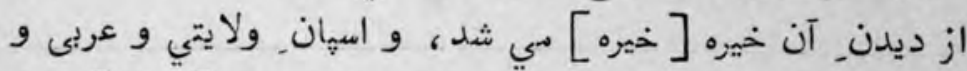

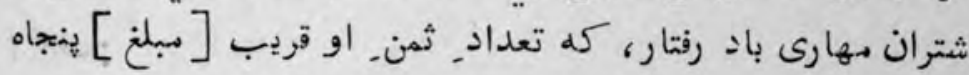

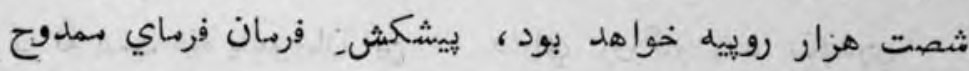

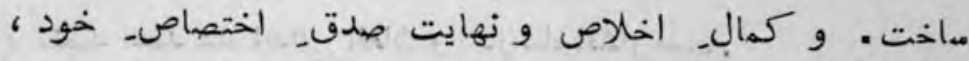

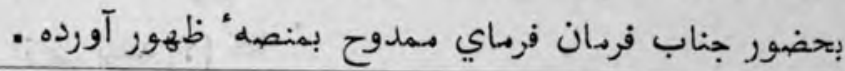
الف : ميكردند . 
تازمنواي معارك

L.

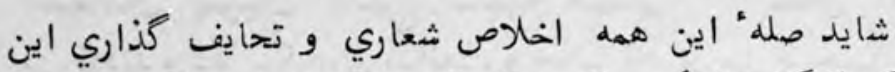

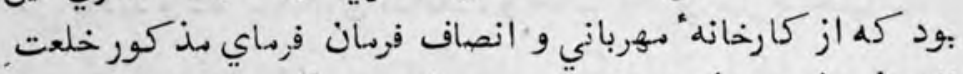

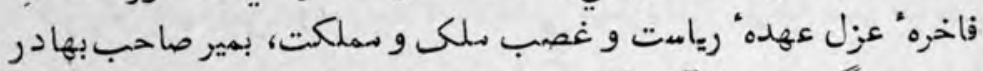

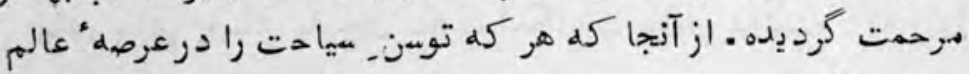

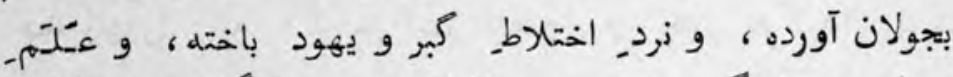

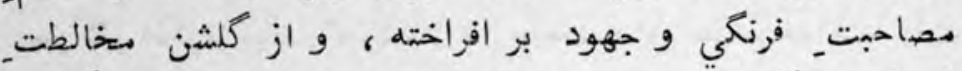

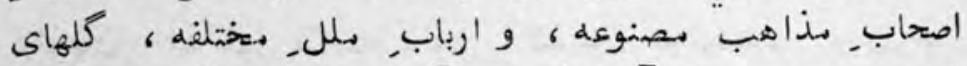

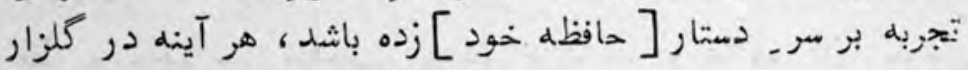

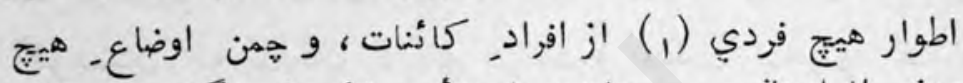

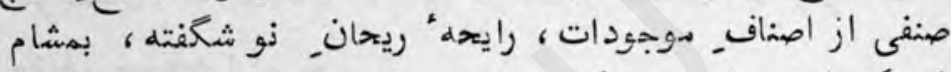

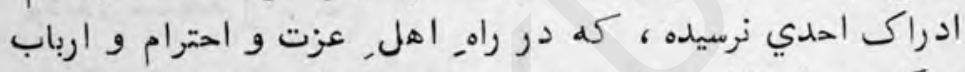

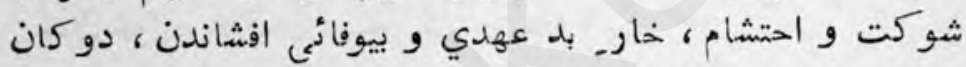

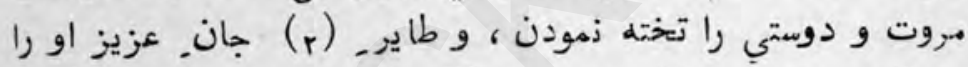

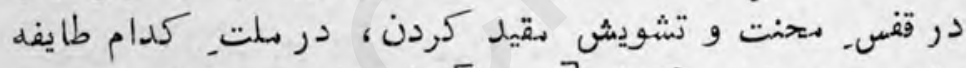

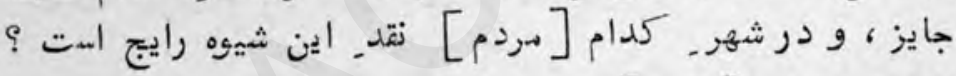
افنسوس مانز

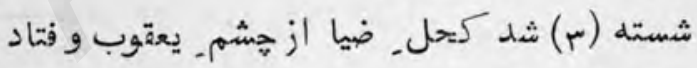

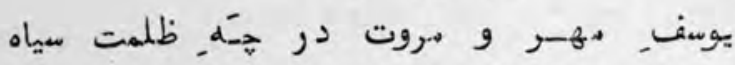

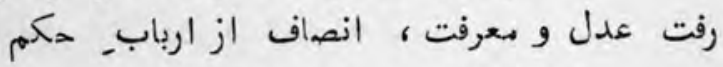

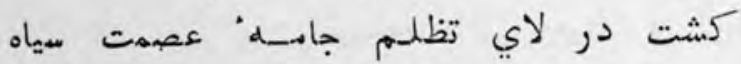

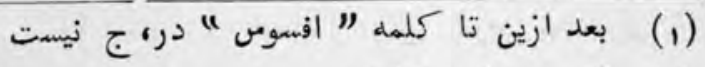

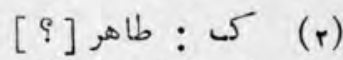

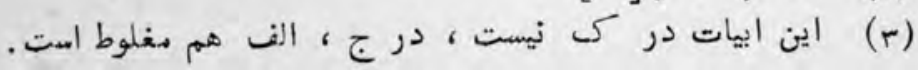

حتي الدقدور از هر دو البلجح شد . 
در بيان ( 1 ) متهم ساختن مدسعيان، مير ماحب بهادر

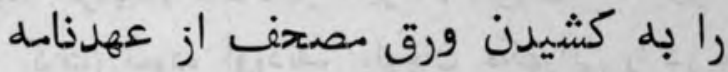

و در اعتبار آوردن, قول مدعيان سركار انكريز بهادر،

و نمى بحرامي شيخ على حسن و نوازشات.

\section{مير صاحب بهادر باو [وغيرهي}

بشير_ (r) قلم كه ناظم ولايت_ سخن داني است، قلم اين

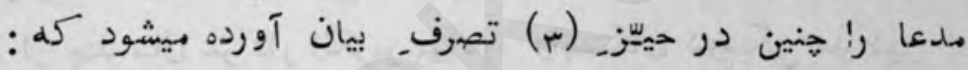

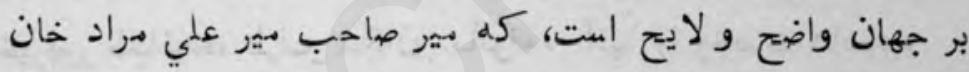

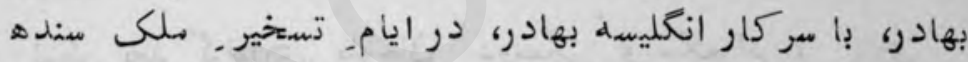

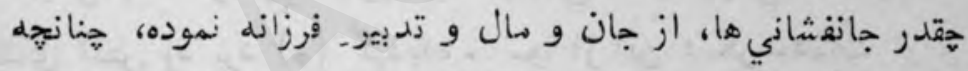

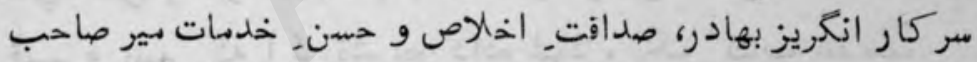

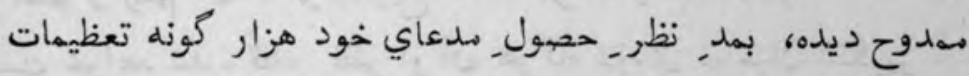

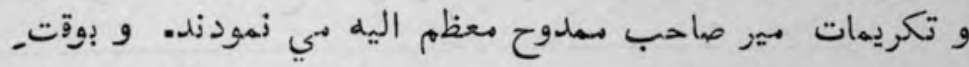

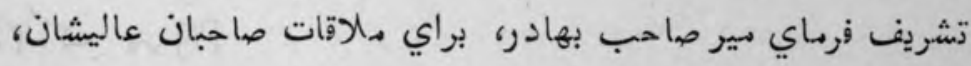

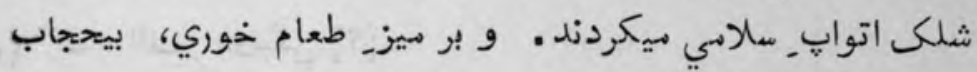

$$
\begin{aligned}
& \text { (1) اين عنوان در ج نيست. }
\end{aligned}
$$

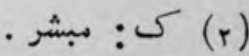

$$
\begin{aligned}
& \text { ك (r) }
\end{aligned}
$$


تازه نواي معارك

C. 7

مير صاحب را جاي بيدادند، كله طعام خود را طلبانيده، يكجا

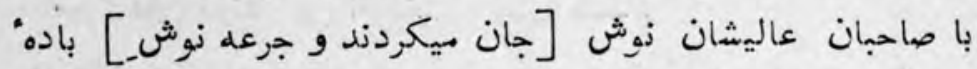

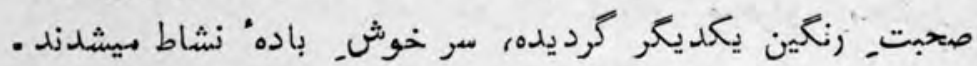
و اينجنين [شيرازه" رساله مروت و يكان وجودي] مابين صاحبان

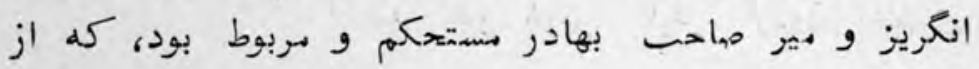
كشا كش هيتج حوادث زا هنظم شدني نبود، بإكه دولت طروفين

واحد بود م

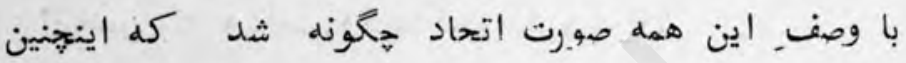
اميز, صاحب عز و تمكين را به قول و فعل ـدعيان زدمى بحرامى

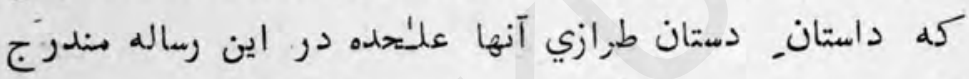
است ، از رتبه و مرتبه عزت و رياست انداختند؟ صورتــ اين

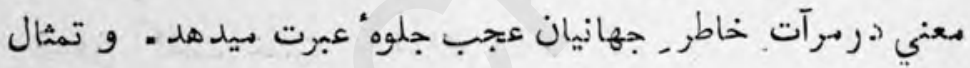

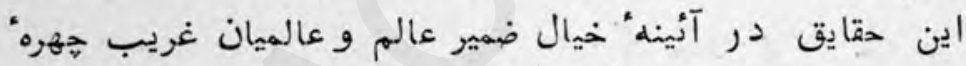

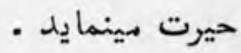

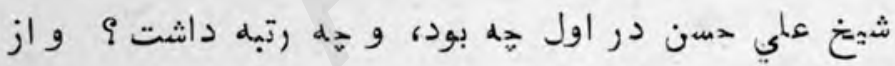

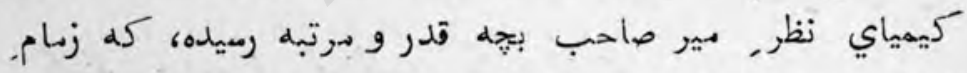

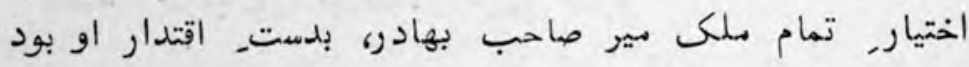

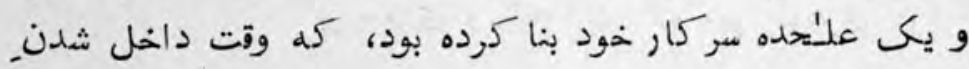

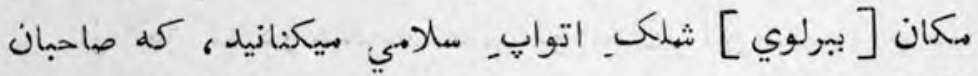

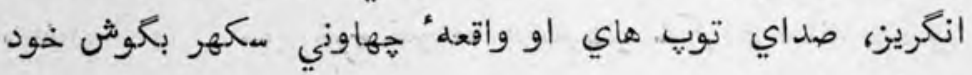

- مي شنيدند از آنجا كه شيخ مذكور، به غرور نفس خطلا كار، هواي 
بلند بروازي در سر كرفته، طريقه" زهك بحرامي در بهيش كرفت،

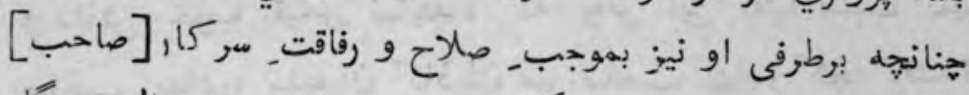

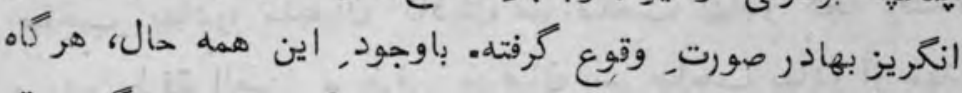
مير صاحبب ورق. عهد نامه از كلاماله كشيده، و ديكر وزق

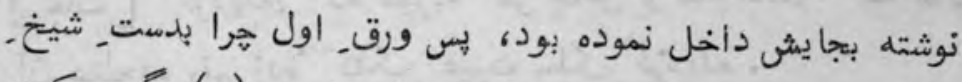

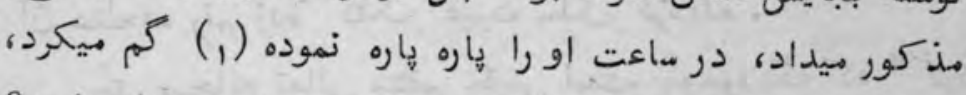

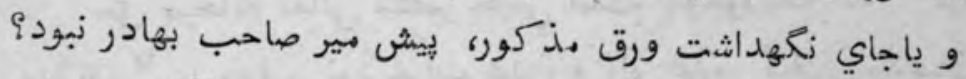

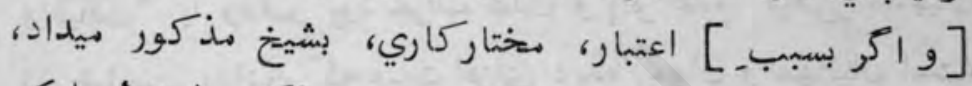

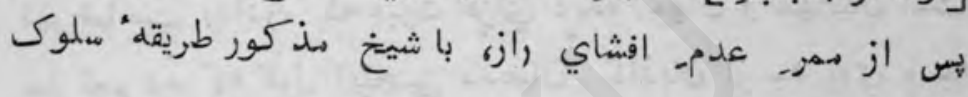
ميكرفت

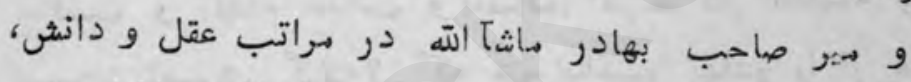

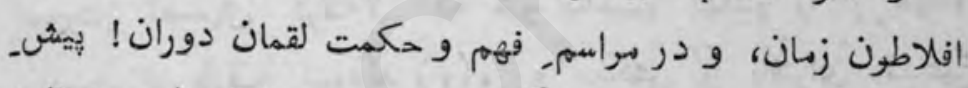

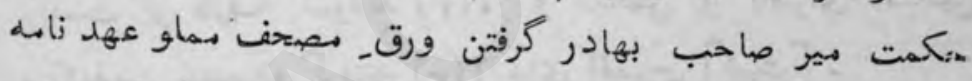

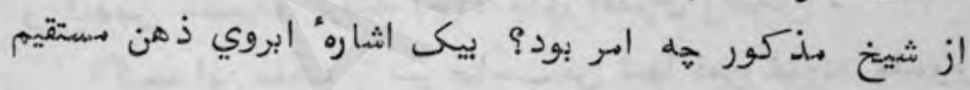

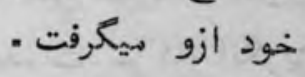

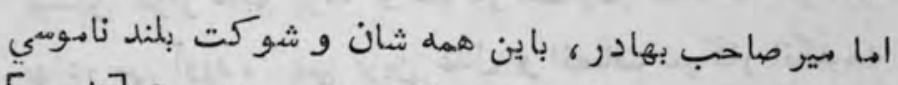

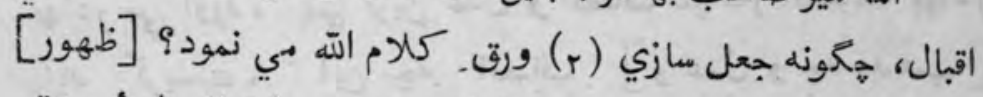

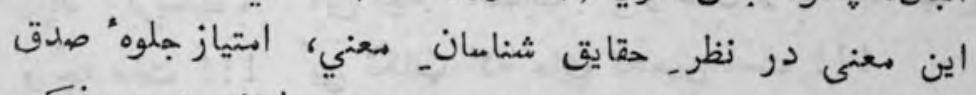

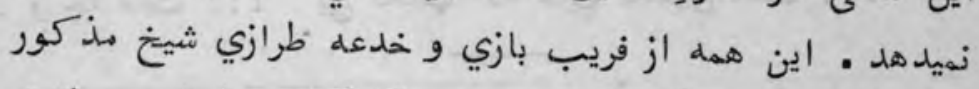

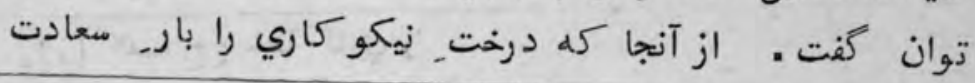

$$
\text { (1) }
$$

[؟] [ 5 (r) 
دو بار، و جفاكاري (1) را دكافات در بي است، اهل ادراك اند

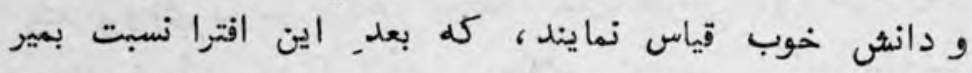

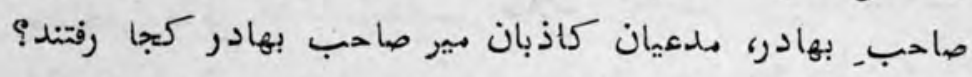

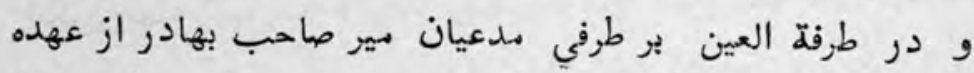

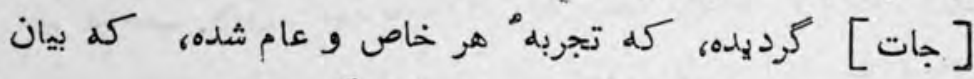

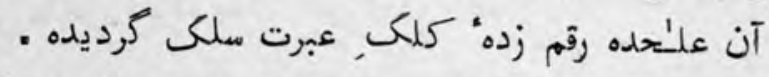

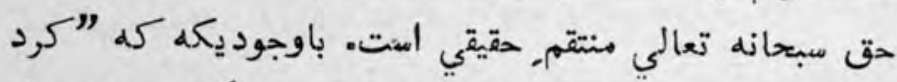

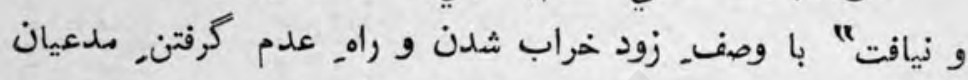

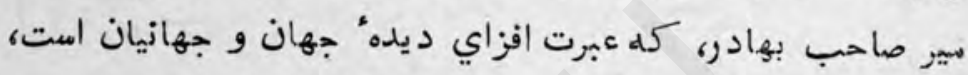

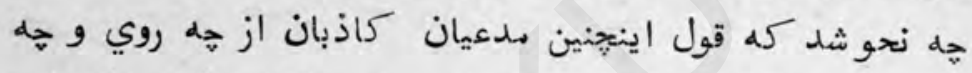

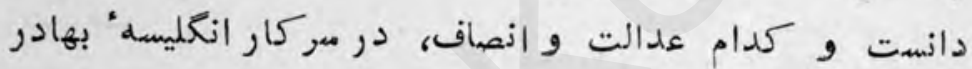

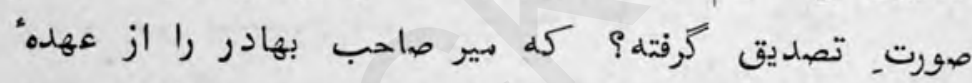

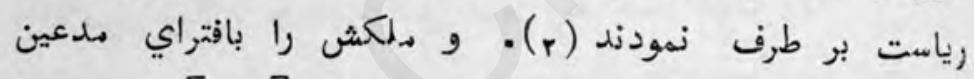

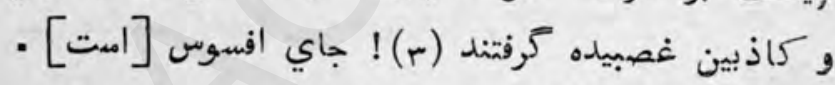

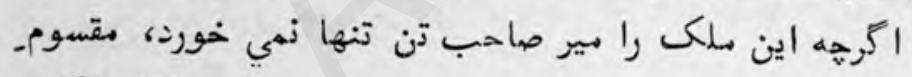

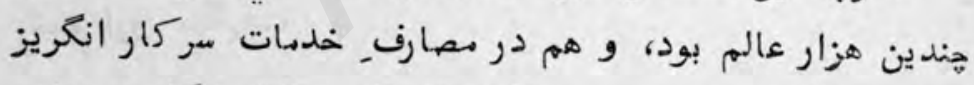

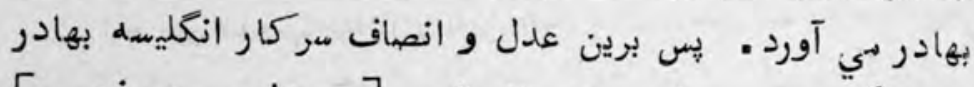

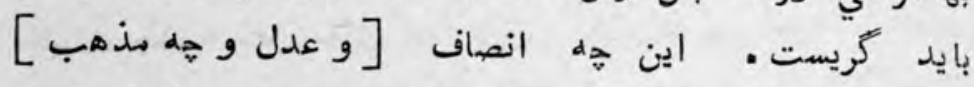

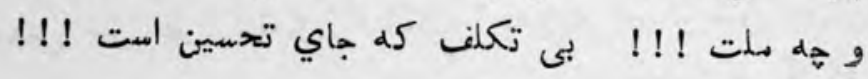

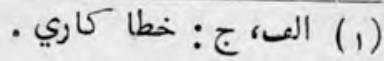

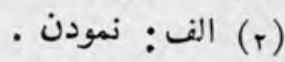

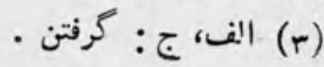


$-90-$

در بيان نمك حرامي شيخ على حسن و

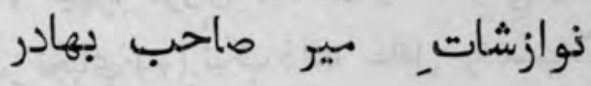

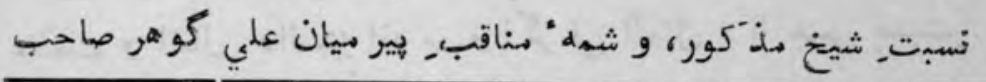
زاغ- قلم- سيه رقم، از مداد. افترا سواد الوجهي حاصل

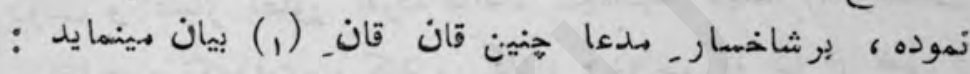

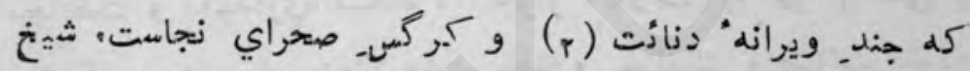

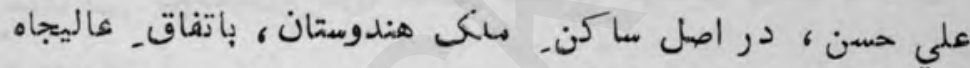

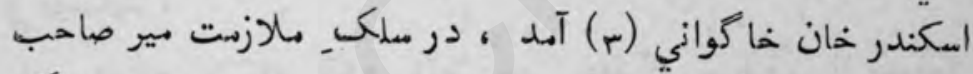

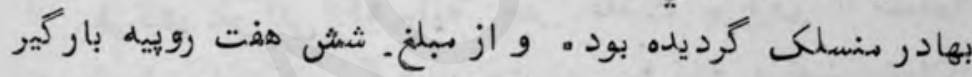

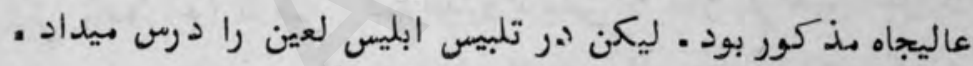

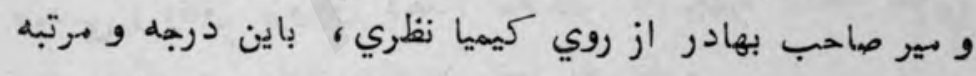

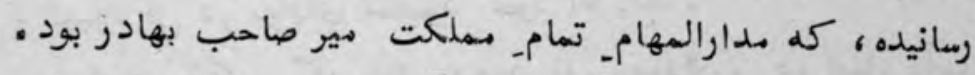

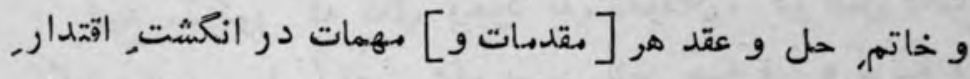

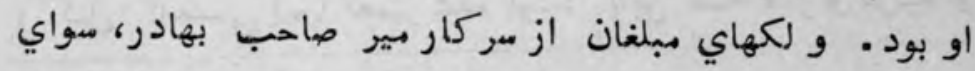

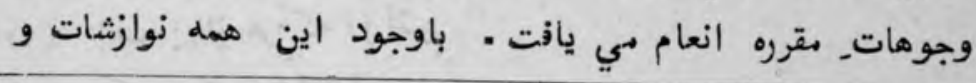

(1) الف : غوناي بيان.

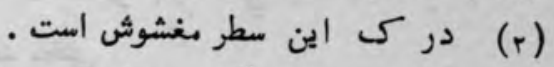

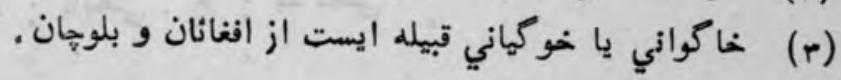


تازه نواي معارك

$<1$.

انعاهات و كمالـ اعزاز مير صاحب بهادر بر طبقـ مضمون [بيت]

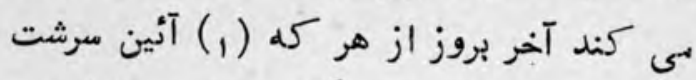

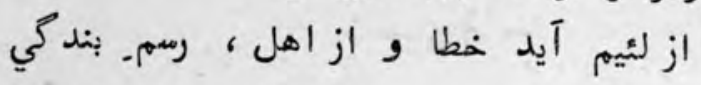

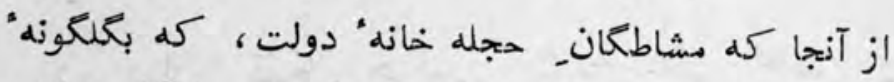

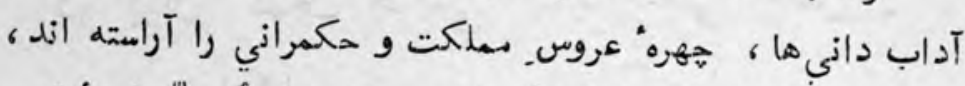

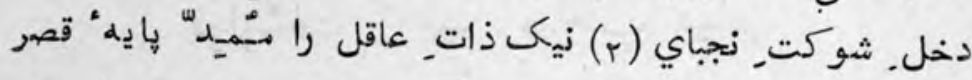

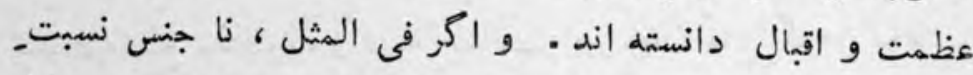

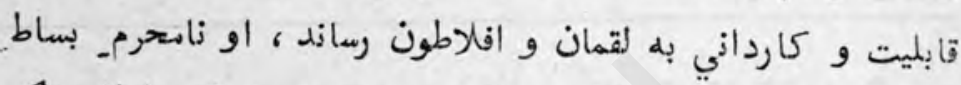

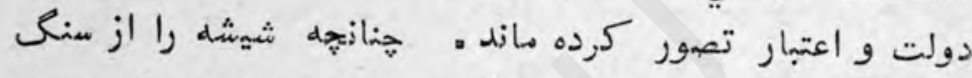

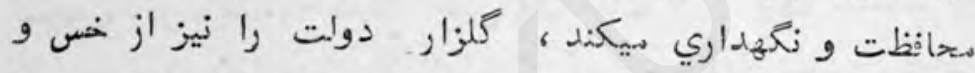

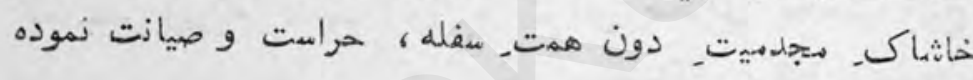

- و مينمايد

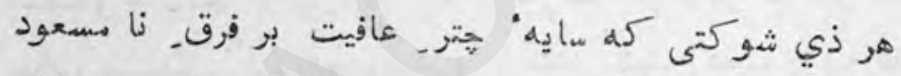

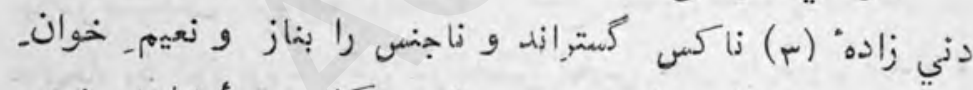

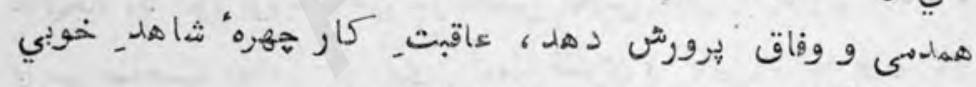

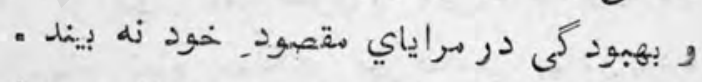

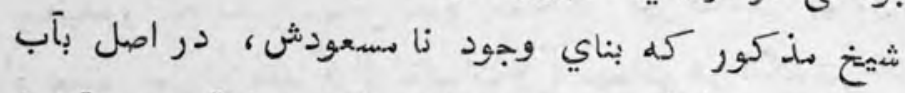

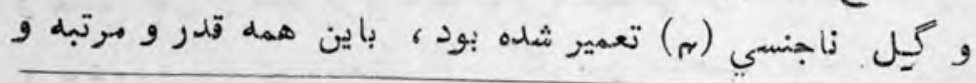

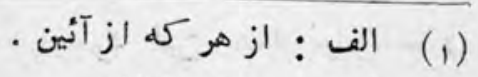

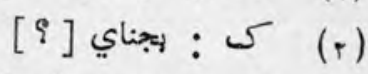

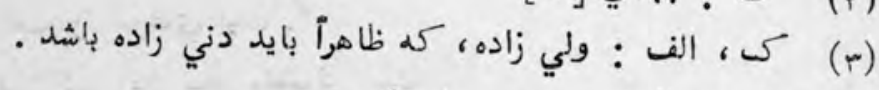

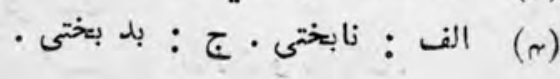


تازه نواي معارك

دولت اقبال ، كه بير صاحب بهادر باو رسانيده بود، حقوق.

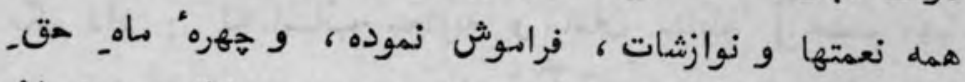
نمك را بخسوف كمفر نمك بحرامي بوشيده، باطاءت و فرمان

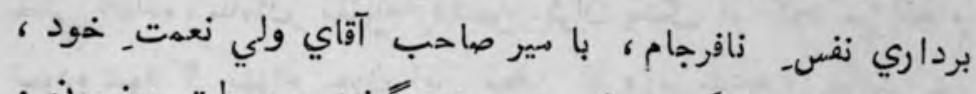

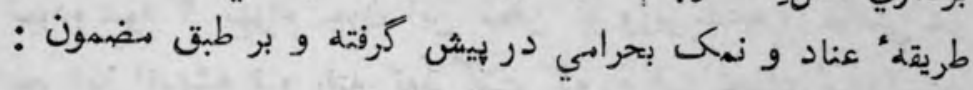

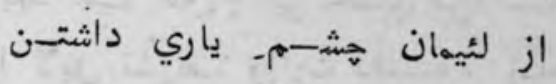

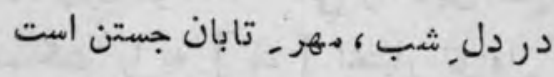

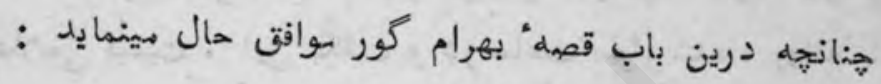

نقل است

كه بهرام كور يكي از ملوك عجمه بود . خود در ايام شباب

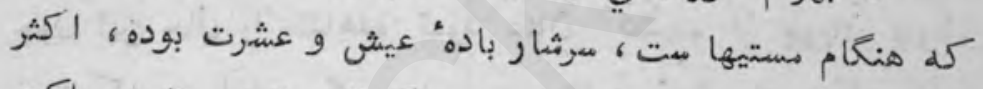

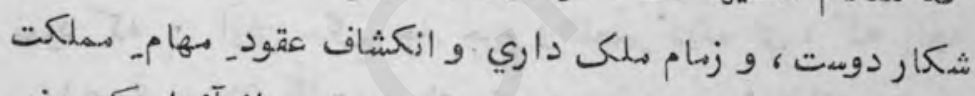

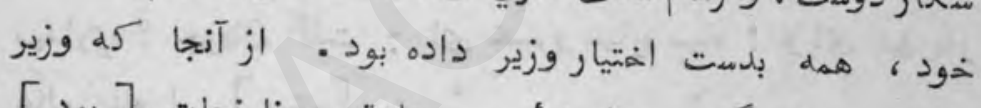

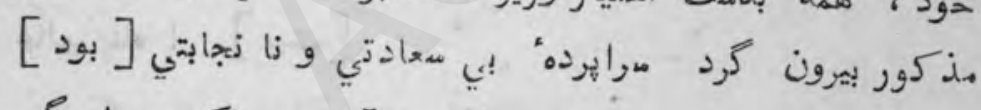

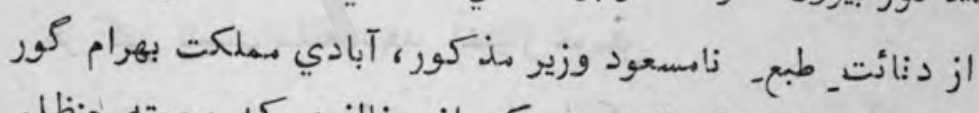

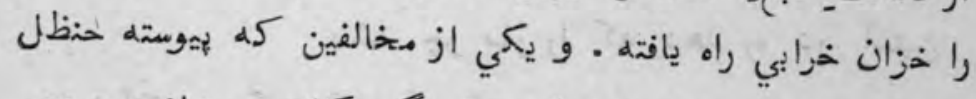

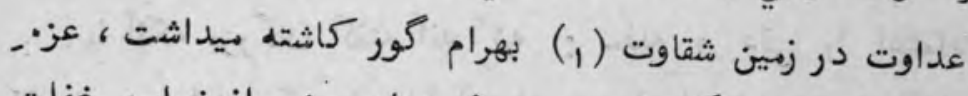

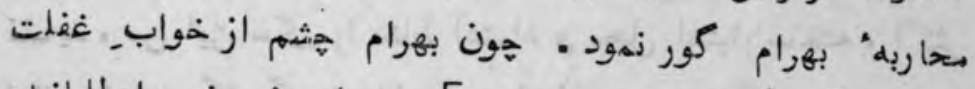
كشاد [ديد، كله عجب رقدمهل]

(1) الف ، ك : شقا · ج : شقاوت. 
حلم داد : كل اسباب محاربه و سمامان مقابله' [خصصم مهيا

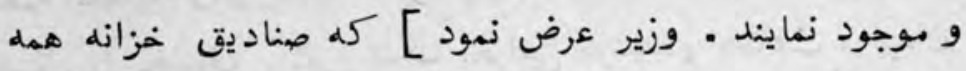

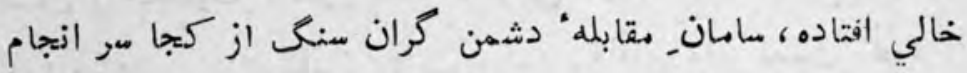

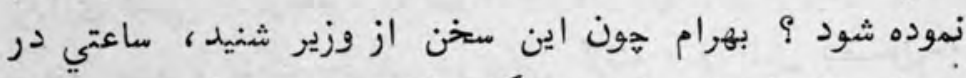

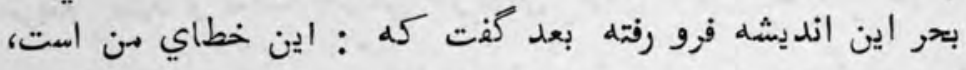

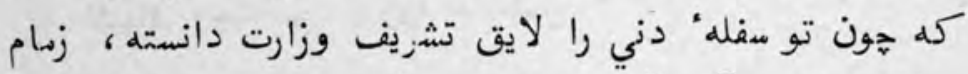

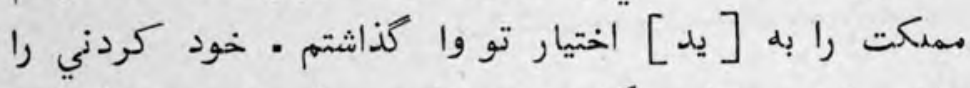

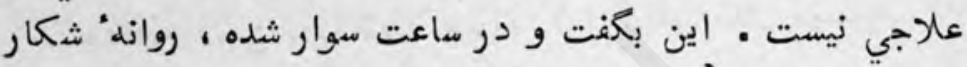

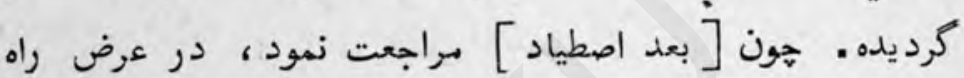

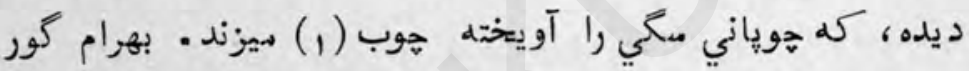

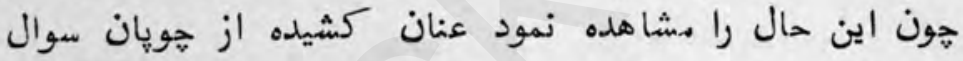

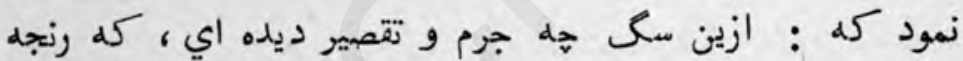

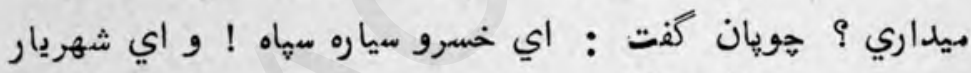

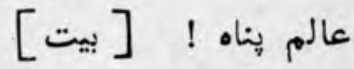

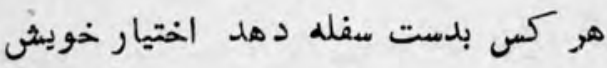
باشد هو مار را كله دمالمد رو در آستين

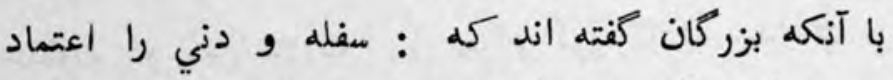

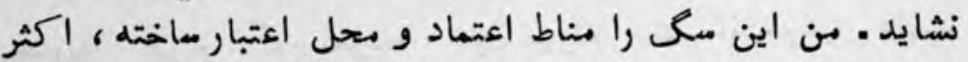

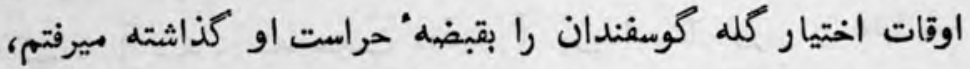

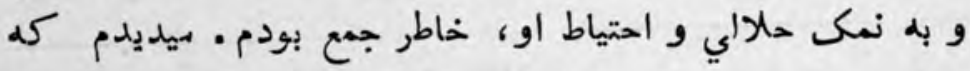

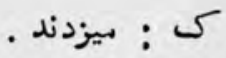


$\angle 1 r$

تازه نواي معارك

روز بروز تنزلي دمر كوسفتدان هميرميد. - و نمى دانستم كم كه اين

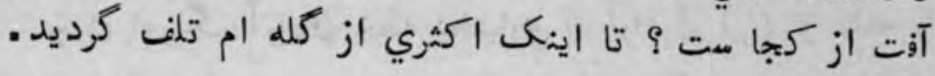

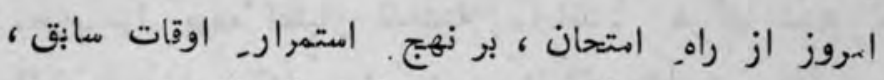

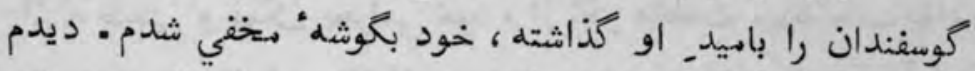

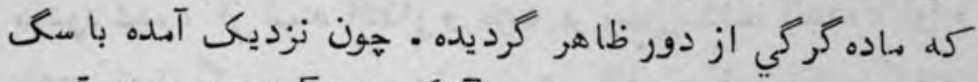

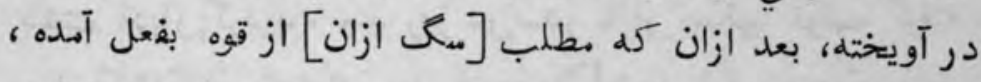

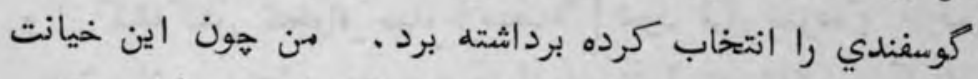

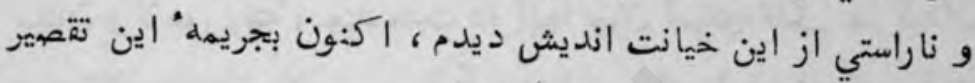

- تنبيهش ميكنه

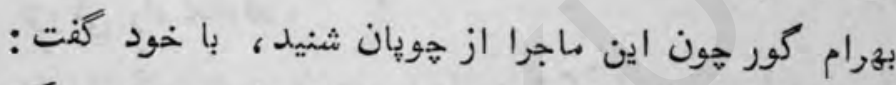

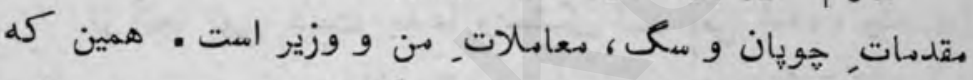

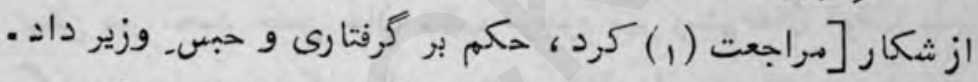

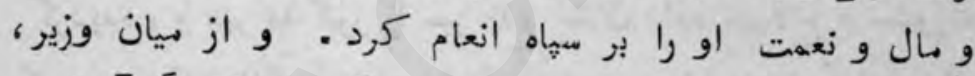

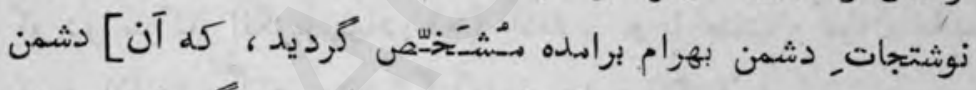

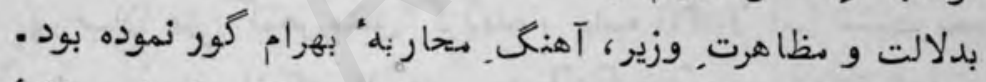

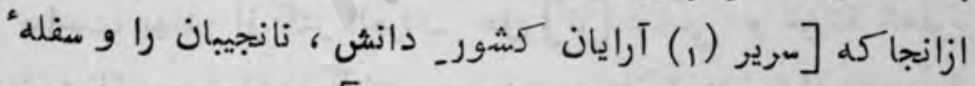

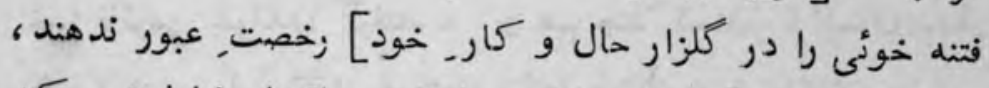

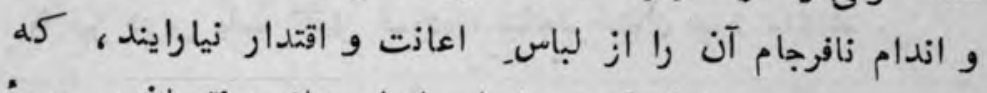

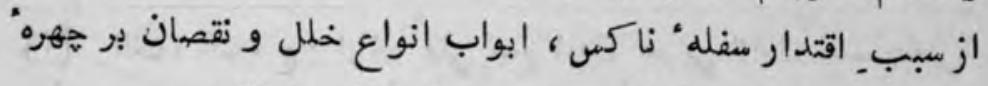

حال خاص و عام كشايد ، و بسي فتنه ها برخيزند . (1) جمالات بين [ ] در الف، كى نيست، از ج تكميل شد . 


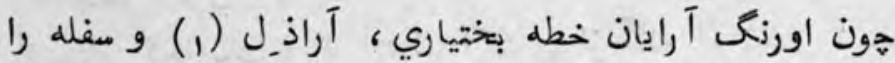

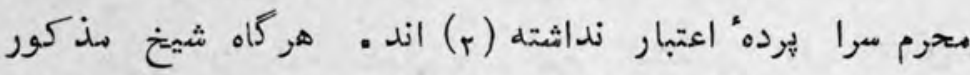

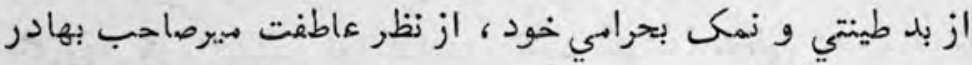

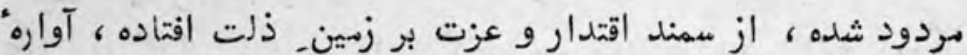

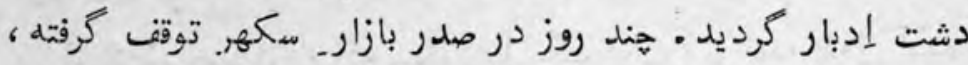

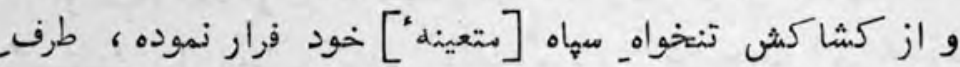

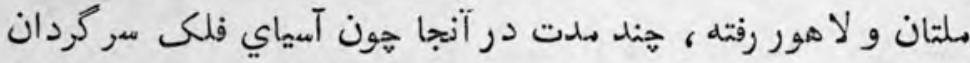

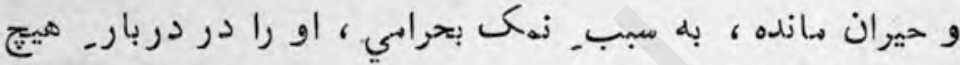

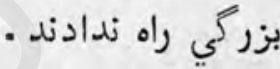

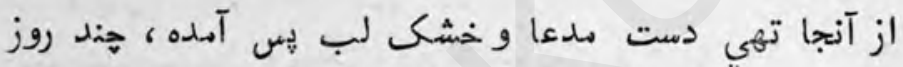

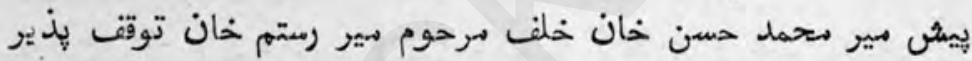

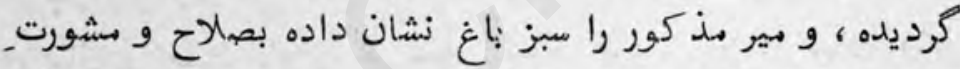

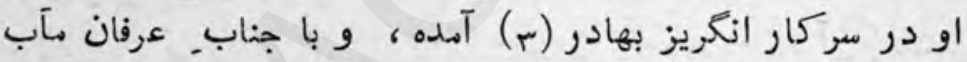

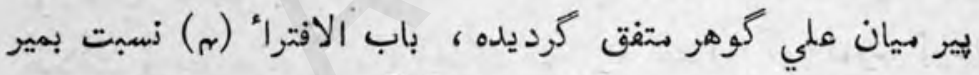

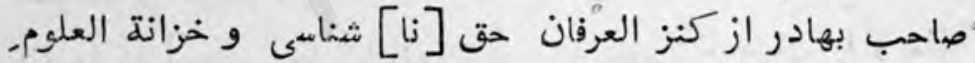

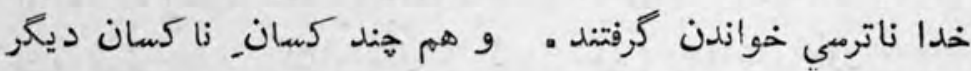

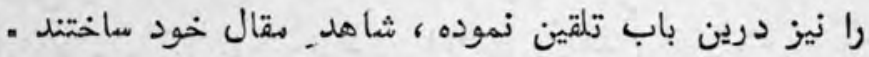

الف، كى، ج: ارازل ولي جمع ارذل عر بي اراذل است بمعني

$$
\text { فرو مايكان . }
$$

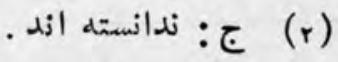

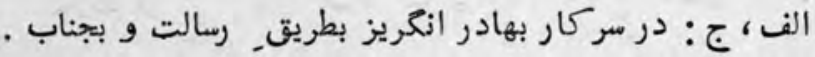

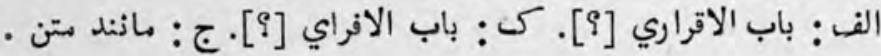


اكرحه اختتيار اين هینين كار هاي افترا بردازي ، ازخخاندان

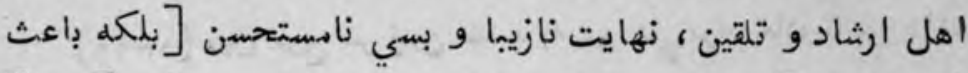

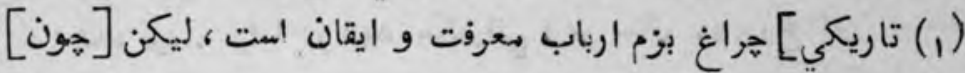

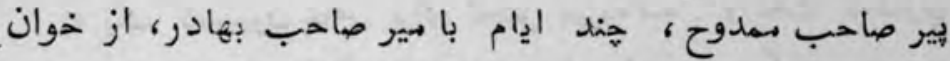

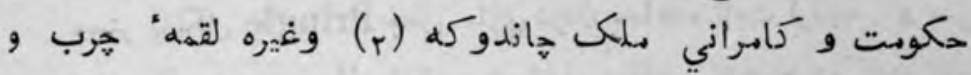

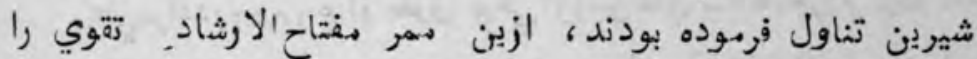

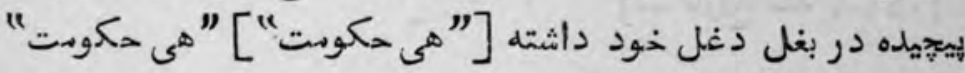

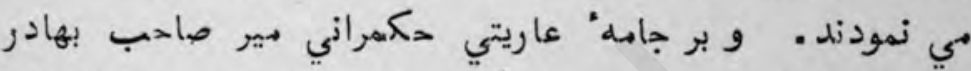

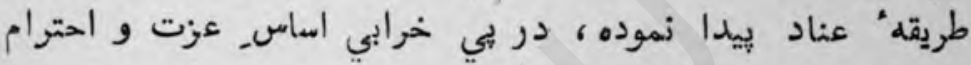

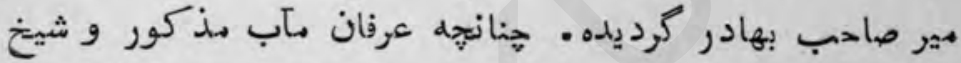

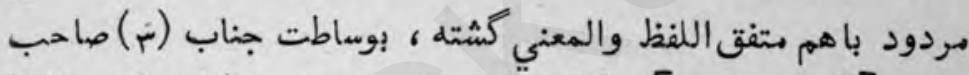

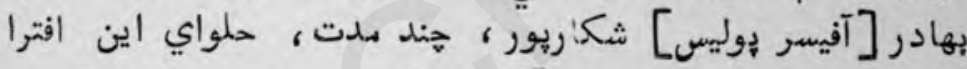

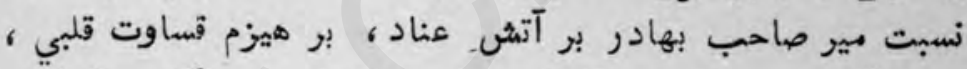

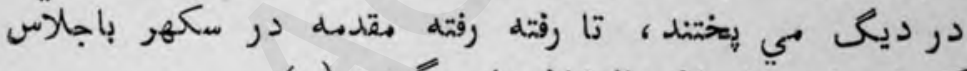

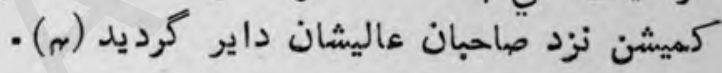

كى : بجاي اين كلمات نقاط كذاشته اند . الف : و بي هراغ بزم.

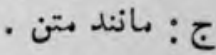

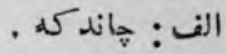

نام اين آفيسر در كل، ج نيست، در الف [هنكصد ؟)] بنظر مي آيد

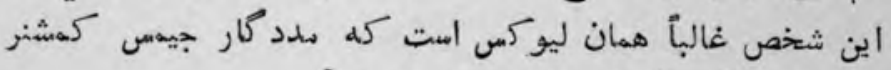

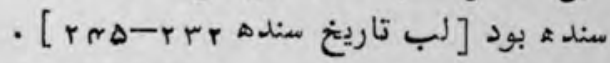

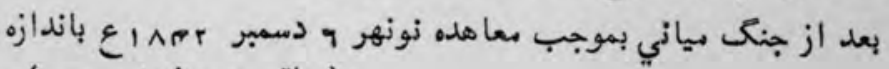
( باقي بر صفهله 
تازه نواي معارك

419

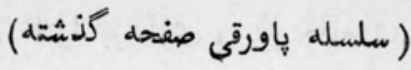

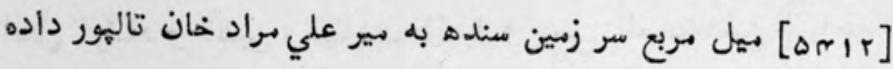

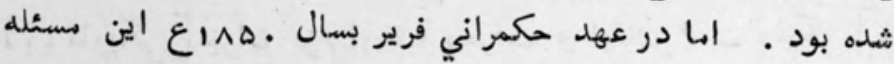

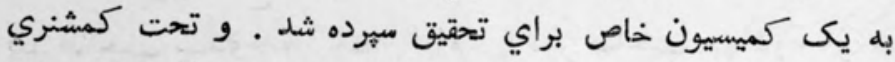

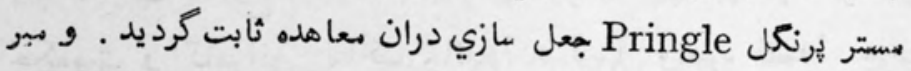

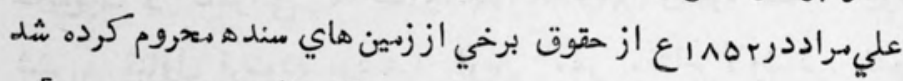

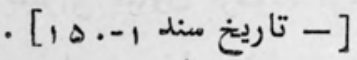




\section{-94 -}

در بيانِ اجلاس صاحبان انخريز در مقدمه دريافت

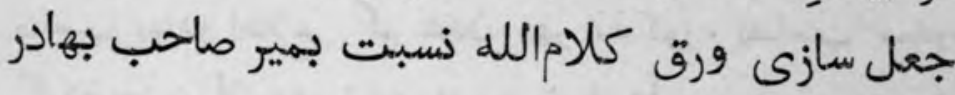

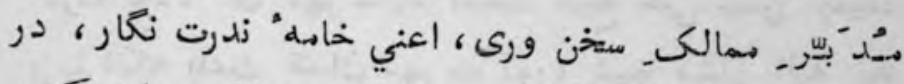

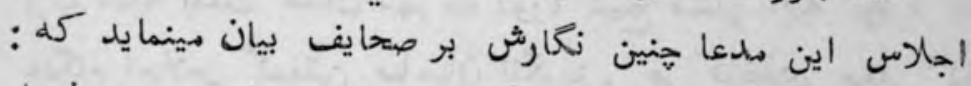

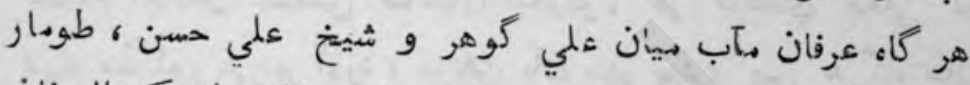

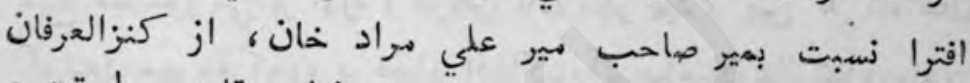

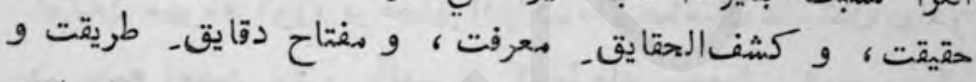

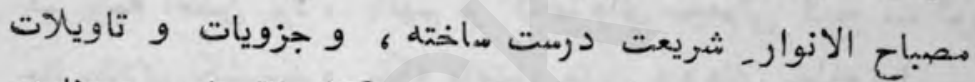

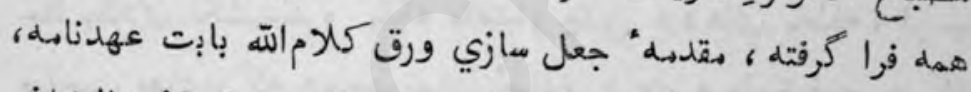

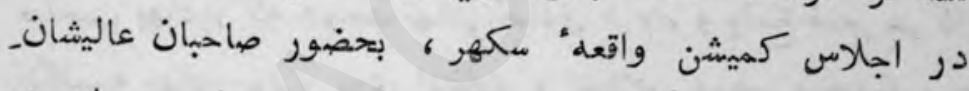

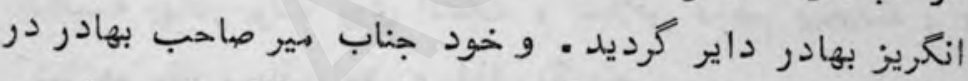

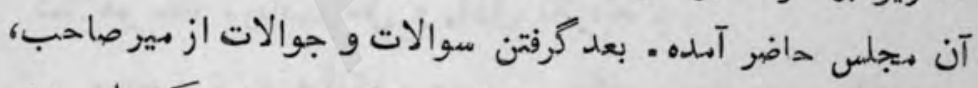

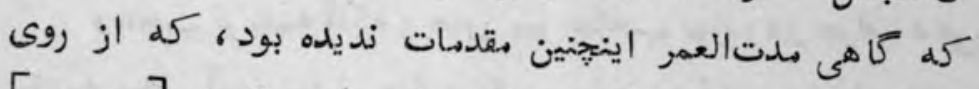

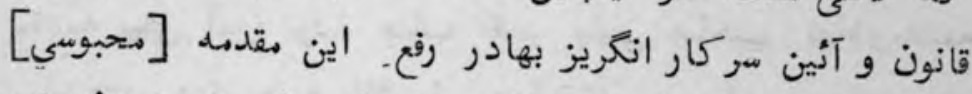

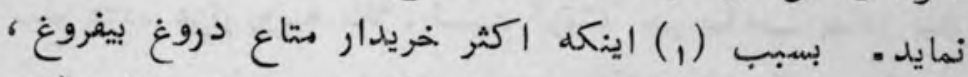

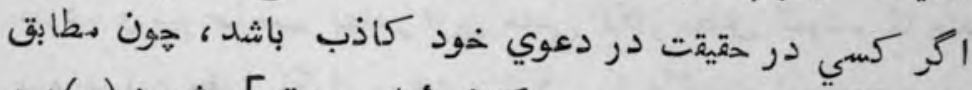

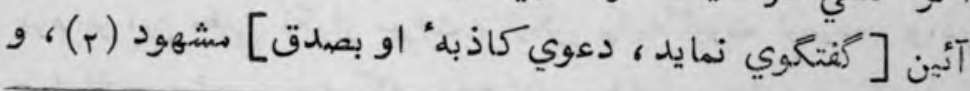

$$
\begin{aligned}
& \text { (1) ج ج : جراكه اكثر . }
\end{aligned}
$$

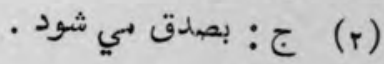


هر كاه صادق و حقدار باشد، هر آكينه بموجب آئين سركار

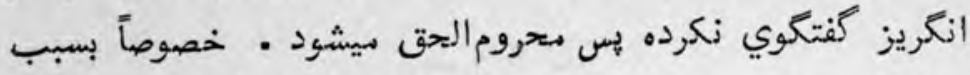

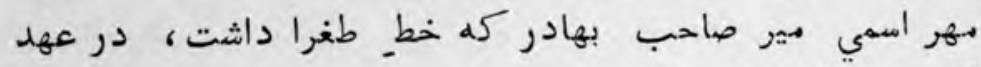

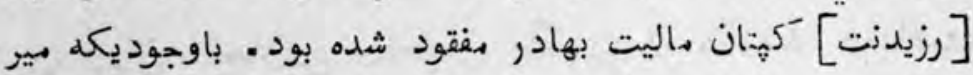

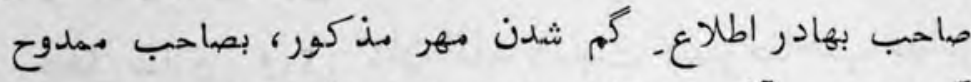

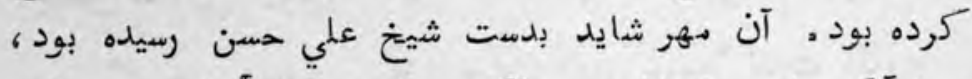

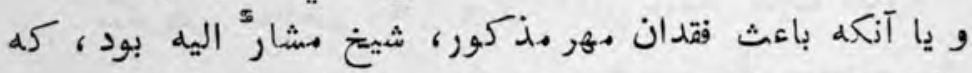

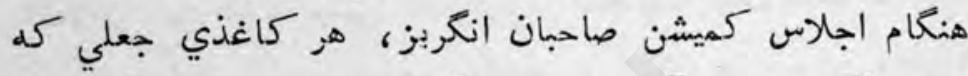

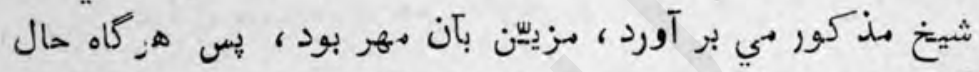

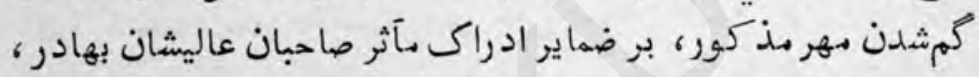

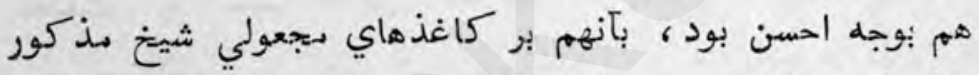

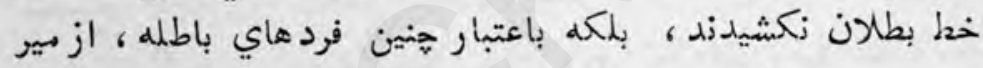

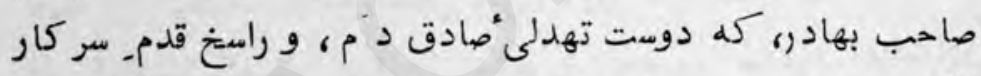

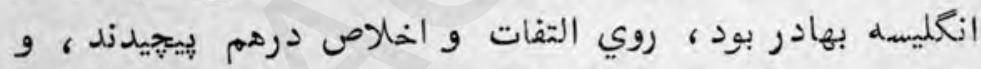

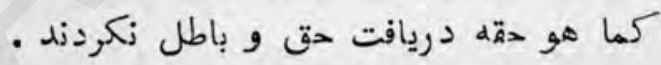

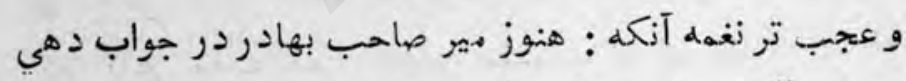

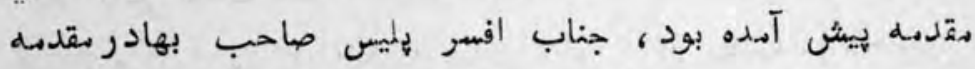

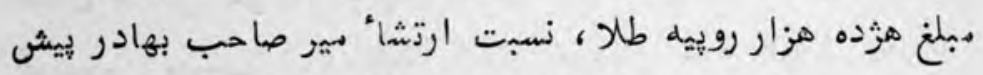

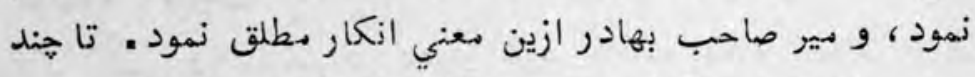

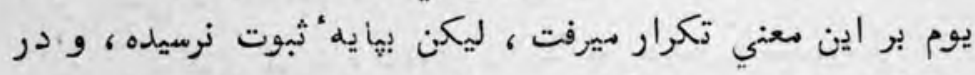

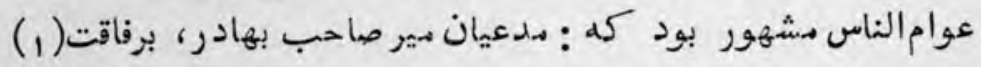

$$
\text { ك.: بر قامت }
$$


ديكر حريفان كه در ظإهر [شهد (1) نوش دوستي، و در

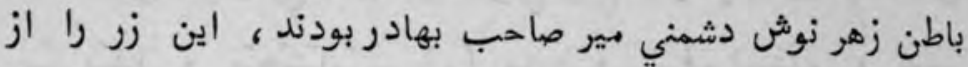

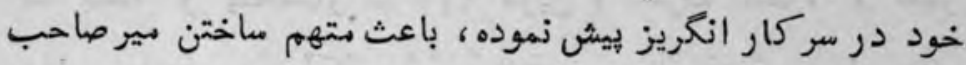

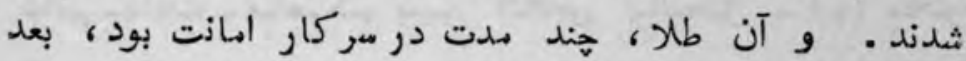

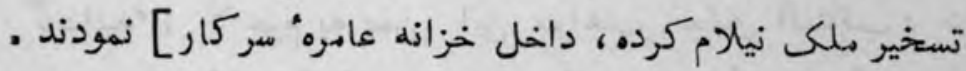

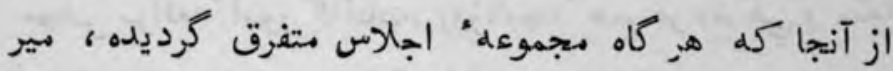

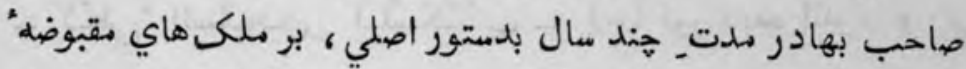

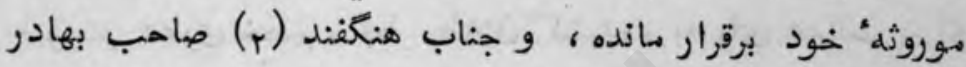

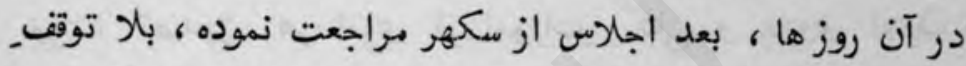

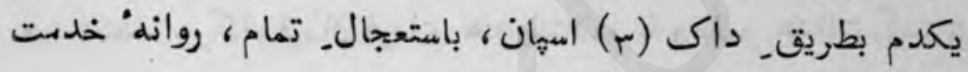

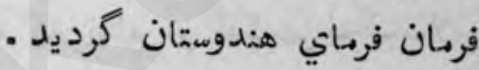

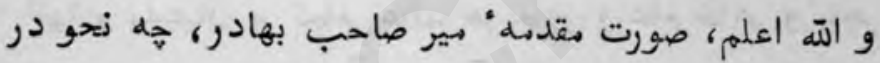

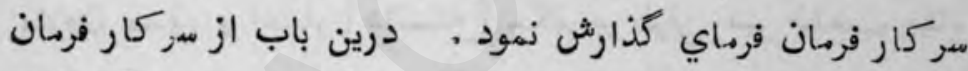

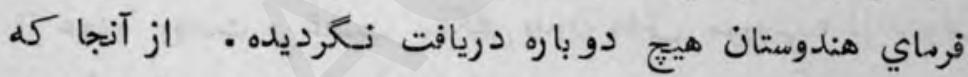

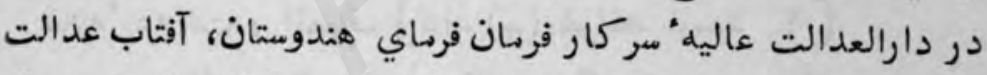

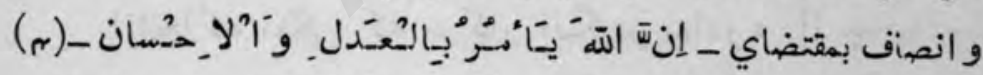

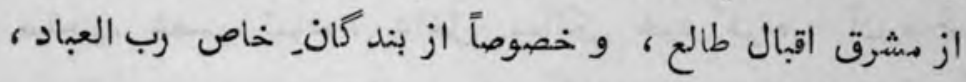

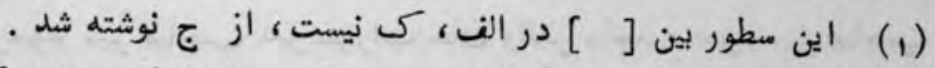

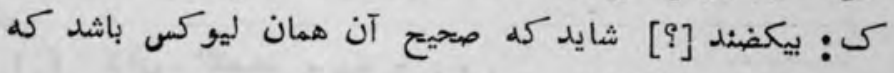

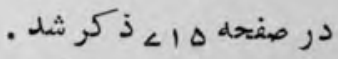

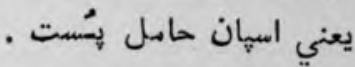

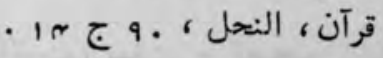




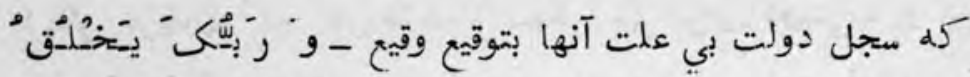

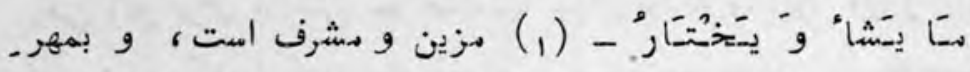

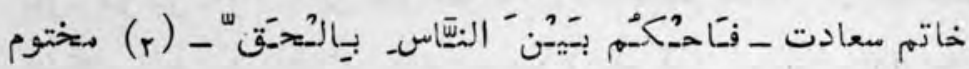

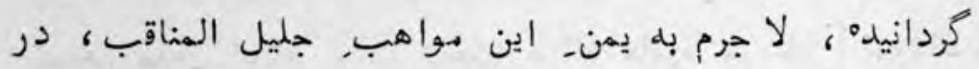

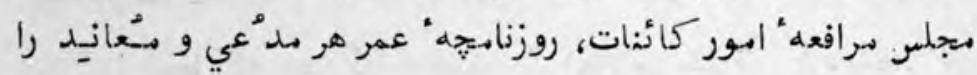

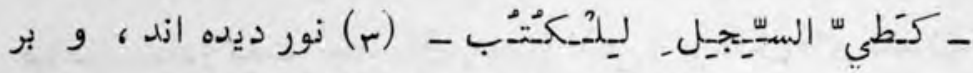
صورت_ دعوي خصمم، خطـ بطلان كشيده، به راي عدالت رييراي

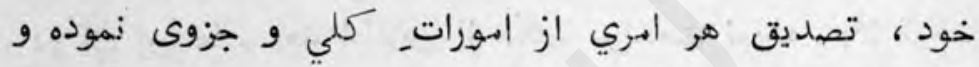

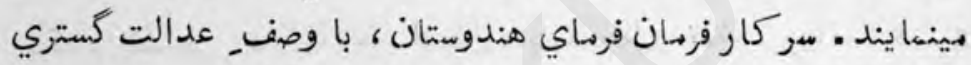

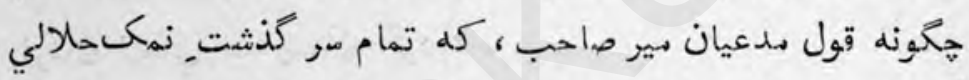

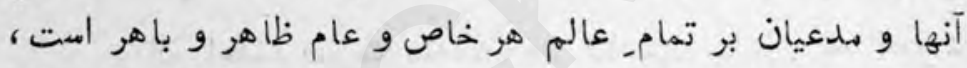

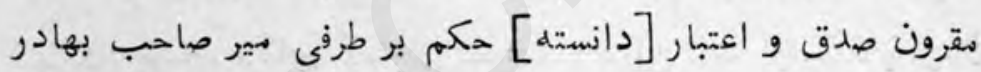

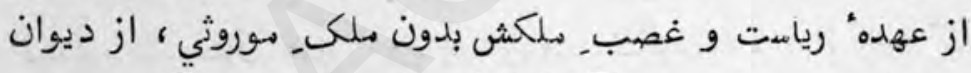

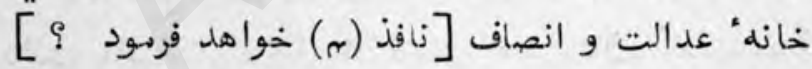

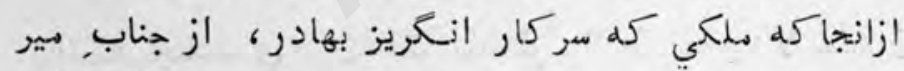

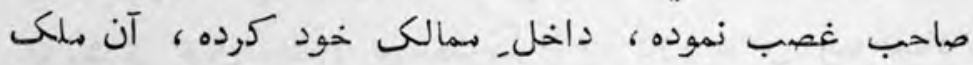

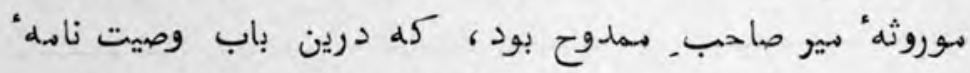

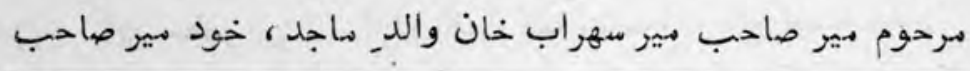

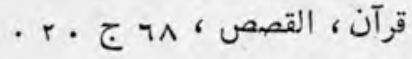

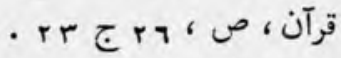

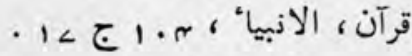

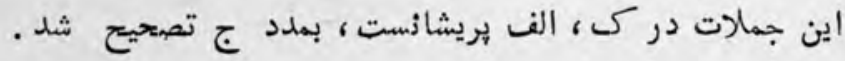


بهادر موجود دارده، و نقلش (1) بدفتر سركار انكريز بهادر نيز

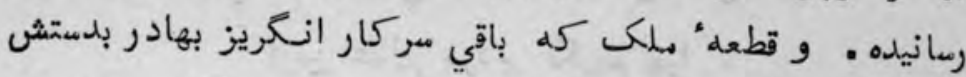

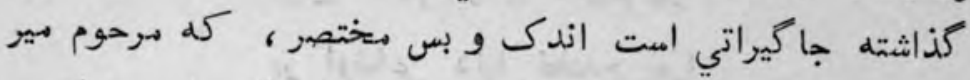

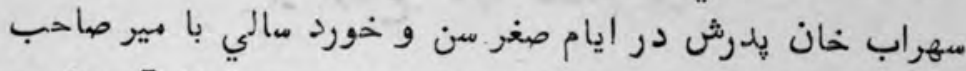

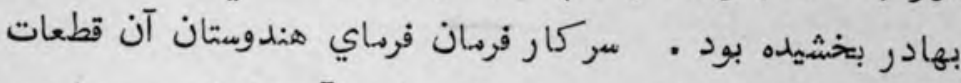

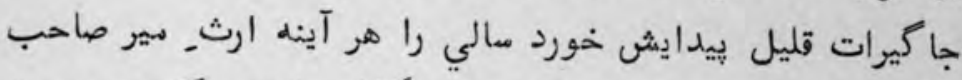

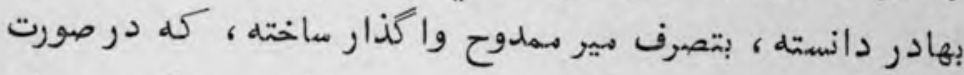

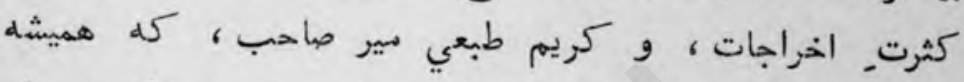

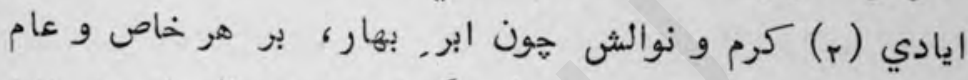

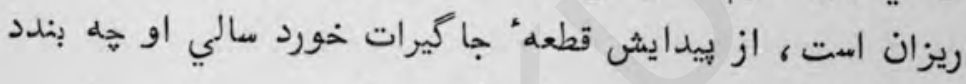

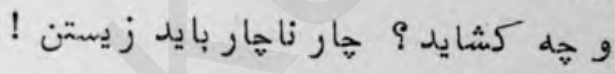

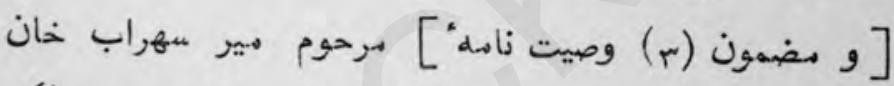

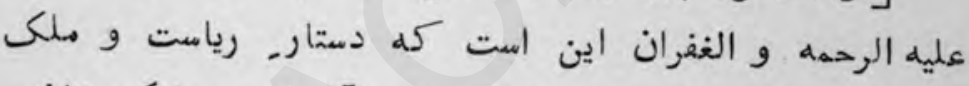

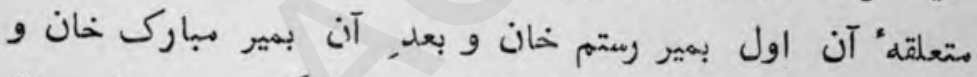

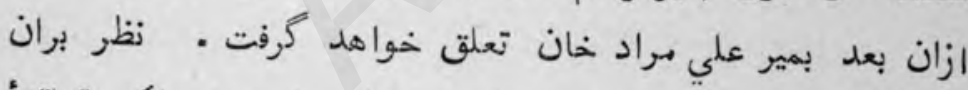

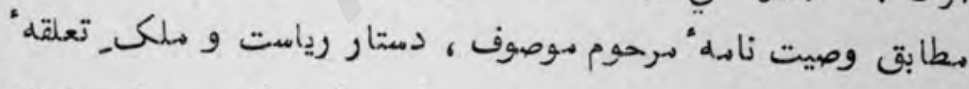

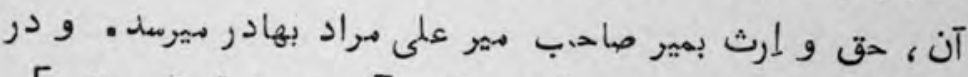

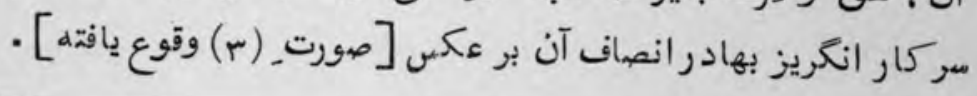

$$
\text { [؟] }
$$

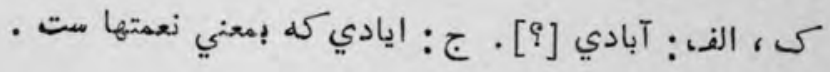
اين كلمات تنها از ج كرفته شد . 
تازه نواي مساركى

مس اين حهه انصاف، و زهي عدل !!!! [بيت] ازين عدل, مردم نكريم ثهرا

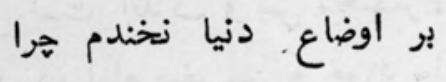


$-9<-$

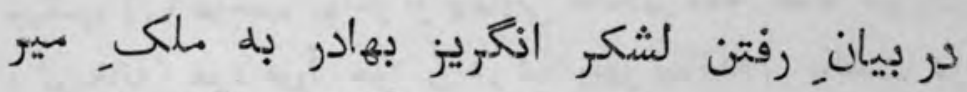

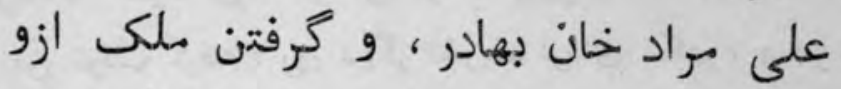

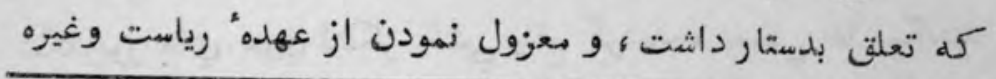

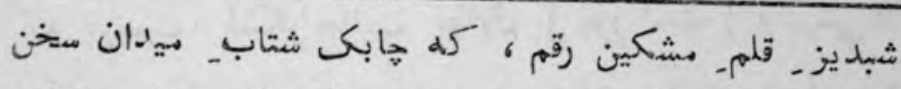

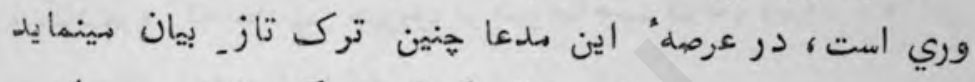

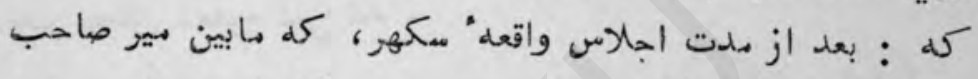

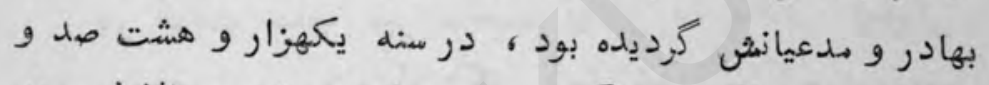

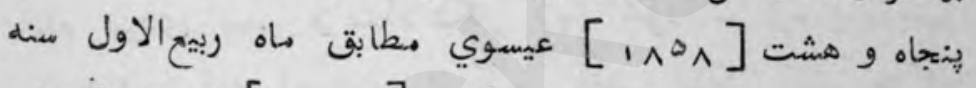

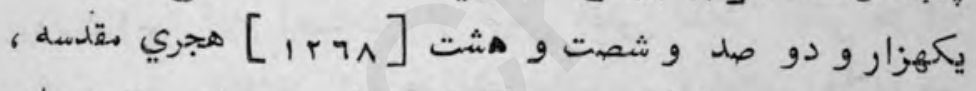

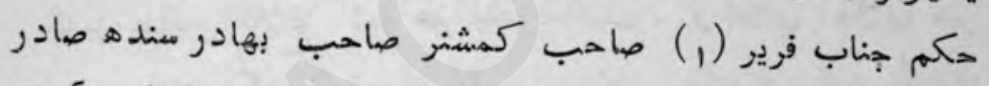

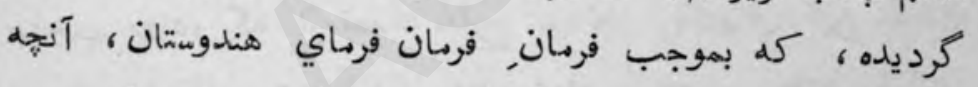

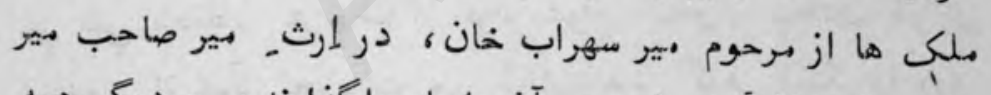

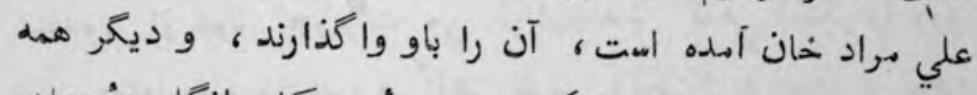

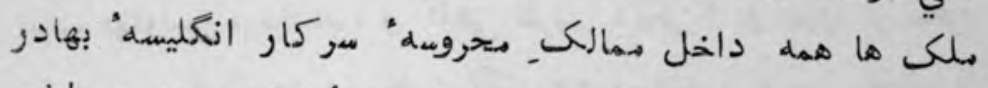

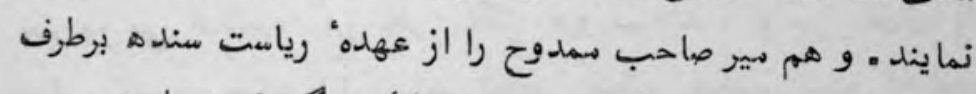

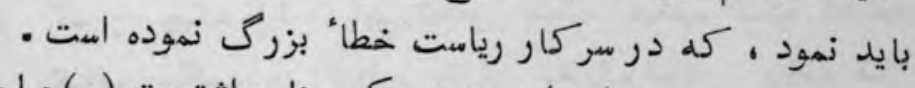

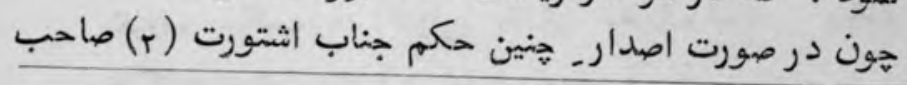

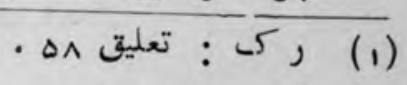
• (r) 
بهادر كلكتر شكاريور و ديكر صاحبان متعينه هيلاتن واقع شكاريور

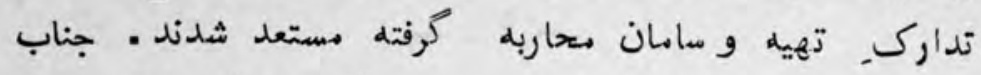

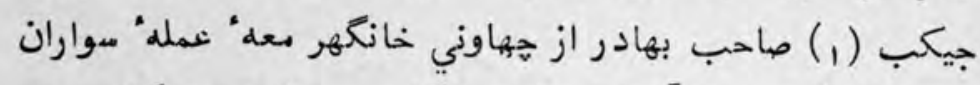

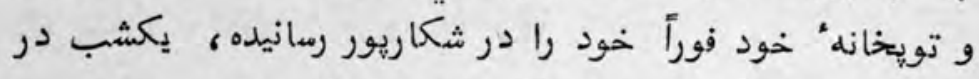

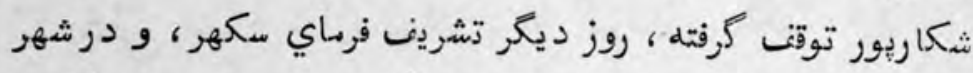

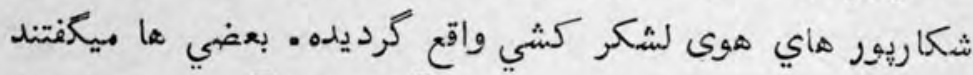

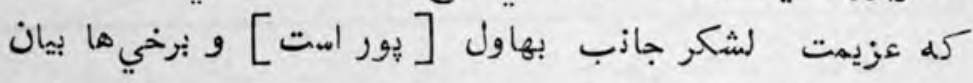

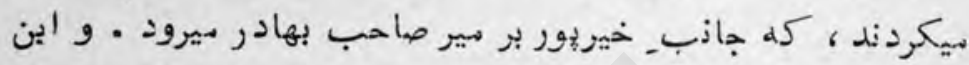

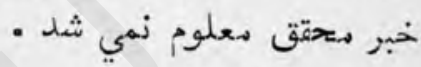

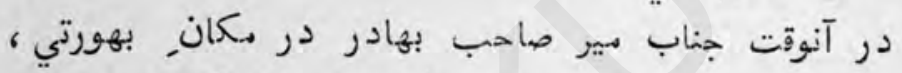

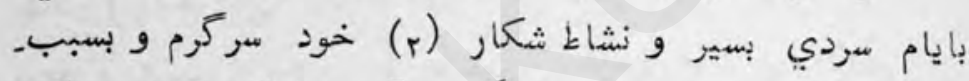

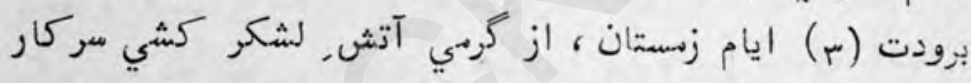

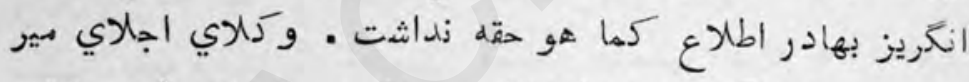

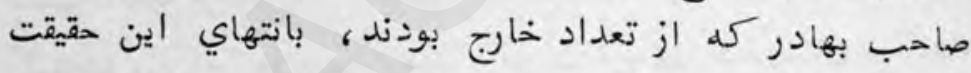

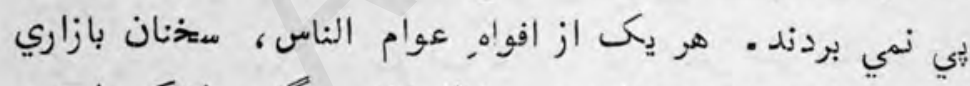

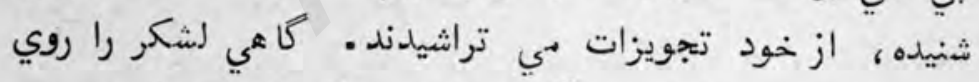

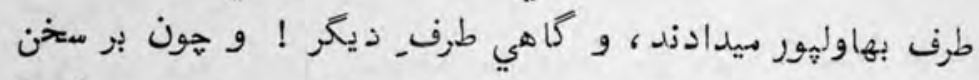

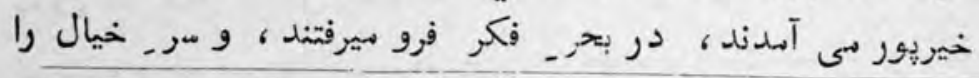

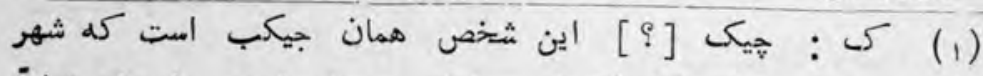

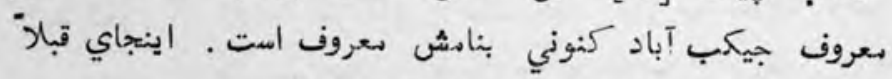

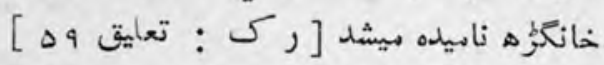

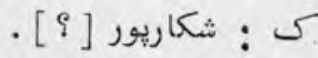

$$
\begin{aligned}
& \text { الف : بردي ايام . }
\end{aligned}
$$




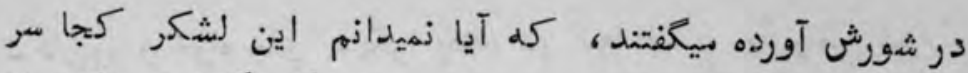

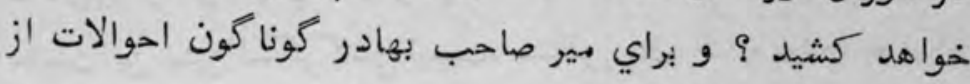
خود تراشيده مينوشتيند -

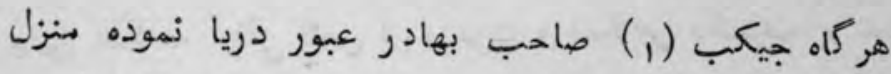

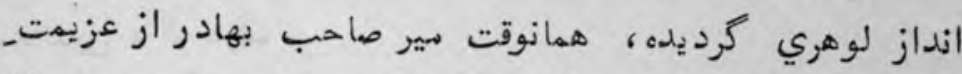

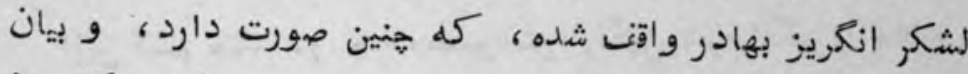

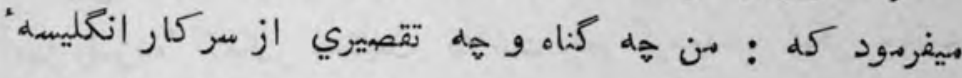

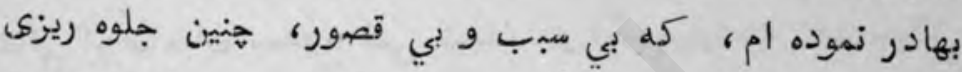

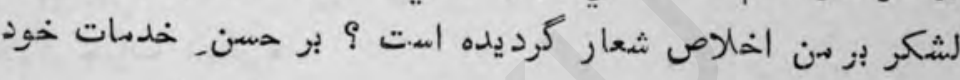

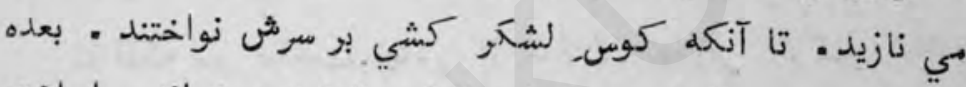

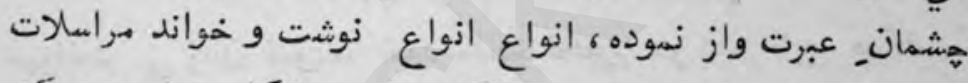

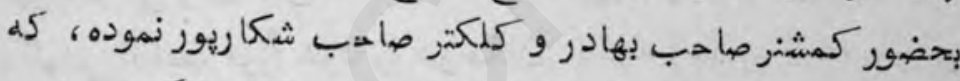

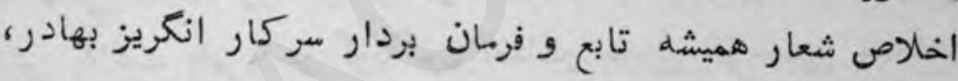

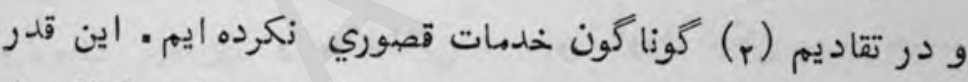

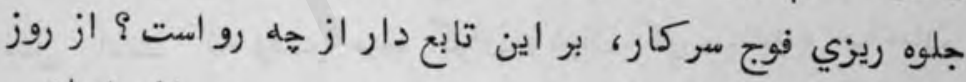

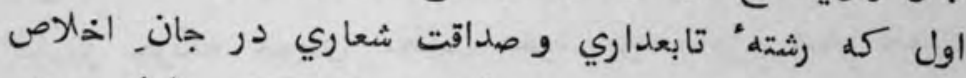

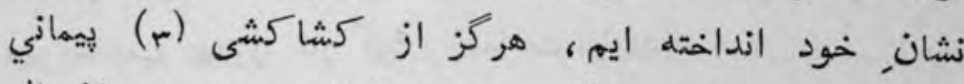

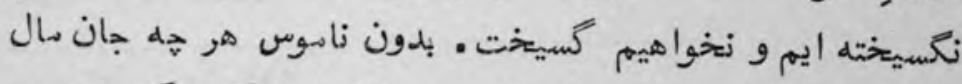

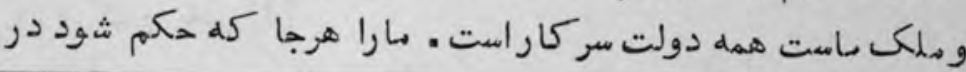

$$
\begin{aligned}
& \text { ك : }
\end{aligned}
$$

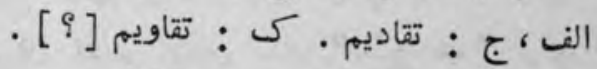

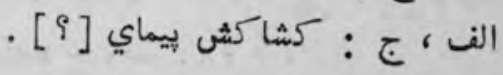


تازه نواي معارك

$\angle r T$

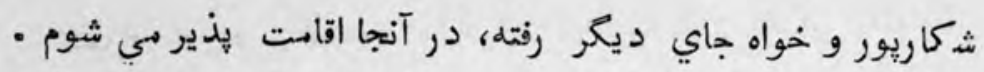

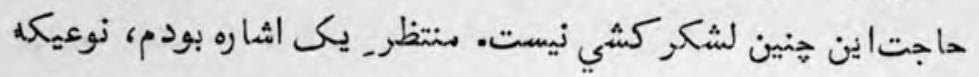

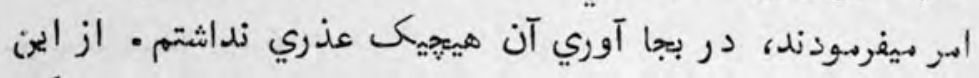

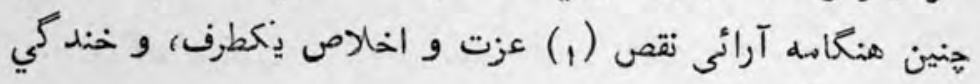

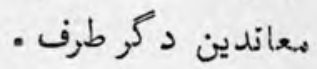

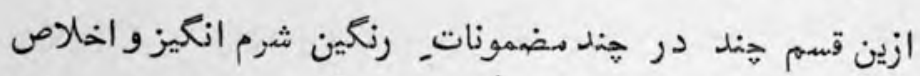

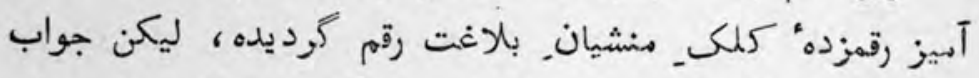

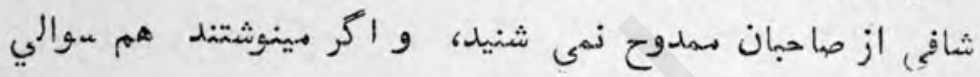

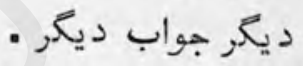

تا آنكه هير صاحبب.بهادر از دمكان بهورتي تركــ شكار

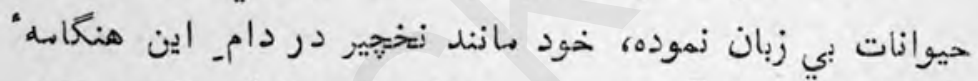

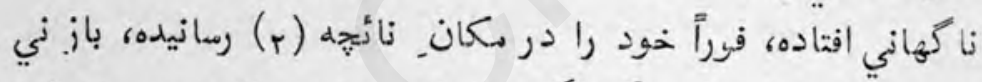

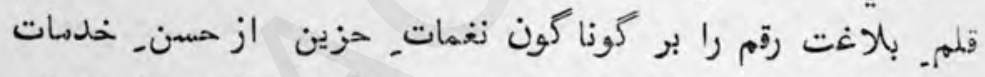

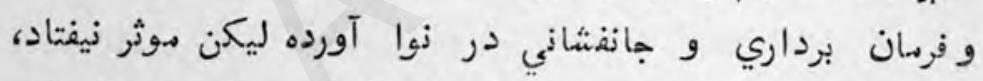
هثل است كله وقت_ ميوه كوش باغبان كر بيباشد . صاحبان. انكريز هونكه جوياي مطلب خود بود، اين همه نغمات

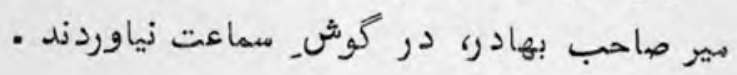

[؟ [ (1)

(r)

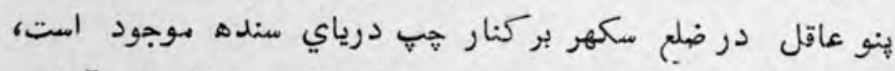

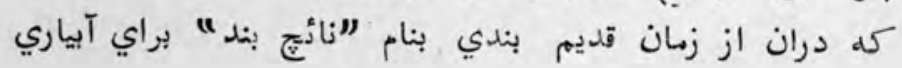

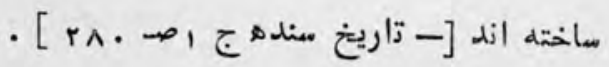


$\angle r \angle$

تازه نواى معار

تا آنكله جناب كمششنر صاحب بهادر و دو سه صاحبان ديكر،

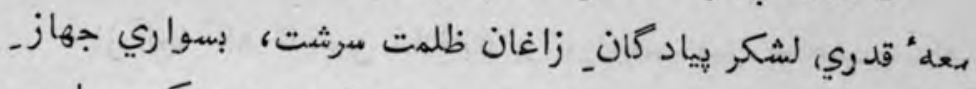

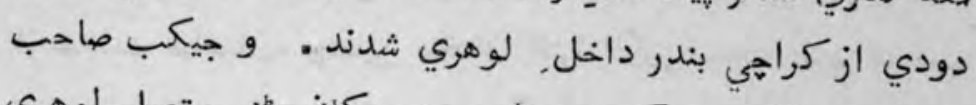

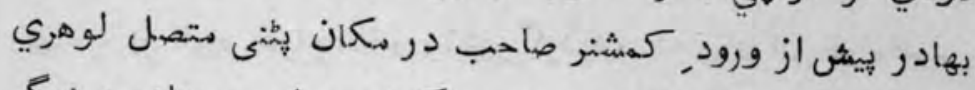
طرف جنوب منزل انداز بوده، و كمششنر صاحب بهن بهادر و وديكر

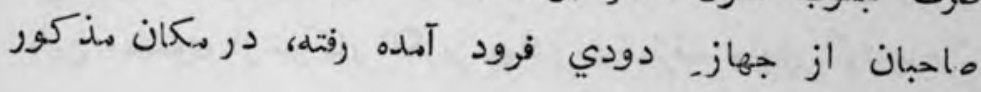
فروكث شدند

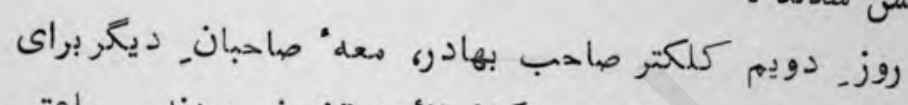
هالاقات دير صاحب بهادر در هـكان نائجه تشريف بردند. ساعتي

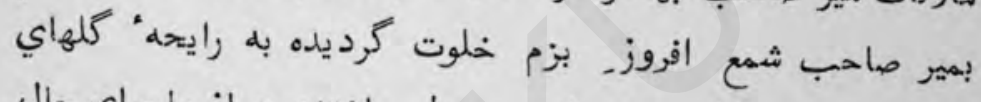

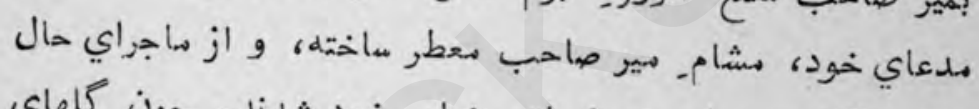

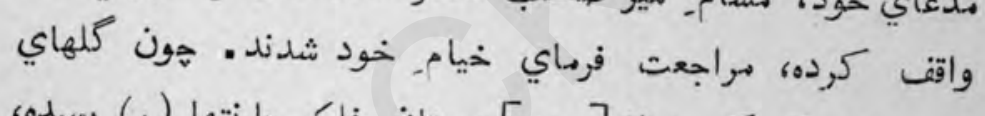

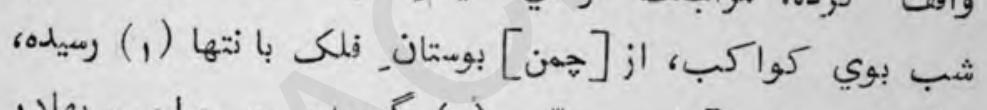

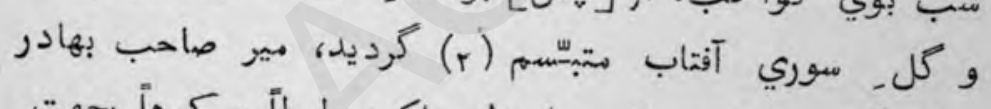

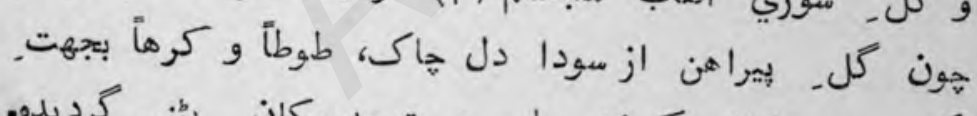

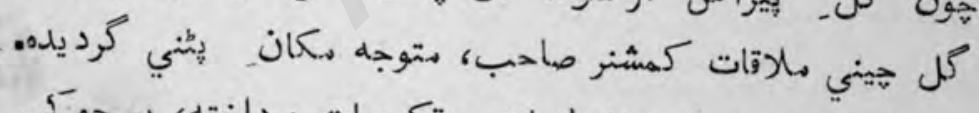

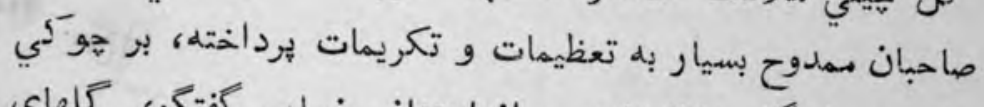

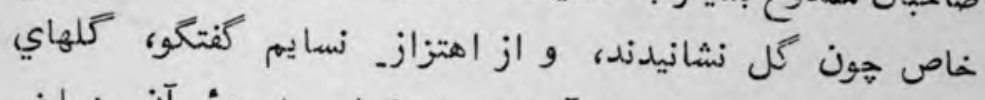

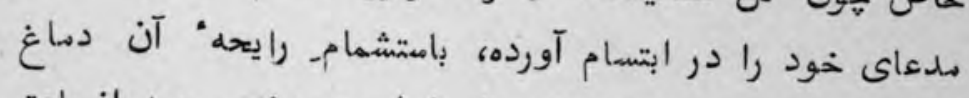

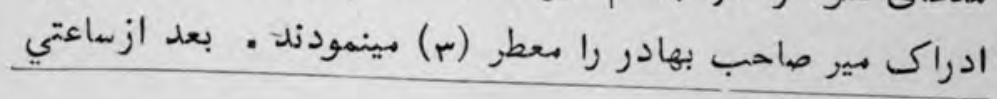

- ناستتهاي

-

( 


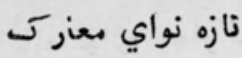

$\angle r A$

كلدستة" رخصت بدستش داده مرخص نمودند ,

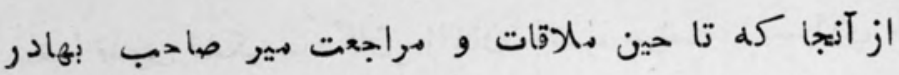

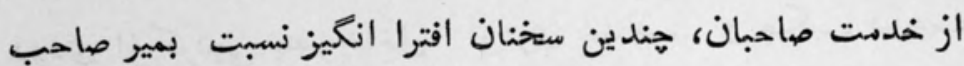

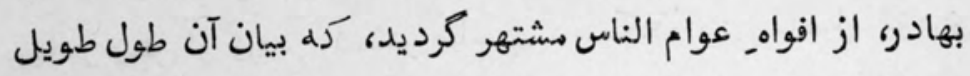

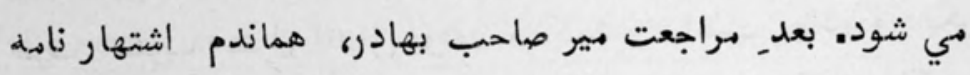

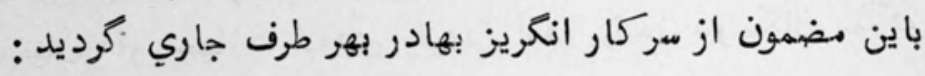


اشتهار ذاملهُ سركار, اذخريز بهادر

نسبت بمير صاحب بهادر، در باب عزلـ عزلـ رياست و غصب ماحب ملكشي

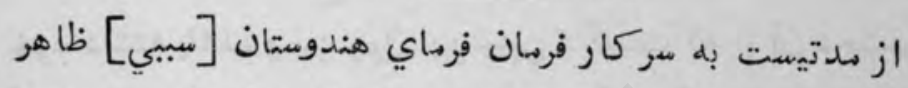

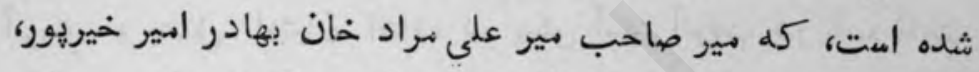

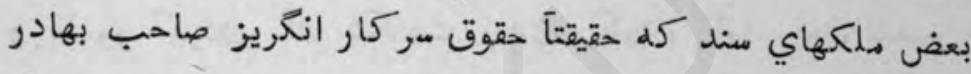

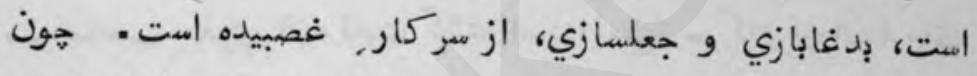

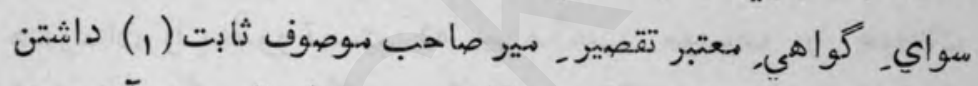

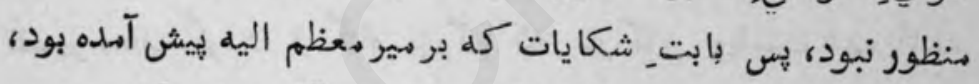

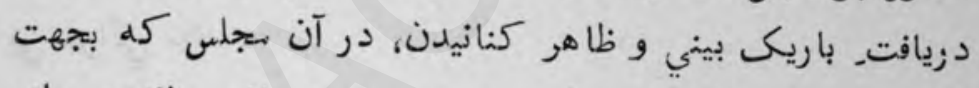

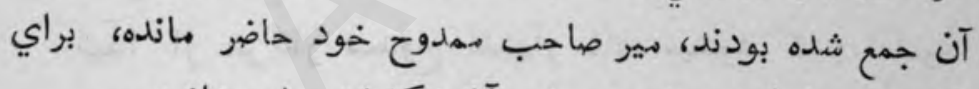

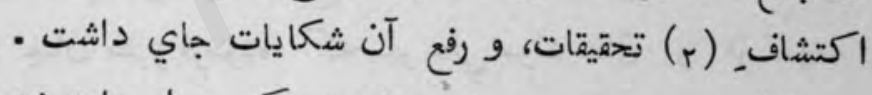

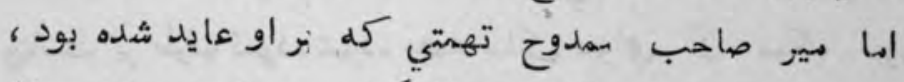

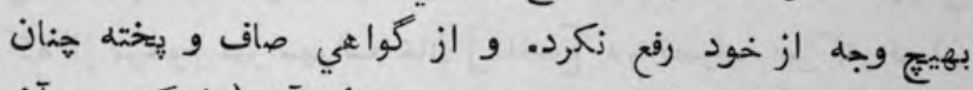

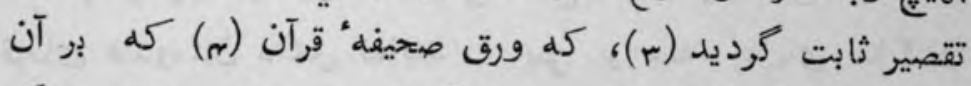

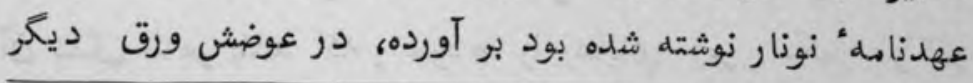

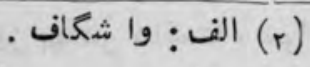

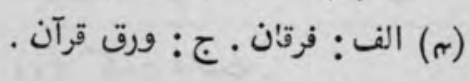

. (1) الف : عابق داشتن

. (r) 
تازه نواى كel

$\angle r$.

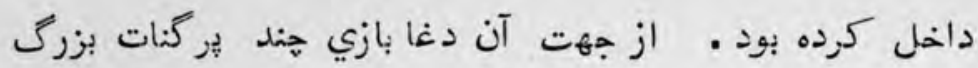

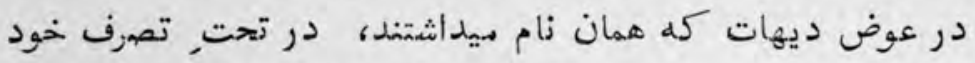

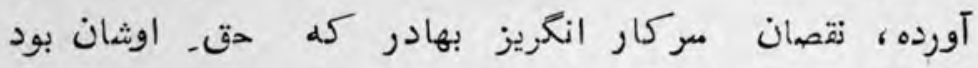

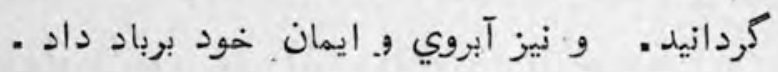

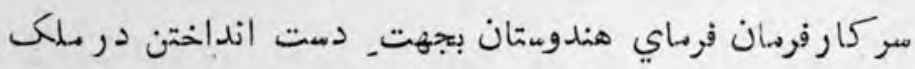

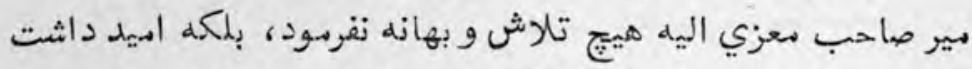

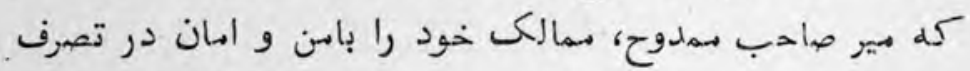

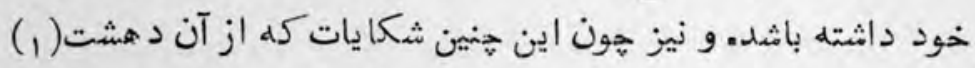

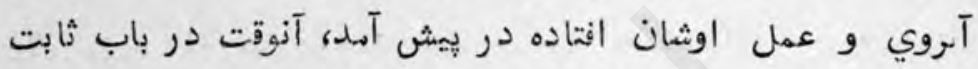

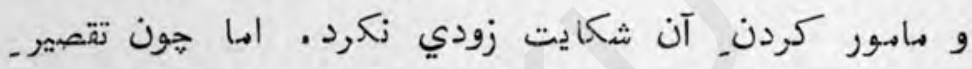
مير صاحب معزي اليه ثابت كثته است، هيس مركار فرومان فرهاي

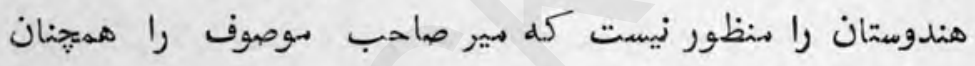

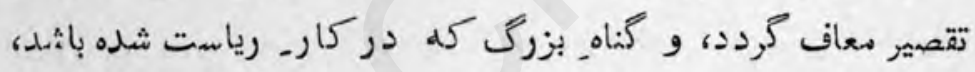

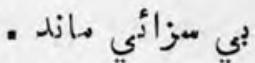

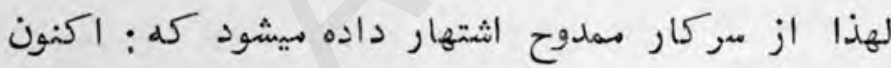

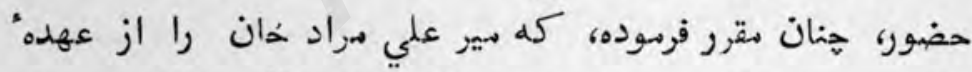

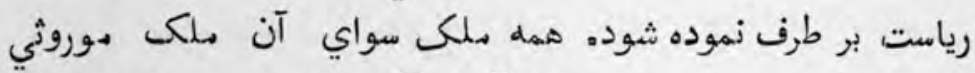

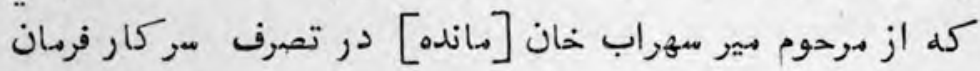

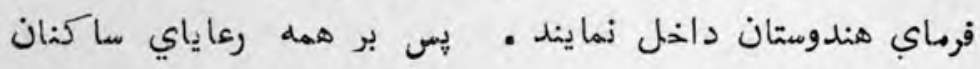

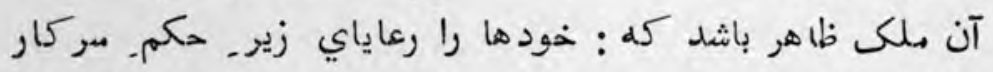

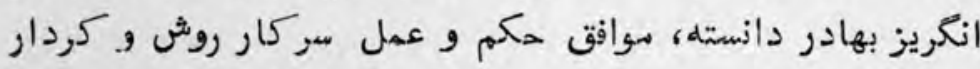

. 5 : داشت 
Cr

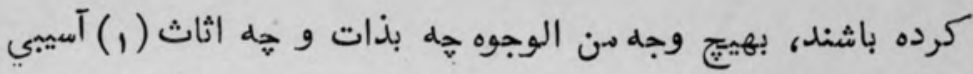
نخواهد وسيد، و در هر باب در حفاظت و عدالت معركار مامون

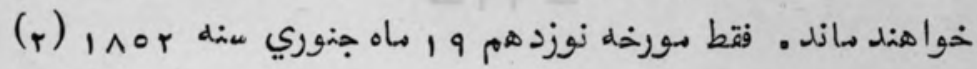

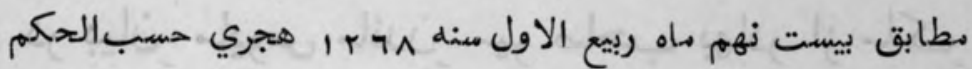
نواب مستطاب [معلى] القاب كورنر صاحب بهادر فرمهان فرماي

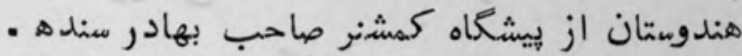

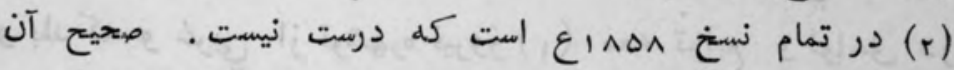

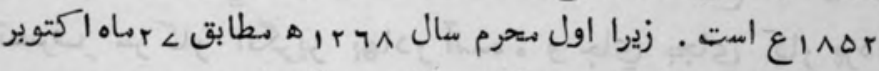

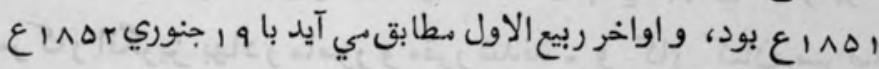


- ११ -

در بيانِ مايوس ماندنِ مير ماحب بهادر از ملكى موروثى متعلقه دستار

و عهد. رياست ، وغيره سر كنشت_ تنخواه داران سهاه

مير صاحب بهادر

معشوقه" قلم- مشكين رقم ، كله يار دلخواه و رفيق همه جائي

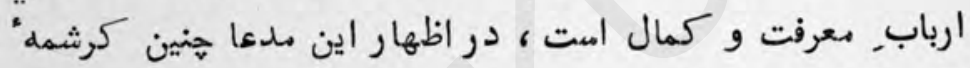

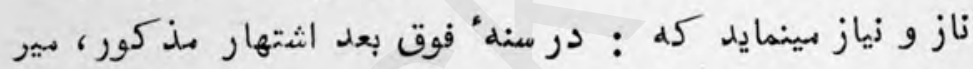

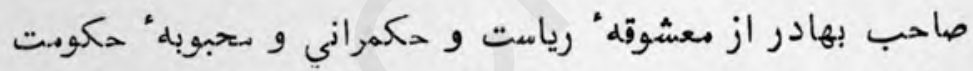

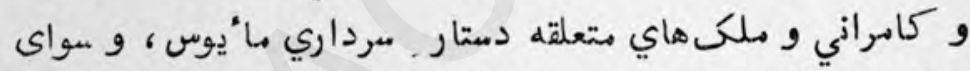

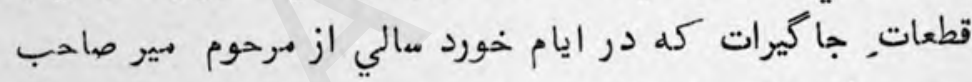

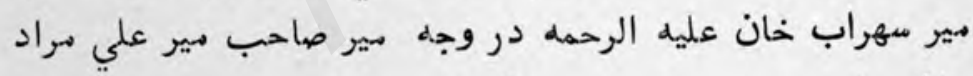

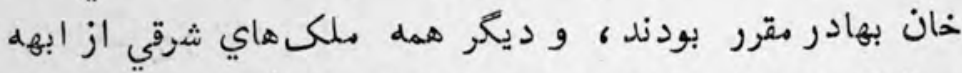

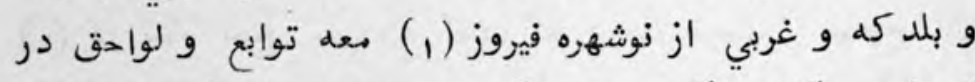

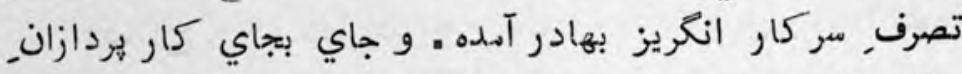

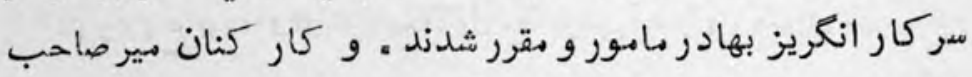

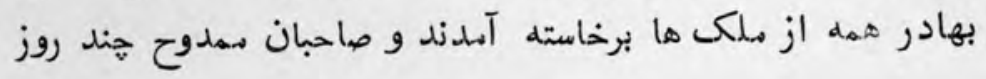

(1) 
در مكان هتيني توقف كرفته ، بندوبست ملكى هاي نومقبوضه نموده ، و كاغذهاي م.حاسبه ملكى هاي نو از دفتر مير صاحب بهادر

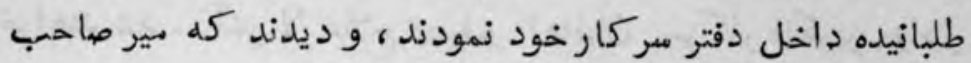

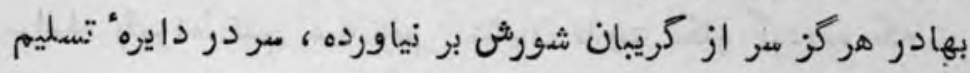
- نهاده الست

بعده بعض صاحبان انكريز بسواري جهازهاي دودي روانهُ

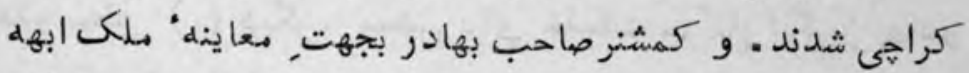
تشريف فرهاي قلعه سبزل ، و اشتورت صاحب بهادر كلكتر شكاريور متوجه حدود ريكستان و ناره، و جيكمب صاحب بهادر

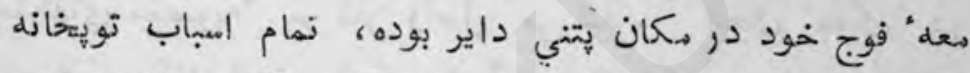

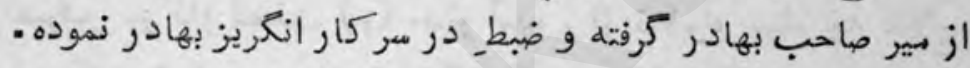
و جناب مير صاحب بهادر در مبكان نائزيه (1) كنار دريا بسعيار مدت لنكر انداز، و از كمال, انصاف و عدالت ظلم نهاي سركار

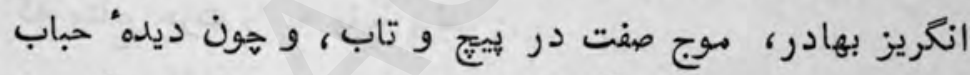
حيران ، و مانند خس سركردان اين حادثره -بود . عالاوه بر آن معهاه هير صاحب بهادر كله حند ماه تنخواه و مواجب مانب طلب داشتند، كل مدار دادن، تنخواه سهاه مذ كور ، بر ملكهاي مغصوبه بود ، تفنم هاي شور شر نر نموده نشانه زن مصول.

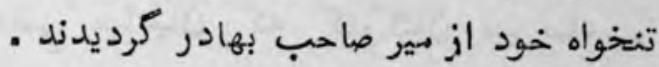
ظهور اين هعنى علاوه باعث بي آراهى كار بردازان سركار

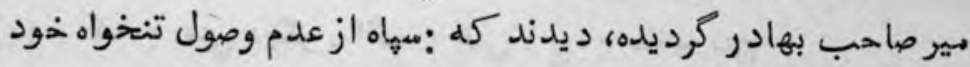


تباه و نتيله ها بر ماشهُ تفنـ سوار دارند ، هر آينه فساد كلي

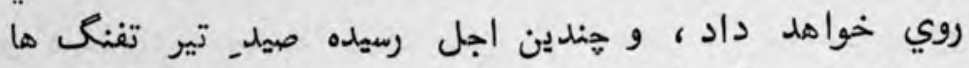

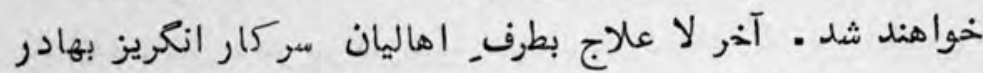

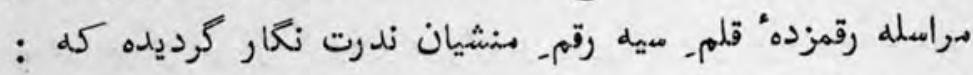

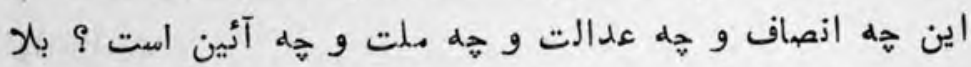

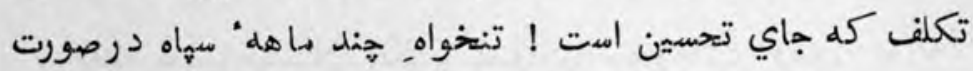

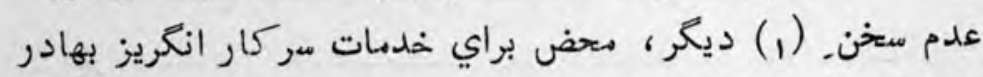

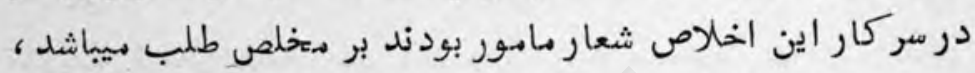

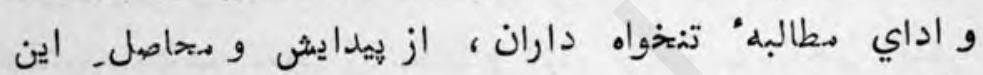

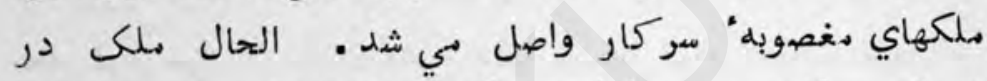

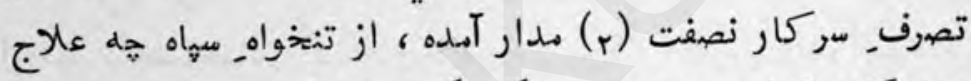

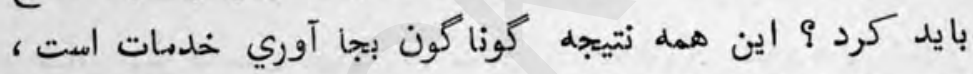

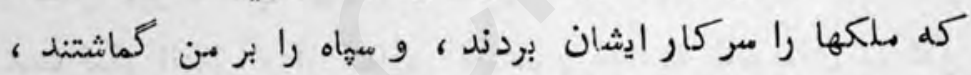

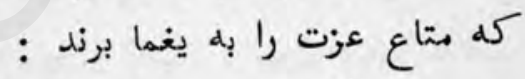

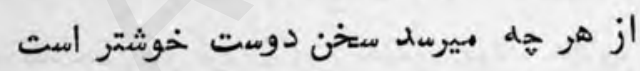

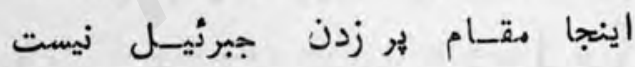

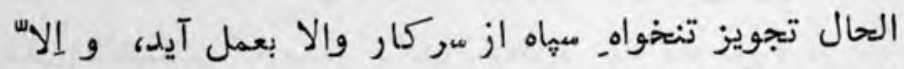

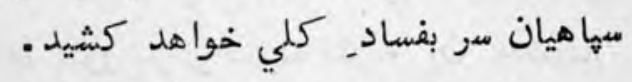

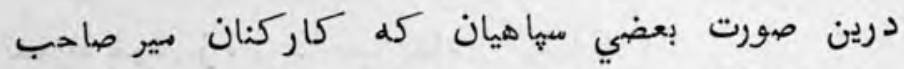
بهادر را سخت كشش نمودند، و نزديكى بود بلمواي عام كردد.

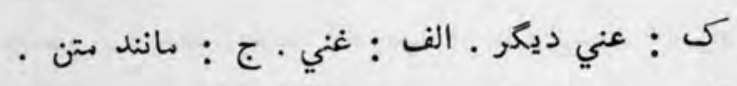

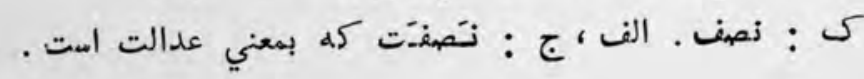


دران اثنا صاحبان_ انكريز، سواران خود جهتــ فهمانشــ مهياه.

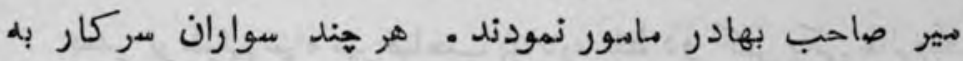

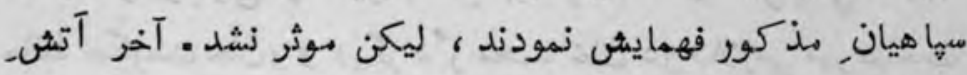

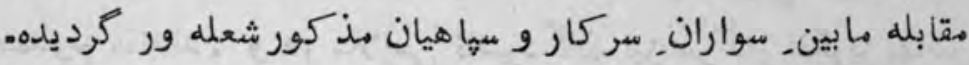

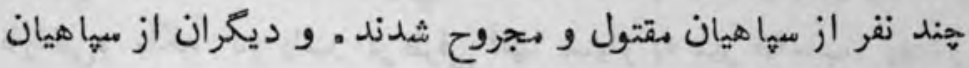

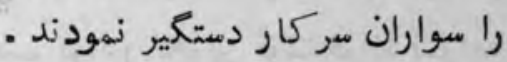

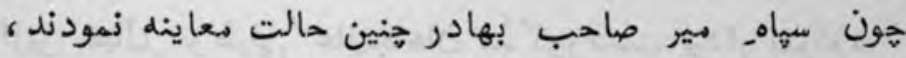

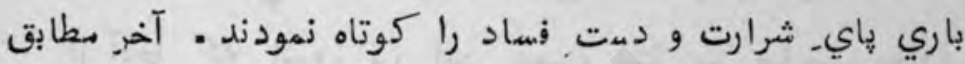

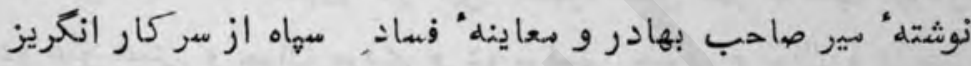

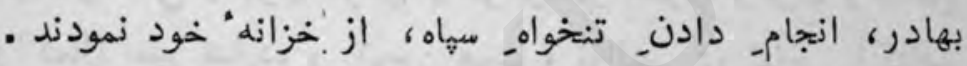

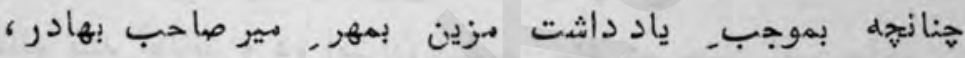

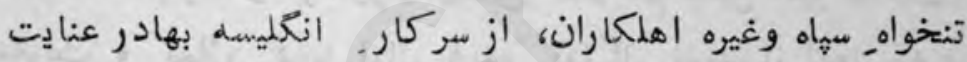

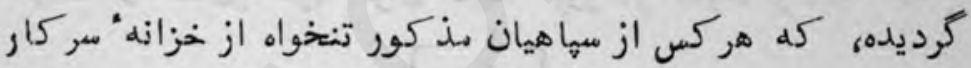

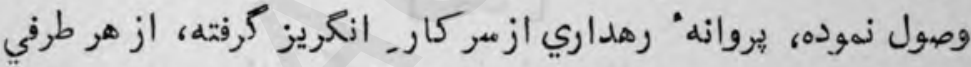

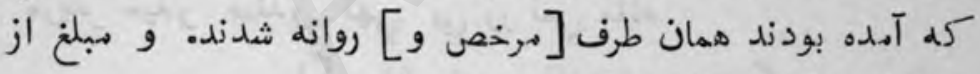

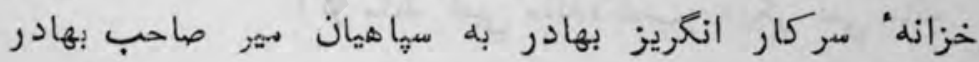
عايد كردميد

و در صورت وصول, تنخواه سهواه، بسياري كسان ازديم كمان

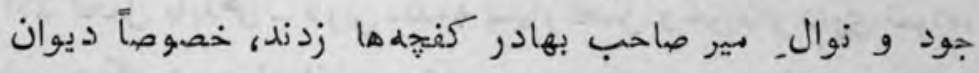

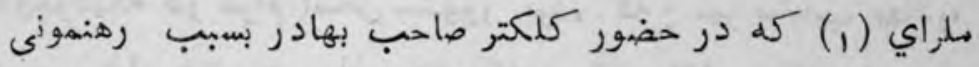
و نشاندهي بعضي مدارجات، شرف احضار يافته، از بسياري سها هيان

$$
\text { (1) الف: ملهراى · ج: املراي . }
$$


سر تراشى نموده، كه از بيان بيرون امت . بعد_ برطرفى سمهاه مير صاحب بهادر، فقط دو كس يكي عاليجآه

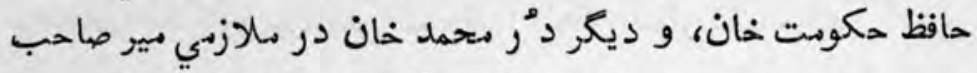

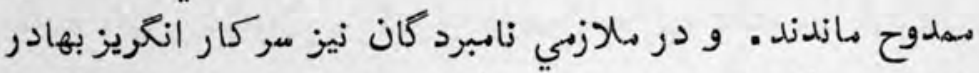

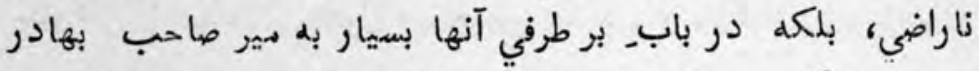

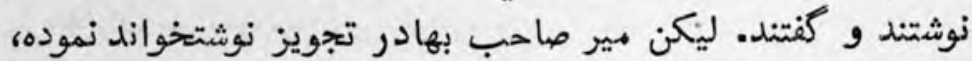

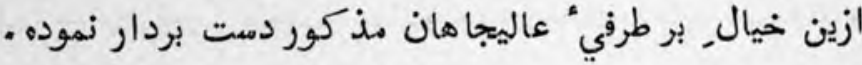

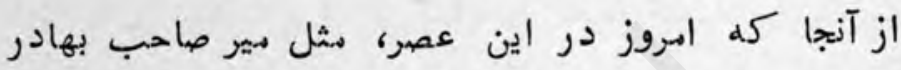

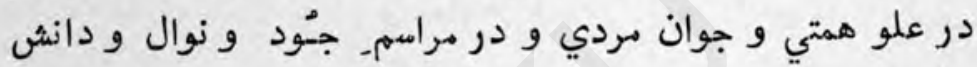

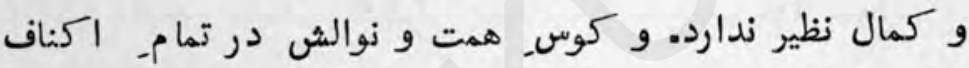

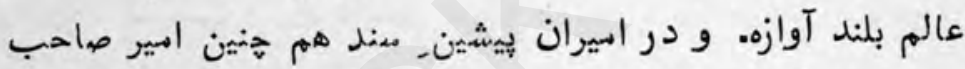

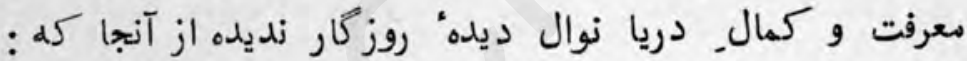

$$
\text { ] [يت }
$$

مريد_ حيدر صفدر كهي بي زر نهي ماند اكر ماند شبي ماند، شبـ دئ ديكر نمي ماند

با اين همه اوصاف شجاعت و جوان مردي و اخلاص سخغاوت

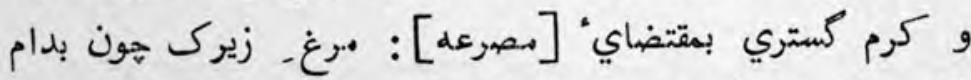

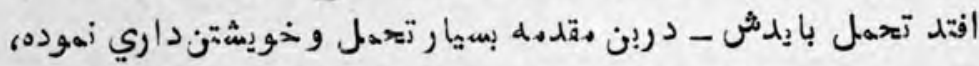

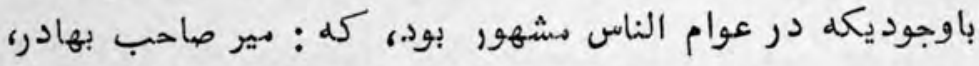

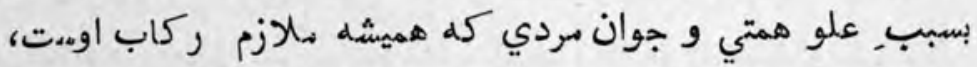

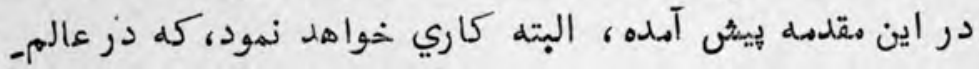


$\angle r \angle$

تازه نواي معاركى

روز كار ياد كار خواهد ماند. حونكله [مصرعd]:

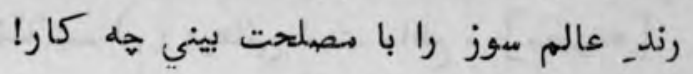
عروس ملك كسي تنط در كنار كشيد كل بوسه بر لبـ شمشير كثيل آبدار دهد

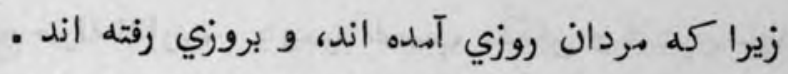

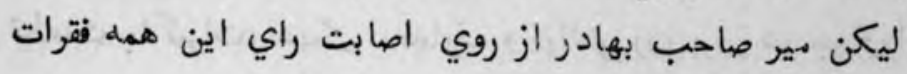

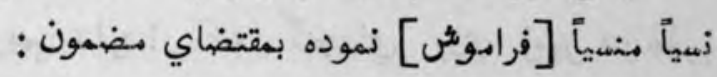

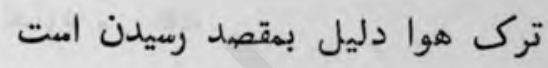

بكذر ز آرزوي دل ول واتياب شو

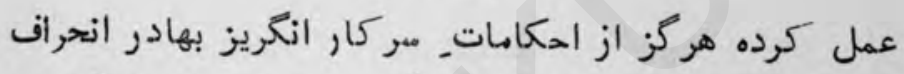

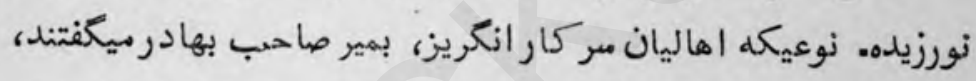

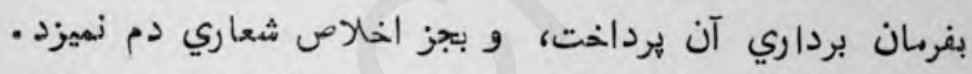

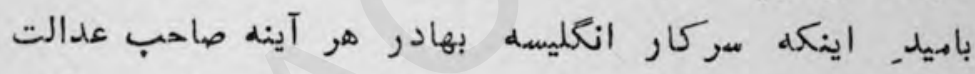

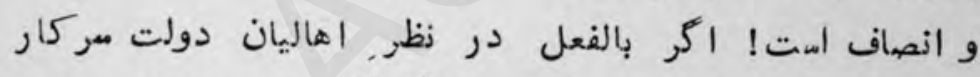

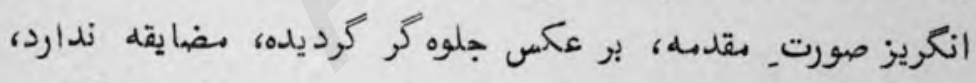

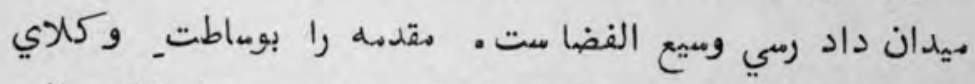

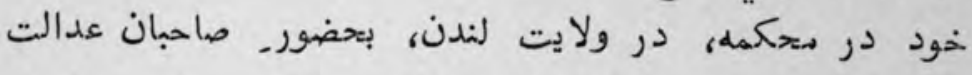
داير نموده است، ديده شود كله : راي عسالت بيراى صاحبان

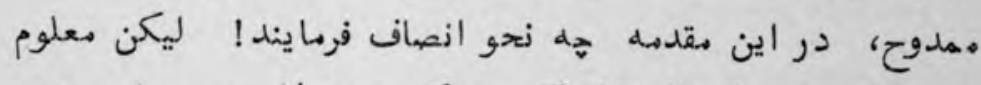

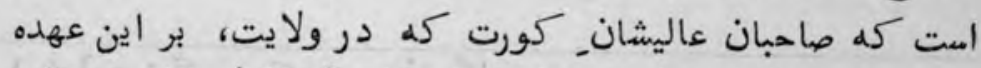

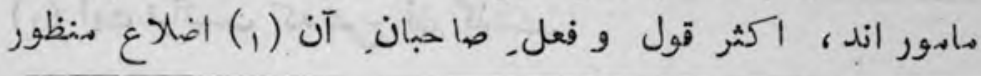

. الف اين 
تازه نواي معاركى

$\angle r A$

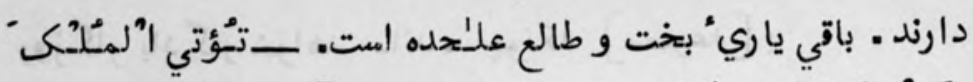

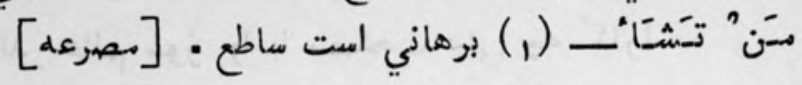

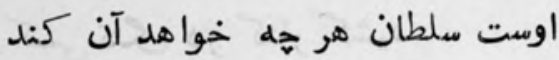

هير صاحب بهادر در اين ابر از تدبير. فرزازه و مصصارف

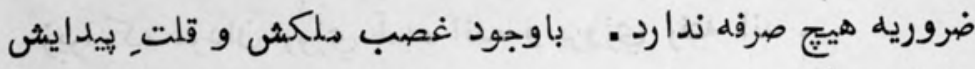

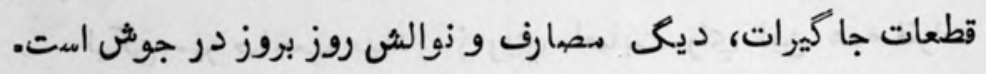

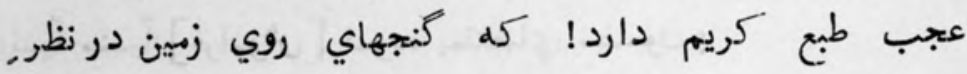

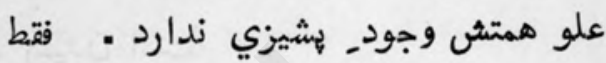

. (1) 


\section{$-1 \cdots-$}

در بيان كوهر درجـ -عرفت، بير بيان علي گوهر كه گوهر بى بهاي حيات را درين آرزو بخاك سهرد ديرد

و شيخ على حسن نيز در تعاقبش با او درخاكى برابر شده و

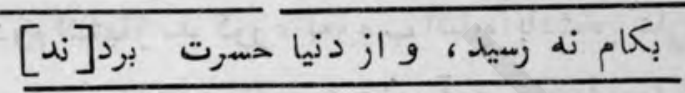

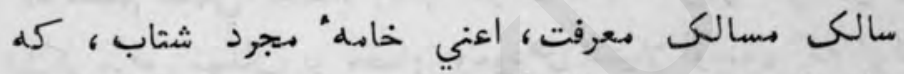

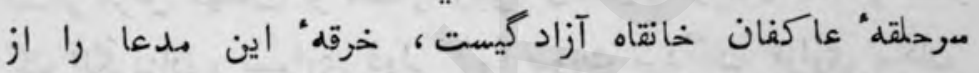

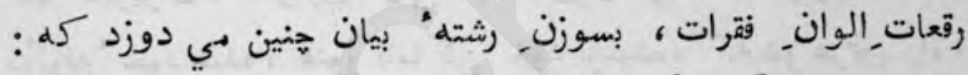

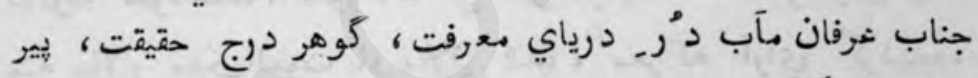

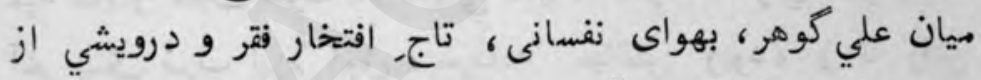

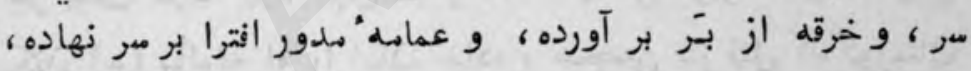

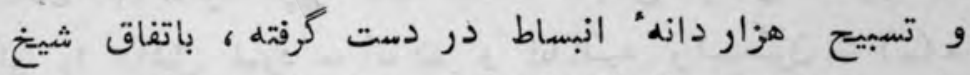

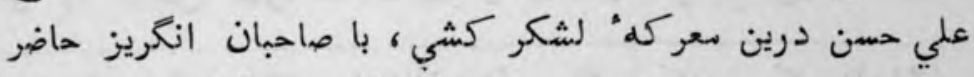

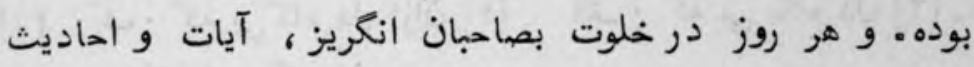

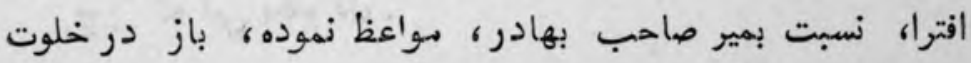

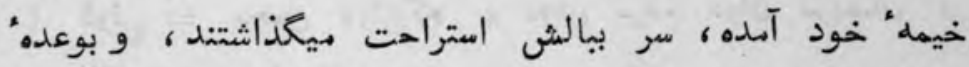

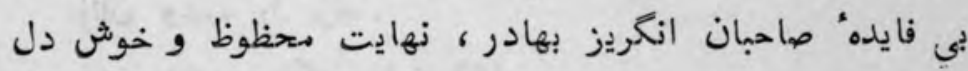

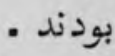
از روزيكه اشتهار عزل رياست و غصب هلك موروثه. 


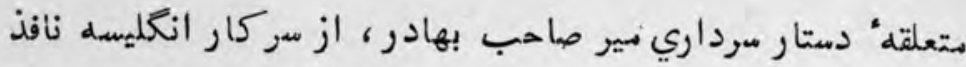

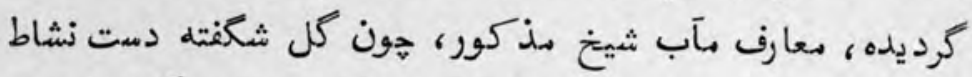

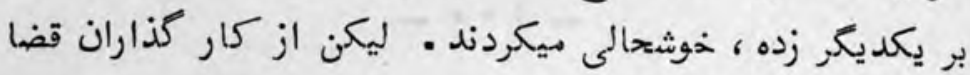

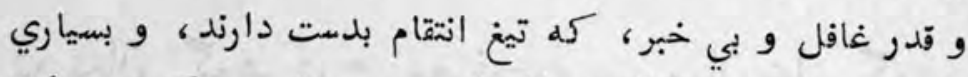

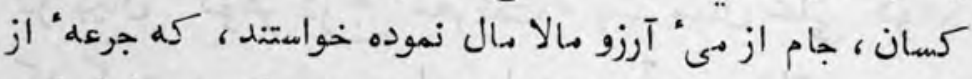

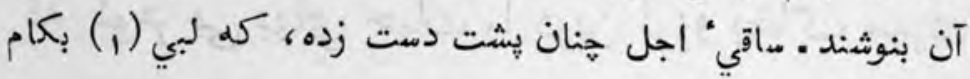

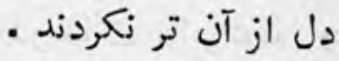

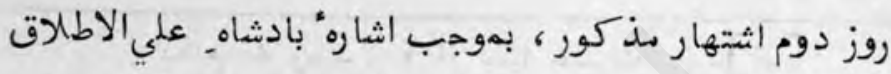

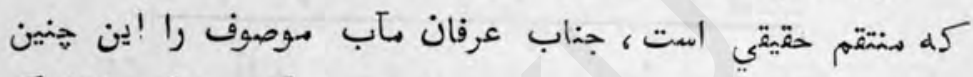

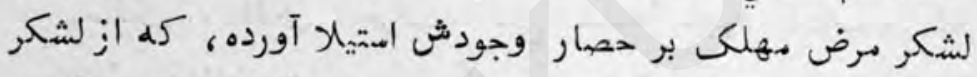

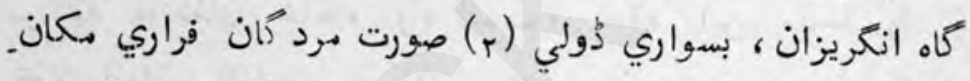

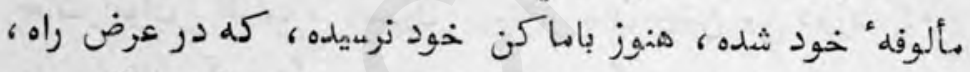

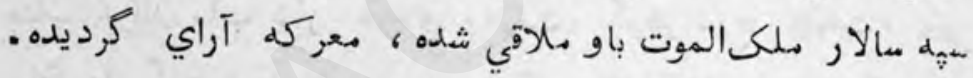

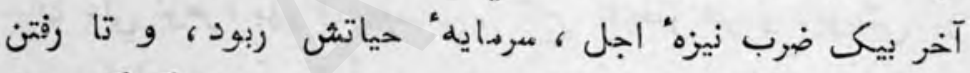

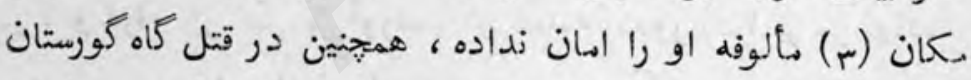

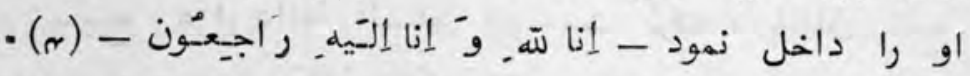

كس: كله بي كام دل ازان [؟]. . الف: كله بي بكام دل [؟؟].

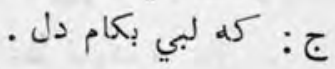

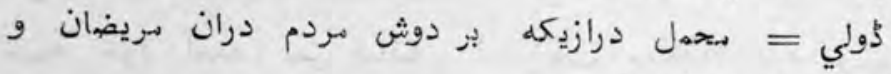

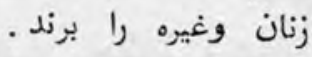

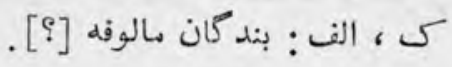

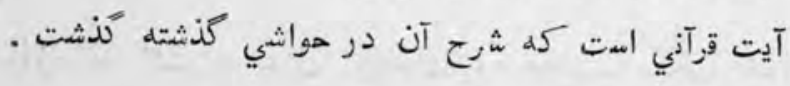


از آنجا كه حال حيات مستعار دنياي نا هايدار همين است، خلق النه

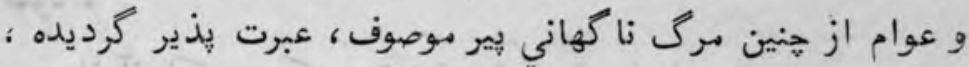

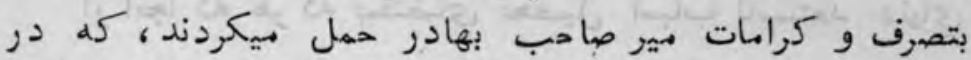

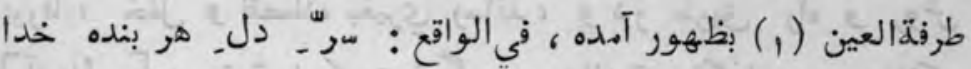

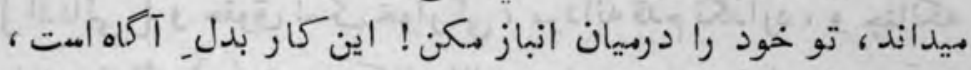

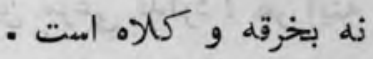

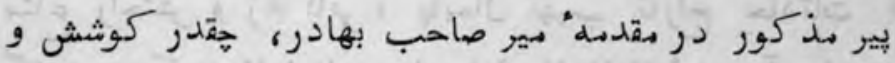

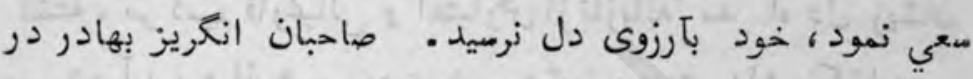

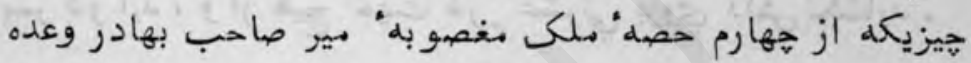

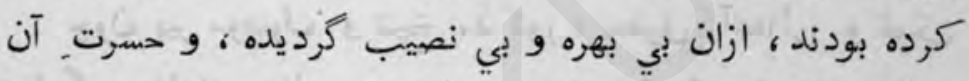

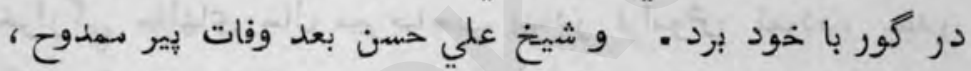

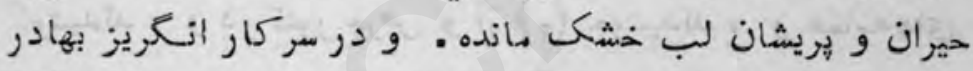

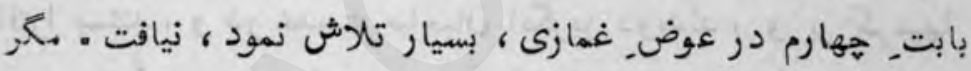

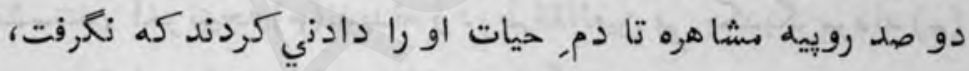

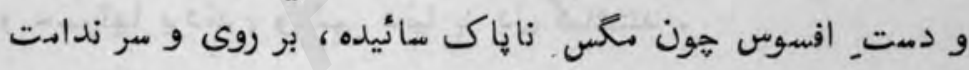

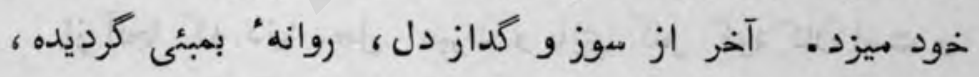

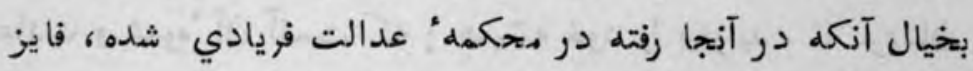

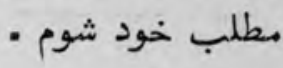

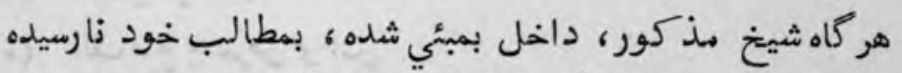

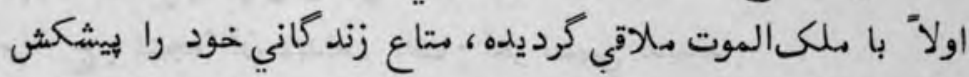

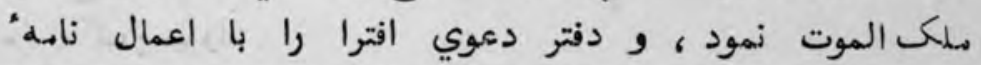


خود بهمراه برد . در كور با منكر و نكير، جواب سوال خواهد

از آنجا كله هركه بمقتضاي تحصيل اسباب نامستعد دنياي

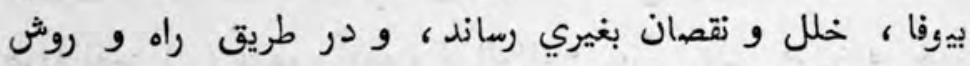

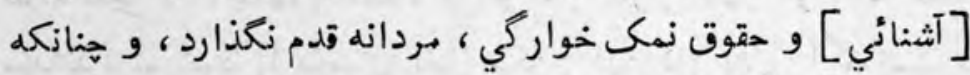

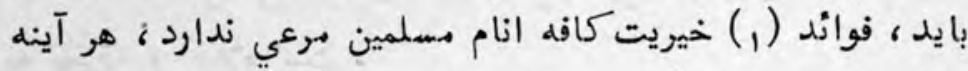

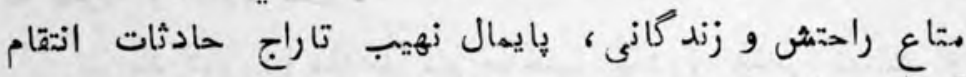

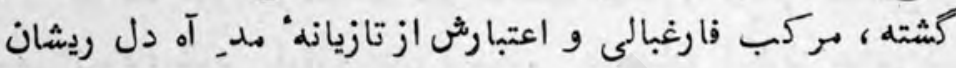

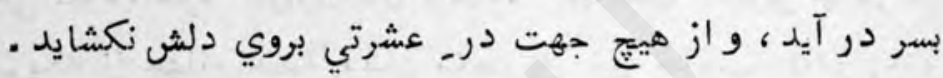

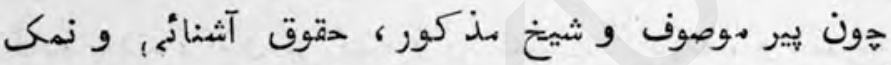

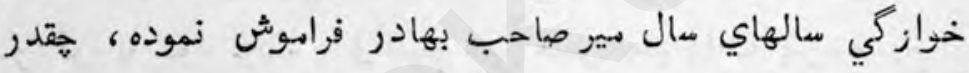
كوشيدند ، و در تنور حرص و آز (r) جوشيدند ، و و عمامه هاي

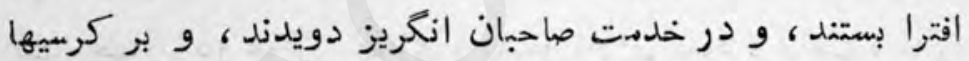

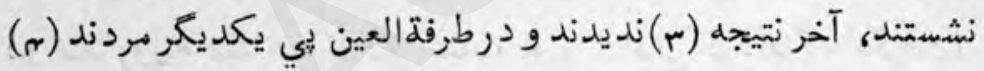

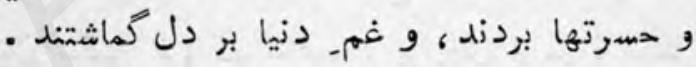

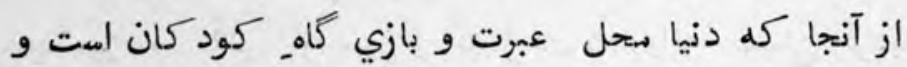

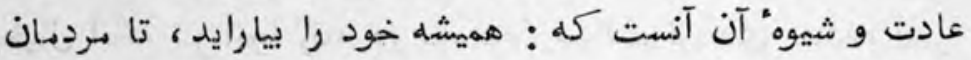

$$
\text { الف : قــاعد. }
$$

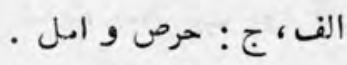

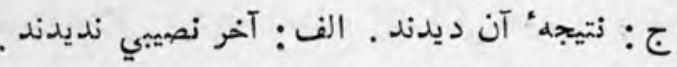

$$
\text { كى: ميروند. }
$$




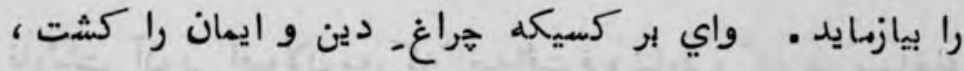

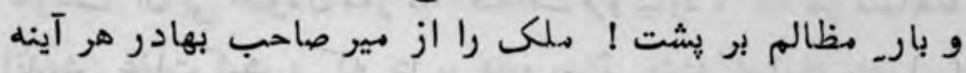

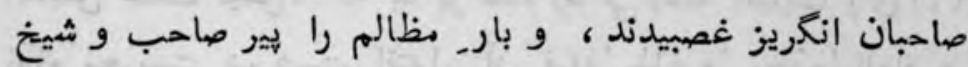
مذكور بردند آندان

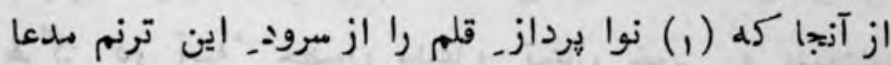

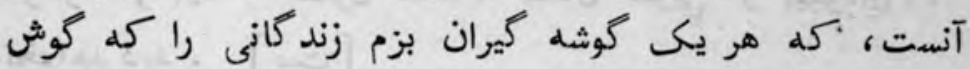

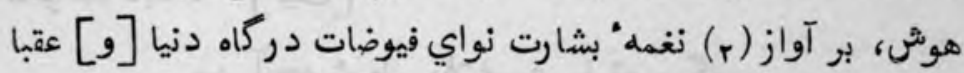

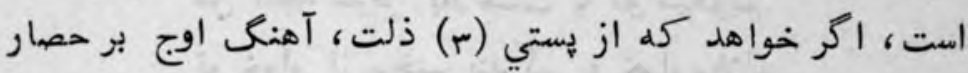

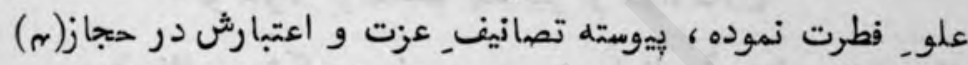

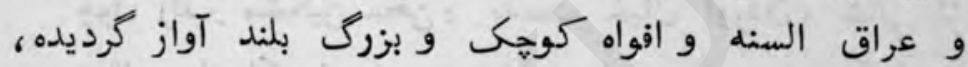

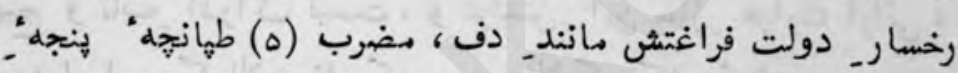

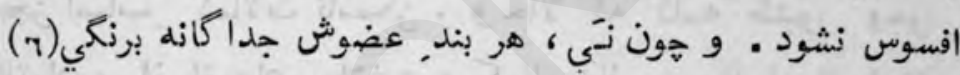

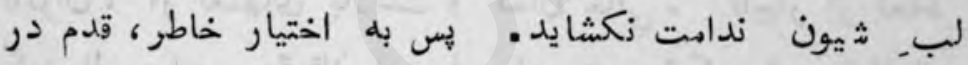

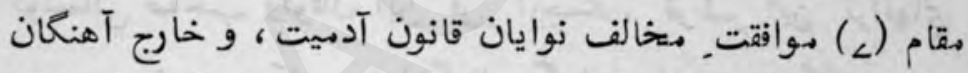

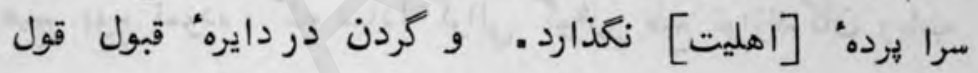

كى: كه نبع نو يرواز قلم را از سرور. الف: ازانجاكه به معي

نوا هرداز قلم را از سرود اين بزم .

$$
\text { الف الف: الف : آورازه . }
$$


تازه نواي معارك

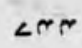

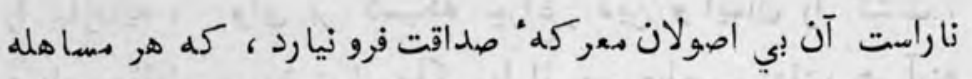

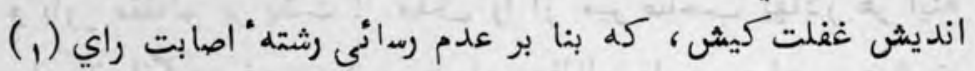

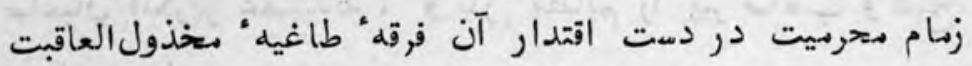

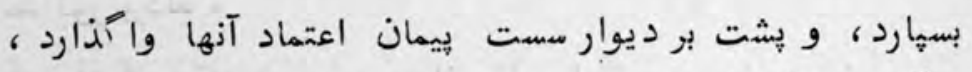

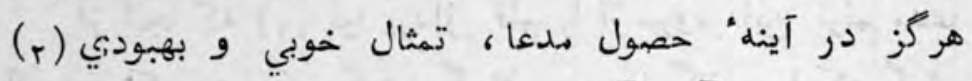

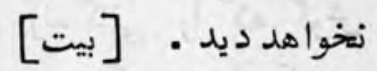

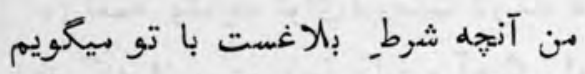

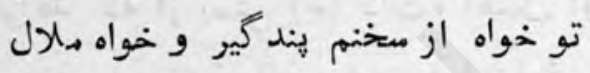

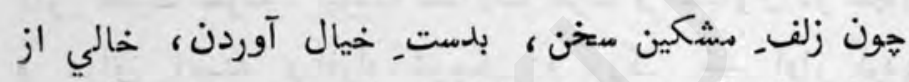

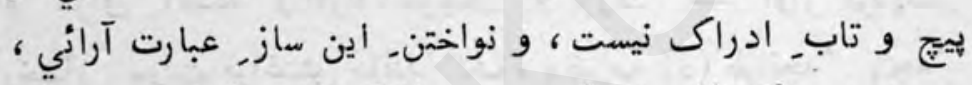

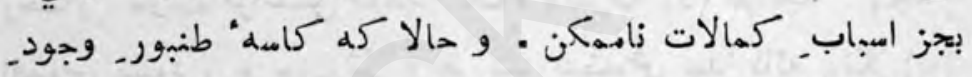

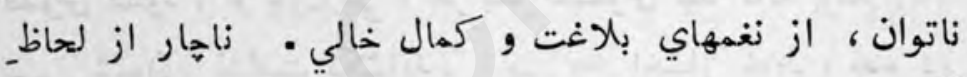

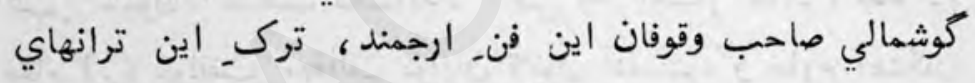

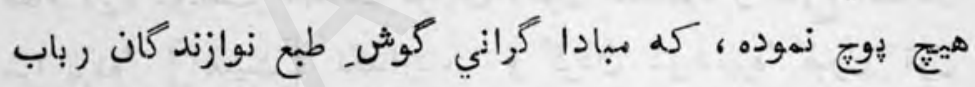

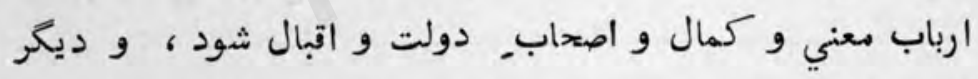

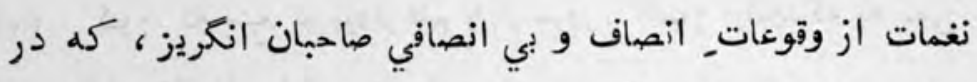

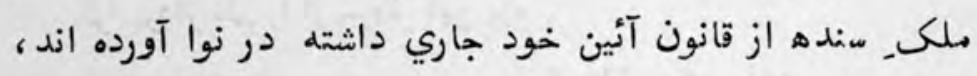

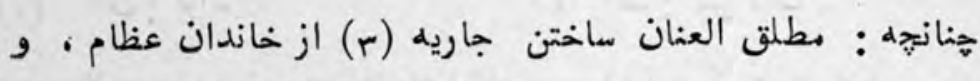

(1)

$$
\text { جاريه = (r) }
$$

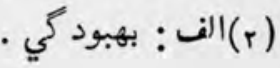


بي بردگي مستورات ازخاص و عام ، و بناي مركها و بازارها :

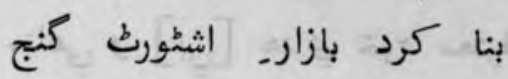
كله يابند مردم ازور نفع و رنج

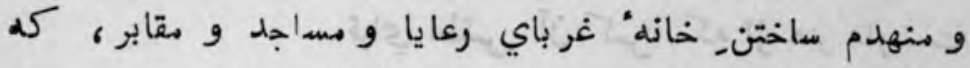

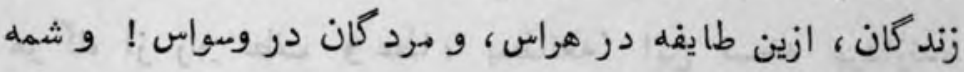

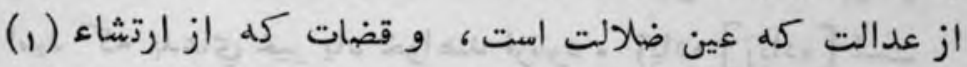

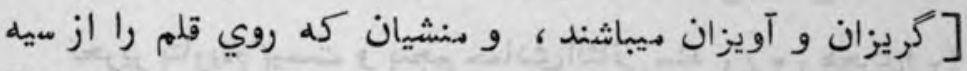

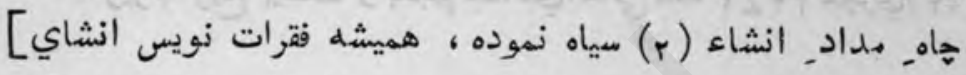

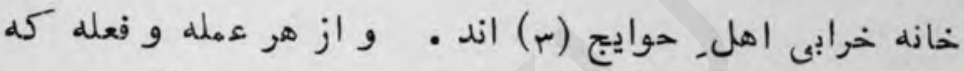

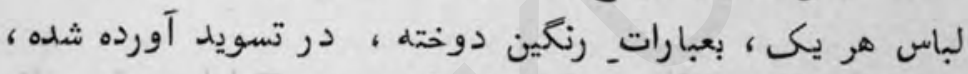

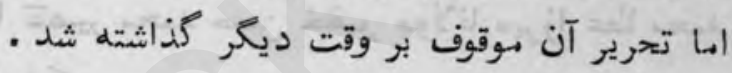

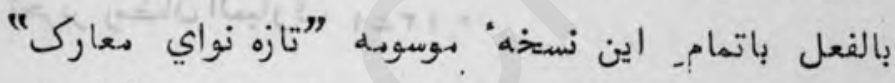

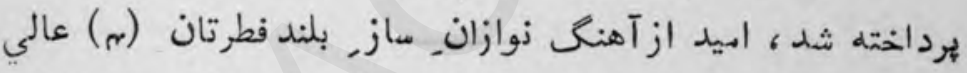

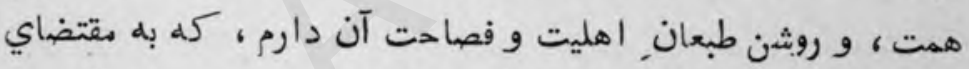

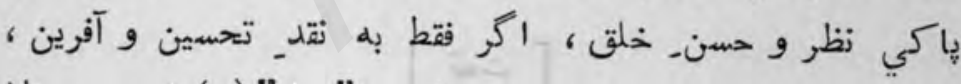

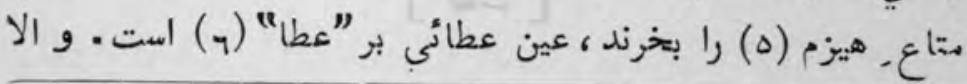

ارتشاء= رشوت ستاني. · جملات بين [ ] ] در الف نيست ، در

$$
\text { ج: كا، جداد ارتوداء است. }
$$

حواجج = جمع حاجت ارتهاء بهني نيازمنديهاست.

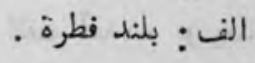

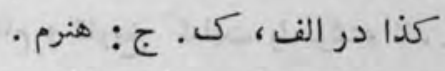

درينجا اشاره است بنام و تخلص مولف كتئاب [ركى: مقدسه]. 


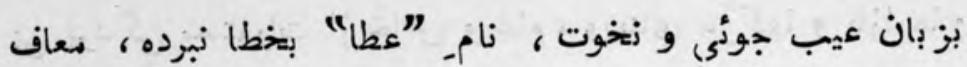

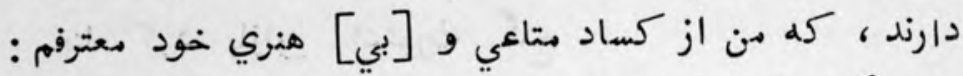

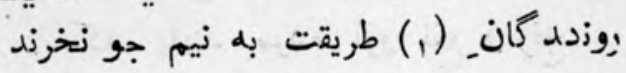
قباي اطلس. آن كس كو كه بز هنر عاريست

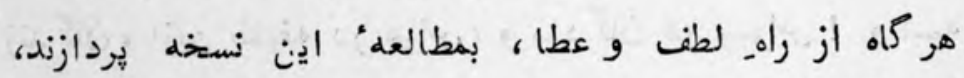

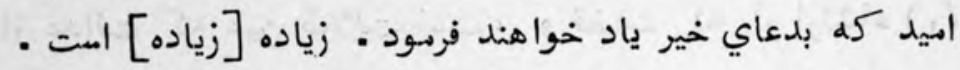

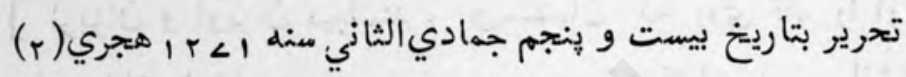

بقلم- حقير سرايا تقصير متحمد حسن خلفـ مولانا هيرزا عطا دهمد

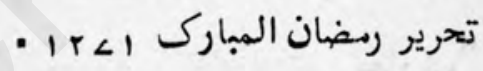

$$
[\text { [ }]
$$

$$
\text { الف، ج : الف مجردان . }
$$

اين تاريخ تاليف كتابست كه در كى ، الف آمده ، و و بعد ازان

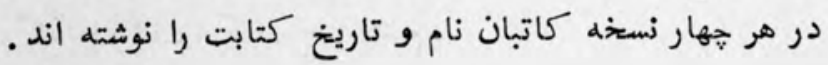

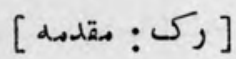


$(r)$

تعليقات

عبدالحي حبيبى افغاني

بر كتاب

تازه نواي شعارك

هنشي عطا متمد شكار يوري 



\section{اينتويك EASTWICK}

باين نام دو نفر برادردر منده و افغانستان كارها كرده اند كهديدر إنان رابرت وليم ايستويك Robert William Eastwick

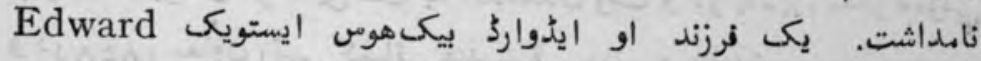
Backhouse Eastwick

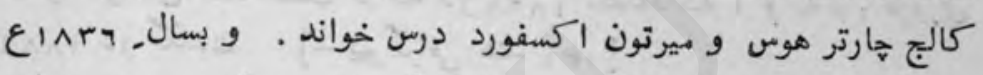

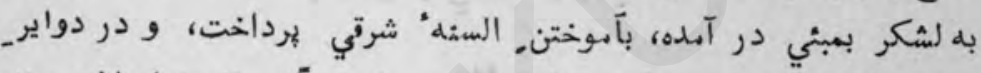

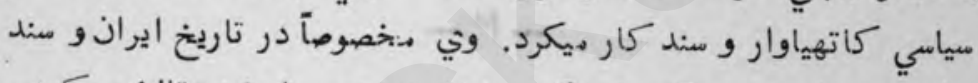

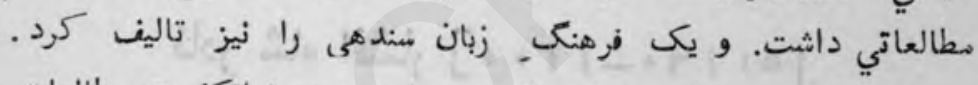

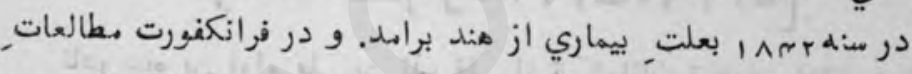

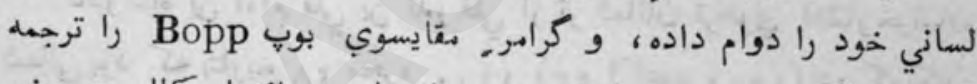

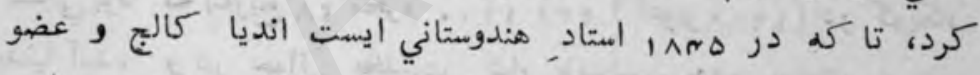

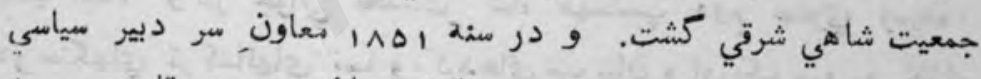

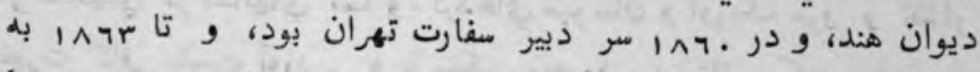

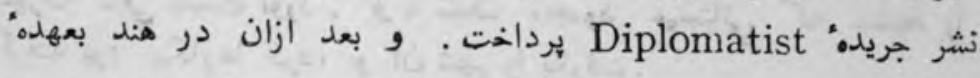

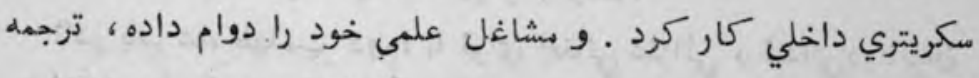

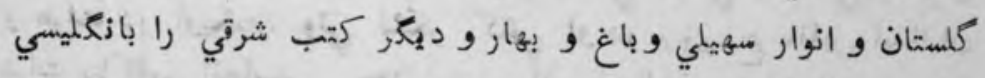

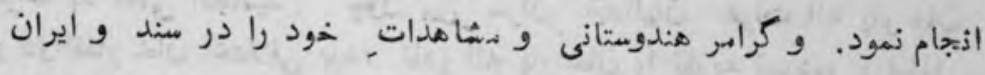

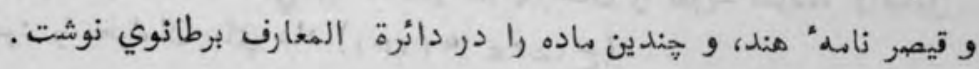

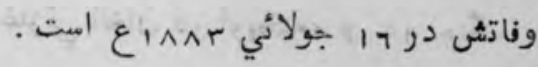




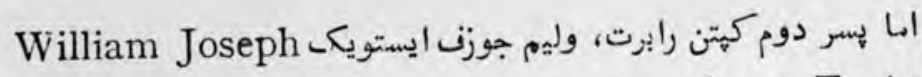
Eastwick

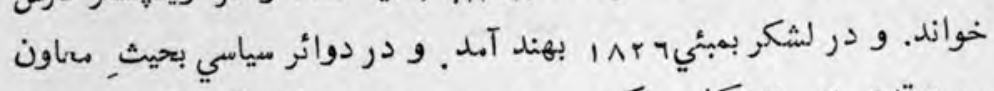

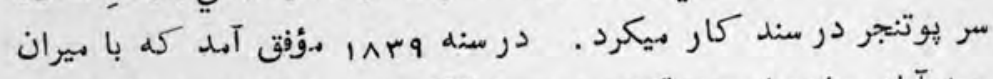

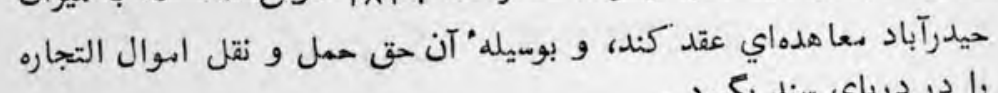

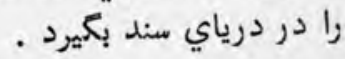

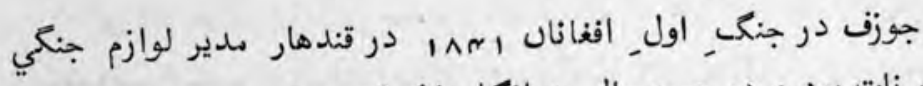

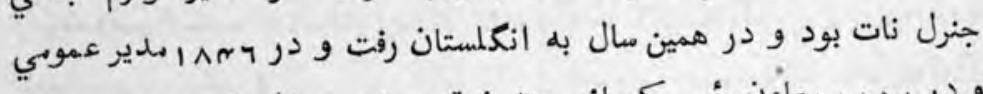

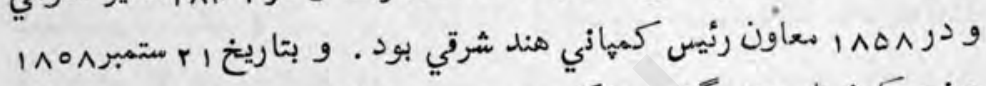

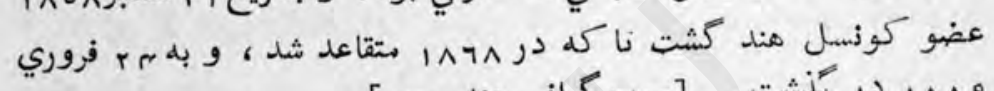

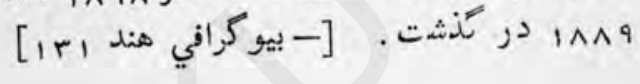

\section{$-r-$}

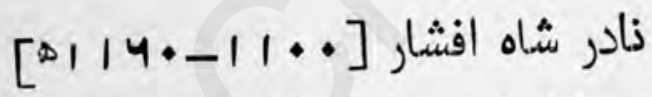

نادر شاه بن ادام قلي بن نذر قلي از تركمانان قرقلوي افشار خراسان

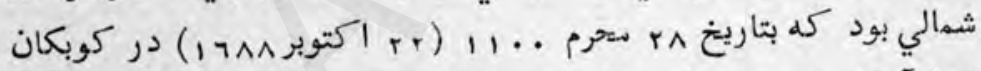

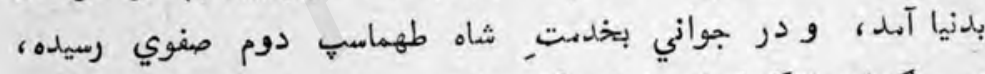

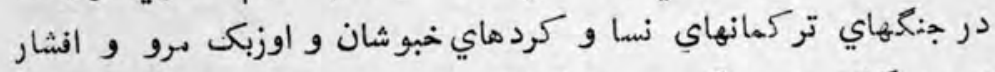

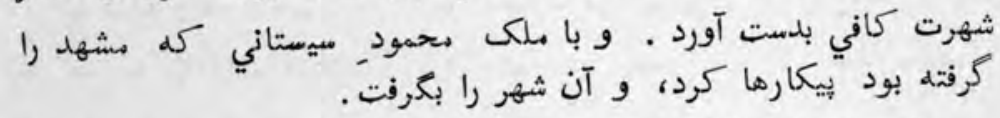

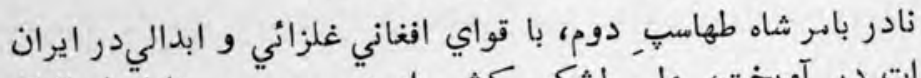

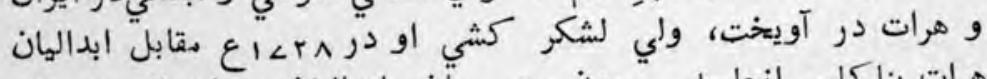

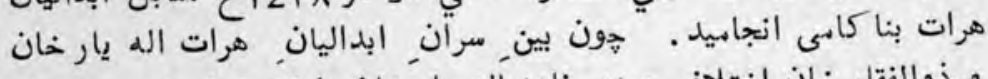

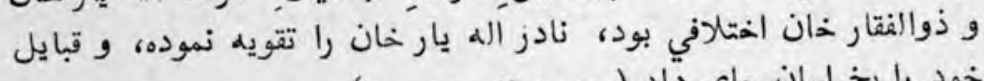

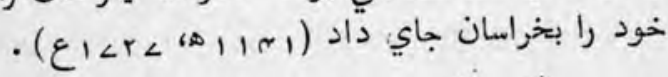

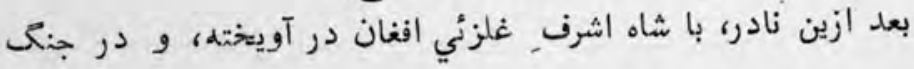


$\angle \Delta 1$

تازه نواي مارك

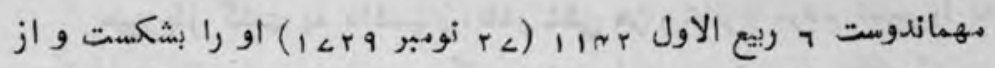

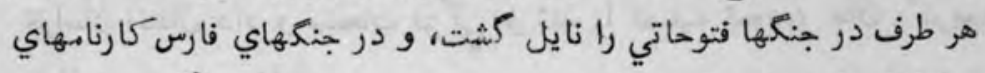

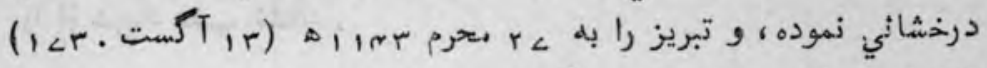

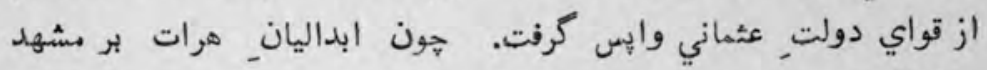

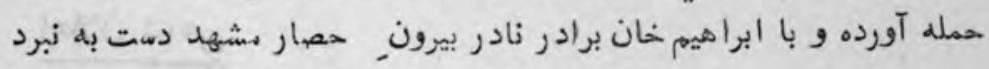

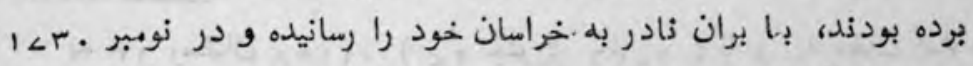

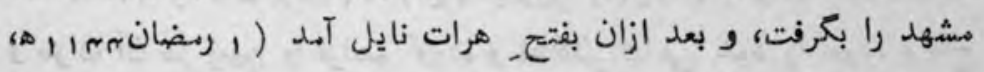

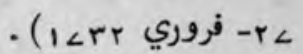

هون نادر بعد ازين نيروي زيادي كسبب كرده، و باعثمانيان و روسيه

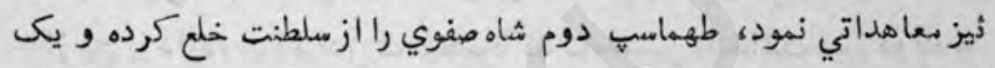

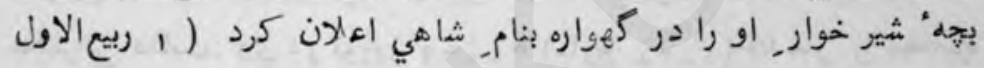

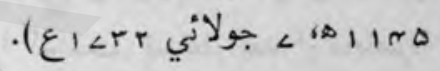

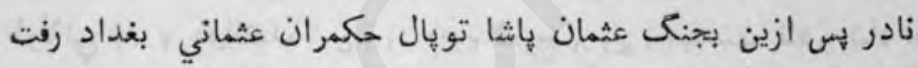

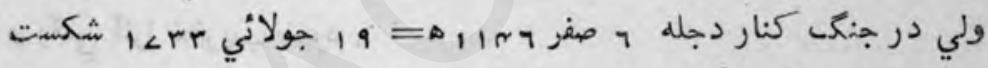

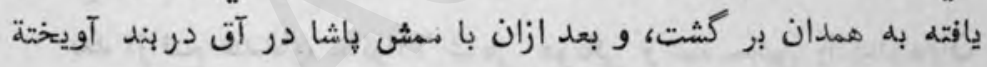

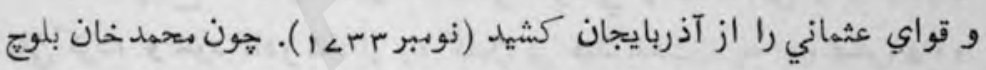

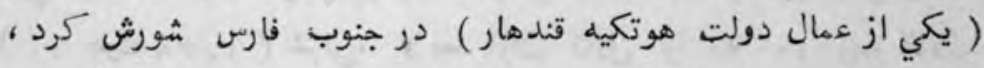

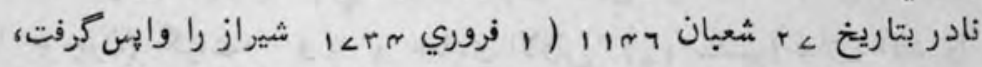

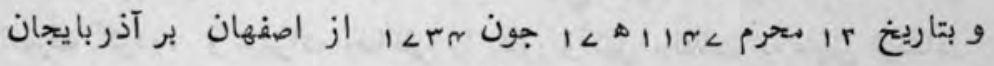

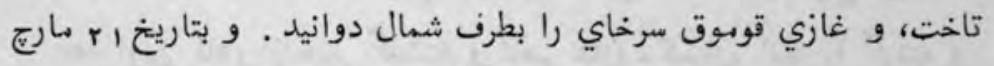

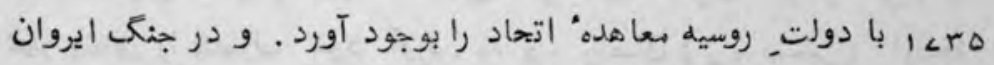

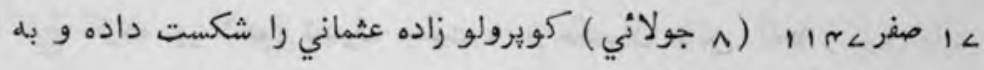

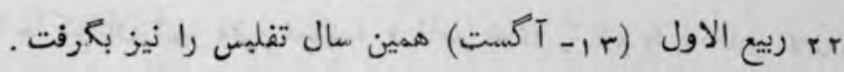


حين باز كثت به داضستان، نادر ثيش هزار خانوار مردم تفليسرا به خرامان انتقال داد و صفحات لزكي و تله را تصفيه نموده، خان بر كريهيا را از دربند عقب نشاند.

\section{اعلان شاهي}

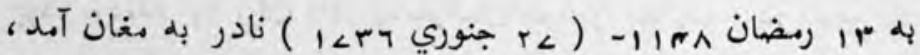

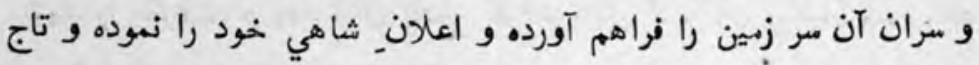

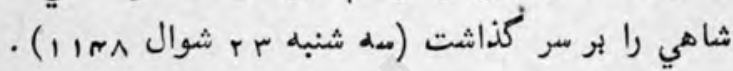
بعد ازين نادر شاهبطرف|فغانستان حركت نمود، تا دولتيـ هوتكيه ق قندهار را از بين بر دارد، زيرا برادر شاه ميحمود كه شاه حسين نامداشت هنوز در رقندهار

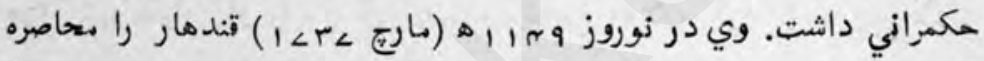

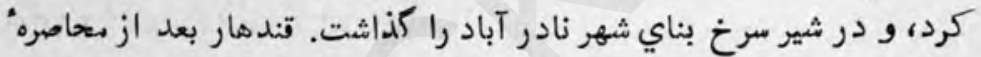

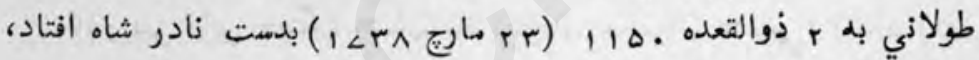

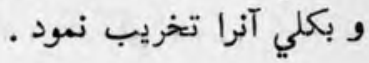

بعد از فتح قندهار، خانوادهُ شاهى هوتكي و شاه حسين را بمازندران

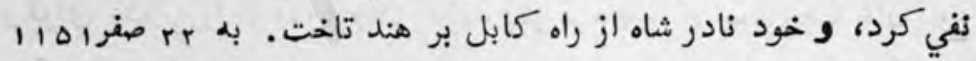

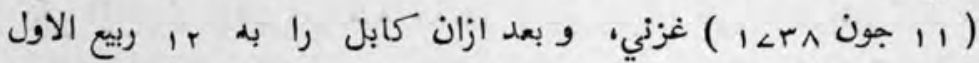

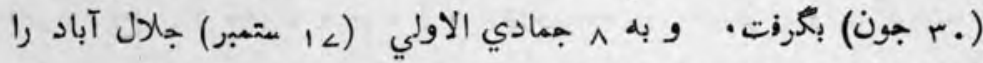
تصرف كرده، و شهزاده رضاقلي را بطور وكيل سلطنت به فارس فرستاد. بعد ازين نادر از خيبر كنشته و زاصر خان حكمران آنجا را كرفته و

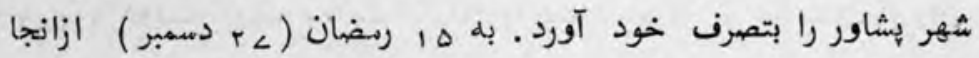
كوت كرده بر لاهور تصرف جست ، و حكمران سابق آنجا زكريا خان

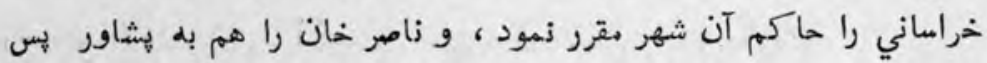

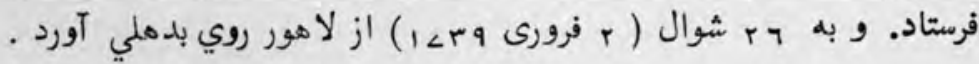


هون معمد شاه دهلي به مقابلت وي تا كرنال آمده بود ، نادر راه لشكر

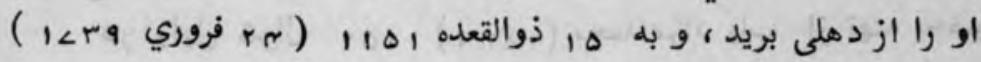

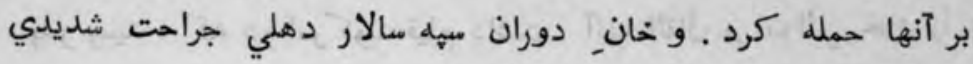

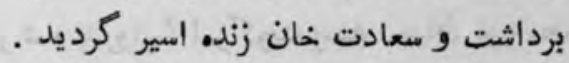

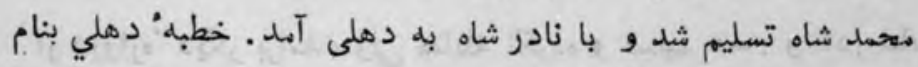

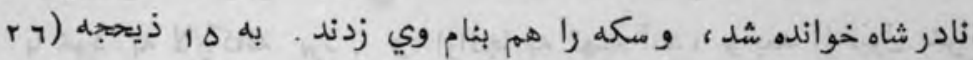

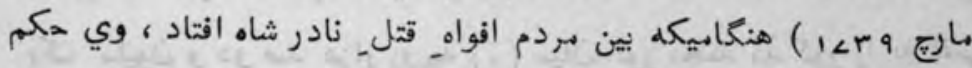

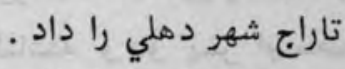

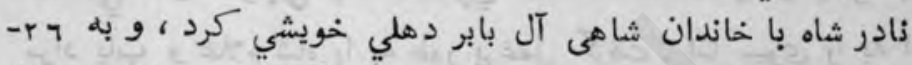

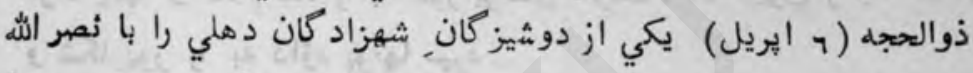

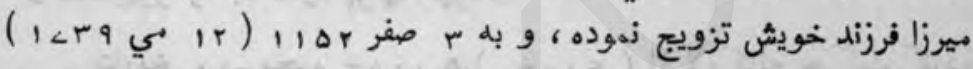

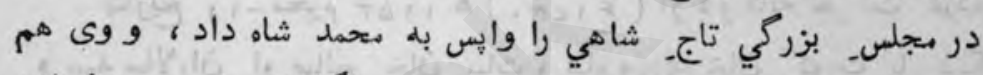

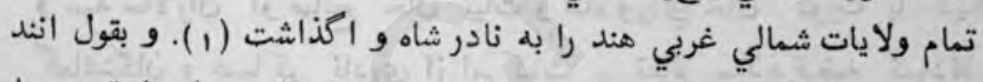

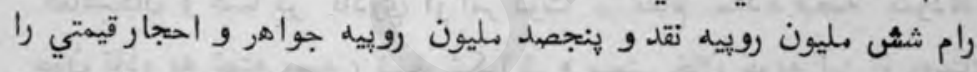

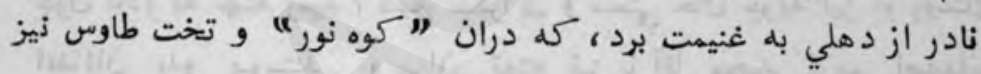

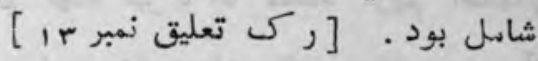

\section{زادر شاه در مسنده}

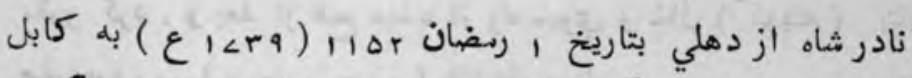

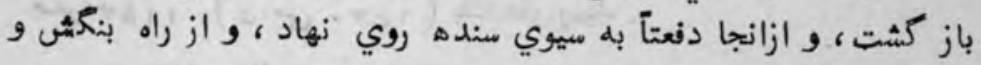

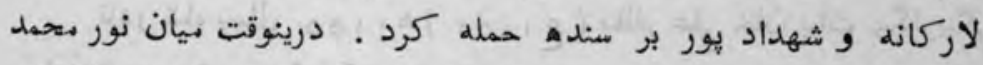

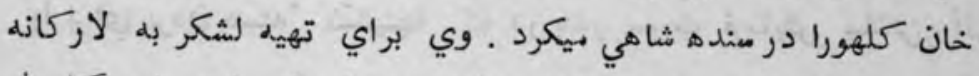

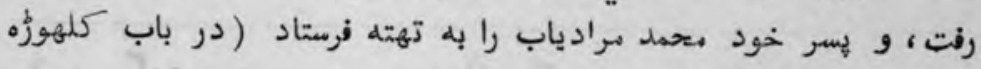


تعليقات

$\angle \Delta r$

) رجوع شود به آخر تعليق r )

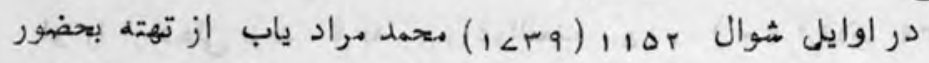

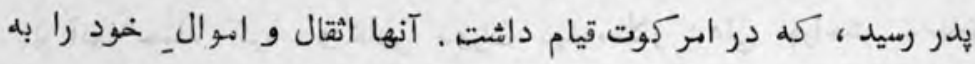

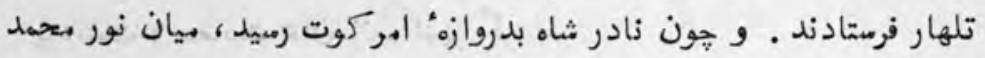

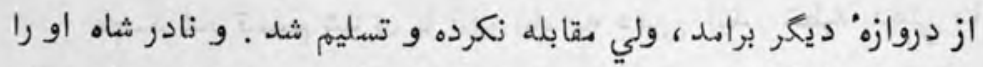

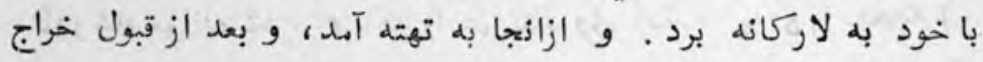

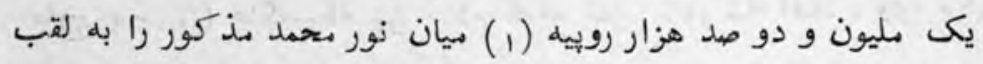

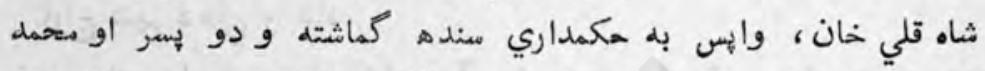

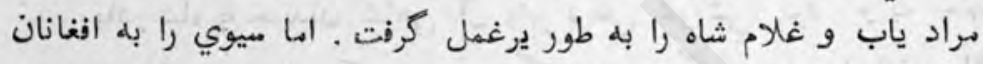

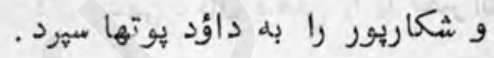

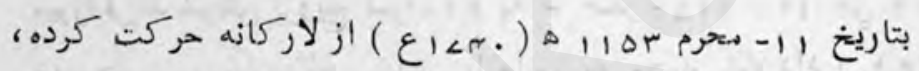

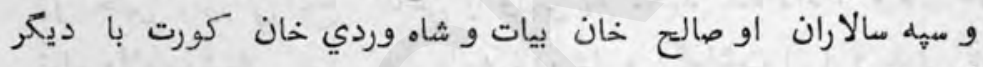

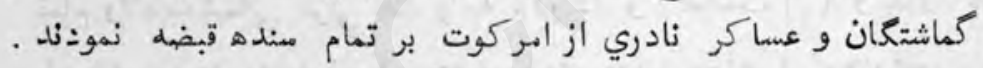

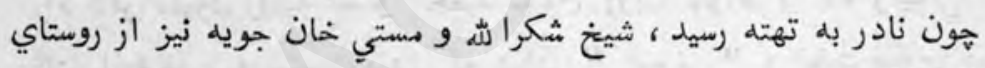

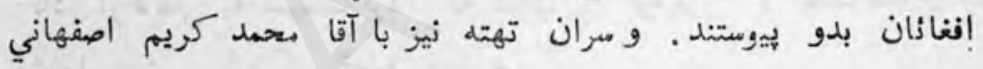

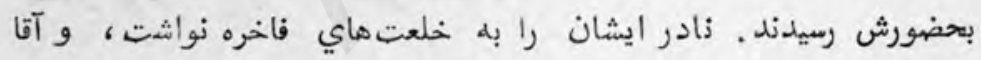

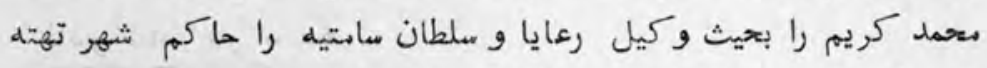

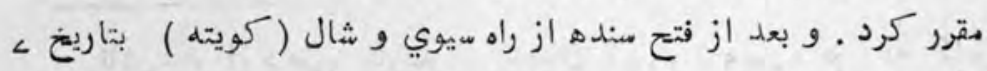

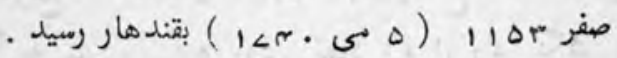

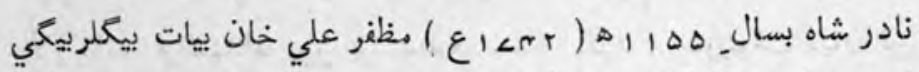

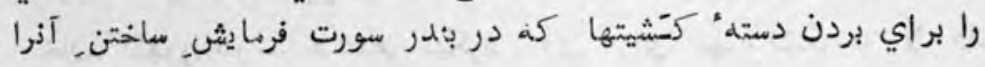

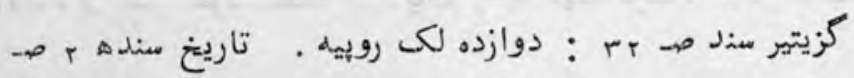

(1)

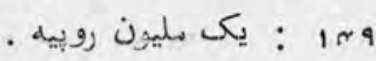




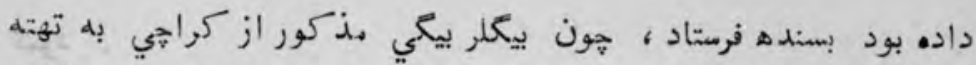

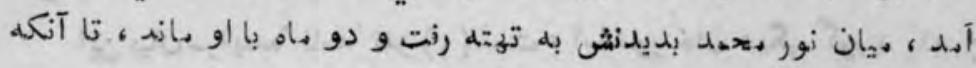

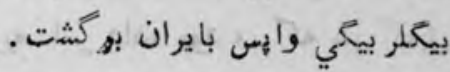

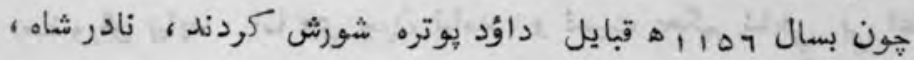

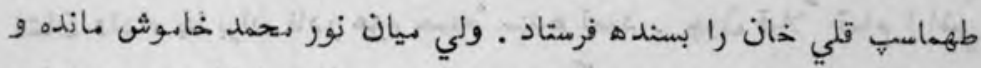

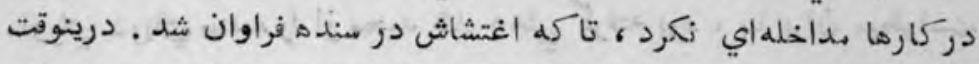

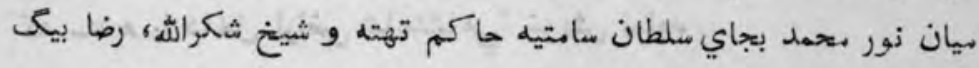

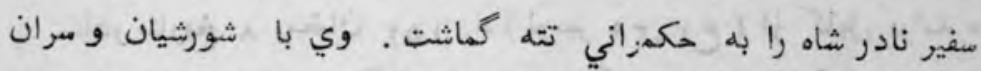

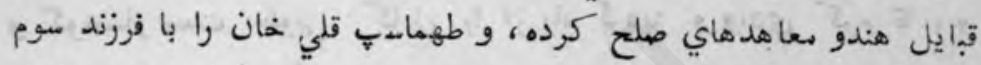

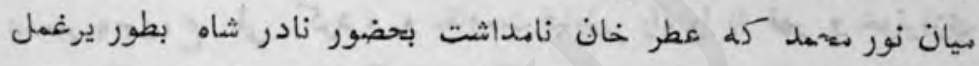

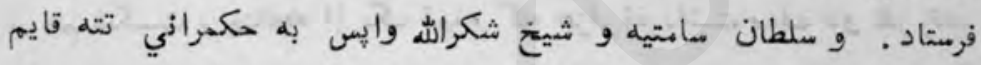

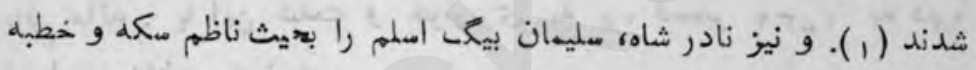

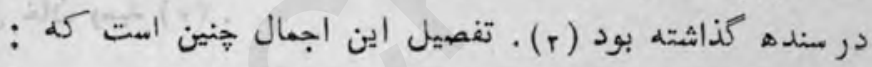

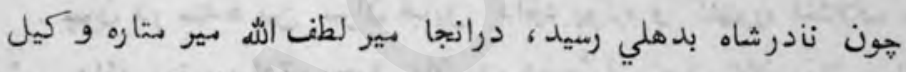

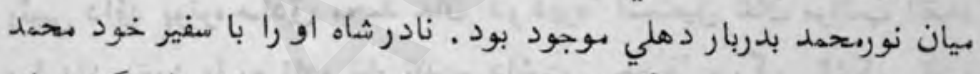

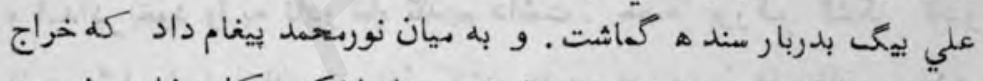

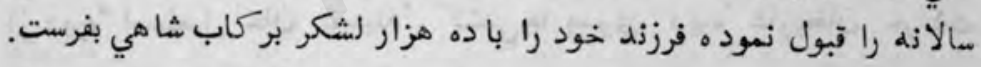

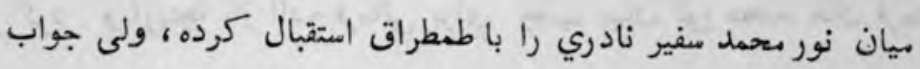

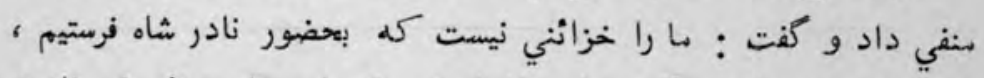

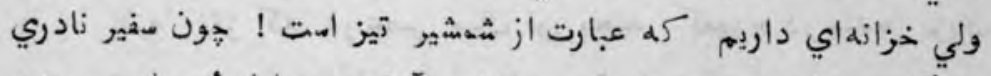

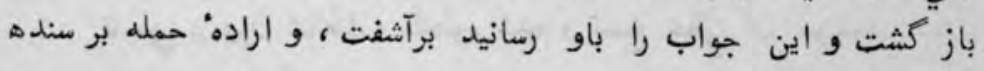

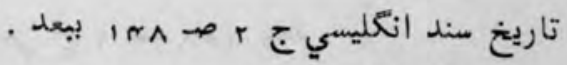

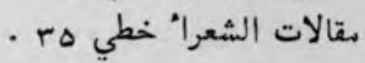




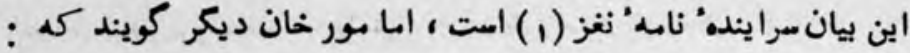

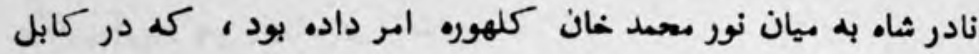

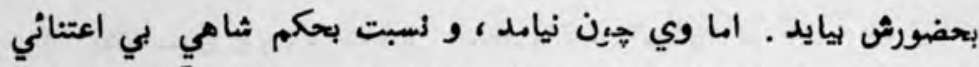

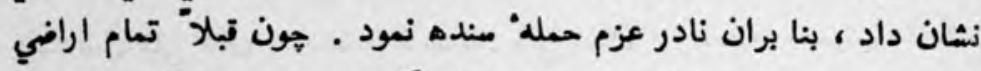

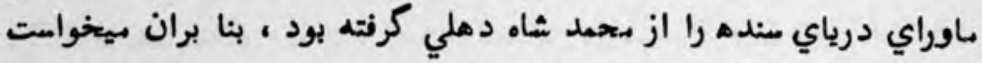

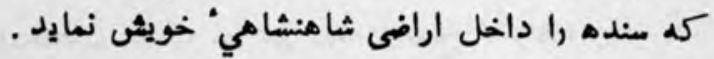

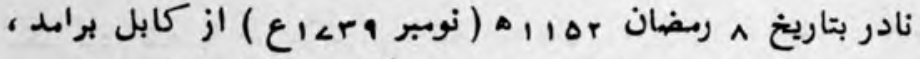

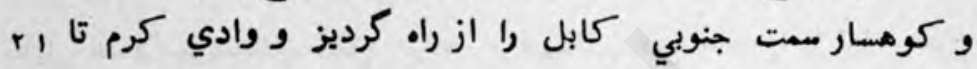

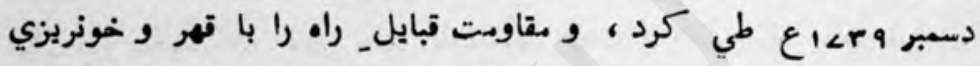

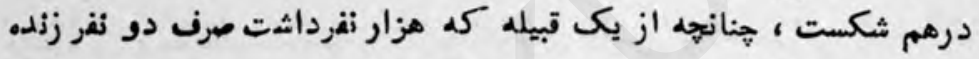

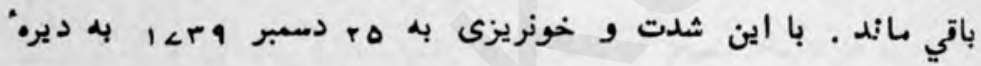

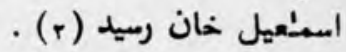

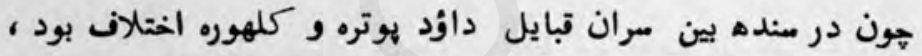

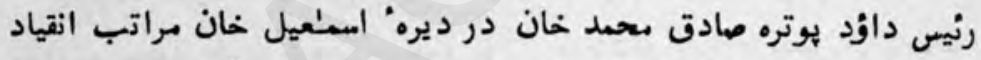

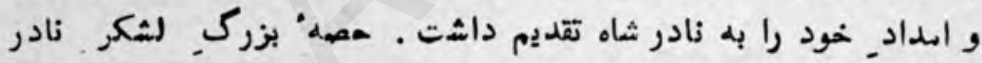

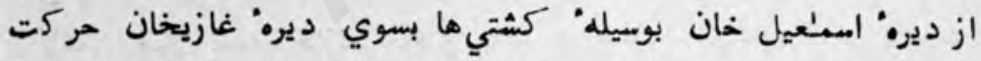

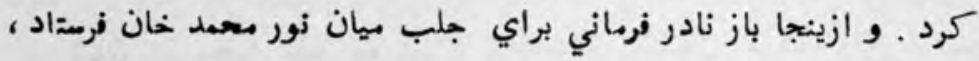

نامه" نغز كم در عصر ميان نور دحمد كلهوره در سنده بزبان

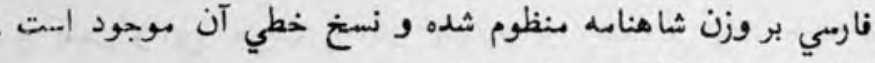

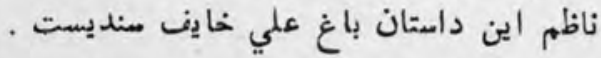

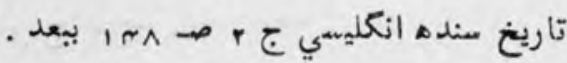


ولي جوابي نياهد (1) ـ و بقول عبدالكريم راههاي دشوار كذار مرحدات

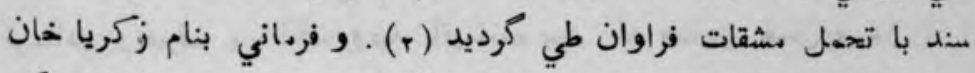

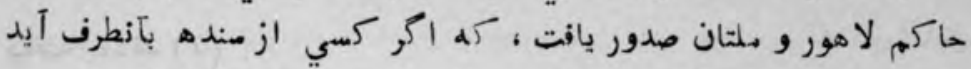

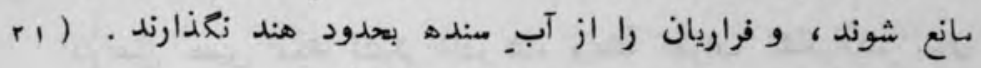

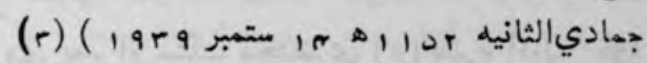

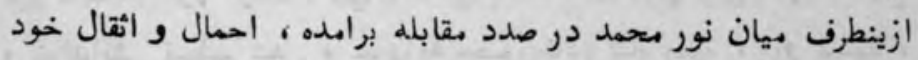

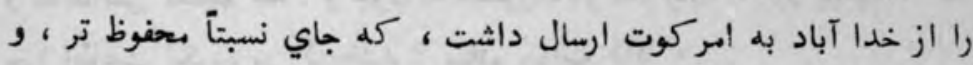

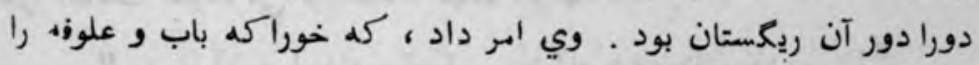

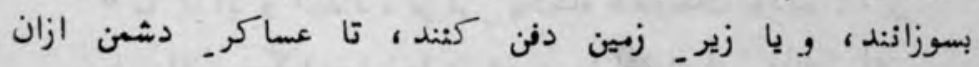

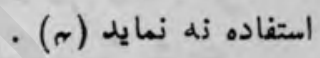

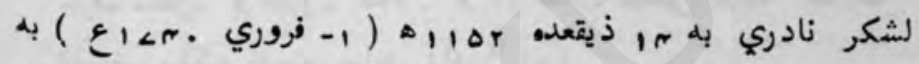

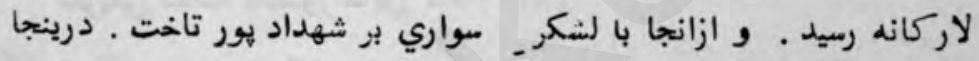

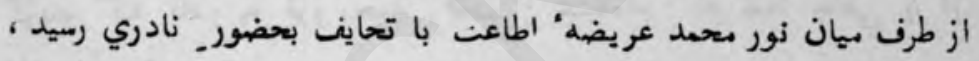

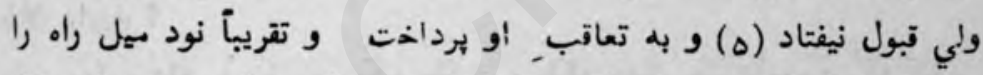

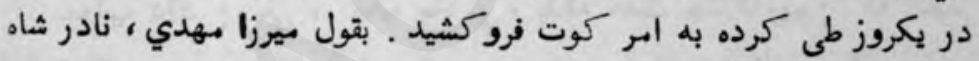

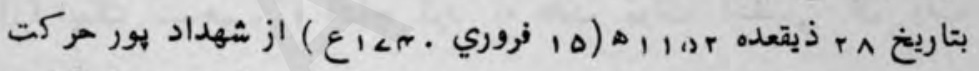

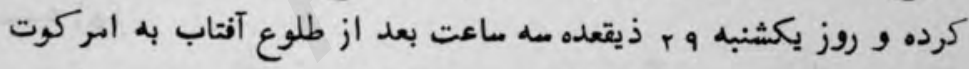

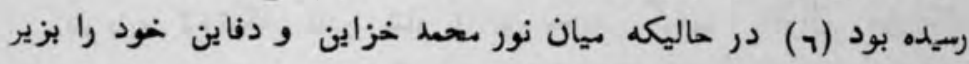

$$
\begin{aligned}
& \text { نادر شاه : از لوكىهارت . } 17
\end{aligned}
$$

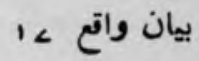

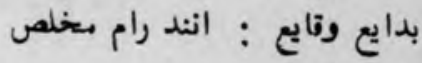

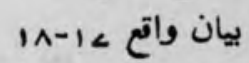

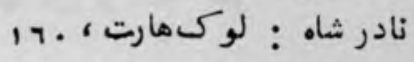

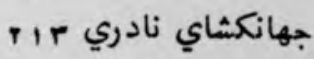


زمين كور كرده و برخي را در كشتيها (1) به مقامات محفوظ تري

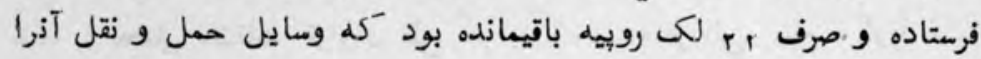
نيافته بودند (r) (r)

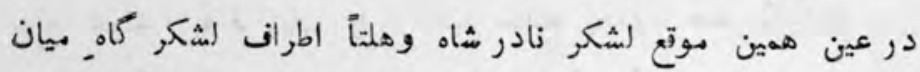

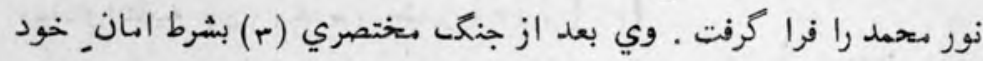

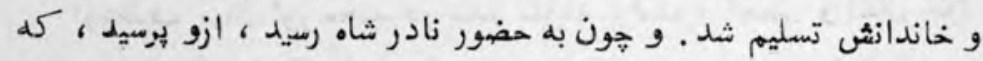

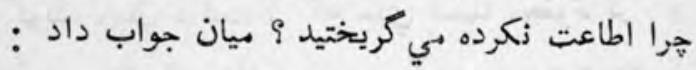

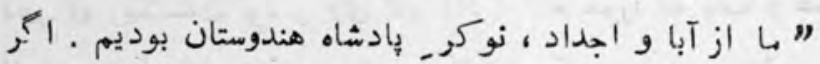

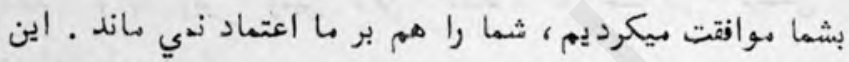

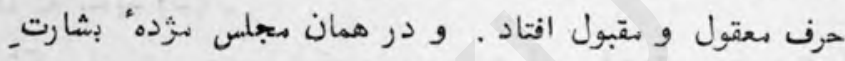

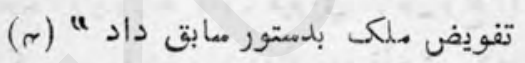

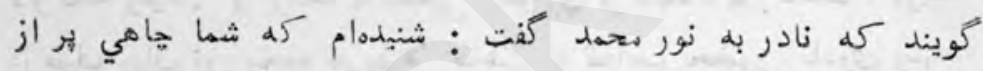
9 ارئ جواب داد : : بلي ، يكى هاه ني، بلكه هفت خاه داريم : كله كليد

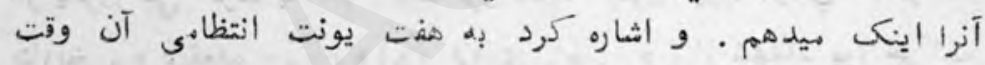
(0) هir (0)

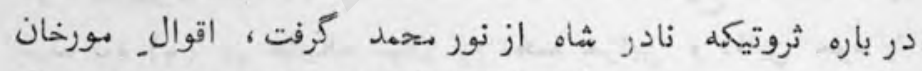

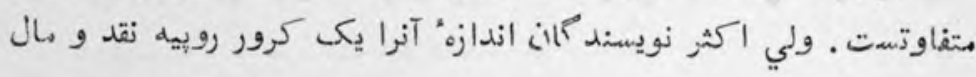

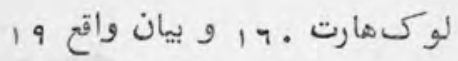

$$
\begin{aligned}
& \text { بدايع وقايع : بخلص }
\end{aligned}
$$

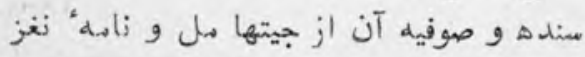

$$
\text { Ar } 9-1 \text { - تان }
$$

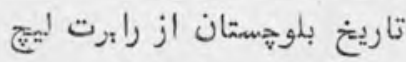




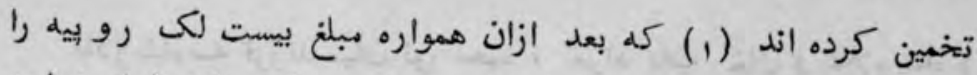

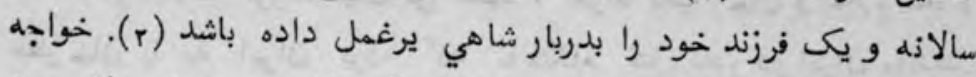

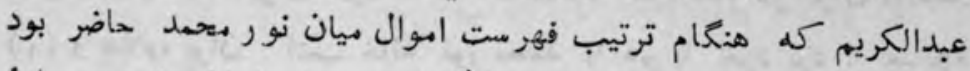

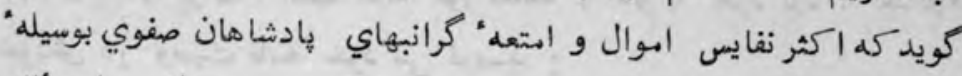

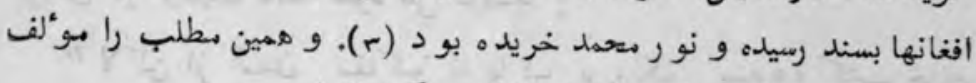

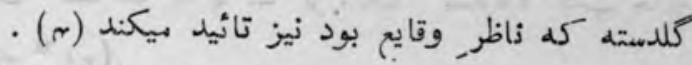

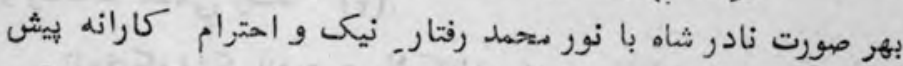

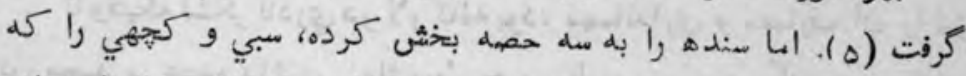

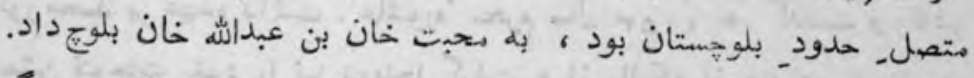

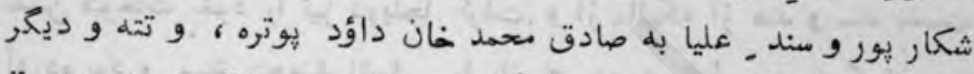

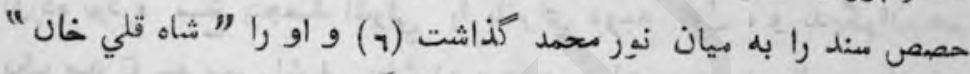

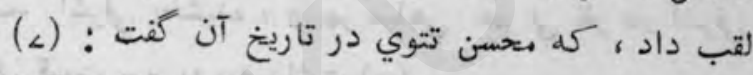

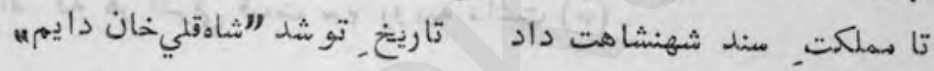
DI I Or

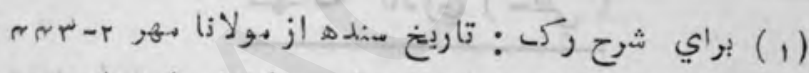

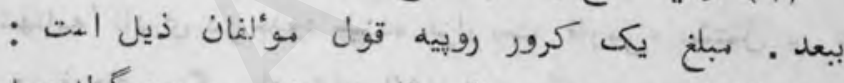

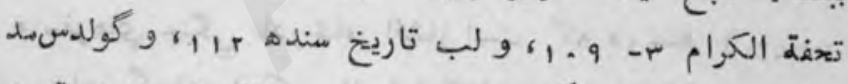

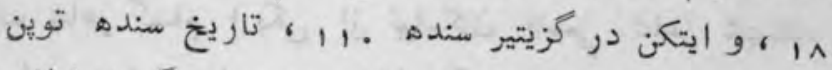

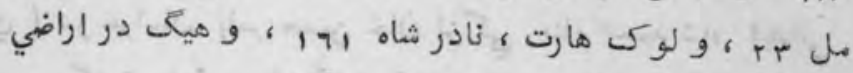

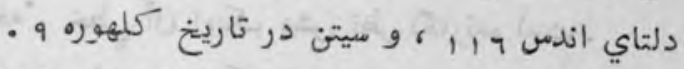

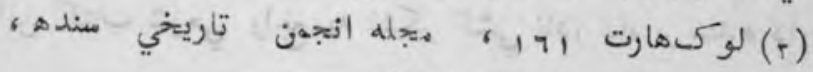

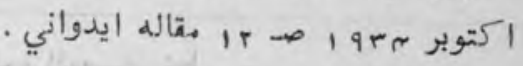
ا

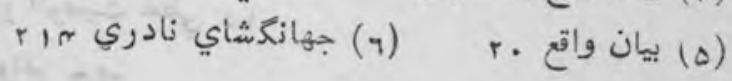
(4) ديوان خعلي دحسن تتوي. 
نادر شاه سه فرز ند بيان نور سحمد ، مراد ياب خان و غلام شاه و

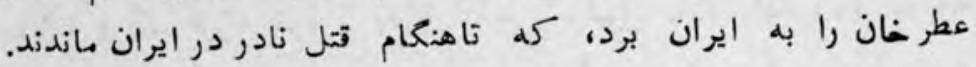

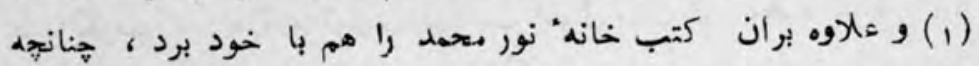

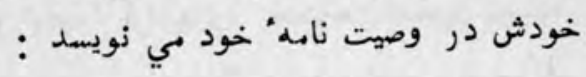

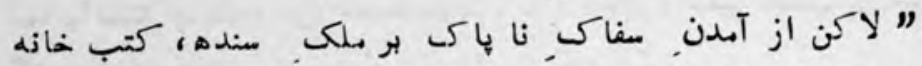

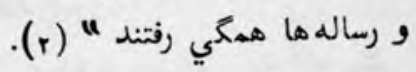

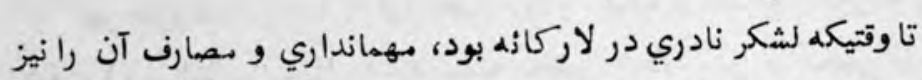

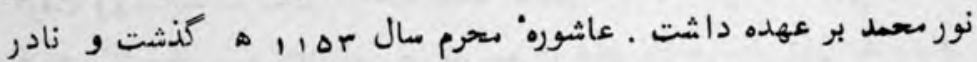

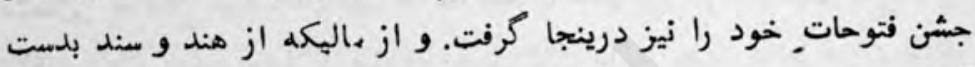

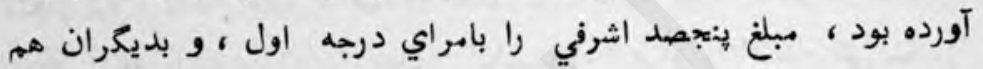

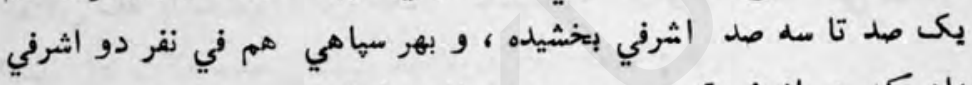

$$
\begin{aligned}
& \text { داد كم هر اشرفي قيمت عب مو رو بيه داشت (r) . } \\
& \text { از } \\
& \text { شهاملهُ نادري ( خطي ) }
\end{aligned}
$$

شهنامه" نادري در حدود سيزده هزار بست فارسى، بشتهمل بر شرح

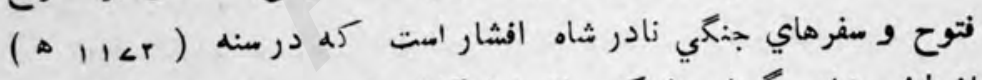

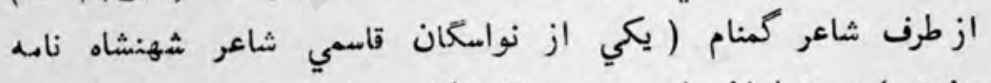

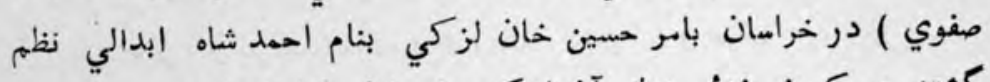

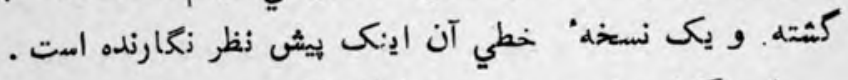

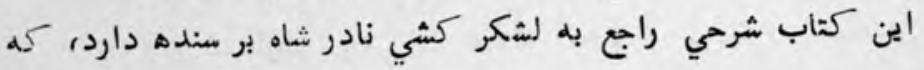

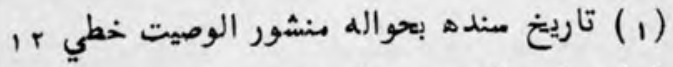

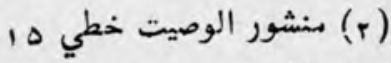

$$
\begin{aligned}
& \text { (r) بيان واقع rr) }
\end{aligned}
$$


ما براي تكميل مبحث ذيلا مي آوريم :

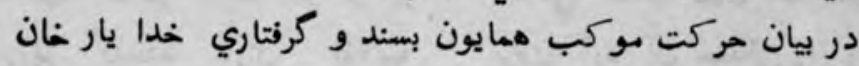

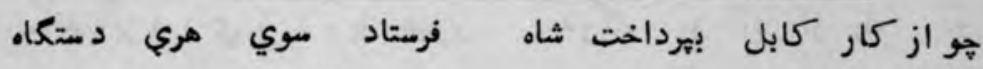

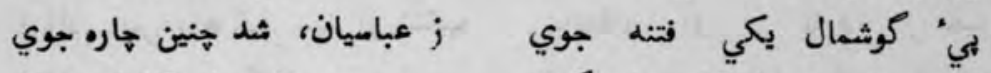

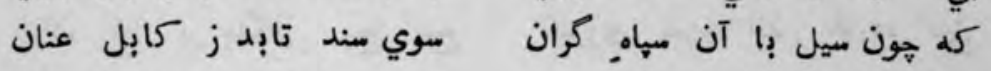

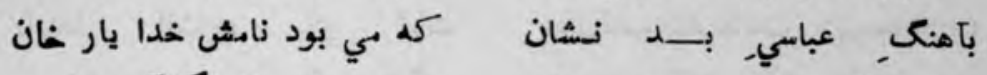

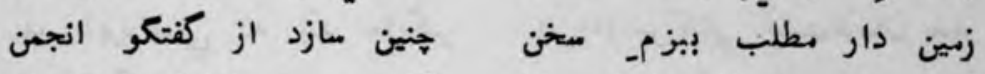

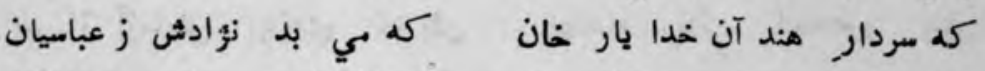

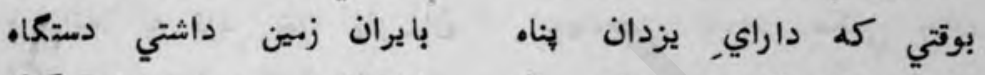

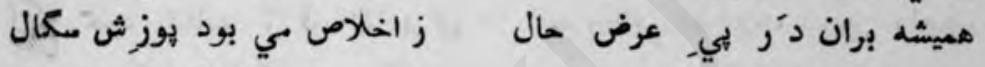

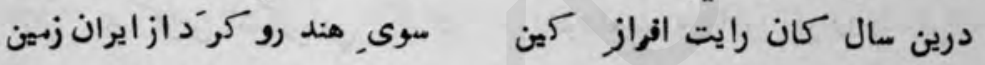

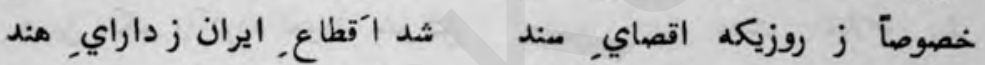

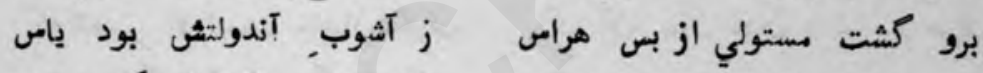

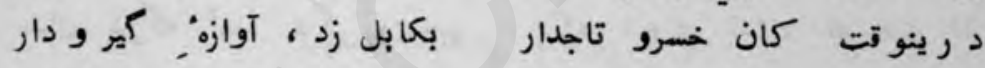

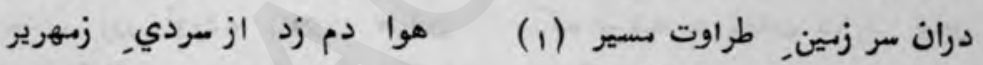

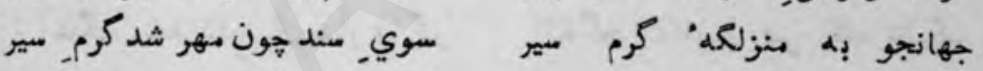

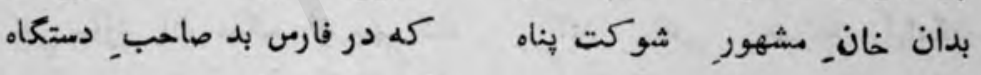

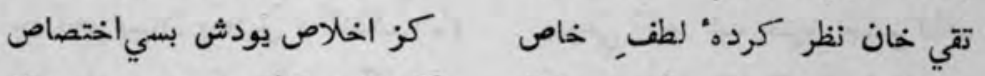

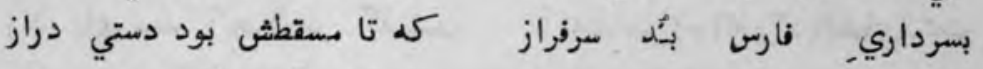

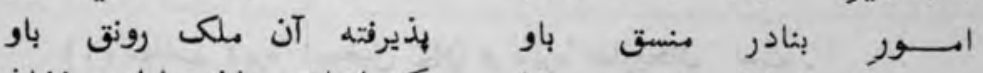

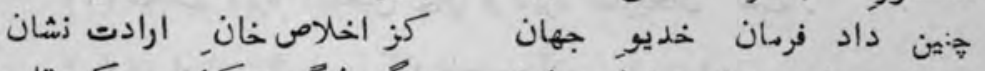

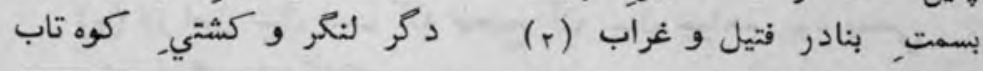

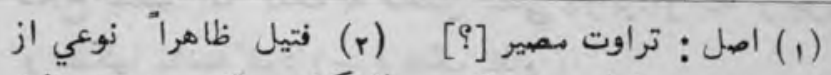

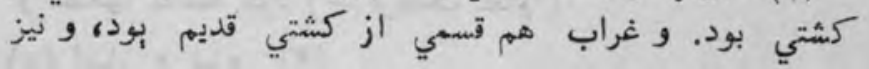

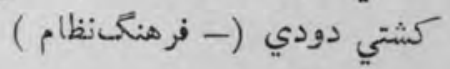


تماسي همان خان صاحب هنر برون آرد آن جملكي را ز آب هاح بدركاه رو رآرد از آ راه بايلغار آور رد باه فتوري بعزم اندر بآورده هيت

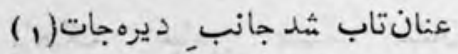
ني از سركشي كُشت فرمان يذير نهادند نائي باخلاص سيش جهانجوي فرسود حكمي روان بد ربار دولت ، درين داوري شود سند ويران كران بان تان كران

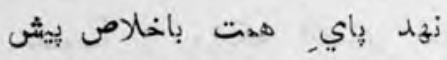

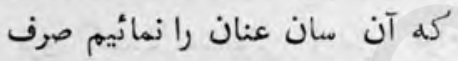
كل دروي ندارد نصيحت اثر كله ازشه به شفقت ندارد كله كجرات ازين نه كند جايكير

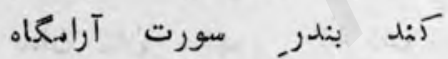
بنوعي كل شل شد خيره هشم فلكى كلشا عين (r) نه بِرّد باقصايدشت
بود آنهه حاضر دران بتر و بـ بر

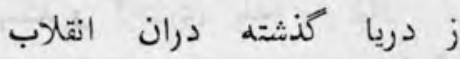

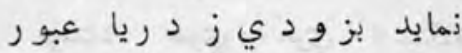

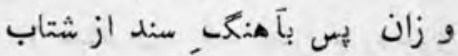

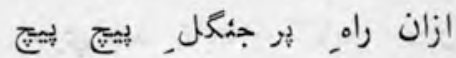

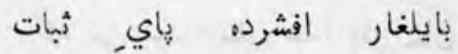
بهر ديره خاني كله بـد بايكير

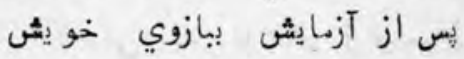

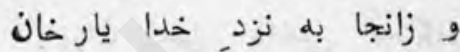

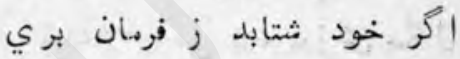
ازان, به كزين لشكر, بي كرد فران

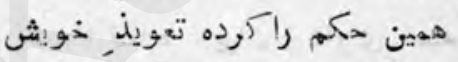

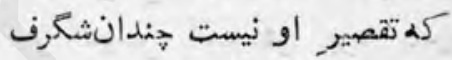

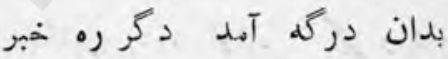

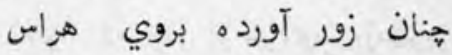

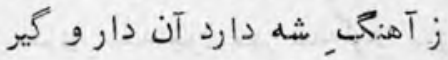
تهي سازد آن ملكى از بيهم, شاه

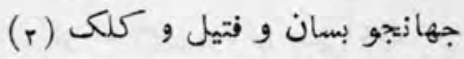

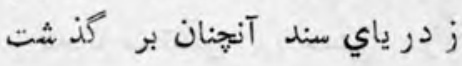

(1) مطلب ديره" اسمعيل خان و ديره غازيخان است . (r) در اصل سال است كله صحيح آن سان خواهد بود بهعني ـلكلح جنحه. اما كلكى به فتحتين كشتي بار بردار كله از هوبها

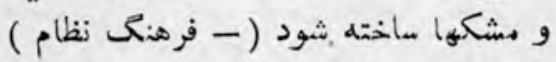

[؟ [ اصل : ماهي 
رهي بُّا همده جنكل وهوب بست كه بعذ ثمت داراي_ ايران ز آب دران فتنه سردار بـ عباسيان نبودش هو در جنكَ تاب و قرار

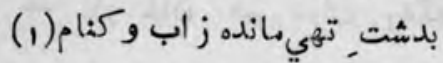

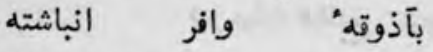
هو بهـد دور سي فرستخ از رهكنار بر ان در نخواهند بيمود درو راه بخود داري ازكين بر آورده دست

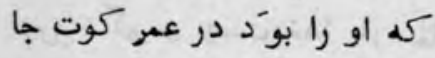
تدارك ز زرد آسمان راحو شب تار كرد نه نزديكـ آن قلعه بردند بي ازان قلعه مي بود بهمن فرار

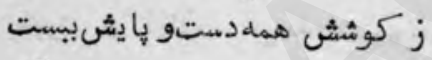
بها كرد دور از افق همد باركاه هو خاتم عمر كوت كوت را دوريان قضا شد دليل طريق. فرار كر فته روه سمت كجرات كرفتند راهش بشاششير كين

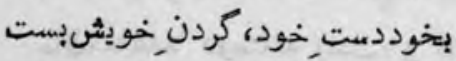
رساندند او را بدرداه
ز دريا كذشته دران كير و بست

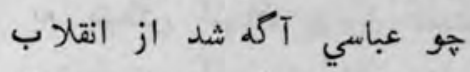

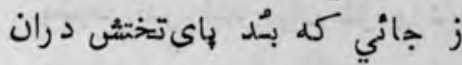

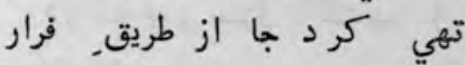
يكي قلعه بودش "عمر كوته نام

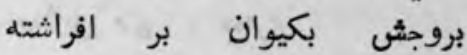

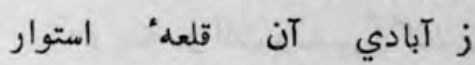
كمان كرد كافواج ايران بدان قلعه آرام كرد ورد نشست

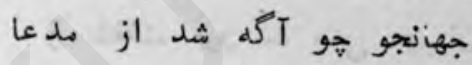
بفرهود روزي كله يكسر سهاه (r)

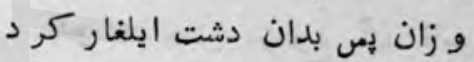
بيكروز و يكشب له به وه كرد طي خدا يارخان رادروز ئران

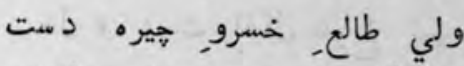

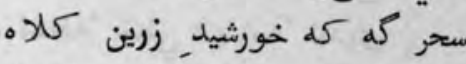

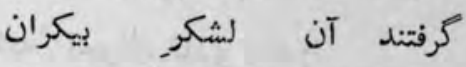
خدا يار خان را دران كير و دان برون آهد از قلهه با فوج. خو يش دران

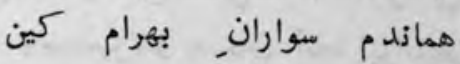

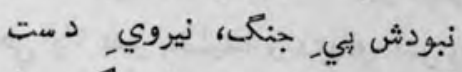

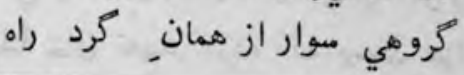

$$
\begin{aligned}
& \text { (1) يكي از معاني كنام حرا كاه اهت (- فرهنح نظام ). }
\end{aligned}
$$

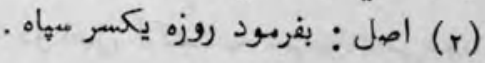




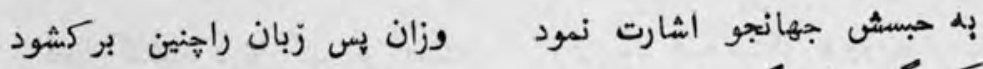

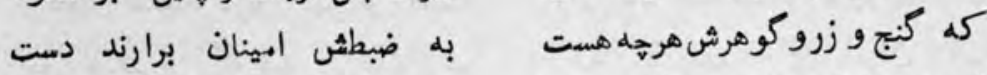

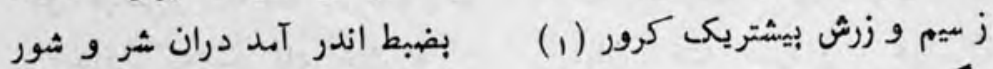

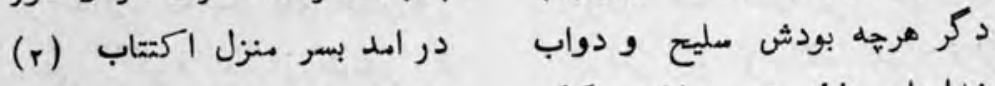

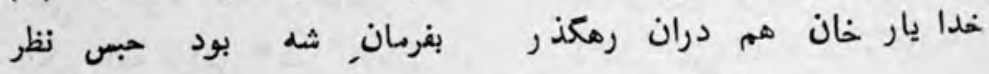

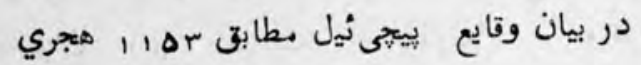

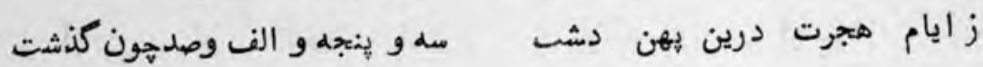

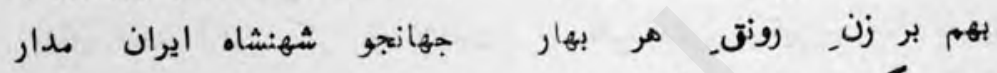

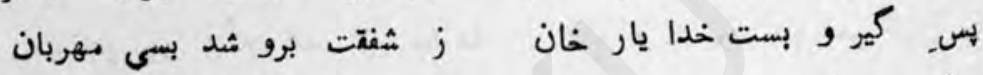

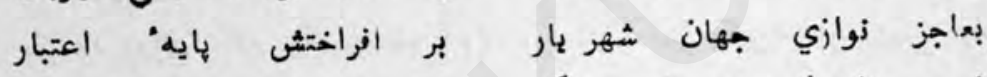

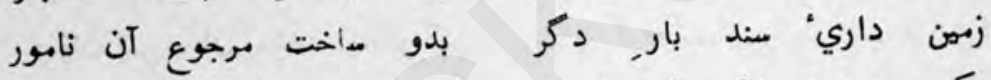

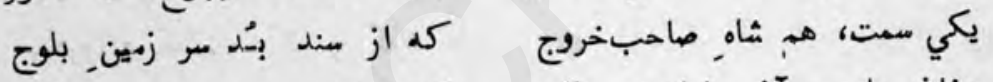

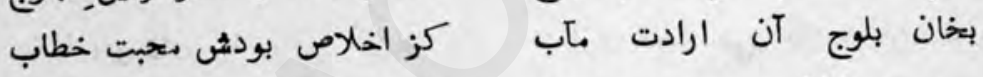

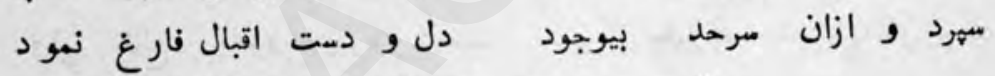

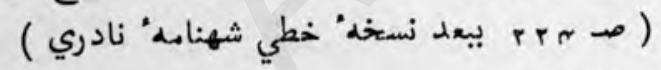

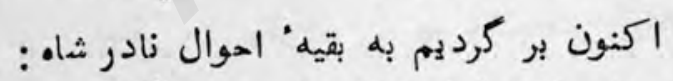

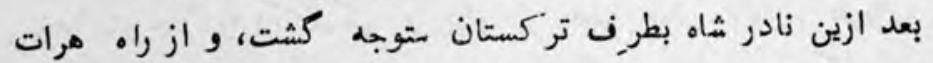

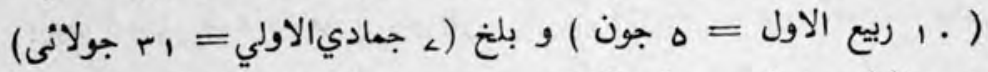

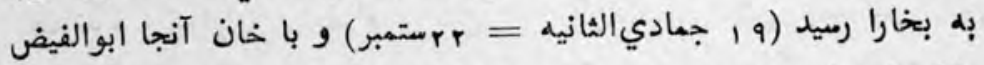

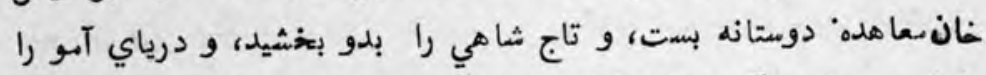

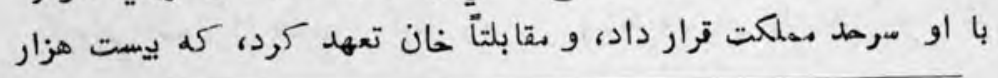

$$
\text { (1) }
$$

(r) يعنينوشتن. اين كلمه در اصل اكتساب عمخواندهيشود. 
$\angle 7 \Delta$

تازه نواي معارك

لشكر اوزبكى و تركمان را به نادر شاه بدهد .

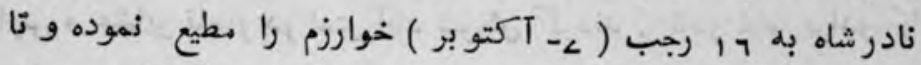

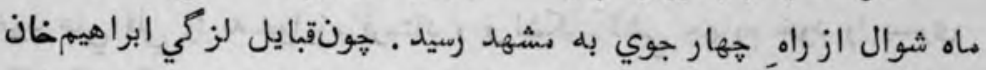

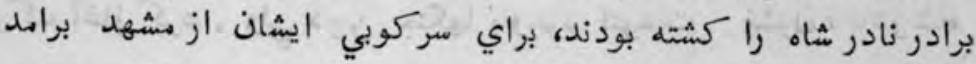

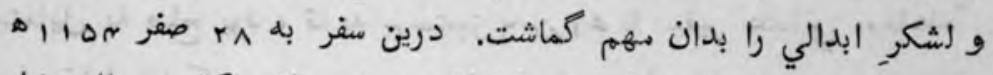

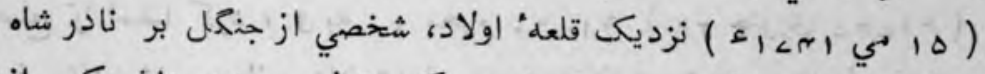

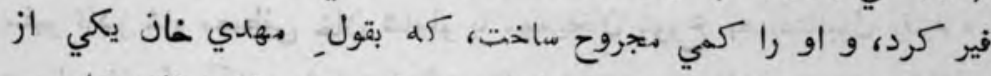

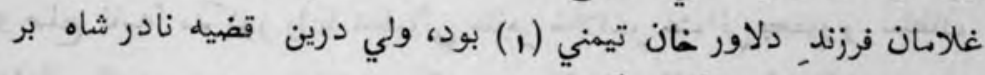
فرزندش رضا قلي بد كان فان كشت فان

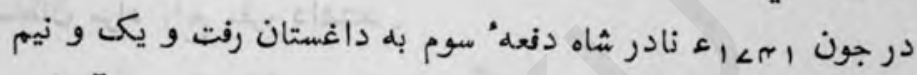

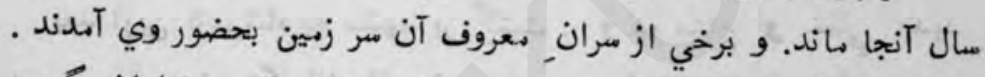

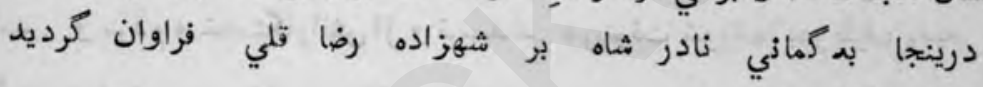

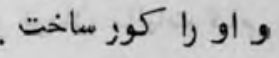

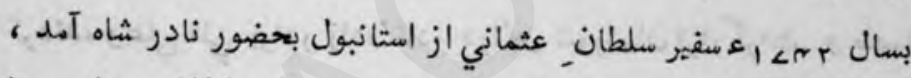

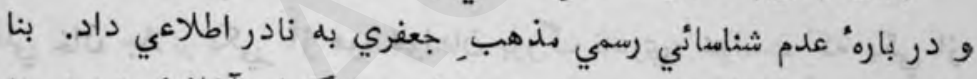

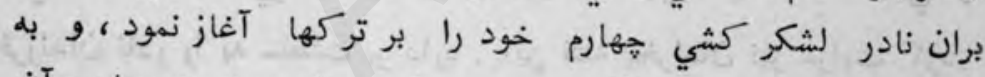

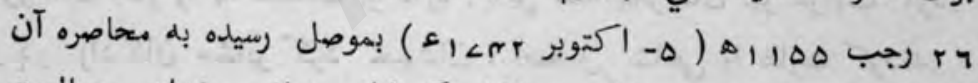

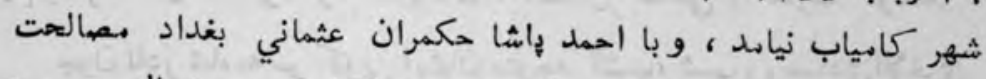

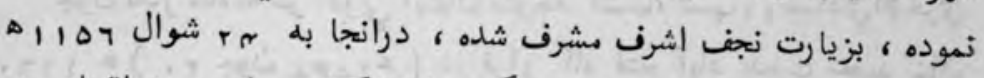

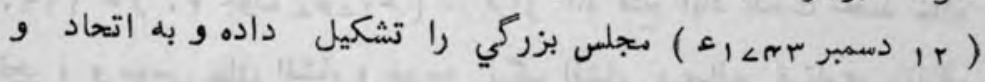

نزديكي شيعه و سني كوشيد ماء

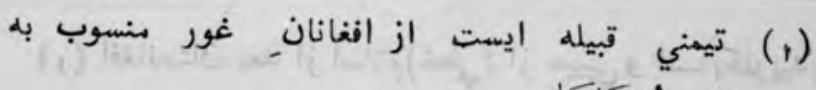




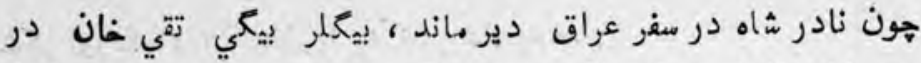

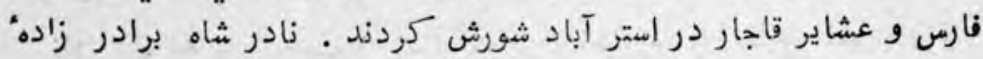

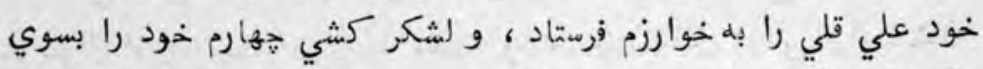

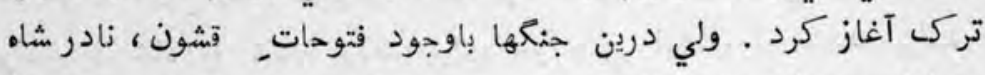

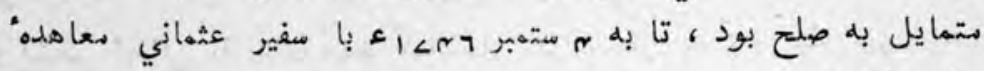

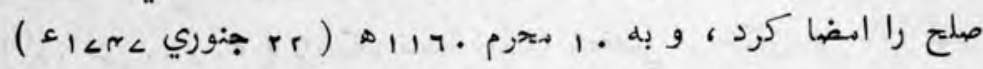

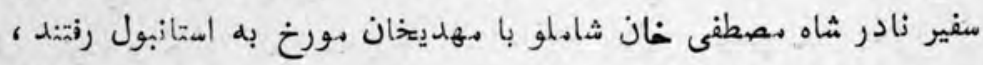

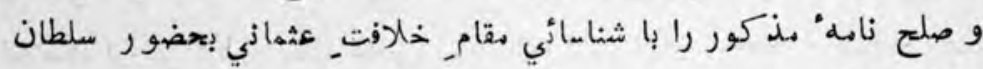

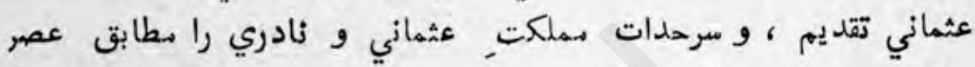

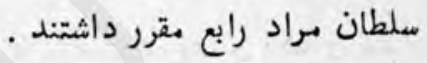

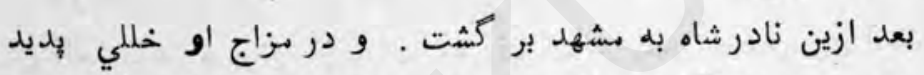

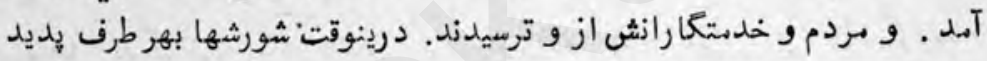

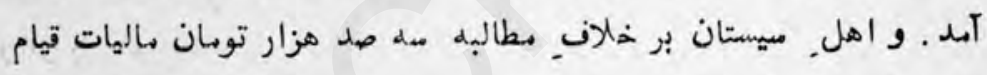

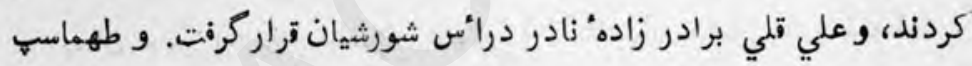

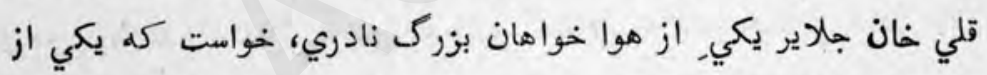

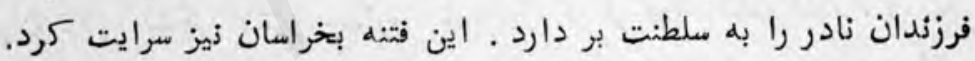

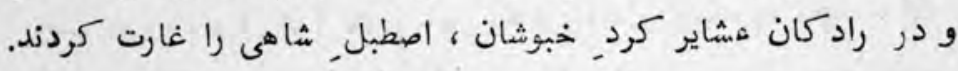

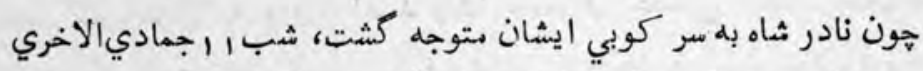

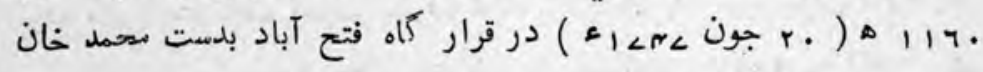

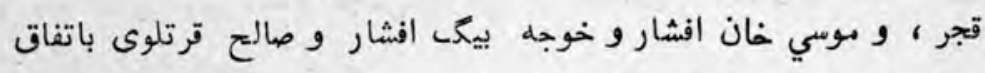

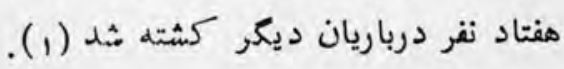

(1) افغانستان بعد از اسلام(خطي) از حبيبي و انسايكلوييدياي

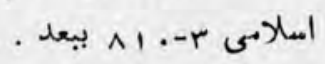


$<7<$

تازه نواي معارك

بعد از قتل زادر شاه خزاين شاهي برباد رفت ، و مسلكت . وسيع او

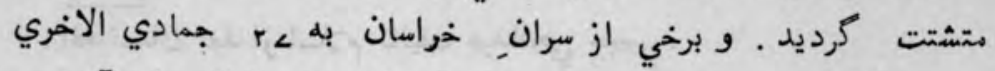

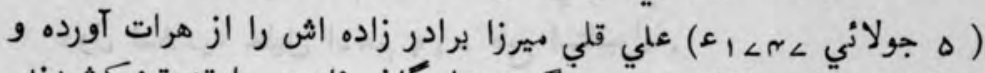

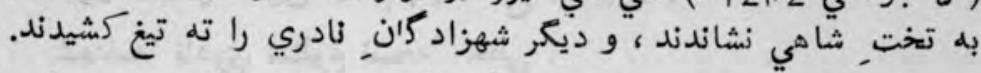

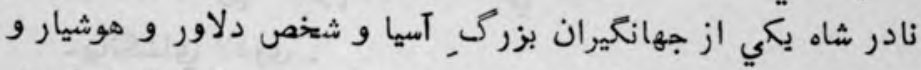

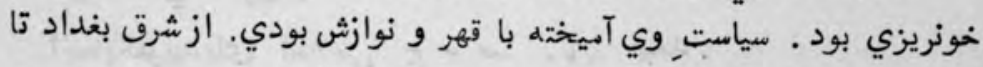

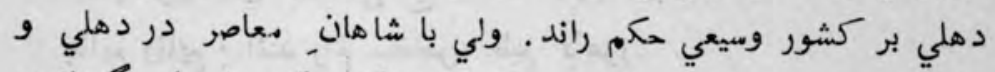

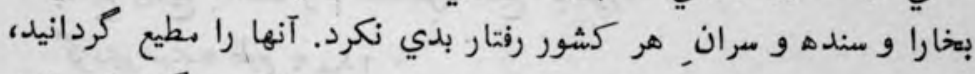

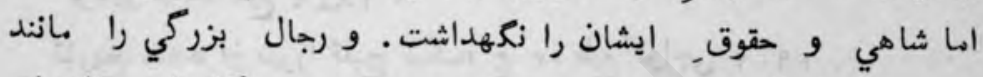

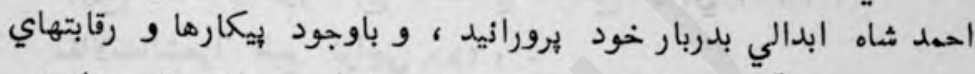

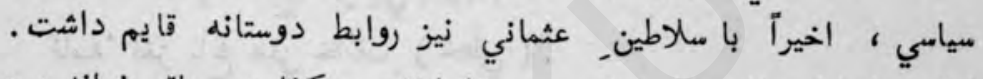

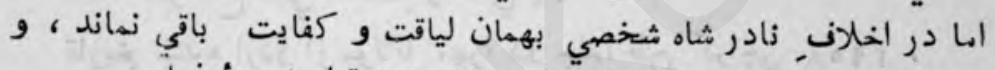

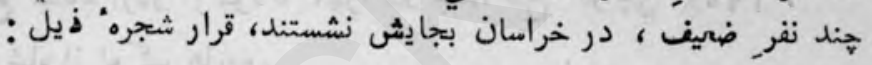

نذر قلي افشار

|مام قلي

ابراهيم خان

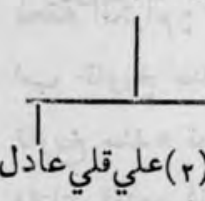

زادر شاه افشار

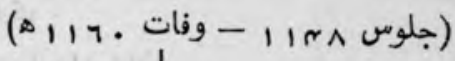

رضا قلي (r) ابراهيم (r) (عليقلي عادل شاه $(\infty, 1,1,1) \quad,(9,1,1)$

از بطن فاطمه سلطان دختر شاه حسين صفوي خे (r) $(\Delta, r,-1, \pi)$ 
افغانستان بعد از اسلام تاليف عبدالحي حبيبي.

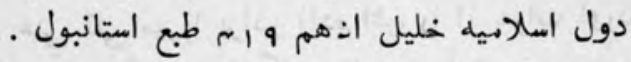

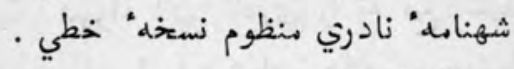
جهانكشاي نادري

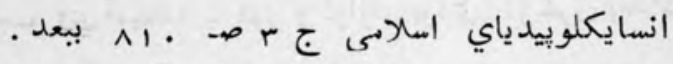

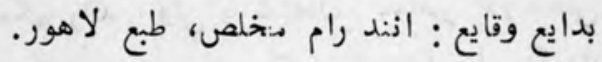
كزيتير سنده طبع

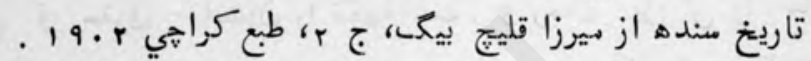

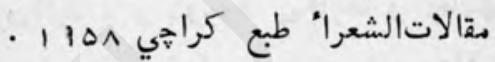
نامهُ نغز باغ علي خائف ( خطي ) )

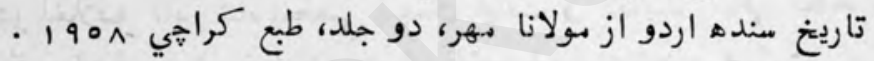

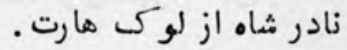
بيان واقع از خواجه عبدالكريج:

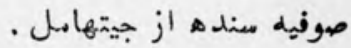

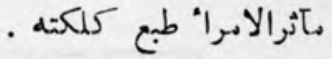

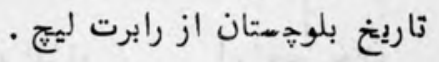

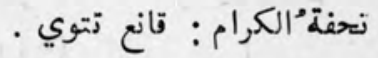

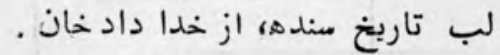

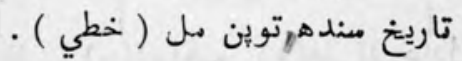

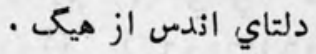
تاريخ كلهوزه از ستين . كالمسته' نورس بهار (خطي) . نشيور الوصيت (خطي) . 


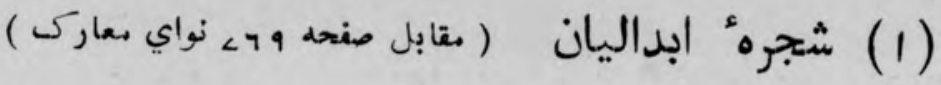

(خط: علامه ' تسلسل نسلي مستقيم و ... خط نقطه دار علامه' تسلسل نسلى غير مستقم )

ملك آودل ( ابدال ) ولد ترين : حدود . بهه

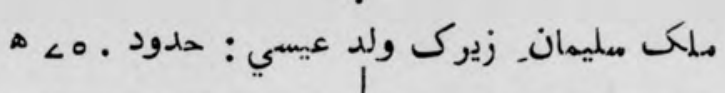

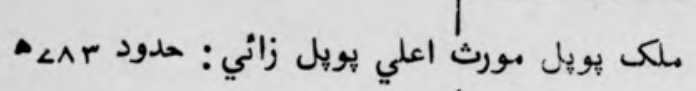

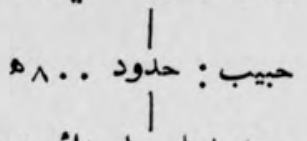

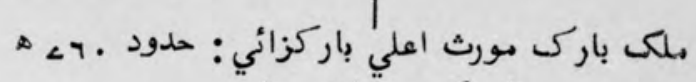

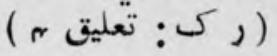

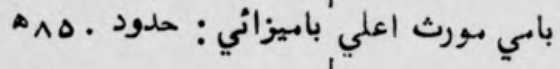

كاني

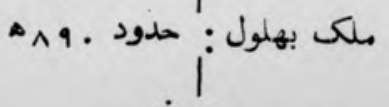

| - معروف

ملك صالح : حدود . مه هـ (معاصر شير شاه).

شاه ولي خان وزير أعظم احمد شاه ابدالي ور دودمانشن

ملكى ستدُ"و مورث اعلي سدوز' ني مرزبان قندهار

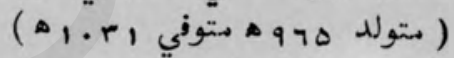

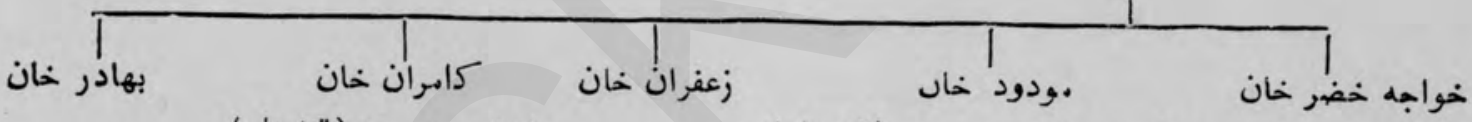

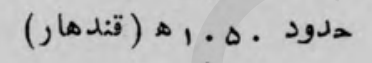

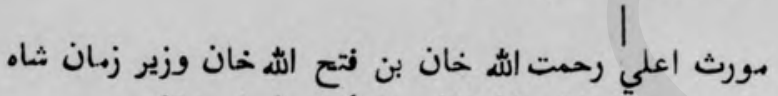

و محمد عثهان خان ناظم ديره" اسمبعيل خان

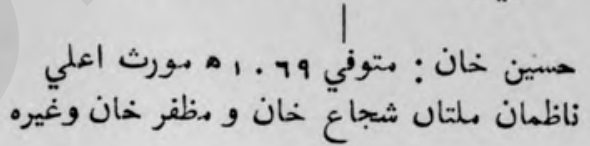

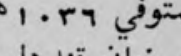
مرزبان قندهار
هداداد سلطان مرزبان قندهار محدود ـه ـ1.

ليكر خان ( ملتان)

حيات سلطان (مثتان و هرات)

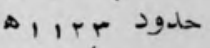

عبد الله خان مكمران هرات

alis

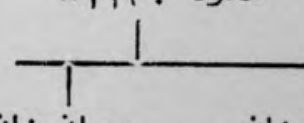

رحمان خان

حكمران هرات

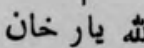
عمبران هرات

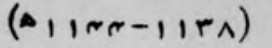

(A, I, מ

اسلد الش خان

مجمد خان

نظر محمد خان

شير خان مرزبان قندهار : حدود . ــ ـ هـ ن

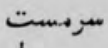

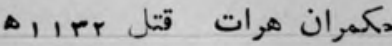

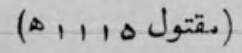

محمد زمان خان

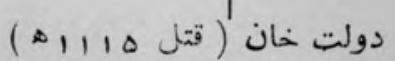

مرزبان قندار تهار

حدود (Tr, ا, هـ)

ذوالفقار خان حكمران هرات

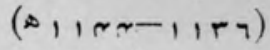

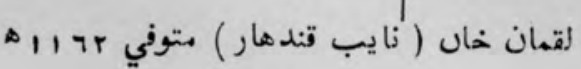

(ركمد شاه ابدالي

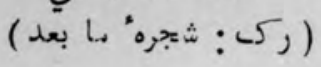

رستم خان

متوفي 91111 مان مرزبان قندهار 


\section{$-\mu$}

\section{احمل شاه, ابذالى و دودمانش}

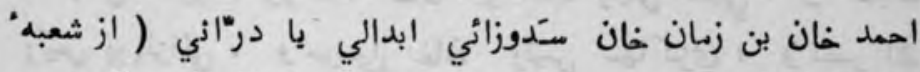

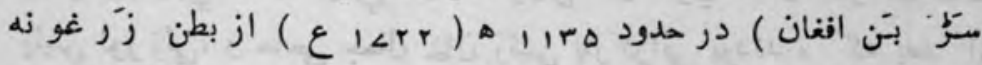

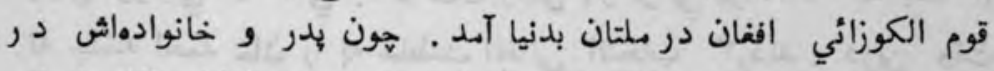

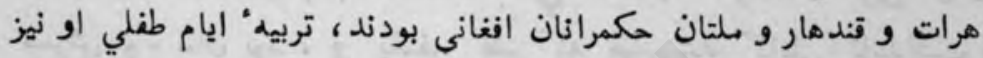

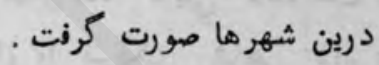

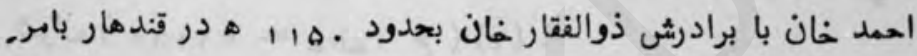

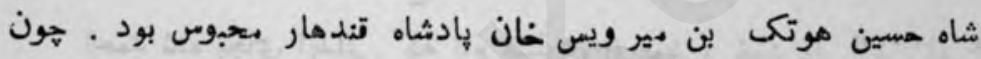

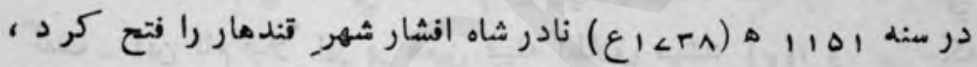

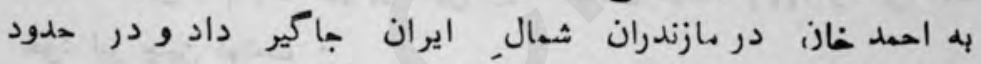

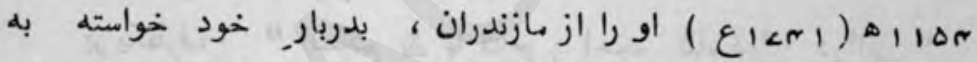

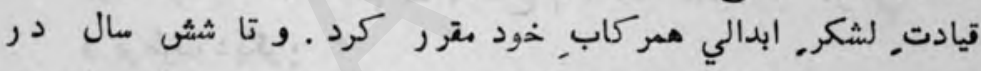

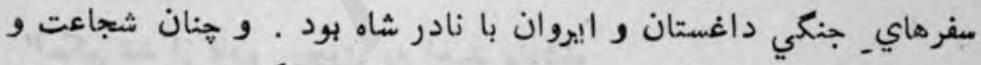

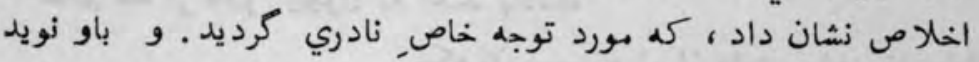

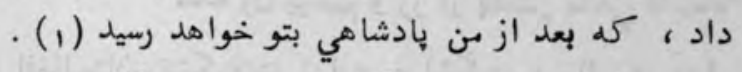

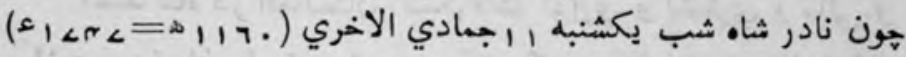

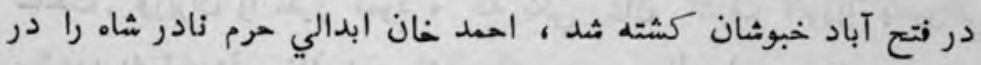

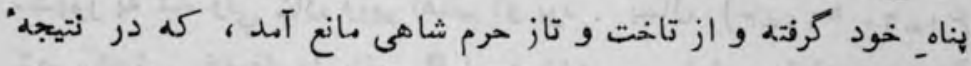

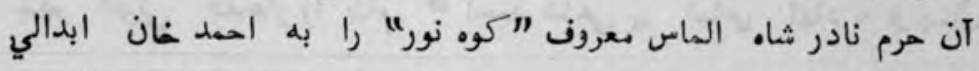

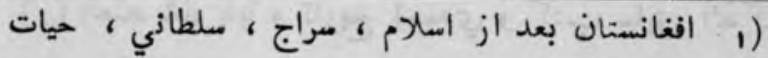

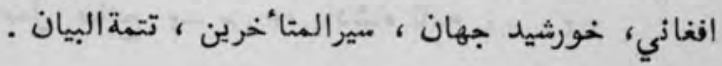


بطور صلم" خلم.ت داد .

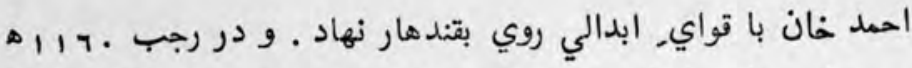

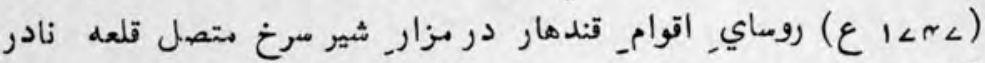

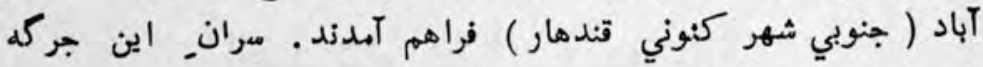

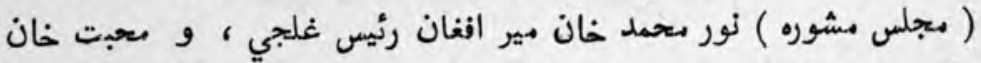

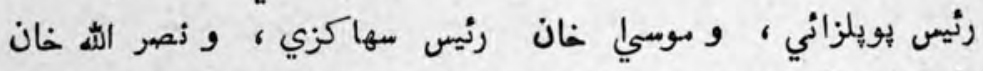
رئيس نور زني، و حاجي جمال خان رئيس باركزائي بودند ، كله بعد ازئ

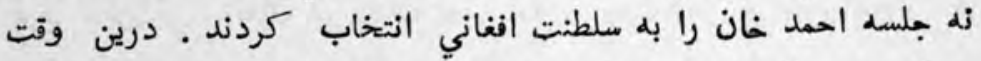

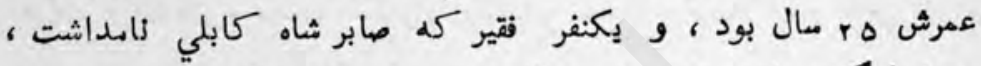

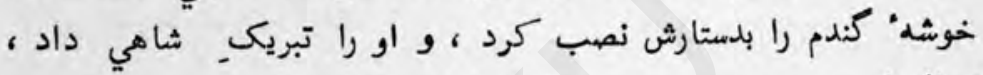

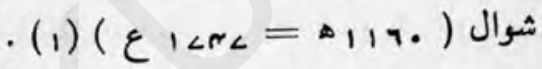

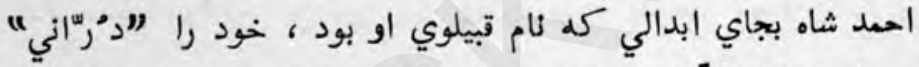

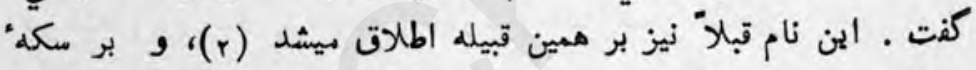

$$
\text { خود ليز حنين نوشت : . }
$$

بر يكطرن: " " الحكم لله يا فتاح ، احمد شاه دره. درَّاني " و برطرف ديكر : "حكم شمد از قادر بيجون به احهد بادشاه

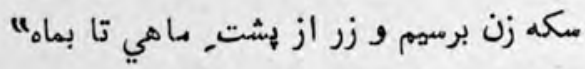
احمد شاه در افغانستان تشكيلات اداري و لشكري و مالى و مدني ماخت. وزيران را مقرر نمود ، كه بكي خان اشرف الوزراء باميزائي مشهور به شاه ولي خان وزير اعظم او بود . بسال (

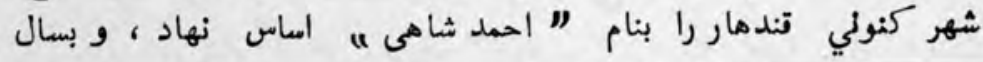

(1) احمد شاه بابا و تاريخ احمدي و كتب سابق الذكر .

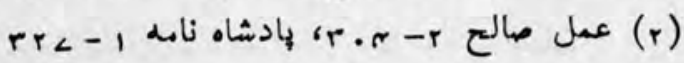




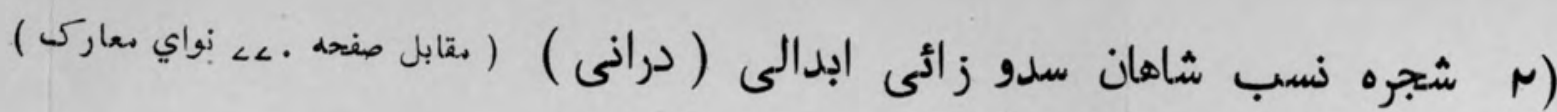

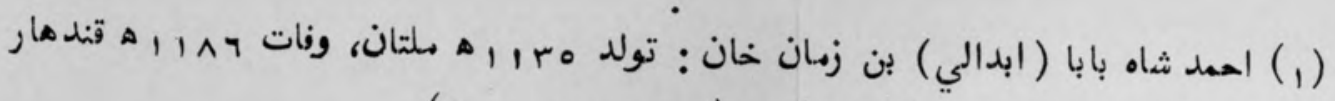

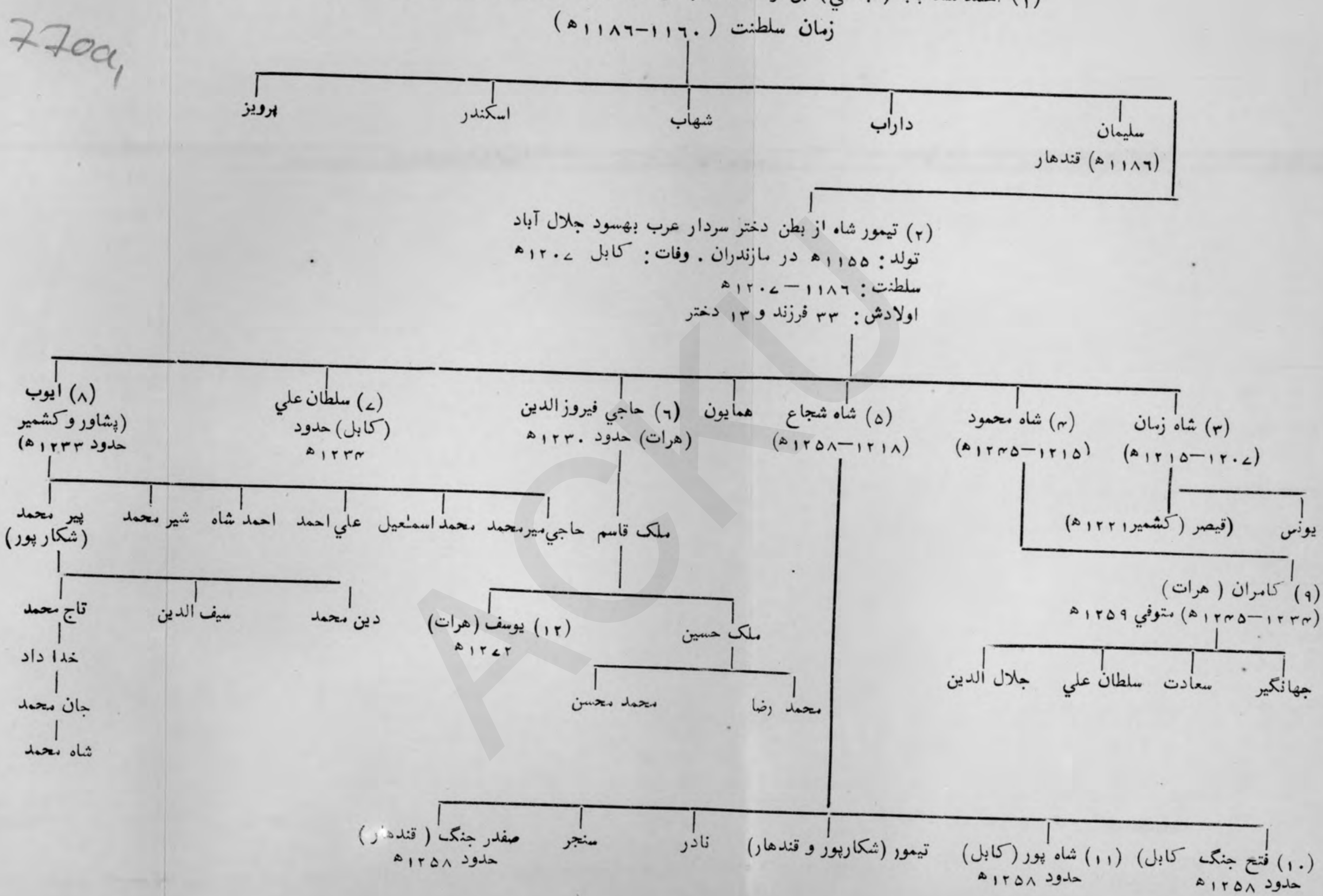

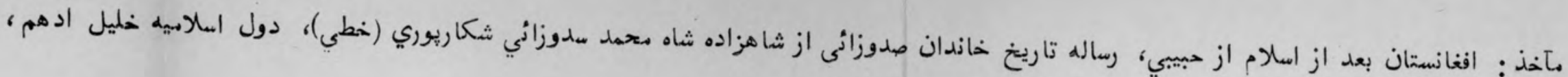
تيهور شاه از عزيز الدين بويلزائي 
را در شهال مندو مصار جنكي كابل را تعمير كرد و هم شهر تاشقرغان

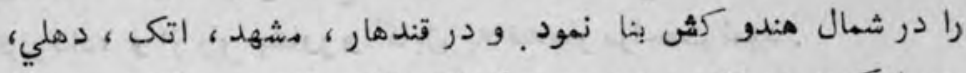

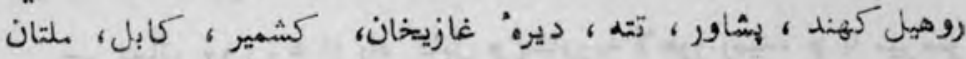

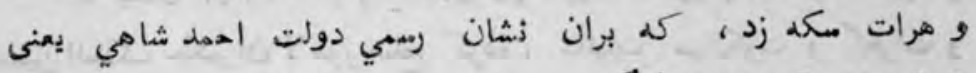

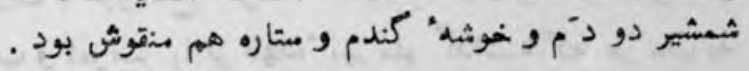

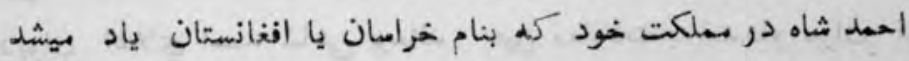

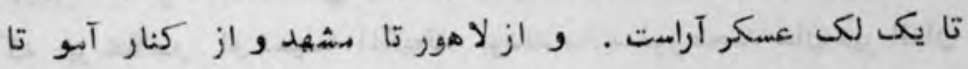

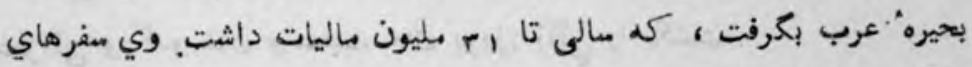

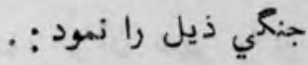

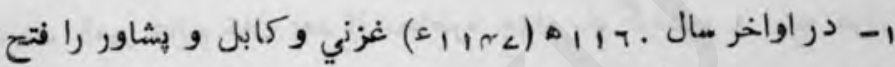

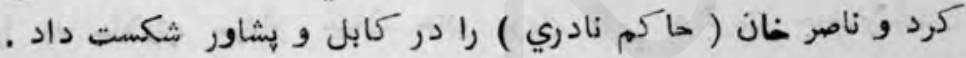

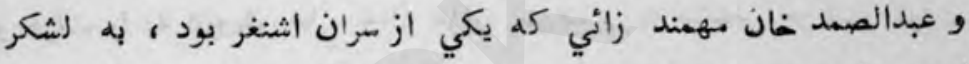

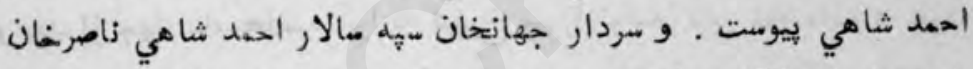

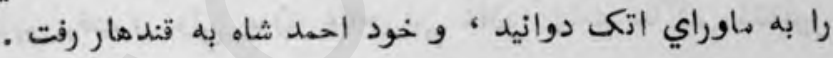

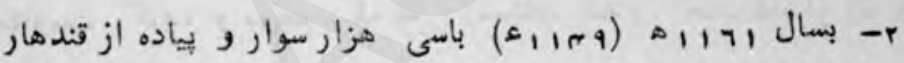

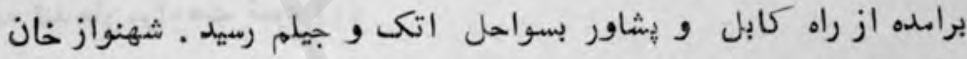

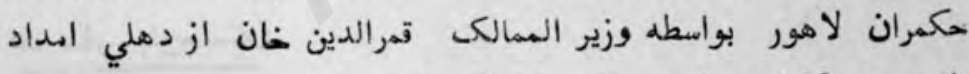

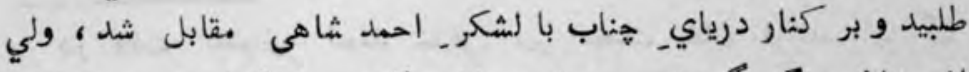

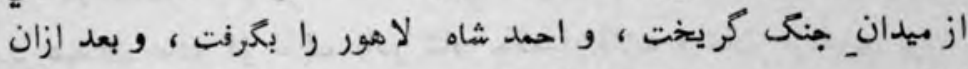

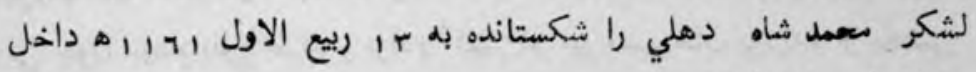
سهرند ( سرهند ) شد.

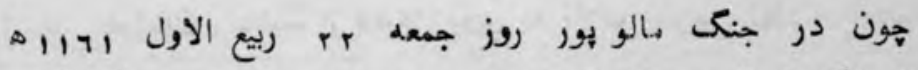

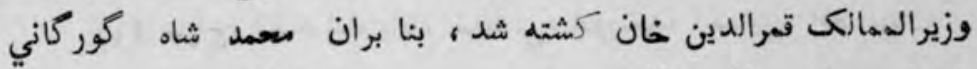

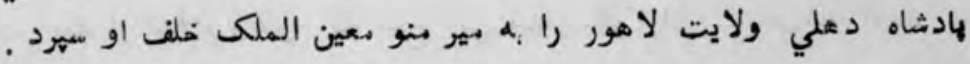


و احمد شاه با دولتي. دهلي مصمالحه كرده و درياي سنده را مرحدد مملكتين

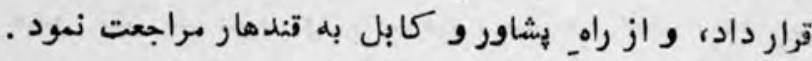

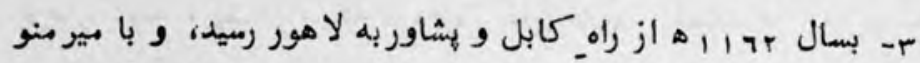

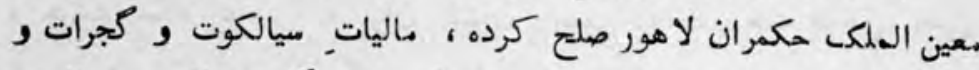

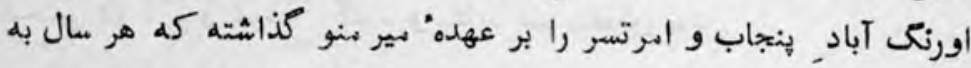

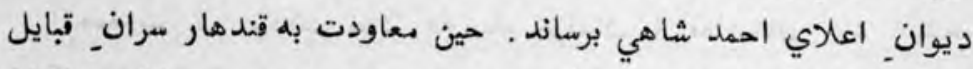

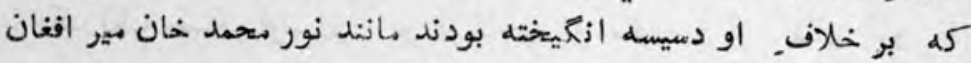

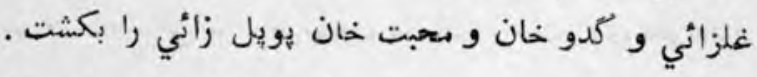

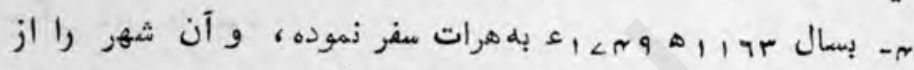

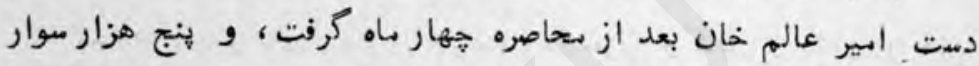

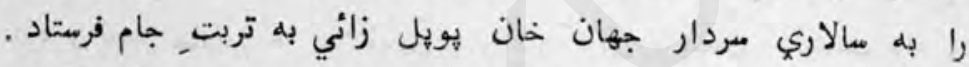

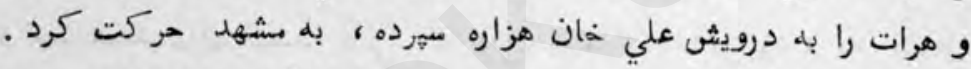

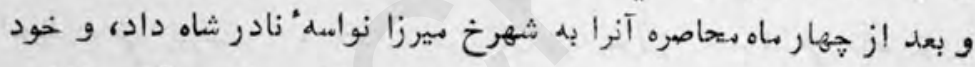

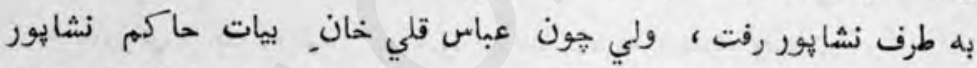

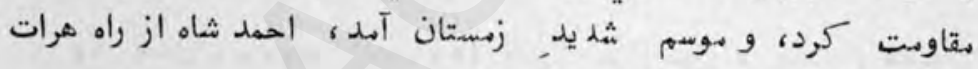

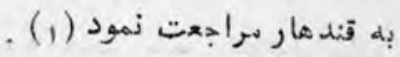

\section{هـ سفر بلوهيشتان}

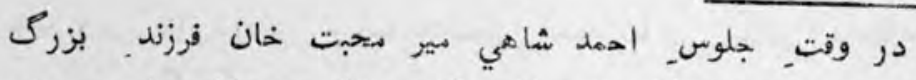

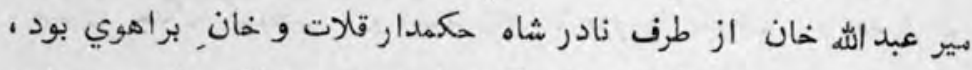

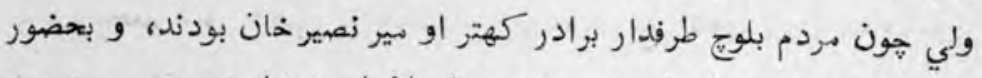

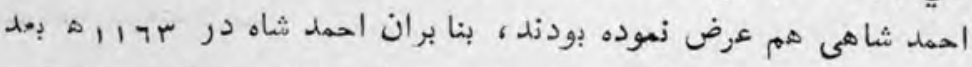

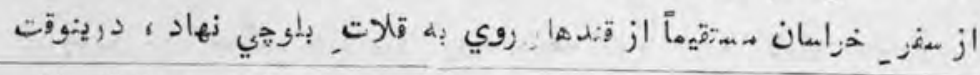

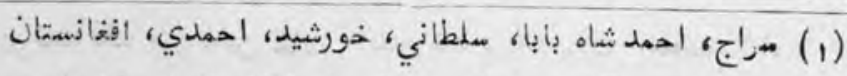
بعد از اسلام وغيره كه شرح اين جهار سفر ازان اقتباس شثده الست. 


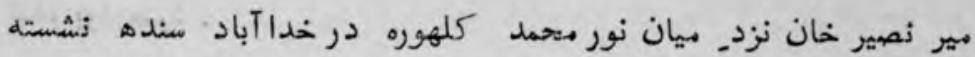

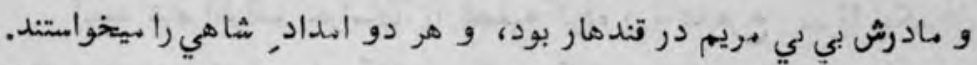

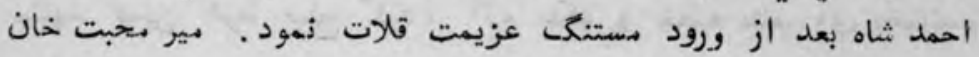

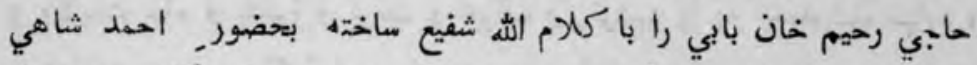

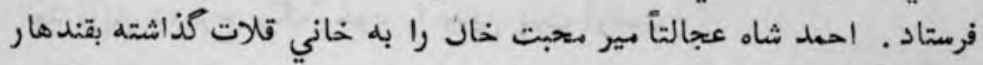

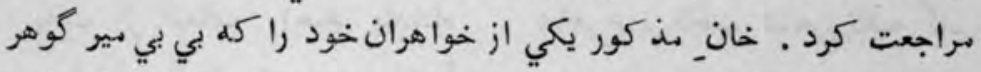

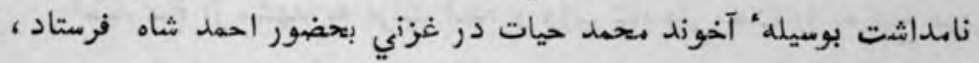

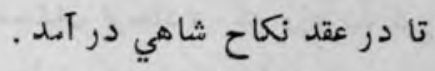

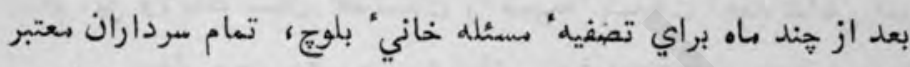

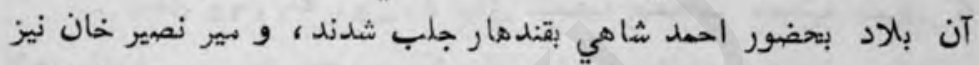

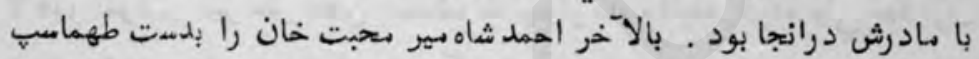

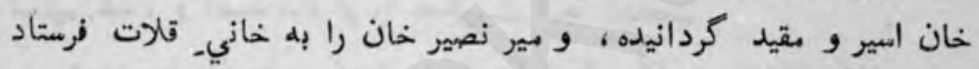
$(\infty, 1, \pi)$

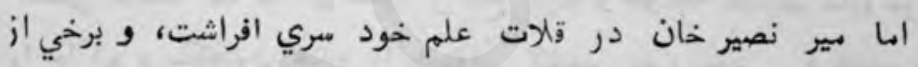

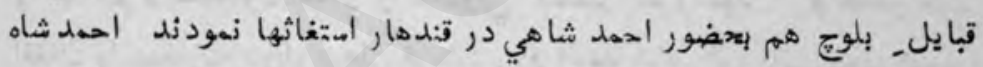

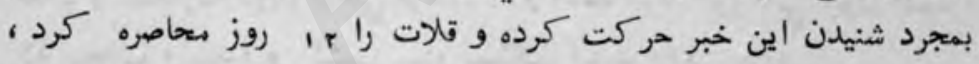

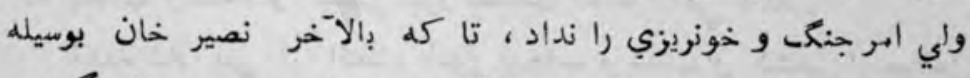

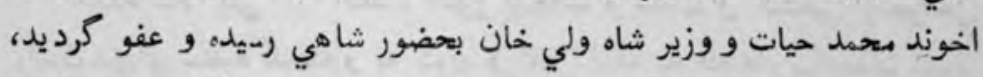

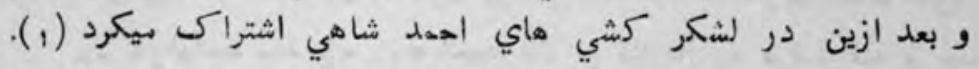
( براي شرح خانان, قلات به تعليق ه ه رجوع كنيد )

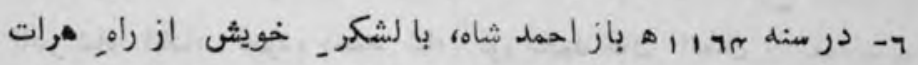

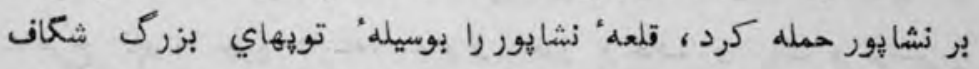

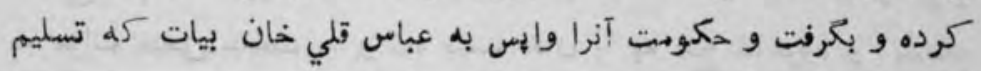

$$
\text { تاريخ بلوحستان و احمد شاه بابا بهو ب بعل }
$$


شده بود ميرد .

احمد شاه اطراف خراسان را تصفيه كرده و با شاهرخ شيرزا هكمران

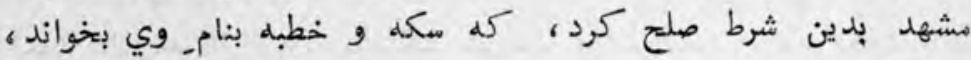

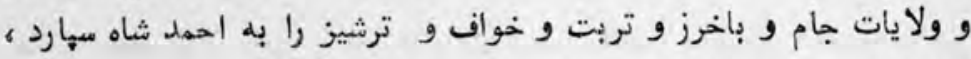
بعد ازين شاهرخ مكله" خود را بدين بيت آراست

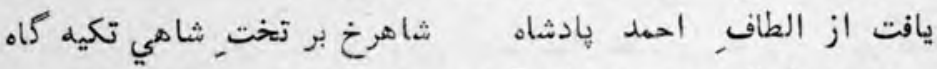

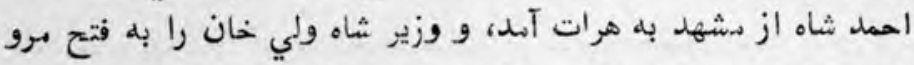

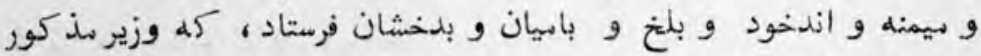
تمام اين ولايات شمال افغانستان را ضميهله" مهلكت احمد شاهي نمود .

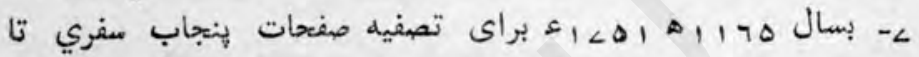

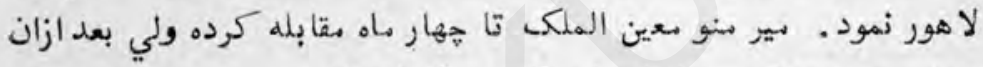

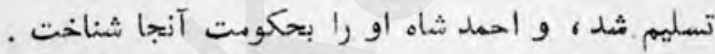

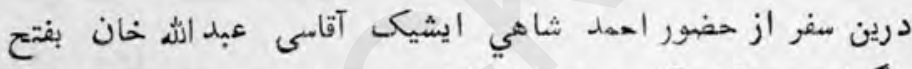

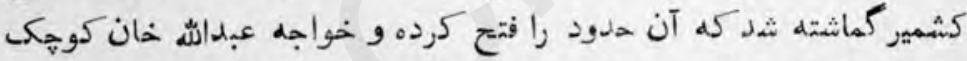
را حاكم و سكجيون هندو را سستوفي كشمير مقرر نمود . . و قلندر خان

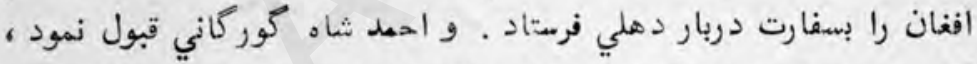

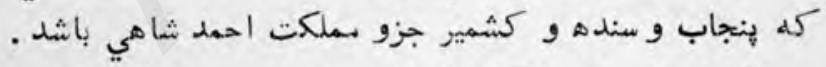

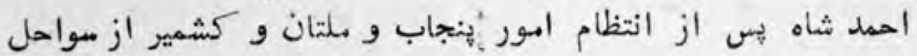

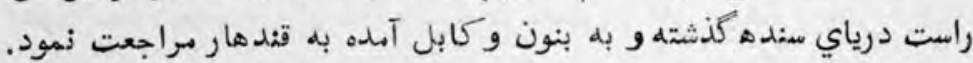

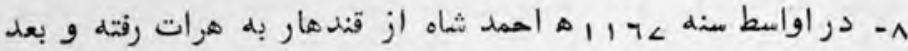

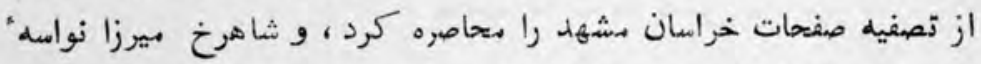

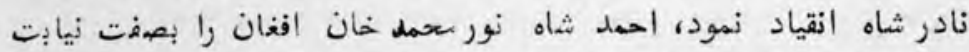

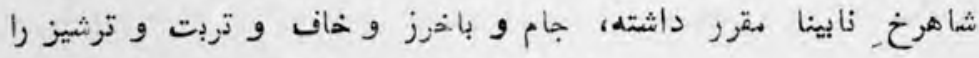

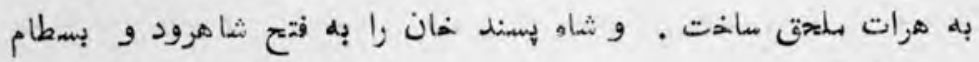

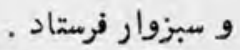


بعد ازين احمد شاه عبام قلي خان بيات را در نيشا يور دحاصره كرده.

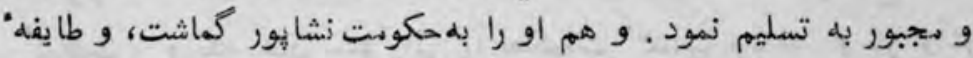

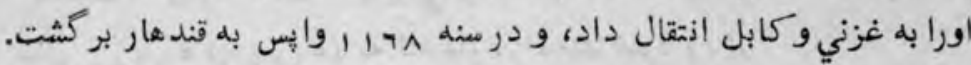

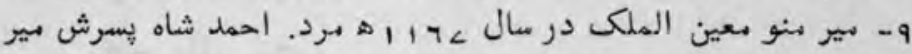

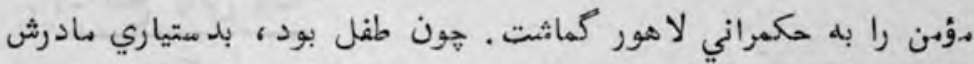

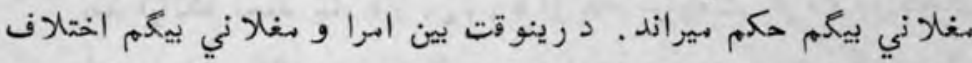

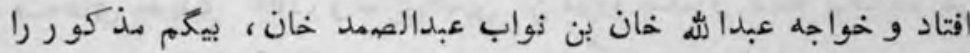

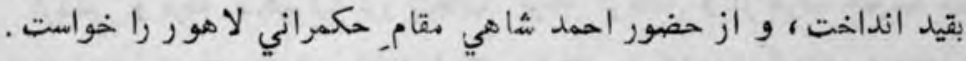

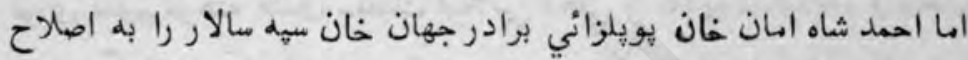

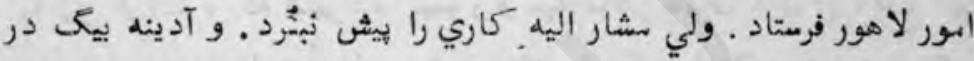

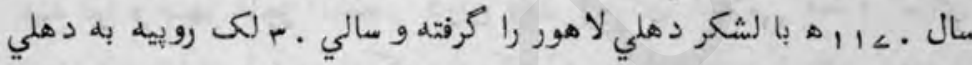

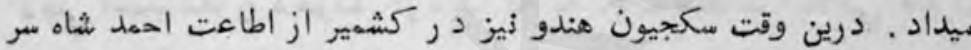

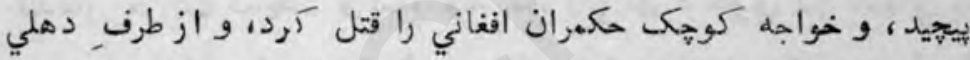

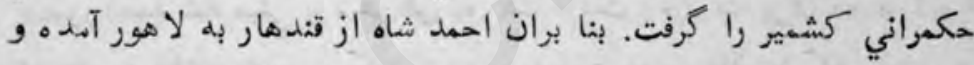

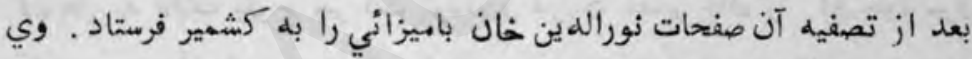
.كجيون را كرفته و كشمير را وايس تسخير نمود .

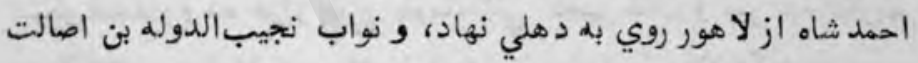

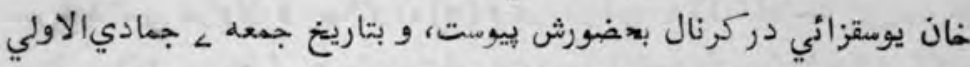

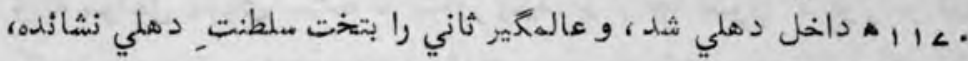

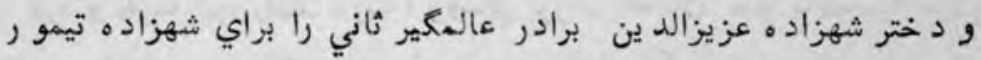

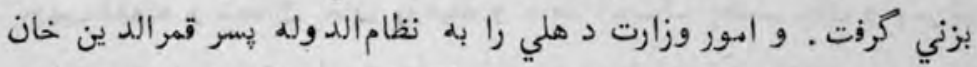

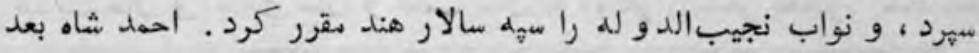

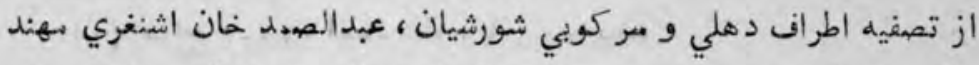

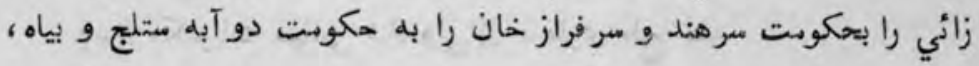

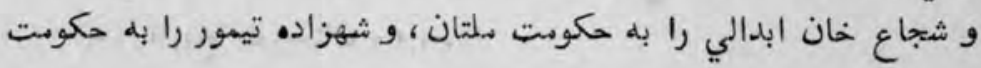




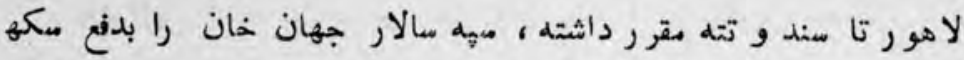

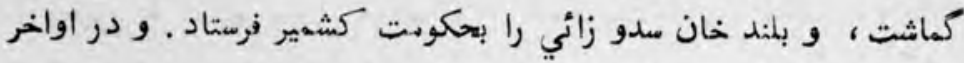

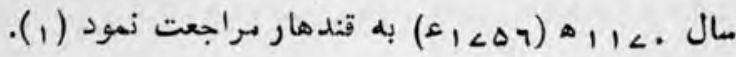
.

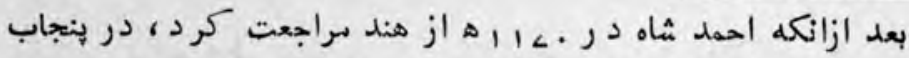

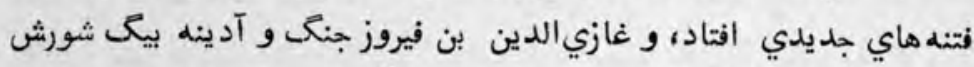

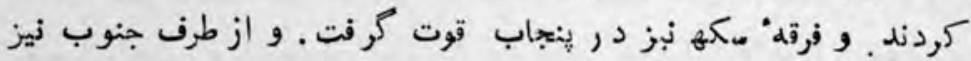

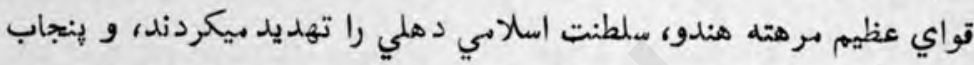

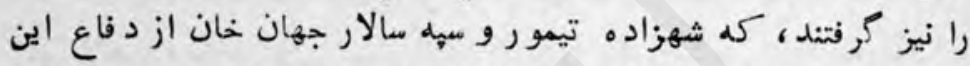

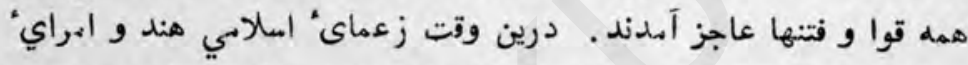

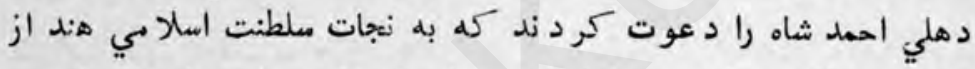

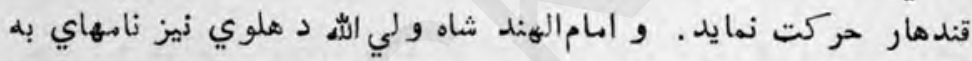

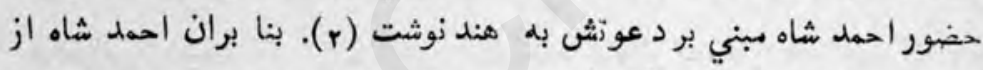

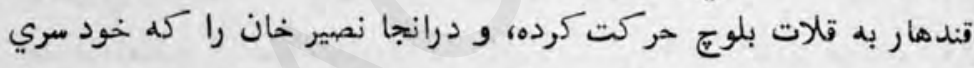

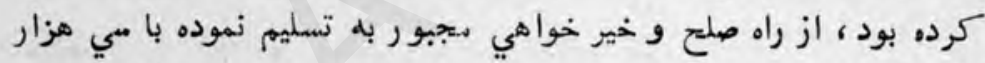

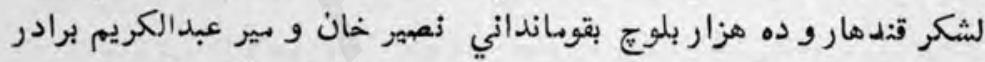

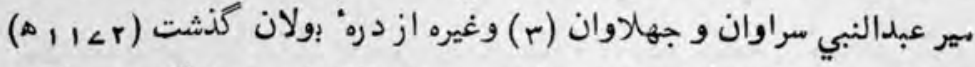

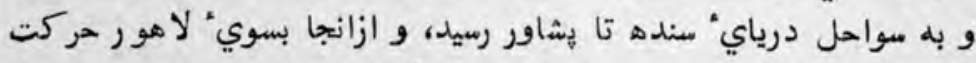

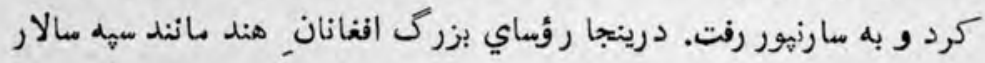

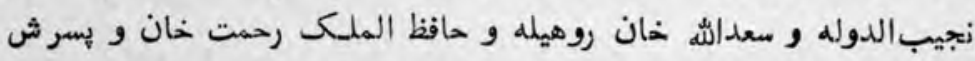

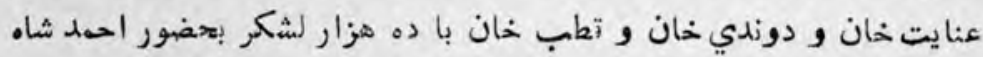

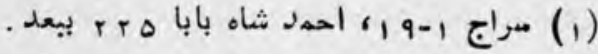

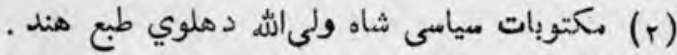

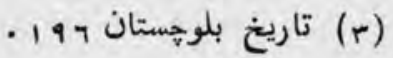




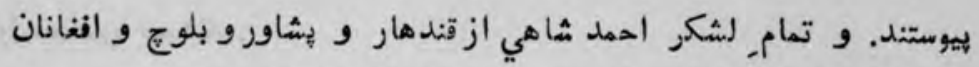
هند تا شصت هزار نغر هياده و سوار و تويخخانه رسيد.

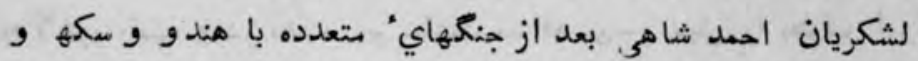

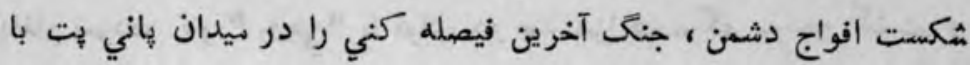

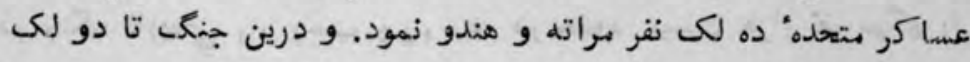

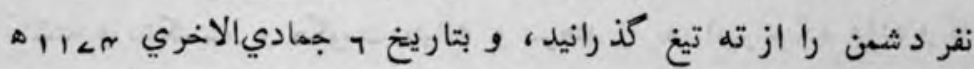

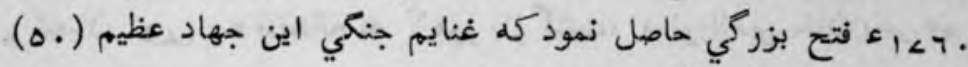

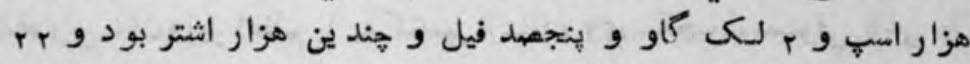

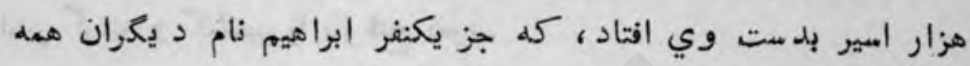

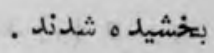

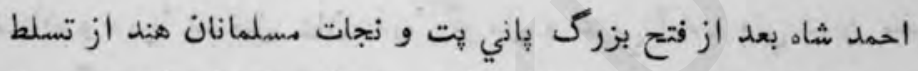

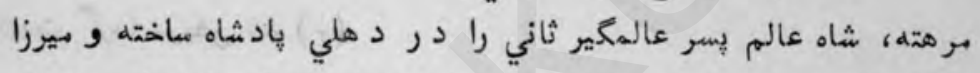

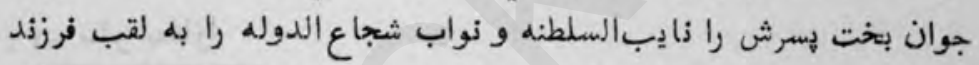
خان و رستم هند، وز ير اعظم، و نواب نجيب الدوله افغان را سهه مالار

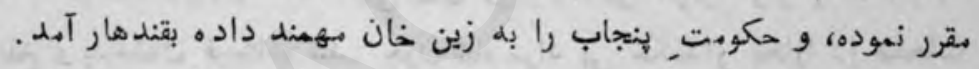

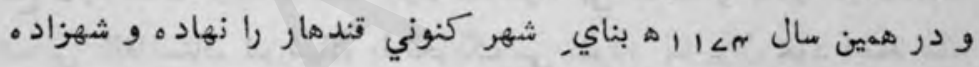

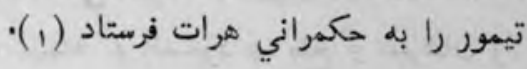

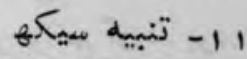

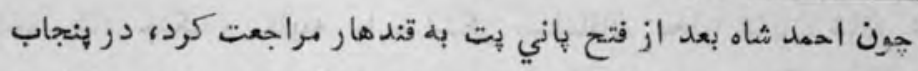

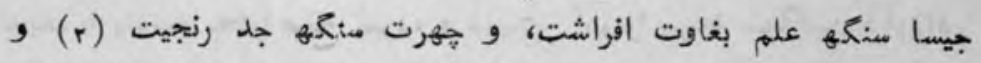
الاجات نيز درين شورش دست داشتند، و نايبالحكومهله هنجاب زين خهان

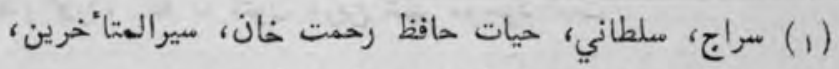

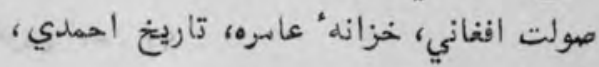

$$
\begin{aligned}
& \text { r ظفر ناهل }
\end{aligned}
$$


1)

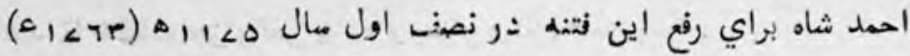

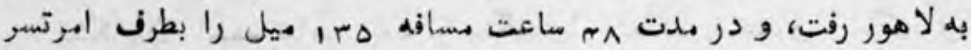

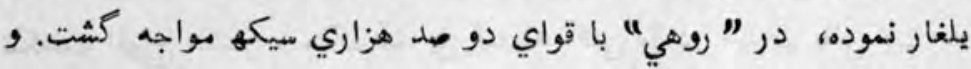

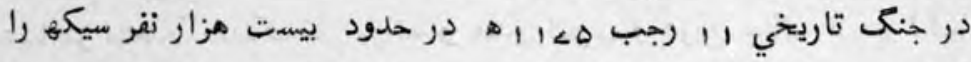

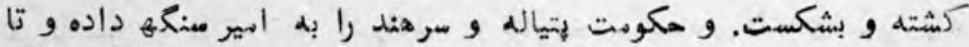

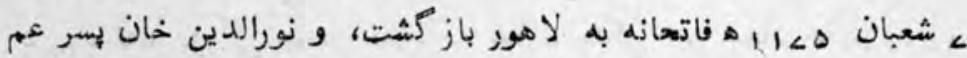

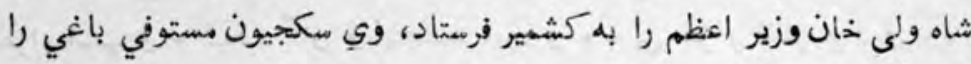
اسير كرفته و كشيمير را باز فتع نمود.

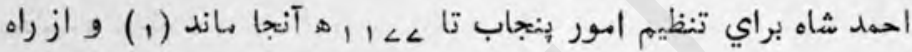

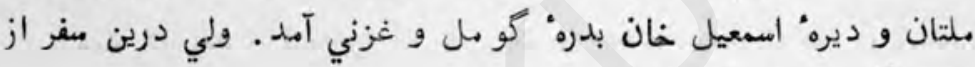

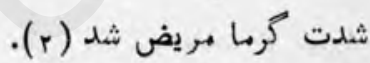

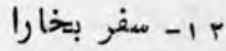

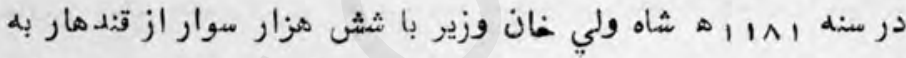
بلخ و بدخشان فرستاده شد. هون شاه مراد بي حكمدار بخارا در صفحات شمالي افغاذستان شورشيان را تيريكى بي نهود، بنا بران خود احمد شاه

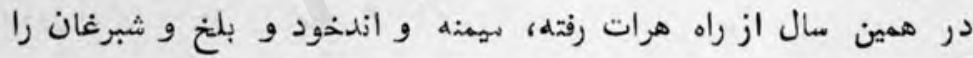

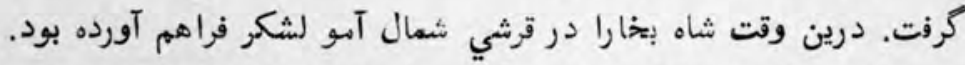

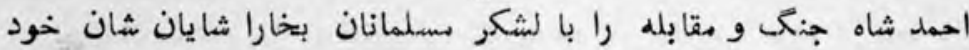
نديده با هادشاه بخارا صلح نمود، و دريايي آنو را مرحد مهلكتين قرارداد. درين سفر خرقه شريف نبوي را شاه ولي خان وزير ازفيض آباد بدخشان

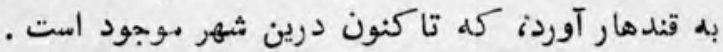

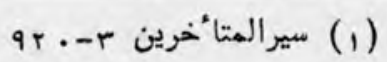

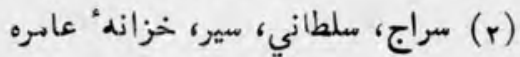




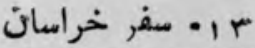

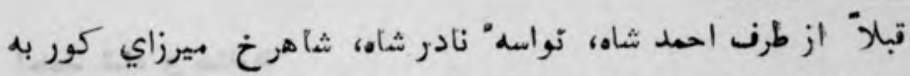

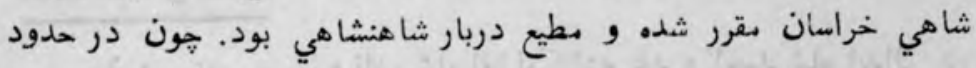

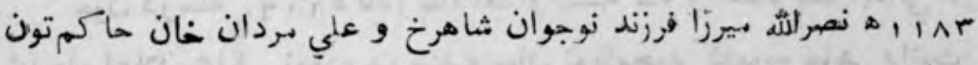

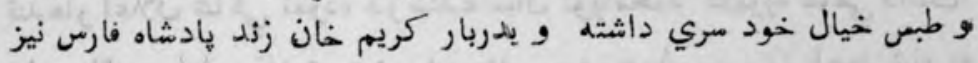

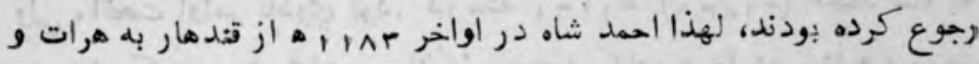

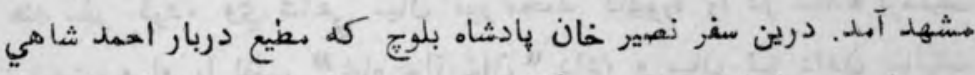

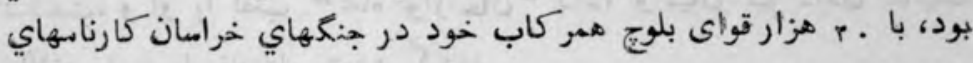

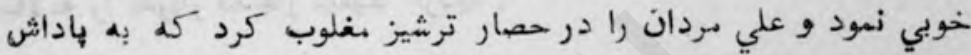

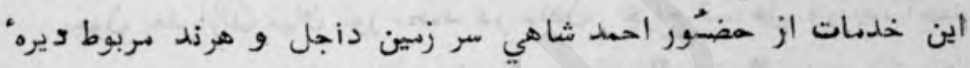

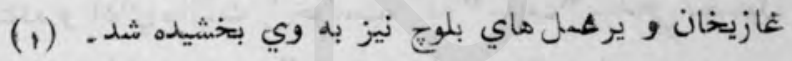

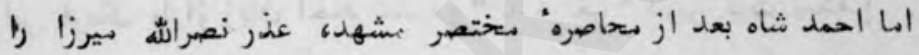

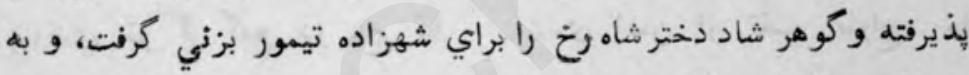

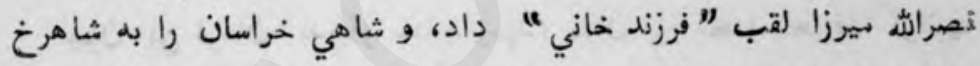

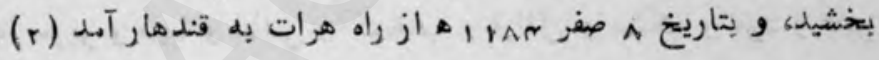

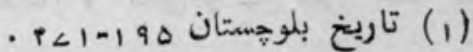

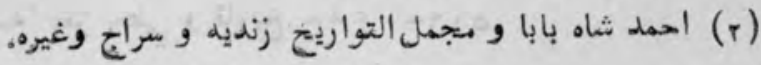




\section{احمد شاه و مندل}

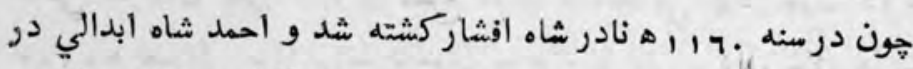
قندهار اعلان شاهي نمود، در سنده ميان نور متحمد كلهوره شاهي داشت،

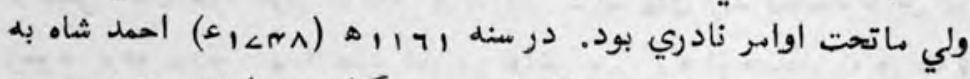
هند سفر كرد، وي ثاهي ميان نور دهمد كلهوره را در سنده برسميت

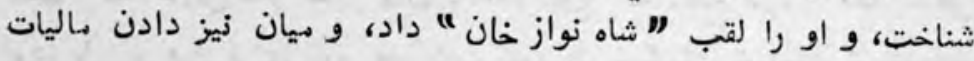

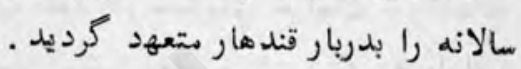

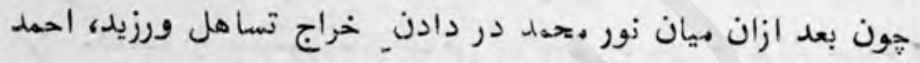

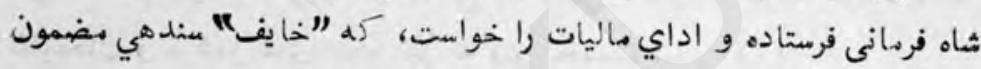

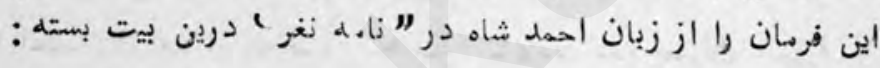

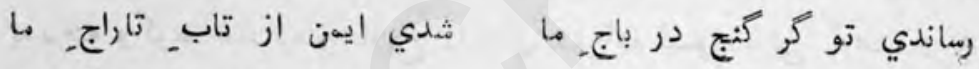

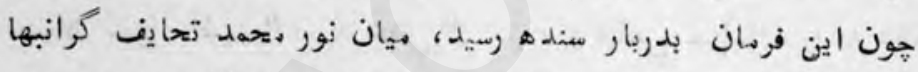

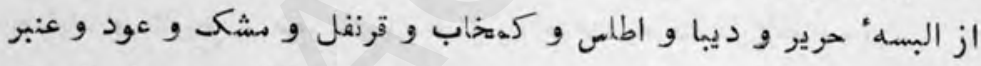

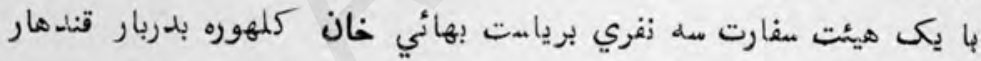
كسيل داشت و كنت

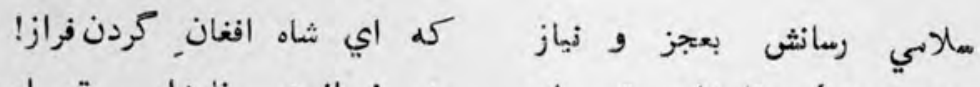

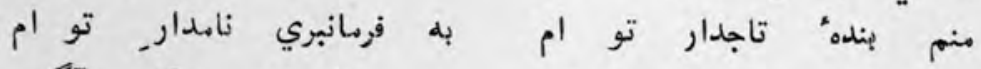

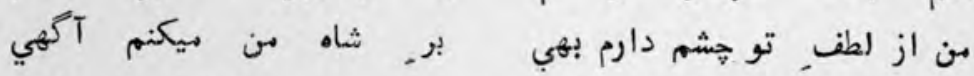
هون اين سفارت به دربار احمد شاهي رسيد، روابط دوبمتانه_" دو

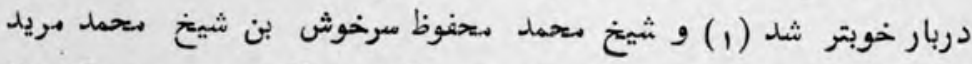

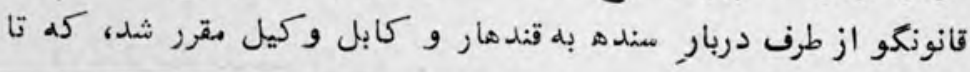

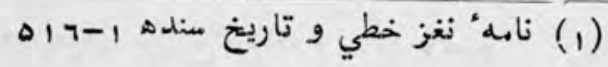




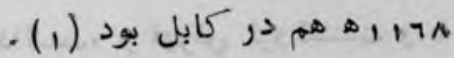

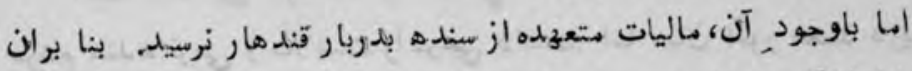

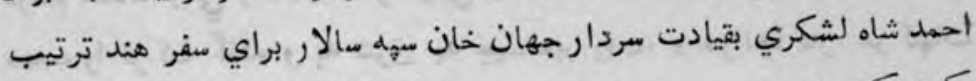

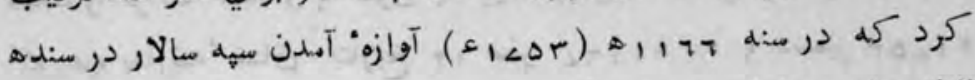

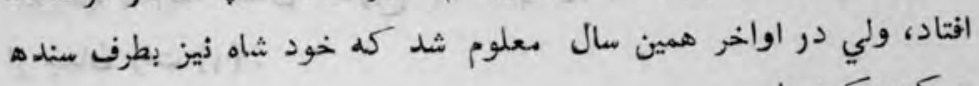
حركت كرده است.

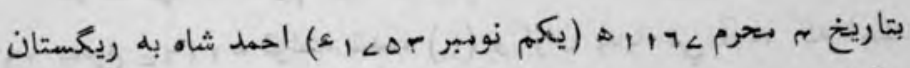

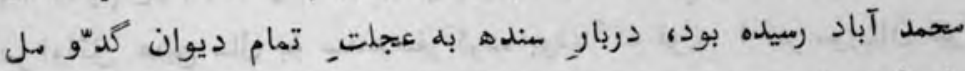

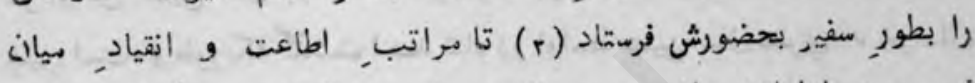

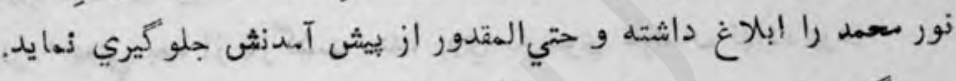

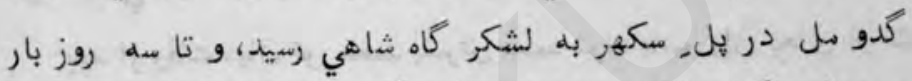

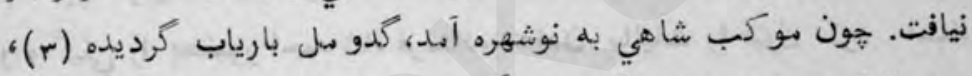
و در ترضيه حضور شاهي كوشيد. كويند احمد شاه خيلي غضبنا كى بوده،

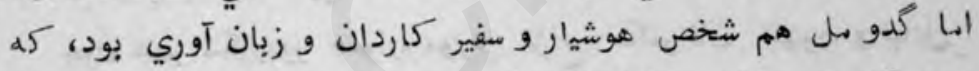
در تسكين قهر شاهي بلطائفالحيل كوشيد. وي مراتبــ عقيدتــ احمد شاد

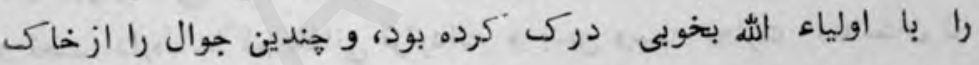

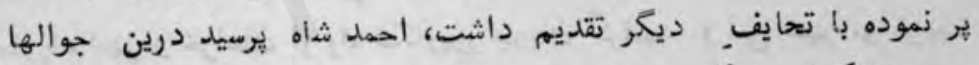

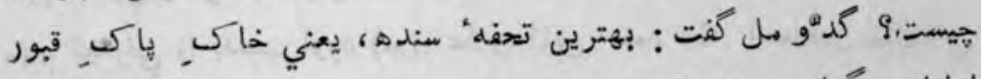

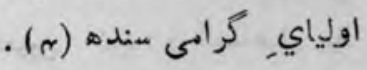

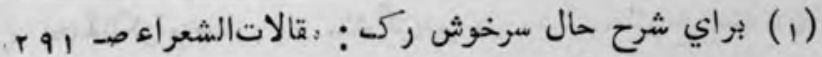

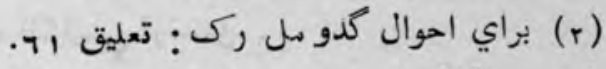

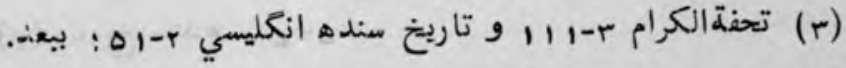

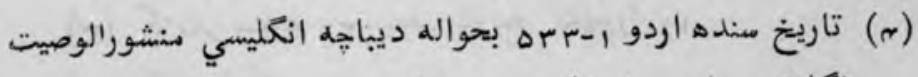
زخارث جناب سيد علي سحمد راشدى. 


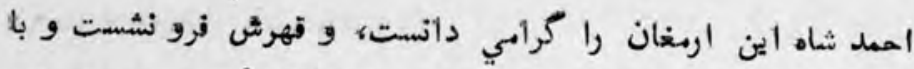

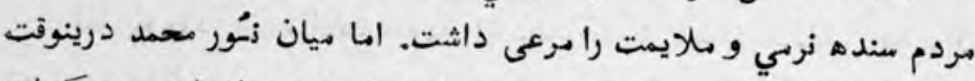

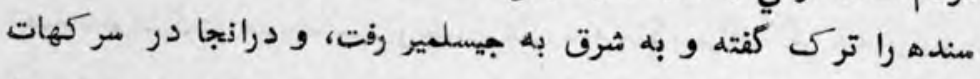

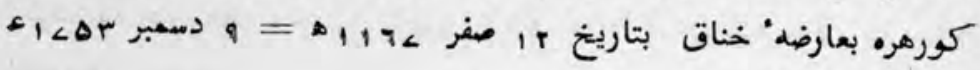
4ز جهان رفت (1) .

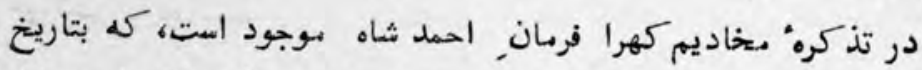

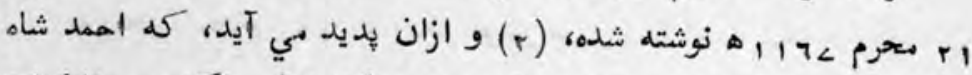

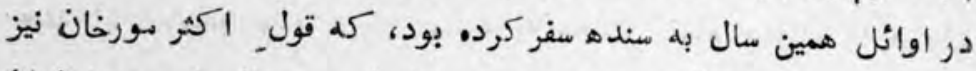

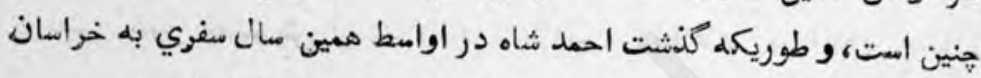

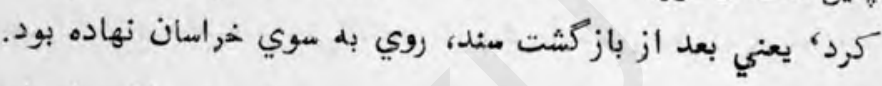

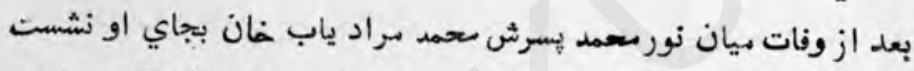

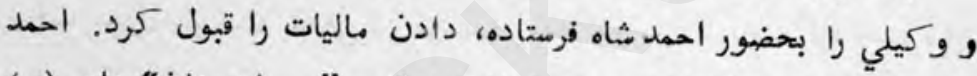

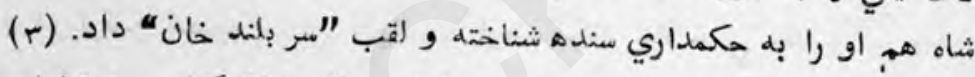

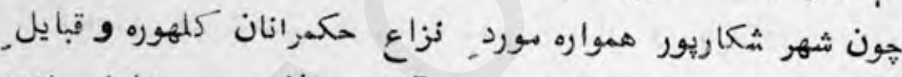

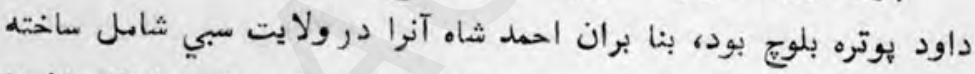

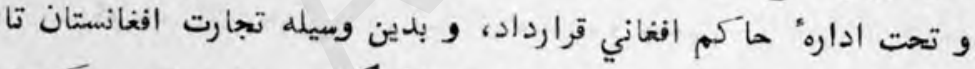

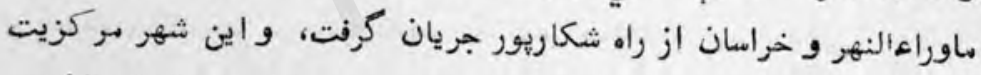

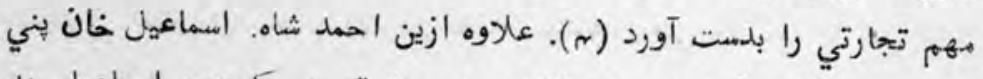

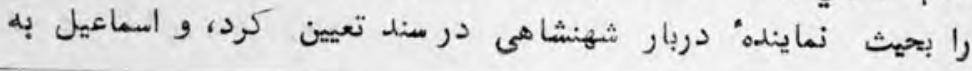

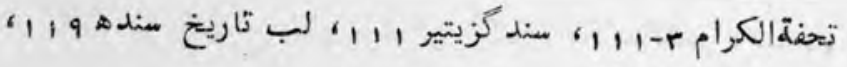

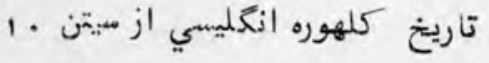

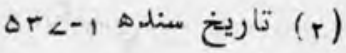

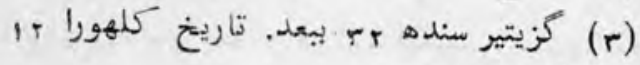

$$
\begin{aligned}
& \text { ه. }
\end{aligned}
$$




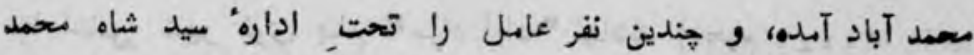
به تته و ديكر بلاد فرمتاد، كم ازانجمله صالع غان بله تته رفت،

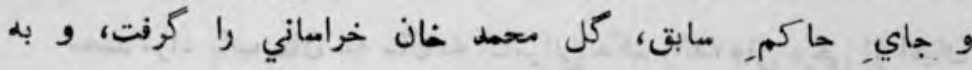
زراهم آوري ماليات برداخت .

درينوقت مفير احمد شاهي، سحمل بيك شاملو نيز به تقه آهد، وي آتا سعمد مالح را حكمران تقه مقرر كرد، و اعيان شهر را بحضور شهرياري برد، هون در بين كماشتعان اسماعيل و شاهلو اختلانف افتاد، بنا بران قاضي دحمد بحفوظ به حاكهي تته برقرار كثت. درينوقت محمد مرادياب غان از طرف احمد شاه، به اتيري سند شناخته و لقب "سر بلند خان" داده شد، در تمام اين مدت ديوان كدّو ملل سفير ميان نور سحمد مرحوم بدربار شاهي فعاليت ميكرد، تاكنه سران فان خانواده

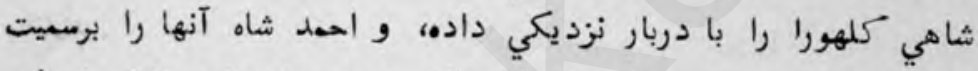

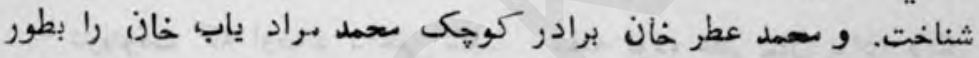

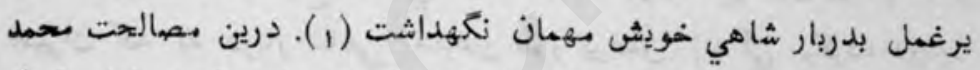
مراد ياب غان ماليات مقرره مند را بدربار احهد شاهي قدرى زياده قبول فرول

$$
\text { كرده بود (r) (r) }
$$

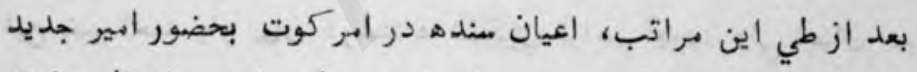

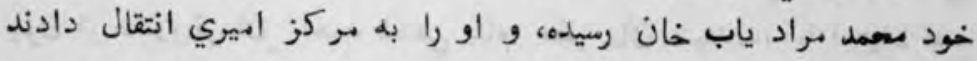

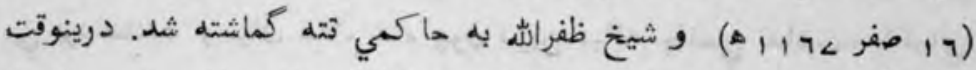

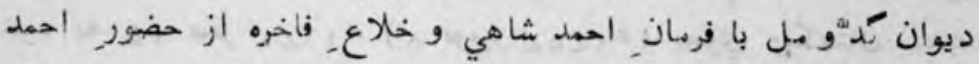

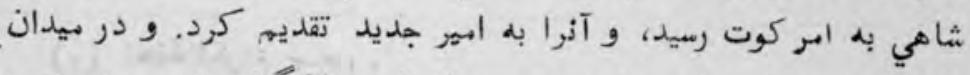

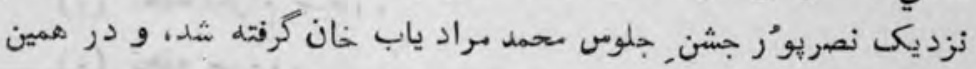

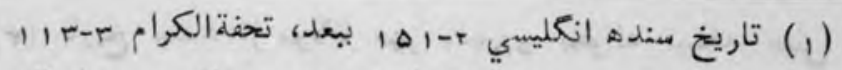

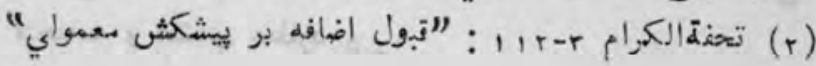




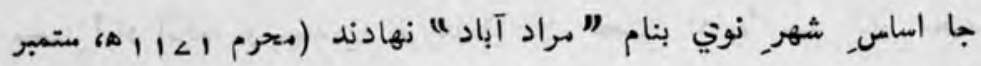
( ( ) $)\left(\varepsilon_{1}<\Delta<\right.$

محمد سراد ياب خان سه سال به كامراني حكم راند، ولي برخي از اعيان

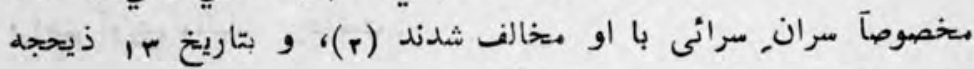

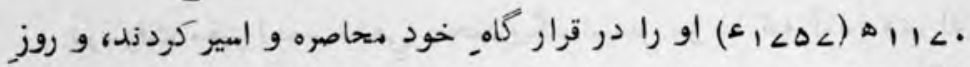
ديكر، برادرش بيان غالام شاه را بر تخت نشاندند. وي به تسلي. سران

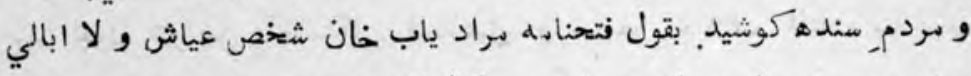

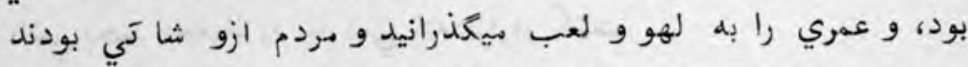

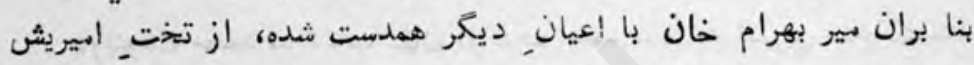

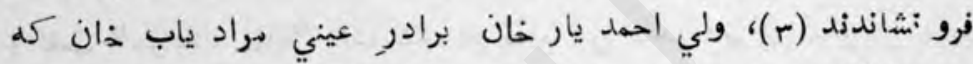

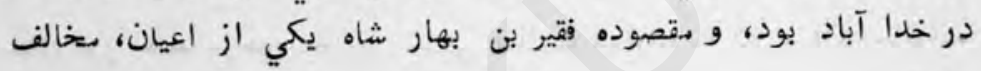
ماندند.

درينوقت كه اوضاع داخلي سندم شفته بود، عطر غان برادر ديكر اميران كه به دربار شاهي, قندهار طور يرغهل زند كي سيكرده، درباره؛

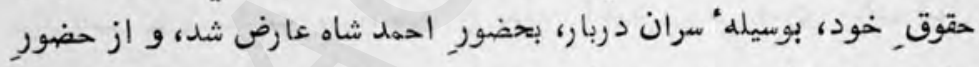
شاهي نيز فرهاني صادر و عطر خان را بحيث انير سنده شناخت. باشيندن

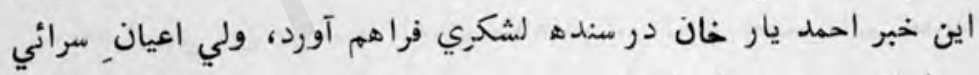

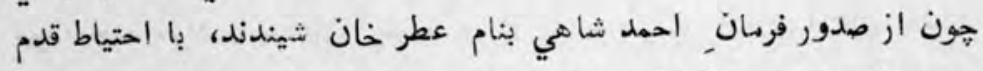
مي برداشتند، و ميان غلام شاه هون درين ميانه خانسي نداشت، با قواي

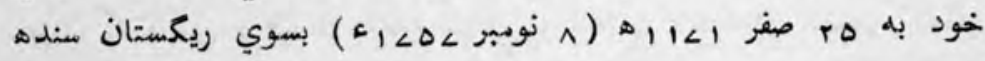

$$
\begin{aligned}
& \text { (1) تحفة الكرام r-r (r) } \\
& \text { | تحفd (r) }
\end{aligned}
$$

(r) فتحنامه و انشاي عطارد 


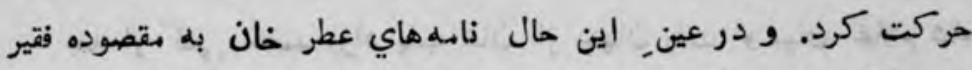

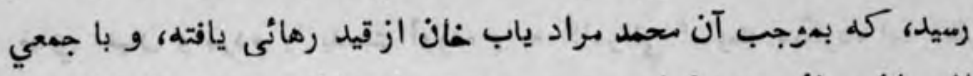

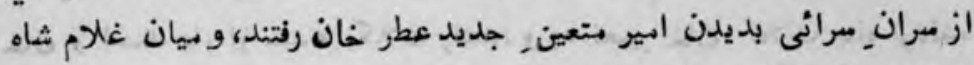

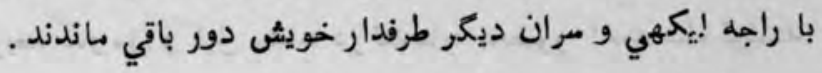

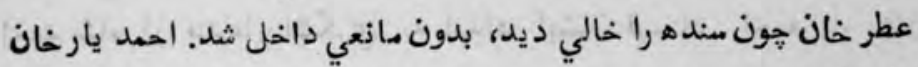

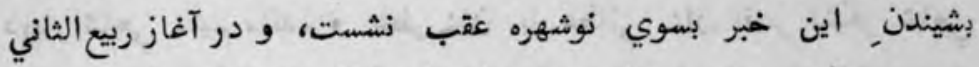

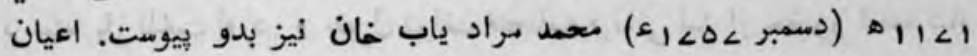

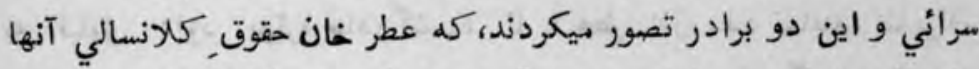

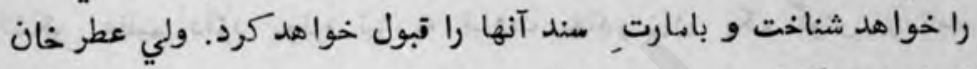

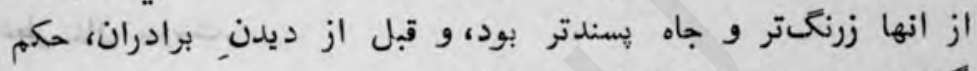

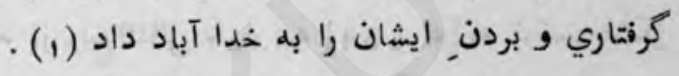

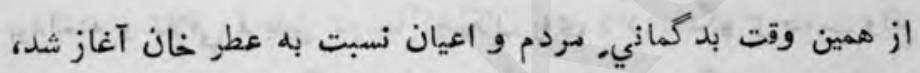

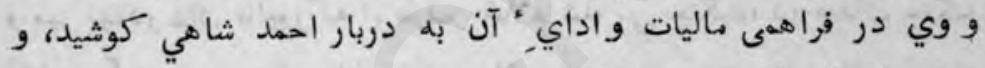

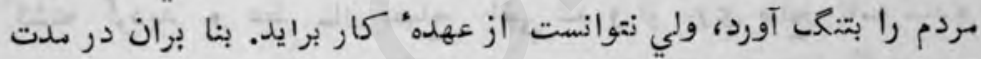

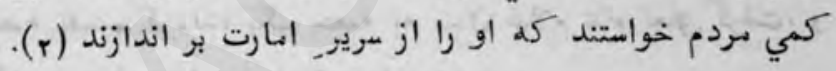

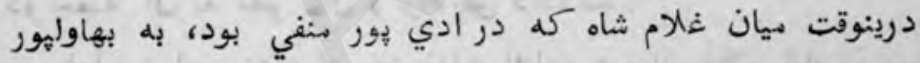

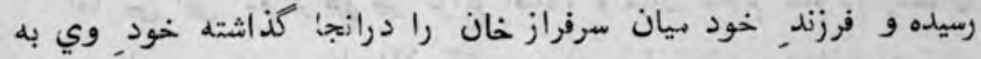

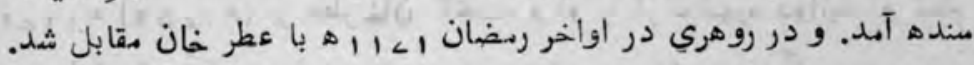

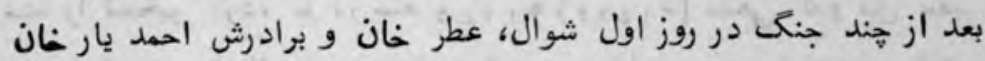

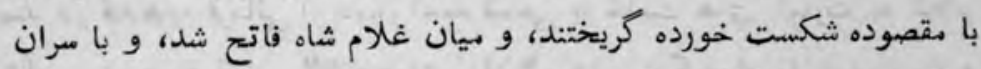

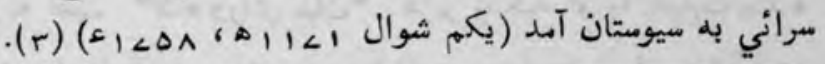

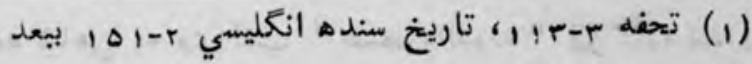

$$
\begin{aligned}
& \text { (r) }
\end{aligned}
$$

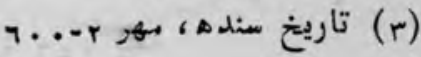


بعد از كمي مععد مراد باب خان از جهان رفت، و بيان غلام ثماء رضاي اعيان و مردم را بدصت آورده و به كا.براني امارت بيكرده اهـا عطر

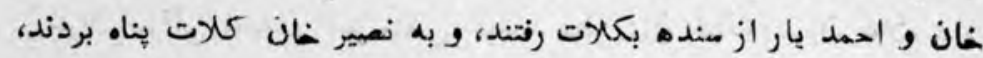

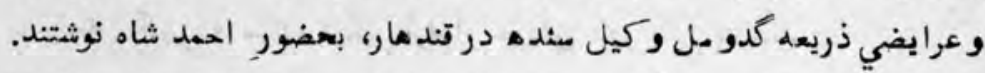

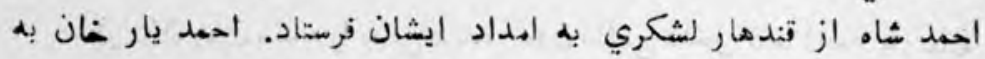

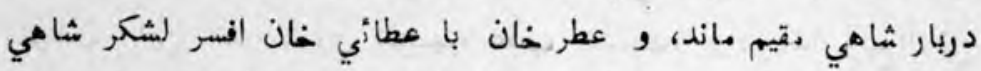

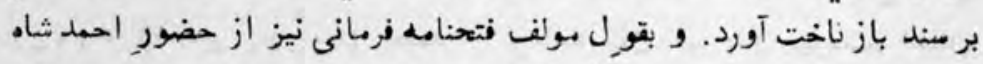

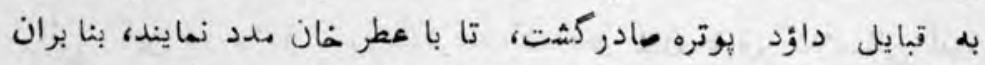

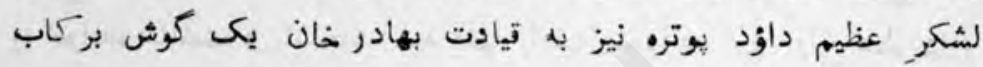

عطر خان קيوست.

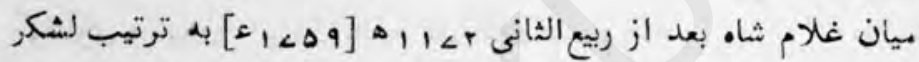

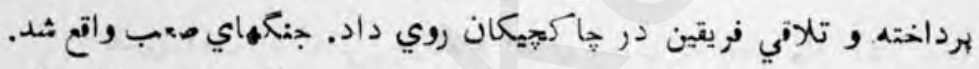

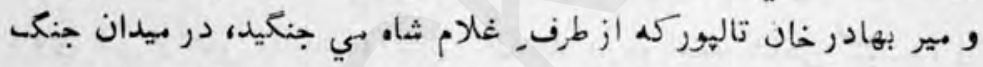

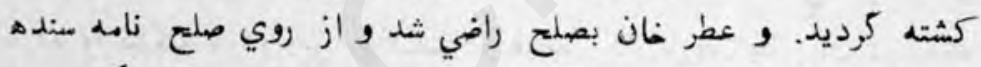

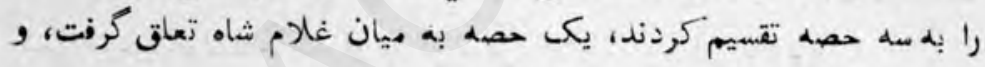

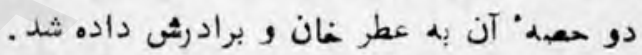
اما بين اين دو برادر نيز نزاع افتاد، و ميان غلام شاه دران در رمفهان

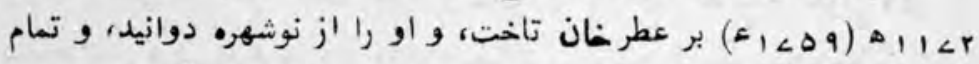

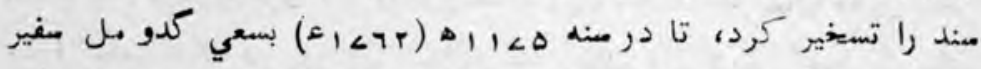

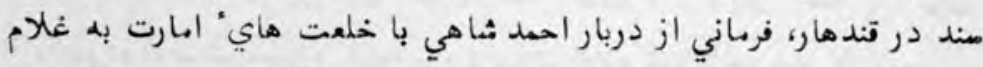

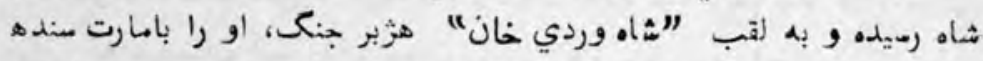

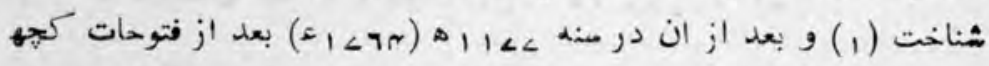

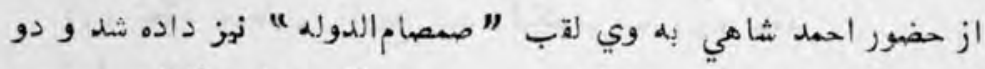

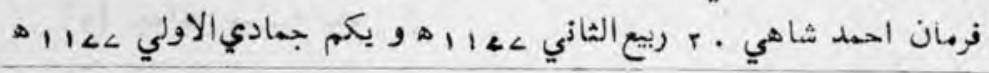
(1) 


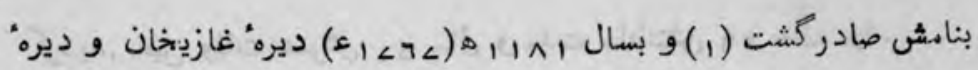

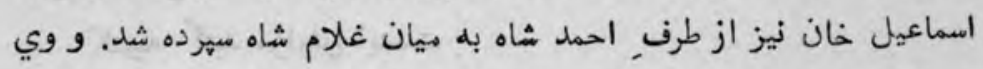

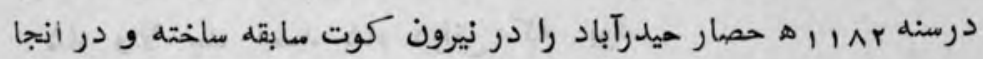

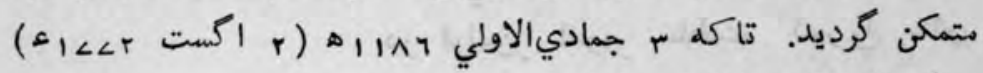

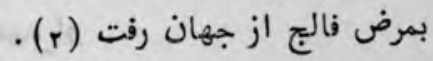

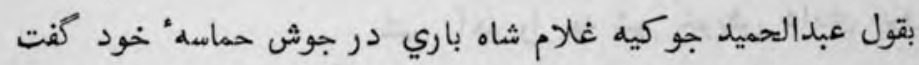

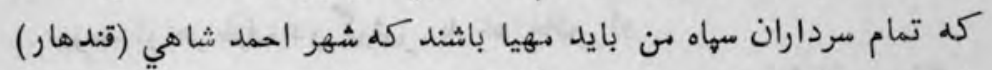

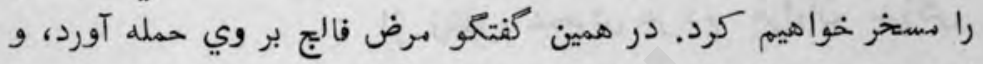

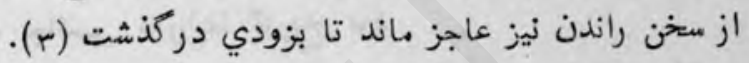

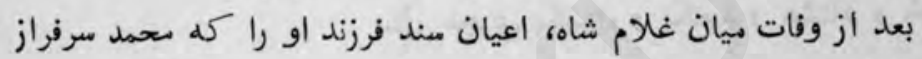

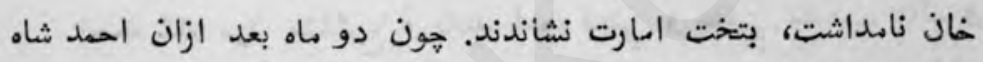

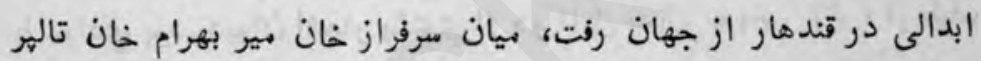

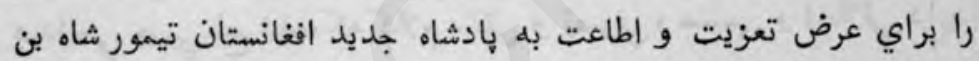

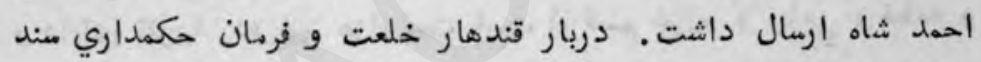

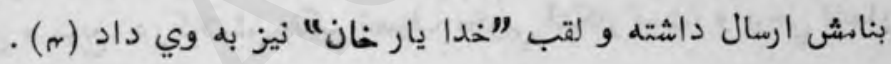

وفات احمد شاه و سجاياي وي

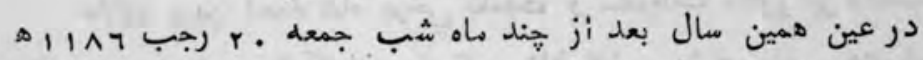

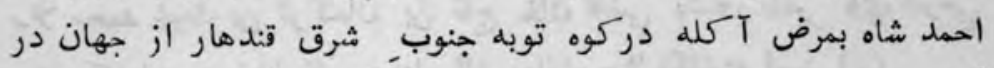

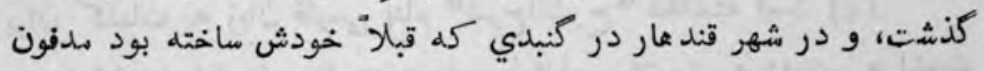

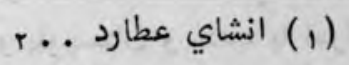

| تاريخ سنده ازكليسي r) (r)

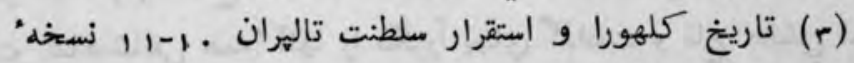

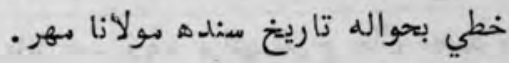

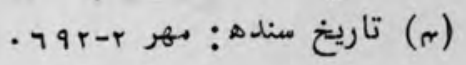


تعليقات

$\angle \wedge \wedge$

كرديد. حين وفات عمرش ره رهال و هدت سلطنتش 7 ب سال بود.

كتيبه كنبد مزارث اينست

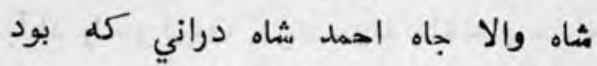

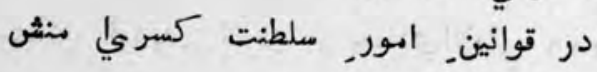

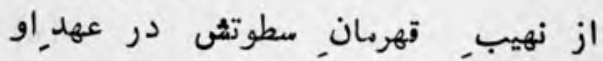

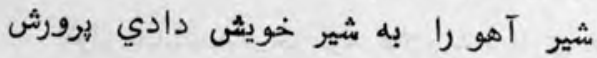

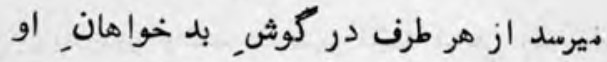

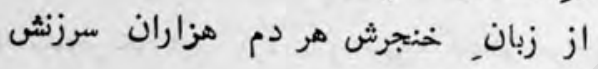

هون روان شيد جانب, دارالبقا تاريخ بود سال هجري يكهزار و يكصد و هشتاد و ششى بود

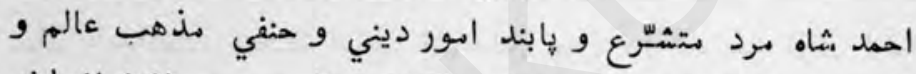

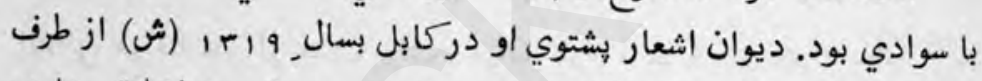

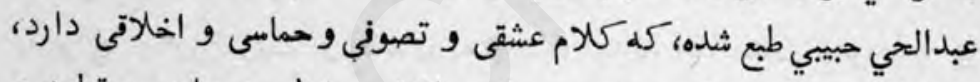

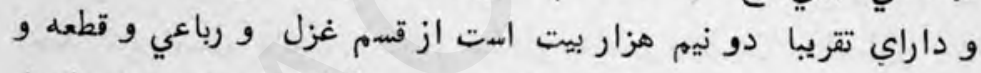
مخمس و مربع. دركلامش رنك تصوف بخوبي آشكار است، و برخي اشعار

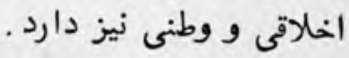

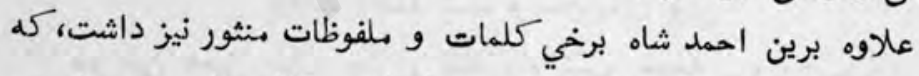

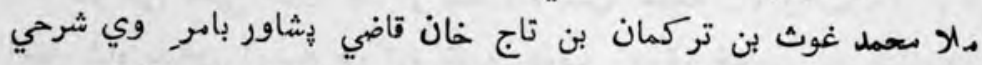

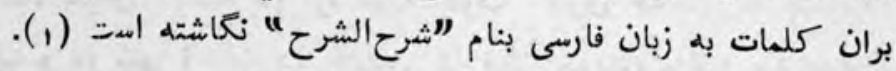

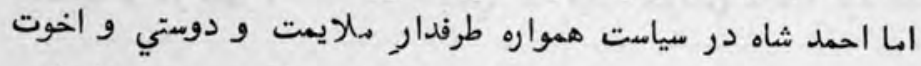

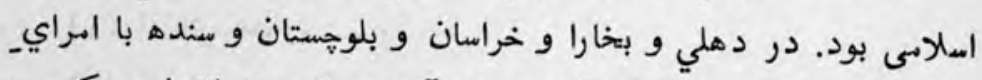

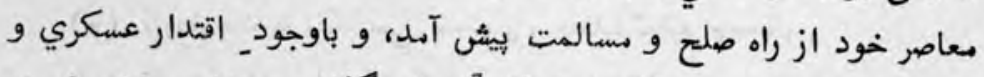

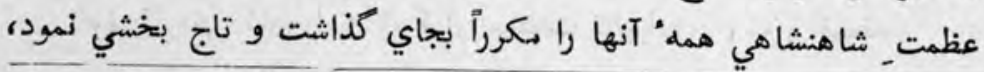

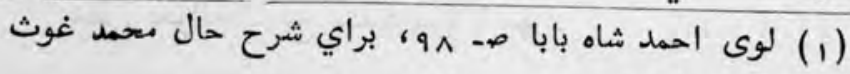

ركى : تعليق احمد ماه بابا 


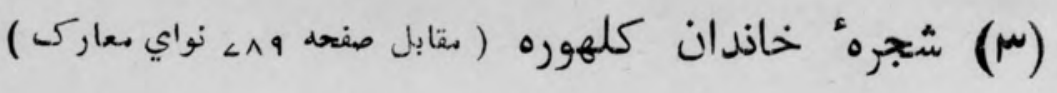

$788 a_{1}$

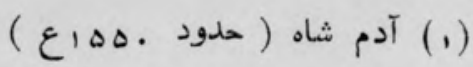

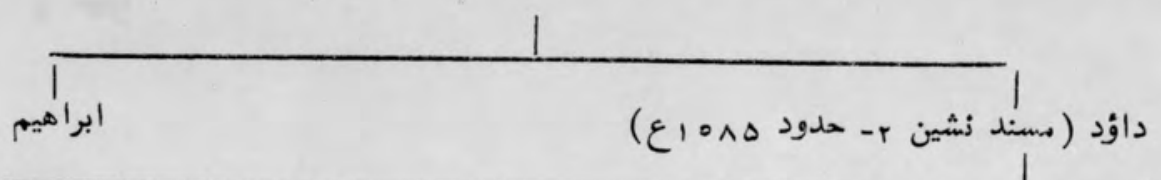

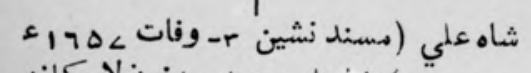

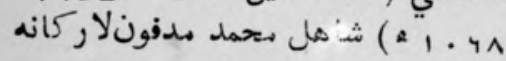

الياس محمد ( حدود . rד الع )

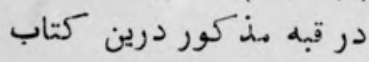

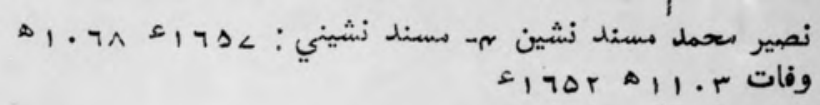

نير محمد خان

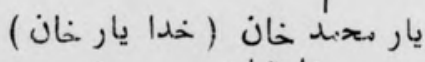

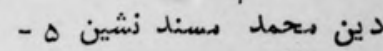

هصب دارشا هي 1 •.

مقتول

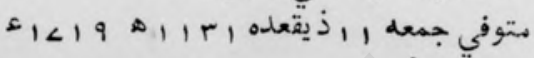

مقتول

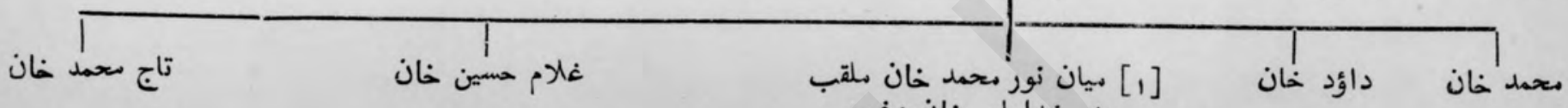

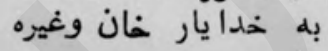

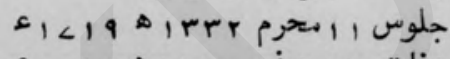

وفات

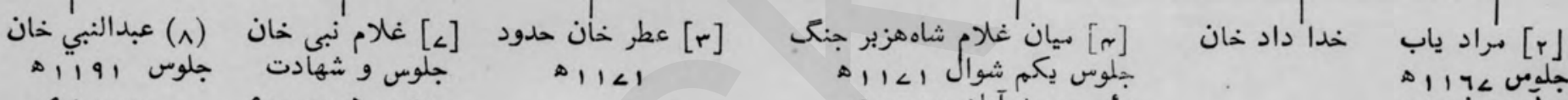

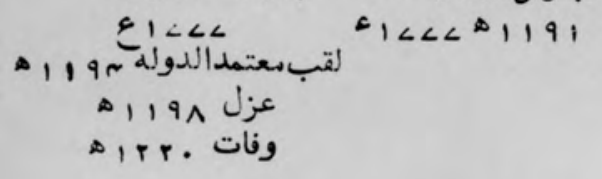

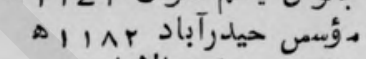

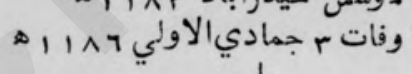

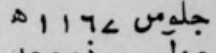

عزل عار آذيحجه

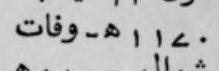

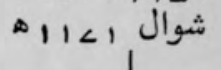

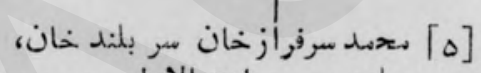

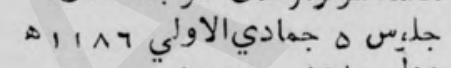

حسين علي [ [7] :تحمود خان

عباس علي

ع ع خ

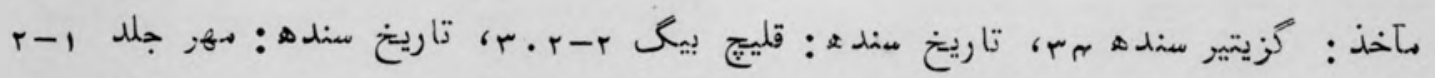


كله حتى مورخان اين وسعت نظر و تاج بخشى هاي احمد شاهي را بهنظر تعجب ديده اند و بقول شاه ولى الله دهلوي اين رويلء ابدالى مانند

$$
\text { امور اين دنيا نبود (1). }
$$

احمد شاه باوجود. جهانكيري، ازخونويزي خود دارى ديكرد. در امور جهانداري به عدالت و انصاف رفتار مي نمود. مردم را مانيد فرزئدان خويش هرورش ميداد، و ازين رو ست كله افغانان او را لبابا") كويند . البته احمد شاه جنكجو و فاتح بود، ولي از تمام. فتوحات و اعمالـ عسكري. او ظاهر است كله جهانكير غارتخر مخرب متم كيش و و مظلوم كشي نبود. و اكر كاري به صلح و مسالمت بريش ميرفت، با مسلمانان

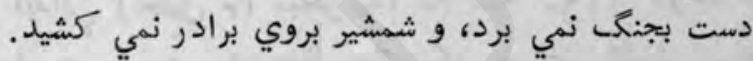

\section{خاندان كلهور}

كلهوره و داؤد يوتره به عباسي مشهور اند، و ظاهراً از قبايل بلوتج اند، كله در ابتداء منصب فقر و درويشي داشتئد، و بعد ازان در مندها

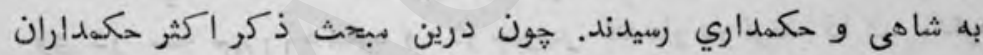

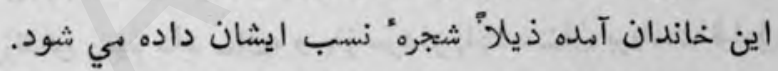
مورث اعلاي مشهور اين خاندان آدم شاه است (مدفون كوه آدم شاه

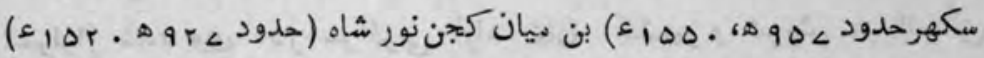

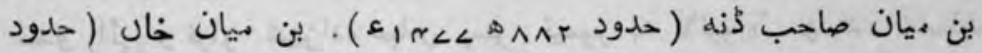

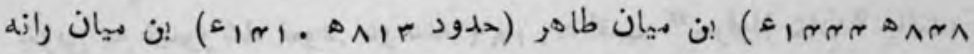

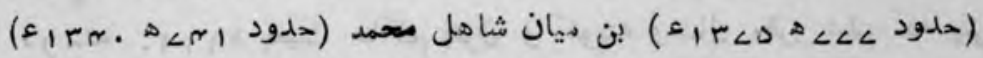

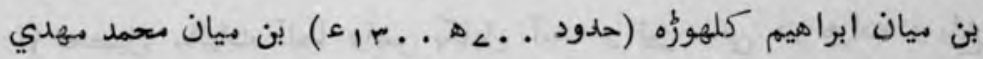

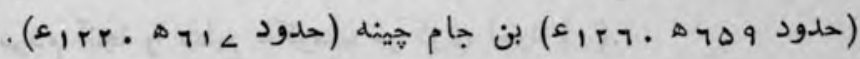

(1) سيرالمتأخرين، تذكره شاه وِلي اله از مناظر احسن كياني

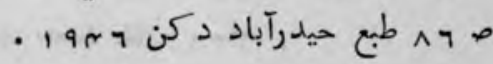




\section{باركزائى و سردار هاينده خان و اولادش}

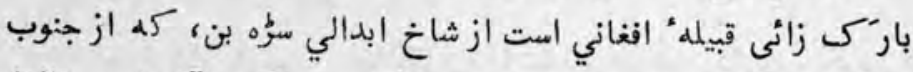

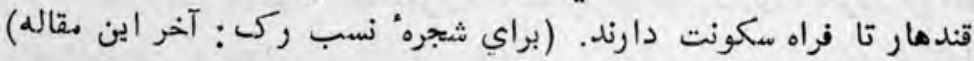

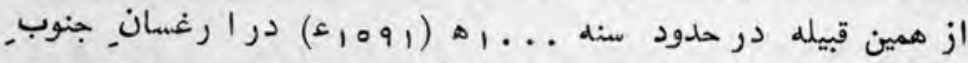

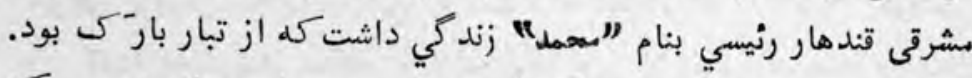

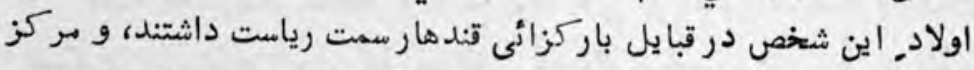

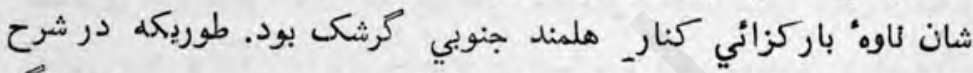

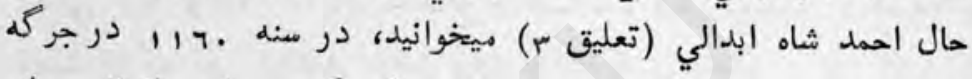

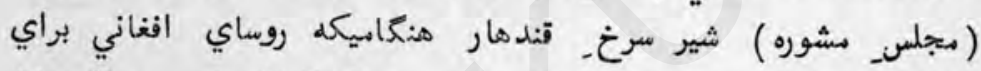

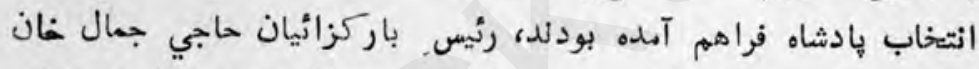

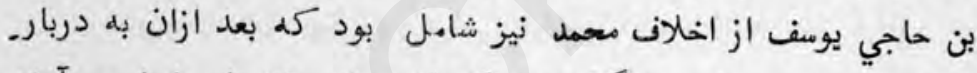

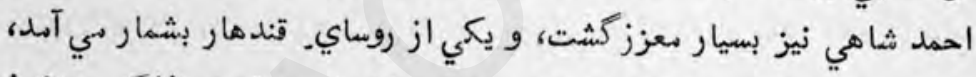

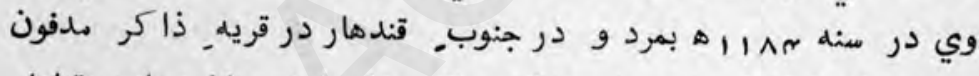

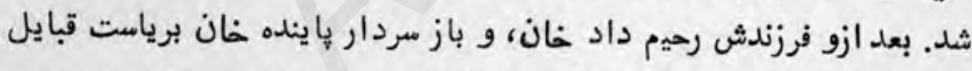

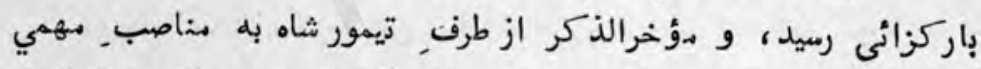

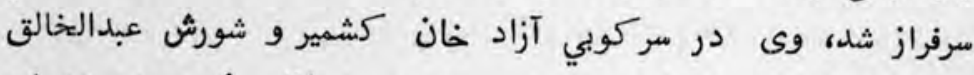

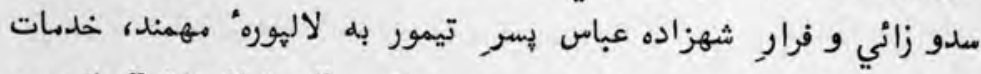

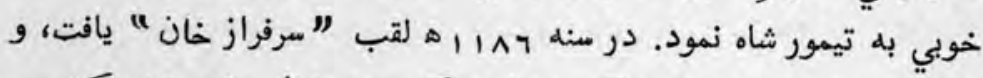

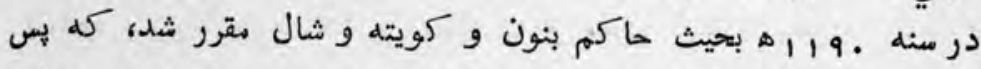

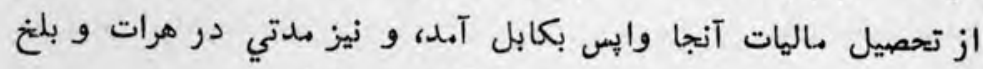

$$
\text { بود، و مردم آنجا را مطيع حكومت مركزي نمود (1). }
$$

(1) حيات افغاني و جr و تاريخ حسيني (خطي)، موهن لال :

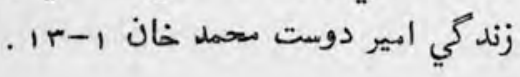




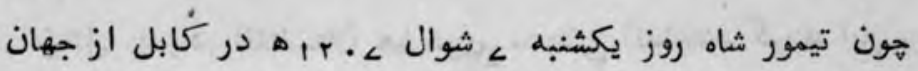

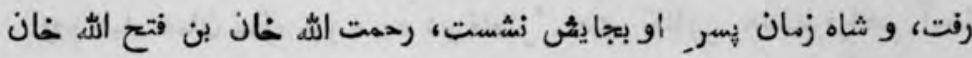

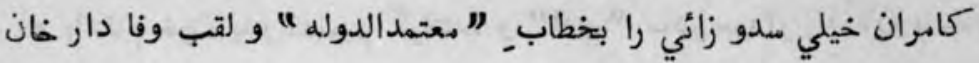

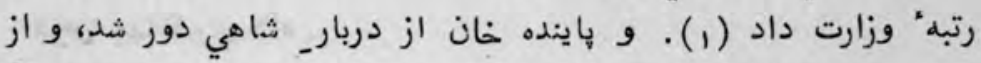

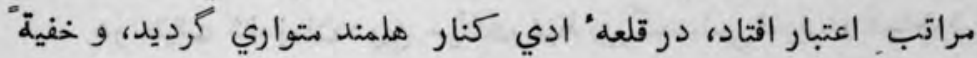
در بر انداختن, سلطنت زمان شاه كوشيد. خهون شاه به قندهار آ.بل، مردار קاينده خان امراي_ دربار مانئد اسلام خان ضبط بيمي و حكمت خان سركاني و محمد عظيم خان بن مير هزار الكوزائي و ابير اصلان خان و

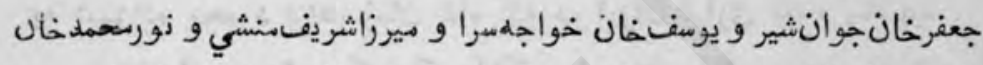

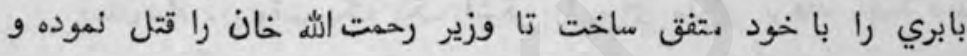

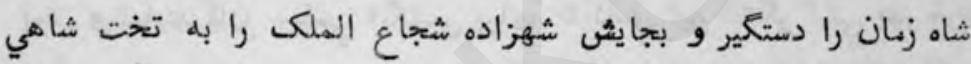
-(r) dijlíj

ولي ميرزا شريف منشي اين دسيسه را قبلا به وزير و شاه خبر داد،

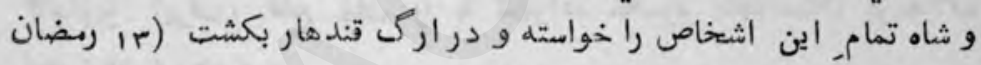

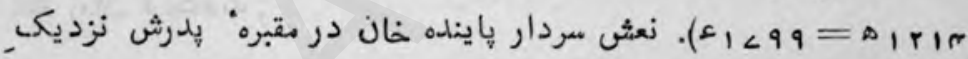

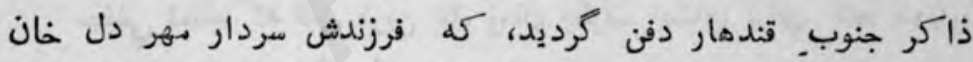

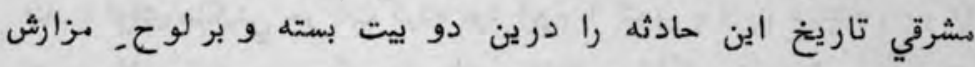
منقور نمود : ز با فتاد هو برخاكى سرفراز ـ جهان بلند ناله و افغان شد از همه افغان

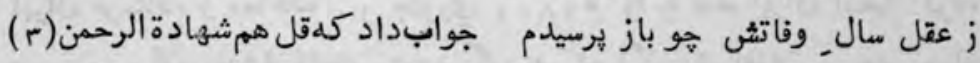

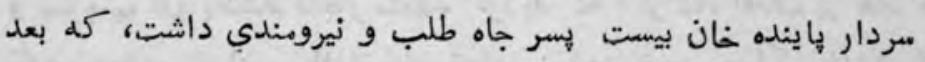

$$
\begin{aligned}
& \text { (1) سراج جم و تاريخ حسيني (خطي). } \\
& \text {. تاريخ مسلطاني (r) (r) (r) } \\
& \text {. }
\end{aligned}
$$




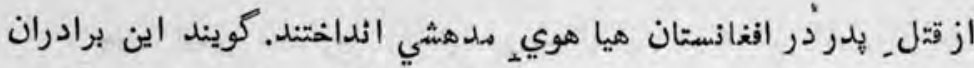

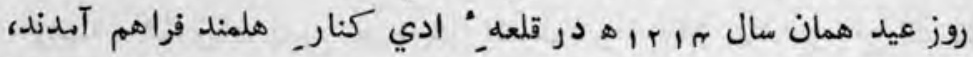

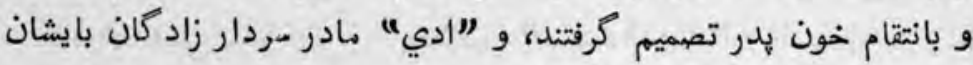

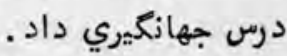
در حقيقت شاه زمان درين حركت خبط بزرك سياسي نمود، و دمشتخوش.

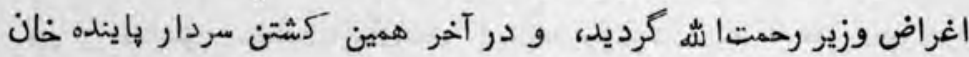

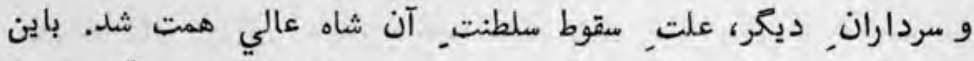

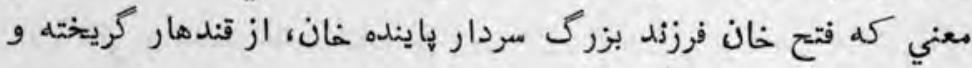

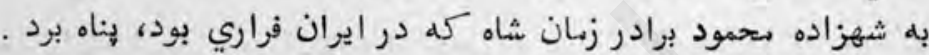
زمان شاه درينوقت يكى لكى لشكر را براي مارش برهند تهيه ديده

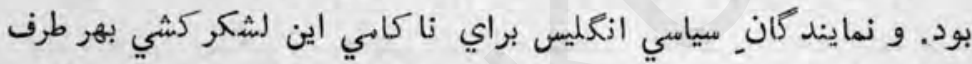

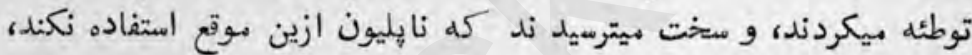

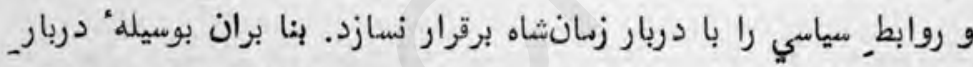

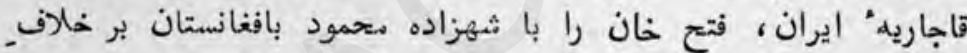
شاه زمان فرستادند.

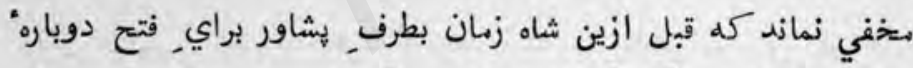

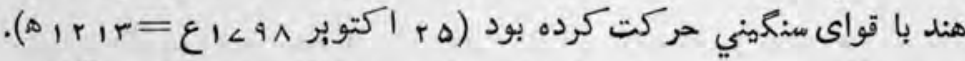

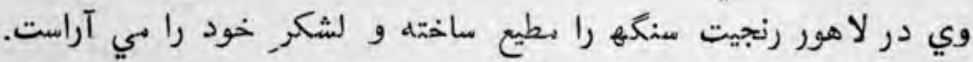

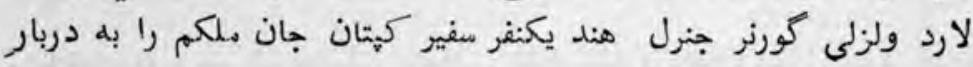

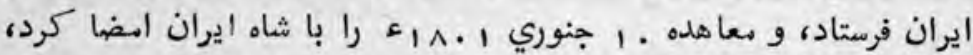

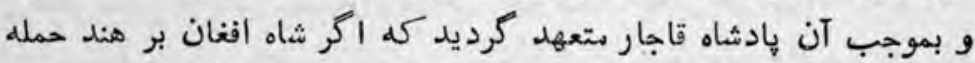

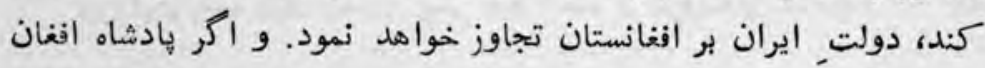

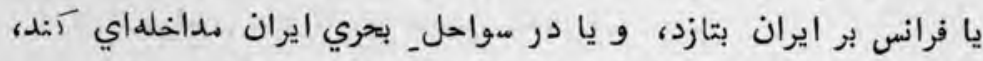

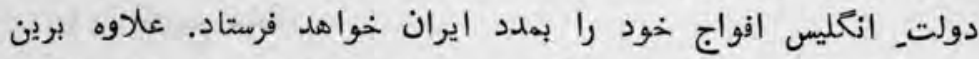

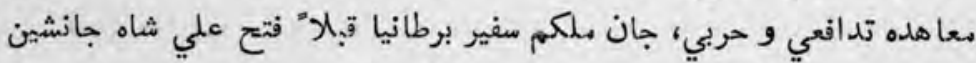




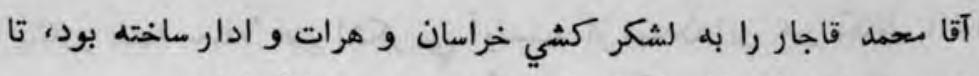

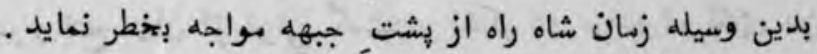

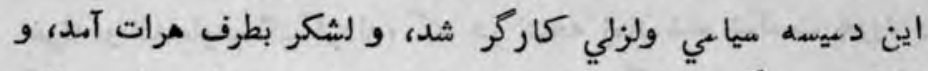

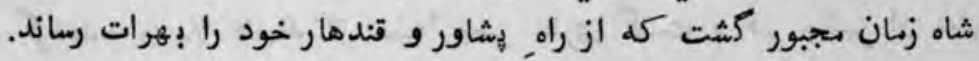

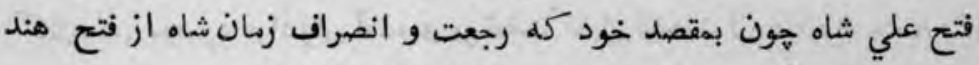

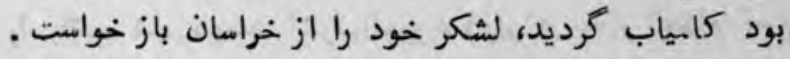

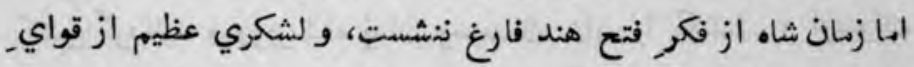
افغان و بلوت وغيره آراست، و در بشاور به تجهيزات قوي تر مشغغول

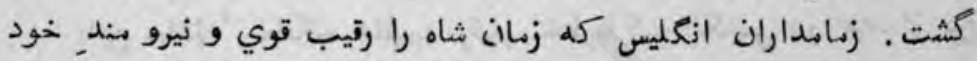

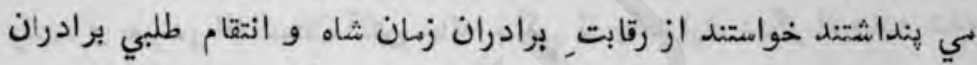
اركزائي كله با غضب دو دلهاي ريثى بهر طرفى هيرا كنده بودند كار بكيرند،

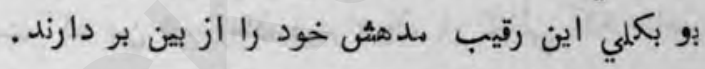

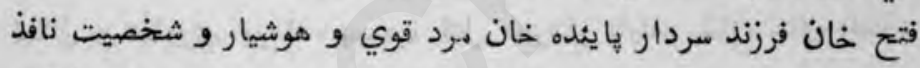
و بر جستهاي بود، كله در قبايل درانى از فروند فرداه تا قندهار ديكانه

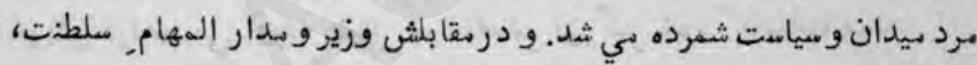

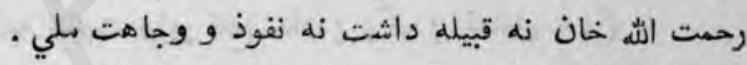

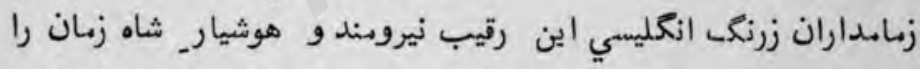

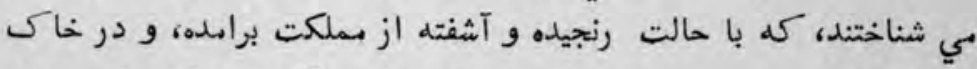

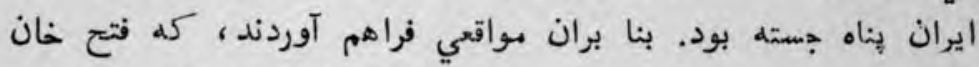

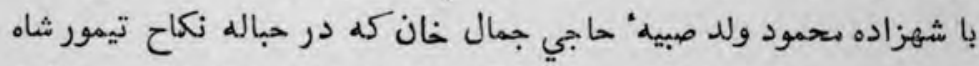

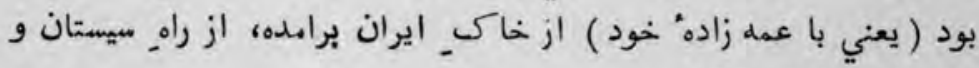
فراه داخل افغانستان شدند. ايشان بمددي قبايل باركزائي كله از خطي مرحد ايران تا قندهار افتاده اند، ميستان و فراه و قندهار را بكرفتند. و بعد از تجهيز قواي

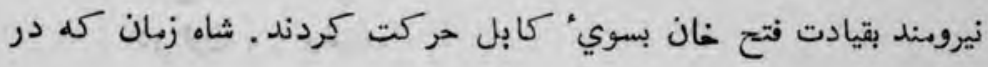


ويشاور بقصد حمله" هند لشكر مي آراست، از شيهدن اين خبر بكابل آمد،

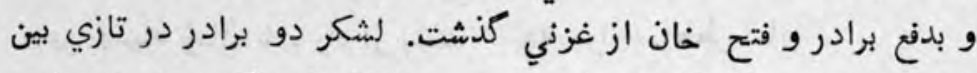

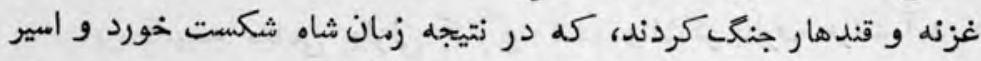

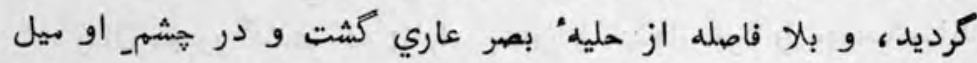

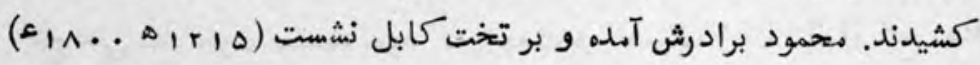
و فتح خان را بلقب شاه دوست اشرفالوزراء وزير و مدار المهام تمام برام

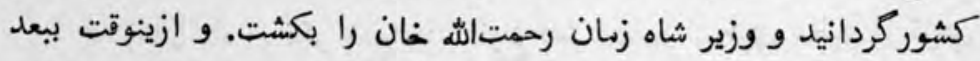

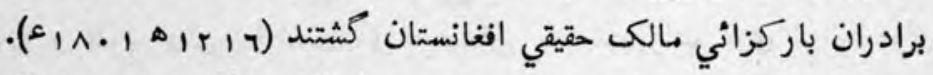

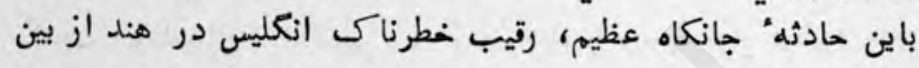

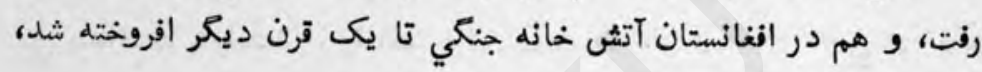

$$
\text { و كسي بفكر ديكري نيفتاد (1) . }
$$

جاي افسوم است كله بين شاه زمان و برادران باركزائي كه عناصر فعتال و دلاوري بودند، بسبب قتل سردار خاينده خان نفاق افتاد، ورنه اكر دربار. شاهي اين اشخاص كار آزموده و دلير و متنفسّن را بدور

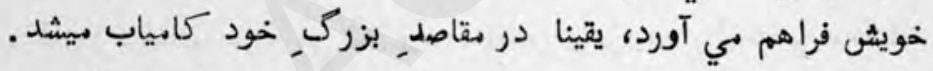
( راجع به عاقبت وزير فتع خان : ركى : تعليق 1 ( ) )

(1) مراج و سلطاني و افغانستان بعد از اسلكام، و افغانستان در قرن و اج و وغيره. 


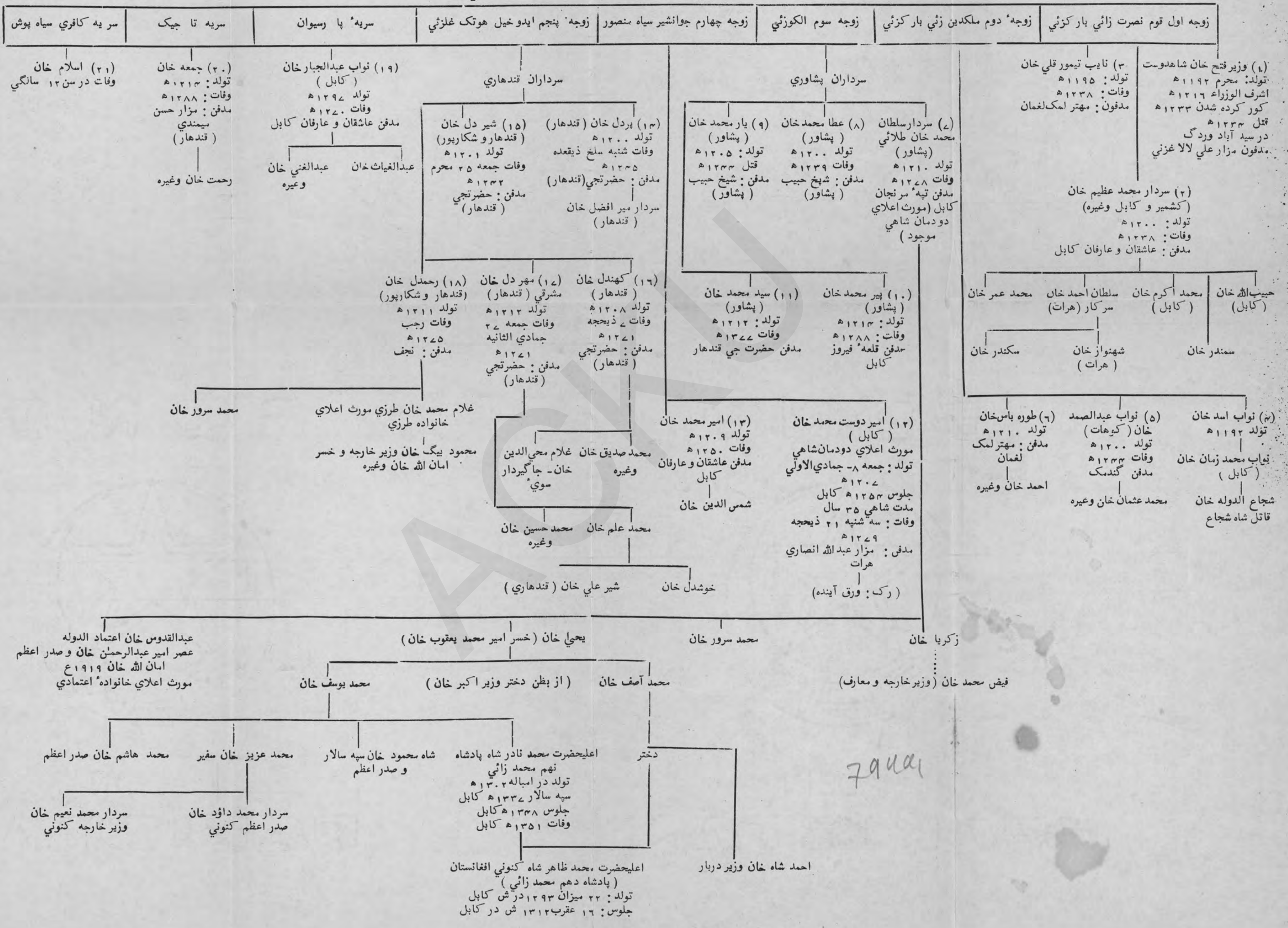




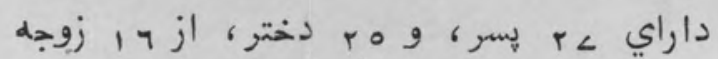

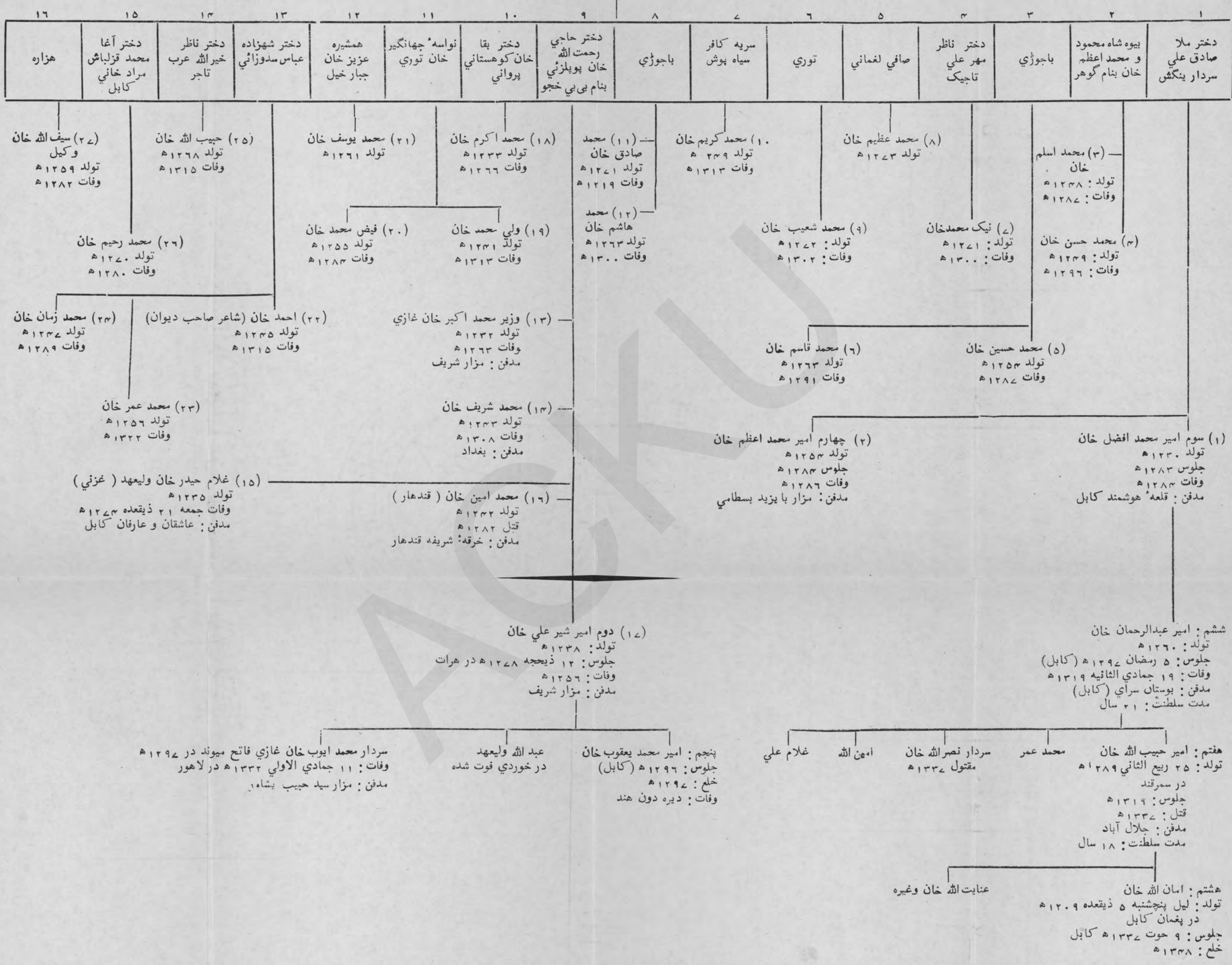




\section{وزير شير محهل خان}

فرزنداشرفالوزراء شاهولي خان باميزائيوزيراعظماحمد شاه ابدالى است.

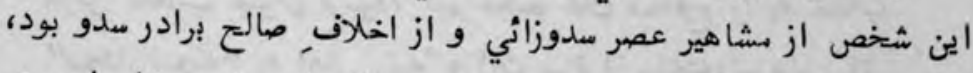

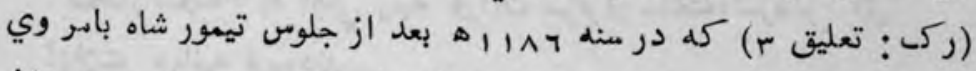

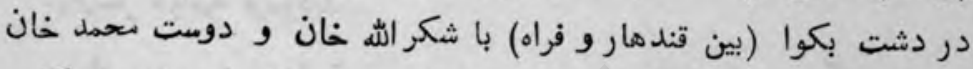

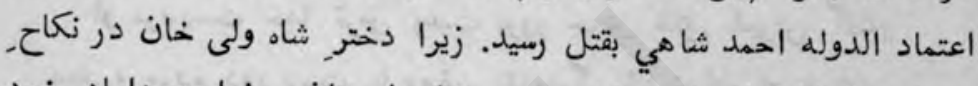

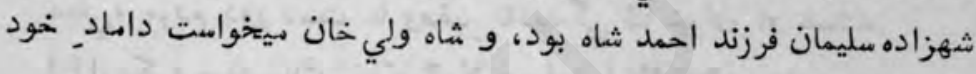

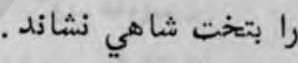

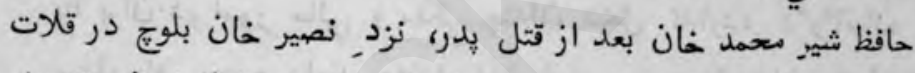

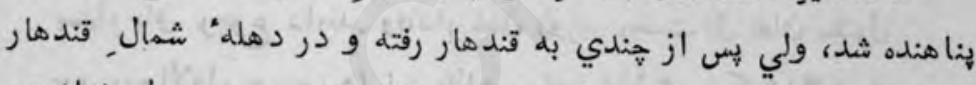

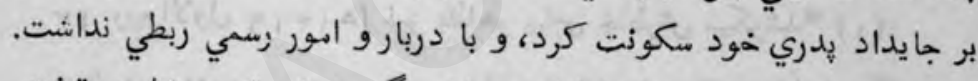

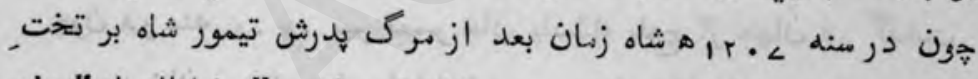

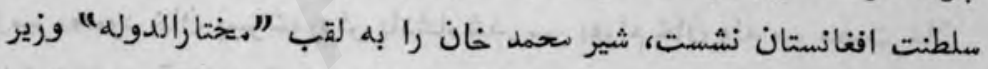

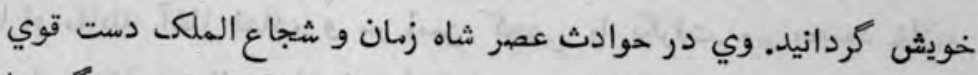

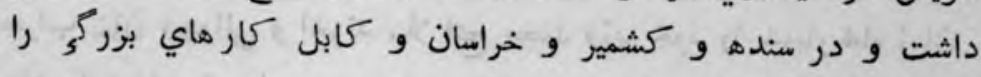

$$
\text { انجام داد (1) واثن }
$$

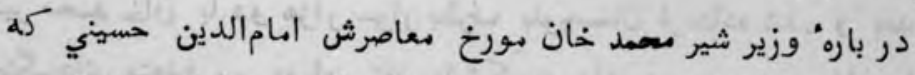

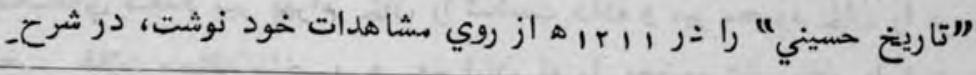

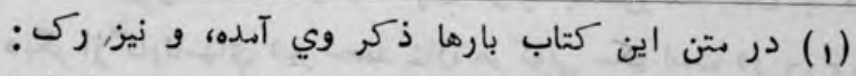

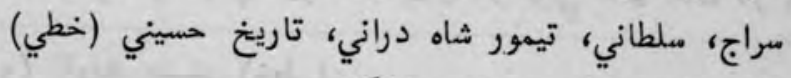
تاريخ احمل شاهي هنشي عبدالكريم. تهرون. 
حال امرا" واركان دربار زمان شاهي هنين مي نويسد : " اشرفالوزراء بختارالدوله حافظ شير بحمد خان بهادر ضيسر اشرفالوزراء شاه ولي خان بهادر باميزائي مرحوم ست. و در زمان حضرت تيمور شاه بغ هفور, هبرور' بعل, كشته شدن

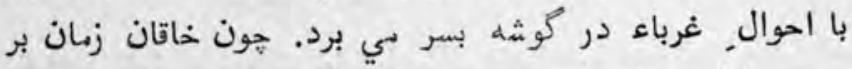

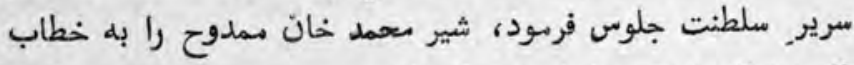

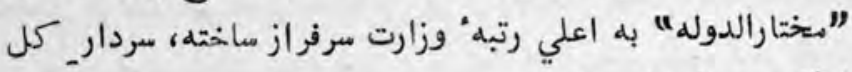
ايلات درانيه فرمودند . بله

او مرديست خدا ترس رعيت يرور خوثى خلق شيرين كفتار سخي، مردم دور دست با وصفـــ ناديدكي ثنا خوان او او هستند.

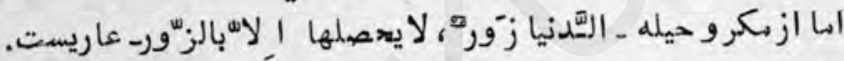

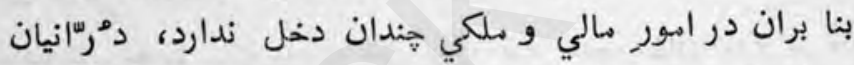
بسيار باو رجوع دارند. وفادار خان (وزير رحمت اله خان مقتول

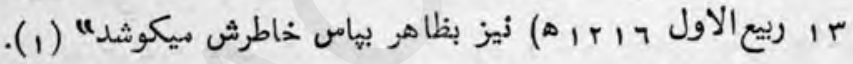

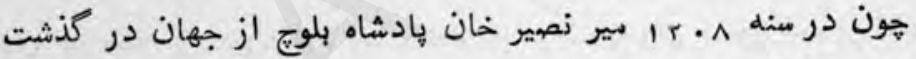
و مير محمود خان يهر خوردش يادشاه شد. دير بهرام خان ولد مير محبت خان با او مقابله آغاز نهاد، و سر زمين كجههي را بكرفت. ثير بحمود خان، متراب خان شهواني و اخوند بلا فتع محمد وزير خود را بدربار شاه زمان براي استمداد فرستاد. درينوقت از حضور شاه زمان، اشرفالوزي دوراء شير معمل خان با دو هزار سوار بطرف بلوحستان فرستاده شد. و و بعد از

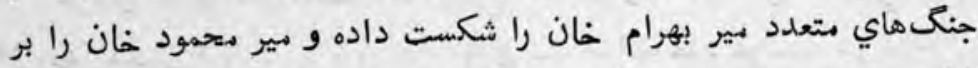

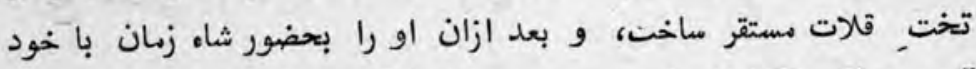

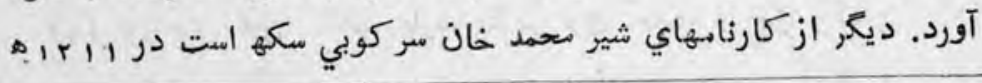

$$
\text { . (1) }
$$




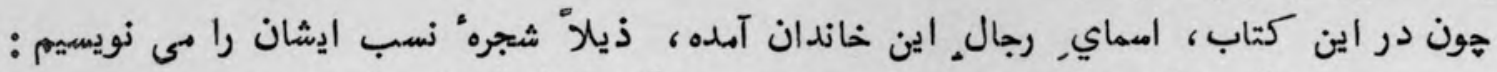

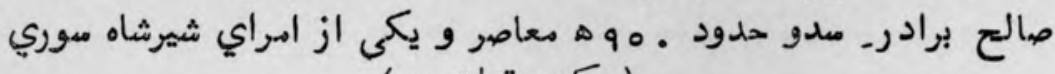

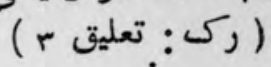

با ميزائي بويلزائي

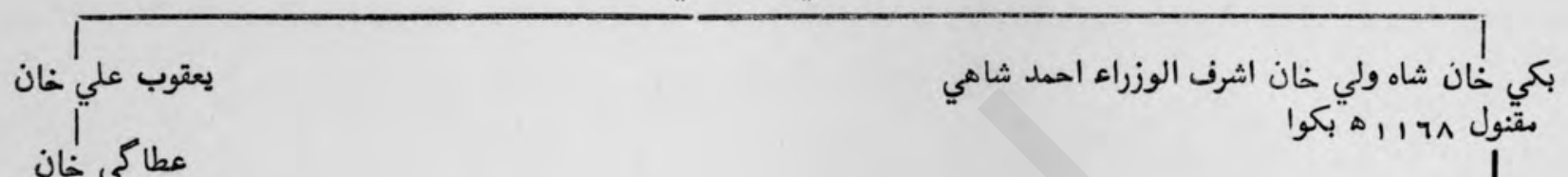

عطاكي خان

شهيد يأني يت

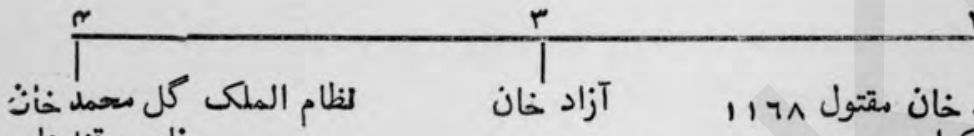

نايب قندهار

بكوا 
كه شيخويوره لاهور را از دست آن مردم كرفت و بنجاب راب را ازيشان

و نيز همين اشرفالوزراء در سنه ب ا ب r ا هـ شهزاد كان نادري عباس ميرزا

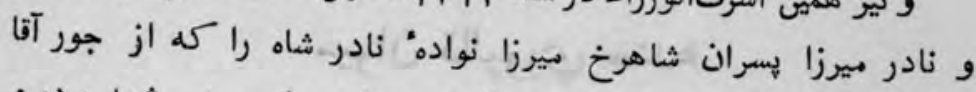

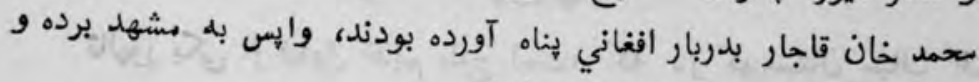
بر سرير حكودت خراسان نشاندند (r) .

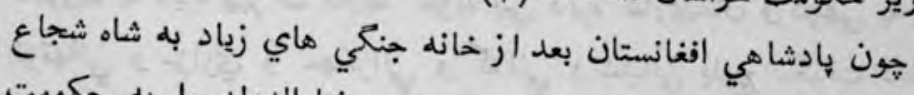

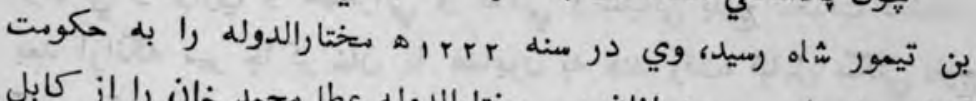

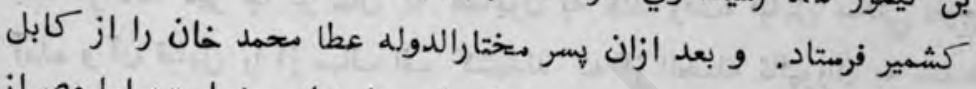

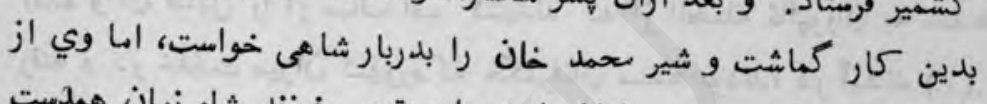

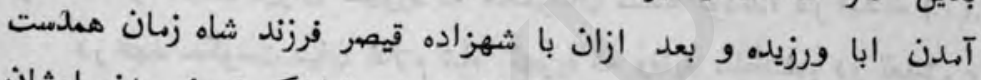

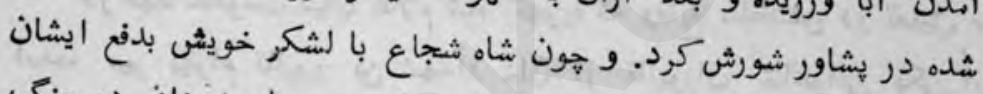

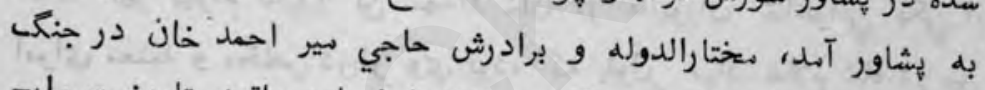

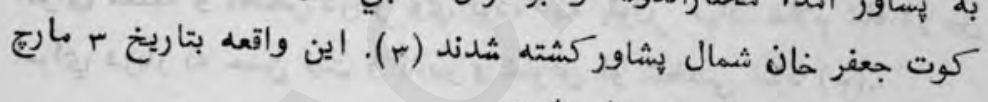

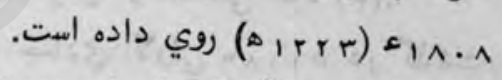

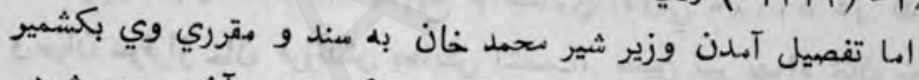

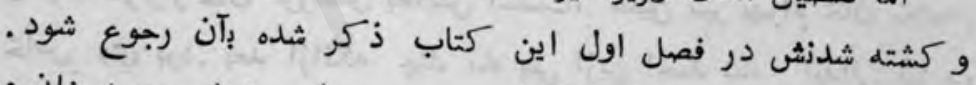

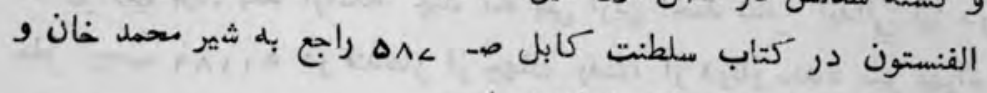
صفات_ او شرحي دارد كه نهواندني است.

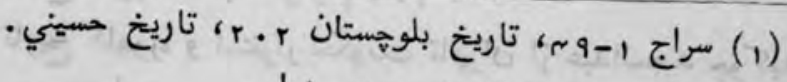

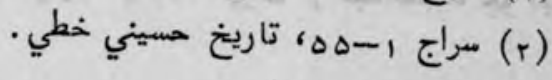

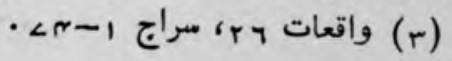




\section{$-4-$}

\section{مير ان تاليوري سنله}

تالهور يكى از قبايل قديم بلوج است، كله در كوهستان مياف اف

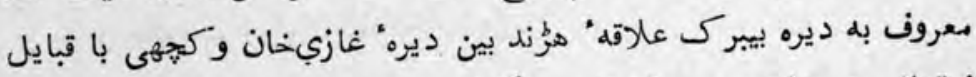

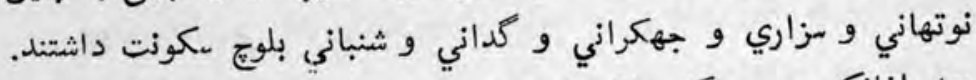

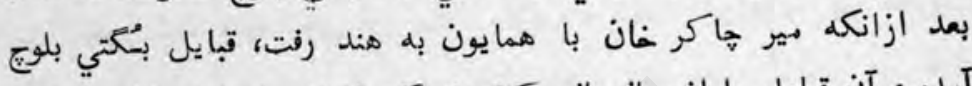

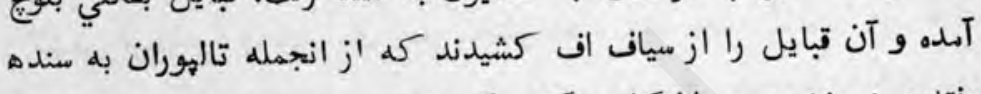

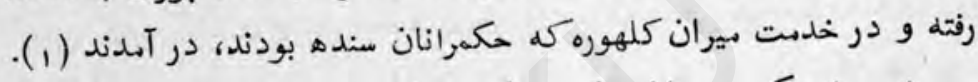

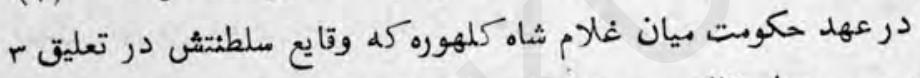

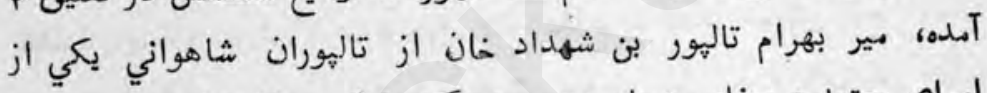

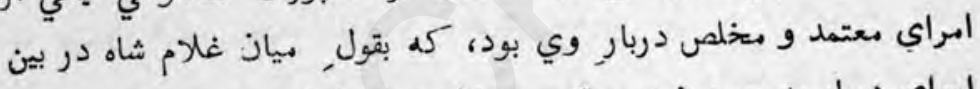

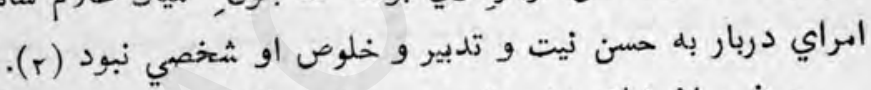

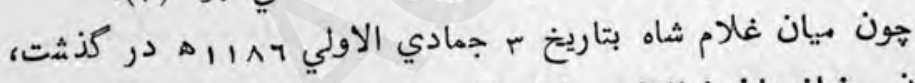

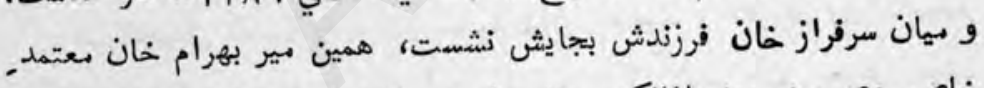

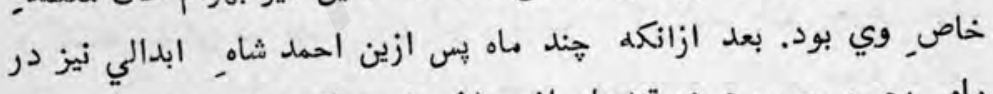

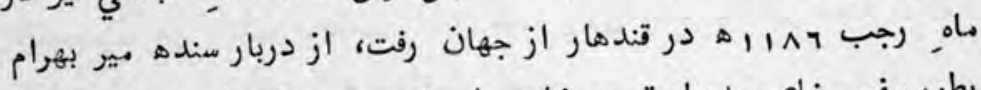

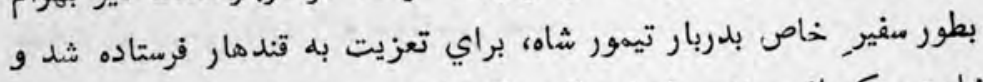

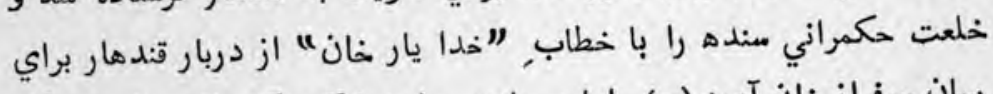

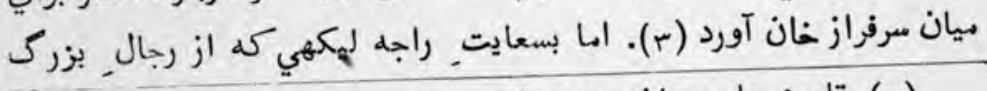

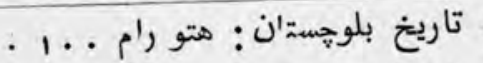

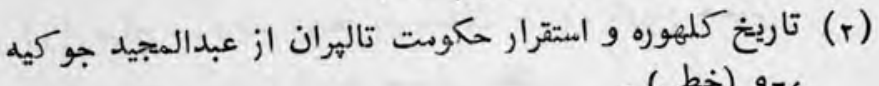

$$
\begin{aligned}
& \text { - (خطى) }
\end{aligned}
$$

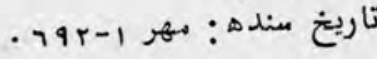




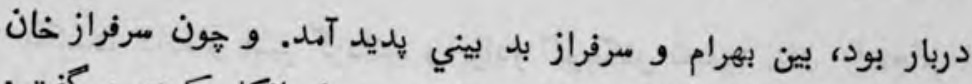

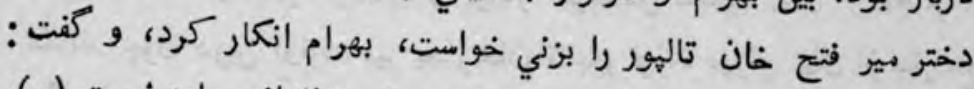

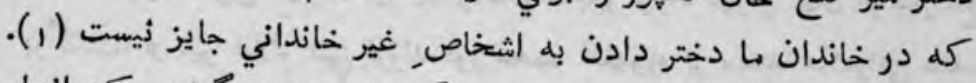

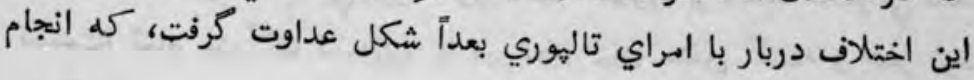

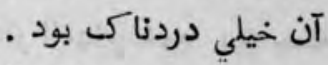

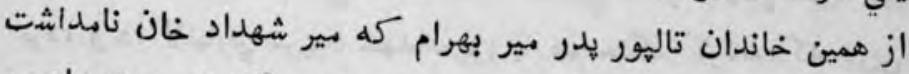

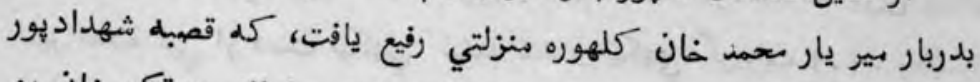

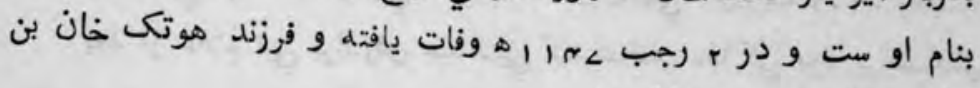

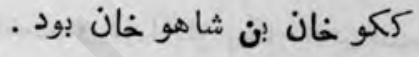

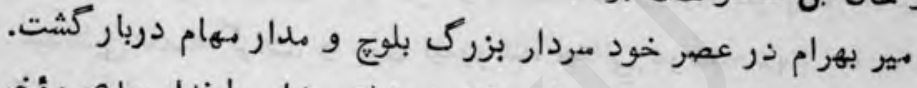

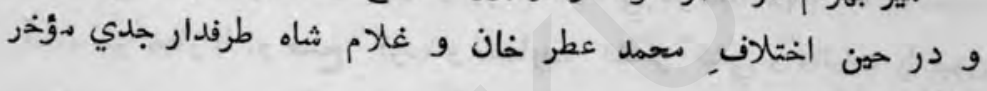

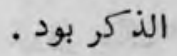

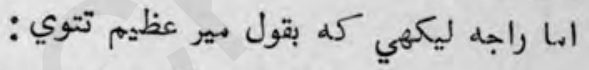

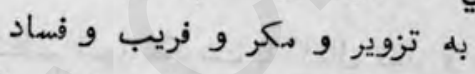

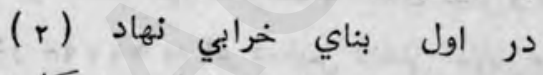

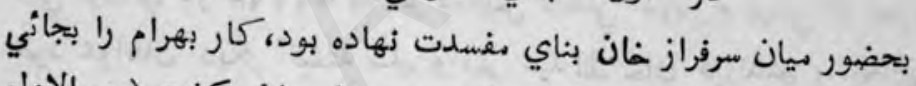

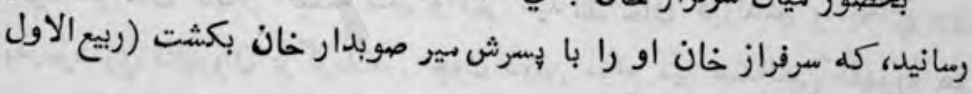

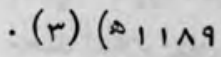

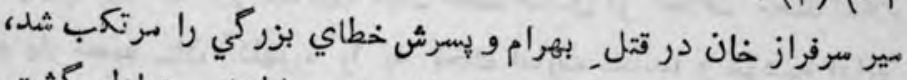

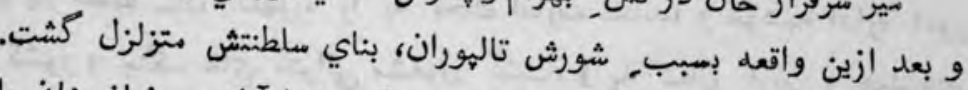

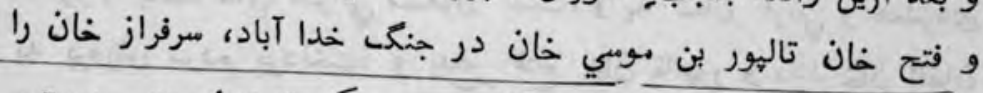

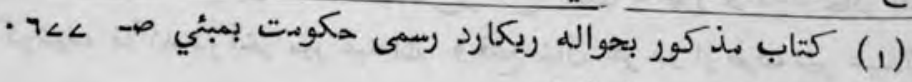

$$
\text { (r) }
$$

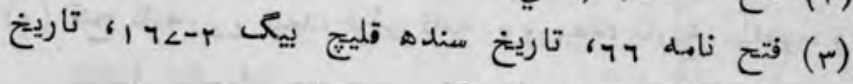

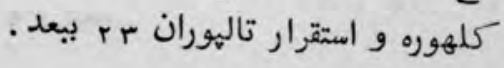




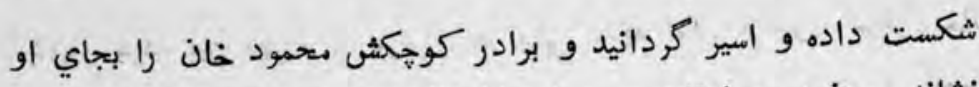

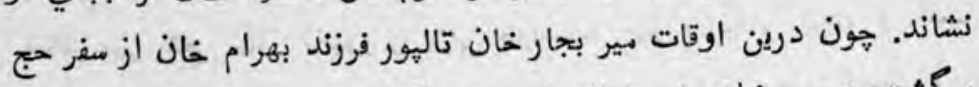

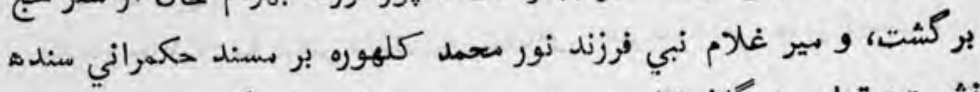

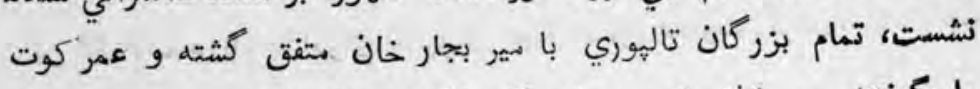

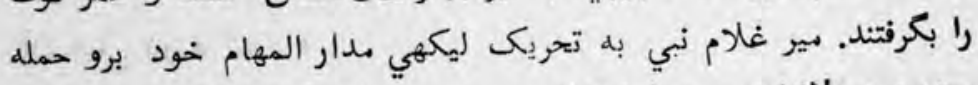

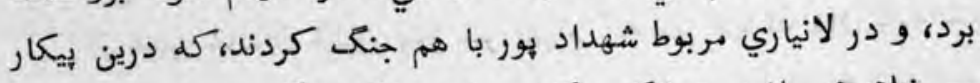

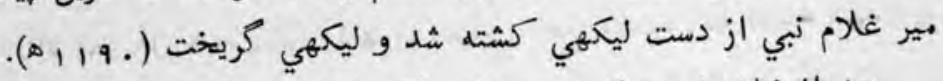

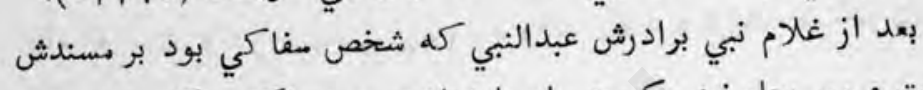

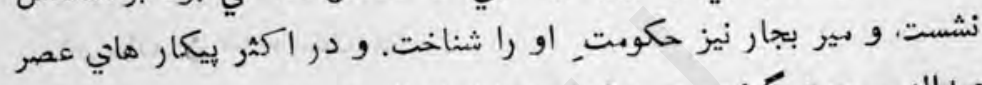

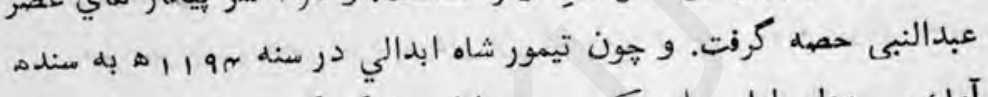

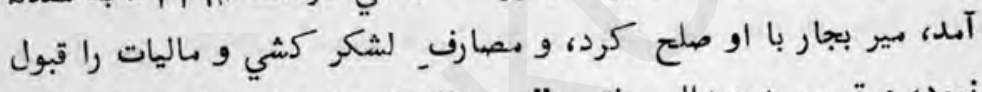

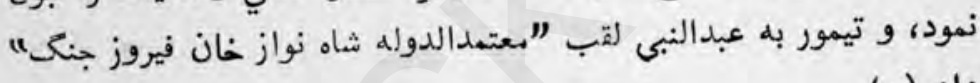

مير بجار در تنظيم امور حكومت با كمال تدبر و دور انديشي كوشيد.

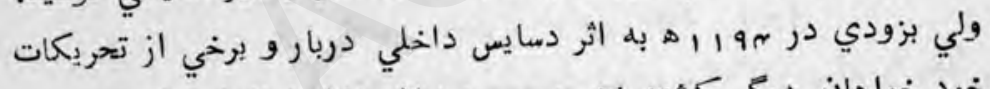

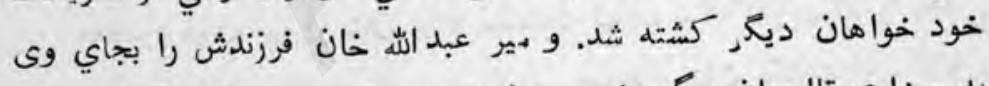

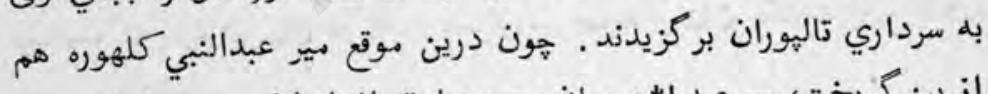

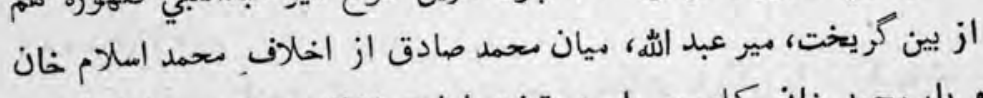

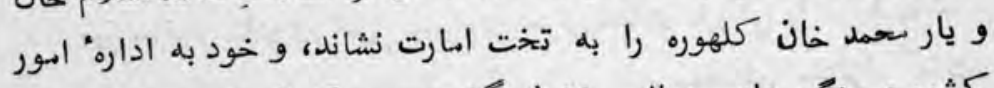

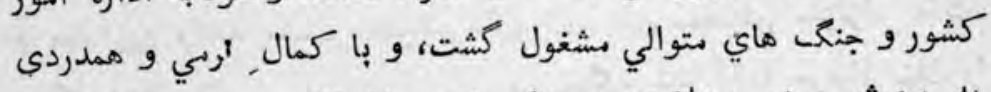

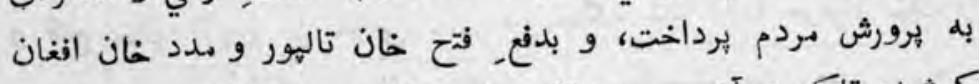

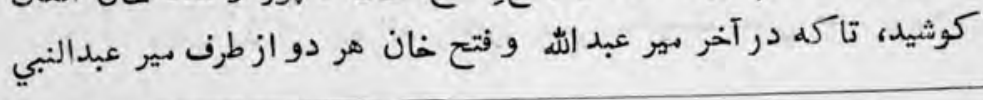

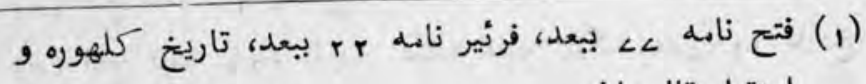

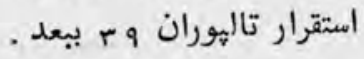




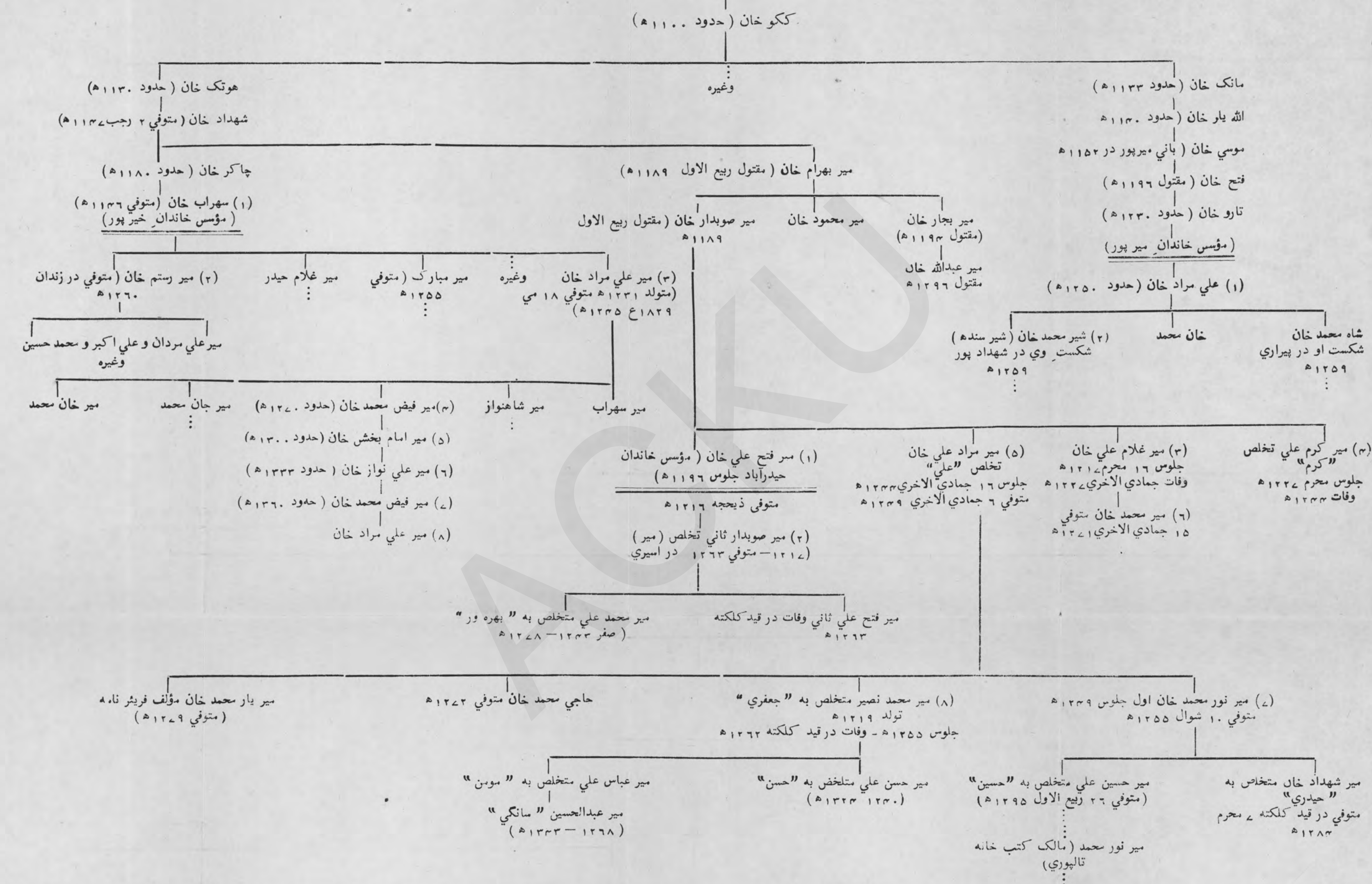

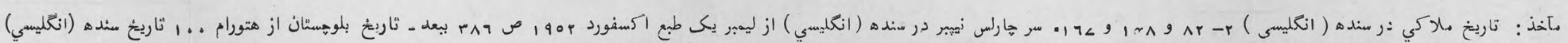

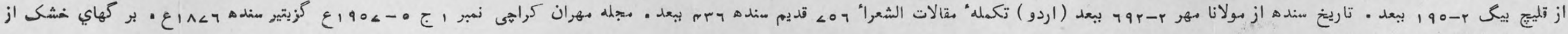

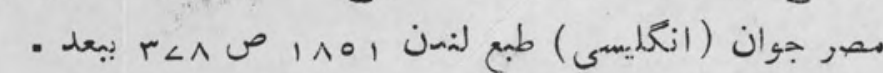




\section{كلهورو كشتd شدند}

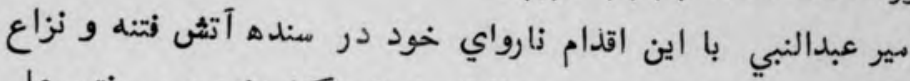
انكيخت، و سرداران تاليوري بعزم انتقام شمشير كشيدند، و بير فتح علي إني

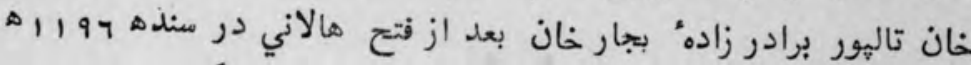

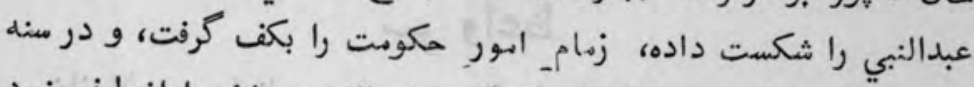

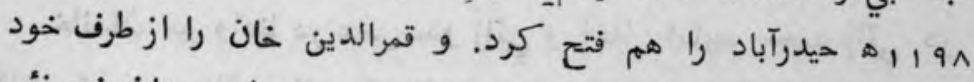

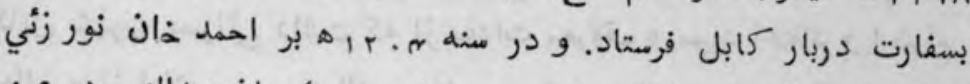

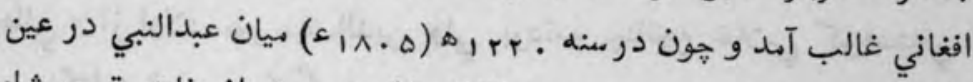

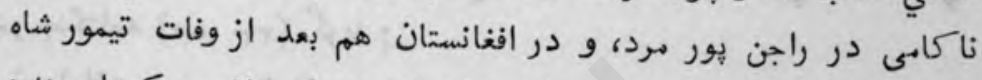

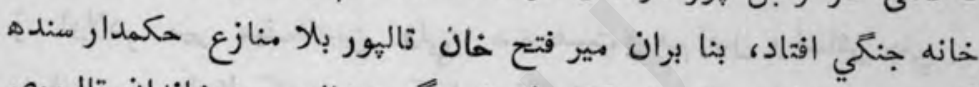

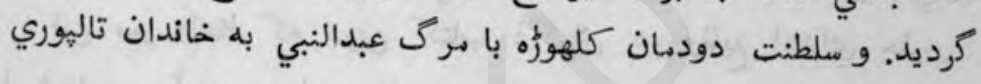
انتقال يافت (r) (r)

اينك شجره حكمرانان تالهوري رال ران براي تكميل معلومات متن كتاب حاضر در ذيل مي آوريم :

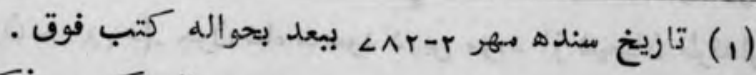

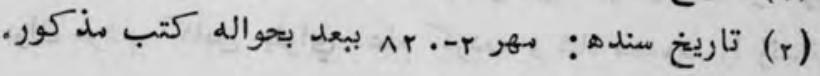




\section{$-<-$}

\section{مير واعظ}

خاندان مير واعظ در عصر سدو زائي و آغاز امارت محمد زائي در

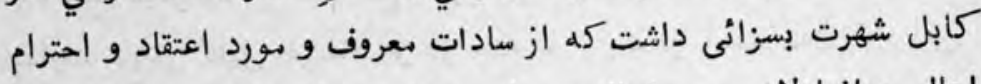

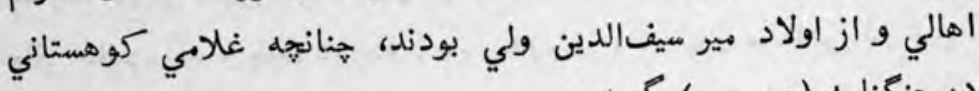

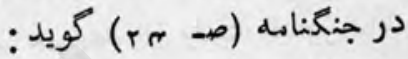

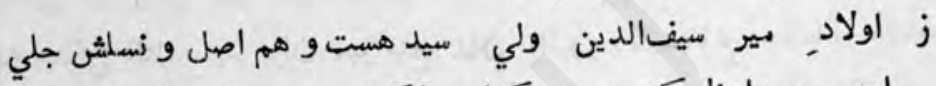

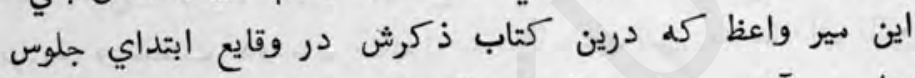

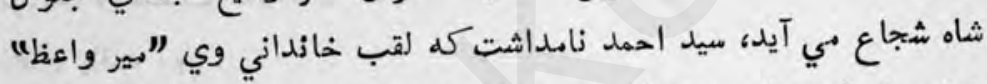

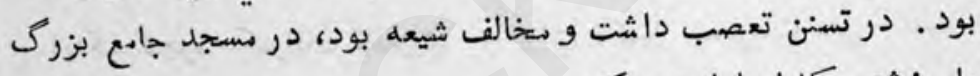

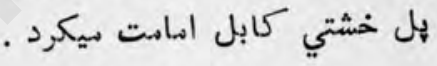

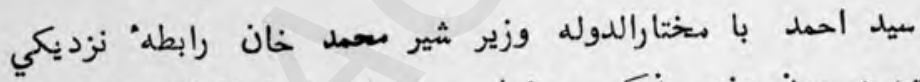

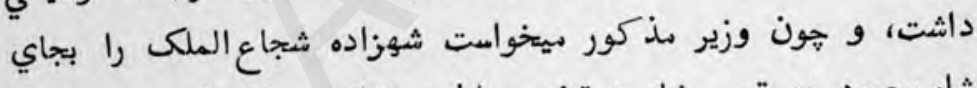

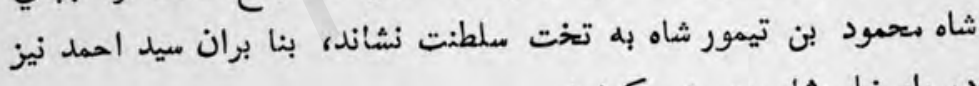

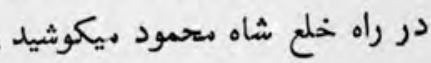
در سنه و ابمارهد در شهر كابل بين اهل, تشيع و سنيان نزاع افتاد.

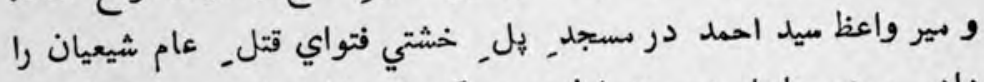

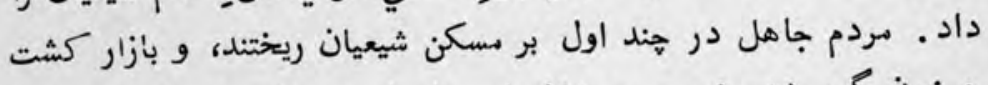

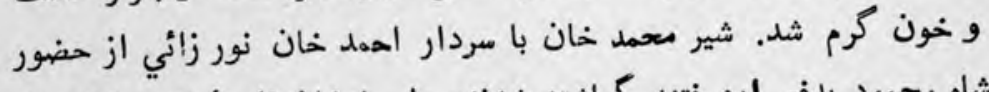

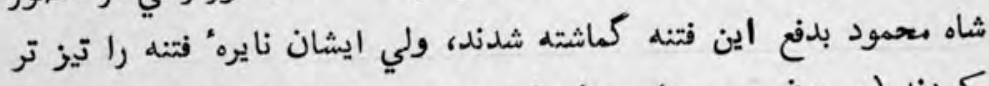

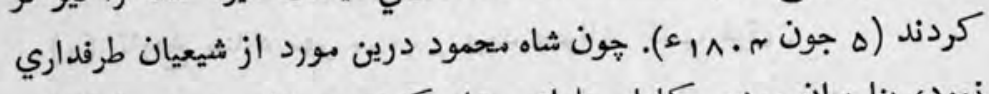

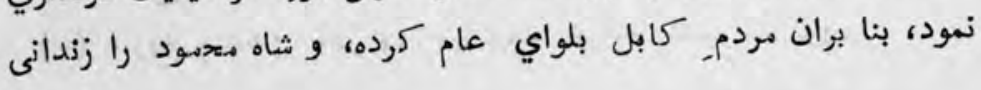




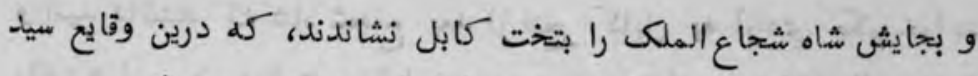

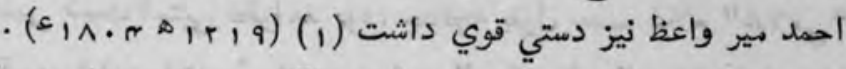

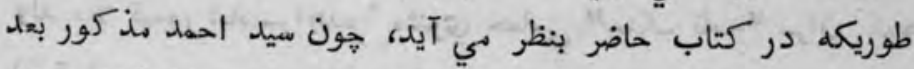

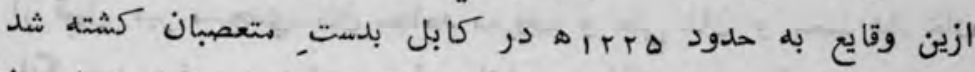

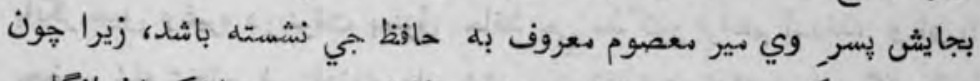

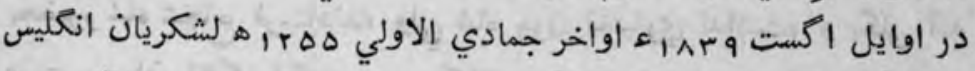

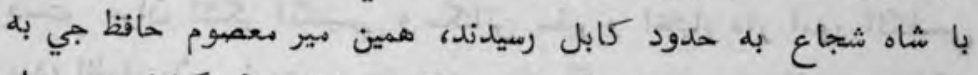

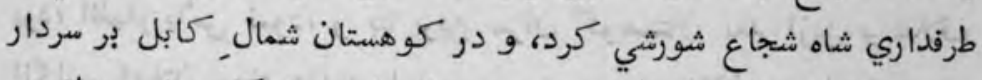

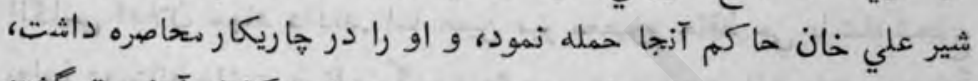

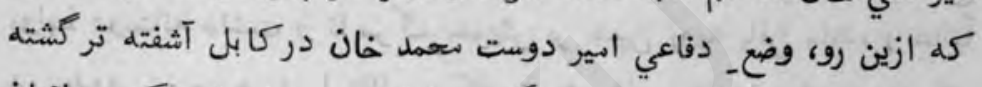

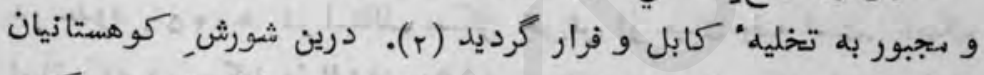

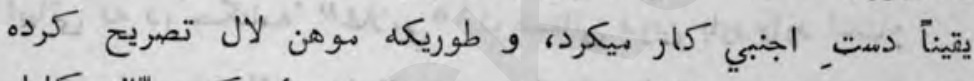

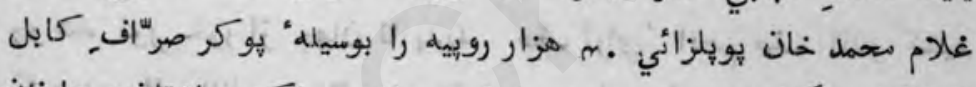

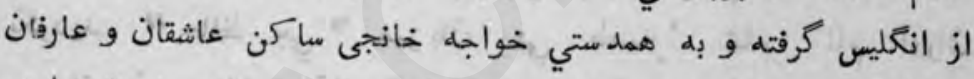

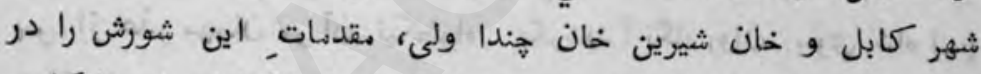

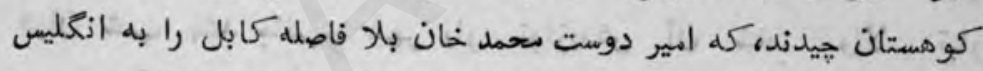

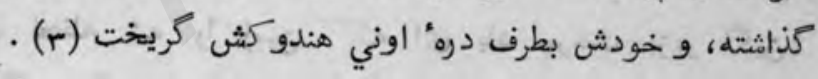

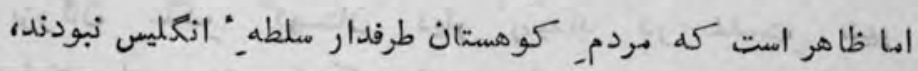

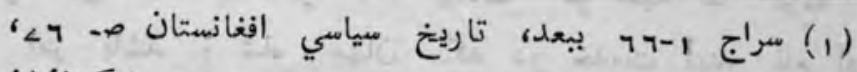

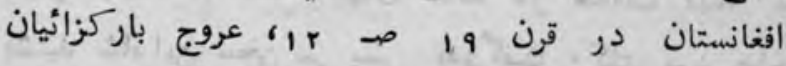

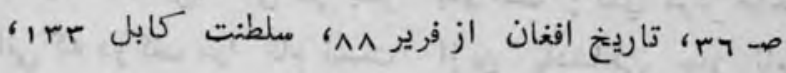

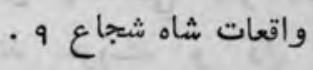

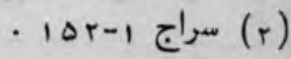

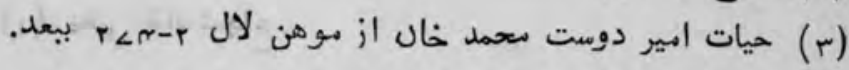


و اميد داشتند كه شاه شجاع بعد از فتح. كابل به آزادي حكم خواهد

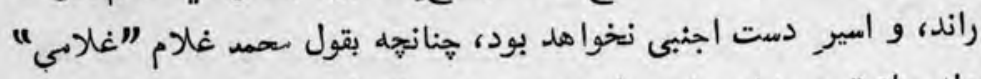

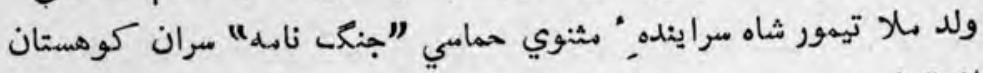

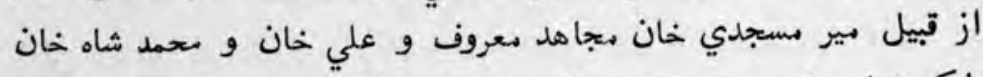

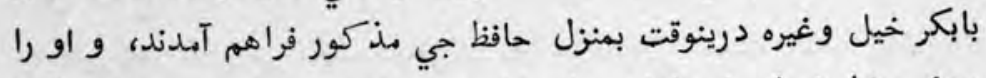

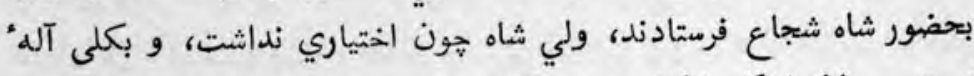

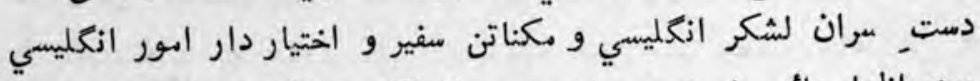

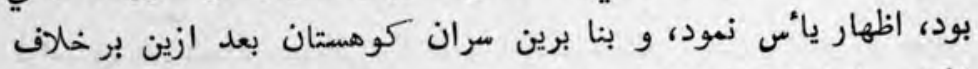

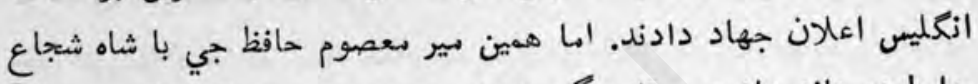

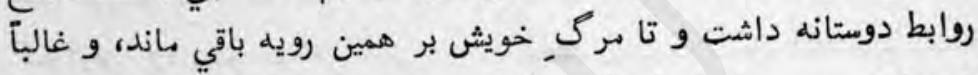

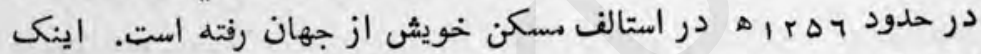

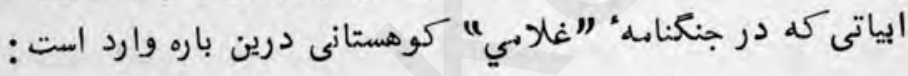

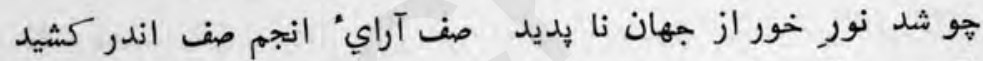

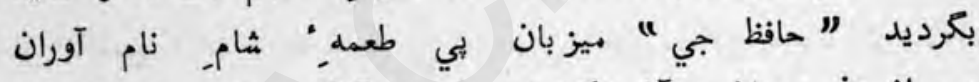

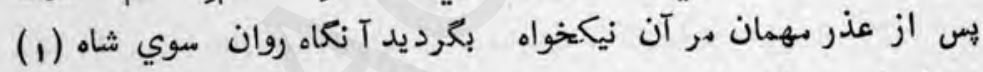

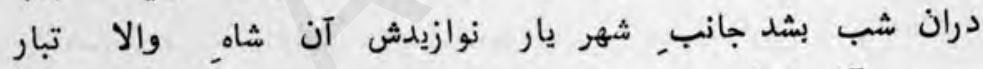

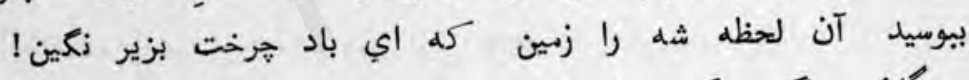

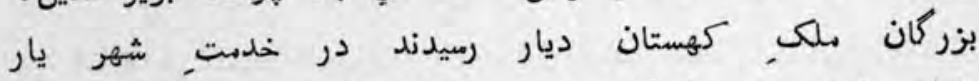

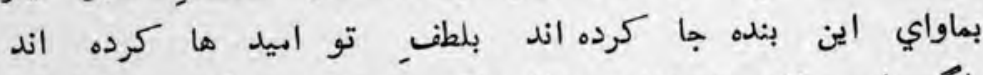

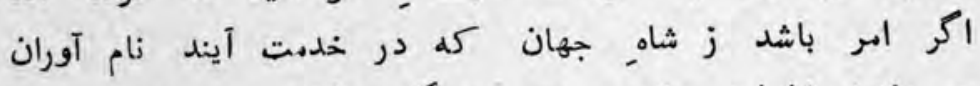

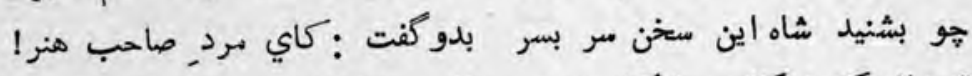

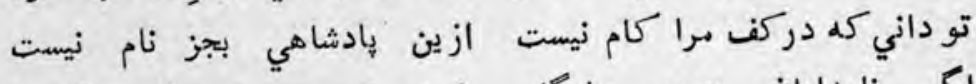

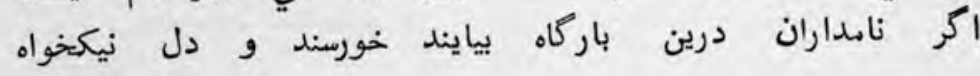




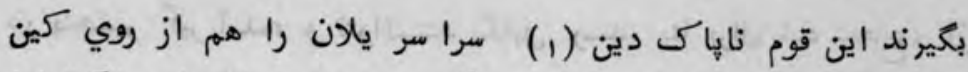

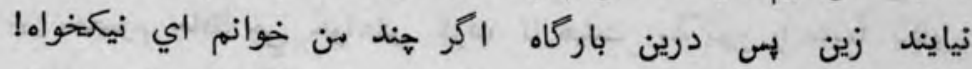

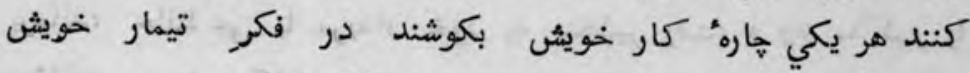

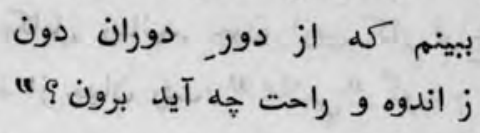

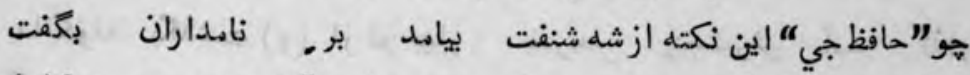

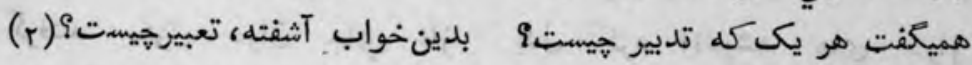

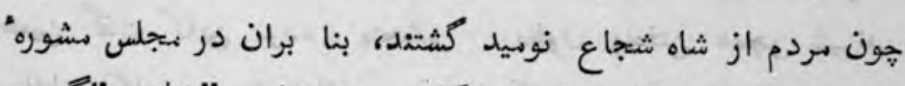

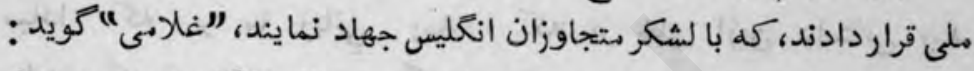

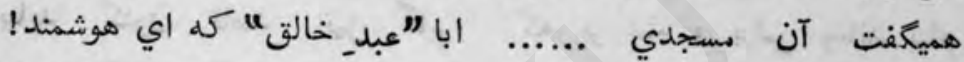

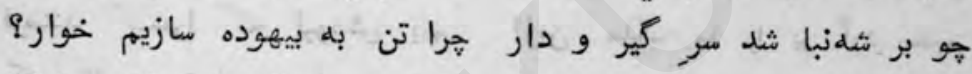

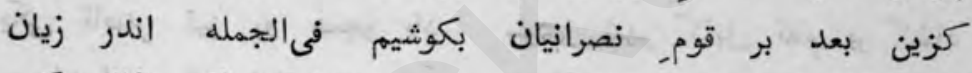

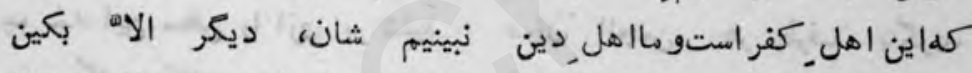

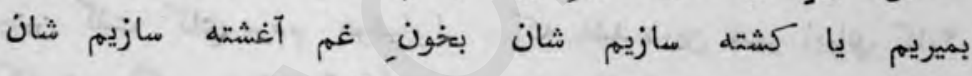

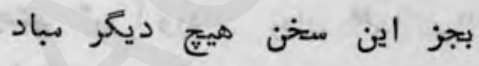

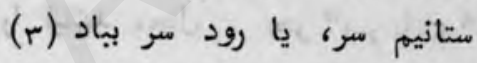

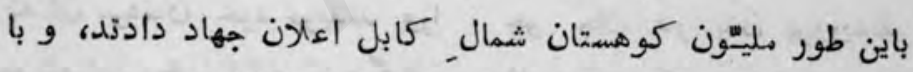

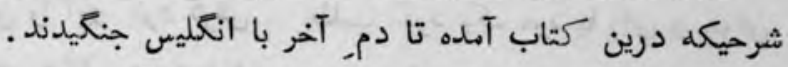

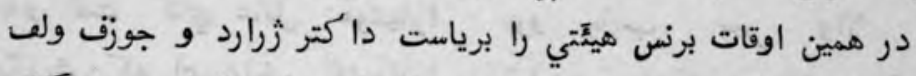

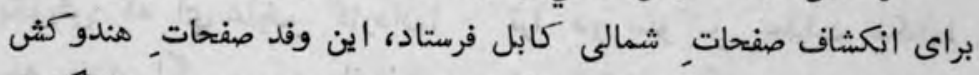

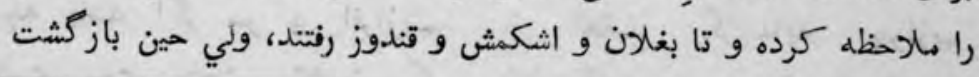

$$
\begin{aligned}
& \text { (1) يعنى انكليسيان. }
\end{aligned}
$$

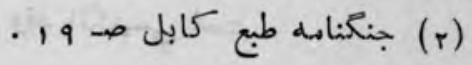

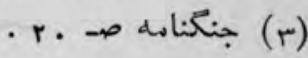


تعليقات

A. 7

در ينجشير كير آهده، و نتوانستيد بكابل رسند، بثا بران شاه شجاع، از

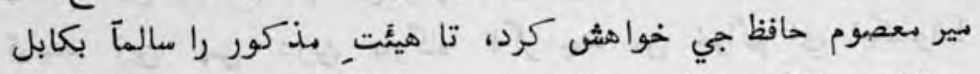

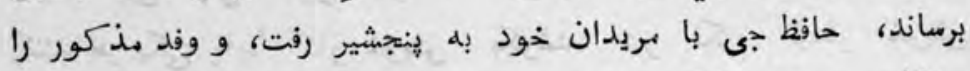

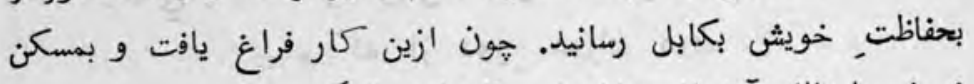

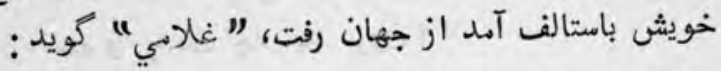

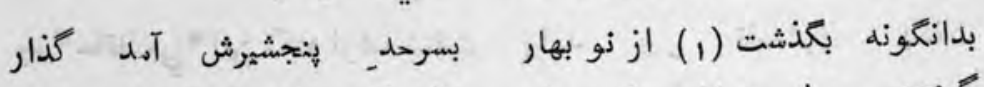

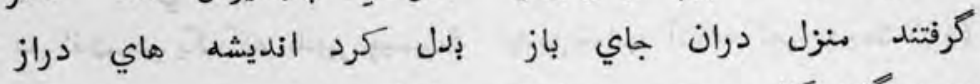

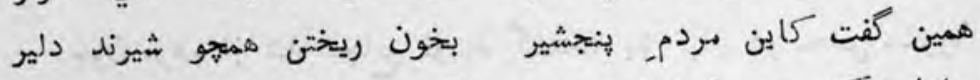

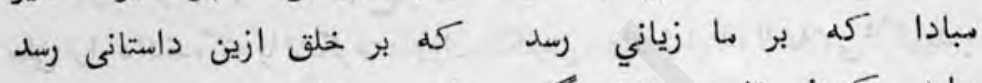

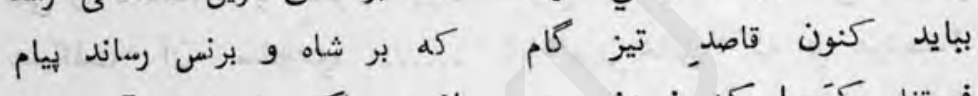

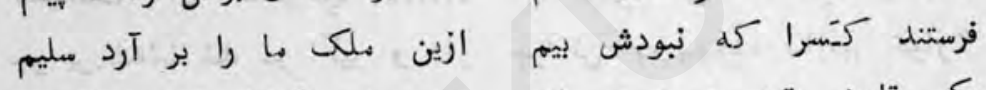

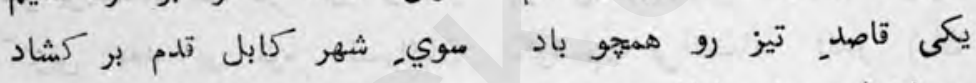

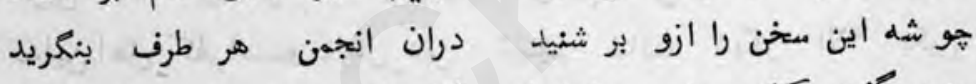

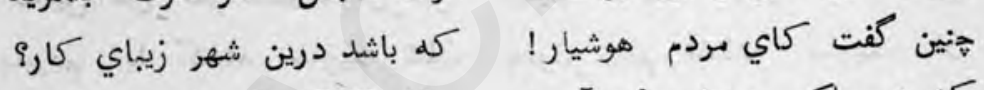

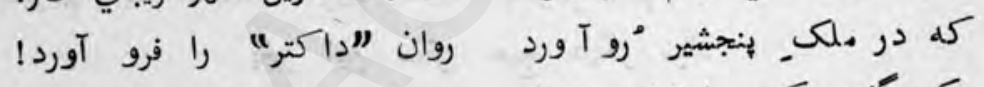

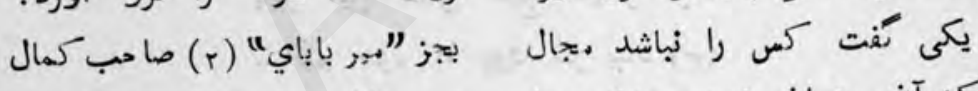

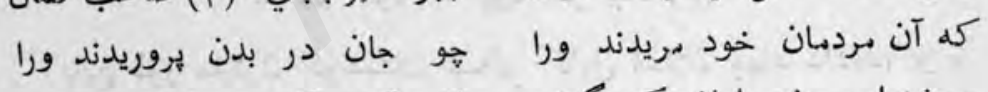

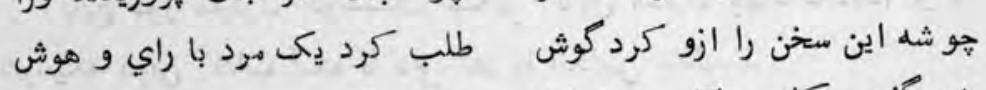

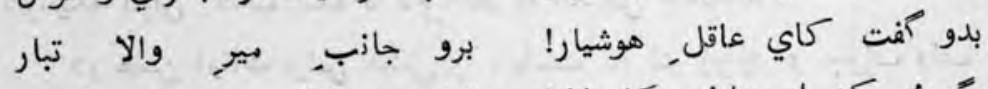

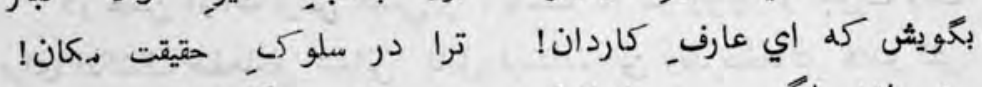

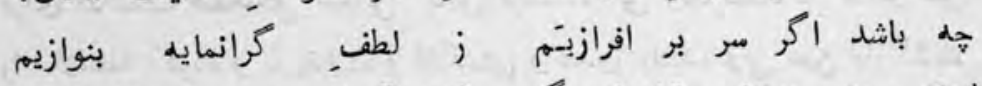

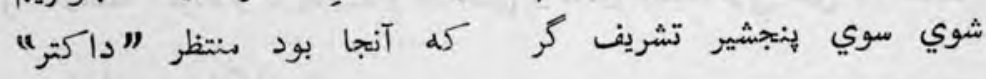

(1) مقصهد همان د كتر رئيس وفد ازحليسي است.

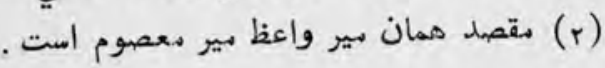




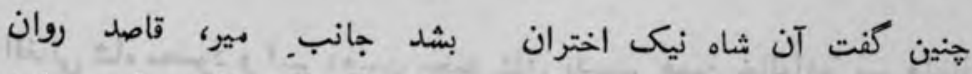

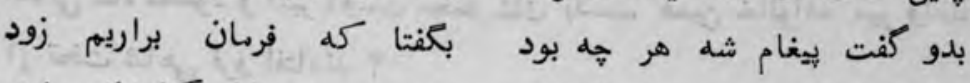

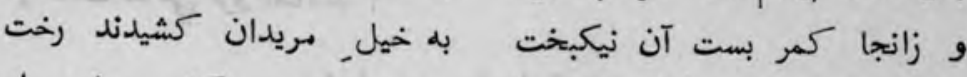

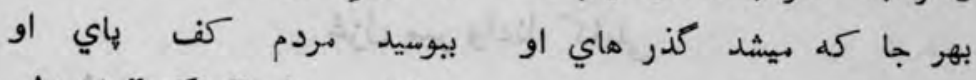

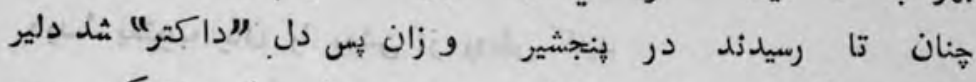

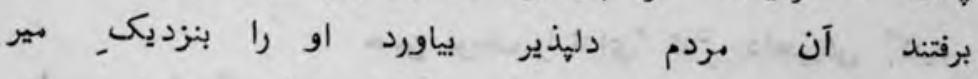
و زانجا سوي شهر كرد كابل خرام

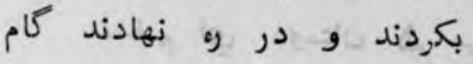

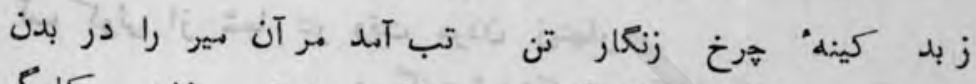

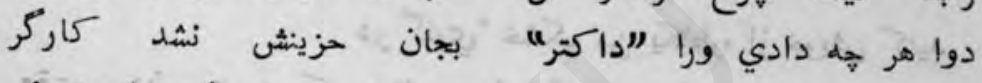

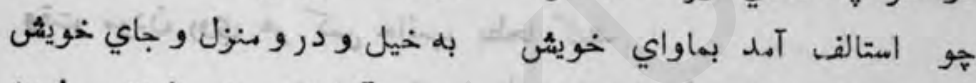

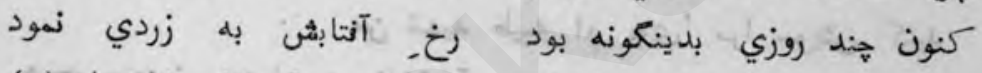

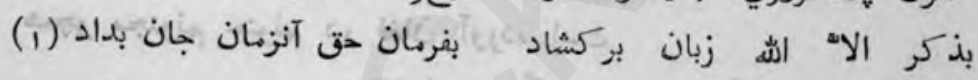

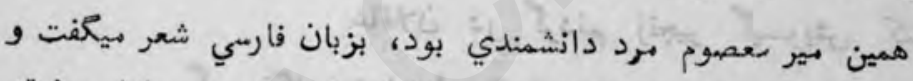

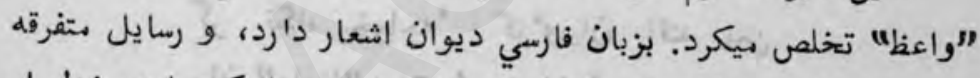

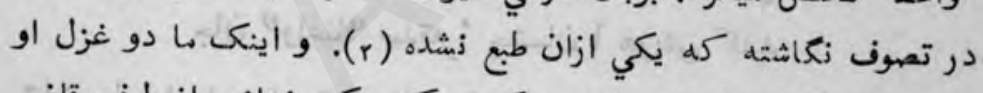

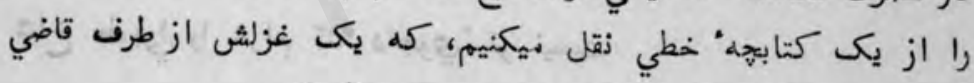

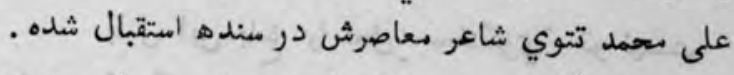

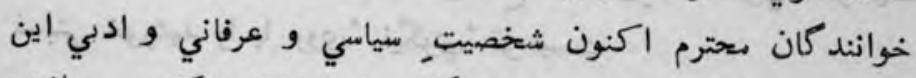

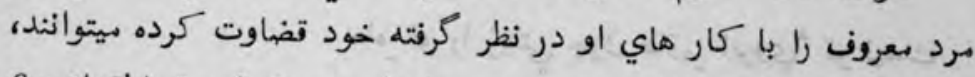

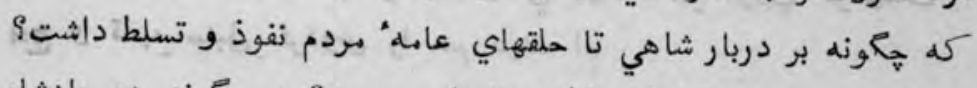

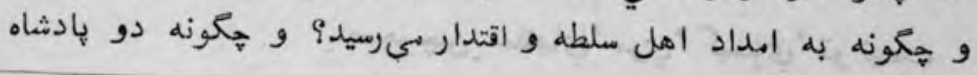

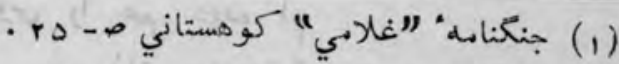

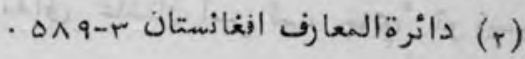


تعليقات

$\wedge \cdot \wedge$

افغانى شاه محمود و امير دومت سحمد خان بدست همين خانوادهُ مير واعظ از تخت شاهي فرو افتادند

غزل مير واءظ كانبلى

ديده" يعقوب جان را روشن از رويش كنيد

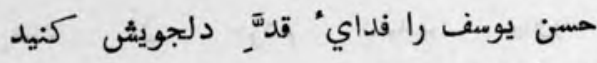

دل همي خواهد كه من دركوي" جانان مرد ممثم

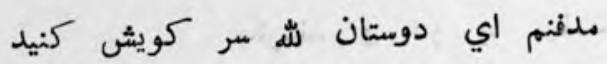

آب كوثر از شما در وقت مردن زينهار

در كلوي" خشك من من يكقطره از خويش كنيد

وقت مردن روي هر كس جانب بطحا كنيد

من شهيد طيبه ام روي" سرا سويش كنيد

همجو مجنونم جنونم در فغان آورده است

عاقلان در كردنم زنجير كيسويش كنيد

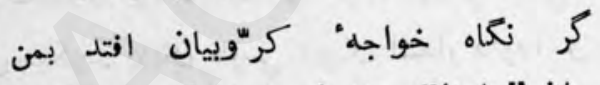

جان "واعظ" صدقه, "حشمان آ هويش كنيد

شاخ طوبيا را خرام قده دايجويث تو نيست

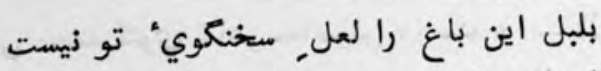

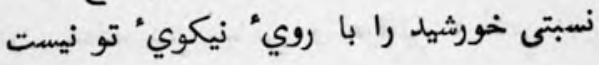

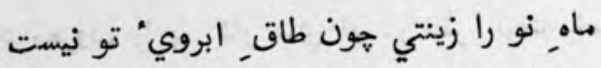

يَي و تاب_ منبل, فردوس را هم ديده ام

همخِو هين, حلقهايث موي" كيسوي" تو نيست

سلسبيل, جنت فردوس را هم ديده ام هوني

در مذاق عاشقان آبـ لب رام جوي" تو زيست 
^. 9

تازه نواي معارك

ايكه ميكوني خه داري آرزو در دل بكو

آرزوي" در دلم جز درو ديدن رون روي" تو نيست

اين همه ديوانكي ها در دلم از بهر هيست؟

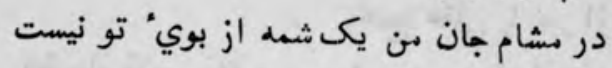

از طبيب, شوق برميدم علاج. درديـ دل

كفت جزعناب آن لب، هيت داروي" تو نيست

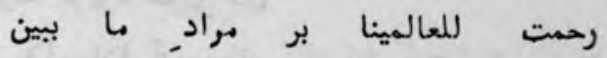

لرشيم اميد_ جهان با لله كله جز سوي" تو نيست

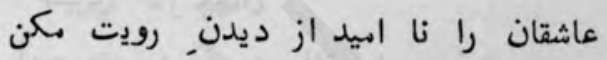

دست را بر سينه_:" دايل زدن خويث" تو نيست

مقصد, اقصاي" هجاج است بستانـ حرم

قصد_"واعظ" جزطواف كعبه " "كوي" تونيست

غزل قاضي علي محمد فقير تتوي

زينتى فردوس را هون كلشن. كوي" تو نيست

روزتي كلهايث جنت را بجز بوريث نو تو نيست

كر

درحقيقت ذرهاي از حسن, دلجوي" تو نيست

ياي بند, عقل مهدانيم كيسويث" تو هستي

باي كيري حهون كمند_ زلف, هندويث تو نيست

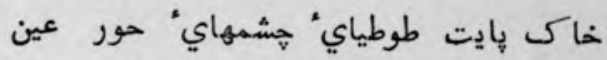

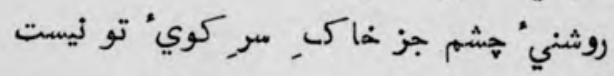

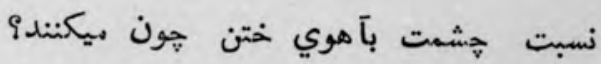

هيتج حششمى راخمار حششمر. جادوي" تو نيست 
تعليقات

AI.

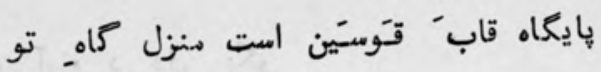
هيجّك را همسرى با زورِ بازوي" تو نيست

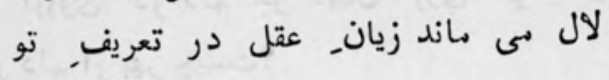
هيتج عقلي راخبر از مدح_ يكى موي" تو نيست

قطع باد آن سر كه در وي نيست سوداي" رخت

تيره آن دل كاندرو سودا و هاهوي" تو نيست نوخت

كور باد آن ديده كز مهرت نريزد خون دي دل

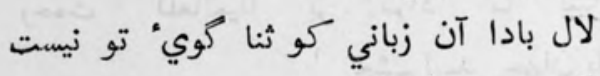

بي رخت هركز نهي بيند "فقيري" در جهان

آرزو بس جز نكه در طاقـ ابروي" تو نيست

اين غزل اندر جوابــ مير واءظ آنكه كفت

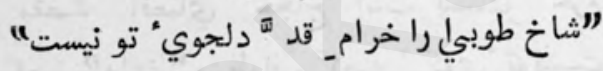


وزير اكرم خان امينالهلك با ميزذي يوِيلزئي

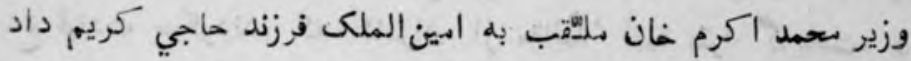

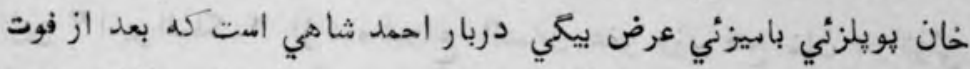

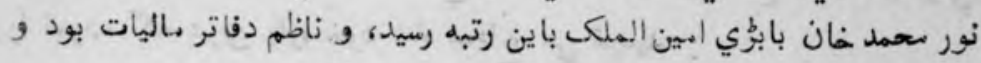

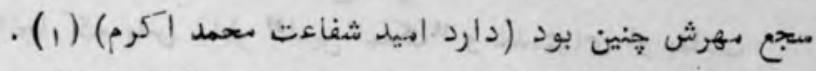

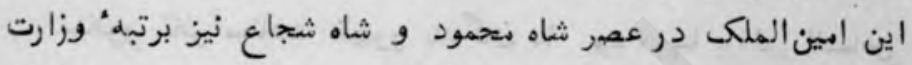

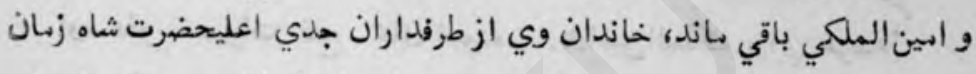

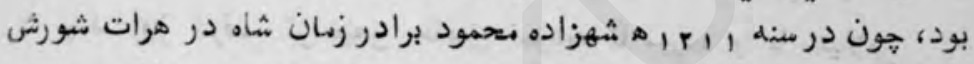

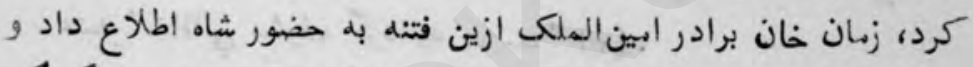

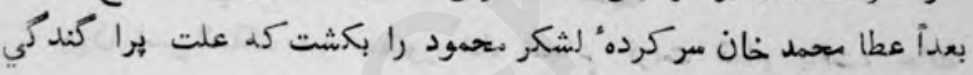

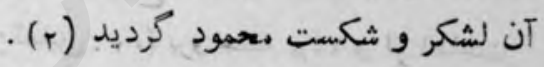

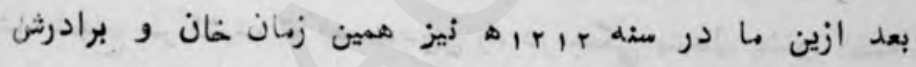

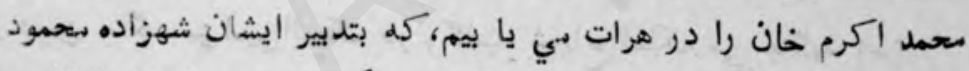

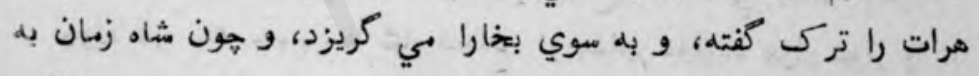

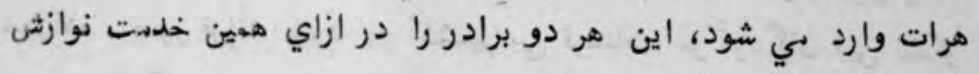

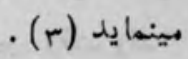

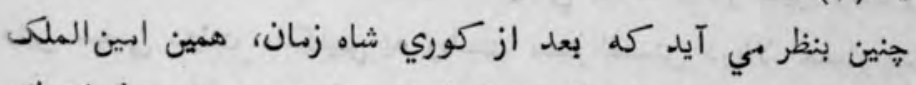

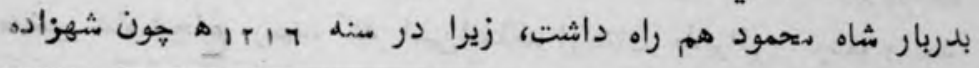

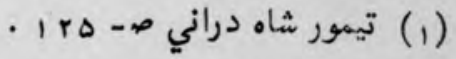

$$
\begin{aligned}
& \text {. سراج (r) } \\
& \text {. مراج (r) }
\end{aligned}
$$


شجاع الملك از بشاور برخاسته و شورش كرد، وي با شصت سوار بركاب

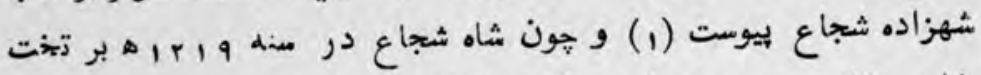

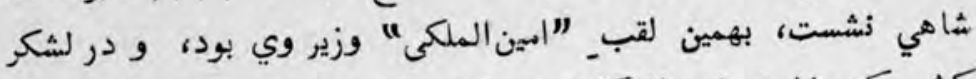

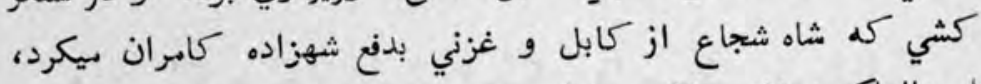

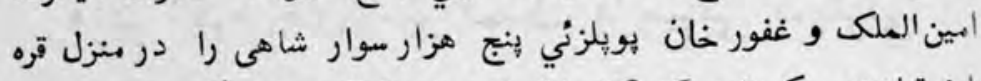

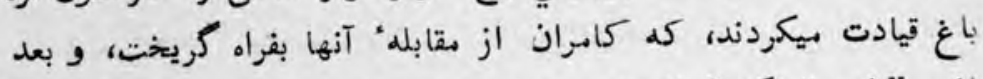
ازين " ا.ين الملك " از شاه شجاع التماس عفو وزير فتع غان باركزئي

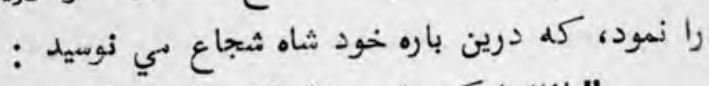

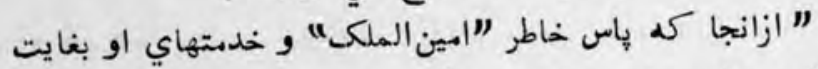

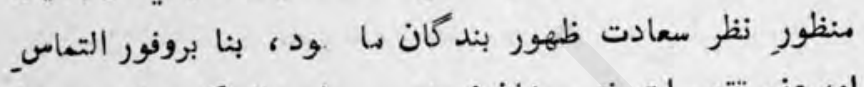

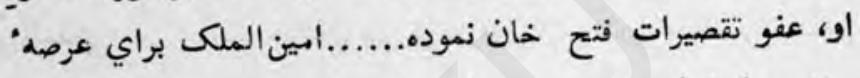
هند روز شرف تر خيص حاصل نموده، نا مبرده را با ستيلامه

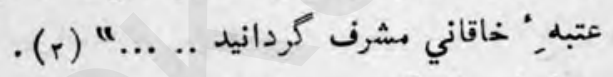

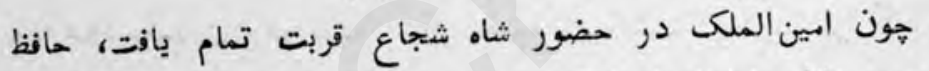

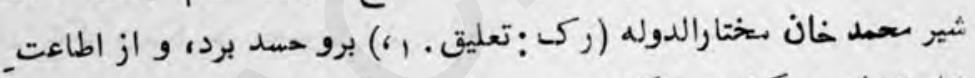

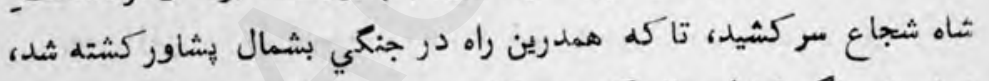
و درين جنكى نيز ابينالهلكى در ركابــ شجاع الملك مي جنميد (r).

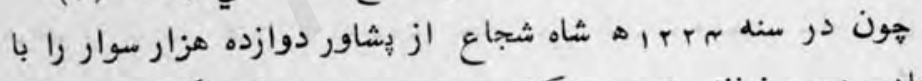

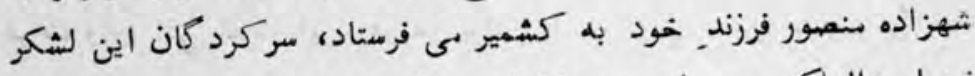

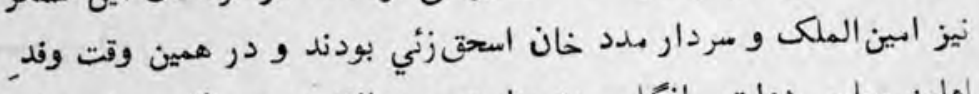

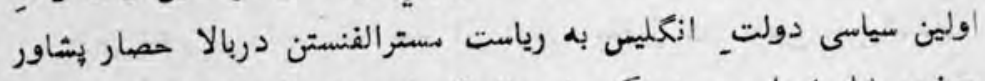

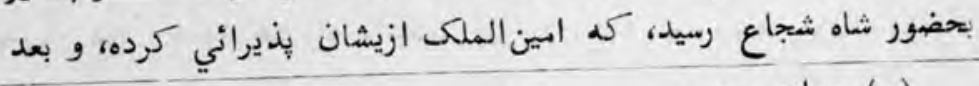

$$
\begin{aligned}
& \text {. } 7 r-1 \text { (1) } \\
& \text { • }
\end{aligned}
$$

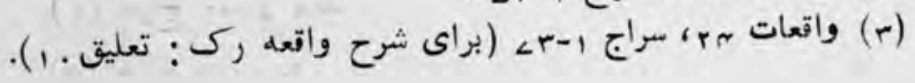




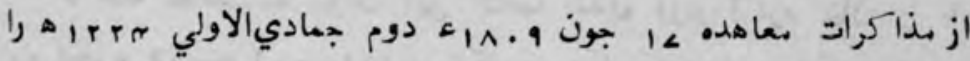
با شاه عقد كردند و خود امين الملكى به كشمير روي نهاد، ولى درانجا

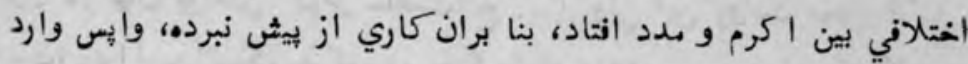

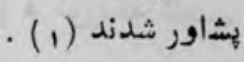

درينوقت شاه دحمود و وزير فتح خان باركزائي از كابن تهيه لشيكر

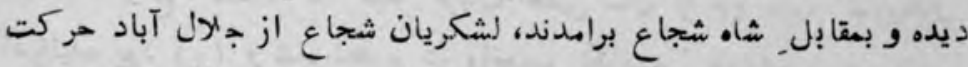

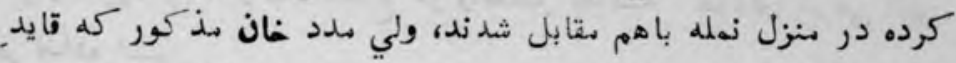

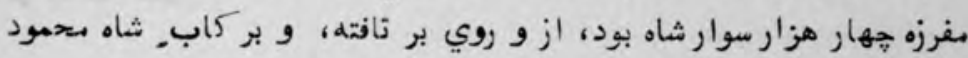

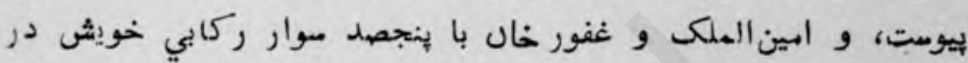

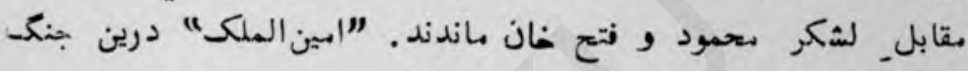

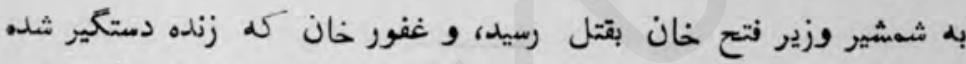

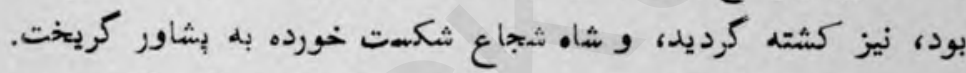

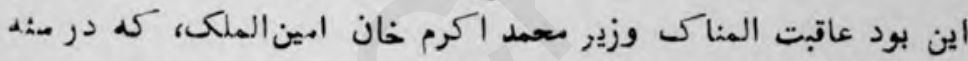

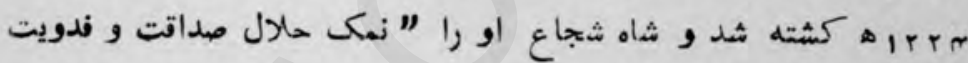

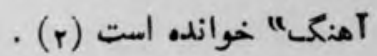

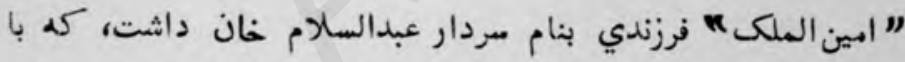

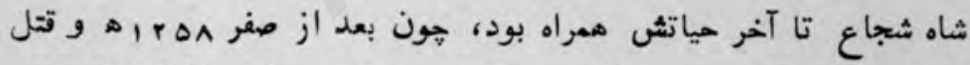

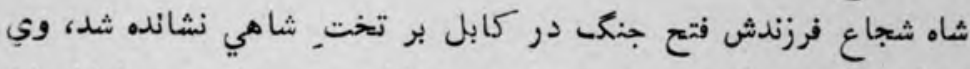

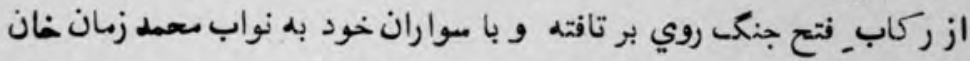

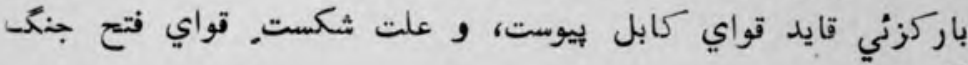
كرديد (r) (باركي

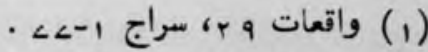

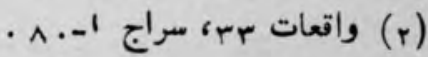

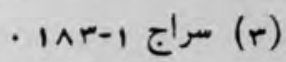


تعليقات

NIN

نا كفته نماند كه مؤلف اين كتاب آمدن وزير اكرم خان ران آمان

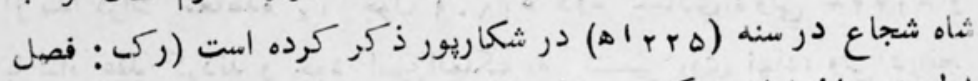

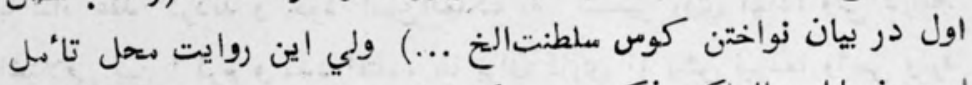

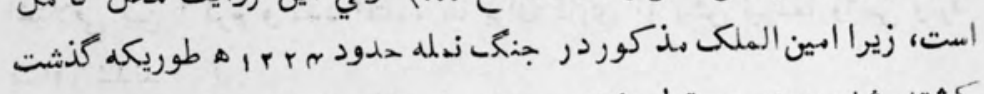

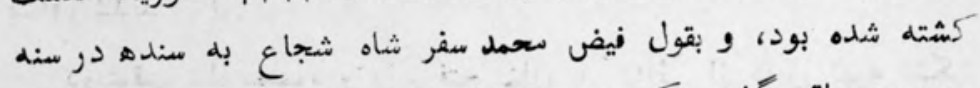

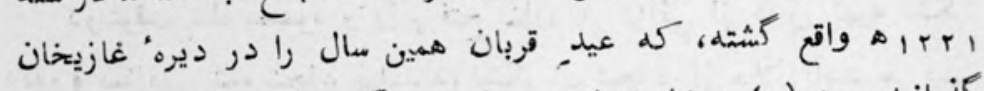

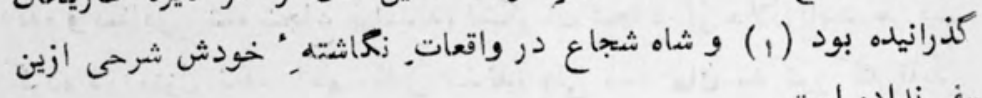

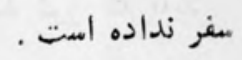

$\cdot 1-1$ - سراج 


\section{$-9-$}

\section{ذواب ولى مجمدل خان لغارى}

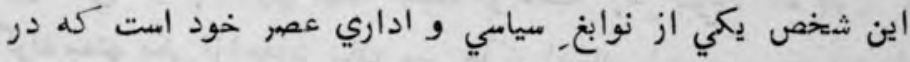
سر زمين سنده همجون او مردى دانشمند و جنكجو و سياست مدار و مدبيّر

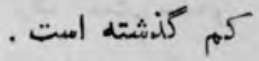

'لغتاري قبيله ايست از بلوج، كله دور سند عليا تا حوالي د ديره جات

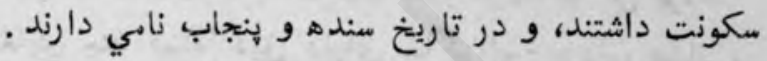

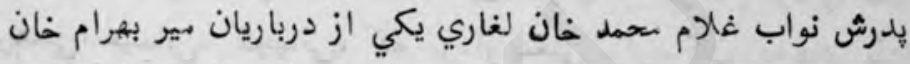

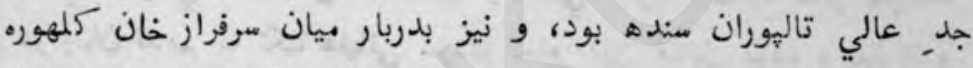

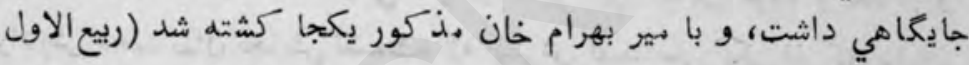

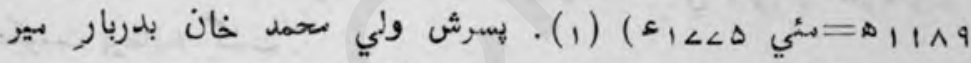

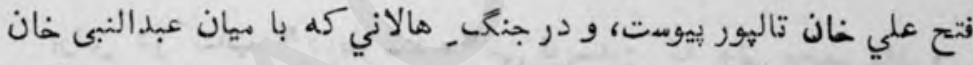

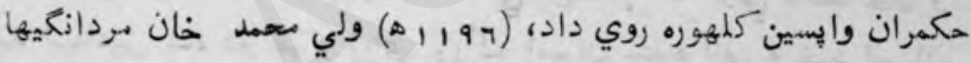

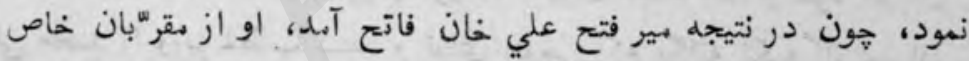

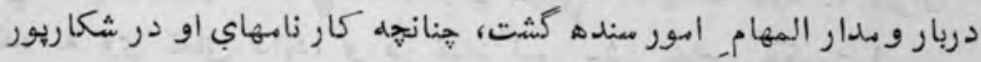

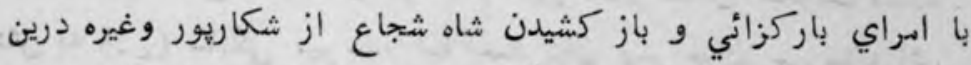

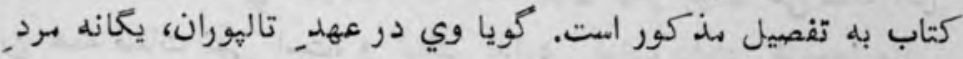

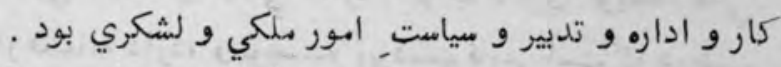

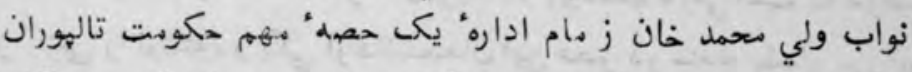

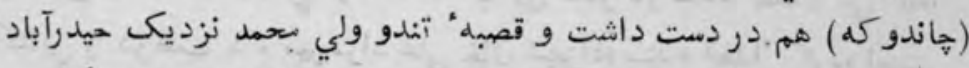

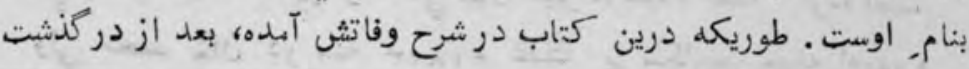


وي رخنه' نفاق در خاندان تالهوريان افتاد، و نظمم و نسق المور ملكى و

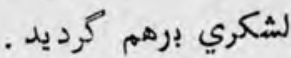

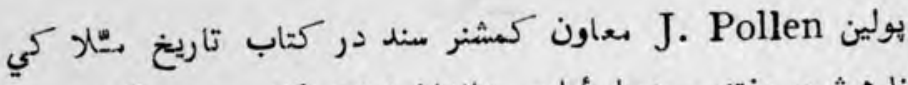

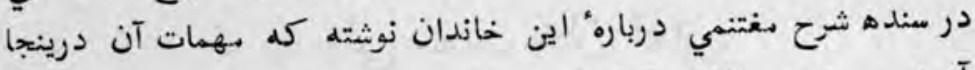

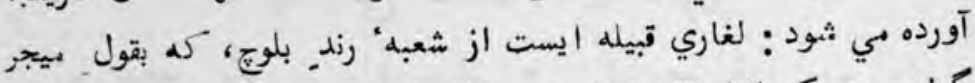

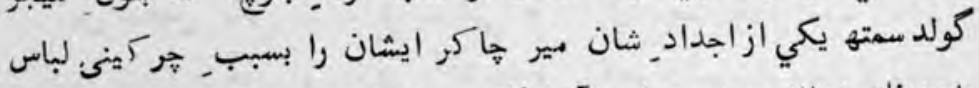

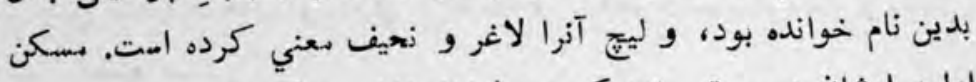

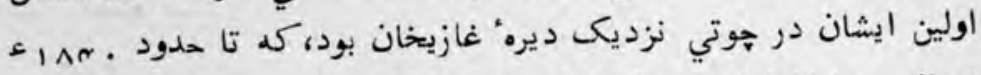

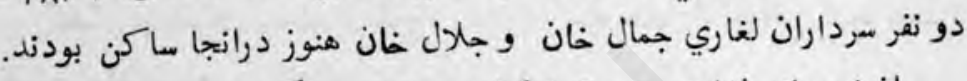

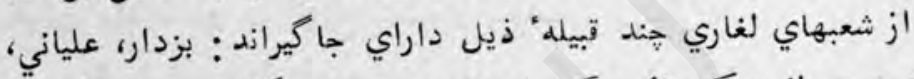
برهمني، عيساني، كجهاني، كله بزدار بمعني دارند كان رمه هاي بهُزاند،

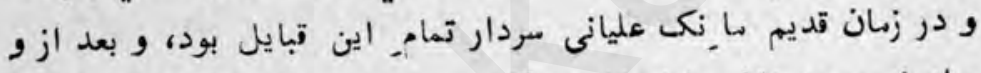

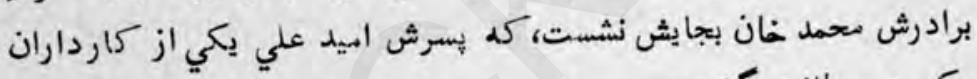

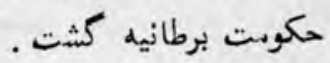

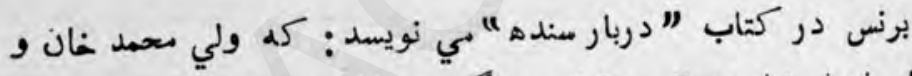
ميد اسماءيل شاه دو نفو و زراي بزرك ابيران سنده اند، و خود ابيران ولي معمد را وزير خطاب كنند، و قواي بلوجي كه يكانه تكيه كاه ايتيران

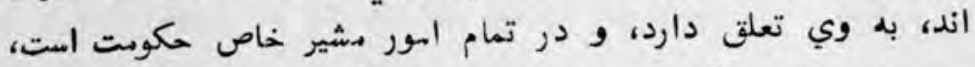

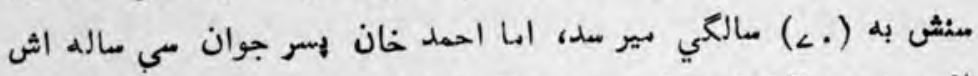

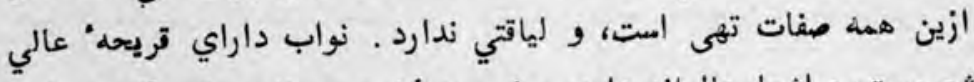

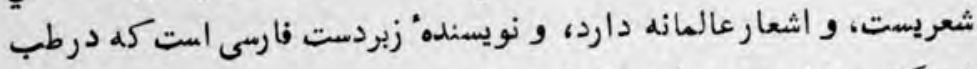

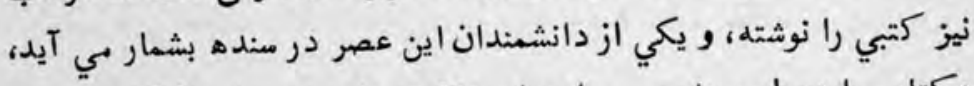

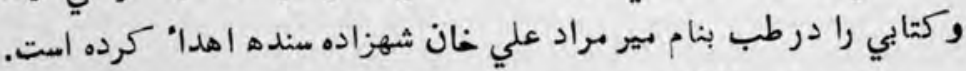

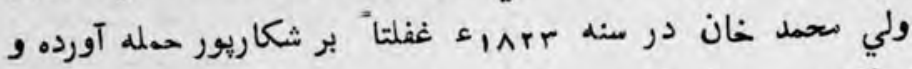

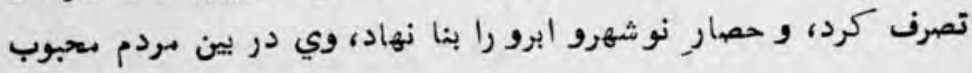




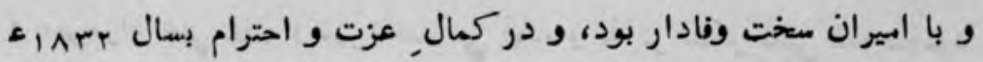

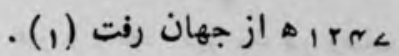

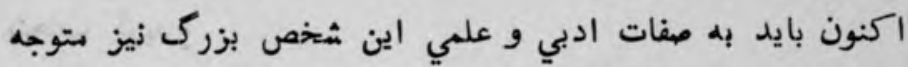

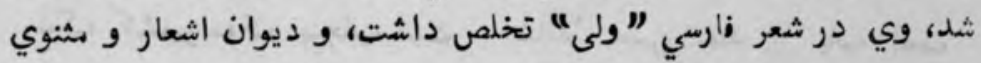

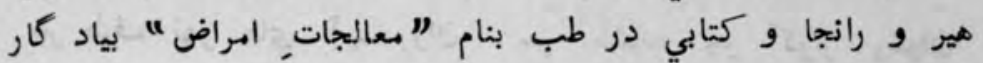
كذاشته است.

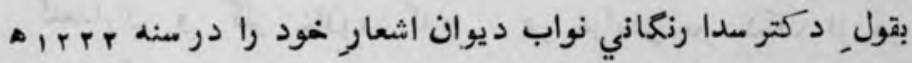

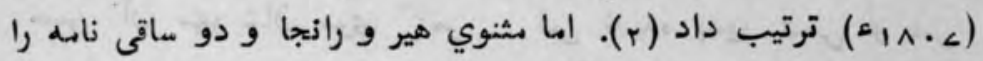

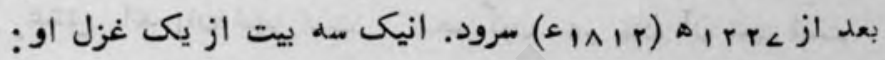
درياي غصه را بن و هايان بديد نيست

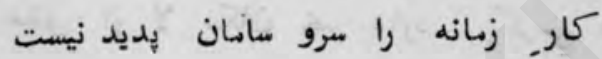

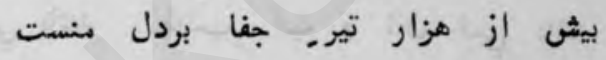

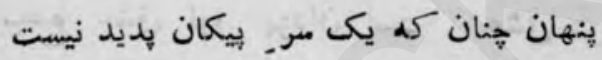
كفتم كه ج'ن ز حادثه برديم بر كنار

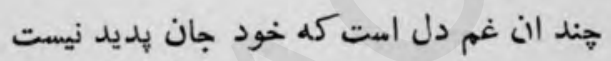

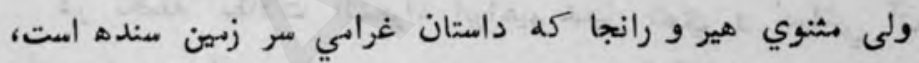

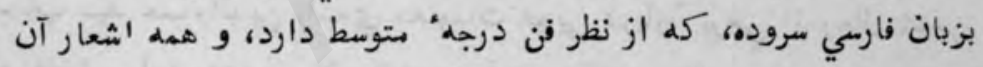

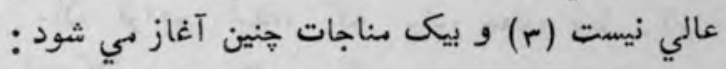

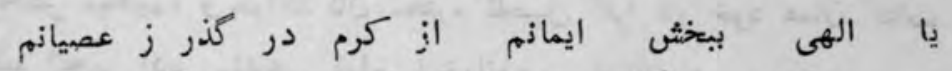

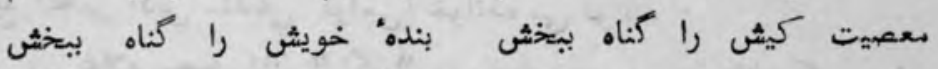

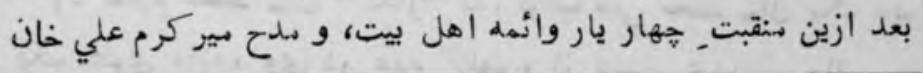

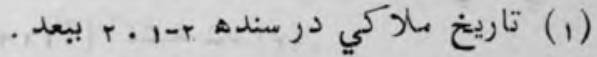

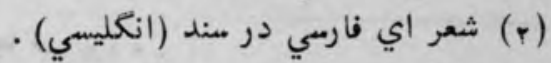

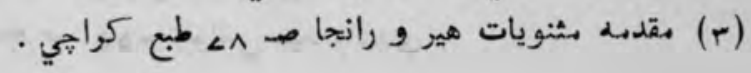




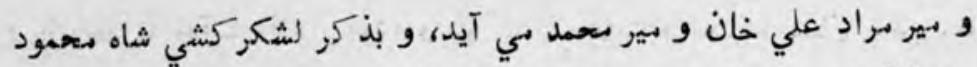

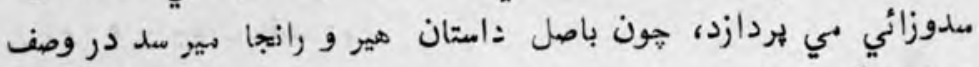
نونجاب كويد

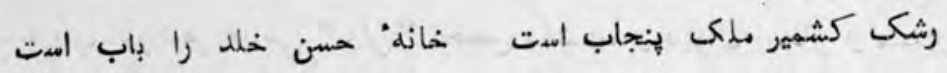

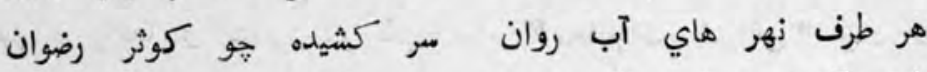
طرفه آن شهر راست آب و هوا

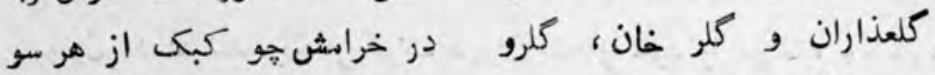

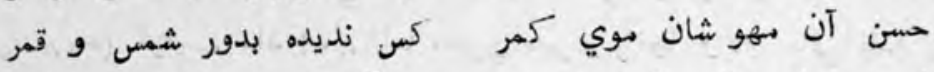

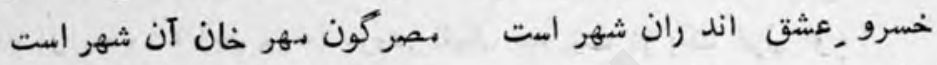

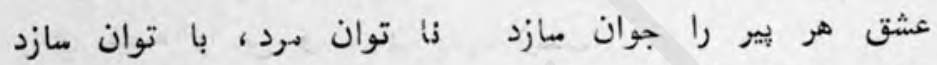

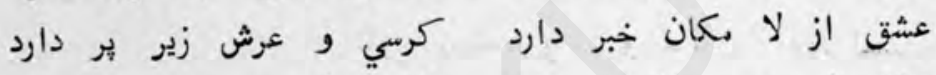

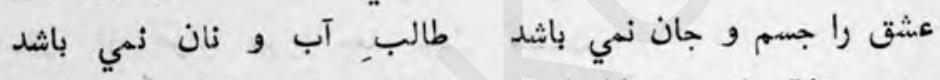

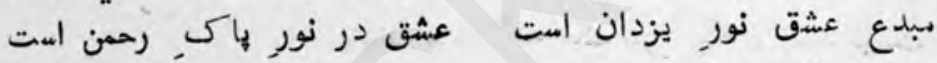

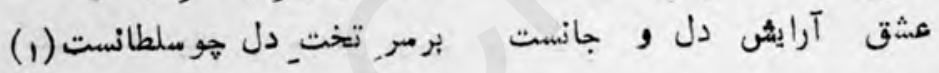
…

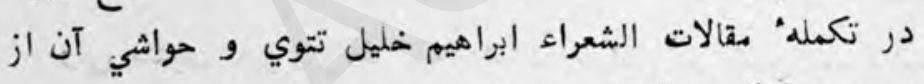

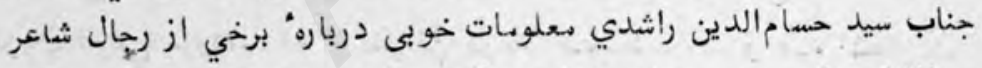

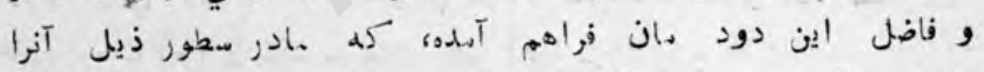

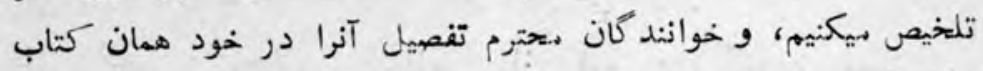

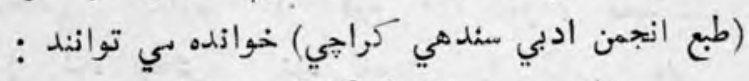

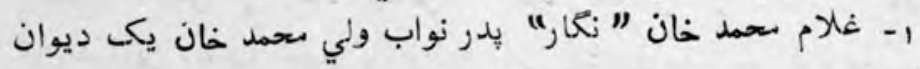
و يكى مثنوي دارد، وي در عهد كلهوره از دست عبد عبدالنبي والي منده

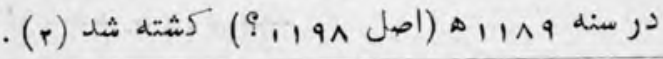

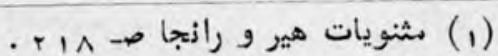

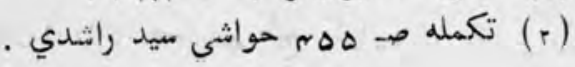




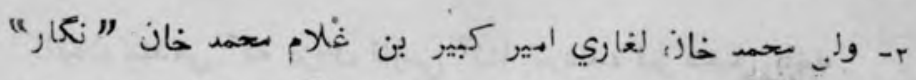

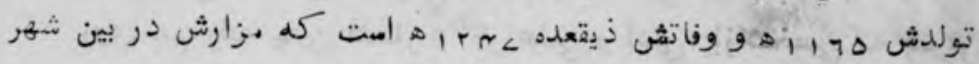

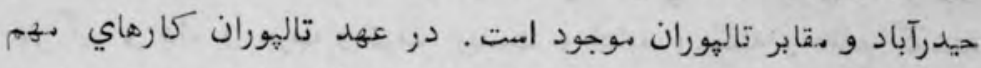

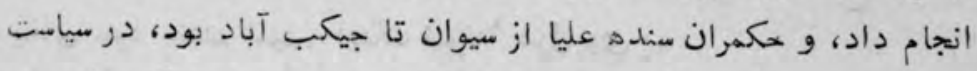
و حكومت و رزم آرائي نامي كشيد، در طب و شعر و ديكر علموم نيز مهارت داشت، آثار علمي وي : ورمي

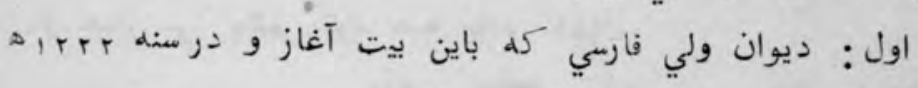
تكميل شده:

آلهي جوهر آرا ساز شمشير زبانم تهوه

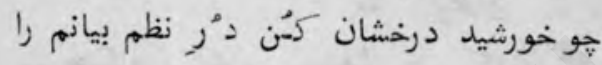

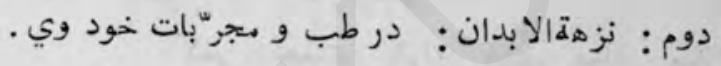

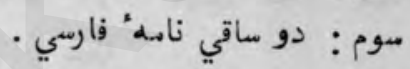

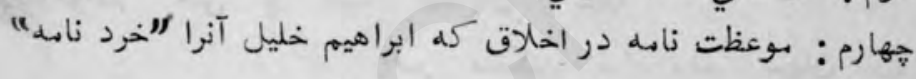

ناميده أست

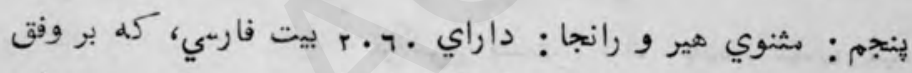

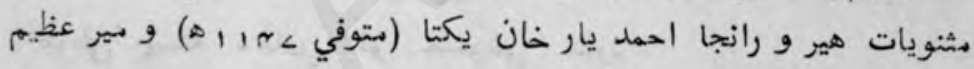

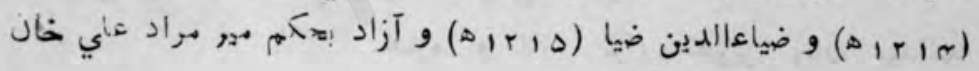
تالهور سروده است، وي وه ويد

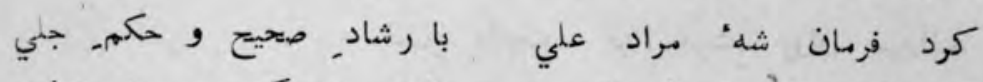

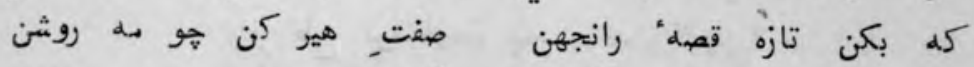

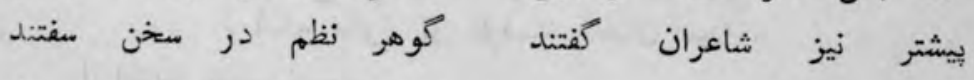

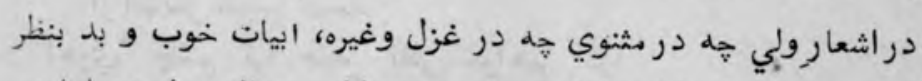
مي آيد، برخي از اشعارش نهايت سليس و روان و جالب است، أسا در برخي شكستكيها و تعقيد و ابهام زيز موجود است، كله دران شايد تصحيفات 
تعليقات

Ar.

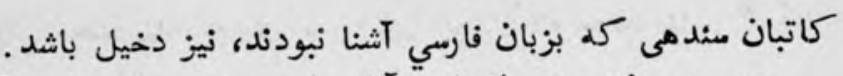

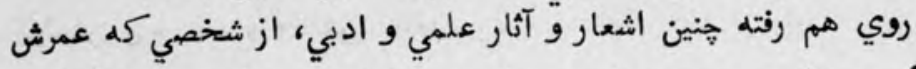

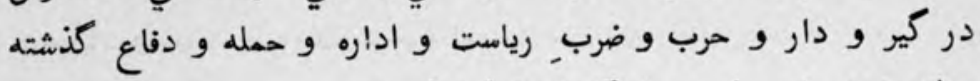

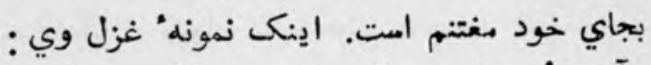

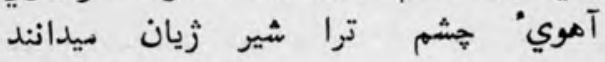

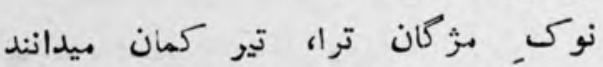

از خمار مي" جشمر, تو، همه باده كشان

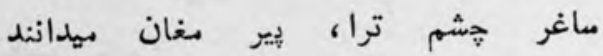

نهل بندان رياض, تو هو قمري بجهمن

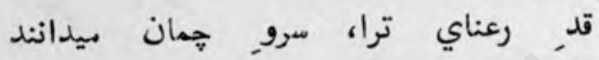

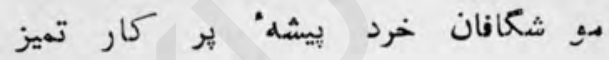

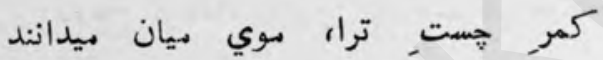

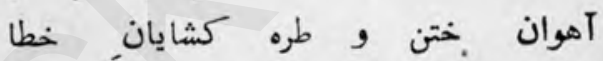
زلف. مشكين ترا، دامر جهان ميدان

من هرا از نظر شوخ. تو شوري فكثم

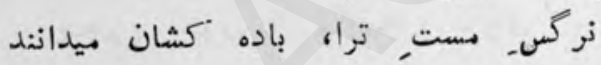

طوطى" بيسته دهان

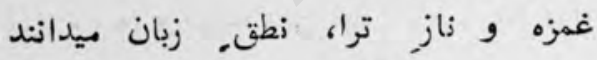

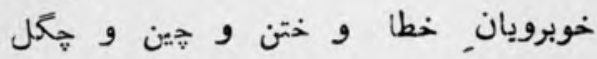

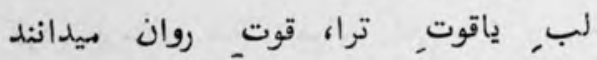

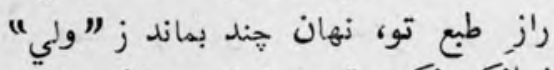

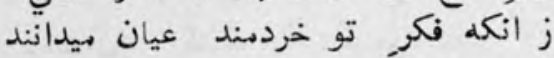

از ابيات_ خوب اوست : هوبه

آهوي" جششم ترا صيد, نظر خواب اهم

دامه تسخيز ترا آه سحر خور خواهم كرد 
NTI

تازه نواي معارك

عقد بروين بسر هرخ هو تابان ديدم

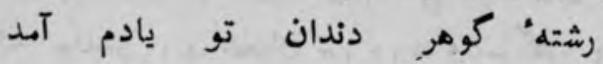

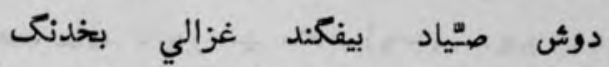

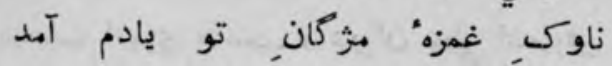

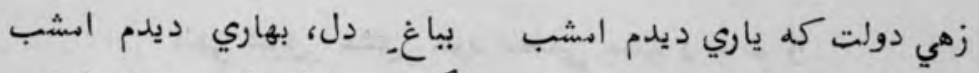

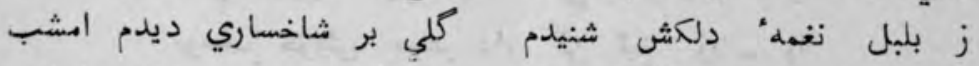

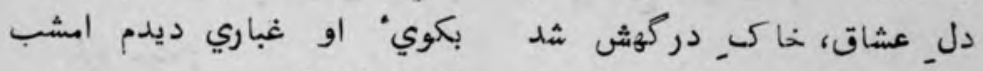

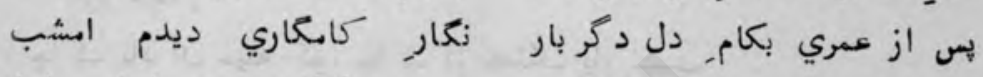

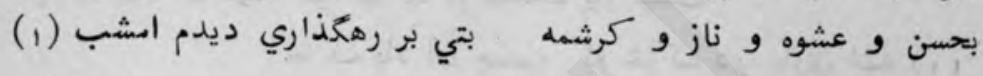

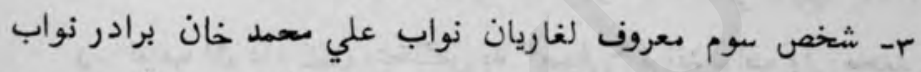

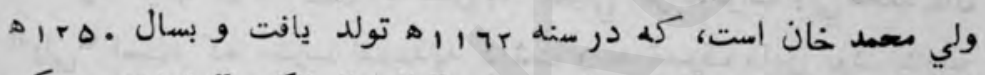

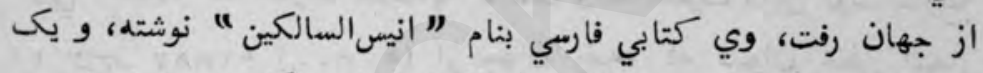

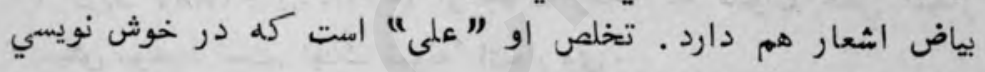

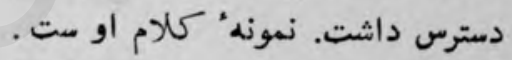

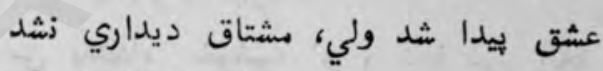

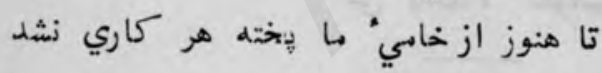

از قساوات طبيعت مانده ام اندر حجاب

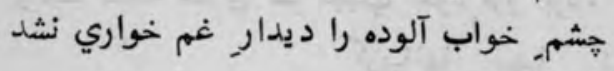

اي "علي" كر محو سازي خويش را در ياد حق خواب الوده راد

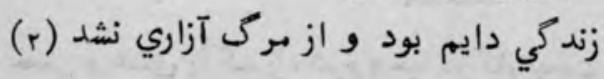

r- ديكر از نوابان خوش قريحه' اين خاندان نواب غلام سعمد خان

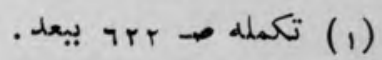

- تكملd ror (r) 
هتخلص به "غالام" فرزند نواب علي سعمد خان "علي" سابق الذكر است،

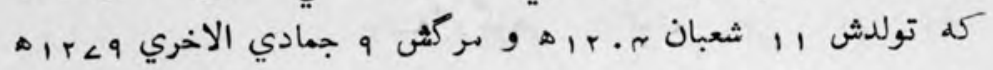

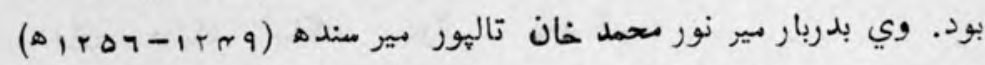
هصب اميزي داشت. و ديوان خطي اشعارش موجود است كه بدين بيت مصدة إنست

الهي شوق, عشق، خود ببخشي جسم و جانم را

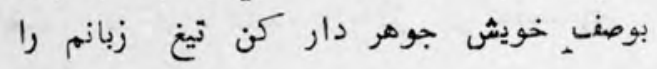

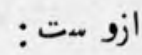

קا

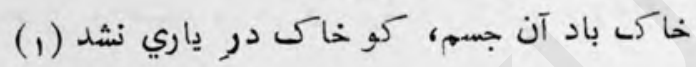

ه- - نواب الله داد خان نتخليّص به "صوفي" فرزند نواب ولي مصمد خان "ولي" است، كه مشرب نقشبنديه داشت و به تصوف مايل بود. بتاريخ

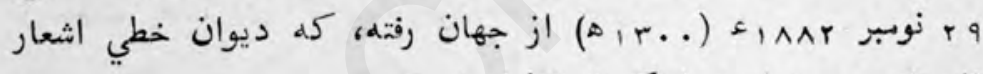

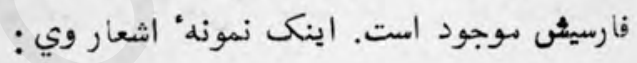
بشنو اين فصه" معكوس كله با ناز و نياز

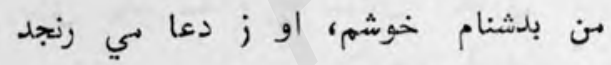

$$
\text { برنك غنتجه عمري سر بجيب خود فرو بردم }
$$

كريبانها مهيا كرد فروم بردم از بهر دريدنها

$$
\text { هسن و عشق باكس را، شرم وحيا دركار نيست }
$$

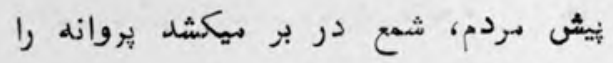

(1) براي نمونهاي اشعارش ركى تكمله ههم ببعد . 


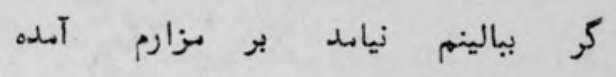

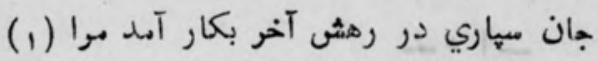

دو فرزند نواب صوفى يكي نواب حسين علي "حسين" و د ديكر نواب ديكي

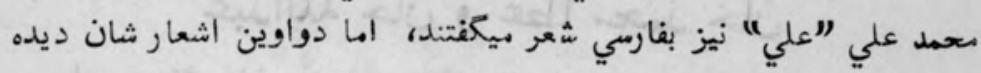
نشده (r) - ن (r)

هـ نواب ولي سمعد خان دوم متخلص به "ولي" فروزند نواب احمد خان

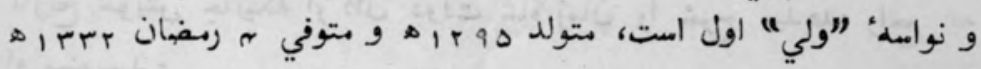

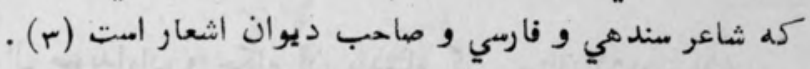

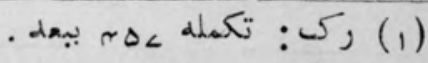

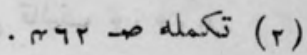

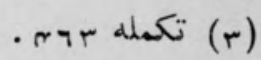




\section{$-1 \cdot-$}

\section{عبدالله خان و عطا محمد خان}

اين عبداله خان بلتب به مخلص الدوله ولد جمعه خان دراني الكوزتي

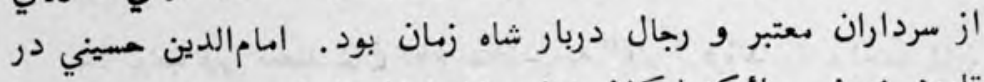

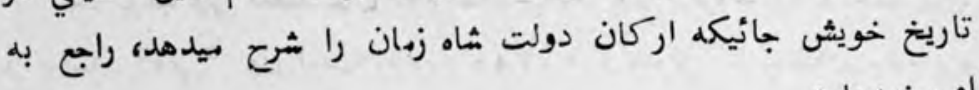
او مينويسد : روبت

"احوال صوبداران و حكام آن بادشاه كيتي ستان (شاء زمان)

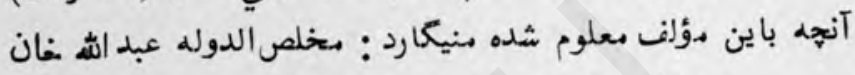

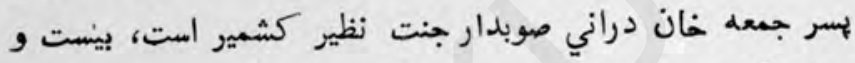

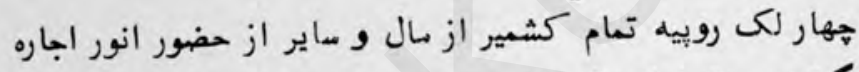

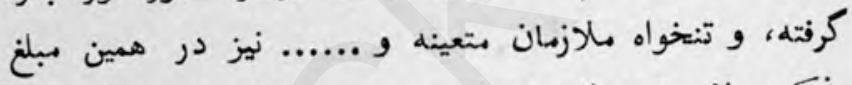

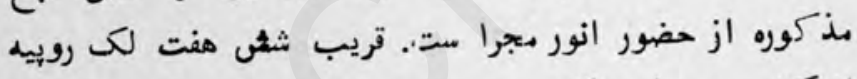

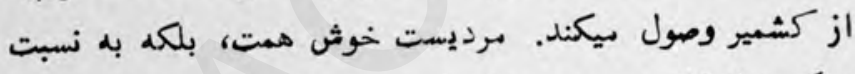

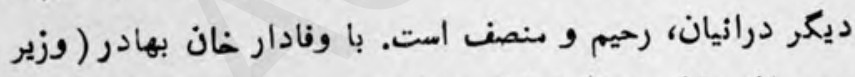

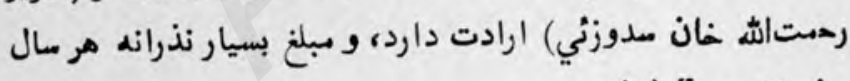

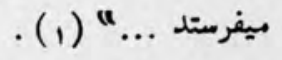

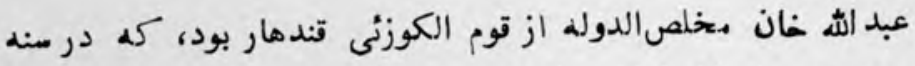

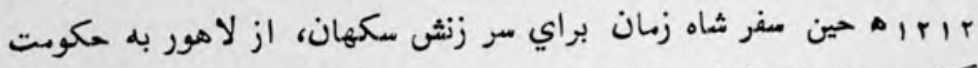

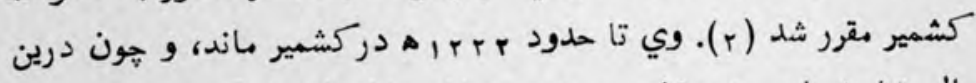

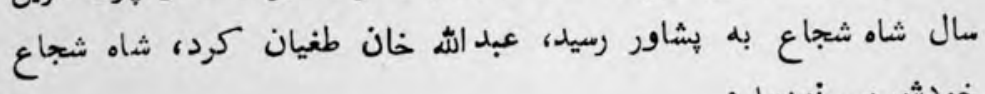
خودش مي نويسد:

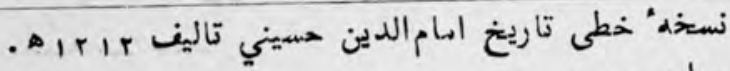


"عبد اله خان ماكم كشمير شيوه" انصاف با زير دستان آن

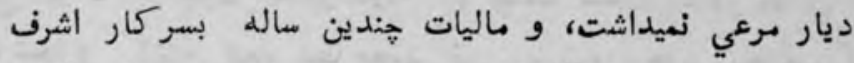

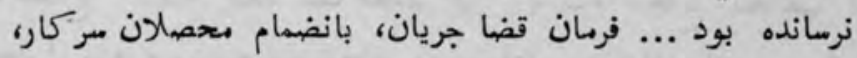

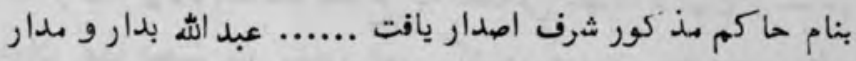

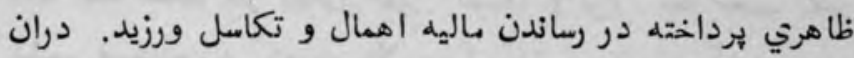

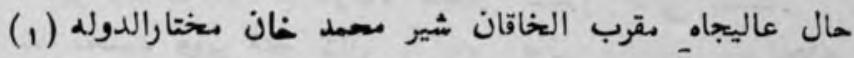

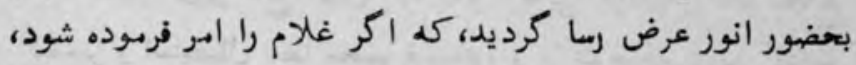

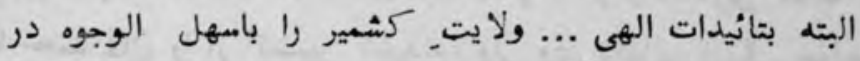

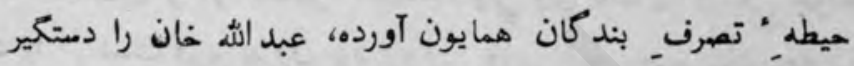

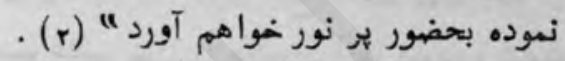

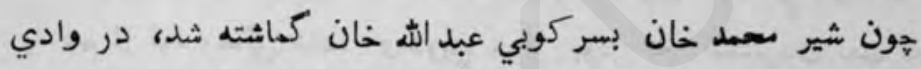

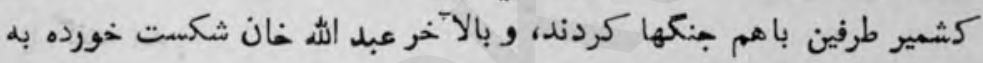

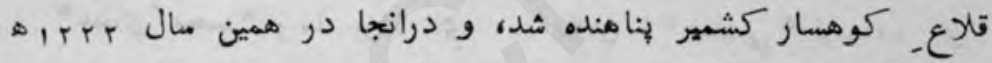

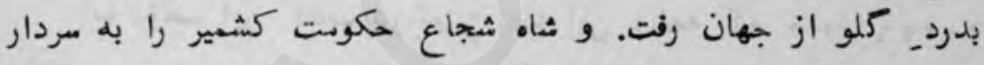

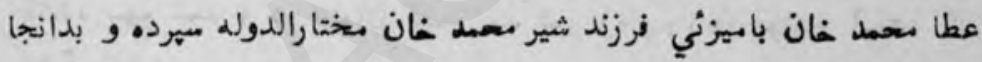

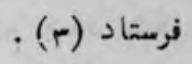

اما درين كتاب در فصهل دوم (كشته شدن عطا سعمد خان باركزاني....)

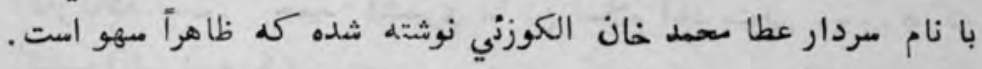

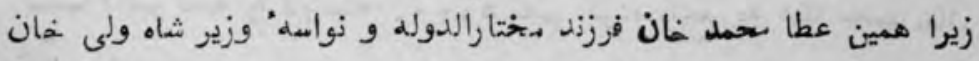

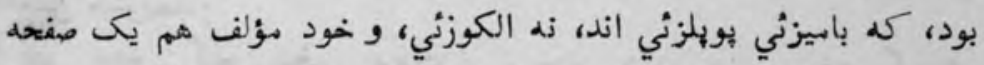

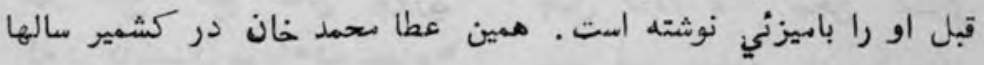

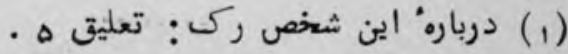

$$
\begin{aligned}
& \text { • (r) (r) واتعات صـ (r) }
\end{aligned}
$$

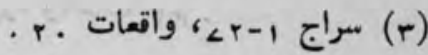


هاكم بود، و مردم ازو راضي بودند، و به خانواده شاهمان سدوزنى نيز

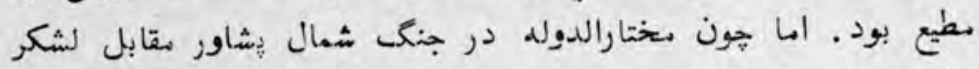

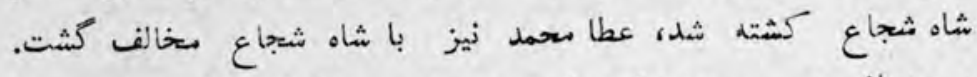

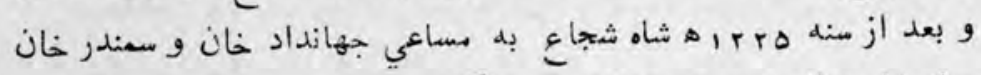

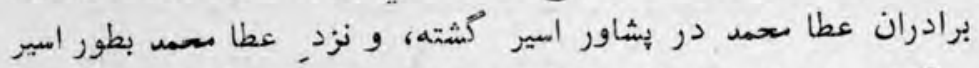

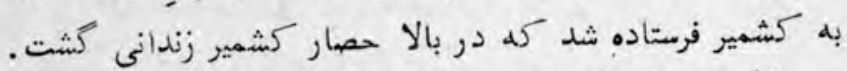

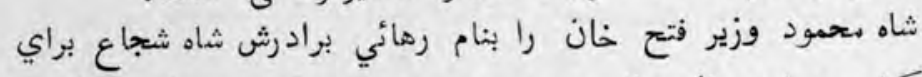

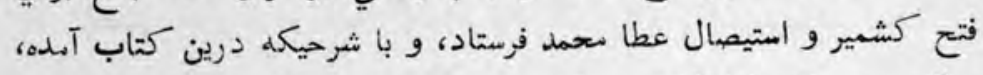

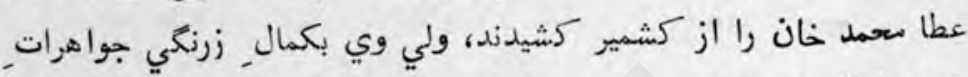

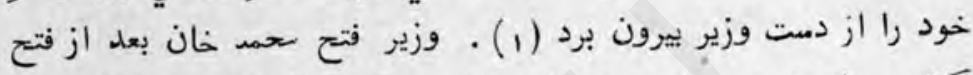

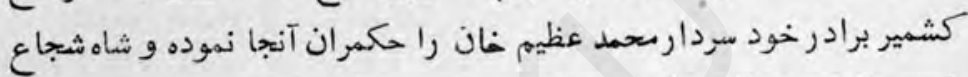

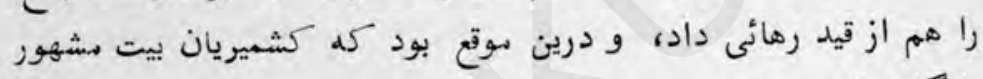
را كفته اند :

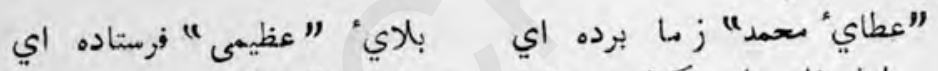

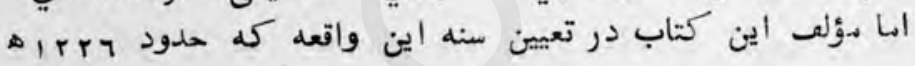

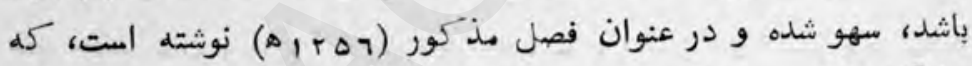

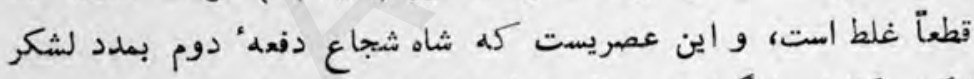

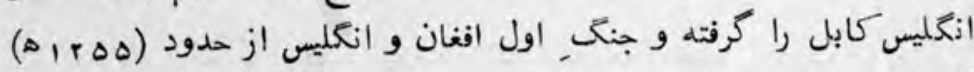

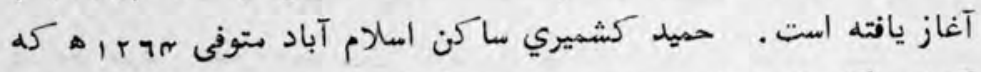

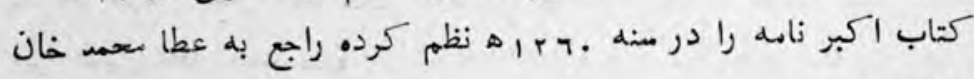

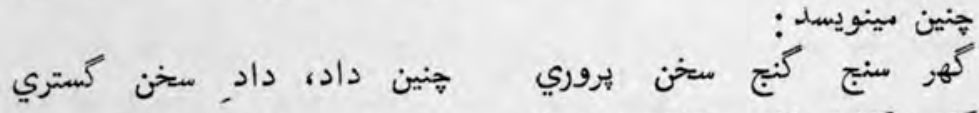

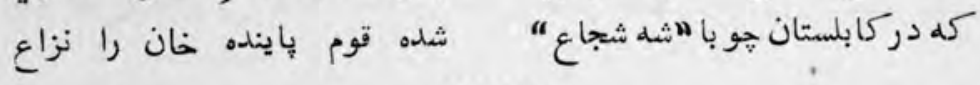
در آخر هو ادبار بروي شتافت زميدان هو اقبال خود روي تافت

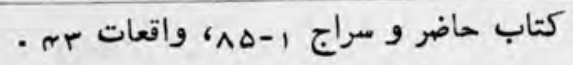


شجرهء دودمان نواب ولى محهد خان لغاري

مقابل صنهd (Arr) نواي معاركى

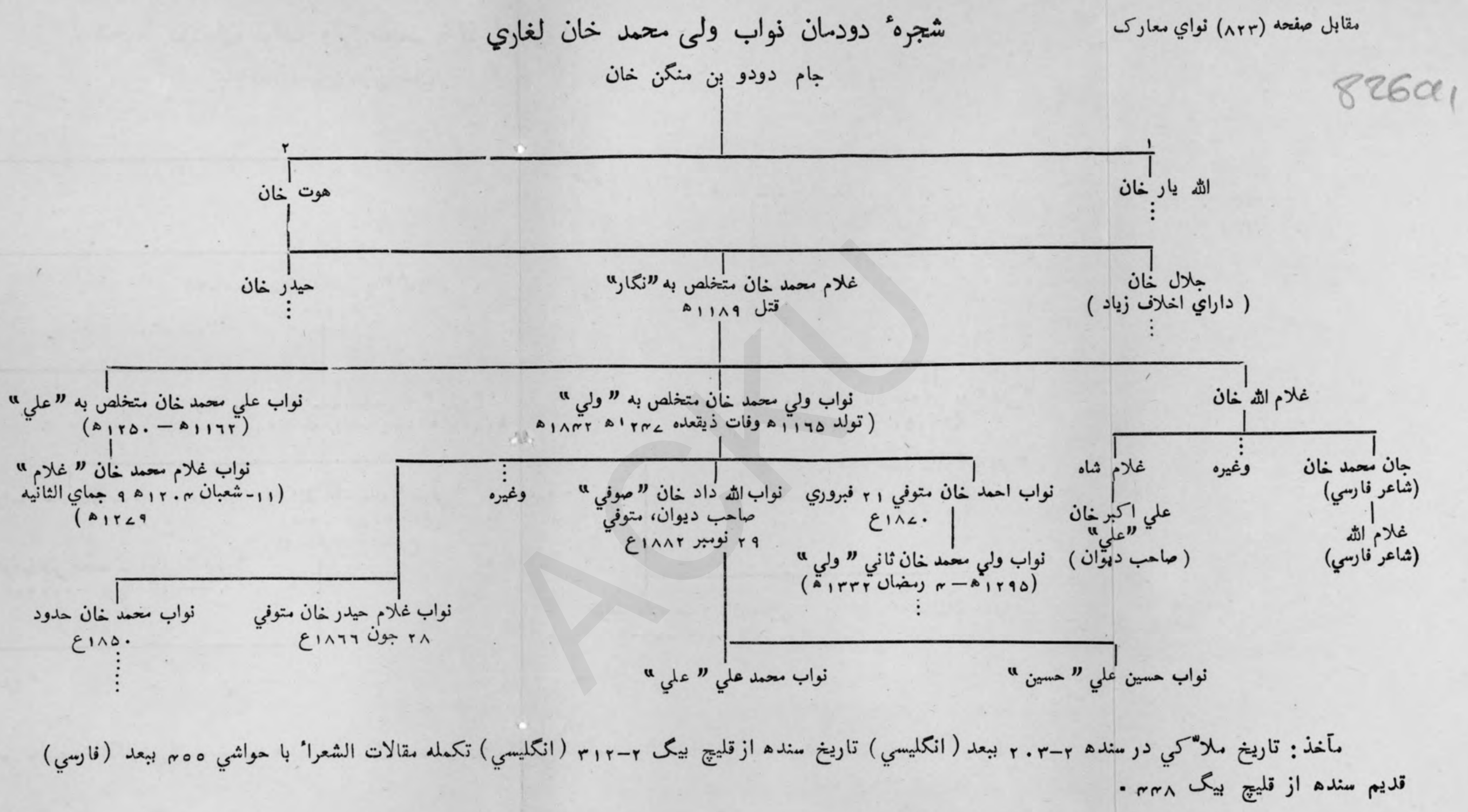




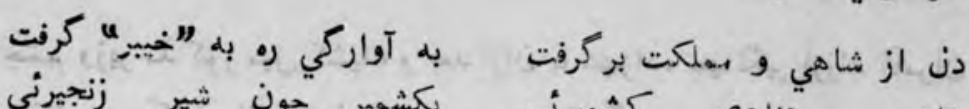

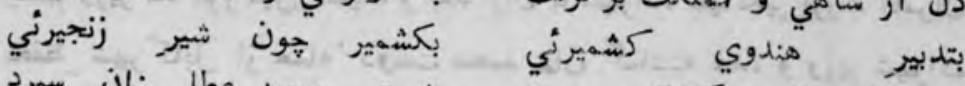

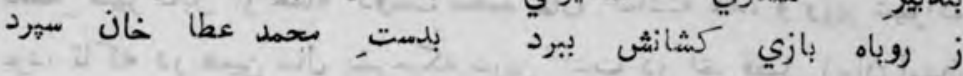

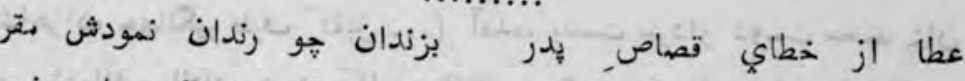

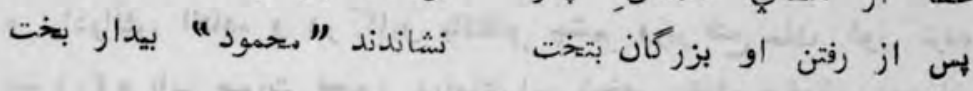

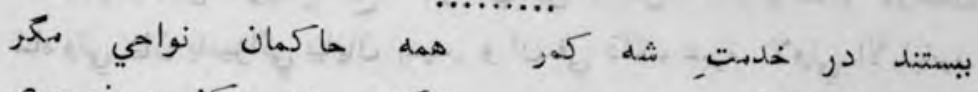

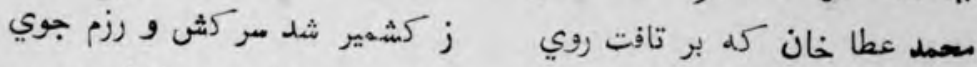

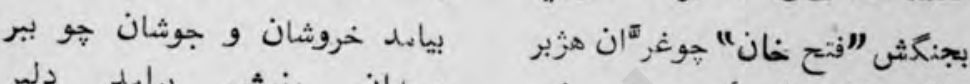

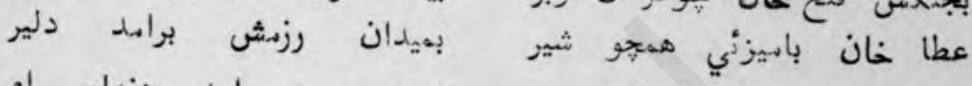

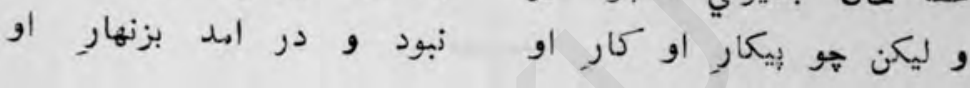

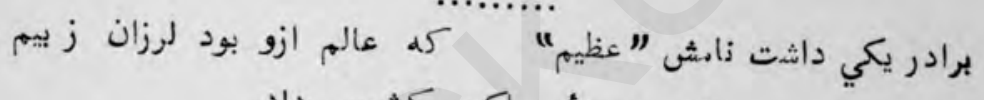

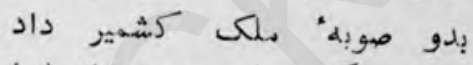

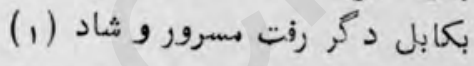

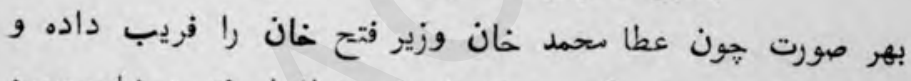

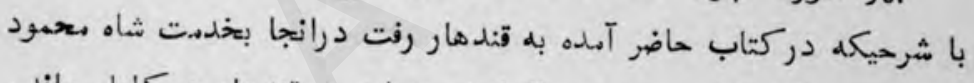

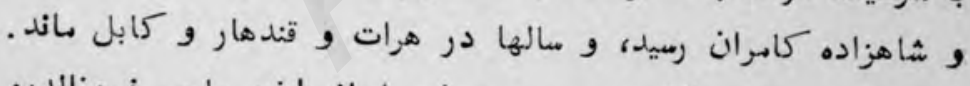

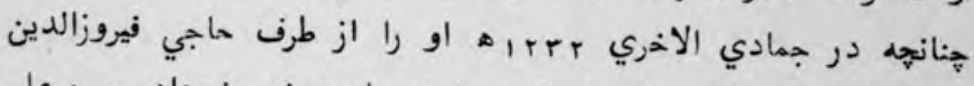

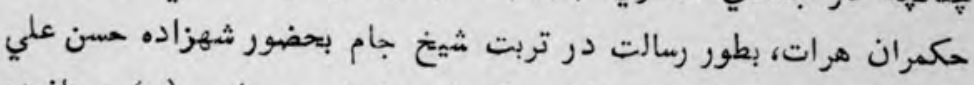

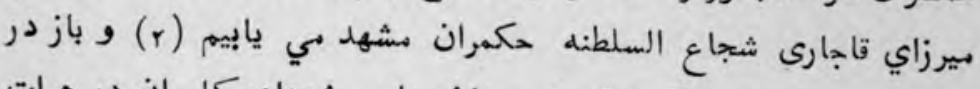

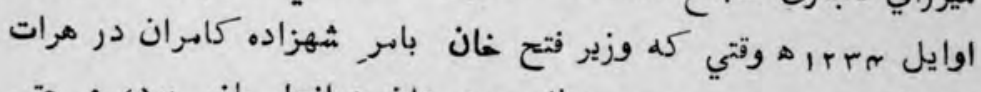

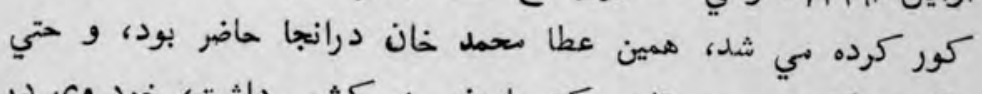

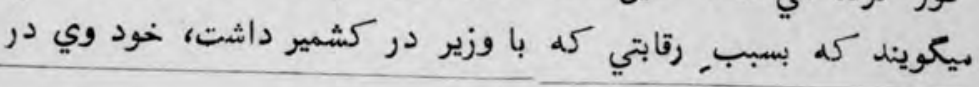

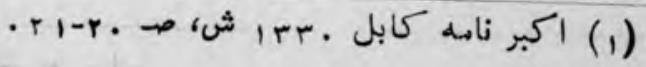

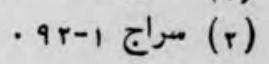


تعليقات

ArA

هُشم وزير مذكور ميل كشيد، و بعد ازان با شهزاده جهانكير فرزند كامران

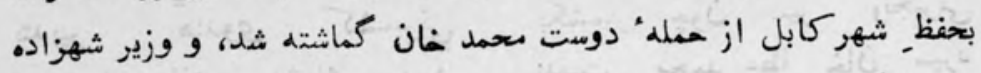

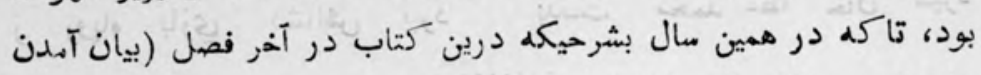

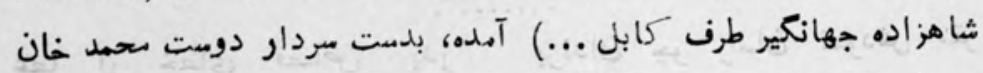

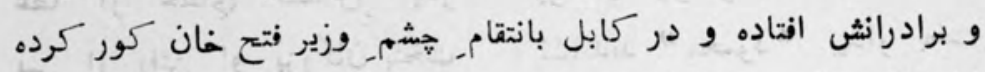

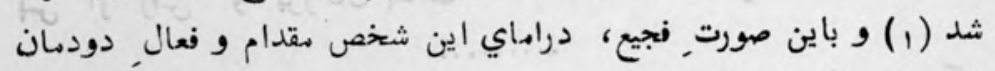

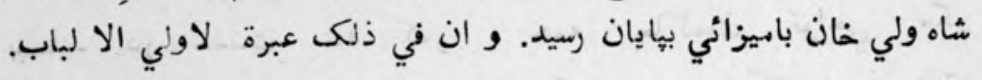

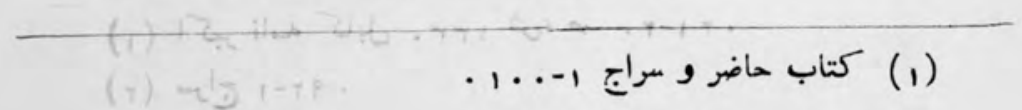


$-11-$

عبدالغفور خان

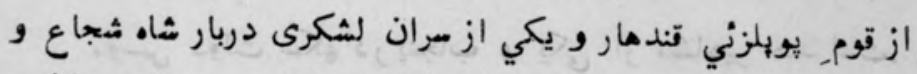

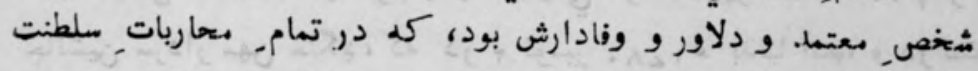

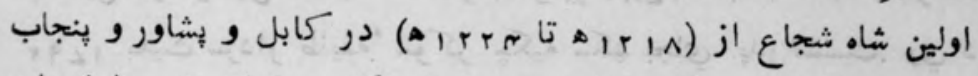

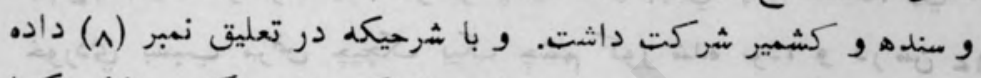

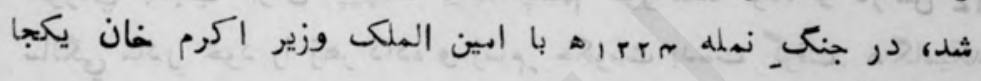

كثته كرديد. 


\section{$-1 h-$}

\section{مهاراجه رذجيت سنخه (}

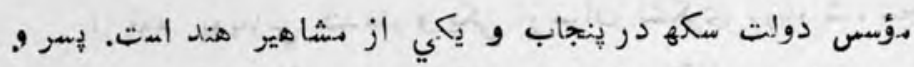

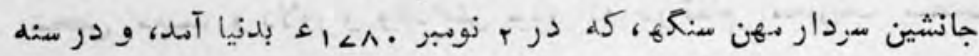

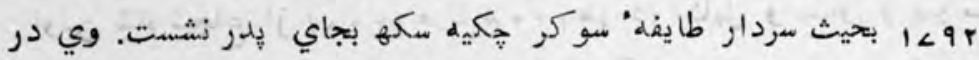

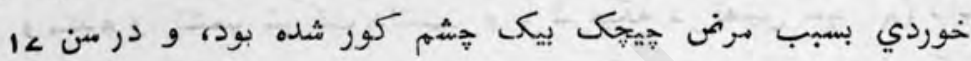

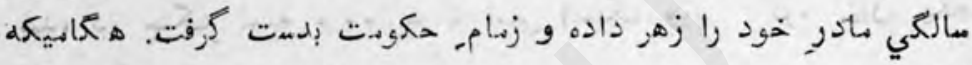

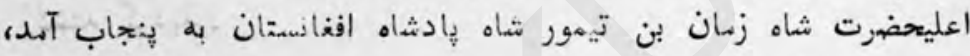

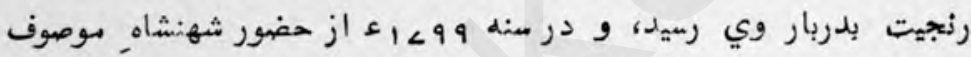

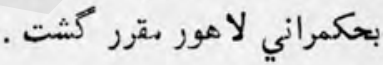

رنجيت در r.11اء بر امرتسر حمله كرد، و آن شهر را ضهيمهن"

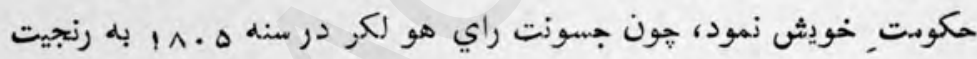

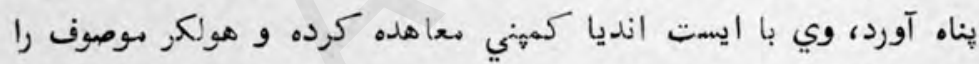

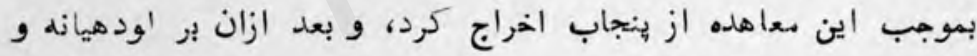

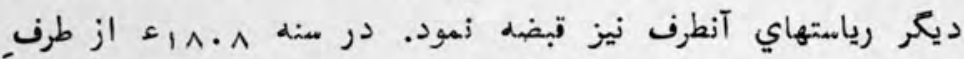

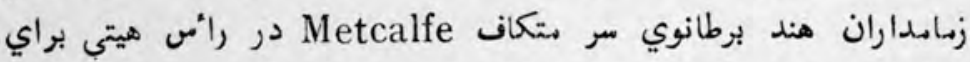

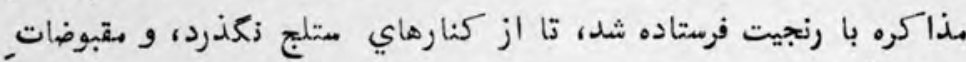

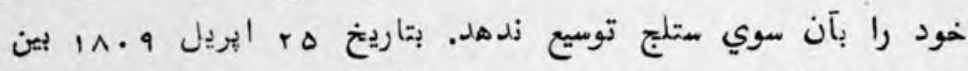

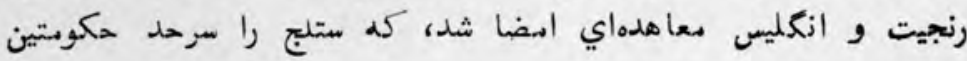

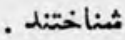

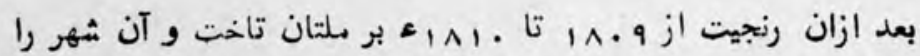

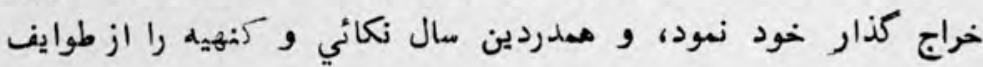


Ars

تازه نواي معار

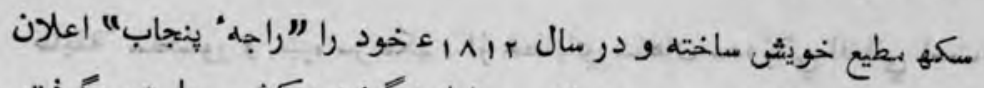

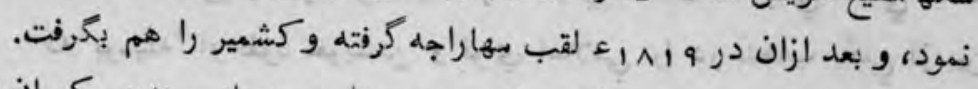

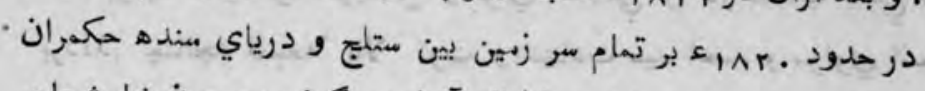
كشت ودربrrar

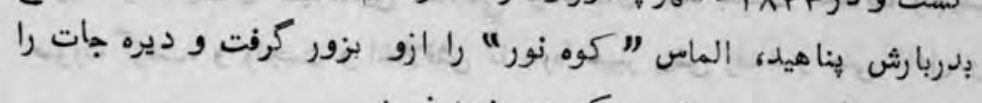

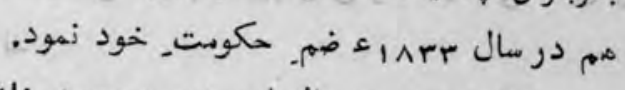

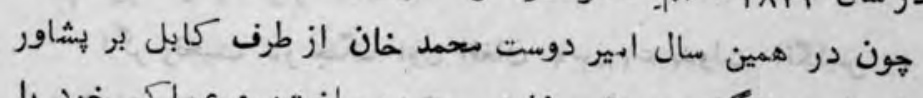

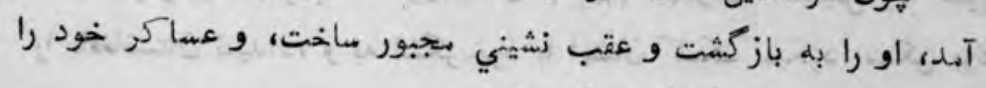

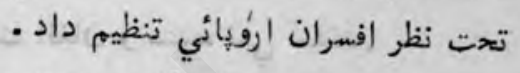

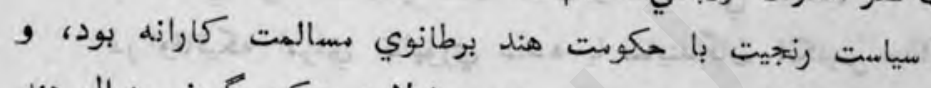

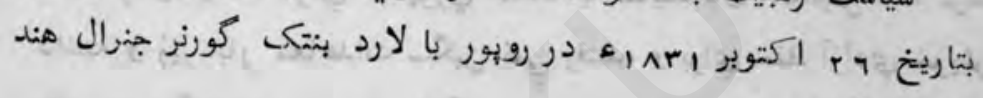
.

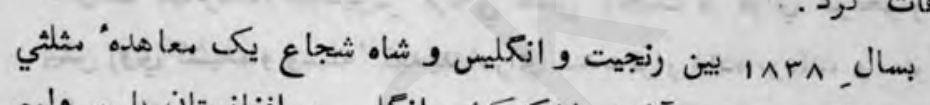

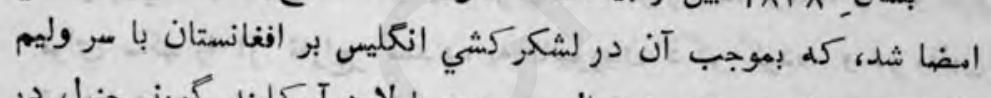

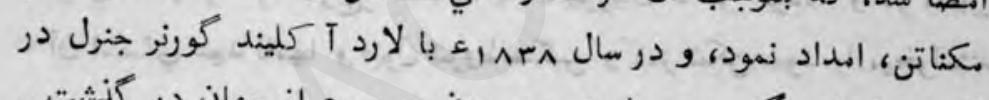

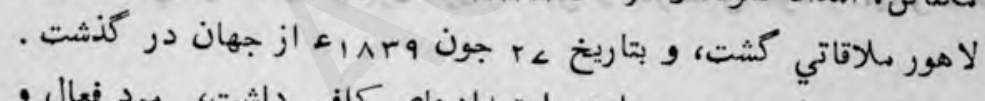

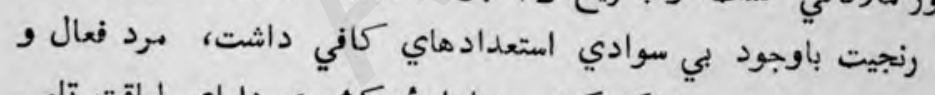

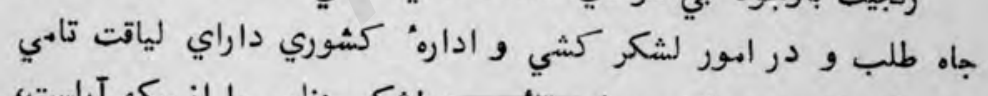

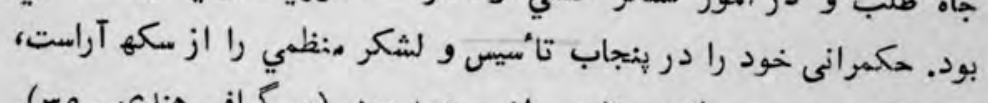

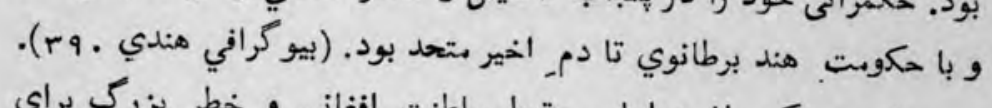

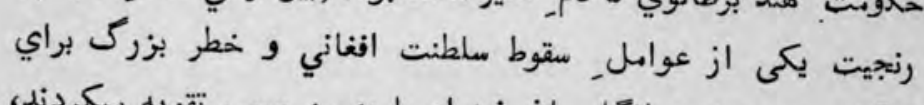

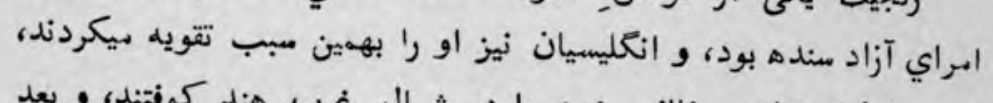

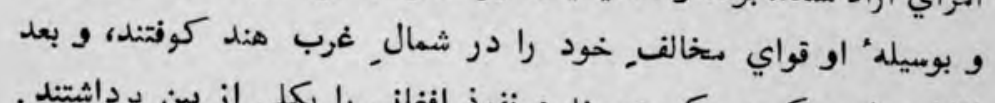

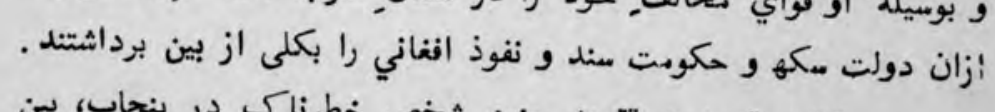

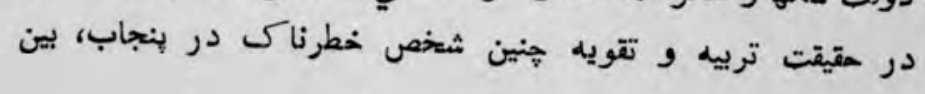




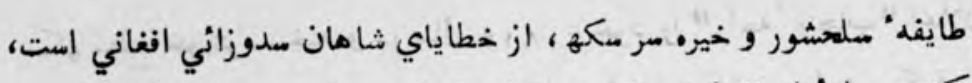
كل بوسيله" او نفوذ خويشتن و قواي اسلامي را در رنجاب بكلي از بين

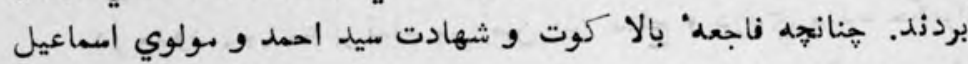

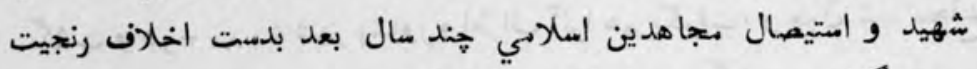

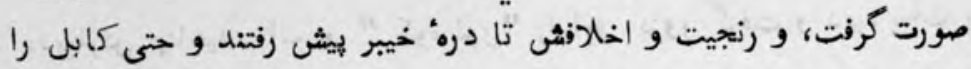

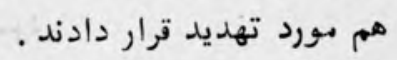

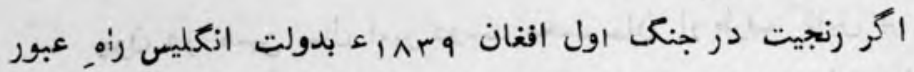

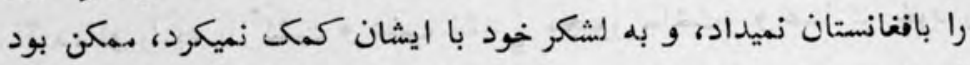
آن فاجعه هاي هولناكى بسر, ملت افغان و منده نمي آمدند.

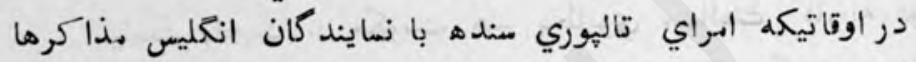

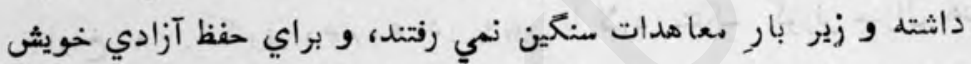

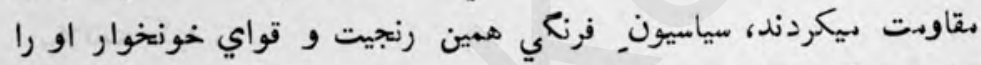

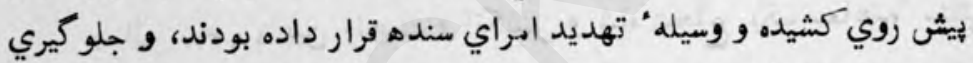

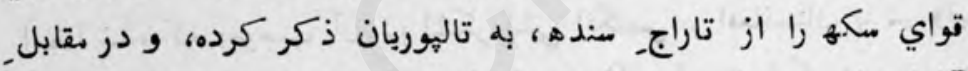

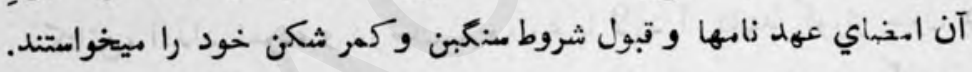




\section{$-I^{m}-$}

\section{الماس كوه ذور}

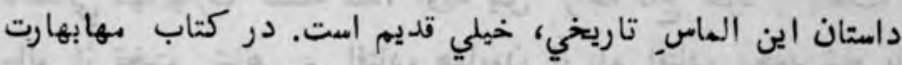

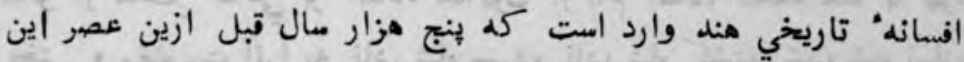

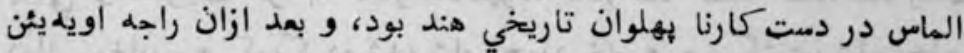

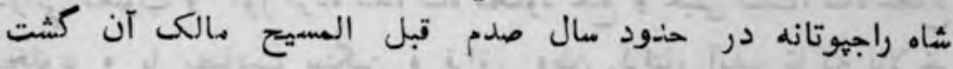

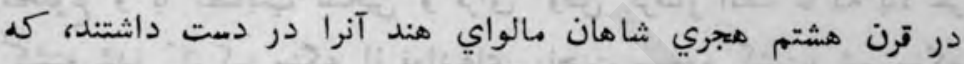

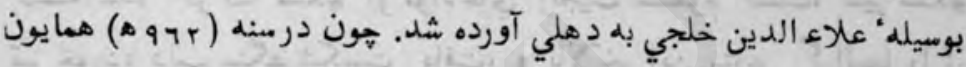

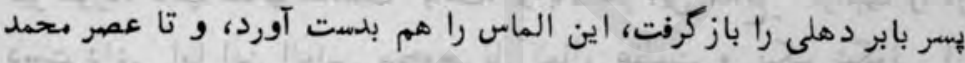

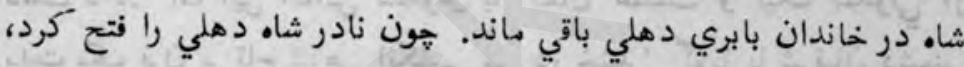

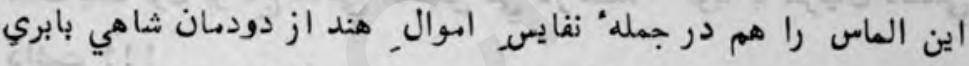

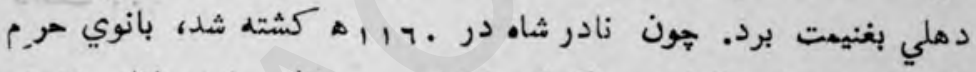

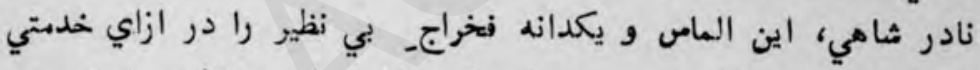

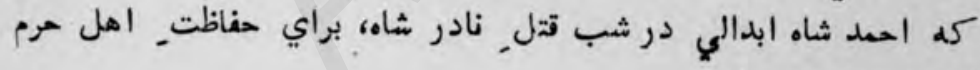
كرده بود، بدو داد . ماهي

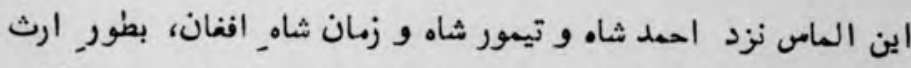

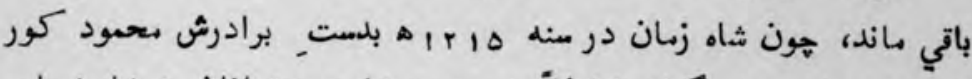

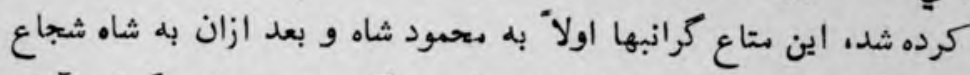

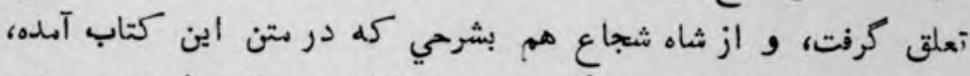

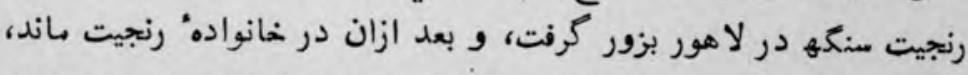

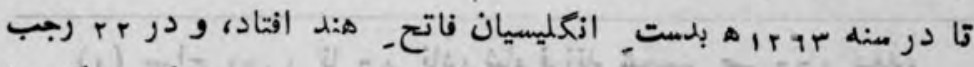

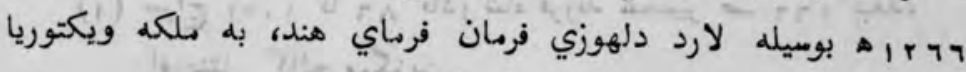


ارمنان فرستاده شد، و ازانوقت ببعد اين الماس به خزانه: شاهي ازمليس

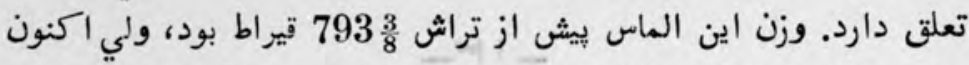

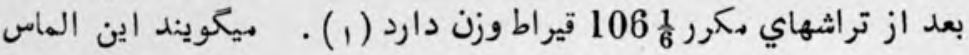

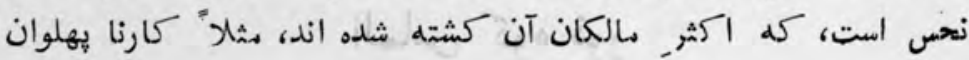

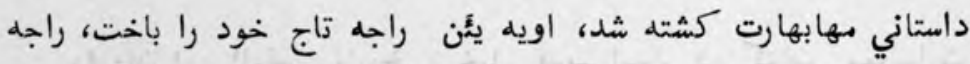

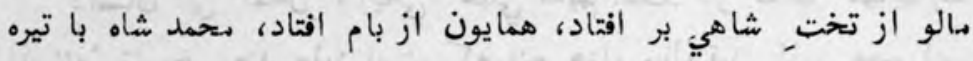

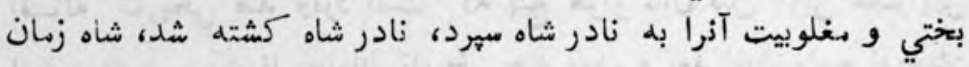

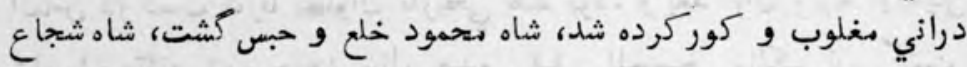

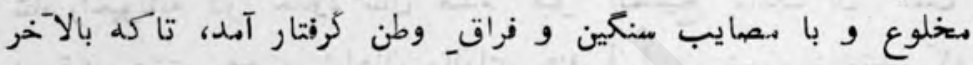

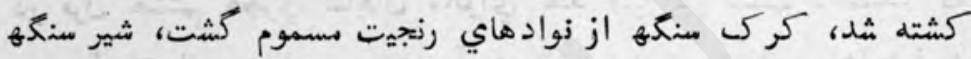

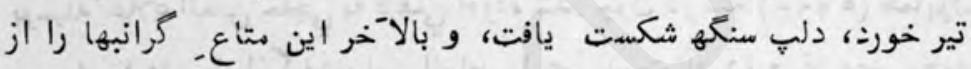

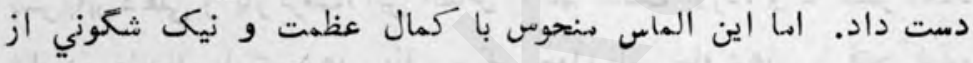

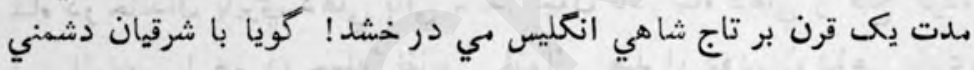

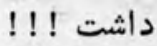

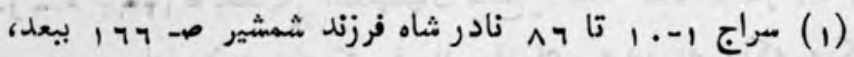

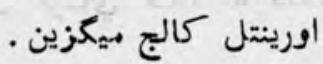




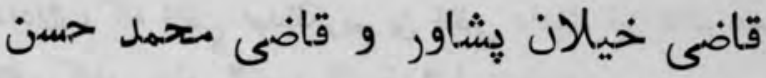

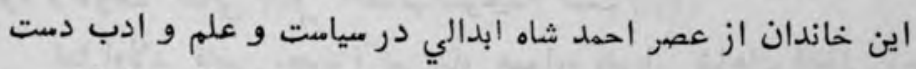

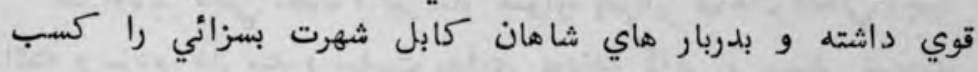
كرده اند. در عصر اورنكزيب عالمكير، مورث اءلاي اين خاندان اخوند تركمان

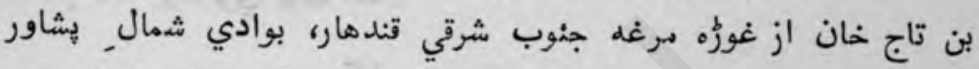

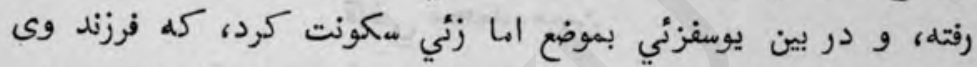

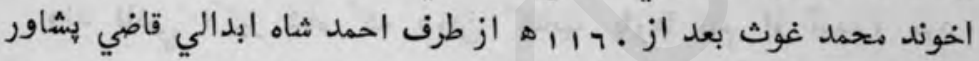

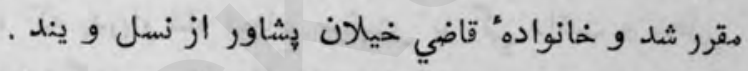

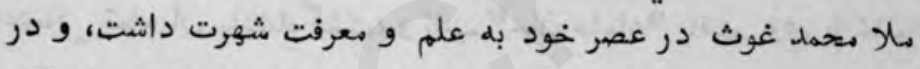

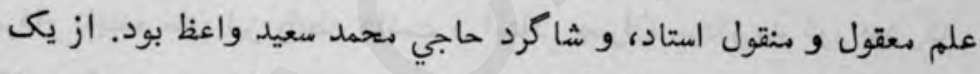

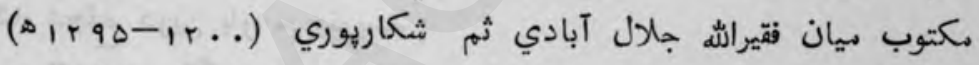

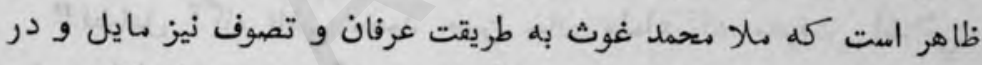

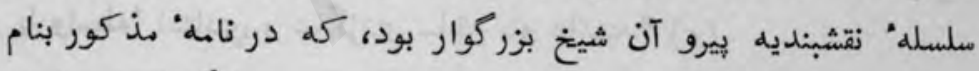

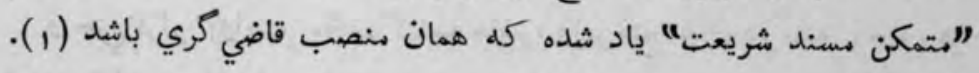

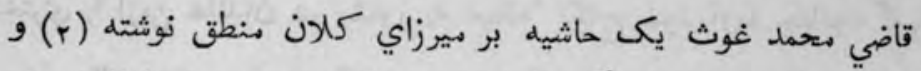

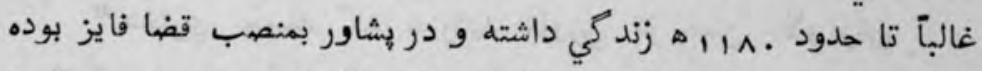

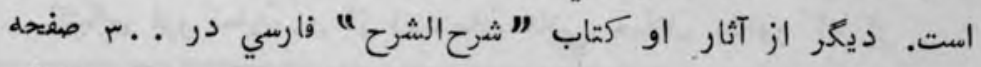

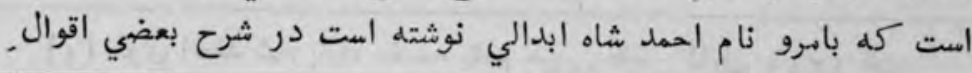

$$
\text { مكتوباب ميان فقيراله r r ب طبع لا هور. }
$$

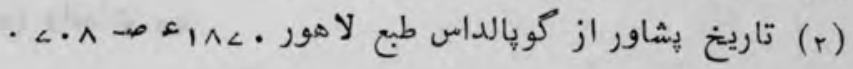


صوفيانه" عربي احمل شاه ابدالي كه نويسنده، نسخه خطي واحد آنرا در منهل

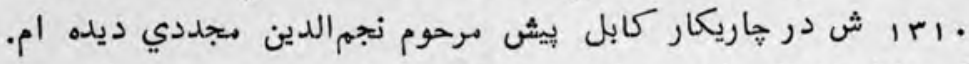

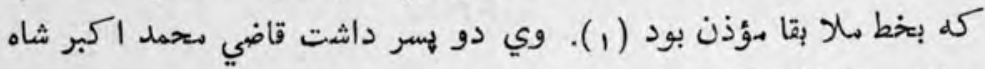
و قاضي دادالله، كه قاضي عبدالكريم بن قاضي داداله نيز عالم عصر خود

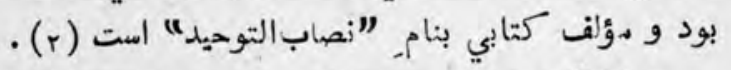

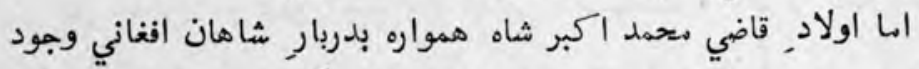

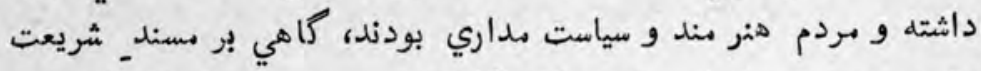
نشسته، و برخي ز مام سياست بكف كرفته، و بعضي هم كاربنان منان متخفي

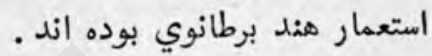

\section{قاضي محمد حسن}

ولد قاضي اكبر شاه كله درين كتاب بارها نام او آمده ، مرد

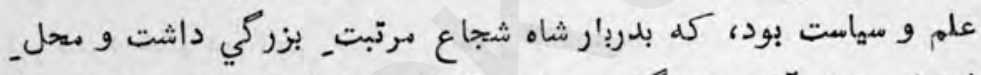

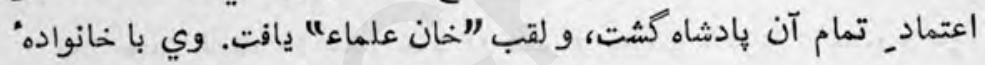

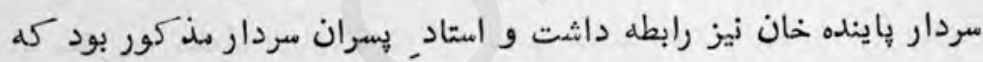
شاه شجاع درين باره مي نويسد :

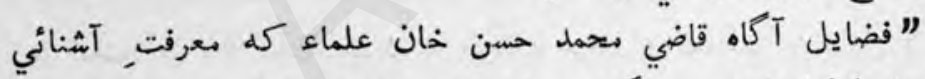
و يا واسطه" استادي و شأخردي سابقه باو داشتندل" (r) .

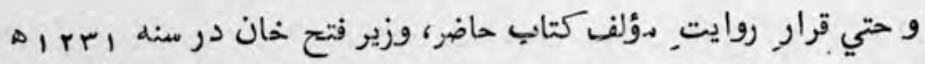

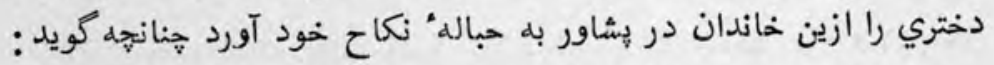
" دختري جميله كله خورشيد خاوري از حسن دلاويزث

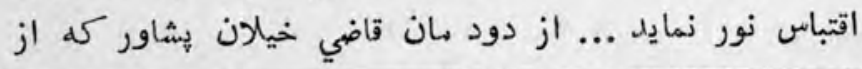

(1) لوي احمل شاه بابا، مقدمه بقلم حبيبي طبع كابل

$$
\begin{aligned}
& \text { (r) } \\
& \text {. 7 r }
\end{aligned}
$$


قديم بار باب دول، قرب و منزل دارند، بدست آورده ..." (1).

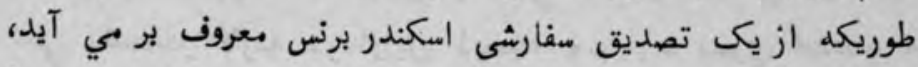

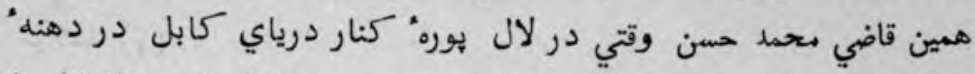

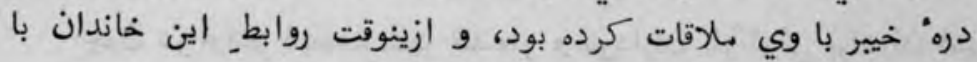

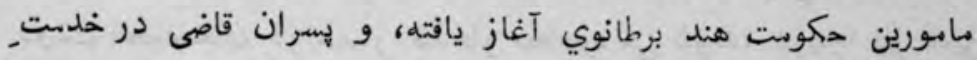

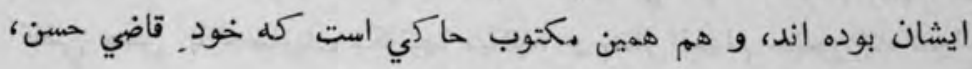
با شاه شجاع يكجا بهند فراري شده بود (r) .

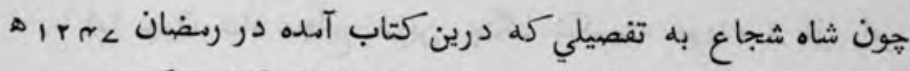
از لوديانه براه سنده و شكاريور بر قندهار الشكر كشيى كرد، همين

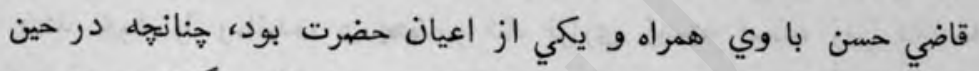

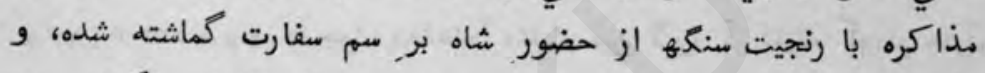

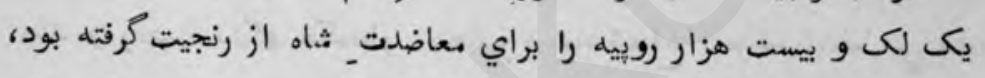
شاه شجاع مينويسمد :

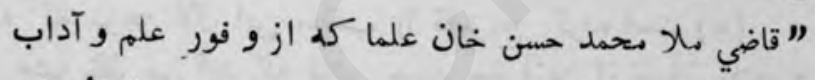

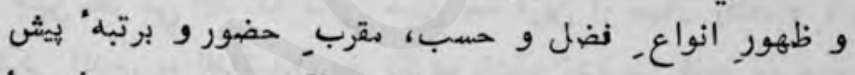

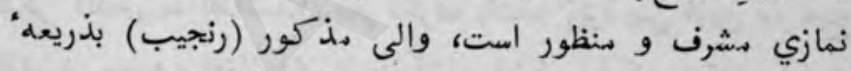
سفير مذكور، بر سبيل. يكانكي، مبلغ يكى لكى و بيست هزار

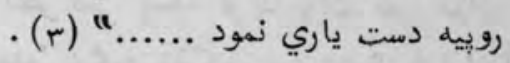

بعد ازين شاه شجاع به منده ميرسد، و در شكاريور بباغ شهزاده

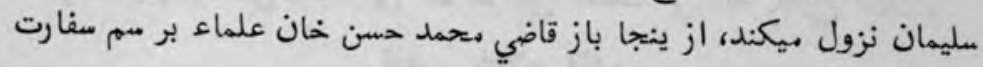

(1) كتاب حاضر در بيان فوتيدن بها كل منكوحه" اشرفالوزراء.

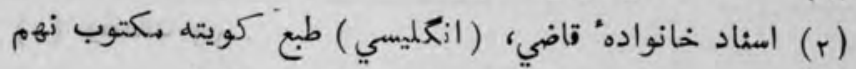

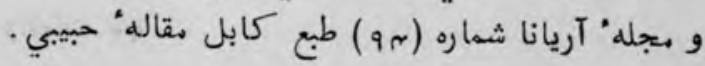


به ميران تاليوري سنده و مير مراد علي خان فرستاده مى شود، و بعد از از

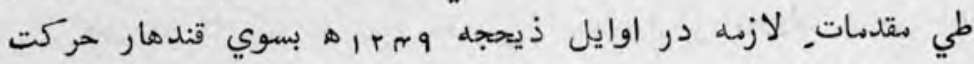

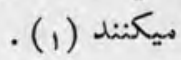

هون در اواخر ذيحجه شهر قندهار و سرداران باركزئي برادران امير دوست محمد خان در حصار قندهار متحاصره مي شوند، درينجا باز همين قاضي حسن با حصاريان دكاتبها ميكند، و مدار المهام حضور شاه شجاع

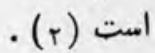

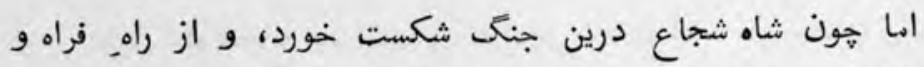

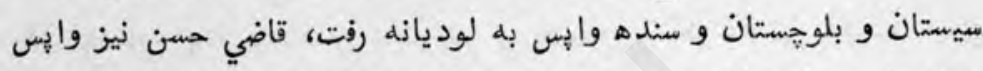
بهند خود را رسانيده، و بحضور شاه فراري زيسته است، زيرا در سنه Ar

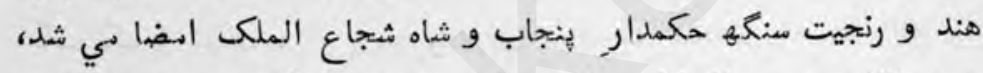

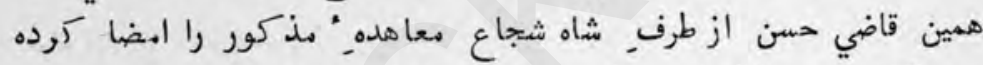

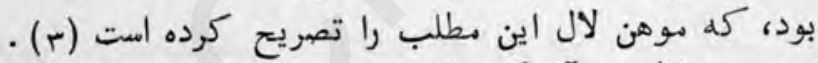

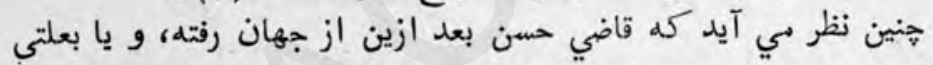

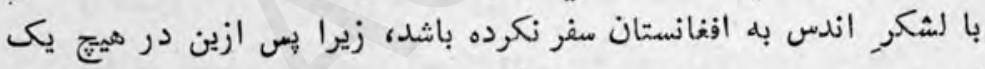

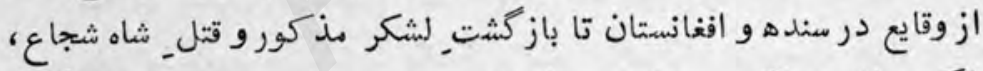

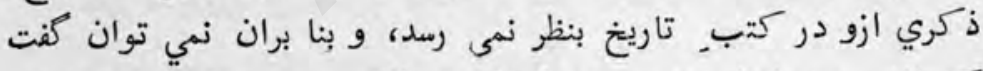

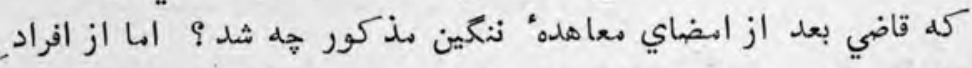

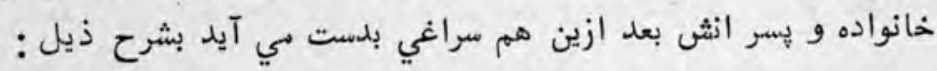
قاضي غلام قادر

فرزندِ قاضي حسن كله از رجال دعروف يشاور در عصر سرداران

• مب (1)

- ar واقعات (r)

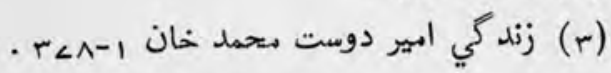


بار كزئي و اوايل و رود انكليس بود، از يكى تصديق نامهُ ايجه، ادواردز

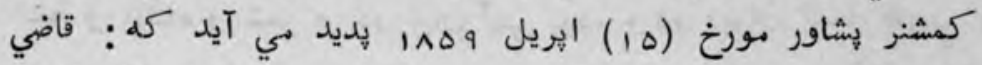

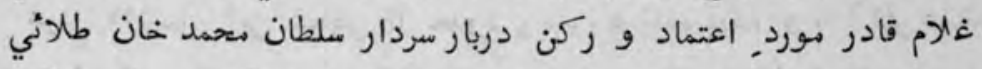

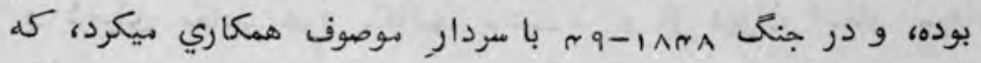

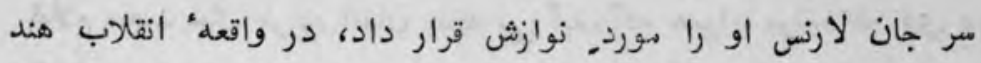

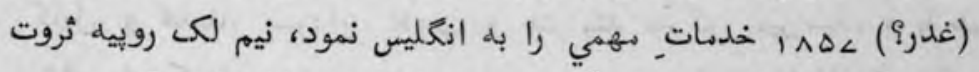

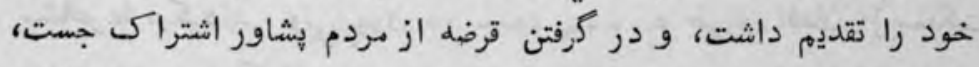

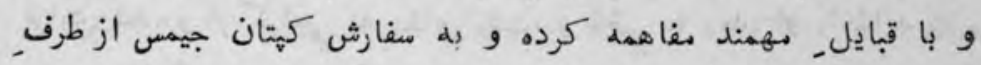

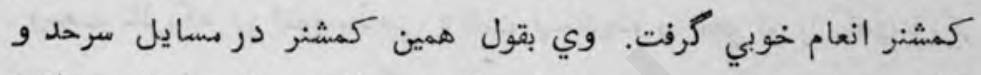

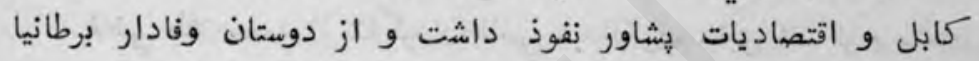

بود (1)

همجنين در يكى تصديق نامه با مضاي اسكندر برنس مورخ (1، (1)

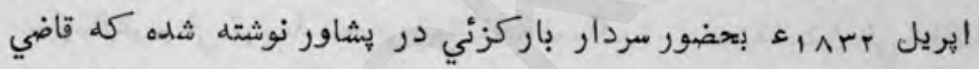

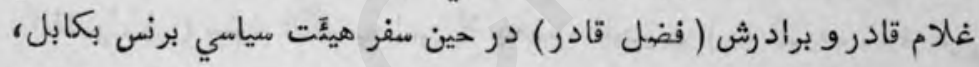

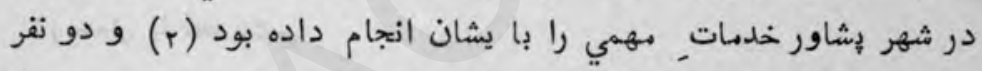

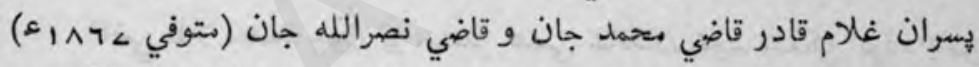

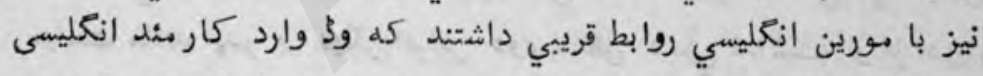

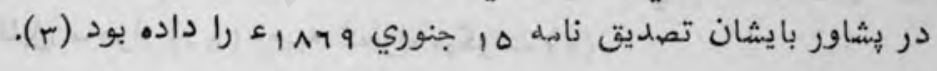
قاضي طلا محمد

فرزند, قاضي حسن زيز از رجال مشهور اين دودمان است، كله دور

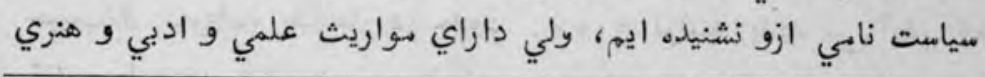

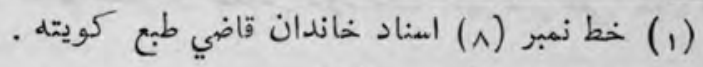
(r)

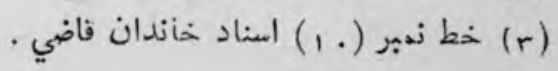




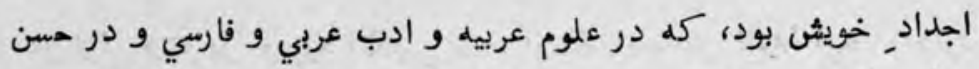

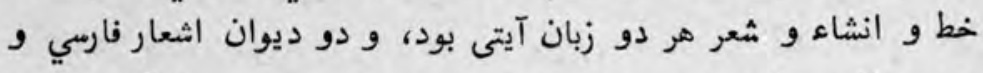

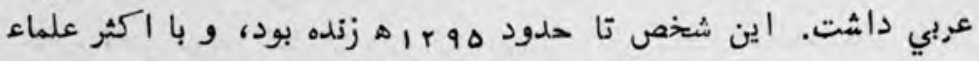

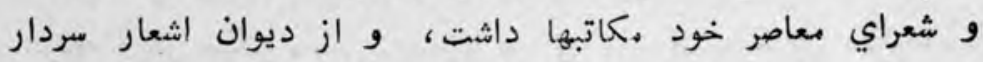

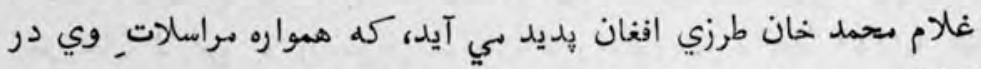

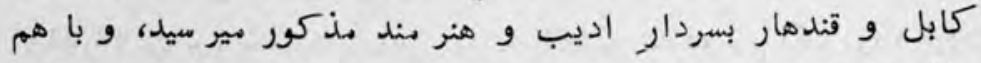

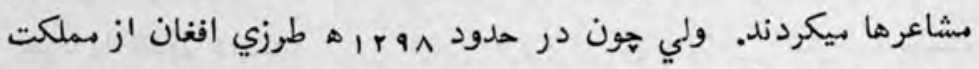

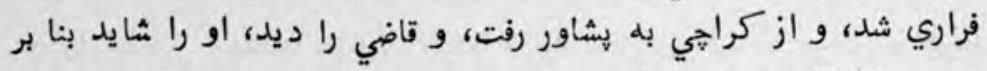

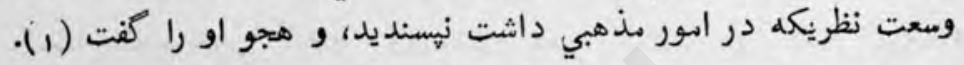

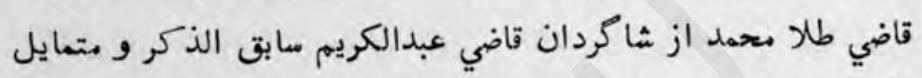

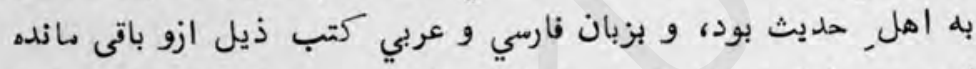

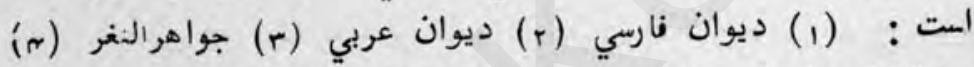

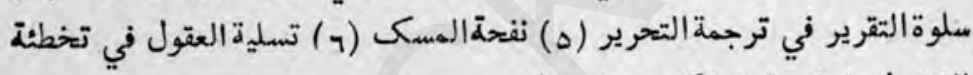

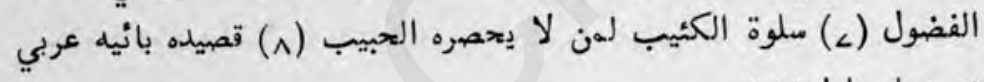
در عمل با لحديث.

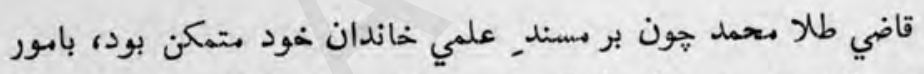

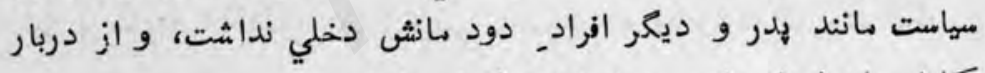

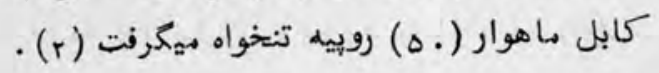

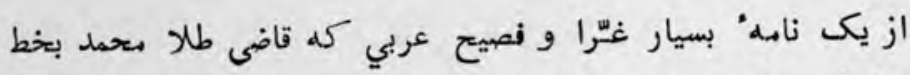

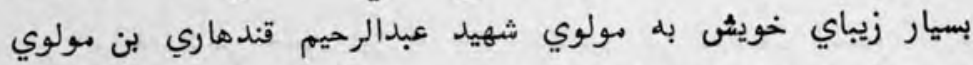

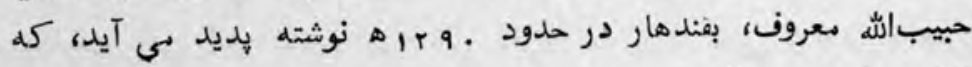

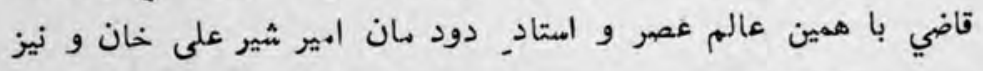

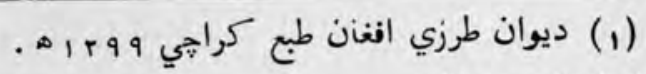

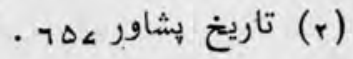


با طرزي افغان، مراتبـ دوستي و وكا تبهاي ادبى و علمي داشته است (1) المري

\section{قاضي عبدالقادر}

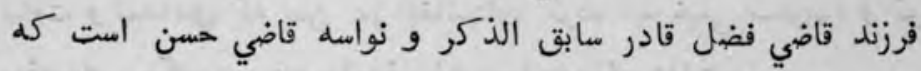

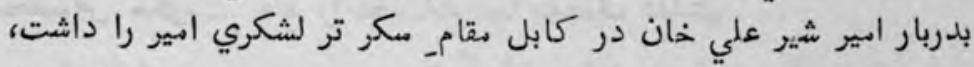

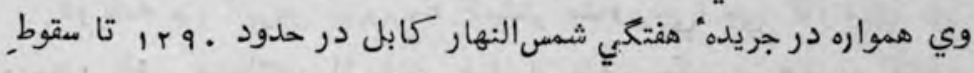

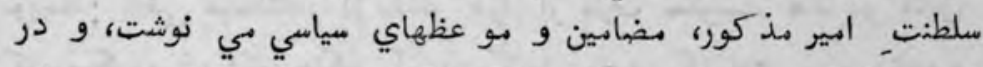

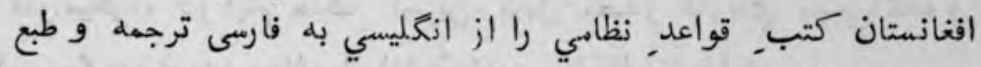

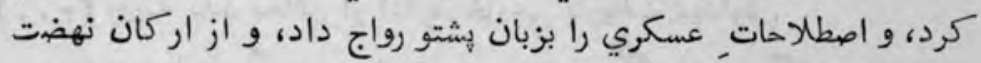

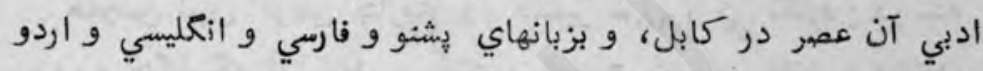
آشنا بود ال آن

قاضي عبدالتادر در كابل به قاضي قادرو شهرت داثت، و از اعيان

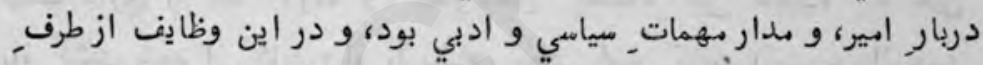

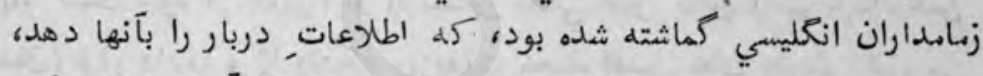

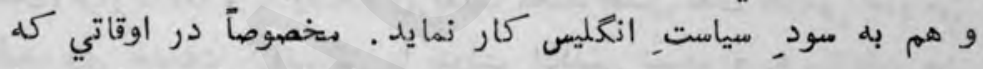

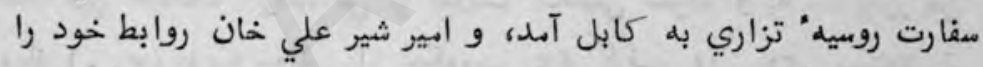

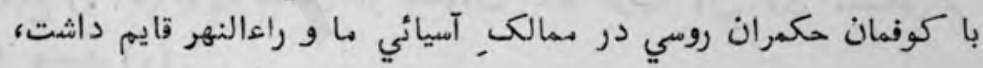

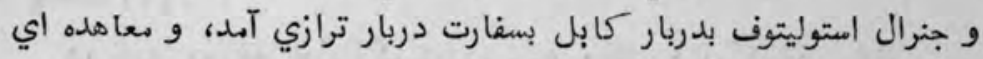

$$
\text { را هم با دربار كابل امضا كرد ( }
$$

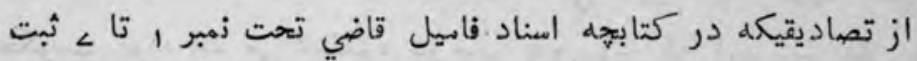

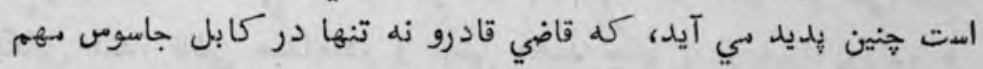

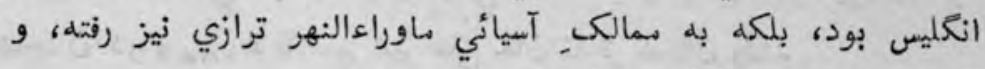

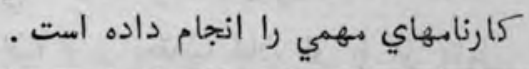

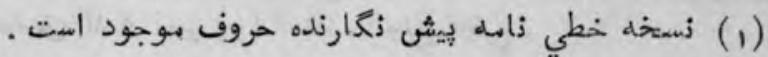




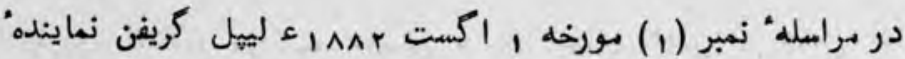

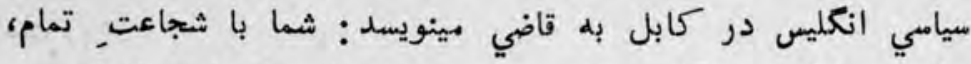

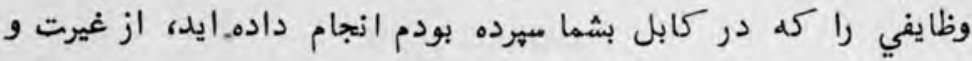

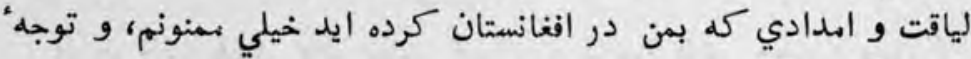
نخصوص حكومت هند را بخدمات شما بعطون داشتم . ...

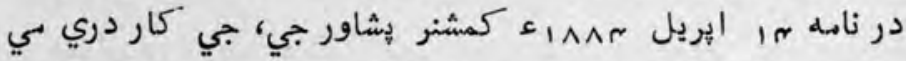

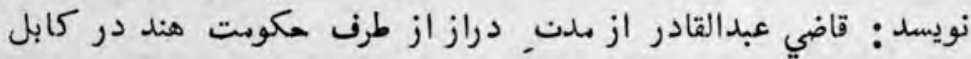

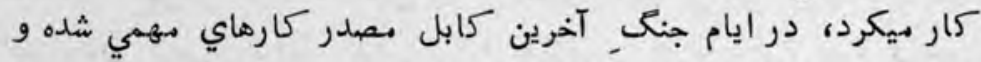

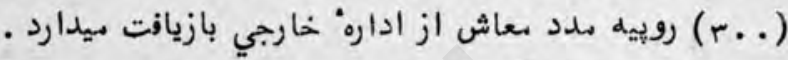

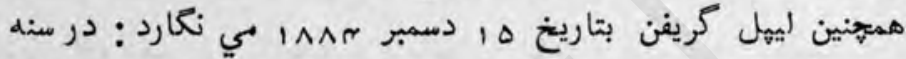

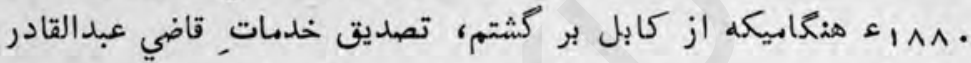

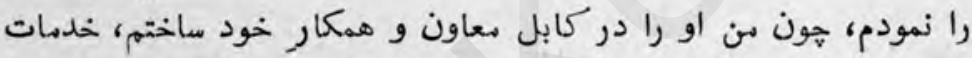

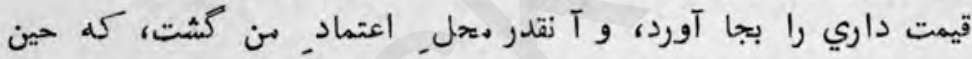

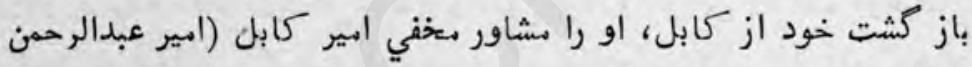

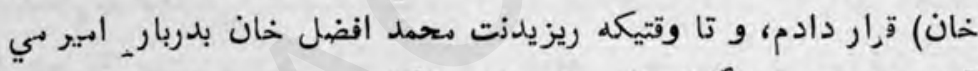

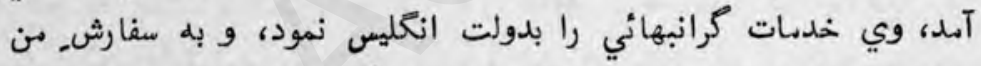

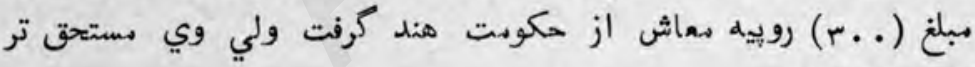

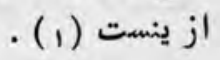

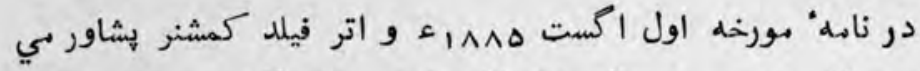

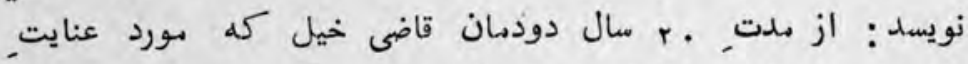

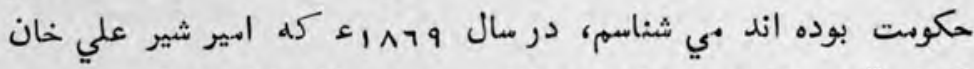

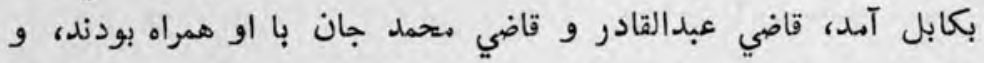

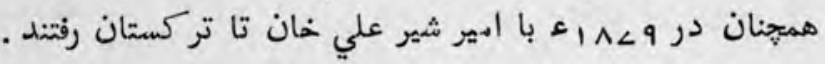

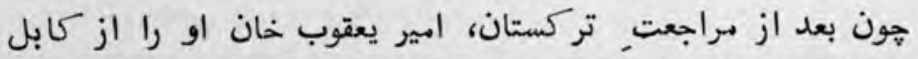

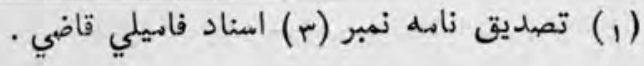


طرد كرد، وي در كنر نزدي. يكي از سادات هناهنده كرديد، و ازانجا

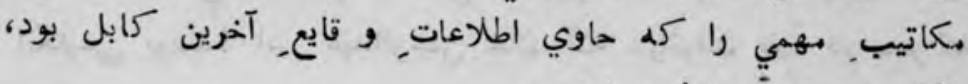

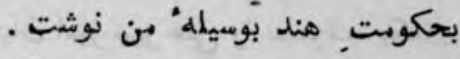

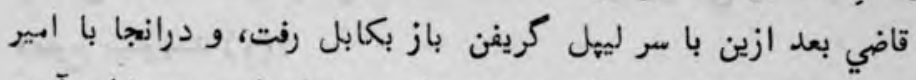

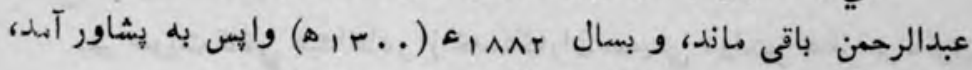

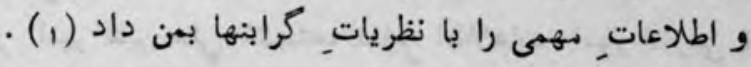

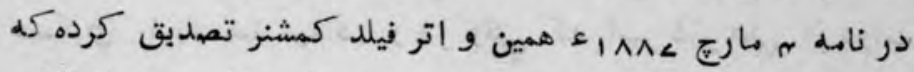

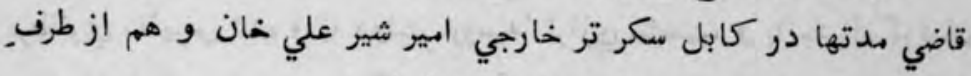

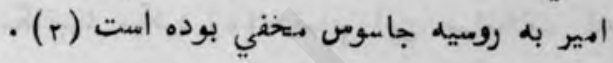

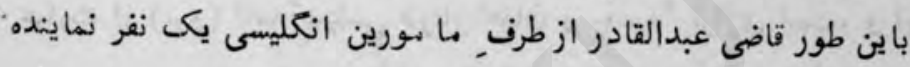

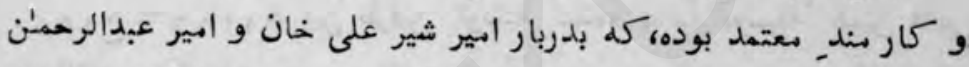

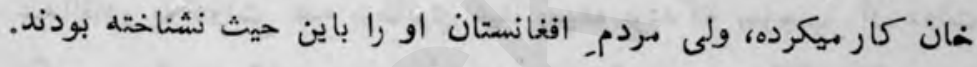

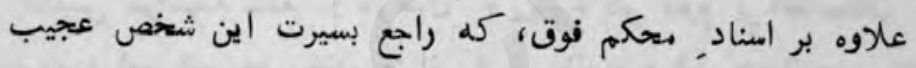

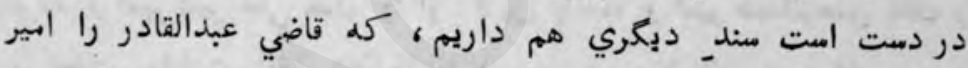

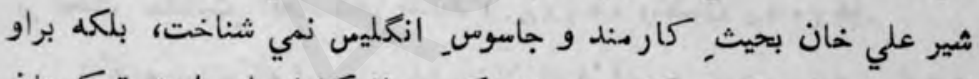

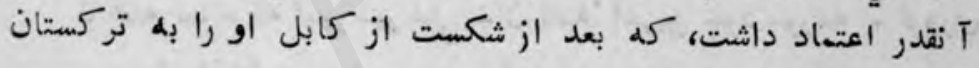

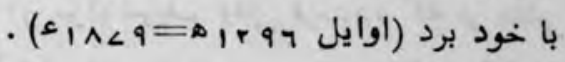

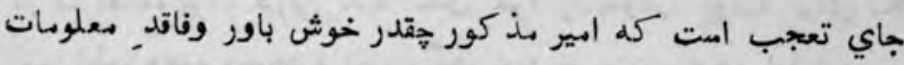

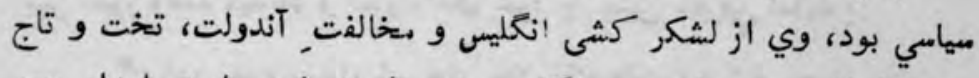

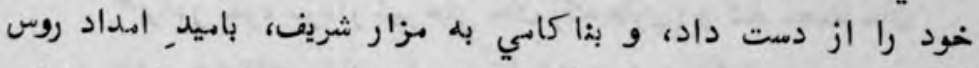

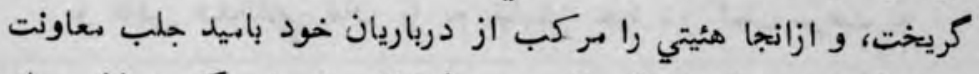

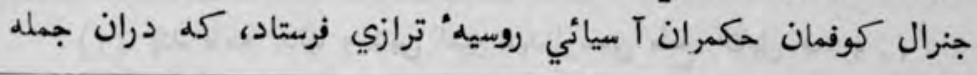

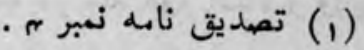

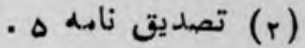


سردار شير علي قندهاري و قاضى هيشاوري دو نفر خدميتكاران صادق.

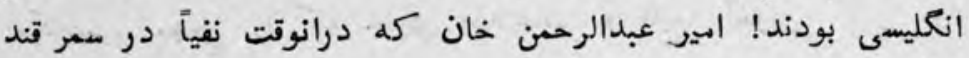

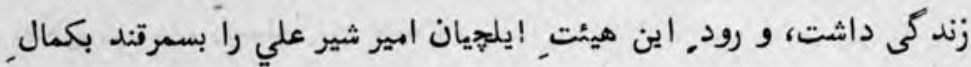
وضوح بينويسد (1)

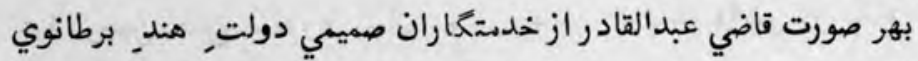

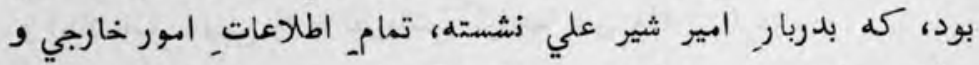

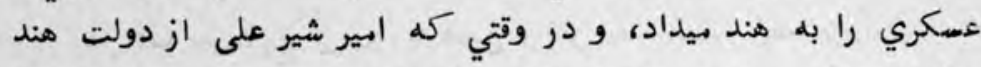

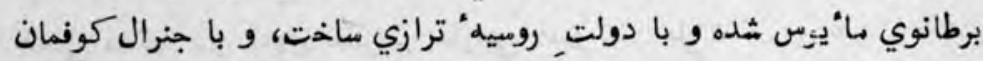

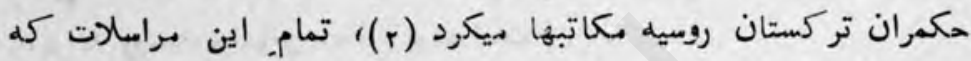

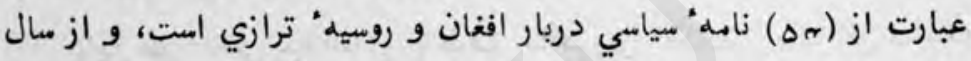

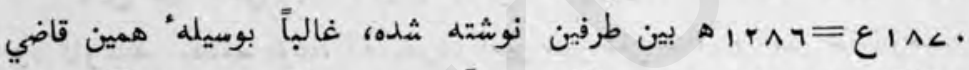

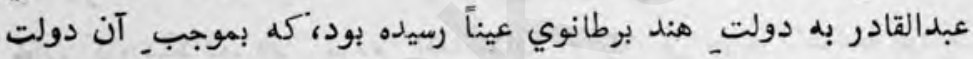

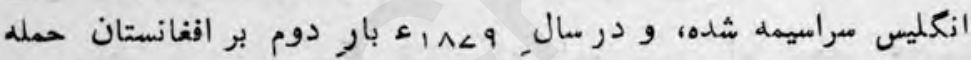

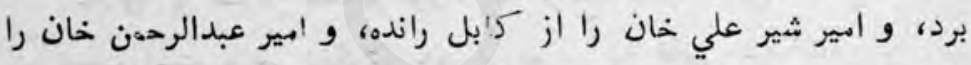

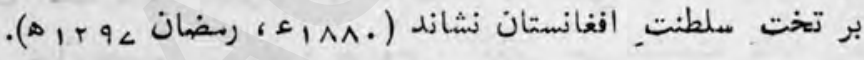

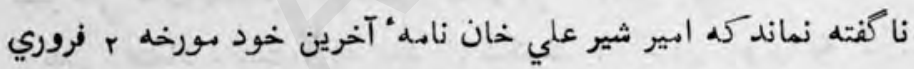

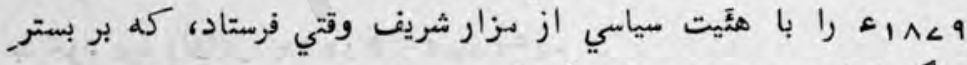

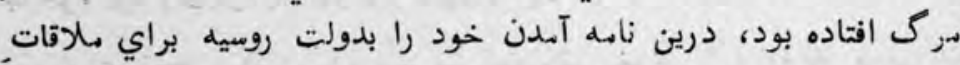

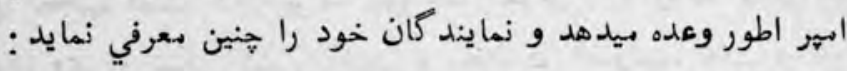

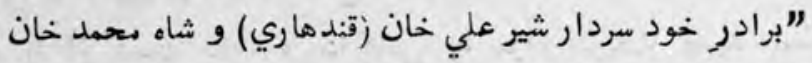

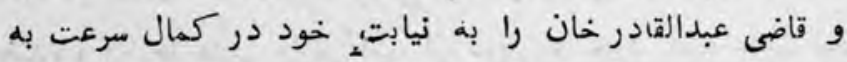

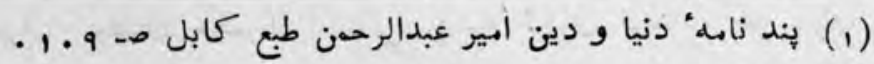

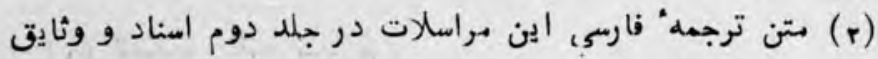

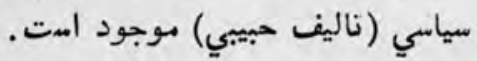


تاشكند روانه داشتم ... ايشان وزراي معتمد دولت افغان

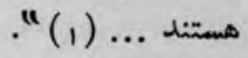

ابن هئيت سياسى كلى ابتير شير علي خان بتاشكند فرستاده بوده،

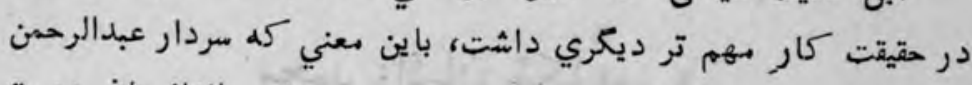

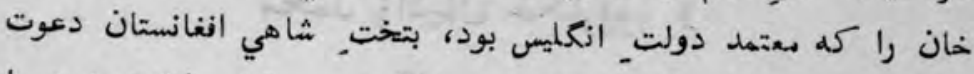

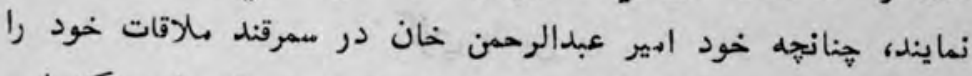

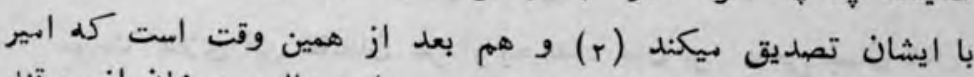

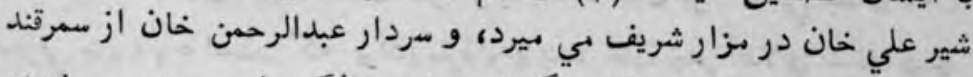

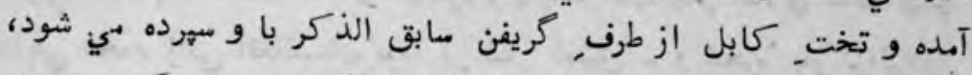

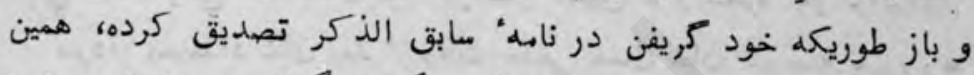

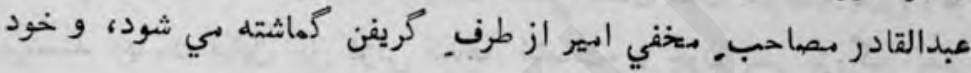

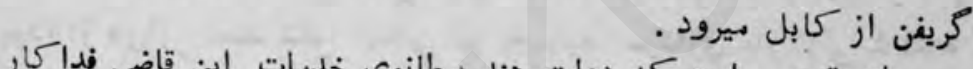

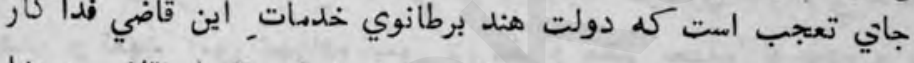
را كماحقه قدر داني نكرد، و از مطاوي تمام اسناد, فاميلي قاضي هويدا

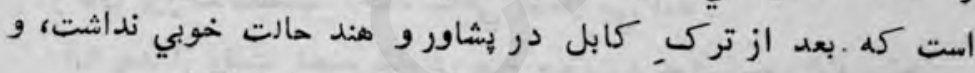

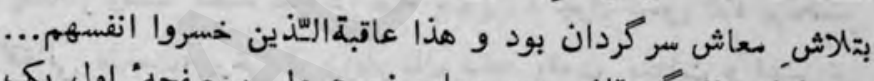

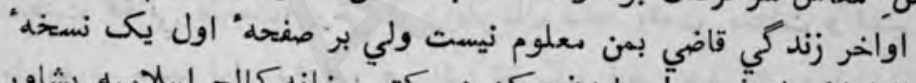

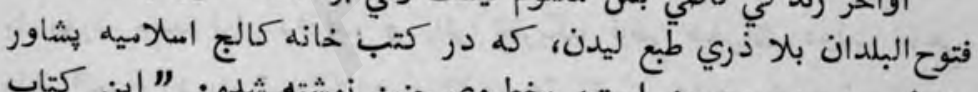

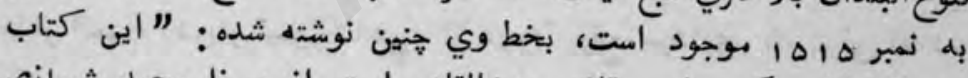

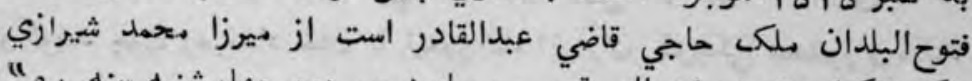

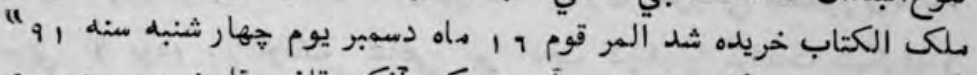

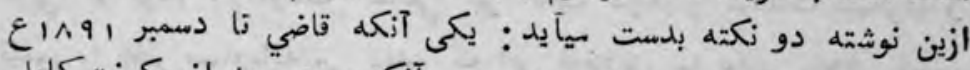

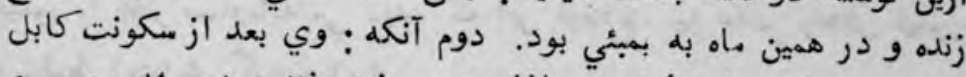

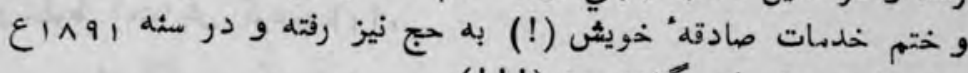

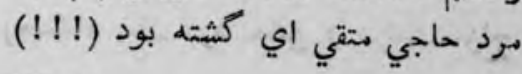

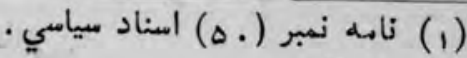

$$
\begin{aligned}
& \text {. } 1 \text { (r) }
\end{aligned}
$$




\section{$-10-$ \\ متمل زائيان شكاريور و \\ كري ياسين}

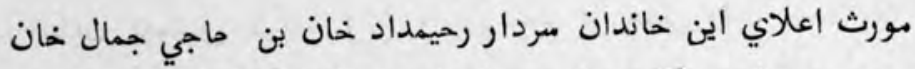

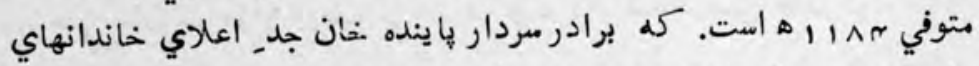

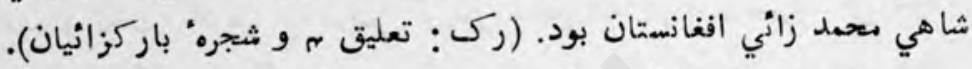

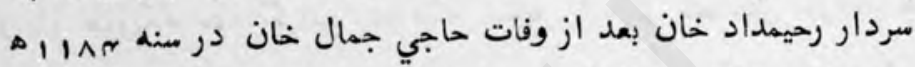

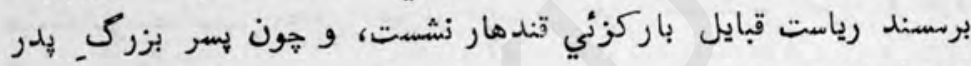

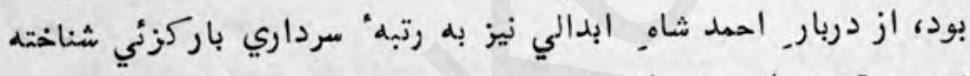

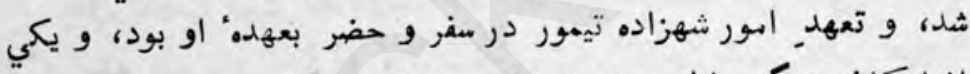

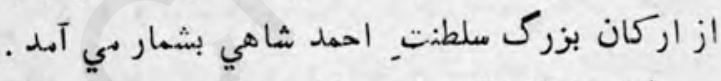

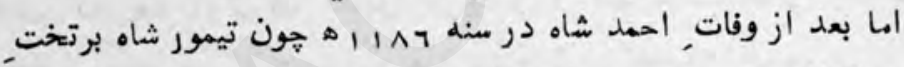

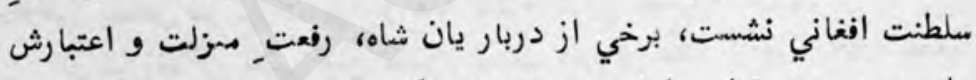

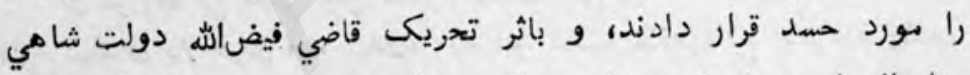

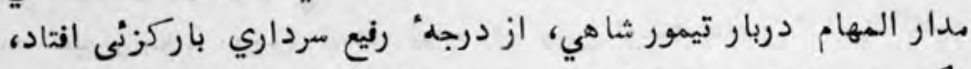

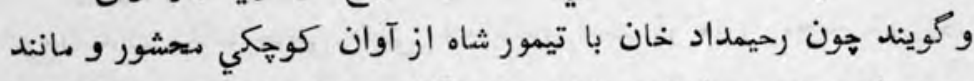

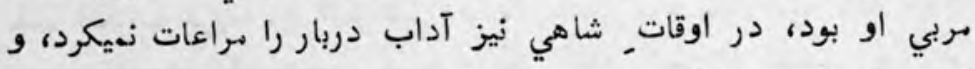

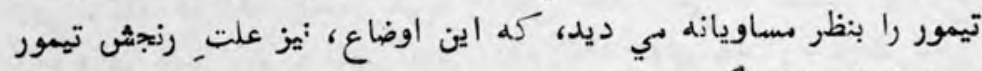
و سقوط. اعتبارش كرديد (1).

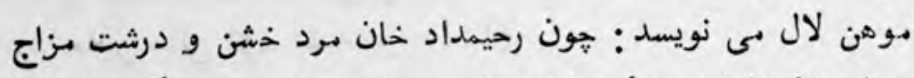

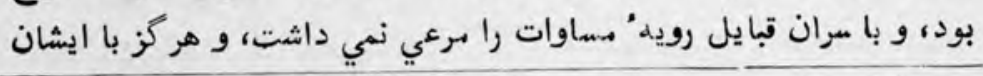

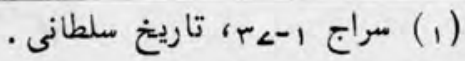


بيكى خوان نمي نشست، بنا بران بدربار شاهي شاكي شدند، و شاه خواهث

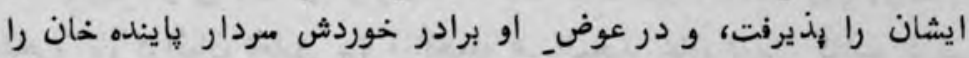

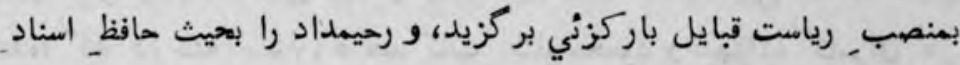

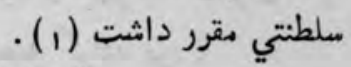

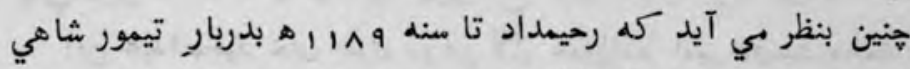
بهمين رتبه باقي بود، زيرا دران عصر بر هيشت فراهين شاهي تمام. رجال

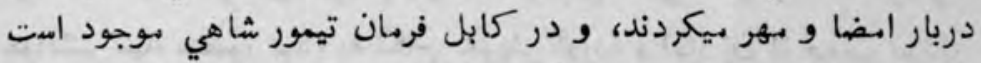
كله در سنه و1111 نوشته شده، و مهر , رحيمداد خان نيز داري. . اما بعد ازين سنه فرامين

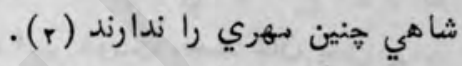

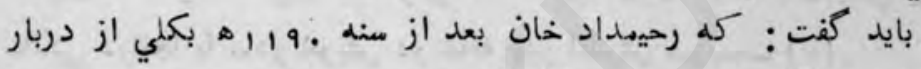

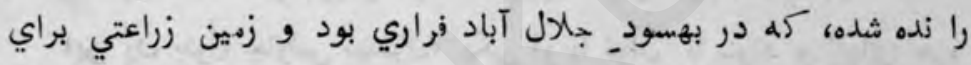
معاش او داده اند، و برخي از اخلاف وي تا كنون درانجا سمكونت

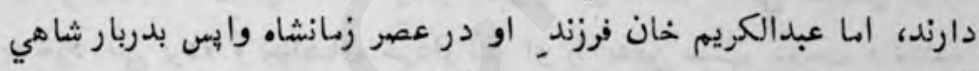

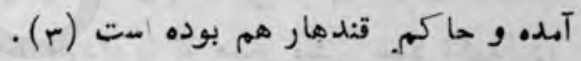

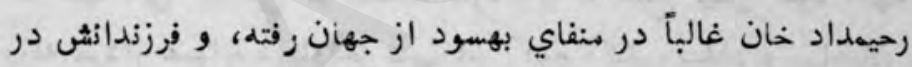
بهسود و شكاريور بامور زمين داري يرداخته اند، هون از همين اوقات

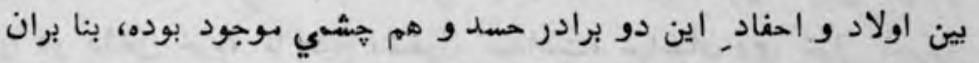

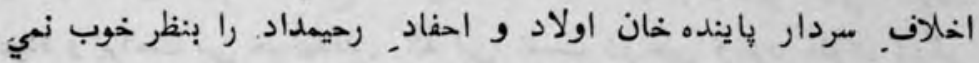

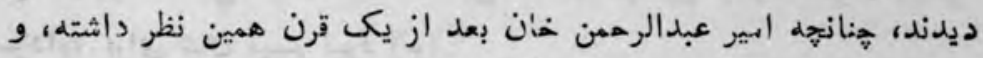

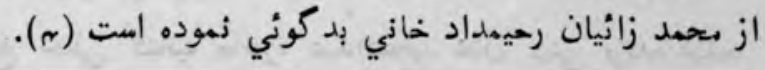

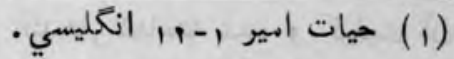

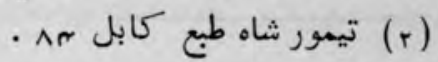

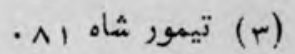

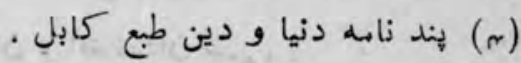




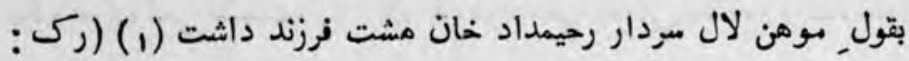

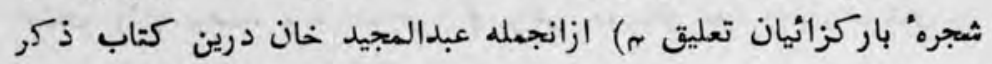

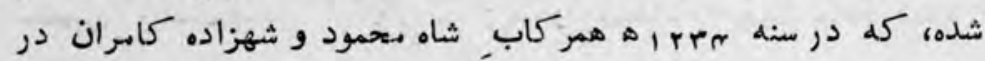

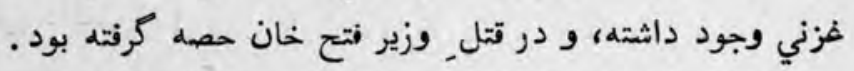

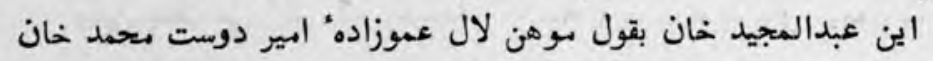

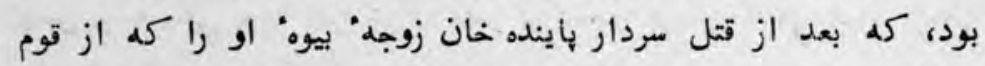

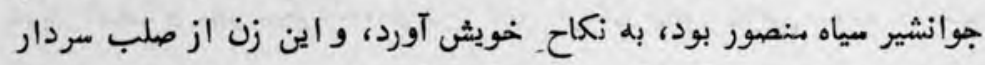

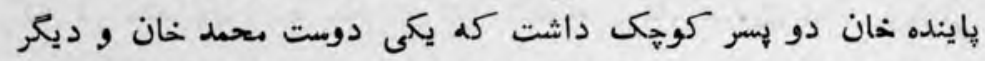

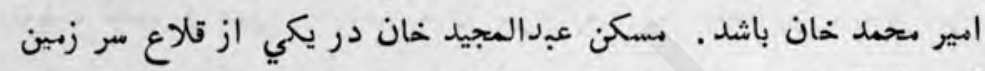

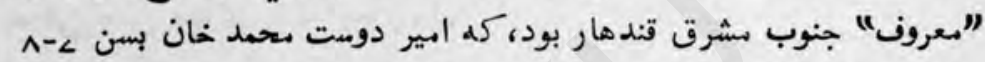

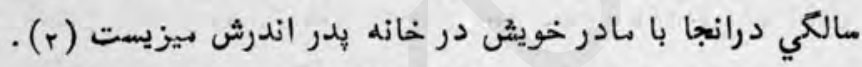

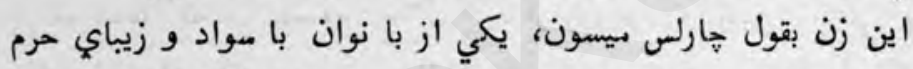

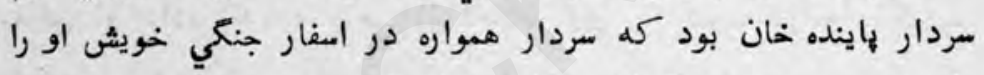

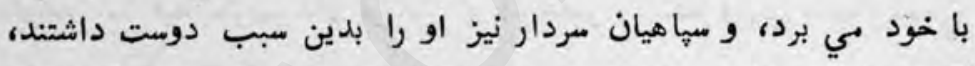

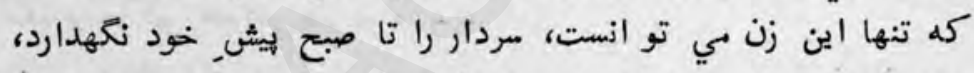

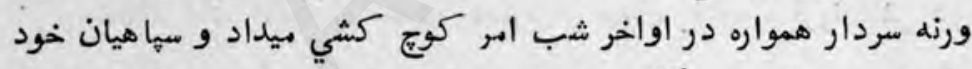

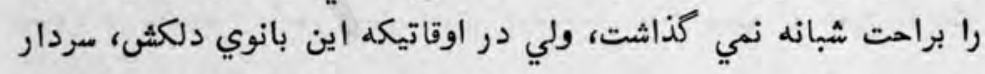

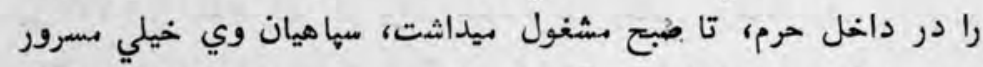

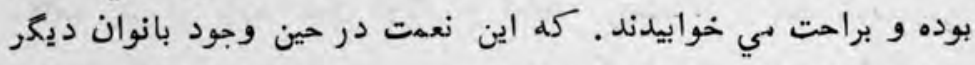

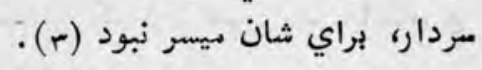

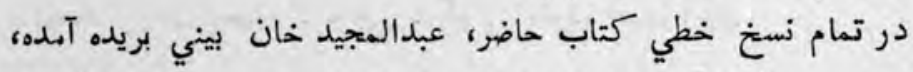

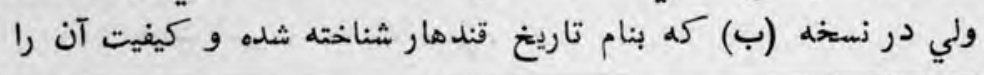

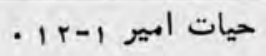

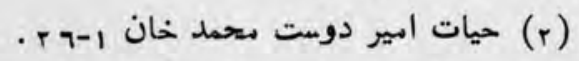

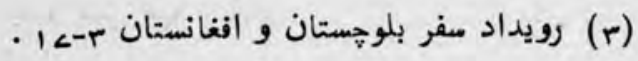




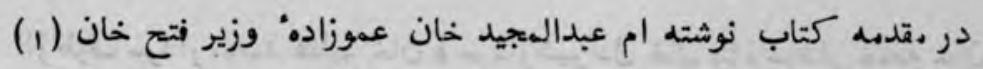

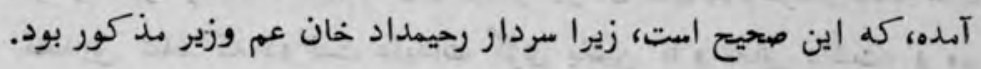
عبدالته خان اول نرس

اهـا فرزند ديكر رحيمداد خان كم غالباً بعد از فرارو سقوطِ اعتبار

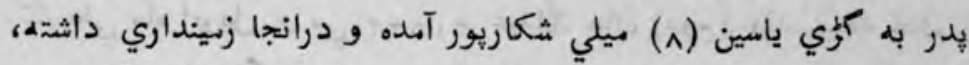

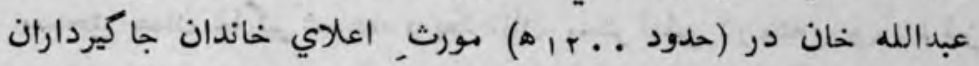

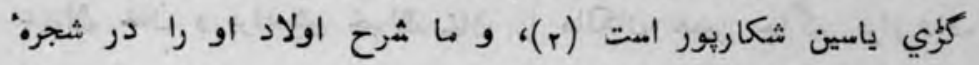

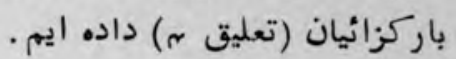

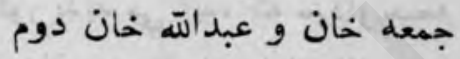

طوريكه درين كتاب به تفصيل آهده، جمعه خان ولد عبداله خان خان

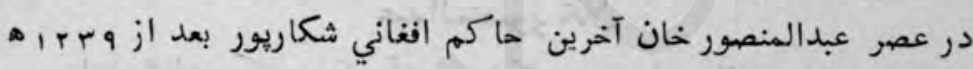

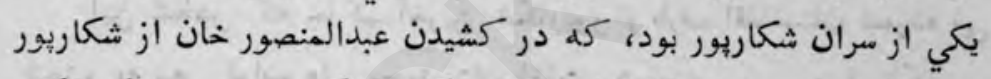

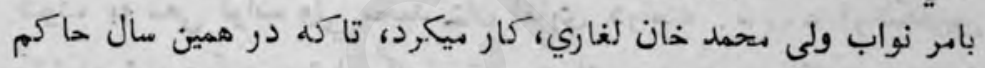

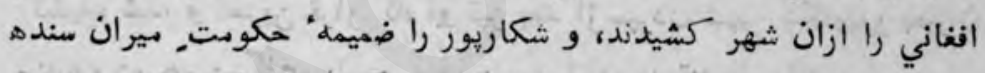

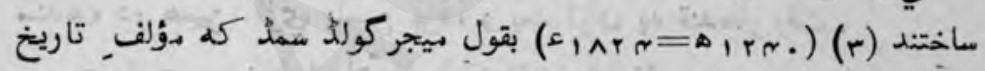

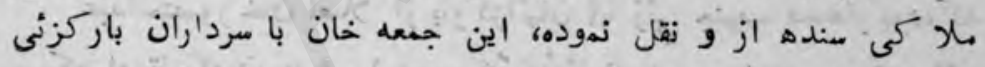

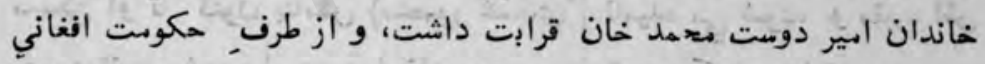

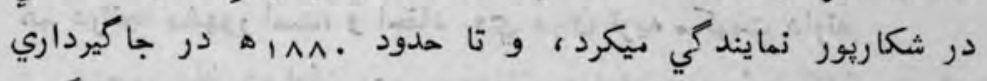

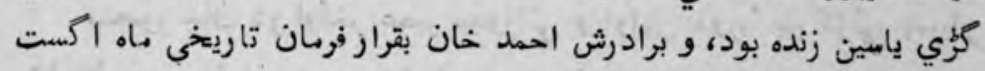

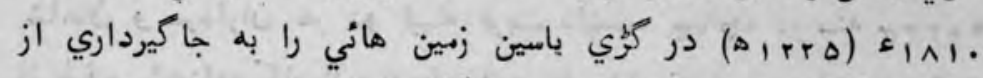

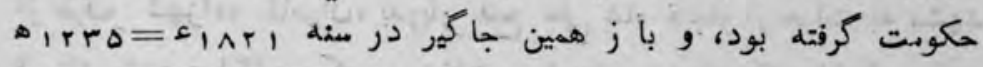

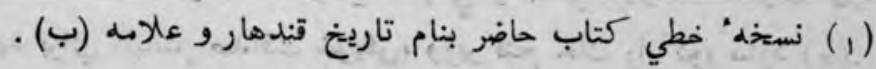

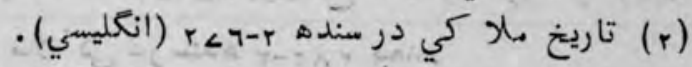

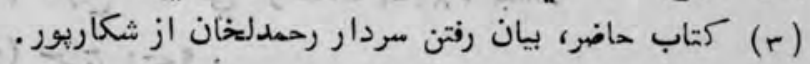


ازطرف سردار محمد عظيم خان وسردار شير دل خان بنام سردار جمعه خان

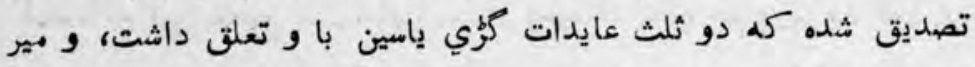

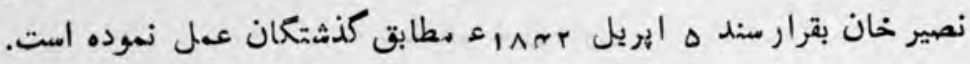

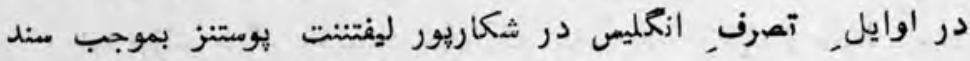

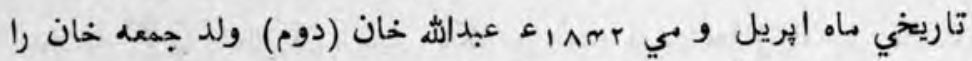

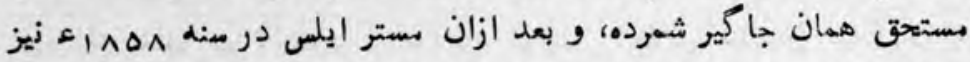

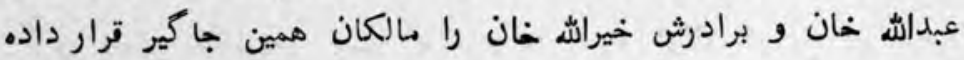
است (1)

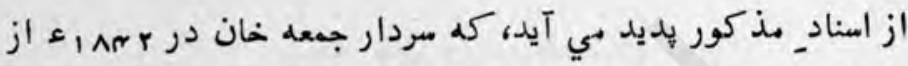

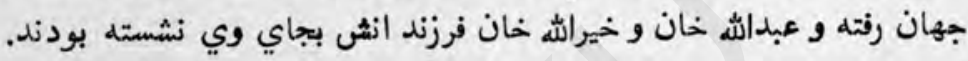

$$
\text { عبد المنصور خان }
$$

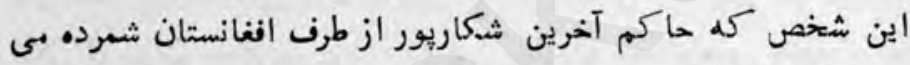

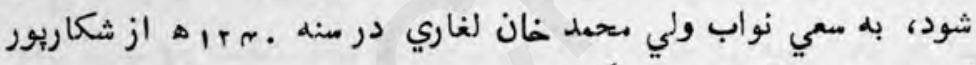

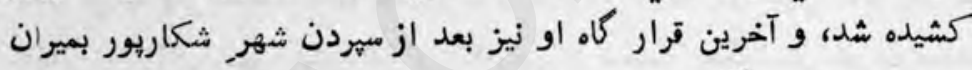

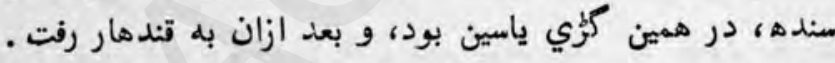

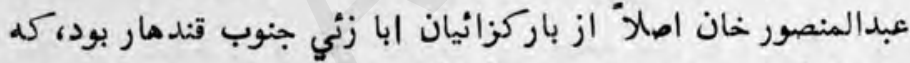

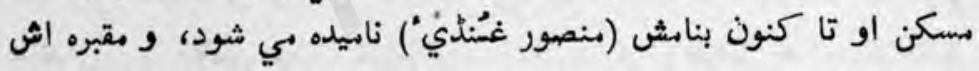

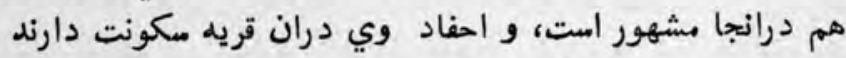

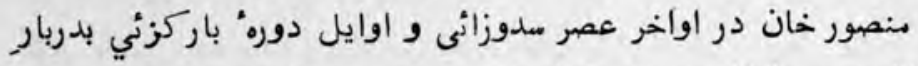

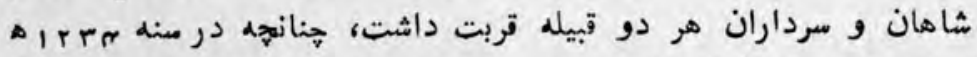

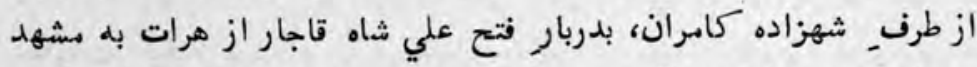

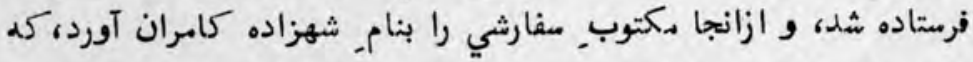

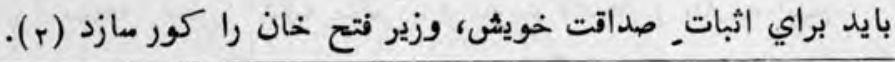

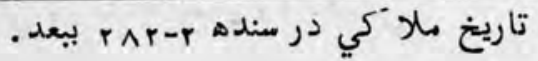

$$
\text { . } 9<-1 \text { (r) }
$$


مؤلف كتاب حاضر نيز كويد: كله عبدالهنصور خان باركزني در ركاب كامران از قندهار بهرات رفته، و در جمعـ دتخالفان وزير لهزي

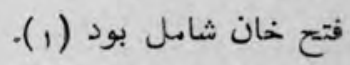
اين عبدالمنصور خان با مرداران ق قندهاري برادران وزير فتع خان

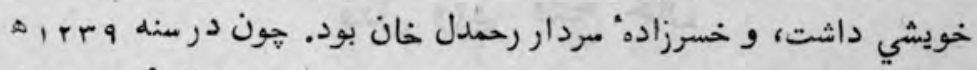

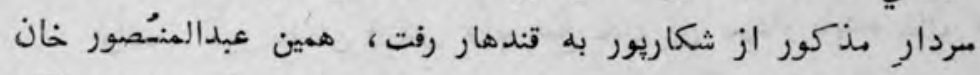

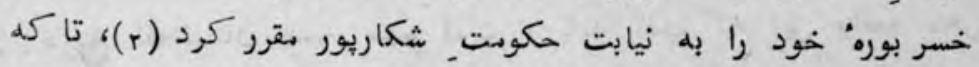

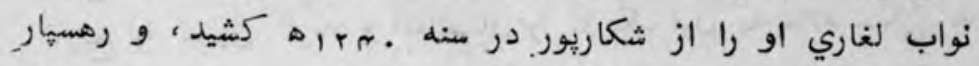
قندهار كرديد.

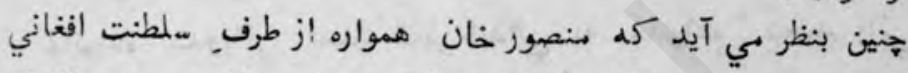

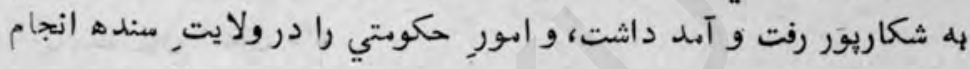

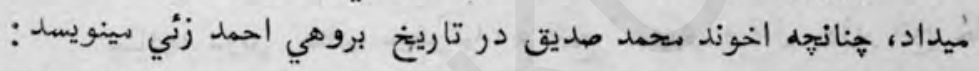

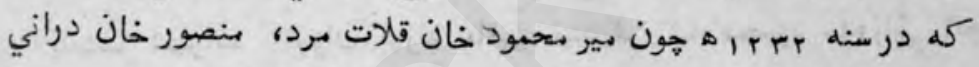

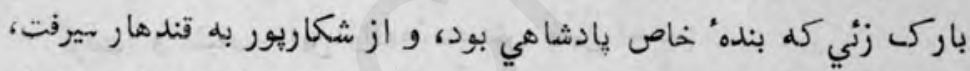

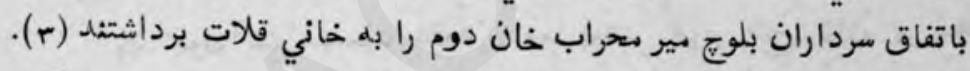

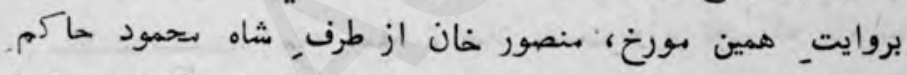

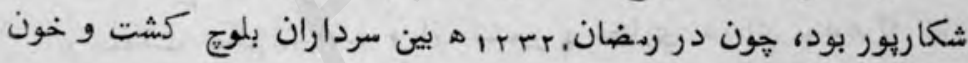

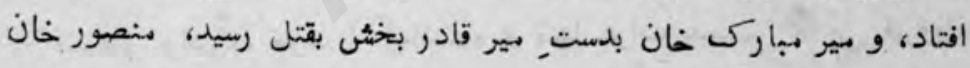

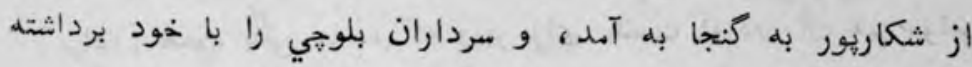

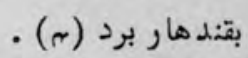

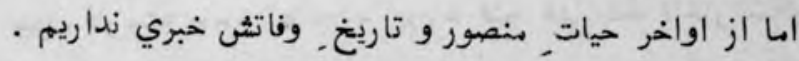

(1) كتاب حاضر بيان رفتن شاهزاده كامران بهرات .

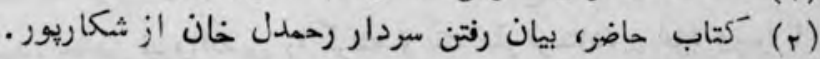

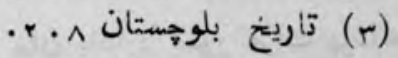

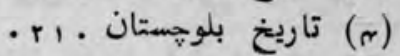




\section{$-14$}

\section{قتل وزير فتح خان}

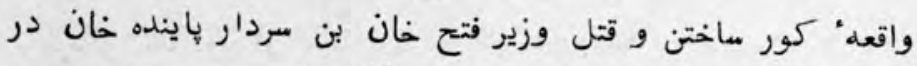

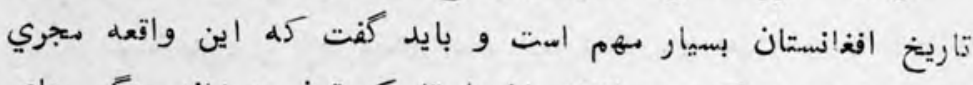

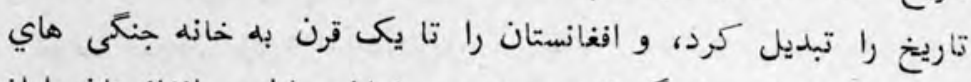

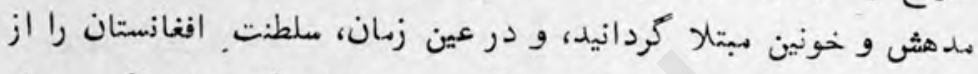

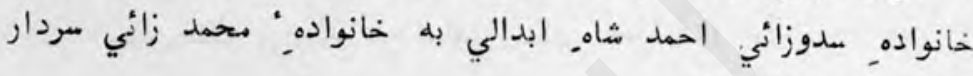

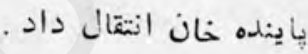

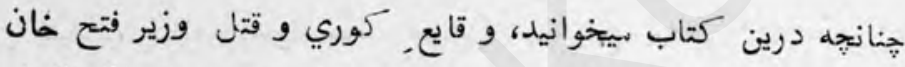

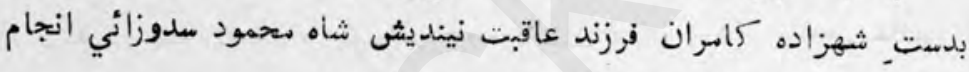

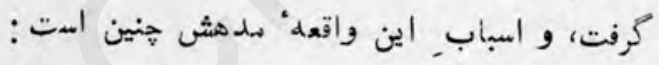

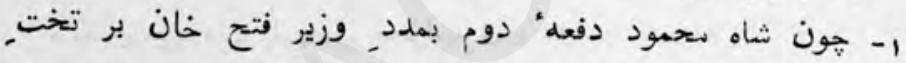

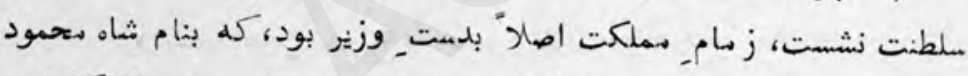

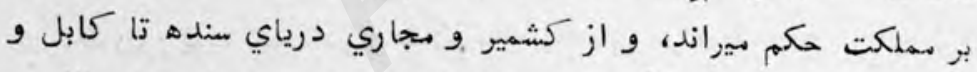

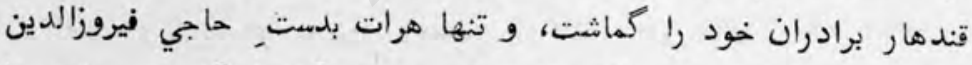

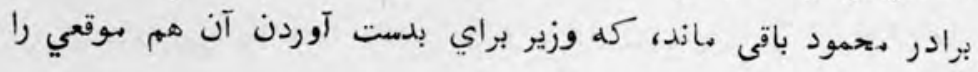

مي ديد.

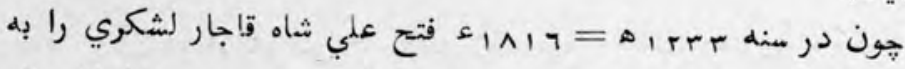

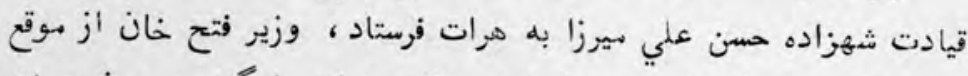

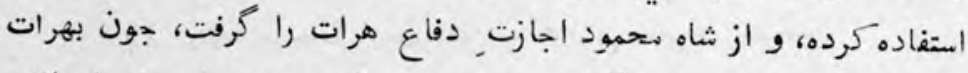

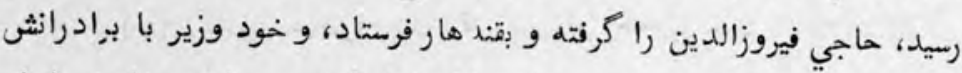

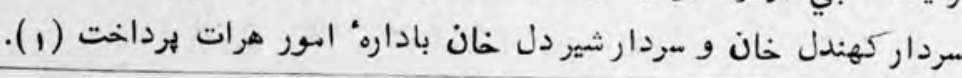

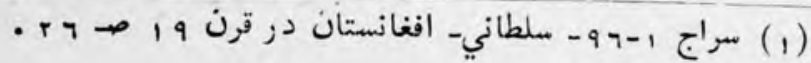


درينوقت شهزاده كامران نفوذ و اقتدار روز افزون وزير را با حاكميتي

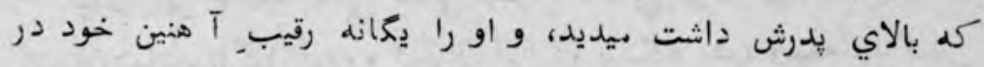

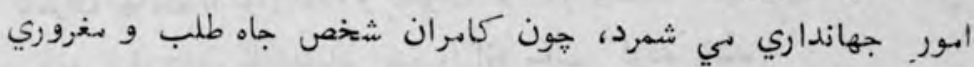

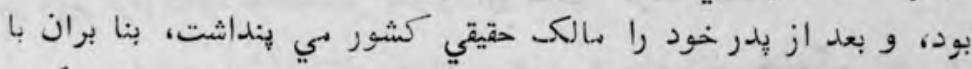

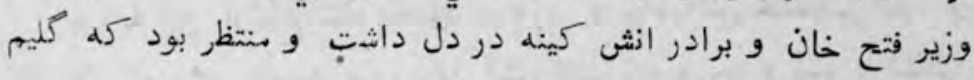

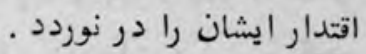

r- هون وزير فتح خان هرات را كرفت، و حاجى فيروز را با سارت

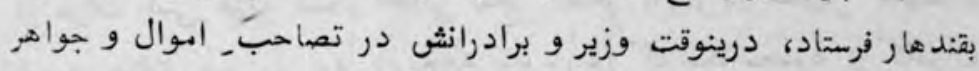

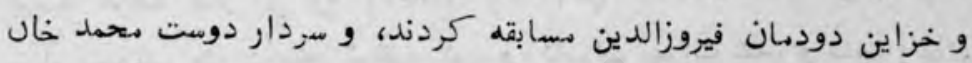

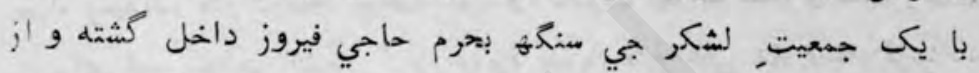

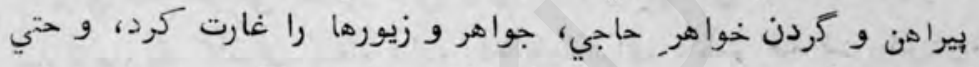

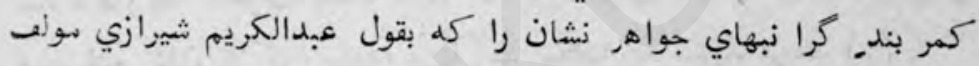

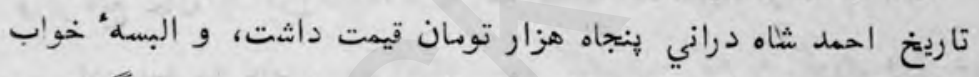

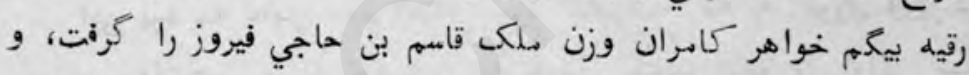

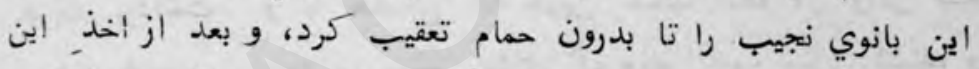

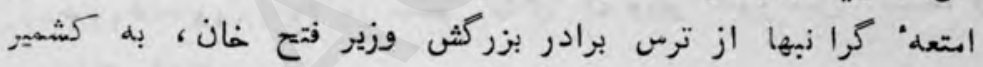

$$
\text { كريخت (1) }
$$

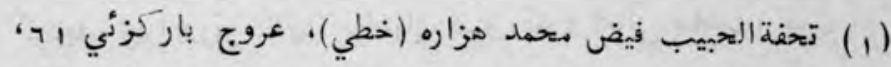

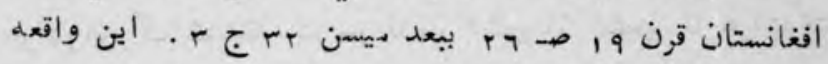

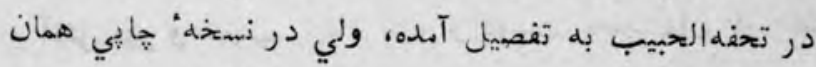

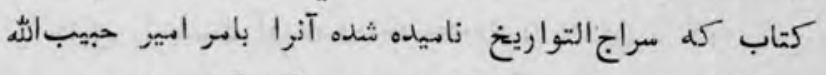

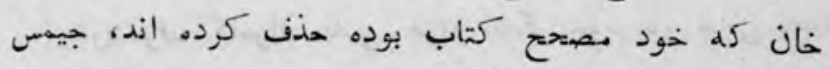

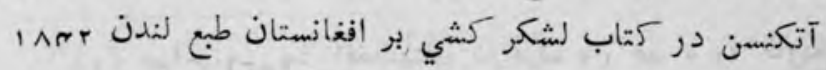

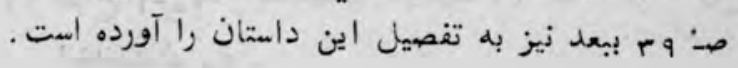


هون اين واقعه بكلي منافي رسوم, افغاني بود، بر شاه محمود و

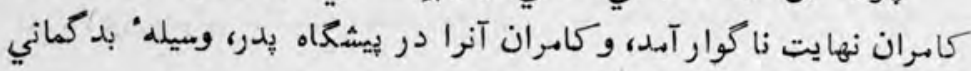

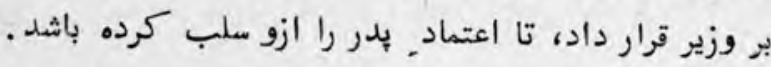

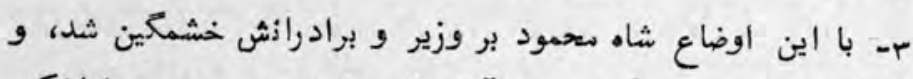

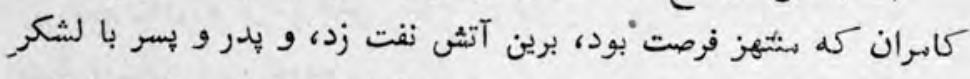

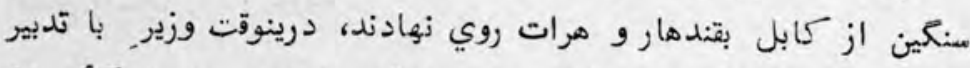

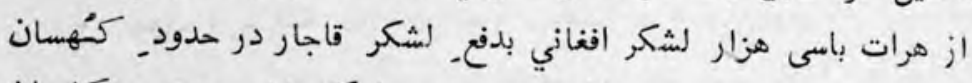

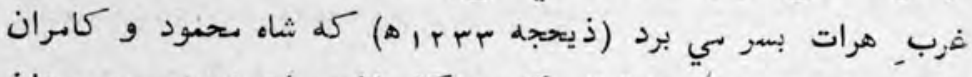

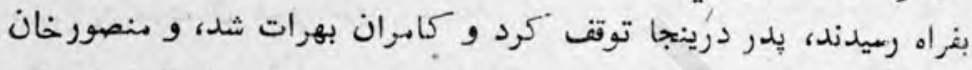

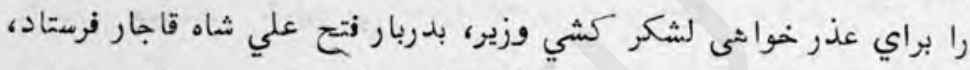

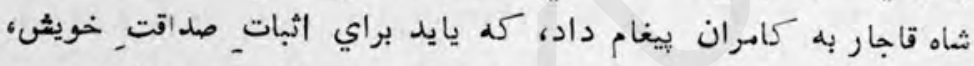

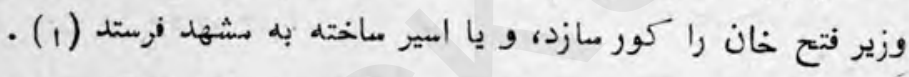

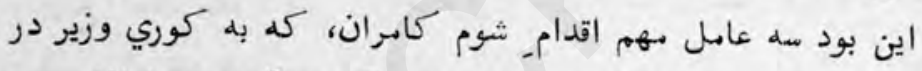

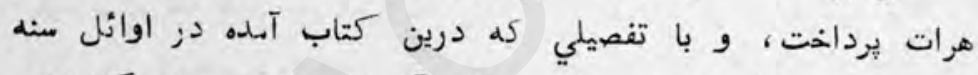

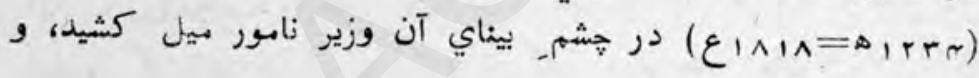
بزندانش انداخت.

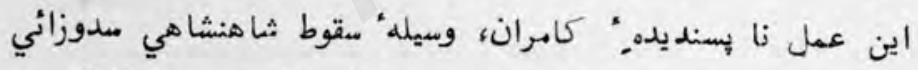

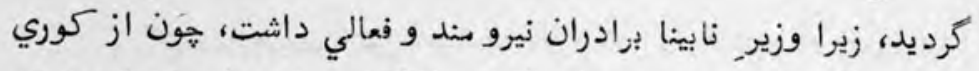

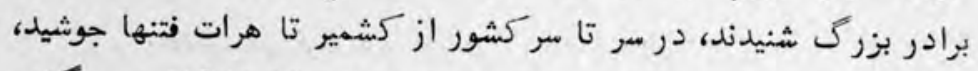

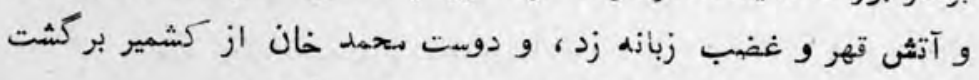

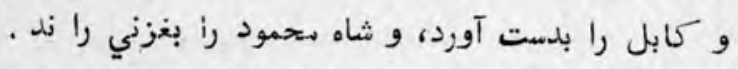

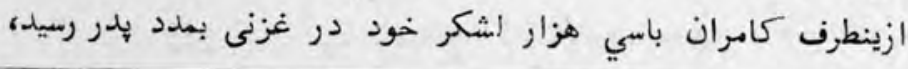

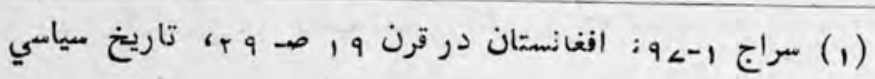
افغانستان 
$\wedge \Delta \Delta$

تازه نواي معاركى

و محمد عظيم خان از كشمير به معاونت دوست محمد خان آمد، هيون

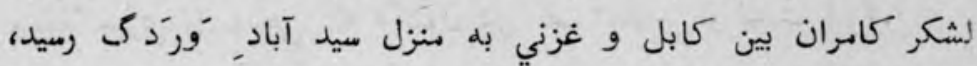

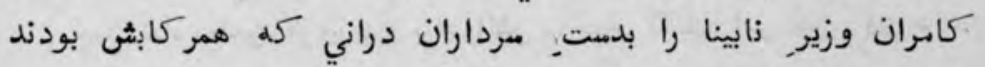
باَّوء عذاب بكشت، و بند از بندش بريد، اين واقعه اليمه در سنه

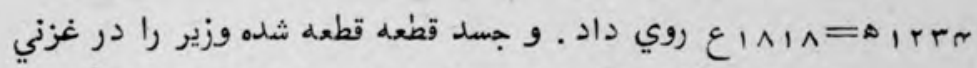

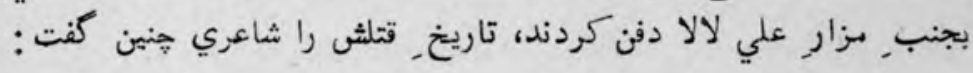

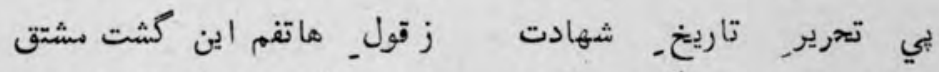

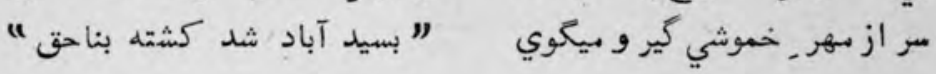
Dirrer = 119m+r.

بر لوحــ مزارش در غزني تاريخــ قتلش هنين نوشته شده :

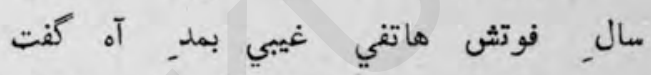

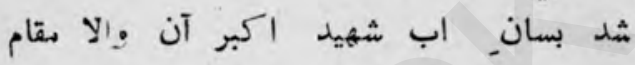

آن ابير نادر و اين نادوه تاريخ

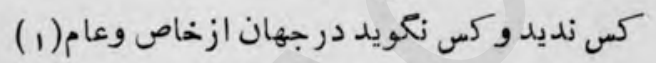

كويند كه قبل از قتل وزير نابينا را بحضور شاه محمود آ وردند،

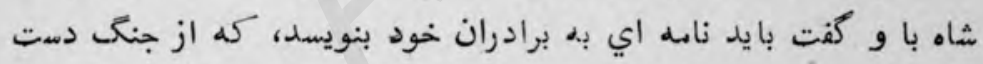

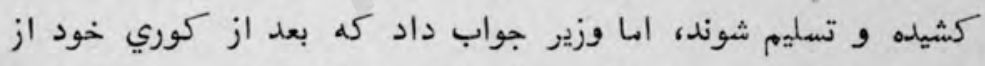

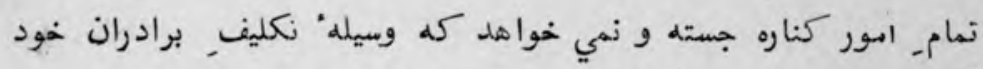

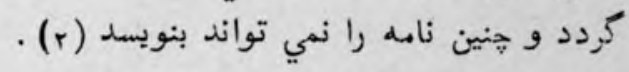

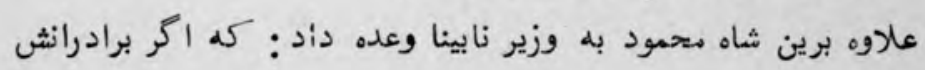

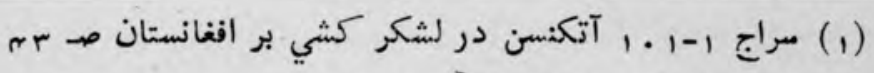

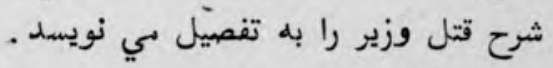

$$
\text { (r) عروج باركزئي } 9 \text {. }
$$


تعليقات

$\wedge \Delta \neg$

رام شوند، بأنها وزارت و رتبه هاي بزرك خوإهد داد، ولي وزير كفت :

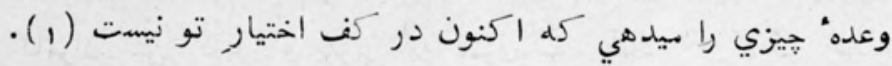

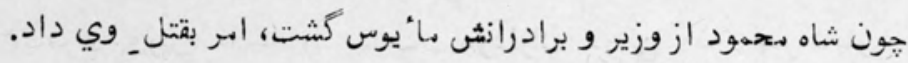

( رابع به نسب نامهه وزير فتح خان و برادرانش تعليق م بخوانيد ) .

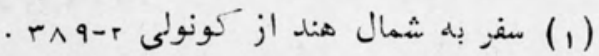




\section{مجدديان سنده و افغانستان}

- اييز غلام محي الدين سروهندي و نظام الدين سرهندي

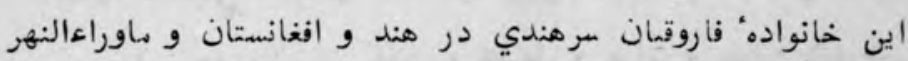

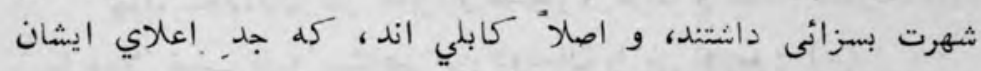

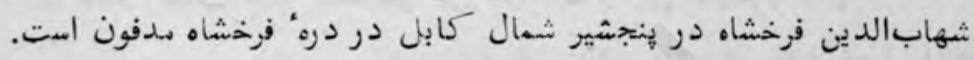

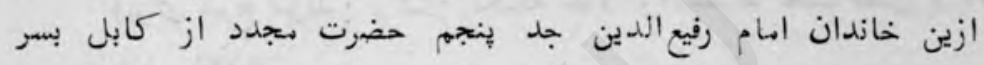
هيد رفت .

الها شهرت اين خاندان بعد از شيخ احهد مجدد الف ثاني سرهنديست

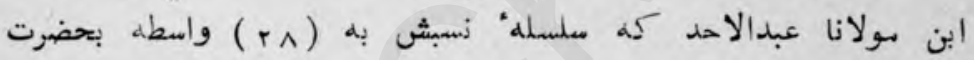

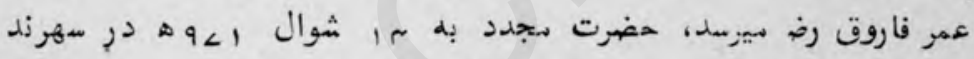

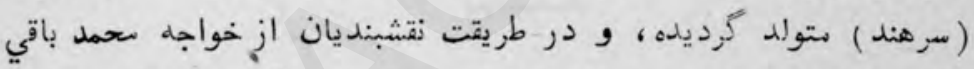

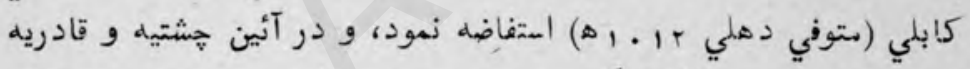

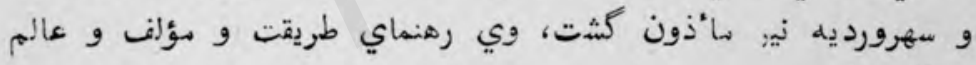

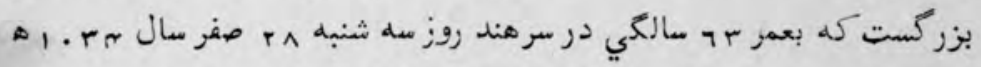

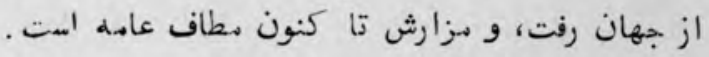

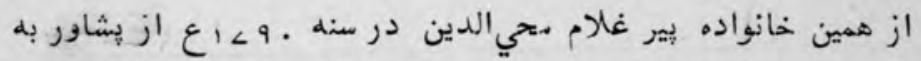

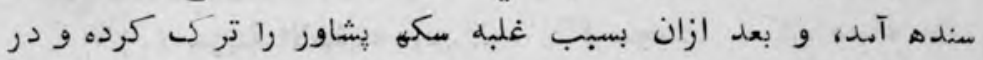

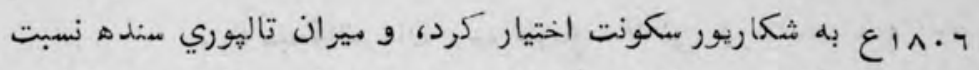

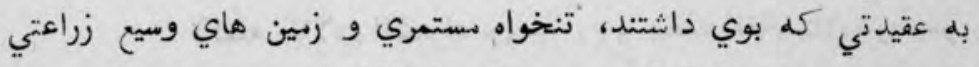

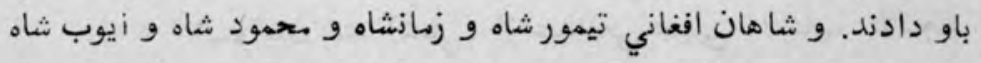

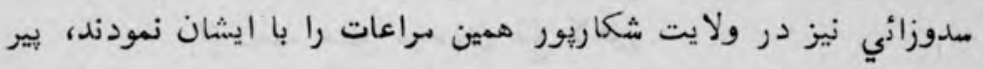


تعليقات

$\wedge \Delta \wedge$

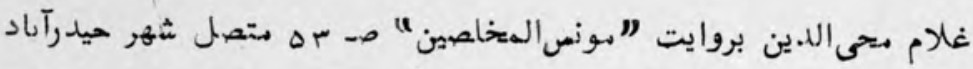

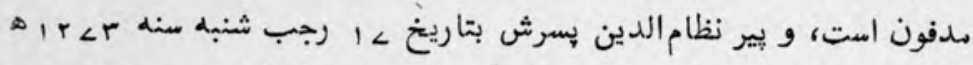

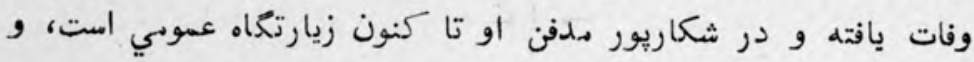
اولادوي در شكاريور موجودند. بير نظام الدين مرد عالم وشاعر و م.تنفذي بود، در فارسي ديوان اشعار

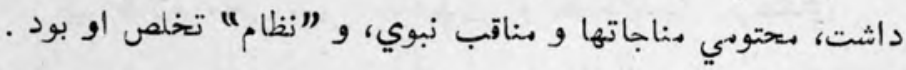

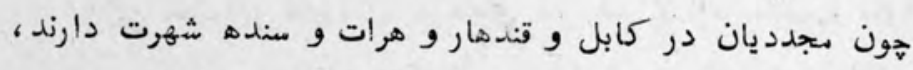

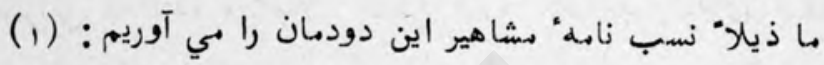
(براي شرح مزيد : ركى: تكمله مقالا.،، الشعراء تحت نضل و باقي

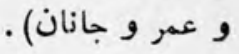

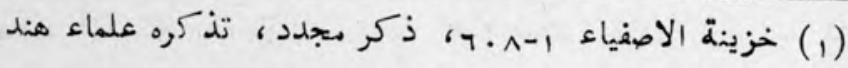

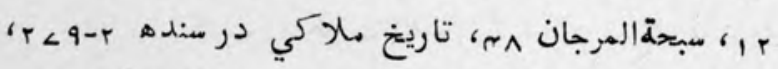

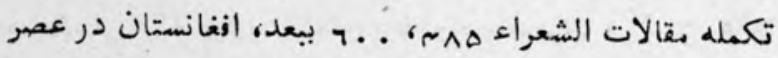

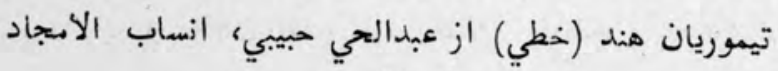
از محمد حسن مجددي طبع لاهور. 


\section{$-11-$ \\ لعل شهباز قلندر}

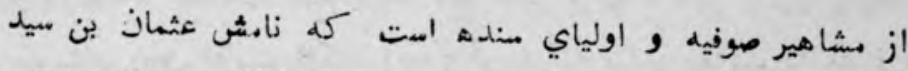

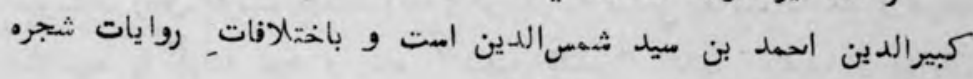

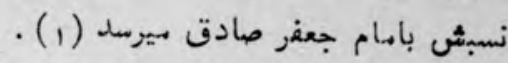

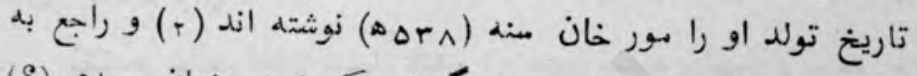

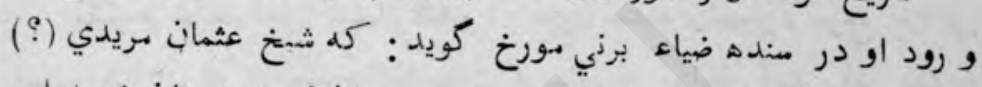

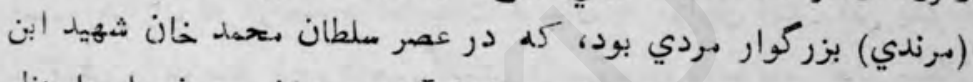

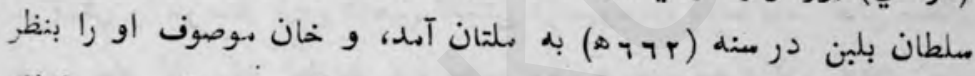

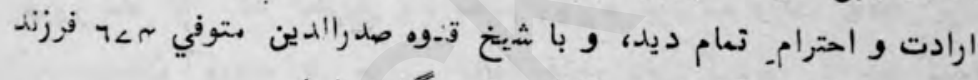

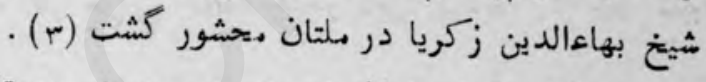

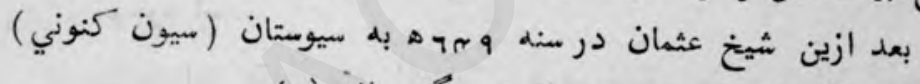

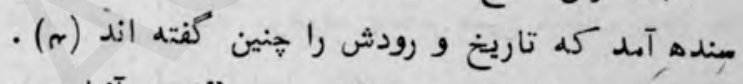

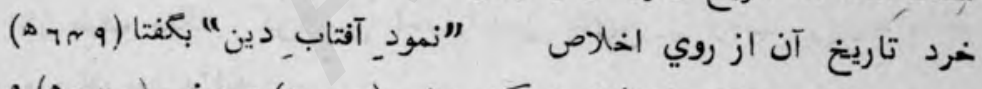

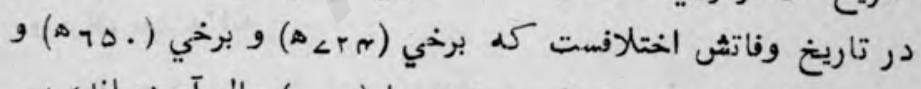

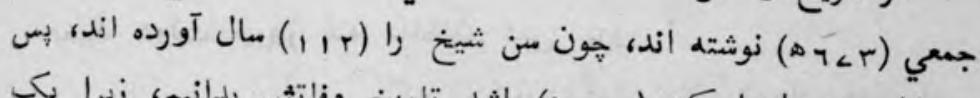

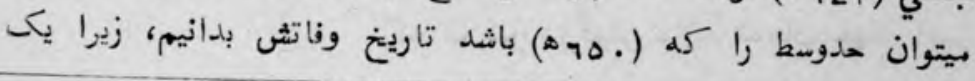

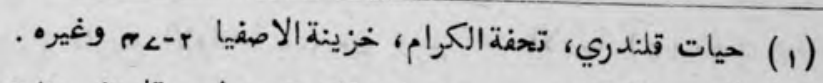

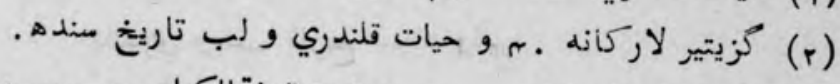

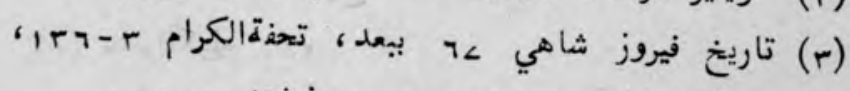

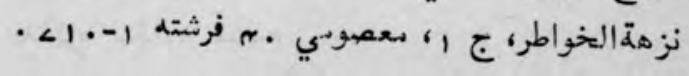

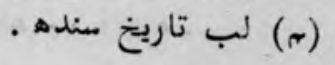


تعليقات

ㄱ.

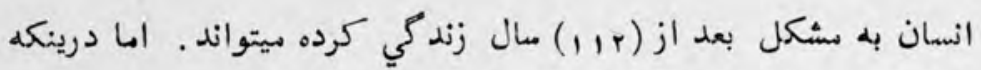

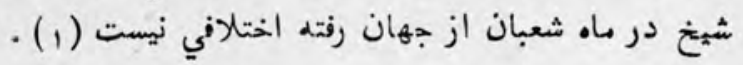

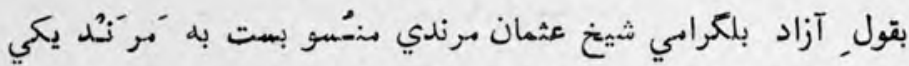

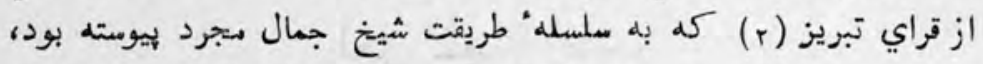

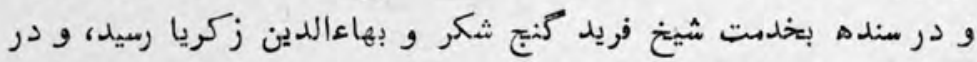

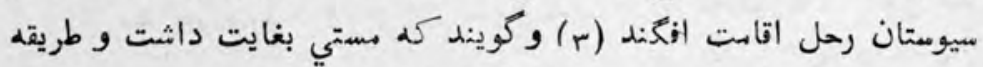

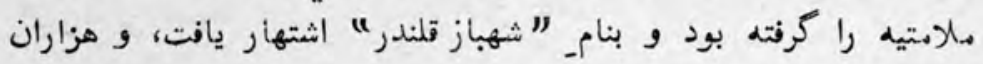

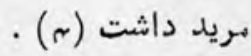

يقبره و خانقاه لعل شهباز قلندر در سيون مينده مشهور و مرجع خلايق

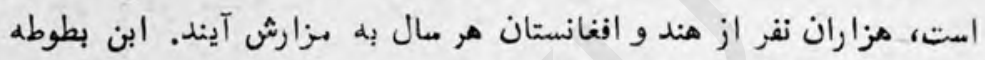

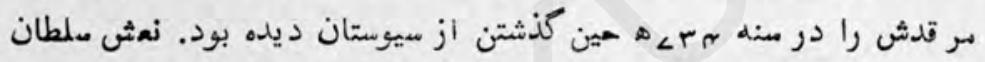

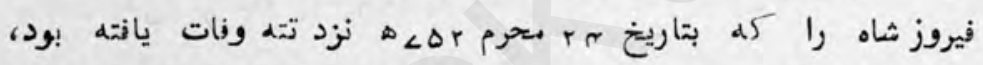

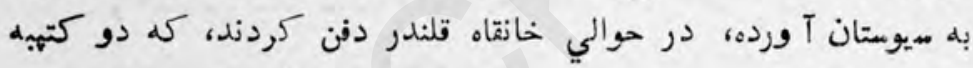

بران موجود است موست

عمارت الهن خانقاه قزار كتيبه' موجوده بحكم همين سلطلان فيروز شاه

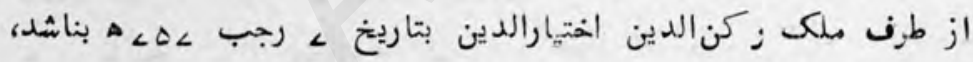

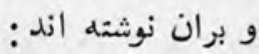

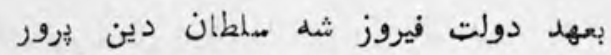

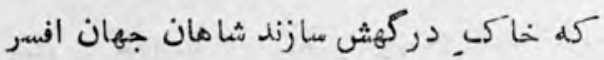

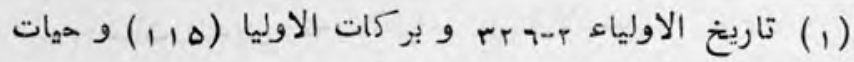

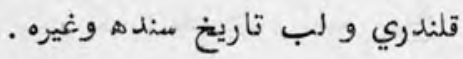

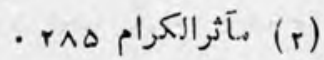

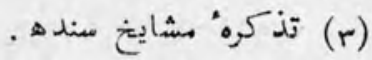

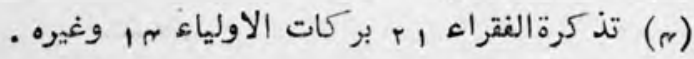


ו

تازه نواي مaارك

عمارت شمد مقامـ شيخ عثمان مرندي، كو

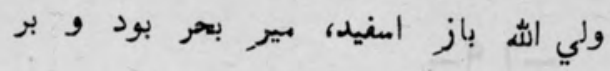

بروز هفتم از ماهـ رجب ببني شد اين روضه

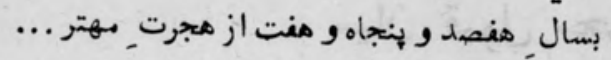

(براي شرح احوال و كتيبهاي مزارشهباز قلمندر،رك :تعليقات_ بقالات الشعراء

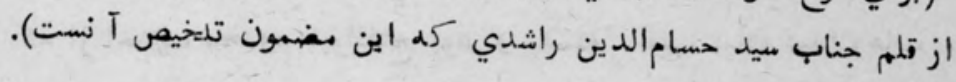




\section{ميان قبول محمد}

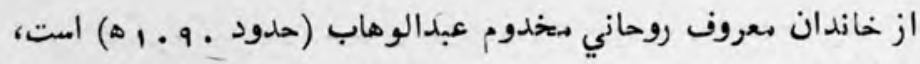

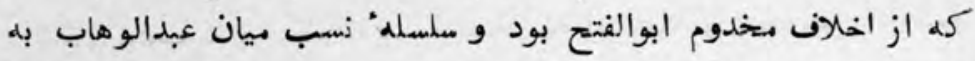

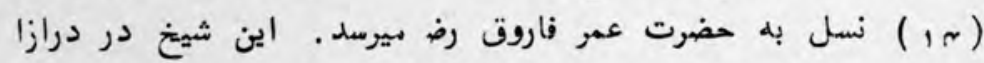

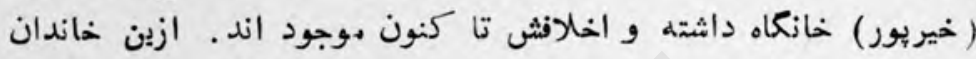
ارباب علم و ذوق و تصوف بر ادده و مورد عقيدت و ارادت_ مردم بودند.

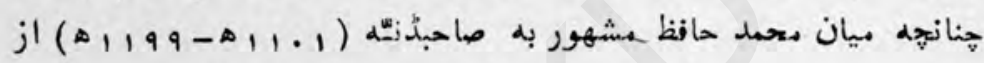

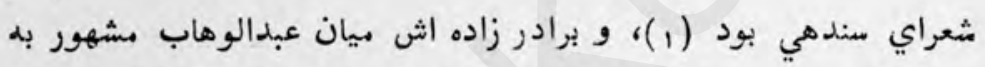

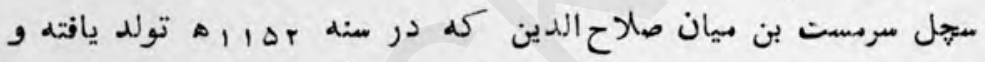

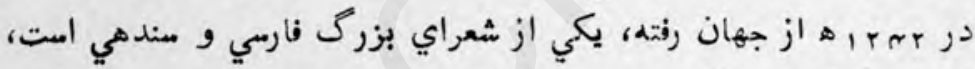

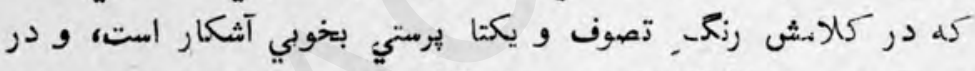

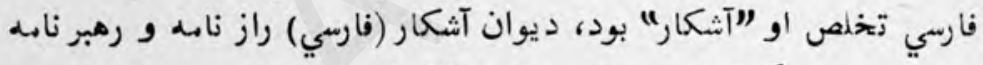

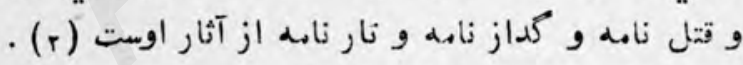

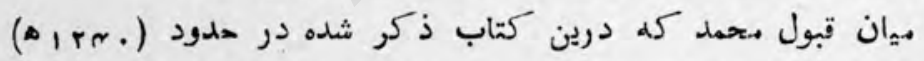

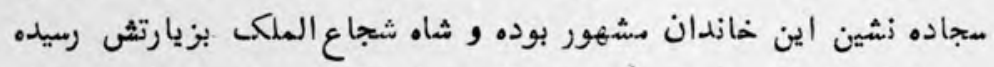

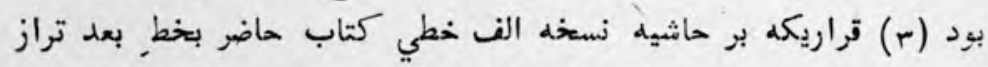

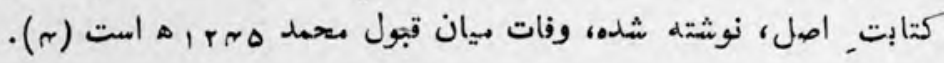

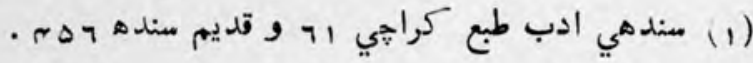

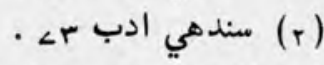

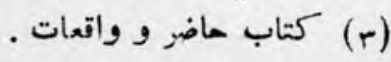

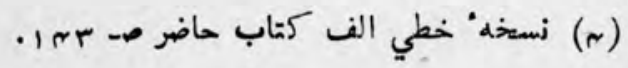




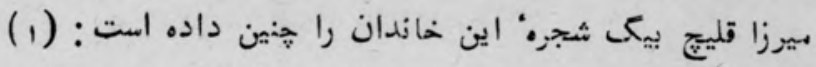

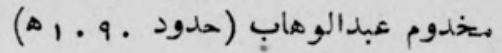

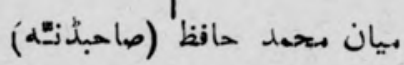

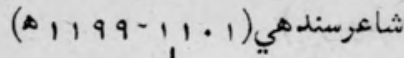

هيان صالح الدين (حدود . r بره)

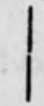

بيان عبد الحق (حدود . r r r ه)

ميان عبدالوهاب نمعروف به مشخل

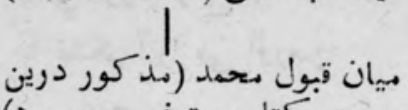

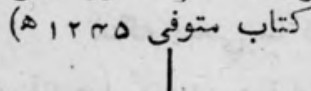

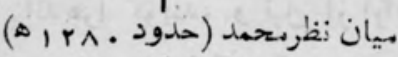

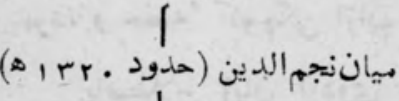

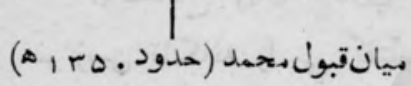

*

*

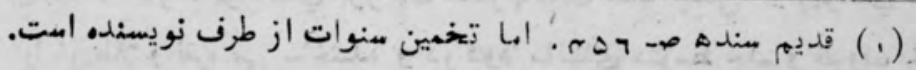




\section{تلir}

\section{(مربوط ص ..< كتاب حاضر)}

در اثناي طبع اين كتاب جناب محمد حبيباله رشدي كارمند سندي

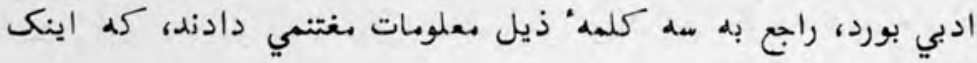
با تشكر آنرا' بي آورم : بادي

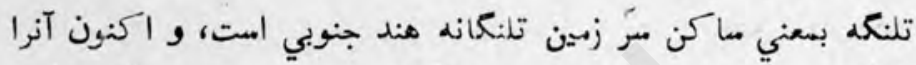

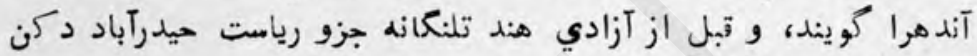
بود، و حصه" كوخهى ازان به مدراس تعلق داشت . باصطلاح زبان اردوي قديم " تلنكه " همان سها هيان سيا. خرده"

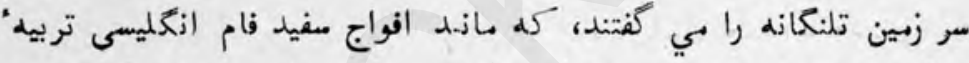

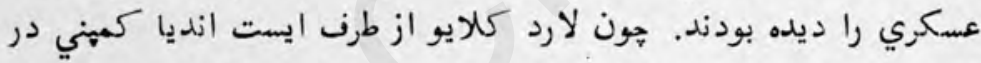

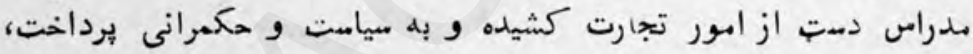

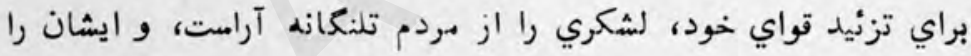

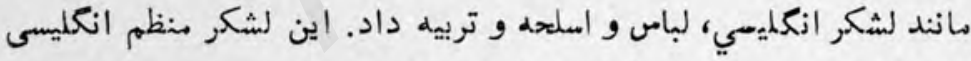

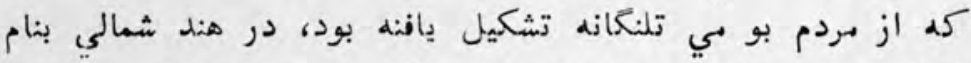

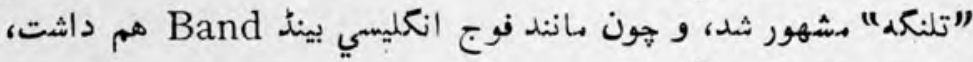

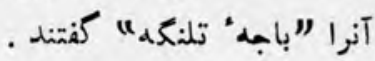

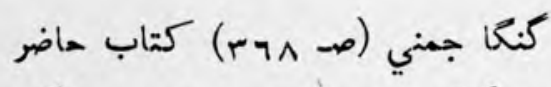

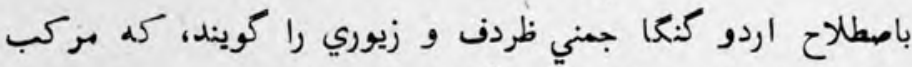

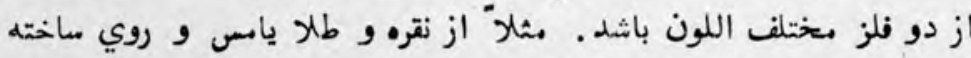

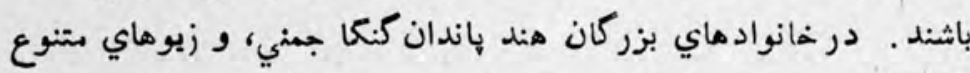

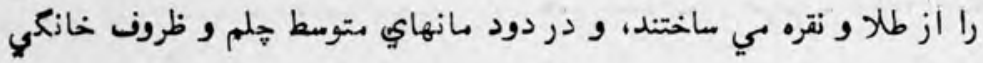




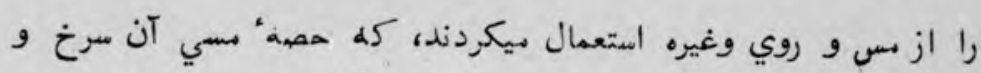

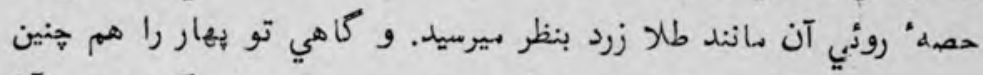

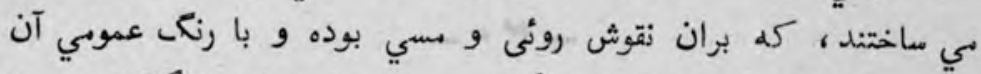

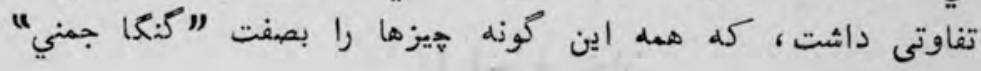

$$
\text { كهار (صـ rero ) كتاب ماضر }
$$

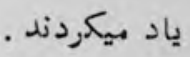

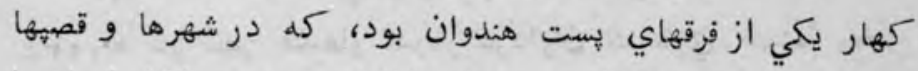

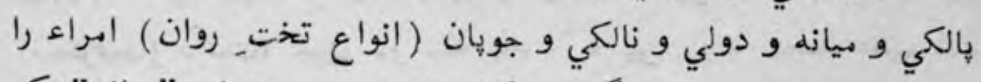

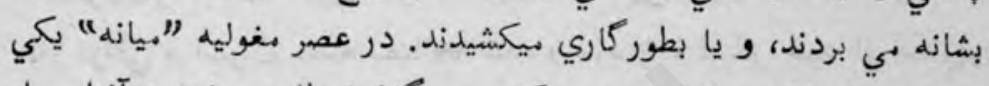

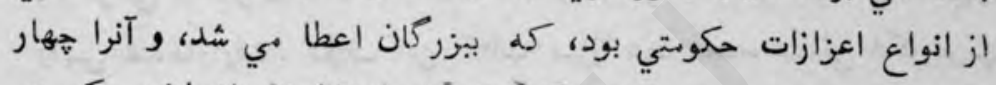

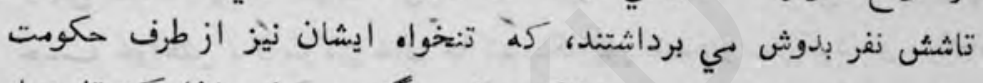

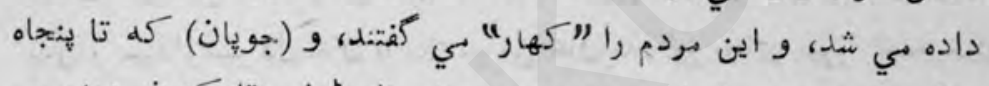

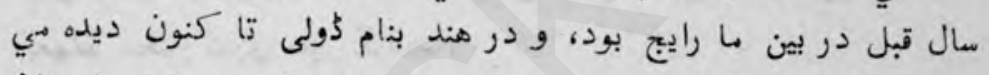

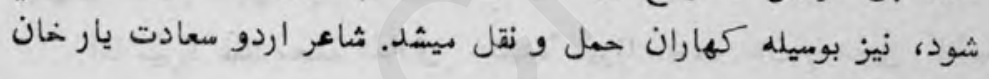

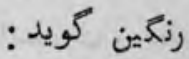

$$
\begin{aligned}
& \text { ذرا كهر كو " رنكين " كم كع تعقيق كرلو }
\end{aligned}
$$

يهاu سان

يعني : اي كهاران! باري خانه' رنكين را تحقيق كند، كه ازبنجا

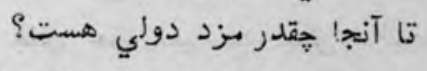

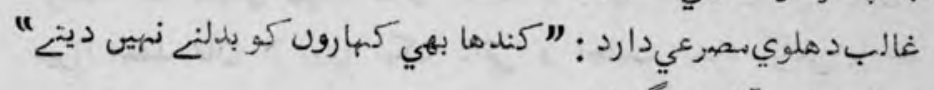
جوش مليح آبادي كويد :

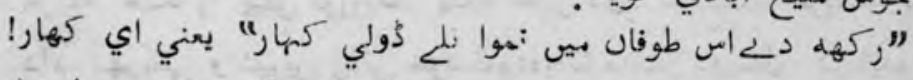

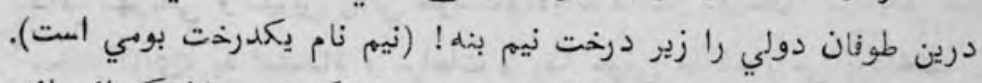

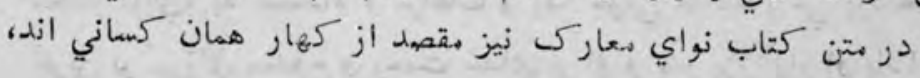

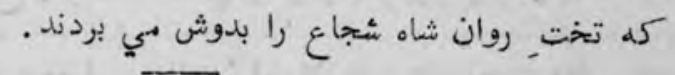




\section{ميرزا احهد خان}

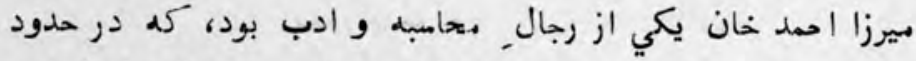

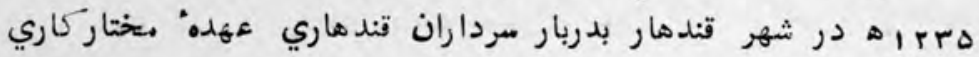

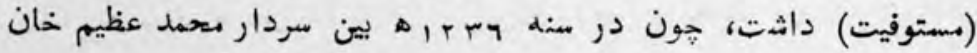

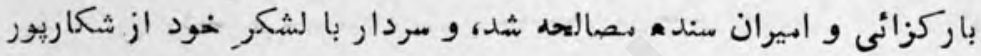

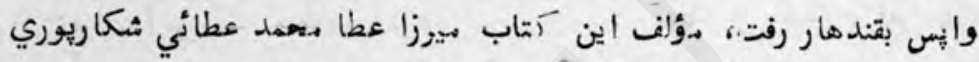
حسب خواهث ملا مؤمن خان حاكم ثكاريور بقندهار سفر كرد، و درانجا

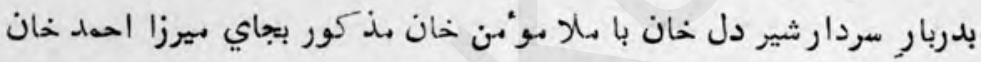

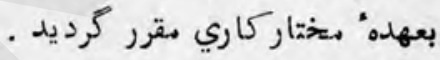

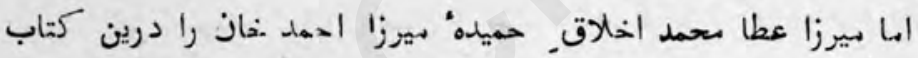

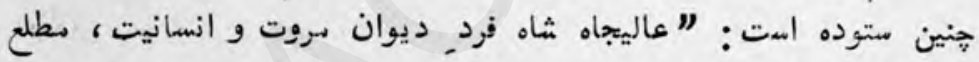

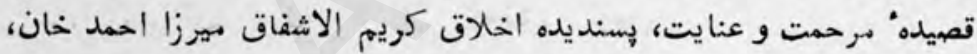

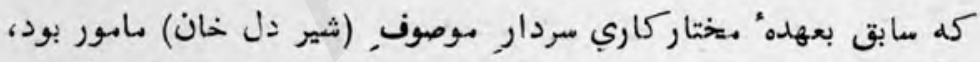

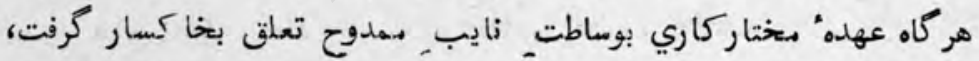

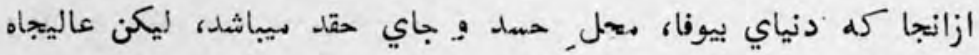

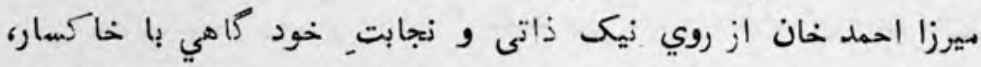

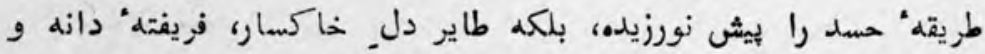

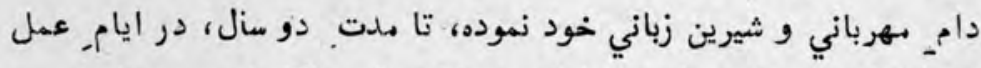

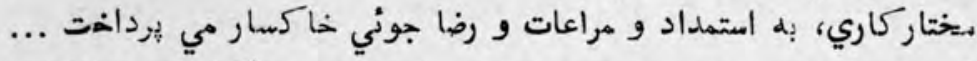

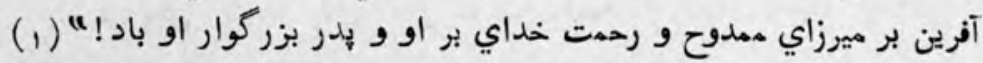
(1) كتاب حاضر، فصل مصالحه" اميران با سردار محمد عظيم خان. 
اين ميرزا احمد خان اكرحه اصلا ز از كابل بود، ولي بدتها در تندمار

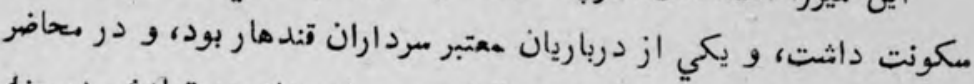

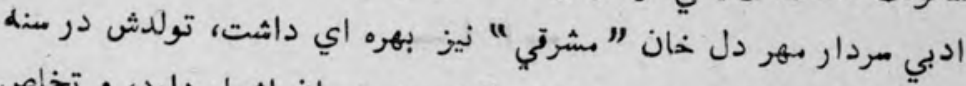

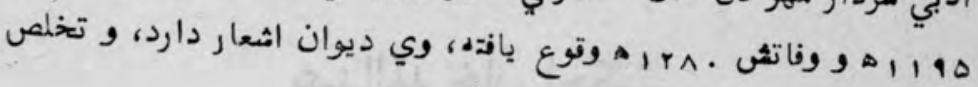

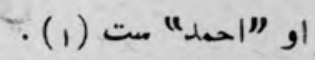

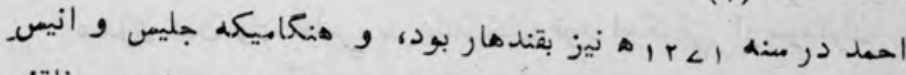

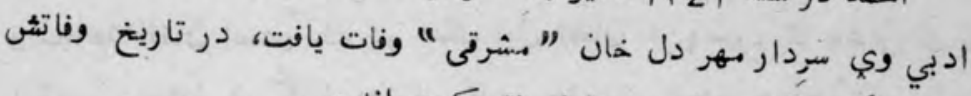

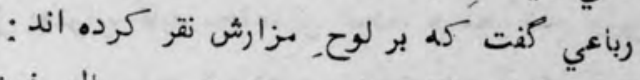

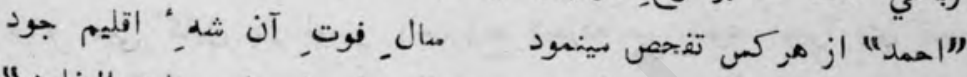

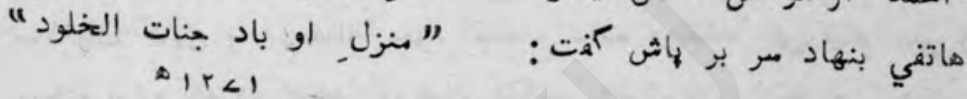

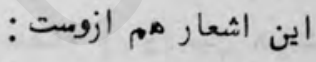

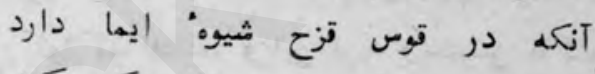

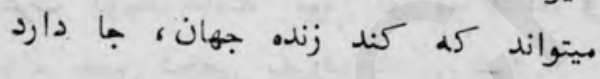
المهدا شاخ. تكمبر بر. تمكين لدهد

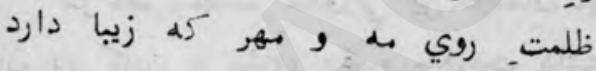

به تقليد حاجي در مزار شريف بلخ كفته :

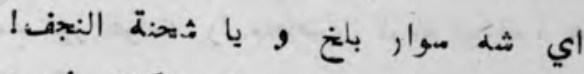

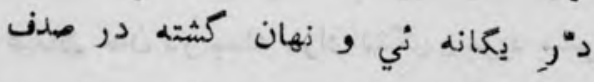
اين آمتان هاكس, تو جاي اجابت امت هر كم كاي هابد دعا رمدث تير بر هدف 


\section{- N1- \\ عبدالله خان احِكزئي}

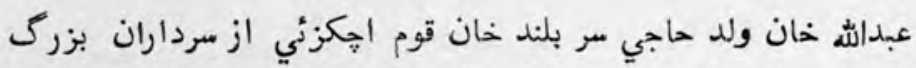

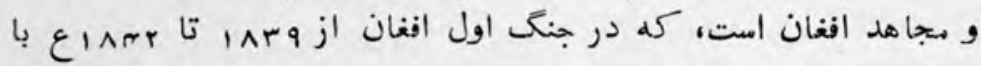

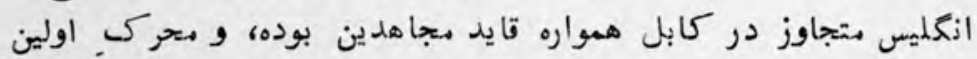

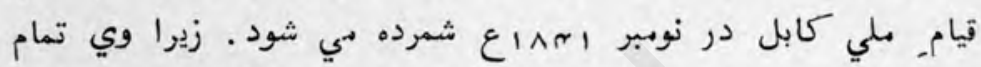

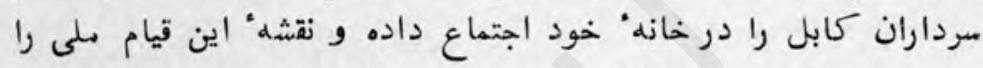

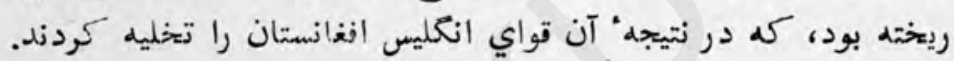

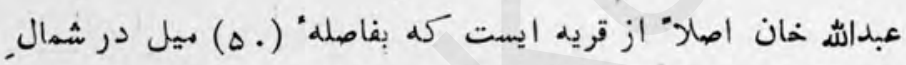

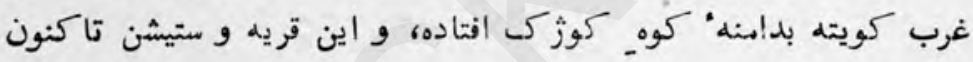

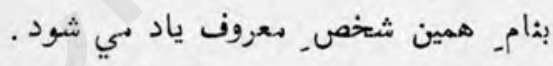

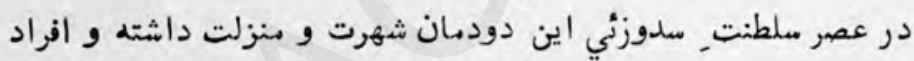

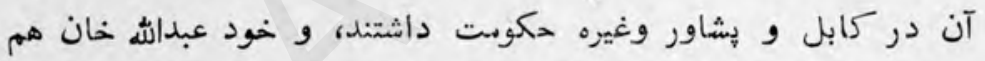

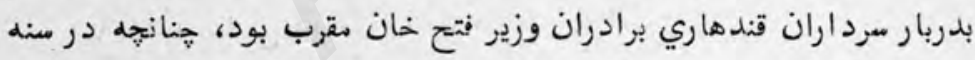

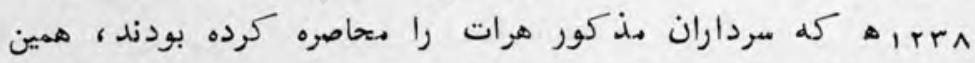

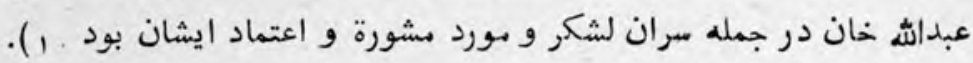

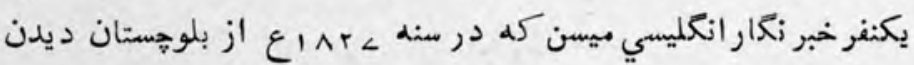
كرد، وي راجع به عبداله خان بينويسد :

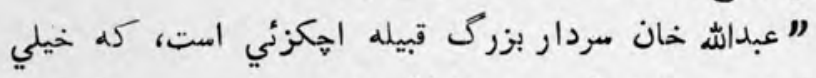

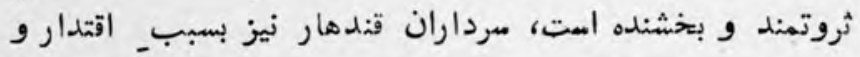

(1) كتاب حاضر، بيان فريب بازي محمل. خان كوهي ... و و

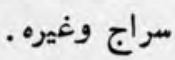




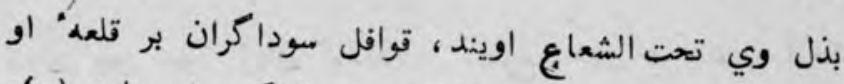

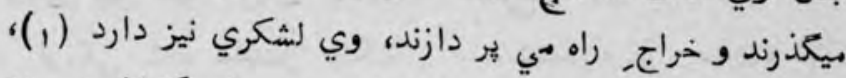

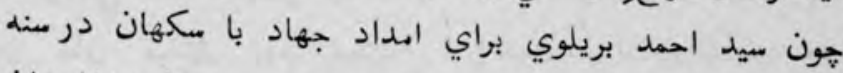

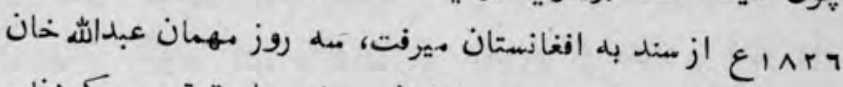

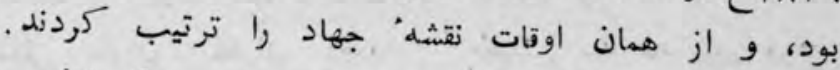

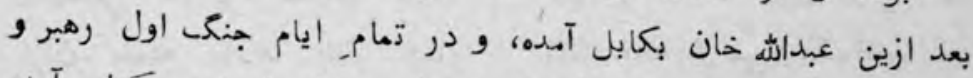

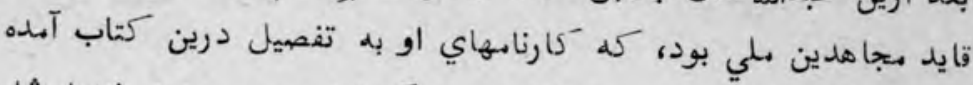

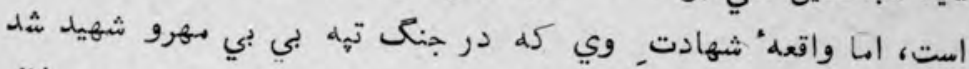

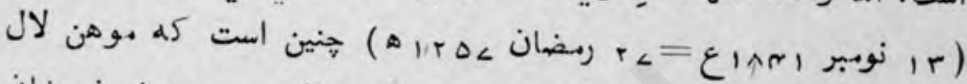

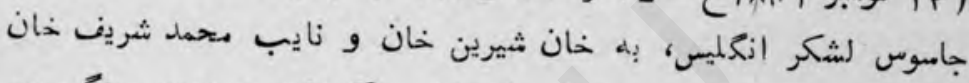

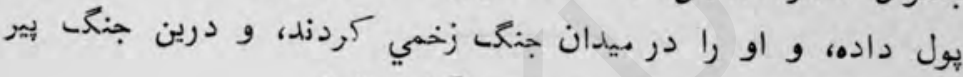

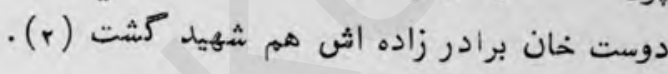

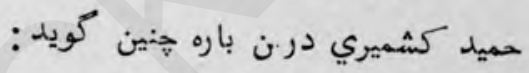

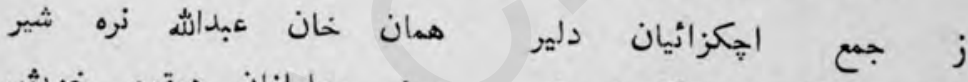

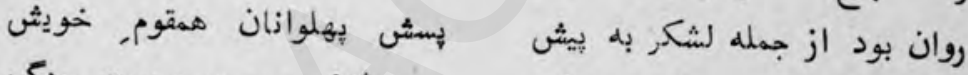

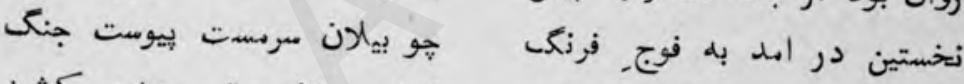

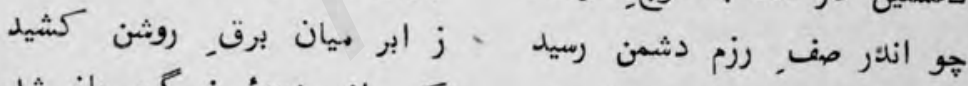

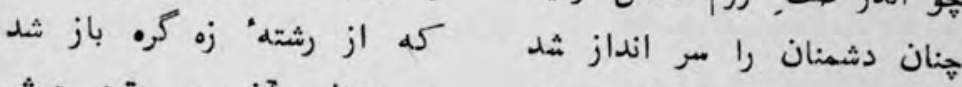

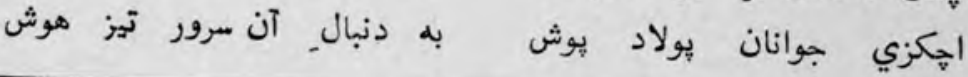

(1) مياحت نامه بيسن (ازخليسي) هيسن در جلد اول رويداد

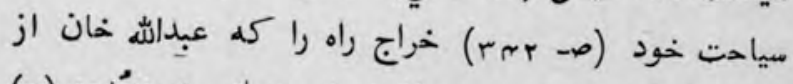

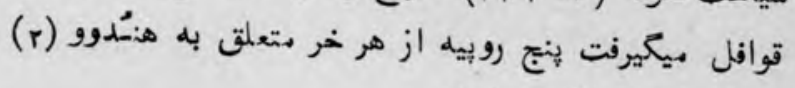
روييه از مسدلمان مي شمارد .

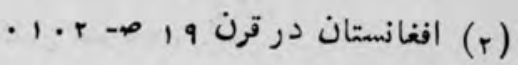


تعليقات

$\wedge<$.

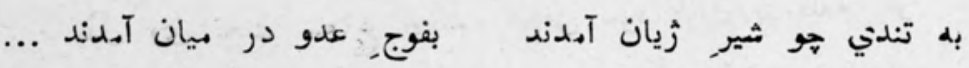

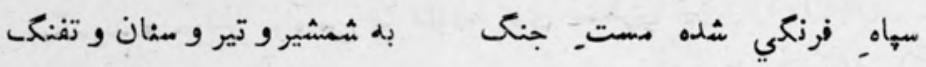

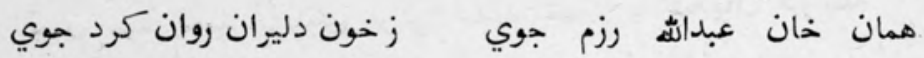

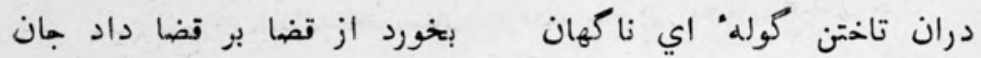

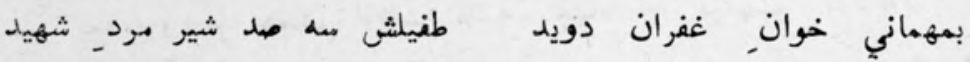

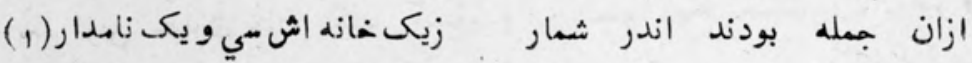
$\cdots$ 之ال

(1) اكبر نامه، طبع كابل حـ 179 
$\wedge<1$

تازه نواي معارك

$-\mu r-$

وفات سردار معمل عظيمم خان

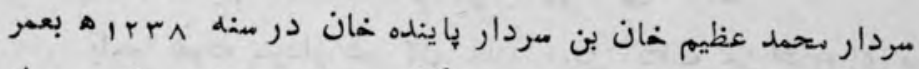

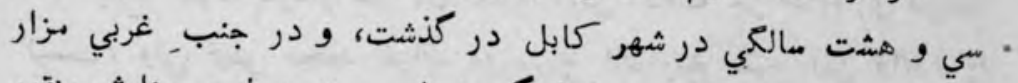

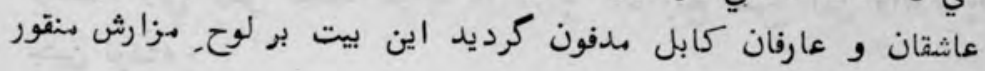

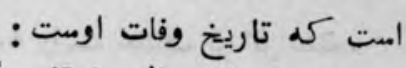

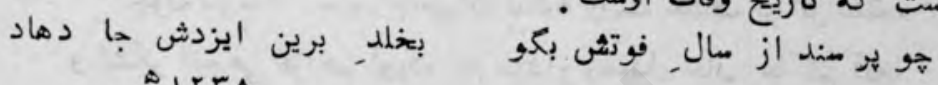
هirt

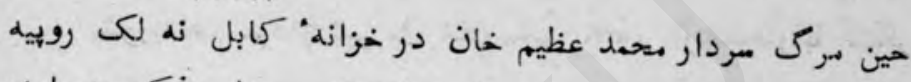

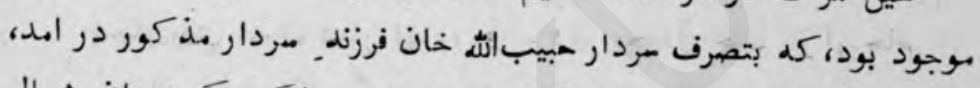

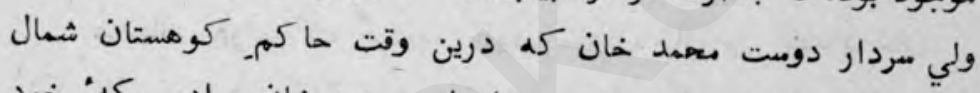

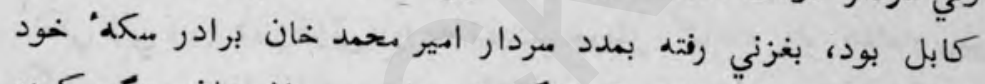

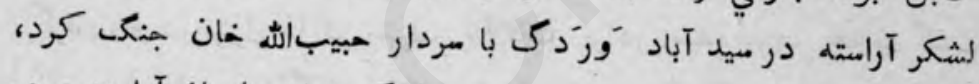

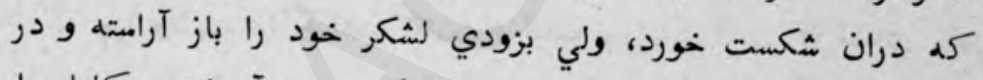

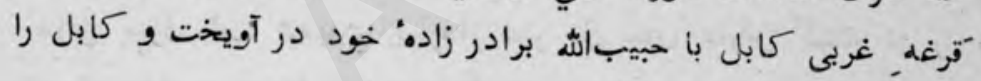
بدست آورد . كرئ

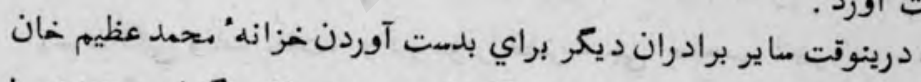

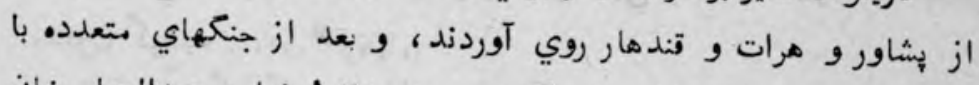

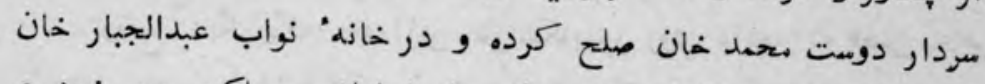

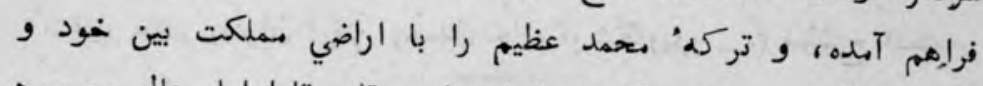

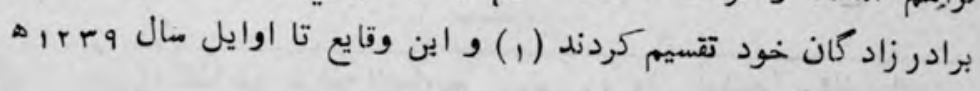

روي داد. - - مراد

$$
\text { • . مراج (1) }
$$




\section{$-\mu \mu$}

\section{وفات سردار شير دل خان}

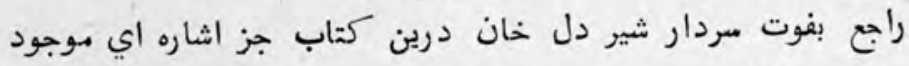

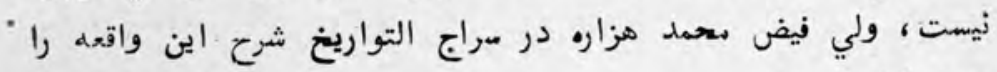

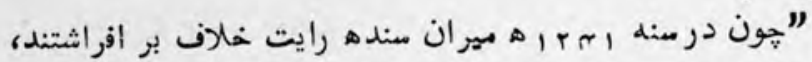

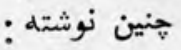

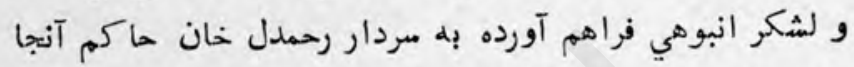

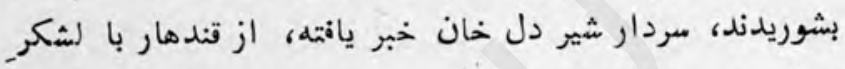

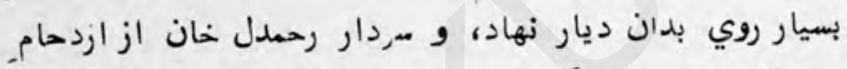

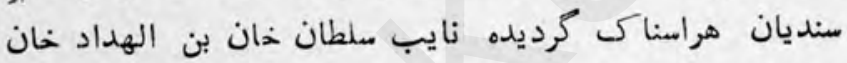

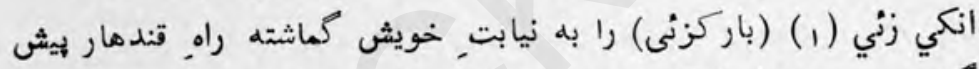

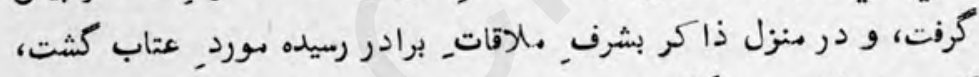

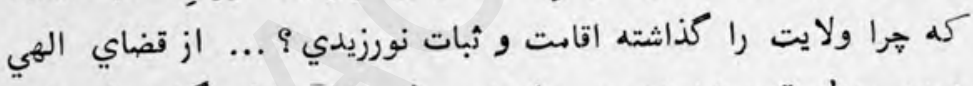

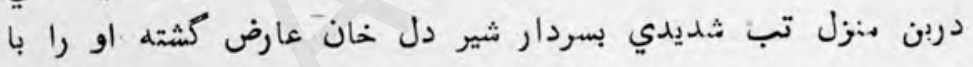

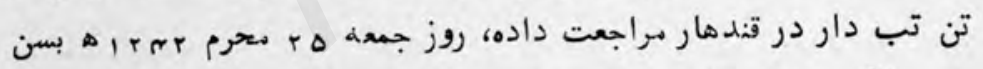

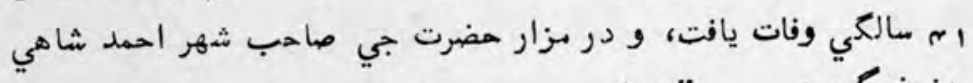

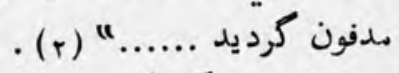

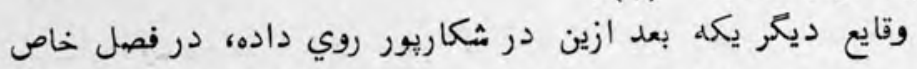

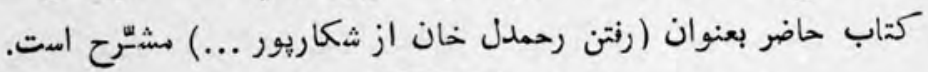

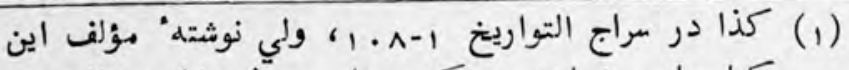

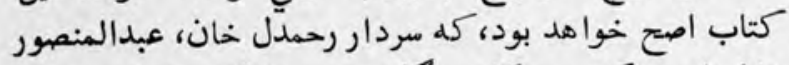
خان را به حكوبت شكاريور كذاشته بود (ركى : تعليق ه 1 ).

$$
\text { . . (r) }
$$




\section{Ventura}

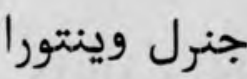

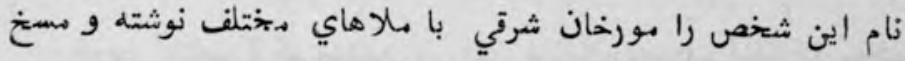

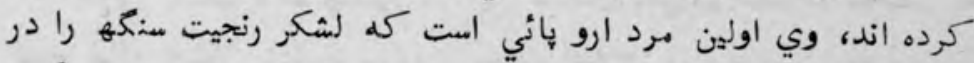

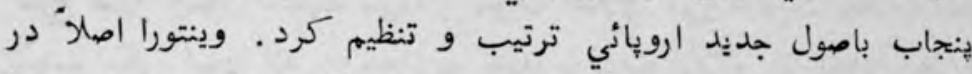

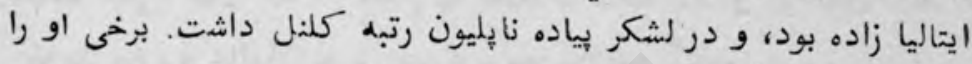

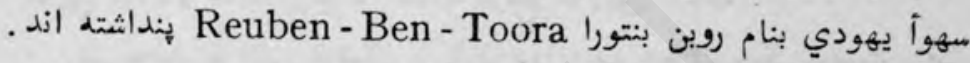

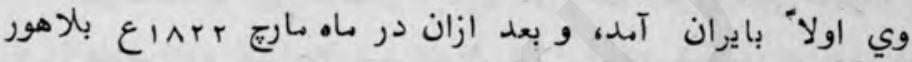

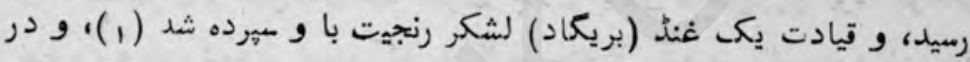

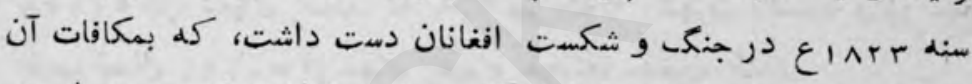

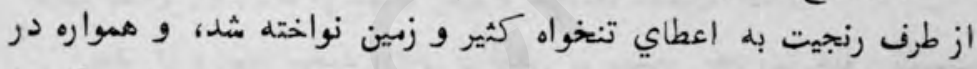

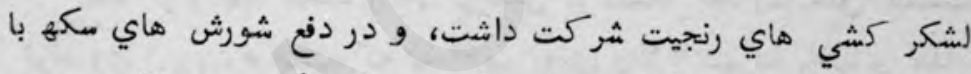

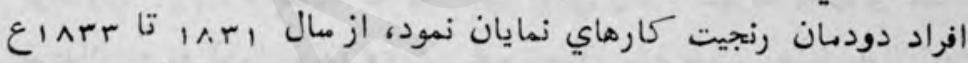

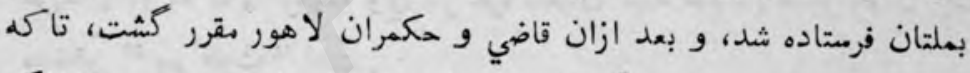

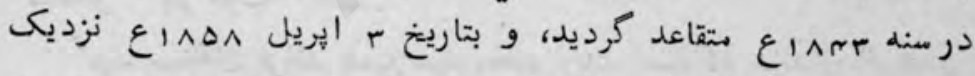

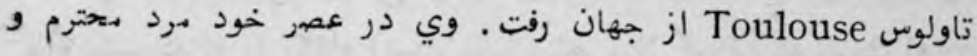

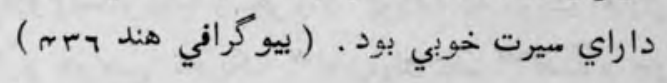

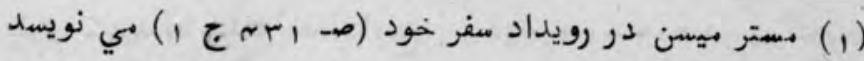

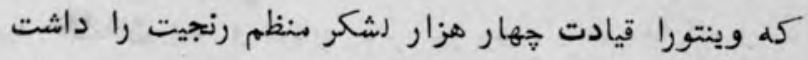

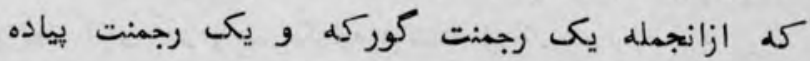




\section{يير صبغةالله و خاندانث}

درين كتاب ذكر هيندين نفر اين خاندان معروف آددهم متختصرآ به ثرح حال ايشان اشارت ديرود : مورث اعلاي اين دودمان مادات ميد

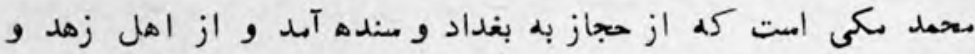

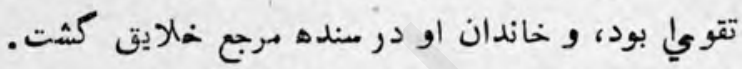

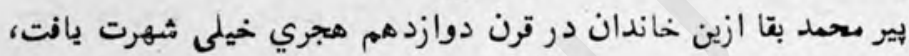

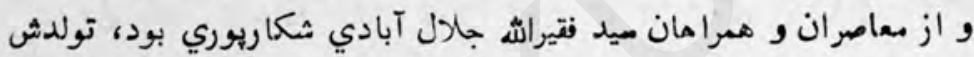

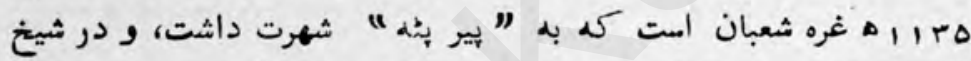

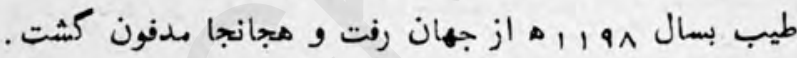

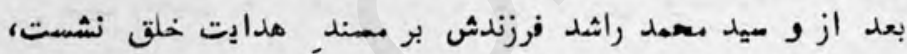

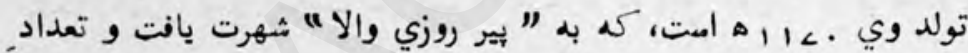

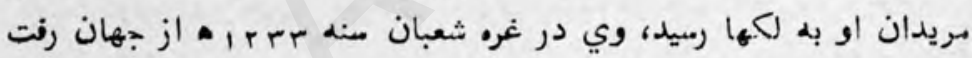

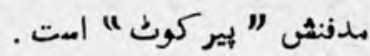
ميد صبغة/اله فرزند همين سيد محمد راثد امت كله خاندان "راشدي"

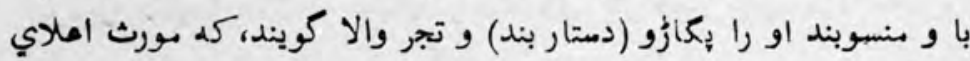

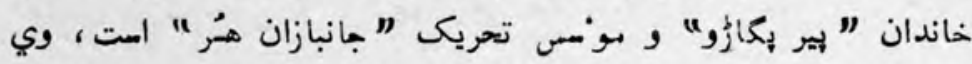

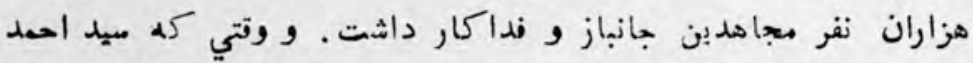

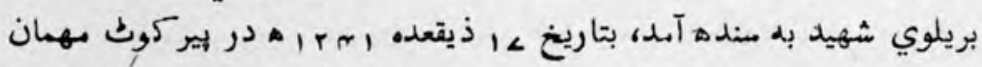

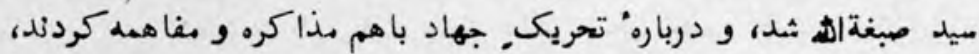

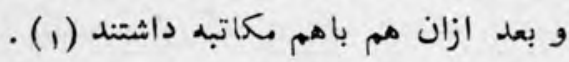




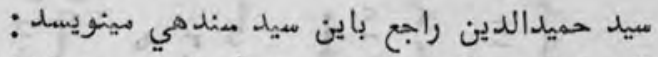

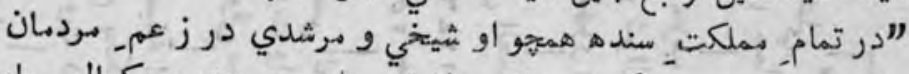

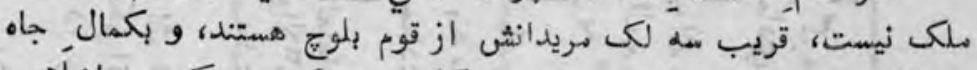

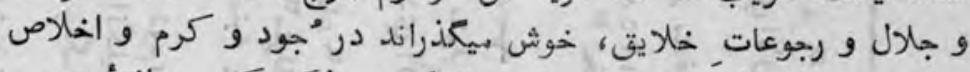

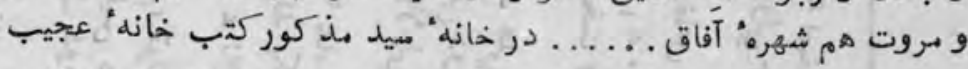

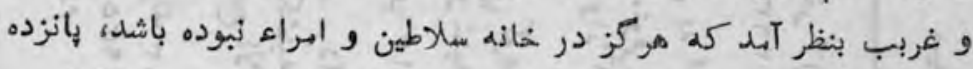

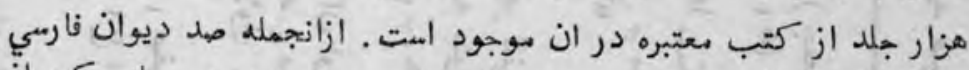

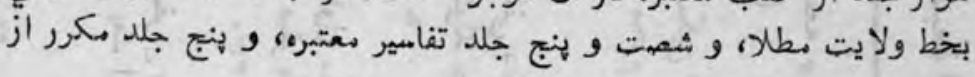

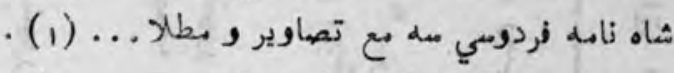

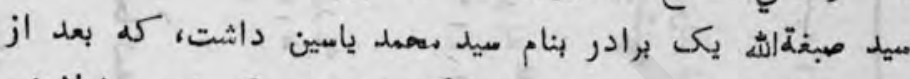

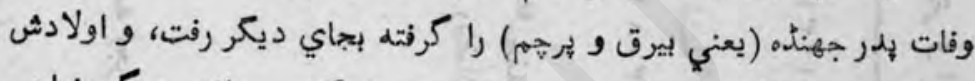

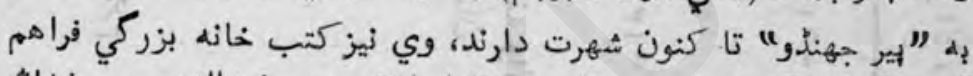

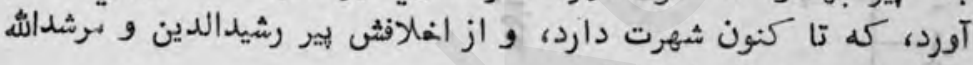

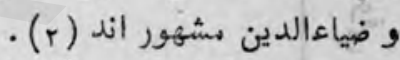

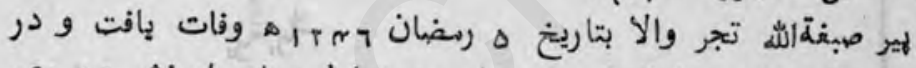

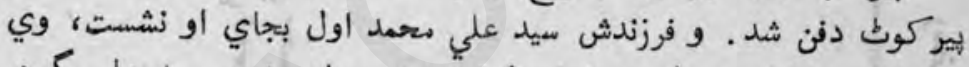

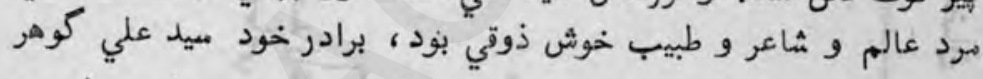

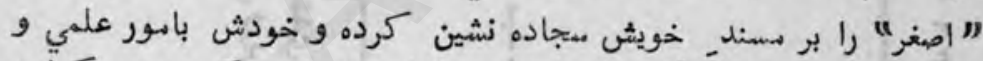

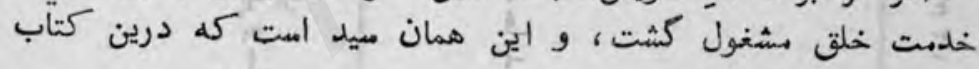

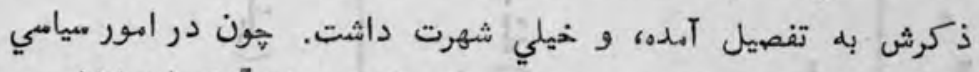

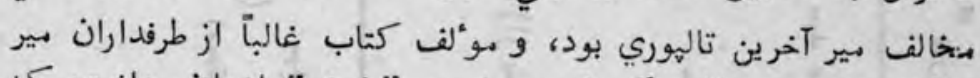

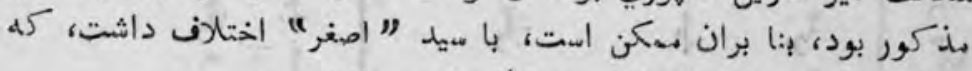

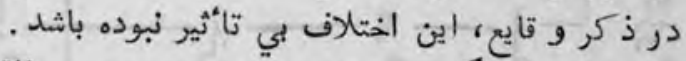

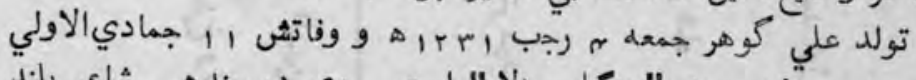

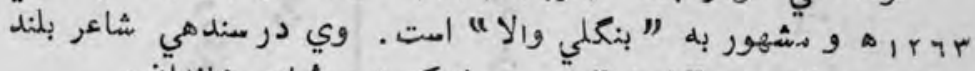

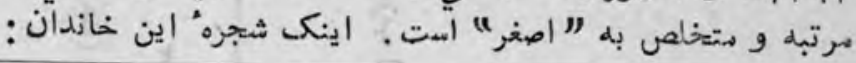

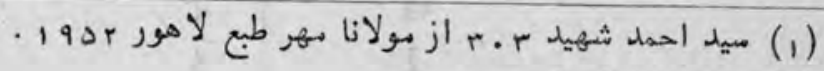

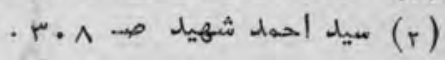




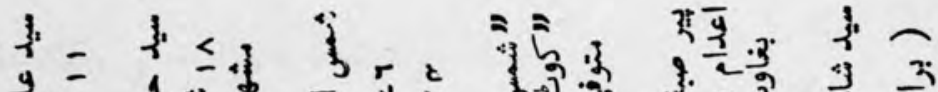

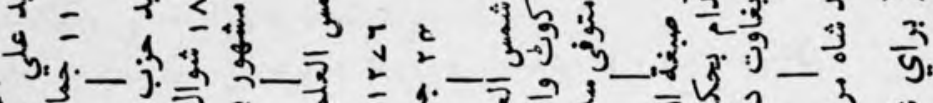
की

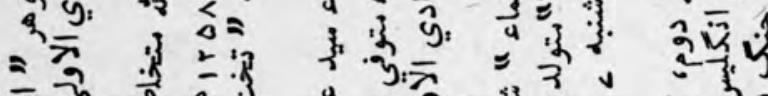

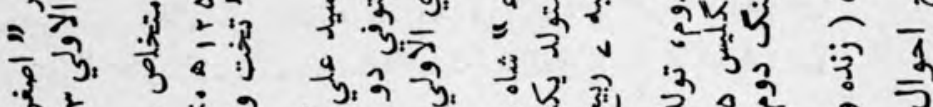

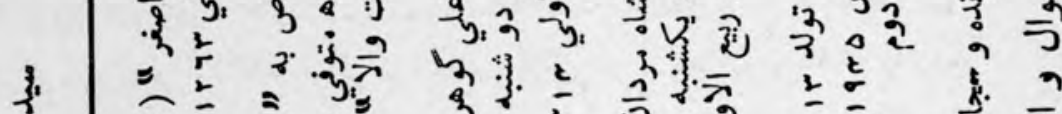

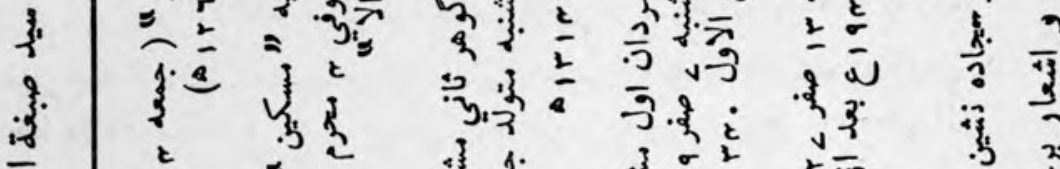

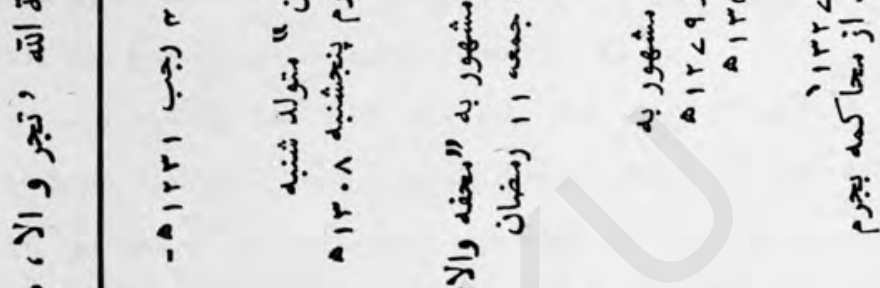




\section{شهادت سيل احمد بريلوى}

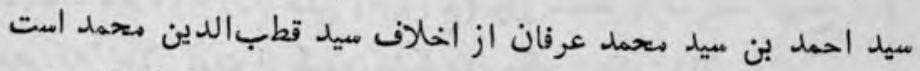

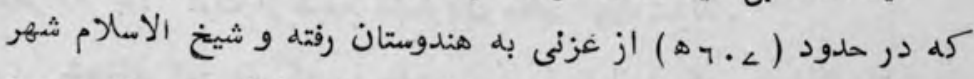

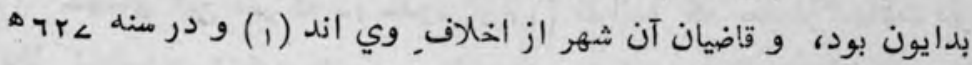
وفات يافت.

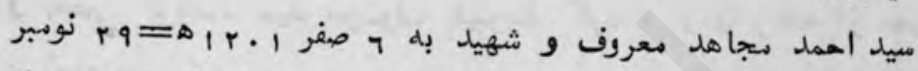

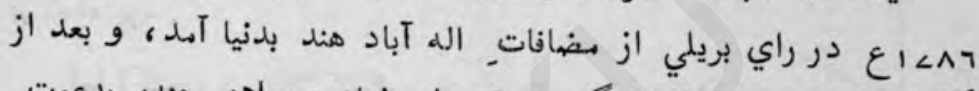

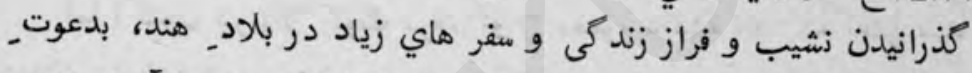

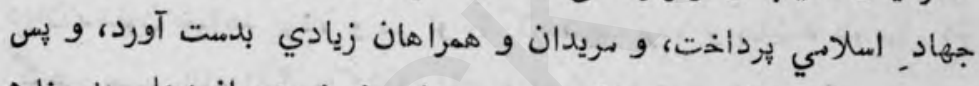

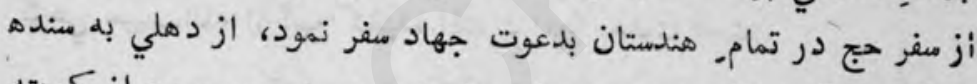

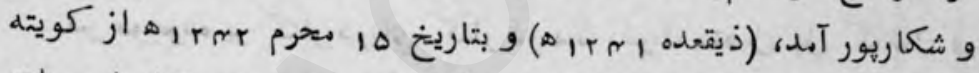

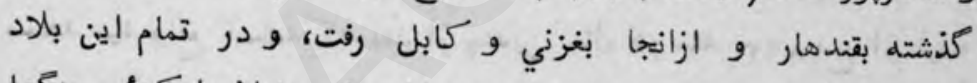

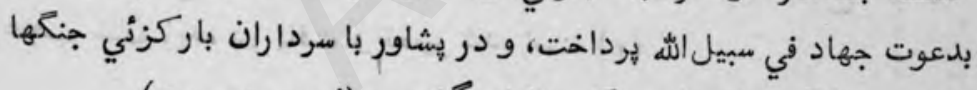

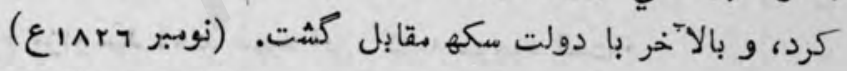

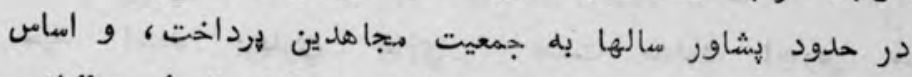

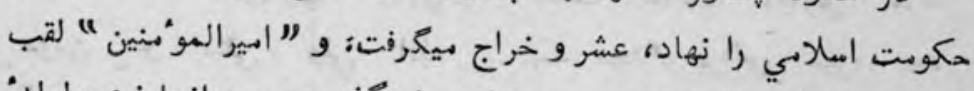

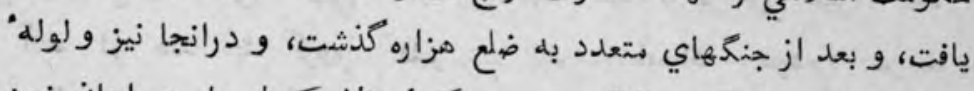

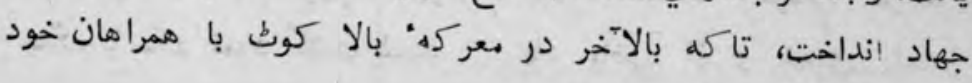

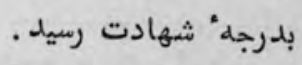

بالا كوث از مانسهره" ضلع هزاره بفاصله به ميل بر كنار درياي

$$
\text { (1) - (1) تاريخ فيروز شاهي 111) }
$$


كاغان ( كُنار ) در مدخل درهُ كاغان واقع است، شير سئكه مر لشكر

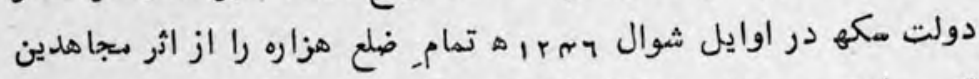

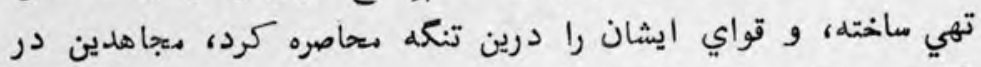

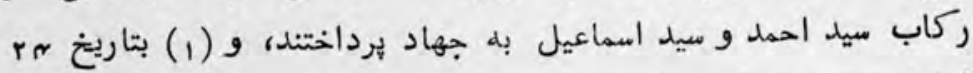

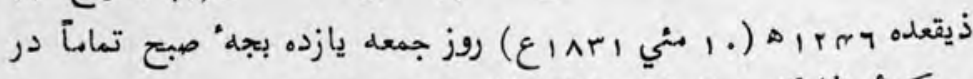

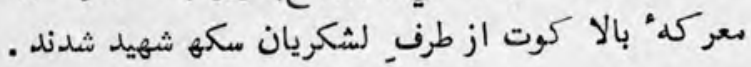

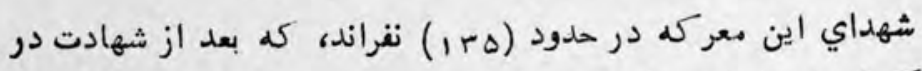

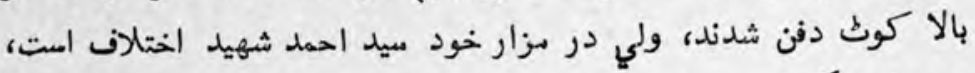

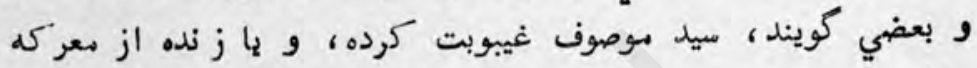
بر امده بود .

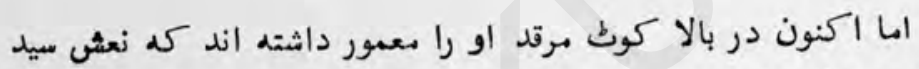

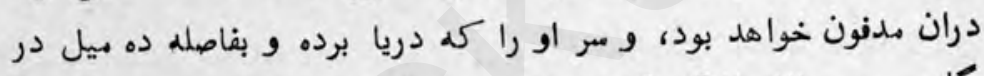

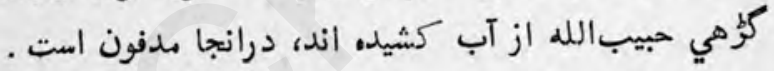

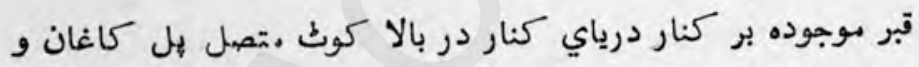

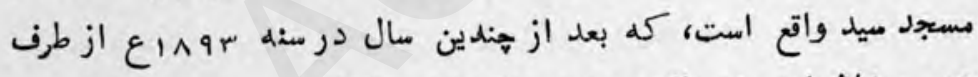

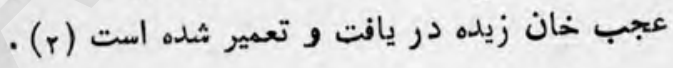

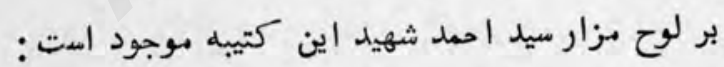

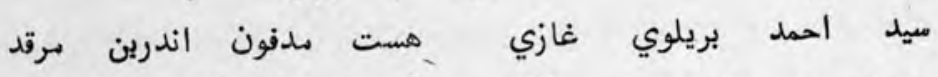

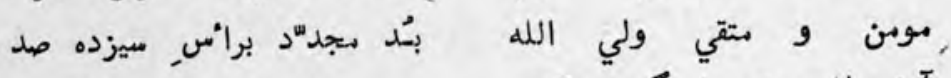

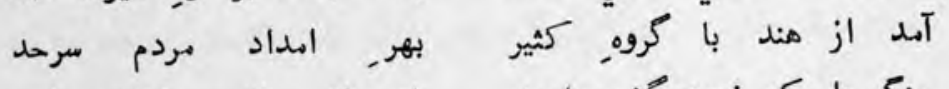

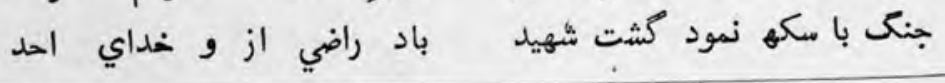

(1) اين تاريخ در كتاب مولانا مهر . r ذبقعده و ج بئي است،

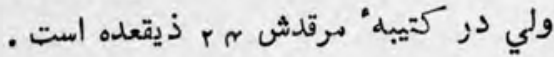

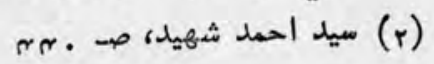




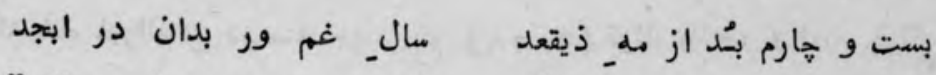
كاف وماء راكشيده"يوسفي" كو

\section{דri}

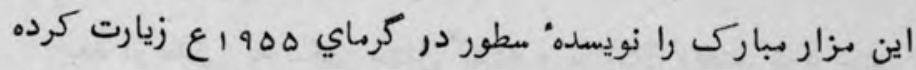
و كتيبه" فوق را ازان ياد داشت كرفته ام، در نزديكيهاي همين مرقد

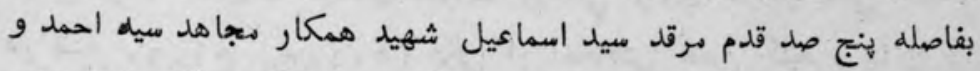

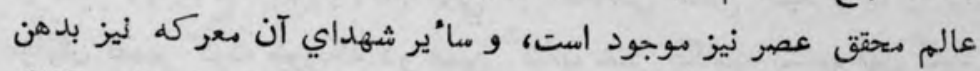

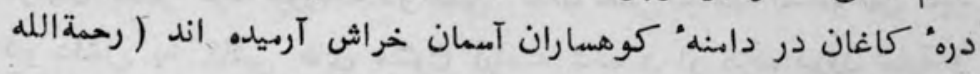
. عليهم اجمعين) صداي تيغ, تو آدد به بزم زنده دلان كدام سر كه درو ذوق اين سرود زماند

\section{$-\mu<-$}

قاضى متمل حسن

رجوع كند به تعليق نمبر (r ) خاندان قاضي خيلان بشاور.

\section{$-\mu \Lambda-$}

\section{دركاه شاه خير اللدين}

در سكهر كهنه زيارتماه معروفي است، كم كنبد آسماني رزكلـ دارد، كزيتير ضلع سكهر تاليف ج، و سمته طبع بمبئي و 9 و اع درين بارو هنين

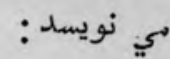
نزد, قاضي مسكهر كتاب خطي موجود امت، و درين كتاب نوشته اند، 


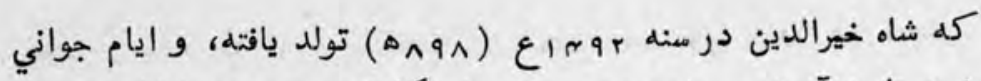

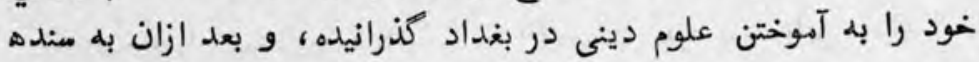
سفلي آهده در بلري سكونت كردد . سوند

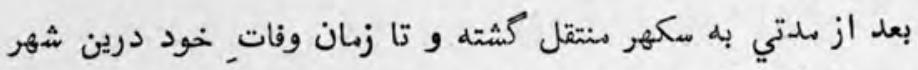
ساكن بود . كل يكى خاندان معروف روحاني از وي درينجا باقي ماند.

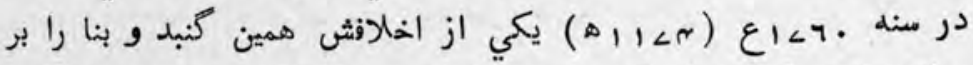

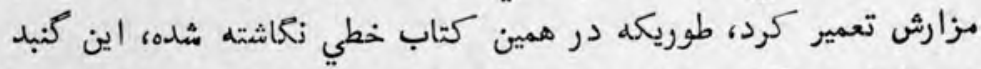
در داخل به كاشي هاي ملسّون آراسته شده و از طرف بيرون سفيد و

سبز بود .

از را بورت مامورين آثار عتيقه ظاهر است، كله حصص بيروني اين كنبد را در • م سال اخير با خشت شاي معمولى ترميم كرده اند (1). در كتاب قديم سنده درين باره هنين وارد است :

شاه خيرالله يا خيرالدين بن احمد شاه به هنج هشيت زنسبش به شيخ

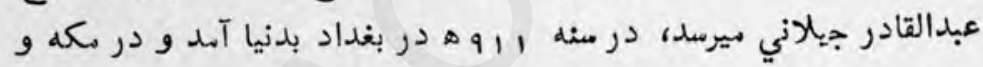
مدينه به تحصيل علم نبرداخت، و بعد ازان در سنده به بلري و سكهي بهر آهد، و به هدايت خلق مشغول كشت، و مريدان فراوان داشت، بتاريخ

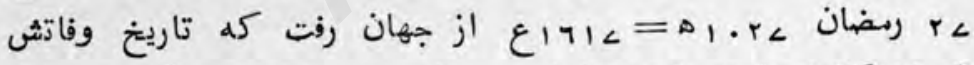

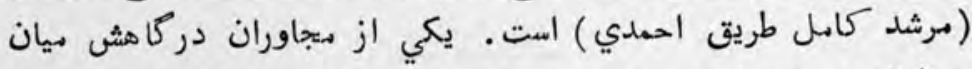

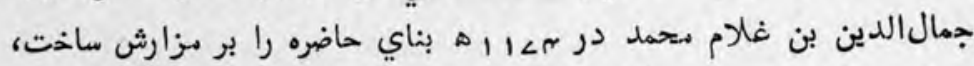

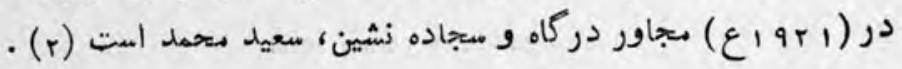
اكنون بايد هر دو قول مذكور را بنظر انتقادي ديد. . موثلف قديم

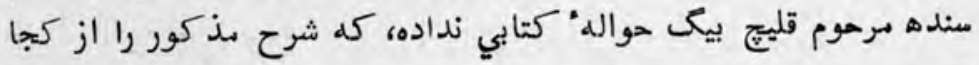

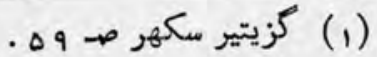

$$
\begin{aligned}
& \text {. }
\end{aligned}
$$


كرفته است و و قول كزيتير في الجمله مستند به يكى كتاب خطي است كه درانوقت موجود بود.

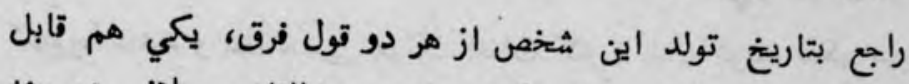

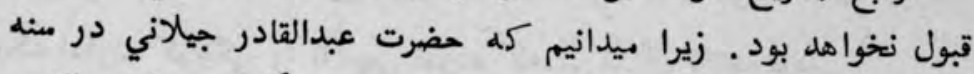

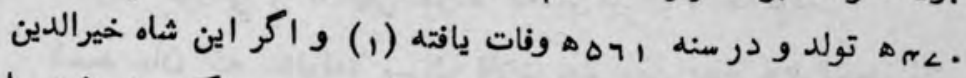

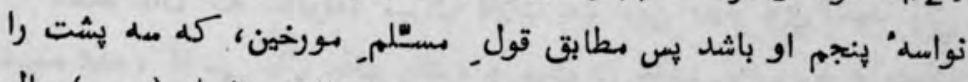

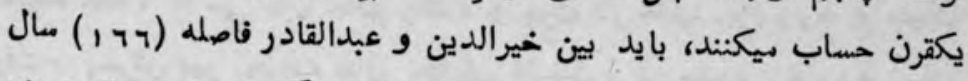

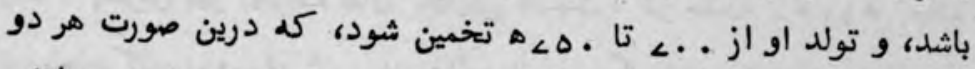

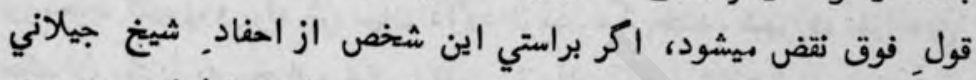

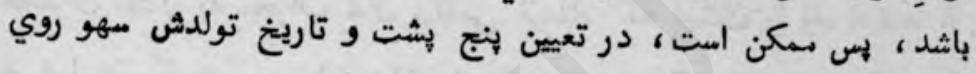

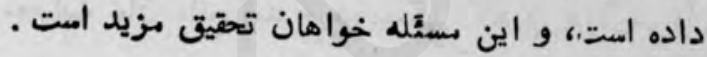

\section{- rq-}

مير محراب خان بلوج و دودمان خانان قلات

\section{(اسمد زني)}

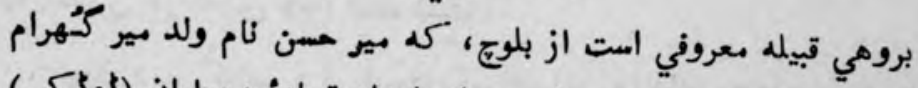

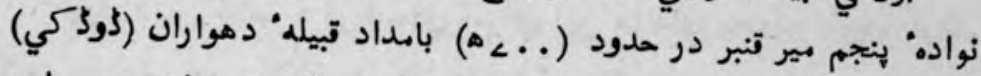

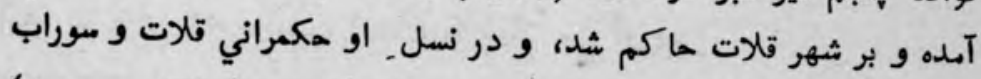

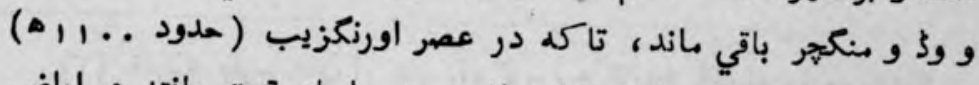

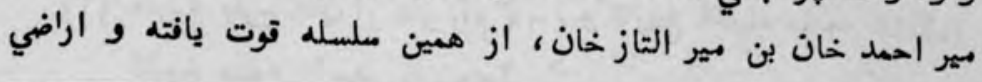

(1) خزينة الاصفيا ر-ه ه و تلخيص دائرة المعارف اسلابي صِه هـ 
باغبانه و خضدار (تزدار تاريخي) و كرخ و هكورا و مستنى را نيز

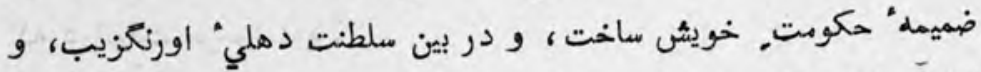

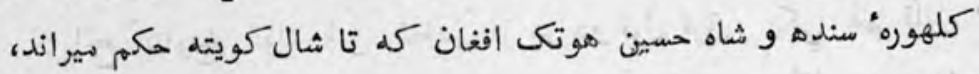

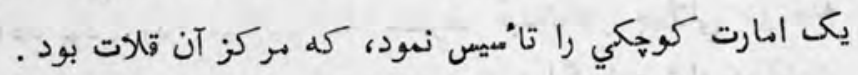

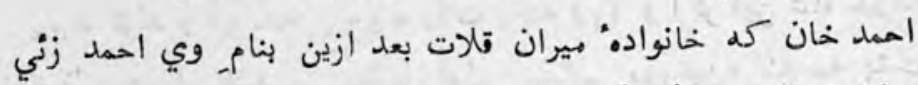

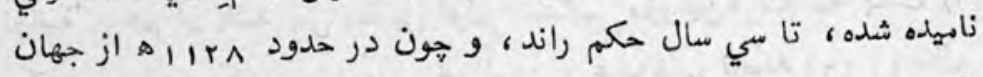

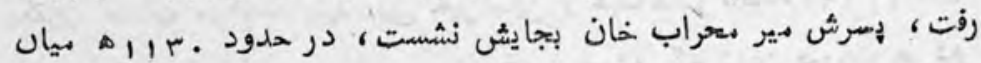

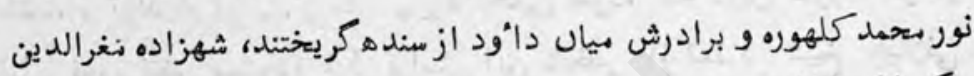

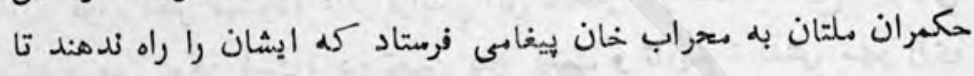

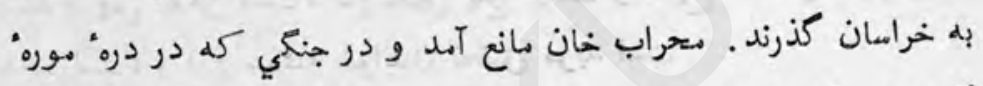

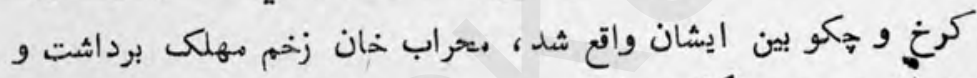

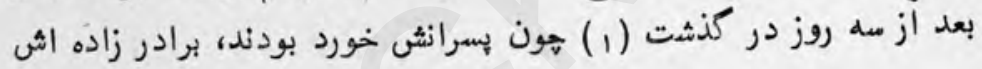

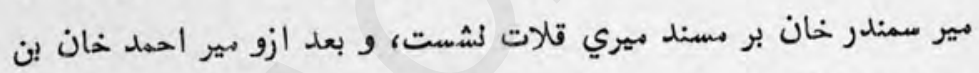

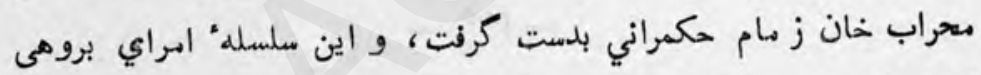

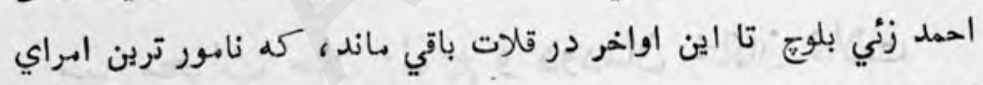

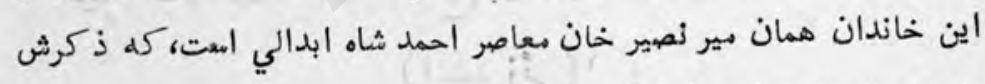

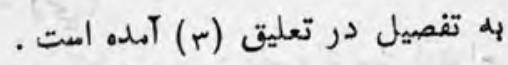
هون درين كتاب ذكر اسماي اسراي اين خاندان معروف بلوج، بارها آهده بنا بران شجره نسب ايشان را ذيلاً مي آوريم :

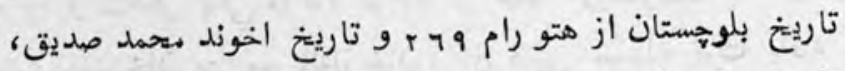

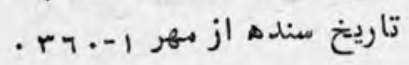




\section{$-\mu \cdot-$ \\ كيول}

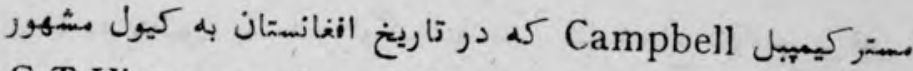

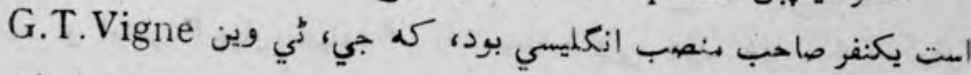

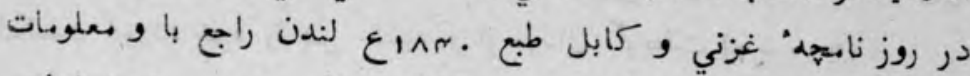

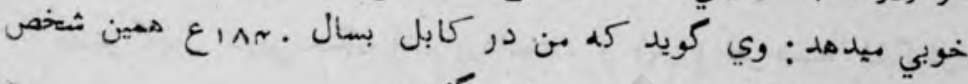

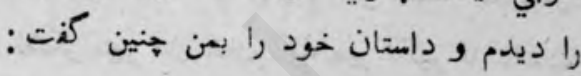

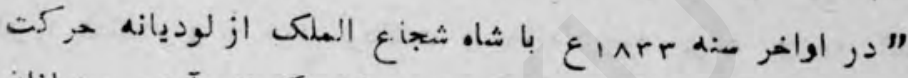

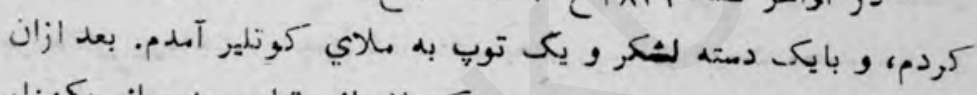

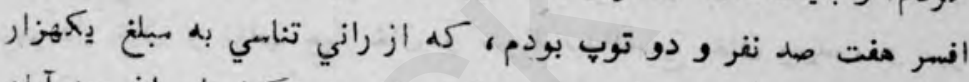

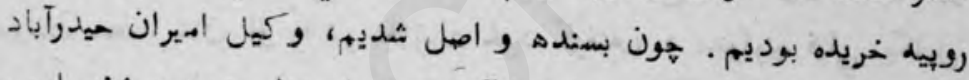

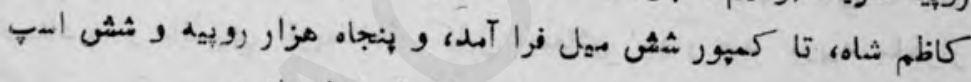

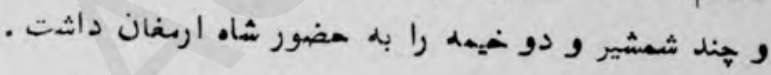

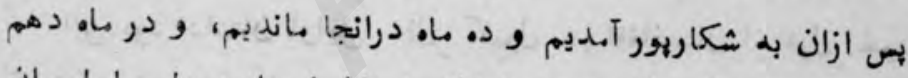

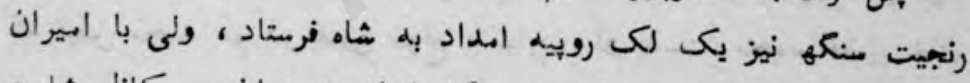

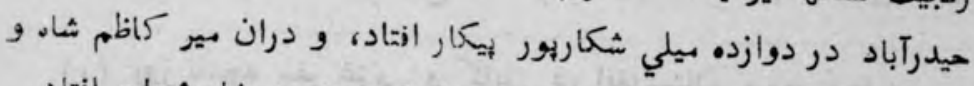

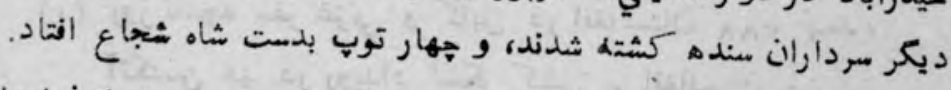

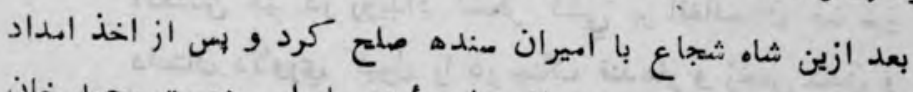

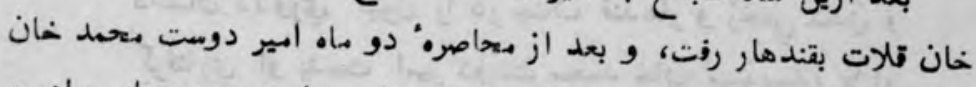

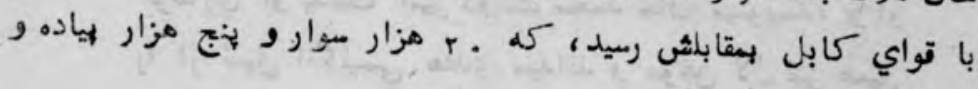
1 ا توب بود.

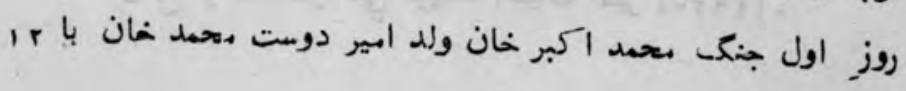




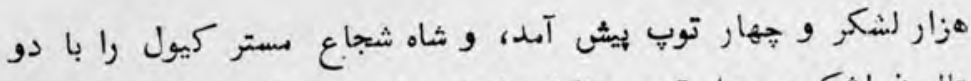

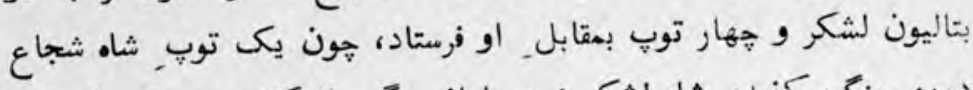

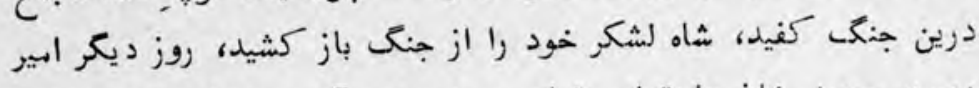

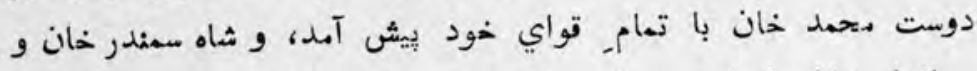

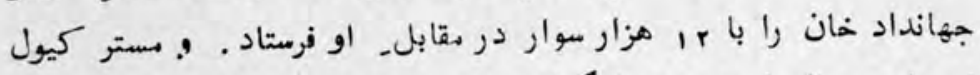

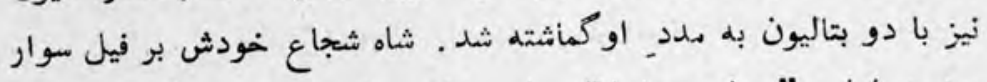

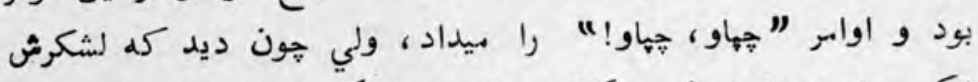

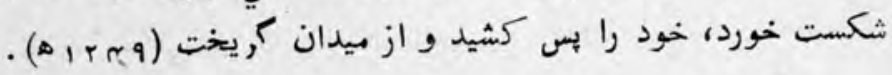

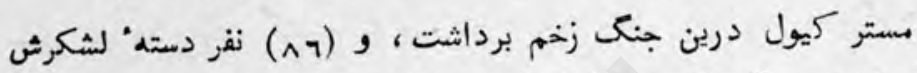

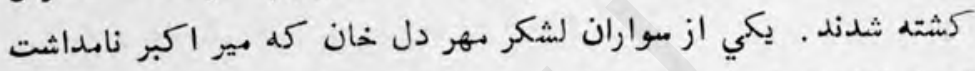

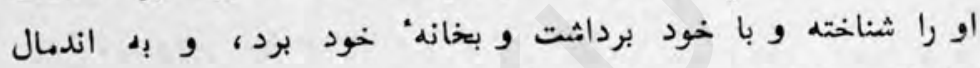

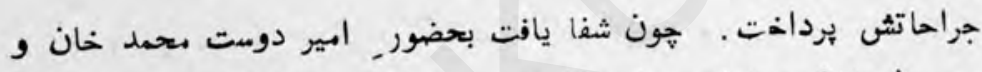

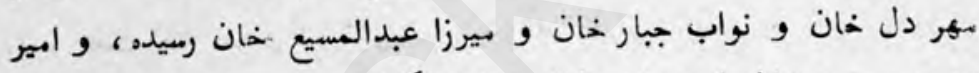

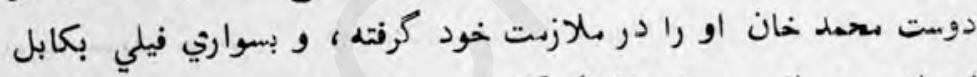

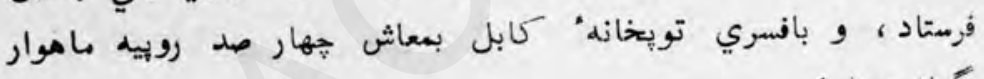

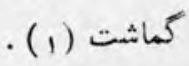

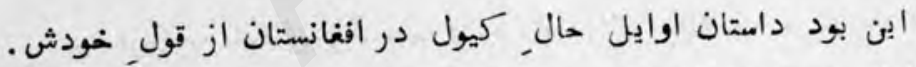

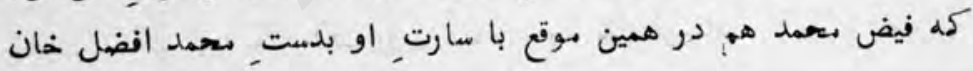

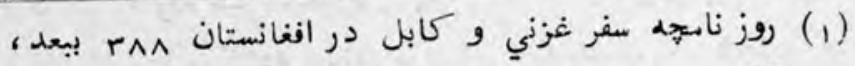

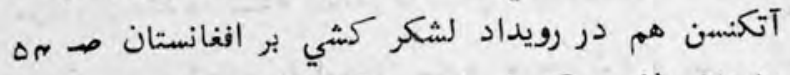

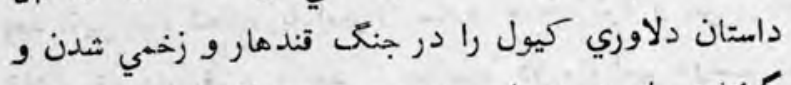

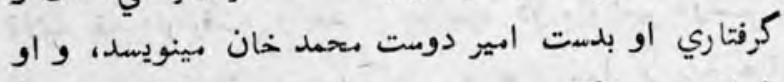

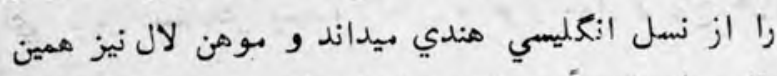

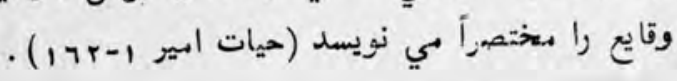


بن دوست متحهد خان اشارو ميكند (1) •

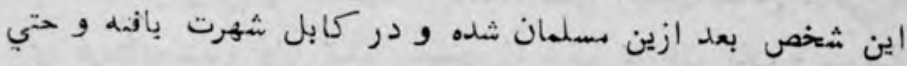

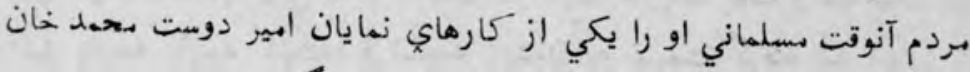

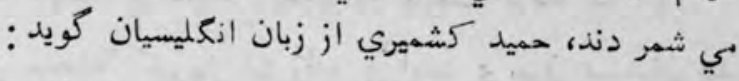

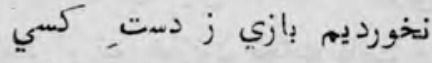

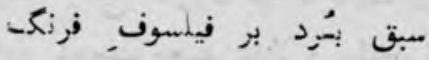

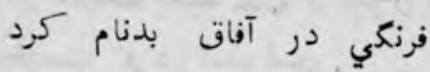

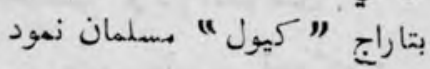

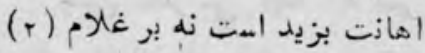

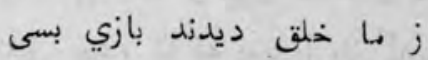

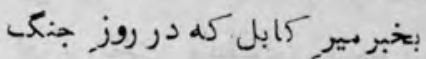

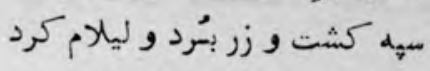

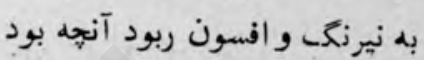

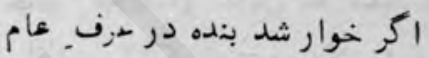

نام_ اسلامي كيول بعد از قبول اسلام (شير ميحمد خان ) بوده، و در

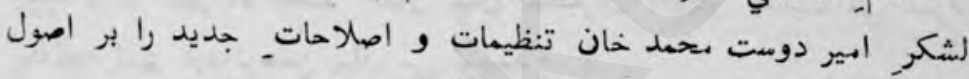

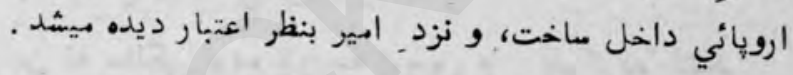

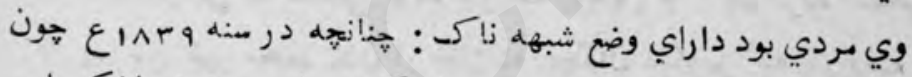

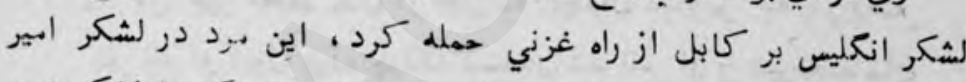

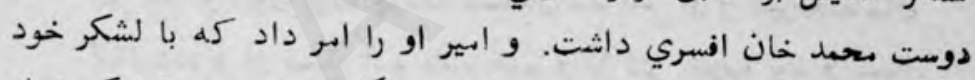
بمقابل حمله آوران برايد. ولى كيول بامير كفت : "دن هون نهى نهوار

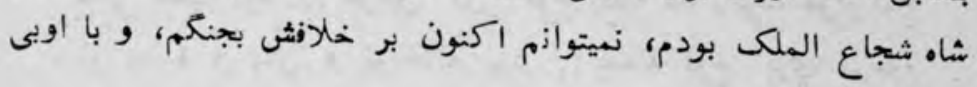

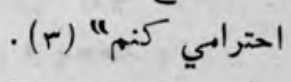

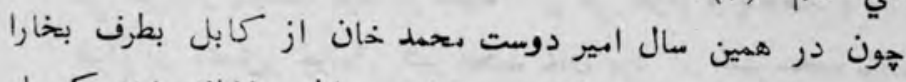

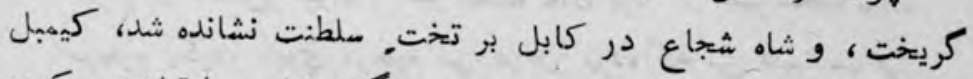

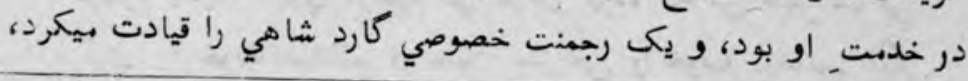

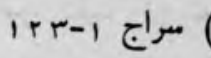

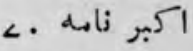

(r) رويداد لشكر كشي بر افغانستان از آتكينسن صه ـ ج r طبع لندن. 


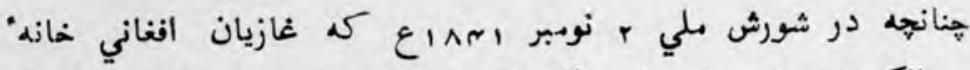

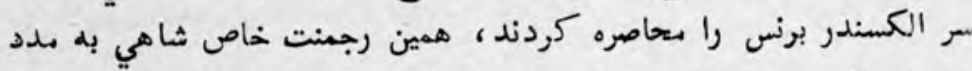

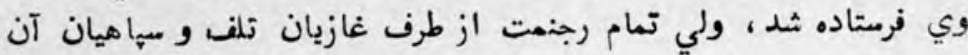

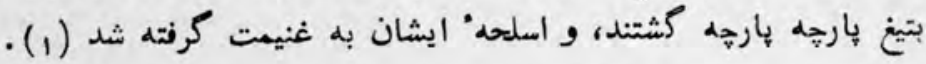

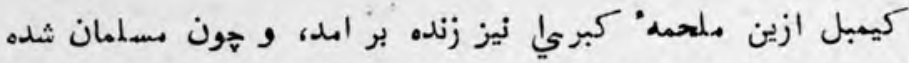

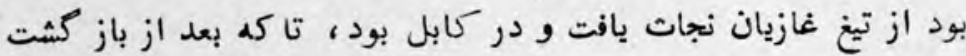

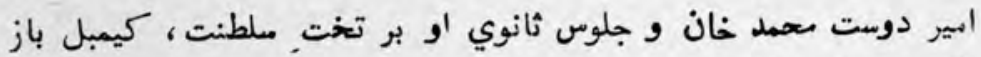
إخذديت. او در امده است.

هنين بنظز بي آيد كه شير محمد خان كيول از كابل به صنحاث

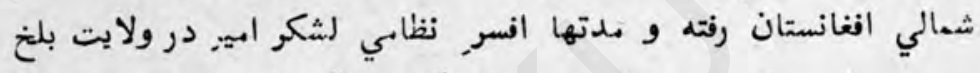

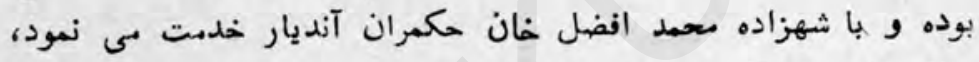

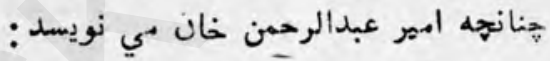

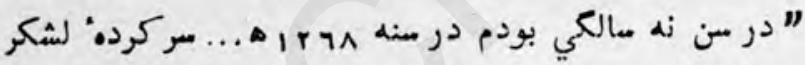

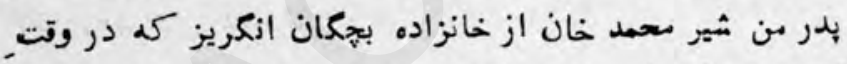

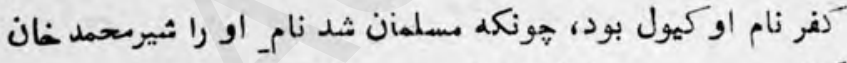

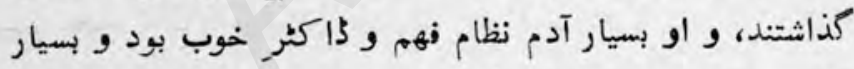

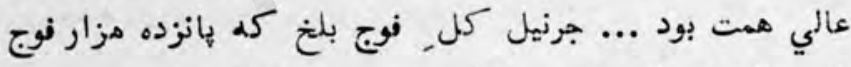

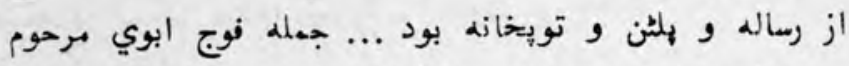

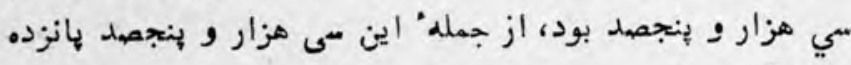

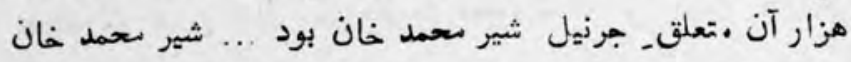

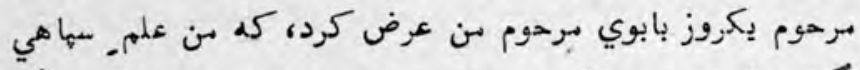

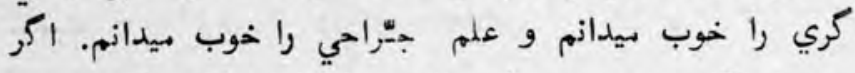

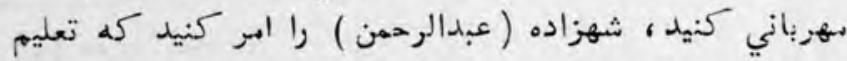




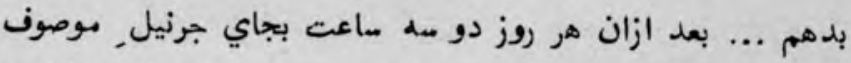

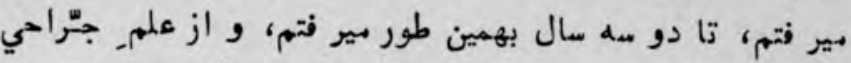
خوب بهره ياب شدم، و تفنك سازي را هم ياد كرفتم ... (1) م. اينست شهادت معاصر امير عبدالرحمن دوباره ثير سعمد كه استاد.

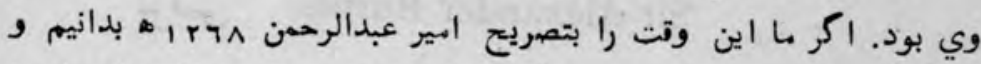

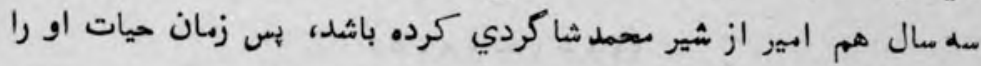

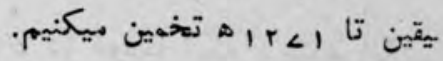

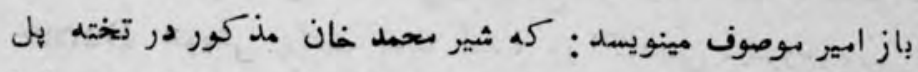

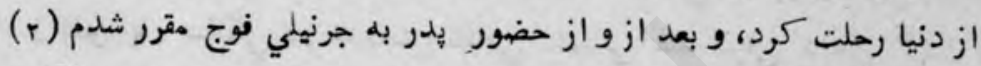

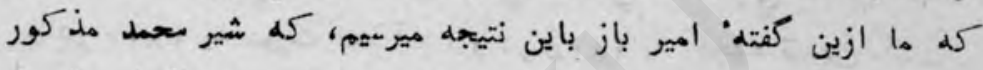

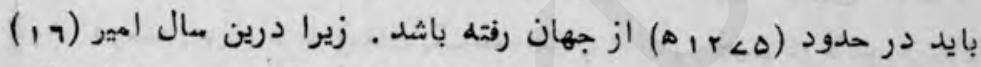
ماله و بسن بلوغ رسيده بود، و هطابق. رواج آن آن عصر جوانان بالغ.

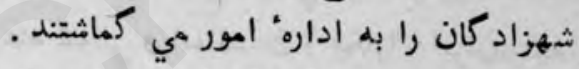

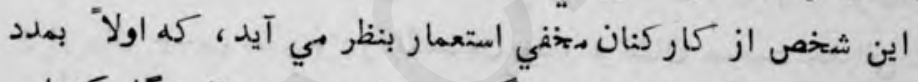

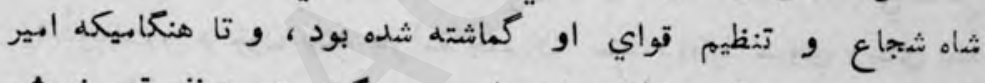

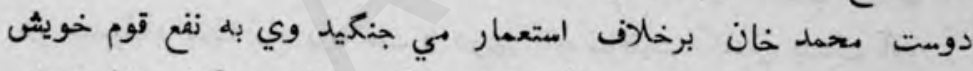

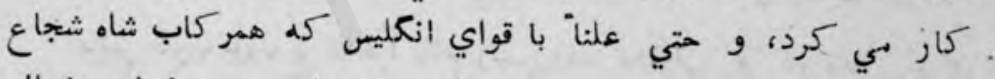

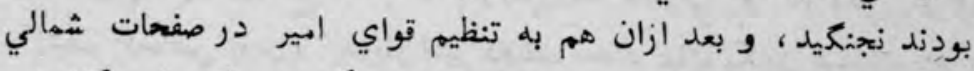

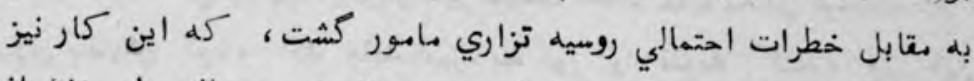

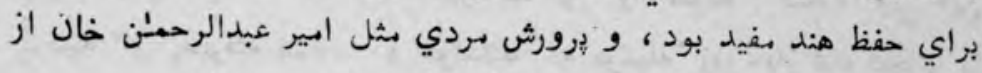

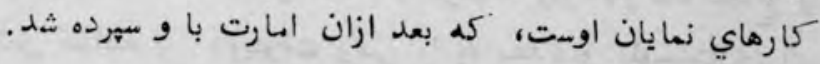

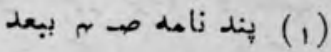

$$
\begin{aligned}
& \text { <-y dis (r) }
\end{aligned}
$$


Sir Alexander Burnes برنس

$$
(1 \wedge r 1-1 \wedge .0)
$$

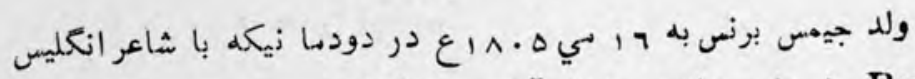

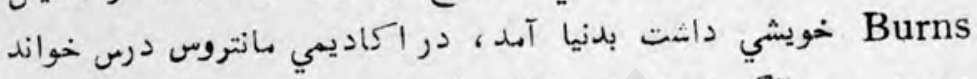

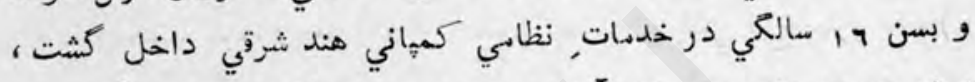

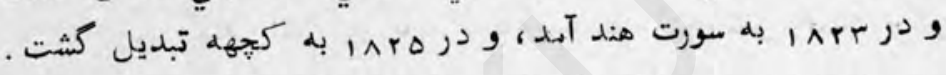

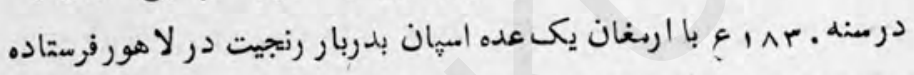

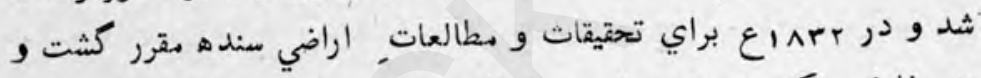

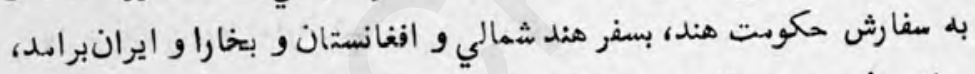
و از سال rrی

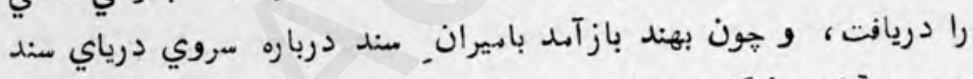

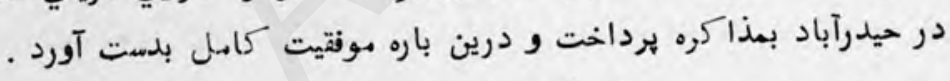

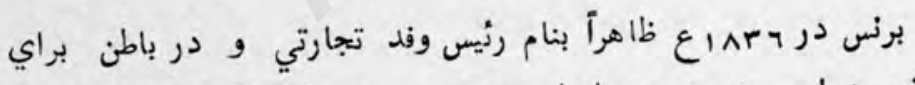

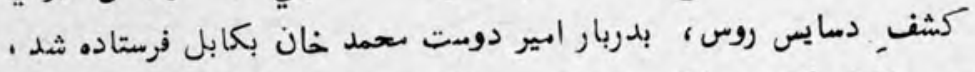

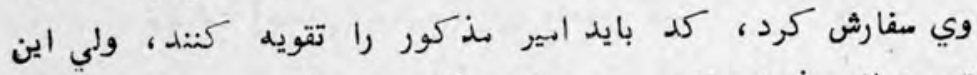

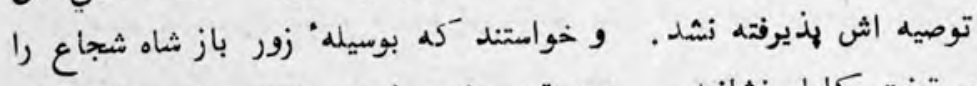

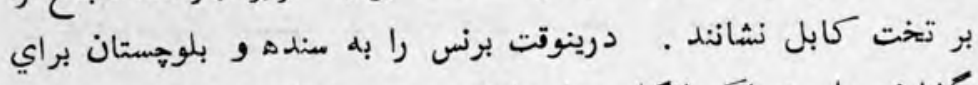

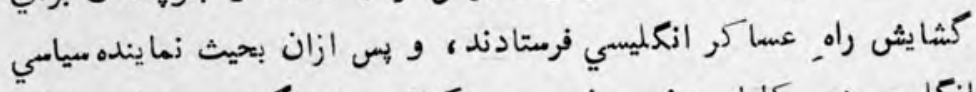

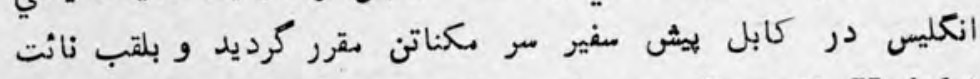
Knight برو شوريدند، و بتاريخ r نومبر امهرا در كابل كشته شد . 
كويند برنس كه بحيث, زير دست بكناتن كار بيكرد ، در سنه و هبها

برخي از حقايق را بحكومت. خود نوشته و توضيح داده بود ، كله مردم.

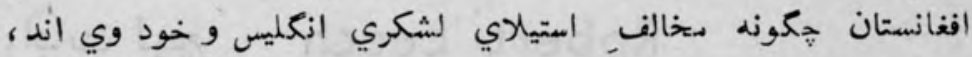

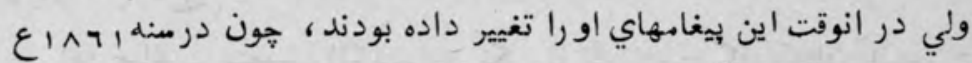
اين حقايق كشف كرديد ، در انكلستاذ آنرا ييش بارليهان بردند ، تادوران

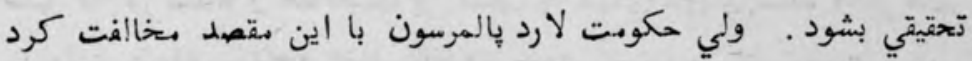

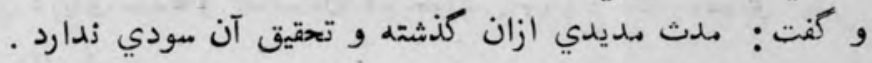

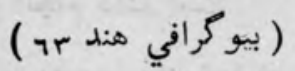

برنس در افغانستان و ايران داراي ـبطالعاث وسيعى بود ، و هندين كتاب درباره" سياحت و معلوماثل خود درين كشورها نوشته و ازان هيديد سي آيد، كل مشار اليه مرد بصير و عالم و سياست مداري بود .

$$
\text { از تاليف او ست : }
$$

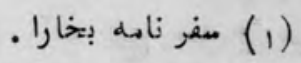

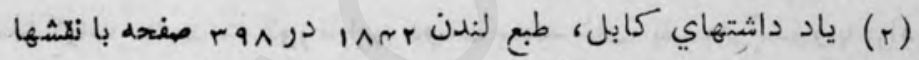

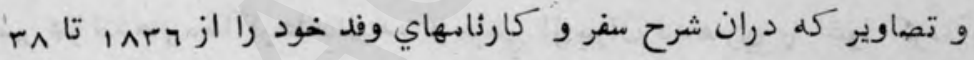

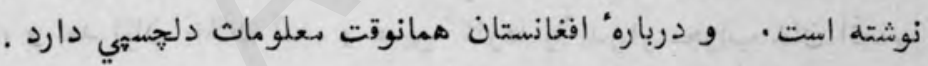




\section{Robert Leech رابرت ليتج}

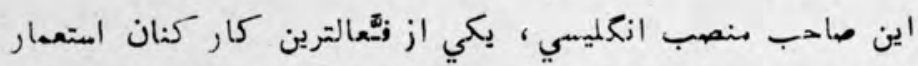

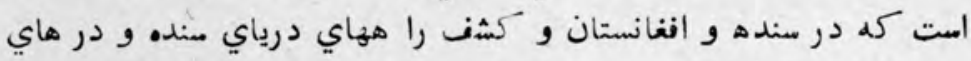

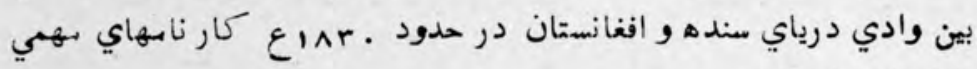
را انجام داده است .

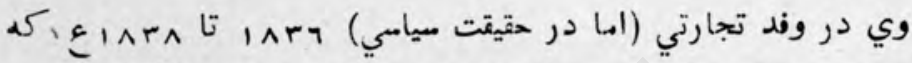

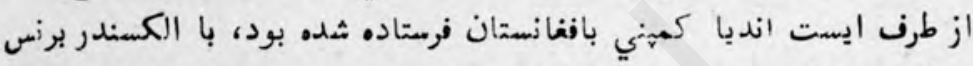

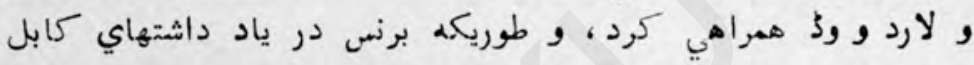

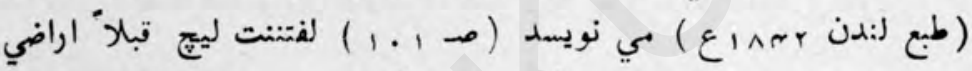

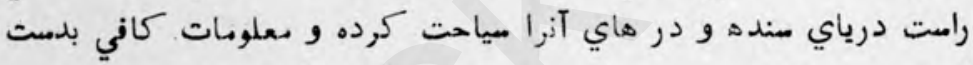

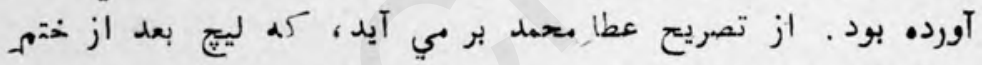

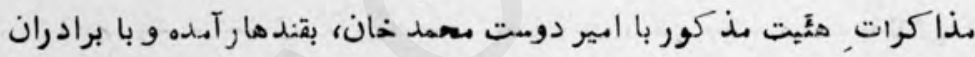

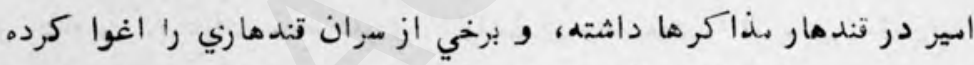

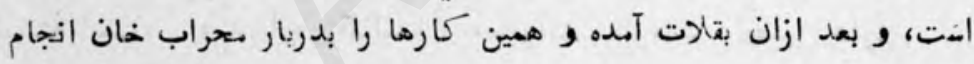
داده است.

$$
\begin{aligned}
& \text { رابرت ليج در ايام مكونت_ خود بقلات كتابي را بنام "تاريخ تلات" }
\end{aligned}
$$

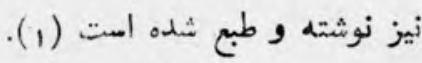

$$
\text { تاريخ سنده مولانا مهر (1) (1) }
$$




\section{- $\mu \mu$}

\section{هوتن:ج}

باين نام دو نفر در تاريخ سنده و افغان كذشته أند، و هر دو براي

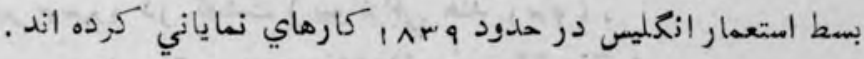

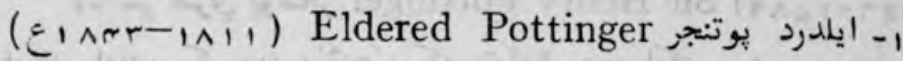

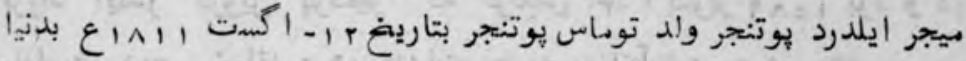

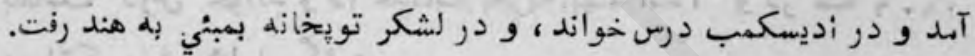

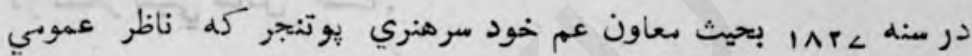

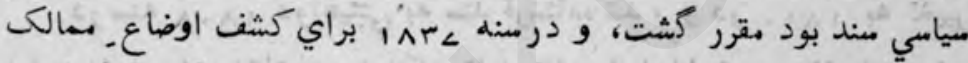

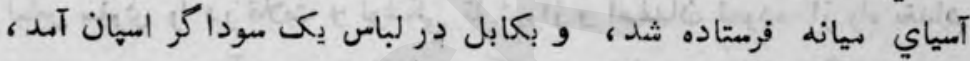
و بعد ازان عباي روحاني و ملاني يوشيده و در سنه >rی ا بهرات رسيد.

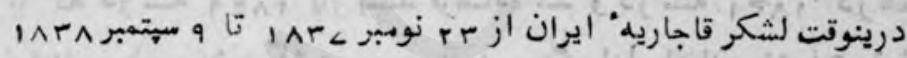
ثهر هرات را دماصره نمودند ، در تمام_ اين مدت بوتنجر ديحاصرين

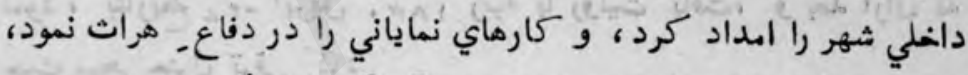

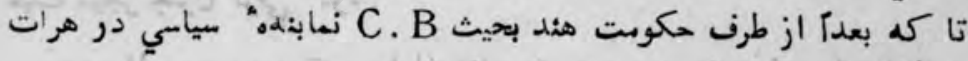
مقرر كرديد.

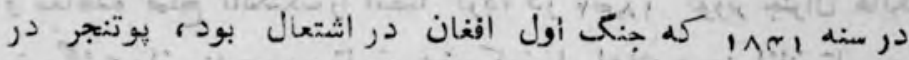

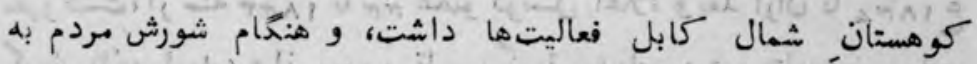

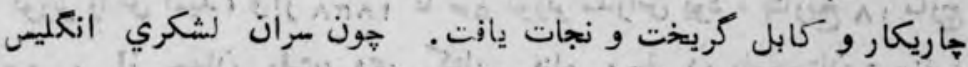

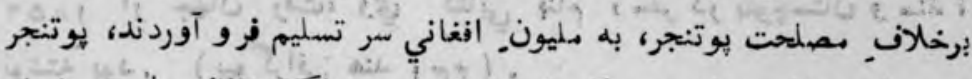

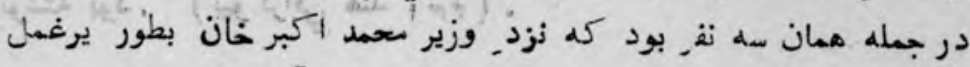

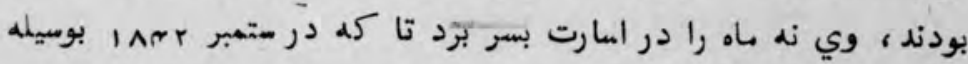


جنرل بالك نجزات يافت .

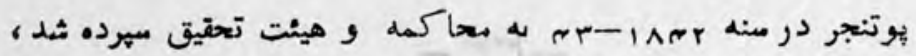

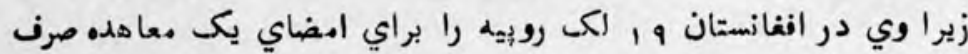

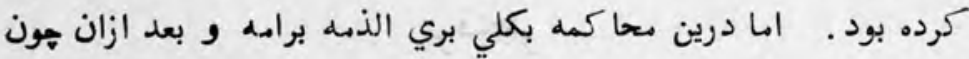

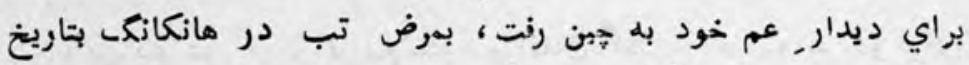

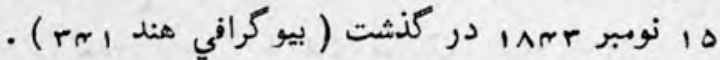
(

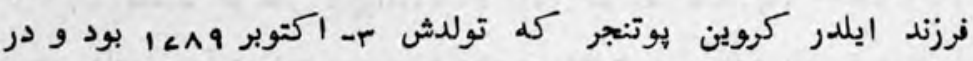

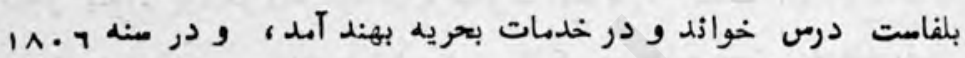
در لشكر بمبثي شاهل كثيت

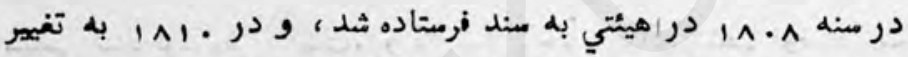
لبام مفري را در قلات و نوشكي تا شيراز و اصفهان نموده از راه بغداد ' و بصره به بمبئي آمد. بعد ازان در كتهه و بونا بحيث لفتنت كلنل بوده

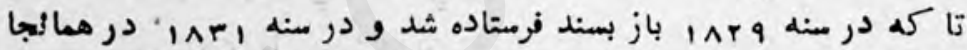
نماينده ميامي مقرر كثت . هون در جنكـ اول ازغان خدمات نماياكي

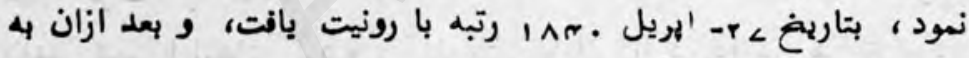

$$
\text { حيث ميجر جنرل ترقي كرد. }
$$

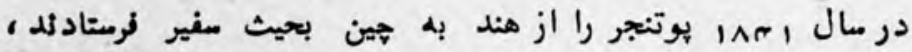

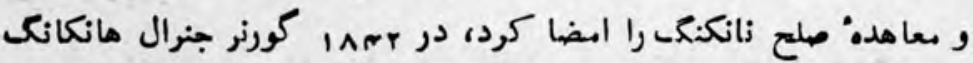

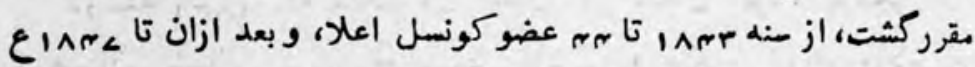

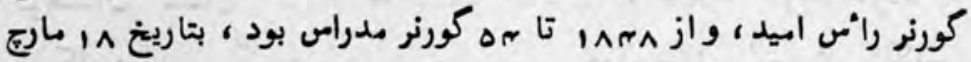

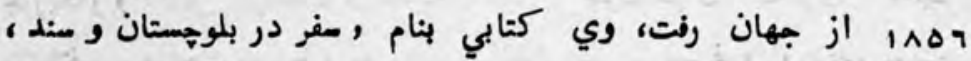

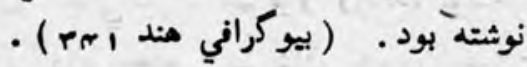




\section{$-M r-$

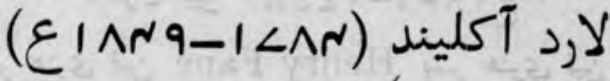

كورنر جنرال, هند ارل جارج ايدن آكليند جبهر دوم لارد آكليند

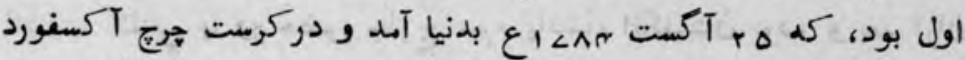

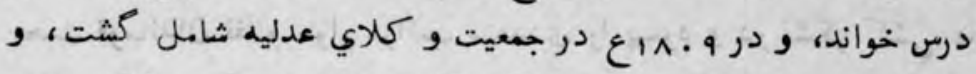

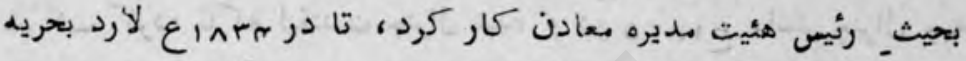

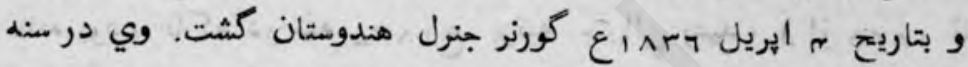

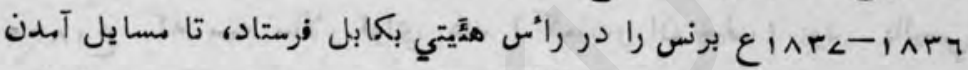

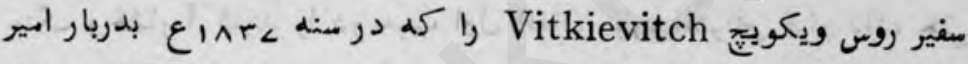

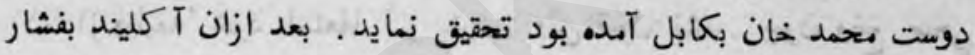

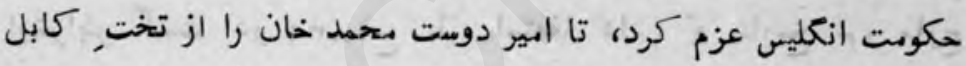

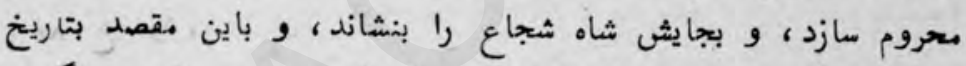

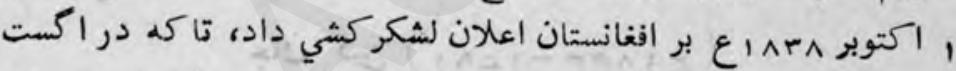

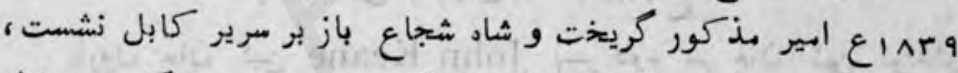

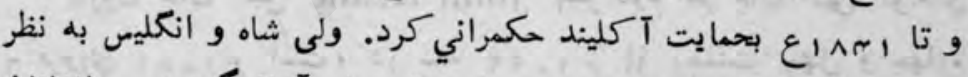
مردم افغانستان هنفور بودند، و شورش هاي بلى آغاز كرديد، و و انغانانان

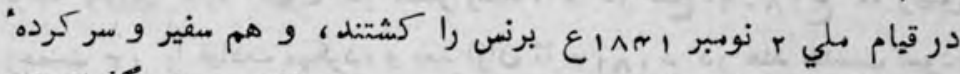

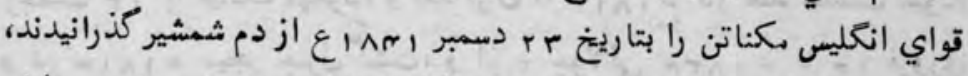

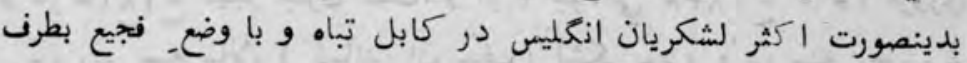

خيبر يس نشستند.

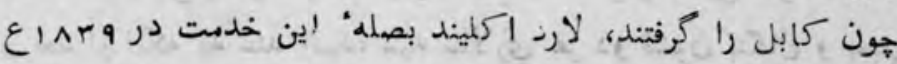

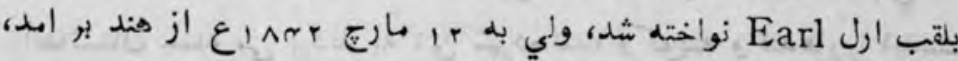


تعليقات

$\wedge 9 \pi$

اكثر ايام هكمراني وي در هند به هسايل جنحه افغان كنشت وي بتاريخ

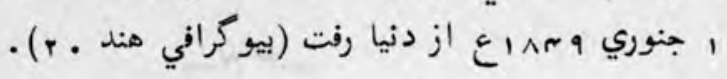
جنرل فين (

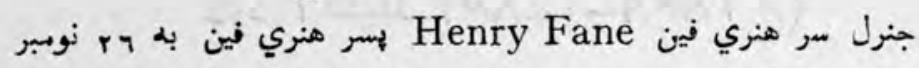

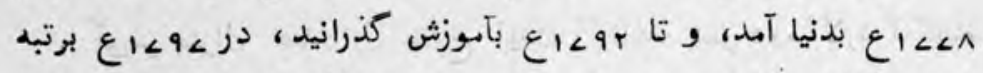

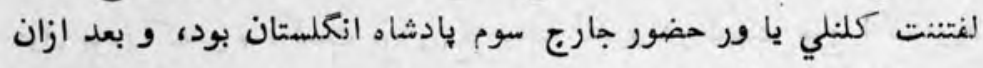

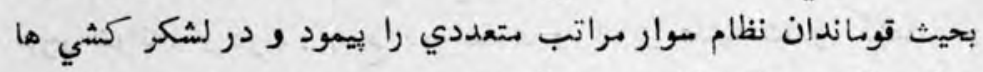

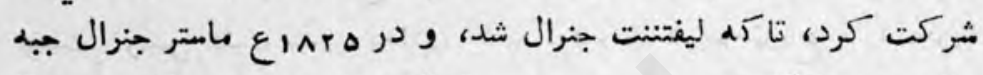

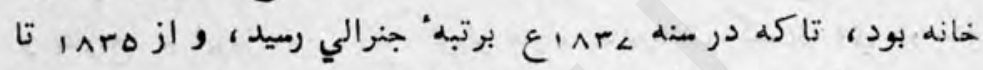
9rAl

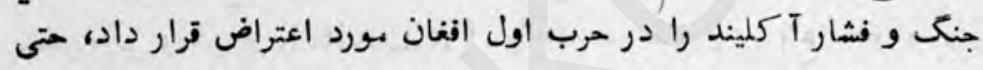

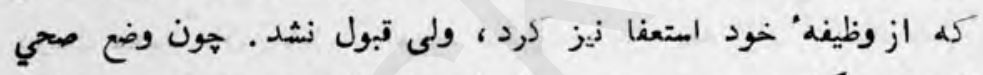

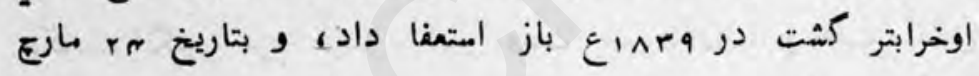

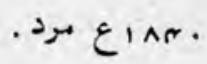

جان كين (

بارون جان كين John Keane بسر دوم سر جان كين تولدش إش

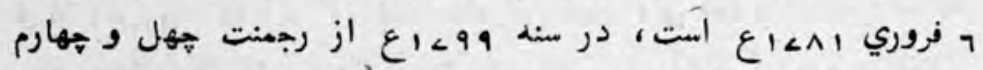

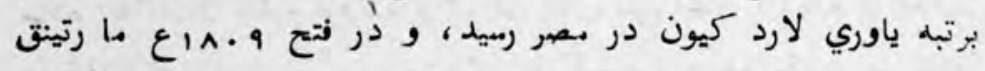

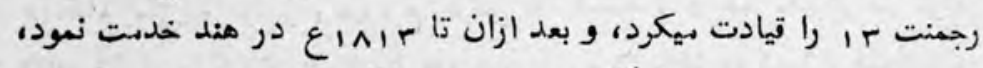

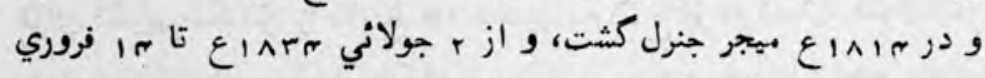

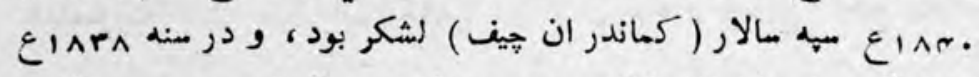

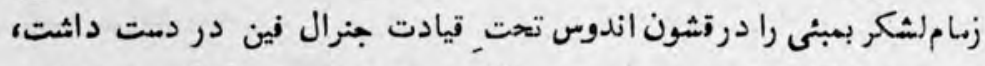

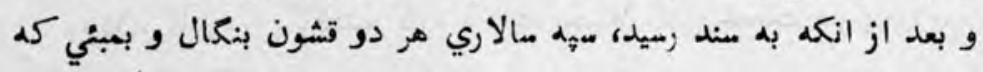

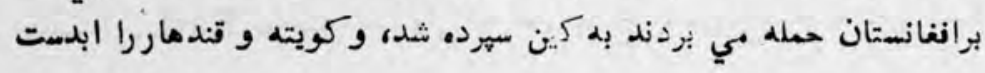


$\wedge 90$

تازه نواى مeار ك

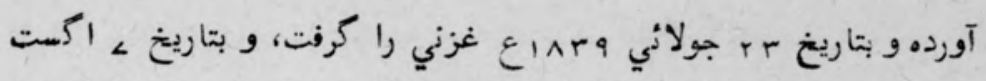

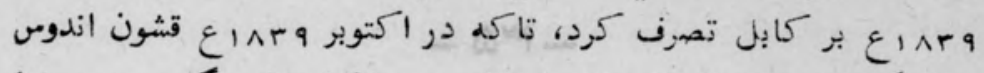

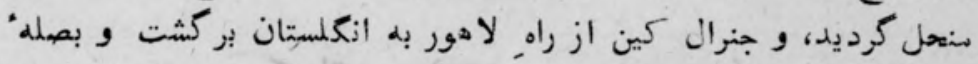

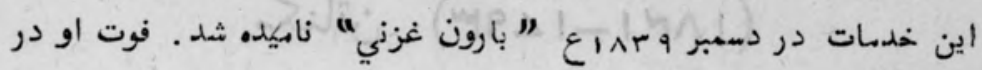

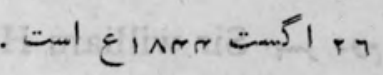
( بيوكرافي هند ir ( ) (ب) 


\section{$-M a-$ \\ ككناتن (}

سر وليم مكناتن Sir william Hay macnaghten بسر دوم

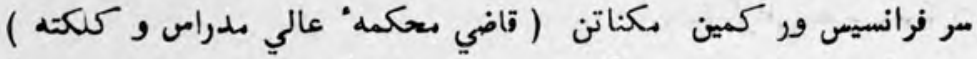

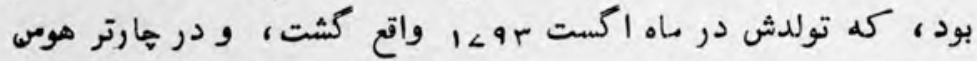

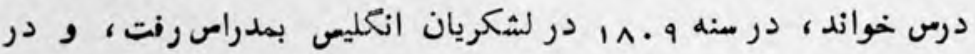

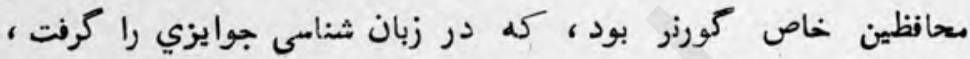

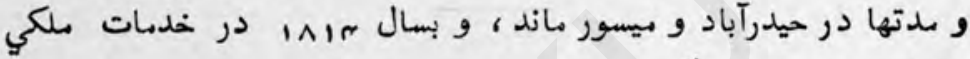

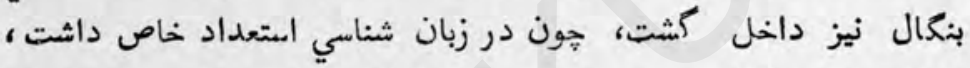

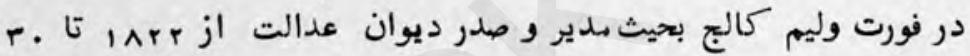

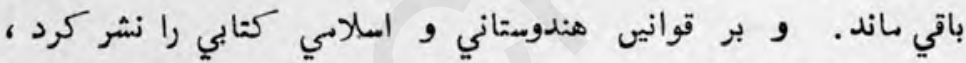

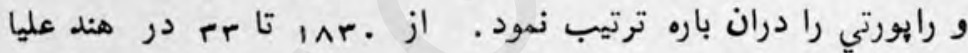

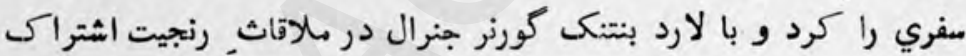

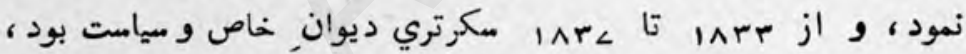

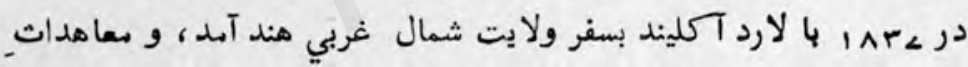

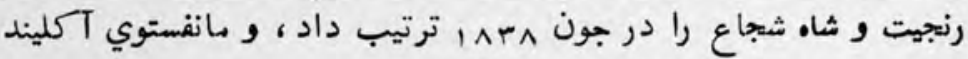

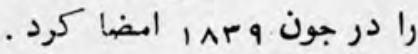

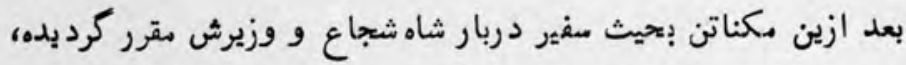

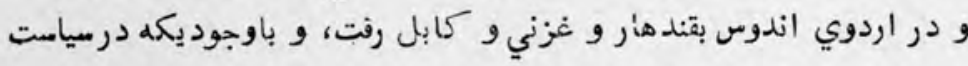

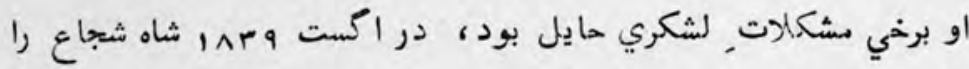

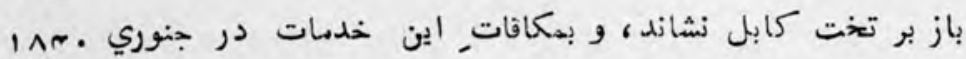
بقام با رونيت رسيد. 
مكناتن در افغانستان با شاه شجاع و قبايل افغاني در ترتيب مجدد

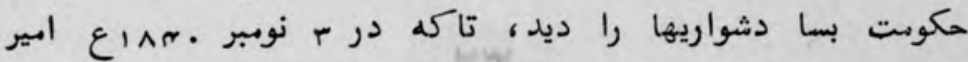

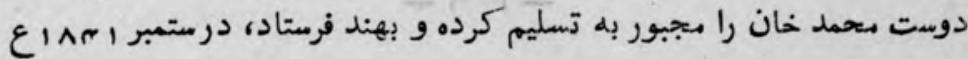

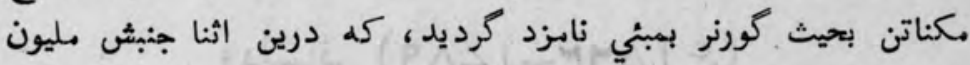

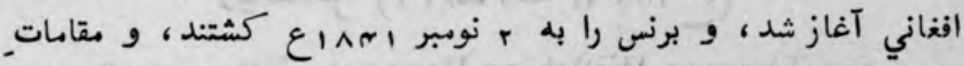
نظامي انكليسي در فرو نشاندن اين قيام ملي ناكام شدند، و لشكر بكلي

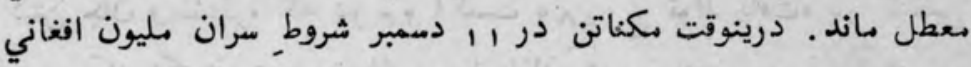

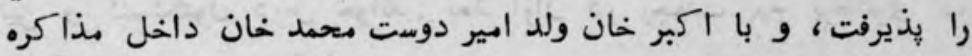

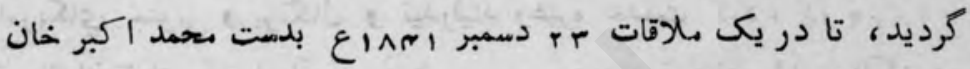
موصوف كشته شيء. ـكناتن داراي سجاياي استوار و استعداد كافي بود ، و باوجود يكه

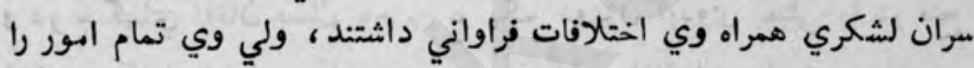
با كفايت اداره ميكرد، و شهرت و وجاهت كافي يافته بود، هنانحه بعد از مركث يادكاري بنام وي در كلكته بنا كردند. ( بو كرافي هندي 


\section{- My -

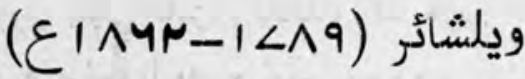

مر توداس ويلشائر Sir Thomas Willshire Baronet فرزند

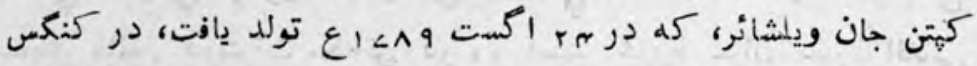

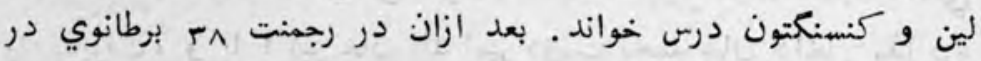

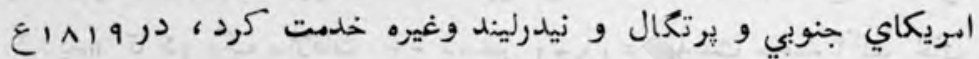

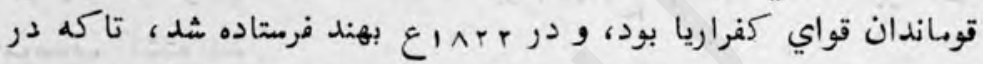

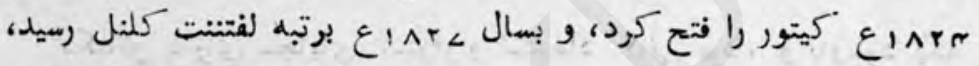

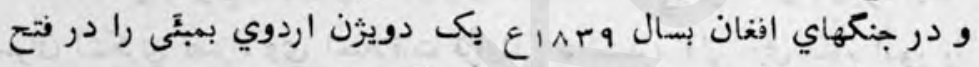

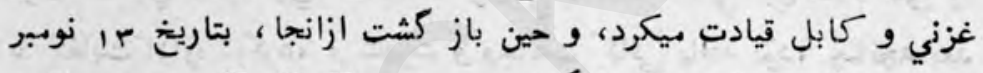

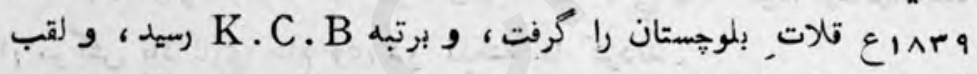

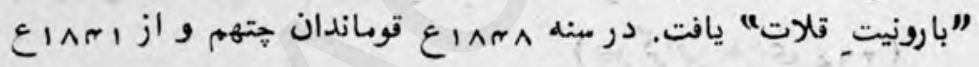

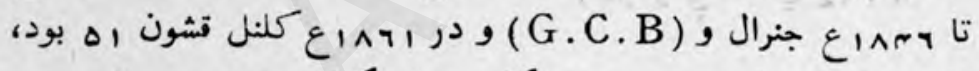

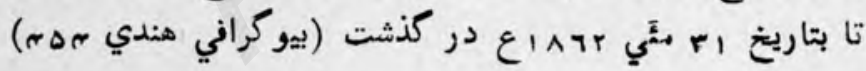

$$
\text { سر جيمز آترم ( }
$$

لفتنت جنرل آترم Sir James Autram, Baronet بتاريخ

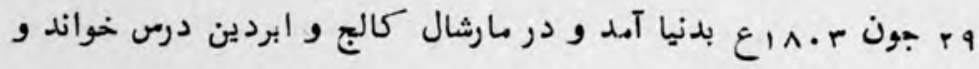

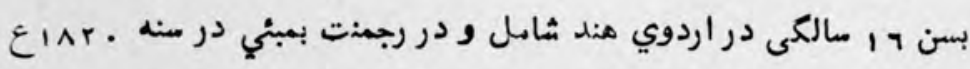

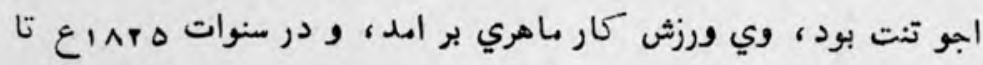

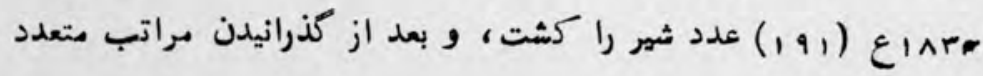




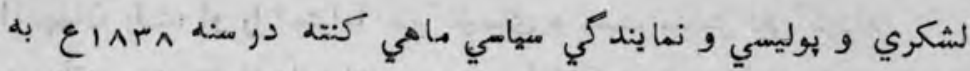

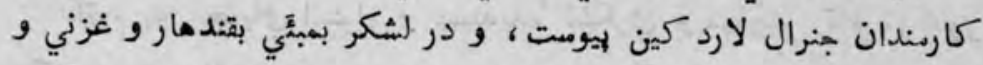

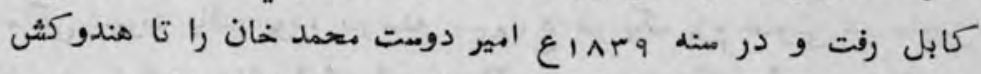

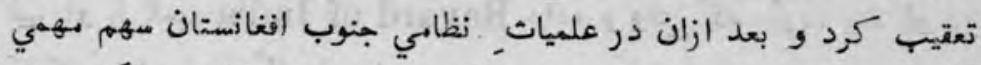

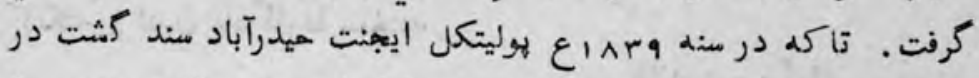

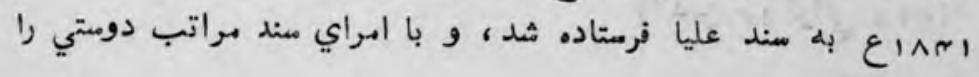
قا يم ماخت

وي با سران انكلميسي سر هارلس نيه و لارد الن برو در اليحاقي سند

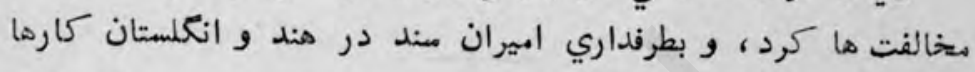

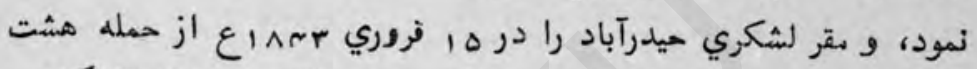

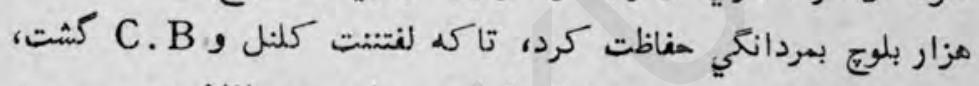

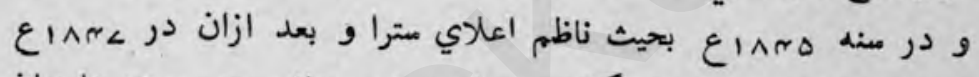

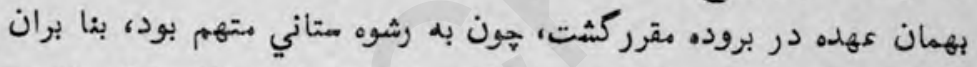

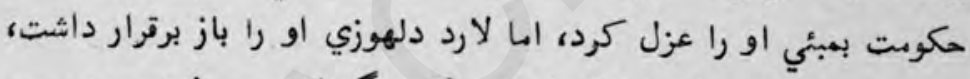

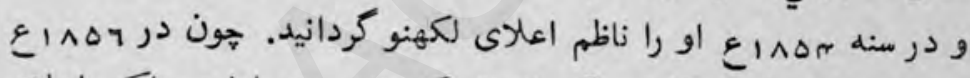
رياست اودها را به سفارش, آترمالهاق كردند، وري اولين حاكم اعلم اعلاي

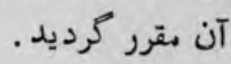

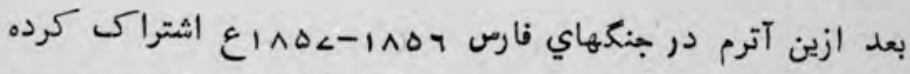

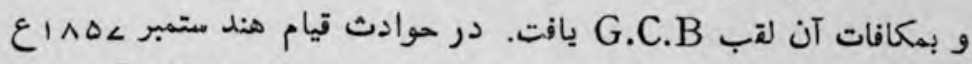

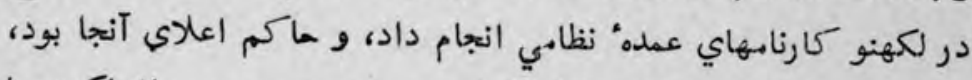

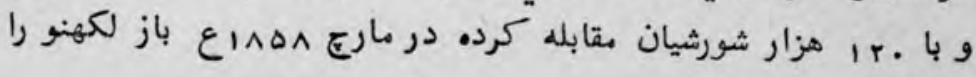
بلدست آورد . با مر

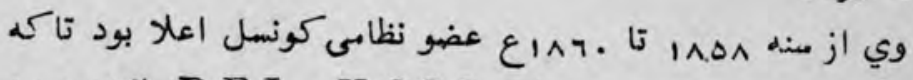

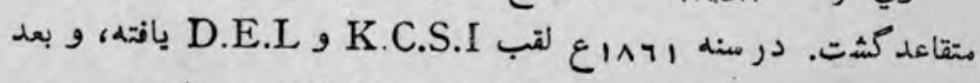

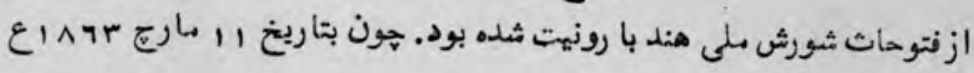


تعليقات

१. .

از جهان رفت، او را احتراما در كليساي و يست منستر دفن كردند.

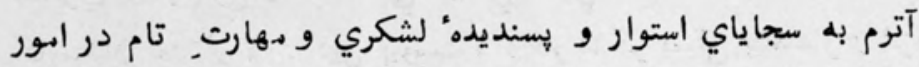

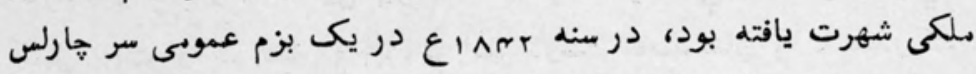

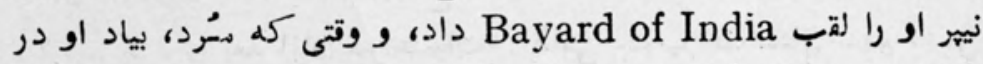
كلكته و لندن ياد كارها ساختيند. (اندين بيوكرافي هrr) 
9.1

تازه نواي معارك

$-\mu /$

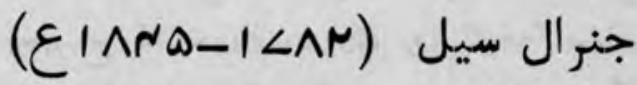

سر رابرت هنري سيل Sir Robert Henry Sale فرزند كلنل

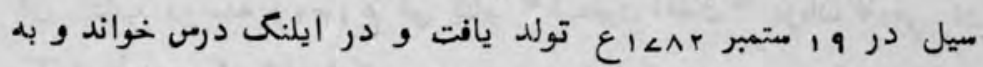

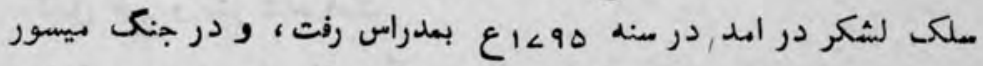

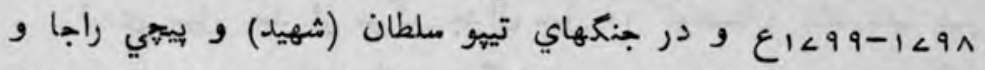

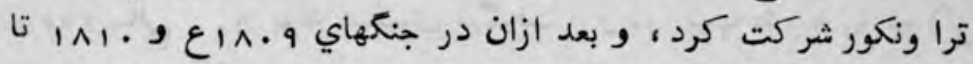

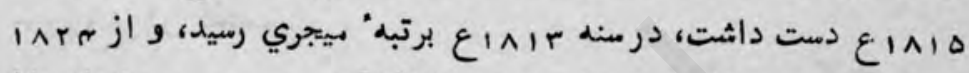

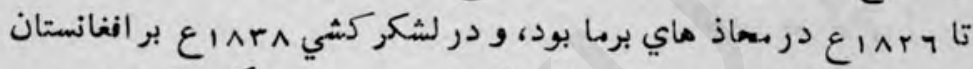

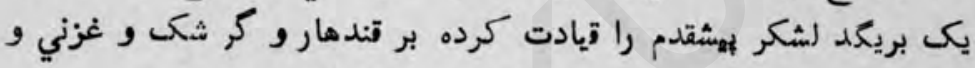

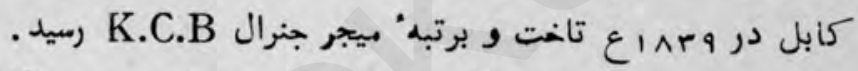

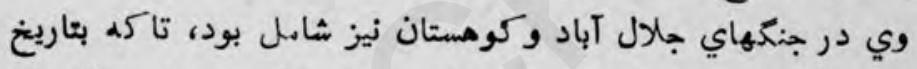

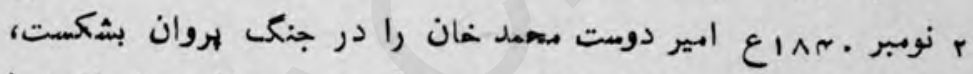

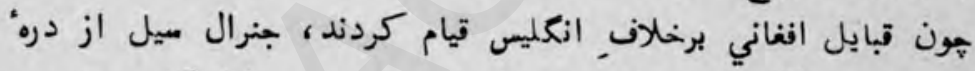

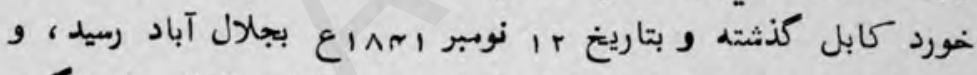

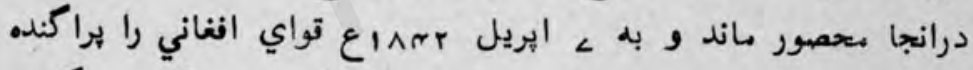

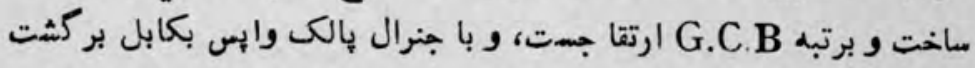

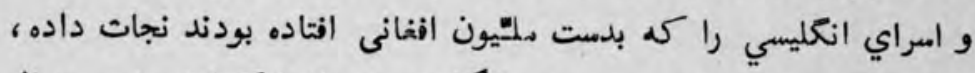

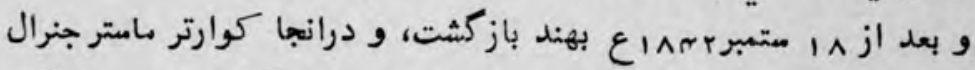
ب.G.G

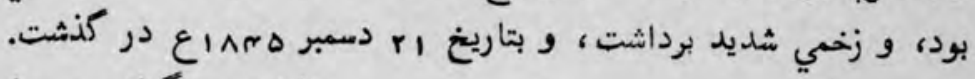

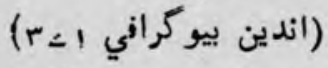

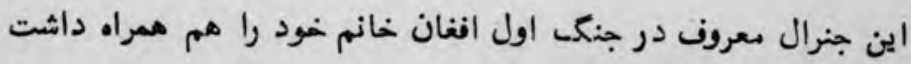

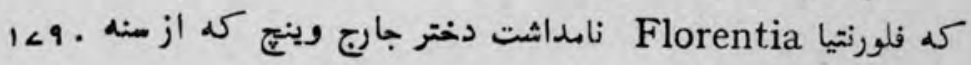


نعليقات

a.r

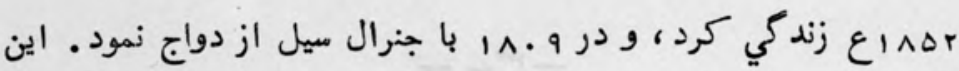

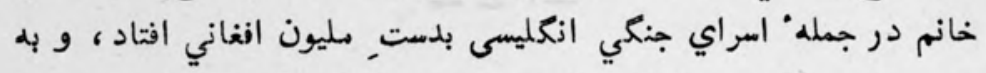

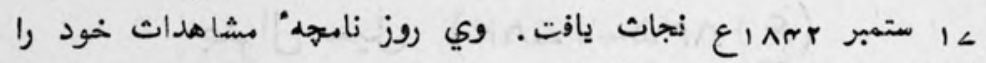

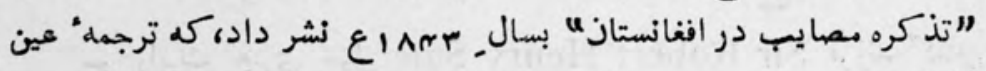

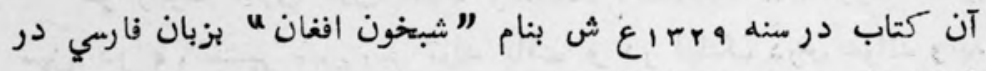

كابل طبع و نشر شده الست.

ليدي سيل بعد از مرك جنوال سيل ذر كوهستان هند فيلد عليا بسر

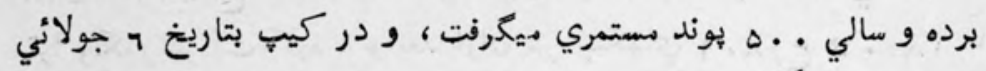

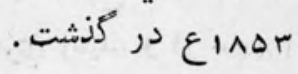

(انُدين ييوكرافي ) 


\section{ماريوت (1^<9 )}

William Frederick marriot جنرال وليم فريد رئكى ماريوت

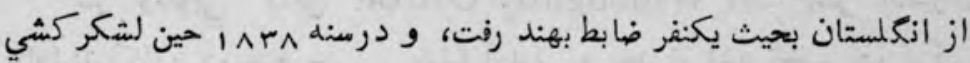

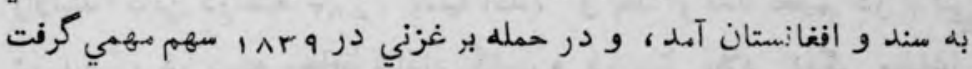

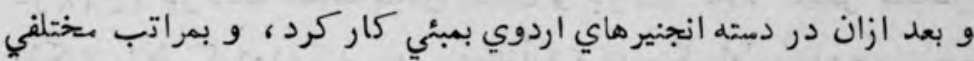

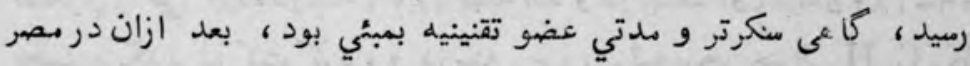

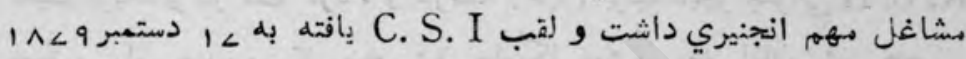
در كنتشت ( اندين بيوكرافي r ( )

\section{$-\mu q-$}

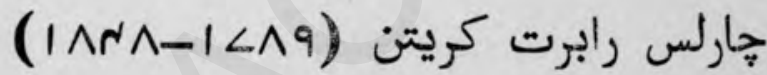

بريكدير جنرال هارلم رابرت كريتن Charles Robert Curreton

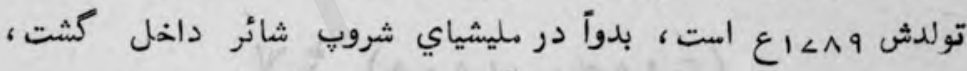

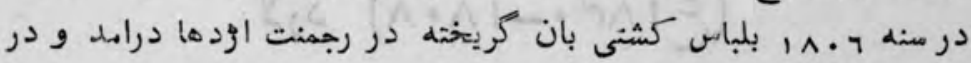

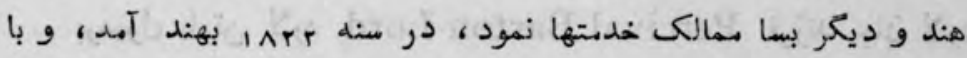

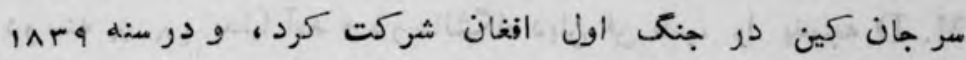

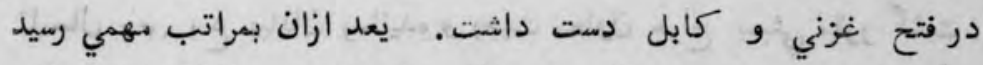

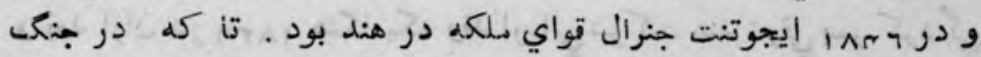

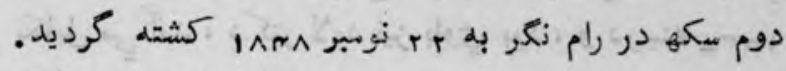

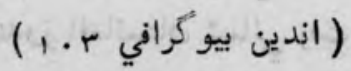




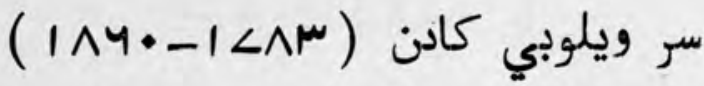

سر ويلوبي كأتن Sir Willoughby Cotton وإسر ادميرال

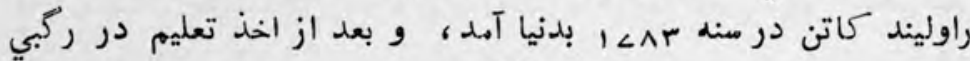

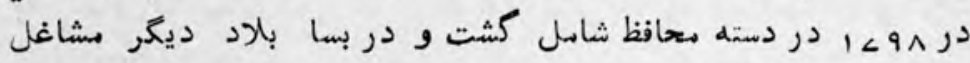

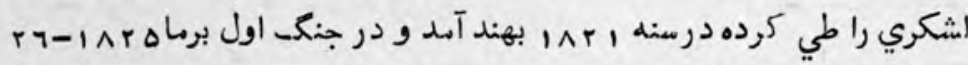

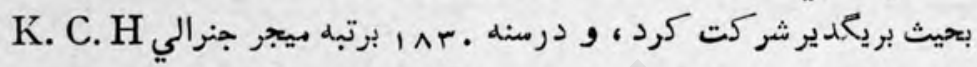

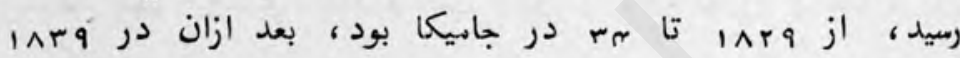

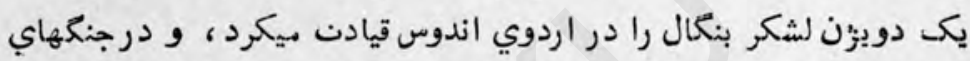

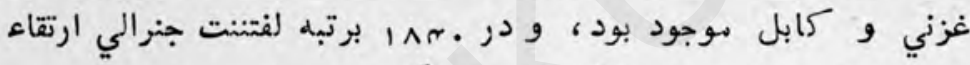

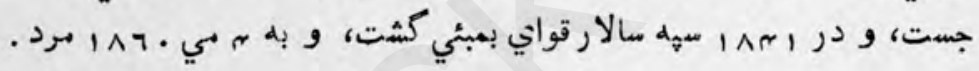

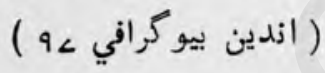

$$
\begin{aligned}
& -N I- \\
& (\varepsilon|\wedge N \cdot-| \wedge \cdot \wedge){ }^{b}
\end{aligned}
$$

يرسيول بارتن لارد Percival Barton Lord فرزند جان لارد

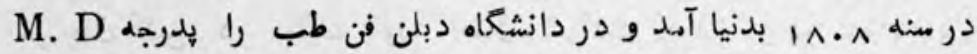

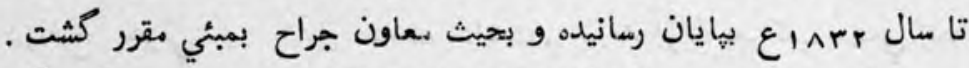

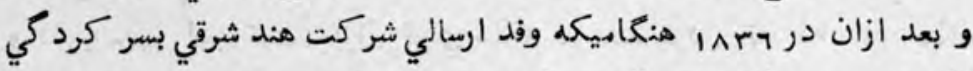

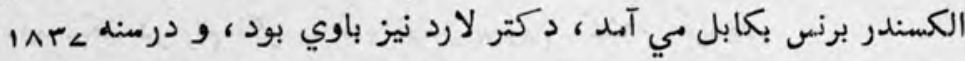

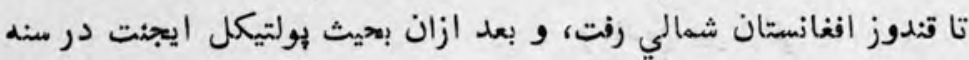

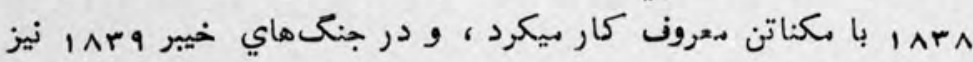


شركت داشت ، هون ابير دوست محمد خان به شمال لـ افغانستان كريخت،

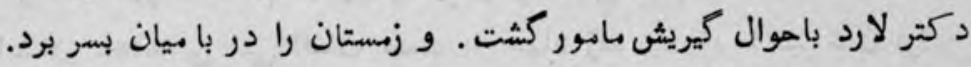

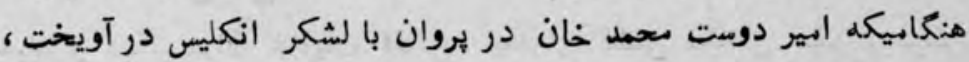
درين جنك بتاريخ r نومبر . می ا د كتر لارد كشته شد .

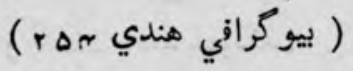

دكتر لارد در فعاليت هاي برنس در افغانستان سهم سهمى داشت

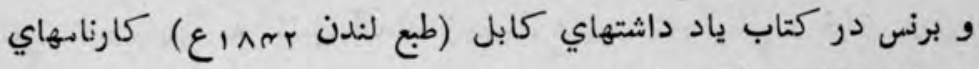
او را فراوان ياد كرده است برد

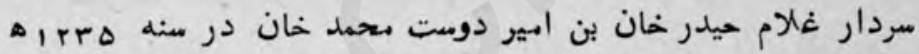
در باغ نمله شرقي كابل تولد يافته و علوم عربي و ادب راب را از ملا متحم اكرم با جوري و قاضي عبدالسلام لوكري فرا كرفت و به به مرتبه

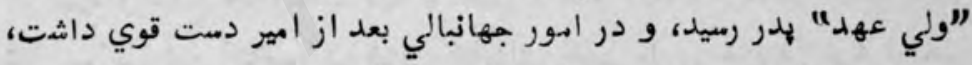

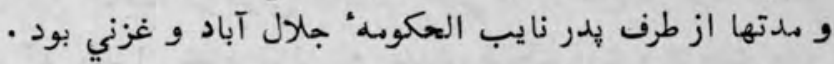

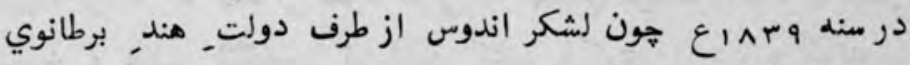
بر افغانستان تاخت، غزني را بعد از فتع قندهار و جلوسي شاه شجاع محاصره كرد، درين وقت شهزاده غلام ميدر از غزنى دفاع ميكرد، تاكس بالآخر، صبع rr جولائي وrیاع بالا حصار غزني سقوط و شهزاده حيدر بذست فرنك اسير شده.

هون در همين سال حند ماه بعد امير دوست متحمد خان نيز خود ران به لشكر فرنك ميرد ، و به كلكته و امباله با تمام. متعلقان خود نفي 
كرديد، شهزاده غلام حيدر نيز در بوناي بهبئي اسير ماند، كه در غيابِ

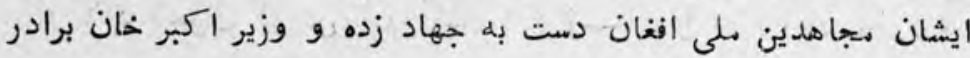

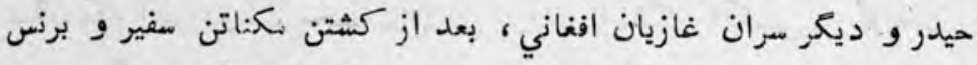

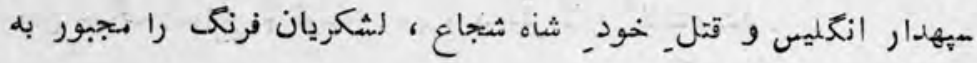
باز كثت مثند نمودند.

درينوقت امير دومت متحمل خان و شهزاده غلام حيدر و ديكر اشخاص

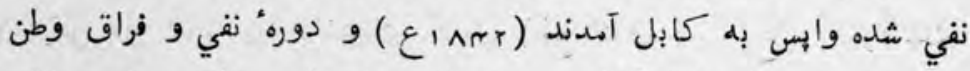

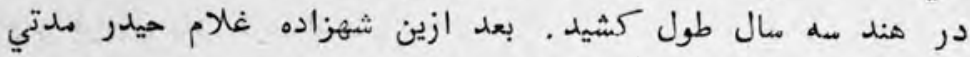

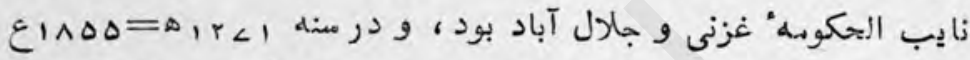

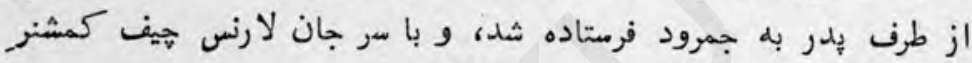

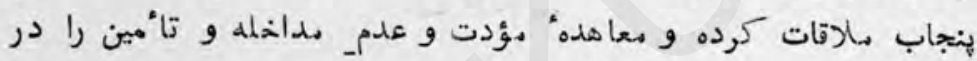

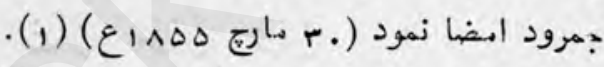

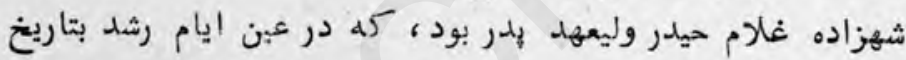

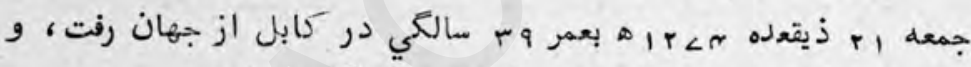

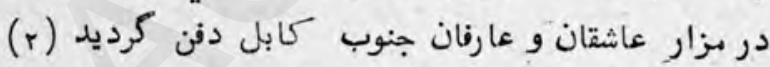

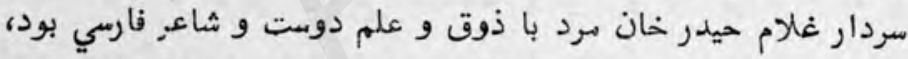

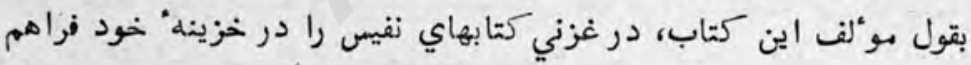

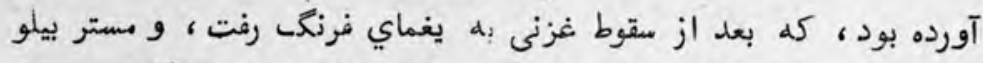

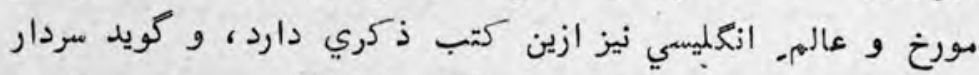

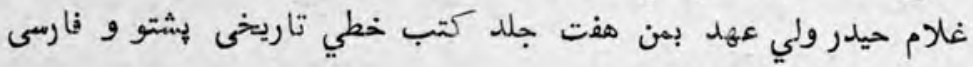

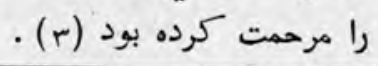

$$
\begin{aligned}
& \text { (1) افغانستان بعد از اسلام (خطي) حبيبى. } \\
& \text { rهו سراج (r) }
\end{aligned}
$$

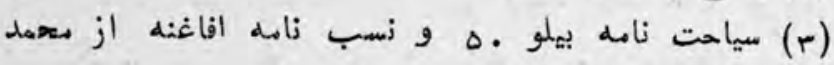

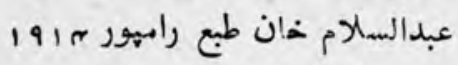


سردار در شعر فارسى طبع. روان داشت، تخلص, وي " حيدر" بود،

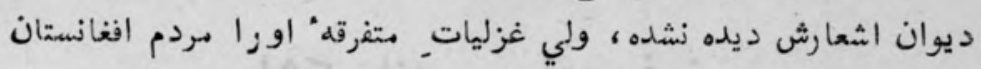

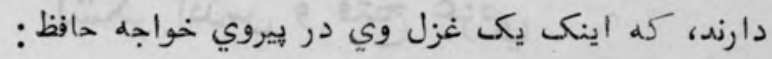

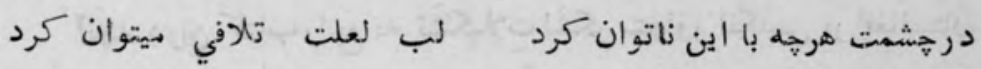

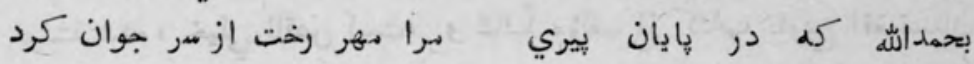

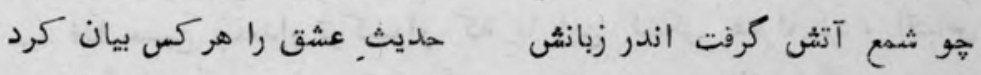

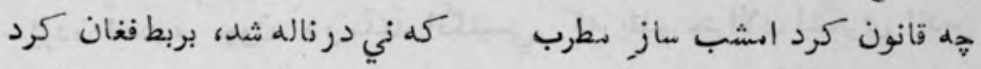

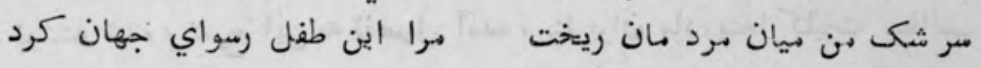

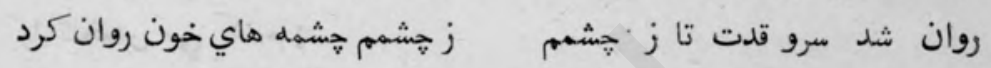

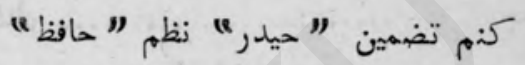

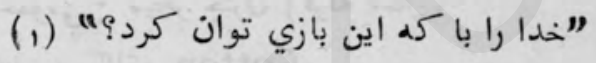




\section{$-4 \mu-$}

\section{لشكر, اندس و فتح غزني}

آنهه درين كتاب راجع به تشكيلات لشكر متجاوز انكليس بر افغانستان

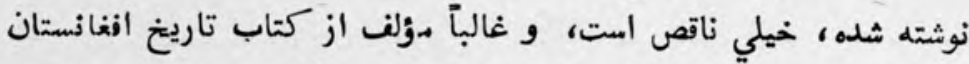

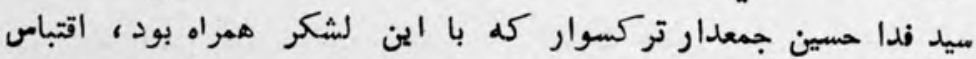

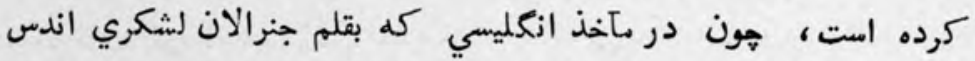

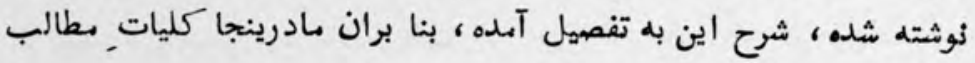

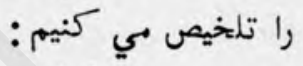

جمله ... هو نغر

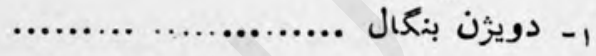

قايد عمومي : ميجر جنرل (فرقه مشر ) بران

سر \$بليو، كاتن Cotton

بريكدُ (غند) اول : بريكدير سيل Sale

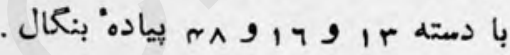

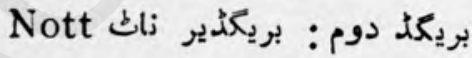

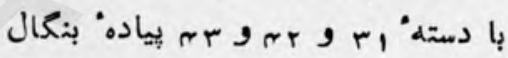
بريكذّ سوم : (غند سوم ) بريكثير

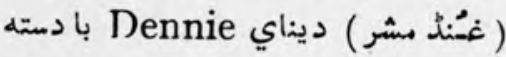

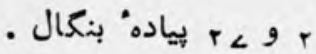

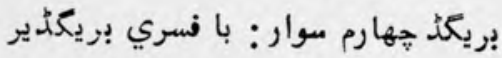
ثلهاكويل Thackwell با دسته r جمله . . حهد نقر

$$
\begin{aligned}
& \text { قايد عموبي : لفتنتت جنرل (نايب سالار) } \\
& \text { سر جان كين J. Keane }
\end{aligned}
$$




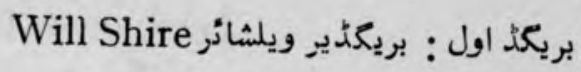

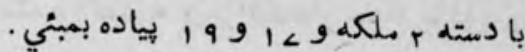

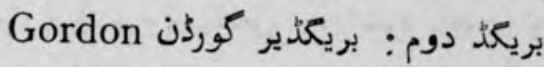

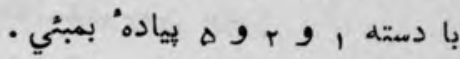

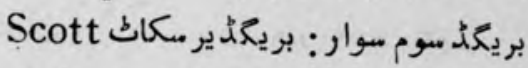

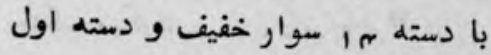

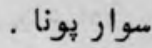

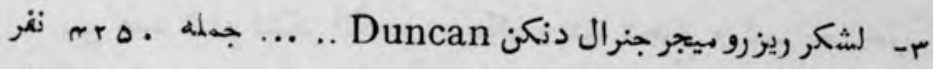

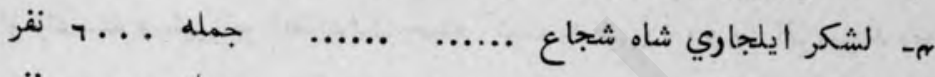

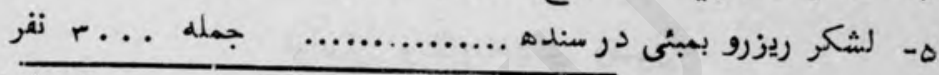

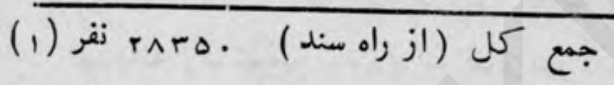

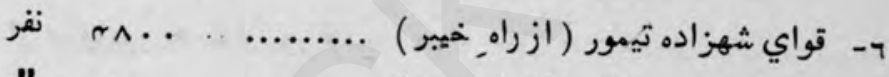

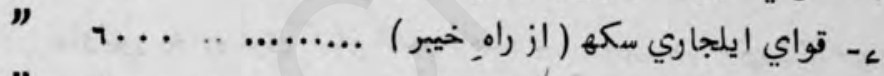

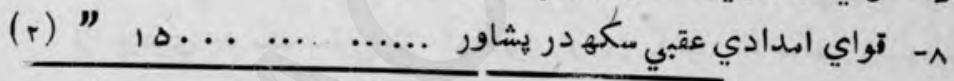

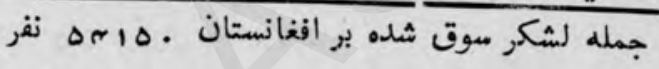

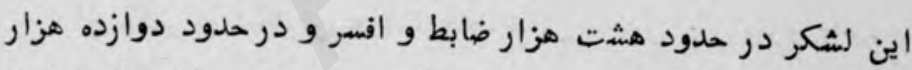

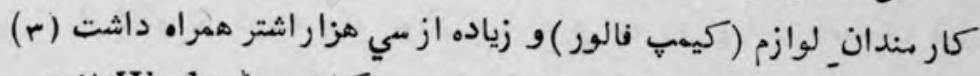

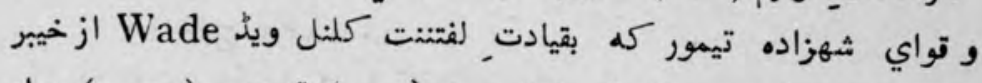

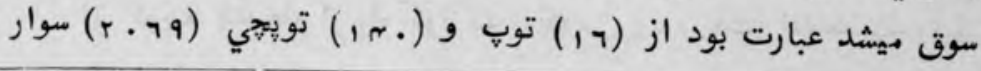
(1) (1) لوي آف دي اندس ص .ه و لشكر اندس از ميجر هيوز طبع

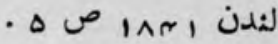
- T r (r)

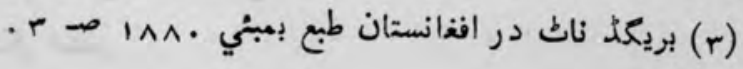




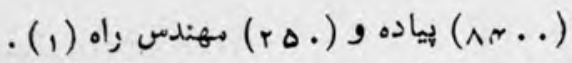

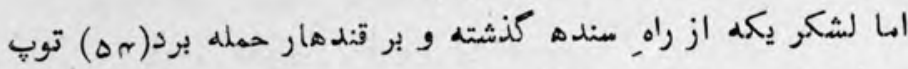

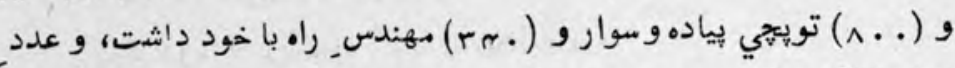

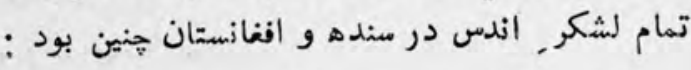

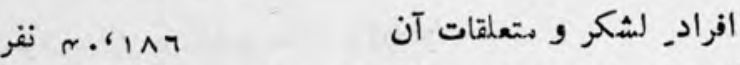

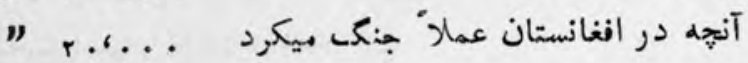

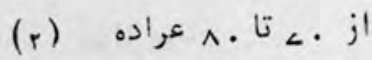

توب

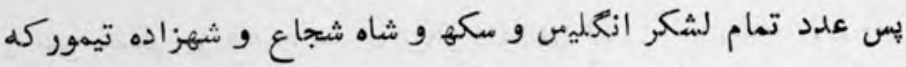

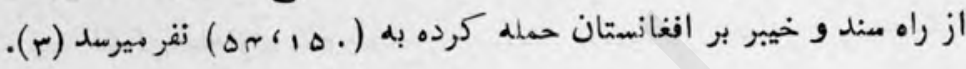

\section{فواصل و تاريخهاي وصول}

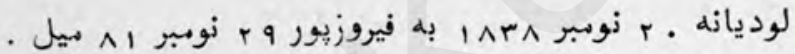

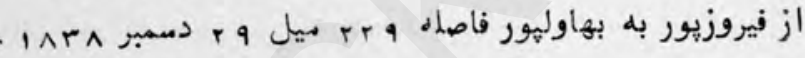

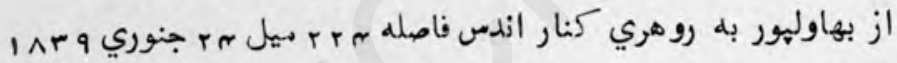

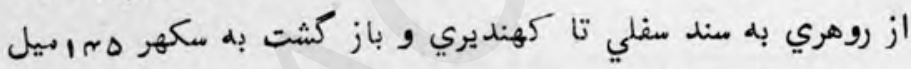

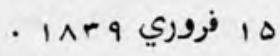

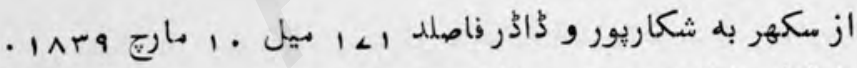

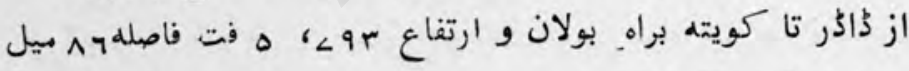

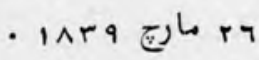

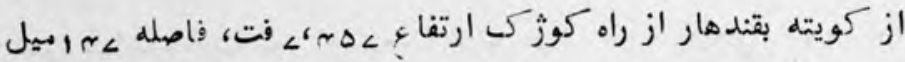

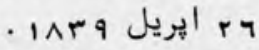

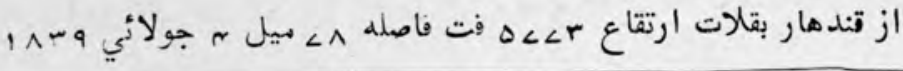

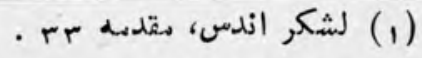

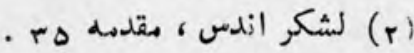

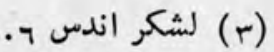




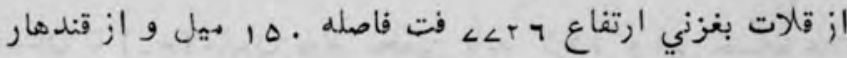

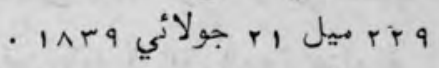

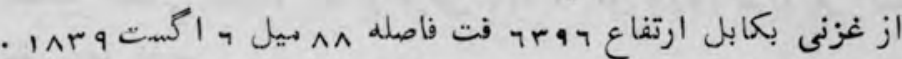

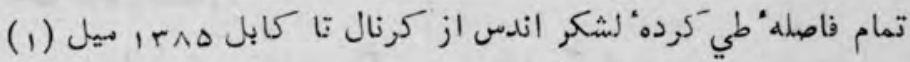

\section{مصارف و تلفات جنم}

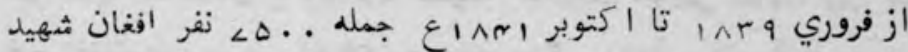

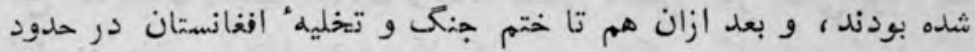

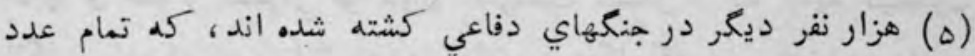

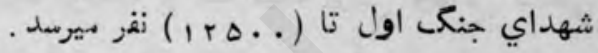

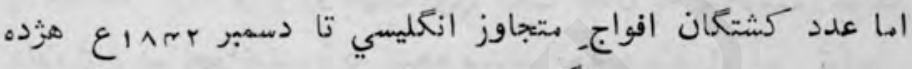

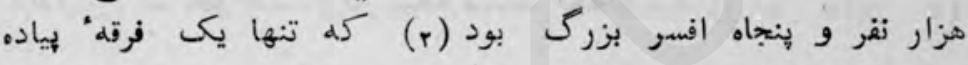

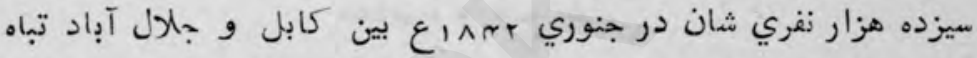

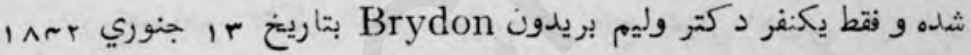
بجالال آباد زنده رسيده بود (r) .

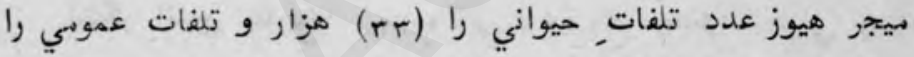

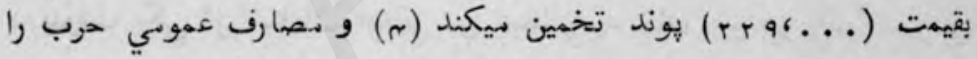

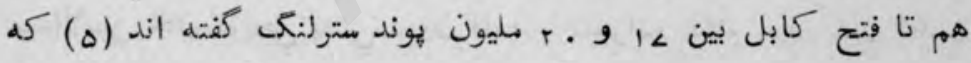

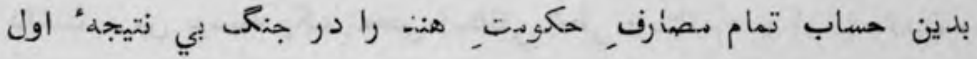

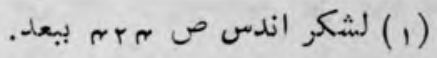

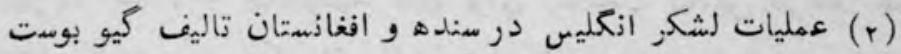

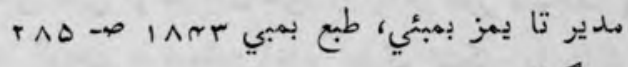

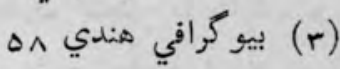

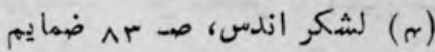

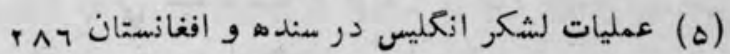


افغانستان تا (.r) مليون بوند تخمين بايد كرد، و اين خساره علاوه بر

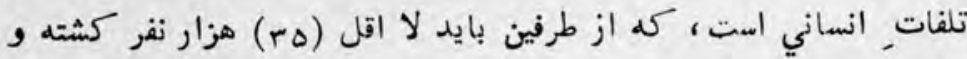
تلف شده باشند.

با دادن اين تلفات سنكين و مصارف كزاف، هم دولت هند برطانوي

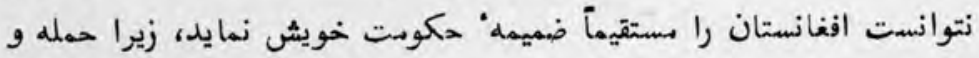

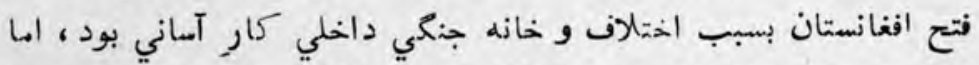

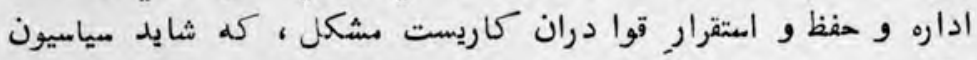

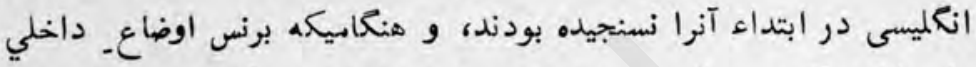

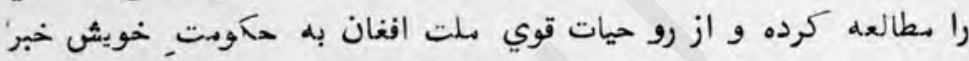

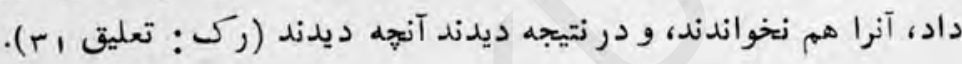

\section{مجاصره و فتح غزني}

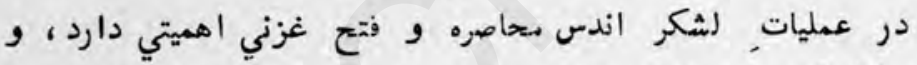

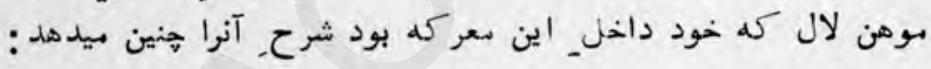

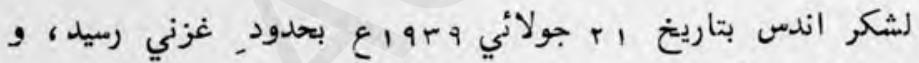

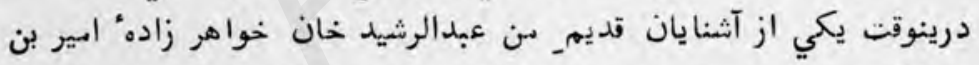

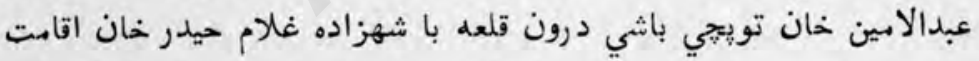

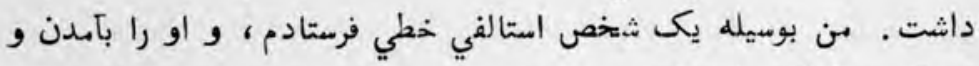

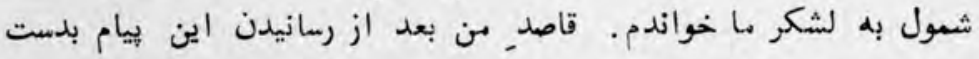

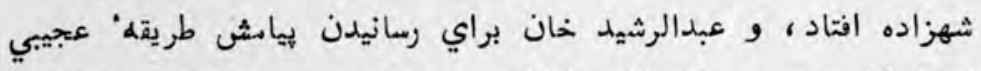

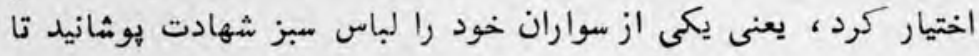

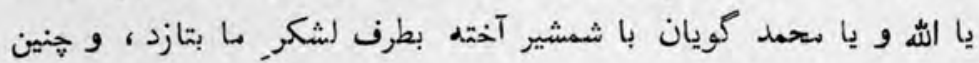

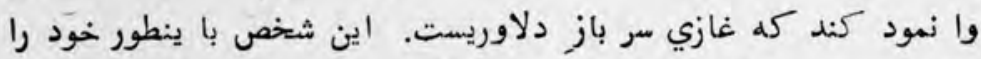

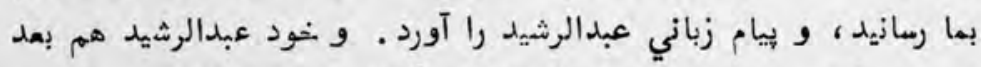

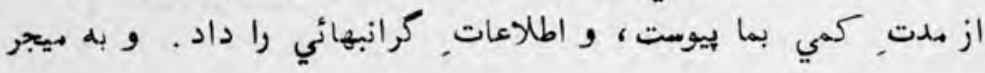


تهامسن انجنير اعلاي لشكر اندس، درباره' وضع دفاعي قلعه خبر ها و مشورهاي مفيدي داد . درينوقت سردار معمد افضل خان با سواران خود بيرون غزني آماده: دفاع بود، و برادرش سردار غلام حيدر خان بالاحصار

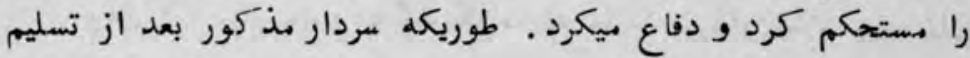

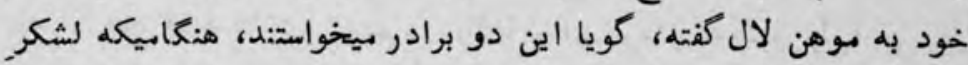

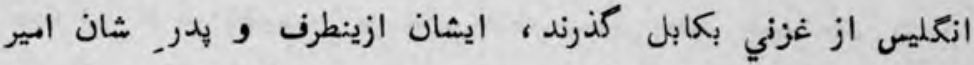
دوست محمد خان از طرفـ كابل، ايشان را خواهند كوفت. ولهي افنسران لشكر انكليس، تا غزني را بدست نياور دند، ازانجا قدي فراتر ننهلدند. درينوقت بين اين دو برادر نيز اختاف و رقابتي بود، كله ميحمد افضل

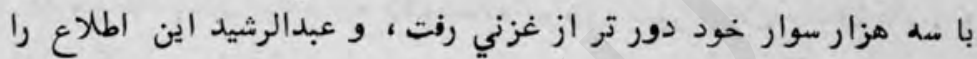
بما رسا نيده، با هيجر تهامسن Thomson راه. وصول به قلعه و ونتع آنرا

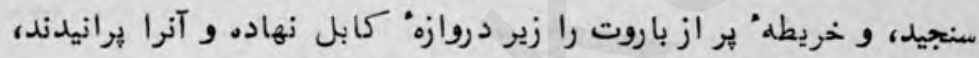

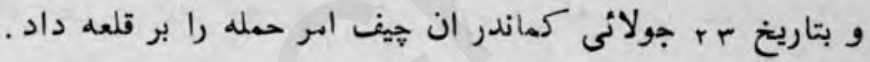
هون تهامسن و كاريتان ريت Peat دروازه را برانيدند، دستهن كلنل ديناي بر قلعه حمله نموده و سر رابرت سيل Sale نيز با و كمكى تهم ميكرد. اين حمله بساعت م صبع آغاز و در مدت (ه م) دقيقه خته شده و قلعه را كرفتند، و سر دبليو كاتن و جنرال ويلشائر بر بالا حصار برامدند.

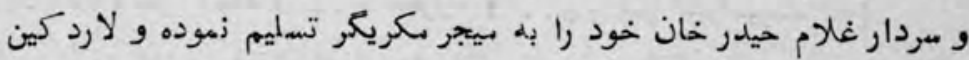
سهه مالار او را باحترام يذيرفت، و بعد ازان درد درد يكى خيمه با بوهن لال

$$
\text { بسر بي برد (1) }
$$

كار, تصفيه" كلي غزني تا بم جولاني دوام كرد، و در همين روز

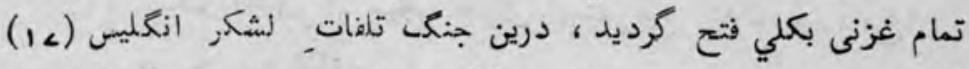

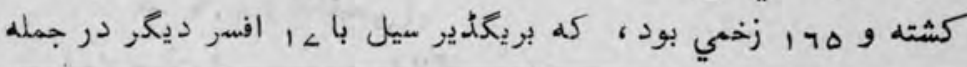

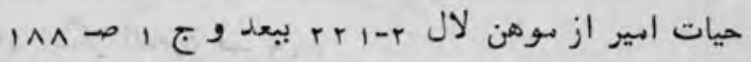




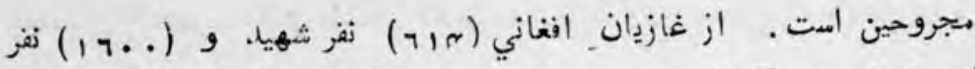

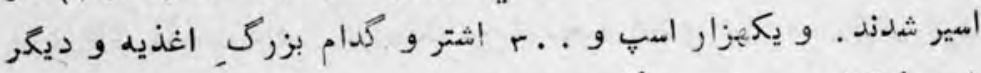

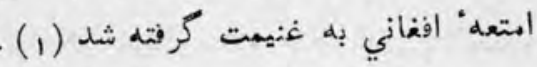

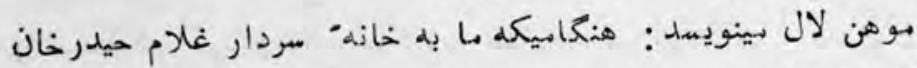

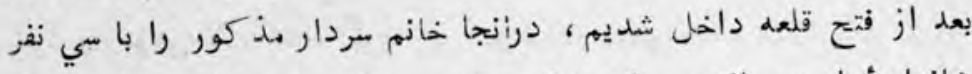

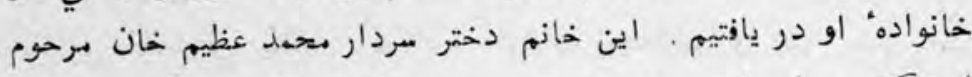

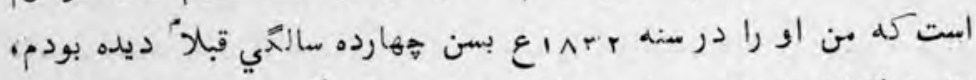

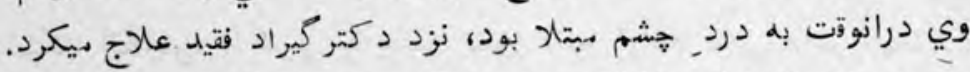

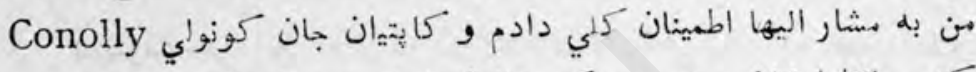

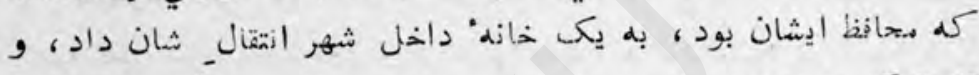

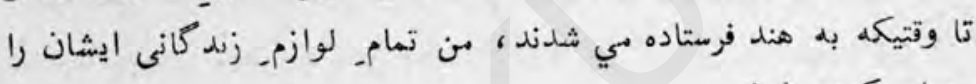

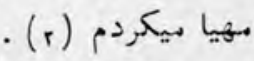

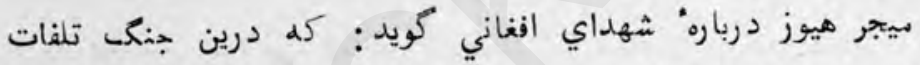

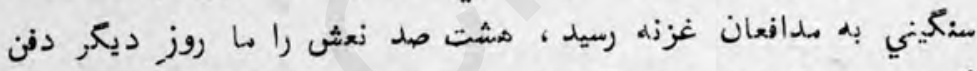

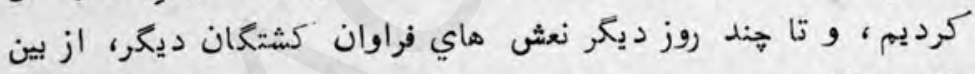

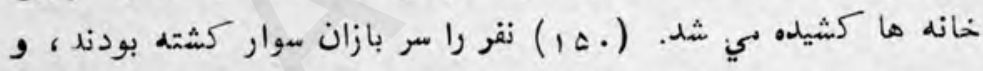

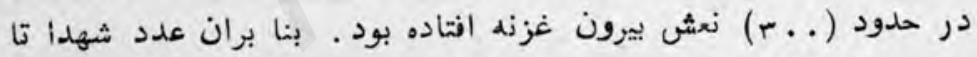

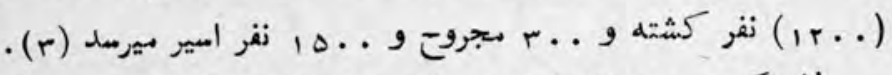

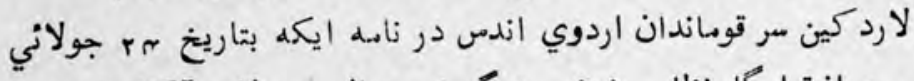

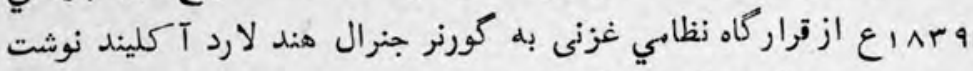

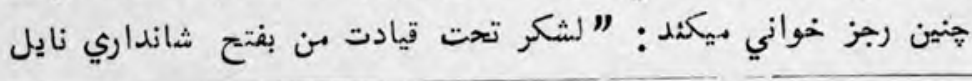

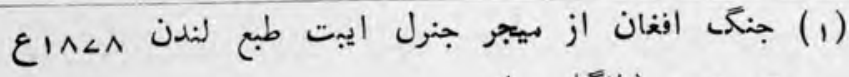

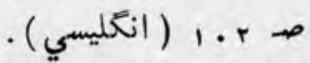

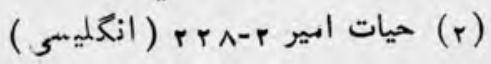

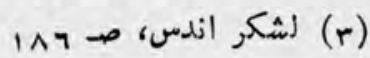




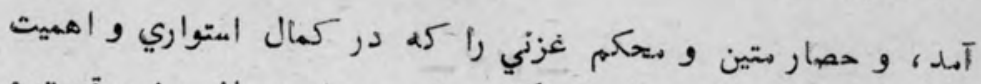

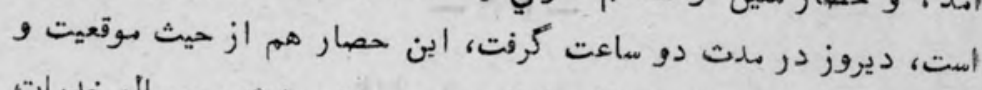

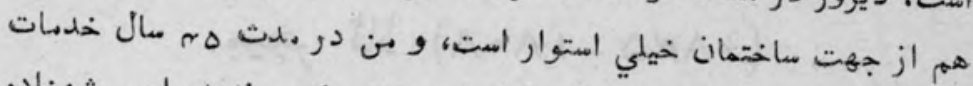

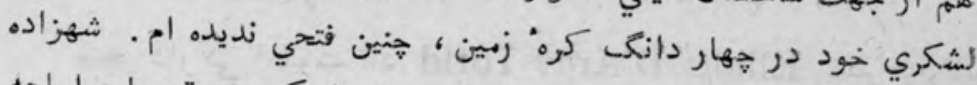

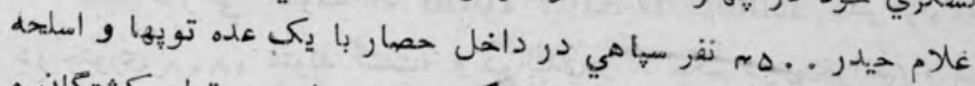

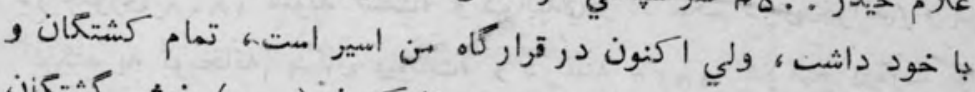

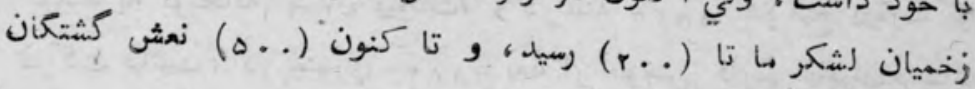

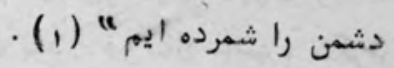

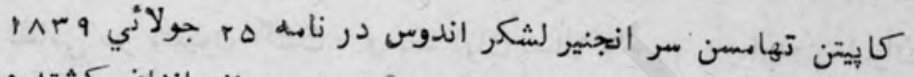

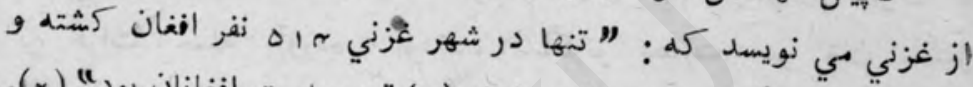

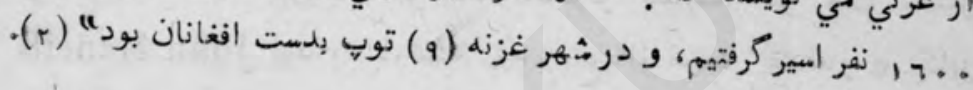

(1) لرشكر كشي بر ازغانستان از -بمس اتكنسن طبع لندن

$$
\begin{aligned}
& \text { - }
\end{aligned}
$$

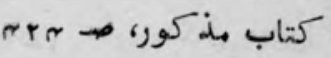




\section{هيج土 دإ}

بيجر داركي ايليوت تاد Elliott D'Arcy Totld بهرب فريرتاد

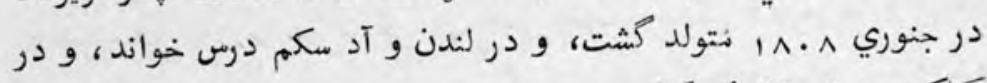

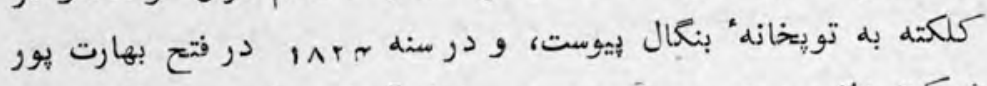

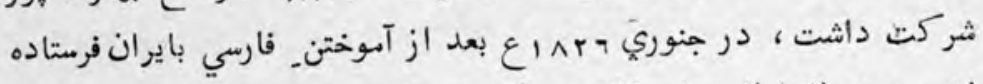

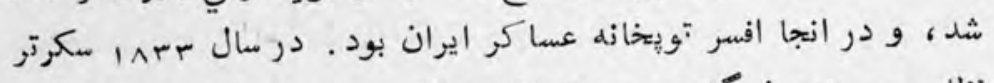

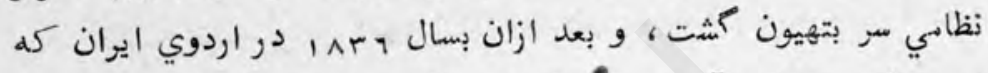

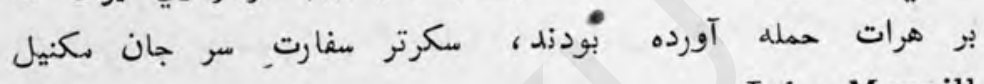

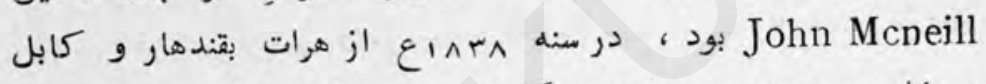

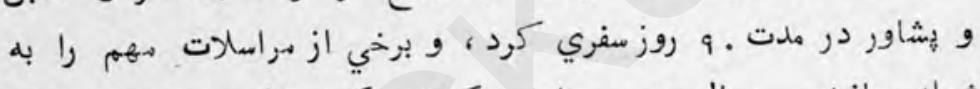

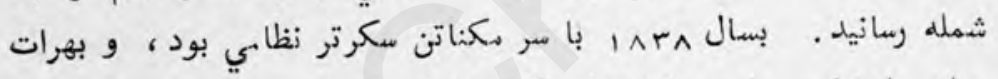

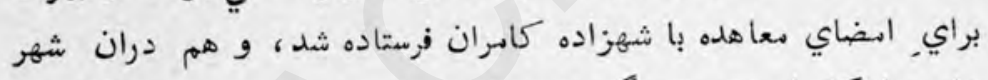

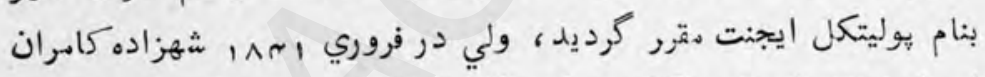

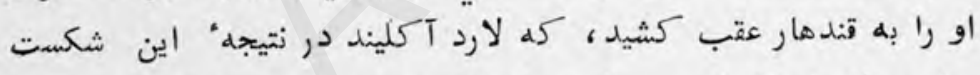

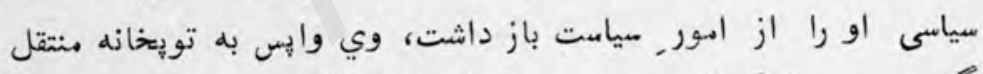

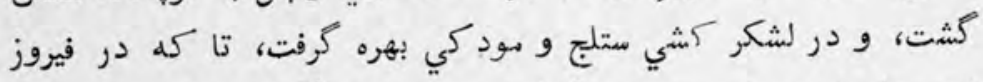

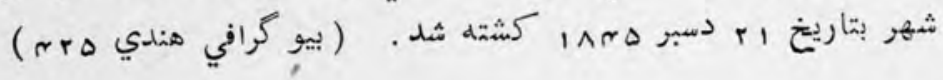

\section{$-4 A-$}

\section{سر كلود ويد (}

•بر كلود مارتن ويد Sir Clude martin wade

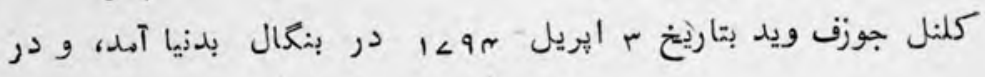


912

تازه نواي معارك

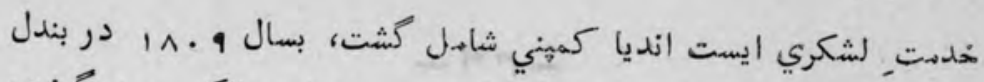

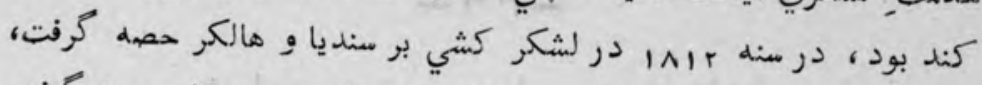

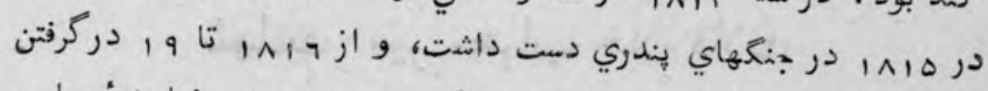

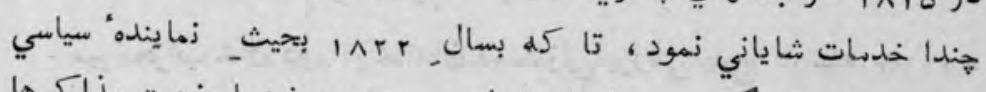

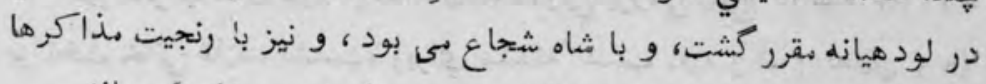

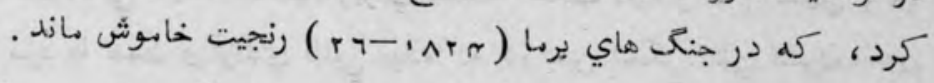

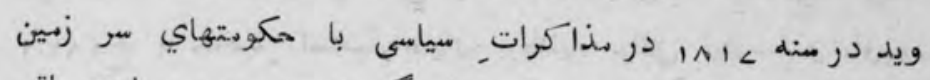

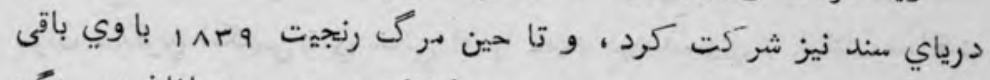

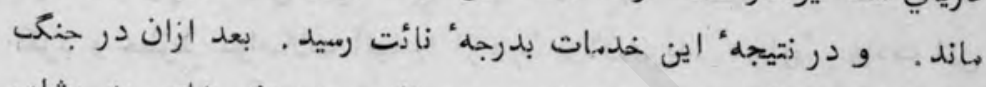

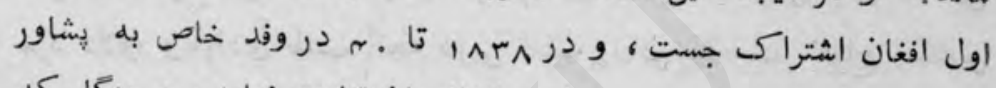

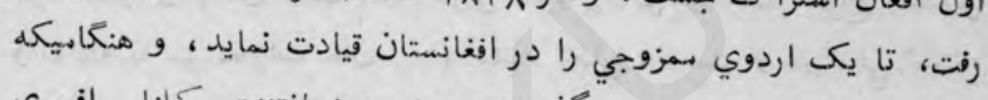

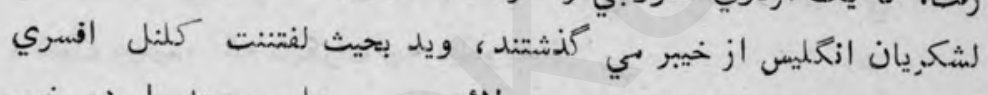

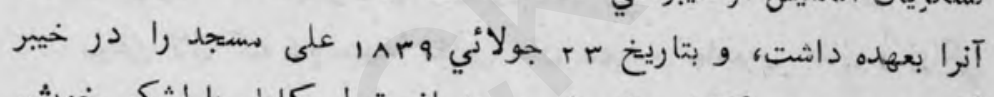

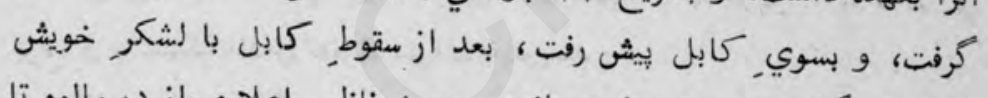

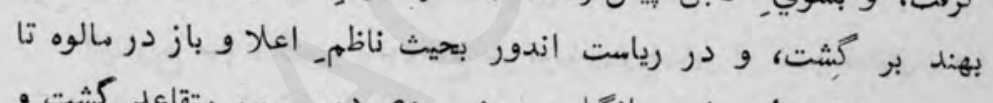

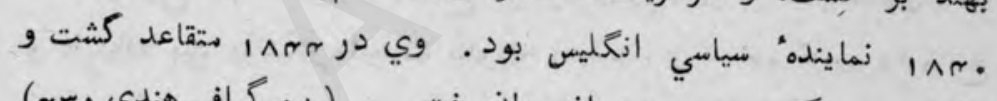

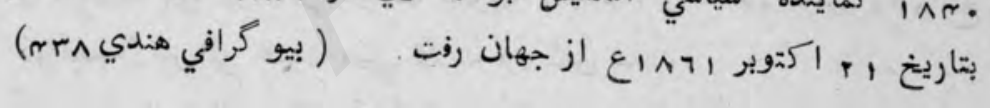




\section{شهادت_ بير متر اب خان قلات}

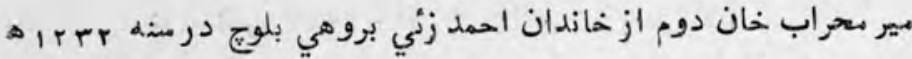

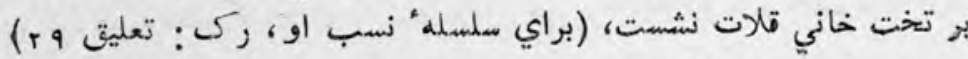
وي مرد با همت و آزادي طلبي بود، كله در حين لشكر كشي قشون اندس

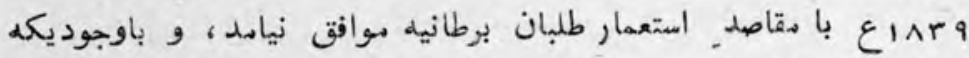

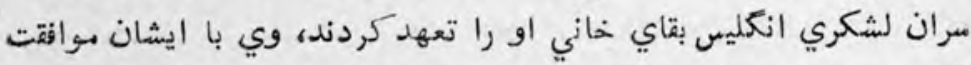

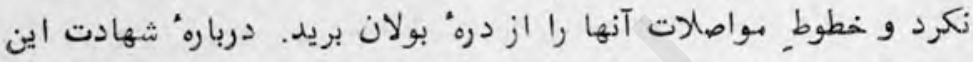

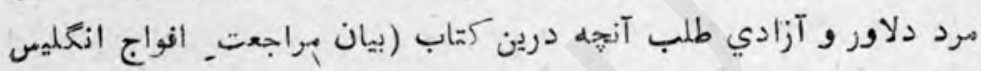

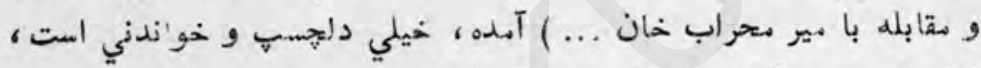

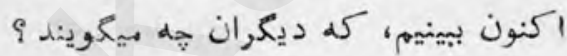

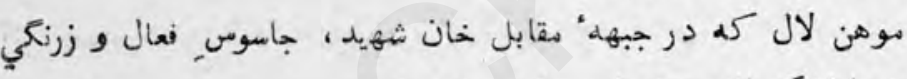

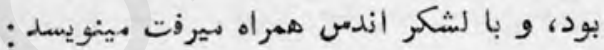

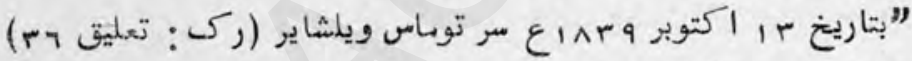

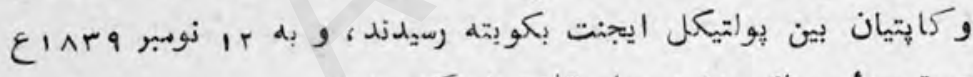
در قصبه "جرياني هشت ميلي قلات فروكث شدند .

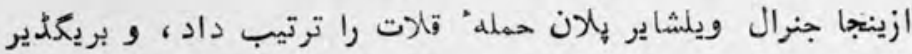
بو.كارگ قيادتي دسته" اول حمله آوران را بر عهده كرفت، كه قوهاندان

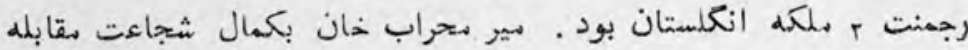
كرده، و در ميدان جنك هiكامي كشته شد كله خود وي شمشير برهنه

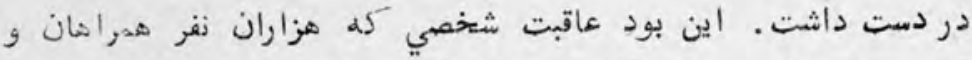

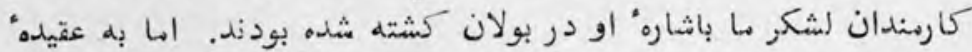

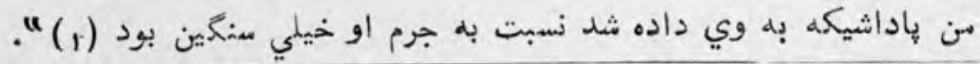

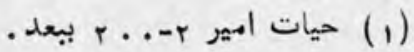




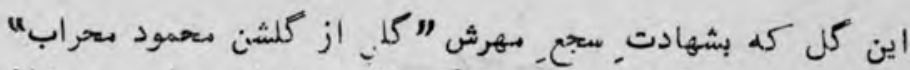

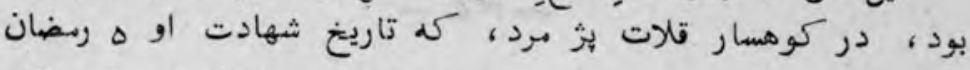

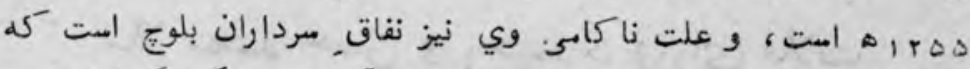

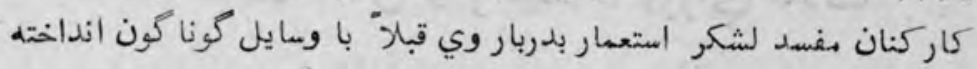

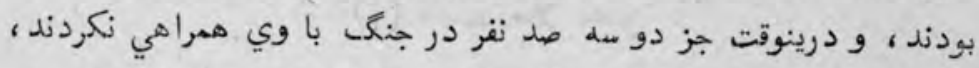

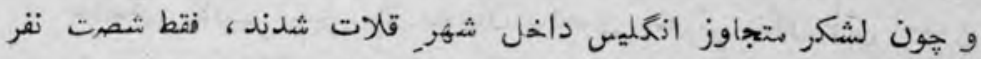

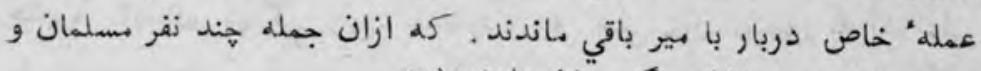

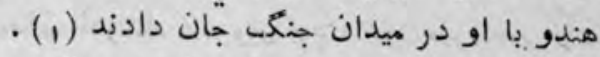

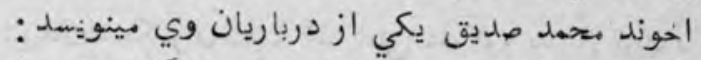

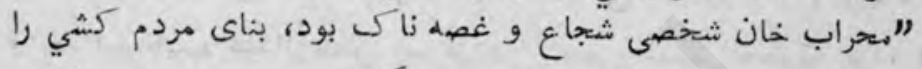

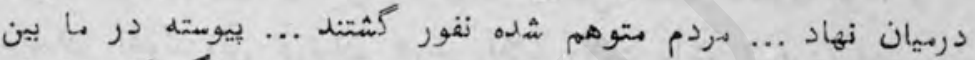

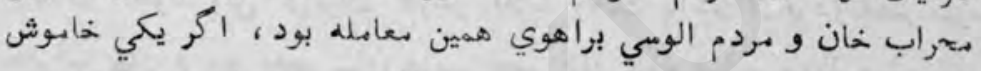

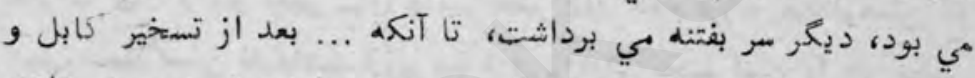

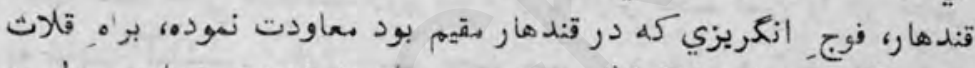

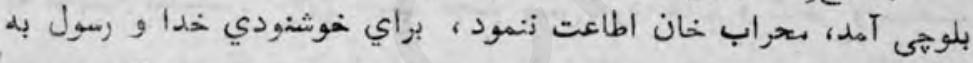

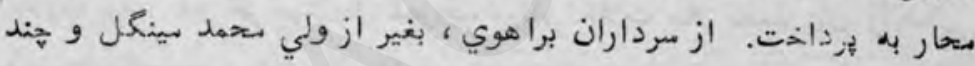

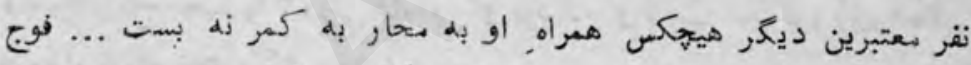

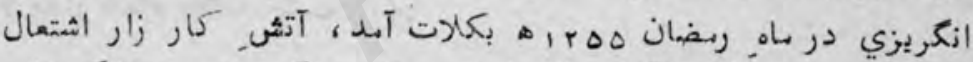

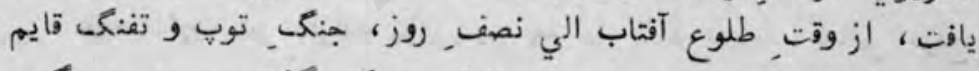

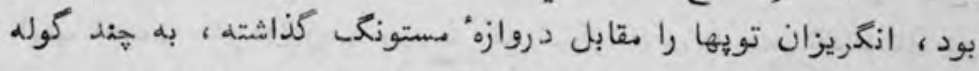

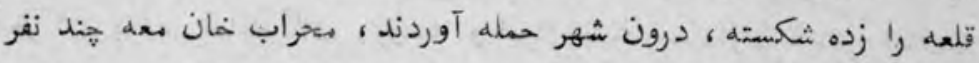

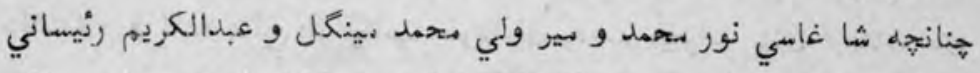
و داد كريهم شهواني و شهباز خان رنهاري و فضل لهري و نبي بخثى

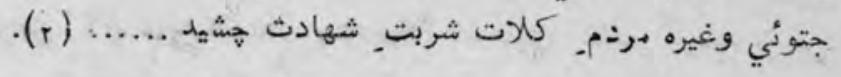

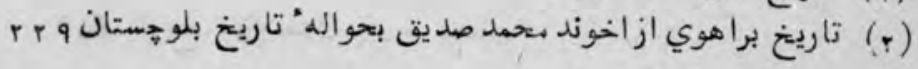


تعليقات

ar.

$-r \angle-$

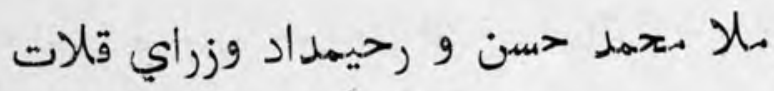
(1)

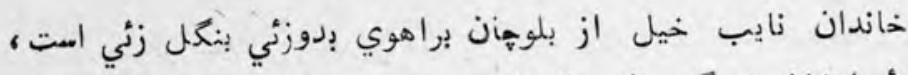

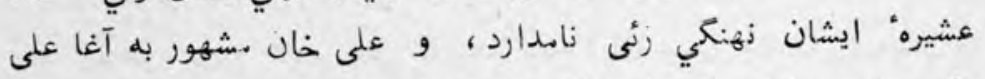

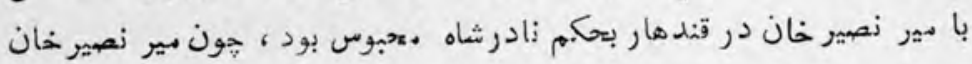

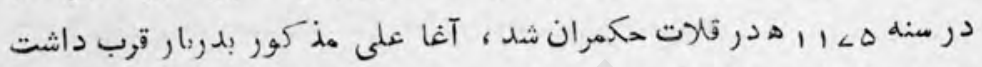

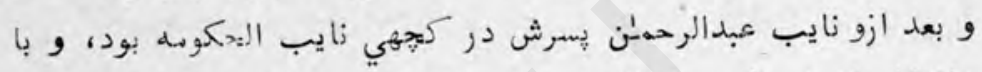

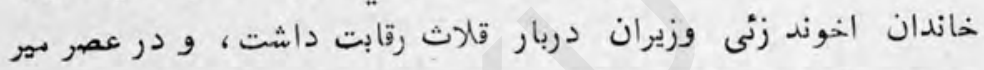

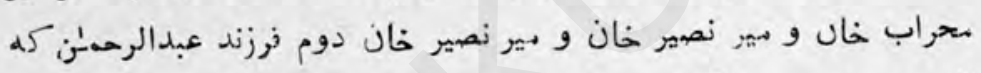

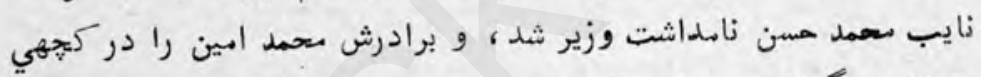

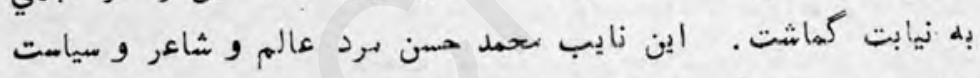

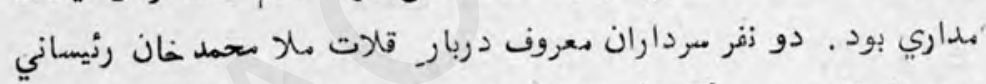

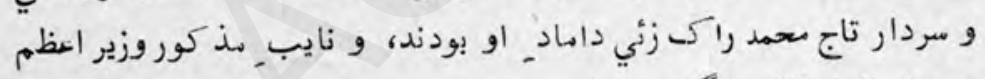

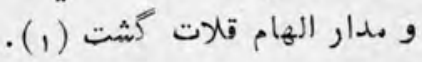

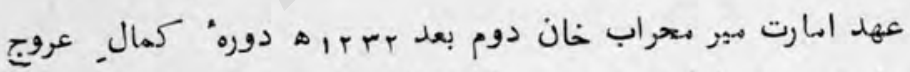

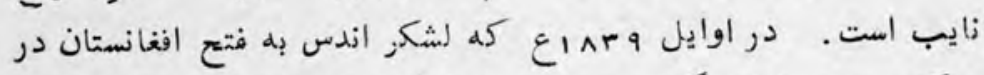

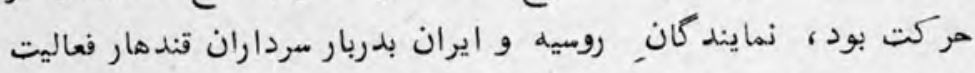

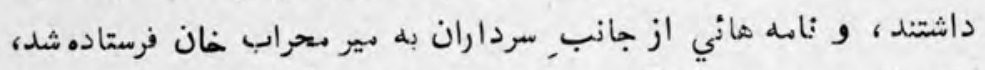

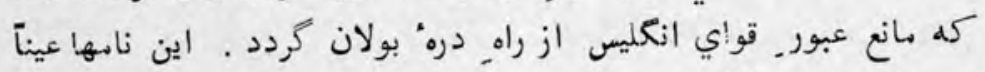

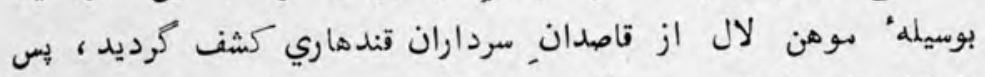

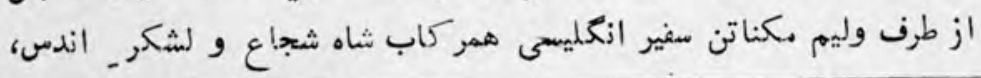

(1) تاريخ بلوهيستان . .. م ببعد. 


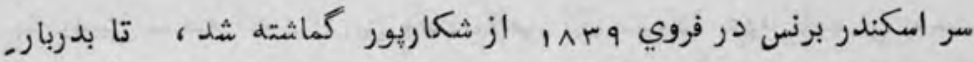

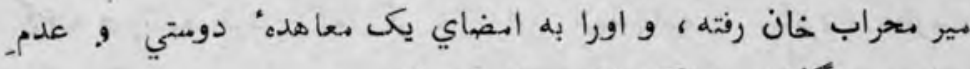

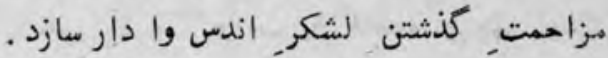

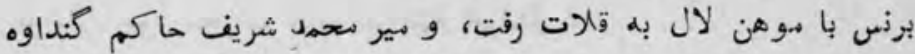

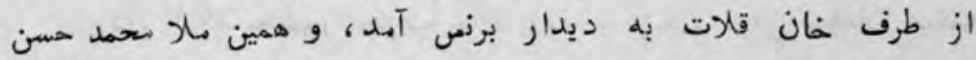

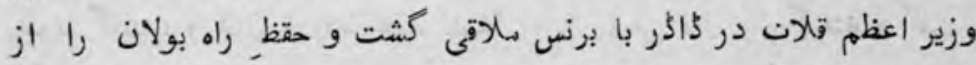

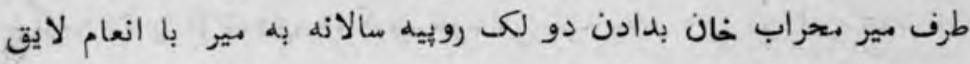

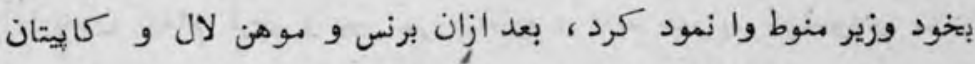

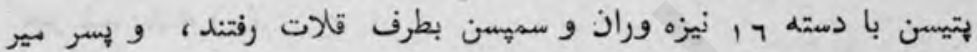

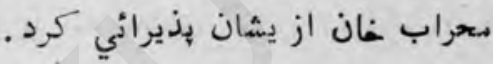

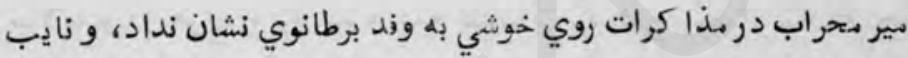

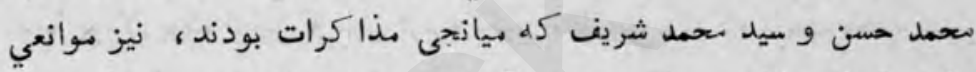

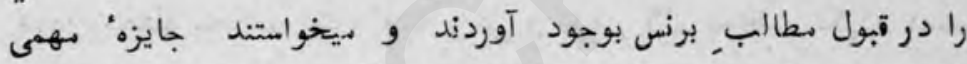

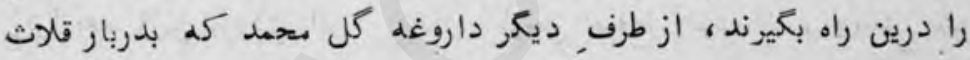

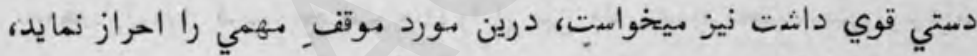

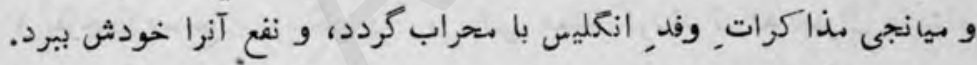

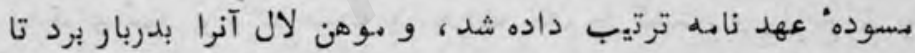

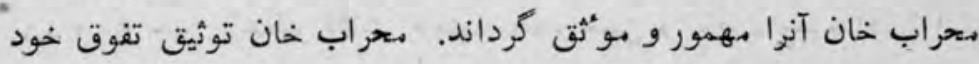

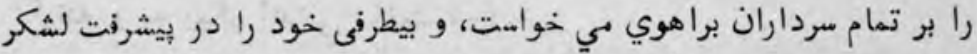

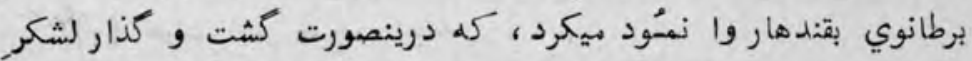

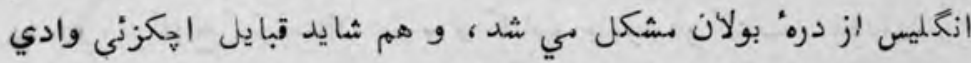

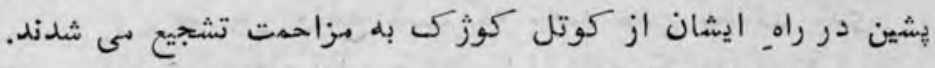

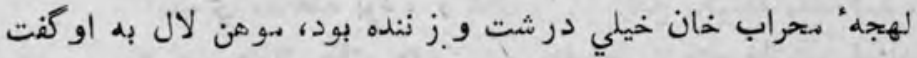

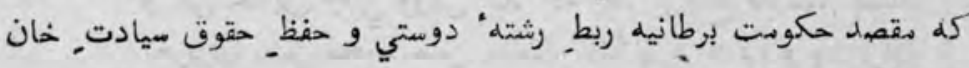

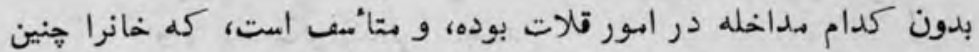




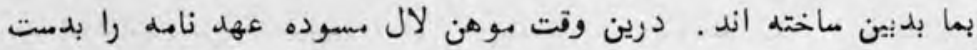

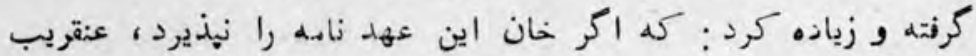

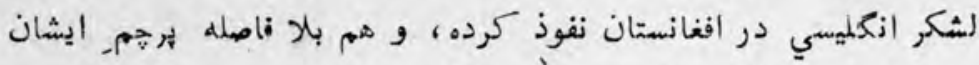
بر مقر خود مهراب خان افراشته خواهد شيد.

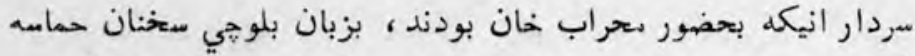

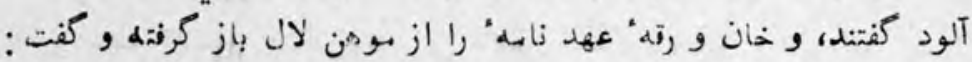

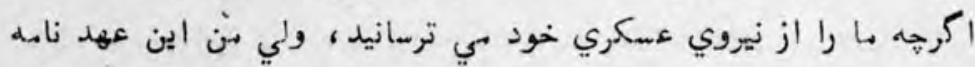

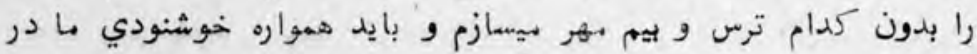

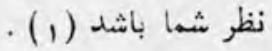

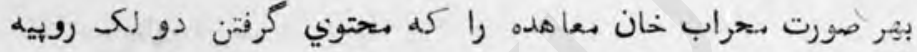
سالانه و دو هزار روبيه نقد و عدم شناسائي رقيبش شما هنواز خان و حفاظت. دره" بولان بوده توثيق و مهر كرح و هنين بنظر مي آيد كه نايب محمد حسن

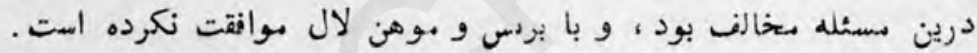

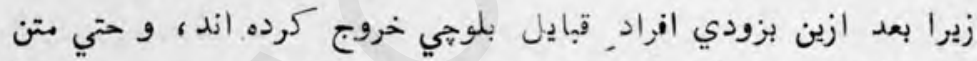

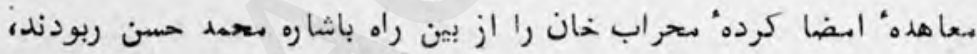

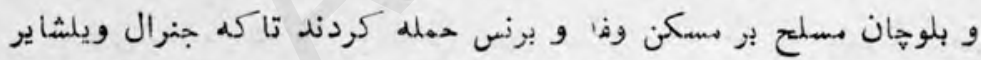

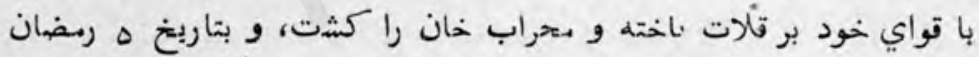
هد r ره حين تسخير قلات نايب مهمد حسن و نايب رحيهداد را اسير

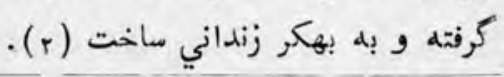

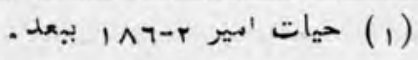

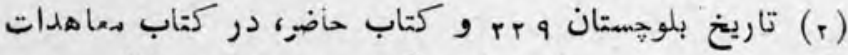

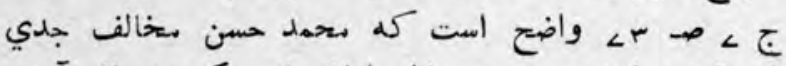

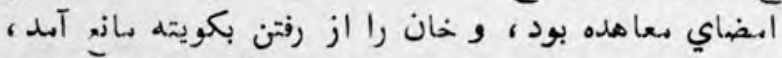

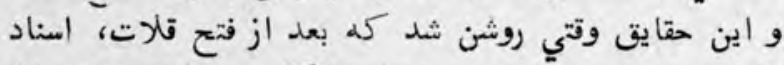

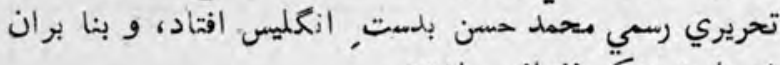

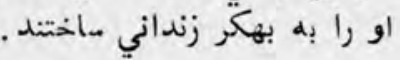


ايام حبس نايب يكسال دوام كرد، و در سنه جه r امه هون نصير حان

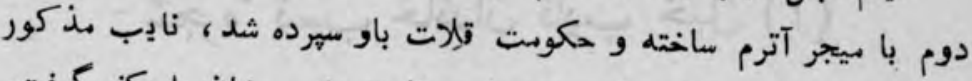

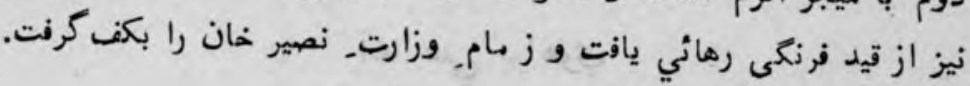

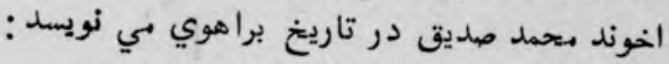

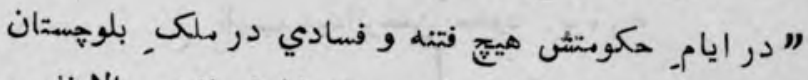

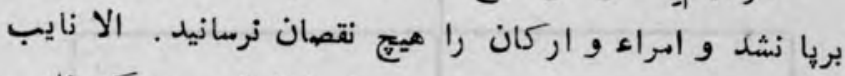

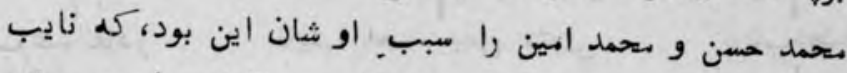

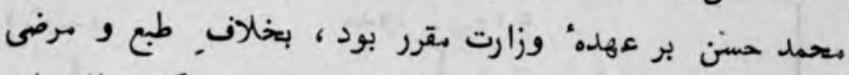

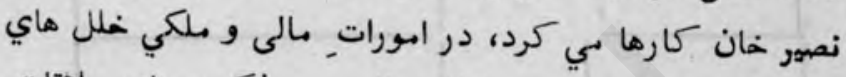

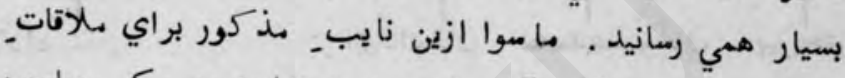
جيكب صاحب بجيكب آباد رفته بود، درخلوت به جيكب صاحب

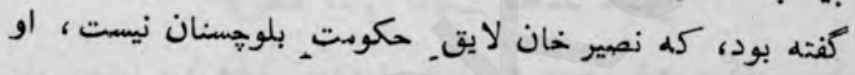

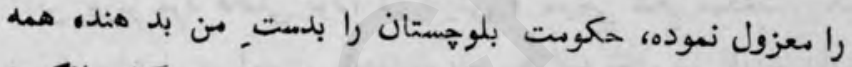

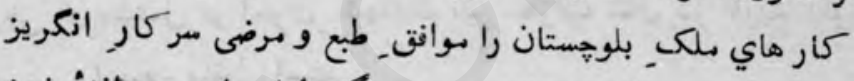

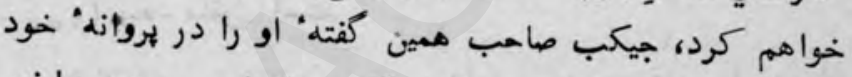

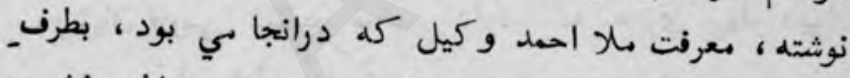

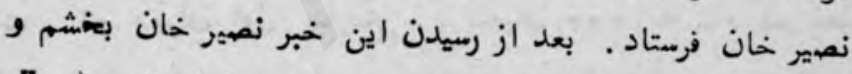

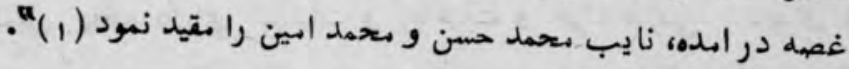
باينطور محمد حسن زنداني شده، و بعد از دو سال در مبس وفات

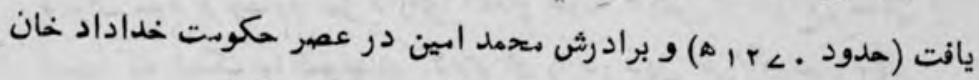

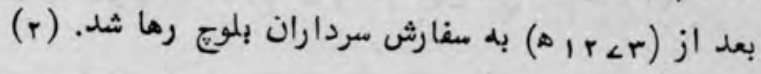

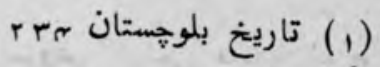
rro (r) 


\section{شجره نسب خاندان ذايب خيل (1)} آغا علي براهوي $\mid$

نايب عبدالرحمن حلود . مriره

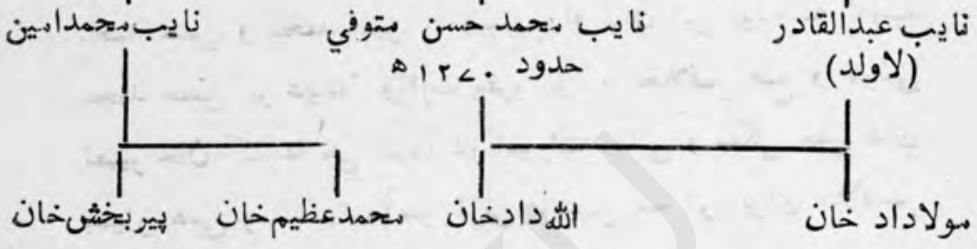

$$
\text { قريحل ادبي نايب متحمد حسن }
$$

اين وزير مرد فاضلي بود، در فارسى و بلوخي شعر ميخفت، يكى شعر بلوهى او دشتهل بر احوال شهادت دير محراب خان در تاريخ بلوخهتان

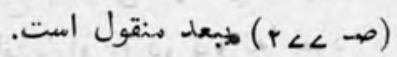

در زبان فارسي كليات ضخيهي دارد، كله دحتوي ههار ديوان اشعار

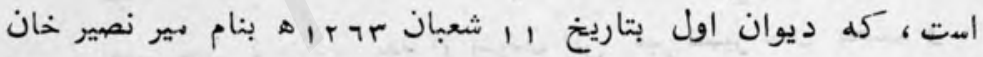

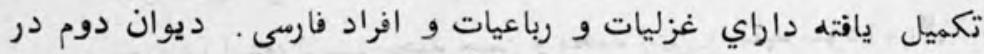

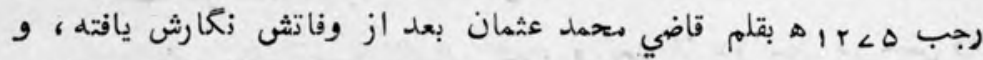

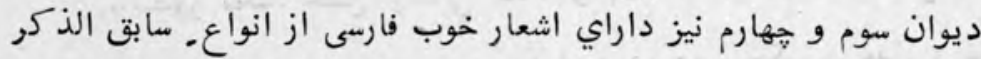
است كه اينك ما نمونهاي كللام او را در ذذيل مي آوريم (r) .

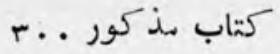

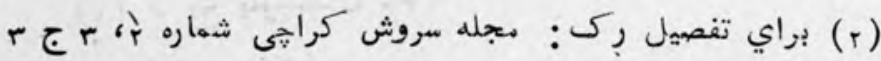

$$
\begin{aligned}
& \text { ·ولائي }
\end{aligned}
$$


ars

تازه نواي عارك

حمد

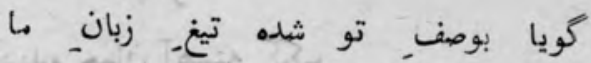

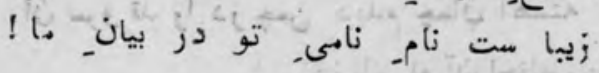

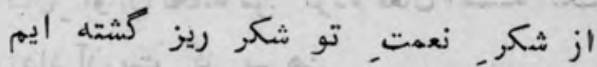

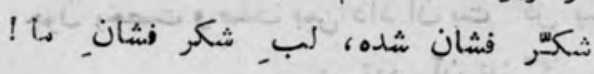

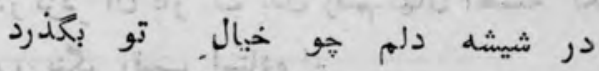
كويا شود هو طوطى, خوش كودهان ييداركن تِ اين " حسن_" خفته را ز خواب

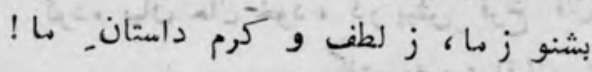

غزل

آن روي نازنين كه برون از ذقاب شد

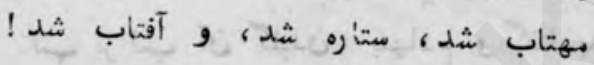
اين سرخي ايكه بر ابـ إعلثى نهاده يار يا قوت شد، عتيق شد، و هم كماده كلاب شد ؛

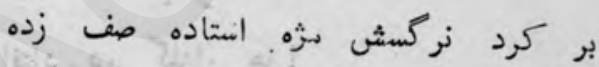

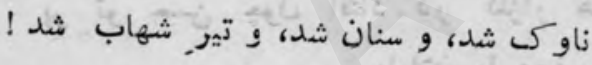

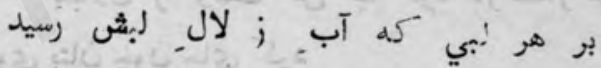

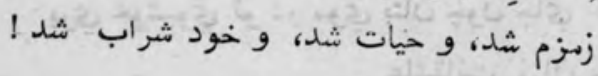
هر قاستي كله دل به قد و قامت تو داد

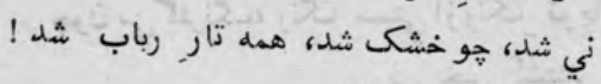

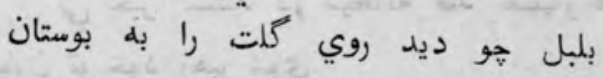

عاشق شد، و حزين شد، و دل ول كباب شد إ

كويا هو شد زبان_ ” حسن " بهر كلر خان ؛

كاغذ شد، و قلم شد، و صاحب كتاب شد إن ال 


\section{ديكر}

آن مرو قد را در همن ديدم حمان آهسته ككل

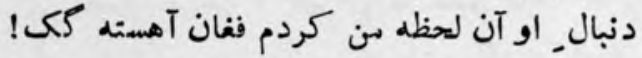

$$
\text { هون رخمت و صلت بمن داد آن بت كل هير هن }
$$

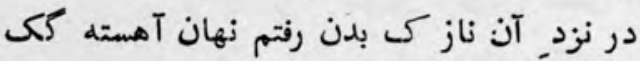

كفتا كه اي دلداده ام، بنمر رقيب استاده ام

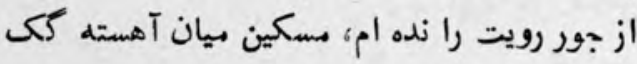

كردم بيان مال خود ، در بيشـ فرخ فال خود

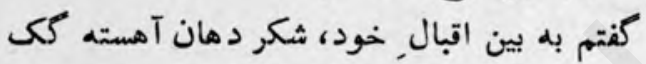

$$
\text { دادم مي كلر زحـــ او، ديدم رخ خوشرنكلـ او }
$$

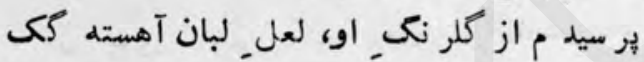

$$
\text { لب بر لب آن كلبدن، بنهادم و كفتا به بن }
$$

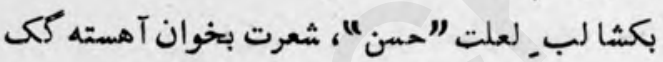

\section{ديكر}

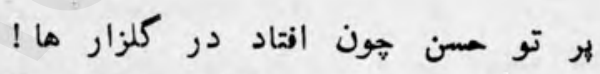

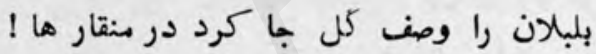

بوي خوشبوي تودر موي بتان هون جاي كرد

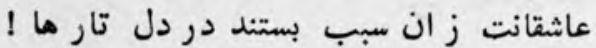

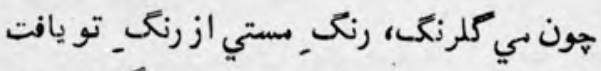

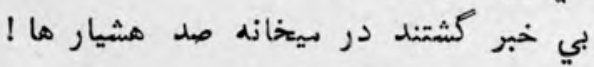

در بيابان رو, خود، هون تو خود رهبر شوي

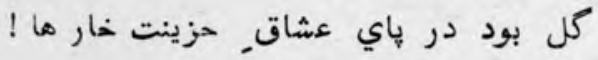

كر نداري جاي، داري جاي، درجان جاي تست

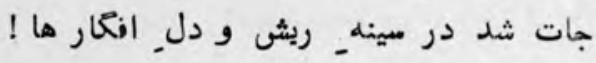


942

كازه نواي معارك

زا هدت جويد به مهسجد را هب و مغ دركنشت

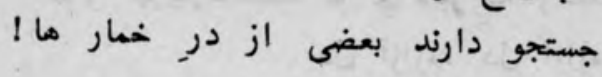

اين مهل حيرانن و حيراني براي روي تست

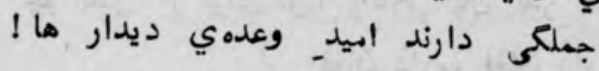

كر "حسن" حسني ندارد واقف. حسن, تو شد!

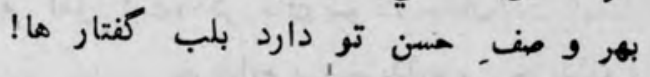

ديكر

با من هرا تو جور و جفا مي كني مكن!

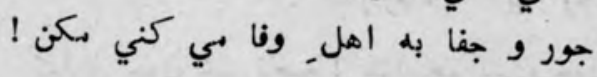

من جان و دل به حلقه بـ بوي تو بسته ام! جور إنه

جانم اكر به شانه جدا بي كني مكن إل

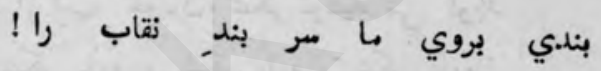

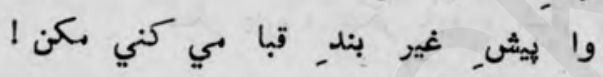

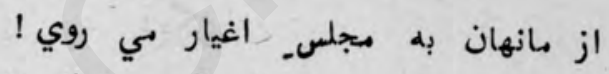

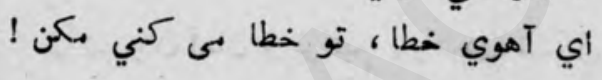

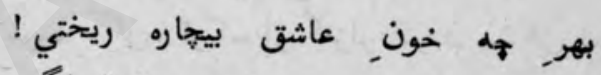

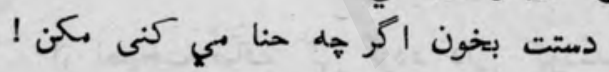

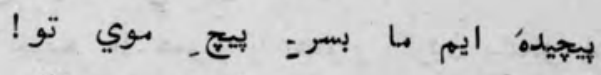

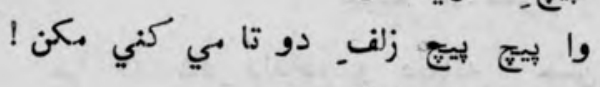

اي بادشاهـ حسن "حسن" كويدت شنو!

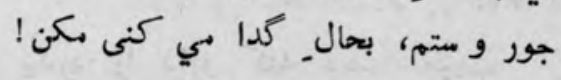

ديكر

جفا هركز مكن بر من تو اي يار جفا كارم!

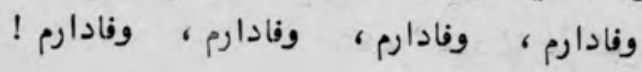


تعليقات

१ห^

دلم را كير دردستت، تو اي دلبر كه از دستت!

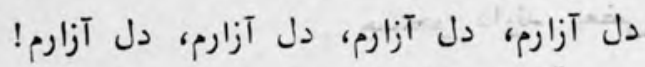

هو بلبل از براي كل، زدرد. دل بدر بارت!

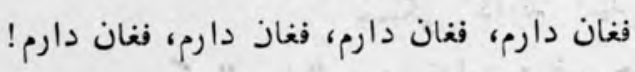

بهاي بوسه " لعل لبت، كر جان بـو د، جانان!

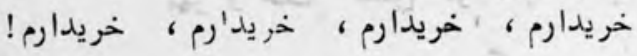

هو زال ـ رشته بر كف با خريداران تو يكى جا!

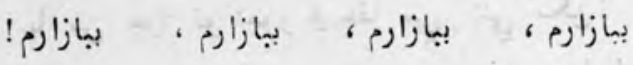

نذاري جون خبر ناصح ! هراسنعم كني، هون سن

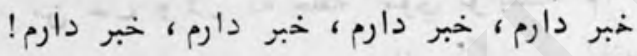

"حسن" خود از لبـ خوبان، شكر نوشيد بي كويد

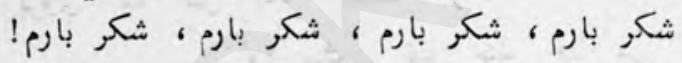

ديكر

تركى جان آسان و تركى, ياركردن مشكل است موسم, كلى، تركى از كلزار كردن مشكل مشل است است

از نصيحت صاف كى كردد دلي كوشتُد سياه

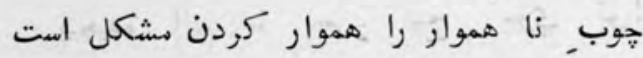

هر كله شد دلداده و ديوازهـ": حسن بتان

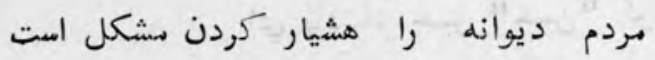

كي دل, بيدرد را دارو كند دست_ طبيب هست_ غفلت برده را بيدار كردن سشكل است

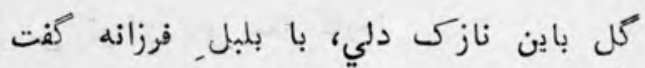
تكيه " خود را بنوكى خلي خار كردن مشكل است 
9เ 9

تازه نواي معارك

تا زگردد همجهو صنعان هر كله عاشق بربتى

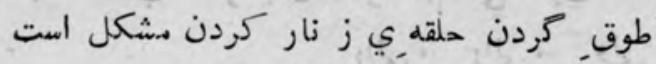

هر كل هون طوطي ننوشد بر لب شكر لبي بي شكر لب را شكر كفتار كردن مشكل امت في في

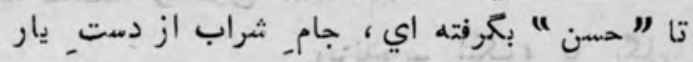

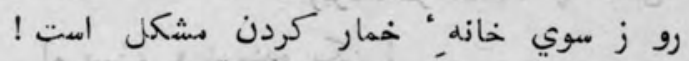

رباءي

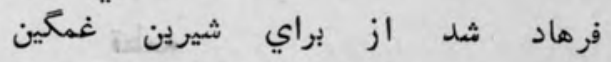

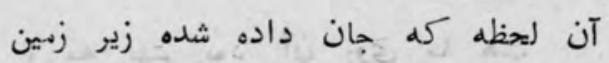

كردند موال زو، ز ز جان كيدن او

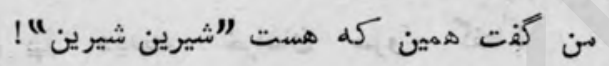

ديخر

هون زندكي تو يكى نفس شد نفسي مركز نفسي مكث تو هون بوالهوسي!

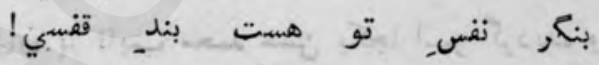

اين هم قفس تو هسيت ، در بند كسي!

ديخ

كفتهم قد تو و كُفت كل سرو حمن است

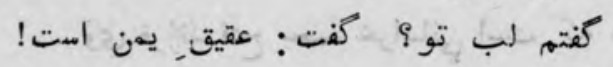

كفتم كل كلت ك كفت : كل يا سمن است

كفتم حه كفت ك؟ كفت : كف. نيزه زن است!

ديكر

دل را به جهان دبند اكر بيداني!

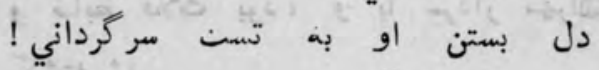


صد مطلب اكر بدل، تو هم مي داري!

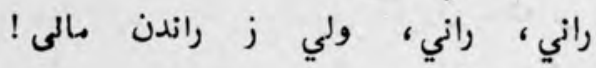

\section{ديكر}

من تو به شكسته و خجل آمده ام !

ريزنده سر شك، إما بكل آمده ام.!

$$
\text { شرمندكي ام بيين، و شرمنده مكن ! }
$$

بنماي بحل بن بحر. بحل آمده 'م !

\section{d*be}

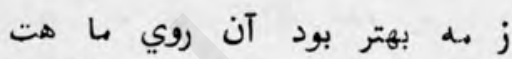

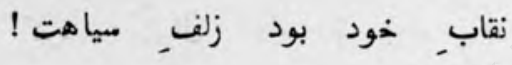

بها ديدت خرامان سرو كفتا

قد تُو شد قيامت شد قيامت

$$
\text { (r) }
$$

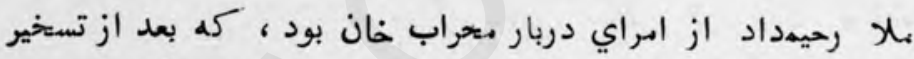

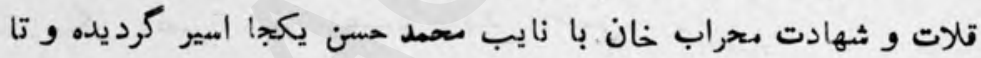

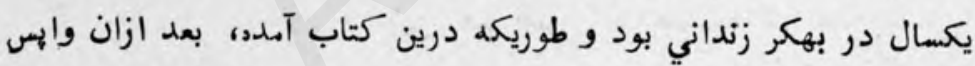

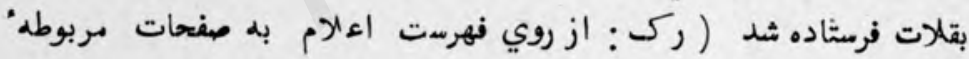

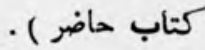

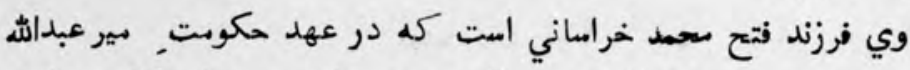

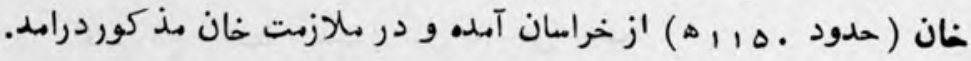

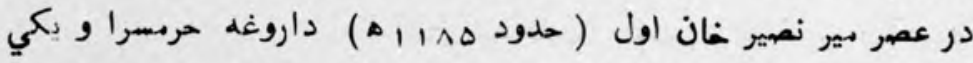

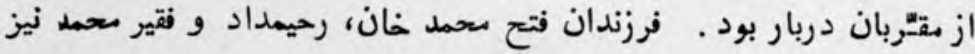

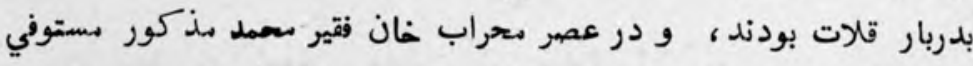
و ضابط تلات بود، و با عردار مهراله خان رئيسانى بجرم بغاوت 


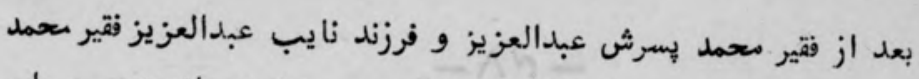

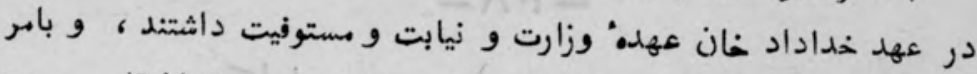

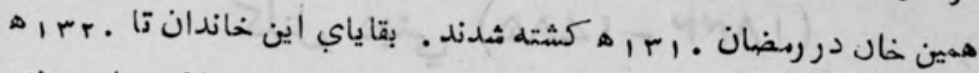
بدربار قات بر هناصب مستوفي كري و وكالت و نيابت از سران دربار بودند،

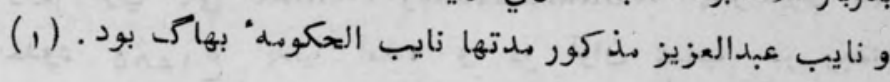

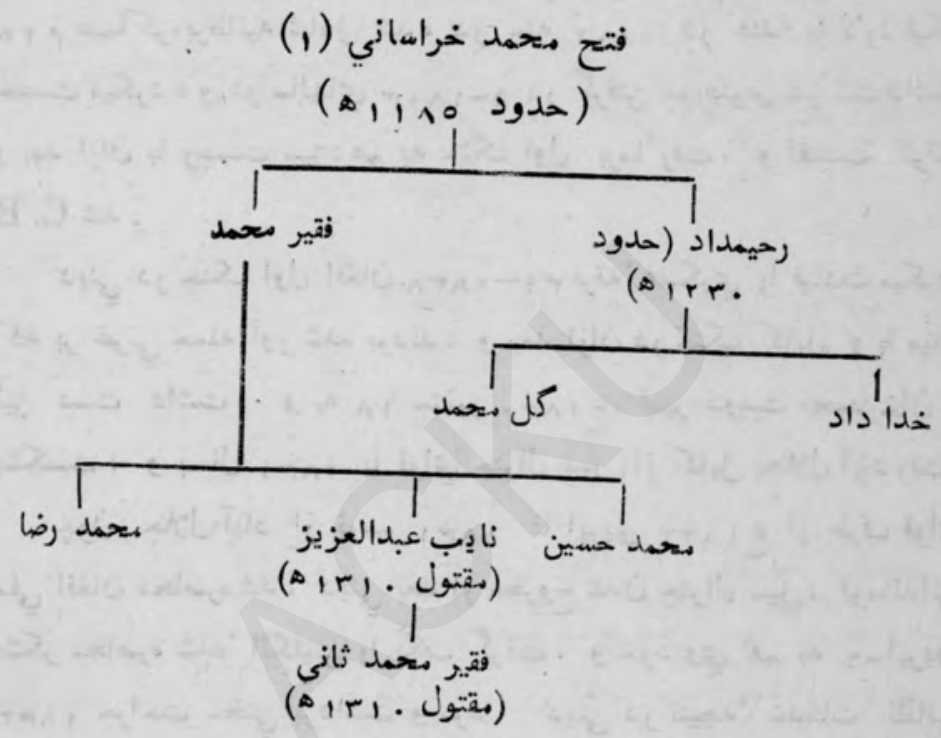




\section{كلنل ديني (1 )}

وليم هنري ديني William Henry Dennie هُهر هنري ديني

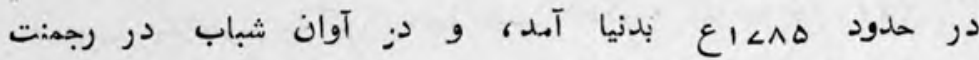

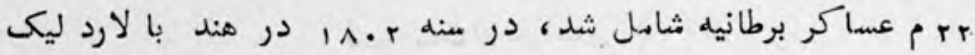

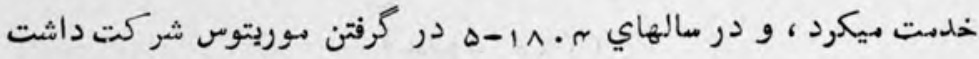

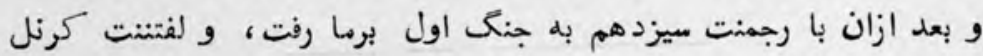
شد C. B

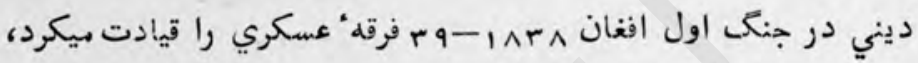

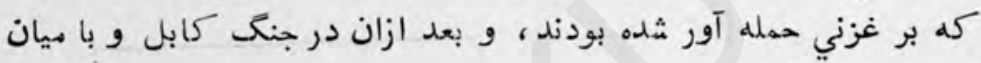

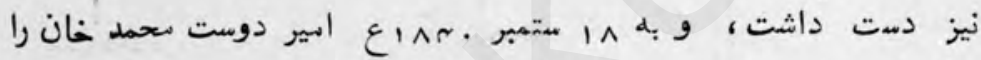

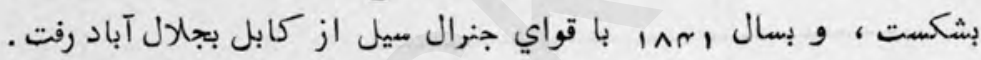

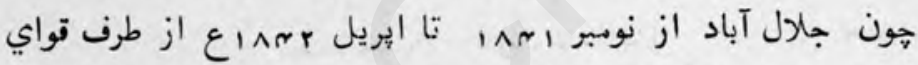

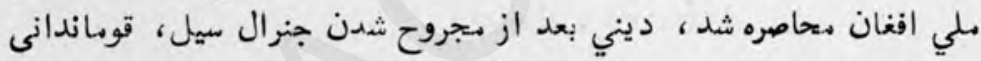

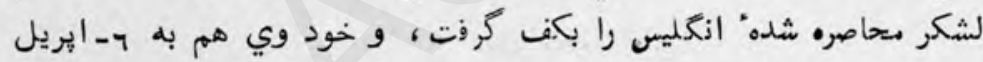

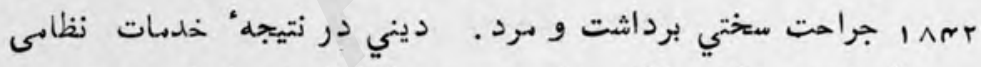

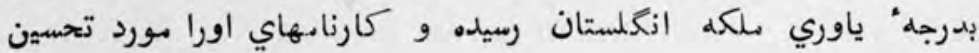

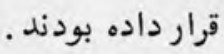
وي مؤلف كتابيست بنام "روز نامجه لشكر كشى بر سند و بلوحيستان

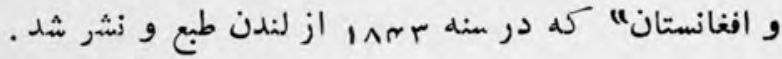

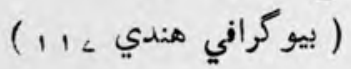




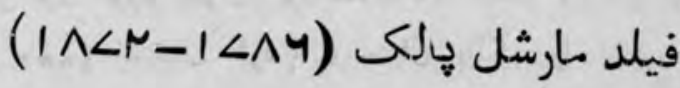

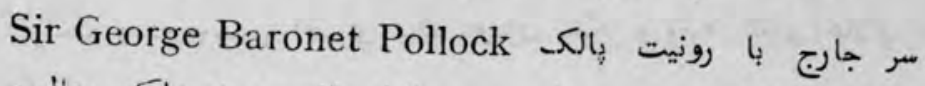

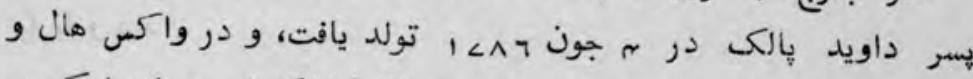

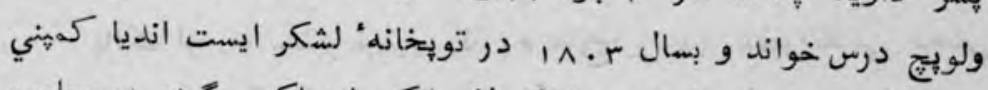

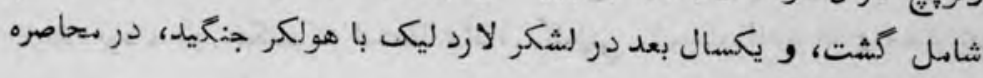

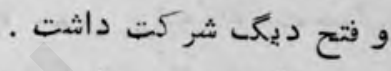

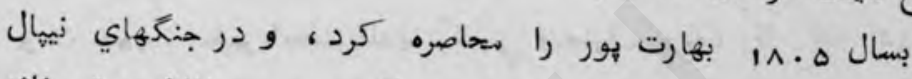

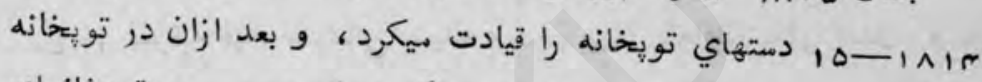

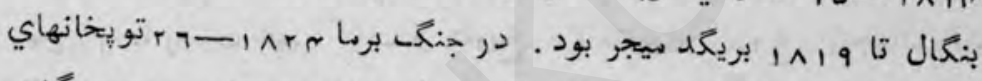

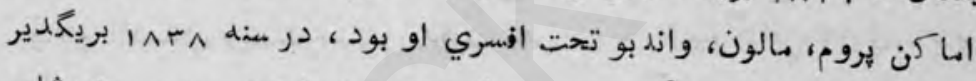

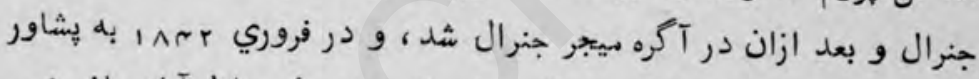

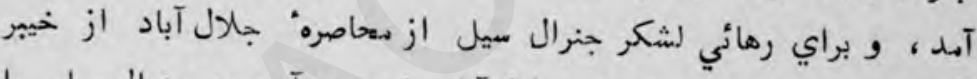

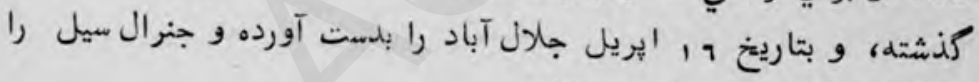

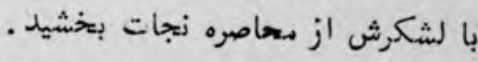

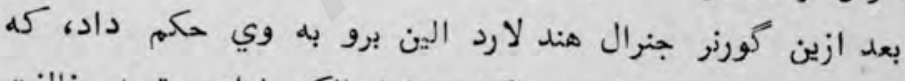

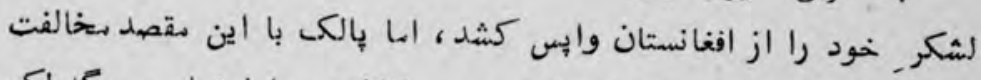

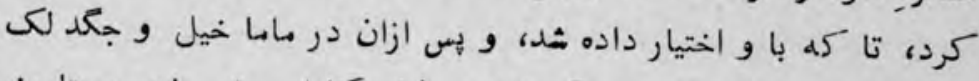

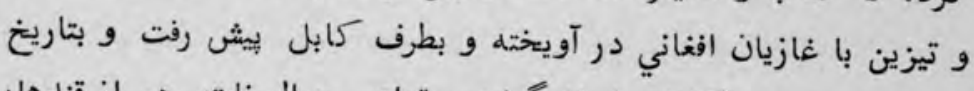

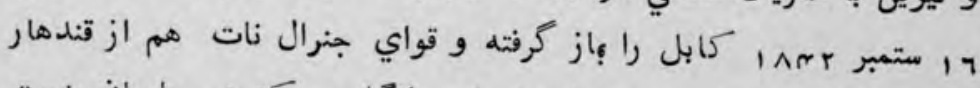

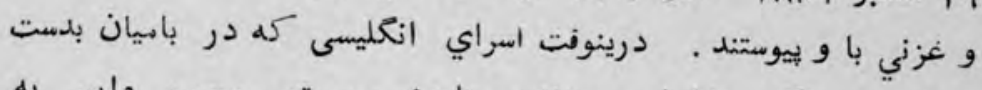

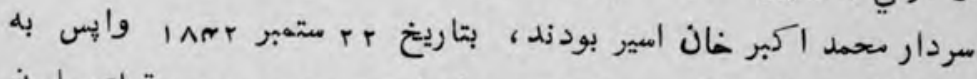

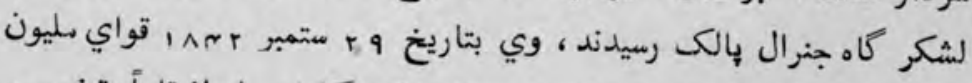

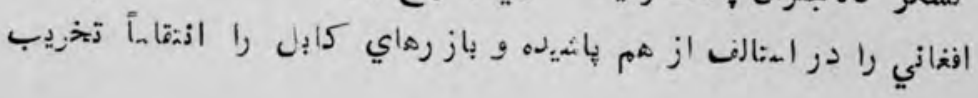


تعليقات

काल

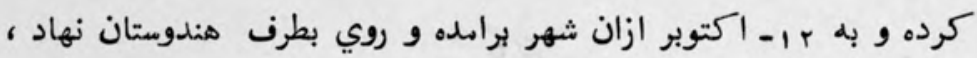

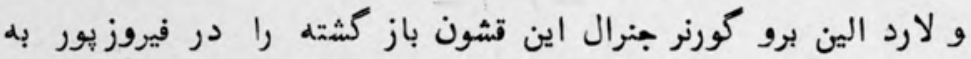

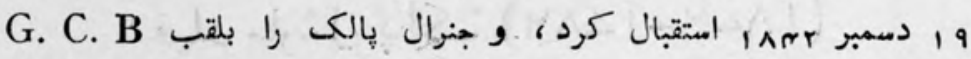

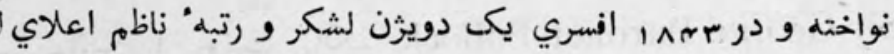

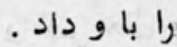

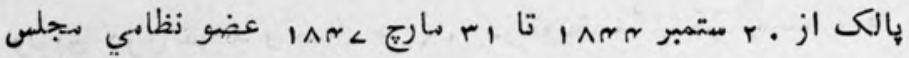

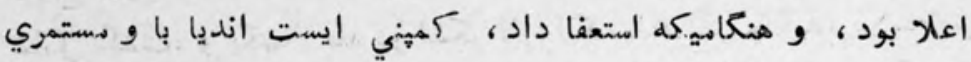

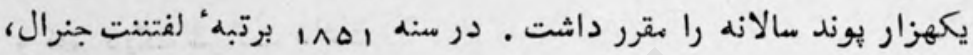

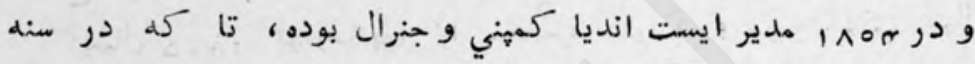

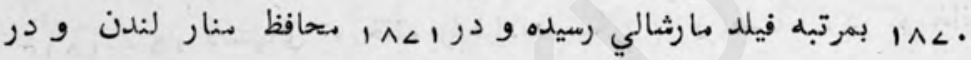

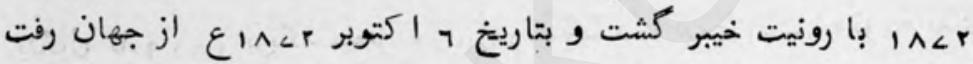

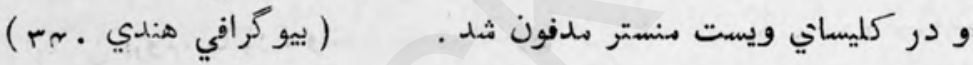




\section{قتل شاه شجإع}

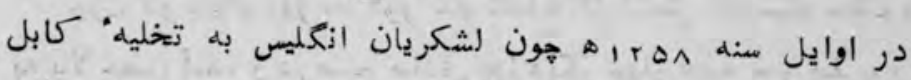

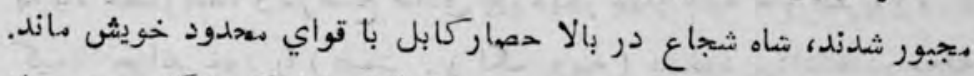

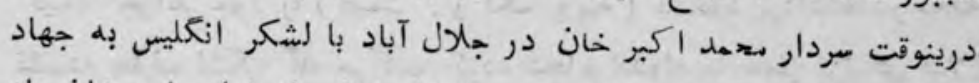

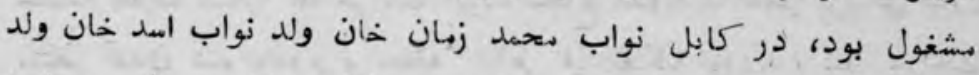

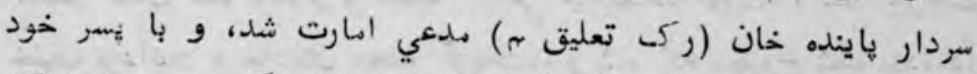

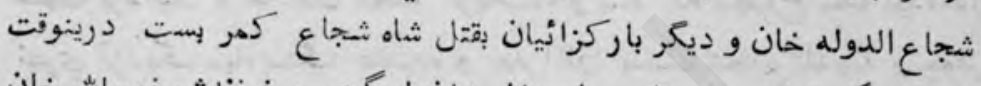

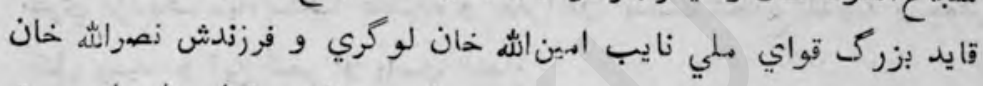

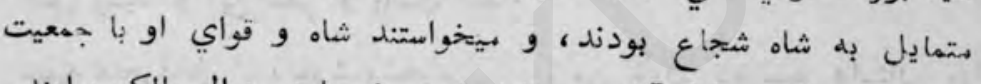

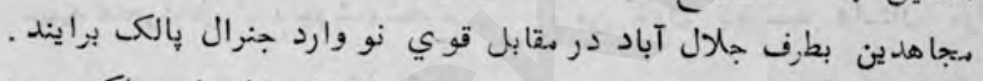

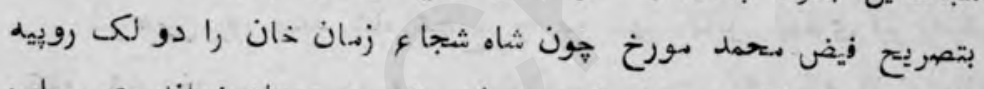

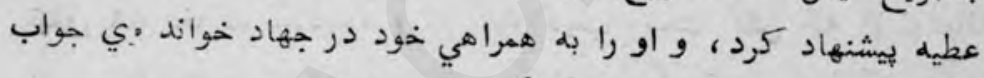

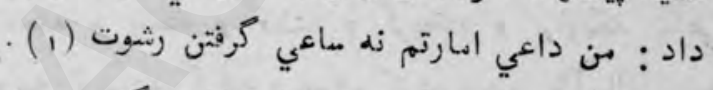

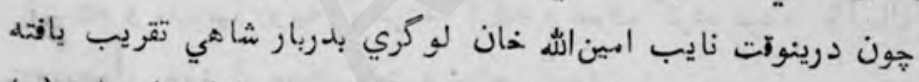

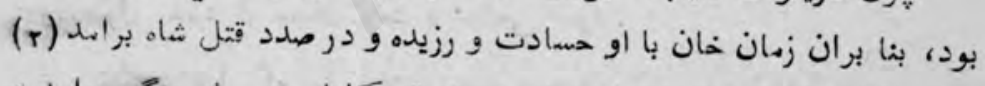

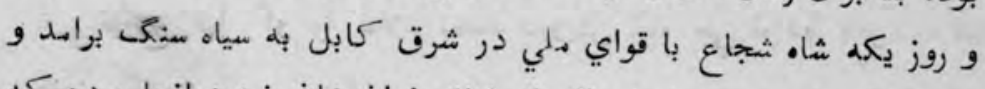

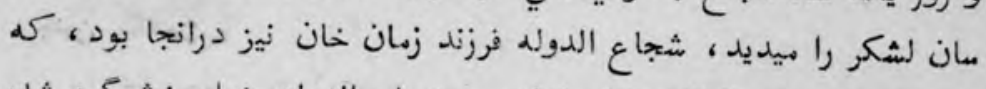

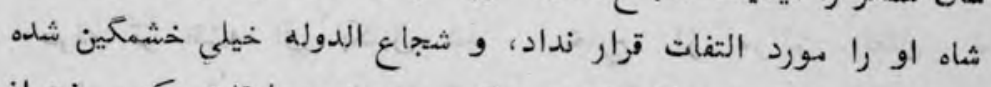

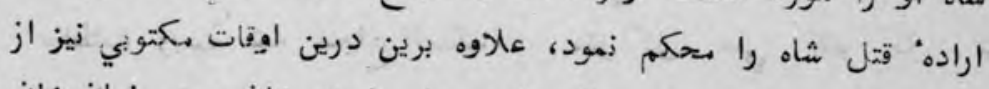

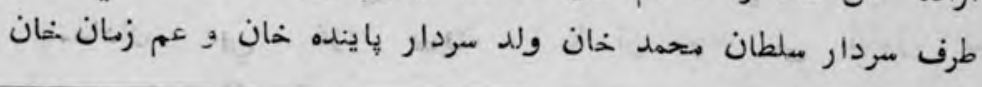

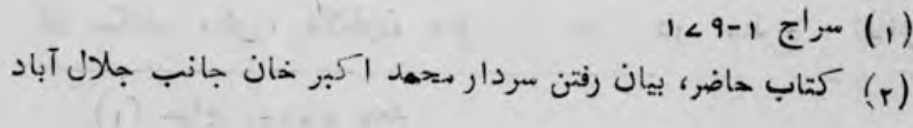


تعليقات

9นา

با و از لاهور رسيده و مسشار اليه را بتقل شاه شجاع ترغيب كرده

بود (1) ب (1)

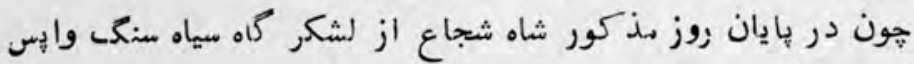

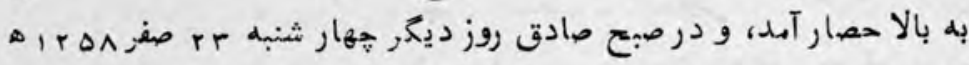

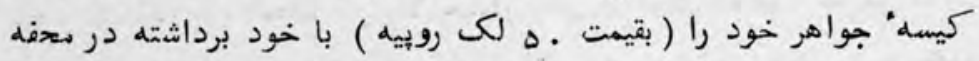

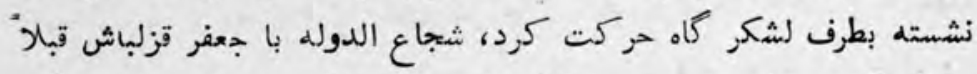

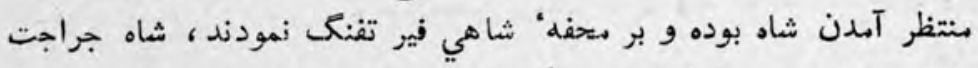

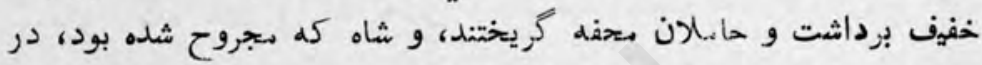

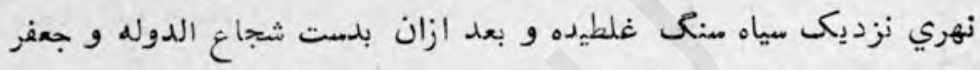

بقتل رسيد، و اين شعر او راست آمد : نداه

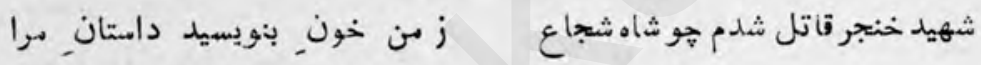
در همين روز جسد شاه شجاع را در شهر كابل بهلوي قبر هدرش

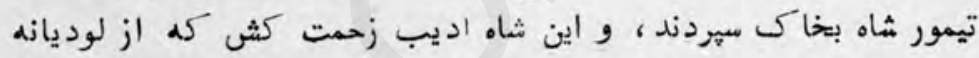

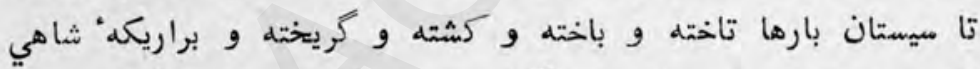

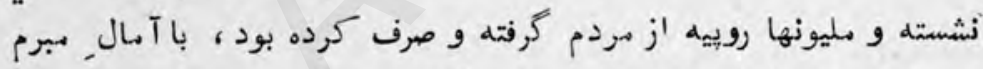

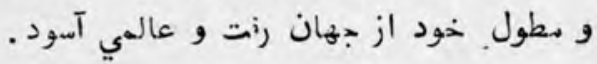

تاريخ قتل او را غلام محمد درويش شاه جي نواده: باقر شاه فقيه

هنين كفت

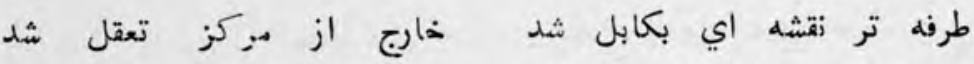

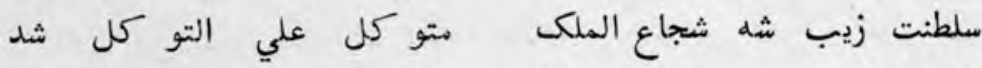

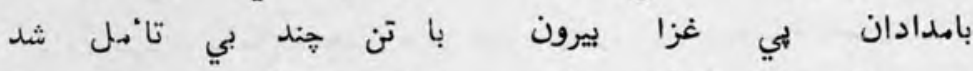

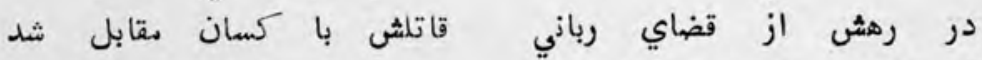

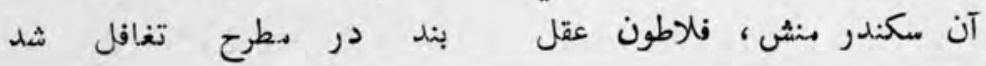
(1) 
$9 \mathrm{r} /$

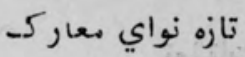

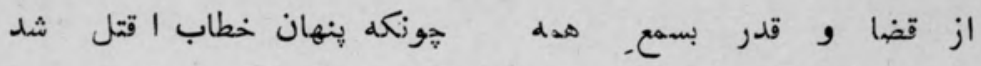

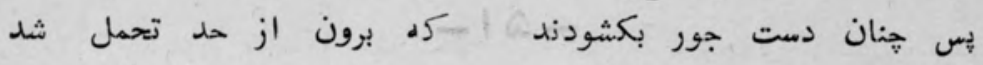

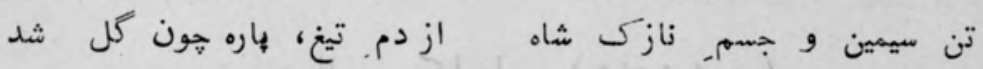

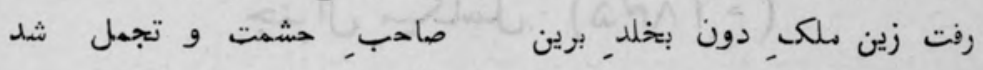

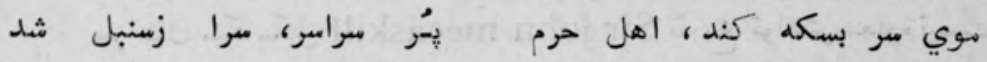

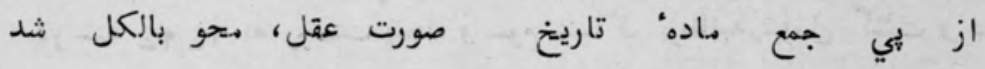
هاتفم كفت : آه و

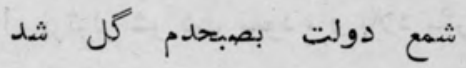

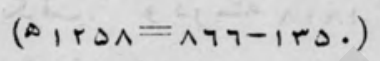




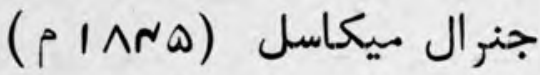

سر جان ميكاسكل Sir john mecaskill تاريخ تولدش معلومنيست.

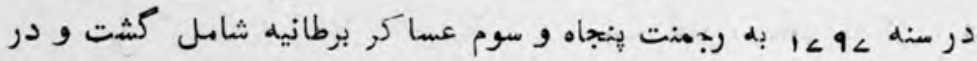

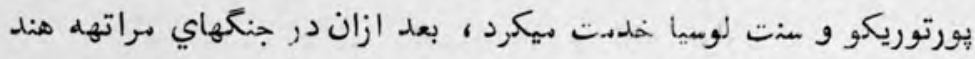

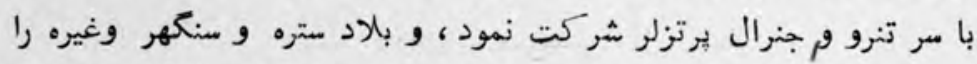

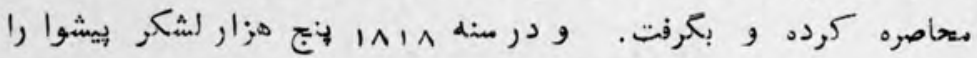

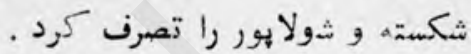

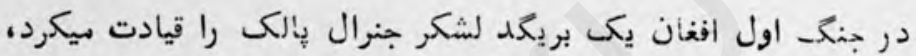

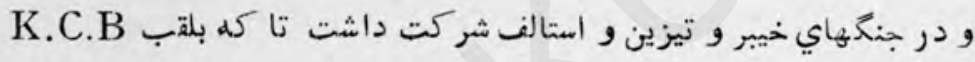
فايز و برتبه" ميجر جنرالي رسيد. ونئ.

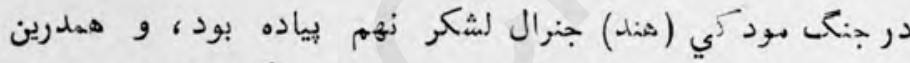

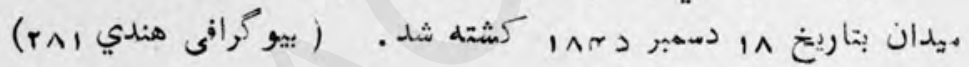

\section{$-\Delta \mu-$}

\section{جنرال ذات (}

ميجر جنرل سر ويليم نات Sir william nott بپر خارام نات

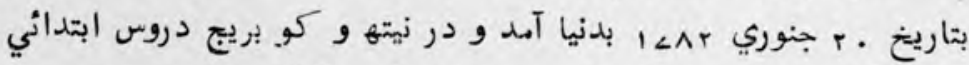

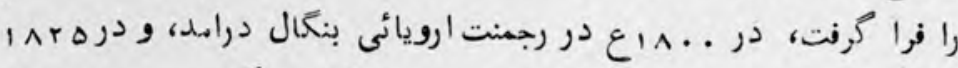

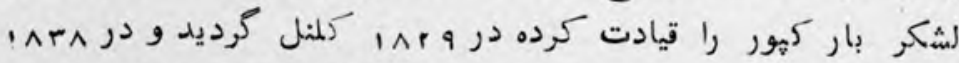

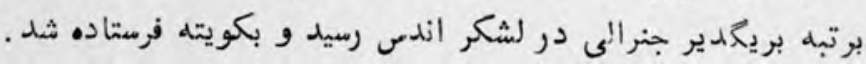

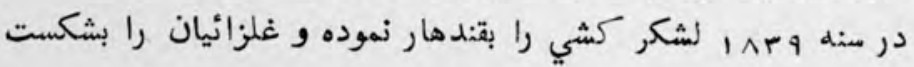




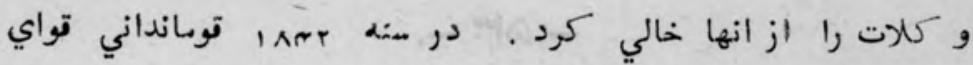

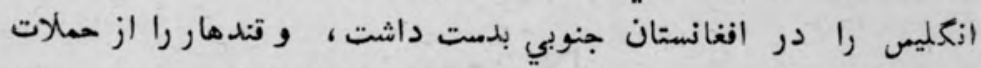

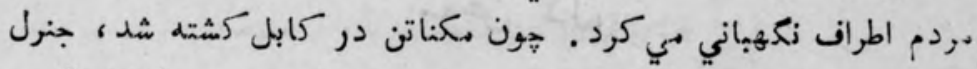

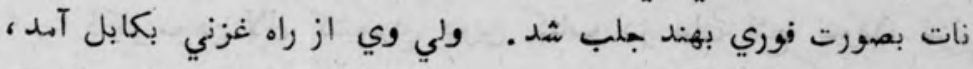

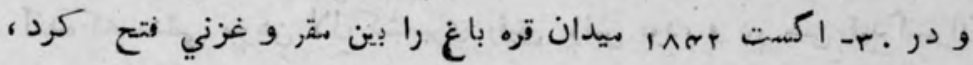

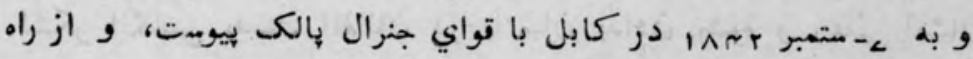

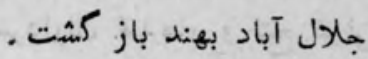
بعد ازين با بالكى در لكههنو با شاه اوده بحيث ناظم اعلا مقرركرديده

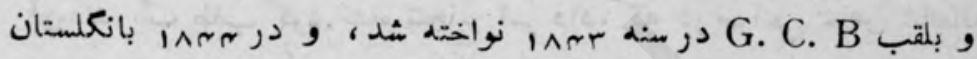

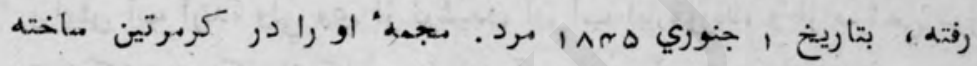

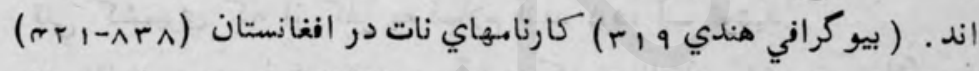

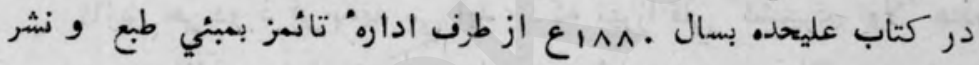
شده است. 


\section{- $\Delta \mu-$ \\ موهن لال}

ذكر موهن لال كشميري درين كتاب در بيان فتح نمودن غزني

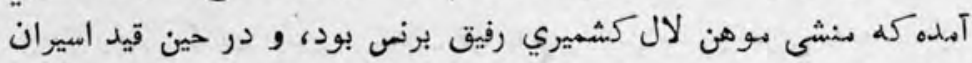

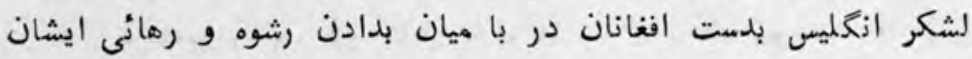

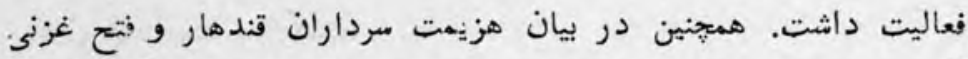

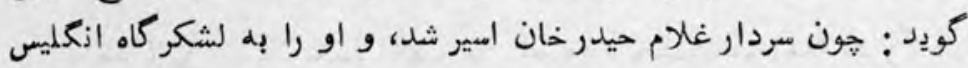

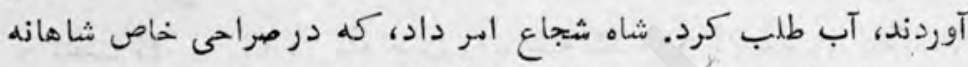

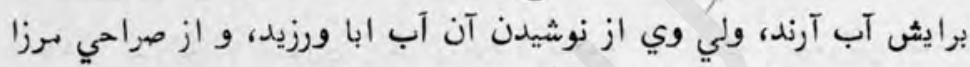

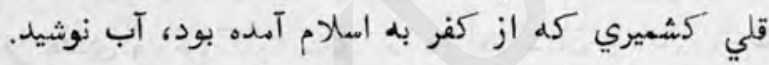

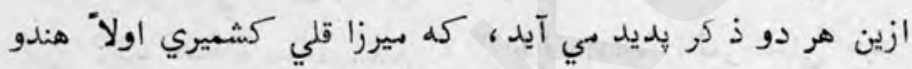

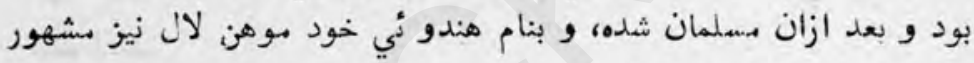

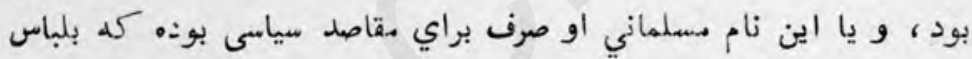

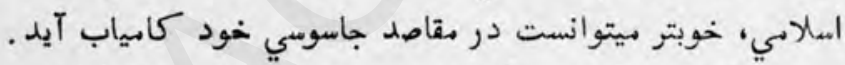

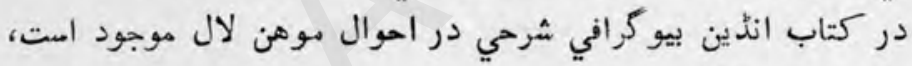

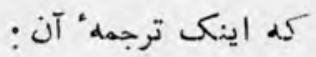

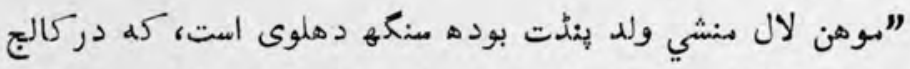

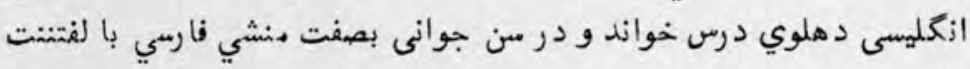

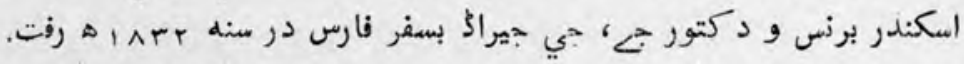

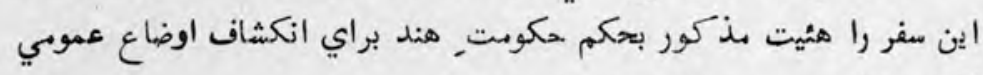

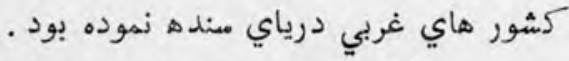

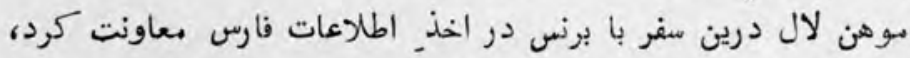

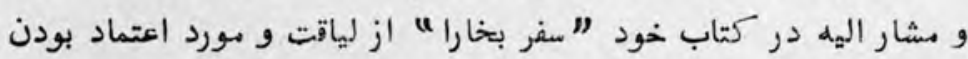

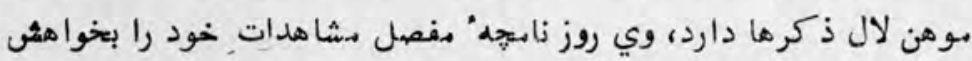




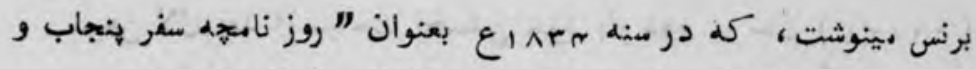

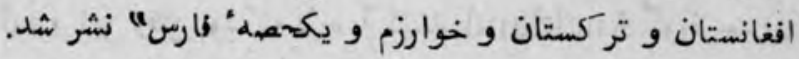

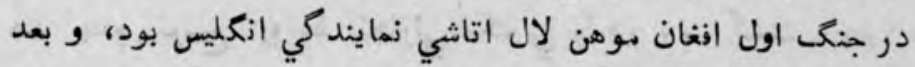

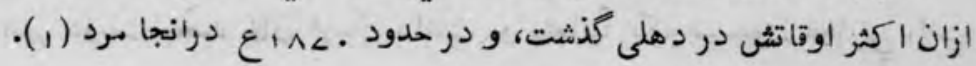

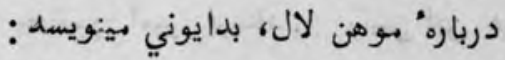

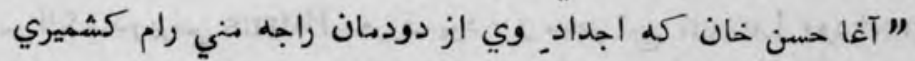
بود، بدين املام مشرف شده بودند، يدرش مرزا محمد شكوه نامداشت

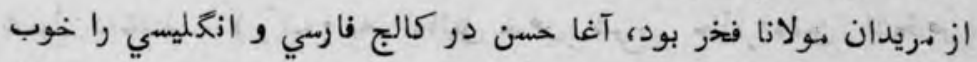

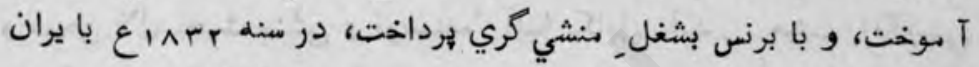

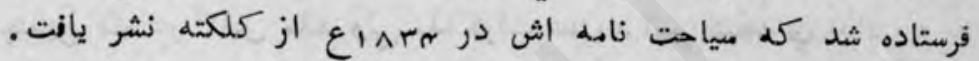

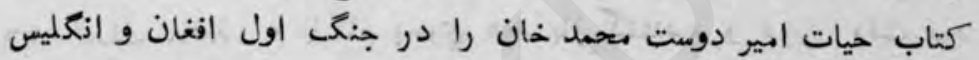

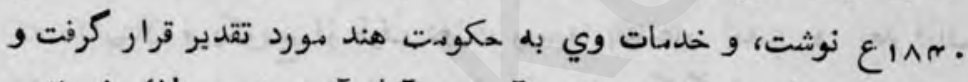
اعزاز (آردر آف دي امهاير، نايت آف دي آرور آن برشبين لائين) يافت. خانم موهن لال (حيدري بيكم) نيز از زنان دانشمند بود، كله روزناميهل

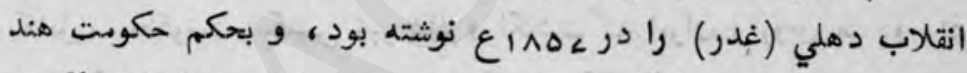

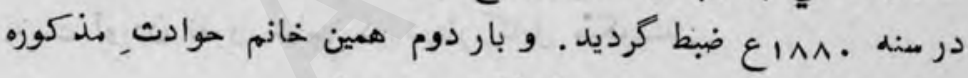

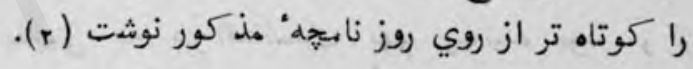

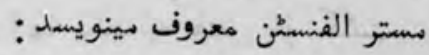

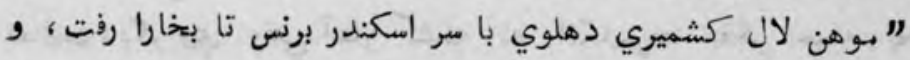

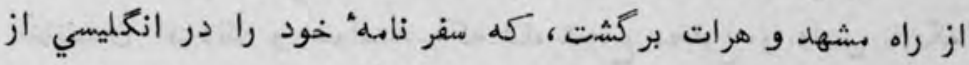

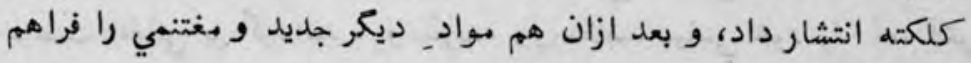

$$
\text { Tورده و نشر كرد " (r) }
$$

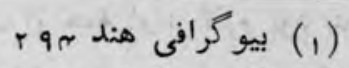

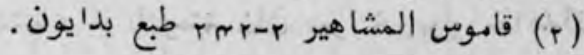

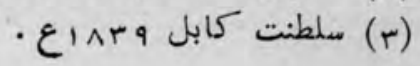




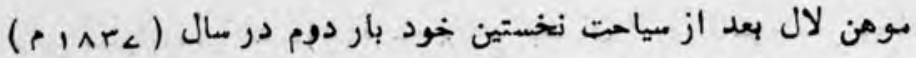

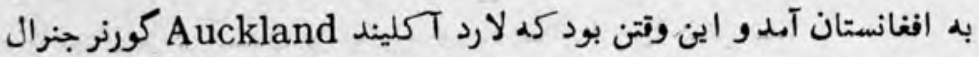

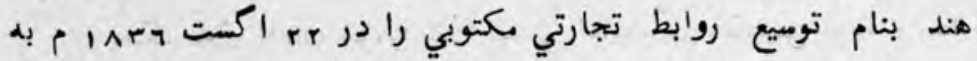

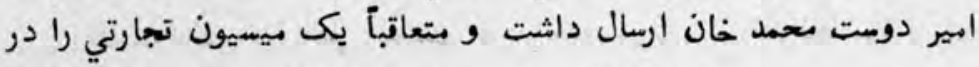
10

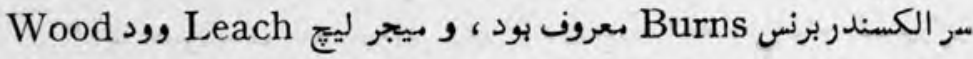

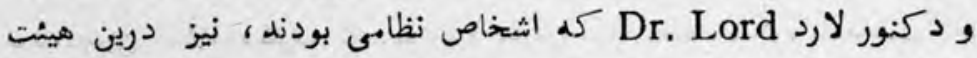

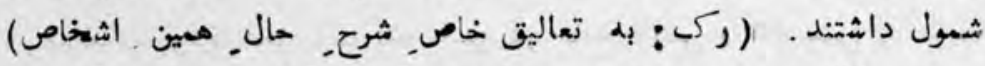

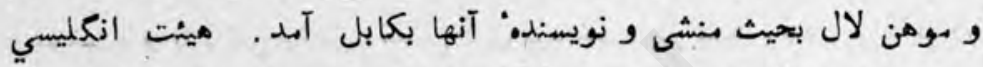

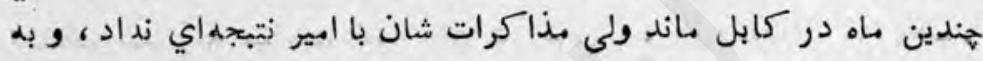

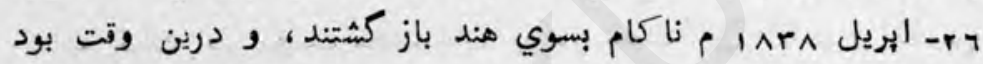

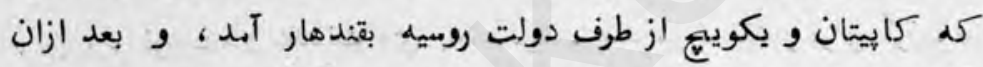

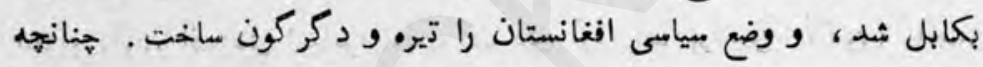

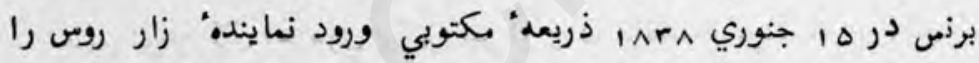

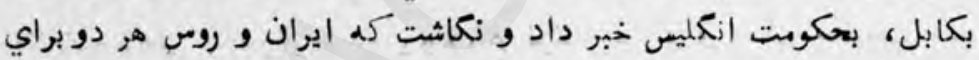

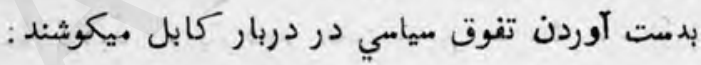

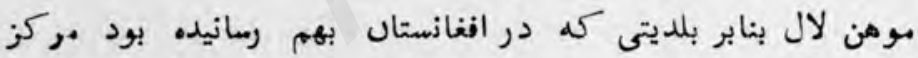

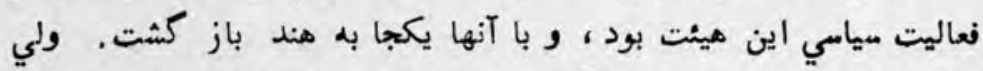

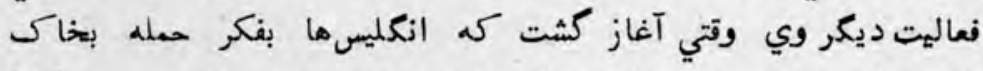

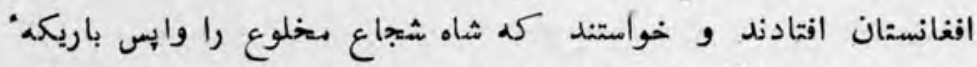

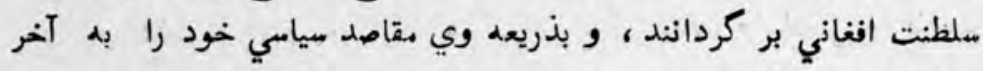
رمانند.

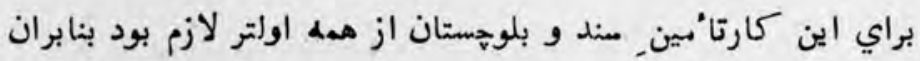

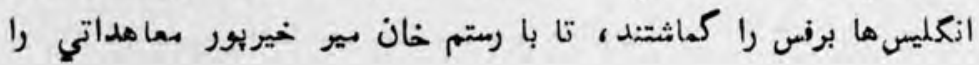


امضفا كند ولي مير به امضاي ابن تعهد تن نداد و برنس ملدتي اندربن كار مركردان بماند.

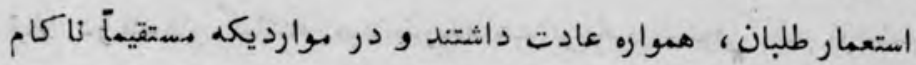

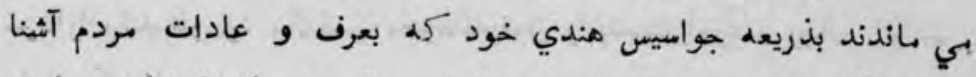

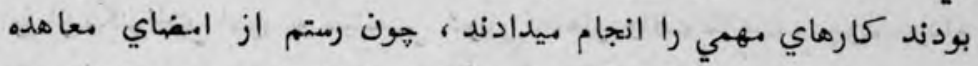

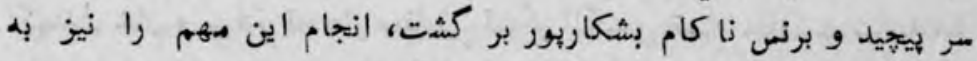

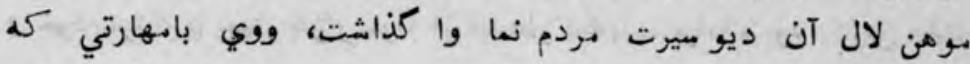

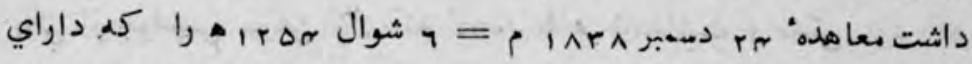

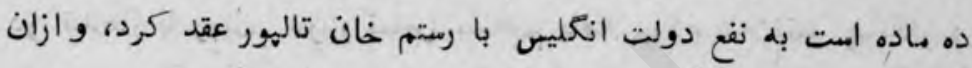

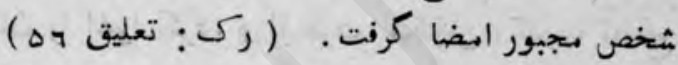

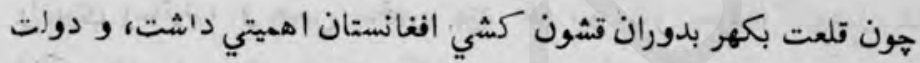

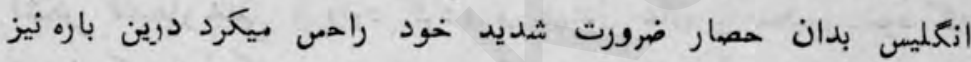

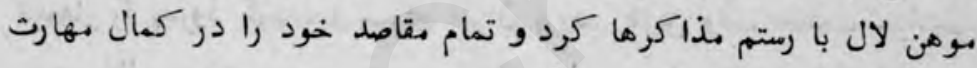

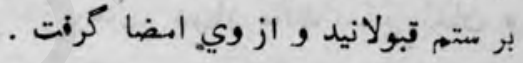

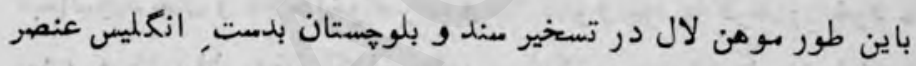

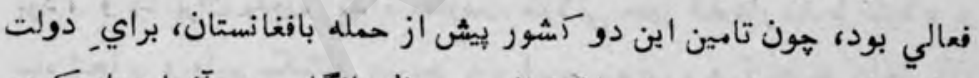

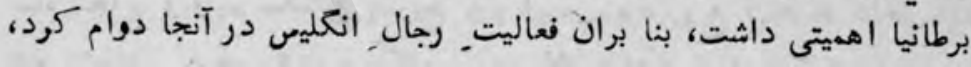

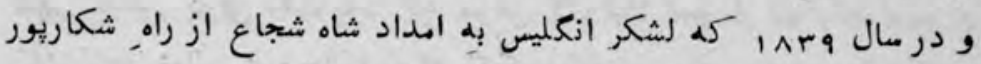

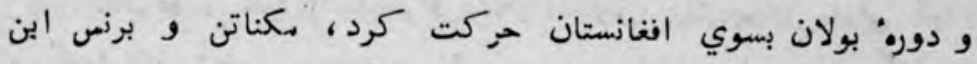

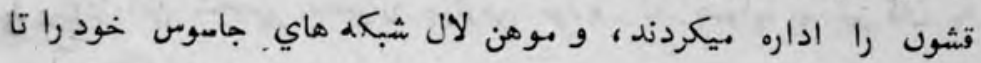
قندهار بهن كرده بود .

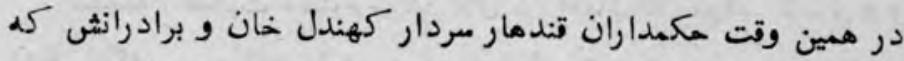

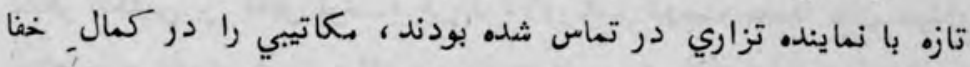

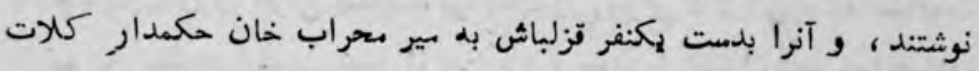


بلوحستان فرستادند، تا بير ششار اليه نكذارد شاه شجاع و لشكر انكليس

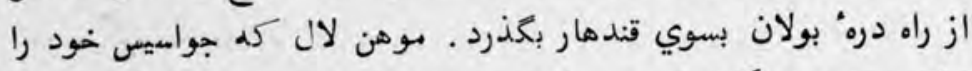

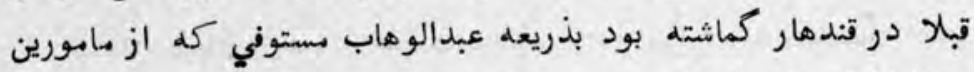

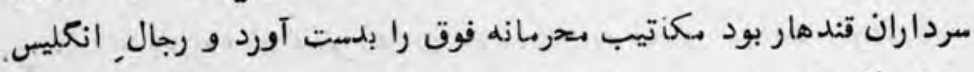

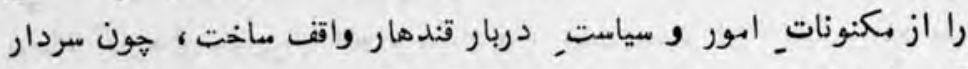

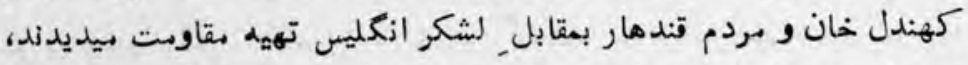

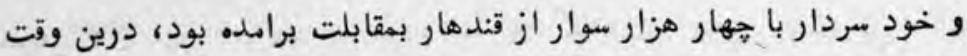

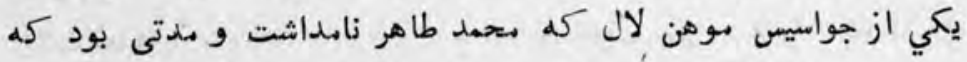

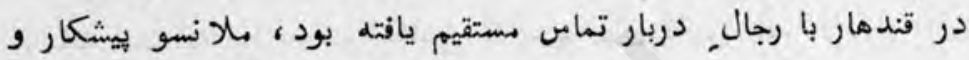

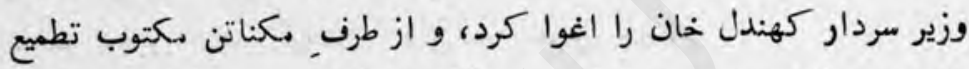
را بوي رسانيد، و همن شخص بود كه در كار سردار كرار كهندل خان و

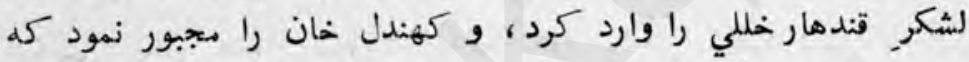

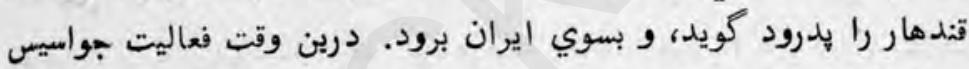

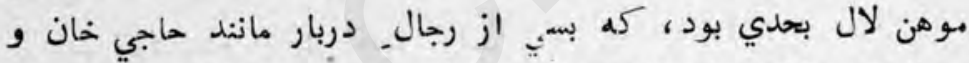

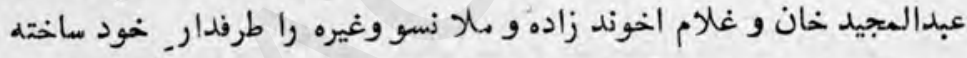

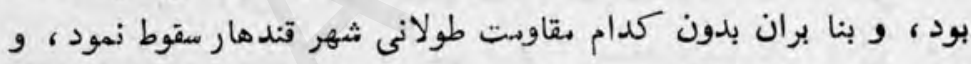

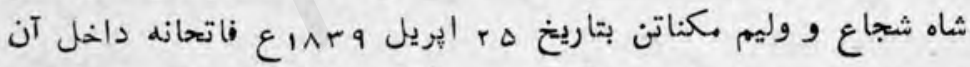

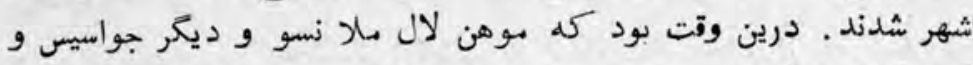

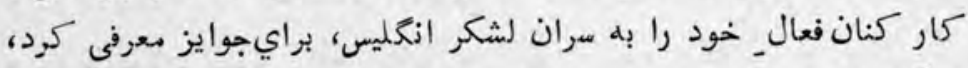

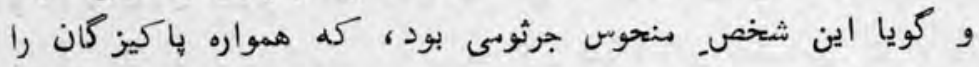
فاسد بميساخت.

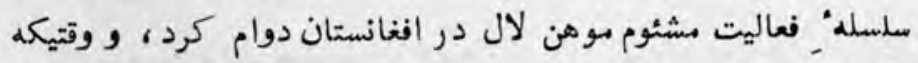

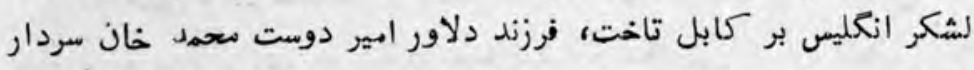

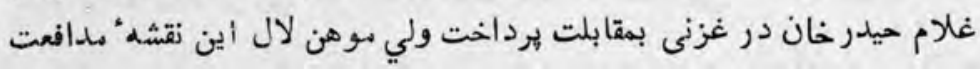

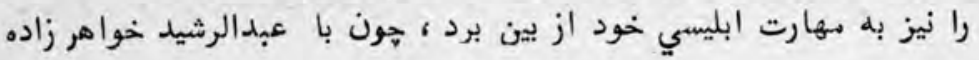




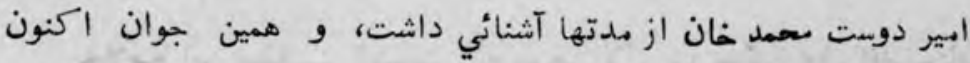

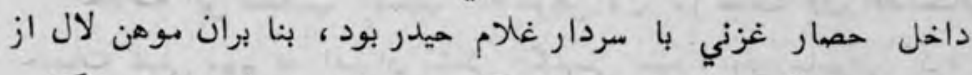

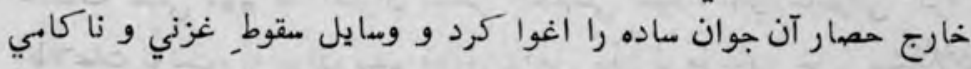

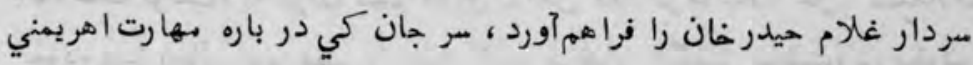

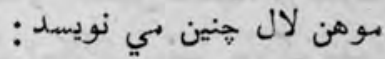
" عبدالرشيد وقتي با لموهن لال بال آشنا شده بود كه هيئت تجارتي

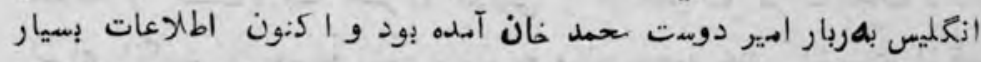

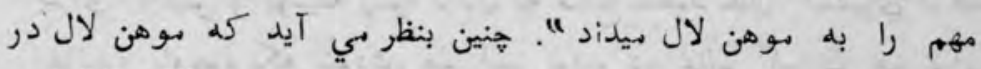

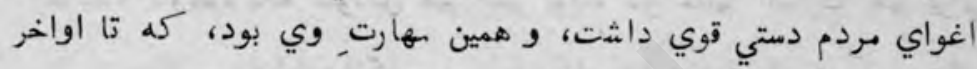

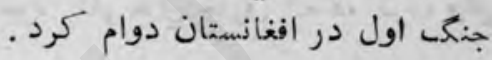

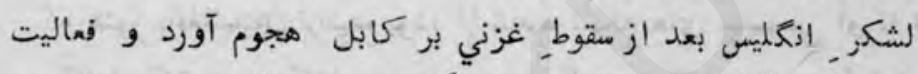

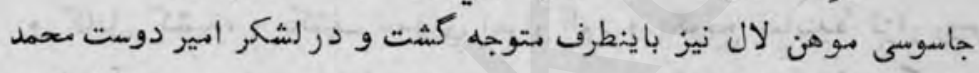

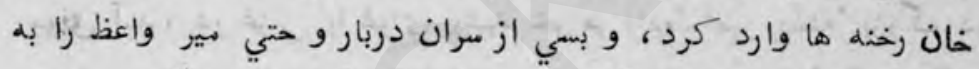

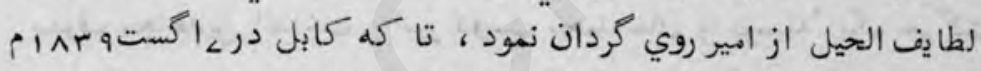

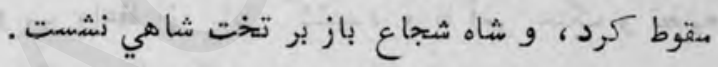

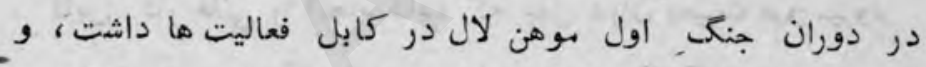

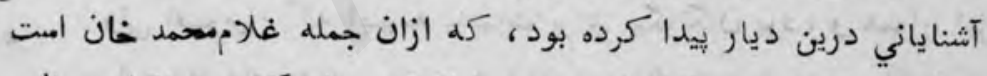

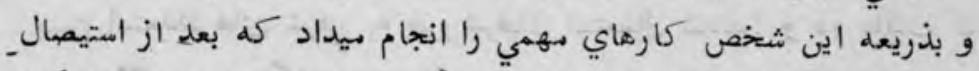

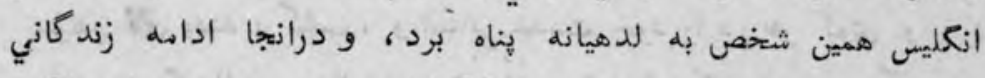

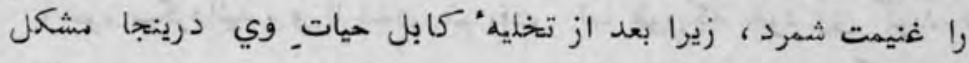
شده بود . موهن لال در دو جلد كتاب خويش كأه بنام زند كاني امير دؤست معهد

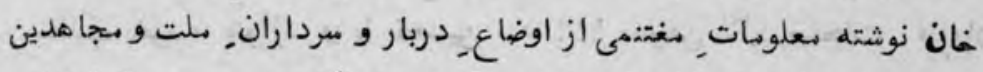

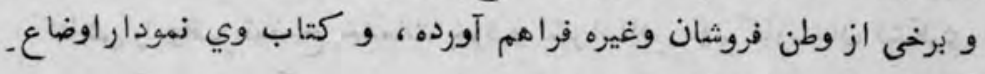

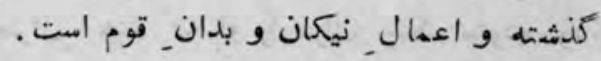


خلاحه اين مطالب اينست كم موهن لال در جنمه اول افغانستان

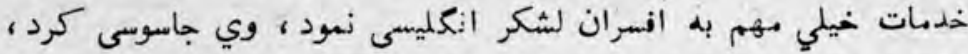

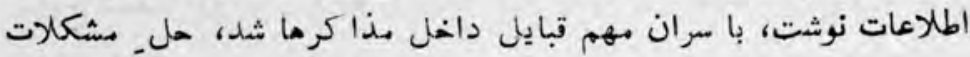

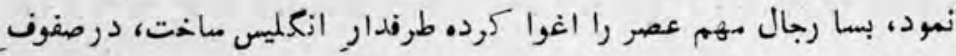

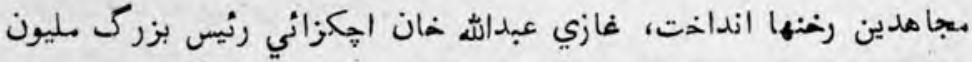

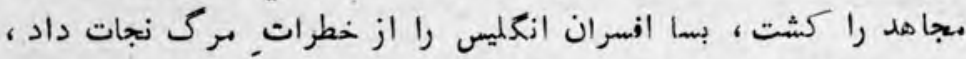

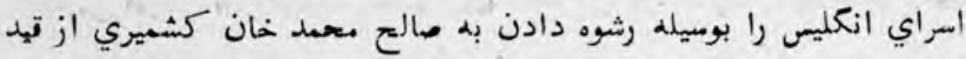

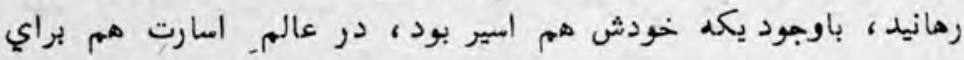
بيشبرد مطالب باداران ازكليسي خود كار هاي خمارت العاد.كرد، وتتي كه هنوز بافغانستان نرسيده بود، از سنده شبكه ماي جاسوسي او تا تندهار

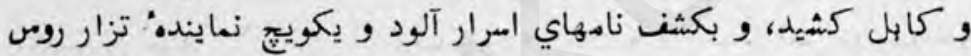

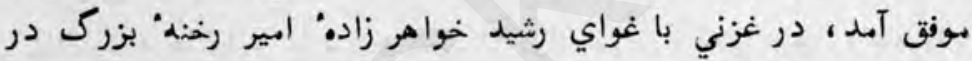

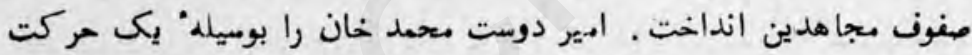

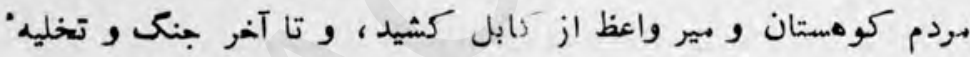

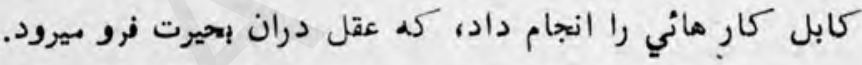

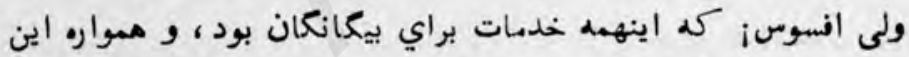

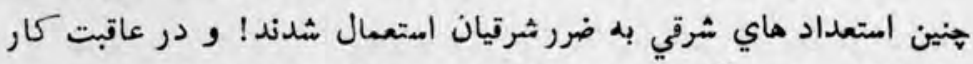

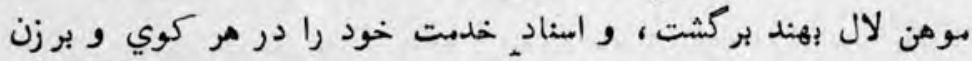

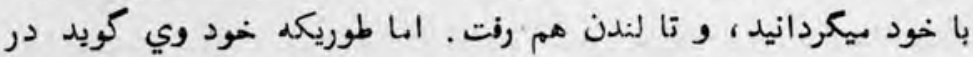

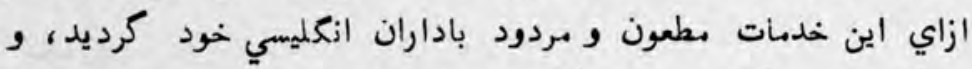

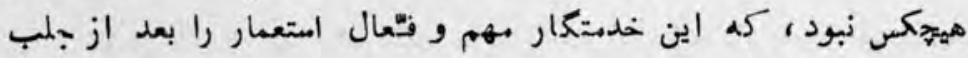
مطاب خود، بنوازد و يا تحسين دهد!!!! موهن لال صفحاتي فراوان

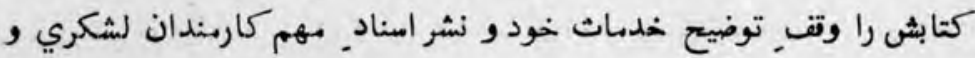

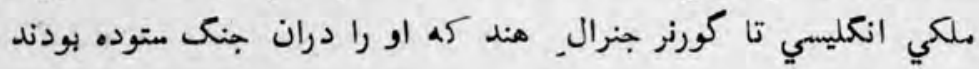




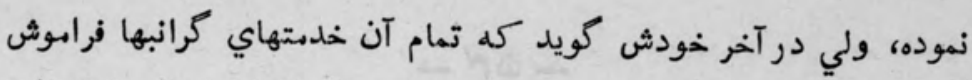

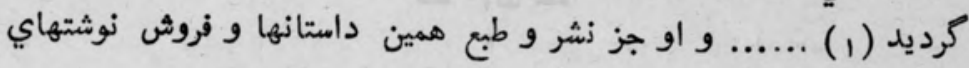

اينست هاداش_ كسانى كل باجنبى خدمت نمايندا

هذا تذكره لمن شاء ذكره 


\section{$-\infty N^{-}$ \\ الين جرو (}

Edward Law First Earl

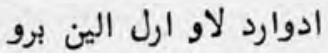

Ellenborough.

كورنر جنرال هند و شخص معروفيست بـر قاضى بزرك ازيخليند ادوارد

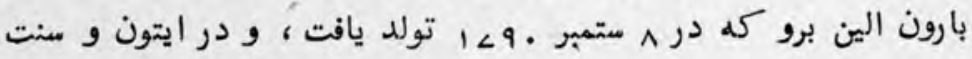

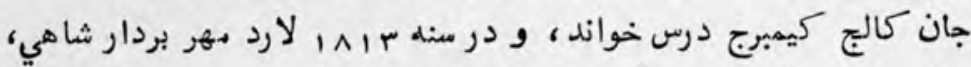

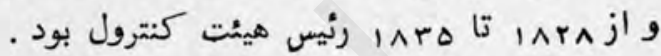

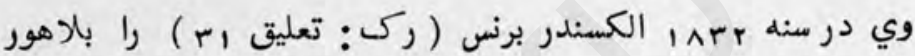

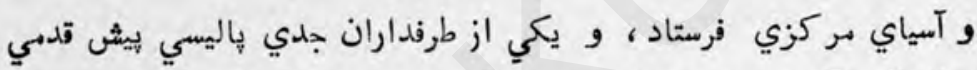

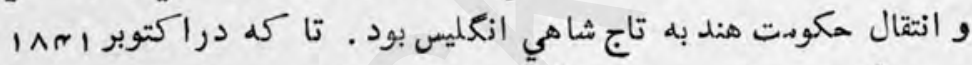

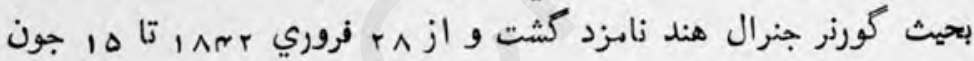
بمشا همين عهده داشت.

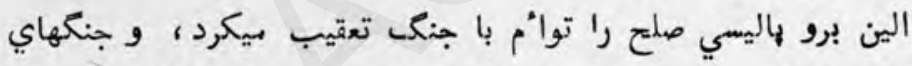

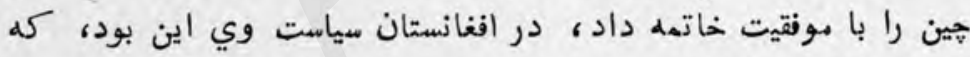

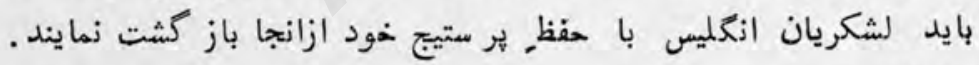

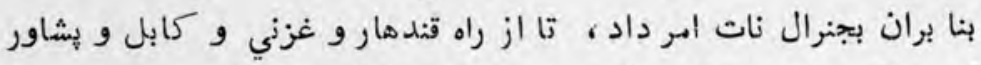

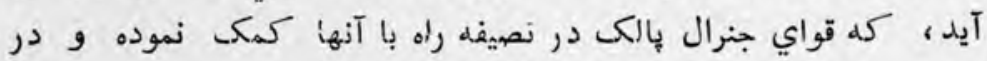

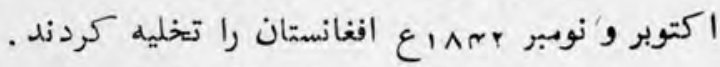

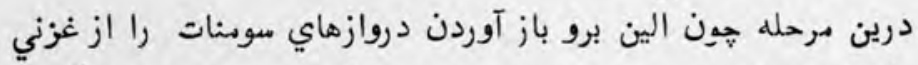

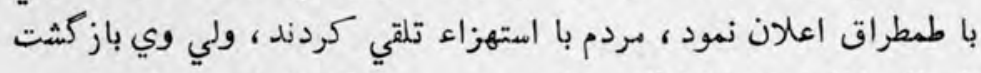

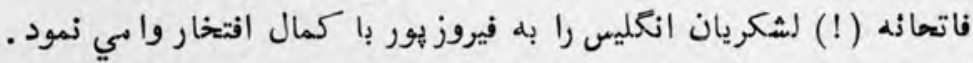

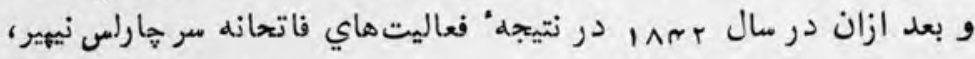

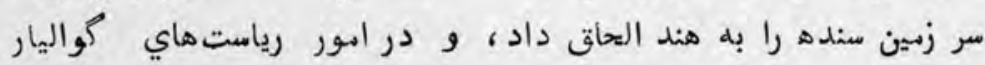


१ก

تازه نواي .عاركى

مداخله زموده و در جنكي بهراج يور حضور داشت، و بتاريخ م م دسمبر

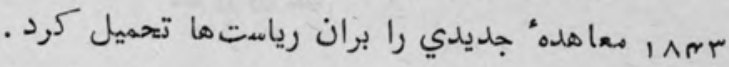

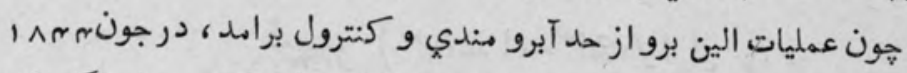

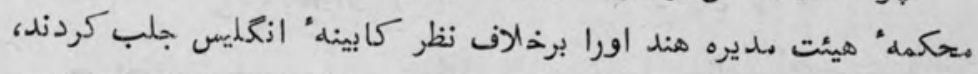

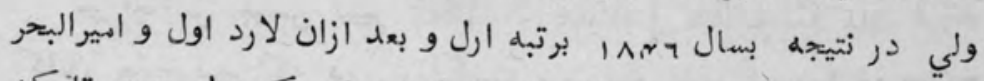

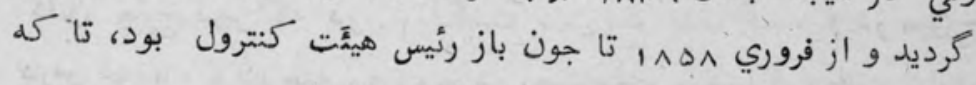

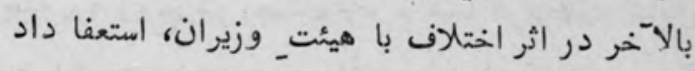

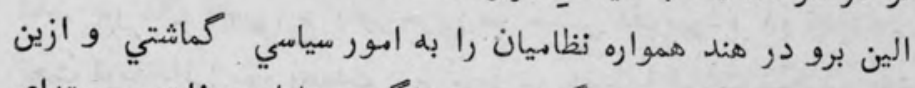

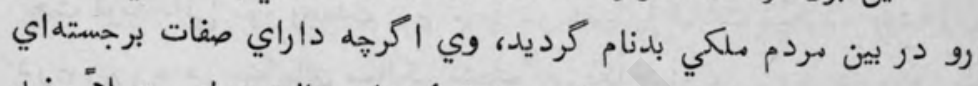

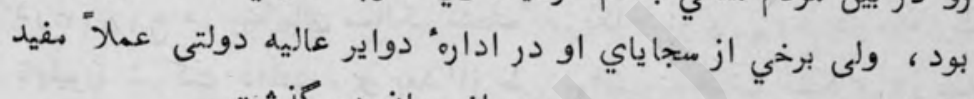

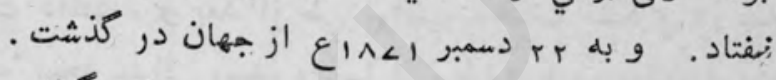

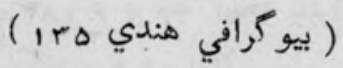




\section{ذيهي⿻}

سر هارلس جيهس نييير Sir Charles James Napier فرزند

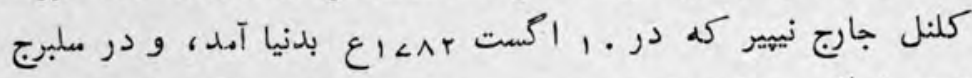

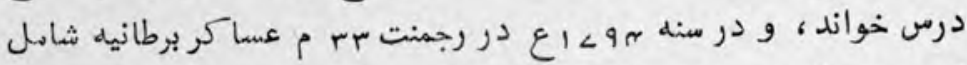

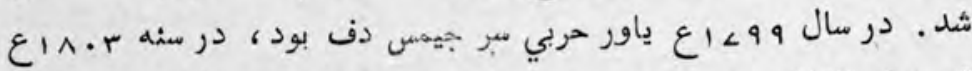

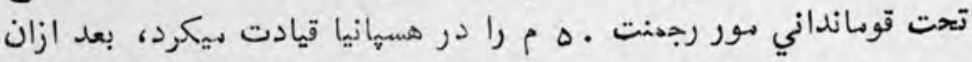

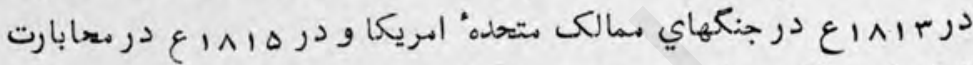

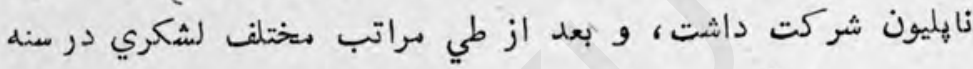

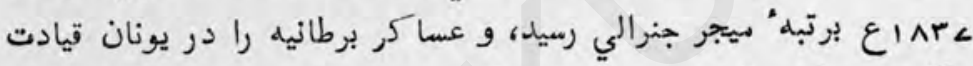

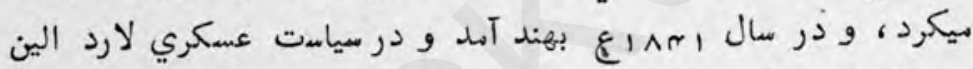

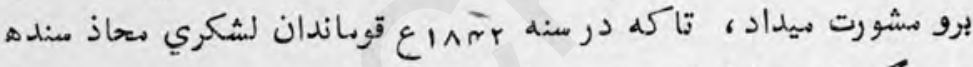

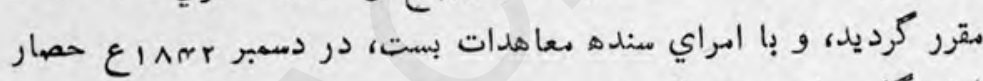

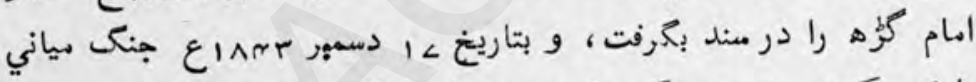

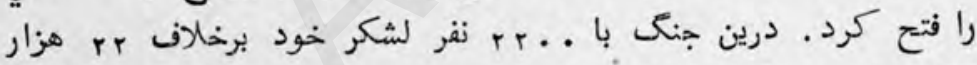

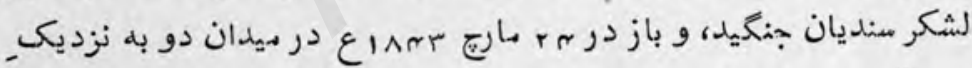

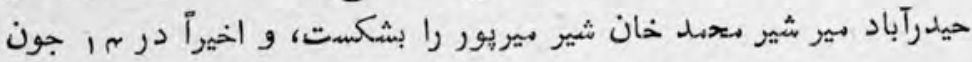

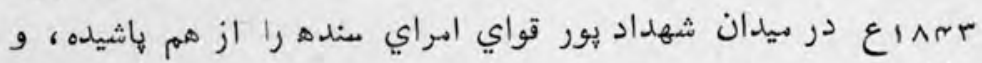

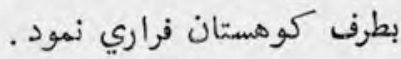

درينوقت بين نيمير و جنرال, آترم درباره مسئله فتح سنده و روائ رويه

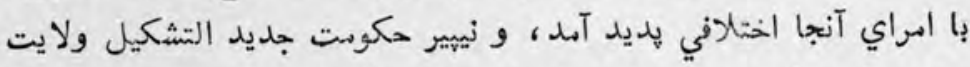

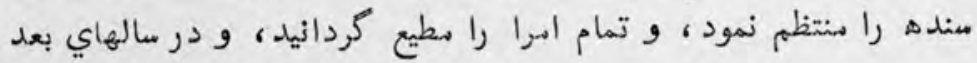

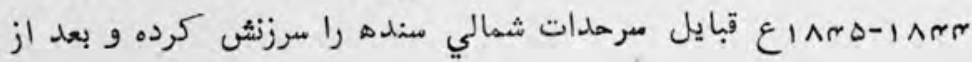


$9 \Delta ।$

تازه نواي معاركى

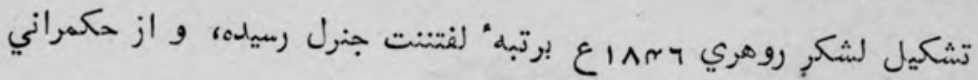

سند استعفا داد.

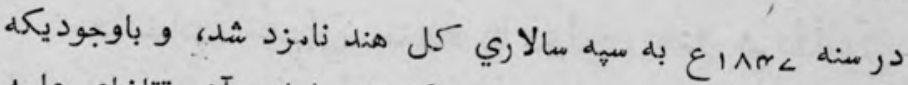

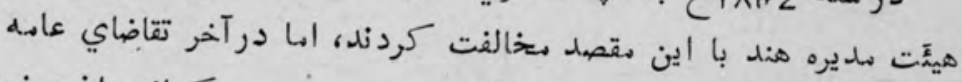

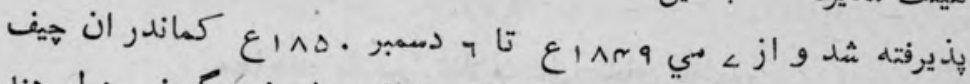

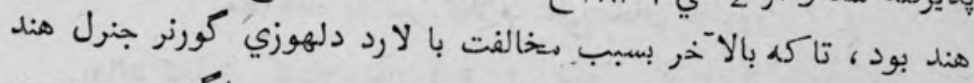

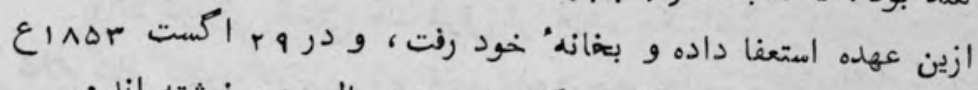

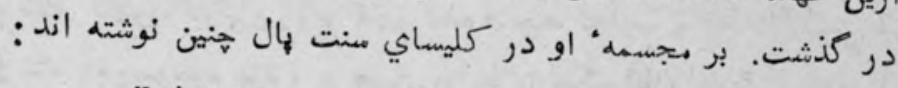

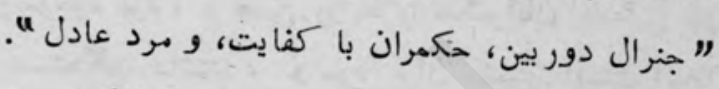

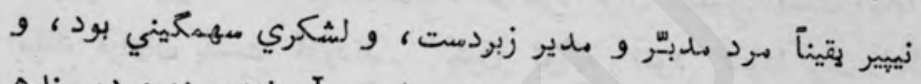

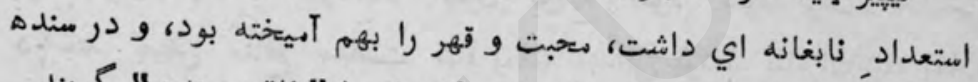

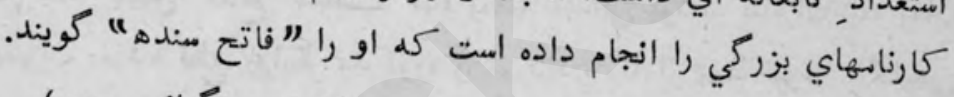

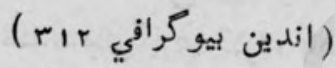


تعليقات

Q४

$-\$ 4-$

معاهلات ميران سنلهذ با دولت هند برطاذوي

(1)

معاهده با مير غلام على خان تالهور

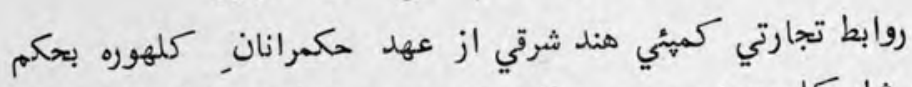

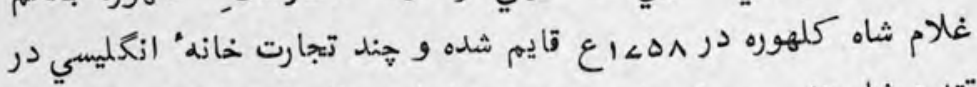

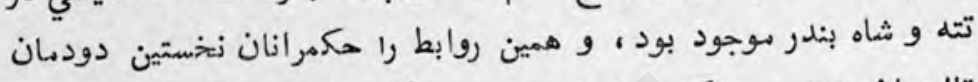

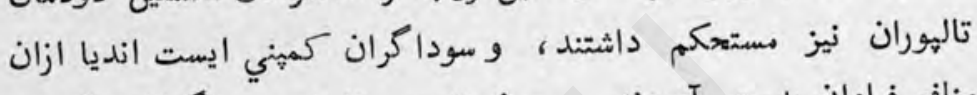

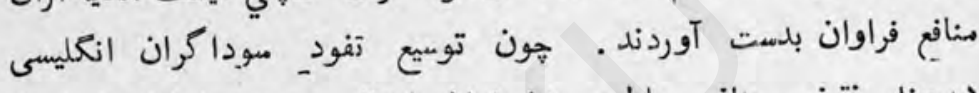

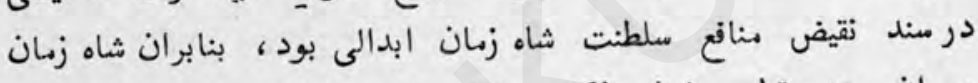

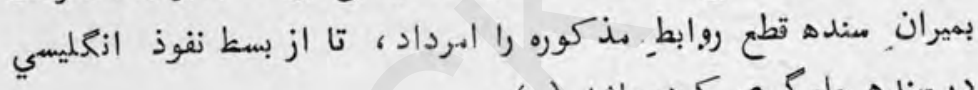

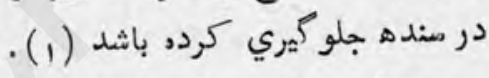

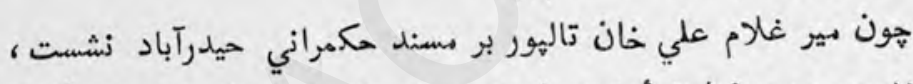

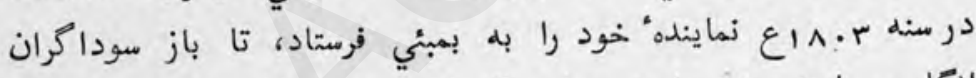

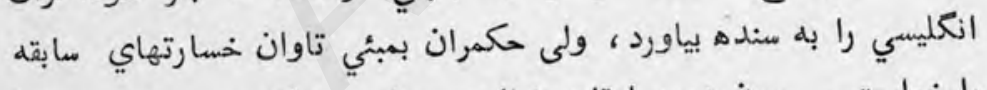

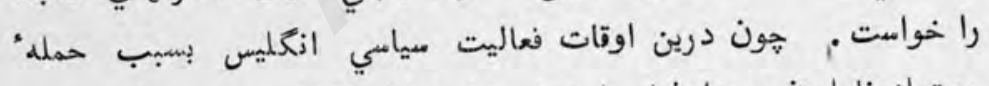

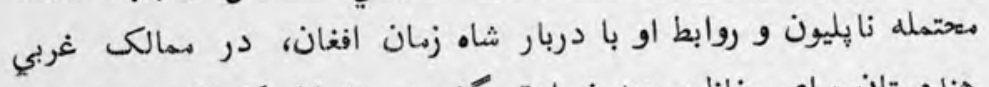

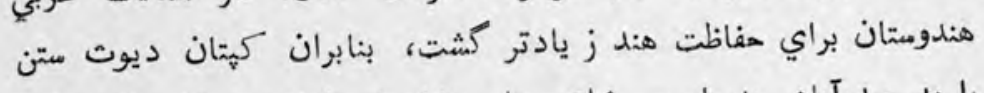

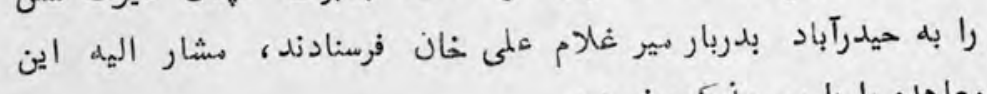

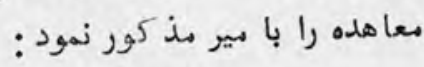

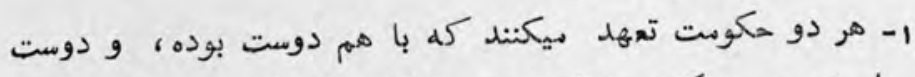

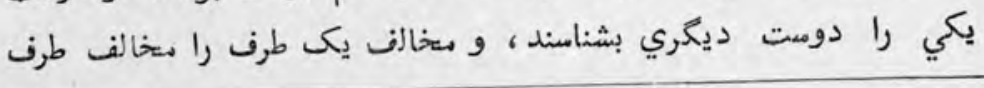

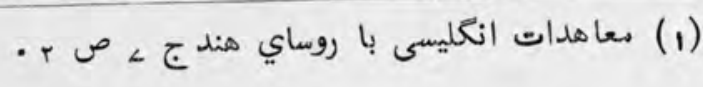


ديكرهم بدانند، و اين عهد همواره دوام خوا هد داشت . مان.

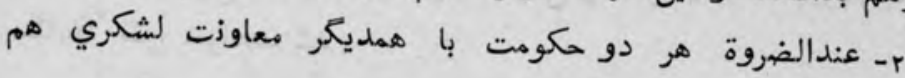
خواهند نمود.

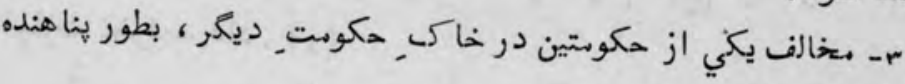

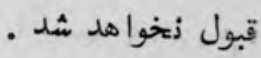

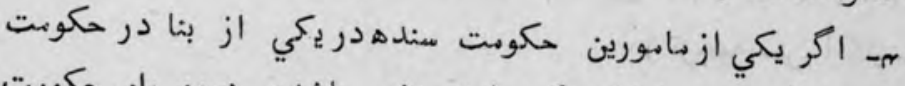

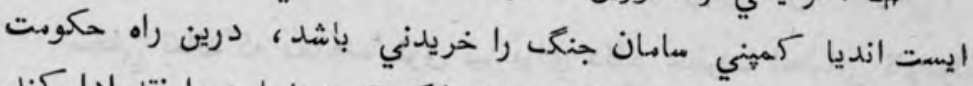

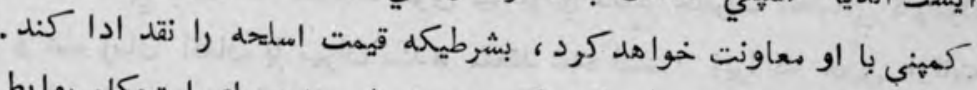

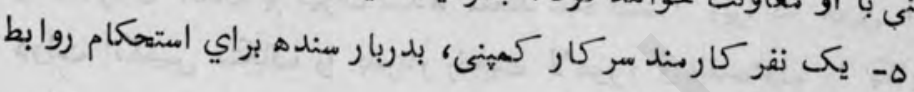

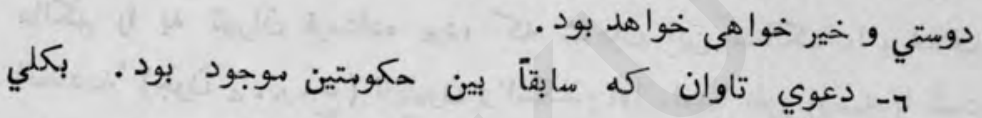

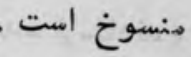

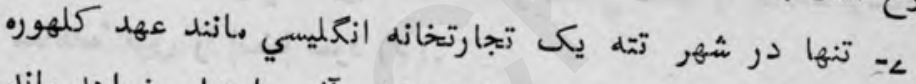

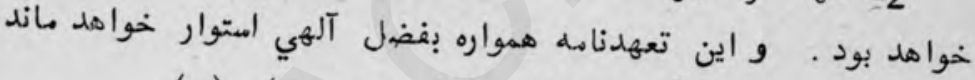
( ترجمه از اردو )

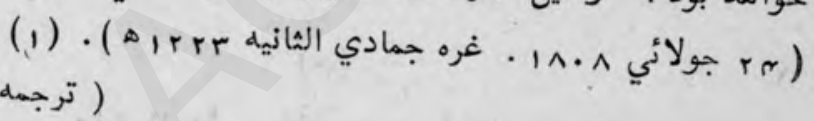

(r)

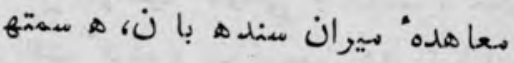

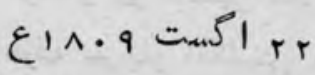

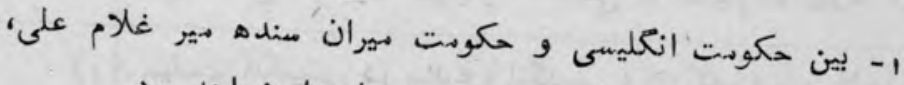

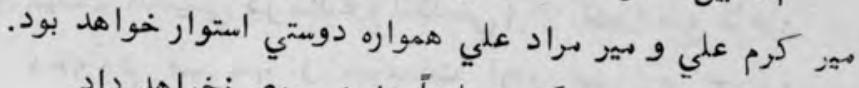

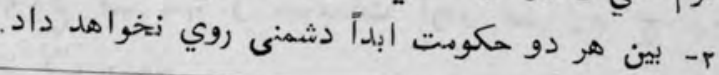

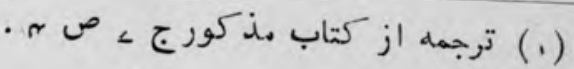


ז- همواره وكلاي حكومتين ازحليسى و حكومت سنده بدريار يكديكر

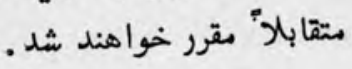

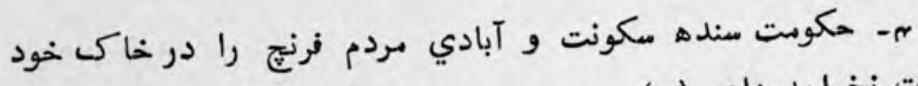
اجازت نتخواهد داد . (1)

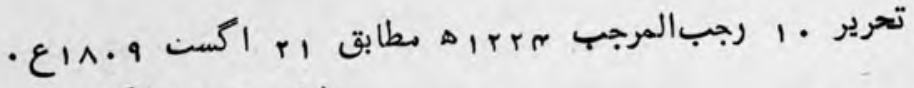
(ترجمه متن انكليسي )

مخفي نماند كه معاهدهُ فوق نيز براي دفاع خطرات احتمالى ناهليون

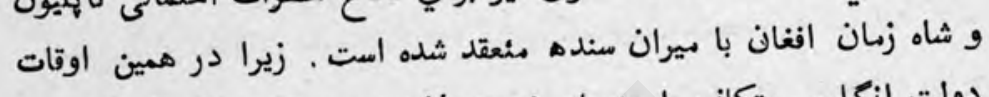

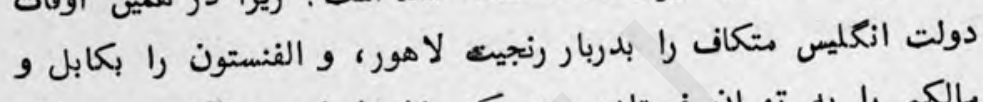

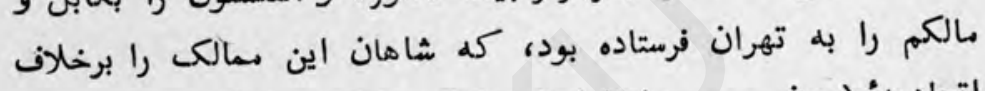

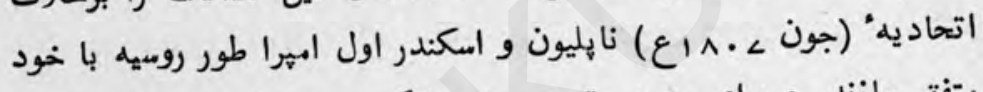

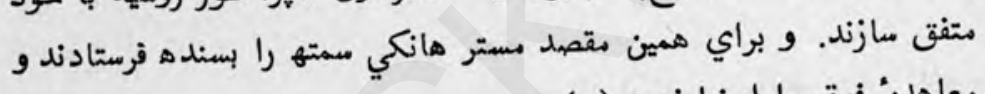

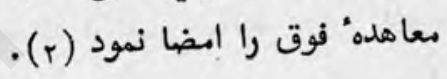

\section{(r)}

عهد زامه" ميران سنده با الفنستن

$$
\text { Q نومبر • }
$$

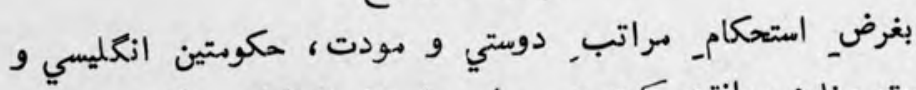

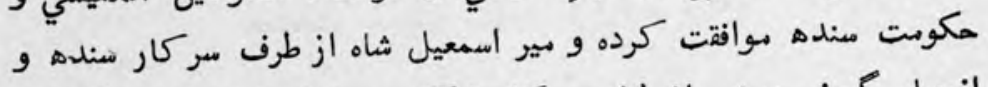

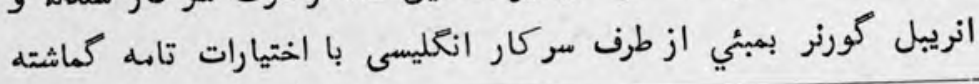

(1) مياست انظليسي در منده ( انكليسي ) از كهيرا طبع لاهور

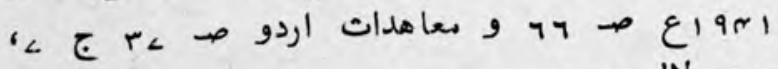

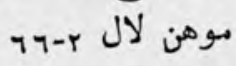

$$
\text { مياست صو صن (r) }
$$


900

شدند و بر مواد ذيل موافقه نمودند :

ا- بين مركار ازكليسي و بـير كرم علي و بير مراد علي مسوار.

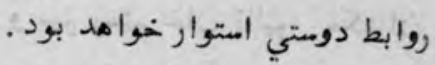

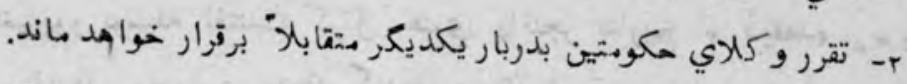

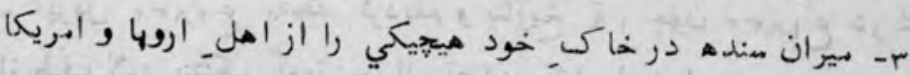

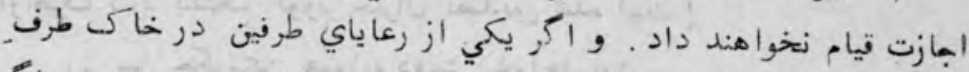

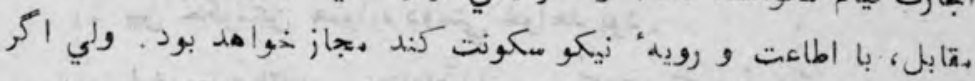

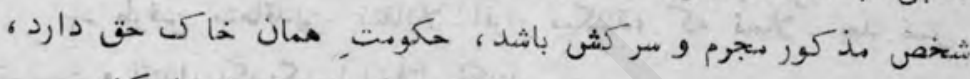

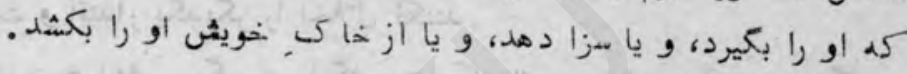

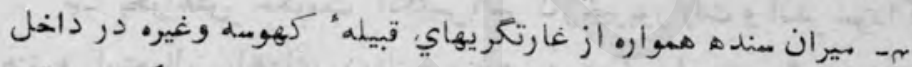

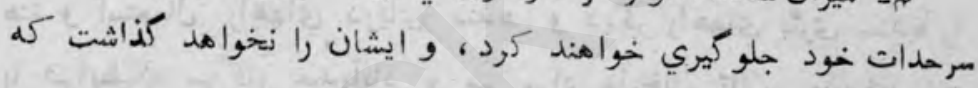

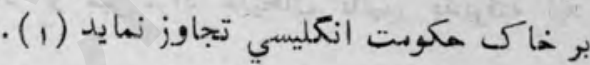

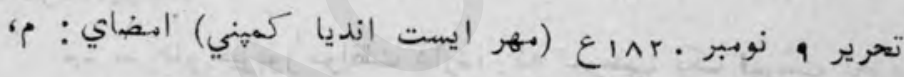

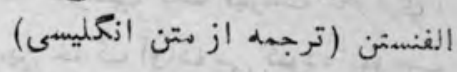

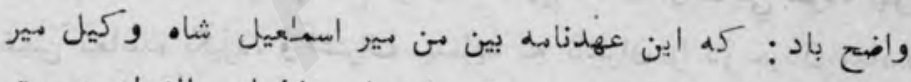

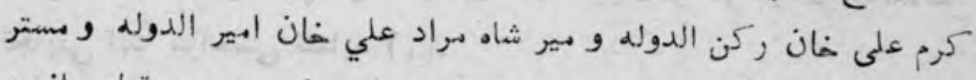

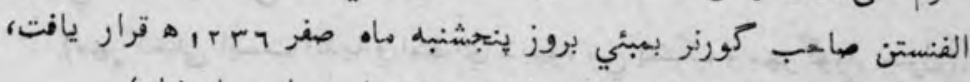

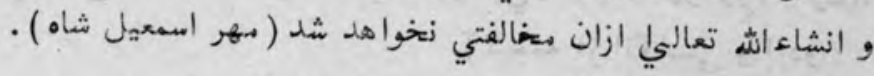

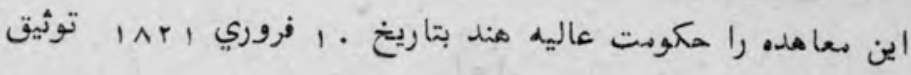

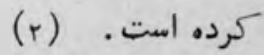

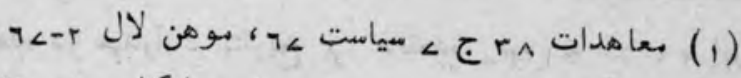

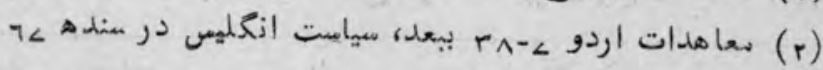




\section{(r)}

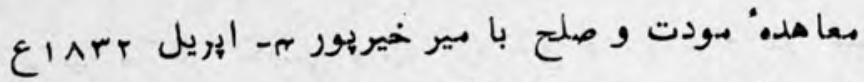
اين مصاهده بين ابست انديا كميني و بير رمتم خان تالهو حكمران

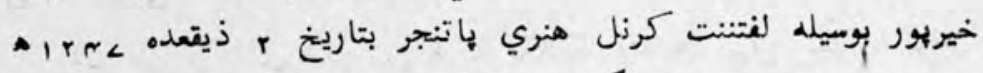

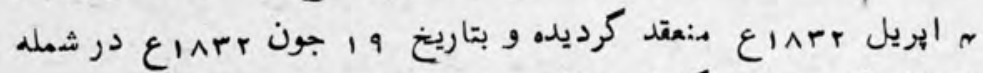

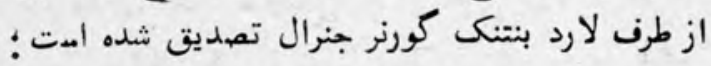

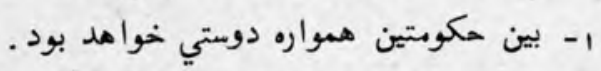

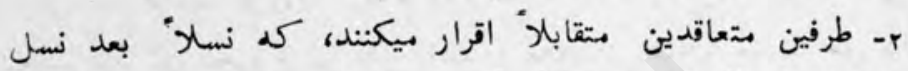

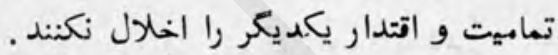

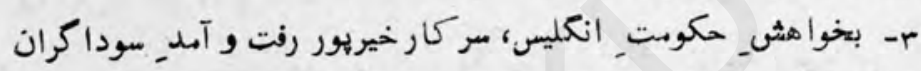

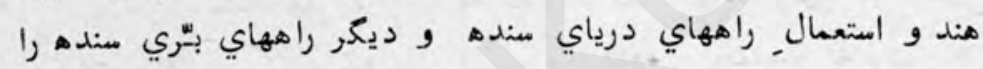

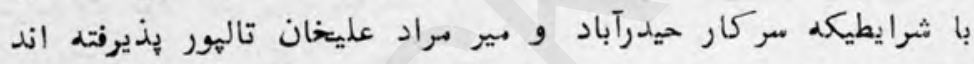

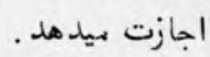

r- سركار خيريور موافتت دارد،، كه بموجب يكى نهرست تحريوي،

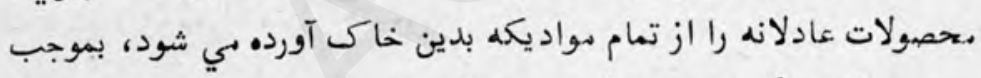

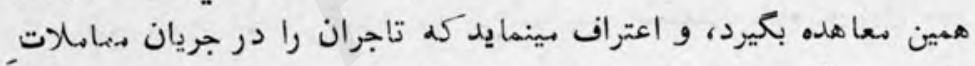

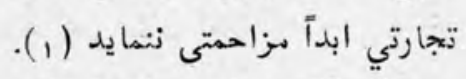
(مهر كمينى ايست انديا و امضاي دبليو، مي بنتيكى و مهركورنو جنرل).

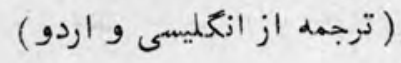

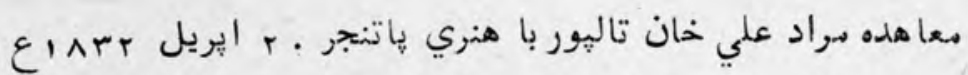

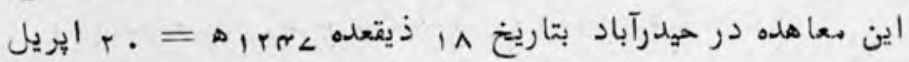

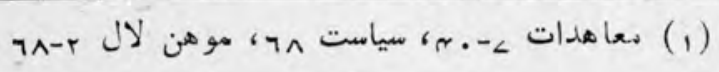


rایrاع بين لفتتنت كرنل جإنتجر نها ينده" انكليسي و مير مراد علي خان

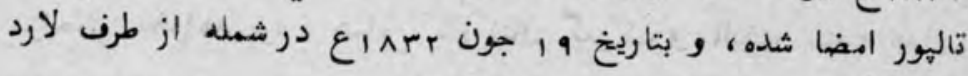

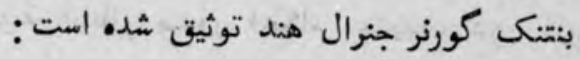

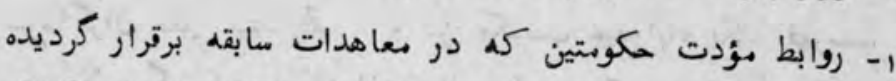

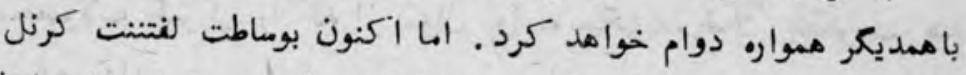

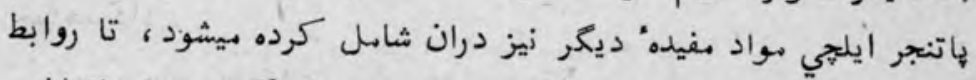

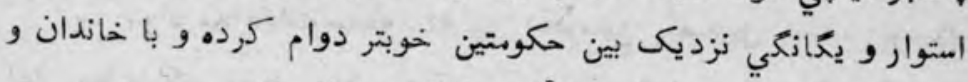

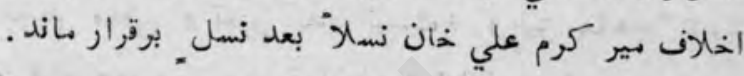

r- طرفين هتعاقدين به خاكى يكديكر بنظر آزو طمع زتخواهند ديدم. r- حكودت ازكلميس خواهش دارد ، كله به سوداكران هند اجازت

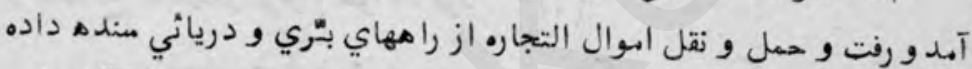

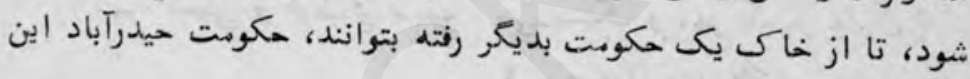

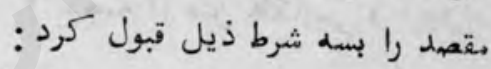

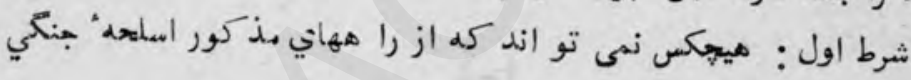
را بياورد .

شرط دوم: از را مهواي مذكور جهاز و كثثتي مسلح نخوا هد آهد.

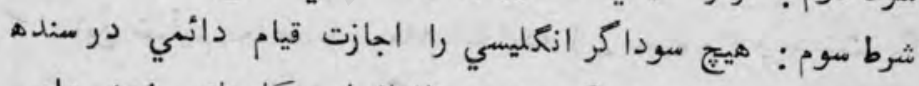

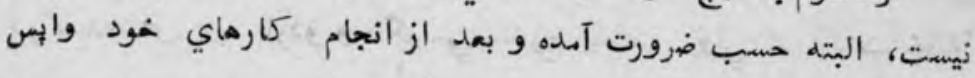

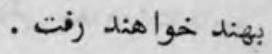

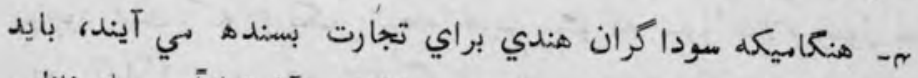

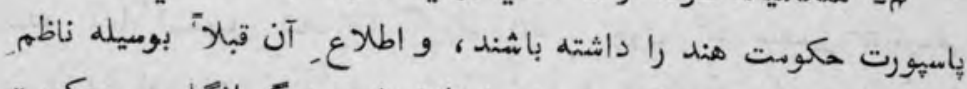

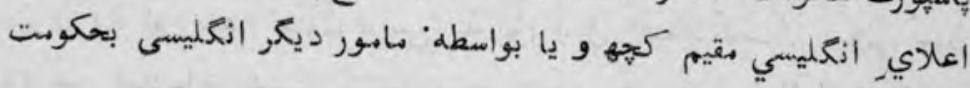
حيدرآباد داده شود ماني

ه- حكومت حيدرآباد مجصولات_ بعينه را بر تمام اشهاي تجارتي 


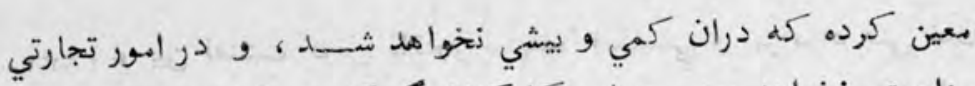

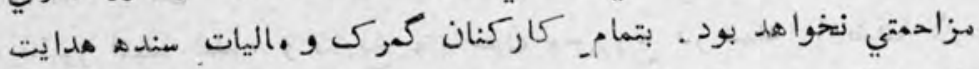

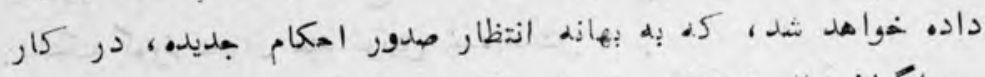

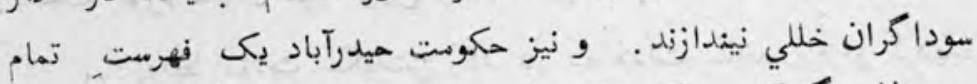

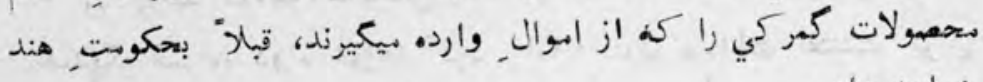
خوا هد داد مولد

ب- مواد معاهدات سابقه كله بين مكوبتين تعهديق شهده، بوسيله

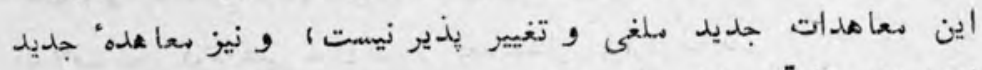

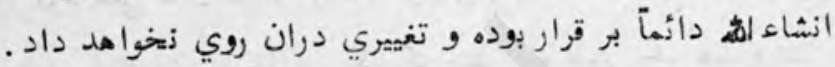

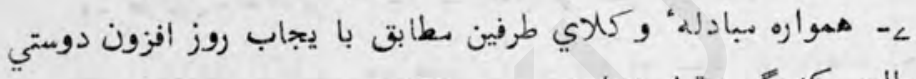
و مصالع يكديمر برقرار خوا هد بود . . (1)

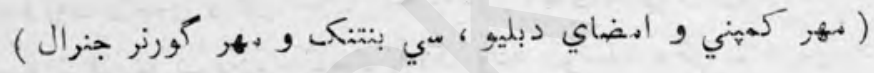

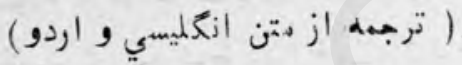

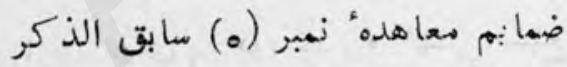

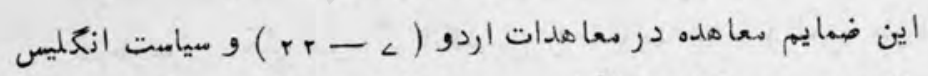

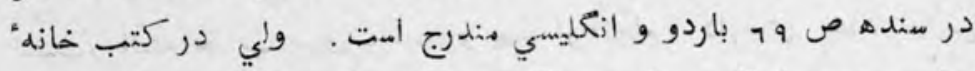
جناب سيد حسام الدين راشدي (كراخي) زقل يكى بياض دعا هدات فارسي

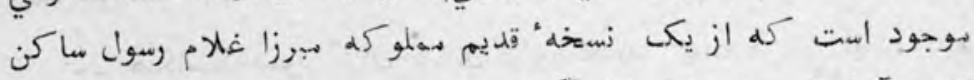

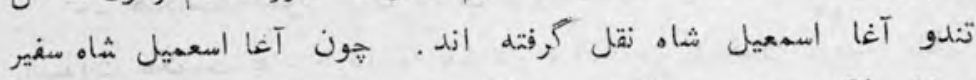

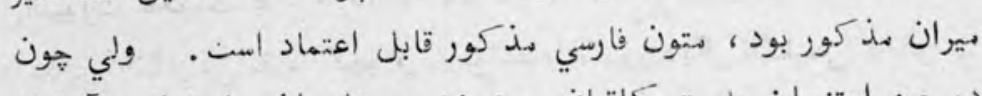

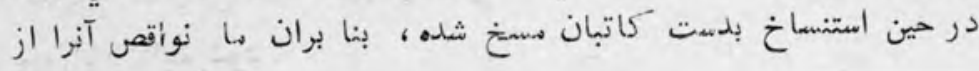

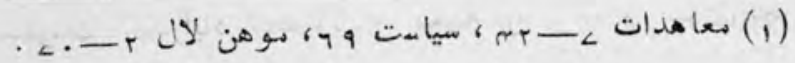




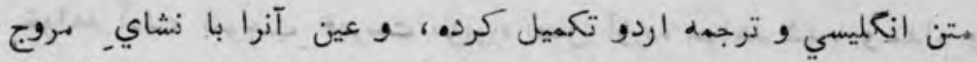

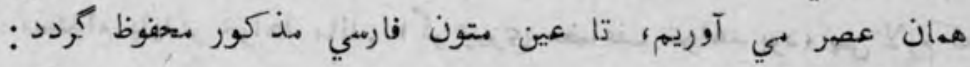

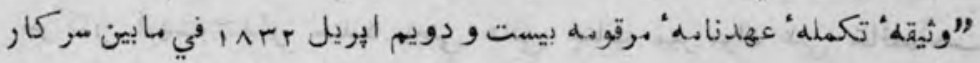

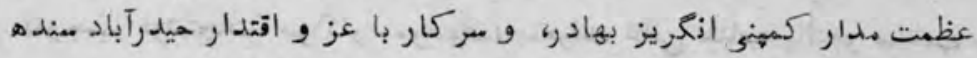
مورخه rr إيريل سنه مذكوره .

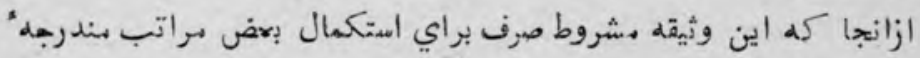

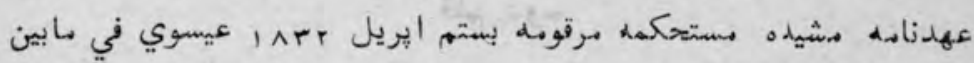

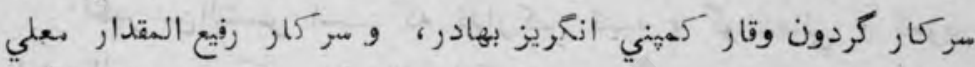

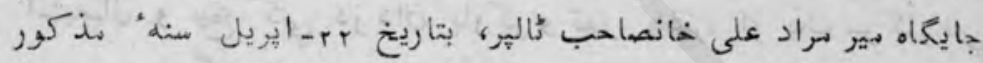

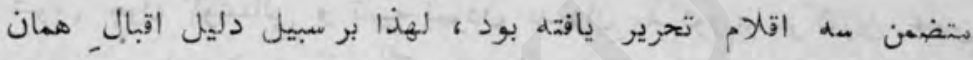

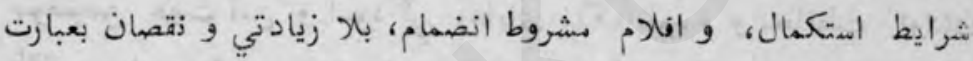

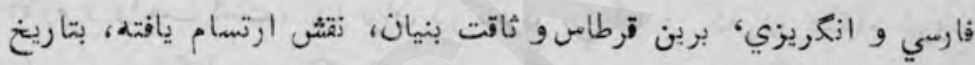

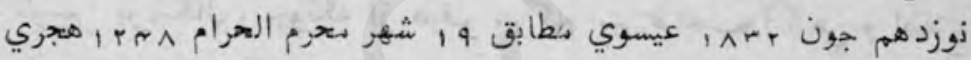

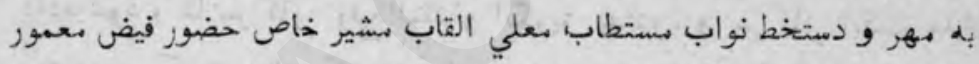

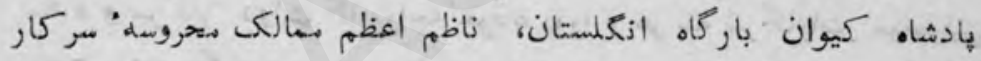

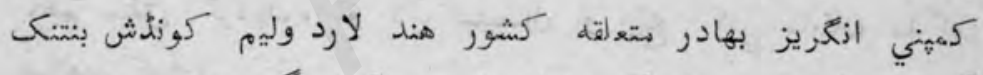
كورنر جنرل بهادر بهقام كوه شملهمرتب و وسكمل كرديد:

\section{قلم اول}

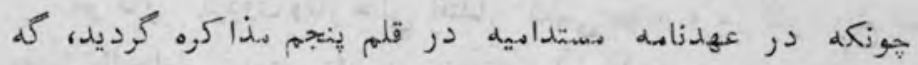

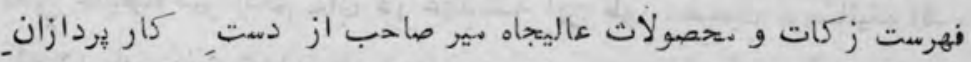

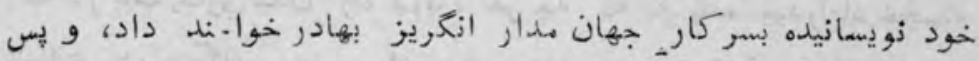

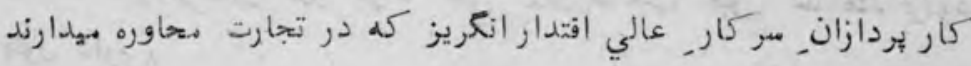

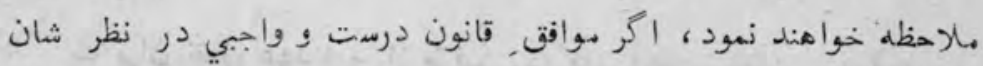




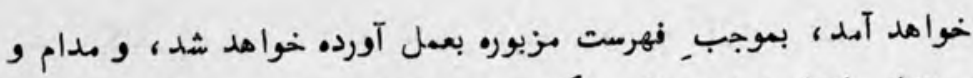

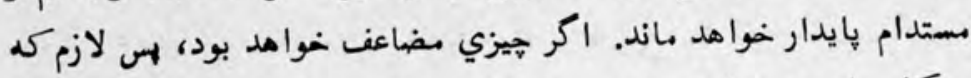

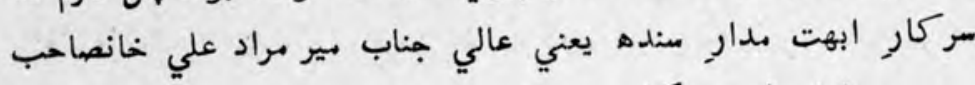

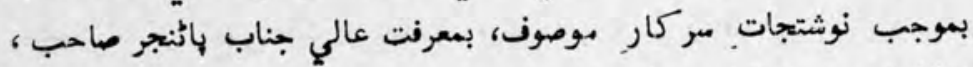

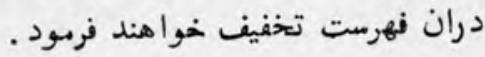

\section{قلم دوم}

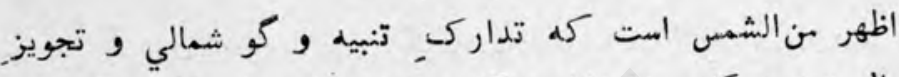

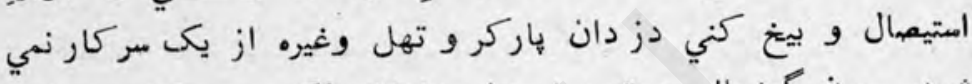

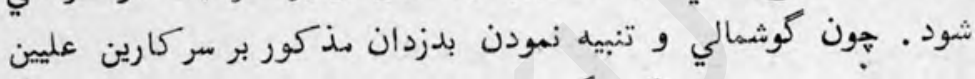

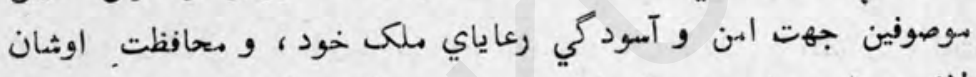

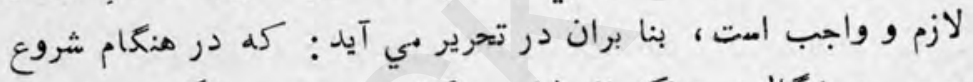

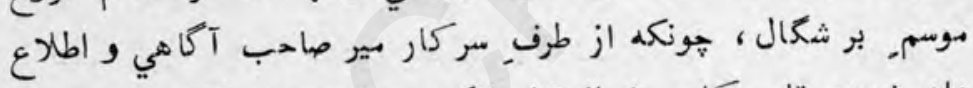

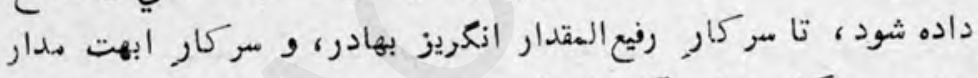

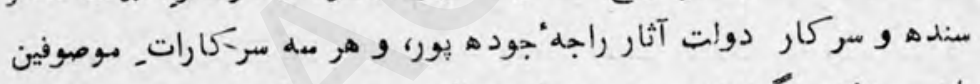

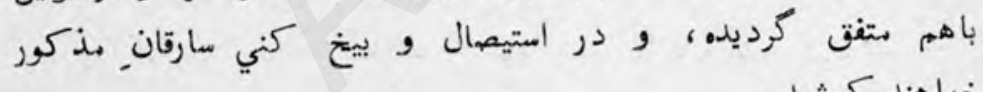

\section{قلم سوم}

سركار, كردون وقار عالي اقتدار كمهني بهادر و سر كار رئم رفيع المقدار

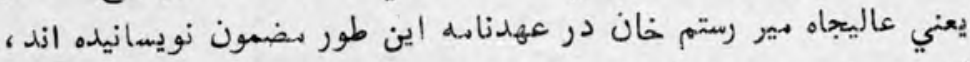

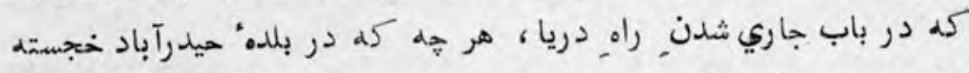

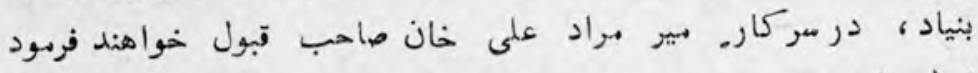

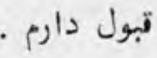

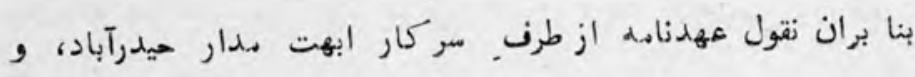




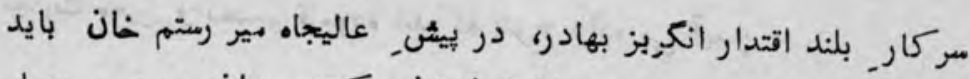

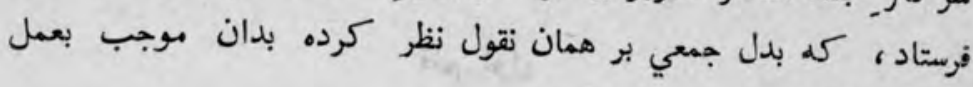

آورند فقط (1)

\section{ضميمهن" ديكر نجارتي}

و ثيقه تكهله" عهدناسه بنابر آهدورفت تجاران و بيويأريان از راء.

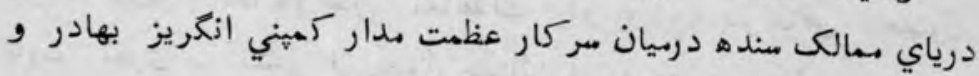

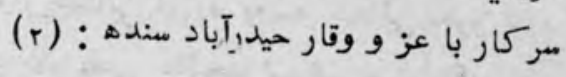

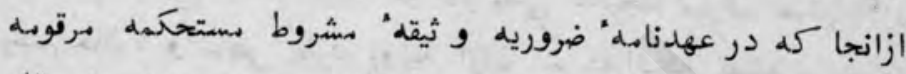

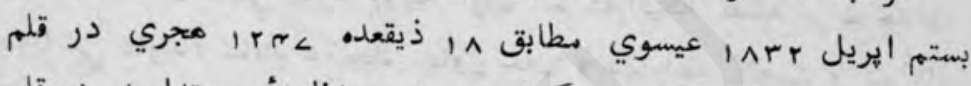

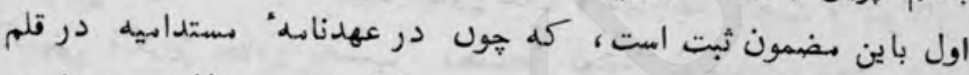

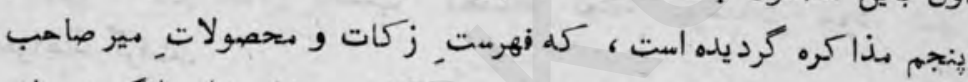

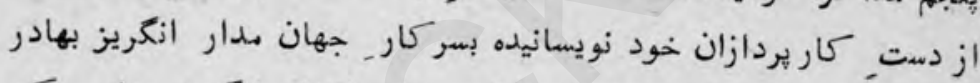

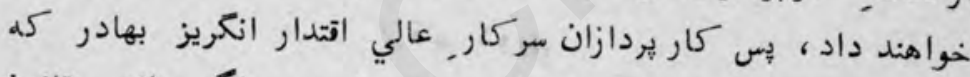

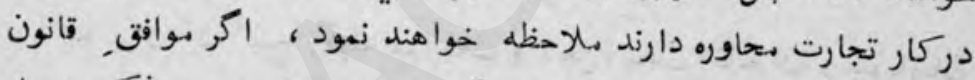

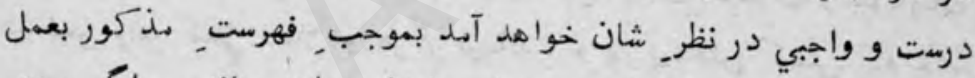

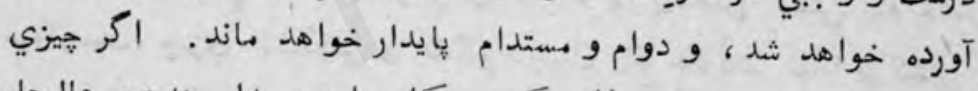

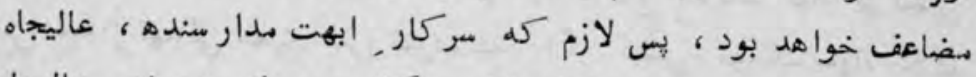

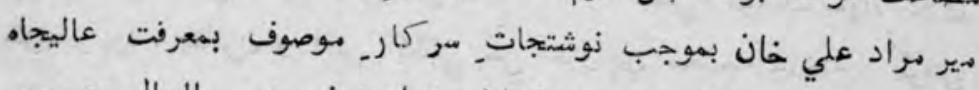

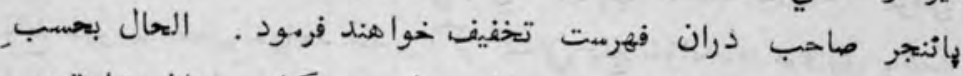

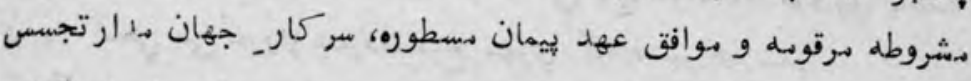

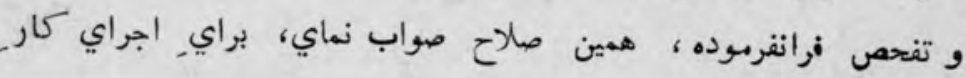

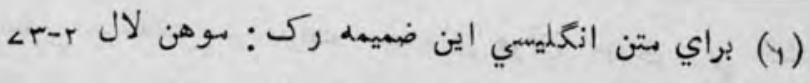

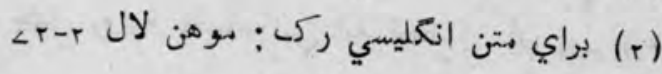


تعليمات

تجارت بعين و معهبم فرموده اند كله شرح داده مي آيد :

\section{تلم اول}

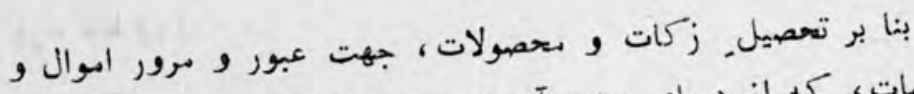

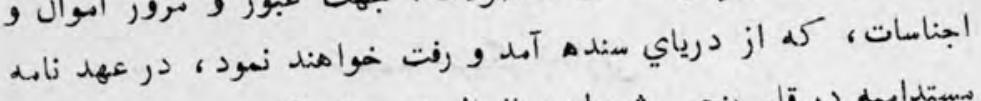

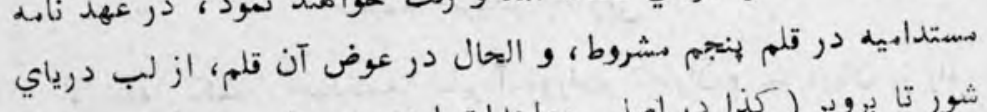

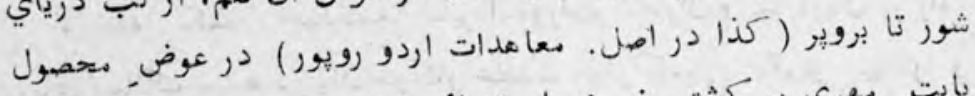

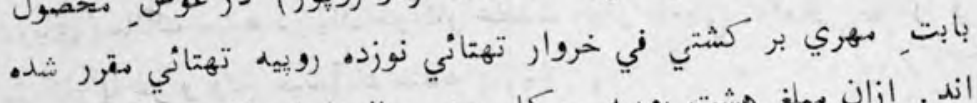

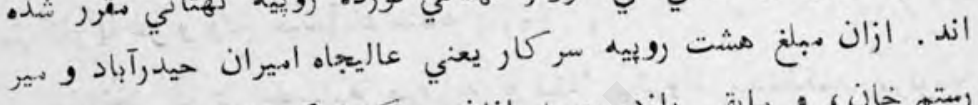

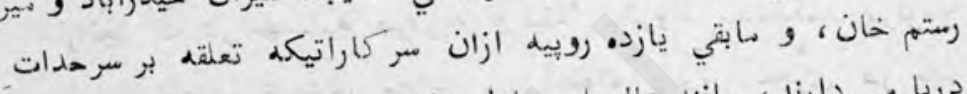

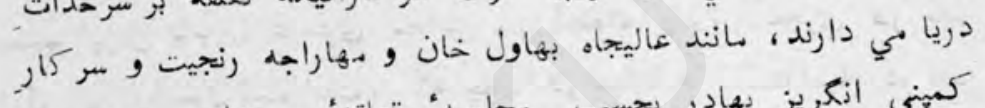

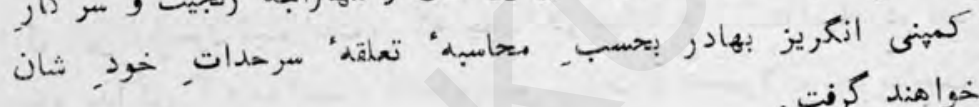
خواهند كرفت.

\section{قلم دويهم}

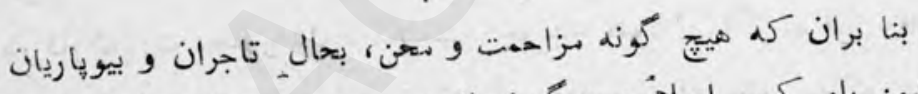

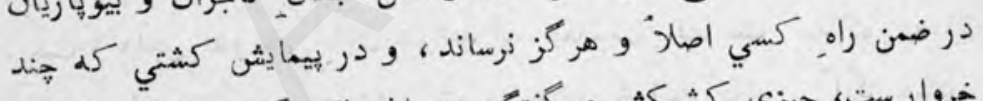

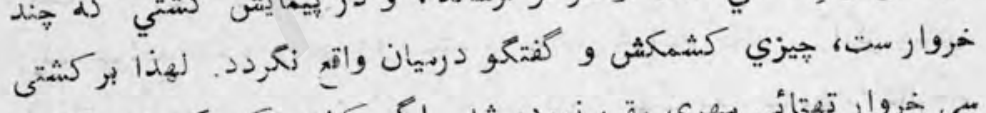

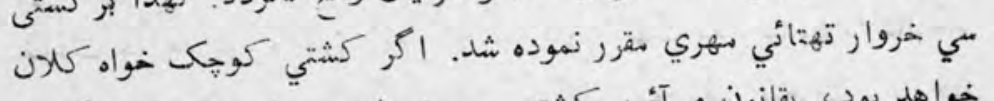

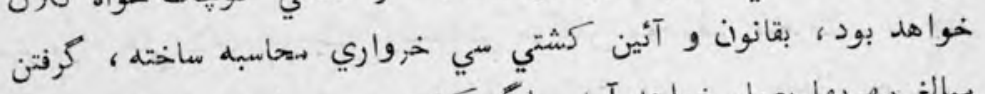

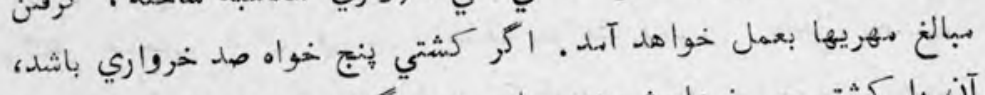

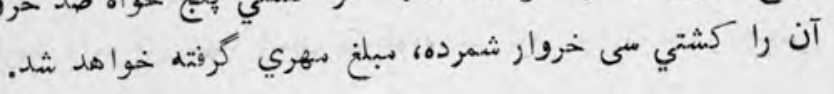

$$
\text { قلم سويم }
$$

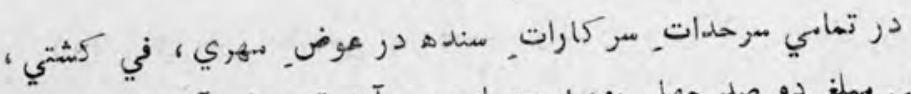

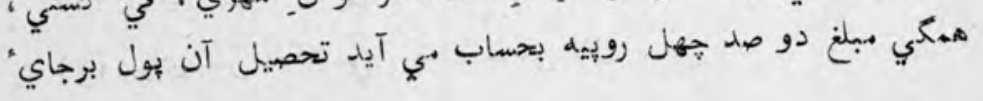


فرضه دريائيكه اسباب از جهاز درياي شور، و در دو زدي يعني كشتي

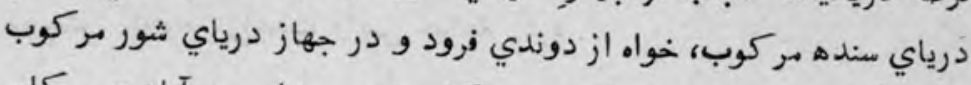

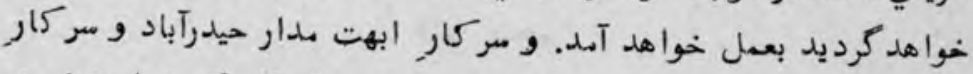

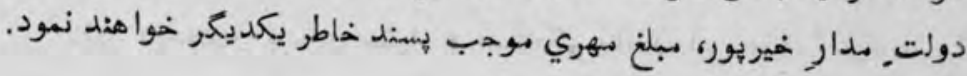

\section{قلم حها}

جهت تحصيل نمود دادن عوض_ يول در باب_ مهرهاي سركارات.

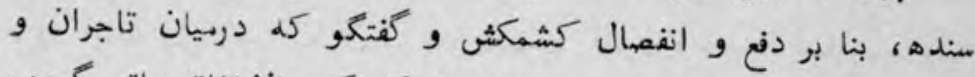

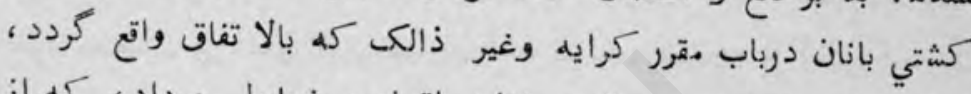

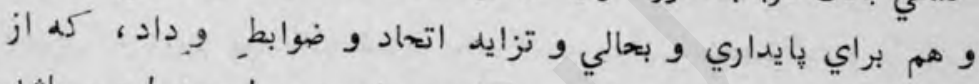

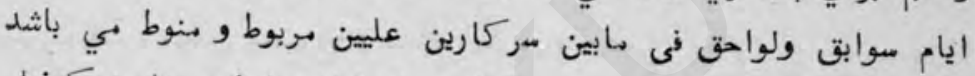

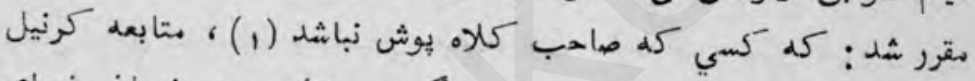

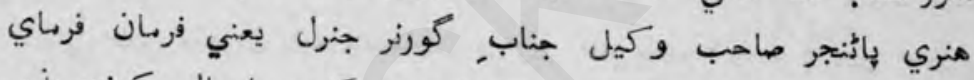

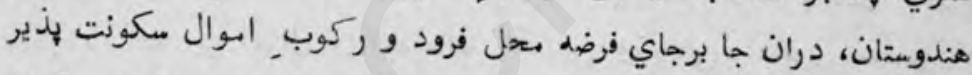

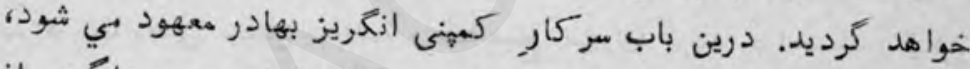

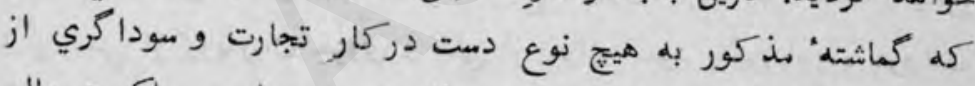

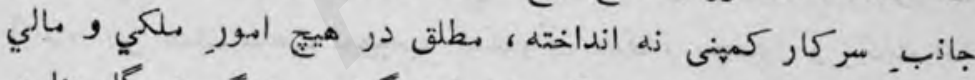

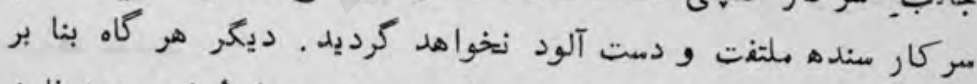

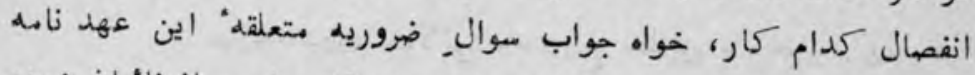

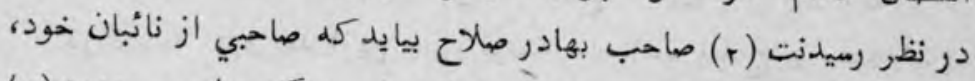

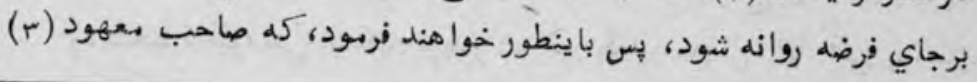

(1) شايد مطلب از كاله بوثى مردم نظامي و مربوط عسكريست.

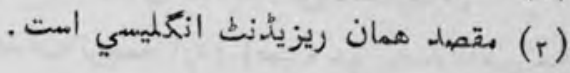


درانجا وارد كرديده، كاري خواه جواب بوال به انصرام رسانيده، باز

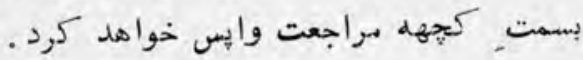
قلم لِينجم

بنابر درمدت و برجاي مشيد و مستحكمم ماندن اين وثيقله" عهد ناهـل

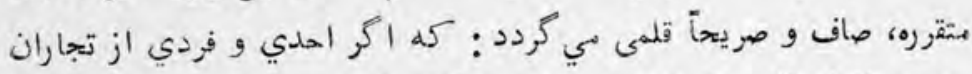

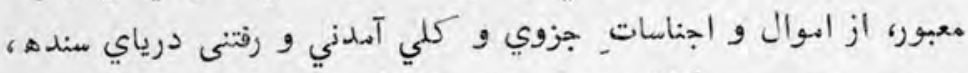

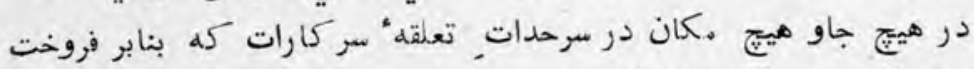

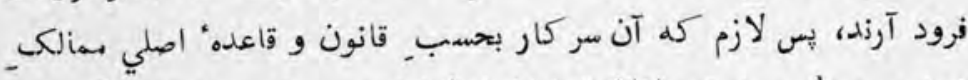

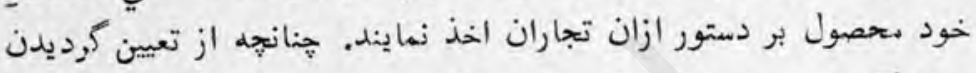

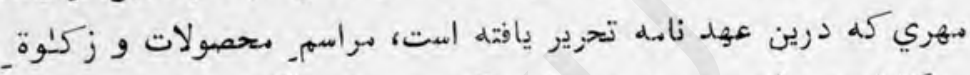

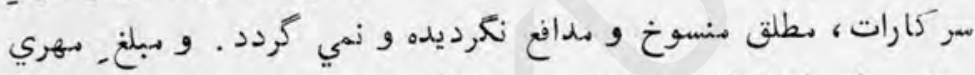

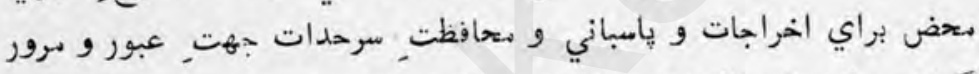

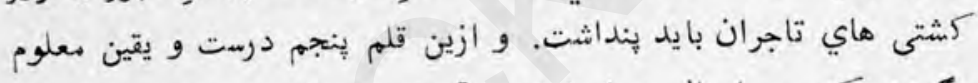

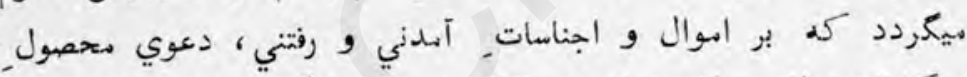

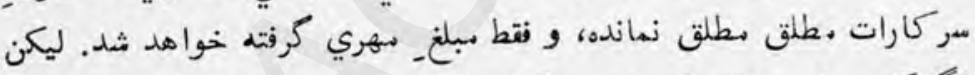

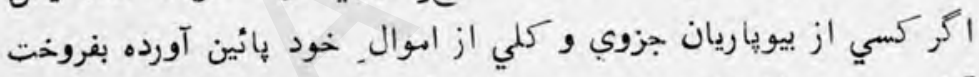

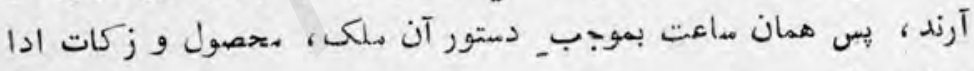
خوا هد ماخت

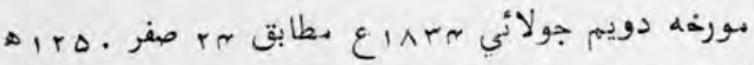

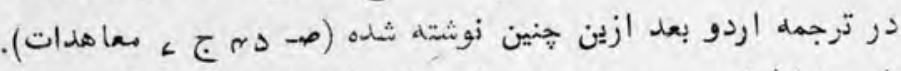

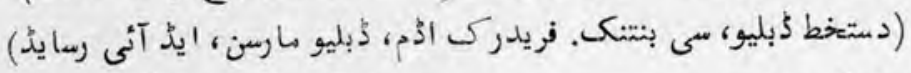

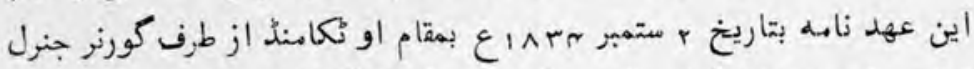

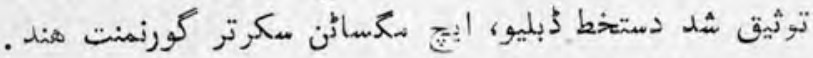

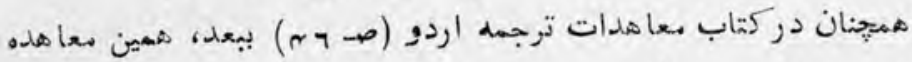

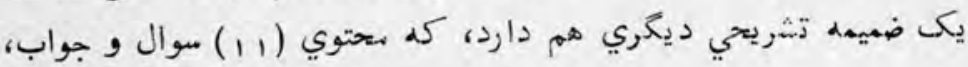




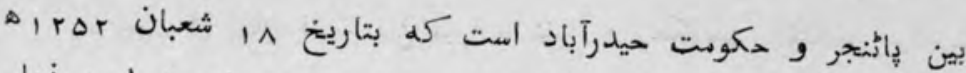

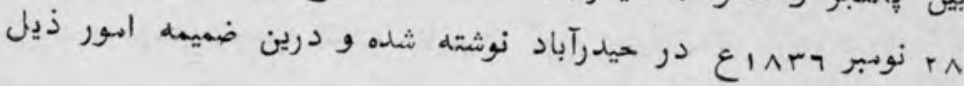

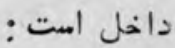

1- نصب علايم راه و لنكر اندازي كشتي در دريا. ז- تعيين مواقع لناه كاهما كشثتى در اوقات طوفان وغيره.

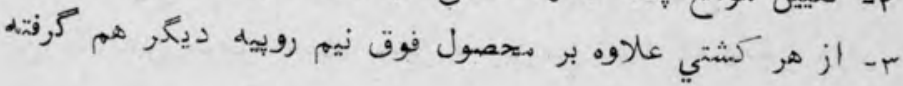
خواهد شد.

r- به سيد عظيمالدين حسين ايجنت كورنر جنرل كله براي سكونت

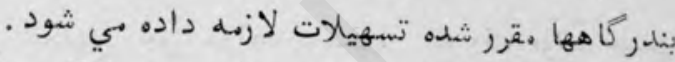

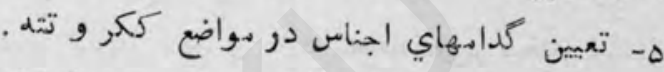
r- تشكيل يكى هيله مـالازه در تته براي نمايش و فروش دور اجناس تجارتي هند و ارويا و خرانسان و تركستان و كابل .

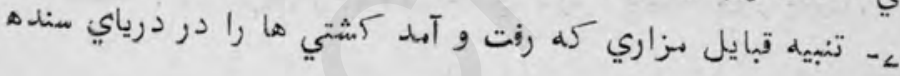
مانع مي شوند.

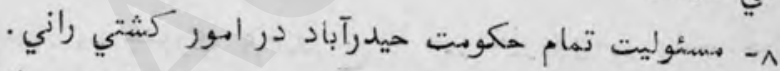
ه- بريدن درختان جنكل در مواضع ضروريه براي سهولت جرئ جريان كشتى ها بغبر از شيكاركا ههاي ميران.

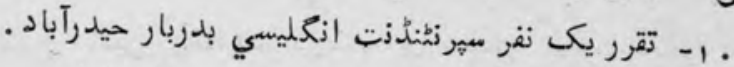

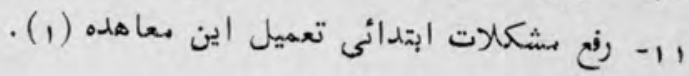
$(<)$

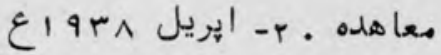

بين هير نور سحمد خان و مير نصير خان ميران سنده و كرنل هن هنري

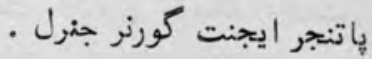


تعليقات

ดับ

ا- هون از زمان فديم بين ميران سنده و و حكومت الخمليم مراتب

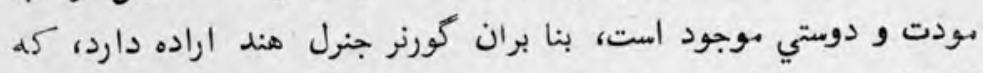

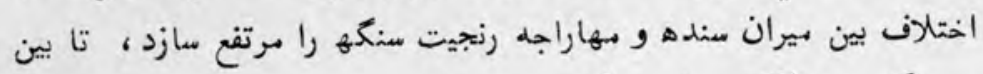
دو حكومت مذكور صلح و آشتي روي دهد.

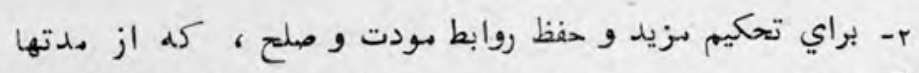

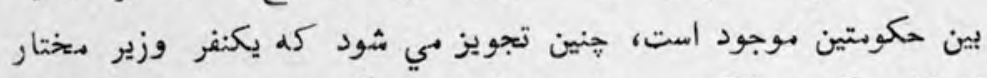

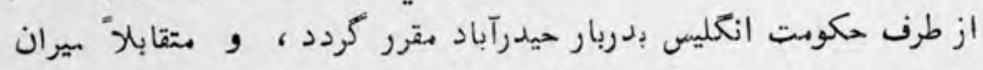

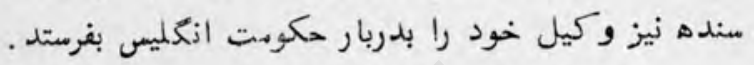

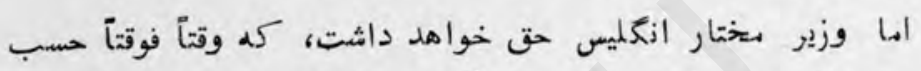

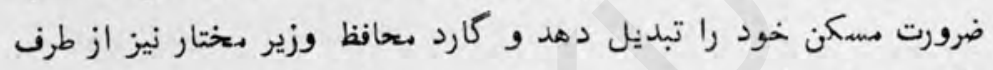

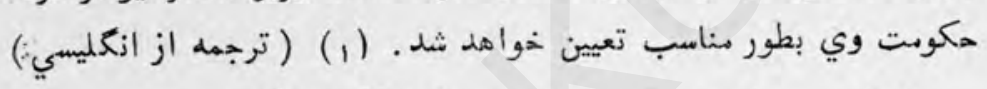

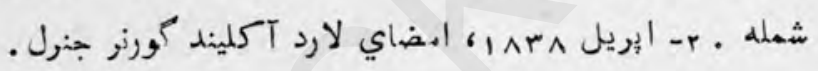

$(\wedge)$

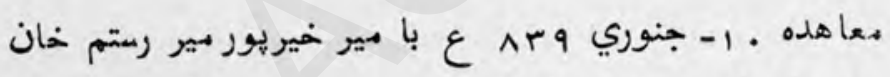

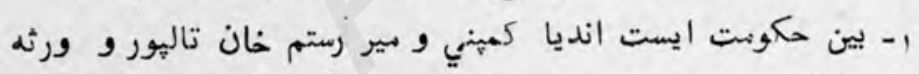

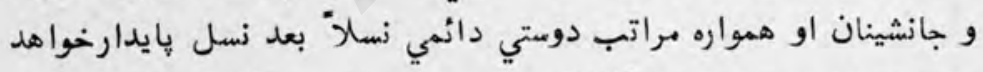

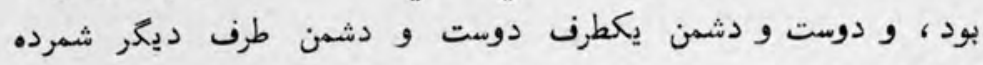

خواهد شد.

ז- هكومت انكليسى، دارالسلطنه و حدود خاكى خيريور را همواره

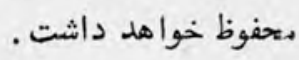

r- بير رستم خان و اخلاف و جانشينان. وي همواره ــطابق راي

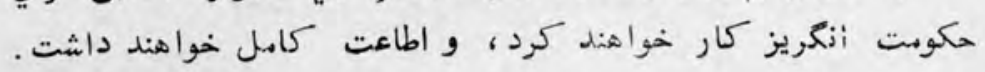

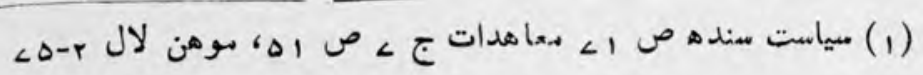


و بجز دولت انحريز با حكومت ديكر و يا مسردار, ديكري رابطه نخوا هند داشت

r- ايير هذكور و ورثه و جانشينان او، بذون منظوري و موانقت

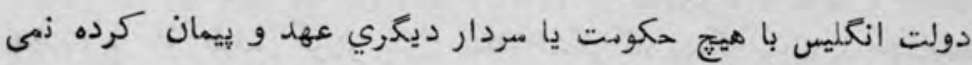

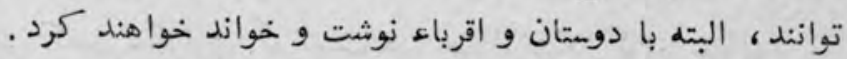
ه- مركار انكليس عندالضرورت به بير صاحب موصوف ابداد نظابي

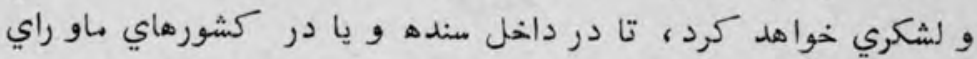

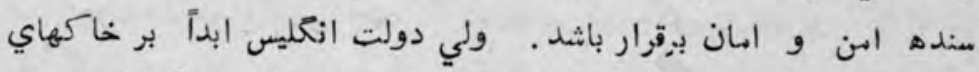
مقبوضله" ابير و جانشينان, او و نيز بر قلاع اين طرف و آنطرف درياي

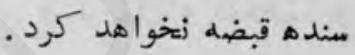

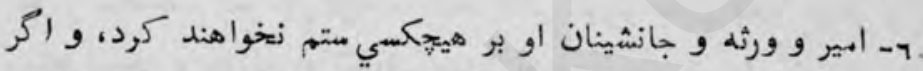

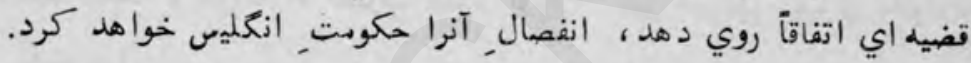

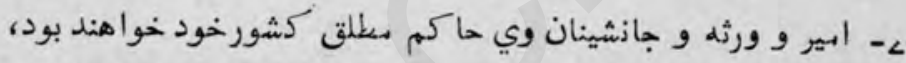

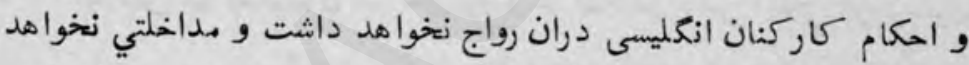

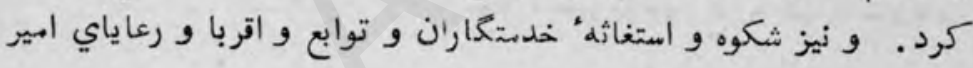
را به نسبت امير نتواه هند شنيد

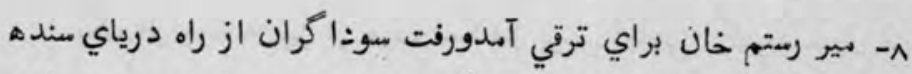

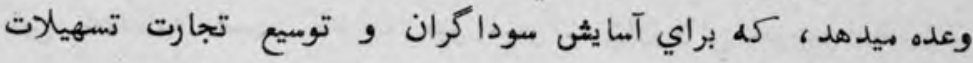

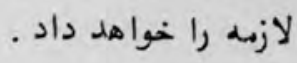

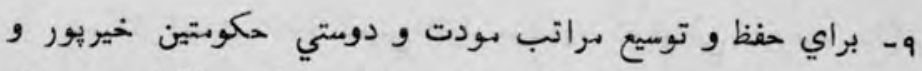

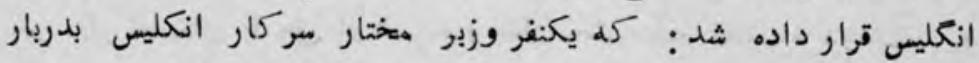

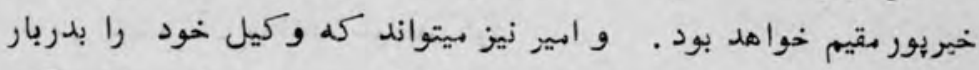

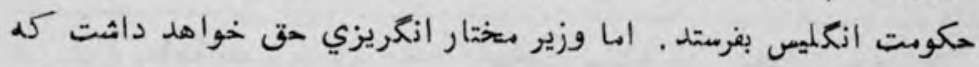

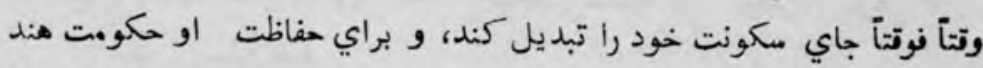


تعليقات

971

محافظاني را بتعداد مناسب، حسب مرضاي خود خواهد كماشت . اسضاي لفتتنت كرنل سر اسكندر برنس ايلجي جارج آكليندكورنرجنرل

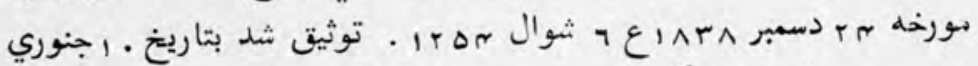

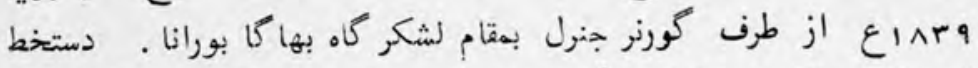

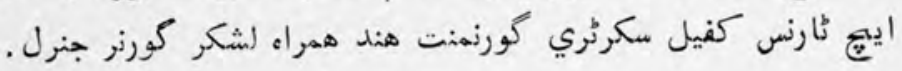

dono

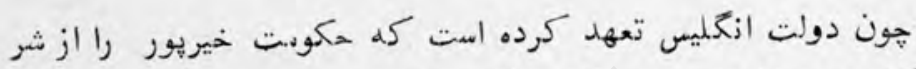

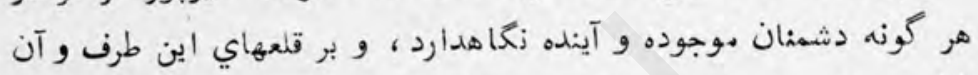

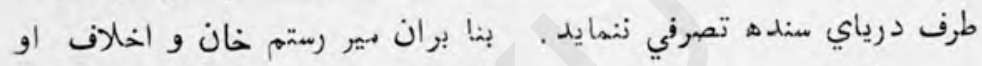

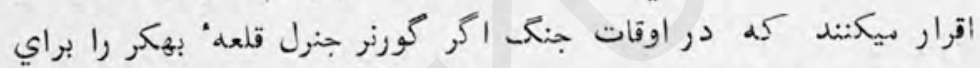

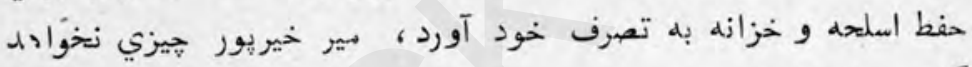

(1) .

تصديق دير رستمخان ابير خيريور و سر اسكندر برنس ايلجي كورنرجنرل

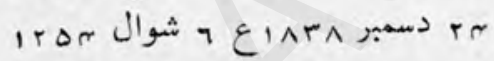

اقرار نابه

يكى اقرار نامه نيز از طرف اسكندر برنس ايلجى كورنر جنرل ضميهل

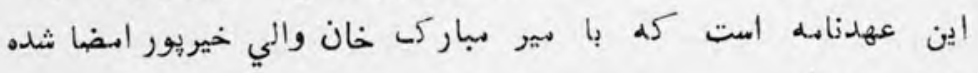

بدين مضمون : بن

سركار ايست انديا كميني اقرار ميهها يد كه اراضي مقبوضه" مالكغاري

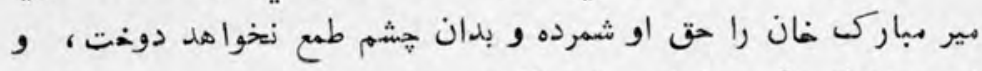

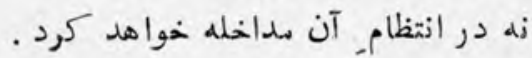

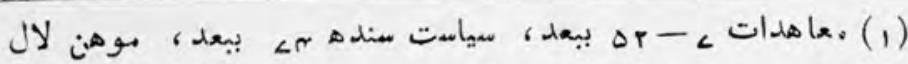

. 
و نيز اقرار مي شود كم سركار انكليس با مير مبارك خان و انخلاف

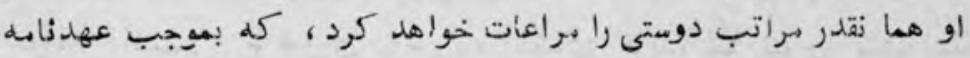

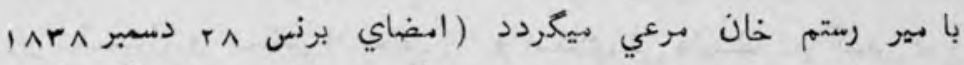

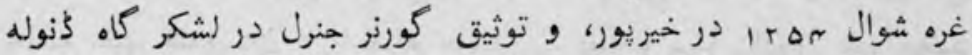

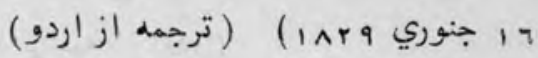

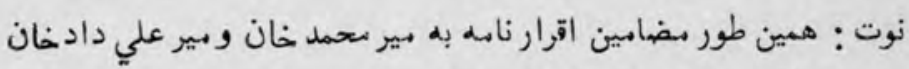

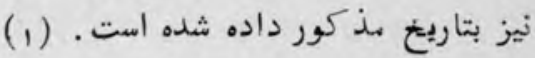

\section{(q)}

عهدنامهُ" تفويض كراهي به حكومت انكليسي

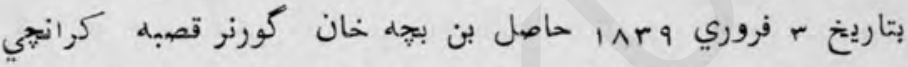

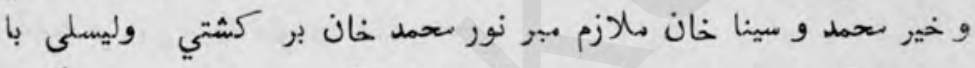

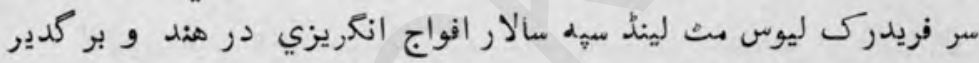

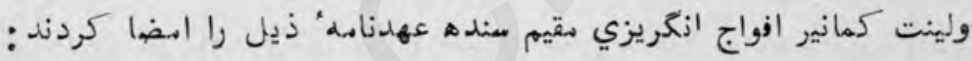

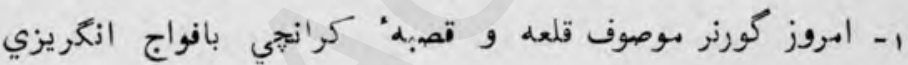
بي سمارد. r- امروز يا بعد ازين در موقعيكه هنظور باشد افواج انكريزيماتحت

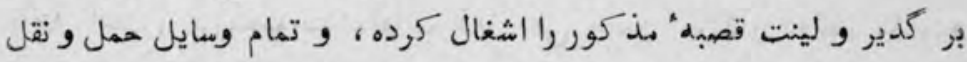

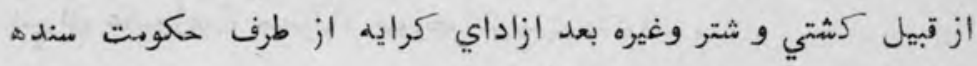

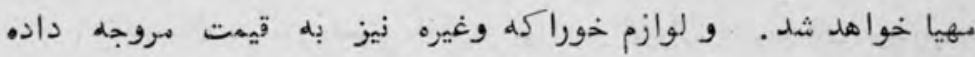

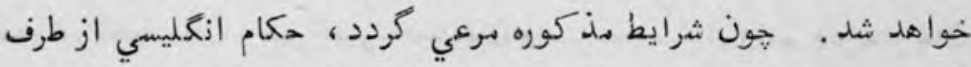

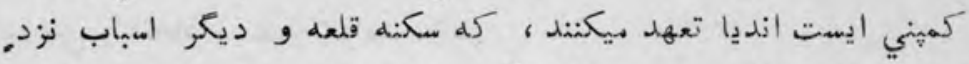

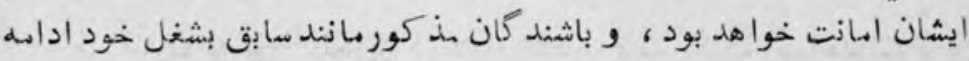


خواهند داد، و جهازهاي تجارتى ايشان به بندر مذكور رفت و آهد

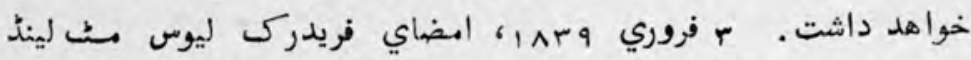

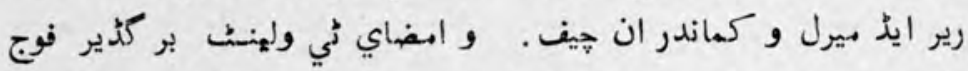

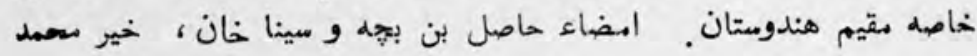

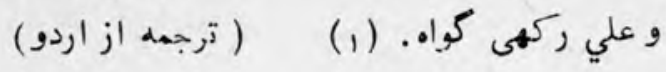

\section{(1.)}

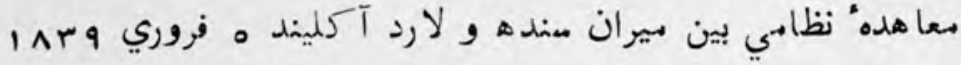

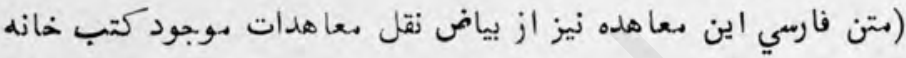

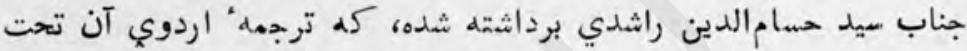

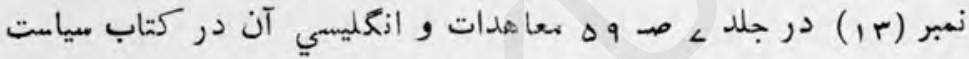

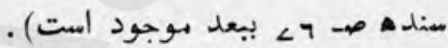

" هون قبل ازين هند مرتبه عهد ناسجات اخلاص و و يكانكت

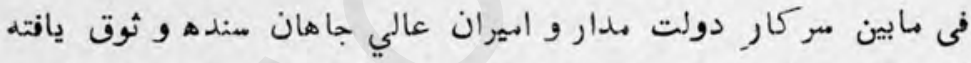

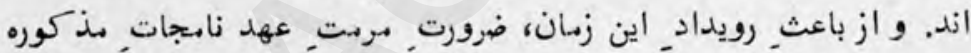

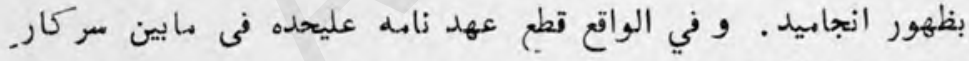

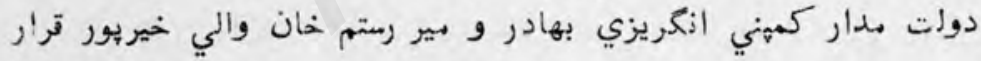

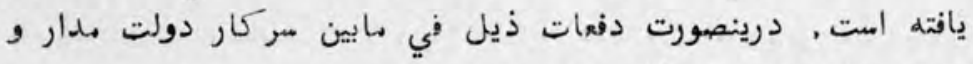

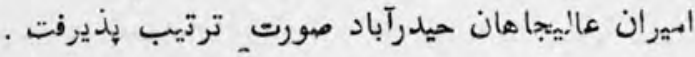

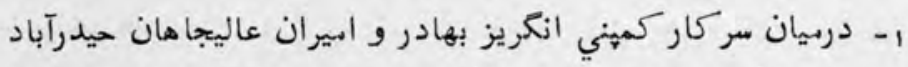

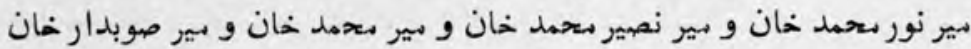

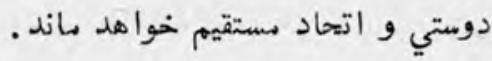
ז- قشون از فوج انكريز در ديار سنده قايم كرده خواهد شدد، و . 


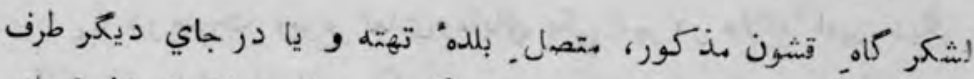

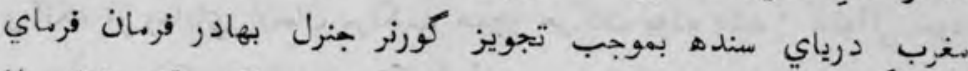

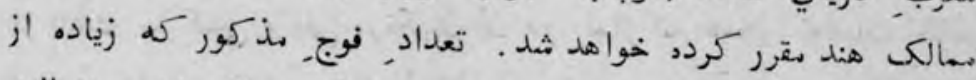

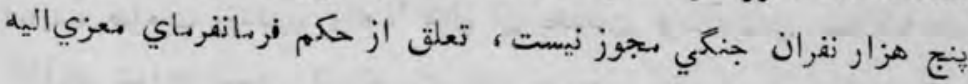
خواهدل بود.

r- عاليجاهان بير نور محمد خان و بير نصير سحمد خان و بيرمحمد خان

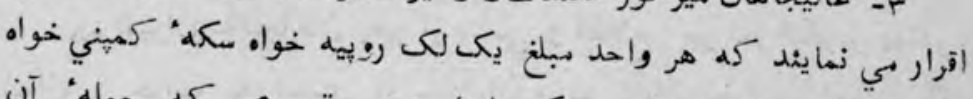

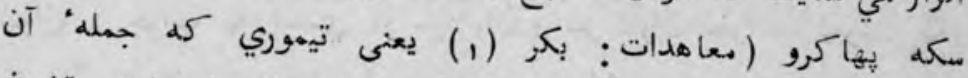

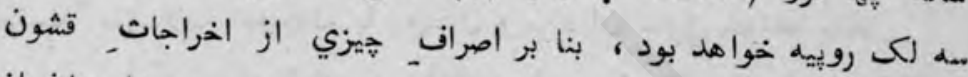

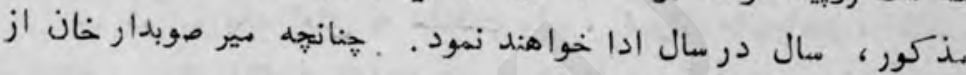

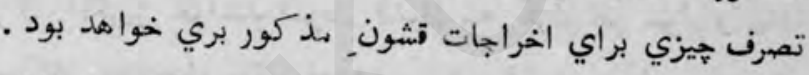

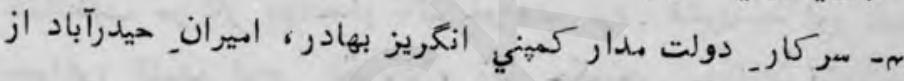

$$
\text { تعدي بيكازهله بر ذمدل خود خواهند دواشت }
$$

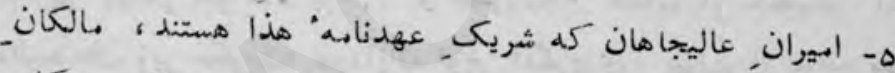

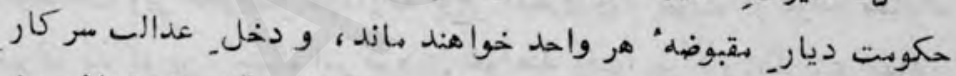

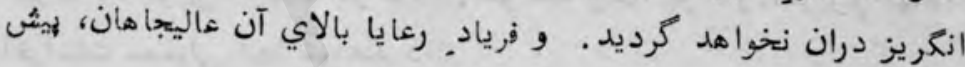

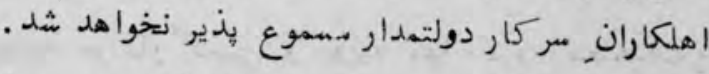

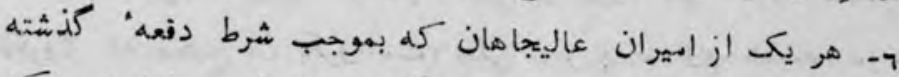

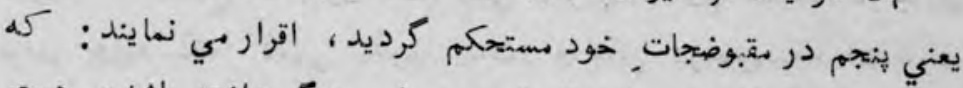

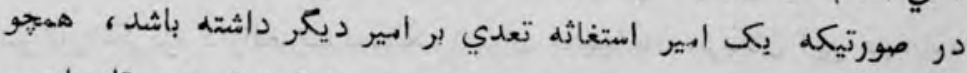

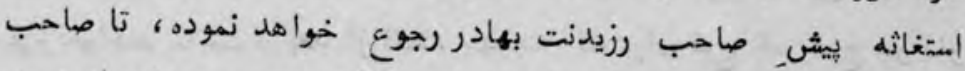
هعزي اليه در صورت, هنظوري فرهانفرماي دهالكى هند .... در فيصله هميجو

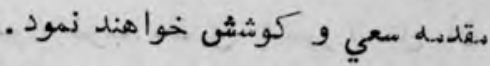

(1) اين كلمه در متن انكليسي موهن لال r-1 . Bakru است. 


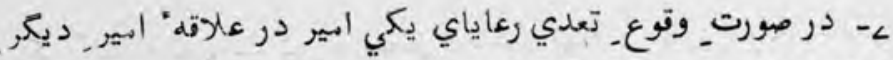

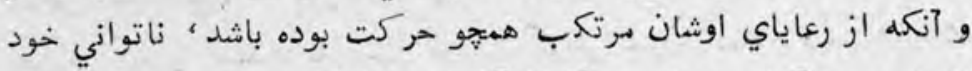

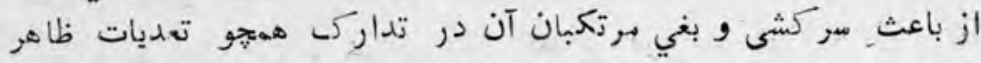

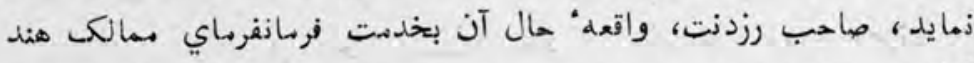

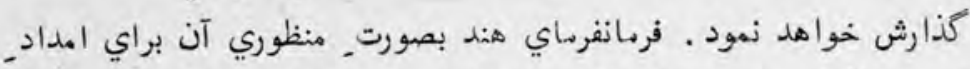

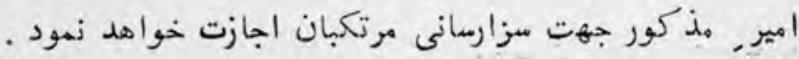

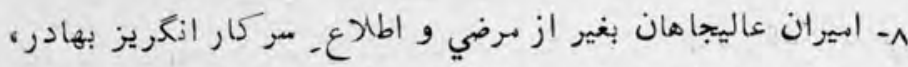

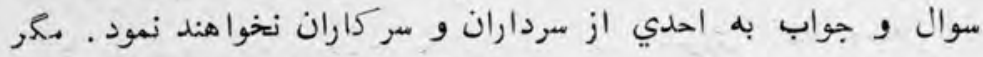

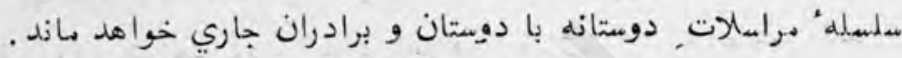

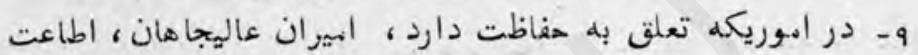

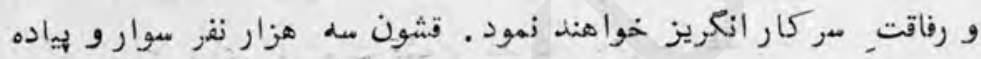

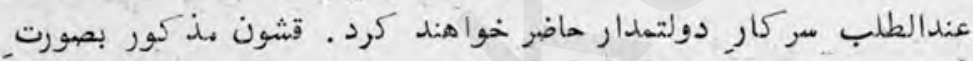

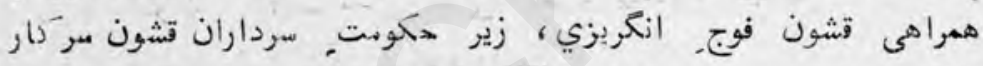

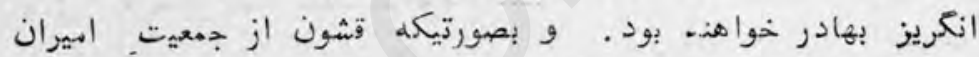

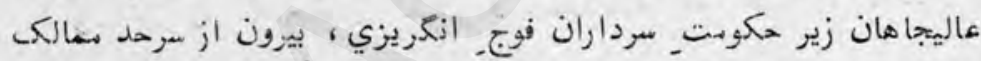

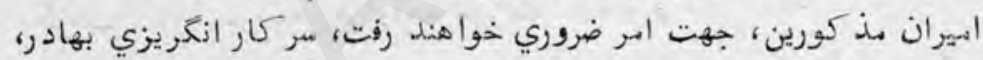

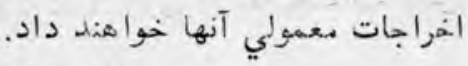
•

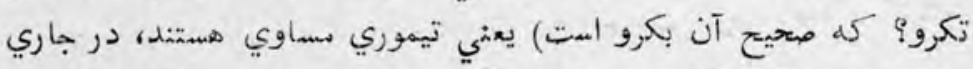

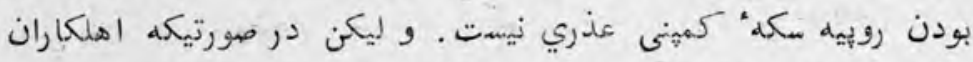
سر كار أنكريز، دارالضرب بمهالكى اميران عاليجاهان شان شريكان اين عهدناهـ

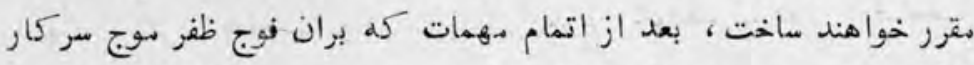

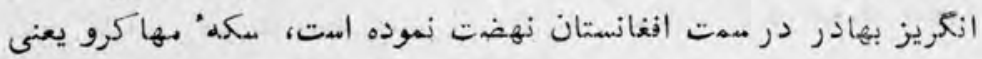

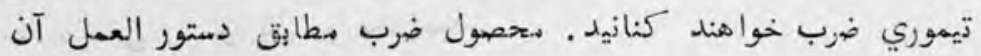

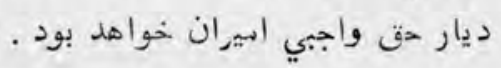


| 1- بر مركب كثتي تجإرت مرسله" ببالا يا ضائين درياي سندها،

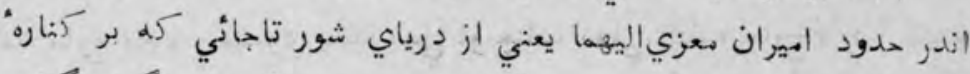

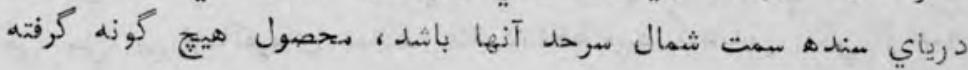
نخوا هد شد.

ז آ- اكر سوداكري هتماع تجارت خود را در اثناي راه از كشثتي

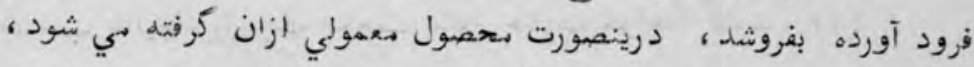

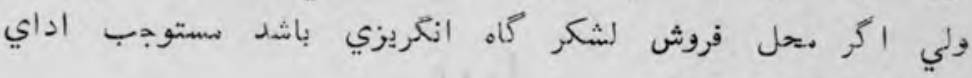
. (1) .

rا- تاجران وغيرهم هالهاي جميع القسام در موسم موافق ، بدهن درياي سنده دركهوره باري خواهند آورد، و اموال بر طبق هرضى مالكان انهان

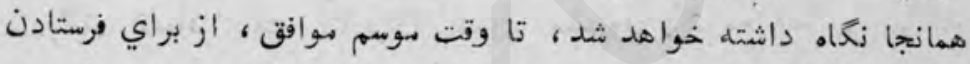

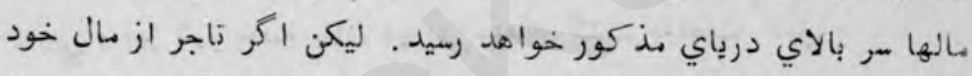

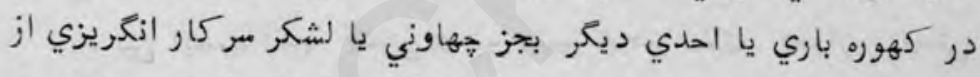

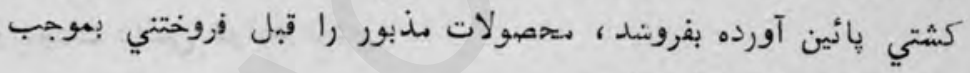

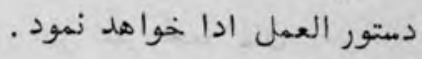

r ا- شرايط اين عهدناهله كله في مابين كورنر جنرل بهادر فروانفرهاي

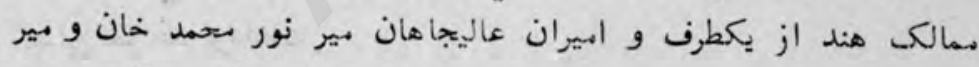
نصير سحمد خان و بير محمد خان و بير صوبدار خان از طرف ديكر، برهمه كورنر جنرالان فرهانفرهاي مهالكه هند آينده و بر وارثان اميران عاليجانهان وهان

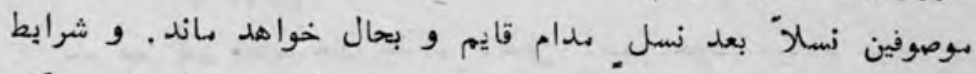

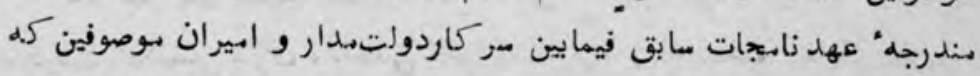

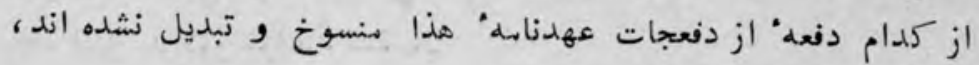
بهال و برقرار خوا هند ماند.

(1) اين ماده در اصل فارسي نيست از معالهدات اردو ترجهه شد. 


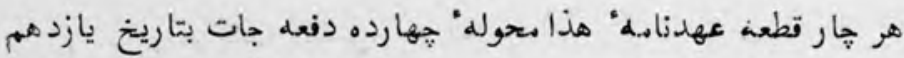

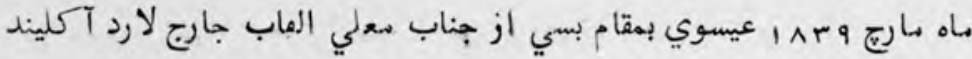

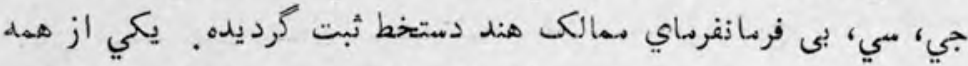

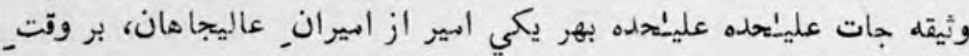

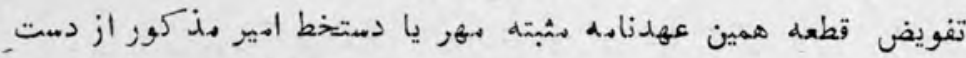

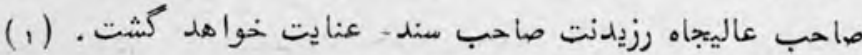

\section{$(1$,}

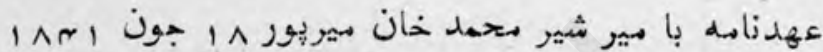

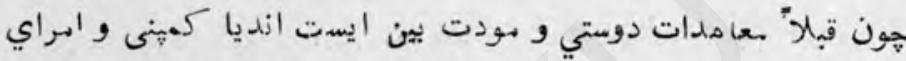

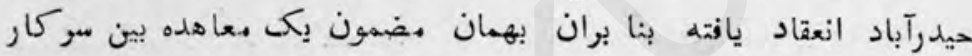

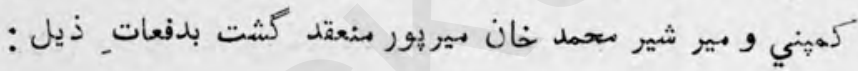

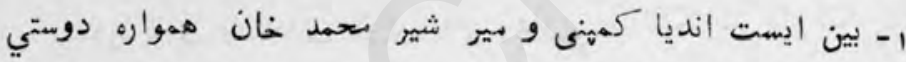
و مؤدت دائمى خواهد بود .

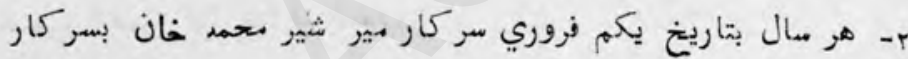

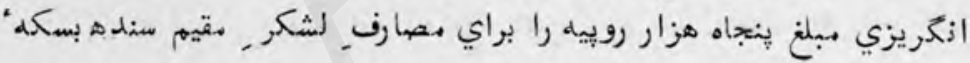

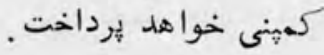

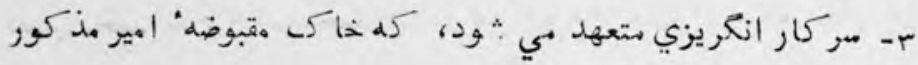

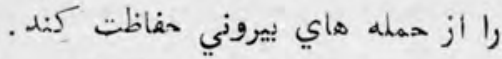

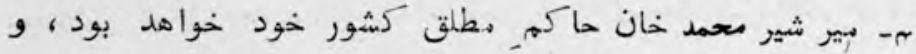

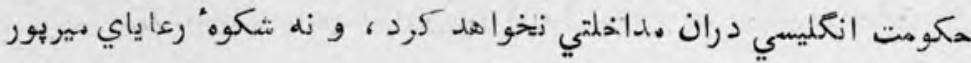
را از امير مذكور خواه هند شنفت فران.

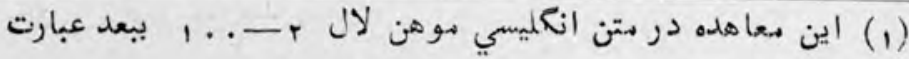

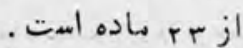


ه- مبطابق ماده: قبل امير موصوف مالرك مطلق كشور خويش است،

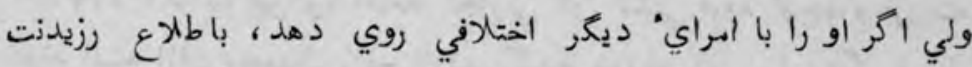
برطانوي هقيم سنده خوا هند رسانيد، تا موصوف بعد از منظوري فرمانفرساي

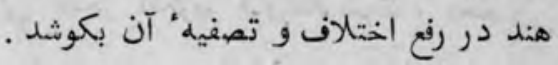

צ- هون مير شير محمد خان را با امراي حيدرآباد درباره: تقسيم اراضي

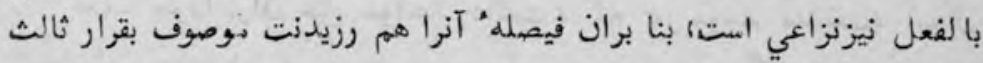

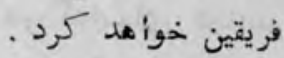
ـ- اكر يكي از رعاياي امراي منكور بر رعاياي امير مديمر ستهى.

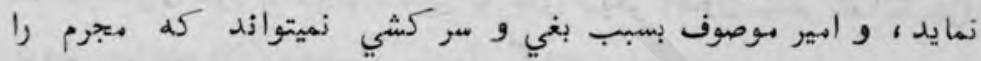

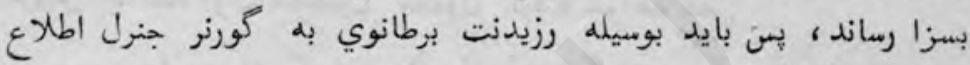

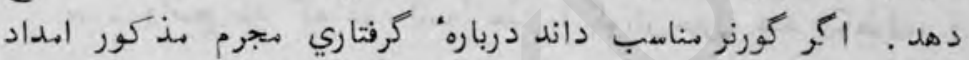
خوا

^- ابير موصوف بذون اطلالع و منظوري سركار انغريز، با هيج حكومت و يا سردار, ديخري داخل عهد و وبيمان يا نوشت و خواند

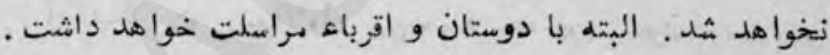
ه- ابير هذكور به مهشورت و صوابديد سر كار انخريز همواره به الهور

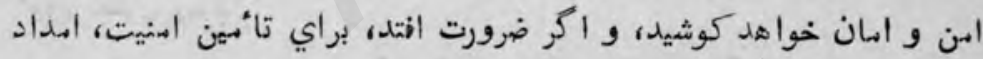
لشكري هم باو داده مي شود ، ولي اين لشكر تحت امر مر كمانير (افسر)

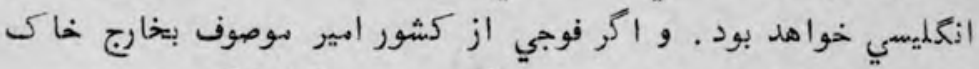

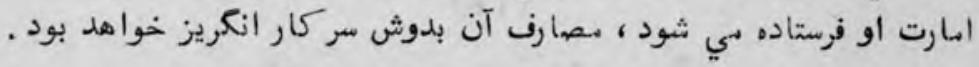
•

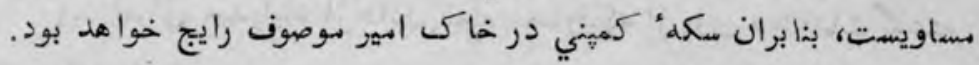
1 1 - از كشتي هائيكله از طرف بحر و جانب, شمال درياي سنده

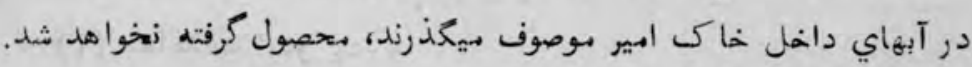


rا

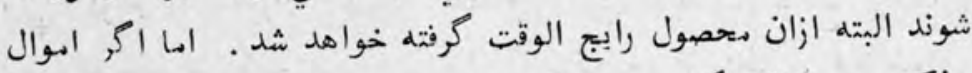

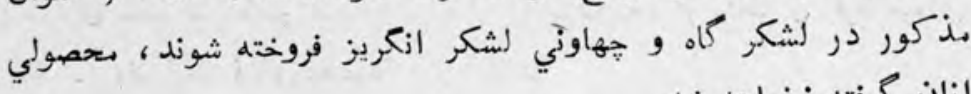

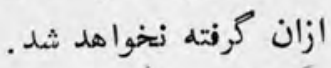

rا- سوداكران حق خواهند داشت ، كله در بوسمم مناسب، الهوال

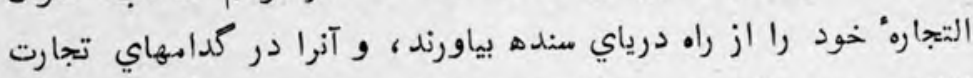
خانهاي خود براي موسم ديكر فروش زماه دارند. ولى اكر اكر سوداكران مذكور اموال خود را دركوره باري يا جاي ديمر (بدون لشكر كاه انكريز)

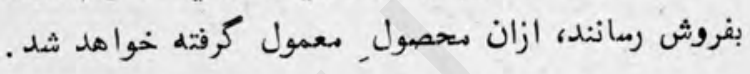

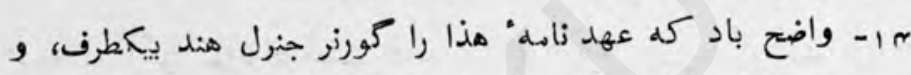

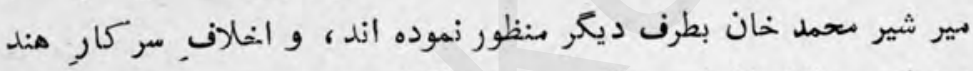

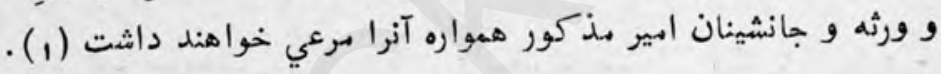
(ترجمه از ارد ا (

اسضا" : آكلينل

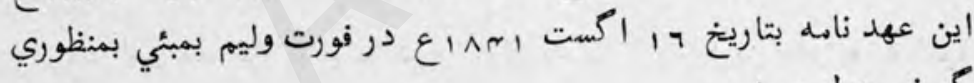
كورنر جنرل رسيد.

لُي، ايتج ميدُكس سمرئري كورنمنظ هند

\section{$(1$,}

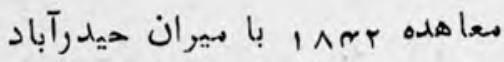

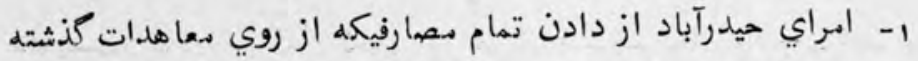

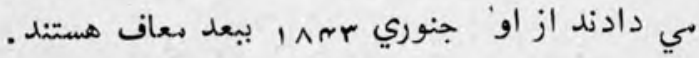


r- بعد از اول جنوري هrی ا در تهامباد امراي حيدرآباد صرف مكله كثبني رايج خواهد بود بون r- مسمكو كاتيه حكومت انعلميسي وقتاً فوقتأ براي امراي حيدرآباد

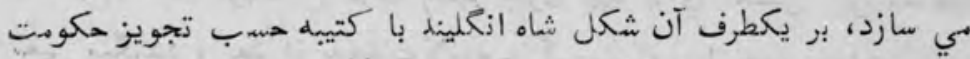

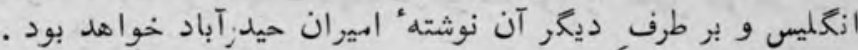
م مسـكو كاتيه براي امراي من كور ساخته بي شوند د روزن و عيار ميهم،

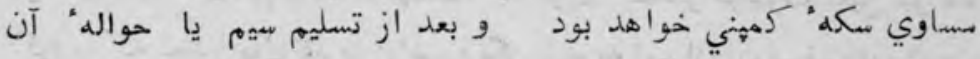

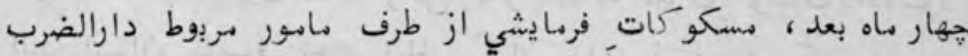

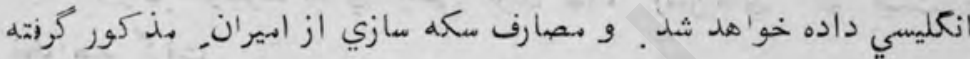

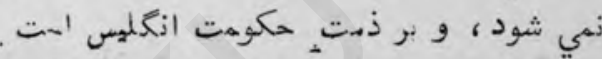
ه- هبطابق اين عباهده اميران حيدرآباد بعد ازين حق ضرب

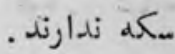

r- براي رفع احتياج كشتي هاي دودي از كناوهاي درياي مندهـ

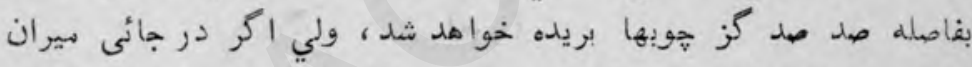

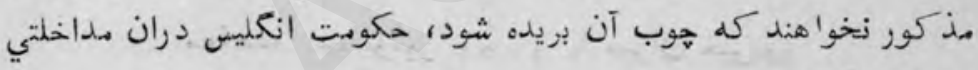

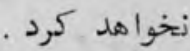

>- با شرائطيكه سر هارلس نيهر ضروري بداند، كرائي و تهته

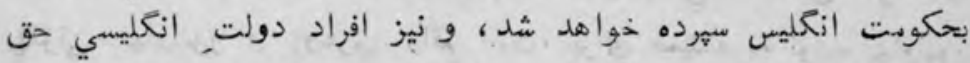

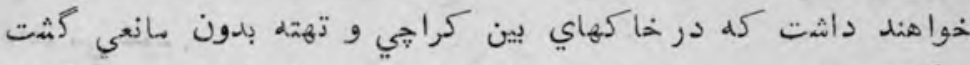

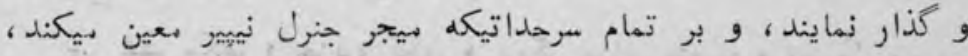

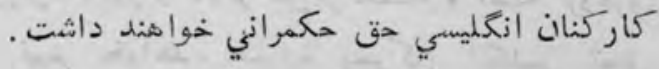
^- اراضي سبزل كوت و از سرهدات سوجوده" :هاولهور تا روهري

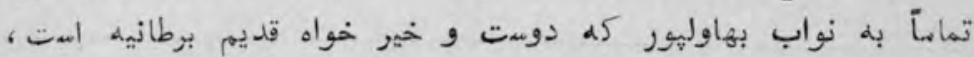
. . 


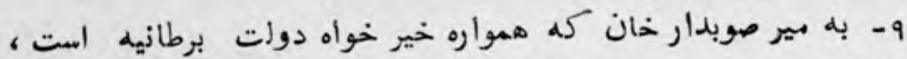

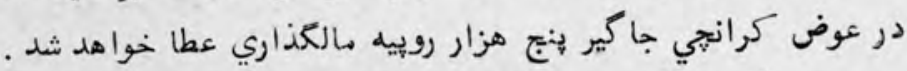
•

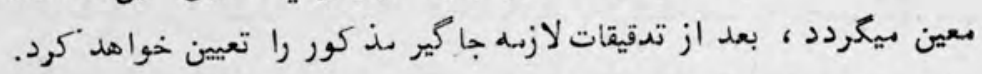
11 بوده و ماليه' آن هم يكسان ذيست، بنا بران كمشنر موصوف تعين خوا هد إند

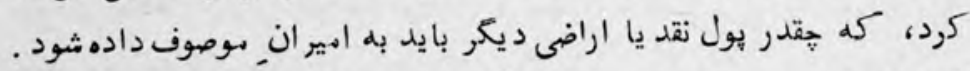

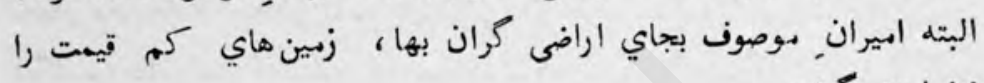
نخواهند كرفت الهين.

r ا- اكر ماليه" زمين با قيمت آن مناسبتى نداشته باثد ، دولت انمليس. آنرا نيز تصفه كرده و صرف به نفع خود كوشش نخواهد كرد. . شهله

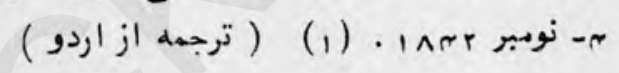

\section{$(, r)$}

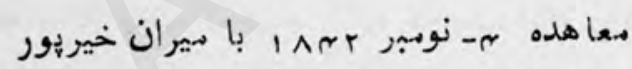

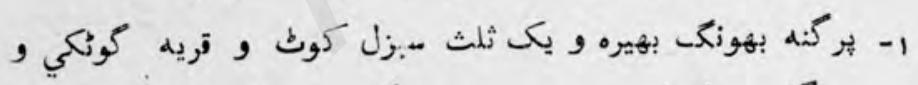
هلادر و هونكا و دادوله و عزيزيور و ديكر اراضي كله بين مرحدات كنونى بهاولهور و روهرثي واقع است، براي هميثشه به نواب بهاولهور داده مي شود .

r- شهر سكهر و جزيره' بكهر و ديكر جزاير ستصله و تصبه " روهري

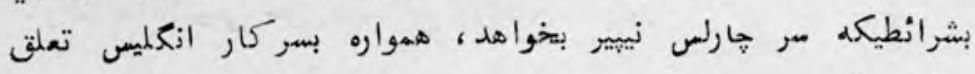
خواهد داشت. 
r- كمشتريكه ازطرف ميجر جنرال مر هاركس نيبير براي تعهيل اين مجأهده و ديكر معا هداتيكه با اميران حيدرآباد شده مقرر بي شودد، ماليات زايده را بهوجب همان معا هده تنقيص كرده و يا در دمقابل آن اراضى ديكر

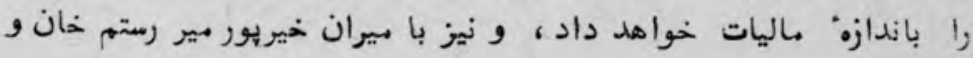

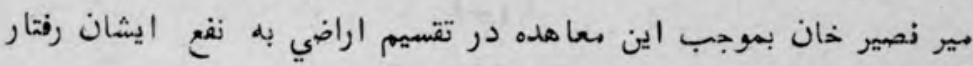

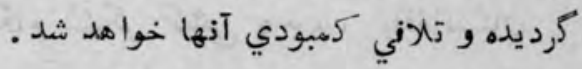

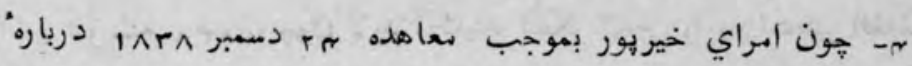
آهايش سوداكران و جريان كشتي هاني تجارتي از راه دورياي سنده تهو توميع

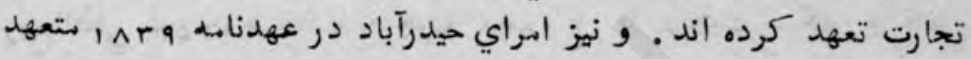

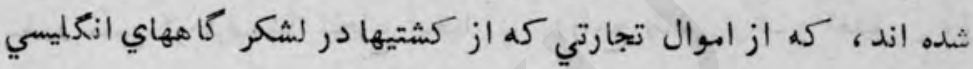
فرود آورده مي شوند دهصول كمركي نميكيرند . بنا بران امراي خيريور

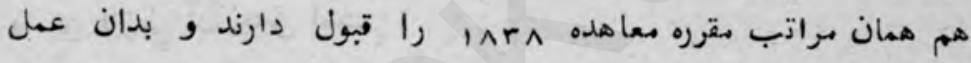

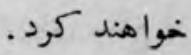

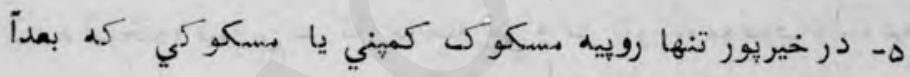

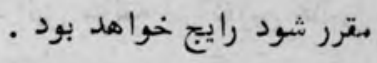

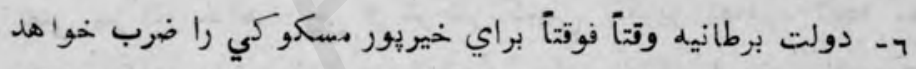

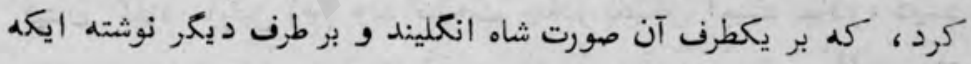

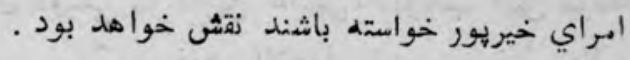

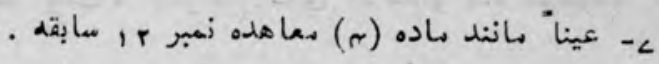

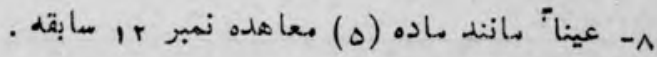

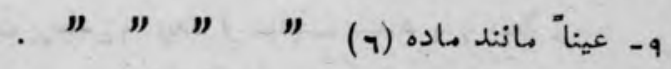

• 1- دولت انعليس تمام آن دعاوي را صرف نظر مينهايد، كم بابت باقيات نذرانه و خراج سالانه' شاه شجاع فقيد بالاي بير مباركى خلان 
متوفي و فرزندث بير نصير خان و ديخر اخلاف بير بباركى خان مرحوم

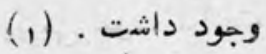

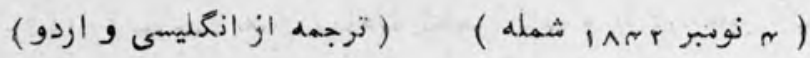

\section{$(1$,}

اسناد سياسي سنده هiكام لشكر كشي و در سنه ^זی ا هون لارد آكليند لشكر اندس را به تستخير انغانستان

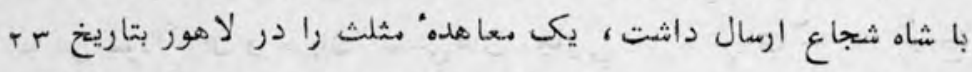

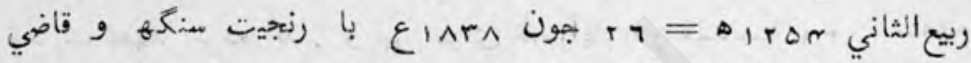

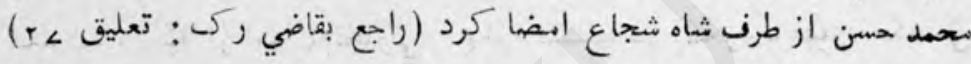

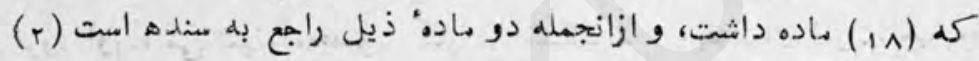
و هتن فارسي آن هنين المت

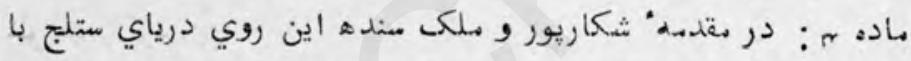

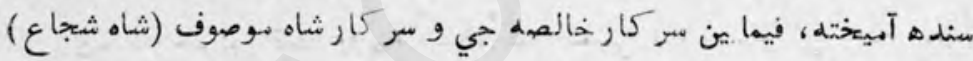
مطابق رويه" بجيه دوستي و يكرنكي قديهه، و آنين موثقه سر كارين عالبين

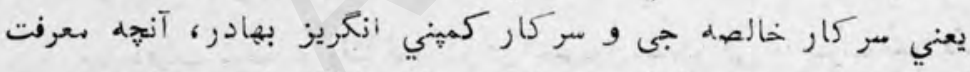

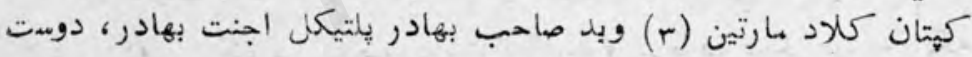

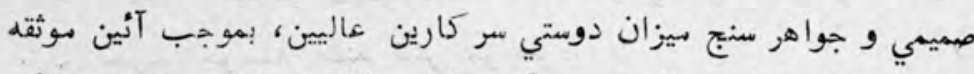

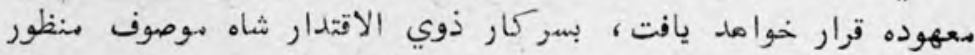

$$
\begin{aligned}
& \text {. }
\end{aligned}
$$

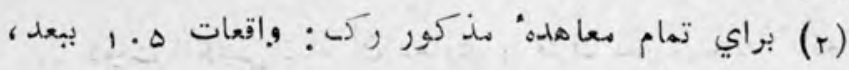

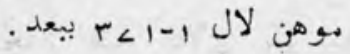

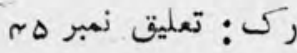




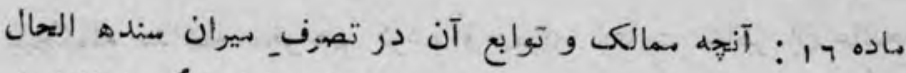

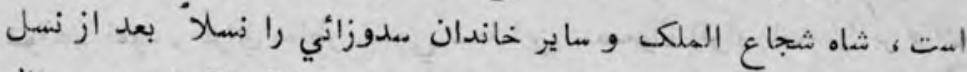

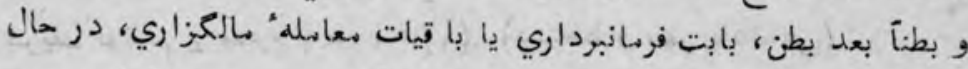

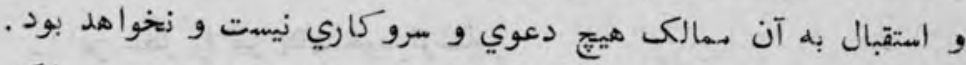

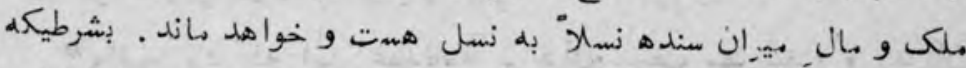

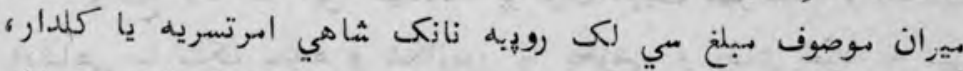

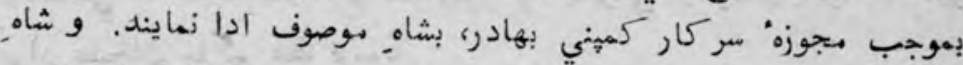

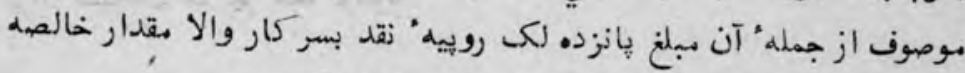

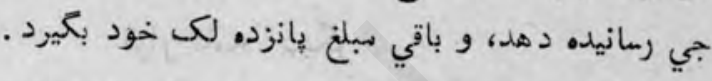

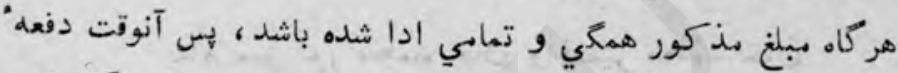

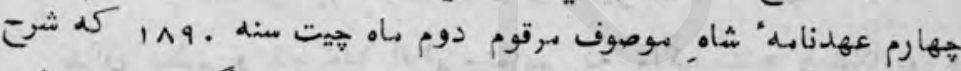

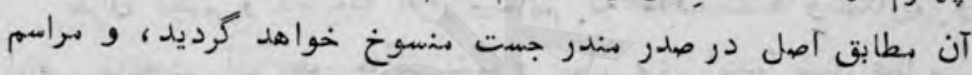

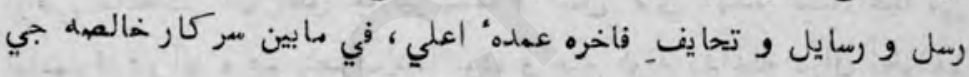

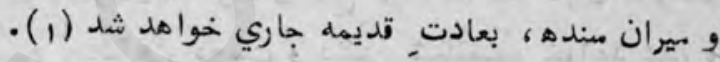

\section{دو اقرار نامه}

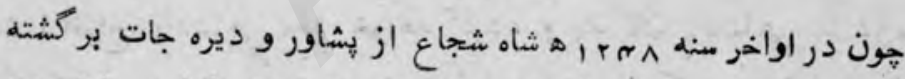

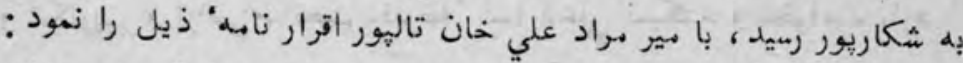

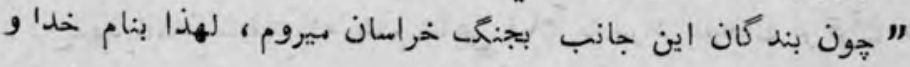

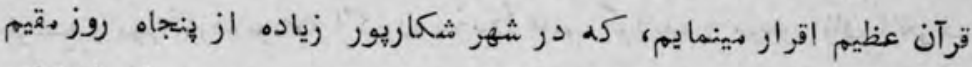

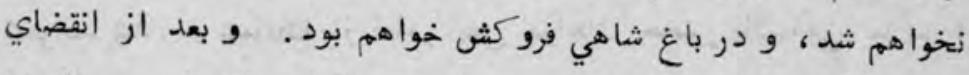

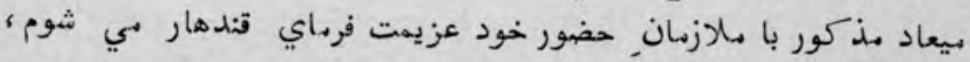

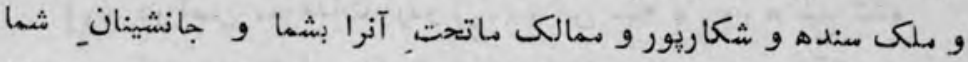
ديكذارم، تا در قبضه' تان بوده و جايذاد شها باشد، و و دران 


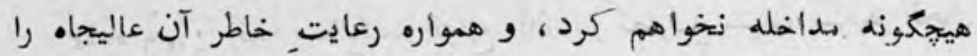
خواهم نهود . براي خاطر جهعي شما اين مضمون اقرار نامه را بر قرآن

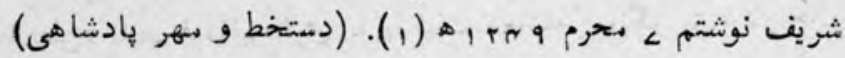
اين سطر را نيز بقلم خود نوشته : "واضح باد كم اين عهدناهله بر قرآن شريف مهر شد ، و بندكان

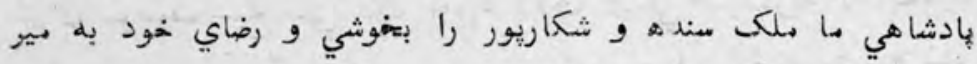
مراد عليخان جاكير عطا فرمود .

\section{اقرار نامه" ديكر}

بنام مير نور هيخهل خان و نصير متحد خان

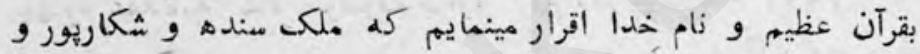

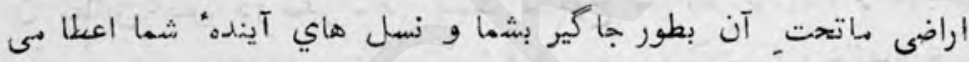

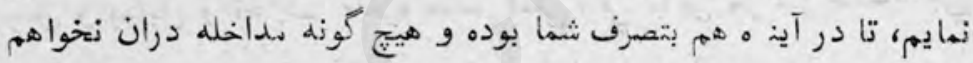

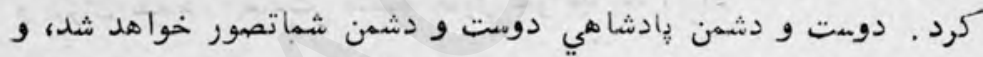

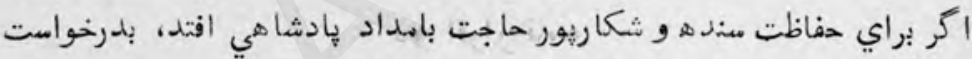

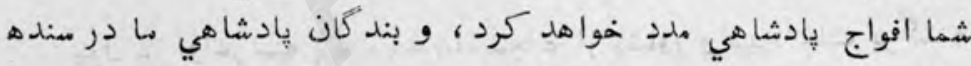
و شكاريور و اراضي ماتحت مقبوضه" شها دخلي نهيكنند و نخوا هند كرد.

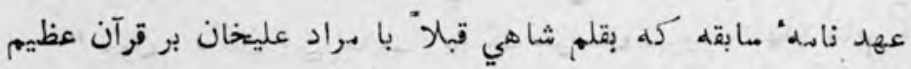

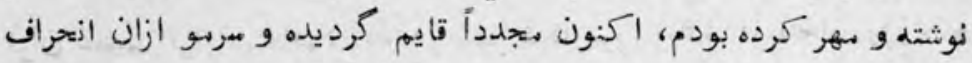

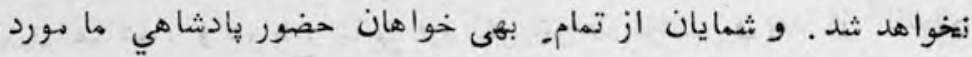

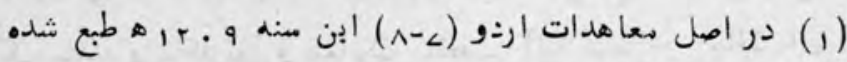

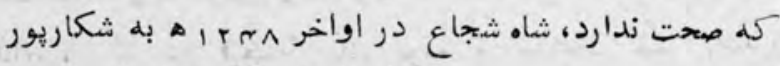

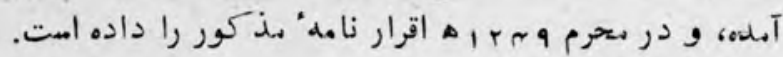




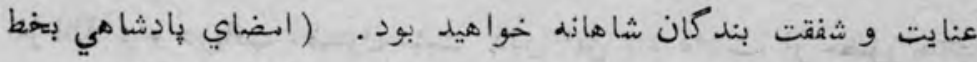

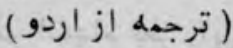

( $)(\dot{\tau})$

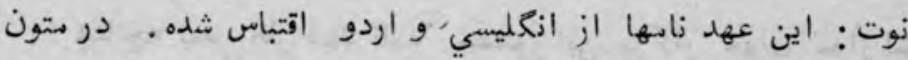

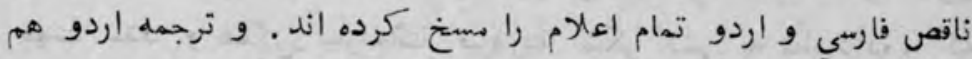

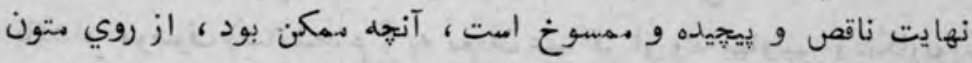
انكليسي اصلاح شد. باز هم اكر نقصي ديده شود، تهناست شماف فرمايند.

زقل ياد داشت مرسلهُ كرنل هنرى هايدّنجر ماحب

اين يأد داشت از طرف رزيدنت سنده كرنل هنري هائنجر بعد از

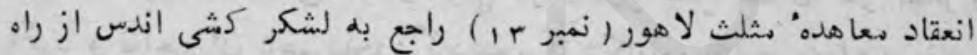

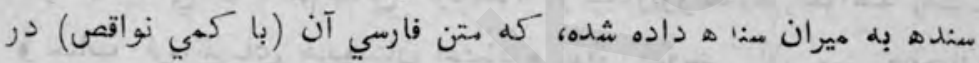

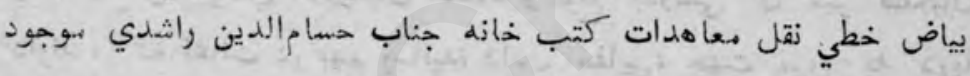

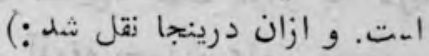

"ياد داشت علي-أحده كه مخلص در باب, مرضى شريف و اداره" جناب

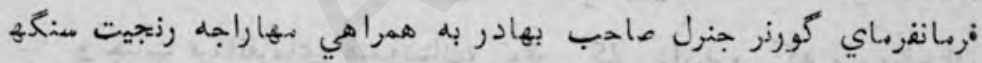

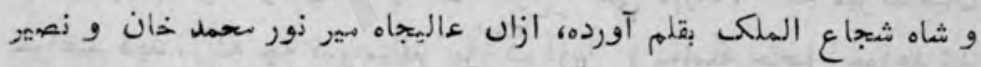

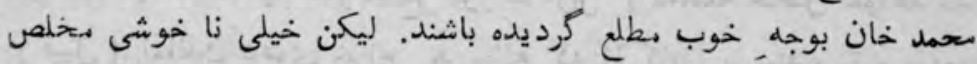

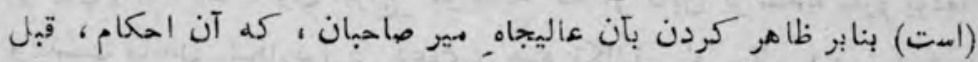

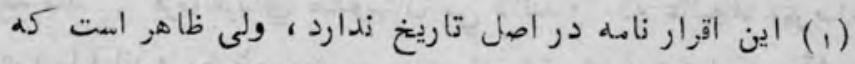

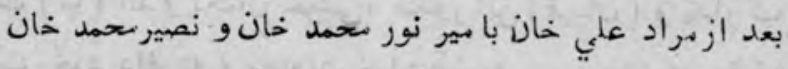

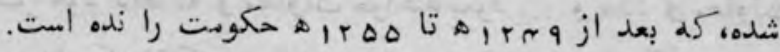

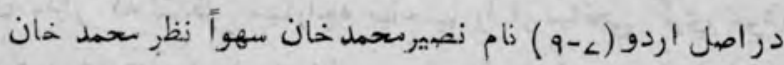


از اطلاع و دريافت مضمون شثبت ذيل اين ياد داشت، از حضور جناب هeظم الدهام بعز ايراد آورده بود ........

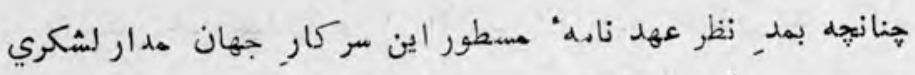

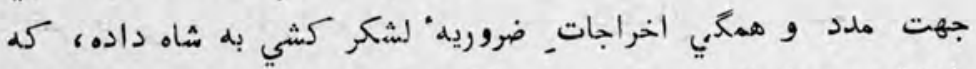

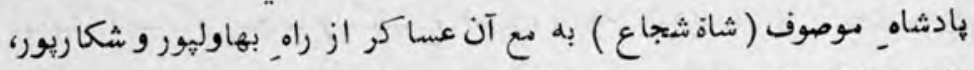

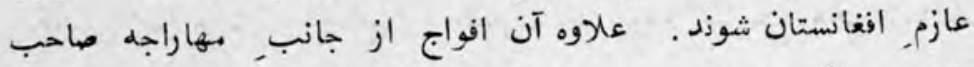

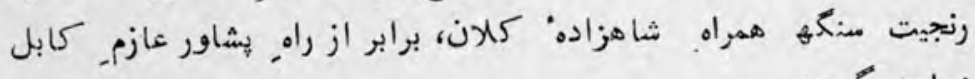
خواهد كرديد

افواتج, شاهى و عسا كر, اين سركار, جهان مدار، از راه سنده عازم

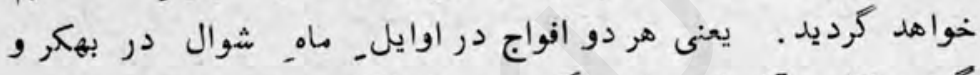

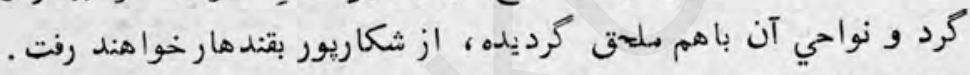

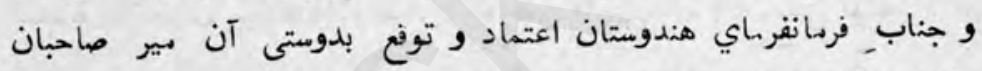

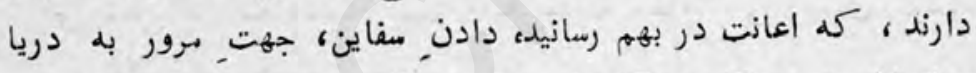
و شتران وغيره بركوب (كرده)، و قيهت, آذوقه بحسابـ واجبي بموجب.

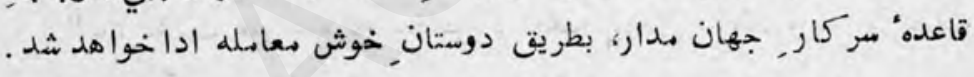
و جناب فرمانفرماي هندوستان، توقع. كلي دارند، كاند كه بير صاحبان

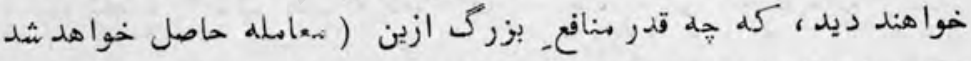

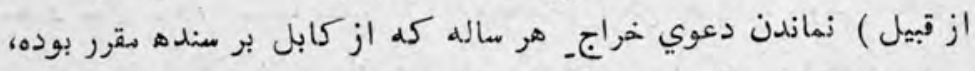

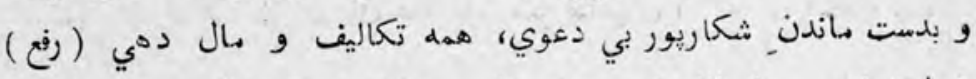

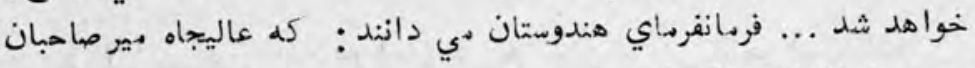

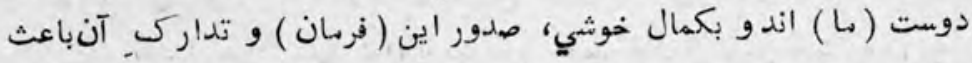

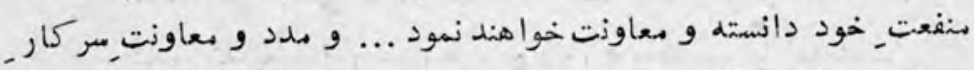

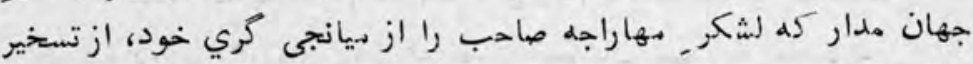

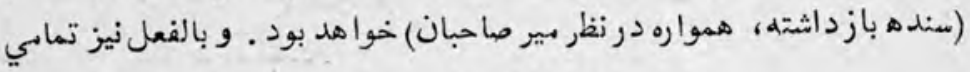




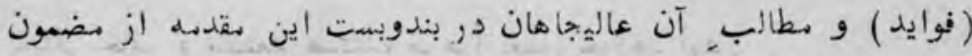

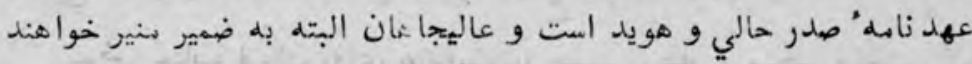

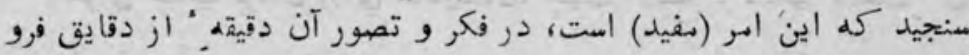

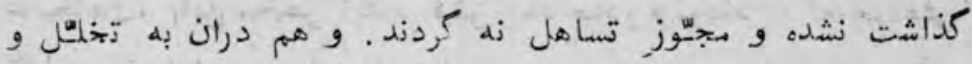

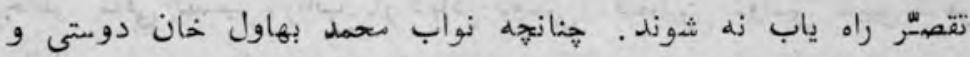

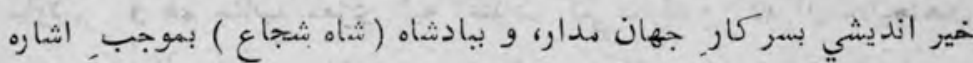

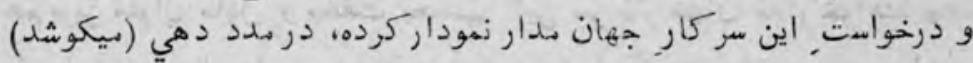

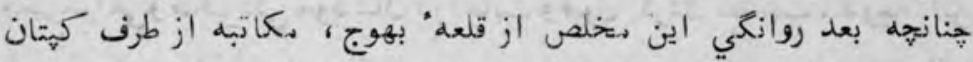

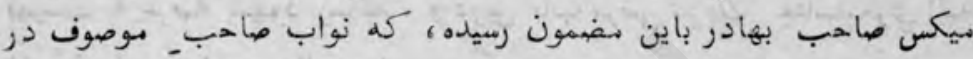

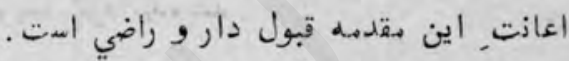

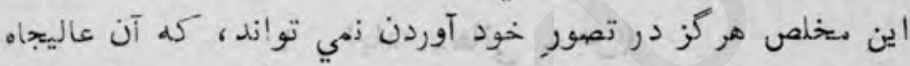

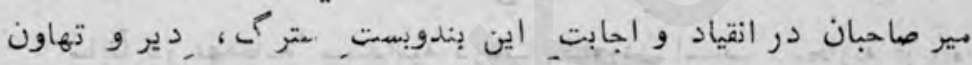

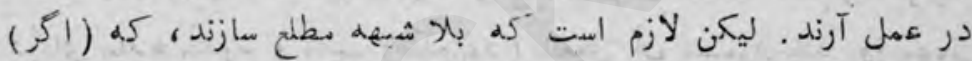

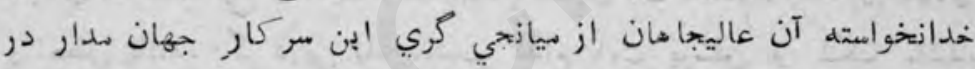

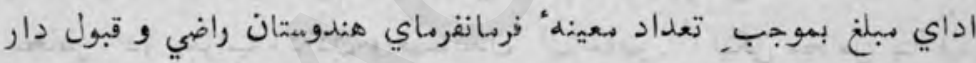

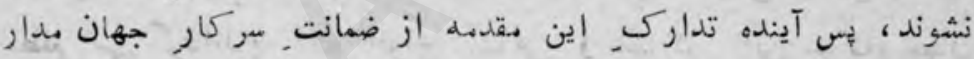
بعيد بايد تصوريد.

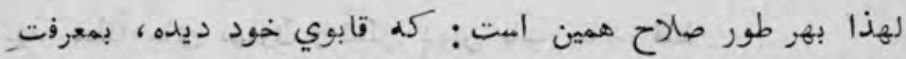

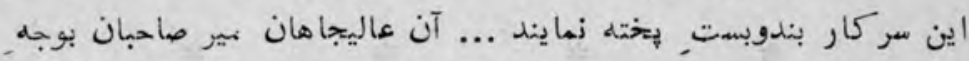

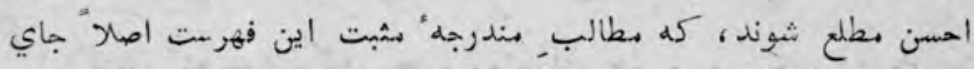

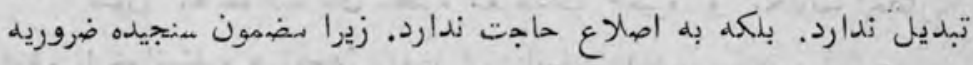

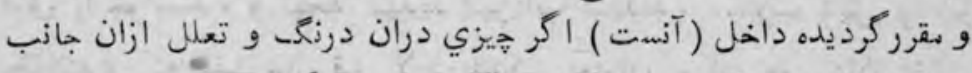

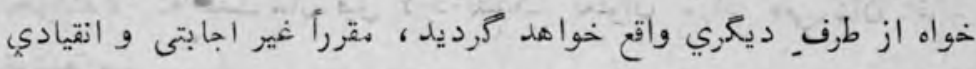

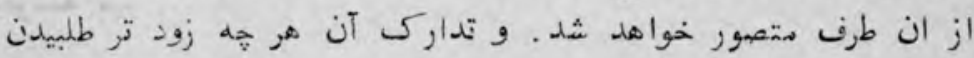

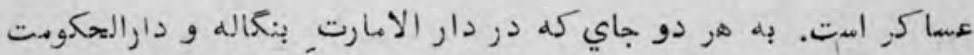


بمبائي حاضر و مستعل هستيند، ظاهراً بعمل خواهد آهد.

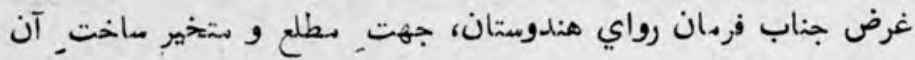

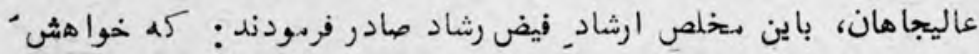

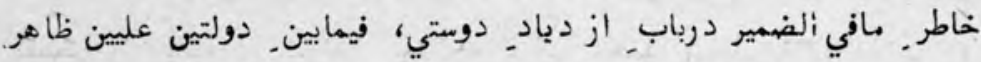

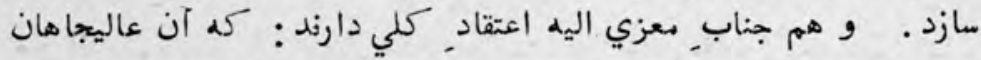

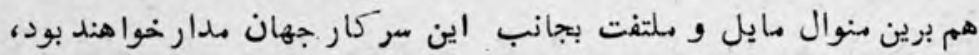

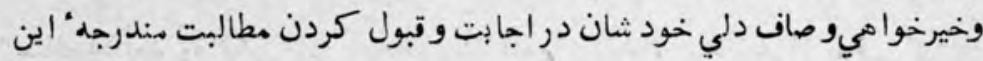

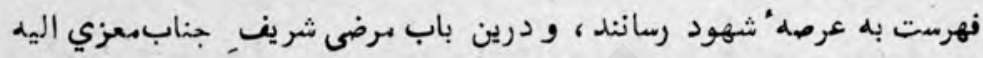

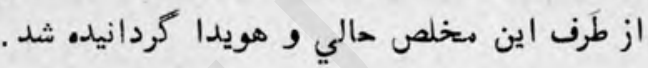

\section{(ياد دهاني خاص)}

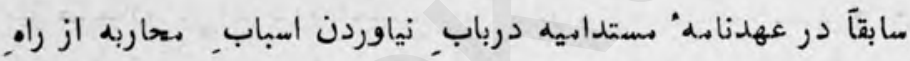

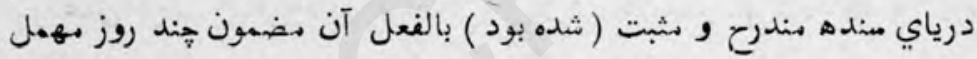

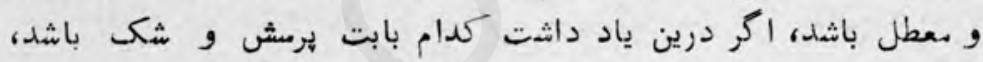

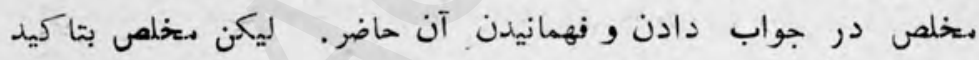

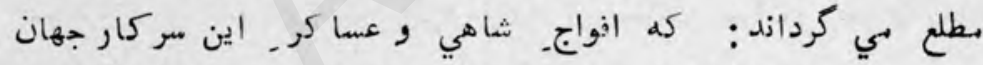

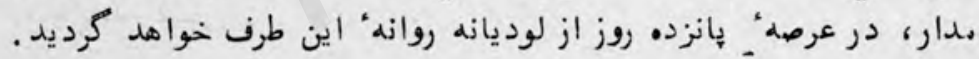

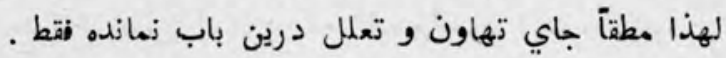
* * * * * *

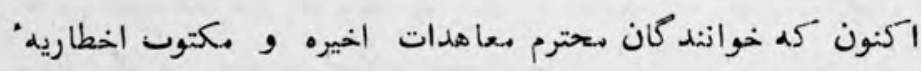

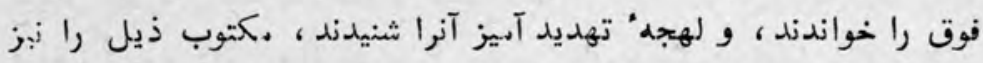

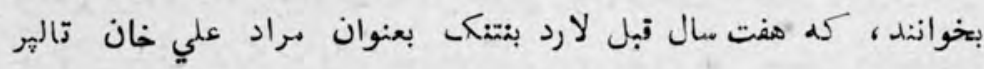

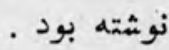




\section{نامه لارد بتتنك بله بير مراد علي خان}

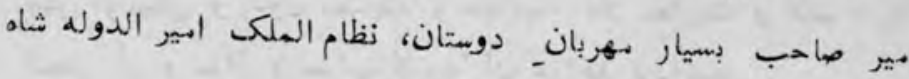

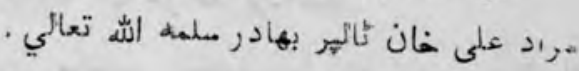

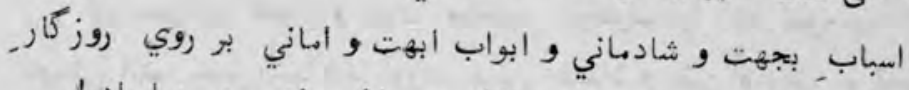

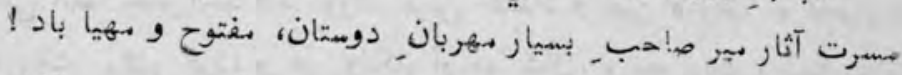
بعد مرفوع راي دحجت بيراي كردانيده مي آيد : درين ولاشجاءت

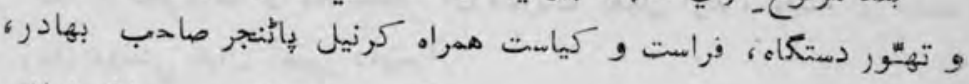

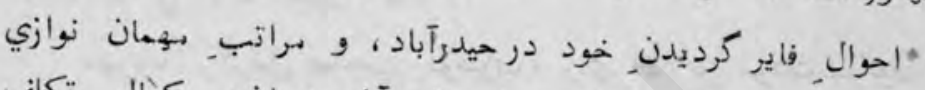

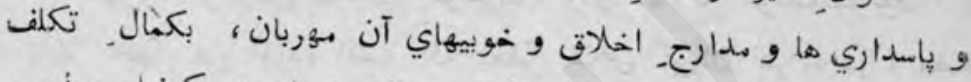

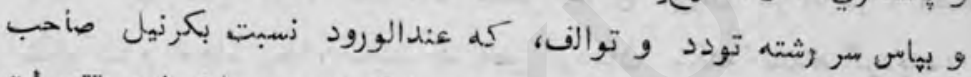
موصوف مرعي و مسبلوكى داشته بودند، با كوايف و ملفخصات تقريرات

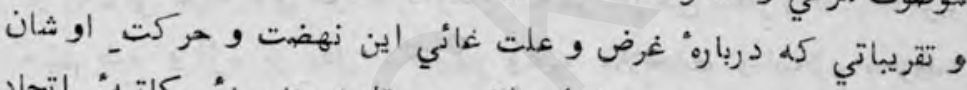

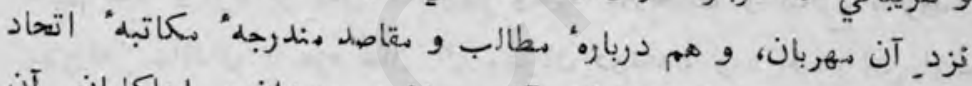

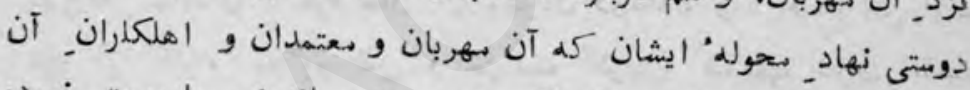

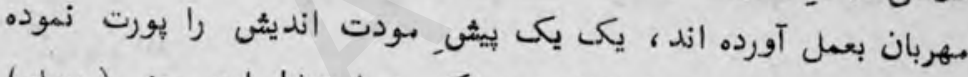

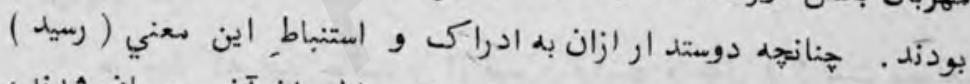

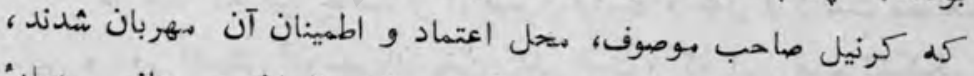

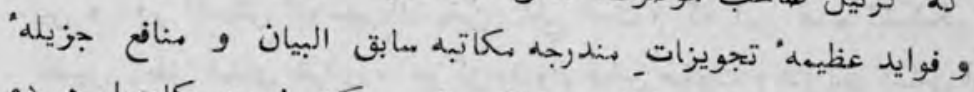

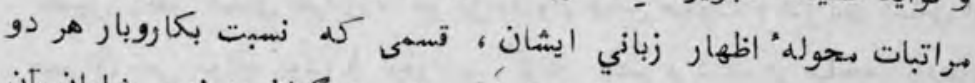

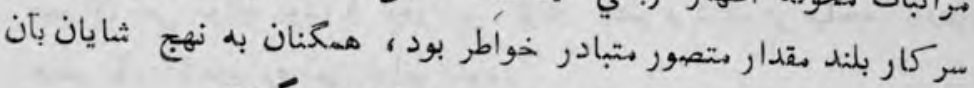

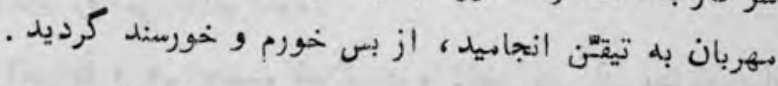
و نيز هرضى و مقصود آن نهربان به نهجيكم اندرين خصوص بوده است

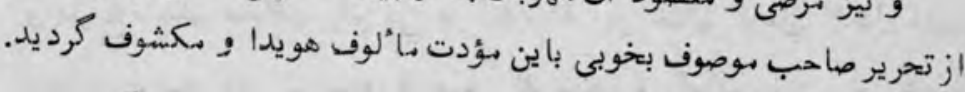

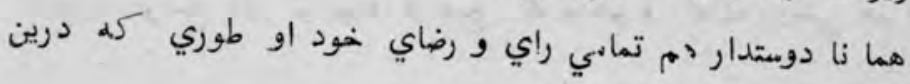


ماده منظور و محظور كرديده، مشرح و مفصل، بكرنيل صاحب معزياليه،

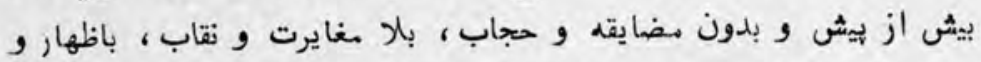

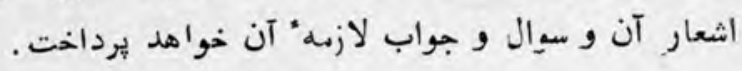

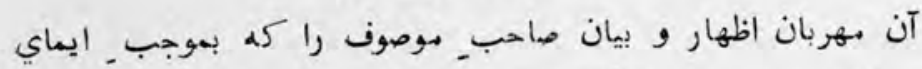

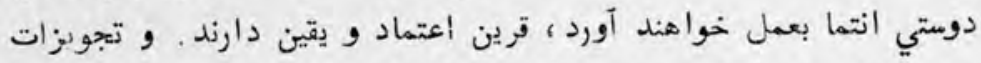

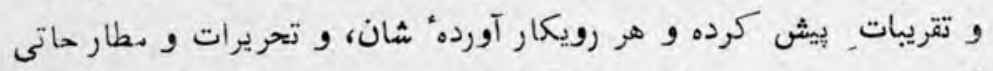

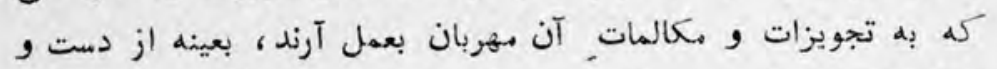
زبان دوستي بنيان نصور دارند.

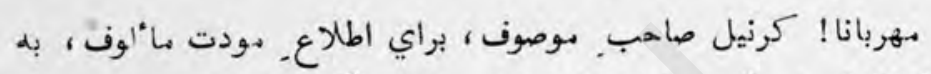

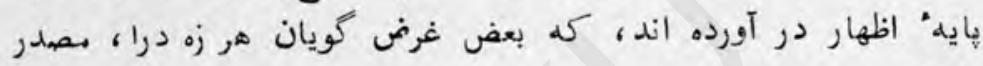

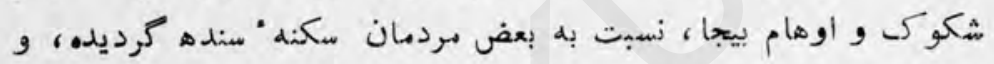
بر زبان بي صرفه كوي خود ها دارند : كله سركار حق شعار (!! (!) انكويزي

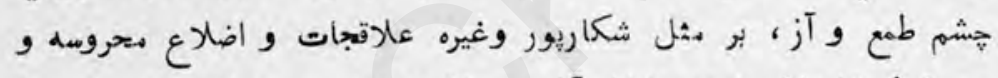

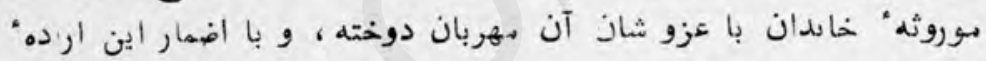

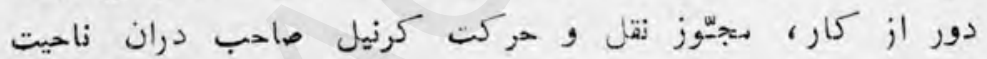
كرد يده ازد .

هر هند كله اين جانب را از فهم و فراست و عقل وكياست مصلحت

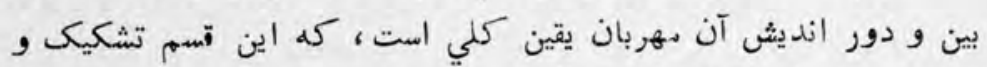

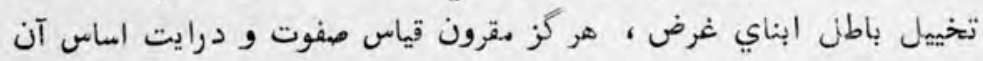

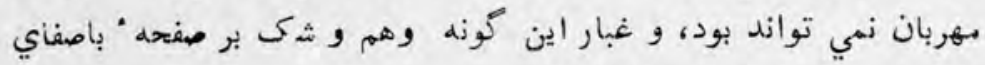

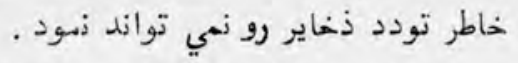

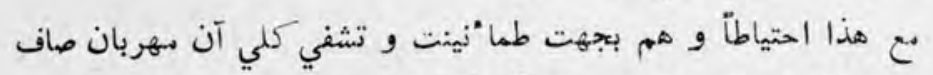

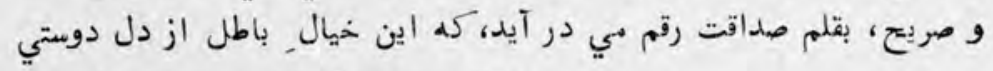
هنزل، بغراستخ دور تر بوده، و ميز كاه بوهم و كمان دوستي هم نرسيده. 


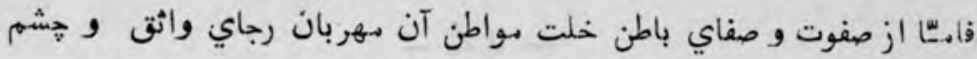

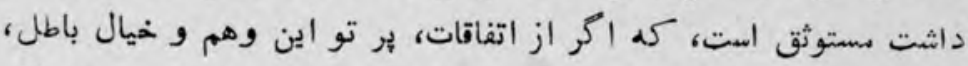

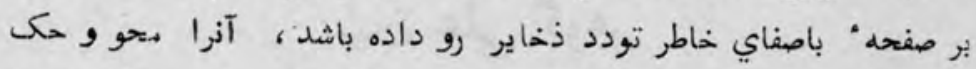

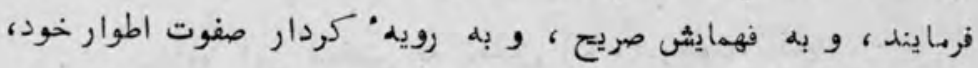

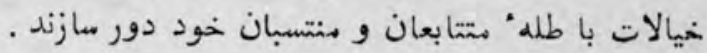
حقا كله صاف و صريح، بدون شايبه؛ تردد و تاثنل ازين طرف

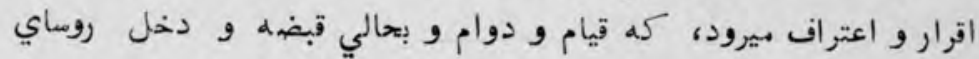

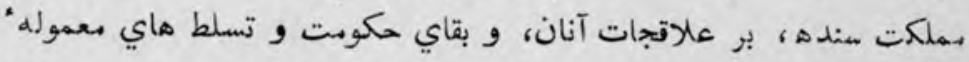

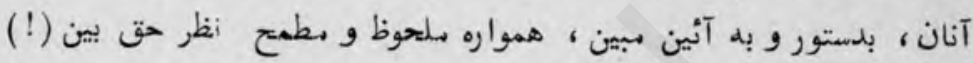

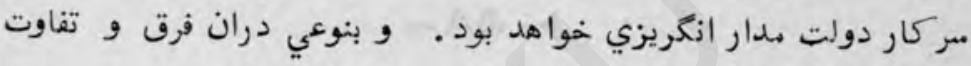

$$
\text { نمي تواند نمود (1) نمان }
$$

لهربانا ! براي اثبات و انكشاف حقيقت حال، تحريراتى كله در باب

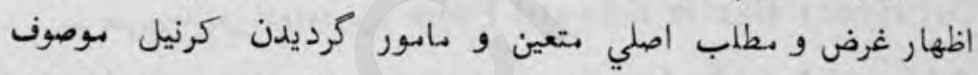

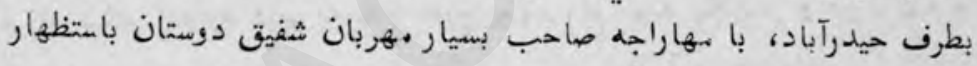
مخلصان مهاراجه رنجيت منكه بهادر رئيس لاهور آديده بود، بجنس بصاحب

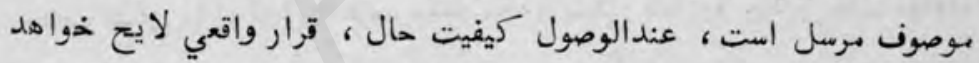

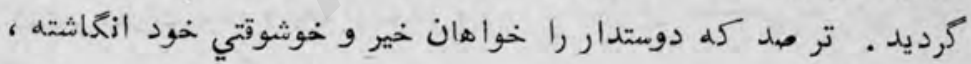

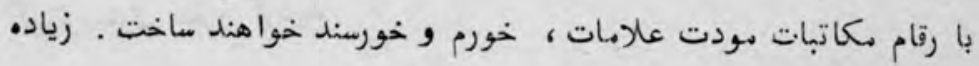
. $2 ز j / \frac{1}{b}$

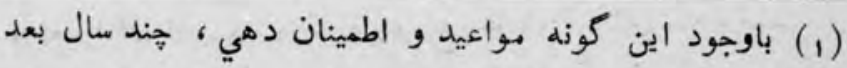

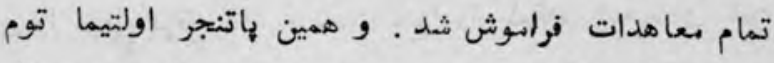
دخول لشكر انكليس را بسنده داد ، و دو دو سال بعد جنرال

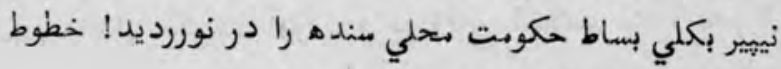
و معامدات اجباري سابقه ديده شود . لمبري 


\section{ميان على كوهر}

درباره" اين شخص به تعليق (م) رجوع كنيد

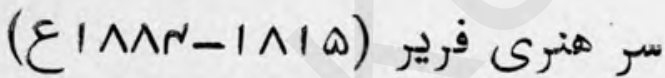

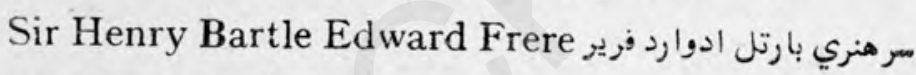

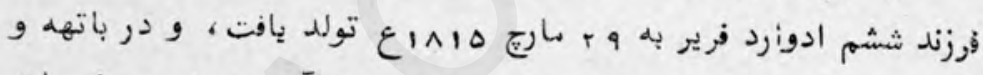

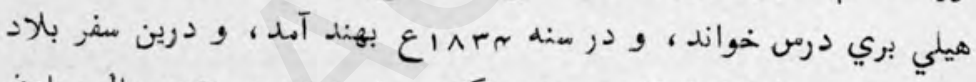

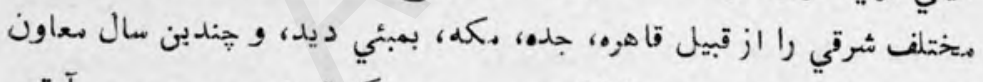

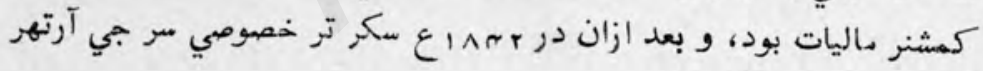
كورنر بهبئى مقرر كرديد.

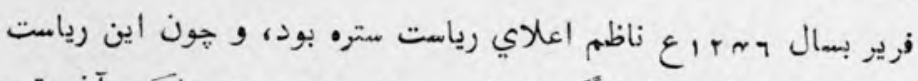

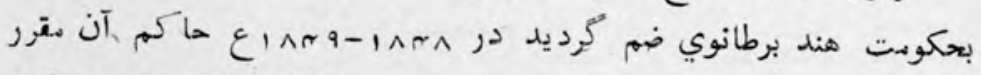

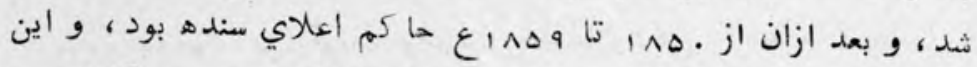

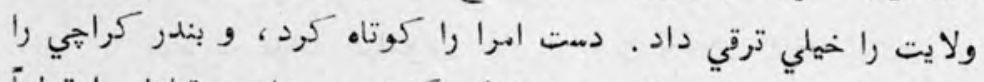

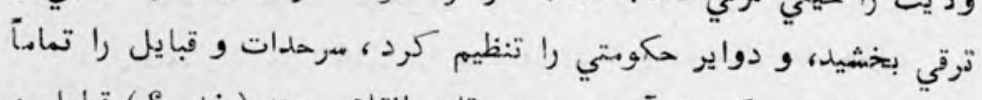

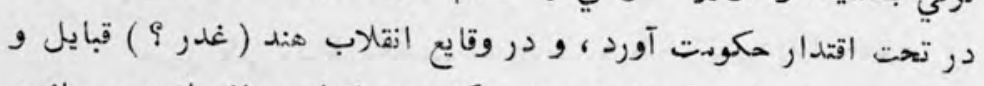

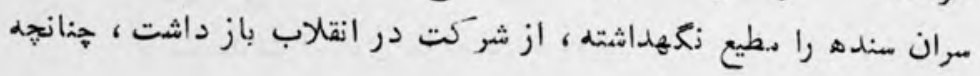


خدمات ـ وي درين مورد در ازخلمتان و هند بنظر تحسين ديده شد، و

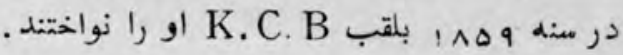

فرير از دسمبر وشهA

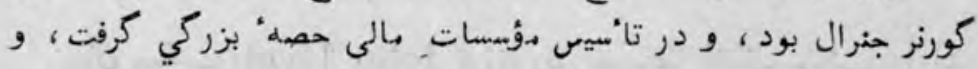

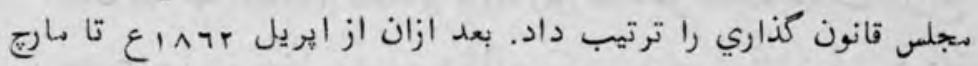

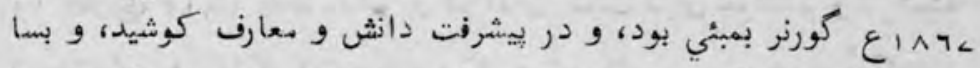

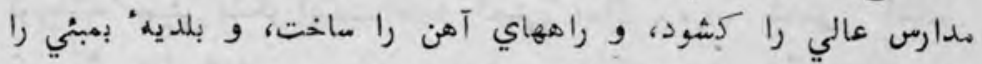
تأسيس كرد. هصص فرسوده: شهر را از بين برد، و تعليه نسوان را رواج

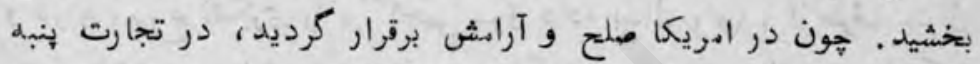
بحراني روي داد، و بانكل بهثي از انرو منهل كرديد، ولي فرير اين بحران

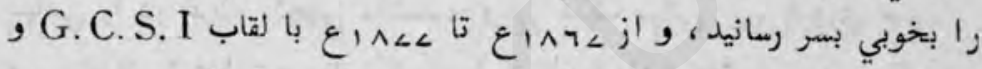

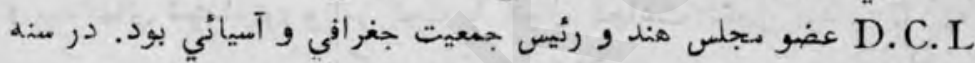

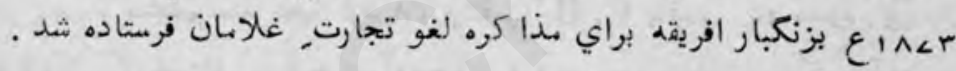

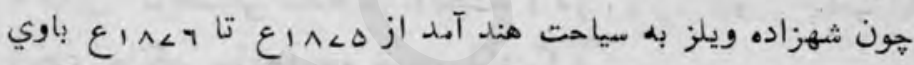

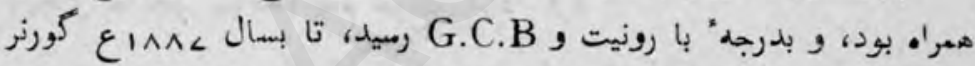

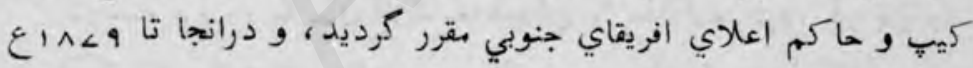

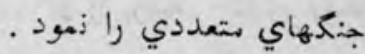

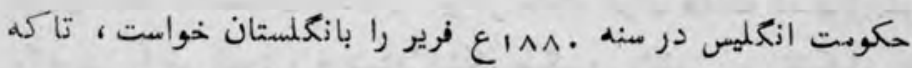

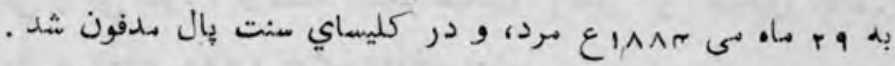
فرير داراي سجاياي قوى و عالي بود ، در هسمله افغانستان والزيسي

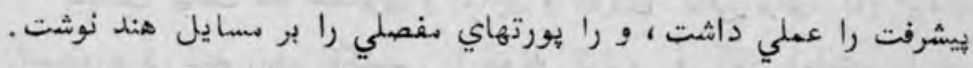
و نيز از تاليفات او كتابي است عبارت از ياد داشتهاي كاكي كاي او، جان

( بيوكرافي هندي به (1) 


\section{جنرال جيكب (}

جان جيكب John Jacob فرزند ريورنت ستفن لانكـ جيكب بتاريخ

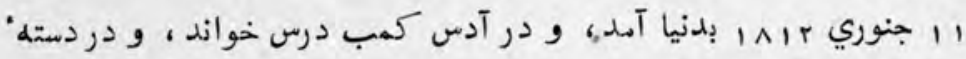

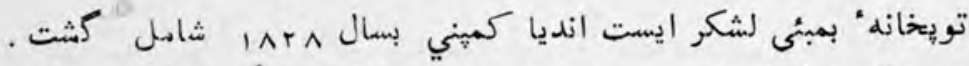

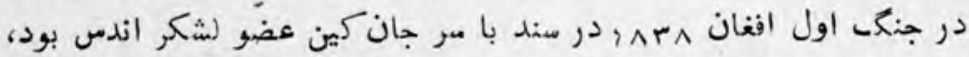

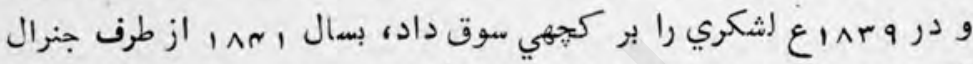

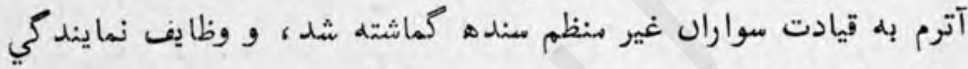

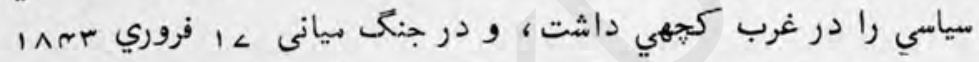

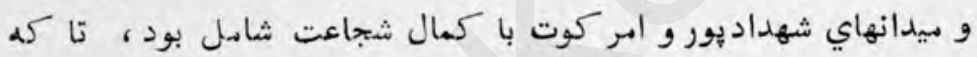

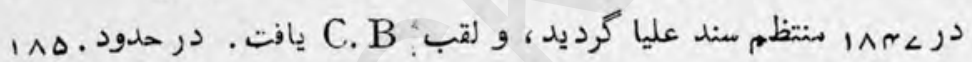

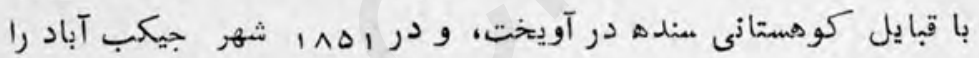

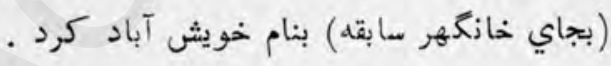

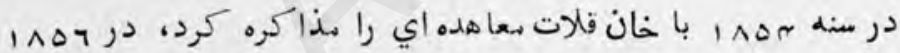

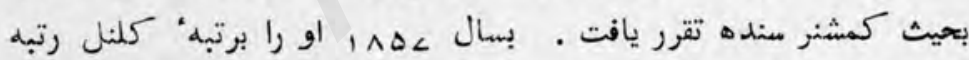

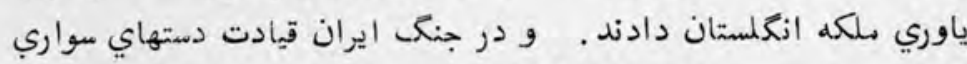

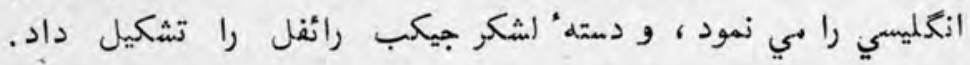

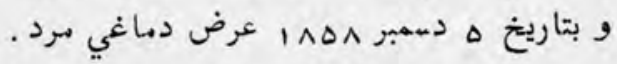

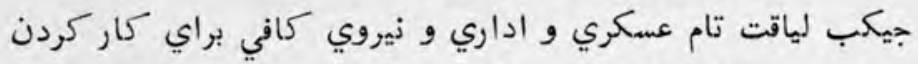

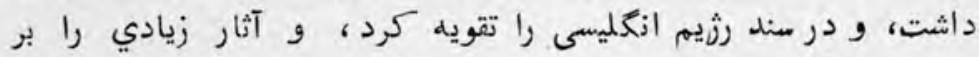

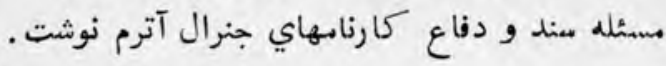
( بيو كرافي هندي هو 1 آم ) 


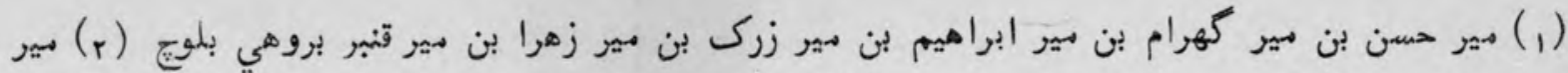

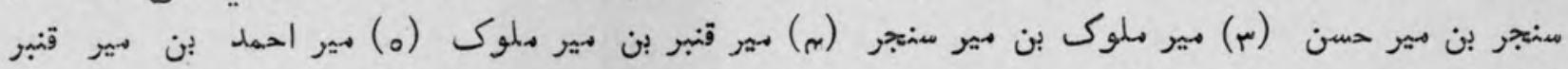

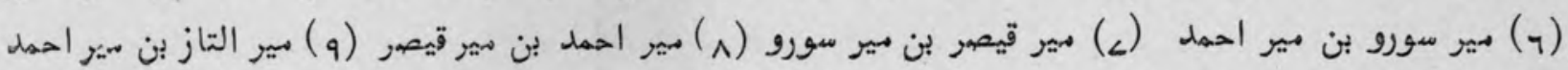

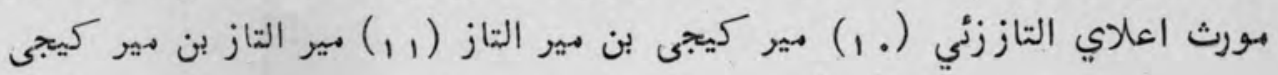

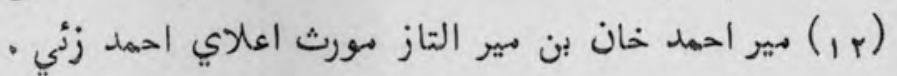

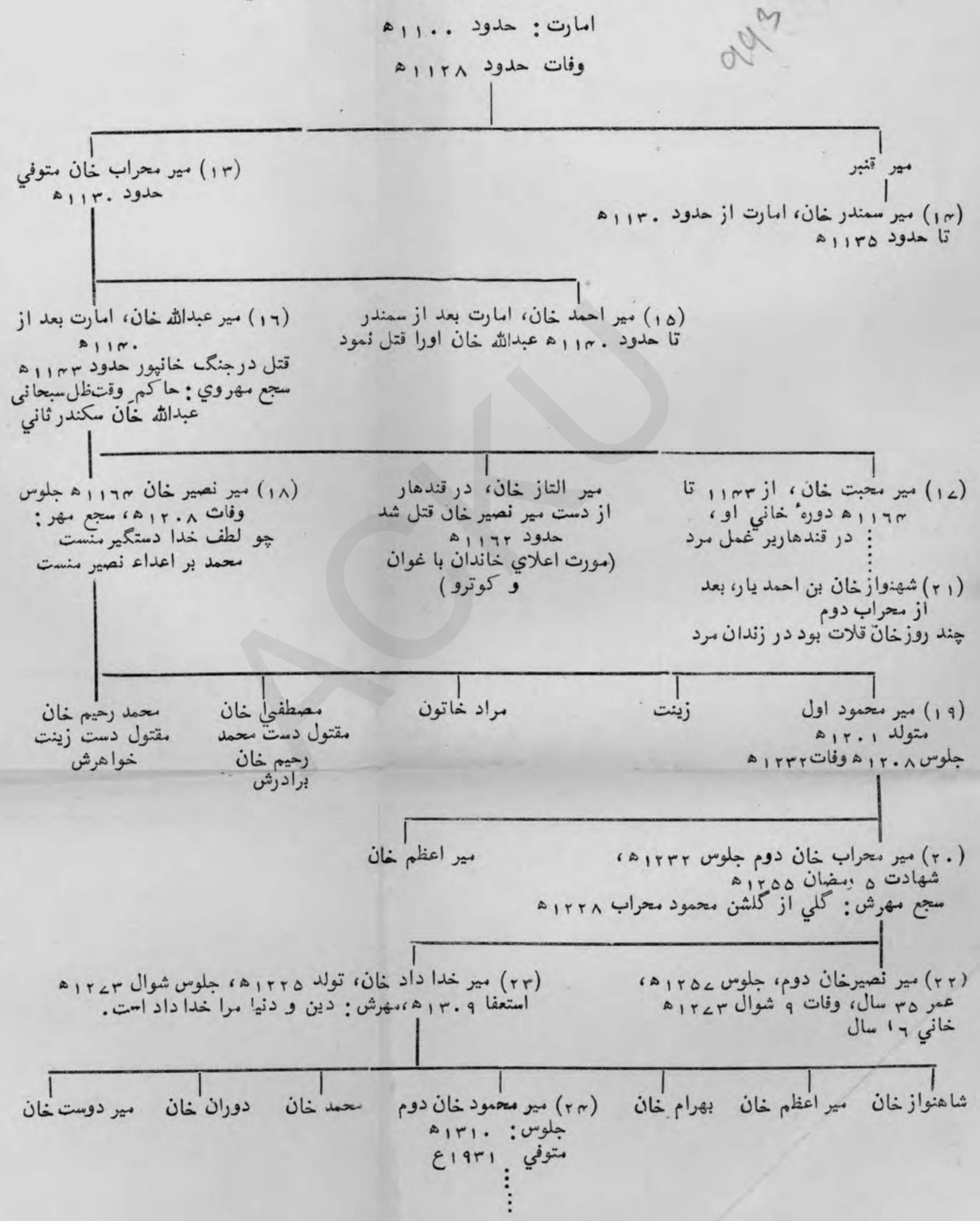

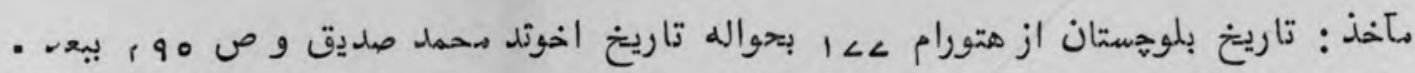

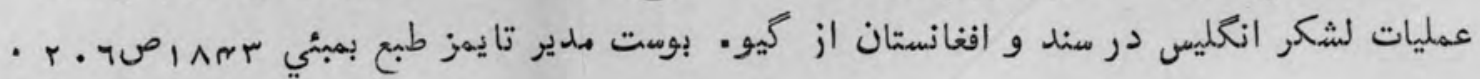



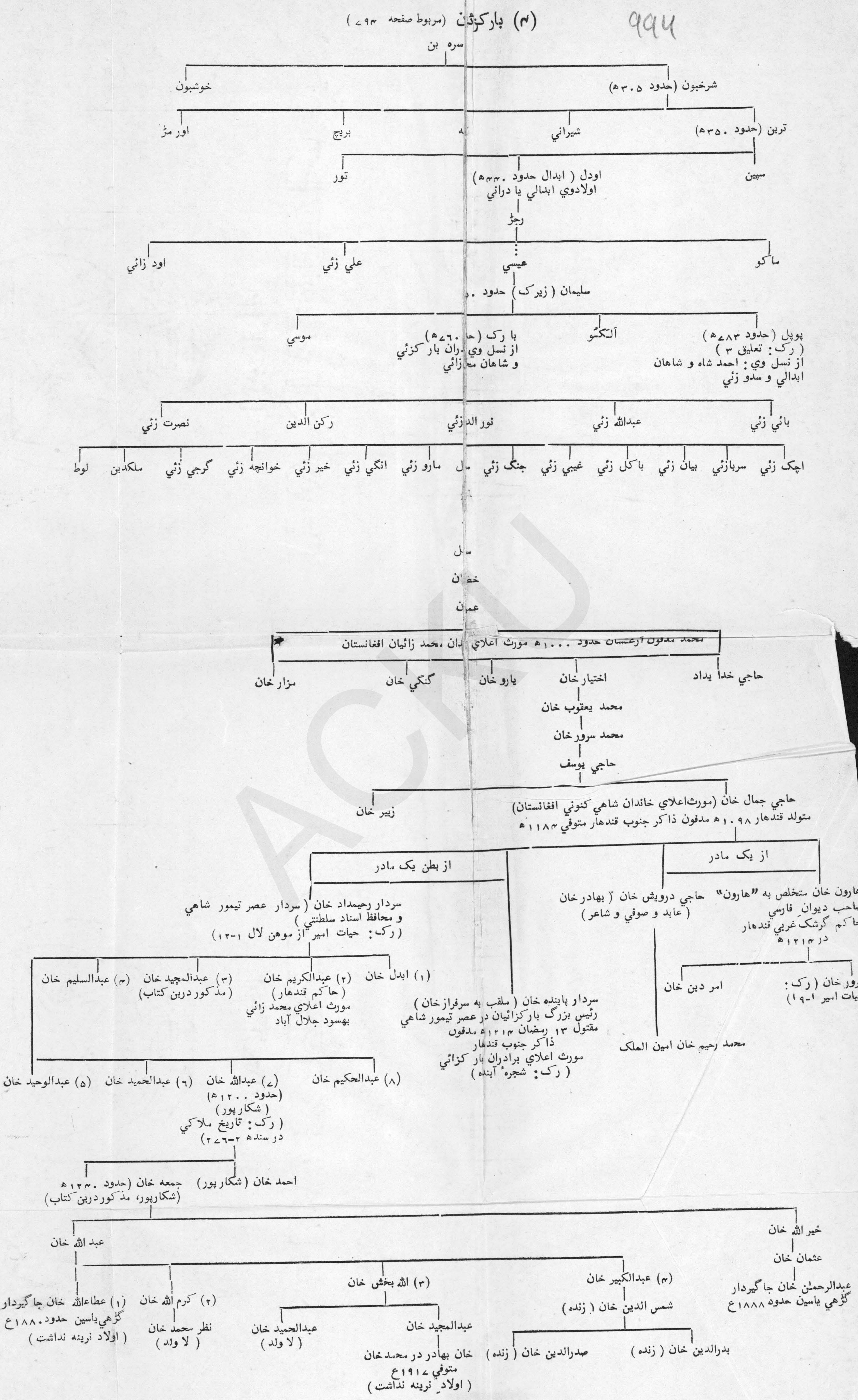


\section{ديوان گدو ـلـ}

ديوان كدومل كه مدتها بدربار احمد شاه ابدالي وكيل (سفير)

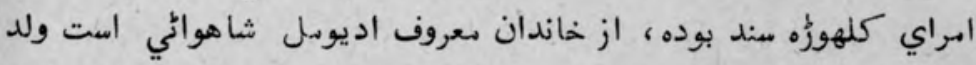

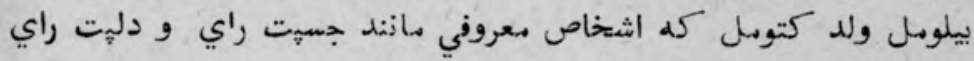

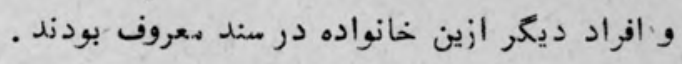

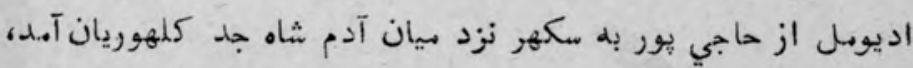

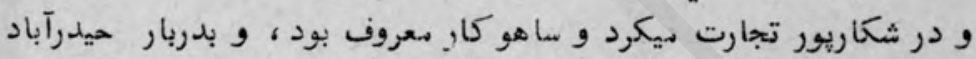

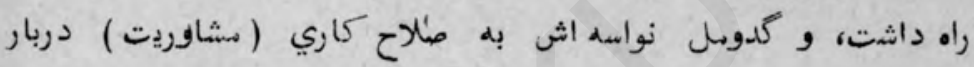

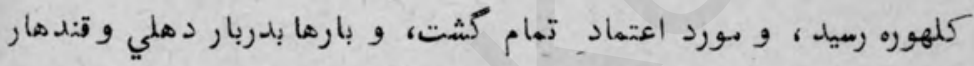

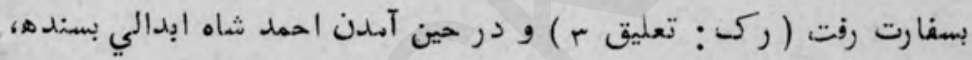

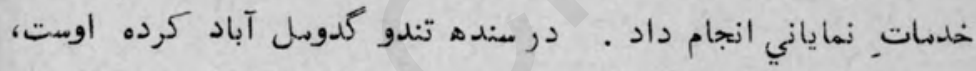

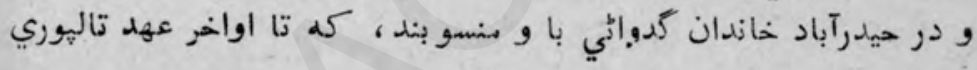

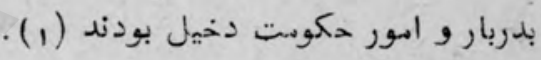


1000 


\section{كشاف}

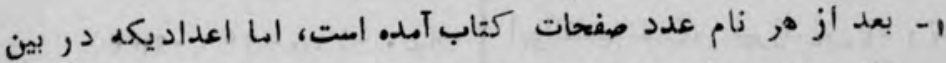

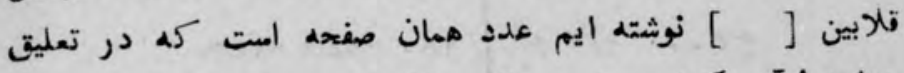

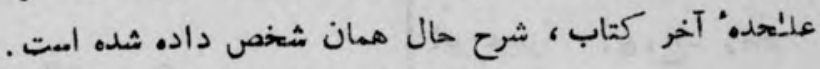

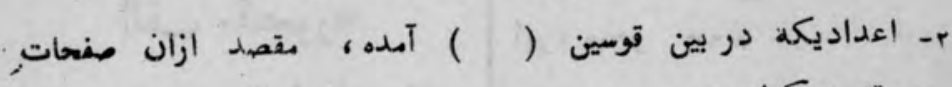
مقدمه كتابست.

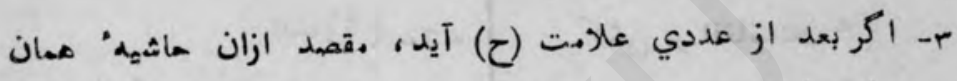

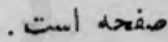

\section{ا- فهرس اسماى )}

99. آرادهر، جي (كورنر بمبني)

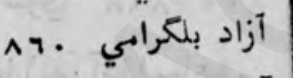

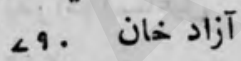
آزاد (سندهي) 919

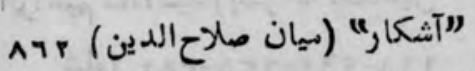

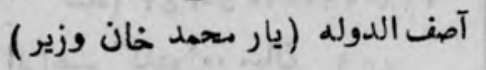

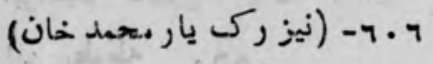

آغا جان، هوه آغا خيلي آغا علي براهوي (علي خان جد" اعليخاندان نائب خيل ) مان ) ore-ar.
الف مهلفوده

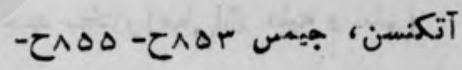

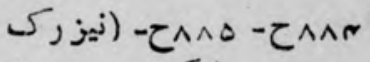
اتكنسن، جيمس) (نئرك)

آترم، جنرل جيمس (ايجنت مندهم)

$-\tau e \cdot<-r a \cdot-\tau r<n-r<\angle$

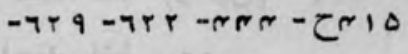

- $\Delta 9 \wedge-709-90 \wedge-7 r$.

-90.-9rr-9..- - 99

१९ร

آدم شاه (كلهوزْه)

१९१ - ८^ १

$$
\text { آدينه بيك }
$$




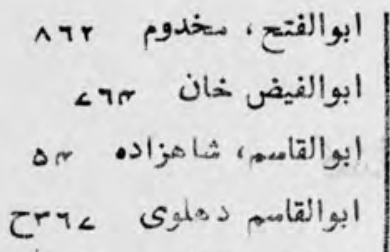
ابوالقاسم خان، ميرزا

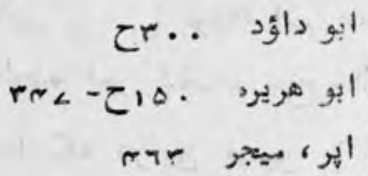

|تكنسن ، جيمس ( مص:ف " رئكر

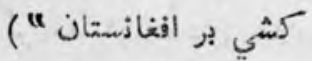

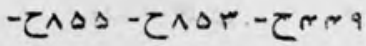

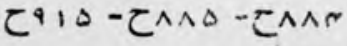
احمد منتبيل (صلي/اله عليه و ملم) $y=0$

احمد بحتار (صلي اله عليه و مـلم) टา-

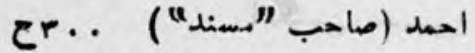
"إحمد" (ميرزا احصد خان) ar احهل احمد خان (احمد ثاه درانى ابدالي) $\angle \angle \cdot-\angle 79$ (نيز ركى احهد شاه ابدالى)

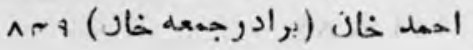

اكليند، لارد ارل جارج ايدن آكليند، كورنر جنرال هند)

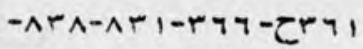
$-9 \mid 7-91 \%-\wedge 9 \%-\wedge 9 r$ -9<. -97^-977-9ल\% $9 \wedge .-9<7-9<0$

\section{النـ مغصومور}

ابراهيم ( برادر زاده: نادر شاه

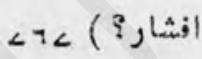

$$
\text { ابرادم (كاردي) }
$$

ابراهيم خان (برادر نادرشاه افشار) $\angle T \angle-\angle T D-\angle Q 1$

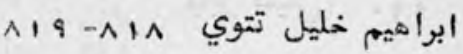
ابراهيم شاه، آغا (بدر آغا اسماعيل १ด^ -ดจน (ث) ابراهيم شاه، ميد (بسر آغ امماعيل

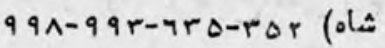

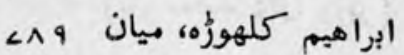
ابن بطوطه

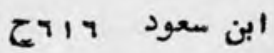

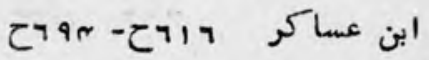

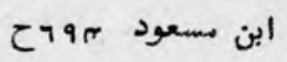

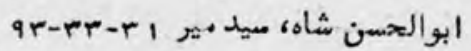


تازه نواي ـعار كى

1..r

تازه نواي معاركي

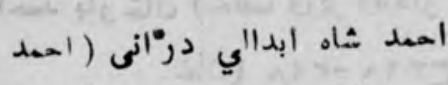

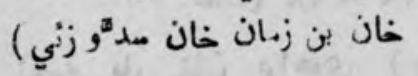

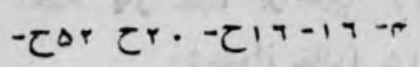

हrer - Eril -

$-\angle T \angle-\angle \tau \cdot-\tau<\cdots-\tau r \Delta \Delta$

$-\angle \angle T-\angle \angle I-\angle L$. $-[\angle T 9]$

$-\angle L T-\angle \angle O-\angle \angle C-\angle \angle T$

$-\angle A .-\angle \angle Q-\angle \angle A \quad-\angle \angle C$

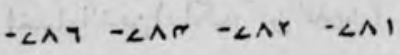

$-\angle Q .-\angle A Q-\angle A \Lambda-\angle A L$

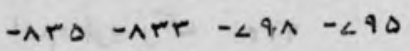

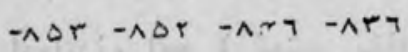

จจจ-AN

احمد شاه غازي ، ميان مير (ميد

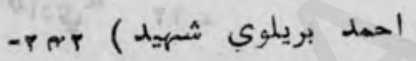

tra tres trut tet

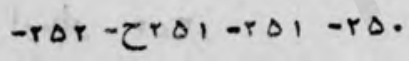

-rOL -rAT - toD -ron

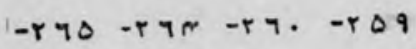

$-[\wedge<\angle]-\wedge<r-\Lambda \neg a-C r q<$

$\wedge<q-\wedge<\wedge$

احمد شاه كوركاني (بادشاه دهلي)

$\angle C C$

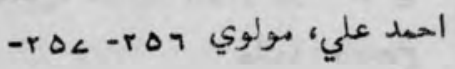
$r \Delta N$

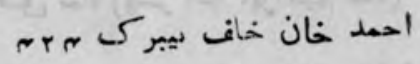

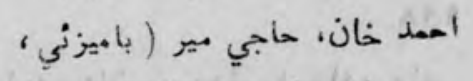
برادر وزير مختارالدوله حافظ

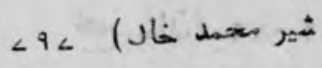

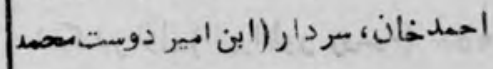
خان) (بs.

الممد خان، مير (بن مير التاز خان)

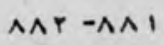

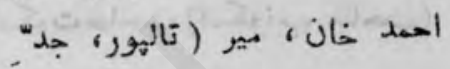

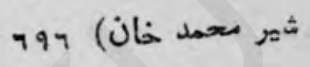

احمد خان، ميرزا (نائب و مشختاركار

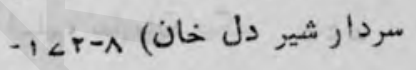

$\wedge \neg \angle-[\wedge \neg 7]-1<\angle$

اهمد خان كفاري، نواب (بن ولى

صحمد ذاذ) (

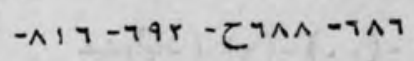

Arr

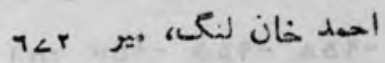

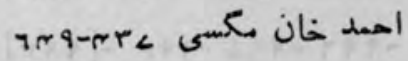

احمد خاز نور زائي ب.ی

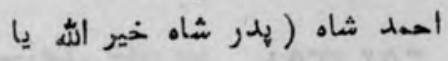

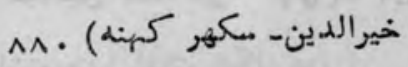

امسد شاه، ميد (بن ميد حامد شاه) $\wedge<7$ 
تازه نواي بماركـ

$1 \cdots \pi$

امتح'تق شاء (يسر آغا ابراهيم شاه)

१९^

الهد غان ، مردار ( برادر وزير

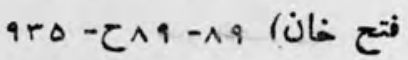

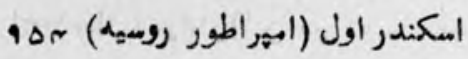

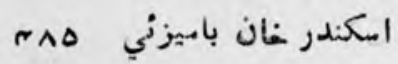

اسمندر خان خاكواني

اسكوت صاحب (امكونب صاحب)

$\tau \tau<0-7<0$

املامم خاز ضبط بيكي

اسلم، سليمان بيك-

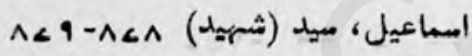

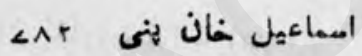

امهاعيل ثماه، ميد (وكيل اميران

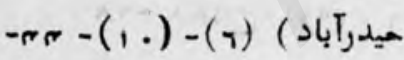

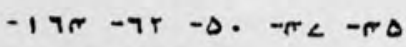

$-9 \Delta \wedge-9 \Delta \Delta-9 \Delta r-\wedge 14$

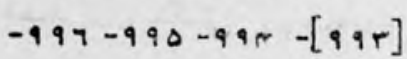

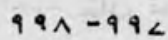

ror ror امعاعيل شاه، بير ror

اشتورت (كلمتر شكار يور )
السمد يار غان (خلف وزير وفادار

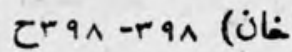

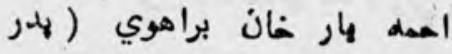

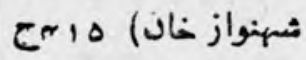

احمد يار خان ( كلهوزٔ برادر

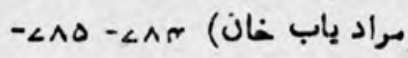
LAT

المهد وار خان "يكتان"

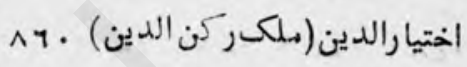

Ars اخوند تركسان

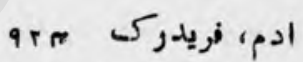

ادواردز، ايتج (كمشثر بشاور) Arq

<ar u|lis"

१९ اديو مل ثماموانى

الرمطو

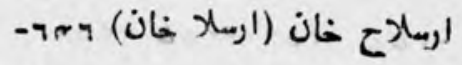
Crm

استوليتوف، جنرال

استويك ، (رابرث وليم جوزن) إسترل)

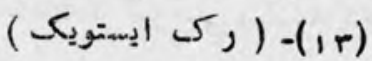

الستق، خواجه (بإر بير مستجدي

eror (ن) 


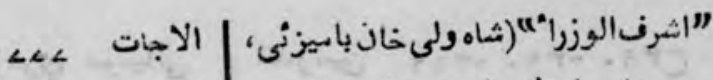

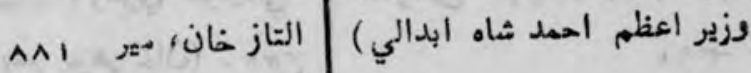

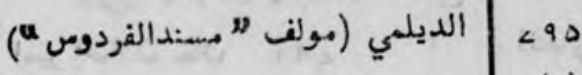

C'।

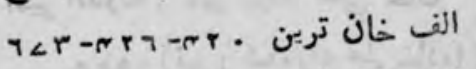

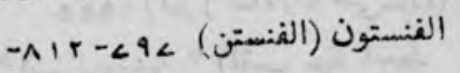

100-90e-9r।

الن برو، لارد (ادوارد لاو ارل الين برو هوه

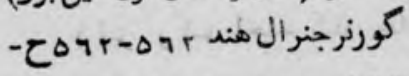

$-\Delta<r-\tau \Delta<1-\Delta<1-\Delta r r$

- $a r r=\wedge a q-\Delta<r-\varepsilon \Delta<r$

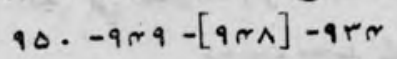

اله داد خان (نانب خيل)

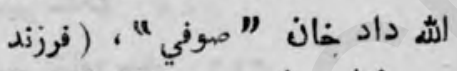

"اثرفالوزراث" ( وزير فتع خان )

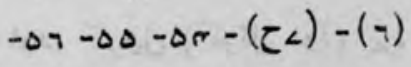

$-4 r-T I-\Delta \Lambda-0<-C \Delta T$

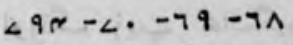

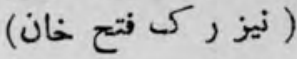

اشرفعلي،مير (بانى "مجهم الاخبار"

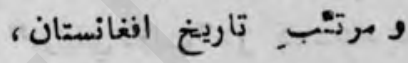

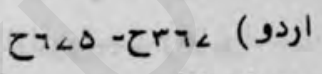

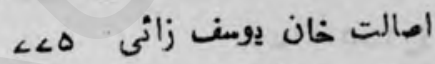

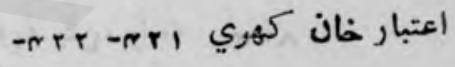

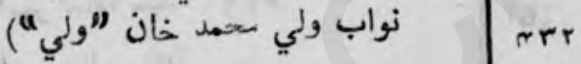

Arr-Arr

الهداد خان انكي زتي

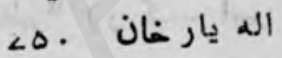

الين برو، ادوارد بأرون (يدر لارد اهد

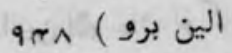

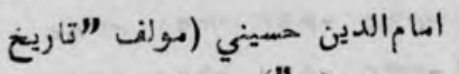

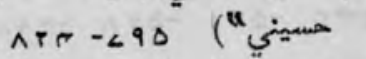

انسام قلي ( بدر نادر شاه اقشار) $\angle \Delta$.

امان خان بويلزاني

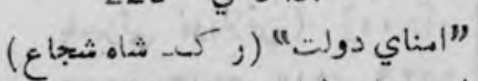

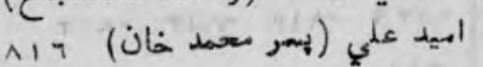

اعتمادالدوله (دومست محمد خان) $\angle 90$

افضل خان استحاق زتي، مير 110

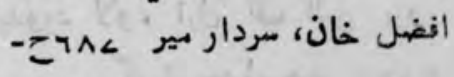
гר^^

$\left.-r<r-\tau^{r}<9-r<9 \quad j \quad b\right)_{01}$

اكبر خان، وزير

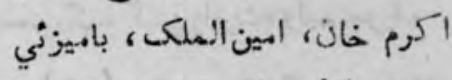
هو يلزني، كوزيو • r-r Arq-nin-nir 
تازه نواي معارك

$1 \cdots 9$

- Crq. -rq. -rq9

ror $r q 1$

انند رام" إخلص"

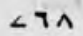

اود، كرنيل (كرنل او\$) ـ. r.

ᄃr.

اورنك زيب عالمكير

A^r -AA।

اوريا، خواجه

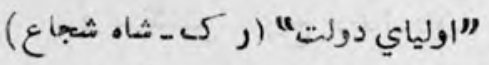

اوليورليجت (اوليولهب، كيتان؟)

$\tau \top<0-\tau<0$

اويه يَّن، رأجه

اياز ه اونه

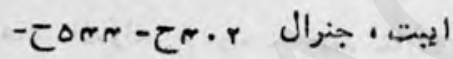

cair

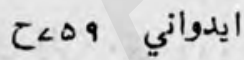

ايدورد لاو، ارل آن الين آن برو

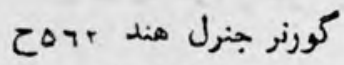

(نيز رك الن الن برول

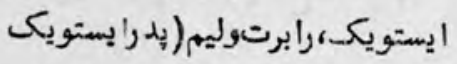

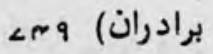

ايستويكى، كمتن رابرت، وليم جوزف

$-41<-51 n-i n$ (ir)

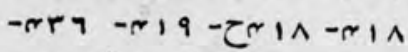

$\angle \Delta$. $-[\angle r q]-r r<$
اميد علي خان (زهري موسياني

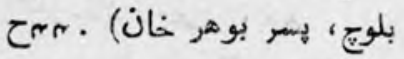

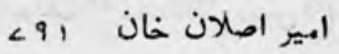

امير الدوله ، مير مراد علي خان الهان

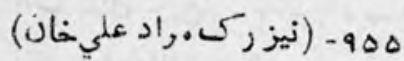

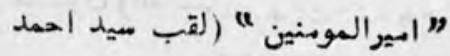
بريلوي)

(نيز رك احهد شاه غهازي)

سيد الحمل بريلوي شهيد)

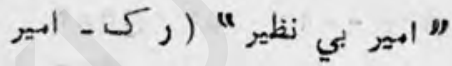

دوست مصدم خان)

امير سنكه

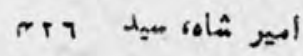

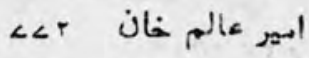

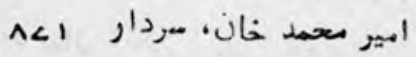

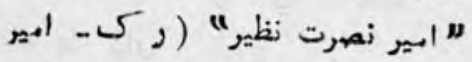

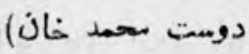

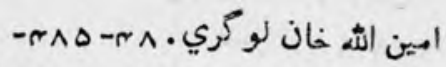
-rag - $-4 a r-m a 1$ - $-4 \lambda<$

- $\Delta r r$ - $\Delta r 1-\Delta r \wedge-r q \wedge$

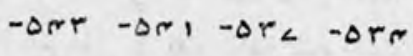

बr० -०१०

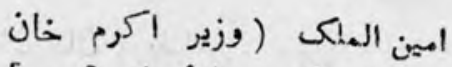

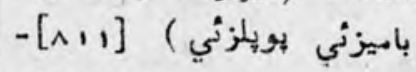

-n+a-nir -nir -Nit 
تازه نواي معارك

1.24

باغ علي " بايف بهن

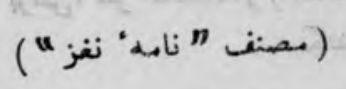

¿A. $-\angle T \wedge-\tau-\Delta T$

باقر شاه ( بسر آغا ابراهيم شاه)

११^

باقر شاء فقيه צr

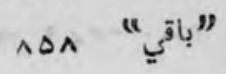

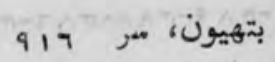

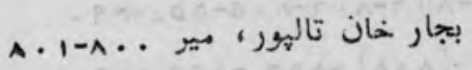

بجأر خان ذومبكي ( تومبكي )

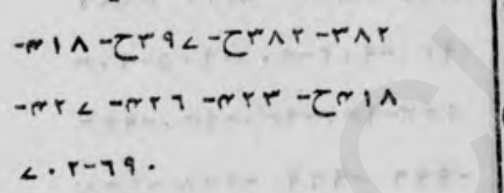

تجل عطار، الخوند بri

بحه خان

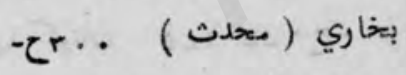

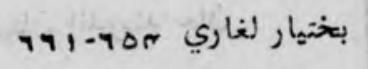

بركت اله خان تعلزني،

$\triangle 90$

برنس، جيهس ( بدر مر الكساندر

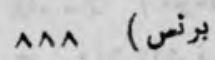

برنس، ( رابرت، " ثـاءر انكليس") برنه A^^

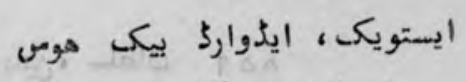

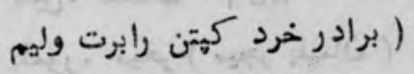

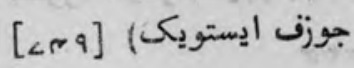

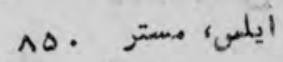

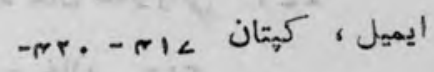

-6teterteteti-get.

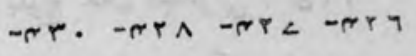

$4 r<-4 r 1$

ايوب شاه سدو زائي

"بابا" (احهد شاه ابدالي، در"اني)

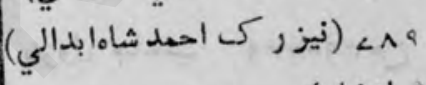

بابر (بادشاه)

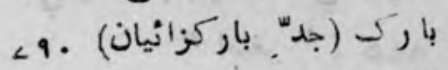

" بارون خيبر" ( مر جارج بالكى ) بان )

9re

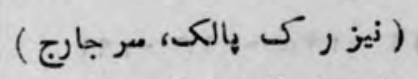

" بارون غزني " ( جنرال جان كين )

$\wedge 90$

( نيز ركى كين، جنرال جان (هان )

"با رون قلات" (سر توماس ويلشائر)

^ง

(نيز رك ويلشائر، مرتوماس) 
كازه نواي معاركى

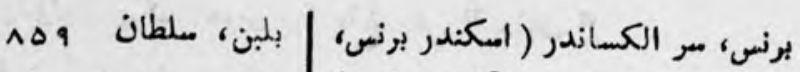
بلمور، بيجر ( ميجر بليهان ) بهان

cerrerter

بلند خان سدوزائي ان بلوت خان

110 بلوع مان إكزني

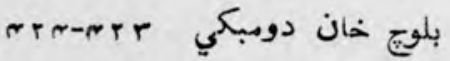
بنتيكى، لارد وليم كوندش

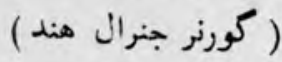

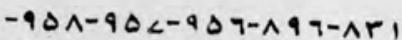

$9 \wedge<-9 \wedge \neg-9 \neg r-9 \Delta 9$

بنزول صاهب "بنكلي والال" ( بير ميد علي كومر صاصي

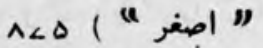

( نيز ركى علي كوهر "اصغر" )

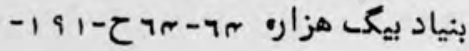

-199-19^-19 - - 9 $r \cdot r-r \cdot 1-r \cdot$.

\section{بوب 9}

بوده خان، مير بوده منكه ( لوده سنكه - برد برادر

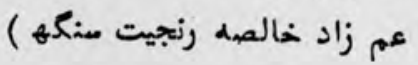
rA.-Zrma-rma

مكندر برنس ( )

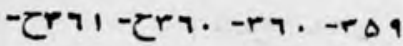

rלד

$-5 r a r-r a .-r<a-r<1$

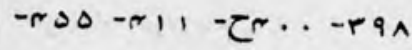

$-r \hat{~}-4<0,-r<r-5 r \Delta \Delta$

-

$-\wedge, \neg-\wedge \cdot \neg-\Lambda \cdot \Delta-\Delta \Delta_{\measuredangle}-\sim 9$.

$-[\wedge \wedge \wedge]-\wedge \wedge ⿱-\wedge r_{9}-\wedge r_{L}$

$-\wedge q<-\wedge 9 r-\wedge q .-\wedge \wedge 9$

-9+ 1-91 $+-9 \cdot 7-9 \cdot 0-9 \cdot \pi$

$9 r r-9 r r-9 r 1-9 r .-9 r t$

- $997-979-97 \wedge-94 \wedge$

टqq<-qq<

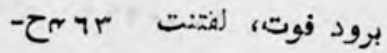

بروس، كهئان

برون، كرتان اندروسئد جان

cer-ert-er.erta-rto

بروى صاحب

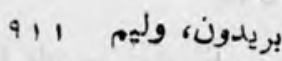

بقا، مبلس ( بؤذن)

بكي خان (اثشرف الوزراء باديزاني،

شاه ولي خان وزير اعظمم)

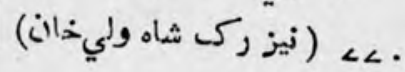


1..9 9

تازه نواي مع

بهرام خان، ميز (تالهور )

A $\Delta-\angle 99-\angle 9 \wedge-\angle 97-\angle A \angle$

به

بي بي كن:جابه

بي بي مبير كوهر

بro-gerrerrer

بيلو، مسترز (مصنف سياحت نامه بيلو )

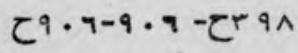

بيلو مل ( بيدر ديوان كدو هل )

१९१

بين، كائتان (كمتان)

باتنجر (ركى إوننجر)

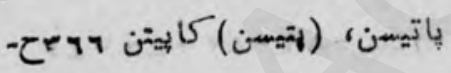

ERA

بالك ، داويد ( بدر فيلد مارثمل

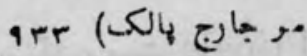

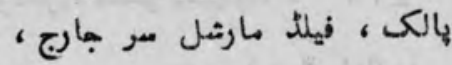

بra-

$-\Delta \Delta Q-\Delta \Delta \Delta-\Delta \Delta r-\Delta r$.

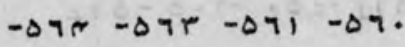

$-q \cdot 1-\lambda q r-2 \Delta<1-\Delta<1$

-arn-ara-are - [arr]

$9 \sim \wedge-9 r 9$

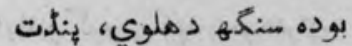

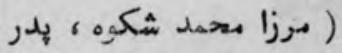

هو

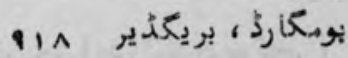

بوهر ضان (مير بوهر سردار مومياني) $441-\operatorname{cen}-4 m$.

بهادر خان تالهور، ثير باد rrr|q-r|N-rq7

$\angle A C$ C :

اشرف الوزرا وزيو تتع خان،

و مادر سر بلند خان و شاه

)

$\tau \wedge r<-[\mu r]-(\tau<)$

بهاول خان، نواب ( داؤد هوتره) - $474-79 r-2 r<\cdot-r<$.

१^จ

بهاء الدين زكريا، ثميغ

$\wedge \neg \cdot-\wedge \Delta 9$

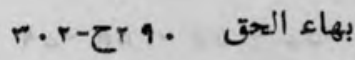

4. باني غان كلهورو 
تاز. نواي معاركى

يوتنجر، ايلدر كروين (بدرسو هنري

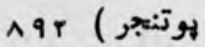

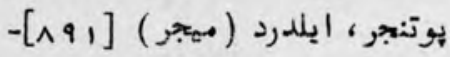

Aง

يوتنجر، توماس (بدر ايلدرد بوتنجر )

[^9, ]

يوستين ، كهتن طاهس (تامس )

-

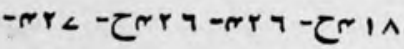

mra -ger< $-4 r_{L}$

يوكر (صراف كابل)

بولين بورئر

بيت، كيتان

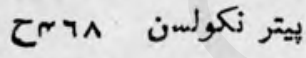

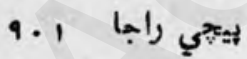

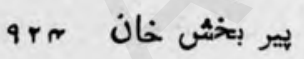

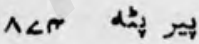

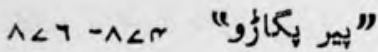

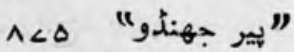

بير دوست خان وهر

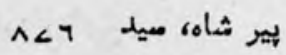

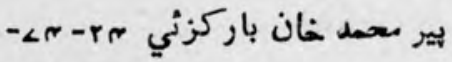

$r \Delta<-r \Delta \Delta-r \Delta O R-\angle 9$
$1 \cdot 1$.

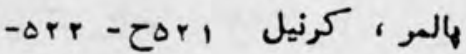
orm-orr

يالمرمتون، لارد

هاتنده خان ، مردار > >

- $\Delta a r-\angle q 1-[\angle q \cdot]-C r r_{L}$

-ArT-ArT -

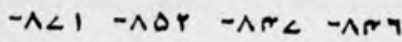

9ro

روت، كوتان (بريتصماهب) روهبटras

هرتاب راي ميومتاني (1<)

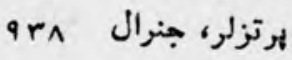

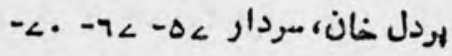

$-1<\angle-\wedge q-\wedge r-\angle r-\angle 1$

$-r \cdot \tau-\operatorname{Cl} \wedge \Delta-1<9-1<1$

rte trta $-t \cdot A$

ر نكل، ديستر Pringle

يوتنجر ، مر هنرى (عمّ ايلدرد

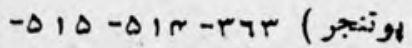

-[^91] $-\angle \Delta \cdot-7 \cdot \Delta-\Delta 1<$

$-97 .-9 \Delta<-9 \Delta 4-\wedge 9 \%$

-qAr -970 - q78 - 971

こ१^9-9^८ 
تازه نواي مaسر

1.11

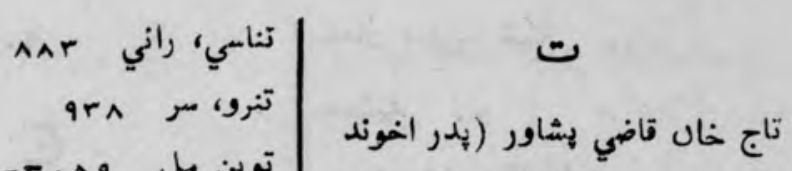

تركمان) توش

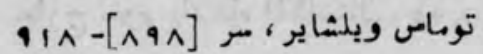
)

تهامسن ( انجنير اعلاى لشكر وليز

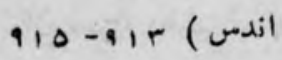

تيزو سلمطان (شهيد) (

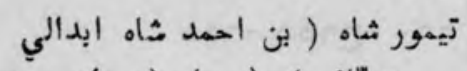

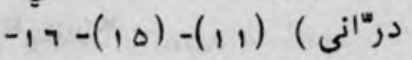

$-\angle \angle \Delta-\tau r<r-\tau<r-\tau \Delta r$

$-\angle \wedge<-\angle \angle Q-\angle \angle \angle-\angle \angle T$

$-<9 \Delta-\angle 9<-\angle 91-\angle 9$.

$-\angle 9 \wedge-\angle 9<-<97-\tau<90$

$-\wedge r .-\Lambda \cdot r-\lambda \cdot 1-\lambda$.

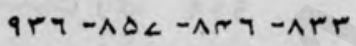

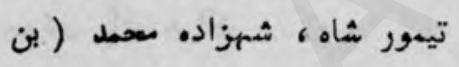

شاء ثمجاع)

ركى معمد تيمور شا.

تيمور شاه، ـقنل ( بدر محمد غلام

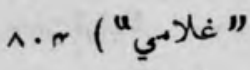

b.

"s

(ركى تاد، داركي ايليوت)

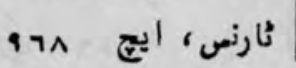

9r. أج سعمد، صردار

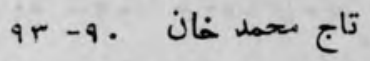

تاجسممد خان (جاجيخان كان كري،

CrA9 (نصيرالدوله

(نيز رك حاجي خان كاكري)

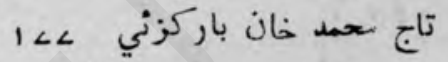

تاد ، داركي اليليوت (كبتان ، بلهي

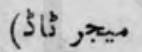

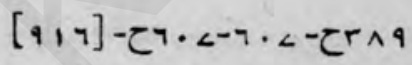

تاد ، فرير ( بدر ميجر داركي

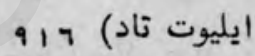

تامسن، كريتان

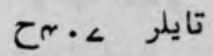

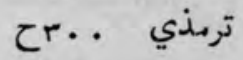

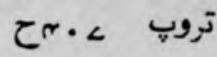

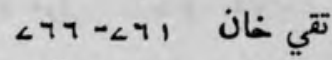

تقي شاه، ميد (برادر آغان ميدكانم

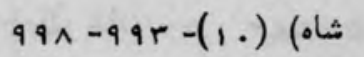

(نيز ركى سحمد تقي شاه) (

تكرنصاaب، كميان

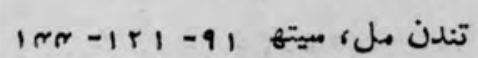




$$
\begin{aligned}
& \text { ㄱ. جمال مبرد، شئخ } \\
& \text { جمشيد } \\
& \text { جمهل خان باركزائي }
\end{aligned}
$$

$-1 \cdot r-1 \cdot r-1 \cdot 1-9 r-91$

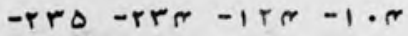

No. -

جمaه خان دراني الكوزني ( يدر عبد الله خان، متخلصالدوله)

Ar

جمه غان فوفلزئ

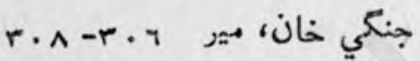

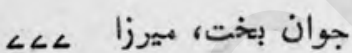
"جوش" مليع آبادي هي جهان خان يويل زاني جهان مان ، مردار ( معه ماللار

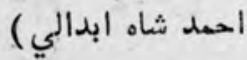

$\angle \wedge 1-\angle \angle \neg-\angle \angle \Delta-\angle \angle 1$

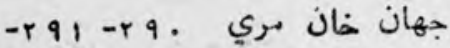
$r .4-r \cdot \Delta-r .0-r d r$ $r<\Delta-r<r \quad$ جr جهان داد خان بانيزني $-410-t 7-60-5 r e-t e$ Aง -ATY-ZR
نهاكويل

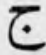

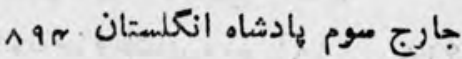

$$
\text { }
$$

71.

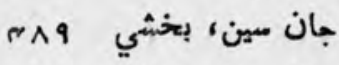
جان مصمد خان، ميرك

7า. $-27 \Delta \Delta-7 \Delta \Delta$

^ه^ "جانان"

جانى جكهراني

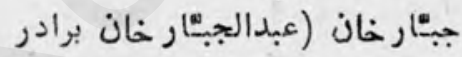

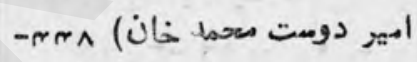

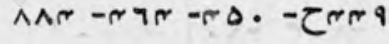

\section{११ ج جست راى}

جr.

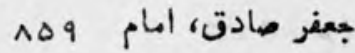

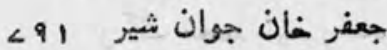
११人 جعفر شاه

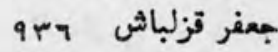
جلال خان لغاري جلال غان مرى بان لمان جمال خان باركزاني، ماجي

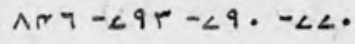

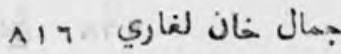


t. ir

\section{تازه نواي بعارك}

$$
\begin{aligned}
& \text { 戸 } \\
& \text { A14 ماكا }
\end{aligned}
$$

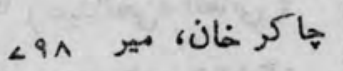
zint حمن ( ه:ندو (ك)

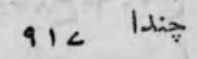
LCL جه من

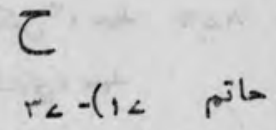

حاجي غان كاكري (تاج مصمدخان،

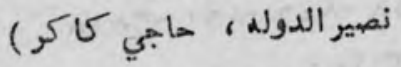

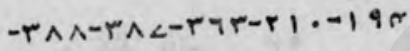
$-414-4 .<-r a \cdot-\sin$ वल्त $-\nabla<r$

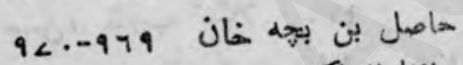

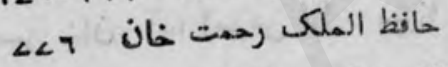

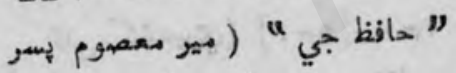

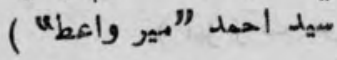
$\Lambda \cdot \Delta-\Lambda \cdot r-\Lambda \cdot r$

9. - - $<1 \quad$ مانظ شيرازي A حبيب الله خان ( امير افغانستاذ ) C^or-crs

حبيب الله خان ( خلف مردار

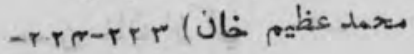
$A \in J$ - etratro
جي، "ي صاهب ، كهيان (جي (جهي ه هامي؟ )

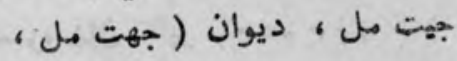

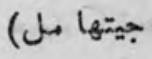

- 7 r - 7 ra -7r< -7rq $-\tau<\Delta \Lambda-7 \Delta 1-70$. -7ल9 $\angle 7 \wedge$

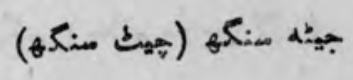

Crin $-41 \wedge$

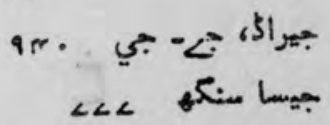

جيكب، جنرال جان (جيكم)

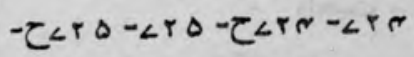

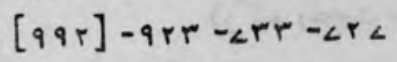
جيكب ، ريورنت متيفن لازيكى ه १ (يدر جنرل جان جيكب) جيمس، كيتان 
تازه نواي معاركى

حسين علي " حسمين علي، مير انين

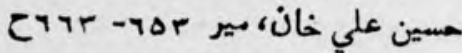

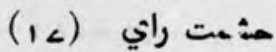
حكمت غان سركاني مكومت غان، حانظ

LrY-yrT-yro

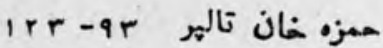
AND-ATT مميد كثميري حميدالدين، سيد

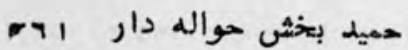
حيات خان مري ميدر

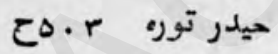
حيدري بيكم (خانم موهن لال ) $9 \sim 1$

\section{$\dot{\check{C}}$}

" غالصه منهه " (مهاراجه رنجيت منكه)

(ر) رنجيت منكه)

خالو خان الكو زني اهـ غان دوران ( مده مالار دهلي ) cor

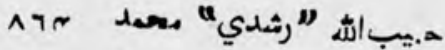

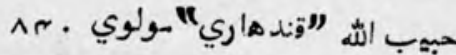
" حبيبي " ( عبدالحي، افغاني ) - Carq - C<ту - (19)

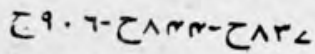
) (نيز ركى عبدالجي هبيبي (1)

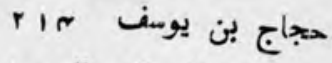

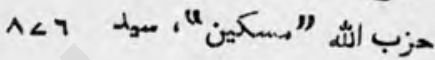

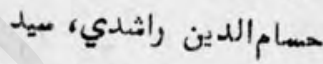
$-\wedge 1 \wedge-(こ \mid q)-(1 \wedge)-(r)$ $-9 \Delta \wedge-\wedge<\neg-\wedge \neg !-\tau \wedge ! \wedge$ 9A $r-9<$.

هm ناظر باثي حسن، تاضي

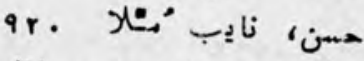
حسن خان، آغا (موهن لال، ميرزا

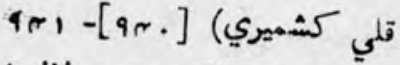

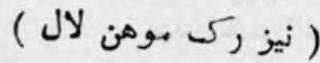
همن خان نوتهاني؛ بير

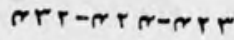
عسن علي ميرزا قاحاري، شهزاده

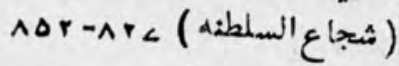

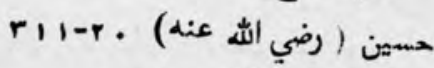

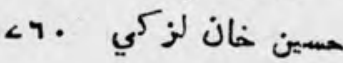

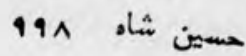




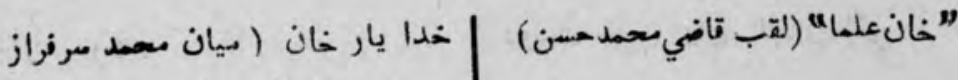

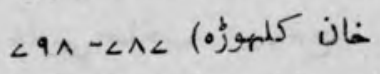
خدا يار خان دراني بان بانيزنى

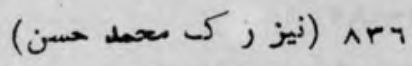
خان سعد ( بـسر مير غلام علي كلي تالهر (

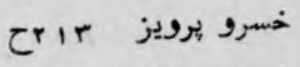

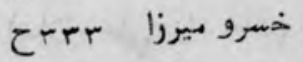

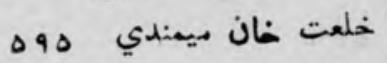

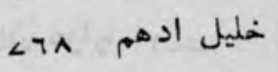
خواجه اوريا لخ ادهم

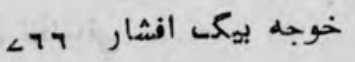

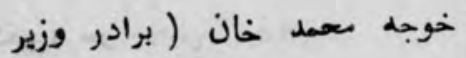

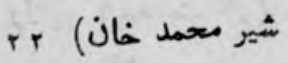

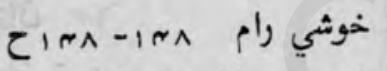
خير الثه خان فوفلزني AD. $-1+r-1 \cdot \Delta-91$

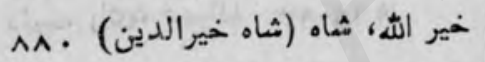
خيرالدين ( عليهالرحهه ) شا.

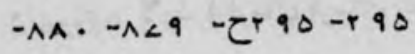

A^I

خيرمعمد (ملازم مير نورمحمد خان) $9<.-979$

\section{د}

داد اله ، قاضي داد كريم شهوانى
خان سممل عمراني خانم سيل (ليدي سيل) ركى نلورنتيا خانم غلام حيدر خان (دختر مرددار

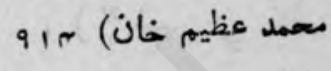

خازم موهن لال ( حيدري بيكم ) $9 \times 1$

"خاثف" سندهي (باغ على مخائف،

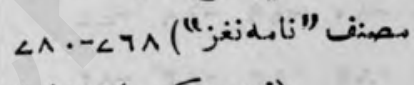
(نيز ركى باع علي) خدا بخشى، حاجي . تحان خدا داد خان ( مكمران قلات ) 9r।-9rr

خدا داد خان (رولف "لب تاريخ

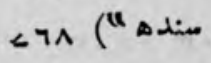

خدا نظر خاذ

tro-tre-tim-t.

خدا يار خان (ميان نور محمد خان كلهوره)

$\angle T r-\angle 4 r-\angle 4 r-\angle T 1$ 
دوست سحمد خان ابدال زثي $|9|-\mid \wedge r$

دوست معمل خان اسحاق زئى، حاجي

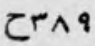

دوست شعمد خان، اعتماد الدوله

< $9 \Delta$ (احمد شاهي )

دومت سمعل خاذ، مردار

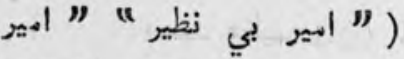

(" نصرت نظير )

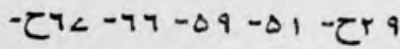

$-\angle T-\angle \Delta \quad-\angle r-\tau<r \quad-\angle r$

$-\wedge 1-\wedge \cdot-\angle 9-\angle \Lambda \quad-\angle<$

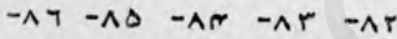

$\begin{array}{lll}-t r & -1<2-1 t r-a .\end{array}$

-trL -trt -trA trte

-rrq -rt< -rry -rro

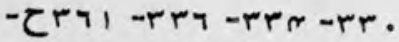

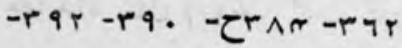

$a \cdot n-m \cdot a-m \cdot r-m \cdot r$

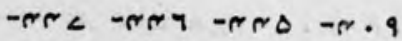

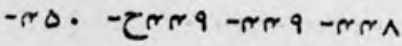

-rar -rar -rop -rai

$-r \Delta \Delta-r \Delta t-r \Delta \Delta-\tau r \Delta r$

$-41 .-r \Delta \Delta-\cos -r \Delta \Delta$
$\Delta \Delta 1 \quad$ ار إد

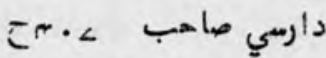

داركي، تاد ، كيتان (نيز رك تاد، داركي ايليوت)

داؤد، ميان

درمدمد خان (بازم علي مراد خان) ميان $<r q$

دويش علي خان هزارو بان دريا خان جكهراني

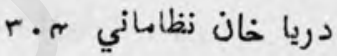

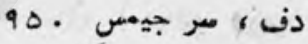

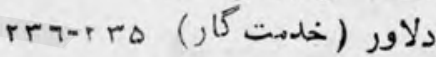
دلاور خان ملاور تحن

دلاور خان تيمني

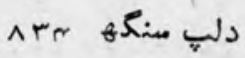

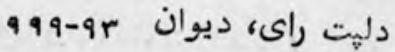

79. دواد غان كوسه دلهوزي، لارد ( فرمان فرهاي هند )

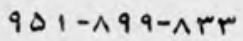

\section{د. دنك، ميجر جنرال 9}

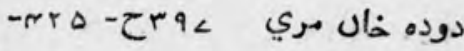

ar. -gerd mr< -rtt ard

دوست علي

دوست سعمد (جخدنت كار) 
Cr.

دين مصدم خان (لاسر دوده خان) Crrq

ديني، كلميل ( كونل وليم هنري

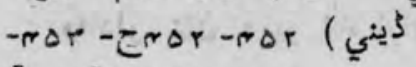
[qrp]-q1r-q.A

ديني، هنري ( بلمر وليم هنري

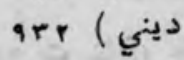

ديا رام؛ ديوان

j

ذوالفقارالدين مجونهوري ، ثهيتخ Cosr-Crq

ذوالفقار غان

رابت، بنرال (جنرل رابرت سيل) - ror ra - Crqr rqr [4.1] جنزال سر رابرك هنري)

رام بيل (ابجنت مندهم)

mra $-4 r e-4 t i t$

rer ari hat

راشد ، "عيد منحمل (يير "روزى والا") $\wedge<r$

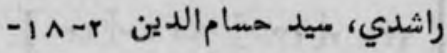

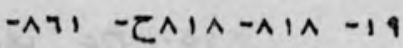

9Ar $-9<\cdot-9 \Delta \wedge-\wedge<7$

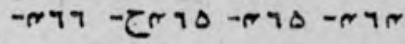

-

$-r<r \quad-r<r-r<1-r<$.

$-4 a t-r \wedge \cdot-4<4-r<0$

$-\Delta, \Delta-\Delta \cdot c-\Delta \cdot r-\Delta \cdot r$

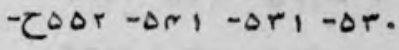

$-\Delta<1-\Delta T<-\Delta T T-\Delta T \Delta$

$-\Delta<r-\Delta<r-\Delta<r-Z \Delta<1$

$-\Delta<A \quad-\Delta<\angle-\theta<T-\Delta<\theta$

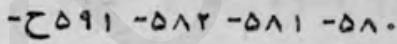

$-91<-710-09<-\Delta 97$

$-\wedge r \wedge-\wedge \cdot \Lambda-\Lambda \cdot r-\eta \wedge \Lambda$

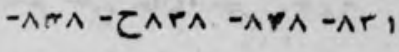

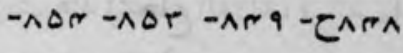

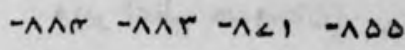

$-\wedge \wedge<-\wedge \wedge \neg-\wedge \wedge \Delta-乙 \wedge \wedge \mu$

$-\wedge 9<-\wedge 9 R-\wedge 9 \cdot-\wedge \wedge \wedge$

-9ir -9.7-9.0 -A99

$\wedge m \mathcal{- q m \Delta - q m - 9 \sim r}$

dونصالهب، كيتان

دوندي غان

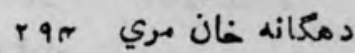

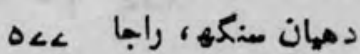

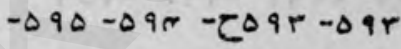


تازه نواي معاركم

1.11

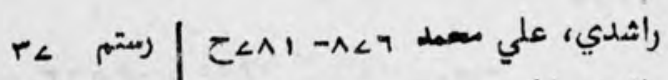

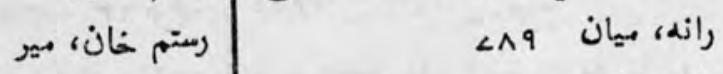
$-170-160-1.9-8$. راني تنامي ت روانهان

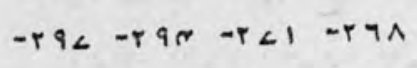
رمتالهخانمدوزتي(معتهدالدوله تفامي

$-r<t-r<r-r<1-r \cdot \theta$

وفادار خان وزير شاه زمانان)

$-4 t,-4 i t-6 r d-4 i d r$ - $\angle 9 r-\angle 9 r-\angle 9 r-\angle 91$

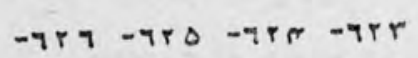
Arr $-\angle 94$

-

- $7 \Delta \Delta-7 \Delta \sigma-7 \Delta r-7 r<$

$-79<-7<1-7<7-709$

-der -ant $-<t 1-<16$

-97r -971 -97. -907

$-979-971-97<-977$

$q<q-q<$.

زبتمي علي خان، بير بهان

رستم هند (شجاع الدوله، فرزتد خان

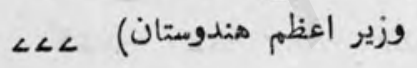

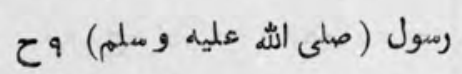

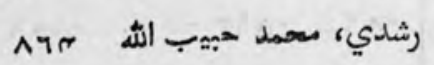

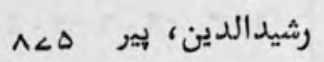

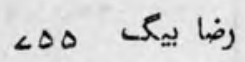

११^ رضا شاه

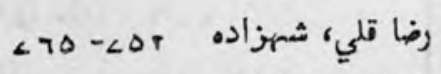

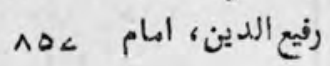

ره ت خان، حافظالملك رهمدل خان، مردار

$-\tau 1$ 乙 $\angle-\Lambda-\angle-(\Lambda)-(\alpha)-(\tau)$

-rt. $-1<\angle-179-17 \lambda$

-rei -re

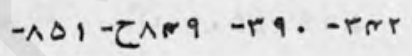

$\tau \wedge<r-\wedge<r-\tau \wedge \Delta 1$

رحيم خان رحيه غان تالهر

رجيم خان كوسه

رحيم داد خان ، سردار ( برادر

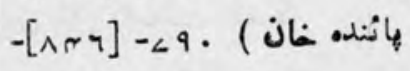

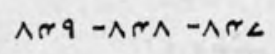

رحيه داد غان، مال (نائب قلات)

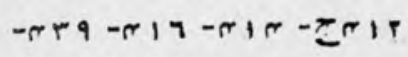

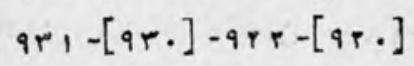

ارنين 
1.19

تازه نواي مalركى

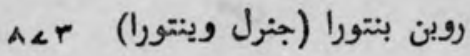

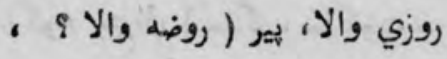

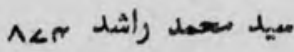

ريت، كهيتان

j

زار jوפ

ز زرغونه

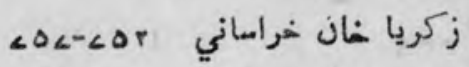

زمان خان سدو زاني ابدالى، دراني

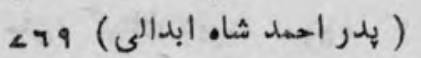

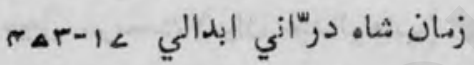

- $49-\angle q 4 \quad-\angle q 1 \quad-r r<r$

$-A 11-\angle 9<-\angle 97-\angle 9 \Delta-\angle 96$

-Ar<-Arr-Arr-Ar--Ar

१ $\Delta r-q \Delta r-\wedge \Delta<$

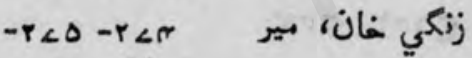

$r<r-r \wedge 9$
رقيه بيمثم (خوا هر شهزاده كامران) $\wedge \Delta r-\tau T<$

ركن الدوله ، مير كرم علي خان 900

(نيز رك كرم علي خانتالهر )

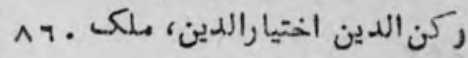

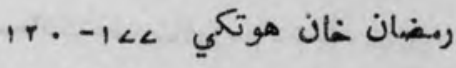

رنجيت سنغكهة ، مهاراجه ("خالصه

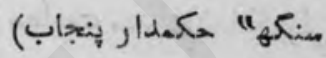

$-r 1-r \cdot-r<-5 r t-t r$

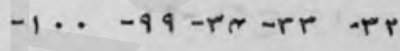

btr-stra -itre-iti

truetrtetrt-5tri

-ror -rar -ra. -rea

-rer -rti -cra. orad

$-r<\cdot-r 4<-r 4 r-2 r \mid$

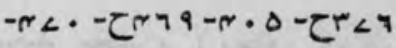

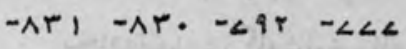

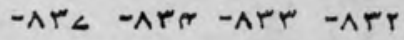

-^^r -

-97r -90N-91< - 99

-qAe -qAr -

१ง จ

رنمين (معادت يار خان) 
كازه نواي معارك

1.9.

"مرفراز غان كلمهوره، ميان

$-\angle 9 . \quad-\angle \wedge<-\angle \wedge \Delta \quad-\angle \angle \theta$

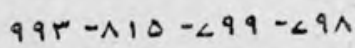

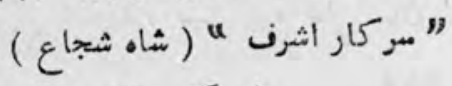

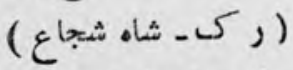

سمادت خان (صوبه دار اودهه)

$\Delta \Delta r$

سمادت سعصدخان (سعادت مند خان)

टal

معادت هند خان الكوزني (سعادت

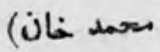

|r. -119- ट $91-91$

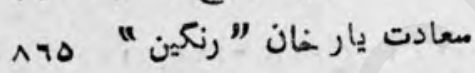

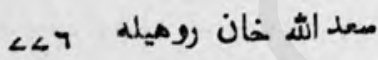

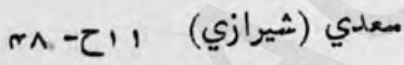

معيد بن مسيب

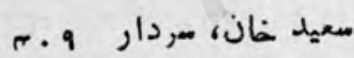

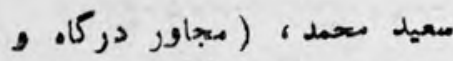

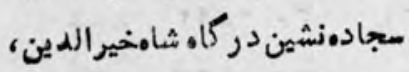

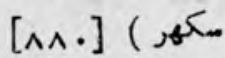

سعيد سممد خان

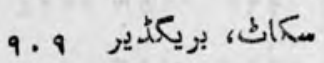

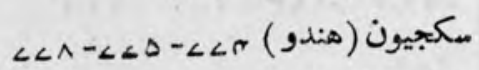

سكندر، كرنيل سu

ساكو، جنرال ( ساكو، ساكوت،

ساكول؟

geit-4it-grat -

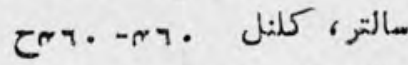

هالو خان

$-r|r-r| 1-r \mid a-r \cdot r$

tra -erre tre-rir

req

ماندرم، كوتان ونr

سرل سرمست (ميان عبدالوهاب) ATr

سجيدنه، مفتي (1<)

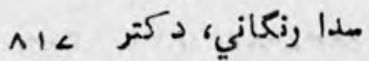
مدوره (وكيل مير علي مراد خان) זיד

سر بلند خان (إبسر وِير نتع خان

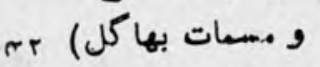

-ر بلد غان (مراد باب غان

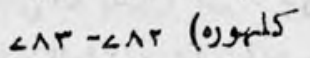

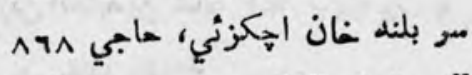

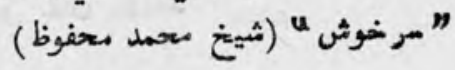

C<A

( ر) S sos ) 
ter trt -rin tit

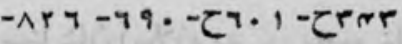
$\wedge \wedge \mathrm{r}$

سوم ماركه جونجه مهراب خان، مير (والين خيزيور) $-15 \Delta-115-1.9-9$.

- $911-911-576-797$

$-\angle T P \quad-\angle T|-\angle T \cdot-T| T$ $\angle r r-\angle r$.

Clar

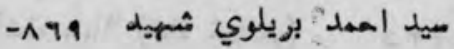
$-\lambda<9 \quad-\lambda<A-\lambda<\angle-\lambda<\pi$

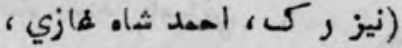
ميان مير )

ميد الممد (مير واعظ) r. Cor ميد مبيب

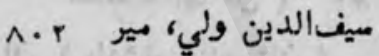
سيل، جنرال مر رابرت هنري

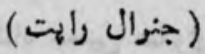

$-4 \cdot<-r a n-c r a r-r a r$ $-r a<-e r \Delta r-r a r-5 r \cdot \sigma$

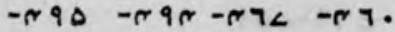
-D. . - - Drq $-\Delta 1 \wedge-01<-\Delta 14$

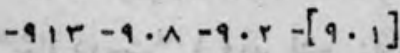
are-qp
ملطان مان (بن الهداد مان انكي زني (رئ

9 مانطان L سلمان على ، ثهيزاده.

$-\angle \angle-\angle T-\angle R-\tau<r-\angle T$

$-r \mid r-1<9-1<1-<1$

$-4|\wedge-4|<-4 \mid T-4 / 0$

Pra - 19

ملعطان معصد خان (طالني، برادر وزيه فتع غان)

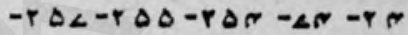

ard $-\lambda \Delta a-n<r-r<1$

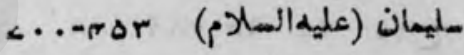
<90 مليمان،

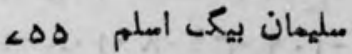
Crar-erta

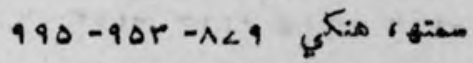
سمنامر مان باميزني، سردار هني

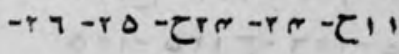

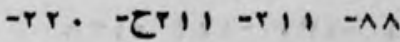
$-r<\angle-r<T-2 r<r-r<r$ $-r .1-r .0-r a r-r a \Delta$ $-r 11-r .9-r .<-r .4$ 
شاه رجب ( بيثى خدمت شماه شعاع) r

ثاه رخ $\angle 9 \angle$

ثاء زمان در"اني، ابدالي

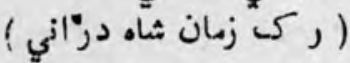

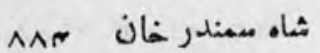

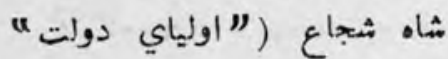
"مركار اشرف " "شاه بابا" ) $-(1)-.(\alpha)-(\tau 0)-(0)$ $-4 \cdot-1 d-1 \wedge-14-(14)$

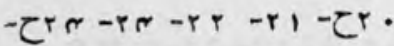

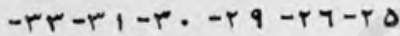

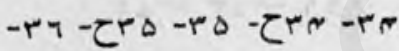
$-\tau a \Delta-a \Delta-a \omega-\lambda d-\lambda \wedge$ $-1 \cdot 1-99-9 \wedge-9<-97$ $-\tau 1 \cdot 7-1 \cdot 7-1 \cdot 0 \quad 1 \cdot r$ $-1 \cdot a-\tau 1 \cdot \Lambda-1 \cdot \Lambda-1 \cdot 2$ $-11 r-111-511 \cdot-11 \cdot$ $-114-110-11 \pi-11 r$ $-|r|-1 r \cdot-119-116$ $-146-1 t r-1 t r-5 i t$ $-1 t<-1 t 2-5 i r \theta-1 t \theta$ $-1 r i-i r \cdot-1 r q-1 r a$ ard -ire-itr -itt $-i n t-i r \cdot-i r a-i r s$ $-1 \pi<-1 \pi d-1 \pi 0-1 \pi m$ - $1 \Delta r-1 \Delta 1-1 m 9-1 \% A$

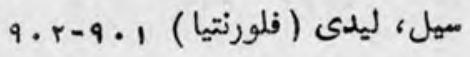
مينا خان (ملازم مير نور سحمد غان) १८. -979

שهوا سنك

\section{قي}

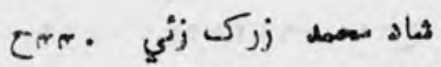

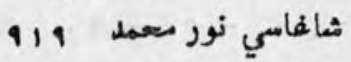

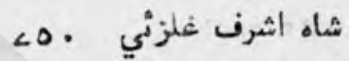
$9<9-9<<\quad$ ثاه ازكلميند

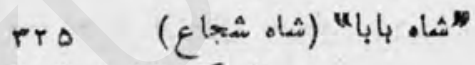
( ع) (

C'

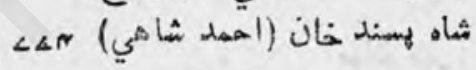

ثاه برإهند خان الكوزئي

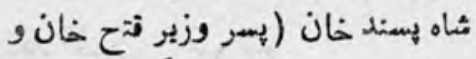
مr ( )

ثاه جهان ( بادشاه هندوستان ) $\Delta \Delta 1-\Delta \Delta$.

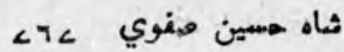

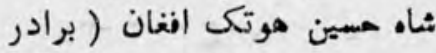

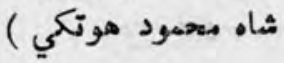
A^r $\angle T q-\angle \Delta r$

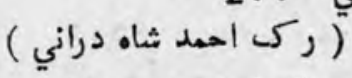
ثاه دراني "עشاه دومت" ( وزير نتع ذان )

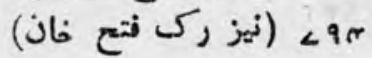


$-\tau r<4-r<r-r<r-r<$.

$-r \wedge$ -

-rqm-rqr -rq। - CrAq

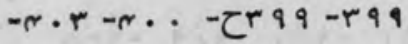

$-\operatorname{cema~}-46 a-414-4 \cdot 4$

$-r 7 r-r \Delta r-r \Delta 1-r \Delta$.

$-\tau r<r-e<-r q 9-r q \angle$

$-r<9 \quad-r<1-r<-r<7$

-rat -nat -riv ma.

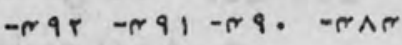

- ir -

$-\Delta r<-\Delta r r-\Delta r r-\Delta r$.

$-\Delta r_{1}-\Delta r \cdot-\Delta r q-\Delta r \wedge$

$-\Delta r \Delta-\Delta r r-\Delta r r-\Delta r r$

$-\Delta r q-\Delta r \angle-$ Corq-orq

$-7 \Delta 1-\tau 9 \cdot 1-\Delta 99-\Delta 7<$

$-\wedge \cdot r \quad-\wedge \cdot r-\angle 9 \Delta-\angle 91$

$-\lambda \cdot \tau-\Lambda \cdot \Delta-\tau \wedge \cdot r-\lambda \cdot \mu$

$-n i r-n i r-n i r-n i t$

$-n t y-n t \theta-n t r-n i o$

-nrr-ntr-nti -ntq

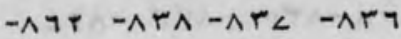

$-\wedge \wedge \Delta-\wedge \wedge r-\wedge \wedge r-\wedge 7 \Delta$

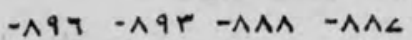

$-107-100-10 r-1 \Delta r$

$-191-17 \cdot-109-101$

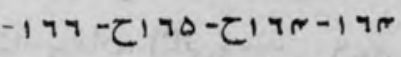

$-C^{r}<m-r<r-r<r-1<$.

$-r \wedge \cdot-r<1-r<9-r<\Delta$

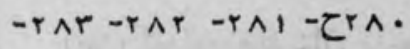

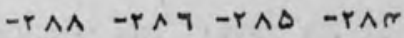

-rqr $-r q 1-r q \cdot-r \wedge 9$

$-r \cdot r-r \cdot$ - + - 99 -

$-r^{\mu} \cdot<-r \cdot<-r \cdot 9-r \cdot 0$

9

$-r r .-4|d-r| \wedge-r \mid<$

-5rte-rte trtr -5trt

-rra -rre -rrq -rro

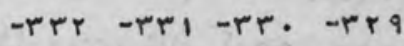

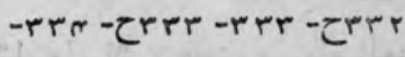

ט

arra

-rer-erer -ret trai

-rם -re-red

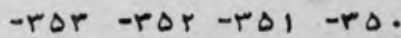

-

$-r \Delta q-r \Delta \wedge-r \Delta<-r \Delta T$

,rq9 -rqa 
شاه مردان إول ، شمس العلماء

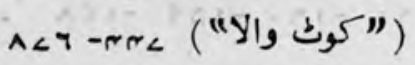
شاه مردان، (ثاني) ميد شاه نواز خان (نور محمد غان

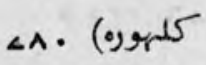

(نيز رك نورمحمد خان كلمبوره)

شاه نواز خان براهوي (بن المديد

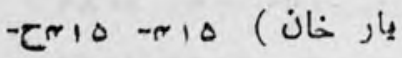

itr erter

شاه نواز خان (متمهد الدوله) فيروز

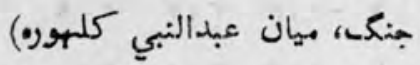
$\wedge$.

شاه وردي غان ( مز بو جنكه،

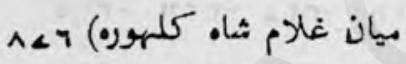

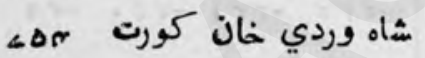
شاه ولي اله دهلوي ، امام الهند СடА $-\angle \wedge 9-\angle \angle T$

ثاه ولى خان باميزثي، اشرفالوزرا ( وزير احهد ثاه ابدالي )

-cL. - Cria - Rा1 -

$-\angle 90-\angle \angle A-\angle \angle C \quad-\angle \angle r$

A A - С T

شا هل سحمد، ميان

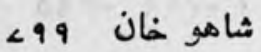

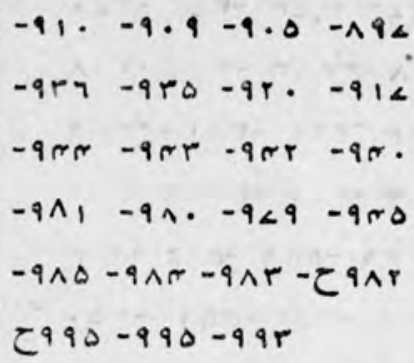

L مشاه عباس شاه قلي خان ثاه معصمد، ميد ثاه محمل خان ثماه محمد خان، بير باه شاه محمود (بن تيمور شاه بن احمه شاه ابدالي )

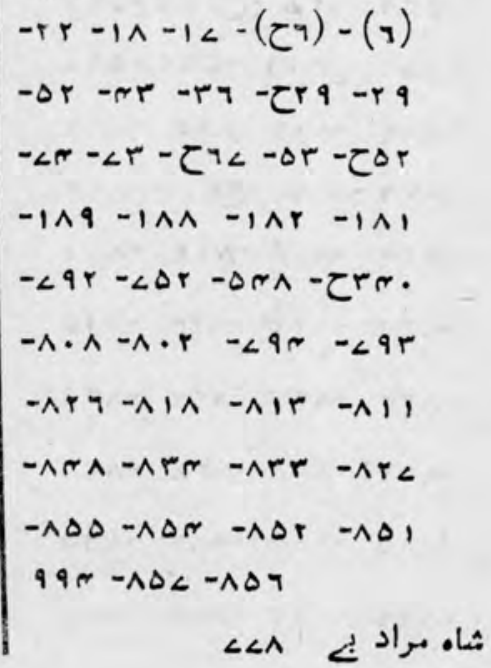


هُ هُباز خان رنهاري مهناد خان، مير مهاد

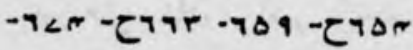
$<99-<9 \wedge-7<7$

شهرخ ميرزا

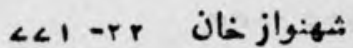
ثميخ احمد مبدد الف ثاني مرهندي $\wedge \Delta<$

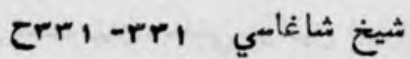

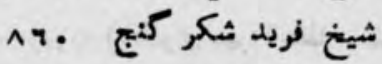
شير دل خان ، سردار (ه)- (A)$-<1-9<-c 7 r-9 r-0<$ $-17<-100-1 r r-12$ $-1<r-1<1-1<--17<$ $-1<9-1<1-1<<-1<r$ $-4 .-19<-$ CIno -1 a. $-r \cdot<-r \cdot 1-r \cdot r-r \cdot 1$ -rtr - ti< - tid -r. trta brti -rta -tre -nor -na. -rr. -crta ALT -ATT

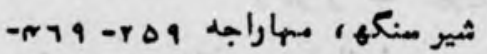
$-\Delta<\pi-\Delta<1 \pi<$ - שथ $-C 011-\theta<<-\Delta<7-0<\theta$

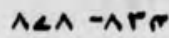

شجاع الدوله ، نواب (فرزند خان، رستم هند، وزيراعظم هندوبمتان) $\angle \angle \angle$

شجاع الدوله (خلف معمد زمان خان) - $\Delta r r-\Delta r r$ - $\Delta r r$ - $\Delta r L$

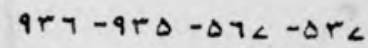
ثجاع المهلطنه، شهزاده مسن علي

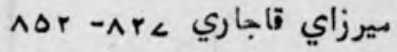

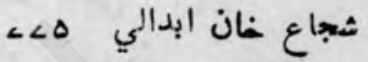

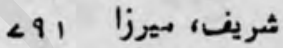

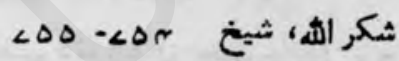
شكر اله شان ثدمان اخند زاده $1 \wedge \wedge-1 \wedge \angle-1 \wedge T$

شهم الدين، ميد (جدة, لعل شهباز

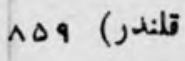

شمسالدين خان باركزانى (برادر زاده' امير دوست مهمد خان لمان

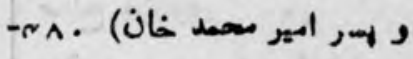
-or. -0.1 -0.. -nad -art -orr -arr -ori - $\Delta \Delta r-\Delta m_{<}-\Delta m \Delta-\Delta r a$ ดัด

Aهابالدين قرخ ثاه 
تازه نواي معارك

$$
1 \cdot \times 7
$$

$-710-9<\angle-9<\pi \quad-9<r$

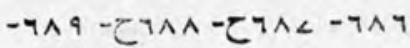

$-79<-799-79 r \quad-791$

$9<7-9<\Delta-9<r-9 \Delta$.

ثميرين خان

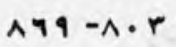

ص

صابر شاه. كابلي

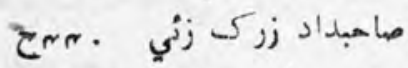

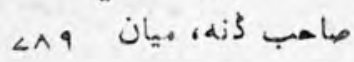

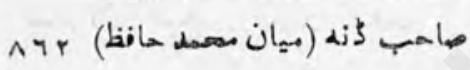

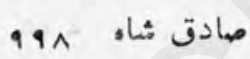

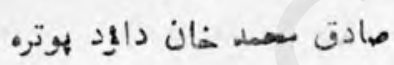

$\angle \Delta Q-\angle \Delta Y$

صالع ( برادر سنو ، جدهّ هدوزاني ) $\angle 90$

صالع ضان صالع غان بيات مان مان مان

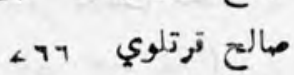

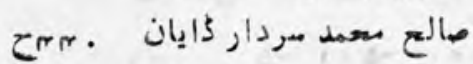

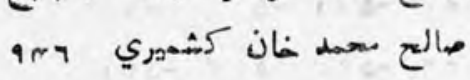

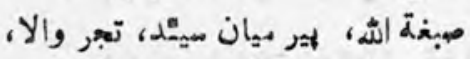
" $\wedge<T-\wedge<\Delta[\wedge<m]$
شير ثماه سوري

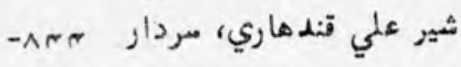

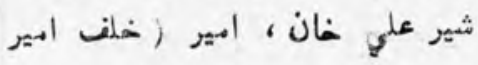

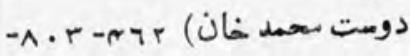
-ant -act -ani -an. ACP -Ame ثهر معمد خان (ثير معمد بليدي)

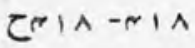

شير سمد خان، هاجي، وكيل ابيران

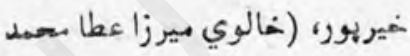

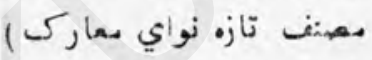

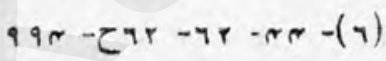
شير مهمد خان، حافظ، بـتتار الدوله (وزيوشاه زمان، إهر شاه ولي هان بامهزني وزبر اعظم اهمديد شاه ابدالي)

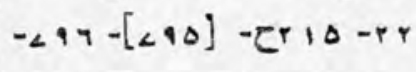
ArD-AIr - A. r $=\angle 9<$

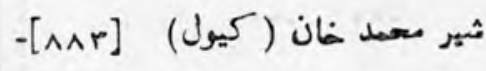
$\wedge \wedge \angle-\wedge \wedge Y-\wedge A \Delta$

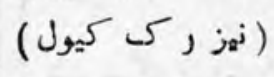

شير سمد خان، مير (والي" ميربور)

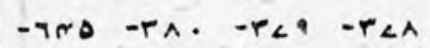


$1 \cdot P 2$

تازه نواي مع

"طرزي" " (غلام سممد خان الفغان) AN - $-\Lambda N$.

طره باز خان ( برادر زاده: نانب 1 1 .

طره باز خان (سردار طايغه" خيبريان) ก 99

طلا معمد، قاضي (فرزند تاضي - مسن) A

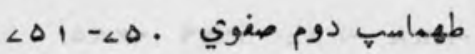

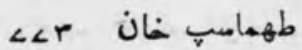

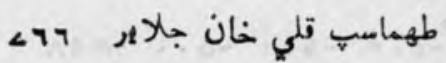

$$
\text { b }
$$

ظفراله، شيخ

$$
\varepsilon
$$

"عابد" (آغا زين المابد بن ثاه) ه9 ه عالهكير ثانى

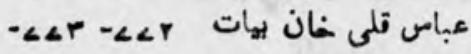
$\ll \Delta$

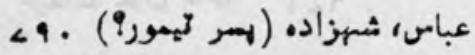
عبام ميرزا ( لهر شاء رخ ميرزا) $<9<$

عباس مهوزا، شامزاده (بن لتع على
صبغة الثه دوم، جير (خلف ثداه مردان اول)

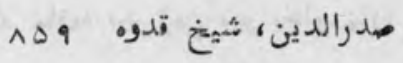

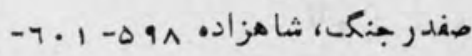
$r \cdot r$

صلابت خان حولدار الح صلاح الدين، بيان

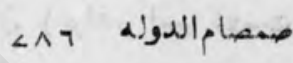
صوبدار خان، مير $-7 \Delta 9-7 \Delta<-7 \Delta r-9 r 1$ $-9<0-794-77 \Delta-74 r$ $-9<r \quad-9<$. $-4<9 \quad-7<1$ $9<1$

" صوفي" ( نواب اله داد خان ) Arr-nTr

ض

ضياء الدين " ضيال " ضياء الدين ضهاء برني b

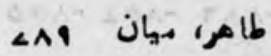
CrAr 
تازه نواي مalرك

I. rA

عبداه خان يفلص الدوله 'Are

Aro

عبداله خان، مير (بن ثير بخار خان

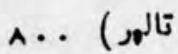

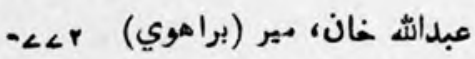
ir.

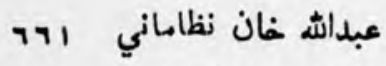
عبدالجبار خان ( برادر امير دومت عبدال

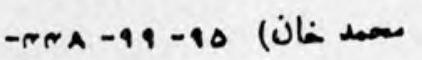
A<1 - שח

عبدالهق، ميان

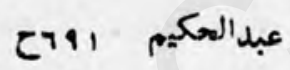
عبدالحي حبيبي انفاني (r) ( ) ( ) )-

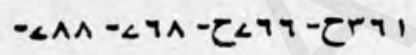

- carer-zarl - cart

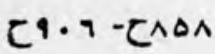

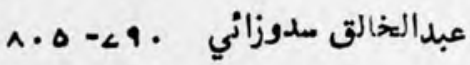
عبدالرحمـن'، (يدر نائب معمد حسن) ire-pr.

عبدالرمدـن غان، امير ( شاه كابل) -ame -art -ant -ar< -ara -rame ANC

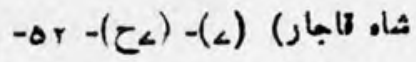
-grtr-tr-tr-4i -cor ट?"N

عهدالاهد، مولانا

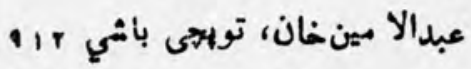

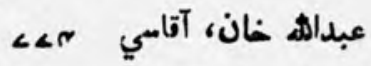

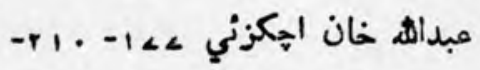
$-4 a t-r a .-r r<\theta-r<0$ -4NA -

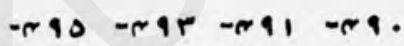
$-0.4-0.1-0 . j-\pi \mid$

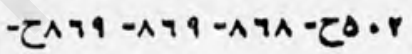
Aก -AL.

عبداله غان الكوزني مبداثه غان اول عيداله هان

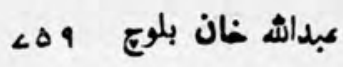
عبداله خان بوهلزني، سردار (وكيل الدوله) ( مبداله خان كالهر صبداله خان دوم و

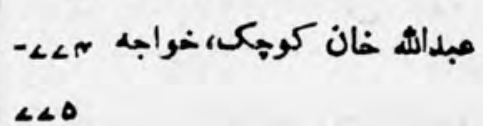




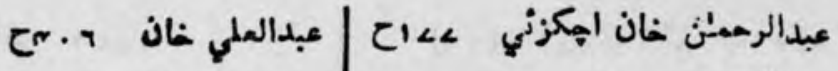

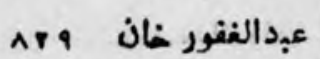

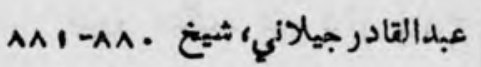

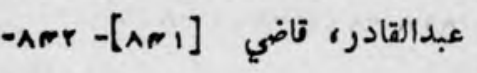

$\Delta \sim \Delta-\Lambda \mu \sim-\Lambda \sim r$

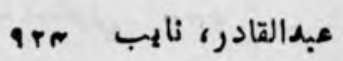

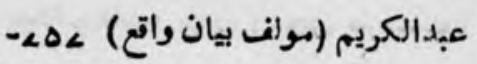

$\angle T A-\angle \Delta 9$

عبدالكريم رئيساني عهب عبدالكريم شيرازي رئري

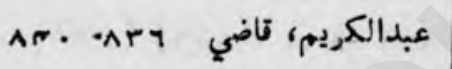

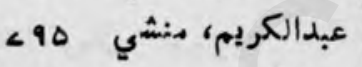

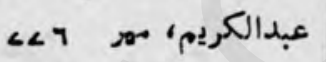

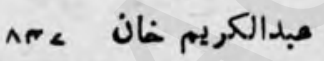

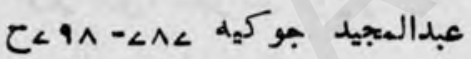

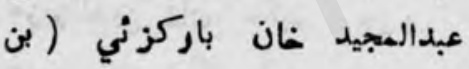

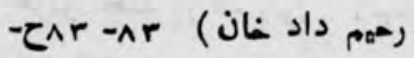

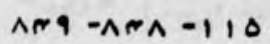

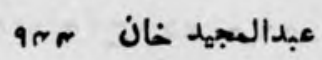

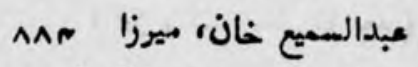

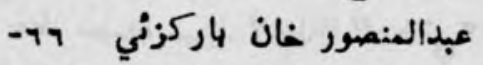

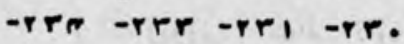

-Amq -rra -rrL -rro CALr-AOI -AO.

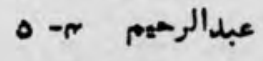

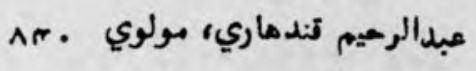

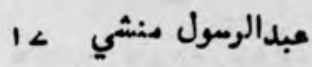

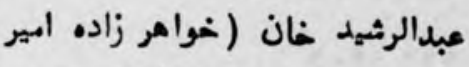

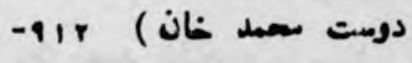

Im

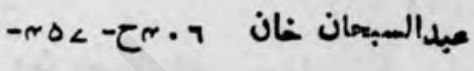

$\sim \Delta \wedge$

مبدالسلام خان نوفلزني

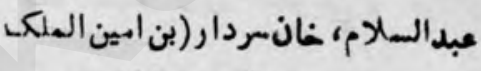
تصمد اكرم خان)

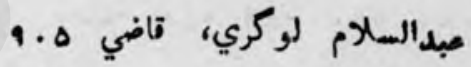
مبدالشكور( هضرتصاهب بتخاكى) ro.r

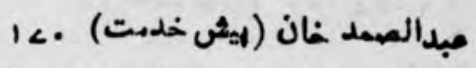
مبدالعهمد خان مهمندزائي (اشنغري) $<\angle \Delta-\angle<1$

مبدالمزيو

عبدالعزيز، كلايب (بن ثقير سممد ) Ir

عبدالعزيز خان (زازٔ- سمادت مند

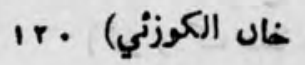


تازه نواي سمارك

1.r.

$-1 r-(1 \wedge)-(1<)-(14)$

$-4 \wedge-\operatorname{sa-5in-14-5it}$

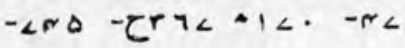

$-\wedge 9 . \quad-\wedge<\Delta-\wedge T T-\angle \pi T$

१९า -9. .

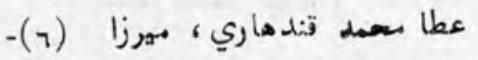
$179-(\wedge)$

عeل معمد خان ( سردار لشيكر شاه

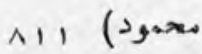

عطل مصمد خان الكوزني ' سردار $-\angle T-\angle \Delta-\angle T-T<-r \Delta-r \pi$

$-\wedge 1-\wedge . \quad-\angle 9 \quad-\angle \wedge \quad-<<$

Ars $-r i \Delta$

عطا معمد غان باركرئي ( برادر

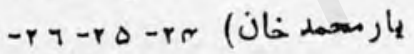

$\wedge \times \Delta$

عطا معمد خان بانيزني (نسمان مختارالدولهشيرمحمدخان وزير )

$-<a<-\pi \cdot 1-r \wedge-T_{1} \mid-r_{1}$

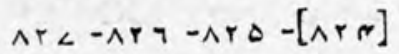

" عطاني" (ميرزا عطا معمد بو (ن)

1 ८. - $r \wedge-\tau \mid r-1 r-(r)$

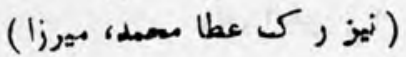

عبدالثبي' مير

عبدالنبي كلمهوره، ميان(مهتهدالدوله، فيروز جنكى، ثماء نواز خان)

$\wedge 1 \wedge-\wedge \mid \Delta-\wedge \cdot 1-\wedge$.

११^-११६ عبدالهادي، سيد

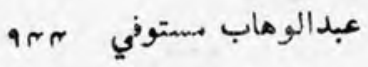
عبدالوهاب، ميهن (متحل مبرهmت ) $\wedge \neg r-\wedge \neg r$

عبدالوهاب خان عثمان برندي، ثيخغ (لمل ثهباز قلندر)

عثمان كاثما تولهال C'l عازيزالدين، شهزاده عزيزالدين خان، حكيهم هنه

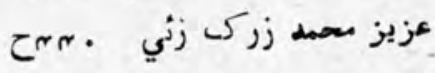

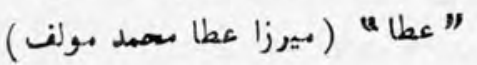

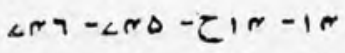

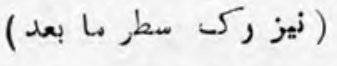

عطا معمدة ميرزا "عط)" "عطاني" (شكارنوري ، مـولف تازه نواي $-(r)-(\Delta)-(\sigma)-(r)(5$, $(r)$ $-(10)-(1 r)-(1, r)-(n)$ 
$1 \cdot r 1$

تازه نواي معارك

علي خان بلوت عطائي خان

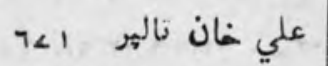
عطر خان كلههوره (بن بهيان نور محمد

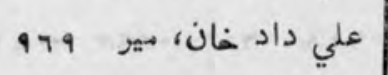
خان )

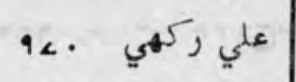
$\angle 99-\angle \wedge \uparrow-\angle \wedge r$

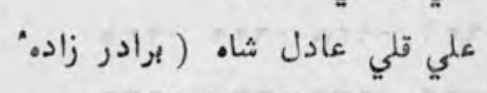

" عظيم" "توي ، ( بير عظيممالدين ) نادر شاه انشار) (مادر زاده 人19-<99 علي كوهر "اصغر" بهر سيد ("بنكلي

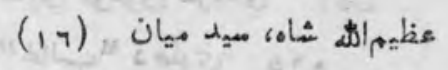

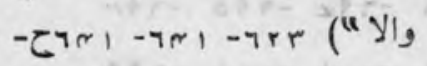

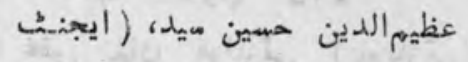

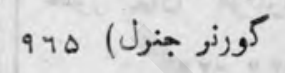

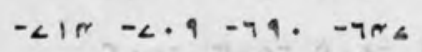

$-\angle C \cdot-\angle T Q-\angle 1<-\angle 10$

$-\lambda<\Delta \quad-\angle \pi r-<\pi t \quad-\angle \pi 1$

$\wedge<7$

علي كوهر ثاني " شئ

علي سعمل اول ، سيد (خلف سيد

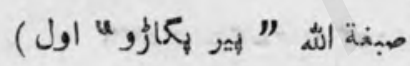
$\wedge<\gamma-\wedge<\Delta$

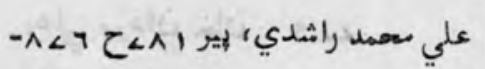

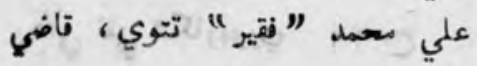
A. $9 \cdot \wedge \cdot<$

علي سحمد خان" ملي " نواب (لماري) Arr-Ari
عاء الدين خلجي

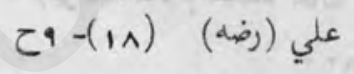
"علي " (نواب علي متحمل خان لفاري) Arl

علي جهكراني، تركس <1< लrA -erT

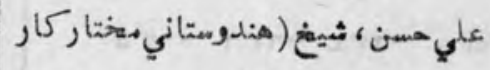

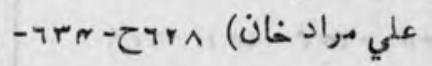
$-\angle \cdot<-<\cdot T-\angle \cdot \Delta-79<$ $-\angle 10-\angle 1 \omega-\angle 1 .-\angle \cdot 9$ $-\Delta \pi \cdot-<r+-\angle 1 N-\angle 1<$ $\angle C r-\angle M T-\angle C I$

علي خان

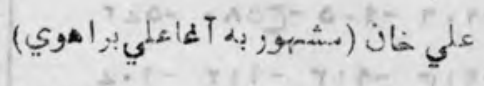

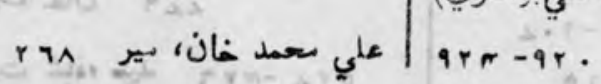


تازه نواي معارك-

$1 \cdot r r$

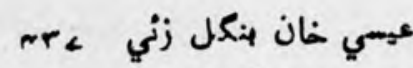

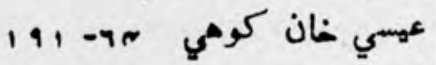

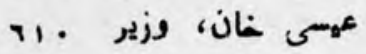

$\dot{\varepsilon}$

غازي الدين

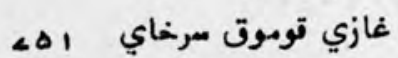

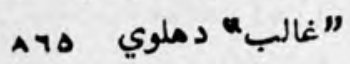

غفور غان فوفلزني ( بوللزني )

nit-nit-ertetr

" غلام " (نواب غلام مسعد خان )

Arr

غلام اخوند زاده غلام

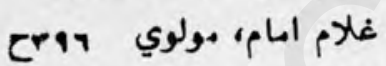

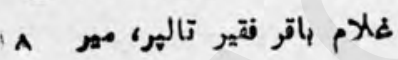

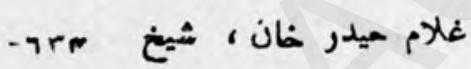

- TrA -tr/ - Try - TRS

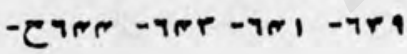

Ter

فلام مهدر غان، سردار (ابن اثدر

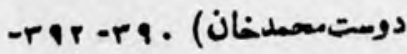

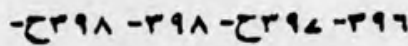

-

$-1.1-9 . \Delta-r \Delta x \cdot-\Delta<T$

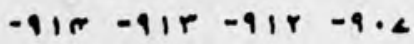

imp-ame-ane - 110
علي مراد خان تالهور، مهر (والي"

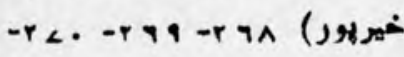

$-21 \wedge-7 i r-606-101$

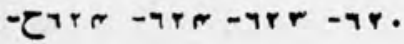

-789 -78 - -479 -780

-

- $1<r-9<r-979-901$

$-791-79<-190-49 m$

$-<.+\quad-<.1 \quad-<. . \quad-799$

$-\angle \cdot T-\angle \cdot \Delta-\angle \cdot N-\angle \cdot r$

$-<1 \cdot-\angle \cdot T-2 \cdot \lambda-<\cdot<$

$-\angle 19-\angle 10-<10-<11$

-ar. $-<19-<1 \wedge-<1<$

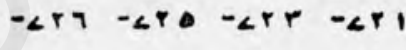

$-\angle r \cdot-\angle r q-\angle P A-\angle r \angle$

- crD -

- $\angle P Q-\angle P A-\angle R<-\angle P A$

$\angle N P-\angle N P-\angle C 1-\angle N$.

علو مردان غان

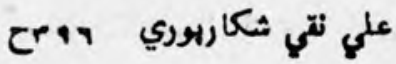

عمر فاروق (رضه) <ح-حه

$\wedge \diamond \wedge$

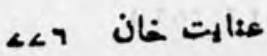

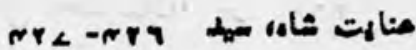


غلام معمد خان لغاري" "كارر" نواب Ar| $-\wedge 19-\wedge 1 \wedge-\wedge 10$

غلام شحمد درويش، شماه جي بrه

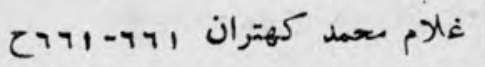
غلام مدي الدين مرهندي ، مير $\wedge \Delta \wedge-[\wedge \Delta<]-r \mid<-1 \sim 4$ ir ir غلام نبي، مير

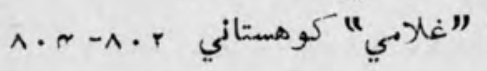
$\wedge \cdot \boldsymbol{\top}-\Lambda \cdot \Delta$

غيبي خان كوهي ن

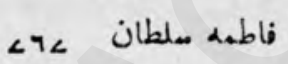
فت فتح اله خان فتع جنك، شهزاده AIr

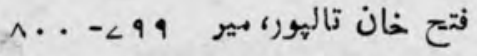
زتع خان باركزني ، سردار ")

وزير شاه .تحمود) (- ه-

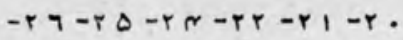

$-r<-r q-r q-\tau r<-r<$

$-\Delta t-\Delta r-\Delta 1-r 1-r \Delta$
غلام حيدر كهو كر ודצ- ודצح

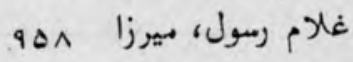
غلام رسول خان ولد مشالو خان crrr

غلام ثشا. كلهوروه، نيان (هزبر جنك، شاه وردي خان )

$-\angle \Lambda T-\angle \Lambda \Delta-\angle \Lambda N-\angle T$.

$-\wedge<T-\angle 99-\angle 9 \wedge \quad-\angle \wedge<$

११^-१४r

غلام شاه، بير (بن دحراب خان تالهر ) 77 .

غلام علي خان، مير (بن عبداله خان تأر

غلام علي خان تالهر، بير (والي a حيدرآباد) (

غلام قادر، قاظي غلام سحمد خان هوبلزئي

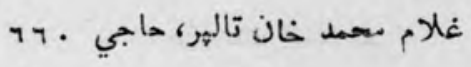
غالِم سممد خان طرزي افغان، سردار $\wedge \sim$.

غلام معمد خان لغاري، كويلي والا $7<r-791-7 \Delta \Delta-7 \Delta r$ ف 
فدا حسين ) سيد ( عرف نبي بتخث

بخاري حيدري جمعدار ترك

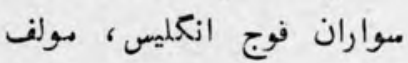

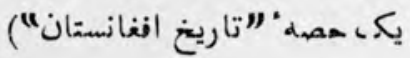

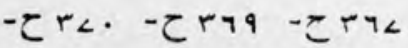

$-\tau r \wedge 1-\tau r<4-\varepsilon r<1$

-гraq -

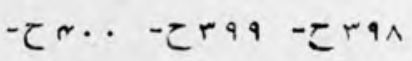

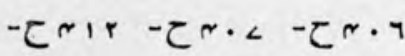

$d \cdot \pi-r<1-r d \wedge$

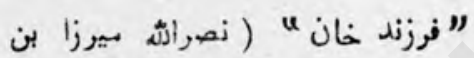

L

فرزند خان (ثباع الدوله، رستم هند،

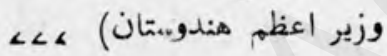

فرنج، كيتان

فريد بتخش، كهيتان فريدركا اظم

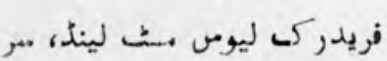

$9<.-979$

فرير، ادوارد ( هلدر مدر هنري فرير)

99.

فوبر، جان هو كم ( 15 كاي سر هنرى 9 १ ।

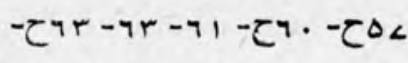

$-<r-<r-\angle r-\angle \cdot-7<-7 T$

$-\wedge r-\wedge r-\wedge \cdot-\angle<-\angle T-\angle \Delta$

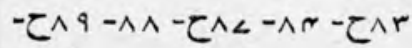

$-1 \Delta a-1 \% \cdot-1<a-1<2$

$-1 \wedge \wedge-1 \wedge \cdot-\underbrace{17 \Lambda}-1 \mathrm{~T}$

$-r \Delta \Delta-r m \cdot \cos -1,1$

-nir - $24 a-\angle a r-\angle a t$

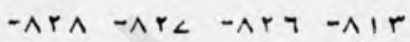

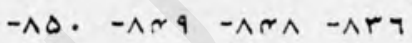

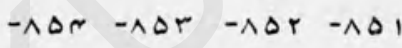

-

१९จ

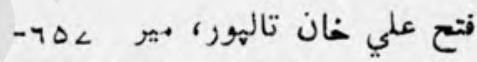
$\wedge \mid \Delta-\wedge \cdot 1-7 \Delta 9$

فتع علي شاه قاجار $\wedge \Delta r-\wedge \Delta r-\wedge \Delta \cdot-\angle 9 r$ فتع دعمد، اخوند هالو" (وزير سير . حمود خان تلات) بونه

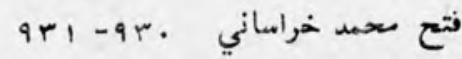
فتع محمد خان غوري ( كوري ) $-r<r \quad-r \cdot 9 \quad-r<r-r+4$

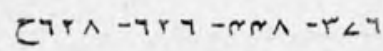

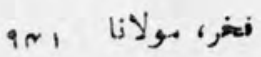


فلورنتيا (ليديسيل، دغتر جارج ونيم)

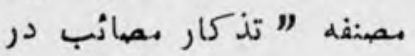

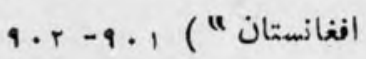
فوبي خان (مهولي خان) بـان فهيم خان مري مهري فيروزالدين ثاه، شهزاده حاجي (برادر شr - Cor - or (

$-7 .-\Delta q-\Delta \wedge-\Delta<-\Delta T$ $-7<-47-74-71-$ CT. $-1 \wedge r-1 \wedge 1-\angle r-7 \wedge-\tau T<$ -nor -nr<-ri. -err. ^or فيروزجنك)(معتهدالدوله، شاهنوازغان ^. . . .

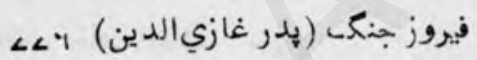
فيروز شاه، سلطان . . فيضالله دولت شاهي، قاضي بهر فيضالله خان فيض سحمد هزاره ( مصنف

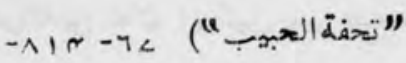

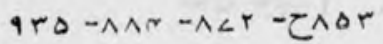
فين' جنرل سعر هنري (كهاندر هيف) [A9r]-Crut-rat
فرير، سر منري بارتل ادوارد ( كمشنر $-<17-(1,1)-(\Delta)-(\infty)(\Delta)$

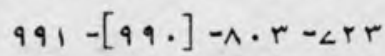
فريزر، كمتان שחים

$$
\wedge \Delta \wedge \text { "فضل" }
$$

فضل قادر، قاضى هrی فضل لهري 919 نضل سحمد خان ، بير ( بـسر ثير

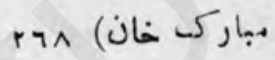

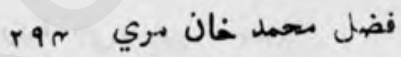

” فقر, " تتوي ( قاضي علي محهد ) $\wedge \cdot 9-\wedge \cdot\llcorner$ فقيراله :جلال آبادي ثكاريوري، سيد $\wedge \angle \pi-\wedge \Gamma \Delta$

نقير عالم خان مري ه وسז- וمזbat -rar -ra. r.

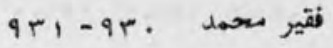

$$
\begin{aligned}
& \text { فقير سحمد ثانى } \\
& \text { |فقيري:" }
\end{aligned}
$$

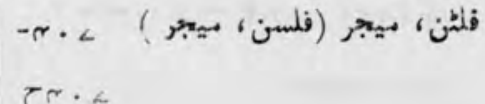




$$
\begin{aligned}
& \text { تيصب، مير شير، شهزاده } \\
& \text { قيصر خان . . تهم } \\
& \text { قيمت راي (هندو) } \\
& 5
\end{aligned}
$$

كاتن، ادبيرال راوليند (بدر جنرال a.

كاتن، جنرال سر ويلوبي وبrع1) $-2 . \wedge-[a . r]-r a c$ كاردري، جي- جي

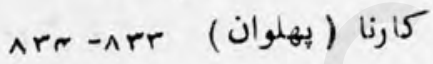
كالس، بيجر rar كاظم شاه الحسيني، ميد ( بيسر سيد

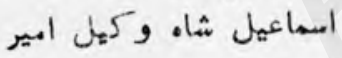

ميدرآباد) ( . (1)-

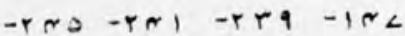

$-r<t \quad-t<1<-t<t \quad-t<t$

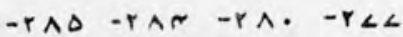

-ris - tid -rQD -rAT

$-r e s-r \cdot s-r \cdot d-r \cdot r$

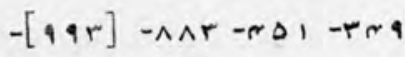

११^-११ๆ

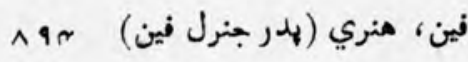

$\ddot{\theta}$

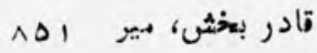

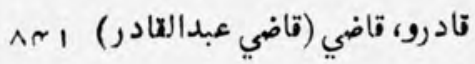

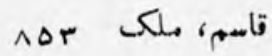

قامبي (شاعر) )

قاسو

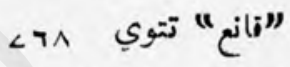

تبول محمد، ميان ז

تبول سحمد دوم، ميان رجی تطب الدين معمد، ميد قطب خان تملدر خان افغان ' قليتج بيكس، ميرزا $\wedge \wedge$. قمرالدين خان ( برادر شمس الدين خان ( براد )

تمرالدين خان (وكيل بير فتحعلي

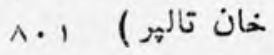

قمرالدين خان، وزيرالهمالكى ــــ- 
$1 \cdot r_{2}$

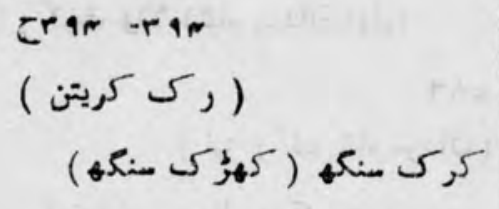

Are tris

كرم علي خان تالهور، مير ("ركن الدوله" واليهميدرآباد) -1त人 -iro -11 . - -

$-A 1<-r T a-r T<-217$

$99 \Delta-9 \Delta<-9 \Delta \Delta-9 \Delta$

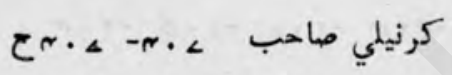
كريتن، بريكدير جنرال هارلس

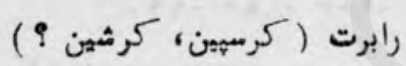

[a.r]-Crachar-rad

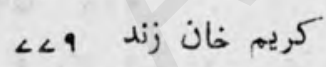

كريم داد خان بولهلزني باميزئي

A ।

كور خان

rra-crur soma

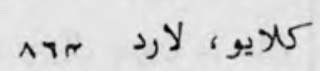

كمال خان مري

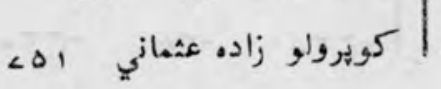

تازه نواي مar

كاله خان، ميرزا له كامران، شهزاده (بن شاه بهمبود) - or - zar -or -(a) - (c)

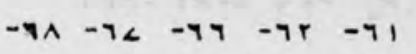

$-\angle C \quad-\angle r \quad-\angle r \quad-\angle 1 \quad-\angle$.

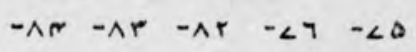

$-1<\gamma-1<\Delta-\wedge 9-\lambda \gamma-\wedge \Delta$

-INT -1A1-1<9-1<N

$-1 \wedge<-1 \wedge 0-1 \wedge \pi-1 \wedge r$

-rio -tim tir -ian

-rr< erre -rre -rti

-graa-erm-rea trea

CY. $-7 \cdot \Lambda-Y \cdot T-Y .0$

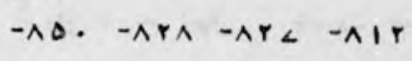

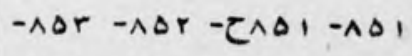

१ा - - $\Delta \Delta-\wedge \Delta N$

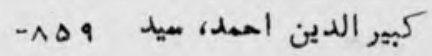

१تو هل

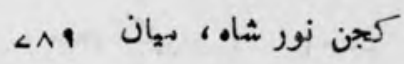

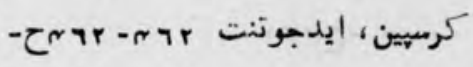

crit

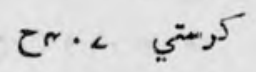

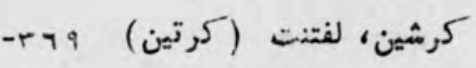


تازه نواي مalرك

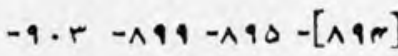

a ar-9ir-qur-a.

كيول ( كيمهيبل، شير سحمد خان) -[ANr] -rrt -rrr -rri

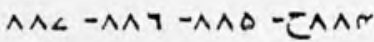

كيون، لارد

5

كما علي شاه كدو غان

كدو مبل، ديوان (وكيل سند)

$-\angle \wedge \uparrow-\angle \wedge r-\tau<\wedge 1-\angle \wedge 1$

[१११]

كرئi AND

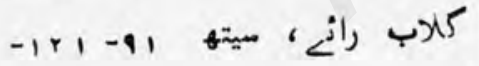
$\operatorname{lnc}$

كلاب . منكه موبدار

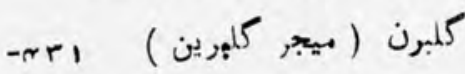
art-enti

كلزارخان باميزني

-rir-194-C। $90-190$

rer -rim
$1 \cdot r \wedge$

كوث والا (شا. مردان اول)

$\angle \wedge Y$

(نيز ركى شاه. مردان )

كوفمان، جنرال (-كمران اسياي

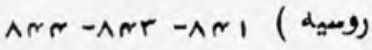

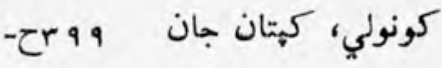
वाल

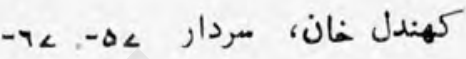
$-1<\wedge-1<<-\wedge<-<1-\angle$.

$-r \cdot r \quad-i a r-1 \wedge a-1<9$

$-r t r-r . \delta-r \cdot \Delta-r \cdot \omega$

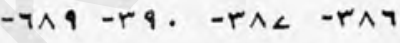

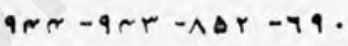

كםth

كي، مر جان

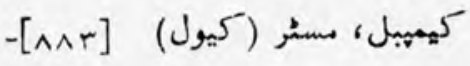
$\wedge \wedge \neg-\wedge \wedge \Delta$

( نيز , ك كيول )

كين ، سر بان ( لهدر بارون

مر جان كين)

كين، لفتنتت بنرال بارون *در جان

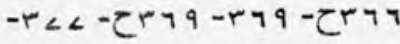

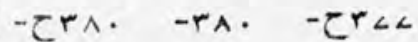




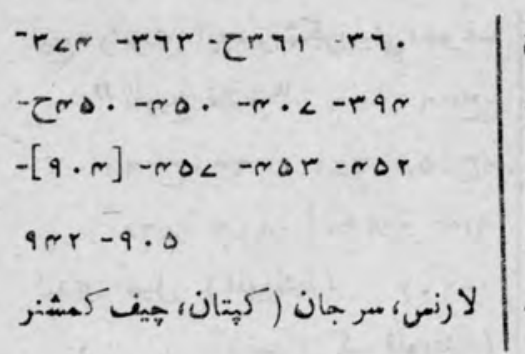

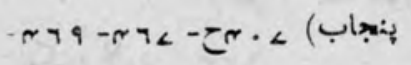

9. $7-\wedge r+-\Delta \Delta<-\Delta \Delta r$

لبدين صاحب (لبلدين ) هاهـ

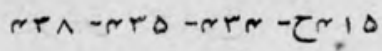

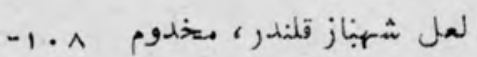

$-\wedge t \cdot-n \Delta a-r<r-g r \Delta r$ $\wedge 71$

Cهالة لطفاله ثير هتاره، مير لطيني كنهيني (لطفي جان) ه هـ

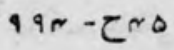

Lانهان

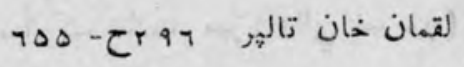
لوده سنمكه (بوده سنكه

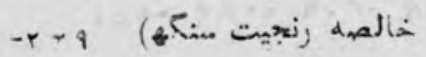

ro. $-\operatorname{crs}^{2}$

$-\tau<\Delta \wedge-\tau<\Delta<\quad$ $\angle \neg \wedge-C<\Delta 9$
كلعذار خان (كلزارخان) r ان كل سحمد ( بن مالَّ رحيم داد ) का

كل معهد خان، iاثب

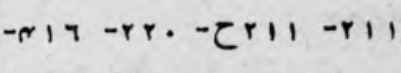

$\sim \wedge \Delta$

كل معمد خان خراسالي ( حاكم LAr ( ت

كوبالداس كrs

كولد سمته ، ميجر ( كولدس مد )

$\wedge 1 \Upsilon-\tau<09$

$$
\text { كورن، بريكنير 9. 9. }
$$

كوله شاه، ميد بيان

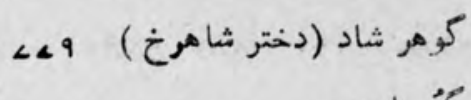
AA كيراد، د كتر

كيو بومت ( مدير تايمز بهبثي ) टा।

\section{J}

لارد، بان (هدر برمسيول بارتن لارد) q.

لارد، د كتور برسيول بارتن (ايم-ذي) 
تمته خان مسم ليند، سر فريدركى ليومى

$9<\cdot-979$

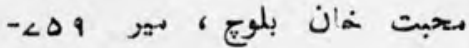
$\angle 97-\angle 7 N$

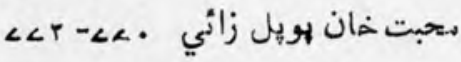
r. rمبت خان غوري

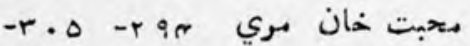
r.

يحراب خان بروهي، مير مبr - Crat-rit tra tre. gnit-4it-417-cram $-610-5 m i n-a 16-4 i r$ -rta $-4 r D-6 r e-617$

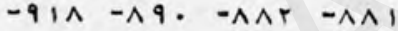
-qr qrr-qr. -qr

محراب خان تالهر . . بح

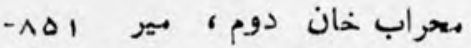
Qr. - -91^

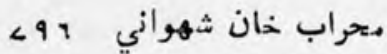
مجسن تتوي " محفه والال" ( شهس العلما ميد علي كوهر ثاني)

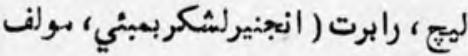
" تاريغ قلات" . . بr- . بrع-

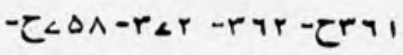

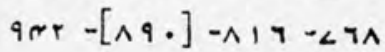

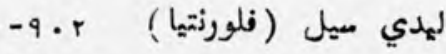
( نيز ر كى فلورنتيا )

$$
\text { ليكى، لارد }
$$

ليكهي؛ راجه ^..

\section{ليوكس 10}

$p$

مارمن، לأبليو

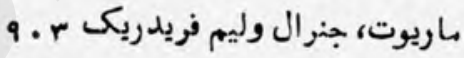
هالو، راجه ماليت، رزيدنت كمهتان

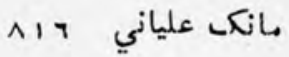
باني هباركى خان ، بير ( والي خيريور )

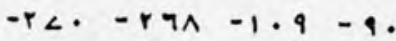
$-r \cdot \wedge-r \cdot 4-r \wedge a-r \leqslant 1$ $-\angle \Delta 1-\angle Y|-7 Y .-7| r$ $9 \wedge .-9<9-979-9 \curlyvee \wedge$ متارو، بير (مير لطف الله)

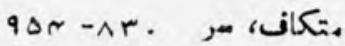


- $\Delta 99-\Delta a r-\Delta q r-\tau \Delta A r$

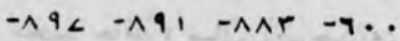
cara-ara-art

معمد اكمبر خان، وزير

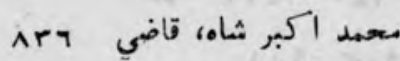

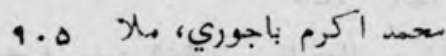
محمد امين خان (ناظم لهندي) . . هـ معمد امين، (نانب كجهي) . . r. are-arer

محمد باقي كابلي، غواجه

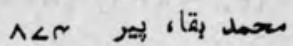

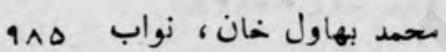
( نيز ركى بهاول خان )

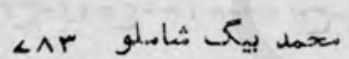
محمد تقي شاه، سيد (برادر آغا سيد

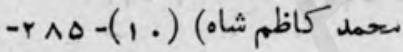

$-r \sim \Delta-r q \wedge-r q<-r \wedge T$

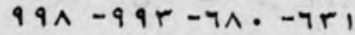

بحمد تيهور ثماه، شهزاده (بن ) شاه شجاع ( -ar $-1 \cdot 0-1 \cdot r-1 \cdot r-1 \cdot 1$

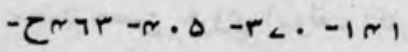
11.
بحمد (مصطفي صلي اله عليه و سلم) $\angle \cdot 1-\sim \wedge<-1 \cdot-9-<-7-\Delta$

49. محمد (رئيس ارغسان)

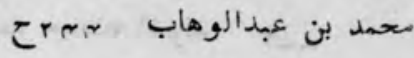

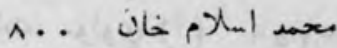

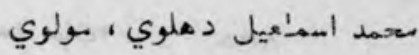

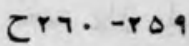

محمد اعظم خان r ro

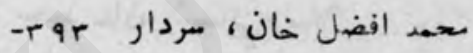

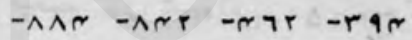

9เトーヘヘフ

معهد اكبر خان، سردار م. r$-4 . v-4.7-4 \cdot \theta-4.4$ $-0 . r-4<4-6 r<-4.1$ $-\Delta .<-0 . \Delta-\Delta . r-\tau \Delta \cdot r$ $-\Delta i r-\Delta, 1-0.9-\Delta . \wedge$ $-01<-\Delta, 17-010-01 \%$ $-\Delta r<-\Delta r \cdot-\Delta, 9-\Delta 1 \wedge$ - $\Delta r 1-\Delta r<-\Delta r a-\Delta r A$ $-\Delta \Delta r-\Delta \Delta r-\Delta \Delta r-\Delta r r$ $-\Delta<1-\Delta 79-\Delta 77-\Delta 7 r$ $-\Delta<A-\Delta<T-\Delta<\Delta \quad-\Delta<r$ $-\Delta \wedge r-\Delta \wedge 1-\tau \Delta \wedge .-\Delta \wedge$. 
كازه نواي سماركى

$$
\text { 1.er }
$$

Zल - CAnr - Cr<T

سعمد حسين خان، داروغد، ( سحمد

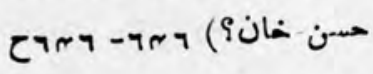

LCr محمد حيات، اخوند

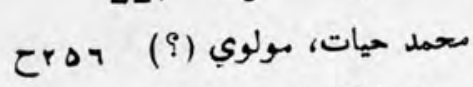

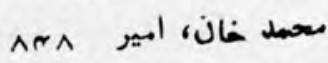

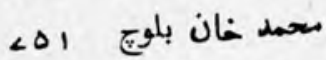

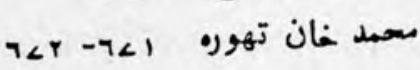

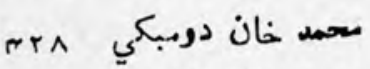

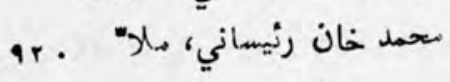

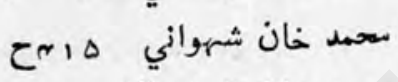

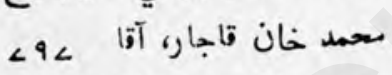

محمد خان قجر (قاتل نادرشاه انشار )

$\angle 97$

معمد خان كوهي (بن عيسىل خان

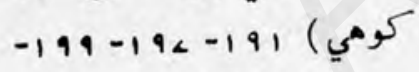

$-r \cdot r-r \cdot r-r \cdot 1-r$.

$-t .5-t \cdot 1-t \cdot 0-t \cdot 4$

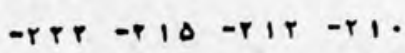

こ^ฯ^

مهمد راشد، سيد (جد" اعلىلى خانداز راشدي)

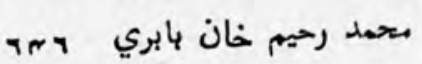

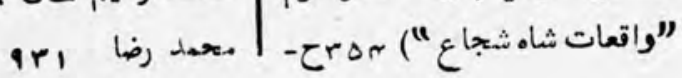

محمد مافظ، ميان (صاهبدُنه، شاعر سندهي)

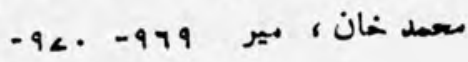
$9<r-9<1$

محمد حسن (خلف ميرزا عطلا محمد) CrT-17-1r-r

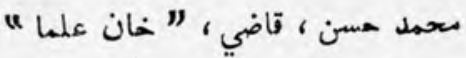

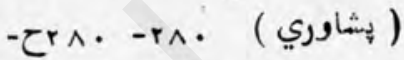

$-\wedge r_{<}-[\wedge r t]-[\wedge r \Delta]-r \mid \wedge$

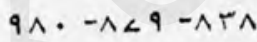

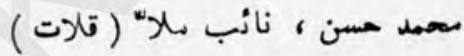

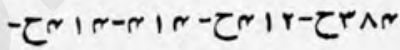
-at) -

-are-atr - cutr-atr ir.

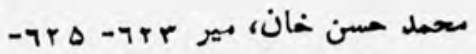
<1 - $92-7 \mid$

معمد حسن مجددي مهر مهن معمد مسين (بن فقير سحمد خراماني) ir

معمد -مسين هروي (بولف دنتر سوم 


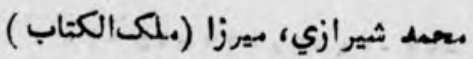
$\wedge \sim 0$

A.. ميهد صادق، ديان معمد مهالع خان، عاليماه المn$-\Delta \Delta r-\Delta \Delta r-\tau \Delta \Delta r-\Delta \Delta r$

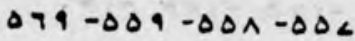

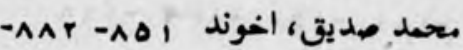

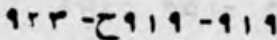

1. .حمد صديق غان.

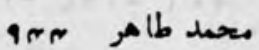
متحمد طونيd، معمد عبدالسمالم غان ( مولف

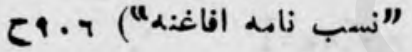

1 بحمد عثمان، قاضي

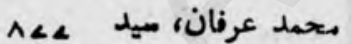
مجمد علي " "علي"

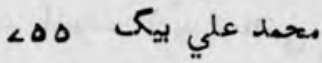
محمد علي فان، بير محمد عطر غان كلمهوره (بن ميان

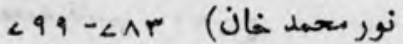
(نيز , ك عطر خاذ)

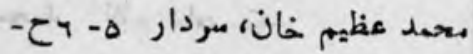

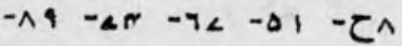

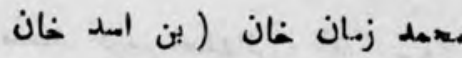
جرادر وزير فتع غان ) $-\Delta r_{1}-\Lambda r_{\Lambda}-\Delta r_{0}-1 \cdot c$ $-\Delta 9 r-\Delta r<-\Delta r r-\Delta r r$ 9ro-AIr

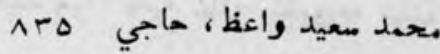
معهد سعيد غان (برادر عبدالمب:جحان $r \Delta 9-r \Delta \wedge-r \Delta<$ (نان معمد شاه (بادثماه دهلي ) Arr-Arr $-\angle<1-\angle \Delta T$

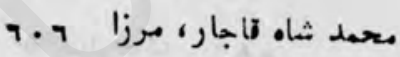

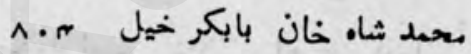

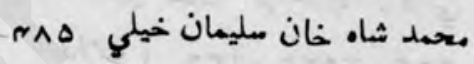

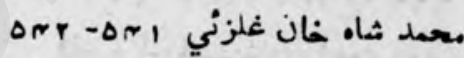

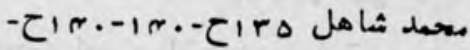
टा०9-109-टाN<-1\%< . همه شريف خان ( ضبط بيكي ) ก १। - । ^ฯ

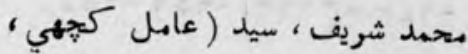
9 $r$ ।

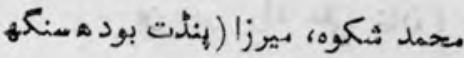

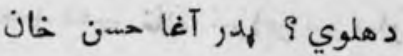

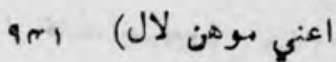




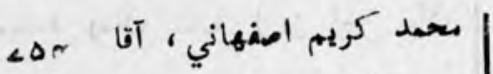

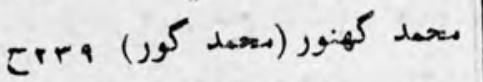
متحمد متفوظ "مرخوش" قاضي شيخ $\angle \wedge r-C \angle \Lambda I-\angle \Lambda$.

متحمد بواد ياب غان كلهوره، مهان

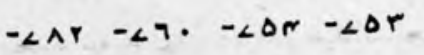
$\angle A T-\angle A O-\angle A N-\angle A T$

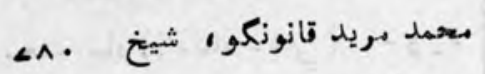

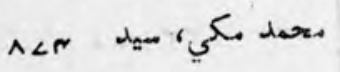
4A9 مجدان بهدي، بيان محمد نصير خان براهوي (والي

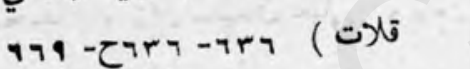
(نيز ركى نصيرغان برامويدوم) محمد نصير خان، مير (بن مير مراد علي خان والي" ميدرآباد ) -trsertr-tal -ra.

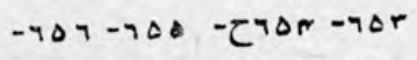
$-7<0-$ CT4R - $09-70<$ $7<<-7<0$

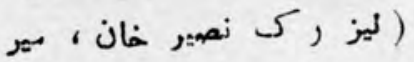
بن بير براد علي غان ) مان ) محمد نصير خان، مير (بن مير مباركى

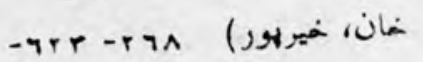

$$
\begin{aligned}
& -99-9 \lambda-9<-94-90-9 . \\
& -1 \text { ro }-1, \lambda-1, r-1,0 \\
& \text {-ird -ira-irt-5iro } \\
& \text {-irt-irt-iri-ir. } \\
& \text {-ird - irs - irs -irs }
\end{aligned}
$$

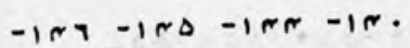

$$
\begin{aligned}
& -101-10 \cdot-109-1 \sim A \\
& -10 \wedge-100-10 r-10 r \\
& \text { - iar-igr-igi - - } 09 \\
& \text {-tr - } 17<-1,14-1,40 \\
& \text {-tra trt< -trte trtr }
\end{aligned}
$$

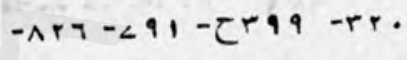

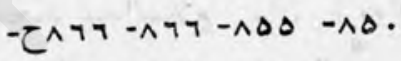

$$
\begin{aligned}
& \text { are }-[\wedge<1]
\end{aligned}
$$

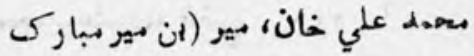

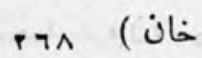

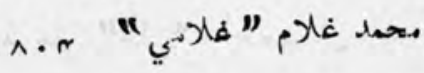$$
\text { متحهد غوث، اخوند ( جدة قاضي }
$$

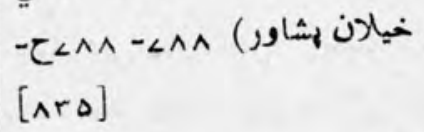

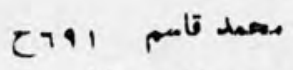

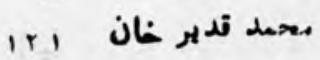
بومد كاظم شاه، ميد ك كاظم شاء. 
مدد خان فوفلزني 1- هـITP

A.. . . Aدد غان اقغان مدد خان امحق زني، سردار A|r-AIr

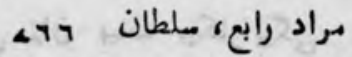

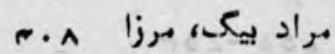

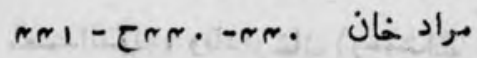
مراد عليخان تالهوركمير (امير الدوله، نظام الملك والي: هيدرآهاد ) - $79-1 \sim A-1 r \Delta-11,-9$.

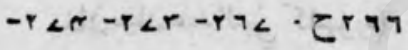
-rA. $-r<A-r<\angle-r<T$

-4ir-tit-di -erte

$-\wedge 19-\Lambda 1 \Lambda-A 1 Y-7 m I$

$-9 \Delta 7-9 \Delta 0-9 \Delta r-\Delta r \wedge$

$-9 \wedge 1-971-97 .-90<$

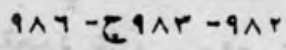

تراد علي خان حانك

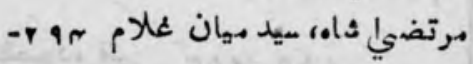
$r \cdot \hat{r}-p \cdot \lambda-r \cdot r-r \cdot r$

A مرثداله

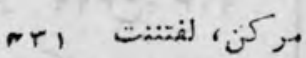

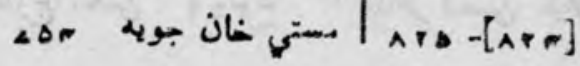

$9<r-9 \Delta r-9 r \mu-7 r 1-9 r \Delta$ (نيز ركى نصير خان بن مانه مباركى غان، خيرهور)

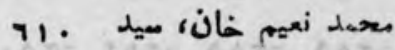

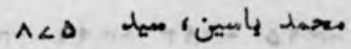

74 . هتمود غان (ترادربهان م-رفرازخان) $\wedge \cdots$

محمود خان، مير (بن مير نصير غان،

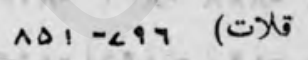

محمود شاه (بن تيمور شاء بن احمد ثماء اهدالي دراني ) $\wedge \Delta_{L}-\lambda \sim \sim$

(نيز ر, ثاه متهود ثماه)

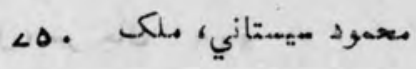
بختارالدوله، حانظ ثير بعمدان خان باميزني

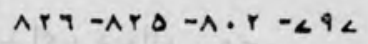

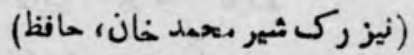

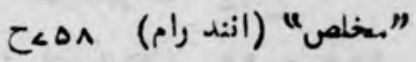
(نيز رك انند رام)

مخذص الدولة ( عبداله مان ) 


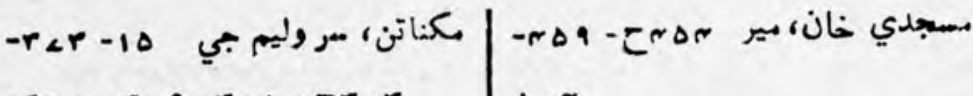
$-r \wedge .-r<1-r<1-c r<r \quad n \cdot \omega$

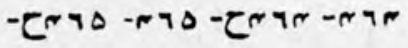

$-r<9-r<1-r<1-r>1$

-6Ni -rap -rat -ri.

$-4 d 0-416-m i 1-61$.

$-9.1-41,-617-612$

$-0.4-0.7-0.0-0 . r$

$-0 i r-\Delta i r-0.9-0.0$

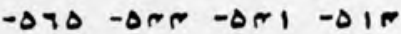

-AN! -ANA -ATI -N.

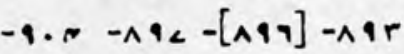

-949-91. - $117-9.7$

du-

مكناتن، -ر فرانسيس وركمين (هدر.

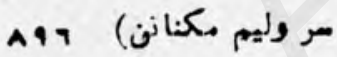

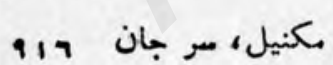
م.2

Ime ملانسو (بيشكار) ملراي، ديوان هب

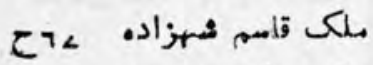

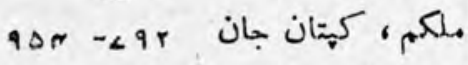

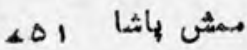

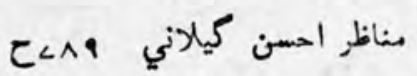

\section{مسلم}

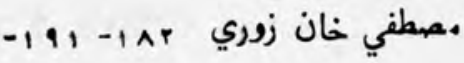
$+\Delta$

مصطفي خان شاهلم مظفر علي غان ايات بيكلمر بيكي $\angle \Delta O-\angle \Delta N$ معتمدالدوله، وفادار غان (رممتاله

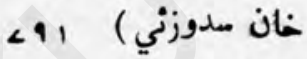
( نيز ر كى رحمت الله غان) متمدالدوله (فيروز جنك ، شاه نواز خانميانعبدالنبي كلهورو). . م (نيز ر كى عبدالنبي خان) AAr معزالدين، ثمهزاده

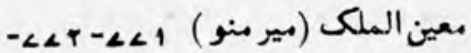
$\angle \angle \Delta-\angle \angle N$

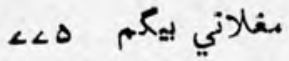

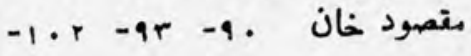
$1+\pi-1 \cdot r$

مقصوده فقير مAN مقدمي

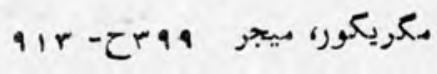
جنرل مدر جارج مكمن 
-cost-come-ren<-4ta

$-\lambda \cdot r-\tau<9 \cdot-\tau \Delta \Delta \wedge-\Delta \Delta<$

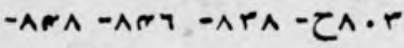

-iir-iir -cane-ati

-qr. - - 1⿵-9im-cair

$-a n 1-[a n \cdot]-a r t-a r \mid$

$-a r p-a m e-a m b \quad-d n t$ I T

• هدي آخرالزمان، امام

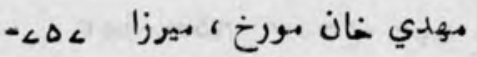
$\angle T Y-\angle Y \Delta$

" "

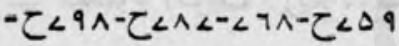

$-\tau \wedge<\Delta-\tau \wedge 10-\tau \wedge \cdot 1$

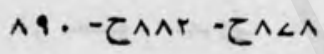

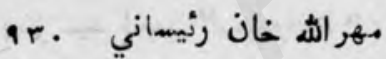

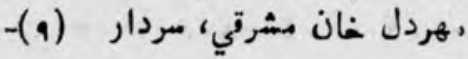

$-r+-r \mid 1-1<<-n<$

ATட -

१ १-१^ مهر علي خان

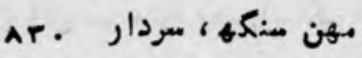

مهولي غان

ميا رام شأهو ( سيته ميا رام)

crompo
منبني صاحب (بنتئ)

مir

منهور خان دراني باركى زني $\wedge \Delta N-\wedge \Delta$ I

منكي زركس زتي .

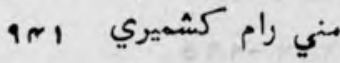

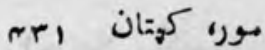

موسي خان افشار بحكان

موسي خان تالهور ( بدر فتع غان ته (تاليور)

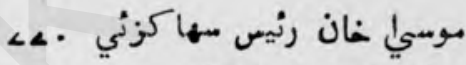

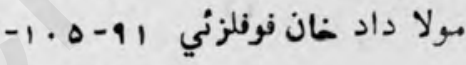
$\operatorname{ser}-\operatorname{tet}$

ro

مومن خان علزائي، مالرّ (غلجي )

$-17<-(9)-(\wedge)-(<)-(7)$

$-n \wedge \Delta-r 1 \cdot-1<-1<1$

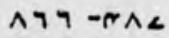

مومن لال كشميري ( ديرزا قلي،

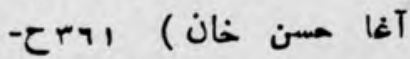

- Cra१-бrai-cram-rt

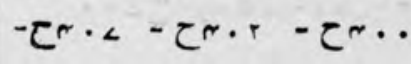

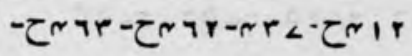


ميرزا تلي كشهيري عرف موهن لال

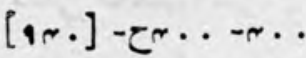

(نيز , كمى موهن لال)

•يسن ( هارلس ميسون ، مصنف

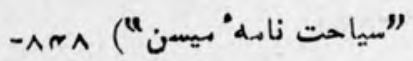

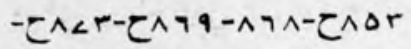

१९५ ११०

ميكاسل، جنرال (سر جأن بيكاسكل) [ara]-are -arr

$$
\begin{aligned}
& \text { ميكائيل، جنرل آه } \\
& \text { هی } \\
& \text { ن }
\end{aligned}
$$

نابليون

نات، جنرل مر وليم ه

- $\Delta \Delta r-\Delta \Delta r-\Delta r a-\Delta r<$

$-\Delta T \pi-\Delta T r-\Delta \Delta q-\Delta \Delta \wedge$

$-9 \cdot \wedge-<\Delta \cdot-\tau \Delta<1-\Delta<1$

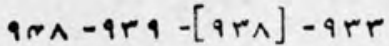

نات، جارلس (هدر مر وليم نات )

9r^

نادر شاه افشار צ-1

$-\angle \Delta r-\angle \Delta 1-[\angle \Delta \cdot]-\tau<\cdots$

$-\angle \Delta T-\angle \Delta \Delta-\angle \Delta C-\angle \Delta r$
ميان خان

ميذ ى، ني - ائج ( سمكريمري

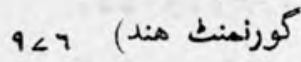

مير اكبر

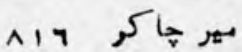
AN

مير علي خان (مير آخور) 1. بير محمد خان تالهور (بن مير غلام علي غان ) $-7<r-\tau T \Delta r-7 \Delta r-7 \Delta r$ $\wedge 1 \wedge$

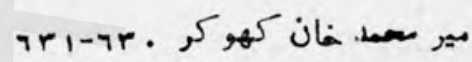
مير معصوم (مولف تاريخ معصومي) こrฯA

بير بعصوم معروف به مافظ جي

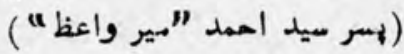

$-\lambda \cdot \gamma-\hat{\lambda} \cdot \Delta-\hat{\Delta} \cdot \omega-\hat{\mu} \cdot r$

$\wedge \cdot\llcorner-\tau \wedge \cdot\urcorner$

مير سنو، معين الملك 1 $\angle \angle \Delta-\angle \angle C$

مير هومن (بن +ير منو، دعين الملك) $\angle \angle O$

مير مزار الكوزتي مهرزا غان نظاهاني 


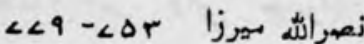
نمراله جان، قاضي ونم نصراله غان (بن نائب امين اله خان iro

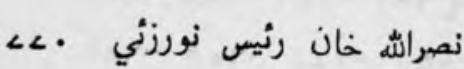
نصيرالدوله (حاجي خان كالكرى ،

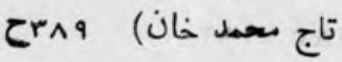

(نيزر ك حاجي خان كاكري) نra_ نصيرالدين، بولوى نصير خان (برادر بنياد خان هزاره) Cר

نبير خان نصير خان براهوي اول، بير، خان

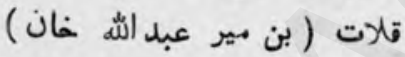

$-\angle \angle Q-\angle \angle T-\angle \angle F \quad-\angle \angle r$

-qr. -ñr <qт - 290 9.

نصير خان براهوي دوم، بير، والمي" تلات (بن مير محراب غان ) موي دومان

-4ra -6ret - $-417-5610$

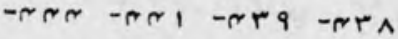

-

are-arr

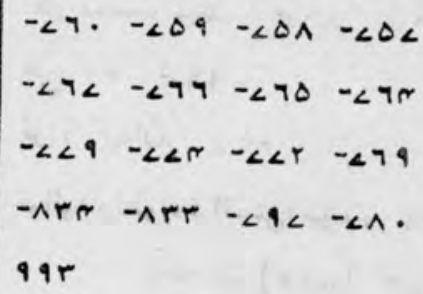

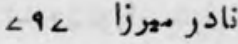

ناراين (هندو)

أصر خان نايب سلطان (خدمتكار امير دومست

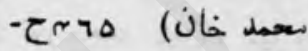

نبي بغش بخاري حيدري (ميد فدا حسين) (كائ)

(نيز ر كى فدا حسين، سيد)

919 نبي بخش جتوني

نبي بضفس مري

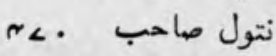

نجم الدين، ميان

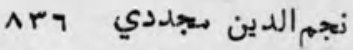

نجيب الدوله، نواب الجن

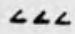

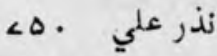

$$
\begin{aligned}
& \text { نذر قلي افنشار }
\end{aligned}
$$

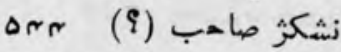

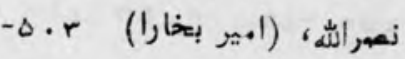

Co.r 
تازه نواي معاركى

1.0.

نظر دحمد، بيان ११^ نقي شاه نل، كمتان

نواليه ونطوره فرانسس، موميو اrrr

C^<r $-[\wedge<r]-\tau r r \mid$

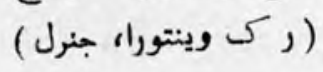

نوتن داسى

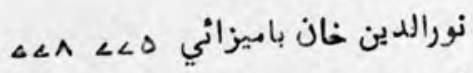

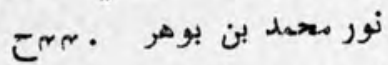

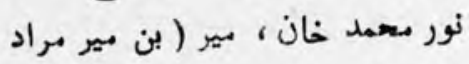

علي خان والي: هيدرآباد )

-grteral tra. $-(4)$

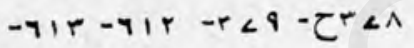

$-9<1-9<0-990-91 \wedge$

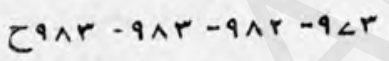

نور محهد خان افغان

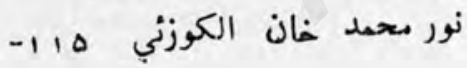

189

نور محمد خان بابري ( بابروي)

Aा - वा

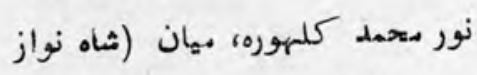

خان )

$-\angle \Delta \wedge-\angle \Delta<-\tau<\Delta T-\angle \Delta q$

$-\angle \Lambda \cdot \quad-\angle \angle T-\angle T \cdot-\angle \Delta q$
لعمير خان ، دير - والي" حيدرآباد

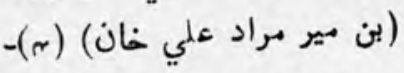

- tir - crer tal ora.

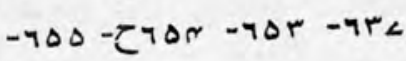

- C79r-709-70< -907

$-\wedge \Delta \cdot-7<<-9<0-7<r$

$-9<r-9<1-9<$. -970

Canr-9Ar-9Ar

نصرو خان ، بير (بن مير مباركى

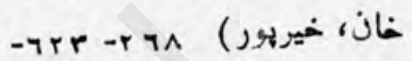

-

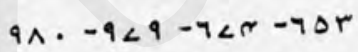

نصير دممدخان،مير،(والي"حيدرآباد،

بن مير مراد علي خان) . . .

- $-9 \wedge r-9 \wedge r-9<r-9<1$

ZaAr

( نيز ركى نصير خان ، مير )

والي" حيدرآباد)

نظام الدوله

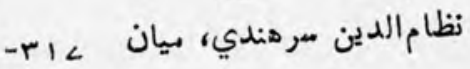
$\wedge \Delta \wedge-\wedge \Delta<-7 \times \neg$

نظام الملكى اميرالدوله شاه مراد علي خان تالهر ( والي" ميدرآباد ) १^८ - Cִrt

(نيز رك مراد علي خان تالهر ) 
1.01

تازه نواي معار

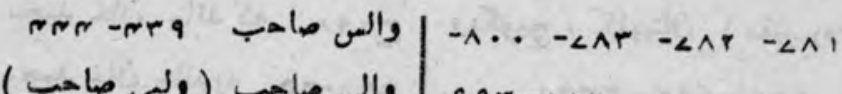
$\tau \curlyvee<\Delta-r<\Delta$ نور معمد خان مير اففان رئيس غلجي

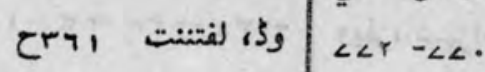

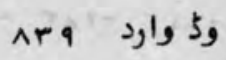
نوشيروان

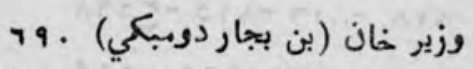
وفادار خاذi، وزير (بدر الهمد يارخان) एवर

وفادار خان (متهددالدوله، رمهمتاله

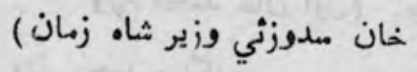
Are $-\angle 97-\angle q 1$ (نيز ركى : رحمت اله انه (نان)

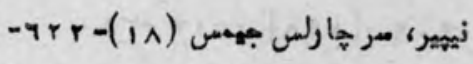

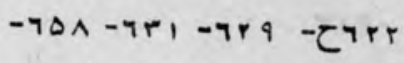
$-9<\cdot-470-97 \pi$ $-<\cdot r \quad-7<-9<r-7<1$

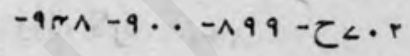
$-9<\wedge-9<<-9 \Delta 1-[q \Delta$. ट१^१ $-9<9$

وكيل الدوله (سردار عبد اله خان نهيم، كرنل جارج (بلدر مر حارلس

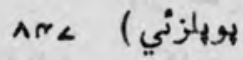

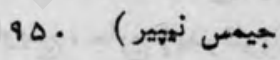

و كيل خان نيكو غان خواجه ولزلي، لارد ( كورنر جنرل هند هند $<9 r-<9 r$

9

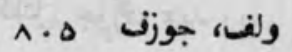

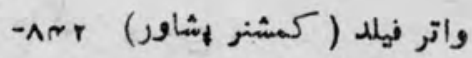

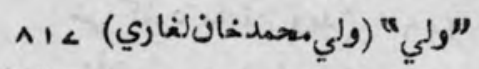
A r

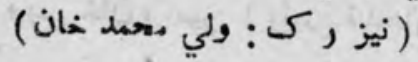
واعظ هير، زبدة العلماء (ميد احمد)

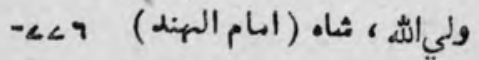
ट๐A- $\angle \wedge 9$

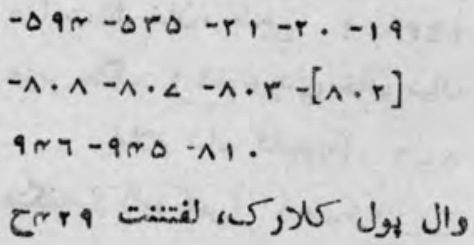
$1 .<-90$ 
تازه نواي مaارك

$1.0 r$

ويكويج ، كابيتان ( سفير رومن)

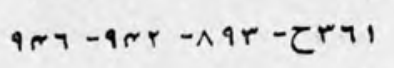

ويلار، كيتان

११ ويلز، ثمهزاده

ويلشائر، مر توماس

- $-1-[\wedge a \wedge]-4 i r-r a$.

arr-air

ويلشائر، كمثن جان (جدر مر توماس

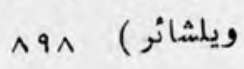

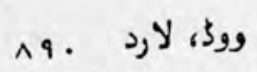

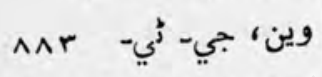

وينتورا، جنرل(نواليه ونطوره فرانسس)

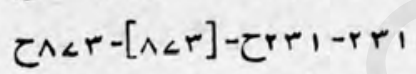

وينج ، جارج (بدرفلورنتيا، ليدي.ميل)

9. 1
ولي محمد خان هاند

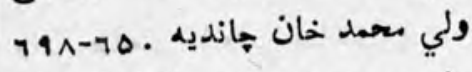
ولي محمد خان لغاري"ولي" هاني (اول) $-r t<-t r e-t r 1-1<r-t$.

$-711-t<r-r<r-r<A$

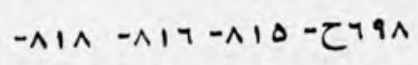

-neq -nrr -nri -niq

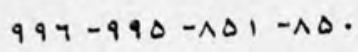

ولي معمد خان دوم "ولي" (نواسه

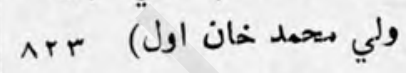

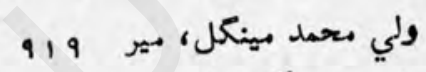

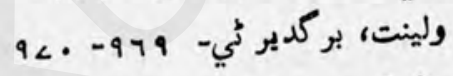

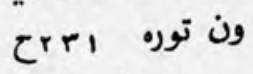

(رك: وينتورا، جنرل)

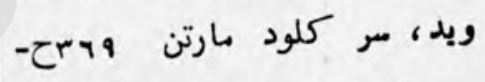
-[a, ] $]-a \cdot a-\tau r \cdot \Delta-r \cdot \Delta$ $9 \wedge .-91<$

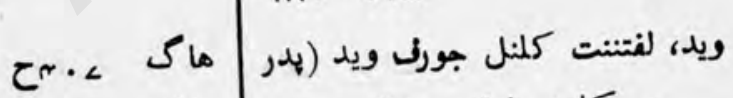

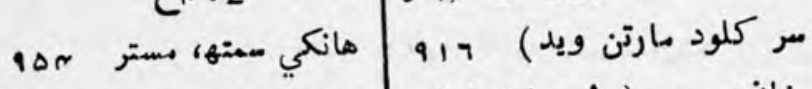

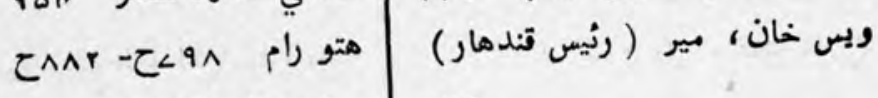

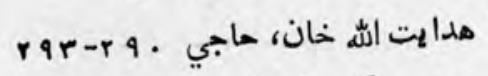

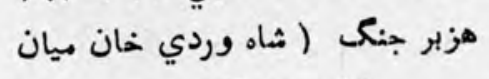
غ غلام شاه كلمهوره) $\angle 79$

ويكتوريا (و, كتوريا،دلكه انكلستان) $-4<a-r<1-r<4-61<$

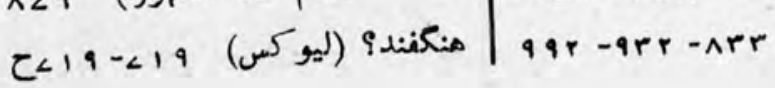




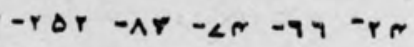

$r \Delta q-r \Delta m-C r \Delta r$

يار معمد خان كلهوره، مير

A … - ४ १

يار معمد خان، وزير (آصف الدوله)

$-9 \cdot 1-7 \cdot<-7 \cdot 9-9 \cdot 0$

CY. 9-7.9

ياقوت، آغا r. يزيد

يعقوب :مان

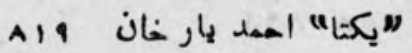

$$
\text { ي يومن" }
$$

يوسف، ثمهزاده ( لمواده مابهي

تيروزالدين سدوزني)

$$
\text { يومف، ماجي }
$$

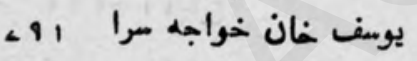

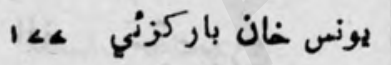

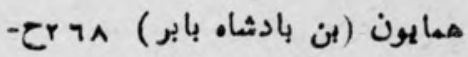
Arr -Arr-<9A

\section{Crro}

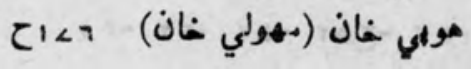
هوت غان غلزئي

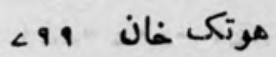

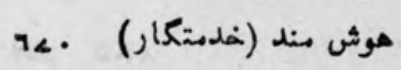
هوركر هوت هن $\angle r A-C<09$ ه

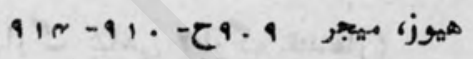

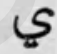

"يار سمنكه" (عارومتمدخان باركزني) $r \Delta Q-r \Delta C-r \Delta P$ (نيز ركى ! يا رمعمدفان بار كزني)

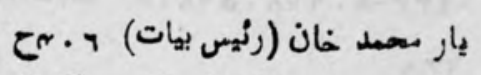

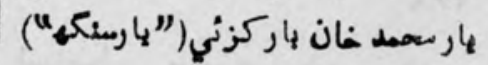




\section{r- اسهاى اماكن جغرافي}

$$
\begin{aligned}
& \text { - or - Car - or tr tri }
\end{aligned}
$$

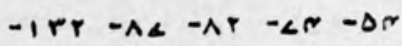

$$
\begin{aligned}
& A \angle P-\angle A \angle-\angle \angle I-\angle \angle . \\
& \text { ادي بور ادمي لمي }
\end{aligned}
$$

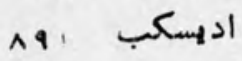

$$
\begin{aligned}
& \text { ارغسان } \\
& \text { ارك شاهي (ارك تمندمار) }
\end{aligned}
$$

Li - Crt

$$
\begin{aligned}
& \text { اروبا }
\end{aligned}
$$

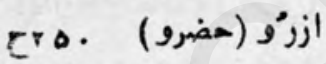

$$
\begin{aligned}
& \text { امهنتجي }
\end{aligned}
$$$$
\text { إستالف }
$$$$
\text { PrA }
$$

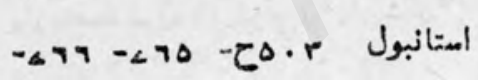$$
\angle 4 A
$$

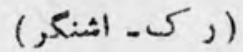

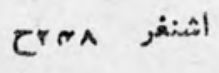

الف مهلفوده

$\angle \Delta<\Delta d i$ آتش اله מה:

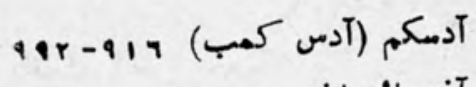
آذر بائيجان ادهنم الهن آمياي مركزي ( آسياي مهانه ) १ัA -А १।

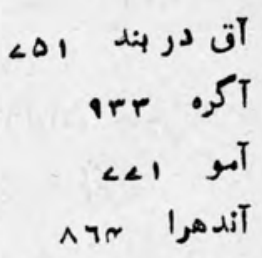
Tوبه

الف مقصوره

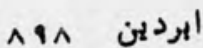

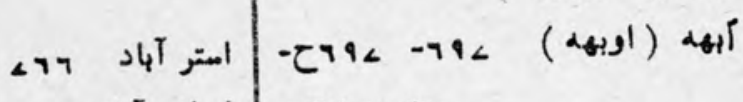
Arr | املام آباد |

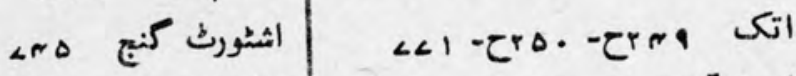

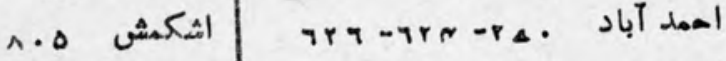
الحمد هور

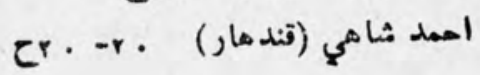


$-8<r-a m a-d \pi d-9 m \Delta$

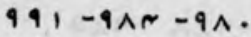

الغانستان جنوبي

ازغانستان ثمهالي

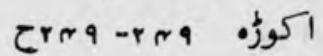

Cle الرور

اله آباد الرور

امازني (دوضع)

r. إمام كهر

$$
\text { امباله }
$$

امرت سر

Ar. $-<<1$

المر كوت

१९ พ

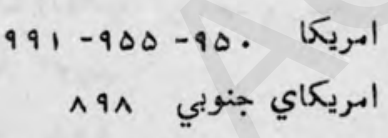

انبرت سر (ابرت سر )

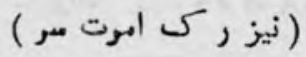

اندبو

اند خود

9 . اندس

اندور، رياست اندسو

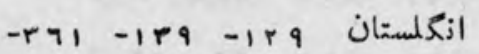

$-\Delta 7<-r<9-r<1-r 9<$

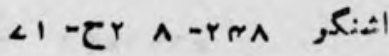

|صفه

|فريقاي جنوبي | |

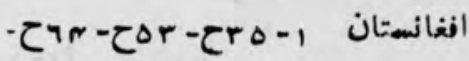

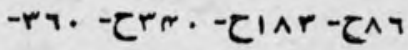

-cris - שrat

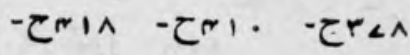

-cetr -cra. - crar

- $\angle \Delta r-\angle C Q-4 r 1-\tau 0<1$

$-\angle \Delta A \quad-\angle \angle A \quad-\angle L I \quad k \angle$.

- $29 r-\angle 9 r-\angle A<-\angle A r$

$-\lambda \cdot 1-<9<-<90-<94$

-ara -arr -kri -ar.

-ner - -ner -net -

- $\wedge \Delta \Delta-\wedge \Delta r-\wedge \Delta \cdot-\tau \wedge \sim \wedge$

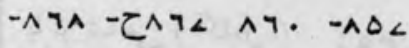

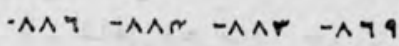

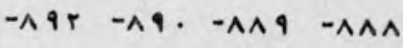

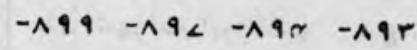

$-9 .<-9.0-9 . r-9.1$

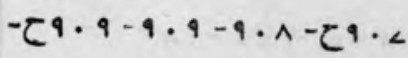

-iir -cail-ail-ai.

-9rr - arr-9r. -91<

-ace -ser -ier -ard 


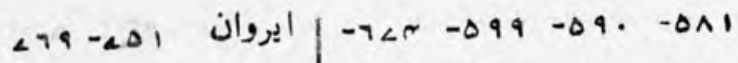

$$
\begin{aligned}
& \text { ૧. } 1 \text { إيلنك } \\
& \Psi \\
& \text { Clar } \\
& \text { باخرز } \\
& \text {-q. -А } \\
& \text {-909-erq - arr - } 11 \wedge \\
& \text { Cr..-Cir بr } \\
& \text { بra باركور }
\end{aligned}
$$

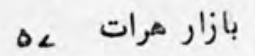

$$
\begin{aligned}
& \text { باغان (باغبانان9) } \\
& \text { بAr باغبانه }
\end{aligned}
$$

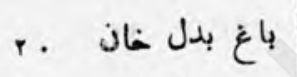

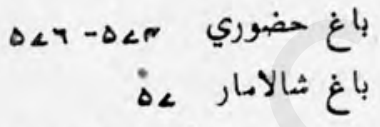

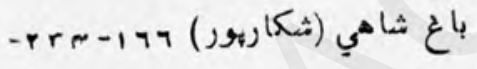

$$
\begin{aligned}
& 9 \wedge 1-r_{1}<-r<< \\
& \text { باغ شاهي (كابل ) أدما } \\
& \text { باغ شاهي (هرات) } \\
& \text { on باغ شهزاده ابوالقاسم }
\end{aligned}
$$

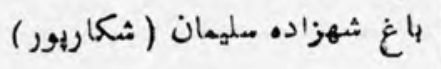

$$
\begin{aligned}
& A r<-r 1<-r<0-1 \wedge \\
& \text { باغ مير زين العابدين }
\end{aligned}
$$

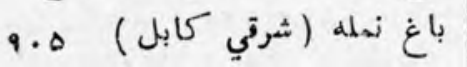

$$
\begin{aligned}
& \text { १९। } \\
& \text { ar } \\
& \text { ( نيز ر ك انعلمستان) }
\end{aligned}
$$

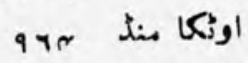

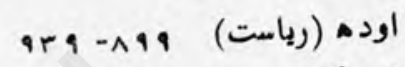

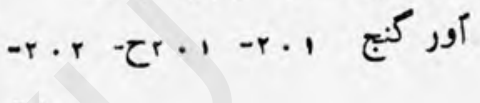

$$
\begin{aligned}
& \text { ri. } \\
& \text { اورزنع آباد (ينجاب) r- rar- rar } \\
& \angle C r-1 \cdot r \\
& \text { CI^< }
\end{aligned}
$$

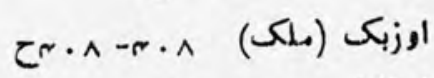

$$
\begin{aligned}
& \text { ايتالها } \\
& \text { १ } \\
& \text { ايران }
\end{aligned}
$$

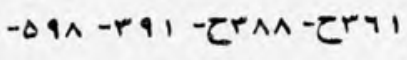

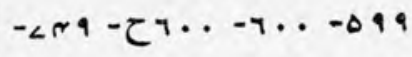

$$
\begin{aligned}
& -\angle T I-\angle T \cdot-\angle \Delta \Delta * \angle \Delta . \\
& \text { - } 294-\angle 79-\angle T N-\angle T R \\
& -\wedge 91-\wedge \wedge 9-\wedge \wedge \wedge-\wedge<r \\
& \text {-amb -ari -ar. -917 }
\end{aligned}
$$

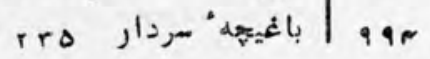$$
19
$$ 


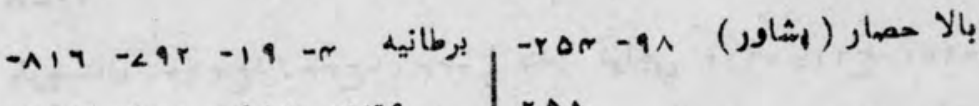

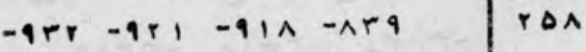

$990-9<<$

بالا حمصار (غزني)

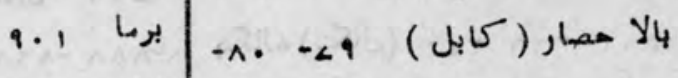

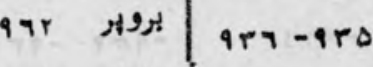

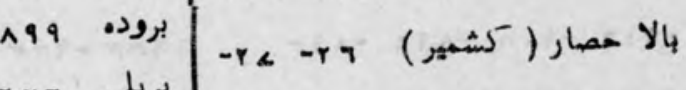

بريلي

$\angle \angle N$ plam?

ATフ С

$\wedge \angle A-\wedge \angle \angle-A r r \quad$

ب بسي

Aqr بar

ma. -

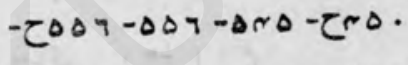

$-\angle T \angle-\angle T \Delta-\angle \Delta I-T A N$ I

Aง $\mathrm{A}-\Lambda \wedge \cdot-A L$

- grr -qrr $-9.0-\angle \angle r$

A. ه ن

< 90 1,

$9 \pi$

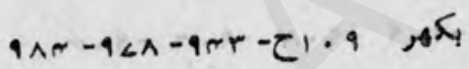
( ب,

$r<r \quad d x$

بلبل بلرب

بلت

- Lla -

AAT $-\wedge T \angle-\angle 9$.

بلد

A^. بلري

a ir بلفاست

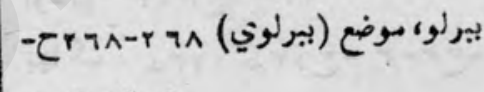

L. T T $\angle N$

१९ بتل

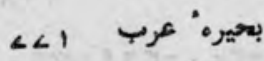

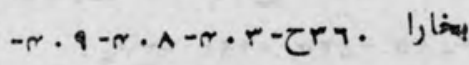

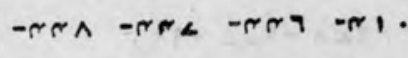

$-\Delta A 1-\Delta T_{1}-\Delta . \Delta-\Delta \cdot r$

$-\angle A \Lambda-\angle \angle A-\angle T \angle-\angle T N$

$-9 \kappa \cdot-\wedge \wedge \wedge-\wedge \wedge \Delta-\wedge \mid 1$

पल।

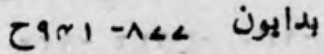

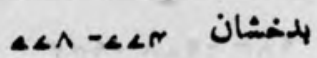


تازه نواي مارك

بلوهيتان 99. -7r । - ¿rr< - ¿ri< - Zrar

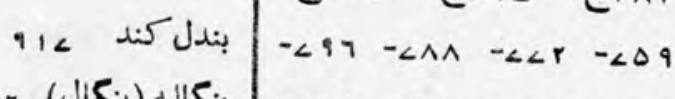

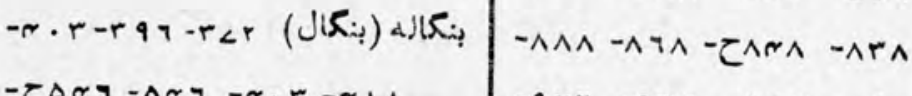
- Cart-art-r<t-ri,

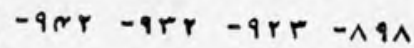
$-917-9 \cdot \wedge-\wedge 97-\wedge 9 \%$

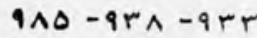

$$
\text { L بr }
$$

بن $<9$.

Crir بوستان سراي بوري 1. بولان - Errr ari-nt<-ert

97^ بهان

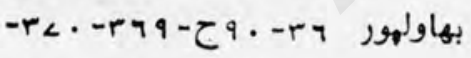
$-\angle N D-\angle r \mu-79 r-$ CrL.

$9 \wedge \sim-9<\wedge-9<<-91$.

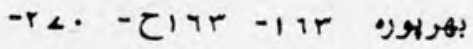
$L \cdot r$

بهر -

-ar. -cart-art-re.

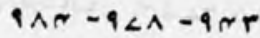

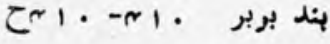
بند ذاكو خدار بمبني اندر ه ه لخدار فيروز 


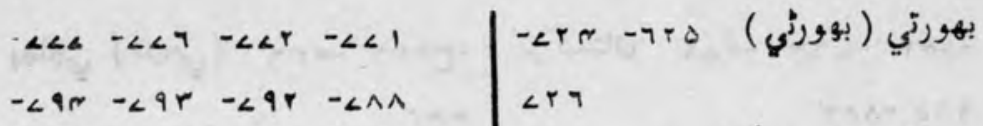

-ntr-nir-nit - ave

$9 \angle 1$ dis of rogt

-nto-nti -nit-ntt

بيحانهية قرية

-ne. -arq -ara-art

Cror-Zrr<

$-A \Delta L-A N \Delta-A N T-A N T$ بيني بادام

$-9 \cdot 9-\wedge<\Delta-\wedge<1-\wedge \top \wedge$

-9ก人 -9rr -91<-917

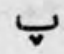

$94 m-9 \wedge m-9 \wedge 1$

CัN Sing

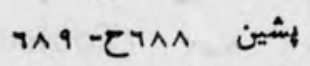
Crer din LA

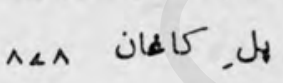
97.

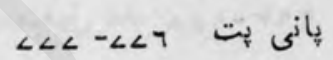
هrت $\angle \angle A$ alling 9. $-1<-\tau \mid \wedge-1 r-(\angle)-(7)$, r.r-er-iar allat. -ta $-t a-\operatorname{trt}-t r-t i$ - Crer - Er< - Err yoin - Cer-er -er $-4<-t d$

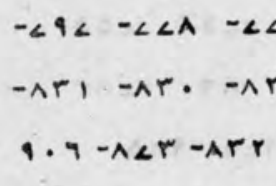

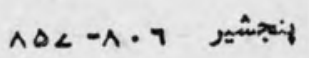
$-\wedge \wedge-\angle C-\Delta r-\Delta 1-\pi \Delta$ $-9 \wedge-97-9 \Delta-9 \pi-9$. -ra Cint - 1. 1-1.. - Crsi - שrथq - Crra

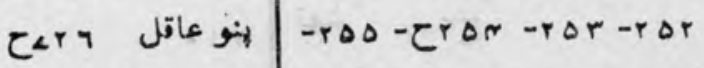

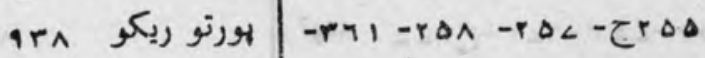

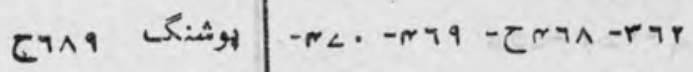

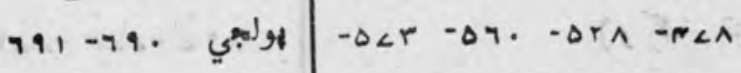

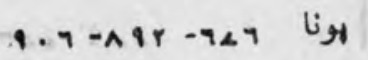
$-\angle \Delta r-\tau \Delta Q 1-\Delta<7-0<r$ 
تركستان

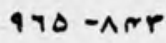

تركستان روسيه تفليس

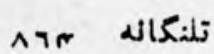
ت تله تنبو (طنبو) : تندو آدم

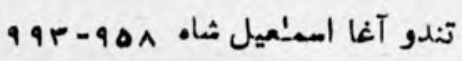

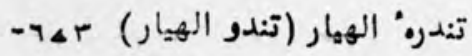
$c r<r$

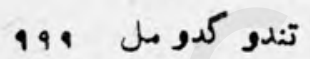

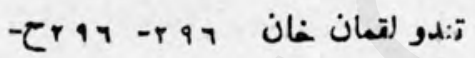
Crus-rqa

تندو مستي

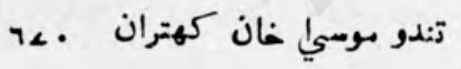

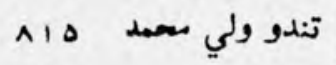
تون تهت - $\angle \Delta O r-\angle \Delta r-9<r-2 r<<d$ $9<\angle-9<1-\angle \Delta \Delta$ ( تهته نكر

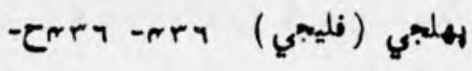
r r

$$
\wedge<0-\wedge<\pi \text { ת }
$$

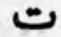

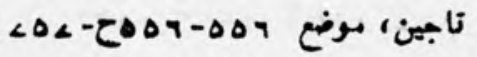
تازي تاشقرغان

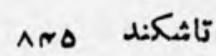

تانيوري (تانوري) تاولوم (Touloose) تبريز

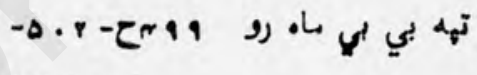
Aบง

تتمدره (وادي بروان) مجr ت $-\angle \angle T-\angle \angle I-\angle \Delta 9-\angle \Delta \Delta$

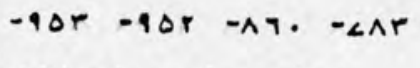
9 $\Delta \Delta-9<<-9<1-97 \Delta$

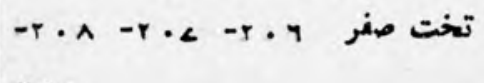
i.

AA< ل J

تراونكور تربت جام تروب

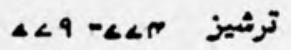


جول

$$
\text { جمرود 949 } 94
$$

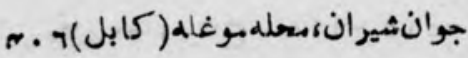

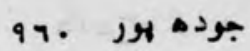

جوين

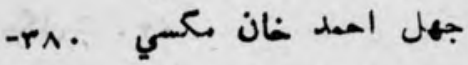

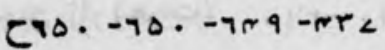

$$
\text { جيرك }
$$

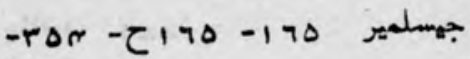
car-zTr. - tr. -eror

جيكب آباد ـ •

-cral - Erat - Clta

- zerr -enia - trar

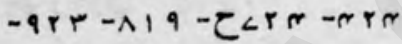

१9

₹

هو هارتر موم

حار حتّه ( حهار مسطح بازار كومابل

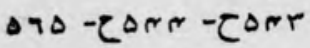

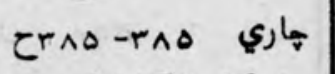

- Cror-rar

-Art-a.r -eran -rar

A

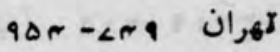
تrer تצ. تهل

تهل هوتالي تهل تيزين

?

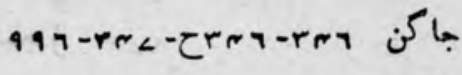
«ام جام جاميكا جاني دمار 99. جد.

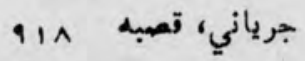
جعفر آباد

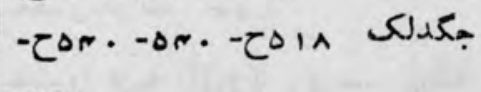
arr - $\Delta r r$ - $\Delta r 1$-or. - $\Delta r A$

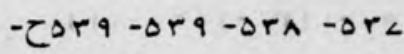
$-\Delta T<-\Delta T r-\Delta T 1-\Delta T$. - $\angle \Delta r-\Delta a r-\Delta q r-\Delta<A$ $-9.7-9 . \Delta-9.1-\wedge i r$

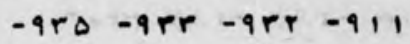
१rq-टaro 


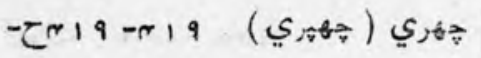
CTI<-YIL

-nar -nr. -req -r< 9กA

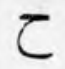

११ حاجي 4ور $\wedge<\pi \quad$ مجن

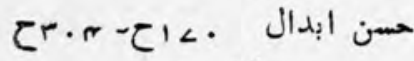
ra. حصار يشاور 9 D-910 Ars zra. व9

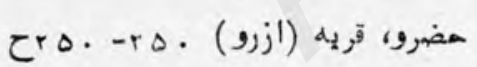

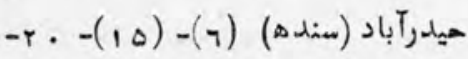

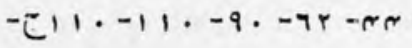

$-11 r-11 r-11 r-111$

$-1 r \Delta-169-1<r-110$

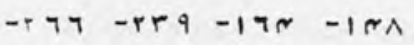

$-r<r-r<r-r<r-r y<$

$-r \cdot 6 \cdot t a g-r \wedge r-r<t$

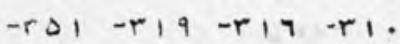

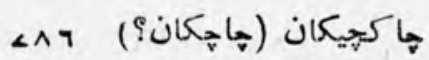
حاندو كن $-\angle 1 \Delta-79 \wedge-\tau r \cdot 1-r<r$ $\wedge 10-\tau<10$

Ani Ar. d la דمن زار (هرات) • • ril

حناب حندول $9<1 \quad$ هون هوتي Cr >

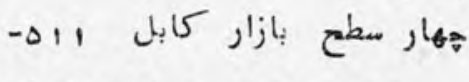
-arer-zarr - $\Delta r r-\Delta i r$ $\Delta \eta \wedge-\Delta \nabla \Delta-\Delta \mu a-\tau \Delta r \omega$ جهار سوق كابل جهاوني خانكهر (خازكزرة)

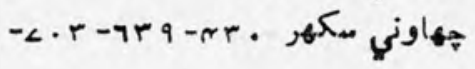
L. T

$\Delta \Delta \wedge \quad$ هاوني كاوني

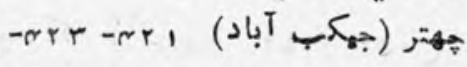
erte-certerte-5ert $791-79 .-4 m r$ 


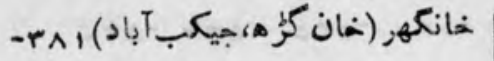

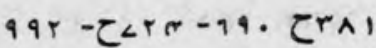

$$
\text { خبوشان . }
$$

A . ختن

- cner - خ

$\angle 99-\angle \wedge \Delta$

خراسان (ه) (1 )

$-110-9 r-9 .-\wedge<-\tau o r$

$-189-18 \Delta-11<-119$

-ira -ire -ita -irt

$-101-1 \pi 9-1 \pi \wedge-1 \pi 0$

$-217 r-17 \cdot-10 m-10 r$

$-1<1-179-17<-177$

trts -tre trte -trt

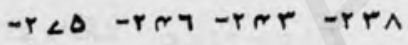

$-r \mid q-r A r-r<6<-r<T$

trel tert -rti her.

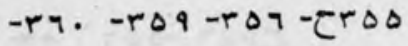

$-r<r-r y \Delta-r 4 r-r 71$

$-r \wedge 1-r \wedge . \quad-r<9-r<T$

$-4<r-5 r 4 a-640-615$

-rar -ra. $-4<-r<\pi$

$-a . j-a . c$-rap -rar

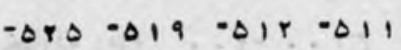

-ro< - Eror -ror -ror

$-c r<1-C r<7-r \rightarrow r-r \Delta \wedge$

-

-

-

gar gar -7هi -7er

$-7 \Delta 9-7 \Delta \wedge-7 \Delta<-7 \Delta \theta$

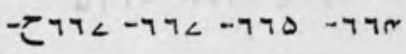

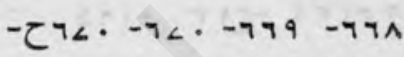

$-7 \wedge r-7<\angle-7<r-\tau T<r$

$-\wedge \cdot 1-\angle \Lambda<-\angle \Delta \cdot-79 \wedge$

$-\wedge \lambda r-\wedge \Delta \wedge-\wedge 19-\wedge 10$

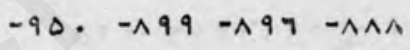

$-97 .-9 \Delta<-9 \Delta 7-9 \Delta r$

$-9<1-9<0-979-970$

$-9<<-9<7-9<0 \quad-9<\pi$

- $99<-9 \wedge 9-9 \wedge<-9<9$

१११ ११४

$$
\begin{aligned}
& \text { حهب } \\
& \dot{C}
\end{aligned}
$$

Cاكل سفيد

خان هوj 


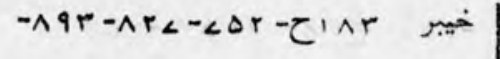

$$
\begin{aligned}
& -9 r r-91<-91 .-9.9 \\
& 9 r \wedge-9 r \% \\
& \text {-qr-q. - غ غ } \\
& -1 \cdot 9-\Sigma_{1} \cdot<-\tau_{1} \cdot 1-9 r \\
& -11 \pi-211 r-11 r-116 \\
& -174-160-16 r-110
\end{aligned}
$$

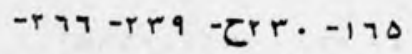

$$
\begin{aligned}
& \text { - Cr<・-r<・-rta - Crta }
\end{aligned}
$$

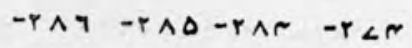

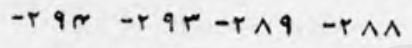

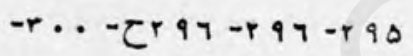

$$
\begin{aligned}
& \text {-ria }-r_{17}-r_{1}-r_{1} \\
& -r<r \quad-r<1-r a r-r r . \\
& -r \mid \wedge-r<\Delta-r<r \quad-r<r
\end{aligned}
$$$$
\text { -7r. -7וr-7ir -rra }
$$$$
\text { -carn-7ro-4re-trr }
$$$$
\text { -yor -7r<-7re -7rq }
$$$$
-7 \wedge \mu-7<n-7 q 9-7 \Delta r
$$$$
\text { -nTr - Lrq- Lre - L. }
$$$$
\text { -97<-977-907-9\% }
$$$$
99 m-9<9-979-97 \wedge
$$$$
\text { Crn-rra }
$$

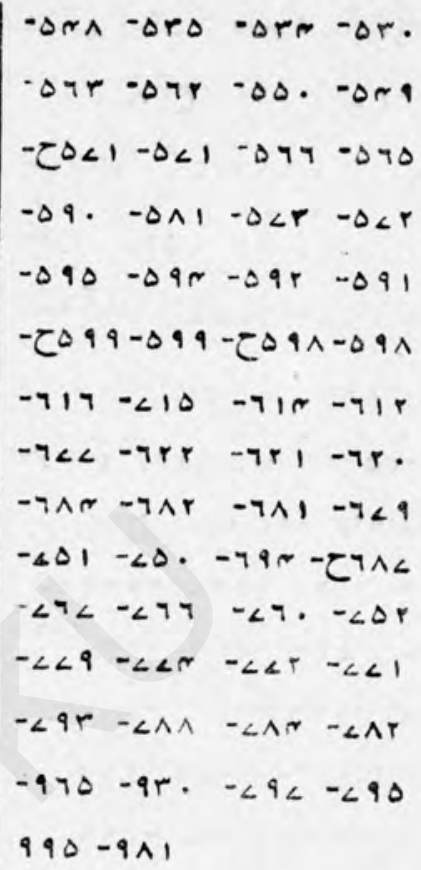




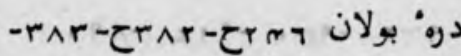
-510.-4ir-gram-grar $-9 r 1-9 r \cdot-91 \wedge-<<7$ $d \sim \pi-9 \pi r-a t r$

$$
\text { درو" خورد كابل }
$$

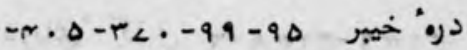$$
-\Delta T_{1}-\Delta T^{-}-e T d-\pi c t
$$$$
-\Delta<\angle-\Delta<7-\Delta<\Delta \quad-\Delta<r
$$$$
\Delta r_{L}-\wedge r r-\Delta<\wedge
$$

دهر

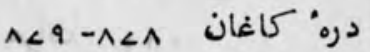
Clar درو كوميل درو موره

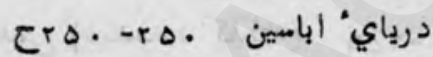
دريايث آتهـك آدرين درياي" آهو د^. درياي" متلج درياي" منده بهاي -ciar -cina -ciro

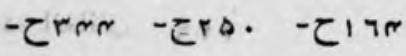

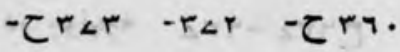
- C<ry - $\tau T<r \quad-\tau r r$

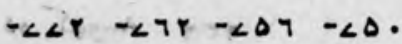
$-\wedge A \Lambda=-\Delta \Delta r-\angle \angle T-\angle \angle C$

\section{2}

cad-erertrer $9<1 \quad$ دادوله

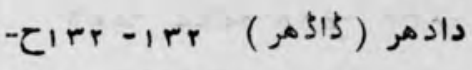
-rat-rt4-5ret-5irs -era -rr< -rar - Erar

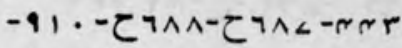
9I

داغستان $\angle \Delta 1$ dia

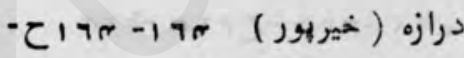
ATr

$$
\text { Lor dis }
$$

دراه ثراه خيرالدين

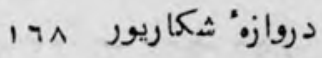

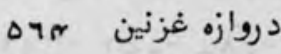

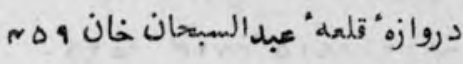
دروازه" قلعه غزنين دورازه كابل دروازه: لكهي

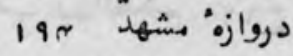

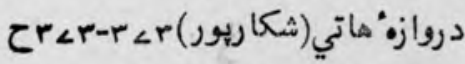

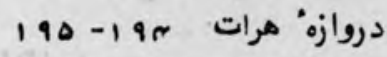

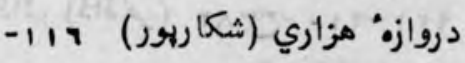
$c r<r-r<r$

$$
\text { دره اوني (هندوكث) م - م. }
$$


- Lar -zrus - שrre

$-\angle T<-\angle \Delta T-\angle \Delta \Delta-\angle \Delta r$

$-\angle \angle \Delta-\angle \angle r-\angle \angle r-\angle \angle I$

-Arr $-\angle A \wedge-\angle L L-\angle \angle T$

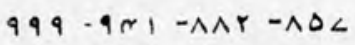

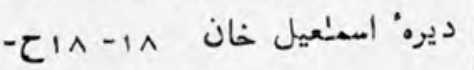

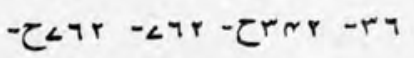

$-\wedge r|-\wedge| \Delta-\angle \Lambda C-\angle \angle \Lambda$

จ^।

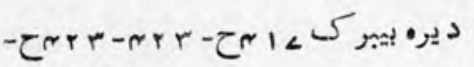

san-crpo-rere -erer

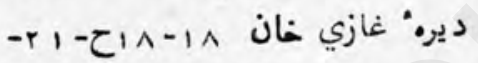

$-9 \Delta-q \cdot-\lambda q-r q-C^{+1}$

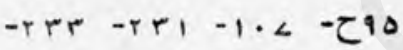

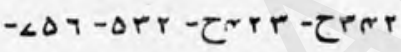

$-\angle A<-\angle \angle I-\tau \angle T r-\angle T r$

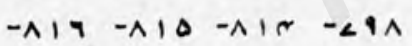

|A| -^ґ|

ديك

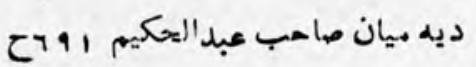

\section{๖}

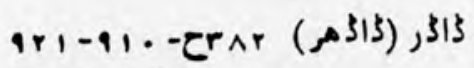
(ر) (ر مادمر )

$-974-96 .-91<-\wedge 9$.
$-97<-970-97<-97 r$
$-9<0-9<r-9<1-971$
$9<9-9<\angle-9<4$

درياي" مراه مباه

درياي" كايل درئ $\wedge r_{L}-\operatorname{Cr}^{r \Delta}$.

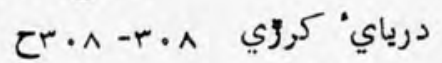

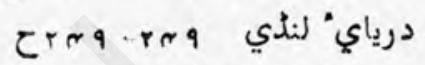
درباي" مظظفر آباد

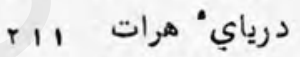

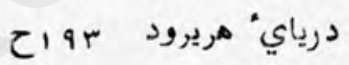

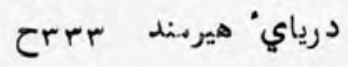
دلتاي سند اله

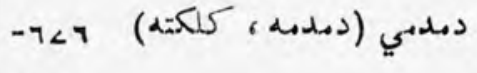
$7<\angle$

دوآبه متلج و بياس دواس

$$
\text { دوده }
$$

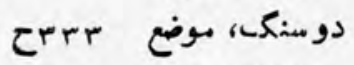
ده انغانان ده جونيجa

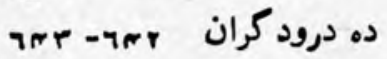

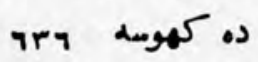

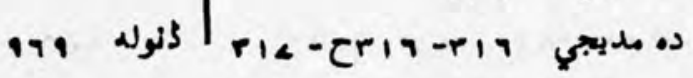




$$
\begin{aligned}
& -901-91 . \\
& 9 \angle A-9<\angle
\end{aligned}
$$

زندان مضرت مدليمان عليهالسملكم ror

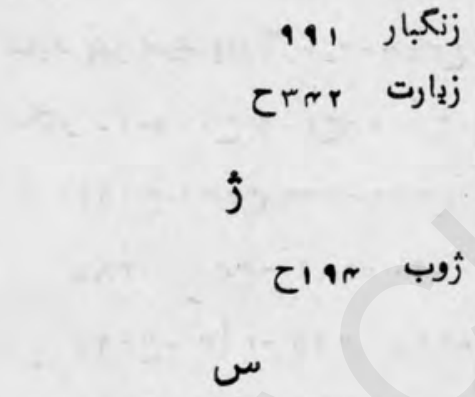

سارتاب (سارتاف، سرتاف) grtr art terte

$$
\begin{aligned}
& \text { L } \\
& \text { L. } 47 \text { gen }
\end{aligned}
$$$$
\text { 1 } \angle A-9 \angle \angle-C 9 .
$$

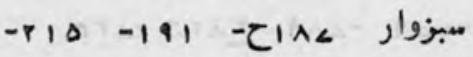$$
-r r \cdot-r 19-r, 7-乙 r 10
$$

$\angle<\pi$

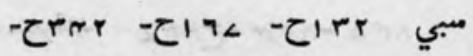
- Crar-rar-ermr-rar j

ذاكر، قريه

)

راجهوتازd راجن بور راد كان נاיهور

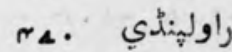
راء بولان راني راس اميد بودم

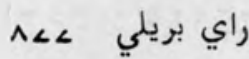

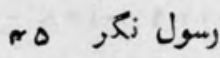
קويور روجهان

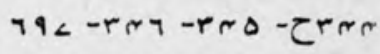

رود فليلي

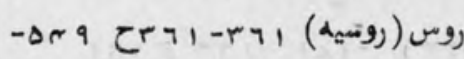

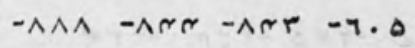
$9 r r-9 r$.

$$
\begin{aligned}
& \text { روامعيه تزالري } \\
& \text { Cr.r og }
\end{aligned}
$$

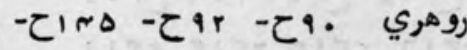
- - $r<1-$ ZाT 
|1. مئد سفلي

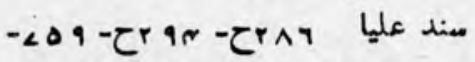

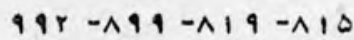
سند $-(1,1)-(1)-.(\Sigma \wedge)-(\alpha)$ $-(\tau, q)-(19)-(1 \wedge)-(1 \%)$ $-2 r-r \Delta-r 7-r 1-19-11$ $-9 r-9 r-$ - $9 \cdot-9 \cdot-7 r$ $-1 \cdot 0-1 \cdot r-1 \cdot r-1 \cdot 1$ $-1 \cdot 9-C^{-1} \cdot \wedge-1 \cdot \wedge-1 \cdot<$ $-11<-117-110-C_{11}$. - Ciro-iro-irm-irr

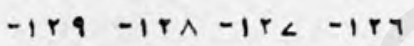
-irr-cirt-irr-iri $-\ln -14,-14 a-1 r_{0}$ $-167-164-16 r-C i n \mid$ $-101-2 \operatorname{ma}-1 \dot{\mu}-1 \%<$ $-17 r-C_{109-10 \wedge-10 r}$ $-r r_{1}-1<1-197$ C I $-r r<-r r o-r r r-r r r$

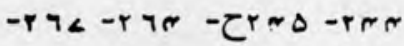
$-r<\Delta-2 r<r-r<r-r<1$ - $r \wedge 9-r \wedge \Lambda-r \wedge r-r<\angle$

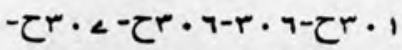
$-r|7-r| r-r|r-r|$ -rrt - rr - r p $-\angle \Delta r-\angle \Delta r-r e r-r r r$ $\angle A T-\angle O A$

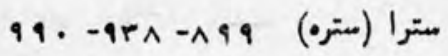

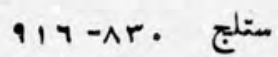

مراى نواب امين الهلك ل مر كهات كورهره $\wedge \Delta \angle-\angle \angle \Lambda-\angle \angle \Delta-\angle \angle 1 \quad$ dis

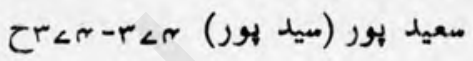

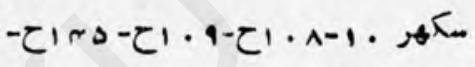

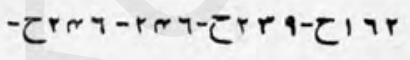
$-r q \cdot-r \wedge q-\circlearrowright r \wedge \wedge-r \wedge \wedge$ -rq< -r90-rqr - $r \cdot 1-r \cdot 1-\tau r \cdot .-r 9 \wedge$ $-n+1,-4 r t-m|<-r| r$ -7rq - -7rr-7r. -rer $-\angle 10-791-7 \% \cdot-7 R 9$ $-\angle r r-<19-\angle 1<-C<10$ $-A<9-\angle A 9-C<T T-\angle T r$

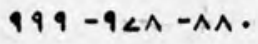

$\Lambda<9-\operatorname{cr}^{10}$ difs

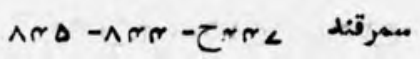
مrA منت لوميا 


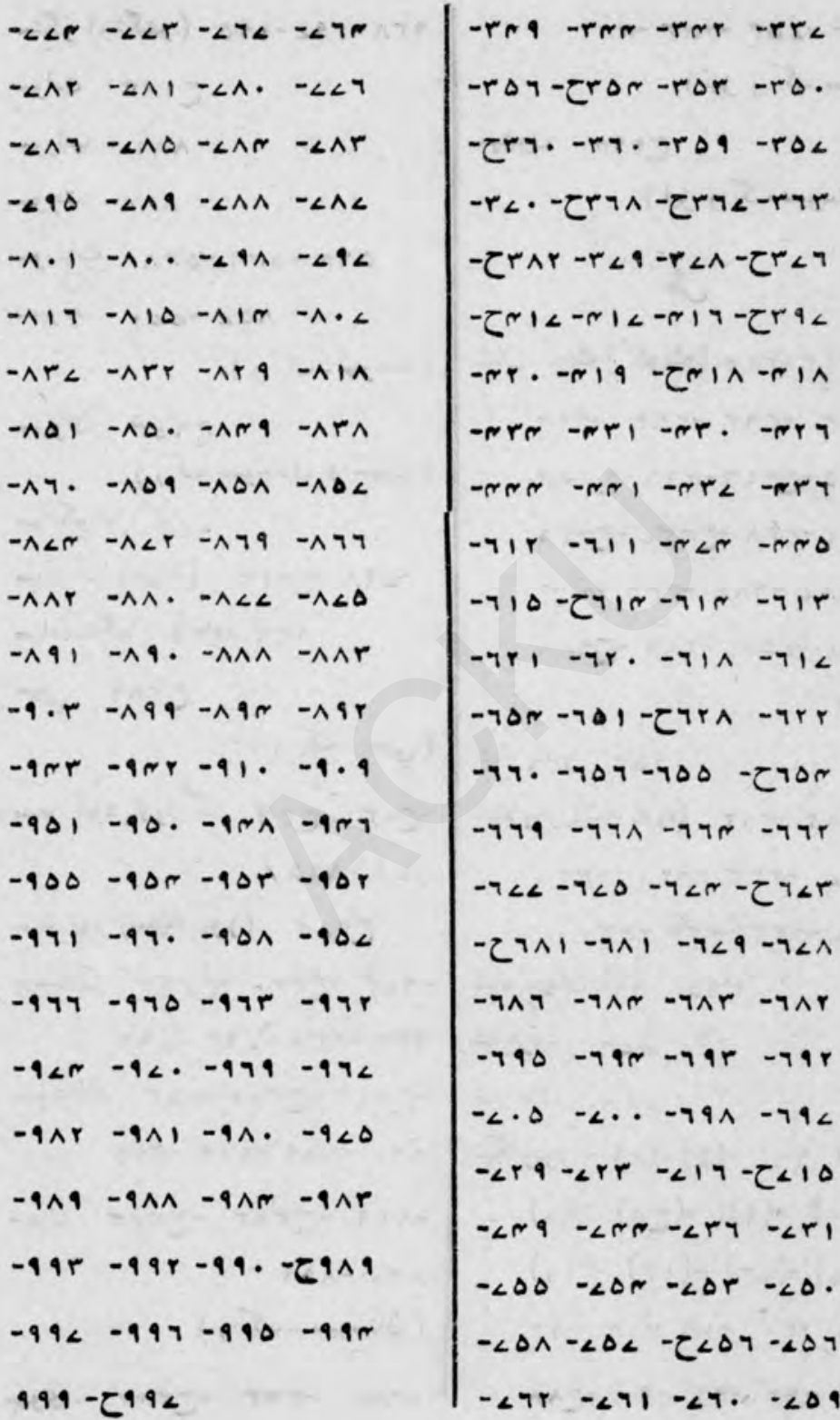




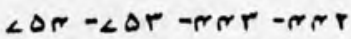

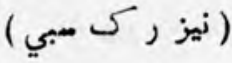

Crar

( نيز ركى ميوسمان )

\section{ش}

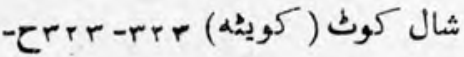

-rae -rte -rte -rte

-6ra-5rit -4itt-5rar

$-4 c 1-6 r a-5 r r<-5 m r a$

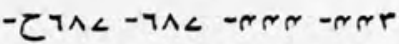

- <9. - 20 - -

$\wedge \wedge r$

Q مشاه بندر

شاه بور (ثاه بوره)

-erts -erte -erti -ert.

cts -ctr-ert - $-4 t$.

ثماه جهان آباد هو هو شامرود ش شبرغان

شكاربور

$-(1)-.(q)-\left(\tau^{\wedge}\right)-(\Lambda)$

$-(1<)-(1 \pi)-(1 r)-(1$,

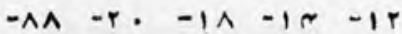

$-9 r-9 r-91-9 \cdot-$ Ena

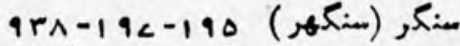
سوات موراب ^^^ مورت

سومنات سورس $\wedge \Delta<-<<1$ مسرند

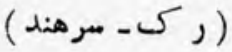

) (ركى سيومتان و ميون )

ميالكوت

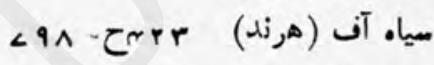

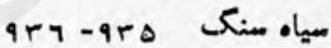

مبي

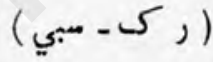

مهد آباد وردكي arar $\wedge<1-\wedge \Delta \Delta$

ميد بور (معيد بور)

$-7<r-$ Crr. - Crrr

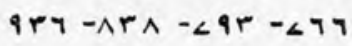

مبيوستان

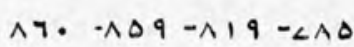

-niq-erar -zror مدون

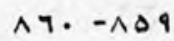

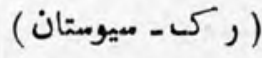

mar -rer -zrer 
$-r<N-r<r-\tau r<r \quad-r<r$ $-417-5 r \wedge r-r a .-r<a$ $-4 t \cdot-41,-610-61<$

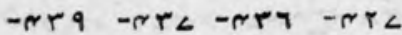
$-r r \cdot-71<-\Delta 9 r-\tau \Delta 91$ - C7r<-7rT -7rd-7rm -uer ded - $71 .-77 r-70 r-9 \pi 7$ $-\angle r \theta-r<t a-\angle t r-\angle 10$ $-\angle \Delta Q \quad-\angle \Delta R \quad-\angle r r \quad-\angle T Y$ $-\Lambda I T-\Lambda 1 \Delta-\Lambda I N-\angle A r$ $-\wedge r q-\wedge r<-\wedge \pi t-\wedge r<$

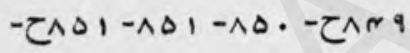
$-\wedge<r-\wedge T t-\wedge \Delta \wedge-\wedge \Delta<$ $-91 .-\wedge \wedge r-\wedge<<-\tau \wedge<r$ $-9 \wedge 1-9 \wedge .-9 \mu r-9 r 1$

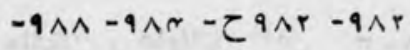

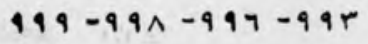
شهال غربي هند ثA 1^. -9<A-974

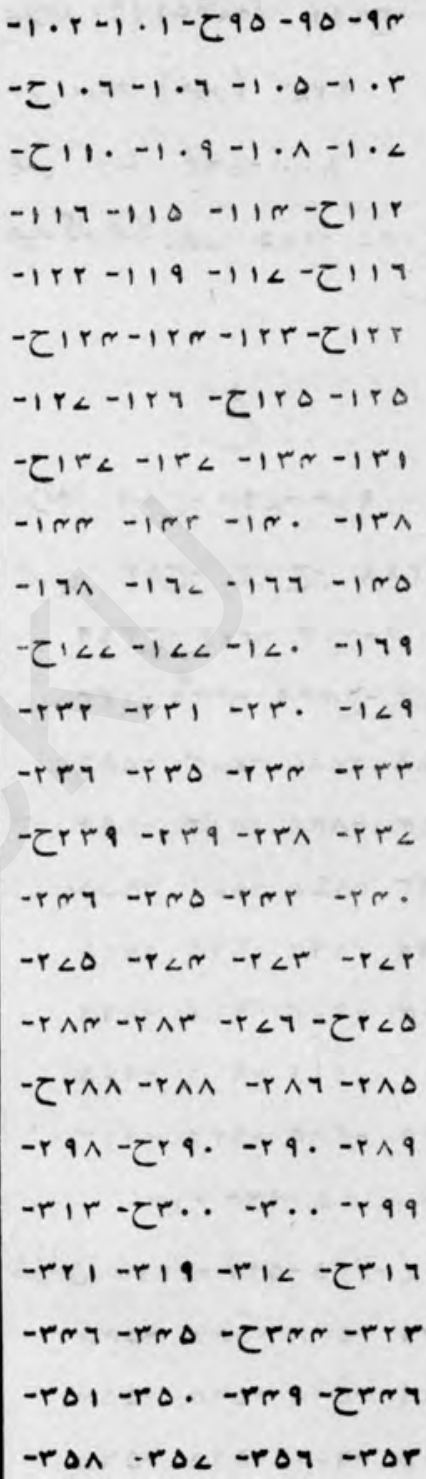


تازه نواي معاركى

C791 $(\alpha \cdot x)$ (i) dixle 1 علي مستجد (خيبر) عمر كوت عيد كاه شكاربور $1 \% 7$

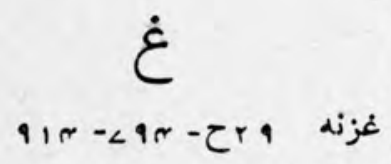

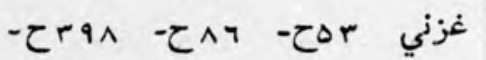

$-411-4 \cdot 4-m \cdot 4-e_{21}$

$-a<r-\operatorname{cen}-a n d-a r t$

$-\angle \angle A-\angle \angle \theta-\angle \angle r-\angle \Delta r$

$-\lambda \Delta a-n \pi \hat{-n i t}-\angle a n$

$-\wedge \wedge r-\wedge<\angle-\wedge<1-\wedge \Delta \Delta$

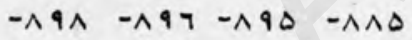

$-9 \cdot r-9 \cdot r-9 \cdot 1 \quad-\wedge 99$

$\begin{array}{lllll}-91 \times & -911 & -9.7 & -9.0\end{array}$

-qra -qrr -qrr -q।

$9 \sim \wedge-9 \sim \Delta-9 \mu \sim-9 \sim$.

غزنين

$-\Delta \mu q-\Delta \sim \Lambda-\Delta r \angle-\Delta \mu \Delta$

$-\Delta \neg \neg-\Delta \neg \Delta-\Delta \neg \mu-\Delta \Delta \mu$

$-\eta \cdot \Delta-\eta \cdot .-\Delta \eta \wedge-\Delta \eta\llcorner$

$7 \cdot<$ شهll بور $-\angle 99-\angle \Delta<-\angle \Delta r-7<r$ 99 - $90 .-\wedge \ldots$

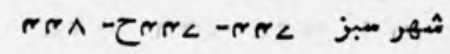
< ا ثيخغو بور -Aqr - شAيراز १९จ

$$
\text { ثميراني (معله) }
$$

شير معرخ (قند (قار)

\section{ט}

صدر بازار (مكهر )

$b$

b طبm

طنبو (تنبو)

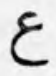

عاثشان و عارفان 15ابل

ع عجم 11

عراق

عرب

عربستان

عزيز 


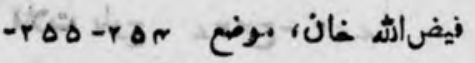
roT

$$
\text { ق }
$$

१9. قامرن

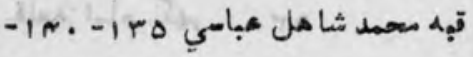
17. - С1 $09-109-1 \% 2$

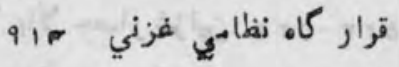

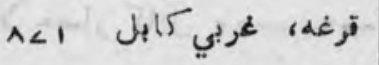
or-nir قريه آ

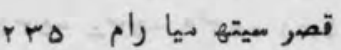
تمبور (كاشور، كامسور)

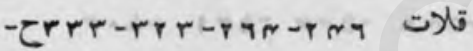
-rey -rmi -rm. arto

-eram-erar-zrytartr

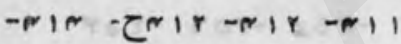

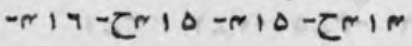

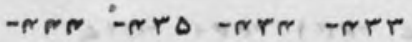
- car -yta -ctry - try $-\angle 9 T-\angle 90-\angle \angle T-\angle \angle r$ -anr -ant -ani -noi $-91 .-\wedge 9 \wedge-\wedge 9 \gamma-\wedge 9$. $-9+\cdot-914-911-911$ -arr-earr - $4 r r-9 r 1$ ari.ar,
791 a)

Cin غورُه مرغه

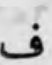

- $\angle T T-\angle Y 1-\angle \Delta r-\angle \Delta 1 \quad$ o 9 $. ~-\angle C 9$

فتح آباد (خبوثان) فرانس فرانكفورت فر في

فراه

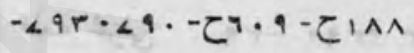
AMr -ArA $<90$

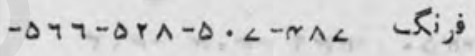

$-79 r \quad-\Delta \wedge 1-\Delta \wedge . \quad-\Delta<1$

$9 . \vartheta-9 . \Delta-\wedge \wedge \Delta-<\cdot 1$

فليجي فليلمي فورت وليهم بهبمي فيروز لهور $-\Delta r r=r<r-\tau r<1-r \pi \wedge$ $-91 \cdot-\tau T 1<-\theta<<-\Delta<r$ $9 \leftrightarrow \wedge-9 r \mu-94 \pi$

$$
\text { C'9. }
$$

فيض آباد، بلهخشان 


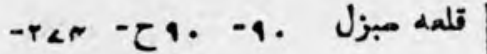
Lrr-7ir

Cr تحل تلعه بميوي rer rer

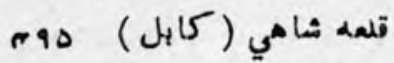

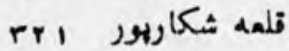
قلعه مالو غان $r r \cdot-r r q$

قلعه عبدالسبعان خان تلمهل " عهر كوت

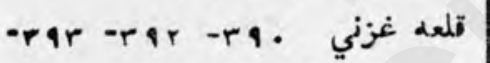
$-r \cdot r-r \cdot 1-r \cdot \pi-5 r a<$

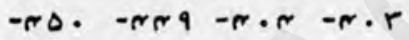
คาง

ق ق $-\Delta r \Delta-\Delta r A-\Delta r T-\Delta r \Delta$

$-\Delta T A-\Delta \Delta r-\Delta r A-\Delta r L$

จั9

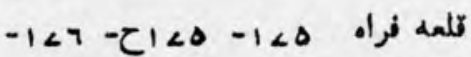

$-1<9-1<1-C 1<\angle-1<\angle$

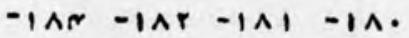

ri $-r+-1 \Lambda 0$

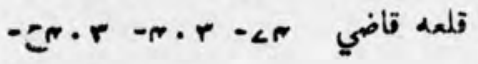

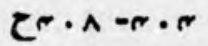

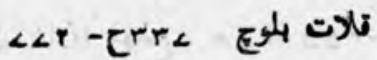
Tr T-yra-r<1 قالمه الدي $r$ o a r.

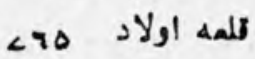
قالفe قلمd بالע مصط $-\Delta r \Delta-\Delta R N-\Delta R \cdot-C Q \Delta$ -orr -orr -or. -orq $\Delta R_{1}-\Delta r q-\Delta r \angle-\Delta r \Delta$

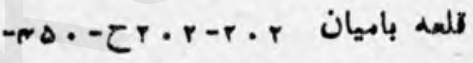
$-\Delta \mu \hat{m}-\Delta m-\Delta m i-\Delta, \mu$ $\Delta \neg ९-\Delta \curlyvee \wedge-\Delta \Delta r$ I -rOA -rOL -rOT -ror $-r 14-r<0-r<r \quad-r<1$

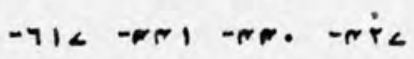
ดงล -ทr.

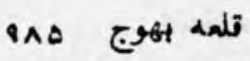
لالمه حيدرآ $77<$

قلهد دبتي

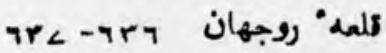
J 


$$
\begin{aligned}
& -1 \wedge t-1 \wedge m-i n r-|\wedge|
\end{aligned}
$$

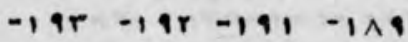

$$
\begin{aligned}
& -19<-110-19 m-\text { CI }^{-19} \\
& -r \cdot r-r \cdot r-r \cdot r-19 A \\
& -r|r-r| \cdot-r \cdot \Lambda-r \cdot 0 \\
& -7 \cdot<-7 \cdot \pi-7 \cdot 0-\text { CrA } \\
& \boldsymbol{\gamma \cdot \Lambda} \\
& \text { ق } \\
& -r \cdot-1 r-(1<)-(10)-(1 r)
\end{aligned}
$$$$
\text { - Cor-ar-rt-er I-Cr. }
$$

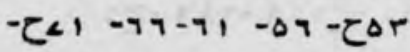$$
-\wedge q-乙 \wedge<-\wedge<-\wedge r-\angle r-\angle r
$$$$
-C 1<r-1<-17 A-10 r
$$$$
-1<7-21<0-1<0-1<\pi
$$$$
-1 \wedge r-|\wedge|-1<9-1<<
$$$$
-1 \wedge \gamma-C_{1 \wedge} \Delta-1 \wedge \Delta=1 \wedge m
$$$$
-r, 1,-214-C, 4 r-191
$$$$
\text { -rim-rit-rit - }
$$$$
-R_{1}-T_{0}-P_{1}-r_{10}
$$

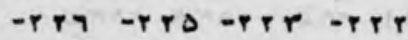$$
\text { - Crmy-rmy-Crrr-rr. }
$$

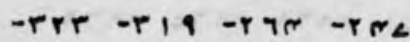

-criatra-crtr-rre

-crra-res -rra -rrt

-rro -rrm-errr -rp.

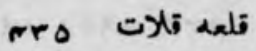

قلad قندهار หง.

$$
\text { I I }
$$

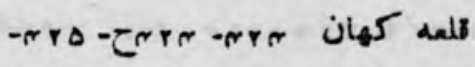
-ert mbi mb. mbi

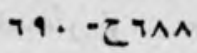

-ra. $7 \cdot 1-791$

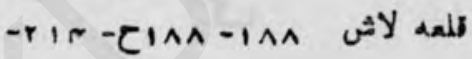
rre-crrori

قلمه لا هور rror

تلعه مباركى

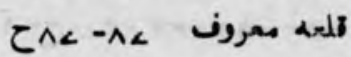
كلمه مير داؤد

كلd مير مستبدي غان

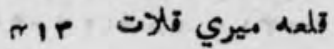

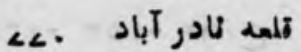

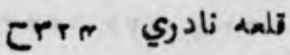

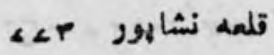

Clis Cr<r

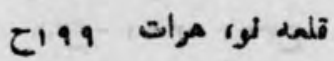

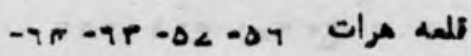
$-1<9-C_{1}<0-41-2 \cdot-7<$ 
-arr-ari-gr. -9ia

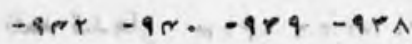

-

ดง $9-990-9 A F-9 \wedge 1$

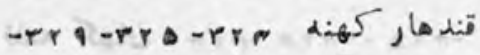
rr.

$$
\begin{aligned}
& \text { تماهدار نو } \\
& \text { ה. הلبوز }
\end{aligned}
$$

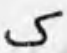

كابل

$r 1-4 .-19-1 r-(1,-)-(10)$

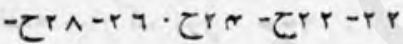

- or-o1-nr-rL- Cra-ra

$-\angle r-C<r-\angle r-\tau o r-\Delta r$

$-A r-\lambda r-\angle q-\angle \angle-\angle T-\angle \Delta$

$-|r|-1+A-1 \times 7-99-A<$

- Ciar-10r-1r<-1rr

otra trte trterter

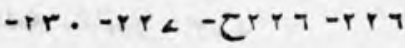

-tum-ren -tes -etr.

-ertr-rea orta ora

- Cryו -ral - שra. -rra

-m.r-erta -raso-rar

$-4 \cdot \lambda-6 c \cdot 4-4 \cdot n-5 r \cdot r$

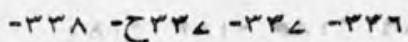

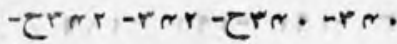

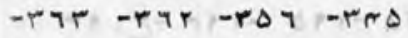

$-r \wedge A-r A T=5 r \wedge m-r \angle L$

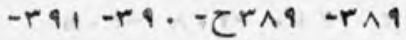

-6ra -ert-ger.r-tat

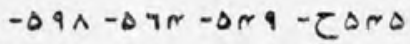

$-9 . r-7.1-7 \ldots-099$

$-7<2-701-70 \cdot-7 \cdot<$

$-27 \wedge<-7 \wedge<-7 \wedge 1-7 \wedge 1$

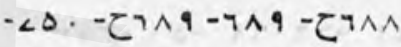

$-\angle T Q-\angle \Delta r-\angle \Delta r-\angle \Delta I$

$-\angle \angle T \quad-\angle \angle T-\angle \angle 1 \quad-\angle \angle$.

$-\angle \angle L-\angle \angle T-\angle \angle D \quad-\angle \angle C$

$-\angle \wedge \mid-\angle \wedge \cdot-\angle \angle 9-\angle \angle \wedge$

$-\angle 9 r-\angle 9 \cdot \quad-\angle A<-\angle A T$

$-\angle 9 \wedge-\angle 9 D-\angle 9 N-\angle 9 r$

-nrs -

-AMt -Am. -ArA -ArL

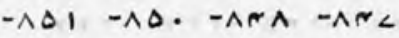

$-\lambda \Delta \wedge-n \Delta r-\lambda \Delta r-n \Delta r$

$-\wedge<1-\wedge \neg \Lambda-\wedge \neg \angle-\wedge \neg\rceil$

$-\wedge 9 \cdot-\wedge \wedge r-\wedge<\angle-\wedge<r$

$-9.1-\Lambda 99-\Lambda 97-\wedge 9 \%$

$-917-211-91 \cdot-9 \cdot 0$ 


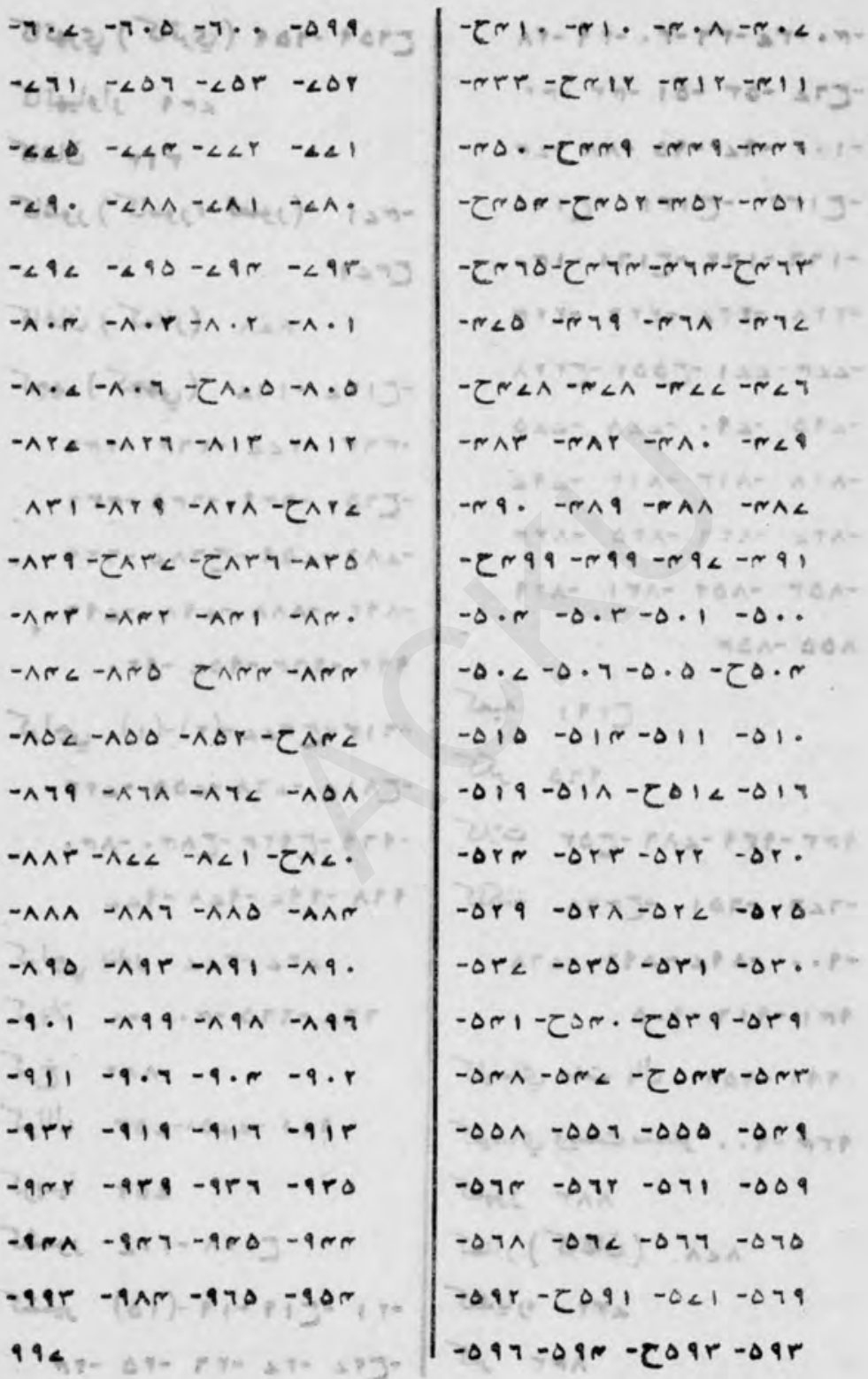


$-r \cdot-r \Delta-r 7-r \cdot-r q-r A$

$-C T<-\Delta r-\Delta,-4 r-r r$

$-1 \ldots-1<-10-\wedge \Lambda-\angle N$

- cirr - ziri - ci..

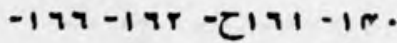

$-r t \wedge-r t<-r i t-r r k$

$-\angle \angle N \cdot \angle \angle 1-$ COOH - Er

$-\angle 90 \quad-\angle 9 \cdot-\angle \angle A-\angle \angle 0$

-nIn-nIr-AIr -

-NTL -NtT-ATO -Ntr

-nor -nor-API -Arq

$\Lambda \Delta \Delta-\Lambda \Delta r$

Cr91

978

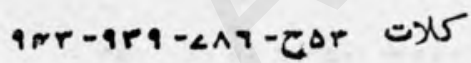

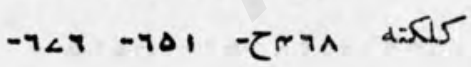

-9.. -А $\angle-\wedge 97-\angle 7 \wedge$

$8 \times 1-917-9.0$

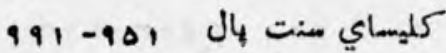

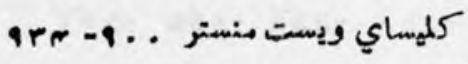
Anr

A<A (jen

كنديارو Sir

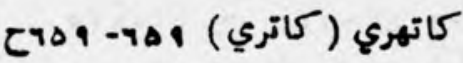
كاتهواوار rir

كاثور (كامور، 3مبر) $C r<1$

A\&A (ر) (515

- $174-174$ (17)

-rgr -r<L-rTr -rry

- CIA. - Thi - -

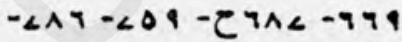

-nit -nNA -

19r-97r-90<-9r.

كراهي

$-C A 1<-\angle T A-\angle O O-\angle P r$

-9.9-Carm-Zan.-An.

$99 \wedge-99<-9<A-9<\angle$

$$
\text { <r<-r<< }
$$

$77<-770-\ldots . .1 \quad x_{4,5}$

An

$111-\angle \Delta \Delta-\angle \Delta$ S

$\Delta \Delta \quad$ r

كinمور

ك, -

$-C r<-r<-r t-r 0-r e$ 
تازه نواي مaرك

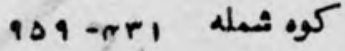
كو. كوز

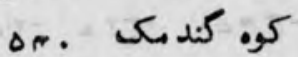

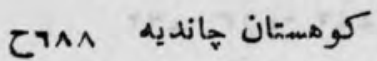

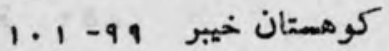
كو هستان مري كو 79r ن45 مه كهت غرب هرات 91.

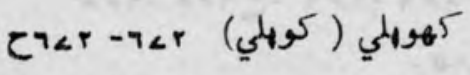
كهوره باري

كوية (ث) كال كوت ) -erar -crat errar

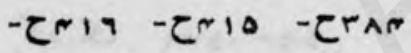
- Lenr - zera - zero

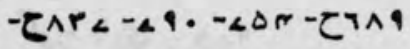
$-41 \cdot-\wedge 9 \mu-\wedge<<-\wedge 7 \wedge$

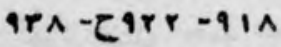

كويل 9. $\mathrm{r}$ A ๆr. 4 CIr
^ง

A9^ كين كوبويج كوبكان 97r<. كوت جعفر غان كوت دעب كونل (كوز5) 9r। $-\Delta r_{0}-\operatorname{cr} \wedge \Delta-r \wedge \Delta$

$$
\text { كوتل كئl }
$$

كوتلd كوتلير كوراנ 11.-Carr

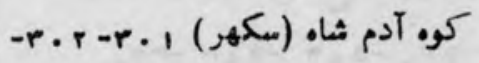
$<\wedge 9$

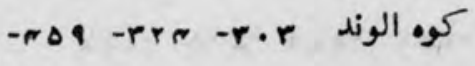
QNT

r r كA< Co1A كوب مedal كرب سيتيور 


\section{J}

$-17 .-$ EIro-iro disjy

- $197-C_{r}<r-r<r-r r 1$

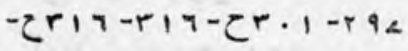

-rea tere -cert tha

$-r m a-r e n-t r<-r e d$

$-t \sim 1$-ra. -ror gra,

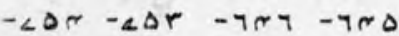

$-99 \Delta-99 r-\angle T \cdot \quad-\angle \Delta \Delta$

ट१९

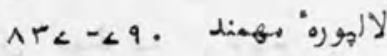
ل. لانياري لاروه

CrAr

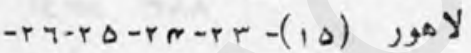

- Ert -rer -ri -r. -ra

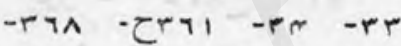

$-\Delta<\angle-\theta<T-\Delta<r-\tau \sim<1$

- $2 \Delta t-c i r-7 a t-t \Delta i$

$-\angle \angle T \quad-\angle \angle I-\angle T A-\angle \Delta L$

$-\angle \angle A-\angle \angle T-\angle \angle D-\angle \angle C$

-Ar. -ArM $\angle q \angle-\angle q r$

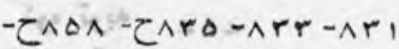

$-\wedge 9 \Delta-\wedge \wedge \wedge-乙 \wedge<\Delta-\wedge<r$

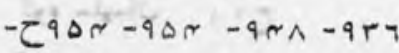

๑ง 9 - १.

\section{5}

$-\tau r<\cdot-C^{r}<-r<\quad-5$ $\angle \angle T-\angle T R-\angle T r$

كرد بـ

S.

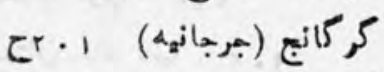

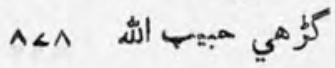

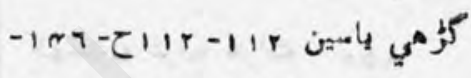

-ter -ter -tal tro

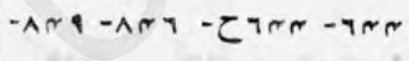
$\wedge \Delta$.

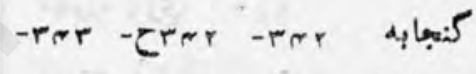

NDा $-e r_{<}-r \sim \Delta$

كنداوه

oor-ars S.jós

كواليار

$9<7$ كوره باري

كو

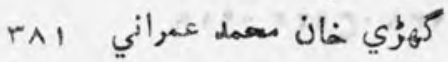

كوزي ياسين

$T r<-1 \pi Y$

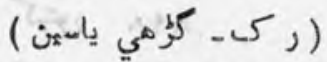

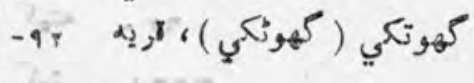

1AN-cit 
-hrt -hr. ht< -erti

$\angle r<-\angle T \theta$

and

r

مالواي هند (مالوه) مra-

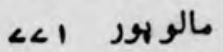
مالون مالون Crro

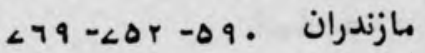
هاما خيل A مانسهره (ضلع هزاره) ماوراء الثهر

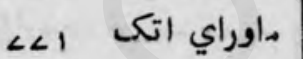

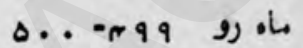
م११ ماهي منته

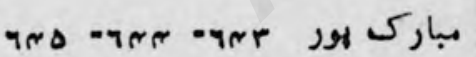
79. معال كومرجي Cirr

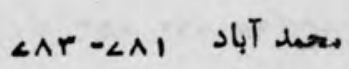

-ayer ront

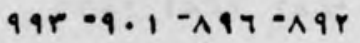

AA. مدينه CAN مراد آلاده
لز

لس بيله

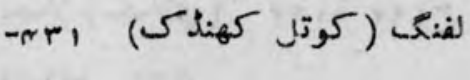
rrr

كس لكىخانd 9

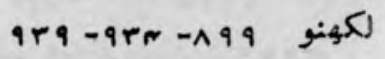

لندن

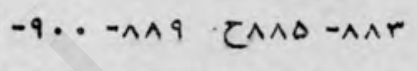

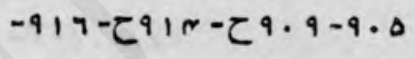

$9 \sim 7-9 r<$

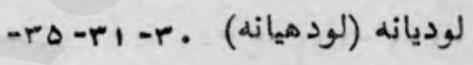

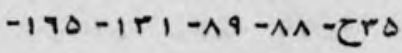

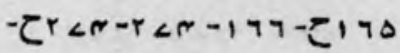

-rar-rer-crn.-crra

-rat-cras-cram-ran

-

$-7 \Delta,-\Delta<r-\Delta<r \quad-r<r$

-q1. -^r^ -Ar< -Ar.

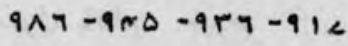

\section{لورلائي}

لوه هرى

$-r \cdot 9-r \cdot<-r 91-r 9 \Delta$

$-r<1 \quad-r<4 \quad-r<1 \quad-r<$.

-erm -rat -rba. tra. 


$$
\begin{aligned}
& \text { مشثهد خورد ريزه r. } \\
& \text { Q مصر }
\end{aligned}
$$

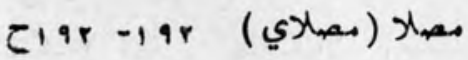
A م مروف Lor ili.

A Aقابر تالهوران (حيدرآباد ) A

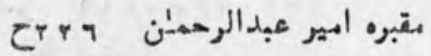
Aqه هقر لمشكري هيدرآباد

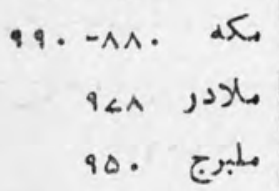
- १९ -

$-\angle \angle 1-\angle 79-\angle O \angle-\angle 1 N$

$-A H \cdot-\angle \angle A \quad-\angle \angle \Delta \quad-\angle \angle r$ $\wedge \wedge r-\wedge<r-\wedge \Delta 9$

CT1< $($ (som -5,$)$

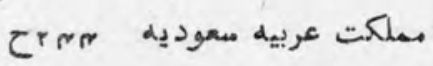

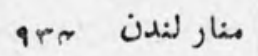
مئز

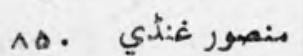
A 1 جरां

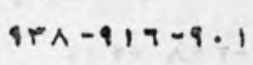

Crم Criv A7. $\angle \angle r-\angle \Delta . \quad 0$ 7زار جاهي (هرات) مزار مضهرت جي (ا-همد شاهي) - - $\wedge\urcorner<$

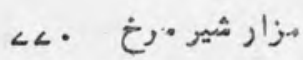

هزارعاشقان و عارفان (جنوب كابل) $9 \cdot 7-\wedge<1$.

$$
\begin{aligned}
& \text { مه } \\
& \text { ه }
\end{aligned}
$$

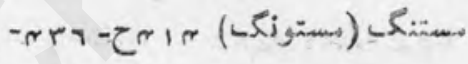
$-\wedge \wedge r-\angle \angle r-\tau R r \angle-\tau r r T$

११९

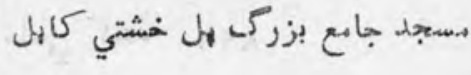
$\Lambda \cdot r$

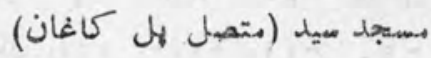
$\wedge<\wedge$ $\angle T 1$ bano

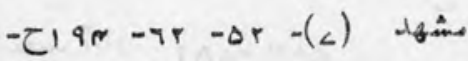
$-\angle 70-\angle 0:-\angle 0 .-C r r r$ $-\angle \angle H \quad-\angle \angle T \quad-\angle \angle 1-\angle T T$ $-\wedge 0 \cdot-\lambda r<-\angle 9<-4<9$ จก1-nor 


$$
\begin{aligned}
& \text { A१ห } \\
& \text { 4. • ناوه باركزني } \\
& \text { CLPT لiئ } \\
& \text { \&rr }-4 r<-<r Y \text { dgili } \\
& \text { نشيا بور }
\end{aligned}
$$

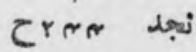

$$
\begin{aligned}
& \text { ن نجف } \\
& \text { نصريور } \\
& \text { نمبير آباد (متصهل جيكب آباد ) }
\end{aligned}
$$

Crin-Cl.

-nir-air-ert-ra da Aห9

تיهו نوبت خانه اهام مهلدي نو سكهر نوشكي نو نو

نوشهره، موضع $\angle \wedge T-\angle A \Delta-\angle \Lambda I-C H I T$

$$
\text { نوثهره ابرو الماح }
$$

نوثهره فيروز

$$
\text { كونار }
$$

نونه

نهر هوتا بيماري

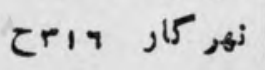

Spr موغلd ب r.

موهنجو ديرو مrو

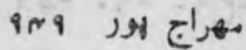

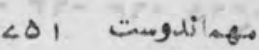

C 10 مياني

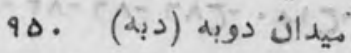

ميدان لاهري

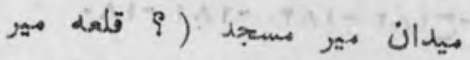

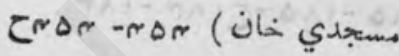

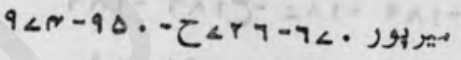

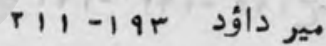

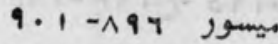

$$
0<r \text { or }
$$

- ميهid $\angle \measuredangle \wedge-\angle \angle N$

$$
\begin{aligned}
& \text { ن } \\
& \text { لادرآباد } \\
& \text { Lr ofl }
\end{aligned}
$$

ناله تانورى لناه

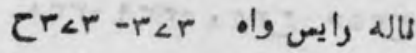
- ir טדוק

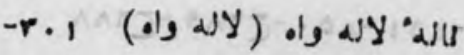
$r \cdot q-c r \cdot \Delta-r . \Delta$ 
$(-10)-(\tau)-(9)-(<)-(7)$ ه $-\Delta \tau-\Delta r-C \Delta r-\Delta r-r a-i r$ $-\tau \cdot \cdot-1 \cdot \Delta 9-\Delta \wedge-\Delta<$ $-270-7 n-7 r-7 r-71$ $-\angle r-\angle r-\angle 1-7<-77$

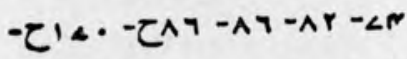
$-1<1-1<1-1<7-1<m$ - Cint-int-ini-in.

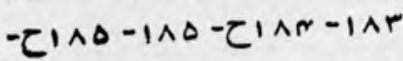

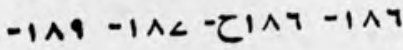
- Ciar-19r - 191-19. - 190-乙।9n-19\%-ट।9 -乙।⿻ $-r \cdot r-r \cdot r-J_{r} \cdot 1-\tau_{r} \cdot$ $-r \cdot t-r \cdot \theta-r \cdot r-C_{t} \cdot r$ $-r \cdot 1-r \cdot n-r \cdot<-c t \cdot d$ $-r|r-r| r-r|1-r|$.

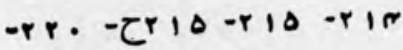
-crai-rtr-trr-rti

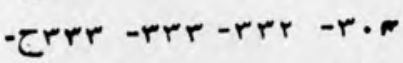

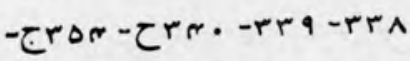
$-7 \cdot<-7 \cdot \Delta-$ $-71 \cdot-C^{7} \cdot 1-7 \cdot 9-7 \cdot 1$ $-\angle \Delta 1-\angle \Delta \cdot-$ $-\angle<1-\angle 79-\angle 7<-<7 \pi$
ف ג

نAC نيرون كوت (سيدراباد) ( نيز ر كى - حيدرآباد ) نيمثا بور

\section{9}

وادي ثروان هبr

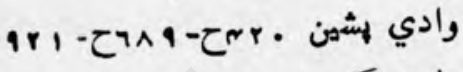
وادي كرم كري وادي روب ارب واشير واكس هال A I S ولويتغ CO. وينزحستر

$7 \Delta \wedge$

هالاني م- 10-10 ه 1 (الكر CrA. مالد كندي a

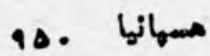




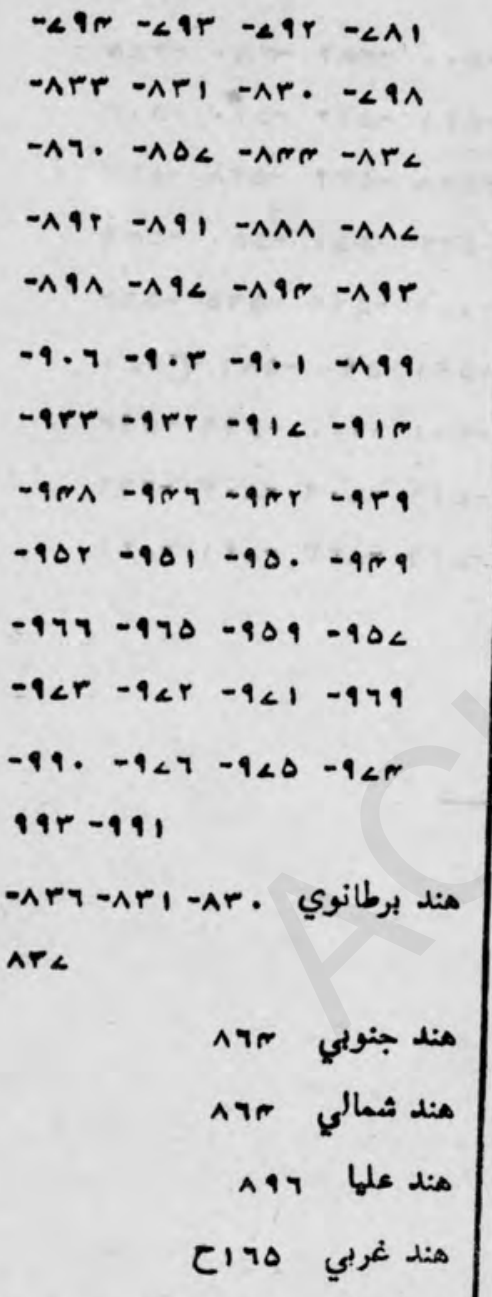

مشت نكر (اثش:كر) ه ه LO

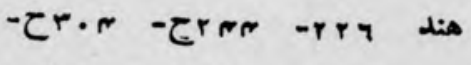

-erti -crt. -rras - Cast -cera - rmit هist-10r-11< $-r i p-r<r-r r a-r m e$ $-m e d-612-611-6.0$

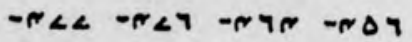

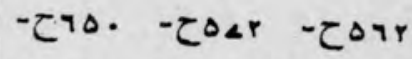
- $\angle \Delta r-\angle \Delta r-\angle \Delta . \quad-\angle m 9$ $-\angle \angle \Delta-\angle T I-\angle T \cdot-\angle O L$ 


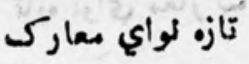

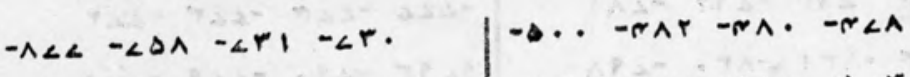

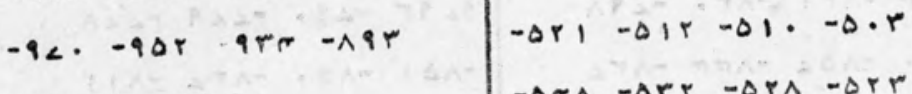

$9 \wedge \neg-9 \wedge \Delta-9 \wedge \sim$

- $\Delta r \wedge$ - $\Delta r r-\Delta r \wedge-\Delta r r$

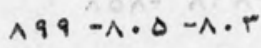

$S$

$-\Delta L 1-879-\Delta 70-074$

$-\Delta Q 1-\Delta 9 \cdot-\Delta \wedge 1-乙 \Delta<1$

$-9 \cdot 1-7 \cdot \ldots-099-09 r$

Crलy

9०. نligs |- 
C४99-CLAT - $\angle T A$ تاريغ مند و افغانستان [ تازه لواي

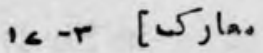

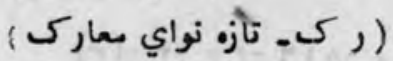

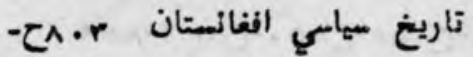

CADN

$$
\text { تاريط فدا هسين }
$$

ركى. تاريغ انفانستان ( سيد

فا فرا مسين )

تاريخ فرثته

CAD

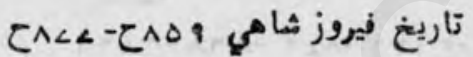

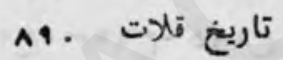

"اتاريخ قندهارو [تازهنوايمسمارك]

CAMQ-A⿱A - (1/4)

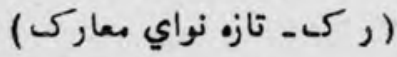

تاريخ كلهور انكليسي (-سينن )

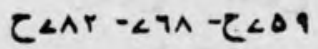

تاريغ كلهوره و استقرار مكومت

- تالهران

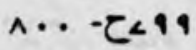

تاريغ مaمهومي

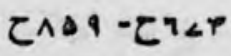

Crro -crra - Erri

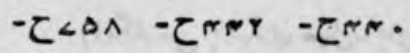

$-\tau<1<-\tau<1-\tau<r<<7 A$

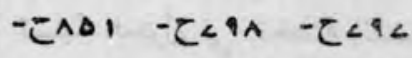

- car. - zaia - zant

-5armate-cabr-cith

टथr।

$$
\text { كاريخ نهاور ( كوهال دام ) }
$$

car. - cart-caro

-乙ட91 -

C<9<- $<<94-\tau<90-<90$

تاريغ ملطاني

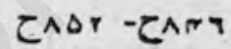

تارئ

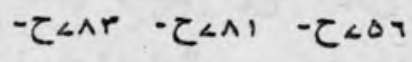

CथA<-C<AD

تاريغ سنده (توين مل)

$\angle A \cdot-\angle T \wedge$

تاريخ مشنده (عالم رمول همر )

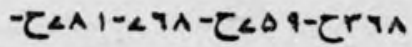

- C<A< - C $2 \wedge \Delta-E \angle A F$

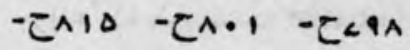

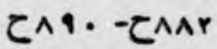

كاريغ هنده (تلمع بيكه)

$-\tau<7 . \quad-\tau<\Delta N \quad-\tau<\nabla$ 


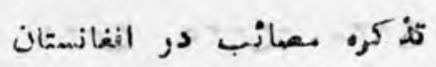
)

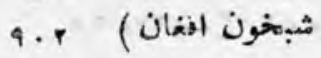

تسميلة العقول في تخغئة الفضون AN.

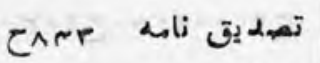
تغيز -nir - Entr - Enei - Enin $\wedge<\neg-\tau \wedge \Delta \wedge-\tau \wedge r r$

تلنخيص دائرة المaارف اسلامي

¿^^1

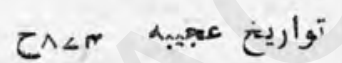

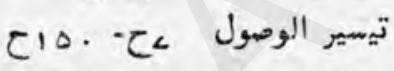

تيمور ثاه دراني

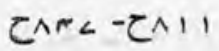

$$
\text { تيموريان هيد }
$$

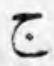

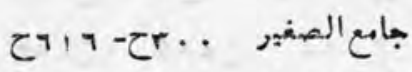

جريله" (2) هلموناتست Diplomatist) सा

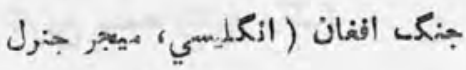

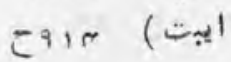

تاريغ مانغ كي در مئد

(History of Alienation in Sind)

$-\tau \wedge 1<-\lambda 14-C^{r}-r-(r)$

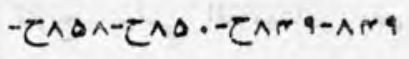

ट१ฯ

تاريخ هرات (ميني) تازه نواي مهاركس (كتاب ماخر ) $-\angle \sim \Delta-(1 \wedge)-(1<)-(r)-(1)$

- Car८-arq-Cara-cary

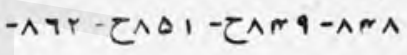

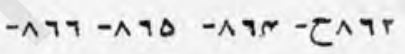
- Carr-n<r -n

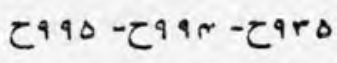

تقهة البيان تحفة|الجمدب (فيض محمد هزاره ) zAor

تصفة الكرام

- ZaAr - Clar - ZlAr

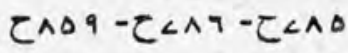

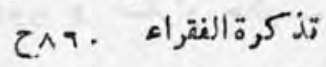

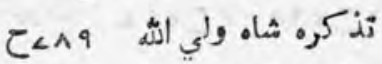

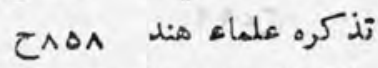

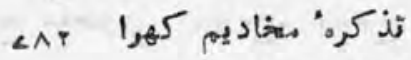

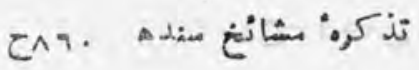




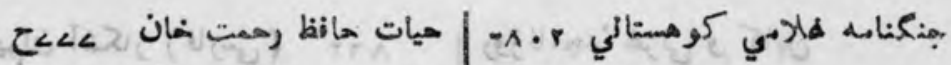

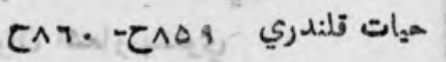

\section{$\dot{c}$}

Ai خرد نمامد

$C<\angle \Lambda-\tau \angle L C \quad$ خزاز خزاين تاريخ

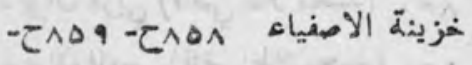
¿^^।

C

(Encyclopaedia of Islam)

\section{Eren}

دائرة المعارف افغازستان

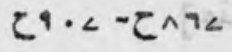

دائرة الهمارف برطانوي

(Encyclopaedia

Britannica)

$\angle m 9$

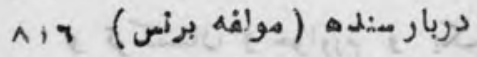

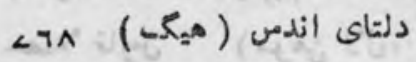

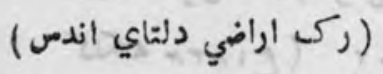

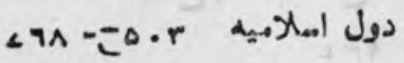

$\zeta \wedge \cdot<-\tau \wedge \cdot \Delta-\Lambda \cdot \omega$

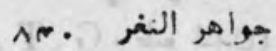

جماهر عباتيه

$-\tau<\Delta 9-\tau<\theta<$ ي

471

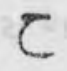

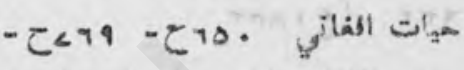
टथ9.

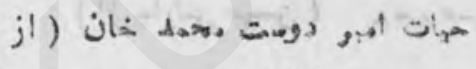

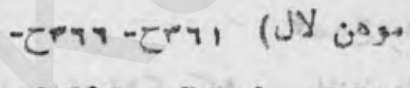

-erar -crai -cram -ce.r -

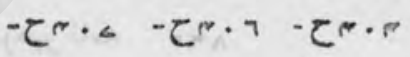

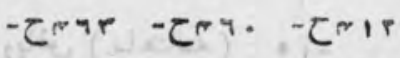

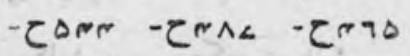

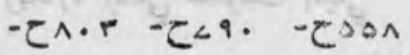
$-\tau \wedge \sim \wedge-\tau \wedge \mu \sigma<-\tau \wedge \mu$ - Cair - CAnT - CANm -rart -rain - Jair $-\tau a \Delta r-\tau a r<-a r \Delta-9 m$

$-\tau a \Delta \wedge-\tau \wedge \Delta \neg-\tau a \Delta \Delta$

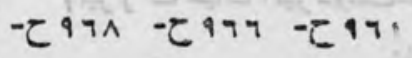

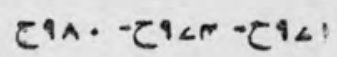


كاز. نواي مal

$1.9 \mathrm{r}$

روزناشجه غزني و كابل

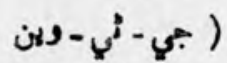

( G. T. Vigne.

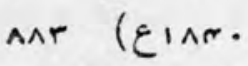

روز نامتهد لهثكر كيثي بر مند و

يلوحستان و اففانستان

(وليم هنري ديني، طبم لندن

arr (Elaer

رويداد مغر بلموخستان و انغانستان

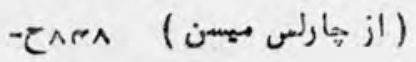

ดง - $\subset \wedge<P$

رويداد ليكر, كشي بر انغانستان

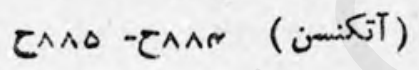

رهبر نامه

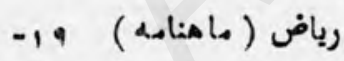

ريكارد رسمي مكومت بهبني

c४1

j

زندكي امير دومت مدمد غان

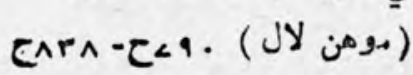

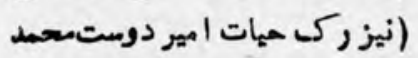

( انة

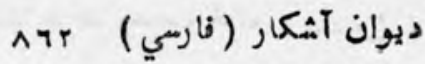

ديوان اشعار إثثتوي

LA^ (احمد ثاء ابدالي)

دبوان مسmن تتوي (خطي)

ट००

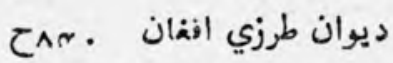

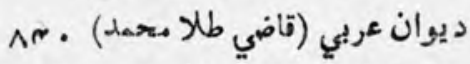

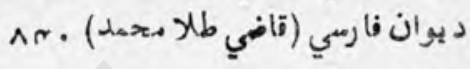

ديوان وني فارمي هوني

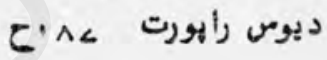

)

هA. رابورت ماهورين آثار عتيفه

راز

روزنامجه انقلاب دملمي

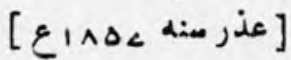

(ميدري ثكم، خانم موهن الال)

(N)

روز نامجه جنرال ايبت مبه

روز ناميجه مغر لخجابه و انفانستان

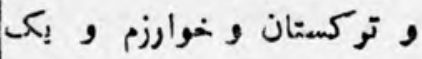

معهد فارس ( موهن لال،

كerer (ciaper 


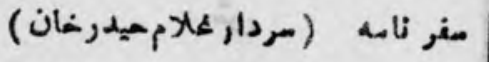
CrA

مفر نامه بخغارا ( If.

- Z $\tau<90-\tau<1 \wedge$ - Ca.rप्रा

ملوة المترير في توجمه التهرير Afe. ملوة الكتيهب لمن لا بهضره الهبيم AN.

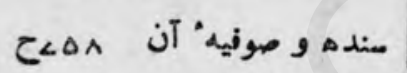
سندي ادب مصنيل

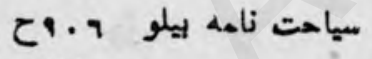

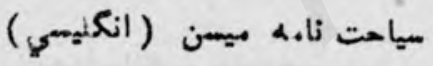
ट^จง سياست ازكلميسي در سنده(انكليسي) - C104 - 1900 -

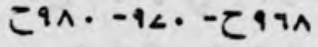

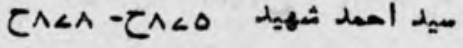
مير المتاخرين C४A - $<<\wedge$

\section{مu}

هاقي نامه فارمي (واي مهمد خان لهاري) هبهة المرجان مبراج التواريخ

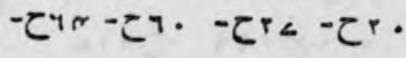

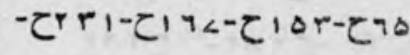
-Cra. -grna -grta -zaar ra.r - renam - C\&4 $-\tau<4 \quad-\tau<19$ - टब98 -rail - Ca.r -

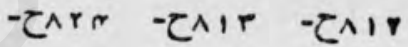
-ents -eart -enta - Eana -rare -eara

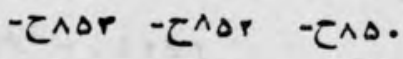

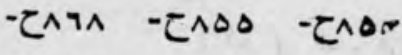
-r^⿸r $-\pi<r \quad-C \wedge<1$

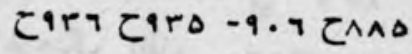

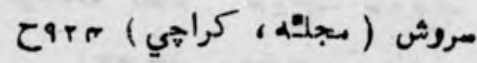

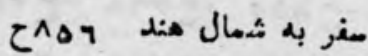

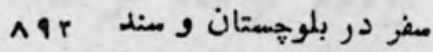

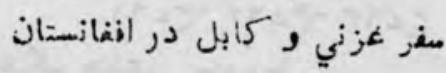
こAลก 


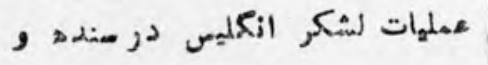

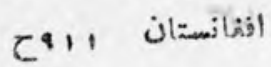

\section{$\dot{\varepsilon}$}

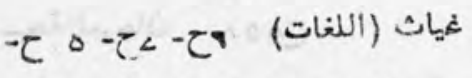

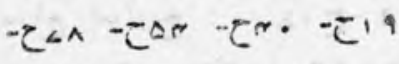

-Crit -

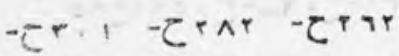

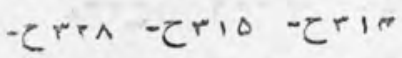

-crea -crra -crrn

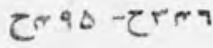

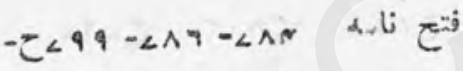

فتوح الماندان ( بلاذري : طنح ليدن ) AND

( ن

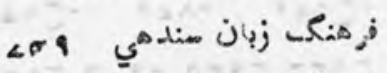
errar -con

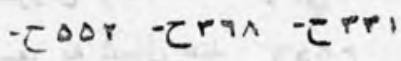

- CaAT-Cant -COAP

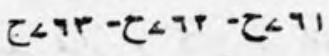

Cवि

\section{N}

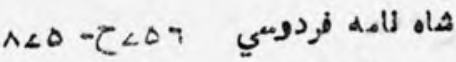

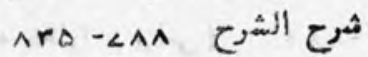
شمراي فارسي در سند (انحلميسي ) ट^।<

ثمس النهار (جريده هنتكي) ثمهناسه زادري هنظوم (خمطي ) $\angle \neg A-\angle T N-\angle T$.

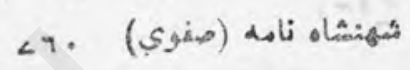

vo

صجيفه " مران

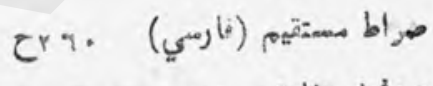

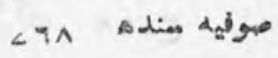

صولت انفاني

b

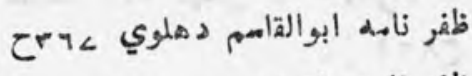

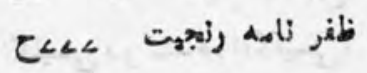

\section{C}

عروج باركزائي ( باركزائيان ) -cran -rrad -cr<i $\zeta \wedge \Delta \Delta-\tau \wedge \cdot r-\tau \Delta<T$

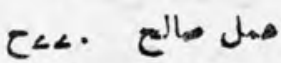




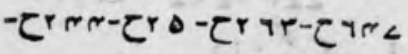

rora rera tert.

$-\varepsilon<4 \cdot-\varepsilon n \cdot t-51 m 4-\delta<$

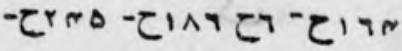

-

- $2, a-2<1 a-2 a-2 r \Delta r$

-crir -cran -zrat

-crar -5l. -cris

-5ram - $5<r .-5 n$.

5ram-gria-grar

قصيده بائهه عربي درعمل بالهديث AN.

قيصر نامه" هid

كتابوه استاد فاميل قاضي EAr

(نيز ركى اسناد خانواده" قاضي)

كتاب خغلي (مدلوكه قاضي سكهر ) $A \wedge I-A \wedge$.

كتاب كتاب بوهن لال ( ميات المير

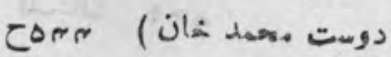

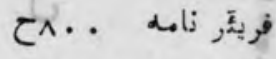

فهرست موزه' برطانيه

\section{ق}

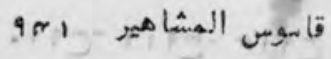

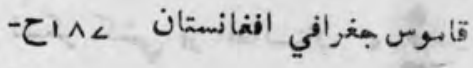
¿ब४

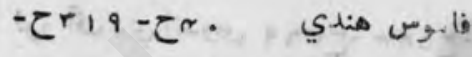

$\tau \Delta<r$

قيل زام

قa

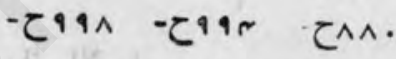

टथ99

قرآن (شريف)

$-9 \wedge r-9 \wedge 1-a<r-乙<r$.

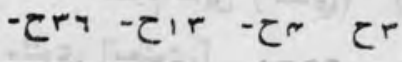

-5int -5int ral

-5ar. -5u-5ira-5ul

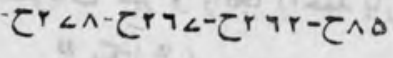

-cris rera tr.r

-rorm - $20.4-\tau a^{2}$

-5ra -5ran -5ide

-cran - rror - tu.

-cria troa terat 


\section{$\bigcup$}

J元

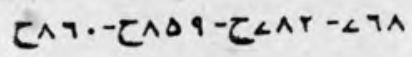

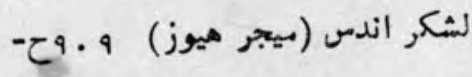
こ9ı - 911 こ91.

لشكر كشي بر افغانستان

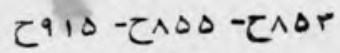

لور آف دي اندوم ه جrح- بمه ट9.9

حالوي امهد ثياه بإبا<smiles>[TeH]</smiles>

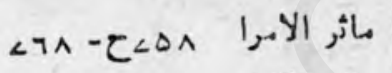
С^. ماثر الكرام

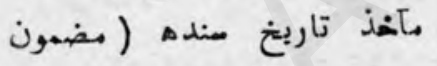
معامالدين راثمدي) (و ( ) مثنوي [منمنوي]

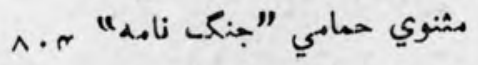
مثنويات هير و رانج) (احمد يارخان $-\tau \wedge 1<-\wedge 1<\quad(") \mid$ ^। -乙^।^

مجrc

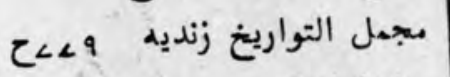

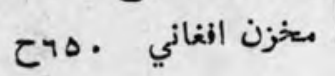

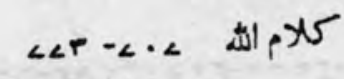

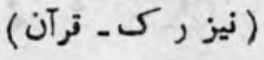

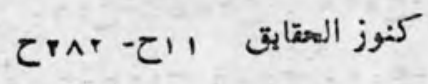

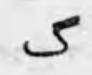

Anr dolijid

كراهر بقايسوى بون

كوامر هندوستاني

- Cr<r - Clir

- Clar - zrin - Crat

$\wedge \wedge \mid-乙 \wedge \wedge \cdot-\wedge<1$

كزيتهر مis

- Cita - Ciro - Cirt

-cran-Crkr - Erra

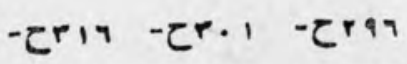

- $r<<-2 r<r-2 r a t$

- Crin - Crar - Cr<a

- zara - Eurn - zari

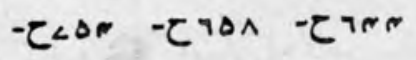

LA - L TA - $C<09$

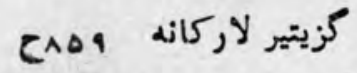

كلدسته نورم بهار ك. 


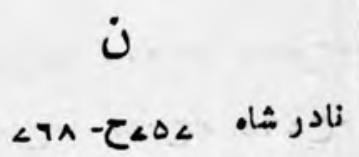
نادر شاه فرزند شمشير نادر نامه

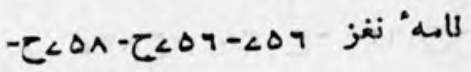

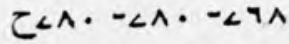

ناهة الابدان

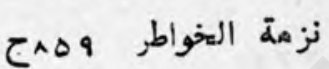
نسب نامه افاغنه نr<. نصاب نصاب التوحيد

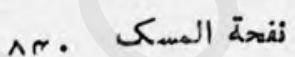
نواي معارك

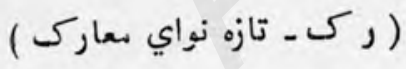

واقعات (ثاه شجاع) هوه

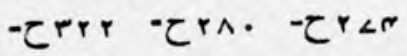

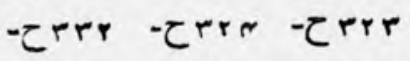

- cror zrer errr

-crat -cros zror

-

-rada -

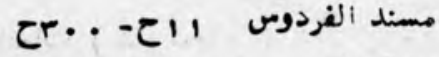

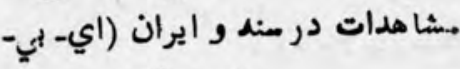
ايستوكل)

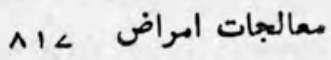

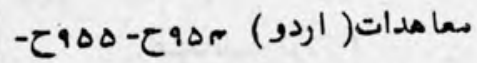
-

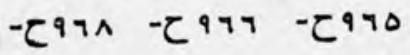

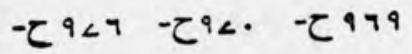

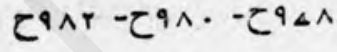

هماهدات ازملميسي با رؤماي هند

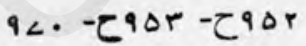

مقالات الثعرا

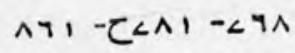

مكتوبات ميامي شاه ولي الله دملوي $c<<$

Cيمتوبات ميان فقيراله ل

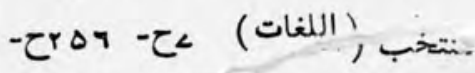
extr

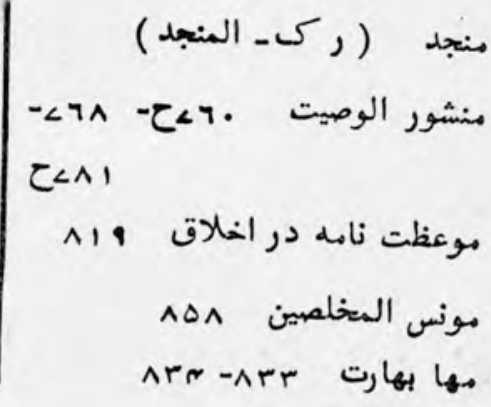


كازمه لواي مارك

$$
\text { 1.9^ }
$$

9 9 Cram-zrom

$$
\text { Zr.r gاقله }
$$

ورق صهيفه قرآن ( ورق مانل بصحف

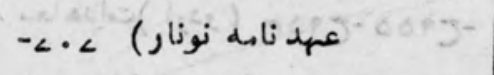

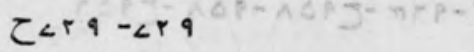

\section{ي}

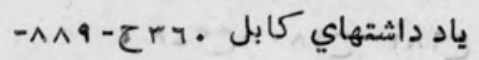
ᄉ9.

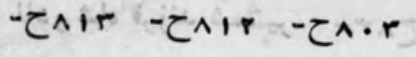

- zart -art -zaro

- vair -rara -zars

こด^। -て१^.

واتعات ( شاه شجاع ) دفتر دوم 


\section{N- اسهاي قرائل و اقوام}

$$
\begin{aligned}
& \text {-rat -rtr -tri - Cint }
\end{aligned}
$$

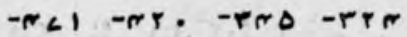

$$
\begin{aligned}
& \text { - } \\
& -\Delta \Delta<-\Delta \Delta T-\Delta \Delta r-\Delta N r
\end{aligned}
$$

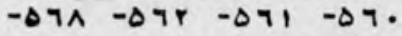

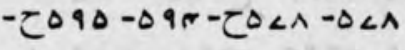

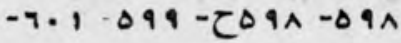

$$
\begin{aligned}
& \text { - }<\cdots-\tau 7 \Delta \cdot-7 r<-7 r 1 \\
& -\angle \angle \Delta-\Delta \Delta Q-\angle \Delta r-乙<\cdot 9 \\
& \text { - L9r - L9. - } \angle 46-\angle \angle Y \\
& \text {-nrt-art-Za. - - }
\end{aligned}
$$

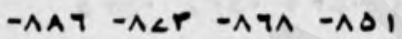

$$
\begin{aligned}
& -9.1-\Lambda 94-\Lambda 9 r-\wedge 91 \\
& \text {-914-911-9.7 -9. } \\
& \text {-ipr 110-9ie } \\
& \text { افغانان غئك } \\
& \text { (ر) - خدكى ) } \\
& \text { ازنانان خهبر }
\end{aligned}
$$

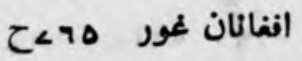

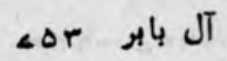

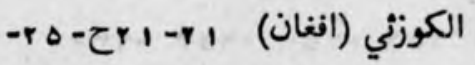

$$
\begin{aligned}
& -91 \quad-A r-\angle 0 \quad-\angle r \quad-r< \\
& \text { الف } \\
& \text { ^ه. ابا زني } \\
& \text { ابدال زئي إني } \\
& \text { ابدالي ror- } \\
& -\angle \angle O-\angle \angle O-\angle T T-\angle T \angle \\
& \text { A.. - <9. }-\angle \wedge 9 \\
& \text { أبدالي سربن } \\
& \text { اهكزंي } \\
& -r<\Delta-r_{1}-r_{1}-\int_{1}<\angle
\end{aligned}
$$

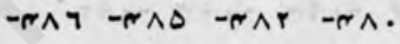

$$
\begin{aligned}
& \text { - } \\
& \text { งัง -ง ง } \\
& \text { احمد زتي ( بروهي بلوع ) اهم- } \\
& \text { ina-nat -ani } \\
& \text { १r. اخوند زني }
\end{aligned}
$$

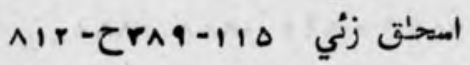

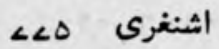

$$
\begin{aligned}
& \text { افاغنه Tr } \\
& \text { ا إشار } \\
& \angle 79-\angle 7 \angle \\
& \text { افغان }
\end{aligned}
$$


كازه نواي معاركي.

$11 \ldots$

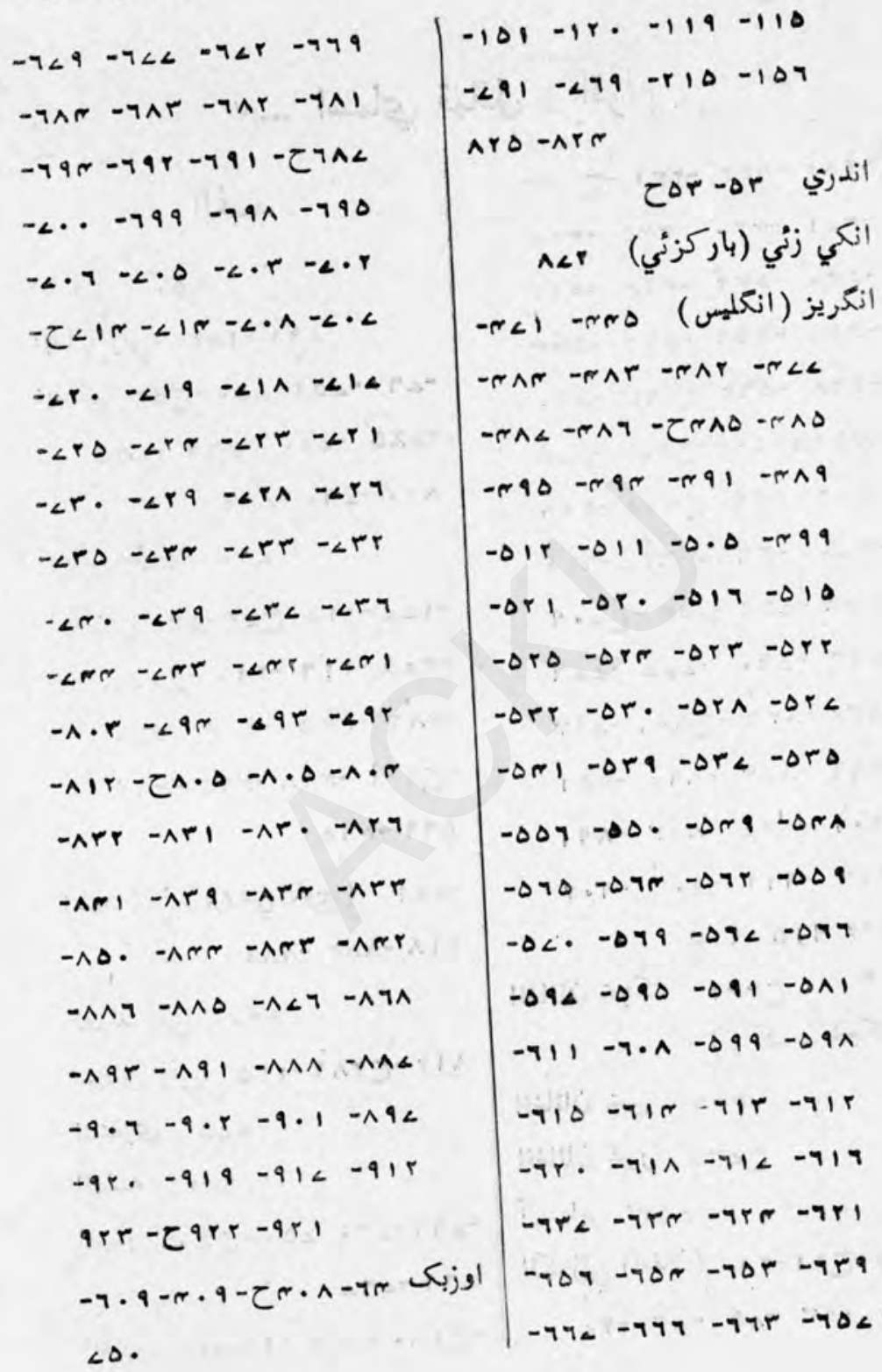


$-\angle 97-\angle 90-\angle \angle 0-71$

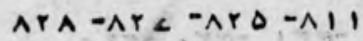

qr.

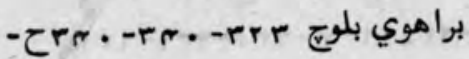

-nim-Crar-crtr-rmi

$-6 r t-6 r a 1<-410$

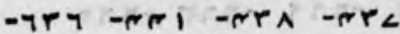

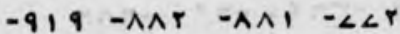

9r।-9r.

Cبو

بردراني (بادراني)

بروهي

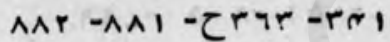

(نيز رك براهوي )

بوهمني

يزدار

بلو

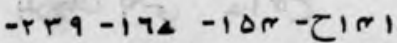

-

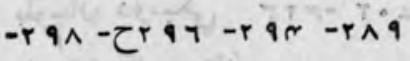

$-r \cdot \lambda-r \cdot \Delta-r \cdot i-r \cdot 0$

$-r|t-r| r-r|r-r| i-r \mid$.

-rai-rer -gra. -

-rar-ernr -rar-crar

$-410-41<-\int 4 i n-m i n$
4

بابري Arr $-\wedge \mid 1-\angle 91$

Cr بابؤي بابكر خيل 1.

Cادراني

باركزني

$-\tau \wedge r-\tau<r-\tau<1-77$

$-1 \cdot 1-98-91-\wedge 9-乙 \wedge<$

$-110-1 \cdot n-1 \cdot r-1 \cdot r$

-rOA -rot -rre-ire

- $\angle 98-\angle 9 \cdot-\angle \angle .-71$.

$-\lambda i 0-\lambda i r-\lambda i r-\angle A 4$

$-A M L-A N Y-\wedge T Q-\wedge r A$

$-\wedge \Delta,-\wedge \Delta .-\lambda \mu q-\wedge \mu \wedge$

$-\wedge<r-\wedge \neg \neg-\tau \wedge \Delta \Delta-\tau \wedge \Delta r$

$9 \Gamma \Delta-\wedge<\angle$

باروزئي (هني افغان) باكراني

باميزئي

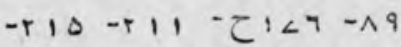

$-\eta \cdot 1-r \wedge \Delta-\tau r n r-r<r$ 
بنكل زني (منكل زني ) عrrer ir. -gers

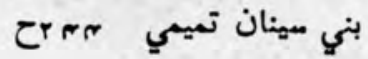

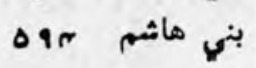
بيات بيرك

\section{$\psi$}

Crrs

كيني انغان

بوليزني

$-\lambda i r-n i l-n \cdot r-\angle<0$

Ar

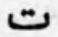

117 تاجك

تالهور (تالهر)

$-\angle 99-\angle 9 \wedge-7<P-P Y T$

$-\wedge 19-\wedge 17-\wedge 10-\Lambda \cdot I$

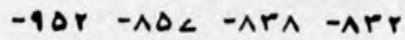

ครา

ترك

تركمانان تَرتُملوي (قرا قويون لو ) $\angle \Delta$.

Co. تركالهاي نسا
|

$-2$

-Surm-4ti-er.

$-g_{n} r_{5}-4 r_{1}-n r_{0}-4 r_{0}$

- - -

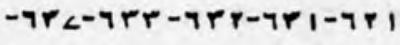

$-7 \Delta<-7 \Delta T-7 \Delta \Delta-7 r 9$

$-771-7 . \cdot-7 \Delta \wedge-\tau \curlyvee \Delta \Delta$

$-7<1-779-77 r-77 r$

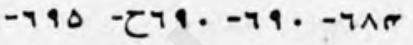

-乙山. -

$-\angle \angle r-\angle T F-\angle \Delta 9-\angle \Delta_{1}$

$-\angle \angle 9 \quad-\angle \angle \angle-\angle \angle T-\angle \angle F$

$-\angle 9 \wedge-\angle 97-\angle 9 r-<\angle 9$

$-\wedge<\Delta \quad-\wedge \Delta 1-\wedge 1 \Delta-<99$

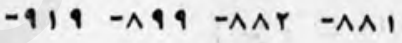

9งจ -9rr-9rr

بلوع مـيسي

بلوت نوماني

بلوهان بكني

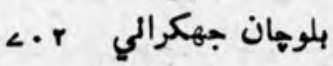

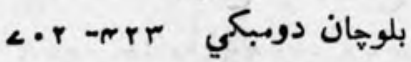

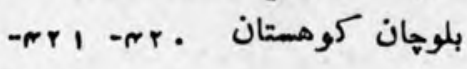
ert

بیوهان موى

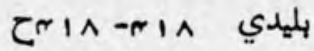

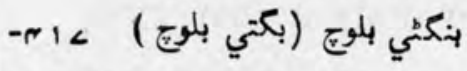

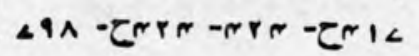


تصن.

En

$<$

عيداضحي

غ

انفعال

لَغَفْهُوز

نشراط

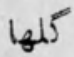

آميده

بساتين

$$
\text { شرر }
$$

مجرمبيت

كوسفندان

زوند كان

موي مندا

نواخت

تجفة الكرام

نغز

آثفته بود

9
غن

$1<$

عيدالضيحي

s)

انفال

لـغفور

نشا

كلهاي

آَدهد آَـده

بسا يتن

شد

مجدهـيت

كوسفتدان

روند د كان

سيوي سنده هـ

نواثت

نيفة الكرام

نغر

شفته بود

بو بكلي
مطر

$d x i v$

$1 \pi$

19

19

$\pi r$

9

o 9

9

11.

ir

11.

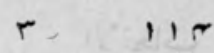

$1 \times 7$

$1<1$

$19 \quad 707$

$11<1$

$\angle 1 r$

$\angle \pi T$

$19 \quad<0 \%$

$17 \quad<0$

$1 \wedge<7 \wedge$

1. $<\wedge$.

ir $\angle A r$

Ir $<9 r$ 
تازه نواي مباركـ

صغنحd غلط

خرشبون

م ش شجره باركزائيان خوشبون

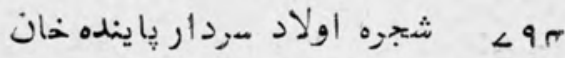

ر سطر آخر درث

divis

درند

A. 1

زبان

زيان

$r$

$\wedge 1$.

od

همدر يدين

Tt

Ar

فاروقيان

فاروقان

ن

الانجاب

الإنجاد

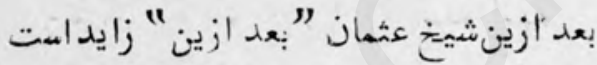

$r$

NoL

dolis

jij

aijl. as

Sist as

ظروف

ظردف

ir

NoL

تقليد جامي

تقليد حاجى

$\ln$

$\wedge \circ \wedge$

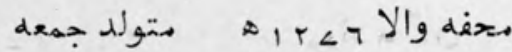

ir n०q

|r < 1 < 11 هتوفى الخّ

متوفى دو شنبه r r

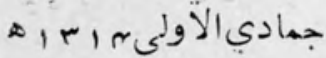

زويستده

نويسده

$\operatorname{lin}$

ATr

1. 5

i.5

1.

คงก

19

ค7ก

17

$\wedge\urcorner \angle$

$\wedge<7$

ش ش

$\wedge<7$

دهلي اورنكزيب

$\begin{array}{ll}r & \wedge<9 \\ i r & \wedge<9\end{array}$

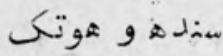

خे।

r $\wedge \wedge r$ 


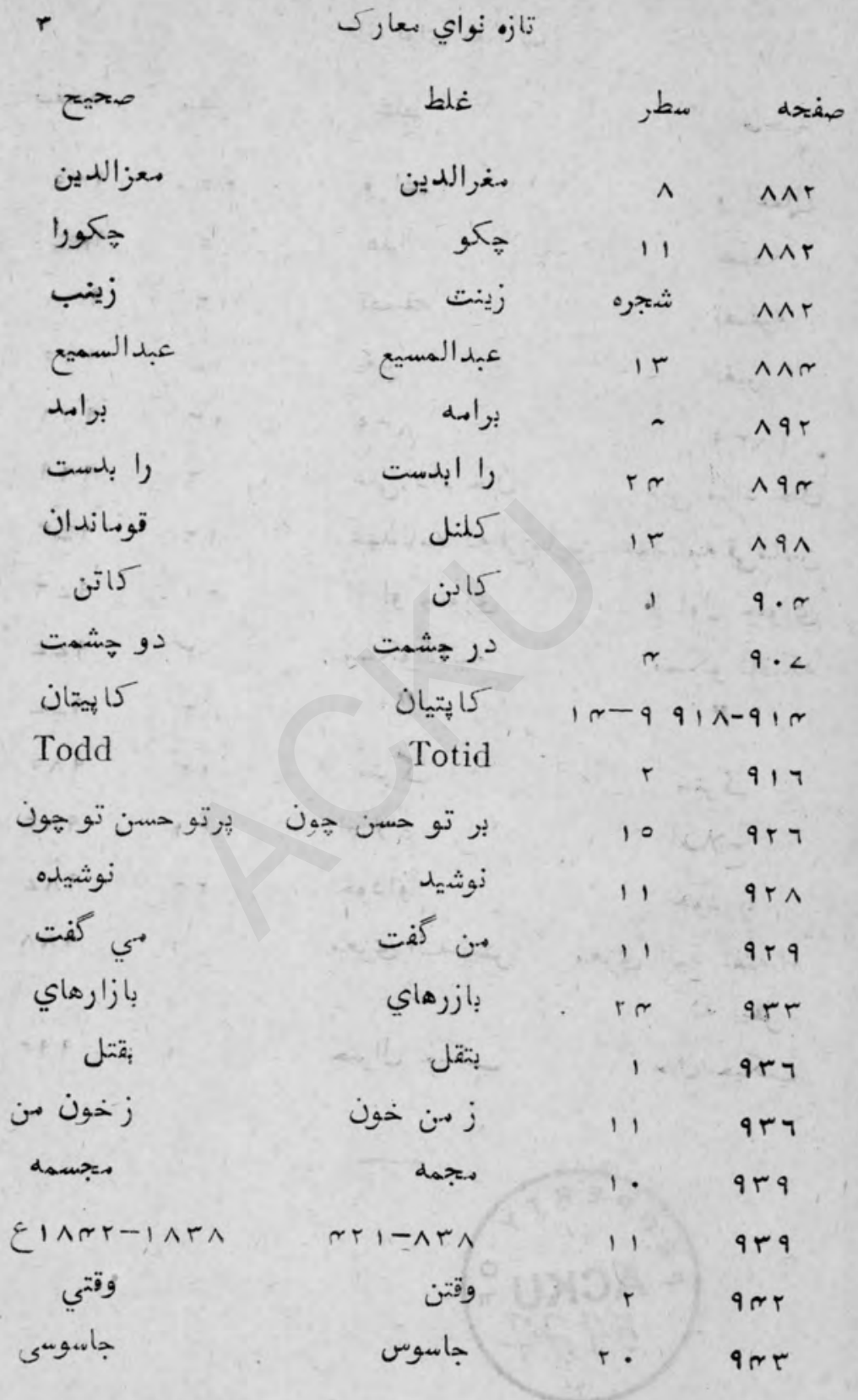




$$
\text { تازه نواي مeسر }
$$

זָ>

غلط

Jasl

هis

تصفيه

بغير

IAr

على مراد

على داد خان

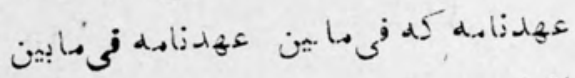
|ز إل جنوري

م.

"

$$
\text { 1 }
$$

d 15 ك.

,

سترك

مترك

\&

$\tau^{\lambda-1}$

1) خود

خود او

معزي اليه بيشث

جنر بل جيكب

1

q9

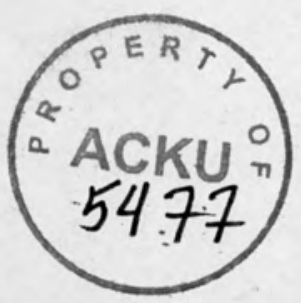

